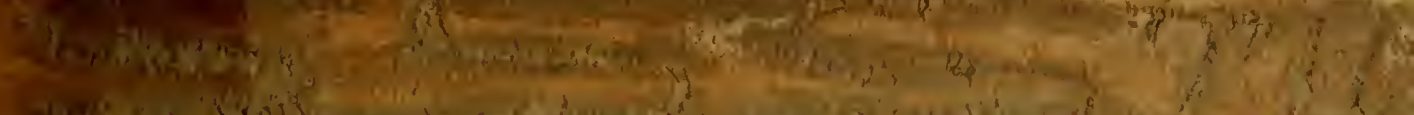

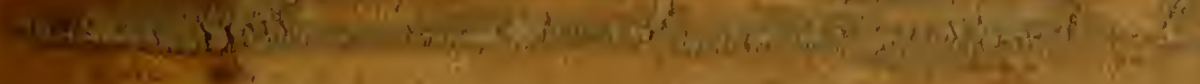
is 1

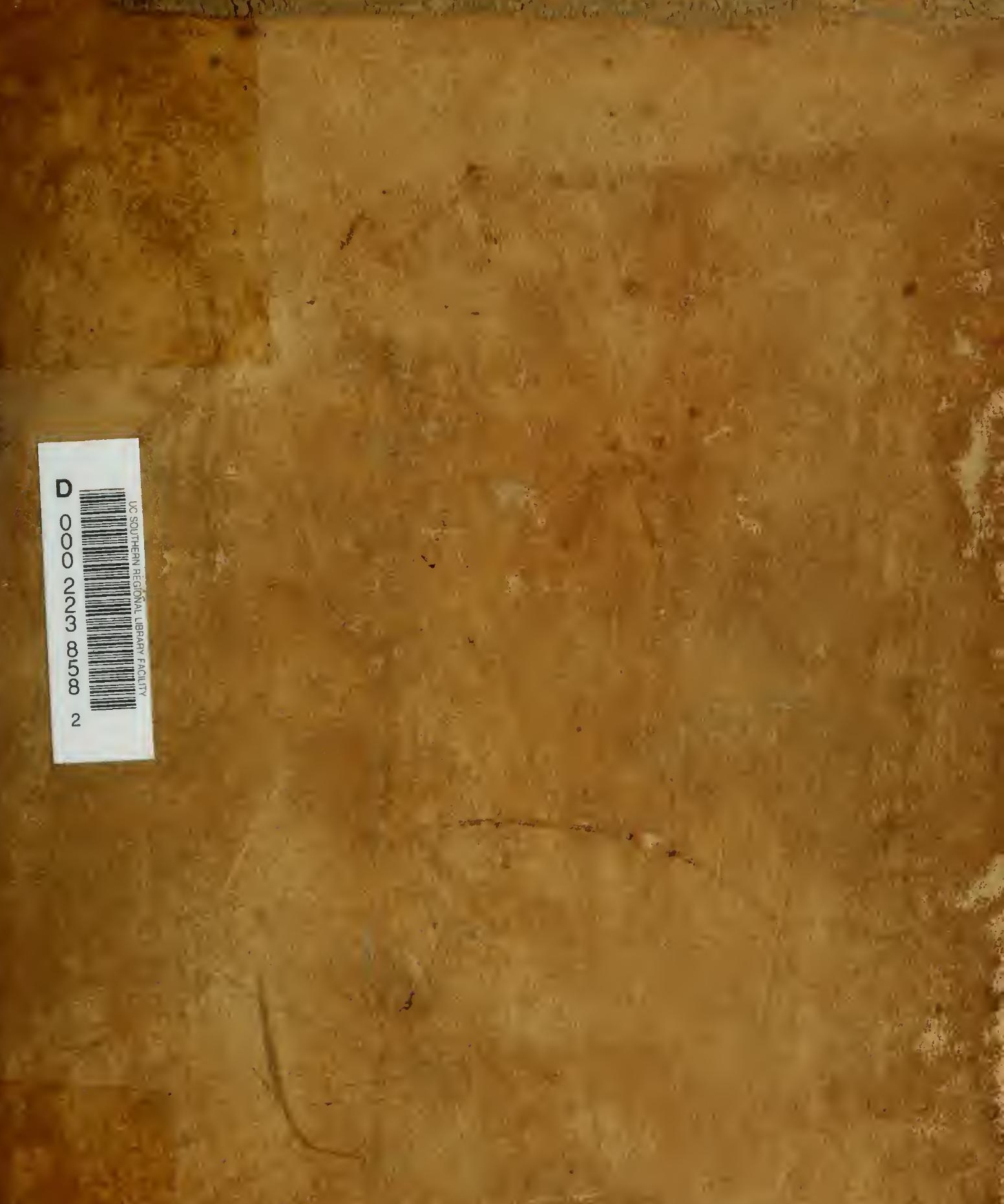

\title{
10. vas?
}




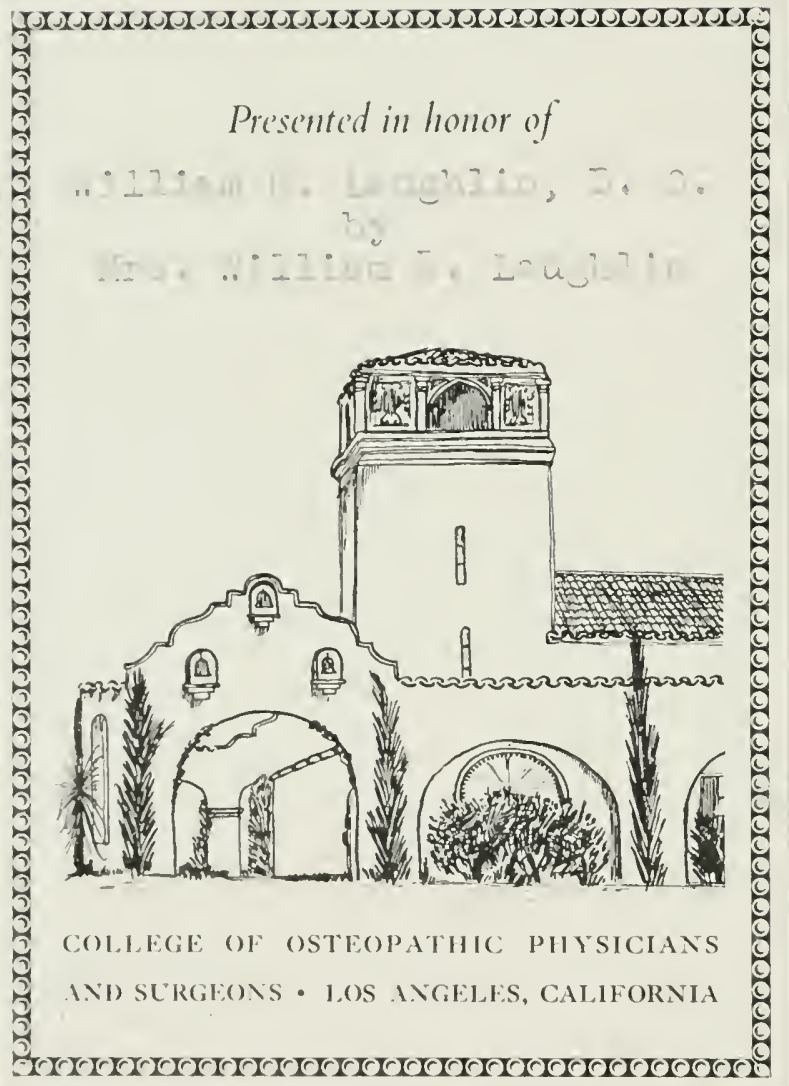


WILLIAM ROSS LAUGHLIN M.S. - D.O.
LOS ANGELES, CALIFORNIA

Vielian Pass Lang Lin

$$
\text { Sn. S. D. C. }
$$

Los angeles - baliforina

UNIVERSITY OF CALIFORNIA A1.IFORNIA COLLEGE OF MEDICINE

LIBRARY

1111261971

IRVINE, CALIFORNIA 92664 



\section{HUMAN ANATOMY}

M ORRIS 


\title{
ARRANGEMENT
}

$\mathrm{OH}$

\section{SUBJECTS AND AUTHORS.}

\author{
SECOND EDITION.
}

OSTEOLOGY. By J. Bland Sutton, F.R.C.S., Examiner in Anatomy in lingal Collegre of surgenns: Lecturer on Comparative Anatomy, and Sinior Denumstrator of Initumy, Midulesex Hospital.

JOINTS. By the Elitor, Henry Morris, F.R.C.s.. Surgeon to, and Lecturer on surgery at, Middlesex Huspital; Examiner on Anatomy in liovil college of sulgems; Eximiner in Surgery in the University of Ininlon, etc.

MUSCLES. By J. N. C. Davies-Colley, F.K.ı.s., Mem. Path. and Clin. Sur. Lumson; Fellow MLedir()-Chir. Soc.; Surgeon to, and Lecturer on sidrery (iate Idecturer on Auatomy), (Fuy's Hospital, ete.

BLOOD-VESSELS AND LYMPHATICS. BY William J. Walsham, r.k.c.s., Author of "Nimual of Practical Surgery," Senior Aristint Surueon to, and Lecturer on Anatomy at, St. Bartholomew's Hospitil : sureon Metropolitum Hospital, ete.

NERVOUS SYSTEM. liv H. St. John Brooks, M.D., of Dublin, Secretary for Ireland of Aust. Soc. of Great britain ; Chief Demoustrator of Inatum, Univensity of Inblin, ete. Revised by Arthur Robinson, Lecturer on Anatomy, II ildlesex Ifospital Melical School.

EYE. liy R. Marcus Gunn, F.R.c.s., Mem. Path., Ophthal,, and Venrol. Sox.; Surqeon to Royal Lombon aud to the Western Ophthalmological Hospitals, ete.

TONGUE, NOSE, EAR, HEART, VOICE, RESPIRATION. liy Arthur Hensman, F.R.C.S., Aural Surgeon (late Senior Denoustrator of Anitomy) Midllesex Hospital ; Lecturer on Aural Surgery and Anatomy, Mindlesex Hospital Medical School. Revised by Arthur Robinson, of the Mirlılesex ILospital Merlical sehool.

ORGANS OF DIGESTION. By Frederick Treves, F.R.C.S., Surrem amd lecturer on Surgery, London Hospital ; late Hunterian I'rotessor ol Anitomy, loyal College of Surgeoms, etc.

URINARY AND GENERATIVE ORGANS. THE SKIN. liy William Anderson, F.R.c.s., Surgeon to, and Lecturer on Anatomy, skin Department st. 'Thomas' Hospital ; Professor of Surgery and Pathology, lioyal Aridemy; late Vice-President Anatomical Society, ete.

SURGICAL AND TOPOGRAPHICAL ANATOMY. BY W. H. A. Jacobson, l'. R.('..., Assistant surgeon to Guy's Mospital ; Surgeon to

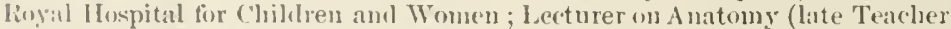
of 'Operative Surgery), (iny's Hospital IIerlical Scluol. Author of "The Uperitions of Surgery," "Diseases of the Male Organs of Generation," etc.

VESTIGIAL AND ABNORMAL STRUCTURES. 1y Arthur Robinson, M.I., M.K.(C..., Le.turer on Anitomy in thr Midllesex Hospital If colical school; Examiner in Inatony tor the Conjoint Board of Englaud.

\section{PUBLISHERS' NOTICE.}

The Illustrations in this look, for the most part, have been (ngrawel foun drawing made ly special artists. They are Fencrally from original sourese; those that are not, have been duly aredited ; all, howerer, with few exceptions, owing to re-trawing and engraving, are proterted hy copyright. 


\section{HUMAN ANATOMY}

I ('OMPLETE SYSTEMATIC TREATISE

BY VARIOL'S ATTHORS

INCLUDING A SPECLAL SEC'TION ON SURGICAL AND TOPOGRAPHICAL ANATOMY

EDITED BY

HENRY MORRIS, M.A. AND M.B. LOND.

SEXIOR SURGEON TO THE MIDDLESEX IOSPITAL; FXAMINER IN SURGERY IN THE UNIVERSITY OF IONDOX; MEMHEK OF THE COCXCIL, AXD CIMHRMAS OF THE COLRT OF HXAMINERS OF THE ROYAL CULLEGE OF SURGBOSS OF EXGLAND; HOSUKARY MFMHER OF THE MEDICAL

SUCIETY OF TIFE COUNTY OF NEW YURK

\section{IIIustrated}

BY SETEN HUNDRED AND NINETY WOODCLTS

THE GREATER PART OF WHIJI ARE ORJGINAL ANH MAIE EXPILESLY FOR TIIS WOIK BY SPECIAL ARTISTS

OVER 200 PRINTTED IN COLORS

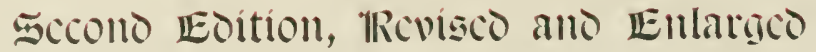

PHILA I) EL L P H I

P. iTA KIE'TON's

$1012 W A L N U T$ S TRET 
('opyruht, lsgk, by P. Buhistox's Sox d Co.

WM. F. FELL \& CO. ELECTROTYPERS ANO PAINTERS, 1220.24 SANSOM STREET,

PHILADELPHIA. 


\title{
ALPHABETICAL LIST OF CONTRIBUTORS
}

\section{TO THE FIRST EDITION}

\author{
WILLIAM ANDERSON \\ II. ST. JOHN BROOKS \\ J. N. C. DAVIES-COLLEY \\ R. MARCUS GUNN \\ ARTHUR HENSMAN \\ W. H. A. JACOBSON \\ HENRY MORRIS \\ J. BLAND SUTTON \\ FIEDERICK TREVES \\ W. J. WALSHAM
}

\section{TO THE SECOND EDITION}

The same, with Artult Robusus in place of H. St. JoHx Bronks and also in place of ARthur Hexsmax 



\section{EDITOR'S PREFACE TO THE FIRST EDITION.}

This Treatise on Human Anatomy is designed for the use of Students preparing for the Conjoint Board of the Roval Colleges of Physieians and Surgeons, for the Fellowship of the Royal College of Surgeons, and for the Examinations in Anatomy at the various Universities.

It ams at being a complete and systematic description of every part and organ of the lumman body so far as it is studied in the dissecting room.

Histology and development-exeept the mode and dates of development of the bones, and in a few other instances-are not included, as it is felt that these suljects are more appropriately dealt with in books on Physiology than they can eonveniently be in rorks on Anatomy.

The different seetions have been written by separate Authors, who are known to have devoted special attention to the subjects allotterl to them. To these gentlemen my best thanks are due for their generous assistance and able cooperation.

Whilst each Author is alone responsible for the subject-matter of the article which follows lis name, the proof-shects of other articles besides his own have in certain eases been submitted to him, so that several of the articles may loe enn-idered to have received the approval and endorsement of two, three, or more Authors. 'This has been partienlarly the ease with the reetions on ()-teoluegr, Arthrologry, Myology, and Teurologr. There is, therefore, reasom to believe that such important points as the attalehments of ligaments and of muscles, and the nerve-inpply of muscles, ete., will be found to be in perfect aceord in the various scetions in which they are referred to or described.

In the illustrations of the bones, the origins of museses are indieated by red lines, the insertions by blue lines, and the attachments of ligaments hy dotted black lines.

A feature of the book which, it is conficlently loped, will facilitate the work of students, is the mode of describing the illustlations.

This plan was decided upon at a conferenee of all the Anthor: and one of the artists. It consists in printing the descriptions in different types at the onel of the pointers. Thus it will be foumd that mucles, fascie, and ligaments ane in one

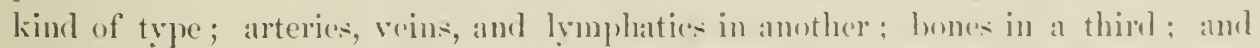
nerve-structures in a fourth. The nanes of special organ-such at the liver, 
hung-, ete.-ane printed in the same type as the hones, so as to aroid too great a vitriety of lettring.

Several of the illu-trations are repeated in different parts of the book, with

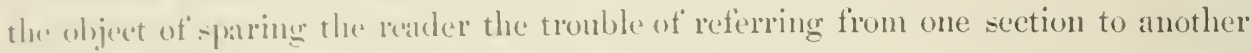
when retereme is male in the letterpuess to snch figures.

1-much unitionity als po--ible has been observert in the size and general style of the drawings; hut exceptions will be fomml in the section on Surgical and Topneraphieal Anatomy, for which many of the illustrations have been borrowed from another work, published hy Messis. J. and A. Churehill, namely, Bellamy's - Simroilual Anatumy.'

I have to acknomledge with gratefin thanks the as-istance I have received from Mr. (rotimos Brode, who male several disscutions from which drawings were taken; from Mr. J. Braxd Suttox and Mr. Fraxk Steele in reading over proot-sheets; from Mr. Burghard for the are with which he has drawn up the Intex and Tables of Contents; and from all the artists named on the title-pinge.

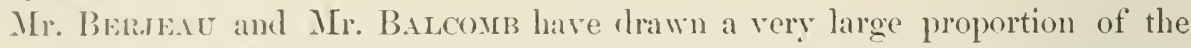
figure; and, with Mr. Sum and Mr. PARkER, have shown a legree of interest in, and given an amount of time and trouble to the illustrations for which they merit the fullest recognition.

The heantiful anatomial discections in the Hunterian Museum which have leen, by permision, eppied for this Treatise are from the hand of Mr. Irildian PEALsox, to whose great skill in disecting I have much pleasure in referring.

Tou mole praise cannot be given to all engaged in the actual printing of the lowk for the painstaking care they have devoted to it ; especially to the diffienlt and preeise work of properly 'registering' and printing the coloured illustrations.

I need only sily, in condusion, that I shall not consider my prolonged and laburious task hat been in vain if it be found that the Treatise adequately meets the repuirements of students, for whom it is witten.

- Caveninisir Square: January 1e93.

Hexty Morris. 


\section{PREFACE TO THE SECOND EDITION.}

In preparing this Edition the work has heen carefully, and it is hoped thoronghly, revised, both in regand to the descriptive text and the ilhustrations. Sime new ents have been added, and in a few instances new ones lave been substituted for those in the First Edition.

A description of the Skin has been added by Mr. Anderson; and an additional section at the end of the volume, on "Testigial and Abnormal Structures," hats been supplied by the pen of Dr. Robinion.

The Editor has been fortunate in obtaining the assistance of the original authors of the various sections in all eases but two. Dr. Arthur Robinson hats revised the section on the Nervous System instead of Dr. H. St. Jolm Brooks; and also those which were written by the late Mr. Artlum Hensman.

The Editor has to thank many kind friend, and other's personally unknown to him, both in the Uniterl Kingdrom and in America, for numerous and valual,le suggestions, and for corrections of trpographical errors, which regrettably but almost mavoidably had erept into the first edition. Great attention has been given to all of these snggestions. Many of them have becr adopted, and, if all have not been, it is because they were not in aecord with the object and intention of the work. For instance, one friendly critie thinks that in order to make it complete as a text-book the Minute Anatomy of the Vircera must be added; thic would he entirely ineonsistent with our ain, which is to make the bock complete as "a systematic description of erery paut and organ of the human lody as it is studied in the dissecting room." Minute anatomy must be studied, of course; but in the histological laboratory, not in the dissecting room, or at the demonstrator's classes on 'Topographical A natomy.

It is hoped that this revised edition will receive the confidenee of the Teachers, and find favour with the Students whose labours the book is intended to ficcilitate.

Cavexdish Square, Loxdon: September $7,189 S$. 



\title{
CONTENTS
}

\author{
SECTION I \\ OSTEOLOGY
}

By J. Brand Suttox

The Skeleton

A Classified List of the Bones to show their Mode of Development . . .

The Spine

Characters of a Typical Vertebra .

The Cervical Vertebræ . . . . . 7-11

The Thoracic or Dorsal Vertebre . . 12

The Lumbar Vertebre . . . . . . . 12

The Sacral and Coccrgeal Vertebræ . 14-17

The Spinal Column in general . . . 17

Ossification of the Vertebra . . . . 19

Serial Morpholngy of the Vertehre . 22

The Bones of the Skull .... 24-6:2

The Appendicular Elements of the Skull

Mandible (Lower Jaw) . . . . .

Hyoid Bone . . . . . . . . . .

Styloid Process . . . . . . . . .

Ear Bones . . . . . . . . .
PAGE
The Skull as a whole-

Exterior of the Skull . . . . . 69

The Orbits . . . . . . 76

The Nasal Fosse . . . . . . $7 y$

Interior of the Skull . . . . . . 81

The Teeth . . . . . . . . 86

Norphology of the skull . . . . . 89

Metamorphosis of the Branchial IBars gil

Skull at Birth . . . . . . . 90

Peculiarities of Individual Bones at Birth .......... 92

Nerve-Foranina of the Sikull . . . 96

The Rilss and Sternum . . . . . . . . 9s

The Thorax . . . . . . . . . 109

The Bones of the Upper Extremity . . 109-139

The Hip-Bone . . . $\quad$. . . . . . . 139

The Pelvis . . . . . . . 145

The Boues of the Lower Extremity . . 147-175

SECTION II

TIEE ARTICLLATIOAS

BY HEXRY MORRIs

Structures entering into the formation of Joints 176

The varions kinds of Artieulations . . 17\%

The varions Mlovements of Joints . . . . 179

The Articulations of tlie Skult . . . . . 179

The Teuporo mandibular Articulation $\quad 180$

The Ligaments and Joints hetween the Skull and Spinal Columu, and between the Atlas and $A$ xis

The Articulation of the Atlas with the Occiput . . . . . . .

The Artieulations between the Atlas and Axis . . . . . .

The Ligaments uniting the Occiput aud Axis . . . . . 1 182

The Articulations of the Trunk . . . . 190
The Articulations of the Vertehra] Colnmn .........

The Articulations of the Bollies of the Vertebrie

The Ligaments uniting the Articular Processe's

The Ligaments uniting the I aminat The Licraments miting the Spinous: I'rocesses.

The Ligaments imiting the Transverse Processes

The Articulations of the felvis with the Spine?

The Articulations of the pelvis

The saro-iliac Synelomirosis and Saero-seiatie Ligaments 
The Silero-roceygeal Articulation

The Inter-coceyceal Juints

The symplysis F'ubis

The Articulations of the Iilis with the Vertebrat

The Costo-erestral Articulation . .

The Costo-t ransierse Articulation .

The Articulations at the Front of the Thorax

The Chonlro-sterual Articulatious

The Costo-chomdral Joints

The Union of the Secrments of the Sternmm

The Interchoniral Articulations

Iuvements of the "Thorax as a whole

The Articulations of the Upper Extremity

The Sterno-celavicular Articulation

The Seapulo-rlavienlar Union . . . .

The Acromio-clavicular Joint . . .

The Coraco-clavicular Union . .

The Proper Scapular Ligaments . .

The Shoulder-Joint . . . . . .

The Elbow-Joint

The Union of the Radius with the Ulna

The snperios Radio-nlnar Joint . .

The Mill Ration-nlnar Union

The Interior Radio-ulnar Joint . .

The Radio-carpal Articulation . . . .

The Carpal Joints

The Union of the First Row of Carpal Bones

The Union of the Pisiform with the Bones of the First Row

The Union of the Second Row of Carpal Bones. . . . . . . . . .

The Medio-earpal Joint . . . . .

The Carpo-metacarpal Joints . . . . .

The Fonr Inner Carpo-metacarpal Joints . . . . . . . . .

The Carpo-metacarpal Joint of the Thumb. . . . . . . . .

The Intemetacarpal Articnlations . .

The Union of the Heals of the Metacarpal Bones
The Metacarpo-phalangeal Joints

The Metacarpo-phalaugeal Joints of the Four Inner Fingers . . . . . .

The Metacarpo-phalangeal Joint of the Thumb.

The Interphalangeal Artienlations * . 245

The Articulations of the Lower Limb . . 246

The Hip-Joint . . . . . . . . . . . 246

The Knee-Joint . . . . . . . . . . . 253

The Tibio fihular Union . . . . . . 263

The Superior Tibio-fibular Joint . . 263

The Middle Tibio-filular Union . . . $\mathbf{2 6 4}$

The Interior Tibio-fibnlar Articulation 265

The Ankle-Joint . . . . . . . 260

The 'Tarsal Joints . 269

The Calcaueo-astragaloid Union . $\quad 269$

The Posterior Calcaneo-astragaloil Joint . . . . . . . .

The Anterior Calcaneo-astragaloil Joint . . . . . . . .

The Articulations of the Anterior Part of the Tarsus . . . . . . 27

The Cubo scaphoid Union . . . 271

The Scapho-cuneiform A rticulation 272

The Intercuneiform Articulation . 272

The Cubo-cuneiform Articulation 272

The Medio-tarsal or Transverse Tarsal Joints

The Astragalo-scaphoil Articulation The Calcaneo-cuboid Articulation .

The Tarso-metatarsal Articulations. The Internal Tarso-metatarsal Joint The Middle Tarso-metatarsal Joint The Cuho-metatarsal Joint . . . .

Intermetatarsal Articulations atarsal Bones.... . . 279

The Metatarso-phalangeal Articulatious 279

The Metatarso-plualangeal Joints of the Four Outer Toes

The Metatarso-phalangeal Joint of the Great Toe . 280

The Interphalangeal Joints . . . . . 280 Morphology of Ligaments . . . . . . . 281

\section{SECTION JII}

\section{TIIE UTSCLES}

\section{IIY J. N. C. DAVIES-COLLEY}

General Remarks on Muscles

II uscles of the Upper Extremity-

l'osterior Ilivision of the Group of Muscles passine from the Trunk to the Upper Extremity First Latyer. Second Layer.

Anterior Division of the Gromp of Muscles pasing from the 'Truuk to the Upler lixtrenity . . . 293 First Latyer . . . . . . . . . . 291-2996 Secoul Layer . . . . . . . . 296-298 Third Layer . . . . . . . . . 298-300 Mruscles which pais from the Scapula to the Upper Limb 300-305
Gronl of Mnseles whiel move the Elbow-Joint . . . . . 300

Fascice of the Upper A rm . . . . 306 Flexors of the Forearm . . . 307-309 Extensors of the Forearm . . . . 309 Muscles of the Forearm . . . . . 311

Muscles of the Fromt of the Forearm 311 First Layer . . . . . . . . 312-315 Second Laver . . . . . . . 315-31R Thirl Layer Fourth Layer . . . . . . . . 321 Jackial Group of Muscles . 321-321 II Superficial Layer . . . . . 321-3?8 Deep Layer . . . . . . . 3:8332 
The Fascice of the Hand The Palmar Fatscia

Mnscles of the Hand .

Superficial

Deep Muscles of the Palm

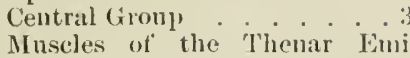

nence $2 . .3:$

Muscles of the Itypothenar Eminence ........ \$43

Muscles of the Lower Extremity -

II suscles and Fisciac of the 'Thigh . . 344

Ifuscles of the Front of the Thigh 346-351

The Gluteal Muscles . . . . . 351

First Layer . . . . . . . . 351-353

Second Latyer . . . . . . . . . 353

Third Lalyer . . . . . . . . 354

The External Rotators of 'Thigh 354-358

The Adluctors of the Thigh . . 358-36\%

The Hamstring Muscles . . . . 363-365

The Anterior Muscles of the 'l'high 365

The Deep Fascia of the Leg and Anumlar Liquments . . . . . 368

Muscles of the back of the Leg . . 369

First Lityer . . . . . . .369-371

Second Layer . . . . . . 371-373

Third Layer . . . . . . . . 373

Fourth Layer . . . . . . 376

The Fascia and Muscles of the Sole of the Foot . . . . . 37

First Layer . . . . . . . 378-381

Second Layer . . . . . . . 38I, 38:

Thirl Layer . . . . . . 382-385

Fourtl Layer . . . . . . 385

Muscles of the Front of the Leg . 387-391

Inscle on the Dorsum of the Foot . . 391

Muscles on the Outer Side of the

Lear . . . . . . . . 392, 393

Muscles of the Thorax . . . . . . 395
The Iiaphratgm ......... 399

The Aldominal l'arictes . . . . . . \$(t)

The Ablominal lluscles. J01

Anterior Vertical Musceles . . . . . 411:2

'Transverse and Oblique Muscles . 404-410

I'osterior Vertical Muscle . . . . 4I0

Ifuscles of the liack . . . . . . . 411

'lhird Layer . . . . . . 411-41:3

Gencral Arrangement of the Muscles acting upou the Spiual Column . . 41:3

The Vertehral A poneurosis . . . 413

Fourtl Lay'r . . . . . . . . 414

Fifth Layer . . . . . . . \$15-4:31)

Sixth layer. . . . . . . 4:01-4:?

Seventh Layer . . . . . . 4.3

The Suboccipital II uscles . . . . . . . 4:24

II uscles of the Heal and Neck . . . . 4.)

Superficial MInseles of Neck and Scial1' . 426-429

II uscles of the Eyelids and Evebrows . 4:29-4:31

Extrinsic Mnscles of the Auricle . . . . 431

Inscles of the Nose . . . . . . . 43:

II uscles of the Month . . . . . . . 434

Transverse Muscles of the Month . . . $436^{\circ}$

Angular Muscles of the Month . . . 436

Labial Group of Muscles . . . . . . . 438

Inscles raliating from the Month . . 440

Muscles of Mastication . . . . . . 440-444

Iuscles and Fasciae of the Font of the Neck

First Gromp . . . . . . . . . 445

Second Group-Infra-hyoid . . . . 447

Superficial Layer . . . . . . . . 417

Second Layer . . . . . . . .44 44

Third Gronj-Supra-hyoid . . 449-451

Extrinsic Muscles of the Tongne . . 451-454

Deep II sucles of the Front of the Neck . 454

Outer Group . . . . . . . . . 454

Inner Gronp

Abuormal Muscles. (By J. Bland Suton) 458

\title{
SECTION IV
}

\author{
ARTERIES, TELIS, AND LYUPIIATICS
}

BY W. J. WALSHAM

The Arteries . . . . . . . . . 46:

The Pulmonary Artery . . . . . . 46:

The Right . . . . . . . 464

The Left . . . . . . . . 466

The Systemic Arteries . . . . . . 466

The Aorta . . . . . . . . . . . 466

Arel of the Aorta . . . . . . . \$67

Variations in the Arch of the Aorta . 170

Branches of the Arch of the Aortal . 47\%

Coronary Arteries and their Variations........ 47?

Innominate Artery . . . . . 47t

Branches and Variations . . . 475

Common Carotid Arteries . . . 475

Thoracic Poltion of Left Common Carotid . . . . . . 47. Common Carotid in the Neck . $\quad 476$ liranches and Variations . . . 479

External Carotid Artery . . . . 450

Branches and Variations . . . . $120-497$

Internal Carotid Artery . . . . . 497

Branches . . . . . . 199-505
Subclavian Artery . . . . . . 50) Variations . . . . . . . 51) Branches . . . . 508-513

Distribution of the Cerebral Arteries 513

Axillary Artery . . . . . . 5?0

Branches and Variations . . . 521

Brachial Artery . . . . . . 5?

Branches amil Variations . . . 599

Uluar Artery

Branches and Variations . . . 5i31

Superficial Palmar Aleh . . . . 5 5ij

Variations ....... . 537

liranches . . . . . . . 53

Ramlial Artery. . . . . . . 533-

Variations . . . . . . 5 5 .

Branches . . . . . . . 5f()

Deep Palmar Arch . . . . . . 543

Branches ambl Variations . . . 54:

Descending, or Thoracic Aurta . . . . 545

Visceral Branches . . . . . . . 545

Parictal Branches . . . . . if

Abdominal Aorta . . . . . . 5 5n 


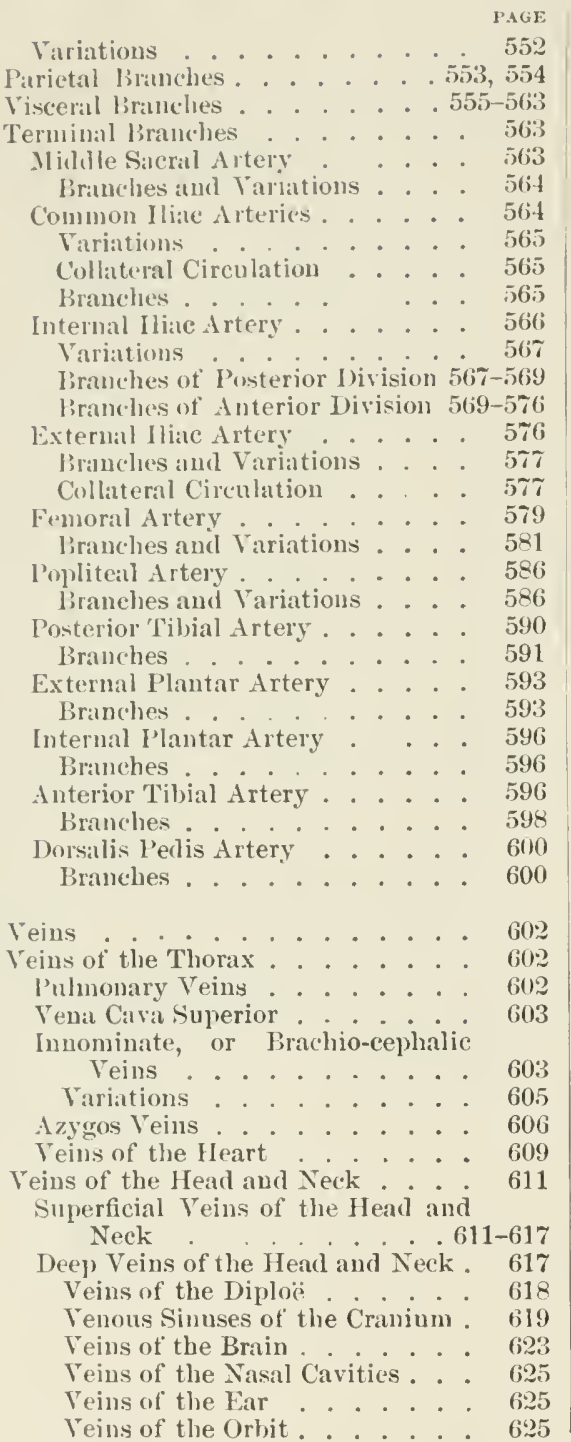

Veins of the Pharynx and Larynx Deep Veins of the Neck . . . Spinal Yeins ........ . . Veins of the Abdomen and Pelvis. Inferior Vena Cava ......

Common Iliac Yeins Variations . . . . . . . $6: 34$ Portal Vein and its Tributaries . . $\quad 634$ Teins of the Pelvis . . . . . 638 Veins of the Upper Extremity . . . 6339

Superficial Veins of the Upper Extremity

Deep Teins of the Upier Extremity Veins of the Lower Extremity . . . Superficial Veins of the Lower Extremity . . . . . .

Deep Veins of the Lower Extremity . . . . . . .

The Lymphatics . . . . . . . . . 648

Lymphatics of the Head and Neck . 648 Superficial Lymphatic Vessels and Glands of the Head and Neck.

Deep Lymphatic V'essels and Glands of the Head and Neck

Lymploaties of the Upper Extremity Superficial Lymphatic Vessels and Glauds of the Upper Extremity .

Deep Lymphatic Vessels and Glands of the Upper Extremity . . . .

Lymphatics of the Thorax . . . . .

Parietal Lymphatic Vessels and Glands of the Thorax . . . .

Visceral Lymphatic Vessels and Glands of the 'Thorax ... 658

Thoracic Duct . . . . . . . 659 Variations 660

Lymphaties of the Abdomen and Pelvis

Parietal Lymphatic Vessels and Glands of the Abdomen and Pelvis. .

Visceral Lymphatic Vessels and Glands of the Abdomen and Pelvis

Lymphatics of the Lower Extremity Superficial Lymphatic Vessels and Glands of the Lower Extremity

Deep Lymphatic Vessels and Glands of the Lower Extremity
PAGE (a) 639

\title{
SECTION $\mathrm{V}$
}

\section{THE NERTOIS SYSTEM}

\author{
BY H. ST. JoHX PRoOKS
}

REVISED FOR SECONI EDITION BY ARTIULR ROBINSON, M. I.

Nenrology

The Ironinges

Lymphatics of the lirain and Spinal Corrl

The Encephaton

Base of the Lrain $*^{*} \cdot *^{*} \quad 679$

Cerebral Hemispheres . . . . . . 681
Lobes of Cerehral Hemispheres with the Fissures and Convolntions . 684 Basal Ganglia of the Hemispheres . . 699 The Thilanencephalon . . . . . 704

The Mesencephalon . . . . . . . 710

The Epeneephalon . . . . . . 713

The Metencephalon . . . . . . 720 
Cranio-cerebral Topography .... 727

The Spinal Cord . . . . . . . . . . 7 73I Extermal Charicters . . . . . . 734 Interual Structure . . . . . . 737 Deep Origin of the Spinal Nerves . . 738

The l'eripheral Nervous System . . . . . 743 Cranial Nerves . . . . 743

First or Olfictory Nerve . . . . 745 Second or Optic Nerve . . . . 746

Third or Oculo-motor Nerve . . . 747

Fourth or Trochlear Nerve . . 748

Fifth or Trigeminal Nerve . . . . 749

First or Ophthalmie Division . . 751

Lenticnlar Ganglion . . . . 752

Second or Maxillary Division . . 753

Meckel's Ganglion . . . . . . 755

Third or Mandibular Division . $756 \%$

Submandibular (Submaxillary) Ganglion . . . . 759

Otic Ganglion : . . . . 760

Sixth or Ablncent Nerve. . . . 760

Seventh or Facial Nerve . . . . . 761

Eighth or Auditory Nerve . . . 765

Ninth or Glosso-pharyngeal Nerve $76 \%$

Tenth or Pnemmogastrie Nerve . . $\quad 769$

Eleventh or Spinal Accessory Nerve $\mathbf{7 7 3}$

Twelfth or Hypoglossal Nerve . . 774

Spinal Nerves. . . . . . 776

Posterior Primary Divisions . . . 779

Anterior Primary Divisions . . . 782

Cervical Nerves ..... . 782
Cervical Plexus ... 783

Superficial Branches . . . 783

Deep Iranches . . . . 785

Brachial Plexus . . . . . 786

Branches given off alıve the Clavicle ...... 787

Branches given off below the Clavicle . . . . . 788

Thoracic Nerves. . . . . 799

Lumbar Nerves . . . . . . 802

Lumbar Plexus . . . 812

Sacral and Coccygreal Nerves . . . 809

Fourtlı Sacral Nerve . . . . . . 809

Coceygeal Plexus . . . . . . 809

Sacral Plexus . . . . . 809

The Great Sciatic Nerve . . . 814

Sympathetic Nerves . . . . . . . 826

Gangliated Cords of the Sympathetie $\quad 826$

Cervical Portion . . . . . . 827

Superior Cervical Gancrlion . . 827

Middle Cervical Ganglion . . 830

Inferior Cervical Ganglion $\quad 830$

Thoracic Portion . . . . . . 830

Lumbar Portion . \$33

Sacral Portion . . . . . . . 8333

Great Prevertebral Plexuses . . . 834

Cardiae Plexus . . . . . . 834

Solar Plexus 835

Hypogastric Plexus . . . 837

Pelvic Plexuses . . . . 837

\section{SECTION VI}

\section{ORGANS OF SPECIAL SENSE}

\section{PART I: THE EYE}

BY R. MARCUS GUNN

The Eye

The Eyeball and its Surronndings. General Surtace View

Examination of the Eyeball . . . 843

Cavity of the Orbit . . . . . . 854

General Arrangement of its Contents $\cdot 0$

85.1
The Optic Nerve . . . . . 860

blood-vessels and Nerres of the Orbit ......... 862

The Evelicls . . . . . . 8605

The Lachrymal Apparatus . . . . $86{ }^{6}$

PART II: THE EAR, THE TONGUE, THE NOSE

lig ARTHCR IIENSMAN

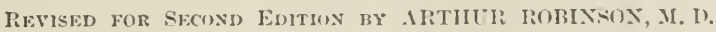

The Ear

The Exterual Ear

The Middle Ear. . . . . . 873

The Internal Ear or Labyrinth . E

The Tongue
The Nose . . . . . . . . . . . 8*9

The Cartilages . . . . . . . . $8 \$ 10$

Muscles . . . . . . . . . 8! 8 !

The Skin . . . . . . 892

The Vessels . . . . . . . 893

Communications . . . . . . . . 897 


\section{SECTION V'II}

\section{THE THORAL, INCLIDING TIIE ORGANS OF VOICE, RESPIRATION, AND CIRC'LLATION'}

BY ARTHLR HENSMAN

REVISED FOR SECOND EDITIOX IBY ARTULT ROBINSON, II. D.

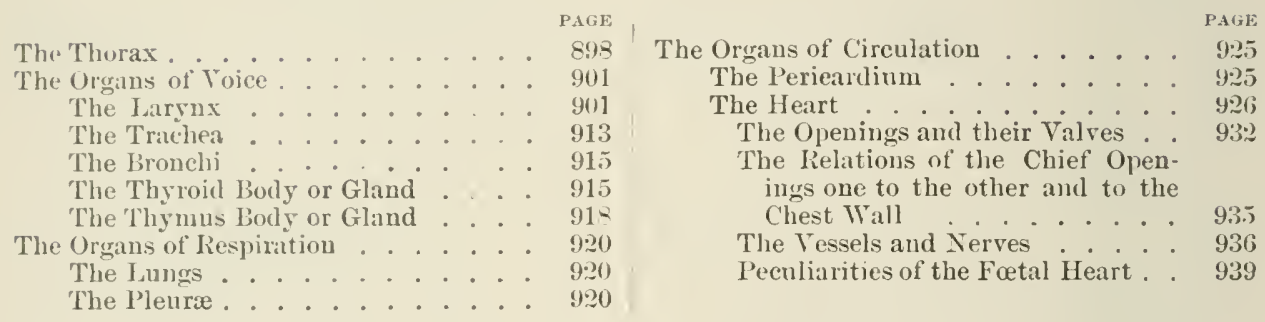

\section{SECTION VIII}

THE ORGASS OF DIGESTION

\section{PART I: THE ORGANS ABOVE THE DIAPHRAGM}

\section{BY ARTHIR HeNsmaN}

REvised for SEcoND EDITION BY ARTIITR ROBLTSON, M. I.

The Mouth

942 The Pharynx . . . . . . . . 949

The Palate

The Esophagus.

\section{PART II: THE ABDOMINAL VISCERA}

By Frenerick Treves

The Peritoneum . . . . . . . 954

The Ablomen . . . . . . . . . 959

The Stomach . . 960

The lutestines . . . . . . . . . . 964

The simall Intestine . . . . . . . 96.t

The Large Intestine . . . . . . . . 969

The Liver
Varieties of the Liver . . . . . 986

The Pancreas . . . . . . . . . . . . 986

The Spleen . . . . . . . . . . 998

The Evolution of the Peritoneum and an Explanation of its Arrangement in the Human Body . . . . . . . . 991

\section{SECTION IN}

\section{THE TRIVARY AND REMRODTRTIVE ORGAVS}

BY WHALAM ANDERSON

The Kidners . . . . . . . . 1005

The Supmarenal Bodies. . . . . . . 1013

The Renal Jucts . 1014

The Bladder . . . . . . . . . . 1016
The Male Reproductive Organs — . 1021

The l'rostate . . . . . . . 1021 The Testicles with their Appendages and Coverings . . . . . . 1023 
The Spermatic Cord . . . . . 1030

The l'enis . . . . . . . . . 1031

The Urethra . . . . . . . . . . 1035

The Female Organs of Generition . . . . 1038

The Vagina . . . . . . . . . 1012

The Uterus. . . . . . 1044

The Fallopian Tuhes or Oviducts . . 10.31

The Oraries ........ 1052
Yessels and Nerves of the L'terus and its Appendages . . . . . . 1053 Derelopment of the Lienitu-Lrinary Organs 1055 The Perin:eum . . . . . . . 10.58 The Male Perinxum . . . . . . . 1058 The Pelvie Fascia and Muscles . . . 1060 The Perinaum Proper . . . . . . . 1065 The Female L'erinæum . . . . . . 1utis The Mamma . . . . . . . . . 1069

THE SKIN.

BY Williay ANDERSON.

Structure of the Skin . . . . . . 107t The Appendages of the Skin . . . . 1077

Vessels of the skin . . . . . 1076

SECTION $\mathrm{I}$

STRGICAL AND TOPOGRAPHICAL ANATOMY

BY W. H. A. JACOB:ON

Superticial Anatomy of the Head and Neck 1080

Cranio-cerebral Topography . . . . . 1086

The Heal and Face . . . . . . . . 1091

The Eyelids and Litchrynal Appara-

tus . . . . 109?

The Month.

The I'alate ... . . . . 1097

The Jose . . . . . . . . . . . 1097

The Neck . . . . . . . , 1099

Superticial Auatomy of the Thorax . . , 110

The Abrlomen . . . . . . . . . . 1114

The Perimenm and Geuitals. . . . . 1122

Female Extermal Genitals . . . . . . . . 1129

Hernia . . . . . . . . 1131

Parts involved in Ineruinal Hernia . . 1131

Parts involved in Femoral Heruia . . 1137

Parts involved in Lmbilical Hernia . 1I41
The Back . . . . 1142

Superticial Anatomy of the Cpper Limb . 1149

The shoulder . . . . . . . . 1149

The Elbow . . . . . . . . . . . 1155

The Forearm . . . . . . . 1159

The Wrist and Hand . . . . . . . 1163

The Lower Extremity . . . . . . 1172

'The Thigh . . . . . . . . . 1172

The Buttocks . . . . . . . . 11-0

The Kuee . . . . . . . . 11=2

The Popliteal Space . . . . . 11-6

The Ler . . . . . . . . . 1188

The Ankle......... . 1194

The Foot . . . . . . . 1193

Arches of the Font . . . . . . 1202

The Regions of the Ablomen . . . . . 1206

\section{SECTION XI}

\section{IESTIGLA AND ABWORHAL STRECTLRES}

\section{Bi Artintr lionisso:}

The Skeleton . . . . . . . . 1209

The skull . . . . . . . . 12119

The Stermmm . . . . . . . 1:210

The Rils . . . . . . . . . . 1211

Epper Limis . . . . . . . . . . . . 1211

Humerus . . . . . . . . 1211

The Luwer Limb . . . . . . . 1211
The Jervous sirstem . . . . . . 1211

The Eve. . . . . . . . 1212

Visculirsysten . . . . . . . . 1213

Genito-L rinary System . . . . . . 1214

Female.......... 1214

IIale . . . . . . . 121.

Integument . . . . . . . . . 1215 



\section{LIST OF TLLUSTRATIONS}

FIG.

1. The Tibia and Fibula in section to show the Epiphyses,

PAGE

2. A Vertebral Centrum in section to show the Pressure Curves

3. A Diagram to show the Pressure and Tension Curves of the Fenur, . After Hagstaffe,

4. A Diagram showing Pressure and Tension Curres in the Hearl of the Humerus,

5. A Thoracic Vertebra (sicle view), After II agstaffe,

6. A Thoracic Vertebra, .

7. A Cervical Vertebra,

8. The First Cervical Vertebra or Atlas, ${ }^{\circ} \cdot 0^{\circ} \cdot$

9. The Axis,

10. The Cervical Vertebra (anterior view) (Colowred), . . . . . . . . . . . . .

11. The Cervical Vertehre (posterior view) (Coloured), . . . . . . . . . . . . . . . .

12. Peculiar Thoracic Vertebre,

13. A Lumbar Vertebra (sirle view),

14. A Lumbar Vertebra. (Showing the compound nature of the transverse process. Upper view),

15. Variation in the Fifth Lumbar Vertebra, . . . . . . . . . . . . After Turner,

16. A Variation in the Fifth Lumbar Vertebra, . . . . . . . . . . . . . After Tumer,

17. The Silcrum and Coccyx (anterior view) (Coloured), . . . . . . . . . . . . .

18. The Sacrum (posterior view) (Coloured)

19. Base of Sacrum,

20. The Spine (lateral view),

21. A Divided Thoracic Vertebra, . . . . . . . . . . . . . After Turner,

22. A Vertebra at Birth, . . . . . . . . . . . . . . . . . . .

23. Lumbar Vertehra at the Eighteenth Year with Secondary Centres, . . . . . . . . . 20

24. Immature Atlas (third year), . . . . . . . . . . . . . . . . . . . 21

25. Derelopment of the Axis, . . . . . . . . . . . . . . . . . . . 21

26. The Axis (from an Arlult) in Section, . . . . . . . . . . . . . . . . 21

27. An Immature Cervical Yertelıi, . . . . . . . . . . . . . . . . . . . 22

29. Osification of the Fifth Lumbar Yertebra, . . . . . . . . . . . . . . . . . . 22

29. Norphology of the Transverse and Articular Processes, . . . . . . . . . . . . . . . 23

30. The Occipital (external view) (Coloured), . . . . . . . . . . . . . . . . 25

31. Occipital Bone, Cerehral Surface, . . . . . . . . . . . . . . . . . . . 26

32. Cerebral Surface of the Occiputal, showing an Occasional Disposition of the Chamels, . . 27

33. The Foramen Magnum at the Sixth Jear, . . . . . . . . . . . . . . . . . . . . 27

31. The Occipital at Birth (anterior view). . . . . . . . . . . . . . . . . . . 22

35. The Occipital with a Separate Interparietal, . . . . . . . . . . . . . . . . . . . . 29

36. The Sphenoid (riewerl from ahove) . . . . . . . . . . . . . . . . 30

3\%. The Left Half of the Spheroirl, . . . . . . . . . . . . . . . . . . . . 31

39. The Sphenoid (anterior view), . . . . . . . . . . . . . . . . . . . . . . . .

39. Right Half of Sphenoid (anterior view) (Coloured), . . . . . . . . . . . . . . . 32

40. The Under curface of Pre-sphenoid at the Sixth Year, . . . . . . . . . . . . . . 33

41. The Sphenoid at Birth, . . . . . . . . . . . . . . . . . . 34

4.. The Jugum Sphenoirale _. . . . . . . . . . . . . . . . . . . 34

43. The Left Temporal Bone (outer viers), . . . . . . . . . . . . . . . . . . . 35

44. The Left Temporal Bowe (imner view), . . . . . . . . . . . . . . . . . 36

45. The Foramina in the Fundus of the Left Interual Auditory Neatus of a Child at Birth (4) (diagrammatic),

46. The Left Temporal Bone (inferior view), . . . . . . . . . . . .

47. Temporal bone with Muscle Attachments (Colomed), . . . . . . . . . . . . . . . . . 38

4\%. The Inner Wall of Trmpanm (coloured), . . . . . . . . . . . . . . . . 10

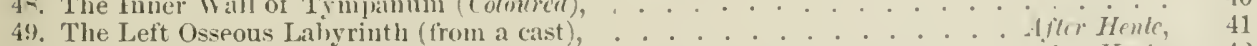

50. The Cochlea in Sagital Sertiou, . . . . . filer Jlente, 4:

51. The Temporal Bone at Birth (outer view). . . . . . . . . . . . . . . 4 43

52. Temponil bone at Birth (imer view), . . . . . . . . . . . . . . . . 13

53. Temporil bone at the sixth lear, . . . . . . . . . 44 
54. The I,eit Parietal (outcr surlace),

5j). The Lett Parietal (inner surface),

56. The Frontal (anterior view),

5\%. The Fromtal Bone (inferior view),

5-. The liroutal lione at Birth,

5y. Section through the Nasal Fossa to sliow the Mesethmoid,

60. The Ethmoid (side view)

61. Section through the Nisal Fossa to show the Lateral Mass of the Fthmoid. It shows also the Unter $1 V^{\mathrm{r}}$ all of the Left Nasal Fossa,

62. The sphenoidal Turbinal at the Sixth Year,

63. The Sphenoidal Turbiuals trom an Old Skull,

64. The Interior Turbinal, Adult sphenoidal Turbinal and Lachrymal Bones, . . . . . . 5:

6.). The Vomer (side view),

66. "The Left Nasal lione,

6\%. The Leit Maxilla (outer view)

6\%. 'lhe Left Maxilla (inner view),

69. 'The Maxilla at Birth,

70. L'alate (Left) Bone (imuer view),

テl. Palate bone (posterior view),

;.). The Le1t Malar Bone

7:3. The Mandible (outer view) (Coloured),

7. The Mandible (inner view) (Coloured),

\%., The Ifandible at Birtl,

76. The skull ot an Uld Woman Eighty-three Years Old, to show the Changes in the Mandible and Ilaxilla,

7. The Hyoid

7.. The Bones of the Ear,

\%.. The șkull (norma lateralis) (Coloured),

Modified from Henle,

80. A Section of the Skull, showing the Inner Wall of the Orbit, the Inner Wall of the Antrum, and the Sphemo-maxillary Fossa,

81. Hard Palate of a Child Five Iears Old,

-2. The skull (norma basilaris) (Coloured),

8:3. The stiull (norma bisilaris).

84. The skull (norma facialis) (Coloured),

8.). The skull (norma taicialis),

86. 'The Imuer Wall of the Orbit,

87. Section through the Tasal Fossa to show the Septum. Left Half, with Septum looking towards Riglt Nasal Fossa,

8?. Section through the Nasal Fossa to show the Outer Wall with the Meatuses,

89. The Posterior Nares

90. The Skull in Sagittal Section,

91. Tluesknll in Horizontal Section,

y:2. The skinll in IIorizontil Section,

93. The Teeth of' an Adult,

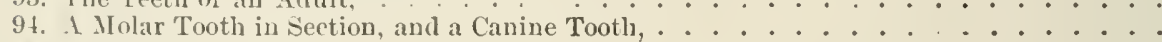

95. The Temporary Teeth,

96. The Chond ro-cranium,

97. The Crinium at Birth,

98. The Cranium at Birth,

99. The Crauium at Birth in Sagittal Section (Coloured),

100). The Orripital at Birth,

101. The siphenoid at Birth,

10:3. The Temporal lione at Birth,

10:3. The Temporal Bone at Birth (outer view),

114. Tenpural Fono at birth (inuer view),

10.). The Frontal at Birth,

106. 'lihe Maxilla at Birth.

10\%. The Mandible at lirth,

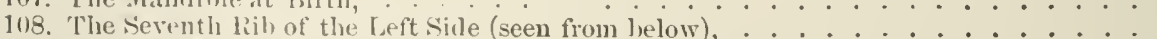

109. First and fiecond Rils. (Colonred).

110. The Tertelial Ends of Tenth, Eleventh, and Twelith Rilos, . . . . . . . . . . . . .

1 [1. Ril at l'ulerty,

112. The Thorax at the Nighth MLonth (Coloured),

113. 'The Sternum (anterior view) (Coloured),

114. 'The sternum (posterior view) (Coloured),

115. Posterior Surfice of the Manuhrium (I're-stermum), with Sternal Ends of Clavicle and the First Costal Cartilace (Colourel)

116. Two Stages in the Furnation of the Cartilaginons Stermm, . . . . . . . Afler Ruge,

117. 'The 'lhorax (tront view)

118. The Left Clavicle (superior surface) (Coloured) Afler Ruge, 10

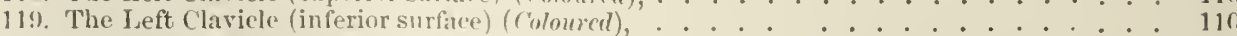

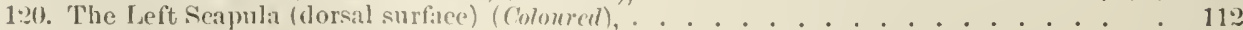

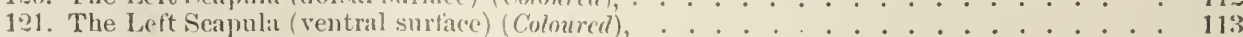

12:. Ossification of the ficapula, . . . . . . . . . . . . . . . . . . . . 115 
1:3. The Left Humerus (anterior view) (Coloured),

124. The left Humerus (posterior view) (Colourerl),

125. The Left Humerus with a Supracomlyloid I'rocess and some Irregular Muscle Attachments (anterior view) (Coloured)

1:26. Ossification of the Humerus,

1:2\%. The Ilead of the Humerus at the Sixth Year (in section),

128. Upper End of Lelt Ulua (outer view) (Coloured),

129. The Lelt Ulna and Radius (antero-intemal view) (Coloured), .

130. The Lelt Ulua aud Rialius (postero-external riew) (Colomerl),

131. Articular Facets on the Lower Eud of Left Ratlius and Lina,

13\%. Posterior View of the Lower End of the Radius and L'na,

133. Ossification of the Radius and Llua,

................. 127

135. The Left Hand (palmar surtace) (Colonerel), . . . . . . . . . . . . . . . . . 13u

136. The Left Scaphoid, . . . . . . . . . . . . . . . . . . . . 131

13\%. The Left Semilunar, . . . . . . . . . . . . . . . . . . . . . . . . . . 131

13\%. The Left Cuneiform, . . . . . . . . . . . . . . . . . . . . . 131

139. The Lett Pisiform, . . . . . . . . . . . . . . . . . . . . . . 131

140. The Left Trapezium, . . . . . . . . . . . . . . . . . . . 131

141. The Lett Trapezoid, . . . . . . . . . . . . . . . . . . . . . . . . . 132

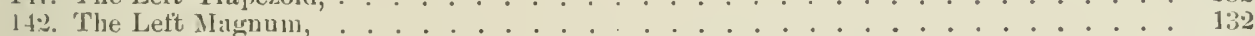

143. The Left Unciform, . . . . . . . . . . . . . . . . . . . . . . 133

14. The First (Left) Metacarpal, . . . . . . . . . . . . . . . . . 134

1.5. The Secont (Left) Metacarpal, . . . . . . . . . . . . . . . . . . 134

14t. The Third (Left) Metacarpal, . . . . . . . . . . . . . . . . . 135

147. The Fourtl (Left) Metacarpal, . . . . . . . . . . . . . . . . . . . . 136

14. The Fiftl (Left) Iletrearpal, . . . . . . . . . . . . . . . . . 136

14!. The l'halanges of the Third Digit of the Hand (Dorsal view), . . . . . . . . . . . 133

150. Ossification of the Metacarpals aud Phalanges, . . . . . . . . . . . . . . . 133

151. The Left Hip-bone (interual surfice) (Coloured), . . . . . . . . . . . . . . . . 1411

15:. The Left Hip-bone (posterior view) (Coloured), . . . . . . . . . . . . . . . . . 141

15:3. An Immature Innominate Bone, showing a Cotyloid Bone, . . . . . . . . . . . . . 14:

151. The Pelvis of a Fotus at Birth, to show the Three Portions of the Innominate Bones, . 14:?

15.5. Ifip-hone, showing Seeondary Centres, . . . . . . . . . . . . . . . . . . . It4

156. Hip-bone (inner surface) at the Eighth Year, . . . . . . . . . . . . . . . . . 14t

15\%. The Yelvis (Male), . . . . . . . . . . . . . . . . . 145

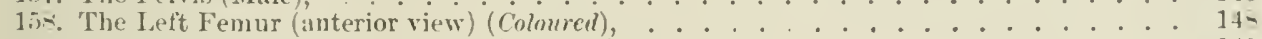

1.59. The Left Femur (posterior viers) (Colmut), . . . . . . . . . . . . . . . . . . 149

160. The Femur at Birth, . . . . . . . . . . . . . . . . . . . . . . . . . .

161. The Left Femur at the Trentieth Year (posterior view), . . . . . . . . . . . . 151

16:. The Left Patella, . . . . . . . . . . . . . . . . . . . . . 15

16:3. The Left Tibia and Fibnla (anterior view) (Coloredi), . . . . . . . . . . . . . . 151

161. The Left Tihia aud Fibula (posterior view) (Coloured), . . . . . . . . . . . . . . . . . 155

165. The Tihia and Fibula at the Sixtecinth Year, . . . . . . . . . . . . . . . 157

166. The Left Font (dorsal surface) (Coloured) - . . . . . . . . . . . . . . . . . . . . . 160

167. The Left Foot (plantar surface) (Coloured), . . . . . . . . . . . . . . . . . . . . 161

$16 \times$. The Left Astragalus (plantar view). . . . . . . . . . . . . . . . . . 162

169. An Astragahos with the Os Trigonmm, . . . . . . . . . . . . . . . . 162

170. The Left Calcanemm (dorsal view), . . . . . . . . . . . . . . . . . . . . . . . . . .

171. The Calcanenm at the Fifteenth Year, showing the Ejpipysis, . . . . . . . . . . . . 16-1

17.2. The Left Cuboid (inner view), . . . . . . . . . . . . . . . . . . . . . . . 165

173. The Left Cuboid (inner view), . . . . . . . . . . . . . . . . . . . . 16.5

174. The Left Cuboid (inner view), . . . . . . . . . . . . . . . 165

17. The Left Scaphoid (anterior view), . . . . . . . . . . . . . . . . . 166

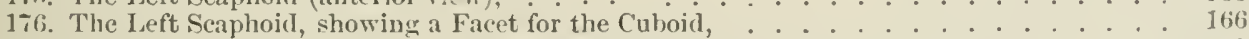

17\%. The left Internal Cuneiform (internal surface), . . . . . . . . . . . . . . . . . . 16 .

178. The Left Intermal Cuneiform (external surface), . . . . . . . . . . . . . . . . 167

179. The Left IIidlle Cuneiform (internal surface), . . . . . . . . . . . . . . . 168

180. The Left Midlle Cuneiforn (exterual surface), . . . . . . . . . . . 160

181. The Left External Cuneiform (internal surface), . . . . . . . . . . . . . . $16-$

182. The Left External Cuneiform (external surface), . . . . . . . . . . . . . . 169

183. The First (Left) Metatarsal, . . . . . . . . . . . . . . . . . . . 169

18. The Second (Left) Metatarsal, . . . . . . . . . . . . . . . . . . . . . . . . . . .

185. The Thirl (Left) Ietatarsil, . . . . . . . . . . . . . . . . . . . . . . . 171

186. The Fourth (Left) Metatarsal, . . . . . . . . . . . . . . . .

167. The Fifth (Left) Metatarsal, . . . . . . . . . . . . . . . . . . . . . . . .

152. The Platanges of the Middle Toe, . . . . 173

1-9. A Longitudinal Section of the Pones of the Lower Limb at Birth, . . . . . . . . . 173

190. The Secondary Osific Centres of the Font. . . . . . . 1it

191. External View of Temporo-nandihular Joint, . . . . . . . . . . . . . . . . . . 121

192. Internal View of Temporo-manlibular Joint, . . . . . . . . . . . . . . . . . 1 1

193. Vertical Section through the Conlyle of Jaw to show the Two Srmovial Sacs and the 1w)

194. Anterior View of the Upper End of the Spine, . . . . . . . . . . . . . . . . . . . . . 
19\%. Vertical Intero-posterior Section of Spinal Column through Median Line, showing Ligauncut:;

196. Horizontal Section through the Lateral Iasses of the itlas and the Top of the Odontoid l'rocess,

197. The supertial Laver of the Posterior Common Vertebral Liganent has heen removed to show its Deep or Short Fibres. These Deep Fibres form the Occipito-cervical Ligament,

192. Vertical Transwerse section of the Spinal Column and the Occipital Bone to show Ligaments,

199. Horizontal Section through an Intervertebral Dise and the corresponding RiJss,

201). The Anterior Common Ligament of the Spine, the Stellate, Interartienlar, and the Superior Costo-transierse Ligannents,

201. Posterior Common Ligament of the Spine (thoracie region),

$20 \%$. Posterior Common Ligament (lumbar region),

203. Limamenta sultlara in the Lumbar Region, seen from within the Spinal Canal,

204 . Sicle Tiew of Ligamentum Nuchre,

205 . The Interspinous and snpraspinous Ligaments in the Lumbar Regron,

:06. Anterior View of the liganents between the Spine and Pelvis,

20\%. Tertical Antero-posterior Section of the Pelvis,

208. Sacro-sciatic Liganeuts (posterior view),

209. Ligaments counecting Sacrum and Coceyx posteriorly,

210. Anterior Tiew of the Symphysis Pubis (Male), showing the Decussation of the Fibres of the Auterior Ligament,

211. Anterior View of the Symphysis Pubis (Female), showing greater Wicth between the Bones,

212. Posterior View of the Symphysis Pubis, showing the Backwarl Projection of the Sym. physial Sulsstance and the Decussation of the Fibres from the Inferior Pubic Ligament,

213. Section of Symphysis to show the Synovial Cavity,

214. The Capsular Ligaments of the Costo-vertebral Joints,

215. Showing the Anterior Common Ligament of the Spine, and the Conuection of the Rilss with the Vertebre,

216. Horizontal Section throngh the Interverteloral Dise and Rihs,

21\%. The Stermum

218. Diagram of $A x$ is of Rilu-movement.

219. Posterior View of the Steruo-costo-clavicular Joint,

200. Anterior View ot the Sterno-costo-('lavicular Joint,

2:21. Section throngh Sterno-clavicular Joint,

23.). Anterior View of Shoulder, showing also Coraco-clavicular and Coraco-acromial Ligaments,

223. Posterior Vies of the Shoulder-joint, showiug also the Acromio-clavicular Joint and the Apecial Ligaments of the Scapula,

:2.t. Vertical Section through the Shonlder-joint to slow the Gleno-humeral Liqament,

2::5. Fietal Shoulder-joint, showing the Gleno-humeral Ligameut, and also the Short Head of the Biceps, heing continuons with the Coraco-acromial Ligament,

2:26. Unter Tiew of the Shoulder-joint, slowing the Coraco-humeral and Transverse Humeral Ligaments,

22\%. Biceps Tendon, hifureating and Blending on each Side with the Glenoid Fihro cartilage,

2.2. Internal View of the Elbow-joint,

23!? External Tiew of the Elbow-joint,

2:30. Orbicular Ligament.

:30 A. Tpper l'ortions of Left Ulna and Ralins with Oblique and Orbienlar Ligaments : to show an Occasioual Slip from the Oblique Ligament to the Lower Part of the Orbicnlar Ligament,

2:31. Anterior Fiew of Wrist,

232. Posterior View of $\pi^{\top}$ rist,

233. Front of Wrist with Anterior Amular Ligament,

234. F'osterior View of Wrist, with Capsule ent to slow Atir

235. Symovial Memliranes of Wrist, Hand, and Fingers,

2:36. Anterior ancl Posterior View of Ligaments of the Fingers,

2:3. Anterior View of the Capsule of the Hip-joint,

23:. Posterior View of the Capsule of the Hip-joint,

2:39. Section through the Hip-joint, showing the Cotyloid Ligament, Liganentum Teres, amb lietinaculat,

240. Hip-joint after diviling the Capsular Ligament and disartienking the Fommr, . .

2.11. Portions of Isehinn and Pubes, showing the Cotyloid Noteh and the Ligamentmm Teres at tacherl outsicle the Acetabilum,

24:. Liqamentum Teres, lax in Flexion,

21:. Ligimentum Teres, very lax in complete Extension,

2.1. Ligamentnm Teres, drawn tiglit in Flexion combined with Rotation outwards and Alluetion,

215. Posterior View of the Knee-joint,

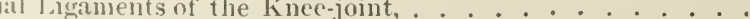

217. Strnctures lying on the Head of the Tihia (right knee), . . . . . . . . . . . 257

218. Anteriol View of the Knee-joint, showing the Synovial Liganents, . . . . . . . 258 
260

250. The Lat (ral Ligaments of the Knee in k"lexion and Extension, . . . . . . . . . . . . 261

251. Section of Knee, showing Crucials in Extension, . . . . . . . . . . . 26:3

25. Crucial Ligancuts in Flexion, . . . . . . . . . . . . . . . . . 263

25:) A. Lower knds of Left Tibia and Fibula, slowing the Ligaments, . . . . . . . . . . $26(65$

25:) 13. Kight $\Lambda$ ukle-joint, showing the Ligaments, . . . . . . . . . . . . . . 266

253. Inner View of the Ankle and the 'Tarsus, showing the Grouve for the Tendon of the T'ibialis Postreus,

254. Ligaments seen from the Back of the Ankle-joint,

255. External View of the Ligaments of the Foot and Ankle,

256. View of the Foot from ahove, witl the Astragalus removed to show the Inferior and Extermal Calcaneo-scaphoil Ligaments,

257. Liginnents of the Sole of the Left Foot,

$2,-4$. Section to show the syonovial Cavities of the Foo

259. Diagram showing Penniform Muscle, the Peroneus Longns; and Bipenniform, the Tibialis Posticus,

260. Diagram illustrating the advautage of Oblique Insertion of Teudons,

261. Dlargram illustrating the alvantage of Oblique Insertion of Tendous,

26:2. First Layer of Muscles of the Back,

264. The Pectoralis Major and Deltoid, . _ . . . . . . . . • * • . . . . 295

265. The Subclavius and the Upper l'ottion of the Serratus Magnis, . . . . . . . . . . . . . 296

266. The Pectoralis Minor, Obliquus Intermus, Pybunirlilis, and Rectus Abdominis, . . . . 297

26i7. Serratus Magums,

268. Back View of the Scapular Muscles and Triceps,

269. Front Yiew of the Seapular IIuscles,

270. Superficial View of the Front of the Upper Arm,

. Deep View of the Front of the Upper Arm,

272. Front of the Forearn : First Layer of IIuscles, . . . . . . . . . . . . . . . 31:

273. Front of the Forearm : Secoud layer of IIuseles, . . . . . . . . . . . . . . . . 316

274. Diagram of the Great Palmar Bursa, . . . . . . . . . . . . . . . . . . 317

2\%5. Front of the Foreirm : Thirl Layer of Mnscles, . . . . . . . . . . . . . . . . . 319

276. Muscles of the Radial Side and the Back of the Forearm, . . . . . . . . . . . . . . 322

27. Tendons upon the Dorsum of the Hand, . . . . . . . . . . . . . . . . . . . . 325

278. The Deep Layer of the Back of the Forearm, . . . . . . . . . . . . . . . . . . 329

279. Diagram of a Vertieal Section through the Middle of the Hand, . . . . . . . . . . . 334

280. The Superficial MLscles of the Halm of the Hand, . . . . . . . . . . . . . . . . 336

281. The Palma Interossei, . . . . . . . . . . . . . . . . . . . . . . 333

282. The Dorsal Interosei, . . . . . . . . . . . . . . . . . . . . . . . . 333

283. The Deeper Museles of the Palm of the Hand, . . . . . . . . . . . . . . . . . 340

284. The Pronator Quadratus and Deep View of the Palm, . . . . . . . . . . . . . . 342

285. Obliguus Externus and Fascia Latı, . . . . . . . . . . . . . . . . . . . . . . . 345

2×6. Psoits, Iliacus, and Quadratus Lmmbormm, . . . . . . . . . . . . . . . . . . . . . 347

2<\%. Muscles of the Front of the Thigh, . . . . . . . . . . . . . . . . . . . . . . . . 349

288. The Extemal Rotators and the Hamstring Muscles, . . . . . . . . . . . . . . . . . 355

2×9. The Deep Ifuscles of the Front of the Thigh, . . . . . . . . . . . . . . . . . . . . 309

290. The Deep Muscles of the Back of the Thigh, . . . . . . . . . . . . . . . . . . . 360

291. Superficial Muscles of the Back of the Thigh and Leg, . . . . . . . . . . . . . . 370

292. The Deep Muscles of the llack of the Leg, . . . . . . . . . . . . . . . . . . . . . 375

293. First Layer of the Mnscles of the Sole, . . . . . . . . . . . . . . . . . . . . . . 37

294. Second Layer of the Muscles of the Sole, . . . . . . . . . . . . . . . . . . . . . . . . 380

295. Thircl Layer of the Muscles of the Sole, . . . . . . . . . . . . . . . . . . . . 383

296. Fouth Layer of the IIuscles of the Sole, . . . . . . . . . . . . . . . . . . 386

297. The In uscles of the Front of the Leg, . . . . . . . . . . . . . . . . . . . . . . . 35

2!). The IIuscles of the Dorsm of the Fout, . . . . . . . . . . . . . . . . . . 390

299. The External Intercostals and Levatores Costarmim, . . . . . . . . . . . . . . . . . . . . 394

310. The Intercostal Muscles, . . . . . . . . . . . . . . . . . . . . . . . . . . 390

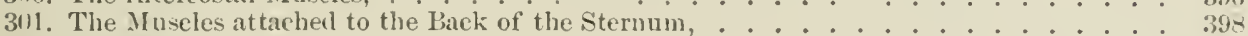

302. Diaphraym, . . . . . . . . . . . . . . . . . . . . 4100

313. External Oblique and Ilio-tihial Band,

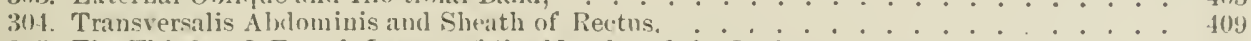

315. The Third and Fourth Layers of the Inscles of the Biack, . . . . . . . . . . . . . . . 412

316. The Fifth Layer of the Iluscles of the liack, . . . . . . . . . . . . . 4 416

307. The Fifth Layer of the IIuseles of the Back, after separating the Unter and iridalle Divisions,

302. The Sixth Laver of the Minseles of the lack.

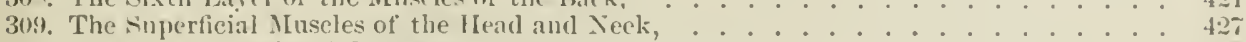

310. The Tensor Tarsi and Cormgator Superilii, . . . . . . . . . . . . . . . . . . 430

311. The Deeper Layer of the IIuseles of the Fice am Veck, . . . . . . . . . . . . .

31:. The Temporal II usele. . . . . . . . . . . . . . . . . . . . . . 442

3[3. The Pteryoir IInseles, . . . . . . . . . . . . . . . . . . . . 443

314. Anterior and Lateral Cervical Ninsles.

315. Sicle View of the IInceles of the Tomme, . . . . . . . . . . . . . . . . . . . . . . . . . . .

316. The Iluscles ol the Frout of the Neck, . . . . . . . . . . . . . . . . . . 4 . 
:31\%. Anterior View of the Ifeart with the Large Arteries and Veins (Coloumd). .

:l৪. 'The lleart, with the Areli of the Aorta, the I'umonary Artery, the Ductus Aiteriosus, and the Vessels concerned in the Frotal Circulation (Coloured,

i19. Dianram of the Relations of the Pulnomary Artery and its light and Left Branches (roluteril),

II alshem

:320. Posterior View of lleart and Greater Vessels (Colourd), .

321. The Arch of the Aortil, with the l'mlmonary Artery and Chief Branches of the Aorta (colourcel),

32.2. Selneme of the Relations of the First Portion of the Arch of the Aorta (Coloured), Irulsham 33:3. Sheme of the Relations of the 'Transverse Portion of the Arch of the Aorta (Coloured), IIalsham

32: The lifeart am Great Vessels, with the Root of the Lungs, seen from belnind (Caloured),

325 . Fineme of the lielations of the 'Third l'ortion of the Alch of the Aorta (Coloured),

IIalsham

326. Scheme of the Coronary Arteries ( Coloured), H"ulsham

3:- Scheme of the Relations of" the Innominate Artery.(Coloned), . . . . . . . Walshom

$\because 3$. Scheme of the Relations of the Lett Common Carotid and Left Snbclavian Arteries within the Thorax (Coloured),

Iralsham

3:9. The Common Carotid, the External aud Intermal Carotic and the Subclavian Arteries of the Right Side and their Branehes (Coloured),

:3io. The Collateral Circulation after Ligature of the Common Carotid and Subclavian Arteries (Coloured),

331. Scheme of Right Ascending Pharyingen Ärtery (Coloured), . . . . . . . . IValsham

3:3.2. Scheme of Lelt Superior 'Thyroid A rtery (Coloured),

33i3. Scheme of the Right Lingual Artery (Coloured),

3:34. Scheme of the Right Facial Artery (Coloumd),

33. Scheme of lioht Oceipital and Posterior Anricular Arteries (Coloured), Julsham

33:3. Scheme of Left Internal Maxillary Artery (Coloured),

IValsham

33\%. The Midmle Meningeal Artery within the Skull (Coloured),

33:- The Internal Carotid Artery, and Deep Branches of the External Carotid Artery, Left Side (Coloured)

3:3:). The Left Ophthalmic Artery and Vein (Coloured),

341). The Arteries of the Brain (Coloured),

341. The Right Subclavian Artery (Coloured),

342 . Scheme of the Left Vertel)ral Artery (Coloured)

343. Acheme of Anastomoses of the Right Scapnlar Arteries (Coloured), . . . . IVulsham

34. Scheme of the light Interual Mammary Artery (Coloured) . . . . . . . J'alsham

34.5. Sclieme of the Right Superior Intercostal Artery (Colouced), . . . . . . . . II ulsham

346. The Lower l'art of the Axillary, the Brachial, and the Radial and Ulnar Arteries, Right Sirle (foloured),

347. The Dorsal Seapular Artery, Right Side (Coloured),

34. The Right Posterior Cirenmflex Artery (Coloured),

34!. The Anastomoses abont the Scapula (roloured), .

3i). The Jiachial Artery, Left Side (Colowed),

351. The Brachial Artery at the Bend of the Elhow, Left Side, Front View (Coloucd),

352. The Arteries of the Forearm with the Superficial Palmar Areh (Coloured),

353. The lbick of the Left Forearm, with the Pusterior Interosseous Artery and Branches of the Ratdial at the Back of the Wrist (Coloured),

3.)4. Anastomoses and Distribution of the Arteries of the Hand (Colmired). "Iralsham

35.5. The Arteries of the Right Forearm and the Deep Palmar A reh (Coloured), . . . . . .

356. Diagram of the Relation of the Arteries of the Left Forearm to the Bones (Coloured),

Halsham

35\%. The Bend of the Elbow, Left Side (Coloured)

540

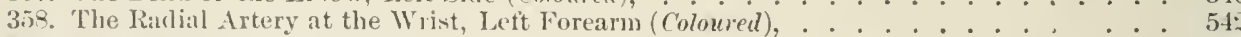

359. A nastomoses and Distrimution of the Arteries of the Hand (Coloured).

360. The A rch of the Aorta, the Thoracic Aorta, aud the Alklominal Aorta, with the Superior and Inferior Vena Cava and the Inmominate and Azygos Veins (Colourcl),

361. Silieme of the Thoracie Aorta (coloured)

31:2. Srheme of Interestal Artery (Colourd),

II ulsham

11 Gelsham

36.;. The Iblominal Aorta and its liranches, with the Inferior Vena Cava aud its Tribntaries (Coloural),

36.t. Scheme of the Ablominal Aorta (Coloured),

3(j). The Coeliae A rtery and its Biranches ( rolourd),

3iti. The Superior Mesenteric Artery and Vein (Coloured),

Ialsham

367. The Interior Mesenteric Artery and Vein (Coloured),

36. Side View of Pelvis and Tprer Thirl of Thigh, with the External iliac, Internal jliac, and lemoral Arteries ant their Bramehes, left Side (Colourd),

369. The Gluteal Region, with the Gluteal, Soitie, and Pudie Arteries (Coloured), . . . .

3\%0. Seheme of the Ovarian and Lterine and Taurinal Arteries (Coloured),

370 A. The Arteries of the Perinxem (Foloured),

3\%1. Scheme of the T'ulic Artery and its lianches (Coloured)

372. The Femoral Artery in sirarpa's Triangle (Colomed).

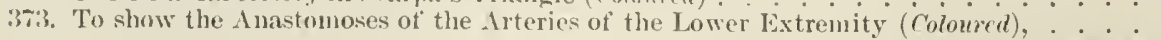

464

465

465

467

$16 \mathrm{i}$

469 
374. Relations of the Popliteal Artery to Iiones and Muscles, Ieft Side (Coloured),

3i). Nide View of the Right Popliteal Artery (Coloured),

:36. The Anastomosis alout the Ieft Knee-joint (Coloured), . . . . . . . . . IFalsham

37\%. The Popliteal, the Posterior Tibial, and the Peroneal Artery, Riglit Sirle (Coloured),

378. The Plantar Arteries, Left Foot (Colourcel),

379. Riglit Plantar Aiteries (Deep) (Coloured),

380. The Auterior Tibial Artery, Dorsal Artery of the Foot, and Anterior Peroneal Artery, and their Branches, Left Sicle (rolowed),

381. Scheme of the Distribution and Austomoses of the Arteries of the Right Foot (coloured), II ctshume

381 A. The Vena Cava Superior and the Innominate Veins (Coloured),

382. The superior and Inferior Vene Cave, the Innominate Veins, and the Azygos Veins (Coloured),

38:3. The Coronary Sinus (Coloived),

394. Scheme of the Coronary Veins (Coloured), . . . . . . . . . . . . Halshem

385. The Superficial Veins and Lymphaties of the Scalp, Face, and Neck (Coloured), Walsham

386. 'The Veins of the Diploë (Coloured),

387. The Venous Sinuses (Coloured), .

388. The Venons Sinuses (longitudinal section) (Coloured), . . . . . . . . . . . . . .

389. The Veins of the Orbit (Coloured),

:390. The Spinal Veins (Coloured),

391. The Abdominal Aorta and Inferior Vena Cava (Coloured),

:392. 'The Veins of the Stomach and the Portal Vein (Coloured), . . . . . . . . . Wulsham

393. The Superior Mesenteric Vein (Coloured),

394. The Interior Mesenteric Vein (Coloured),

395. The Bend of the Elhow with the Superficial Veins, Left Side (Colonred),

396. Superficial Veius and Lymphatics of the Left Forearm and Arm (Coloured), . Halsham

397. The Superfieial Veins and Lymphatics of the Left Lower Limb (Colonred), . Halsham

393. The Superficial Lymphaties of the Scalp, Face, and Neck (Coloured), . . . Walsham

392 . Diagram of the Superficial Lymphatic Vessels and Glands of the Heact and Neck,

398B. Diagram of the Deep Lymphatic Vessels and Glands of the Head and Neck, Afer Shoruod After Sherwood

399. The Sinperficial Lymphaties of the Left Upper Limb and Axillary Glands (Coloured),

399 A. Diagram of the Superficial and Deep Lymphatic Vessels and Glands of the Upper Extremity including the Superficial Lymphatic Vessels of the Back and Chest,

After shenvod

399в. Diagram of the Arrangement of the Lymphatics of the Uterus, Fallopian Tuhes, Ovaries, Vagina, and Exterual Vulva,

400. The Superfieial Lymphaties of the Left Lower Limb (Coloured), * . . . I"ulsham

400A. Diagram of the Superficial and Deep Lymphatic Vessels and Glands of the Lower Extremity, ineludiug the Superficial Lymphatics of the External Genitals and the Lymphatics of the Gluteal and Ischial Regions, . . . . . . . After sheriooul

401. Diagrammatic Sagittal Section of a Vertebrate Brain,

Afler IIuxley

40:2. Diagrammatic Horizontal Section of a Vertebrate Brain,

ifler Iluxley

40:3. Coronal Section of the Head passing through the Mastoid Process,

404. Coronal Section of the Head passing through the Posterior Horns of the I-iteral Ventricles,

405. The Cranium opened to show the Falx Cerebri, the Tentorium Cerebelli, and the places where the Cranial Nerves pieree the Dura Mater (Colourell), . . . S Sippey

406. Coronal Section through the Great Longitudinal Fissure, showing the Meninges, . . . .
Kcy and Retzius

407. Cranial Nerves in the Base of the Skull (Coloured),

408. View of the Base of the Brain (Coloured), . . . . . . . . After Beaunis

40\%. The Fissures and Convolutions of the Cerebrum, viewed from alove (Colourell),

410. Lateral View of the Fissures and Convolutions of the Cerebrum (coloured),

411. Convolutions and Fissures on the Mesial and Tentorial Surfaces of the Hemisphere (Coloured),

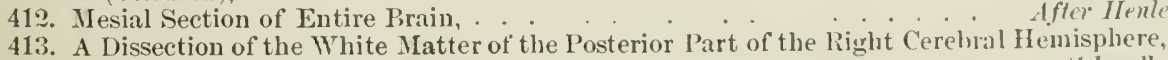

iffer IItenle seluralle

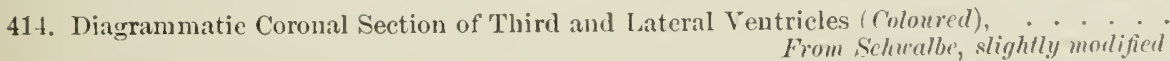

415. Coronal Section of the Hemispheres passing throngh the Anterior Cornua of the Lateral Veutricles,

416. Coronal Section of the Head passing through the Posterior IIorus of the Lateral Ventricles, .

417. A Dissection of the Descenting Cornu of the Lateral Ventricle, with a Sagittal Section through the Basal Ganglia, .

418. A Dissection showing the Free or Intraventricular Portion of the Cauclate Nucleus. The Mesial and Tentorial Surfaces of the Iemisphere are also shown.

419. Horizontal Section of the Cerebrum, . . . . . . . . fter Landnis and Stirling

$4: 0$. Horizontal Section of the Cerebral Hemisplueres, 
Fiti,

4:1. Coronal Section through the Anterior Part of the Third Ventricle,

1:-). Cormal section thoum the Middle Commissure of the Thiru Ventricle, . . Sehwalbe

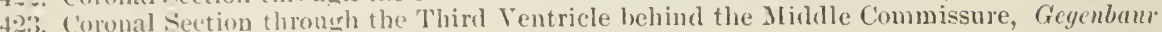

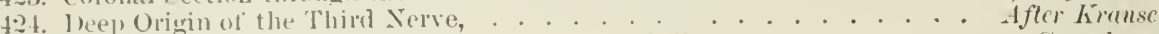

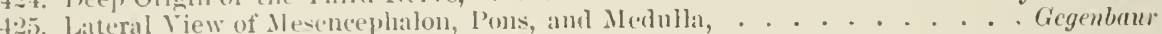

4:06. Interior sintice of the C'erebellum,

4:F. Right Halt of the Enceplalic I'rimucle as seen from the Inside of a Median Section ('ulourel), Allen Thomson, after licichert

4:- Metencephalon, Mesencephalon, and Thalauencephalon, from the Dorsal Surtace rolourcul)

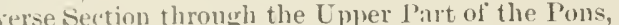

430. Transierse Section of the l'ous near the c'entre of the Fourth Ventricle. . . Schuculbe

431. Transerse Section of the Medulla a little above the Lower Extremity of the Fourth Ventricles

Afler Krallse

432. Transverse section of the Medulla in the Recrion of the Decussatio Lemmisci, . Schralue

433. Drawing of a Cast of the Mead of an Adult Male (Coloured), . . . . . Cunninghum

4:34. 1) lawing of a Cast ot the Head of a Newly-horn Male Infant (Colonred), . Cuminglum

4:5. Transierse Sertion of the Spinal Cord and its Membranes, . . . Afler Key und lietzius

4:36. View of the Membranes of the Spinal Cort,

Fllis

43. Posterior View of the Mednlla Oblongata and of the Spinal Cord, with its Coverings and the Roots of the Nerves,

43- Anterior and l'osterior View of the Spinal Corl,

Hirsehfeld and Lereillé Modified from Quaiu

439. Sections through Different Regions of the Spinal Cord, . . . . . . . After Schurbe

44). Dianram showing Paths Traversed by Sensory and Motor Nerve-fibres and their Course to and lirom the Cortex of the Brain (Colowed),

440. I. Diagram of the Tracts of the Spinal Cord and ot the Deep Origins of the Spinal Nerves (roloured),

411. Surtace Origin of the Cramial Nerves (Coloured), After Allen Thomson.-Qunin

14. Nerves of the Nasal Cavity (Coloured),

443. Deep Origin of the Thirl Nerve,

44. Sections througl the Urigin of the Fourth Nerve,

445. Nerres of the Orbit, from the Outer Side (Colourud)

From Sappey, after Hirscheld and Leveille.

446. The Maxillary Nerve seen from without (Colonred),

Benumis

4. Distribution of the Maudibular Division of the Trigeminal Nerve, . . . . . . . Mcnle

413. Diagrammatic Lateral View of the Origin of the Facial Nerve, . . . . . . Krause

449. Superficial Distribution ot the Facial and other Nerves of the Head (Colourel), After Hirsch feld and Leville

450. Transverse Section of the Pons, passing through the most Distal of the Strixe Medullares, Kranse

451. Distribution of the Pnemmogastric Nerve, viewed from behind (Coloured), * . Krause 45:- 1)istribution of the l'osterior Primary Divisions of the Spinal Nerses, . . . . . Ilenle

453. Diagram of the Cervical l'lexus,

454. smperficial Liranches ot the C'ervical Plexus (Colomred), . . Afler Hirschfeld tud lacreille

fī́. I Diagram of the Brachial Plexus,

456. Distribution of Cutancous Nerves on the Anterior and Pusterior Aspects of the Superior Extremity,

45i. A Disscction showing the Arrangement of the Nerves in front of the Elbow (Colourcl),

$15 \%$. Dissection of the Lett Arm from the Front, Showing Portions of the Uluar, Median, Musculo cutaneous, aud Musculo-spiral Nerves (Coloured), . . . . . . . . .

458. Superficial Nerves of the I'alm (Colomred) . . . . . . . . . . . . . . . . . . Ellis

459. A Dissection of the Cutaneous Nerves on the Dorsal Aspect of the Hand and Fingers (Colomerl)

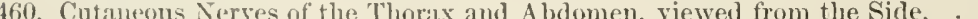

461. Diauram of the L,umbil aml sacral Plexuses.

46:. Branches of the Lumbar and Sicral Plexus viewed firom betore (Coloured), II. St. J. B.

After Hirsiffeld and Lercille

463. Anterior Crural and Oluturator Nerves (Coloured), . . . . . . . . . . Ellis 4(it. Distribntion of ('utaneons Nerves on the Posterior and Anterior Aspects of the Inferion Extremity

465. Diagram of the Lumbar am1 Sacral Plexuses,

66i. A Dissection of the Lumbir and Sacul l'lexuses, lrom behind (Colourd),

4iz. A bissection of the Nerves in the filuteal lingion (Colomed).

46k. Distribution of the Museulo-futaneus and Anterior Tibial Nerves on the Anterior Aspect

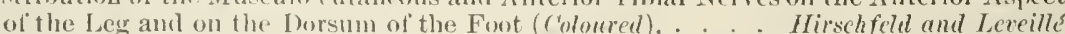
46:). Superticial Nerves in the sole of the Foot (culoured), . . . . . . . . . Ellis 46i). Diarram of tle Cutameous Nerve Areas of the lleal and Neck (Colourd). . . . . 469). Diagram sluwing the Areas of l)istribution of Cutaneons Nerves (Colourel), . . . . . 470. The Cervical lontion of the Sivmpathetic and the I)istrilntion of the l'nemmogastric Nerve, viewal tirom behiul (Coloured),

Krause 470.1 .

47. Lumbar Portion of the Cimerliated Corl, with the Solar and Hypogastrie Plexuses (Colomind).

472. View of lyeball, ete., olstimed ou drawing the Lids foreibly apart, . . . . . . . . 
Fig.

473. Left Funtus Oeuli, as seen by direet Ophthialmoscopic Methor,

474. Diterammatic View of the Insertions of the Ocular MIuscles, .

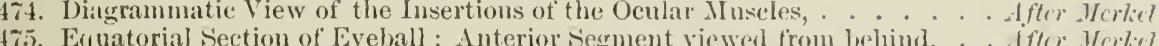

476. Diagranmatic IIorizontal Section of Eyebull aud Orbit (Coloured),

After Fichs, much morlifich

4\%. Semi-rliagrammatic Iforizontal Section through Eyeball and Optic Nerve,

After Eifinger, reduced and allered

478. Diagrammatic Representation of the Blood-vessels of the Eychall (Coloured), . . . Leber

479. Surface of Choroid and Iris exposed by removal of Sclerotic aud Conea, showing I)istributiou of Blood-vessels and Nerves (colourcl), . . . . . . . . . . . After Zim

480. The Iymphaties of the Eyehall (Colamed), . . . . . . . . . Dingrummatie, afler F'ucles

481. Lett Eyeball seen in its Normal Position in the Orhit, with View of the Ocnlar Mluscles, After Merkel, modificel

482. Section through Contents of Iight Urhit, 8-11 mm. behind the Lyeball, viewer from

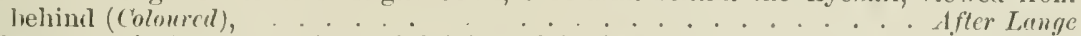

483. Diagrammatic Representations of Origins of Ocular Muscles at the Apex of the Right

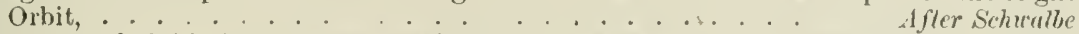

484. View of Left Orbit from above, showing the Ocular Mruscles, From IIrsch folul und Lccillé 485. Vertical Section through the Eyeball and Orbit in the direction of the Orl,ital Axis, with Closed Eyelirls (Coloured), . . . . . . . Semi-nlagremmatic, after sekuculbs"

4\%6. Horizontal Section through Left Orbit, viewed from alove, . . . . After Tron Gerlach

487. Transverse Section throngh Optic Nerve, showing the Relations of its Sheaths and Connective Tissue Framework,

429. Iongitudinal Section tlrough Termination of Optic Nerve,

4x?. 'The Blood-ressels of the Left Orbit, viewed from above (Colourea),

490. Section through Contents o1 Right Orhit, 1-2 mm. in front of the Optic Foramen, viewel from behind (Colourcel),

491. Vertical Transverse Section throngh the Upper Eyelid, . After Fuldeyer and Fuds:

492. I achrymal Apparatus, . . . . . . . . . . . . . . . . After Schulbe

493. Exterual View of the Left Auricle,

494. Seetion through the Orifice of the Right Extemal Auditory Meatus,

495. External and Interual Surface of the Cartilage of the Right Pinna and its Minseles, etc.,

496. Section of the Middle and External Ear, .

497. External View of the Left Membrama Tympani,

498. Interual View of Right Membrama Tympani (Coloured),

498A. Horizontal Section of Let' Temporal Bone, showing the Various Parts of the Far, . . 499. Section of the Tympanum, ete.,

500. The Ossens Labyrinth of the Right Sirle, . . . . . Iodificil from socmmerring

501. Interior of the Osseous Lahyriuth of the Left Side, . . . . Moelified from soemmerring

502. Interior of the Osseous Cochlea, .

503. Section of the Osseous Cochlea,

504. Nembranous Labyriuth (magnified), with Nerves, . . . . . Modificl from Bresehet

505. Enlarged Diagrammatic View of Membranons Labyrinth,

506. Eularged View of Longitudinal Section of the First Turn of the Cochlea, showing the Positions and Boundaries of the Three Scalie,

507. Dorsum of the Tongue,

508. The Fretal 'Tougue,

509. Under Surface of the Tongne with Muscles,

510. Transverse Section through the Left IIalf of the Tongue (maguified),

511. Sirle View of the Tongue, with its MInscles,

512. Sille View of the Nose, showing its Cartilages, etc.,

513. Anterior View of the Nose, showingr its Cartilages, etc.,

514. Under View of the Nose, showing its Cartilages, ete.

515. Seetion showing Bony and Cartilaginous Septum,

516. Muscles of the Nose,

1 ftur Bomrgery

517. Oblique Section passing through the Nasal Fosse, just in front of the Posterior Nares (seen from behind),

518. Section of the Nose, showing the Turbinal Bones and Meatuses, with the Openings in Dotted Outline, .

519. Trausverse Section passing through the Nasal Fosse and Antra at the Posterior Fxtremity of the Middle Turbinal Tione (seen from the lront),

520. Nerves of the Nisal Cavity (Coloured,

521. Anterior View o the 'Thomx, with Ontlines of the Diaphagm and Lumgs,

522. Superior View of a Section of the Thorax, passing through the stermm inmediately helow the lirst Costo-sterual Artirulation, thromgh the Trachea at its Division, and through the Body of the Fourth Thoracic Vertebra (Colourcil). . . . Tirume

523. Front View of the Cartilages of the Laryx, . . . . Iodificel from Bomgery amd. Jumb

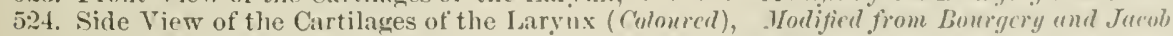

525. Front View of the Cricoill and Arytenoid Cartilages (Colmmed),

Indificil from Bomergery and Jacol

526. Back View of the Cricoid and Arytenoid Cartilages (Coloured),

Indified from Bowergery amd Jucols

527. Superior View of the Cartiluges of the Laryux.

528. Side View of the Muscles and Ligaments of the Larvin 
5:20. Scheme of Rima, showinu Aetion of Crico arytenoicleus Posticus, which draws the Aryte-

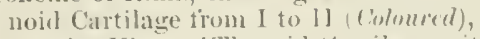

Hodified from stirling

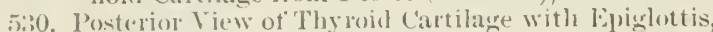

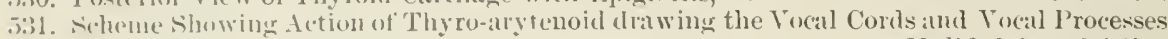
1 rom 11 to 1 (Foturied),

5...). Seluenre showing hetion of " Arytenoidens drawing Position I to II (Colonied).

5i3:3. View of Interior of Laryux as seen oluring Inspiration,

5i3t. View of Interior of Larrux as seen during Voralisation,

5i3.). Nerves of the Larym (posterior view) (colonme).

536. Anterior View of the Larynx, with the Trachea and Bronchi, . Yodified from Bourgery

i:37. View of Thyroid lonly,

5i:- Thyoll Boity, with Hidlle Lobe aud Levator Muscle,

.3:). The suspensory Ligaments of the Thyroid Body, Modified from stirliun Hodified from stirling

.) fo. Thymus (iland in a Cluild at Birth,

541. Thymus Gland in a Child at the Age of Two Years,

After Berry

54:?. Anterior View of Fretal Heart, Vessels, abd Lungs,

5.13. Anterior View of the 'Thorax with Chest Wall removed, showing the Lungs, . . . . .

Iorlified from Bourgery

544. Posterior View of the Thorax with Chest Wall removed, showing the Lungs, · • • . . .

545. Anterior View of the Lungs: Perieardium,

546. Anterior View of the Heart with the Larger Vessels (Coloured)

54\%. Showing the Josition of the Heart and its Valves in Relation to the Cliest Walls (Colourde),

liduced from Hensman and Fisher

54- Tramsverse Section passing through the Auricles of the Heart, showing the Auriculo ventricular Urifices and the Semilumar Valves of the Pulmonary Artery and Aorta (seen from alwe),

549. Anterior Yiew of the Right Chambers of the Heart, with the Great Vessels,

550. Transverse Section throngh the Heart near its Apex, Showing the Relative Thickness of it: Muscular Walls, the Bniging of the septum towards the Right Ventriele, and the shape of the Cavities,

5.)1. Interior V"iew of the Aortic Semilunar Valves,

552. View of the Auricular Cavities from below (the Transverse Section passing above their Miclile),

5.5. l'osterior View of the Left Chambers of the Heart, with the Great Vessels and the Coronary Sinus laid open, .

5i) I. Shwing the Position of the Heart and its Valves in Relation to the Chest Walls (coloured),

lieduced from Hensman and Fisher.

55.5. Anterior View of the Feart, showing its Arteries and Veins (Coloured),

5.). P'osterior View of the Heart, showing its Arteries and Veins (Colonced), . . . . . . . .

5.5\%. Anterior View of a Futus. The Heart, Yessels, and Chief Organs displayed, with the Placenta and Cmbilical Cord (Colmured),

5.5. Anterior Yiew of Heart and Great Vessels of Fetns, the Anterior Chest Wail being removed and the Heart Sac opened.

55. 1. Palato glossns Muscle, seen from the Month, with Section of Base of Tongue (modified),

5.5 2 3. Tiew of Muscles of Soft Palate, as seen from within the Pharynx,

Irodified from liourgery

5.59. The Salivary Glands,

$91 \%$

919

921

$92: 2$

923

(1): 21

127

$9: 3$

ing 9 . The Mluscles of tle Pharyux, . . . . . . . . . . . . . . . . .

560. Section showing the Posterior Wall of the Pharynx, with the Pharyngeal Bursa, Fauces, etc., . . . . . . . . . . . . . . . . . . .

561. Transverse Section of the Peritoneal sac at abont the Level of the Umbilicus, . . . .

is(i). Transverse Seetion of the Ahdomen at the Level of the Foramen of Winslow,

56:3. Diagram to show the Peritoneum as seen in a Vertical Section, . . . . Allen Thomson

5ifl. Diagram to show the Peritoneum as seen in Vertieal Section, . . . . Itlen Thomson

565. The Viscera as seen on fully opening the Abdomen without Disarrangement of the Internal Parts,

566. Postei jor Surface of the Stomach,

56). Interior Surface of the Stomach,

5ck. Muscular Coat of the Stomach, . . . . . . . . . . . . . . . . . Kuschke

After Saruzin

569. Muscular Coat of the stomach, . . . . . . . . . . . . . . . . . Iusehlint

5\%0. The Duodenum from in front,

5\%1. The Inodenum from hehind, .

$5 \% 2$. The liossa Duorleno-jejumalis,

573. Portion of the Small lutestine, laid open to show the Valvila Conniventes, . . Brintom

57. Vessels of the Small Intestine,

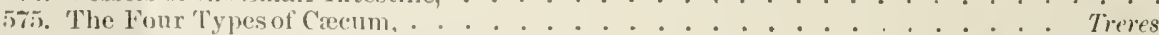

576. Section of the Ascending Colon, . . . . . . . . . . . . . Allen Thomson

5\%. View of the Deeper Ihdominal Viscera, . . . . . . . . . . . . Riullinger

$5 \% 8$. The Viscera of the Futns, . . . . . . . . . . . . . . . . Rällinger

579. Superior Surlace of tlye Liver.

520 . The Inferior Surface of the Liver, 
58:. Relation of the Alulominal Viscera to the Parietes,

$5-3$. lielation of the $A$ bdominal Viscera to the l'ariet

Tieres

584. Relation of Structures at and below the Transverse Fissure, . . . . . . . Thame

58.). Siection of a l'ortal Canal,

5\&6. Iblonimal Viscera, from helind,

5x.7. 'lie Pancreas and its Inct,

liudinger

5ox. Unter Aspect of the splectu,

5x?. Inner Aspect of the Sinlecu,

590. Transverse Section of the bodly at the Lower Part of the Epigastric Region, . Rüdinger.

59). View of the spleen, ete., from behind,

59:). Diagran of the P'rinitive Alinentary Camal,

5!).3. Diagram of the Primitive Alimentary Camal,

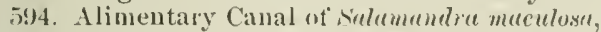

595. Alimentary Canal of Nulamendra maculosa, .

5i)6. Alimentary Camal of Choloms Hoffimemi,

5:77. Diagran to show the Rotation of the Intestinal Canal,

594. Diagram to show the Relation of the Peritoneum to the Dnodenum,

599. Diagram to show the Lines along which the l'eritonemm leaves the Wall of the Abdomen to invest the Viscera, . Cumnimolim

600. Diagran to show the Formation of the (ireat Omentum,

601. Great Umentum in Ifueropus penicillulus,

60:3. Formation of Great Umentum as seen in Vertical Section,

(ivi:3. Relation of Great Umentum to Transserse Colon,

Rï̈dinger

(60). Transverse Section of the Abdomen at the Level of the Foranen of Winstow,

601.5. Intestine of Mntropus ponicillutus,

6uri. Dnodenal fold ut Marropus penicullatus,

(i0\%. Postero internal Aspect ot the Left Kidney,

61). I lagram showing lielation of Kidney to Capsule,

6u9. section of Kidney showing the Sinus,

610. Diagram of Relations of Posterior Surface of' Kidney,

611. The Ahdominal Viseera, seen from behind.

61:2. Diagram showing Anterior lielatıons of Kidneys and Suprarenal Bodlies,

613. Horizontal Section of Killney. slowing the siums,

1007

614. Scheme of 'Tubules and Vessels of the Kirlney,

61.5. Diagram showing Anterior Relations of Kidneys and Suprarenal Bodies,

616. Upper Portion of Dnct,

61\%. Nedian Sagittal Sertion of the Male l'elvis,

(i)R. The Posterior Wall of the Bladeler,

10118

1009

1011

1012

$101: 3$

Afler Henle 1015

1017

619. Section of the Female Pelvis,

6:30. Semi-diagrammatie Seetion of the Male I'elvis,

Afler Henle

1019

(i)I Horizontal Section ot the Srotum aul Testicle

Aftor Henle 10:20

(diagrammatic),

1022

$10: 2: 3$

After simpey 10:25

6:3.). Diagram of the Testicular Tubules.

6:24. Visa Deferential and Vesiculæ Semunales,

6:25. Vas Deferens and Vesicula Seminalis disserted,

1027

626. Section of the Spermatic Cord,

After suppey 1028

After sorppry 10:29

tifer Henle $10: 31$

627. Transverse Section through the Body of the Penis (Colomed), . . . . . . . . . 10:32

629. Transverse Section of the Penis through the Base of the Glans, . . . . . . . . . . 1033

629. The Male Perineum (Coloural). . . . . . . Modified from Hirschfeld and Livillé 103!

630. The Male Urethra, clett dorsally to show Ventral Mucons Vall, . . . . . . . . . . 10:30

631. The Extermal Genitals of the Female. 1039

632. Diagrammatic Representation of the Perinaal Structures in the Female, . . . . 1040

63:3. Section of the Female Pelvis,

634. Horizontal Section of Yagina and aljacent Structures, .

After Ifenle 1041

ifler Henle 1043

63.). The Female Organs of Generation,

6:36. The Posterior Surface ot the Uterus,

Modifica from sirnum 1045

ifter Nilprey 1045

637. Frontal Section of the Virgin Uterus,

638. Sagittal Section of the Virgin Vterus,

639. The Broad

640. Diagrammatic Section of the Broad ligament,

641. Section of the Pelvis showing the Ligaments of the Uterus.

6.12. The Broad Ligament and its Contents, seen from the Front,

64:3. Diagram of the Arteries and Lymphaties of the Female Crenerative Organs.

644. Diagram of the Primitive Genito-nrinary Organs hefore Differentiation of Sex,

645. Development of the Urino generative Organs, Female Type.

646. Development of the Urino-generative Organs, Male Type.

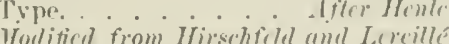

647. The Male Perinæum (Coloured),

648. Diagram of the Pelvic Fascia.

649. Nuscles of the Floor of the P'elvis,

650. Diagram showins Lines of Attachment of the Fascix and II Inscles of the l'elvis,

6ii1. Iruscles of the Floor of the Pelvis,

65:. Sagittal Section through the Perineal Lerlue and Ischio-rectal Fossa to the Left of the Middle Line (diagrammatic).

6.53. Section showing the Ischio-rectal Fossa in its Relations to the Pelvic Viscera,

1046

104 -

$1(1.1 !)$

$10 \div 0$

10.21

10.54

10.55

10ลก

10:\%

1กับ9

$10(; 0)$

1061

1062

1063 
Firt.

65\%. Diagram of the Superficial and Dce], Triangular Ligaments (Coloureul),

65i). Tertical Frontal suction of the Pelvis, showing latscia, . . . Modified from Braune

656. I)iagrammatic Representation of the l'erinaal structures in the Female,

6.5\%. The Female Mamma during Lactation,

6.58. Developsuent of the Mammil of the lemale Embryo,

6.5\%. The sikull ( (oloured).

(i60. 'Temporal Bone, showing Suprameatal 'Triangle,

(i61. Sagittal Section through liont' and F'loor of 'Iympanic Cavity,

$66 \%$. Inrizontal section of Ieft Temporal Jone, showing the Various Parts of the Ear, . *

6(i3. Section througl the Scal]), Skull, aud Dura Mater.

664. The Untline of the Jiaiu and its Fissures in helation to the Sutures of the Skull, .

66.5. Drawing of a Cast of the Ilead of an Adult Male (Colonred), . . . . . . . Cunningham

666. Cranio-cereloral 'Topography

(667. Solicme of the Ficial Artery (Coloured), Anderson and Hakins

66-. Tertical Transverse Section throngh the Upper Evelid, - . . After Wialdeyer and Fuchs

669. The Lachrymal Apparatus and Nasal Duct, . . . . . . . . . . . . . . . . Bellamy

670. Side of the Face and Mouth Cavity, showing the Three Salivary Glands, . . . . . .

671. Section of the Skull and Frain in the Median Plane, . . . . . . . . . . Brune

672. Section of the Nose, showing the Turbinal Bones and Mieatuses, with the Openings in Dotted Outline,

673. Section showing Bony and Cartilaginous Septum, . . . . . . . . . . . . . . . . .

6\%4. Thymus Gland in a Child at Birth

6\%.). Anterior and Lateral Cervical Muscles,

6r6. Region of the Third Part ot tlie Śabclavian Artery, . . . . . . . . . . . . Bellamy

6\%. The Collateral Circulation after Ligature of the Common Carotid and Subclavian Arteries (colomed)

67. Diagram of the Layers of the Deep Cervical Faseia in an Antero-posterior Section opposite to the Stermmm, Tillaut

679. Diagram of the Arrangement of the Deep Cervical Fascia, the Section passing througl the Clavicle.

680. Section of Neek thingh the Sixth Cervical Vertelira, . . . . . . . . Brume

681. The Areh of the Aorta, with the Pulmonary Artery and Chief Branches of the Aorta (Coloured)

6-2. Section of the Sixth Left Intercostal Space, at the Jumetion of the Anterior and Posterion Thirls, 7 Tillum $^{\circ}$

6×3. Ontline of the Heart, its Valves, and the Lungs (sliaded), . . . . . . . . . . Holulon

6-4. Diagram of the Relations of the Thoracic Viscera to the Walls of the Chest, . Bellamy

(j<5. Obliquus Externus and Fascia Lata,

6s6. The Viscera as seen on tully opening the Abdomen withont Disarrangenent of the Inter. nal l'arts,

687. Section of Ahdomen hetween the Third and Fourth Lumbir Vertebrx, . . . Brane

6x8. Diagram showing Relation of Kilney to Capsule,

689. Trinsverse Section of the AbJonen thromoh the Kidners and Pancreas, at the lesel of the First I,minar Vertebra,

690. The Ibdominal Aorta and Interior Vena Cava (Coloured)

691. The Male l'erineum (C'olonred), . . . . . . Modifich from Mirsehfeld and Leveillé

(i9:). Deen Dissection of Jale berinasum,

(i!):3. TJe Arteries of the l'erinemu (Colonred),

(i) 4. Sacrittal Section of Male Pelvis in the Mesial ine, * * * * * * * *.*.

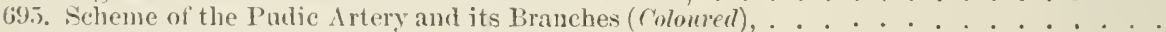

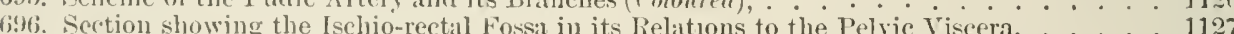

6!). Diagram of the Pelvic Fascix, . . . . . . . . . . . . . . . . . . . . . 1128

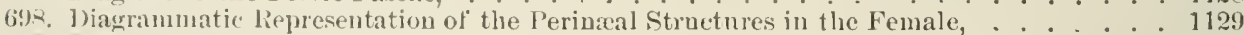

6.)!). Sertion of the Female Pelvis, . . . . . . . . . . . . . . . . . . Afler Henle 1130

700. The l'arts concerned in Ingninal Jernia, . . . . . . . . . . . . . . . . . . . . . . . 1132

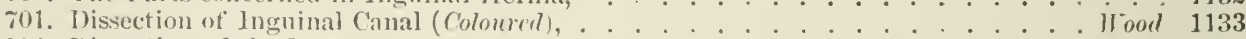

70\%. Dissection of the Jower I'art of the Ablominal Wall from within, the l'eritoneum hasing been jemoved, . . . . . . . . . . Jood

704. Irregularities of the Oloturator Artery, . . . . . . . . . . . . . . After Gray

\%(t). Diagram and Table slowinu the Ipproximate lielation to the Spinal Nerves of the varions Mlotor, Sensory, and lieflex Functions of the Spinal Cord, . . . . Gorrers

706. Clief Arterial Imastomosis on the Seapnla (Coloured)

1140

707. Arrangement of Lmmbar A ponemrosis at Level of Thiri Lumbar Vertebra, . . . . . 114

708. Relation of the Abiominal Tiscera to the Anterior I'arietes, . . . . Treves 1145

709. lielation of the Aludominal Viscera to the Parietes, . . . . . . . . . . . . . . . Tire's 1146

710. Ablominal Viscera, from beliud

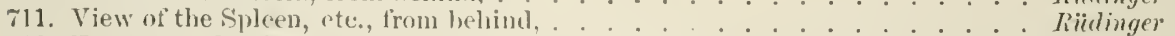

712. Transverse Section through the Right Slonlder-joint, showing the Structures in contact with it,

713. The lirachial Artery (rolowed)

Braune 11.50

714. Section through the Midale of the Right Tpper Arm, . . . . . . . . . . . . . Mcath 1152

75. Diagrammatie Section of Shomler tluough Oepiuital Groove. . . . . . Anderson. 1152

zif. Jack View of the Scapular Muscles and Triceps, . . . . . . . . . . . . . . . . 1153 
717. Vertical Section of the Elbow,

71). Bend of the Elhow,

720. The Beml of the Elhow with the Superficial Veins (Colourd),

721. The Brachial Aitery at the Bend of the Elbow (Colourd),

722. Diagram of the A nastomoses of the Brachial Artery,

1156

$115 \tilde{\jmath}$

724. The Arteries of the Forearm with the Superticial lalumar Arch (Coloumd), . . . . 1160)

725. Distribution of Cntaneons Nerves on the Anterior and l'osterior Aspects of the Superior

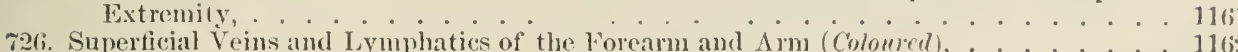

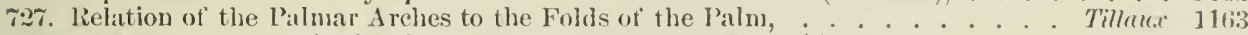

7.2. Anastomoses and I)istribution of the Arteries of the lland (Coloned . . . . . . . . 116it

72!). 'The Superticial Muscles of the Palm of the Haud, . . . . . . . . . . . . . . . . . 116.5

730. The Deeper II uscles of the Palm of the Hand, . . . . . . . . . . . . . . . 1160

731. Section through region of "Wrist, a little alove the Joint. Right sirle, "pper Half of the Section, . . . . . . . . . . Tillau,

73. Transwerse Section of the Wrist through the Middle of the Pisiform Bone,

73is. Diagram of the Great Palmar Linrsa, 116

734. Section of Carpus, through the Unciform Bone, . . . . . . . . . . Bellumy afler IIrne 1169

735. Horizontal Sertion of the Iland through the Carpo-metacarpal Joints, Bellamy after Henle 116 (6)

736. Tentons upon tlie Dorsum of the Hand, . . . . . . . . . . . . . . . . . . . . 1170

737. Diagram of a Vertical Section through the Middle of the Hand, . . . . . . . . . . . 1171

738. Transverse Section of the Hip-joint and its Relations, . . . . . . . . . . . Hrume 1173

739. The Inscles attacherl to the l’ubes, . . . . . . . . . . . . . . . . . . 1174

740. Diagram of Arteries of Thigh, . . . . . . . . . . . . . . . . . . . . 1175

741. Section of the light Thigh at the Apex of Scarpa's Triangle. . . . . Ifcall 1176

74. Snperficial Dissection of the front of the Thigh, . . . . . Hinclifid ind Lecrille 11 fif

743. Anterior Crural and Obturator Nerves (Coloured), . . . . . . . . . 11\%

74. Section of Thigh through upper part of Huntes's Canal, . . . . . . . . . . . H* A. 11\%

75. Superficial MI uscles of the Back of the Thigh and Leg, . . . . . . . . . . . . . . . . 1179

746. Position and Direction of the Superficial Incisions which mint be male to receive the Gluteal, Sciatic, and Pudic Arteries, . . . . . . . 1120

747. Section throngh the IIip and Gluteal Region, . . . . . . . . . . . . . . . . . . 1181

74R. The Gluteal Recion, with the Ghuteal, Sciatic, and Pudic Arteries (Colonrcd), Halsham 1182

749. Deep Dissection of the Gluteal Region, . . . . . . . . . . . . . . . . . 11R3

750. Horizontal Section of the Knee joint,

751. Vertical Section of the Knee-joint in the Antero-posterior Direction, . . . . . . . . 1185

752. Side View of the Popliteal Artery (Coloured) . . . . . . . . . . . . . . . . . 1127

75:. Deep View of the Popliteal Space, . . . . . . . . . . . Mirschfeld amd Lereille 11 se

754. A nastomoses of Tibial Arteries. . . . . 11ng

755. The Anterior Tibial Artery, Dorsal Artery of the Foot, and Anterior Peroneal Artery, and their Branches (Foloned), . 1190

756. Relations of the Popliteal Artery to Bones and Muscles (Colomer), . . . . . . . . 1191

757. Section of the Right Leg in the Upper Thirl. . . . . . . . . . . . . . . IIenth 11()$^{\circ}$

758. Branches of the External Popliteal Nerve (Coloried), . . . . . . . . . . . . . . . . 11!3

759. The Muscles of the Front of the Leg.

760. Transverse Section throngh the Lower Thirl of the Left Leg, immediately above the . . . . . . . Brmune

761. Relations of l'arts behind the Ininer Kallenhs, . . . . . . . . . . . Itenth

762. Articnlations of the Foot, Dorsal Aspect, . . . . . . . . . . . . Bellumy

ซ6:3. Vertial Section through the Cuneiform and Culoir Bones, . . . . . . . . . . . 11:4?

764. Superficial Nerves in the Sole of the Foot (Colourel) . . . . . . . . . . . . . Ellis 1:00

\%65. Plantar Arteries (Deep) (Colomral), . . . . . . . . . . . . . . . . . . 1 1

766. Longiturliual Section of Foot, . Brme 1201

767. The Arch in the Ordinary Position of Standing. . . . . . . . Enis (of riloucester) 1202

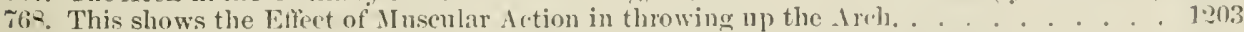

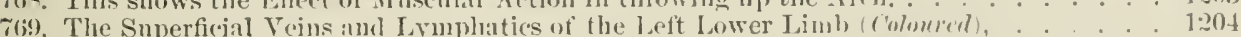

\%o. Distribution of Cutaneons Nerves on the Posterior and Anterior Aspects of the Inferion Extremity.

\%1. Diagram of the Abjominal Reurions, . . . . . . . . . . . . . . 1207 



\section{SECTION I \\ OST E O L O G I}

BY J. BLAND SITTON, F.R.('...

A - ISTAXT-SURGEON TO THE MIDDLESEX HOSPITAL, AXD SLRGEON TO THE CHELSEA HOSPITAL FOR WOMEX, LUNDON

\section{THE SKELETON}

$\mathrm{T}^{\mathrm{H}}$

IE skeleton contains 206 distinet bones. They are arranged hy anatomists in two sets:- the lones of the trunk and the hones of the limbs. Ther skeleton of the trunk is made up of the skull, which contains twenty-nine bones exclusive of the teeth; the vertebral column, consisting of twenty-six sejarate hones; twenty-four ribs, and the sternum. The skeleton of the upper limb comprises sixty-four bones; and that of the lower limbs, including the patellat, sixty-two.

Several of the skull bones are compound, that is, in the immature skeleton they consist of separate elements which ultimately unite to form a single bone. In orcher to comprehend the nature of such homes, it is necessary to examine them in the various stages through which they jass in the embryo and child. Thus the student, anxions to (onvince himself of Man's place in nature, studies anrefully the development and ossification of homes, and compares them with the bomes of ither Vertebrata. He then finds that many elements which make a compound bone are osteological units for the Comparative Anatomist.

Comparisons of this nature constitute the science of Morphology, one of the most fascinating departments of Biology.

It is the duty of the student to follow the descriptions with the actual hones in his hand. He should also remember that mamy variations oceur in the outlines and markings of bones. Hence the varions types described and figured represent the average of a large number of bones examined. It is very rare to meet with bones which accurately eorrespond to the description in erery iletail.

In orker to apprectate the morphology of the skeletom, the osteogenesis or mode of elevelopment of bones must he studied as well as theij topography or pesition. some bones arise by ossification in membrane, others in cartilage. In the cirly (anhryo, many portions of the skeleton are represented hy cartilage which hocomses infiltrated by lime salts-calcification. This (arthy material is talkell ul) and

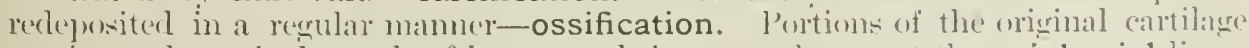
persist at the articular ends of lomes, and, in rome lones, at the epiphysial lines. Long bones increase in length at the epiphysial cartilages, and increase in thickness ly ossifieation of the deeper layers of the investing memhanc or periosteum.

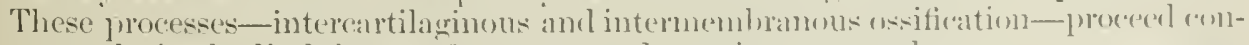
currently in the limb-lones of a young and growing mammal.

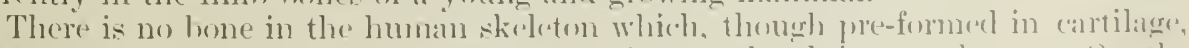
is perfected in this tiswore. The ossitication is completed in memblame. On the 
other hand, there atre numelous instaness in the skull, of lomes the ossifieation of

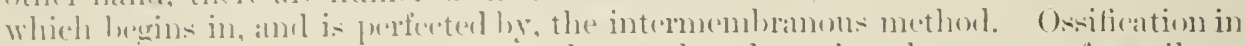
a few instanes's commences in membrane, hut later invades tracts of eartilager; wecasiomally the process lexins in perichondrium anch remains restricted to it, never invaling the underlying artikage, which gradually disappean's as the result of

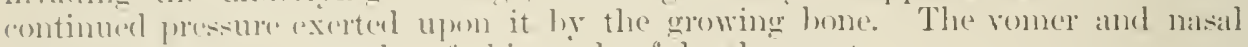
homes are the hest examples of this mode of derelopment.

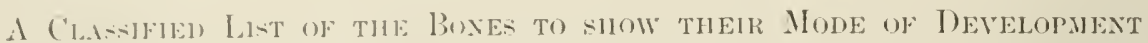

1. Sll the limb-bones aml thuse of the vertebral column are pre-fomed in eartilage and pertected in momhrane, with the exception of the clayeles. These begin in membrane, prexed in cartilage, and are finally perfected in membrane.

‥ The Skull.

\section{MEMBRANE-BONES}

Parictals.
Frontal.
Aquamesals.
Maxillar.
Malans.
Palates.
Yilsals.

P'arictials.

Frontal.

squammisists.

Yraling.

Nilsals.
Interparintal portion of occipital.

IFomian bones and the epipterics.

Tympanic's.

Miandible (except part near the spmplissis).

Lachrymals.

Vomer.

\section{Cartilige Boyes}
Sphemoil.
Petrisals.
Mallei.
Stapes.
Hyoirl.
Inferior turhinals.
Occipital (except interparictal purtiou). Ethmoirl.
Incueles.
Stroid processes.
Srmphrsial portion of the mandilule.
Intemal pteryoid plate.

Many of the skull hones are composite, that is, they consist of two or more telements which remain separate in other vertebrates. To this group belong:-

The Oneipital.
Temporals.
Ethmonil.

\author{
Maxillax. \\ Hyoil. \\ Sipenoil.
}

Frontal.

Malars.

Mandilile.

The details of the development and ossification of each bome ane arkled to the descriptions.

The limb-bones riffer in several important particulars from those of the skull. Some of the long homes have many centres of ossification, but the centres are of very lifferent morphological value from those of the skull. speaking generally, it is inly the primary nucle that have any especial value for the morphologist. "The primary nucleus if a long bone appears before hirth. In only three instances does a secondary centre alpuear hefore hirtli; e.g. the condyles of the femur, the head of the tibia, and accasionally in the head of the humerus. Many primary ossitic muclei appear after hirth; for "xample, those for the "arpal bones, the eunciform and seaphoid (navieular") homes of the foot, the coracoid process of the seapula, and the third, fourth and fifth pieces of the sternum.

When a bone oseifics from one nucleus only, this nuclens may apporar before or after lirth. Examples: the astragalus at the serenth month of embryone life,

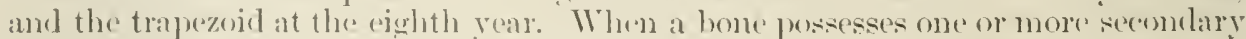
centres, the primary moclets, as a rule, appenas eally. Examples: the femur, humerus, phalanges, and the "al lanemm.

Serenclary entres which remain for a time distinct from the main portion of a

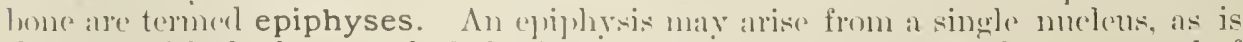

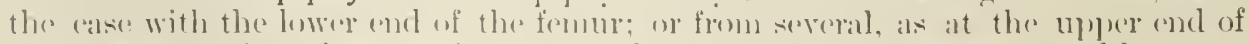

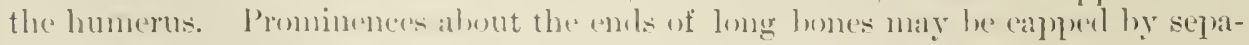


rate epiphyse, as is the case at the uppere cont of the fommr. Eppiphyses, though of no morpholegical value, seem to follow certain rules, thus:-

1. Those epiphyses which appear last are the first to unite with the shaft.

Exception.-The clistal rpiphysis of the fibula is visible threse vears before the poximal, lut fuses with the shatt much earlier than it. It should lo rememberes that the proximal enel of the fibula in man ame many other manmuals is vestigial.

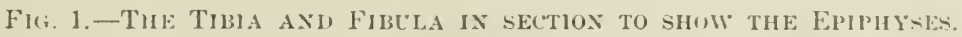

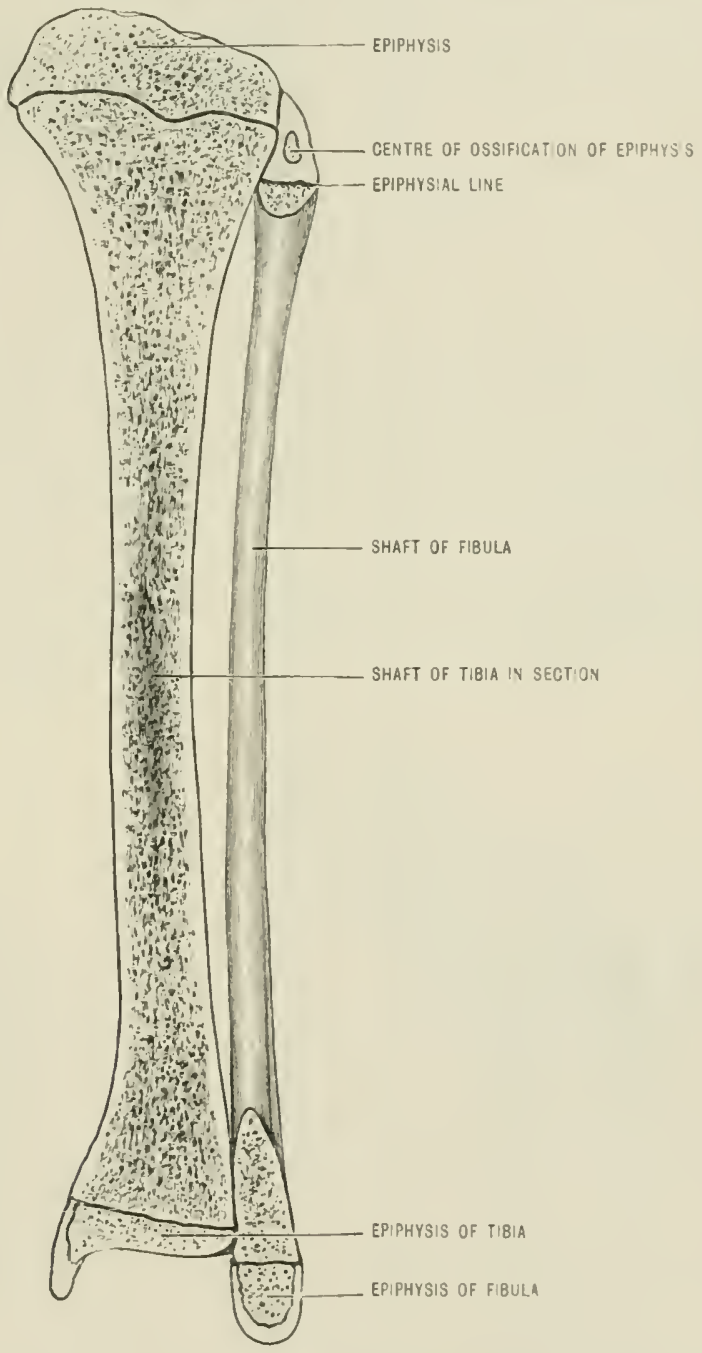

2. The epiphysis towards which the nutrient artery is directerl unites first with the shaft.

3. When a bune has only one epiphysis, the nutrient artery is directed tomalris: the extremity which has no ephiphysis.

4. The centres of ussification alpear carliest for those cyphlyses which bear the latrest relative proportion to the shate of the lones to which they helenge.

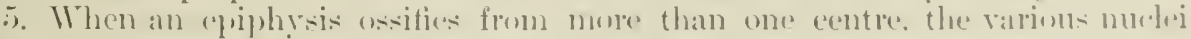
conlesce hefore the shat and epiphysis comsislirlate.

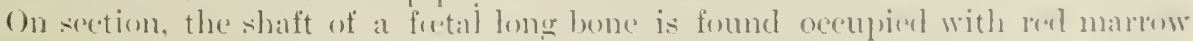
lorlged in bony (eells which do not present any definite arranegensent. In an arlult. the central prition of the shaft of a long home is tilled with fiat, or marrow, hall 


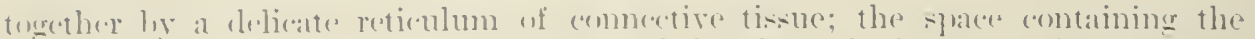
matrow is the medullary areity. The expanded ands of the bone contain a network

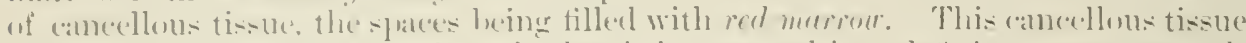
differs from that of the futal lome in that it is a rangerl in a definite mammer accorling to the dirmtion of pressure and the tension exerted ly museles. Pressure

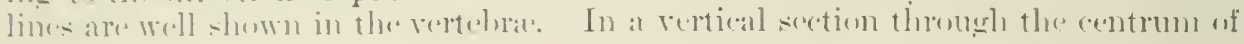

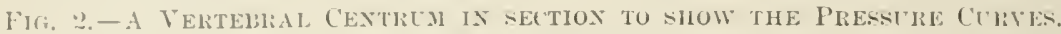

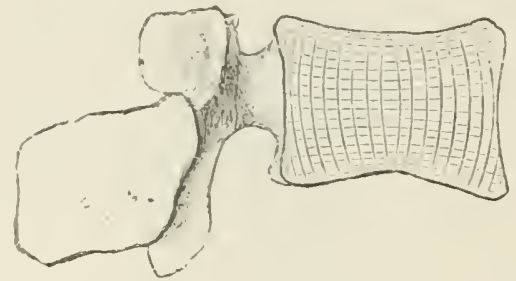

a rutehra the fihres of the cancellous tissue are seen to be arrangecl vertically and horizminlly: the rertical filures are curred with their concavities directed towards the rentre of the hone. The horizontal filores are slightly eurved parallel with the nyprer and lower surfaces. with their convexities towards the centre of the bone. Ther are mot so defined as the rertical set. (IVarstaffe.)

The arangement of the cancelli in individual bomes is a consequence of the

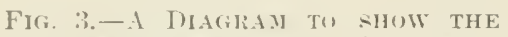
PRERTRE AND TEXSIUN CURVES OF THE FEMLR. (After Wagstaffe.)

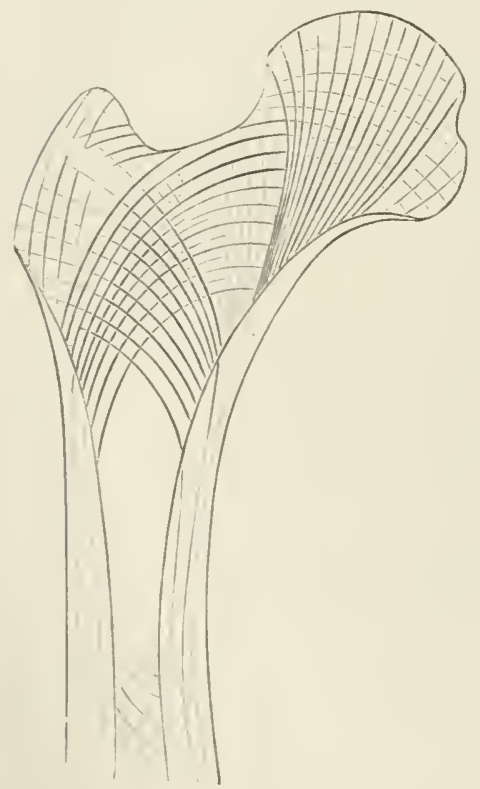

Fig. 4.-A DIAGRAM SHowjyg PresSURE AXD TEXSION CTRVES IN THE HEAD OF THE HUMERLS. (Alter Wagstaffe.)

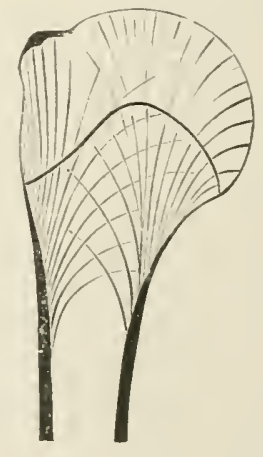

mechanical anditions to which the bone is sulject. This is well illustrated in the

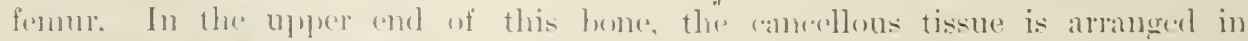

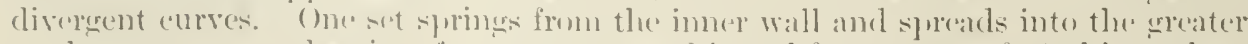

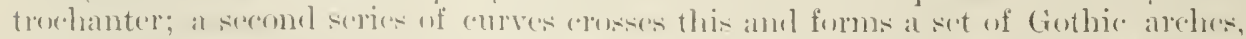

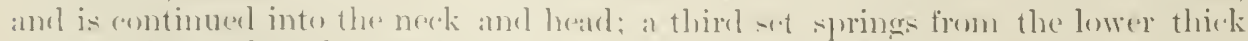
wall of the neck and spreats inte the uppur part of the head, and enets perpendieularly in the articular surfare mainly alome the lines of greatest pressure. A 
nearly vertinal plane of compact ti-sur projerts into the neck of the lome from the inferior corvical tuberele towark the great trochanter. This is placer in the line through which the weight of the body falls, and ards to the stalility of the neck of the bone: it is sairl to be liable to absorption in old atre. In the lower end of the bone, the rertical and horizontal filmes areso disposed as to form a rectancular meshwork.

The plan of construction exhilited by the femur is the most complex in the skcluton, hut the principles involved are the sane in all lonnes. An interesting disursition of these eurves is rxhibiterl in the head of the humerns. The pressur. curves radiate in two direetions: one set at right angles to the articular surface of the head of the hone; the other at right angles to the greater tuberosity. The last set, like those in the greater trochanter, are the result of tension exertiel by the nutuseles attarhed to these prominences.

The shafts of long bones at the time of lirth are mainly crlindrical and froe from ridges. The majority of the lines and ridges so eomspicumis on the shafts of long lones in arlults are due to the osifieation of musele-attachment.s. The more developed the muscles, the larger the ridges berome.

The surfaces of bones are variously morlified by environing conditions. Pressure at the extremities causes anlargement, and movement renters them sunoth. The two eatues (omblined produre an articular surface. When rombled and sup)ported upon a constricted portion of bone, an articular surface is temed a head, sometimes a condyle ; when depressed, a glenoid fossa. Blunt, nom-articular proecses are called tuberosities; smaller ones, tubercles; sharp projections, spines. slightly elerated ridges of bones are crests; when narrow and pronounced, lines ant borders. A shallow depression is a fossa; when narrow and deep, a groove; a perforation is usually called a foramen. The majority of terms-such as canal, spine, notch, sulcus, and the like-are so obvious as to render explanation necrlless.

\section{THE SPINE}

The spine (vertehral column) consists of thirty-three superinmoserl bones temed vertebræ. Of these the upper twenty-four remain separate throughout life and form three groups. The first seven are called cervical, the sucoseding twre thoracic (dorsil), and the next five lumbar. In adult life the last nine vertelure ankylose to form two eomposite lones named the sacrum and the coccyx. The sacrum is formed by the furion of five vertelsue from the twenty-fifth to the twentyninth inclusive; the four terminal are vestigial, and form the corers. In order to gain a greneral notion of the characters of a vertehra, it is clesirable to select a bume from the middle of the thoracic sories.

A rertebra consists of a boly and an areh: The body or centrum is a solinl disc of hone slightly concare on its sulerior and inferior asjects, and wider transwersely than antero-posteriorly. The upper anel lowrer surfares are rough for intervertehrail dises, and the margins are sightly lippert. The circunference of the bouly is in front, concare rertically, hut convex from sile to side; posteriorly it is excarated.

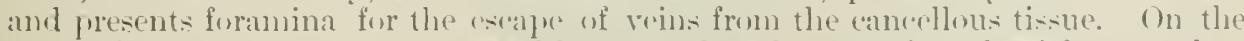
sides of the bouly, at the upuer and lower angles, three arr four demi-facets; when two vertehre are superimposed, the arljacent demi-faceds form al enmplete articular facet for the hearl of a rib.

The arch is formed by two pedicles and two laminas, and has anmected with it seren puroescos-one spinous, two transwerse and four articular. The pedicles are two (onstricterl short piers of home porogeting horizontally hackwarke from the

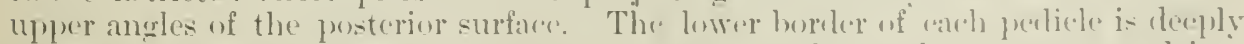

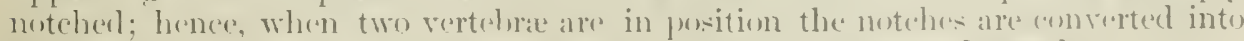
intervertebral foramina for the transmis-ion of spinal mepres amel res-als. 
The lamina are boal plates of bome continums with the perlicles; each lamina moets its fellow dorsilly to complete the neural arch, and conjointly form the spinous process. The siperior burters of the laminat are rough for the inser-

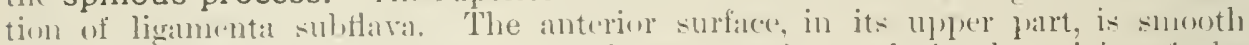
where it beunds the neural canal. The lower loat is reugh for the origin of the

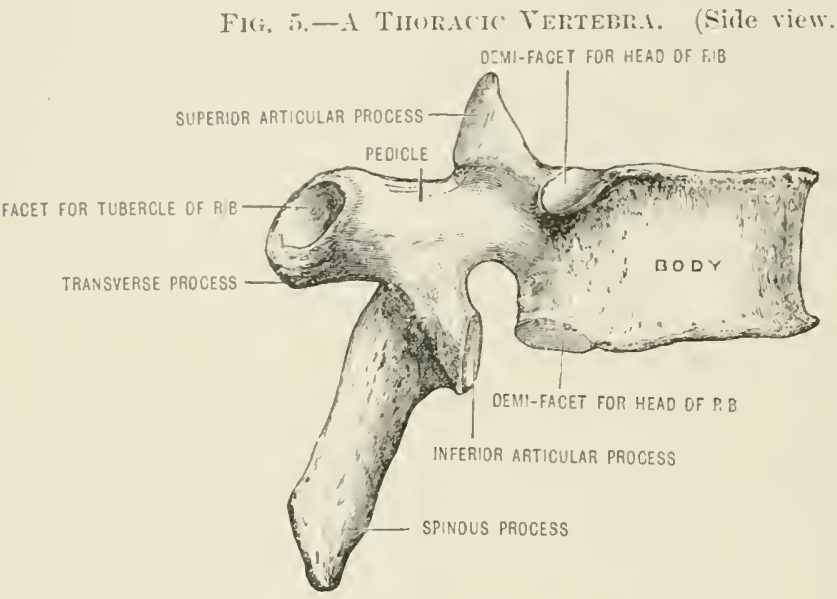

ligamenta subflava. This rough surface is continuous with the inferior border of the spinots jocess.

The spinous process projects hackwards and downwards from the confluent laminate. To its upper and lower horders the interspinous liwaments are attacherl; its tip is rounded for the supraspinous liganent. It is mainly an mecular process.

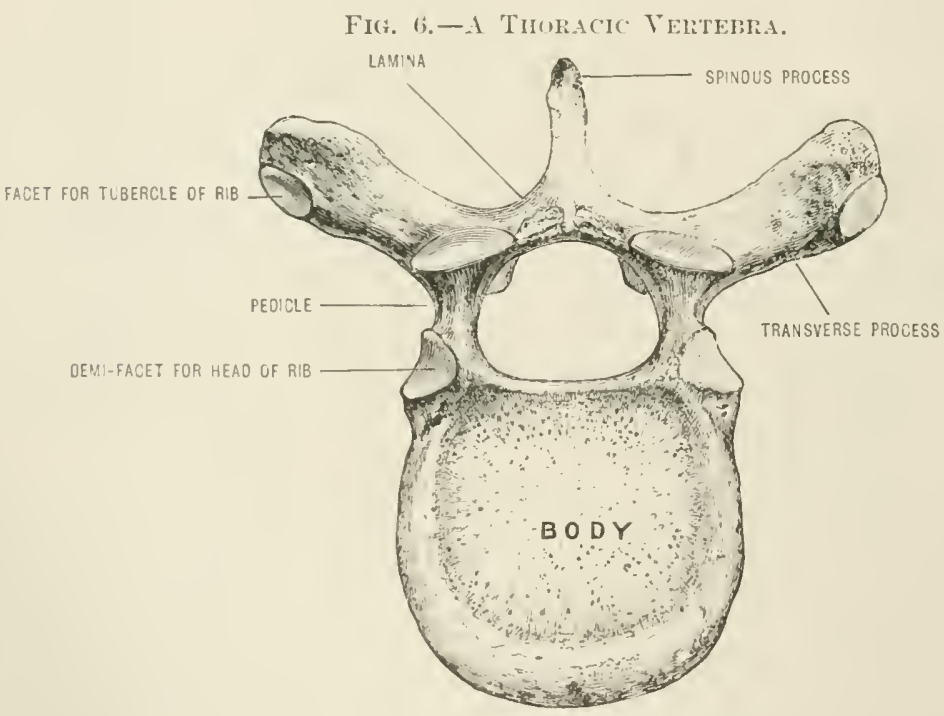

The articular processes are four in number: tro alre superior; the sy shing from the jumetion of the perlecles with the laminae and have their articular fances

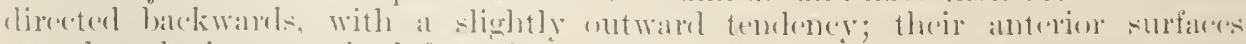

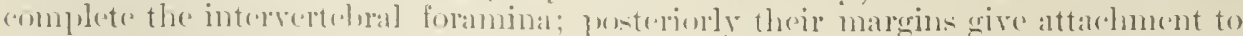

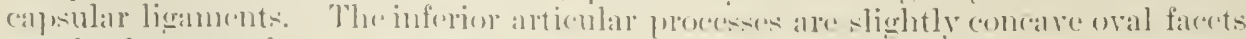
on the lower and outer anglese of the anterior surlares of the laminas. There are directed forwards and slienhtly inwarkls. 
The transverse processes are two in mmbler. and jut out warls from the prediches and lamince hetween the superior and inferior antirular processes. The tip presents an wal facet for articulation with the tuberele of the rib. " Ithen the rib is in situ, its noek forms with the process a costo-transverse formmen. The transiel'se processes, in addition to sulphorting the ribs, afford fomproful leverage to musedes.

\section{THE CERYICA, VERTEBRE}

A typical cervical vertebra (from the third to sixth inclusive) presents the fellowing (haracters: The centrum is smaller than in other recrions of the eolumm, and is of oval shape, the major axis being transverse. The unler surfate has its lateral margins raised into prominent lips, whilst the lower surface is somewlut comeave, its anterior margin being lipped so as to slightly overlap the anterior surface of the vertebra helow. "The inferior lateral margins are reunded. and (o)me into relation with the raised edges of the centrum next below.

The pedicles are directed oldiquely outwards, and the intervertelmal noteh is narrower above than below. The laminæ are long and narrow. The spinoms pureess is short, and bifid at the extremity.

Articular processes.--Both the upper and lower articular processes are situated at the junction of the pedicle with the laminge and they form the upper and lower extremities of a small column of houe. The facets of the uplere pro-

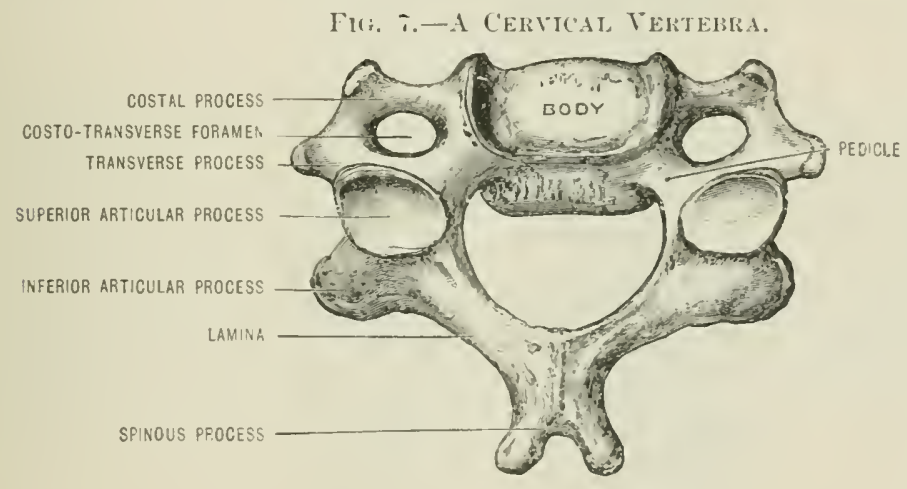

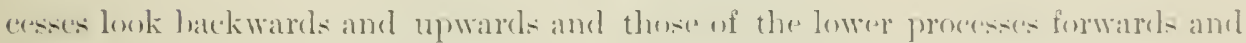
downwarkls.

The transverse process presents near its bise the costo-transverse formunn for the transmission of the vertebral artery, vein, and a plexus of symplathetic nerves. The process behind the foramen has a shallow groure for the correpunding spinal nerve. The extremity of the transverse puocess is lifid: "ach arm is truminatul hy a tuberele referred to as anterior and posterior. The costo-transverse formus is

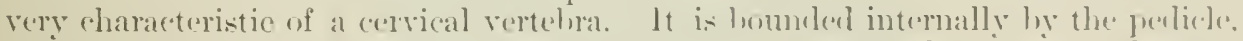

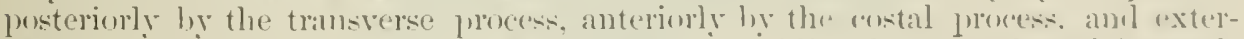

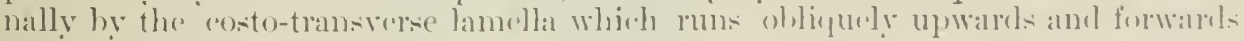
in the iujlere vertebra and horizuntally in the lower.

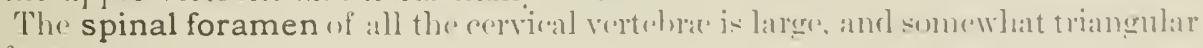
in fornt.

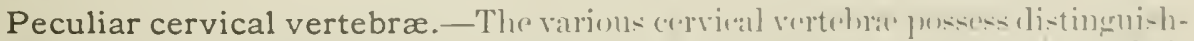

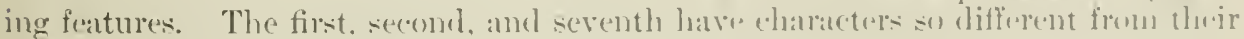
frilows as to render them peruliar.

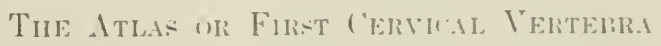

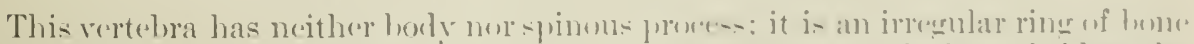
with two thicker portions, the lateral masses, muted antriorly ly a hrider, the

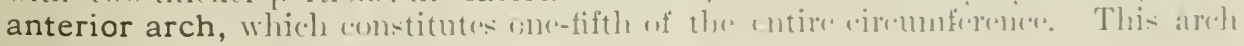


mesents a tubercle on its anterior face for the anterior vertethal ligament and the

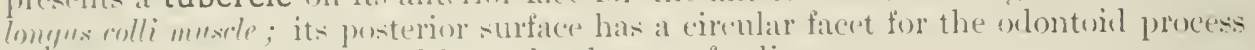
of the axis. The uplerer and lower horelers are for ligaments.

The lateral masies are miterl posteriorly hy a larger arch of home, forming twofifths of the circumference. Posteriorly this arch has a tubercle, repuesenting a rulimentary spinous proces. The upjer and under surfaces of the arch afforel attarduments to ligaments. At the junction of the posterior areh with the lateral

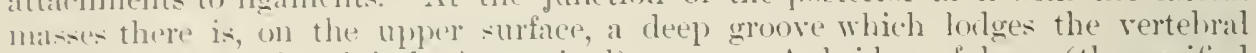
artery and the suboceipital (first spinal) nerve. A bridge of lume (the ossified

Fit. - - - The First Cervical Vertebra or Atlas.

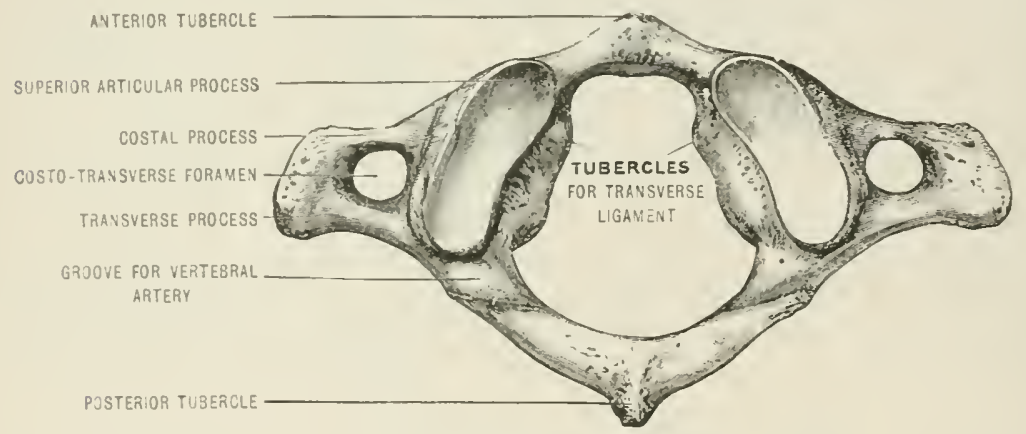

ohligue ligament) sometimes converts this into a formen. A similar, but much shallower, notch is present on the under surface; this. with the axis, forms an intervertehral formen for the second nerve. The atlas and axis are peculiar in that the first and second spinal nerves issue behind the articular processes, whereas the remaining spinal nerves emerge in front of the articular facets of the rertebra. Each lateral mass has, on its upper surface, an elongated, deeply concare articular fusia or cup. These articular cups converge anteriorly. Occasionally each presents. two oral facets united by an isthmus. These cups receive the occipital condyles and permit nodding movenents of the head. The inferior articular processes are

Fig. 9.-ThE AXIs.

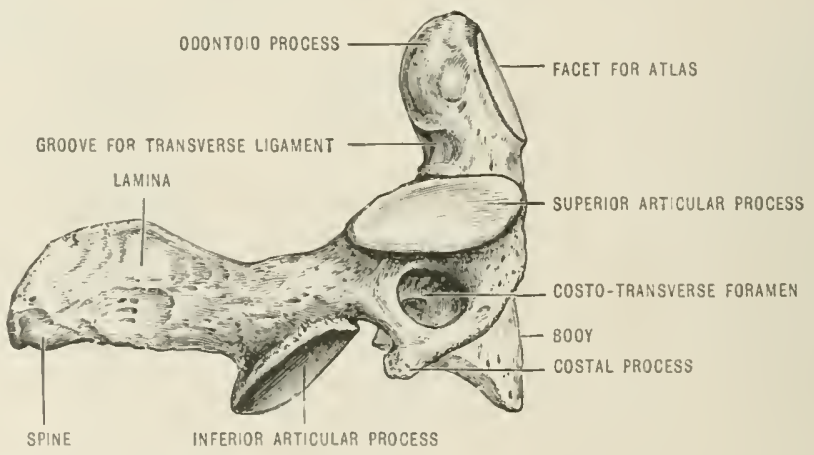

rimular and atmost fiat; they are directed downwards, with an inclination inwards, resit upon the axis. and premit rotatory movements of the heak. Between the

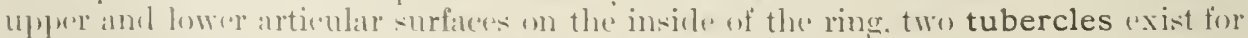
the transirerse ligament. This ligament livieles the spate within the ring into an

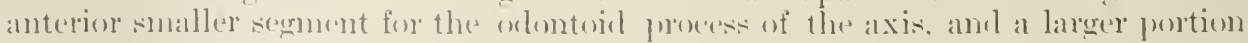

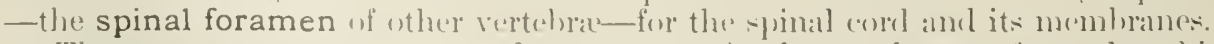

The transverse processes a re large, to s'rve fur the attar.hment of muscles which help to rotate the lowal. The costo-transverse forminina ale litree, lut the costal processes are sluter. 


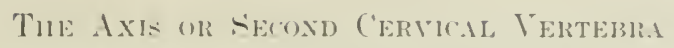

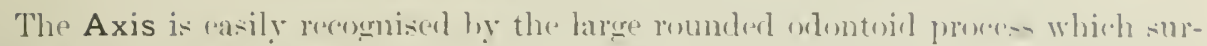
mounts its upper surfare. The centrum has a more prominent lip than the other

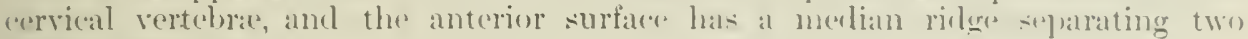
laterial ilenressions.

The odontoid process is an irrecularly romeler peg of home. The anterior surface has an oval facet for the anterior arch of the atlas. Posterionly it presents a deeply eut smooth grower for the transverse ligament. To the apex, a thin marow

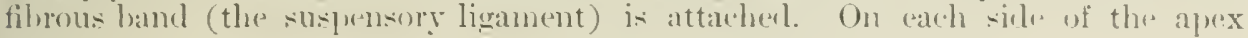

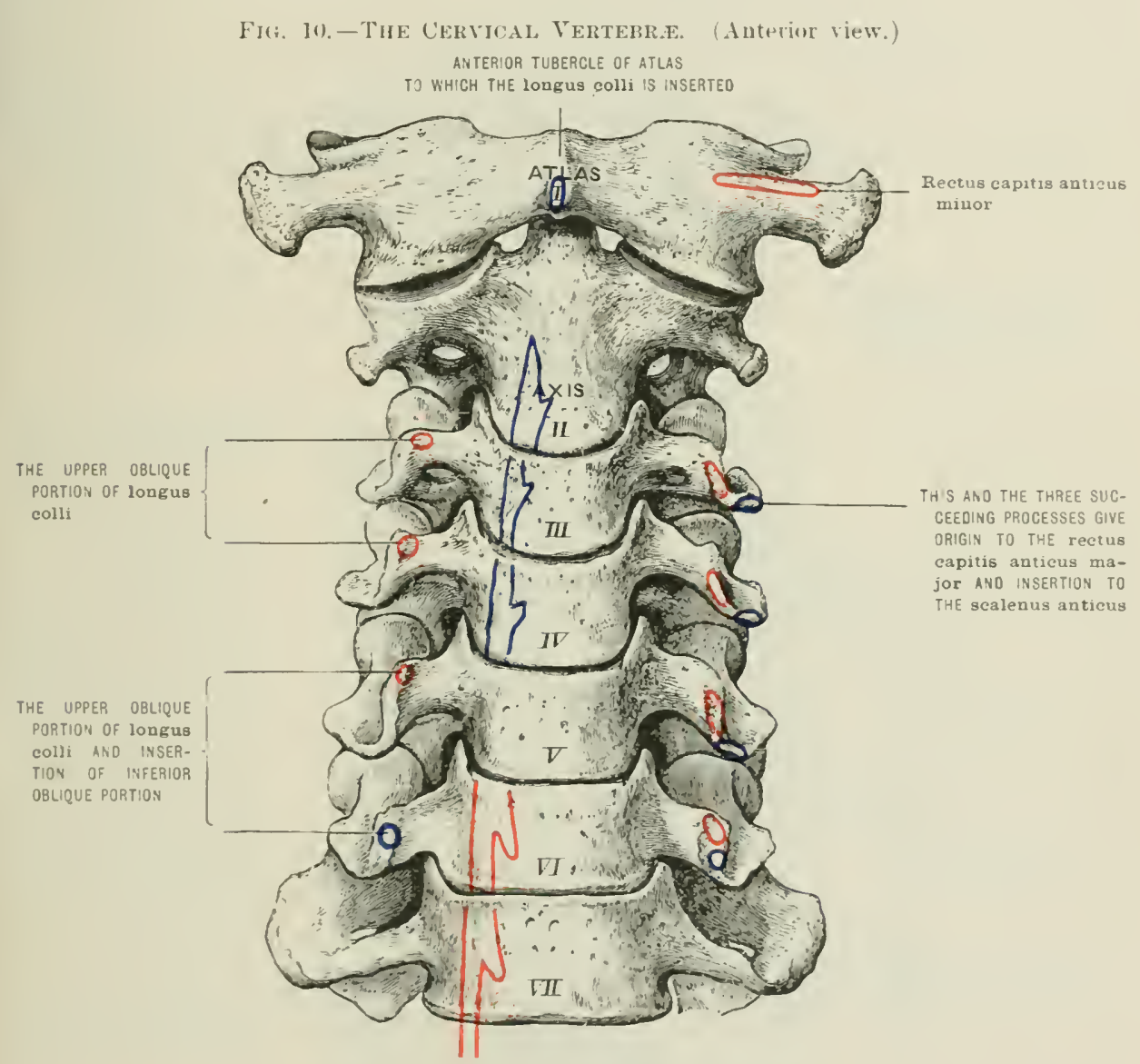

ORIGIY OF VERTICAL, PORTION OF THE lOngUS cOlli;

ITS IYSERTION IS INTO THE SECOND, THIRD, ANO FOURTH VERTEBREE

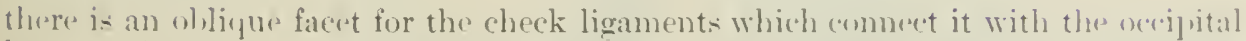
lwom. The pedicles are stout and hroul; they support the oval, upwarlly directerl. articular surfares for the atlas. The inferour articular surfares de met differ from the cervical true. The transverse are smaller than the costal processes.

The spinous process is stout and stronge, derply comcate on jt-umeler a-purt,

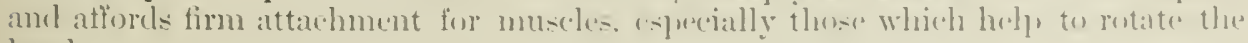
liearl.

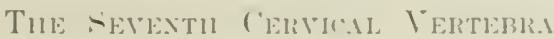

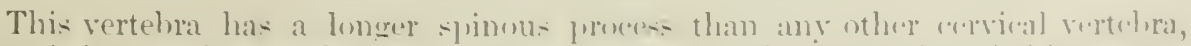

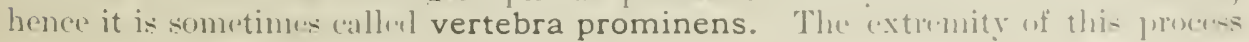


is nut lificl, hut has two small litchill tulureles which give attachment to the ligatmentum muchle. The transverse processes are of large size; the costal processes :Ir" V'r small: and the costo-transverse formmina are the smallest of the series or wanting. Very frequently the costal process is segmented off, and eonstitutes a "ervical ril, sometines of larese size.

Onearionally a demi-facet exists on each sille of the lower borkler of the centrum for the lanul of the first rib. When this demi-facet is present, there is usually a well-chereleneel rervical rib.

\section{Fir, 11.-The Cervichl Verterr.a. (Posterior view.)}

Rectus capitis posticus minor

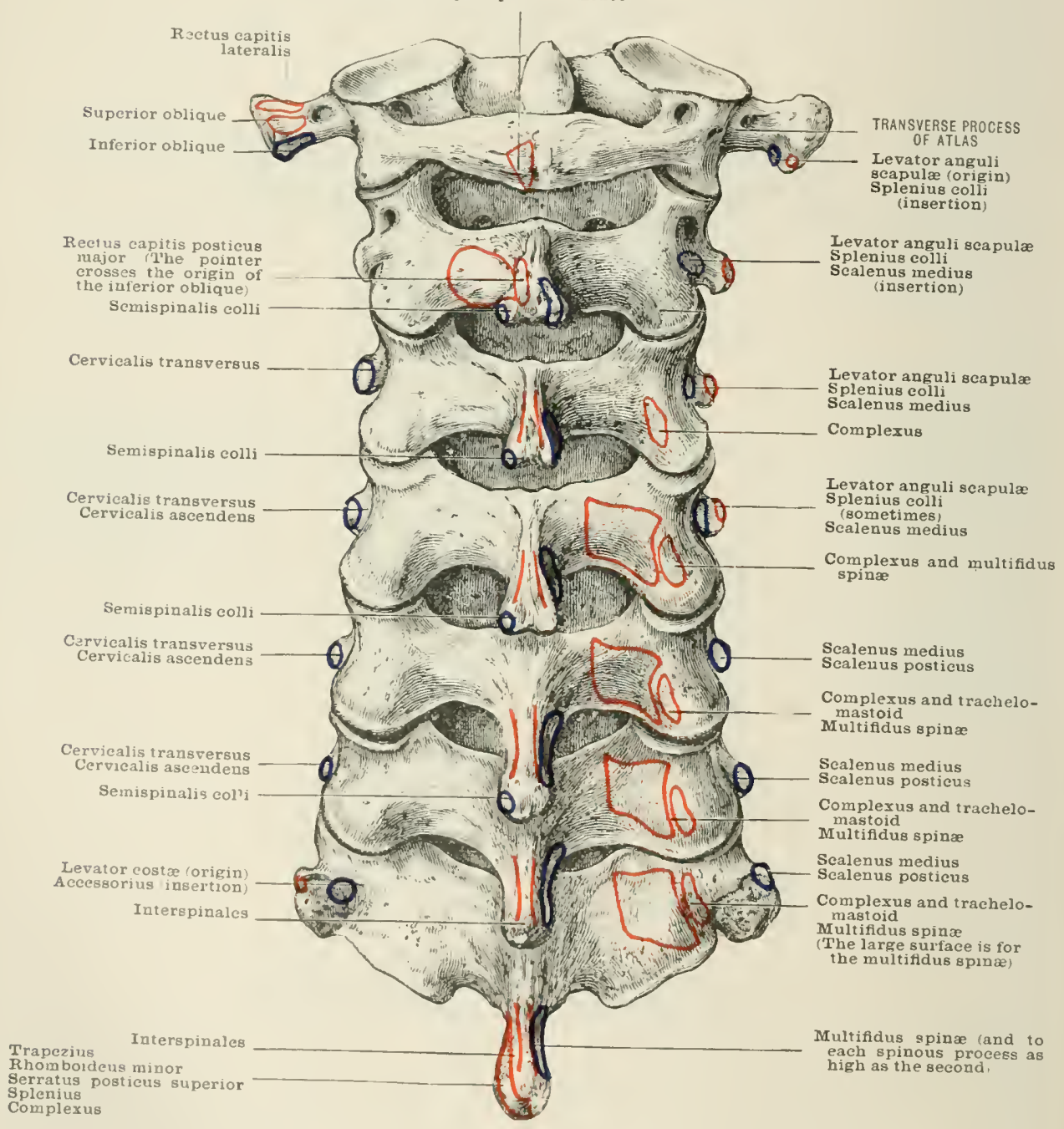

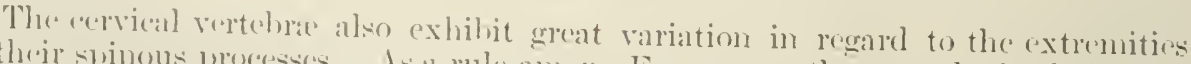

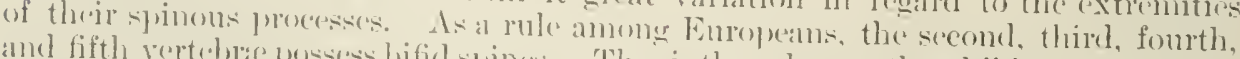

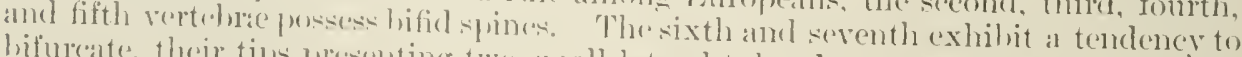
hifureate, their tipe fursenting two small lateral tubereles; sometines the sixth has

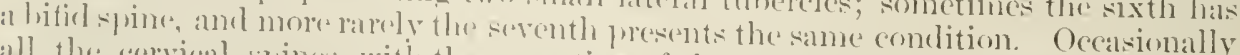

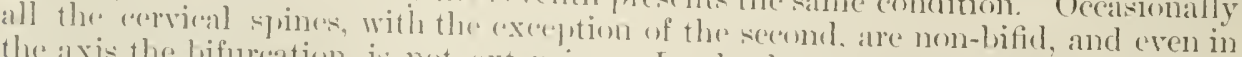
the axis the hifureation is not axtensive. In the lower races of men the cervial spines are relatively slorter and more stunted than in Europeans gemerally, and, as 
a rule, are simpie. The only cervical vertehra which presents a hifid spine in all rares is the axis; eren this may be non-bifid in the Negro. and oecrsionally in the European. (Owen, Turner, ('umningham.)

The lamine of the lower cervical vertebre frequently present over the inferion articular processes distinct tubereles from which fascieuli of the multifidus spinit muscle arise. They are usually confined to the sixth and seventh vertebra, but are fairly frequent on the fifth, and are occasionally scen on the fourth.

Fig. 12.-PeCcliar Thoracic Vertebre:.

AN ENTIRE FACET ABOVE: A OEMIFACET BELOW. IN SHAPE THE BOOY RESEMBLES THAT OF A CERVICAL VERTEBRA

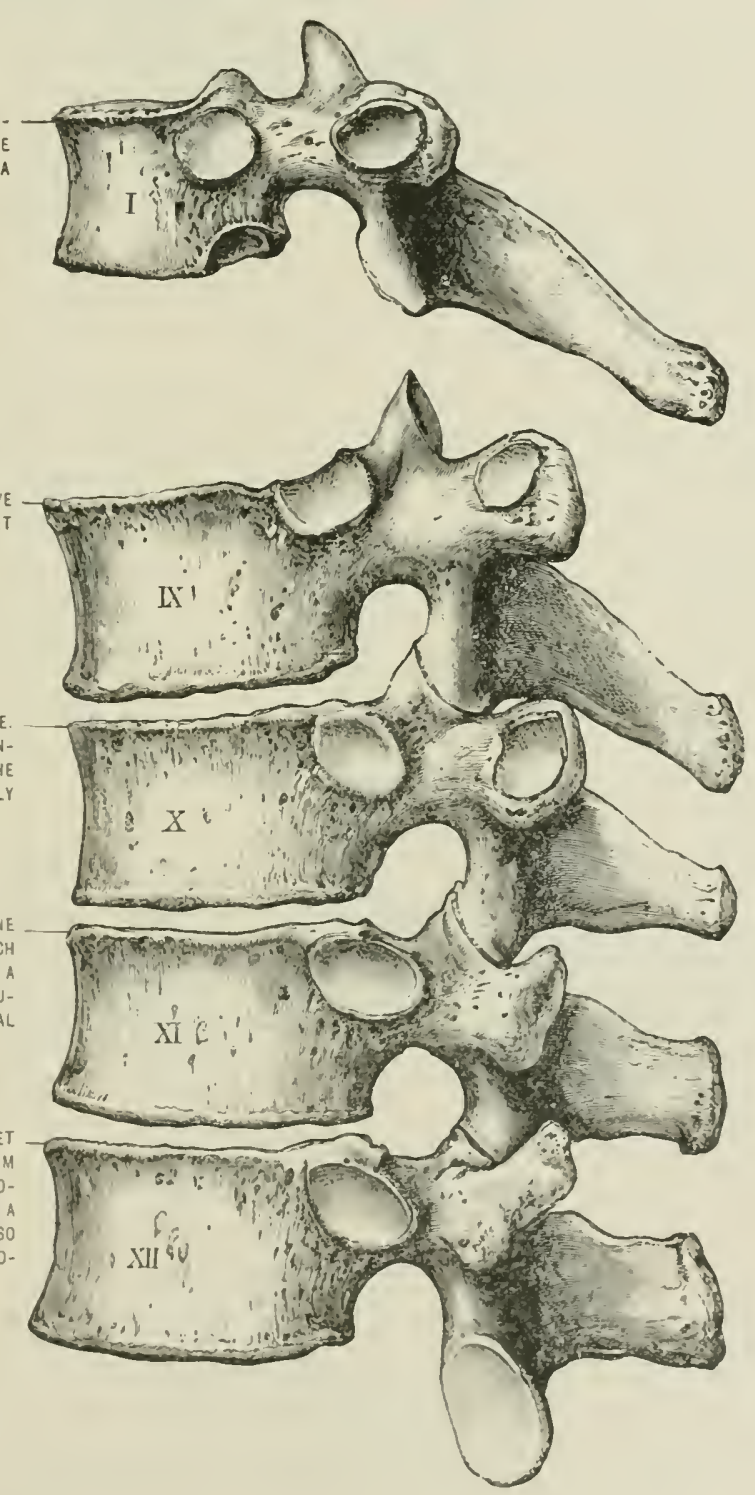

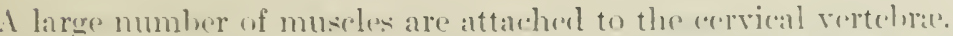

To the atlas:-Rectus "alpitis anticus miner, rectus capitis posticus minor. restus "appitis lateralis, superior oblique. inferior oblique. longue colli, splenius colli, intertransrerales, levator aneruli scapulute.

To the axis:- liectus capitis posticus major, inferior olligur. Ionerus anli, 
splenius colli, intertanswersales, interspinales, levator anguli scapula, transversalis rervicis. scalemus medius, semispinalis colli, and multifidus spinae.

To the seventh:-Trajezius, (')mplexus, sorratus postieus superior, splenius, rhombeichs minor, multifilus spinde, somispinalis, eight intertransversales, interspinales, levator costar, sallenus pusticus, acessorius, scalenus medius, trachelomilsteid, and the longus colli.

\section{THE THORACIC OR DORISAL VERTEBRE}

The general characters of the thoracic vertebre have already been considered in the lescription of the type rertehra. Their most distinguishing features are the facets on the transverse processes and sides of the bodies for the tubercles and heads of ribs.

Peculiar thoracic vertebræ.- Several rertebre in this series fiffer from the trye form. The execptional are-the first, ninth, tenth, eleventh, and twelfth.

The first has a body resembling a cervical vertebra, the upper surface being concave and lipped laterally; it has two entire facets above for the first pair, and two rlemi-facets below for the secont pair of ribs. The spinous process is thick, strong, almost horizontal, and more prominent than that of the rertebra prominens. Occasionally the transverse process is perforated near its root.

The ninth has demi-facets above, and usually none below; when the inferior demi-facets are present, this vertebra is not exceptional.

The tenth usually has an entire costal facet at its upper border, on each sirle, but oceasionally only demi-facets. It has no lower demi-facets, and the facets on the transwerse jrocesses are usually small.

The eleventh has a large body resembling a lumbar vertebra. The rib facets are on the pedicles; they are complete and of large size. The transverse processes are short and have no facets for the tubereles of the eleventh pair of ribs.

In many mammals, the spines of the anterior vertebræ are directed backwards, and those of the posterior directed forwards; in the centre of the column there is unally one spine vertical. This is called the anti-clinal vertebra. It is at this joint that the thoracie begin to assume the characters of lumbar vertebra. In man, the eleventh thoracic is the anti-clinal vertebra.

The twelfth resembles in general charieters the eleventh, but may be distinguished from it in having the inferior articular processes convex and turned outurats as in the lumbar vertebre. It also resembles a hmbar vertehra by possessing well-marked mammillary and accessory tubercles. These tubereles are ocasionally present on the tenth and eleventh rertebre.

A peruliarity, more frequent in the thoracic and lumbar than in the ecrrical and sacral regions of the column, is the existence of a half-yertebra. Such specimens have a wedge-shaped half-centrum, to which are attached a lamina, a transverse, superior and inferior articular, and half a spinous process. As a rule, a half-rertelora is ankylosed to the vertebrae above and below.

\section{I.TMB.IR YERTEBR.E}

The ristinguishing foatures of lumbar rertelore are their large size; the margins of the centrun are prominent; the pedicles are stout and strong; the inferior intervertebral notrhes are derp, and the lamina are thick and strong. The superior articular processes have concave facets directed hackwards and inwards, and their

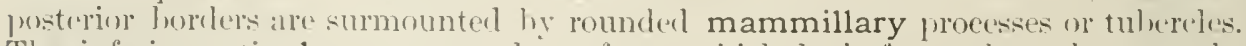
The inforior articular procesies have facets which lowk forwark and outwards. The transverse processes an long, slenter, and "areh presents near the hase, on the posterior as acet, a small accessory tulwele. The spinous processes are thick, hroal, and project horizontally backwaris.

The transverse processes of the humbur vertebre are more (omplex than they at first

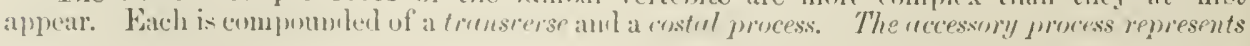




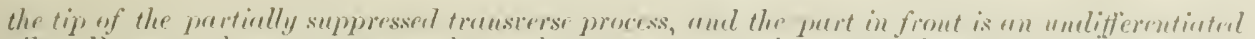
rib. lisetween the transerese and costal denents sume large vascular foramina are uslatly. present, representing the costo-forenserse formmina of uther vertebrat. Oecalsionally the contil

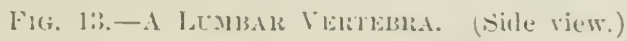

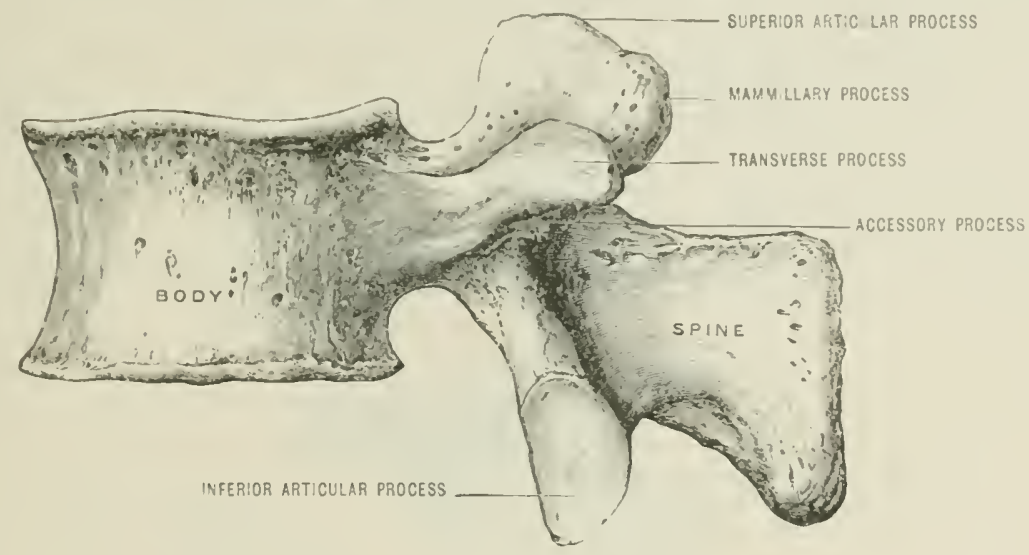

thment differentiates, and beromes a well-rleveloperl lumbar rib. A glance at the - pine will sluw that the acces-ury tuberdes are in line with the thoracie transwerse processes, and the costal elements are in series with the rils (see also fig. 29).

Fig. 14.-A Lemisal VFrTẺzR.

(Fhwing the eomponml nature of the transwerse process. Luper view.)

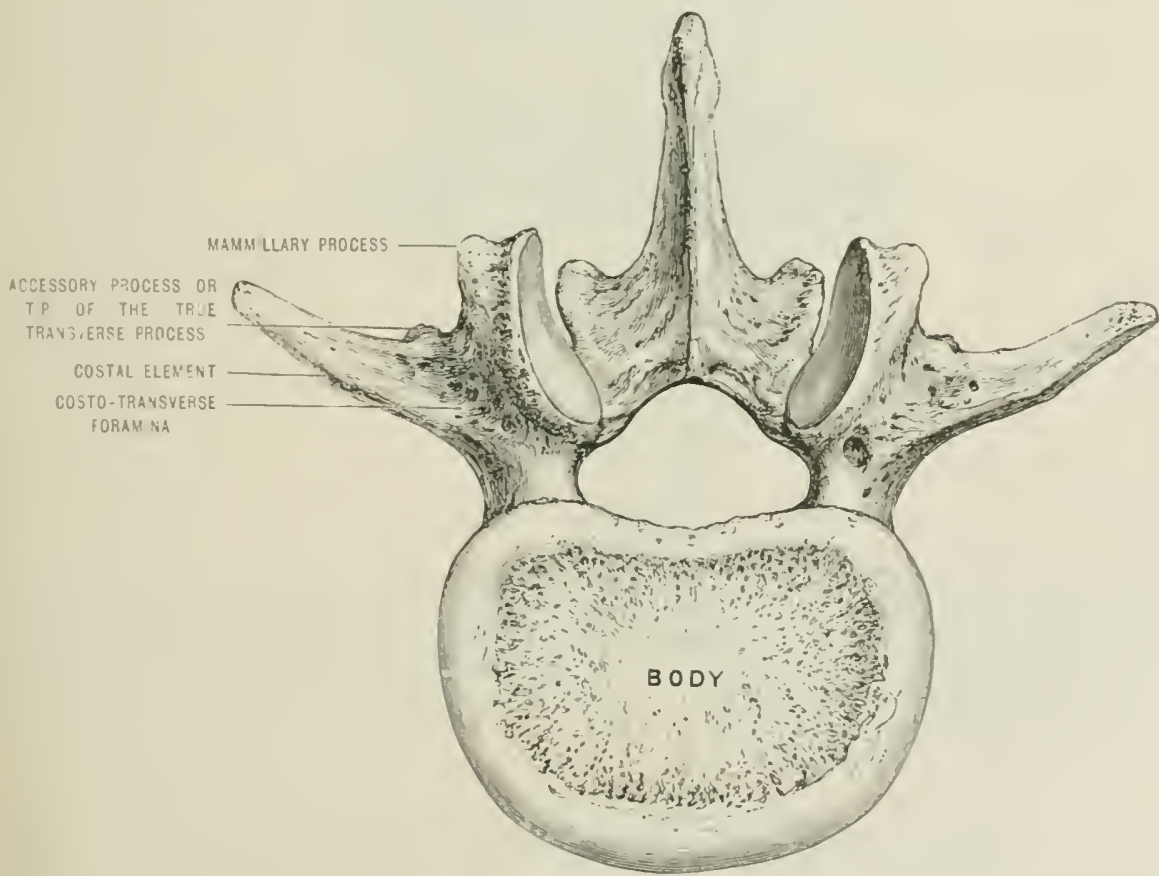

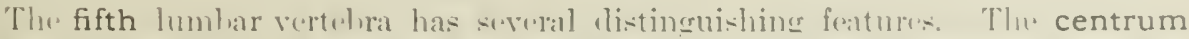

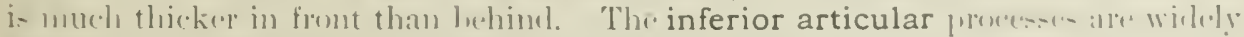

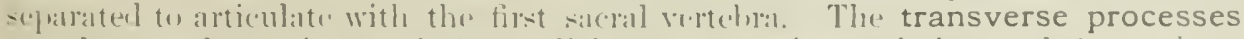

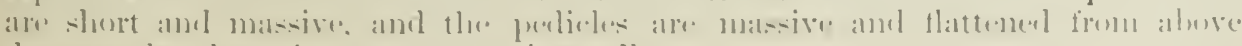
(lowmatrls: the spinous process i- -muall. 
'The pedicles of this vertebra are liable to a remarkable deviation from the conclitions found in other parts of the spine. The jeculiarity consists of a eomplete solution in the contimnity of the areh inmediately behind the superior artieular proceses. In such specimens the anterior

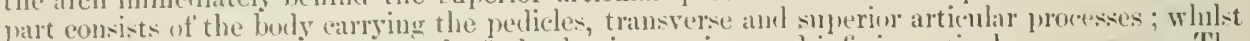

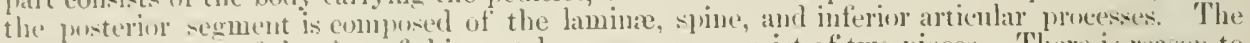

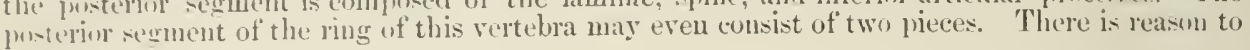

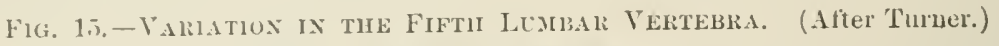

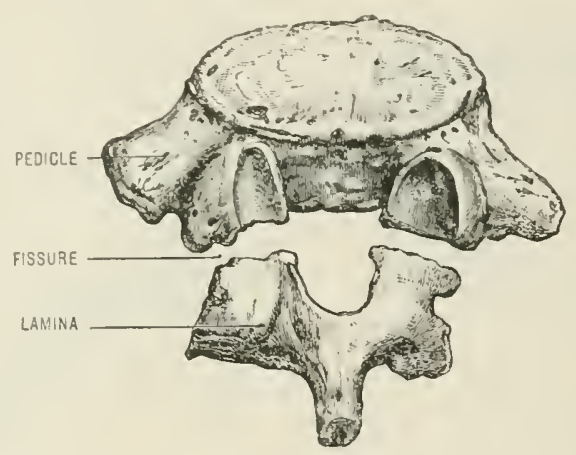

ledieve that this abnoruality of the fifth lumbar vertebra occurs in five per cent. of all sulpjects cximined. Sir William Turner, in his report on the human skeletoms in the Challenger Reports, found seren examples among thirty skeletons examined. The skeletons in which this occured were: a Malay, an Andamanese, a Chinese, two Bushmen, an Esquimau, and a Negro. Tumer has also seen it in the skeleton of a Sandwich Istander. A similar condition is occusionally net with either laterally or bilaterally in the thoracic vertebra.

Fig. 16.-A Varitiox in the Fifth Lembar Vertebra. (After Turner.)

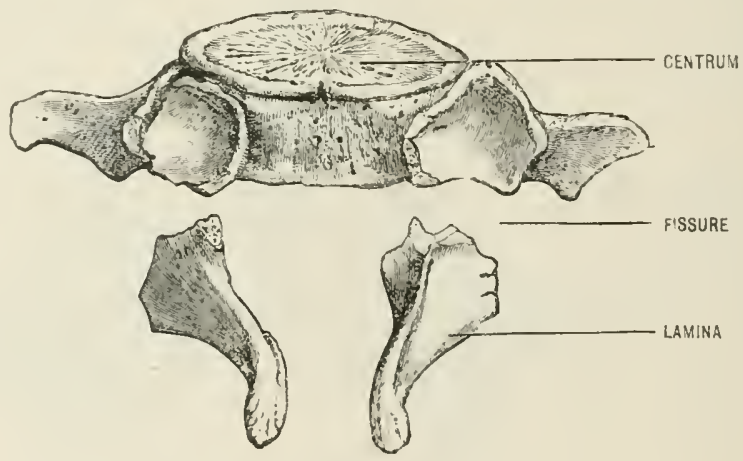

Eich of the five lumbar vertebre is readily recognisable. The body of the first is deeper behinl than in front, the body of the second is of ermal depth in front and behind, the boties of the thirl, fourth and fifth are deeper in front than behind, but the third has long transterse pro"rsac's and its lower articular facets are not rery widely separated; the fouth has much shorter transverse jucesses and the lower anticular facets are very wide apart, and the fitth is easily distimguished by the special features already described.

\section{THE SACRAL AND COCCYGEAI, VERTEBRA}

In the alult skeleton, the five vertelma sucereding the lumbar series are fimmly ankylesed to form a single bone, the sacrum: the eompenents of the sarerum are

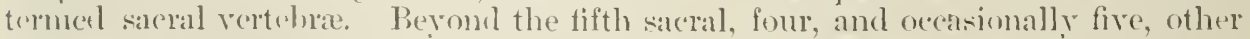
rulimentary vertedue to which the adjection coccygeal is appliul. are ankylused in arlult life, to form a single piece, the coccyx. In atvanced life the cocerx unites with the siserum. 


\section{THESSAREII}

This is a large triangular bone, fimsly wedged between the innominate lomes.

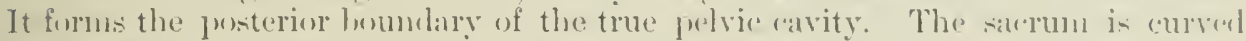
mon itself with the eomeavity looking forwards. The mpurer end of the curve forms, with the body of the fifth lumbar vertebra, an anterior projertiens knesm as the promontory. The mirldle purtion of the anterior fare of the sarem exhilits four transerse ridges arresponding to the intervertebral spares. The

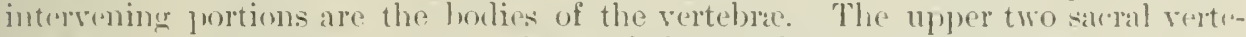
hras are almost equal in size to those of the lumbar series, but the three lowre rapidly diminish in size from above downwards. The ridges terminate laterally in the anterior sacral foramina, four pairs in all, which are the intervertebral foramina of the salcral rertebrat, and transmit the anterior divisions of the first

Fig, 17.-Tine Sactrat axn Coccix. (Anterior view.)
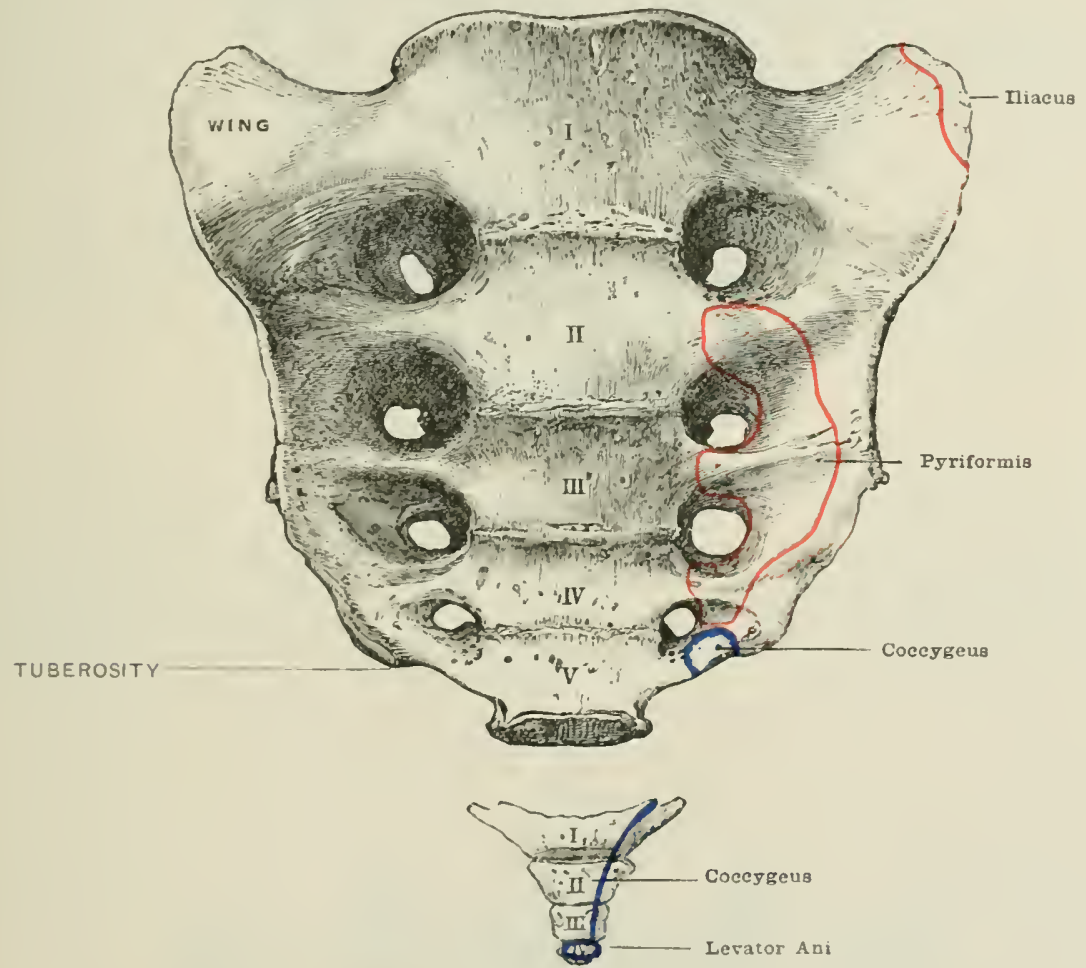

four sacral nerves. The upyer two are also traversed hy the lateral salcral arteries. The boue immerliately wutside the fermuna erresponds to the costal processes, and the portion formed by the secomel, third, and fourth saldal rertubar grives origin to the pyriformis muscle. The lateral part of the fifth saleral vertedrat gives partial insertion to the rorrygens.

The pusterior surface is strongry anvex and rough. The midllle line is oredpind hy four tulereles representing the suppresed spinous processes. ()f

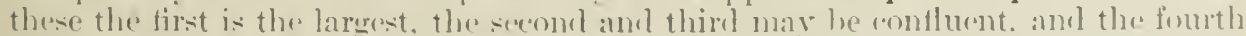

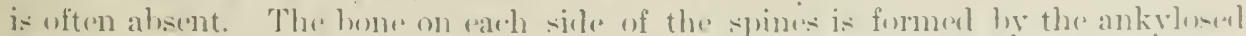
lamina. In the fourth sometinese. lut alwass in the tiftl, the limnina fail to

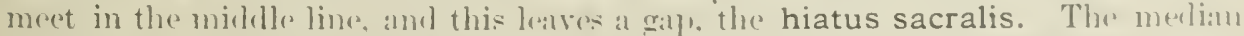

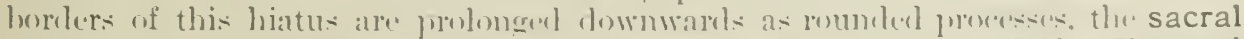

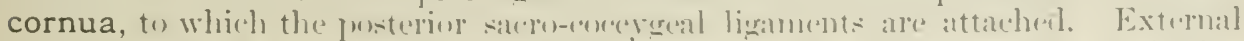
to the lamine is a serend series of smatil pominenews these are the articular 
processes. The first pair are large for the last lumbar vertehra, the second and thinl alre sulall, and the fourth and fifth are inconspicuous.

Immerliately external to the articular proceses atre the posterior sacral foramina, foul on "ach side; they are smaller than the anterior, and give exit to the posterior livisions of the tirst four sacral nerres. External to the formma

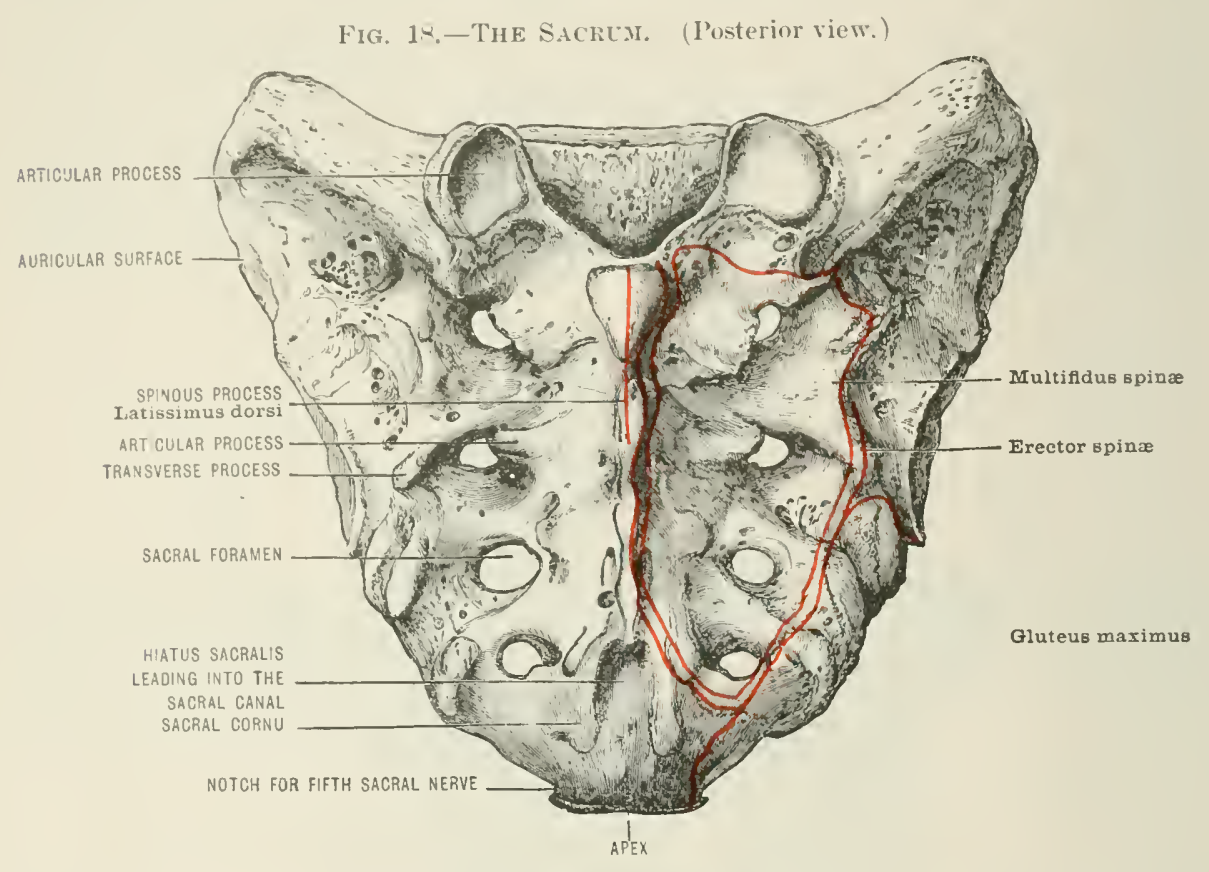

there are five eminentes on each side, representung the fused transverse processes. The first pair are large and conspicuous, and all give attachment to ligaments and muscles; the second form part of the articular surface for the ilium. The furrow formed by the lamina, and bounded on the median aspect by the spinous, and

FIG. 19.-BASE OF SACRUM.

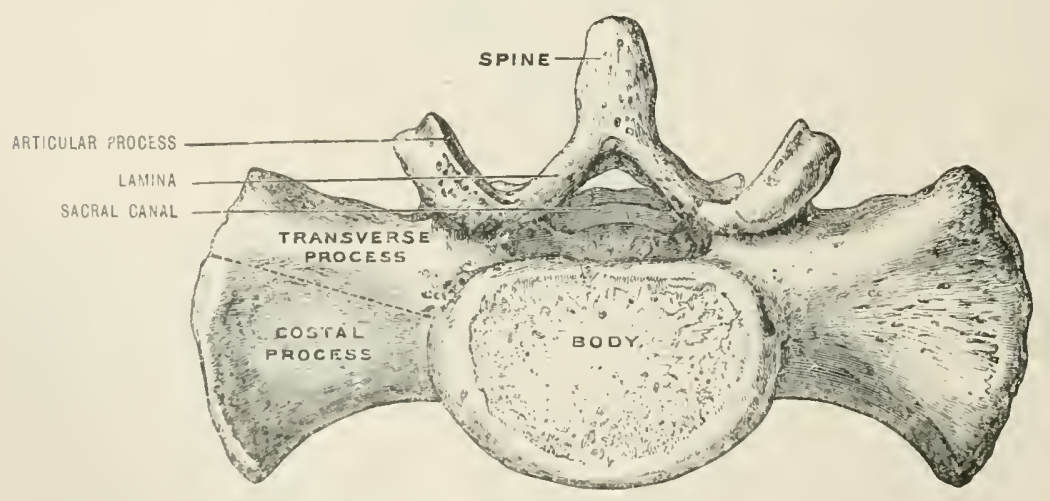

rxtemally by the artienlar processes, is known as the sacral groove, and it lodges the mellifieles springe mons les.

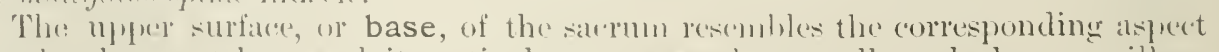
of a lumbill vertelma, amel its artienlar froceses have well-marked mammilary tuhereles. The anjont transverse and costal processes form m each side a broad surfice, the wing or ala. From its margin the iliacns has a small point of origin. 
The apex is directed downwarels and forwarls, and is fomed hy the inferien

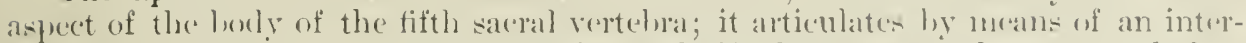
vertebral dise with the cocerx. In advaneed life the cocerx and ralermu ankyluse at this sjot.

The lateral surface presents in the upper two-thire a l,roul irregular tract allerl the auricular process, which is rough anch, in the rent state, corered with tibro-cartilage for mion with the ilium. The margins are mugh for liestnents. Below the aurieular surface each lateral horder forms a tuberosity and gives attachment to the greater and fesser sacro-sciatic ligaments. Nour the cxtremity it presents a notch which is comverted into a foramen by articulation with the eocery. Through the space thus enclosed, the anterior banch of the fifth sacral nerve issues. Sometines the formen is represented by a noteh even when the sacrum and eocerx are articulated. The middle of the sacrum is oecupied ly a continuation of the spinal canal. It is triangular in form at the base, and flattened towards the apex. It lodges the terminal hranches of the cauda equina, the filum terninale, and the lower extremity of the clura mater.

The sacrum exhibits scxual and racial differences. In the female it is usually wider, much less curverl, and is directed more obliguely backwards, than in the male, and in the lower races the sacrum is relatively longer than in the higher.

Muscles.-The following muscles are attached to the sacrum:-Pyrifornis, (oc'yene, iliacus, latissimus dorsi, multifidus spina, erectror spina, gluteus maximus; and the occasional muscles, namely, curvator coceygis, extensor cocergis, and the agitator caudse.

Ligaments.-Anterior and posterior common ligaments of the spine; anterior and posterior sacro-coccygeal; greater and lesser sacro-sciatic, anterior and posterior satro-iliae, two capsular, liganenta subflava, and the supmejpinous.

\section{TIIE COCCYX}

The coeser in the adult is made up of four and occasionally five vestigral vertrhac ankylosed to one another. Rarely the number of scoments is reduced to three. The first two segments contain, in addition to the body of a reetebra, traces of articular and transverse processes: the rest are mere nodules of bone, representing centra. The anterior surface gives attachment to the anteror sacro-ocergral ligament; and mear its tip to the lecator ani; it is in relation with the posterior surface of the second part of the reetum.

The posterior surfure is comvex, and presents abore a laterally projecting process. the pulimentary transwerse process of the first segment, and aloner its margin affords attachment to the gluters marimus muscle.

The lateral borkers are thin: there receive parts of the greater sacro-selatie ligaments and of the coccygers murele. "The hase has an wal facet for the fifth sacral vertelial, and presents the two long coccygeal cornua, formed by the remains of the pedicles and superior articular processes of the first serment. for the posterior

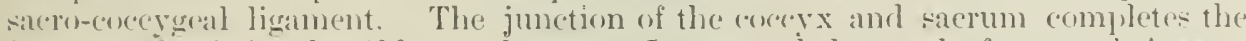
foramen of exit for the fifth sacral nerve. In many skeletons the foramen is incomplete externally. The apex is rombled and gives attachment te the sphimeter uni, and in front to the lecotur ani nussedes on ateh side of the median line.

\section{TIIE SPINAL COLLMN IN (IENERAL}

When the various verteluse are in their relative positions, the whele is termed the spinal column. It uceupies the median line of the posterine aspert of the trunk. superiorly, it supports the head; laterally; it gives attachment to the ribs: these in their turn receive the weight of the upjer limbs. Inferiorly, the sicrum afford. attachment to the innominate homes, by which the weight of the trunk is trammitted to the lower limbs. The spinal column is the axis of the skeleton.

It varies in length in different persons. But on an aveluge it uncasures. from the atlas to the tip of the cocerx, following the curve, 70 ans. (2x"). () thi-. the 


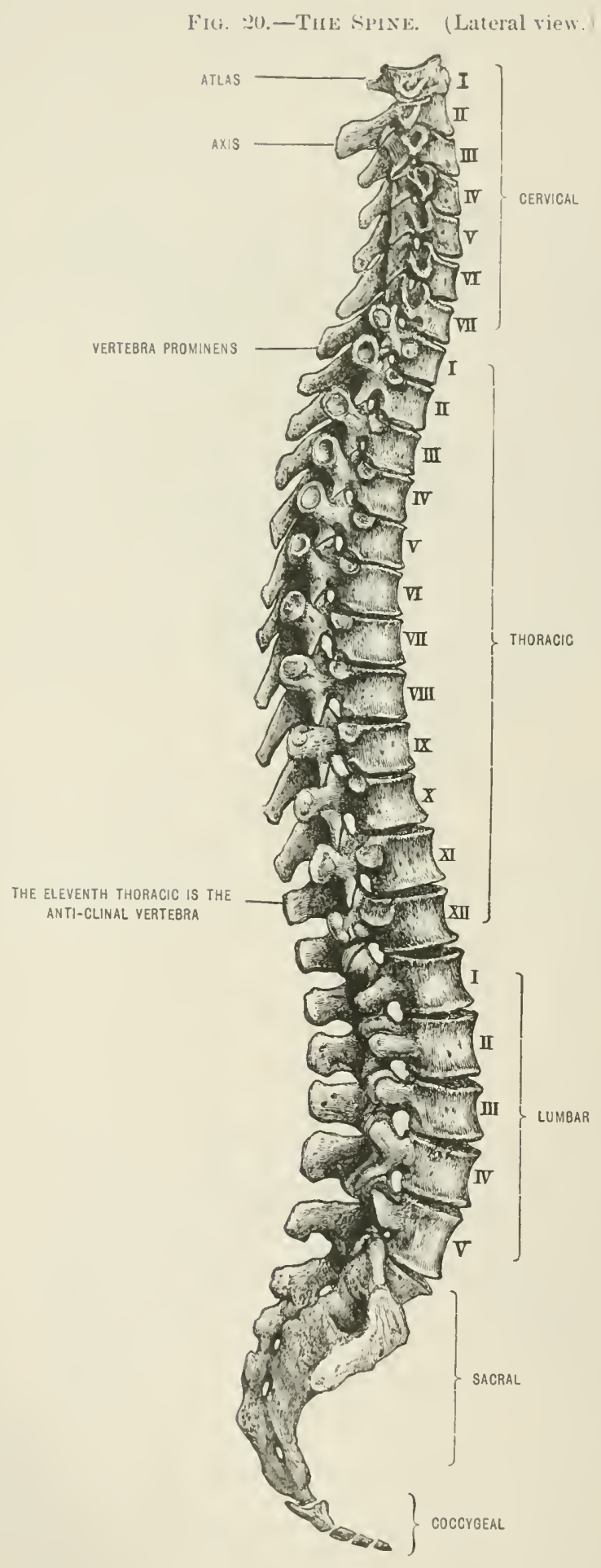


cervical spine measures $12 \%$ cm. (5"), the thoracic 27.5 ('m. (11"), the lumbar

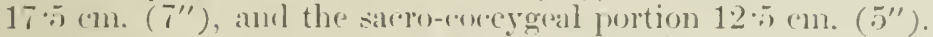

licwed in profile, the colmmn presents four curves: the first, or cervical, is comvex anteriorly; the thoracic is much latrel and lonerer, with its (oncavity forwarl; the lumbar eurve las its comvexity directed anteriolly, and conds sonewhat aloruptly at the sacro-vertebral angle; and to this snecects the pelvic curve, whirh corresponsls to the Irollow of the sarem. In adclition to these, the whole. column has a slight lateral curve with the convexity to the right, probably due to muscular action.

Viewel from the front, the superimposed hodies present threp pramids. The first is formed hy the cervical vertebre from the second to the screnth. The bodies of the lumbar and thoracic vertebre form a much longer lyramid. The third is inverted, and formed by the sacrmon and cocerx.

Pesteriorly, the columm presents a median and two lateral rows of processes. The nerdian row is formed hy the spinous processes. In the cervical spine, with the execption of the first and the serenth, they are bifid. In the thoracie set they rent in rombed tulureles, are long, and for the nost part rirected obliquely downwards, luat in the lower part they become more horizontal until the eleventh is reached. The spine of the eleventh thoracie vertebra is small and almost horizontal; this is the anti-rlimal vertebra. In the lumbar region the spinous processes are short,

\section{Fir, 21.-A Divined Thor.sir Vertebla. (After Turner.)}

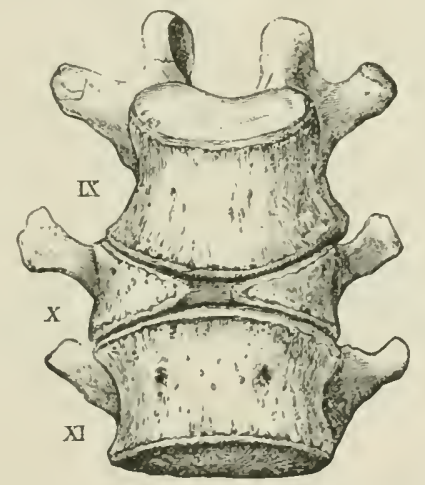

stout plates of hone, with their horders set rertically; in the sarrum they are vertigial, and in the coceyx completely suppressed.

The lateral rows are formed hy the transverse processes, which are most marked in the thoracie region, where they are rib-bearers. In the cervical spine they are in the same plane as the rihs. The articular processes in the cervical region are in series with the transwerse processes of the thoracic vertelora.

Between the ridges formed by the spinous and transwere processes we reegnise the verteloral grooves in which musches are lodeded. The floor of each groove is formed by the laminae and articular processes, with their mammillary tubereles in the lumbiar and lower thoracie regions. Similar tubercles are present on the inferior articular processes of the there lower eervieal rertelora. The intervertelual foramina, oval in shape, are small in the cervical, but gradually inerease in size in the thoracie, ancl are laturest in the lumbar region.

Ossification.-The various ossific centers for the vertebra are depositerl in the cartilage which, very carly in embryonic life, surrounds the notochord and gradually encloses the spinal cord.

A typical vertelura arises from theer primary and numerous secomelary eentres. The primary centres appear during the sixtli week of embronic life. In the thoracie region the nueleus for the body is tirst sern, but in the cervical reurion the lateral centres make their appearane somewhat earlier. The nudeus for the lowly is deposited around the centre, and yuickly becomes biloberl. This hiloherb, in dumb-bell, shape is oftens so promement as to give rise to the alplearance of twe 
distinct nuclei. Sometimes the nucleus is louble, and remains separate throughout life, the vertebra being divided hy a vertical fissure (fig. 21). The bifid eharacter of the nuchers of the vertebrel bidy is further emphasised by the oceasional oceurrence of half-rertebrat. The lateral eentres are deposited near the bases of the superior articular processes, and give rise to the pedicles, lamina, articular pro(e'ses, and a largo part of the transverse and spinous processes.

It hirth a rertehra comsists of three parts-a body and two lateral masses comnceted ly hraline eartilage. The line of union of the lateral masses with the budies is knowin ats the menro-central suture (fig. 2.2), and this is not obliterated for screral rears after birth. An examination of a thoracie vertebra at the fifth year will show that a portion of the body of ach rertebra is derived from the lateral

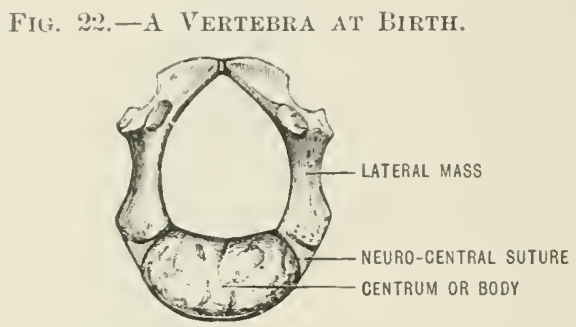

masses, and that the demi-facets for the rib-heads are situated behind the neurocentral suture, and therefore belong to the pedicles.

During the early years growth progresses rapidly, and at puberty the secondary centres make their appearance in the cartilaginous tips of the transverse and spinous processes. During the seventeenth year a meniscus of bone forms around the marcins of the superior and inferior surfaces of the centra. These are the cpiphysial discs; they are thickest at the periphery, and gradually beeome thin towaris the central perforation. By the twenty-fifth year the rarious secondary nuclei have coalesced with the main hone, and the vertebra is then complete.

In several vertebræ the mode of ossification deviates from the account given ahove, and requires separate consideration.

The atlas.-This bone has three primary centres-one for each lateral mass

Fig. :3.-Lumbar Vertebra at the Eighteenth Year with Secondary Centres.

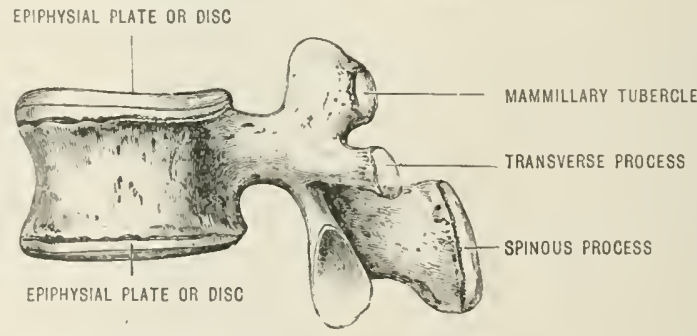

(neural arch) appearing in the sixth week of embryonic life. The third appears a few months after hirth for the anterior arch. The lateral portions coalesce posteriorly about the fourth year; the mion with the anterior nucleus is delaverl until the sixth year. An additional centre oceasionally appears for the posterior segurent.

The axis.-This is the most exceptional of all the vertelore. It has the usual three prinary nuclei-one for the body, and one on each side for the neural arrh. The centre for the body apporars in the embryo about the fifth month, and a few weeks later, two laterilly disposed nuclei are seen for the base of the odontoid process; these fuse together in the midtle line, and hy the third year ankylose peripherally to the centrum of the axis. The line of cinion leetween the borty of the axis and the odontoid process is indieated cren in arlvanced life by a persistent 
lenticular-shaped cartilage. During the second year a nurleus appears at the tip of the odontoid process; it joins the main mass at the fourth year. An epiphysial menisens for the inferior and superior surfaces of the centrum of the axis appear about the seventeenth year. $\quad$ s a rule, the superior menisens is representerl hy it few carthy gramules.

Fig. 24. - IMмateke Atras, Third year.)

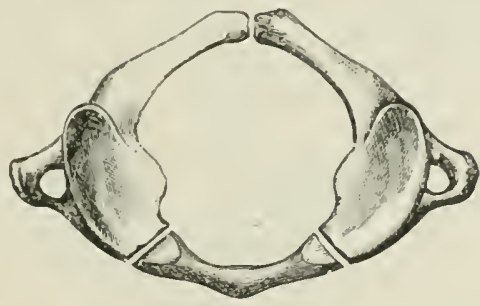

The sixth and seventh vertebræ.-In the cervical vertelire the pedicles, or anterior extremities of the neural arches, take a much larger share in foming the centrum than is the case with the remaining vertebre. The sixth, serenth, and possibly other cervical vertebræ present an additional centre on each sicle of the neural arch for the costal process; it appears before hirth. The costal processes of

Fig. 25.-DEVELOPMENT OF THE AXIS.

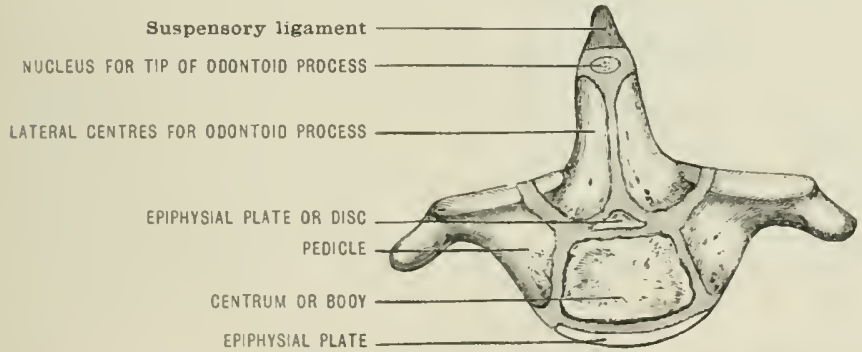

the serenth cervical not infrequently fail to ankylose with the vertebra; when this is the case, the processes lweome cervical ribs. sometimes these ribs are of large size.

The lumbar vertebræ. - In the lumbar rertehre, two additional centres makr

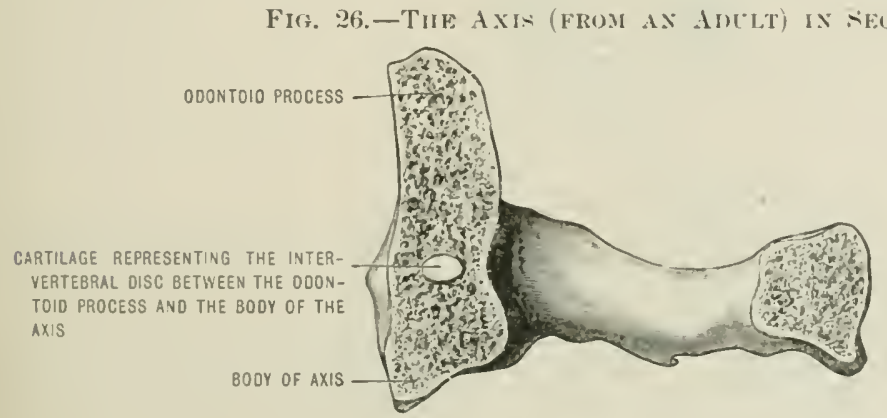

their apperance, about puberty, namely, for the mammillary tubereles on the posterior aspect of each superior articular prowess.

The fifth lumbar oceasionally differs in the mode of as-itiation of it-allec in many slieletons this arch is deriverl from four nuclei. There is a nueleus on tach side for the pedicle, the transverse process, and the superior articular promes-; and 
one on each sicle for the lamina, inferior articular process, and the lateral half of the spinous process (fig. 28). The pedicles may fail to join the lamine; more ralcely the laminat fail to fuse (fig. 16).

The sacral vertebræ.-In addition to the three primary vertebral centres, the three upper sacral vertebre have each an extra pair corresponding to the costal puocesses of the seventh cervical rertehra; they appear at the serenth nonth. These processes are rery large in the first sacral, smaller in the second, and rery small in the third. Although the various primary centres of the sacral vertebre appear much later than in other regions of the colimm, yet they are all visille at lirth. The centrum of each sacral vertebra develops a superior and an inferior

Fig. 27.-Air Imatere Cervical Vertebra.

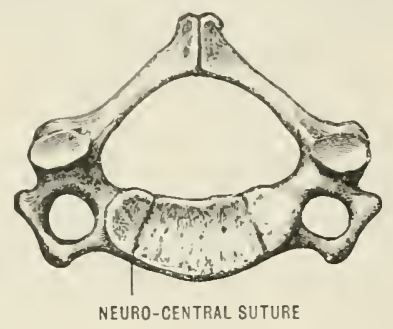

"piphysial meniscus, and eventually the five vertebræ fuse to form a single bone, the sacrum. Even in advanced life the intervertebral discs between the sacral vertebre persist in the centre of the bone. The ear-shaped lateral articular facet un the side of the sacrum arises from two additional centres on each side, about the eighteenth year. The total number of ossific centres for the sacrum is thirty-five.

The coccygeal vertebræ.-These are cartilaginous at birth. A few months later the first segment ossifies. The remaining three ossify from above downwards before the twentieth year. By the twentieth year the first three have usually coalesced. The fourth fuses with them later, and the coccyx ankyloses with the sacrum, as a rule, late in life.

Fig. 28. - Ossification of the Fifth Lumbar V'ertebra.

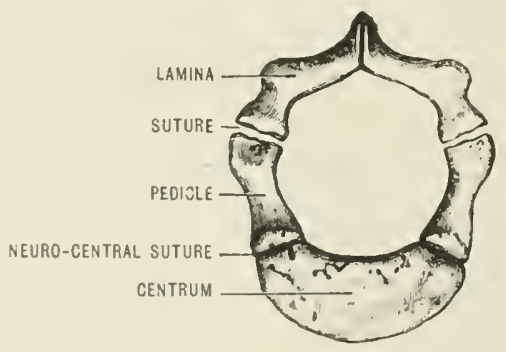

The Serinl Horphology of the Tertebre

Although at fist sight many of the vertebra exhibit peculiarities, nevertheless a study of the mode ly which they develop, and their variations, indieates the serial homology of the constituent parts of the vertebre in each region of the column.

The centrum, or body of the vertebra, is that part which immediately surroumds the notochord. This part is present in all the vertebre of man, but the centrum of the atlas is dissociated from its neural arch, and ankylosed to the hody of the axis. The reasons for regarding the odontwiil process as the body of the atlas are these: In the embryo the notuchord passes through it on its way to the base of the cranimm. Between the odontuid process and the body of the axis, there is a swelling of the notuehord in the early cmbryo as in other intervertebral regions. This swelling is later indicated by a small interrertebral disc lichlen in the bome, but persistent even in old age. The odontuid process arises from primary centres, and in chelonians it remains as a separate osicle thronghont life ; in Ornithorhynchus it remains distinet for a long time, and it has been fiound separate even in an arhlt man. Lastly, in man and many mammals, an epiphysial plate develops between it and the true body of the axis. 
The anterior segment of the atlas is most probably an enlarged hyporpophysis ur subvertebral wedge-bone, which, in lizarls, exists on the ventral aspect of the columu between indivilual centra. Similar ossicles occur in the lumbar region of the mole. (Froriep regards this segment as the ossified primitive ventral arch which precedes the borly and which disappears after the formation of the latter in all the other vertebre.)

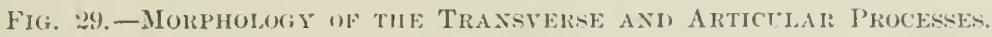
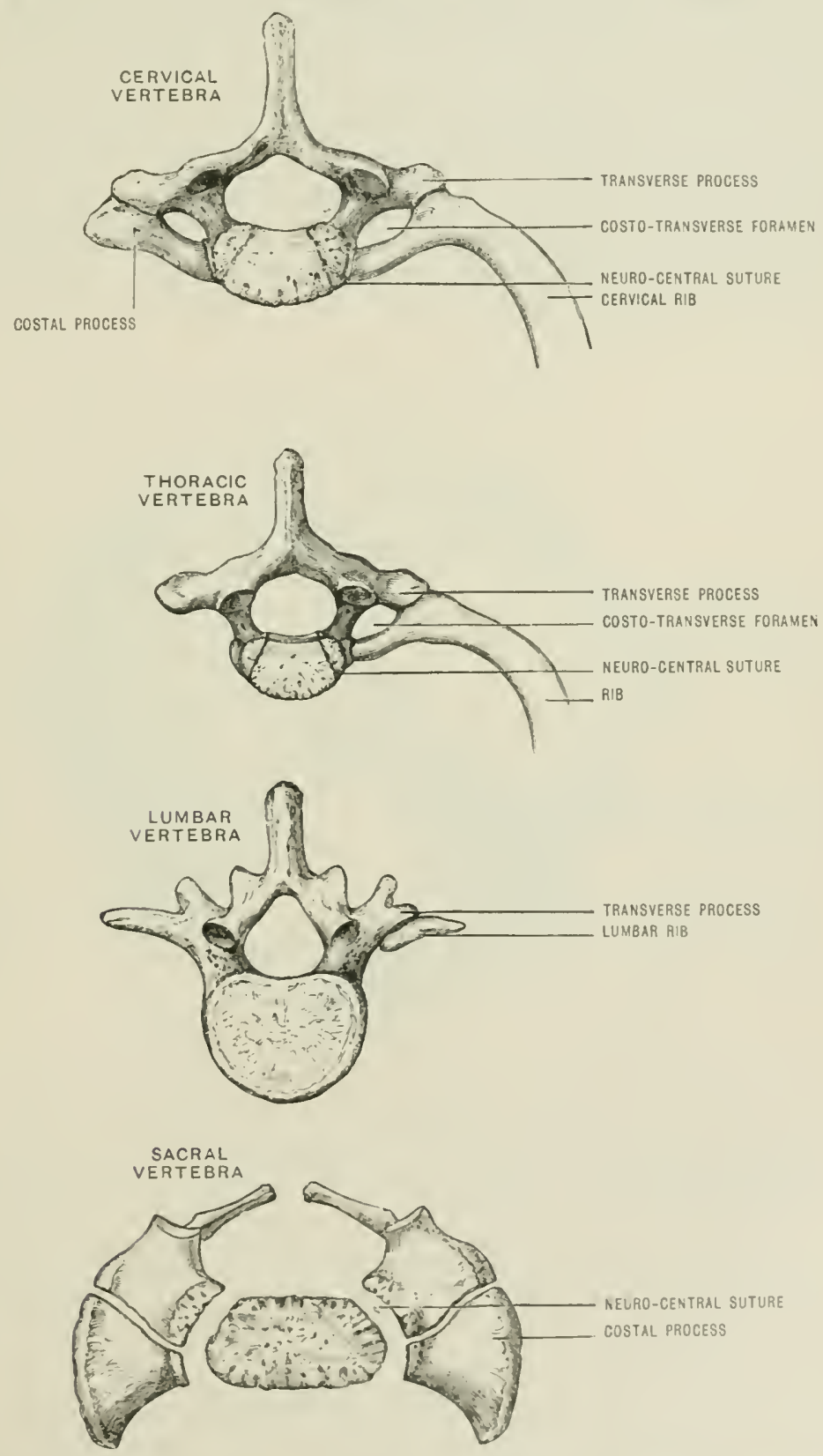

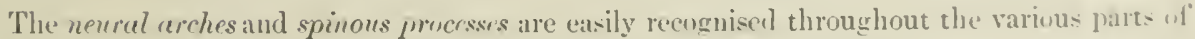
the column in which complete vertebra are present.

The articular procrses are of no morphological value, and do not require consicleration here.

The trenswerse processes nffer uore diffienlty. They present themselves in the simplest finm in the thoracic series. Here they articulate with the tuberoles of the ribs. 'The transerse 1 ro- 
cen... and the neek of the rib enelose an arterial formen, the costo-transverse. In the cervical region this rib, or costal element, and the transverse process are fused together, but the conjoint prouess thus tormed is piereed liy the costo-transverse foramen. The compound nature of the froces is indicated by the fact that the anterior or costal processes in the lower cervical vertebra arise from additinnal centres and vecasibnally retain their independence as cervical ribs. These moceses in Sauropsida (birls and reptiles) are represented by tree rils. In the lumbar region, the compound nature of the transverse process is further maked. The true transverse process is greatly suppressed, and its extremity is indicated by the accessory tubercle. Anterior to this in the alult rertebra a group of holes represents the costu-transverse foramen, and the portion in front of this is the contal element. Oceasionally it will persist as an indejendent ossicle, the lumbilr rib.

In the sacral scries the costal elements are peculiarly modified in the first three vertebre to form piers of bone for articulation with the ilium. The costo-transverse foramina are completely 1) sicured. In rare instances the first sacral vertebra will articulate with the ilium on one side, but remain free on the other. Under such conditions the free process exactly resembles the chunated transverse prucess of a lumbar vertebra. The first three sacral vertebra which develop a costal process (rib) for articulation with the ilium are true sacral vertebra. Those ankylosed below these are pseudo-sacrul. A glance at fig. 29 will show the homology of the various parts of a vertebra from the cervical, thoracic, lumbar and sacral regions.

The mammillary processes are vestiges of the greatly elongated articular processes of such mamuals as the dog, armadillo, \&c.

\section{THE BOAES OF THE SKULL}

The skeleton of the head is called the skull : it contains, in the adult, twentynine separate bones. For lescriptive purposes they are divided in two groups: those of the skull proper, and the appendicular elements.

\section{THE SELLL}

(1) Basilar Bones $\left\{\begin{array}{l}\text { Occipital. } \\ \text { Sphenoid. } \\ \text { Temporals. }\end{array}\right.$

(b) Roof Bones

\section{(r) Nasal Region}

Epipterics.
Ethmoid.

sphenoidal turbinals.

Turbinals.

Lachrrmals.

Vomer.

Yasals. (d) Facial Bones $\left\{\begin{array}{l}\text { Maxillax. } \\ \text { Palatines. } \\ \text { Malars. }\end{array}\right.$

II. Appexdicular Elemexts

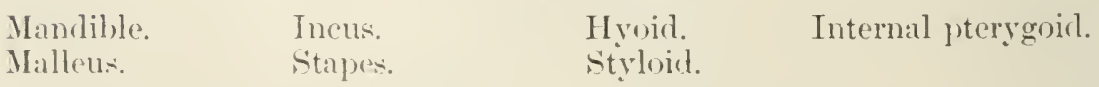

The epipterim are not alwars separate in the adult skull: the styluid ankyloses with the tenporal, and the internal pterygoid with the sphenoid.

\section{TIIE OCCIPITAI}

This bone forms the back and a portion of the base of the skull. At birth it (onsists of four rlistinct parts risposed around the formen magnum (fig. 34). These, in the adult, fuse together and form a single bone, which ankyloses with the sphenoid. The four parts of the eccipital are-the squamo-occipital, two ex-occipitals, and a basi-occipital. The lines of union of these parts are easily distinguisherl eren in tho olilest skull. 


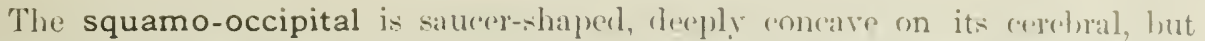
convex on its external aspect. It consists of two prirts which have rlifferent muxles of origin. The posterior surface is divided by a ridere, the superior nuchal line, into a lozenge-shaped superior portion with a smooth surface and an infrerior rourh portion. The upper is the interparietal, and the lower the supra-occipital ingment. The inter parietal portion not infrequently persists as an independent osiciele (fig. 35 ).

The supra-oecipital is clivider into two lateral halves by a median vertical rielexe - the external occipital crest-which ascents from the middle of the posterior margin of the formmen magnum, to terminate at the external occipital protuberance, or inion, near the middle of the squamo-oceipital. The protulrerance and crest give attachment to the ligamentum nueha.

Each lateral half of the supra-oecipital presents three pairs of transwerser ridges, the nuchal lines. Of these the superior is usually the least conspicuous, but most curved; frequently it is alsent; begimning at the extemal oceipital protuherance, it curves outwards to the lateral angle. It affords attachment to the epicranial aponeurosis and to few fibres of the occipito-fiontulis muscle.

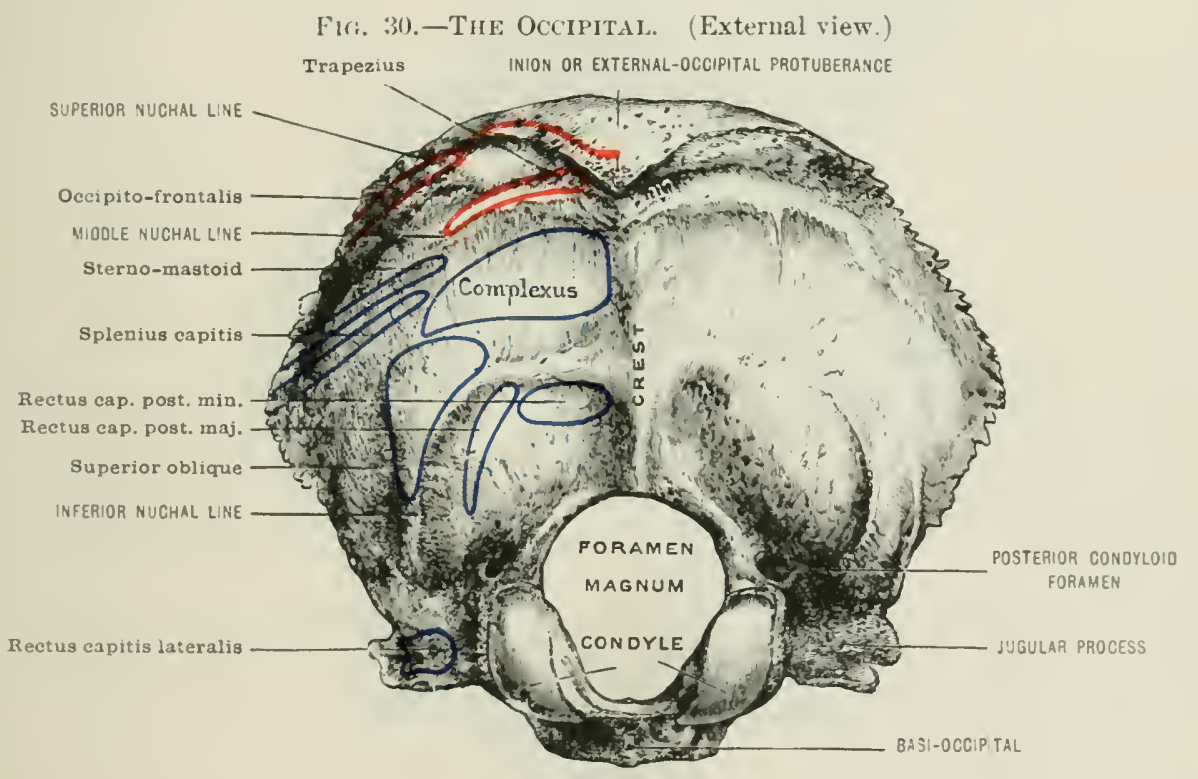

The middle nuchal line (sometimes called the superior curverl line) commences a little distance below the putuberance, and curves outwats to end helow the lateral angle. In some cases the superior and middle nuchal lines are confluent in their outer thirds, and form a prominent ridge for the insertion of the sternomastrid and splenius cupitis muscles. When these muscles are well developed. there is a fairly wide interval between the lines.

The inferior nuchal line begins near the middle of the crest and curves dermwards to the jugular juress.

Of the spares cleliminated hy these lines, that hetween the superior and midull.

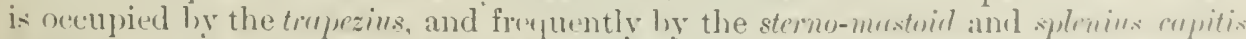

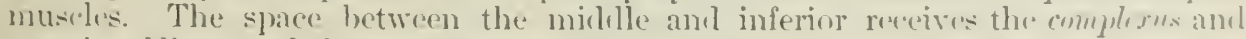
sinferior oblique, and the space between the inforior line and the foramen manum

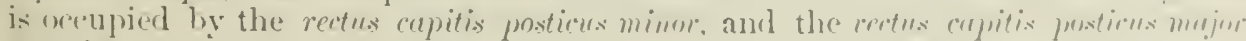
musters.

The cerebral surface is deeply concare, and livillexl by crucial ridges into

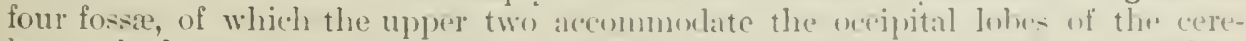
brum, the lower pair the cerehellar hemispheres. The rielere intrinet one another, and at the point where they "ros, an whineme, the internal occipital protuber- 


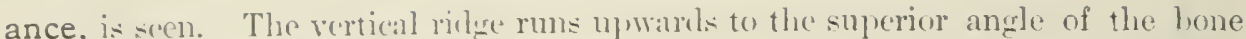
and furmishes attarlnment for the falx cerelur; the portion of the ridge below the

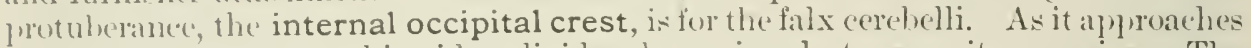
the folanneln magnum this ridge divides, hecoming lost upon its mangins. The

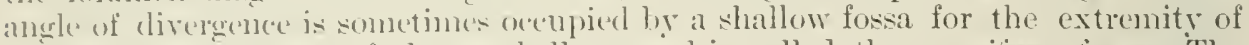
the vermifurm process of the cerelullum, and is called the remitom fossa. The

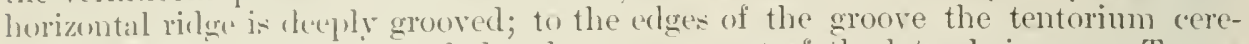
lulli is attarlhert: the glowes lodge the groater part of the lateral sinuses. To one side of the iutermal aceipital protuberance. usually the right, the furrow for the sinus is de'prre and frepuently forms a circular fossa which receives the torcular. This fossa is sometimes exactly in the micllle line.

'The squame-exipital has three angles and fowr horlers. The superior angle fits into the space formel ly the union of the two parietals. The lateral angles mark the extrmal limits of the middle nuchal lines, and ocoupy the angle formed hy the parictal and mastoid portion of the potrusal on each side. The ridge

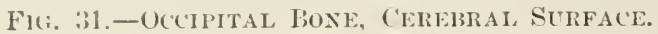

SUPERIOR ANGLE

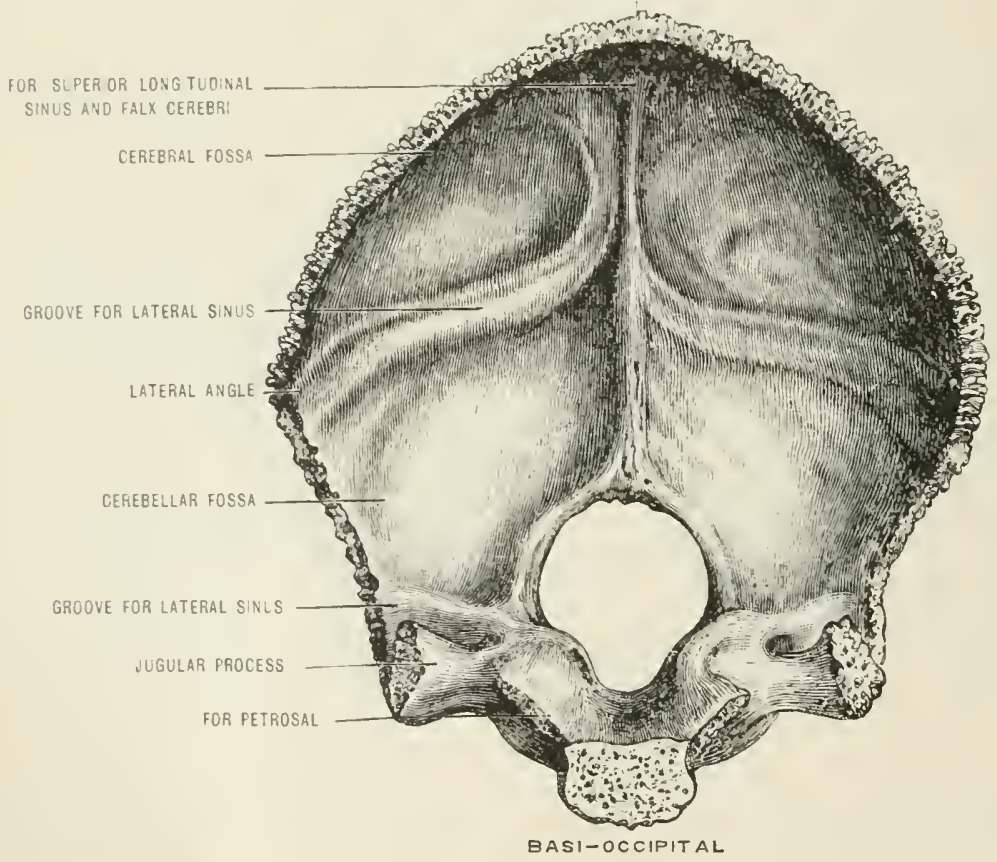

lutween the superior and lateral angles is the superior border; it is serrater lecply, and articulates with the posterior borker of the parietal to form the lamhdoit :uture. The inferior border extends from the lateral angle to the jugular process ; it articulates with the mastoid portion of the petrosil.

The ex-occipitals form the lateral boundaries of the foramen magnum. The lateral surace of calle ex-ocoipital is extencled outwarls to form al quadrilateral huttress of bone, the jugular process. This has an outer rough surface for articulation with the jugular surface of the petrosal. Its anterior border is deeply notrhed to form the posterior bommdary of the jugnlar formmen, and the notch is diroctly continunus with a grone on the mplor surface which lolges the temination of the lateral sinus. Its under surface grves attachmont to the rectus copitis luteralis and

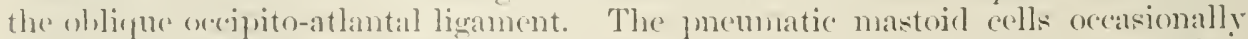

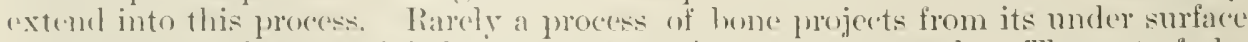

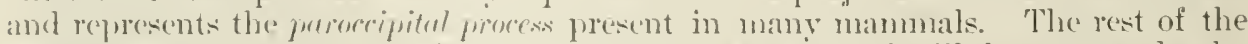
rx-ereipitals enter into the formation of the rondyles, and will le separately descriliecl. 
The basi-occipital is a quadrilateral plate of hone. Its superior surface is concave for the medulla oblongata. Inferiorly it is rough, and presents the. pharyngeal tubercle, to which the median portion of the fibrous bag of the pharyux is attached. In front of the tubercle near the anterior end of the bone there is:

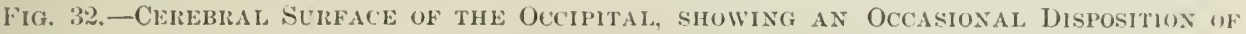
THE CHANNELS.

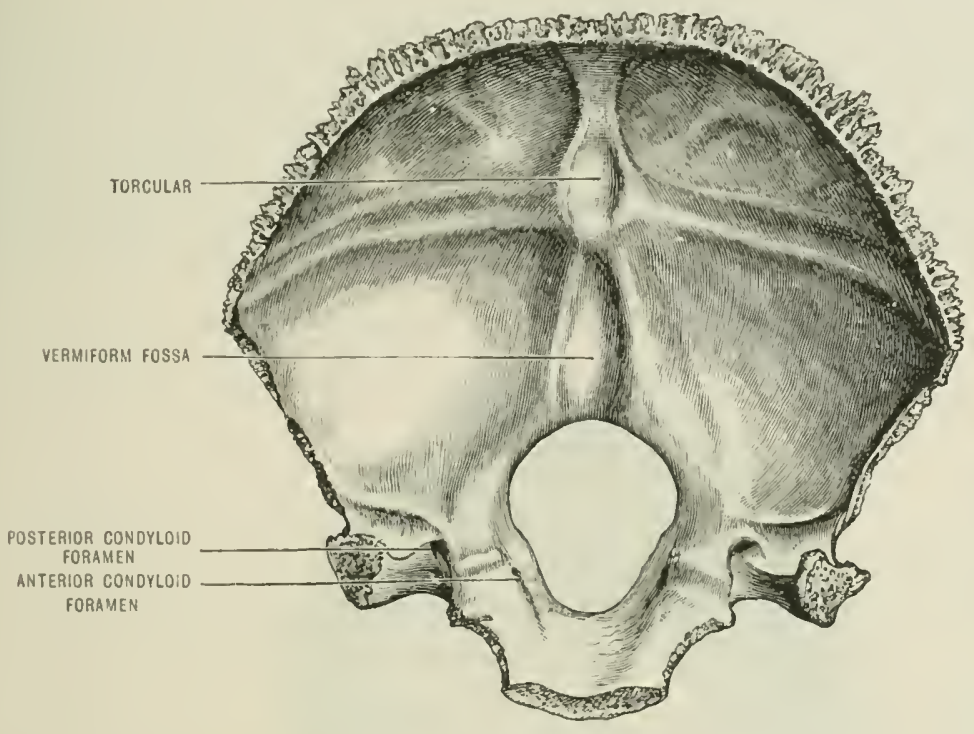

often a shallow fossa, which originally received the primitive anterior extremity of the foregut. The rectus cupitis anticus major and minor muscles are inserted into this surface. Anteriorly the basi-oceipital is, in the adult, ankylosed to the basisphenoid. Postcriorly it has a smooth, rounded, narrow, concave horder forming the anterior boundary of the foramen magnum.

Fig. 33.-Tine Foramen Magnum at the Sixth Year.

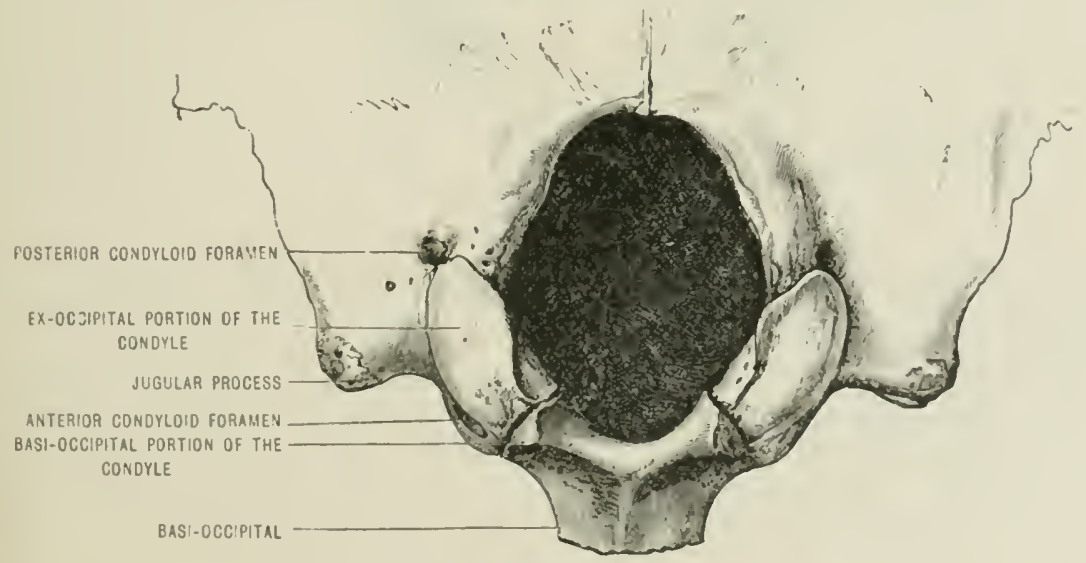

The extrenitiss of this horler enlarere to join the ex-occipitals, and form the anterior extremities of the condrles. The lateral horders are rough below, and artieulate with the inferior borders of the petrosals. Ahove they are eroused for the inferior petrosal sinus.

The foramen magnum is oval in shape, with its major axis in the hong axis of 
the skull. In front of the middle it is encroached mon by the condrles. It is bounded zosteriorly by the suprateceipital, anteriorly by the basi-occipital, and laterally liy the ex-occipitals. Sometimes a facet exists at the anterior margin for articulition with the odontoid process. This is the tertiuny occipital comdyle. The malrgin of the foramen gives attachment behind the condyles to the posterior oceipitoatlantal ligament.

The condyles are two oral processes of hone, with smooth articular surfaces, covered in the recent state with cartilage. They are received into the superior articular cups of the atlas. The condyles converge anteriorly but diverge posteriorly. Their margins give attachment to capsular ligaments, and a prominent tubercle in the middle of the median border of each condyle is for the check ligament. A for:men. the anterior condyloid, traverses the upper part of each condyle; it transmits the hypoglossal nerve, and a twig of the ascending pharyngeal artery with its renæ comites; frequently this foramen is divided by a delicate spicule of bone. l'osterior to each condyle is a depression, the posterior condyloid fossa, which receires

\section{Fig. 34. - The Occipital at Birth. (Anterior view.)}

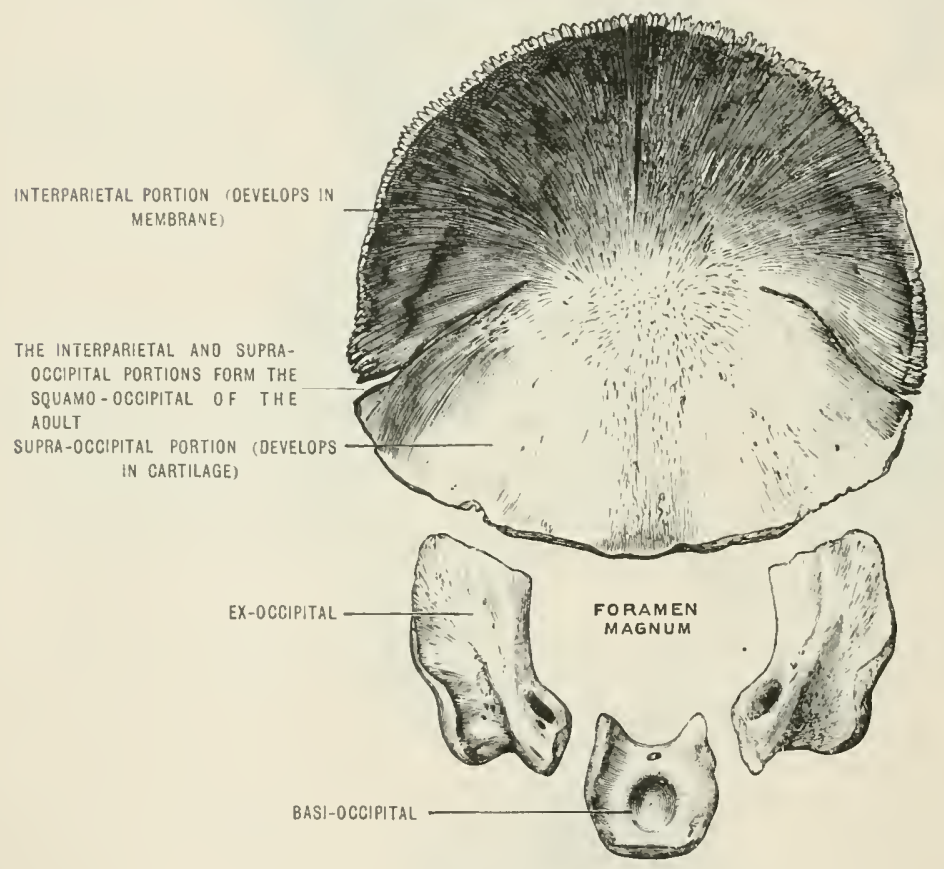

the hinder edge of the articular carity of the atlas when the head is extended; the floor of this depression is occasionally perforated by the posterior condyloid forcumen, which transmits a rein from the lateral sinus.

Articulations. - The occipital bone is connected by suture with the two parictals, the two temporals, and the sphenoid; by means of the condyles it articulates with the atlas; and under the exceptional condition of a tertiary oceipital condyle, with the odontoid process of the axis.

Muscles.-Attached to the accipital bone:-

Oecipito-frontalis.

Trapezius.

Sterno-cleido-mastoid.

Complexus.

Splenius cappitis.

Superior oblique.
Rectus eapitis anticus major.

Rectus capitis anticus minor.

Rectus capitis postieus major.

Rectus caputis posticus minor.

Rectus capitis lateralis.

Azrgos pharygei (when present). 


\section{Ligaments :-}

Ligamentum nuelhax.

(a)sular.

Posterior oceipito-atlantal. Anterior occipito-atlantal. Ohlique occipito-atlantal.
Suspensory ligament.

('heck ligaments.

Vertical slip of the erucial.

Posterior common ligament of spine.

Anterior common limanent of spine.

The fibrous big of the pliaryux.

Blood-supply.-The oecipital bone receives hranches from the occipital, justerior auricular, middle meningeal, vertebral and asconding pharyougal arteries.

Development. - The interparietal portion of the oceipital is a menthane-lone. and arises usually by two and oceasionally by four centres about the twelfth week; these nuclei rapidly become confluent and fuse with the supla-occipital portion about the fifteenth week. Occasionally this fusion fails. The centres for the rest of the bone are deposited in cartilage. The nucleus for the hasi-oceipital appears

Fig. 35.-The Occipital Witi a SEPARATE INTerparietal.

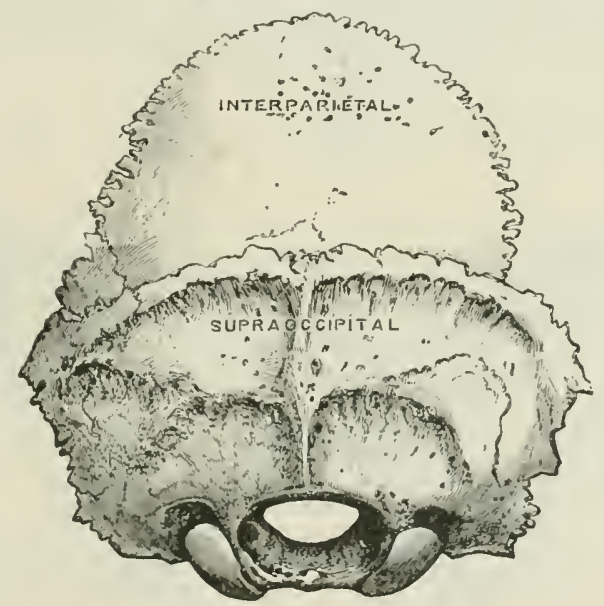

in the tenth week, and is quickly followed hy a nucleus for each cx-ocripital; the supra-occipital ossifics from two laterally disposed nuclei, which quickly coalesee and fuse with the interparietal portion near the situation of the future occipital protulerance. For many weeks two deep lateral fissures separate the interparietal and supra-oceipital portions, and a memhranous space, extending from the centre of the sfuamo-oceipital to the foramen magnum, partially separates the latiral portions of the supra-oceipital. This space becomes occupied by a spicule of bone. and is of interest, because through it hemia of the brain and its nembinner. known as ocribital meningocele or eneephalocele, oceurs.

At lirth the occipital consists of four parts: the squamo-occipital, two ex-oceripitals, and the basi-occipital, united by strips of cartilage. The ex-orecipitals and syuamo-oceipital fuse together about the fifth year, and unite with the basi-occipital before the serenth year. The posterior two-thirds of each ocripital condyle belongr: to the ex-oweipitals, and the anterior third to the hasi-occipital (fig. 38 ).

Not infrequently the interparictal portion remains separate throughut life, and may even be represented by numerous detahed osiclese or Wormian hunes. By the twonty-fifth year the bisi-oceipital is firmly ankylosed to the sphenoid.

\section{THE SPHENOID}

The sphenoid forms a large part of the hase of the skiull in the reerion of the anterior and middle fosse. It is very irregular in shape, and is lust descrilnd as consisting of a hody, two pairs of wings, and two pairs of proceseres. 
The body is irregularly cuboidal in shape. The superior surface presents the following points for cxamination, In front, there is a prominont spine, which is received between the diverging alae of the crista galli. and is knom as the ethmoidal spine. The surface lehind this is smonth, and is formed he extensions of the lesser or orbital wings; it frequently presents two parallel longitudinal groures for the olfictory lublbs. This smootli surface is teminated ly a rilge, the limbus, behinel which is the optic groove loclying the optie eliasma, and leats on anch side into the optic foramen. The grome is bounded posteriorly by the olivary eminence, a ridge of home indicating the line of mion of the pre-and post-sphenoid. Behind this ridge the hone presents a deep hollow, the pituitary fossa, in which the pituitary body is lodged. "The floor of this fossa presents numerous formuna for hood-resecls, and at birth the superior orifice of a narrow passage termed the cranio-pharyngeal canal. The pituitary fossa presents on each side, slightly posterior to the olivary eminence, a tubercle of variable size, the middle clinoid process. This is oceasionally prolonged to meet the anterior clinoid process on the orlital wing. The justerior bomdary is formed by a yuadrilateral plate of bone, the dorsum ephippii. The superior angles of this plate are sumominted hy the posterior clinoid processes, which give attachment to the tentorium cerphelli. A little below the clinoid process, on each side of the: dorsum ephippii, there is a deep notch, converted into a foramen by the dura

Fic: 36.-The Sphexom. (Tiewed from ahove.)

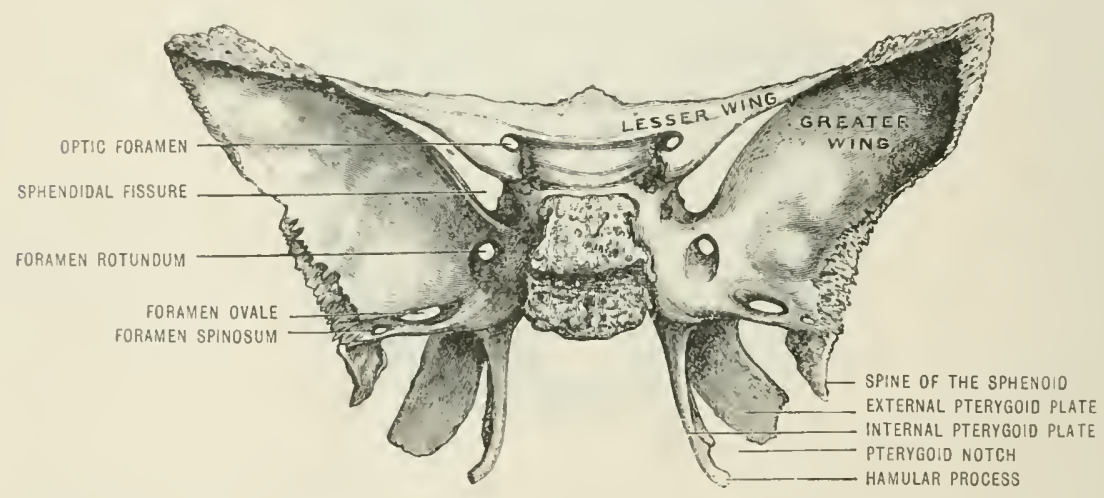

mater, for the passage of the sixth cranial nerve. The dorsum is slightly concare proterimly, and supports the basilar artery and the pons.

The inferior surface of the body has a prominent median ridge, the rostrum, which is received between the alw of the romer. The rest of the surface is rough, and covered hy the mucous membrane belonging to the roof of the pharrmx.

The anterior surface presents in the middle line a rertical ridge of bone, the sphenoidal crest, which articulates with the perpenclicular plate of the ethmoid. On each sicle of the arest is a groove which forms prart of the roof of the nose; it is bounderl externally hy a more or less cireular orifice which leads into the sphenoidal sinuses. Still more externaly is a rough area for articulation with the lateral mass of the ethmoid. These sinuses are irregularly shaped, uns rmmetrical eavitics, separated from one another by a thin rertical septum; in adult bones they may extend into the roots of the pteryoid processes, and cren into the hase of the oecipital lone. The sinuses emmmunieate with the nasal fossa of their respective sicles. The lateral margins of the anterior surface are serraterl forr articulation with the posterion border of the os planum on each side of the ethmoid. The sujerior matrin articulates with the cribriform plate of the ethmoirl.

The posterior surface or basi-sphenoid is, in the adult, ankylosed to the basi-

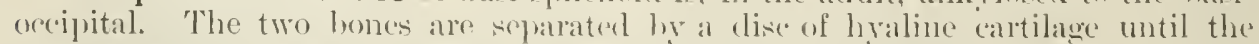
righteenth year; hy the twenty-fifth real ankylosis is complote.

The lateral surface enters into the formation of the posterior part of the imer 
wall of the orbit; it forms the inner boundary of the splhenoirlal fissure, and mores posteriorly is growed for the internal carotid artery and earernous sinus.

The process of bone orer which this artery tums is the lingula ; it comstitutes a Hyiner buttress for the support of the grater wings.

The lesser or orbital wings (orlito-sphemoicls) are thin, triangular, horizontal plates of bone resting 11 mon that portion of the sphenoid anterior to the oliviry ridge (pre-splenoid). The stuperior surface of aleh wing is smooth and slightly

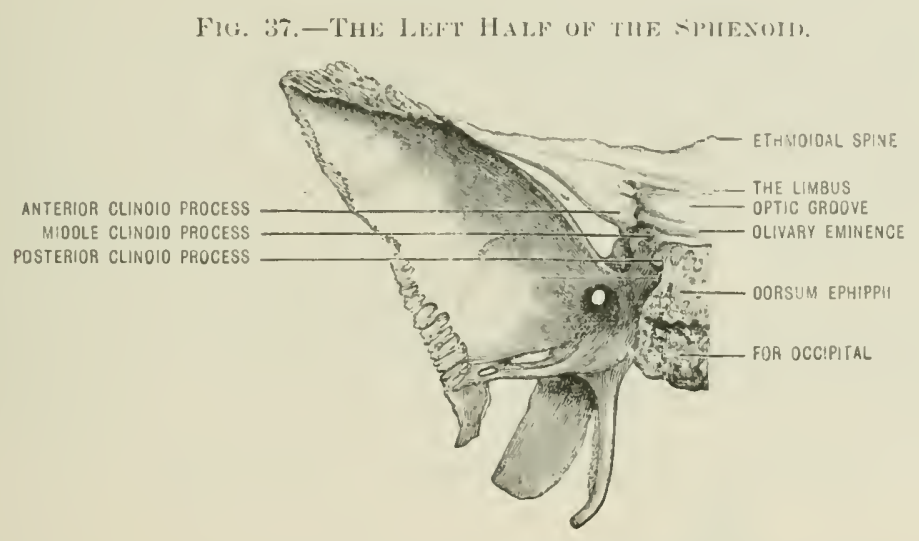

concave, and forms the posterior part of the anterior fossa of the skull; the under surfaces constitute a portion of the roof of ach orbit, and hound superiorly the sphenoidal fissures. The anterior border is irrated for articulation with the horizontal plate of the frontal bone. The posterior border, smooth and romelesl, is received into the sylvian fissure of the cerebrum. The inner extremity is prolongerl to form the anterior clinoid process to which the tentorium cerohelli is attached. Eich lesser wing is comnected to the borly of the bone by two procestes

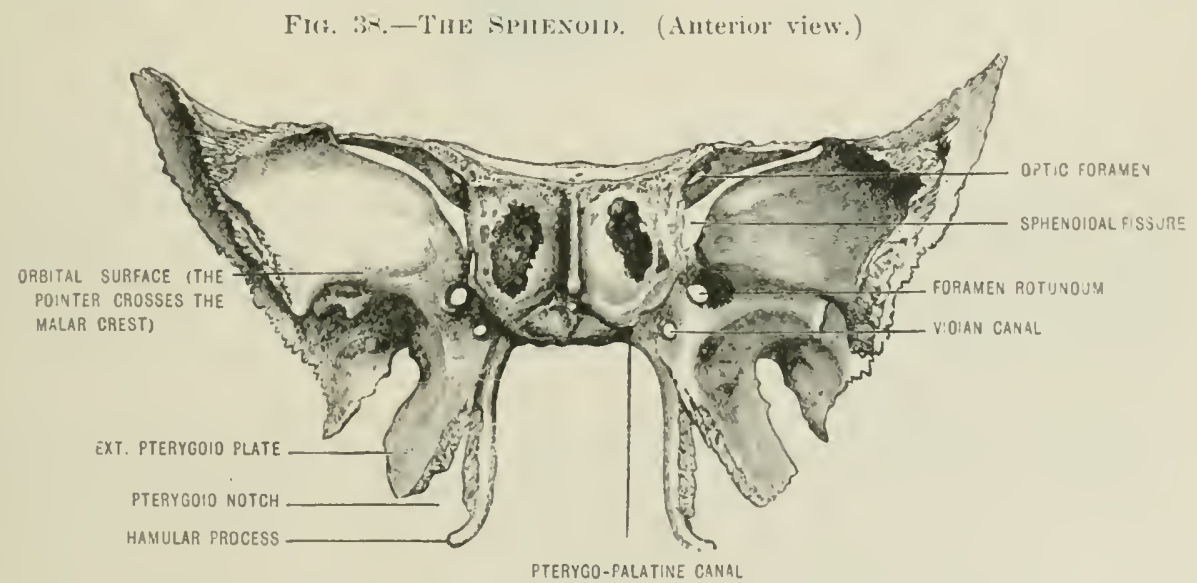

or roots; of these, the upper is thin and Hat, the lowrer one is thieker, and prenents near its junction with the body a small tuberede for the attaclument of the commen trimbon of three ocular muscles. The opening betwern the routs is the optic foramen, and transunits the optic nerve and opluthalnue artery.

The greater wings (ali-sphemoids) are two large platws of home ank losed to the lyuly by means of the lingula. Farh wing has three surfaces. The sujuriter or

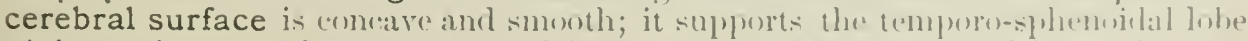
of the cerehrum, and presents several foranina. At the anterior and internal part is 
the foramen rotundum for the second division of the fifth nerve; behind and "xternal to this is the foramen ovale, for the motor root and the third division of the fifth nerve, the small petrosal nerve, the small meningeal artery, and an emissary voin from the arepnous sinus. Behind and external to the formmen orale is the small cireulin foramen spinosum, for the miclelle meningeal artery, its renre comites, and the recurrent branch of the third division of the fifth nerve. To the immer side of the foramen ovale a small opening, the foramen Vesalii, is oceasionally present; it transmits a vein. A foramen may exist near the foramen ovale for the sullll superficial petrosal nerve, the eanaliculus innominatus. The external surface is divided by the prominent malar crest into an orbital and a temporozrenmatic jortion. The orbital surface forms the chief part of the outer wall if the orbit; its internal secment forms part of the spheno-maxillary fossa, and presents the anterior orifice of the foramen rotundum. Near the middle of the upper border there is a small tuberele for the origin of the outer head of the oxternal rectus muscle: and at the highest part of this surface one or more foramina are often present, for the transmission of twigs from the middle meningeal artery to the orbit ancl the lachrymal gland. The malar crest is serrated for articulation with the malar bone; its lower angle, in many bones, articulates with the maxilla. A foramen exists in the suture between the sphenoid and malar, for the temporal twig of the orbital nerve. The surface of bone outside this ridge is subdivided by a low

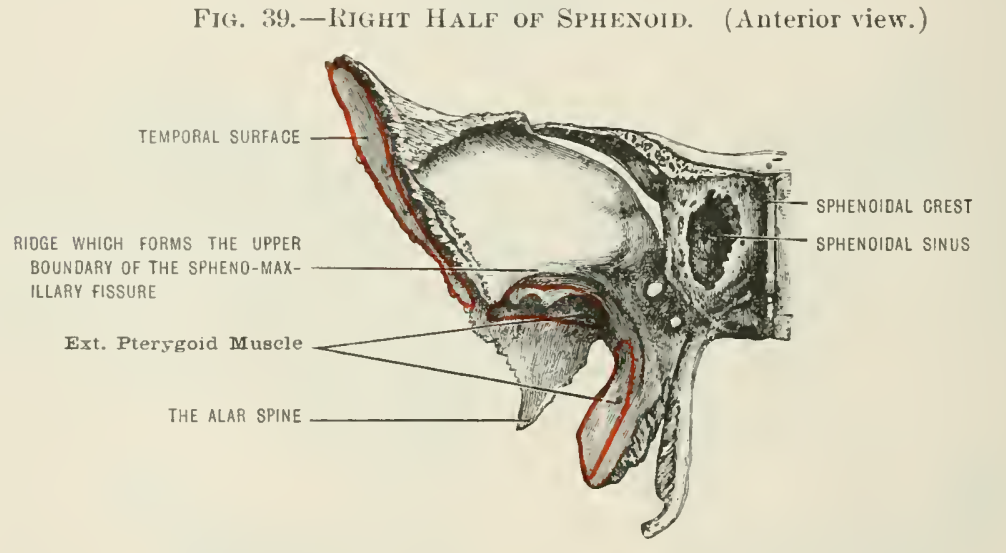

(rest, the pterygoid ridge. The surface above the ridge forms part of the temporal fossa, and affords attachment to the temporal muscle; the part below the erest belongs to the zyomatic fossa; it furnishes attachment to the external pterygoid muscle, and is continuous with the outer surface of the external pterygoid plate; it contains the inferion orifices of the foramina spinosum, ovale, and Vesalii, and forms part of the roof of the zyomatic fossa.

The circumference of the great wing, commencing at its anterior attachment to the body, is at first smonth, and forms the lower beundary of the sphenoidal fissure ; this sirves for the pastage of the third, fourth, tirst division (ophthalmic) of the fifth, and the sixth nerves, with the ophthalnie: vein. External to this, the margin is broad and serrated for the frontal bone; quite at the tip it is bevelled on its inner aspect for the anterior inferior angle of the parietal; behind this, the ectere, at first thin and bevelled, becomes gradually broader, and deeply serrated for the squamosal, and runs into the prominent alar spine of the sphenoid, to which the spheno-mandibular ligament is attached and which is groover internally lyy the chorda tympani nerve. That portion of the circumference extending from the spine to the borly of the sphenoid articulates by the outer third with the petrosal, but the inner two-thirds forms the anterior boundary of the foramen lacerum medium, and contains the posterior orifice of the Vidian canal.

Projecting at right angles from the greater wing, near its junction with the lingula, are the pterygoid processes. Of these, the external plate, broad and 
thin, forms by its outer surface the inner wall of the zyonomatic fos:al, and affords attachnent to the external pterygoid musche. From its inner surtane the internal pteryegoid takes origin.

'The internal pterygoid plate is narrowere and longere than the external. Its inner surface forms part of the outer houndary of the wasal fossal, and hy a thin ledge of hone, called the vaginal process, extends to the under surfaler of the hatssphenoid to articulate with the ala of the vomer, and anteriorly with the sphenoilat precess of the palate bone. Immediatcly ahore this lectere of lome is the pterygopalatine groove (converted inte a eanal by the spluenofidal process of the palate lume $)$ for an artery and nerve of the same name. At the point where the internal fterygoid plate comes inte relation with the great wing and the lingula, there is the Vidian canal. This canal is 3 cm. long, and transmits the Vidian nerve ant artery. The outer surfice of the internal pitereroid plate forms the inmer boundary of the pterygoid fossa ; its pusterior border is prolongerl into a hamular process, smooth on its moler asject, for the lumsa betwo's it and the tewsor (circumflexus) pulati. From the lower third of the posterior border and the hamular process the superior constrictor of the pharyx takes origin.

The anterior borler's of these promesses cliverge below, and have rough odges for artienlation with the tulwersity of the palate bone; the gap leetween them is the pterygoid notch. Superiorly, the pterygoid processes form a triangular surface. which constitutes the posterion boundary of the sphemo-maxillary fosia, and presents: alove the anterion orifice of the Vidian, and more intermally the (ommenencenent of

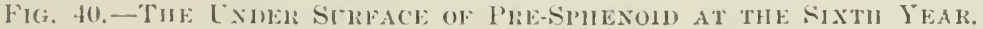

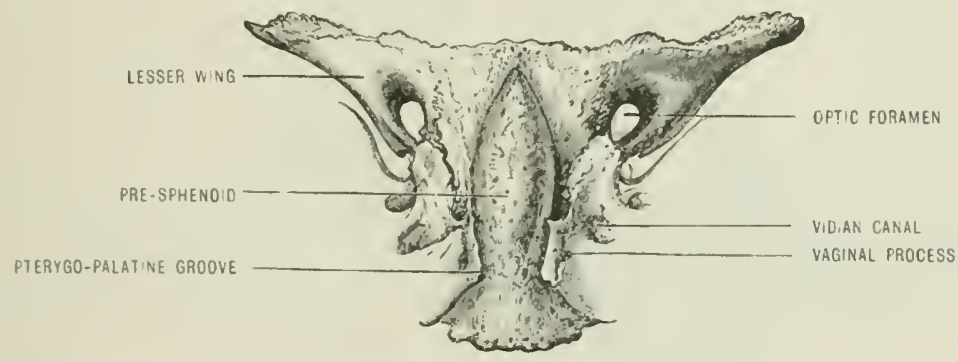

the pterygo-palatine eanal. The anterior horder of the intemal pterrogoid plate articulates with the posterior lincler of the vertical plate of the palate home.

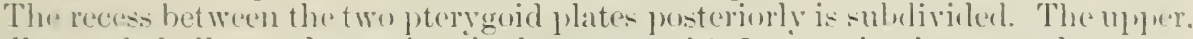
sualler and shallower depression is the scaphoid fossa; it wives attalnuentit to the tensin (circumflexus) puldti externally, and the eartilage of the Eustachian tube internally. The lower, derefer and larger, is the pterygoid fossa; it lonlger the

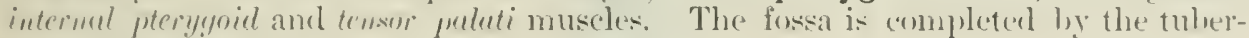
wity of the palate hone.

Articulations. -The sphenoirl articulates with the following lomes: ethmoril,

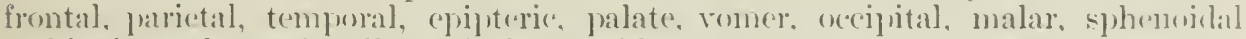
turlinals, and ocasiomally with the maxilla.

Muscles. - It gives origin to the following musde:-

Temporal.

Intermal potervereicl.

Extrmal pteryoid.

Temsor trmpanis.

Temsor jalati.
External rectus of the erohall.

Internal rectus ".

superior rectus “

simprerior oblique ".

Laviator" palpulure.

Ligaments.-The sphenoid has numerous intrinsic liganents which oecasionally osify and produce adventition- foramina. (If these, the more innertant are:-

Inter-clinoid. -This pasies from the anterion to the pusterior alimend procenses. 
Carotion-elimend. From the anterion to the midelle clinoid process. The ossification of this liganent gives rise to a ring of bene through which the intemal carotill artery pisiscis.

I'teryga-xpinom.-This is attached to the spine of the sphenoid and the extermal pteryoid plite near the upper third.

Sereral other insigniticant hamds have received names, but they are of no importince.

Blood-supply.-The sthenoid is suppliert hy branches of the middle and small meningeal arteries; also the anterior deetr temporal and other brandhes of the in-

Fili, H1.-THE sphexom at likth.

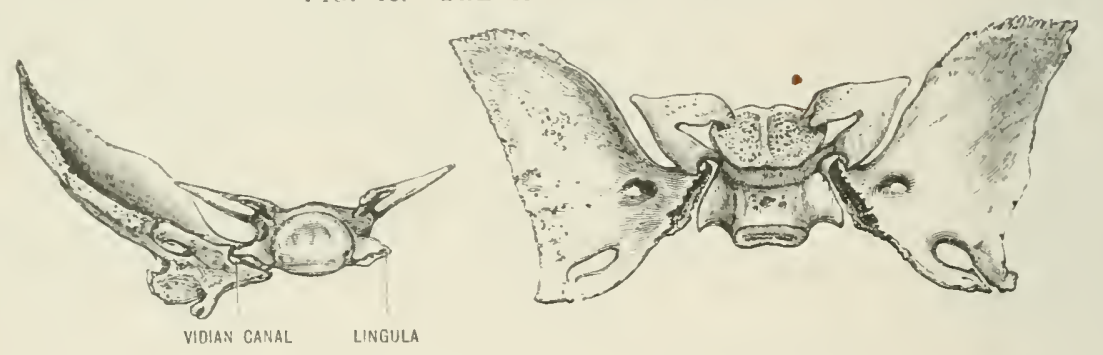

ternal maxillary, such as the Vidian, pteryo-palatine and spheno-palatine. The body of the bone also receives twigs from the internal carotid.

Ossification.-The sphenoid is ossified in cartilage from twelve ossific nuclei which appear in pairs. The nuclei are divisible into two sets, - those for the prosphenoid, and those for the post-sphenoid.

The post-sphenoid centres consist of four pairs disposed as follows:-One for each ali-sphenoid (great wing). A pair of median nuclei for the basi-sphenoid, and a nucleus for each lingula (sphenotic nucleus), and one for each intermal pterygoid. The external pterygoid is an outgrowth from the great wing.

The pre-sphenoid centres consist of a nuelens for each orbito-sphenoid (lesser wings), and a median pair for the body of the pre-sphenoid. These nuclei appear

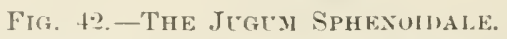

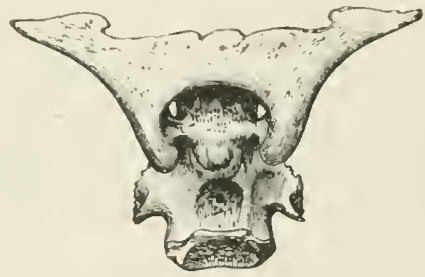

at intervals from the righth week to the end of the thind month in the following order: ali-sphenoid, hisi-sphnoid, lingular, internal ptergoids, orhito-sphenoid, and pre-splienoisl. The various earthy spots fuse together, so as to form at birth three pieces. The modian piece comsists of the basi-sphenoid and lingule. ennjoined with the pre-sphenoid arrying the orbito-sphenoids; the two lateral piness are the ali-sphenoids (wreater wings) carrying the intemal pteryogid plates. The greater wings are joinel to the lingula by cartilage. The dorsmu ephiphii is calltilaginous at hirth. In the course of the first vear the orhito-sphenoids fuse in the midrle line to form the jugum sphenoidale, which exchules the anterior part of the pre-sphenoil from the cranial cavity. The greater wings fuse with the lingulat in the course of the first yeir. 


\section{THE TEMIPR.IL, BONE}

The adult temporal bone consists of three parts, so firmly united as to afforel little traee of its complex origin. At lirth the three parts are asily separable ats thr' squamosal, petrosal, and tympanic.

The squamosal resembles a lirge seale; it is attacherl at right angles to thr. petrosil, anel forms part of the side wall of the skull. It is thin, and in planes transluerent. The outer surface is smooth and forms part of the temporal forsia it presents one, and oceatsionally two nearly rertical grooves for the deep temporal arteris. 1 rirlge of bone, the supra-mastoid crest, runs immoriately ahore the external auditory meatus, and is continued onwards to the zromoma.

The zygoma is a narrow projecting bar of bone. jutting forwards and lying parallel with the sefumusal. It has two surfaces and two horrlers. The outer surfare is sulucutaneous; the inner looks towards the temporal forsia. The inner surface and lower loorder give origin to the masseter muscle. The upler border receives the temporal fascia. The tip of the zyoma is serrated for articulation with the malar. Posteriorly, the lower border ends in a tubercle, which is the menting joint of two rilges; of these, the anterior lasses inwark at right anglus to the zygoma, and expands into the articular eminence which serres as an

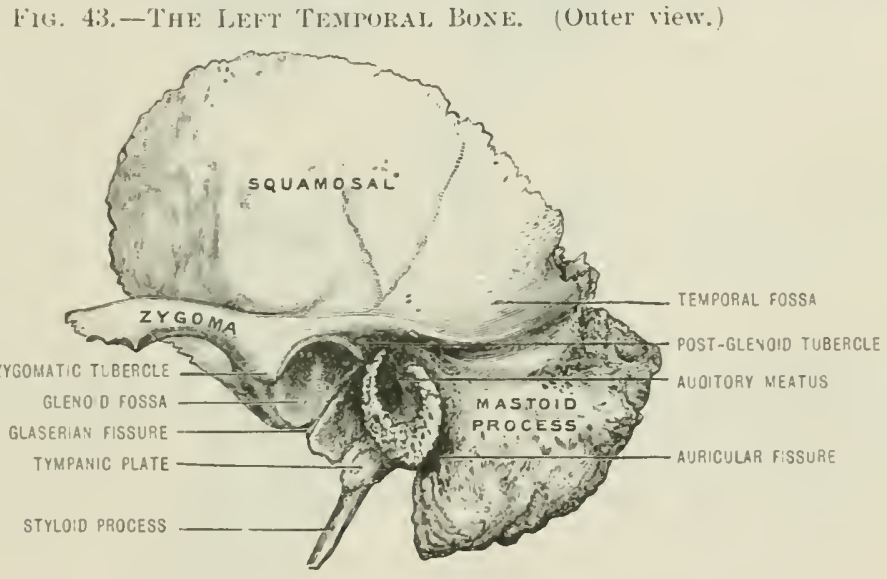

articular facet for the condyle of the mandible when the mouth is opener. The second ridge runs hackwards and forms the upper boundary of the glonoid forsia, and curving lownwards ends in a tuhercle, the post-glenoid tubercle, immerliatrly. antrior to the Glaserian fissure. The oval deep depresion hetween these riclges: is the glenoid fossa, which recuives the condyle of the manlible. This forsil is limited posteriorly by the Glaserian tissure.

The inner surface of the stuamosal presents furrows for the consolutions of the hrain and groves for the middle meningeal arteries. The line of union hetwen thespulmosal and petrosal is sometimes inclieated hy a persistent petro-squamosal suture. Rarely the two portions remain permanently separate.

The superior horler of the squamosal is thin, and bevelled on the corethal surface where it overlaps the parietal: anteriorly it is serrated for the postorior loreler of the erreater wing of the sphonoid. Posteriorly it joins the rough sorraterl margin of the petrosil to form the parietal noteh.

The petrosal element is a four-siled pramid of rery dense lone; it: base is formen by the mastoid process; the apex is mold and forms part of the loumelary of the formene lacerum medium. Two sides of the pramid projeet inter the eranial eavity, of which one forms the posterior loundary of the miklle fossa, and the other the anterior houndary of the posterior fossa of the cranim. of the two remaining surfices, one aplears on the under surface of the skull, and the fourth constitutes the inner wall of the recess called the trmplanum. 
The posterior surface is hounded ahove ly the superior lorder, which serves for the attachnent of the tentorium cerebelli, and is grooved for the superior fetrosal sinte; near the aljex, this border presents the trigeminal notch (converted into a foramen be the tentorimm) for the transmission of the trigeminal nerve. This moler in whi skulls sometimes terminates in a spiculum of hone-the petro-sphenoidal process-and extends to the dorsum ephippii, and completes a formmen (petro-sphenoidal) which transmits the sixtl nerve. Near the middle of the pesterior surfice is an oblique inlet, the internal auditory meatus, which receives

Fig. 44.-Tine Left TEMPORAL Bone. (Inner view.)

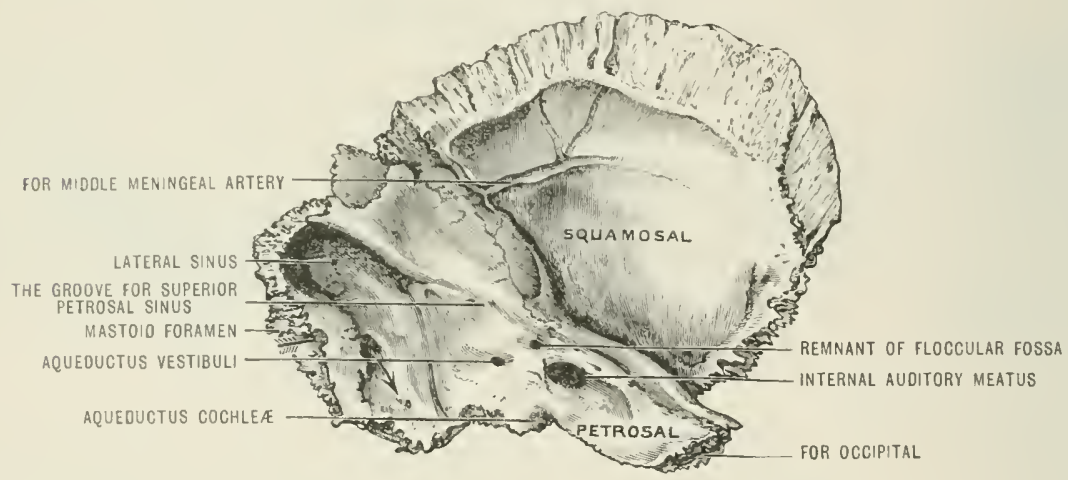

the auditory and facial nerves and the auditory artery. The meatus is about 10 mm. deep, and to be properly eximined the surface of the bone should he cut away, or the parts studied in the petrosal of a foetus at or near the ninth month, for it is at this date relatively large and shallow.

The fundus of the meatus is divided by a transverse ridge of bone, the fulciform crest, into a superior and inferior fossi. Of these, the superior is the smaller, and presents anteriorly the beginning of the aqueduct of Fallopius; this transmits the seventh nerve. The rest of the surfice above the crest is dotted with small foramina (the superior cribriform area) which transmit nerve-twigs to the fovea hemielliptica and the ampulla of the superior and external semicircular (anals. Below the crest there are two clepressions and an opening. Of these, an anterior eurled

Fig. 45. - Tile Foranina in tile Fundes of the Left internal Auntory Meates of a Cinld At Birti $\left(\frac{4}{1}\right)$. (Diagrammatic.)

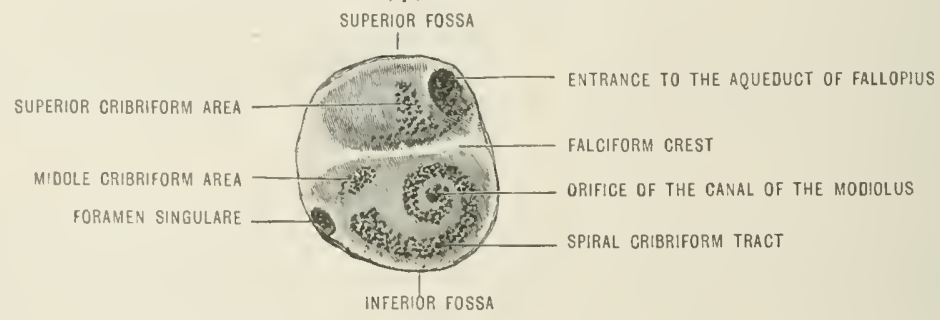

tract (the spinal eribriform tract) with a centril formen (foramen centrale cochleare) marks the base of the cuchlea; the central foramen indicates the orifice of the camal of the modiohus, and the smaller formina transmit the cochlear twigs of the anditory nerve. The posterior opening (formen singulare) is for the nerve to the ampulla of the posterior semicircular anal. The middle depression (midille cribriform area) is dotted with minute foramina for the uerve-twigs to the saecule, which is lodged in the fovea hemispherica. The inferior fussa is subdividerl by a low vertienl erest. The fossa in front of the erest is the fossula cochlereris, and the recess behind it is the fossula vestibularis.

Behind the meatus is a small slit (aqueductus vestibuli) which lorges the ductus endolymphaticus; in the adult it is oceupied by a small arteriole and venule 
and a process of dura mater. Oerasionally a bristle ran he pasered along this passage into the vestilule. Ahore, and antrior to this, is a second slit also loulging a process of the rlura mater. This is a remmant of the floccular fossa, so (monspicuwus in the fortus. Posteriorly, this surface has a cleep groove for the lateral sinus.

The anterior face of the pyramid is separated from the squamosil by the petro-squamous suture, which may persist throughout life. It presents the following points of interest: near the apex it has a shallow depression for the Gasserian ganglion, and thr recest of clura nuter (Meckel's cave) in which it lies. Behind these are two small foramina, overshadowed by a thin oseous lip. (of these, the larerer and more internal is the hiatus Fallopii, which tramsmits a sulall artery from the middle meningeal and the greater petrosal nerve. The smaller and cexternal foramen is for the lesser petrosal nerve. Still more externally there is a thin translucent plate of - wone, the tegmen tympani. Behind, and slightly internal to this, there is a ridge formed by the superior semicircular canal.

The inferior or basilar surface is very irregular, and has the following points of interest. At the apex is a quadrilateral smooth space for the tensor tympremi and levator paluti muscles. Behind this is the large circular orifice of the carotid canal, for the transmission of the earotid artery and a plexus of sympathetic nerves. Internal to this, near the inner border of the bone, is the orifice of the aqueductus cochleæ (duretus perilymphatieus). In the arlult it transmits a small vein from

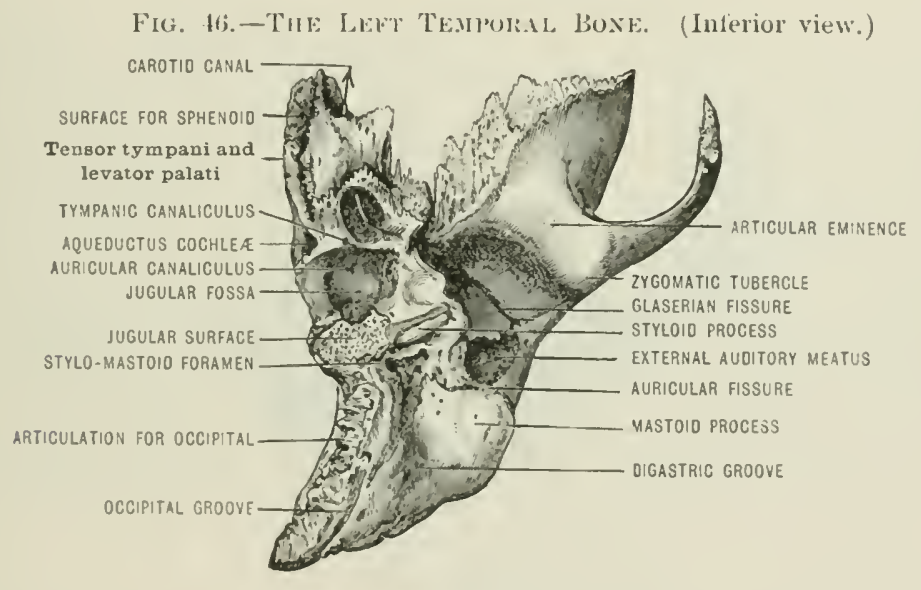

the enchlea to the internal jugular. Posteriorly is the elliptical jugular fossa with smoxth walls: for the ampulla which receives the lateral and inferior petrosal sinuses. and forms the commonement of the internal jugular vein. In the ridge of lome hetwern the fossa and the carotid rana! there is a small forancen, the tympanic canaliculus, for the trmpanic manch of the glosiso-pharyogeal nerve. On the wuter wall of the fossal a similar minute foranen, the auricular canaliculus, per-

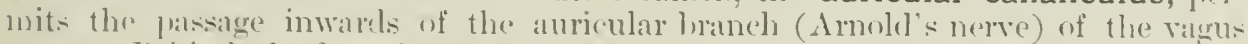
nerve. Behinel the fossa is the rough jugular surface, which revives the jugular flueres of the oceipital. Fimbly ankylosed to the inner surface of the tympanic plate is the styloid process, varying in length from one to five "all. It its laise" is the stylo-mastoid formmen, from which issues the facial norve: the strlomastoil artery (nters the Fallopian canal through this npening. Running biakwatrls from this formusen are two groures; the outer is the digastric groove,

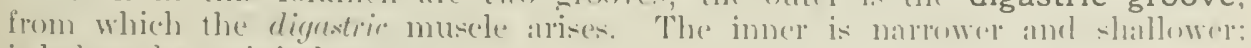
it lowleres the oxeripital artery.

Of the outer surface, the mly palt which aplears externally is the mastricl

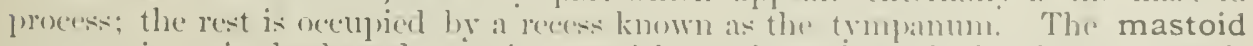

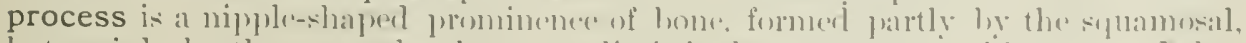

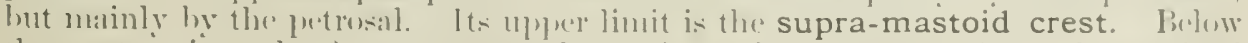

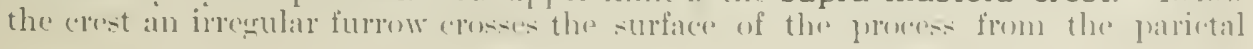


notch downwarls, to the midelle of the meatus. This furrow (squamo-mastoid) is often dottey with heles. and represents the line of uniom of squamosal and petrosil.

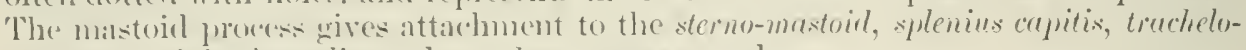
mustrid, erecipito-fiontulix, and retrahens antem museles.

The tympanum is hidlen ly the tympanir plate, which extends downwarks from the Glaserian fissure to form the vaginal process. Anteriorly it extends forwards and ankyleses with the onter wall of the carotid camal. The Glaserian fiscure sepaliates it from the squamosal. This fissure transmits the tympanic branch of the intemal maxillary artery, and lodges the slender process of the mallens. A narrow subdivision of this fisure, canal of Huguier, is traversed hy the chorcla tympani nerro. The tympanis plate forms the anterior, lower, and pirt of the posterior walls of the external auditory meatus. It is limited posteriorly hy the auricular fissure, through which the auricular twig of the ragus nerve istues.

The external auditory meatus assumes the form of an elliptical bony tule. Its onter margin is rough and gives attachment to the cartilaginous portion of the finna. Between the posterior edge of the meatus and the mastoid process is the anricular fissure. The tympanic orifice of the meatus is smooth, and presents a

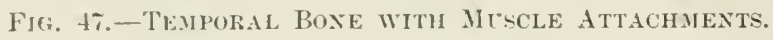

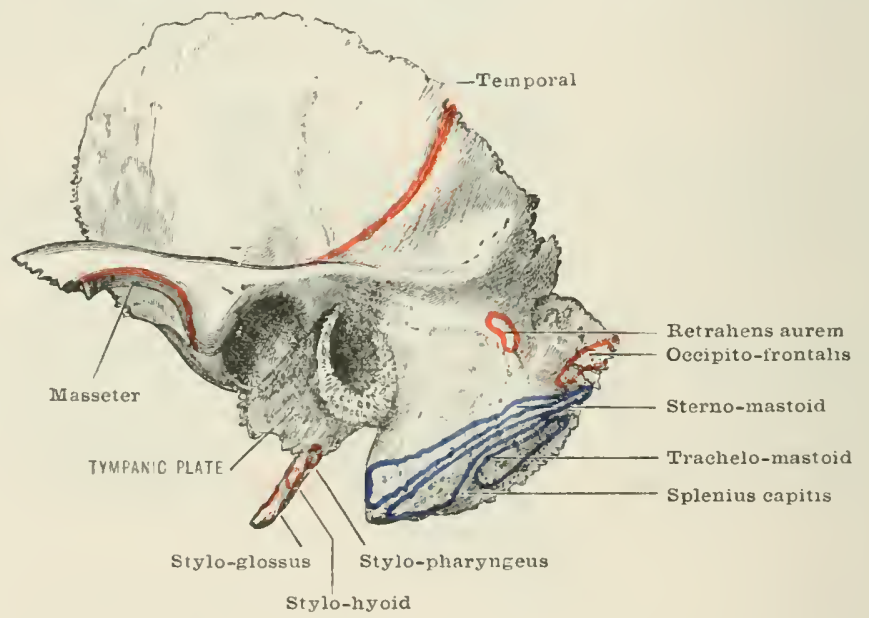

well-marked grone for the tympanic membrane. This is very conspicuons in romug bones. Tho direction of the meatus is somewhat oblique. In chilelren, and ixcasionally in adults, a circular opening exists in the anterior wall of the meatus (tig. ¿is).

Articulations. - The temporal lone articulates with the oceipital, larietal, -phemoirl, matar. aml hy a movahle joint with the manclible. Oecasionally the sfuanosial presents a process which artirulates with the frontal. A frontosquamosal suture is common in the skulls of the lower races of men, and is nomal in the skulls of the ahimpanzee, gorilla, and gihhon.

The muscles ammentinl with the temporal home are:-

'To the mastuid process . 
To the styluid process

To the zyegroma

Intrinsic muscles

Tos the petrosal sitylo-rr]osis.

Stylo-hyoid.

Stylo-pharyngeus.

Masseter.

stapedius.

\{ Tensor tyoulami.

Levator palati.

\section{Ligaments :-}

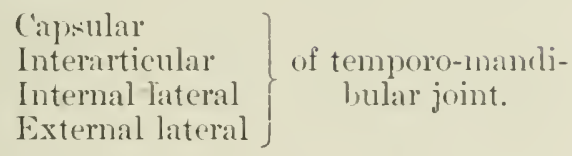

Ligaments comnected with the ear-bones:-
Styla-hyoid.

Stylo-maxillary.

Petro-sphenoidal.

Anterior ligament of mallews.

External ligament of malleus.

Superior ligament of malleus.

Ligament of incus.

The blood-supply.-Arteries supplying the temporal bone are lerived from various sources. The chief are:-

Strlo-mastoid from posterior auricular: it enters the stylo-mastoid foramen.

Tympanic from internal maxillary: it passes through the Glaserian fissure.

Petrosal from middle meningeal: transmitted by the hiatus Fallopii.

Tympanic from internal carotid whilst in the carotid canal.

Auditory from the basilar: it enters the internal auditory meatus, and is clistriluted to the cochlea and restibule.

Other less important twigs are furnished by the middle meningeal, the meningeal branches of the occipital, and hy the ascending pharyngeal artery. Thr. syuanosal is supplied on its internal surface hy the middle meningeal, and extemally by the branches of the deep temporal from the internal maxillary. $6,6,-68$

Nore. -The description of the Styloid Process and of the Far-bones is giren on pages:

\section{THE TYMIPANLY}

The trmpanum is an irregular cavity in the temoral hone. At lirth it is a reress in the outer wall of the petrosal, partially closed externally by the syuamosal. When the rarious elements of the temporal bone coalesee and the trompanic plate heromes fully developed, then the cavity is completely surmumled hy hony walls. except where it communicates with the extemal auditory meatus.

The roof, or tegmen tympani, is a translucent plate of lome leclonging to the petrosal; it separates the trmpanum from the niddle fossil of the skull. The flome is the plate of bone which forms the rouf of the jugular fossia.

The inner wall is formed by the external surface of the pretrosal lomes and presents the following points for sturly:-In the angle hetwerin it and the roof is a horizontal ridge which extends backwards as far as the posterior wall, and then turns downwards in the angle between the inner and posterior walls. This is the Fallopian canal; it is oreupied by the facial nere (seventh). Nor the rout. Int helow the Fallopian canal, is the fenestra ovalis, which learls inte the restilumle: this fencstra receives the base of the stapes. Below and in front of the fenestrat wali: is: the promontory, which contains the commencement of the first turn of the cochlea. In the lowere and posterior part of the promontory is the fenestra rotunda; this, in the recent state, is closed he the secondary inembrane of the trmpanum. In the macerated hone it leads inter the suiral canal of the corelslea. Ther promontory is also furrowed hy some delicate chammels (sometimes (antals) fors 


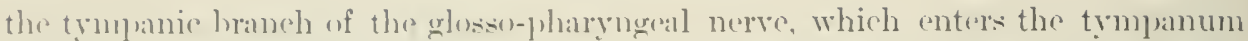
throuth the tympanic canaliculus. "The posterior wall of the trimpanm is formed ley the mastoid process. It the superior amel external angle of this wall an opening leads into the mastoid antrum. Immediately lestow this olening there is a small hollow cone, the posterior pyramid; its eavity is continuous with the

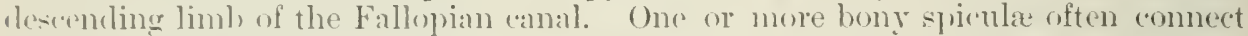
the apex of the pramid with the promentory. The eavity of this cone is oceupied hy the staperlins and the tendon of the muscle emerges at the apex.

The roof and floor converge towards the anterior extremity of the tymunum, which is, in enserpuence, vere namow, and oceupied ly two canals: the lower for the Eustachian tule, the upper for the tonsor tympuni inusele. These grooves are smotimes described together as the canalis musculo-tubarius. In carefully prepared homes the upper (anal is a small horizontal hollow cone (anterior pyranid), 1.2 $11 m$. in length, which loclges the trnsor tympani muscle; the apex is just in front wf the fenestra oralis, and is perforated to permit the passage of the tendon of the musche. As a rule the thin walls of the canal are damaged, and represented merely ly a thin ridere of bone. The posterior portion of this ridge projects into the trmbinum, and is known as the processus cochleariformis. The thin septum fretween the canal for the tensor trmpani and the tube is pierced by a narrow eanal which is traversed by the small deep petrosal nerve. The outer wall is oceupied mainly hy the extemal auditory meatus. This opening is closed in the recent state

\section{Fig. 4\%,-The Ixyel Wall of TyMPAxty.}

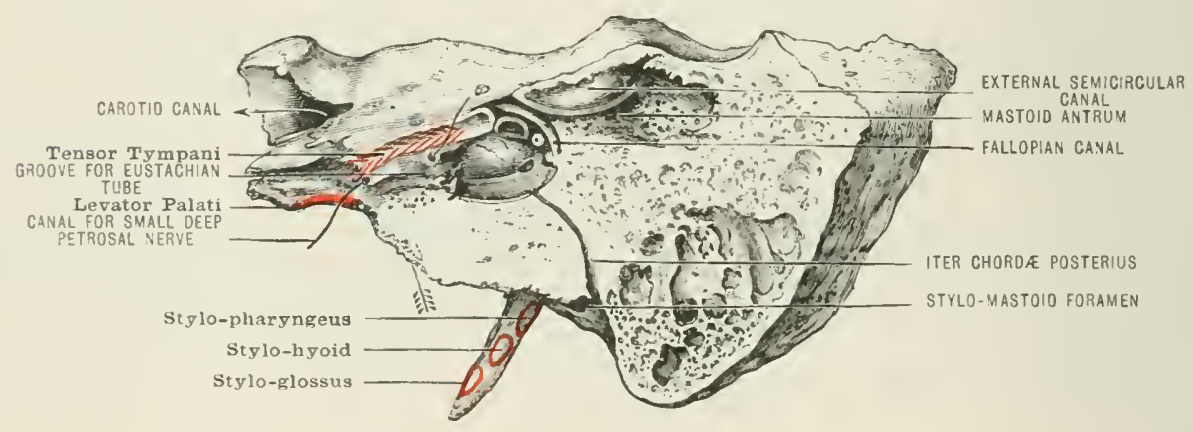

he the trompanie membrane. The rim of hone to which the membrane is attached is inimplete aloove; the defect is kmown as the notch of Rivinus. Interior to this: nestrh, in the angle hetwen the sumamosal and the trmpanic plate, is the Glaserian fissure, and the small pasige which transmits the chorda tympani nerve sometimes: alled the canal of Huguier.

The tympanic eavity may be divisted into these parts. The part below the level

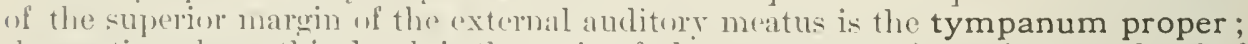
the portion alure this lerel is the attic of the tympanum; it receives the hearl of the mallens. the lumly of the incus, and leats posteriorly into a recess known as the malstoicl antrun.

The mastoid antrum. - This is quite distinet from the mastoid cells. It is an

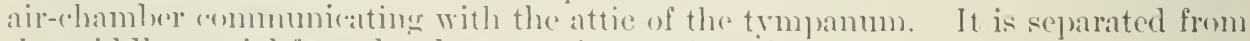

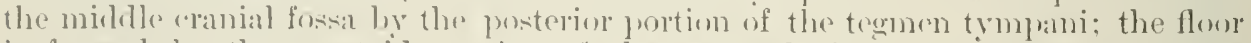
is formed ly the mastoil portion of the petrosil; it communieates with the mastrid cells. The outer wall is fermed ly the seynamesal below the supra-mastoid "rest. In whildren, the outer wall is exoerdingly thin, hut in the ardult it is of con-

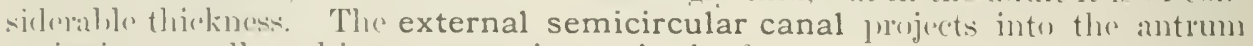

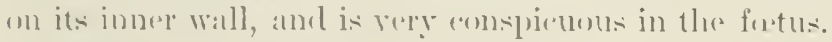

A canal occasionally leats from the mastinil antrum thromgly the petrous bone to open in the recess which indicates the position of the flexeular fiessa; it is temenl the petro-mastoid eamal. (imber.) 
The Fallopian canal.-"This canal begins at the anterior angle of the superior fossa of the internal auditory meatus, and passes direetly outwards to the hiatus Fallopii; it then turns abruptly backwards and forms a horizontal rielge on thes inner wall of the tympanum, lying in the angle between it and the tegmon tympani. It passes immerliately ahove the fenestra oralis, and watends as fill hackwarls as the entrance to the mastoid antrum; here it comes into contact with the inforion aspect of the projection formed hy the external semicircular camal. It then turns vertically downwards, running in the angle between the internal and posterior walls of the trmpanmun to terminate at the stylo-mastoid formen.

The canal is traversed by the fardal (seventh) nerve. Numerons openings exist in the walls of this passige. It the hiatus, the greater and smaller superficial petrosal nerves escape from, and a hranch from the middle moningeal artery enter: the canal. In the vertical part of its course the cavity of the posterior prramis opens into it. There is also a small orifice by which the auricular branch of the vaus joins the facial, and near its temination the iter chorda posterius for th. chorda tympani nerve learls from it into the tympanum.

The vestibule. - This is an oval chamber situated leetween the lase of the internal auditory meatus and the inner wall of the tympanum. with which it communicates by way of the fenestra nvalis. Anteriorly the vestibule leads into the crchlea, and posteriorly it receives the extremities of the senicircular canal-. It measures about $3 \mathrm{~mm}$. transversely, and is somewhat longer antero-posteriorly.

Its inner wall presents at the anterior part a circular depresion, the fovea hemispherica, which is finely perforater for the passage of nerve-twigs. This fovea is sematerl hy a rertical rirlge (the crista vestibuli) from the restihular

Fig. 49.-The Left O-seor's Labyristir. (After Henle. From a cast.

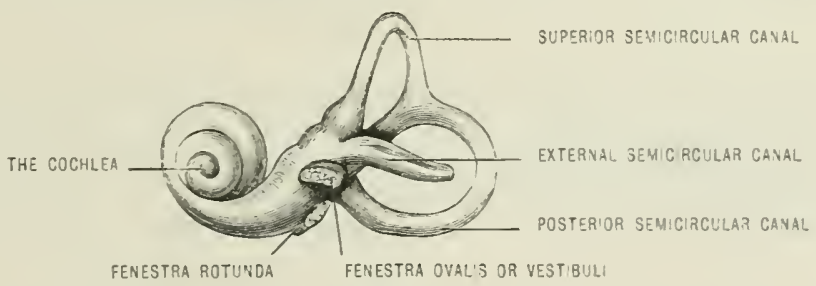

orifice of the aqueductus vestibuli, which passes ohliquely lrackwamls to open on the posterior surface of the petrosal bone.

The roof contains an oval depression-the fovea hemielliptica. Anteriorly the restibule leads into the cochlea. Posteriorly it receives the five openings of the semicircular canals.

The semicircular canals are three in number. Each forms alwut two-thirks of a circle; they lie in different planes. One extremity of each canil is dilaterl to form an ampulla.

The superior canal lies transversely to the long axis of the petrosal, and is: nearly rertical; its highest limb makes a projection on the anterion surfare of the bone. The ampulla is at the outer end; the inner end opens inter the vastibule conjointly with the superior limb of the posterior (anal.

The posterior canal is nearly vertical and lies antero-pustriurly. It is the longest of the three; its upper extremity joins the inner limb of the superior canal, and opens in common with it into the vestilude. The lower is the annpullated encl.

The external canal is placed horizontally and arches outward:; its extrual limb forms a prominene in the mastoid antrum. This eamal is the shortest: its ampulla is at the outer end near the fencstra ovalis.

The cochlea. - This is a cone-shaped cavity lying with its hase mon the internal aurlitory meatus, and the apex directerl outwards. It meisules almut five millimetres in length, and the diancter of it: lase is alonit the same. The centre of this carity is occupied hy a column of from-the modiolus-and which a deliente hony lamella appears to be womml. This lamella is the osseous spiral lamina, 
which erives attachnent to the structures which form collectively the membranous cochlea. The lamina makes two and a half turns in all. The first turn is the largest, and forms a hulging, the promontory, on the inner wall of the trmpanmm. Thr lamina terminates at the apex of the cochlea in a hooklike process-the hamulus.

The modiolus is traversed by a central canal, and presents many canaliculi for the transmission of the twigs of the cochlear division of the auditory nerve. There is also a canal which winds round the modiolus at the base of the spriral lamina, known as the spiral canal of the modiolus.

The portion of the cochlea above the lamina is the scala vestibuli; the part helow, that is, on the basal aspect of the lamina, is the scala tympani; it opens into the tympanum by way of the fenestra rotunda. Near the commencement of the scala tympani, anit close to the fenestra rotunda, is the cochlear orifice of the aqueductus cochleæ (ductus perilymphaticus). In the adult this opens on the

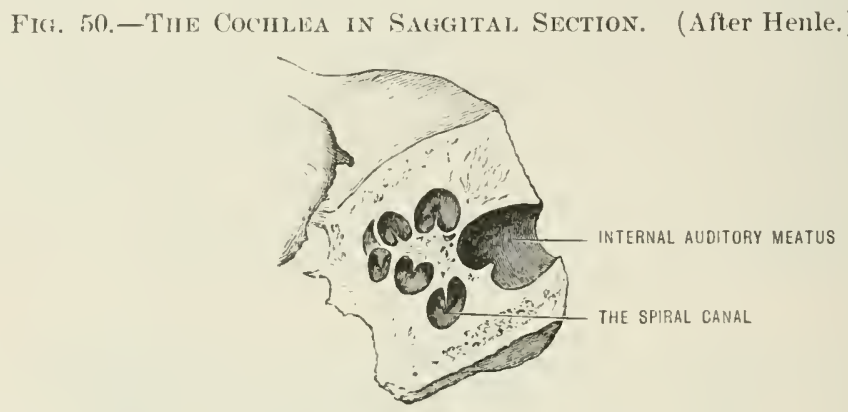

inferior surface of the petrosal near the apex, and transmits a small vein from the rochlea to the jugular fossa.

Measurements of the principal parts connected with the auditory organs:-

Internal anditory meatus . . . . Length of anterior wall, 13-14 mm.

" posterior wall, $6 \cdot 7 \mathrm{~mm}$.

External atuditory meatus . . 14-16 mm. (Gruluer.)

Tyrupanum . . . . . . Length, $13 \mathrm{~mm}$.

Height in centre of cavity, $15 \mathrm{~mm}$.

Width opposite the membrana tympani, $2 \mathrm{~mm}$. " " $\quad$ tubal orifice, $3-4 \mathrm{~mm}$.

(Von Tröltsch.)

The capsule of the osseous lahyrinth is in length $22 \mathrm{~mm}$. (Schwalbe.)

superior semicircular amal measures along its convexity $20 \mathrm{~mm}$.

The posterior " " " " " " " "

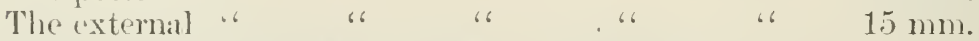

The canal is in diameter $15 \mathrm{~mm}$. (Huschke.)

The ampullat of the canal, $2.5 \mathrm{~mm}$.

\section{The Ossification of The Temporal Bome}

At hirth the temperal hone consists of three parts casily separable in the macerated sknll: they are the pretrosel, squemessel, and the tympanic. (The styloid process is cartilaginous with the axteption of its hasial element, the tympano-hyal, which, with the ear-bones, will be described with the appendieular elements of the (Tamimm.)

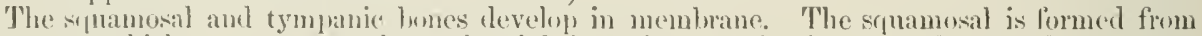

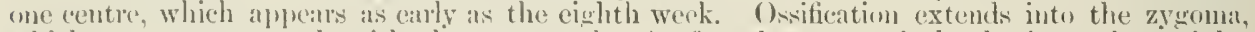
which grows concurently with the somammsil. At first the tymanic borler is nearly straight, but som assumes its charareteristie horseshoe shape. At birth the post-glemeinl tuberele is

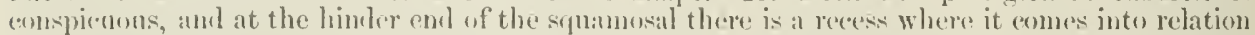
with the mastoid antrmm. The centre appears fin the tympanie lone alosut the twelfth week. At birth it is a horseshoreshaped ossicle slightly ankylosed to the lower border of the squamosal, the enen arms being direeted upwards. 'The tip of' the anterior an terminates in a small 
irregular process, and the inner aspect presents, in the lower half of its circumference, a grouve for the reception of the tympanic membrane.

Up to the middle of the fifth month the periotic capsule is cartilaginous; it then ossifies so rapidly that by the end of the sixth month its chief portion is converted into porous bone. 'The ossific material is deposited in four centres, or groups of centres, uamed according to their relation to the ear-capsule in its embryonic position.

The melei are deposited in the following order :-

1. The opisthotic alpears at the end of the fifth month. The osseous material is seen fir:t on the promontory, and it quiekly surrounds the fenestra rotunda from above downwards, and forms the floor of the vestibule, the lower part of the fenestra ovalis, and the internal auditury

Fig. 51.-The Tempolal bone at Bintir. (Onter view.)

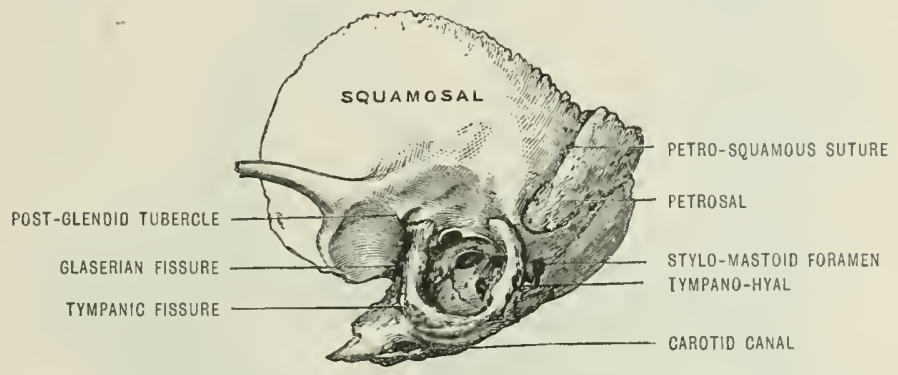

meatus; it also invests the cochlea. Subsequently a plate of bone arises from it to surround the internal carotid artery and form the floor of the tympanum.

2. The pro-otic nucleus is deposited behind the internal auditory meatns near the inner limb of the superior semicircular canal. It covers in a part of the cochlea, the vestibule, and the internal auditory meatus, completes the fenestra ovalis, and invests the superior semicircular cimal.

3. The pterotic nuelens ossifies the tegmen tympani and covers in the external semicireular canal; the ossific matter is first deposited over the outer limb of this canal.

4. The epiotic is the last to appear, and is first seen at the most posterior part of the posterior senicircular canal ; it is often double. This centre gives rise to the mastoid process.

At birth the bone is of loose and open texture, resembling bisenit or unglazed yorcelain, thus offering a striking contrast to the dense and ivory-like petrosal of the adult. It also differs from

\section{Fig. 52.-Temporal Boxe at Binth. (Inner riew.)}

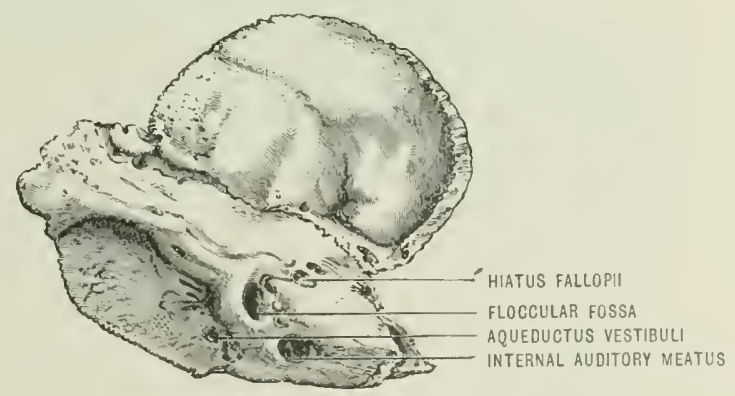

the adult bone in several other particulars. The floceular fossa is wirlely open and conspicums.. Voltolini has pointed out that a small canal leads from the floor of the floecular fissa and onens prosteriorly on the mastoid surfice of the bone; it may open in the mastricl antrum. 'The hiatns Fallopii is unclosed, and the tympanic reeess is filled with gelatinnus comnectire tissne. The mastriid process is not developed, and the jugular fossa is a shallow depression.

After birth the parts grow rapidly. The tympamm becomes permeated with air ; the rarious elements fuse; and the tympanic anmulus grows rapidly aud forms the tympanic plate. Crowth in the tympanic bone takes place most rapilly from the tubereles at its ripper extremitir.s. and in conservience of the slow growth of the lower segment a deep notch is formed : gradually the tubercles coalesce, leaving a foramen in the anterior part of the hony meatus which persists until puberty, and even in the alult. In most sknlls a cleft capable of receiving the nail remains between the tympanic element and the mastoid proeess; this is the anricular fisture. The anterior portion of the tympanic plate forms with the inferior borter of the sruamusil a deft known as 
the Cilaserian fis-sure, which is subsequently encroached upon by the growth of the petrosal. As the tỵmanic plate increases in size it joins the outer wall of the carotid eanal and presents a prominent lower edere, known is the vaginal proces:.

The mastoid process lrecomes distinct about the first year, ecineident with the obliteration of the petro-squanons suture. It increases in thickness by deposit from the periostemur. Towarls puberty, rarely carlier, the process becomes pnematie, the air-eells being lined by deli-

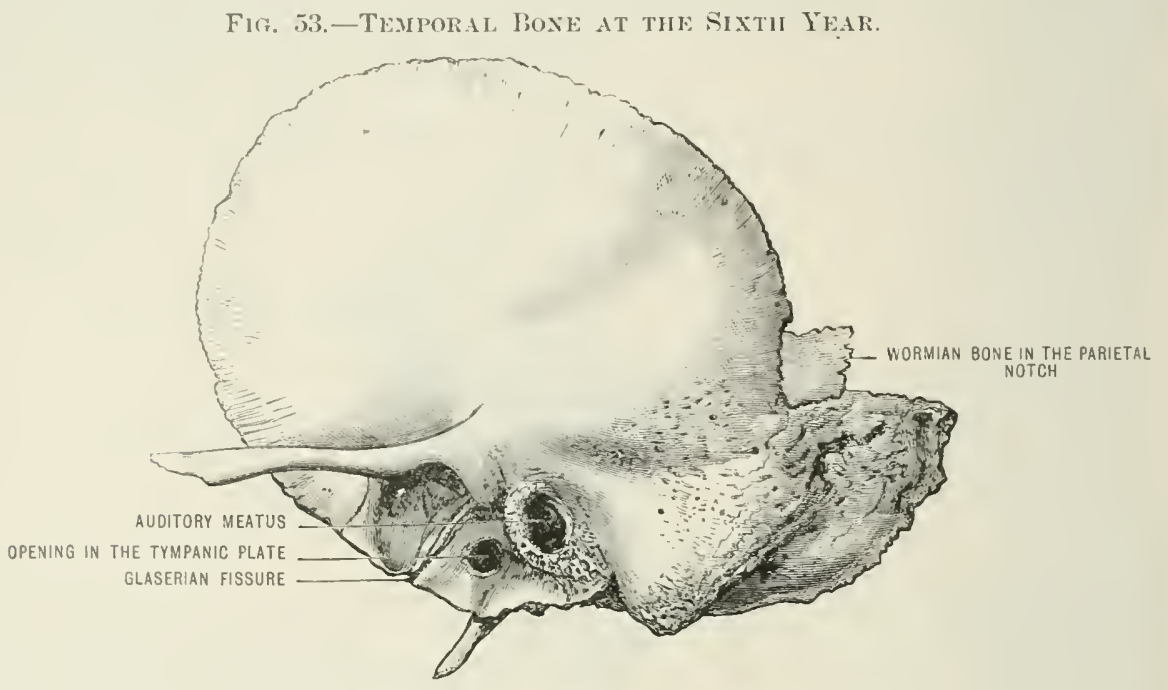

cate mucous membrane. In old skulls the air-cells may extend into the jugular process of the vecipital bone.

At birth the mastoid antrum is relatively large and bounded externally by it thin plate of bone belonging to the squamosal. As the mastoid inereases in thickness the antrum eomes to lie at a greater depth from the surface and becomes relatively smaller.

\section{THE PARIETAL}

The two parietals form a large portion of the vault and sides of the skull; they are interposid between the frontal anteriorly and the occipital posteriorly. Wach parietal presents two surfaces, four borders, and four angles. The external surface is convex and smoth: the convexity, best marked in young bones, is greatest near the centre, which is termed the parietal eminence. Crossing the mirklle of the bone are the two temporal ridges; the low is frequently the better marked, and limits the origin of the temprobl. musele. The upuer ridge is less constant, and gives attachment to the temporal fascia. The intemal surface is concave and marked with lepresions arresponding to the cerebral convolutions. Numerous vertical dere furrow for the branches of the middlo meningeal artery radiate from the anterior inferior angle and lower lurter of the bone. Along the superior margin of the bone there is a gronve which, when articulated with the opposite hone, forms a furrow which receives the superior longitudinal sinus. In adult lones numerous deepe eirreular depressions for Pacchionian bodies are found near this groove. The superior horder is deeply sorrated for the opposite parietal, the union with which forms the sagittal suture. The anterior and posterior borders aredecply serrated: the anterior articulates with the frontal to form the coronal, and the posicrior with the sfrumomereipital to form the lambdoid sutures. The inferior horder is bevelled and overlapled liy the sejumosil to form the squamous suture. Of the angles. the anterior inferior is prolongerl clownwarls and anticulates with the sum-

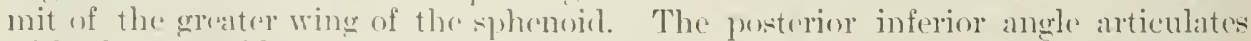
with the mastoicl portion of the pretrosal; on its immer surface it has a horizontal groove for ledging a portion of the lateral sinus. The superior angles present nothing worthy of uote. 
FiG. 54.-THE LEFT PARIETAL. (Outer surface.)

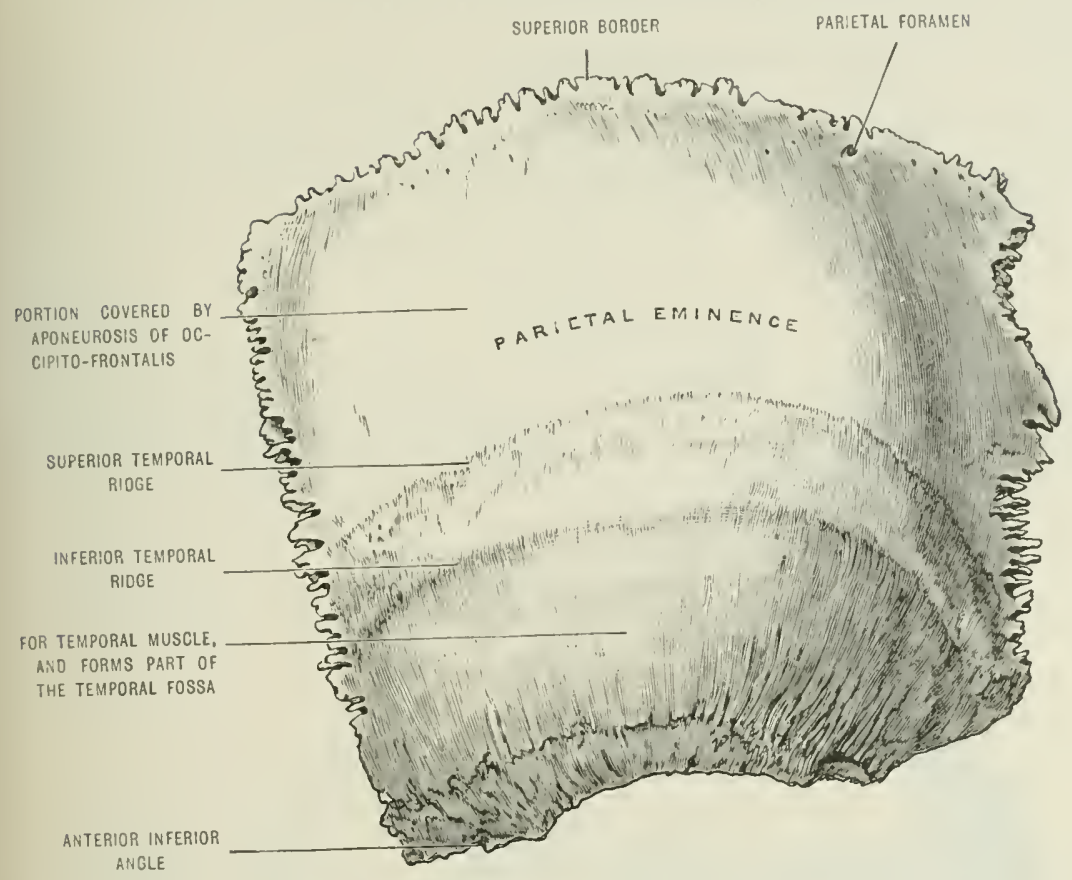

Fic, 55,-Tire Left PARIETAL. (Inner surface.)

PARIETAL FORAMEN GROOVE FOR SUPERIOR LONGITUDINAL SINUS DEPRESSIONS FOR PACCHIONIAN BODIES

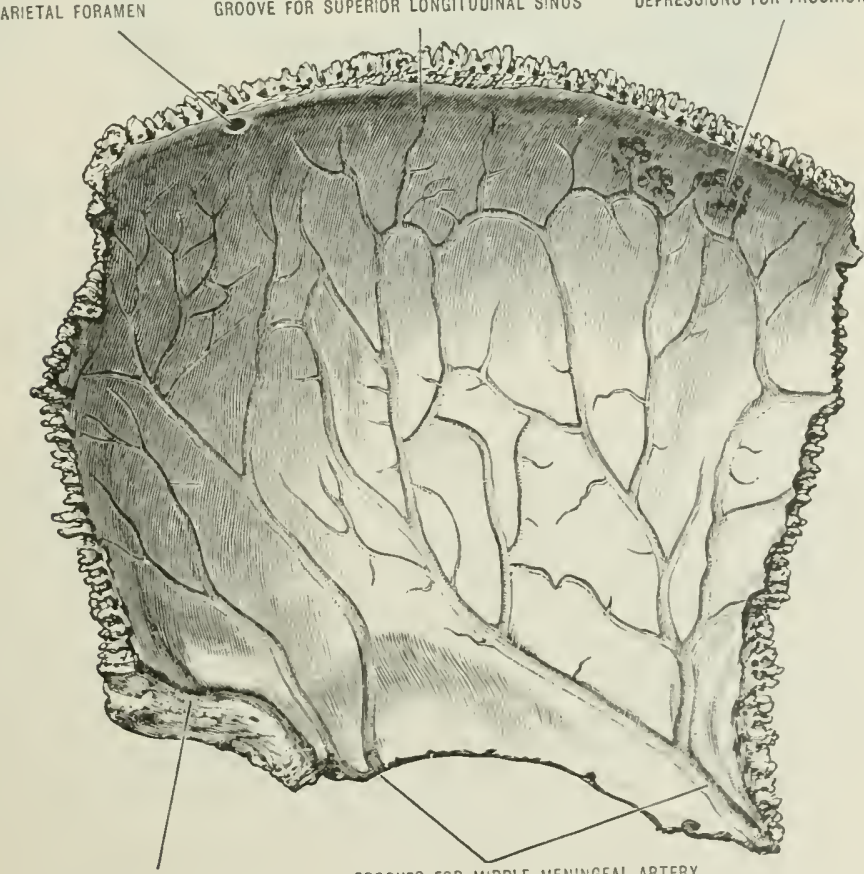

GROOVE FOR LATERAL SINUS

GROOVES FOR MIDOLE MENINGEAL ARTERY 
Articulations.-The parictal artieulates with its fellow, the oecipital, syuamosil. fromtal, sphrousd, and the epipteric bones when present. (ocasionally the sefummsil and epipteric may exclude the parictal from mion with the greater wing of the sphenoid.

Blood-supply.-From the middle meningeal, ocripital, and supraorbital arteries.

Ossification.-The parietal ossifies from an earthy spot deposited in the outer larer of the membranums wall of the skull about the serenth week. This bone is sometimes divided hy a horizontal suture.

\section{THE FRONTAL}

This bone bears much the same relation to the anterior part of the skull that the occipital hears to the posterior. It has, not inaptly, been compared to a cockle. shell. The inner or posterior surface is concare, forming a deep fosta for the

Fic. 56.-The Frontal. (Anterior view.)

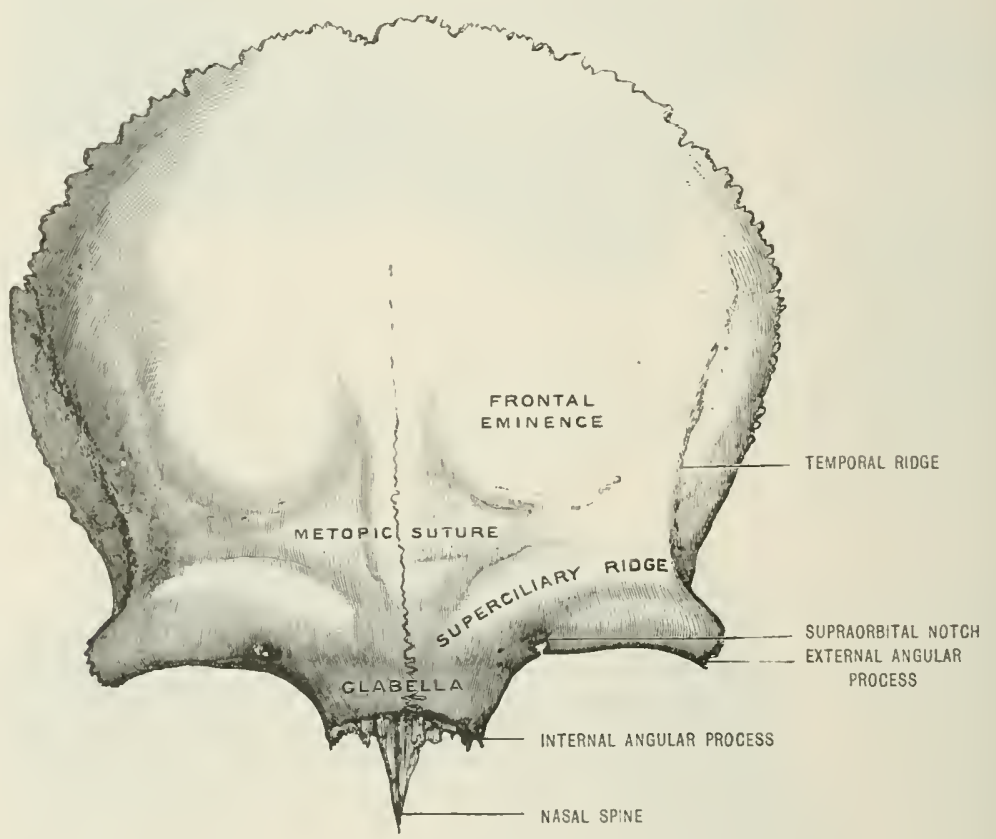

reception of the frontal lobes of the cerebrum. There is a gap in the lower part of the hene known as the ethmoidal notch, which overlaps hy its thin edges the cribriform plate of the ethmoid and forms. with that bone, the internal orifices of the anterior and postcrior' ethmoidal canals. 'The anterior part of this notch articulates with the cristal galli, and the small hole in the line of suture is the foramen cæcum. Prolonged rertically upwarls from the point of union with the crista is a riclge of bone, which gratlually opens out to form a furrow for the reception of the superinr longitudinal sinus; the ridge serves for the attachment of the anterior jart of the falx cerebri. The thin lanine of bone on each side of the ethmoidal noteh are termed orbital plates, because they form the greater part of the roof of wath writ. Is a rule, they present deep depressions for the convolutions on the orthital surfice of the ecrehrum. The rest of the cerehral surface of the frontal is fairly smooth, and presents a few furrows for meningeal arteries, and, near the median groove, pits for Pacehionian borlies.

The external surfice is eomvex and smooth, often divided by am imperfect 
fissure, the remains of the metopic suture, which indicates the line of union of the two bones representing the frontal in early life. On aach sirle of this suture a little below the centre is the frontal eminence. Below the eminences, scparaterl liv shallow grooves, are the two converging superciliary ridges, which appronch each other in the median line to form the nasal eminence. The smooth space hounded hy the converging superciliary ridges is the glabella. Bulow these ridges the hone presents the sharp supraorbital ridges which end internally at the internal angular, and externally at the external angular processes. Each ridge hus a narrow, deep supraorbital notch (sometimes a complete foramen) at the junction of the inner with the middle third. At the bottom of this notch or foramen a small opening communicates with the diploë. The external angular processes are prominent and articulate with the malar bones; from each process a rielge extends upwards and backwards, marking off the lateral aspecet of the bone, where it assists in the formation of the tomporal ridge and fossa. The internal angular processes articulate with the lachrymal bones, and are separated by a serrated interval, the nasal notch, which receives the upper borders of the nasil bones, and outside these the nasal processes of the maxilla. The notch has in the middle a long pointed process, the nasal spine, which lies between the upper frart of the nasal bones aud the mesethmoid. On each side of the spine an opening leads into the large frontal sinuses.

The under surfaces of the orbital plates are smooth and concave; they form the

Fig. 57.-Tine Froxtal Bone. (Inferior view.)

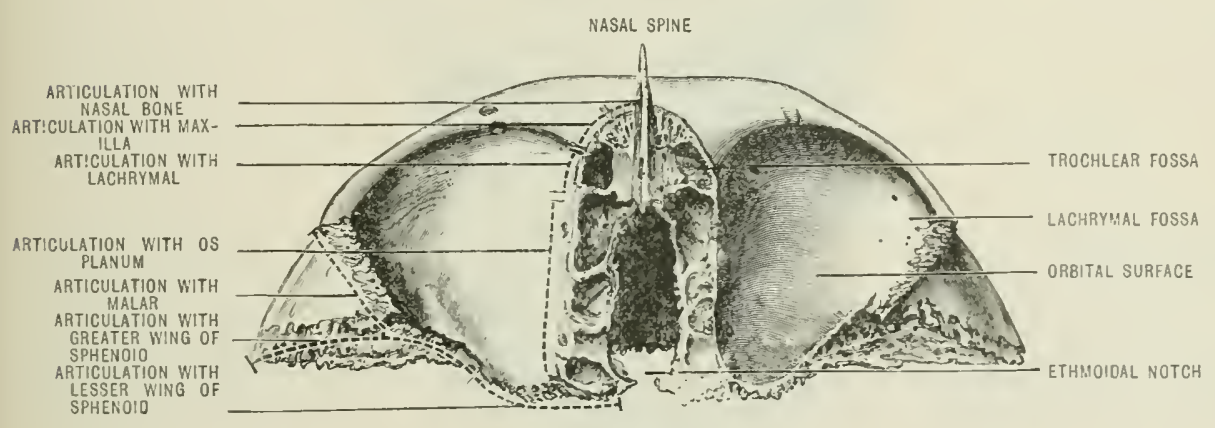

roofs of the orbits. Each is sharply limited anteriorly ly the supraortital ridge, and presents at the outer angle the lachrymal fossa for the reception of the lachrymal gland. Near the internal angle there is the small shallow supratrochlear fossa for the pulley of the superior oblique muscle. A sharp ridge runs backwards from the internal angular process, and articulates successively with the lachrymal and the os planum of the ethmoil. It has two notehes. which are converted into the anterior and posterior ethmoidal canals by articulation with the os planum. The posterior borcler of each orbital plate articulates with the leser wing of the sphenoid (orbito-sphenoid), and is continuous with a rough triangular surface for the greater wing (ali-sphenoid). This triangular surface is continuous anteriorly with the scrrated malar ridge of the frontal, and, laterally, with that border of the bone which articulates with the parietals to form the coronal suture. Between the ethmoidal notch and the inner marsin of the orlital surface there $i$ an irregular surface which forms the roofs of the ethmoidal cells.

Articulations. - The frontal articulates with the pariotal, sphenoid, etlimoicl, lachrymal, malar, maxilla, and nasal lones; with the cpipteries when present, and occasionally (as explained on page 3S) with the squamosal, and with the sphenoidal turbinal when it ereeps into the orbit.

It has the following muscles attached to it:- 
The blood-supply. - Arterial twigs derived from the midlle and small moningreal arteries enter it on the ("ret)ral, and branches form the fromtal and supratorbital arteries on the outer surfiae. The horizental plate derives twigs from the ethmoidal ancl other loranches of the ophthahnic artery.

Ossification.- The fontal derelops from two earthy spots deposited in the

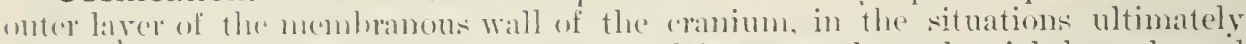

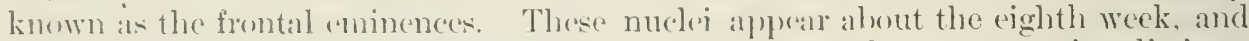
guickly sumad through the membrane. It hirth the bones are quite distinct. sulserguently they articulate with each other in the merlian line to form the motopic suture. In a fow cases, the hones remain distinct throughout life. In the matjurity of "ases the stoture is obliterated; ankylosis commences about the second

Fig. 58.-The Frontal bone at Binth.
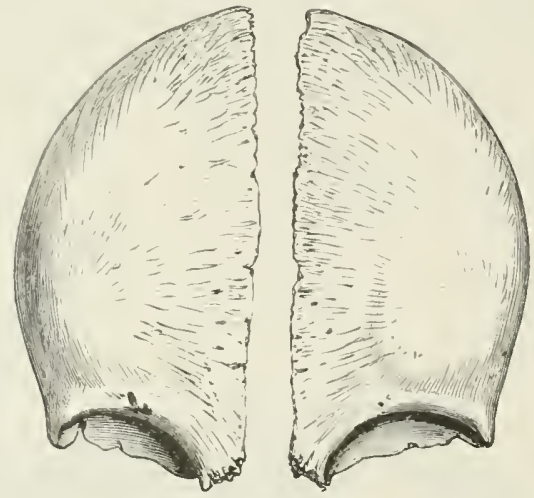

your. In adult skulls, traces of the metopie suture nay often be seen in the region of the glabellit.

After the two halves of the bone have mited, osseous material is deposited at the lower end of the nuetopic suture to form the nasal spine, which is one of the distinguishing foutures of the luman frontal bone. The spine appears ahout the twolfth year, and soon comsoliclates with the bone above. Aecessory nuclei are sometinies secen between this bone and the lachrymal; they inay persist as ITormian ossicles.

The frontal sinuses alpear about the seventh year as prolongations from the anterior cthmoiclal cells. Occasionally they invade the horizontal plate, and extend over the roof of the orbit.

\section{THE EPIPTERIC AND WORMIAN BONES}

The epipteris are hones of variable size which oecupy the antero-lateral fontanelles, regions indicated in the arlult skull by the name pterion. Each epipterie bone is wedged between the squamosal, frontal, greater wing of sphenoid, and the parietal, and is present in most skuls letween the second and fifteenth year. After that date it may fersist as a separate ossicle, or mite with the frontal or the sepamosil. In this (ase it will cause a fronto-spuamosil suture, and exclude the pirietal from the sphenoil. More commonly the "lipteric joins the sphenoid. In some skulls it is searrely as large as a split pea, in ofthers it is as broad as the thmmb-nail. The epiptric. home is preformed in membrane, and appeats in the courise of the first year.

The Wormian bones are small, irregular-shaped ossicles, often fomel in the sutures of the skull, especially those in relation with the pariotal hones. Wormian bones sometines oceur in great number; as many as a hombled have been counted in one skull. They are rarely present in the facial sutures. 


\section{THE ETHMOID}

The ethmoid is a bone of delicate texture, situated at the anterior part of the skull-base; it is roughly coboidal in shape, and its delicary is due to the fact that it is honercombed hy air-cells. The hone consists of four parts: the horizontal or cribriforni plate, two lateral masses, and a perpendicular plate.

The cribriform plate forms jart of the anterior cereblal fossil, and is recerver into the ethmoidal notch of the frontal hone. Standing vertically upon this plate is the crista galli. To the posterior border of the crista the falx cerelri is attached; this borker divides posteriorly to enclose the ethmoiclal spine of the spheneid. The anterior aspect of the hase of the crista constitutes the anterior horder of the cribriform plate; it is rough for articulation with the frontal. In the suture between the two hones there is usually an opening, the foramen cæecum, which when present transmits a small rein. On each sicle of the crista galli the ('ribriform plate lodges the olfactory bulb, and is perforated for the transmission of the filaments of the olfactory norres. On each side, near the anterior part of the crista, there is a narrow longiturlinal slit for the nasal hranch of the fifth nerve.

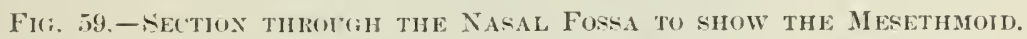

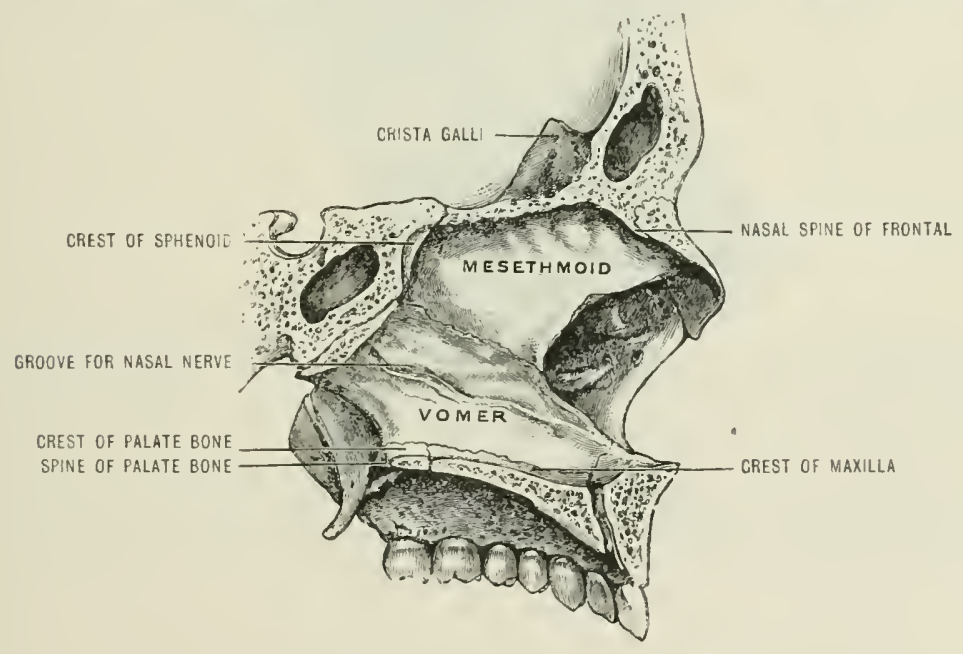

The perpendicular plate (nesethmoid) is directly continuous with the crista (n) the under asject of the cribriform plate. It is a lamella of bene. trapezoid in shape, which forms the upper part of the nasal septum; usually it is laterally. deflecterl. Its anterior horder articulates with the nasal spine of the frontal, and the crest of the nasal hones. The inferior border has the triangular cartilage attacherl to it. The posterior border is subdivided: the upler lalf articulates with the crest of the sphenoid, and the lower articulates with the vomer. The surfares of this plate present, especially in their upper parts. numcrous formmina for vessels, and grooves for filaments of the olfactory nerves.

The lateral mass, or labyrinth, of the eflumoil (rmwists of two scroll-like picces of bone, the superior and inferior turbinals ("thmo-turlinals); a smowth, yuadrilateral plate of bone, the os planum, and a number of air-cells.

The os planum is on the onter sirle of the lateral niass, and forms a large len'tion of the inner wall of the orbit. By the anterior horder it articulates with the lachrymal, by the posterior horder with the sphenoid and the orhital process of the pralate bone; the inferior horder articulates with the inner margin of the orbital plate of the maxilla, and by the superion horder with the horizmal plate of the frontal. Two notehes in the superior horder lead into grooves running horizontally acruss the lateral masses to the eribriform llats. These ethmoidal grooves are 


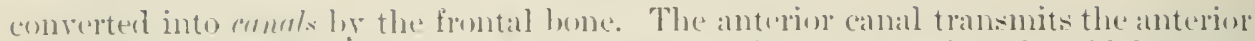

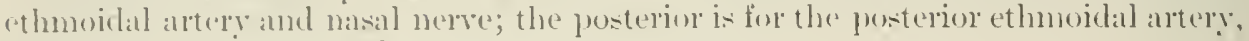
and a lranch of the nitial nerve.

'The superior and mirldle turbinals project on the immer alspeet of the lateral mass: ther coalesere anteriorly, but are separated posteriorly by a space, termed the superior meatus. Eiuh turhinal has an attached upler, and a free, slightly (onroluted, lower borkers: In the recent state they ale corered with mucous meminame. and present numbens foramina for blood-ressels, and grooses for twigrs of the olfictory nerves.

On the under surface of atach lateral mass, near the anterior corner of the os planmm, an imegular lamina of bone projects downmals and backwarls. This is the unciform process: it articulates with the ethmoidal process of the inferior turbinal, and forms a small part of the immer wall of the antrum. The anterior part of the lateral mass projects forwards in front of the os planmm and articulates with the imner surface of the masal process of the maxilla.

The ethmoidal cells oceupy the space between the os planmm and the turbinals; they are divided by a thin septum into an anterior and a posterior set. The cells are inperfect in the ethnoid; they require the juxtaposition of other bones to make them complete. Above, they are closed by the horizontal plate of the frontal,

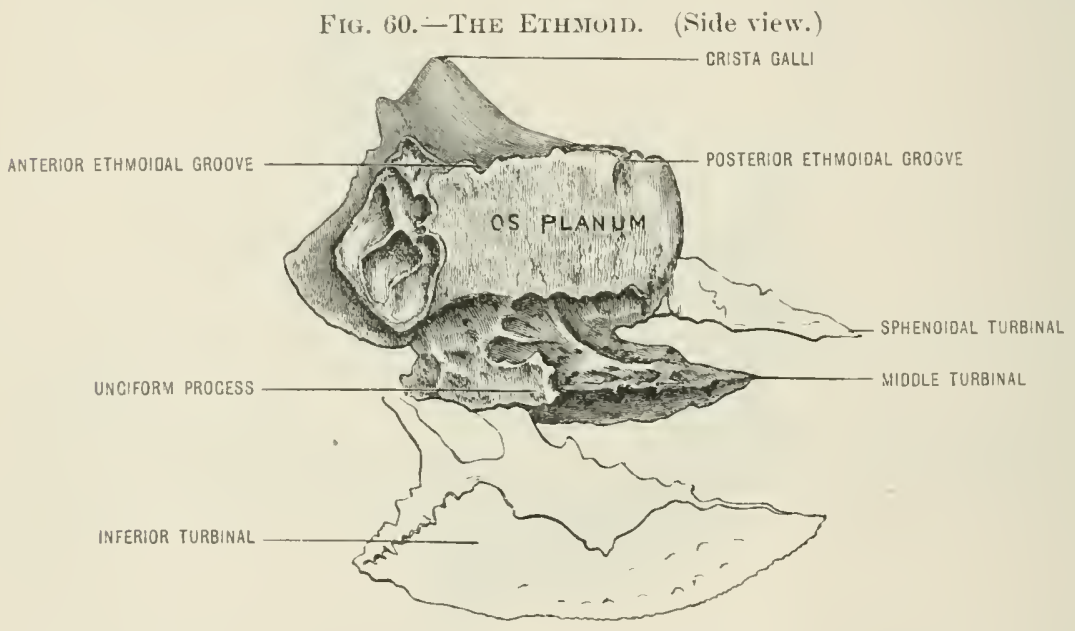

posteriorly by the sphenoidal turbinal and the orhital process of the palate, inferiorly hy the mixilla, and anteriorly by the lachrymal. The anterior set communicate with the frontal cells above, whilst below they open into the middle meatus of the nose by a sinuonis (anal, the infundibulum. The josterior cells open into the superior meatus, ame oceasionally communieate with the sphenoidal cells.

The cells are sometimes divided into groms, aceording to the bone which lies in immeriate juxtaposition. Those along the superior erlge are the fronto-ethmoidal ; those berseath the lachrymal, lachrymo-ethmoidal, nsually two in number. These along the lower erlge are the maxillo-ethmoidal ; and josteriorly there are the spheno-ethmoidal, (ompleted by the sphenoilal turbinals, and a palatoethmoidal (eell.

Articulations. -The ethmoid articulates with the frontal, sphenoid, two palate bones, two nasals, vomer, two inferion turbinals, the sphenoidal turbinals, two maxillar, and two lachrvmal bones. The posterior surface of each lateral mass eomess into relation with the sphenoich on each side of the arest amel rostrum, and helps to reluse in the sphemoinlal sinus.

Blood-supply.-The anterior and posterior ethmovilal, and from the nasil or spheno-palatine branch of the intermal maxillary artery.

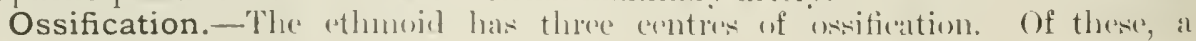
nuclens appears in the fourth month of intra-uterine life in each lateral cartilage. 
At hirth this bone is represented by two seroll-like bones, very dedicalte, and corereal with irregular depressions, which give it a worm-raten appearance. Six months after birth a nucleus appears in the cthno-vonerine plate for the mesethmoid. This gradually extends into the crista galli. During the third year the bateral masses and the mesethmoid (perpendicular plate) ankylose. The cribriform plate is derived from the lateral masses.

The ethmoidal cells do not make their appearance before the third yar, and they grarlually produce attenuation of the lateral masses. In many places there is an

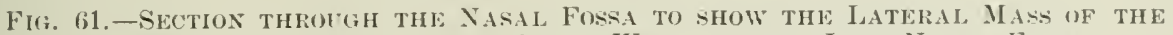

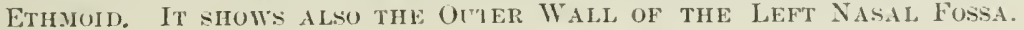

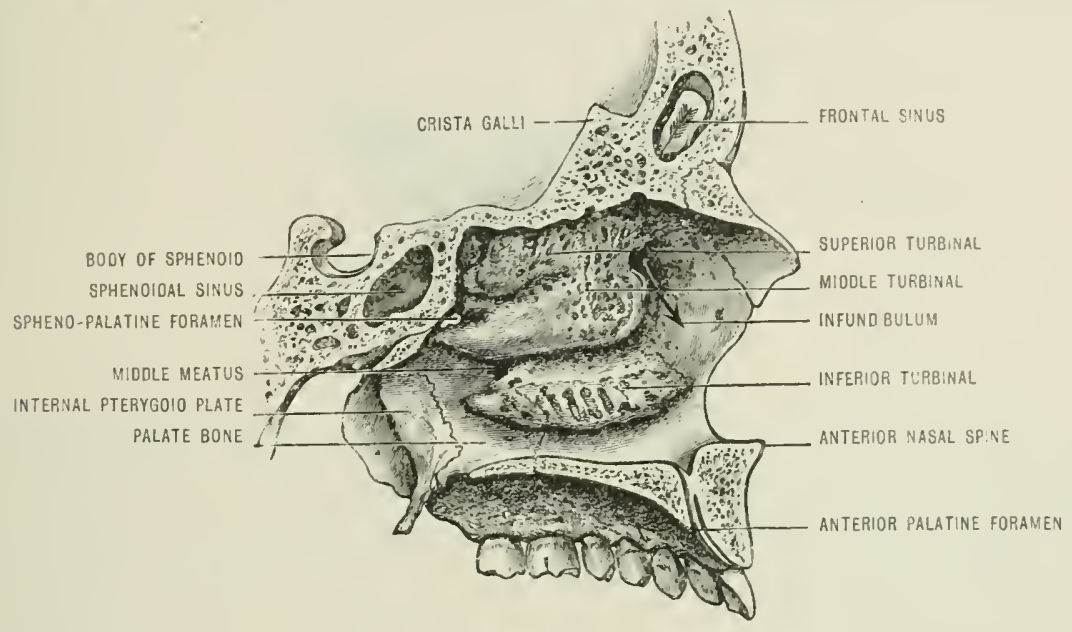

much absorption of hone that the cells perforate the ethmoid in situations where it is overlapjed by other bones. Along the lower border of the bone, near its articulation with the maxilla, the absorption leads to the partial detachment of a narmw strip, known as the uncinate or unciform process. Sometimes a second but smaller hook-like process is formed, above and anterior to the large one. This process is so very fragile that it is diflicult to preserve it in disarticulated bones. The relations of the uncinate process are best studied by removing the outer wall of the antrint.

\section{THE SPHENOIDAL TLRBINAL,}

These bones (often referred to as the bones of Bertin) are two hollow conc. flattener externally in three planes. They may he obtained as distinct ossicles alout the fifth rear. At this date they are wedged in lowwen the moler surfar..

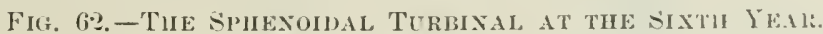

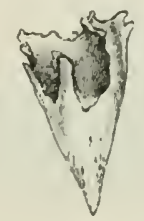

of the presshenoid and the orhital and sphenoidal processes of the palate bonte. The apex of the cone is directed backwards, and appears near the vaginal process of the sphenoid. Of its three surfaces. the outer one is in relation with the spheno-maxillary fossa, and ocedsionally extends upwads between the sphenoid and the os planum of the ethmuid to appear on the inner wall of theorlit (fig. 54 ). 
The inferior surface forms the upper homelary of the spheno-palatine formune and enters into the formation of the posterior jart of the loof of the nasal fossa. The superior surface lies flattened atgainst the under surface of the pre-sphenoid. The hase of the cone is in eontact with the posterior surface of the lateral mass of the rethmoid.

The deposits of earthy matter from which the sphenoidal tumbinals are formed are laid down at the tiftli month.

At birth these hones are visible as mall triangular ossifications in the peri"hondrium of the ethno-vomerine plate near it: junction with the pre-splenoid, and encloses a smatl recess which becomes a sphenoblal sinus. By the third year the receses have heconne eompletely enclosed and the hones have heeome hollow

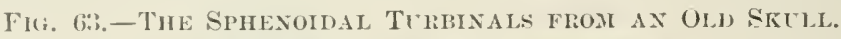

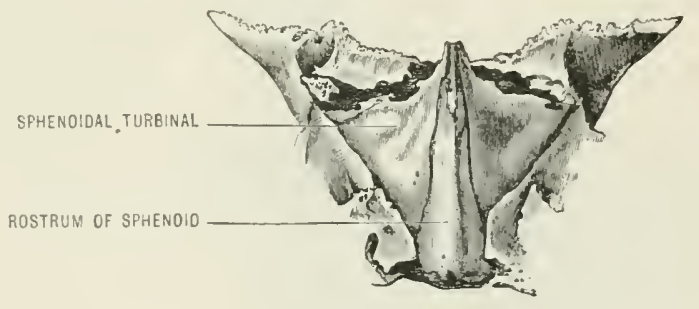

cones, the circular orifice representing the base eventually becoming the orifice of the sphenoidal sinus. As the cavity enlarges, the median wall atrophies so that the inner wall of the sinus is formed by the pre-sphenoid. As the turbinal enlarges it ankyloses with adjacent hones. In many skulls it joins the lateral mass of the ethmoid; more frequently it fuses with the pre-sphenoid; less frequently with the palate. Ifter the twelfth year they can rarely be separated from the skuil without damage. In many disarticulated skulls they are so broken up that a prrtion is found on the sphenoid, fragnents on the palate bones, and the remainder attached to the ethmoid.

sometines, even in very old skulls, they are represented by a triangular plate of extreme tenuity on each side of the rostrum of the sphenoid (fig. 63).

Fig. 64.-The Inferioli Timinal, Adult Sphexoludl Turbindl axi Lachryal Boxes.

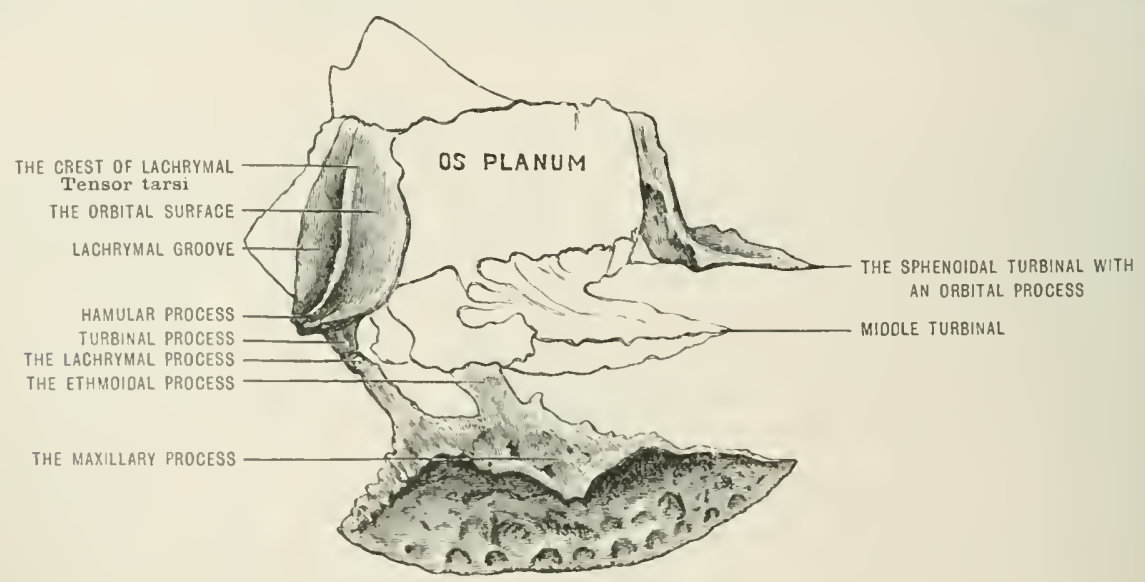

THE INFERIOR TLRBINAL

These are a pair of delicate, scroll-like bones, and may be regarded as dismemberments of the literal masses of the ethmoid, with which they are elosely relatid. Each hone presents two surfaces, two border's, and two cxtremities. 
The outer surface is concave, and orerhung by the auricular or maxillary process. The inner surface is convex and pitted with depresims. The superior border presents from before backwarts three proceses: the first is called the lachrymal process, hecause it articulates with the turbinal process of the lachrymal hone. The marerin of bone at the hase of this process comes into relation with the nasil process of the maxilla. The serond rertical spiculum is the ethmoidal process, which joins the uncinate process of the ethmoirl. The third or maxillary process is a thin lamella of bone, turned clownwarls; it orerhangs the oritice of the maxillary sinus, and serves to fix the bone firmly to the outer wall of the nasal fossa. The margin posterior to the maxillary jrocess comes into relation with the inferior turbinal erest of the palate bone. The inferior border is roumlerl and free. It is the thickest part of the bone. The extremities are narrow, the posterior being the more pointerl.

Articulations.-The inferior turbinal articulates with the maxilla, lachrymal, palate, and ethmoid.

The inferior turlinal is ossified in cartilage from a single nuclens which alppears about the fifth month of intra-uterince life.

At birth it is a relatively large bone, and fills up the lower part of the nasal fossa.

\section{THE LACHRYMAL}

The lachrymal bones are extremely thin and delicate, quadrilateral in shape, and situated at the anterior part of the imner wall of the orbit. They are the smallest of the facial bones.

The outer or orbital surface is liviled by a rertical ridge into two unequal portions. The anterior smaller portion is deeply groover to form the lachrymal sulcus, which lodges the lachrymal sac and forms the commencement of the lachrymal duet. The portion behind the ridge is smooth, and forms part of the innes wall of the orbit. The ridge gives origin to the tensor tarsi muscle, and terminates inferiorly in a hook-like process, the hamulus, which (urves forwards to articulate with the lachrymal tuberele of the maxilla and completes the superior orifice of the lachrymal canal. The inner surface is in relation with the two anterior cells of the ethmoid (lachrymo-ethmoid), and forms part of the infundibulum. The superior border is short, and articulates with the intemal mgular process of the frontal. The lower border posterior to the erest joins the inner edge of the orbital plate of the maxilla. The narrow piece, anterior to the ridge, is prolonged downwards to join the lachrymal spine of the inferior turbinal, and is called the turbinal process. The anterior borrler coms into relation with the posterior border of the nasal process of the maxilla. The posterior border articulates with the os planum of the ethmoid.

Articulations. - The lachrymal articulates with the ethmoid. maxilla, frontal and inferior turbinal bones.

Blood-supply.-Its arteries are derived from the infraorlital, the masal branch of the ophthatnic, and the anterior ethmoidal.

Ossification.-This bone arises in the membrane overlying the cartilage of the fronto-nasal plate. Its mode of ossification is rery varial,e. As a rule it is described as coming from one nucleus. Fot unfrequently the hamulus is a separate element. Sometimes the lone is divided horizontally, and a process of the os planum projects between the two halves to join the nasal process of the maxilla. Wore rarely the bone is represented hy a group of detacherl ossieles resembling Wornian bones.

\section{THE VOMER}

The romer is an irregular four-sirled plate of hone constitnting the lower jurtion of the nasal septum. It is usually described as resembling a plomghahare in shilpx. Each lateral surface is covered by the thick mucous membrane of the nasil sinus, and is traversed hy a narrow but well-marked groore. which lodges the nasis- 
palatine nerve from the spheno-palatine ganglion; henee it is sometimes called the mestr-pulatiue groure.

The superior border of the home is expanded laterally into two alie. The groove herween them lorlges the rostrum of the shlemoid, whilst the margin of each ala (onues inter contact with the sphenoidal process of the palate bone. Between the ale and the sphemeid a canal exists on each siele of the rostrum for blood-ressels. The inferior bureler is meven, and is received into the grouve formed by the crests of the opposet maxille and the palatine bones of each sicte. The anterior border joins prosteriorly the mesethmeid, and in front the trimgular (nnedian) nasil

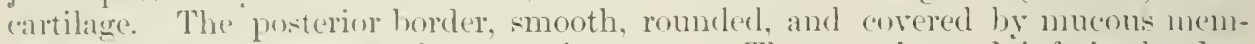
lowne, serves to starate the posterior nares. The anterior and inferior borders neet each other at the apex of the bone.

Articulations.-The vomer articulates with the sphenoid, palates, ethmoirl, and maxillee, and with the triangular cartilage.

Trri. 65.-The Vumels. (Sirle riew.)

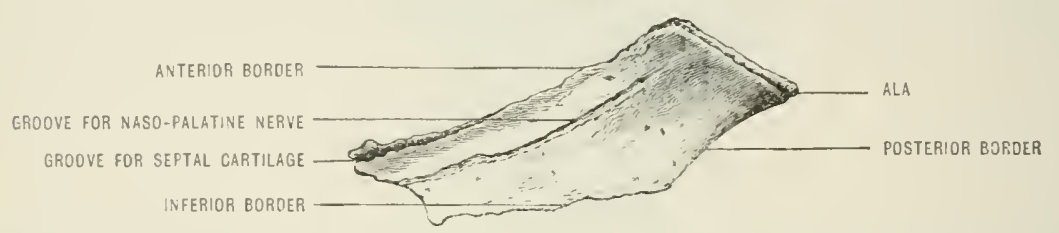

Blood-supply.-Its arteries are derived from the anterior and posterior ethmoidal, the nasi-palatine, and the pterrgo-palatine arteries, and twigs from the fosterior palatines through Stenson's canals.

Ossification.- The vomer is a membrane-bone, and arises from a single centre depusited in the lower hroter of the perichondrim of the cthmo-romerine plate as carly as the eighth week. From this single rentre a lamina of bone extends on each sicle of the eartilage plate. For many woeks the vomer is a shallow bony trough. Ciradually it presses upon and induess absorption of the enclosed cartilage, and liv degrees the lamine fuse, and form a rectamgular plate of bone. At hirth the vomer presents an expanded lorrer horder, especially in cases of cheft prilite.

\section{THE NASAL}

These are two oblung hones situated in the midlle line at the upper part of the fares and forming the bridge of the nose. Each bone has two surfaces and four borters. The fictial surface is enncave from alove downarels, but convex from sile te sicle. Near its centre is a foramen for the transmission of a small tributary

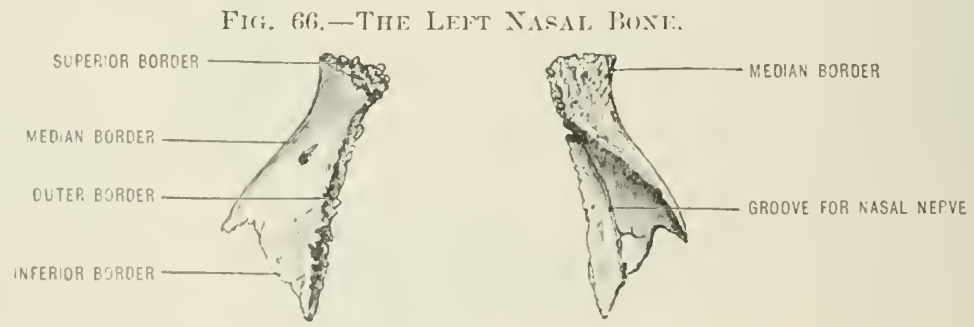

to the facial vein. The pusterior or nasal surrace is concalo laterally, and travered hy a lomgitulinal growe for the nasal branch of the ophthalnice nerve. In life this surface lats a corering of mueous membrane. The short superion border is thick and selrated for articulation with the nasal noteh of the frontal. The inferior horder is thin, and serves for the attachment of the lateral nasal cartilages. Each home articulates with its fellow by the moelian border, which is 
prolonged halckwards to form a crest: this crest comes into relation with the natial spine of the frontal and the anterior horder of the mesethmeid. The outer borker articulates with the nasal process of the maxilla.

Articulations.-The nasal hene articulates with it fellow, the frontal, maxilla and ethmoit.

Blood-supply.-Twigs to this hone are furnished hy the nasal branch of the ophthalmic, the frontal. the angular, and the anterior ethincidal arteries.

Ossification.-Earh nasal hone is developed from a single earthy nueleus in the membrane overlying the fronto-natal cartilage. The nucleus is asily seen during the eighth week. The hone hy its pressure som probluess alsorption of the underlying eartilage. At birth the nasal bones are nearly as wide as they are long. whereas in the adult, the length of the hones is three times greater than the width.

\section{THE IIAXILLA}

The maxilla are two hollow irregular euboidal homes with two prominent proresses. They form a large portion of the facial skeleton.

This bone is occupied hy a laree cavity, the antrum. The body presents four surfices. Of these the facial surface looks forwarts and outwards and presents the following points of interest:-The socket for the canine tooth eauses a low deration, the canine eminence, having to its inner side the incisive fossa, from which the depressor alip nasi arises. On the outer side of the eminenee is the canine fossa, which gives origin to the lecator anguli oris. Ahove this fossa is the infraorbital foramen, through which the teminal luanches of the infraorbitil nerve and artery emerge. From the ridge above this formen the lecutor labii sujurimin arises.

A ridge of bone extending upwark from the socket of the second molar tooth s'larates the facial from the zygomatic surface. Near the middle of the zygomatic surface are the orifices of the canals for the posterior clental nerves and vesiels. The posterior inferior angle of this surface is termed the tuberosity ; from it a few fibres of the intemal pterygoid muscle arise. This tuherosity is most proninent after eruption of the wisclon tooth; the rough surface along its inner border is for the tuberosity of the palate hone; the smouth surface immediately above forms the anterior boundary of the spheno-maxillary fossa, and enters into the formatim of the descending palatine eanal.

The orbital surface is irregularly triangular and forms the greater part of the Hexor of the orbit. Anteriorly it is rounded and forms part of the circumferenes of the orhit; externally it is rough for suture with the malar bone: the rough surface ends in a backwardly projecting spine which occasionally joins the sphenoid and forms the anterior limit of the spheno-maxillary fiscure. The posterion margin, smootl and rounded, forms the inferior limit of the sphemo-maxillary fiscure. The internal border is nearly straight; quite at the posterior mat is at galp for the orbital process of the palate bone; anteriorly it articulates with the of planmm of the ethmoid; leyond this it receives the lachrymal bone. and in the anterior angle it is smooth and romelect, forming part of the circumference of the orlital orifice of the lachrymal duct.

The orbital surface is traversed by the infraorbital groove, which. (ommeneing at the posterior border, recpens as it passes forwarts and entars the infraorbital canal. This groove receires the seeond division of the fifth nerve and the infrarbital artery. The infraorbital canal runs moler the nurgin of the ortit and opens on the facial surface. It transmits the infrachlital artery and nerve. At the termination of the groove a smaller canal tumnels the anterior wall of the antrum, and conveys the anterior dental nerves and vessels to the uplere inciser. (amine, and hieuspid terth. External to the commeneement of the lachrymal duet there is a shallow depression from which the infrior oblique takes urigin.

The internal or nasal surface forms the inter wall of the nawal forsa, and is: prolonged inwarks to form part of the floor of this fossa. The posterion late of this surface is rleficient, and leads by a large irrecular aperture into the antrum; helow and behind this opening the lione is rough for articulation with the rertical plate 
of the balate home. The extreme posterior border lecerves the tuberosity of the palate hone: the grome in front of it forms pant of the pusterior palatine canal.

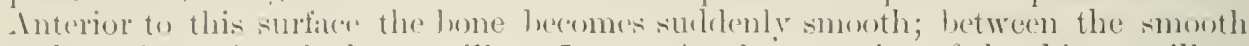
and rough portions is the maxillary fissure for the rereption of the thin maxillary process on the antrion borker of the vertical plate of the palate bone. In the

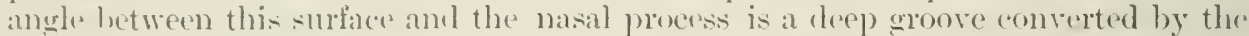
larhromal and inferior turbinal into the nasil duet. Rumning backwards from

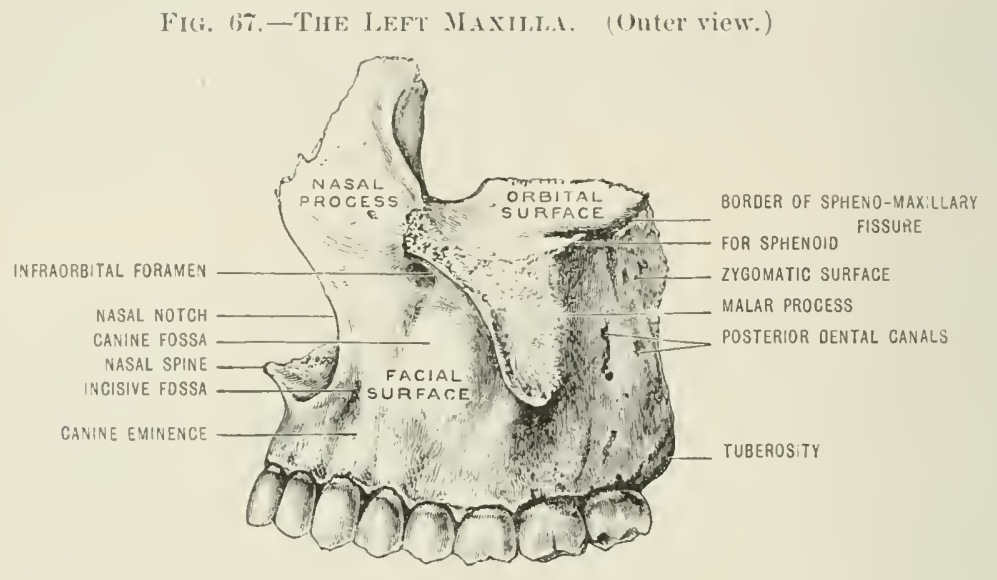

the anterior margin is the inferior turbinated crest which articulates with the lowest turbinal bone. The surface above the erest forms part of the middle meatus, and the surface below belongs to the inferior meatus of the nose, and is lirerty continuous with the superior surface of the palatine process. Near its anterior border is the orifiee of the anterior palatine canal.

The inferior or palatine surface is formed by the palatine process and the alveolar horker. The palatine proeess forms the anterior part of the rouf of the

Fig. 69.-The Left Maxifla. (Inner view.)

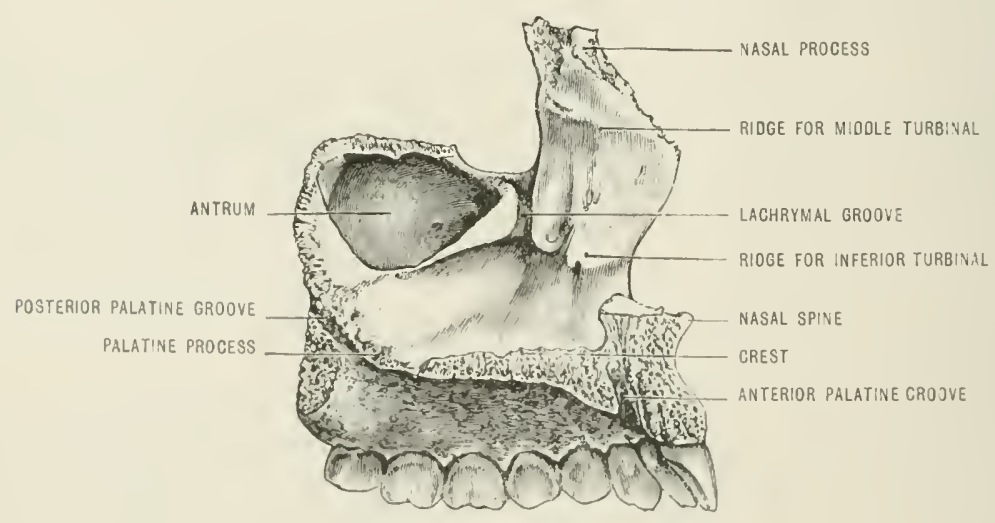

mouth. It is concalve, rough, and pitton with formmina for vesscels. Where it joins the alvolitr horder a grome (somotimes a amal) rxists for the anterior follatine nerve and posterior palatine ressels. When the bumes of opposite sides are placed in alpustiom the palatine fossa is formed; rmming wotwols from this to the sare between theserencl incisor and eanine tooth, the maxillo-premaxillary suture can be detected in young bones. The pusterior lorder artieulates with the horizontal proxse of the jalate bone. Whilst the median border joins its fellow to form ahore, a prominent crest upom which the remer is received. 
The anterior palatine fossa is situatel in the meso-palatine suture near its anterior termination. In its typical form the fossa contains four passages: two are small and rlisposed one hehind the othere exinetly in the suture; these are the foramina of Scarpa for the naso-palatine nerves, the left nerve emereing from the anterior foramen. The lateral and larger orifices diverge to open on each sicle of thes west. They are ealled Stenson's canals, and lodge recesies of the nasal mulecule. membrane and remuants of Jacobson's organs.

The alveolar ridge foms the outer limit of this surfare; it is cresentic in shape, spongy in texture, and presents cavities in which teeth are lodged. When the tecth are complete in number, eight cavities are present; of these the pit for the canine tooth is the deepest, those for the molars are the widest and present subdivisions. Along the outer aspect of the alveolar border the buecinutwe arises as far forwarks as the first molar tooth.

The nasal process is somewhat triangular, rising rertiually from the nasal angle of the maxilla. Its outer surface gives attachment to the orbirmlaris pulpebramm, the tendo oculi, and the lecator labii superioris rolidur masi. The internal surface forms one of the lateral boundaries of the nasal fossia. Superiorly it articulates with the frontal; below this is the superior turbinated crest for artieulation with the middle turbinal. The space between this and the inferior turlinaterl (rest forms part of the middle meatus. The anterior horder articulates with the nasal bone; the posterior is thick and rertioally errovest to form part of the

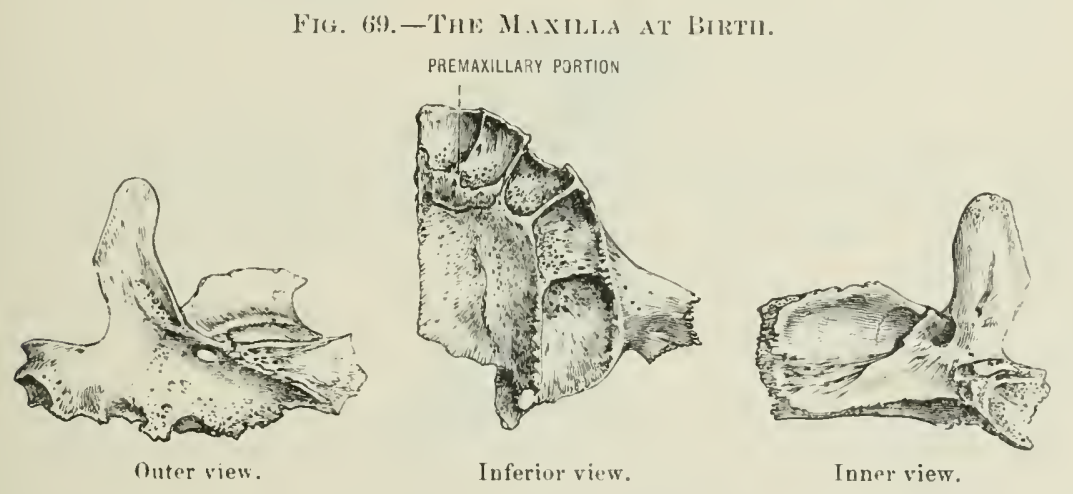

nasal duct. The inner margin of this groove articulates with the laxhromal bune. The point where the outer margin of the groove joins the orbital plate is indicalted by the lachrymal tubercle.

The malar process is rough and triangular, and forms the summit of the riclge of bone separating the farial and zygomatic surfaces. It articulates with the malar bone, and from its inferior angle a few fibres of the mosseter take origin.

The antrum or maxillary sinus, as the air-chamber ocetupying the body of the bone is ealled, is somewhat prramidal in shape; the base being lepresented ly the nasal or internal surface, and the apex corresponding to the malar procens. In acklition to these it has four walls: the superior is formenl by the orbital plate, and the inferior by the alveolar ridge. The anterior wall rorresiunds to the facial surfare of the maxilla, and the posterior is formed by the zyomatie surface. The inner boundary or base presents a rery imegular orifice at its posterior part; thin is partially filled in by the vertical plate of the palate bone, the uncinate frement of the ethmoid, the maxillary process of the inferior turbinal, amel a small pertion of the bachromal bone. Even when these bones are in situ, the nasal oritien is verre irregular in shaje, and requires the mueous membrane to form the definite mumederl aperture (or apertures, for they are often multiple) known ats the opening of the antrum. The cavity of the antrum varies eomsiclerably in size and slalle. In the young, it is small and the walls are thick: as life arlianers. the antrum enlanges it the expense of its walls, and in old age they are often of extreme temulity; oc(asionally the eavity extends inte the sulstance of the matar lone. Thr Hoor of 
the antrum is, as a rulu, very unevers, due to frominences corresponding to the lonts of the molar teeth. In most calses the bone separating the teeth from the antrum is very thin, and not rarely the roots project movered into it. The terth which come into clesest relationship with the antrum are the first and secomel molars. hut the sordects of any of the teeth lodgerl in the maxilla may, under distansed comditions, communicate with it. Although, as a rule, the "arity of the antrum is single, ret specimens oecatsionally come to hand in which it is divided ho hony septia into chambers, and it is far from uneommon to find it divided into receses ly bony processes. In many maxillat, the roof of the antrum presents near its anterior aspect what appears to be a thick rib of bone; this is hollow and comesponds to the infraorlital eanal.

The most satisfactory nethorl of studying the relation of the bones asing in the base of the antrum is to eut away the outer wall of the cavity (see fig. s0).

Articulations. - The maxilla articulates with its fellow, and with the frontal, nasal, lachermal, ethmoid, palate, vomer, malar and inferior turbinal bones. Oc("isionally it articulates with the greater wing, and less frequently with the pteryonid process of the sphenoid bone.

The muscles attached to it are mainly those known as muscles of expresion:-

(omplessor naris.

(H) ricularis palpebrarum.

(Irbicularis oris.

Levator labii superioris.

Levator laliii superioris alæque nasi.

Masicter.
Levator anguli oris.

Inferior oblique.

Depressor alæ nasi.

Buccinator.

Internal pteryoid.

Blood-supply.-The maxilla is a very vaseular bone, ancl its arteries are mumurous and large. They are derived from the infraorbital, alveolar, descending lalatine, naso-palatine, ethmoidal, frontal, nasal, and facial vessels.

Ossification.-The maxilla arises from four centres which are deposited in membrane.

The various centres may he termed premaxillary, maxillary, malar, and prepalatine. Ther arise about the eighth week of embryonic life, and fuse very rapiclly.

(ii) The premaxillary nuclens gives rise to that portion of the bone which luclges the incisor teeth. It sencls a narrow process upwards which forms part of the outer boundary of the anterior narial aperture. On the palatine asject it furnishes a spiculum which surrounds the anterior and mesial aspect of Stenson's ranal. The pusterior limit is inclicated up to the end of the first dentition by the maxillo-premaxillary suture. The greater part of this centre is formed in memhrane, thut the inner part suberpuently invarles the ethmo-romerine eartilage.

(b) The maxillary nueleus forms the nasal process, and the greater part of the horly of the maxilla.

(c) The malar (entre gives origin to that portion of the bone lying external to the infracrloital groove.

(1) The prepalatine centre gives rice to the nasal surface of the maxilla and the palatine process postrior to Ftenson's eanal. This portion is in shape similar to the palate bone.

\section{THE PALATE BONE}

The palate bone is rectungular in shape. and wedged loctreen the maxilla and

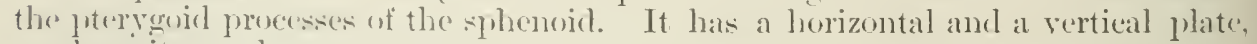

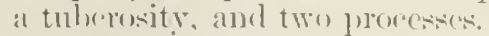

The horizontal plate is snaller than the vertical; it is quachilateral in slanes. The "le]er surface foms the posterior part of the flom of the nasal fossa; the inferior surface completes the larel palate posteriorly, and presents near its pos-

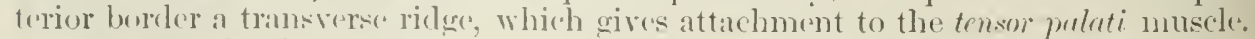
The anterior borler is roush for antioulation with the palatine process of the maxilla. The posterior lomber is free, curved, and sharp; it gives attachment to 
the soft palate. The inner borker is broad, and rough for articulation with its fellow. When the palate bones are in apposition, these borders forn a ridge continuing the erest formed hy the palatine processes of the maxillas; this erest rereives the inferior border of the vomer. The posterior extremity of the cret forms the posterior nasal spine, from which the azygns urulie arises.

The vertical plate is thin; of its two surfaces, the outer is rough for articulation with the maxilla, exeept a small portion near the middle close to the anterior border where it looks into the antrum, and a small triangular surface at the upper end where it forms part of the spheno-maxillary fossa. Towards the posterior border there is a vertical groove, which forms with the maxilla the posterior palatine canal; it transmits the descending palatine nerves and vessels. The canal may be more or less complete in the palate bone. The internal surface has two transierse ridges separating three shallow depressions. Of these depressions the lower forms part of the inferior meatus of the nose, and the limiting ridge or crest articulates with the inferior turbinal. Above this is the depression for part of the midcle meatus; the ridge above is for the second turbinal. The upper groove is narrower and deeper than the lower two, and forms a large part of the superior meatus. The ridges are known as the turbinated crests. The borders of the vertical plate are trminated by irregular prominene's, which enter into complex union with surrounding bones.

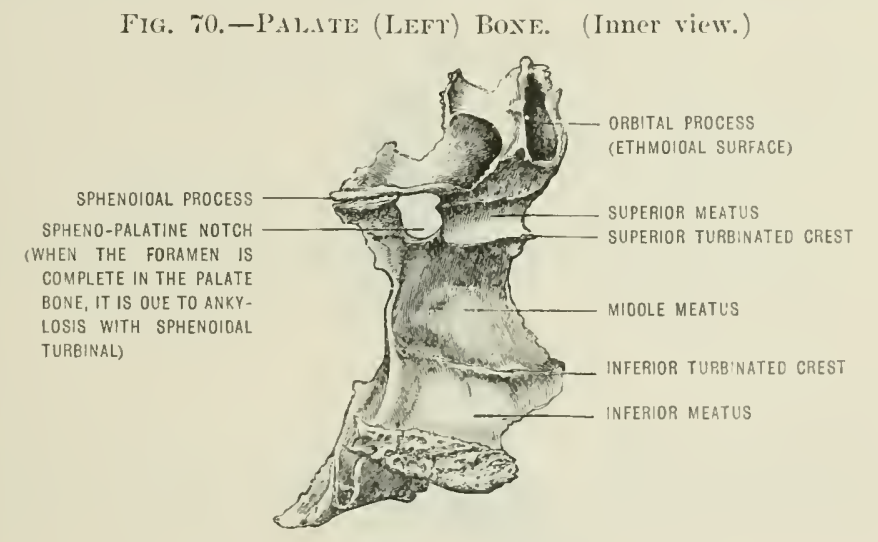

The posterior border is rertical, and comes inte relation with the anterior border of the internal pterygoid process; lekow, it terminates in a prominent tuberosity. This presents three grooves or flutes: the inner reecives the intemal pterygoid, the outer the extemal pterygoid process, while the midlle groore completes the pterygoid fossa, and afforis attachment to a fer filures of the internal plerygoid nuscle; the superior comstrictor of the pharymx also arises from this process. The tuberosity is tumnelled hy canals: to the nasal side are the accessory palatine canals; near its junction with the horizontal plate is the orifice of the posterior palatine canal; and outside this ox'asionally may be found the minute external palatine canals (fig. 81 ).

The sphenoidal process, which is a process of variable shape, sumounts the posterior border; it has three surfaecs and two borders. The superior surface comes into apposition with the sphenoidal turbinal hone, and forms part of the pterygo-palatine canal. The internal surface forms part of the outer wall of the nasial fossa, and is prolonged on to the roof, and comes in eontact with the ala of the yomer. The outer surface is subdivided by a thin lip into an anterior smooth portion for the spheno-maxillary fossa, and a posterior rough part for the hase of the internal pteryoid plate. Of the borders, the posterior is thin and artirulates with the internal pterrgoid plate; the anterior border forms the posterior houndary of the spheno-palatine foramen.

The anterior border of the vertical plate is thin, sharp, and presents near the middle the maxillary process, which is received into the maxillan'y fiswere of the maxilla near the lower border of the opening of the antrunl. 
Superiorly this borler is terminated hy the orbital process. This process presents five surfares; of these, three are articulas. The pusterior surfice joins the Walls of the sphenoidal turbinal home, its air-eells rxtencling oceasionally into this part of the palate bone. In the same way the posterior ethmoidal cells extend into the inner surfiere of the orhital proess. where they articulate with the lateral mass. The anterior surface is a continuation of the outer aspect of the rertical plate, and rest: upon the maxilla. Ot the two non-artivular surfaces, the one directed upwarls and outwards is slightly concare, and forms part of the floor of the urbit at its junction with the imer wall. The outer smooth surface looks rirectly into the zycromatic fossa, extends into the spheno-maxillary fossa, and forms the anterior houndary of the spheno-palatine foramen. These surfaces are often "onveniently named acmording to the bones with which they articulate, or the fosse which they help to form: thus, the anterior or maxillary; internal or ethmoidal; posterior or sphenoidal; superior or orbital; external (1) zygomatic.

Betweren the orthital and sphenoidal processes is the spheno-palatine notch, which is converted by the sphenoidal turbinal into a complete foramen. Occasionally it is complete in the palate bone. It transmits the spheno-palatine nerve and artery; the foramen opens into the back part of the nasal fossa, close to its roof. When the spheno-palatine formen is complete in the palate bone, it is

Fic. 71.-PALAte Buxe. (Posterior view.)

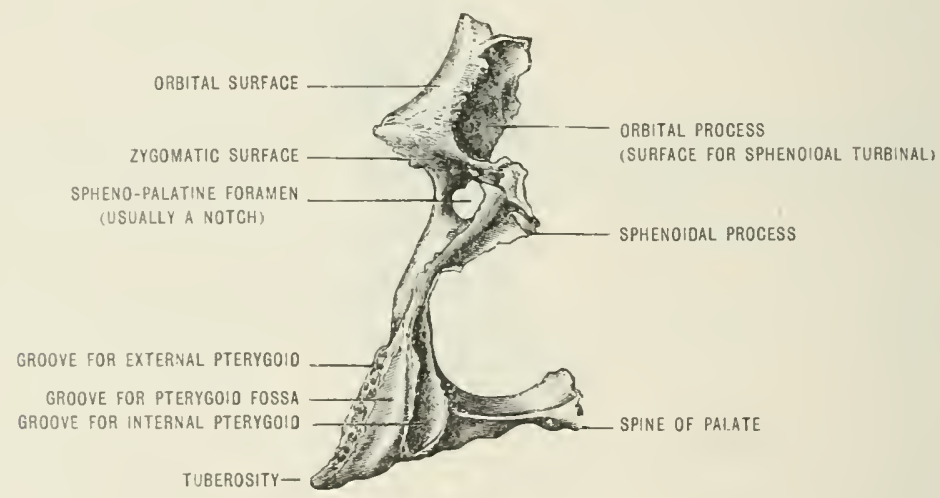

often due to ankylosis between the palate and the sphenoidal turbinal; the latter, being extremely fragile, easily breaks during the process of disarticulation.

Articulations.- The palate bone articulates with its fellow, the sphenoid, maxilla, roner, sphenoirlal turbinal, inferior turbinal, and ethmoil bones. As the surfaces and lines of mion of the orbital and sphenoidal processes are somewhat intricate, the student should, when studying this hone, refer to the following figures. The orbital and zygonatic surfaces are shown in fig. S0. The relation of the sphenoidal process to the nasal fossa in fig. 61. The relations of the pterygoid processes to the tuberosity of the palate are shown in tig. 81 . With the help of these drawings the student will be ahle to understand the position of this bone, which assists in forming the boundary of the following cavities: vize the masal, orhital, spheno-naxillary, anel antral; and the ethmoidal cells.

Thı muscles attatched to it are:-
Internal pteryogoid.
T'ensor palati.
Azygos uvila.

superior constrictor of pharynx.

Blood-supply.-Its arteries are derived lrom the descending palatine, the spheno-palatine, and pterygo-palatine.

Ossification.-The palate bone arises from one nurleus, which is depositer in membrane, and appears ahout the eighth week of enbryonic life. The spot where the earthy matter is first seen ultimatrly becomes the angle where the rertical and 
horizontal plates join. At birth the two plates are nearly equal, but as the nasal sinuses increase in height the rertical plate is lengthened, until it becomes twice the length of the horizontal plate.

\section{TIIE MALAR}

The malar bone, somewhat quadrilateral in shape, is situater at the outer and upper part of the side of the face, and forms the proninence known as the cheek.

Each bone has a convex external surface, presenting near the centre one or two minute orifices for the transmission of the malar nerves and arteries. This surface is largely covered by the orbicularis palpehrarmm, and gives origin to the zygomuticus major and minor.

The internal surface is concave, and abruptly excluded from the orbit by a prominent ledge of hone, the orbital process, which forms the anterior houndary of the temporal fossa. A large part of this surface is rough for articulation with the malar process of the maxilla. The orbital process of the malar is at right ancles with the external surface, and presents the orbital orifice of the malar canal;

Fig. 72.-THE LAFT MALAR BONE.
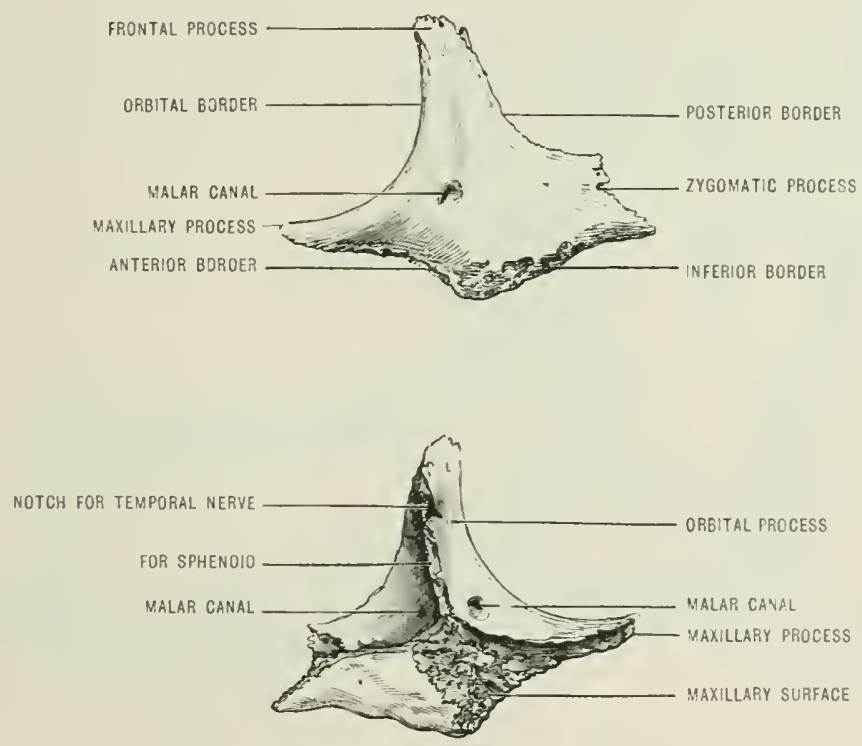

this canal is usually single, but it may bifureate as it traverses the bone, one branch emerging on the external, the other on the internal surface. The thin edge of this process articulates inferiorly with the orbital plate of the maxilla, and encls in a point known as the maxillary process. The superior portion articulates with the malar crest on the extemal surface of the greater wing of the sphenoid; in the suture between these bones a noteh (sometimes a foramen) exists for the temporal branch of the fifth nerve. When the orbital surface is large, it exeludes the sphenoidal wing from articulation with the maxilla at the anterior cxtrenity of the spheno-maxillary fissure. When this is the ease, the border presents near its micldle a short non-serrated margin.

The malar bone presents superiorly the frontal process, which articulates with the external angular process of the frontal bone. The maxillary process articulates with the maxilla, and oceasionally forms the superior segment of the infraorhital foramen. The zygomatic process is directed lackwark, and is serrated mainly on its inner aspeet for articulation with the zygoma.

Of the four horders, the orbital is the longest, and extends from the frontal to the maxillary process. It is thick, rounded, and forms the anterior third of 
the outer and a larere portion of the lower wall and inferior circumference of the orbit. The inferior is continuous with the $\% y$ goma, and gives origin to the anterior fibres of the massete. The anterior horder is in relation with the maxilla, and near the manerin of the orbit gives origin to a portion of the levetor labii sinperiwis. The posterior border extends from the frontal to the zygomatic process, and juresents a double curve; it gives attachment to the temporal fascia. This lorder is dircetly continuous below with the ulener border of the zyoma, and alove with the temporal ridge.

Articulations.-The malar articulates with the maxilla, frontal, sphenoid, and temporal bones.

Blood-supply. - The arteries of the malar are derived from the infraorbital, lachrymal branches of the ophthalmic, transwerse facial, and deep temporal arteries.

The muscles comnected with it are:-

Zygomatirus major.

livator latiii superioris.
Zyomaticus minur.

İंasseter.

Ossification.-The malar is a membranc-lone, and arises from two and occasionally three centres, which appear in the cighth week of embryonic life, and grow with astonishing rapidity: the bone quickly attains a relatively latre size.

Occasionally the two primary nuclei fatl to coalesce, and the bone is represented in the adult by two portions separated by a horizontal suture. Such bipartite malars have been observed in skulls oltained from at least a dozen different races of men. Bipartite malars have been seen with the suture rertical. That the bone maly arise from three centres is shown by the fact that tripartite malars have been (b)served.

It birth the maxillary process reaches as far forwards as the outer border of the infurbital canal; subsecpuently it may send a proeess over the camal.

\section{THE APPEVDICULAR ELEMENTS OF THE SKULL}

The bones which form this group are the mandible (lower jaw), malleus, incus, stapes, hyoid, the styoirl process of the temporal bone, and the internal pterygoid process of the sphenoid.

\section{THE MANDIBLE OR LOWER JAW}

The mandible (loner jow or imferior maxilla) is in shape like a horseshoe; it consists of a horizontal portion or body, and two vertical portions or rami.

The body consists of a right and a left half, meeting in the middle line to form the symphysis. Walch half presents two surfaces and two borders. The external surface is smooth and generally convex, and presents the following points of interest:-The symphysis ends inferiorly in a triangular surface which forms the chin. Near the srmphrsis is the incisive fossa, from which the levator menti arises; extemal to this is the mental foramen through which the mental nerve and artery issue. This formen is in a line with the second bicuspid tooth. Extending backwards and upwarls from the mental protuberance, so as to become continuous with the anterior border of the coronoid process, is the external oblique line; along its uppere border the depressor latii inferioris and depressor anguli oris arise. The internal surface presents, at a point corresponding to the symphysis, two pairs of genial tubercles. The upper pair give origin to the gemio-hyo-glossi, and the lower par afford insertion to the arrio-hyoid muscles. The tuberdesocasionally form a single, median, imegrularly shaped eminence. By the side of 
the and nial tubereles there is a shallow smooth depression, the sublingual fossa; betow this is the digastric fossa for the insertion of the anterior belly of the digatstric muscle. Posterior to the aenial tubercles, the internal oblique line (mylohyvid ridge) eommenees and extends backwards, becoming more and nore prominent as it approaches the alveolar border. The mylo-hyoid muscle arises along the whole length of this ridge. At the posterior part the superior constrictor takes origin, and the pterygo-maxillary ligament is attached to its posterior extrenity. Below the internal oblique line is the submaxillary fossa, which is in relation with the submaxillary gland.

The inferior borler of the body of the mandible is smooth and rounded; in the anterior part of its extent it gives attachment to the platysma; near its junction with the ramus there is a groove for the facial artery. The superior boreler is composerl of spongy bone, and is named the alveolar process; it presents sockets or alreoli for eight teeth. From the external surface of the alveolar process, as far forwarls as the first molar tooth, the bucrinator muscle takes origin.

Fig. 73.-THE MaxuIbIs. (Outer view.)

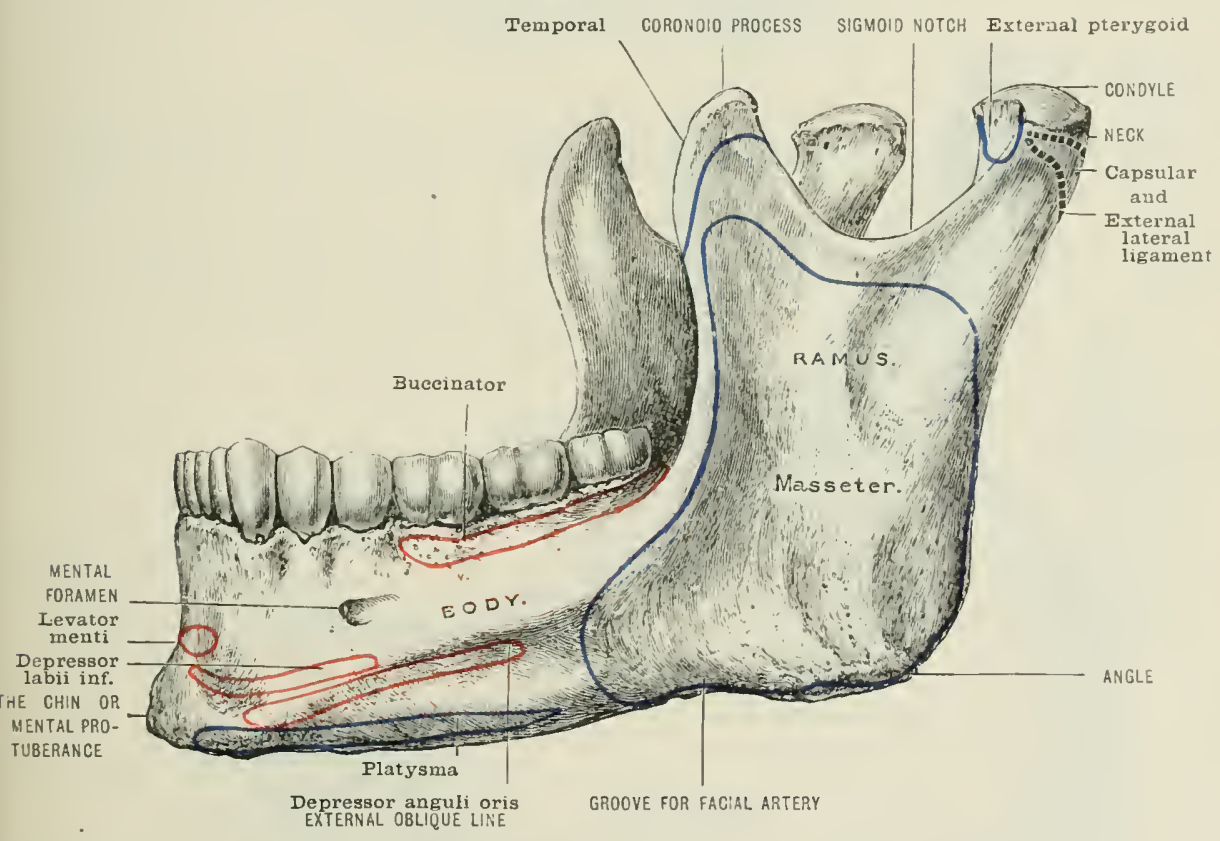

The ramus is quartrilateral in shape. It has two surfuees, four lorders and two processes. The external surface is for the insertion of the masseter musclu. The internal surface presents near its middle the mandibular (inferior dental) foramen which leads into the mandibular (inferior dental) canal which traverses the body of the bone and emerges at the mental foramen. This camal presents a series of fine apertures above, through which filaments of the mandibular norve and artery pass to the teeth. In its posterior two-thirds, the canal is nearer the internal, in its anterior third, it is nearer the external surface of the manrlible. The posterior orifice of the canal is surmounted by the mandibular spine to which the spheno-mandibular ligament is attached. Pimning olliquely downwark behimel this spine is the mylo-hyoid groove, which lodges the mylo-hyoicl nerve and artery. In the embryo, Meckel's cartilage aleo octupies the groove. The triangular rongh space hehind this groove is for the insertion of the intermal pterygroil muscle.

The inferior border of the ramus is thirk, rombled, and continuons with the lower border of the body of the lone. The posterior horder is rommlext: to its lower part the stylo-mandibular ligament is attached. This border is surmounterl 
by the condyle, which is commecter with the rmus ly a somewhat constricted jurtion, the neck.

'The condyle is oval in shane, with its long axis transerse to the upper horder of the ranus, hut ohligue with regarel to the median axis of the skull, so that the outer is more anterior than the inner angle, and presents the condyloid tubercle for the external lateral liganent of the temporo-mandibular articulation. The comver surface of the combly is covered with cartilage and rests in the grlenoid fossa; the neck is flattened in frent and presents a pit, for the insertion of a portion of the exteruel pterygrid muscle. The superior border of the ramus is known as the sigmoid notch; it is trminated anteriorly by the coronoid process. This is a peinted process with two horders and two surfaces; the inner surface presents a ridge. commencing at the tip, and becoming continnous with the inner edge of the alveolus. To this ridge, to the area of bone in front of it and the tip of the coronoid process, the temporcl muscle is inserted; its outer surface affords attachnent to the masseter and a fer fibres of the temporal. The anterior border of the ramus is continuous with the external oblique line on the body of the bone.

Blood-supply.- The mandible is very vascular, and receives a large supply

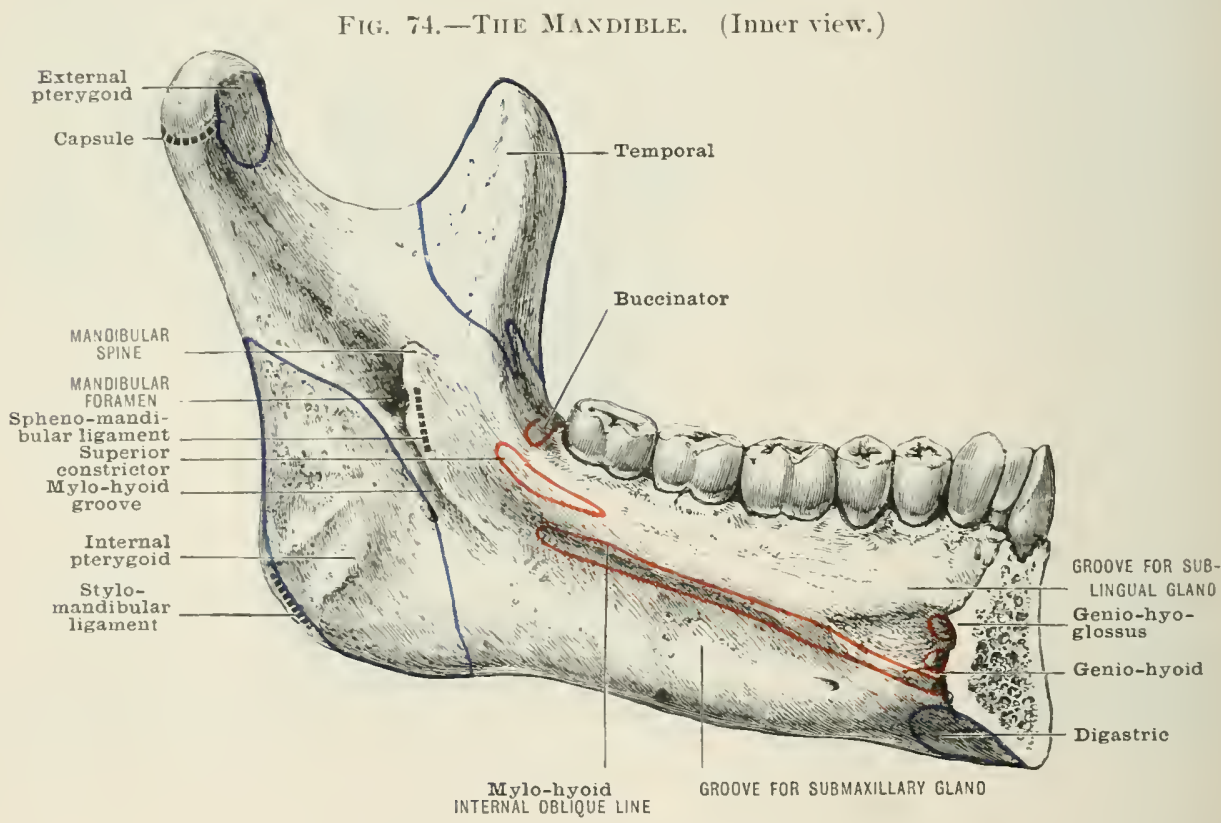

from the mandibular brancl of the internal maxillary artery. This constitutes its main supply. It receives twigs also from the facial artery.

It gives attachment to the following muscles:-

Buccinator.

Depressor lathii inforioris.

1)epressor anguli oris.

Levator monti.

Genio-hyo-glessus.

superior constrictur of pharynx.

Masseater.
Intermal pterygoicl.

External pteryoid.

Platysma myoides.

(ienio-hyoid.

Mrlo-hyoid.

I)igastric.

Temporal.

Orbieularis oris.

Ossification.-The manclible has six points of ossification for each lateral half. All these, with the exception of one, are leposited in membrane. The nuclei are deposited very early (luotwern the sixth and ("ighth week), and fuse so rapidly that observations on the derelopment of this lone are unusually difficult. 
Its six centres are mainly namerl afecorling to their position.

The mento-Meckelian.-This is depositerl in the distal ond of Merked's (mandibular) cartilage, and gives rise to that portion of the bone between the symphysis and the mental foramen.

The dentary.-This forms the lower border and outer plate, and supports the teeth, hence it: name.

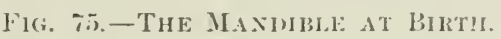
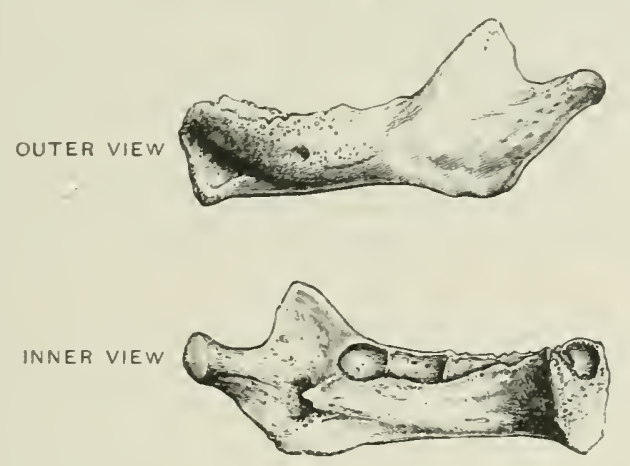

The coronoid.-This gives rise to the process of that name.

The condyloid.-This forms the condyle and adjacent portion of the ner $k$ of the hone.

The angular.-This gives rise to the angle of the bone.

The splenial.- This fentre appears three weeks later than the portinns already

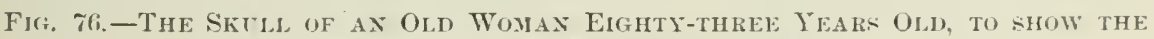
CHANGES IN THE MANDIBLE AxD MaxILLA.

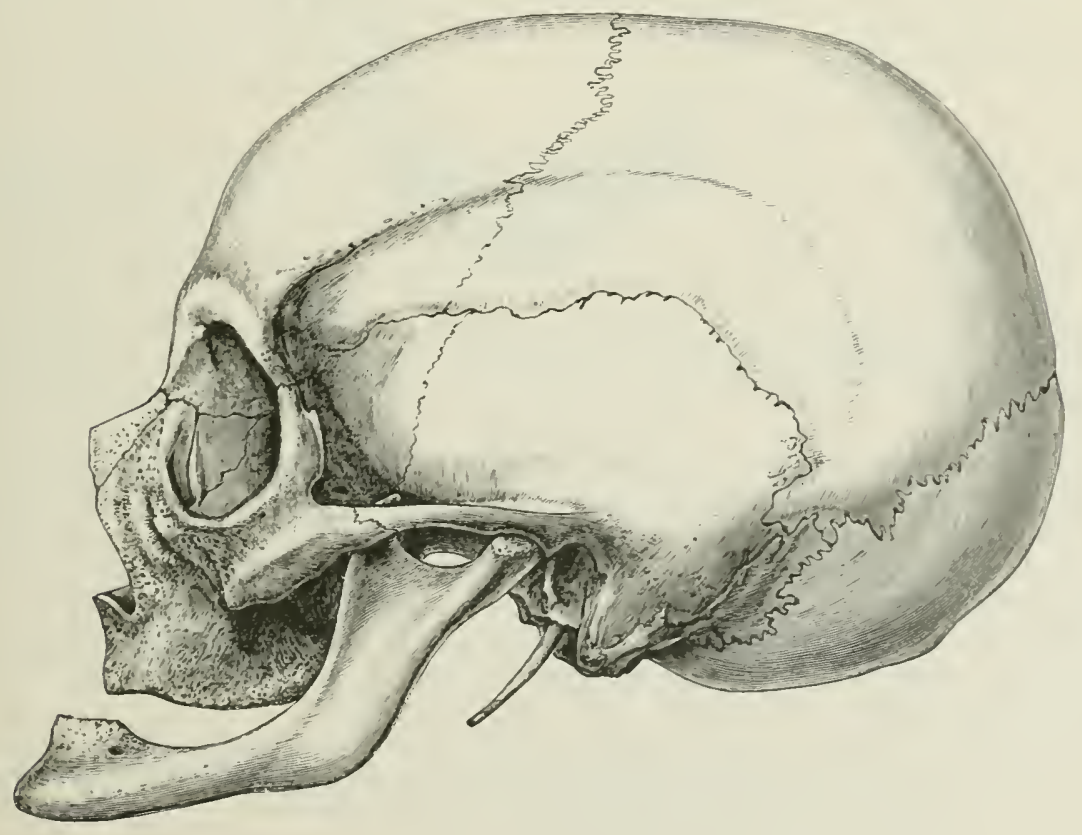

mentionerl. It forms the inner plate of the mandihle from near the symphysis to the mandibular foramen. The mandibular spine represents the posterior extrenity of the splenial. Its line of junction with the dentary is inclicated in the aclult bone by the mylo-hyoid groove.

At birth the mandible is represented by two nearly horizontal tromels: of home 


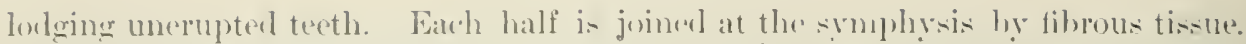

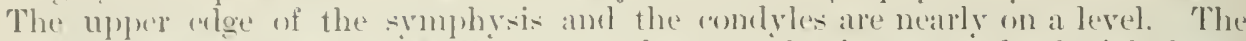
mandibular nerve hes in a shallow grove between the dentary and splenial plates.

During the first rear the two halves ankylose, union taking place from below upwarks, lut the ankylosis is not complete mntil the second rear. Aiter the first dentition, the rames forms with the body of the mandible an angle of about $140^{\circ}$, and the mental formen is situated midway between the upper and lower borters of the home oppresite the seconel milk-molar. In the adult, the angle formed hy the ramus and body is nearly a light angle, and the mental foramen is opposite the second hicuspid, so that it relative position remains unaltered after the first dentition. In old age, after the fall of the teeth, the alveolar margin is absorbet, the angle formed by the ramus and body becomes obtuse, and the mental formen approaches the alveolar margin. In a young and vigorous adult the manclible is, with the exception of the petrosal, the densest hone in the skeleton, and resists decay longest; in old age it becones exceedingly porous, and often so soft that it may be broken easily.

\section{THE HYOID, THE STYLOID PROCESA, IND THE EAR-BONES}

The hyoid or lingual bone consists of a body and four processes. The body (basi-hyal) forms the central portion of the bone; it is somewhat oblong in shape. Its anterior aspect is convex and divided ly a transverse ridge into a $-m$ morior and an inferior portion. Frequently it presents a median rertival ridge, and at the:

Fis. it.-The Hrom.

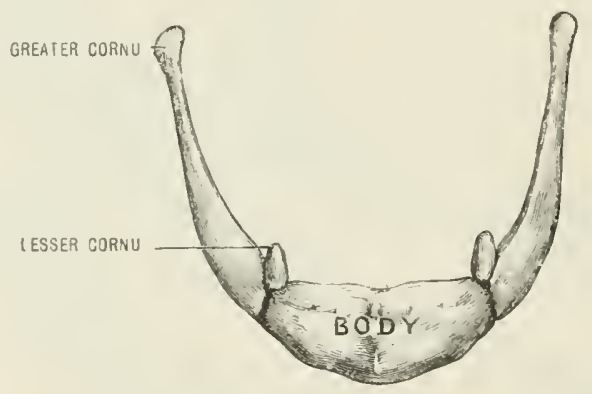

point where the horizontal and vertical ridges intersect, a tulercle, sometimes measuring four millimetres in length, is formed. The whole of the anterior surface is crowded with the origin and insertions of muscles. The posterior surface is deeply concave.

The inferior border is free, the superior gives attachment to the thyro-hyoid membrane. Between this membrane and the concavity of the hyoid there is a large bursa. The lateral borders are in relation with the greater cornua, lut remain separated from them until late in life.

The greater cornua (thyro-hyals) project backwards and upwards. Their upper and lower borders and anterior surfaces are oceupied with museles. Each comer terminates posteriorly in a rounded tuberele, to which the thyro-hyoid ligament is attacherl.

The lesser cornua (criato-hyals) are small conical pieces of bone occupying the upper part of the suture between the boty and the greater eornuil. Their tips are continuous with the stylo-hyoid ligaments.

Muscles attached to the hyoid bone :-

Lingualis.

Genio-hyo-glositus.

Nicklle constrictor.

Sterno-hyoid.
Digrastric.

(ienio-hyoirl.

'Thyro-hyoid.

Onio-hyoil.
Mryo-hyoid.

Hyo-glisists

Hyo-epiglottidensis

(when present). 


\section{Ligaments :-}

Thyro-hyoid.

Stylo-hyoid; and the thyoro-hyoid nembrane.

Blood-supply.-The hyoid reeeives twigs from the arterins supplying the muscles attarhed to it, in ardition to direct supply from the superior thyoroid and lingual arteries.

Ossification.- At the thirl month the hyoid consists of hyaline cartilage; it is directly continuous with the styloid process. In the fourth month, a anclens alprears on each side of the middle line; they become quickly confluent to form the berly of the bone. In the fifth month each greater cornu has a consiveuous nuclens. The centres for the lesser cornua are delayed until the second year.

The greater cornua remain separate from the body until after middle life. The lesser cornua rarely ankylose with the body of the bone. As a rule, they are small and inconspicuous; oceasionally they are very long, and are sometimes continuous with the styloid process of their respective sides.

The styloid process is a thin eylindrical spike of bone wedged in between the tympanic plate and the petrosal immerliately anterior to the stylo-mastoid foramen. It consists of two parts: a tympano-hyal segment which in the actult is hidden behind the tympanic plate, and a free projecting portion of variable length. As a rule it varies from five to fifty millimetres. When short it is hidden by the vaginal process, but it may reach to the hyoid bone. Its base forms the anterior boundary of the stylo-mastoid foramen. The free portion gives origin to the following muscles: The stylo-pharyngeus arises from the base posteriorly; the styln-hyoid from the outer aspect near the middle; and the stylo-glossus from the front near the tip. The extremity of the process is continuous with the stylo-hyoid ligament. A band of fibrous tissue-the stylo-mandibular ligament-passes from the process below the origin of the stylo-glossus to the angle of the mandible.

\section{Muscles attached to the styloid process :- Ligaments :-}
Stylo-glossus.
Stylo-hyoid.
Strlo-hyoid.
Stylo-mandibulas.

stylo-pharingens.

The morphology and development of this process are describer on page 90 .

The malleus.- This is the most external of the auditory osicles, and comes in relation with the tympanic membrane. Its upper portion, or head, is loxlged in the attic of the tympanum. It is of rounded shape, and presents posteriorly an elliptical depression for articulation with the incus. Below the head is a constricterl portion or neck. From beneath the neck three processes diverge. The largest is the handle or manubrium, which is slightly twisted and flattened. It forms an obtuse angle with the head of the bone, and lies between the membrana tympani and the mucous membrane covering its inner surface.

The tensor tympani tendon is inserted into the manubrimm near its junetion with the neck on the inner side. The slender process (gracilis or Folian) is a long, slender, delicate spieulum of bone (rarely seen of full length except in the foetus), projecting nearly at right angles to the anterior aspect of the neck, and extending obliquely downwards. It lies in the Glaserian fissure, and in the arlult usually becomes eonverted into connective tissue, except a small basal stump. The short process is a conical projection from the outer aspect of the base of the manubrium. Its apex is connected to the upper part of the tympanic memlime, and its hase reeives the external ligament of the malleus. The malleus also gives attachmont to the suspensory ligament, and to the long anterior ligament of the malleus which was formerly described as the laxator tympani muscle.

The incus.-This bone is situated betreen the malleus extemally, and the stapes internally. It presents for cxamination a body and two processes. The body is deeply exeavated anteriorly for the reception of the head of the mallens. The short process projects backwards, and is comnected by muans of ligamentous fibres to the posterior wall of the tympanum, near the entrance to the mastoid antrum. The long process is slender, and directed downwals and inwards; it 
lin paralle] with the handle of the malleus. On the imner aspect of the clistal extrenity of this proces is the orbicular tubercle, connected with the process by a namew neck. Its free surface articulates with the head of the stapes. The orbicular tuberele is seprarate in early life.

The stapes is the immermost ossicle. It has a head directed horizontally outwards. capped at its onter extremity by a disc resembling the head of the radius. The cup-shiped dipresion receives the orbicular tuberele of the incus. The base

Fiti. T.-The Boses of the Ear. (Moditied from Henle.)
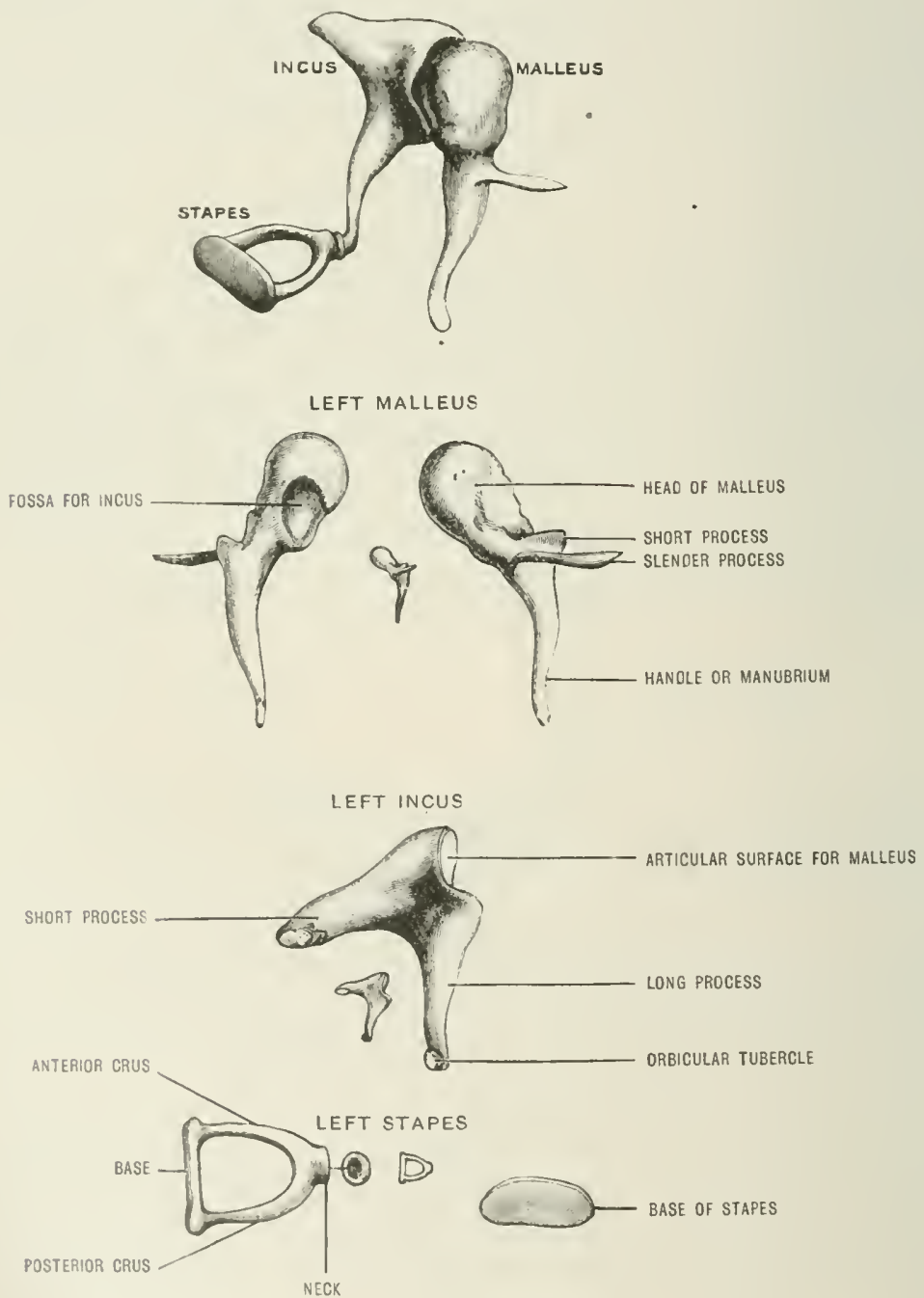

merupies the fenestra ovalis, and like this opening the inferior border is straight, and the superior curvel. The base is connected with the head by means of two crura, and a narrow piece of bone called the neck. Of the two crura, the anterior is the shorter and straighter. The crura with the base form a stirrup-shaped arch, of which the inner margin presents a groove for the reception of the membrane which is stretehed across the hollow of the stapes. In the early embryo this hollow is traversed ly the stapedial artery. The neck is very short, and receives on its posterior borler the tenton of the stupedius muscle. 
THE EXTERIOR OF THE SKLLL

The skull, when rieued fiom above, presents an oval outline; the posterior part is broader than the anterior. The bones seen in this view are the frontal, parietals, and the interparietal portion of the occipital. In a skull of average width the zygomata come into view, but in rery broad skulls they are obseurer.

The sutures of the vertex are:-

The metopic, which is. in most skulls, merely a median fissure in the frontal bone just above the glabella; occasionally it involves the whole length of the hone. It is due to the persistence of the fissure normally separating the two halres of th. bone in the infant:

F1(i, 79.-Tine SkUll. (Norma lateralis.)

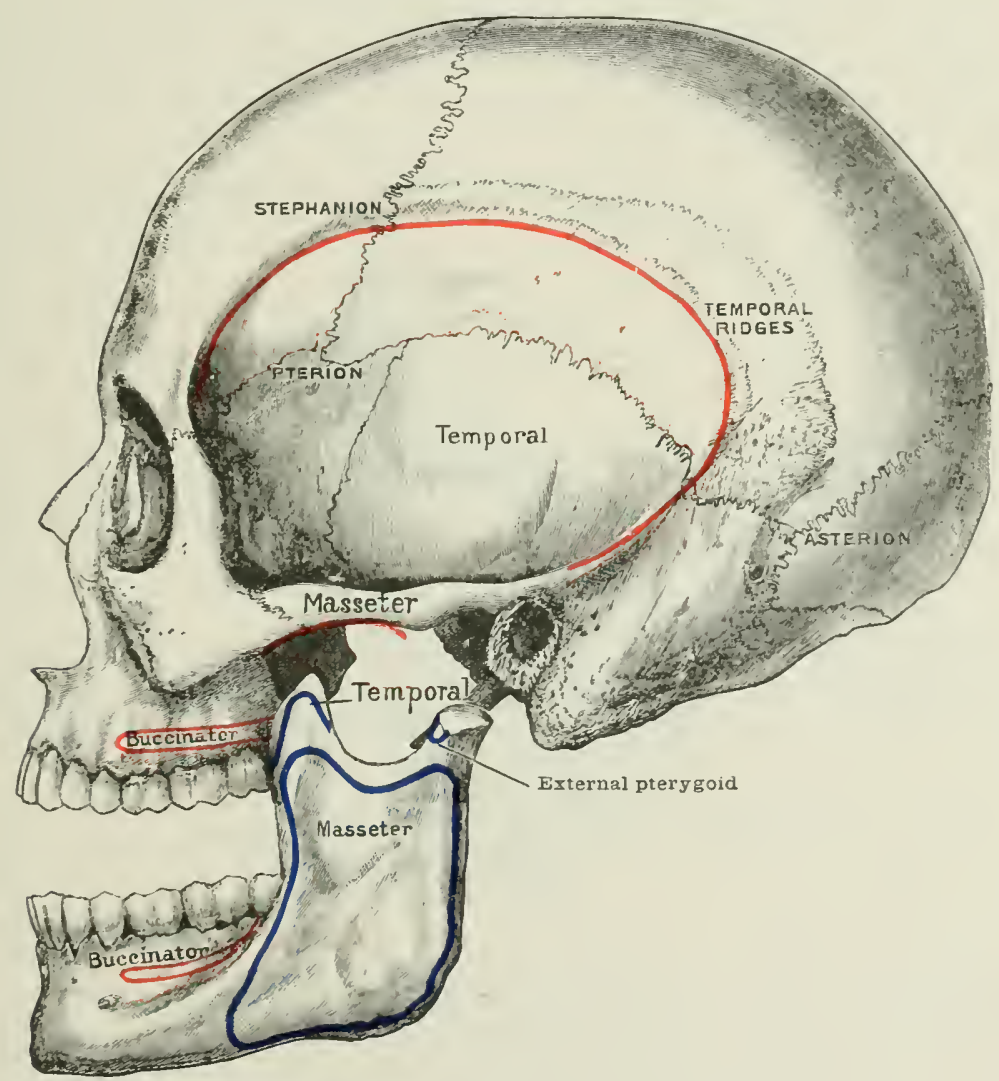

The sagittal is situated between the two parietals, and extends from the bregmin to the lambda.

The coronal lies between the frontal and parietals, and extends from pterion to pterion.

The lambdoid is formed by the parietals and interparietal portion of the oceipital. It extends from asterion to asterion.

The occipital suture is only present when the interparietal exists as a suparate element (fig. 35).

The more important regions are:-

The bregma, which inclicates the situation of the anterior fontanelle, and marks the confluence of the comnal, the sagittal, and, when present, the metropic sutures.

The lambda, where the sagittal enters the lambdoid suture; it marks the situation of the posterior fontanelle. 
The obelion, a little anterior to the lambela. is wsually indicated by a merlian (1) two lateral for:muina. It indioates the spot where the sagittal suture first suffers (bliteration.

liewed firm luhind, the skull appears irregularly globular; the inferior part of its cireumference leing somemlat flattenecl. The limits of the flattened portion are inclicited by the mastoid processes.

The'(')tre is ocenpied hy the occipital protuberance; this, with the occipital (rest and the three pairs of inuchal lines. grive to the lower half a rough and uneven appenance. The sutures in this view are the teminations of the sagital, lambdoidal and, when present. the oceipital suture.

The occipital point (fig. $9(0)$ is the most posterior part of the skull, and is "xactly (1) pusite the (1) hryem.

The inion correpumls to the extemal occipital protuberance.

The luteral aspert of the skull is rery uneven; it presents three recesses or fosse. lts irregularity is increased by the zygoma.

The temporal fossa, semilmar in shape, is limited above by the superior timpinal riclge, and below by the zygoma.

The temporal ridge huins at the external angular proess of the frontal bone, anel curves upwarls and hackwarels to crose the frontal and parietal bones; it then desends along the mastoid portion of the temporal bone to become continuous with the apper horder of the zygoma. In many skulls this ridge is double. The lower rilge gives origin to the temporal muscle. The upper is the least constant; it cliveres from the lower rilge as it approaches the coronal suture. At the middle of the pariatal hone the two ridges are often ten millimetres apart. This ridge gives attarchment to the temporal fascia. The fossa is almost entirely oceupicel by the teinumiril muscle.

The zygomatic fossa is limited anteriorly hy the zygomatic surface of the maxilla; intemally by the extemal pterygoid plate; externally by the zygomatic arch and the ramius of the mandible; and posteriolly by a line drawn from the formen spinowm to the zygomatic tuhercle. The outer surface of the greatcr wing of the splenoid internal to the pterygoid ridge and a small piece of the syuminsal form lart of the upper bomdary of the fossa.

The chief oljects of interest in this region are:-The spheno-maxillary and pterygo-maxillary fissures, the pterygoid ridge on the sphenoidal wing, the foramen ovale, foramen spinosum, and the articular eminence of the sulummosal.

The spheno-maxillary fissure is horizontal in position, and lies between the orthitil border of the maxillat and the greater wing of the splenoid; externally it is completed usually by the malar; frequently the sphenoid will join the maxilla and 'xilude the malar hone from the fissure; internally it is teminated hy the zyogmatic surface of the orhital proecss of the palate liome. Through this fissure the ortital, sphomo-maxillary, and zygomatic fossc communicate. The zygomatic fossa lorlese the tempural, external pterygoid, and internal pterygoid muscles.

The pterygo-maxillary fissure forms a right angle with the preceding. It is situated between themaxilla and the anterion border of the pteryoid process of the shemoil. At its lower angle the extemal pterygoid plate occisionally articulates with the maxilla. The ptrergo-maxillary fissme leads from the zyematic fossa diretly into the spheno-maxillary fossa, a small space shaped like an inverted lyrmid, situated between the maxilla and the roots of the pteryesoid processes.

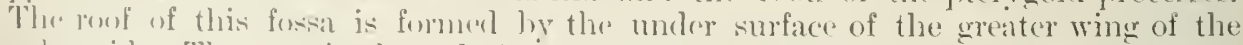

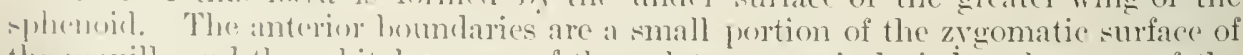
the maxillat ancl the orlital process of the palate; posteriorly it has the roots of the

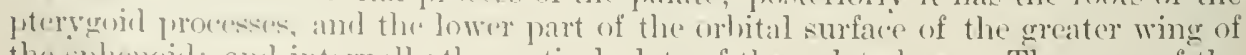
the spluenoil; anel intemally the vertical plate of the palate hone. The apex of the Hramid lasks into the posterior palatine canal. The immer wall presents the spheno-palatine foramen which leads into the nasal fossa. The posterior wall

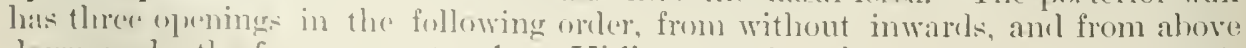
dowmarls: the foramen rotundum, Vidian canal, aml pterygo-palatine canal. Anteriorly it communims with the colbit ly the spheno-maxillary fissure; aml "xtermall!" the pterygo-maxillary fissure learls inte the zyonatic fossa. 
This fossa is mainly of interest on account of its relation to the spheno-palatine (Meckel's) ganglion. The various foramina and canals connected with the fossa serve for the transmission of the nerves comnected with this ganglion and the terminal branches of the internal maxillary artery.

In addition to the fossen, the lateral region presents the glenoid fossa with it: articular eminence, the external auditory meatus, the mistoid and styloid processes, and the following sutures:-

The spheno-parietal, which lies between the greater wing of the sphenoid and the :nterior inferior angle of the parietal.

The squamous is formed by the squamosal overlapping the lower border of the parietal.

The parieto-mastoid, which lies between the posterior inferior angle of the parietal and the mastoid portion of the petrosal.

The zygomatic suture is formed by the union of the zyoma with the malar bone.

The squamo-sphenoidal is situated between the anterior border of the squamosal ancl the greater wing of the sphenoid.

The spheno-malar suture is formed by the orlutal process of the malar and the

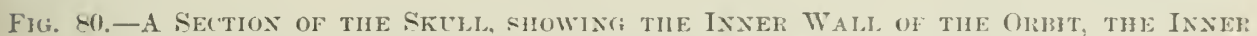
WALL OF TIE ANTITH. ANI THE SIHEXO-JAXILLARI FOSSA.

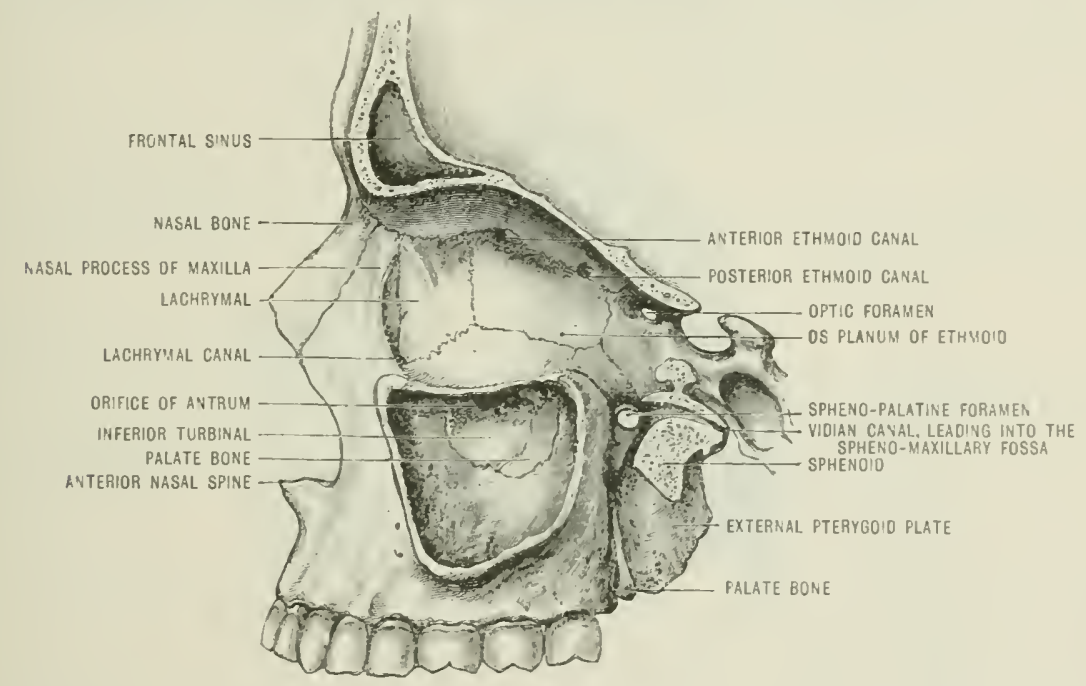

malar rielge on the greater wing of the sphenoid. Nour its midule the suture is perforated by the spheno-malar foramen, which allows the tomporal branch of the orbital nerve and a branch of the lachrymal artery to escape from the orhit. This foramen in some arlult skulls is complete in the millar.

The fronto-squamosal is an occasional suture; when it is present, the anterior' inferior angle of the parietal is excluded from the greater wing of the sphenoid.

The more important regions are:-

The pterion, which marks the situation of the anterior lateral fontanelle is: the meeting-place of the coronal, squamous. spheno-parietal, squano-sphenoidal. and the fronto-squamosal sutures. Frequently it is recupied in the adult ly the epipteric ossicle.

The asterion indicates the situation of the posterior lateral fontanclle and marks the confluence of the squamosal, fririeto-mastoid. lambdoid, the occipitomastoid, and occasionally the occipital sutures. Sometimes it is oceupied hy a ITormian bone. suture.

The stephanion is the spot where the superior tanpural ridge cuts the coronal

The auricular point is the eentre of the extemal anditriry meatus. 


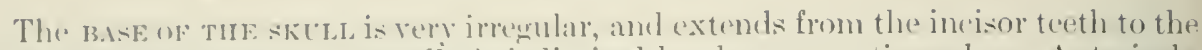

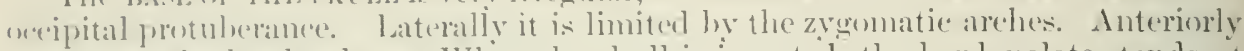
it presents the harel palate. When the skull is inverterl, the haml palate stands at a higher level than the rest; it is bounded anteriorly and laterally by the alventar

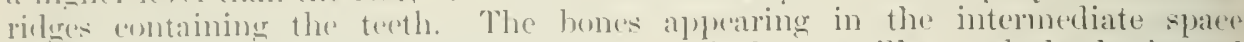
are the premaxillary and palatine portions of the maxille, and the horizontal plates of the palate ixones. The lone is rough for the attachment of the mucoperinstemon. The following points are readily recognised (fig. s1):-

The meso-palatine suture commenes at the alveolar point, trarerses the anterior palatine fossi. and terminates at the pusterior nasal spine.

The transverse palatine suture between the palate bones and palatine processes of the maxillit.

In young skulls the maxillo-premaxillary sutures, and behind the incisor teetlı four snall openings know as the gubernacular canals.

The anterior palatine fossa containing the termination of four ("anals: two small urifice, foramina of Scarpa, situated one lehind the other in the mesopalatine suture; and two larger openings, the foramina of Stenson. Fearpals foramina transuit the naso-palatine nerves; Stenson's are in relation with Jacubsion's orgaths.

At the posterior angles of the hard palate are the posterior palatine foramina,

Fili. Ri.-Hard Palate of a Child Five lears Old.

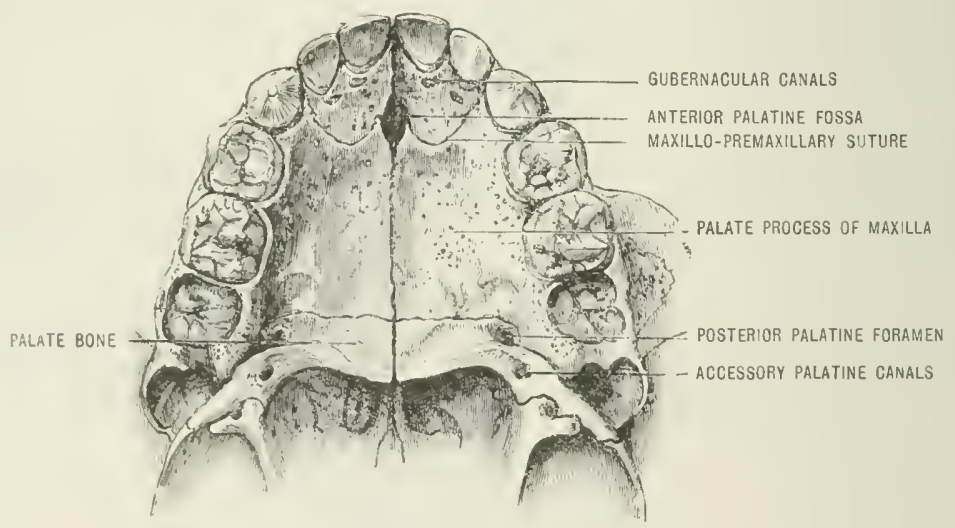

through which the posterior palatine ressels and the anterior palatine nerves "merese on to the palate; a thin lip of bone separates them from the accessory palatine foramina for the posterior palatine nerves. The accessory foramina are in the tubseresity of the pallate bone.

The hamular process of the internal pteryoirl plate is the most posterior limit of the harel palate.

At the pustriole extremity of earhalveolar ridge is the tuberosity of the maxilla. Puetwen the tuberesities of the maxilla and the palate bone ale a few minute: foramina (variable in number and not always present), the external palatine canals for the "xternal palatine nerves.

behind the haml palate are the posterior nares, sejarated from each other by the romer. Eald is lemoled externally by the internal pterygoid plate; below by the horizontal plate of the palate bone; above by the under surface of the borly of the sphemeid, with the ala of the vemer and a prortion of the sphenoidal proeesis of the palate bene.

Extermal to the names there is on each side a rertieal fossa lying between the

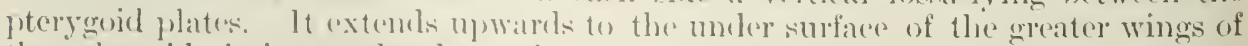
the sphemoid: it is ampleter anterionly by the rulcserne of the pterygoid plates, and below by the tuberosity of the palate bone. It contains the following points of interest:- 


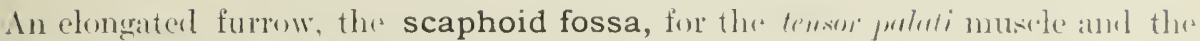
rartilage of the Eustallian tube.

The general cavity of the pterygoid fossa which loxlges the tenson paluti anel internal pterygoid musedes.

Frequently there is a notch in the external poteryogid plate chese besirle the foramen ovale.

The pesterior termination of the Vidian canal.

If a line be chawn across the skull-base from one zygomatic tuberele to the other, it will fall inmerliately behind the external pterregoid plate and bisert the foramen spinosum on eatch side. A second transverse line, hrawn actoss the opisthion or posterior margin of the foramen magnum, will fall leehind the mastoil processes. The space between these imaginary lines may be called the smb-comingl region; that behind the second line the sub-orcipital region. In addition to these there is a lateral space anterior to the first line known as the zygomatic region. Eirch will repuire separate consideration.

The s[B-r'RANIAL REGION is formed by the following bones:- In the centre, the under surfice of the bodies of the sphenoid and oecipital hones. Laterally, the petrusil, a small piece of the greater wing of the sphenoid and of the squamosial, and part of the occipital. It presents the following points in the middle line for sturly:-

The pharyngeal tubercle.

The foramen magnum and the occipital condyles. The most anterior point of the formen is termed the basion, and the most posterior point the opisthion.

On each side will be seen:- The anterior condyloid foramen for the hypghisial nerve and a meningeal branch of the atsecnding pharyngeal artery.

The posterior condyloid fossa with the posterior condyloid foramen (this formen is not (onstant).

The sphenotic (middle lacerated) foramen and the orifice of the Vidian canal. tule.

The canalis musculo-tubarius for the tensor tympani muscle and Eustachian

The carotid canal.

Aqueductus cochleæ, or ductus perilymphaticus.

The jugular foramen and fossa for the glosio-pharyngeal, ragus, and spinal accessory nerres, the internal jugular rein, and a meningeal brandh of the anecending pharyengeal artery.

The tympanic canaliculus for Jacolson's nerve. (Tympanic of glosict)pharyngeal.)

The alar spine of the sphenoid; this is sometimes fifteen millimetres in length.

The glenoid fossa with the Glaserian fissure. This lorlges the slemeler process of the malleus, the tympanie twig of the internal maxillary artery. A small passage besile it, the canal of Huguier, conducts the chordal tympani nerve from the tympanum.

The external auditory meatus.

The auricular fissure for the tympanic lianch of the vigus.

The tympanic plate and vaninal process.

The styloid process.

The stylo-mastoid foramen for the stylo-mastoid artery and the exit of the facial nerve.

The mastoid process with the digastric: and oceipital groores.

The sub-occipital, Regios presents cluefly museular ridges. They are the superior, middle, and inferior nuchal lines, with the cxternal oecipital protulerance and the external oceipital crest. Behind the mastoid process is an oprening of variahle size, the mastoid foramen; a hranch of the oeropital artery enters, and a rein from the lateral sinus issues from this formon.

The ANTEIor Asiect of the skull jis oval in ontline, lunt presents a very irregular surface. Its upper portion, or forchead, presents the frontal eminences and

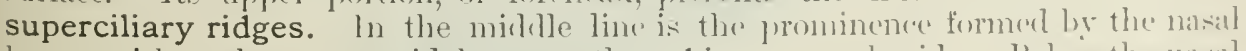

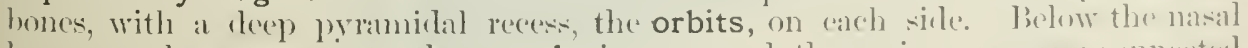
bones are the entrances to the nasal sinuses and the varions recesses (a)nnecterl with them. The teeth form a renspirenous frature in this riew of the skull, the outline of which is completed hy the mamlible. 
Fl木. 8.2.-THE skter. (Norma basilaris.)

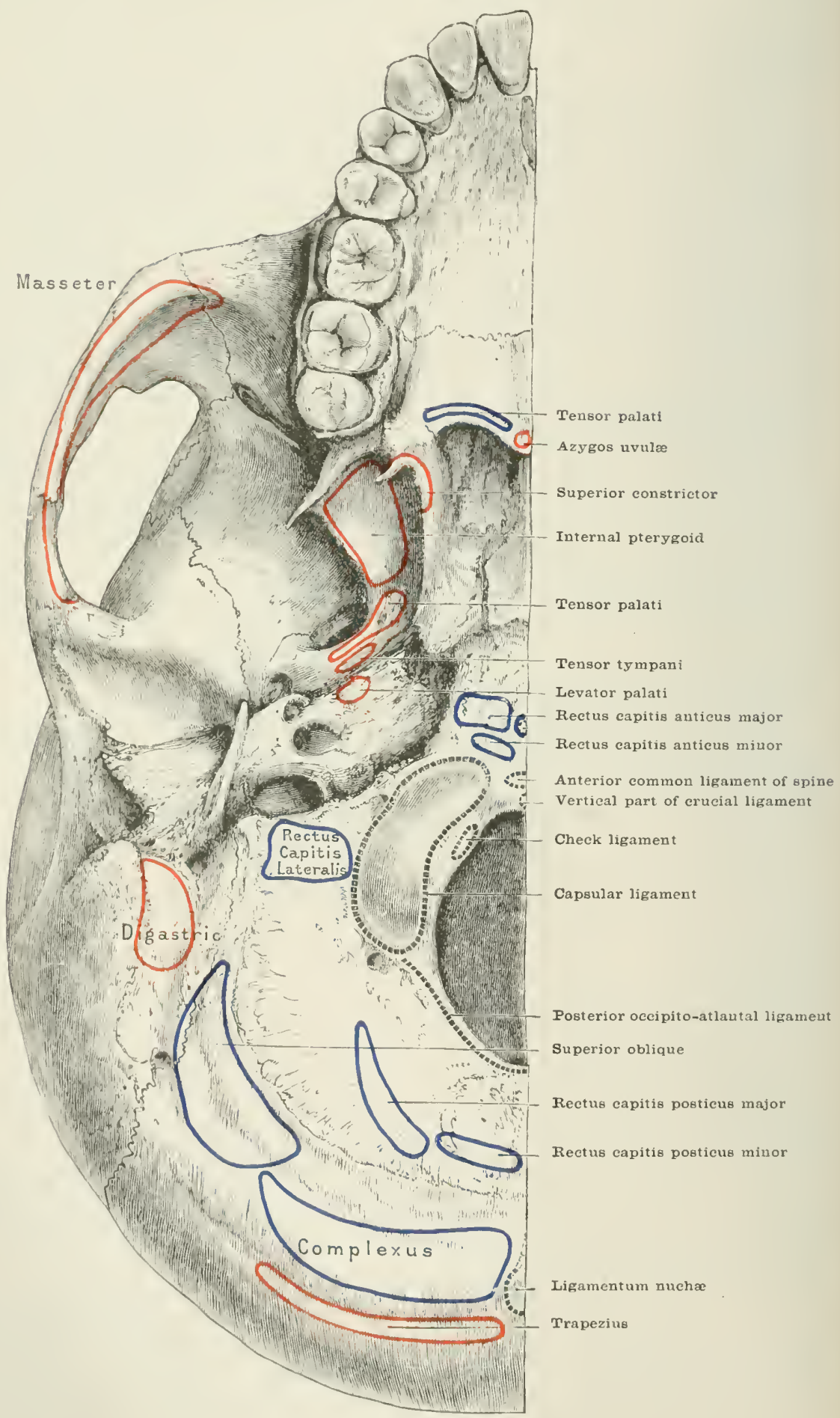


Fin. 83.-THe skute. (Norma basilaris.)

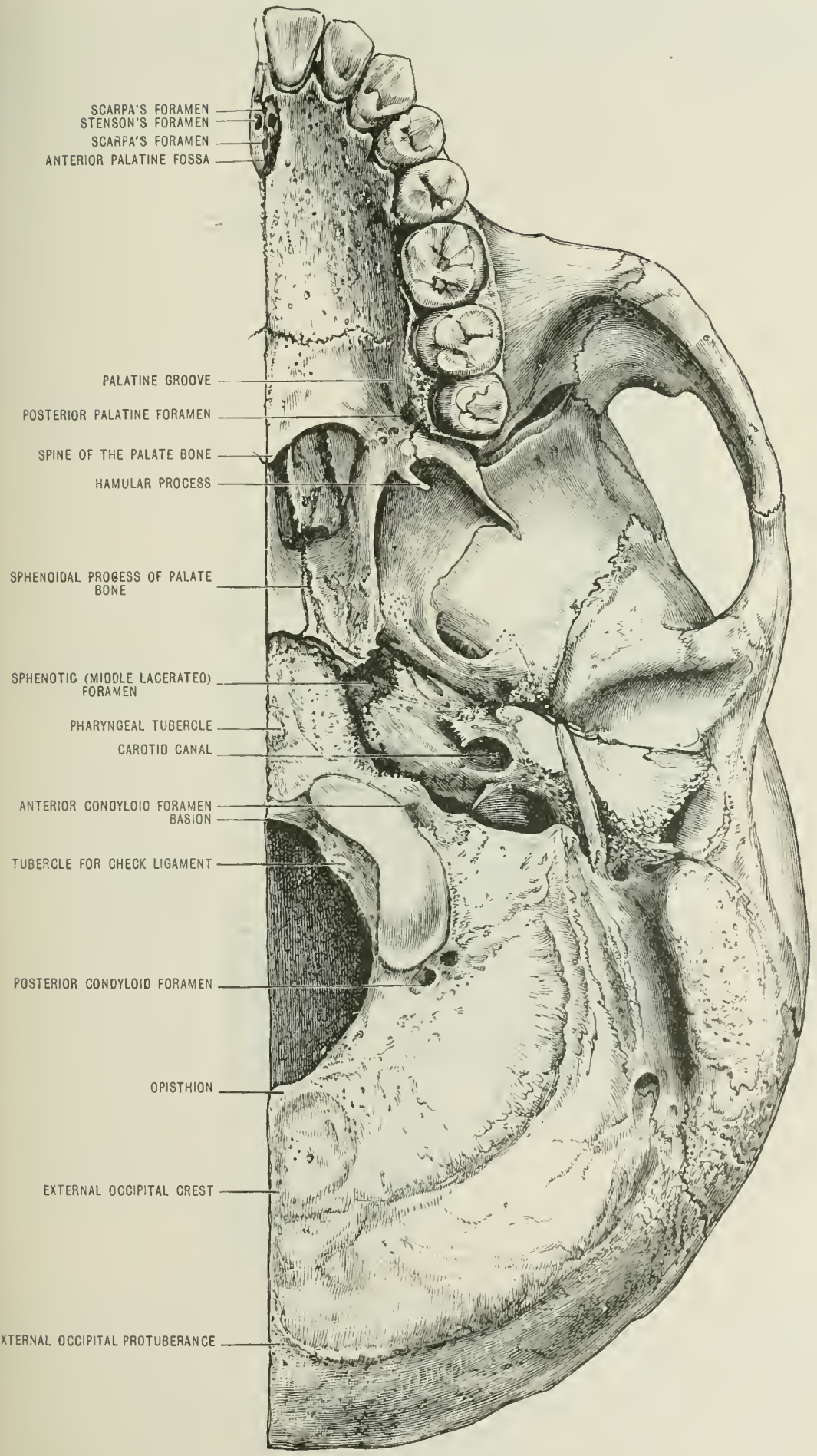


The bones visible in this view of the skull are: the frontal, nasals, lachrymals, orthital surfiaces of the lessere and the greater wings, and a portion of the body of the sphenoil, the ossa plana of the ethmoid, and the orbital processes of the palate bones, the malars, maxille, inferior turbinals, and the mandible.

The foramina are: the supraorbital, infraorbital. optic, temporal, and nental; the lachrrmal duet; the malar and ethmoidal canals; and the spheno-maxillary and sphenoilal fissures.

The orbits are two cavities of prramidal shape, which lodge the eyeball and its

FIG. Q., The skelL. (Norma lavialis.)

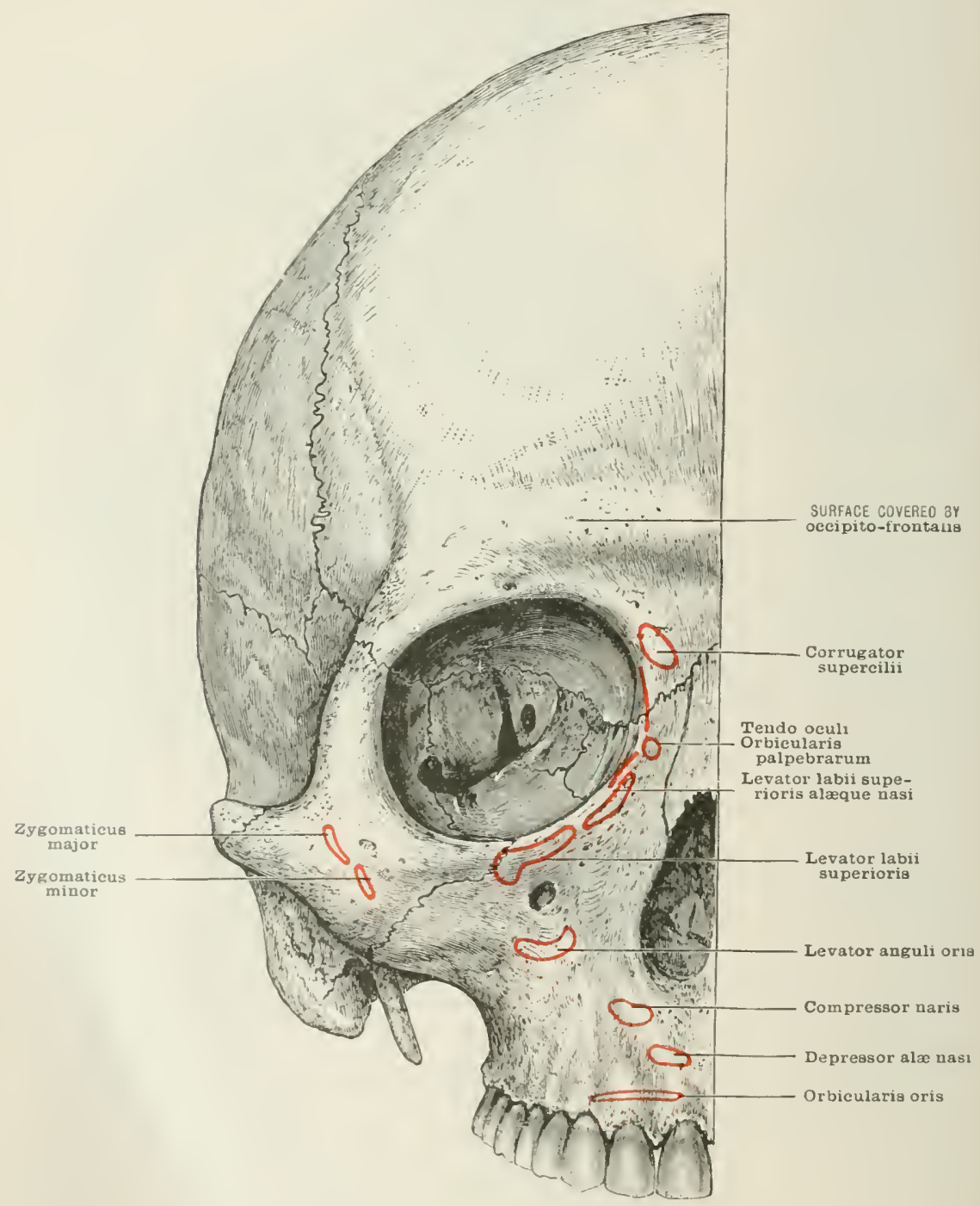

associater museles, nerves, and vessels. The apex of each orbit corresponds to the optic foramen, a circular orifice which transmits the optic nerve and ophthalmic artery. The base looks forwarls and outwards. It is formed by the frontal bone above, the nasial process of the maxilla on the inner side, the malar bone externally, and below by the malar and hody of the maxilla. The following points are seen around the base:-The suture between the external angular process of the frontal hone and the malar; the supuorbital notel (sometimes a romplete 
formene) and the suture between the frontal bone and the nasal process of the maxilla; and in the inferior segment of the cireumference is the malo-maxillary suture. Oecasionally, the infraorbital furamen opens hy a narrow fissure into the orbit.

The roof of the orhit is formerl mainly by the orbital plate of the frontal bones, and completer posteriorly by the lesser wing of the sphenoid. At the outer angle it presents the lachrymal fossa for the lachrymal gland, and at the inner angle a degression for the pulley of the superior oblique muscle.

FIG. - -i.-THE SKLLL. (Norma facialis.)

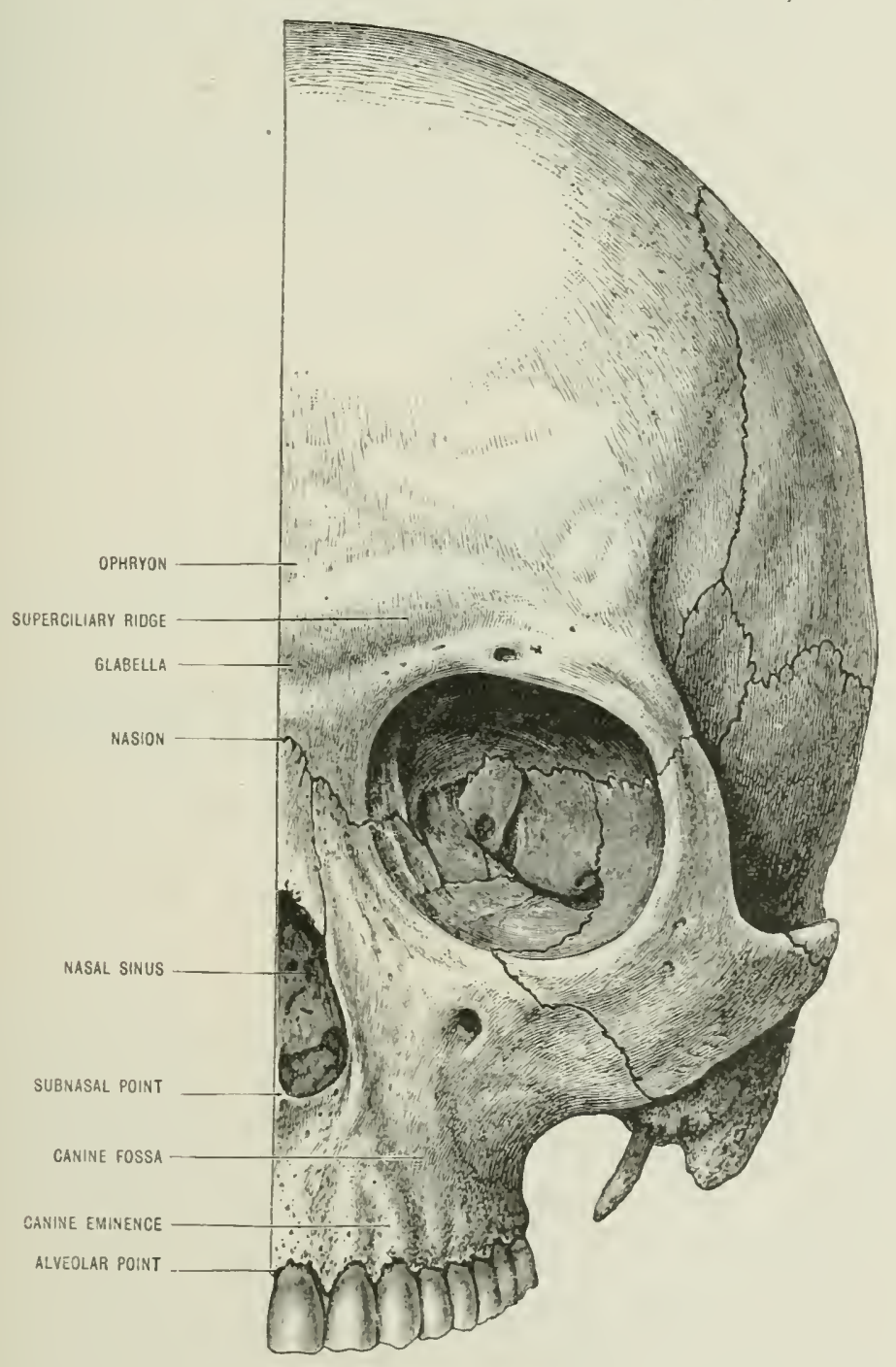

The floor is formed by the orbital plate of the maxilla, the crlital process of the malar, and the orbital process of the palate bone. At its inner anerle it presints the lachrymal canal, and near this a depression for the origin of the inferior oblinger muscle. The floor has a furrow for the infraorbital artery and the second division of the fifth nerve. The furrow terminates anteriorly in the infracrlital canal, through which the infraorbital nerve and artery emerge on the face. Near the commencement of the canal a narrow passage, the anterior dental canal, runs for- 
wards and hownwarls in the anterior wall of the antrum; it conducts nerves to the incisior and canine tecth.

The outer wall is very oblique; it is formed ly the orbital surface of the greater wing of the sphemoid, and the malar. Between it and the roof, near the apex, is the sphenoidal fissure, hy means of which the third, fourth, ophthalmic division of the fifth, and sixth nerves enter the orbit from the cranial avity. The lower marein of the fissure presents near the midule a small tubercle, from which one head of the cxternal rectus muscle arises. Between the outer wall and the floor, near the alpex, is the spheno-maxillary fissure, which allows the second division of the fifth nerve to enter the infraorbital groove from the spheno-maxillary fossa. It the anterior marein of the fissure, the sphenoidal wing oceasionally articulates with the maxilla, but frequently it is excludecl by the malar. In front of the anterior "xtremity of this fissure is the orbital orifice of the malar canal. Near the outer extremity of the sphenoidal fissure a few small formma may be seen, especially in old skulls, which allow branches of the midlle meningeal artery to creep into the orbit. A rertical fissure, the spheno-malar, traverses the outer wall. It contains the very small spheno-malar formen, which allows the temporal branch of

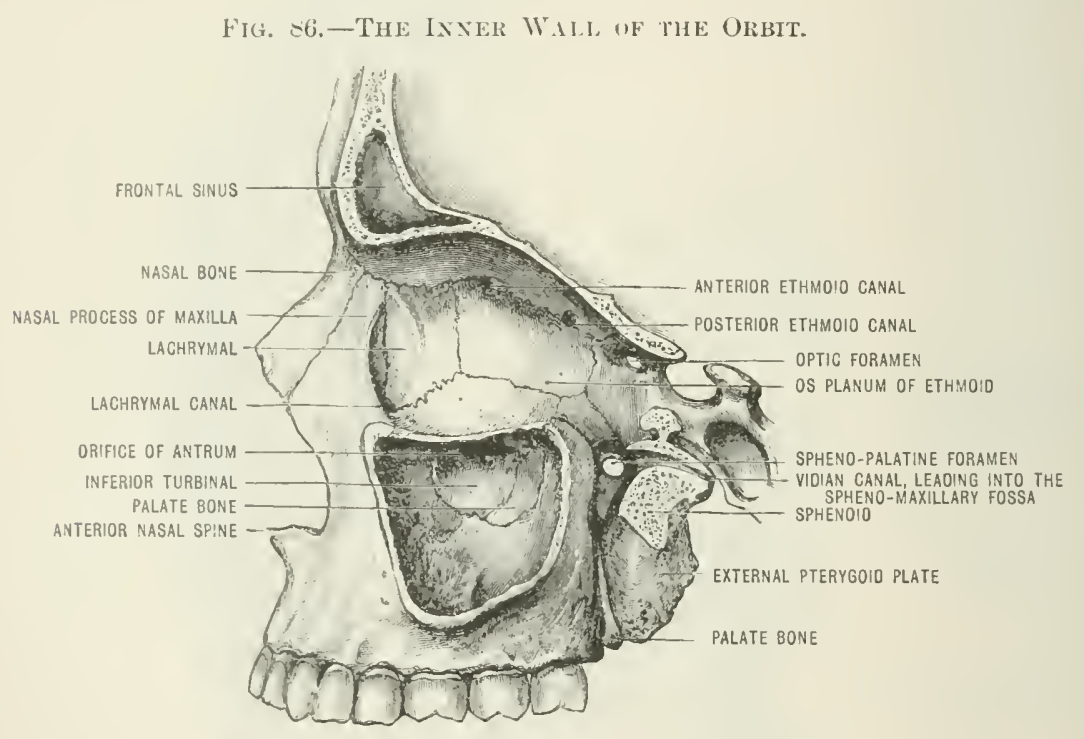

the orhital nerve to escape from the orbit. This foramen is sometimes confined to the makar bone.

The inner wall, narrow and straight, is formed by the lachrymal, os planum of the ethmoid, and a part of the body of the sphenoid. The ethmoid section of the transverse suture contains the orifices of the anterior and posterior ethmoidal canals: the former transmits the nasal nerve and anterior ethmoidal artery; the latter the posterior ethmoidal artery, and a lianch of the nasal nerve.

Anteriorly is the lachrymal groove, and behind this the erest which gives origin to the tensm" tursi. This wall has three vertical sutures: one between the nasal process of the maxilla and the lachrymal, the ethmo-lachrymal, and one between the os planum and borly of the splienoid. Occasionally the sphenoidal turbinal bone alpears in the orlit between the os planum of the ethmoid and the body of the splienoil (tig. (6t).

The orbit commmicates with the cranial cavity by the optic foramen and sphenoidal fiswure; with the nasal fossa by means of the lachrymal duct; with the zygormatic and spheno-naxillary fosse by way of the spheno-maxillary fissure. "In adrlition to these large openings, the orlut has five other foramina-the infra-orbital, malar, spheno-malar, and the anterior and posterior cthmoidal canals-opening into it or learling from it. 
In old skulls the frontal sinuses occasionally extend into that portion of the horizontal plate of the frontal bone which forms the roof of the orlit.

The following muscles arise within the orbit:- the four rerti, the smprior oblique, and lecator palpebrix superioris, near the apex; the inferior oblique on the floor of the orbit external to the lachrymal canal; and the trisor tursi from the lachromal crest. The margins of the spheno-maxillary fissure give attachment to the orbitulis muscle (see section on the Eye).

The nasal fossæ or sinuses are two irregular cavities situated on each side of a median vertical septum, extending from the anterior part of the skull-base to the superior surface of the hard palate. They are somewhat oblong in section, but are narrower above than below.

Each fossil presents a roof, floor, inner and outer wall, and opens in front ly the anterior naris, and communicates behind with the pharynx by the posterior naris.

The roof resembles that of a house with two sloping edges and an intermediate level portion. The anterior slope is formed by the posterior surface of the nasal bone and the nasal spine of the frontal. The horizontal portion corresponds to the cribriform plate of the ethmoid and the sphenoidal turbinal. The posterior slope

Fig. 87.-Section throlgh the NAsAL Fossa to show the Septum. Left HaLF, With Septum louking turardos Right Nasal Fossa.

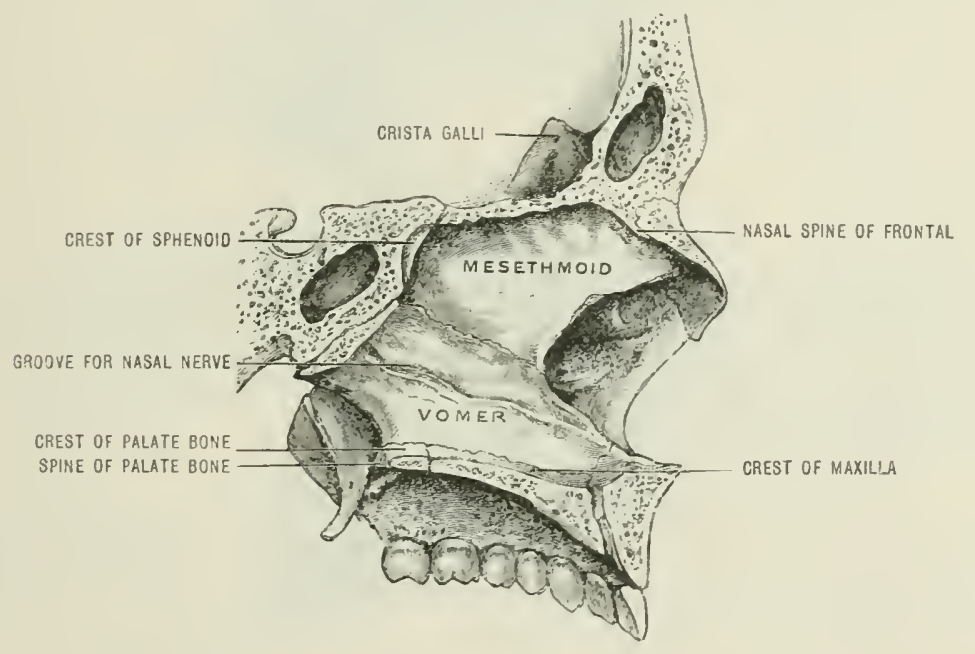

is formed by the inferior surface of the body of the sphenoid, an ala of the vomer, and a small portion of the sphenoidal process of each palate bone. The sphenoidal sinus opens at the upper and back pirt of the roof into the spheno-ethmoirlal recess or superior meatus of the nose.

The floor is wider than the roof, concave from side to side, and has a slight backward slope. It is formed mainly by the palatine process of the maxilla, and completed posteriorly by the horizontal plate of the palate bone. Near its anterior part, close beside the septum, is the anterior palatine canal.

The septum, or inner wall, is formed by the erest of the sphenoid, the crest of the nasal bones, nasal spine of frontal, the mesethmoid, vomer, and the median crest formed by the apposition of the palatine plates of the maxilla and the horizontal plates of the palate bones. The anterior borter has a triangular outline. limited above by the mesethmoid, and below by the romer. This receives the triangular cartilage of the nose. The posterior border is formert by the pharrugeral edge of the vomer. The septum is usually deflected to one side, and is ocrasionally perforated. Sometimes a strip of cartilage, contiumous with the triangular cartilage, persists between the romer and mesethmoid.

The outer wall is formed by the nasal process and inner wall of the maxilla, the lachrymal, the ethmoidal and inferior turbinals, the rertical plate of the palate 
lune, and the innere surface of the internal piteryeroid plate. The onter wall presents three recsis or meatuses. The superior meatus, the shortest, is situated hetween thesuperion and middle turbinal; it opens postrionly; two orifices are in relation with it, namely, the oritice of the posterior ethmoidal cells and the sphenopalatine foramen. The middle meatus liss hetween the midclle and inferior turbinals. It opens anteriorly and posteriorly. This meatus has two orifices communicating with it-the opening of the antrum (which is of very irregular shape) and the termination of the infundibulum. The inferior meatus is situated between the inferior turhinal and the floor of the fossar it presents near its anterior jart, undere covere of the turbinal, the terminal orifice of the nasal duct. This is the largest meatus, and, like the middle, opens anteriorly and posteriorly.

The anterior narial orifices are bounded above by the lower border of the nasal benes, laterally by the maxille, and inferiorly by the premaxillary portions of the maxillix. In the recent state they are separated by the triangular cartilage; in the dried skull the most anterior inferior limit is the anterior nasal spine.

The posterior narial orifices are bounded alove by the alie of the vomer, the sulienoidal process of the palate bones. and the under surface of the sphenoid; reternally by the internal jeterygoid plates; and inferiorly by the posterior border

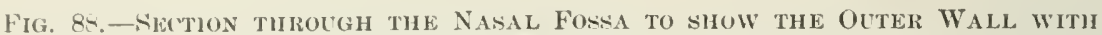
THE MEATLSES.

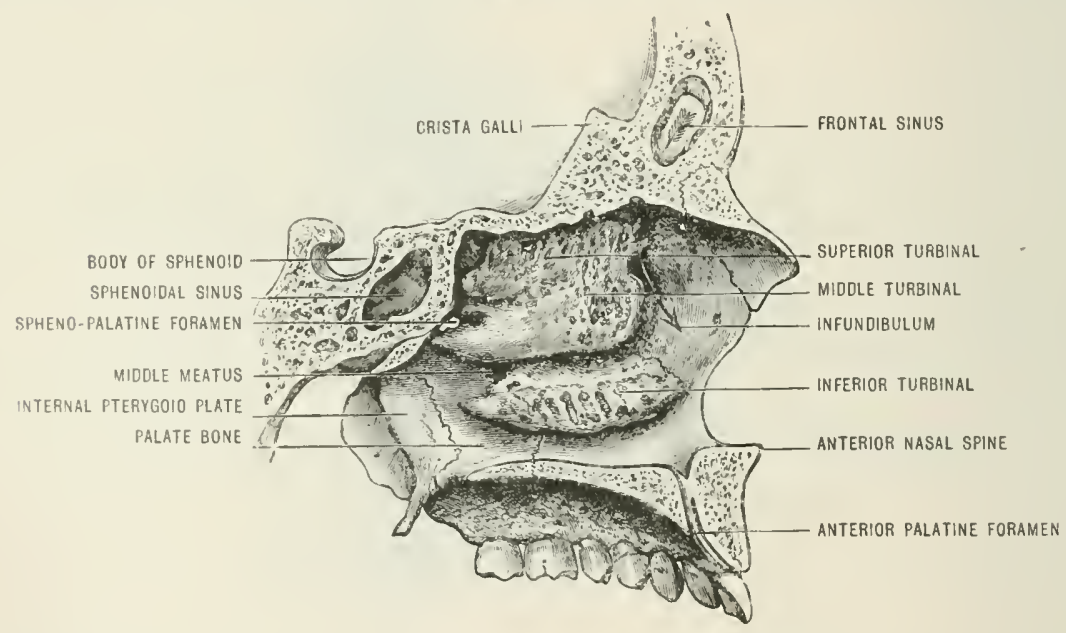

of the horizontal julates of the palate bones. They are divider by the posterior border of the vomere and the posterior nasal spine.

The nasal fosse communicate with all the more important fossa and sinuses of the skull. By means of the formmina in the roof they are in connection with the rranial cavity. The infundibulum brings each fossa in communication with the frontal and anterior ethmoidal cells. The posterior cthmoidal and the sphenoidal celks open into the superior meatuses. The spheno-palatine formina eonnect them with the spheno-maxillary fosse, and an irregular orifice in each outer wall eauses them to (emmmunicate with the antra. The nasal ducts connect them with the orbits, and the anterior palatine canals with the luecal eavity.

The sutures visible in an anterior view of the skull are numcrous, and for the most part unimportant:-

The transverse sutme "xtencls from one external angular poess to the other. The upper part of the suture is formed hy the frontal bone; below are the malar, greater and lesser wings of the sphenoid, os plamm, lachrymal, maxillary, and nasal bones. A portion of this complex suture, lying between the sphenoidal and frontal bones, appears in the anterior cranial fossi.

Other and less important fissures are the internasal, naso-maxillary, inter- 
maxillary, and malo-maxillary. The small sutures visible in the orthit have been alrealy mentioned in describing that cavity.

The following points are seen in an anterior view of the cranimu:-

The glabella, a smooth space between the converging supereiliary ridges.

The ophryon is the most anterior point of the metopice suture.

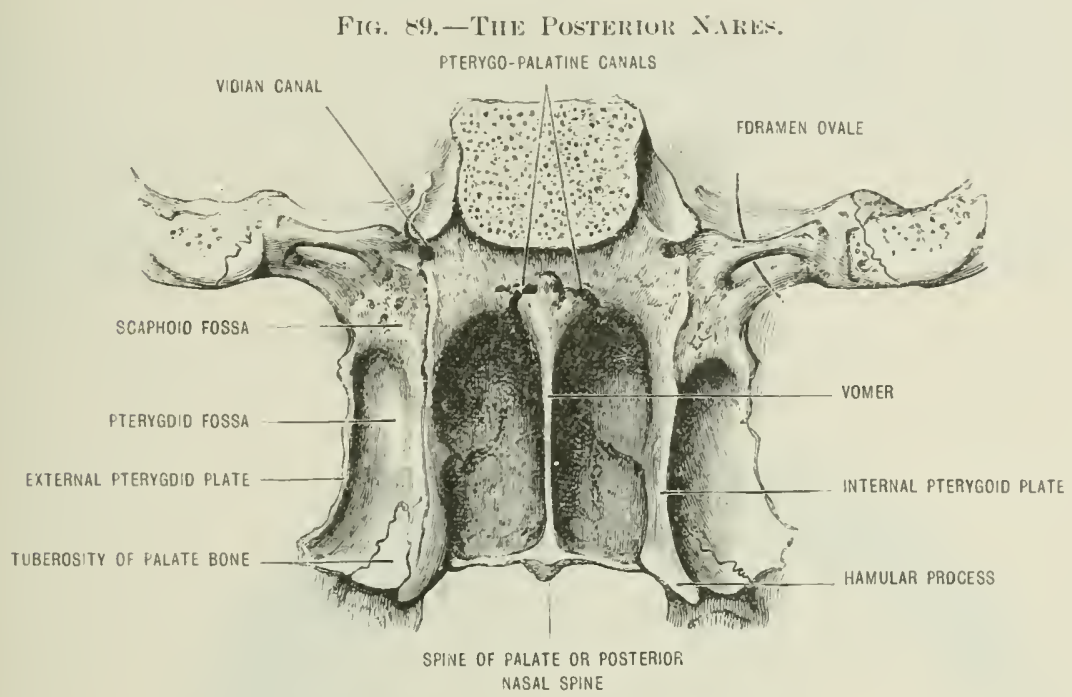

The nasion is the central point of the transverse suture.

The subnasal point is the midelle of the inferior border of the anterior nasal aperture at the base of the nasal spine. arch.

The alveolar point is the centre of the antrior margin of the upper alveolar

\section{THE INTERIOR OF THE SKLLLL}

In order to study the interior of the skull it is necessary to make sections in three directions, - sagittal, coronal, and horizontal. This enables the student to examine the various points with facility, and displays the great proportion the lrain cavity bears to the rest of the skull. The sagittal section should be made slightly to one side of the median line in order to preserve the nasal septum. The batck line (fig. 90) drawn from the basion (anterior mangin of the foramen matrmumi to the gonion (the anterior extrenity of the sphenoirl) represents the basicranial axis; whilst the line drawn from the gonion to the subnasal point lies: in the basi-facial axis. These two axes form an angle termed the cranio-facial, which is useful in making comparative measurements of crania. A line prolonereel vertically upwards from the basion will strike the bregma. This is the basibregmatic axis, and gires the greatest height of the cranial cavity. 1 line clrawn from the ophryon to the occipital point indieates the greatest longth of the cranium.

Near its midlle, the cranial cavity is encroached upon by the petrosal; the walls are channelled vertically he narrow gronoves for the middle and small meningeal arteries, and towards the base and at the rertex broader furrows are found for the venous sinuses.

The coronal section is most instructive when made in the basi-bregmatic axis. The section will pass through the pectrosal in such a way as to traverse the two external auditory passages and expose the tympanmm and restilute, and will also partially traverse the intemal auclitory meatuses. Such a section will divide the parictal houes slightly pesterior to the parietal eminences, and a line dram transversely acruss the section at the mirl-point will give the greatest transwerse 
measurement of the amial cavity. I skull divided in this way facilitates the (ximination of the parts about the posterior nares.

The horizontal section of the skull should he made through a line extenching from the ophryon to the occipital point, passing laterally a few millinetres above the pterion on each side. It is of great arlvantage to study the various parts on the flow of the cranial cavity in a second skull having the dura mater and its varinus processes in situ.

The foor of the cranial cavity presents three irregular depressions termed the anterior, milllle, and posterior fossed.

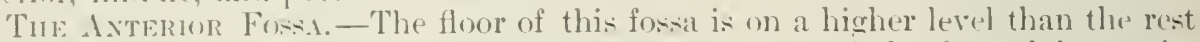
of the "ranial floor. It is formed by the horizontal plate of the frontal bone, the cribriform plate of the ethmoid, and the lesser wings of the sphenoid, which meet weh other and "xelucte the pre-sphenoid from the anterior fossa. The free margins of the lesser wings and thr optic groove mark the limits of this fossa posteriorly. The central portion of the fussa is depressed on each sicle of the crista galli, the

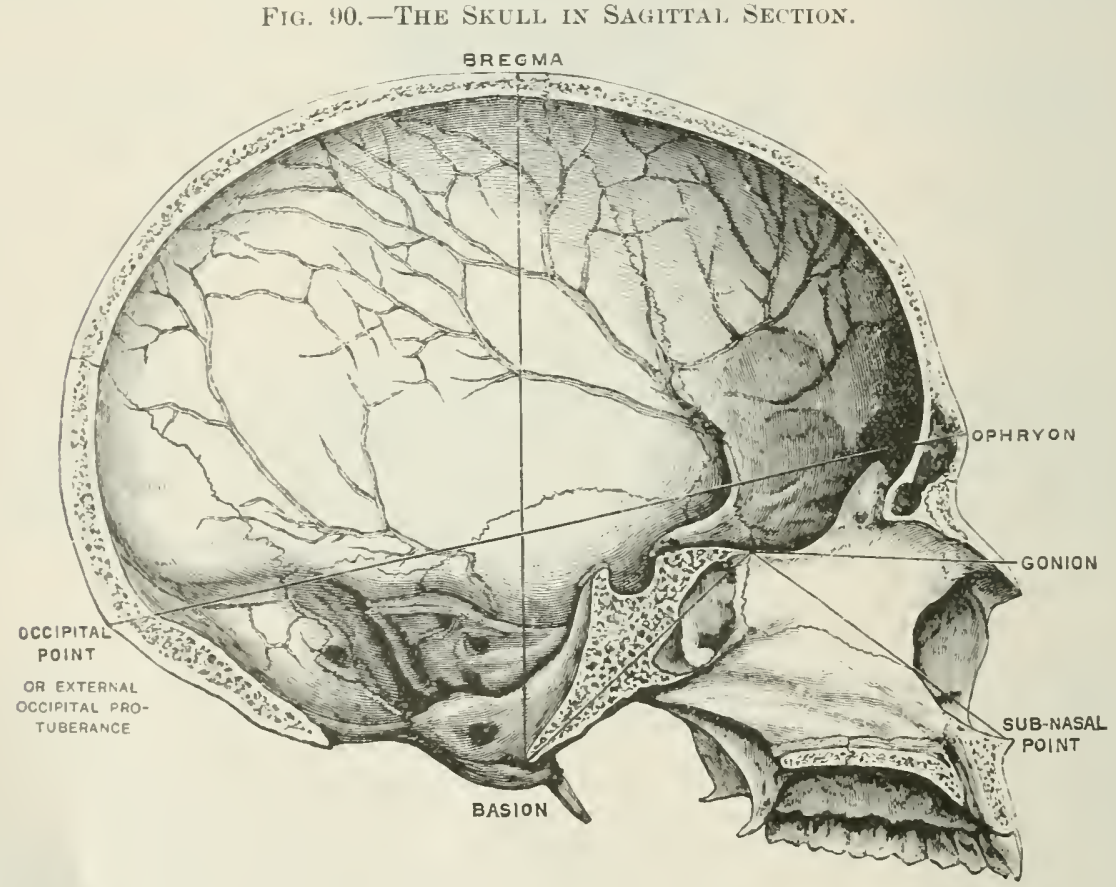

depresions forming a part of the roofs of the nasal sinuses; laterally, the floor of this fossa is convex where it corresponds to the roof of the orbits, and is narked by irregular furrows. It supports the frontal lobes of the cerebrum. The sutures traversing the thone of the fossa are the fronto-ethmoidal, forming three sides of a roctangle, that portion of the transverse facial suture which traverses the roof of the orbit, and the ethmoido-sphenoidal suture, the entre of which corresponds to the gonion. The proints of interest in the fossa are:-

$A$ groove for the suprerior lonertudinal sinus.

The foramen cæcum which transmits a small vein.

The crista galli.

The ethmoidal fissure for the nasal branch of the fifth nerve.

The cranial orifice of the anterior ethmoidal canal, transmitting the nisal branch of the fifth nerve, and a meningeal hranch of the anterior ethmoidal artery.

Ethmoidal foramina for the olfietory filaments.

('ranial orifiec of the posterior ethmoidal canal, transmitting a meningeal braneh of the posterior cthmoiclal artery. 
The ethmoidal spine of the sphenoid.

Furrows for meningeal arteries.

The MIDDLE (RAXIAL Fossid presents a central isthmus and two lateral depressed portions. It is limited anteriorly by the posterior borders of the lesser wings of the sphenoid and the anterior margin of the optic groove. The posterior limits are the dorsum ephippii and the superior borders of the petrosals. Laterally it is bouncled hy the squamosils. the great wings of the sphenoid, and the parietil hones. The floor is formod by the body and greater wings of the sphenoid, and the anterior surfaces of the jetrosals. It contains the following sutures: sphenn-parietal, petro-sphenoid, squamo-sphenoidal. squamous, and a portion of the transwerse suture. The central portion or isthmus of the middle fossal presents the following points from before backwards:-

The optic groove, which lodges the optic chiasma.

The optic foramina, transmitting the optie nerve and ophthalmic artery.

The olivary process, indicating the line of ankylosis between pre- and postsphenoid.

The anterior clinoid processes.

The pituitary fossa, with the middle clinoid processes, and grooves for the internal carotid arteries. The dorsum ephippii, with the posterior clinoid processes, and notches for the sixth pair of cranial nerves.

This central depression is in direct ruation with the parts of the brain surrounding the circle of IVillis.

The lateral depressions receive the temporo-sphenoidal lobes of the brain. and are marked by numerous furrows roughly corresponding to the convolutions of the rerelnum. Numerous narrow diverging channels pass upwards from the fossi towards the rertex; these lodge the ramifications of the middle and small meningeal arteries.

The following openings occur on each side of this fossa:-

The sphenoidal fissure, leading into the orbit and transmitting the third, fourth, ophthalmic division of the fifth and the sixth nerves, and ophthalmic rein.

In the greater wing of the sphenoid near its mion with the frontal bone there are small openings allowing twigs of the midclle meningeal artery to unter the orbit.

The foramen rotundum, which conducts the second division of the fifth nerve into the spheno-maxillary fosis.

The foramen ovale: this transmits the third division of the fifth nerve with its motor root. the small meningeal artery, and the small superficial petrosal nerre.

The foramen Vesalii (not always present) for a small rein.

The foramen spinosum, for the middle meningeal artery and its vena comites.

The middle lacerated foramen, which transmits at its innor angle the internal carotid artery, with the carotid plexus of nerves.

On the posterior wall of this fossa the objects of interest are:-

A rlepression which lodges the Gasserian ganglion.

The hiatus Fallopii, for the great superficial petrosal nerve, and a twig from the midile meningeal artery.

A foramen for the small superficial petrosal nerve.

A minute foramen for the extemal superficial petrosal nerve.

An eninence formed by the superior semicircular canal.

Anterior and slightly extemal to the ridge formed $h y^{\circ}$ the superior semicircular canal, the bone is exceedingly thin and translucent. This is the roof of the tympanmm (tegmen trmpani). When the dura mater is in situ, the depresion lowleing the Gasserian ganglion is converted into a foramen, traversed by the fifth nerve. The sotch in the side of the dorsum ephipuii for the sixth nerve is also a formun when the dura mater is present. In many skulls the midlle clinoid process is prolonged to meet the anterior clinoid process, and thus forms a foramen for the internal carotid artery. The grooves for the midclle meningeal arteries are sonctinu canals or tumels in a part of their course. especially in old skulls. The erroures radiate from the foramen spinosum and extend to the rault. The lones most deeply marked are the squmosal, the greater wing of the spluenoid, and the parietal. 
FIt, !1.-THE SKIIL IN HoRIZUNTAL SECTIOx.

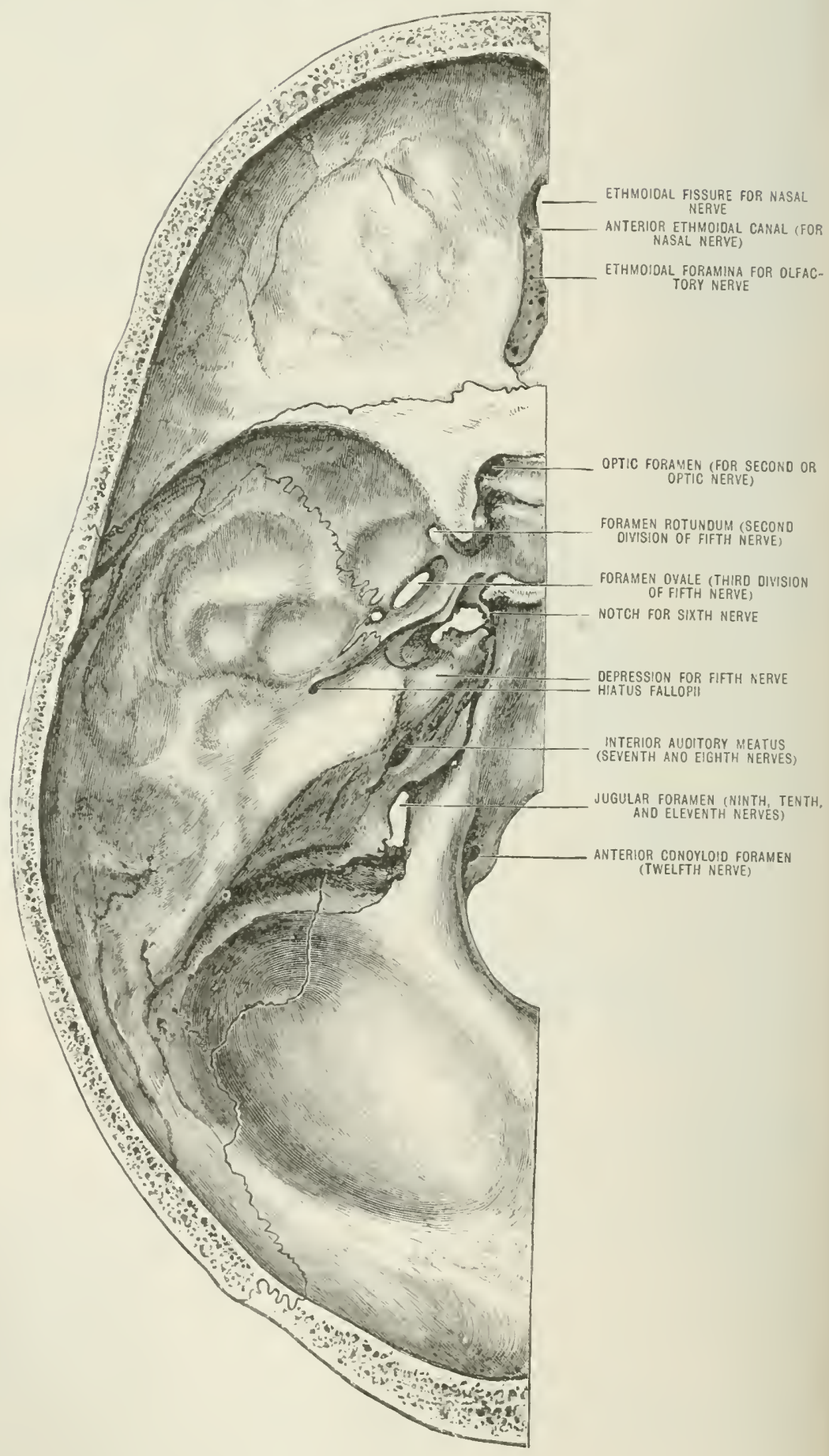


Fig. 92.-The Sktll ix Horizontal Section.

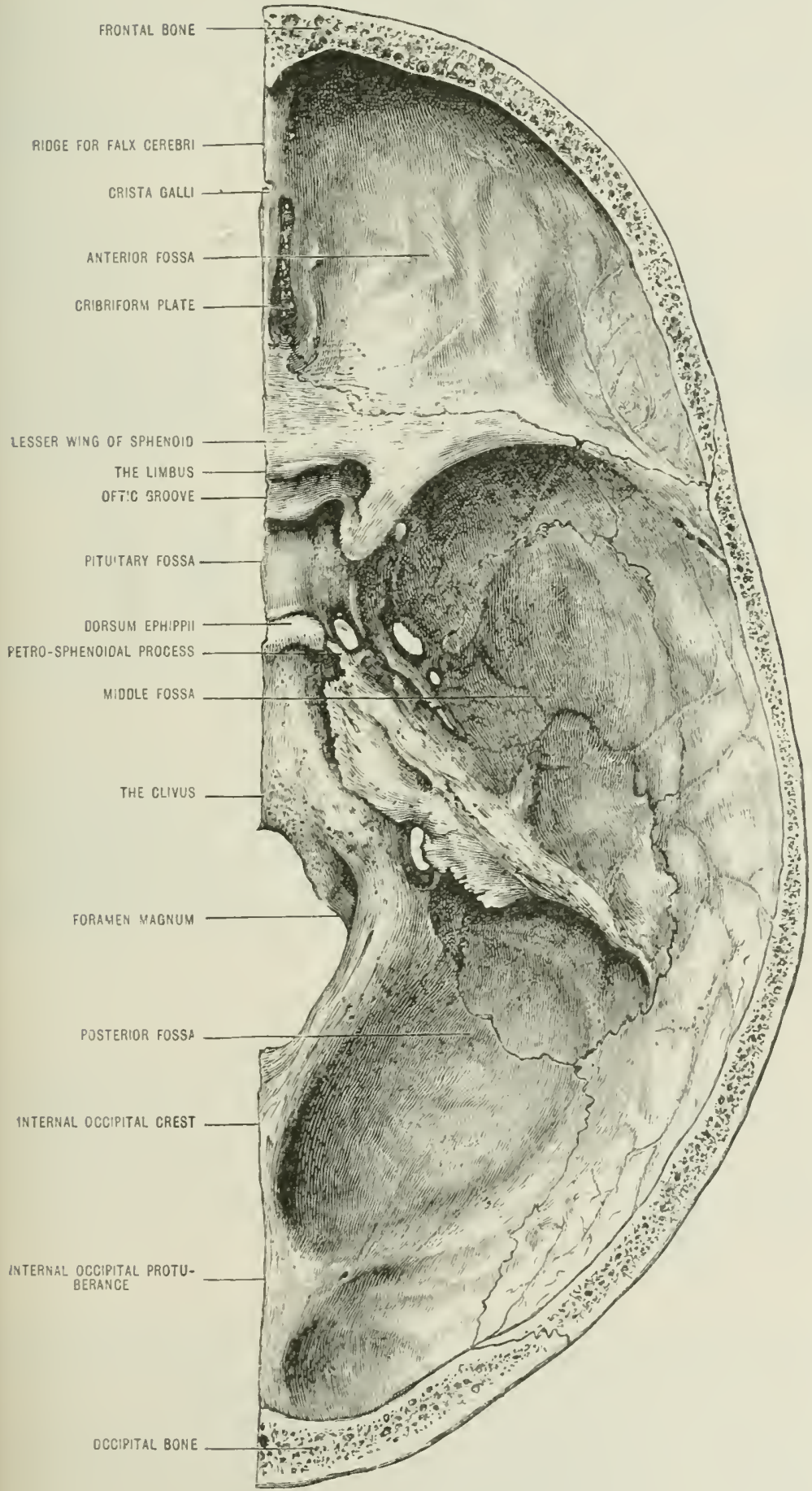




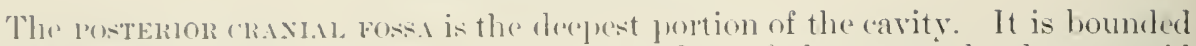
by the dorsum aphippii and the superior borders of the petrosials, the mastoid

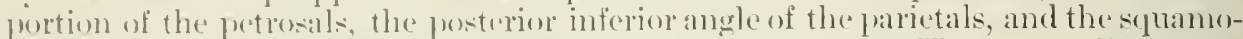
oceipital below the level of the arest (smpratoceipital). The upper linits are indieated by the errooves for the lateral sinuses. It is marked by the following sutures:- the petro-oceipital, oecipitomastoid, parieto-masterd, and, in young skulls, the hasilar suture.

The ridges limiting this fossa gire attachment to the tentorimm cerebelli, and

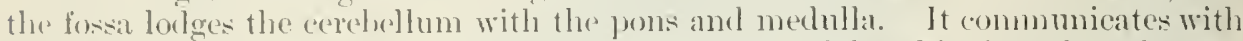
the ereneral cranial cavity hy means of the formen of l'acchionius when the tentorium is in sitn.

It has the following ohjects of interest:-

The clivus, extending from the dorsm ephippii to the anterior margin of the formmen magnmm. This is in relation with the basilar artery, the pons, the medulla, the sixtl nerves and the basibar sinus.

The notch for the sixth nerve on atch sicle of the dorsm ephippii. This is sonctimes a formen, termed the petro-sphenoid.

The foramen magnum, presenting on each side a tubercle for the check ligaments; and the anterior condyloid foramen (sometimes subdivided by a spiculum of bone) for the hypoglossal nerve. Behind the foramen there is a rertical ridge of bone, the internal occipital crest. for the falx cerehelli. This sometimes presents a depression known as the vermiform fossa.

The anterior boundaries of the fossa present:-

A notch for the passage of the fifth nerve. This is a foramen when the tentorium is present.

Tho internal auditory meatus, for the farial and anditory nerves, and the aurlitory branch of the basilar artery.

The jugular foramen, which transmits the glosio-pharrngeal, vagus, and spinal acressory nerves, the internal jugular vein, the meningeal branch of the asconding pharvengeal artery, aqueductus vestibuli and hiatus subarcuatus.

The termination of the groove for the lateral sinus, with the internal orifice of the mastoid foramen.

The cranium of an average European has a capacity of $1450 \mathrm{ce}$. The cirrmferemer tiken in a plane passing through the ophryon anteriorly, the occipital point posteriorly, and the pterion laterally, is $52 \mathrm{~cm}$. The length from the ophryon to the occipital point is $17 \mathrm{~cm}$; the width between the parictals at the level of the zygomata is $12.5 \mathrm{~cm}$; and the height from the basion to the bregma is nearly the same. 'The cranio-facial angle is about $96^{\circ}$.

\section{THE TEETH}

In adult individual with perfect dentition possesses thirty-two teeth, equally distributed to the maxilla and mandible. The upper set are (alled maxillary tecth and the lower sot mandibular. The four central teeth in each dental arch are termed incisors; the tooth next these on each side is the canine; behind these are two premolars or hicuspiels: and lastly, three molars. This relation of teeth is expressed hy means of a formula:-

$$
i_{2}^{2}{ }_{1}^{1} p^{p r m}{ }_{2}^{2} m_{3}^{3}=32 .
$$

Eish torth has a fortion coated with onamel exposed above the gum-named the crown; and a portion coated with comentmum embedded in bone-this is the root. 'The line of union of the crown and root is termed the neck.

The surface of the tooth diresterl towarts the lips and check is called labial and huceal resperetively, and that towarels the tomgue lingual. It is also necostiry to apply definite trims to the opposed surfices of teeth, hemere the surface directed towards the middle line of the month if the alveolar areh were straightened out is median, and the oppositu sule is distal. Euch tooth has distinguishing featiurs. 
The incisors.-The central maxillary incisor is vory much larger than the lateral, the crown is somewhat oblong in outline, its length excereling the breadth. The median is longer than the distal border. The labial surface is convex, the lingual coneave, and terminates near the gum in a low eminence, the hasal ridge or cingulum. In recently erupted teeth, the cutting edge is elevated into three small cusps; these soon wear down and leave a straight edge. The root is long, single, and tlattened laterally.

The maxillary lateral incisors are much smaller than the centrals, which they

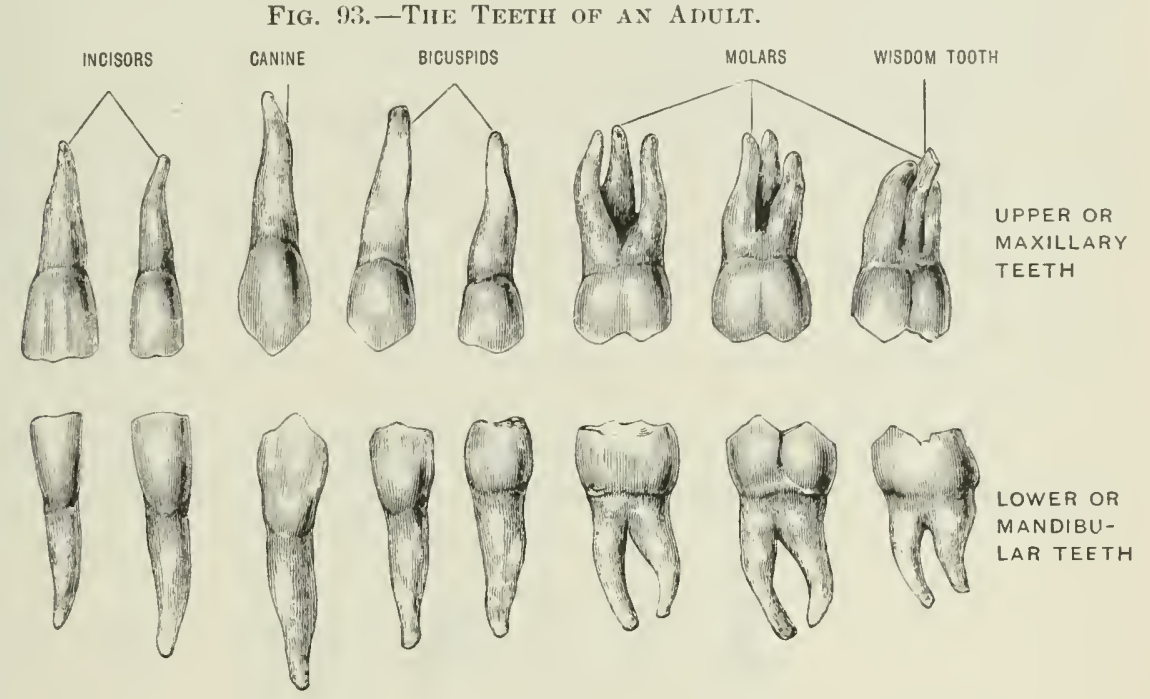

resumble in the general contour of the crown. The distal angle of the erown is more rounded than in the central incisors, and the cingulum is nore pronounced. The root is single. The maxillary ineisors are lodged in the premaxilla.

The mandibular central incisors are much narrower than those of the upper set. and less than half their width in the cutting edges, and the erown becomes contracted towards the neck. The cingulum is scarcely marked, and the root single. The lower lateral ineisors are distinctly larger than the lower centrals in every direction.

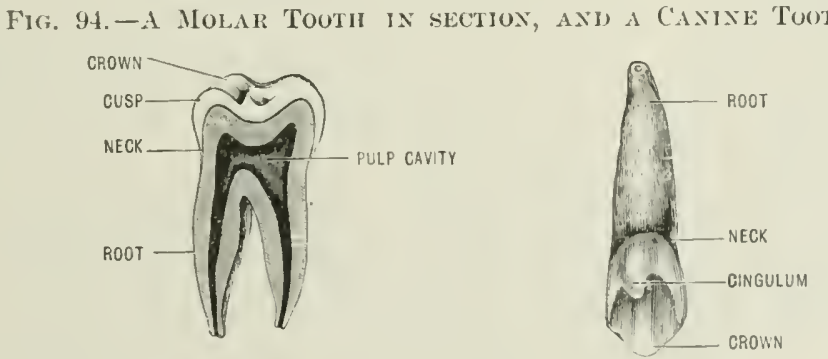

The distal angle of the crown is rounded off; the root is single and frequently presents on each side a longitudinal groove.

The canines.-These differ from the incisors in possesing larger crowns, and thick long roots. The crown ends in a blunt point, and the cutting edge slopes away on each side. The slope towarls the bicuspid is the longer, and causes the crown to be asymmetrical. The lingual surfare presents a median and two lateral ridges; they converge towards the well-marked (ingulum, which is often produced into a distinct cusp. 
The manditular cannes have not sueh promounced features as the maxillary; the point is blunter, and the median ridge is absent from the lingual surfiren.

The maxillary premolars or bicuspids. - The crown of the first pmolar has a crinding surface which is somewhat puadrilateral in outline; the labial is, howerer, longer than the lingual horder. It has two (usps, of which the labial is much the larger. The "usper or tubercles are separated by a pit, but are commered

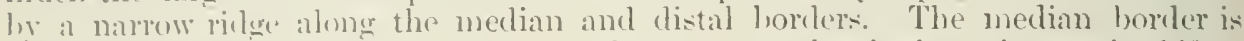
nearly straight. the distal is convex. The root may be single or it may be bifur("ited near the il]ex or marked hy a longitudinal depression, or be doulite throughout the greater part of its length; it may in some sirecinens have these distinet mouts like a molitr.

The seronel hieuspid differs from the first in having its ensiss nearly equal in sizx. Its ront is more deeply grooved.

The mandibular bicuspids are smaller than the upper and differ from them in shilpe. The labial cusp is larger than the lingual; the cusps are commected by at low ridge, the griuding surface presents two small pits. The root is single, romeled, and t:ipering.

The secomd lower bicuspid is larger than the first. The labial cusp is higher and stouter, and the distal borker is much more pronouncerl. Its root is also single and talering.

The maxillary molars. - The first and second resemble each other so closely

Fir: 9.5.-The TeMPUR.IRT TeETH
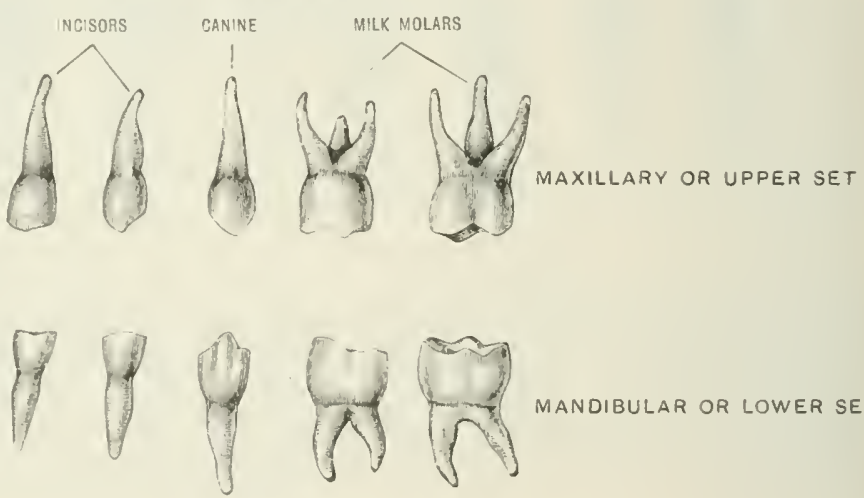

MANOIBULAR OR LOWER SET

that one description will serve for the two. The grinding surface is quadrilateral but with romuled angles. It has four cusps, two buccal and two lingual. Of these, the anterior lingual is the largest, and is eonnected with the posterior buceal by an oblinge ridge of enamel. The groove separating the buceal and lingual cusps cxtencls on to the sintes of the crown and is lost near the neck. The median and distal borders moully present a slight ridge. The roots are thee in mumber, two on the lalial, ancl one on the palatine aspect; this last is usually referred to as the palatine ront, and often diverow from the crown at a comsiderable angle.

The mandibular molars. - The first is the most (onstant in form. It hils five? "usps on the grineling surfine. Four aceupy the angles and are separated by a crucial fissure. The fifth cusp is situated at the posterior extremity of the longitudinal fissure. It has two ronts, placed one in front of the other; they are inclined somemhat backwarks, and present a vertical groove which is sometinies so derefo as to divide arah rext, producing four ronts. One root only may divide in this way.

The second molar differs from the furst in the frequent absence of the fifth cusp; when present it is fechly dereloped. The roots have a tendency to become confluent.

The third molars (mixlom terth). - The upper thirl molar resembles in its grinding surface the arljacent molars. The two palatine tubercles are usually 
lilended, and the roots roblesere and taper to a cone. The apex is often lexit. The characters of this tosth are very variable.

The third lower molar has a larger crown than the corresponding tonth in the upper set; it resembles the adjacent molars and has usually tive ("uspes. It has two roots which mal he comfluent.

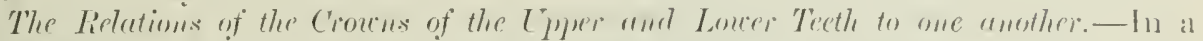
nomal condition the upper teeth form il larger arch than the lower. The uprer incisors and caniues close in front of the lower; acrasionally they fall upon, but rarely fall behind thent. The labial tuhereles of the bicuspirls and molars of the lower jaw are rereived in the depressions between the labial and lingual tulsereles of the upper set of teotl; hence the labial tubercles of the upper arerlinl the corresponding tubereles in the lower teeth.

In conserpune of the rifference in width of the crowns of the upper and lumer incisors, it happens that in closure of the mouth each tooth impinges upon two terth.

The milk teeth.-These are smaller in number and size than the teeth of the permanent set. The formula is:-

$$
\text { di } \frac{2}{2} \text { alc } \frac{1}{1} \text { alm } \frac{2}{2}=20
$$

The temporary teeth are smaller than their successors; the enamel of the crom terminates in a thick crlge; and the tubercles on the croms of the molars are lexs regular and pronounced.

The incisors are similar to those of the promanent set, l,ut the canines have shorter and hroader erowns than their sucessors.

\section{TIIE MORPIIOLOGY OF TIIE SKLLL}

In M:m the skull during development passes through three stages. It first the brain vesicles are encksed in a sic of indifferent tissue which ultimately beeomes tongh and fibrums. This is the membranous cranium; a portion of it is represented in the adult by the clura mater, the remainder is (-onverted into the membrane-bones. Gradually the sides and base of the membranous chanm become cartilaginous: in dne course ussents tisme alpears in the menbranous tracts, and later in the cartilage. Eventually an osseous box is formed, consirting of membrane-bones and eartilage bones intricately interwoven.

A stndy of the skull in the chomdral stage is very instructive. It con-ists of two lants: (1) The skull proper; and (:2) the appendicular elements.

The skull proper consists of three regions:-

The basi-cranial or notochordal region, which ultimately gives riee to the chief garts of the occipital bone and a part of the sphenoid.

Anterior to this is the trabecular region, from which the remantuler of the silhomolid is sulsesquently developecl.

The most anterior portion is the ethmo-vomerine region, from which the nasal septum and its assuciated eartilages arise. Wedged in on each side between the basi-cianial and traberolin regions is the complicated periotic capsule.

The appendicular elements of the cranium are a number of curtilaginons rools, which underer) a remarkable metamorphosis, and, in the adult, are representerl ly the ear-bones, thr styloid process, and the hyoid.

The chondro-cranium at the third month presents the following parts. Seen fiom alurer, the cartilage extents from the cranial base to a spot millway between the base and the vertex, shading off indefinitely on the membranous wall. The conspicums oval masses on each side are the periotic cartilages, in which the flocenlar fosse are conspicnons olyjects. Harch perintic eartilage is joinel to the sphenoid l,y a strip, termeri the sphenotic cartilage, which ustially

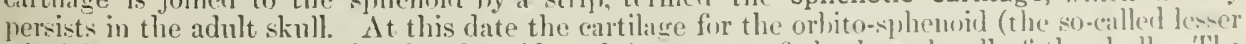
wing) is co-extensive with the ali-splienoid, and forms part of the lateral wall of' the skull. 'The snont-like appearance of the anterior part of the skull is an-ed ly the fronto-nasal plite. (hit each sille of the ethmo-romerine plate near its anteriur termination there are two snall connare pieces of cartilage for. Jacolswn's organ. They are sometimes referred to as the ploughishare cartilages owing to their shape. 


\section{The Metemerphlessis of the Bunchinel Burs}

These rods of eartilage are namenl, from lefore latekwarls, the mandibular, hyoid, and thyroid bars. They may with eare be easily dissected in the foetus between the third and fourth months. Their metanorphosis is als folluws:-

The two extremitios of the mandibular bar osify ; the distal end nlimately forms that portion of the mandible adjacent to the symphysis; the proximal end ossifies as the malleus. The intermediate portion lisaypears; the unly ventige is a band of filmous tissue, the spheno-mamlibular liganent, extending fiom the spine of the sphenoid to the spine of the mantible.

The hyoid bar fuses distally with the thyroid bar, and is represented by the hyoid bone. Its proximal end hecomes the incus, tympano-hyal, and styloid process; the intervening strip is reprented in the wlult by the stylo-hyoil ligament.

'The styloid process has two centres of ussifieation. A nucleus appears anterior to the stylo-

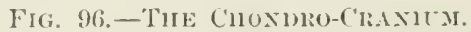

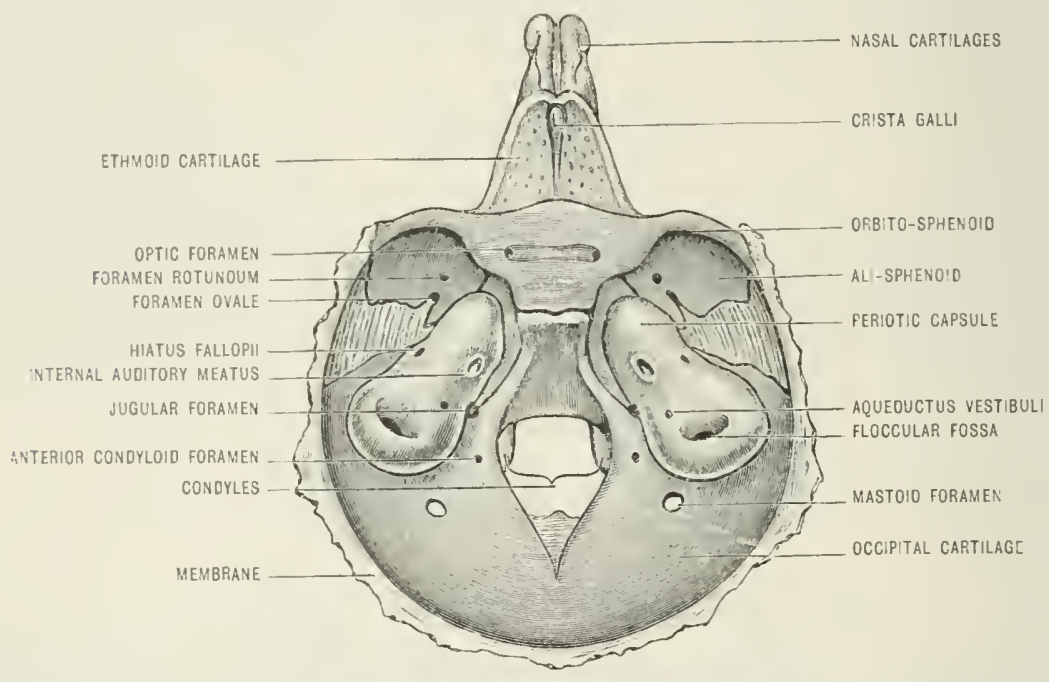

mastoid forauen, and is known as the tympano-hyal. It birth the true styloid process is cartilaginums. In the second year it ussifies, and sulserfuently becomes firmly ankvlosed to the tymuano-Jyal. Ocrasionaliy the hyoid bar ma ossify throughout. When this is the "ase the styloin process reaclies to the liyvill and replaces the stylo-liyoid ligament.

'Tlue stapes uriginates in a jiece of cartilage which is traversed by the temuoray stapedial artery. Its centres of ossification require investigation. The internal pterygoid plate arises in a jiece of cartilage which represents the palato-quadrate of lumer vertebrates. The internal pterysuid plate is an appendicular element engrafted on to the sphenoid. In many mammals it is a separate bone throughout life. Tn the same way the styloid process is an appendicular Mement ankylosed to the petrusal and the tympanic plite; in miny mammals it remains separate throughout life.

\section{The Skull "I Birth}

The skull at birtl presents, when eomparenl with the adult skull, several important and interesting fiatures. Its perwliarities may be considered under three headings :-The peculiarities of the foetal skull as a whole; the eondition of individual bones; the remmants of the cloudral skull.

The general characters of the foetal skull. - The most striking features of the skull at hirth are, its relatively large size in onmparison with the body, and the predominance of the cereloral over the facial purtion of the skull; the latter is, in fact, very smill.

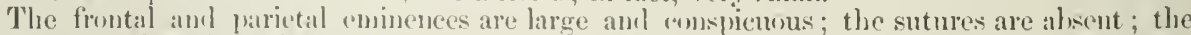
aljacent margins of the lomes of the vault are seluated by septa of fibrous tis-me continums with the lura mater interually ame the [uricranimu externally; hence it is difficult to separate

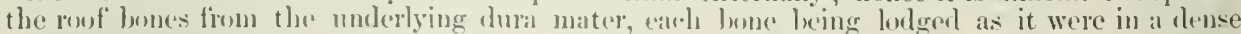
membranous sac. 'The lunes of the vault ennsist of' a single laver without any diploë, and their cranial surfaces present uo rligital impressions. Six numbranous spaces exist, named fontanelles: two are molian, named anterior and pusterior; and two exist on each sirle, termed anterior and josterior lateral fontanelles. Wilch angle of the parietal bones is in relation with a fontanclle. 
The anterior fontanelle is luzenge-shaped, the posterior triangular. The lateral foutanclles are irregular in outline.

Turning to the base of the skull, the most striking points are the absence of the mastoid

Fig. 97.-The Cranity at Birth.

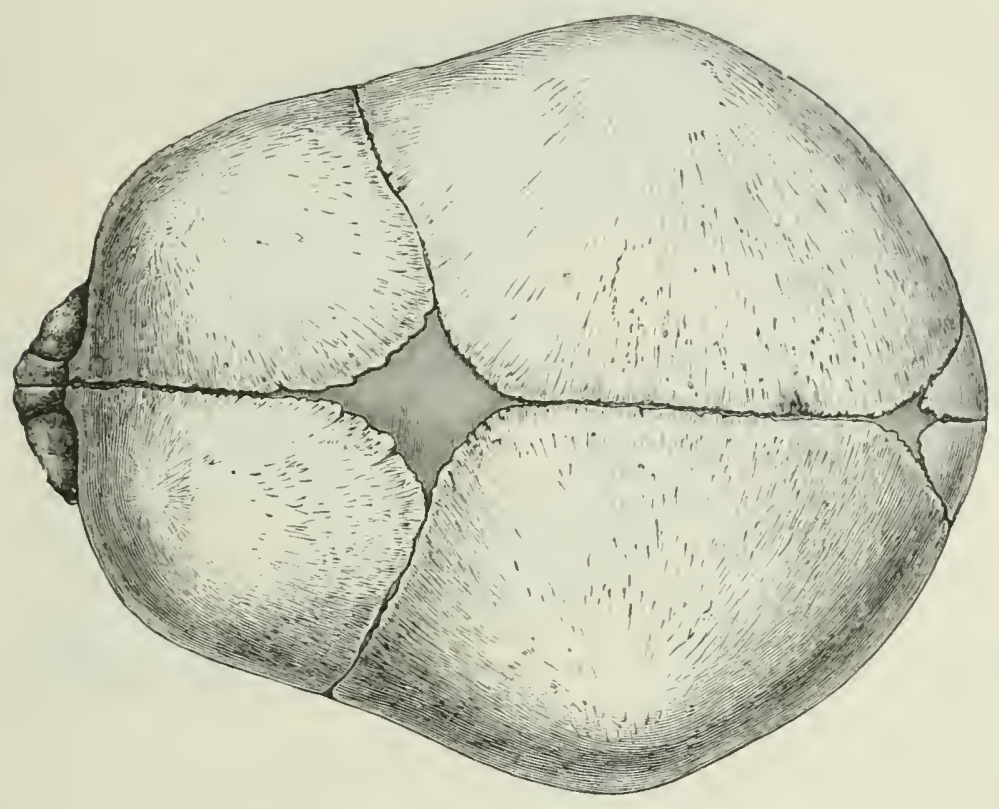

Fig. 98.-The Craxicu At Birth.

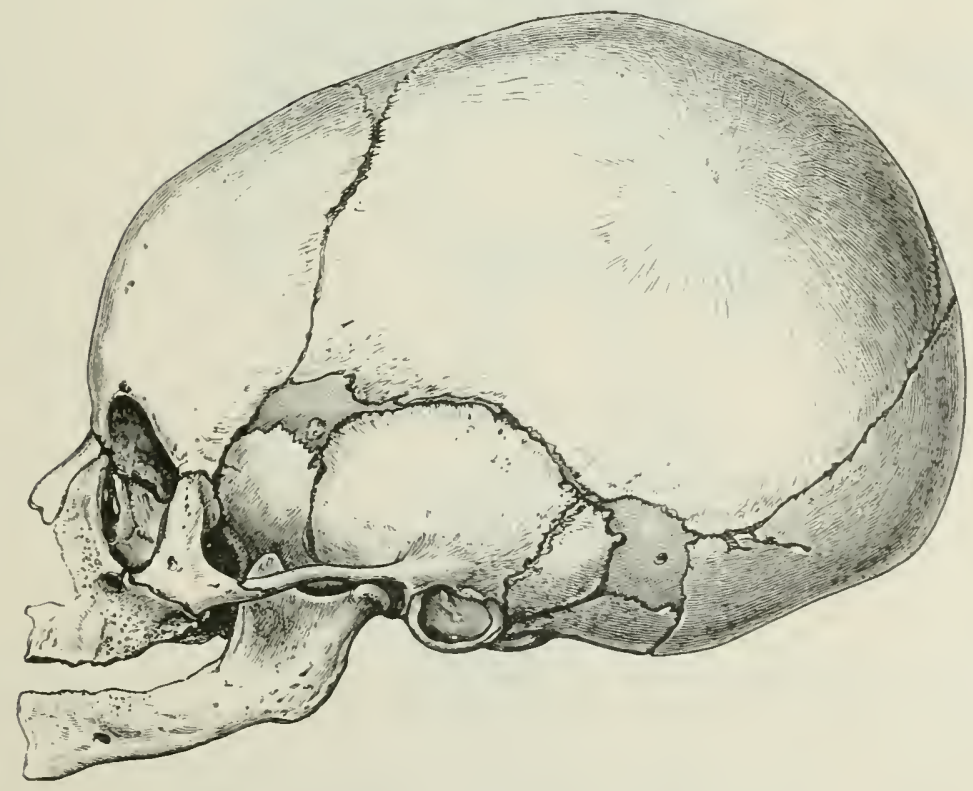

processes and the large angle which the pterygoid plates form with the skull-base, whereas in the adult the angle is almost a right one. The base of the skull is relatively short, and the lower border of the mental symphysis is on a level with the occipital condyles. 
The facial skeleton is relatively small in consequence of the small size of the nasial fossie, the smill size of the antrum, and the rudimentary condition of the alvewlar borders of the mixille and mandible; these are as wide as they are high, and are almost filled with the turbinals.

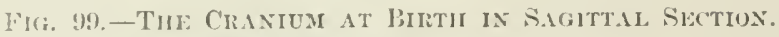

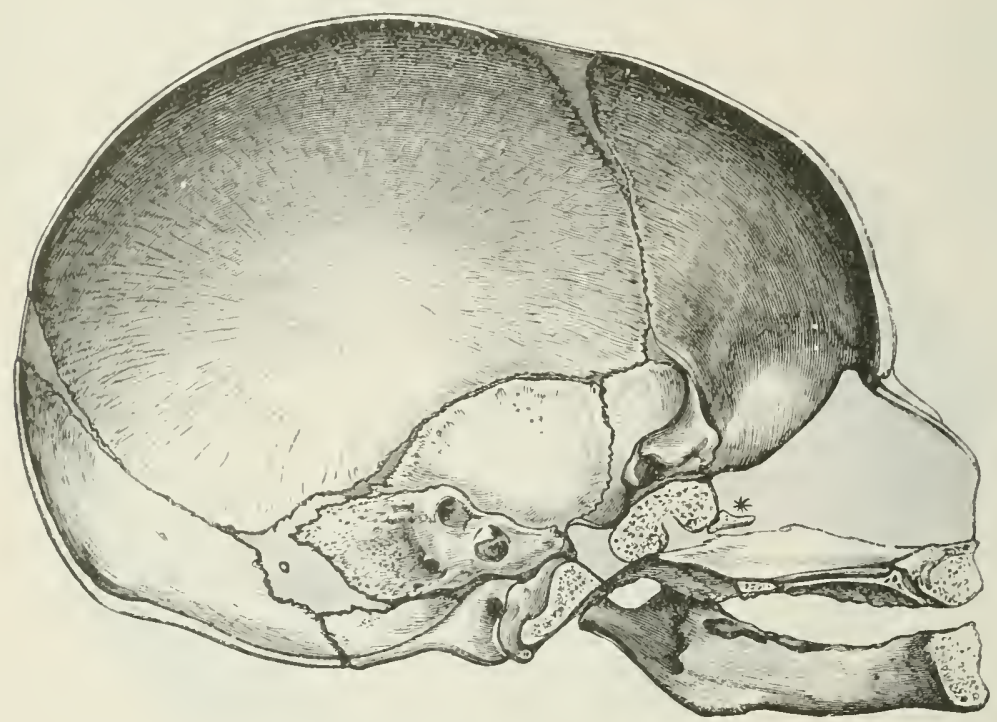

Fig. 100.-The Occipital at Birth.

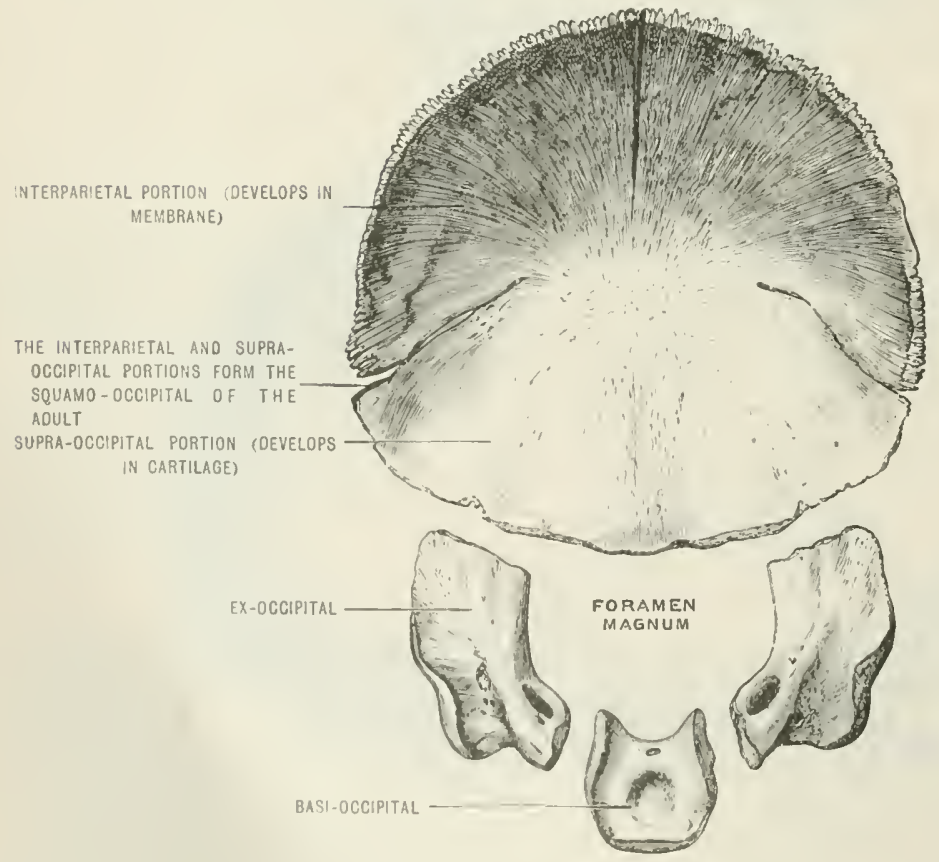

The Peculiarities of Individual Bones at Birth

The occipital consists of funr listinct prirts: the basi-occipital, two ex-occipitals, and the squamo-occipital; these four parts are uniter by hyaline cartilage. ('onpared with the alult bone, the following are the most important points of distinction:- There is 110 pharyngeal 
tubercle or jugular process; the squano-vecipital presents two deep fissures separating the interparietal from the snpraoccipital portion, and extending nearly as far inwards as the recipital protuberance. The grooves for the literal sinus are absent.

The sphenoid in a macerated foetal skull fills into three pieces. The main portion eon-irts of the united pre- and post-sphenoid with the orbito-sphenoids and lingulæ. The presphenoid is quite solid and commecterl with the ethmo-vomerine entilage, and presents no trares of the air sinuses which ocming this part in the adult skull. The pre-sphenoid by it: upper surfice forms gart of the interior cranial fissa, from which it is sulserguently excluded by the orbito-sphenoids. The optic foranna are large and triangular in shape. The lingulæ stand out from the basi-sphenoid as two lateral buttresses, and the floor of the sella tureica presents the cranio-pharyngeal canal, which in a recent hone is occupied by filbrous tissue. The dorsum

\section{Fig. 101.-The SpILeNoln at Birth.}

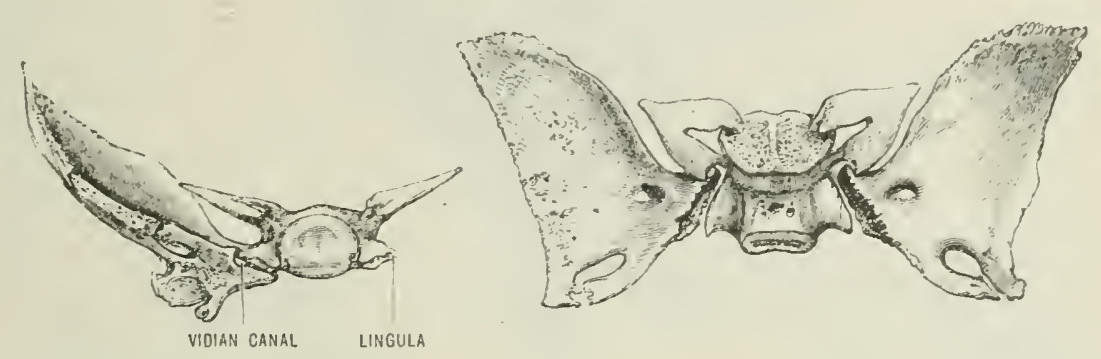

ephippii is yet cartilaginous. The ali-sphenoids with the pterygoid processes are separated fiom the rest of the bone by cartilage. The formen rotundum is complete, but the finture foramen oviale is werely a deep noteh in its posterior border, and there is no foramen spinosum. The pterygoid processes are short, and each internal pterygoid plate presents a broad surface for articulation with the lingulae. The Vidian canal is a groove between the internal pteryerid plate. the lingula, and greater wing.

The temporal bone at birth consists of three parts (excluding the ear-lones) : the petrosal, squamosal, and tympanic. The petrosal presents a large and conspicnous floccular fossa; the hiatus Fillopii is a shallow bay lodging the geniculate ganglion of the facial nerve. There is a

Fig. 102.-The Tesporal, buse at Birth.

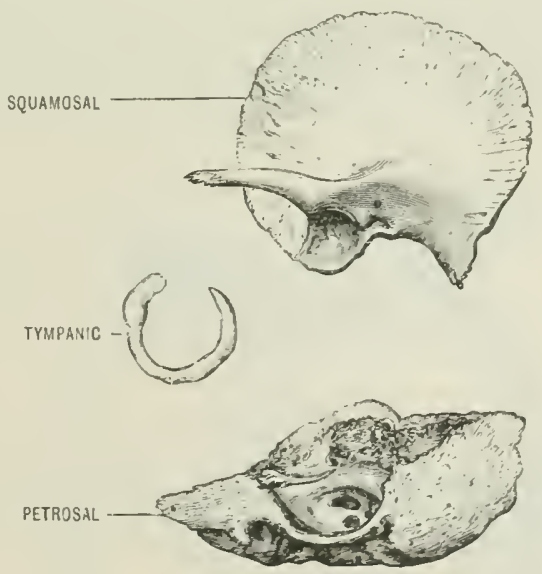

relatively large mastuid antrum, but no mastoid process. The styloid process is mursified, lut the tympano-hyal may be detected as a minute rounded nodule of bone near the styli-mastojil forimen.

The squamosal has a very shallow glenoid fussa and a relatively lirger pret-glenoil tubercle. The pusterior part of the inferior border is prolonged downwards into an uncinate firucer- to close externally the mastoid antrum.

The: tympanic bone or annulus is a delicate horseshoe-shaped ossicle, attuched ly its anterior ant pusterior loorus to the inferior horder of the siluamosal.

The ear-bones are chicfly of iuterest from their size, for they are as large at lirth an in the adult. The processus gracilis (Folian process) may be 2 cm. in length. 
T'he frontal (onsists of two bones separated by a modian vertical (metopic) suture. The frontal eminence is very entspicuous, but the smpereiliny ridges and frontal sinuses are wanting.

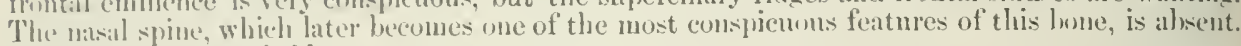
'Tleere is nus temporal ridge.

'llhe parietal is simply at ynadrilateral lamina of bone, concave on its inner and convex on the

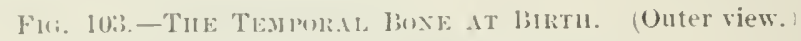

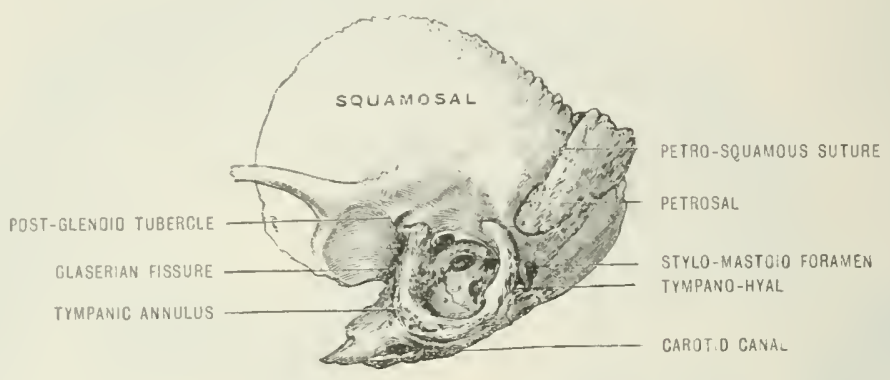

Fig. 104.-TeMPoral Boxe it Bintir. (Inner view.)

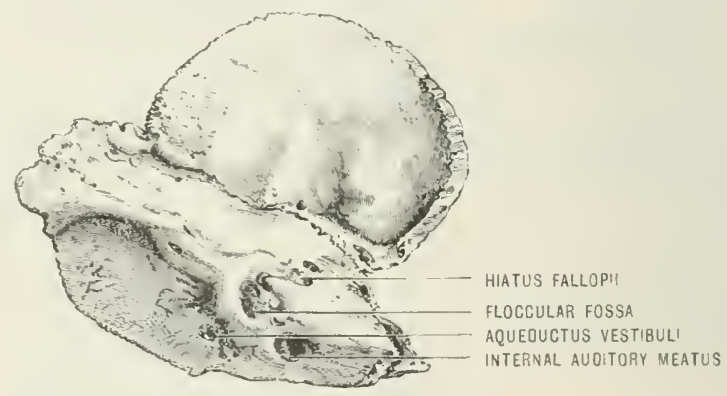

outer surface. 'The parietal cminence, which indicates the spot in which the ossitication of the bone commenced, is large and conspicuous. The grooves for blood-siuuses, as in other cranial bones, are absent. Each angle of the marietal is in relation with a fontanelle. As in the alult, the anterior inferior angle of the bone is prolonged downwards towards the ali-sphenoid.

The ethmoid comsists of two lateral portions separated by the still cartilaginous etlumo-

Fig. 105.-The Frontat, at Biriti.
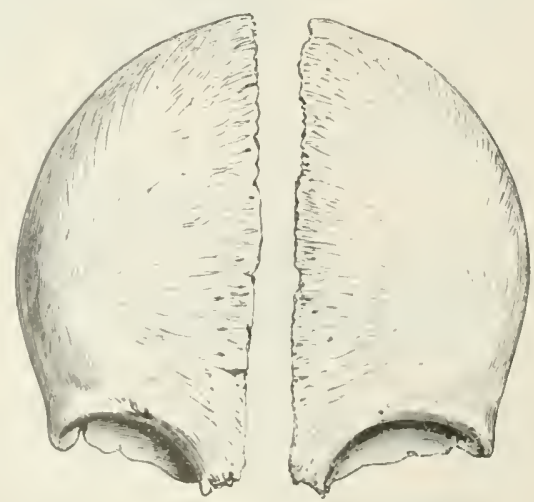

vimerine plate. The ethmoil cells are represented by shallow ilepressions, and the uncinate process is umlevelopuerl.

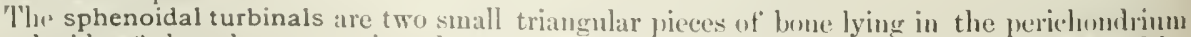
on "ach side of the ethmo-vomeriue plate near its junction with the pre-sphenoil. (Indieaterl by the * in fier. 99.) 
The maxilla presents the fullowing characters:-The maxillo-premaxillary suture is visible on the palatine aspect of the bone. The alveular border presents fire sockets for teeth. 'The infiarbital toramen communicates with the floor of the orbit by a deep fissure; this fissure sometimes persists in the adult. The autrum is a shallow groove.

The mandible at birth consists of two halves united hy fibrous tissue in the line of the future symphysis. Eateh half is a bony trough lodging teeth. "The trough is divided by thin osseous partitions into five compartments : of these, the fitth is the largest, and is often sulxlivided by an rillge of bone. The floor is traversed by a furrow as far forward as the fourth socket (that for the first milk molar), where it turns outwards at the mental foramen. This finrow lodges the unandibular (inferior dental) nerve and artery, which enter by the large mandibular foramen. The condyle is on al level with the mental extremity of the bone.

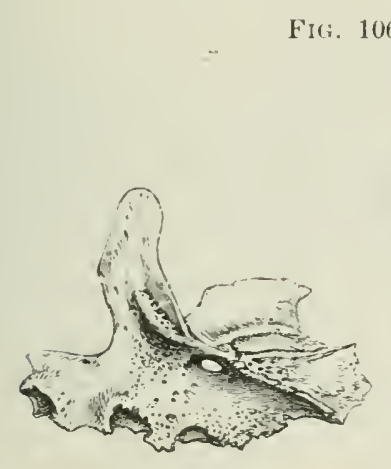

Outer riew.

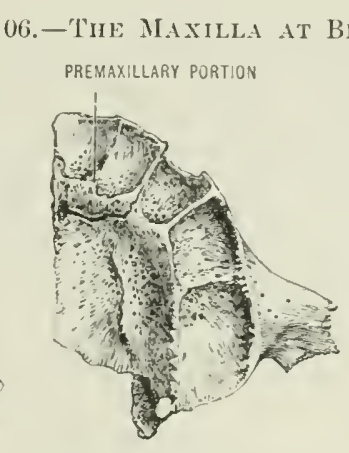

Inferior view.

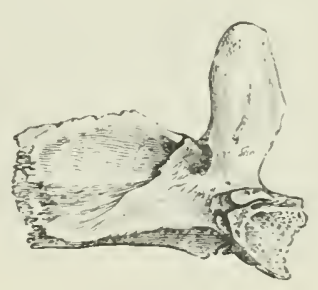

Inner view.

The palate bones differ mainly from the arlult bone in that the vertical and horizontal plates are of the same length; thus the nasal fosse in the foctus are as wide as they are high, whereas in the adult the height of each nasal fussa greatly exceeds the width.

Concerning the remaining bones little need be said. The vomer is a delieate trough of bone for the reception of the inferior burder of the ethmo-romerine plate; its inferior border, that which rests upon the palate, is broad, and the bone presents quite a different appearance from the adult vomer. The nasal bones are short but broad; the malar and inferior turbinals are relatively very large; and the lachrymals are thin, fiail, aud delicate lamellee.

The hyoid consists of its usual five parts. There is a median mucleus for the basi-liyal, and one on each side for the greater cormua (thyro-hyals). The lesser eornua are cartilaginous.

Fig. 111\%.-The Maxnible it BirTh.
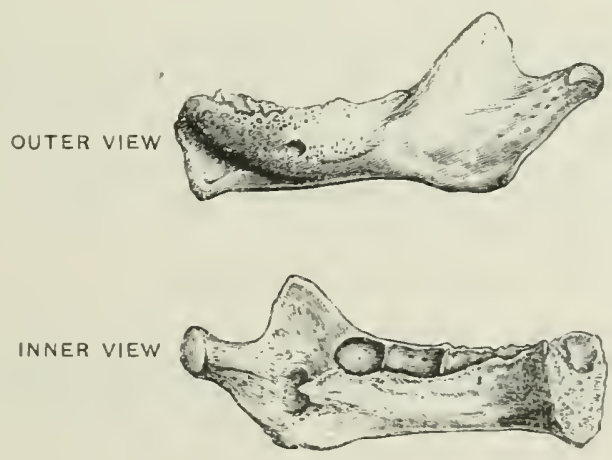

Remnants of the cartilaginous cranium.- It has alrearly been pointed out that at an early date the base of the skull and the face are represented by hyaline eartilage, which for the mont part is replaced by bone before birth. Fven at birth remmants of this jrimitive chondral skull are abundant. In the cranium, eartilaginous tracts exist hetween the various portions of the occipital bone, as well as at the line of junction of the oecipital with the petrosil aml splenoid. The dorsum ephippii is entirely cartilagiuons at birth, and the last portion of this cartilane disappears with the ankylosis of the lasi-oecipital and hasi-sphenoid about the twenty-fiftl year. A similar strip of eartilage lying between the jugular process and the jugular surface of the petrosal persists until late in life. A strip of eartilage mnites the ali-sphenoids with the lingulae, and for at least a year after birth this cartilage is eontinuons with that which thronehout life 


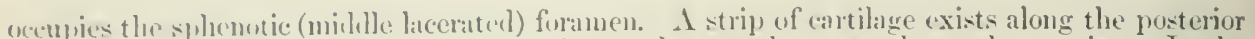
berrler of the orbitu-sphenvid, and not unfierpuently extends outwarls to the piterion. In the adult skull it is replated ly ligamentoms tissue.

The ethmo-romerine plate is pntirely cantilaginous, and near the end of the nose smpports the lateral nilsil cartilages, remuants of thro fronto-nasal plate. The fate of the ethmo-vomerine

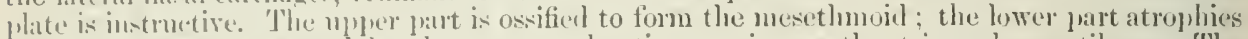
fim the presure "xerted hy the vomer; the tip remains as the triangular eantilage. 'The litcral smont-like extremities of the fronto-nasil gitate jersist as the lateral cartilages of the nosi.

Ammg the anpendicular elements of the skull, the stykid jrocess and a large fortion of the ligoid are cartilaginus at birth.

\section{The Nerre-foramina of the SHinll}

The villuts formuina and canals in the skull which give passage to nerves may be arranged in two groms, primary and secondary. Primary formmina indicate the spots where the nerves ifuit the general cavity of the dura mater, and as this membrane indicates the limit of the primitive cramium, a cranial nerve, in a morphological sense, beromes extra-cranial at the point where it pierees this membrane. In conseruence of the complicated and extrandinary modifioutions the vertebrate skull has undergone, many nerves traverse, in the adult skull, bony tumbls and canals which are not represented in the less complex shulls of low vertebrates such is shatris aml lays. To such foramina and eanals the terms secondary or adventitious may le al]plichl.

Nerve-formina are further interesting in that they oceupy sutures, or indicate the points of minom of $t$ two w' more ossific centres. 'Tu this rule the foramen rotundum is the only exception in the human skull.

\section{The Primary Foramina}

1. Foramen magnum.-This is bounded by four distinct centres, the supra-, basi-, and two rx-crifitals. It transmits the spinal accessory nerve, the vertebral artery and its anterior and justerior spinal branches, the spinal cord and its memlranes.

2. The anterior condyloid. - At birth this is a dee] notch in the anterior extremity of the

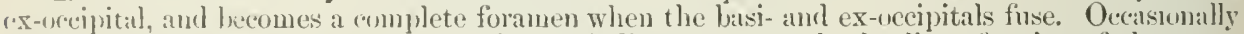
it may be (omplete in the ex-occinital, but it indicates accurately the line of union of these two chanents of the occipital bome. It transmits the hypoglossal nerve, the meningeal branch of the ascomding pluryogral artery, and its vena comites.

3. Jugular foramen. - This occupies the petro-vecipital suture, and is formed by the basi- and rx-orcifital in conjunction with the petrosal. It transmits the glosso pharyngeal, puemugastric, amb spimal acesenry nerves, a meningeal branch of the ascending phangugeal artery, and receives the lateral and infirior petrosil simuses.

4. Auditory. - 'lhis marks the point of confluence of the gromps of centres termed pro-otic ind opisthotic. It transmits the facial and auditory nerves with the auditory twig of the hasilill antery.

5. Trigeminal.-This is muly a foramen when the dnra mater is present in the skull. It is a

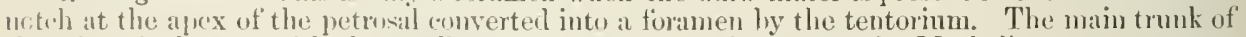
the trigmainal nerve with the small motor loot traverses it to enter the Meckelian cave.

6. Petro-sphenoidal. - This is a notch betwern the sirle of the dorsum ephippii and apex of the petrosil which becomes converted into a foramen by dura mater.

7. Optic.-This fin'uncen is formed hy the confluence of the orlyito- and pre-sphenoidal centres. It onems into the orbit and tramswits the optic nerve and ophthaluic artery.

\section{The Secondary Nerve-foramina}

Foramina transmitting the various subdivisions of the fifth nerve.--The primary foramen of exit for the trigeminal nerve is formerl partly of bone and partly of membrane at the apex of the petrosil. 'Jlhe three divisinns of the nerve issue though seendary foramima.

(a) 'Ihe sphenoidal fissure is an clomeated clink, bumedel above by the orbital wing and bolow by the greater wing of the splienoid, internally by the ludy of the sphenoid, and externally hy the firoutal. It epenss inte the orhit, and transuits the thirrl, fourth, first (oplithahnic) division of the fiftl, and sixth nerves, alsi the ophthalmic vein.

(b) 'The foramen rotundum is the only exception to the lule relating to the formation of nerva-foramina: it is molmbly a semment of the sphenoblal fissure. 'The foramen is really a camal rumbing forn the midelle eranial fissa to the spllemomaxillary fossa, and transmits the second or maxillary division of the triegeminal.

(c) 'The foramen ovale at lirth is a galp in the himler borler of the greater wing (ali-sphemoid) of the splemenid, and is anverterl into a formmon by the petrosal; subseguently it hecomes (omplete in the splemeicl. It transmits the third or mamdilualar division of the trigemimal and

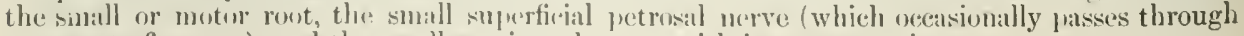
a separate foramen), and the small meningeal artery with its vena comites. 
The ethmoidal canals. -These eommence in the suture betwern the os plamum and the

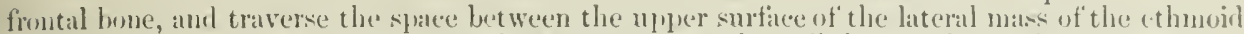
and the horizontal plate of the fiontal, to emerge on the cribriform plate; they are situated outsile the dura mater. The anterior foramen transumits the nasal branch of the oplithalunic, which subsednently gains the nasal eavity by jassing through the nasal slit (ethmoidal firsure) ly the side of the cristis gralli.

The infraorbital canal indirates the line of confluence of the maxillary and malar centres of the superior maxilla ; vcasionally it is completed by the malar; rarely it is incomplete above, and communicates by a narrow fissure with the orbit. It lodges the infinorbital nerve and artery.

'The spheno-malar foramen is situated in the suture between the walar and the greatip. wing of the sphenoid (ali-sphenoid); it transmits the temporal branch of the orbital nerve and a bianch of the lachymal artery. In the aclult this formen may be wholly confined to the malar lune.

The malar canals truverse the malar bone, and indicate the line of confluence of the two chicf centres for this bune. 'Ihe malar twigs of the orbital nerve isoue from them accomplanied by arterial twigs.

The spheno-palatine foramen is a deep groove between the orlital and spluenoidal procesces of the jalate bone, converted into a foramen by the sphenoidal turbinal. It is trarersed by the? nasu-palatine nerve and artery as they enter the nasil fiom the spheno-maxillany fossal.

Scarpa's foramina are two minute openings in the meso-palatine suture where it is in relatinu with the anterior palatine fossa. 'They are traversed by the naso-palatine nerves.

The pterygo-palatine foramen is situated between the sphenoidal process of the palate lume. the internal pteryguil plate of the splenoid, and the splienoidal turbinal. The pterygo-palatine nerv' and artery pass through it.

The Vidian canal is trumpet-shaperl : the narrower end is situated in the sphenotic foramen : the broader orifice opens on the pusterior wall of the spheno-maxillary fossa. The eanal is 10) mm. long; in the foetal skull it is a chink lietreen the base of the internal pterygoid plate. the ali-sphenoid, and the lingula of the splienoid. The canal is traversed by the Vidian branch of the sphenu-palatine ganglion and the Vidian artery.

The posterior palatine canal is a passage left between the maxilla, the vertical plate and tuberosity of the jalate bone, and the internal piterygoid plate; it commences on the hard palate ly the pusterior palatine foramen. The desceuding palatine nerve and artery traverse this canal. Several formina open from it. In the suture between the rertieal plate of the palate hone and the maxilla, two small openings allow minute nerves to issue for the middle and interior turbinals. In the fistures between the tuberosities of the palate aml maxillae, and the pteryorid plites. the milille and external palitine nerves issue. These formmina are sometimes called aceessory and external palatine cauals.

'The mandibular or inferior dental canal runs between the dentary and splenial elements of' the mandible. The posterior orifice of the canal is the mandibular (inferior dental) foramen : the anterior orifice, the mental foramen, indicates the line of union of the mento-Mechelian ancl dentary centres. The mandibular nerve and artery enter the eanal at its posterior orifice; the mental formen allows the mental nerve to eseape from the canal aceompanied by the mental artery.

Foramina transmitting the facial nerve and its branches. - The main trunk of the facial enters the internal anditory meatus and traverses the Fallopian canal. In the early embryo the nervelies on the petrosil, and is not covered in with bone until the fifth month of foetal life. The terminal orifice, the stylo-mastoid foramen, is situated between the tympanic, tympanuhyil. and epiotic elements of the complex temporal bone.

The "iter chordx posterius" is a chink between the squawosal and the tympranic element.and allows the chorda tympani nerve to enter the tympanum. The fissure of exit for this nerv" is the subdivision of the Glaserian fissure termed the canal of Huguier. "Ir "iter chordx anterius.' 'The Glaserian fissure lies between the tympanic plate and the sigmmosal. It transmits the tympanic branch of the internal waxillary artery, and lodges the slender process of the malleus.

The spheno-maxillary fissure is situated between the posterior borler of the orbital plate of the maxilla and a smooth ridge on the orbital surface of the greater wing of the sphenoid. It transmits the superior maxillary division (sceond) of the fifth nerve. 


\section{THE RIBS AND STERITH}

The ribs.-Thue form al series of marrow flattened bones. twonty-four in number, arranged in twelve pairs, extending fom the sides of the thoracie vertebrat towards the mertian line on the anterior aseject of the trunk.

The first sern pairs an termerl true ribs, beatse their anterior ends are directy comnered by means of cartilage with the sides of the sternum. The bwer five false ribs-are clasicel into two sets: the eighth, ninth, and tenth are connererel towether by their costal cartilages; the eleventh and twelfth have their anterior cxtremitis free, and are called in consequence floating ribs. Thus the first serell are, vertebro-sternal; the eighth, ninth, and tenth, vertebro-chondral; the eleventh and twelfth, vertebral ribs.

The ribs increase in length from the first to the seventh, and then decrease from this rib to the twelfth.

In brealth they increase from behind forwards; the groatest breadth of a rib is at it: junction with the eostal cartilage. The two or three upper ribs form nearly a right angle with the spine, but the succeding sot enre obliquely downwards. The ohlicuity is greatest at the ninth, and then decreases in the ribs below.

Typical characters of a rib.-The seventh is regarded as the most typical rib. It presconts a rertebral extremity or head; a narrow portion or neck; a sternal end; and an intermediate portion, the shaft.

The head has two facets divided hr a horizontal crest. The crest is connected hy an interosons ligament with an intervertebral disc; the facets articulate with the lemi-facets on the sicles of the hodies of two vertebre. As a rule, the lower facet is the larger, and artivalates with the thoracie vertebra, to which the rib corresponds: in number. This is the primary facet, and is the one represented in those rihs which possess only a single facet on the rib-head. The anterior margin is lipped for the costo-rertebral (stellate) ligament.

The neck is that portion of the rib extending from the head to the tubercle. The posteriou surface of the neck is in relation with the transverse process of the lower rertebra with which the head articulates; it forms the anterior boundary of the costo-transverse foramen, and is rongh where it gives attachment to the mirlule costo-vertelinal ligament. The superior border of the neck is continuous with the corresponding border of the shatt, and at the point where the neck ends this lwoler is produced so as to form a crest (rister colli superior) for the anterior costo-transwere ligament. The inferior border of the neck is continuous with the rilder of the subcostal groove. This difference in the relation of the neck to the upper and lower borders of the rib shaft is useful in determining to which side a rib helongs.

The tubercle consists of an upper part, rough for the posterior costo-transwerse (rhomboid) ligament, anel a lower faceted portion for articulation with the tip of the transwerse proxess. The tuberele projects below the lower edge of the rib to form a crest (rrista colli inferior), marking the beginning of the subeostal groove.

The shaft has two surfaces and two borders. It is strongly eurver. At first the rure is in the same plane as the neck, hut it puickly tums forwards at a spot (in the posterior surface of the shaft known as the angle, where it gives attachment to the sarro-lumbulis musede and some of its suldivisions. The rib has also a seeond

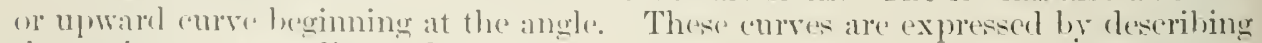

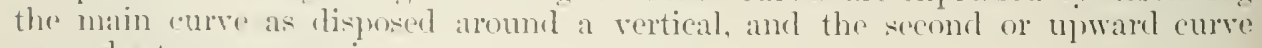
aromel a transerere axis.

When a ril, except the first and twelfth, is laid with its lower edge upon the table, the rib-head rises and the rib tomehes the table at two places, vize at the stemal ent, and in thes neightourhoml of the angle.

The extermal smrface of the rib is (x) nex, and gives attachment to muscles. Near its anterior extremity it forms a somemhat abrupt curve, indieated by a ridge on the bone, which gives attachment to the serrotus magnms muscle, and is sometimes called the anterior angle. 
The internal surface is concave and presents the subcostal groove near its inferior border. The groove is best marked near the angle, and lodges the intercostal ressels and nerres. The ridge limiting the groove ahore is continuous with the inferior border of the neck of the rib; its gives attachment to the intermol intercostal muscles.

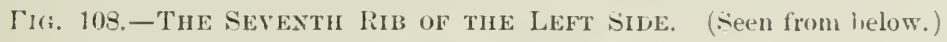

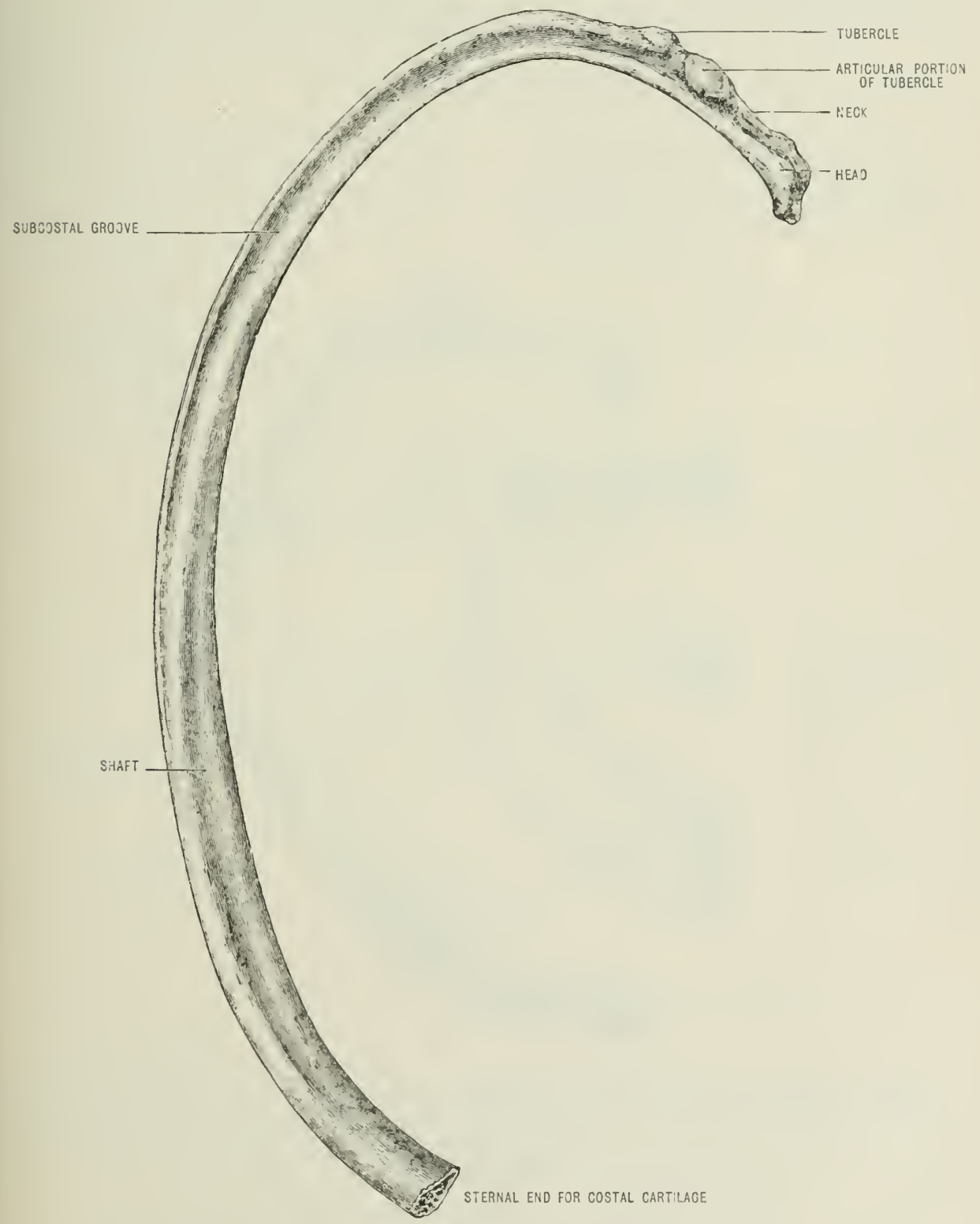

The superior border is rounded, and affords attachment to the internal and external intercostal muscles. The inferior border commences ahruptly near the angle, and gives attachment to the external intercostal muscles. tilagre.

The sternal end of the shaft is cupped for the reception of the costal car- 
The sipenth rib and its costal cartilage give attachment to the following muscles :-

Internal interentals (sixth and sexenth). External oblique abdominis.

External interestals (sixth and seventh). Rectus abdominis (costal cartilage).

Levatores costarum (serenth).

lufracostal (when present).

I)iajh hagm.

Transwersalis.

Lomgissimus dorsi.

Triangularis stemi (costal cartilage).

Serratus magnus.

Ilio-costakis, or sacro-lumbalis.

Musculus accessorius.

\section{It gives attachment to the following ligaments :-}

Anterior (osto-rertuliral or custorentral (stellatr).

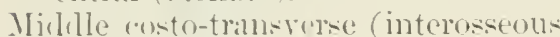

The (alpsular.

Fig. 109. - FiRst AND SEcoNi Ribs.

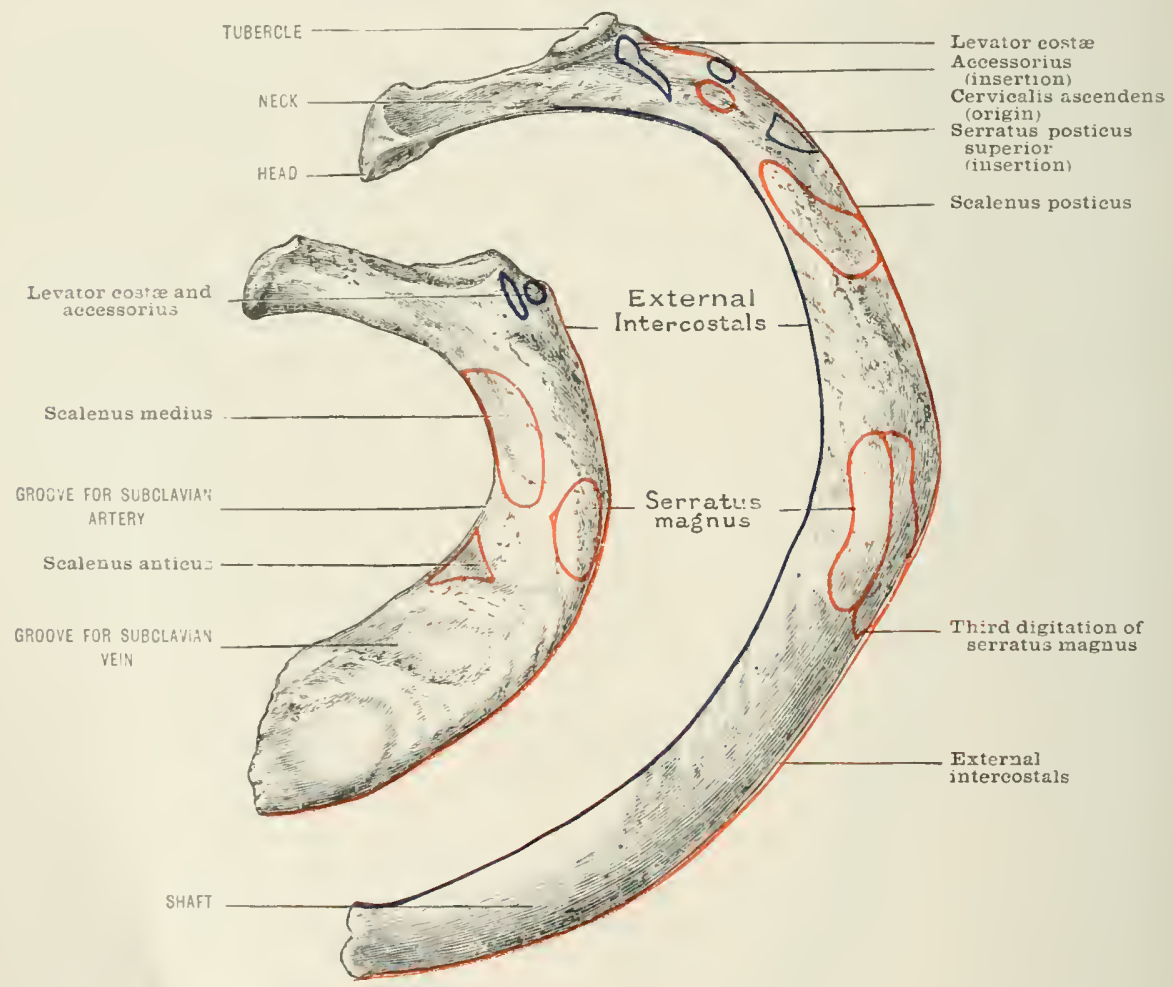

Blood-supply.-The ribs are very vascular and derive numerous braneles from the interental arteries. The branches in the shaft run towards the rib-hearl. Those of the hearl and reck take a contrary direction, and run, as a rule, towards the slaft. In the neighbourhood of the tuberosity the ressels secm to rum in any direction.

Peculiar ribs.-Sierral of the ribs differ in many particulars from this general ilescription. They are the first, scoond, tenth, eleventh, and twelfth.

The first rib is the broadest and most shamply eurved. The head is small, and, as a rule, is furnislaed with only onc articular facet. The tuberele is laree and prominent, the neck narmw. The shaft is Jrrad, has no angle, and is eurved around a rertical axis only. The upper surface presents two shallow grooves separated near the inner border by a rough surface (Lisfrances or scalene tubercle) 
for the scalenus anticus muscle. The gronve in front of this surface is for the subclavian vein, the groove behind it is for the subclarian artery. Betreen the groore for the artery and the angle there is a rough surface for the scalemus medius muscle; anterior to this rough surface and close beside the groove is an area from which the first digitation of the serratus maymus takes origin. The under surface is smooth and lacks a groove. The outer border is thick, and rounded for the internal and external intercostal muscles.

The costal cartilage of this rib fuses with the manubrim of the sternum; occasionally the sternal extremity and costal cartilage of this ril, are replaced by fibrous tissue. When a well-developed cervical rib is present, the head of the first may present two facets as in a typical rib.

The first rib, with its costal cartilage, gives attachment to the following muscles:-

Internal intercostal.

External intercostal.

Levator costæ.

Scalenus anticus.

Scalenus medius.
Sulclavius (costal cartilage).

Sterno-hyoid (costal eartilage).

Pectoralis major (costal cartilage).

Serratus magnus.

Iusculus accessorius.

Fig. 110.-The Vertebral Exis of Texth, Elevexth, axi Twelfth Ribs.

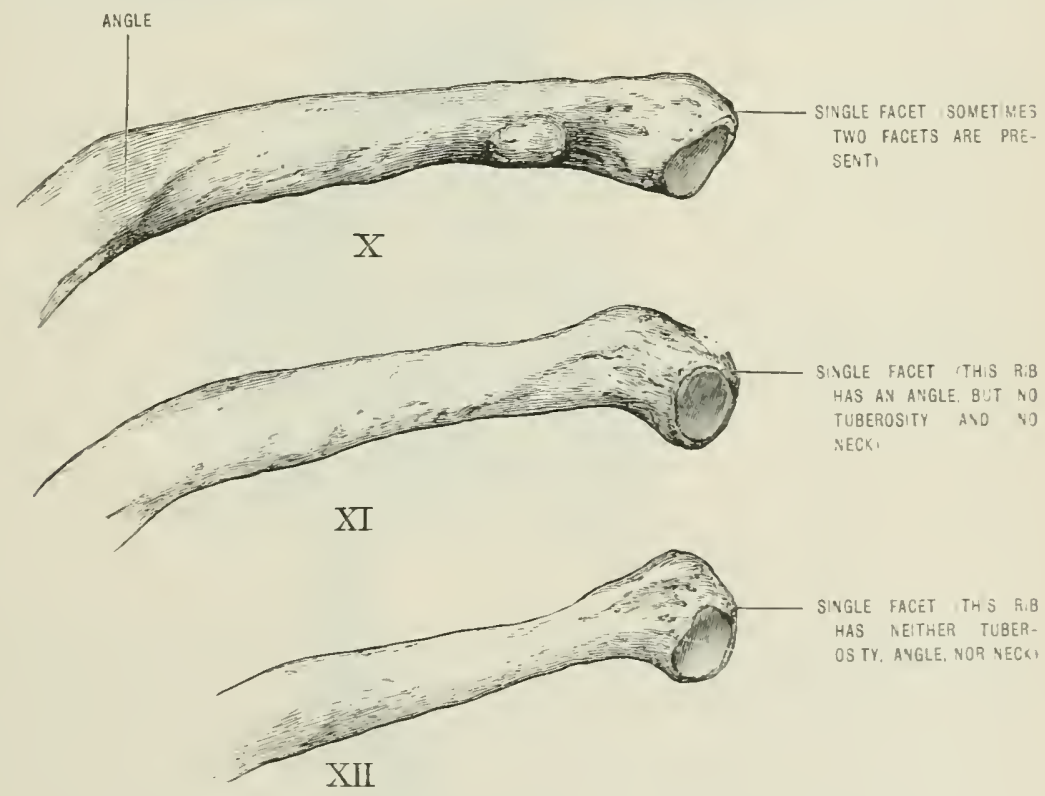

Blood-supply.-This is derived mainly from the superior intercostal branch of the subclarian artery.

The second rib, like the first, is strongly curved; its posterior angle is faintly narked; and the shaft, like that of the first, can lie flat on the table. It has it prominent anterior angle for the serratus magnus.

It gives attachment to the following muscles :-

Internal intercostals (first and second).

External intercostals (first and second).

Levator costæ.

Pectoralis major (costal cartilage).

Cerricalis ascendens.
Serratus magnut:

Serratus posticus superior.

Scalenus posticus.

Musculus accessorius.

Blood-supply.-Superior intereostal hranch of the subclivian artery, anct the first aortic intercostal. 
The tenth rib has mally a single facet on its head. Oceasionally a second is present. When this is the case, the ninth thoracie vertebra is not exceptional, and presents two demi-ficents.

The eleventh rib has a single facet on the head. The angle is feebly marked, and the suluestal groove shallow. It lacks a neck and tubercle.

The twelfth rib has a large head furnished with one facet. The shaft is narrow, and its length extremely variable. It may be as short as $3 \mathrm{~cm}$, or attain a length of $20 \mathrm{~cm}$. ( $\left(\delta^{\prime \prime}\right)$.

The twelfth rib gives attachment to the following muscles:-

Internal intercostal.

External intercostal.

levator costae.

Diaphragm.

Transversalis abdominis.

External obliegue.
Internal oblique.

Serratus posticus inferior.

Musculus accessorius.

Sacro-lumbalis or ilio-costalis.

Erector spine.

Quadratus lumborum.

Latissimus dorsi.

Fig. 111.-Rib at Puberty.

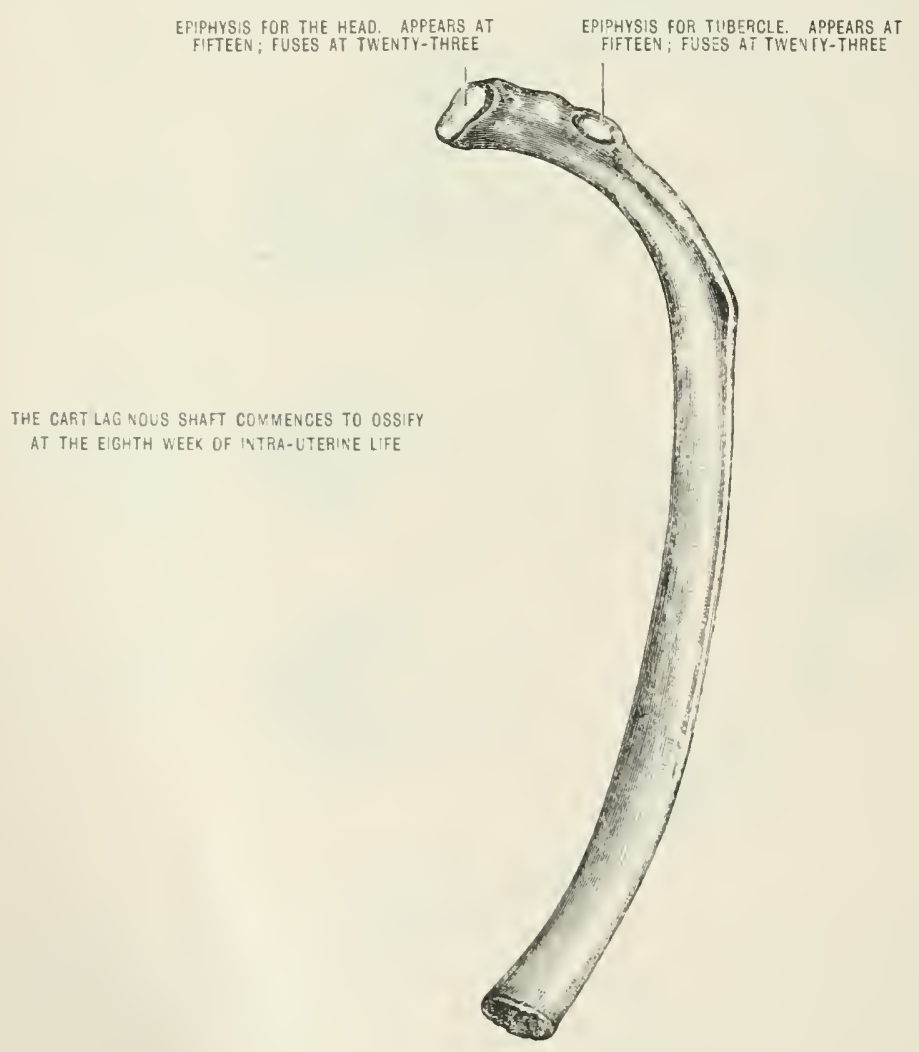

The costal cartilages are bars of hyaline cartilage attached to the anterior extremities of the ribs; they represent unossified epiphyses. Like the shaft of a rib, arch has an outer and inner surface; the outer surfaces give origin and insertion to large museles; and the inner surfaces, from the secend to the serenth inclusive, are in relation with the trimguluris sterni. 'The upper and lower horders sorve for the attachment of the intermal interostal muscles. The upper seren cartilages, and oceasionally the eighth, are connected with the sternum. The first fuses with the manubrim; the remaining six are received in small artieular conarvities, and retained by means of ligaments. The cartilages of the vertebro-chondral 
ribs are uniter to one another and to the serenth costal cartilage by ligament: (sometimes by short vertical bars of eartilage). ancl those of the vertebral rilss end freely. The imner surfaces of the lower six afford attachment to the diruhragm and the transersulis muscle.

The second, third, fourth, and fifth costal cartilages articulate with the sides of the sternum, at a spot corresponding to the junction of two stemelnre. The sixth and serenth (and eighth when this reaches the sternum ) are arranged irregularly. As a rule the sixth lies in a reress in the sicle of the fifth stemebra; the serenth corresponds to the line of junction of the meso- and nuetastemum; and the eighth articulates with the metastemmu (see fig. 112).

Blood-supply. - The twigs for the costal cartilages are derived from the terminal twigs of the aortic intercostals, anil from the internal mammary arteries.

Development.- At the eighth week of intra-uterine life the ribs are cartilaginous. About this date an earthy spot appears near the angle of each rib, and spreads with great rapidity along the shaft, and hy the fourth month reaches as far as the costal cartilage; the proportion borne hy the rib-shaft to the costal cartilage is about the same at this clate as in adult life. Whilst the ribs are in a cartilaginous condition, eight of them reach the sternmm; even after ossification has taken place,

\section{Fiq. 112.-The Thorax AT tile Eighth MoNth,}

(On the left side eight "artilages reach the sternum.)

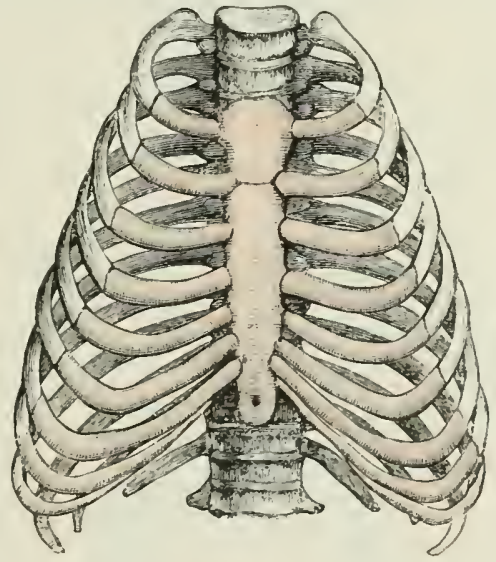

the costal cartilage of the eighth rib, in many instances, articulates with the stemum as late as the eighth month (fig. 112). This relationship may persist through life, but usually the cartilage retrogresses, and is replacerl by ligamentous tissue. About the fifteenth year a secondary centre appears for the head of each rib, and a little later one makes its appearance for the tubercle, except in the tenth, eleventh, and twelfth ribs. The secondary centres fuse with the ribs abont the twenty-third year. The rib-shaft increases in length mainly at its line of junction with the costal cartilage.

\section{Tariations in the Number and Shape of the Rils}

The ribs may be inereased in number by addition either at the cervical or lumbar emd of the series, but it is extremely rare to find an additional rib or jair of ribs in both the cervieal and lumbar regious in the simue subject.

Cervical ribs are fairly common; as a rule they are of small size and rarely extend more than a few millimetres beyond the extremity of the transverse process. Oecasionally they exceed such insignifieant proportions and reach as far as the sternum: between these two extremes many varieties ocem. As a rule, the existence of a cervical rib is not detected until the skeleton is macerated; hence we know little of the comelated arrangement of soft parts. In one fortunate ease Turner was able to make a thorongh discection of a specimen in which a complete cervical rib existed. Its head articulated with the borly of the seventh enrvical vertebra and hat a stellate ligament. The tuberde was well developed, and articulaterl with the transverse process. The costal cartilage blended with that of the first thoracic rib, and gave 
attachment to the ensto-clavioular lieriment. Botwecu it anl the first thoracic rib there was a

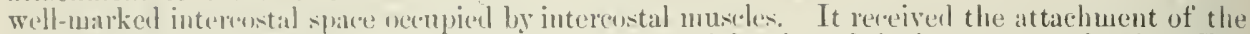

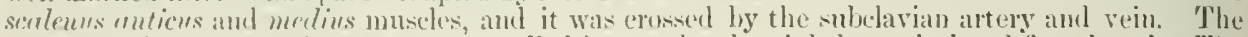

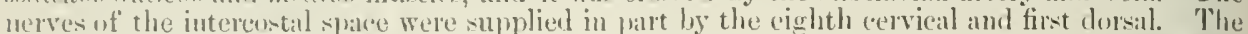
artery of the spare was derivent fiom the deep rervical, which, with the superior intercostal, arosi finn the root of the verteholal. The heal of the first thoracie rib in this speroimen articulatel with the seventh cervical, as well as with the first thoracic vertebra. An interesting fact is alsi recorded in the careful aceount of this specimen:-There was no movable twelfth thulacis. rib un the same sile as this well-cleveloped cervical rib, and the twelfth thoracic vertebra hand mammilling and acecsiory processes, and a strong elongated costal process, and was in lincar series with the lumbar trinsverse prueesses.

Gruber and 'Tumer fiom a carefil and elaborate study of this question summarise the variatims in the cervical rib thas :- It may be very short and pussess only a head, neck, and tuberele. When it extends beyom tle transverse proeess, its shaft may end fieely or join the first thoracie. ril, : this mion may be effected ly bone, eartilage, or ligament. In very rare instances it may have a costal eartilige aml join the mambrimm of the sternum. Not unfiequently a process, ol eminence, exists on the first thoracie rily at the spot when it articulates with a cervical rib.

Lumbar ribs are of less significance than cervical ribs and rarely attain a great length. Their presence is easily aceounted for, as they are the differentiated costal elements of the transverse processes. They are never so complete as in cervical rils, and articulate only with the tratusverse proceses; the heall never reaches as far as the boxly of the vertebra, and there is no neck or tubercle. An extra levetor coster muscle is associaterl with a lumbar ril).

Not the least interesting variation of a rib is that know as the bicipital rib. This condition is seen exchsively in connection with the first thoracic rib. The vertebral end comsists of two limbs which lie in different transverse planes. These bicipital rils have been especially stulind in whales and man. This abnormality is due to the fusion of $t w o$ ribs, either of is cerviuil rib with the shaft of the first thoracic; or the more common form, the fusion of the first anil secound true ribs.

Anomg unusual variations of ribs should be mentioned the replacement of the costal eartilage aml a portion of thr rib-shaft by fibrous tissue, a jorocess which occurs as a normal event, during development, in the eighth rib.

Sometimes the shafts of two or more ribs may become united by small quadrilateral plates of hme extending across the intercostal spaces.

'The sternum is a thin flat bone situated in the anterior wall of the thorax. In the young subject it consists of six pieces, or sternebræ. Of these, the four midelle fuse twether to form the gladiolus (mesostermum); the superior remains distinet throughout life as the manubrium (pre-sternum); and the lower segment, alsu distinct until very advanced life, is the xiphoid (metastemum). The anterior surface of the arlult sternum is eonvex, and gives origin to the pectoralis majom musele of earh side; near its superior angle the stemo-mastorl musele arises. This smrface is traversed by five lines, indicating the former segmentation of this bone. The puterior surface is concave, and triversed by five lines corresponding to those on the anterior surface. At the upper part it gives origin to the stemo-hyoid and stemothrmid muscles. The posterior surface of the lower four segments gives origin to the trimgularis stemi. The xiphoid is usually perforated; a branch of each internal mammary artery traverses the foramen; and on each side of it a portion of the dimphrom is attacherl. Oreasionally the xiphoid is bifid. The superior border presents the interclavicular notch, to which the fibres of the interchavieular ligitwent are attareherl; this horder terminates at eateh end in an artirular noteh for the sternal encl of the clavicle. The nargins of the noteh give attachment to the sternorlavieular ligamenti. Tho lateral borelers of the stermum present a series of depres-

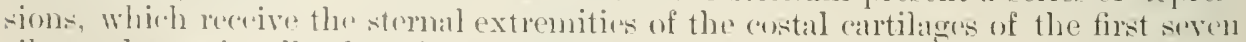
libs, and oceasionally that of the eighth (sed fig. 112). The borders intervening he-

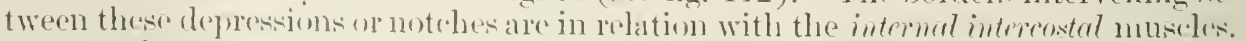

In order to aplurediate the nature of these notehes, it is arlvantageous to sturly the sternum in a young sulject. Each typical sternebra presents four angles; weil angle presents a diemi-facet. Butwern every tro sternebre there is an intersternebral dise; when two stemelnax are in position, each noteh for a costal cartilage is

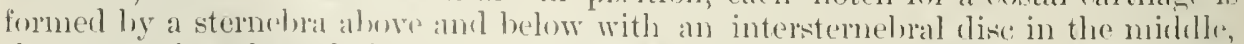
thus repeating the redation of the rib-heal to the rertehral rentra. Later in lifs? these fuse more or lesis tegethere racept in the case of the lirst and sereond stementar, which nsually remain separate to the anet of life. The lirst (p)re-sternum) is the

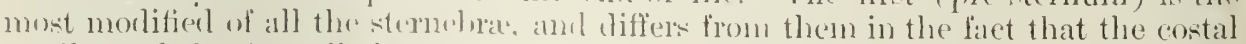
cartilage of the first rib is continuous with it, and in the fitet that it sulports the 
clavicles. Oeeasionally a rounded pisiform bone is seen on each sicle, immediatcly internal to the articular notch for the clavicle; these are the episternal lunes. The last sternebra, or xiphoid, is the least developed and, though calcificed in oln age, rarelr ossifies. Its tip is directly continuous with the linea alba, and the bates gives slight attachment to the rectus abdominis muscle.

Fig. 113.-The Sternum. (Anterior view.) INTERCLAVICULAR NOTCH

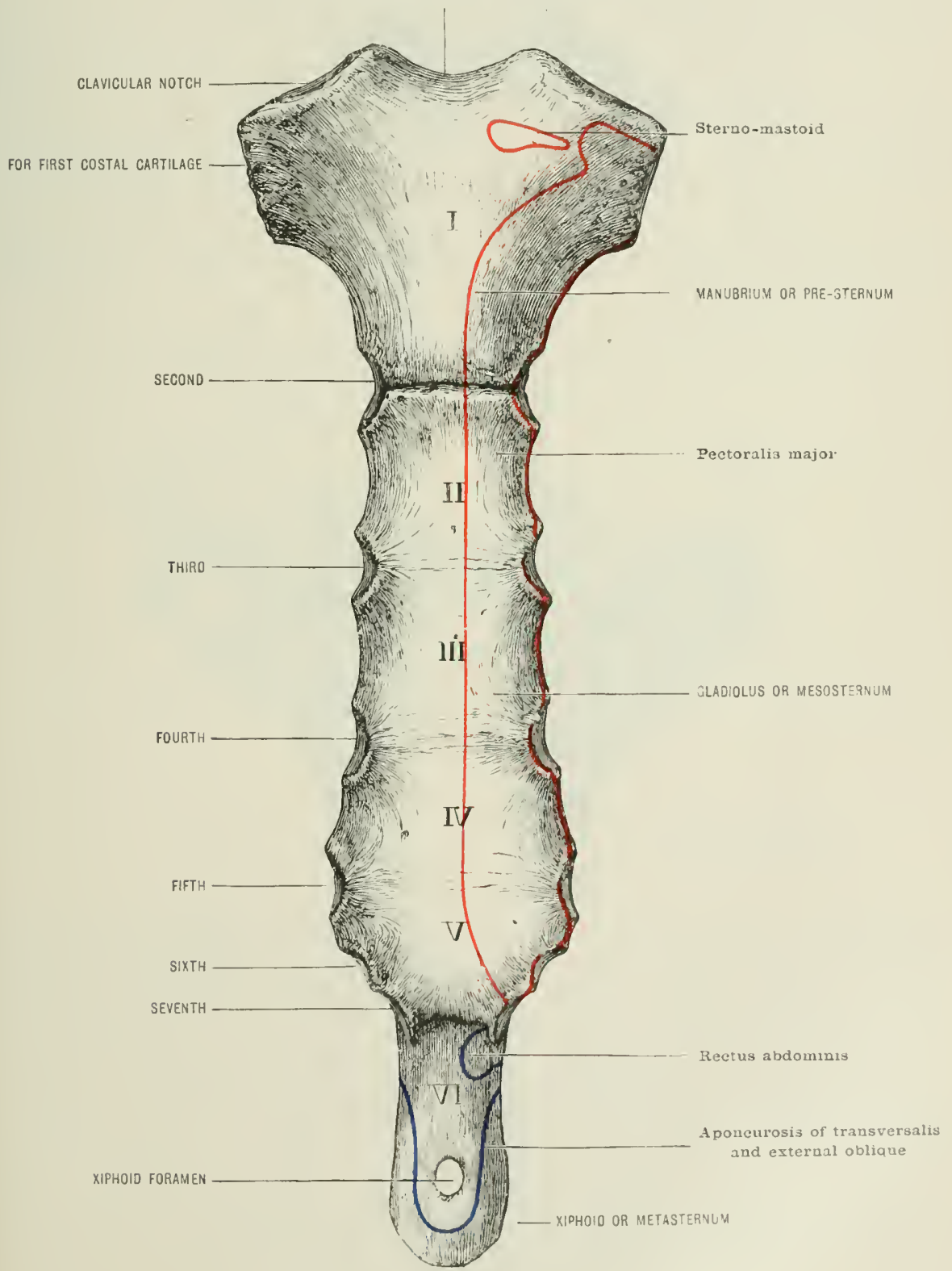

The following muscles are attached to the sternum:-

Peetoralis major.

Sterno-cleido-mastoid.

Internal intereostals.

Rectus abdominis.
Triangularis sterni.

Transiersali-

Diaphriagm.

Sterno-hyoid. 
Ligaments. - In addition to the ligaments proper to the costal cartilages, the following require enmmeration:-

Interclaricular.

Anterior sterno-clavicular.
Posterior sterno-clavicular.

Interarticular fibro-cartilage.

Linea alba.

Fig. 114.- T'ue Stensu. (Posterior view.)

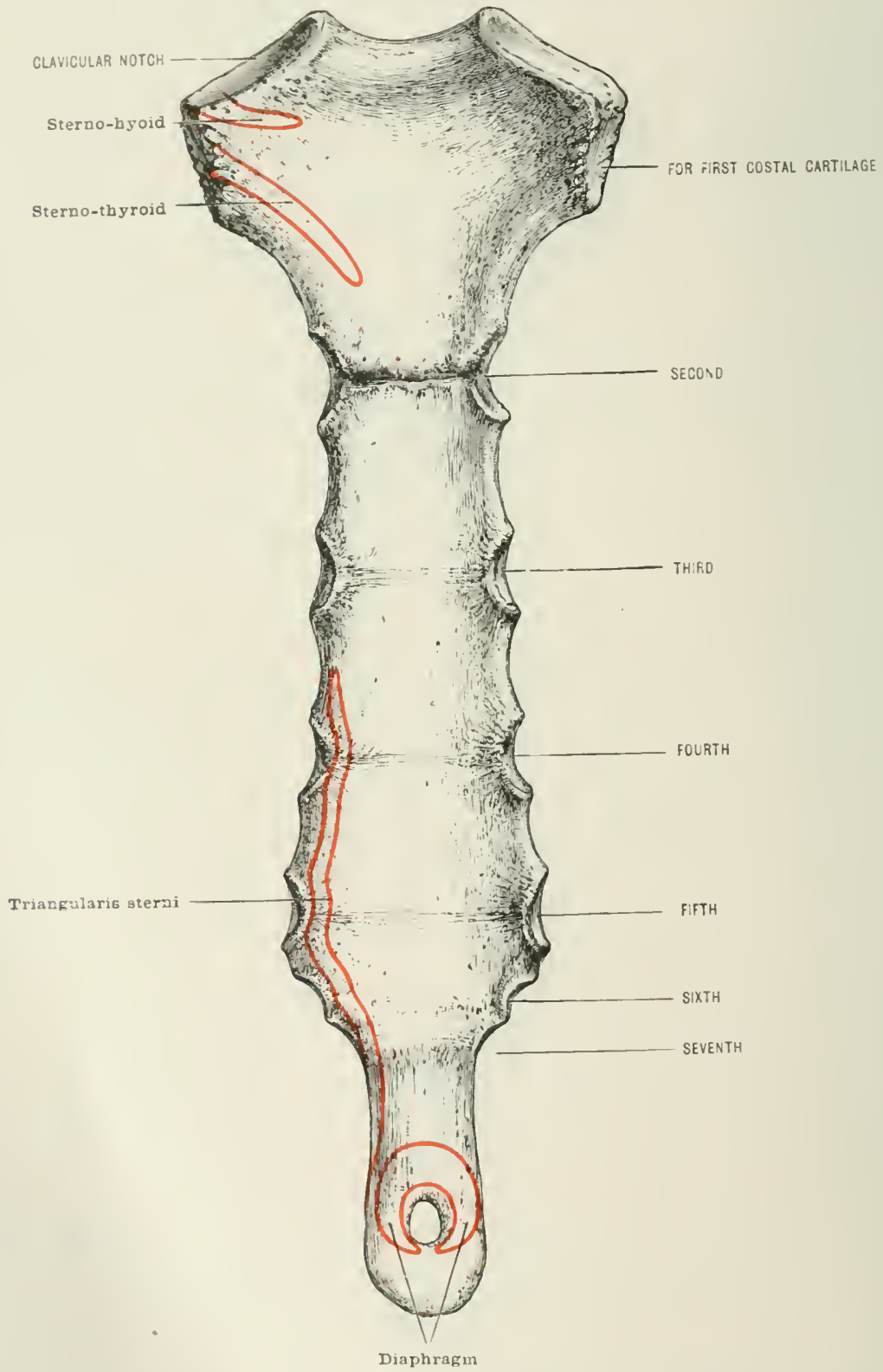

Blood-supply.-The artirics of the sternum are derived mainly from the internal mammary arteries by direet hranches termed sternal: many twigs are furnished by the perforating branches of the internal mammary, and also by the torminal twigs of the aortic interenstak.

Development.-The sternum results from the fusion of the ventral ends of the 
cartilaginous bars which in the early embryo represent the ribs. At first these bars fuse together laterally, and for some time the stermum is represented by two strips of cartilage separated by a median fissure. Very early this gap is bridger over anteriorly. Nine costal cartilages are in relation with the sternum at this stage. Gradually the lateral strijs unite with each other to form the mesosternum. The ninth costal eartilage divides: one part remains attached to the sternum and becomes the xiphoid, whilst the end still attached to the rib acyuires a new attachment to the eighth cartilage. The ends, still adherent to the sternum, may remain separate and give rise to a bifid metasternum (xiphoid); much more frequently they unite, leaving a small foramen. The eighth cartilage may retain its stemal attachment permanently.

At first the sternum and costal cartilages are continuous; a joint soon forms between the pre-sternum and mesosternum. Gradually joints arise between the costal cartilages and the sternum (except in the case of the first). The division of the mesosternum into sternebre is a still later process, and arises during the process of ossification.

Ossification.-The transformation of the sternum into bone is a slow and irregular process. The pre-sternum (manubrium) has a mesial nucleus ahout the sixth month of intra-uterine life; later, several smaller accessory centres may

Fif. 115.-Posterior Surface of the Maxlbrium (Pre-sterncy), With Sternal Exid of Clavicle axd the First Costal Cartilage.

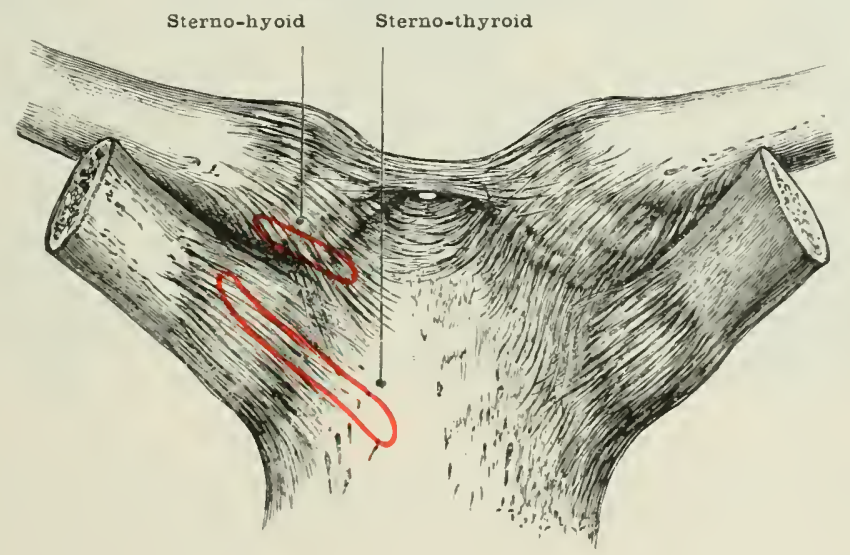

appear. The mesosternum usually ossifies from seven centres. The second sternebra ossifies from a single median nucleus about the eighth month. Below this, three pairs of ossific nuclei appear, and they may remain long separate. Of these, two pairs for the third and fourth sternebre are visible at birth. The pair for the fifth sternehra make their appearance towards the end of the first year. The various lateral centres unite in pairs, and at the sixth rear the sternum consists of six sternebre, the lowest (metasternum) being eartilaginous. Graclually the four pieces representing the mesosternum fuse with one another, and at twenty-five they form a single piece, but exhibit, even in advanced life, traces of their original separation.

The metasternum is always imperfectly ossified, and does not ankylose with the mesosternum till after middle life. The pre-sternum and mesosternum rarely fuse. The dates given above for the various nuclei are merely approximate, for they are extremely variable, not only in appearing, but in their number. The same remark applies also to the age at which the various segments ankylose; hence the sternum affords very uncertain data as to age.

Abnormalities of the sternum. - The morle of development of the sternum as described above is of importance in connection with some leviations to which it is oceasionally subject. At an early periorl it consists of two lateral halves: in some rare instances these have failed to unite, and thus gire rise to the anomaly of a 
completely cleft sternum. The union of the two halles may occur in the region of the manulnium, but fail below this point; in some instances the upper and lower serments have duly coalesed with the opposite side, hut union has failed in the mildlle secrments. "The refte resulting from these foilures of coalescence are in mamy instances so small as not to le of any moment. and not even recognised until

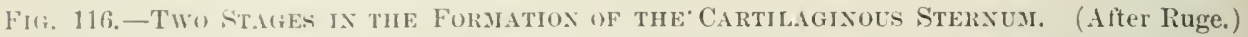

A

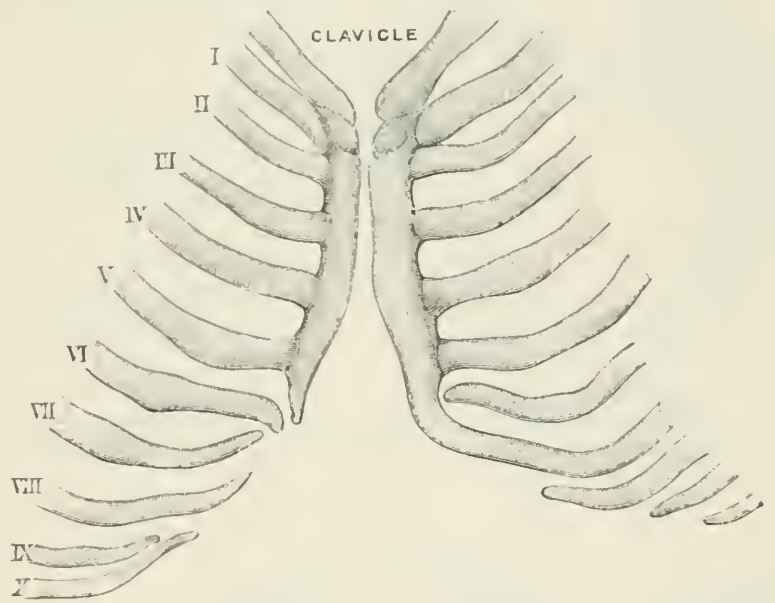

B

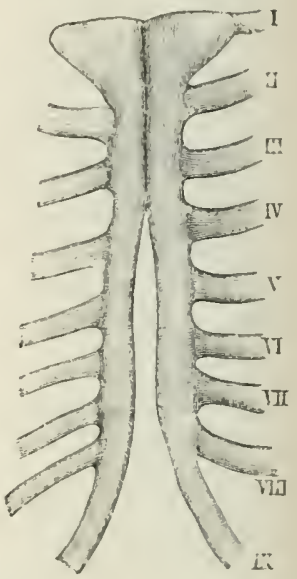

the skeleton has been prepared. In a few individuals they have been so extensive as to allow the pulsation of the heart to be perceptible to the hand, and eren to the eye, through the skin covering the defect in the bone.

A common variation in the sternum is asymmetry of the costal cartilages. Instead of (orresponding, the cartilacres may articulate with the sternum in an alternating manner. The catlec of this asymmetry is not known.

\section{THE THORAX}

The thorax is a bony cage of conical shape, formed by the thoracic vertebre, the ribs with their costal cartilages, and the sternum. The thorax is compressed antero-posteriorly so that it measures less in the sagittal than in the transverse axis; it is also deeper jostriorly than anteriorly. Its josterior boundaries are formed by the thoracie vertellate and the rils as far outward as their angles; the backwarl curve of the rils produces on each siele of the reptebre a deep furrow, the costovertebral groove, in which the crector simit muscle and its subdivisions are lodoced.

The anterior boumdary is formed hy the sternum and costal cartilages. This surface is slightly convex, and hats a slight inclination forwards in its lower part.

The lateral boundaries are formorl by the ribs from their angles to the costal cartilages.

The top of the thorax presents an elliptioal anserture, the thoracic inlet, which

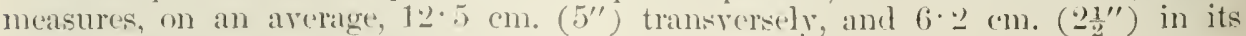
sagittal axis.

The lower opening of the thomix is very irregular, and forms two eurved lines 
ascending from the last rils to the lower border of the gladiolus (nososternum). These two borders form the subcostal angle, and the xiphoid (metasternmm)

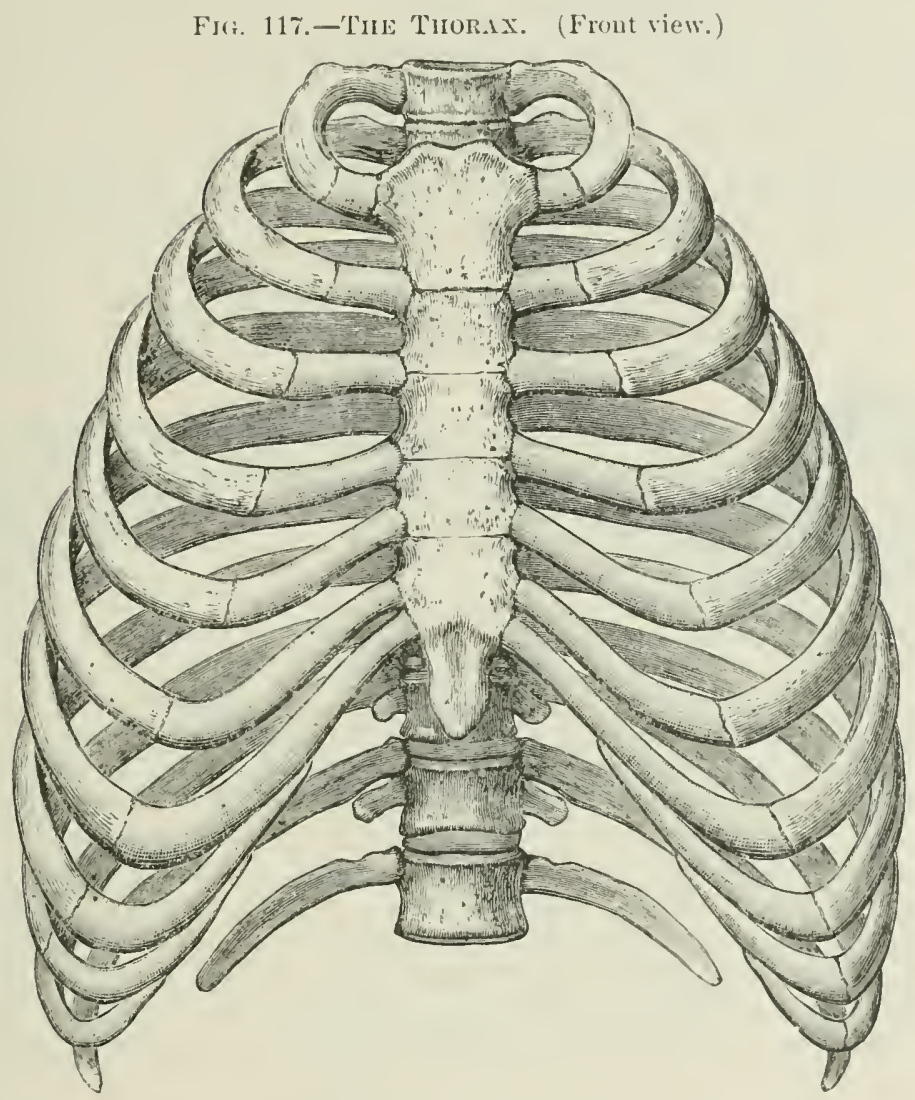

projects into the middle of it. The intervals between the ribs are the intercostul. spares, and are eleven in number on each side.

\section{TIIE CLA VICLE}

The clavicle is a rod of bone passing from the top of the sternmm to the acromion process of the scapula. It presents two curves: an inner, with the convexity direeted forwards; and an outer, the smaller, with the convexity directed backwards. The clavicle consists, for descriptive jurposes, of an onter flattened, and an inner prismatic portion.

The outer third has two surfaees and two borders. The superior surface looks directly upwards, and affords attachment to the tiopezins musde posteriorly. and the deltoirl anteriorly; a small tract intervening hetween the museles is suberutaneous. The inferior surface is rongh, and at its most posterior part precents the tuberosity (or conoid tubercle) of the clavicle; it orerhangs the coracoid process and gives attachment to the conoid ligament. From the tuherosity a ridge, the oblique line, runs outwarls and forwards: to it, the trapezuid ligamont is attached. The anterior border is thin; presents often a small prominence, the 
doltoil tuberde, and gives origin to the deltoil muscle. The posterior border is thick and rounded; into it the trapezius is inserted.

'The inner two-thirds is prismatic in form; it has three surfaces and three horlders. () th these. the anterior surface is convex and presents near the sternal cond a rough surfice for the clavicular portion of the pectoralis major, and is rongh surfice abore for the sterno-deda-mastoid. Near the middle of the shaft it is smooth and covered by the thin jilatysma myoides; sometimes at small canal patses at right angles through this surface of the clavicle; it is traversod hy a cutancons branch from the cervical plexus. The posterior surface is concare, and forms an arch orer the brachial plexus and subclavian artery.

Fig. 118.-The LefT CuAIClE. INuperior surface.)

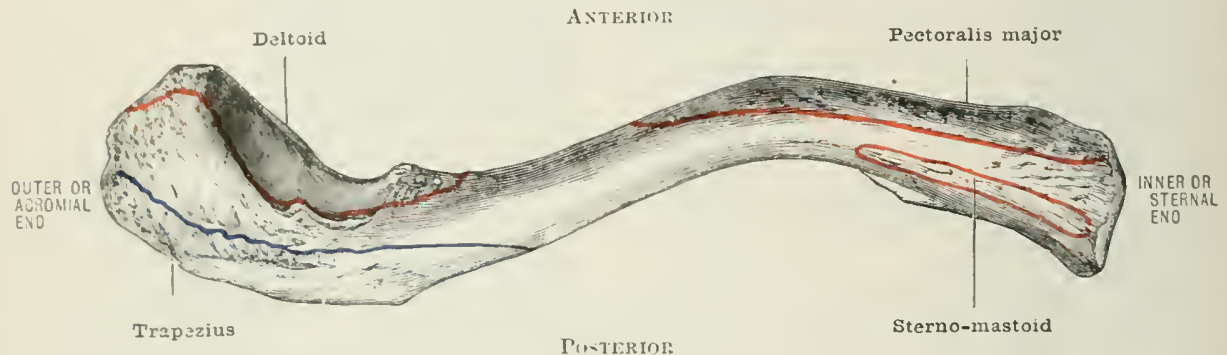

The inferior surface commences externally as a groove for the subclurins, the floor of the croove being continuous with the inferior surface of the outer third of the clavicle, and frequently presents the orifice of the nutrient formen. Intemally, this groove becomes very narrow; and runs on to the rough surface for the rhomboid ligment. On the stemal side of the rhomboid impression there is often a facet where the clavicle plays on the first costal cartilage. Near this facet the sterno-hyoid muscle finds an attachment, and occasionally the stermothyroid. Of the three borders, the superior separates the anterior and posterior surfaces; it is faintly marked towards the stemal end; extemally, it becomes continuous with the posterior border of the outer third. The anterior border

Fic. 119.-Tite Left Chalvicie. (Inferior surlace.)

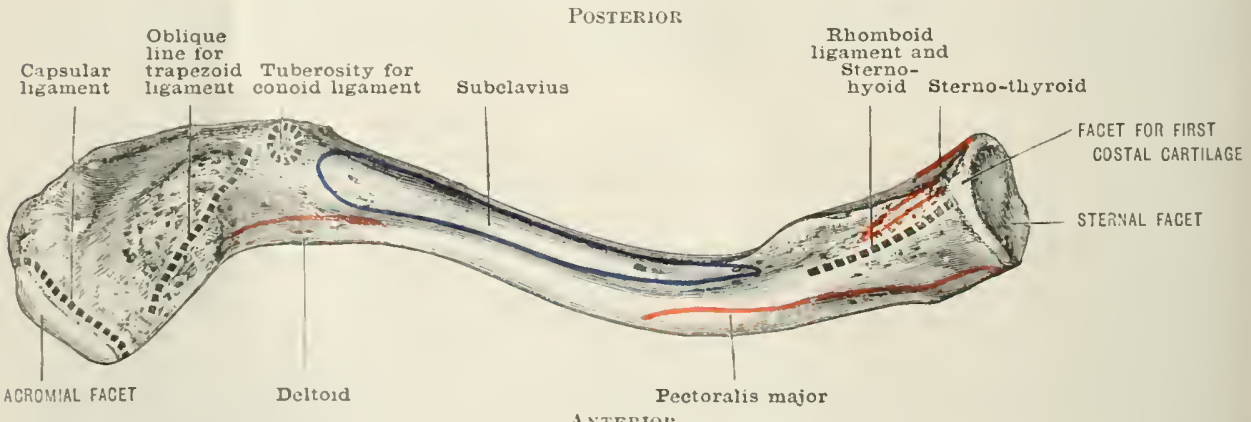

A XTERIOL

separates the anterior and inferior surfaces; it is continuous with the anterior horder of the flattened portion. The posterior border sepantes the inferior and posterior surfares, and forms the posterior lip of the groove for the sublucius; it begins at the conoid tubercle, and ends at the rhomboid depression. The inner or sternal end of the elavicle is broal and expanderl; it plays upon a fibro-eartilane inter]osed hetween it and the clasicular faret of the mamubrium of the stemum, and its borders are rough for the attadhment of the stemo-elarieular and interrlavicular ligaments. The acromial, or outer end, presents a smooth articular facet, directed slightly downards for the arromion; its adges, especially the superior, are rough for the attachment of the aremuio-clat vicular ligaments. 
The following muscles are attacherl to the clavicle:-

Sterno-eleido-mastoid.

Pectoralis major.

Subelavius.

Deltoicl.

\section{Ligaments :-}

Interclavicular.

Interarticular (sternal).

Capsular (sterno-clavicular).

Rhomboid or costo-clavicular.

Capsular (acromio-clavicular).
Trapezius.

- iterno-hyoirl.

Stemo-thyroid (occasionally).

Blood-supply.-The nutrient artery is a branch of the suprascapular; it enters the bone on the under surface of the shait near the middle of the subclavian groove. It is clirected towards the acromial end. The acromial end of thr davicle receives numerous branches from the acromio-thoracic artery, and twigs from the arteries in the muscles attached to it.

Ossification.-The clavicle is ossified from two centres. The primary nucleus appears in the sixth week of embryonic life in the tissue immediately orerlying the cartilaginous pre-coracoid bar (see p. 115). The clavicle begins as a membranebone, but the ossification quickly extends into the underlying cartilage; it is therefore a dermal splint engrafted on cartilage. Alont the serenteenth rear a secondary nucleus appears at the sternal end. Consolidation is complete by the twentieth year.

\section{THE SCAPULA}

The scapula is a large flat bone, triangular in shape, situated on the posterior aspect of the thorax, and resting on the ribs from the second to the seventh. Of its two surfaces the anterior is deeply concave, forming the subscapular fossa, which is marked by several ridges conmencing at the posterior borter of the bone and passing obliquely upwards; these ridges divide this surface into sereral shallow grooves from which the subscapularis muscle takes origin: the highest groove is the deepest. The outer third of this surface is smooth. and overlapped by the subscapultir muscle: the superior and inferior angles are somerhat triangular, and connected by a narrow ridge of bone along the posterior border. This ridge and its terminal surfaces serve for the insertion of the serratus matmus.

The posterior surface, or dorsum, is generally convex; it is uneyully divided by a prominent ridge of bone, the spine. The hollow above the spine is the supraspinous fossa, and lodges the supra-spinatus muscle. The part betow the spine is the infraspinous fossa; it is larger than the supraspinous fossa, and is limited inferiorly by a ridge which runs from the glenoirl fossa hackwarks to join the posterior border a short rlistance above the inferior angle. 'To this oblique ridge the stout aponeurosis is attached which separates the teres major and tere minom muscles from the infira-spinatus muscle. The infia-spinutus arises from the inner two-thirds of the infraspinous fossa, and overlaps the outer third. The suprat and infraspinous fossæ communicate with ach other around the outer and of the spine; this part corresponds to the neck of the scapula, and the groor is the scapular notch; it transmits the supusasapular nerve and artery from one fo--a to the other. The surface of hone lowlow the olligue risge presents two, and areasionally three, facets for muscles: the long narrow outer one is for the origin of the teres minor; this is crossed near its mirlille ly a groove for the dorsal artery of the 
seapula. The seconel facet is broacler, and gires attachment to the teres major muscle. In hones from a muscular subject the third facet, quite at the inferior angle, is for a few tibres of the latissimus dorsi.

The spine commences at the posterior border of the scapula ly a hroarl trianEulin surfices: it then crosices the dorsal surface obliquely to the glenoid fossa, heroming more prominent as it passes outwards till it reaches the neck of the salulat from this point it forms the overhanging acromion process. The spine fresents a superior surface which gives origin to the supra-spinatus muscle, and an inferior surface whith afforels origin to the infia-spinatus muscle. It has a prominent crest, which is continuous posteriorly with the vertebral border, and, at its

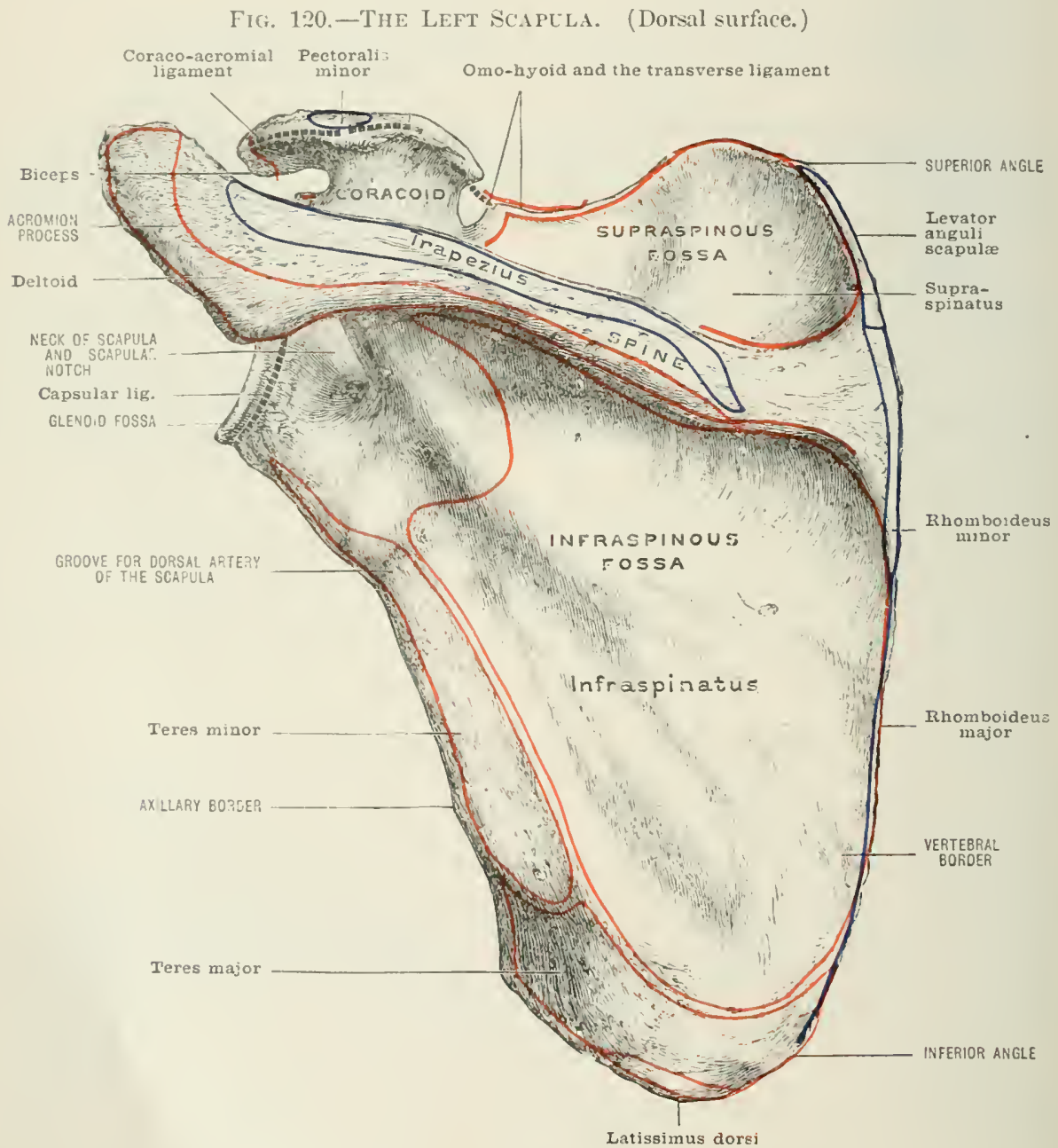

commencement, is smooth for a bursa between it and the tropezius. The crest is subcutaneous, and presents two lips-a superior for the insertion of the trapezins, and an inferior lip for the origin of the deltoid. The crest is continued into the acromion process.

The acromion process forms the summit of the shoulder, and presents two surfaces, two borders, and a tip. The upluer surface affords origin at its posterior part to a portion of the deltoirl. The under surface is concave and smooth. Its inner border, a continuation of the superior lip of the erest, receives the trapezius, and presents near the tip a small articular facet for the outer end of the clavicle; the edges of the facet are rough for the acromio-clavicular ligaments. The outer 
border is continuous with the inferior lip of the crest, with which it forms an angle; it gives origin to the deltoid. The tip of the arromion affords attachnent to the coraco-actomial ligament.

of the three borders presenterl by the scapula, the external, or axillary, in the thickest, and extencts from the posterior inferior angle to the lower margin of the glenoid cavity. Vear its junction with the glenoid ravity there is a rough surface, from which the long head of the triceps arises; betow this is the groowe for the chrsal artery of the seapula. The subsedpularis muscle encroaches on this border from the anterior surface, and the teretes from the posterin aspect. The posterior, or vertebral, border, sometimes called the base, is the longest; it extends from the posterior superior to the posterior inferior angle. It is rery narrow, hut

F1G. 121.-The Left SCAPLLA. (Ventral surface.)

Serratus magnus SUPRASCAPULAR NOTCH Conoid lig. Trapezoid ligament

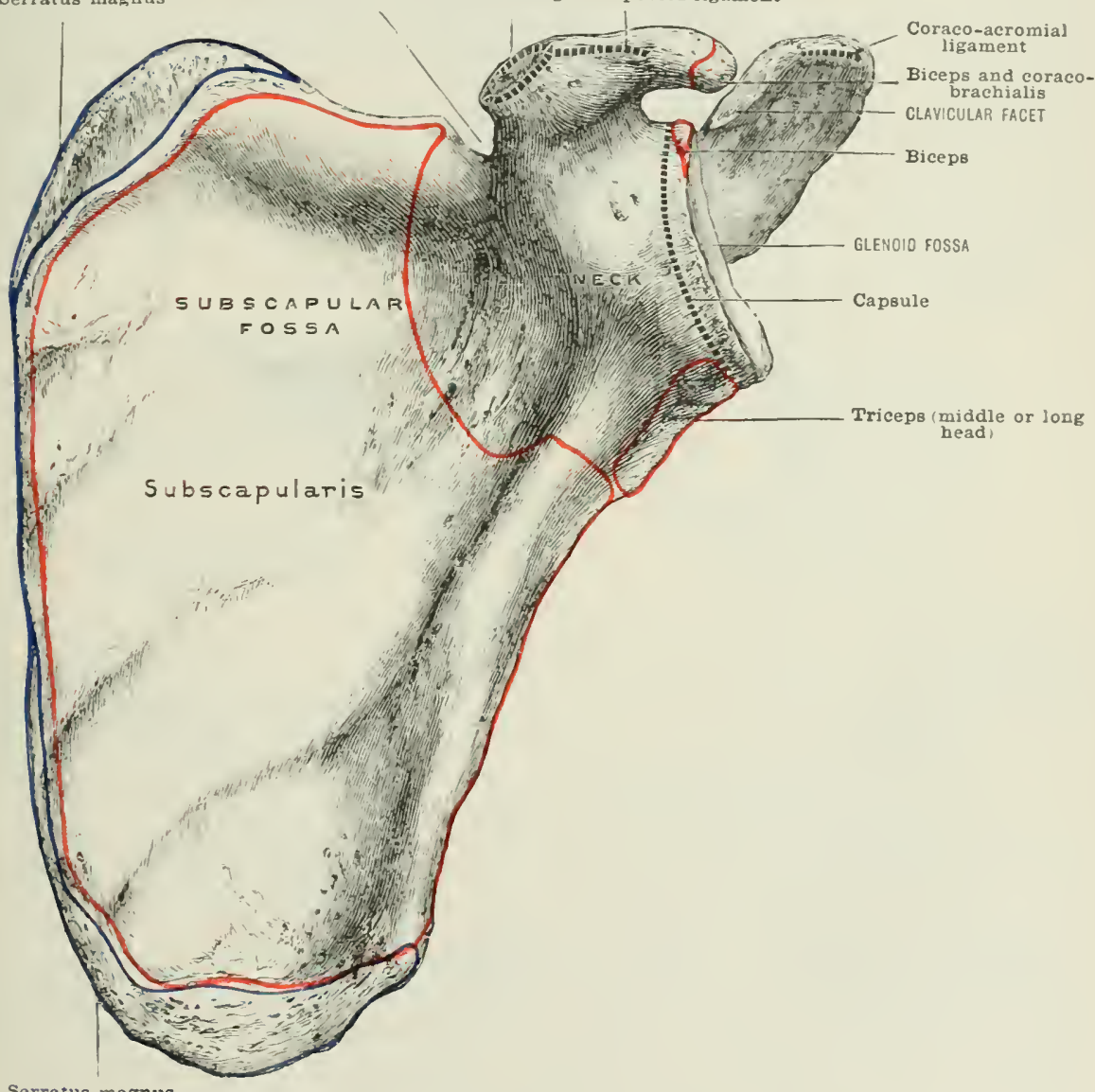

Serratus magnus

affords attachment to three muscles: namely, the locutor anguli scrupula above the spine; the rhomboidens minor on a level with the suine; and the rhumbridens major, through the intervention of a fibrous arch from the spine to the inferior angle. The superior border is the shortest and thinnest, ending extemially in the coracoid process. At the base of the coracoid is the suprascapular notch to the edges of which the transverse ligament is attached. Sot unfreyuently the notch is replaced by a suprascapular foramen. This notch or formm transmits the suprascapular nerve, and oc("isionally the suprasopular artery. but as a ruls the artery passes over the ligament. From the adjacent burder- of the notch and from the ligament, the omo-hyoir take- origin. The anterior angle of the sealunta is formed by the glenoid cavity. This cavity is shallow and prifom, with its 


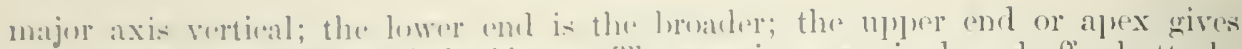

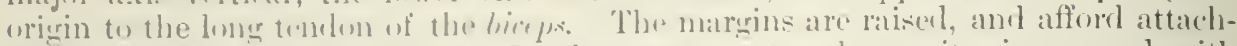
ment to the gremenil liganent. In the recent state, the ravity is covered with hraline artilinge, and forms an articular fossia for the head of the hmmerus. The

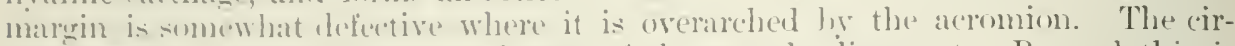

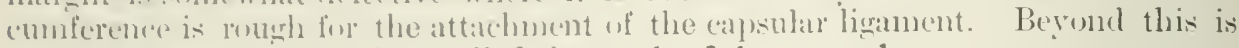
at narow constricterl jurtion, callew the neck of the scapula.

l'rujuting upwarls from the neck is the coracoid process, a prominence of bons anterior to, lut parallel with, the acromion. It comsists of two parts-rertical and horizontal. The vertical part is compressed from within outwareds; it is continums above with the horizontal part and below with the nock of the seapula; its

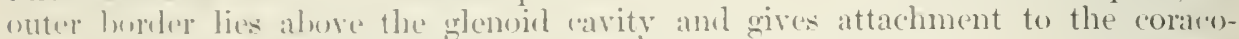
humeral limanent, and its inner border which forms the outer bomdary of the supraseatpular notrh gives attachment to the suprascalutar ligament; its anterior and posteriog surfaces are in relation with the substapuluris and supraspinates respectively. The horizontal part runs forwards and ontwards; it is compressed from above downwards; its inner extromity rives attachment to the conoid ligament, and its onter extrenity, or apex, is for the attachment of the short hearl of the

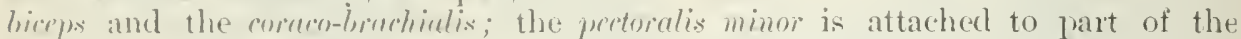
anterior borter and the upper surface, and the prostero-internal part of the upper surface is oceupied by the trapezond liganent. The posterior border gives attachment to the coraron-acromial ligament.

Muscles.-The fullowing are attached to the seapula:-
Suprit-spinatus:
Infrit-spinatus.
Sulscapularis.
Teres major.
Teres minor:
Omo-liyoid.
Pretoralis minor.
Sirratus magnus.

\section{Ligaments :-}

Conoil.

Traprezoill.

Cesto-(n)acoid membrame.

Costo-(o)racoid ligiment.

Calsular (acromio-clavieular).

Coraten-acromial.

Supuatanpular (transverse).
Latissimus dorsi.

Trapezius.

Rhomboideus major.

Rhomboideus ninor.

Levator anguli seapula.

Biceps.

Coraco-brachialis.

Triceps (long head).

Deltoicl.

\author{
Capsular (shoulder-joint). \\ Corico-humeral. \\ Gleno-humeral. \\ Glenoid. \\ Rhomboid loop. \\ Spino-glenoid or inferior \\ tramsrerse.
}

Blood-supply.-The seapula is supplied ly the following arteries:-Twirs

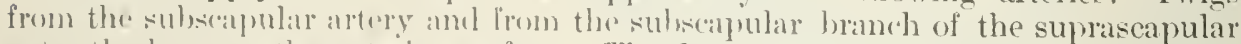
enter the hene on the antrerior surfece. The dorsel artery of the seapula distributes lranches in the infraspinous, whilst the suprascapular artery supplies the supraspinous fossi, the spine, the glenoid fosian, and sends branches into the infraspinous

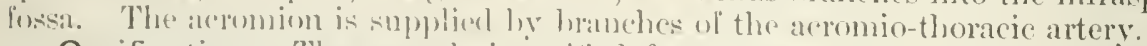

Ossification.-The seapulat is issitied from seren centres. Two may be considered as primary, aml the remainder as secondary nucled. The centre for the

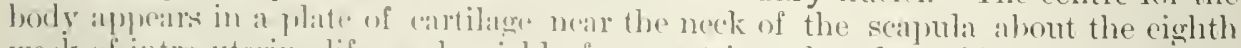
werk of intratuterine life, am puldkly forms a triangular plate of hone. from which

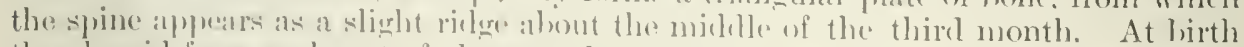

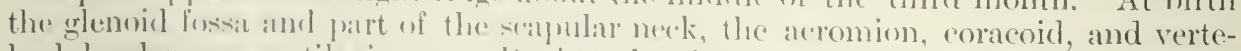
bral burder are "artilaginum. Doring the first rear a nuclous appears for the

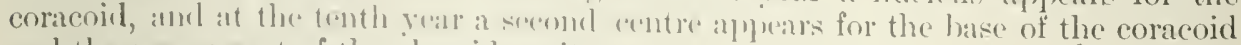

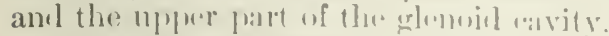

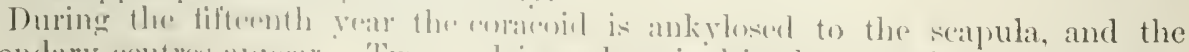

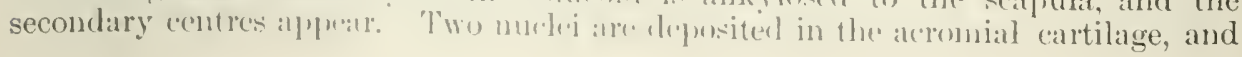


fuse to form the acromion, and join the spine at the twentieth vear. This union of the acromion and spine may be fibrous, hence the acromion is often found separate in macerated specimens. The cartilage along the vertebral horder osifies from two centres: one in the middle, and one at the posterior inferior angle. A thin scale may occasionally be detected at the tip of the glenoid fossa.

Morphology.- It is impossible to comprehend the significance of the scapular nuclei without considering brietly the morphology of the shoulder (pectoral) girdle.

In its most generalised form the shoulder girdle consists of cartilage, which is disposed in three parts. Of these, a dorsal segment represents the scapula and a ventral bar, reaching to the sternum, represents the coracoid. The meeting place of the coracoid and seapula is the glenoid fossa. Anterior to the coracoid there is

Fig. 122.-OSisfication of the Scapula.

The Scapula at the third year,

showing the coracoid element. (Anterior view.)

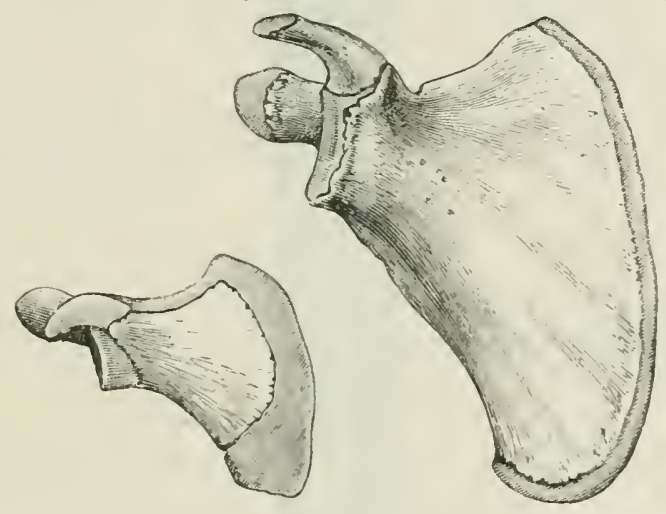

The Scapula at birth. (Anterior view.)

a third piece, more or less parallel with the coracoid, named the pre-coracoid. The human shoulder girdle is modified from the trpe form, mainly in the suppression of the pre-coracoid and, in part, of the coracoid. The suppression is brought about by the clavicle, which commences to ossify in the membrane overlying the precoracoid; it then invades and replaces the cartilage.

The scapular end of the coracoid ossifies and becomes the coracoid process of the scapula; the ventral end degenerates to form the costo-coracoid ligament, which lies in the free border of the membrane of that name. The dorsal cartilage ossifies and becomes the scapula; the large tract of cartilage on the rertebral border of the young scapula represents the laree suprascapular cartilage of batrachians. The suprascapular notch indicates the line of union of seapular and coracoid elements. In the embryo the notch is bridged over by cartilage, which may ossify or become ligament.

\section{THE HUMERUS}

The humerus is the longest bone of the upper limb. Its upper extremity presents a hemispherical surface covered with cartilage, and known as the head. The head articulates with the glenoid cavity of the scapula, and is directed upwards, inwarls, and backwards. Below the articular surface, the hone is rough and constricted, constituting the anatomical neck. To the outer sicle of the head are two tuberosities, separated by the bicipital groove. The greater tuberosity is the 
higher and more posterior; it is markel he thre facets for the insertion of muscles:

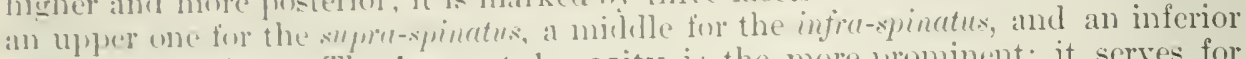
for the tros mimm. The lesser tuberosity is the more frominent; it serves for the insertion of the subsupulurix. The furrow between the tuberosities lodges the lometendon of the licens, extends dewmwats in the axis of the humeral shaft, and,

Fici. 123. -Tin: Left Humelil's. (Anterior view.)

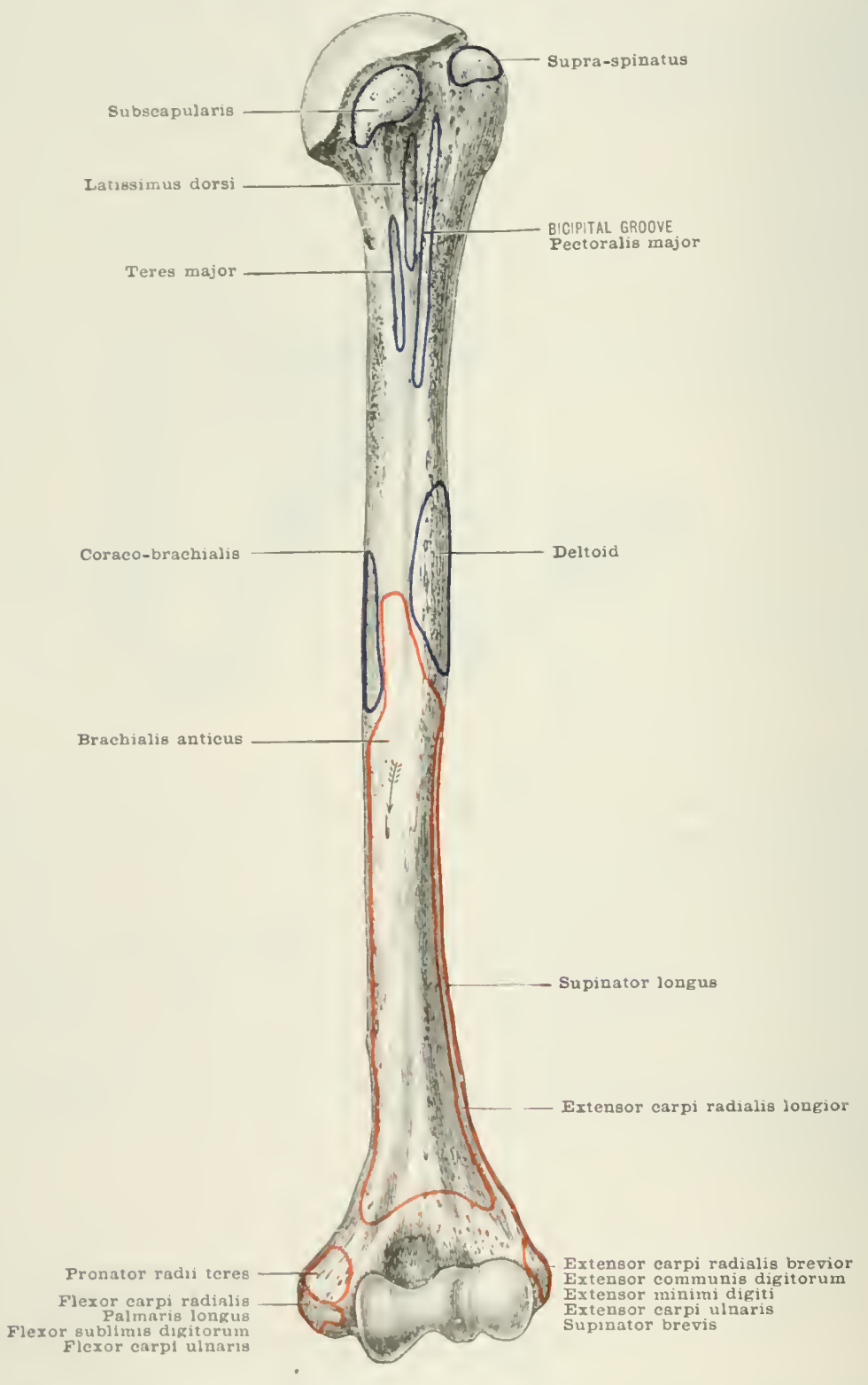

gradually luecoming shallewrer, ands near the juncetion of the upper and midelle thirl of the bone. The matreins of this, the bicipital groove, are called lips, and

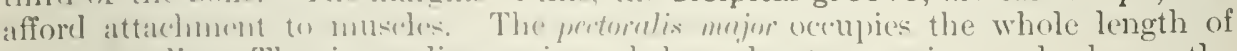
the outer lip. The innar lip rereives, bedow, the tres major, and ahove, the lutissimus dormi: the tendon of the latter numsede is also attached to the flon of the erroove. Butwent the tulneresities, the transierse humeral liganent converts 
the groove into a canal. In addition to the long tendon of the biceps and its tube of synorial membrane, the groove transmits a branch of the anterior circumflex artery. The constriction immediately below the tuberosities is the surgical neck.

The shaft is prismatic in its upper third, but flattened below. Three borders and three surfaces may be recognised. The anterior border commences at the

Fig. 124.-The Left Hemeres. (Posterior view.)

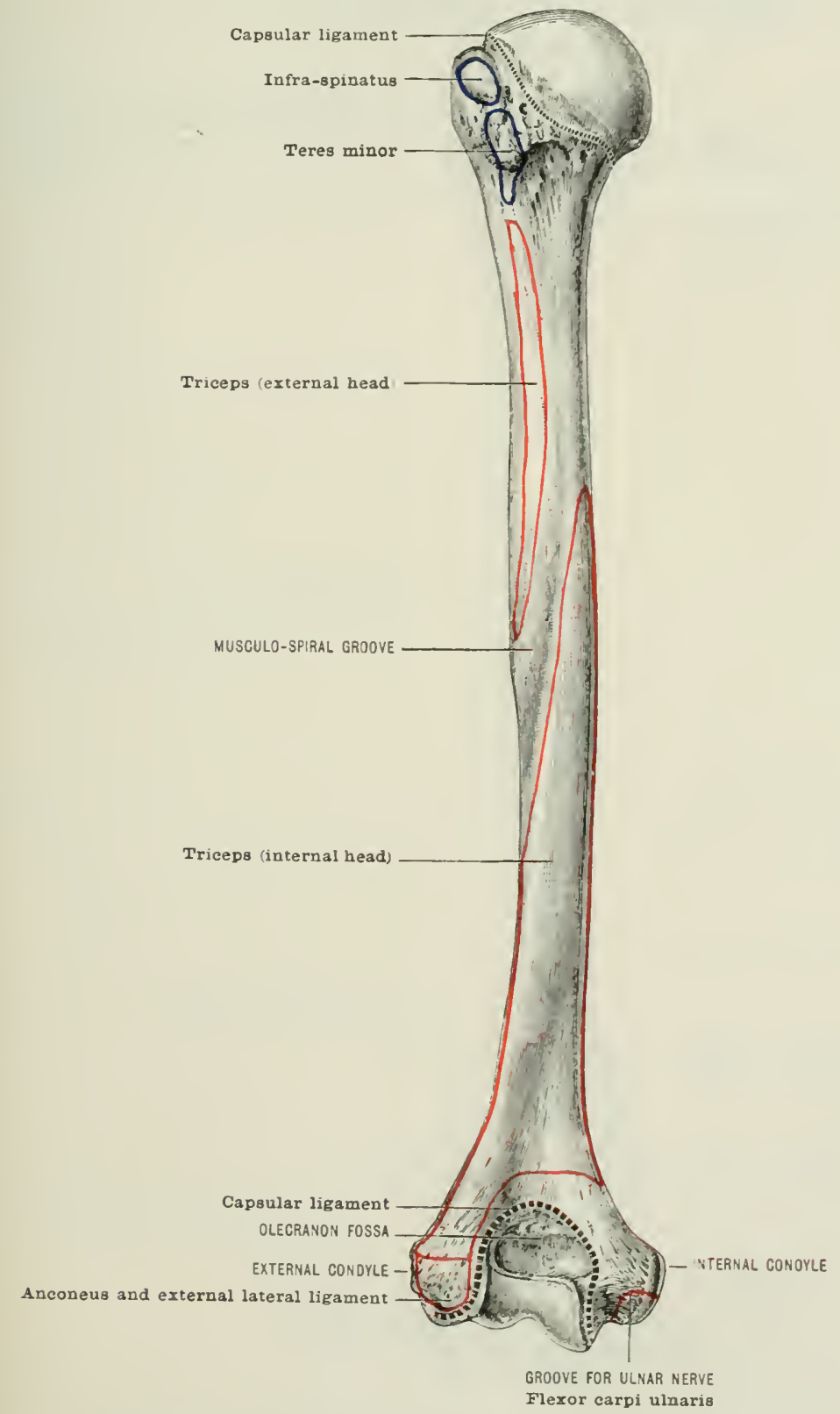

greater tuberosity, as the anterior or outer lip of the bicipital groove, and, passing downwards, skirts the radial side of the coronoid fossa, to become continuous with the ridge separating the capitellum and trochlea. The radial or outer border extends from the posterior border of the greater tuberosity to the radial condrle. This border is not well marked in the upper part of the shaft; near the middle it is 
interrupted by the musculo-spiral groove; the lowe half is temed the external condylar ridge, and affurds attichment to the sifninator lomens and cetensm carpi melialis lompion muscles, and the external intermuscular septum. The ulnar or internal border commences at the lescer tuberosity, as the mmer lip of the licipital wrove, and extends downards to the uhare (intermal) condyle. Near its centre

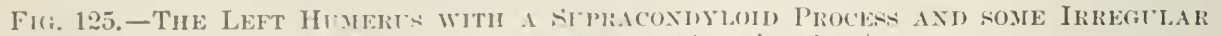
ML:LE ATTACHMETS. (Anterior view.)

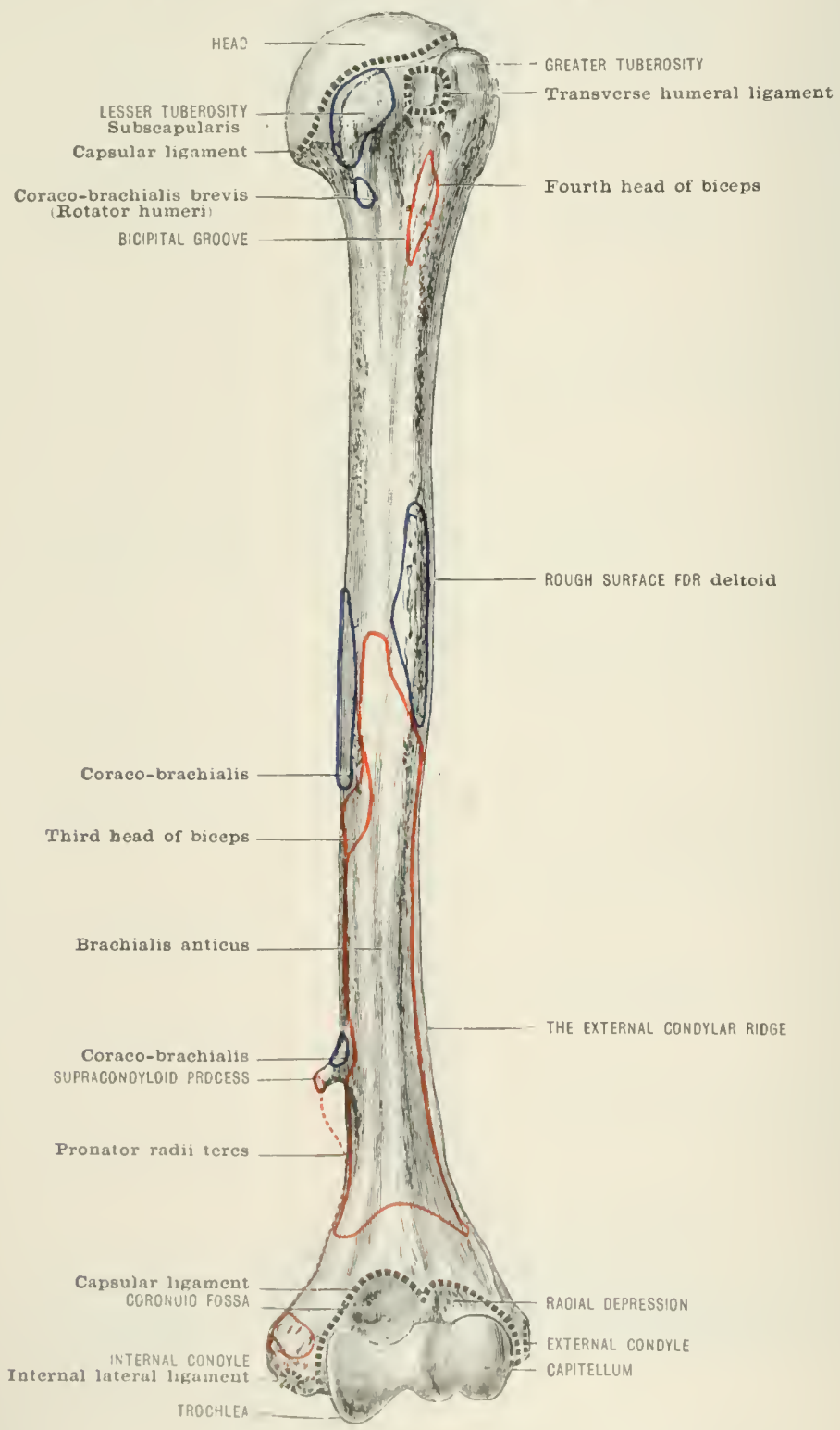

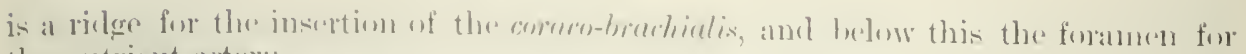
the mutrient artery.

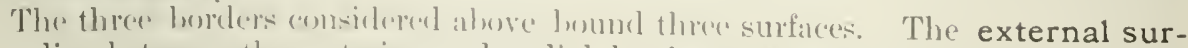

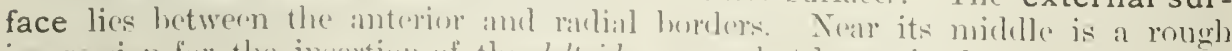
impresion for the inseretion of the detwerl; somewhat lower is the tommation of 
the musculo-spiral groove. The internal surface lies between the anterior and ulnar borders. The lower halves of the internal and external surfaces afford oricrin to the brachialis anticus muscle. The internal surface usually presents, about 5 ''m. ( $2^{\prime \prime}$ ) above the ulnar condyle, an elongated rough surface. This is the supracondyloid ridge ; it is occasionally replaced by a prominent spine of bone, the supracondyloid process (fig. 125), from which a band of fibrous tissue

Fig, 126.-Ossification of the Humerus.

UNITES WITH THE SHAFT AT THE. TWENTIETH YEAR, THE UPPER EPIPHYSIS IS FORMEO BY THE UNION OF THE NUCLEUS FOR THE HEAD, GREATER TUBEROSITY, AND THAT FOR THE LESSER TUBEROSITY. THESE FORM A COMMON EPIPHYSIS BEFORE UNITING WITH THE SHAFT

SHAFT BEGINS TO OSSIFY IN THE EIGHTH WEEK OF INTP.A-UTERINE LIFE

NUCLEUS FOR THE INTERNAL CONOYLE APPEARS hT FIFTH; FUSES AT THE EIGHTEENTH YEAR NUCLEUS FOR TROCHLEA APPEARS AT THE TENTH YEAR

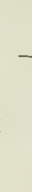

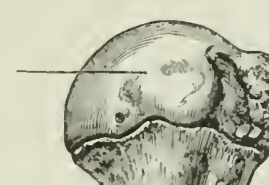

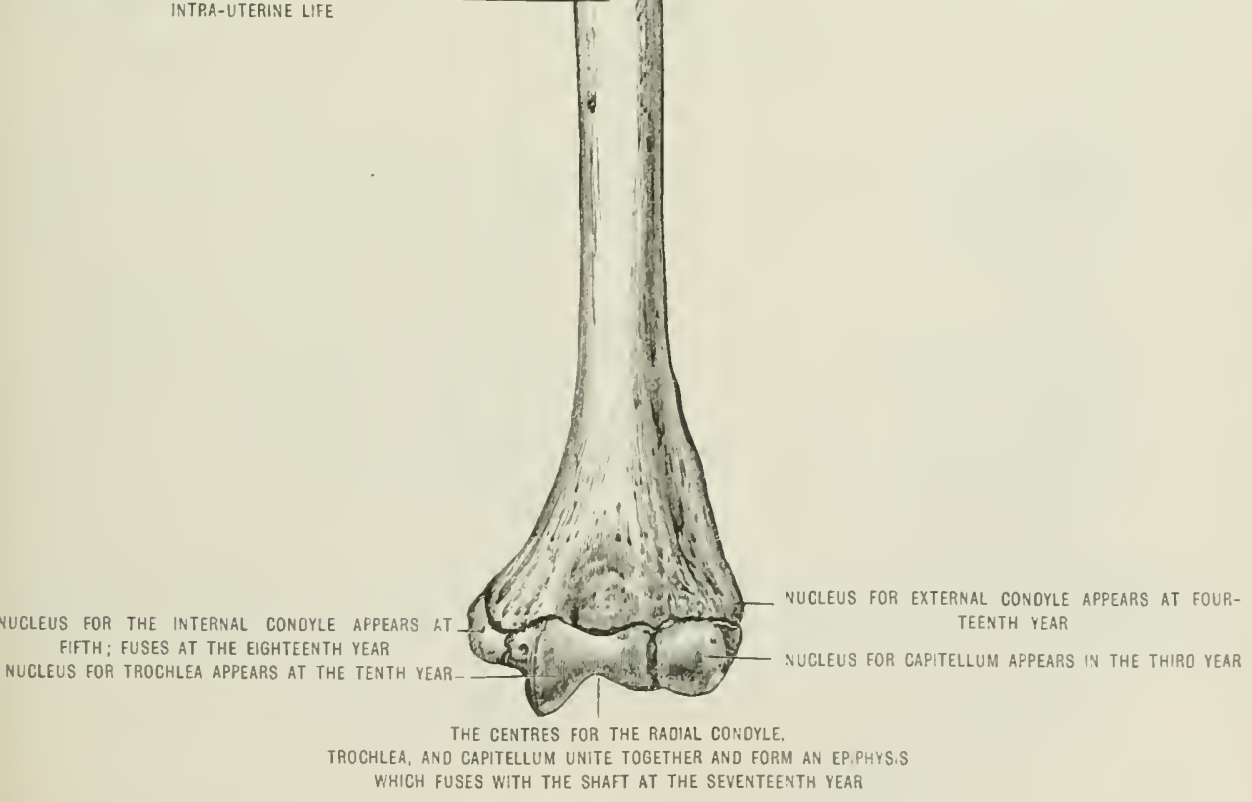

extends to the ulnar condyle, forming a ring, transwitting the median nerve and the brachial artery. The inerve is not always accompanied by the artery; in some instances of high clivision of the hrachial the foramen transmits the interosicous artery. The process gives origin to the pronutor radii teres, and sometimes affords insertion to a part of the coraco-brachiclis:

The posterior surface lies between the ulnar and radial horders. It is obliquely divided by the musculo-spiral groove. The surface above the groove 
serves for the origin of the external head; the part below for the internal head of the triceps.

The lower extremity of the humerus is flattened, and presents from the uhnar to the radial side the following parts:- a prominent process, the ulnar (internal) condyle, from which the pronstor adii teres arises, and to the lower part of which the internal lateral liganent is attached. From this ligament the flexor carpi rulialis, pulumeris longus, flesor smblimis aligitorum, and flexor carpi ulnaris muscles alise. Posteriorly the condyle forms with the trochlea a groore traversed by the ulnar nerve. External to the condyle there is the inferior articular surface, subdivided hy a low ridge into the trochlea and the capitellum. The trochlea is, in shape, like the section of a pulley whecl; the ulnar extends much lower than the radial edere; the articular surfice is sharply indicated anteriorly and posteriorly. The trochlea fits inte the encater sigmoid cavity of the ulna. Above the trochlea on the anterior surface is the rounded coronoid fossa, which receives the coronoid process of the ulna when the forearm is flexed. On the posterior aspect there is the olecranon fossa, for the reception of the anterior edge of the olecranon in extension of the forearm. These fowe in most humeri are separated by a thin translucent disc of bone, sometimes merely by fibrous tissue, so that in macerated bones a perforation, the supratrochlear foramen, exists. The radial head or capitellum is receiverl by the depresion on the summit of the radius; it is limited to the anterior and lower surface of the humerus. Above, it terminates in a shallow fossa, which receives the edge of the radius in flexion. The ridge between the trochlea and the capitellum corresponds to the interval hetween the uha and radius; the shallow groove on the outer sirle of the ridge receives the imner margin of the head of the raclius. Extemal to the capitellum is the external or radial condyle. It is less prominent than the ulnar condyle, and gives attachment to the extemal lateral ligament of the elbow, and to a tendon from which fire extensor muscles arise-viz. estensores curpi radiulis brevion, digitorm communis, minimi digiti, carpi ulnuris, and the smpinutor brexis. On the posterior aspect this condrle extends to the edge of the trochlea, and gives origin to the anconer.s.

Muscles.- The humerus affords attachment for the following muscles :-
Supra-spinatus.
Infra-spinatus.
Teres major.
Teres minor:
Subscapularis.
Deltoid.
Pectoralis major.
Coraco-brachialis.
Latissimus dori.
Bieres (oceasionally).
Brachialis anticus.
Tricepls.
Promator raclii teros.
Flexor carpi radialis.
Palmaris longus.
Flexor sublimis digitorum.
Flexor carpi ulnaris.
Supinator longus.
Extensor carpi radialis longior.
Extensor carpi radialis brevior.
Extensor digitorum communis.
Extensor minimi digiti.
Extensor carpi ulnaris.
Supinator brevis.
Anconens.

Ligaments. - To the upper extremity of the humerus the following ligaments are attacherl:-

Capisular.

Corace-humeral.

To the lower extrenity:-
Glono-humeral.

Transverse humeral.

Internal lateral ligament

Extremal lateral ligament

Anterior ligament

P'ostrrior liganumt

of the ellww-joint.

Arteries.-The hlowl-supply of the humerus is leriver from the suprascapular, and the antrior and posteriol circumtlex arteries. Branches from these arteries 
enter the foramina which cluster aromel the circumference of the hearl and tulnerosities. It the top of the bicipital groove there is a large nutrient foramen, which transmits a branch from the anterior ciremflex artery. The nutrient artery of the shaft is derived from a muscular branch of the brachial; it enters the bone near the middle of the imner border immediatcly below the insertion of the coraco-brachialis, and is directed to the distal end. The lower extremity is nourished by mumerous twigs derived from the anastomotic, the superior and inferior profunda, and thr recurrent branches of the radial, ulnar, and interosseous arteries.

Ossification.-The humerus ossifies from one primary and six secondary nuclei. The centre for the shaft appears about the eighth week of intra-uterine life, and extents very rapitly. At birth the bone presents two cartilaginous: extremities, which ossify in the following manner:-A nucleus for the head appears early in the first year; it is not infrequently present at birth (Spencer). The nucleus for the greater tuberosity appears in the third year. In the fifth year a centre may he deposited for the lesser tuberosity, but this is not constant. The three nuclei coalesce to form a disc of bone, which unites with the shaft about the twentieth year.

The inferior extremity osifies from four centres: the centre for the capitcllum

Fig. 12\%.-The Head of the Humeres at the Sixtil Year. (In section.)

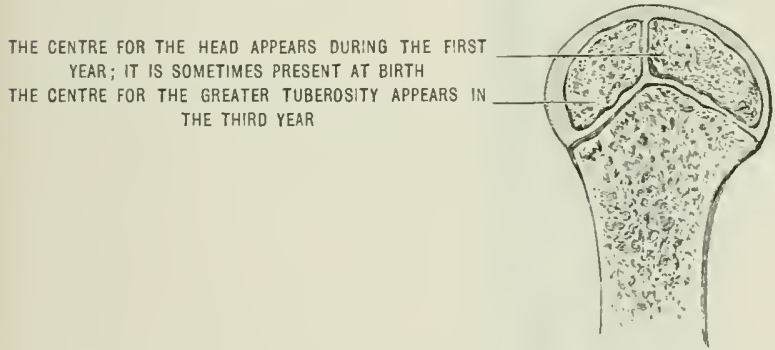

appears in the third year, and those for the imner (ulnar) enndyle, the trorhlea, and extemal (raclial) conclyle at the fifth, tenth, and fourteenth years respectively. The nuclei for the capitellum, trochlea, and radial condyle coalesce before uniting with the shaft, which they do in the seventeenth year. The ulnar condyle joins the shaft somewhat later.

A sturly of the upper end of the humeral shaft before its mion with the epiphysis is of interest in relation to what is known as the neck of the lumerus. The term neck is applied to three parts of this bone. The anatomical neck is the constriction to which the eapsular ligament is attached. This is aecurately indicated hy the constriction which lies internal to the tuberosities; the upper extremity of the humeral shaft before its mion with the epiphysis terminates in a low threesided prramid, the surfaces of which are separated from one another by ridges. The imner of these three surfaces underlies the head of the bone, and the two outer surfices underlie the tuberosities. The axis of the imner, isolated portion forms with the shaft an angle of $130^{\circ}$; it constitutes the morphological neck of the humerus, and is of the sane nature as the neck of the femur. The surgieal neck is an indefinite area below the tuberosities where the hone is liable to fracture. 


\section{THE LLNA}

The ulna is the inner heme of the foreann: it lies parallel with, but is longer than, the radius. The upper extremity is the thickest and strongest part of the ulna, amel is of irroular shape. The superior articular surface is called the greater sigmoid cavity, and receives the trochleal of the humerus; it is transversely constricted near its midelle. The prominence above the constriction is termed the olecranon, the pirt helow the coronoid process.

The olecranon process is the highest part of the ulna; into its upper surface the tricess is inserted, and the anterior margin of this surface affords attachment to the posterior ligament of the elbow. The anterior surface of the olecranon is

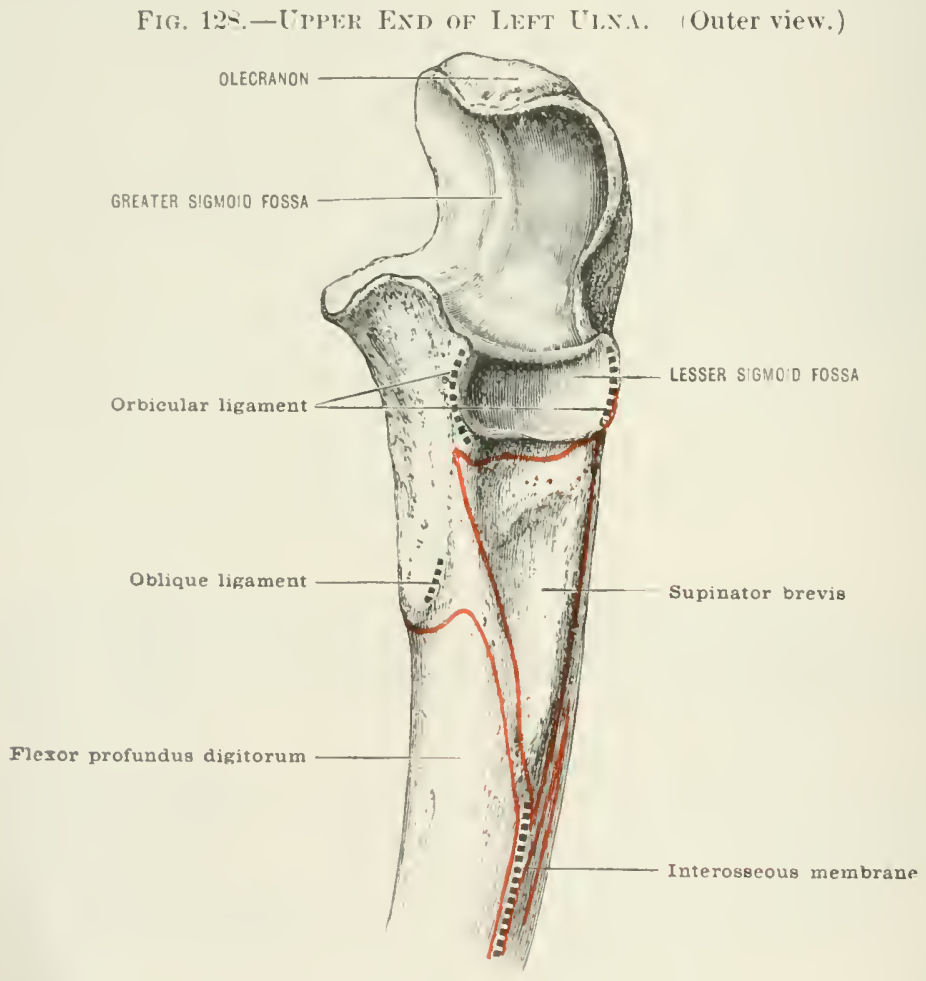

articular, and forms the mpler and hatek part of the greater sigmoid cavity, and its margins give attarhment to ligaments. The posterior surface of this process is

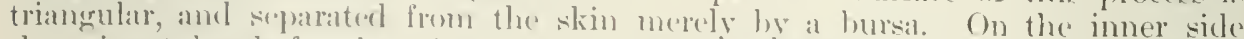

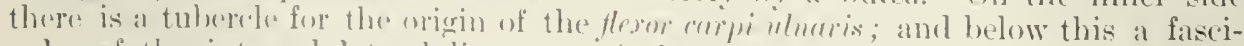
culus of the intermal literal ligament of the allow is inserted. The onter sirle

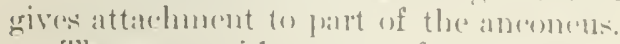

The coronoid process forms the lowe lip of the greater sigmode arity: its uplere surface is artionlar and forms nearly a right angle with the olceramon portion.

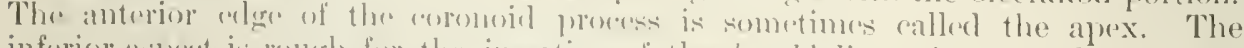

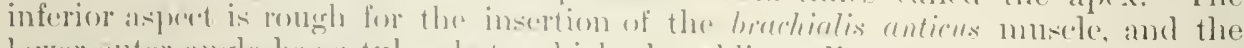

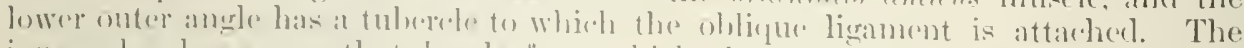

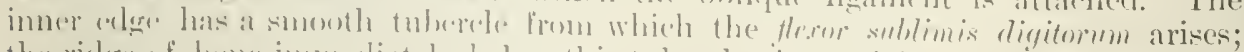

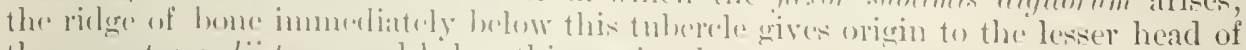

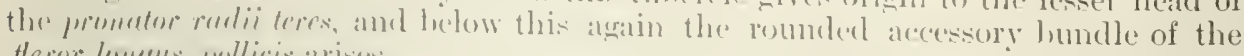
flemer lom!gus polliris arises. 
A triangular depressed surface, posterior to the sublimis tubercle, gives origin to the upper fibres of the Hexor profundus digitorum. To the outer side of the rough surface for the brachialis anticus is a triangular space, the base of which is represented by the lesser sigmoid cavity, which reecires the lateral articular surface of the head of the radius; the anterior and posterior margins of this carity afforl attachment to the orbicular ligament. The rest of the triangle is depressed, and gives origin to the supinutor brevis.

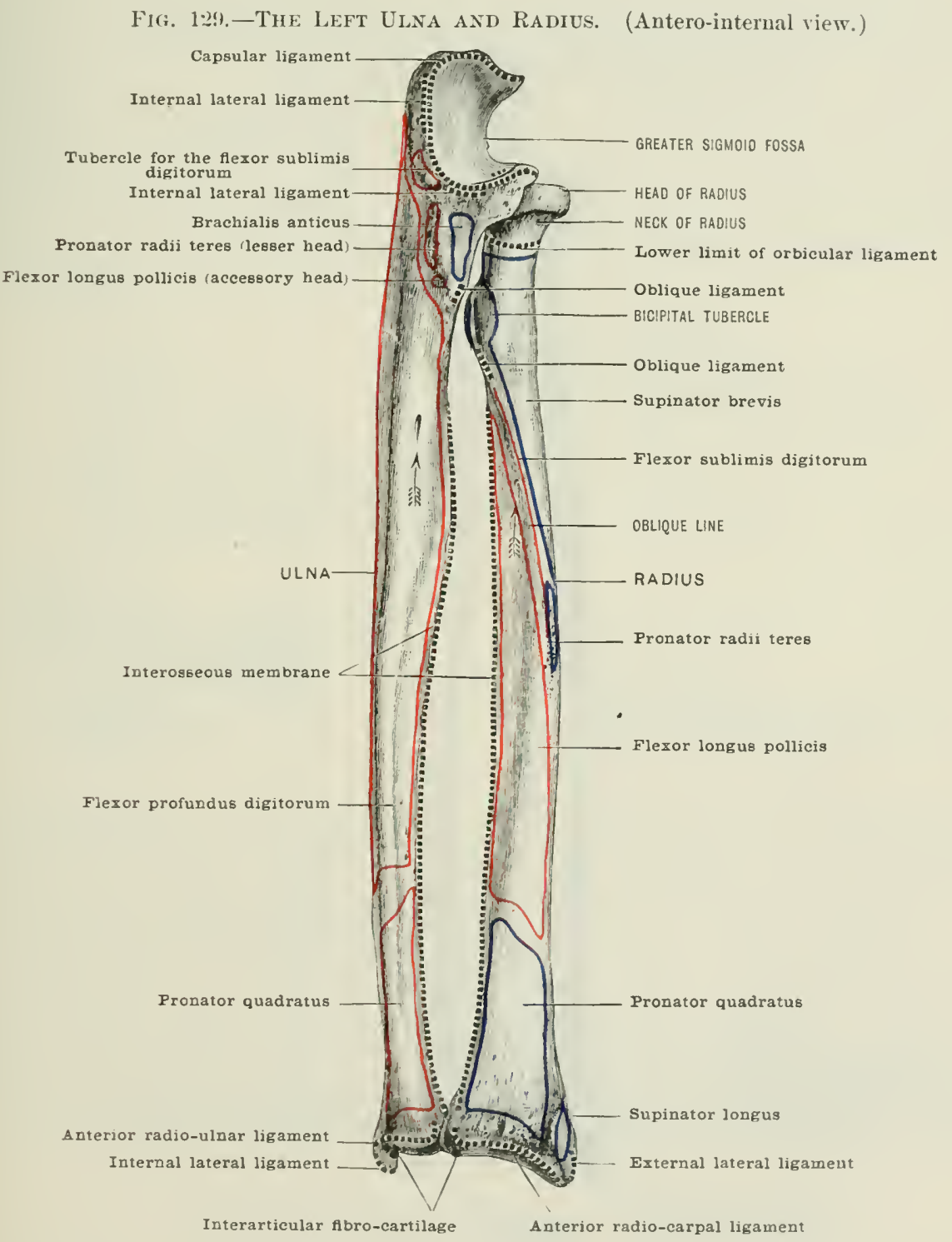

The shaft throughout the greater part of its extent is prismatie, but tapers towards the lower extremity, becoming thin and rounded in its lower third. It has three borders and three surfaces.

Of the three borders, the outer (or interosseous) is the most marked: it commences at the apex of the triangle from which the supinator hrevis arises. becomes very prominent in the middle of the bone, but is indefinite near its termination; the interosseous membrane is attached to it. The anterior border is directly continuous with the inner exge of the rough surface for the brachialis anticus, and 
terminates inforionly in front of the styloid process; throughout the greater part of its extent it is rounderl, and aftorels origin to the flexor profundus digitorum; in its lower fourtle it is rough and prominent for the promitor quadratus. The posterior border extends from the tuberele, near the tip of the olecramon, to the back part of the sty hicl process. The upper three-fourths gives attachment to an

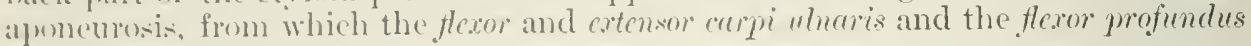
digiturmm muscrels: arise.

FIr. 1:30,-THE LEFT LLIA AXI LADILA. (Postero-external view.)

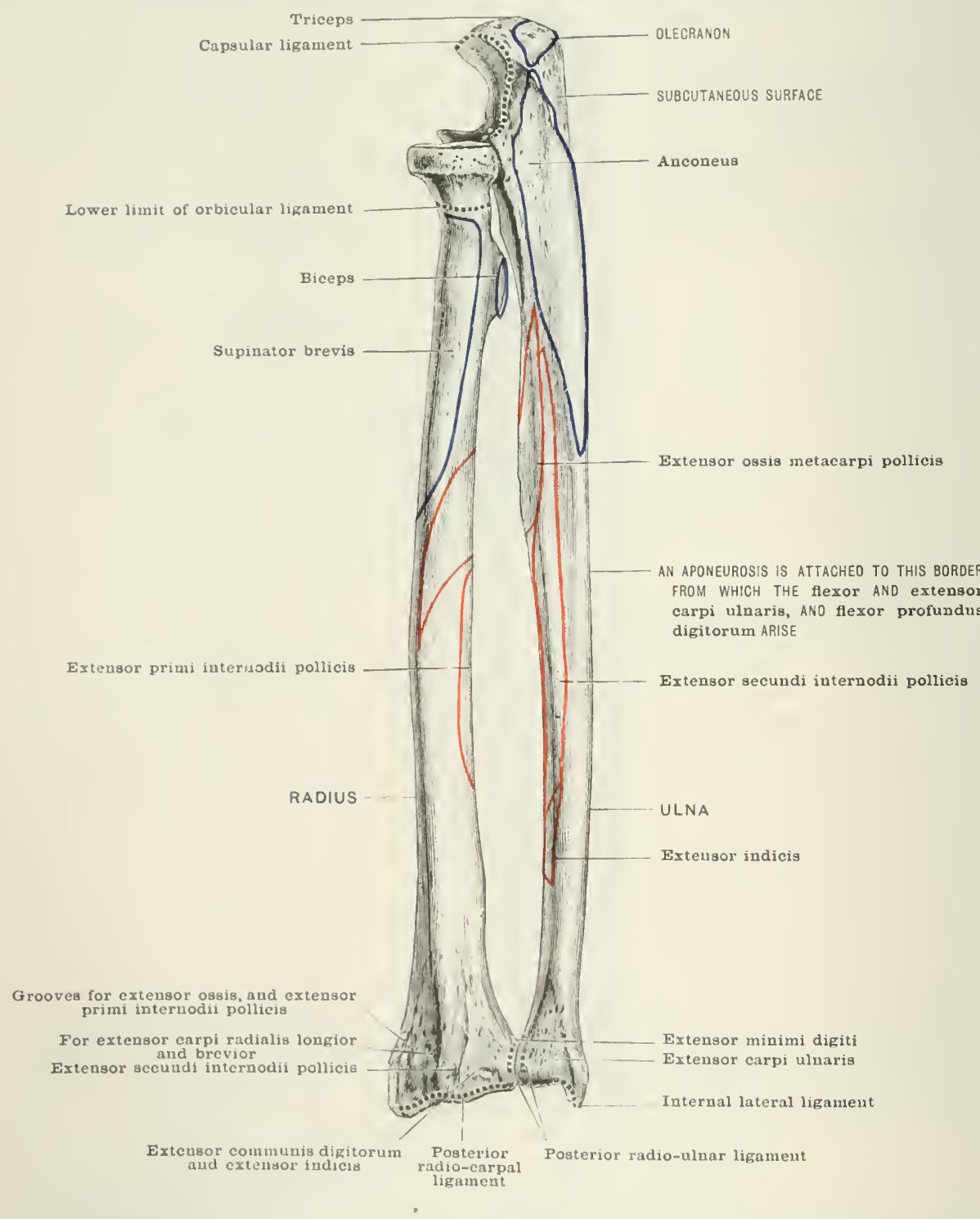

Of the three surfaces, the anterior lies hetween the anterior and interosseous

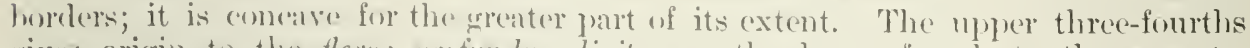
gives origrin to the flerur profmolus digitormm, the lower fourth to the fromator

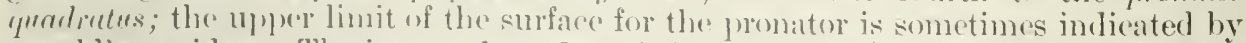
an oblique ridge. The internal surface is bumblerl hy the anterior and posterior borders. The upper therefourths is aecupied by the flexor mofumlus digitorum; the

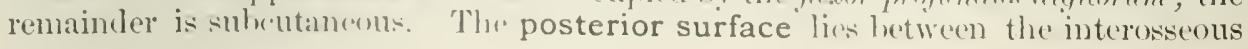


and posterior borders. Its upper fourth is marked off by an oblique ridge running from the lesser sigmoid cavity to the posterior border. The surface above the line receives the insertion of the anconens; from the line itself a few fibres of supinutor brecis arise. The surface below the oblique line is subdivided by a rertical ridge; the portion lying between this ridge and the posterior border is in relation with the extrusm curpi unaris. Between this line and the interosseous borler the following muscles arise in order from above downwards: cxtensor oswis metacaryi pollicis, the extensm secundi internodii pollicis, and the extensor indicis.

The lower extremity of the uhat is of small size and consists of two parts, a head and styloid process, separated from each other, on the under surface, by a groove into which an interarticular cartilage is inserted. That part of the hear adjarent to the groove is semilunar in shape and plays upon the interarticular cartilage which excludes it from the wrist-joint. The margin of the head is also semilunar, and is received into the sigmoid cavity of the radius. The styloid process projects from the inner and back part of the bone, and appears as a continuation of the posterior border. To its extremity the internal lateral ligament is attached, and its posterior surface is grooved for the passage of the tendon of the extensor curpi ulnaris.

Muscles.-The following are attached to the ulna:-

Triceps.

Anconeus.

Brachialis anticus.

Pronator quadratus.

Flexor sublimis digitorum.

Flexor profundus digitorum.

Flexor longus pollicis.

\section{Ligaments:-}

Internal lateral of elbow.

Anterior of elbow.

Posterior of elbow.

Orbicular.

Oblique.
Flexor carpi ulnaris.

Extensor ossis metacarpi pollicis.

Extensor secundi internodii pollicis.

Extensor indicis.

Pronator radii teres.

Supinator brevis.

Extensor carpi ulnaris.
Interosseous membrane.

Anterior radio-ulnar.

Posterior radio-uhnar.

Internal lateral of wrist-joint.

Interarticular fibro-cartilage.

Blood-supply.-The nutrient vessel enters the shaft near the middle of the anterior surface; it is deriver from the anterior interosseons trunk, and is directed towards the proximal end. The upper extremity receives branches from the anterior and posterior ulnar recurrent and from the interosseous recurrent. The lower and receives twigs from the anterior and posterior interosseons arteries.

Ossification.-The ulna is ossified from three centres. The primary nucleus appears near the middle of the shaft in the eighth week of embryonic life. At birth the greater portion of the olecranon process is cartilaginous. During the fourth year a nucleus appears for the distal epiphysis. The cartilaginous olecranon is mainly ossified from the shaft, and in the course of the tenth year a scale-like epiphysis appears at its summit. This unites during the sixteenth year. The distal epiphysis consolidates about the eighteenth year. 


\section{THE R.LIILS}

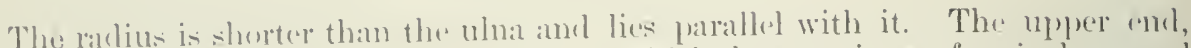

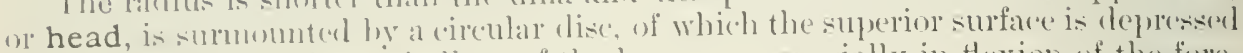
for the reception of the "apitellum of the humerus, especially in Hexion of the fore-

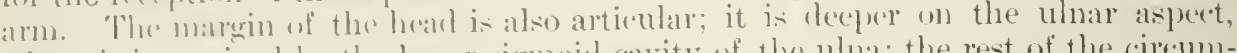

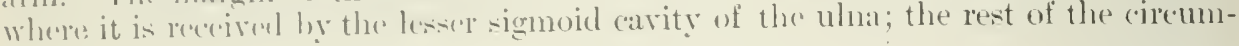

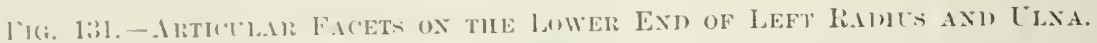

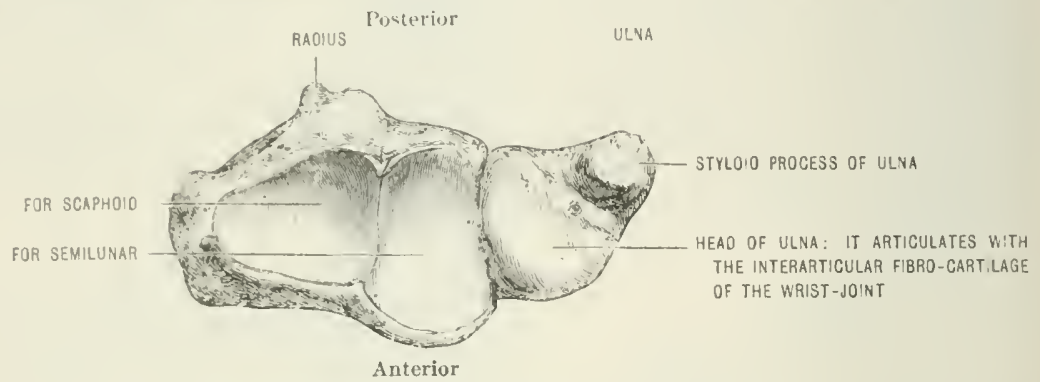

ference is mbraced he the orbicular ligament. Below the cartilage-covered surfare of the bone there is a constricted portion, or neck, which is in relation by its outer sille with the supinutor brenis.

Beneath the neck, on the antero-internal aspeet of the bone, there is an oral eninener, the bicipital tuberosity, divided longitudinally into a rough posterior portion for the biceps tendom, and a smooth anterior surface in relation with the bursa which is situated betreen the tendon and the tulnerosity.

The ratius has three borders and three surfaces. Of the three borders, the

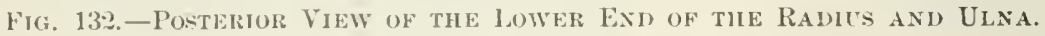

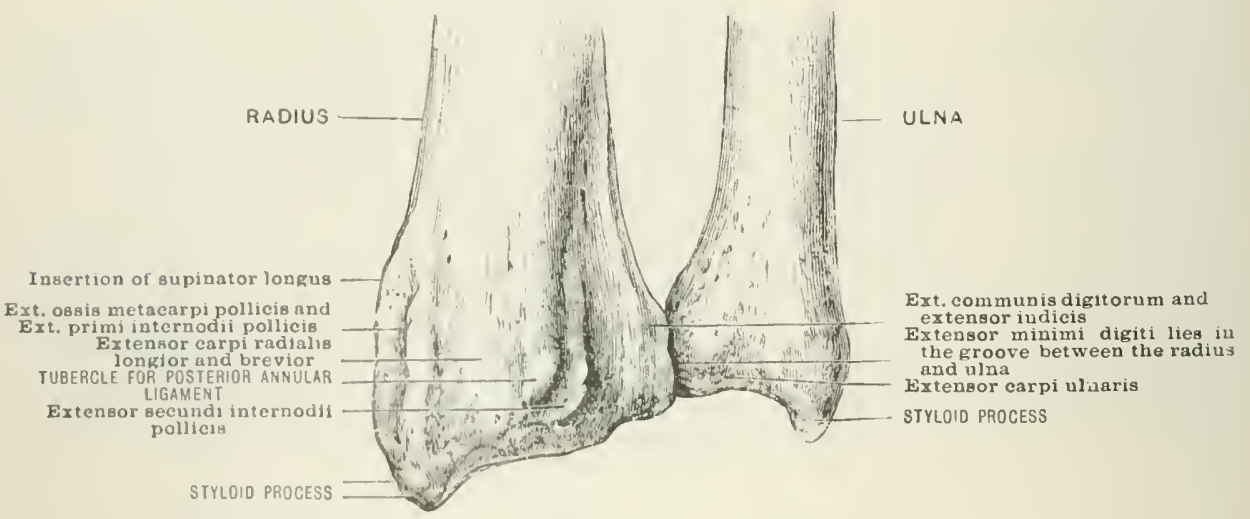

interosseous is the best malkw. Commeneing at the posterior alge of the

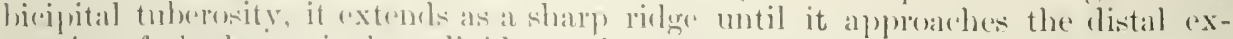
tremity of the hune; it then divites to heomene continuous with the anterior and posterior mareins of the sigmoid cavity. It afforts attachment to the interosseoms memhlane. The anterior border starts form the bicipital tuborosity, crosses

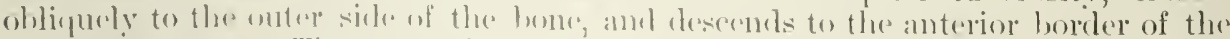

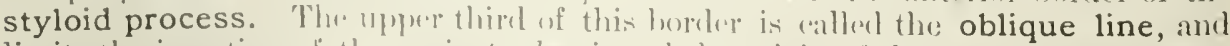

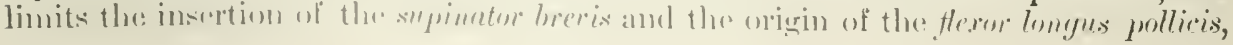


and affords attachment to the flexom sublimis digitomu. The posterior border begins at the back of the tuberosity and extends to the midrlle tubercle on the posterior aspect of the lower extremity. The anterior surface is bounded by the anterior and interosseons borders. The upper two-thirds is occupied by the flexor longus pollicis, and a little less than the lower third by the pronator quadiatus. The external surface lies between the anterior and posterior borders. The upper third affords insertion to the supinator brevis; at its centre there is a rough, low, vertical ridge for the pronator radii teres; below this, the bone is smooth and overlapped by the tendons of the extensores carpi radialis longior and brevior, and crossed by the ertensor oswis metacami pollicis and extensor primi internodii pollicis. The posterior

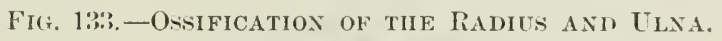

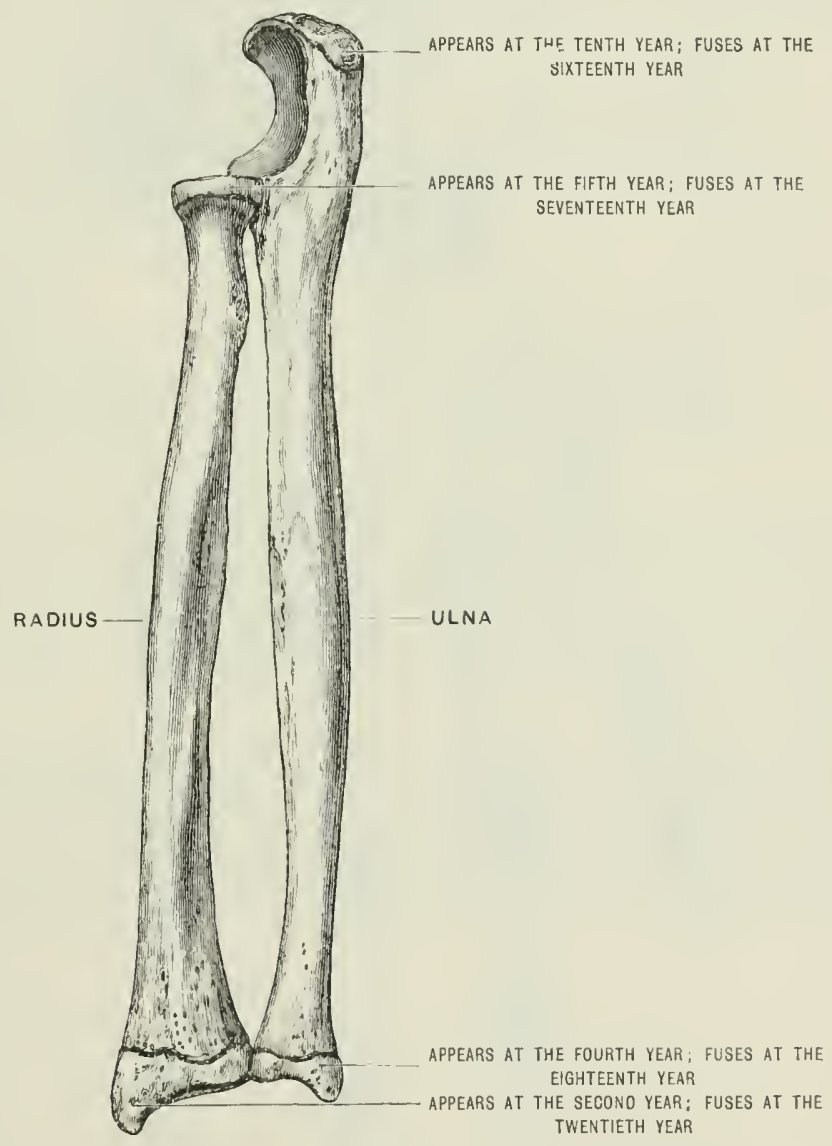

surface lies between the interosseous and posterior borders. The upper third gives origin to the extensor ossis metacarpi and the extensor primi internodii pollicis, and the lower third is covered by tendons.

The lower extremity of the radius is quadrilateral; its carpal surface is articular and divided by a ridge into an inner quadrilateral portion, concave for articulation with the semilunar bone; and an outer triangular portion, extending on to the styloid process: this is concave to receive the superior surface of the seaphoid bone. The inner side of the lower end presents the sigmoid cavity for the reception of the rounded margin of the head of the ulna. The anterior surface is a raised ridge to which the anterior ligament of the wrist-joint is attached. The onter surface is represented by the styloid process, to the base of which the supinaton. longus is inserted; and the tip of the process serves for the attachment of the external lateral ligament of the wrist. It is also marked by a shallow furrow 
for the temdens of the extensor assis metactipi and extenser primi internodii pollicis. 'The proterior' surfice is convex, and marked by three prominent ridges separating three furmow. The posterion' ammular ligament is attached to these ridges, to thesploid process, and to the inner margin, thus forming with the bone a series of tunnels. The ontermost is brond, shallow, and frepuently suldivided by a low rislge. The outre sublivision is for the estcusen curpe radiatis longion, the inner

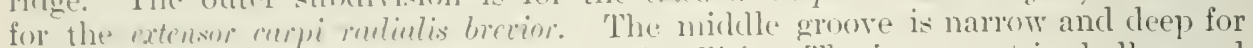
the tendon of thre extenson aecundi internodii polliris. The innermost is shallow and transmits the exteusir indicis and the extensor communis digitorum whieh orerlies the indicis, the posterior branch of the anterior interosseons artery and the posterior interessents nerve. When the radius and ulna are articulated, an additional errowe is formed for the extrustr minimi digiti.

Muscles.-The following muscles are attached to the radius:-

Bicerps.

Supinator hrevis.

Supinator longus.

l'romator radii teres.

Pronator yuadratus.

Extensor osis metacarpi pollicis.

Extensor primi internodii pollicis.

Flexor longus pollicis.

Flexor sublimis digitorum.

\section{Ligaments:-}

Oblique ligament.

Interosseous membrane.

Anterior radio-ulnar.

Posterior radio-ulnar.
Posterior amular.

Extemal lateral of wrist.

Interartieular fibro-eartilage of wrist.

Anterior radio-carpal.

Posterior radio-earpal.

Blood-supply.- The nutrient artery is derived from the anterior interosseous trunk; it cuters the shaft near the middle of the anterior surfice, and runs towards the proximal end of the bone. The head of the bone is supplied by the radial recurrent and interossons recurrent arteries. The lower end is supplied by the anterior and posterior interosens arteries and numerous twigs from the carpal arehes.

Ossification.-The radius is ossified hy one primary and two seeondary centres. The shaft begins to osify at the eighth week of embryonie life. The nucleus for the lowerend appears in the second year, whilst that for the upper end is deposited in the fifth rear. The hracl ankyloses with the shaft at the seventeenth rear, but omsolislation is deliyed at the lower end mutil the twentieth year.

\section{THE $I A N D$}

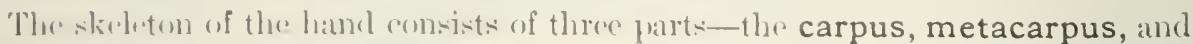
phalanges.

\section{THE ('AlPL'S}

The carpus contains aight lones, arrangerel in two rows, four bones in each row. Enumerated from the radial to the mlnar sicle, the benes of the foroxinal row are, the scaphoid, semilunar, cuneiform, and pisiform; those of the distal row, the trapezium, trapezoid, magnum, and unciform. 'The anterior and posterior'

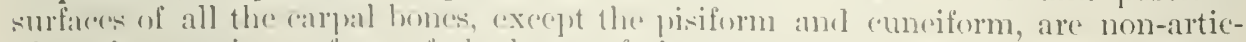
ular; the anterior surtares of the lunes of the uplepe row are larger than the posterior, lut in the lower row this arrangement is reverserel. 


\section{THE SCAPHOID}

This is the largest bone of the proximal row. Its superior surface is somewhat triangular and convex for articulation with the lower end and styloid process of the radius. Its inferior surface has two facets: a large one for the trapezimm, and a small one for the trapezoid. The dorsal surface is occupied by a long, deep groore for ligaments. The palmar surface is rough and concave above; below, it las a prominent tuberosity for the attachment of the anterior annular ligament and

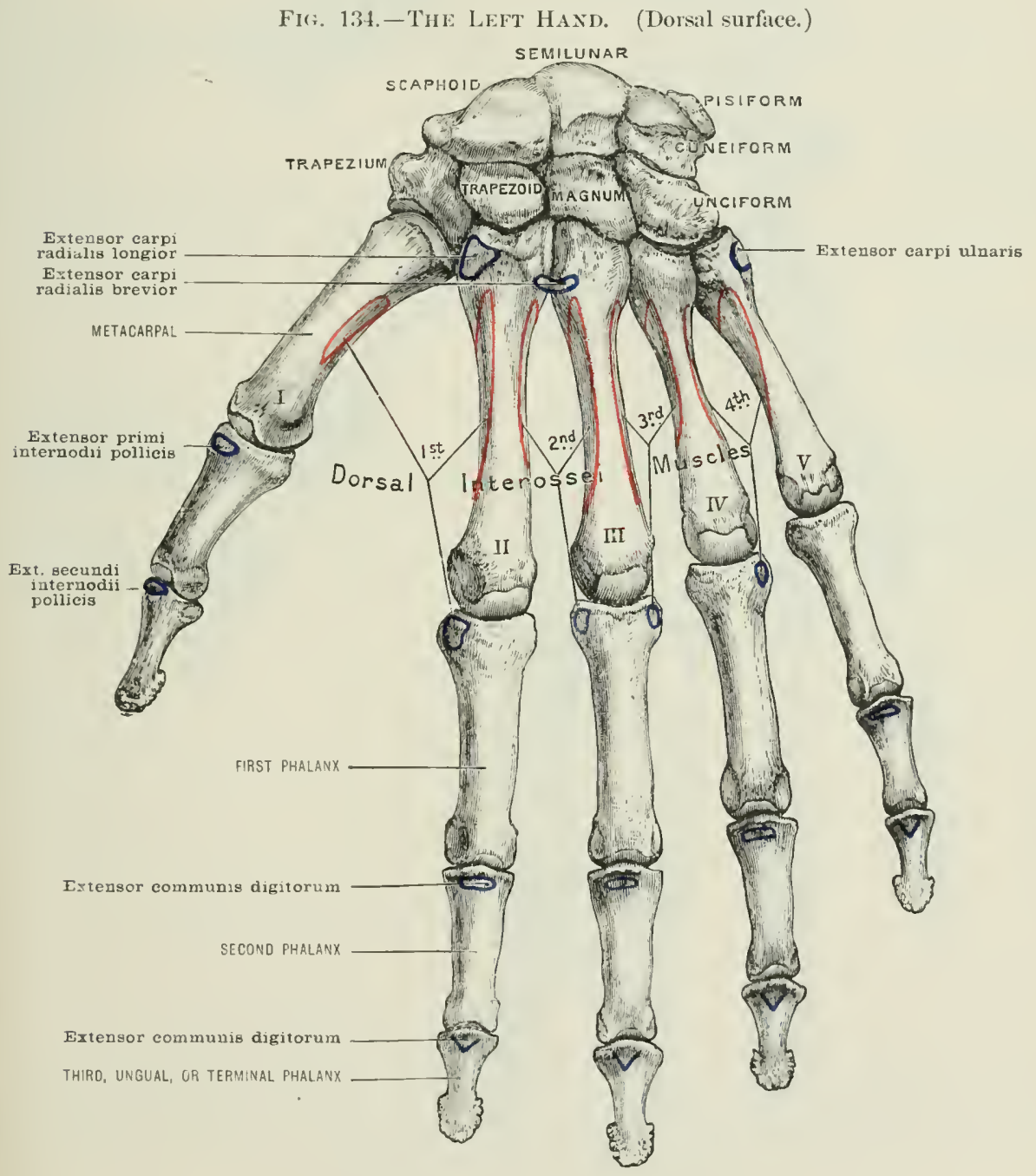

the abluctor pollicis muscle. The outer (raclial) surface is rough for ligaments. The inner (ulnar) surface is ac'upied by two articular facets, of which the upper one is crescentic in shape for the semilunar bone, whilst the lower is deeply concave for the reception of the head of the magnum.

Articulations.-With ratius, trapezium, trapezoid, magnum, and semilunar.

\section{THE SEMILTNAR}

The semilunar has a convex superior surface for articulation with the lower end of the radius and the fibro-cartilage of the wrist. Its inferior surface is 


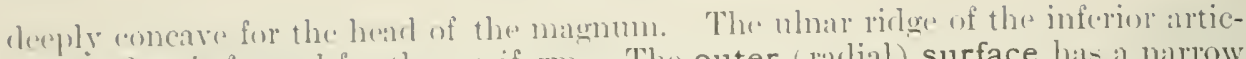
ular surface is fareted for the une iform. The outer (raclial) surface has a marrow semilumar facet for the seaphoil, whilst the inner (ulnar) aspect of the lone presents a puadrilateral facet for the bise of the cunciforu. The palmar and dorsal surfaces are rough and mom-inticular.

Articulations. - With the ratius, scaphoid, cumeiform, manum, and unciform.

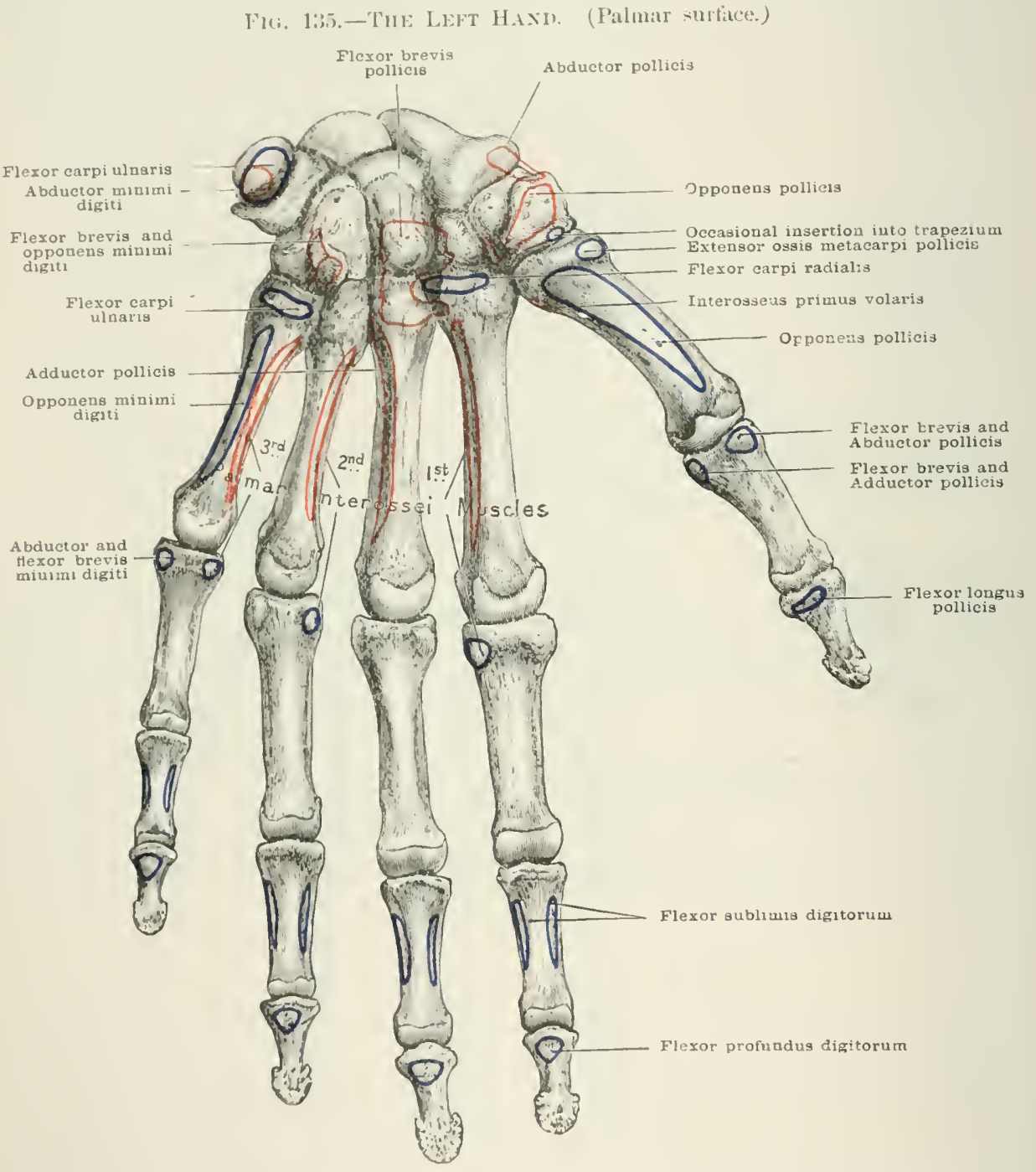

Tue Cuxbifom

The cuneiform (or priamilal home) rests he its bise on the ulnar sile of the semilunar; its apex is dimeted (lownwarts and to the mhatr side, and serves for the attachment of the internal lateral ligament of the wrist. The base presents a fited for the semilunar. The inferior surface has a sinnows articular surface for the mneiform bone. The superior surface has a convex smoth portion, where it plars 11 jou the interarticular "artilage which intervenes between it and the lower end of the ulna; the remainder of this surface is rough for liganents. The palmar 
surface has a conspicuous facet for the pisiform bone near the inner extremity, and the dorsal surface is rough for ligaments.

Articulations.-Pisiform, semilunar, and uneiform.

Fig. 136.-THE LEFT S'APHOID.
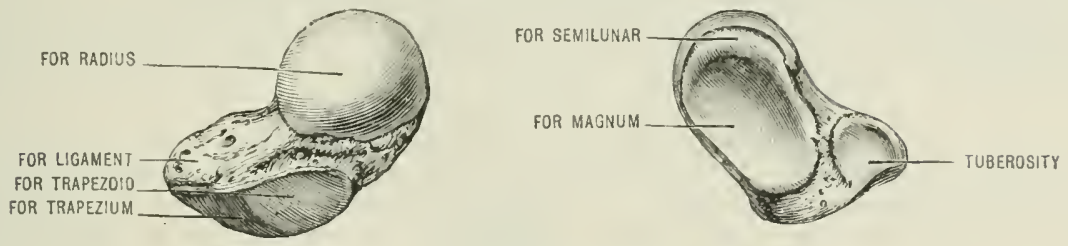

Fig. 1:37.-THE LefT SeMILexar.

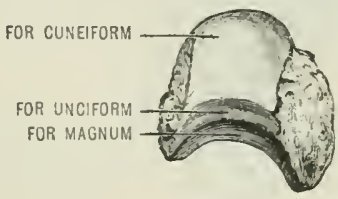

THE PISIFORM

The pisiform resembles closely a split pea. Its dorsal aspect, corresponding to the cut surface of the pea, articulates with the facet on the palmar surface of the cuneiform. The rest of this bone is rough for the anterior annular ligament and the tendon of the flexor carpi ulnaris.

\section{Fig. 139. - The Left Ctxeifori.}

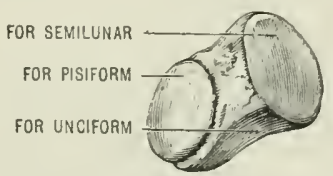

Fig. 139.-The Left Pisifory.

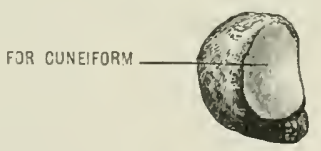

The Trapezilin

The trapezium is the first bone of the distal row; it is very irregular in shape. The inferior surface is saddle-shaped, and articulates with the base of the first

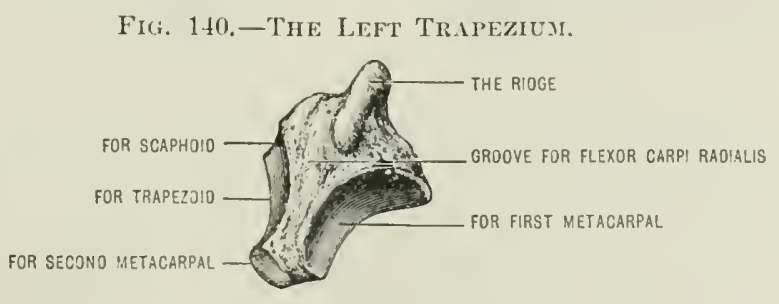

metacarpal bone. The superior surface has a facet for the seaphoicl. The inner (uhar) surface has two facets; the lower and smaller is for the base of the second 
motacarpal, the upper and larerer for the traperoid. The radial and dorsal surfaces are rough for ligaments. The palmar surface presents a prominent ridge,

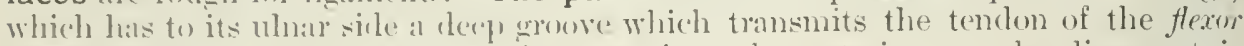
cerpi redtinlis. To the ridge of the trapezim the anterior annular ligament is attacherl. The palnuar surfice affords attarhment to the abductor, flexor ossis, flexur

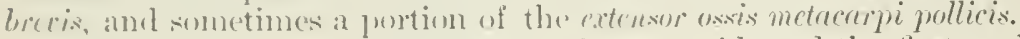

Articulations. - Il ith the scaphoid, trapezoid, and the first and second metacarpal homes.

\section{TIIE TRAPETOIN}

The trapezoid is also very irregular in shape, and much smaller than the traproimm. It has a broad dorsal surface; the narrow palmar surface grives orienin to a far filores of the inner hearl of the flexor breris pollicis. The portion of

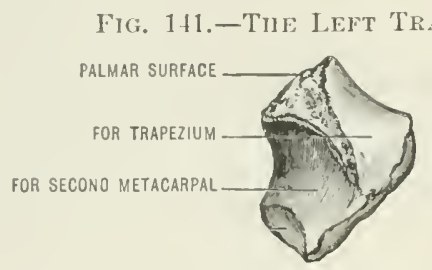

lune between these surfaces is constricted and mapped out into artieular facets; of these, the inferior is most conspicnous; it is saddle-shaped for the base of the scond metacarpal. The radial surface has a facet for the trapezium; the ulnar surface is articulal for the magnum; and the superior surface has a facet for the saaplioid.

Articulations.-With the trapezium, magnum, scaphoid, second metacarpal.

\section{The Magney}

The magnum is the laresest earpal hone, and occupies the centre of the wrist. The superior surface is globular, and sometimes called the head. It is received into the cup formed he the semilunar and seaphoid. The articular surface of the head rxtends some distance on to the dorsal aspect of the bone. The inferior surface has three facets. The middle is the largust for the base of the third metaarpal. The small ulnar facet is for the fourth, and the radial facet is for the second metacarpal. The outer (radial) surface articulates with the trapezoid, and

Fig. 142.-THE LeFT IAGiNuM.
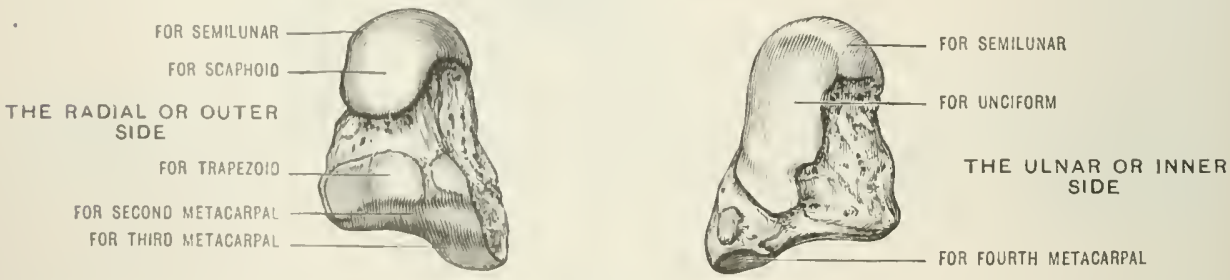

presents alose this smatl facet a there groove for an interosseous ligament. The inner (ulnar) surface of the lume hals a long articular surface for the unciform (somentimes the lower part of this surface forms a detacherl facet), but is rough near its anterion part for ligiments. The palmar surface is convex and rough,

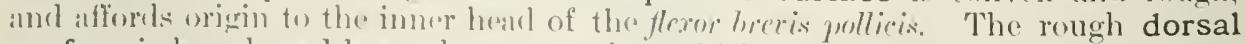
surface is hroal, and has a deep emonvity which sorves to make the hearl of the lone more prominent, and gives rise to the alpleatranee of a neck.

Articulations.-Trinjezoid, unciform, semilumar, sciploid, and second, third, and fourth metalcirpuls. 


\section{THE UNCIFORM}

The unciform is the most readily recognised of all the carpals, as its palmar surface presents a prominent hook-like process; this, the unciform process, has its concavity directed towards the radial side, and forms part of the inner houndary of the passage for the flexor tendons; to the apex of the process the anterior amnular ligament gains an attachment. It also affords origin to the flexor brevis minimi and opponens minimi digiti muscles. The dorsal surface is rough for ligaments. The

Fig. 143.-The LeFT UNCIFori.

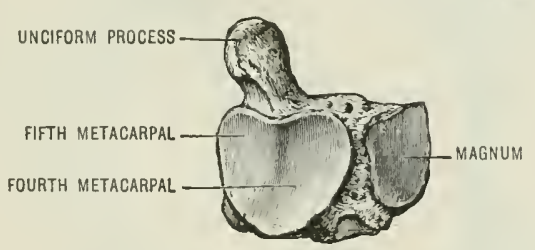

inferior surface has two facets for the bases of fourth and fifth metacarpals. The superior surface forms the apex of a wedge, and is smooth and rounderl for articulating with a narrow facet on the ulnar side of the lower surface of the semilumar. 'The ulnar surface is milinly articular for the cuneiform, whilst the radial surface is faceted for the magnum.

Articulations. - With the cuneiform, semilumar, magnum, and the fourth and fifth metacarpals.

The central is an occasional clement of the carpus. It is situated on the dorsal aspect of the carpus, between the scaphoid, magnum, and trapezoid. This bone is a normal element of the carpus in many mammals, even in the orang and gibbon. It is represented in the carpus of the human embryo, but in most individuals it undergoes suppression or coalesces with the scaphoid.

Blood-supply.-The arterial twigs to the carpal bones are derived from the anterior and posterior carpal branches of the radial and ulnar arteries. A large branch from the anterior interosseous is also distributed to the carpus, and twigs are fumished to it from the posterior interosseous artery.

Ossification.-At birth the carpal elements are cartilaginous, and the nucleus for each bone appears in the following order:-

Magnum, first yrar.

Unciform, second year.

Cunciform, third year.

Semilunar, fourth year.
Trapezium, fifth year. Scaphoid, sixth year. Trapezoid, eighth year. l'isiform, twelfth year.

\section{THE METACARPLS}

The metacarpus consists of fire bones. Each metacarpal bone has a shaft, a rounded distal end termed the head, and a square-shaped proximal extremity named the base. The shaft is prismatic; two surfaces of the prism are lateral, and the third dorsal. The lateral surfaces afford attachment to the interosseous muscles: on the palmar aspect of the shaft these surfaces apmoach each other, and for some distance are only separated by a prominent ridge. The dorsal surface is smooth and covered in the recent state by the tendons of the extensor muscles of the fingers. Near the base, this surface is clivided by a median ridge; as this ridge passes to the distal end of the shaft, it divides and forms two ridges which terminate in a prominent tubercle on each side of the hear of the lone. The smooth surface on each side of the median ridge on the dorsal aspect, near the hase, is for a dorsal interosseous muscle. The base is quadrilateral; its palmar and dorsal surfaces are rough for liganents; the upper end articulates with the earpus, and its lateral aspects have facets for adjacent metacarpals. The head has a semilumar 
articular surface for the base of the first fhalamx, and is more extensive on the falmar than the lorsil aspect. On its palmar surface the hear is grooved for flexor tonkhns. each conner of the groove being surmounted by a tuberele. The sides of the head are compresed, and each side is oceupind hy a well-marked fossa.

The werall metacarpals present distinetive characters. The Filser is the most

Fig. 14.-TIE FIRST (LEFT) METACALPAL.

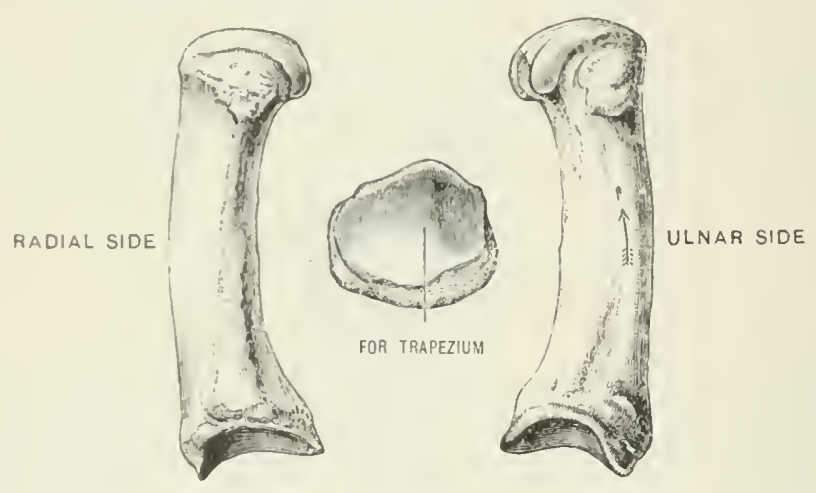

jeculiar; it is the shortest. and its shaft resembles that of a phalanx. It has a roncave palmar surface, and the dorsal surface lacks the bifurcated ridge. The base has a saddle-shaped articular surface for the trapezium, and at its outer (radial) corner presents a tubercle for the insertion of the extensor ossis metacurpi polliris. The head of the bone presents on its patmar aspect two shallow groores for the sesamoids in the flexor brecis pollicis.

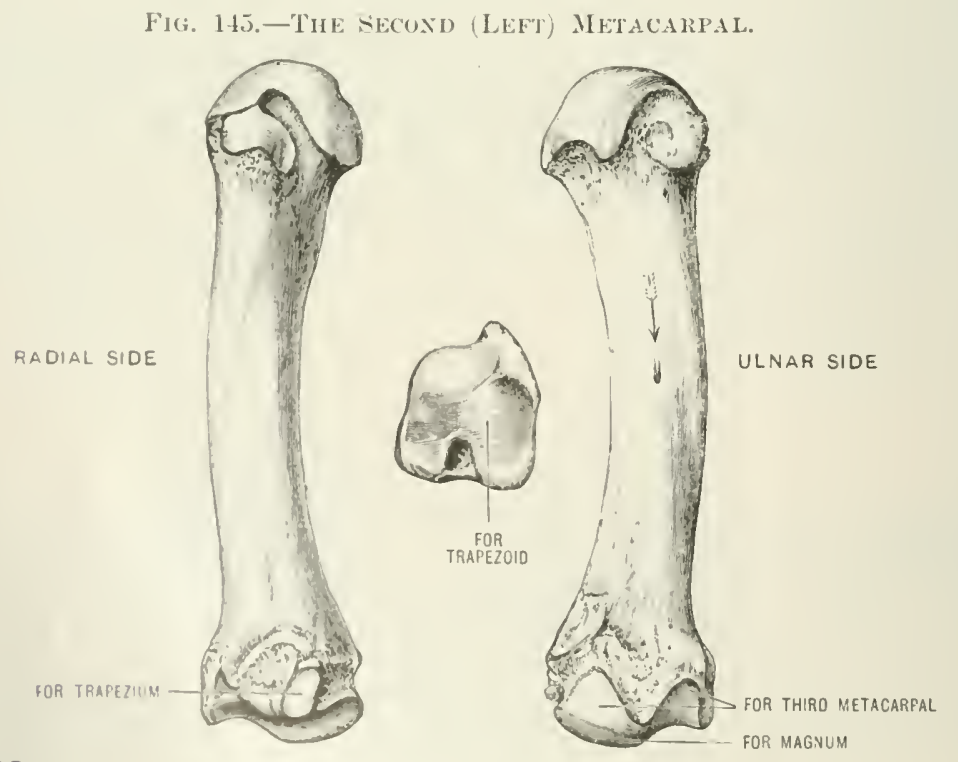

Muscles :-

Extmath ar-is metmanthi pullicis. ()pyon(11: pollicis.
First dorsal interosicous. Interosseus primus volaris.

Blood-supply.-The nutrient resel is herivel from the princeps pollicis artery: it enters on the uluar side. and is dirceted towarls the head of the bone. 
The SEroxp Metacafral is the longest, and is easily recognised by its large (leeply cleft base.

The dorsal surface affords attachment to the tendon of the estensor carpi radialis lomgrim and a lart of the extensor corpi rurlialis brevion; to the palmar surface the tendon of the flexrr curpi rarlialis is inserted. The remaining surfaces present four articular facets. The end of the bone is occupied by a deep groore for the trapezoid; the ulnar ridge of this concavity is smooth for the magnum, and is directly "ontinuous with a long narrow facet for the third metacarpal. 'The radial surface of the base has a small. somewhat quadrangular facet for the trapezium.

\section{Muscles:-}

Flexor carpi radialis.

Extensor carpi rarlialis longior.

Extensor carpi raclialis hovior.
First and second dorsal interosseous. First palmar interosieous. Flexor brevis pollicis.

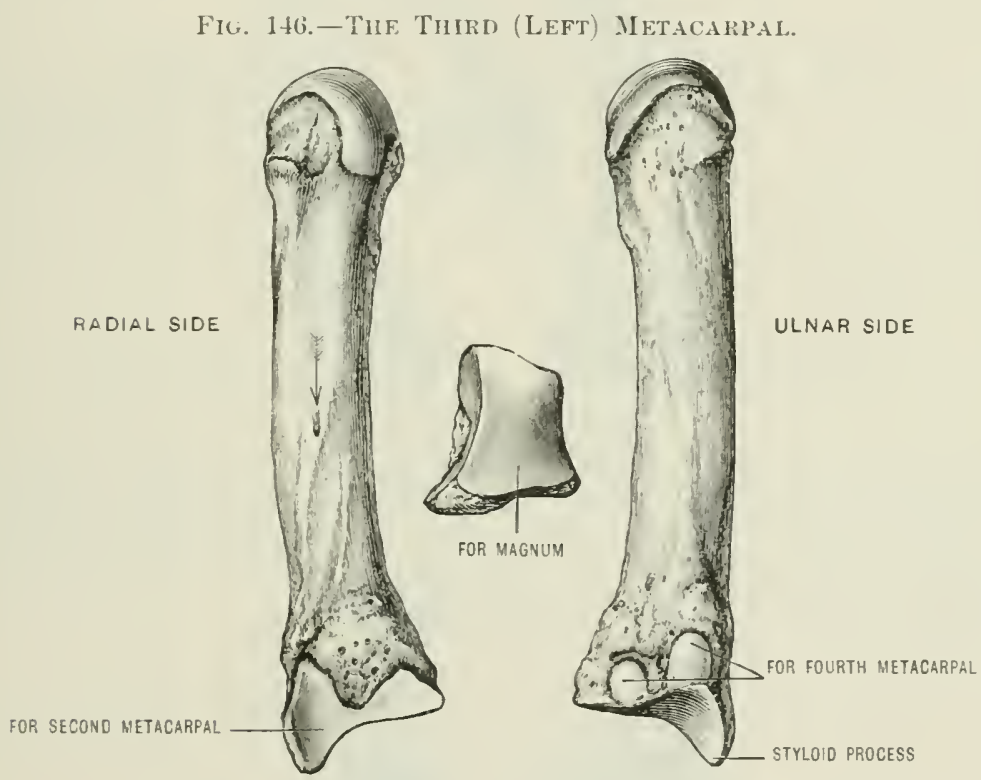

Blood-supply.-The nutrient artery is derived from the first palmar interosscons. It enters on the ulnar side, and is directed towards the proximal end or lase of the hone.

The Third Metacarpal is easily recognised by the prominent styloid process which projects from the radial comer of the dorsal surface of the base. A little helow this process the extensor carpi radialis brevior finds insertion. The carpal surface of the base is nearly plane for the magnum. The radial surface has a long narrow facet for the second metacarpal. On the ulnar side, two rounded facets are usially seen for the fourth metacarpal. Not unfrequently one of them is absent.

\section{Muscles :-}

Extensor carpi radialis brevior. Adrluctor pollicis.
Second and third dorsal interosseous. Flexor carpi radialis.

Blood-supply.-The mutrient artery is derived from the interosseous: it enters: as a rule, on the radial sicle, and is directed towards the base.

The Foc RTH MEtacakpal has a very small base. By its carpal surface it articulates with the unciform. The radial surface has two rounded facets for the thind metacarpal; there is a small facet for the magnum at the posterior radial corner. The ulnar side has a narrow articular surface for the fifth metacarpal. 


\section{Muscles :-}

The thirel dorsil interesseous. The fourth dorsil interosseous.

The serond palmar interosicusts.

Blood-supply.-The nutrient artery is furnisher hy the second interosseous; it (enters on the ratlial side of the shaft, and is directed towards the proximal end.

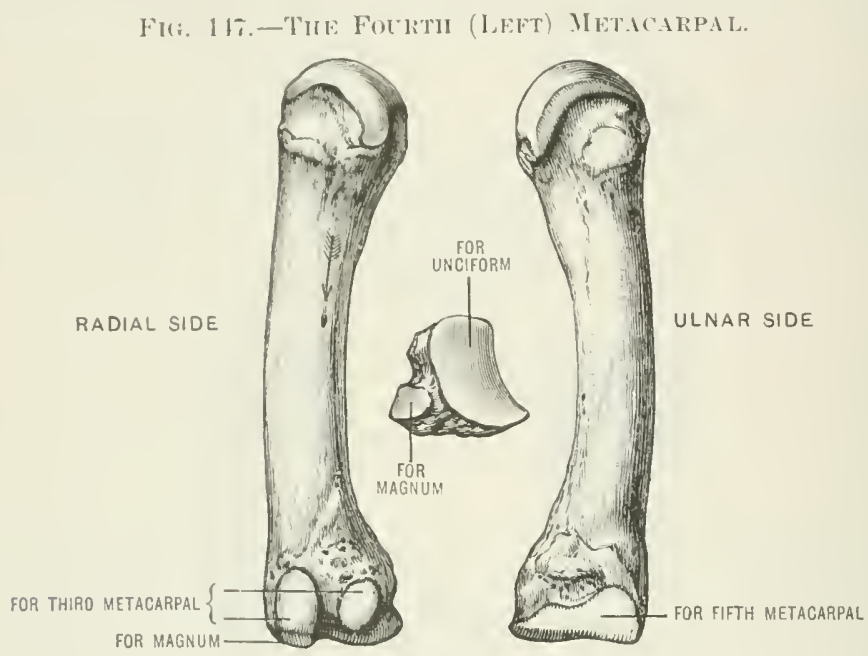

The Fiftu Meracarpal is readily distinguished. The carpal facet is convex for the unciform. The uhnar aspect of the bise forms a rounded tubercle for the rrtensor corpi ulnaris, whilst the radial side has a semilunar facet for the fourth metacarpal bone. The radial border of the dorsal surface of the shaft often has a prominent lip for the fourth dorsal interosseous muscle.

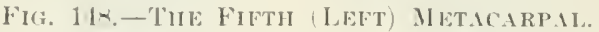

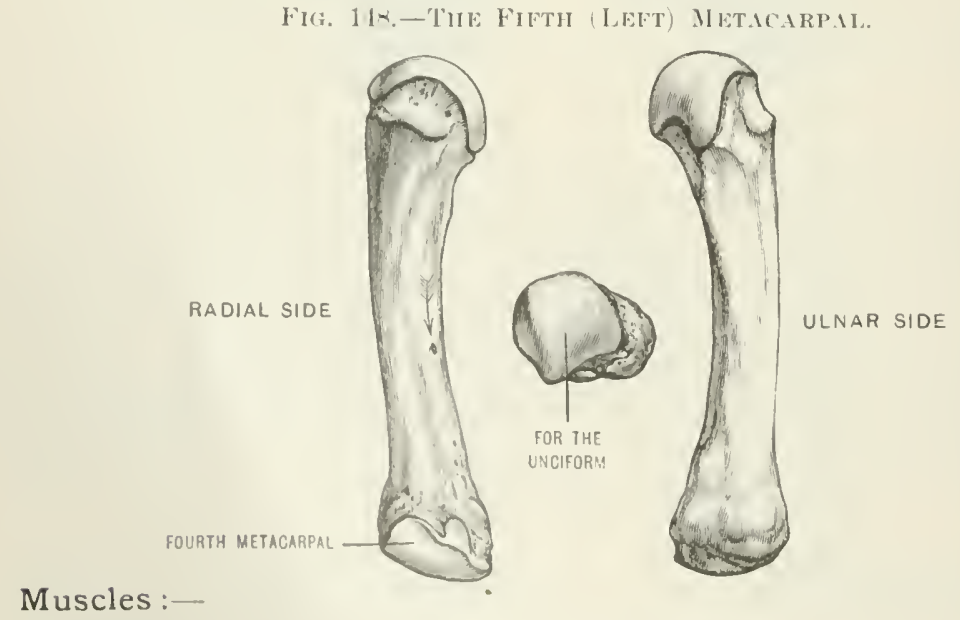

Flexor carpi ulnaris.

Ext(nsor ("ilpi ulnaris.

Fourth ilorsal interosisens.

Third palnalr interosseous.

()lencess minimi digiti.

Blood-supply.-The mutrint artery is incived from the thind interossents. It enters the shaft on the radial siche, and is directed towards the proximal end. 
Ossification.-Each metacarpal is ossified from two centres. The nucleus for the shaft appears about the eighth week of embryonic life. At birth the shafts are well ossified, hut each end is eapued by a piece of cartilage. In the case of the first metacarpal, a centre for the epiphysis appears at the proximal end in the course of the third year. The bases of the remaining metacarpals are ossified from the shaft, but an epiphysis forms for the head of each hone in the third year. The bones are usually consoliclated by the twentieth year.

In many eases the first meticarpal has two epiphyses, one at the base and an alditional one at the hearl; the latter is never so large as in the other metacarpal bones.

The third metacarpal oceasionally has an additional nucleus for the prominent styloid process which constitutes such a distinguishing feature of this bone.

The styloid process sometimes remains distinct, and is then known as the styloid bone. Occasionally it fuses with the trapezoid or magnum.

\section{THE PHALANGEN}

The phalanges are the bones of the fingers. They number in all fourteen: the thumb has two, the other fingers three each.

Each phalanx has a shaft, which is broad and slightly concave on the palmar,

Fig. 149. - The Phalanges uf the Third Digit of the Hand. (Dorsal view.)

THIRD TERMINAL OR UNGUAL PHALANX
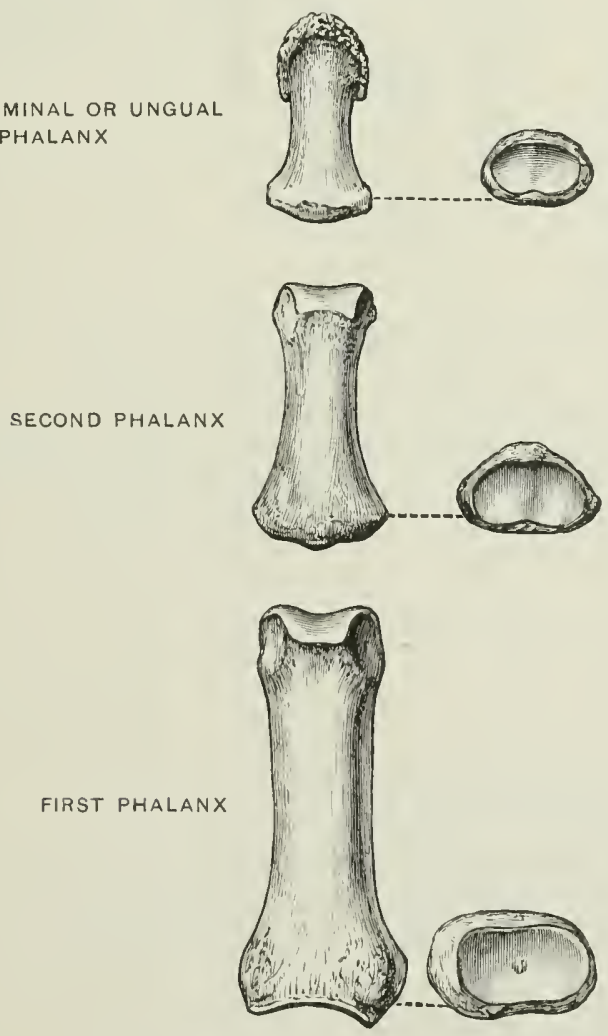

rounded and smooth on the dorsal aspect. The sicles of the pahmar surface are raised where they give attachment to the sheaths of the flexor tendons. The base of each phalanx of the first row presents a glenoid fossa which plays upon the convex head of the metacarpal bone. The listal end is surmounted liy miniature condyles. 
The phalanges of the second row are shorter tham those of the first row. Their bises furesent two shallow pits, separated hy a ridge.

The terminal, third, or ungual phatanges have an "xpanded shaft for the supwart of the mail. The lases arre identical in shape with those of the second row.

Ossification.- Each phalanx osities from two eentres: one for the shaft, which

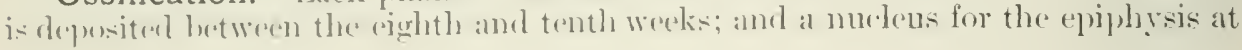

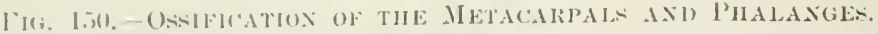

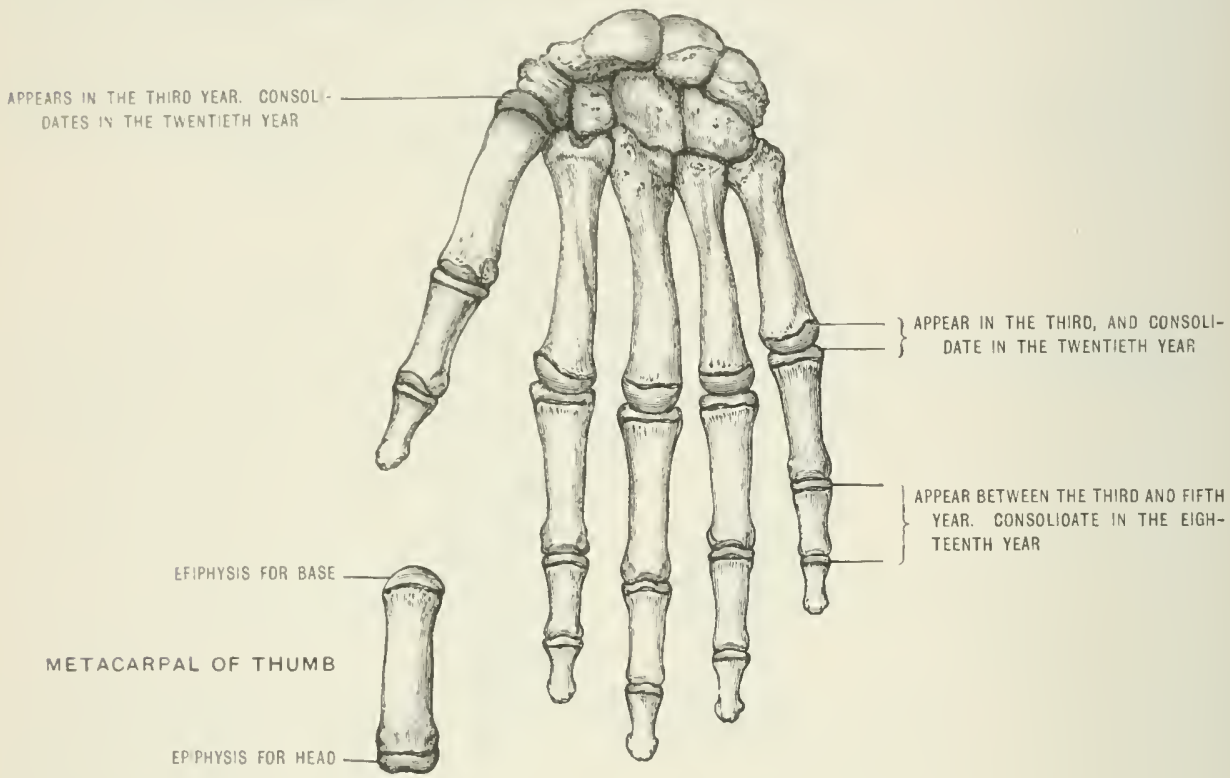

the proxinal end, which appears between the third and fifth rears. Consolidation begins at the serenteenth, and is complete by the eighteenth year.

The ossification of the tominal phalanx is peculiar, Like the other phalanges it has a nucleus for the shaft and a secondary nucleus for the epiphysis; but the centre for the shaft appears at the tip of the phalanx; whereas in the other phalanges the eartlyy matter is deposited in the middle of the shaft.

\section{TIIE' IIII-B(I) NE}

The hiph-hone (imnominate heme) is of irregular shape, resemhling somewhat the blade of a serere propeller. It consists of there falts, which, though separate in early life, slre, in the anlult, firmly ank loserl. The three parts meet together at the cotyloid cavity ") acetabulum. They are nancel ilium, ischium, and pubes.

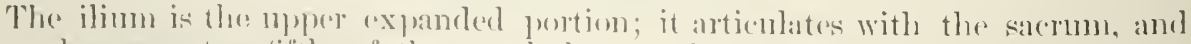
forms the uplese twe-lifths of the acetabulum. The ischim is the lowest part of the lone; it forms the posterior and inferion two-fiftls of the aretalulum, and assists the pulus to form the obturator foramen. The pubes forme the anterior fifth of the acctahnlum, (a)mpletes the obturator loramen, and stretehes towarls the median line to meet with the opposite fubes to form a symphysis. Eareh part repuires separate consideration. 
The ilium has two surfaces: the external surface, or dorsum, is convex in its ureneral contour. It is limited superiorly by the semicircular crest, and is crossed hy the three gluteal ridges. The superior gluteal ridge commences at the erest about $5 \mathrm{~cm}$. ( $\left.2^{\prime \prime}\right)$ from its posterior termination, and passes downwards to the middle of the greater sciatic (ilio-sciatic) notch. The space included between this riclge and the crest gives origin to the glutens maximus, and at its lower part to a few fibres of the pyriformis. The middle gluteal ridge extends from the crest $2.5 \mathrm{~cm}$. $\left(1^{\prime \prime}\right)$ behind its anterior extremity, and passes across the clorsum to terminate near the posterior end of the superior gluteal ridge, at the greater stiatic notch. The surface of bone between this ridge and the crest is for the origin of the gluteus merlius. The inferior gluteal ridge begins in the notch separating the anterior iliac spines, and terminates posteriorly in the middle of the greater sciatic notch. The space between the middle and inferior ridges gives origin to the gluteus minimu.; except a small area adjacent to the anterior superior iliac spine for the tensor vagina: femoris. The bone between the inferior gluteal ridge and the margin of the acetalyulum affords attachment to the capsule of the hip-joint. Towards its anterior part there is a rough surface for the reflected tendon of the rectus.

The internal surface of the ilium consists of an anterior concave portion, termed the iliac fossa; it lodges the iliacus muscle. The fossa is limited below by the ilio-pectineal line; this line receives, at its anterior part, the insertion of the psous pereves. A small portion of the ilium extends below the ilio-pectineal line to mect the ischium. The surface posterior to the fossa is divided into an auricular surface for articulation with the lateral aspect of the upper portion of the sacrum, and a superior rough surface-the tuberosity-for the posterior sacro-iliae and iliolumbar ligaments. The crest extends from the anterior superior iliac to the posterior superior iliac spine. It is thickest at its extremities. The prominent edges, or lips, are for the attachment of muscles and fascia.

The outer lip affords attachment to the gluteal portion of the fascia lata. The exterual oblique is inserted into the anterior half, and the latissimus dorsi arises for about an inch more posteriorly. The anterior two-thirds of the intermediate space gives origin to the internal oblique. The inner lip, by its anterior three-fourths, gives attachment to the transuersalis; behind this is a small surface for the quadratus lumbrum, and the remainder is occupied by the erector spinx. The extreme inner margin of the lip in the anterior two-thirds serves for the attachment of the iliac fascia.

The anterior border of the ilimm extends from the anterior superior spine to the margin of the acetabulum. The anterior superior spine gives attachment to Poupart's ligament, and the surtorius which also arises from the upper half of the superior iliac notch. This notch is terminated inferiorly by the anterior inferior spine; it is smaller, less prominent than the superior, and gives origin to the straight head of the rectus femoris and the main limb of the ilio-femoral band of the capsule of the hip-joint. Beneath the inferior iliac spine is the inferior iliac notch; it is broad, but shallow, and limited by an eninence, the ilio-pubal ridge, which indicates the line of ankylosis of the pubes and the ilium. A fow fibres of the iliacus arise from this noteh.

The posterior border of the ilium presents above the posterior superior spine, which gives attachment to the greater sacro-sciatic ligament and the multifidus spinx. and a portion of the oblique sacro-iliac ligament. Below this is a shallow notch terminating below in the posterior inferior spine, corresponding to the posterior border of the auricular surface. This spine receives a portion of the greater sacrosciatic ligament. Below the spine the posterior border of the ilimn forms the upper segment of the greater sciatic noteh.

The ischium consists of a thick solicl body, a prominent tuberosity, and a ramus.

The body is triangular; its outer surface forms the posterior and inferior section of the acetabulum. The inner surface forms part of the true pelvis, and meets the ilium a little distance below the ilio-pectineal line. It also forms the floor, ol non-articular portion, of the acetabulun, and meets the pubes anteriorly; the line of junction is frerpuently indicated in adult bones by a rough line extending from the ilio-pubal ridge to the margin of the obturator formen. The free borker of 
this surface forms the posterior lumedary of the obturator foramen. The inner surfare of the ischium gires origin to the obtureter interms. The posterior surfare

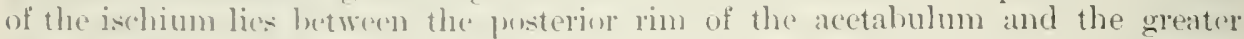
sciatic noteh, lnferiorly this surfies is limited by the obturator groove, which

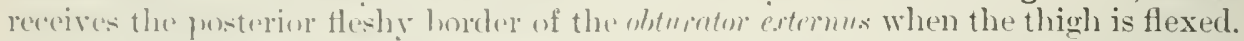
The ("ipsule of the hip-joint is attached to the outer part of the posterior surface.

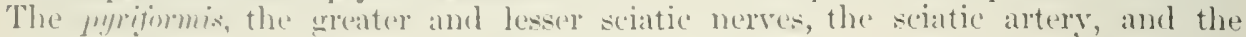

Fic. 151.-Tin LeFt Hil'Boxe. (Internal surfice.)

Quadratus lumborum

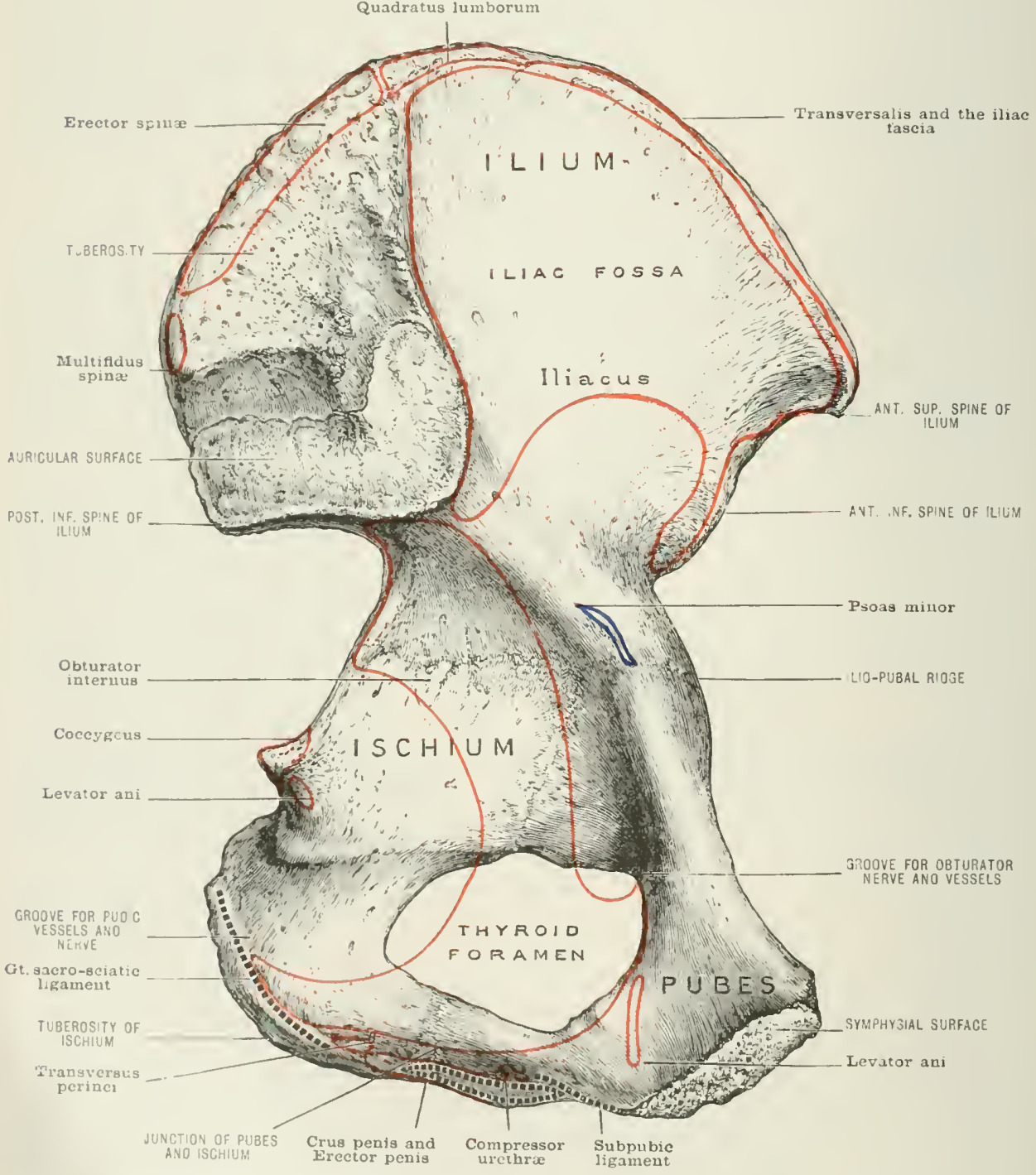

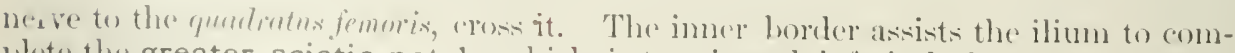
plete the greater sciatic notch, which is teminated inforiorly by the prominnit ischiatic spine, which gives attarehment to the lesser salero-sciatic liganent, the Irentor ani, and corrygene. From the base of the spine, posteriorly, the gemellu.s.

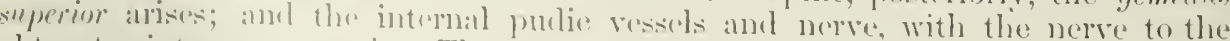
obturater internus, aress it. The recess below the ischiatic: spine is the lesser sciatic notch; in the recent state it is covered with eartilage, and presents two, three, or four groures for the tendinus umeler surface of the obturetor internus muscle. 
The tuberosity is that portion of the ischimm which supports the body in the sitting posture. It is clivided into an anterior and a posterior part by a transverse line. The posterior portion is subdivided by an obligue ridge into an upper and outer part for the semimembranosus, and a lower and imner fart for the common tenclon of the biceps and the semitendinosus. The anterior portion is separated into an inner and outer section by an antero-posterior line, the outer part gives origin to the posterior part of the adductor magnus, and the inner part serves for

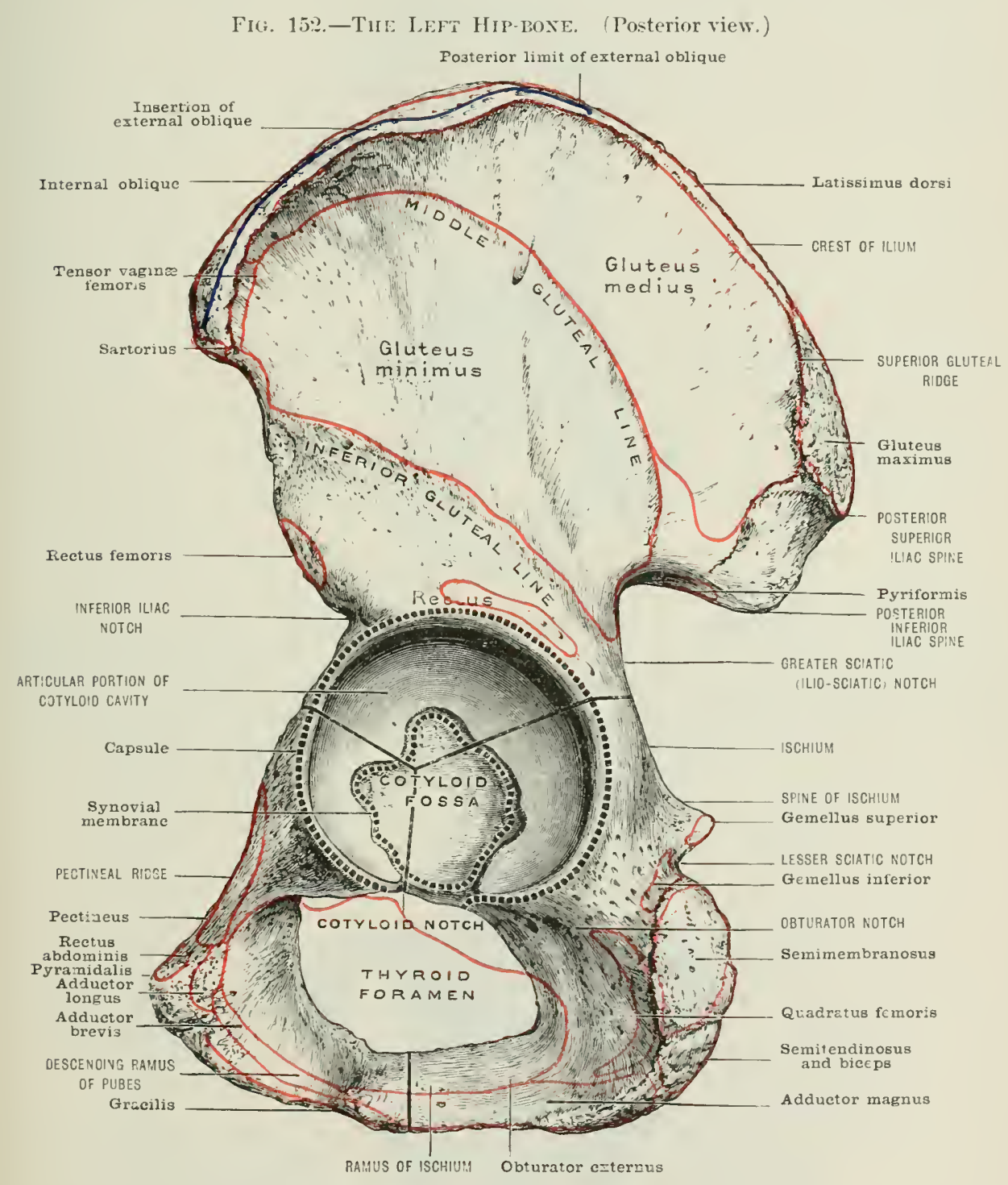

the attachment of part of the falciform process of the great saero-seiatic ligamerit. The surface of the tuberosity above this lip is in relation with the internal purlic: vessels and nerves. The outer lip is occupied by the quadratus fomoris musche, and the surface adjacent to this is occupied by the aiddector magnus. The surfaces thin away to a sharp marcin. which forms part of the boundary of the oliturator foramen.

The ramus of the ischium is a continuation of the tubernsity running upwards to join the descending ramus of the pubes, to complete the obturator formen. The outer surface of the ramus gives origin to the adductor magnes and the obturator 
cxtemms. To its immer surface the cros penis is attached; it also gives origin to the

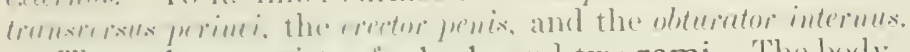

Th" pubes mun-ints of a body and two rami. The horly, quadrilateral in shape,

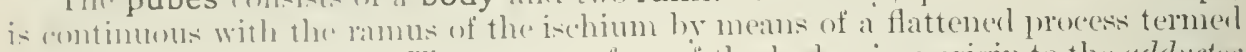
the descending ramus. The outer surfite of the boty gives origin to the adductor

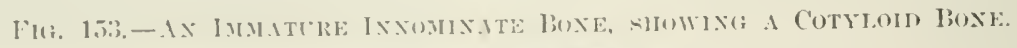

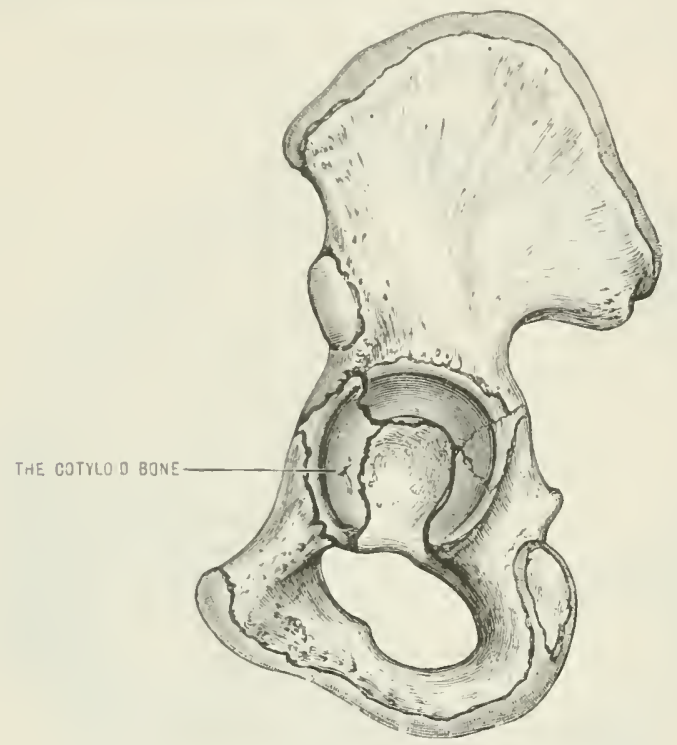

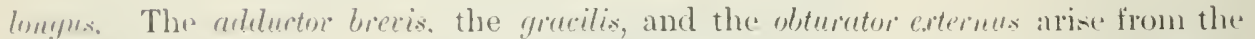
miter surfare of the body and descending ranus. A small portion of the adductor mugnus also arises from the descending ramus. The posterior surface of the body and that of the descending lanus is continuous with the corresponding surface of the ramus of the ischium, and aftords attachnent to the lecator ani and wbturetor

Fig. 1.j1.-TIL l'klyis of a Fietes at Birtil, to show the Three Portons of the IXN⿴囗十八TE PONLE.

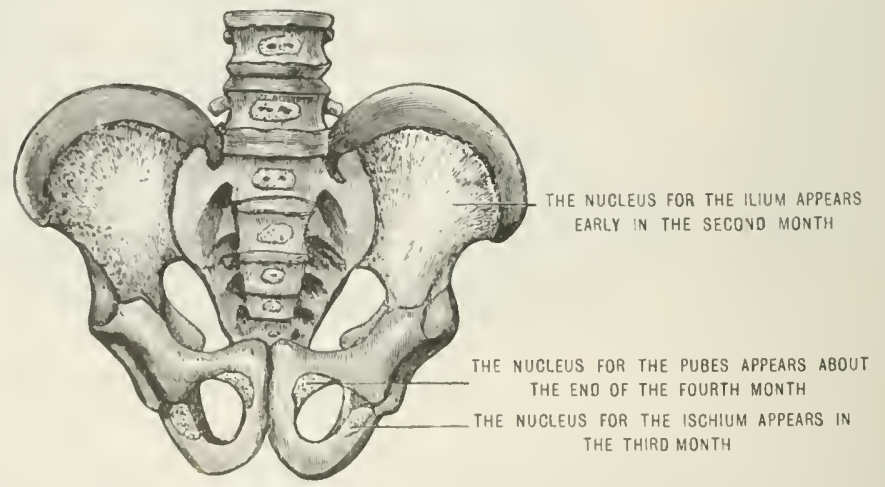

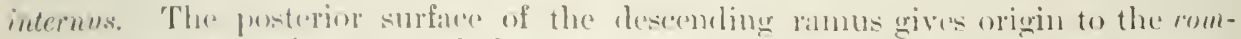

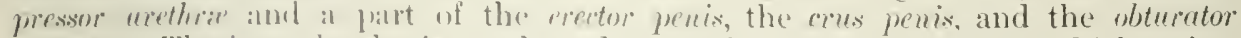

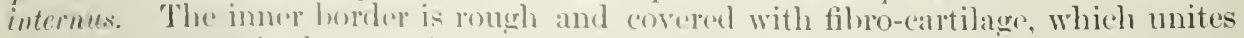

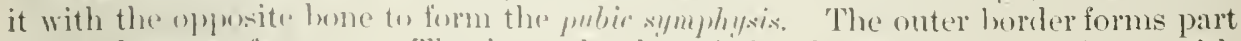
of the obturater formmen. 'The inner horder of the descending ranus forms with the ramms of the ischimm the pulife alleh. 
The upper surface or crest of the pules is linited externally by the pubic spine, which gives attachment to the outer (inferior) pillar of the ('xternal abdominal ring or Poupart's ligament. The inner extremity of the erest is the angle of the pubes. Betreen it and the spine the following structures are attached:- the linea alba, the rectus mbdominis, the pyomidalis, and the conjoined tendon of the intemal oblique and tirnsersalis nuscrles. The horizontal ramus extends from the body of the pubes to the ilium, forming by its outer extremity the anterior one-fifth of the articular surface of the acetabulum. Its line of junction with the ilium forms the ilio-pubal ridge. Stretching from this ridge to the pubic spine there is a laised edge continuing the ilio-pectincal line. The surface of bone in front of the line is the pectineal surface ; it gires origin to the pertinews muscle, and is limited below by the obturator crest, which extends from the pubic spine to the cotyloid notch. The under surface of the horizontal ramus forms the upper boundary of the obturator foramen, and presents a deep groove for the passage of the olvturator ressels and nerve.

The acetabulum is a circular depression in which the head of the femur is lodged. It consists of an articular and a non-articular portion. The articular portion is circumferential and horseshoe-shaped; the deficiency is in the lower segment. The pubes forms one-fifth of the acetabulum, and the ischium two-fifths; the rest is formed by the ilium. In rare instances the pubes may be excluded hy a fourth element, the cotyloid bone. The non-articular portion is formed mainly by the ischium, and is continuous below with the margin of the obturator formen. The articular portion presents an outer rim to which the cotyloid ligament is attached, and an inner margin to which the srnorial membrane is connected which excludes the licamentum teres from the synovial cavity. The opposite angles of the horseshoe-shaperl margin which limit the cotyloid notch are united by the transverse ligament, and through the cotyloid foramen thus formed a nerve and resel enter the joint.

The obturator (thyroid) foramen is situated between the ischium and pubes. Its margins are thin, and serve for the attachment of the obturator foramen. At the upper and posterior angle it is deeply grooved for the passage of the obturator vessels and nerve.

Muscles attacherl to the hip-bone are:-

Gluteus maximus:

Gluteus medius:

Gluteus minimus:

Tensor vaginæ femoris.

Rectus femoris.

Obturator externus.

Obturator internus.

Latissimus dorsi.

Internal oblique.

External oblique.

Transwersalis.

Erector spinae.

Multifidus spina.

Quadratus lumborum.

Iliacus.

Psoas parves.

Quadratus femoris.

Accelerator urince (occasionally).
Sartorius.

Pectineus.

Pyramidalis.

Pyriformis.

Gemellus superior.

Gemellus inferior.

Gracilis.

Adeluetor magnus.

Adductor longus.

Adductor brevis.

Levator ani.

Coccrgeus.

Transversus perinei.

Erector penis.

Compressor urethræ.

Biceps femoris.

Semitendinosus.

Semimembranosus.

The ligaments attached to the hip-bone are:-

Greater sacro-sciatic.

Lesser sacro-sciatic.

Ilio-lumbar.

Anterior sacro-iliac.

Posterior sacro-iliac.

Capsular and its accessories.

Cotyloil.
Transverse.

Round (ligamentum teres).

Anterior pubic.

Posterior pubic.

Superior pubic.

Subpubic.

Trianeular. 
Blood-supply.-The ilium receives on its anterior surface, twigs from the iliolumbir, clerp cirrumflex iliac, and olsturator arteries. On the dorsum, arteries (ntere it from the gluteal and sciatic trunks.

The ischium is supplied hy the obturator, internal, and external circumflex.

Fi(ז, 1.ॅ.-HIP-BUNE, SHOWING SECONDARY CENTRES.

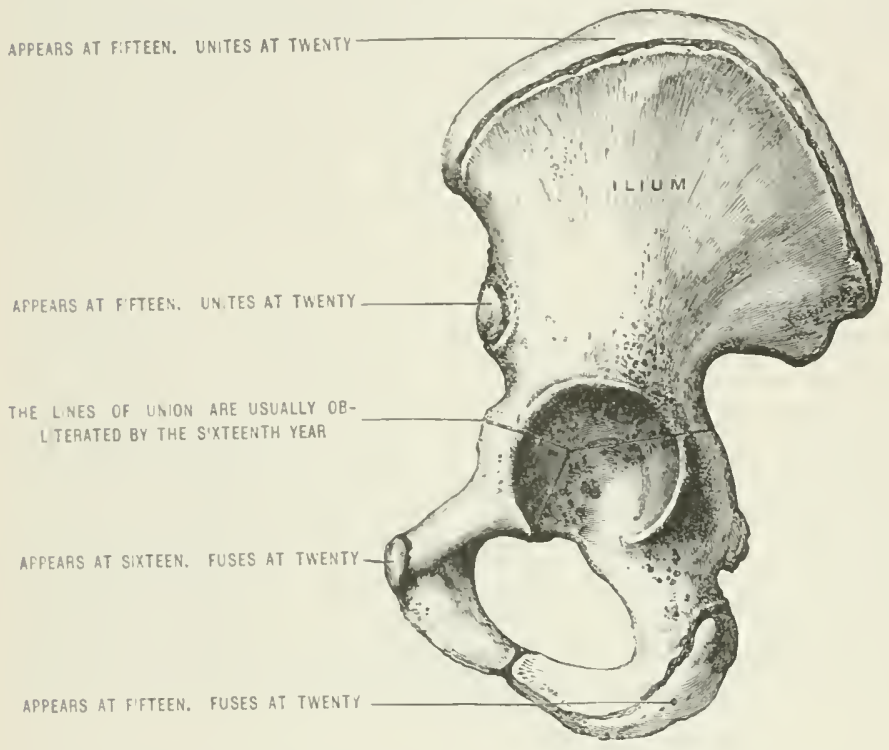

Fig. 156.-Hhp-Buxe (Ix.er Strface) at THE Eimith Year.

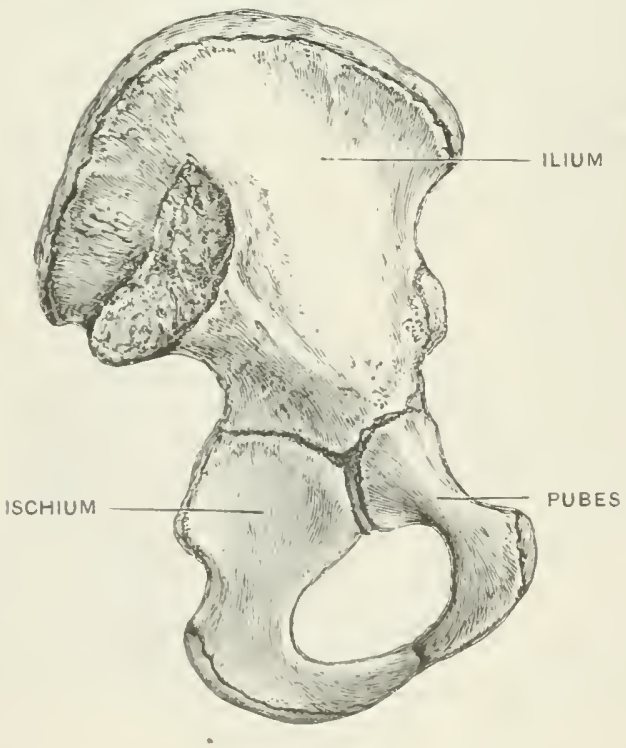

The pubes recoives twigs from the obturator, intermal and external circumflex,

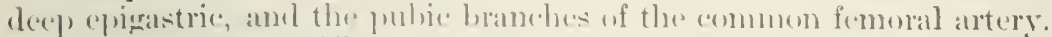

Development. - The "artilarinoms representative of the hip-bome consists at first of an ilio-ischiatic and a pubic seroment. These puirkly fuse and form a eontinuous

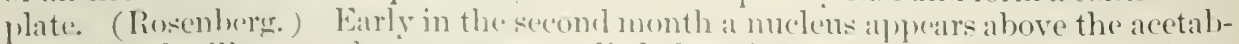
ulum for the ilium, and one appears a little bater luelow the cavity for the ischium. 
In the fourth month a nucleus is seen in the jubic portion of the cartilagre. At birth these three nuclei are of considerable size, but surmonded by relatively wide tracts of eartilage. At the twelfth year the trirarliate cartilage which scparates the three segments of the innominate bone at the acetabulum begins to ossify by severa] "entres, which unite with the surrounding elements causing their consoliclation from the righteenth to the twentieth year. One of these nuclei is larger than the others and is the acetabular nucleus. The segment it forms is regarded by some morphologrists as the representative of the cotyloid or acetabular bone constantly present in a few mammals, and is of sufficient size to exclurle the pubes from the cotyloid carity. l) ming the eighth year the rami of the ischium and pubes coalesce. About the fifteenth vear two secondary nuelei appear in the iliac eartilage to form the erest and the anterior inferior spine. In accessory nucleus appears for the ischial tuberosity, and subsequently one for the pubic crest. These fuse with the main bone about the twentieth year. The fibrous tissue connected with the pubic spine represents the epipubic bone of marsupial mammals.

\section{THE PELITS}

The pelvis is composed of four bones: the two hip-bones. the sacrum, and the coccyx. The hip-bones form the lateral and anterior boundaries, meeting each other to form the jubic symphysis; posteriorly they are separated by the sacrum. The hollow of the fuelvis is divided into the false and true pelvic cavity.

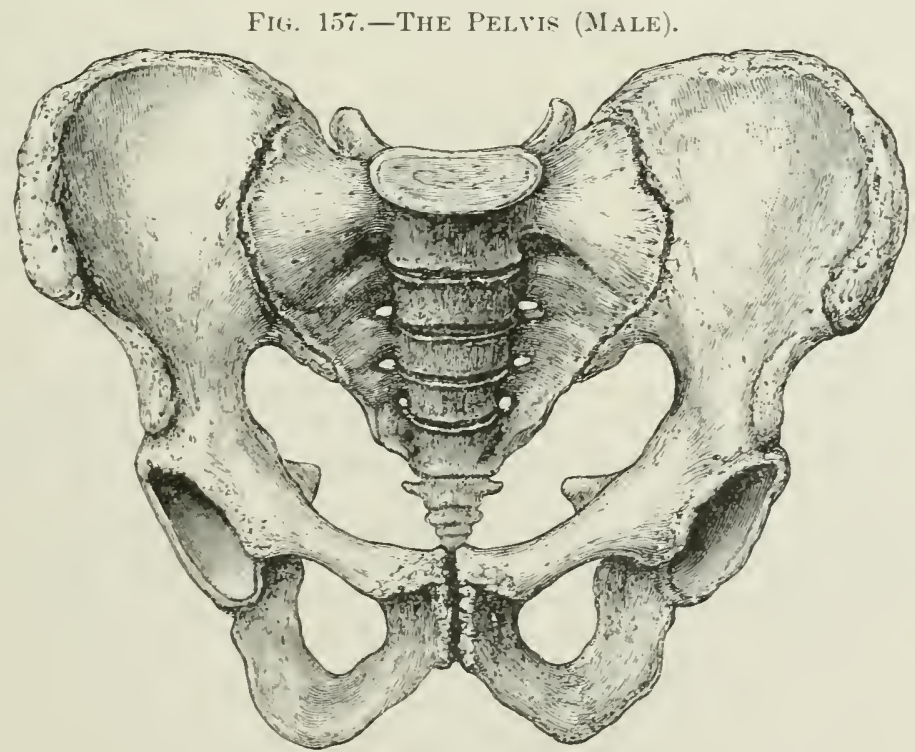

The false pelvis is that part of the carity which lics above the ilio-pectincal lines; this part is in relation with the hypogastric and inguinal regions.

The true pelvis is situated below the ilio-pectineal lines. The upper ciremforence, ealled alson the inlet of the pelvis, is hounder anteriorly hy the spine and (rest of the pubes, posteriorly by the base of the sacrum, and laterally by the iliopectineal lines. The inlet in nomal pelves is ardate. being obtusely pointed in front; posteriorly it is encroached upon hy the promontory of the sacrim. It has three principal diameters; of these, the antero-posterior, callerl the conjugate 
diameter, is meatsured from the sacro-vertebral angle to the symphysis. The transverse diameter represents the greatest width of the pelvic avity. The oblique is meatured from the sicro-iliale symehondrosis to the ilio-pubal ridge.

The eavity of the true pelvis is bounded in front by the symphysis pubis, behind he the salcrum and cocerx, and laterally by a smooth wall of bone formed in part bi the ilium, in part by the ischium; it corresponds to the acetabulum. The cavity is shallow in flont, where it is formed by the pubes, and is deepest posteriorly.

The lower circumference, or outlet, of the pelvis is very irregular, and eneroached upon by three hony processes: the posterior process is the encerx, and the two lateral processes the ischial tuberosities. They separate three notches. The anterior is the pubic arch, and is bounded on each side by the conjoined rami of the pubes and ischimn. The two remaining gaps correspond to the greater and lesser sciatic notches; they are bounded ly the ischium anteriorly, the sacrum and "ocerx posteriorly, and the ilimm above. These are converted into foramina by the grouter and lesser salcro-sciatic ligaments.

The position of the pelvis. - In the erect position of the skeleton, the plane of the pelvic inlet forms an angle with the horizontal, which varies in individuals from $500^{\circ}$ to $1 ; 0^{\circ}$. The base of the sacrum in an average pelvis lies nearly $10 \mathrm{~cm}$. (4") above the upper margin of the symphysis pubis.

The axis of the pelvis. - This is an imaginary line drawn at right angles to the planes of the brim, cavity, and outlet, through their centres.

The average measurements of the diameters of the pelvis in the three planes are given below (after Lusk):-

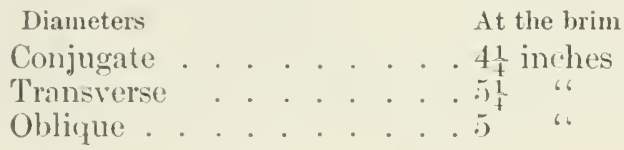

At the outlet

$3 \frac{3}{4}$ inches

$4 \frac{1}{4}$ " 6

$4 \frac{1}{2} \quad$ "

\section{Sexual differences :-}

MALE

Bones heavier and rougher.

Ilia less vertical.

Iliac fossie rleeper.

False polvis relatively wider.

True pelris decper.

* 6 n narrower.

Inlet more heart-shaped.

simplhysis deeper.

Tuberosities of ischia inflexed.

l'ubic arch narrower amel nore pointed.

Margins of isthio-pubic rani more everted.

Obturator foramen oval.

Sierum narrower and nore eurved.

Capacity of true pelvis less.

\section{FEMALE}

Bones more slender.

Ilia more vertical.

Iliac fosse shallower.

False pelvis relatively narrower.

True pelvis shallower.

"6 " wider.

Inlet more oval.

Symphysis shallower.

Tuberosities of ischia ererted.

Pubic areh wider and mor' rounded.

Margins of ischio-pubic rami less everted.

Olturator foramen triangular.

Sacrum wider and less curved.

Capacity of true pelvis greater. 


\section{THE FEMUR}

This bone is the largest and longest in the skeleton. The upper extremity is surmounted by a hemispherical cartilage-covered articular portion called the head, which is lirected upwards and inwards, to be received in the acetabulum of the hipbone. A little below and behind the centre of the head is a small rough depression to which the ligamentum teres is attached. The head is connected to the shaft by the neck, a stout reetangular process of bone which forms with the femoral shaft, in the adult, an angle of $125^{\circ}$. Its anterior surface is in the same plane with the front aspect of the shaft, but it is marked off from it by a ridge to which the capsule of the hip-joint is attached. This ridge commences at the greater trochanter in a small prominence, the superior cervical tubercle, and extends obliquely downwards to the inferior cervical tubercle, and, winding to the back of the femur, becomes continuous with the inner lip of the linea aspera. The whole of this ridge is called the spiral line, but the part between the cervical tubercles is often called the anterior intertrochanteric line. The superior and inferior tubercles receive the limbs of the ilio-femoral thickening in the capsule of the hip-joint. The posterior surface of the neck is smooth and concave, its inner two-thirds is enclosed in the capsule of the hip-joint. The superior surface is narrow, and pitted with nutrient foramina; it runs downwards to the greater trochanter. The inferior surface, concave in outline, terminates at the lesser trochanter.

The trochanters are prominences which afford attachment to muscles which rotate the thigh; ther are two in number, the greater and the lesser.

The greater trochanter is quadrilateral, and surmounts the junction of the neck with the shaft. Of its two surfaces, the external is the broader; it is bisected diagonally by a ridge rumning from the posterior superior to the anterior inferior angle. The gluteus medius is inserted into this ridge; a bursa occasionally is interposed between the tendon and the bone. The inner surface presents a deep pit, the trochanteric fossa, which receives the tendon of the obturator externus. The upper border, called the tip, gives attachment from before backwards to the tendons of the obturator interus with the gemelli, and the pyriformis. The anterior border receives the gluteus minimus. The posterior border is thick, rounded, and continuous with the posterior intertrochanteric line, which runs downwards to terminate at the lesser trochanter, a conical prominence on the posterior aspect of the femur to which the psoas is inserted. Rumning downwards from the lesser trochanter to meet the spiral line is a slender ridge, to which the iliacus is inserted. The surface of bone slightly posterior to this ridge is occupied by the pectineus. This part of the femur presents several converging ridges, which will be most conveniently considered with the linea aspera.

The shaft of the femur is cylindrical in shape, and presents, in the midlle third of its posterior aspect, a prominent vertical ridge of bone, the linea aspera, for the origin and insertion of muscles. In the middle of the shaft the linea asperal presents an imner lip, an outer lip, and an intervening space. Towards the upper third of the shaft these three parts diverge: the outer lip becomes continuous with the gluteal ridge, and ends at the base of the greater trochanter. When very frominent the gluteal ridge is termed the third trochanter. It affords attachment to the gluteus maximus. The inner lip curves inwards below the lesser trochanter, and becomes the spiral line. The middle portion of the linea aspera bifureates, the inner portion as it runs on to the lesser trochanter receives the iliacus; the outer lasses upwards to the centre of the posterior intertrochanteric line; it receives the cuculrutus femoris, and is called the linea quadrati. The upper limit of this line is often indicated by a rounded tubercle which projects on the posterior intertrochanteric line. Towards the lower third of the shaft, the inner and outer lips of the linea aspera diverge to become continuous with the condylar rilges. Several muscles are connected with the linea aspera. The vastus interms arises from the whole length of the inner lip, and the castus exterms from the outer lip. The adductor magnus is inserted into the upper half of the outer lip, and the lower half 
Fut. 15\%.-The Left Femir. (Anterior view.)

GREATER TROCHANTER

Capaule

OF THE HIP-JOINT ATTACHEO TO THE ANTERIOR INTERTROCHANTER C LINE

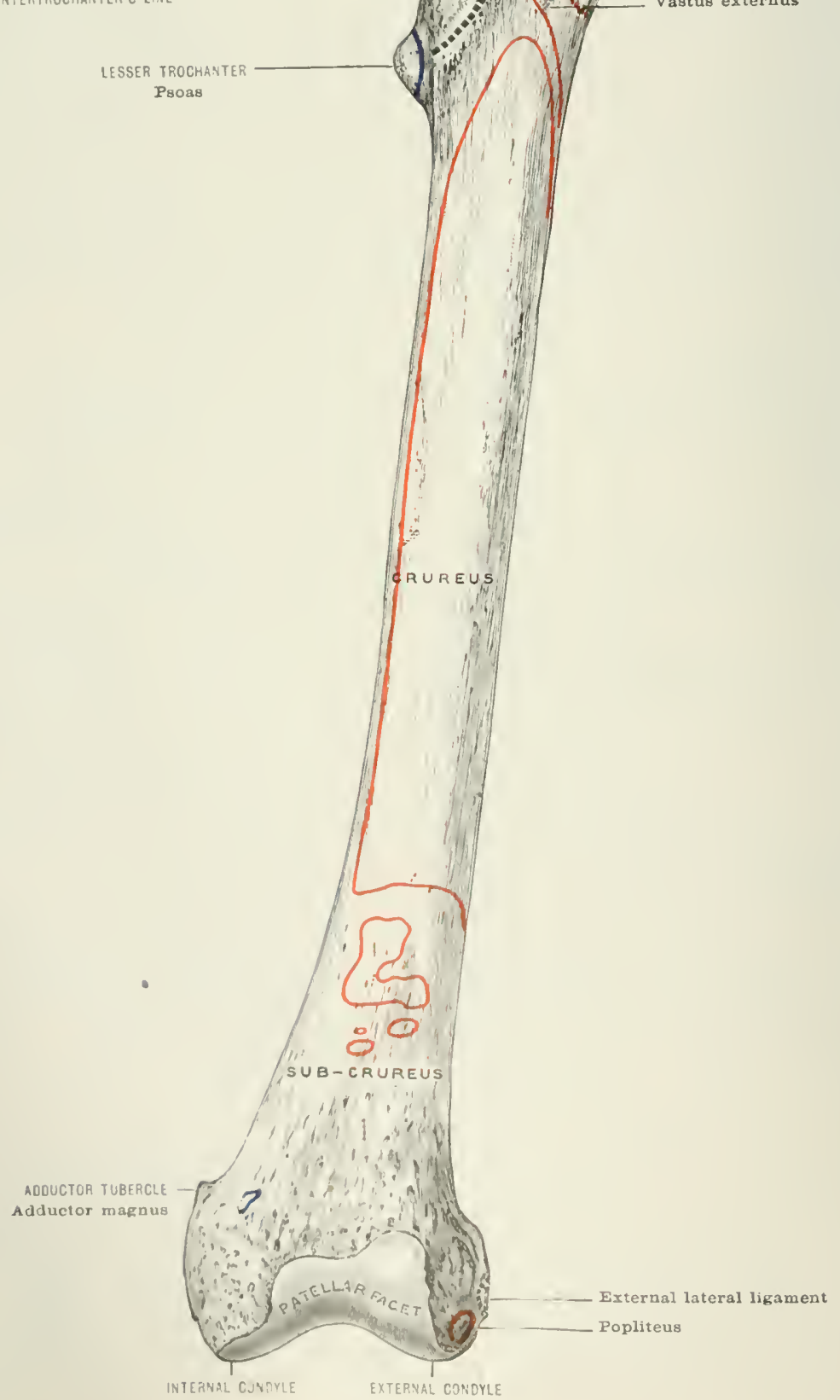


Fig. 159.-The Leff Fejur. (Posterior view.)

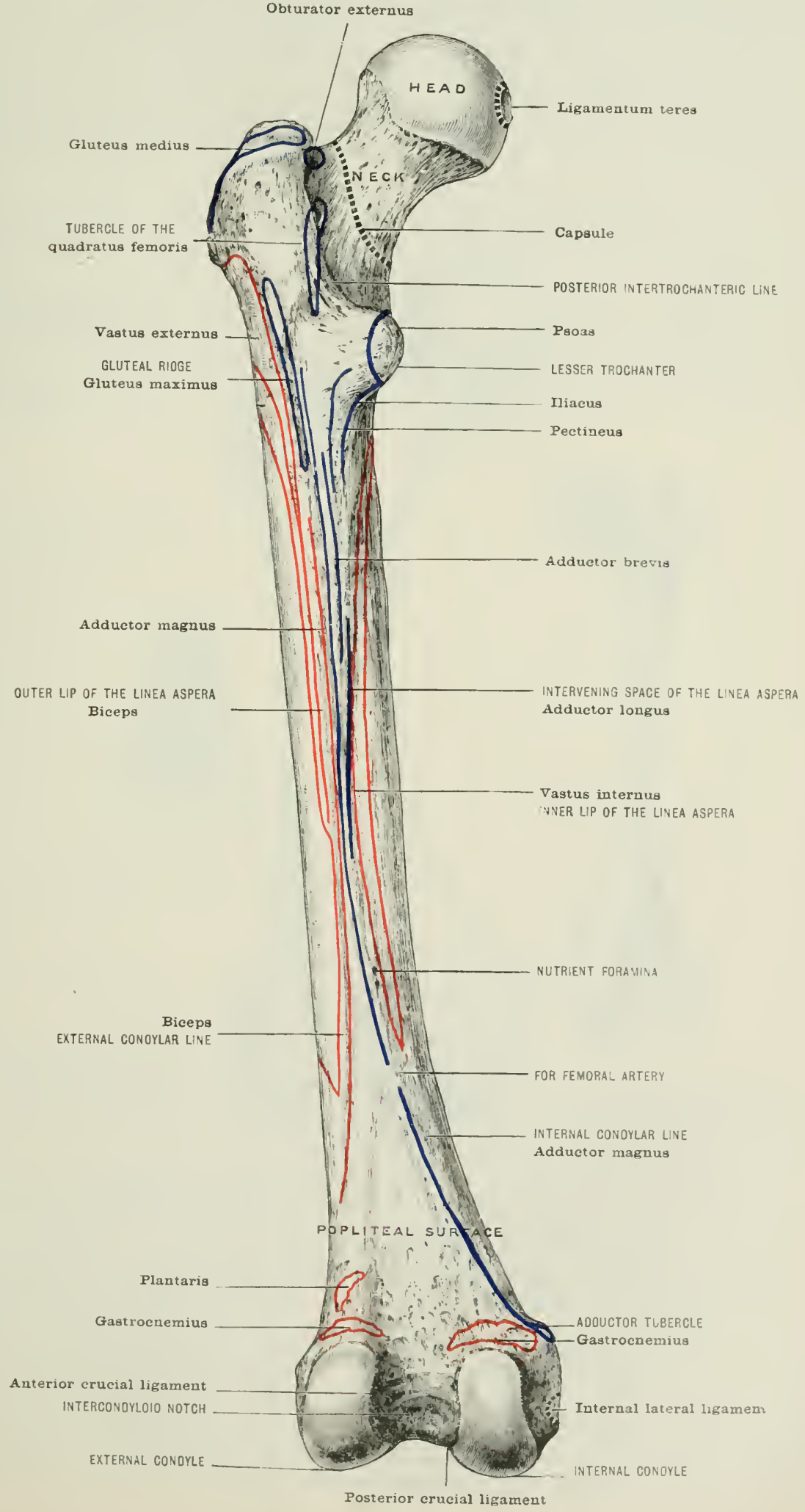


of the inner lip. The adductor longus and brevis are inserted into the intervening spare; the adductor longus takes rather more than the middle third, and overlaps the lower part of the adeluctor brevis, which takes rather more than the upper third. The outer lip in its lower two-thirels gives origin to the shorter head of the bir f... The condylar lines are two in number; the outer is contimus with the cuter lip of the linea ispera and teminutes inferiorly on the outer edge of the external condyle. From the upper half of this line a part of the short head of the biceps arises. Near its termination the line expands to give origin to the plantaris and the outer hearl of the unstrocnmin.s. The inner condylar line is not so promiment as the outer; it in continuous with the inmer lip of the linea aspera, and terminates at the adductor tubercle. The adduetor ma!mms is inserted into the whole length of the line and to the tubercle. Near the niddlle of the line there is an interruption where the femoral artery gasses through the opening in the tendon of the addurtor magnus. The inner head of the gastrocnemins arises from the fomur immentiately alove the internal condyle. The space enclosed between these divereing lines forms part of the anterior boundary of the popliteal space, and is in rluse relation with the popliteal vessels. The shaft of the femur is overlapper on

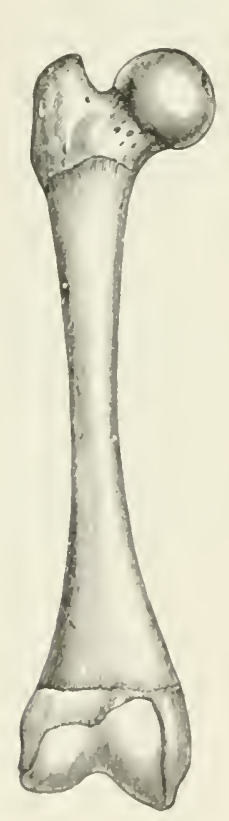

Fig. 160.-The Femitr At Bintil.

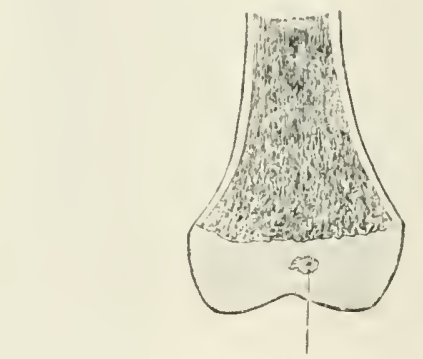

APPEARS EARLY IN THE NINTH MONTH OF INTRA-UTEFINE LIFE

the inner side by the vastus intermus, and on the outer side it gives origin in the upper three-fomithe to the crmens and is overlapjed by the custus catemus. The upper threefourths of the anterior surface serves for the origin of the erureus, and the lower fourth gives attathenent to the sulwerureus.

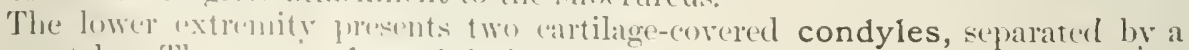
deep noteh. The external condyle is more pominent anteriorly and wiler than its fellow. The internal is more puminent jwsteriorly, and namower; it is also

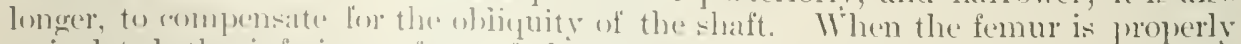
articulated, the inferien surfices of the condyles are nearly on the same plane, and almost paralled to (onme inte centaret with the articular surfares on the lead of the tihia. I'osteriorly the cmlyles are seprated ly a deel' pit or notch; anteriorly they are uniterl liy an articular surface, osor which the patella glides. The inner surface of the internal endyle lias, near its posterior border, a rough surface for the intemal lateral liganuent of the know-joint; above this is the adductor tuberele. The surface of this comlyle, which lumels the intercondyloid notch, affords

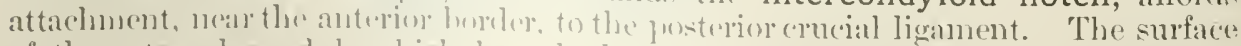
of the external condyle which bounds the notch gives attachment, at its posterior 
part, to the anterior crucial ligament. The outer surface of the extemal condyle presents near the lower and posterior margin a deep groove, which receives the tendon of the popliteus muscle when the leg is flexed. The anterior end of the groove terminates in a pit which gives origin to the popliteus tendon. The groove is surmounted by a tubercle for the external lateral ligament of the knec.

The patellar facet is trochlear in shape; its outer portion is more extensive than the inner, corresponding to the disposition of the articular facets on the posterior surface of the patella.

Fig. 161.-The Left Femor at tile Twextieth Year. (Posterior view.)

APPEARS IN THE FIRST, AND FUSES IN THE TWENTIETH YEAR

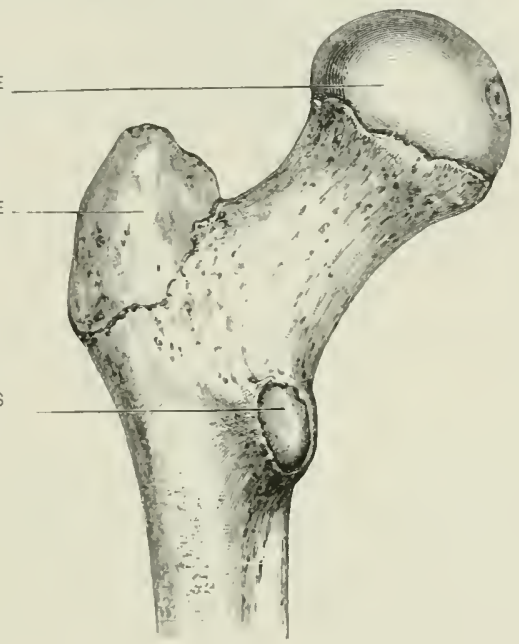

APPEARS IN THE FOURTEENTH, ANO UNITES IN THE EIGHTEENTH YEAR

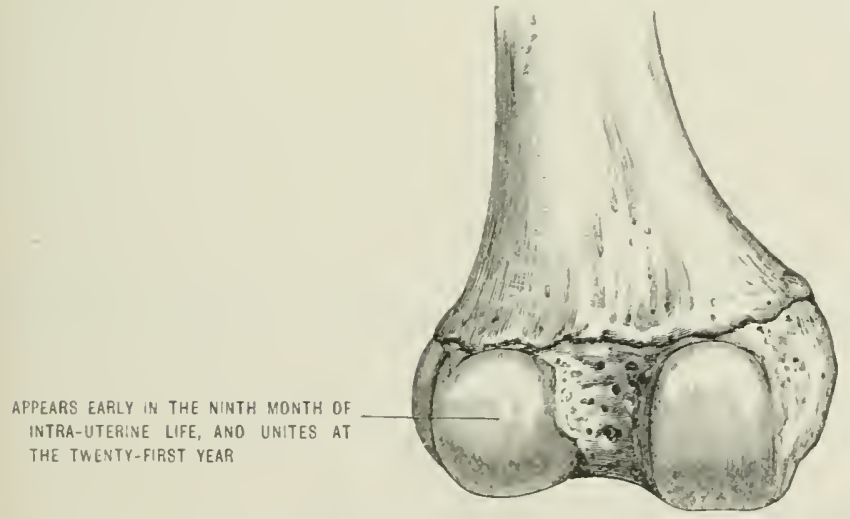

Muscles attached to the femur:-

Pyriformis.

Obturator internus and femelli.

Obturator externus.

Pectineus.

Quadratus femoris.

Gluteus maximus.

Gluteus medius.

Gluteus minimus.

Proas.

Iliacus.
Adductor brevis.

Vastus internus.

Adductor magnus.

Adductor lonerus.

Vastus externus.

Crureus and suberureus.

Biceps.

Gastrocnemins.

Plantaris.

Popliteus. 


\section{Ligaments :-}

Capsular of hip-joint.

Ligimentum teres.

linternal lateral of knee-joint.
External lateral of knee-joint.

Anterior crucial.

Posterior crucial.

Pisterior, or W'inslow's.

Blood-supply.-The had and neek of the fentur meive branches from the sciatic, ohturator, and circumflex arteries. The trochanter receives twigs from the circumflax arteries. The nutrient vessel for the shatt is derived from the second pertorating; it enters near the middle of the linea asperan, and is directed towards the head of the bone. The condyles are nourished by articular branches from the popliteal and the anastomotic of the fenoral.

Ossification.- The shaft of the femur begins to ossify in the seventh week of intra-uterine life. Early in the ninth month a nuclens appears for the condyles. J) uring the first rear the nucleus for the head of the bone is visible, and one for the greater trochinter in the fourth rear. The centre for the lesser trochanter is visible about the thirteenth or fourteenth vear. The lesser trochanter joins the shaft at the eighteenth, the greater trochanter at the nineteenth, the head about the twentieth, and the condyles at the twenty-first year.

The neck of the femur is an apophysis, or outgrowth from the shaft. The line of fusion of the condrloid "piphysis passes throngh the adductor tubercle.

The norphological relation of the patellar facet to the articular portions of the condres is worth notice. In a few mammals, such as the ox, this facet remains separated from the condyles hy a furrow of rough bone. In the human femur it is faintly mirked off by a shallow rroove in the cartilage, best seen in a recently opencil knee-joint. Some anatomists attribute these grooves in the cartilage to the pressure of the semilumar fibro-cartilages.

The angle which the neck of the femur forms with the shaft measures at birth, on an average, $160^{\circ}$. In the arlult it varies from $110^{\circ}$ to $140^{\circ}$; hence the angle Inereases greatly during the period of growth. When once growth is completed, the angle, as a rule, remains fixed. (Humphry.)

\section{THE PATELLA}

The patella is a sesmois bone, somewhat triangular in shape, situated in front of the knee-joint. Its anterior surface is slightly eonvex, and pitted with

\section{Frg. 16:- Time LefT PATElla.}
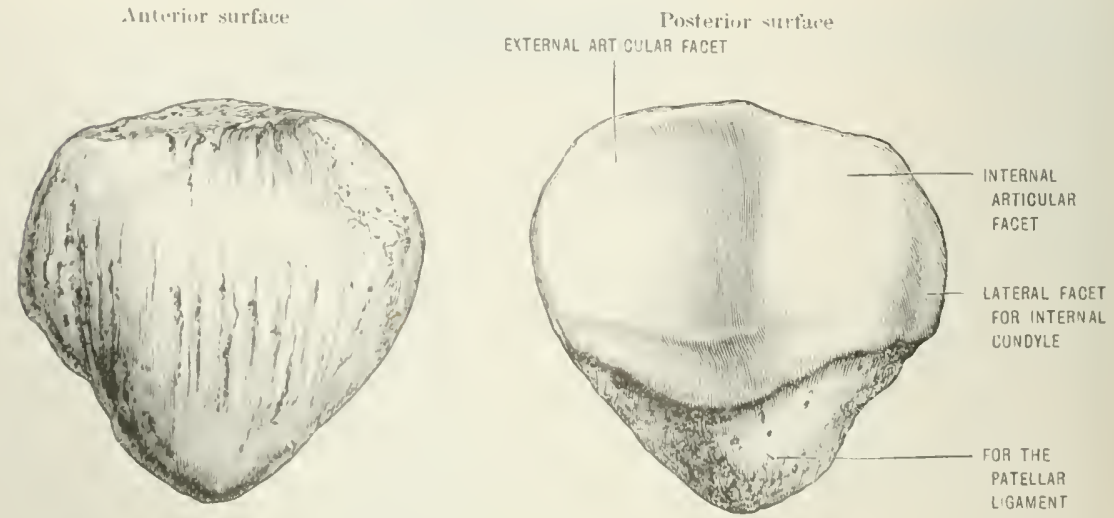

small openings, which transmit nutrient vessels to the interior of the bont. This 
surface is subcutaneous; a bursa intervenes between it and the skin. The posterior surface is concave, and in great part cartilage-covered, forming a compound articular surface for gliching upon the femoral condyles. A slightly marked vertical ridge divides this surface into an outer larger portion for the external condyle, and an inner portion for the internal condrle. A slender articular facet close to the inner edge is sometimes marked off by a faint vertical ridge; this facet comes in contact with the internal condyle in extreme flexion of the leg. The lower part of the bone is terminated by a blunt point, which is emberded in the patellar ligament, wpecially on the posterior aspect. The upper two-thirds of the circumference recoives directly the fibres of the vastus internus and coternus, the crureus and rectus temoris muscles.

Blood-supply.-The patella receives twigs from the superficial branch of the anastomotica, anterior tibial recurrent, and the inferior articular of the popliteal.

Ossification.-The rartilage for the patella appears in the fourth month of intra-uterine life. The ossitic nucleus is visible in the third year.

\section{THE TIBIA}

The tibia is the larger bone of the leg; it is situated on the inner side of, and nearly parallel with, the fibula. The upper extremity, or head, consists of two lateral eminences, or tuberosities. The superior surfaces of the tuberosities receive the condyles of the femur, the articular surfaces being separated by a non-articular ricige, to which ligaments are attached. The internal articular surface is oval in shape and concave for the internal condyle of the femur. The external articular surface is snaller, somewhat cireular in shape, and presents an almost plane surface for the external condyle. The peripleral portion of each articular surface is overlaid by a filmo-cartilage of semilunar shape, connected with the margins of the tuberosities by bands of fibrous tissue temed coronary ligaments. Each semilunar fibro-cartilage is attached firmly to the rough tract sciparating the articular surfaces. This intermediate space is broad and depressed in front, where it affords attachment to the anterior limb of the internal and external semilunar cartilages and the anterior crucial ligament. Projecting upwards from the midclle of this surface is the spine of the tibia. The posterior aspect of the base of the spine affords attachment to the posterior limb of the external and internal semilunar fibro-cartilages, and linits a deep notch inclined towards the inner tuberosity; this noteh gives origin to the posterior crueial ligament. Anteriorly; the two tuberosities are confluent, and form a somewhat flattened surface of triangular outline; its apex forms the tubercle of the tihia. The liganentum patella is inserted into the lower part of the tubercle; the upper part is smooth and separated from the ligament ly a bursa. Laterally; the inner tuberosity is less prominent though more "xtensive than the outer; near the posterior part of its circunference there is a deep horizontal groove for the eentral portion of the semimembranosus tendon. Tha margins of this groove and the surface of hone below give attachment to the internal lateral liganent of the knee. At a corresponding point of the outer tuberosity there is a rounded articular facet for the head of the fibula; the circunference of the facet is rough for liganents. Abore and in front of it is a ridge for the ilio-tibial band.

The shaft is prismatic, and very thick near the head; towards the lower third it is thinner and tapering, and gradually expands towards the lower end. It has three borders: the anterior is very prominent, and known as the crest of the tibia: commencing on the outer edge of the tuberele, it runs downwarls and eurves inwards, to teminate at the anterior margin of the malleolus. This border gives attachment to the deep fascia of the leg. The internal border starts from the back of the intemal tuberosity, and ends at the posterior margin of the malleolus. 


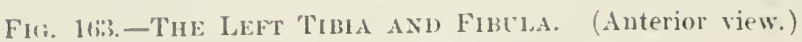

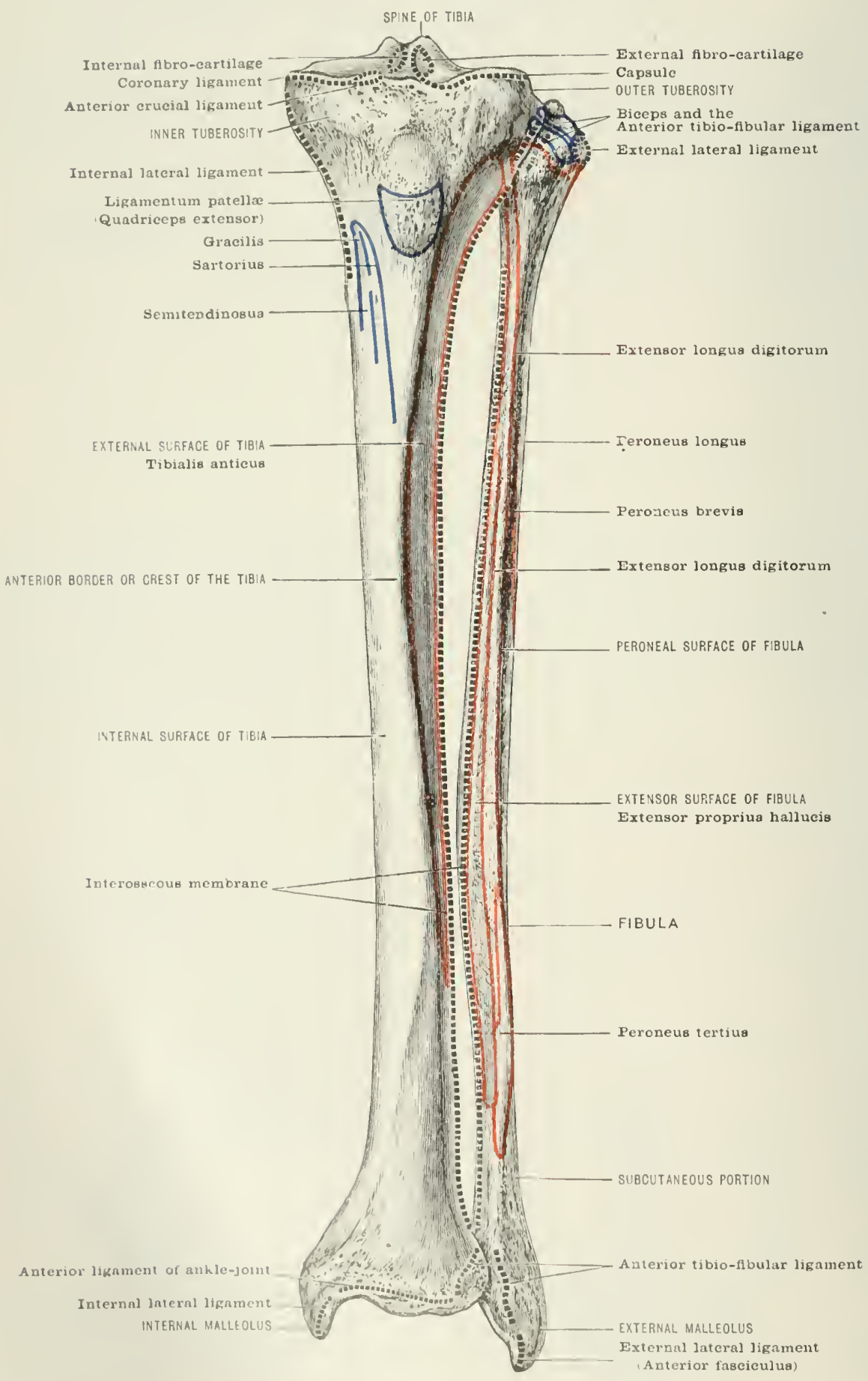


Fig. 164.-The Left Tibia and Fibula. (Posterior view.)

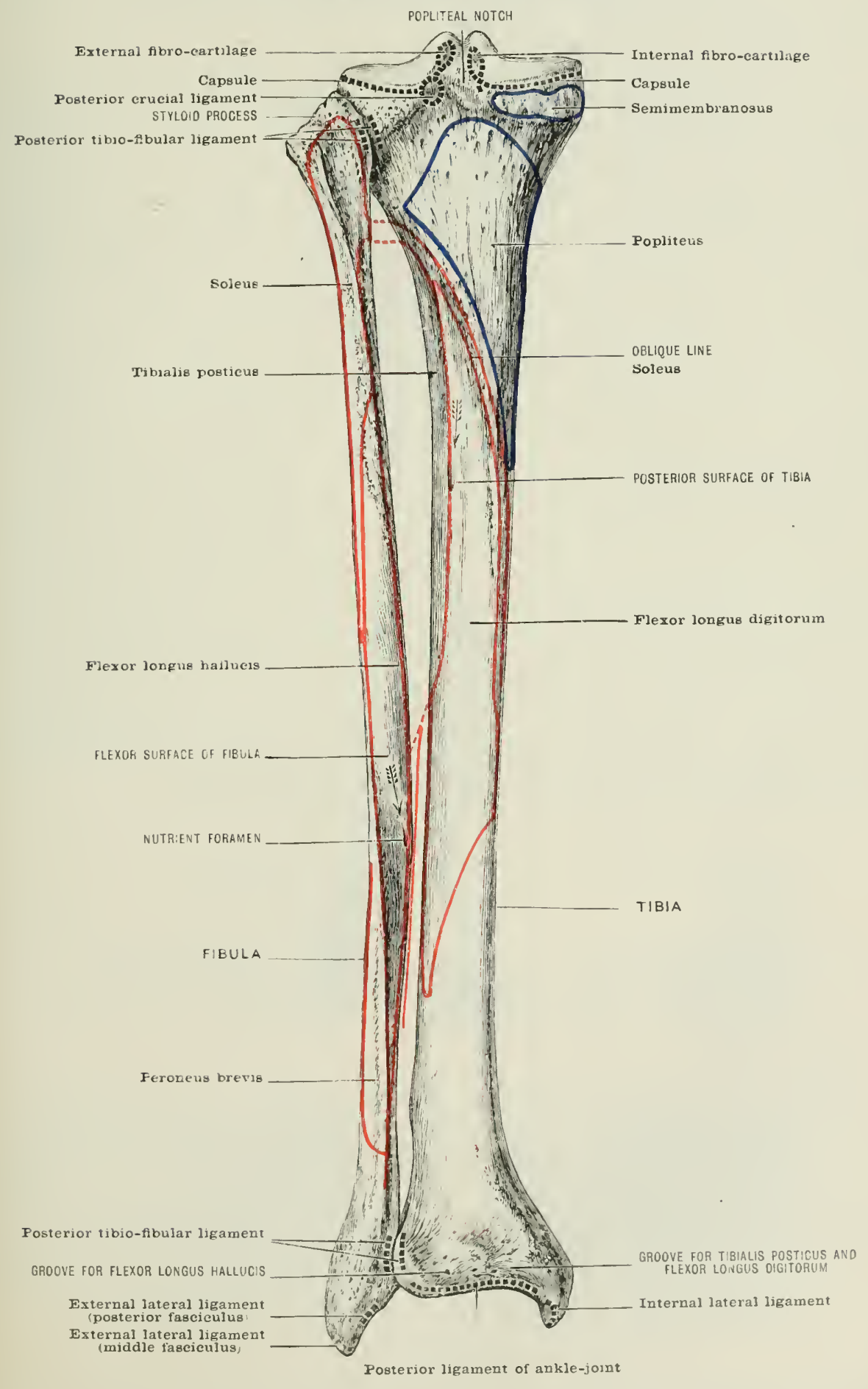


The intemal lateral ligament is attacherl to its upper 7.5 ('m. (3"), and the middle thim gives wrigin to the suleus. The interosseous border extends from the fibular face on the nuter tulwerosity to the lower end of the bone; towarls its termination the lorder lifureates to enclose a triangular space for the attachment of the interosseous ligannent lutween the tibia and fibula. The part above the bifurcation is connected with the interoricous membrane.

These borders linit three surfaces. The internal surface is bounded by the intemal horder and the arest; it is broal above, where it receives the insertion of the striturins, gracilis, and semitendinoses; the rest of the surfare is convex and subcutaneouls. The external surface lies between the erest of the tibia and the interosicols: horler. The upler two-thirds presents a hollow for the origin of the tibialis cutire!s; the rest of the surface is orerlaid by the extensor tendons and the anterior tibial ressels. The posterior surface is linited by the interosseous ridge and the internal border. The upper part presents a rough oblique ridge, extemling from the fibular facet on the outer tuberosity to the internal border, a little above the middle of the bone. This oblique ridge gives origin to the soleus and attarhment to the popliteal fascia; the surface above is for the insertion of the popliters. An indefinite rertical ridge commences near the middle of the oblique line, and marks oft a semilunar space, linited externally by the interosseous borler. This is for the tibialis posticus; it extends as low as the junction of the middle and lower thirds. The portion of bone inside this vertical line is for the flexor longus digitrum. The lower third of the posterior surface is covered by flexor tendons.

The inferior extremity is somewhat quadrilateral, and resemiles the distal end of the rarlius. Its inferior surface is articular for the upper surface of the astragalus and is continuous with the external surface of the malleolus. which articulates with the facet on the inner side of the astragalus. The outer surface has a triangular rough area for the lower end of the shaft of the fibula, its margins being rough for ligaments. The anterior border is slightly convex, and by its margin gives attachment to the anterior ligament of the ankle. The posterior surface has two grooses: the one which ancroaches on the malleolus is for the tendons of tibialis posticus and Hexor lomgus digitorum, and an outer shallow groove for the tendon of flexor Inngis: hulluris. The immer surface is prolonged cownwards to form the malleolus; from its tip and margins the internal lateral (deltoid) ligament of the ankle-joint arises. The imner surface of the malleolus is convex and subcutaneous; the outer, as already stated, has a facet for the inner surface of the astragalus.

The tihia affords attachment to the following muscles:-

Simimembranosus.

Sartorius.

(iratilis.

simentendinosus.

Quadriceps extensor.

Popliteus.

T(ust)r vaginate femoris (indirectly).
Tibialis postieus.

Tibialis anticus.

Soleus.

Peroneus longus.

Flexor longus digitorum.

Extensor longus digitorum.

Bicegs femoris.

\section{Ligaments :-}

\begin{tabular}{|c|}
\hline 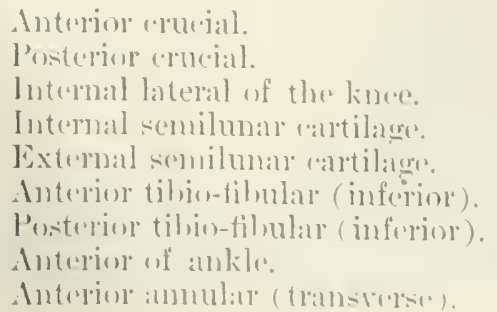 \\
\hline
\end{tabular}

Antrior revejil.

losterior erucial.

Intermal lateral of the kise.e.

Intermal semilunalr ariltilan.

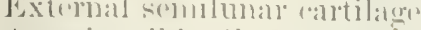

Posterior tihio-filoular (inforior)

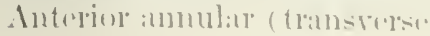

Thansтerse

\author{
Coronary \\ Anterior tilio-fibular (superior). \\ Posterior tihio-fibular (superior). \\ Tlio-tibial band. \\ Interosisous membrane. \\ Anterior annular (oblique). \\ Internal amular. \\ Internal lateral of ankle (deltoid). \\ Posterior (of ankle).
}

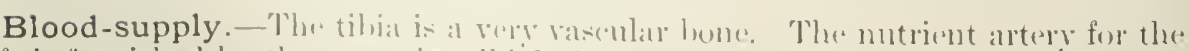

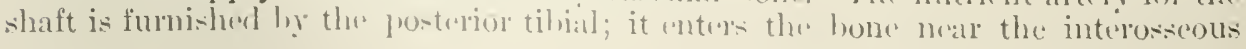


border at the junction of the upper and middle thirds, and is directed clownwarls. The head of the bone recires numerous branches from the inferior articular arteries of the popliteal, and the recurrent branches of the anterior and nosterior tibial arteris. The lower extremity receives twigs from the posterior and anterior tibial. the anterior peroneal, and intemal malleolar arteries.

Fig. 165.-The Tibia Axd Fibled at the Sixteextir Yedr.

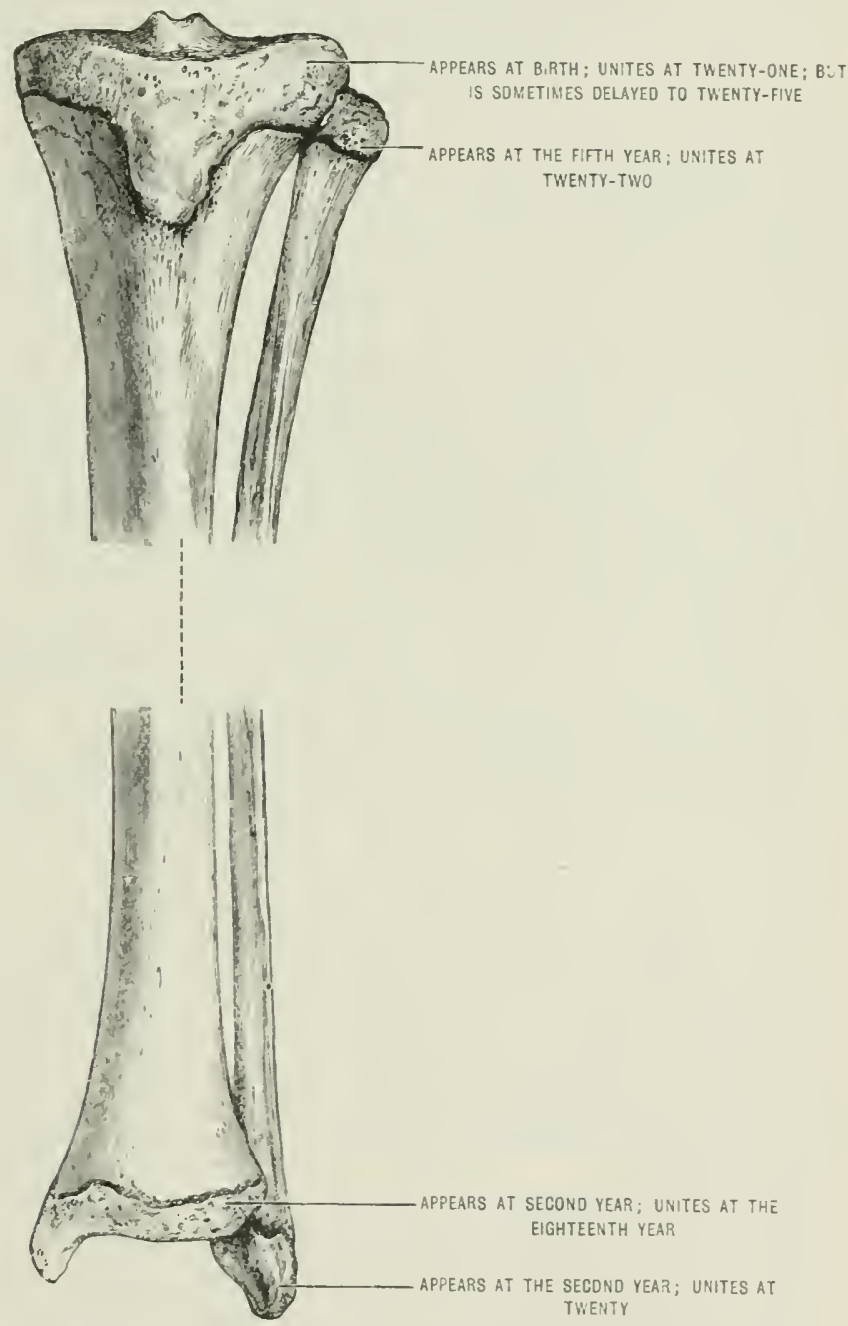

Ossification.-The centre for the shaft of the tilia appears in the eighth week of intra-nterine life. Towards the end of the ninth month, a small earthy nucleus appears in the cartilaginous head of the tibia. The nucleus for the lower extrenity appears in the second rear, and unites with the shaft at eighteren. The epiphysis for the head of the bone is one of the last to unite with its shaft; this. event usually occurs about the twenty-first year, but nuay be delaved until twentyfive. The tubercle of the tibia is usially ossified from the epiphysis; orcasionally it has an indejendent nucleus. 


\section{TIIE FIBULA}

This is a long slender bone lying postero-externally in the leg, to the outer side of and somewhat justerior to the tibia, with which it articulates both above and below. It is reluted from the knee-joint l,ut forms the outer boundary of the ankle-joint.

The upper extrenity, or head, is a rounded prominence. Its upper surface is mong externally for the attachment of the biceps tendon and the long external lateral ligament of the knee-joint; internally it presents a round or oral artieular facet for the outer tuberosity of the tibia; the margins of this facet give attachment to

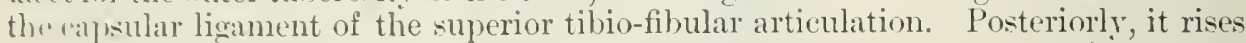
into a pointed process, the styloid process, which gives attachment at its apex to the short external lateral ligament of the knee and laterally to part of the biceps tendon. The posterior aspect of the head gives attachment to the solens, the outer to the pernens longus, the anterior to the extensor longus digitorum, and the inner lies acljacent to the tibia.

The lower extremity, external malleolus, is a triangular piece of bone placed with the base uppermost. Its outer surface is convex and subeutaneous. The inner surface is divided into an anterior and upper area, triangular in outline and convex from above downwards for articulation with the outer side of the astragalus, and a lower and posterior excavated area, the digital fossa, in which are attached the transverse inferior tibio-fibular ligament and the posterior band of the external lateral ligament of the ankle. The anterior border is rough; it gives attachment to the anterior band of the external lateral ligament of the ankle, the anterior inferior tibio-fibular ligament, and the anterior annular ligament. The posterior border is grooved for the peronei tendons, and the apex gives attachment to the middle band of the external lateral ligament of the ankle.

The shaft is quadrangular, possessing four horlers and surfaces. The anteroexternal border commences in front of the head and terminates below liv dividing to ('nclose the subcutaneous surface on the outer side of the external malleolus. The antero-internal border also commences in front of the head, close to the anteroexternal horder; it terminates below by dividing to enclose a rough triangular area immediately above the facet for the astragalus; this area gives attachment to the inferior interosseous ligament, and sometimes bears at its lower end a narrow facet for the tibia. The postero-internal border commences at the inner sick of the hear and terminates below by joining the antero-internal border at the upprer part of the lower fourth of the shaft. The postero-external horder rums from the back of the hearl to the inner border of the peroneal groose on the back of the lowrex extrenity; it gives attachment to the fascia separating the peronei and the flexur mustes.

Th. anterior or extensor surface between the antero-internal and antero-external borkes is narow above but broader below; three museles spring from it: externally in the upper two-thirds the extensor longus digitomm, and in the lower third the permens: tertins; internally in the middle third the extensor longus hallucis. The internal surface hetween the antero- and postero-internal borders is usually concare; it is narrow abore and below, and broalest in the middle; it is frequently crossed hy come or more obligue ridges, and it gives attachment to the tibiulis posticus. The posterior surface between the postero-internal and external borders is twisted; it lowks backwards alsowe and inwarls below; in its upper third it gives attarhment to the solens and in the lower two-thirkls to the flemor longus hallucis. The external surface between the antoro- and postero-external borlers is also twisted, looking outwarls ahowe and barkwarks below, where it is continuous with the groove on the peronei tomdoms; it gives attachment in its upper two-thirds to the permens longus and in the lower two-thirds to the peromens brevis.

The muscles arising from the fibula are:-

Soleus.

Tibialis posticus.
P'eronens tertius.

Flexor longus hallucis. 
Peroneus longus.

Peroneus brevis.
Extensor longus digitorum.

Extensor proprius hallucis.

The fibula affords insertion to the biceps.

The following ligaments are connected with it:-

External lateral of the knee.

Anterior tibio-fibular.

Posterior tibio-fibular.

Interosseous membrane.

External lateral ligament of ankle.
Transverse.

Anterior tibio-fibular (inferior).

Posterior tibio-fibular.

External annular.

Anterior annular (vertical).

Blood-supply.-The fibula receives the nutrient artery of its shaft from the peroneal branch of the posterior tibial. The head is nourished by branches from the inferior external articular branch of the popliteal artery, and the malleolus is supplied mainly by the peroneal, anterior peroneal, and external malleolar arteries.

Ossification.-The shaft of the fibula commences to ossify in the eighth week of intra-uterine life. A nucleus appears for the lower in the second year, and one in the fifth year for the upper extremity. The lower extremity fuses with the shaft about twenty, but the upper one remains separate until the twenty-second year.

The human fibula differs from all others in the excessive length of its malleolus; in no other vertebrate does this process descend below the level of the tibial malleolus. In the majority of mammals the tibial descends to a lower level than the fibular malleolus. In the human embryo of the fourth month, the outer (fibular) is very much smaller than the inner (tibial) malleolus. At the serenth month they are equal in length; at birth, the fibular malleolus is the longer; and by the second year it assumes its adult proportion. (Gegenbaur.)

The fibula is a restigial bone in man, and survives mainly on account of the excessive development of its malleolus. This accounts for the fact that the lower epiphysis, though appearing first, unites with the shaft before the upper epiphysis. In hirds, the head of the bone is large, and enters into the formation of the kneejoint, whilst the lower end atrophies.

\section{THE FOOT}

The bones comprised in the skeleton of the foot are arranged in thrce groups:tarsus, metatarsus, and phalanges.

The tarsus consists of seven bones:-The astragalus, os calcis or calcaneum, scaphoid, cuboid, and three cuneiform bones.

\section{THE ASTRAGALLS}

This bone may, for descriptive purposes, be divided into a body, neck, and head. The body is quadrilateral. Its upper aspect resembles a segment of the wheel of a pulley; hence it is called the trochlear surface. It is broader in front than behind, and articulates with the lower end of the tibia.

The inferior surface is occupied by an elongated concave facet for articulation with the calcaneum.

The internal surface presents a pyriform facet, broad in front, and continuous with the trochlea: it articulates with the tibial malleolus. Below this facet, the inner surface is rough for the attachment of the deep fibres of the dcltoid ligament.

The external surface is almost entirely occupied by a triangular concare facet, broad above where it is continuous with the trochlea, for articulation with the fibular malleolus. 
The posterior surface is little more than a ridge of bone traversed obliquely hy a deere rroove, which receives the tendon of the flexor longus hallucis musele. Extemally, this groove is limited by a prominent tulerele, which affords attachmont to the posterior fasciculus of the external lateral ligament of the ankle.

Fis. 166.-TuE Left Foot. (Dorsal surface.)

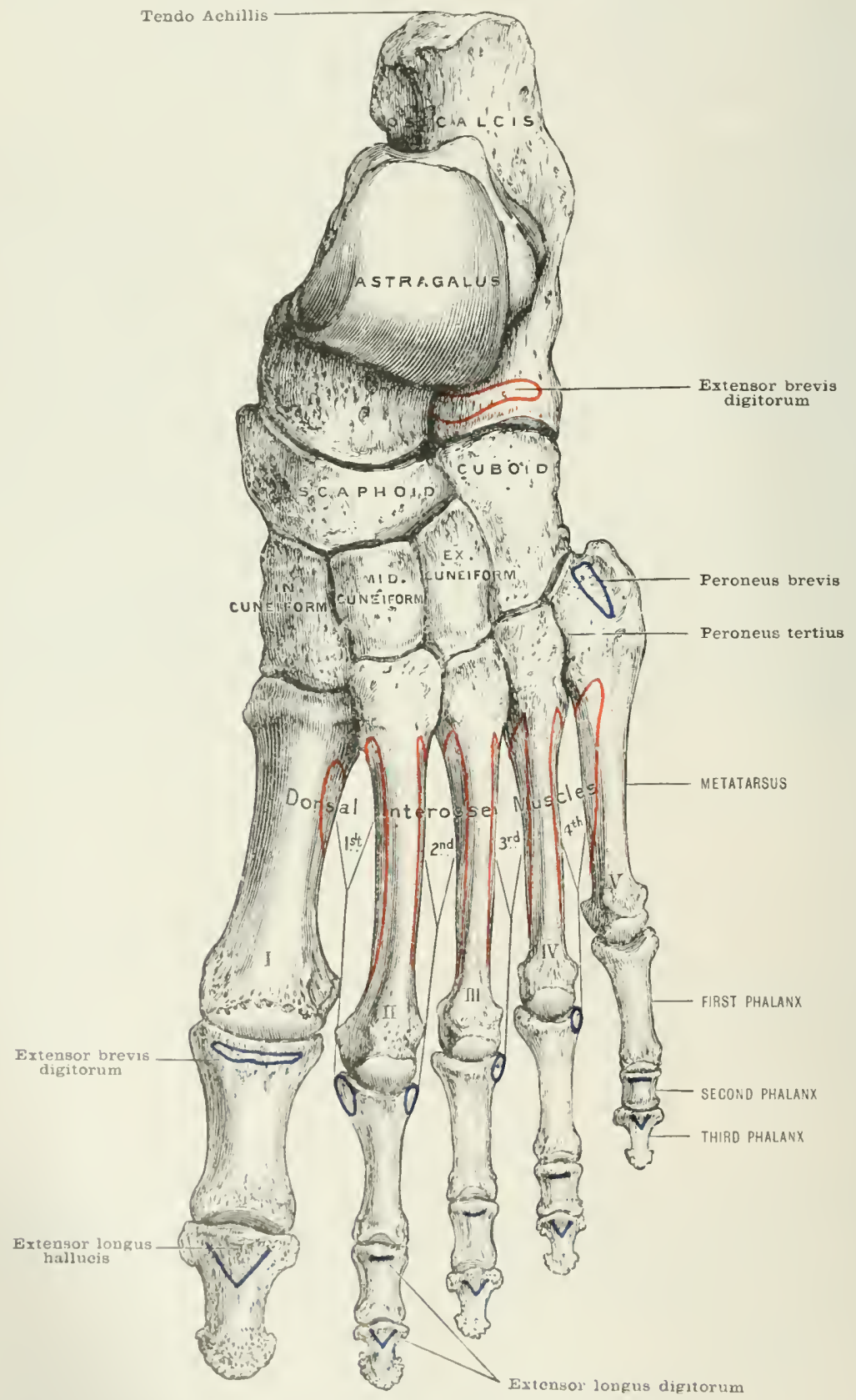

The neck is the constricterl portion of the home, and is continuous posteriorly with the body of the astragalus. Superiorly, the neck is rough, and has numcrous foramina for blood-ressels. Inferiorly, it puesents a deep groove, directed from 
behind forwards and outwards. When the astragalus is articulated with the calcaneum, this furrow is converted into a canal in which is lodged the calcancoastragaloid (interosseous) ligament. The inner edge of this furrow is limited by an articular facet, which runs forwards to become continuous with the facet on the

Fli. 16i.-The LeFt Foot. (Plantar surface.)

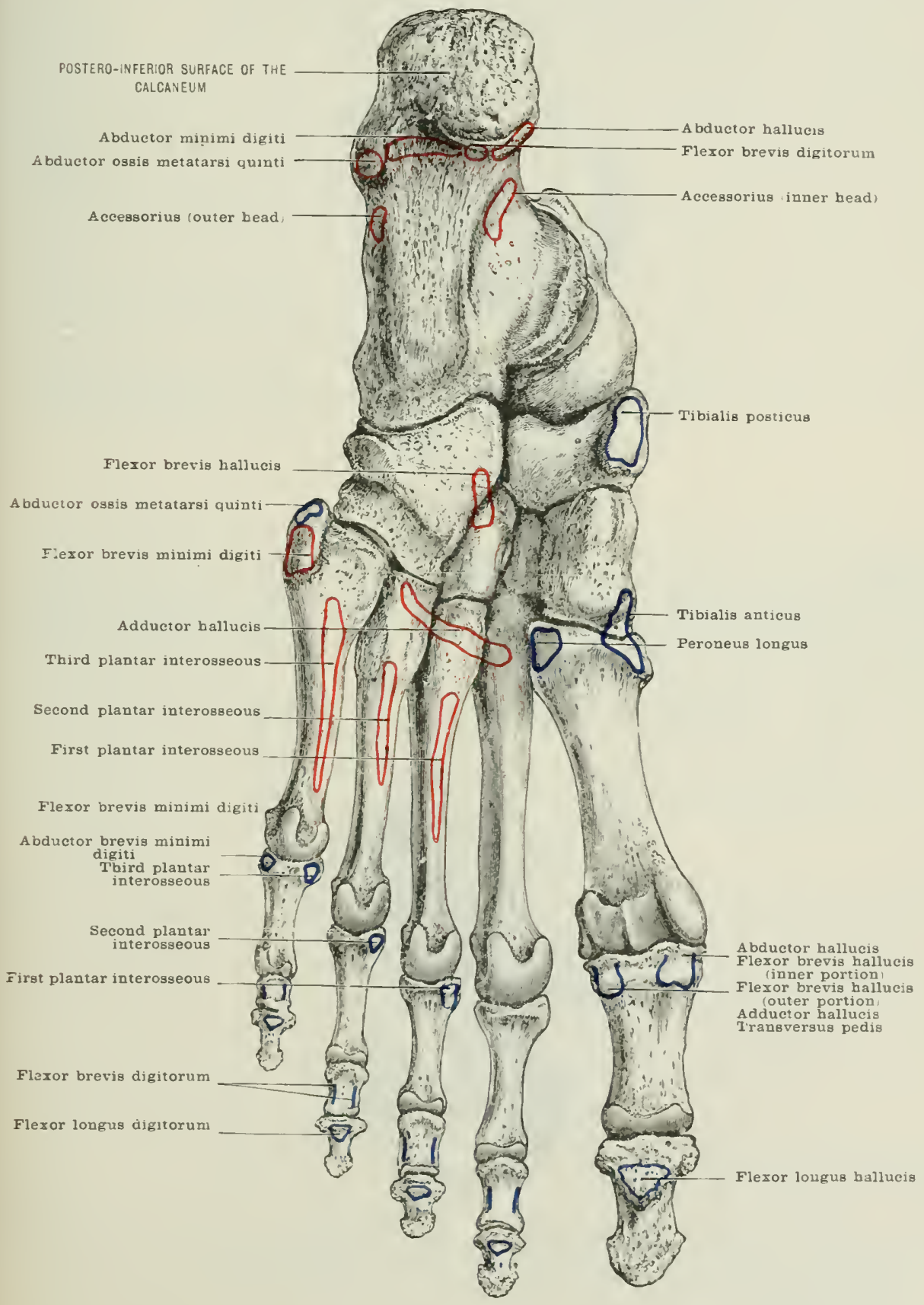

head of the bone, and. like the articular surface of the sustentaculum tali of the calcaneum on which it glides, is sometimes divided.

The head of the astragalus is furnished anteriorly with an ovoid facet, which 
is reservent by the posterior surfine of the seaphoist. On the inner and lower part, at the spen where the sustentareular fareet becomes (o)nfluent with that on the head, there is a smaller facet separated by a ridge: this plays upon the calcaneo-scaphoid or spuning ligament.

The os trigonum.-Ocrasionally the small portion of the astragalus posterior to the trochleale surfice containing the groove which lodges the flexor longus:

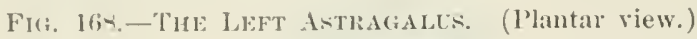

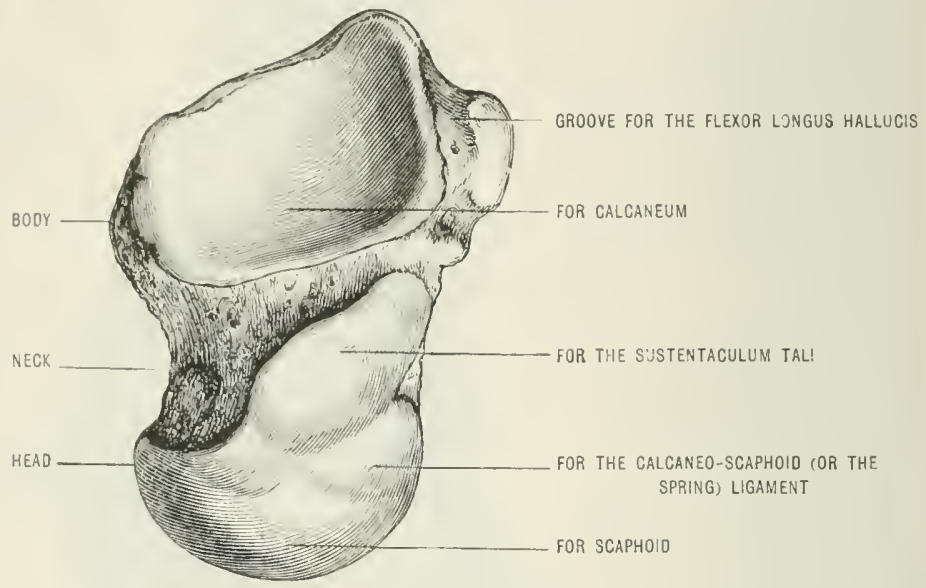

lulluris tendon is separate from the rest of the astragalus, and is known as the os trigonum, or secondary astragalus (fig. 169).

Articulations.-The astragalus articulates with four bones, the tibia, fibula, scaphoirl, and culcancum; and presents seven articular facets; and when the facet for the sustentaculum tali is divided, as is so often the case, the articular surfaces

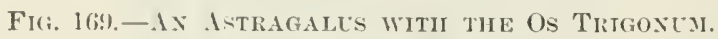

CS TRIGONUM

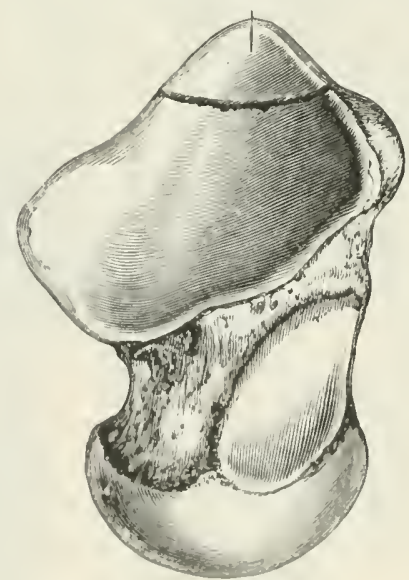

are increased to eight. Sometinses it presents a fincet on the outer margin of its heal for the cuboil, thus increasing the articubar surfiers to nine.

Ligaments :-

Internal lateral licrament (ctultoicl). Extermal bateral liganment. Astragalo-scaphoid.
Caleane(r)-astragaloid (interosseous). Extermal ("aleanerr-astriagaloid. Posterior calcanne(o-astragaloid. 
Blood-supply.-The astragalus is supplied by the dorsalis pectis artery and its tarial branch.

Ossification.-The astragalus is ossified from one, oreasionally from two, nuclei. The principal centre for this bone appears in the niddle of the cartilaginous astragalus at the seventh month of embryonic life. The additional centre is deposited in the posterior portion of the bone, and forms that part of the astragalus which, when it remains separate from the rest of the bonc, is known as the os trigonum. At birth, the astragalus presents some important peculiarities in the disposition of the articular facet on the tibial sirle of its borly, and in the obliquity of its neck. If, in the adult astragalus, a line be drawn though the middle of the trochlear surface parallel with its inner border, and a second line he drawn along the outer side of the neek of the bone so as to intersect the first, the angle formed by these two lines will express the obliquity of the neek of the bone. This in the adult varies greatly, but the arerage may be taken as $10^{\circ}$. In the fortus at hirth the angle averages $35^{\circ}$, whilst in a young orang it measures $45^{\circ}$. In the nomnal adult astragalus the articular surface on the tibial side is limited to the body of the bone. In the foetal astragalus it extends for some distance on to the neck, and sometimes reaches almost as far forward as the seaphoid facet on the head of the bone. This disposition of the inner malleolar facet is a characteristic feature of the astragalus in the chimpanze and the orang. It is related to the inverted position of the foot which is found in the human embryo to near the period of birth, and is of interest to the surgeon in comnection with some varieties of club-foot. (Shattock and Parker.)

\section{TIIE CALCANEUM}

The calcaneum, or os calcis, is the largest tarsal bone. It is cuboidal in shatpe, and presents, for exanination, six surfaces.

The superior surface has in its middle a large, oval, convex, articular facet for the unter aspect of the body of the astragalus; behind the facet, the bone is rough and convex laterally. In front of the facet the bone presents a deep depression, the floor of which is rough for the attachment of ligaments, especially the alcaneo-astragaloid, and the origin of the extensor breris digitorum muscle; when the calcanem and astragalus are articulated, this portion of the bone forms a floor to a cavity sometimes ealled the sinus pedis. Internally, this upper surface of the bone presents a well-marked lip, the sustentaculum tali, fumished with an clongated concare facet, occasionally divided into two, for articulation with the neck of the astragalus.

The inferior surface is narrow and rough; it ends posteriorly in two tubercles: the inner is the larger and broader, the outer is narrower but prominent. The inner tubercle affords origin to the abductor hallucis, the flexm brevis digitorum, and the abductor minimi digiti; the last muscle also arises from the outer tubercle, and the ridge of bone connecting the tubcreles. The outer tuberele aftords attachment to the abductor ossis metatarsi quinti. The rough surface in front of the tulnercles gives attachment to the long plantar ligament (calcaneo-cuboid) and the outer head of the flexor accessorius. Near its anterior end this surface forms a rounded cminence, the anterior tubercle, from which (and the shallow groove in front) the short plantar (calcaneo-cuboid) ligament arises.

The external surface is rougl and slightly convex. Near the middle of this surface there is a small tubercle for the middite fasciculus of the extemal lateral ligament of the ankle-joint. Anteriorly, we notice the two shallow peroneal grooves, separated by a tubercle, which is sometimes very prominent. The upper groove is for the tenton of the peronens brexis, and the lower lodges the tendon of the peroneus longus.

The inner surface is deeply concave, the hollow being increased by the overhanging sustentaculum tali in front and above, and the prominent inner tubercle posteriorly. The under aspect of the sustentaculum is deeply grooved for the tendon of the flexor longus halluris, whilst the hollow below receives the plantar vessels and nerves. Its lower border serves for the attachment of the inner head 
of the Hecor aceessmius. The margin of the sustentaculum has attached to it a part of the deltoid ligament.

The anterior surface is a concare articular farcet for the posterior surface of the (ubuil. Its outer and superior angle is somewhat prominent.

Fig. 170.-The Left Calcaxecy. (Dorsal view.)

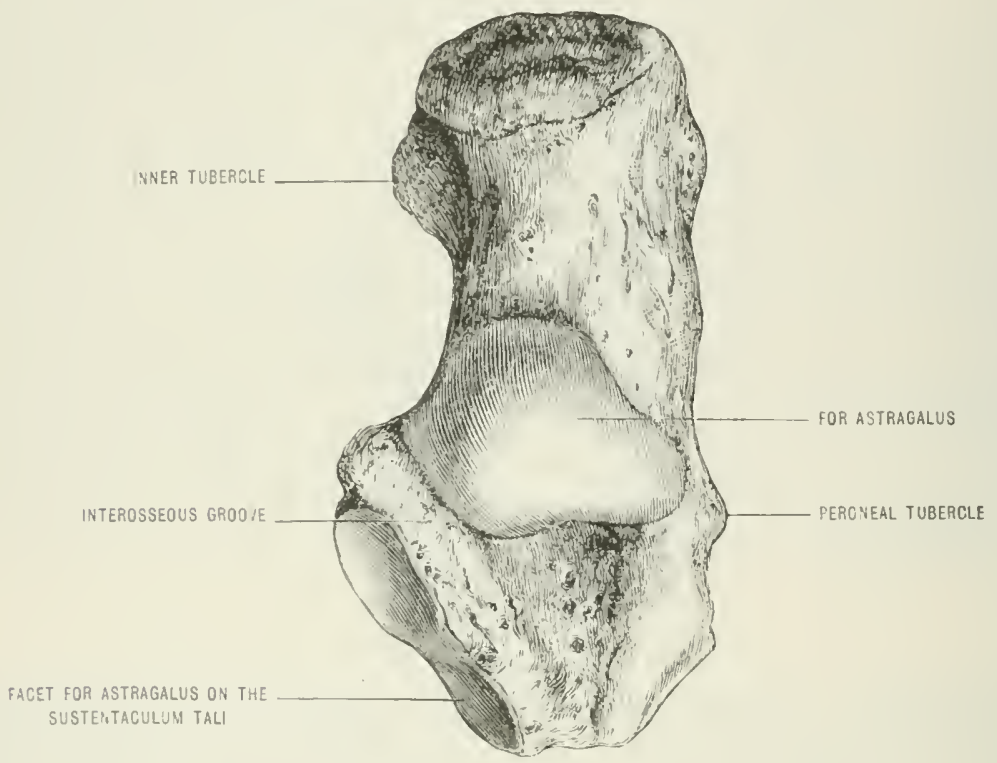

The posterior surface is roughly romeled: the lower part gives attachment to a pad of fat; the middle part serres for the attachment of the tendo Achillix. At its mper part it is smooth, and is in relation with a bursa.

Articulations.- The (alcaneum articulates with the cuboid, the astragalus, and with the os trigonum whon it exists as a separate element.

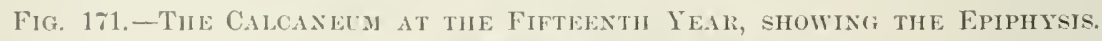

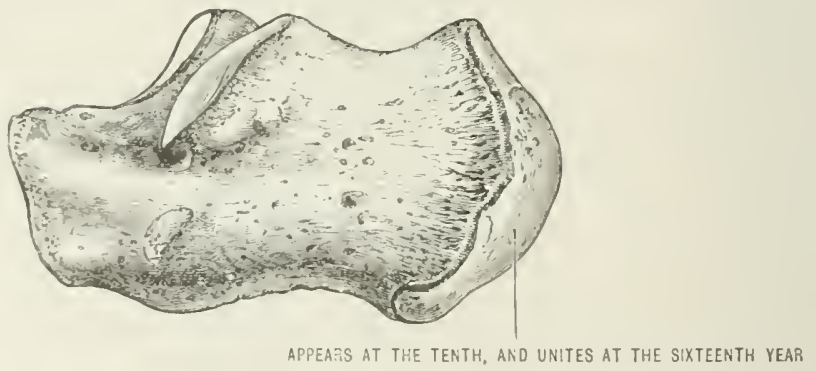

Muscles attached to the calcaneum:-

Extensor lireris digiterum.

Alrluctor hislluejs.

Flexor lorevis digitormm.

Abductor minimi digriti. And a slip, from the tibialis posticus.

\section{Ligaments :-}

Intermal lat trail of ankle.

External lateral of ankle.
Mrluctor ossis metatarsi quinti.

Arecsionilus.

Temrlo Achillis.

Plintaris. 
Superior calcaneo-cuboid ligaments. External calcaneo-astragaloid.

Inferior calcaneo-cuboid ligaments. Posterior calcaneo-astragaloill.

Intemal annular.

External annular.

Superior calcaneo-scaphoid.

Inferior calcaneo-scaphoict.

Blood-supply.-The calcaneum is a rascular bone, and derives its blood from the posterior tibial, and the internal and extemal malleolar arteries.

Ossification.-The primary nucleus for this bone is deposited in the sixth month of embryonie life. In the tenth year a nucleus appears for the epiphysis at the heel, and unites with the body of the bone at the sixteenth year. The inner and outer tubercles are formed by the epiphysis.

\section{THE CLBOID}

This bone is situated on the outer side of the tarsus; its posterior surface is reniform in shape and articular for the anterior face of the calcaneum. The anterior surface is smaller, and divided by a low rertical ridge; the imner facet is for the base of the fourth, the outer facet receives the base of the fifth metatarsal bone. The upper (dorsal) surface is rough and non-articular. The inferior (plantar) surface is divided by a prominent ridge, which limits a deep furrow

Fig. 172.-The Left C'boid. (Inuer view.)

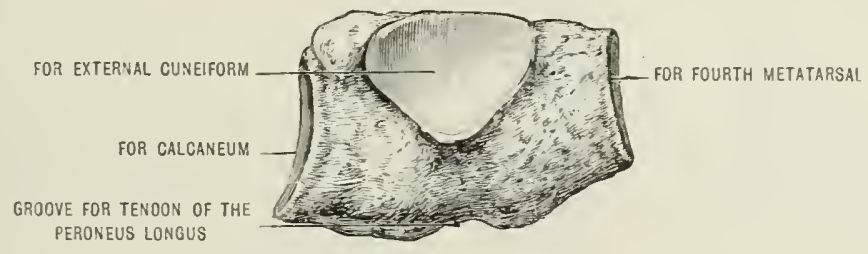

Fig. 173.-The LEFT CuBoid. (Inner riew.)

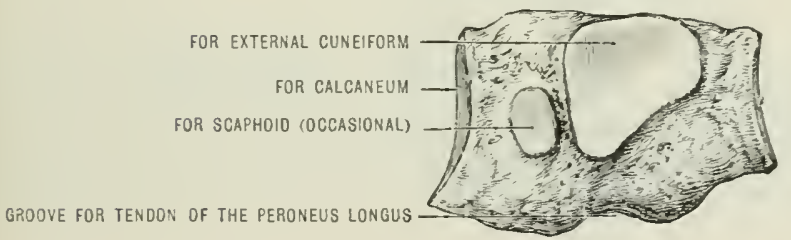

Fig. 174.-TIIE LEFr C'ciBoIn. (Inner view.)

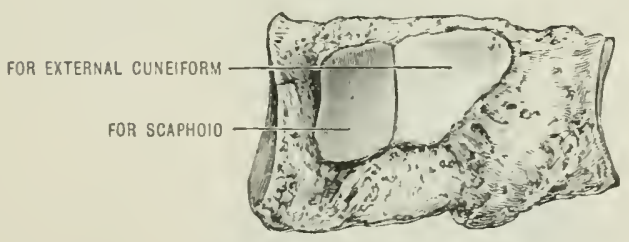

directed from without forwards and inwards. This, the peroneal groove, lodges the tendon of the peroneus longus.

The corner of the ridge on the narrow outer (fibular) border of the hone is usually faceted for a sesamoid bone frequently found in the tendon of the peroneus longus. The margin of the ridge and the surface of hone hehind it afford attarchment to the long and short plantar (calcaneo-cuboirl) ligaments. The flexor breris hallucis muscle has a small attachment to this part of the cuboid. 
The internal surface presents near its middle anel upper part an oval facet for articulation with the external (anneiform lone (fig. 17.2): lechind this, a second facet for the seaphoid is frecuently sren (fig. 173). (iencrally the two facets are contlume and form an elliptical surface (fig. 17t). The remainder of the internal surface is romerh, and has strong interosiseons ligaments attached to it.

Jutting from the inferior internal angle of the posterior surface is a process of home calcancan process of euboid), which projects heneath the sustentaculum tali. This process nceasionally terminates in a rommled facet. which plays on the heacl of the astragilus externil to the face for the spring ligament.

Articulations. - The cuboid articulates with the calcanemm. the external cumeiform. the fourth and fifth metatarsal bones, frequently with the scaphoid, and oce:sionally with the astragalus.

Muscles attached to the cuboid:-

Tihialis posticus.

Flexor brevis hallucis.

\section{Ligaments :-}

Siuprior calcaneo-cuhoid.

Inferior calcaneo-cuboid.

Interosseous and the cubo-scaphoid ligaments.

Ossification.- The cuboid is ossified from a single centre which appears a few weeks after hirth. Oceasionally the nucleus is visible as a minute earthy spot in the middle of the cartilage at hirtli.

\section{THE SCAPHOID}

The scaphoil (navicular) bone receives in the hollow of its posterior surface the head of the astragalus. Anteriorly it is convex, and dividerl by two vertical ridges into three facets, for the internal, middle, and external cuneiform bones.

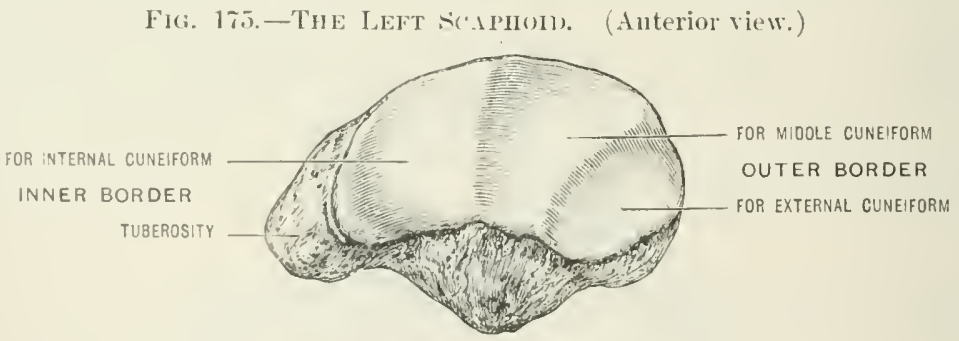

Occascionally a fourth facet, "xtrenely rariable in size, is seen at the outer inferior angle for thi. "ulviel.

The upper (dwrial) surface is rough and broad; the inferior (plantar) surface

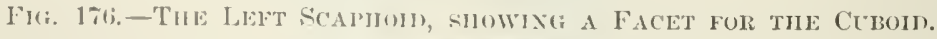

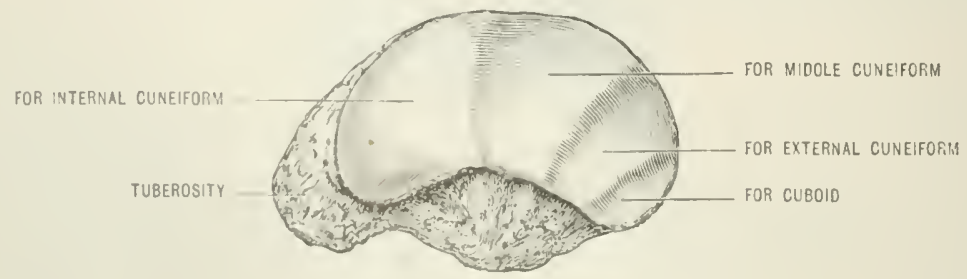

is mothing more than al ridgre. The outer surface is romely for ligaments; whilst the inner forms a large :met prominent eminener. the scaphoid tuberosity, which

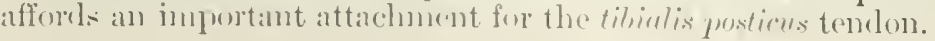


Articulations. - With the head of the astragalus, with the three cunciform bones, and frequently with the cuboirl.

Muscle attached to the scaphoid.-The tibialis posticus is inserted.

Ligaments :-

Dorsal, plantar, and interosseous cubo-scaphoid.

Dorsal and plantar scapho-cuneiform.

External and inferior calcaneo-scaphoirl.

Astragalo-seaphoid.

Ossification.-The nucleus for the scaphoid appear's in the course of the fourth year. The tubercle of the scaphoid, into which the tibialis posticus aequires its main insertion, oceasionally develops separately, and sometimes remains distinct from the rest of the bone.

\section{THE CUNEIFORM BONES}

The cuneiform bones, three in number, are named from within outwardsinternal, middle, and external. They are wedge-shaped.

The INTERNAL CUNEIFORM is distinguished by its large size, and from the ficet that, when articulated, the base of the wedge is directed downwards, and the

Fig. 177.-The Left Intersal Cuneifoki. (Internal surface.)

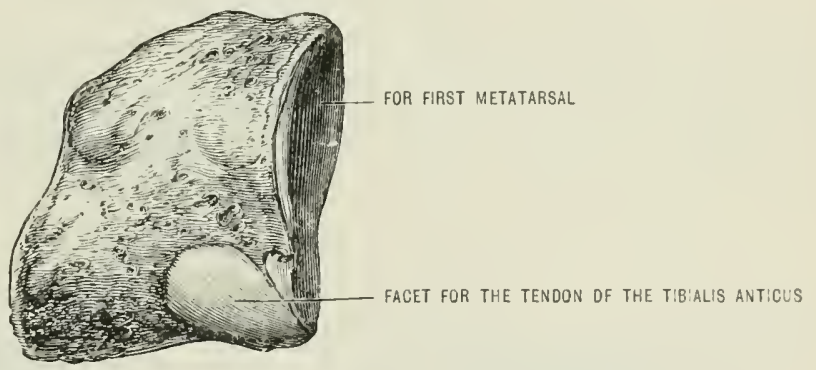

sharp border upwards. The posterior surface is concave and pyriform for articulating with the immer facet of the scaphoid. The anterior surface is a reniform articular facet for the base of the first metatarsal. The internal surface is rough, and presents an oblique groove for the tendon of the tibialis anticus: this groove is limited inferiorly by an oval facet into which a portion of the tendon is inserted.

Fig. 178. -The Left Interial Cuxeifols. (External surface.

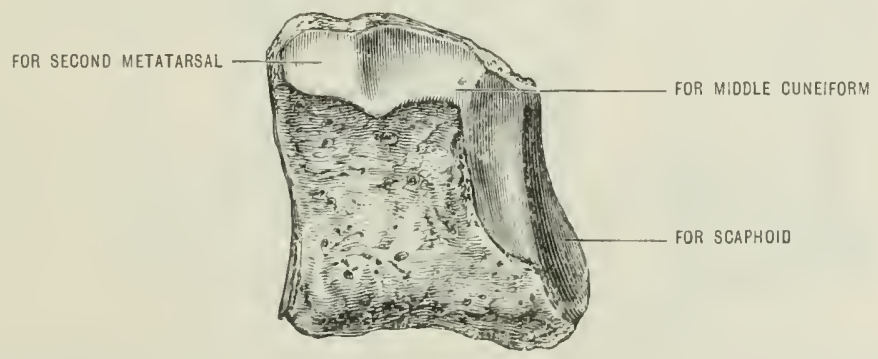

The external surface is concave and rough, except along the posterior and superior borders. Near the anterior extremity of the superior border there existe a distinet circular facet for the inner side of the base of the second metatarsal. In front of the facet a few fibres of the first dorsal interossous muscle arise. The remaining sinuous artieular facet is for the imner surface of the middle cunciform. 
Articulations. - With the scaphoid, midelle cuneiform, and the first and second metiltarsial.

Muscles.-Tihialis antieus and posticus, the peroneus longus, and first dorsal interosionts.

Ossification. - A single muclens, which appents in the course of the third year.

"The MIDDLE CUNEIFORM, the smatlest of the three, has its base directed upwards and the sharp border clownwards. The posterior concave surface is

Fu. 179.-TиE LEFT Minde ('uxemfory. (Internal surtace.)

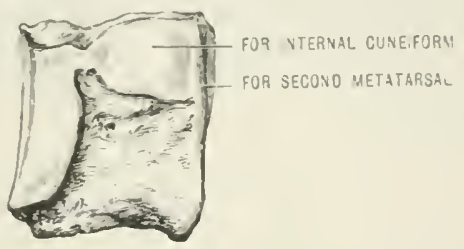

articular for the middle facet of the scaphoid. The anterior, somewhat narrower tham the posterior surface, articulates with the base of the second metatarsal. The internal surface has a facet extending along its upper and posterior borders for the

Fid. 1 $>0,-T i n$ Left MiDnle Crxeiforis. (External surface.)

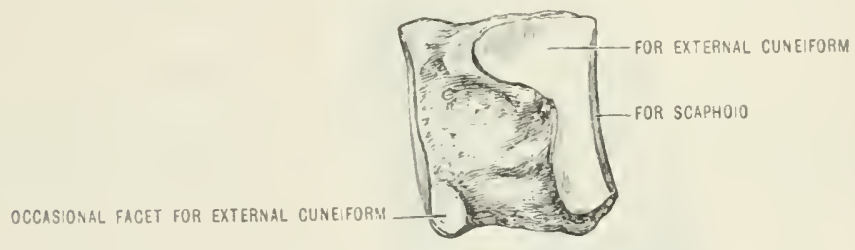

internal cunciform. The external surface has a facet along the posterior border, and occasionally one at the anterior inferior angle for the external cuneiform.

Articulations. - With the internal and extemal cuneiformi bones, the scaphoid and the second metatarsal.

Ossification.-A single nucleus appears in the fourth year.

The EXTERNAL CUNEIFORM has its base direeted upwards, and its narrow border lownwards. The posterior surface is faceted for the scaphoid; and the anterior, triancular in shape, articulates with the base of the third metatarsal.

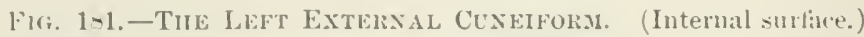

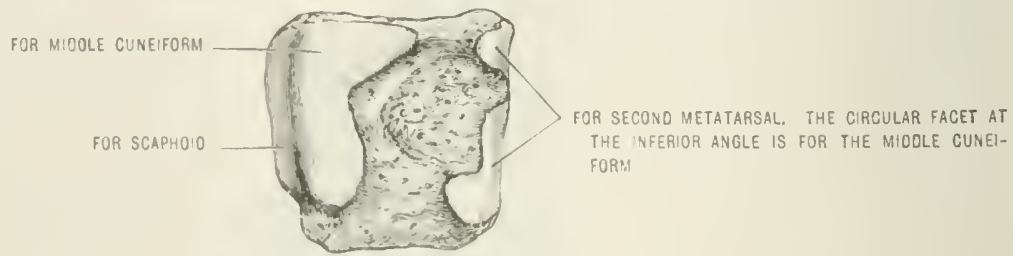

The internal surface has a linger ficet, "xtending along the posterior border, for the miclelle cumeiform; and on the anterior horder, a narrow irregular facet for the

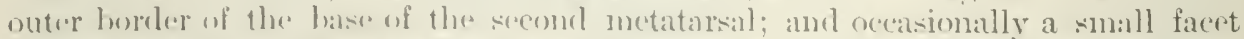
at the anterion inferior angle for the micllle cuneiform. The outer surface has a

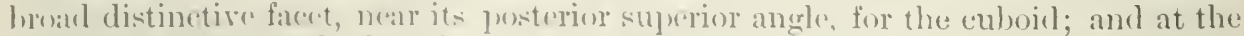
anterior superior angle there is ustally a fact for the inner side of the base of the fourth inctiatirsal. 
Articulations.-With the middle cuneiform, the scaphoid, the "uboid, and the second, third, and fourth metatarsals.

Muscles.-The flexor brevis hallucis and a slip from the tilialis posticus.

Ossification.-A single nucleus appears in the course of the first year.

Fig, 182,-The Left Exterial Cuxemorim. (External surfice.)

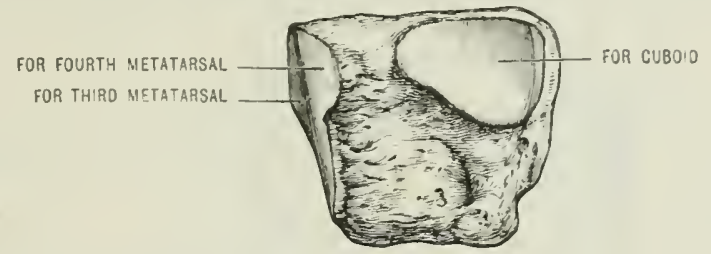

The three cunciform bones rest posteriorly against the scaphoid; and as rhey are of unequal length, the middle being the smallest, it follows that when the bones are placed in their natural positions a deep gap or recess is formed in front. Into this recess the base of the second metatarsal is receiverl, thus explaining the small facets at the anterior superior angles of the internal and external cuneiforms.

\section{THE METATARSUS}

The metatarsus consists of five bones, numbered one to five, beginning at the hallux. Each metatarsal presents a proximal portion termet the base, and a distal end or head. The shaft of each bone, with the exception of the first, is prismatic; the base of the prism is directed upwards, and the narrow edge downwards. The shaft tapers gradually from the base to the head and is slightly bowed, the concarity being on the jlantar aspect.

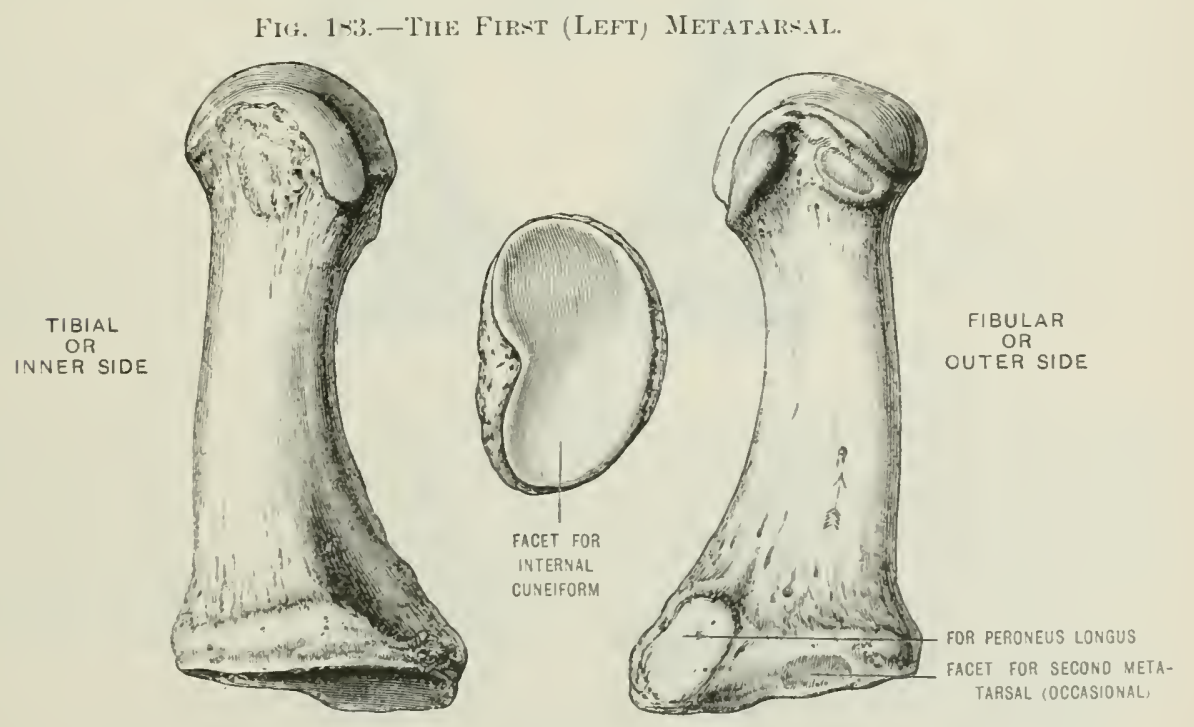

The base is prismatic: its terminal surface is faceted for articulation with the tarsus, and the arljacent horders of the base present small facets. in most cases for adjacent metatarsals.

The head is semicircular, forming a convex articular surface for the base of the first phalanx. The compresed sides of the head present near their centres a drpression sumounted hy a prominent tuberede. The plantar surface is deeply 


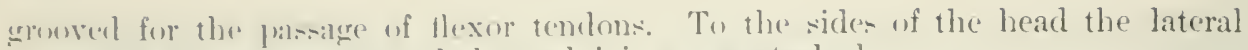

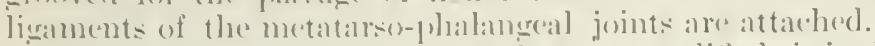

The FIRST METATARSAL is the now moxlified: it is shorter, hut much thicker than its fellows. Thr base presents a reniform, slightly concave facet for the internal eneiform lnue. On the onter (fibular) side of the base, near its lower anghe there is a tuberche into which the pormens longus is inserted. A little above this. there is fresuently a shallew hut asily recognised falcet where it comes into centact with the hase of the secenel metatalsal.

'Thr head of the lume has two deel' grooves on the liantar surface for the

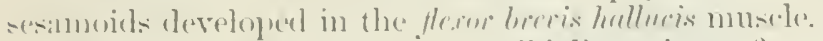

Muscles.-Peromens longur; tilialis antinas: first dorsal interosseous.

Blood-supply. - The nutrint vessed (nters the thaft on the fibular side, and is directed towards the heald of the lone.

The SECOND METATARSAL is the longest of the series. Its base is prolonged balckwards to occupy the space lectween the internal and extemal cuneiform boncs; this leads to the formation of a small facet at the sulerior angle on the tibial side

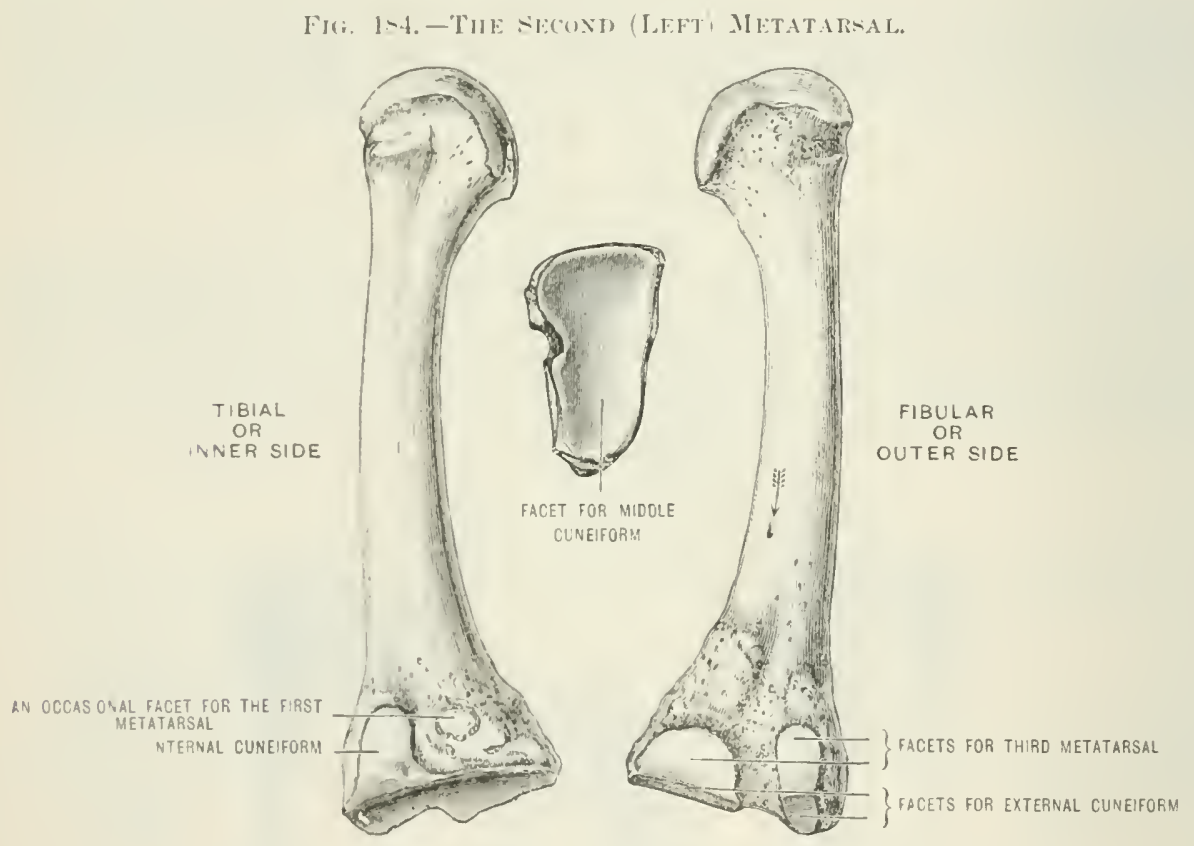

where it articulates with the intermal cunciform. It oreasionally presents a small ficest for the first metatamal. 'The outer (fitmlar) side of the hise has two facets,

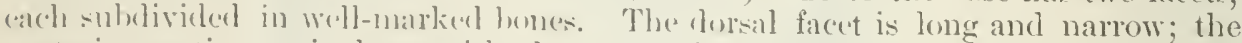

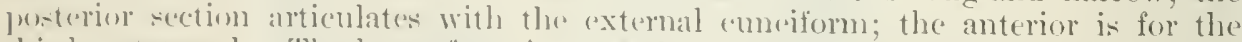
thim metatarsal. The lower lace is somewhat cireular: its posterior section is for

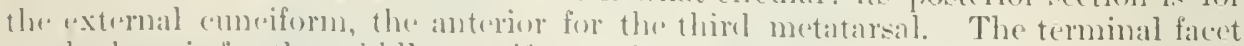
(1) the hase is for the millle "uncifollu: thus the second metatarsal articulates with three cuneiform bones.

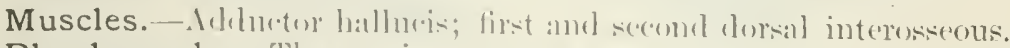

Blood-supply. - The nutrient alteryonters on the fibular sicke near the middle of the shalt, and is ilirecterl towalels the base of the bome.

The THIRD METATARSAL articulat(s) by it: base with the external cuneiform.

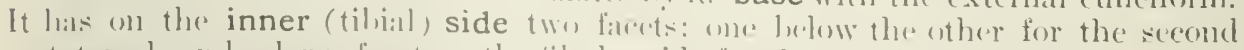

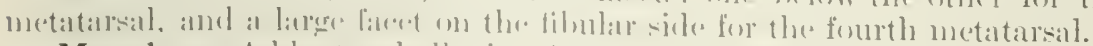

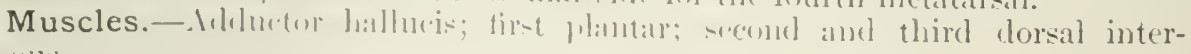
(1)-(1)!1s. 
Blood-supply.-The nutrient artery enters on the inner (tibial) side of the shaft near its middle: it is directed towarls the base.

The FOURTH METATARSAL has a somewhat quarlilateral teminal facet for the euboid bone. On its inner (tibial) side it has a large facet for the thirr metatarsal: the posterior part of this is occasionally marked off for the external

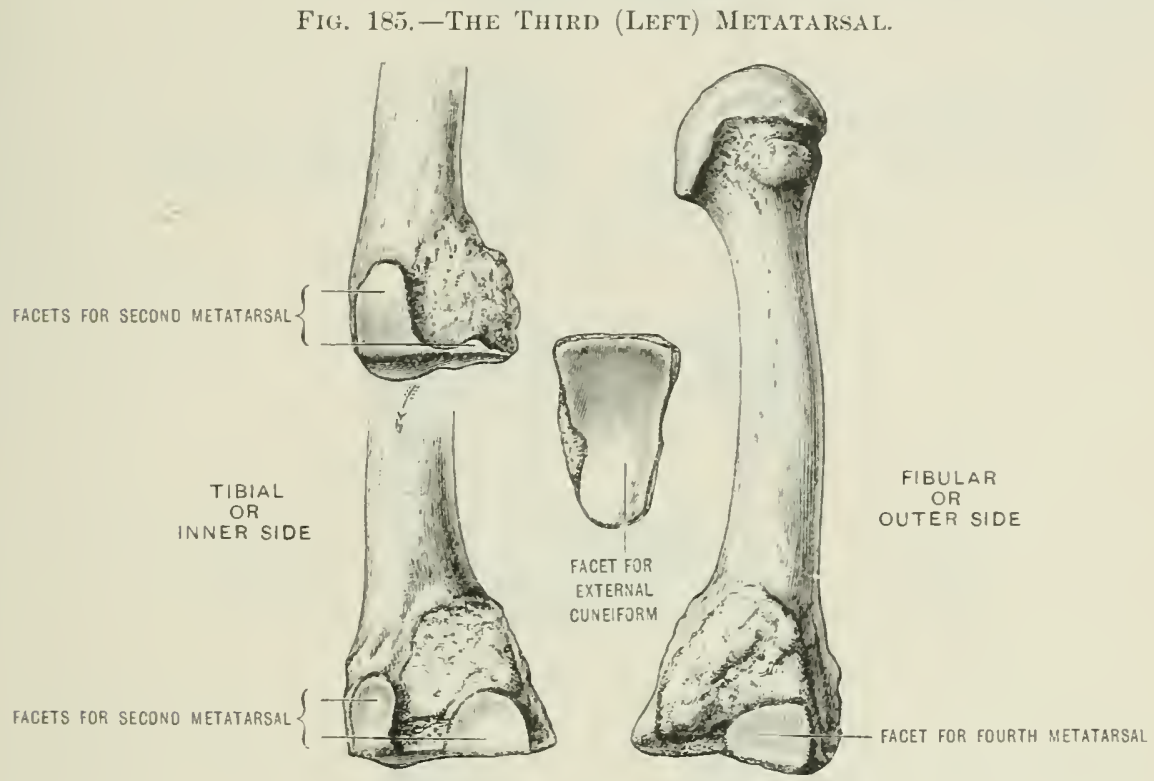

Fig. 186. - The Folrth (Left) Metatarsal.
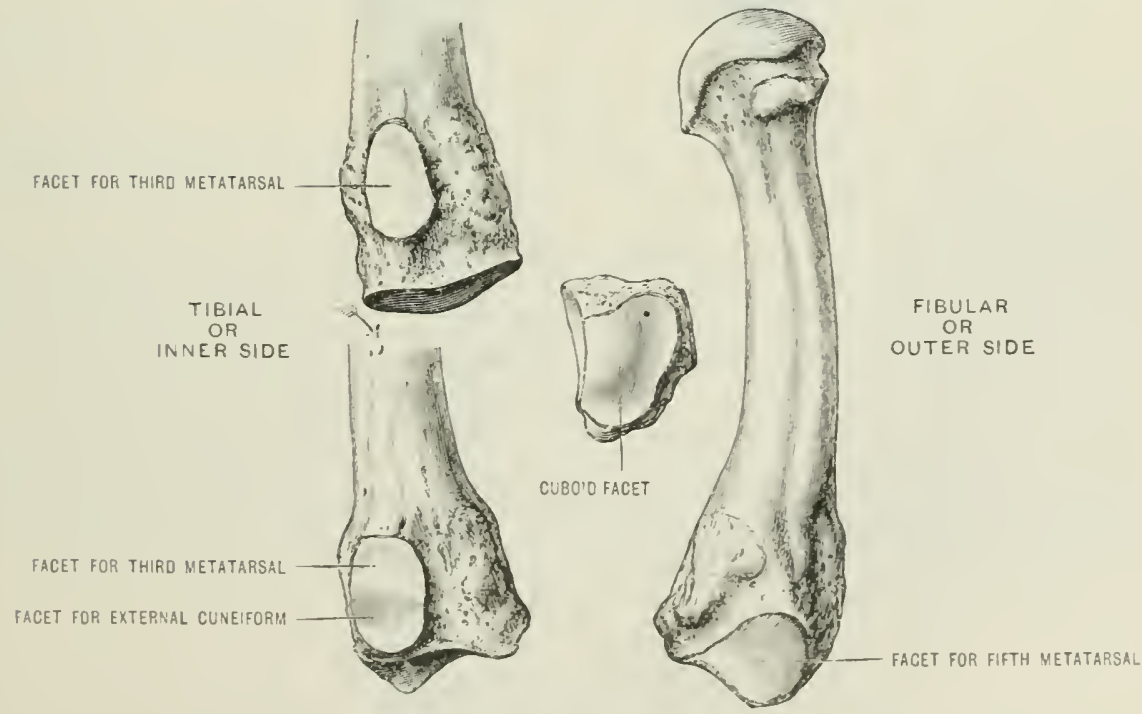

cumeiform, but this is far from constant. When this cuneiform facet is present. the facet extends to the base of the hone. When absent, the surface is rough for ligaments. The outer (tibular) side has a single facet for the fifth metatarsal.

Muscles.-Adductor hallucis; second plantar interosseous; third and fourth dorsal interossens. 
Blood-supply.-The nutrient artery of the shaft enters on the inner (tibial) side and runs towarls the linse.

The FIFTH METATARSAL has on the fibular side of its base a large nippleshiped tuberosity, to which the trudon of the pronews bretis is inserted. Its obligue teminal fireet articulates with the cuboirl, and on the tibial side it has a lare facet for the fourth metatarsal. The plantar aspect of the hase has a shallow erenes which lorlges the abductor minimi digiti.

Muscles :-

Thirel plantar interosseous.

Fourth dorsal interosicents.

Peroneds brevis.
Peroneus tertius.

Abluctor ossis metatarsi quinti.

Flexor brevis minimi digiti.

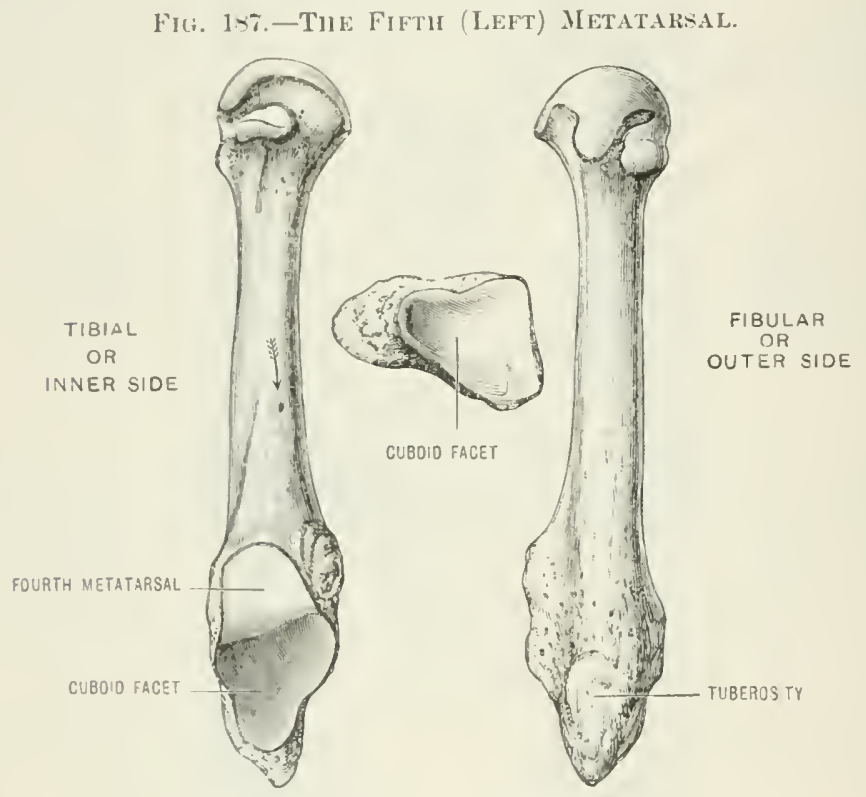

Blood-supply.-The mutrient artery enters on the tibial sirle of the shaft and runs tomaris the base.

Ossification.- Each metatasal nsifies from two centres. The prinary nucleus for the cliaphysis appears in the eighth week of embryonic life in the midrle of the (artilarinous metataral. At birth, each extremity is represented by cartilage, and that at the proximal encl is osifiod hy extemsion from the primary indeles, except in the "as" of the first metatarsal. For this, a nucleus apprears in the third year.

The distal ands of the four onter metatarsals are ossified by secondary nuclei which make their appearanere alont the thirel vear. Terefrequently an epiphssis is fomel at the distal end of the first motatarsil as well is at its base. The slafts and epiphyses (onsolidate at the twentieth year. The sesamoids belonging to the

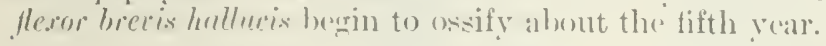

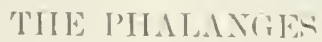

There are fourteen phalanges to (arlh foot. The hallux has two, and the remaining tors threse each. They are usually distinguisherl as first, second, and third. The last are sometinus ailled the ungual phalanges, because they support the mail.

The phalanges of the first row have narrow latrially complessed shafts, roumler on the dorsal and comeare on the plantas" asperts. The base of "ach has a deep 
THE PHALANGES

173

Fig. 189. -The Phalanges of the Middle Toe.
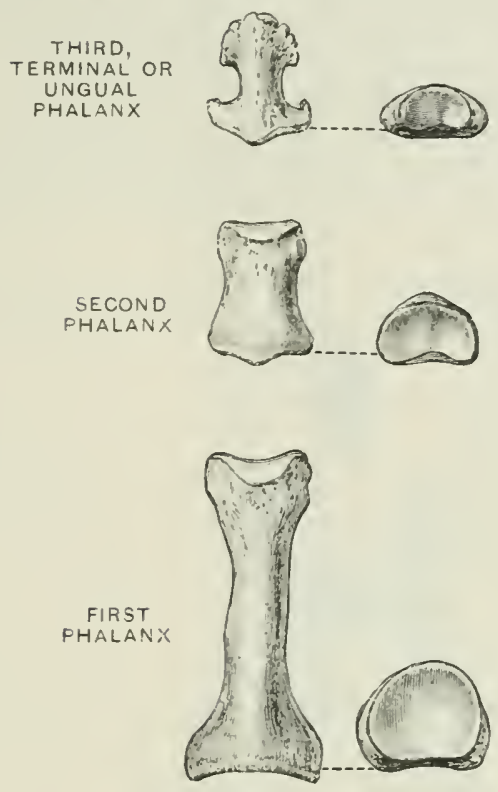

Fig. 199.-A Longitudinal Section of the Bones of the Lower Limb at lith.

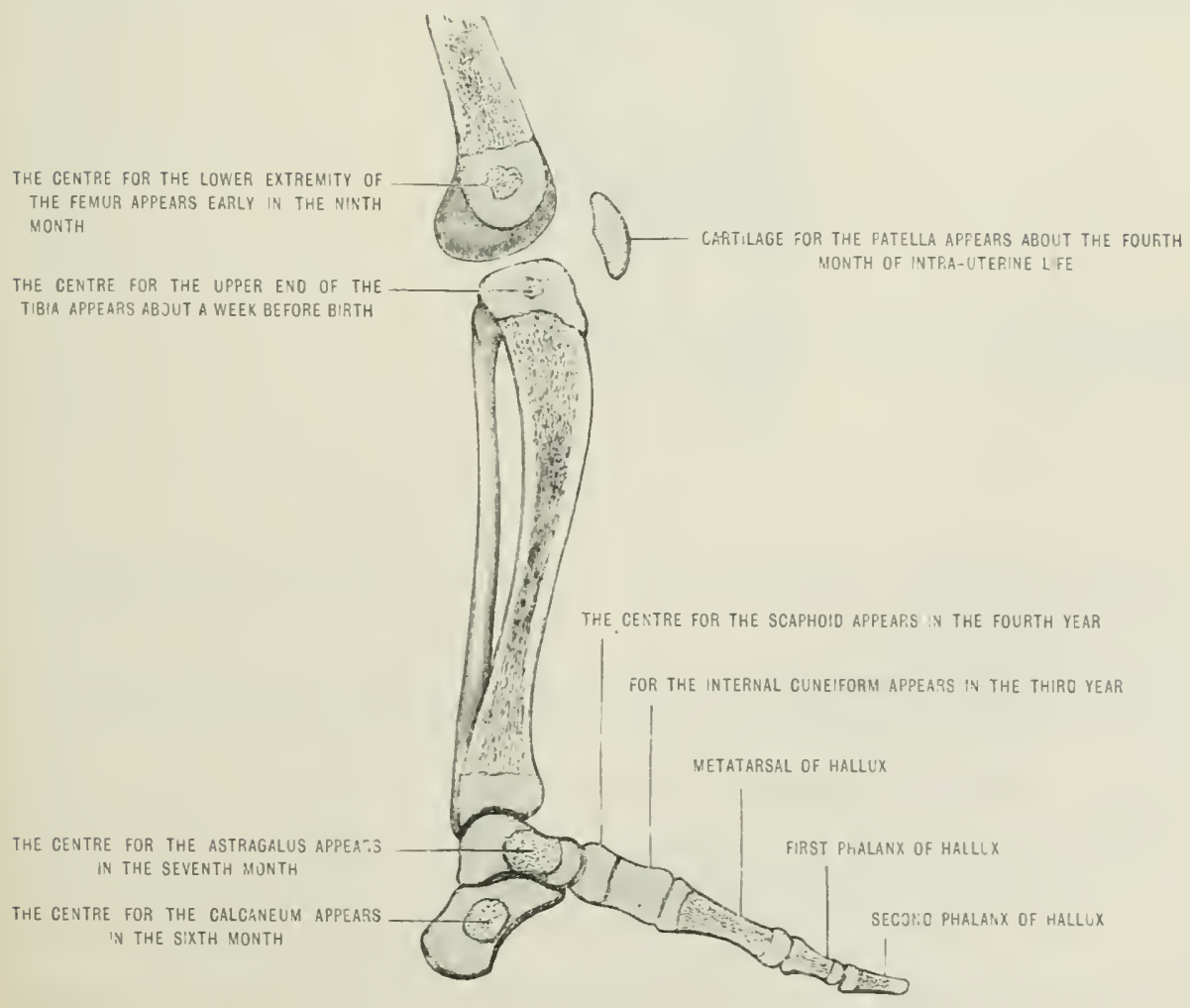


glenuid fossa for the conver hearl of the corresponding metatarial, whilst the head has a trochlear surfaee for the second phalanx.

The phalanges of the second row are stunted, insignificant lones. Their shafts are flatter than those of the first row, besides being much shorter. The bases have two depresioms, separated by a rertical ridge. The heads present trochlear surfaces for the mingul phalanneses.

The third, terminal, ol ungual phalanges are asily recognised. The hases articulate with the second phalanes: the shafts are expanded to support the nails. and their flantar surfaces are rough where they come into relation with the pulp of the digit.

Fig, 191.-The SecoNdary Usific Cextres of the Foot.

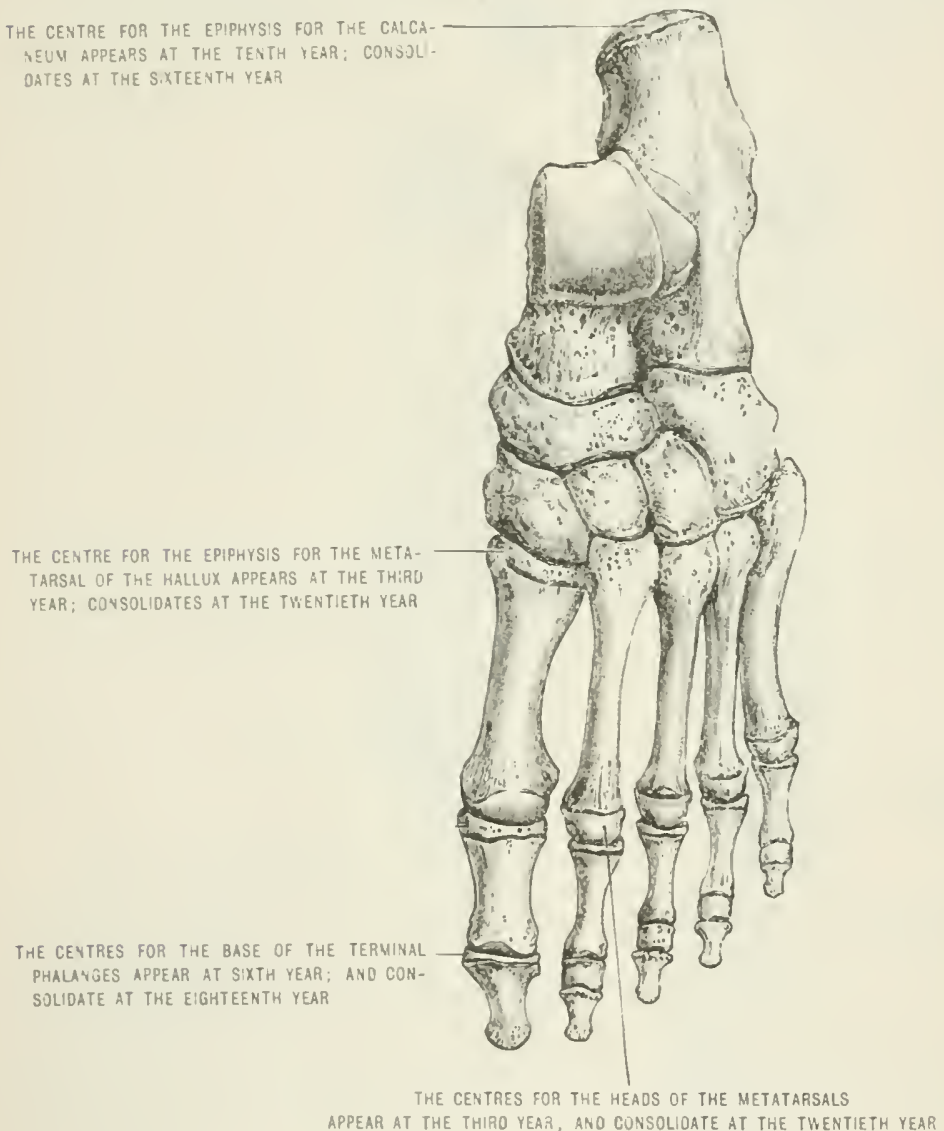

The first phalanx of the hallux gives insertion to the following muscles:Flexor brevis hallucis; alducter hallucis; trantrersus pedis; adductor hallucis; extensor brevis digitorum.

The first phalanx of second toe: The first and second dorsil interosscous.

The first phalanx of third toe: Third dormal interosscour; first plantar interosseolls.

'The first phalanx of fourth toe: Feromel plintir interossensis; fourth dorsal interosicouls.

The first phalanx of fifth toe: Thinel plantar interossons; flexor brevis minimi digriti; ancl aluluctor minimi dieriti.

The second phalanx of hallux: Flexor longus hallueis; (xtensor proprius hallur.is.

'The second phalanges of the remaining toes: Ext(1)=(o) longus ligitorum; flexor brevis diritorum. 
The third phalanges: Flexor longus digitorum; extensor longus digiturum.

Ossification.-Like the phalanges of the fingers, those of the toes osify from at primary and a secondary nucleus. The centres for the shaft appear during the righth and tenth weeks of embryonic life; the secondary centres alpear as thin scale-like epiphyses at the proximal ends between the fourth and righth years. Ther consolidate earlier than the corresponding epiphyses in the fingers.

The ungual phalanges, like those of the fingers, ossify from the distal extremity.

The average dates of resification of the bones of the fort:-

Calcaneum . . . . . . . . . Sixth month.

Epiphysis . . . . . . . . . . Tenth yeall.

Astragalus . . . . . . . . Serenth month.

Cuboid. . . . . . . . . . At, or near, the ninth month.

Scaphoid . . . . . . . . . . Fourth or fifth rear.

Internal cuneiform . . . . . . . . Third year.

Middle cuneiform . . . . . . . Fourth year.

External cuneiform . . . . . . . First year.

Metatarsals . . . . . . . . . Eighth to ninth week.

Epiphyses . . . . . . . Third year; consolidate at the twentieth year.

Phalanges . . . . . . . . . Fighth to tenth week.

Epiphyses . . . . . . . Fourth to eighth year; consolichate about the eighteenth year. 


\section{SECTION II}

\section{THE ARTICULATIONS}

13Y HENRY MORRIS, M.A., M.B., JoNd.: F.R.C.S.ENG.

-EXIOR SLRGFOX TU AXI LATE LECPLKER UX SIRGERY (FORMERLY LECTURER ON AXATOMY) AT THE MIDDLESEX

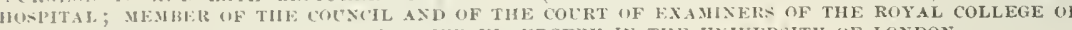
SURTEUS, EXGLAXD: EXANIXEK IX SLRGERY IX THE CXIVERSTY OF LONDON

$\mathrm{T}^{\prime \prime}$

TIE section revoted to the Artienlations or Joints deals with the union of the various and disimilar parts of the human skeleton. The following structures enter into the formation of joints.

Bones eomstitute the basis of most joints. The articular ends are expanded, and are composed of cancellous tissue, surrounded by a dense and strong shell of ronnpat tisile. This shell has no Haversian canals (the vessels of the cancellous tisisue turn back and do not perforate it), or large lacme, and no canaliculi, and is thus well adapted to bear pressure. The long bones articulate by their ends, the flat he their edges, and the short at various parts on their surfaces.

The Cartilage which corers the articular ends of the bones is called articular, anel is of the hyaline variety. It is tirm ly implanted on the bone by one surface, while the other is smooth. polished, and free, thus reducing friction to a minimum, while its slight elasticity tends to break jars. It ends abruptly at the edge of the articulation, and is thickest orer the areas of greatest pressure.

Anether form of cartilage, the white fibrous, is also fomd in joints:-

(i) As interarticular cartilage in diarthrolial joints-riz., the knee, temporo-

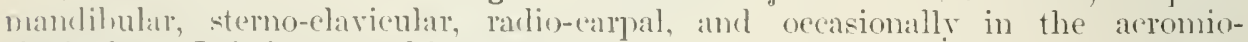

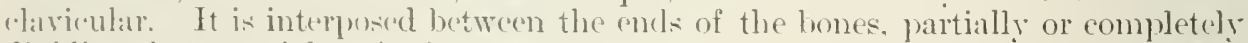
diviling the symovial (a) ity into two. It sorves to adjust dissimilar luny surfaces, arkling to the security of while it increases the extent of motion at, the joint: it also acts as a buffer to hrouk shoreks.

(ii) As circumferential or marginal fibro-eartilages, which serve to deepen the

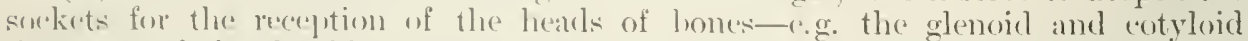
limanents of the shoulder and hip. Another form of maremal plate is seen in the

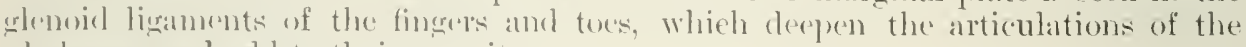
phalameres amel and to thrie sicurity.

(iii) Is connecting fibro-cartilage. The more pliant and clastic is the more

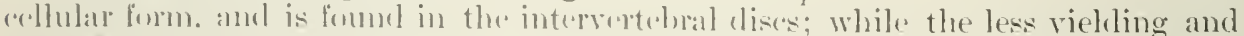

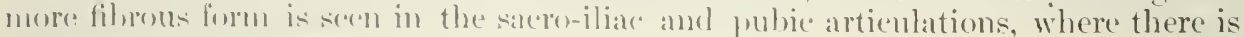
little or 110 merementent.

The Ligaments which hind the ofoues tugether are strong banch of white

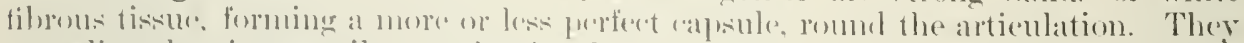
are pliant lut incxtonsile, varying in shape, strength, and thickness arcording to the kind of articulation into which they enter. They are elosely connected with the periostem of the bume they unite. In sume "ases-as the ligamenta subflava which mite parts not in contacet - thery are formed of yellow clastic tissue.

The synovial membrane lines the interior of the filnous ligaments, thus a $\mathrm{x}$ 176 
clurling them, as well as the cushions or parts of fatty tissue situate within and the tendons which perforate the fibrous apsule, from the articular "arity. It is a thin drelicate membrane, frequently forming folds and fringes which project into the (avity of the joint; or, as in the knee, stretches across the "avity, forming a socalled smovial ligament. In these folds are often found pads of fattr tissue, which fill up interstices, and form soft cushions between the contiguous bones. Fometimes these fringes become villous and pedunculated, and cause pain on morenent of the joints. Ther contain fibro-fatty tissue, with an isolaterl cartilage cell or two. The srnovial membrane is well supplied with blood, especially near the margins of the articular cartilages and in the fringes. It secretes a thick glairy fluid like white of exge, callerl synovia, which lubricates the joint. Another variety of synorial nembrane is seem in the burse, which are interposed hetween various moving surfaces. In some instances burse in the neighbourhood of a joint may communiate with the synorial carity of that joint.

\section{THE VARIOUS KINDS OF ARTICULATIONS}

There are three chief varicties of joints-riz., synarthrodial, or immorable; amphiarthrorlial, or vielsling; and cliarthroelial, or movalsle joints.

Synarthrosis is the term applied to all immorable joints in which the apposerl surfaces or erlges of the bones are in clirect contact, as in the face bones, except the mandible, and all those of the skull; or where bone and cartilage are in immediate union, as in the case of the first rib and the sternum, and the costal cartilages and the ribs. The unions of the hones of the skull and face are usually called sutures, of which there are three chief varieties -

(1) True sutures, where the edges of hones are firmly implanted into one another by means of projecting processes, as in the sagittal, lambloid, and coronal sutures.

(2) False sutures, where the rough edges of the hones are in simple contact without interlocking. as in the intermaxillary suture; or where they orerlap one another, as in the squamous suture.

(3) Grooved sutures, where the edge or plate of one bone is received into a corresponding groove in the other, as in the rostrum of the sphenoid and romer, or vomer and palatine processes of the maxilla, and the horizontal plates of the palate bones.

Amphiarthrosis is the term applied to mixed joints which permit of slight morements, the opposed bony surfaces being firmly united by a llate or disc of fibro-cartilage. There is sometimes a partial synovial memhrane. Examples are seen in the spine, sacro-iliac, and pubic joints.

Diarthrosis is the term applied to all movable joints in which the bones have smooth cartilage-covered surfaces. lubricated by syoria, and bound together by more or les perfect capsules. This class is subdivided into the following varieties:-

1. Enarthrosis, or ball-and-socket joint. where the more or les spherical head of one bone is adjusted to a socket on the other. as in the hip- and shoulder-joints. They are the most movahle of all articulations, combining angular morements in all directions with axial rotation.

2. Condylarthrosis, or an articulation having on one hone an elongated surface callerl "condyle" and on the other a glenoid surface. They permit all the movements of a ball-and-socket joint except axial rotation.

3. Ginglynus, trochlearthrosis. or hinge-joint. where there is a pulley or trochlea on one bone and a surface adapted for moving round it on the other. The morement is principally in two directions. namely. flexion and extension, though some slight amount of lateral novement is also permitted. The most perfect 
examples of this form of joint are the ellow and ankle. The knee is a much less perfect instance.

4. Trochoides, or wheel-like joints. where one bone rotates upon another. This name is given to an articulation in which either a pirot revolves in a ring, as in the superior raclion-ulnar; or the ring revolves about a pirot, as in the atlanto-odontoid, and in a much less perfect form in the inferior radio-ulnar joint. liotation is the only morement.

5. Arthrodial, a more or less simple gliding joint formed hy the apposition of two plane, or nearly plane, or encalvo-convex surfaces. The anount of movenent is rery valliable in the different joints. Whilst in some, as the intermetacarpal, it is so sight that the joints have, hy some writers, been described as amphiarthrosis, others are calpable of all the movements of a ball-ancl-socket joint except rotation.

The articular processes of the vertebre and the carpal and tarsal joints are good examples of the ordinary arthrodia, but under this head are also included the "saddle-shaped" articulations, such as the stemo-costo-clavieular and the carpometacarpal of the thumb, which permit the four angular movements and circum(luction, lut not rotation.

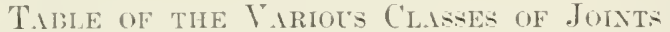

\section{Clus:}

\section{Synarthrosis}

(i) 'Trul sutures

(b) False sutures

(r) Groveres sutures.

II. Amphiarthrosis

\section{Diarthrosis}

(a) Enurthrosis . . . . . . Shoulder. Hip. Astragalo-scaphoid.

(b) Condylarthrosis . . . . Temporo-mandibular. Oceipito-atlantal. Radio-earpal. Netacarpo-phalangeal. Metatarso-phalangeal.

(r) Ginglynus or Trochlerthrosis. Elbow. Ankle. Knee. Interphalangeal

(d) Trochroides or Lateral (imgly1111: . . . . . .

(e) Irthroclia:

1) Simple . . . . . Lateral atlanto-axoidean. The joints between the articular processes of the vertebre, costo-transverse and interchondral. Aeromio-clavieular. Campal. Carpo-metacarpal of four fingers. Intermetatarpal. Tarsal. Tarso-metatarsal. Intermetatarsil. Calcaneo-astragaloid. sujerior and inferior tillo-fibular.

(2) Sachlle-shapond
Sterno-rosto-claricular. Carpo-metacarpal of thumh. Calcaneo-cuboid. 


\section{THE TARIOLS MOYEIEENTS OF JOINTS}

The morements which may take plaee at a joint are either glieling, angular, rotatory, or circumductory.

The gliding motion is the simplest, and is common to all diarthrodial joints: it consists of a simple sliding of the apposed surfaces of the bones upon one another, without angular or rotatory motion. It is the only kind of motion permitted in the carpal and tarsal joints, and in those between the articular processes of the rertebra.

The angular motion is more elaborate, and increases or diminishes the angle between different parts. There are four varieties, viz.: flexion and crtension, which bend or straighten the various joints, and take place in a forward and backward direction (in a perfect hinge-joint this is the only motion permitted); and adduction and abduction, which, except in the case of the fingers and toes, signifies an approach to, or deviation from, the centre line of the body. In the case of the hand, the line to or from which adduction and abduction are made is drawn through the middle finger, while in the foot it is through the second toe.

Rotation is the revolution of a bone about its own axis without much change of position. It is only seen in enarthrodial and trochoidal joints. The knee also permits of slight rotation in certain positions, which is a distinctive feature of this articulation.

Circumduction is the morement compounded of the four angular morements in quick succession, by which the moving bone describes a cone, the proximal end of the bone forming the apex, while the distal end destribes the base of the cone. It is seen in the hip and shoulder, as well as in the carpo-metacarpal joint of the thumb, which thus approximates to the ball-and-socket joint.

In some situations where a variety of motion is required, strength, security, and celerity are obtained by the combination of two or more joints, each allowing a different class of action, as in the ease of the wrist, the ankle, and the head with the spine. Many of the long muscles, which pass over two or more joints, act on all, so tending to co-orlinate their movements and enabling them to be produced with the least expenditure of power. Muscles also act as elastic ligaments to the joints; and when acting as such, are diffusers and combiners, not producers of movement; the short muscles producing the movement, the long diffusing it, and thus allowing the short muscles to act on more than one joint.

Inscles are so disposed at their attachments near the joints as never to strain the ligaments by tending to pull the bones apart, but, on the contrary, they add to the security of the joint by bracing the bones firmly together during their action.

The articulations may be divided for convenience of description into those: 1 . of the SkLLL; 2. of the Trixk; 3 . of the LPper Limb; and 4. of the Lower Limb.

\section{THE ARTICLLATIONS OF THE SKLLL}

The articulations of the skull comprise (1) the temporo-mandilutar; and ( 2 ) those between the skull and the spinal columm, namely $(a)$ between the occiput and atlas; $(b)$ between the atlas and axis; and $(c)$ the ligaments which connect the occiput and axis.

The mion of the atlas and axis is described in this section because, firstly, there is often a clirect communication between the srmovial cavity of the transverse axoidean and the occipito-atlantal joints; sccondly, the rotatory movements of the heal take place arounel the odontoid process; and, thirdly, important ligaments from the odontoid process pass orer the atlas to the occiput. 


\section{(1) THE TEMPORO-MANDIBLLAR ARTICLLATION}

Class.-I Hirith"osis:

Subdivision.-Condylathrosix.

The parts entering into the formation of this joint are:-the anterior portion of the glenoid fossa and glenoid ridge (cminential anticularis) of the temporal bone alore, and the complyle of the lower jaw liclow. Both are covered with articular cartilage, which axtencls over the front of the glenoid rielge to facilitate the play of the interarticular cartilage. The ligaments which unite the bones are:-

1. ('alpstlar.

2. Interarticular fibro-cartilage.
3. spheno-mandihular.

4. Stylo-nandibular.

The capsular ligament is often described as consisting of four portions, which are, lowerer, continuous with one another around the articulation.

1. The anterior portion comsists of a few stray fibres comected with the anterior margin of the fibro-cartilatge, and attacherl below to the anterior edge of the conclyle, and athore to the front of the glenoid ridge. Some fibres of insertion of the exterual pterygoid pass between them to be inserted into the margin of the fibro-cartilage.

2. The posterior portion is attached above, just in front of the Glaserian fissure, and is inserted into the back of the jaw just lulow its neck.

:). The external portion or external lateral ligament (fig. 191) is the strongest part of the capsule. It is broader abore, where it is attached to the lower crlge of the zyroma in nearly its whole length, as well as to the tuberele at the point where the two ronts of the zyomna meet. It is inclined downwards and backwarls, to he inserted into the outer side of the neck of the condyle. Its filmes diminish in oblifuity and strength from before backwards, those coming from the tubercle being short and nearly rertical.

4. 'The internal portion if short internal lateral ligament (fig. 192) consists of well-elefined fibres, having a broal attachment, above to the onter side of the alar sline of the sphenoid and inner exlge of the glenoid fossa; and below, a narrow insertion to the imer sile of the nerk of the condyle. Fatty and cellular tissue scparate it from the spheno-mandihular ligament which is internal to it.

The interarticular cartilage (fig. 193) is an oval plate interposed between and arlapterl to the two articular surfaces. It is thimner at the centre than at the rircumference, and is thicker hehind where it corers the thin bone at the bottom of the glemoid fossil which separates it from the lura mater, than in front where it (o) rers the glenoid ridere. Its inferior surface is concave and fits on to the condrle of the Inwer jaw; while its superior surface is concavo-convex from hefore backwards, and is in contact with the articular surface of the temporal bone. It clivieles the joint into two separate synovial eavities, but is oceasionally perforated in the eentre, and thus allows them to communicate. It is connected with the eapsular ligament at its circumference, and has some fibres of the external pterygoid musclo inserted into its anterior nargin.

There are usually two synovial membranes (fig. 198), the superior being the larger ancl looser, phising down from the margin of the articular surface alove, to the upper surface of the interarticular cartilage helow; the lower and smaller one passes from the interarticular cartilage above to the condyle of the jaw helow, extencling somewhat further sow brehind than in front. When the interarticular cartilage is perforated, the two sales remmmunicate.

'The spheno-mandibular ligament (long internal lateral) (fig. 192) is a thin, loose band, situated some little listaner from the joint. It is attrached above to the alar spine of the sphenoid and contiguous part of the temporal bone, and is inserted into the manclibular spine of the lowe jaw. It covers the upper end of the mylo-hyoirl groove, and is here pieresel by the mylo-hyoirl nerve. Its origin is a little intemal to, and immerliately behind, the origin of the short internal lateral ligament. It is separaterl from the joint and ramus of the jaw by the extermal pterygoid muscle, intermal mexillary artery and vein, the mandibular nerve and 
artery, and the middle meningeal artery. It is really the fibrous remnant of a part of the manclibular (Meckelian) bar.

The stylo-mandibular ligament (strlo-maxillary) (figs. 191 and 192) is a process of the deep cervical fascia extending from near the tip of the styluid process to the angle and posterior border of the ramus of the jaw, between the maseter and

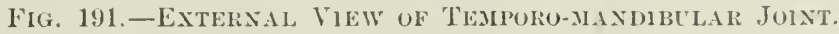

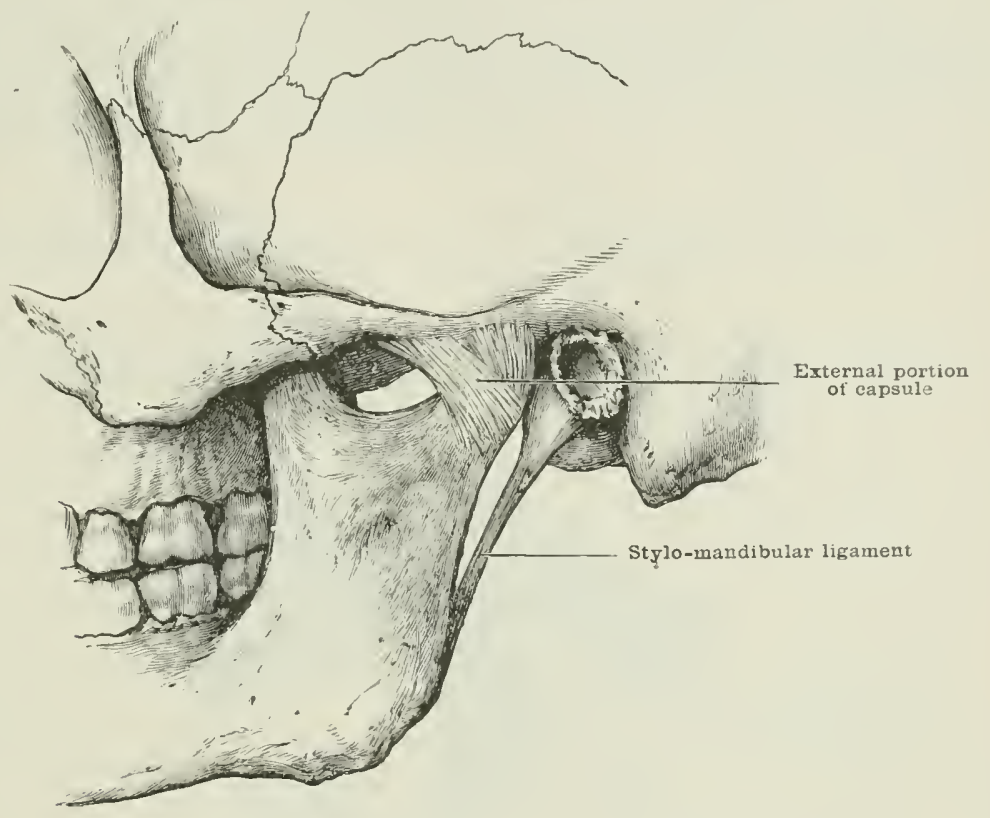

Fig. 192.-INTERNAL VIEW OF TeMpoRo-MANDIBLlar JUINT.

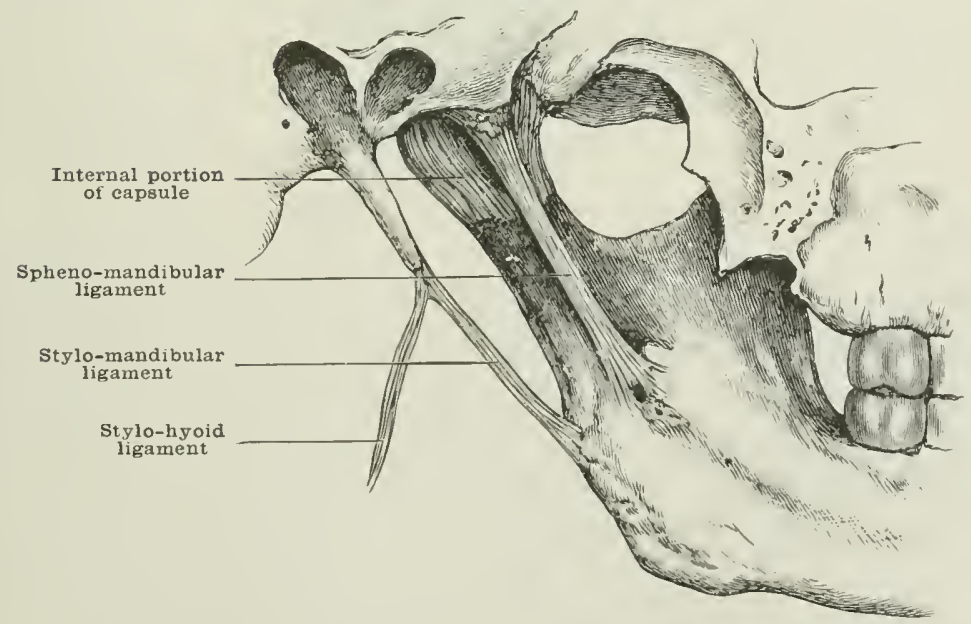

internal pterygoid muscles. It separates the parotid from the submaxillary ghand, and gives origin to some fibres of the stylo-g/mass ms muscle.

The arterial supply is derived from the temporal, midclle meningeal, and ascending pharyngeal by its branches to the Eustachian tube.

The nerves are derived from the masseteric and auriculo-temporal. 
Movements. - The rhiof movement of this joint is of (i) a ginglymoid or hinge character, acom pounierl by a slight gliches action, as in opening or shutting the mouth. In the opening moviment the condyle turns like a hinge on the fibro(a)tilage, while at the same time the fibro-rartilage, together with the eondyle, gricles forwards so as to rive upon thr eminentia articularis: the filoro-cartilage reaching as fiar as the anterior edege of the minenees, which is coated with articular (artilage to receive it: hut the condrle nevere reaches quite so falr as the summit of the "minence. Should the "omlylu, howerer, by excessive movement (as in a convulsive rawn), glicle orer thesumit, it slips into the zyomatic fossa, the mandible is diskcaterl, and the posterior portion of the capsule is torn. In the shutting movement the condrle revolves back again, and the fibro-cartilage glides back, "arring the conclyle with it. This combination of the hinge and gliding motions gives a tearing as well as a cutting action to the incisor teeth, without any extra muscular exertion.

There is (ii) a horizontal gliding action in an antero-posterior direction, by which the lower teeth are thrust forwark and drawn back again: this takes place

Fig. 193. - Vertical. SeCtion throlgh the CoNirle of JAW TO SHOW THE TWO

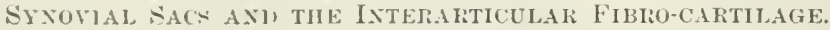

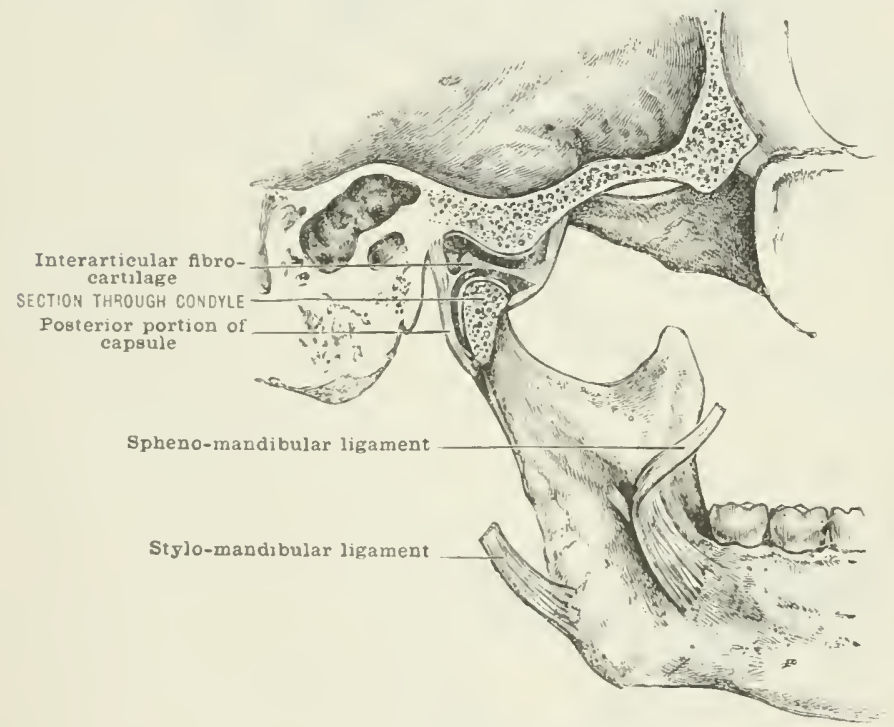

almost entirely in the uppere compartment, hecause of the clnser connection of the fildo-cartilage with the comrly the insertion of the cotermel perrygrid into both bone and cartilage. In these two sets of movement: the joints of hoth sickes are simultaneously and similarly engaged.

The thirel form of morement is called (iii) the oblique rotatory, and is that by which the grinding and ehering actions are jertermed. It consists in a rotation of the eond yle albout the vertical axis of its neck in the lower compartment, while the cartilage glides olsliquely forwards and inwarls on one side, and hackwarls and

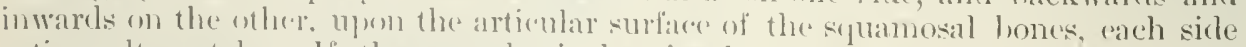
arting altemately. If the symphysis lo simply mofer from the centre to one side and hack again, and not from sicle to side as in grincling, thromelyle of that side moves romel the vortical axis of its neck, and the oppresite ondyle and cartilage

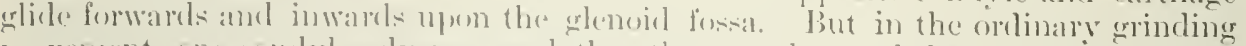

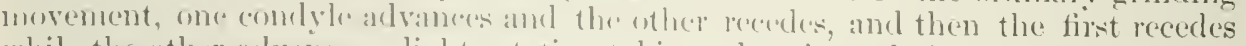
while the oflaer advances. slight rotation taking place in cach joint meanwhile. 


\title{
(2) THE I.IGMENTS AND JOINTS BETWEEN THE STILL AND SPINAL COLUMN, AND BETITEEN THE ATLAS ANI) AXIS
}

\section{(1) ThF Articllatiox of tine Atlas With the Occiput}

\author{
Class.-Dinthrosis. Subdivision.-Dumble Condylarthrosis.
}

This articulation consists of a pair of joints symmetrically situated on either side of the middle line. The parts entering into their formation are the cup-shaped superior articular processes of the atlas, and the condyles of the occipital bone. They are united by the following ligaments:-

\section{Anterior occipito-atlantal.}

2. Posterior occipito-atlantal.
3. Two capsular.

4. Two anterior oblique.

The anterior occipito-atlantal ligament (fig. 194) is less than an inch (about 2 ('m.) wide, and is composed of densely woren fibres, most of which radiate slightly outwards as they ascend from the front surface and upper margin of the anterior arch of the atlas, to the anterior borcler of the foramen magnum; it is continuous laterally with the capsular ligaments, the fibres of which overlap its edges, and take an opjosite direction inwards and upwards. The central fibres ascend vertically from the anterior tubercle of the atlas to the pharrngeal tubercle on the occipital bone; they are thicker than the lateral fibres. and are continuous below with the superficial part of the anterior atlanto-axoidean ligament, and through it with the anterior common ligament of the rertebral column. It is in relation, in front, with the recti capitis antici minores; and behind, with the central odontoid or suspensory ligament.

The posterior occipito-atlantal ligament (fig. 195) is loroader. nore membranous, and not so strong as the anterior. It extends from the posterior surface and upper border of the posterior arch of the atlas to the postcrior margin of the foramen magnum from condyle to condyle; being incomplete on either side for the passage of the reitebral artery into, and suboccipital nerre out of, the canal. It is somewhat thickened in the middle line by fibres, which pass from the posterior tubcrcle of the atlas to the lower end of the occipital crest. It is not tightly stretched between the bones, nor does it limit their morements; it corresponds with the position of the ligamenta subflava, but has no elastic tissue in its composition. It is in relation in front with the dura mater, which is firmly attached to it; and behind with the recti corpitis prostici minores, and enters into the floor of the suboccipital triangle.

The capsular ligaments (figs. 194 and 195 ) are very distinct and strongly marked, except on the inner side, where they are thin and formed only of short membranous fibres. They are lax, and clo not adel much to the security of the joint. In front, the cipsule descenrls upon the atlas, to be attached, some distance below the articular margin, to the front surface of the lateral mass, and to the base of the transverse process; these fibres take an ohlique course upwards and inwards, overlapping the anterior occipito-atlantal. It the sides and lehind, the capsule is attached above to the margins of the oceipital condrles; helow, it skirts the inner edge of the foramen for the rertebral artery, and behind is attached to the prominent tubercle overhanging the groove for that vesel; these latter fibres are strengthened ly a band ruming obliquely upwards and inwards to the posterior margin of the foramen magnum.

The anterior oblique or lateral occipito-atlantal ligament (fig. 194) is an accessory band which strengthens the calsule on the outer sicke. It is an ohlique, thick band of fibres, sometimes quite separate and distinct from the rest. pas-ing upwards and inwards from the upper surface of the transerse process beyond the costo-rertehral foramen to the jugular process of the occipital bone.

The synovial membrane of these joints occasionally communicates with the synovial sac between the odontoid process and the transierse ligament. 


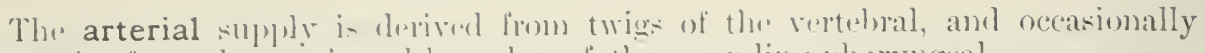

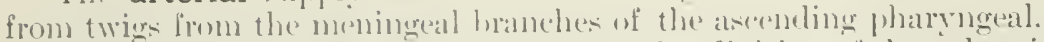

The nerve-supply antes from the anterior division of the suloceipital nerve.

Movements. B Br the simmetrical and lilateral arrangement of these joints,

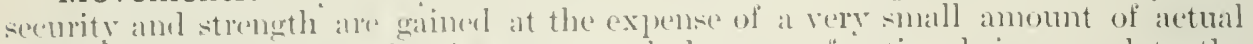
articular surface; the basis of support and the area of action heing equal to the width hetween the most distant borders of the joint.

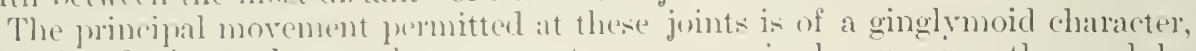

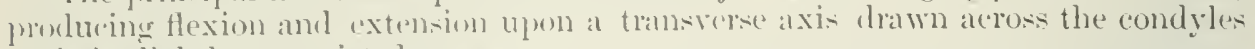
at their slierlitly comstrieted palts.

In Hexion, the foreheal and whin drop, and what is called the nodding movement is made; in extension, the whin is elevated and the forehead recedes.

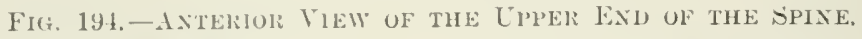

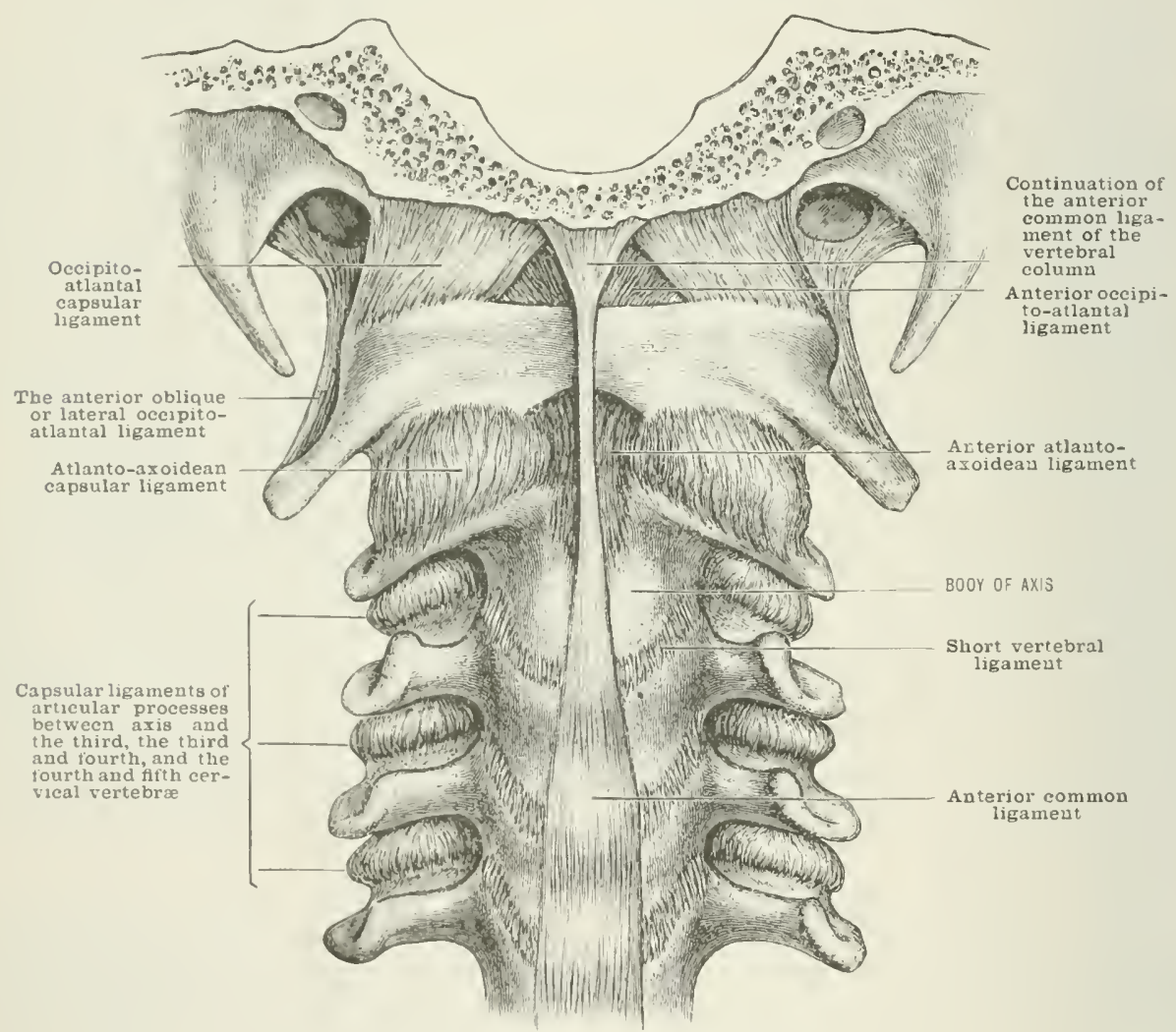

There is also a slight amount of gliling movenent, oither directly lateral, the outre edge of one condyle sinking a litthe within the outer edge of the socket of the atlas, and that of the opposite andyle jougeting to a correspomeling degree. The

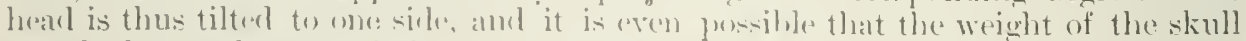

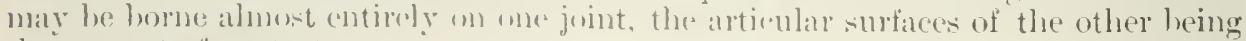
thrown ont of antat.

Or the mownent may lu obliquely lateral, when the lower side of the head

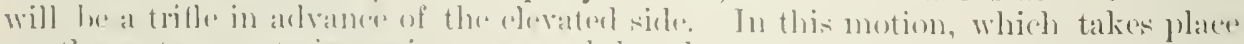

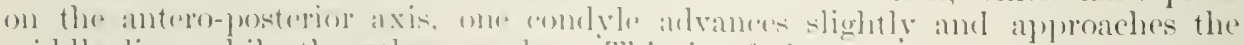

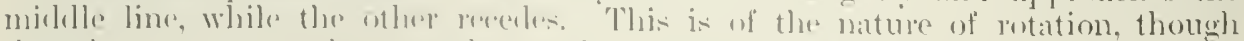

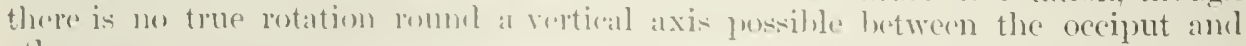
atlas.

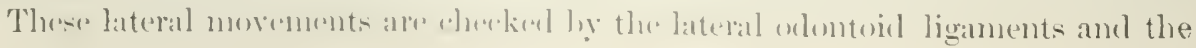


outer part of the capsules; extension is checked by the anterior necipito-atlantal and anterior oblique ligaments, and flexion by the posterior part of the capsule and cervico-basilar ligaments.

\section{(b) The Articulations between the Atlas axi Axis}
1. Tine L.iteral Athanto-Axoidean Joints.
2. The Central Atranto-AXoidean Joint, or
Class.-Diarthersis:
Subdivision.-Aithrouirs.
THE ATLANTO-ODONTOID.
Class.-Diarthrosis.
\{ Subdivision.-Tiorhoides.

The bones that enter into the formation of the lateral joints are the inferior articular processes of the athas and the superior of the axis; the central joint is formed by the odontoid process articulating in front with the atlas, and behind with the trinsverse ligament.

The ligaments which unite the axis and atlas are:-

1. The anterior atlanto-axoidean.

2. The posterior atlanto-axoidean.
3. Two eapsular (for lateral joints).

4. The transverse ligament.

5. The atlanto-odontoid capsular ligament.

The anterior atlanto-axoidean ligament (figs. 194 and 195 ) is a narrow hut strong membrane filling up the interval between the lateral joints. It is attacherl. above to the front surface and lower border of the anterior arch of the atlas, and below to the transverse ridge on the front of the body of the axis. Its fibres are vertical, and are thickened in the median line by a dense band which is a continuation upwards of the anterior common ligament of the spine.

This band is fixed abore to the anterior tubercle of the atlas, where it becomes continuous with the central part of the anterior occipito-atlantal ligament (fig. 194); it is sometimes separated by an interval from the deeper ligament, and is often described as the superficial atlanto-axoidean ligament. It is in relation with the longus colli muscle.

The posterior atlanto-axoidean ligament (fig. 195) is a deeper, but thinner and looser membrane than the anterior. It extends from the posterior root of the transverse process of one side to that of the other, projecting outwards beyond the posterior part of the capsules which are connected with it. It is attached above to the posterior surface and lower edge of the posterior arch of the atlas, and helow to the superior edge of the laming of the axis on their dorsal aspect. It is denser and stronger in the median line, and has a layer of elastie tissue on its anterior surfare like the ligamenta subflara, to which it corresponds in position. It is comnected in front with the dura mater; behind, it is in relation with the inferior oblique muscles, and is perforated at each side by the second cervical nerre.

1. The Lateral Atranto-Axolden Jonts are provided with short, ligamentous fibres, forming capsular ligaments (fig. 194), which completely surround the lateral articular facets. Outside the eanal, they are attached some little distance from the articular margins, extending along the roots of the transverse processes of the axis nearly as far as the tips, but between the roots they skirt the inner edge of the costo-rertebral formina. They are strengthened in front and hehind by the atlanto-axoidean ligaments. Internally each capsule is thimner, and attacherl elose to the artieular margins, being strengthened behind by a stroag band of slightly oblique fibres passing upwarks along the outer edge of the eervico-basilar ligament from the body of the axis to the lateral mass of the atlas behind the transverse ligament; some of these fibres pass on, thickening and blending with the occipito-atlantal capsule, to be inserted into the margin of the foramen magnum. This hand is sometimes ealled the accessory band (fig. 198).

There is a synovial sac for each joint.

2. The Cextrai, Atianto-Axomeix Jorvt, althongh usually deseribed ats one, is composed of two articulations, which are quite separate from one another: an anterior between the odontoid process and the arch of the atlas, and a josterior between the odontoid process and the transierse ligament. 
The transverse ligament (figs. 195, 196, and 198) is one of the most important structures in the hedy, for on its integrity and that of the check ligaments our lives largely depend. It is a thick and rery strong hand, as rlense and closely woven as filure-cartilige, alout a cuarter of an inch ( $(5 \mathrm{~mm}$.) ) derp at the sides, and somewhat more in the middle line. Ittached at ach end to a tuberche on the inner side of the lateral mass of the atlas, it crosses the ring of this hone in a curved manner, so as to have the concavity formard: thus dividing the ring into a smaller anterior portion for the oflontoid process, and a larger posterior part for the spinal cord and its membranes, and the junal accesory nerves. It is flattened from before backwards, being smooth in front, and covered by synovial membrane to allow it to glide freely over the posterior fiacet of the odontoid process. Where it is attached to the atlas

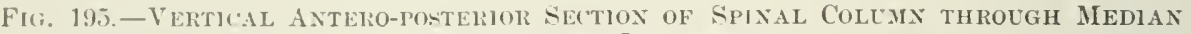
LINE, SHOWIXG LIGAMENTS.

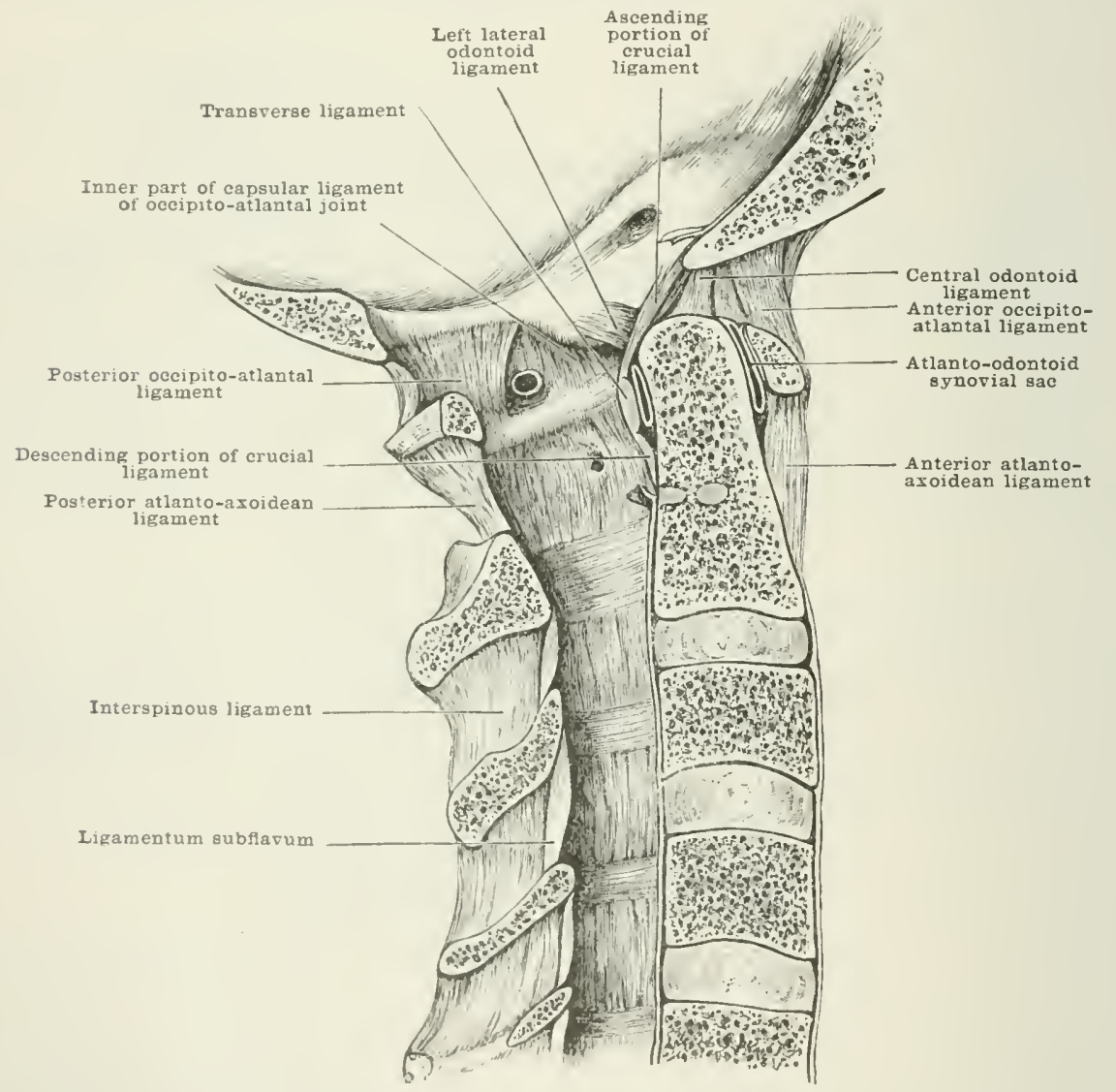

it is smoth and wrell rounded off to provide an casy floor of rommunication between the trans:rerso-exlonteriel and ocedpitoratlantal joints.

To its pusteriog surface is adede in the mildle line, a strong fasciculus of vertical fibres, passing upwark from the root of the odontoid process to the basilar borler of the formmen magnmo on its cranial aspect. some of these fibres are derived from the transwerse ligument. These vertical fihes give the transierse

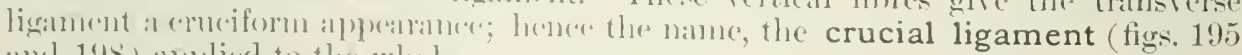
amel 1!s) alplierl to the whelle.

The atlanto-odontoid capsular ligament (fig. 196) is a tough, loose membrane, completely surpommline the alymsed articular surfaces of the atlas and orlontenid process. At the urlontoid process it blends above with the front of the 
check and central occipito-odontoid ligaments, and arises also alongr the sides of the articular facet as far as the neck of the process; the fibres are thick, and hlend with the capsules of the lateral joint. At the atlas they are attached to the non-articular fart of the anterior areh in front of the tubercles for the transverse ligament, blending, above and below the borlers of the bone, with the anterior occipito-atlantal and atlanto-axoidean ligaments, as well as with the inner portion of the capsular ligaments. It holds the axis to the anterior arch of the atlas after all the other ligaments have been divided.

The synovial membranes (figs. 195 and 196) are two in number:-one for the joint between the odontoid process and atlas; and another (transwerso-odontoid) for that between the transverse ligament and the odontoid. This last often conmunicates with the occipito-atlantal articulations; it is closed in by membranous tissue between the borlers of the transverse ligament and the margin of the facet on the odontoid, and is separated from the front sac by the atlanto-odontoid capsular ligament.

The arterial supply is from the vertehral artery, and the nerve-supply from the loop between the first and second cervical nerves.

Movements.-The chief and characteristic movement at these joints is the rotation, in a nearly horizontal plane, of the collar formed by the atlas and trans-

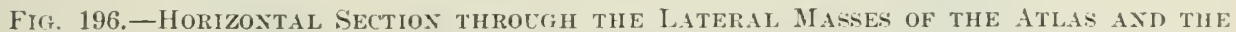
TOP OF THE ODONTUII PIRUCES:

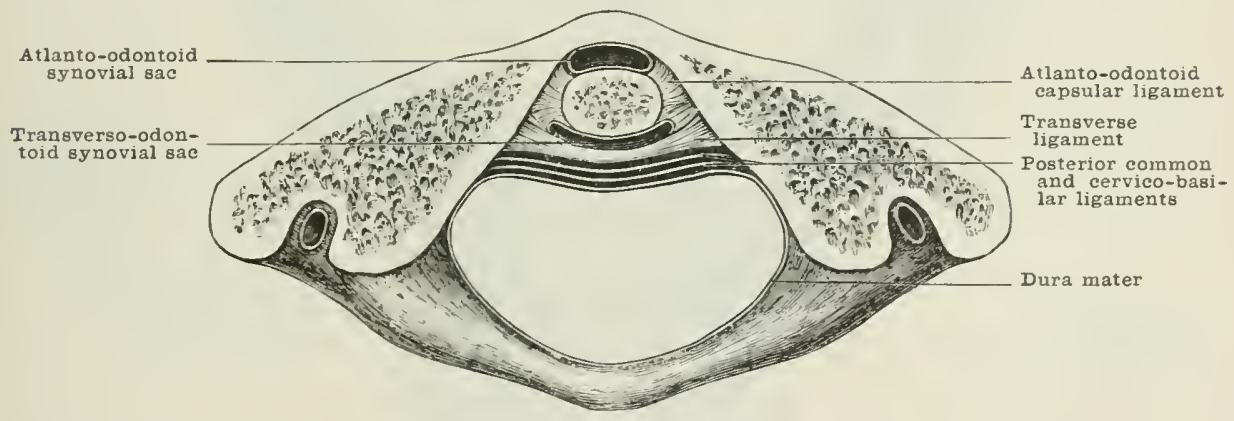

verse ligament, round the odontoid process as a pivot, which is extensive enough to allow of an all-round view without twisting the trunk. Partly on account of its ligamentous attachments, and partly on account of the shape of the articular surfaces, the cranium must be carried with the atlas in these morenents. The rotation is ehecked by the ligaments passing from the axis to the occiput (check ligaments), and also by the atlanto-axoidean. Owing to the fact that the facets of both atlas and axis, which enter into the formation of the lateral atlantoaxoidean articulations, are convex from before backwards, and have the articular cartilage thicker in the centre than at the circumference, the motion is not quite horizontal but slightly curvilinear. In the erect position, with the face looking directly forwards, the most convex portions of the articular surfaces are alone in contact, there being a considerahle interval between the edges; churing rotation. therefore, the prominent portions of the condyles of the atlas descend upon those of the axis, diminishing the space letween the bones, slackening the ligaments. and thus increasing the amount of rotation, without sacrificing the security of the joint in the central position.

Besides rotation, forward and backward movements and some lateral flexion are permitted between the atlas and axis. even to a greater extent than in most of the ither vertebral joints. 


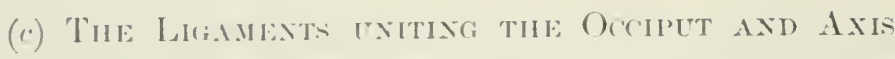

The following ligaments unite bunes not in contact, and are to be seen from the interior of the wankl aftere removing the posterior arches of axis and athas and posterior ring of the formen mannm:-

1. The coripito-cervical.

2. The erucial.
3. Two lateral odoutoid or check.

4. The central odontoid or suspensory.

The occipito-cervical or cervico-basilar ligament (figs. 196, 197, and 198) consists of a very stromer hand of fibres, commered helow to the upper part of the bexly of the thisd reptehra and lower part of the hody of the axis as far as the root of the olontoid process. It is narrow below, but widens out as it ascends, to he

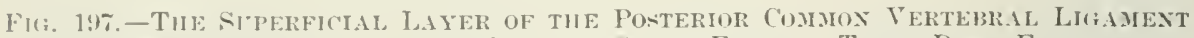

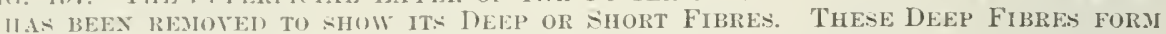
TIE UCCIPITU-CERVICAL LIGAHEXT.

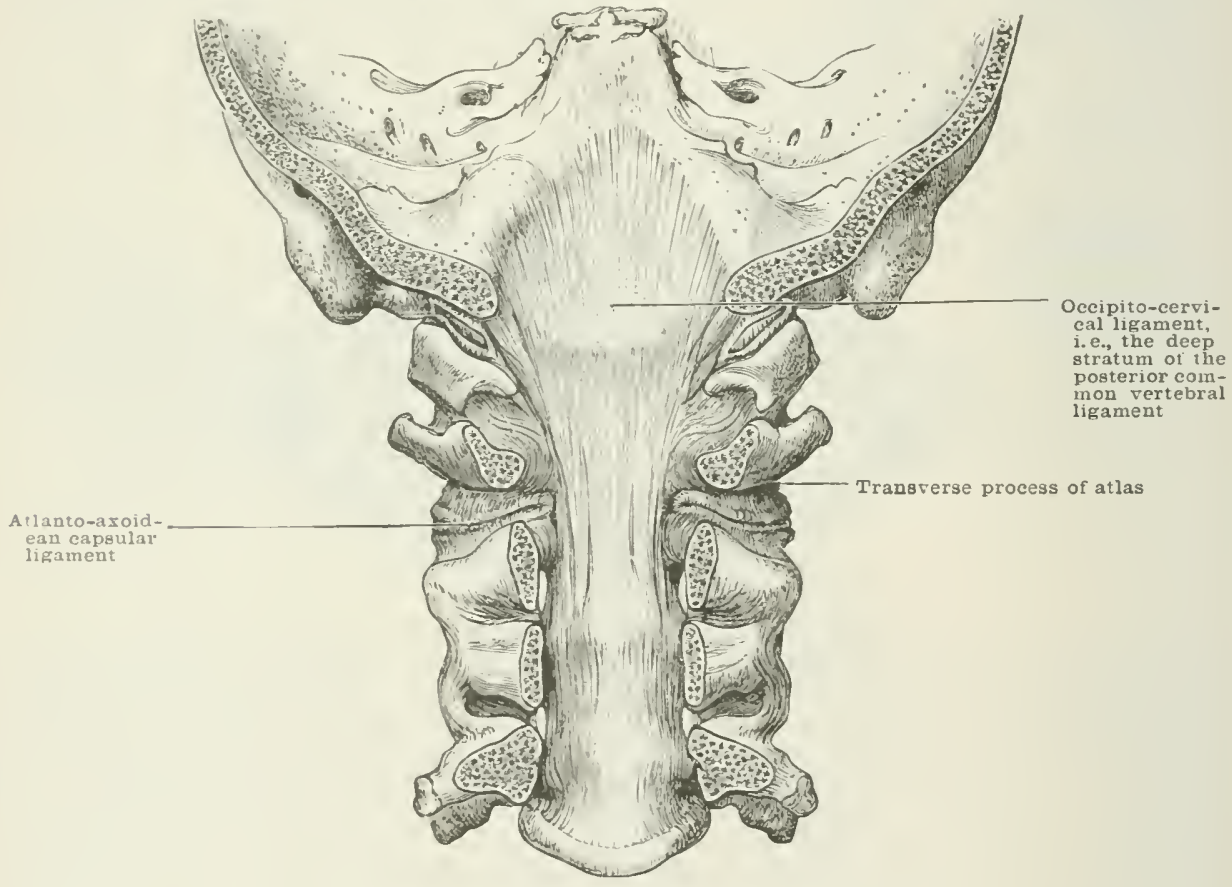

fastemed to the basilar coroore of the oceiput. Laterally. it is comnecterl with the

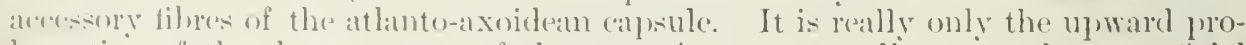
longation of the chepe stratum of the posterion common ligament, the superficial fibres of which run om to the oreipital bene without touching the axis, thus giving ris. (1) two strata. It is in relation in front with the erucial liganent.

The crucial ligament has heen allealy describerl (soe page 186i).

Thu lateral occipito-odontoid or check ligaments (figs. 19\%) and 198) are two stronger loundel cords, which extent from the sides of the alpex of the odontoid process, transpraty mutwards to the immere adge of the anterior portion of the

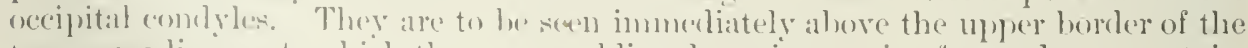
transwerse liginnont, which they cross ohliquely owing to its forwarel curve at its

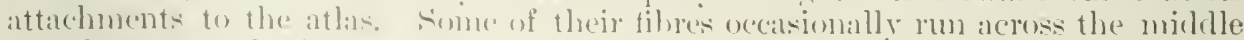
line from one wheck lignunent to the other. At the whontoinl process they are

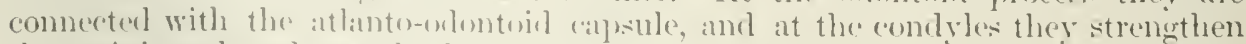

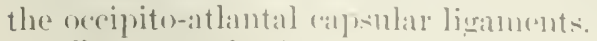

The central odontoid ol' suspensory ligament (firs. 195) and 198) consists of 
a slender hand of fibres ascending from the summit of the olontoid proesss to the unrler surface of the oxeipital bone, chose to the foramen magnum. It is best sen from the front, after removing the anterior occipito-atlantal lisament, or from behind by drawing aside the crucial ligament.

The suspensory ligament is tightened hy extension and relaxed hy flexion on nodding; the lateral odontoirs not only linit the rotatory movements of the hearl and atlas upon the axis, but by binding the occiput to the pivot. round which rotation orcurs, they steady the head and prevent its undue lateral inclination upon the spine. (Sce Transverse Ligament, p. 1S6.)

By experiments, it has been proved that the head. when placed so that the orbits look a little upwards, is poised upon the occipital condyles in a line drawn a little in front of their middle; the amomnt of elevation varies slightly in different cases, but the balance is always to he ohtained in the human body-it is one of the characteristics of the human figure. It serves to maintain the head erect without undue muscular effort, or a strong ligamentum nuche and prominent dorsal spines

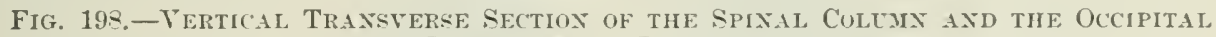
BONE TO SIIOW LIRAMEXTS.

(The cervico-basilar (1), though shown as a distinct stratum, is really the deeper part of the posterior common ligament $(2)$.)

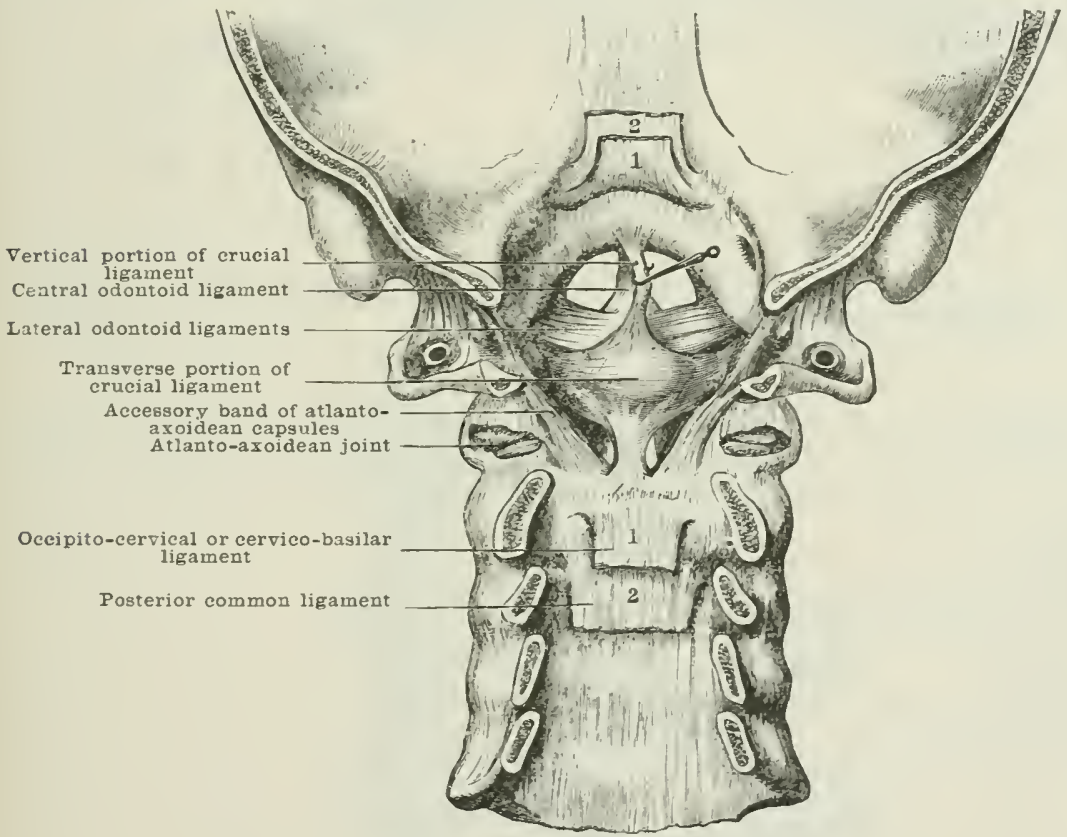

such as are scen in the lower animals. Disturl this balance, and let the muscles cease to act, the head will either drop forwarls or backwards according as the centre of the gravity is in front or behind the balance line. The ligaments which pass over the odontoid process to the occiput are not quite tight when the head is erect, and only beronne so when the head is Hexed; if this were not so, no flexion would be allowed; thus, muscular action. and not liganentous tension. is cmployed to steady the head in the erect position. It is through the combination of the joints: of the atlas and axis, and occiput and atlas (consisting of two pairs of joints placed smmnetrieally on either side of the median line. while through the median line there passes a pivot, also with a pair of joints) that the head enjors such freedonn and celerity of action, remarkable strength, and almost absolute security against riolence, which could only be obtained by a ball-and-socket joint; but the ordinary ball-and-socket joints are too prone to dislocations by even moderate twists to bic reliable enough when the life of the individual depends on the perfection of the articulation: hence the importance of this combination of joints. 


\section{THE ARTICULATIONS OF THE TRUNK}

These may be divided into the following sets:-

1. Those of the rertebral column.
(a) Union of the boties.
(b) Union of the articular processes.

2. Vertebral column with the pelvis.

3. Pelvis.
(a) Silcro-iliac synchondroses.
(b) Sacro-coecygeal.
(c) Intereocygeal.
(d) Symphysis pubis.

4. Ribs with the vertebral columm.

5. The articulations at the front of the thorax.

(a) Costal cartilages with the stemmm.

(b) Costal cartilages with the ribs.

(c) Sternal.

(d) Certain costal cartilages with each other.

\section{THE ARTICLLATIONS OF THE VERTEBRAL COLUNS}

There are two distinct sets of articulations in the rertebral column:-

(a) Those hetween the bodies and intervertebral discs which form amphiarthroclial joints.

(b) Those between the articular processes which form arthrodial joints.

The ligaments which mite the various parts may also be divided into two sets, riz. -immediate, or those that bind together parts which are in contact; and intermediate, or these that linel together parts which are not in contact.

\section{Immediate.}

(a) Those between the bodies and dises.

(b) Those between the articular processes.

\section{Intermediate.}

(c) Those hotween the lamina.

(d) Those between the spinous processes.

(e) Those botween the transverse processes.

(a) The Artieulations of the Bodies of the Verterre

Class.-Imphicurthrosis.

The liganents which mite the hodies of the vertehre are:-

Intervertehral dise's.

Short lateral liganents.
Anterior common.

P'osterior' eommon.

The intervertebral substances (figs. 195 and 199) are tough, but elastic and compressible dises of eompesite structure, which sorve as the chief bond of union between the vartehre. They are twenty-thre in number, and are interposed between the borlies of all the rertehrae from the axis to the saerum (figs. 195 and 206i). Similar substances are fomel betwern the sogments of the sacrum and encerx, but they undergo osvitication at their surfixes and often throughout their whole extent. 
Each disc is composed of two portions-a circumferential laminar, and a central pulpy portion; the former tightly surrounds and braces in the latter, and forms somewhat more than half the disc. The laminar portion consists of alternating layers of fibrous tissue and fibro-cartilage; the component fibres of these layers

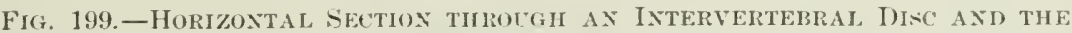
CORRESPUNDING RIIBS.

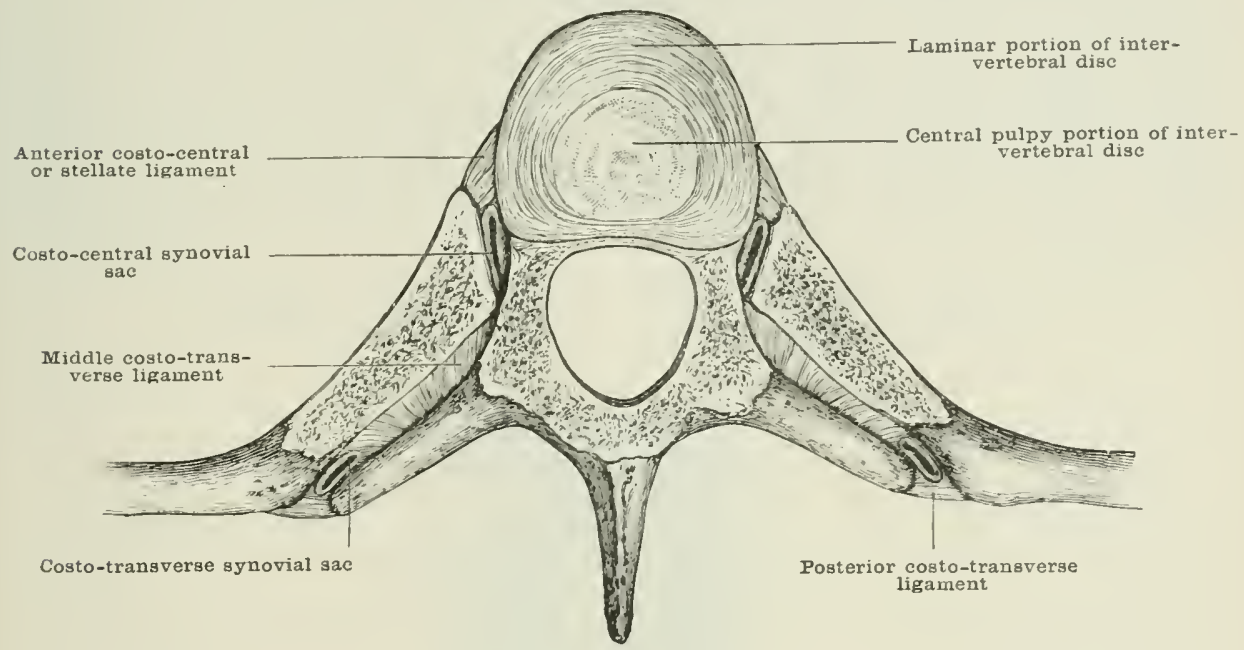

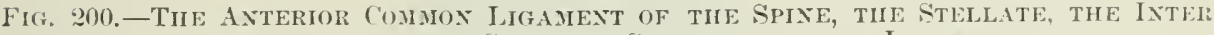
ARTIELAR, AND THE SFPERIOR CONTO-TRANAYERSE LIGAMENTS.

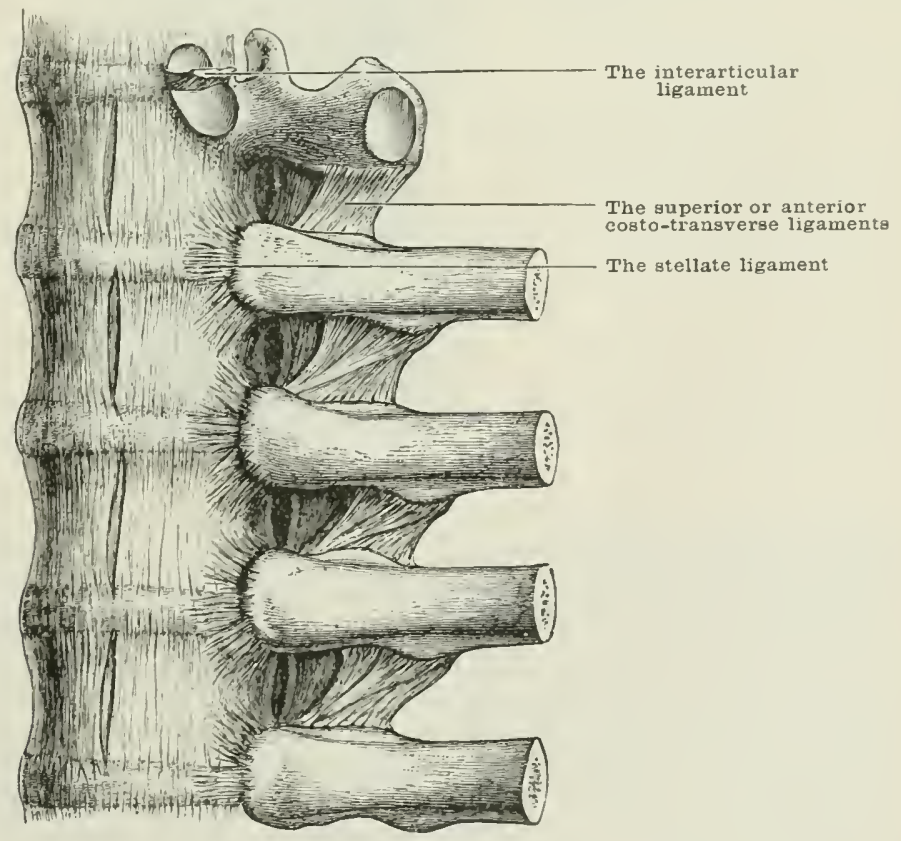

are firmly connected with two vrrtebre, those of one passing olsliquely down and to the right, those of the next clown and to the left, making an $X$-shaped arrangement of the alternate layers. A fow of the superficial lamella project beyond the edges of the bodies, their fibres being connected with the edges of the anterior and 
lateral surfares: amel somo in not completely surromul the rest, lut terminate at the intervertebral foransina, so that on horizontal sertion the circunferential portion

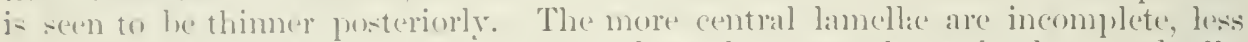
firm. and not so distinet as the rest; and as they near the pulp they gratually

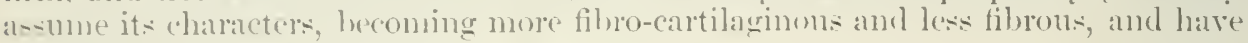
(artilatere colls in their structure.

The central portion is situated somewlat lehind the centre of the dise, forming a ball of very elastic and tightly compresed material, which bulges frecly when the anfining puesure of the laninar portion is renored by either horizontal or rertical section. Thus, it has a constant tendency to spring out of its confinement in the direction of least resistance. and constitutes a pirot round which the bodies of the reptehrie ("an twist, tilt, or incline. It is rellowish in colour, and is compused of a fine fibrous matrix containing cartilage cells and fluid in its meshes. Therether with the most central hamine, it is separated from immediate contact

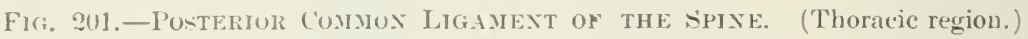

Pedicles eut through, and posterior arches of vertebra removed.)

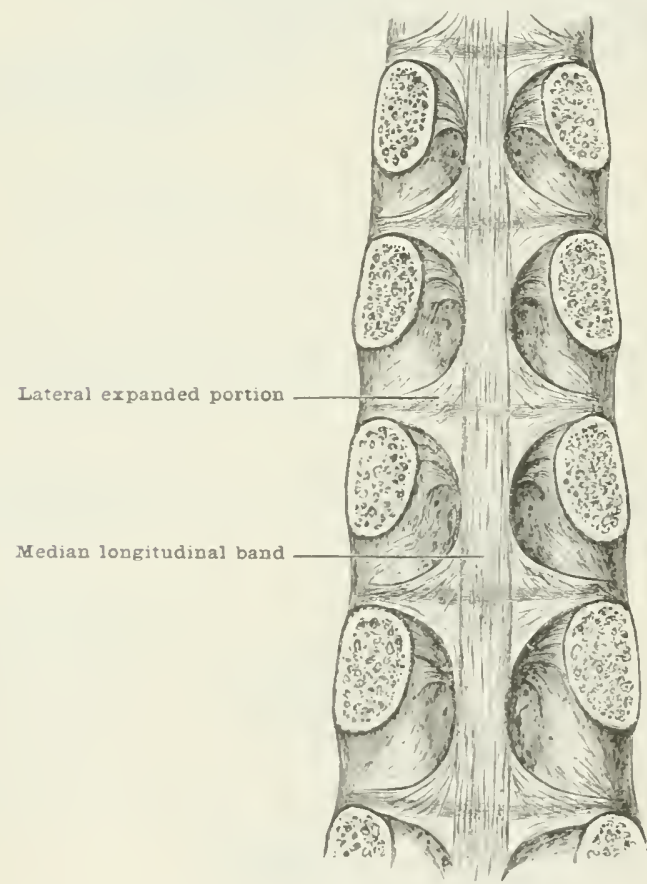

with the bune by a thin plate of articular cartilage. The central pulp of the interrertebral substance is the persistent part of the notorbond.

The intervertebal sulstances vary in shape with the luelies of the rertebra they unite, and ane willest and thickest in the lumbar rexion. In the corvionl and lumbir recions they are thickor in front than behind, and canse the convexity forwatrls of the crovical, and incrense that of the lumbar; the curve in the thoracic region, almost antirely due to the shape of the bolies, is, however, somerwat increased hy the dists. Without the disces the colum loses a quarter of its length. ame astumes a curve with the omeavity forwarts, most marked a little below the

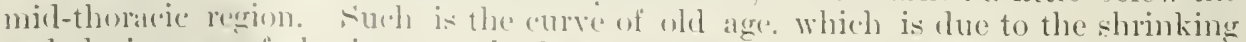
and drying up of the interverteblal sulstances. The lise between the axis and third cervical is the thimmest of all (fig. 19);); that between the fifth lumbar and salerum is the thickest, and is much thicker in front than hehind (fig. 206). The interverteloral dises are in relation. in front with the anterior common liganent: 
behind, with the posterior eommon ligament; laterally, with the short lateral; and in the theracede rexion with the interarticular and stellate liganents.

The anterior common ligament (figs. 194 and 200 ) (ommences as a narrow band attarhed to the under surfice of the occipital bone in the median line. just in front of the oxeipito-atlantal ligament, of which it forms the thickened central pertion. Attacherl fimly to the tuherele of the atlas. it pastes clown as the "entral portion of the atlanto-axoidean ligament, in the mirl-line, to the front of the borly of the axis. It now begins to widen out as it rescends, until it is nearly two inches ( 5 em.) wirle in the lumbar rexion. Below, it is fixed to the mpler soment of the sacrum, becoming lost in periosteum alout the mirlde of that bone; but is again distinguishable in front of the sacro-cocergeal joint, as the anterior sacro-cocergeal ligament. Its structure is hright, pearly-white, and glistening with well-defined borders lest marked in the thoracic region. It is thickest in the thoracie region, and thicker in the lumbar than the rervical. It is fimly connerted with the bodice of the rertelure and is composed of longitudinal

Fig. 202.-Posterior Commox I.rianest. (Lumbar region.)

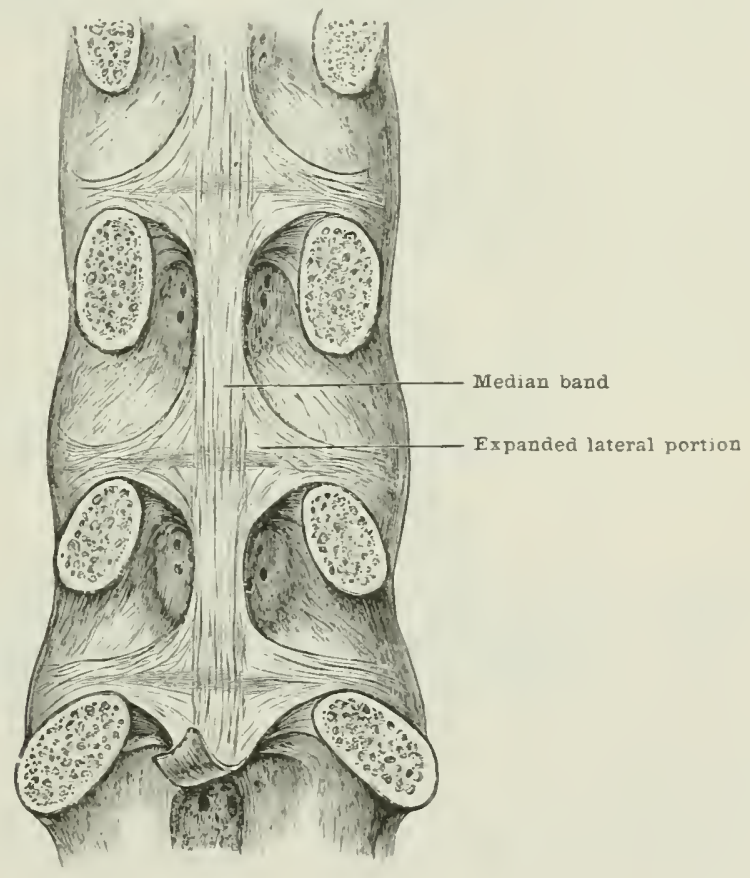

fibres of which the superficial extend over several. while the deeper pass over only two or three vertehre. It is amnerted with the tendinous expansion of the prerertehral muscles in the cervical. and the crura of the diaphragm are closely attareherl to it in the lumbar region.

The posterior common ligament (figs. 19S. 201. 202. and 209) extends from the oceipital bone to the coecry. It is witer alwow than below, and commences ly a broad attachment to the eranial surface of the basi-oceipital. In the rervial region it is of nearly uniform width. and extends completely across the bodies of the vertebre, upon which it rests quite flat. It does. howerer. extend slightly further outwarks on each side opposite the intervertednal clises. In the thoracie and lumbar regions it is distinctly dentated, being broader orer the interertebral sul,stances and the orlges of the bones, than orer the middle of the hodies. where it is a narrow band stretched ore the bemes without resting on them, some areolar tissue and blook-rescels being interposed. The narow median portion ronsists of longitudinal fibres, some of which are superficial and fass orer sereral rertebrac; 
and others are derper, and extend only from one verteblat to the next hut one lum.

The dentated or bromer portions (tig. 202) are formed hy oblipue filmes which, springine from the holies near the intervertedoral foramina, take a curved course chwowals and backwark over an intervertehral substance, and reach the narrow portion of the ligament on the eentre of the vertelora next below; they them diveree

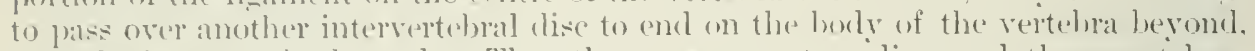

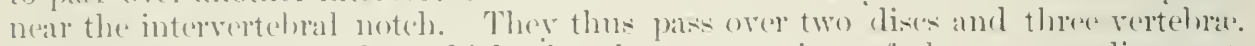
Derene still are other fibes thickening these expansions of the common ligament. and extemling from one bone to the next.

The last woll-marked expansion is situated between the first two segments of the silerun: below this, the ligament becomes a delieate central band with rurlimentary expamsions, lucing nore fronounced again orer the sarero-cocreyeal joint, and losing itself in the ligimentous tissue at the back of the rocerx. The dura mater is tightly attacher to it at the oceipital bone and margin of the formen magnum, but is separater from it in the rest of its extent by lowe cellular tisise. The filmu terminale becomes liended with it at the lower part of the sarrm and hack of the cocerx.

The lateral or short vertebral ligaments (fig. 200) ("onsist of numerous short filure silnated betwen the anterior and posterior common ligaments, and passing from one vertebra over the intervertebral disc, to which it is firmly adherent, to the next vertebral below. The more superficial filmes are more or less vertical, but the deeper deensate and have a crucial arrangenent. They are commected with thre (leep surface of the anterior common ligament, and so tie it to the erlges of thr. bulies of the rertobre and to the intervertebral dises. They blend hehind with the expansions of the posterior common ligament, and so complete the calsing romel atch amphiarthrodial joint. In the thoracic region, they orerlie the stellate ligament, and in the lumbar they rarliate towards the transverse processes. In the cervical region they are less well marked.

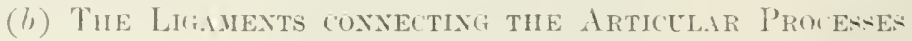

\section{Class.-Dirathrosis. Subdivision.-Athrodia.}

The capsular ligaments (fig. 194) which mite these frocesces are composed partly of yellow elastic tissue, and partly of white fibrous tissue. In the cervical region cmly the immer side of the eapsinle is formed by the ligmmenta suhflara, which in the thoracic and lumbar regions, howerer, extend anteriorly to the margins of the intervertebral foramina. The part formed of white fibrous tissue ansists of short. Woll-market filmes, which in the cervical region pass obliquely chwmwals and forwarls over the joint, between the articular processes and the pesiteriol routs of the transverse processes of two contiguous rertebra. In the theracice rexion the fihres are shorter, and rertical in direction. and are attached to the bass of the transwere processes; in the lumbar, they are olliquely tranrivere. Tha (anpsular ligaments in the cervical region are the most lax, those in the lumbar regim are lather tighter. and those in the thoracie region are the tightest.

There in one synovial membrane to ath capsule.

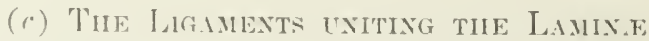

The ligamenta subflava (fig. 203) are shallow plates of cluschy-woven yellow

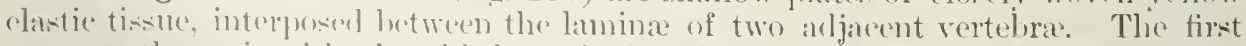
commeres the axis with the thid corvieal, and the last the fifth lumbar with the

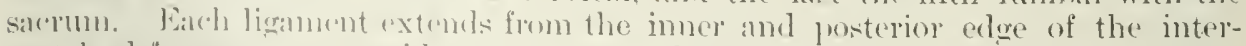
vertebral formonen on one sicle to a corresponding point on the other; above, it is attached ("lose to the immer marein of the inferion articular process and to a wellmarked risese wh the inmere surface of the laminas as far as the root of the spine;

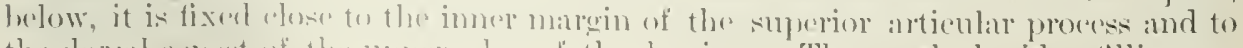

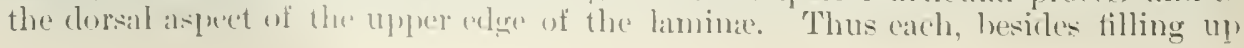


the interlaminar space, enters into the formation of two eapsular ligaments; they do so to a greater extent in the thoracic and lumbar regions tham in the cervical, where the articular processes are placed wider apart. When seen from the front after removing the hodies of the vertebre, they are concare from side to sicle, but convex from abore downwards; they make a nore decided transwerse curve than the arches betwen which they are placed. This conearity is more marked in the thoracic, and still more in the lumbar region than in the cervical; in the lumbar region the ligamenta subflava extend a short distance between the roots of the spinous process, blending with the interspinous ligament, and making a median sulens when seen from the front: there is, however, no separation between the two parts. In the cervical region, where the spines are bifid, there is a modian fissure

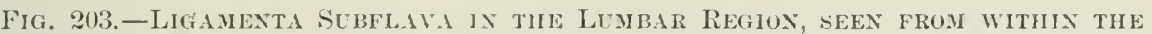
SIINAL CANAL.

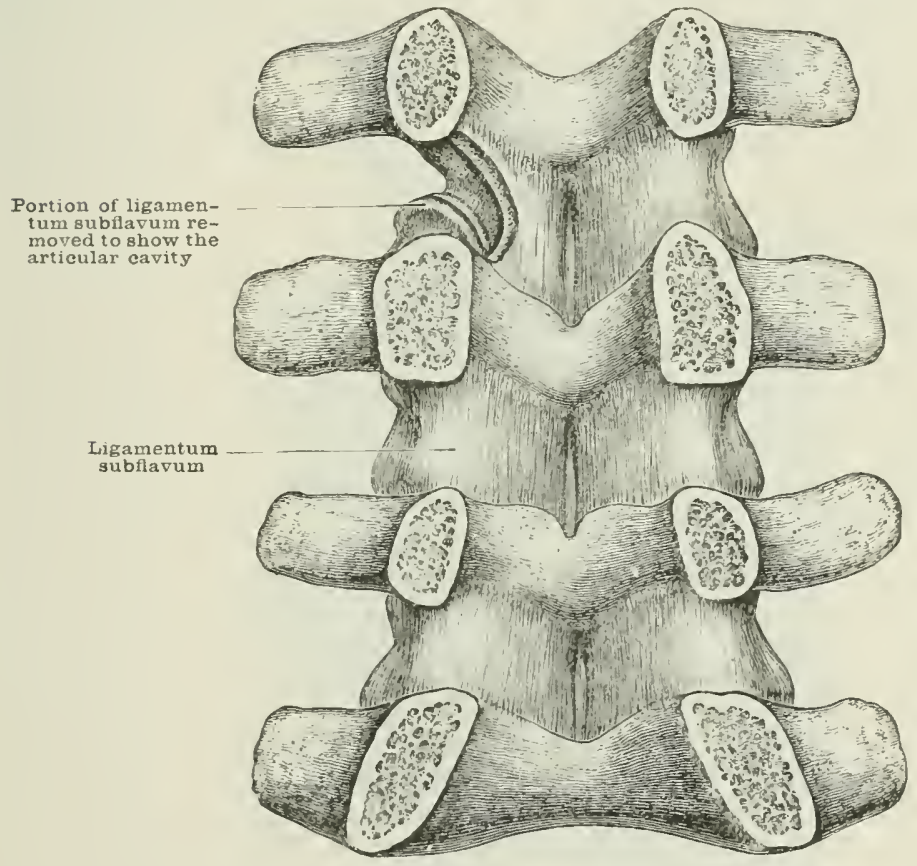

in the rellow tissue which is filled up by fibro-areolar tissue. The ligaments are thickest and strongest in the lumbar region; narrow but strong in the thoracic; thinner, broader, and more membranous in the cervical region.

\section{(d) The Lighinexts cosxectha the Spinots Processes with oje hother}

Supraspinous ligament, interspinous ligaments, and the ligamentum nuchæ.

The supraspinous ligament (fig. 20.j) extends, without interruption, as a well-marked band of longitulinal fibres along the tips of the spines of the vertelorix from that of the seventh cervieal downwark till it hlends with the fibrous tissue on the back of the cocerx. It covers in the lower end of the spinal canal, and arlds to the security of the sacro-cocergeal articulation.

Its more superficial fibres are much longer than the deep. The deeper fibres pass over adjacent spines only, while the superficial overlie several. It is connected laterally with the ajoneurotic structures of the back; inderel. in the lumbar region, where it is well nurkerl, it appears to result from the interweaving of the tendinons fibres of the sereral muscles which are attached to the tips of the spinous processes. 
In the dorsil regrion it is a roumel stemeler cord which is put on the streteh in Hexion and relaxcel in extension of the back.

The ligamentum nuchæ, or the posterior cervical ligament (fig. 204), is the montinuation in the neres of the supurapinons liganent, from which, howerer, it

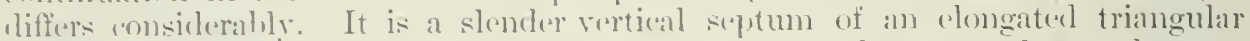

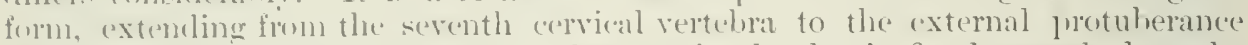
and the erest of the oreipital lome. It- anterior border is firmly attached to the

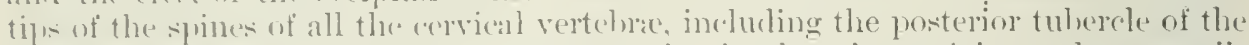
atlis. as well as to the oreiput. Its posterior horder gives origin to the trapezii, with the temelimus filmes of which muscles it hlends. Its lateral, triangular sur-

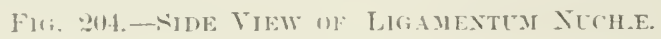

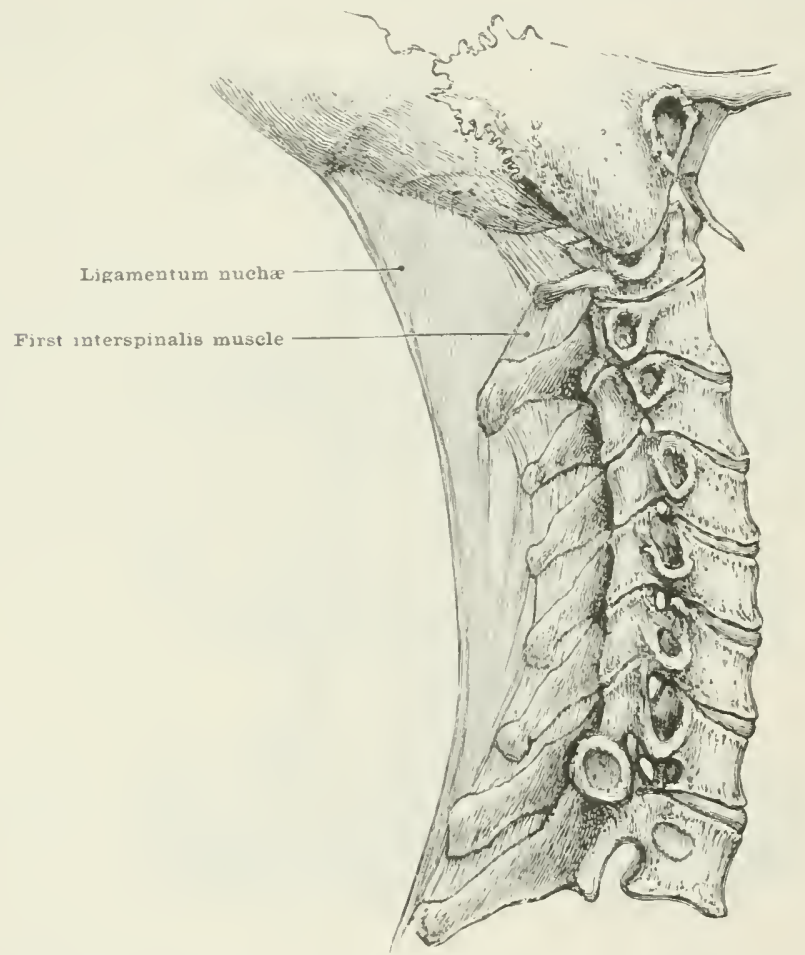

facess affiord numerous points of attachment for the posterior museles of the head and noek.

In man it is rulimentary, and consists of clastic and white fibme tissues. As seen in the horse, elephant, ox, and other mammiferous quadrupeds, it is a great and impurtant elastic ligament, which eren reaches along the dorsal part of the frinal colmun. Tn these anmals it serves to support the head and neck, which otherwise from their own weight would hang down. Its rudinentary state in man is the direct enterepuence of his erect position.

The interspinous ligaments (fig, 205) are thin menbranons structures which

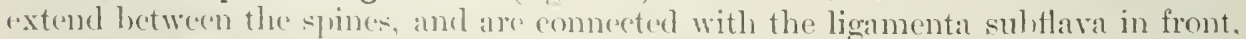
and the supraspinous ligament helinel. The fibres pass oblicuely from the root of one spine to the tip of the next; they thus decussate. They are liest marked in the lumbar region, and are replaced ly the well-developed interspinales muscles in the ecrvieal regrom. 


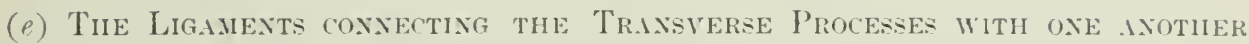

The intertransverse ligaments are barely worth the name; in the thoriciv region they form small romoled hundles, and in the lumbar they are thin menbranous bands, quite incapable of action as honds of union. They consist of filnres passing between the apices of the transverse processes. In the cervical region they are replaced hy the intertionicersules museles.

The arterial supply for the column comes from twigs of the rertebral, ascending pharyngeal, ascending cervical, superior and aortic intercostals, lumbar, iliolumbar, and lateral sacral.

The nerve-supply comes from the spinal nerres of each region.

Movements.-Thespinal column is so formed of a number of loones and intervertebral discs as to serve many jurposes. It is the axis of the skeleton; upon it the skull is supported; and with it the carities of the trunk, and the limbs are connected. As a fixed column it is capable of hearing great weight; and, throngh the elastic intervertebral substances, of resisting and breaking the transmission of

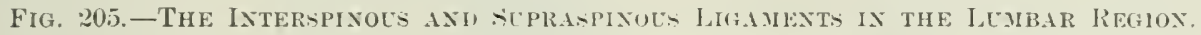

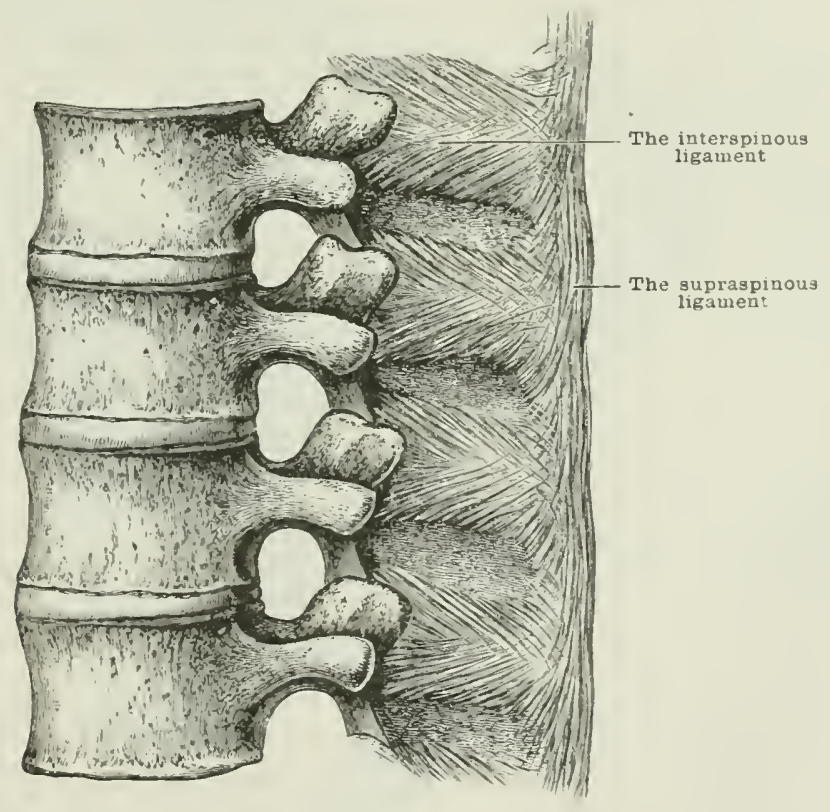

shocks. Moreorer, it is flexible, and therefore capalle of movement. Now, the range of movements of the column as a whole is very considerahle; hut the morements between any two vertebre are slight, so that motions of the spine may take place without any change in the shape of the column, and without any marked rlisturbance in the relative positions of the rertebra. It is abont the pulpy part of the intervertebral dises, which form a central elastic pirot or ball, mpon which the nicldle of the vertebre rest. that these movements take place.

The amount of motion is everywhere limited hy the common vertehral ligaments, but it depends partly upon the width of the bodies of the rertebrae, and partly upon the depth of the dises. so that in the loins, where the bodies are larget and wide, and the dises very thick, free motion is permitted; in the cerrical region, though the dises are thinmer, ret, as the hodies are smaller, almost expully free motion is allowed. As the ball-like pulpy part of the intervertebral disc is the centre of movement of each vertebra, it is olvious that the motion would he of a rolling character in any direction but for the articular jroceses. which serve also to give steadiness to the colmm and to assist in bearing the superincumbent weight. 
Wre it not for these processes, the column, insteal of being a stationary one, andower with the aifuacity of mosement by muscular ageney, would be a tottering (met, refuiring musches to steady it. The influence of the articular processes in limiting the firection of inclination will appear from a study of the morements in the three regions of the syine.

In the neck, the obliguity of the proesses premits all movements, but is expecially farourable for cxtension. Flexion is less free here than in the lumbar region, while extension is frere. Lateral flexion is more free in the neck than in any other region. liotatery morements are also frese in the neck, especially in the lower part. There is hut slight movement of any sort between the axis and third cervical vertwbra, owing to the shillow intervertebral disc and the great prolongation of the anterior lip of the inferior surface of the body of the axis, which checks forward Hexion considerat)ly.

In the thoracic region, especially near its midlle, antero-posterior flexion and "xtension are very slight; and, as the concavity of the curve here is forwards, the Hat and nearly vertical surfaces of the articular processes prevent anthing like slidine in a curvilinear manner of the one set of processes over the sharp upper (rlges of the other, which would be necessary for formarl flexion. A fair amount of lateral flexion wonkl be permitted but for the impediment offered by the ribs; while the shichtly outward inclination of the superior process, and inward inclination of the inferior, allow a little rotation, which is freer in the upper than in the lower part of the thoracic region.

In the lumbar region, extension and flexion are very free, especially between the thirel and fourth, and fourth and fifth vertelore, where the lumbar curre is - lanpest; lateral inclination is also rery free between these same vertebrae. It has bern stated that the shape and position of the articular proecsses of the lumbar and the lower two or three dorsal are such as to puevent any rotation in these regions; lut, cwing to the ficet that the inferior articular proesses are not tightly embraced he thesuperior, so that the two sets of articular processes are not in contact on hinth sicles of the borlies at the same time, there is always some space in which lurizontal notion can occur round an axis drawn through the central part of the luxlies and intervertebral dises. Thus, the motions are most free in those regions of the column which have a convex curve forwards, due to the shape of the interrertchinal discs, where there are no bony walls surromding solid viscera, where the slinal camal is langest and its contents are less fimly attached, and where the fulicles and artionlar procesces are more nearly on a transwerse level with the jostrior surface of the burlies of the rertobre.

Normust the nses of the ligamental subthava he forgotten: these useful little struetures (1) complete the roofingrin of the spinal canal, and yet at the same tinse fermit an erer-ehanging variation in the willth of the interlaninar spaces in flexion and extension; (2) they also restore the artieulating surfaces to their nomal gosition with rearal to ach other after movements of the columm; (B) and lye foming the inner prortion of arch eapsular ligament they take the place of miscle, in fureventing it from being nileped between the articular surfaces during morement.

\section{THE SACRO-VERTERRAL ARTICLLATIOA-, OR THE ARTICLLA-} TIONA UF THE PELVIS WITIL THE SPINE

(11) Class. - Imp himithroxis

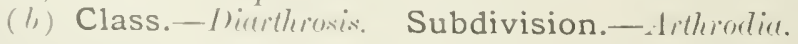

As in the intervertednal antienlations, sil in the mion of the first portion of the sarerum with the lase lumbar vertebra, there alle two sots of joints-viz. (a) an

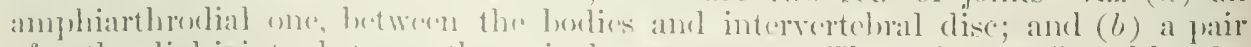
of artherelial joints, luetwen the artienlar proesses. The union is effereted by the following liganents, which aro (x)mmon to the spinal columm:-(i) anterior, and (ii) posterior, ("ommmon: (iii) lateral or shent rerteloral; (iv) (apsular; (v) ligamentum subliamm; (vi) sujpal- and (rii) interspinous ligaments. Two sperial 
accesory ligaments on either side, viz. the sacro-lumbar and the ilio-lumbar, connert the pelvis with the fourth and fifth lumbar vertebre.

The sacro-lumbar ligament (fig. 206) is strong, and triangułar in shape. Its apex is above and internal, being attached to the whole of the lower border and front surface of the transverse process of the fifth lumbar vertebra, as well as to the peelicle and borly. It is intimately blended with the ilio-lumbar ligament. Below, it has a wide fan-shaped attachment, extending from the edge of the ilio-lumbar ligament forwards to the brim of the true pelvis; b'ending with the periosteum on the lase of the saerum and in the iliae fossa, and with the superior sacro-iliac ligament. By its sharp internal border it limits externally the foramen for the fast lumber nere. It is pierced by two large foramina. which transmit arteries to the sacro-iliac synchondrosis. This ligament is in series with the intertransverse liguments of the spinal column.

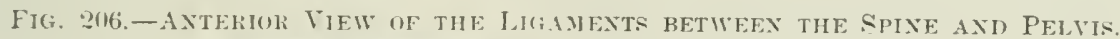

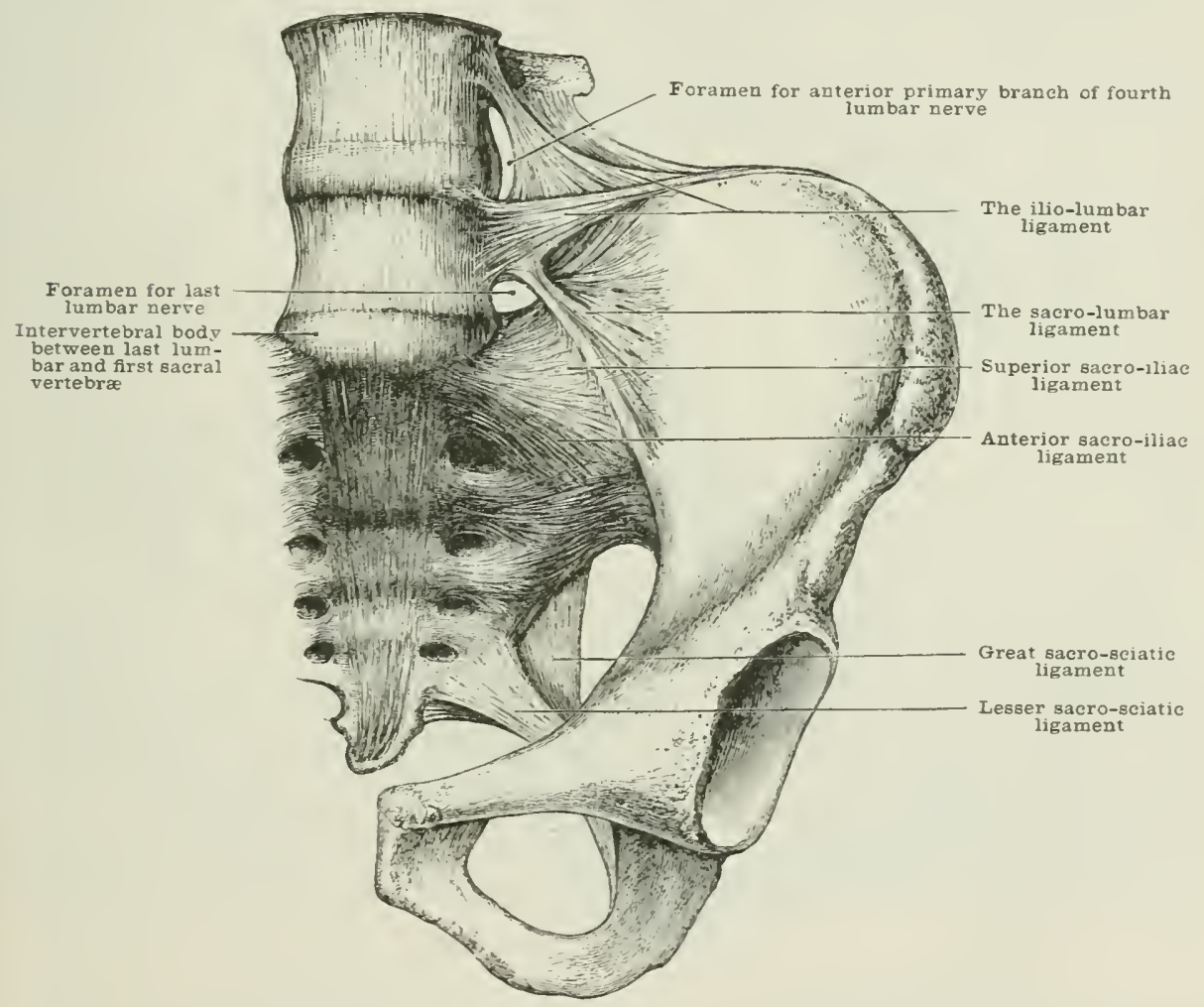

The ilio-lumbar ligament (fig. 의(f) is a strong, lense, trangular ligament. which spring: from the front surface of the transverse process of the fifth lumbur vertehra as fin as the borly, by a strong fasciculus from the posterior surface of the frocess near the tip, and also from the front surface and lower edge of the transverse process and perliele of the fourth lumbar vertebra as far inwards as the body. Betwern these two lumbar restebre it is inseparable from the intertianserese ligament. It its origin from the transwerse process of the fifth lumbar rertebra, it is clo-ely interworen with the sacro-lumblar ligament, and some of its fibres sprearl downwards on to the hody of the fifth rertebrat, while others aseend to the disc above.

At the pelvis it is attached to the inmer lip of the erest of the ilium for about two inches ( $j \mathrm{~cm}$.$) . The highest fibres at the spine form the upper edge of the$ ligament at the pelvis. those which come from the posterior portion of the transverse process of the fifth lumbar vertebra forming the lower. while the filores from the front of the same process pass nearly horizontally outwarls. 


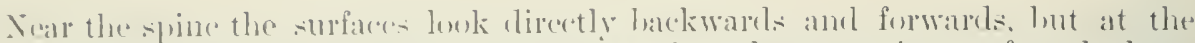
ilium, the liganent wets somewhat twisted, so that the posterior surface looks a little upwarts, and the anterior looks a little downwarels.

The anterior surface forms part of the posterior boundary of the false pelvis. and overlies the upper part of the posterien sacro-iliac liganent; the posterior surface lorme part of the floor of the spinal growere, and gives origin to the multificlus spina musele. Of the herrlers, the upler is obligue, has the anterier lamellat of the lumbar fascial attacher to it, and gives origin to the quadrutus lumbman; the lower is horizontal, and is adjacent to the upperedge of the sacro-lumbar liganent; while the inner is creseentic, ant forms the outer boundary of a foramen through which the fourth lumber nedve basics.

'The arterial supply is rery frere, and comes from the last lumbar, ilio-lumbar, and laterial silelial.

The nerve-supply is from the smmpathetir, as well as from twigs from the fouth and filth lumbar nerves.

Movements.-The anglo formed l,y the sacrum with the spinal column is called the silcro-rertohal angle. The pelvic inclination does not depend entirely upon this angle, hut in great part upon the obliquity of the imnominate hones to the sacrum, so that in malcs in whom the arerage pelvic obliquity is a little greater, the arelage sacro-rertebral angle is considerably less than in fenales.

The sarro-vertolual angle in the male shows that there is a greater and mor sulilen change in clirection at the sacro-vertebral union than in the female. A part of this change in tirection is due to the greater thickness in the anterior part of the

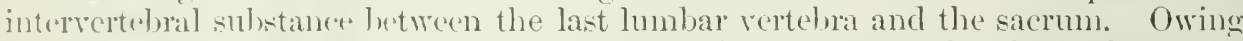
to the greater thickness of the intervertebral dise here than clsewhere, the movements permitter at this joint are very free, being freer than those hetween any two inmbar vertehres. Is the rianeter of the two contiguous bones is less anternmoteriorly than laterally, the forware and backwarl motions are much freer than the lateral oncs. The backward and forward motions take place every time the sitting is exchangerl for the standing position, and the standing for the sitting posture; in rising, the back is cxtended on the sacrum at the sacro-lumbar union; in sitting down it is floxerl.

The artienlar procestes provide for the gliding movement incidental to the (xtension, flexion, and lateral novements; they also allow some horizontal movement, neressiry for the rotation of the spine on the pelvis, or pelvis on the spine. The inferior artienlar prousses of the fifth differ considerably from the inferion proesses in the rest of the lumbar vertehras, and in direction they resemble some-

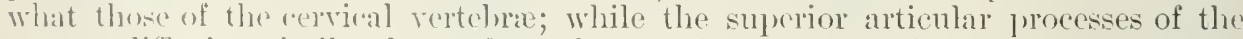
sar pum differ in a sintal degre from the superior processes of the lumbar vertebras. This differenese allows for the frecer rotation which oceurs at this joint.

The salerelertelnal angle averages $117^{\circ}$ in the male, and $130^{\circ}$ in the female; white the frelvie inclination arerages $1.55^{\circ}$ in the male, and $150^{\circ}$ in the fomale.

\section{THE ARTICLIATIONA OF THE PELVIS}

This group, naly again be sublivided into-

(11) The sacro-iliac.

(b) Th" sacro-coccygeal.

(r) The intercoccygeal.

(d) The symphysis pubis.

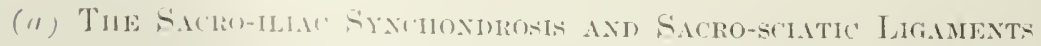

\section{Class.-. l mphinethrosis.}

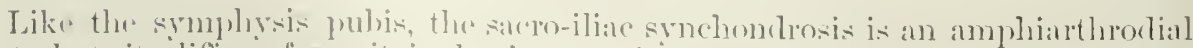
joint. Jut it ilffers from it in laving an interosicous liganent as woll as an 
interosseous, or symphysial, eartilage. The bones which enter into the joint are che silcrum and ilimu, and they are bound together by the following liganents:-

$$
\begin{aligned}
& \text { Anterior sacro-iliac. } \\
& \text { Posterior saero-iliae. }
\end{aligned}
$$

Suprrior sacro-iliac.

Inferior silcro-iliate.

Interosseous.

The anterior sacro-iliac ligament (figs. 206 and 207) consists of well-marked glistening fibres which pass above into the superior, and helow into the inferior, ligaments. It extends from the first three bones of the sacrum to the ilium hetween the brim of the tme pelvis and the great sacro-sciatic notch, hlending with the periostemm of the sacrum and ilium as it passes away from the miterl ertges of the hones.

The superior sacro-iliac ligament (figs. 206 and 207 ) extends acruss the upper margins of the joint, from the base of the sacrum to the iliac fossat being well

Fig, 20\%,-Verticil Axtero-posterior Section of tile Pelvis.

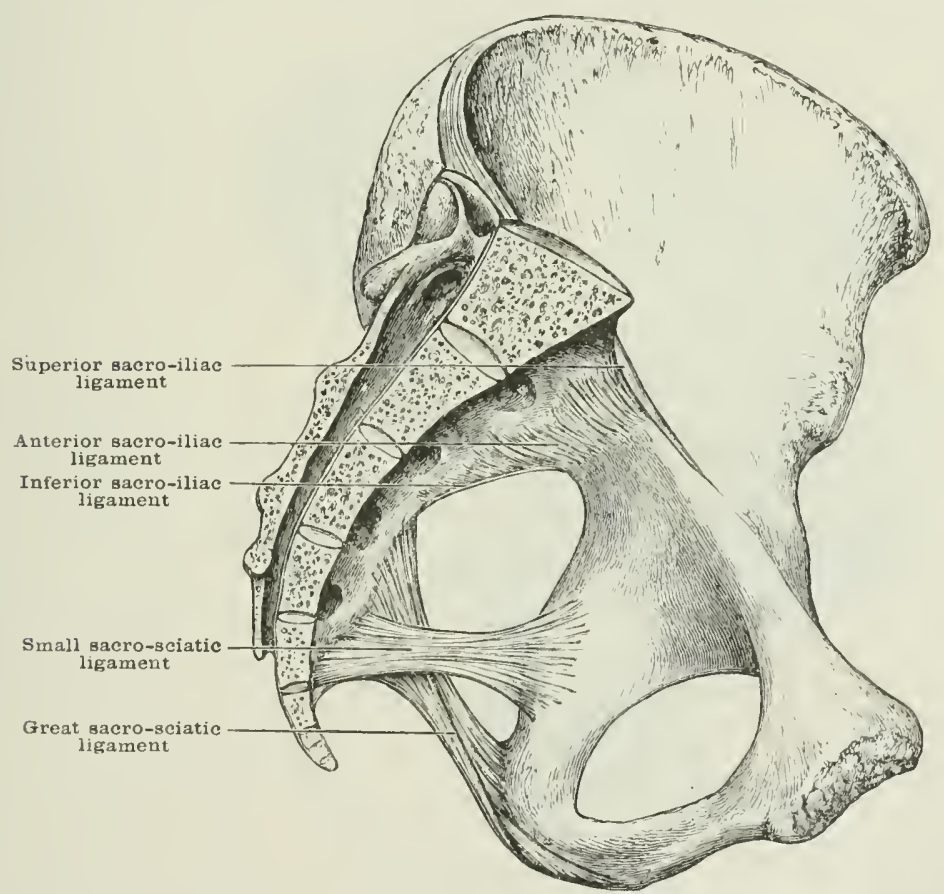

marked along the brim of the pelvis, where it is thickened hy some chosely-packed fibres. Behind, it is far stronger, especially beneath the transwerse process of the fifth lumbar vertebra. This ligament is comnected with the strong sarro-hmbar ligament, which spreats outwards and forwards over the joint to reach the iliac fossa and ilio-pectineal line.

The posterior sacro-iliac ligament is of very great strength, extending hetween the back of the sacrum and the posterior two inches of the iliae crest, inchuring the posterior superior spine. Strengthening the upper and back part of this filirous expansion are some strong lomdles of ligamentous fibres, which "xtencl more or less transversely from the immer surface of the iliac erest: (i) to the articular process of the first sareral vertelia; (ii) to the bone between the articular process and the first sacral foramen; and (iii) to the articular tuberele of the second sacral rertolora, forming a ridge over the second sacral foramen molor which the nerre passes; an oblique band often comects this last fasciculus with the artionlar process of the first salcral vertebra. Below this, the fihres pass downwards and inwaris from the 


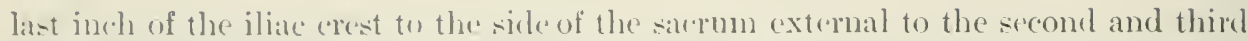
pusterior sateral formmina. To the outer alge of this ligament is attached the fascia (o)

The inferior sacro-iliac ligament (1iw. 207 ) is corerel behind ly the upper enct of the great sacro-sedatic ligament; it consists of strong fibres extenting from the lateral horder of the sacrum below the articular facet, to the pesterior iliae spines: some of the filores are attached to the deep surface of the ilium and join the introsseons ligimment.

The interosseous ligament is the strongest of all, and consists of filures of different lengths passing in rarious directions between the two hones. Inmerliately above the interspinous noteh of the ilimm the fibres of this ligament are very strong, and form an open network, in the interstices of which is a quantity of fat in which the articular vessels ramify.

The ear-shaped cartilaginous plate, which units the bones firmly, is accurately applied to the auricular surfaces of the sacrum and ilium. It is about onetwelfth of an inch (2 2 mm. ) thick in the centre, hut hecomes thinner towarls the cofges. Though closely adherent to the bones, it tears away from one entirely, or from both partially, on the application of violence, sometimes breaking irregularly so that the ereater jurtion remains connected with one hone, leaving the other bone rough and bare. It is raally one mass, and is only occasionally formed of two plates with a syovial eavity betweren them. Becaluse of the occasional presence of a more or less cxtensive spovoval cavity within the fibro-artilage, and also of a srnovial lining to the liganents passing in front ame behinel the articulation, the term 'Diarthro-amphiarthrosis' has been given to this joint, and also to the symphrsis puhis. Testut mentions certain folds of synovial menblune filling up gaps which here and there occur at margin of the fibro-cartilage, but 1 have not myself seen stleh.

The great or posterior sacro-sciatic ligament (figs. 206, 207 and 208 ) is attilcherl alrove to the posterior extremity of the crest of the ilimm and the extemal an feret of the posterior iliac spines. From this attachment some of its fibres pass downwarts and backwards to be attached to the outer borklers and posterior sur-

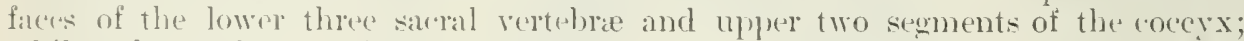
while others, after passing for a certain distance backwarks, corve forwarks and downwals to the ischimm forming the anterior free margin of the ligament where it limits posteriorly the sacro-sciatir foramina. These fibes are joined by others which arise from the josterior surfaces of the lower three sacral vertebre and uperer pineses of the cocerx. At the isehim it is tixed to the inner border of the great tulwerosty, and sends a thin sharp proess upwards along the lamus of the ischim which is callerl the falciform process (fig. $20 \mathrm{~s}$ ), and is a prolongation of the posterior edge of the ligament. A great many tilnes pasis on directly into the tendon of the hiceps muscle, so that traction on this muscle haces nu the whole ligament, anel the cocesx is thus made to move on the sacrum. The liganent may net unfairly be deseribed ats a tendinous expansion of the nuscle, wherehy its action is extended and a more actrantageous leverage given. It is broad and flat at its attacherl enels, hut narrower and thicker in the eantre, looking like two triangular axpansions joined by a flat band, the largere triangle lexing at the ilium, and the smaller at the ischimm. The fibres of the ligament are twisted uyen its axis at the narrow part, se that some of the suyerior filnes pass to the lower borter.

The josterior surfiace gives origin to the glutens maximus muscle, and on it ramify the lowp from the josteriol branches of the sacral nerves; its anterior surface is rlosely connected at its origin with the snull sacro-sciatic ligament, amel some

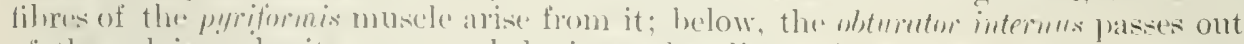

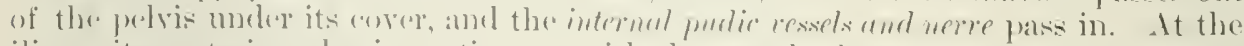

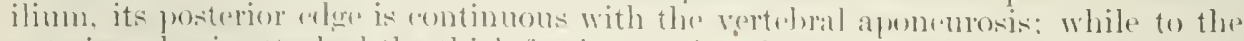

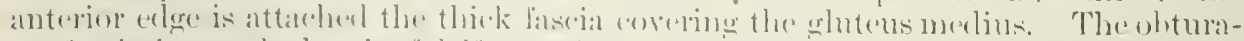

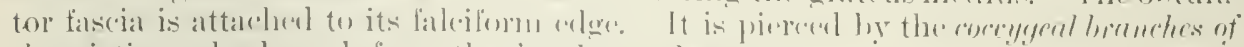

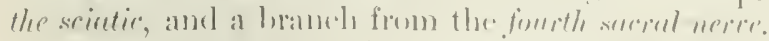

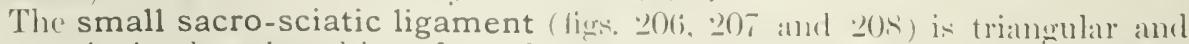

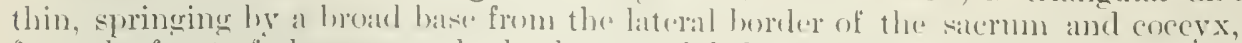
from the front of the salerum both alowe and lrew the lavel of the fourth sareral 
foramen, and from the cocyx nearly as far as its tip. By itsapex it is attached to the front surface and the horders of the ischial spine as far outwards as its base. Its fihres decussate so that the lower ones at the cocerx become the highest at the ischial spine; muscular fihres are often seen intermingled with the ligannentous.

It is situated in front of the great sacro-sciatic ligament, with which it is closely connected at the sacrum, and separates the greater from the lesser sancrosciatic foramen. Its front surface gives attachment to the coccygens muscle, which overlies it. Behind, it is connected with, and hidden hy, the great sacro-sciatic higament, so that only the outer inch or less (2 cm.) and a small part of its attachment to the coccyx, can be seen; the internal pudic nerve also passes over the posterior surface.

The arterial supply comes from the gluteal, ilio-lumbar, and lateral sacral.

The nerve-supply is from the superior chluteal, sacral plexus, and external twigs of the posterior divisions of the first and second sacral nerves.

The movements.- It is quite clear, from the nature of the osseous surfaces,

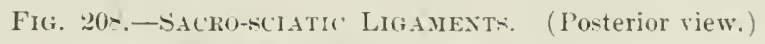

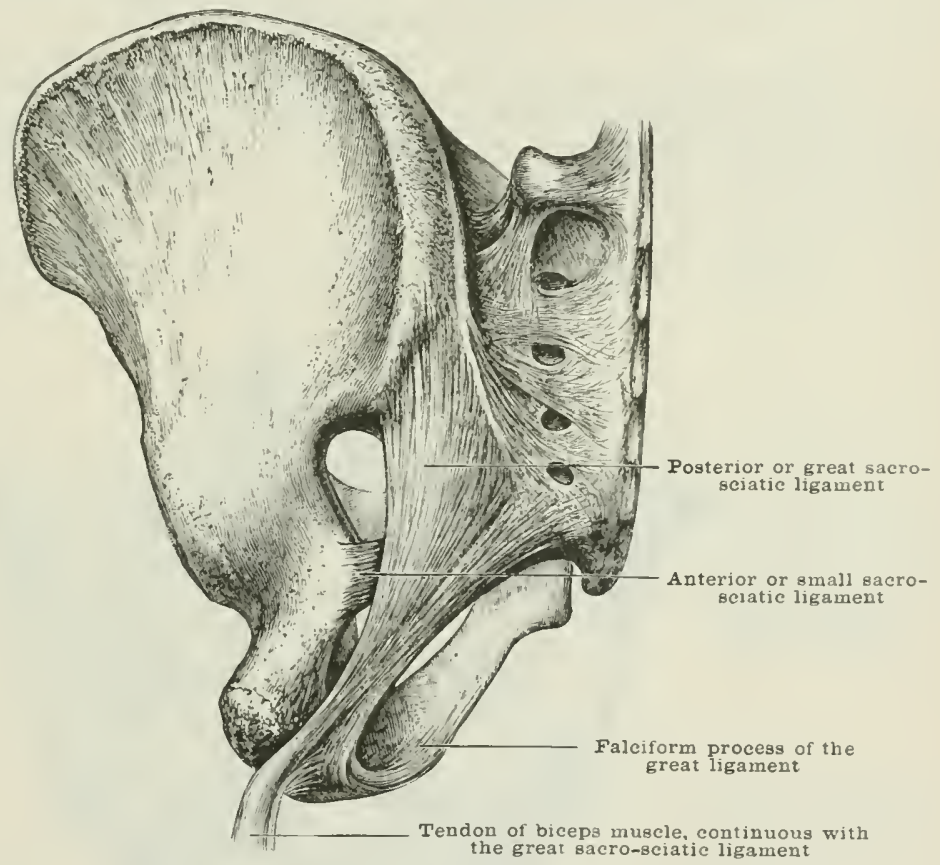

from the wedge-shape of the sacrum. and the manner in which it is locked in between the hip-bones, as well as from the amphiarthrodial character of the articulation, that there can be no movement at the sacro-iliac joint. While the joint serves the useful purpose of breaking shocks, the eartilace is too thin and too firmly fixed to the bones to allow eren of appreciable riclding, such as occurs upon the intervertebral disc:s.

The double wedge-shape of the sacrum, with its broader surface at the base and in front, prevents dislocation from forces acting from above downwards, and from before backwards.

The sinnous character of the opposed surfaces of the sacrum and ilium, the forward and inward direction of the fibres of the posterior sacro-sciatic ligament which pass from ilium to sacrum, as well as the ilio-lumbar and sacro-lumbar ligaments, frevent forward displacement of the base of the sacrum; while the sacro-sciatic ligments prevent the tilting backwards of its apex. Thus rotation forwards is entirely prevented.

The shape of the sacrum prevents its downward displacement. while the weight 
of the spine and the ligaments, which fasten the sacrum to the ilium, are suflicient to (heek its upwarl displenement.

The anteriog and downwarl displacements of the sacrmm are prewnted hy the interossous and posterior salcro-sciatie ligaments, which pass from the ilia to the silcrum, and suspend the lattrer. acting somewhat in the sane mamner as the chatins of at suspension bribge. They also bind the two bones more tightly together: the ereater the presure, the tighter the mion. The suspension bridge arrangement of the sacre-iliac synchundrosin is admirably adapted to give strength to the pelvis.

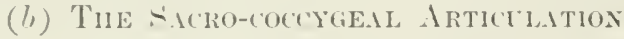

\section{Class.-Amphinathroxis.}

The last piece of the sacrum and first piece of the cocerx enter into this union, and are bound together by the following ligaments:-
Interior sacro-coecrgeal.
Posterior sacro-coceygeal.
Supracornual.
Intertransverse.

Intervertebral substance.

The intervertebral substance is a small oral disc, three-quarters of an inch (alonut 22 ('nll.) wide, and a little less from before backwards, closely connected with the suroumling ligaments. It resembles the other dises in structure, but is softer and more jelly-like, though the lamine of the fibrous jortion are well marked.

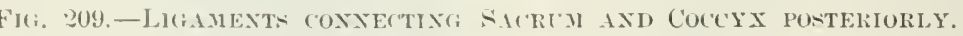

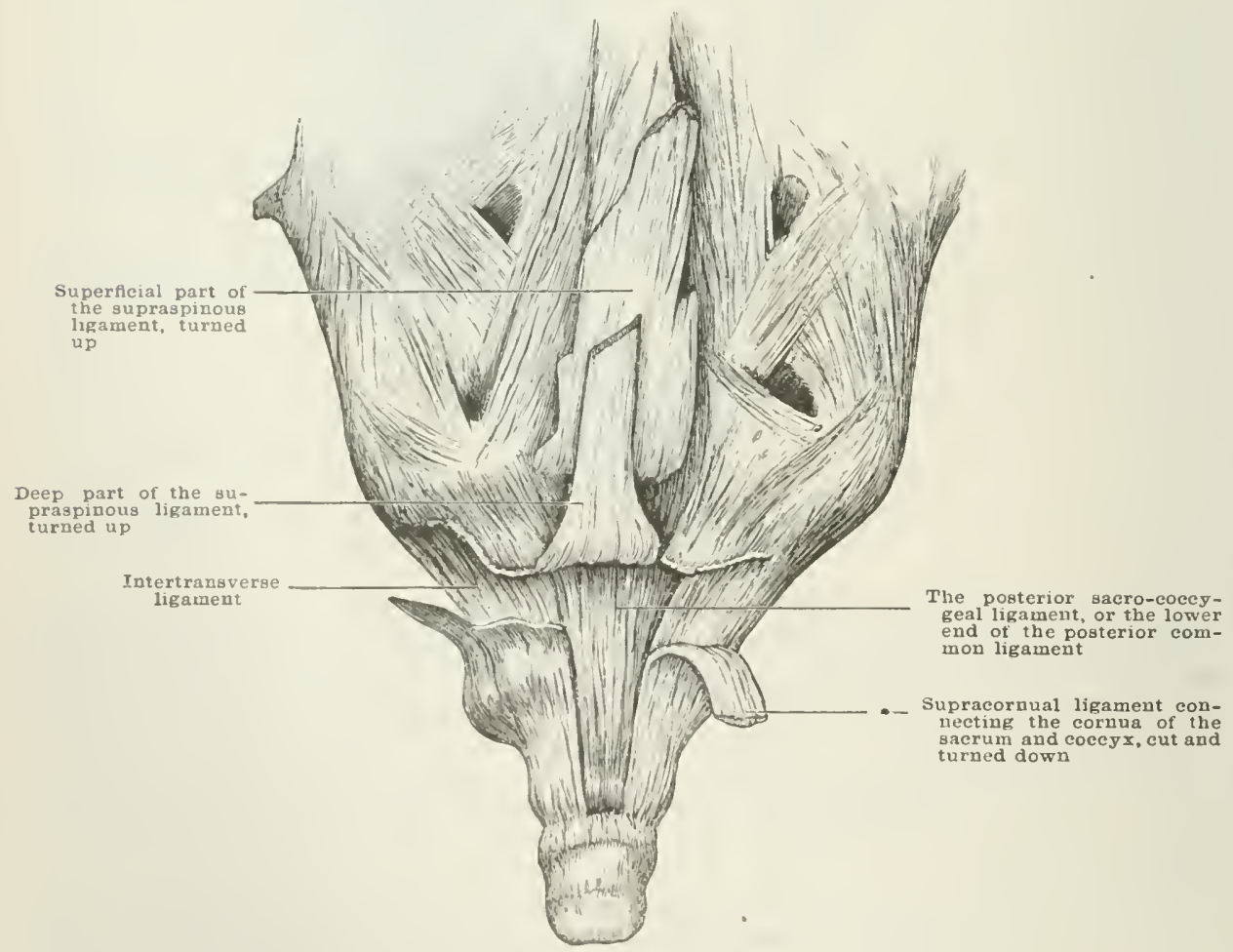

The: anterior sacro-coccygeal ligament is a prolongation of the ghistening fibrous strueture on the front of the salcrum. It is really the lewere extremity of the anterior anmon ligament, which is thicker orer this joint than orer the central i'at of either of the bones. 
The posterior sacro-coccygeal ligament (fig. 209) is a direct continuation of the posterior eommon ligament of the column, consisting of a narrow band of clusely parked fibres, which become blended at the lower lorder of the first segment of the coccry with the filum terminale and supracornual liganent.

The supracornual ligament (fig. 209 ) is the prolongation of the supraspinous, which becones inseparably liknded with the aponeurosis of the enetor spinx opposite the lamine of the third sicral vertehra, and is thus prolongert downwards upen the lack of the coceyx, pasing over and roofing in the lower end of the spinal canal where the lamina are defieient. The median fibres (the supraspinous ligament) extend orer the back of the coccyx to its tip, blending with the posterior sacrococrgeal ligament and filum teminale; the deeper fibres run across from the stunted laminie on one side to the next below on the opposite side, and from the sacril cornua on one sirle to the coccrgeal on the opposite, some passing between the two cornua of the same side, and hridging the aperture through which the fifth sacrul nerve passes. Its posterior surface gives origin to the gluteus maximus muscle.

The intertransverse ligament (fig. 209) is merely a quantity of fibrous tisne which passes from the transwerse process of the coceyx to the lateral edge of the sacrum below its angle. It is connecter with the sacro-sciatic ligaments at their attachments, and the fifth sarral nerve escapes behind it. It is perforated by twigs from the lateral sacral artery and the cocergeal nerve.

The arterial supply is from the lateral sacral and sacro-median arteries.

The nerves come from the fourth and fifth sacral and coccrgeal nerves.

The movements permitted at this joint are of a simple forward and backward, or hinge-like character. In the act of defecation, the bone is pushed hack ly the ficcal mass, and, in parturition, by the foetus; but this backward morement is controlled by the upward and forward pull of the levator ani and cocergens. The external sphincter also tends to pull the cocerx forwards.

\section{(c) Intercoccygenl Joints}

The sereral segments of the coccrx are held together by the anterior and posterior common ligaments, which completely cover the bony nodules on their anterior and posterior aspects. Laterally, the sacro-sciatic ligaments, being attached to nearly the whole length of the coccrx, serve to connect them. Between the first and second pieces of the cocey there is a very perfect amphiarthroctial joint, with a well-marked intervertebral substance.

\section{(d) Tine Sryiphysis Pubis}

\section{Class.-Amphirerthrosis.}

The hones entering into this joint are the pulic portions of tho hip-bones. This joint is shorter and hroador in the female than in the male. The liganents, which completely surround the articulation, are:-

Superior.

Inferior.
Interior.

Posterior.

Intcrosisous cartilage.

The superior ligament (figs. 210 and 211) is a well-marked stratum of yellowish fibres which extends outwarks along the crest of the pulcs on each side, blending in the midlle line with the interosseous cartilage. It is continuous in front with the deep transwerse fibres of the anterior liganent, and behind with the posterior ligament. It gives origin to the rertus abdominis tendon.

The posterior ligament (fig. 212) is slight, and, excepting alove and below, consists of little more than thickened periosteum. Near the mper part is a hand of strong fibres, reaching the whole wirlth of the puhic hones, and continuous with the thickened perinsteal fibres along the ilio-pectineal line. Below. many of the upper and superficial fibres of the infrapubic ligament ascend orer the hack of the 
joint, and interlace across the molian line with fibres from the opposite side nearly as high as the midhle of the symplyesis.

The anterior ligament ( tigs. 210 and 211 ) is thick and strong, and is closely (o)mecter with the filscial covering of the muscles arising from the hody of the pubes. It consists of siveral stratal of thick decussating fibres of different degrees of obliquity, the superficial being the most oblique, and extending lowest orer the joint. The most superficial descending fibres extend from the upper border of the

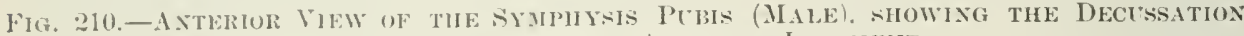
(OF TIIE FIBRES UF THE ANTERIOR LIGAMENT.

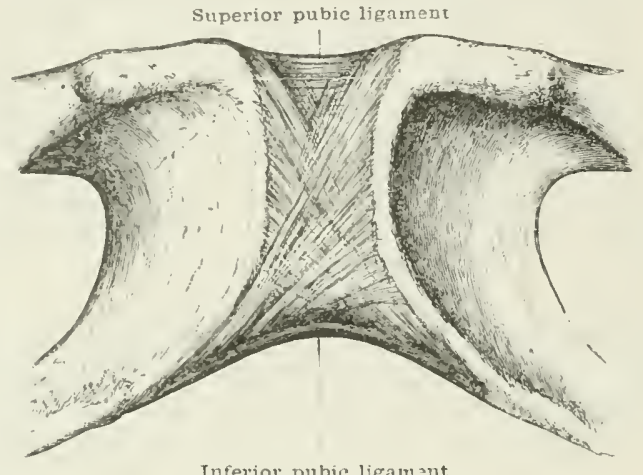

pubis. aross others from the opposite side about the middle of the symplysis, and are attached to the ramus of the opposite bone. The most superficial ascending filres come from the infrapubic ligament, areh upwards, and decussate with other fibes arcoss the midcle line, and are lost on the opposite side beneath the descending set. 'There is amother derper set of descending fibres which arise below the angle, but lo not descenct so far as the superficial; and a deeper set of ascending, which derussate, and reach higher than the superficial set, and are connected with

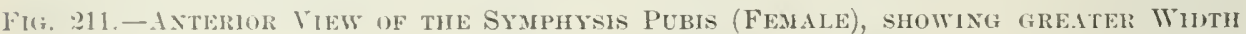
BETWEEN THE BONES.

Superior pubic ligament

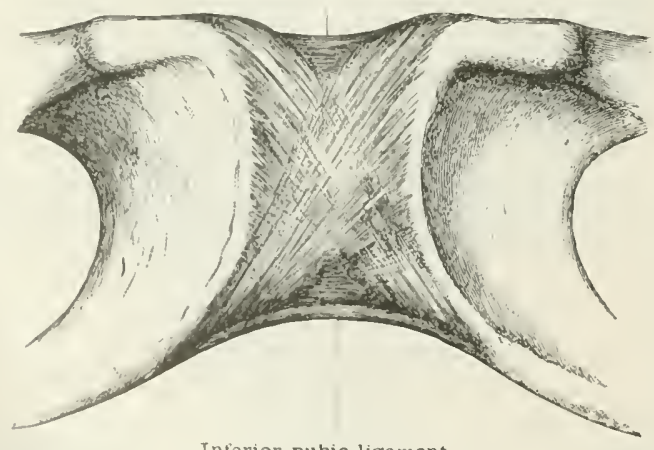

Interior pubic ligament

the infrapulic liganent. Some few transwerse fibres basis from side to side, (s)erially above amel below the prints of derussition.

The inferior or infrapubic ligament (figs. 210, 211 and 212 ) is a thick, ardhlike hand of eloscly packed fibres which fills up the angle between the pubic rami, and forms a smooth, romeled smmmit to the pubie areh. On section, it is yellowish in colour and three-(ighths of an inch (1 cm. ) thick in the middle line; it is inseparably connected with the interosseous cartilage. Both on the front and back asperets of the joint it grives off decussating fibres, which, hy their interlatement over 
the anterior and posterior ligaments of the symphysis, add very materially to its security. In fact, the ligancent may be said to split superiorly inte two layers, one passing over the front, and the other orer the back of the articulation. It is conotimes known as the ligamentum arcuatum.

'The interosseous fibro-cartilage varies in thickness in clifferent suljects, but is thicker in the fomale than in the male. It is thicker in front than hehind, and projerts beyond the adges of the bones, wercially posteriorly (nee fig. 212), blenting intimately with the ligaments at its margins. It is sometimes uminterruptedly

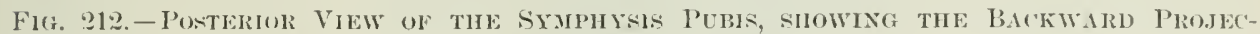
TION OF THE SYMIPISIAL, SUISTANCE AND THE DEUESSATION OF THE FIBRES FROM TIE INFERIOR PIBIT JIGANENT.

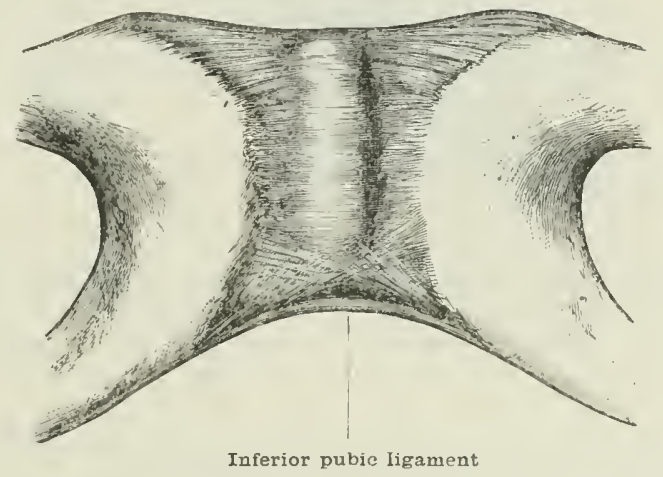

wowen throughout, lut at others has an elongated narrow fissure, partially lividing the cartilage into two plates, with a little fluid in the interspace (fig. 21:3). This is situated towards the upper and posterior aspects, but does not ustally reach either; it generally extends about half the length of the eartilage. When this eavity is large, especially if it reaches or approaches rery near to the circumference of the artilage (which, however, it very rarely does), it is thought hy some anatomists that it more nearly resembles a diarthrodial than an ampliarthrodial joint. and it is then classed with the sacro-iliac joint under sinilar' conditions, as 'diarthro-

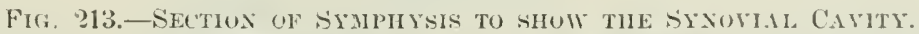

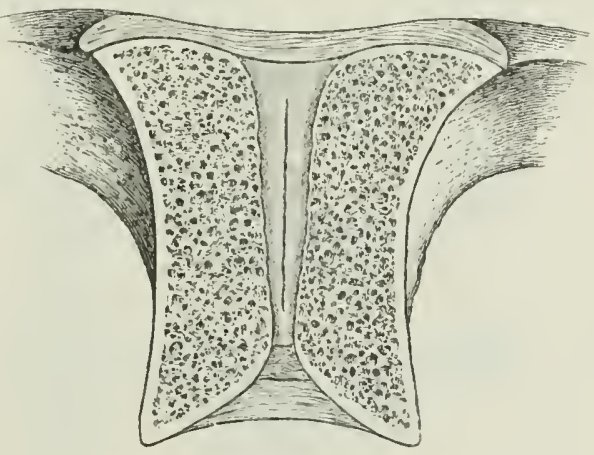

ampliarthrosis.' 'The interossenus cartilage is intimately arlherent to the rough ossenus surface of the bone, which is rielged to give it a firmel attachnent; and, on forcing the bones apart, it does not frequently split into two plates, but is torn from the hone on one side or the other.

The arterial supply is from twigs of the intermal purlic, pubic linandus of the obturator and epigastric, and aseencling branches of the internal ciremuthex and superficial extermal pudic.

The nerve-supply lats not been satisfactorily male out. hut it probahly enmes, 
in part, from the internal pudic and in part from the ilio-hypogastrie and ilioinguinal.

The movements amomnt mly to a slight yielding of the cartilage; neither muscular fores nor extrinsit forces pouluce any appreciable movement in the ordinary (ondition. Oecasionally, as the result of child-hearing, the joint becomes munaturally Iouse, and then walking and standing are painfully unsteady. It is known that, sturing joegnancy and parturition, the symphysial cartilage becomes softer and mure vascular, so as to permit the temporary enlargement of the pelvis; lint it munt lue romenlureel that the fibres of the oblique museles decusiate, and thuk, during lalwur, while they force the hear of the foetus down, they strengthen thr. joint ly hracing the bones more tightly together.

\section{THE ARTLCLATIONS OF THE RIBS WITH THE VERTEBRE}

Therese consist of two sets, viz.:-

(1) The costo-central: i.e. the articulation of the head of the rib with the wirteliries.

(b) 'The costo-transverse, "11 the articulation of the tuberele (of each of the first ton rils, with the transverse process of the lower of the two vertelna, with whin the hearl of the rib articulates: i.c. the one bearing its own number, as the first ril, with the first thoracic vertebra, the second rib with the second thoracic rertelora, and so on.

\section{(a) The costo-cextral irticulation}

\section{Class.-Dintheres. Subdivision.-Condylarthosis.}

It is a very perfect joint, into the formation of which the head of the rils and two varteras, with the intervertehral disc hetween them, enter. In the case of the first, tanth, elesenth, and twelfth ribs, it is formed by the head of the rib articulating with a single rertelori.

The ligaments are:-

$$
\begin{aligned}
& \text { (a) sular. Interarticular. } \\
& \text { Stellate or anterior costu-central. }
\end{aligned}
$$

The capsular ligament (fig. 21t) consists of short, strong, woolly filres. completcly surrounding the joint, which are attached to the Jones and intervertehral substances, a little beyond their articular margins. At its upper part it reaches throumh the interverteinal formen towards the back of the bodies of the vertebre, hering strengthaned here hy fibres which at intervals connect the anterior with the josterior comnom licaments. The lower fibres extend downwards noarly to the deni-face of the rib lrelow; behind, it is continuous with the middle costotransverse ligament, and in front is orerlairl by the stellate.

The interarticular ligament (fio. 215) consists of short, strong fibres, closely interworen with the ontermest ring of the intervertebral dise, and attached to the transverse ridge separating the artieular facets om the head of the rib. It completely divides the articulations into two parts, but does not brace the rib tightly to the spine, being loose ('nomgh to allow a moderate amount of rotation on its own axis. Thore is no interarticulas liganent in the costo-rertelual joints of the first, tenth, eleventh, and twelfthe rils.

The anterior costo-central or stellate ligament (figs. 215 and 216 ) is the most striking of all, and consists of bright, pearly-white fibres attached to the anterior surface, and mpler and lower borders of the neek of the rib, a little way beyond the articular facet: from this ther racliate upwarks, forwards, and downwards, so as to form a continmous layer of clistinct and sharply defined fibres. The middle fibres rum strajght furwarl to be attached to the intevertebral disc; the upper ascend to the Iowrer half of the lateral surface of the reptebra above, and the

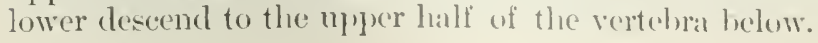


The stellate ligament is overlapped at the spine hy the short rertelial ligaments.

In the case of the first, tenth, eleventh, and twelfth ribs, each of which articulates with one vertebra, the ligament is not quite so distinctly stellate, but erm

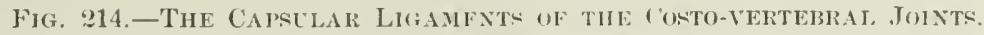

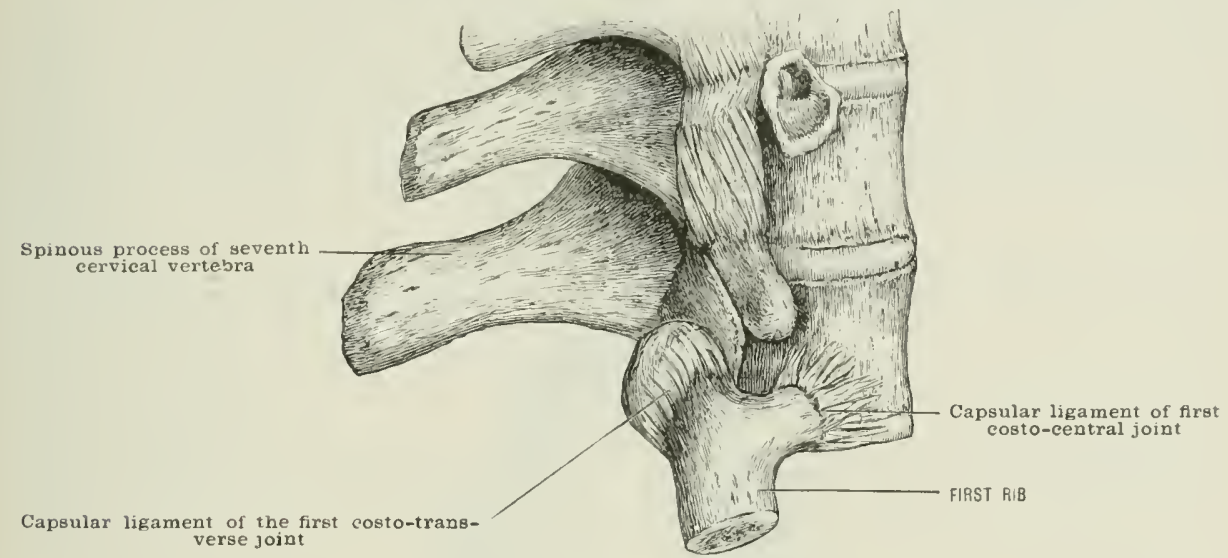

in these the ascending fibres reach the vertebra above that with which the rib articulates.

The synovial membranes (fig. 216) consist of two closed sacs which do not communicate: one above, and the other below the interarticular ligament. In the

Fig. 215.-Showing the Anterior Comion Liganent of the SPINe, ANd the CoxyecTION OF TIL RIBS WITI THE. VERTEBR:.

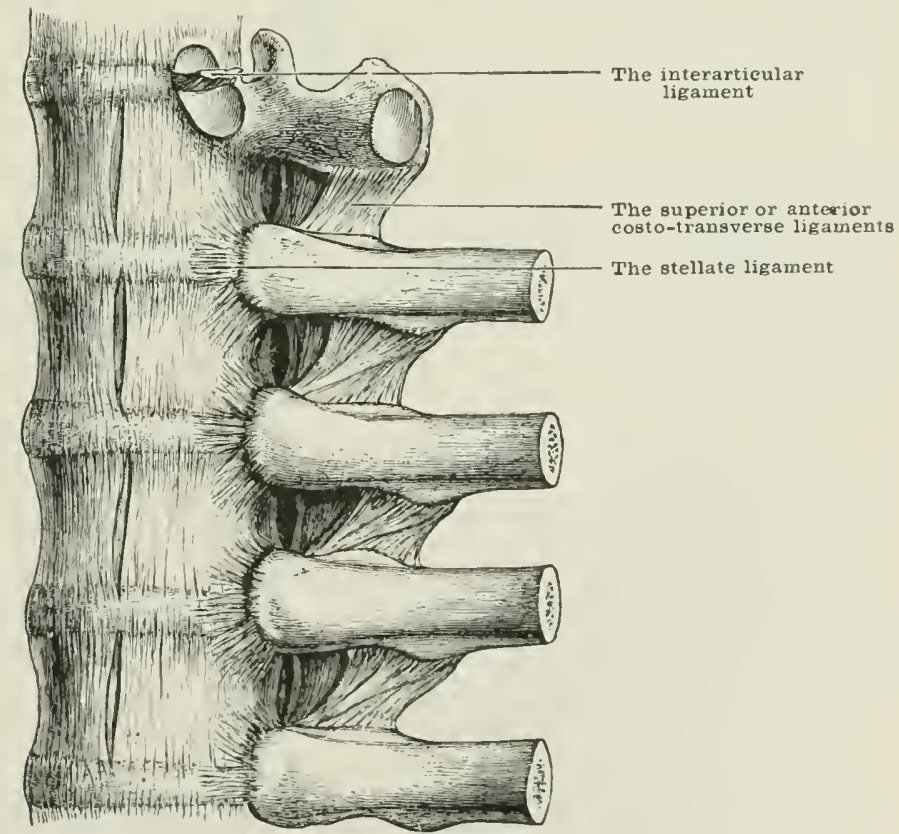

case of the first, tenth, eleventh. and twelfth articulations, there is but one synorial membrane, as these joints have no interarticular ligaunent.

The arterial supply is from the interostal arteries, the twigs piercing the stellate and calusulir ligaments. 
The nerve-supply (onnes trom the anterior primary branches of the intercostal nerver.

These joints alpurouch most nearly in their morements to the condylarthroses.

The movements are ginglymoid in character, consisting of a slight degree of devation and depresion around an obliquely horizontal axis corresponding with the interarticular ligament; there is also a slight amount of forward and backward glicling; and a slight degree of serewing or rotatory movement is also possible. There is a considerible difterenes in the degree of molsility of the different ribs, for While the first rib is almost immobile except in a very deej inspiration, the molility of the others increases from the seconel to the last; the two floating ribs leeing the most molile of all. The heart of the rib is the most fixed point of the costal arch, and upun it the whole areh rotates; the interarticular ligament allows only a very

Fig. 216.-Hurizoxtal, section thrucgh the Ixtervertebral Disc axd Ribs.

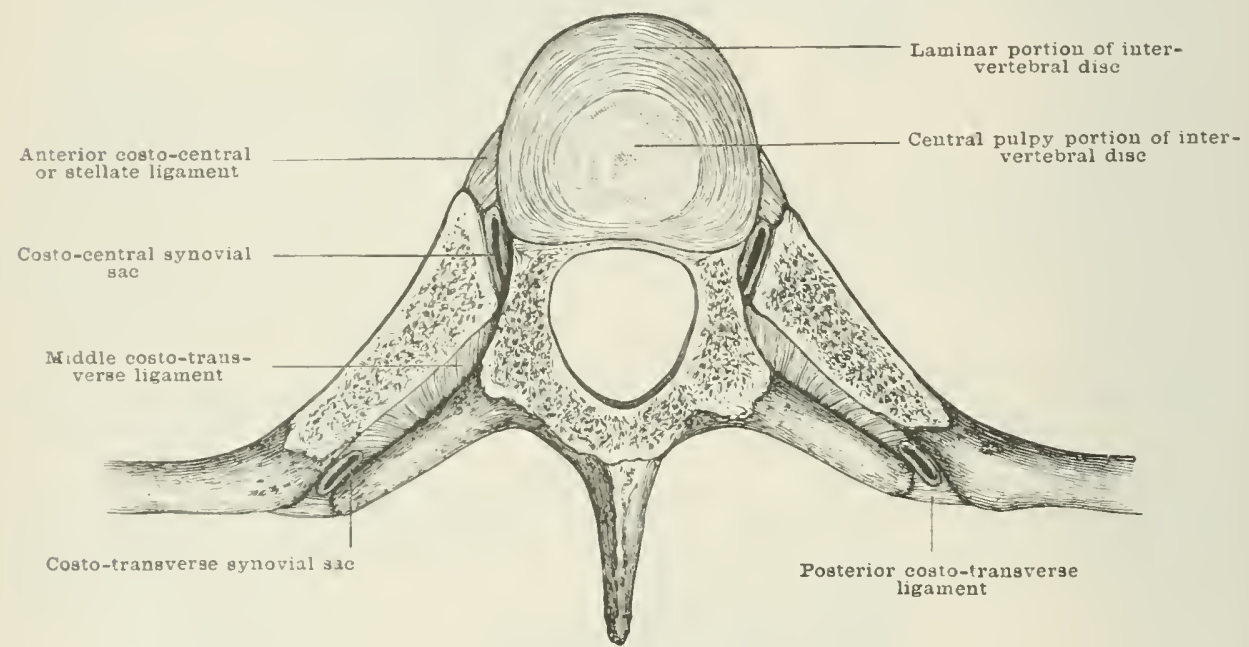

limited anount of flexion and extension (i.e. elevation and depression), and of yliting. (iliding is ehecked hy the stellate ligament.

In inspiration, the rib is elevated, and glides forwards in its socket, too great alevation being checked not only by the ligaments, but also hy the overhanging upper edge of the eavity itself. In expriration, the rib is chejressed, and ghides backwards in its carity.

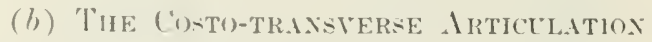

Class.-. Dirrethrowis.

Subdivision.-Athrodia.

This joint is formed hy the tuberele of the rib articulating with the anterior part of the tip of the transverse process. The arewth and twelfth rils are devoid of these joints, for the tuhereles of these ribs are absent, and the transverse processes of the elerenth and twolfth thoracie rertebre are rudimentary.

The liganents of the union are:-

Cajsular.

Michlle coston-transwerse.
Superior (onsto-transierses.

Posterior (ensto-t ransterses.

The capsular ligament figr. 214 and 216 ) forms a thin, loose, fibrous (mvelope to the symovial memhrane. Its fildes are attacherl to the bones just lreyond the articulan malegins, and ane thickest below, where thes are not strengthened by any other structure. It is connected on the inner side with the middle, 
above with the superior, and on the outer sile with the posterior costo-transverse ligaments. The eleventh and twelfth ribs are mprovided with a capsule.

The middle costo-transverse, or interosseous ligament (fig. 216), consists of short filores passing between the back of the neck of the ril) and front of the transierse process, with which the tubercle articulates. It extends from the capsule of the central costo-rertelural joint to that of the costo-transwerse. It is best seen on horizontal section through the bones. In the eleventh and twelfth rils this ligament is rudimentary.

The posterior costo-transverse ligament (fig. 216) is a short but thick, strong, and broad ligament, which extends outwards and wwards from the extronity of the transserse process to the non-articular surface of the tubercle of the corresponding ril). The eleventh and twelfth ribs have no posterior ligament.

The superior costo-transverse ligament (fig. 21.j) is a strong, lroad band of filores which ascends outwards from the crest on the upper lworder of the nerk of the rib, to the lower horder of the transverse process above. I few scattered posterior fibres pass upwarls and inwards from the neck to the transwerse proces: It is best seen from the front. Its inner horder hounds the foramen through which the posterior branches of the intercostal vessels and nerves pass. To the extemal border is attached the thin aponeurosis covering the external intercostals. Its anterior surface is in relation with the intereostal ressels and nerve; the posterior with the longissimus dorsi. The first rib has no superior costotransverse ligament.

The synovial membrane (fig. 216) is a single sac.

The arterial and nerve supplies come from the posterior lianches of the intercostal arteries and nerves.

The movements which take place at these juints are limited to a gliding of the tuhercle of the rib upon the transverse process. The exact position of the facet on the transverse process varies slightly from above downwats, being placed higher on the processes of the lower vertebrix. The plane of movement in most of the costo-transrerse joints is inclined upwards and lackwarls in inspiration, and downwals and forwards in expiration. The point round which these morement: oceur is the hearl of the rib, so that the tubercle of the rib glicles upon the transierse process in the circumference of a circle, the centre of which is at the costo-central joint.

\section{THE ARTICLLATIONS AT THE FRONT OF THE THORAX}

These may be divided into four sets, viz.:-

(a) The intersternal joints, or the union of the several parts of the sternum with one another.

(b) The costo-chondral joints, or the mion of the rils with their costal cartilages.

(c) The chondro-sternal articulations, or the junction of the costal eartilagen with the stemum.

(d) The interchondral joints, or the mion of five (ostal eartilages (sixth, serenth, eighth, ninth, and tenth) with one another.

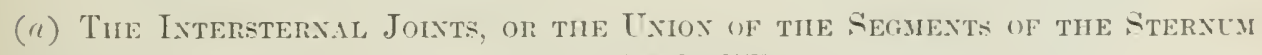
WTH OXE ANOTHER

The sternum being conmosed, in the adult, of three distinet pieces, - the manubrimm, the gladiolus or borly, and the xiphoid, - has two articulations. viz., the superior, which unites the manubrim with the gladiolus, and the Inferior, which unites the glarliotus with the xiphoid. 


\section{The suprerior Intersternal Articulation.}

\section{Class. - A miphieththosis.}

The lower horter of the manubrimm and the upper border of the body of the sternum present oval-shaped, flat surfaces, with their long axes transverse, and covered with at thin layer of hyaline cartilage. In interosseous fibro-cartilage is interpused loctwen the hony surfaces: it corresponds exactly in shape and intimatcly adheres to them. At each lateral border this fibro-cartilage enters into the formation of the second chondro-sternal articulation (fig. 21\%). In consistence it varies, being in some "ases uniform throughout, in others softer in the centre than at the circumferenee, and in others again an oval-shaped synovial calvity is found towards its anterior part. When such a cavity exists in the fibro-cartilage this joint has a remote resemllance to the diarthrodes, and is classed, with the sacro-iliac joint and the symphysis puhis under similar conditions, as "diarthro-amphiarthrosis.

The periostem passes uninterruptedly over the joint from one segment of the sternmm to the other, forming a kind of capsular ligament. This capsule is strengthened, ('specially on its posterior aspect, by longitudinal liganentous fibres as well as by the radiating and decussating fibres of the chondro-sternal ligaments.

In some instances the fibro-cartilage is replaced by short bundles of fibrous tissue which mite the cartilage-coated articular bony surfaces.

2. The Inferior Intersternal Articulation.

$$
\text { Class.- Synarthroxis. }
$$

The gladiolus is joined to the xiphoid cartilage by a thick investing membrane, by anterior and posterior longitudinal fibres. and by radiating fibres of the sixth and seventh chondro-stemal ligments. The chondro-xiphoid ligament also connects the xiphoid with the anterior surface of the sixth and seventh costal cartilages, and thus indirectly with the gladiolus; and some fine fibro-areolar tissue also eonnects the xiphoid with the back of the seventh costal cartilage.

The junction of the xiphoid with the stemum is on a level somewhat posterior to the junction of the serenth costal cartilage with the stemum. The union is symurthorlial.

\section{(b) Tile Costo-chondrai, Jonts}

\section{Class.-Synurthrosis.}

The extrenity of the costal cartilage is received into a euj-shaped depression at the end of the rib, which is somewhat larger than the cartilage. The two are joined together by the eontinuity of the investing membranes, the periosteum of the rib leing continuous with the perichondrim of the eartilage, much in the same way as the epiphyes of the bones are joined to their shafts.

\section{(c) The Chosinio-sterial Artivlations}

\section{Class.-Dinerthersis.}

Subdivision.- Ciinglymus.

These articulations are between the lateral horders of the sternum and the ends of the costal cartilages. The union of the first rib with the stemmm is symarthodial, and therefore forms an exception to the others. From the seend to the seventh inclusive, the articulations have the following ligaments, which togrether form a complete capsule:-

Anterior rhondro-sternal.

Posterior chondro-sternal.
Superior chondro-stemal. Inferior chondro-sternal. 
The anterior chondro-sternal ligament (fig. 217) is a triangular band of strong fibres which cover the inner half-inch of the front of the costal cartilage, and radiate upwards and downwards upon the front of the sternum. Sonre of the fibres decussate across the middle line with fibres of the opposite ligament. At it upper and lower borders it is in contact with'the superior and inferior ligaments respectively.

Fig. 217.--THE STERNLM.

(Jeft side, showing ligaments; right side, the synovial cavities.)

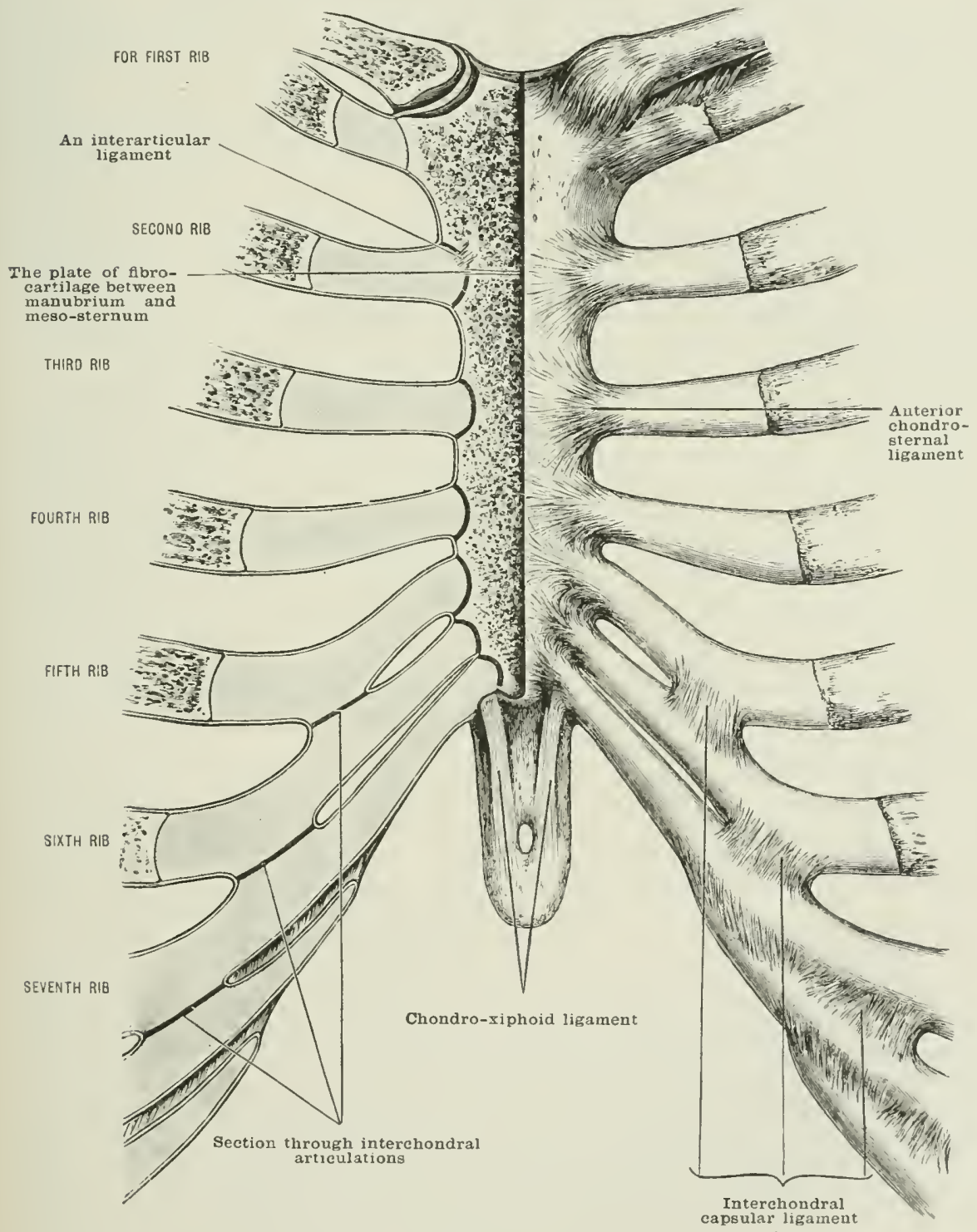

The posterior chondro-sternal ligament consists of little more than a thickening of the fibrous envelopes of the bone and cartilage, the joint heing completed hehind by a continuity of perichondrium with periostem.

The superior and inferior ligaments are strong, well-marked bands, which pass from the upper and lower borders respectively of the costal rartilage to the lateral edges of the sternun. The sixth and seventh cartilages are so close 
What the superior ligament of the serenth is blended with the inferior of the sixth ril).

Decper than the filres of these ligaments are short fibres passing from the margins of the sternal farets to the edges of the facets on the cartilages; they are most listinct in the front and lower part of the joint, and may encroach so nuch upon the srmorial cavity as to reduce it to a very small size, or almost obliterate it. This ox'urs mestly in the case of the sixth and seventh joints, especially the latter.

The interarticular ligament (fig. 217 ) is by no means comstant, but is usually fresent in the second joint on one, if not on both sides of the same suljexct. It consists of a strong transverse liundle of tibres passing from the rirlge on the facet on the cartilage to the srmphysial sulstance between the manubrium and lody; sometimes the upper part of the synovial cavity is partially or entirely obliterated hy short, fine, ligamentous fibres.

The chondro-xiphoid ligament (fig. 217) is a strong flat band of fibres passing obliquely upwards and outwards from the front surface of the xiphoid cartilage to the anterior surface of the sternal end of the serenth costal cartilage, and most frempently to that of the sixth also.

Synovial membranes. - The union of the first cartilage with the sternum being symarthrodial, it has no srnovial membrane; the second has usually two, separated liv the interarticular ligament. The rest usually have one synovial membrane, which may oceasionally be suldivided into two (fig. 217).

The arterial supply is derived from perforating branches of the internal mammary: and the nerves come fom the anterior branches of the intercostals.

Movements.-Excepting the first, the chondro-sternal joints are ginglymoid, lut the motion of which they are capable is very limited. It consists of a hingelike action in two directions: first, there is a slight amount of elevation and depres-ion which takes place round a transverse axis, and, secondly, there is some forward and backwarl morement round an obliquely vertical axis. In inspiration the "artilage is elevated, and the lowest part of its articular facet is pressed into the -temal socket, and the stemum is thrust forwards so that the upper and front edges of the articular surfaces separate a little; in expiration the reverse movement takes flice. Thus the two extremities of the costal arches move in their respective sorkets in opposite directions.

This difference results neressarily from the fact that the costal arch moves upon the vartehral column, and, having been elevated, it in its turn raises the sternum ly pushing it upwards and forwarks.

The chondro-xiphoirl ligament tends to prevent the xiphoid cartilage from leeing draw backward: by the action of the diaphragm.

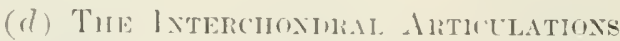

Class.-Dinthiris.

Subdivision.-.-Athererlirt.

A little in front of the point where the eostal artilages hend upwards towards the median line, the sixth is mited with the seventh, the seventh with the eighth, the righth with the ninth, and the ninth with the tenth.

At this point, ateh of the cartilage's from the sixth to the ninth inclusive is

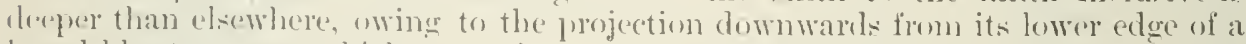

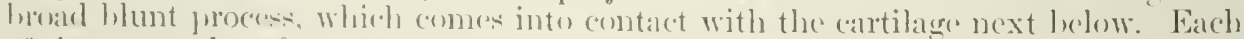
of the apjosed surfarees is sunowth, and they are connected at their mangins by ligamentons tissue, which forms a complete capsule for the articulation, and is lined hy a spmovial mombrame (tig. 217). The latrest of these cavities is hetween the siventh and righth; those hetween the eighth and ninth, and ninth and tenth, are smaller, and are not free to play ujwn each othere in the whole of their extent, being held togetler hy ligamentrins tiscure at their anterior marerins. Sometimes

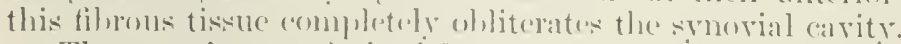

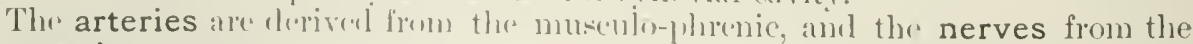
interenstals.

Movements.-By monsis of the custal caltilages and interhondral joints, 
strength with elasticity is given to the wall of the trunk at a part where the cartilages are the only firm structures in its composition; while a slight gliding movenent is permitted between the costal cartilages themselves. which takes place round an axis corresponding to the long axis of the cartilages. By this means, the outward projection of the lower part of the thoracic wall is increased by (leep inspiration.

\section{MOVEMENTS OF THE THORAX AS A WHOLE}

Before describing these movements as a whole, it must be premised that there are some few modifications in the movements of certain ribs resulting from their shape. Thus the first ril, (and to a less extent the second also), which is flat on its upper and under surfaces, revolves on a transverse axis drawn through the costovertebral and costo-transverse joints. During inspiration and expiration, the anterior extremities of the first pair of costal arches play mp and down, the tubercles and the heads of the ribs acting in a hinge-like manner, the latter having also a slight screwing motion. By this novement the anterior encls of the costal arches are simply raised or depressed, and the stemum pushed a little forwards: it may be likened to the movement of a pump-handle, as in fig. $218, a, b$.

The movements of the other ribs, particularly in the mid-region of the thorax, are more complex, for, besicles the elevation of the anterior extremities, the bodies

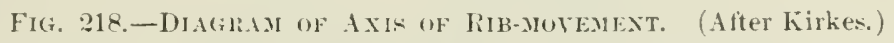

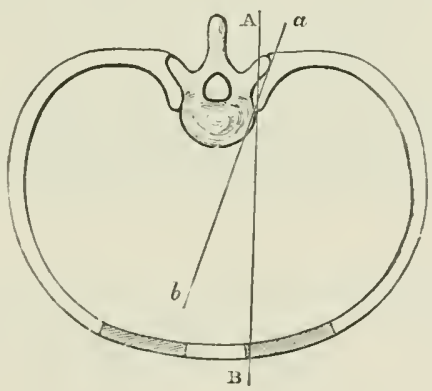

and angles of the ribs rise nearly as much as the extremities themselves. In this novement the tubereles of the ribs glide upwards and backwards in inspiration, and downwards and forwards in expiration; and the movement may be likened to that of a bucket handle, as in fig. $218, \mathrm{~A}, \mathrm{~B}$.

During inspiration, the cavity of the thorax is increased in every direction. The antero-posterior diameter is increased by the thrusting forwards of the sternum, caused by the elevation of the costal cartilages and fore part of the rils. whereby they are lirought to nearly the same level as the heads of the ribs. The transverse diameter is increased: (i) Behind, by the elevation of the middle part of the ribs; for when at rest the mid-part of the rib is on a lower level than either the costo-rertebral or chondro-sternal articulations. Owing to this obliquity the transverse diameter is increased when the rib is raised, and the increase is proportionate to the degree of obliquity. (ii) $B y$ the eversion of the lower border of the astal arch, which rolls outwards as the arch is raised. (iii) The transwerse diameter is increased in front by the abduction of the anterior extrenity of the rib at the same time as it is elevated and thrust forwards.

The increase in the vertical diameter of the thoma is due to the elevation of the ribs, especially the upper ones, and the consequent witlening of the intereostal spaces; but the chief increase in this direction is due to the rlescent of the diaphragm.

The greatest increase both in the antero-posterior and transwerse diameters takes: place where the rils are longest. most chligue, and most curved at their angles. and 
where the bulkicst part of the lung is enclosed. This is on a level with the sixth, s.'enth, and eighth ribs.

At the lower part of the thorax, where the ribs have no relation to the lungs, and do not affect respiration directly by their movements, it is innortant that the costal arches should be thrown well outwarls in oreler to counteract the compression of the abchminal viscera hy the contraction of the diaphragm.

By widening and stcadying the lower part of the thorax during inspiration, the attachments of the muscular filmes of the diaphragm are widened, and their power increased.

\section{THE ARTICILATTONS OF THE LPPER EXTREMITY}

The articulations of the upper extremity are the following:-

1. The sterno-costo-clavicular.

2. The scapulo-clavicular union.

3. The shoulder-joint.

4. The elbow-joint.

5. The radio-ulnar union.

6. The radio-carpal or wrist-joint.

7. The carpal joints.

8. The carpo-metacarpal joints.

9. The intermetacarpal joints.

10. The metacarpo-phalangeal joints.

11. 'The interphalangeal joints.

\section{THE STERNO-COSTO-CLAVICLLAR APTICULATION}

\section{Class.-Dinthrosis. Subdivision. - Suddle-shaped Aithrodiu.}

At this joint the large inmer end of the clavicle is united to the superior angle of the manulurim sterni, the first costal cartilage also assisting to support the claviele. It is the only joint between the uluer extrenity and the trunk, and takes part in all the movenents of the upper limb. Looking at the bones, one would say that they were in no way alapted to articulate with one another, and yet they assist in constructing a joint of ereat sereurity, strength, and importance. The bones are nowhere in artual contact, heing completely separated by an interarticular cartilage. The intrrval between the joints of the two sides varies from one inch to an inch and a half $(2 \cdot 5-4$ cms.). The ligaments of this joint are:-
(1) Cajosular.
(2) Interelavicular.

(:) Interarticular fibro-cartilage.

(4) Rhomboid or costo-clavicular.

The capsular ligament (figs. 219 and 220) consists of fibres, having varying directions and being of rarious strength and thickness, which completely surround the articulation, and are fimly (ommecterl with the erlges of the interarticular fibro"artilage. The fibres at the lack of the joint, sometimes styled the posterior sterno-clavicular ligament, ane stronger than those in front of below, and (onsist of two sets: a superficial, parsing mowark and outwards from the manubrium sterni, to the projecting posterior colge of the imner end of the elavicle, a few being prolonger onwards upon the posterior surface of the bone. A deeper set of fibres, especially thick and numerous betow the clariede, eomect the interarticular cartilage with the elavicle and with the stemum, hut clo not extend from one lone 
to the other. The filmes in front, the anterior sterno-clavicular ligament, are well marked, but more lax and less tough than the posterior, and are overlail by the tendinous sternal origin of the sterno-mastoid, the fibres of which run parallel to those of the ligament. They extend obliquely upwards and outwards from the margin of the sternal facet to the anterior surface of the clavicle some little listance from the articular margin. The fibres which cover in the joint below are short,

Fig. 219.-POSTERIOR VieW OF THE STERxo-costo-ClAVICLLAR JoINT.

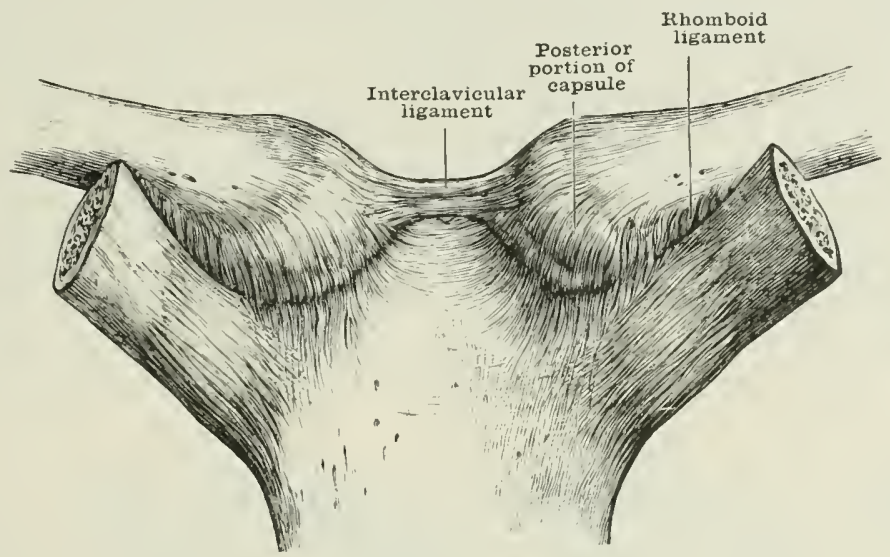

woully, and consist more of fibro-areolar tissue than true fibrous tissue; they extend from the upper border of the first costal cartilage to the lower border of the ravicle just external to the articular margin, and fill up the gap betreen it and the rhomboid ligament. The superior portion consists of short tough fibres passing from the sternum to the interarticular cartilage; and of others welding the filmo-

Fif. 2:0.-Axterior Tiew of Sterno-costo-clavicular Jorst.

(The capsule is cut into on the left side to show the interarticular fibro-cartilare dividing the joint into two cavities.)

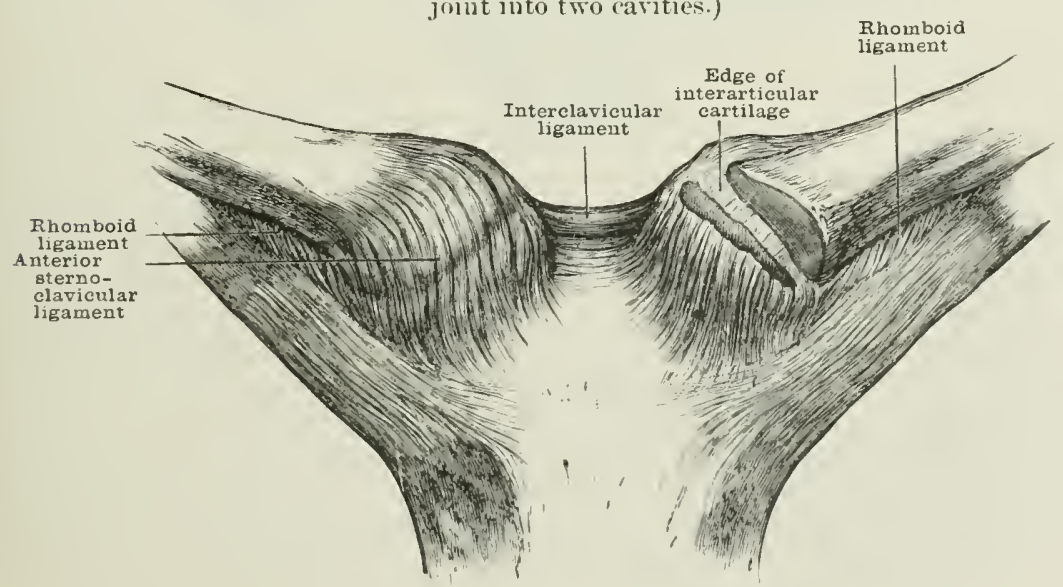

cartilage to the upper edge of the clavicle, only a few of them passing from the clavicle direct to the sternum.

The interclavicular ligament (figs. 219 and 220) is a strong. (oncare band, materially strengthening the superior portion of the eapsule. It is nearly a quarter of an inch $(6 \mathrm{~mm}$.) deep, with the concavity upwards, its upper border tapering to a narrow, almost sharp edge. It is connected with the posterior superior angle of 
the strmal extremity of each clavicle, and with the filmes which weld the interarticular cartilage with the clavicle; and then passes across from elavicle to clavicle along the pustrior aspect of the upper horler of the manubrium sterni. The lowest fibres are attached to the sternum, and join the posterior fibres of the capsule of cach joint. In the middle line between the ligament and the stemum there is an aperture for the passage of a small artery and vein.

The rhomboid or costo-clavicular ligament (figs. 219 and 220 ) is a strong lense hand. composed of fine fibres massed together into a membranous structure. It extends from the anterior edge of the mper borcter of the first costal cartilage, upwards, lackwards, and distinctly cutwards to the rhomboid impression on the muler surface of the inner extrenity of the clavicle, to which it is attached just "xternal to the lower part of the capsule. Frequently some of the outer fibres jass upwards and inwards lehind the rest, and give the appearance of decusating. It is from half to three-guarter's of an inch $(1.5-2 \mathrm{~cm}$.) broad.

The interarticular fibro-cartilage (figs. 220 and 221) is a flattened dise of nearly the sime size and outline as the inner articular end of the clavicle. which it finirly accuratcly fits. It is attached, above to the upper border of the posterior clge of the clavicle; and below to the cartilage of the first rib at its union with the

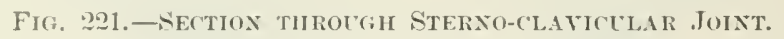

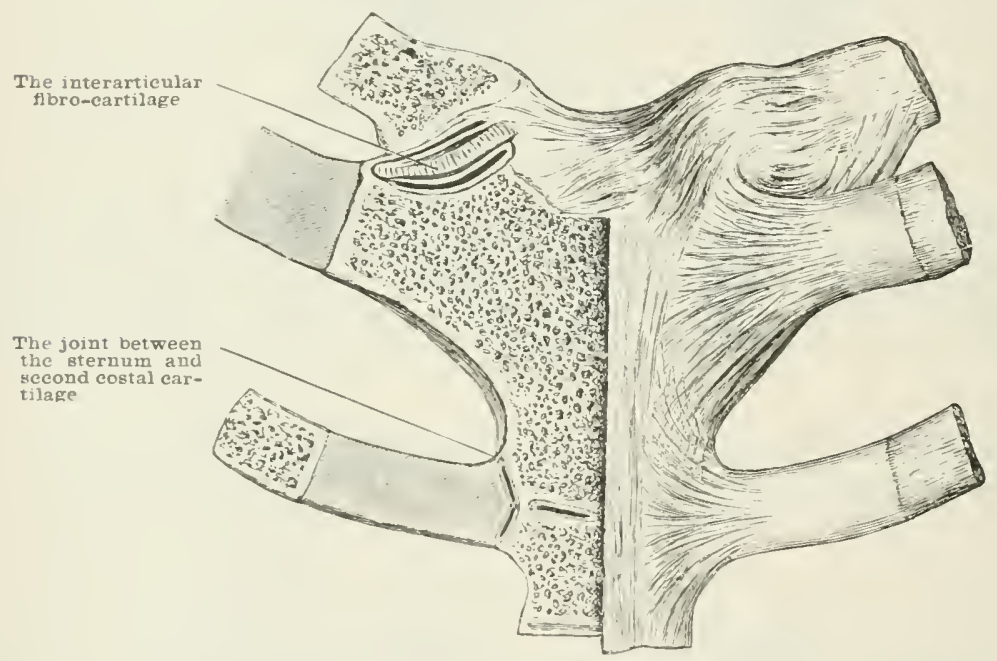

-ternum, where it assists in forming the socket for the raricle. At its circumference it is comnected with the capsular limament, and this connection is very strong behind, and still stronger above where it is blended with the interclavienlar ligament. It is nsually thinnest lrelow, where it is comnected with the costal cartilage. It varies in thickness in different parts, sometimes being thimmer in the "entre than at the circumference, smotimes the reverse, and is occasionally perforaterl in the contre. It diviles the joint into two compartments.

There are twr synovial membranes (figs. 220 and 221 ): an out (reme, which is reflectrd from the clavicle and capsule over the outer side of the filoru-cartilage, and is lowser than the inner; the inner is reflecterl from the sternmm over the inner

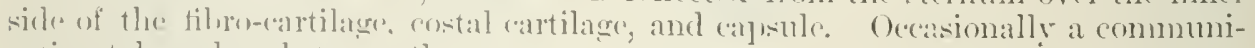

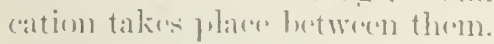

The arterial supply is lerived from hranches (1) forn the internal mammary;

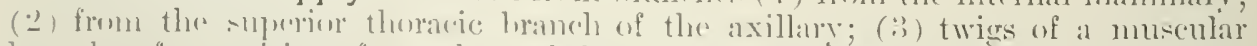

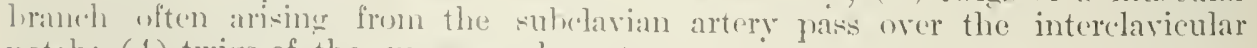
noteh; (t) twigs of the supraseapular artery.

The nerve-supply in derived from the nerve to the subdarius and stemal descendine branch of the ecrvical pllexus.

The movements fremitter at this joint are varions, thougl limiterl owing to

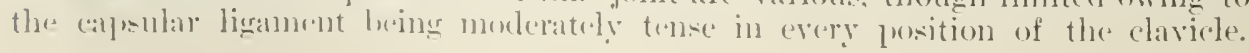


Iotion takes place in nearly every direction-riz. upwards, downwards, fon'wands, hackwards, and in a circuniluctory mamner. The upward and downward motions occur between the clavicle and the fibro-artilage; during elevation of the arm, the nuper edge of the rlavicle with its attached fibro-cartilage is pressed into the stemal socket, and the lower edge glides away from the cartilage; during depression of the limb, the lower edge of the clavicle presses on to the cartilage, while the rest of the articular surface of the clavicle inclines outwards, bringing with it to a slight degree the upper arlge of the fibro-cartilage. These morements occur on an anteroposterior axis drawn through the outer compartment of the joint. The forward and backward motions take place between the cartilage and sternum, the claricle with the cartilage rolling backwards upon the sternum when the shoulder is brought forwards, and forwards when the shoulder is forced backwards; these movements occur round an axis drawn nearly vertically through the stemal socket.

The interarticular cartilage serves materially to lind the bones together, and to prevent the inward and upward displacements of the clavicle. It also forms an elastic buffer which tends to break shocks. The capsule, by being moderately tight, tends to limit movements in all directions, while the interclavicular ligament is a safeguard against upward displacement during depression of the arm. The rhomboid ligament prevents dislocation upwards during elevation of the arm, and resists displacements backwards.

\section{(2) THE SCAPLLO-CLAYICLLAR TNION}

The scapula is connected with the clavicle by a synovial joint with its ligaments; and also by a set of ligaments passing between the coracoid process and the clavicle. So that we have to consider-

(i) The acromio-clavicular articulation.

(b) The coraco-clavicular ligaments.

(c) The proper scapular ligaments are also best described in this sectionviz. the coraco-acromial and transverse.

\section{(11) THE A'ROMIO-CLATI'TLAR JOINT}

\section{Class.-Direthrosis. Subdivision.-1ithrodia.}

The acromio-clavicular joint is surrounded by a capsular ligament and frequently contains an interarticular fibro-cartilage.

The capsular ligament (tigs. 223 and 226 ) completely surrounds the articular margins, and is composed of strong, coarse fibres arranged in prarallel fasciculi, of fairly uniform thickness, which are attached to the borders as well as the surfaces of the bones. It is somewhat lax in all positions of the joint, so that the clavicle is not tightly braced to the acromiom. The fibres extend three-quarters of an inch (2 (m.) along the clavicle posteriorly, but only a quarter of an inch (6 $\mathrm{mm}$.) anteriorly. superiolly they are attacher to an obligue line joining there two points, while inferiorly they reach to the ridge for the trapezoid ligament with which they blend. At the arromion they extend half way across the upper and lower surfaces. lut at the anterior and posterior londers if that process they are attached close to the articular facet. The antrior filures become blenderl with the insertion of the erraco-acromial ligament. The fibres are strengthenerd above ly the alponemoses of the tropezius and deltoid musche; and all rum from the acromion to the clavicle inwards and backwarls.

The interarticular fibro-cartilage is ocrasionally present, lut is lisllally imperfect, only occupying the upper part of the joint; it may completcly divide the joint into two cavities, or be perforated in the centre. It is nsully thicker at the edge than in the centre, and some of the filmes of the capsular ligament are blended with its edges.

The synovial membrane lining the joint is necasionally either prartially or entirely divided into two by an interarticular fibro-cartilage. 


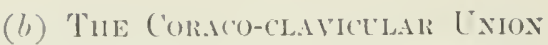

The coraco-clavicular ligament (figs. 22.2, 223 and 226 ) consists of two parts, the conoil and the trapezoid ligaments.

The conoid ligament is the internal and postrior portion, and passes upwarts and ontwards from the coracoid process to the clavicle. It is a very strong and (")arsely farciculated band of triangular shape, the apex being tixed to the inner and posterior arlere of the root of the coracoid process just in front of the supraseapular noteh, some fibres joining the transerse ligament. Its base is at the elavicle, where it widens out. to he attached to the posterior edge of the under surface, as well as to the eonoid tuberele. It is easily separated from the trapezoid without heing alsolutely distinct. $\Lambda$ small bursa often exists between it and the coracoid process: intrrnilly, some of the fibres of the subclacius musele are often attached to it.

The trapezoid ligament is the anterior and outer portion. It is a strong, flat,

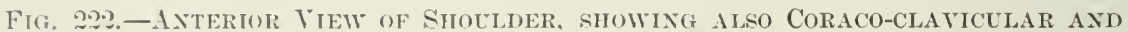 ('IRICO-ACROMIAL LIGAMENTS.}

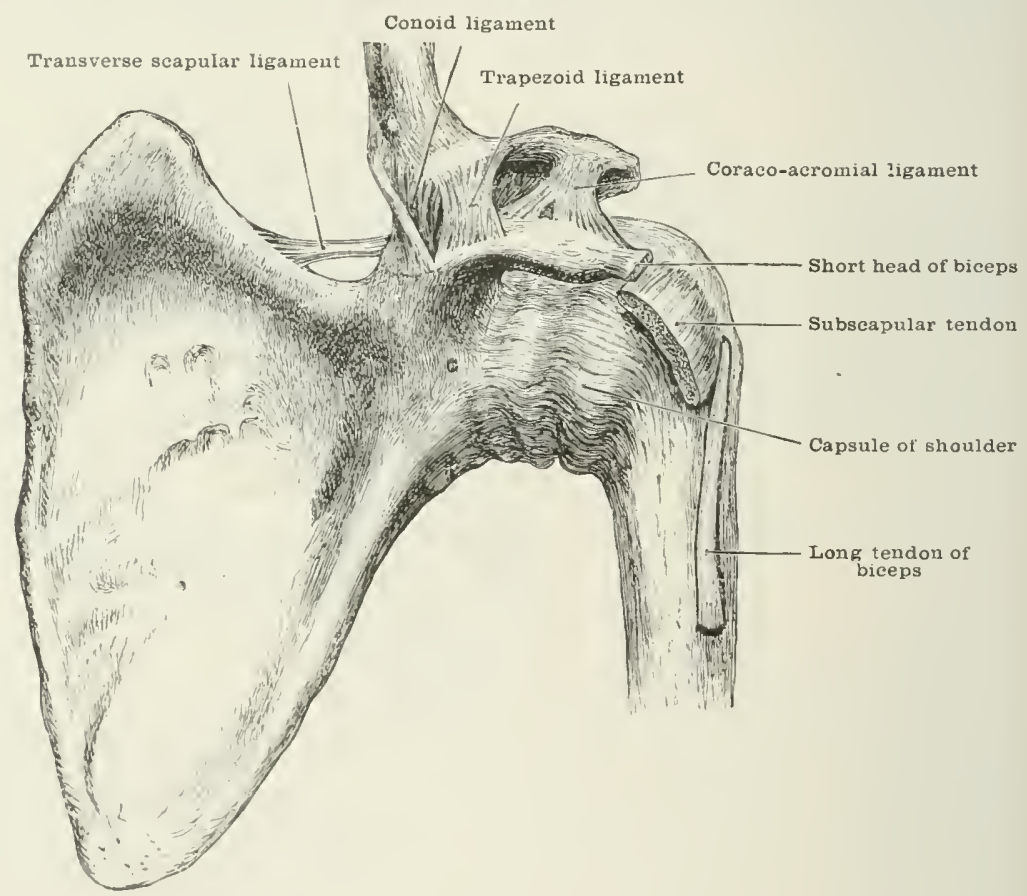

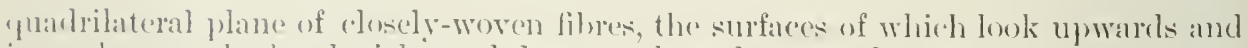
inwards towards the clavicle, and downwark and outwards over the upper surface

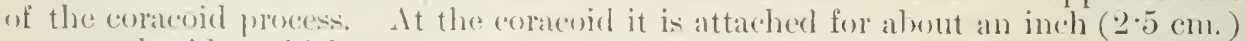
to a rough ribge which rums forwards from the angle, along the anterior horder of the process. It the davicle, it is attacherl to the olsigue ridge which runs outwards and forwark from the conned tuberele, reaching as far as, and blending with the inferior part of the aceminio-elatvicular ligament. Its anterior edge is free, and

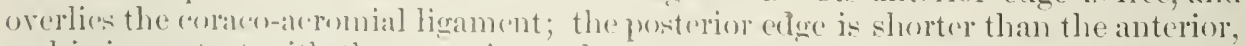
and is in contact with the gosterior and onter portion of the comolid ligament.

The arterial supply is derivel from the smplasmplar, acromial branches of

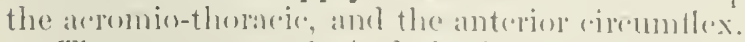

The nerve-supply is derived from the sty rascapular and ciremuflex nerves.

Movements. - In the merements of the shoulder crirlle, the scapula moves

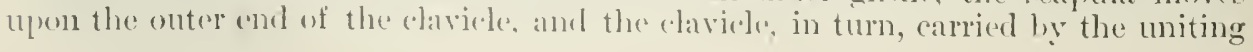


ligaments, moves upon the stermum; so that the entire seapula moves in the are of a circle whose centre is at the sterno-elavicular joint, and whose radins is the elavicle. The seapula, in moving upon the elavicle, also moves upon the thorax forwarks and backwards, upwards and downwards, and also in a rotatory direction upon an axis drawn at right angles to the centre of the bone. Throughout these novernents the lower angle and base of the scapula are liept in contact with the ribs by the latissimus dorsi which straps down the former, and the rhomboids and servatus magnus which brace down the latter. The glenoid cavity could not have preserved its obliquely forward direction had there been no acromiro-clavicular joint, but would have shifted round a vertical axis, and thus the shoulder would have pointed inwards when the scilpula was adranced, and outwards when it was drawn backwards. By means of the acromio-clavicular joint, the scapula can be foreibly advaneed npon the thorax, the glenoid eavity all the time keefing its face duly forwards. 'Thus the muscles of the shoulder and forearm ean he with advantage combined, as, for example, in giving a direct blow. The acromio-clavicular joint also permits the lower angle of the sapula to be retained in contact with the chest wall during the rising and falling of the shoulder, the scapula turning in a hinge-like manner round the horizontal axis of the joint.

There are no actions in which the scapula moves on a fixed elaviele, or the rlavicle on a fixed scapula; the two bones, bound together by their connecting ligament, must more in unison.

\section{(c) The Proper sicapular Liganexts}

There are three proper ligaments of the scapula, which pass between different portions of the bone, viz.-

Coraco-acromial.

Inferiol transverse.
Transverse.

The coraco-acromial ligament (figs. 22.2 and 226) is a flat, triangular hand with a broad hase, attached to the onter border of the coracoid process, and a lilunt apex which is fixerl to the tip of the acromion. It is made up of two broad marginal bands, and a smaller and thinner intervening portion. The anterior band, which arises from the anterior portion of the coracoid process, is the stronger, and some of its marginal fibres ean often be traced into the short head of the biceps, which can then make tense this edge of the ligament. The posterior band, coming from the posterior part of the coracoid process, is also strong. The intermediate part, of variable extent, is thin and membranous, containing but few ligamentous filses; it is often ineomplete near the eoracoict process. leaving a small gap (fig. 2222). The superior surface of the ligament looks upwards and a little forwards, and is covered by the deltoid muscle; the inferior lonks downwards and a little backwards, and is separated from the capsule of the shoulder-joint by a bursa. At the coracoid process it overlies the coraco-humeral ligament. It is barely one-third of an inch ( $8 \mathrm{~mm}$.) above the capsule of the shoulder, and in the mdissecterl state there is searcely a quarter of an inch $(6 \mathrm{~mm}$.) interval. The anterior band projects orer the centre of the hear of the humerus, and is continued into a tough fascia mnder the deltoid; the posterior hand is continuous with the fascia over the supra-spinatus muscle. It binds the two processes firmly together, and so strengthens each; it holds the deltoid off the capsule of the shoulder, and protects the joint from slight injuries directed downwards and backwards against it.

The transverse, coracoid, or suprascapular ligament (figs. 222, 2223 and 224 ) is a small triangular band of fibrous tissue, the surfaces of which look forwards and backwards; and its edges, which are thin and sharp, are turned upwards and downwards. It continues the superior horder of the scapula, bridging orer the supraseapular notch. It is broader intemally, where it springs from the upper border of the scapula on its dorsal surface; and narrow externally, where it is attached to the base of the coracoid process: some of its fibres are inserted mnder the edge of the trapezoid ligament, and othors pass upwards with the conoicl to 


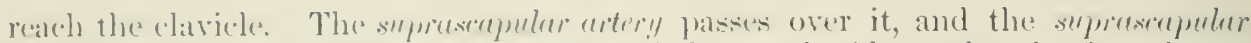
nerr beneath it. Internally, some fibres of the ome-hyoul muscle arise from it.

The inferior transverse or spino-glenoid ligament (fig. 22.3) reaches from

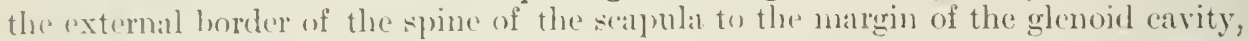

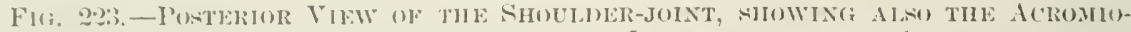

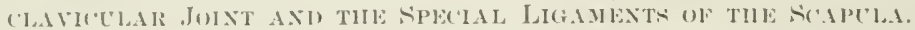

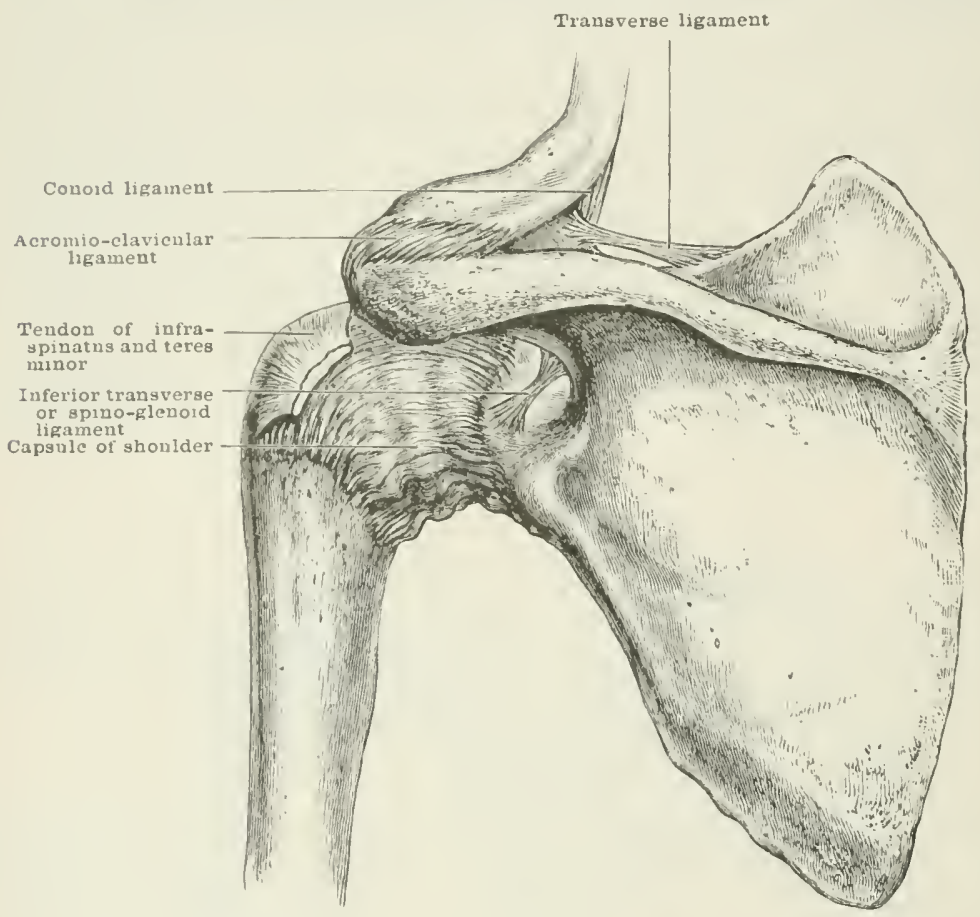

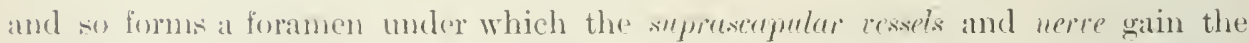
infraspinous fossal. It is usually a weak membranous structure with hut few ligamentrus fibres.

\section{THE SHOLLDER-JOIN'T}

Class.-Ininithrosis.

Subdivision.-Enarthodia.

The shoulder is one of the most perfect, and most movable of joints, the large upper and of the humerus playing upon the shallow glenoid eavity. Like the hip, it is a ball-and-socket joint. It is retained in position much less by liganents than by muscles and the effects of atmospheric pressure; and, owing to the looseness of its eapsule, ats wrell as to all the oflere conditions of its construetion and position, it is exereclingly lialse to be displaced; on the other hand, it is sheltered from violene ly the two projecting processes-the acromion and coracoid.

The ligranents of the shoulder-joint are:-

('ilpsular.

(ileno-humeral.
Coraco-humeral.

(illenoicl.

The capsular ligament (figs. 222, 2.23 and 224) is a loose sac, insufficient in itself to maintain the bones in contact. It comsists of fairly distinet but not conrse fihres, clessely wowen together, amd directed, somestratight, others obliquely, between the two bones, a fin cireular ones being interworen anongst them. At the seapula, 
it is fixed on the dorsal aspect to the prominent rough surface of the glenoid proress, reaching as far as the neek of the bone. Alove, it is attached to the root of the roracoid process: in front, to the ventral surface of the glenoid process, at a variahle distance from the articular margin, often reaching half an inch (12 $11 m$.) upon the neck of the lone, and thus allowing the formation of a pouch; it may not, however, extend for more than a yuarter of an inch ( 6 mm.) beyond the artienlar margin: helow, it blends with the origin of the long hearl of the triceps. At the humerus, the upler half is fixed to the anatomieal neck, sending a prolongation downwards between the two tuberosities which attenuates as it descends. and covers the transverse humeral ligament. The lower half of the eapisule descends upon the humerus further from the articular margin, some of the deeper fibres being reflected upwards so as to be attached close to the articular edge, thus forming a kind of fibrous investment for the neck of the humerus. This ligament is more uniform in thickness than that of the hip.

Gleno-humeral bands of the capsule (figs. 224 and 225 ). - There are three

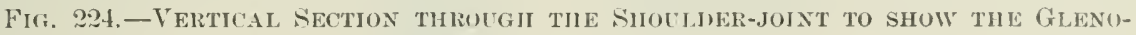
IIIMER.IL LIGAMENT.

(The joint is opened from behind.)

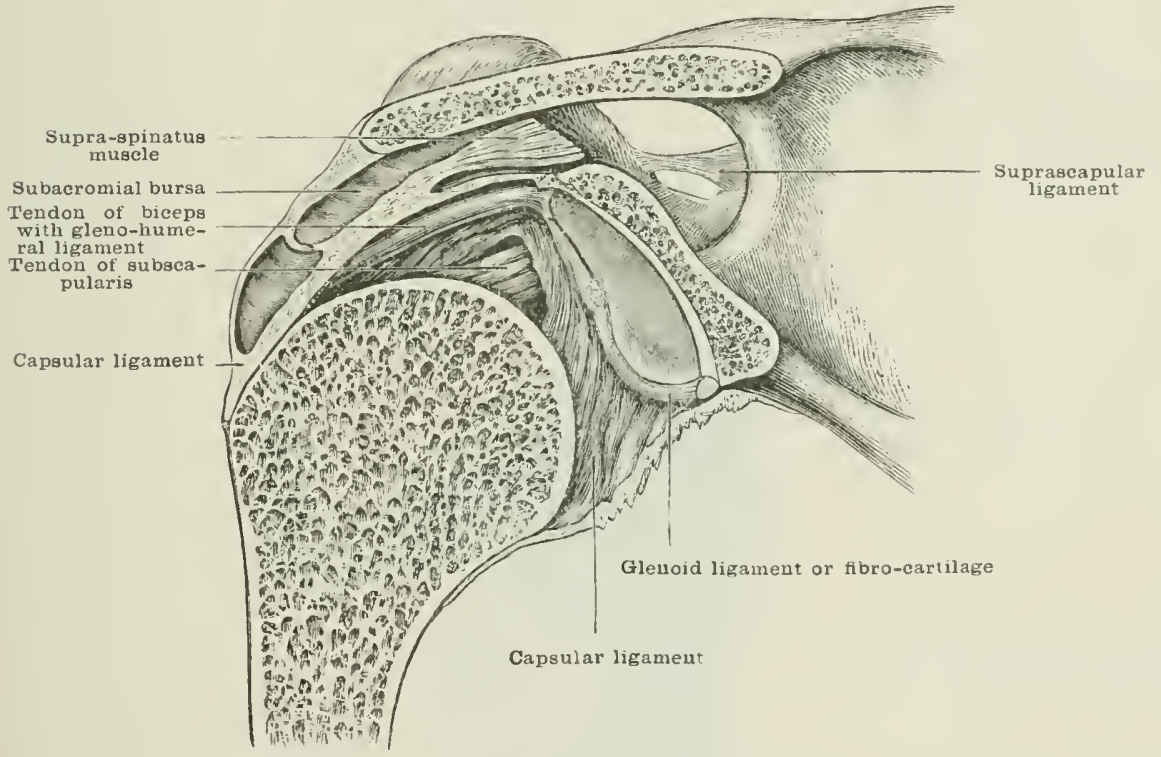

accessory bands which strengthen the eapsuke, two of which are seen superficially, and consist of a few strengthening filsres, one on the inner aspect reaching from the glenoid cavity to the lower border of the lesser tulerosity along the lower borker of the subseapularis tendon; and the inferior raching from the under part of the glenoid cavity to the under part of the neck of the hmmerus. The third, the superior band, is known as the gleno-humeral ligament, and ean only be seen after of*'ning the capsule. It runs from the exlge of the grlenoid eavity at the root of the coracoid process, just internal to the origin of the long temdon of the biceps, and, passing inwards and downwards at an acute angle to the tendon, for which it forms a slight groove ol suleus, is fixed to the lesser tulurosity of the humerts. It is at thin, ribbon-like band, of which the upper surfare is attachert to the earsule, while the other is free and turnesl towards the joint. In the fortus it is often, and in the adult occasionally, quite free from the capsule, and may be as thick as the long tendon of the bieeps (fig. 2.2.5).

The tendons of the snpure and infia-spinutus, teres mimor, and subscrpmlaris muscles strengthen and suplurt the capsule, especially mear their points of inser- 
tion, and can be with difliculty dissected off from it. The long head of the trieps supports and strengthens the apsule below. The eapsule also receives an upward slip from the jurtoralis major. The supra-spinatus often sends a slip into the capsule from its upper e(lge (tig. 22.24).

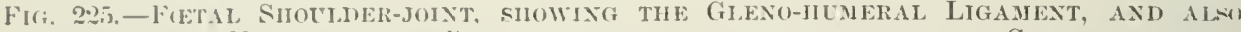

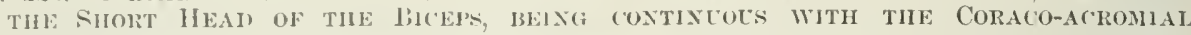
LIIAYENT.

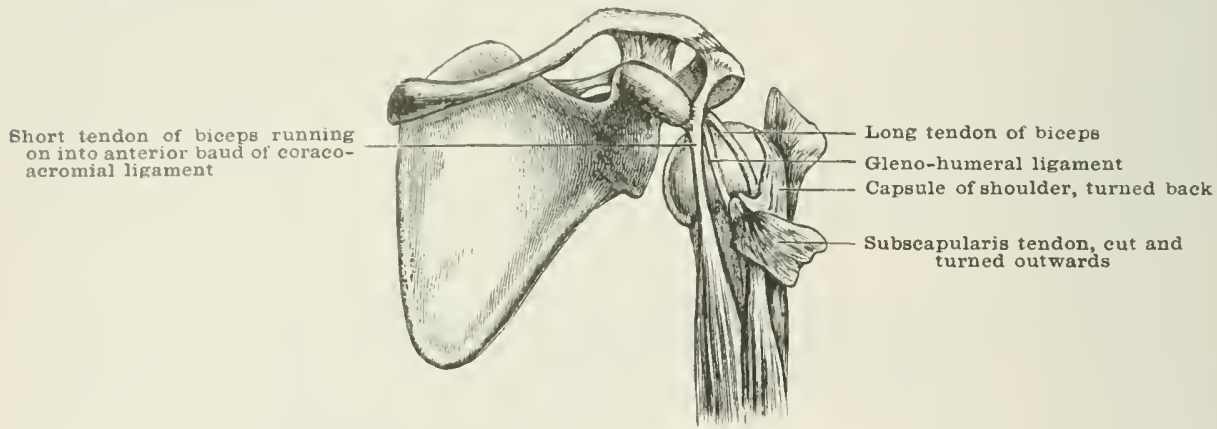

The coraco-humeral ligament (fig. 226 ) is a strong broad band, which is attached alrove to the outer edge of the root and horizontal limb of the coracoid jucess nealy as far as the tip. From this origin it is directed backwards along the line of the hiceps tendon to blend with the capsule, and is inserted into the greater

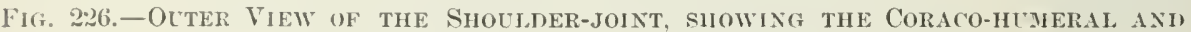
TRANSYERSE HIMERAL LIGANENTS.

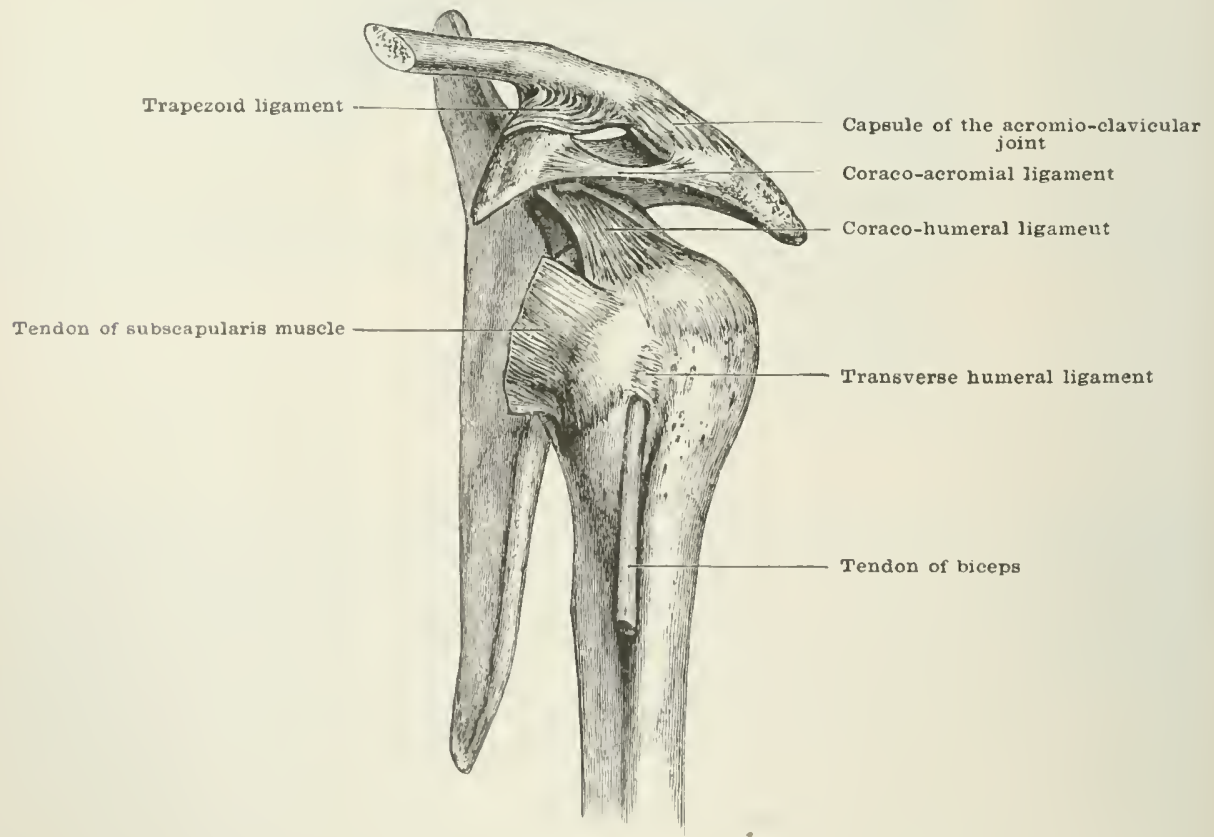

tuherosity of the humerus. Seen from the back, it looks like an minterrupted continnation of the capsule, while from the front it looks like a fan-shaped prolongation from it werlying the rest of the ligament. At its origin there is sometimes a bursa between it and the capsule. 
The glenoid ligament (figs. 224 and 227 ) is a narrow rim of dense fil,ro-cartilage, which surrounds the erlge of and deepens the glenoid socket. It is about a quarter of an inch $(6 \mathrm{~mm}$.) wide above and below, but less at the sicles. Its onter edge is inseparably welded, near the bone, with the capsular ligament. Its structure is ahmost entirely fibrous, with but few eartilage cells intermixed. At the upper jart of the fossa the biceps tendon is prolonged into the glenoid liganent, the tenrlon usually diricling and sending fibres right and left into the ligament, which may wind round nearly the whole eireumference of the socket. It may, however senct fibres into one side only, usually into the outer.

The articular cartilage covering the glenoid fossa is thicker at the circumference than in the centre, thus tending to deepen the cavity. It is usually thickest at the lower part of the fossa; over the hear of the humerus the cartilage is thickest at and below the centre.

The synovial membrane lines the glenoid ligament, and is then reflected over the capsule as far as its attachment to the humerus, from which it ascends as far as the edge of the articular cartilage. The tendon of the bicep. reecives a long tubular sheath, which is continuous with the synovial membrane, both at its attacherl extremity and at the bicipital growe, but is free in the rest of its extent. The

\section{Fio. 227.-BICEP TExION. BHFURCATING AND BLENDING ON EACH SIDE WITH THE} (ilenoin Fibro-cartilage.

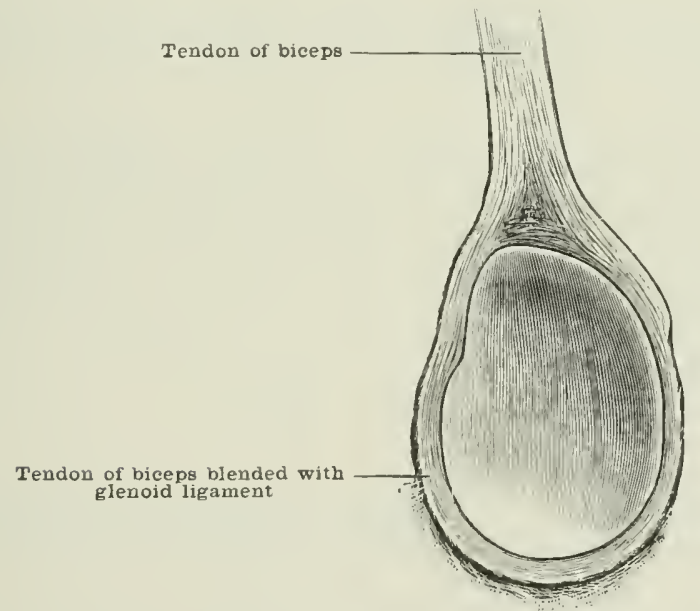

-rnovial cavity sometimes communicutes with the bursa under the subscapnlaris, and less frequently with one under the infra-spinatus muscle. It also sends a pouch-likr prolongation beneath the coracoid process when the fibous capsule is attached wide of the margin of the glenoid fossa. A few fringes are seen near the erlge of the glenoid eavity, and there is often one which runs down the inner erlge of the biceps tendon, extending slightly below it and making a slight groove for the tenrlon to lie in.

The transverse humeral ligament (fig. 226) is so clusely connected with the capsule of the shoulder that, although it is a proper ligament of the humerus, it may well be deseribed here. It is a strong band of fibrous tissue, which extends between the two tuberosities, roofing in the bicipital canal. It is covered by a thin expansion of the capsule. It is linited to the portion of the bone above the line of the epiphysis. (C. Gordon Brodie, Journ. Anat. xxiv. 247.)

The following muscles are in relation with the capsular ligament: ahove, the supra-spinatus; externally, the infir-sprimatus and teres minor; helow; the long head of the triceps; intemally; the tendon of the subscomularis. The deltoid covers the outer and upper surfaces of the joint, but is separated from the capsule by a bursa, and the tendons of the short rotator muscles. An upwarl slip from the pectoralis 
mujor joins the capsule below. Internally are the long tendon of the biceps and the gleno-humeral ligament.

The arterial supply is derived from the suprascapular, anterior and posterior cireumflex, sulseapular, dorsalis seapulie, and a branch from the sceond portion of the axillary artery.

The nerve-supply is derived from the supraseapmar, by branches in both fosse; ambl from the cirementlex and subseapular nerves.

The movements of the shoulder-joint consist of flexion, extension, adduction and abluction, rotation and circumduction.

Flexion is the swinging forwards, extension the swinging backwards, of the humerus: aluluction is the laising of the arm from, and alduction depression of the arm to, the side. In flexion and extension the head of the humerus moves upon the centre of the shenoid fossa round an oblinge line corresponding to the axis of the head and neek of the humerus, flexion being more free than extension, and in 'xtreme flexion the scapula follows the head of the humerus, so as to keep the articular surfiees in apposition. In extensiun the scapula moves nuch less, if at all.

In aluluction and adduction the scapula is fixed, and the humerus rolls up and Awro upon the glenoid fossa; during abduction the head descends until it projects lexpmel the lower edge of the glenoid carity, and the great tuherosity in pinges against the arch of the acromion; during adduction, the head of the humerus ascencls in its socket, the arm at length reaches the side, and the calsule is combletely relaxed.

In circunduction, the humerus, by passing quickly through these movements. describes a wone, whose apex is at the shoulder-joint, and the hase at the distal "xtremity of the lone or limh.

Rotation takes place round a rertical axis drawn through the extremities of the humerus from the centre of the head to the inner condyle; in rotation forwards (that is. inwarls) the head of the bone rolls back in the socket as the great tuberusity and shaft are turned forwards; in rotation backwards (that is, ontwards) the hratil of the lone glides forwards, and the tuberosity and shaft of the humerus are tumed hackwarls, i.e. outwards.

(ireat fredom of movement is permitted at the shoulder, and this is increased hy the molitity of the scapula. Restraint is scarcely exercised at all upon the minvements of the shoulder by the ligaments, but chiefly by the muscles of the juint.

In abluction, the lower part of the capsule is somewhat, and in extreme abduction considerally, tightened; and in rotation inwards and ontwards, the upper part of the capule is made tense, as is also, in the latter movement, the coraco-humeral ligrament.

The morements of aldolution and extension have a most decided and definite resistallere offered to them other than hy muscles and ligaments, for the great tuhcresity of the humerus, by striking against the acromion process and coracoacomial ligament, stops short any further advance of the lone in these directions, and thus abdurtion reass altogether as soon as the arm is raised to a right angle with the trunk; and extension shortly after the humerus passes the line of the trunk.

Further alevation of the arm berond the right angle is effected by the rotation of the seapula round its own axis by the action of the trapezius and serratus magnus muscles npon the stemo-chvicular and acromio-clavicular joints.

The actomion and enraceiel preceses, togrether with the coraco-acromial ligamont, form an ande. Which is seprament hy a hursa and the tendon of the supraspinatus from the calpsule of the shomleler. Buneath this arch the morements of the joint take plare, and acrainst it the head and tuberositios are pressed when the weight of the trunk is supportel lyy the arms; the greater tuberosity and the upper part of the shaft impinge upen it whem aloduction and extension are carried to their fullest ixtent.

No description of the should re-joint would be complete without a short notice of the peculiar relintion which the bieps tenchon bears to the joint. It passes over the head of the humerus a little to the inmer side of its summit, and lies free 
within the capsule, surrounded only by a tubular process of synovial membine. It is flat, with the surfaces looking upwards and downwards, until it reaches the bicipital groove, when it assumes a rounded form. It strengthens the articulation along the same course as the coraco-humeral ligament, and tends to prevent the head of the humerus from being pulled upwards too forcibly against the under surface of the acromion. It also serves the purpose of a liqament by steadring the head of the humerus in various movements of the arm and forearm, and to this end is let into a groove at the upper end of the bone, from which it cannot escape on account of the abutting tuberosities and the strong transverse humeral liganent which binds it down. Further, it acts like the four shoulder muscles, which yass over the capsule to keep the hear of the humerus against the glenoid socket; and, moreover, it resists the tendency of the pertoralis major and latissimus dorsi muscles, in certain actions when the arm is away from the side of the body, to pull the head of the humerus below the lower edge of the carity.

\section{THE ELBOW-JOINT}

\section{Class.-Diverthrosios.}

\section{Subdivision.-Ginglymes.}

The elbow is a complete hinge, and, mlike the knce, depends for its security and strength upon the configuration of its bones rather than w the number, strength, or arrangement of its ligaments. The bones composing it are the lower end of the humerus alove, and the upper ends of the radius and ulna below; the articular surface of the humerus being rereived partly within the great sigmoid cavity of the ulna, and partly upon the cup-shaped surface of the radius. The liganents form one large and capacious eapsule, which, by blending with the orbicular ligament, and then passing on to be attached to the neck of the raclius, embraces the elbow and the superior ralio-ulnar joints, uniting them into one. Laterally, it is considerably strengthened by superadded fibres arising from the condyles of the humerus and insejarably connected with the capsule. For conrenience of description it will be spoken of as consisting of four portions:-
Anterior.
Internal.
Posterior.
External.

The anterior portion (fig. 228) is attached to the front of the limnerus almere the articular surface and coronoid fossa, in an inverted V-shajed manner, to two very faintly marked ridges which start from the front of the internal and extemal condrles, and meet at a variable distance above the coronoid fossa. Below, it is fixed, just berond the articular margin, to the front of the coronoid process; it is intimately blended with the front of the orbicular lisament, a few fibre pasing on to the neck of the radius. It varies in strength and thickness, being -mmetimes so thin as barely to cover the synovial membrane; at others, thick and strong, and formed of coarse decussating fibres, the majority of which descend from the inner side outwards to the radius.

The posterior portion (fig. 229), thin and membranous, is attached superiorly to the humerus, in much the same inverted $V$-shaped way as the anterior; ascending from the internal contyle, along the inner side of the olecranom fossa nearly to the top; then, crossing the bottom of the fossa, it rlescends on the outer side, skirting the outer margin of the trochlear surface, and turns outwards along the posterior edge of the eapitellum. Inferiorly, it is attached to a slight groove along the superior and extemal surfaces of the olecranon, and the rough surface of the ulna just heyond the leserer sigmoid notch, and with the orbicular higament, a few fibres passing on to the neek of the rarlius. It is composed of decussating filures, most of which pass rertically or olikquely downwark, a few taking a transwerse course at the summit of the oleeranon fossi where the liganent is usually thimnest.

The internal portion (fig. 22.S) is thicker, stronger, and denser than either the anterior or posterior portions. It is triangular in form, its apex being attacherl to the anterior and under aspect of the internal condyle, and to the endrind edge of 
the groure between the trochlea and the condyle. The fibres radiate downwards from this attachment, the anterior passing forwark to be fixed to the rough overhimering inmer edge of the coronoid process; the midlle descend less obliguely to a riblere rumning between the coronoil and olecranom processes, while the posterior

FIr, :28.-INTERxAl, VIEW OF THE ELIBOW-JOINT.

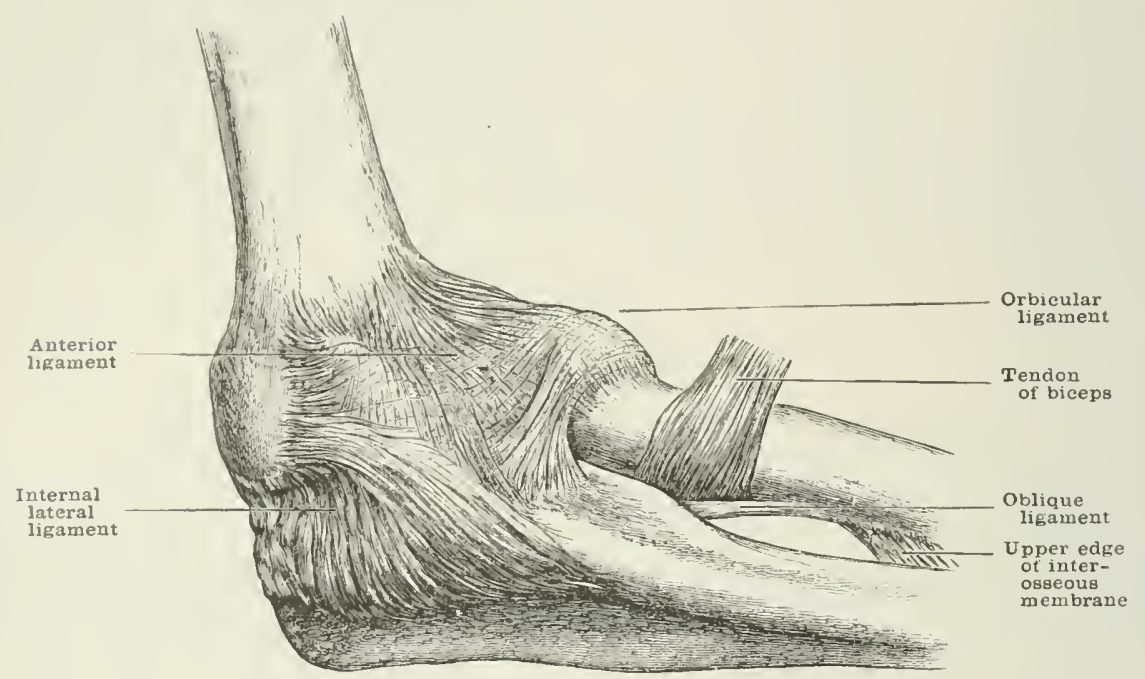

pass obliquely hackwards to the inner edge of the olecranon just beyond the articular margin. The anterior fibres are the thickest, strongest, and most jonounced.

The external portion (fig. 229) is attached above to the lower part of the external condyle, and from this the fibres radiate to their attachment into the outer

Fig. 229.-External, View of the Eibow-Joint.

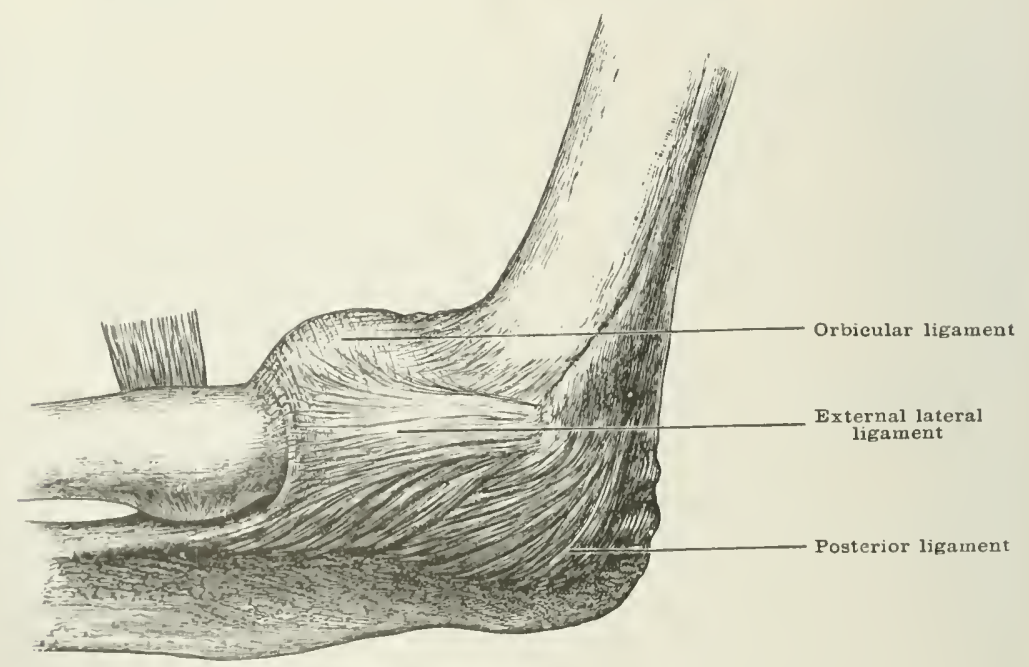

side of the orbicular ligament, a form fibres being prolonged to reach the neck of the radius. 'The anterior fibres reach further forwards than the posterior do behind. It is strong and well-marked, hut less so than the internal portion.

The synovial membrane lines the whole of the capsule, and extends into the 
superior ralio-uhar joint, lining the orbieular ligament. Outsicle the synovial membrane, hut inside the eapsule, are often seen some pads of fatty tissue; one is sitnated on the immer side at the base of the olecranon, another is seen on the outsick projecting into the eavity between the radius and ulna; this latter, with a fold of symovial membrane opposite the front of the outer lip of the trochlea, suggests the division of the joint into two parts-one internally for the uha, and anothere externally for the radius. There are also pads of fatty tissue at the bottom of the olecranon and coronoid fossa, and at the tip of the olecranon process.

The arterial supply is derived from each of the vessels forming the free anastomosis around the elbow, and there is also a special branch to the front and outer sicte of the joint, from the brachial artery, and the arterial branch to the brachicalis anticus also feeds the front of the joint.

The nerve-supply comes from the musculo-cutaneous chicfly; the uhnar, merlian, and museulo-spiral also give filaments to the joint.

The movements permitted at the elbow are those of a true hinge joint, viz. flexion and extension. These movements are oblique, so that the forearm is inclined inwards in flexion, and outwarts in extension; they are limited by the contact respectively of the coronoid and olecranon processes of the ulna with their corresponding fossie on the humerus, and their extent is determined by the relative proportion between the length of the processes and depth of the forsa which receive them, rather than by the tension of the ligaments, or the bulk of the soft parts over them. The anterior and posterior portions of the capsule, together with the corresponding portions of the lateral ligament, are not put on the stretch during Hexion and extension; but, although they may assist in checking the relocity, and thus prevent undue force of impact, they do not control or determine the extent of these movements. The limit of extension is reached when the uha is nearly in a straight line with the humerus; and the limit of flexion when the ulna describes an angle of from $30^{\circ}$ to $40^{\circ}$ with the humerus.

The obliquity of these movements is due to the outward inclination of the mprer and back part of the trochlear surface, and the greater prominence of the inner lip of the trochlea below; thus the plane of motion is directed from behind inwards and forwarks, and carries the hand towards the middle third of the elavicle. The obliquity of the joint, the inward twist of the shaft of the humerus, and the hackward direction of its head, all tend to bring the hand towards the mid line. under the immediate olsservation of the eye, whether for defence, employnent, or nourishment. This is in striking contrast to the lower limb, where the dirction of the font diverges from the median axis of the trunk, thus preventing awkwardness in lucomotion. In flexion and extension, the eup-like depression of the rarlial head glicles upon the eapitellum, and the inner margin of the radial head trares. in the groove between the capitellum and the trochlea. This allows the radius to rotate upon the humerus while following the ulna in all its movements. In full extension and supination, the head of the ratius is barely in contact with the inferior surfice of the capitellum, and projects so much hackwards that its posterior mingin ean he felt as a prominence at the back of the elhow. In full flexion the anterior edge of the radial head is received into, and checked against, the depression alrove the eapitellum; while in mid-flexion the eup-like depression is fairly received upon the capitellum, and in this position, the radius heing more completely starlied by the humerus than in any other, pronation and supunation take place niost perfectly.

\section{THE UNION OF THE RADIUS WITH THE ULNA}

The radius is furmly united to the ulna ly two joints, and an intermerliate filurous union, viz. :-

(r) The superior radio-ulnar,-whereat the head of the ratius motes within the lesser sigmoid cavity and orbieular ligament.

(b) The union of the shafts, - the mid radio-ulnar union.

(c) The inferior radio-ulnar, - whereat the lower end of the ractius indls round. the head of the ulua. 


\section{(11) Tile superior Radio-clinar Joint}

\section{Class.-Dinthroxis. Subdivision.-Trochoides.}

The lones which enter into this joint are, the ulna hy its lesser sigmoiel eavity, and the radius by the smooth rertical horder or rim on its head. There is but one ligament special to the joint, viz. :-

\section{Orbicular.}

The orbicular ligament consists of bands of strong fibres, somewhat thicker than the arpsule of the elbow-joint. which encircle the head of the radius. retaining it against the sicle of the ulna. The bulk of these fibres forms about three-fourths of a cirele, and they are attached to the anterior and posterior margins of the lesser signoid arity; some few are continued round below the lesser sigmoil cavity, and form a complete ligamentous circle. The ligament is inseparably comnectid along its upper elge and extemal (i.e. its non-articular) surface with the anterior, posterior, and external portions of the rapsule of the elbow, a fer of the filmes of these portions, especially of the external, descending

\section{Fig. 230.-Orbicular ligamext.}

(The hear of the ralius removed to show the mentranous connection of this ligament with the radius.)

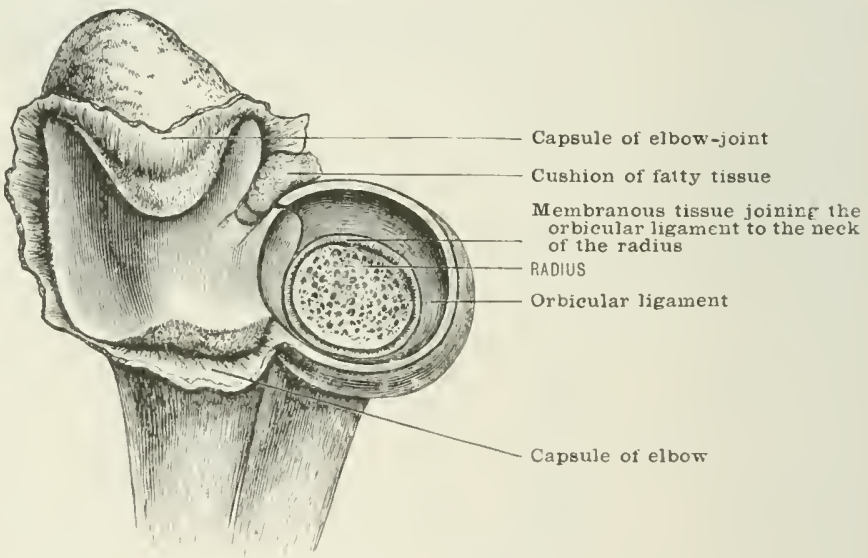

to be attached to the nexk of the radius. The lower fart of the articulation is resered in by a thin indrpenelent menbranons laver, which passes from the Inwer edge of the orbicular liganent to the neck of the raclius, strengthened on the outer siste ly those filmes passing down from the capsule. They are loose (nomgh to allow the home to rotate upen its own axis (fig. 280 ).

The synovial membrane is the same as that of the elhow: and, after lining the oflicilar liganent, pasices on to the neck of the ratius, and thence up to the articular cartilaser.

The: arterial ancl nerve-supply are the same as those to the wuter part of the ellow-joint.

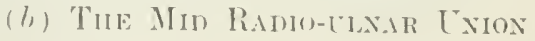

There are two intoressoms liganents which pass between the shafts of the bones and muite them firmly tugether, viz:-

$$
\text { Oblique ligament. }
$$

Introrsecous membrane.

The oblique ligament (figs. 22. 2 and $230 \Lambda$ ) is a fairly strong, narrow bant.

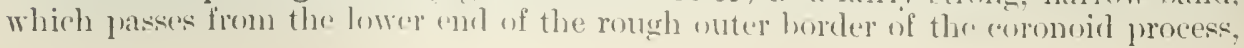


downwards and outwards to be attached to the posterior erlge of the lower end of the bicipital tuberosity of the radius and the rertical ridge rumning from it to the immer border of the bone. Some of its fibres blend with the fibres of insertion of the biceps tendon; behind, it is in close contact with the supuntor brecis; helow, a thin memhrane passes off from it to the upper edge of the interosscotis membrane; the posterior interosscons ressels pass in the space between it and the interosseous membrane; occasionally a slip is continued into the orlicular ligament of the superior raclio-ulnar articulation (see fig. $230 \mathrm{~A}$ ).

The interosseous membrane (fig. 228) is attached to the ulna at the lowert part of the ridge in front of the depression for the supinator brevis, and along the whole length of the interosseous border as far as the inferior radio-uhar articulation. approaching the front of the bone in the lower part of its attachment. To the radius it is attached along the interosseous border, from an inch (2.5 ens.) below the hicipital tuberosity to the sigmoid notch for the lower end of the ulna. It is strongest and broadest in the centre, where the fibres are dense and closely packed; it is also well marked beneath the promator quadratus, and thickens considerably at the lower end, forming a strong band of union between the two bones. Its fibres pass chiefly downwards and inwards, from the radius to the ulna, though some

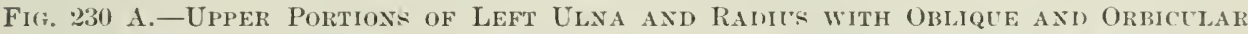

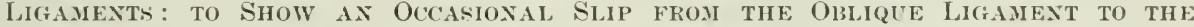
Lower PART OF THE ORBICULAR LIGAMENT. This condition is present in the spider monkey (Ateles), which has no external thumb but only rudimentary boves of one.

(From a dissection by Mr. Wr. Pearsou, Royal College of Surgeous, Englaud.)

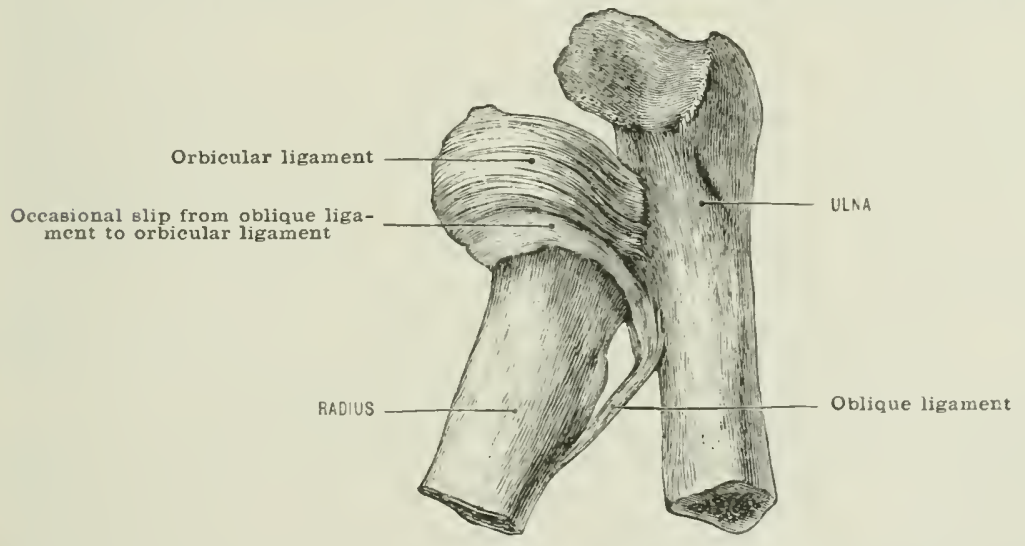

take the opposite direction; at the lower end some are transwerse. On the posterior surface are one or two bands, which pass downwards and outwards from the uha to the radins, and frequently there is a strong bundle as large as the ohlique ligament; this, which should he called the inferior oblique ligament (fig. 234 ), stretches from the ulna, an inch and a half above its lower extremity, downwards and outwards to the ridge above and behind the sigmoid notch of the radius.

At its attachment to the bones, the interosseons membrane blends with the periosteun. Its upper border is comnected with the oblique ligament hy a thin membrane, which is piereed by the posterior interosseous vessels; and the lower border, which stretches across butween the two bones just abore the inferior radioulnar articulation, assists in eompleting the capsule of that joint. lts anterior surface is in relation with the flexor profumelus digitorum and flexor lomenss pollicis in the upper three-quarters, the lower fourth being in relation with the promator quadratus. The anterior interosseous ressels and nerve descend along the middle of the membrane, the artery being bound down to it. About an inch from the lower (mol, it is piereed by the anterior interossous artery. The posterior surface is in

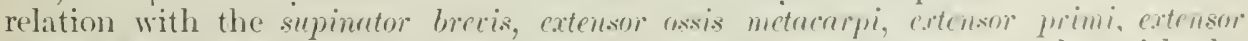
secundi internorlii pollicis, and the extensor indicis; at its lower lart, alse with the posterior branch of the anterior interosscous artery. 


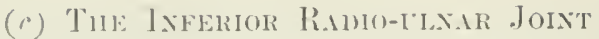

\section{Class._-Diuthinsis.}

Subdivision.-Tiochoides.

This is, in ons resceet. the reverse of the superior; for the rartins, instead of presenting a circular head to rotate upon the facet on the ulna, presents a concave fared which retls round the ulnat. The articulation mas be said to eonsist of two palts at right angles to each other: one hotwern the radius and uha, and the other between the ulna and triangular fibro-cartilage.

The ligaments alle:-

Anterior radio-ulnar.

Posterior radio-ulnar.

Triangular filıro-cartilage.

The triangular fibro-cartilage (figs. 234 and 235 ) assists the radius in forming an areh uncer which is received the first row of arpal bones. Its hase is attached (1) the marein of the rarlins, separating the sigmoid cavity from the articular surfiue for the arpus, while its apex is fixed to the fossa at the base of the styloid proes of the ulna. It gratually and uniformly diminishes in width from base to andex, heoming rounded where it is fixed to the ulna; it is joined by fibres of the intemal lateral ligament of the wrist. It is about three-eighths of an inch (1 cm.) wick and the same from base to apex; thicker at the circumference than in the contre; smooth and concave above to adapt itself to the uhna, and smooth and slighty concave below to fit over the cunciform bone. Its anterior and posterior lurder's are united to the anterior and posterior radio-uhnar and radio-carpal liganeent.s. It is the most important structure in the inferior radio-carpal articulation, at it is a very fim hond of mion between the lower ends of the bones, and serves to limit their movements upon one another more than any other structure in either the upurer or lower ralio-ulnar joints. Its structure is fibrous at the circumference, whil in the centre there is a preponderance of cells. It differs from all other fibrocartilages in entering into two distinct anticulations; and separates entirely the s!murial membrane of the radio-ulnar joint from that of the wrist.

The anterior radio-ulnar ligament (fig. 231) is attached by one end to the anterior alge of the sigmoid cavity of the ladius, and by the other to the rough lume alwre the artieular surface of the ulna as far inwards as the notch, as well as into the anterior margin of the triangular cartilage from base to apex.

The posterior radio-ulnar ligament (fig. 232) is similarly attached to the prsterior margin of the sigmoid "avity at one end, and at the other to the rough lmme alme the articular surface of the extremity of the ulna as far inwards as the srowe for the extenson cripi ulumis, with the sheath of which it is comnected, as Wril as inter the whole length of the posterior margin of the triangular fibro-cartilage. buth the rarlin-ulnal ligaments consist of thin, ahmost scattered, fibres, but they scrve to form a capsule for the support and protection of the sinovial membrane.

The lower "mel of the interosseous membrane extends lietween the ulna and radius immeliately above their points of contact. Transverse fibres between the two bones form a solt of arch above the concave articular facet of the radius, and, joining the anterior and posterior radio-nlnar limments, complete the capsule of the inferiur raction-nluar joint.

The synovial membrane, sonctimes called the membrana sacciformis, is liare and lonse in propertion to the size of the joint. It is not only interposed between the riklial and ulnar articular surfaces, hut lines the terminal articular surface of the ulna and the upprer surface of the triangular fibro-cartilage.

The arterial supply is cleriver from the anterior interosscous artery, and hranches of the anterico)" (ar) and anch.

The nerve-supply comes from the anterior interosseons of the median, and the posterion interosicous lianch of the musculo-spiral.

The movements of the radius. - The upper end of the radius rotates upon an axis drawn through it wwn had and neck within the collar formed by the leserer signoid eavity and the oftheular ligament. while the lower end, retained in position ly the triangular liganent, rells remel the head of the ulna. This rotation 
is called pronation, when the radius from a position nearly parallel to the uha turns: inwards so as to lie obliquely across it; and supimotion, when the radius turns hack again from within outwarels, so as to uneross and lie nearly parallel with the ulna. In these movements, the rarlius carries with it the hand, which rotates on an axis passing a little to the immer side of the midrlle line; thus, the hand when pronated, lies with its dorsum upwards, as in playing the piano, while when supinated, the palm lies upwards-the attiturle of a beggar asking alns. Ward thus expresses the relations of the two extremities of the radius in pronation and supination: "The. head of the raclius is so disposed in relation to the sigmoid earity at the lower end that the axis of the former if prolonged falls upon the centre of the circle of which the latter is a segment;' the axis thus passes through the lower end of the ulna at a point at which the triangular fibro-cartilage is attached, and if prolonged further, passes through the ring finger. Thus the radius rlescribes, in rotating, a hluntpointed cone whose apex is the centre of the radial head, and whose hase is at thr wrist; partial rotation of the hone being unaccompanied by any hinge-like or antero-posterior motion of its head, and pronation and supination occurring without disturbance to the parallelism of the bones at the superior radio-ulnar joint. Associated with this rotation in the ordinary way, there is some rotation of the humero-ulnar shaft, which causes lateral shifting of the hand from side to side; thus, with pronation there is some abduction, and with supination some adduction combined, so that the hand can keep on the same superficies in both pronation and supination. The power of supination in man is much greater than pronation. owing to the immense power and leverage obtained by the curve of the radius. and hy the attachment of the biceps tendon to the back of the tubercle. For this reason all our serew-driving and horing tools are made to be used ly supination movements.

In the undissected state, the amount of rotation it is possible to ohtain is about $13.5^{\circ}$, so that neither the palm nor the fore part of the lower end of the radius can he turned completely in opposite directions; yet in the living subject this anount can be greatly increased by rotation of the humero-ulnar shaft at the shoulder-joint.

Pronation is checked in the living subject by (a) the posterior inferior ralioulnar ligament, which is strengthened by the comnection of the sheath of the extensor tentons with it; (b) the lowermost fibres of the interosseons memlrane; (c) the back part of the internal and adjacent fibres of the posterior ligament of the wrist, and (d) the meeting of the soft parts on the front of the forearm.

supination is checked mainly (a) by the internal lateral ligament of the wri-t. but partly also by (b) the oblique radio-ulnar ligament; (c) the anterior inferior radio-ulnar ligament, and (d) the lowest fibres of the interosseons membrane.

The interosseous membrane serves, from the direction of its fibres dowmarts. and inwards from the radius to the ulna, to transmit the weight of the body from the ulna to the radius in the extended position of the elbow, as in pushing formard: with the arms extended, or in supporting one's own weight on the hands, the ulna being in close contact with the humerus, but scarcely at all with the carpus; while the radius is scaredy in contact with the humerus, but in rlose contact with thr arpus. Inence the weight transmitted by the uha is communicated to the radius by the tightening of the interossens memlirane. Conversely. it falls upon the ham with the arm extended, the interossens membrane acting as a sling to hreak th. violence of the shock, and preventing the whole force of the impact from expenting itself directly upon the capitellum.

\section{THE RADIO-CARPAL ARTICLIATION}

\section{Class.-Dinithrosis. Subdivision.-Condylarthrosi.s.}

The wrist-joint is formed loy the union of the radius and triangular fitho-cartilage above, articulating with the scaphoid, semilunar, and cuneiform hones below; the ulna heing (xchuded hy the intervention of the triangular fibro-cartilage. The radius and triangular cartilage together present a smonth surface, slightly concare both from before hackwards, and from sicle to side; whilst the three bones of the 
(arpus present a smouth. comvex surface, made uniformly even by the interosseous ligiments which hind them togethere.

The capsule of the wrist-joint has been usually described as four separate ligamonts, and it will he convenient for the sake of a complete description to follow this methenl; lunt it must he understond that these four portions are continuous around the joint, extending from styloid process to styloid process on both its asplects.

The four portions: are:-

Anterion radio-carpal.

Posterior radio-carpal.
Internal lateral.

External lateral.

The anterior radio-carpal (fig. 231) is a thick strong ligament, attached -uperorly to the radius immediately above the margin of the terminal articular facet. to the curved ridge at the root of the styloid process of the radius, and to the. anterior marrin of the triangular cartilage, blending with some fibres of the capsule

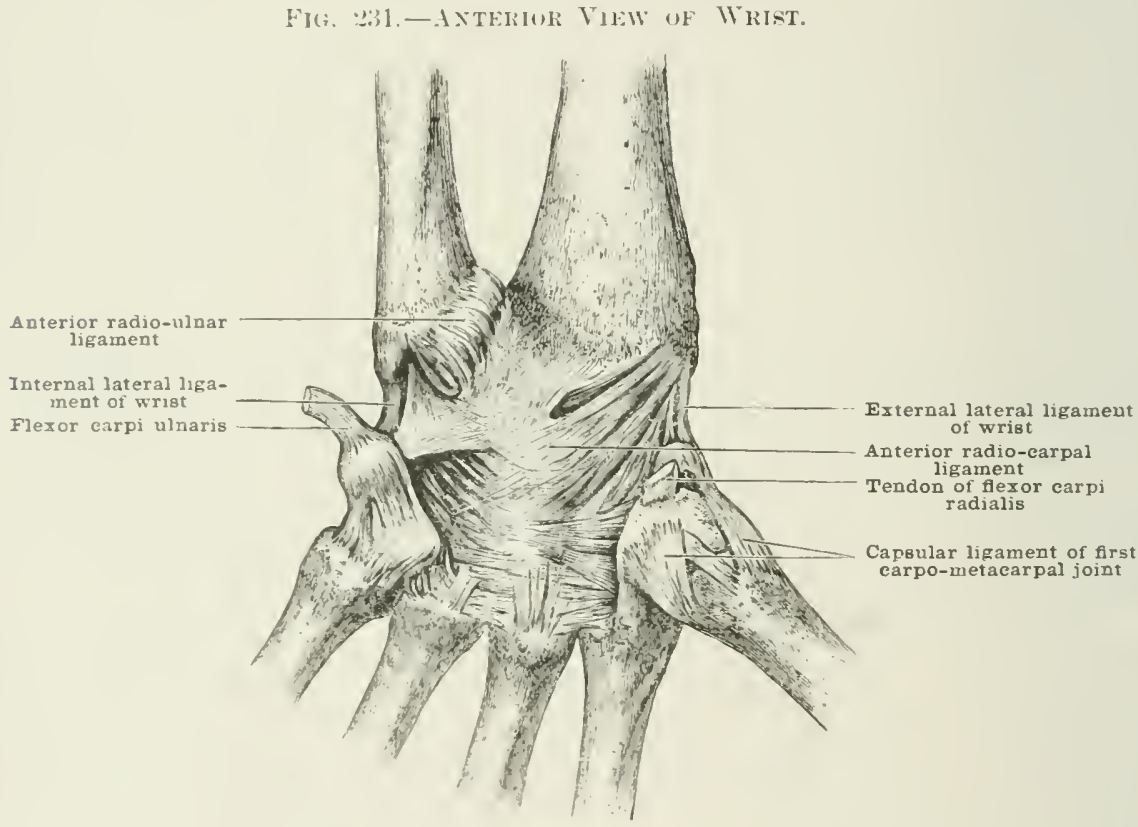

of the inferior radio-unar joint. It passes downwark and inwards to he attached to both rows of carpal lumes, especially the second, and to the anterior intercarpal ligament. The stromgest and most oblique fibres arise from the root of the styloid

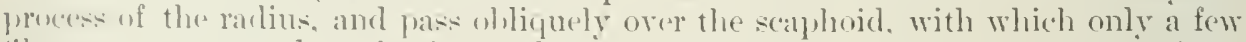
filnes are annereterl, to be inserted into the somilunar, nagnum, and cuneiform lumes. Another sot, lass ulligue. basses from the margin of the facet for the semilumar to lwa attached to the adjacent jarts of the magnum, unciform, and

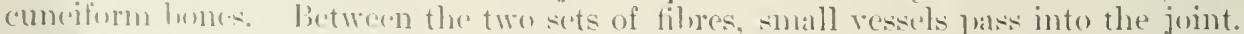

The posterior radio-carpal ligament (fig. 2.32) is attached ahore the dorsal colere of the burce rmel of the ratlius, the hack of the strloid process, and the

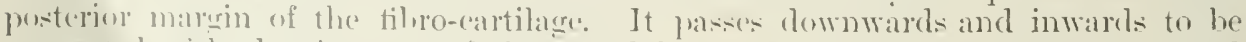
commecterl with the lirst mes of the (alpal homes. ehiefly with the semilumar and (omeiform, and the fusteriole interearpal ligament. This ligament is thin and

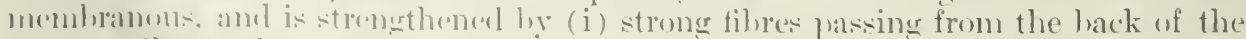

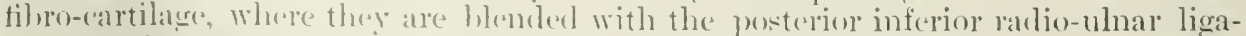
mont, and. from the mlere of the radius just hehind the lesser sienoid fossa, to the cunciform bene; (ii) from the rislge and growe for the extensor secundi internodii 
pollicis to the back of the semilunar and cuneiform bones; and (iii) from the groove for the radial extensors to the back of the scaphoid and semilunar. It is in relation with, and strengthened hy, the extensor tendons which pass over it.

The internal lateral ligament (fig. 232) is fan-shaped, with its apex abore, at the styloid process of the ulna, to which it is attached on all sides, blencling with the apex of the fibro-cartilage. Some of the fibres pass forwards and outwards to the base of the pisiform bone and to the inner part of the upper border of the anterior anmular ligament, where it is attached to the pisiform bone; they form : thick, rounded fasciculus on the front of the wrist. Other fibres descend rertieally to the inner side of the cuneiform bone, and others again outwarts to the dorsal surface of the cuneiform. The tendon of the extensor carpi uluaris is posterior to, and passes over, part of the fibres of the ligament.

The external lateral ligament (fig. 231) consists of fibres which radiate from the fore part and tip of the styloil process of the radius. Some pass downmards and inwards, in front, to the scaphoid and adjacent edge of the magnum; some downwards, a little forwards and inwards, to the tubercle of the scaphoid and ridge

FIG. 232.-P'OSTERIOR VIEW OF WRIST.

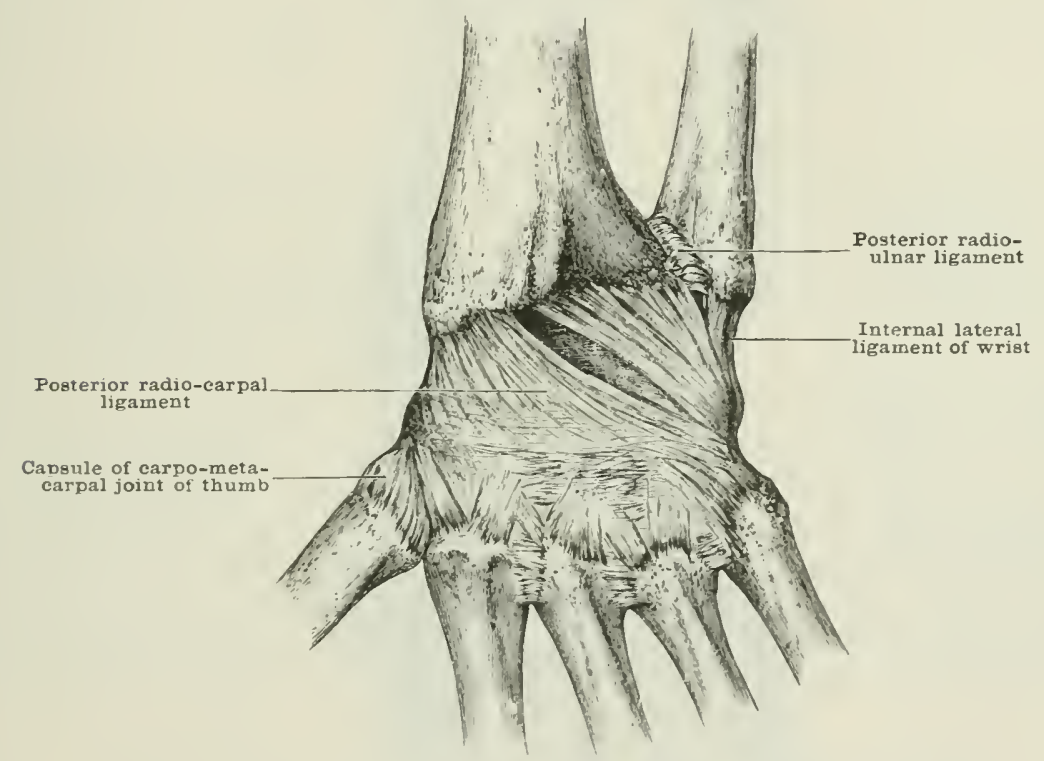

of the trapezium: and others downwards and outwards to the rough dorsal surface of the scaphoid. The fibres of this ligament are not so long and strong. nor (l) they radiate so much as those of the internal lateral ligament. It is in relation with the rediul ritery, and the extensor ossis metacompi and primi internodii pollicis, the artery separating the tendons from the licament.

The synovial membrane is extensive, but does not usually conmunicate with the srnovial nembrane of the inferior radio-ulnar joint. being shut out by the triangular cartilage. It is also excluded, in almost every instance, from that of the rarpal joint: by the interosseous liganents hetween the first row of carpal hones. The styloid process of the radius is cartilage-covered intemally; and fomm part of the articular cavity, while that of the ulna does not.

The arterial supply is derived from the anterior and posterior carpal ardhes, the posterior division of the anterior interosceons, from twigs direct from the raclial and ulnar arteries, and from reeurrent branches from the first dorsal interosicoutc.

The nerve-supply is derived from the ulnar and median in front, and the posterior interosscous behind.

Movements.-The wrist is a condvloid joint, the earpus forming the condyle. It allows of movements upon a transwerse axis, i.e. flexion and extmion; ind 
around an antero-posterior axis, i.e. abduetion and arluction; together with a combination of these in quick succession-circumduction. Lacking only rotation (n) a vertieal axis, it thus possesses most of the movements of a ball-and-socket joint, without the weakness and liability to dislocation which are peculiar to these joints. This deficieney of rotation is compensated for by the movements of the rarlius at the radio-ulnar joints, viz. supmation and promation. Its strength depends chiefly upon the number of tendons which pass over it, and the close connection whicli exists hetween the fibrous tissue of their sheaths and the capsule of the wrist; also upon the proximity of the medio-carpal and earpo-metacarpal joints, whieh germits shocks and jars to be shared and distributed between them; another souree of strength is the ahsence of any long hone on the rlistal side of the joint. In flexion and extension the (arpus rolls forwards and backwards beneath the areh formed by

Fig. 233.-Front of Wist With Axterior AxNilar Ligajent.

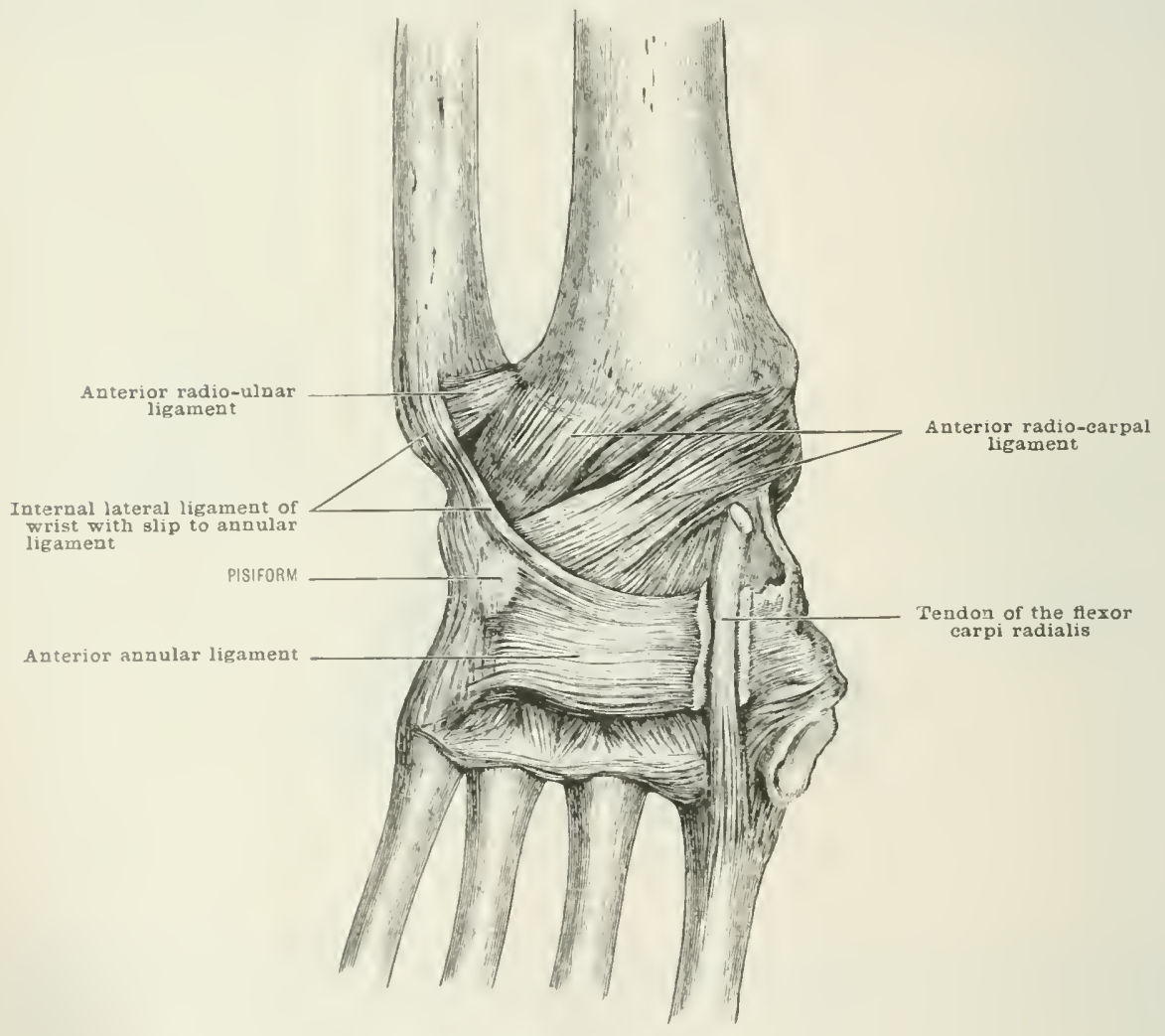

the radius and fibro-eartilage: flexion being linited by the posterior ligament and posterior furtions of the laterial: extension by the anterior, and anterior portions of the lateral liganents. In adduction and abduction, the carpal bones glide from without inwards and from within ontwards. Abduction is more linted than adduction, and is checked by the internal lateral ligament and by contact of the stroid process of the radius with the trapezimm; adduction is elsecked by the external lateral ligament alone. One reasin for adduction being more free than aluluction is that the ulna does not reach so low down as the radius, and the vielding fibro-cartilage allows of errater morement upwards of the immer end of the carpus. In circumduction the hamel moves sols to deseribe a eone, the apex of which is at the wrist. These movenents are male more easy and extensive by the slight glicling of the carpal hmes mpu one another, and the comparatively free motion at the medio-arpal joint. Theoblinue clirestion of the fibres of the lateral 
ligaments prevents any rotation at the rarlio-earpal joint, while it permits consirlerable freedum of abduction and adduction.

\section{THE CARPAL JOINTS}

The joints of the earpus may be subdivided into-

(a) The joints of the first row.

(b) The joints of the second row.

(c) The medio-carpal, or junction of the two rows with each other.

\section{(a) Tine Lijon of tile First Row of Carpal Bones}

\section{Class.-Dienthrosis. Subdivision.-Arthrodia.}

The bones of the first row, the pisiform excepted, are united by two set: of ligaments and two interosseous fibro-cartilages.

$$
\text { Dorsal. Palmar. }
$$

Interosseous fibro-cartilages.

The two dorsal ligaments extend transversely between the bones, and romnect the seaphoid with the semilunar, and the semilunar with the euneiform. Their poterior surfaces are in contact with the posterior ligament of the wrist.

The two palmar ligaments extend nearly transversely between the bones connecting the scaphoid with the semilunar, and the semilunar with the cuneiform. They are stronger than the dorsal ligaments, and are placed beneath the anterinr ligament of the wrist.

The two interosseous fibro-cartilages (fig. 2.35) are interposed between the scaphoid and semilunar, and the semilunar and euneifom hones, reaching from the dorsal to the palmar surfaces, and being connected with the dorsal and pahnar ligaments. They are narrow fibro-cartilages which extend between small portions only of the osseous surfaces. They help to form the convex carpal surface of the radio-earpal joint, and are somewhat wedge-shaped, their bases being towards the wrist, and their thin edges between the adjacent articular surfaces of the bones.

The synovial membrane is a prolongation from that of the medio-carpal joint.

The arterial and nerve-supplies are the same as for the medio-arpal joint.

\section{The Union of the Pisiforis Bone with the Clieifori}

This is an arthrodial joint which has a loose fibrous capsule attached to both the pisiform and euneiform bones just bevond the margins of their articular surfaces. It is lined by a separate synovial memibrane. Two strong rounded or flattened hands pass downwards from the pisiform, one to the process of the unciform, and the other to the base of the fifth metacarpal bone; these may be regarded a. prolongations of the tendon of the flexor crepri uturis, and the pisiform bone may. be looked upon in the light of a scsamoid bone developed in that tendon.

\section{(b) The Cyiox of the second Row of Carpal Bones}

\section{Class.-Diurthrosis. Subdivision.-Arthrodia.}

The four bones of this row are united by three dorsal, three palmar, and two interosseous ligaments.

The three dorsal ligaments (fig. 234) extend trinswersely and connect the trapezium with the trapezoid, the trapezoid with the magnum, and the magnum with the unciform. 
The three palmar ligaments are stronger than the dorsal, and are deeply placed heneath the mass of extensor tendons; they extend transwersely between the bones in a similar manner to the dorsal ligaments.

The two interosseous ligaments are situated on either side of the magnum, which ther connere with the trapezoil on the onter, and the unciform on the inner, side. That between the magnum and trapezoid is attached to the apposed surfaces neall their dorsal, i.e. the posterior aspect. That hetween the magnum and unciform (tig. 235) is attached to the apposed surfaces at their lower and anterior, i.e. their jalmar aspect.

The synovial membrane is a prolongation of that lining the medio-rarpal joint.

The arterial and nerve-supplies are the same as for the medio-carpal joint.

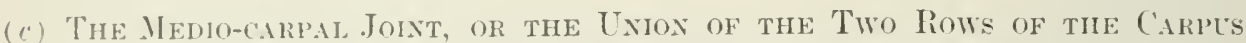
WITH EACII OTHER
(I) Class.-Dieithrosis.
Subdivision.-Arthrodir.
(II) Class.-Diarthrosis.
Subdivision.-Condylarthrosis.

The inferior surfaces of the bones of the first row are adapted to the superior articular surfaces of the bones of the second row. The line of this articulation is concaro-convex from side to side, and is sometines described as having the course

Fig. 2:4-l'osterior View of Wrist, With Capsule cut to sinow Articliar Surfaces.

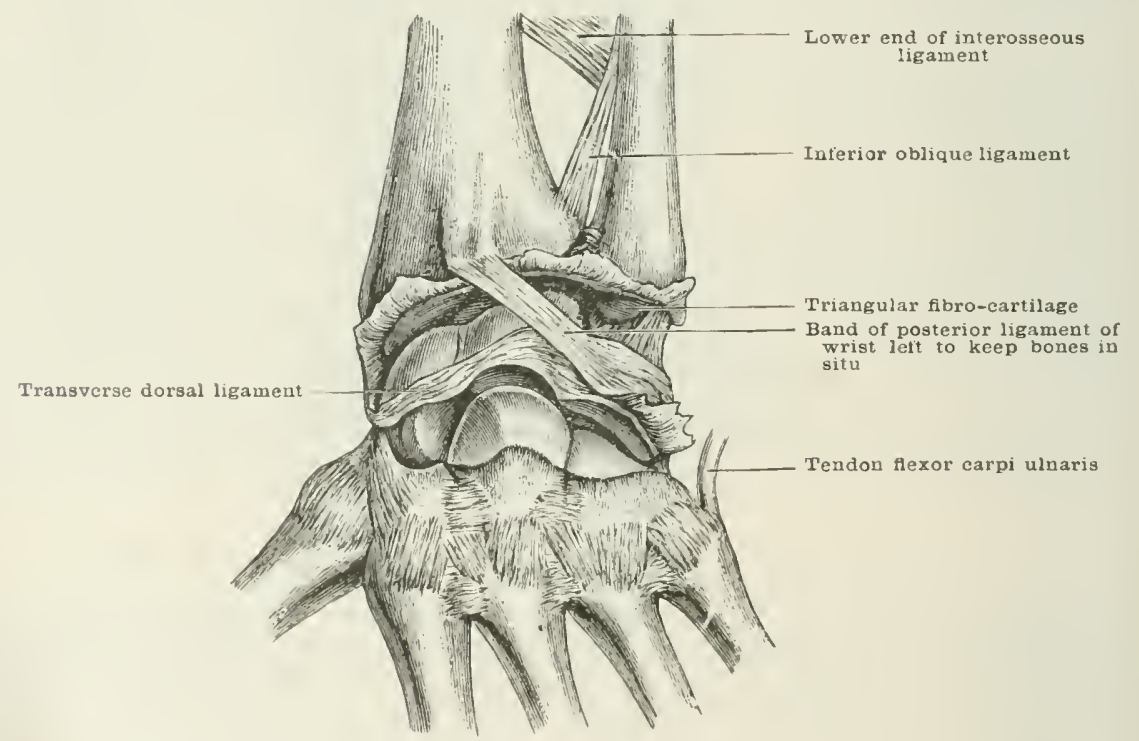

of a Roman $\mathbf{S}$ placerl horizontally $\boldsymbol{n}$, a lesemblance l,y no means strained. (i) The enter part of the first row consists of the seaphoid alone; it is convex, and bears the trapezium and thiluzoid. (ii) Then follows a transversely plongated socket

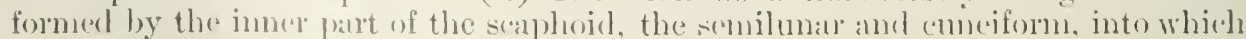
are received (a) the heasl of the nagnum, which artienlates with the seaphoid and semilunar; (b) the upper and suter angle of the umeifom, which articulates with the semilunar; and (c) the upper convex portion of the internal surface of the unciform, which articulates with the external and roneave portion of the inferion surface of the emmeiform. (iii) The immerumst part of the inferior surface of the cunciform bone is anvex, and tumed a little backwarls to fit into the lower portion of the internal surface of the unciform, which is a little comeave and turned forwards to recerve it. The erontral jalt, which forms a socket for the magnum and 
unciform, has somewhat the character of a rondyloin joint, the os mannum and unciform being the eondyle, to fit into the eavity formerl by the saluhuid, semilunar, and cuneiform; the other portions are typually arthriblial. The ligaments are: (1) anterior medio-carpal; (2) posterior medio-carpal; (:3) transverse dorsal.

The anterior or palmar medio-carpal is a ligament of comsiderable strength, consisting mostly of tibres which radiate from the magnum to the saluphord, semilunar, and cuneiform; some few fibres connect the trapezoid and trapezium with

Fig. 235.-Syyovil Membrayes of Wrist, Haxd, AND Fisciers.

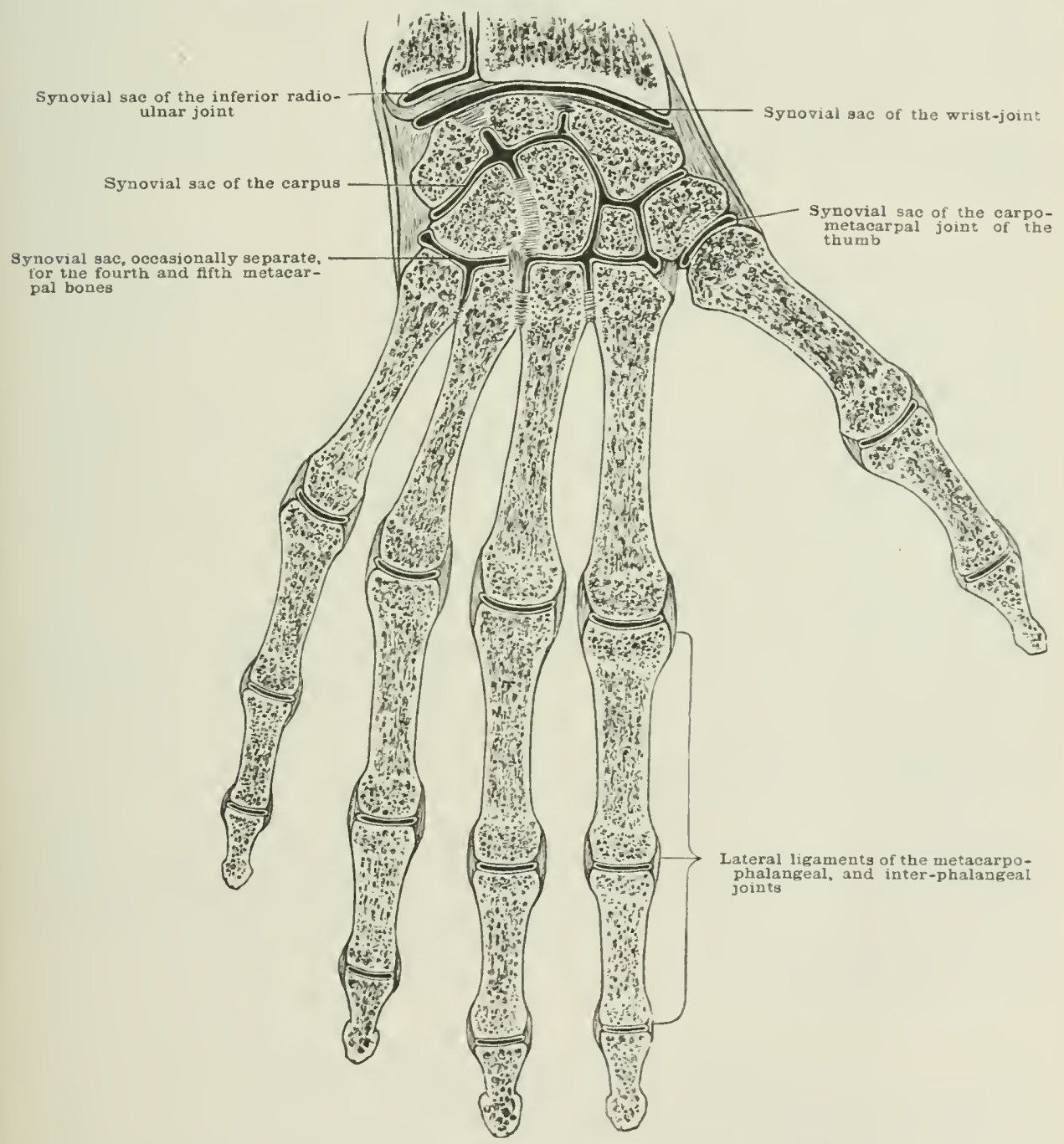

the seaphoid, anel others pass leetween the unciform and cunciform. It is covered over and thickened hy fibrous tissue derived from the sheaths of the flexin tendons and the filres of origin of the small muscles of the thumb and little finger.

The posterior or dorsal medio-carpal ligament consists of fibres fris-ing

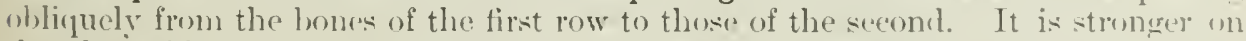
the ulnar sicle than on the rarlial, hut is not so strong as the palmar liganent.

The transverse dorsal ligament (fig. 23t) is an adlitional haml, well markert and often of eonsiderable strength, which passes across the hearl of the magmum 
from the souphoiel to the cumeiform hone; besides linding down the head of the matgnum, it serves to fix the mpleer and onter angle of the unciform in the socket formed lo the tir:t row.

The dorsal ligaments, like the paluar, are strengthened hy a quantity of fibrous ti-sue hedenging to the sheathe of the extensor tentons, and by an extension of -rine of the fibres of the ealpsule of the wrist. There are no proper lateral mediocarpal ligaments; they are liut prolomgations of the lateral ligaments of the wrist.

The synovial membrane (fig. 235) of the carpus is common to all the joints of the "arpus, and "xtencls to the latses of the four inner metaearpal bones. Thus. hesiles lining the inter- or nedio-carpal joint, it sends two processes upwards between the three bones of the first row, and three downwals letween the eontienous surfaces of the trapezoid and trapezium, the trapezoid and magnum, and matrumm and unciform. From these latter, prolongations extend to the four inner (arjo-metacaryal joints and the three intermetacarpal joints.

The arterial supply is derived from (a) the anterior and posterior carpal hranches of the radial and uhnar arteries; (b) the earpal branch of the anterior interuscous; (c) the recurrent branches from the deep palmar arch. The terminal twigs of the anterior and posterior interosseous arteries supply the joint on its dorsal aspert.

Thr nerve-supply comes from the ulnar on the ulnar side, the median on the rartial sirle. and the posterior interosseous behind.

The movements of the carpal articulations hetween bones of the same row are vary limited and ('onsist only of slight gliding upon one another; but, slight as ther are. they give elasticity to the carpus to break the jars and shocks which resuit from hlows or fills upon the hand.

The moxements of one row of hones upon the other at the medio-carpal joint are more extensive, especially in the direction of flexion and extension, so that the hand cnjoys a greater range of these movements than is pernitted at the wrist-joint alone. It the wrist. extension is more free than flexion; but this is balancer by the greater freedom of flexion than of extension at the medio-carpal joint, and by flexion at the carpo-metacarpal joint, so that on the whole the range of flexion of the hand is crreater than that of extension.

A shight anount of lateral motion accompanied by a limited degree of rotation also takes filace; this rotation consists in the head of the magnum and the superior and outer angle of the unciform bone rotating in the socket formed hy the three bones of the ilpper row, and in a gliding forwards and backwards of the trapezim and traperoid upon the scaphoid.

In arklition to the ligaments, the undulating outline and the rariety of shapes of the apposed farets remerer this joint very secure.

Bearing in mind the mobility of this medio-earpal joint and of the carpometacarpal. Wesee at once the reason for the radial and uhiar flexors and extensors of the carpus lexing prolonged down to their insertion into the base of the metacarpus, for they produce the combined effect of motion at each of the three transvorse articulations: (1) at the wrist; (2) at the medio-carpal; (3) at the carpo-metacarpal joints.

\section{THE CARI'O-IIETACARPAL, JUANTE}

These nay le divided into two serts, namely:-

(a) The carpo-metacarpal joints of the four inner fingers.

(li) The carpo-metacarpal joint of the thumb.

The inferior surfaces of three of the bones of the second row of the carpus present a compesite surface for thr four inner metacarpal bones; the trapezium presents a distinct and separate saddle-shaped surface for the base of the metacarpal bone of the thmub. 
(a) Tine Four Ixwer Cirpo-metacalip.l, Joints

\section{Class.-Diathrosis. Subdivision.-Athrolice}

These joints exist between the trapezimm, trapezoirl, magnum, and unciform hones above, and the four inner metacarpal bones below. The liganents which unite them are, dorsal, palmar, and interosseons.

The dorsal ligaments (fig. 234).-Three dorsal ligaments pass to the seeond metacalual bone: one from each of the carpal hones with which it articulates, riz. the trapezium. trapezoid, and magnum. Two dorsal bands pass from the magnum to the third metacarpal bone. Two dorsal bands pass to the fourth bone: viz. one from the unciform, and another from the magnum; the latter is sometines wanting. The fifth bone has only one band passing to it from the unciform.

The palmar ligaments (fig. 231). - One strong band passes from the second metacarpal bone to the trapezium internal to the ridge for the amnular ligament; it is covered by the sheath of the flexor carpi radialis.

Three bands pass from the third metacarpal: one outwards to the trapezium, a micldle one upwards to the magnum, and a third inwards over the fourth to reach the fifth metacarpal and the unciform bones.

One ligament connects the fourth bone to the unciform.

One ligament connects the fifth bone to the unciform, the fibres extending internally, and connecting the dorsal and palmar ligaments. The ligament to the fifth hone is strengthened in front by the prolonged fibres of the flexor curpi ulnuris and the strong inner slip of the ligament of the third metacarpal bone; and posteriorly, by the tendon of the extensor carpi ulnaris.

The interosseous ligament (fig. 235) is limited to one part of the articulation, and comsists of short strong fibres comecting the contiguous angles of the unciform and magnum with the third and fourth metacarpal bones towards their palmar aspect. There is, however, a thick strong ligament comnecting the edge of the trapezium with the outer border of the base of the second metacarpal bone; it helps: to separate the carpo-metacarpal joint of the thumb from the common carpo-metacarpal joint, and to close in the radial side of the latter joint.

The synovial membrane is a continuation of the medio-carpal joint; occasionally there is a separate membrane between the unciform and fourth and fifth metacarpal bones (fig. 235); while that between the fourth and magnum is lined by the symovial sac of the common joint.

The arteries to the four inner carpo-metacarpal joints are as follows:-

(1) For the index finger: twigs, are supplied ly the trunk of the radial on the dorsal and palmar aspects, the metacarpal, the dorsalis indicis, and the radialis indicis.

(2) For the mictlle finger: the metacarpal, first dorsal interosseons by the branch which passes upwards to join the posterior carpal arch, and a branch from the deep palmar arch which joins the anterior earpal arch.

(3) For the ring finger: the deep palmar arch and recurrent twigs from the second dorsal interosseous in the same manner as for the middle finger.

(4) For the little finger: the ulnar and its deep branch; also twigs from the second dorsal interosseous.

The nerves are supplied to these joints by the deep palmar branch of the ulnar, the posterior interosseous, and the median.

The movements permitted at these joints, though slight, serve to increase those of the merlio-carpal and wrist-joints. The joint between the fifth metacarpal and the unciform bones approaches somewhat in shape and molility the first carpometacarual joint; it has a greater range of flexion and extension, but its lateral movement is nearly as limiter as that of the three other metacarial hones; the process of the unciform bone limits its flexion. Lateral motion towards the unar side is checked by the strong jalmar band which unites the base of the fifth metacarpal to the base of the thirrl, and the strong transverse liqament at the head of the bones. The mobility of the second, third, and fourth metacarpal bones is very limited, and consists almost entirely of a slight gliding upon the carpal bones, i.e. Hexion and extension; that of the third and fourth bones is extremely 
slight, as there is no long flexor attached to either; lut, owing to the close connection of the hases of the metalarpal hones, the radial and unar flexors and extensors of the eapus acet on all by their pull on the particular bone into which they are inserted.

Abduction, or movenent toward the radial side, is prevented by the impaction of the serond bone against the trapezium; a little adduction is permitted, and is firvured by the slope given to the uneiform and fifth metacarpal bones.

There is also a slight grlinling between the fourth and fifth bones, when the concavity they present towirls the palm is deepened to form the 'cup of Diogenes.'

\section{(b) The Carpo-metacarpal Joryt of the Thumb}

\section{Class.-Diarthrowis.}

\section{Subdivision.-Saddle-shaped Arthrodia.}

The bones putering into this joint are the base of the first metacarpal, and the trapezium. The first metacarpal bone diverges from the other four, contrasting very strongly with the position of the great toe. It is due to this divergence that the thumly is able to be opposed to each and all the fingers. The ligament which unites the hones is the

$$
\text { Capsular. }
$$

The capsular ligament (figs. 231 and 232 ) consists of fibres which pass from the margin of the articular facet on the trapezium, to the margin of the articular facet at the hase of the tirst metacarpal bone. The fibres are stronger on the dorsal than on the palmar aspect. They are not tense enough to hold the bones in close contact, so that while they restrict they do not prevent motion in any direction. The interual fibres are stronger than the external.

The synovial membrane is lax, and distinct from the other synovial membranes of the carpus.

The arteries of the carpo-metacarpal joint of the thumb are derived from the trunk of the radial, the arteria prineejs pollicis, and the dorsales pollicis.

The nerves are supplied by the branches of the median to the thumb.

The movements of this joint are regulated by the shape of the articular surfaces, rather than by the ligaments, and consist of flexion, extension, abduction, adduction, and circumduction, but not rotation. In flexion and extension the metacarpal bone slides to and fro upon the trapezium; in abduction and adduction it slicles from sicle to side or, more correctly, revolves upon the antero-posterior axis of the joint. The power of opposing the thumb to any of the fingers is due to the forward and inward obliquity of its flexion movement, which is by far its most extensive motion. Abduction is very free, while adduction is limited on account of the proxinity of the second metacarpal bone. The morement of the trapezium upon the rest of the carpus somewhat increases the range of all the movements of the thumb.

\section{THE INTERIETACARPAI ARTICLLATIONS}

\section{Class.-Dirmthosis. Subdivision.-Arthorlia.}

The metacarpal of the thumb is not connected with any other metacarpal bone. The seend, third, fourth, and fifth metacarpal homes are in actual contact at their lassis, and are held firnly together by the following ligaments:-

Dorsal.

Palmar.

Intertisenens ligaments.

The dorsal ligaments (tig. 2:3:3) are layers of varialle thiekness of strong, short fibres, which pass transversely from home to bone, filling up the irregularities on the dorsal surfiar's.

The palmar ligaments are transverse layers of ligamentous tissue passing from 
bone to bone; they cannot be well differentiated from the other ligaments and fibrous tissue covering the bones.

The interosseous ligaments (fig. 23.5) pass between the apposer surfaces of the bones, and are attached to the distal sides of the artieular facets, so as to close in the synovial eavities on this aspect; where there are two articular facets, the fibres extend upwards between them, nearly as far as their carpal facets. That between the fourth and fifth is the weakest.

The arteries to the intermetacarpal joints are twigs from the palnar and dorsil interosseous arteries; the twigs pass upwards hetween the interosseous museles.

The nerves are derived from the ulnar and the posterior interosicous.

The synovial membrane is prolonged downwards from the common carpal sae.

\section{The Union of the Heads of the Metacarpal Bones}

The distal extremities of these bones are conneeted together on their palmar aspects by what is ealled the transverse ligament. This consists of three short bands of fibrous tissue, which unite the seeond and third, third and fourth, and the fourth and fifth bones. They are rather more than a quarter of an inch $(6 \mathrm{~mm}$.) leep, and rather less in width, and limit the distance to which the metacarpal bones can be separated. They are continuous above with the fascia covering the interosseous muscles; below, they are eonnected with the subeutaneous tissue of the web of the hanrl. They are on a level with the front surfaces of the bones, and are blended on either side with the edges of the glenoid ligament in front, with the lateral ligaments of the metacarpo-phalangeal joint, and also with the sheaths of the tendons. In front, a lumbrical muscle passes with the digital arteries and nerves; while behind, the interossei muscles pass to their insertions.

\section{THE IETACARPO-PHALANGEAL JOINTS}

(a) The Metacarpo-phalaxgeal Jonts of the Folr Ixier Fixgers

$$
\text { Class.-Diarthrosis. Subdivision.-Condylathrosis. }
$$

In these joints the eup-shaped extremity of the lase of the first phalanx fits on to tho rounded head of the metacarpal bone, and is united by the following ligaments:-

$$
\text { Lateral. Glenoid. }
$$

The glenoid ligament (fig. 2.36) is a fibro-cartilaginous plate which seems morte intended to increase the depth of the phalangeal articular fates in front, than to unite the two bones. It is much more firmly attached to the margin of the phalanx than to the netaearpal bone, being only loosely connected with the palmar surface of the latter by some lonse areolar tissue which eovers in the srmorial sac, here prolongerl upon the surface of the bone some little distance. Laterally; it is comnected with the lateral ligaments and the transverse metacarpal ligament. It corresponds to the sesamoid bones of the thumb; a sesamoid bone sometimes exists at the inner border of the joint of the little finger.

The lateral ligaments (figs. 235 , and 236 ) are strong and firmly connect the bone's with one another; each is attached above to the lateral tulercle, and to a depression in front of the tubercle, of the metacarpal bone. From this point the fibres spread widely as they deseend on the side of the base of the phalanx; the anterior fibres are comneted with the glenoid ligament; the posterior blend with the tendinous expansion at the back of the joint.

The joint is covererl in posteriorly he the expansion of the extensor tendon, and some loose areolar tissue passing from its under surface to the bones (fig. 236).

The synovial sac is lonse and capacious, more especially over the base of the phalanx behind, and the head of the metacarpal bone in front.

The arteries come from the digital or anterior interosseous vessels of the deep arch. 
The nerves are derived from the digital branches, or from twigs of the branches of the ulnar to the interosienus muscles.

The movements jumited at these joints are: flexion, extension, abchuction, adduction. and ciremuluetion. Flexim is the most free of all, and may be continued until the phalanx is at a right angle with the metacarpal bone. It is on this ac'ount that the articular surface of the head of the bone is prolonged so much further on the palmar aspert, and that the symorial sac is here so louse and ample. Extension is the most liniterl of the moremonts, and can only be carried to a little heromd the straight line. Alduction and adduction are fairly free, but not so free as thexion. Frexion is associated with adduction, and extension with abductiom. This may be proved ly opening the hand, when the fingers involuntarily separate as they extend, while in rosing the fist they come together again. The free aluluetion, arluetion, and circumduction which are permitted at these joints are clur to the falct that the long axes of the articular facets are at right angles to one amother.

Fiti, 2:36. - Axterior axd Posteriols View of Liganests of the Finciers.
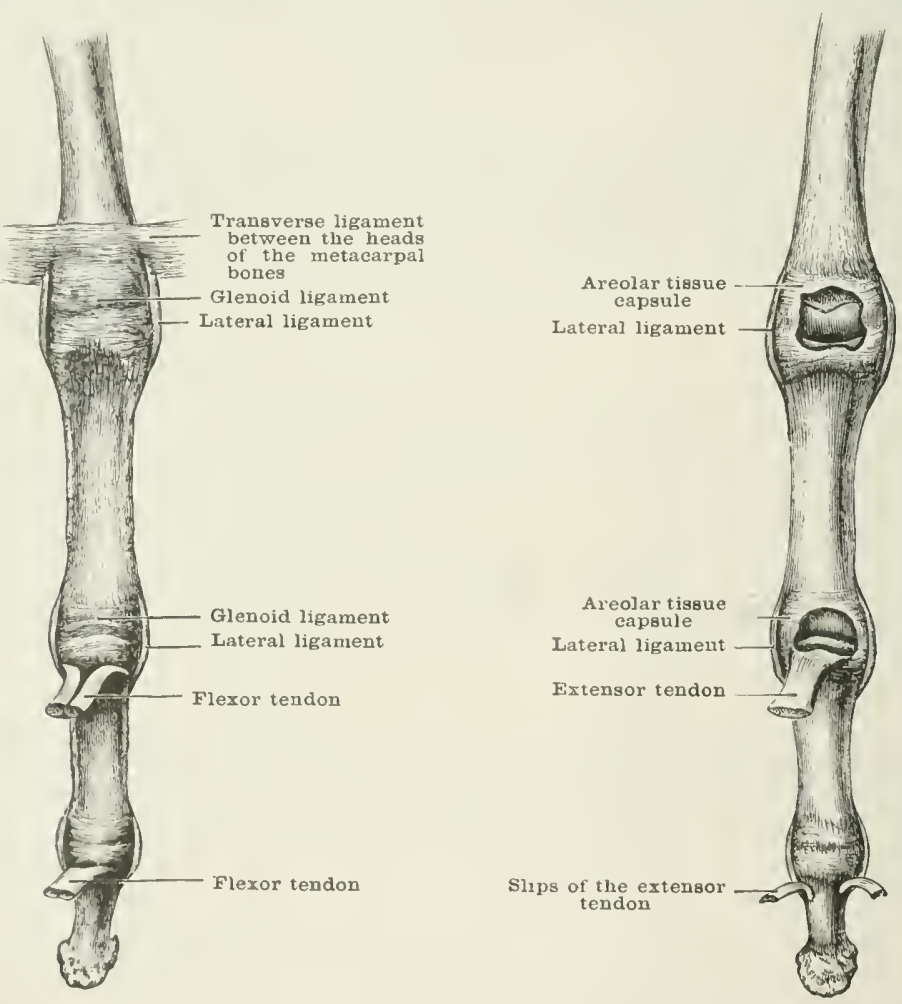

(b) The Metacarpo-phalangeal Joint or the Thumb

\section{Class.-Dinthroxis.}

Subdivision.-Comdylarthroxis.

The head of the metacarpal bone of the thumb differs comsiclealbly from the corresponding ands of the metacarpal bones of the fingers. It is less eomvex, wider from sicke to side, the palmar edge of the artieular surface is raised and irrogular, and here on either side of the median line are the two faects for the sesamoid hones. The hase of the first phalamx of the thumb, too, is more like the lase of the second phalanx of one of the other fingers. The ligaments are:-

Ialteral.

Posterior.

Sccianoid homes in place of a glonoid ligament. 
The lateral ligaments are short, strong hands of fibres, which radiate fiom depressions on either sicle of the head of the metacarpal bone to the base of the first phatanx and sesamoid bones. As they deseend they pass a little forwards, so that the greater number are inserted in front of the centre of motion.

The posterior ligament consists of sattered fibres which pass across the joint from one lateral ligament to the other, completing the capsule and protecting the synovial sac.

The sesamoid bones are two in number, situated on either side of the middle line, and connected together hy strong transverse fibres which form the floor of the groove for the long flexor tendon; they are connected with the base of the phalanx and head of the metacarpal bone ly strong fibres. Anteriorly they give attachment to the short museles of the thimb, and posteriorly are smooth for the purpose of gliding over the facets. The lateral ligaments are partly inserted into their sides.

The arteries and nerves come from the digital branches of the thumh.

The movements are chiefly flexion and extension, very little lateral morement being permitted, and that only" when the joint is slightly bent. Thus this joint more nearly approaches the simple hinge character than the corresponding articulations of the fingers. The thumb gets its freedom of motion at the carpometacarpal joint; the fingers get theirs at the metacarpo-phalangeal, but they are not endowed with so much freedom as the thumb enjoys.

\section{THE INTERPHALANGEAL APTICULATIONS}

\section{Class.-Diarthrosis. Subdivision.-Ginglymus.}

The ligaments which unite the phalanges of the thumb and of the fingers are:Glenoid.

Lateral.

The glenoid ligament (fig. 236), sometimes called the sesamoid body, is very fimly connected with the base of the distal bone, and loosely, by means of fibroareolar tissue, with the head of the proximal one. It blends with the lateral ligaments at the sides, and over it pass the flexor tendons. Occasionally a sesamoid bone is developed in the eartilage of the interphalangeal joint of the thumb.

The lateral ligaments (figs. $2: 35$ and 236) are strong bands which are attacherl to the rough depressions on the sicles of the upper phalanx, and to the projecting lateral margins of the lower phalanx of each joint. They are tense in every position, and entirely prevent any lateral motion; they are comnected posteriorly with the expansion of the extensor tendon.

Posteriorly (fig. 236) the joint is covered in ly the deep surface of the extensor tendon, and a little fibro-areolar tissue extends from the tendon, and thickens the posterior portion of the synovial sac, completing the capsule.

The synovial membrane is loose and ample, and extends upwards a little way along the shaft of the proximal bone.

The arteries and nerves come from their respective digital branches.

The movements are limited to flexion and extension. Flexion is more free, and can be continued till one bone is at a right angle to the other, and is most free at the junction of the first and second bones; the second phalanx can be flexed on the first through $110^{\circ}$ to $115^{\circ}$ when the latter is not flexed. The greater freedom of flexion is due to the greater extent of the articular surface in front of the heads of the proximal hones, and to the direction of the fibres of the lateral ligaments, which pass a little forwards to their insertion into the distal bone. 


\section{THE ARTICULATIONS OF' THE LOWER LIMB}

The articulations of the lower limb are the following:-

1. The hip-joint.

2. The knee-joint.

3. The tibio-fibular union.

4. The ankle-joint.

5. The tarsal joints.

(i. The tarso-metatarsal joints.

7. The intermetatarsal joints.

8. The metatarso-phalangeal joints.

9. The interphalangeal joints.

\section{THE HIP-JOIN'T}

\section{Class.-Dierthionis. \\ Subdivision.-Enarthrodia.}

The hip is the most typieal example of a ball-and-socket joint in the body, the round head of the femur heing received into the cup-shaped cavity of the acetahulum. Both articnlar surfaces are coated with cartilage, that covering the head of the femur being thicker above where it has to bear the weight of the body, and thinning out to a mere edge below; the pit for the ligamentum teres is the only part uncoated, lmt the cartilage is somewhat heaped up around its margin. ('overing the acetalmlum, the cartilage is horseshoe-shaperl, and thicker above than ledow; heing defirient over the depression at the bottom of the acetabulum, where a mass of fatty tissne-the so-called synovial or Haversian gland-is lodged.

The ligaments of the joint are:-

\section{(apsular.}

Transwerse.
Ligamentum teres.

Cotyloil cartilage.

The capsular ligament is one of the strongest ligaments in the body. It is large and somewhat lows. so that in every position of the hody some portion of it is relaxed. It the pelvis it is attached, superiorly, to the lase of the anterior inferior iliae spine; curving backwards, it hecomes llended with the deep surface of the reflected tendon of the rectus femoris; posteriorly, it is attached a few lines from the aretalublar rin: and bolow, to the upper edge of the groove between the acetabulum and tuberosity of the ischimm. Thus it reaches the transverse ligament, being fimly hlonled with its outer surface, and frequently sends fibres beyond the moteh to blend with the obturator membrane. Anteriorly it is attached to the pubes near the motcll, to the pertineal cminence, and thence backwards to the base of the iliac spine. I thin strong stratum is given off from its superficial aspect behime; this extends beneath the glutens minimus, and small rotators, to lie attached above to the clorsum of the ilium higher than the reflected tendon of the rectus, and postrionty to the ilimu and ischium nearly as far as the sciatic: moteh. As this aplansion passes over the lone tencton of the rectus, the tenclon may be deseribed as being in part contained within the substance of the capsule.

At the femur, the capsular liemenent is fixel to the anterior portion of the upper border of the great trochanter, and to the superior ecrvieal tuberele. Thenee it runs down the spiral lime as far as the immer lovelere of the femur, where it is on a level with the bewer part of the lesere trochanter. It then runs upwark and backwards along an obligue line about two-thimls of an inch $(1.6 \mathrm{~cm}$.) in fromt of the lesser trochanter, and continues its ascent alomg the lack of the neek nearly parallet to the posterior intertrowantere line, and from one-laslf to two-thirds of an inch (12 to $16 \mathrm{~mm}$.) alme it; finally, it passes along the imner siele of the digital fossa to reach the anterion : 
On laying open the eapsule, some of the deeper filmes are seen reflected upwards alomg the neek of the femur, to be attached much nearer the head: these are the retinacula. One corresponds to the upper, and another to the lower part of the spiral line; a third is seen at the upler and back part of the neck. They form flat batnds, which lie on the femoral neck.

Superadded to the capsule, and considerably strengthening it, are three auxiliary bands, whose fibres are intinately blended with, and in fact form part of, the capsule, viz. the ilio-femoral, ischio-femoral, and pectineo-femoral bands.

The ilio-femoral (fig. 23i) is the longest, widest, and strongest of the bands. It is of triangular shape, with the apex attached above to a curved line on the ilium immediately below and behind the anterior inferior spine, and its base below to the anterior edge of the greater trochanter and to the spiral line as far as the inner horder of the shaft. The highest or outermost fibres are coarse, almost straight, and shorter than the rest; the innemost fibres are also thick and strong, but oblique. This

FI(i. 2:37.-ANTERIOR VIEW OF THE CAPSUle OF THE HIP-JOINT.

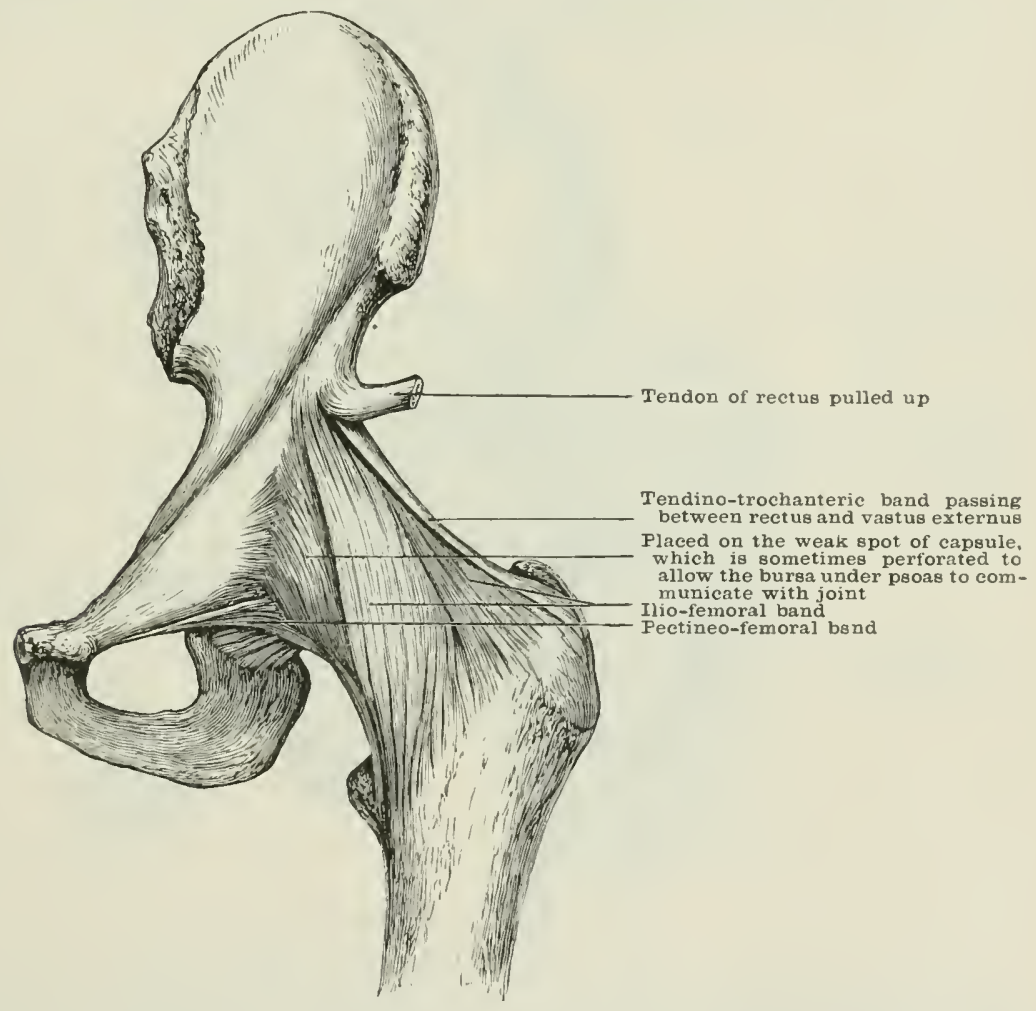

varying obliquity of the fibres, and their aecumulation at the horlers, explain why this hand has been descriher as the $Y$-shaped ligament. About the centre of its hase, near the femoral attachment, is an aperture transmitting an articular trig from the transverse branch of the external (ir'umflex artery.

The ischio-femoral band (fig. 2.38) is formed of very strong fibres attached all along the upper border of the growe for the extemal obturator, and to the ischial margin of the acctabulum ahove the groove. The lighest of these incline a little upwards as they pass ontwards to be fixed to the greater trochanter in front of the insertion of the pyriformis tendon, while the other fibres curve nure and more upwards as they pass outwarls to their insertion at the inner side of the dierital fossa, blending with the insertion of the external rotator truslons. When the joint is in flexion these fibres pass in nearly struight lines to their femoral attachnent, and spread out uniformly orer the hearl of the fernur; but in extension they wind 
orer the back of the femur in a zonular manner, embracing the posterior aspect of the neek of the femur.

The pectineo-femoral band (fig. 237) is a distinet but narrow set of filmes which are individually les marked than the filmes of the other two hands; they are fixcl alwove to the anterior horder of the pectineal eminence, reaching as far town as the pulic end of the cotyloich notch. Below, they reach the neck of the femmr, and are fixed above and behinel the lowermost fibres of the ilio-femoral band, with which they lient.

In thickness and strength the capsule varies greatly; thus, if two lines be drawn, one from the anterior inferior spine to the inner border of the femur near the lesser trochanter, and the other from the anterior part of the groove for the external oliturator to the digital fossa, all the ligament between these lines on the outer and upper aspeets of the joint is rery thick and strong. while that below and to the inner side, except at the narrow pectineo-femoral hand, is thin and weak, so

Fig. 23:--Postertol View of the Capstle, of the Hip-joint.

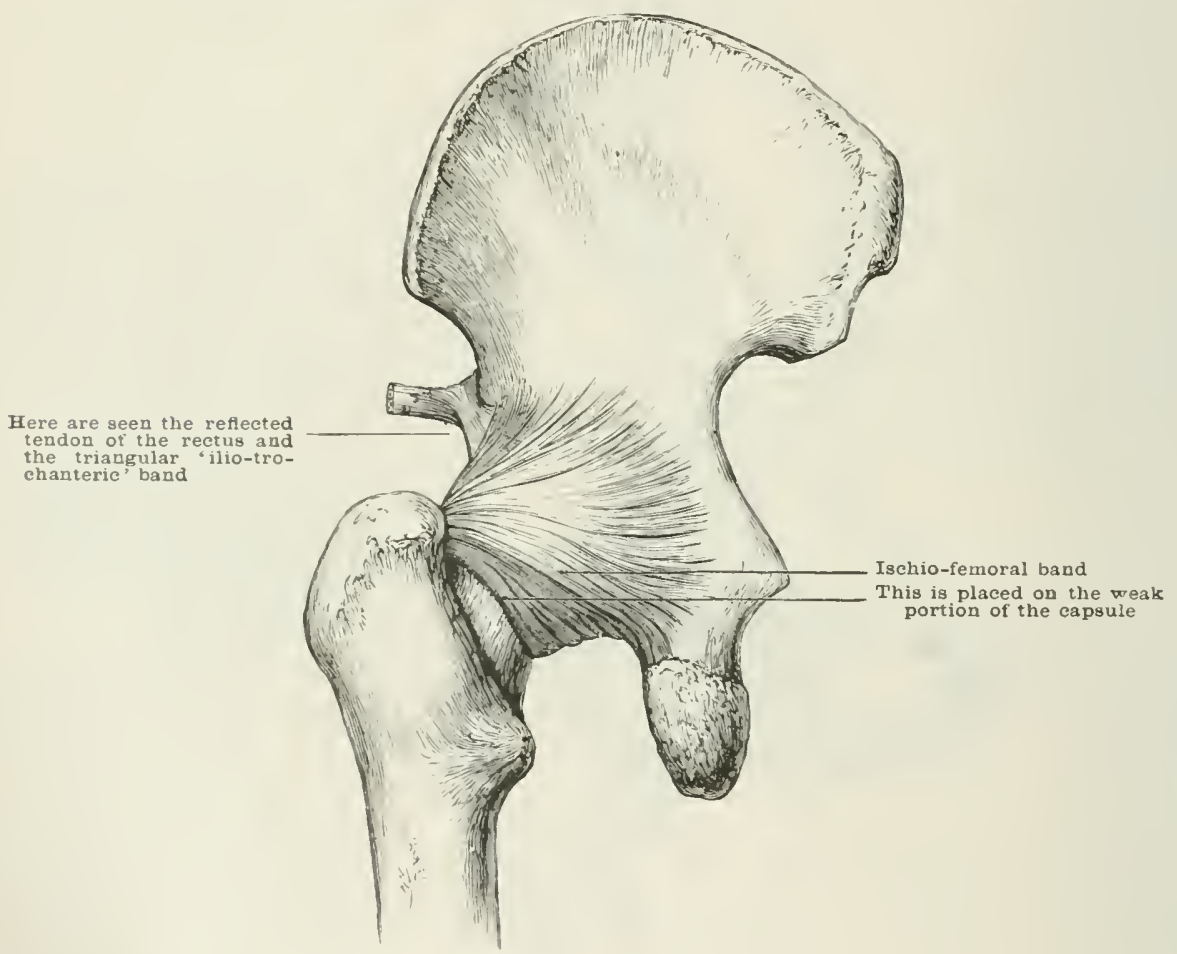

that the hrarl of the hone can be seen through it. The capsule is thickest in the course of the ilio-femoral band, towards the outer part of which it measures over a quarter of an inch (6 $\mathrm{mm}$.). Between the ilio-femoral and ischio-femoral bands the capsule is very strong, and with it here, near the acetabulum is incorporated the reflected tendion of the rectus, and here also a triangular band of fibres runs downwarts and forwarls to he attacherl by a narrow insertion to the ridge on the front horder of the greater trochanter near the gluteus minimus (the ilio-trochanteric band) (fig. 23s).

The calsule is strengthemed also at this point hy a strong hand from the under surfate of the gluteus minimus, and hy the tendino-trochanteric band which passes down from the reflectent tenclon of the rectus to the vastus externus (fig. $237)$. This is asely blended with the (apsule near the outer erlge of the iliofemoral ligamment.

The thinnest part of the eapsule is between the prectineo-femoral and ilio-femoral 
bands; this is sometimes perforated, allowing the bursa under the psoas to communicate with the joint. The capsule is also very thin at its attachment to the back of the femoral neck, and again opposite the cotyloid notch.

The ligamentum teres (figs. 239 and 240 ) is an interarticular flat band which extencls from the acetabular notch to the head of the femur, and is usually ahout an inch and a half $(3 \cdot 7 \mathrm{~cm}$.) long. It has two bony attachments, one on either sirle of the cotyloid notch immediately below the articular cartilage, while intermediate filmes spring from the umler surface of the transverse ligament. The ischial portion is the stronger, and has several of its fibres arising outside the cavity, below and in connection with the origin of the transverse ligament. where it is also continuous with the capsule and periosteum of the ischium. At the femur it is fixed to the front part of the depression on the hearl, and to the cartilage round the margin of the depression. It is covered by a prolongation of srnovial membrane, which also covers the cushion of fat in the recess of the acetabulum;

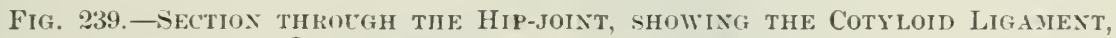
Liganextu TERES, ANO RETIxaClia.

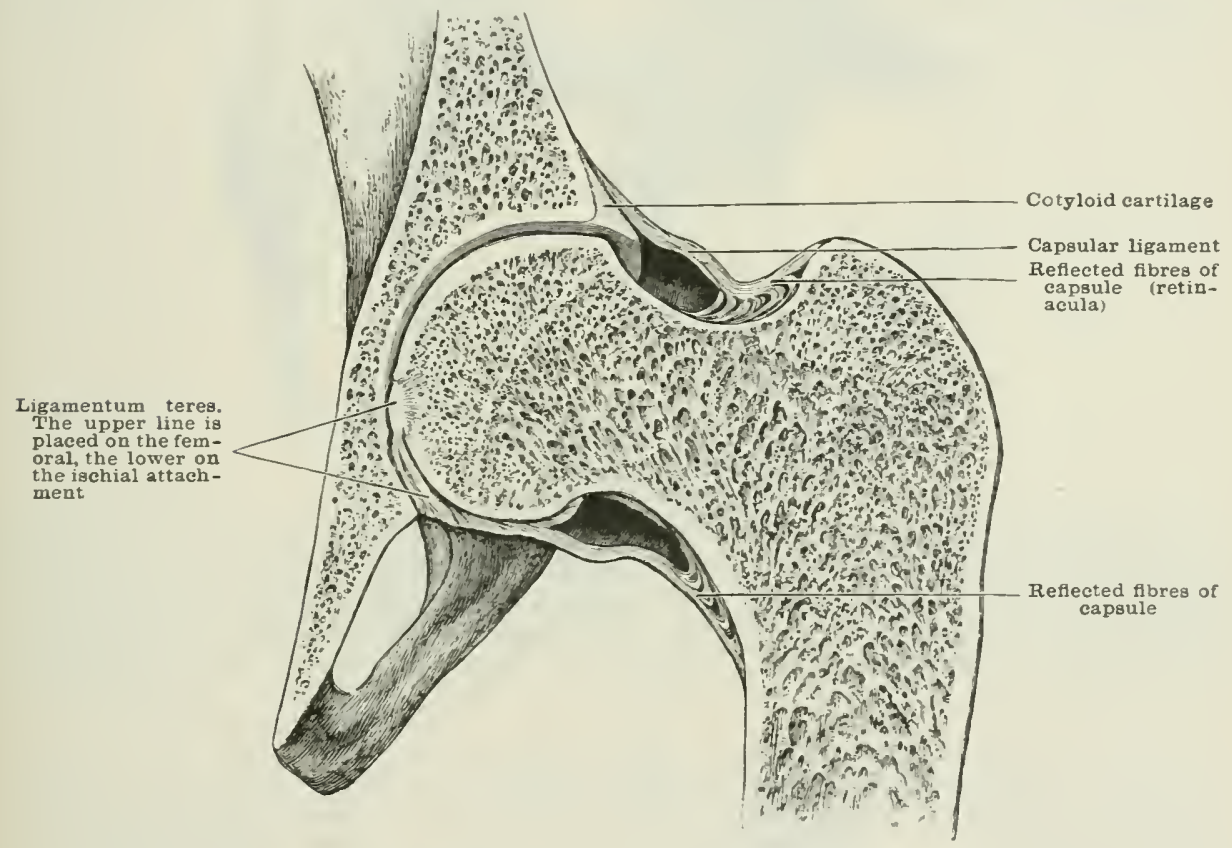

the portion of the membrane reflected over the fatty tissue does not cling rlosely to the round ligament, hut forms a triangular fold, the apex of which is at the femur.

The transverse ligament (fig. 241) passes across the cotyloid notch and converts it into a foramen; it supports part of the cotyloid fibro-cartilage. and is connected with the ligamentum teres and the capsule. It is composed of decussating fibres, which arise from the margin of the acetabulum on either side of the notch, those coming from the pubes heing more superficial, and passing to form the deep part of the ligament at the ischium, while those superficial at the ischimm are deep at the pubes. It thus completes the rim of the acetaluulum.

The cotyloid fibro-cartilage (figs. 239 and 240) is a yellowish-white structure, which deepens the acetabulum hy surmounting its margin. It varies in strength and thickness, but is stronger at its iliac and ischial portions than elsewhere. Its base is broad and fixed to the bony rim as well as to the articular cartilage of the acetabulum on the inner, and the periosteum on the outer side of it, and blends inseparably with the transverse ligament which supports it over the cotyloir notch. Its free margin is thin; on section it is somewhat lunaterl, having its outer surface 
convex and its articular face concave and very smooth in adaptation to the head of the bone. which it tightly cmbraces a little lieyond its greatest circumference. It somewhat contracts the aperture of the acetabulum, and retains the head of the femur within its grasp after clivision of the muscles and capsular ligament. It is covered on both aspects by synovial nembrane.

Fig. 240,-Hup-JoINT AFTER DIVIDING TIE CAPSLLAR LIGAMENT AND DISARTICULATING THE FEMLR.

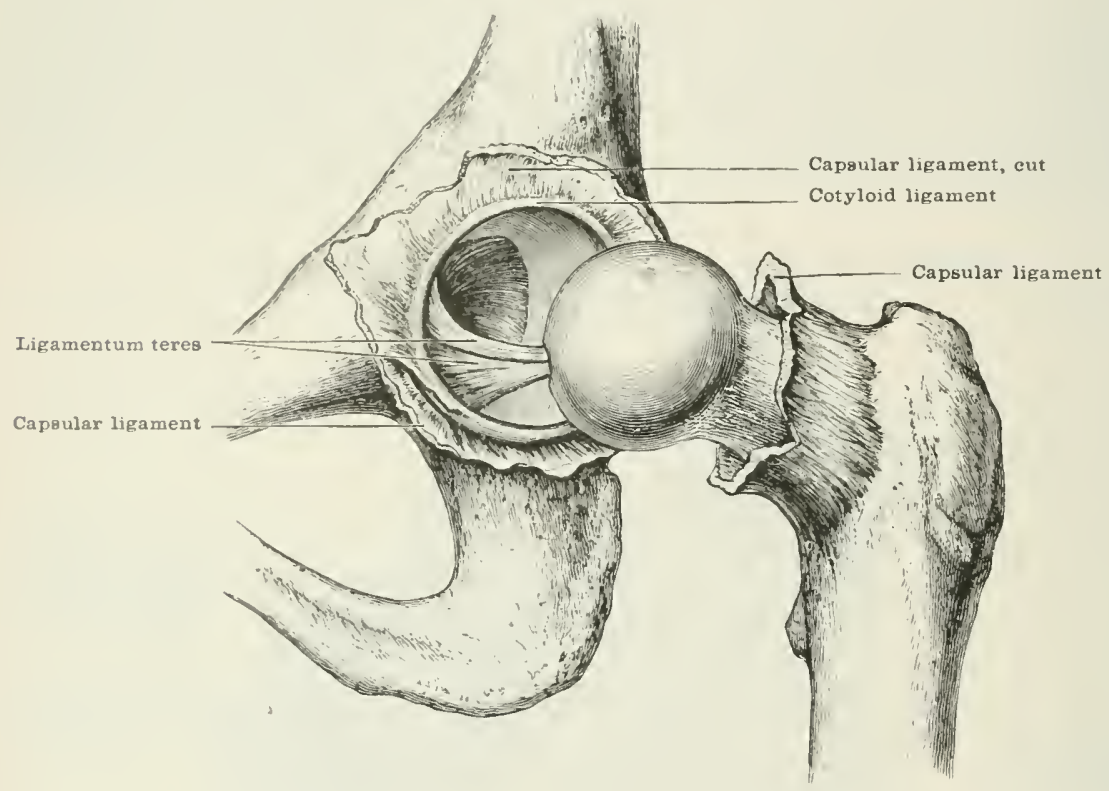

The synovial membrane lines the capsule and both surfaces of the cotyloid ligament, and passes over the border of the acetabulum to reach and cover the fatty cushion it contains. The part covering the fatty cushion is unusually thick, and is attached round the edges of the rough bony surface on which the cushion rests. The membrane is lonsely reflected off this on to the ligamentum teres, along which

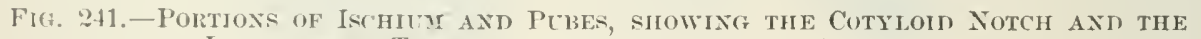

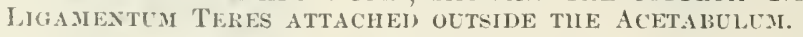

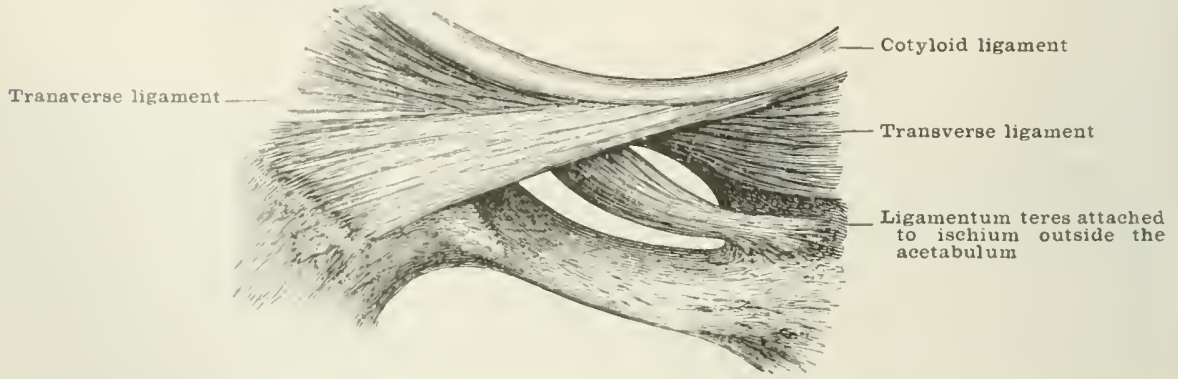

it is prolonger to the luearl of the femur: thus the filores of the round ligament are shut ouf from the joint auvity. From the eapsule the synovial membrane is also reflecterl helow on to the neck of the fomur, whence it passes over the retinacula to the margin of the articular cartilage. A fold of synovial membrane on the uncler aspect of the neck often convers to the hrart of the femur a branch of artery-generilly a branch of the internal cireumflex. 
The arterial supply comes from $(a)$ the transverse branches of the internal and external circumflex arteries; $(b)$ the external branch of the obturator sends a branch through the cotyloid notch beneath the transverse ligament, which ramifies in the fat at the bottom of the acetabulum, and travels down the round ligament to the head of the femur; $(c)$ the inferior branch of the deep division of the gluteal; and $(d)$ the sciatic arteries. The branch from the obturator to the ligamentum teres is sometimes very large when the branch from the internal circumflex does not also supply the ligament.

The gluteal and sciatic send sereral branches through the immominate attachment of the capsular ligament: these anastomose freely beneath the capsule around the outer aspect of the acetabulum, and supply some branches to enter the bone, and others which enter the substance of the cotyloid ligament. There is quite an arterial crescent upon the posterior and postero-superior portions of the acetabulum; but no ressels are to be seen on the inner aspect of the cotrloid ligament.

The nerve-supply comes from $(a)$ anterior crural, $(b)$ anterior dirision of the obturator, (c) the accessory obturator, and (d) the sacral plexus, by a twig from the nerve to the quadratus femoris, or from the upper part of the great sciatic, or from the lower part of the sacral plexus.

The muscles in relation with the hip-joint are: in front, the psoas, which is

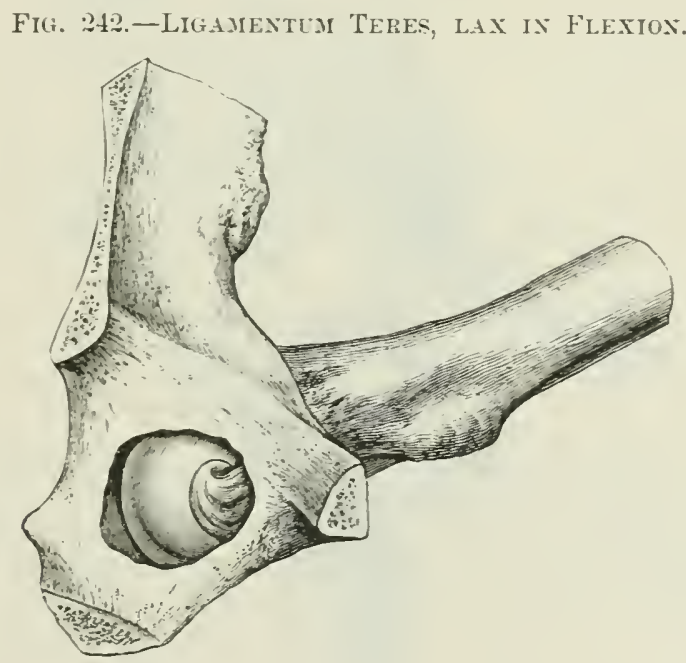

separated from the capsule by a hursa, and the iliacus, which in part arises from the capsule: above are the straight and reflected tendons of the rectus, the reflected tendon being enclosed between the fibres of the capsule, and a band which passes down from the reflected tendon to the vastus externus; also the gluters minimus, which is lowely arlherent to the capsule; above and behind are the pyriformis, which sometimes sends a slip into the capsule; the internul obturator, which acts as a powerful strap to the back of the joint. and the two gemelli; below and behind is the extermal obturutor, passing orer the capsule, whilst a dense land of fibrocellular ti-sue connects the sheath of the obturator externus with the eapsule along the posterior edge of the muscle; internally is the pertinens.

The movements. - The hip-joint. like the shoulder. is a ball-and-sock joint, but with a much more complete socket and a corresponding linitation of movement. Each variety of morment is permitterl, viz. flexion. extension, abduction. adduction. circumduction, and rotation; and any two or more of these morements not being antagonistic can be combinerl, i.e. flexion or extension associated with abluction or adduction can be combined with rotation in or out.

It results from the ohliquity of the neck of the femur that the movenents of the head in the acetabulum are always more or less of a rotatnry character. This is more especially the case during flexion and extension, and two results follow 
from it. First, the hearing surfaces of the femur and acetahulum preserse their apposition to each other. so that the amount of articular surface of the head in the acretabulum des not sensibly diminish peri passe with the transit of the joint from the extrucled to the flexed position, as woukl necrsarily be the case if the movement of the femmral head, like that of the thigh itself, was simply angular, instead of rotatory and angular. Secondly, as rotation of the head can continu. until the ligannents are tirht without being checked hy contact of the neek of the thich hone with the rin of the acetahulum, flexion of the thigh so far as the joint is concerned is pratically unlimited. Flexion is the most important, most frefurnt, and most extensive movement, and in the dissected limb, before the ligaments are disturbed, can be carried to $160^{\circ}$, and is then checked by the lower fibres of the ischio-femoral ligament. In the living sulject simple flexion can continue until checked ly the contact of the soft parts at the groin, if the knee be bent; if the knce be striight, flexion of the hip is checked in most persons by the hamstring muscles at nearly a right angle. This is rery evident on trying to touch the ground

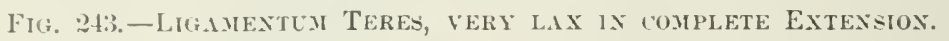

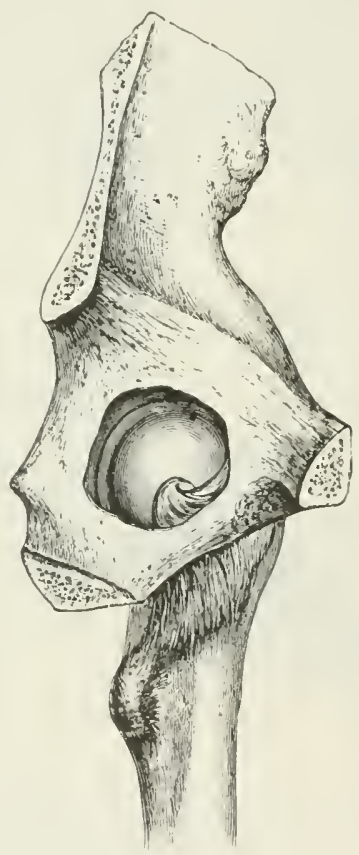

with the fingers without bending the knees, the chief strain being felt at the popliteal spare. This is clue to the shortness of the hamstrings. Extension is linited by the ilio-femoral ligament.

Abduction and ontwarl rotation can be performed freely in every position of flexion and extension-abluetion heing limited by the pectineo-fenoral ligament; outward rotation hy the iliofemoral ligament, especially its inner portion, during extension; lut hy the outer jortion, as well as hy the liganentum teres, during Hexion.

Afluction is very limiter in the extenderl thigh on account of the contact with the opposite limb. 'In the slightly flexed position alduction is more free than in rxtension, and is then hinited by the outer fibres of the ilio-femoral hand and the superior portion of the capsule. In flexion the lange is still greater, and liniter by the ischiofenoral ligament, the ligamentum teres being also remilered nearly tight. Inward rotation in the nearly extenderl position is liniter by the iliofemoral ligancent; and in flexion by the ischio-femeral ligament and the portion of the eapsule between it and the ilio-femoral band. 
The ilio-femoral hand also prevents the tendency of the trunk to roll hackwark: on the thigh bones in the ereet posture, and so dloes away with the necessity for muscular power for this purpose; it is put on stretch in the stand-at-ease position.

The ligamentum teres is of little use in resisting violence or in imparting strength to the joint. It assists in rhecking rotation outwarks and adduction during flexion. A ligament can only be of use when it is tight, and it was found by trephining the

Fig. 244.-Ligayextry Teres, nRAwy tight Ix Flexion conbined with Rotation

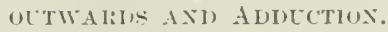

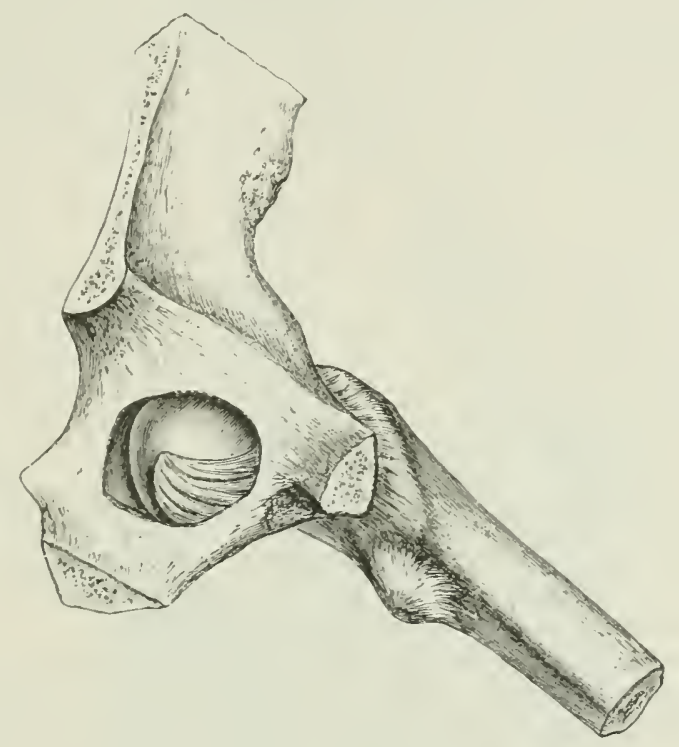

linttom of the acetahulum, removing the fat, and threading a piece of whipcord round the ligament, that the ligament was slack in simple flexion, and very loose in complete extension, but that its nost slack condition was in aluduction. It is tightest in flexion combined with adduction and rotation outwards, and almost as tight in flexion with outward rotation alone, and in flexion with adduction alone (figs. 242 to 244 ).

\section{THE KNEE-JOINT}

Class.-Diarthrokis.

Subdivision.-Ginglymus.

The knee is the largest joint in the body. It is rightly descrihed as a ginglymoid joint, but there is also an arthrodial element; for, in addition to flexion and extension, there is a sliding hackwards and forvards of the tibia upon the femoral condyles, as well as slight rotation round a rertical axis. It is one of the most superficial, and, as far as adaptation of the bony surfaces goes, one of the weakwt joints, for in no position are the bones in more than partial contact. Its strength lies in the number, size, and arrangement of the ligaments, and the powerful muscles and fascial expansions which pass over the articulation and enable it to withstand the leverage of the two longest bones in the body. It may be sain to (omsist of two articulations with a common synovial membrane-the patellofemoral and the tibio-femoral, the latter being double. It is composed of the condyles and trochlear surface of the fernur, the tuberosities of the tibia, and the patella, united by the following ligaments, which may be divided into an external and internal set:- 
Exterial.

(1) Fibrons expansion of the extensors.

(2) Capsular or anterior ligament.

(3) Posterior ligament.

(4) Extemal lateral.

(5) Internal lateral.

(6) Ligamentum patellæ.

\section{INTERNAL}

(1) Anterior crucial.

(2) Posterior crucial.

(3) Internal semilumar fibro-cartilage.

(4) External semilumar fibro-cartilage.

(5) Coronary.

(6) Transverse.

\section{External Jiganents}

Superficial to the fibrous expansion of the quadriceps extensor tendons the fascia lata of the thigh covers the front and sides of the knee-joint.

The deep fascia of the thigh, as it descends to its attachment to the tubercle and oblique lines of the tibia, not only overlies but blends with the fibrous expansion of the cxtensor tendons.

The ollique lines of the tibia curve upwards and backwards from the tubercle on each sicle to the postero-lateral part of the tuberosities. The process of fascia attached to the onter ridge of the tilia and to the head of the fibula, descends from the tensor viginæ femoris and is rery thick and strong. It is firmly blended with the tendinous fibres of the vastus externus. The fascia lata, on the inner side of the patella, besides being attached to the inner oblique ridge of the tibia, sends some longitudinal fibres lower down to become blended with the fibrous expansion of the surtorius. The fascia is much thimer on the immer side of the patella than on the outer, and blends much less with the tendon of the vastus internus than the outer part of the fascia does with the vastus externus. A thin layer of the fascia lata in the form of transverse or arciform fibres passes over the front of the joint. These filmes are specially well marked over the ligamentum patellse, and blend here with the central portion of the quadriceps extensor fibres.

The fibrous expansion of the extensor tendons consists (1) of a central portion, densely thick and strong, an inch and a half $(3.7 \mathrm{~cm}$.) broat, which is inserted into the anterior two-thircls of the upper borler of the patella, many of its superficial fibres passing over the subcutaneous surface of the bone into the ligamentum patellax; (2) of two lateral portions thimner, but strong. The lateral portions are inserted into the patella along its upper border on either side of the central portion and also into its lateral borders, nearer the anterior than the posterior surface, as low down as the attachment of the ligamentum patellæ; passing thenee along the sirles of the higamentum patella to the tibia, they are attached to the oblique lines which extend laterally from the tubercle to the inner and outer tuberosities, and reach as far as the internal and external lateral ligaments. On the outer side, the fibres blend with the ilio-tibial land of the fascia lata, and on the inner ther extend below the oblique line to blend with the periostem of the shaft. Thus there is a large hool sprear over the whole of the front of the joint, investing the patella, and reaching from the sides of the ligamentum patellæ to the lateral ligaments, attached below to the tikia, and separated everywhere from the synovial membrane by a layer of fatty tissue.

The ligamentum patellæ (fig. 247) is the continuation in line of the central portion of the conjoincel tenclon, some fibres of which are prolonger over the front of the patella into the ligament. It is an extremely strong, flat band, attached above to the lower horder of the patella; below, it is fixed to the lower part of the tuberele and upper part of the crest of the tibia. somewhat olliquely, being prolongerel downwarls further on the outer sicle, so that this horder is fully an inch longer than the imner which measures two inches and a half $(6 \cdot 7 \mathrm{~cm}$. $)$ in length. Behind, it is in contact with a mass of fat which separates it from the synovial membrame, and a small bursa intervenes between it and the head of the tibia. In front, a large bursa separates it from the subentancous tissue, and laterally it is contimus with the filions expansion of the extensors.

The internal lateral ligament (fig. 245) is a strong. flat hand. which extends from the depression on the tubercle on the inner side of the internal condyle of the 
femur, to the inner border and internal surface of the shaft of the tibia, an inch and a half $(3.7 \mathrm{~cm}$.) below the tuberosity. It is three inches and a half $(8.7 \mathrm{~cm}$.) long, well defined anteriorly, where it blends with the expansion of the conjoined extensor tendons; but not so well defined posteriorly, where it merges into the posterior ligament. Some of the lower fibres blend with the descending portion of the semimembianosus tendon. Its deep surface is firmly adherent to the edge of the internal semilumar cartilage and coronary ligament, while part of the semimembranosus tendon and inferior internal articular vessels and nerve pass between it and the bone. Sujerficially, a bursa separates it from the tendons of the gracilis and semitendinosus muscles and from the aponeurosis of the sartorius muscle.

The external lateral ligament (fig. 245) consists of two portions: the anterior, which is the longer and better marked, is a strong, rounded cord, about two inches (5 cm.) long; attached above to the tubercle on the outer side of the external con-

Fig. 245.-Posterlol View OF THE KNEe-JuINT.

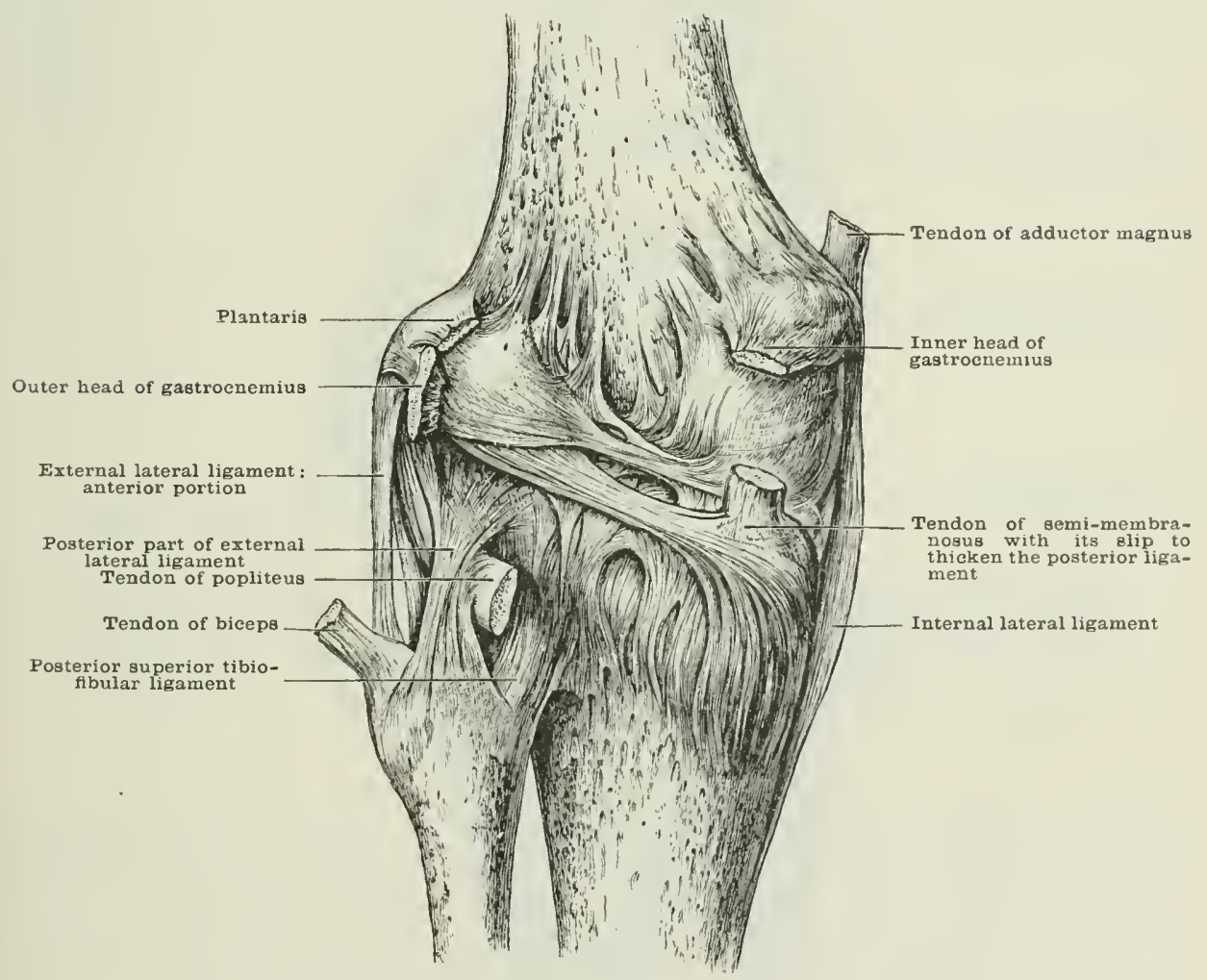

dyle of the femur, just below and in front of the origin of the onter head of the yastrocnemius, whilst the tendon of the poplitens arises from the groove below and in front of it. Below, it is fixed to the middle of the outer surface of the head of the fibula, half an inch $(1 \cdot 25 \mathrm{~cm}$.) or more anterior to the strloil process. Superficially is the tencton of the biceps, which splits to embrace its lower extremity; while beneath it pass the poplitew. tendon in its sheath, and the inferior external corticuler ressels and werve. Some fibres of the peroneus longus occalsionally arise from the lower end of the ligment. The posterior portion is a third of an inch ( $8 \mathrm{~mm}$.) behind the anterior. It is broader and less defined; fixed below to the styloid process, it inclines upwards and sonewhat backwards, and ties down the popliteus against the outer tuberosity, blending beneath the outer head of the yostrocnemius with the posterior ligament of the knee, of which it is really a portion.

The posterior ligament or ligamentum Winslowii (fig. 24.5) is a broad dense structure of interlacing fibres, with large orifices for vessels and nerves. It is 
attached ahove to the fommer elose to the articular margins of the condyles, stretching areme the wpper margin of the interemelyoid moteh, to which it is comnected by fibro-fatty tissue: it thus reaches aeross fiom the internal to the external literal ligaments. Below. it is fixul to the horler of the onter tuberosity of the tibia, to the bome just below the perpliteal notch, and to the shaft of the tilia below the inner tuberosity, blending with the descending slip of the semimembirnosus and intemal lateral liganent. Superficially, an oblique firsciculus from the semimembrenosus rums actoss the centre, passing upwards and outwards from noar the back part of the inner tuberosity of the tilia to the external condyle of the femur where it joins the outer head of the gastrocnemius, a sesamoir plate being sometimes developed at the point of junction. This slip greatly strengthens

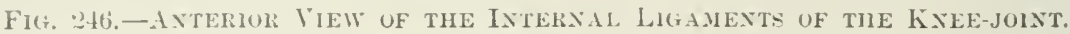

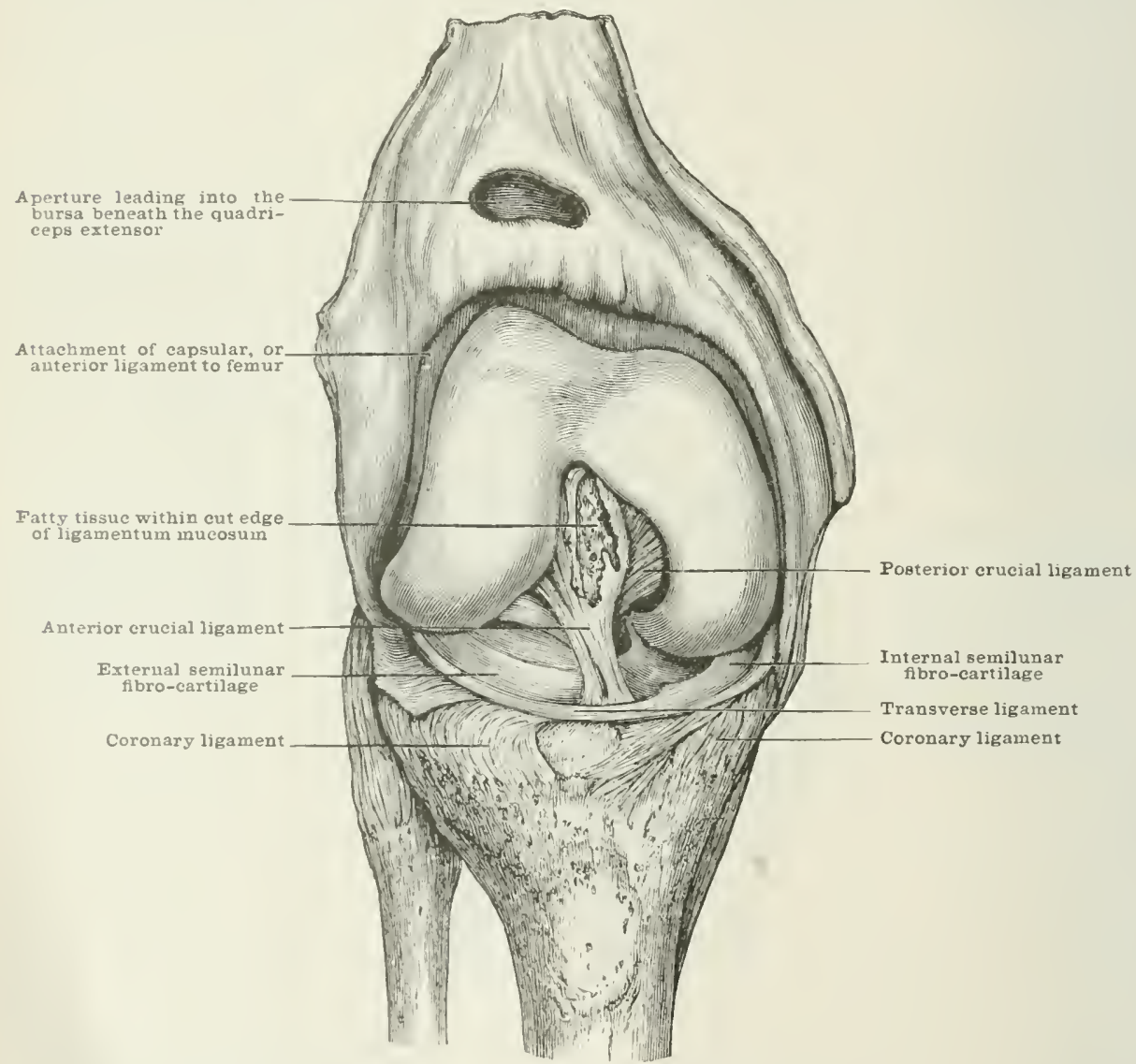

the postrior ligament, of which, if not the chicf constituent, it is at least a very importint part.

Its deep surface is rosely commered with the semilunar cartilages (especially the inmere and comonary ligaments, and in the interval between the eartilages with the posterior arurial liginnent and fibro-fatty tiswe within the joint. Superficially it forms part of the floor of the popliteal space.

The capsular (1) anterior ligament (fig. 246) is thin but strong, covering the synovial membrane under the quadriceps extensor tendon, and looking like a loose sac. It is attacheel to the femur near the articular margin on the inner side, but furthor away on the outer; it passos beneath the external lateral ligament to join the sheath of the proliten.. Internally it joins the int "mal lateral ligament. Below, it is fixed to the upper and lateral birders of the patella and the anterior border 
of the head of the tibia. It is strengthened superficially between the femur and patella by an expansion from the subcrureus, and is separated from the fibrous expansion of the extensor tendon by a larer of fatty tissue. The synorial membrane lines its deep surface, and holds it against the borders of the semilumar cartilages; it is also attached to the coronary ligaments.

\section{INTERAL LIGAMENTS}

The anterior crucial ligament (figs. 246 and 247 ) is strong and corl-like. It is attacherl to the inner half of the fossa in front of the spine of the tibia, and to the outer border of the inner articular facet as far back as the inner tulercle of the spine. It passes upwards, hackwards, and outwards to the hack part of the intemal surface of the external condyle. 'To the tibia, it is fixerl behind the anterior extremitr of the internal semilunar cartilage. Behind and to the outer side it has the antcrior extremity of the external semilunar cartilage, a few fibres of which blend with the outer edge of the ligament. Its anterior fibres at the tibial and are strongest and longest, being fixed highest on the femur; while the posterior, springing from the spine, are shorter and more oblique. Near the spine, a slip is sometines griven off to the posterior crucial.

The posterior crucial ligament (figs. 246, 247, and 248) is stronger and less

Fig, 247.-Strictires limig on tile Head of the Tibia. (Right knee.)

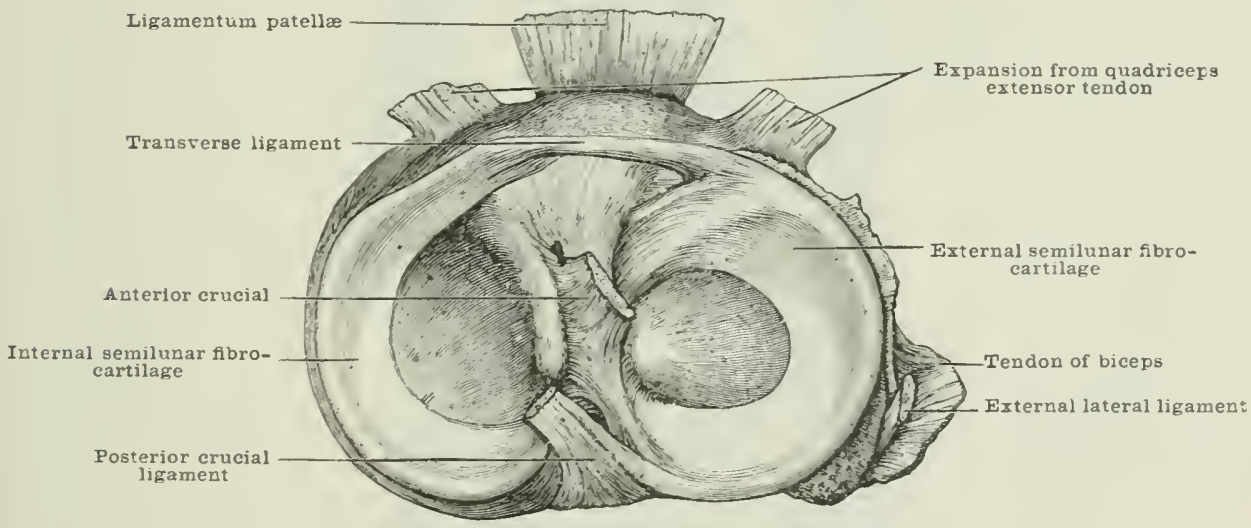

ollique than the anterior. It is fixed below to the greater portion of the fossa behind the spine of the tibia, especially the outer and posterior portion, and then inwards and upwards along the popliteal noth; heing joined hy fibres which arise between the tubercles of the spine, it ascends to the anterior part of the onter surface of the inner condyle, having a wide erescentic attachment mor than half an inch $(15 \overline{c m}$. ) in extent just above the articular surface. Behind, it is connected at the tibia rlirectly with the posterior liganent, and a little higher up by means of a quantity of interposed areolar tiscue. In front it rests upon the josterior horn of the internal semilmar cartilage. and receives a large slip from the external cartilage, which ascends along it either in front, or behind to the femur; higher up in front it is connecterl with the anterior crucial ligament.

Until they rise above the spine of the tibia the two crucial liganonts are closely bound together, so that no interspace exists between their tibial attachments and the point of decussation; the only space between them is therefore a $V$-shaped one corresponding to the upper half of their $X$-shajed arrangement, and this is a mere chink in the undissected state, and can he seen from the front only, owing to the fatty tissue beneath the swnovial membrane which surrounds their fenoral attachment.

The interarticular or semilunar fibro-cartilages (figs. 246 and 247 ) are two crescentic plates resting upon the circumferential portions of the artieular facets of the 
tibia, and moving with the tibia upon the fenmen. They somewhat deepen the tibial articular surfices, and are dense and compact in structure, becoming looser and more fibrous nean their extremities, where they are fimly fixed in front of and behind the spine of the tibia. The circmuforential horder of each is convex, thick, and somewhat loosely attached to the borders of the tuberosities of the tibia by the coronary ligaments, and the reflexion of the synovial membrane. The imner border is eoncave, thin, and free. Half an inch $(1 \because 3 \mathrm{~cm}$.) broad at the widest part, they taper somewhat towards their extremities, and cover rather less than two-thirels of the articular facets of the tibia. Their upper surfaces are slightly concave, and fit on to the femoral condyles, while the lower are flat and rest on the head of the tibia: both surfaces are smooth and covered by synovial membrane.

The external semilunar cartilage (fig. 247) is nearly eircular in form and less firmly fixcl than the intemal, and consequently slides more freely upon the tibia.

Fil, 24--ANTERIOR VIEW OF TIE KNEE-JOINT, SHOWING TIIE SFNoviat İGAMENTS.

(Anterior portion of capsule with the extensor tendon thrown downwards.)

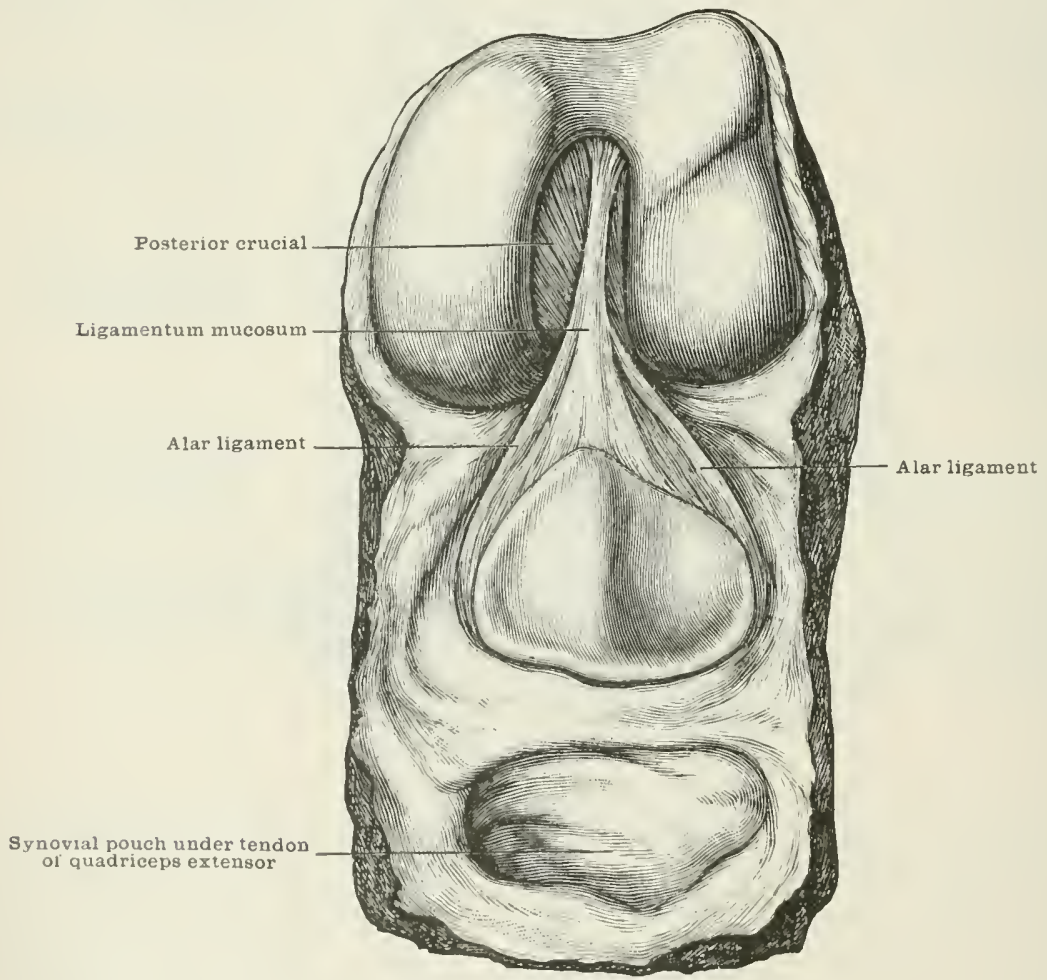

Its anterion wornu is attached to a narrow depression along the outer articular facet, just in fromt of the external tuberele of the tibial spine, close to, and on the outer side of, the anterior eruedal ligament; a small slip fom the eorm is often fixed to the tibia in frent of the arucial ligament. The posterior comu is fimly attacher to the tibia bohind the extenal tuberele of the spine, blending with the posterior crucial ligament, and griving off a well-makied fasciculus, which runs up alone the anterior borker of the ligmment to he attacherl to the femur (ligament of Wrisheres). It also semls a narrow slip inte the hack part of the anterior erucial ligament.

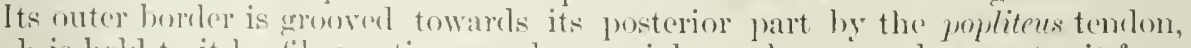
which is held to it hy filmons tissue and synovial memhame, and separates it from the extemal lateral liganent. From its anterior borler is given off the transverse ligiment.

The internal semilunar cartilage (fig. 247 ) is a segment of a larger circle than 
the external, and has an outline more oval than circular. Its anterior cornu is wide, and has a broad and oblique attachment to the anterior margin of the head of the tibia. It reaches barkwards and outwards from the margin of the tuberosity towards the middle of the fossa in front of the tibial spine, being altogether in front of the anterior erucial ligament. The posterior cornu is firmly fixed by a broad insertion in an intero-posterior line along the inner side of the josterior fossa. from the intemal tubercle of the spine to the posterior margin of the head of the tihia. lts convex border is connected with the internal lateral ligament and the semimembremosise tendon.

The transverse ligament (figs. 246 and 247 ) is a rounded, shender, short cord, which extends from the convex borter of the extemal semilunar cartilage to the concave border or anterior cornu of the internal, near which it is sometimes attached to the bone. It is an accessory band of the external cartilage, and is situated beneath the symovial membrane.

The coronary ligaments (fig. 246) connect the margins of the semilunar filorocartilages with the head of the tibia. The external is much more lax than the internal, permitting the outer cartilage to change its position more freely than the inner. They are not in reality separate structures, but consist of fibres of the several surrounding ligaments of the knee-joint which become attached to, as they pass over the margins of the fibro-cartilages.

The synovial membrane (fig. 249) of the knee forms the largest synovial sac in the body. Bulging upwards from the patella, it follows the capsule of the joint into a large cul-de-sac beneath the tendon of the extensor muscles on the front of the femur. It reaches some distance beyond the articular surface of the bone, and communicates very frequently with a large bursa interposed between the tendon and the femur above the line of attachment of the capsular ligament. After investing the circumference of the lower end of the femur, it is reflected upon the fibrous envelope of the joint formed by the capsular, posterior, and lateral ligaments. It covers a great portion of the crucial ligaments, but leaves uncovered the back of the posterior crucial where the latter is comnected with the posterior ligament, and the lower part of both crucial ligaments where they are united. Thus the ligaments are completely shut out of the synovial cavity. Along the fibrous envelope the synovial membrane is conducted down to the semilunar cartilages, orer lroth surfices of which it passes, and is reflected oft the under surface on to the coronary ligaments, and thence down to the head of the tibia, around the circumference of which it extends a short way. It dips down hetween the extemal cartilage and thes head of the tibia as low as the superior tibio-tibular ligament, reaching inwards nearly as far as the popliteal notch, and forming a bursa for the play of the popliteal tendon.

At the back of the joint two ponches are prolonged beneath the muscles, one on each side between the condyle of the femur and the origin of the gastrocnemins.

Large processes of synovial membrane also project into the joint, and being occupied by fat serve as padting to fill up spaces. The chief of these processes, the ligamentum mucosum (figs. 248 and 249 ) springs from the infrapatellar fatty mass. This so-called ligament is the central portion of the large process of synorial membrane, of which the alar ligaments form the lateral free margins. It extends from the fatty mass, below the patella, backwards and upwards to the intercondyloid notch of the femur, where it is attached in front of the anterior crucial, and to the outer side of the posterior crucial ligament. Near the femur it is thin and transparent, consisting of a double fold of synovial membrane. but near the patella it contains some fatty tissue. Its anterior or upper edge is free, and fully an inch $(2.5 \mathrm{~cm}$.) long; the posterior or lower edge is half the length. and is attached to the crucial ligaments above, but is free below.

Passing backwards from the capsute on each side of the patella is a prominent crescentic fold formed by reduplications of the synovial membrane-these are the alar ligaments (fig. 248). Their free margins are concave and thin, and are lost below in the ligamentmo mucosmm. There is a slight fossa above and another below each ligament.

The arterial supply is derived from the anastomotica femoris; the superior and inferior internal and external articular; the azygos articular; the descending 
branch of the external circumflex; the anterior recurrent branch from the anterior tibial; and the posterior tibial recurrent.

The nerve-supply comes from the great scintic, anterior crural, and obturator sumres. The great sciatic gives off the internal and external popliteal; the internal pepliteal sends two, sometimes thee branches-one with the aygos artery; one with the inferior internal, and sometimes ome with the superior internal articular artery; the (xtemal popliteal gives a branch which acompanics the superior, and another which accompanies the inferior articular artery, and a recurrent branch

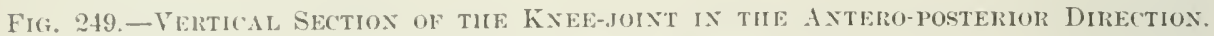

(The bones are somewhat drawn apart.)

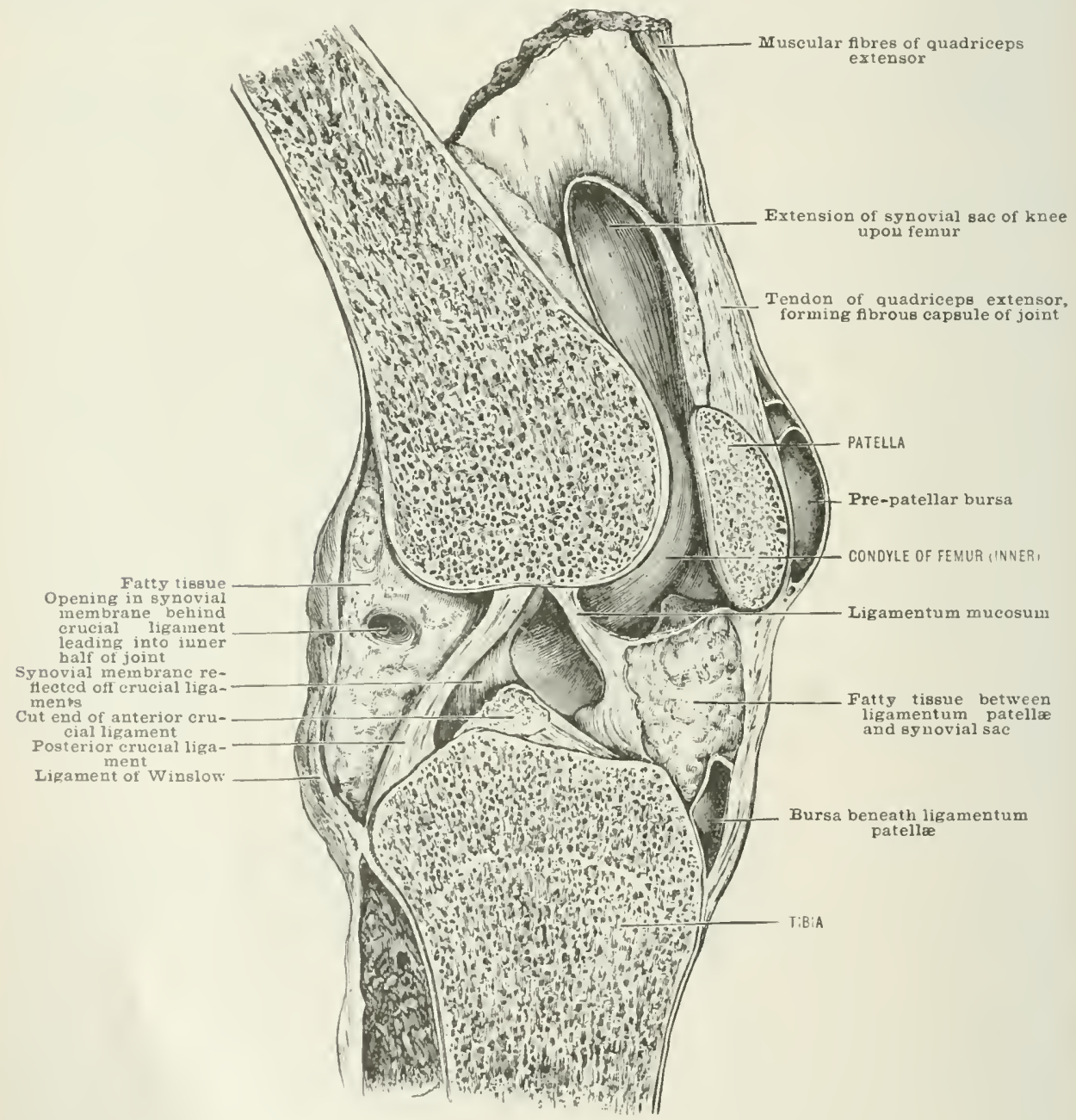

which follows the course of the anterior recurrent branch of the anterior tibial artery. The anterior crural sends an articular branch from the nerve to the vastus externus; a semel from the nerve to the vastus internus; and sometines a third from that to the arurens. Thus there are three articular twigs to the knce derived from the muscular branches of the anterior crubal. (Roger Villiams, Journ. Anat. Ihysiol., 1879.) The obturator hy its feep division sends a branch through the arkluetor magnus on to the popiliteal artery, which enters the joint through the posterior ligament.

The movements which oceur at the knee-joint are flexion and extension, with 
some slight amount of rotation in the bent position. These movements are not so simple as the corresponding ones at the elbow, for the knee is not a simple linge joint. The rotation inwards and outwards are movements of the tibia with the fibula upon the condyles of the femur.

The knee rliffers from a true hinge joint like the cllow or ankle, in the following particulars:-

1. The points of contact of the femur with the tibia are constantly changing.

Fig. 250.-Tine Lateral Liganexts of the Kive in Flexion and Extexsion.
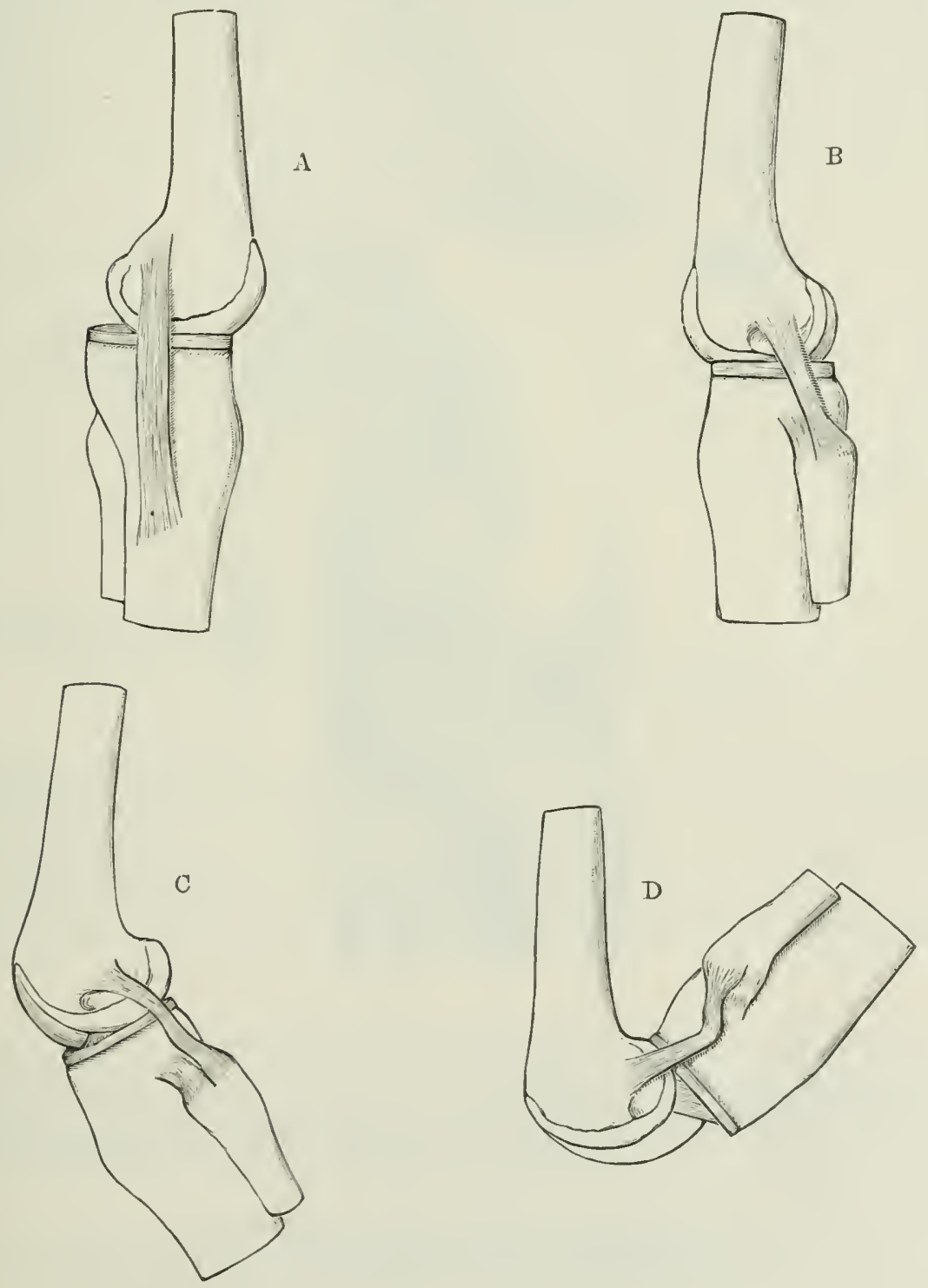

Thus, in the flexed position, the hincler part of the articular surface of the tibia is in contact with the rounded back part of the condyles; in the semitlexed position the midlle parts of the tibial facets articulate with the anterior rounded part of the condyles; while in the fully extended position the anterior and midelle parts of the tibial facets are in contact with the anterior Hattened portion of the condyles. So with the patella: in extreme flexion the inner articular facet rests on the outer part 
of the internal condyle of the femur; in flexion the upper pair of facets rest on the lower part of the trochlear surface of the femmr; in mil-flexion the michle pair rest on the middle of the trochlear surface; while in extension the lower pair of facets on the patella rest on the upper portion of the trochlear surfice of the femur.

This difference may be deseribed as the shifting of the points of eontact of the articular surfinee.

2. It differs from a true linge in that, in passing from a state of extension to one of flexion, the tibia does not revolve round a single transverse axis llawn through the lower end of the femur, as the ulna does round the lower end of the limmerus. The articular surface of the tibia slicles forwards in extension and backwards in flexion; thus the axis romkl which the tibia revolves upon the femur is a shifting one, as is seen by reference to fig. $250, \mathrm{~B}, \mathrm{C}, \mathrm{D}$.

3. Another point of difference is that extension is accompanied by rotation outwards, and flexion by rotation inwards. This rotation oceurs round a rertical axis

Fig. 251.-SEctiox of Kxie, shomixg Cructals ix Extexsion.

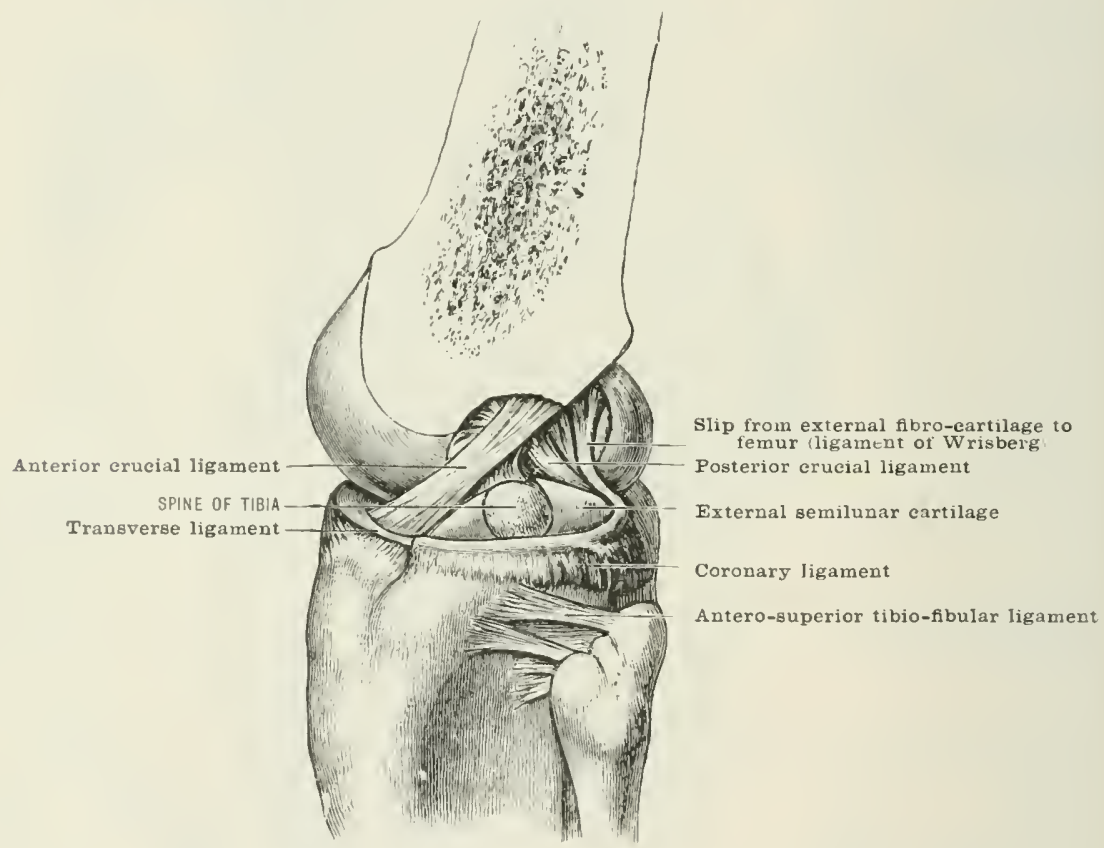

dran through the midclle of the outer condyle of the femur and the outer tuberosity of the tibia, and is nost marked at the termination of extension and at the aminencensent of flexion. This rotation of the leg at the knee is a trute rotation about a rertionl axis, and thus differs from the olliguity of the flexion and extension movements at the allow which is due to the obligue direction of the articular surfates of the bones.

4. The antero-posterior spiral curve of the femoral comlyles is such, that the anterior part is an are of at greater airele than the posterior; henee certain ligaments which are tiglitened during rextension are relaxed during flexion, and therehy a consislerahle amount of motatory movement is pornitter in the flexed position. The axis of this jotation is rertical, and passes through the imner tubercle of the spine of the tilia, so that the onter tuberosity moses in the are of a larger circle than

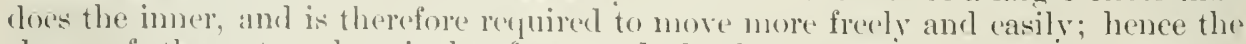
shape of the external articular facet and the loose comnetion of the external semilunar cartilage which is allapted to it.

In extension, all the ligaments ane on the stretch with the exeeption of the 
ligamentum patellæ and front of the capsule. Extension is checked by both the (rucial ligaments and the lateral ligaments (figs. 250, A, B, and 251).

In flexion the ligamentum patellæ and anterior portion of the capsule are on the stretch; so also is the posterior crucial in extreme flexion, though it is not quite tight in the semiflexed state of the joint. All the other ligaments are relaxed (fig. $250, \mathrm{C}, \mathrm{D})$, although the relaxation of the anterior crucial ligament is slight in extreme flexion (fig. 252). Flexion is only checked during life by the contact of the soft parts, i.e. the calf with the back of the thigh.

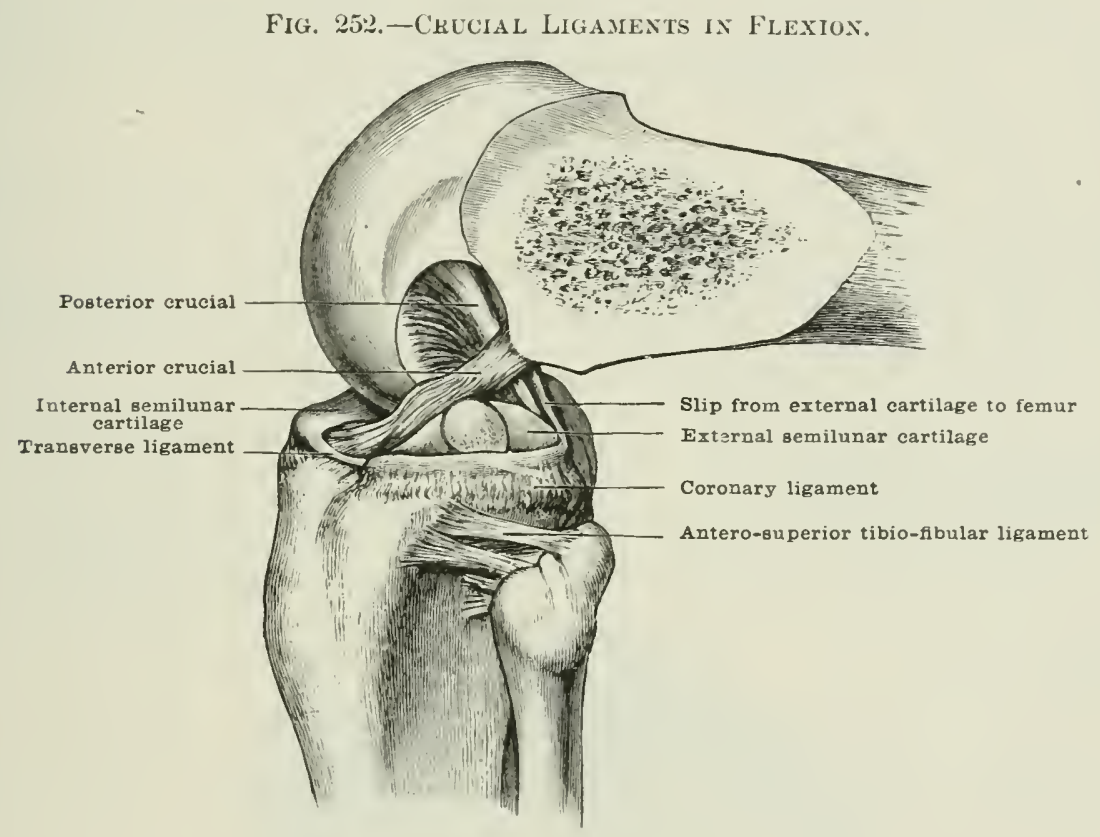

Inward rotation is checked by the anterior crucial ligament; the lateral liganients being loose.

Outward rotation is checked by the lateral ligaments; the crucial ligaments have no controlling effect on it, as they are untwisted by it.

Sliding movements are ehecked by the crucials and lateral ligaments-sliding forwards especially by the anterior, and sliding backwards by the posterior crucial.

\section{THE TIBIO-FIBLLAR LYION}

The fibula is connected with the tibia throughout its length by an interossenus membrane, and at the upper and lower extremities by means of two joints. Very little movement is permitted between the two bones.

(a) The superior tibio-fibular joint.

(b) The middle tibio-fibular union.

(c) The inferior tibio-fibular joint.

\section{(a) The Superior Tibio-fibllar Joint}

\section{Class.-Diarthrosis.}

Subdivision.-Athrodia.

The superior tibio-fibular joint is about a quarter of an inch ( $6 \mathrm{~mm}$. ) helow, and quite distinct from, the knee at its upler and anterior part; but at its posterior and 
superior aspect, whare the border of the outer tuberosity of the tibia is berelled by the popliters muscle, the joint is in the elosest proximity to the bursal beneath the tendon of that muscle, and is only separated from the knee-joint by a thin septum of areolar tissue. There is often a communication between the synovial carities of the two joints. The ligaments uniting the bones are:-

\section{Capsular.}

Anterior tibio-fibular.

\section{Posterior tibio-fibular.}

The capsular ligament is a well-marked fibro-areolar structure; it is attached close round the articular margins of the tibia and fibula. In front it is shut off completely from the knee-joint by the capsule of the knee and the coronary ligament; but behind, it is often very thin, and may communicate with the bursa under the popliteus tendon.

The anterior tibio-fibular ligament (fig. 251) consists of a few fibres which pass upwarks and inwards from the fibula to the tibia. It lics beneath the anterior portion of the tendon of the biceps.

The posterior tibio-fibular ligament (fig. 245) consists of a few fibres which pass upwards and inwards between the adjacent bones, from the head of the fibula to the outer tuberosity of the tibia.

The superior interosseous ligament consists of a mass of dense yellow fibroarcolar tisste, binding the opposed surfaces of the bones together for three-quarters of an inch ( $2 \mathrm{~cm}$. ) below the articular facets. It is continuous with the interosseous membrane along the tibia.

The biceps tendon is dirided by the long external lateral ligament of the knee; of the two divisions the anterior is by far the stronger, and is attached to the cxternal tuberosity of the tibia as well as to the front of the head of the fibula, and thus the muscle, acting on both bones, tends to brace them more tightly together; indeed, it holds the bones strongly together after all other connections have been severerl.

The synovial membrane which lines the joint sometimes communicates with the knee-joint through the bursa beneath the popliteus tendon.

The arterial supply is from the inferior external articular and recurrent tibial arteries.

The nerve-supply is from the inferior external articular, and also from the recurrent branch of the external popliteal.

The movements are but slight, and consist merely of a gliding of the two bones upon each other. The joint is so constructed that the fibula gives some support to the tibia in transmitting the weight to the foot. The articular facet of the tibia orerhangs, and is received upon the articular facet of the head of the fibula in an ohlique plane. This joint allows of slight rielding of the external malleolus cluring Hexion and extension of the ankle-joint, the whole fibula gliding slightly upwards in flexion, and downwards in extension of the ankle.

\section{(b) The Minde Tibio-fiblear Union}

The interosseous membrane is attached along the outer border of the tibia and the interosseous border of the fibula. It is deficient above for ahout an inch $(2.5 \mathrm{~cm}$.) or nore, measural from the under aspect of the superior joint. Its upler border is concare, and over it pass the anterior tibial vessels. The membrane consists of a thin aponeurotic and translucent lamina, formed of oblique fine fibres, some of which run from the tilia to the fibula, and some from the fibula to the tibia, but all are inclined downwark. They are best marked at their attachment to the bones, and gralually grow denser and thicker as they approach the inferior interosseous ligament. 'The rhief use of the membrane is to afford a surface for the origin of muscles. It is continuous below with the inferior interosscous ligament. 


\section{(c) The Inferior Tibio-fibllar Artictlatios}

\section{Class.-Dianthrosis. Subdivision.-Aithrodia.}

This junction is formed by the lower ends of the tihia and fibula. The rough triangular surface on each of these bones former by the bifurcation of their interosseous lines is closely and firmly united by the inferior interosseous ligament. The fibula is in actual contact with the tibia by an articular facet, which is small in size, crescentic in shape, and continuous with the articular facet of the malleolus.

The ligaments which unite the bones are:-

1. Anterior inferior tibio-fibular ligament.

2. Posterior inferior tibio-fibular ligament.

3. Transverse ligament.

4. Inferior interosseous ligament.

The antero-inferior tibio-fibular ligament (figs. 2.52 $\mathrm{A}$ and 2.55 ) is a strong triangular band about three-quarters of an inch $(2 \mathrm{~cm}$.) wird , and is attached to the lower extremity of the tibia at its anterior and external angle, close to the margin of the facet for the astragalus, and passes downwards and outwards to the anterior

Fig. 25: A.-Lower Exps of Left Tibia AND Fiblla, showixg tife Ligayexts. The synovial fold between these bones has been removed to show the transverse ligament forming jart of the capsule of the joint, and the deeper fibres of the anterior inferior tibio-fibular ligament which come into contact with the astragalus.

(From a dissection by Mr. W. Pearson, of the Roval College of Surgeons' Museum.)

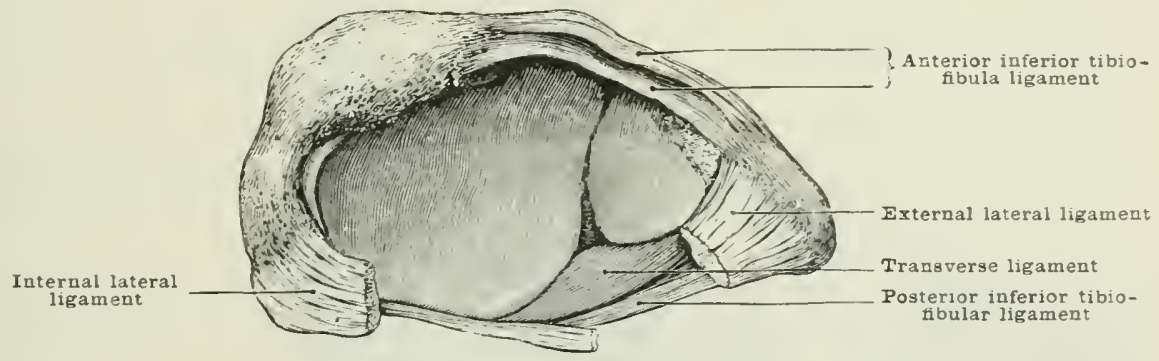

border and contiguous surface of the lower end of the fibula. some fibres passing along the edge nearly as far as the origin of the anterior fasciculus of the external lateral ligament. The fibres increase in length from above downards. In front it is in relation with the peronems tertius and deep fascia of the leg, and gives origin to fibres of the anterior ligament of the ankle-joint. Belind. it lies in contact with the interosseous ligament, and comes into contact with the articular surface of the astragalus (see figs. $252 \mathrm{~A}$ and $252 \mathrm{~B}$ ).

The postero-inferior tibio-fibular ligament (figs. 2.54 and 25.5 ) is very similar to the anterior, extending from the posterior and extemal angle of the lower end of the tibia downwards and outwards to the lowest half-inch $(1.5 \mathrm{~cm}$.) of the border separating the internal from the posterior surface of the shaft of the fibula, and to the upper part of the posterior horder of the external mallenlus. It is in relation in front with the interosseous ligament; below, it touches the transverse liganent.

The inferior interosseous ligament is a dense mass of short felt-like fibres, passing transversely between and fimly uniting the opposed rough triangular surfaces at the lower ends of the tihia and fibula. except for three-eighths of an inch (1 cm.) at the extremity. where there is a synovial cavity. It extends from the anterior to the posterior tibio-filular ligaments. rearching ujwards an inch and a half in front ( $4 \mathrm{em}$.). lut only half this height lehinel.

The transverse ligament (fig. 2.54) is a strong rounded hand, attacherl to nearly the whole length of the inferior border of the posterior surface of the tibia, just above 
the articular facet for the astragalus. It then inclines a little forwards and downwarls, to be attacherl to the internal surface of the external malleolus, just above the fossa. and the upper part of the fostia itself.

The synovial membrane is (ontinums with that of the ankle-joint; it projects upwarks between the bones beromel their articular facets as high as the inferior interossenus ligrament.

The nerve-supply is the same as that of the ankle-joint; the arterial supply is from the peroneal and the anterior leroneal. and sometimes from the anterior tihial. or its extemal malleolar hranch.

The movement permitted at this joint is a mere gliding, chiefly in an upward and downorel direction, of the fibula on the tibia. The bones are firmly braced together and yet form a slightly yielding arch, thus allowing a slight lateral rxpansion during extreme flexion, when the broad part of the astragalus is brought under the arch, by the upward gliding of the fibula on the tibia. To this end the direction of the fibres of the superior and inferior tibio-fibular ligaments is downwarls from tibia to fibula. This mechanical arrangement secures perfect contact of the articular surfaces of the ankle-joint in all positions of the foot.

\section{THE ANKLE-JOINT}

\section{Class.-Diarthrosis.}

\section{Subdivision.-Ginglymus.}

The ankle is a perfect ginglymus or hinge joint. The bones which enter into its formation are: the lower extremity and internal malleolus of the tibia, and the external malleolus of the fibula, above; and the upper and lateral articular surfaces of the astragalus below. The ligaments uniting the bones are:-
Anterior.
Internal laterat.
Josterior.
External lateral.

Fir. 25:2 R.-RigitT AxkLE-JoINT, showtag THE LIGANENTs.

(From dissection hy Mr. W. Pearson, of the Royal College of Surgeons' Musemm.)

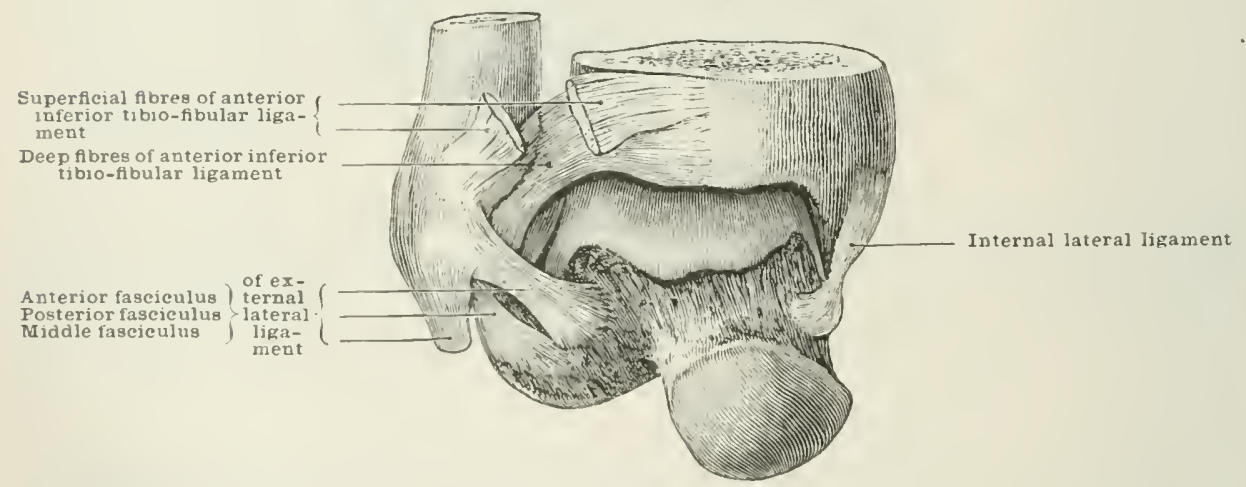

The anterior ligament (fig. 255) is a thin, memblunous structure, which extencls letween the lateral liganents. It is attached above to the anterior border of the internal malleolus, to a crest of bone just above the transverse groove at the lower and of the tibia, to the anterior inferior tibio-fibular ligament, and to the anterior loreler of the external malleolus. Below, it is attached to the rongh upper surface of the neck of the astragalus, in front of the fossil. Internally it is thicker, and is fixed to the astragalus close to the facet for the imner malleolus, loeing continuous with the intemal lateral ligament, and passing forwards to blend with the dorsal astragalo-scaphoid ligament. Externally it is attached to the astragalus, just ledow and in front of the angle between the superior and lateral facets close to their edges, and joins the anterior fascienlus of the external lateral ligament. It is in relation, in front with the tibialis anticus muscle, the anterior 
tibial vessels and nerve, the extensor tendons of the toes, and the peroneus tertius; and hehind with a mass of fat and synovial membrane.

The posterior ligament (fig. 254) is a very thin and disconnected membranous structure, connected above with the extcrnal malleolus, internal to the peroneal groove; to the posterior margin of the lower end of the tibia external to the groove for the tibialis posticus; and to the posterior inferior tibio-fibular ligament. Below, it is attached to the posterior surface of the astragalus from the intemal to the external lateral ligaments. The passage of the flexor longus hallucis tendon orer the back of the joint serves the purpose of a much stronger posterior ligament.

The internal lateral or deltoid ligament (fig. 253) is attached superiorly to the internal malleolus along its lower border, and to its anterior surface superficial to the anterior ligament; some very strong fibres are fixed to the notch in the lower border of the malleolus, and, getting attachment below to the rough depression on the inner side of the astragalus, form a deep portion to the ligament. The ligament radiates; the posterior fibres are short, and incline a little backwards to be fixed

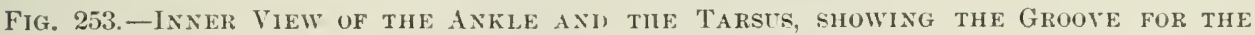
TeNoun of the Tibialis Posticts.

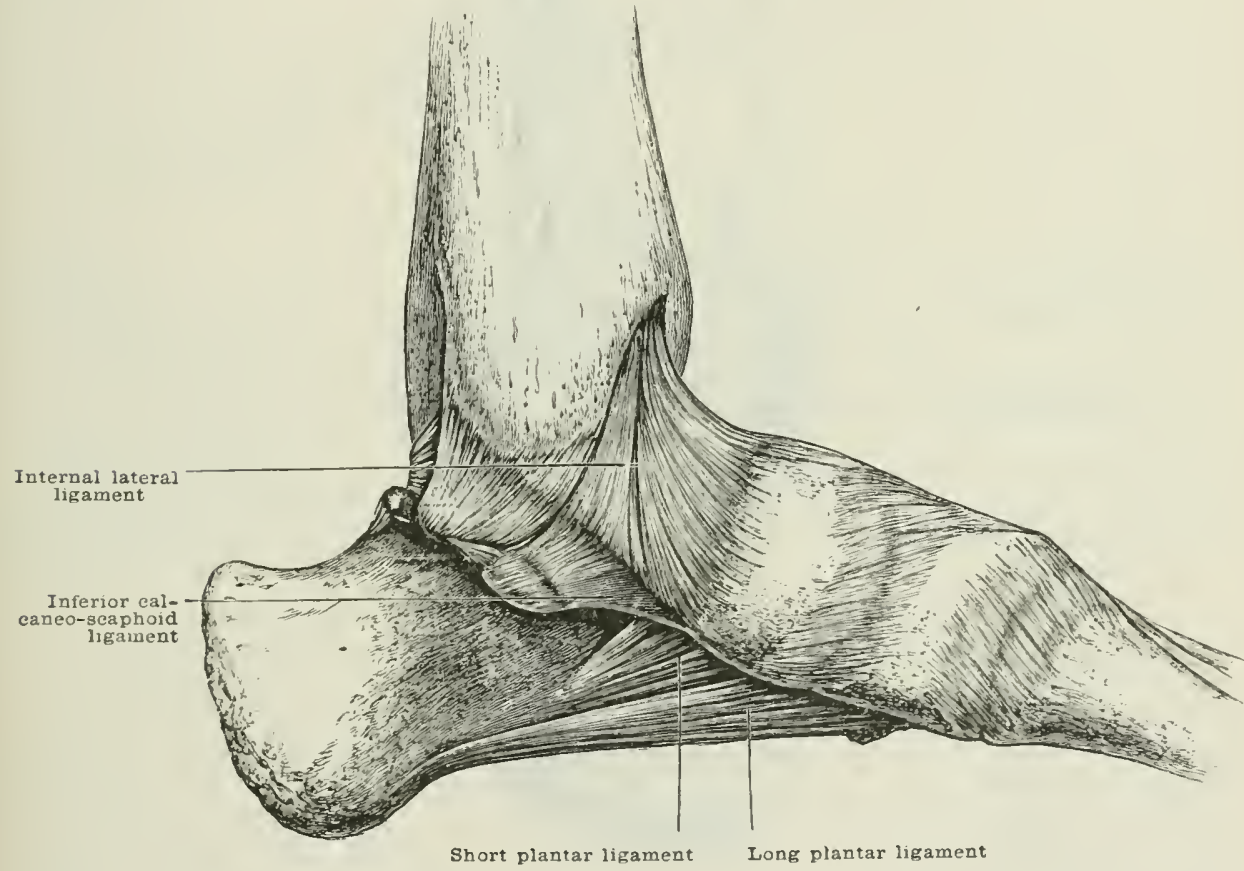

to the rough inner surface of the astragalus, close to the superior articular facet, and into the tubercle to the inner sille of the flexor longus hallucis groove. The fibres next in front are numerous and form a thick and strong mass, filling up the rough depression on the inner surface of the astragalus, whilst some pass over the calcaneo-astragaloid joint to the upper and inner border of the sustentaculum tali. The fibres, which are comnecterl above with the anterior surface of the malleolus, pass downwards and somewhat forwards to be attached to the scaphoid and to the margin of the calcaneo-scaphoid ligament.

The external lateral ligament (figs. 254 and 255) consists of three distinet slips. The anterior fasciculus is ribbon-like and passes from the anterior horder of the external malleolus near the tip to the rough surface of the astragalus in front of the external lateral facet, and overhanging the sinus pelis. The middle fasciculus is a strong roundish bundle, which extends downwards and somewhat backwards from the anterior border of the external malleolus close to the attachment of the anterior faseiculus, and from the outer surface of the malleolus, just in front of the alpex, 
to a tubercle on the midale of the outer surface of the calcanem. The posterior fasciculus is almost horizontal; it is a strong, thick band attached at one end to the posterior londer of the malleolus, and slightly to the fossit on the internal surface; and at the other enel to the astragalus, lochind the articular facet for the fibula, as well as to a tubercle on the outer side of the groove for the flexor longr. hallucis. The middle fisciculus is covered by the tendons of the peronei longus and breris; and in extension, the posterior fasciculus is received into the pit on the imner surface of the axternal malleolus.

The synovial membrane is very extensive. Besides lining the ligaments of the ankle, it extencls upwarls between the tibia and fibula, forming a short cul-clesuc as far as the interosscous ligament. Upon the anterior and posterinr ligaments it is very loose, and extends beyond the limits of the articulation. It is said to contain more symovia than any other joint.

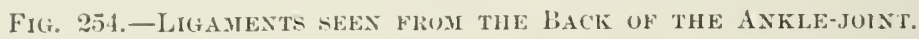

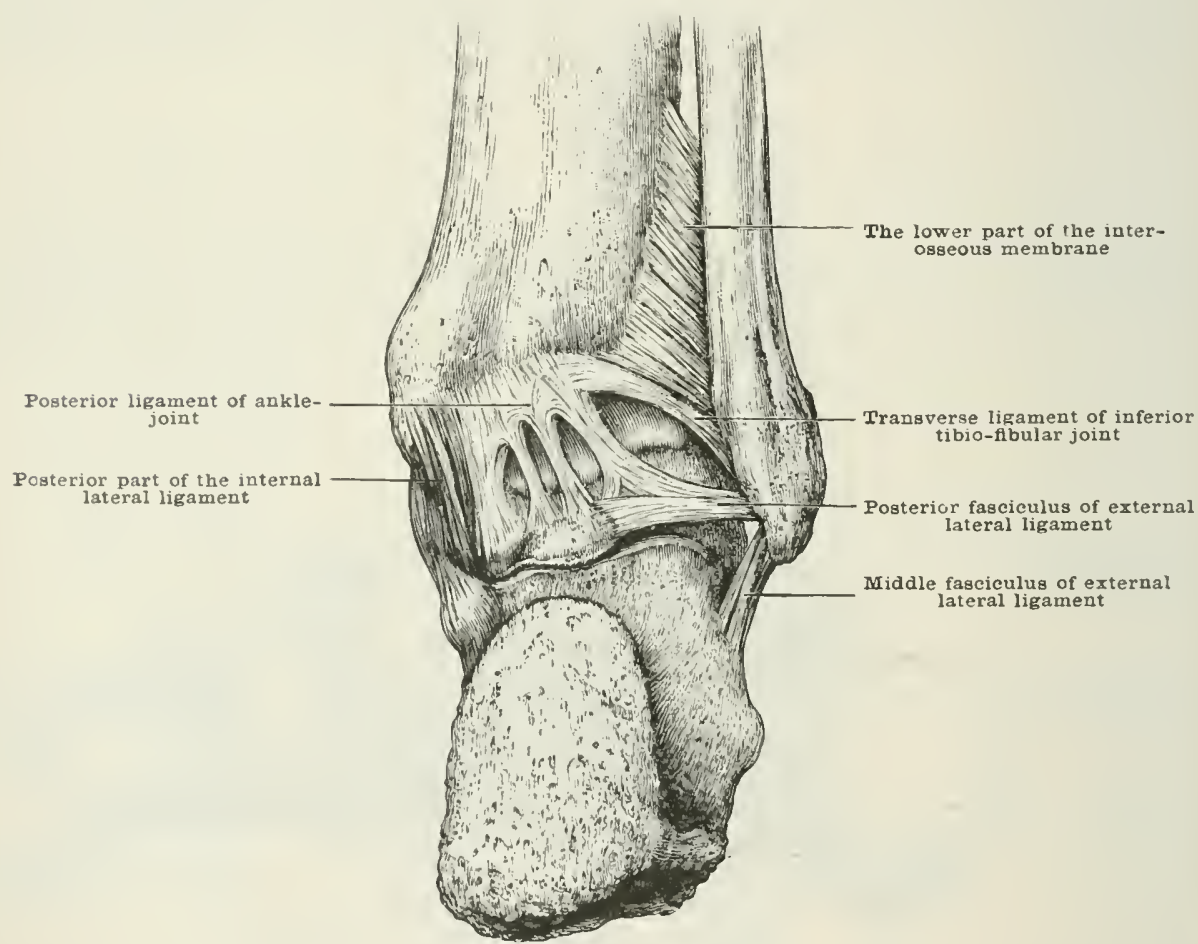

The nerve-supply is from the internal saphenons, posterior tibial, and the external division of the anterior tilial.

The arterial supply comes from the antrior tihial, the anterior peroneal, the external malleolar, the posterior tibial, and posterior peroneal.

Movements.-This heing a true hinge joint, flexion and extension are the only movements of which it is capalile, there being no lateral motion, except in extreme extension, when the narrowest part of the astragalus is thrust forwarts into the widest part of tho tibio-filular arch. In flexion the astratgalus is tightly embracol by the malleoli, and lateral movement is improsilole. Flexion is limited by: (i) nearly the whole of the filmes of the internal lateral ligament. none lut the most anterior leing relaxel; (ii) the justerior and millle portions of the external hateral ligament. especially the posterion; (iii) the posterior ligament of the ankle. It is also limited by the neck of the astragalus abutting on the relge of the tibia. Extension is linited ly: (i) the anterior fibres of the internal lateral ligament; (ii) the anterior and midclle frortions of the external lateral ligament; (iii) the 
inner and stronger fibres of the anterior ligament. It is also limited hy the posterior portion of the astragalus meeting with the tilia. Thus the middle portion of the external lateral ligament is always on the stretch, owing to its obliquely backward direction, whereby it limits flexion; and its attachment to the fibula in front of the malleolar apex, wherehy it prevents over-extension as soon as the foot begins to twist inwards. This inward twisting, or adduction of the foot, is martly due to the greater posterior length of the inner border of the superior articular surface of the astrigalus, and to the less proportionate height posteriorly of the external border of that surface, but chiefly to the lateral movement in the calcaneo-astragaloid joints. Flexion and extension take place round a transverse axis drawn through the body of the astragalus. The movement is not in a direct antero-posterior plane, but on a plane inclined forwards and outwards from the middle of the astragalus to the internetatarsal joint of the second and third toes.

\section{THE TARSAL JOINTS}

These may again be divided up into the following sub-groups:-

(a) The calcaneo-astragaloid union.

(b) The articulations of the anterior portion of the tarsus.

(c) The medio-tarsal joint.

\section{(a) The Calchine-astragaloid Uxiox}

There are two joints which enter into this union-riz. an anterior and a posterior.

\section{(i) The Posterior Calcaneo-astragaloid Joint}

\section{Class.-Diarthrosis. Subdivision.-Aithrodia.}

The calcaneum articulates with the astragalus by two joints. the anterior and postrior: the former communicates with the medio-tarsal: the posterior is separate and complete in itself. The two bones are united hy the following ligaments:-

Interosseous.

Posterior calcaneo-astragaloid.
External calcaneo-astragaloikl. Intemal calcaneo-astragaloid.

The interosseous ligament (figs. 25.5 ant 2.56) is a strong band connecting the apposed surfaces of the calcaneum and astragalus along their oblique grooves. It is composed of several vertical lamine of fibres, with some fatty tissue in between. It is lietter marked, deeper, and broader externally. Strong laminæ extend from the rough inferior and external surfaces of the neck of the astragalus to the romgh superior surface of the os calcis anteriorly, forming the posterior boundary of the anterior calcaneo-astragaloid joint; these have been described as the anterior interosseous ligament. The posterior laminx extend from the roof of the sinus pedis to the os calcis immediately in front of the external facet, thus forming the anterior part of the capsule of the josterior joint.

The external calcaneo-astragaloid ligament (fig. 25.5) extends from the groove just below and in front of the external articular facet of the astragalus, to the os calcis some little distance from the articular margin. Its fihres are nearly parallel with those of the middle fascieulus of the external lateral ligament of the ankle, which passes over it and adds to its strength. It fills up the interval hetween the micklle and anterior fasciculus of the extemal lateral ligament, a considerible bundle of its fibres blending with the anterior horder of the middle fasciculus.

The posterior calcaneo-astragaloid ligament passe from the external tubercle and lower edge of the groove for the Hexor longus hallucis to the os calcis, a variable distance from the articular margin.

The internal calcaneo-astragaloid ligament is a narrow band of well-marked 
fibres jassing obliquely clownwarks and backwark from the depression on the astragalus, just behind the inner end of the sinus pedis, to the os ralcis hehind the sustrintaculum tali, thus completing the floor of the grome for the flexor longus hallucis tenclon.

The synovial sac is distinct from any other.

The nerve-supply is from the posterior tibial or one of its plantar lianches.

The arteries are, a hranch from the posterior tibial, which enters at the inner enel of the sinus pedis; and twigs from the tarsal, external malleolar, and the peroneal, which enter at the outer end of the sinus.

\section{(ii) The Anterior Caleaneo-astragalvid Joint}

\section{Class.-Diarthrosin. Subdivision.-Arthrodia.}

This joint is formed hy the anterior facet on the upper surface of the os caleis and the facets on the lower surface of the neek and head of the astragalus; it is bounderl laterally and behind by ligaments, and communicates anteriorly with the astragalo-scaphoid joint. The ligaments are:-

Interosseous. Internal (or antero-internal) ealcaneo-astragaloid. External calcanco-scaphoid.

The interosseous ligament by its anterior lamina limits this joint posteriorly. It has been already described (1. 269).

The antero-internal calcaneo-astragaloid ligament consists of short fibres attached above to the rough depression on the internal surface of the neck of the astragalus, and below to the upper edge of the free border of the sustentaculm tali. blending posteriorly with the inner extremity of the interosseous ligament, and anteriorly with the upjer border of the inferior ealcanto-saphoid ligament. It is strengthened by the internal lateral ligament, the anterior fibres of which are also attached to the inferior calcaneo-seaphoid ligament.

The external calcaneo-scaphoid (sup)erior calcaneo-seaphoicl, Gray) (figs. 25) and 256 ) limits this, as well as the astragalo-scaphoid joint, on the outer side. It is a strong, well-marked bant, extending from the rough upper surface of the ealcanem, external to the anterior facet, to a slight groove on the outer surface of the seaphoid near the posterior margin. It blends below with the inferior caleaneo-scaphoid. and above with the astragalo-scaphoid ligament. Its fibres run obliguely forwards and inwarks. The internal lateral, and middle fasciculus of the external lateral ligaments of the ankle-joint also add to the security of these two joints, and assist in limiting movements between the bones by passing orer the astragalus to the os (alcis.

The movements of which these two joints are capable are altuction and abduction, with some amount of rotation. Adeluction, or inclination of the sole inwark. being combined with some rotation of the toes inwards, and of the heel outwards; while abduction, or inclination of the foot outwards, is associated with turning of the toes outwards and the heel inwards. Thus the variety and the range of movements of the foot on the leg, which at the ankle are almost limited to flexion and extmsion, are increaserl. The cuboid moves with the calcaneum, while the scaphoid revolves on the head of the astragalus.

In walking. the heel is first placerl on the gromml; the fout is slightly adducted; hut as the body swings forwarls, first the outco then the inner tors touch the ground, the astragalus presies against the seaphoil and sinks upon the spring ligament; the fort then bocomes slightly aluluctul. When the foot is firmly placed on the ground, the weight is transmitted to it ohliguely clownwals and inwards, so that if the ligaments between the ealeaneme and astragalus dirl not theek abduction, inward displacenent of the astragalue from the tibio-fibular arch would only lie prevented by the tendons passing romet the inner ankle (especially the tibialis posticus). If the ligamonts be tor watk to limit abduction, the weinht of the borly increases it, and forces the inner mallowlus and astragalus ilownwark and inwards, giving rise to tlat foot. 
The advantages of the obliquity and peculiar arrangement of the posterior calcaneo-astragaloid articulation are seen in walking: (i) for the posterior facet of the calcaneum receives the whole weight of the body when the heel is first placed on the ground; (ii) by the upward pressure of this facet against the astragalus it transfers the weight to the ball of the toes as the heel is raised, the hinder edge of the sustentaculum tali and the anterior and outer part of the upper surface of the calcaneum preventing the astragalus from being displaced too far forward by the superineumbent weight; and (iii) the calcanem serves to suspend the astragalus when, with the heel raised hy muscular action, the other foot is being swung forwards.

The synovial membrane is the same as that of the astragalo-scaphoid joint. The arteries and nerves are derived from the same sources as those of the medintirsil joints.

Fig. 255.-Extersal View of the Ligamexts uf the fout and ANkLe.

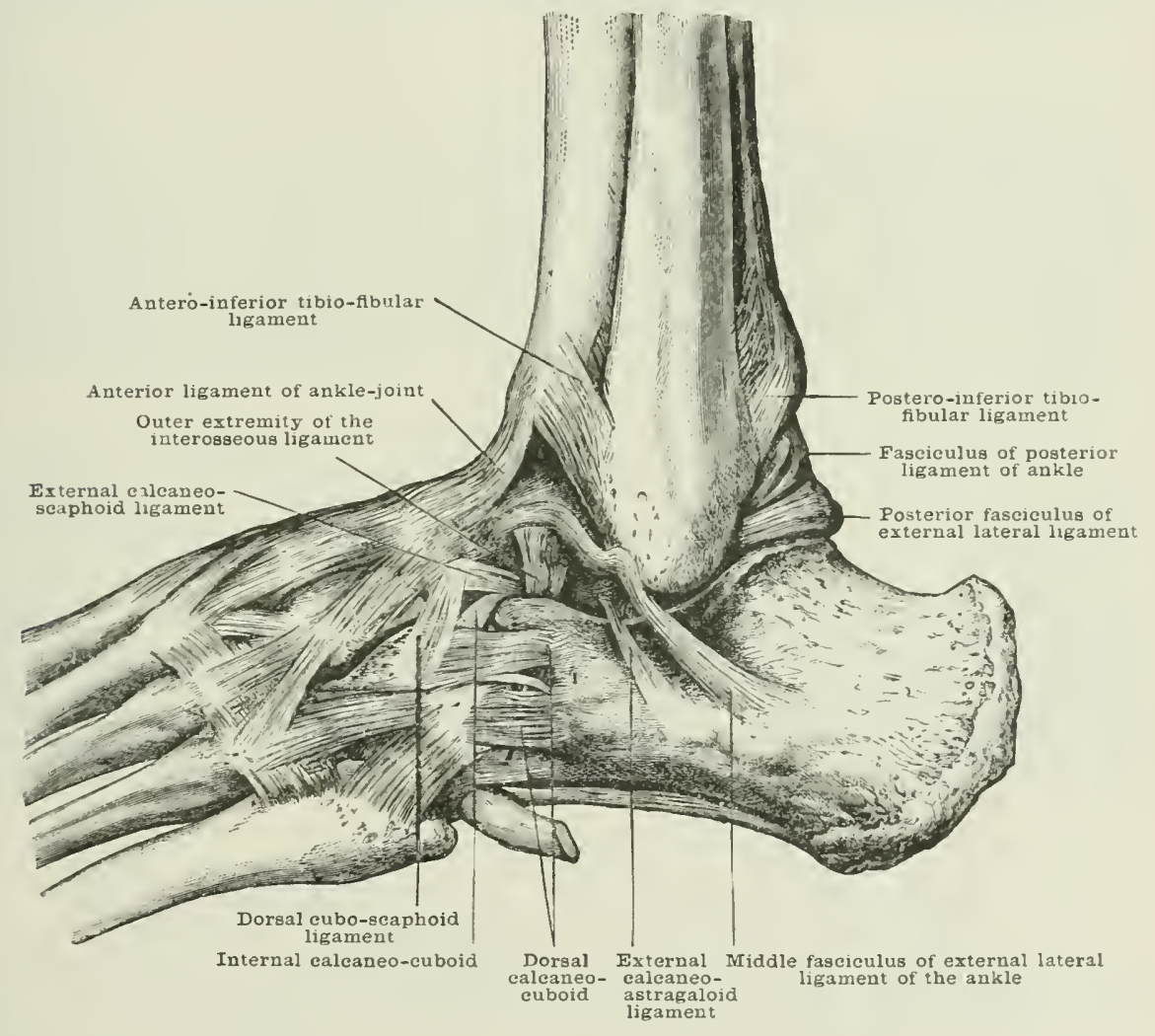

(b) The Articulations of the Axterior Part of tile Tarses

These inchule (i) the cubo-scaphoid; (ii) scapho-euneiforn; (iii) intercuneiform; and (iv) cubo-cuneiform joints.

\section{(i) The Cubo-scaphoid Lnion}

\section{Class.-Diarthrosis. \\ Subdivision.-1, throrlia.}

The ligaments which unite the cuboid and scaphoid are:
Dorsal.
Plantar.
Interosseous.

The dorsal cubo-scaphoid ligament (fig. 2.56) rum. forwards and outwards from the outer end of the dorsal surface of the scaphoid to the middle third of the inner 
burrler of the cuboil on its elorial a-pect, passing over the posterior external angle of the external cumeiform bone. It is wider externally.

The plantar cubo-scaphoid ligament is a well-markerl strong band, which runs forwards and outwalels. from the plantar surface of the seaphoid to the depresion on the inner surfice of the enheirl, and slightly into the plantar surface just helow it.

The interosseous cubo-scaphoid ligament is a strong band which passes

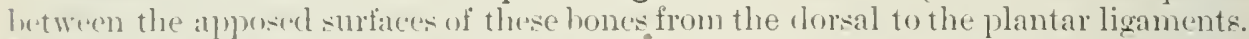
some of it posterior filnes reach the plantar surface of the foot behind the cubosabuhoil ligannent, anet radiate ontwards and harkwards over the inner horder of the culsoid to blend with the anterior extremity of the short ealcaneo-cuboid ligiment.

\section{(ii) The screpho-enneiform Aitivulation}

Class.-Dirithrosis.

The liganents uniting the saphoid with the three (mneiform bones are:-

\section{Subdivision.-Arthrodia.}

\section{Internal.}

The dorsal scapho-cuneiform ligament is very strong, and stretehes as a continuous strueture on the dorsal surface of the scaphoid, between the tubercle of the salphoid on the inner side, and the dorsal culoo-scaphoid ligament externally, passing forwarls and a little outwark to the dorsal surfaces of the three cuneiform bones.

The internal scapho-cuneiform ligament is a very strong thick band which (onnerts the tuherele of the scaphoid with the inner surface of the internal cunciform hone. It is continuous with the dorsal and plantar ligaments. Its lower bercher tomches the tendon of the tilialis posticus.

The plantar scapho-cuneiform ligament forms, like the dorsal. a eontinuous structure extending between the plantar surfaces of the lones. Its fibres pass forwark and ontwarks. It is in relation bolow with the tendon of the tibialis fustiens.

It mmst be noticed that the expanded tendon of insertion of the tibictis posticus, and the liwaments uniting the scaphoid with the cuboid and cuneiform bones pass forwards and uutwarls, while the perouens lougus tendon and the ligaments uniting the first and second rows of bones, except the immer balf of the clursal astragalo-scaphoid licaments, pass forwards and inwards. 'This alrangement is admirably adapted to preserve the arches of the foot, and especially the transrerse

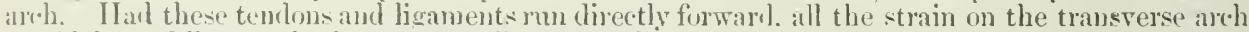
woull have fillen on the interoscrous ligaments, but as it is, the arch is braced up by the abovementioned structures.

\section{(iii) The Interenneiform and (iv) The Cubo-runciform sitientations \\ Class.-I)iretheris. \\ Subdivision.-1, lethordie.}

The miting ligaments of these bones are divicled into three sets:

$$
\text { ]) () } 1: i 1 \text {. }
$$

T'lantar.

\section{Interosicouls.}

The dorsal ligaments are three in number, two (onnecting the three anneiform bones, and a third mniting the external eunciform with the cuboid. They fass betweres the contignoms margins of the bones, and are blended behind with the dorsal ligaments of the cuho-seaphrid and scapho-emeifom joints.

The plantar ligaments are two in number: a very strong one passes outwarks anet forwards from the outer sicle of the hase of the internal cuneiform to the apex of the mirdle cumeiform, winding somewhat to its outer side. The sorond connects the apex of the extrmal cunciform with the anterior half of the inner surface of the cuboid along its plantar horder, joining with the plantar scapho-cuboid ligarnent behincl.

The interosseous ligaments are three in numbrer. They are strong and deep 
masses of ligamentous tisure which connect the middle cunciform with the intemal and external cuneiform hones, and the external cmeiform with the culwid; oecupying all the non-articular portions of the apposed surfaces of the bones. The ligaments extend the whole vertical depth hetween the midrlle cuneiform and the external, and the external cunciform and the cuboid, and blend with the dorsal and plantar ligaments; they are situated in front of the articular facets, and completely shut off the synovial eavity behind from that in front. The liganent hetween the internal and middle cuneiform bones oceupies the inferior and anterior two-thirds of the apposed surfaces, and does not generally extend high enough to scparate the synovial cavity of the anterior tarsal joint from that of the second and third metatarsal and cumeiform bones. If it does extend to the dorsal surface, it divides the facets completely from one another, making a seventh synovial sac in the foot.

The synovial cavity will be described later on.

The arterial supply is from the metatarsal and plantar arteries.

The nerves are derived from the anterior tibial, and internal and extemal plantar.

The movement permitted in these joints is very limited, and exists only for the purpose of adding to the general pliancy and elasticity of the tarsus without allwwing any sensible alteration in the prsition of the different parts of the foot, as the medio-tarsal and calcaneo-astragaloid joints do. It is simply a gliding motion, and either deepens or widens the transverse arch. The external cuneiform being wedged in between the others is less movable, and so forms a pivot upon which the rest can move. The movement is more produced by the weight of the body than by direct muscular action; and of the muscles attached to this part of the tarsus, all deepen the arch save the tibialis anticus, which pulls the internal cuneiform up, and so tends to widen it.

\section{(c) The Medio-tarsal or Transverse Tarsal Jonnts}

The articulations of the anterior and posterior portions of the tarsus, although in the same transverse line, consist of two separate joints, viz. (i) an inner, the astragalo-scaphoid, which communicates with the anterior calcaneo-astragaloid articulation; and (ii) an outer, the calcaneo-cuboid, which is complete in itself. The movements of the anterior upon the posterior portions of the foot take place at these joints simultaneously. It will be most convenient to deal with the joints separately as regards the ligaments; while the arteries, nerves, and movements will be considered together.

\section{(i) The Astragalo-scaphoid Articulation}

\section{Class.-Diarthrosis. Subdivision.-Enartherodia.}

This is the only ball-and-socket joint in the tarsus. It communicates with the anterior calcaneo-astragaloid articulation, and two of the ligaments which close it in do not touch the astragalus, but pass from the calcaneum to the scaphoid. The uniting ligaments are:-

$$
\begin{gathered}
\text { External calcaneo-scaphoid. Inferior calcaneo-scaphoid. } \\
\text { Astragalo-scaphoid. }
\end{gathered}
$$

The external calcaneo-scaphoid has been already described (page 283).

The inferior calcaneo-scaphoid ligament (figs. 256 and 257 ) is an exceedingly dense thick plate of filoro-clastic tisene. It extends from the sustentaculum tali and the under surface of the calcanem in front of a ridge curving outwards to the anterior tubercle of that bone, to the whole width of the under surface of the seaphoid, and also to the imner surface of the scaphoid behind the tuhercle. Internally it is blended with the anterior jortion of the intemal lateral ligament of the ankle, and externally with the lower horder of the external calcaneo-scaphoid ligament. It is thickest along the inner border. Its upper surface loses the well- 
marked fibrous appearaner which the ligament has in the sole, and becomes smooth and faceted. In contact with the under surface of the ligament the tendon of the tibialis postims passes, giving considerable support to the head of the astragalus by assistine the power and protecting the spring of the ligament. The fibres of the ligiment run forwards and inwards.

The astragalo-scaphoid ligament is a hroad, thin, but well-marked layer of fihres which passes from the dorsal and external surfaces of the neck of the astragalus to the whole length of the clorsal surface of the scaphoid. Many of the fibres converere to their insertion on the scaphoid. The fibres low down on the outer side

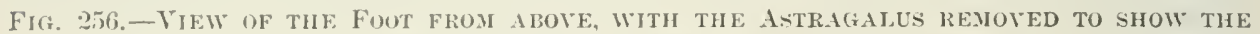
IXEERIOR ANI EXTERAAL CAlCANEO-SCAPHOID LILAMENTS.

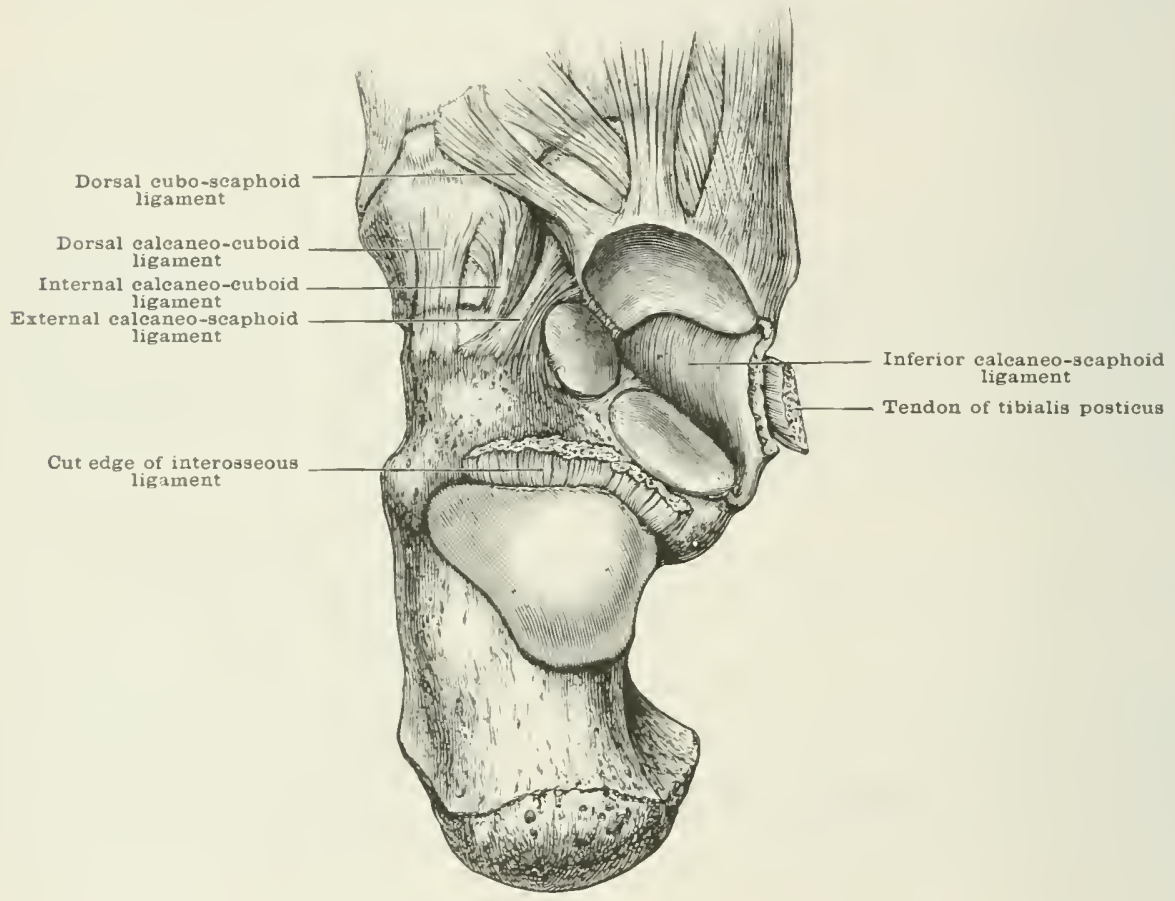

blond a little way from their origin with the upper edge of the external calcaneoscaphoid liganent, and then pass forwards and inwards to the seaphoid; those next above pass obliquely and with a distinet twist over the upper and outer side of the head of the astragilus to the centre of the dorsum of the scaphoid, overlapping fibres from the inner sille of the astragalus as well as some from the anterior ligament of the ankle-joint.

Synovial membrane.-The astragalo-seaphoid is lined by the same synorial nembrane as the anterior calcaneo-astragaloid joint.

(ii) The Culcaneo-cuboid Articulation

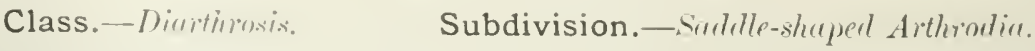

The ligaments which mite the lounes forming the outer part of the nedio-tarsal joint are:-

Internal or interosicous (allaneo-cuboid.

Inong inferior calcaneo-cuboil.

Dorsal caleaneo-cuboid.

Short inferior calcaneo-cuboir.

The internal or interosseous calcaneo-cuboid ligament (fig. 256) is a strong band of fibres attached to the os calcis along the imere prart of the non-articular 
rilge above the articular faret for the cuboid, and also to the upuer part of the internal surface close to the articular margin, and passes forwards to be attached to the depression on the internal surface of the euboid, and also to the rough angle between the internal and inferior surfaces. At the calcaneum this liganent is dosely connceted with the "xternal calcaneo-scaphoid ligament. Toware the sols it is connecter with the short inferior calcaneo-cuhoid ligament, and superiorly with the ilorsal alcaner)-cuboicl.

The dorsal calcaneo-cuboid (fig. 2.5 $(i)$ in attached to the dorsal surfaces of the two hones, exteuding low down externally to blend with the outer part of the short plantar ligament. Over the inner half, or nore, the ligament stretches some distance lerond the margins of the articular surfaces, reaching well forwarls upon the ruboid to be attached about miclway between its anterior am posterior borders;

FIG. 25\%.-LIGAMENTS OF THE SULE OF THE LEFT FUUT.

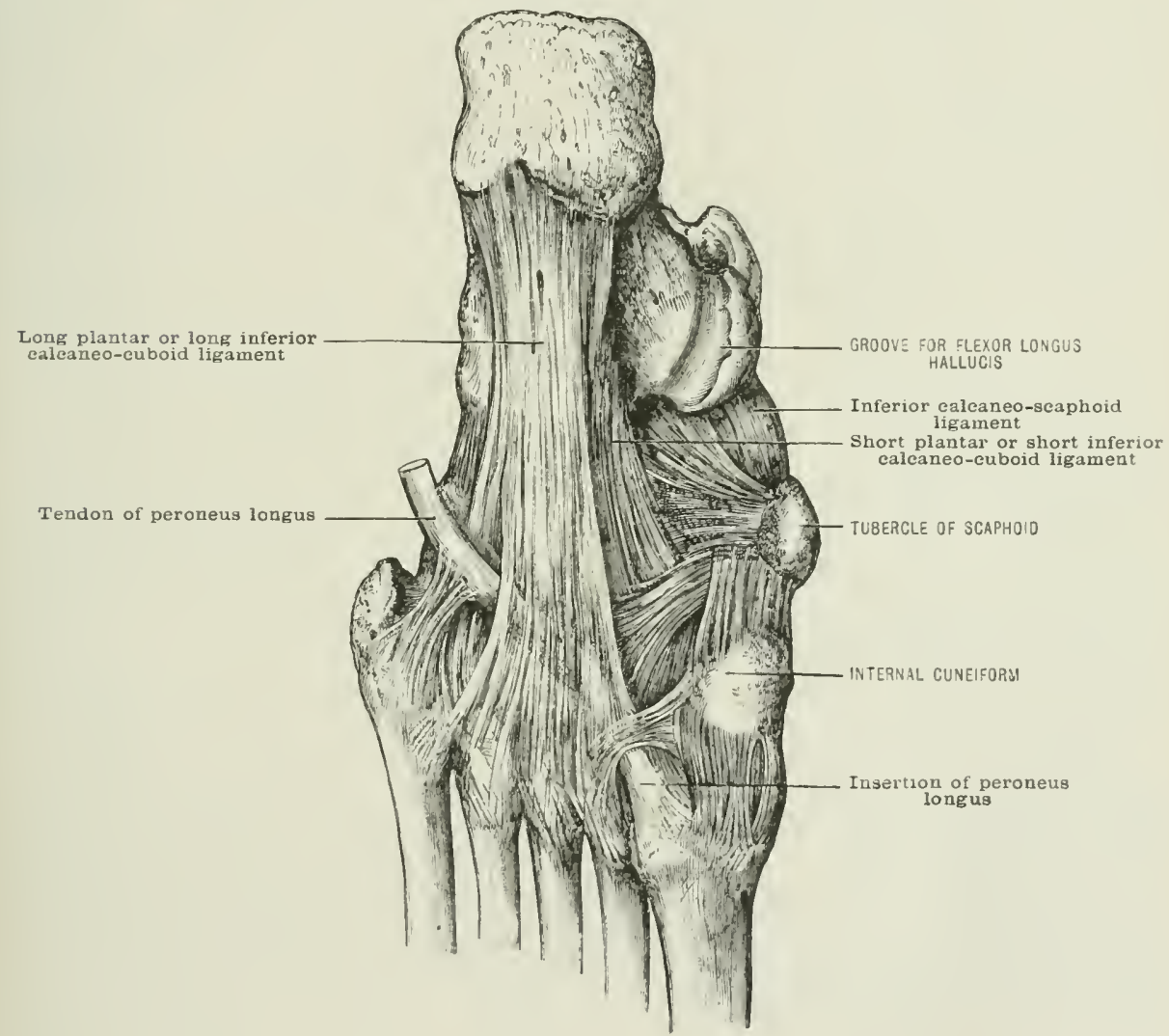

hut towark the outer side, the ligament is much shorter, and is attachect to the culudid behind its tulwele.

The long inferior calcaneo-cuboid (the long plantar) (fig. 22.7) is a strong dense band of fibres which are attached posteriorly to the whole of the under surface of the calcanem between the posterior tubercles and the romblerl eminenee (the anterior tubercle) at the anterior end of the bone. Most of its fibres pass directly forwarels, and are fixed to the outer two-thires or more of the obligur ridge behind the peroneal groove on the eubod, while some pass further forwards and inwards, expanding into a broad layer, and are inserted into the hases of the second, thirl, fourth, and immer half of the fifth metatarsal bums. This anterior expanderl portion completes the canal for the peronens longus temlon, and from it: under surface arise the adductom hollncis and the flexor bretis minimi digiti muscles.

The short inferior calcaneo-cuboid (short plantar) (fig. 25\%) is attached to 
the rounded eminence (anterior tubercle) at the anterior end of the under surface of the ealeanemm, and to the lone in fromt of it, and then takes an oblique course forwarks and inwards, and is attareded to the whole of the depressed inferior surface of the cubsid behind the olligue ridge, except its outer angle. It is strongest near

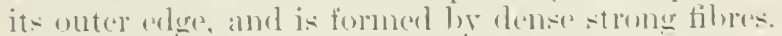

The synovial membrane is listinet from that of any other tarsal joint.

The arterial supply of the merlio-talsal joints is from the anterior tibial, from the tarsal ancl metatarsal branches of the dorsalis pedis, and from the plantar arterius.

The nerve-supply of the medio-tarsal joints is from the external division of the anterior tilial, and occasionally from the musculo-cutaneous or external plantar.

The movements which take place at the medio-tarsal joints are mainly flexion and extension, with superadded lateral and rotatory movements. Flexion at these joints is simultaneons with extension of the ankle. and rice rerki. Flexion and extension do not take place upon a transverse, but round an ohlique axis which latseses from within outwards. and somewhat backwards and downwards through the astragalus and calcaneum.

Combind with flexion and extension is also some rotatory motion round an antero-posterior axis which turns the inner or outer border of the foot upwards. There is also a fais amount of lateral motion whereby the foot can be inclincel inwarks (i.e. arklucted) or outwards (i.e. abrlucted).

These movements of the medio-tarsal joint oceur in conjunction with those of the ankle and calcaneo-astragaloid joints. Rotation at the calcaneo-astragaloid joint is, liowever, romol a vertieal axis in a horizontal plane, and so turns the tocs inwards or outwards; whereas at the medio-tarsal union, the axis is anteroposterior and the inner or outer edge of the foot is turned upwards. Gliding at the ("alcanco-astragaloid joint elevates or depresses the edge of the foot. while at the medio-tarsal it adduct: or abducts the toes without altering the relative position of the calcaneum to the astragalus.

Thus flexion at the medio-tarsal joint is associated with adduction and inward rotation of the foot. oreuring simultaneousy with extension of the ankle; and extension at the medio-tarsal joint is associater with aluduction and outward rotation. octurring simultaneously with flexion of the ankle.

Flexion and adduction are far more free than extension and aluluction. which litter morements are arrested by the ligaments of the sole as soon as the foot is hought into the presition in which it rests on the ground.

Although the astragalo-saphoid is a lall-and-socket joint, ret, owing to the union of the scaphoid with the cuboid, its movements are limited by the shape of the calcaneo-culvid joint; this latter being coneavo-convex from above downwards, prevonts rotation round a rertical axis, and also any side-to-side motion except in a direetion obliquely downwards and inwards, and ipwards and outwards. This is also the direction of freest movement at the astragalo-seaphoid joint. Movement is alse limiter ly the ligamentous union of the calcaneum with the scaphoid. The twisting movement of the foot. such as turning it upon its inner or outer edge, and the increase or chiminution of the arch, take place at the tarsal joints, capecially the medio-tarsal and (aleane(1-instragaloid artieulations. Here too those changes oceur which, owing to paralysis of some muscles or contraction of others, result in talipes cepuino-varus, or valinis.

\section{TIIE TARSO-METATARA AL ARTICLLATIONS}

There may he said to le thee articulations betwen the tarsus and metatarsus, viz:-

(a) The Internal, between the inner anneiform and first metatarsil bones. bones,

(b) The Middle, hetween the three cunciform and seeond and third metatarsal

(c) The Outer, or cubo-metutarsal. betwern the cuboid and fourth and fifth metatarsal bones. 
The arteries for the tarso-metatarsal joints are derived: (1) for the internal. from the dorsalis pedis and internal plantar; (2) for the rest, twigs from the metatarsal and deep plantar arches.

The nerve-supply comes from the anterior tibial and plantar nerves.

The movements permitted at these juints are flexion and extension of the metatarsus on the tarsus; and at the imner and outer divisions, slight adduction and abduction. In the outer, the lateral motion is freer than in the inner joint, and frest between the fifth metatarsal bone and the cuboid. In the inner joint, flexion is combined with slight alyduction, and extension with adduction.

There is also a little gliding, which allows the transrerse arch to be increased or diminished in depth; the inner and outer two bones sliding downwards, and the two middle a little upwards, when the arch is increased; and rice rerat when the arch is flattened.

(a) The Internal Tario-metatarsal Joint

\section{Class.-Diathrosis. Subdivision.- - tithrodia.}

A complete capsular ligament unites the first metatarsal with the internal cumeiform, the fibres of which are very thick on the under and inner aspects; those on the outer side pass from behind forwards in the interval between the interosseous ligaments which connect the two bones forming this joint with the second metatarsal. The ligament on the plantar aspect is by far the strongest, and blends at the cuneiform bone with the scapho-cuneiform ligament.

\section{(b) The Middle Tarso-Metatarsil Joint}

\section{Class.-Diathrosis. Subdivision.-Arthrodia.}

Into this union there enter the three cuneiform and second and third metatarsal bones, which are bound together hy the following ligaments: dorsal, plantar, interosseous.

The dorsal ligaments.-1. Some short fibres cross obliquely from the outer cdure of the internal cuneiform bone to the inner border of the base of the second metatarsal bone; they take the place of a dorsal metatarsal ligament which is wanting between the first and second metatarsal bones.

2. Between the middle emneiform and the base of the second metatarsal bone some fibres run directly forwards.

3. The external cuneiform is connected with (1) the outer corner of the second metatarsal bone by a narrow band passing obliquely inwards; ( 2 ) with the third metatarsal by fibres passing directly forwards ; and (3) with the fourth metatarsal by a short band passing obliquely outwards to the inner edge of its base.

The plantar ligaments. - A strong ligament unites the internal cuneiform and the bases of the second and third metatarsal bones. The tibialis posticus is inserted into these bones close beside it. Other slenter ligaments connect the middle cuneiform with the second, and the external cunciform with the third metatarial bones.

The interosseous ligaments.-(1) A strong broad interosseous ligament extends between the outer surface of the internal cuneiform, and the inner surface of the hase of the second metatarsal bone. It is attached to both bones below and in front of the articular facets, and separates the middle from the internal tarso-metatarsal joint. (2) $\mathrm{A}$ second band is attached behind to a fossa on the anterior and onter edge of the extemal cuneiform and to the interosseous ligament botween it and the cuboid, and passes horizontally forwards to he attached to the whole depth of the fourth metatarsal bone hehind its internal lateral facet, and to the opposed surfaces of the third and fourth helow their lateral articular facets. It separates the middle tarso-metatarsal, and intermetatarsal between the third and fourth bones, from the cubo-metatarsal joint. It is more fimly connected with the third bone than with the fourth. (3) i slender ligament composed only of a few fibres often passes from a small tubercle on the inner and anterior edige of the 
"xternal cuneiform to a eroove on the outer eflere of the second metatarsal bone letween the two lateral facets.

The synovial membrane is prolonged forwarls from that of the scapho-euneiform and inter-e-unciform anticulations:

(1.) THE ('TBO-Metatahsal Jont

\section{Class.-I Initherix. Subdivision.-Athrodiu.}

The bones amprising this joint are the fourth and fifth metatarsal, and the anterior surfare of the culworl. firmly commected on all sides by
Hor:il
Plantar.
Interosseous ligaments.

The plantar cubo-metatarsal ligament is a broul, well-marked ligament, which extends fronl the cuboid behind to the bases of the fourth and fifth meta-

Fig. 25.-—iection to sHow the syovial Cavities of the Foot.

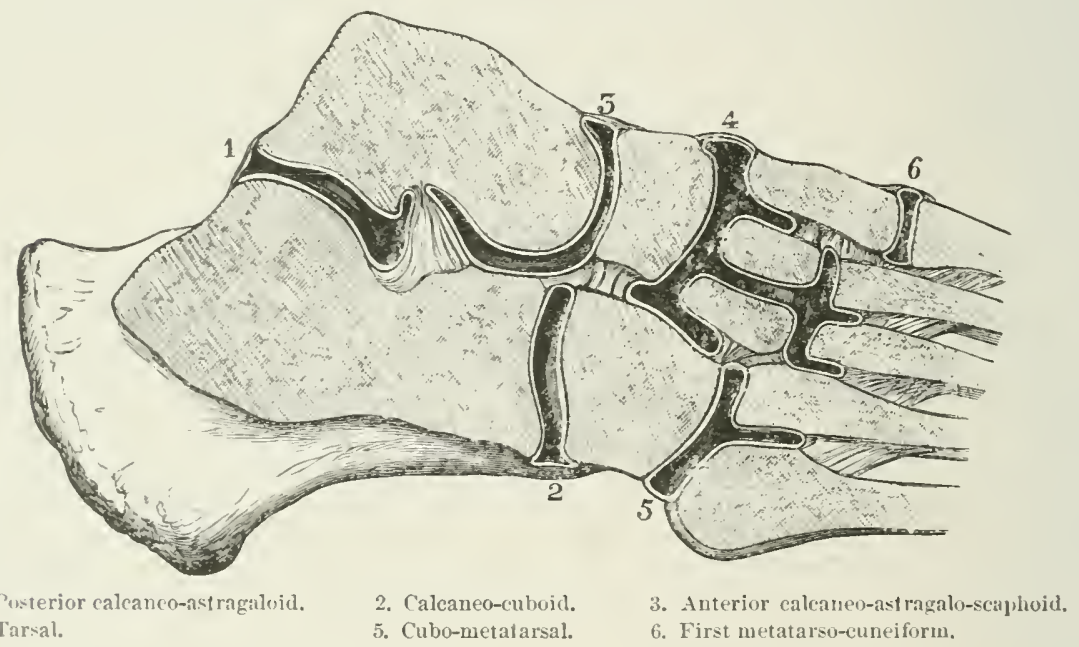

tarsal bones in front. It is continuous along the groove at the base of the fifth metatarsal bone with the dorsal ligament, and as it passes romet the outer borter of the fort it is somewhat thickened, and may be described as the external cubometatarsal ligament. On its inner sicle it joins the interosseous ligaments, thus (ompleting the calmole below. It is not a thick structure, and to see it the long phantar liganent, the peronens longus, and extemal slip of the tibialis posticns must be removed; the attadment of these struetures to the fonth and fifth metatarsal bomes comsillorahly axists to mite them with the tarsus.

The dorsal cubo-metatarsal ligament is composerl of fibres which pass obliguely ontwards and forwards from the "uberel to the hases of the fourth and

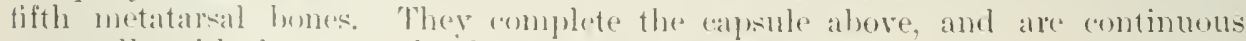
externally with the extemal cibu-metatarsal ligannent.

The interosseous ligament huts off the culx-metatarsal from the midkle tarsonetatalsal joint. It is attacherl to the external (omejform behind, and to the whole depth of the fourth meetataral behind its internal lateral facet, anel to the appesed surfaces of the thiml ame fourth lomes lwew their articular facets. It $j$ continuous below with the plantar licament.

The synovial membrane is selvitute from the other syovial sacs of the tarsus, and is continued between the fourth and fifth metatarial hones. 


\title{
7. THE INTERMETATARSAL ARTICILATIONS
}

\author{
Class.-Dierthrowis. Subdivision.-Aithrodia.
}

The bases of the metatarsal bones are fimly held in position hy dorsal, plantar, and interosseous ligaments. The first occasionally articulates by means of a distinct facet with the second metatarsal (figs. 183 and 184, Section I).

The dorsal ligaments are broad, membranous bands passing between the four outer toes on their dorsal aspect; but in place of one between the first and second metatarsal bones a ligament extends from the internal cuneiform to the base of the second metatarsal bone (page 277 ).

The plantar ligaments are strong, thick, well-marked ligaments which connect the bones on their plantar aspect.

The interosseous ligaments are three in number, very strong, and are situated at the points of union of the shaft with the bases of the bones, and fill up the sulci on their sides. Ther limit the srnovial carities in front of the srnovial facets.

The common synovial membrane of the tarsus extends between the second and third. and third and fourth bones; that of the cubo-metatarsal joint extending between the fourth and fifth.

The arterial and nerve-supply is the same as for the tarso-metatarsal joints.

The movements consist merely of gliding, so as to allow the raising or widening of the transverse arch. Considerable flexibility and elasticity are thus given to the anterior part of the foot, enabling it to become moulded to the irregularities of the ground.

\section{The Lijon of the Heads of the Metatarat Bones}

The heads of the metatarsal bones are connecter on their plantar aspect hy the transverse ligament, consisting of four bands of fibres passing transversely from hone to hone, hlending with the fibro-cartilaginous or sesamoid plates of the metatarso-phalangeal joints, and the sheaths of the flexor tendons where they are connected with the fibro-cartilages. It differs from the corresponding ligament in the hand by having a band from the first to the second metatarsal bone.

\section{\&. THE YETATARSO-PHALANGEAL ARTICLIATIONS}

(a) The Metatarso-phalaxgeal Jonts of the Folr Outer Toes

$$
\text { Class.-Diathirasis. Subdivision.-Condylarthrosis. }
$$

These joints are formed by the concare proximal ends of the first phalanges articulating with the romded learls of the metatarsal bones and united by the following ligaments:--

$$
\text { Two lateral. Dorsal. Plantar sesamoid plate. }
$$

The two lateral ligaments are strong bands passing from a ridge on each sicle of the head of the metatarsal bone to the sides of the proximal end of the first fhalanx. and also to the sides of the sesamoirl plate which mites the two bones on their plantar surfaces. On the dorsal aspect they are united by the dorsal ligament.

The dorsal ligament consists of lonse fine fibres of areolo-fibrous tissue, extending between the lateral ligaments, thus completing a capsule. It is connecterl by fine fibres to the under surface of the extensor tendons, which pass over and ennsiderably strengthen this portion of the capsule.

The plantar sesamoid plate helps to deepen the shallow facet of the phalanx for the head of the metatarsal hone, and colresponds to the glenoid ligament of the fingers. It is firmly onnected to the lateral ligantents and the transverse ligament, and is gronved inferiorly where the Hexor tendons pass orer it. It serves to prevent dorsal dislocation of the plualamx. 
The secomel metatarso-phalangeal joint is a quarter of an inch in front of both the first and third metatarso)-platang(al joints.

The third metatarso-phalangal joint is a yuarter of an inch in front of the fourth. and the fourth three-eighths of an inch in front of the fifth.

The head of the fifth metatarsal is in line with the neck of the fourth.

Thus the outer side of the longitudinal arch of the foot is shorter than the inner; it is also distinetly shallower.

\section{(b) The Metatako-phalangeal Jolnts of the Great Toe}

The metatarso-phalangeal joint of the great toe differs from the rest in the following particulars:-

(1) The bones are on a larger sciale, and the articular surfaces are more extensive.

(2) There are tro grooves on the plantar surface of the metatarsal hone, one on eich sille of the merlian line, for the sesamoid bones.

(:) The sesamoid bones replace the fibro-cartilaginous or sesamoid plate. They are two smatl hemispherical bones developed in the tendons of the flexor hrevis hallucis, convex below, but flat above where they play in grooves on the head of the metatarsal bone; they are united by a strong transverse ligamentous band, which is smooth below and forms part of the chamnel along which the long flexor tendon plars. They are firmly united to the base of the phalanx by strong short fibres, hut to the netatarsal bone they are joined hy somewhat looser fibres. Laterally they are connected with the lateral liganents and the sheath of the flexor tendons. They provide shifting leverage for the flexor brevis hallucis as well as for the Heror longus hullucis.

The arteries come from the digital and internssens limehes; and the nerves from the cutaneous digital, or from small twigs of the nerves to the interossei muscles.

The movements permitted are: flexion, extension, abduction, adduction, and circunduction.

Flexion is more free than extension, and is limited by the extensor tendons and dorsil ligaments; extension is limited hy the flexor tenclons, the plantar fibres of the lateral ligaments, and the sesamoid plates. The lateral motion is possible from the shape of the hony surfaces, hut is very limited, heing most marked in the great toe. It is limited by the lateral ligaments and sesamoid plates.

\section{THE INTERPHALANGE\L JOINTS}

\section{Class. - Diverthrosis.}

\section{Subdivision.-Ginglymus.}

The articulations between the first and scoond, and second and third phalanges of the toes are similar to those of the fingers, with this important difference, that the hones are smaller and the joints, especially between the second and third phalanges, are often ankylosect. The liganents which unite them are:-
Two lateral.
Dorsal.
Glenoid ligament.

The two lateral liguments are well marked, and pass on eadr sicle of the joints from a little rough depresion on the head of the proximal, to a rough border on the sicke of the hase of the distal phalinx of the joint.

The dorsal ligament is thin and memlownous, and extends across the joint from one lateral ligament to the other heneath the extensor tendon, with the deep surface of which it is eommertext, and hy which it is strengthened.

The glenoid ligament corrers in the joint on the plantar surface. It is a fibrocartilaginous plate, commerted at the sides with the lateral liganents, and with the bones by short ligamentous fibres; the plantar surface is smooth, and grooved for the thexor temelons.

The arteries and nerves are derived from the eorresponding digital branches.

The only movements permitted at these joints are flexion and extension. 
At the interphalangeal joint of the great toe there is very frequently a small sesamoid bone which plays on the plantar surface of the first phalamx, in the same way as the sesanoid hones of the nnctatarso-phalangeal joint play upon the plantar surface of the head of the metatarsal bone.

\section{Horphology of Ligaments}

The various ligaments of the human body have, in very many instances, been evolved as the result of secondary changes in muscles aljacent to joints. In a few instances, ligaments represent the degenerate remnants of eartilaginous and bony elements. Cilysular ligaments are in most joints derived from the periosteum, but they may be strengthened by the incornoration of tendons detached from adjacent muscles.

Muscles arising fiom, or inserted into bones in the inmediate vicinity of a joint tend to become metamorphosed into tendon near their attachments, and a comprehensive sturly of myology in low vertebrate forms indicates that there is associated with this tissue-thange at tendency for the muscle to alter its point of attachuent; hence a muscle originally inserter below a joint inay eventually come to have its insertion above the joint. In the same way, a muscle arising above a joint may, as a result of altered environment, shift its origin to some point below the joint. To this change of position the term migration of muscles has been applied. In many instances a portion of the muscle equivalent to the distance between the original and the aequires attachment persists as a fibrous band and fulfils the function of a ligament. This is well seen in the knee-joint, where the internal literil ligament is derived from the adductor magnus, this muscle having shifted its insertion from the tibia to the femur. In the same way the external lateral ligament represents the tendon of the peroneus longus, which has migrated from the feruur to the head of the fibula.

One of the most remarkable examples of a tendon divorced in this way is the ligamentun teres in the hip-joint. 'This curious structure was in all probaloility the tendon of the pectineus, which has been cletached from the muscle in consequence of the profound alterations which have taken place in the limb during its evolution.

Among other ligaments derived in a similar way from museles may be mentioned the greater sacro-sciatic ligament. 'This was originally the tendon of origin of the biceps femoris. $(\mathrm{H}$. Morris, "A Note on Three Points in Anatomy," Med. Times and Gazette, April 7 , 187 7 , p. 361.) The lesser sacro-sciatic is derived from the fibrous retrogression of portions of the coccygeus. The sicro-coceygeal ligaments represent the muscles which lift, depress, and wag the tail in those nammals furnished with such an appendage; indeed, these ligaments are oceasionally replaced by muscle-tissue.

The coraco-humeral ligament is deriver from the original tendon of insertion of the pectoralis minor, and not unfrequently the uuscle is inserted into the lesser tuberosity of the hmmerus, the ligament being then replaced by the tendun of the musele. 'The coraco-clavieular, rhomboid, and gleno-humeral ligaments are probally derived from modifications of the subclavius muscle.

The vertebral column contains several ligamentous structures of great morpholugical interest. The pulpy substance in the centre of each intervertebral dise is derivel from the notochord; the suspensory ligament passing from the tip of the odontoirl process to the anterior margin of the furimen magnum is a remnant of the sheath of the notochord, and indieates its position as it passed from the vertebral column into the base of the cranium. 'The transverse ligament of the atlas (as pointed out by Professor Cleland in 1859 and 1861), is a persistent and functional form of the posterior eonjugal ligament uniting the rib-heads in seals and many other mammals, whilst the interosseous ligament of the head of a rib in man is the feeble representative of this structure in the thoracic region of the spine. 'The ligamentum conjugale enstarum was described hy Mayer in 1834 (Arehives d'Anatomie de Muller). According to Luschka's aceount of this ligament it would seen as thou chl the posterior superior fibres of the capsule of the costo-central joint represented it in man, rather than the interosseous ligament.

Many of the subcutaneous tracts of fascia and many aponeuroses in the human body are derived from the metamorphosis and retrogression of muscle-tiscue. 


\title{
SECTION III
}

\section{TILE MUSCLES}

\author{
BY.J. Y. C. DAYTES-COLLEY, M.A., M.C.CANTaB., F.R.C.S.
}

SURGEON TU ANI) LECTURER ON SURGERY AT GUY'S HOSPITAL; MEMBER OF THE COURT OF EXAMIXERS OF THE ROYAL CULLEGE OF SLRGEONS UF ENGLAND; FORMERLY LECTURER ON ANATOMY AT GUY'S IIOSPITAL,

$T^{\text {H }}$

HE Muscles consist chiefly of transversely striated fibres arranged in fasciculi or bundles of rarious sizes; and also of white fibrous tissue, which forms the flattened cords or sheets, the tendons and aponeuroses, as they are called, by which most of the muscles at one or both ends are attached to the bones or (artilages.

In the account of each individual muscle, it is convenient to divide the description into s'ven hards, viz.:-1. the name; 2. the shape; 3 . the attachments; 4. the stucture: 5 . the nerve-supply; 6 . the action; and 7 . the relations. A short account al:o of the more important rariations will be added.

1. The name is given for various causes, and frequently when it consists of more than one word, for two or even three causes, viz.: ( $(1)$ the supposed action, \&.g. adductor and sartorins; (b) the shape, e.g. triangularis and lumbricalis; $(c)$ the direction, e.g. rectus (straight), ohliquns (slanting); (d) the position, e.g. sublinis (neal the surface), profundus (far from it), gluteus (in connection with the nates); (e) its livisions and complexity, e.g. biceps, triceps, multifidus; $(f)$ its size, as nagnus. minimus, fe.; (g) its attachments, e.g. stemo-cleidomastoidens.

2. The shape is sometimes difficult to define on account of the irregularity of the coutline, and curviture of the surfaces of the muscle. Some are narrow and of a flattrued crlindrical form, which may be designated ribbon-shaped. Many of these are lininished at their cxtremitios, and may be called fusiform or spindleshapued. ()ther's are lroad, and form sheets of various thicknesses, which, according to their outline, may be described as fan-shaped, rhomboidal, triangular, or quadrilateral. Nany, again, are compound muscles with double or multiple origins or insertions, which are callerl, from this canse, bicipital, trifid, \&e. This is often the rase when a strong musele arises from many points of hone, or when a nuscle divides into many tendoms lwow to movesereral small levers, such as the bones of the fingers and toes. I few have temdons interealated in their length, and are called liventral or digastric musches. It is in some cases diflicult to comprehend why certain muscles, wn the me hand, which appear to be sejarate, are grouped moler cme name as a compromul muscle; and, on the other hand, muscles which might very well he combined are distingmished hy separate names. The principle of distinction appears to have beren to group muscles which ambine to form one lwelly, and to selarate those in which the tendons alone are minted.

3 . Of the attachments, the more fixed end of the muscle is usually ealled the origin, the more movalle the insertion. In enumerating the various points of 
attachment, it is rery necessary to bear in mind not only those to hone and cartilage, but also those to the filorous septa and alponeuroses which lie between and around the muscles. Such attachments are best seen when the area of bone surface available for origin or insertion is small. By this means a very great extension is given to this area, and a small bony process, such as the inner condyle of the humerus, is able to give a firm resistance to the traction of many strong muscles.

4. The structure will inclurle not only the direction and curvature of the fleshy fibres, and the extent of fibrous tissue by which these fibres arise or are inserted; but also the internal arrangement of tendons and muscular fibre, which is often of a somewhat complicated character. The simplest structure of all is that of muscles with no tendons, in which the fleshy fibres run parallel from one end to the other. Many of the small muscles of the face are of this character. The sterno-mastoid and sartorius are examples also of muscles in which the parallel Heshy fibres form nearly the whole of the structure. It will be found that in these muscles, on account of the number of joints passed over and the distance of the line of the muscle from the axes of these joints, the range of movement is very great. In most parts of the body, howerer, there would be a great waste of fleshy fibre if this arrangement prevailed. Roughly speaking, we may say, that when fleshy fibres contract fully, their length is diminished by one half. Now, if the distance between the movable points of the skeleton which are joined by the muscles cannot be lessened by this amount, it is obrious that some of the contractile power of the muscle would be wasted. When, therefore, the movable points of the skeleton bridged by a muscle can only be approximated through a limited space, it will be found that the parallel fleshy bundles are about twice the length of this space, and that the rest of the muwe consists of inextensible tendon, which acts simply as a liganent to attach the contractile muscle to the bones. But this addition of tendon to the fleshy part of the muscle is effected in various ways. The simplest plan is that in which the addition is made at one end or the other of the muscle. The pahnaris longus is to some extent an example of such an arrangement. By examining the bones it will be seen that the front of the carpus camnot be approximated to the internal condyle of the humerus by more than thre inches. The tleshy bundles are, therefore, of about twice this length, and they are accumulaterl towards the upper end of the musele, while the rest of its length is ocenpied by a long tenckm. A more common arrangement is for the short fleshy fibres to arise in succession along the surface of a long bone or from an intermuscular septum, and to patss in parallel lines to the end and side of a long tendon, which gradually thickens with the increase of the number of the fibres inserted into it. Such a muscle is like a feather, of which the quill with its diminishing upuer extremity will represent the tendon. and the barbs upon one side of it the fleshy fibres. Hence this arrangement is called jenniform, from penna, a father (fig. 259). This form is found when considerable power is required, but with only a small range of movement. To appreciate fully the effect of such a muscle, we should in our imagination take all the short parallel fibres and place them side by side at the end of the tendon. The muscle would then be converted into a very thick and short fleshy mass with a very loug tendon.

Frequently a muscle arises in two lines from the adjacent surfaces of two bones. from which two sets of parallel fibres converge upon a tendon which runs down in the interval between the bones. This arrangement resembles a feather with larbs on either side of the quill, and is called bipenniform. Examples of both these forms are found in the leg. The peromei arising from the fibula alone are penniform, while the tibialis posticus and soleus, arising from both tibia and fibula, are bipenniform.

In some cases a further complication is introduced by the origin of a muscle from both sides of several fibrous septa, as well as from the intermerliate surfaces of the bone to which the septa are attached. The insertion may also be of the same character. A good example of this, which is alled the multipenniform arrangement, is the deItoid, a very powerful muscle with a short range of movement.

In some fer cases the tendon is interalated between two fleshy masses. Such museles are called biventral. The central tendon may represent a hony structure 
found in lower Vertebrata; and the two bellies mar sometimes be fairly regarded as distinct muscles. e.g. those of the digastric muscle. In some eases the central tendom may be of some service in preventing the pressure upon subjacent tissues which would nceur if the muscle were at this point floshy and free to thicken as it contracted. For cxample, it has been suggested that the central tendon of the omo-hyoid prevents that muscle from compressing the great vessels of the neck as it crosis them buneath the stemo-mastoid. In one muscle, the rectus abdominis, several of these tendinoms intersections are found.

5. Nerve-supply.-This is of much importance, not only from a medical and surgionl point of view, when the paralysis or spasmodic contraction of individual muscles has to he accounted for, but also because of the light which it throws

Fig. 259.-Diagay silowixg Pexxiform Muscle, the Peroneus Loxges; And BIPENTIFORH, THE THBAlds Posticts.

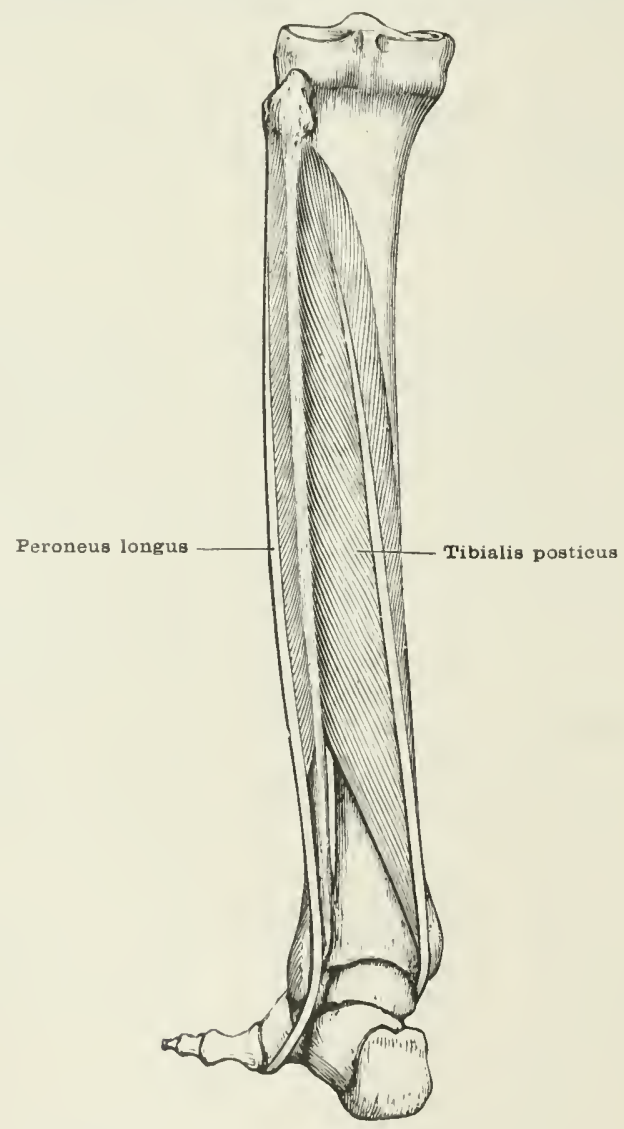

upon the actions of muscles, and the assistance which it sometimes gives us in grouping them.

6. Action.-Most museles act upon the bevers formed by the movable bones and eartilagrs. It will be anveniont, however, first to speak of those which do not ax in this manner. When a muscle passes from a fixed point like a bone to a freely movable point such as the under surface of the skin or muenus membrane. it will simply tend to approximate the movable point to the fixed origin. Such museles are found in abundanee in the face, and the azygos uvula is a good example of one which acts upon mueous membane. Again, the fibres of many muscles rum in parallel curves, which combine to form a curved hand or sheet. The first offert of the contration of such a musele will he to straighten or flatten out the curve. If this lies over al comver surface, as is usually the case, the action 
of the muscle will be to eompress the structures lying in its concavity. The buccinator and abtominal muscles are good examples of this form of nuscle. Or if the surface upon which the curved sheet lies is concare, the muscle will tend hy its contraction to lift up the soft parts upon its deep or convex surface. $A$ s an instanee of this we have the influence of the platysma myoides upron the fascia and other structures which overlie the great vascular channels of the neck and the apices of the lungs.

In estimating the effect of muscles acting upon the levers formed hy the bones, each of which moves upon a joint as its fulcrum, three points have to be taken into consideration:- (1) the order of lever; (2) the distance from the fulcrum, of the points of application of the force at the insertion of the muscle, and of the resistance to be overcome; and (3) the clirection in which the force is applied. It will be found that whereas in most levers employed in mechanics the object aimed at is what is called mechanical advantage, i.e. by the application of a small force to overcome a greater resistance; in the human body the object is, on the contrary, by the exertion of a great force through a small space to overcome a small resistance, but at the same time to cuuse motion through a much greater space, and with a much greater speed. In the three orders of levers, the fulcum is placed cither hetween the power and the resistance (first order); or at one end, with the power at the other, and the resistance to be overcome between (second order); or at one end with the power in the middle, and the resistance to be overeome at the other end (third order). The power required to orercome the resistance varies inversely with the distance of its point of application from the fulcrum. Where this distance, or the arm of the lever as it is called, is short compared with the arm at which the resistance acts, then the power has to be greater than the resistance, and rice rer.ti. In the first order of levers, if the power and resistance act parallel to one another, there may or may not be a gain of mechanical advantage, accorting as the arm at which the power acts is greater or less than the arm at which the resistance acts. In the second order of levers there must necessarily be mechanical advantage; and in the third order the power must be greater than the resistance, as it has to act upon a shorter arm, so there will be what may be termed mechanical disadrantage.

In the human body there is hardly a single muscle which forms a good example of a lever of the second order, for the simple reason that mechanical adrantage is of so much less importance than a wide range of movement with its attendant rapidity. The best example that can be given is that of some of the muscles which depress the mandible, e.g. the anterior belly of the digastric, which is inserted into the extremity of the lever formed by that lione, while the resistance to be orercome - viz. the tonic contraction of the masseter, temporal, and intemal pteryoid-is exerted at a point much nearer to the fulcrum upon which the mandible turns.

The muscles which are inserted upon the tendo Achillis are often given as an example of this order of lever, when by their contraction ther raise the heel and lift uy the body, the weight of which acts upon the lever of the foot through the ankle-joint. This would be a goor example if another person were to lay hold of the tendo Achillis, and by draving upon it to raise the individual from the ground. But the fact that the other end of the muscle springs from a part of the mass to be raised alters the conclitions, and, as a matter of fact, the muscle, instead of obtaining any mechanical atrantage in its artion, has to contract with a force four or five times as great as the weight to be raisel.

It will be found that most of the museles belong either to the third order, in which there is necessarily mechanical disadrantage, or to the first order; and in this case, the am at which the power acts is usually the shorter, sor that the power has to be greater than the resistance. In the movements of the forearm about the elbow as a fulcrum, the triceps acting with the very short arm afforded by the projection of the oleeranon and overeoming a resistance experienced by the hand at the other end of the radius and ulna, will be a lever of the first order. The brachio-raclialis (supinator longus) when used to flex the forearm acts at the lower end of the radius, so as to overcome the weight of the forearm and hand, which will act through a centre of gravity, which is about the middle of the radius. and therefore much nearer to the fulcrum at the ellow. It therefore forms a lever of the second order. If its angle of insertion were not so rery small, the muscle 
would thus shtiln a consirlerable mechanieal advantage. This extreme obliquity, howerer. artually places the musele in a condition of mechanical disadrantage. Lastly, the hicepis and brachialis antiens are hoth of them good examples of the thirl order of lever, when they act hy their insertion close to the fulcrum of the rlhow to Hex the forearm, the centre of gravity of which is much farther from the joint.

The direction of the temen at its point of insertion is of great importance in estinating the effect of the eontraction of any muscle. It is rarely perpendicular to its lever. There is, the efore, in nearly every ease, a considerable loss of mechanical advantage; but it should be remembered that this is more than counterbalanced by important gains. In the first place, the range and rapiclity of morment are greatly increased for a given contraction of the muscle; and in the second place a power is also produced by which the articular ends of the bones commected hy the muscle are pressed together, so that the tendency to dislocation of the joint is diminished. A third advantage is the compactness given to the limb by the tendons being placed in close apposition to the bones, an object which could not be attained unles their insertions were very oblique.

Take the case of the brachio-radialis flexing the forearm. In the adjoining cliagram let $\mathrm{E}$ he the ellow, $\mathrm{B}$ E the humerus. $\mathrm{E} R$ the radius, and $\mathrm{B} \mathrm{R}$ the line of the brachio-radialis. To estimate how much of the contracting foree of the muscle is actually expended in flexing the forearm, all that is neeessary is to take any point $\mathrm{K}$ in $\mathrm{B} \mathrm{R}$, to draw $\mathrm{KA}$ perpendicular to $\mathrm{E} \mathrm{R}$, and form a rectangle $\mathrm{R} \mathrm{A} \mathrm{K} \dot{\mathrm{C}}$, on $\mathrm{P} A$. If the forre of the muscle acting along $\mathrm{R} \mathrm{B}$ be represented by the line $\mathrm{R} K$, then $\mathrm{R} C$ ' will represent that portion of the foree which tends to flex the

FIG. 260.

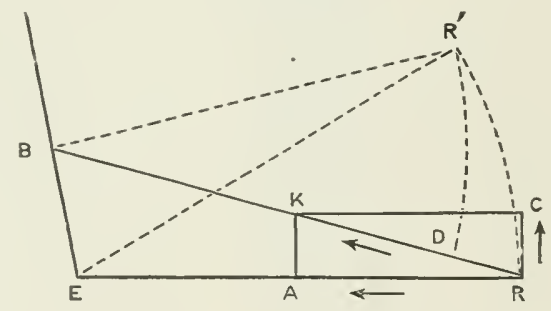

clbow, and R A the portion which is devoted to compression of the head of the radius against the capitellum of the humerus, so as to strengthen the elbow-joint. Again, let $E R^{\prime}$ be the new position of the forearm after the brachio-radialis has contracted. The are of the eirele through which it has moved will be indieated by $R R^{\prime}$. a small are drawn with radius $R E$, and centre $E$. Now join $R^{\prime}$ to $B$, and draw another small are $\mathrm{R}^{\prime} \mathrm{D}$ with centre $\mathrm{B}$ and radius $\mathrm{R}^{\prime} \mathrm{B}$. $\mathrm{R}$ D being the clifference between B R and B R', will indieate the amount by which the length of the musedr has diminished during its eontraction, and $R R^{i}$ will represent the sprace through which the lower end of the radius has moved. A comparison of the lengths of $R$ D and R R' will show how great has been the gain in range of moremont hy the oblique insertion of $B R$. If the muscle had been inserted at right angles to E R, it would, in order to produce the same effect, have had to contract through a spare equal in length to $R R^{\prime}$. With its ollique insertion a contratction equal in length to $R$ D) has sufliced. The gain in range (and therefore in rapidity of morement, for br eontrating through the short distance it eauses a simultaneons motion through the longer space) may be roughly represented by the fraction $k n$. In museles in which the insertion of the tendon is at a very small angle, the loss of power is proportionately greater, and the gain in speed and range enormous. As instances of this may be mentioned the insertions of the tendons of the phalanges, which produce the comparatively feeble, but excepdingly nimble, movements of the fingers with a very small eontraction of the forearm muscles.

In speaking of the direction of the muscles, it should dearly be understood that 
this refers to the angle of the attachment of the tenclon to the lever which has to be moved, and not to the general direetion, which is often changed by thr passige of the tendon or muscle over projections of bone or under arehes of ligament before it reaches its insertion.

The advantage of an oblique incertion may also be illustrated by the action of muscular fibres, which eross one another like the two barts of the letter $X$ in their passage between two parallel hones: e.g. in the external and internal interenstal muscles connecting adjacent ribs, or in the extemal and internal oblique muscles of the abdomen in their passage from the crest of the ilium to the last ril,. If the muscles connecting the parallel bones ran at right angles to them, they conld only by their contraction climinish the intervening space by one-half; whereas, ruming oliliquely, they produce by their contraction a much greater approximation of the bones. For let $\mathrm{A} B$ and $(\mathrm{I})$ represent two parallel bones, and $\mathrm{E} F$ a museular fibre rumning perpendicularly from one to the other. If its full contraction reduced the length of the fibre by one-half, it would merely draw the point $E$ to $E^{\prime}$. But suppose that two muscular fibres C E and D E converge at right angles to each other ujw the point $\mathrm{E}$; the amount that they will have to contract to draw $\mathrm{E}$ to $\mathrm{E}^{\prime}$ may be readily found by describing the arc of a circle $\mathrm{E}^{\prime} \mathrm{K}$ or $\mathrm{E}^{\prime} \mathrm{L}$ about $\mathrm{C}$ or $\mathrm{D}$ as a centre, and with $\mathrm{C}^{\prime} \mathrm{E}^{\prime}$ or $\mathrm{D} \mathrm{E}^{\prime}$ as a radius. $\mathrm{E} \mathrm{K}$ and $\mathrm{E} \mathrm{L}$ will represent the contraction

FIG. 261.

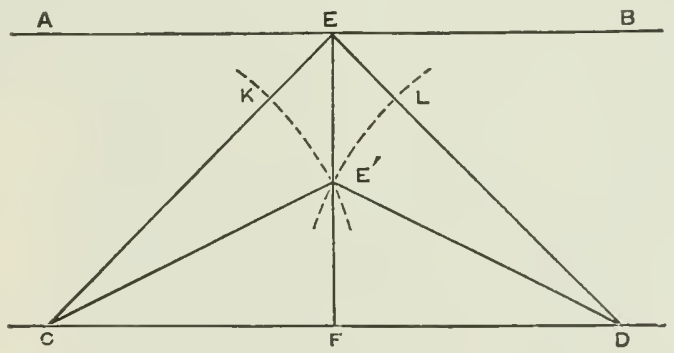

required; and it is evident that if these oblique fibres eontract more strongly, they an bring the bone A B into alose apposition with C D.

When muscles pass over more than one joint, their action is somewhat more complicated. Usually other muscles are at the same time called into play, so as to fix some of the joints, and enable the muscle to act solely upon others. For example, when the museles arising above the wrist are used to extend the phalanges of the fingers, it will be found that some of the flexors of the carpus contract so as to fix the wrist. Similarly, if the fingers are flexed in grasping an object, it is easy to feel the tendons of the carpal extensors starting up into firm contraction.

Occasionally the passage of a muscle over two joints is used to obtain rery swift and vigorous action. For example, if the $\mathrm{long}$ head of the triceps, which extends from the axillary border of the shoulder-blade to the olecranon process, were replaced by an inextensible ligament. which should be tight with the arm down and the elbow flexed, the elevation of the humerus by the deltoid muscle would necessitate a corresponding extension of the elbow. Now put in the place of the inextensible ligament an actively contracting muscle, and it is clear that the combination of this elevation of the arm $h$ whe deltoid with contraction of the triceps will produce a much more rapid extension of the elbow, such as is seen in throwing a spear or a stone. 


\section{MUSCLES OF THE UPPER EXTREMITY}

The first group consists of those which, arising from various parts of the hear, neck, and trunk, are inserted into the bones of the shoulder girdle, viz. the clavicle and scapula, or into the humerus. Of this group there are two divisions: the one comprising the muscles which take their origin from the back of the head, neck, and trunk; the other, those which arise from the front and sides of the thorax.

\section{POSTERIOR DIVISION OF THE GROUP OF MUSCLES PASSING FROM 'THE TRUNK TO 'THE UPPER EN'TREMITY'}

This division consists of two layers, which lie superficial to the proper back muscles. Orerlying these layers is, first, the superficial fascia, which is strong, well provided with fat, and continuous with that of the head, neck, axilla, and other adjacent regions; and, secondly, the deep fascia, which is thin and forms the sheath of the trapezius and latissimus dorsi muscles. Above and in front, the deep fascia is continuous with the deep cervical fascia; lower down, with the axillary fascia. and that covering the thoracic and abdominal parietes. Internally it is attached to the spines of the rertebre, and below it blends with the lumbar aponeurosis.

\section{FiRst LAYER}

Consisting of one muscle-the trapezius.

\section{THE TRAPEZILS}

The trapezius (or cucullaris, as it has been called from its resemblance to a rowl = (ucullus) is named from $\tau \rho \dot{a} \pi \varepsilon, \alpha$, a table, on account of the four-sided figure formed by the muscles of the two sides. It is a fan-shaped sheet forming an ohtuse-angled triangle. the long side of which corresponds with the spine.

Origin.-(1) The inner third of the superior nuchal line of the occipital bone, anil the external occipital protuberance; (2) the posterior border of the liganentum nucha; (3) the spines of the seventh cervical and all the thoracic vertelnre, together with the supraspinous ligament.

Insertion.--(1) The posterior border of the outer third of the clavicle and the adjacent part of its upper surface; (2) the inner edge of the upper surface of the aromion process; (3) the upper border of the spine of the scapula, and a small tuberde at its inner extremity.

Structure.-The origin of the muscle is by short tendinous intermingled with fleshy filures, except at two places. where the tendinous fibres form a continuous sheet. The first of these is from the middle of the ligamentum nuche to the secomb thoracic spine; here a conspicuous oval aponeurosis is formed by the tendons of the two sides. The second is at the lower acute angle of the muscle where it arises from the lowest thoracic vertelora. The muscular fibres converge from the extensive origin, and just before their insertion, the shect of the muscle is folded upon itself, to adapt it to the V-shaperl process of the shoulder girdle. into which it is inserted by fleshy fibres, excest at the inner extremity of the spine of the scapula, where a tinclinous shect plays over the triangular base of that process, before it is inserted into the tubercle at the imner end of the spine. Sometimes a bursa intervenes between this sheet and the triangular sturfice of the scapular spine.

Nerve-supply.-From the spinal accessory; and from the deep cervical plexus by branches of the third and fourth cervical nerves, which, after communicating 
Fig. 262.-First LAYER OF MCSClis UF THE BACK.

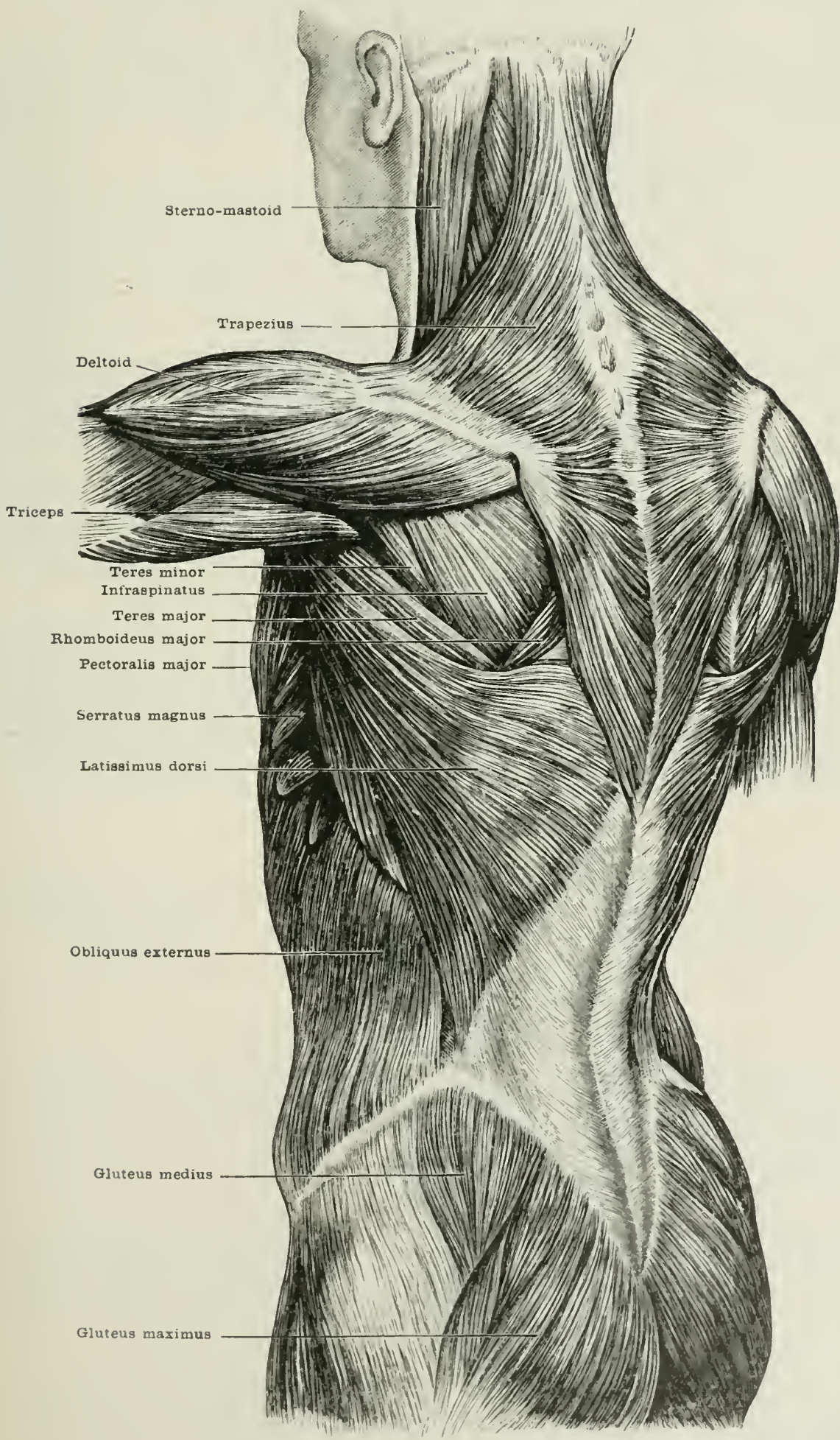


with the spinal accessory, enter with it the deep surface of the muscle a short distance above the chavide.

Action.-Its upper tibres draw upwards the outer end of the clavicle and the point of the shoulder; and acting from below, they extend the head, flex the neck towats the sime side, and turn the face to the opposite side. Its middle fibres draw the scapula inwards towards the spine; at the sime time they produce a rotation of the scapula on the thorax, by which the point of the shoulder is raised. The lower fibres draw the scapula downwards and inwards, and at the same time rotate it so as to raise the point of the shoulder.

Acting as a whole, the muscle draws the scapula towards the middle line of the back, and elevates the shoulder by the rotation it impresses upon the shoulder blate. By drawing the scapula hackwards, it gives some help to the pectoralis minor and other muscles which elevate the ribs in foreed inspiration. When it takes its fixed point from the shoulder blade and clavicle, as when the hand grasps firmly some immorable object, the muscle will draw the spines of the rertebra toriards the scapula.

The presence of the oval aponeurotic patch may be explained by the fact that the range of movement of the scapula in a horizontal direction backwards and inwards is more limited than when the inward norement is combined with an upwarl or domnard direction. This linitation is due to the ligamentous attachments of the clavicle and shoulder blade.

Relations. - Supcrficially, the integuments and subcutaneous nerves; deeply, the complexus, splenii, serratus posticus superior, rhomboidei, the rertebral aponeurosis covering the continuations upwards of the erector spina, the external intercostals, latissimus dorsi, levator anguli scapula, omo-hyoid, scalenus medius and posticus, the supraspinatus, and a small portion of the infraspinatus.

Variations.-Ocasionally the upper or the lower part of its origin mas fiil. The claricular part of its iusertion sometimes extends far forwards upon the clavicle. Frequently fibres pass from its anterior border to the inner end of the clavicle either in front of or behind the sternomastoid, forming an arch under which run some of the superficial cervical nerves. This arch may even extend to the sternmm. A similar transverse band is occasionally found in the upper part of the posterior triangle, the transversus nuchce. Sometimes a longitudinal band of fibres covers the spinal origin of the trapezius.

\section{SECOND LAYER}

Consists of four muscles-the levator anguli scapulæ, rhomboideus minor and major; and the latissimus dorsi.

\section{LEVATOR ANGULI SCAPUL.E}

The levator anguli scapulæ (figs. 26?, and 266), named from its action in raising the posterior superior angle of the scapula, is a ribbon-shaped muscle.

Origin.-By four short tendons from the posterior tubercles of the transverse processes of the fomr upper cervical rertebre.

Insertion.-The rertebral border of the scapula opposite the supraspinous fossia.

Structure.-The tendons of origin, which are closely connected with the insertion of the splenius colli, after a short course are succeeded by muscular fasciculi, and these unite to form a thick band of parallel tibres which remain fleshy to their insertion. The plane of the muscle changes as it decends. Above, while lying in the posterior triangle of the neek. it: sulfiees look outwards and inwards; below, they are directed backwarks and forwark.

Nerve-supply.-From the crrical plexus by branches from the third and fourth cervical nerve which enter the front of the outer surface near the origin of the muscle.

Action.-It raises the pusterior superior angle of the scapula; but, by causing 
rotation of that bone, it depresses the point of the shoulder. Taking its fixed point from below, it is an extensor and lateral flexor of the neck.

Fig. 263. -The Levator ANGLLI SCAPLLE AND RHoMBUIDEl.

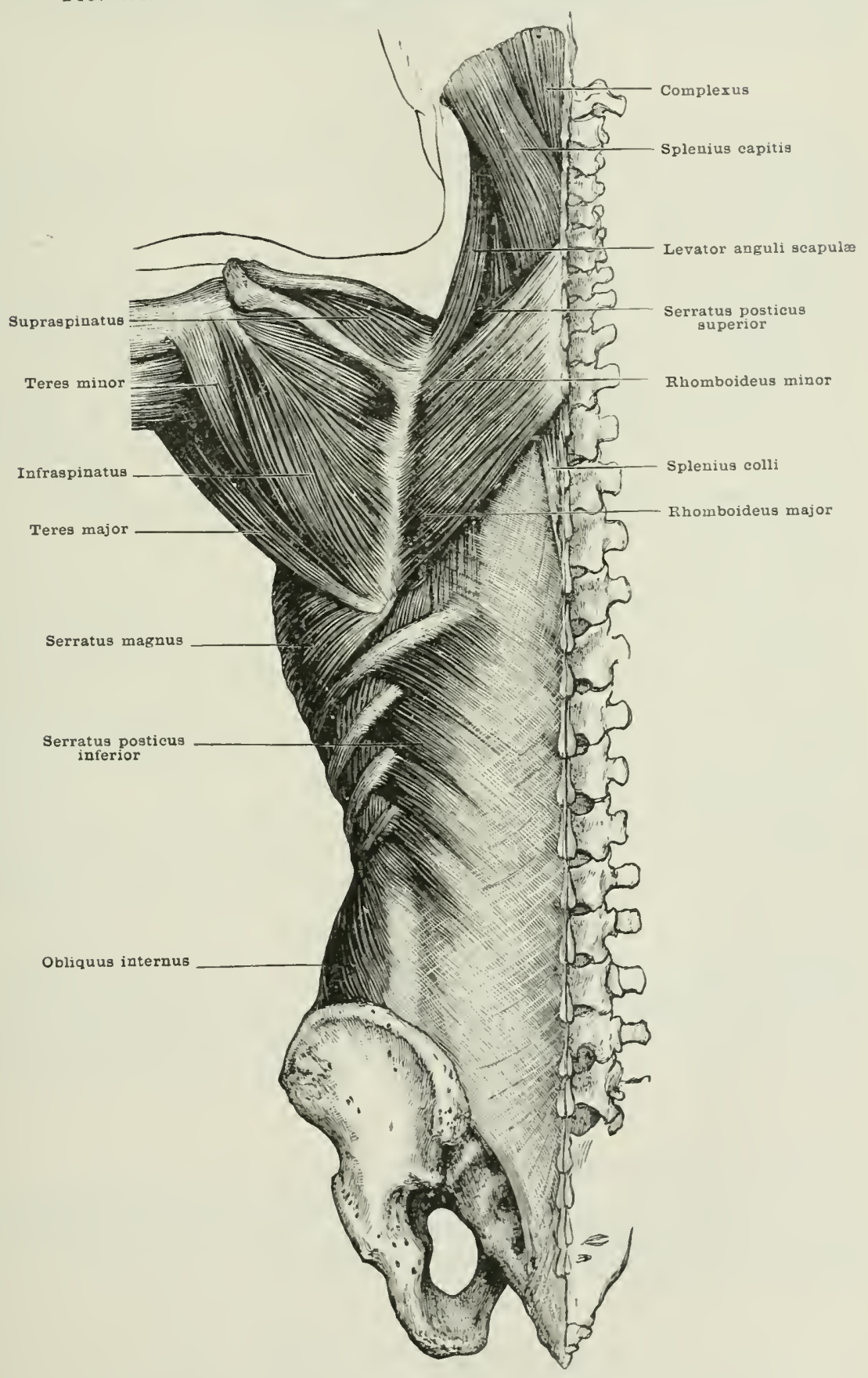

Relations.-Superficially, the deep cervical fascia, the platrsma myoides, the sterno-mastoicl, the trapezius, the scalenus merlius, the internal jugrular rein, the spinal accessory nerve, and some of the descending branches of the cervical plexus; 
deeply, the splenius colli, the cervicalis aseendens, the serratus posticus superior, and the posterior scapular vessels.

Variations.-The number of cervical vertebre from which the muscle arises varies, and it may even arise frem the mastoid process or veeipital bone. It may send slips to the serratus mainus, the seriatus posticus superior, and other adjacent muscles; occasionally also to the elavicle and first two ribs.

\section{AND 3. RHOMBOIDEI}

The rhomboidei-named from their shape, which is rhomboidal, or like a parallologram-are sometimes looked upon as a single muscle, but may be usually sejuarated into the following:-

The rhomboideus minor, the lesser and upper of the two, is a four-sided sheet, forming an elongated parallelogram.

Origin.-The lower part of the ligamentum nuchæ, the spines of the seventh cervieal and first thoracie vertebre, and the supraspinous ligament between them.

Insertion.-The vertebral border of the seapula opposite its spine.

Structure.-Its origin and insertion are by short tendinous fibres, between which its fleshy fibres run parallel to one another, downwards and outwards.

Nerve-supply.-From the brachial plexus by a branch of the fifth cervical nerve, which enters its deep aspect near the upper border a short distance above its insertion.

For action and relations, see the account of the following muscle.

The rhomboideus major-the lower and larger of the two muscles-is a broad rhomboidal sheet.

Origin.-The spines of the four or five upper thoracic vertebræ, and the supraspinous ligament between them.

Insertion.-The vertebral border of the scapula opposite the infraspinous fossa.

Structure.- At the origin, it consists of short tendinous fibres, sueceeded by parallel fleshy bundles, which pass downwards and outwards to a narrow tendinous expansion which is feebly attached to the scapula over the upper three-fourths of its insertion, but with thick and strong fibres near the inferior angle of that bone.

Nerve-supply.-The same as the preceding, and entering the upper part of the reep surface near its insertion.

Action.-The rhomboidei draw the scapula inwards and backwards towards the mirldle line, and at the same time upwards. They also rotate the scapula so as to depress the point of the shoulder. In this way they, together with the levator anguli scapula, will help in drawing down the arm, after it has been elevated through the rotation of the scapula by the trapezius and serratus magnus.

Acting from the seapula, the rhomboidei will help the trapezius in drawing the midclle line of the haek towards that hone.

Relations of the two rhomboidei.-Superfieially, the trapezius and, at the lower jart of the rhomboideus major, the deep faseia, and latissimus dorsi; deeply, the serratus posticus superior, splenius colli, the external intercostals, the posterior scapular vessels, the angles of the upper ribs, and the vertebral aponeurosis covering the upper continuations of the erector spinæ.

Variations. - The rhomboiders minor is frequently absent, and oceasionally there is no rhomboileus major. The fibres of the latter muscle may be inserted almost entirely into the lower angle of the seapula. Oceasionally its lower fibres join those of the latissimus dorsi, and they have also been found contimous with is part of the teres najor. An aecessory band may join the rhomboidei from the vecipital bone (the occipito-seapularis).

\section{LATISSIML'S DORSI}

The latissimus dorsi (figs. 262 and 269 ) -named from its being the loroadest of the back muscles-is a fan-shaped sheet forming a right-angled triangle, the right angle being contained hetween its uper and vertebral borlers.

Origin.-(1) The five or six lower thoracic spines, and the supraspinous liga- 
ment; (2) the lower part of the vertebral aponeurosis (see account of Lumbak FAscli, prage 408), by which it is attached to the spines of all the lumbar and sacral rertebre; (3) the posterior third of the onter lip of the crest of the ilium: (4) horizontal lines crossing the outer surface of the last thee or four ribs external to their angles (these lines by their lower borders give origin to processes of the external oblique musele, which thus interdigitates with the latissimus dorsi); and sometimes (5) the dorsal aspect of the inferior angle of the scapula.

Insertion.-The bottom of the bicipital groove of the humerus, as far upwarls as the lesser tuberosity.

Structure.-Its first and third parts arise by short tendinous fibres. The origin of the second part from the vertebral aponeurosis is by fleshy fibres in a line which descends obliquely downwards and outwards from the last thoracic spine to the back of the crest of the ilium. Its origin from the ribs and scapula is muscular. The fleshy fibres are of nearly equal length, and they converge upon the tendon in such a way that those which arise from the ribs and crista ilii are inserted highest into the humerus, while those which spring from the thoracic spine are attached to the lower part of the bicipital groove. The broal sheet wraps round the side of the thorax, and is also folded upon itself, so that the anterior surface at the origin becomes the posterior at the insertion. A groove is thus formed, in which lie the outer border of the scapula and the teres major. The tendon of the teres major is usually attached at the borders to that of the latissimus dorsi by strong connective tissue; but a bursa intervenes between them near their insertion.

Nerve-supply.-From the posterior cord of the brachial plexus by means of the long subseapular nerve. This is derived from the sixth and seventh cervical nerves, and enters the muscle upon its deep surface in the lower part of the axilla.

Action.-It draws the humerus backwards, downwards, and inwards; at the same time rotating it inwards. The movement of the arm in swimming is a good example of its action. When the arm is placed close to the side, it will draw the shoulder backwards and downwards.

Acting from the humerus as a fixed point, it is very important in climbing, as it draws the pelvis and lower part of the trunk upwards and forwards towards the arms.

By its costal origin it will assist in foreed inspiration when the arm is fixed.

Relations.-Superficially, the trapezius, fascire, and integument behind, and the pectoralis major, axillary vessels, and branches of the brachial plexus in front; deeply, the rhomboideus major, the vertebral aponeurosis covering the upward continuations of the erector spinæ muscle, the serratus posticus inferior, extemal intercostals, external oblique, infraspinatus, serratus magnus, and teres major mutiscles.

Variations.- It varies in the height of its origin from the spinal column, and also in the number of ribs from which it arises. From its axillary border slips may cross the axilla to the tendon of the pectoralis major, or may cruss the great vessels and nerves to the coracoid process or the deep fascia at the upper part of the arm. A slip of fascia or muscle may be continued duwn from its tendon of insertion to the olecranon in association with the triceps.

\section{ANTERIOR DIVISTON OF THE GROLP OF MTSCLES PASSING FROM THE TRUNK TO THE UPPER EXTREMTTY}

These musches are arrangerl in three layers, of which the first two are formed hy museles which arise from the front of the thorax: viz, the peetoralis major in the first layer, and the subclarius and pectoralis minor in the second; the last ly a single musele, the scrratus magnus. Which takes origin from the sirle of the thorax.

The superficial fascia, which corers all these layers, is but molerately supplied with fat, and is continuous with that of all the arljacent regions. It lies both over and beneath the mammary gland, and sends fibrous septa between its lobules.

In addition to the superficial fascia, there are three other important fascia in this region. 
1. The pectoral fascia, a thin membrame which forms the sheath of the peetoralis major, and is attached to the clavicle above; while below it passes over the free colge of the great pectoril mnscle, and there unites with the axillary fascia.

2. The clavi-pectoral fascia arises in two sheets from the anterior and posterior borders of the uncler surface of the clavicle. These sheets unite after enchosing the subelavius muscle, and form a single membrane (the costo-coracoid), which, after hridging the space between the subelavius and pectoralis minor, divides again to form the sheath of the pectoralis minor. At the lower border of this muscle, the clari-pectoral joins the axillary fascia. The costo-coracoid membrane, which is the midclle portion of the chavi-pertoral fascia, is of a quadrilateral shape, and is attached above and below to the sheaths of the subclavius and the pectoralis minor muscles; externally, where it blends with the sheath of the axillary vessels, it is very strong; internally, where it joins the fascia covering the front part of the first and second intercostal spaces, it is thin and weak.

3. The axillary fascia is a strong memhrane which stretches across the triangular floor of the axilla. In front, it joins the pectoral and elavi-pectoral fascix; behind, it joins the sheath of the latissimus dorsi; above, it is continuous with the deep fiscia of the upper arm, and below with that of the thorax.

The concarity of its surface, which is directed downwards and outwarks, is maintained to a great extent by the attachment of the clavi-pectoral fascia above mentioned.

\section{First Liyer}

\section{PECTORALIS MAJOR}

The pectoralis major-named from its being the larger of the two muscles which arise from the front of the ehest (pectus = breast) - is a thick, triangular, fanshaped sheet; or, more accurately, it nay be likened to the segment of a curcle on account of the curved origin, from which all the fibres converge to the upper part of the humerts as a centre.

Origin.-(1) The anterior surface of the inner half of the clavicle and the adjacent part of the stemo-clavicular joint; (2) the sicke of the front of the sternum, from the stemo-clavicular joint to the lower extremity of the gladiolus; (3) the front of the cartilages of the second to the sixth ribs; (4) a small part of the outer surface of the sixth rib close to its anterior extremity; (5) the upper part of the aponemrosis of the external oblique muscle which forms the front of the sheath of the rectus abdominis.

- Insertion.-(1) The external bicipital ridge of the humerus from the greater tuberusity down to the impression for the reltoid; (2) adjacent fibrous structures, especinlly the tendon of insertion of the deltoid muscle.

Structure.-The clavicular portion is distinct from the rest, and might be described as a separate muscle. It forms a thick band of parallel fihres, which, arising tendinous from the clavicle, become almost immediately fleshy, and are inserted into the humerus by short tendinous fibres in front of the rest of the tenclon of inscrtion.

The rest of the muscle (the sterno-costal portion as it is usually named) consists of fleshy fibres which, arising directly from the four other parts of the origin enumerated, converge and cross one another to be inserted into the humerus behind the clavicular portion by means of a peculiar tendon.

In a vertical section (fig. 271) near the humerns this tem lon is seen to be folded upon itself into a compresed lorseshot-shapre. The convexity of the foldeci tendon is dimeterl downmards, and the anterior segment of the horseshoe is shorter than the posterior.

The anterior segment reecives the muscular fibres which proceed from that part of the origin of the stemo-costal portion which lies above the third costal cartilage, and with the front of this seament, the insertion of the clavieular portion is closely blencted. The posterior segment receives the fibre from the lower part of the stemo-costal portion. the lowest fibres (viz. those from the external ohlique aponeurosis) being inserted highest, and the highest (viz. those from the middle of 
the sternum) being attacherl to the lower part of the horseshoe, where they become continuous with those forming the anterior segment of the tendon.

In conseguence of this arrangement the fower fihres of the muscle disappear from view soon after their origin, and are concealed by the davicular and upper sterno-costal fibres. This arrangement gives to the anterior horder of the axilla a concave outline. Were it not for this decussition, the muscle would be broader and thinner, and would cause an inconvenient and unsightly projection in front of the axilla.

The sterno-costal portion may usually be divided into a superficial and deep blane, the superficial heing composed of the stemal and external oblique origin; the deep, of the fibres which spring from the cartilages and the sixth rib.

Fig. 264.-The PeCtoralis Major and Deltoid.

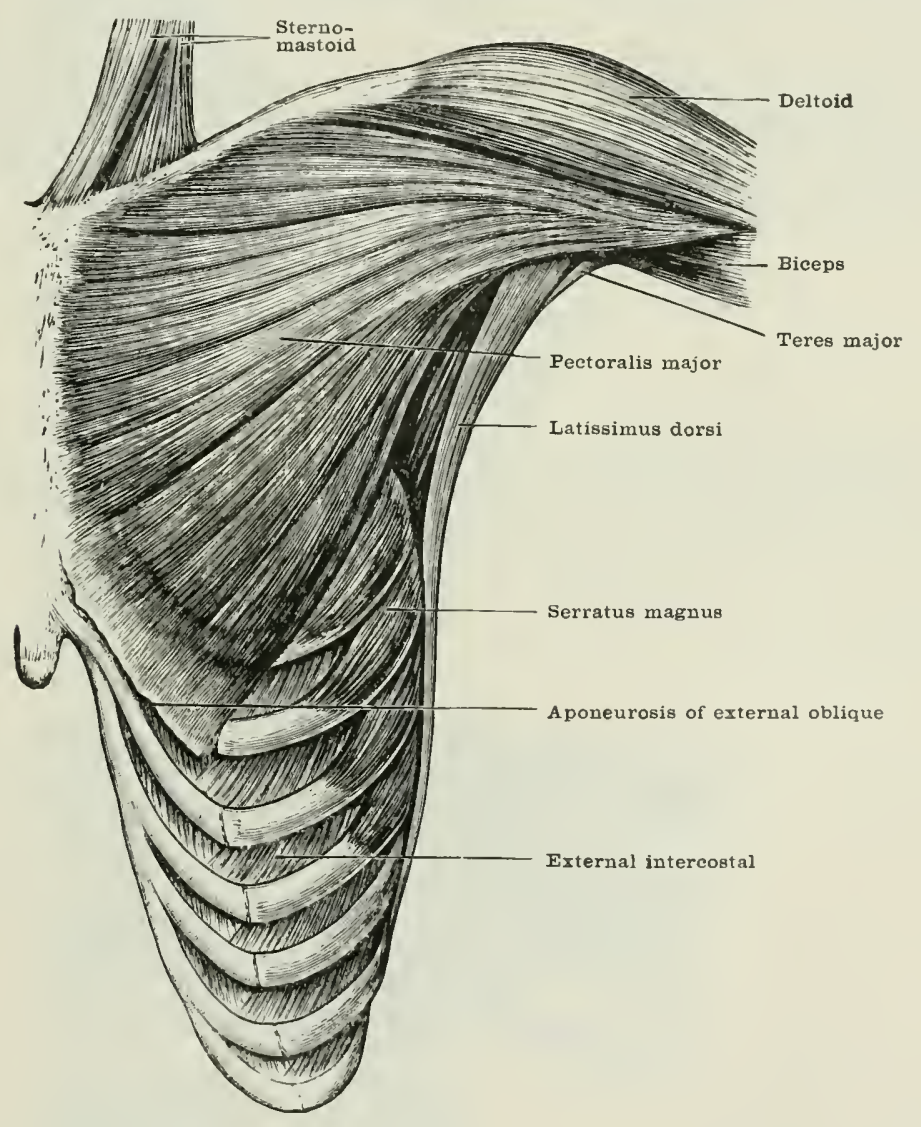

Nerve-supply.-From all the nerves of the brachial plexus:-(1) through the external anterior thoracic nerve, which entris the deep surface of the muscle just below the millle of its upper horder; and (2) througl the internal anterior thoracic, which, after piercing and supplying the pectoralis minor, enters the derep surface of the muscle a little lower down, half-way between its origin and insertion.

Action.-To adduct, flex, and rotate inwards the upper arm. By its clavieular portion it will draw the arm more directly forwards, as in round-hand bowling, while the stemo-costal portion will draw the arm more downwards than forwards. The whole muscle will be used with great foree in striking a blow downwards and forwarls. When the arm hangs close to the side, the pectoralis major will draw the scapula forwards and downwards, so as to atlvance and depress the point of the shoulder, as may be seen in a person shivering with cold. When the arm is 
elevated and fixed, this muscle will draw the front of the chest up to it, as in climbing. It will also raise the upuer rils in forcerl inspiration.

Relations. - Superticially, the platysma myoides, the mammary gland, and the cutaneous nerves from the ilescending branclies of the cervical plexus, as well as the lateral and anterior perforating branches of the upper intercostals.

Beneath, lie the subclavius, jectoralis minor, and serratus magnus, the fascia covering the external and internal intercostal muscles, the coracoid process, and costo-coracoid membranc, with the structures which pass through the membrane, viz. the eephalic rein, acromio-thoracic ressels, and the extemal anterior thoracic nerve. Further outwards it forms part of the anterior wall of the axilla, and enters into relation with the biceps, the coraco-brachialis, and the axillary ressels and nerves.

The upper border is separated from the deltoid by the cephalic vein and the humeral branch of the acromio-thoracic artery.

Variations.-The clavicular and sterno-costal portions are often widely separated. They may also be further sublivided into separate bauds or sheets, and they may be wholly or partly absent. Occasionally, the muscles of the two sides join across the sternum, or muscular bands may unite the stermal ends of the clavicles. Bands may cross from the axillary border to the latissimus dorsi or the deep fascia of the upper arm; deeper bands may also pass to the insertion of the pectoralis minor, or the capsule of the shoulder-joint.

\section{SECOND IAYYER}

\section{SUBCLAVIUS}

The subclavius-named from its position beneath the clavicle (=claris) - is ahmost cylindrical, but may be more accurately described as a thick sheet of the shape of a low obtuse-angled triangle, the obtuse angle being contained between the lavicular attachment and the inner free border of the muscle.

Fig. 265.-The Subclayus and the Upper Portion of the Serratus Magnes.

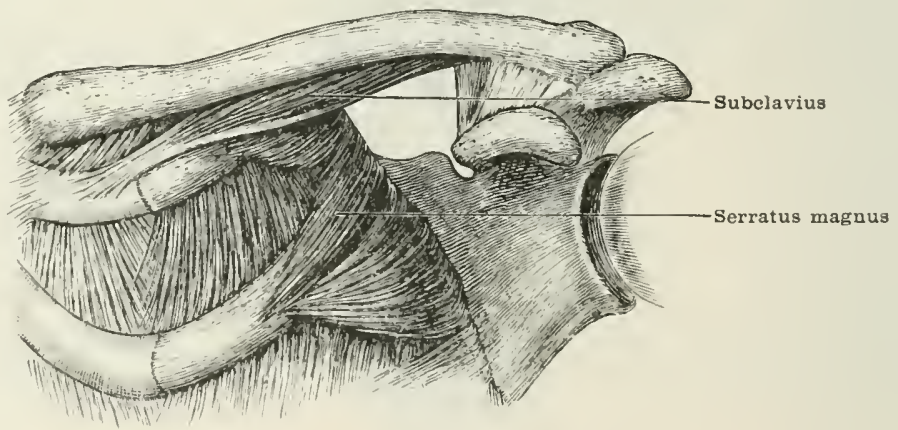

Origin.-The upper and anterior surface of the first ril and its cartilage at their point of junction.

Insertion. - The groese on the lower surface of the clavicle from the rhomboid impression to the conoid tuberele.

Structure.-It arices hy a strong tendon, flattenerl from before backwarls, which lies alose to the frent of the rhemboiel ligament, and is continued for a considerable distance along the lower lurer of the numscle. Its insertion is by fleshy filres which ratiate npwards, outwards. and a little hackwards, in a pemniform mamner, from this tenden; the immer aseending more vertically, and the outer very ohliguely.

Nerve-supply.-From the hrachial plexus hy a small branch which, arising from the fifth and sixth corvical nervers, passes hehind the claviele and enters the midelle of the back of the muscle. 
Action.-To draw the outer end of the clavicle, and with it the point of the shoulder, downwards and slightly forwards; but chiefly by pulling the bone inwards to supplement the ligaments which prevent dislocation of the sterno-clavicular joint.

Relations.-In front, the clavi-pectoral fascia and the pectoralis major; behind,

Fig. 266.-Tine Pectoralis Mixol, Obliquis Internes, Prramidalis, and Rectes ABDOJINIS.

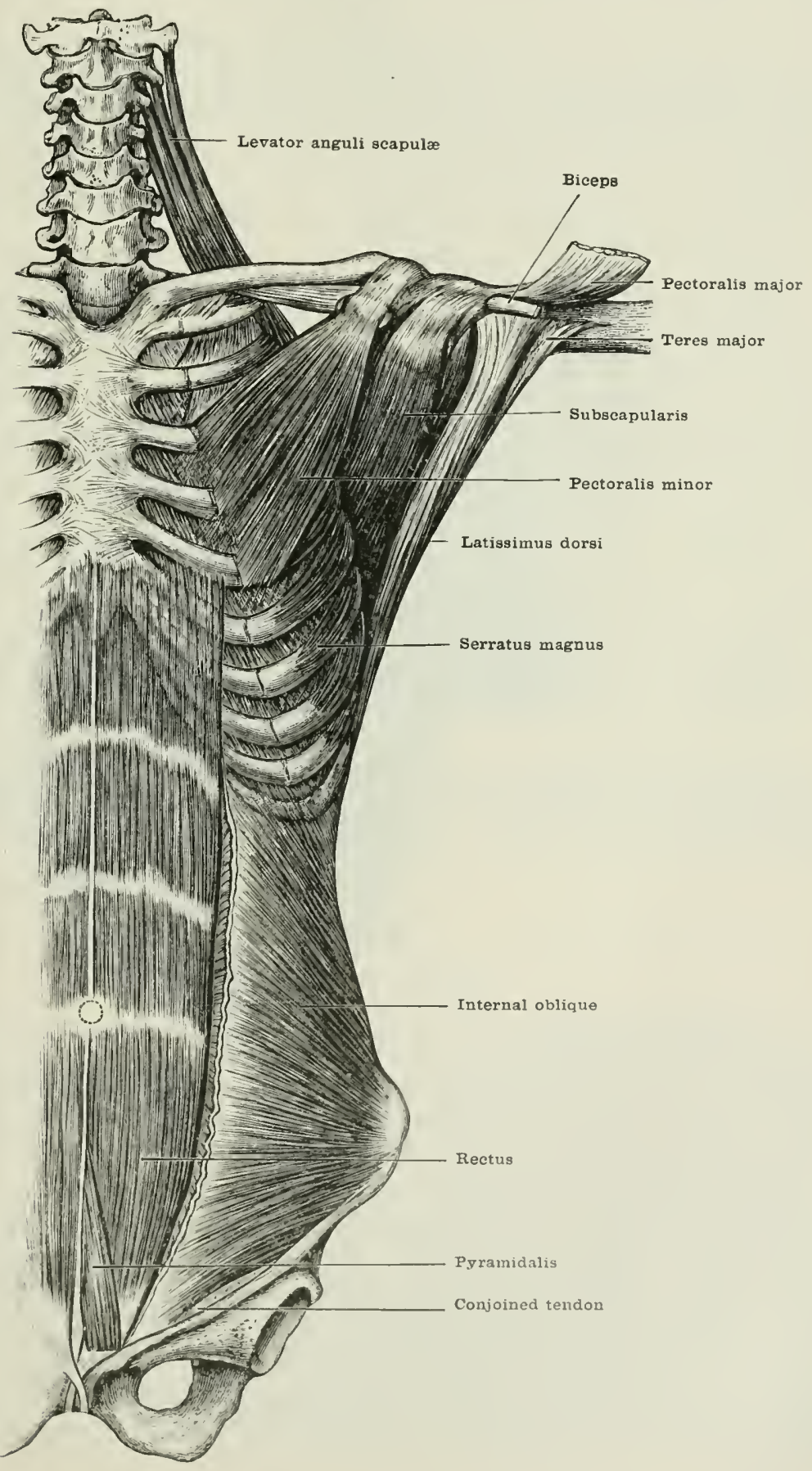


the posterior division of the same fascia, the rhomboid ligament, the subcharian vesicls, and the brachial plexus.

Variations.-The subchrius nay be absent, or its insertion may extend to the eoracoid process, transerse ligament, atul up per border of the scapula. Oecasionally the costo-clavicular purtion is separate from the costo-scapular. Again, its origin may extend inwards to the sternum, and the portion which arises from the sternum may be separate from the rest of the muscle.

\section{PECTORALIS MINOR}

The pectoralis minor-naned from its being the smaller of the two muscles which arise from the front of the chest-is a fan-shaped or triangular sheet, with its inner erlge divided into three teeth.

Origin.-(1) The upurer borders and outer surfaces of the third, fourth, and fifth rils near their anterior extremities; (2) the fascia corering the intercostal muscles in the spaces between these ribs.

Insertion.-(1) The upper surface of the coracoid process of the scapula; (2) the upper part of the tendon of the coraco-brachialis along its imner border.

Structure.-Its origin is by aponeurotic ships, which, after becoming fleshy, conrerge upwards, ontwards, and somewhat backwards, upon the flattened tendon, which is attached chicfly to the coracoid process, but blends for an inch or more below that process with the origin of the coraco-brachialis.

Nerve-supply.-From the inner cord of the brachial plexus (through the eighth cervical nerve) by the internal anterior thoracic, which enters its deep surface near the upper border, the nerve subsequently piercing the muscle to send filaments to the pectoralis major.

Its action is to draw downwards and forwards the scapula, depressing at the same time the point of the shoulder. Taking its fixed point from the coracoid process, it draws upwards and outwards the ribs to which it is attached, and so helps in forced inspiration. Its connection with the tendon of the coracobrachialis will enable it to act slightly as a flexor and adductor of the humerus.

Relations. - Superficially, the pectoralis major; deeply, the external intercostal muscles; and, near its insertion, the axillary ressels and brachial nerves.

Variations.-The origin may extend upwards as far as the second, or downwards to the sixth rib, and it may receive adlitions from the peetoralis major. It is occasionally altogether absent. It insertion may be continued over the coraeoid process to the capsule of the shoulder-joint, the greater tuberosity of the humerus, or the claviele.

\section{ThIRD LAYER}

\section{SERRATLS MAGNLS}

The serratus magnus-named from its serrated or saw-like anterior border and lime size - is an irregular quadrilateral sheet curved to the shape of the side of the thorax. Its anterior attachel border has a somewhat sinuous curve, and arises from the side of the thorax hy nine or ten digitations or teeth, which, by their sawlike ajpearance, give the muscle its name. The muscle may be divided into an upper, midclle, and hwer part.

Crigin.-First part, by two tecth from the middle of the outer surface of the first and second rihs, and from the fascia covering the first intercostal space. Second part, by two or three heals from the second, third, and sometimes the fourth ribs mon their onter surface. Third part, by far the largest and strongest portion of the muscle, arises from the fourth or fifth to the eighth or ninth ribs by a series of tecth, which are attacherl in front near the upper border of each rib, and behind to a line ruming backwards across the outer surface of the rib from its upper to its lower lowiter. These attachments form a curved line with the convexity forwards, the attachment to the sixth rib being the most anterior and prominent. 
Insertion.-The first part is attached to an oral space upon the venter of the seapula close to the posterior superior angle. The second part, to the whole of the vertebral border of the seapula upon its ventral aspect. The third part to the large oval space on the renter of the seapula close to its inferior angle.

Structure.-The origin of the muscle is by fleshy or short aponeurotic fibres, and in the first part these fibres converge very slightly towards their fleshy insertion. In the second part they diverge and form a thin sheet attached to the rertebral border of the seapula. In the third part of the muscle the fibres converge fanwise and form a very thick and strong fleshy mass which is inserted directly into the inferior angle of the seapula. It their origin the teeth of this part of the muscle interdigitate with or fit in hetween those of the origin of the obliquus abdominis externus. All the fibres are curved to adapt themselves to the convex wall of the rhest.

Nerve-supply.-From the brachial plexus by the posterior thoracic nerve,

Fig. 267.-Serrates Magxes.

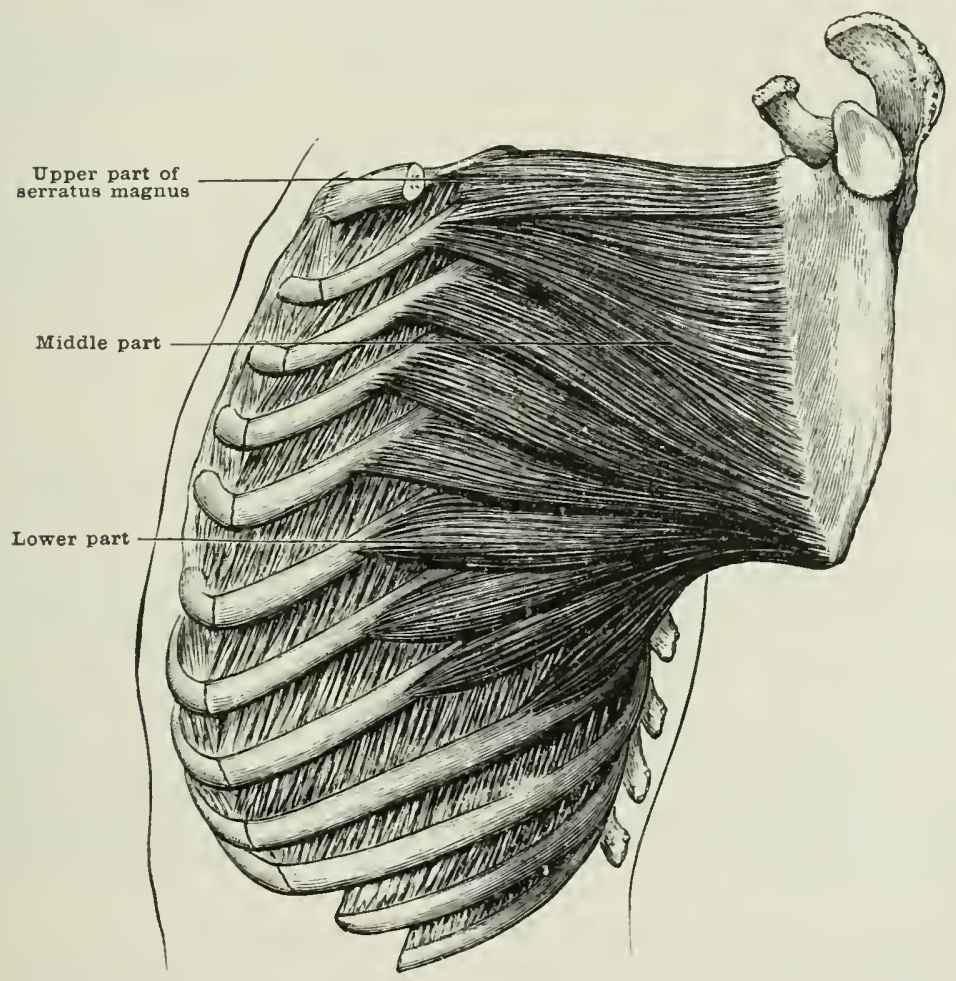

which is derived from the fifth, sixth, and seventh cervical nerves. After rumming down the side of the chest upon the outer surface of the muscle, the nerve is distributed by many branches to the various digitations.

Action.-By its contraction, this muscle draws forwards the vertebral border of the scapula and, as the third part of it is much the strongest, it will act especially upon the inferior angle, and will rotate the scapula so as to raise the point of the shoulder. It will therefore help the trapezius muscle in raising the shoulter. and it will he brought powerfully into play whenever the shoulder is used in pushing in a forwarel direction. It is most important, however. in relation to the morements of the arm. In order that the deltoid muscle mar raise the humerus, it is necessary that the fulcrum formed by the glenoil portion of the scapula should be held steady. For this reason the scapula extends so far downards in order that the leverage given to the thirl and most powerful portion of the surratus may be as great as posibible. When the serratus magnus is paralysed, all the eftorts of 
the cleltoid to elerate the arm are unsucessful, and only cause the lower angle of the scapula to project from the back of the thorax. When the arm has been eleriated to its full extent by the deltoid, that is, through about a right angle, the rotation of the scapula die to the serratus magnus and trapezius will produce a further elevation through another right angle, and so place the arm in a rertical position. One of the results of the action of this muscle is to keep the lower angle of the seapula in close contact with the wall of the thorax. When the muscle is laralyed, the posterior borders and the inferior angles of the scapulx project backwards from the thorax like small wings (sccupulix alutie).

Acting from its seapular insertion, the muscle tends to draw the front of the chest towards the scapula, e.g. when it supports the thorax in crawling on the hands and knees. Judging from the direction in which its fibres are inserted into the ribs, most of them can have little if any action in elevating the ribs, as in foreed inspiration.

Relations.-Superficially, the pectoralis major and minor, the subscapularis and latissimus clorsi, the subclarian and axillary vessels and the brachial plexus; decply, the external intereostal muscles, and seriatus posticus superior.

Variations.-It may arise as low as the tenth rib; and above, it may receive slips from the cervical transverse processes, or the levator anguli scapula. Part or the whole of the muscle may be deficient.

The SECOND Group comprises the muscles which pass from the scapula to the upper limb, and move the upper arm. Some of the most important adductors, flexors, and extensors belong to the first group; but abduction and rotation in both directions are provicled for by the second group.

\section{MUSCLES WHICH PASS FRON THE SCAPULA TO THE UPPER LIMB}

These are nine in number, viz. the deltoid, supra-spinatus, infra-spinatus, teres minor, subscapularis, teres major, coraco-brachialis, biceps, and triceps. The two last, however, as they act chiefly upon the foream, will not be deseribed in this grouly.

The superficial fascia covering the muscles contains but little fat. The deep fascia is thin where it covers the front of the deltoid, and is continuous with that which invests the pectoralis major and the axillary fascia. Behind, it is thicker, especially where it covers in the lower prart of the infra-spinatus. Below, it blends with the deep fascia of the upper arm. Above, it is comnected with the clavicle and scapmata above the upper attachment of the deltoid.

It is also comnected, either directly or by strong intermuseular septa, with the rertebral and axillary borlers of the scapula.

Processes from it cover the deeper surfice of the deltoid, and form sheaths to all the muscles of this groul).

\section{DELTOID}

The deltoid muscle (figs. $2(62$ and 264) - namer from its resumblance to the Creek letter delte when inverterl-is a very thick triangular sheet, with the ajex directed downtwark, and with its plane enrved ujon itself from before backwards, so as to wrip round the front, cuter side, and back of the upper end of the huminerus.

Origin.-(1) The anterior lwoler and adjacent part of the upper. surface of the onter thirel of the clavide: (2) the outer borler and acijacent part of the upler surface of the acromion; (3) the lower borker of the spine of the seapula and the fiscial corering the infra-spinatus muscle, near the rertebral border of the scaipula. 
Insertion.-A rough triangular impression, with the apex downwards, and from two to three inches long, just above the middle of the outer surfice of the humrerus.

Structure. - It the front and back part of its origin it arises hy short, tendinons fibres which end in parallel muscular bundles. At the middle part, strong fibrous septa three or four in number pass clownwards from the acromion process into the substance of the muscle, upon the surface of which their outer edges are visible. The fleshy fibres of this part of the muscle arise both from the acromion and from the surfaces of these septa. The short strong tendon of insertion is prolonged upwards into three fibrous planes, which, as well as the tendon, receive the fleshy fibres of the midlle part in multipenniform fashion. The muscular bundles from the front and back parts of the origin are inserted upon the anterior and posterior surfaces of the tendon of insertion. In front, this tendon is connceted with that of the pectoralis major; below, it gives fibres to the external intermuscular septum, and also to the upper part of the brachialis anticus.

Nerve-supply.-From the posterior cord of the brachial plexus (through the fifth and sixth cervical nerves) by means of the circumflex nerve. This nerve cnters the deep surface of the muscle by scveral filaments about half way between the origin and insertion.

Action.- When all its fibres contract together, it will abduct the humerus through a right angle. If the first and second parts act alone, ther will flex and abduct the arm, as when it is raised to the level of the shoulder and at the same time directed forwards. The posterior and middle portions of the muscle by their contraction will abduct the arm, and at the same time extend it, as when the arm is elevated, and at the same time dirceted backwards.

The movements of abduction, or of abduction combined with flexion, are through $90^{\circ}$; of abduction combined with extension, only through $45^{\circ}$. In its action the muscle forms a lever of the third order. The greater adrantage which it gains by its insertion at a considerable distance from its fulcrum at the shoulderjoint is lost by the extreme obliquity of its direction. Hence the great thickness and strength of the muscle, and the facility with which this movement is lost by injury or disease. For the proper action of this muscle in elevation of the arm, it is necessary that the scapula should be held firm by means of the serratus magnus.

Relations.-Superficially, the integument and deep fascia; upon its front border, the pectoralis major, a small artery, and the cephalic rein; deeply, the coracoid process and upper extremity of the humerus, the tendons of the pectoralis minor and major, the short head of the biceps, coraco-brachialis, subscapularis, supra-spinatus, infra-spinatus, teres minor, the long heads of the biceps and triceps, the outer head of the triceps, the coraco-clavicular and coraco-acromial ligaments, the circumflex arteries and nerve, and a large bursa which separates the muscle from the greater tuberosity of the humerus and the structures attached to it; below, it comes into contact with the upper part of the brachialis anticus.

Variations.-The elavieular portion of its origin may reach inwards as far as that of the pecturalis major, and the two museles may blend along their adjacent borders. Behind, it may receive separate bands from the fascia infra-spinata or the borders of the scapula. Occasionally transverse fibres have been found lying in the substance of the musele elose to its aeromial origin.

\section{SLPRA-SPINATES}

The supra-spinatus-named from its position above the spine of the seapulais a somewhat fin-shaped, thick triangular sheet.

Origin.-(1) The inner two-thirds of the supraspinous fossia; (2) the unper surface of the spine of the seapula; and (3) the fascia covering the muscle.

Insertion.-(1) The upper ficet of the greater tuberosity of the humerus; and (2) the capsular ligament of the shoukler-joint.

Structure.-It arises by floshy fibres which converge upon a tendon which is concealed in the suhstance of the imuscle almost to the point of its insertion.

Nerve-supply.-From the brachial plexus (through the fifth cervical nerve) 
by the suprascapular branch which enters the muscke upon its deep aspeet near its upper borter.

Action.- - lt assists the leltoid in alulucting the am; it also strengthens the shonlder-joint by resisting the tendency to upward displacement of the head of the humerus, and ly drawing the head of the humerus firmly towards the centre of the glenoid earity.

Fig. 26r--Back View of the Scapllar Muscles and Triceps.

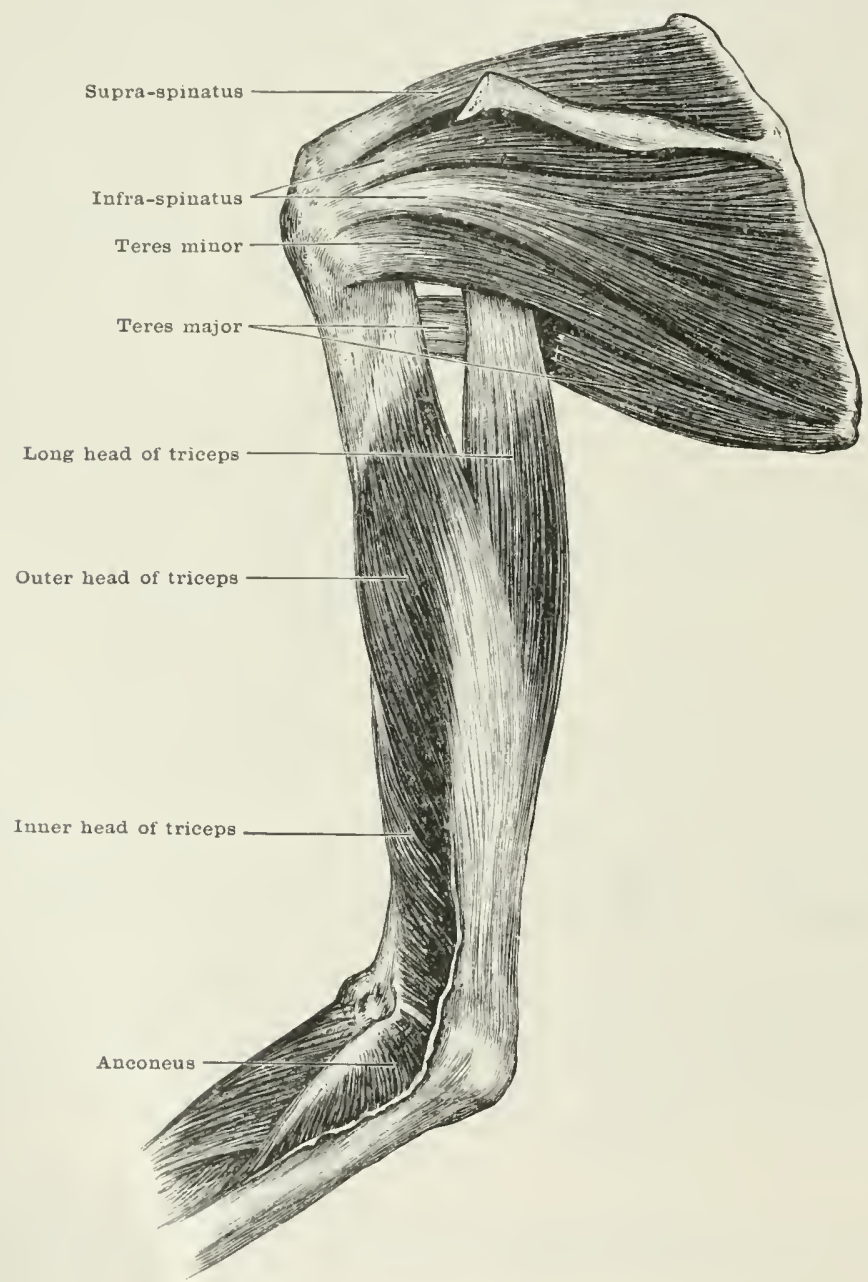

Relations. - Superficially, the traperius, deltoid, and coraco-acromial ligament; deeply, the omo-hyoid musche anch capsular ligament, the supraseapular vessels and nerve.

\section{INFRA-SPINATUS}

The infra-spinatus-named from its position below the spine of the scapulais a thick, fan-shatuerl sheret.

Origin.-(1) 'The inner two-thirds of the infraspinous fossa; (2) the under surface of the spine of the seapular; (B) the infraspinous fascia, and a thick intermuseular septum which separates it from the teres minor and major muscles.

Insertion.-(1) The millile facet on the grater tuberosity of the humerus; and (2) the calysuld of the shoukler-joint. 
Structure.-Its origin is by fleshy fibres which converge outwards in bipenniform fishion won the tendon. Frequently that part which arises from the lower surface of the spine of the scapula orerlies and is somewhat separate from the rest. Its insertion into the capsule and tuberosity is by a tendon which is almost entirely concealed by fleshy fibres.

Nerve-supply.-From the brachial plexus (through the fifth cervical nerve), by the suprascapular branch which enters the deep surface of the muscle at its onter part and near its upper border.

Action.-It is the chief external rotator of the humerus. This movement of external rotation is through about $90^{\circ}$, and is of great importance. When the elhow is bent, it produces the lateral movement of the hand by which, in writing, the pen is carried from left to right across the pagc. When the elbow is extended, the rotation of the humerus adds considerably to the range of rotatory movement enjoyed by the hand. The infra-spinatus also adducts the clevated arm, at the same time drawing it slightly backwards, or extending it. It helps to hold the head of the humerus in contact with the glenoid cavity.

Relations.- Superficially, the infraspinous fascia which separates it from the deltoid, trapezius, and latissimus dorsi; deeply, the suprascapular and dorsalis scapulæ ressels, and sometimes a small bursa which intervenes between its tendon and the capsule of the shoulder-joint; externally, the teres najor and minor.

Variations.-The slip from the under surface of the spine is frequently almost as separate from the infra-spinatus as the teres minor, and sumetimes there is no separation between the infra-spinatus and teres minor.

\section{TERES MINOR}

The teres minor-named from its loeing the lesser of two somewhat cylindrical muscles (teies = round or cylindrical) - is a thick but narrow triangular or fanshaped sheet.

Origin.-(1) The impression which oceupies the upper two-thirds of the axillary border of the infraspinous fossa; (2) septa which separate it from the infra-spinatus behind, and the teres major in front.

Insertion.-(1) The lowest of the three facets on the greater tuberosity of the humerus and the posterior surface of that bone for one inch $(2.5 \mathrm{~cm}$.) below the facet; (2) the capsule of the shoulder-joint.

Structure.-From a fleshy origin which terminates in a point below, its fibres pass upwards and outwards to their insertion, which is by a short strong tendon into the lowest facet on the tuberosity, and the capsule of the shoulder-joint; below the facet it is inserted by fleshy or very short tendinous fibres.

Nerve-supply.-From the posterior cord of the brachial plexus (through the fifth cervical nerve) by the lower division of the circumflex nerve which enters the muscle upon its anterior surface near its insertion. The nerve is remarkable on account of the ganglion upon its trunk shortly before it passes into the muscle.

Action.-The same as that of the preceding muscle, of which it may be consiclered to form a part. It will therefore rotate the arm outwards and at the same time adduct.

Relations.-Behind, the deltoid; in front, the long head of the triceps, the teres major, and subscapularis. Above and internally, the dorsalis scapulat ressels run between it and the axillary border of the seapula.

\section{SUBSCAPULARIS}

The subscapularis muscle-named from its position beneath the scapula-is a thick triangular and somewhat multipenniform sheet.

Origin.-(1) The whole of the ventral surface of the scapula with the exception of the part near the neck, and the spaces at the upper and lower angles occupied hy the serratus mannus; (2) the lower two-thirds of the groored outer border of the seapula; and (3) the intermuscular septum between it and the teres major. 
Insertion.-(1) The lesser tuherosity of the humerus, and the part of the shaft immediately below it; ( $(2)$ the front of the capsular ligament of the shoulder-joint.

Structure.-Its migin is by fleshy filmes from the surface of the bone, and also by hipenniform bundles from the uppere and lower surfaces of three or four septa which are attached to the transerse ridges upon the venter scapuln, so that the whole muscle has a multipenniform amangement. The fibres converge upwards and outwards upon a strong tenclon which is hidden by fleshy fibres to within a short distance of its insertion, the lower part of which is also fleshy. A bursa intervenes between the tendon and the base of the coracoid process, and is usually in comnection with the shoulder-joint.

Nerve-supply.-From the posterior cord of the brachial plexus (through the fifth and sixth cervical nerves), by the short and part of the lower subscapular nerves. They enter the front surface of the muscle, the former near its upper, the latter near its outer border.

Action.-It is the chief internal rotator of the humerus; at the same time it addlucts it after it has been elevated. It also has an important influence in

Fig. 269.-Front View of the SCAPUlar Muscles.

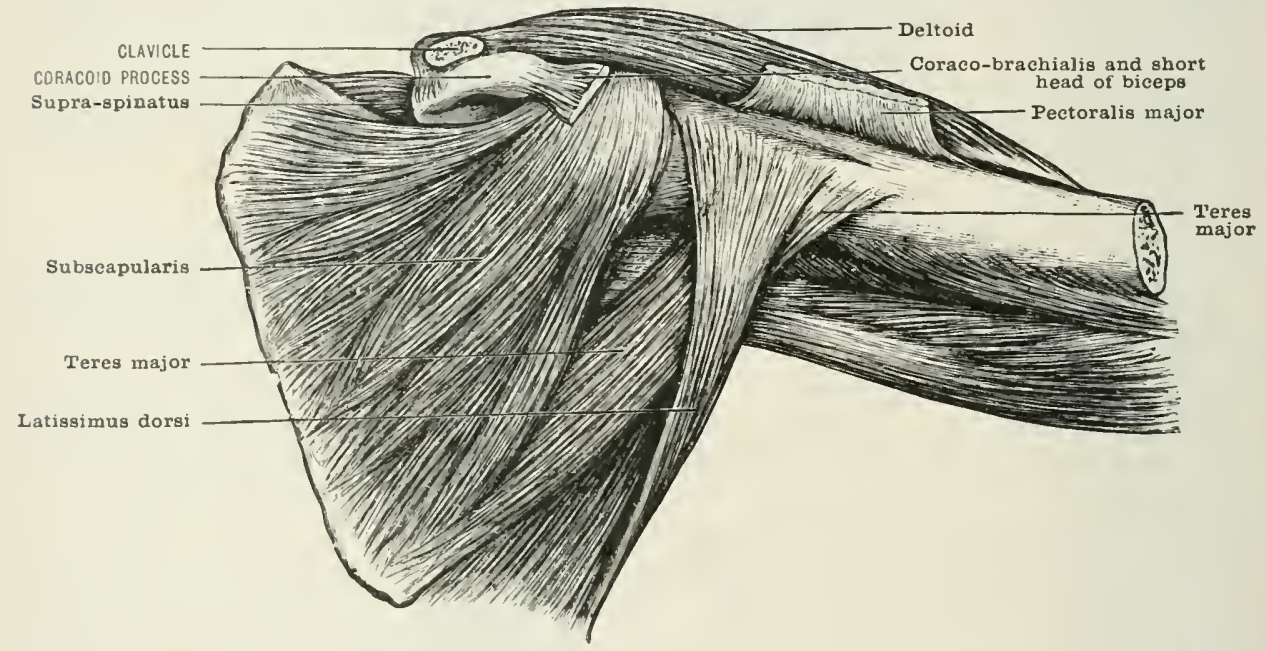

strengthening the shoulder-joint by drawing the head of the humerus towards the glenoid cavity.

Relations.--Its anterior and internal face forms the greater part of the posterior wall of the axilla, and is in contact with the serratus magnus, the short head of the liceps, and the coraco-lurachialis, the axillary vessels with many of their branches, the brachial plexus and its branches, the lymphatic glands and ressels; its outer horder lies in contact with the teres major; the posterior circumflex and dorsalis sapula resscls, and the circumflex nerve; behind lie the long head of the triceps and the teres minor muscle, and the bursa which intervenes between its tendon and the capsule of the shoulder-joint.

Variations.-Occasionally a separate slip arises from the axillary border of the seapula, and is inserted into the capsule of the shoulder-joint or into the humerus.

\section{TERES MAJOR}

The teres major-named from its somewhat cylindrical shape and its size-is a thick ribbon-shajeed musele.

Origin.-(1) The oval facet which oecupins the lower third of the axillary border of the infraspinous fossa; (2) the infraspinous fascia and the intermuscular 
septa, which separate the musele from the subscaypularis, the teres minor, and infrispinatus.

Insertion.-The inner lip of the hicipital groove from the lower border of the lesser tubcrosity for about two inches ( $5 \mathrm{~cm}$.) down the humerus.

Structure.-Its origin is hy fleshy fibres which pass upwards, outwards, and somewhat forwards, to be inserted $h y$ a strong tendon, which is first visible upon the outer border, and then upon the anterior surface of the muscle, and which is in close relation with the back of the tendon of the latissimus dorsi. A small bursa intervenes between the two tendons.

Nerve-supply.-From the posterior cord of the brachial plexus (through the sixth and serenth cervical nerves) by the lower subscapular nerve, which enters the muscle upon its anterior aspect close to the middle of its inner border.

Action.-It assists the latissimus dorsi as a strong adductor, and in some positions of the aim as an internal rotator of the humerus.

When the arm is fixed it will act with the latissimus dorsi in drawing the body upwarls, as in climbing. Its influence, howerer, will be exerted upon the lower angle of the scapula, while that of the latissimus dorsi is chiefly upon the trunk and pelvis.

Relations.-In front lie the latissimus dorsi, both heads of the biceps, the coraco-brachialis, the pectoralis major, the axillary vessels, and the lower branches of the brachial plexus; behind, the latissimus dorsi, teres minor, the long and outer hearls of the triceps; between its upper border and the subscapularis muscle are the posterior circumflex and dorsalis scapulæ ressels. and the circumflex nerve; below are the superior profunda ressels and the musculo-spiral nerve.

\section{CORACO-BRACHIALIS}

The coraco-brachialis-named from its attachment to the coracoid process and the upper arm (brachium) -is a cylindrical muscle, but somewhat fusifom at the extremities.

Origin.-(1) The tip of the coracoid process; (2) the inner side of the tendon of the short head of the biceps.

Insertion.-(1) The rough impression two or three inches long upon the inner horder of the humerus in its middle third, and in front of the internal intermuscular septum (see page 306); (2) the internal intermuscular septum and an aponeurotic hand which extends upwards from the septum in front of the tendons of the teres major and the latissimus dorsi to the lesser tuberosity of the humerus.

Structure.-It arises from the coracoid process by a short tendon, which is blended upon its inner side with the insertion of the pectoralis minor, and from the short hearl of the biceps by fleshy fibres for three or four inches $(\mathrm{S}-10 \mathrm{~cm}$. below the coracoid process. From this origin the fibres run parallel to one another, and are inserted by a short tendon. The muscle is frequently divided into two llanes between which the extemal cutaneous nerve passes.

Nerve-supply.-From the outer cord of the brachial plexus (through the seventh cervical nerve) br the musculo-cutaneous brancl. which either pierces it about the mirldle upon its way to the liceps and brachialis anticus, or sends a branch to it in this position, while the rest of the nerve gasses in front of the muscle.

Action.-To adduct and flex the humerus. As it lies at so small an angle with the axis of that bone, it assists materially in pressing the head of the humerus against the grenoid cavity, and so helps to prevent dislocation.

Relations.-Superficially, the deltoid and pectoratis major; deeply, the subseapularis, latissimus dorsi, teres major, and triceps. Upon its outer side lies the short head of the bieces; upon its inner side the pectoralis minor, the axillary and brachial vessels, with the nedian nerve ant other hranches of the brachial plexus.

Variations.-The eoraco-brachialis varies chicfly in its insertion, which may extend as high as the capsule of the shouller or the lesser tnlernity, ocensionally forming in this position a separate musele (the rotator humeri); or it mas descend as low as the inner condyle. It sometimes sends a slip to the triceps or brachialis anticus. 


\section{GROLP OF MLSCLES WHCH MOVE THE ELBOW-JOLNT}

\section{FAscla of the LPPER ArM}

The deep fascia of the upper arm forms a strong tube, thicker upon the posterior than the anterior aspect, enclosing all the museles and most of the ressels and nerres. Alove, it is continuous on the outer side and front with the fascia covering the doltoid and pectoralis major, and internally with the axillary fascia. In the

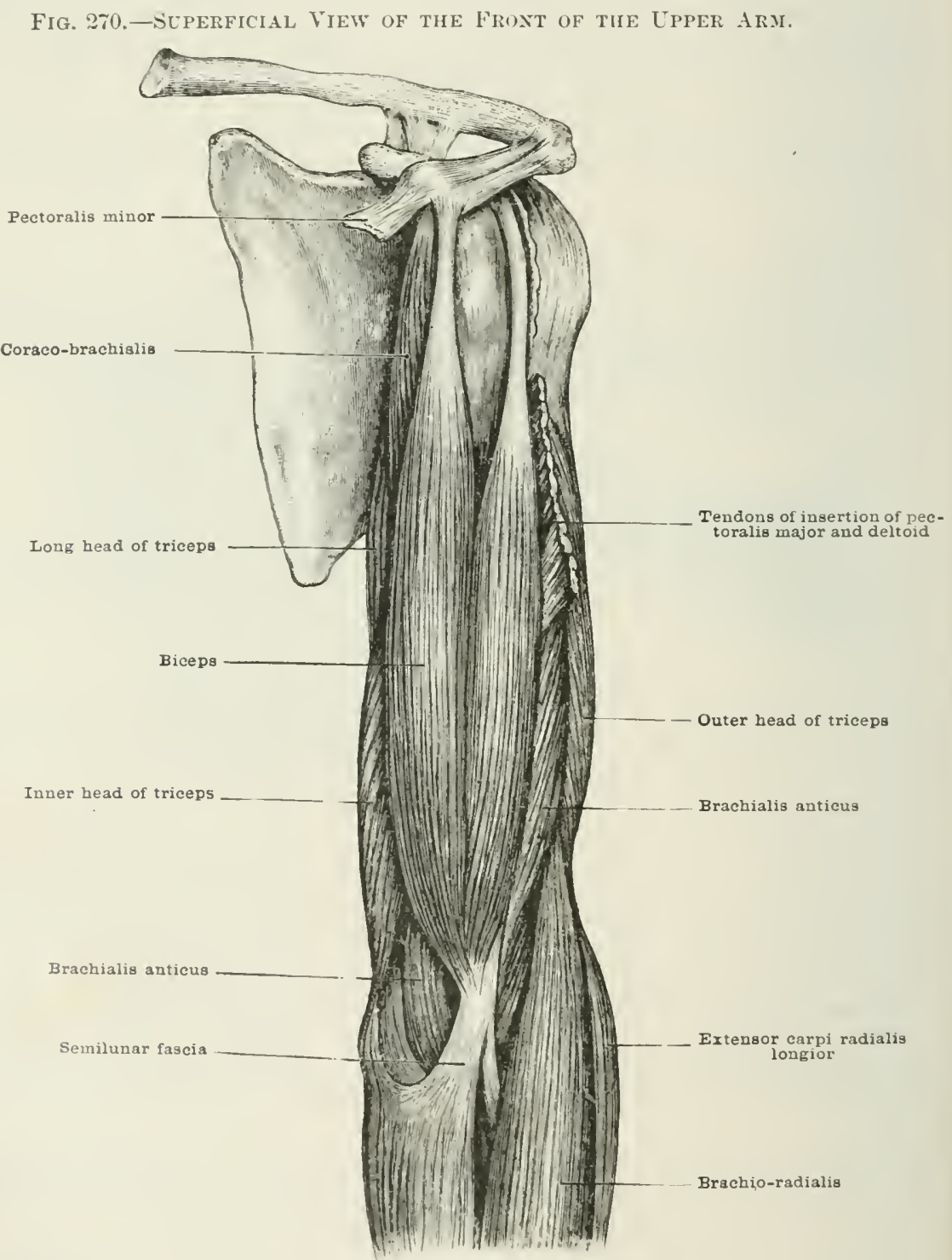

lower two-thirds of the upper arm it is joined upon its deep aspect hy two strong processes: the externol intermensenler aptum, which arises from the external condylar rilge and the outer berrler of the humerus; and the intermal intermusentar septum, which arises from the internal eondylar ridge and the inner horder of the humerus. The tube formed hy the dees fascial is thus divided by the hone and these two septa into two compartments. In the front iompartment are placed the flexors of the elhow-joint, and in the hack conneartment the great extensor muscle. 


\section{Fiexuls of the Foreari}

The flexor muscles are three in number. The most superficial is the liceps. which arises from the scapula; while more deeply lie the brachialis anticus and brachio-radialis (supinator longus), which arise from the humerus.

\section{BICEPS}

The biceps flexor cubiti-named from its two heads and its action upon the culitus, or elbow-is a thick, somewhat flattened fusiform muscle with a bific "pper extremity.

Origin.-(1) The short head from the outer side of the tip of the coracoid process, in close comnection with the coraco-brachialis muscle; (2) the long head, from the upper border of the glenoid fossa of the scapula and from the glenoid ligament.

Insertion.-(1) The posterior border of the tubercle of the raclius; (2) the upper part of the deep fascia on the inner side of the front of the forearm, two inches (i) cm.) below the imner condyle of the humerus.

Structure.-The short head arises by a short tendon from which the fleshy fibres diverge in a somewhat conical form until they meet and blend with the outer and longer head about the middle of the upper arn.

The long head arises by a thick ribbon-like tendon three to four inches (about $9 \mathrm{~cm}$.$) long, which at its origin upon the upper border of the glenoir fossa lifur-$ cates and blends with the glenoid ligament of the shoulder-joint. It first pasees outwards and arches over the rounded head of the humerus. It afterwards enters the canal formed by the bicipital groove internally, and externally by the capsule of the joint, together with the aponeurotic expansion derived from the tendon of the pectoralis major. Down to this point it is invested hy synovial nembrane, which is reflected upon it from the adjacent bone and capsule. After emerging at the lower end of the bicipital groove it gives origin to a conical mass of Heshy fibres. which meet with the fibres derived from the shorter head about the middle of the upper arm. The fleshy bundles loelonging to the two hearls mar he separated for a considerable distance by careful dissection. A little below the midclle of the upper arm, the tendon of insertion commences as a septum between the two bellies of the muscle. It rapidly increases in thickness, and about the level of the condries it becomes free. and as a flattened cord passes clown in the middle of the bend of the elbow and turns upon itself so that its anterior aspect now hecomes external; before its insertion into the posterior border of the tulercle of the radiuit is separated from that process by a small synovial bursa. About an inch and a half ( $4 \mathrm{~cm}$.$) from its insertion it gives off from its inner borter a strong loand of$ fibrous tissue three-quarters of an inch broad and one inch long (the semilunar fatsia), to the cleep fascia covering the uhar surface of the forearm.

Nerve-supply.-From the outer cord of the brachial plexus (through the sixth and serenth (ervical nerves) by a branch of the musculo-cutaneous nerve which enters the muscle on its posterior aspect near its inner borler.

Action.-(1) It flexes the cllow-joint by means of its radial insortion, and also by the attachment of the semilunar fascia to the immer side of the forearm. (2) It supinates strongly the foream by means of the radial tendon which wraps: round the tubercle of the radius. This movement will be most powerful when the elbow is bent to a right angle, as the tendon is then perpendieular to the hone, which it causes to revolve. To increase its leverage, the tendon is lifted away from the axis of the bone hy the prominence of the tubercle. (3) It will assist sompwhat feebly in the movements of the shoulder-joint, its short head being. like the coraco-brachialis, a flexor and adductor of the upper arm. By its long hear it binds down the upper portion of the humerus, and prevents the tendeney to distocation upwards. When the formarm is fixed, the liceps will help in flexing the elbow, as in climbing or in trawing up the trunk to a horizontal bar.

Relations. - Superficially, the deltoid and pectoralis major, the deep fascia, 
and at the bend of the elhow the merlian ceplatic rein and brachio-radialis; deeply, the humerus, the brachialis anticus, and supinator brevis; mon its inner sicle lie the corace-brathialis, the brathial ressels, and the median nerve. The semilumar fascia separates the median basilic vein from the brachial vessels and median nerve.

Fig, 271.-DeEp View of the Froxt of the UpPer Arit.

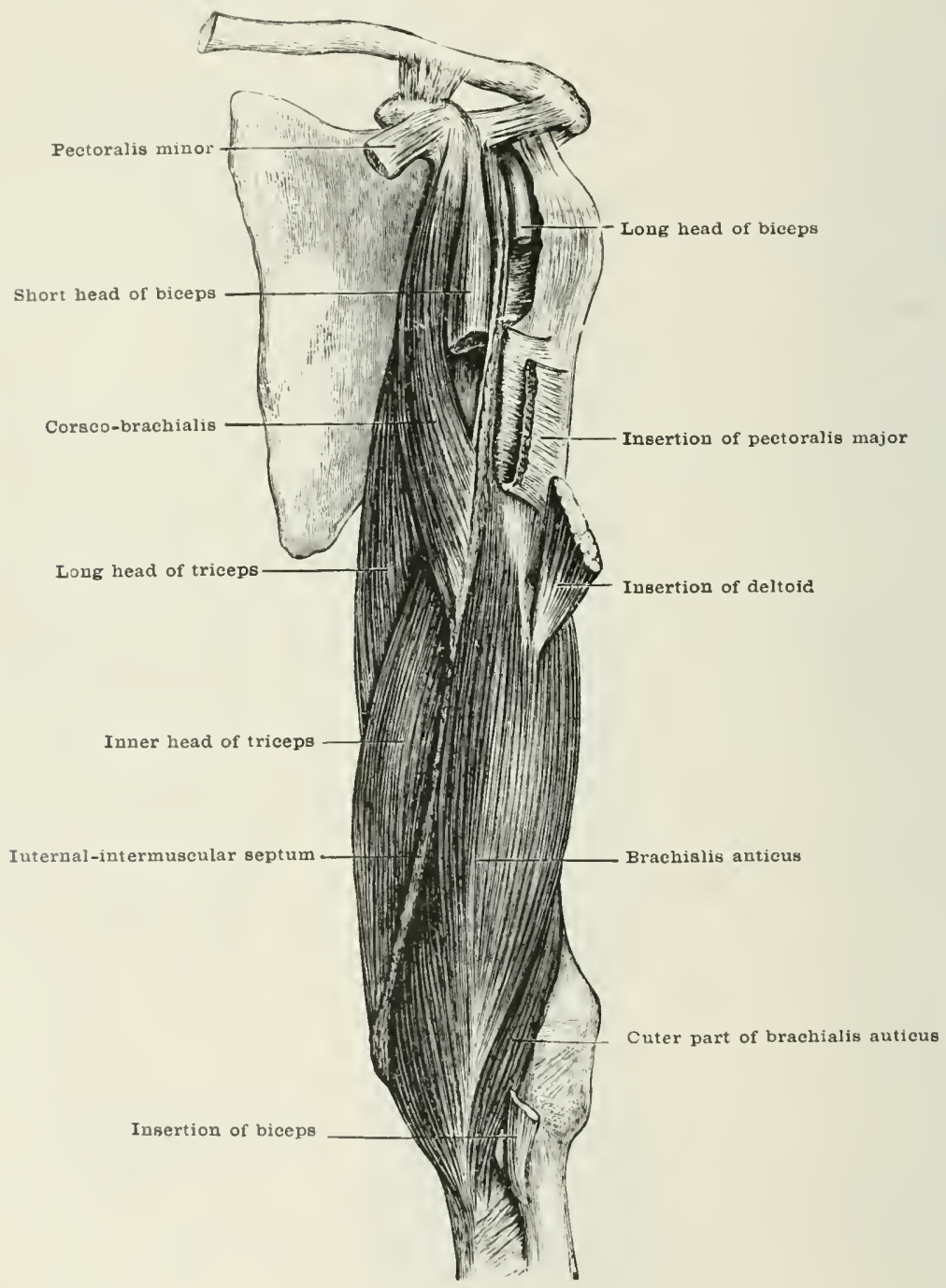

Variations.-The origin of the hiceps is remarkably variable. Sometimes one of the heads is deficient. IIore often at thirl head in deriver from the middle of the inmer border of the humerns, and sometimes as many as three ahditional heads have been found arising from the humerns. Occasionally it sends slips to the interual intermuscular septum, internal condyle, or coronuid process.

\section{BRACHIALIS ANTICLS}

The brachialis anticus-named from its intimate relation with the front of the humerns (bicthimm) - is a thick, somewhat fusiform sheet, curved from side to side to fit on to the front of the humerus. and slightly bifid above. 
Origin.-The whole of the lower three-fifths of the front of the humerus, with the exception of the small space on its imner aspect occupied by the coracobrachialis and the impression upon the outer aspect for the deltoid inuscle, upon either side of which it sends up two small pointed processes; (2) the front of the internal intermuseular septum; (:3) a small portion of the upper part of the front of the external intermuscular sentum above the point where it is pierced by the musculo-spiral nerve.

Insertion.-The inner and lower part of the rough triangular impression upon the front of the coronoid process of the ulna.

Structure.-The greater part of its origin is hy fleshy fibres which converge upon a tenclinous sheet which makes its appearance at first upon the anterior surface of the muscle, just abore the level of the ellow-joint. This tendinous shect receives the converging fleshy fibres upon its posterior aspect, and becones gradually. thicker until it forms a very strong tendon of insertion which is closely connectei with the front of the anterior ligament of the elbow-joint. The lower and outer portion of the muscle is deeply grooved by the brachio-radialis (supinator longus). so that it often looks like a sejarate muscle.

Nerve-supply.-(1) From the external corr of the brachial plexus (through the sixth cervical nerve) hy branches of the musculo-cutaneous nerve which enter the anterior surface of the muscle near the inner border of its upper third; (2) from the posterior cord of the brachial plexus (through the seventh cervical nerve) hy a small filament from the musculo-spiral nerve which enters the front of that part of the muscle which is concealed by the origin of the brachio-radialis (supinator longus).

Action.-To flex the ulna. Like the biceps, it will form a lever of the thim order, but with much mechanical disadrantage on account of the proximity of its insertion to the axis of the elbow-joint. There will be, however, a propritional gain in speed and range of movement.

Relations.- In front, the deep fascia on the outer side of the arm which separates it from the cephalic vein, the hiceps, coraco-brachialis, deltoid. hrachioradialis (supinator longus), and extensor carpi radialis longior, the brachial vessels, median and musculo-spiral nerves; behind, the triceps and elbow-joint.

Variations. - The brachialis anticus is sometimes dividerl into two hearls by a continuation of the cleft between the two pointed prneesses above mentioned, or by a separation of a part of the outer half. Oceasionally it gives off muscular slips to the radius or the fascia of the forearm, also to arljacent museles such as the pronator teres, the brachio-radialis, and the extensor carpi radialis longior.

\section{BRACHIO-RADIALIS}

The Jrachio-radialis (supinator longus) is described with the radial group of muscles (page 321 ).

\section{EXTENSORS OF THE FOREARM}

The extensor muscles are two in number-the triceps and the anconeus.

\section{TRICEPS}

The triceps extensor cubiti-naned from its three heads and its action upon the elhow or cubitus-forms a thick fusiform sheet wrapping round the posterior' surface of the humerns in its whole lemeth.

Origin.-The long head arises from the lower edge of the grenoin carity and the axillary borter of the scapula for one inch $(2.5 \mathrm{~cm}$.) below it.

The external head arices (1) from the posterior surfice of the humerts alove the musculo-spiral gromre. reaching as far up as the lase of the greater tuluerosity and the insertion of the teres minor; () from the hack of the external intermuscular septum above the point where it is pierced hy the musculu-spiral nerre. 
The internal head aris's (1) from the whule of the posterior surface of the humerus lestreen the musculo-spiral groove and the olecranon fossa: (2) on the inner side, from the back of the whole of the internal intermuscular septum; (3) on the outer side, from the hack of that portion of the external internuscular septum which lies below the point where it is piereet hy the mruseulo-spiral nerve.

Insertion.-(1) 'The prosterior prat of the upluer surface of the olecranon pro(ess; and (2) on either sicle by aponeuroses which are continuous with the deep) fiacia on the back of the forearm.

Structure.-The long hearl forms a strong fusiform muscular band, arising by tendinous fibres which blend with the lower part of the capsule of the shoulderjoint. The surfaces of the band at first look inwards and outwards. The tendon of origin extends for some distance further on the inner than on the outer surface. As the muscular band passes downwards, it twists upon itself so that what was the intemal surface now becomes posterior, and the external surface becoming the anterior is applied to the back of the rest of the muscle. ${ }^{r}$ pon this anterior surfice the common tendon of insertion beyins as a broad aponeurosis about three inches ( $S \mathrm{~cm}$.) from the seapula, and receives the fleshy fibres of the long head in penniform fashion chiefly upon its upper border and posterior surface. These Heshy filores are continued as a thick band along the inner borker of this common tendion, and terminate in a blunt point a little below the junction of the middle and lower thirds of the arm.

The external head arises by fleshy fibres which are inserted in penniform fitsion into the outer horder of the common aponemrosis. The lowest of these fibres arise from a tendinons arch which bridges over the musculo-spiral nerve.

The internal head. which is much stronger than the outer, forms a thick triangular sheet, wrapping round the back of the bone, and arising also from the lack of the intermuscular septa on either side. The apex of this triangle extends upwarks along the lower borker of the nusculo-spiral groove to a point just below the insertion of the teres major. Its fleshy fibres pass downwards and somewhat backwards to the broad aponeurosis, which, after receiving the fleshr fibres from the outer and long heads, completely covers the whole of the posterior surface of the muscle in the lower third of the arm. A few fleshy fibres of this head are inserterl dircetly into the olecranon and the arljacent posterior ligament; the slip attached to the ligament is sometimes called the subanconeus.

The insertion of the tenrlon into the back part of the upper surface of the olecranon is usually separaterl from the adjacent part of the olecranon and the posterior ligament of the elbow-joint hy a small bursa. That part of the aponeurotic continuation of the tendon which lies between the olecranon process and the back of the external (ondyle is by far the stronger.

Nerve-supply.-From the posterior cord of the brachial plexus (through the seventh and eighth cervical nerves) by means of the musculo-spiral, which supplies branches to the long and inner heads in the first part of its course; and numerous other liranches to the immer and outer heads while passing through the musculospiral groove.

Action.-To cxtend the elhow-joint, the muscle acting as a lever of the first corler, at a rery great mechanical disadvantage on aceount of the short distance which intervenes between the olecranon process and the axis of the elbow-joint; but at the same time with a great grain in speerl and range of movement. Hence this mucele is the chief agent in movements of the arm in which great speed is attainel, such as in throwing a stone or striking a blow. The long head has some influence as an alductor of the shoulder-joint; it has also a supplementary ligamentous artion upon that joint similar to that of the coraco-brachialis by holding the hear of the humerus in close contact with the glenoid carity. As it passoserer both the shoukder- and the allow-joints, the long head enables the powerful aluduetors of the shoulker to axert it peeuliar influence upon the extension of the elhow joint. If it were merely a pasive ligament, the long head would extend the elhow whenever the humerus was aluducted he the doitoid muscle. As, howeror. the long head contracts at the same time with the deltoicl, we have an apparatus by wheh, so to speak, a rouble mapility of extrnsion is sceured for the elhow-joint. This attachment, thercfore, of the long head of the triceps to the sealpulat is the chief 
cause of the rapid movements of the lower end of the forearm which are made use of in thowing and striking.

Acting from below, the triceps will extend the upper arm upon the forearm, as in the use of the parallel bars, and in many other grmmastic exereises.

Relations.-The long head lies behind the subsapularis, teres major, and latissimus dorsi, in front of the teres minor, with the dorsalis seapulae ressels upon its posterior, and the posterior circumflex vesecls and the circumflex nerve upon its anterior border. Lower down, the pusterior surface of the muscle is only separated from the integuments by the leep fascia; in front lie the brachialis anticus, brachioraclialis (supinator longus). extensor carpi radialis longior, and coraco-brachialis, with the superior and inferior profundal ressels and the ulnar and musculo-spiral nerves. A small bursa intervenes between the tendon and part of the olecranon process. The muscle is also in relation with the shoulder-and elbow-joints.

Variations.-The internal hearl sometimes arises as high as the greater tuberosity. An additional slip is vccasionally received from the capsule of the shonliter-joint, the coracoid process, or the tendon of the latissimus dorsi. A slip of muscle is fiernently separated from the lower border of the internal head, and, passing from the inner condyle to the olecranon, bridges over the ulnar nerve.

\section{ANCONEUS}

The anconeus is described with the Muscles ox the Back of the Foreary (page 327 ).

\section{MUSCLES OF THE FOREARM}

The muscles of the forearm are enveloped by a strong deep fascia which is continuous with that of the upper arm. It is thickest upon the posterior aspect, where it is attached to the sides of the triangular posterior surface of the olecranon, and to the whole of the posterior ridge of the ulna. Below the internal condyle it receives the broad band of the bicipital fascia; and behind. the aponemotic insertion of the triceps. In the bend of the elbow it is pierced by a commmicating rein. On the outer side and back of the forearm the deep fascia has numerous connections with the longitudinal ridges on the lower ends of the radius and ulna. It also becomes much thickened by the addition of transverse bands, so as to form the posterior annular ligament, which passes from the outer border of the lower end of the radius, inwards and at the same time a little downwards, to the ulnar border of the carjus, where it is attached to the inner sides of the pisiform and euneiform bones. On its anterior surface this ligament is attached to the ridges upon the back of the lower extremity of the radius, and so forms canals through which pass the tendons of the long muscles upon the radial border and posterior surface of the forearm. The ligament is also in contact with the lower end of the ulna, which it binds in its place, much in the same mamner as the head of the radius is held in position by means of the orhicular ligament, but it has no insertion into this bone.

In the front of the wrist the deep fascia forms a thin layer, which overlies the anterior annular ligament. The latter is sometimes described as a thickening of the same fascia, but really it is continuous with a thin aponemrosis which separates the first and second layers of the muscles of the forearm shortly to be described. It is a strong band of fibrous tisisue, whirh stretches transversely from the pisiform bone and unciform process on the ulnar side of the carpus to the scaphoid and the trapezium on the radial side.

\section{IISCLES OF THE FRONT OF THE FOREARM}

The muscles upon the front of the forearm form four planes or layers: the first two layers having their origins from the front of the internal condyle; the last two from the bones of the forearm alone. 


\section{FIRT LAYER}

The first layer consists of foml muscles-the pronator radii teres, flexor carpi radialis palmairis longus, and flexor carpi ulnaris-which all arise by a common

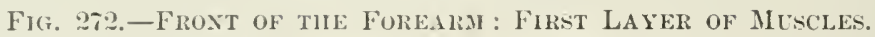

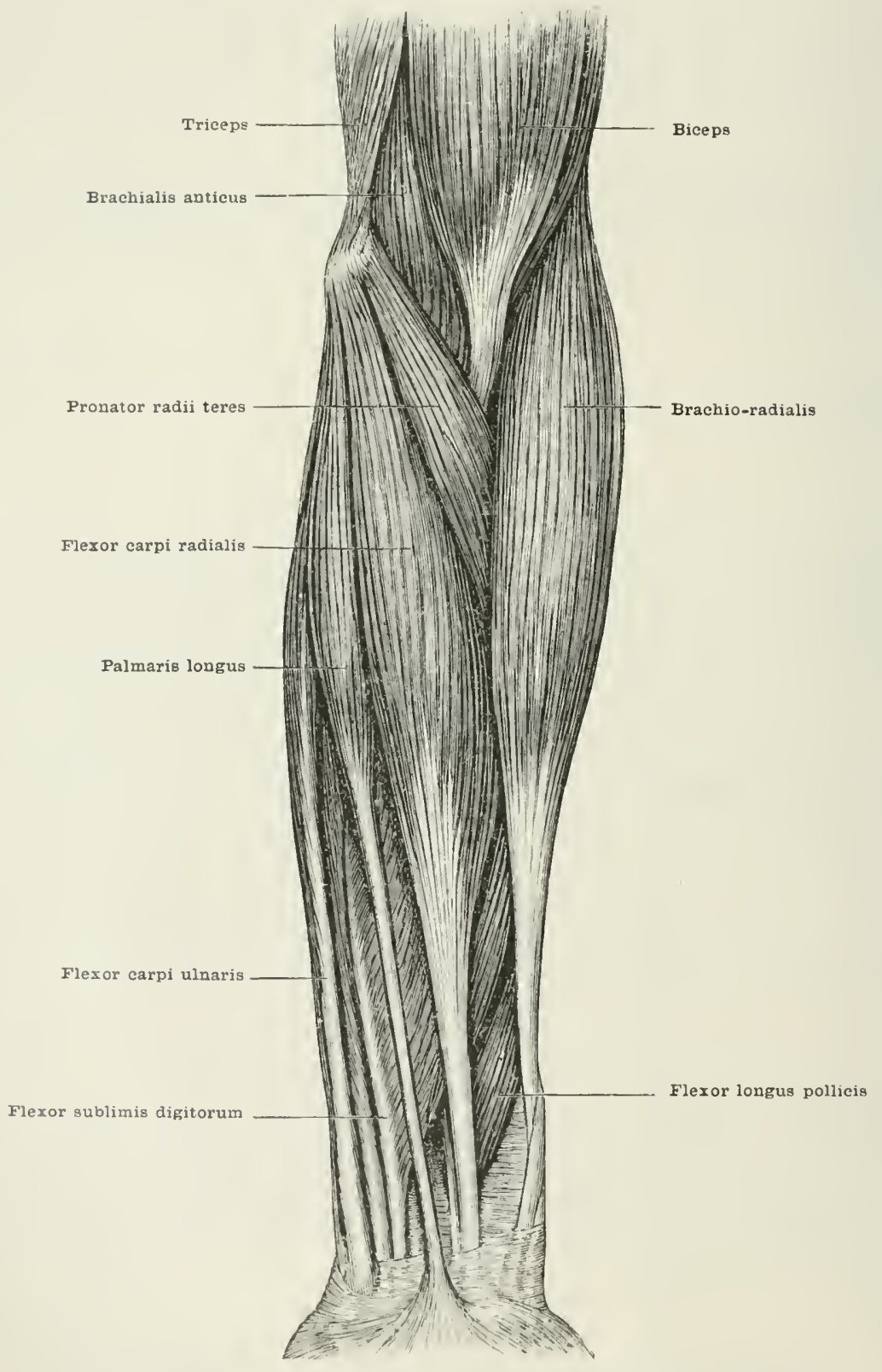

tenclon from the front of the internal conclyle, and by separate attachments from the deep faseria of the foream amel the intemusular septa; while the imnermost and ontermost have adelitional origins from the uha. 


\section{PRONATOR RADII TERES}

The pronator radii teres-named from its action and somewhat cylindrical shape-is a thick ribbon-shaped muscle.

Origin.-First head: (1) by the common tendon from the front of the internal condyle; and (2) from the lowest part of the internal conclylar riclge; (3) from the deep fascia covering it, and the intermuscular septum which separates it from the flexor carpi radialis and the flexor sublimis digitorum.

Second head: from the inner border of the coronoid process.

Insertion.-The rough impression on the middle of the outer surface of the radius.

Structure.-The higher of the two heads, which is much the larger, arises partly by a short tendon, and partly by muscular fibres, and is separated from the lower head by a small tendinous arch through which passes the median nerve. The lower head, which lies concealed by the rest of the muscle, arises hy a small aponeurotic band. The thick fleshy muscle passes obliquely downwards and ontwards across the front of the forearm. Below the middle of its anterior surface begins the tendon of insertion, which expands and covers the whole of the muscle for a short distance before it is inserted by a strong filorous band into the sprecial impression for it upon the most prominent portion of the outward curve of the radius.

Nerve-supply.-From the outer and inner cords of the brachial plexus (through the sixth cervical nerve) by means of filaments derived from the median nerve just before it passes through the arch between the two heads. These filaments enter the muscle at its deep surface a short distance above the michlle of its outer border.

Action.-(1) To pronate the forearm. In supination, the tendon is to some extent wrapped round the radius, as the tendon of the biceps is in pronation. In contraction, the muscle so to speak, unwraps itself and so causes the radius to revolve around the axis, which passes through the micklle of its head and the lower end of the ulna. Its insertion into the convexity of the curve of the radius places the line of the muscle as far as possible from this axis, and so gives it some mechanical advantage. On the other hand, the obliquity of its insertion climinishes the power of the muscle, and is one of the causes which make pronation a more feeble movement than supination. (2) It will also assist in the Hexion of the forearm.

Relations. - Superficially, the bicipital and deep fascire and superficial reins, the radial ressels and nerve, and, lower down, the brachio-radialis (supinator longus) and radial extensors. Deeply, the brachialis anticus, Hexor sublimis digitorum, supinator brevis, and the median nerve. By its outer border, it forms the imner boundary of the space at the bend of the elbow, and hy its inner border it $i_{\text {s }}$ in contact with the flexor carpi radialis.

Variations.-The pronator radii teres frequently extends at its origin for some distance further up the interual condylar ridge. It may also receive a separate head from the internal intermuscular septum, the inner border of the humerus, or an abmurmal supraconilylar process ; sometimes also from the biceps or brachialis antieus. This third head bridges over the brachial artery and median nerve.

\section{FLEYOR CARPI RADIALIS}

The flexor carpi radialis-named from its action as a flexor of the wrist and its position on the radial side of the joint-is flat and fusiform.

Origin.-(1) The common tendon from the front of the internal condyle; (2) the deep fascia and the intermuscular septa which lie between the nusche and the jronator radii teres, the flexor sublimis digitorum, and the palnaris longus.

Insertion.-The front of the base of the second metaearpal bome; and usually by a smaller slip into that of the third as well.

Structure. - Its fleshy filmes are contained in an aponeurotic case which forms an elongated four-sided piramid, the apex being at the internal eondyle, and the 
fills consisting of the lew fitsia and the intemuseular septa which intervene hetween it and the aljacent museles. The fleshy fibres converge rownwarls and comewhat outwarls ujum the hack of the temelon which begins at the jumetion of the mprer and midclle thirels of the foream, and is free a little betow the micldle of the foreatrit.

At the wrist the tenclon passes throush a special compartment external to the tube formed by the anterior ammular ligament. This compartment is bounded hehinel by the seaphoid bene and the groove upon the trapezimm; externally, by the tuleresity of the sonphoirl bone and the ridge upon the trapezium; and in front and internally by a thickening of the deep fascia of the forearm. It is lined by a suecial synovial memhrane.

Nerve-supply.-From the outer and inmer cords of the brachial plexus (through the sixth cervical nerve) hy filaments from the median nerve which pass to) its posterior surface in its uppere third.

Action.-(1) To Hex the wrist. By its insertion into the metaearpus it bends not only the raclio-(arpal joint (which is the wrist-joint proper), but also the inter(arpal and the carpo-metacarpal joints, which really take part in all the movements of what mar be called the wrist as rlistinguished from the wrist-joint. (2) When the hand is fully supinated, it helps in pronation. (3) It is also a feeble flexor of the elhow:

Relations.-Sinperficially, the deep fascia and the superfieial veins; deeply, the flexor sublimis digitormm, the flexor longus pollicis, the median nerve, the wrist and some of the carpal joints; on the outer side of it lie the pronator radii teres and the radial vessels; on the inner side it is in contact above with the palmaris longus.

Variations. - The flexor carpi radialis may have a second origin from the tendon of the biceps wr the ratius, and its insertion may be extended to the base of the fourth metacarpal bone or to some of the bones of the carpus. It is sometimes absent.

\section{PALMLARIS LONGLS}

The palmaris longus-named from its length and its insertion upon the palm of the hand-is flat and fusiform.

Origin. - (1) The common tendon from the front of the internal condrle; (2) the deep fascia of the forearm; and (3) the septa which lie between the muscle and the fluxor earpi ratialis, the flexor carpi ulnaris, and the flexor sublimis digitorm.

Insertion.-(1) The upper end of the strong central portion of the patmar fascia; (2) the lower part of the front of the anterior annular ligament; and (3) the eleep fascia covering the thenar eminence.

Structure.-Like the preceding muscle it eonsists of fleshy fibres which rise in a long four-sicled prramid from the aponeurotic case formed by the cleep fascia and the intermuscular septa. Its tendon appears first upon the anterior surfaee of the muscle at the junction of the middle and upper thirds of the forearm, and is free ahout the midille of the forearm. It passes almost direetly downwards to the miclle of the wrist, where it descends in front of the upper part of the anterior ammular ligument, and then becomes attached to its lower edge as well as the arljacent faicice.

Nerve-supply.-From the outer and inner eords of the brachial plexus (through the eighth cervical nerve) by filaments from the median nerve which enter the dexp surfice of the muscle.

Action.-(1) To flex the wrist; (2) to a slight extent to flex the elhow also; (3) it makes tense the contral portion of the palmar fascia, so that when an object is grasped tirmly by the fingers no injurious presure is exerted upon the important vescels and nerves wheh liw honeath that strueture; (4) its attachments to the fascia of the thenar eminenceseses a firm origin to some of the short museles of the thumb.

Relations.- Superficially, the Ieep fascia and superficial veins; deeply. the flexor sublinis digitorum anel metian nerve, and the upues part of the anterior ammular ligament. 
Variations.-The palmaris lougus is very variable. It may be double, and it is often alsent. The fleshy belly is sometimes below, and the tendon in part or entirely above. It may take an additional head from the radius or the coronoid process. Its insertion may be into the fascia of the forearm, the flexor carpi ulnaris, the short muscles of the little finger, or one of the carpal bones.

\section{FLEAOR CARPI ULAARIS}

The flexor carpi ulnaris-named from its influence upon the wrist and its position-is a thick sheet of muscular fibre, somewhat fusiform in shaye, which wayse round the convex ulnar border of the forearm.

Origin.-First head: (1) by the common tendon from the lower part of the front of the internal condyle; (2) the deep fascia of the forearm; and (3) the septa which intervene between the muscle and the palmaris longus and flexor sublimis digitorum.

The second head: from the inner surface of the olecranon process, and the upper two-thirds of the posterior border of the ulna.

Insertion.-The upper surface of the pisiform bone, beyond which fibres are continued to the unciform process and the front of the base of the fifth metacarpal hone.

Structure.-The origin of the upper head is tendinons, and that of the lower is partly Heshy, partly aponeurotic; the aponeurosis from the posterior ridge of the ulna being common to it with the flexor profundus digitorum and the extensor carpi ulnaris, and being closely blended with the deep fascia of the back of the forearm. The two heads are united by a fibrous arch under which passes the ulnar nerve. From this tendinous and bony origin the fleshy fibres pass downwards and forwards in a penniform manner to be inserted into the posterior aspect of a tendon which appears on the front of the muscle a little above the middle of the foream, and becomes free just above the wrist-joint, where it lies superficial and internal to the anterior annular ligament.

Nerve-supply.-From the inner cord of the brachial plexus (through the eighth cervical and first thoracic nerves) by filaments from the ulnar nerve which enter the deep surface of the muscle above the middle of the forearm.

Action.-(1) To flex the wrist. The pisiform bone assists this action by lifting the line of the tendon a little from the metacarpal bone, much as the patella assists the ruadriceps femoris. (2) It assists somewhat feebly in adduction of the wrist. (3) It helps in the flexion of the elbow.

Relations. - Superficially, the deep fascia and superficial reins; deeply, the flexor sublimis and profundus digitorum, the ulnar ressels and nerve. At the ellow the posterior ulnar recurrent artery with the ulnar nerve passes between the two hearls of this muscle. Near the wrist the ulnar artery lics along the outer border of the tendon.

Variations.-Its insertion sometimes extends to the anterior annular ligament, and oceasionally it sends a slip to the base of the fourth metacarpal bone.

\section{SECOND LAYER}

The second layer consists of one muscle-the flexor sublimis digitorum.

\section{FLEXOR SLBLIMIS DIGITORLM}

The flexor sublimis digitorum-named from its action as a flexor of the fingers, and from its position in relation to the reep flexor (sublimis = superficial) is a fusiform sheet, with two hearls ahove. and dividing into four tendons below:

Origin.- The first head arises from (1) the front of the internal condyle by the common tendon: (2) the intermuscular septum which separates it from the muscles of the first shert; (3) the internal lateral ligament; and $(t)$ a tubercle at the upper part of the inner borker of the coronoid process of the ulna. 
The second head arises from the oblique line on the anterior surface of the ratlins.

Insertion.-Br four tendons into the mithle of the sirles of the second phalanges of the four fingers.

Structure.-The first head arises hy short tendinous fibres from the humerus

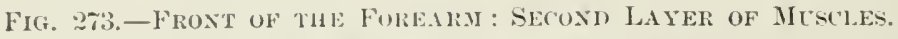

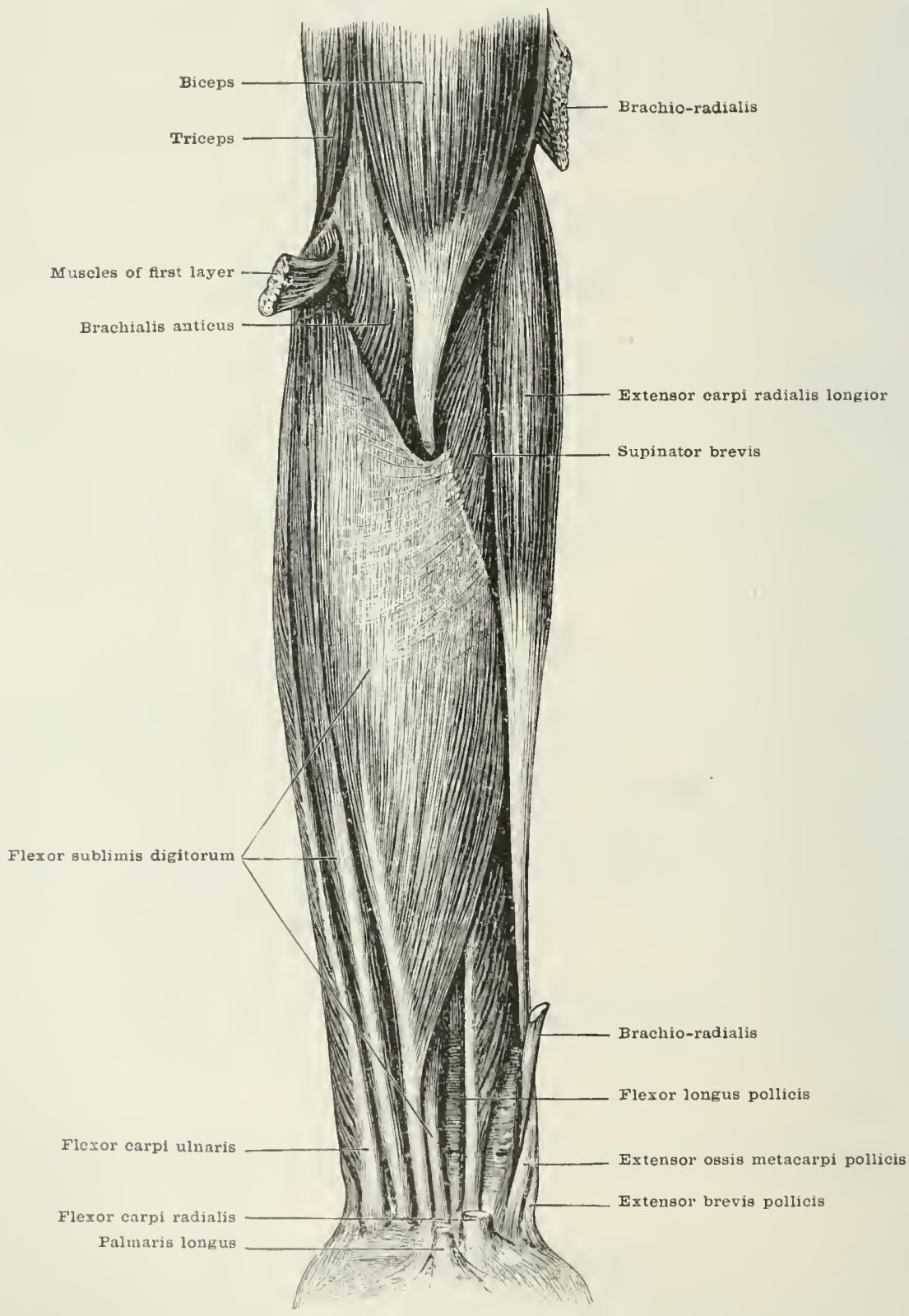

and ulna, and from the ligament between them. The second head, which is much smaller, by fleshy fihres which form a thin sheet covering a part of the flexor longus pollicis. Butwren these two heads the mortian nerve and the unar artery are placed. Converging from these two hearls. the Heshy filnes ocemp almost the whole breath of the forcarm, but soon clivide into a superticial and derap plane. From the former, 
which contains the radial hear and the more superfieial fithes of the first hear, the tendons to the middle anil ring fingers are derived. The tendon to the mirklle finger receives the greater part of the radial head in penniform fashion, beconing free close to the anterior ammular ligament. That to the ring finger separates high up, and is soon free from fleshy fibres. The deeper plane of the muscle is crossed by a strong tendinous intersection soon after its origin from the first head. It then gives off a fleshy band to join that part of the sujerficial plane which goes to the ring finger, and afterwards bifureates to form the tendons for the index and little fingers. I am indebted to Profesior Thane for calling my attention to this arrangement. Beneath the anterior annular ligament the tendons of the superficial plane, viz. those going to the middle and ring fingers, lie in front of the other two tendons. Here they are invested by the synovial sheath or great palmar bursa, which is common to them and the other tendons which pass through this space, and which

Fig. 274.-DIAgRaM of THE GREAT PALiAR Bursa.

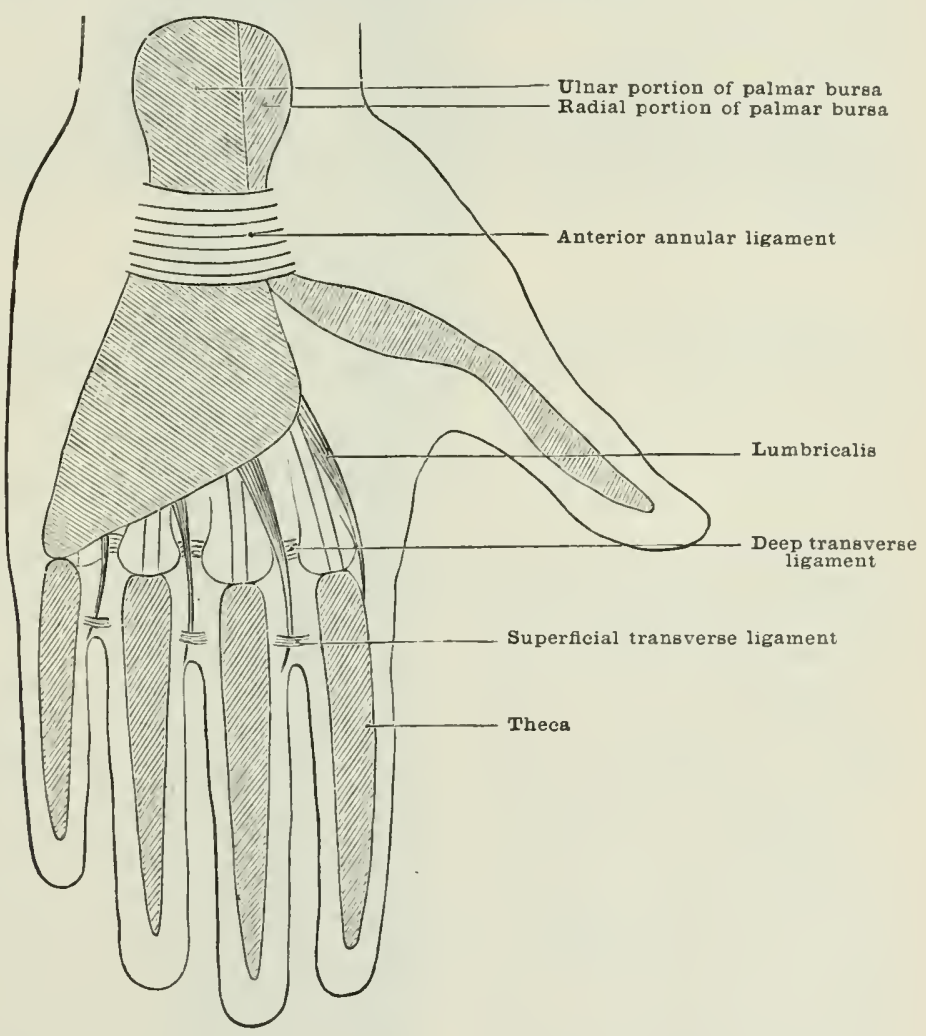

extends from a short distance above the wrist-joint to about the middle of the palm. At the heads of the metacarpal bones the tendons enter the raginal sheaths of the flexors of the fingers, and each tendon hecomes concave hehind to corres]ond with the eonvexity of the tendon of the derp flexor upon which it now rests. At the middle of the first phalanx the tendon splits, and the halves separate to allow the passage of the tendon of the flexor profunclus. The two hatres arain unite olposite the base of the second phalanx in such a way that the parts now in contact are a direct continuation of what were bufore the horders of the tendon; while the parts of the tendon which correspond to its nesial line above are now most wickely separated (see fig. 280$)$. After a contar of about a quarter of an inch ( 6 cm. ), the halves of the tendon again separate in order to be attached to the sides of the shaft of the second phalanx.

Nerve-supply.-From the outer and inner cords of the brachial plexus (through 
the serenth and eighth cervical and first thoracic nerves) by branches from the neclian nerve which enter the deep surface of the muscle at its upper part.

Action.-To thex the second phalanges of the four fingers. Being inserted rery obliguely, it acts under a comsiderable mechanical disadvantage, hut at the same time the speed and range of movement corresponling to a slight contraction of the muscle are rery great. The size of the angle which it makes with the shaft of the phalanx at its point of insertion is somewhat increased by the raising of its tendon from the palmar aspect of the first phalanx by the tendon of the deep flexor. After bending the second phalanx of the finger, it will bend also the metacarpophalangeal joint; then the three joints which together produce flexion of the wrist; and finally it will feebly assist in the flexion of the elbow-joint.

Relations.- Superficially, the four muscles of the first sheet and the radial ressels and nerves; deeply, the flexor longus pollicis, flexor profundus digitorum, and pronator quadratus, the ulnar artery and veins, and the median nerve. In the hand, it lies beneath the anterior amular ligament, the palmar fascia, and the superficial pahmar arch, and upon the tendons of the flexor profundus digitorum with the lumbricales.

Variations.-The flexor sublimis digitorum varies very little in its origin. It has been seen to arise partly from the pronator radii teres. Occasionally its tendon to the little finger fails, and the place of this tendon may be taken by a lumbricalis or a special slip from the flexor profundus. Sometimes accessory heads join the tendons in the hand from the flexor profundus or the annular ligament.

\section{THIRD LAYER}

The third layer consists of two muscles-the flexor profundus digitorum and the flexor longus pollicis - which arise from the ulna and radius respectively.

\section{FLEXOR PROFUNDLS DIGITORUM}

The flexor profundus digitorum-named from its action upon the fingers and its relation to their superficial flexor-is a strong fusiform sheet of muscular fibres which wraps round the anterior and inner surfaces of the ulna, and divides below into four tenclons for the fingers.

Origin.-(1) The upper three-fourths of the anterior surface of the ulna; and (2) the arljacent part of the interosseous membrane; (3) the upper two-thirds of the inner surface of the uha; and (4) the posterior ridge of that bone by the aponeurosis common to it, the flexor carpi ulnaris, and the extensor carpi uinaris.

Insertion. - The front of the bases of the third phalanges of the four fingers.

Structure. - Arising directly from the bones and fibrous structures which form the origin of the muscle, the fleshy fibres converge below upon the back of four tendons, which. appearing about the midrlde of the forearm, hecome free at the upere horeler of the anterior annular ligament. That part of the muscle which is insorted into the index finger is separable from the rest of the muscle in nearly the whole of its extent; the part to the little finger is also generally more separable than that to the other two fingers. As they pass beneath the anterior anmular ligament, the tendons are invested by the common srnovial sheath. At the metacarpophalangeal joints they enter the vaginal sheaths belonging to their respective fingers. Oplusite the first phalangeal joint each tendom jakses through the opening formed hy the splitting of the flexor sublimis tendon; and on the palmar aspect of the second phalanx it passes orer a slight eleration formed by the union of the two halves of the companion tendon before they are inserted into the sides of the second phatanx. The deep tendon finally pasces over the second phalangeal joint, to be inserted into the front of the bise of the third phalanx. In the pain of the hand the lumbricales (which will afterwards be lescribed) arise from the tendons of the flexor profundus.

Nerve-supply.-By two somres from the luachial plexus (through the eighth cervical and first thoracic nerves :-(1) by the anterior interossenus lopanch of the median nerve, which sonds a filanent to the portion of the musele betonging 
to the index finger, and part if not all of that belonging to the middle finger upon the raclial border of its anterior surface, about the midclle of the forearm. (2) $\mathrm{Br}$ the ulnar nerve, which distributes branches to the rest of the muscle near the inner border of the superficial aspect of the muscle in the upper part of the forearm.

Action.- It is a powerful flexor of the third phalanges of the fingers. As with

Fig. 275.-Front of THE Forealiu : THIR LAYER of MUscles.

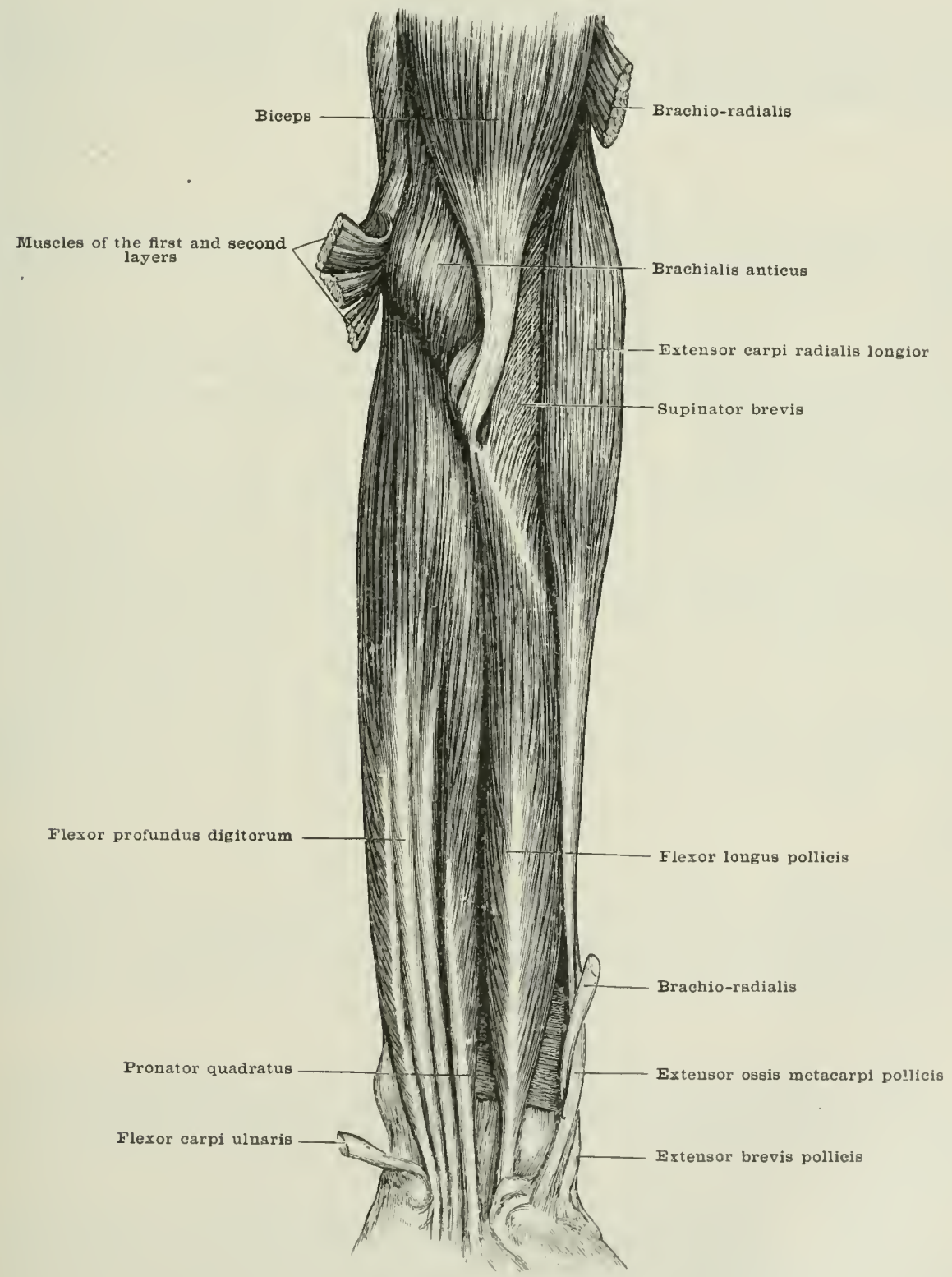

the superficial flexor, the extreme obliquity of the insertion of the tendons gives great speed and range of movement. but increases the nechinical disadrantage with which this muscle (being a representative of the third order of lever) must act. The slight elevation formed hy the union of the two halves of each tendon of the flexor sublimis upon the second phalanx diminishes to a small extent the 
extreme obliquity of its insertion. Ifter hending the third phalinx, the muscle will assist in the Hexion of the other phalanges and the wrist.

Relations.- Superficially, the flexor sublimis digitorm and flexor carpi ulnaris, the ulnar ressels, the methim and ulnar nerves; deeply, the pronator quadratus and wrist-joint. In the hand, it lies beneath the tendlons of the flexor sublimis digitorum and the lumbricales, and upon the adductor of the thumb, the interossei muscles, and the deep palmar arch.

Variations.-The flexor profundus digitorum frequently receires, like the flexor longus nollicis. a slip from the superficial muscles of the forearm. Sometimes the part which goes to the index finger may take part of its origin from the radius; and occasionally slips may pass from the flexor profundus to the flexor longus pollicis, or vice versâ. A slip has been observed to end in the synovial membrane of the palmar bursa.

\section{FLEXOR LONGLS POLLICIS}

The flexor longus pollicis-named from its action upon the thumb and its length as compareel with the short muscles of the ball of the thumb-is a fusiform shert.

Origin.-(1) The anterior surface of the radius below the oblique line, with the exception of the last two inches $(5 \mathrm{~cm}$.) of the surface; and the adjacent surface of the interosseous membrane. (2) A second head arises from the inner border of the coronoid process of the ulna, but oecasionally it may come from the internal condyle of the humerus.

Insertion.-The front of the base of the last phalanx of the thumb.

Structure.-A penniform muscle arising fleshy from the bone and the interosseous membrane. The tendon first appears upon the anterior surface near its ulnar horder about the middle of the forearm. It receives the fleshy fibres upon its outer border and posterior surface and becomes free at the level of the wristjoint, where it enters the canal formed by the anterior ammular ligament and the front of the carpus. It is here invested by a special compartment of the great synovial bursa, and this compartment is continuous with the synovial sheath of the tendon as it lies in the thumb. After entering the palm of the hand, the tenclon passes beneath the outer head of the flexor brevis pollicis, then through the groove formet by the two sesamoid bones which belong to the tentlons of this muscle, and after lying in close contact with the concave palmar surface of the first phalanx of the thimb, it is inserted into the front of the base of the second phalanx.

Nerve-supply.-From the outer and inner cords of the brachial plexus (through the eighth cervical and first thoracic nerves) by means of the anterior interosseous branch of the median nerve, which sends filaments to it upon its anterior surface near its ulnar border about the midclle of the forearm.

Action.-It is a powerful flexor of the last phalanx of the thumb. It will also flex its metacarpo-phalangeal joint, and afterwards it will assist the other flexors of the wrist.

As the bones of the thumb are not in the same plane with those of the fingers, but rotated so that their palmar surface looks towards the rest of the hand, their flexion will be accompanied by adduction; as when the thumb meets the other fingers in pirking up any small object, or in grasping anything between the fingers and thumb.

Relations.-Superficially, the flexor sublimis digitorm, flexor carpi radialis, hrachio-radialis (supinator Iongus), and the radial vesels; deeply the pronator quadratus and wrist-joint. In the hand, after passing beneath the anterior anmular liganent, it is coverest by the opponens pollieis and the outer head of the flexor lirevis pollicis, and it lies on the inner head of the flexor hrevis pollicis.

Variations.-Bexiles the communication with the flexor profundus digitornm, we oceasionally find slips passing fiom the tenclon of the flexor longus pollicis to join the first lumbricalis muscle. 'The seeond head may be atsent, its in fig. 275. 


\section{Fourth Layei:}

The fourth layer consists of one muscle-the pronator quadratus.

\section{PRONATOR QUADRATLS}

The pronator quadratus (fig. 28t) is a thin quadrilateral sheet, named from its action and its nearly square shape.

Origin.--The inner part of the front surface of the lower fourth of the ulna.

Insertion.-The lower two inches ( $5 \mathrm{~cm}$.) or rather less of the outer border and the anterior surface of the radius.

Structure.-The greater part of the muscle consists of fleshy fibres which pass transversely between its two attachments. Its inner third, however, is covered by a strong aponeurosis which arises from the inner border of the ulna. The radial insertion is of a somewhat triangular shape, the outer side of the triangle passing obliquely from the interosseous line downwards, and joining the outer border of the rarlius a short distance from the base of the strloid process; while the inner side corresponds to the interosseous ridge, and the base crosses the front of the radius abore the attachment of the anterior radio-carpal ligament.

Nerve-supply.-From the outer and inner cords of the brachial plexus (through the eighth cervical and first thoracic nerves) by means of the anterior interosseous branch of the median nerve which terminates by filaments which enter the front of the musele near its upper border.

Action.-By drawing the outer border of the anterior surface of the radius towarts the inner border of the anterior surface of the ulna, it pronates the radins upon the ulna.

Relations.-Superficially, the flexor longus pollicis, the flexor carpi radialis, the flexor profundus digitorum, and the flexor carpi ulnaris, the rarlial artery, and the ulnar nerve; deeply, the anterior interosseous artery, the interosseous membrane, and the inferior radio-ulnar joint.

Variations. -The pronator quadratus is sometimes abseut. It sometimes gives off slips to the scaphoid or trapezium, the base of the first metacaryal bone, or to the origins of the short thumb inuscles.

\section{RADLAL GROLP OF MLSCLES}

Along the radial border, between the groups which clothe the front and hack of the forearm, lie three long muscles, one upon the other-viz. the brachio-ractialis (or supinator longus); the extensor carpi radialis longior; and the extensor carpi raclialis brevior.

\section{BRACHIO-RADIALIS}

The brachio-radialis, or supinator radii longus-named from its attachment to the humerus and radius, and sometimes ealled the supinator longus from an erroneous view of its action-is a fusiform sheet.

Origin.-The upper two-thirds of the external condylar ridge, and the front of the external intemuscular septum of the upper arm.

Insertion.-The base of the styloid process of the radius.

Structure.-Arising by fleshy fibres from the septum, and by short tendinous fibres from the condylar ridge, the muscle passes downwarls and forwards in penniform fashion to its tendon which lies first on its deep surface. Becoming free just helow the middle of the forearm, the tendon runs directly downwards and expands hefore its insertion upon a horizontal line at the base of the styloicl process of the radius. At first the plane of the muscle is clirected outwards and inwards; but lower down the outer surface becones anterior, and the inner posterior.

Nerve-supply.-From the josterior cord of the brachial plexus (throngh the $\because 1$ 
sixth cervical nerve). hy branches from the musculo-spiral nerve which enter the upper part of the muscle upon its inner surface.

Action.-To flex the forearm. Its insertion at the lower end of the long arm

Fig, 276. - ilescles of the Radial Side axd the Back of the Forearis.

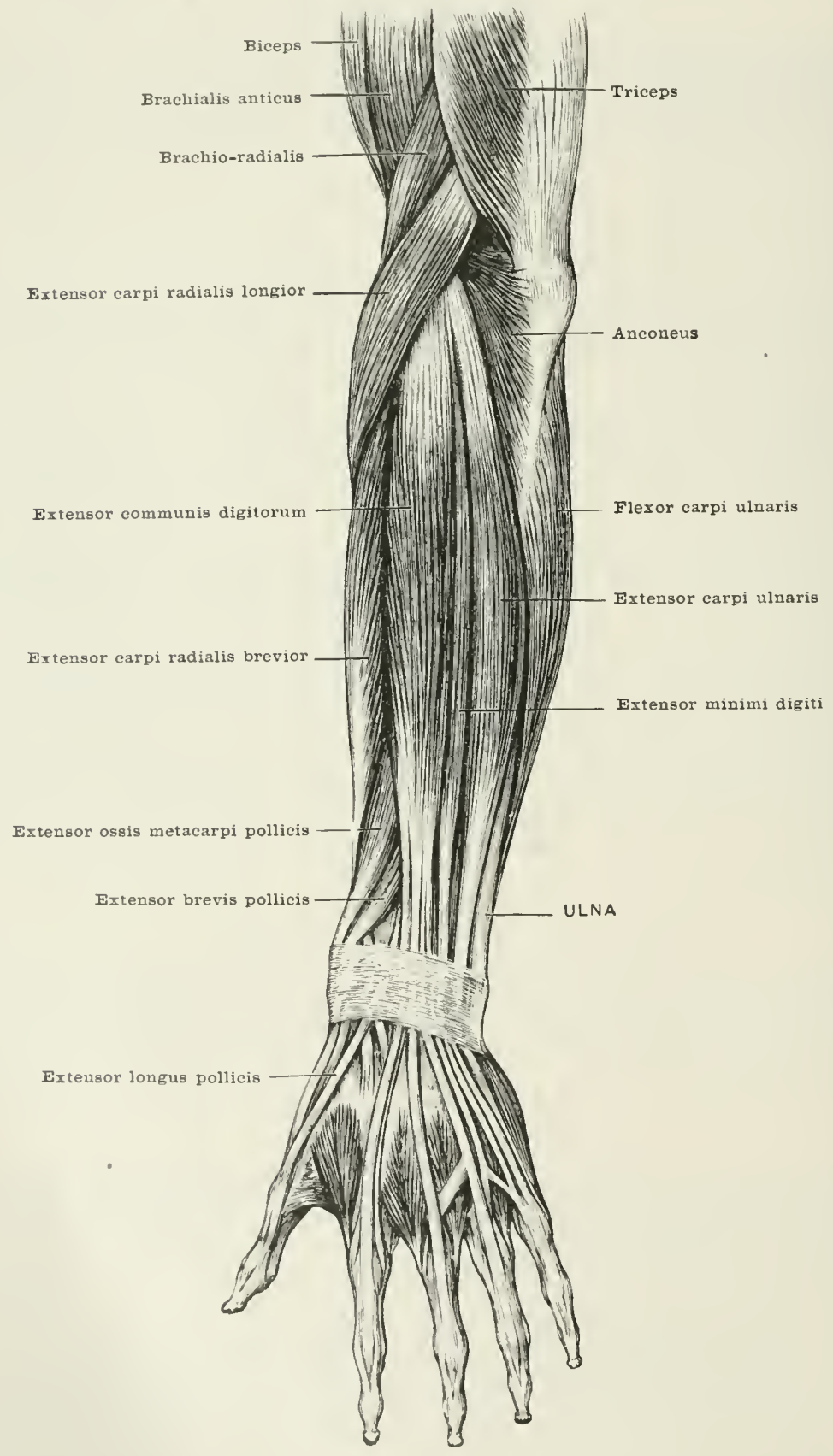

formed by the radius makes it one of the few examples of the second order of lever when the muscle is userl to raise only the weight of the forearm; but whatever advantage is obtained by the position of this insertion is lost by the extreme 
obliquity of the tendon. This obliquity (Introduction, page 286) will, howerer, ardd speed and range of movement, and at the same time it will assist in drawing the articular surfaces of the elbow together, and so give strength to the joint.

If the forearm be fully supinaterl, the contraction of the brachio-radialis will canse some pronation; and it is only when the forearm is in the position of full fronation that it will produce a slight supination. It is therefore incorrect to describe the muscle as a supinator.

Relations.-In the upper arm, it has at its inner side the brachialis anticus, in which it forms a deep groove, and the musculo-spiral nerre and superior profunda vessels. Outside and behind lies the inner head of the triceps. Below, it rests on the upper border of the extensor carpi radialis longior. In the forearm it is covered, above by the deep fascia and superficial reins; below, by the extensor ossis metacarpi and the extensor brevis pollicis. Beneath it lie the extensor carpi radialis longior, the supinator brevis, the pronator radii teres, the flexor sublimis digitorum, the flexor longus pollicis, and the radial ressels and nerve.

Variations.-The brachio-radialis is sometimes absent. It may receive a slip from the brachialis anticus. It may give slips to various parts of the radius, to the carpal bones on the radial side of the hand, to the tenrlons of the extensor earpi radialis longior, the extensor ossis metacarpi pollicis, the flexor longus pollicis, or to the supinator brevis muscle.

\section{EXTENSOR CARPI RADIALIS LONGIOR}

The extensor carpi radialis longior-named from its action, position, and length in comparison with its fellow extensor-is a narrow fusiform sheet.

Origin.-(1) The lower third of the external condylar ridge; (2) the front of the external intermuscular septum; (3) the front of the common tendon by which the extensors at the back of the forearm arise from the external condyle.

Insertion.-The back of the base of the second metacarpal bone near its radial border.

Structure.-Arising by fleshy fibres, this muscle has a somewhat penniform arrangement. Its tendon is first seen near the outer border on the deep surface of the muscle, and becomes free at the junction of the middle and mper thirds of the foream. It lies upon and in close association with the tencton of the short extensor, and passes through the second compartment in the posterior annular ligament to its insertion upon the metacarpal bone. Its surfaces, like those of the preceding muscle, are at first directed ontwards and inwards, and afterwards forwards and backwards.

Nerve-supply.-From the posterior cord of the brachial plexus (through the sixth cervical nerve), by a branch from the musculo-spiral nerve which enters the muscle at the upper part of its deep surface.

Action.-(1) To extend the wrist; including under this appellation the carpometacarpal, intercarpal, and radio-carpal joints. It is also a slight abductor of these joints. When the fingers have to be bent by the long flexors, it steadies the carpus and metacarpus so as to linit the action of the flexors to the phalanges. (2) It has also some influence in flexion of the elbow-joint.

Relations.-In the arm, it lies between the brachialis antieus and the triceps. and it is covered by the brachio-raclialis. In the forearm, it orerlies the short rarlial extensor and wrist-joint, while it lies beneath the brachio-radialis and the extensors of the thumb.

Variations.-The extensor carpi radialis longior may be united with the brevior. It may give tendinous slips to the bases of the first or third metaearpal bones, or to the trapezinm; or a slip may join the extensor ossis metacarpi pollicis, or some of the interossei.

\section{EXTEASOR CARPI RADIALIS BREYIOR}

The extensor carpi radialis brevior-named for similar reasons to those which give its name to the preceding muscle-is also flat and fusiform.

Origin.-(1) The common tendon attached to the external conclyle; (2) the 
intermuscular septa which separate it from the origins of the adjacent muscles; and

(3) the extemal lateral ligament of the ellow-joint.

Insertion. - The back of the bases of the second and third metacarpal bones near the lower part of their line of contact.

Structure. - This muscle is thicker than the preceling, and its fibres have a more decidedly penniform arrangement, as they pass from their long fibrous origin obliquely dowmingl: and forwards to the tendon which appears first upon the inner border of the anterior aspect of the muscle about the middle, and is free at the junction of the lower and middle thirds of the forearm. It passes through the second compartment of the posterior ammular ligament with the tendon of the precerling muscle. The tendons of this and the preceding muscle are invested in a srmorial sheath as they pass through the posterior annular ligament, and a small bursa lies beneath each of them close to its insertion.

Nerve-supply.-From the posterior cord of the brachial plexus (through the sixth and serenth cerrical nerves) by filaments from the posterior interosseons Iranch of the musculo-spiral nerve which enter the upper part of the anterior surface of the muscle.

Action.-(1) To extend the wrist; and (2) to feebly extend the elbow-joint.

Relations. - It is covered br the extensor carpi radialis longior and the tendons of the three thumb extensors. It lies mpon the supinator brevis, the pronator radii teres, the outer surface of the radius and the wrist-joint.

Variations.-Its muscular portion may be blenderl with that of the preceding muscle, or slips may pass between the muscles. The tendon is often divided, and may send separate insertions to the second and third metacarpal bones.

\section{MUSCLES OF THE B.ACK OF THE FOREARM}

The muscles upon the back of the forearm form two layers: the superficial. consisting of those arising from the back of the extemal condyle of the humerus: and the deep layer, of those which, with one exception, arise from the bones of the forearm only.

The superficial layer continues upon the back of the forearm the series of the radial extensors. It consists of four muscles: the extensor communis digitorum; the extensor minimi digiti; the extensor carpi ulnaris; and the anconeus.

\section{SUPERFICIAL LAYER}

\section{EXTENSOR COMMUNIS DIGITORUM}

The extensor communis digitorum-named from its common action upon the four fingrem-is fusiform and somewhat flattened, and divides below into four tendons.

Origin.-(1) The common tendon from the lower part of the external condrle; $(2)$ the dece fascia of the foream; and (3) the intermuscular septa which separate it from the extcnsor carpi raclialis brevior, the extensor minimi digiti, and the supinator brevis.

Insertion.-(1) The lateral liqaments of the metacarpo-phalangeal joints of the four fingere; the back of the bases of (2) the second, and (3) the third phalanges of the four fingers.

Structure.-Arising from the interior of the aponeurotic case formed by the deep fascia and the intrimuscular septa, the fleshy fibres soon break up into separate masses, and converere upon the four tenclons which, beginning about the middle of the forearm, herome free a short distance above the wrist, and lie side by side in the fourth emmartment of the posterior ammular ligment; those for the ring and little fingers being more clusely comneced than the others. After their emergence at the lower border of the ligament, the four tendons, which still retain their flat- 
tenerl cylindrical shape, diverge to their respective fingers. Opposite the heads of the metacarpal bones, each tendon gives off fibrous banch to the lateral ligaments of the corresponding metacarpo-phalangeal joint. Lpon the first phalanx the tenrlon expands into a broad aponeurosis which fits closely by its concare anterior surface

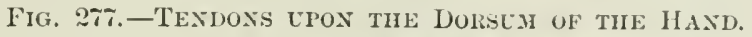

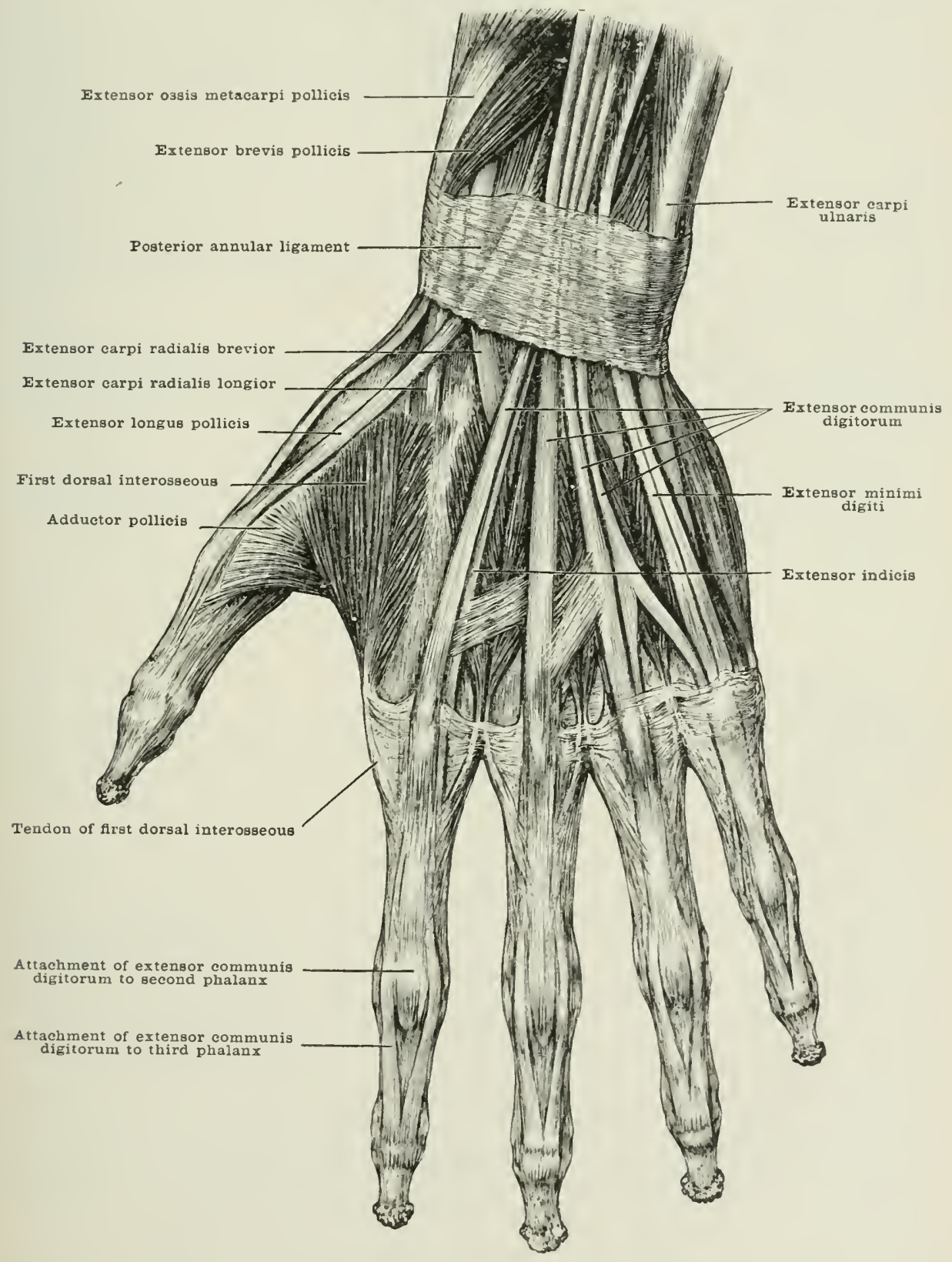

upon the back of the bone and affords attachment by its lateral margins to other muscles. After passing over the back of the first whalangeal joint, the central portion of this aponeurosis is inserted into the hase of the secencl phalanx. while its lateral portions converge and, passing ower the second phalangeal joint, are attacher to the back of the base of the ungual phalanx. A transverse band usually unites the 
tendons of the index and middle fingers above the heads of the metacarpal bones. A stronger hand patses dommwads and outwards from the ring finger tendon to that of the midcle finger at the same level. The fourth tendon divides into two parts. The one joins with the tendon of the ring finger, which immediately afterwards gives off a transverse band to the extensor tendon of the little finger, and the other part joins the tendon of the extensor minimi digiti upon the metacarpal bone of the little finger.

Nerve-supply.-From the posterior cord of the brachial plexus (through the serenth cervical nerve) by several branches from the posterior interosseous division of the musculo-spiral nerve which enter the upper part of the deep surface of the muscle.

Action.- (1) Chicfly to extend the first phalanges of the fingers. (2) It has some power of extending the second and third phalanges; but this part of the tenclon of the muscle is chicfly under the control of the lumbricales and interossei, which are attached to the sides of the expansion covering the first phalanx. After extending the fingers, it will also (3) heh, in the extension of the wrist; and (4) to a slight extent, of the elbow-joint. The bands by which the tendons are attached to one another upon the back of the hand hinder inclependent extension, especially in the ring finger. The little and index fingers, having special extensors, do not labour under this disadvantage.

Relations.-Fuperficially, the deep fascia and posterior annular ligament; deeply, the supinator brevis, the extensors of the thumb, the extensor indicis, the clorsal interossei, the nosterior and anterior interosseous arteries, the posterior interosseous nerve, the wrist and carpal joints; on the radial side is the extensor carpi radialis brevior; and on the ulnar, the extensor minimi digiti.

Variations.-Some of the tendous may be deficient, or more frequently the muscle divides into more than four tentons, two or even three of which may be attached to one finger. Occasionally a teudon joins that of the extensor longus pollicis.

\section{EXTENSOR MINIMI DIGITI}

The extensor minimi digiti-named from its action upon the little finger-is small and fusiform.

Origin.-(1) The common tendon from the back of the extcrnal condyle by a long fibrous process; (2) the deep fascia; and (3) the intermuscular septa which intervene between it and the adjacent muscles.

Insertion. - With the corresponding tendon of the preceding muscle.

Structure.-Arising from the interior of the elongated case formed by the various aponeuroses which diverge from the back of the external condyle, the flushy filures, which do not begin till some distance below that point, are inserted into the raclial border of a tendon which begins about the middle of the forearm, and becomes free a short ristance above the wrist-joint, a little higher than that of the corresoncling part of the preeeling muscle. Passing through the fifth compartmont of the josterior annular ligament, which lies upon the line of junction of the radius and una. the tendon reaches the back of the fifth metacarpal bone, and there blends with the fourth tenton of the extensor conmunis digitorum immediatcly above the motacarpo-phalangeal joint.

Nerve-supply. - From the posterior cord of the brachial plexus (through the seventh cervi(al nerve), hy a luanch from the posterior interosseous division of the musculo-spiral which enters the deep surface of the upper part of the muscle.

Action.--(1) To extend the first phalanx of the little finger; (2) to extend the second and thind phalanges; (3) to extend the wrist; and (4) very slightly the elbow alsor.

Relations.-Superficially, the deep fascia of the forearm and the posterior ammular ligament; derply, the supinator lrevis, the extensors of the thumb, and the extensor inclicis, the inferior raclio-ulnar joint, and the posterior interosseous artery. On the outer sicle lies the extensor communis digitorum; and on the inner, the extensor carpi ulnaris.

Variations. -The extensor minimi ligiti is rurely absent, but it is sometimes blended with the preceling muscle. Its tentun is often divided, sometimes into as nany as three siips. 


\section{ENTENSOR CARPI ULNARIS}

The extensor carpi ulnaris-named from its action upon the carpus and its position on the ulnar borler of the forearm-is a fusiform sheet.

Origin.-By two heads. The first head: (1) By the common terron from the back of the external condyle; (2) the front of the deep fascia of the forearm; and (3) the intermuscular septa which separate it from the extensor minimi digiti, the anconeus, and the supinator brevis.

The second head: from the posterior borter of the ulna, by the aponemrosis common to it, the flexor carpi ulnaris, and the flexor profundus digitorum.

Insertion.-The back of the base of the fifth metacarpal bone, elose to its ulnar horder.

Structure.-The fleshy fibres converge below upon the tendon of insertion, which, beginning in the interior of the muscle in the midllle of the forearm, soon becomes visible upon the radial borkler of the back of the muscle. It receives fleshy fibres in penniform fashion upon its ulnar border and deep surface nearly as far as the wrist, where it enters the sixth compartment of the posterior annular ligament, and lies in a special groove to the outer side of the styloid process of the ulna.

Nerve-supply.-From the posterior cord of the brachial plexus (through the eighth cervical nerve) br branches from the posterior interosseous division of the musculo-spiral nerve which enter the deep surface of the muscle about the middle of the forearm.

Action.-(1) To extend the wrist, acting upon the three articulations involved in this movement; (2) to adduct the wrist, espeeially when the hand is pronated; (3) it will also help in the extension of the elbow-joint.

Relations.-Superficially, the deep fascia of the forearm, and the posterior annular ligument; deeply, the supinator brevis, the extensors of the thumb, extensor indicis, posterior interosseous artery, the imner half of the posterior surface of the ulna below the middle of the forearm, the wrist, and some carpal joints. On the outer side lies the extensor minimi digiti; on the inner, the anconeus muscle.

Variations.-Frequently a small slip of tendon passes downwards to join the tenton of the preceding muscle, the first phalanx, or the hearl of the metacarpal bone. Occasionally the fourth or even the third metacarpal bone may receive a slip.

\section{ANCONEUS}

The anconeus-named from its intimate relation with the elbow (ar\%w. ) -is a triangular fan-shaped sheet.

Origin.-(1) The lower part of the back of the external condyle; and (2) the adjacent part of the posterior ligament of the elbow-joint.

Insertion. - The rough triangular impression upon the outer surface (1) of the olecranon, and (2) of the upper third of the back of the ulna.

Structure.-This muscle is a continuation downwards of the lower part of the inner head of the triceps. Arising by a short tendon, which is prolonged upon the deep surface of the muscle and along its outer lorder, the fleshy fihres diverge in a fiu shape, and are inserted either directly or hy short tendinous fibres into the large special impression upon the ulna; the highest fibres being nearly horizontal, and the lowest approaching more nearly to a vertical direction.

Nerve-supply.-From the posterior cord of the brachial plexus (through the seventh and eighth cervical nerves) by a long branch from the musculo-spiral nerve, which, after passing through the inner head of the triceps muscle, enters the reep aspect of the anconens close to its unurer border.

Action.-To extend the elbow, in association with the triceps, of which some authors consider it to form a fourth head.

Relations.-Superficially, the deep fascia of the forearm; deeply, the supinator 
Irevis, the interosseons recurrent artery which runs through the deeper fibres of the muscle, the clbow and upper radio-ulinar joints; on its outer border, the extensor carpi ulnaris.

\section{DEEP IAYER}

The deep layer consists of five muscles: the supinator radii hrevis; extensor ossis metacarpi jollicis; extensor lorevis pollicis; extensor longus pollicis; and the axtensor indicis. Four of these arise from the bones of the forearm, and one only from the humerus also.

\section{SUPINATOR RADII BREVIS}

The supinator radii brevis-named from its action and size in comparison with the brachio-radialis (= supinator longus) - is a rhomboidal sheet of muscular fibre curved upon itself into a somewhat cylindrical shape to wrap round the upper third of the radius.

Origin.-(1) Lower and back part of external condyle; (2) the external lateral ligament of the elbow-joint; (3) the orbicular ligament; (4) the triangular depression below the lesser sigmoid carity of the ulna, especially along its posterior margin, which forms the upper part of the external border of the ulna.

Insertion.-(1) The back of the neck of the radius; (2) the anterior and outer surfaces of the radius above and at the upuer border of the oblique line.

Structure.--Its origin is partly fleshy and partly by a strong aponeurosis which covers the upper half of the musele and gives attachment to some of the muscles in the superficial layer. The line of origin runs downwards and somewhat inwards from the external condyle to the outer border of the ulna, while that of insertion runs downwarls and outwards from the tubercle of the radius to the impression for the pronator rarlii teres.

Between these lines the fleshy fibres run in parallel curves wrapping round the upper third of the radius. The inuscle is divided into a small superficial and more extensive deep plane by the posterior interosseous nerve which perforates it on its way to supply the muscles at the back of the forearm. The line of insertion is broken at the tubercle of the rarlius ly a notch in which lies the bursa in front of the attachment of the biceps tendon.

Nerve-supply.-From the posterior enrl of the brachial plexus (through the sixth cervical nerve) by branches derived from the posterior interosseous division of the musculo-spiral nerve, which are given off from this nerve as it perforates the muscle.

Action.-To supinate the rarlius upon the ulna. By its contraction the muscle unwraps itself from the radius; the tuberele of the raclius is drawn forwards, and the outer border of the hone hackwards; and if the radius at the commencement of action be in the position of complete pronation, it will he cansed by this muscle to revolve ahout the axis which passes through the centre of its head and the midclle of the lower extremity of the nha through nearly $180^{\circ}$.

The action of this muscle will, mlike that of the biceps, be maffected by the position of the albow.

This completes the list of muscles by which the rotation of the radius upon the ulna is effected. The liceps and supinator hrevis are the supinators; the promator teres and quadratus, the pronators. It should be remembered, howerer, that ordinary pronation and supunation are effecterl by a more complicated movement than simple rotation of the radius, which would eause the hand to revolve around the axis of the little finger. The ustal rotation, the axis of which movement passes through the line of the mirlle finger, involves a shight flexion and extension of the ellow with some movement of the shoulder-joint.

Relations.-Guperficially, the liceps, loracho-radialis, pronator radii teres, extensor carpi raclialis brevior, extensor communis digitorum, extensor minimi 
digiti, extensor carpi ulnaris, anconeus, the radial vessels and nerve, the interosseous recurrent artery; deeply, the superior radio-uhnar joint.

Variations. $-A$ second head has been seen from the humerus near the insertion of the deltoid, and it may receive fibres from the brachio-radialis.

Fig, 278. - The Deep LAYer of the Back of the Foreari,

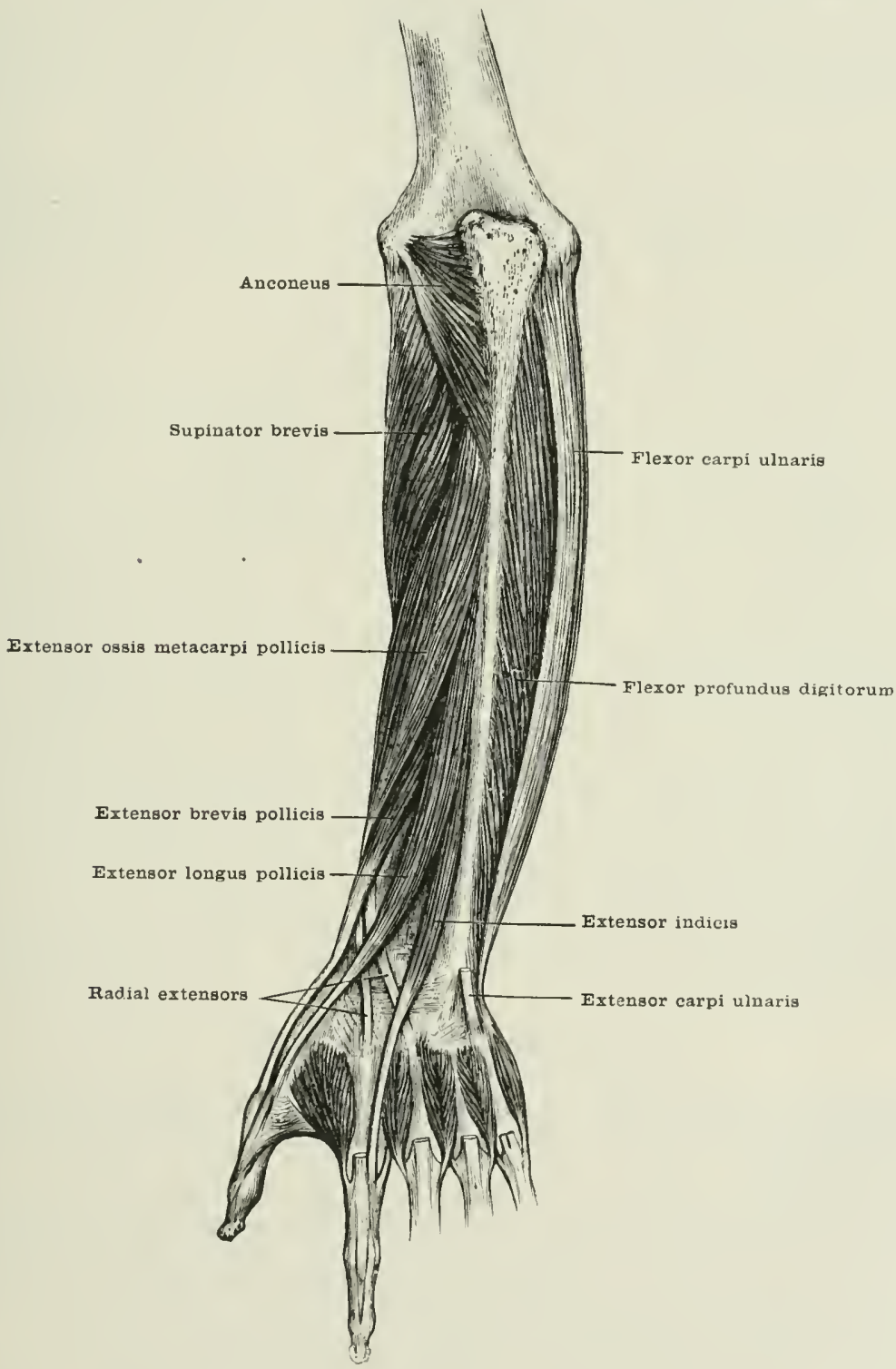

\section{EXTENSOR OSSIS METACARPI POLLICIS}

The extensor ossis metacarpi pollicis, or abductor longus pollicisnamed from its action upon the metacarpal bone of the thumb-is a fusiform sheet.

Origin.-(1) The outer division of the posterior surface of the uha for a short distance below the junction of the upler and middle thirds of that bone; (2) the adjacent portion of the interosseous nembrane; (3) the pusterior surface of the 
radius near the midlle of that bone for ahout two inches $(5 \mathrm{~cm}$.) below the insertion of the supinator lirevis; and (4) the septa which separate it from the supinator brevis, extensor carpi uharis, and extensor longus pollicis.

Insertion.-(1) The small inpression upon the radial side of the hase of the first metacarpal bone; (2) the fascia covering the ball of the thumb; and frequently (i) the back of the trapezimo

Structure. - A somewhat bipenniform muscular sheet arising by an origin which stretches obliguely downwark and outwards from the back of the ulna, at the upper part of its mitcle third, to the middle of the back of the radins. The tendon appears first as an aponeurosis mon the anterior aspect of the muscle just helow the middle of the forearm. The fleshy fibres pass obliquely downwards and cutwarls to be inserted upon the posterior face of this aponcurosis. This as it descends thickens into a rounded tendon, which, becoming free from its muscular fibres just ahore the posterior annular ligament, crosses the back of the two radial extensor tendons, and enters the first compartment of the posterior annular ligament upon the outer surface of the lower end of the radius. After leaving this compartment, the temdon passes vertically downwards, lying upon the external lateral ligament of the wrist-joint and the radial artery, to be inserted into the first metacarpal bone. From its anterior border a strong aponeurosis is given off to that part of the palmar fascia which corers the ball of the thumb, and which forms a part of the origin of the alsductor pollicis. Frequently this division of the inscrtion is indicated by a groove ruming up the tendon, or by a more complete separation which may extend as high as the fleshy fibres of the muscle.

Nerve-supply.-From the posterior cort of the brachial plexus (through the seventh cervical nerve) by filaments derived from the posterior interosseous dirision of the musculo-spiral nerve which enter the muscle upon the upper part of its superficial aspect.

Action.-(1) It abducts and extends the first metacarpal bone, drawing the thumb away from the middle line of the hand, and slightly forwards. (2) It abducts the wrist. It should be remenhered that on aceount of the plane of the thumb being clifferent to that of the palm and fingers, its abduction involves a considerable forward movement, which must not be confounded with flexion.

Relations.- Superficially, the extensor communis digitorum, extensor minimi digiti, extensor carpi uharis, the posterior interosseous artery, and posterior annular ligament; deeply, the extensor brevis and the extensor longus pollicis, the two ratial extensors, the radial artery, and the wrist-joint.

Variations.-The extensor ossis metacarpi pollicis may receive an accessory slip from the radial group of extensors.

\section{ENTENSOR BREVIS POLLICIS}

The extensor brevis pollicis-sometimes ealled the extensor primi internodii pollicis, from its action upon the first phalanx (internodius) of the thumbis flat and fusiform.

Origin.-(1) The middle of the posterior surface of the interosseous membrane just below the precelling muscle; (2) an elongated impression upon the inner part of the posterior surface of the radins extending from the miclle of that bone for about three inches ( $5.5 \mathrm{~cm}$.) ) lownwark and slightly outwards; (3) an aponeurosis which separates it from the preceling muscle.

Insertion. - The back of the base of the first phalanx of the thumb.

Structure.-1 penniform musele arising by short tendinous fibres. These soon hecome fleshy, and pass downwals and outwarls to a tendon which begins in the lower third of the forearm upon the radial horder of its superficial aspect. Iring beneath the tendon of the precerling muscle and in close connection with it, this tendon passes wer the tendoms of the raclial extensors, runs through the first compartment of the posterior annular ligament, crosses the first metacarpo-phalangeal joint on the ulnar side of the tendon of the preceling musche, and then expands into a broat aponeurusis which is inscrted into the whole of the posterior surface of the hase of the first phalamx. 
Nerve-supply.-From the posterior cord of the brachial plexus (through the serenth cervical nerve) by a lranch from the posterior interosseous division of the musculo-spiral nerve, which enters the upper part of the muscle on the uhnar border of its superficial aspect.

Action.-It is a feeble muscle, the chief function of which is (1) to extend the metacarpo-phalangeal joint of the thumb; at the same time it will assist the extensor ossis metacarpi pollicis in (2) abducting and extending the first metacarpal bone; and afterwards it will assist in (3) the abduction of the wrist.

Relations. - Superficially, the extensor ossis metacarpi pollicis, extensor communis digitorum, extensor minini digiti, and posterior annular ligament; deeply. the radial extensors, the radial artery, the wrist and first metacarpo-phalangeal joints.

Variations.-The extensor brevis pollieis may be absent, or it may be blended with the preceding muscle. It may have insertions upon the metacarpal bones or the last phalaux. An accessory slip has been observed from the external condylar ridge of the humerus.

\section{EXTENSOR LONGLS POLLICIS}

The extensor longus pollicis, or extensor secundi internodii pollicisnamed from its action and length-is flat and fusiform.

Origin.-(1) An elongated impression upon the outer part of the posterior surface of the ulna, extending from the middle of that bone for three or four inches $(7 \cdot 5)$ to $10 \mathrm{~cm}$.) downwards and slightly outwards close to its external border. (2) The adjacent part of the back of the interosseous membrane, and a septum between it and the extensor indicis.

Insertion.-The back of the hase of the last phalanx of the thumb.

Structure.-This musele, which is stronger than the preceding, has also a penniform arrangement. Its fibres pass downwards and outwards from their fieshy origin to be inserted into the tendon upon the back of the muscle, which, appearing about two inches $(5 \mathrm{~cm}$.) from its upper extremity near its radial border, gradually thickens as it passes obliquely downwards and outwards. Becoming free from muscular fibres at the upper border of the posterior annular ligament, it enters the deep groove which forms the third compartment beneath that ligament. At the lower extremity of this canal it crosses obliquely the two radial extensor tendons at the back of the wrist-joint, and upon the back of the first metacarpal bone it lies in close contact with the inner border of the tendon of the preceding muscle, and expands into a flat and broad aponeurosis which covers the back of the first phalanx before its insertion into the last phalanx. Whilst spread over the convex surface of the shaft of the first phalanx, it receives small tendinous insertions from the abductor and adductor muscles of the ball of the thumb.

The three tendons of the extensor muscles of the thumb cnclose a triangular space which is visible upon the outer side of the wrist-joint, and is bounclerl by the tendons of the extensor ossis metacarpi pollicis and the extensor breris pollicis uyun its radial side, by the tendon of the extensor longus pollicis upon its ulnar sicle. and ahove by the lower end of the raclius. Across this triangle stretches the rarlial artery, in its passage beneath the tendons from the anterior surface of the wrist to the upper part of the back of the first interosscous space.

Nerve-supply.-From the posterior cord of the brachial plexus (through the serenth cervical nerve), by branches from the posterior interosseous division of the musculo-spiral nerve which enter the upper part of the muscle upon its superficial aspert.

Action.-It is (1) a strong extensor of the second phalangeal joint of the thumb; and afterwards (2) of the first phalanx. It will (3) (xtend, anel at the same time adduct, the first metacarpal bone so as to draw the whole thumb in the extended position backwards, and at the same time inwards. It will also (t) assist in the extension of the wrist, and (5) in the supunation of the forcarm.

Relations.-Superficially, the extensor ossis metacarpi pollicis, extensol conmunis digitorum, extensor minimi digiti, extensor carpi ulnaris. posterior interosseous artery, and posterior annular ligament; deeply, the radial extensors, the 
anterior interosseous and radial arteries, wrist, metacarpo-phalangeal, and phalangeal joints.

Variations.-This muscle may senil a slip to the base of the first phalanx of the thumb. It may also receire a tendinous slip from the fullowing muscle.

\section{EXTENSOR INDICIS}

The extensor indicis-named from its action upon the index finger-is flat and fusiform.

Origin.-(1) An elongated impression which stretehes downwards and slightly ontwarks from the junction of the middle and lower thirds of the outer division of the posterior surface of the ulna, immediately internal to the impression for the preceding muscle, but at the same time rather lower down, to within a short distance of the lower extremity of that hone. (2) For a short space from the part of the interosseons ligament which is adjacent to the lower part of this impression. (3) The septum between it and the preceding muscle.

Insertion.-The inner sicle of the aponeurosis of the first tendon of the extensor communis digitorum.

Structure.-This penniform muscle arises by fleshy fibres which pass obliquely downweds and ontwards to the anterior surface of a tendon which is first seen upon the radial border of its posterior surface in the lower third of the forearm, and, becoming free just above the mrist, passes beneath the tendon of the extensor minimi digiti, and enters the fourth compartment of the posterior ammular ligament, where it lies beneath the imner tendons of the extensor communis digitorum. It is then inserted into the inner edge of the aponeurosis of the tendon of the common extensor belonging to the index finger, at about the level of the metacarpophalangeal joint.

Nerve-supply.-From the posterior cord of the brachial plexus (through the seventh cervical nerve), by a branch from the posterior interosseous division of the musculo-spiral nerve which enters the mper part of the nuscle near the raclial border of its smperficial aspect.

Action.- It assists the extensor communis digitorum in (1) extending the index finger, and especially its first phalanx. At the same time, on account of its direction, it will (2) adduct the index finger, while the action of the extensor communis digitorum upon this finger is that of extension combined with abduction. It will then assist feebly in (3) the extension of the wrist.

Relations.-Superficially, the extensor communis digitorum, the extensor minimi rligiti, extensor carpi ulnaris, and posterior ammular ligament. Deeply, the dorsal interosseons muscle of the second space, the wrist, and some carpal joints.

Variations. - The extensor indicis may give slips to the extensor longus pollicis and to the midlle finger. It may receive slips fiom the posterior carpal ligaments or the bases of the metacarpal bones, and these slips may be inserted into several digits, so as to form an exteusor brevis digitorum manûs.

\section{THE FASCT OF THE HAND}

The dorsal fascia is a thin layer, continuous with the posterior annular ligiment, and, like it, composed chielly of transerse filmes. It covers the extensor tendons, and connects them together upon the back of the hand; and upon the first phalanges it hlends with the aproneureses which sucoed to the tendons. Between the fingers it dips down to join the superficial transverse ligament which forms the web by which the bases of the fingers are enmectert.

$A$ deeper layer of the dorsal farcia covers the back of the dorsal interossei, and is attached to the back of the metacarpal bones. 


\section{THE PALMAR FASCIA}

The palmar fascia takes the place of the deep fascia in the palm of the hand, and is for the most part formed by the expansion of the tendon of the palmaris longus. It is also continuous with the lower margin of the anterior annular ligament. It may be divided into a central and two lateral portions. The central division, which is by far the strongest, is of a triangular shape, the apex being continuous with the tendon of the palmaris longus, and also attached to the low border of the anterior annular ligament; the base corresponding to the hearls of the four inner metacarpal bones. It consists in front of longitudinally arranged bundles of fibrous tissue derived from the palmaris longus tendon, and behind of transverse fibres which continue those of the amnular ligament. Below, the fascia rivides into four processes which join the ligamenta vaginalia of the finger tendons. Each of these four processes forms a bridge across the tendons, and is inserted, at the sides of the metacarpo-phalangeal joint, into the lateral and the deep transverse ligaments. This strong central portion of the palmar fascia is closely connecterl upon its anterior surface with the skin by fibrous septa, which form small compartments in which are lodged pellets of the subeutaneous fat. Lpon its posterior surface it is smooth and in contact with the srnovial membrane of the great palmar bursa above, and of the thecæ below. Between its four processes there are three spaces left through which the digital nerres and arteries emerge. These are bridged orer by transrerse fibres which connect the processes, and which form the superficial transerse ligaments lving in the webs between the fingers.

The outer division, or thenar fascia, is that portion of the palmar fascia which covers the ball of the thumb. It is comnecterl abore with the anterior annular ligament, the tendon of the palmaris longus, and an aponemosis from the tendon of the extensor osis metacarpi pollicis. After covering the short muscles of the thumb, it is continuous below with the ligamentum vaginale of the flexor longus pollicis tendon. The inner division, or hypothenar fascia, is of a triangular shape, the base being above and the apex below. Arising from the anterior annular ligament and the deep fascia of the forearm at the inner side of the wrist, it invests the short palmar muscles peeuliar to the little finger, and terminates upon the ulnar horder of the hand close to the fifth metacarpo-phalangeal joint. It is corered above by the palmaris brevis.

A reep layer of fascia covers the front of the interossei muscles, and is attached by thin longitudinal septa to the posterior surface of the central part of the palmar fascia.

The ligamenta vaginalia are strong bands of transverse fibres which are attacherl to the borders of the first and second phalanges, and serve to bind in their places the long flexor tendons. Opposite the joints the ligaments are thin, and crmposerl chiefly of obliquely decusisating fibres.

The sheaths of the flexor tendons, or thecæ as ther are called, are blind tubes of srnovial membrane which invest the back of the ligamenta vaginalia and the front of the three phalanges and the interphalangeal joints. They extend from the metacarpo-phalangeal joint to the middle of the last phalanx: and at the extremities of the tube, the synovial membrane is reflected upon the surface of the flexor tendons. small folds and cords containing connective tissue and blood-ressels. and invested hy the synovial membrane. stretch across the intervening space. Thes are called vincula accessoria (fig. 2-9). One set of these, the ligamenta brevia, are of triangular shape, and pass directly forwards from the front of the lower part of the first and second phalanges to the back of the orerlying tendons; while the other set-which are callet the ligamenta longa-are small cords rmning lownwarts and somewhat forwarls from the phalanges to the tendons. at a higher level than the liganenta brevia. The compartnent of the palmar bursa belonging to the flexor longus pullicis tendon is continuous with the theca of the thumb. The theca also of the little finger is cluse to, and frequently in communication with, the lower part of the great palmar bursa upon its ulnar side (tig. 27t). 


\section{MUSCLES OF THE HAND}

The muscles of the hand proper consist:-first, of a superficial one, which lies upon the filmar fascia; and, secondly, of a deeper set, which may be divirlerl into a central group belonging to the fingers generally, and two other groups. which are associated with the thumb on the radial, and the little finger on the ulnar side of the palm.

\section{Superfichll Muscle of the HAND}

\section{PALMIAIS BREVIS}

The palmaris brevis (fig. 280)-named from its position in the palm of the hand, and its small size-is a small quadrilateral sheet.

Fig. 279.-Diagray of a Vertical Section throcgh the Middle of the Haxd.

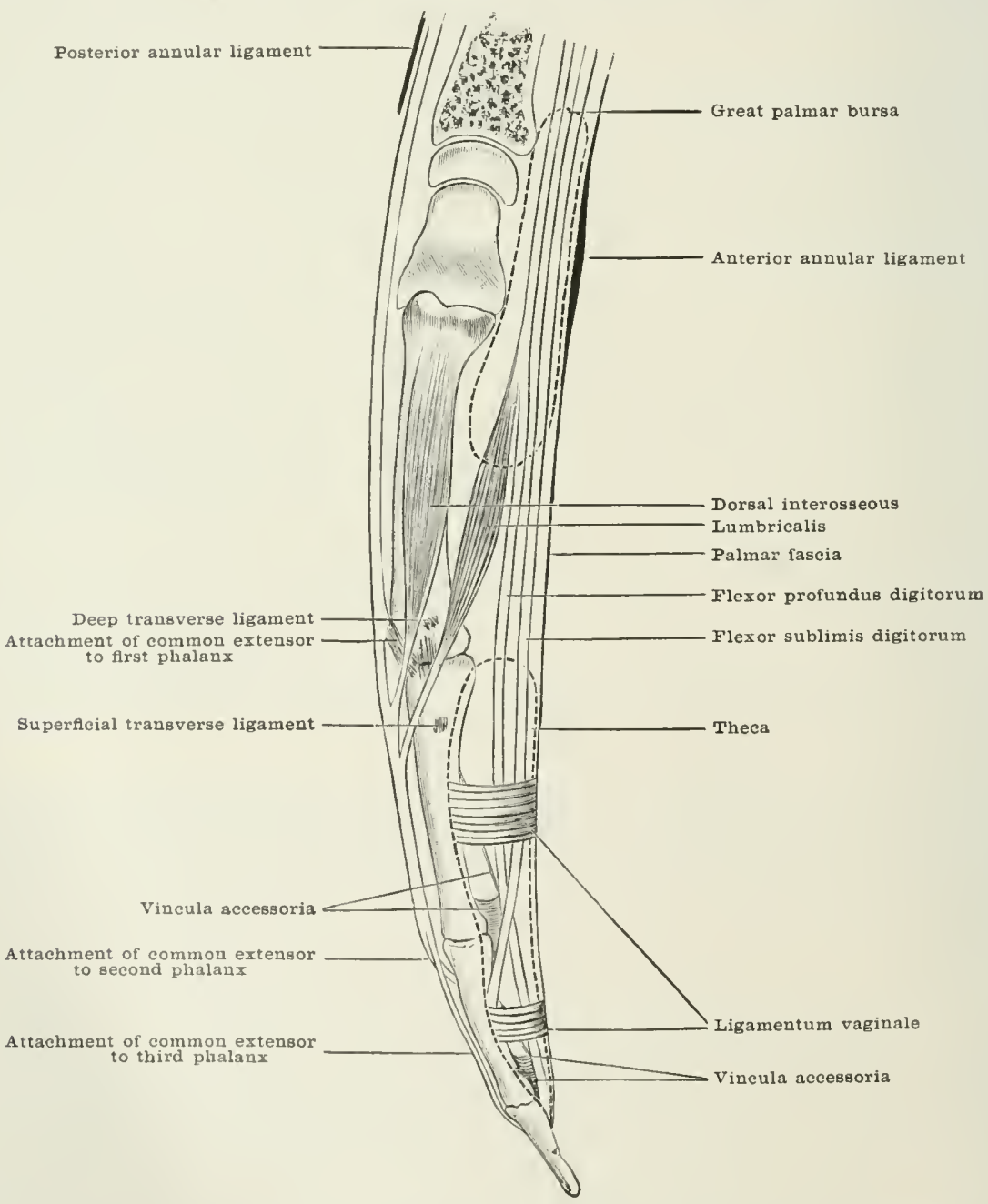

Origin.-(1) The front of the lower part of the anterior annular ligament about its mirlule; aml (ㄹ) the adjacent part of the palmar fascia at the inner elge of its great central clivision. 
Insertion.-The deep surface of the skin and the subcutaneous fat, along the ulnar border of the upper part of the jalm.

Structure.-Arising by Heshy and short tendinous fihres, this muscle prasses in transverse fasciculi to its insertion, which is of a similat character to its origin. It belongs to that type of muscle of which the panniculus carnosus in the mammalia is the best example, and lies in the subcutaneous tissue superficial to the deep fascia like the platysma myoides and the superficial muscles of the face.

Nerve-supply.-From the inner cord of the brachial plexus (through the first thoracic nerve), by filaments from the superficial division of the ulnar nerve which enter the muscle upon its deep aspect near its upper border.

Action.-It draws the skin and the superficial fascia of the ulnar border of the hand towards the middle line of the palm, forming a deep dimple or groore upon the upper part of the ulnar border of the hand, and at the same time raising the soft parts into a prominent vertical ridge, the object of which appears to be to prerent the ulnar nerve and artery from being pressed upon when a hard substance is grasped by the hand. It also helps to deepen the eup-shaped hollow when the palm is used to convey fluid to the mouth.

Relations.-Superficially, the skin; deeply, the hypothenar fascia, which separates it from the abductor and flexor brevis minimi digiti, and from the ulnar ressels and nerve.

Variations.-This muscle may be entirely absent.

\section{Deep Muscles of the PALM OF THE HAND}

\section{Certral Group}

Consisting of two sets of muscles-the lumbricales and the interossei.

\section{THE LUMBRICALES}

The lumbricales-named from their resemblance to earth-worms (=lumbrici) -are four small muscles of a fusiform shape.

Origin.-The two outer ones from the outer side of the first and second tendons of the flexor profundus digitor'um; the two inner from the adjacent sides of the second and third, and third and fourth tendons of the flexor profundus digitorum respectively. All four are attached to the palmar aspect of the deep flexor, and the origin begins at the lower border of the anterior annular ligament.

Insertion.-The aponeurosis of the extensor communis digitorum tendon on the rarlial side of the first phalanx of each of the four fingers.

Structure.-Arising fleshy from the tendons of the deep flexor. the fibres converge upon a small tendon which becomes free a short distance abore the metacarpophalangeal joint. The tendon passes in front of the deep transwerse metacarpal ligament, below which it expands, and is attached to the border of the extensor tendon.

Nerve-supply.-From the outer and inner cords of the brachial plexus; the first and second receiving small filaments from the digital branches of the median nerve, which enter the muscle near the radial border in the middle third of their palmar aspect. The third and fourth lumbricales are supplied hy filaments of the deep branch of the ulnar nerve, which enter their respective muscles in the middle third of their deep surfaces.

Action.-Their chief action will he (1) to flex the first phalanges upon the metacarpal bones; and at the same time (2) to extend the second and third phalanges by their traction upon the sides of the extensor aponeurosis which covers the back of each of the first phalanges. In this action they assist the interoseous museles; but the lumbricales have this advantage over them. that when the second and third phalanges are flexed by the flexor sulhimis and jurundus, the lumbricales will Hex the first phalanges with inereased force, inasmuch as the tendons from which they 
arise have been retracted, whereas the origins of the interossei are practically fixed. The first and secomd lumblicales will ace feebly as abrluctors of the index and middle fingers; the third and fourth as adductors of the ring and little fingers. They will also have some influence, together with the interosice upon the aponeuroses of the extensor communis digitorum tendons in binding them down upon the first

Fig, 2 2 0. - The superficial Muscles of the Palim of the Haxd.

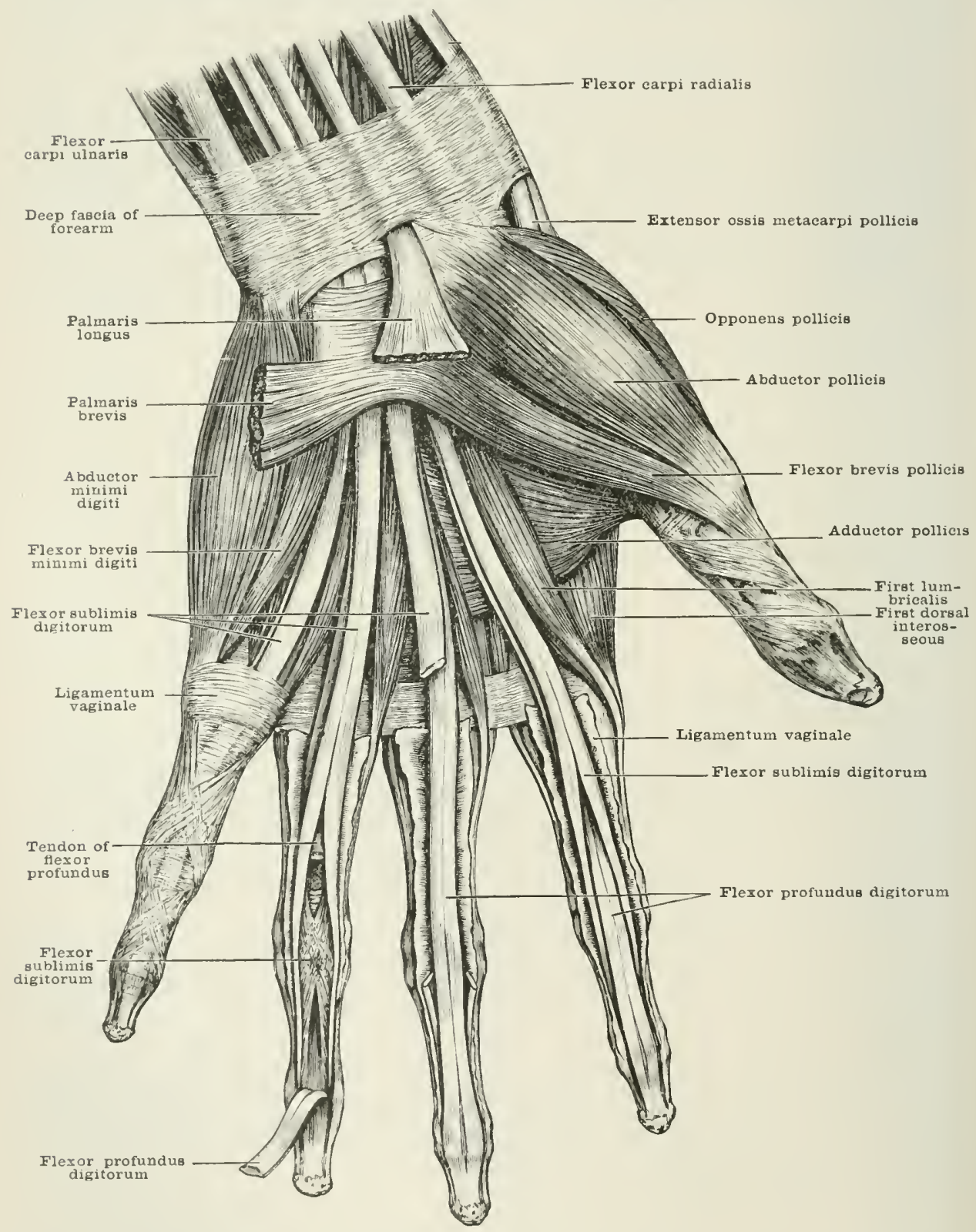

phalanges. In this way they gerform for the rlorsal tencton a similar function to that which is exercised hy the liganentmm vaginale upon the two pralmar tenrlons.

Relations.-Fiperficially, the tenchons of the flexor sublimis digitorm and the superficial transverse liganents; deeply, the interossei muscles, the atductor 
and part of the flexor brevis pollicis, and the deep transverse ligaments; on the ulnar side their tendons are in contact with the metacarpo-phalangeal joints.

Variations.-The fourth lumbricalis is sumetimes absent. They may vary in their origins, sometimes arising from one, and sometimes from two adjacent tendons. Occasionally one may arise from the flexor longus pollicis tendon. They may be inserted into the uluar side of a finger, or into the adjacent sides of two finger's.

\section{THE INTEROSSEI}

The interossei-named from their position between the metacarpal bones-are seven in number, three being palmar and four dorsal. They are small muscles. of penniform or bipenniform structure. Both sets are easily exposed to view hy a

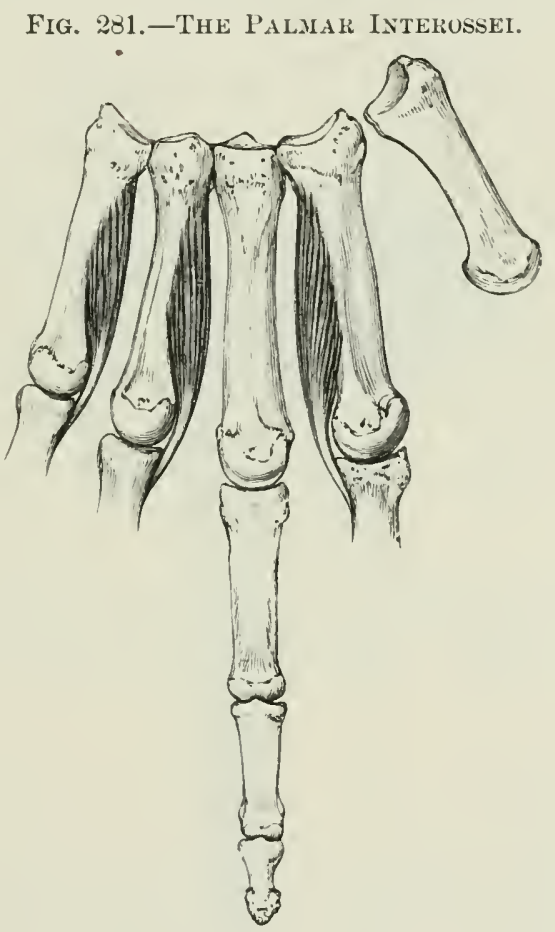

leep dissection in the palm, but the dorsal set is alone visible in the back of the hand.

The three palmar interossei are fusiform in shape.

Origin.-They arise from the sides of the metacarpal bones: the first occupying the whole of the uhar side of the second metacarnal hone; the second, the radial side of the fourth metacarpal bone; the third, the radial side of the fifth metacarjal bone.

Insertion.-By small tendons (1) into the aponeuroses of the extensor tendons upon the back of the first phalanges of the index, ring, and little fingers; and (2) the adjacent prortion of the side of each first phalanx near to its base; the first heing attached to the ulnar border, and the second and third to the radial horders of their fingers.

Structure.-Fleshy fibres arising along the whole length of the metacarpal bone are inserted in pemniform fastion upon the tendon, which, beginning on the mattached border of the musele near the midelle of the interosseous sprace hecomes free just above the metacarpo-phalangeal joint, and passes beneath the deep transverse ligament which separates it from the tendon of the lumbriealis muscle. 
At this place a small hursa separates the tendon from the deep transwerse ligament, and the lateral ligament of the metacarpo-phalangeal joint.

Nerve-supply.-From the inner cord of the brachial plexus (through the eighth cervical nerve), hy small filaments which, eoming from the decp branch of the ulnar nerve pass into the mper part of the mucles upon their anterior aspect.

Action and relations. - Fide infir.

Of the four dorsal interossei, the first forms a thick triangular shect, while the other three are fusiform and prisuatic.

Origin.-From the five metacarpal bones, each muscle arising from the adjacent surfaces of the two bones bounding an interosseous space.

Insertion.-(1) Into the sides of the aponemroses of the extensor conmunis digitorum tendons; and (2) the adjacent parts of the first phalanges.

Structure.-The Heshy fibres arise from the adjacent surfaces of the metacarpal hones in bipenniform fashion, and converge upon a tendon which, heginning about the midkle of the interosseous space, becomes free just above the metacarpo-

Fig. 20:-The Dorsal INTerossei.

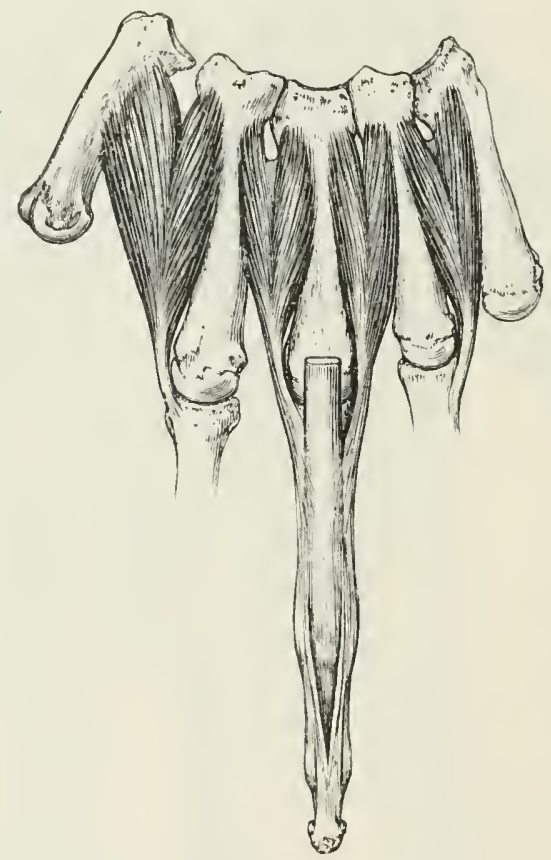

phalangeal joint, and then passes upon the dorsal aspect of the decp transverse higament to its insertion into the side of the aponemrosis, and into the upper prart of the borter of the first phalanx.

The first muscle is thick and hy far the strongest, and forms with the adductor pollicis the fleshy web) which tills the interval between the metacarpal hones of the thumb and the inclex finger. Its origin from the first metacarpal bone oceupies the upper half of that bone, while that from the second is more extensive. It is inserted into the raclial sicte of the aponemosis upon the back of the first phalanx as well as into the upper part of the outer borker of that lone. The second is inserted into the radial side of the apomemosis mon the first phalanx of the midelle finger and into the aljacent bone. The thivd into the ulnar side of the aponemrosis upon the hack of the first fhalanx of the midile finger and into the arljacent bone. The fourth into the ulnar side of the apmenesis mpon the back of the ring finger and the adjacent hone. Of the two heals of each of these muscles, the one arising from the metacarpal bone of the finger into which the muscle is inserted, is always the larger. 
Nerve-supply.-From the inner cord of the brachial plexus (through the eighth cervical nerve), by branches from the deep division of the ulnar nerve which enter the museles at the unjer part of their anterior aspect.

Action of the interossei muscles. - First, the common action of all the introssei is (1) to flex the first philanges; and (2) to extend the serond and third. Their power of flexion depends upon their insertion into the sides of the first phalanges as well as the edges of the aponeuroses by which the backs of these phalanges are corered. The extension of the second and third phalanges depends upon the fact that the portion of the aponeurosis into which each of them is inserted is continuer downwals to the bases of these phalanges. A good example of the action of these muscles and of the lumbricales is given in the movements of the fingers which hold the pen in writing. In forming the light upstroke it will be seen that flexion of the first, accompanies the extension of the second and third phalanges. This movement is due to the contraction of the lumbricales and interosici. On the other hand, the thick downstroke is formed by the extension of the first. and the fiexion of the second and third phalanges; this strong morement being due to the action of three powerful muscles, the extensor communis, the flexor sublinis, and the flexor profundus digitorum. Secondly, the prolmar interossi adduct the index, ring, and little fingers towards the middle line of the hand which passes through the middle finger. Thirdly, the dorsal interossei abduct the index, middle, and ring fingers from the middle line of the hand. As the middle finger can be drawn either to the radial or ulnar side from the middle line of the hand, it has two dorsal interossei to abduct it. The first dorsal interosseous muscle will also assist in addueting the thumb.

Relations.-On the palmar surface of the interossei. separated from them by the deep layer of fascia, lie the flexor profundus digitorum tendons and the lumbricales, the adductor and part of the short flexor of the thumb, the deep palmar arch above, and the deep transverse ligaments below; behind, lie the tendons of the extensor communis digitorum and extensor indicis, separated from the dorsal interossei by the deep dorsal fascia.

Variations.-Sometimes the dorsal interossei receive small accessory heads from the posterior earpal ligaments, the lower end of the radius, or the adjacent deep fascia. A part of the first dorsal interosseous has been seen rumning separately from the fiont of the metacarpo-phalangeal joint of the thumb to the teudon of the first humbricalis. Occasionally the second dorsal interosseous is inserted upon the ulnar side of the inclex finger, so as to resemble the same muscle in the foot.

\section{Muscles of the Thendi Eminexce}

These are four in number, and they form a fleshy mass at the radial borter of the palm, covered by the thenar portion of the palmar fascia, and called the thenar eminence or ball of the thumb. They are the abductor pollicis, the oplonens pollicis, the flexor brevis pollicis, and the adductor pollicis.

\section{ABDLCTOR POLLICIS}

The abductor pollicis-named from its action upon the thumb-is a small thick triangular sheet.

Origin.-(1) The tuherosity of the scaphoid hone; (2) the uprer part of the ridge on the trapezium; (3) the outer part of the front of the anterior anmular ligament; (4) the outer or thenar division of the palmar fascia by which the ball of the thumb is cosered; and (5) the slip from the tendon of the "xtensol osis metacarpi pollicis which joins this part of the palmar fascia.

Insertion.-(1) With the outer tendon of the flexor brevis pollicis into the raclial side of the base of the first phalanx of the thumb; and into ( 2 ) the outer edge of the aponeurosis of the extensor longus pollicis upon the back of the first phatanx.

Structure.-Arising hy fleshy or short tendinous fihres from the anterior annular ligament and some or all of the other four origins, the muscle eonverges upon a short tendon which blends with the adjacent tendon of the llexor brevis. 
Nerve-supply. - From the outer and inner cords of the brachial plexus (through the sixth (ervieal nerve), by a branch from the palmar division of the median nerve, which, after passing imler the anterior ammular ligament, goes upwards and outwards to enter the upper part of the deep aspect of the muscle near its ulnar borter.

Action.-(1) To abduct, and (2) to flex the first phatanx of the thumb. As the lomes of the thumb are in a different plane to those of the fingers, this morement will elraw the thumb forwards and at the same time slightly inwards. By it:

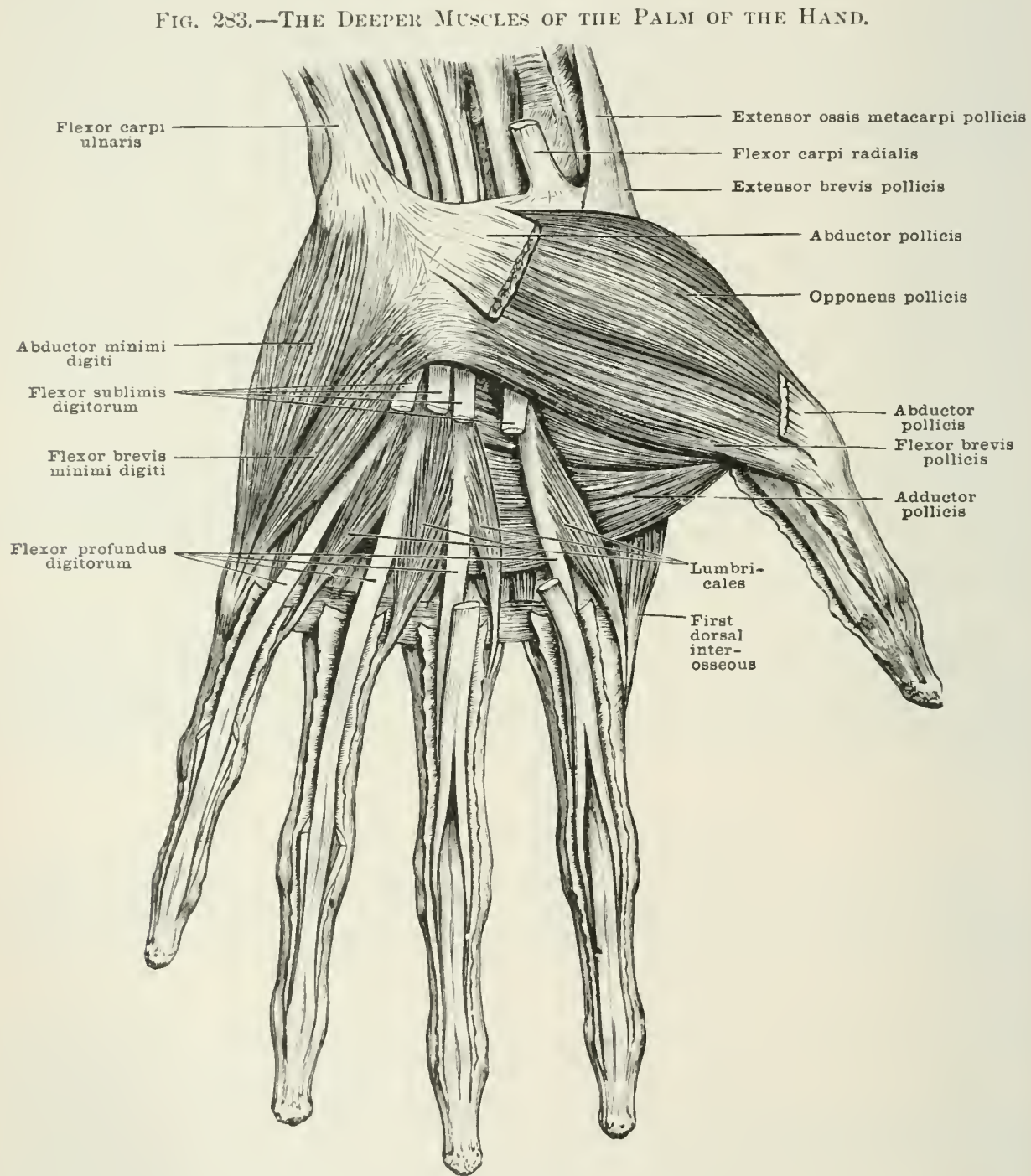

inscrtion into the aponemrosis of the extensor longus pollicis, this muscle will help) (:) to (xtemel the last phalanx of the thumb.

Relations.- Superficially, the thenar fascia, and the superficialis rola artery, which usually perforates thrimuscle; deerly, the outer head of the flexor brevis pollicis and the opponens pollicis.

Variations. - As already mentioned, it reeeives occasional slips from the radial extensors of the carpus and the extensor ussis metacarpi pollieis. It frequently receives a thin muscular slip from the skin over the trapezinus ; it may also besupplemented by the onponens pollicis or a suall slip from the styluid process of the rallius. 


\section{OPPONENA POLLICIS}

The opponens pollicis, or flexor ossis metacarpi pollicis, is named from it: action, as it helps in opposing the thumb to the other finger's and at the same time is a Hexor of the first metacarpal hone. It is a short, thick, triangular shect.

Origin.-(1) The front of the ridge on the trapezium below the frecerting; and (2) the lower and outer jurt of the front of the anterior amnular ligament.

Insertion.- The whole of the outer horder of the anterior surface of the shaft of the first netacarpal bone.

Structure.-Arising ly a short tendinous or fleshy origin, the muscular fibres diverge fanwise to their insertion. The lower border of the muscle is often so l)lended with the outer head of the next muscle that the separation is somewhat artificial.

Nerve-supply.-From the same source as the preceding; the filaments entering the anterior surface of the muscle near to the uyper part of its ulnar border.

Action.-To Hex the first metacarpal bone, which it draws forwards and inwards. This movement, on account of the shape of the carpo-metacarpal joint, is accompanied by a certain amount of rotation inwards, by which the palmar aspect of the thumb is made to look backwards and inwards.

Relations.-Cuperficially, the abductor pollicis and the thenar fascia; deeply; and upon its uhnar borler, the flexor brevis pollicis. It also lies upon the joint between the metacarpal bone and the trapezium.

\section{FLEXOR BREYIS POLLICIS}

The flexor brevis pollicis-named from its action and short length in comparison with the long Hexor-consists of two heads: each forming a flat triangular sheet.

Origin.-The outer head arises from (1) the outer two-thirds of the lower border of the anterior annular ligament; (2) the lower part of the ridge of the tralerzium. The inner head, from (1) the front of the os mannm; (2) the front of the bases of the first, second, and third metacarpal bones; and (3) from the front of the sheath of the flexor carpi radialis tendon.

Insertion.-The outer and immer sides of the front of the base of the first phalanx of the thumb.

Structure.-Arising by short tendinous as well as by fleshy fibres, the two heads become tendinous a short distance above the first metacarpo-phalangeal joint. and have imbedded in their substanee sesamoid bones of a somewhat hemispherical shape, and about one-sixth of an inch (nearly $1 \mathrm{~cm}$.) in diameter, which rest by small articular facets covered with cartilage upon the palmar aspect of the condrles of the first metacarpal bone. Close to their insertion the tendinous fibres are blended with those of the abductor pollicis externally, and the adductor internally. In the inner head, three distinct divisions may generally be ohserved. The first or" outermost division is a small fusiform slip which passes beneath the tenelon of the flexor longts pollicis to join the outer head, and to be inserted into the radial sesamoid bone. The serond dirision is fan-shaped, and its fibres, which form the greater' part of the inner hearl, eonverge to embrace the ulnar sesamoid hone. The thind division lies moler cover of the second. It is a small fleshy slip, which arises from the unar side of the base of the first metacarpal bone. and passes downwarls to be inserted with the adductor pollieis into the ulnar side of the base of the first fhalanx. Some authors discribe this thirl division as the inner head of the flexor brevis pollicis, and the first and second divisions as the adductor pollicis obliquus.

Nerve-supply.-The outer head is supplied (thromgh the sixth cervical nerve) by the palmar branch of the median, which enters the midlle of its anterior surface near its ulnar borker. The inner head is supplied (through the dighth cervical nerve) by the deep branch of the uhar nerve which enters the upler part of its cleep surface close to its ulnar border. 
Action.-Both heads will flex the motacarpo-phalangeal joint of the thumb. The outer head will flex alse the carpo-metacarpal joint, while the inner head will be an adduetor as well as flexor of this joint. The former will aet in assuciation with the abducter and opponens, and will draw the thmob forwards and inwards, keeping it at some listane from the palm of the hand. The latter will act with the adeluetor, and draw it more directly inwards in elose proxinity to the palm of the hand.

Relations.-The nuter head lies beneath the abductor pollicis, and in contact hy it: rallial border with the opponens pollicis. The inner head is partly separated from it hy the tendon of the flexor longus pollicis; upon its ulnar border it is in

Fig, :-4. - The Prosator Qeadrates axd Deep View of the Pali.

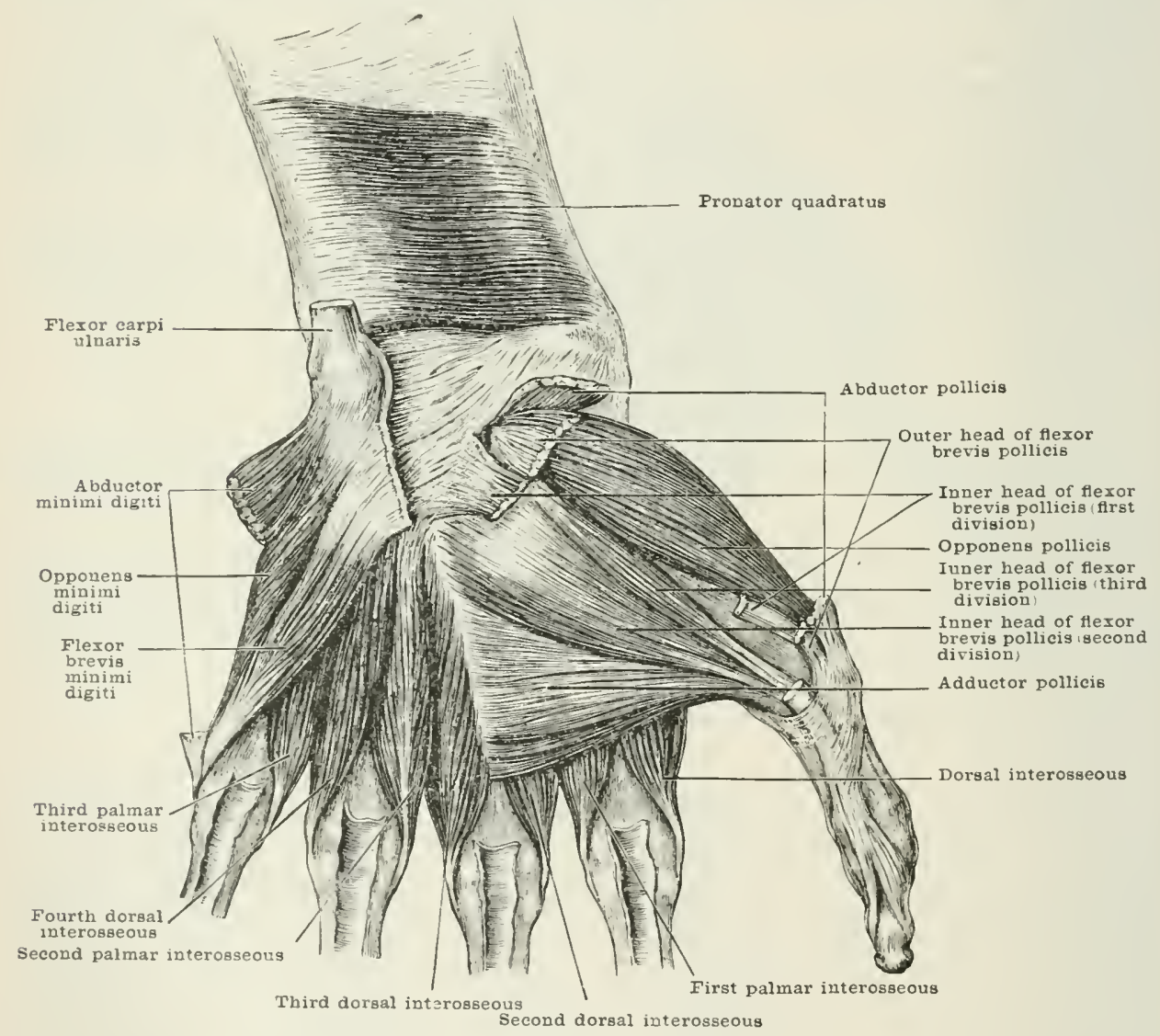

contact with the ardnctor. In front of it lie the tendons of the flexor profundus with the outer lumbriales: lehind, are the third part of the radial artery and the interossei muscles of the first two spaces.

\section{IDDTCTOR POLLICIS}

The adductor pollicis, sometimes called the adductor pollicis transversusnamerl from its action-is a thick triangrular sheet.

Origin.- The front lwreler of the shaft of the third metararpal bone.

Insertion.-(1) The inner sicle of the hase of the first phalanx of the thumb: (2) the inner side of the aponemrosis of the extensor longus pollieis which covers the first phalanx. 
Structure.-Arising by short tendinous or fleshy fibres, the muscle converges upon a short tendon, which liends on its outer sile with the imner trudlon of the flexor brevis pollicis, and sencts a fibrous slip to the inner sicle of the aponeurosis of the extensor longus pollicis.

Nerve-supply.-From the lower cord of the brachial plexus (through the eighth cervical nerve), by the deep branch of the ulnar which senels filaments to the upper border and deep surfice near the origin.

Action.-(1) To flex the first phalanx of the thumb; (2) to adduct and flex the earpo-metacarpal joint of the thumb; (3) to extend the second phalanx of the thumb. This latter action of the adductor and alductor pollicis is useful in many of the movements of the thumb, in which it will be found that the second phalanx has to be kept extended, while its palmar aspect is being opposed to the tips of the other digits.

Relations.-Superficially, some of the tendons of the flexor profundus digitorum and the two outer lumbricales; deeply, the abductor indicis and the interossei of the space between the second and third metacarpal bones. Part of the lower border is subeutaneous.

Variations.-The adductor pollicis is often lifficult to separate from the inner head of the flexor brevis pollicis.

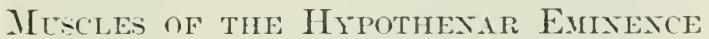

These are three in number-the abductor minimi digiti, the opponens minimi digiti, and the flexor brevis minimi digiti. They lie under corer of the thin internal division of the palmar fascia.

\section{1. $\triangle B D C C T O R$ MIYIMI DIGITI}

The abductor minimi digiti-named from its action-is fusiform and somewhat flattened.

Origin.-(1) The lower half of the pisiform bone; (2) the continuation of the tendon of the flexor carpi ulnaris below this bone.

Insertion.-(1) The uluar sicle of the base of the first phalanx of the little finger; and (2) the adjacent portion of the aponeurosis of the extensor minimi digiti.

Structure.-Arising by short tendinous fibres, it soon forms a flat fleshy mass which contraets slightly below, and just before its insertion having again become tenclinous, it is for the most part attached to the first phalanx, but it also sends a small slip backwards to the extensor aponeurosis.

Nerve-supply.-From the ulnar nerve through the eighth cervical nerve. It receives small filanents at the outer and deep aspect, usually from the deep palmar division of the ulnar nerve.

Action.-To abduct. and at the same time flex, the metacarpo-phalangeal joint of the little finger; it will also assist, like an interosseous musele, in the extension of the sucond and third phalanges.

Relations.-Superficially, the hypothenar part of the palmar fascia and the palmaris hrevis; deeply, the flexor brevis and opponens minimi digiti. Cpon its radial border are placed the rleep palmar branches of the ulnar artery and nerve.

\section{FLEXOR BREYIS MIXIIIL DIGITI}

The flexor brevis minimi digiti-named from its action-is small and fusiform.

Origin.-(1) The ulnar surface of the hook of the uneiform bone; (2) the adjacent part of the front of the anterior annular ligament.

Insertion.-The ulnar side of the hase of the first phalanx of the little finger.

Structure.-Its origin and insertion are by short tendinous tibres, and the rest of the muscle is fleshy. 
Nerve-supply.-Through the eighth cervical nerve, from the deep branch of the ulnar nerve which sends filaments to the upper part of its deep and ulnar surfice.

Action.-To flex the first phalanx of the little finger.

Relations.-Superficially, the hypothenar part of the palmar fascia, the lower part of the abluctor minimi digiti, and the superficial palmar arch; deeply, the opponens minimi digiti and the fifth metacarpal bone; and to its radial side lie the tlexor tendons of the little finger. This musele is closely eonnected with the previous one, from which it is separated above by the deci palmar branches of the ulnar artery and nerve.

Variations.-It may fail, or be blended with the abductor or opponens minimi digiti. An accessory slip may come to it from the lower third of the uha at its inner border. from the tenton of the flexor carpi uharis, or the deep fiscia of the forearm.

\section{OPPONENS MINIMII DIGITI}

The opponens minimi digiti (= flexor ossis metacarpi minimi digiti)-named from its action-is a triangular fan-shaped sheet.

Origin.-(1) From the hook of the unciform bone deeper than the preceding; (2) from the adjacent part of the anterior annular ligament.

Insertion.-The whole of the ulnar border and part of the head of the fifth metacarpal bone.

Structure.- Arising by short tendinous fibres, the fleshy bundles diverge downwards and outwards, and are inserted by short tendinous fibres.

Nerve-supply.-Through the eighth cervical nerve, from the deep branch of the ulnar nerve which sends filaments to the upper part of its ulnar aspect.

Action. - To flex the fifth metacarpal bone, and at the same time slightly to adduct it. This movement is observed when the palm is cupped, as when the hand is used to lift water to the mouth.

Relations.- Superficially, the abductor and the flexor brevis minimi digiti; and deeply. the interossei of the fourth interspace, and the deep branches of the ulnar artery and nerve.

Variations.-It may receive a slip from the deep fascia of the forearm.

\section{THE MUSCLES AND FASCIA OF THE THIGH}

Superficial fascia.-The greater part of this is of loose adipose tissue, and, without any deep connections, is continuous with the superficial fascia of the abdomen and back. In the mperer and front part of the thigh a deep layer of a more membranous structure may be distinguished, and this has deep connections where the Iorer limb joins the trunk, being attaresert to the rest of the ilimm and to the fascia lata just below its insertion into Pompart's ligament and the rami of the pubis and ischium. Bewow the inner half of l'oupart's ligament several lymphatic glands are arrangert hongiturlinally betwern these two layors of the superficial fascia.

The deep fascia or fascia lata is a very strong layer of fibrous tissue, the fibres of which are arrangel for the most part transversely as an aponenrosis of inrestment; but many of them, especially upon the outer side where it is much thicker, are longitudinal, and sorre for the insertion of important muscles. The whole of the rleep fascia foms a stmong eylindrical tube investing all the muscles of the thigh. It is attached ahow, in the groin, to Poupart's ligament, where it blends with the 
aponeurosis of the external oblinue; on the outer side and behind, to the onter lip of the crest of the ilium, and to the lower part of the vartebral ajonemosis; upon the imner side, to the border of the tuberosity and ascemling ranus of the ischium, to the descending ramus of the putes, the symphysis pubis, and the anterior lip of the crest of the pubes. Below, it becomes much thimmer, and is continums with the deep fiscia of the leg; it has also a deeple attachment to the tuberosities of the tibia and the outer surface of the head of the fibula. 'The thickening of its outer portion, which passes clown like a tenchon to the external tuberosity of the tibia, and is also attached to the outer side of the ligamentmm patellae, is called the iliotibial band. From the deep surface of this great cylindrical tule are given off various processes which assist in the formation of the sheaths of some of the more superficial muscles. There are also three strong intermuscular septa, which extend from it to the linea aspera in the lower part of the thigh dividing the flexor, extensor, and adductor groups of museles from one another. At the upyer part of the thigh, below the imner third of Pompart's ligament, is the saphenous opening, for

Fig. 285.-Obliques Exteries axd Fascia Lata.

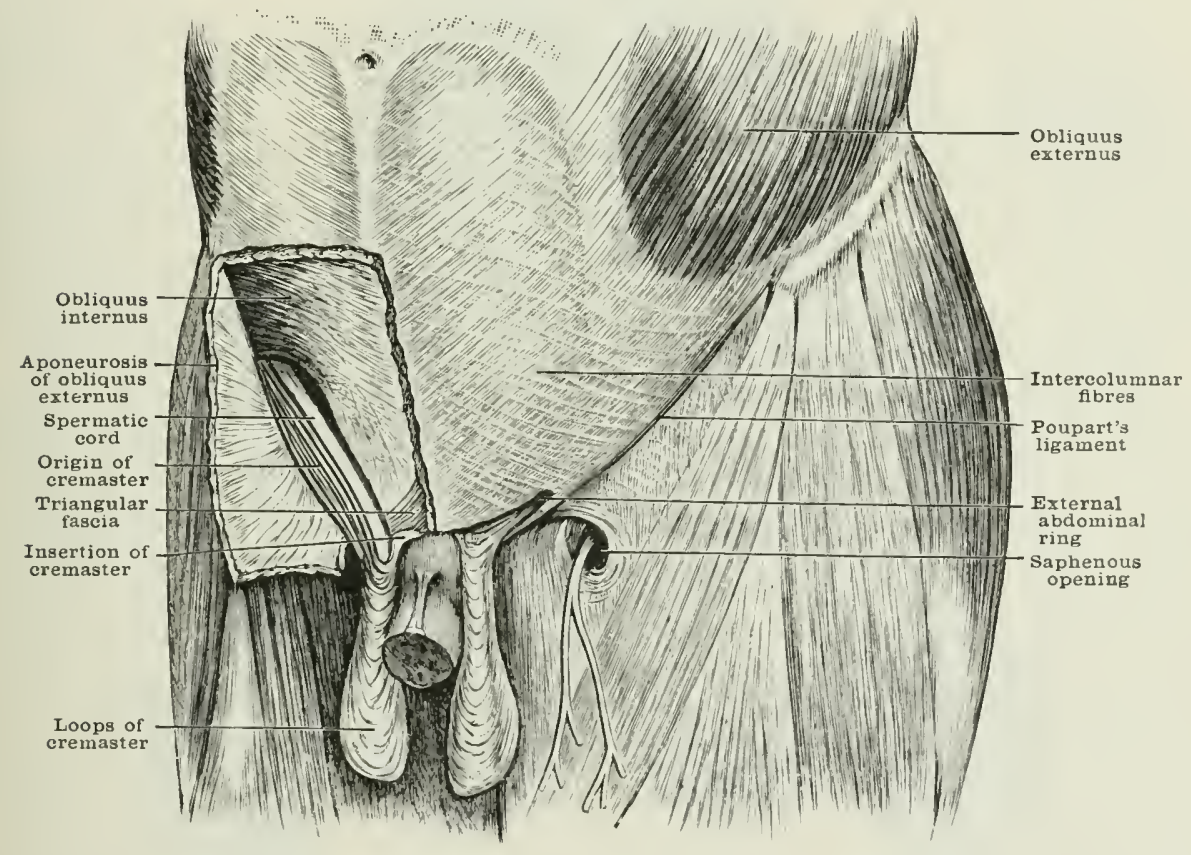

the passage of the internal saphenous vein, which, after rumning up the thigh in the superficial fascia, enters the deep femoral rein in this situation. This opening is not, as might have been expected from the character of these openings in other parts, a mere circular foramen. It is formed by the division of the fascia lata into two parts, which do not unite together again, but are inserted separately along the line of attachment of the lower limh to the trunk. It legins below the inner thim of Poupart's ligament, and is of a somewhat oral shape, measuring about one inch

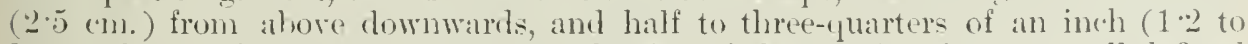
$2 \mathrm{~cm}$.$) from side to side. The lower border of the opening forms a well-definerl$ edge which occupies the angle hetween the saphenous and femoral veins rlose to their point of junction. Externally, the fascia lata is attacher alone along the whole length of Poupart's ligament, and its free internal edger arches inwarts towards the spine of the pubes in front of the femoral vein. This external and hroad division of the upler part of the fascia lata is callecl its iliac portion, and the free erlge which lies in front of the femoral vescels is linown hy the namo of the falciform border or process. Intemally, the fascia lata is in cluse contact with 
the pectineus muscle which lies heneath it, and with that muscle it dips beneath the femoril rein and the sheath of thr ressels to be attached to the ilio-pectineal line. This intemal division is called the pubic portion of the fascia lata. The deep layer of the superficial fascia stretches across the opening, and is fimly attached to the exlge of the falciform process. From the numerous openings which give passage to the ressels and lrmphatics, it is here called the cribriform fascia (cribrum being the Latin for a sieve).

\section{MUSCLES OF THE FRONT OF THE THIGH}

In front of the thigh there is a group of four muscles, the chief function of which is to flex the hip-joint. Two of these muscles arise within the abdomen, and two from the margin of the innominate bone. The two which come from within the abdomen are the psoas and iliacus, and they act together as one muscle, and have been rescribed as such under the name of the ilio-psoas. The third and fourth are the sartorius and pectineus.

\section{PSOAS}

The psoas, or psoas magnus-named from the Greek word chor, meaning the muscles of the loins-is thick, rounded, and fusiform.

Origin.-Inner part, hy five processes which arise from (1) the sides of the intervertebral cartilages which intervene between the hodies of the last thoracic and the five lumbar vertebre; and (2) the adjacent part of the sides of the bodies of these vertebræ; and between these processes from (3) tendinons arches which bricles over the sides of the hodies of the first four lumbar vertelurg. Outer part, from the lower border and the front of the transverse processes of all the lumbar vertebre.

Insertion.- The lower and hack part of the lesser trochanter of the femur.

Structure.- With the exception of the small tendinous arches which span the sides of each of the four upper lumbar vertebre from its upper to it= lower borler, and which give passage to the lumbar vessels, the whole origin of the muscle is fleshy. The fibres pass lownwards and forwark in penniform fashion, but with a slight convergence, to the inner sirle of the tendon. which, beginning in the interior of the muscle about the level of the crest of the ilium, hecomes free upon its outer and posterior surface a short distance above Poupart's ligament, while upon its inner surface it receives fibres down to its insertion. The nuscle, having hitherto run in a downward, forward, and slightly outward direction, changes its course at Poupart's ligament, and passes domwaids and backwards to be attached to the lesser trochinter of the femur. In its passage along the brim of the pelvis and over the lower part of the iliac fossa, the trudon mon its outer aspect begins to recure the insertion of the iliacus muscle. Between the tendon and the capsule of the hip-joint which is in close connection with it, is placed a bursa which frequently communieates through an opening in the capsule with the interior of the hip-joint.

Nerve-supply.-From the anterior primary branches of the second and third lumbar norves hy filaments which are given off from the lumbar plexus whilst it is passing through the muscle.

Action.-The psoas is a porrerful flexor of the thigh upon the polvis, e.g. in walking, rumning, or going upstairs. The change in the direction of the tendon after crossing the horizontal ramus of the pulses makes its insertion nearly perpendicular to the axis of the femur. The poas therefore acts with less mechanieal disalvantage than is usual with the muscles of the limbs. It has been sometimes described as an external rotator of the lip; and its insertion into the lesser trochanter at the inner sirle of the femur would appear to favour this view. In orler to detemine whether it has this action, it is necessary to ascertain whether the line of the tendon of the pasts lies internal or external to the axis of rotation. This axis may be found hy drawing a straight line from the ecntre of the head of the femur to the centro of eravity of the lower limb. which, when.the knee is extended, will be about the mirlille of the intereondylar noteh. By reference to the articulated skeleton it will be seen that on account of the position of the lesser trochanter in 
the angle which exists between the neck and shaft of the femur, the line of the tendon of the psoas passes either through or external to this axis. The action, therefore of the muscle when the knee is extended will be either to produce no rotation at all, or to rotate inwards. I'hen the knee is flexed or when the thigh is broken the axis of rotation is altered, and in the latter case the psoas may becone an external rotator. It will follow, therefore, that any power of rotation excreised by this muscle will be rather internal than external.

Acting from helow, the psoas will Hex the lower thoracic and the lumbar spine upon the pelvis and the pelvis upon the thigh, as when the body is raised from the reclining to the sitting position, or when the trunk is bent forwards in rowing.

Fig. 286.-Psoas, Illaces, axi Quadrates Lemborum.

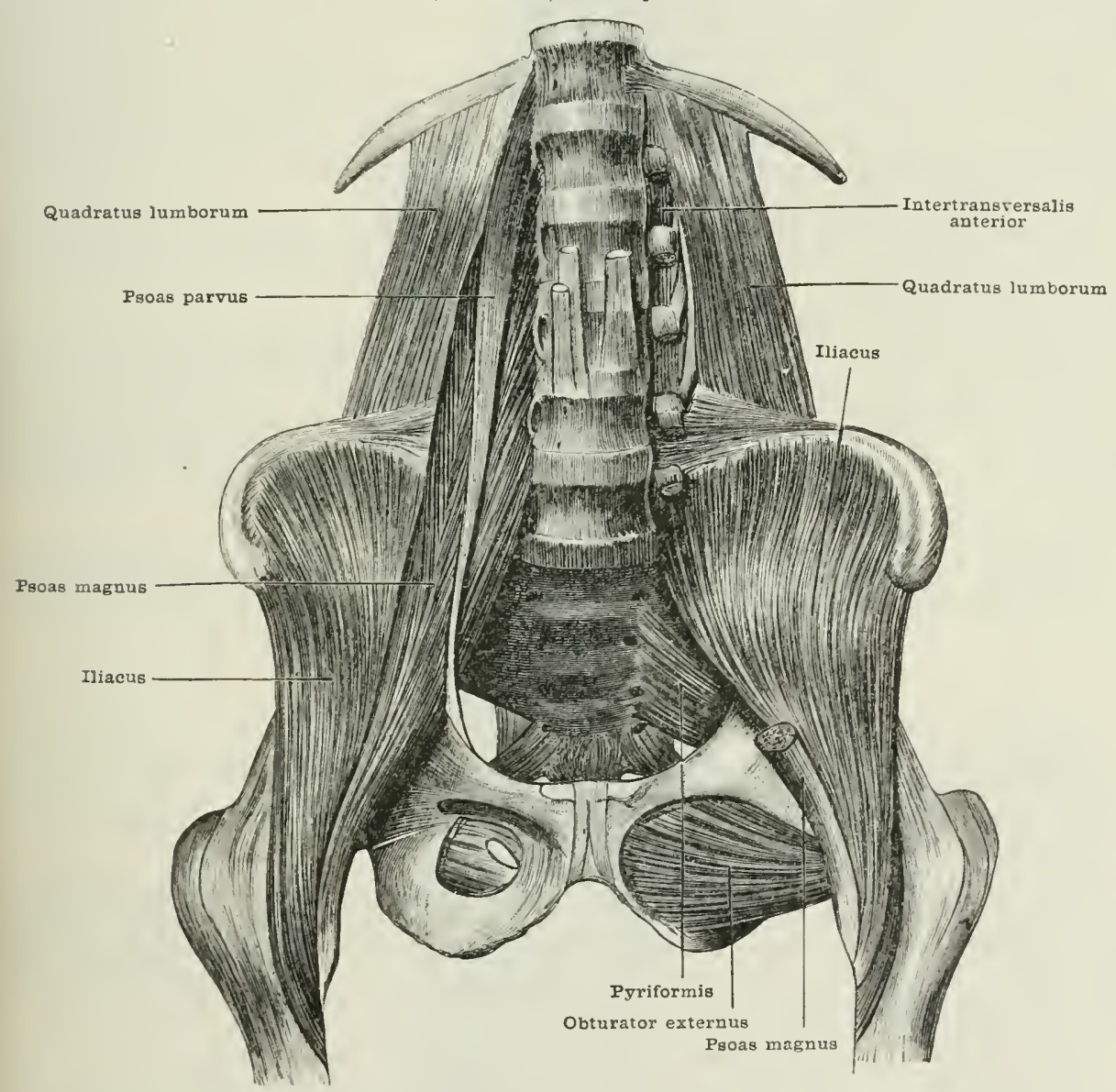

Relations.-The front and inner surfaces are corered by the iliac fascia, which at the upper part of the muscle is thickened, and forms the liganentum arcuatum internum of the diaphragm. In front lie also the peritoneum, the intestines, the kidney, ureter, and the renal ressels, and the spermatic or ovarian ressels. On the outer side is the iliacus muscle. In the interior of the muscle is the lumbar plexus, the nerves from which run for some distance in its sulstance. On the inner side lies the external iliac artery; and brhind is the inner horder of the quadratus lumbormm and the brim of the pelvis. In the thigh, after passing beneath Poupart s ligament, it is corered by the femoral artery, the pectineus lies along its inner borker. and the capsule of the hip-joint lies behind it, together with the intervening bursa.

Variations.-Sometimes the part of the psoas which arises fom the lower lumbar vertebra forms a distinct muscle. Occasionally fibres fiom the jisuas parrus join the jovas magnus. 


\section{IILACLS}

The iliacus-named from its attachment to the ilium-is a thick, triangular sheet.

Origin.-(1) The upper surface of the ala of the sacrum; (2) the front of the ilio-lumbar, lumbo-sacral, and anterior sacro-iliac ligaments; (3) the upper and outer half of the venter of the ilium; $(t)$ the origin of the upper tendon of the rectus femoris and the ilio-femoral ligament near the anterior inferior spine of the ilium.

Insertion.-(1) The outer surface of the tendon of the psoas, through which it is attached to the back of the lesser trochanter of the femur; (2) the upper and hack part of the shaft of the femur in a line about one inch $(2.5 \mathrm{~cm}$. ) long leading downwark from the lesser trochanter.

Structure.-Arising by fleshy fibres, the muscle converges in a fan-shape downwards and inwards, and its filnes enter the outer surface of the tendon of the psoas muscle from about two inches ( $5 \mathrm{~cm}$.) above Poupart's ligament to its insertion. The lowest fibres are also continued, still fleshy, into their insertion on the lack part of the shaft of the femur.

Nerve-supply.-From the lumbar plexus (through the second and third lumbar nerves) by the anterior crural nerre, which gives branches to its anterior surface about the middle of its inner border.

Action.- Similar to that of the psoas, as a flexor of the thigh; and acting from the femur as a fixed point, it will draw forwards and flex the pelvis upon the thigh.

Relations.-The iliac fascia in front separates it from the peritoneum and intestines. The profunda femoris artery and sereral nerves from the lumbar plexus lie upon it. On its inner side lies the poas. After passing under Poupart's ligament, it is crossed by the sartorius, and behind lie the rectus femoris and the capsule of the hip-joint.

Variations.-A small detacherl muscle occasionally arises from the anterior inferior spine, and is inserted iuto the lower part of the auterior intertroehanteric line, or the ilio-femoral ligameut.

\section{PsOAS PARYLS}

The psoas parvus - a small muscle, only oceasionally present, named from its position in the loins and its small size-is fusiform and somewhat flattened.

Origin. -The sile of the intervertebral dise between the last thoracie and the first lumbar vertubra and the adjaeent borders of the bodies of these vertebre.

Insertion.-The ilio-jectineal line.

Structure.-Arising fleshy, the fibres converge and are inserted in a somewhat penniform manner into the back and inner surfice of a teudon which appears about two inches below the origin of the muscle upon its outer and anterior aspect, and becomes free about the level of the fifth lumbar vertebra. The tendon, a narrow fibrous band, lies upou the inner aspect of the psoas magnus on the brim of the pelvis, and expands at its lower extremity to be attaehed along the ilio-pectineal line and the ilin-pubal ridge.

Nerve-supply.-By small filanents from the first nerve of the lumbar plexus.

Action.-T', flox the pelvis upon the thorax; or, taking the pelvis as a fixed point, it will flex the lower rart of the thoracic spine as well as the lumbar spine upon the pelvis. It is a nuscle which is well developed in some animals, having for its function the drawing forwarls of the lower part of the pelvis, accompanied by the arching of the lumbar spine which is seen when they are ruming swiftly.

Relations. - In front, the iliae fascia, peritonemm. ligamentum areuatum internmm, intestines, renal vessels, ureter, extermal iliate vessels, etc. Behind and exterually, the psoas maguus.

\section{ILIAE FASCIA}

Investing the alulominal portion of the ilin-psoas is a strong memhrame. called the iliac fascia, which is attached to the crest of the ilium cxternally. and internally to the posterior part of the ilio-jectincal line which forms the brim of the pelvis. 
Between these attachments it invests the front of the iliacus and psoas muscles. Ahore, it is continued upwards as the covering of the latter numscle, at the sides of which it is attached to the transverse processes and hodies of the lumbar vertebra, as well as to the intervertehral discs and the small. tendinous arehes which bridge the side of the bodies of these vertebre. At the diaphragm it is thickened, and

Fig. 28\%.-IICscles of the Froxt of the THigh.

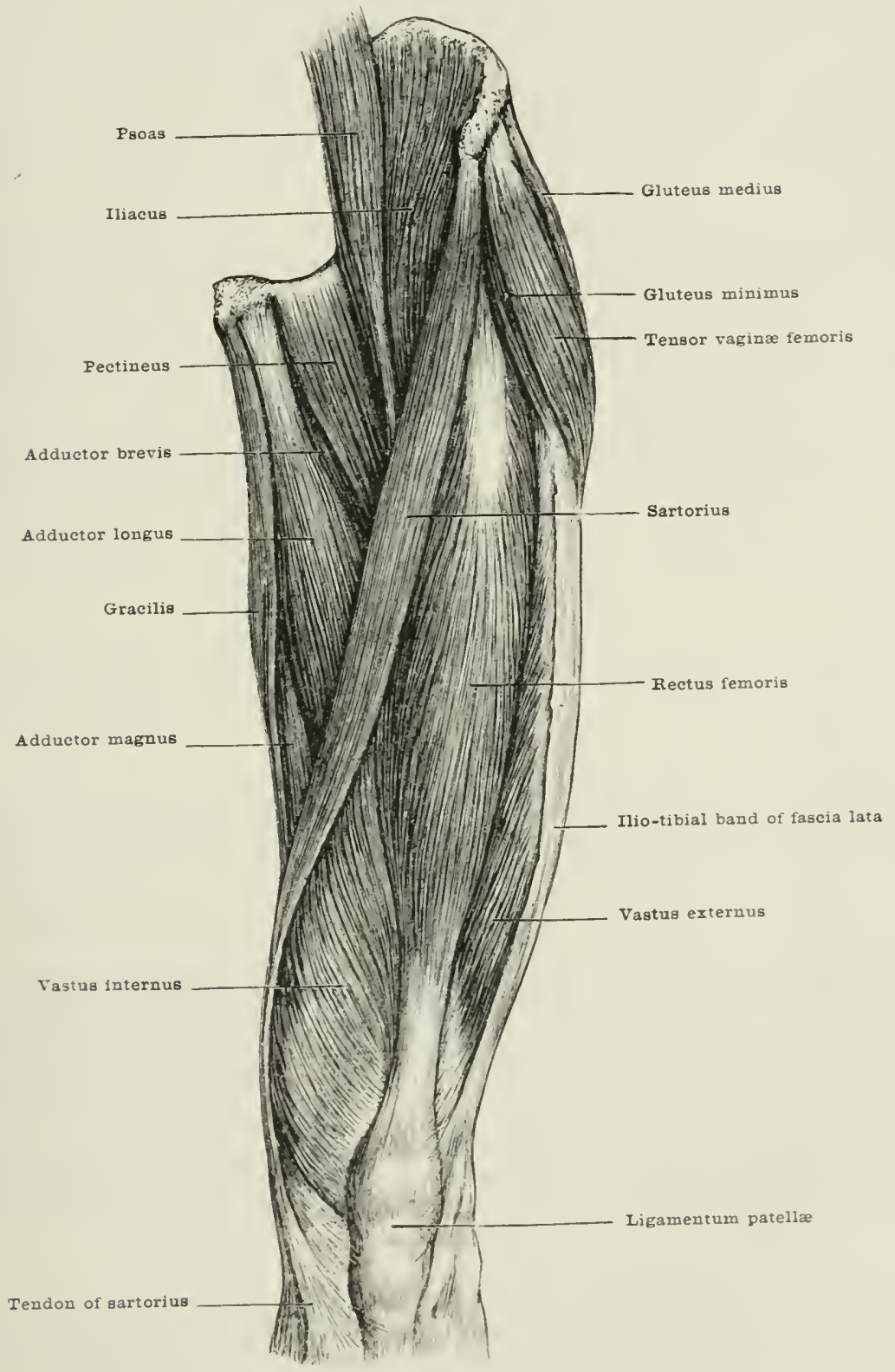

forms the ligamentum arcuatum internmm; near the tip of the transwerse processes of the lumbar vertehre it is attached to the anterior laver of the lumbar fiscia (page 408). Below, it joins beneath the outer half of Poumart s ligament with the transversalis fascia. but intemal to this it passes downwarls into the thigh. forming with the transversalis fascia the sheath of the femoral vescels. Still further 
inwards. it is continuous with the pulie portion of the fascia lata which invests the pectineus musele, and it alsi sends hackwarls a septum between the psoas and the pectineus which is attacherl to the ilio-pubal rielge.

\section{SARTORILS}

The sartorius-named somewhat erroneously from sartor, a tailor. because it has been supposed to be the muscle by which the cross-legged sitting fosture is produced-is a loner, ribbon-shaped muscle slightly fusiform at the two ends.

Origin.-The anterior superior spine of the ilium and the adjacent part of the notch between this process and the anterior inferior spine.

Insertion.-(1) The front part of the inner surface of the tibia, just internal to the tubercle; (2) the upper part of the deep fascia corering the internal surface of the leg.

Structure.-Arising by short tentinous fibres, the fleshy fibres which are the longest in the whole body, run parallel to one another inwards and downwards across the front of the thigh, and after reaching the inner surface of the thigh ahout the middle, the muscular band runs almost vertically downwards to the back of the internal condyle of the femur. At this point the tendon of insertion makes its appearance as an alponemosis which corers the deep aspect of the muscle and becomes free from fleshy fibres just below the knee-joint, where it turns formards and corers the inner surface of the inner tuberosity of the tibia, being separated from it as well as from the tendons of the gracilis and semi-tendinosus by a large bursa. The upper border of this aponenrosis is thick and tendinous and is inserted directly into the bone. The lower part of the aponeurosis, which is of a much more menhranous character, is continued downwarks and forwards and blends with the deep fascia of the inner sicte of the leg, of which it is one of the chief constituents.

Nerve-supply.-From the second, third, and fourth branches of the lumbar plexus" by filaments which are usually derived from the middle cutaneous branch of the anterior crural nerve as it pierces the muscle at the junction of its middle and upper thirds.

Action.--(1) To flex the thigh, and at the same time rotate it slightly outwards and abluct it. (2) To flex the knce, and when the knee is in the lent position it will also help in rotating the leg inwards. (3) Being contained in the close-fitting sheath formed by the fascia lata and its deep processes, it will tend when it contracts to draw the soft parts upon the inner surface of the thigh forwards, and so make tense the inner portion of the fascia lata. (4) Acting from below, it will flex the pelris upon the thigh.

Relations.--In front above lies the fascia lata; internally below lie the fascia lata and internal saphenous rein; beneath lie the rectus femoris, iliacus, pectineus, adductor longus and magnus, vastus internus, and the inner hamstring tendons, the fenoral rescels, the anterior crural nerve and its internal saphenous and rastus internus branches.

Variations.-The sartorius is occasionally absent ; it may also be divided longitudinally. It may have insertions into the fascia lata, or the ligamentum patella. A tendinous intersection sometimes crusess the muscle.

\section{PEC'TINEL'S}

The pectineus-named from perten (= pubes) on account of its origin from that bone-is a quadrilateral shecet.

Origin.-(1) The ilio-pertineal line between the spine of the pubes and the iliopubal ridge; (2) the surface in front of the inner end of this line; and (3) the deep surface of the pubie portion of the fascia lata close to its attachment to the iliopectineal line.

Insertion. - The hack of the femur in a ratical line about two inches $(5 \mathrm{~cm}$. long, begimning just behind the lesser trochanter. 
Structure.-The origin is hy fleshy and tendinous fibres intermingled. The fibres then run parallel to one another to a tendinous insertion between the iliacus and the adductor brevis. The direction of the surfaces changes so that that which looks forwards above is directed outwarks below.

Nerve-supply.-From the lumbar plexus (through the third and fourth lumbar nerves). by a branch of the anterior crural nerve, which, after pasing behind the femoral artery and rein, enters the muscle about the middle of its external border. When there is an accessory obturator nerve, it passes orer the brin of the pelvis to supply this muscle at the upper part of its anterior surface. Occasionally the muscle receives a branch upon its deep surface from the anterior division of the ohturator nerve.

Action.-To flex and at the same time adduct the thigh; as, for example. in crossing the legs, when one thigh is brought forwards and inwards to place it in front of the other thigh. It is also a slight extemal rotator. Its predominant action is that of flexion, as is indieated by the fact that it receives the same nerresupply as the sartorius and ilio-psoas. The tendency which it has to adduct during flexion is comnteracted by the slight abduction produced by the sartorius. They will together produce the slight external rotation, which is observed during the adrance of the leg in walking.

Relations.-In front, the pulic portion of the fascia lata, the femoral and profunda vessels, and at its insertion the psoas and iliacus muscles; behind, the adductor brevis, olturator externus, hip-joint, and obturator nerre.

Variations,-Sometimes a slight blending of the lower filses of the pectineus with the adduetor longus has been observed.

\section{THE GLUTEAL MIUSCLES}

These are arranged in three layers.

\section{First LAYer}

The first laver consists of two muscles-the gluteus maximus and the tensor ragina femoris.

\section{GLUTELS MAXIMLS}

The gluteus maximus (figs. 291 and 303) - named from its great size and from the region which it occupies (rine $\dot{o}_{5}=$ the buttoek) - is a very thick and strong rhomboidal sheet.

Origin.-(1) The posterior fifth of the outer lip of the crest of the ilimm, and the outer surface of the ilium between the outer lip of the crest and the superior grluteal line; (2) the lumbar aponeurosis betreen the posterior superior spine of the ilium and the side of the sacrum; (3) the lateral portion of the posterior surface of the two last pirces of the sacrum: (4) the sirle of the coccry; (5) the back of the great sacro-sciatic ligament; $(i)$ in front of its attachment to the ilium a few of its fibres arise from the strong process of the fascia lata which invests the ylutens medius.

Insertion.-(1) The upper part of the strong aponeurnsis of the fascia lata. called the iliotibial band; (2) the gluteal ridge of the fomur which leads from the lower borter of the greater trochanter to the linea aspera: (:3) the adjacent prart of the tendinous origin of the vastus extemus.

Structure.-Its origin is ahmost entirely fleshy, a few tendinous fibres only being intermingled between the coarse hundles which run parallel to one another downwards and outwarls to the aponeurosis of insertion. The upper half of this aponeurosis passes over the outer surface of the great trochanter to be attached to the upper part of the ilio-tibial band. Lower down the insertion ennsists of short 
tendinous fibres, which are not only attached to the rough process of the bone but to the adjacent tendon of the vastus extermus, while the more superficial fibres still pass on to be attacherl to the fascia lata. The whole muscle forms a parallelogram of which the upper and lower parallel sides are formed by the origin and insertion which run in olligue lines downwards and inwards, while the outer and inner borters of the musele running downwards and outwarts form the other two sides of the parallelogram. This muscle is especially remarkable for the large size of the fasciculi in which its fleshy fibres are arranged, and which give the muscle its peculiarly coarse appearance.

There are two well-marked burse in comnection with the deep surface of this muscle: the one orer the tuberosity of the ischium, which is partly covered by the muscle and partly projects from the middle of its lower border in such a way thait when the thigh is extended it intervenes between the muscle and the prominence of bone, and when the thigh is flexed it lies between the tuberosity of the ischimm and the subcutaneous fat. The second is a large, often multilocular cavity which separates the outer surface of the greater trochanter from the aponeurosis of insertion of the upper part of the musele. A small bursa is also oceasionally found between the lower part of the musele and the tendon of the vastus externus.

Nerve-supply.-From the sacral plexus (through the fifth lumbar and the first and second sacral nerves), ly means of the inferior gluteal branches which enter the deep surface of the muscle close to its inferior and internal border.

Action.--To extend the hip-joint. The upper part of the muscle, passing over the greater trochanter, is placed at a considerable distance from the axis of movement which passes through the centre of the hip-joint. A similar object is obtained by the insertion of the lower fibres of the muscle at some distance down the back of the f(mur. The whole muscle therefore is able to act as an extensor of the hipjoint with much less mechanical disadvantage than is usual in the body. The gluteus maximus is not used in the movements of extension which require but little muscular power, such as those which draw the thigh backwards in walking; for this purpose the contraction of the hamstring muscles at the back of the thigh is alone employed. Where, howerer, a greater effort is required, as in ascending a hill or in running and leaping, the gluteus maximus acts with great power.

It has some influence as an external rotator. With respect to abduction and arlduction, the action of the muscle is neutral. Acting alone, its upper fibres will ascist in the former, and its lower fibres in the latter movement. By means of the ilio-tibial band it makes tense the outer portion of the fascia lata and is able to exert some force in the extension of the knee, especially when that morement is nearly completed. Taking its fixed point from below, the gluteus maximus is a powerful extensor of the pelvis and in some degree of the lower part of the spine, e.g. in rising from the stroping position or where the trunk in a sitting posture is drawn foreibly hackwarts as in the action of rowing. The influenee which it has upon the back by means of its attachment to the lumbar aponeurosis is shown by the great pain which is felt in rising from the stooping position when there is any inflammation of the fascice in this region, as in lumbago.

Relations.-Behind, the thick adipose tissue of the buttock and numerous cutaneous nerves; in front, the gluteus medius, pyriformis, gemelli and obturator internus, qualratus femoris, arkluetor magnus, biceps, semi-tendinosus and semimembranosus, the gluteal, sciatic and pudic vessels, the great and small sciatie, the putlic and intermal oluturator nerves, the two sacro-sciatic ligaments, the tuber ischii, and greater trochanter.

Variations.-These are rare. Occasionally a biliminar arrangement has been observed.

\section{TENSOR VACINA FEMORIS}

The tensor vaginæ femoris (figs. 2s. and 303 ) - named from its function of making tight the fascial lata, or sheath of the thigh (= vagina femoris) is an elongaterl, fortr-siderl sheet.

Origin.-(1) The front of the outcr lip of the crest of the ilium; (2) the upper 
part of the noteh between the anterior superior and the anterior inferior spines of the ilium; (3) the inner surfaee of the farcia lata, loy which it is closely investerl.

Insertion.-The fascia lata about one-fourth of the way down the outer side of the thigh.

Structure.-The muscle consists of parallel Heshy fibres which arise by a short tendinous sheet, pass obliquely downwards, outwards, and backwarels, and are inserted between two layers of the unper part of the strong aponemrosis of the fascia lata on the outside of the thigh called the ilio-tibial band, which also gives attachment to the majority of the fibres of the gluteus maximus. The two muscles meet by their adjacent borders a little below the upper part of the greater trochanter at an angle of about $60^{\circ}$. As they pass upwards, the two divisions of the fascia lita form a strong sheath for the muscle.

Nerve-supply.- Through the fourth and fifth lumbar nerves, and the first sacral, by the terminal branch of the superior gluteal nerve which enters the muscle about the middle of its deep surface near its posterior border.

Action.- To abduct and rotate inwards the thigh, and, taking its fixed point from below, to support the pelvis and to rotate the other side of it forwards. Acting with the gluteus maximus, it will draw upwards the ilio-tibial band, the obliquity of its fibres enabling it to counteract the tendency of that muscle to draw the band backwards. The chief consequence of this traction upon the ilio-tibial land will be to assist in the latter part of the extension of the leg, by the drawing upwarls of the external tuberosity of the tibia.

Relations.-Sipperficially, the fascia lata and the origin of the sartorius; deeply, the deeper layer of the fascia lata, the ghuteus medius, the upper part of the rectus femoris and the vastus externus, with some of the branches of the external circumflex artery.

\section{SECOND LAYER}

The second layer consists of one muscle-

\section{GLL'TEL'S MEDIL'S}

The gluteus medius (fig. 2. $\$ S$ ) - named from its size and position, which are intermediate between those of the great and small gluteal muscles-is a strong triangular sheet.

Origin.-(1) The anterior four-fifths of the outer lip of the crest of the ilium; (2) the outer surface of the ilium, borkered ahove by the middle portion of the outer hip of the crest of the ilium, and in the posterior fifth by the superior gluteal line, below by the middle gluteal line; (3) the strong process of the fascia lata which invests the outer surface of the muscle and separates it behind from the gluteus maximus; (4) the intermuscular septum which intervenes between it and the gluteus minimus just below the anterior superior spine of the ilium.

Insertion.- The well-marked ohlique impression extending from the posterior superior to the anterior inferior angle on the outer surface of the greater trochanter.

Structure.-Arising by fleshy and tendinous fibres intemingled, the musele converges fanwise upon both surfices of a strong flat tendon which is visible rather higher upon the deep, than the outer surface of the muscle. The front part of the muscle is stronger, and it gradually decreases in thickness towarls its posterior edge. A bursa is contained between the deep portion of the temdon and the triangular space that lies in front of the impression upon the outer surface of the greater trochanter.

Nerve-supply.-From the fourth and fifth lumbar nerves, and the first sacral nerve ly branches of the superior gluteal nerve which enter the deep surface of the muscle near the middle of its posterior border.

Action.-To abduct the hip-joint. It will also by its thicker and stronger anterior fibres rotate the thinh inwards. Its posterior filbess on the other hand, which are not so strong will tend slightly to rotate the thigh outwarks. Acting from helow, it tends to support the pelvis upon the femur and to approximate the 23 
crest of the ilium to the greater trochanter. This is by far the most important and frequent of its actions. In walking. if it were not for the powerful contraction of the gluteus medius and its associated muscles the grluteus minimus and the tensor ragine femoris, the pelvis would not be held fim upon the upper part of the thigh when one leg is upon the ground and the other is being advanced in the forward step. In fist walking the rotatory action of the muscle comes into play, for not only does the gluteus medius of the limb which is resting upon the ground support the pelvis by drawing lownwards the crest of the ilimm, but, by drawing backwards the front portion of that erest, it throws forwards the opjosite side of the pelris and increases the length of the strirle.

Relations.- - Superficially, the fascia lata, gluteus maximus, and tensor raginte frmoris; deeply, the gluteus minimus, superior gluteal ressels and nerve, and the greater trochanter.

Variations.--Sometimes a partially distinct bundle of fibres is inserted into the front of the upper border of the greater trochanter. A slip may be giren from the lower border to the 1)yriformis.

\section{THIRD LAYER}

The third layer consists of one muscle-the gluteus minimus-which is continuous with the extemal rotators which form the next group.

\section{GLUTELS MINIMIUS}

The gluteus minimus (fig. 290)-mamed from its position and smaller size-is a thick triangular sheet.

Origin.-(1) The outer surface of the ilium between the middle and inferior gluteal lines; (2) a fibrous septum which intervenes between its fibres and those of the gluteus medius below the anterior superior spine; (3) the front of the eapsule of the hip-joint.

Insertion.-The well-marked vertical impression which forms the anterior border of the greater trochanter.

Structure.-From the fleshy origin the fibres conrerge fanwise upon the deep surface of the tendon which is first seen about the middle of the anterior border, and then covers the lower part of the muscle. By its anterior border this muscle is closely blended with the anterior horder of the glutens medius and with some of the ligaments of the hip-joint. Like the preceding muscle, it is also much thicker and stronger in front.

Nerve-supply.-From the same sourees as the preceding by the superior gluteal nerve which distributes filaments to the midile of its outer surface near its posterior border.

Action.-The same as the precerling: viz. to abduct and rotate inwarls the hi])joint; and when it takes its fixed point from helow. as is most usually the case, to flex the pelvis laterally and at the same time to rotate the other side forwards.

Relations.-. Superficially, the gluteus medius, the superior gluteal ressels and nerve; deeply, the capsule of the hip-joint, and posterior head of the rectus femoris.

Variations. - The front part of the muscle may be separate from the rest. It occasionally sends slips to the adjacent muscles.

\section{THE EXTERNAL, ROTATORS OF THE THIGH}

This group (onsists of six somewhat short muscles, which run transversely from the pelvic bones to the femur, and which follow immediately after the lower fibres of the glutens minimus-viz, the gyrifomis, the obturator internus with the two gemelli, the quadratus femoris, and the obturator externus. 


\section{PYRIFORIIS}

The pyriformis-named from its pear shape ( pirus = pear)-is a thick triangular sheet.

Origin.-(1) The side of the front of the sacrum between and to the outer side

Fig. 288. -The Exteris. hotators and the Hahistrixg Mescles.

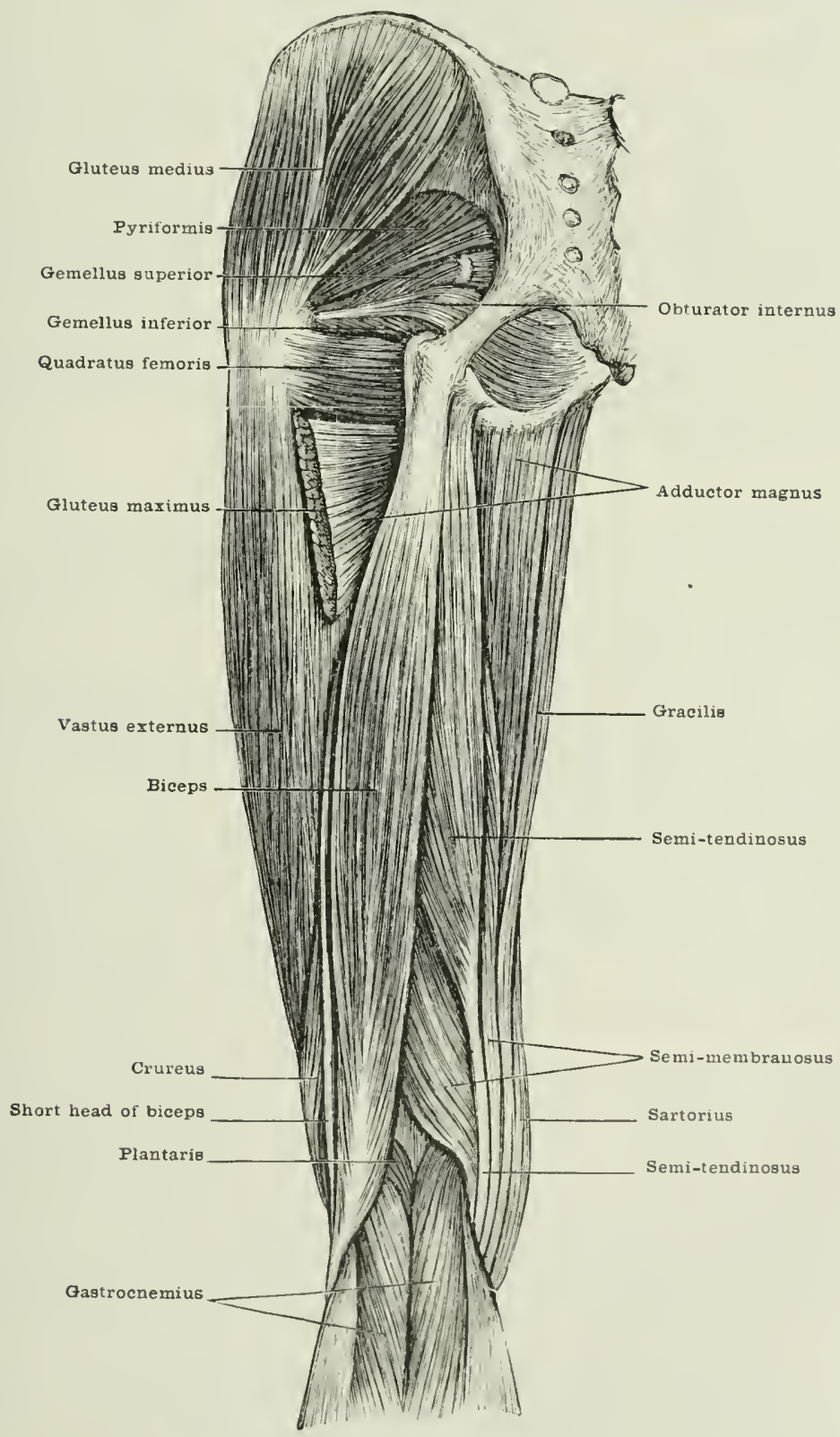

of the first, second, third, and fourth foramina; ( 2 ) the deep surface of the great sacro-sciatic ligament; ( 3$)$ the posterior horder of the hip bone at the upluer frirt
of the great sacro-sciatic notch.

Insertion. - I small facet upon the front and inner aspect of the upper horder of the greater trochanter. 
Structure.-The greater part of the musele arises by three fleshy slips on the ridges of bone between, and external to, the anterior sacral foramina. From this origin, which receives aceessory slips of small size from the great sacro-seiatic ligancent and the upper portion of the great sacro-sciatic noteh, the fihres converge as they pass transiersely outwards and somewhat hackwark through the great sacro-sciatic foramen. The tenclon is first visible upon the deep aspect of the muscle, and it beomes free near the posterior border of the greater trochanter. Shortly before its insertion it is closely blended with the tendon of the obturator internis muscle.

Nerve-supply.-From the sacral plexus by small branches which pass from the second sacral nerve into the anterior surface of the muscle near its origin.

Action. - To rotate the thigh outwards. When the thigh is fixed, it will rotate the pelvis so that the face is turned to the opposite side; if the thigh be flexed, the priformis will abduet it.

Relations.-In front, the sarral plexus and rectum, the back of the hip-joint, and some of the branches of the internal iliac artery; behind, the gluteus maximus; above, the gluteus medius and minimus, with the superior gluteal ressels and nerve; below, the coccrgeus, the lesser saero-sciatic ligament and gemellus superior, the sciatic and puclic vessels, and most of the branches from the sacral plexus.

Variations.-The pyriformis may be absent. It is often divided by a part of the great sciatic nerve into two muscles, and sometimes into three. It may be more or less blended with the gluteus medius or minimus above, and the superior gemellus below.

\section{2, 3, AND 4. OBTURATOR INTERNC'S AND GEMELLI}

The obturator internus and gemelli form really a single muscle, the greater part of which arises inside the pelvis; while the gemelli form two accessory slips which join it from the margin of that carity.

The obturator internus-named from the fact that it arises from the membrane which closes up the obturator foramen, and from its position within the pelvis-is a somewhat triangular sheet, or rather, perhaps, it should be described as the sector of a circle, for its origin within the pelvis is bounded by a curved line like a part of the circumference of a circle.

Origin.- The whole of the interior of that part of the pelvis which is formed by the innominate bone: viz. (1) The lack of the body and descending ramus of the os pubis, and of the aseending lamus of the ischimin; (2) the whole of the inner surface of the oloturator membrane; (3) the broad surface of hone behind the foramen, corresponding to the acetahuhm on the exterior: (4) the outer surface of the pelvic and olsturator fascix. These extend from the ilio-peetineal line above to the great sacro-sciatie foramen behind, and to the spine and tuberosity of the ischium bedow.

Insertion.- The immer aspect of the upper border of the greater trochanter at the print where it unites with the upper horder of the neck of the femur:

Structure.-The musch arises fleshy from the whole of the interior of the pouch-like earity formed ly the pelvic and obturator fasciac intemally and the bony wall of the jolvis externally, and opening hackwards and clowmaris at the lesser sacresciatic formen. From this extensive origin the fibres converge downwark and backwarkw mon a boad tendinous expansion which begins ahout one inch $(2 \cdot 5 \mathrm{em}$. abese the lesser salere-sedatic formen upon the outer surface of the muscle. This expansion is corrugated into four or five folds, which are separated from the cartilaginous lining of the lesere sacro-sciatic notch hy a hursal cavity which allows of the snooth play of the tenton upen the bone. This cartilage presents corresponding

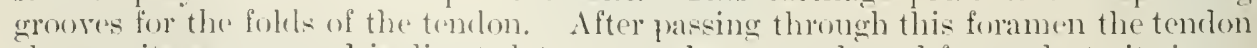

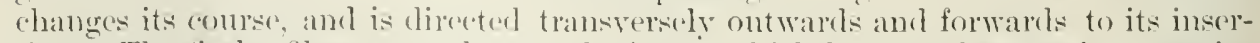
tion. The fleshy fihes extend upon the inner, which has now breome its posterior surface for abovit half the distaner from the noteh to the facet upon the greater trochanter. For a short distane before its insertion it is intimately connecterl with the temton of the priformis.

Nerve-supply.-From the first and second sacral nerves of the sacral plexus 
by a special nerve which, after passing through the lesser sacro-sciatic notch, is distributed to the muscle, entering its imner surface near its upper border and close to the lesser sacro-sciatic foramen.

'The gemellus superior-named from gemollus = a twin, because it is the upper' of the two twin muscles which nearly surround the tendon of the obturator internus at its point of emergence from the jelvis-is a somewhat triangular sheet curved upon itself to embrace the rounded tenclon of the olsturator internus.

Origin.-(1) The outer surface of the spine of the ischium; (2) the upper half of the outer edge of the lesser sacro-sciatic notch.

Insertion.- The upper lorder and the anterior surface of the ohturator internus tenolon, a short listance from it: insertion.

Structure.-Arising fleshy from the bone at the margin of the lesser sacrosciatic foramen, the muscular filses converge slightly and form a sheet which is curved upon itself so as to fit round the upper border and anterior aspect of the obturator internus tendon, with which, after a course of about two inches $(5 \mathrm{~cm}$.) in length, it blends.

Nerve-supply.-The first and second nerves of the sacral plexus by a small special branch which enters the muscle at the upper part of its anterior surface near its origin.

The gemellus inferior - the lower of these twin muscles-is also triangular in shape, but is somewhat broader and stonter than its fellow.

Origin.-(1) The upper part of the imner border of the tuber ischii; and (2) the lower half of the outer elge of the lesser sacro-sciatic notch.

Insertion.-The lower border and anterior surface of the tendon of the obturator internus, a short distance from its attachment to the greater trochanter.

Structure. - Its fibres, arising fleshy from the lower half of the outer border of the lesser sacro-sciatic notch, converge and form a sheet which wraps round the lower part of the anterior surface of the tendon of the ohturator internus. The two gemelli therefore together form an envelope which embraces the whole of the tendon of the obturator internus after its emergence from the pelvis, with the exception of a part of its posterior surface.

Nerve-supply.-From the sacral plexus (through the fifth lumbar and first sacral nerves), by filaments from the special nerve to this muscle and the quadratus femoris, which enter the upper part of its anterior surface near its origin.

Action. - The obturator internus with it: two satellites, the gemelli. powerfully. rotates the femur ontwarks. It should be observed that, although the fibres are mostly rirected backwards and downwards within the pelvis, the action of the muscle is really determined by the outward and slightly forward clirection of the tenchon outsirle the pelvis; and the notch upon the bone plays the part of a pulley in changing the direction of the force.

Besicles its action as an external rotator, the muscle will be able to assist abluction when the thigh is bent through a right angle.

Relations.-The obturator internus in the pelvis is in contact externally with the innominate bone and obturator membrane; above. with the obturator artery and nerve; internally, with the pelvic and obturator fasciae, the levator ani, the pelvic viscera, and the pudic vessels and nerve.

Outside the pelvis, the tendon of the obturator internus. with the gemelli. is in contact. in front with the capsule of the hip-joint and the tendon of the ohturator extremus; behind, with the glutens maximns, great sacro-sciatic ligament, the sciatic ressels and nerves; ahove, with the prrifornis and the structures which mme out of the pelvis below it; below, with the quadratus femoris and a branch of the internal ciremitlex artery.

Variations.-One or nther of the gemelli may be absent, but more frecuently the upper one. An accessory slip to the obturator interuus has been observer coming from the thirl piece of the sacruin. 


\section{QLADRATLS FEMORIS}

The quadratus femoris-named from its scyuare shape and its insertion into the femur-is a four-sided sheet.

Origin.-The upper part of the outer border of the tuber ischii.

Insertion.-The verticil ridge which begins just above the middle of the posterior intertrochanteric line of the femmr, and is called the 'linea cquadrati.'

Structure.-Its fibres are fleshy and run parallel to one another ahmost horizontally outwards and slightly forwards.

Nerve-supply.-From the sacral plexus (through the fifth lumbar and first sacral nerve) hy a special branch which, after furnishing filaments to the inferior gemellus, cnters the muscle near the upper part of its anterior surface close to its origin.

Action.-It approximates the posterior border of the greater trochanter to the tuber ischii, and so assists powerfully in the external rotation of the femur.

Relations.-Behind, the gluteus maximus and the two sciatic nerves; in front, the oliturator extermus and the termination of the internal circumflex artery. Ahore is the inferior gemellus, and below the adductor magnus.

Variations.-This muscle is not unfrequently absent.

\section{OBTLRATOR EXTERNUS}

The obturator externus is a strong external rotator of the thigh, but it is also an adductor, and on account of its nerve-supply and position it is better described in that group of muscles.

\section{THE ADDUCTORS}

The adductor muscles form a distinct group on the inner side of the thigh, and are all supplied by the obturator nerve with the exception of a small part of the adductor magnus. They consist of the adductor longus, adduetor brevis, adductor magnus, gracilis, and obturator externus.

\section{ADDECTOR LONGTS}

The adductor longus-so named from its action and its length compared with that of its immediate neighbour-is a thick triangular sheet.

Origin.- A romaled impression on the front of the body of the os pubis immediately below the erest and angle.

Insertion.-(1) The lower two-thirds of the inner lip of the linea aspera (in the middle third of the thigh); and (2) the adjacent internal intermusenlar septum.

Structure.-Arising by a strong rounded tendon, which extends alout two inches $(5 \mathrm{~cm}$.) downwards upon the inner horder of the musele, the fleshy fibres diverge in a fan-shaped expansion, and are inserted by short tendinous fibres which blend behind with those of the adductor brevis and adduetor magnus.

Nerve-supply.-From the third and fourth nerves of the lumbar plexus, by branches from the anterior division of the obturator nerve which enter the muscle on the upler part of its posterior surface rather below its middle.

Action.-To adduct and flex the femur, and at the same time to rotate it outwarls.

Relations.-In front, the fascia lata, sartorius, vastus intermus, and superficial frmoral resscls; behind, the arduetor brevis and magnus, the profunda resicels, and the olsturator nerve; its uper berder touches the pretineus.

Variations.-The adductor longus may arise by two heads, the outer being attached to the crest of the pubes, and scpirate from the ordinary head which arises below the angle. Oceasimally the muscle is diviled by the passige of vessels into an upper and a lower portion. 


\section{ADDUCTOR BREVIS}

The adductor brevis-named from its action and its size as compared with the preceding muscle-is a thick quadrilateral sheet.

Fig. 289. - The Deep Muscles of the Front of the Thigh.

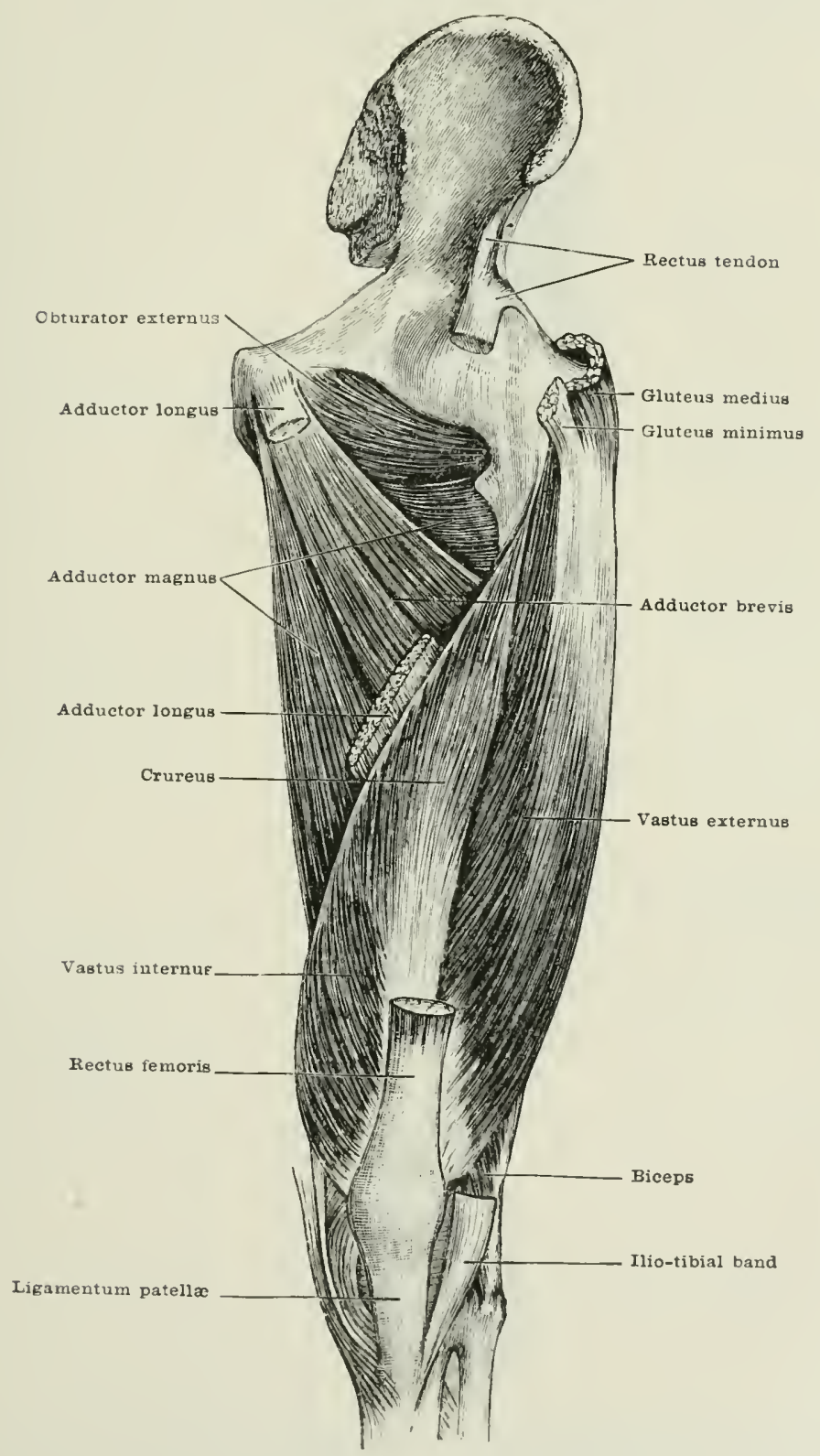

Origin.-The body and the descending ramus of the os pubis, below, and somewhat external to, the origin of the adductor longrus.

Insertion.-The inner lip of the linea asperia in its upper half, extending from just below the lesser trochanter to about the middle of the back of the femur.

Structure.-Arising by short tendinous fibres, the muscle diverges into a fan- 
shaped fleshy exprusion, which ents in short tendinous fibres blending with those of the adiluctor longus and adductor migmus.

Nerve-supply.-From the third and fourth nerves of the lumbar plexus by the superficial branch of the oldurator nerve, which sends filaments to the anterior surface of the muscle near the lower part of its upper border. Sometimes, however, it derives its nerve-supply from the deeper division of the obturator nerve, and in that case the nerves enter the muscle from behind.

Fig. 290.-The Dete II Téles of tile Back of the Thigh.

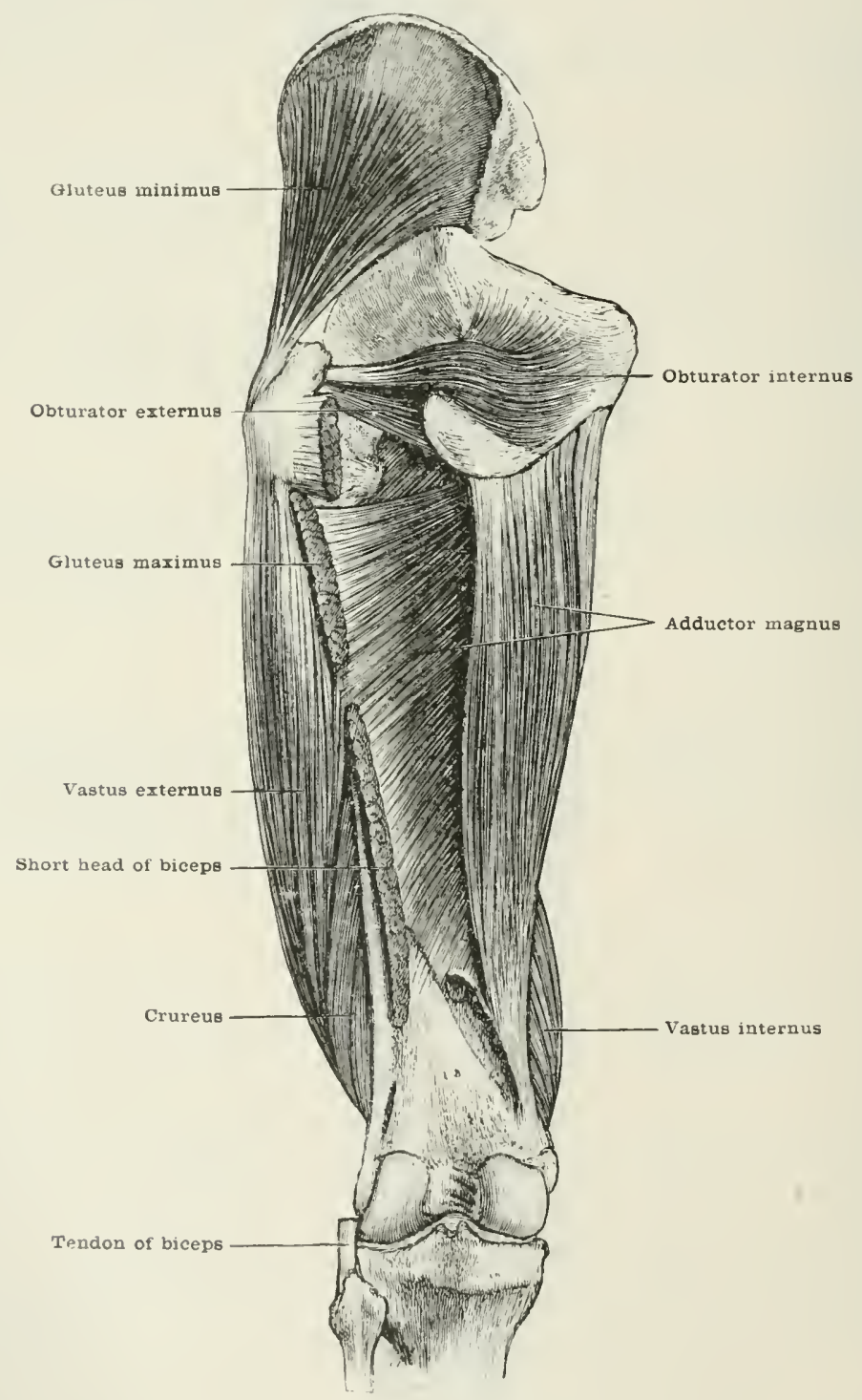

Action.-Like the precerling, it is an adductor and rotator outwards of the femur, but it will not assist so powerfully in Hexion.

Relations. - In front, the pertineus, adductor longus, the profunda vessels, and superficial brinch of the obturator nerve; behind, the obturator externus-and adductor magnus, and the deep branch of the obturator nerre.

Variations. - It is sometimes lividerl into an npper and a lower portion. Occasionally it joins above with the obturator externus. 


\section{ADDLCTOR MAGIUS}

The adductor magnus-named from its action and its great size-is a thick fan-shaped sheet, forming a riglit-angled triangle, the right angle of which is contained between the side corresponding to the insertion of the muscle at the back of the fenur and the side formed by the free upper border of the muscle.

Origin.-(1) The lower part of the outer horder of the tuber ischii: (2) the outer surface of the ascending ramus of the ischium near its inner border; (3) the front of the outer surface of the descending ramus of the pubes.

Insertion.-(1) The lack of the femur, in a line beginning at the lower extremity of the linea quadrati, and extending along the imer border of the gluteal ridge and the middle of the linea aspera down to its bifureation; (2) the adductor tubercle on the upper and posterior part of the internal condyle; (3) the lower part of the internal intermuscular septum.

Structure.-Its origin and insertion are by short tendinous fibres, with the exception of the insertion of the bundle of filsres which passes from the tuber ischii to the adductor tubercle. These arise by a long tendon above, and again become tenclinous three or four inches ( $\mathrm{T}$ to $10 \mathrm{~cm}$.) above the knee-joint, so as to form a long and conspicuous tendon on the lower part of the inner border of the muscle. Between this part of the insertion of the muscle and the linea aspera, the fibres are atiached to the back of the internal intemuscular septum and to a tendinous arch which allows of the passage of the superficial femoral artery and rein from Hunter"s canal into the upper part of the popliteal space. Between the origin and insertion the fibres diverge; the anterior fibres of origin passing horizontally outwards to their insertion into the upper part of the back of the femur, while the fibres which arise behind pass rertically downwards from the tuber ischii to the intemal condyle. Noreover, the muscle is twisted upon itself so that the surface which above looks inwards and rather backwards is directed forwards below. A deep longitudinal groove is thus formed upon the upper part of the back of the muscle, in which lie the hamstring muscles and the great sciatic nerve. The upper fart of the muscle, which arises in front, and is inserted into the inner bolder of the gluteal ridge, forms a triangular sheet, usually separate from the rest, and sometimes descrilied as a distinct nuscle, the adductor minimus.

In addition to the opening for the superficial femoral ressels, the muscle is pierced close to the bone by the perforating arteries and the teminal branch of the profunda femoris. Upon its anterior surface it receives a menbranous expansion from the vastus internus, which passes inwards beneath the sartorius to the adductor longus and magnus, forming the anterior wall of a sort of tumnel which contains the superficial femoral ressels in the middle third of the thigh, and is called Hunter's canal.

Nerve-supply.-Chiefly from the third and fourth nerves of the lumbar plexus by the deep division of the obturator nerve which supplies the muscle upon the outer part of its anterior surface. The lower filnes of the nusche, howerer, are supplied upon their posterior surface by the great sciatic nere, a banch of the sacral plexus.

Action.- This muscle is the most powerful of the aduluctors. The upper three fourths of its fibres will also rotate outrards the femur, while that part of the muscle which arises from the tuher ischii and is inserted into the inner condrle will tend slightly to rotate the thigh inwark, and will at the same time extencl as well as arduct the thigh.

Duehenne suggests that this is the part of the muscle which efuestrians should esprecially develop. Otherwise the atduction of the thighs in mipping the saddle is apt to throw out the tors. which is ungainly, and, if the vider have spurs on, mily learl to unpleasant consequences.

Relations. - In front lie the adduetor hrevis and longus. and hower down the rastus internus. Behincl are the hamstrine museles, the erlutens maximus, and the great sciatic nerve. At its upler loriler are the gualratus femoris and oloturato: externus. Along its immer borter lie the gracilis and part of the salrturius. It is alson in relation with the superticial and deep fenoral rescels. and the obturator merve. 
Variations.-The pusterior part of the muscle may form a listinct slip. Accessory bundles from the semi-membranosus or biceps may join the lumer tendun. The upper border of the muscle may be blended with the guadratus femoris.

\section{GRACILIS}

The gracilis-named from its form (gracilis= slender) -is long and ribbonshapeel.

Origin.-The immer edge of the anterior surface of the body and descending ramus of the os pubis from about the midcle of the symphysis to the junction of the rami of the pubes and ischium.

Insertion.-The inner surface of the tibia below its inner tuberosity; behind the insertion of the sartorius.

Structure.-Arising by a broad and thin aponeurosis, the muscular fibres pass down the inner surface of the thigh almost parallel to one another, but with a slight convergence. so that the muscle in descending increases in thickness as it diminishes in brealth. Alont two inches $(5 \mathrm{~cm}$.) above the inner condrle it becones a rounded flattened tendon. This runs behind the inner condrle, and, after forming one of the two hamstring tendons which can be easily felt at the inner horder of the popliteal space, it passes forwards to be inserted in a slightly expanded form helow the inner tuberosity. A few filures pass from its lower border to the deep fascia of the les.

Nerve-supply.-From the third and fourth nerves of the lumbar plexus by a branch from the superficial division of the obturator nerve which enters the deep surface of the muscle above its middle.

Action.-To adduct the thigh and flex the knee. When the knee is flexed, it will help in rotating the leg inwards.

Relations.-It lies superficially in its whole course under cover of the fascia lata. Upon its deep surface lie the adductor brevis and magnus, and lower down the semi-membranosus muscle. It has in front of it the sartorius muscle which orerlaps it slightly at the lorer part of the thigh, and behind it is the tendon of the semi-tendinosus. The internal lateral ligament of the knee and a large bursa lie beneath its tendon.

\section{OBTURATOR EXTERNUS}

The obturator externus (figs. 2S6, 289, and 290)-named from its attachment to the oliturator memlorane upon its outer surface-is a triangular sheet.

Origin.-(1) 'The imner half of the anterior' surface of the obturator membrane; (2) the descending ramus of the os pubis immediately internal to the foramen; (3) the ascending ramus of the ischim internal to the foramen.

Insertion.-The digital fossa upon the inner surface of the great trochanter.

Structure.- It is a fan-shaped triangular muscle which arises fleshy from the adjacent surfaces of bone and membrane, in a curve which is convex forwals and inwards. From this wide origin the fibres converge ontwards, and end below the acetabulum in a rounded tendon which passes hehind and in close contact with the eapsule of the joint to its insertion in the digital fossa. Not unfrequently a small portion of the musche is seprarated at its mpper border from the rest hy one or both of the divisions of the oluturator nerve.

Nerve-supply.-From the third and fourth nerves of the lumbar plexus by the deep dirision of the oliturator nerve which distributes filaments to the deep surface of the muscle as it is passing through it.

Action.- To arleluet and rotate ontwarls the thigh.

Relations.- Behind. the obturator pesels. and at its insertion the quadratus femoris; in front, the pros musele, the pectinens, and arductor lrevis; above, the ohturator nerve, one or loth lianches of which perforate it, and more externally the eapsule of the hip-joint. 


\section{THE HAMSTRING MUSCLES}

The hamstring muscles form a group at the back of the thigh, separated liy intermusular septa from the vastus externus on the outer, and the adductor magnus on the inner side. They consist of the biceps, semi-tendinosus and semimembranosus, and are supplied by the great sciatic nerve. Like the gluteus maximus their action is to extend the hip.

\section{BICEPS FEMIORIS}

The biceps femoris (figs. 2SS and 290)-named from its two heads-consists of two parts: the longer head being somewhat fusiform, and the shorter a triangular sheet.

Origin.-The long head from (1) the lower and inner facet at the back of the tuber ischii by a tendon common to it and the semi-tendinosus; (2) the lower part of the great sacro-sciatic ligament. The short head from (1) the outer lip of the hinea aspera from a point just above the middle of the bone down to the bifurcation; (2) the upper two-thirds of the outer condylar ridge; (3) the external intermuscular septum.

Insertion.-(1) A fossa below and in front of the styloid process of the head of the fibula; (2) the decp fascia covering the peronei muscles; (3) the outer tuberosity of the tibia.

Structure.-The origin of the long head is by a short tendon which is continued down to the middle of the thigh by a sejitum which divides this muscle from the semi-tendinosus. From this tendon and the outer surface of the septum the muscular fibres arise in penniform fashion and form a fusiform belly, which receives at the junction of the middle and lower thirds of the thigh the thick sheet of muscular fibres derived from the short outer head. The tendon commences upon the posterior surface of the muscle near its outer border about the middle of the thigh. At the back of the external condyle the fleshy fibres cease. The rounded tendon here widens into a thick aponeurosis, which embraces the anterior portion of the external lateral ligament at the point of its insertion into the outer and anterior facet of the head of the fibula. Between this tendon and the external lateral ligament is a bursa. From the borders of the tendon at this point a thinner aponeurosis is given off to the outer tuberosity of the tibia in front and the deep fuscia of the leg behind.

Nerve-supply.-From the first, second and third nerves of the sacral plexus by the crreat sciatic nerve which sends branches to the anterior and inner surfaces of the muscle about the middle of the thigh. The short head of the biceps receives its supply from the external popliteal nerre.

Action.-To extend the hip and flex the knee. Its shorter head acts upon the knee only. When the knee is flexed, both hearls will unite in rotating the leg outwards. When the knee is extended. the long head will have a slight influenec in rotating the hip outwards. Aeting from below, the long head will assist in raising the body from the stonping position.

Relations.-Behind, the gluteus maximus, the plantaris, the outer head of the gastrocnemius, gluteus maximus, fascia lata, and the small sciatic nerre. In front, the tendon of the semi-membranosus, the adduetor magnus, and the great sciatic nerre. Tpon its inner horder lie the semi-tendinosus, semi-membranosus, and the external popliteal nerve. Bencath the lower tendon is a bursa which separates it from the extemal lateral ligament of the knee-joint.

Variations.-The short head of the hiceps may be absent. Aceessory heads may be derired from the tuber ischii, the upper part of the linea aspera, the fascia lata, or the inner surface of the tendon of insertion of the gluteus maximus. It may send a slip to the gastrocnemius. 


\section{SEMI-TENDINOSLS}

The semi-tendinosus (fig. 2-si)-named from the long tendon which forms the lower half of the musche-is fusiform and somewhat flattened.

Origin.-By a tendon which is common to it and the preceding muscle, from the lower and inner of the facets at the hack of the tuher ischii.

Insertion.-(1) The upper prart of the inner surface of the tibia below and behind the insertion of the gracilis; (2) the deep fiscia of the inner side of the leg.

Structure. - The romeled and somewhat flattened tendon of ahout two inches (5) cm.) in length is succeded ly a fusiform mass of muscular fibres, which end just below the midlle of the thigh in a flattencel erlindrical tendon. This rums directly downwarls along the inner side of the popliteal space, where it can easily be felt beneath the skin, behind and external to the tendon of the gracilis, in conmany with which it passes downwards and forwards behind the internal condrye to its insertion below the inner tuberosity. From the lower border of the flattened tendion an aponemrosis passes downwards to the deep fascia of the leg. The fleshy part of the inuscle is crossed about its middle by a thin tendinous intersection rumning downwarls and outwards.

Nerve-supply.-From the first, second, and third nerves of the sacral plexus by means of branches from the great sciatic nerre which enter the outer jart of the deep surface of the muscle two or three inches (about $6 \mathrm{~cm}$.) below the tuber ischii.

Action.-To extend the hip and flex the knee, and when the knee is flexed to rotate the leg inwards. Acting from below, it lifts up the body from the stooping position.

Relations.-Behind, the ghuteus maximus and fascia lata; on its outer side the biceps; in front, the semi-membranosus, adductor magnus, and near the knee the gracilis, sartorius, and the imner head of the gastrocnemius. The large bursa beneath the sartorius tendon also wraps round the lower part of the tendon of the semi-tendinosus, and separates it from the internal lateral ligament of the kneejoint.

\section{SEMI-MEMBR.AYOSLS}

The semi-membranosus (fig. 2SS) - named from the broad memhrane-like aponeurosis which forms the upper third of the muscle-is strong. flattened, and fusiform.

Origin.-The anterior and upper of the facets upon the back of the tuber ischii.

Insertion.-(1) The lower part of the posterior extremity of the groove upon the back and inner sicle of the inner tuberosity of the tibia; (2) by a band of filures which pass upwards and outwards to the upper and back part of the rxternal condyle of the femur, and hend with the posterior ligament of the linee-joint; (3) hy a broad expansion which, passing downwards and outwards from its insertion inte the inner tuberosity to the oblique line at the back of the titia, forms the aponeurosis which invests the posterior surface of the poplitens; (4) a few fibres pass downwards and forwards from the lower border of its tibial insertion to blend with the internal lateral ligament.

Structure.- The upper part of the muscle consists of a strong flat tendon about three-cularters of an inch (nearly 2 con.) hroarl, which extends along the outer border of the musele to the midille of the thigh. The tendon of insertion is not quite so broad but much thicker. and reaches upon the immer border of the muscle also as ligh as the middle of the thigh. Betweren these two tendons the muscular fibres which are comparatively short pass downwarts and inwards. lecginning upwn the upper tendon about four inches (10 cm.) helow the tuber ischii, and ending upon the lower tenclon chese to the upper part of the inner endyle. The muscle has therefore a very distinctly penniform arrangement, but it is peculiar in this respect that the Heshy fibes are at each extremity attached to a tenclon, and are not, as is usually the ease, at one extrennity attached to the hone. It is also unusual for a muscle to have so long a tendon at its proximal end. One effect of 
this arrangement is to allow of the free action of the long head of the hiceps which croses orer this part of the semi-membranosus. Otherwise the swrelling of the fibres of the biceps during contraction might have pressed upon and interfered with the action of the semi-membranosus, which usually contracts at the same time.

Nerve-supply.-From the first, second, and third nerves which enter into the formation of the sacral plexus through the great sciatic nerve which sencls branches to the deep surface of the muscle about the mirlde of the thigh.

Action.-To strongly extend the hip and to flex the knee. When the knee is flexed it will also assist in the internal rotation of the leg, but with less mechanical arlvantage than the semi-tendinosus and gracilis, as its line of action is so near to the axis of movement.

Like most penniform muscles, the semi-membranosus is very powerful, as is shown by the thickness of its tendons. This strength is necessitated by the fact that its line of action is so much nearee to the axis of movement both in flexion and rotation inwards of the knee. Like the other muscles which arise from the tuber ischii, it will co-operate powerfully in raising the body from the stooping position, this prominence of bone forming the short arm of the lever by which the trunk is raised. This group of museles affords a good example of the peculiar action obtained by long muscles passing over two joints. If all three muscles were to remain passive, like so many ligaments, it is obvious that on flexion of the hipjoint by means of the ilio-psoas and other muscles, the hamstrings would ensure the sinultaneous flexion of the knee; or, again, on extension of the knee by the action of the powerful muscles of the front of the thigh, the hamstrings would produce a corresponding extension of the hip-joint. Secing, however, that these hamstrings are not passire, but that they contract powerfully at the same time in many of these movements, it follows that in flexion of the hip in such movements as those of ruming, the knee is at the same time flexed with increased rapidity; and again, when the knees are extended by the powerful contraction of the quadriceps muscle, the simultaneous action of the hamstring muscles will produce a still more rapid elevation of the trunk.

Relations of the semi-membranosus.-Behind, the gluteus maximus, biceps, and semi-tendinosus; in front, the adductor magnus, posterior ligament of knee, and the popliteus. Along its outer border lies the great sciatic nerve, and just bcfore its insertion the inner head of the gastrocnemius hooks round this border, being separated from it by a bursa which communicates with the knee-joint. There is also usually a small bursa between its tendon and the back of the inner tuberosity of the tibia.

Variations.-The semi-membranosus has oceasionally been defieient, or only representerl ly a thin musculo-tendinous band. It has also been found duuble.

\section{ANTERIOR MUSCLES OF THE THIGH}

This group consists of the sartorius and the quadriceps extensor.

\section{SARTORILS}

This musche has already been desclibed (see page 350 ).

\section{QL'ADRICEPS EXTEASOR}

The quadriceps extensor ( tigs. 257 and 289 ), als its name implies, (onsists of four heads. (Jit these, one, the rectus, arises from the immominate hone; and the three others. the vastus externus, vastus internus, and crureus. from the femur; while the common tendon is inserted into the mpler lorder and sides of the patella. 


\section{(11) Recte's FeMoris}

The rectus femoris-named from its long straight course-is strong, fusiform, and flatteneel from hefore backwarls; it aris by an anterior and a posterior head.

Origin.-Auterion head. from the front of the anterior inferior spine of the ilium; posterior hearl, from the upper surface of the rim of the acetabulum just external to the attachment of the capsular ligament.

Insertion.- The front of the upper border of the patella.

Structure.-This muscle consists of two strong tendinous expansions joined by fleshy fihres. The upper expansion is formed above by the union of the two tendinous heads in a small arch, which is intimately connected with the capsule of the hip-joint. From this arch the tendinoms expansion descends upon the front of the muscle as far as the middle of the thigh. getting thimner and narrower as it descends. The tendon of insertion begins upon the back of the muscle also about the middle of the thigh, and soon expands into a broad aponeurosis which covers the back of the muscle at its lower end; about three inches $(7.5 \mathrm{~cm}$.) above the patella, it becomes free of muscular fibres, and forms a strong tendinous band which is inserted into the upper border of the patella. The fleshy filures pass from the hack and sicles of the upper expansion to the front and sides of the tendon of insertion. Seen from the front, these fleshy fibres appear to diverge on both sides from the upper expansion, and, after passing round the border of the muscle, they converge upon the tendon of insertion so as to give the muscle a bipenniform appearance.

Nerve-supply.-From the lumbar plexus (through the second, third, and fourth lumbar nerves), by the anterior crural nerve which sends filaments to the posterior aspect of the muscle in the upper half of its course.

Action.-To assist in the powerful extension of the knee by the quadriceps. It will also help in flexion of the hip; and it will be a powerful agent in preventing dislocation of the hearl of the femur. When the hip-joint is flexed, the muscle will act chietly from its posterior head; but when the hip is extended, the anterior head of the muscle will act with more power.

Relations.-In front lie the sartorius, tensor raginz femoris, and the fascia lata; lehind. it lies on the hip-joint and the crureus muscle; upon its inner border above is the iliacus; and outside it lie the gluteus medius and minimus.

\section{(b) Vastes Exterics}

The vastus externus-named from its great size and its position upon the outer surface of the thigh-is a thick rhomboridal sheet.

Origin.-(1) The upper half of the anterior intertrochanteric line and the front of the upper prart of the femur along the anterior horder of the greater trochanter; (2) a horizontal line which forms the lower horder of the greater trochanter; (3) the outer lip of the gluteal ridge; (4) the upper half of the outer lip of the linea asperat and the adjacent portion of the slaft of the femur for about one-sixth of an inch ( $4 \mathrm{~mm}$.$) ; (5) the external intermuscular septum in the neighbourhood of its attach-$ ment to the linea aspera.

Insertion.-(1) The outer half of the upper borler of the patella. hehind the precerling temlon, with which it also blends: (2) the mper third of the outer borler of the patella; (3) by an aponeurnis which is inserted partly into the front of the external tuberosity of the tilia, partly into the deep fascia of the legr.

Structure.-Arising partly directly from the bone, and partly by a strong aponeurosis which covors the miter surface of the musede in its upper two-thirds, the fleshy fibres run parallel to one another downwals, forwarls, and inwards, at the same time curving slightly as they pass over the romuled mass formed by the crureus muscle. The aponeursis of insertion lies upon the inner surface of the muscle and reesires fleshy filures to within one inch $(2 \cdot 5 \mathrm{~cm}$.) of its insertion into the patella and its hemeling with the other tendons of the quadriceps muscle. Cpon its anterior surface it unitus with the tendon of the reetus muscle, and upon its posterior surface is receiverl a part of the insertion of the crureus.

Nerve-supply.-From the anterior crural (through the second, third, and 
fourth lumbar nerres), ly several hranches which enter the internal surface of the musele in the upper third of the thigh.

Action and relations.- These will be eonsidered with those of the two following muscles.

\section{(c, d ) Vastes Ixterit's and Critiel's}

The vastus internus and crureus are so closely lilended that it is better to describe their origins together before mentioning the way in which they may lx separated. They have received their names, the former from its size and position: the latter from its intimate comnexion with the whole of the front of the thigh bome. the term 'erus' being often used synonymously with the femur. The blenderl muscle is a somewhat fusiform sheet which is so curved laterally as to form it cylinder embracing the whole of the front and sides of the shaft of the femur.

Origin.-(1) The outer lip of the lower half of the linea aspera and its external bifureation, together with the adjacent external intermuseular septum; (2) the lower part of the anterior intertrochanteric line and the suiral line of the femur; (3) the inner lip of the whole length of the linea aspera and its internal bifurcation. together with the adjaeent part of the internal intermuseular septum, and the front of the tendon of the adductor magnus; (4) the greater part of the front and sides of the femur within the limits formed by the three preceding attachments and the origin of the vastus externus.

Insertion.-(1) The front aspeet of the upper borler of the patella immediately behind the insertion of the rectus femoris tendon; $(2)$ the upmer half of the inner border of the patella; (3) ly a strong aponeurosis into the front of the inner tubrrosity of the tibia and into the adjacent deep fascia of the leg.

Structure.-The fibres of this large muscle arise fleshy from the surface of the femur and eonverge, from the outer side downwards, forwards, and inwards; from the front directly downwards; from the inner side downwarls, forwards, and outwards, upon the back and sides of a strong aponeurosis which covers the front of the muscle from about the middle of the thigh downwarls. The filres which arise from the tendon of the adductor magnus and the adjacent intermuseular septum form the lowest part of the thick muscular belly of the vastus internus, and are directed almost transversely outwards to get to their insertion upon the inner border of the patella. The substance of the musele is arranged in layers which wrap rounil the front and sides of the femur; and between the attachment of these lavers to the bone, longitudinal strips of bone may be found upon dissection without any museular attaehment. The deepest of these layers in the lower fourth of the thigh forms a separate sheet of muscular fibre, sometimes called the subcrureus, which is inserted into the upper reflexion of the svnovial membrane of the knee-joint. $B$ meath this musele is the bursa underneath the quadriceps, which in the adult conmunieates with the upper part of the knee-joint.

A somewhat arbitrary division may be made between the vastus internus and erureus by dissceting at the lower third of the thigh in a line with the inner borker of the patella. With a few touches of the sealpel a longiturlinal separation may he mate clear, which extends upwards to the lower part of the anterior intertmchanteric line. The part of the muscle external to this line is the crureus, and the part internal the rastus intermus.

The ligamentum patellæ may be looket upon as the common tendon of the

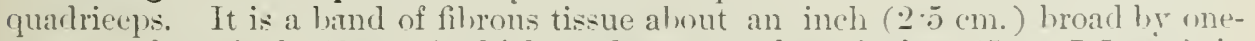
quarter of an inch $(6 \mathrm{~mm}$.) thick, and two or three inches $(5$ to $7.5 \mathrm{em}$. ) in length, which is attached above to the apex and to the lower part of the postreior surface of the patella; and, after passing domwards and rery slightly ontwarls. it is inserted into the anterior surface of the tubercle of the tibia. Attacher to its sides are strong aponeuroses he whieh the lower fibres of the ristus externus and vastus internus and the ilio-tihial band are inserted into the tubroseities of the tibia, and which blend on their deep surface with the lower part of the calsule of the knee-joint.

Nerve-supply.-Numerous hranches from the antrior cruml are distributed to the upper half of the front of the crureus muscle and to the inner surface of the vastus internus at the junction of the middle and lower thirds of the thigh, the 
nerve to the vastus internus being a large and conspicuous branch which lies close to the outer side of the superficial femoral artery in the uprer part of Hunter's tainal.

Action.-The vastus extrunus, crureus, and vastus internus, together with the rectus fomoris, extend powerfully the knee. Their intermediate insertion into the sesanoid hone formed by the jatella serves to lift from the line of the tibia the liganentum patellax, which may he looked upon as the lower part of their common trinton. The enormous power of the whole of this combination of muscles is necessitated partly by the fact that the whole of the weight of the body has to be rased by it, and partly by the great mechanical disadvantage which results from the short arm of the lever upon which the tendon acts, and the obliquity of its insertion.

On ac'ount of the direction of the femur, which is downwards and inwards, the tendeney of the quadriceps is to draw the patella outwards at the same time as upwards. This is in some degree comnteracted by the position and direction of the ristus internus. The great mass of the fibres of this part of the quadriceps arises in the lower part of the thigh, and is directed so transversely outwards towards the inner border of the patella, that when it contracts it tends to draw the patella inwards as well as upwards, and so the resultant of the various divisions of the (quadriceps when contracting simultaneously is to draw the patella more directly upwards. If it were not for this arrangement, the contraction of the quadriceps wonld have a strong tendeney to produce outward dislocation of the knee-cap.

Relations of vastus externus, crureus, and vastus internus.-In front lie the fascia lata, tensor vagina femoris, rectus femoris, and sartorius. To the inner sicle lie the femoral vessels and anterior crumal nerve. On the outer side are the gluteus minimus and maximus. Behind are the biceps on the outer side of the femur, and the adductor longus and magnus on the inner side.

Variations.-These are few in number. An accessory head to the rectus from the anterior superior spine of the ilium has been described, and occasionally the outer head is absent.

\section{THE DEEP FASCIA OF THE LEG AND ANNULAR LIGAMENTS}

The deep fascia of the leg is continuous above with the fascia lata of the thigh and receives important additions from the tendons of the quadriceps, biceps, sartorius, gracilis, and semi-tendinosus. It is also attached to the lower prat of the outer and inner tuberosities of the tibia and to the head of the fibula. At the back of the knee it is strengthened by transverse fibres which serve to bind together the muscles which form the boundaries of the popliteal space; the extemal saphenous win also perforates it about the centre of the space. It is very thick and strong at the upper and outer part of the front of the leg; but hehind, where it covers the musces of the ealf, the fascia becomes much thinner. The internal surface of the tibia is not coverel by this fascia, which blends with the periostem covering its anterior and inner horders throughout their whole length. It is also attached to the borders of the fihula by two strong intermuseular septa which form the anterior and posterior walls of a compartment containing the long and short premei. In the lower thirl of the leg it is attached to the horders of the sulbutaneous surface of the fibulat. In the noighbourhood of the ankle the deep fascia is thickened by the adclition of numerous transerese fihres, and forms the annular liganents.

The anterior annular ligament (fig. 29s) eonsists of two parts, an upper and a lower. The "pper port is a strong hand of transverse fibres just above the anklejoint, which extemels from the anterios horeler of the tibia to the anterior border of the subcutaneous surface of the filula. Behind it there is a separate synovial sheath for the tenclon of the tilialis anticus. The lower pret of the anterior anumbar ligament arises from the uprer surface and outer horeler of the great process of the ealcanem in two hands, a superficial and a deep, which, passing transversely inwarels, unite after a course of alrout an inch $(2.5 \mathrm{~cm}$.), and thus form a loop in which are containes the temelons of the cxtrusor longus digitorum and the leroneus tertius, torether with part of the origin of the extensor brevis digitorum. 
From the inner extremity of this loop, two bands of filores of varying distinetness proceed: one passes upwards and inwards to join the front border of the internal malleolus; the other, which is usually the waker, more directly inwards ower the scaphoid bone to join the inner borter of the plantar fascia. Beneath this inner portion of the lower part of the anterior annular ligament the tendons of the extensor proprius hallucis and tibialis anticus are contained in separate synovial sheaths.

The external annular ligament passes from the posterior borcler of the external malleolus to the outer border of the tuberosity of the ealcancum and to the posterior fart of the junction of the lower and outer surfaces of the caleaneum. It is continuous above with the deep fascia covering the ealf museles and the peronei; and also with the shect of fascia which separates the two superficial from the two deeper layers of muscles at the back of the leg. Its deep surface is attached to the peroneal tubcrcle on the outer side of the calcaneum.

The internal annular ligament extends from the posterior border of the internal malleolus to the inner borcler of the tuberosity of the calcaneum. It is also continuous above with the deep fascia of the leg and with the sheet of fascia which intervenes between the soleus and the deeper layers of muscle at the back of the leg.

\section{IIUSCLES OF TIIE BACK OF THE LEG}

The muscles in this region are arranged in two lavers above, in four below. The first layer consists of the gastroenemius and plantaris.

\section{FIRST LAYER}

\section{GASTROCNEMIIS}

The gastrocnemius-named from rugryp $=$ the belly, and $x r_{j} \mu r=$ the ealf, because it forms the enlargement of that part of the leg-is doulle-headed, each head consisting of a fusiform muscle, the lower part of which blends with its fellow so as to form a common tendon of insertion. These two heads constitute the femoral origin of the great tricejs suræ muscle.

Origin.-Outer head: a well-marked impression upon the upper and prsterior f lart of the outer surface of the external condyle and the adjacent part of the posterior surface of the femur just above the cxternal condyle.

Inner head: an oval impression placed transversely across the posterior surface of the femur above the internal conclyle, and reaching inwards to the back of the adductor tubercle.

Insertion.-By the tendo Achillis (so named from the legend that the hee?, into which this tenclon is inserted, was the nnly rulnerable part of the hero Achilles) into the michlle area on the postorion surfice of the calcaneum.

Structure.- The two heals arise by short strong tendons; that of the inner is the stronger and thicker. These tendons converue downards and are succrerterl by large fleshy expansions which unite at the upper part of the miclde third of the leg. Near this point the tendon of insertion begins as an intermuscular soutum between the two belies of the muscle. This hecomes thicker and -tronger, and expands into a broard aponeurosis which covers the ant reror surface of the united muscle. Just below the midclle of the leg the fleshy filmes terminate upon the back of this aponeurosis in two curves the consexity if which is downwarls, that of the inner portion of the muscle descending alout half an inch

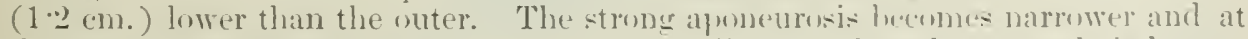
the same time thicker, and after receiving the filbres of the sulens muscle is known by the name of the tendo Achillis. 


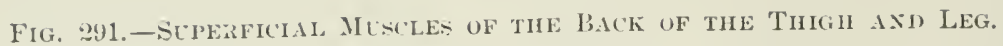

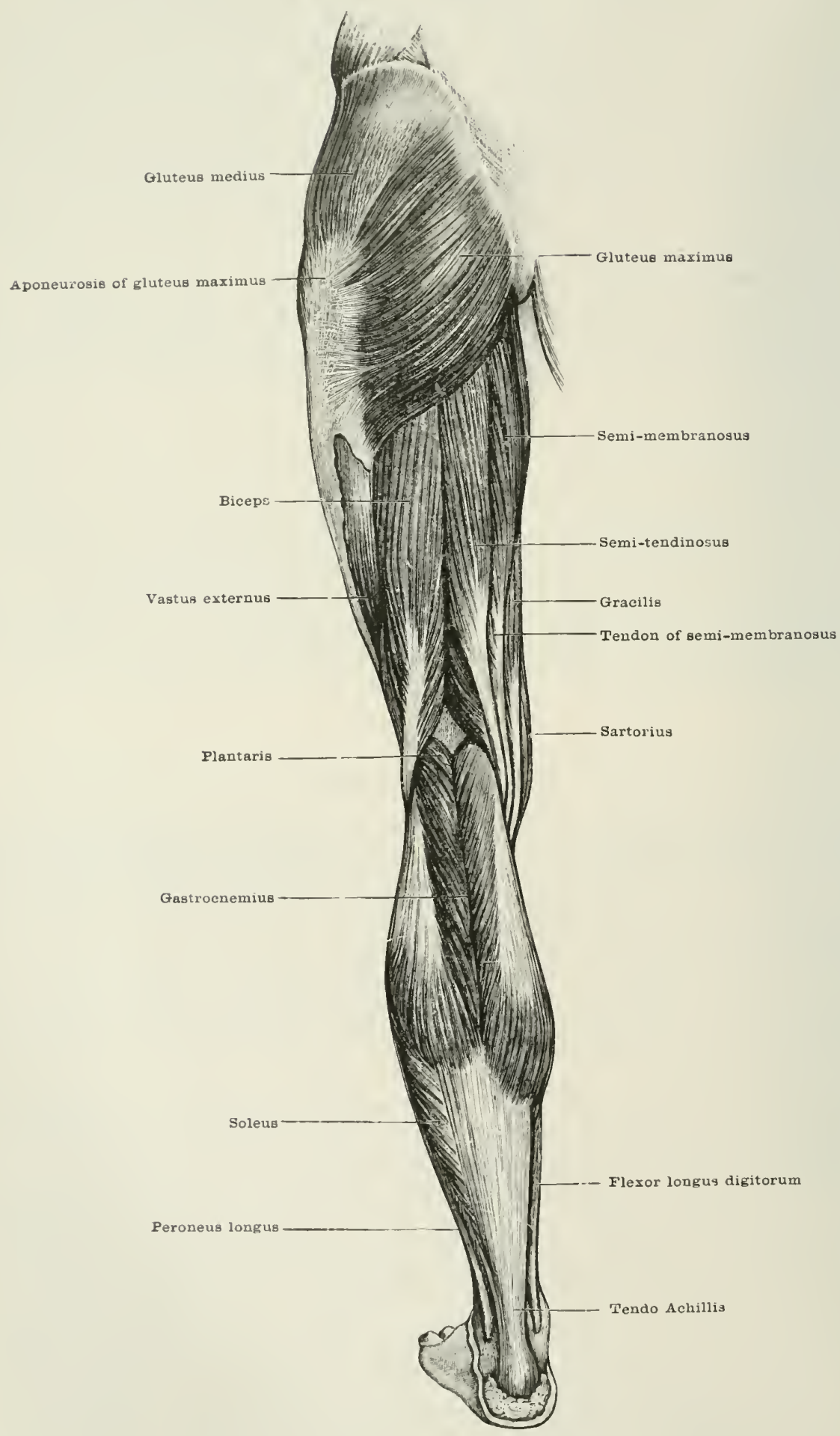


Nerve-supply.-From the internal popliteal hranch of the great sciatic nerve, which sencls sural branches to the acljacent portions of the anterior surfaces of the two heads, in the upper third of the leg.

Action.-Its action will be deseribed with that of the soleus, which forms a part of the same muscle.

Relations.-Behind, the dere fascia, the external saphenous rein and nerve, and the communieans peronei nerve. Between the two heats above is the plantaris muscle. In front lie the knee-joint, the tendon of the semi-membranosus, the popliteus, the plantaris tendon, the soleus, the popliteal vessels, and internal popliteal nerve. On the outer sicle, above, are the biceps tendon, and extemal popliteal nerve; on the inner side, above, are the tendons of the semi-tendinosus, gracilis, sartorius, and adductor magnus. A hursa lying beneath its inner head seprates it from the tendon of the semi-membranosus, and communicates with the knee-joint.

Variations. - The most common rariation is the addition of a third head from the posterior surfice of the lower end of the femur. This may cross, or even run between, the popliteal ressels.

\section{PLANTARIS}

The plantaris-named from its occasional attachment to the fascia covering the sole of the foot (=planta) - is a fusiform, sonewhat flattened musele with a very long ribbon-shaped tendon.

Origin.-(1) The lower two inches $(5 \mathrm{~cm}$.) of the outer condylar ridge together with the posterior surface of the femur immediately below that ridge; and (2) the adjacent part of the posterior ligament of the knee-joint.

Insertion.-The inner side of the lower portion of the posterior surface of the calcaneum; sometimes, however, it blends with the inner border of the tendo Achillis, and sometimes it is continued into the inner division of the plantar fascia.

Structure.-Arising fleshy, the filores of this small muscle have a somewhat penniform arrangement and converge upon the thin tendon, which appears first on the inner side of the muscle, and soon beeming free, runs downwarls and slightly inwards across the calf between the gastrocnemius and the soleus. In the lower third of the leg it lies along the inner border of the tendo Achillis, with which it is sometimes blended.

Nerve-supply.-From the intemal popliteal branch of the great sciatic nerve by a small filament which enters the deep aspect of the muscle near the upper part of its imer border.

Action.-This restigial muscle is a feeble extensor of the ankle and a flexor of the knee-joint. By its attachment to the posterior ligament of the knee-joint it will tend to draw backwards that ligament fluring flexion of the knee, and so prevent its being caught between the articular surfaces.

Relations.-Behind lie the fascia of the pophiteal space, the biceps, the gastrocnemius. and the external popliteal nerve; in front are the popliteal ressels and internal popliteal nerve, the popliteus muscle and the solcus.

Variations.-In addition to the above-mentioned variations in the point of insertion, this muscle may sometimes be double at its origin, and it is not unfrequently absent.

\section{Secoxd LaYer}

The second laver is formed above by the popliturs, which is covered hehind hy the aponeurosis ilerived from the semi-membranosus: and below by the solens, which is the lower head of the great triceps sure muscle.

\section{POPLITELS}

The popliteus (fig. 292)-namer from its position on the floor of the ham (= poplex) -is a triangular sheet.

Origin.-The bottom of the anterior portion of a horizontal groore on the lower 
pirt of the outer surface of the (xternal conclyle of the femur; also by a small slip from the posterior ligiment of the knee-joint.

Insertion.-(1) The lack of the tibia from lolow the attachment of the posterior ligannent of the knee-joint to the olnlique line; (2) the fascia derived from the tenclon of the scmi-nembranosus, which covers the posterior surface of the muscle.

Structure.-Arising by a somewhat flattened cylindrical tendon which passes at first backwards and slightly downwards within the knee-joint, grooving the posterior border of the external semilunar cartilage; it then escapes from the capsule of the knee-joint, receiving a small slip from the posterior ligament, and inmediately expands into a fan-shaped muscle which forms a thick sheet, covering the upper fourth of the back of the tibia, and is inserted by fleshy fibres into the pouch furmed br the bone in front and the aponeurosis derived from the semi-membranosus belind. The tendon of origin is surrounded by synovial membrane, which is reffected upon it about half an inch $(1 \% 2 \mathrm{~cm}$.) herond the opening, through which it emerges from the posterior ligament of the knee-joint.

Nerve-supply.-From the sacral plexus by the internal popliteal division of the great sciatic nerve, which sends a special branch round the lower border of the muscle to distribute itself to the lower part of its deep or anterior surface.

Action.-To flex the knee, which it will do but feebly on account of the olnliquity of its direction and its proximity to the axis of the joint. When the knee is flexed it will act as an internal rotator of the leg. In this position the tendon of origin lies wholly in the groove for its reception upon the onter surface of the external condyle. It is possible that the attachment of the tendon of origin to the posterior ligament of the knee may enable the muscle when it contracts to draw backwards the ligament, and so prevent the srnorial membrane upon the anterior aspect of the ligament from being nipped between the articular surfaces.

Relations.-Behint, the aponeurosis of the semi-membranosus, the gastrocnemius, plantaris, and the popliteal ressels, the internal popliteal nerve, and the lymphatic glands. In front, the knee-joint. Superficial to the tendon of origin is the external lateral ligament of the knee.

Variations.-A second head of origin has been seen from a sesamoil bone in the outer tendon of the gastrocnemius.

\section{SOLELS}

The soleus-named from solea, the Latin for a sole-fish, heeanse of the resembuarer of the muscle to this flat fish-is a thick, fusiform sheet which forms the lowest head of the triceps surie musele.

Origin.-(1) The obligue line of the tibia and the inner border of its posterior surfare, from the lower end of the oblique line to a little below the middle of the legr: (2) the back of the head and the upper thirr of the outer border of the posterior or flexor surface of the fibula and the adjacent external intermusenlar sclutum; (3) a tendinous arch which stretches across the interval between the ulper part of the hack of the tibia and fibula.

Insertion.-By a stroner aponemesis which hends with the anterior surface of the tendon of the gastronenomius, and forms the tendo Achillis.

Structure.-The musele arises partly by fleshy fibres and partly by a strong apencurosis, which lies in front of the fleshy fibres, and is especially noticeable in the neighlourhoor of its tibial attachnent. From the tibia and fibula the fibres pass in a hijemniform arrangenent downwards and towards the middle line, and after a rery short course, not exceeding two inches (5 cm. ) in length, they blend with the tendem of insertion which begins near the upper part of the origin of the muscle, and in arossections of the muscle resmbles in shape the letter $T$; one part of it forming a lorakl apomeurosis upon the posterior surfaee of the muscle. the other part a strong tendinous sejtum which pasies forwarks from the midcle of the broar aponemrosic above mentionerl, so as to separate the fleshy fibres into two portions. Alout the junction of the midelle and lower thirds of the leg, the tendori of insertion joins by its pesterior asperet with that of the gastromemins musele, but 
upon its anterior aspect and sides it receives fleshy fibres nearly as far down as the bark of the ankle-joint. The tendo Achillis is a strong rouniled loand of tench about three-quarter's of an inch ( 22 cmo.) from side to side, and alout half as murh from before backwards; it is narrowest at the level of the ankle-joint, and expands. slightly before it is inserted into the lower part of the posterior surfare of the callcaneum. A bursa intervenes between the tendon and the sunooth upper pant of the posterior surface of this lone.

Nerve-supply.-From the internal popliteal division of the great sciatic nerve by sural branches which enter the upper half of the muscle upon the posterion surface; and lower down by a branch from the posterior tibial nerve, which enters the anterior surface of the muscle.

Action.- The chief action of the combined gastrocnemius and soleus is to extend the ankle-joint. It is an extremely powerful muscle, as it acts with considerable mechanical clisalvantage. The lever by means of which it acts may be best described as one of the first order (see page 255 ); the lever heing that part of the fort which lies between the heel and the heads of the metatarsal bones, the ankle being the fulcrum; a pressure equal to the weight of the body being exerted hy the ground at the anterior extremity of the lever; and the arm, at the end of which the muscle acts, being the comparatively short distance between the back of the heel and the centre of the ankle-joint. When the ankle-joint has been completely extended, this muscle will tend to adduct shightly the foot, and to invert the sole, this movement being carried out in the joint between the astragalus and calcancum. Besides extending the ankle, the gastrocnemius will assist in flexing the knee-joint. The chief object, howerer, which appears to be gained by the femoral attachment of this muscle is the addition to the rapidity of extension of the foot. Like some of the other long muscles which pass over two joints, the gastrocnemius, if it were an inextensible ligament, would cause extension of the ankle as soon as the knee was straightened by means of the great quarlriceps muscle. Seeing, however, that during the contraction of the quadriceps the gastrocnemius is at the same time acting, it follows that the rapidity and anount of the extension of the ankle-joint is almost doubled. By these means we obtain that rapid and powerful contraction which gives the spring to the body in leaping and rumning. We may see also how enormously strong the tendo Achillis must be. as it has not only to bear the contraction of the gastrocnemius and soleus, but the additional strain thrown upon it by the simultaneous action of the quadriceps. extensor of the knee. The soleus will assist in the extension of the ankle, and will even be ahle to perform this morement somewhat feebly by itself, when in extreme flexion of the knee-joint the gastrocnemins is so relaxed as to be alnost powerless. It is much stronger than the gastrocnemius, as may be inferred from the enormou nmmber of short fibres of which it is former. At the same time, howerer. as it only passes orel the ankle and calcaneo-astragaloid joints, the range of its morements is rery short.

Relations.-The soleus is in relation belind with the gastrocnemius and plantaris; in front, with the flexor lomgus digitorum, flexor longus hallucis, and tilisalis posticus, and with the posterior tilhial vessels and nerve.

Variations. - A second soleus is sometimes found beneath the normal muscle, amd more or less separate from it. It is usually inserted into the calcaueum or internal annular ligament.

\section{THIRD LAYER}

The third layer is separated from the superficial layers by an aponemosis called the deep tibial fascia. This is attached to the inner border of the tilia intemally. and externally to the outer horder of the flexor surface of the fibula, and the posterior of the two external intermuscular septa. It is thin ahove, hut below it is strengthened by transwerse fibes, and becomes muel thicker. At the ankle it b)ends with the deep fascia of the leg and the extermal and intrual anmulan ligaments. The thirel layer ansists of two museles-the flexor longus digitorum and the flexor longus hallucis. 


\section{FLEXOR LONGUS DIGITORUM PEDIS}

The flexor longus digitorum-named from its being the longer of the two flexors of the toes-is a fusiform sheet.

Origin.-(1) The inner purt of the posterior surface of the tilsia, hegimning with the lower half of the oblique line, and ending about three inches $(7.5 \mathrm{~cm}$. ) alose the inner ankle; ( 2 ) the front of the deep fascia which covers the sheet; (3) a thin intermuscular septum which intervenes botween this muscle and the tibialis posticus.

Insertion.-The under surface of the base of the ungual phatanx of each of the four outer toes.

Structure.-Arising fleshy from the tibia and adjacent fascix, the fihres pass in a penniform manner into the front and outer side of a tendon which, lreginning alout the middle of the leg, gradually becomes thicker and stronger, and receives its last fleshy fibres about two inches (5 cm.) above the ankle-joint. It then passes beneath the internal annular ligament in a compartment posterior and external to that for the tibialis posticns. Thence it runs downwards, forwards, and outwark beneath the first layer of the sole muscles, and, after having received flehy fibres from the accessorius pedis and a small tendinous slip from the tendom of the flexor longus hallucis, divides, about half-way between the tuberosity of the calcaneum and the heads of the metatarsal bones, into four tendons. These enter the theee of the four outer toes, and each tendon passes through the splitting of the tendon of the flexor lorevis digitorum to its insertion upon the under surface of the base of the third phalanx. The lumbricales arise from its tendons in the sole of the foot.

Nerve-supply.-From the posterior tibial nerve ly lmanches which enter the superficial aspect of the musele near its outer border about the middle of the leg.

Action.-To flex the last phalanges of the four outer toes; it will then help to flex the second and first phalanges and the medio-tarsal joint of the foot. It will also help slightly in the extension of the ankle-joint. In flexing the medio-tarsal joint, it will tend to preserve the arch of the instep.

Relations.- Superficially, in the leg the soleus, posterior tibial ressels and nerve; in the foot, the abductor hallueis and flexor hrevis digitorm. Deeply, the tibialis posticus in the leg, and in the foot the tendon of the flexor longus halluris, the accessorius, and the muscles which form the inner part of the third layer of the sole of the foot.

Variations.-An accessory head sometimes arises in the leg from the fibula, the tibia, or the deep fasciar of the leg; it may join the rest of the muscle in the leg, or in the sole. Some of the tendons to the toes may be wanting; more often they are increased in number and supply the deficiencies of the flexor brevis digitorum, and especially by sending slips to the little toe.

\section{FLEXOR LONGLS HALLECIS}

The flexor longus hallucis-named from its action upon the great toe (hallur. and its lemeth - is a strong fusiform sheet.

Origin.-The lower two-thirds of the posterior (or flexor) surface of the fibula external to the chligue line; (2) the intermuseular septa between it and the thinalis postins in front, and the peronei outside; (3) the deep fascia covering its posterior surface; and sonetines (4) the lowest portion of the interosseous membrane.

Insertion.-(1) The uncler surface of the hase of the last phalanx of the great toe; (2) hy a small slip into that part of the flexor longus digitorum tendom which is rlistributed to the serend and third toes.

Structure.-The muscle arises by thesy fibres which pass with a bipenniform arrangement into the tendom. This tendon appears first just holow the middle of the leg at the bark of the muscle near its inner border. The fleshy fibres are inserterl into it as far as the ankle-joint, and just above this point the teindon passes through the groove at the onter pant of the back of the lower end of the tibia. The tendon then greoves the back of the atratralus, and afterwards the under surface of 
the sustentaculum tali, where it lies external to the tendon of the flexor longus digitorum. From this point it passes forwark in the second layer of the muscles of the sole, lying ahove and crosing the tendon of the flexol longus digitorum, to

Fig. 292.-The Inerp Mésciar of the Back of the Leg.

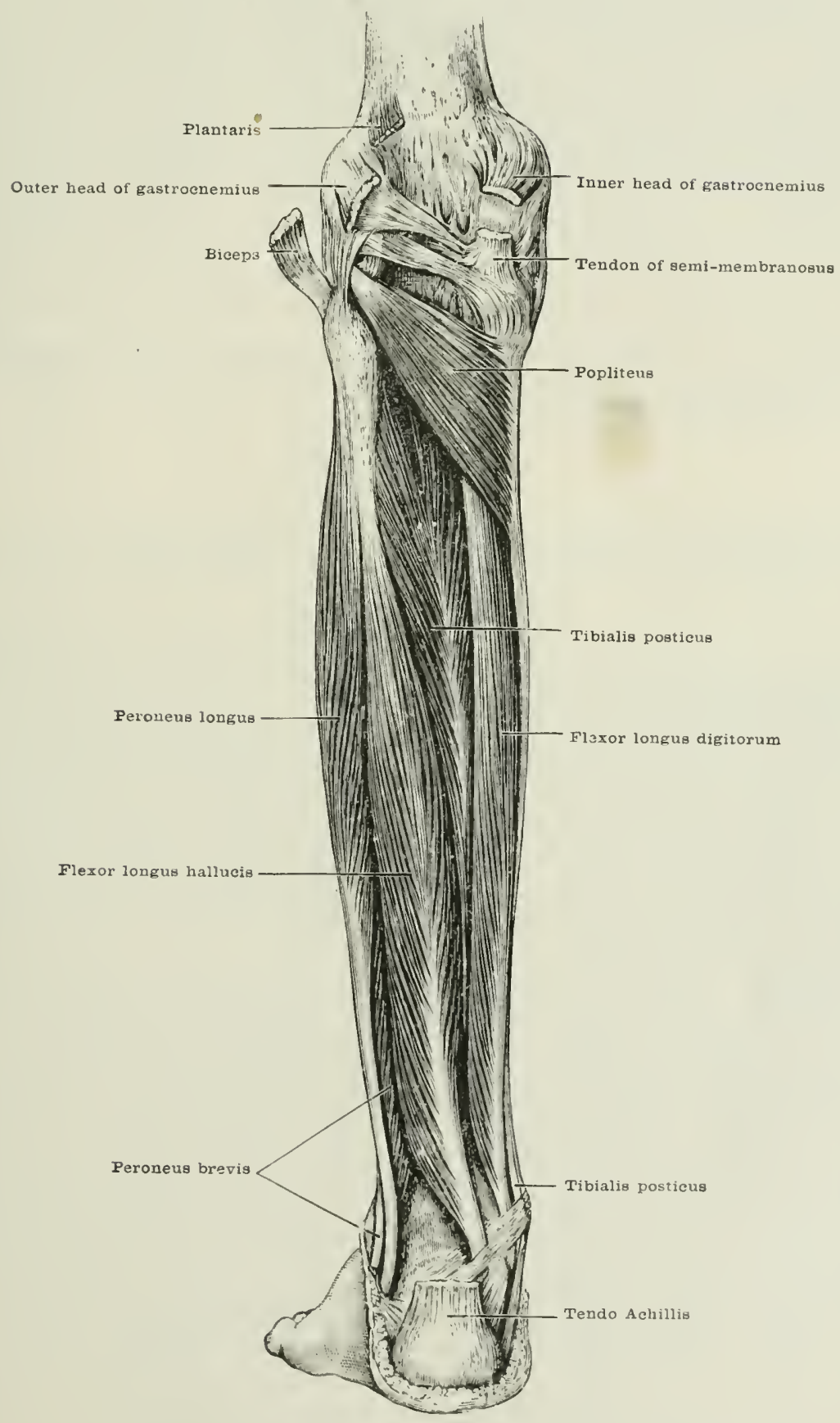

which it grives a small slip. It then wosses leneath the inner hearl of the flexor luevis hallucis. lies in the groove between the sesmonol bones of that muscle, and is finally inserted into the hase of the last phalanx. 
Nerve-supply.-From the posterior tilial norve by hranches which enter the muscle in the nupere part of its prosterior surface near its inner borler.

Action.-This muscle, which is much more powerful than the flexor longus digitorum, is a strong llexor of the last phalanx of the great toe, and is of great importane in walking, as it presses the great toe firmly against the ground. The mugual phalanx of the great toe is the last prart of the foot to leave the gromel when thestep is completed; and until this is the case the flexor longus hallucis is strongly contrated. It will also help to thex the first phalanx of the great toe mon its metatarsal bone and it will act upon the joints which intervene between the first metatarsal bone and the astragalus so as to support, the areh of the instep; and, finally, it will assist in the extension of the ankle-joint. By the slip which it gives to the flexor longus digitorum it will help that muscle in flexing the adjacent toes.

Relations. - Superficially, in the leg, it is covered by the soleus, and in the foot by the aluluctor hallucis, the flexor longus digitorum, the external plantar vessels and nerre; on its outer side are the peronei; on its deep aspect in the leg lie the tibialis posticus and the peroneal ressels; and, after passing over the back of the ankle and other joints, it lies upon the inner head of the flexor breris hallucis.

Variations. - An accessory portion of the muscle may be inserted into the sustentaculum tali or the inner surface of the calcaneum. The slip to the flexor longus digitorum tendon may rary in the number of toes to which it is distributed.

\section{Folrtil IAYER}

The fouth layer consists of one muscle-the tibialis posticus.

\section{TIBLALIS POSTICLS}

The tibialis posticus-named from its position in the back part of the leg and its origin from the tibin-is a thick fusiform sheet.

Origin.-(1) The whole of the hack of the interosseous ligament with the exception of the lowest portion; (2) the posterior surface of the tibia close to the interosseous line, from the upper end of the oblique line to the junction of the midrlle and lower thirds of the shaft; (3) the internal (or immer part of the flexor) surface of the fibula at the back of the interosseous ridge to within a short distance of the ankle; (4) the intermuscular septa which intervene between it and the muscles of the third laver, viz. the flexor longus hallueis and the thexor longus digitorum; and (5) a small portion of the deep tibial fascia which separates the second from the third layer.

Insertion.-(1) The tuberosity of the scaplooid bone; (2) by serral smaller offsets into the front of the lower surface of the sustentaculum tali and the under surface of all the other tarsal bones with the exception of the astragalus; and (3) the under surface of the bases of the second, third, and fourth metatarsal bones.

Structure.-A strong bipenniform muscle, the eentral tendon of which, lying upon the micldle of the lack of the muscle, lregins ahout the middle of the leg, and patses downwals and inwark upon the hack of the muscle, recoiving its last Heshy filmes about an inch $(2.5 \mathrm{~cm}$.) aloore the ankle. Having passed inwarks beneatl the temelon of the flexor longus digitorum, it enters the imnermost groove on the back of the internal malloolus, and is contained in a srnovial sheath which aceompanies it to its insertion upon the seaphoid hone. From this insertion strong fibrous bankls lacliate backwards. ontwards, and forwards to the tarsal and netatarsal hones, being intimately blemelecl with the ligaments by which these bones are helel together. This muscle, which is rery strong, is contained, so to speak, in a long four-siblet abse formed in the front by the interossons membrane; at the sibles, by the opposing surfaces of the tibia and fibula; and hehind, at a distance of nearly half an inch (1..) (mo.) from the interossenus membrane, by the intermuscular septa which sepalate the musele from the flexor longus hallueis and the flexor longus digitorum.

Just alove its insertion into the tuherosity of the seaphoid bone, the tendon often contains al scsalluoid bone. 
Nerve-supply.-From the posterior tibial, which sends branches forwards to the back of the nuscle in the upper third of the leg.

Action.-(1) To adduct the front of the foot; (2) to invert the sole: (3) to extend the ankle-the last of these moxements is somewhat limited; (4) to support the longitudinal arch of the foot-first, he drawing backwards the lower part of the scaphoid, and so preventing the descent of the head of the astragahus between the scaphoid and caleanemm, and secondly ly its traction upon the other tarsal bones into which the secondary offsets of its tendon are inserted.

Relations.- Superficially, the soleus and third layer of muscles of the leg, the posterior tibial and peroneal ressels and the posterior tibial nerre above; in the sole the tendon of the flexor longus digitorum and the abductor hallueis; deeply. the ankle-joint and inferior calcaneo-scaphoid ligament. The anterior tibial ressels pass through a notch at the upper extremity of the muscle, between its tibial and fibular origins.

\section{THE FASCIA AND MLSCLES OF THE SOLE OF THE FOOT}

The plantar fascia is, like the corresponding fascia in the palm, very strong. and is dirided into three parts. The central part, which is the strongest, arises from the under surface of the calcanemm at the back of the tubercles. It is triangular, the apex being attached behind, and the expranded hase dividing near the heads of the metatarsal bones into five divisions, one for each of the toes. Each division forms an arch over the tendons entering the toe, and is continuous with the ligamentum vaginale of the theca. The sides of the arch pass upwards to be attached to the deep transverse ligament which connects the heads of the metatarsal bones, and to the lateral ligaments of the metatarso-phalangeal joints. The under surface of the fascia is attached to the deep surface of the skin by small filrous bands which form the walls of compartments containing pellets of fat. These tibrous connections give firmmess to the skin of the sole and prevent it from being noved about upon the subjacent fascia. The borclers of the central portion of the plantar fascia are continued upwards into the sole by the intemal and extermal intermuscular septa, which are attached above to the fibrous structures on the under surfaces of the tarsal bones. The inner portion, which is the thinnest clivision of the plantar fascia, is attached behind to the inner horder of the great tubercle of the calcaneum and to the lower border of the internal annular liganent. It is inserted in front upon the inner side of the base of the first phalanx of the great toe, and above it becomes continuous with the deep fascia corering the instep. The external portion is very thick, and arises from the outer border of the lesscr tubercle of the calcaneum and the lower borker of the external annular ligament. It terminates in front in the base of the first phalanx of the little toe, and at its inner horder it blends with the central portion of the plantar fascia, where it is joined ly the external intermuscular septum; upon its outer borler it is closely connecter with the base of the fifth metatarsal bone, and it is continuous with the deep fiscia corering the instep.

In the web between the toes some thin transverse fibres are foumd, the superficial transverse ligament of the toes. They bridge orer part of the interval letween the tive slips into which the front jart of the cantril division of the plantar faseia breaks up.

The muscles and temelens in the sole of the foot are divided into four layers. The first layer (onsists of three muscles, which orrespund in their position to the three compartments formed ly the plantar fascia and the two internuscular septat. viz. the abluctor hallucis, the flexor hevis digritorum, the ahduetor minimi digiti. 


\section{Finst LAYER}

\section{ABDLCTOR HALLLCIS}

The abductor hallucis-named from its action upon the great toe-is a thick triangular shect, with a hroal origin hehind, which is divided into two heads.

Origin.-Outer head: (1) The front and imner surfaces of the inner or greater tubercte on the undere surface of the calcancum; (2) the leep surface of the inner

Fig. 293.-First LaYer of tile MLscles of the Sole.

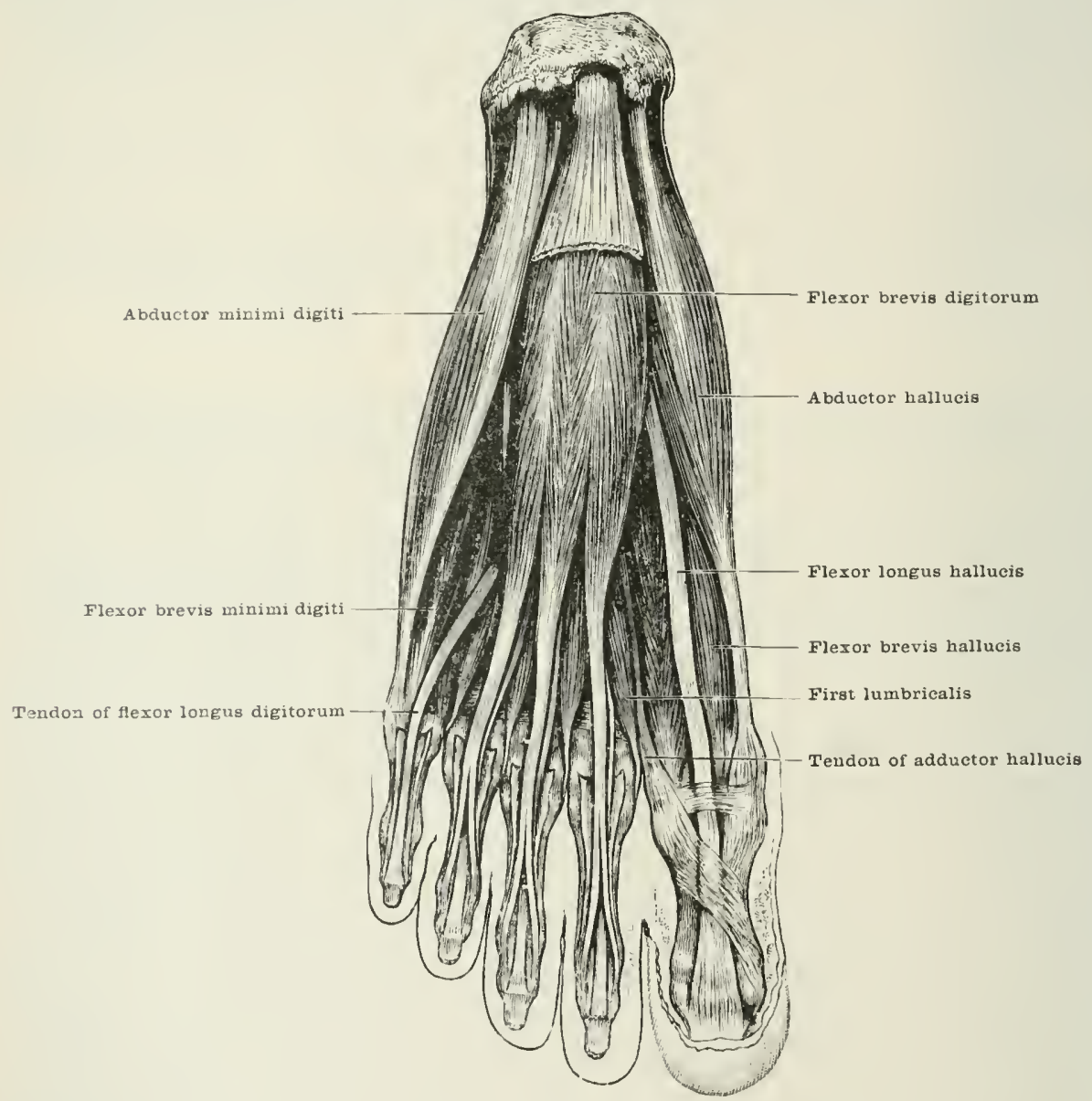

portion of the plantar fascia: (3) the intermuscular septum which separates it from the flexor huris digitormm. Inner head: (1) The deel aspect of the lower horker of the internal amnular ligament: (2) the under surface of the attachment of the tencton of the tibialis pestiens to the tulerosity of the seaphoid bone and the adjacent probongations of this temilon.

Insertion. - The inner part of the lower surface of the base of the first plualanx of the great tex: and the inner sile of the internal sosanoid hone. Oecasionally, also, the inmer lomder of the expansion of the extensor proprius hallucis on the hatel of the first phatamx.

Structure.-The onter heal arises in elose annetion with the flexor brevis digitorum hy short tomlinous filmess som suceceled hy a divergent fleshy bumble which is joined alout two inches (5 cm. ) from itsorigin by the fleshy sheet formed 
by the inner hearl. The tendon to which these fleshy fibres converge appears first mpon the inner and lower aspect of the musche, and receives fleshy fibres nearly to its insertion, which is closely bleneled with that of the inner portion of the Hexor brevis hallucis. The decp surface of the muscle arises from a fibroms arch attached on the one side to the septum hetween it and the flexor hrevis digitorum; on the other side to the tibialis posticus tendom and the filmous tissue covering the muder surface of the tarsal hones along the inner border of the foot. Through this arch pass the plantar vessels and nerves.

Nerve-supply. - The internal plantar division of the posterior tilial nerve, ly filanents which enter the deep surface of the midlle of the muscle.

Action.-(1) To flex the first phalanx mpon the metatarsal bone; (2) to abduct from the middle line of the font the first platanx of the great toe.

Relations.-Superficially, the intemal division of the plantar fascia; upon its onter border, the flexor brevis digitorm; deeply, the tendons of the tibialis anticus, tihialis posticus, flexor longus digitorum, flexor longus hallucis, the plantar vessels and nerves.

Variations. - I thind head is oceasionally derived from the deep surface of the skin upon the inner border of the foot, or from the long plantar ligament. The muscle may give a slip to the secund toe.

\section{FLEXOR BREVIS DIGITORUN PEDIS}

The flexor brevis digitorum pedis, or flexor perforatus-named from its heing the shorter of the flexors of the four outer toes-is a triangular sheet, divided in front into four processes corresponding to the tendons of the toes.

Origin.-(1) The outer part of the front of the lower surface of the great tuluerele of the ealcaneum; (2) the deep surface of the back part of the central portion of the plantar fascia; (3) the back part of the intemuscular septa on either side.

Insertion.-The sides of the middle phalanx of each of the four outer toes upon its plantar aspect.

Structure.-Arising tendinous by a pointed process from the under surface of the great tubercle, the fleshy fibres extend in a fan-shaped sheet, which, about halfway between the origin and the heads of the metatarsal bones, divides into four Heshy processes which soon hecome tendinous. The tendons are arranged in a similar manner to those of the Hexor sublinis digitorm in the hand. After spulitting beneath the first phalanx of the toe, the two halves of each tendon fass round the sides of the flexor longus digitorum tendon, and about the level of the base of the second phalanx they mite hy their adjacent margins, and again diverge to be attached to the sides of the plantar surface of the second phalanx.

Nerve-supply.-From the intemal plantar division of the posterior tibial, by brunches which enter the hack of the deep aspect of the muscle near its immer borkler.

Action.-This muscle, which is comparatively feeble, will flex the second phalanges of the toes, and in combination with the flexor longus digitorum it will assist in walking, hy pressing the under surface of the phalanges of the toes aganint the ground. After it has flexed the second phalanges, it will act in a similar manner upon the metatarso-phalangeal and medio-tarsal joints.

Relations.-Superficially, the plantar fascial on either side, the other muscles of the first layer of the sole; deeply, the tenclons of the flexor longus digitorum and the lumbricales, the accessorius niusele, and the extemal plantar resels and nerve.

Variations.-The part of the muscle which belongs to the little toe is often alsent (sce fig. 294), and its place may be supplied by a small perforated slip from the tendon of the flexur longus chigitormm.

\section{ABDUCTOR MINIMI DIGITI PEDIS}

The abductor minimi digiti (pedis) -named from its action upon the fifth and smallest tow-is a thick triangular sheet, partly muscular and partly aponcentice.

Origin.-(1) The outer side and the miler surface of the front of the lesser 
tulnerele of the ealeanemon and the arljacent portion of the under surface of that bone in front of the great tubercle; (2) the mpler surface of the lack part of the outer division of the plantar fascia; (3) the outer surface of the back part of the extromal intermuscular septum; (t) the long plantar ligament and other ligamentous structures lying upon the outer borler of the sole, and more especially an aponeurotic band which runs from the outer sirle of the lesser tubercle of the calcaneum to the onter side of the base of the fifth metatarsal bone, and of the lase of the first whalamx of the fifth toe.

Insertion.-(1) 'The outer part of the under surface of the base of the first phalanx of the litthe toe; (2) usually also the outer part of the under surface of the hase of the filth metatarsal bone; (3) the outer erlge of the fourth tencion

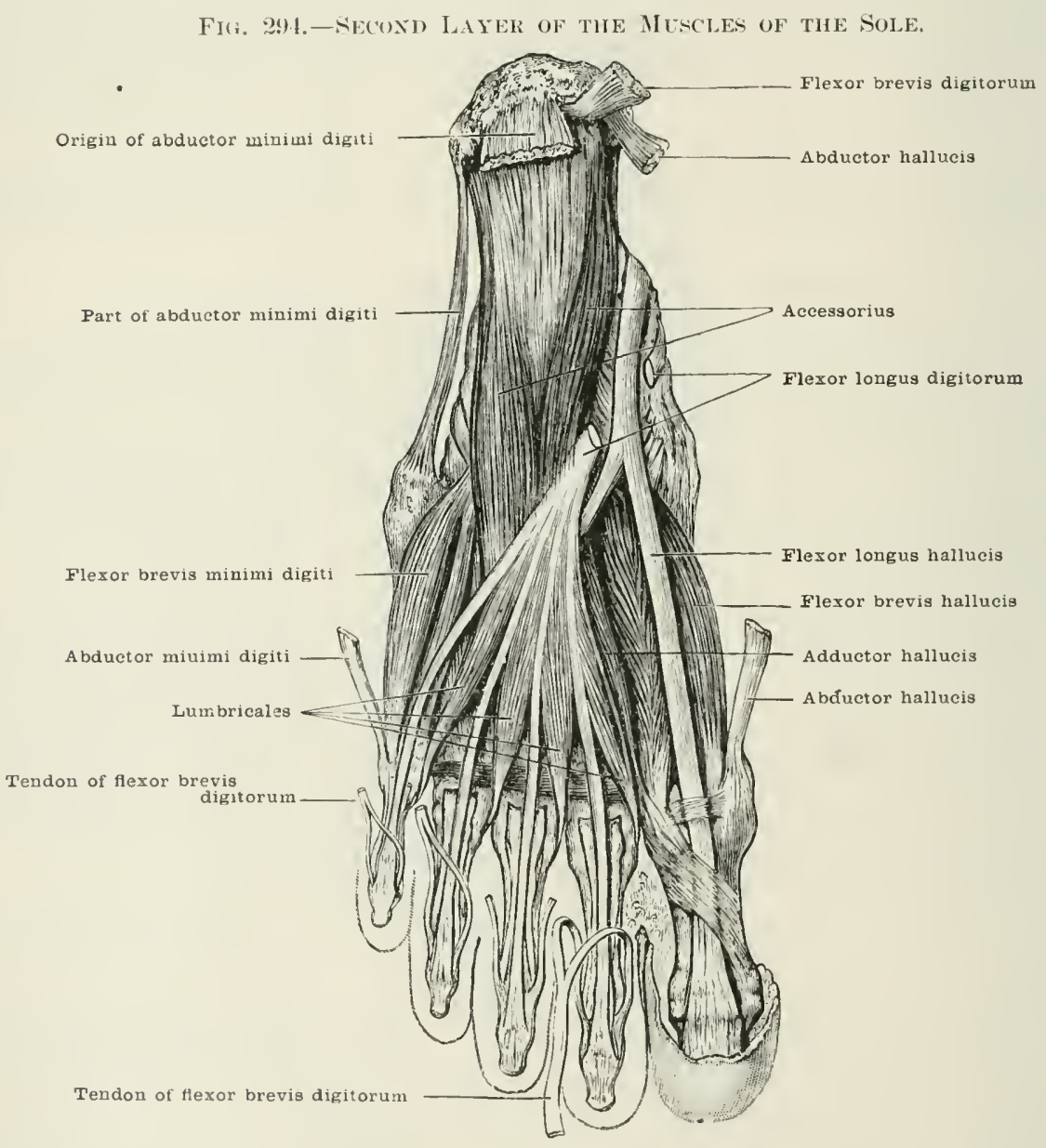

of the extensor longus aigitorum upon the back of the first phalanx of the little toe.

Structure.-The nuscle, which is at first encased in the aponeuroses, from which as well as from the bone it takes origin, convereres from loth sider upon a tendon which is first visible on its under' surfice at the front of the calcaneun. A suall portion of its outer part is now inserterl into the tubercle of the fifth metatarsal hone, internal to the strong aponeurotic band which is also here attacherl. From this puint the temelon of insertion is free on its inner siste, lut receives fleshy fibres still from the ontinuation of the apronemrotie band just mentioned, until it is inserterl into the hase of the first phalamx.

Nerve-supply.-From the rexternal plantar division of the postorior tibial 
nerve, hy filaments which enter the hack part of the deep surface of the muscle near its imner border.

Action.-(1) To abruet the first phalanx of the little toe from the middle line; (2) to flex the metatarso-phalangeal joint of the little toe.

The usual atetion of the muscle will be a eombination of these two morements.

Relations.- Superficially, the plantar fascia, the flexor brevis digitorum, and even a small portion of the abductor hallucis. Deeply, the areessorius, flexor brevis minini digiti, long plantar ligament, and peroneus longus tendon.

Variations. -The muscular slip attached to the base of the fifth metatirsal bone is often so distinct als to form a separate muscle, the abductor ossis metatiusi quinti.

\section{SECOND LATER}

The second layer consists of the flexor accessorius muscle, the four lumbricales, and the tendons of the flexor longus hallucis and the flexor longus digitorm.

\section{FLEAOR AC'ESSORIL'S DIGITOREM PEDIS}

The flexor accessorius digitorum pedis - named from its acessory or supplementary action in assisting the flexion of the toes by the flexor longus digitorumis a double-headed quadrilateral sheet.

Origin.-Inner head: The whole of the concave inner surface of the calcaneum below the groove for the flexor longus hallucis.

Outer head: (1) The junction of the lower and outer surfaces of the calcaneum in front of the lesser tubercle; (2) the under surface of the back part of the long plantar ligament.

Insertion.-The upper surface and outer border of the flexor longus digitorum tendon alout midway between the tubercles of the ealeaneum and the heads of the metatarsal bones.

Structure.-Its inner head consists of fleshy fibres which converge from their origin in a somewhat fin-shaped sheet, and are joined shortly hefore their insertion into the tendon by the outer head, which consists of a pointed tendinous origin, from which the fleshy fibres form a somewhat smaller fan-shaped sheet which Hends with that from the inner hearl, to be inserted hy fleshy fibres upon the upper surface and outer border of the flexor longus digitorum, at its point of division into the tendons for the four outer toes.

Nerve-supply.-From the extemal plantar division of the posterior tibial nerve, W branches which enter the uncler surface of the muscle near its origin.

Action.-To help in the flexion of the last phalanges of the four outer toes. and at the sime time to hraw the toes somewhat outwards. On aceount of the oblinue direction of the tenclons of the flexor longus digitorm in the font, they would tend in flexing the toes to traw them at the same time inwarls. This temelency will be somewhat nentrilised hy the simultaneous contraction of the accesirius. The accessorius will also be able to flex the toes when, on account of the extension of the ankle-joint, the muscular fibres of the flexor longus cligitorm are so relaxed as to be werkenerl in their action.

Relations.- Superfieially, the flexor brevis digitorum, the abductor minimi digiti, the tendons of the flexnr Iongus digitorum and flexor longus hallueis, with the external plantar ressels and nerve; de'ply, the flexor brevis hallucis and long plimtar ligament.

Variations. - An additional hear may arise above the ankle from the flexor longus digitormm, Hexor longus hallucis, or suleus. Sumctimes the outer heal is wanting. and ocensionally the whole muscle is absent. 'The distrilution of its filmes to the tendons of the long flexor is very virvable. 'It may send fibres to the tendon of the flexor longus hallucis. 


\section{THE FOLR LLPNBRICALE}

The four lumbricales - named from their shape (lembricus = an earthworm) are, like those in the palm, four small fusiform muscles.

Origin.-The tirst, from the inner loreler of the immermost tendon of the flexor longus cligitorum, from the point of division of the main tendon for about an inch $(2 \%$ cm. ) forwarls; the other three, from the adjacent surfares of the first and secomel, the second and third, and the third and fourth tendons of the flexor longus digitorum on their plantar aspect.

Insertion.-The inmer lureler of the expansion of the extensor longus digitorum tenton upon the back of the first phalanx of each of the four outer toes.

Structure.-The origin of the muscle is entirely fleshy. It ends in a small rounded tendon a short distance alove the web of the toes. This tendon runs forwards and upwarels upon the inner side of its toe, above the superficial transverse ligament of the toes and beneath the deep transrerse ligament of the metatarsus, to the side of the expansion of the extensor tendon.

Nerve-supply.-The innermost is supplied by the internal plantar division of the posterior tibial nerve, by filaments which enter the back part of the lower surface of the muscle near its inner border; the three outer, hy the external plantar nerve, by filaments which enter the deep part of each miuscle near its onter border.

Action.-(1) To flex the first phalanx of the toe; (2) to straighten the second and third phalanges. (3) The first will alduct the second toe from the axis massing through it, which is looked upon as the middle line of the foot. The three others will alduct. The humbricales vill he able to act upon the first phalanges, even when the second and third have been thexed by means of their special flexors. The chief adrantage derived from the simultaneous extension of the two terminal phalanges and the flexion of the first phalanx is the application of the whole length of the toe to the ground in walking; otherwise there would be a strong tendeney to the flexion of the phalanges of the toes, which would prevent the proper application of the soft plantar aspect of the ungual phalanx to the ground.

Relations.- Superficially, the flexor brevis digitorum. Deeply, the flexor longus digitormm tendons, the transversalis pedis, and the interossei.

\section{TIIRD IAYER}

The thirel laver consists of four muscles-the flexor brevis hallucis, the adductor hallucis, the transsersus pedis, and the flexor brevis minimi cligiti.

\section{FLEXOR BREVIS MALLCCIS}

The flexor brevis hallucis, or flexor brevis pollicis pedis-named from its action, and its size in comparison with the other flexor of the great toe-is a thick triangular sheret with a forked insertion.

Origin.-(1) 'The plantar' ligaments and the continuations of the tibialis postiens tenton in the middle of the sole; (2) the inner part of the under surface of the euhoil hone.

Insertion.- The inner and outer borters of the plantar aspect of the base of the first phalamx of the great toe.

Structure. - Arising filmous hy a pointed process in the middle of the sole, the fibres diverge as they pass forwards and slightly inwark, and form two fleshy bundles of roual size, which are succerled by short tentons. In each tendon is contained a sesamoicl lone of ovoid shape alout three-eighths of an inch (1 cm. ) in the long antero-posterior diameter. and a quarter of an incle (7 mm.) from side to side, with a cartilaginoms articular facet upon the upper surface which plays upon the lower surface of the condyle of the first metatarsal bone. At their insertion 
into the inner and outer part of the lower borker of the base of the first phalanx, they are blended with the tendons of the abdurtor and the aldnetor halluris.

Nerve-supply. - From the internal plantar division of the posterior tilial nerve, by filanents which enter the under surfice of the muscle near the middhe of its imer border.

Action.- To flex and slightly adcluct the first phalanx of the great toe. The sesamoid bones give a slight obliquity to its insertion, and so enable it to act with more power; at the same tine they form a groove in which the stromg temelon of the flexor longus hallueis plays. They also form a somewhat elastic support when the weight is placed upon the ball of the foot.

Relations. - Superficially, the abductor hallucis, the tendom of the flexur longus hallueis, and the inner tendons of the flexor hongus digitorum with the fumbricales; deeply, the interossei and the termination of the external plantar ressels and nerve.

Variations.-A simall slip is oceasionally given to the first phalanx of the seeond toe.

Fig. 295.-THIRI Layer of the Muscles of the Sole.

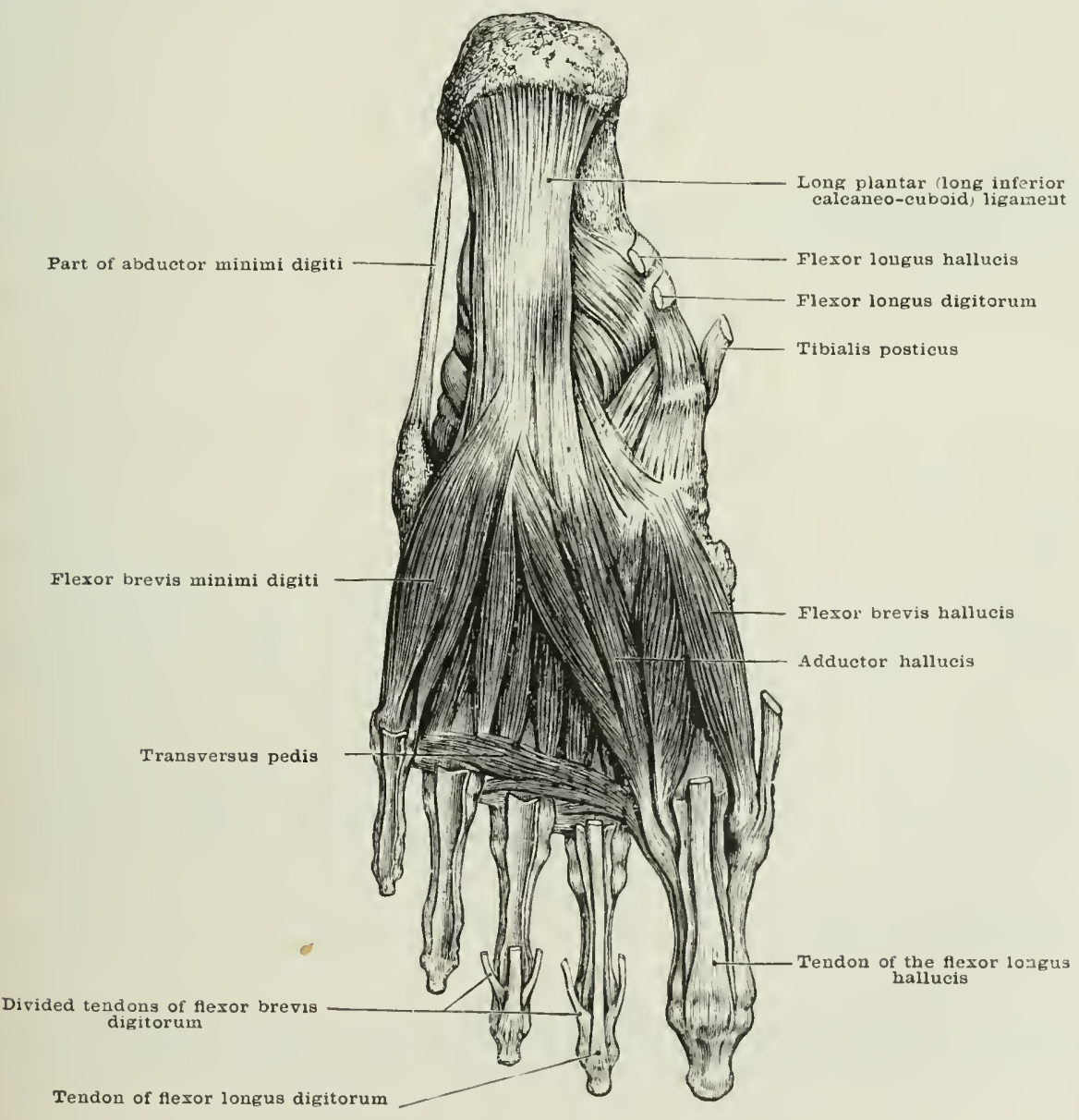

\section{ADDLCTOR HALLUCIS}

The adductor hallucis-named from its action upon the great toe-is a triangular sheet, the apex of which is directer forwats and inwarls.

Origin.-(1) The continuation forwarls of the long plantar ligment which forms the sheath of the peromens longus tendon; (2) the under surface of the bases of the second, third, and fourth metatarsal bones. 
Insertion. - The outer part of the under surface of the base of the first phalanx of the erealt toe.

Structure.-Arising hy short tendinoms fibres, the muscle converges in bipennifom fashion upon a short tendon, which hends with that of the tlexor breris hallucis and the outer sesimoid bone internally, and the transversus pedis externally.

Nerve-supply.-From the external plantar division of the posterior tilial nerve by filanents which enter the upper surface of the muscle upon its outer borler near its origin.

Action.- 1) To adduct the first phalanx of the great toe towards the middle line of the foot; (2) to Hex the first halanx. L'sually it will act during walking in combination with the flexor brevis hallucis and abeluctor hallucis, and the three muscles contracting together will produce direct flexion of the first phalanx, so that when the weight of the body rests upon the front part of the foot the second fhalanx is pressed firmly against the ground by the action of the flexor longus hallucis. while the first phalanx is acted upon in the same manner by the conbination of these three short muscles. As Ducheme has pointed out, the abductor and adductor will have an important function in adjusting the pressure when the step has to be nade upon meven ground. Thus, in walking upon a slope the adductor hallucis of the one foot will direct the pressure downwards and slightly outwards, while the abductor of the other foot will direct the pressure downards and sightly inwards.

Relations.- Superficially, the flexor longus digitorum tendons and their lumluieales; deeply, the interossei with the external plantar ressels and nerve; at the sides. the flexor brevis hallucis and transversus pedis. toe.

Variations.-The adductor hallucis sometimes sends a slip to the first phalanx of the second

\section{TRANSTERSLS PEDIS}

The transversus pedis-named from the direction of its fibres-is a small muscle consisting of three or four fusiform bundles lying side by side, and uniting in a single tendon.

Origin.-(1) The plantar ligaments of the three onter metatarso-phalangeal joints: (2) the under surface of the adjacent deep transrerse metatarsal ligaments.

Insertion. - The outer side of the base of the first phalanx of the great toe.

Structure.-The fleshy tibres form a series of small bundles which converge slightly as they pass inwards and somewhat forwards, and after uniting terminate in a short tendinous insertion which is closely blended with the outer surface of the tarcion of the adliuctor hallucis.

Nerve-supply.-From the external plantar division of the posterior tibial nerve hy filaments which pass to the upper part of the posterior edge of the musele.

Action.- (1) To adduct the first phalanx of the great toe; (2) to draw together the heads of the metatarsal bones after they have been separated by the pressure of the weight of the body during the tread.

Relations. - iupurficially, the flexor longus digitorum tendons and lumbricales; decply, the intereseci.

Variations.-Some or all of the lundles may be absent ; most frequently the outermost one. () easionally fibres join the muscle from the fascia covering the interossei leetow the lower border of the adductur hallucis, so that the two muscles are more or less blended.

\section{FIEXOR BREYIS MIXIMT DIGITI PEDIS}

The flexor brevis minimi digiti pedis-named from its action upon the little tox-is small, Hattened, and fusiform.

Origin.-(1) The uncler surface of the hase of the fifth metatarsal bone; (2) the alliacent part of the sheath of the perenems lomgrus tendon.

Insertion.-(1) The outer part of the under surfice of the base of the first 
phalanx of the little toe; (2) the outer part of the front of the under surface of the fifth motatarsal hone.

Structure.-Arising tendinous, the fleshy fibres run forwards and a little outwards to their short tendon of insertion, which is closely blended with that of the abluctor minimi digiti. A few of the feeper fibres end in the metatarsal bone.

Nerve-supply.-From the external plantar nerve ly a branch which enters the under surface of the muscle.

Action.-To flex and slightly abduct the first plialanx of the little toc.

Relations. - Cuperficially, the flexor longus digitorum and abductor minimi digiti; decply, the interossei of the outermost interspace.

Variations.-The insertion upon the metatarsal bone may form a separate unscle, the opponens digiti pedis quinti, or it may be entirely absent.

\section{Fourth Layer}

The fourth layer consists of the seven interosseous muscles.

\section{INTEROSSEI}

The interossei-named from their position between the metatarsal hones-are, like those of the hand, seren in number, three being plantar and four dorsal. The plantar are small and narrow fusiform bundles; the dorsal are bipenniform and of a somewhat broader fusiform shape than the plantar. The interossei of the foot differ from those of the hand in the fact that they adduct and abduct with respect to a longitudinal axis through the line of the second toe; whereas in the hand the median line passes through the middle finger.

The plantar interossei.-Origin.--(1) The imer and lower surfaces of the three outer metatarsal bones; (2) the adjacent part of the sheath of the peroneus longus tendon.

Insertion.-(1) The inner side of the hases of the first phalanges of the three onter toes; (2) the inner border of the expansions of the long extensor tendons on the lack of the first phalanges of the same toes.

The dorsal interossei arise from the adjacent surfaces of the metatarsal bones bounding each interosseous space. The first dorsal interosseous, however. differs somewhat in its internal head, which is from the base only of the first metatarsal bone and the adjacent outer surface of the internal cuneiform bone.

Insertion.-The first dorsal interosseous is inserted into:-(1) the inner side of the base of the first phalanx of the second toe; (2) the inner edge of the aponeurosis of the extensor tendon upon the back of the first phalanx. The second, third, and fourth are inserted respectively into:-(1) the outer sides of the bases of the first phalanges of the second, third, and fourth toes; (2) the outer borders of the extensor tendons upon the backs of the same phalanges.

Structure.-The plantar interosei are penniform muscles consisting of fleshy fibres which run forwards to the outer side of a tendon which begins about the middle of the space and becomes free opposite the heads of the metatarsal bones.

The dorsal interossei are bipenniform, and consist of fleshy fibres which converce from both sides of the space upon a central tenrlon which begins alout the middle of the interossous space and becomes free opposite the hearls of the metatarsal bones. The tendons of both sets of nuscles before their insertion lie alnve the deep transverse metatarsal ligament which separates them from the tenrlons of the lumbricales. On the lorsum of the font the dorsal interosed are alone visible; in the sole of the foot both sets are seen.

Nerve-supply.-From the external plantar nerve ly filaments which enter the plantar aspect of the muscles. somewhat behind the inidrlle of the internseculs sprace.

Action.- The common action of all the interossei is (1) to flex the first phalanges of the four outer toes; (2) to extend the second and third phalanges. In 25 
these two morements they are assisted by the lumbricales. In walking, this move. ment is of great importanes, as it keeps the toes straight when the weight of the bodr rests upon the front part of the foot. When these movements are paralysed, the action of the long and short flexors of the toes is to curl them up, and the ends of the toes are subjocted to considerable pressure, which may set up inflammation in the berls of the nails.

The special action of the plantar interossei is to adduct the first phalanges of the three outer toes; and of the dorsal interossei to ahduct the second, third, and

Fig. 296.-Fourth L.iven of the Muscles of the Sole.

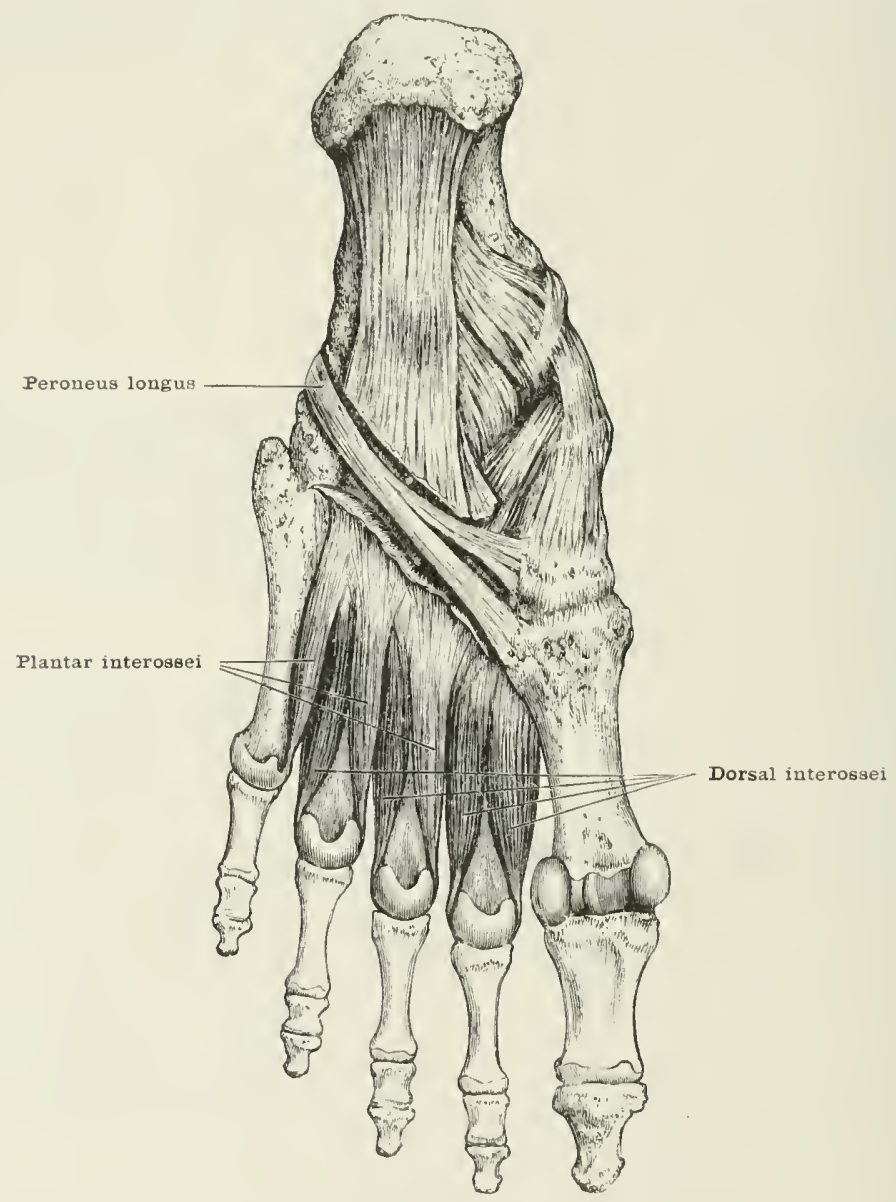

fourth toes from the middle line of the second toe. As the second toe can be alducted from its own middle line in two directions, it of course requires two abductors.

Relations.-On the plantar surfaces both sets of interossei are in contact with the muscles of the third layer, and with the external plantar ressels and nerve; on the dorsal surface the dorsal interossei are covered by the tentons of the extensor longus and lorevis digitorum. The dorsalis pedis and other perforating arteries pass through the back of the interosscous spaces between the dowhle origins of the dorsal interossei. 


\section{MLSCLES OF THE FRONT OF TIIE LEG}

Between the anterior border of the tibia and the anterior of the two external intermuscular sopta, are placed four muscles: the tilialis anticus, the extensor proprius hallucis, the extensor longus eligitorum, and the peroneus tertius.

\section{TIBLALIS ANTICLS}

The tibialis anticus-named from its attachment to the tibia and its position in the front of the leg-is fusiform and somewhat flattenerl, with a long terminal tendon.

Origin.-(1) Part of the under surface of the outer tuberosity of the tiljia; (2) the outer surface of the upper two-thirds of the tibia; (3) the adjacent part of the anterior surface of the interosseous membrane; (4) the posterior surfince of the upler part of the deep fascia of the leg; (5) an intermuscular septum which separates it from the extensor longus digitorum in the upper third of the leg.

Insertion.- The lower part of the front of the immer surface of the internal cuneiform bone and the adjacent part of the base of the first metatarsal bone.

Structure. - A strong penniform muscle the fibres of which, arising fleshy from the bone and the fascix, pass forwards and most of them somewhat outwards to be attached to the drep surface and outer border of a tendon. which, beginning below the middle of the leg, beeomes free of fleshy fibres two or three inches ( 5 to $8 \mathrm{~cm}$.) above the ankle-joint; and, after passing first beneath the upper portion of the anterior ammular ligament, then partly under and partly over the lower portion, expands slightly to be inserted upon the inner margin of the foot. In passing over the instep it turns upon itself so that its anterior surface becomes below internal.

Nerve-supply.-From the anterior tibial division of the external pophiteal nerve by branches which enter the upper third of the muscle upon the outer part of its rleep aspect.

Action.-(1) To flex the ankle-joint; (2) to draw upwards the inner border of the foot and so invert the sole; (3) to adduct the front portion of the foot. The first of these movements will be performed chicfly at the ankle-joint; the second and third at the medio-tarsal and calcaneo-astragaloid joints. This muscle is of great importance in walking, as it raises the anterior part of the foot and so enables the toes to clear the ground when the leg is swinging forwards to lecgin another step.

Relations.--Superficially, the deep fascia; on the outer side, the extensor longus digitorum and extensor proprius hallucis with the anterior tibial resseds and nerve; decply, the interosscous membrane and the tibia. The tendon lies in a special synovial sheath beneath the two portions of the anterior annular ligament, and upon the ankle-joint and inner bones of the tarsus. A small bursil separates the tendon from the upper part of the inner surface of the internal cuneiform bone.

Variations.-A small tenton is sometimes sent to the head of the first metatarsal bone, the base of the first phalanx of the great toe, or to the fascia covering the instep.

\section{EXTENSOR PROPRITS HALLTCIS}

The extensor proprius hallucis-named from its heing the special extensor belonging to the great toe ( momius = peculiar to ) - is a somewhat trimgular shert.

Origin.-(1) The mirldle two-fourths of the anterior (o) extrnsor) surfice of the fibula external to the attachment of the interossons membrane; (2) the adjacent portion of the anterior surface of the interosicous membrane.

Insertion.-(1) The ligamentous struetures at the back and sirles of the first 
metalarso-phalangeal joint; $(2)$ the dorsal aspect of the base of the second phalanx of the great toe.

Structure.-Arising by fleshy fibres from the hone and interosseous membrane,

Fig. 297.-THE Miseles of the Froxt of the Leg.

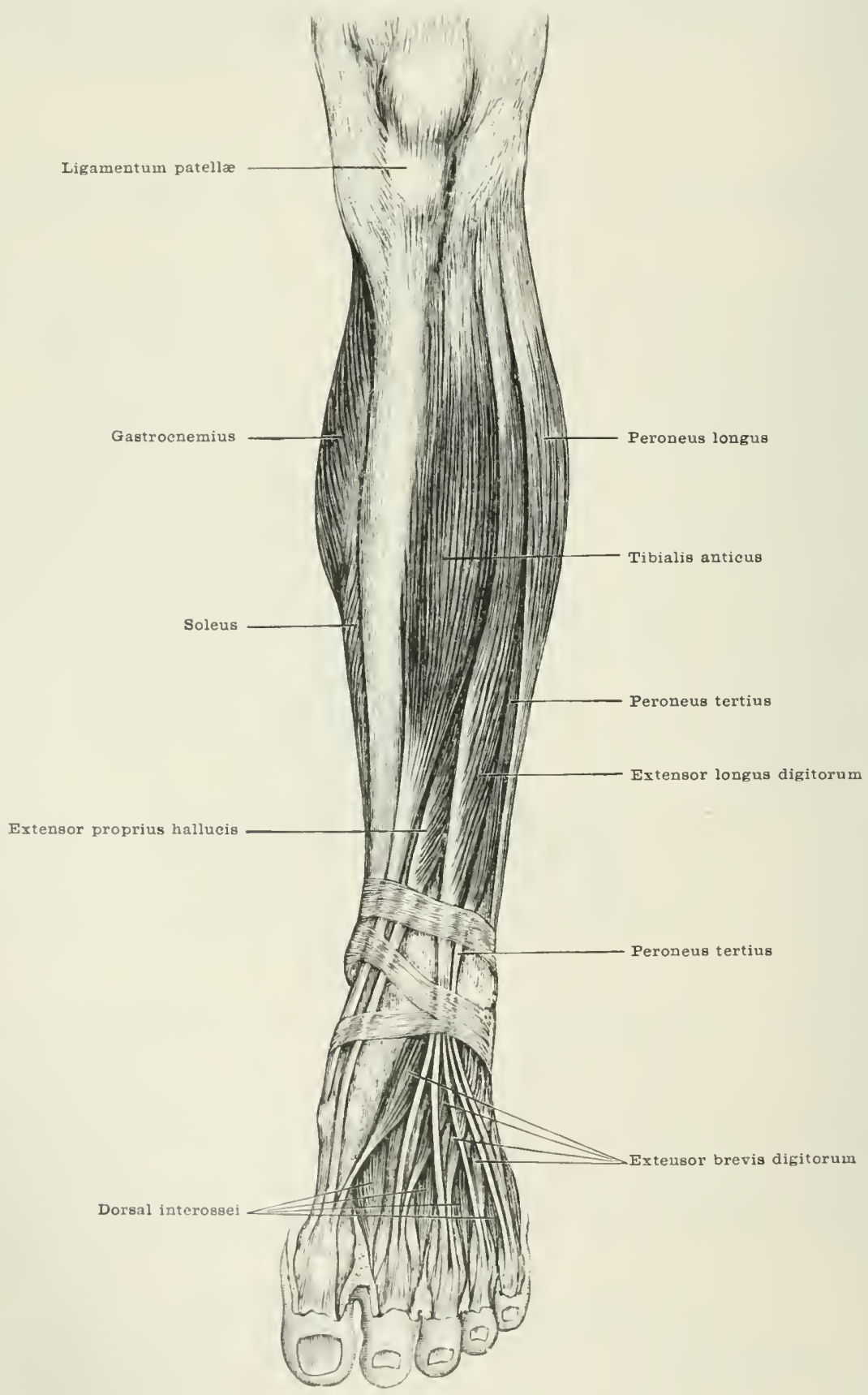

the muscle is inserterl in a pemiform manner into a tendon which appears about the mirldle of the leg upon its imner and front asjeet, and becomes clear of muscular filores about the level of the ankle-joint. The tenclon after passing bencath the 
up)er part of the anterior annular ligament is included in a special sheath beneath the lower frart of the same ligament. Opposite the first metatarso-phalangeal joint, it gives off from its sides and under surface bands of connective tissue which unite partly with the two lateral ligaments, especially the internal one, and partly with the periosteum upon the sisles of the first phalanx. The rest of the tendon is Hattened out and fits chosely to the dorsal aspect of the first phalanx; it is finally attacher to the second phalanix in a transverse line which crosses the upper surface of its base.

Nerve-supply.-From the anterior tibial by filaments which enter the inner and deeper aspect of the muscle ahout the middle of the leg.

Action.-(1) To extend the fir:t phalanx of the great toe; (2) slightly to extend the second phalanx, hut this movement is chiefly prerformed hy the small muscles of the sole of the foot, which give off expansions to be attached to the borders of the tenclon at the sides of the first phalanx; (3) to flex the ankle, and at the same time it will slightly adduet the front of the foot and invert the sole. When the muscle contracts strongly it will liyper-extend the first phalanx, and at the same time flexion of the second phalanx will be produced by the resistance of the flexor longus hallucis tendon.

Relations. - Superficially, the deep fascia, the tibialis anticus, and the extensor longus digitorum; internally; the tibialis anticus; externally, the extensor longus digitorum; deeply, the interosscons membrane, the tilia, and the anterior tibial resols and nerve. The tendon lies beneath the two portions of the anterior annular ligament, and after crossing the anterion tibial artery near the ankle-joint it runs to its insertion with the dorsalis pedis artery and the innermost tendon of the extensor brevis digitorm on its outer sicle.

Variations.-The muscle is occasionally divided, and a smaller external portion joins the first tendon of the extensor brevis digitorum, or is inserted separately into the head of the first metatarsal bone or the base of the first phalanx.

\section{EXTENSOR LONGIS DIGITORUM PEDIS}

The extensor longus digitorum-named from its length and its action upon the toes-is fusiform and somewhat flattened, with a four-divided tendon.

Origin.-(1) The outer part of the under surface of the extemal tuberosity of the tiljia; (2) the upper three-fourths of the anterior or extensor surface of the fibula; (3) the outer border of the anterior surface of the internsseons memlirane in its upper third; (4) the posterior surface of the deep fascia of the leg; (5) the intermuscular septa which separate it from the upper part of the tibialis antiens and from the long and short peronei.

Insertion.- The three phalanges and the metatarso-phalangeal joints of each of the four outer toes.

Structure.-This is a penniform muscle, and its fibres arise fleshy from the bones and the fascix, and pass forwarls and inwards to the back and outer side of the long tendon of insertion. This begins about the mildle of the leg, and hecomes free from fleshy fibres about the level of the ankle-joint: it passes behind the upper part of the anterior annular ligament, but not in a sirecial synorial sheath; then beneath the lower part of the antrior ammlar ligament in a special synovial sheath with the peronens tertius. At this point it divides into four tendons. which diverge upon the back of the fuot to the bases of the four outer toes. Each tenton first gives off some stroner fibre, which hlend with the lateral ligaments of the metatarso-phalangeal articulation, and with the periostem along the borlers of the first phalanx. It then forms a broarl cxpansion rovering the back of the first phalanx, and divides into three parts: the central part is inserted into the clorsal aspect of the hase of the second fhalanx; and the two lateral parts jats.s forwarts with a slight convergence upon the back of the seconel phalanx to be inserted into the dorsal aspect of the hase of the thirr phalanx.

Nerve-supply.-From the anterior tibial by filaments which enter the deep aspect of the muscle in its upper third.

Action.-(1) To extend the first phalanges of the four outer tocs. It has some 
influmee upon the second and third phalanges, hut the distal part of its tendon is acted upon chiefly ly the short muscles in the sole of the foot, which are attached to the border of the expansion upon the first phalanx. When the muscle contracts to its fullest extent, the tirst phalanges are extended, while the second amd third phalanges are somewhat flexed by the long and short flexors. (2) To Hex the ankle-joint. (i) slightly to aliknet and wert the front part of the foot.

Relations.--Superficially, the deep fascia of the leg and the anterior annular

Fig. 298.-Tite Mrseles of THE Dorsery of the Foot.

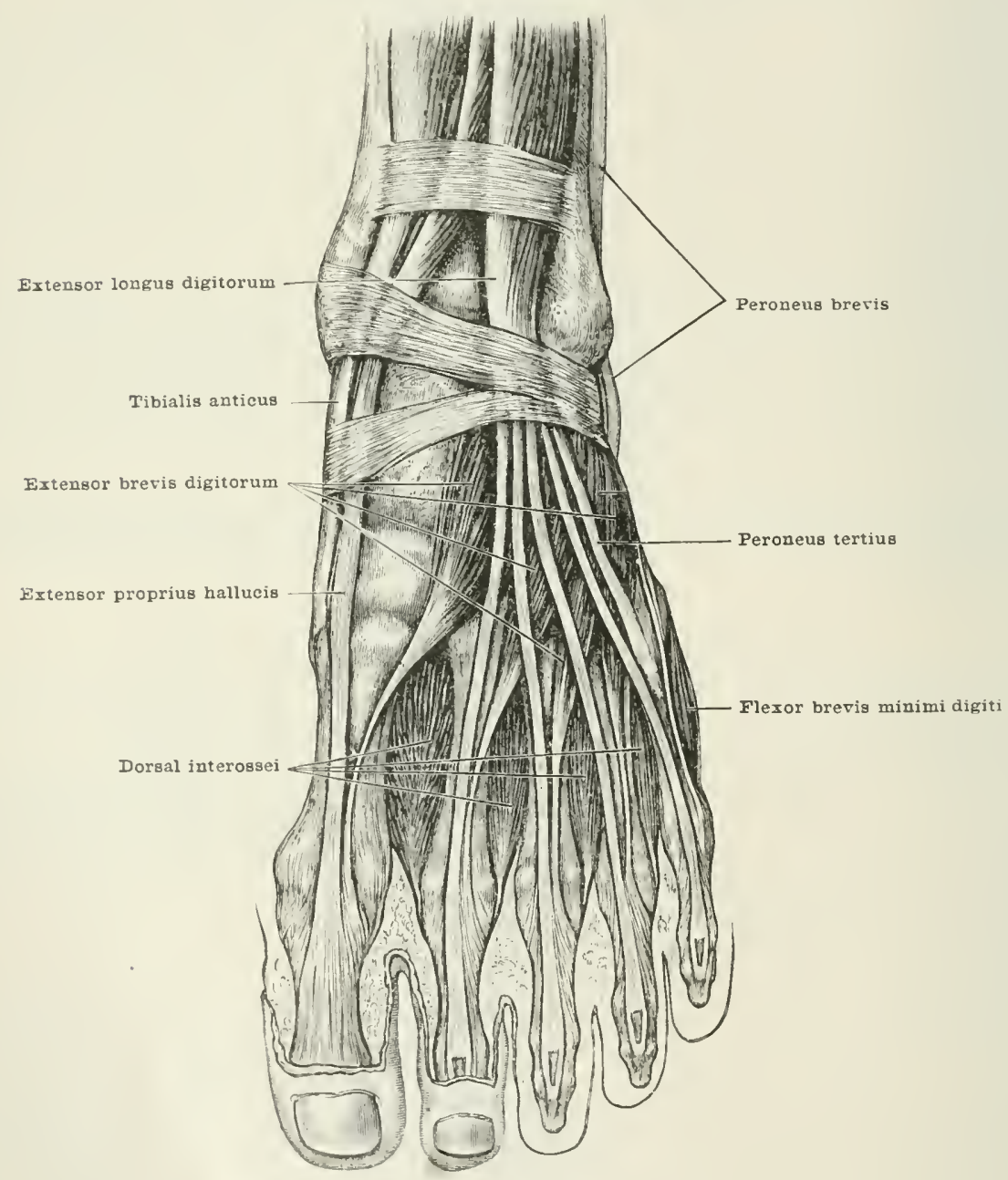

ligaments; on its inner sicle, the tibialis anticus and extensor proprius hallucis, the anterior tibial resseds and neve with their antinuations in the foot. Externally, the peroncus longus and brevis, the musculn-cutaneous nerve, and, lower down, the peronens tertius. Behinel, the anterior tilial nerre above, and the ankle-joint, tarsal and metatarsal lemes, and the extensor brevis digitorum below.

Variations. - The musde may be diviled nearly up to its origin. It may give off slips to the extensul proprins hallucis, extensor krevis digitorm, or une of the interussed. Sometimes also it has an insertion intu some of the metatarsal hones. 


\section{PERONELS TERTILS}

The peroneus tertius - naned from $\pi$ sovior, the fibula, and called tertins because it is the third of the muscles which pass from the fibula to the metatarsus-is a small triangular shest which is elosely blended with the preceding muscle.

Origin.-(1) 'The lower fourth of the anterior (or extensor') surface of the fibula; (2) the front of the interosseous membrane for a short distance above the ankle-joint; (3) the external intemuscular septum and the dere fascia of the leg.

Insertion.-The upper part of the base of the fiftl metatarsal bone.

Structure.-Arising fleshy, the muscular fibres pass downwards and inwarls in penniform fashion to a tendon which appears on the inner border of its anterior surface. It becomes free from fleshy fibr's at the level of the ankle-joint, and after passing beneath the upper part of the anterior annular ligament, it is included with the extensor longus digitorum in a special svnovial sheath beneath the lower part of the ligament, and finally diverges from it to be inserted into the inner part of the upper surface of the base of the fifth metatarsal bone.

Nerve-supply.- Inlike the other peronei, which are supplied hy the musculocutaneous nerve, it receives filaments from the anterior tibial which enter the inner and (leep aspect of the muscle in the upper part of its course.

Action.-(1) To flex the ankle-joint; (2) to alduret the anterior part of the foot; (3) slightly to elevate the outer border of the foot and so to produce eversion of the sole.

Relations.-Superficially, the anterior annular ligament and branches of the musculo-cutaneous nerve; on the inner side, the extensor longus digitorum, of which it is really a subdirision; on the outer side, the peroneus brevis; deeply, the ankle and outer tarsal joints with the extensor hrevis digitorum.

Variations.-The peroncus tertius is often closely blended with the extensor longus digitorum. It is sometimes wanting, and replaced by a slip of tendon from the extensor longus digitorum. Occasionally it sends slips of tendon to the expansion of the extensor longus digitorum on the first phalanx of the two outer toes, or to the fourth dorsal interosseous.

\section{MLSCLE ON THE DORSUII OH THE FOOT}

This consists of the four bellies of one muscle-the extensor brevis cligitorum.

\section{EXTENSOR BREVIS DIGITORUM PEDIN}

The extensor brevis digitorum-named from its being the shorter of the two muscles which extend the toes-is a triangular sheet which breaks up in front into four small divisions.

Origin.-(1) The outer part of the upper surface of the great process of the (alcaneum; (2) the interior of the loop of fascia which forms the outer part of the lower anterior annular liqament.

Insertion.-By four tendons into the four inner toes: the innermest is attached to the outer borter of the upper surface of the first phalanx of the great toe nowe its base; the three other tentons to the out re horder of the tentons of the extensor longus digitorum just in front of the hases of the first phalangers.

Structure.- Irising stuperficially by fleshy, and on the dece surfice ly short tendinous tilires, the muscle diverges inwarls and forwarks, and soron divides into four fleshy bellies, of which that to the errat the is the largest and most separate. Each portion has a bipenniform arrangement, with its central temilon upon the dorsal surface, and becoming free opposite the middle of the metataris. 
Nerve-supply.-From the anterior tibial nerve hy small filments which enter the cleep surfice of the muscle near its inner border as it crosses the cuboid and external cuneiform hone:

Action.-(1) To extend the four imner toes. In the case of the outer toes the two last phalanges will be chiefly extended, and the obliquity of its insertion, hy cansing it to draw the toes sonewhat outwards at the same time that it extmils them, will enable it to correct the opposite tendency of the long extensor. (2) The innermost tendon will act as an adductor of the first phalanx of the great toe.

Relations.- Superficially, the tendons of the extensor longus rigitorum and peroneus tertius; deeply, the tarsal and tarso-metatarsal joints; and, in the case of the tendon to the great toe, the dorsalis pedis ressels and the termination of the anterior tibial nerve.

Variations.-The number of tendons may be diminished or increased. Sometimes a tendon is given to the little toe. Accessory bundles may be lerived from some of the tarsal or metatarsil bunes, and slips have been found running to the dorsal interossei; and also a small slip between the first and secoml bellies, going to the inner side of the second toe or its metatarsal bone.

\section{MLSCLES ON THE OUTER SIDE OF THE LEG}

These are two muscles-the peroneus longus and brevis-situated upon the outer side of the fibula in a compartment of quadrilateral section, hounded internally by the fibula, in front and behind by internuscular septa, and externally by the deep fascia of the leg.

\section{PERONELS LONGLS}

The peroneus longus (figs. 292-2 and 296) - named from its being the longer of the two fibular muscles-is long and fusiforn.

Origin.-(1) The onter tuberosity of the tibia hy a few fibres; (2) the front of the head of the fibula; (3) the upper two-thirls of the outer (or peroncai) surface of the fibula, oceupying the whole of this surface above, and the posterior half of it helow; (4) the inner surface of the reep fascia of the leg. and the opposed surfaces of the two extemal intermuscular septa.

Insertion.-(1) The lower part of the outer surface of the base of the first metatarsal hone; (.2) the lower uart of the outer surface of the internal cuneiform bone chose to its articulation with the first metatarsal bone.

Structure.-This is a strong pemiform muscle, the short fleshy fibres of which pass clownwarks, and for the most part forwards, to be inserted into the tendon which, beginning albont three inches $(7.5 \mathrm{~cm}$.) betow the hearl of the fibula, runs along the front if the outer surface of the nuscle, and becomes fiec in the lower third of the leg. It then passes behind the outer ankle, heneath the external amular ligament, in a special sheath with the tendon of the peroneus brevis, which lies in front of it. On the outer surface of the calcancmm, it runs forwards and downards in a special compartment of the external amnular ligament below the companion tendon. At the outer londer of the foot it again changes its direction, and passes obliquely inwark and forwards acrose the sole of the foot, in a canal formed by the long plantar ligment beneatl, and by the groove in the culoid bone ahove, to its insertion near the inner sile of the sole. In the upper two-thirds of the log the peroneus longus almost entirely conceals from view the peronems brevis, which lies beneatlı and slightly anterior to it.

The srnovial tube which it rnters at the outer ankle is common to it and the peroneus hrevis, and hifureates to accompany the two tondons where ther are separated by the peroneal tulnerele of the os calcis. A second sheath envelopes the 
tendon in the sole, and where the tendon enters this canal it often contains a sesamoid bone which play's upon the front of the ridge of the culooid bone.

Nerve-supply.-Fron the musculo-cutaneous branch of the extrmal popliteal nerve by filanents which enter the deep and posterior aspect of the muscle in its ulper third.

Action.-(1) To extend the ankle-joint; (2) to abduct the anterior part of the foot; (3) to kepress the inner horder of the fort, and so to evert the sole; (4) hr. drawing backwards and outwards the base of the first metatarsal bone. it tends tis render more concave the antero-posterior and transirese arches of the foot. In the former action it assists the tilialis posticus and flexor longus hallucis.

In walking, it will act with the gastrocnemius and soleus in lifting the heel from the ground, and its tendeney to evert the sole and abduct the foot will counteract the opposite tendeney of the muscles attached to the tendo Achillis. Moreorer. the tenclency of this latter set of muscles is to press the onter part of the ball of the toes firmly upon the ground. On the other hand, the influence of the peroneus longus in extending the foot is especially excrted upon the ball of the great tore. By the combined action of all these extensors of the ankle the whole of the ball of the foot is pressed evenly upon the ground and firmmess of tread secured.

Relations.- Superficially, the deep fascia, the external amnular ligament; and in the sole, the abductor minimi digiti, the adductor hallucis and long plantar ligament; in front, the peroneus brevis, the extensor longus digitorum, and the musculo-cutaneous nerve; behind, the soleus and flexor longus hallucis; deeply, the external popliteal nerve which occupies a fibrous canal below the head of the fibula, the ankle-joint, caleaneum, cuboid, and the bases of the second and third metatarsal bones.

Variations.-Sonetimes a second peroneus arises between the peronens longus and breris. and sends its tendon to join that of the peroneus longns. A slip may be given to the external anmular ligament. The insertion of the muscle may extend to the bases of the adjacent metatarsal bones.

\section{PERONETS BRETIS}

The peroneus brevis (figs. 292 and 298 ) — named from its being the shorter of the two fibular muscles-is also a triangular sheet.

Origin.-(1) The lower two-thirls of the outer (or peroneal) surface of the fibula; (2) the deep fascia of the leg and the intermuscular septa in front and hehind.

Insertion.-(1) The outer part of the base of the fifth metatarsal hone; (2) the outer borker of the expansion of the tendon of the extensor longus digitorum upon the first phalanx of the little toe.

Structure.-This is also a pemiform muscle. The short fibres pass obliquely downwarls to the tendon which lies upon the outer surface of the muscle. It becomes free from fleshy fibres just above the extemal malleolus where it pasioce beneath the external amnular ligament in the same sheatl with the peroneus longu: tendon, and after changing its direction, runs forwares and somewhat dowmands upon the outer surface of the caleaneuni and abore the prencal tuberele.

Nerve-supply.-The museulo-cutaneous branch of the popliteal nerra by filaments which enter the deep aspect of the muscle ahout the middle of the leg.

Action.-(1) Slightly to extemsl the ankle; (2) to aluluct the anterior part of the foot; (3) slightly to elerate the outer lowed of of the foot, and so erert the sole.

Relations.- -uperficially. the peroneus longus, leep fiscia of the leg and external annular ligament; in front, the extensor longus digitorum and peronets. tertins; behind, the peronens longus and Hexor longus hallucis; deeply; the anklejoint. ealeaneum, ant euboid bones.

Variations.-The small slip which the temdon sends on to the expansion upon the little tue. may be wanting, or it may be inserted into the first or eren the second phallans. This slip may be entirely separate, so as to form a fourth peroneus. 
Fig. 299.-The Exterial Ixtercostals Axn Levatokes Costarur.

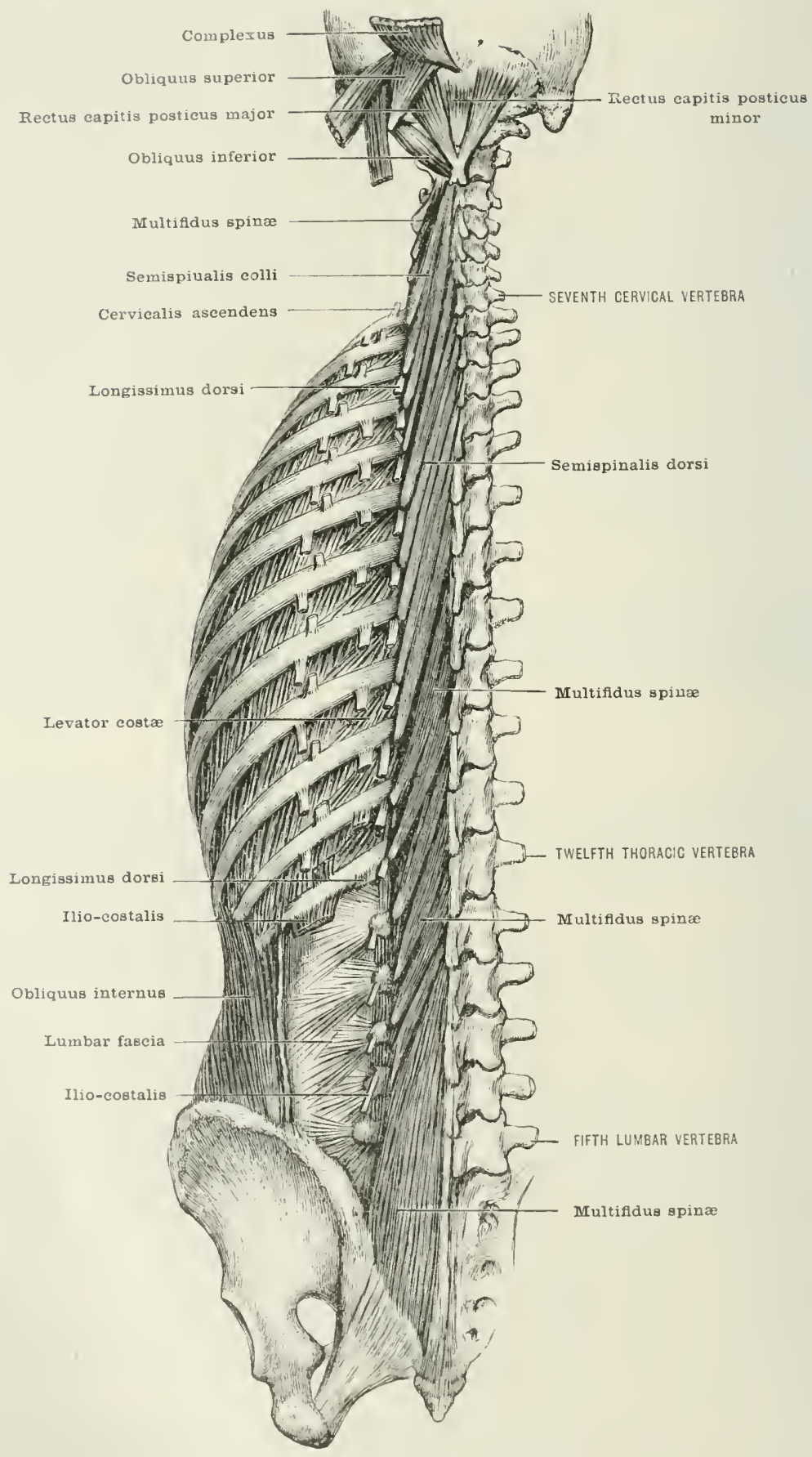




\section{TIIE MLSCLES OF THE THORAX}

These consist of six muscles, or sets of muscles, which are attacherl chiefly to the ribs, their cartilages, and the sternum: viz. the external and internal intercostals, the levatores costarum, the triangularis stemi, infracostales (or subeostales), and diaphragrn.

\section{INTERCOSTAL Muscles}

The intercostal muscles-named from their position-are long narrow sheets of short oblique muscular fibres which occupy the intercostal spaces. The fibres of the outer sheet run downwards and forwards, and those of the inner downwards and backwards; and the two sleets are the upjer continuations of the obliquus externus and internus of the abdominal wall.

\section{THE ENTERNAL INTERCOSTALS}

The external intercostals, which are stronger than the internal, are eleven in number, and fill the spaces between the ribs from the tubercle to the tip. In the higher spaces, however, they ro not come quite so far forwards as below. Above, the lower attachment barely reaches the tip of the rib; while below, the upper attachment reaches the tip, and the lower is upon the cartilage.

Origin.-The lower or outer border of all the ribs except the last, from tubercle to anterior extremity.

Insertion.-The outer aspect of the upper border of all the ribs but the first from a little in front of the tuberele to the tip, or in the lower ribs for a short distance upon the cartilage.

Structure.-Composed of obliquely directed parallel bundles of fleshy fibre, with a short tendinous origin, and with a slight admixture of fibrous tissue. The posterior are more oblique than the anterior fibres. The sheet formed by their fibres is thickest behind, and becomes gradually thinner forwards. Between the cartilages it is succeeded by a thin membrane. the external intercostal fascia, which is composed of fibres running with the same slope as those of the muscle.

Nerve-supply.-The intercostal nerves as they run forwards give numerous filaments to the inner surfaces of the muscles.

Action.- See later.

Relations. - superficially, the pectoralis major and minor. the serratus magnus, the extemal oblique, the latissimus rorsi, the trapezius, rhomboidei, the serrati postici, the continuation upwards of the erector spine, and the levatores costarmm; deeply, the internal intercostals and infracostales, the interostal ressels and nerves.

\section{THE INTERIAL INTERCONTAIS}

The internal intercostals are eleven in number, and fill the spaces from the angles of the ribs to the anterior 'xtremities of the cartilages. The fildes, which are shorter and not quite so oblique as those of the outer sheet, are directed clownwards and backwards.

Origin.-The upper border of the subeostal groove of the elcren ulper ribs from the angle forwards, and the continuation of this border upon the cartilages.

Insertion.-The inner aspect of the upper border of the eleven lower ribs and cartilages.

Structure.-The shects are thicker in front. There is less filmons tiscur mixerl with the fleshy fibres than in the outer sheet. In the uppor and lower spaces the fleshy fibres are continued a little further lack than the angles. The rest of the 
space behind the thin posterior borker of the sheot is filled by a thin membrane composed of tibres rumning in the same direction, and is called the internal intercostal fascia.

Nerve-supply.-Branches from the interestal nerves, which are supplied to its outer surface or are given off where the nerves are concealed in the interior of the muscle.

Action.--See below.

Relations.-Superticially. the extemal interenstal muscles, and the intrenstal arteries and nerves; deeply, the triangularis sterni, infracostales, diaphragm, and the pleura.

The action of the intercostal muscles generally is to approximate the rils to one another, and they are chiefly used in inspiration. The obliquity of their fibres en-

Fig. 300.-The Intercostal Muscles.

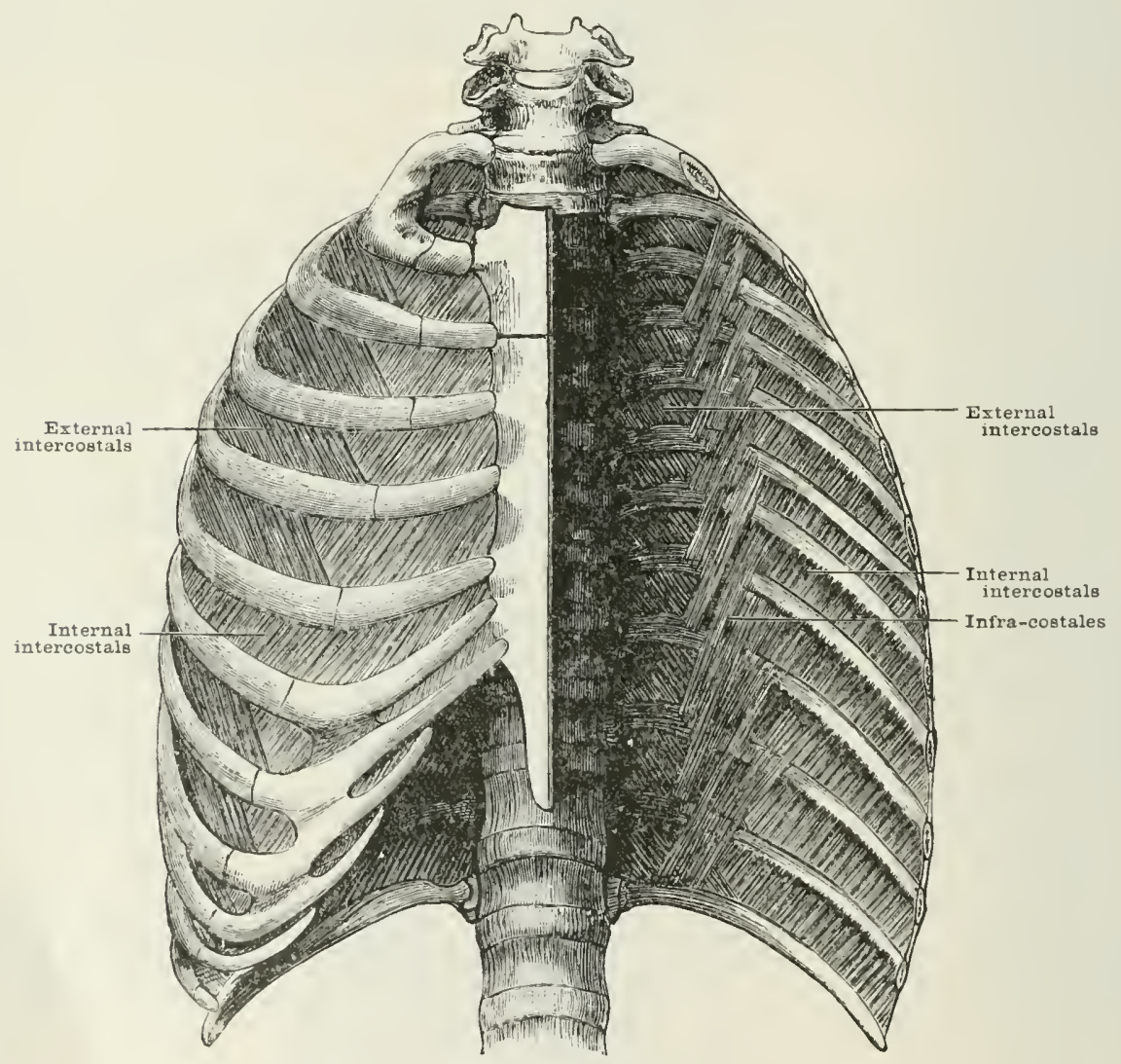

ables them with a small contraction to produce a groater aploroximation than if they ram perpenticularly between the ribs (page 287). Noreover, if the tibres were all directerl, like those of the onter sheet, downards and forwards, there would he a tendency for the lower ribs to be drawn backwarks as well as upwards in inspiration; and if, on the other hand all the fibres were directed downwads and backwards like those of the inner sheret, the tendiner would be for the lower ribs to be drawn forwards as well as upwards in inspiration. The combined action of the two sets produres the direct clevation of the ribs, the forward pull of the inner shect being wounteracted by the hax kward pull of the onter sheet. If the extermal intercostals were carried forwards as far as the stermum, they would tend to take the sternum as a fixed point and to clepress the anterior extremities of the rils. 1 similar result would follow the continuation backwark of the internal intereostals to the rertebral 
column. It will be also noticed that the front part of the external, and the back part of the internal intereostal sheets are thin and weak, so as to diminish this tendeney torvarels an expiratory movement. It has been urged that both sets of intercostals cammot approxinate the rilse, as in inspiration some of the interenstal spaces are seen to open out and become wider. To this it may be replied that, whaterer happens in some of the spaces, it is certain that the general tendency is that of approximation of the ribs, and diminution of the intervals between them, as after a full inspriration the last rib is nearer to the first rih. Moreover, it does not always follow that because a muscle is lengthening it is not acting (eff. such eases as that of the long hearl of the triceps when it is used in extenfling the elbow during the clevation of the arm). If when most of the ribs are being approximated it should happen that some of the spaces are found to be widened, the action of the muscle in these widened spaces will probably be to prevent a greater separation, and by steadying the lower ribs to enable the muscles which descend from them to act. When the lowest rib is fixed by the quadratus lumbormm and other muscles, it is probable that the intereostals, at any rate those of the lower spaces, by approximating the lower ribs to the last rib, may act as muscles of expiration. The following are some of the arguments which may be adduced in support of the riew that both sets of intereostals act together, and also that their action is usually inspiratory.

1. The advantage already mentioned, from their ohlique decussation enahling them to approximate the ribs more completely and at the same time to elevate them directly when they act in combination (cf. the action of the external and intemal oblique in approximating the last rib to the crest of the ilium).

2. Muscles supplied by the same nerve are rarely antagonistic.

3. In long-standing paralysis of the intercostals the sternum is depressed, the chest flattened, and kept in a permanent condition of exaggerated expiration.

4. Galvanism of the intercostals produces expansion of the chest. In Duchenne's experiment he found that when he galranised so slightly as only to affect the extemal intercostals, the inspiratory movement was small; but when he galvamised so strongly as to affect the nerre, and through the nerve the internal intercostals - as was known by the contraction of muscular fibre heing felt between the cartilages of the ribs, in which situation the only fleshy fibres are those of the inner set-a strong inspiratory movement was produced.

From the peculiar shape of the ribs and the mode of their articulation, their elevation is accompanied by a rotation of the ares formed by them upon their chords so that their planes from a sloping attain an almost horizontal position. Hence the widening of the chest during inspiration, in addition to its expansion from before backwards due to the forward elevation of the tips of the ribs.

\section{LEVATORES COSTARUII}

The levatores costarum (fig. 299)-named from their action, as elevators of the ribs-are twelve triangular sheets, which eover the back part of the intercostal spaces, and are continuous with the fibres of the external intercostal muscles.

Origin.-The tips of the transverse processes of the last cervical, and all the thoracic vertebre except the last.

Insertion.- The outer surface of the ribs from the tuherele to the angle.

Structure.- - Irising by short tendinons fibres the muscle axpands in a fan shape, and is attached to the noxt rib helow. Frequently fibres pars orer one ril, and are inserted upon the next hut one.

Nerve-supply.-The intereostal nerves which send branches to their deep surfaces.

Action.-To elevate the ribs in inspiration.

Relations.- Superficially, the outer and upwarl continuations of the erector spina; clepply, the extemal intercostals, which are continuous with the outer border of the muscles. 


\section{TRINAGULARIS STERNI}

As the extermal and intemal ohlique museles of the abdomen are represented by the external and internal intercostals in the thorax, so also the transversalis aidominis has its counterpart in the thin stratum of muscular fibre at the sides of the sternum called the triangularis sterni, and the still thinner expansion behind of the inflacostales.

The triangularis sterni-mamed from its shape and its eonnection with the sternum-is a thin, museulo-membrimons, triangular sheet, with the apex below and directed internally, while the serrated base is external.

Origin.-(1) The side of the lower third of the back of the stermum; (2) the upper and lateral part of the back of the ensiform cartilage; (3) the back of the imer ends of the fith, sixth, and seventh costal cartilages.

Fig. :301.-The Muscles attachen to the Back of the Stersy.

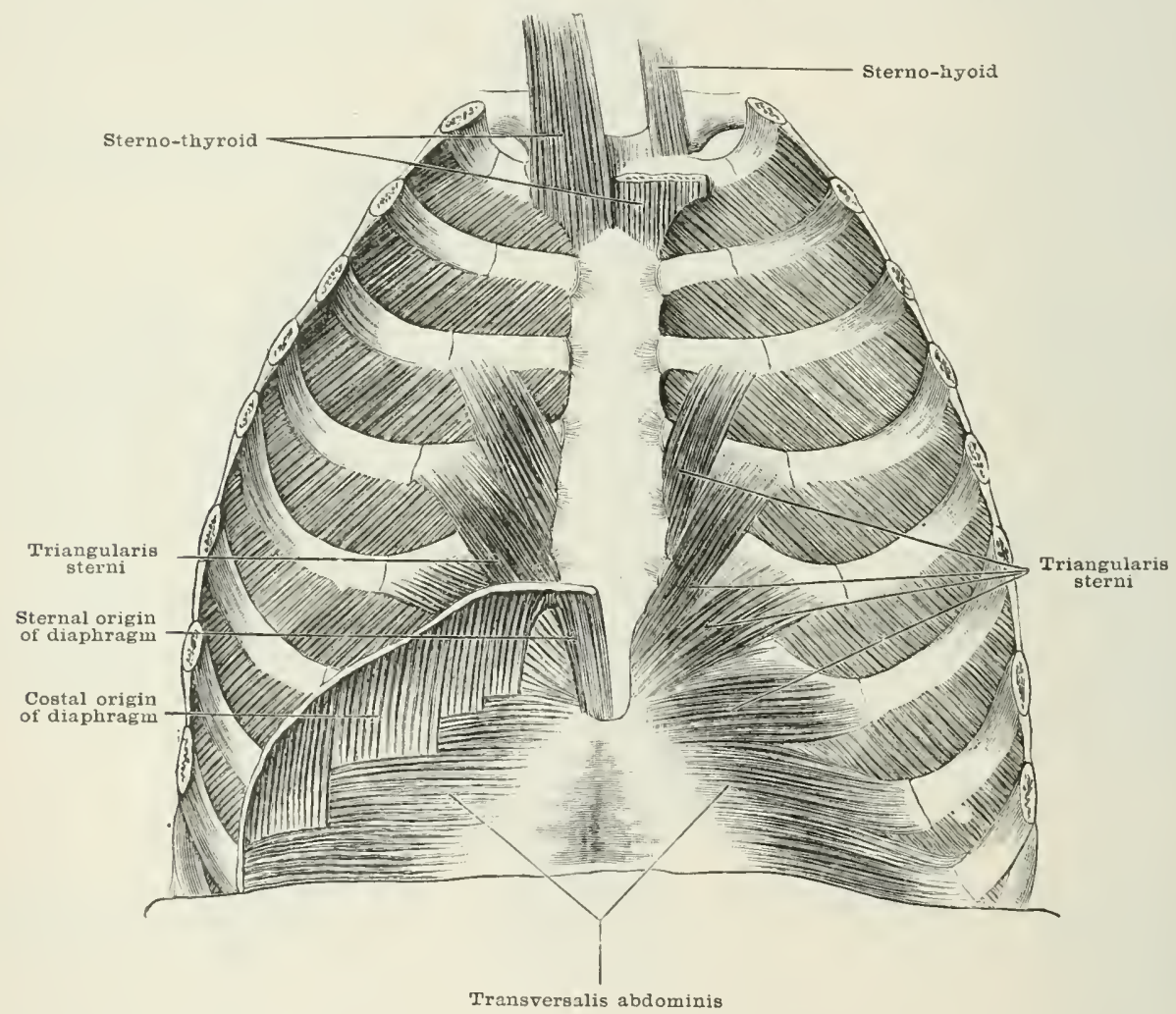

Insertion. - The outer ends of the posterior surfaces and lower horders of the cartilagess of the second or thirel to the sixth ribs, and occasionally the tips of the libs also.

Structure.-The muscle is membranous at its origin and insertion, and it contains many bands of filmous tissue. Its filres cliverge fanwise, the lower ones being horizontal, anel in serial continuation with the mpler digitations of the transversalis aldominis, while its higher fibres run obliquely upwards and ontwards.

Nerve-supply.-The upper intreostals, which seind filaments to its anterior aspect.

Action.-To depress the anterior extremities of the rils to which it is attached, and so to help in expriration.

Relations. - In front, the internal intercostals and internal mammary vessels; behind, the pleura and pericardium. 


\section{INFRACOSTALES}

The infracostales, or subcostales-named from their position beneath the rihs -form a thin museulo-membranous sheet lining the back of the thorax extrinal to the tubercles of the ribs; broaler and better developed below, becoming narrower and thimner above. Freguently it consists of only a few bundles of fibres which can be distinguished from the internal intercostals by the fact that they are not eonfined to one interestal space.

Origin.- The lower part of the inner surface of the rils near their angles.

Insertion.-The upper part of the inner surface of the ribs, each bundle of fibres usually passing over one rib to be inserted upon the next higher.

Structure.-The fibres arise tendinous, run upwards and outwark, and have tendinous insertions. The higher fibres min more vertically. The lower approath nearer to the vertebral columm, arising from the ribs just extemal to their tubercles.

Nerve-supply.-The interestal nerves, which enter their outer surface.

Action.-To depress the ribs, and assist in expiration.

Relations.-Externally, the external and internal intereostal museles; internally, the parietal layer of the plema, which is separated from them by a thin aponeurosis sometimes called the endothoracic fascia.

\section{THE DIAPHRAGM}

The diaphragm-named from its function as the stacparpo, or partition wall between the thorax and abdomen-is a dome-shaped musenlo-membranous sheet of a kidney-shaped outline when seen from above, and consists of a pair of muscles with a lateral origin and a central aponeurotic insertion, resembling the two transversales abdominis, which unite in the linea alla so as also to form a single dome-shaped biventral muscle.

Origin.-By three portions:-

1. Anterior or sternal portion.-The lower borler and back of the ensiform cartilage, and the adjacent part of the back of the anterior aponeurosis of the transversalis abdominis.

2. Lateral or costal portion.-The lower borders and inner surfaces of the cartilages of the six lower ribs, and sometimes also from the adjacent part of the ribs.

3. Posterior or vertebral portion.-(1) The ligamentum arcuatum externum, a fibrous thickening of the anterior layer of the lumbar fascia. which stretehes from the tip of the transverse process of the second lumbar vertelira to the tip of the last rib; (2) the ligamentum arcuatum internum-a fihrous thickening of the iliac faseia, which arches over the upper part of the psoas from the sirle of the borly of the second lumbar vertehra to the tip of its transverse process; (3) the crus of the diaphragm - a strong vertical band, fleshy extemally, tendinous internallyarising on the right side from the front of the hodies of the first to the thirct or fourth lumbar vertebre, from the intervening vertelual discs. and the anterior common ligament; on the left side, from the bodies of the first to the second or third vertebrae only, as well as the dises and anterior common ligament.

Insertion.-The front, silles, and hack, of the eentral temdon.

Structure.-The fihres, arising theshy from their extensive origin, pass at first vertically upwards, and then arch inwards to be attached to the borelers of the ecutral tendon. The sternal filmes are the shortest, and ther are often separaterl from the costal portion by a small triangular interval filled with areolar tiscure, and giving passage to the superior epigastric vessels. The ontal origin forms a series of teeth which do not eorrepond accurately with the number of rilss some rib) (artilages having two teeth attached to them. They interdigitate with the serrations. of the transversalis abdominis (lig. 301). The iponemotic fibes which form the inner portion of the two erura, after arching in fromt of the aldominal aorta, are continued hy fleshy fibres which rlecussate, and so (hanging sides form a loop round the oesophagus before joining the central aponeurosis. 
The central tendon, or aponeurosis, forms the summit of the dome, and is of a sinilar outline to the diaphraym, being kielney-shaped, with the concarity behinel. It approaches nearer the back than the front of the thorax. There is a slight notching of its outline in front, which divides it into three parts, so that it has somewhat of a trofoil shipe, the right leatlet being the largest, and the left the smallest. Its fibres run in many directions.

The diaplurann contains three large foramina, for the passage of the rena cara inferior, oesophagus, and aorta.

Furamina. - C'lose to the posterior border of the central tendon at the junction of the right and midclle leaflet is a quarlrilateral opening with rounded angles, the foramen for the rena cara inferior, the outer coat of which vessel is blended with its fibrous exlges. The asophageal opening is oval, with the long diameter directed forwards. It is surromnded by fleshy fibres, and lies to the left of the middle line, (1)posite the body of the tenth thoracic vertebra. Through it passes the osophagus, with the left ragus nerve in front, and the right behind; also a few small osophageal branches from the thoracic aorta, on their way to join some small osophageal

Fig. 302.-DiAPHRAGi.

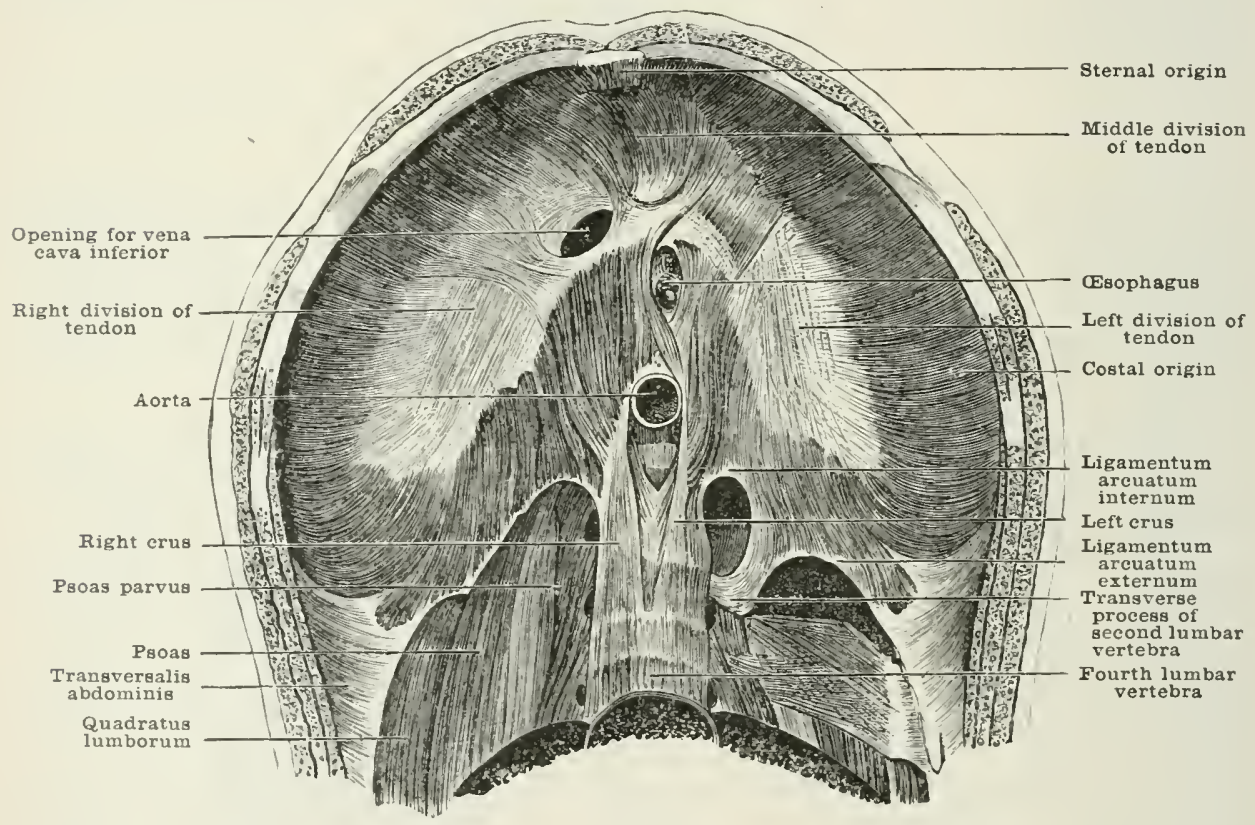

hranches from the gastric artery. The antic opening, formed by the union of the crura, is fibrons, and of oval shape. It is situated in front of the twelfth thoracic rertebra, and is completed behind by the anterior common ligament. Through it pass the aorta, the rena azrgos major, and the thoracic duct. In the crula on wither side are small openings which allow of the passage of the great splanchnic nerves, and the left erus is usually perforated also by the vena azyos minor.

Nerve-supply.-The two phrenic nerves, chiefly derived from the cervical plexus of each side through the fourth cerrical nerves, break up close to the diaphragm into many filanents, which penetrate the muscular structure near the anterior horder of the rentral tendon, and are distriluted to the under surface of the muscle. Sympathetic filaments are also given to it from the plexuses which accompany the jhrenic arteries.

Action.-To deepen the chest from ahove downwards, and so produce a movement of inspiration. The central tenclon, especially the middle part of it, which is chosely ennnected by means of the pericardium with the deep fascia of the neck, is but little depressed; but the arched fleshy fibres all around flatten, and so 
increase greatly the eapracity of the sirles of the thoracic cavity. At the same time the abdominal viscera are driven clownwrols, and as the front part of the parietes is the nost vielding, ther are also displaced formards, so as to cause a greater prominence of this part of the abdomen. In the expulsive efforts of defecation and parturition, after the diaphragm has first contracted in a deep inspiration. and the glottis has been closed so as to prevent the escalpe of air from the chest. the abdominal muscles are able to contract with full effect upon the viscera, which have been pressed down by the previous descent of the diaphragm.

The lower six ribs are slightly elevated by the diaphragm, and the hypochondria somewhat dilated, this latter norement being due to the forward and ontward pressure of the depressed riscera.

Relations.- thove lie the pleure and perieardium, the heart and the lungs. Below are the peritonem, the liver with its ligaments, the stomach, the spleen, pancreas, kidneys, and suprarenal capsules. The dome-shaped upper convex sulface rises higher upon the right than the left side. On the right side, being raised hy the liver, it reaches to the level of the junction of the fifth costal cartilage with the sternum, and on the left side only to the level of the junction of the sixth costal cartilage.

Variations.-The xsophageal opening has been found in the right crus, instead of being surrounded by decussating fibres from both crura. The sternal portion of the muscle is not unfrequently absent.

\section{THE ABDOMINAL PARIETES}

The superficial fascia covering the walls of the abdomen is continuous with that of the thorax and lower limbs, and is usually divided into two layers.

The first layer is well provided with fat, which in many individuals attains to a considerable thickness, especially in the lower part of the anterior wall.

The second or deep layer (Searpa's fascia) is of a more membranous character and contains a quantity of elastic tibres. Near the groin it is scyarated from the more superficial layer by blood-ressels and lymphatic glands. Upon its deeper surface it is loosely connected with the deep fascia which invests the external ollique muscle; but it is closely lilended with the linea alba, the fibrous structures in front of the pubic bones, the fascia lata inmediately below Poupart's ligament, and the crest of the ilium.

Both layers are continued downwards upon the external genital organs. In the male they lose their fat and blend with the suspensory ligament of the penis, the fascia covering that organ, and the dartos and septum of the serotum. In the female they are continuous with the superficial fascia of the vulva.

\section{THE ABDOMINAL ITLSCLES}

The muscular portion of the ahdominal wall forms a lozenges-shaped figure of which the rertical diagonal extends from the ensiform process to the srmplnyis puhis. while the transierse encireles the aldomen from tip to tip of the transwerse processes of the thirel hmmar vertelira.

The boundaries of this muscular wall are formerl, alowe by the costal cartilages of the six lower ribs; hehind. he the tips of the transwerse processes of the lumbar rertehre; below, by the crests of the ilia and the pubes. Nore aceurately, earch 
latcral half may be looked upon as a four-sided figure of which the upper boundary slopes lackwarls and clownwards; the lower. Jackwards and upwards; while the longe anterior bomblary and short posterior bommlary are vertical and parallel. The museles contained in the parietes may be divided into revtical amel trenserse. The former, thee in number, are situated two in front, and one behind; while the litter, also three in number, palss trimsversely, or with some obliyuity, letween the anterior and posterion loundaries of the space.

The two lateral halves unite in front in a strong fibrous band called the linea alba, which stretehes from the tip of the ensiform cartilage to the upper part of the symphrsis pulis. It is partly formed by vertical fibres stretching hetween these two joints, but chicfly by the interlacenent of the transserse and oblique bancls of fibrous tissue which pass letween the aponeuroses of the museles upon cither sicle. In its lower two-fifths it is not more than one-eighth of an inch (3 mm.) broad; in its mper three-fifths it is broader, usually not less than a quarter of an inch $(6 \mathrm{~mm}$.) in width, lut in some bodies it may he stretched to a much greater extent. At the junetion of the lower two-fifths and upper threefifths is the small tibrous ring of the umbilicus through which pass the remnants of the fuetal vesseds.

\section{Axterior Tertical Muscles}

These are two in number-the pramidalis and rectus alodominis.

\section{PYRAMIDALIS}

The pyramidalis (fig. 266)-named somewlat fancifully from its triangular shape-is a fan-shaped sheet of museular fibre forming a right-angled triangle, of which the shortest side corresponds to the origin, and the other side containing the right angle to the linea alba.

Origin.-(1) The front of the pulie erest; and (2) the filmrous structures which cover the front of the body of the os pubis and its symphysis.

Insertion.-The linea alba at a point about half-way between the pubes and the umbiliens.

Structure.-Arising by a short tendinous sheet, the fleshy fibres converge as they pass upwards. Those nearer to the middle line ascend vertically, while those which arise near the pubic spine pass obliquely upwards and inwards to the tendinous insertion of the muscle into the linea alba three or four inches (S to 10 cm. ) above the symphysis pubis.

Nerve-supply.-From the eleventh and twelfth thoracic nerves and from the ilio-hypogastric branch of the lumbar plexus, through their terminal filament: whicli enter the deep surface of the muscle.

Action.-By its contraction, it pulls upon the linea alla and so upon the lower (nol of the ensiform cartilage. It will therefore assist the rectus in flexion of the thorax upon the pelvis, or of the pelvis upon the thorax. It cam also halp feetsy to compress the abrominal viscera.

Relations. - Superficially, the aponeuroses of the transere aldominal muscles; deeply, the rectus abdominis, from which it is separated hy a thin fibrous lamella.

Variations.-The height to which this muscle extends is variable. It is often absent on one or both sides; or it may be double.

\section{RECTLS IBDOMINIS}

The rectus abdominis (fig. 266i)-named from its straight direction-is a strong ribhon-shaperl muscle romning vertically on either side of the linea allat from the pubes to the ensiform and aljacent costal cartilages.

Origin.-By two tendons: (1) the outer head from the whole of the crest of the pubes; (2) the inner head rosies the milklle line of the bedy, and arises from the tibrous structures lying in front of the symullysis. 
Insertion.-(1) The anterior sulfilce of the tip of the fifth ril); (2) the front of the costal cartilages of the fifth, sixth, and serenth rils; sometimes also (a) the anterior surface of the base of the 'nsiform cartilage near its outer border.

Structure.-The inner heal arises tendinons from the other sicle of the middle line, decussiting with its fellow; the outer and stronger head arises by a shorter tenrlon, and is soon joined by the imner head. About an inch (2.5 em. ) albore the pubes, a fleshy mass is formed, which expands as it ascends into a broal sheret, which below the mubilicus lies close to its fellow of the opposite side. Ahore, the two nuscles are separated by an interval of at least a quarter of an inch ( 6 mun.). The insertion, which is by short tendinous fibres, is three or four times the wiclth of the origin. The muscle is also curved considerahty forwards to correspont with the convexity of the front wall of the abdomen. At certain intervals, transverse bands of fibrous tissue extend in an irregular zigzag manner across the muscle, especially upon its anterior surface. These are called the lineæ transversæ, and the transverse depressions which they produce are usually to be seen and felt through the skin. They are generaliy three or four in number on either side. One is situated opposite the umbilieus; the second opposite the tip of the ensiform cartilage; the third half way between these points; and a fourth is sometimes present which extends incompletely across the muscle at some distance below the umbilicus. They are firmly connected with the anterior layer of the strong sheath of the muscle, which will afterwards be described. They do not extend through the whole thickness of the muscle, being deficient behind.

Nerve-supply.-From the terminal filaments of the anterior branches of the six lower thoracic nerves which enter the muscle on its posterior surface near the outer border; and from the ilio-hypogastric branch of the lumbar plexus.

Action.-(1) By the tendency of the curved bands of the muscle to become straight during contraction, all the viscera contained in its concavity are compressed. It will, therefore, help in defecation, micturition, and parturition; also in expiration, and especially in strong expiratory efforts, such as coughing and sneezing. (2) By drawing down the ensiform cartilage and the anterior extremities of the middle ribs, it flexes the thorax upon the pelvis, and at the same time acts as a flexor of the thoracic and lumbar portions of the spine. Aeting less strongly, it fixes the stemum, so that the sterno-mastoids by their contraction may flex the hearl, e.g. in rising from the recumbent position. (3) Taking its fixed point from above, it will draw upwards the pubic portion of the pelvis. and so flex the pelvis upon the thorax, as when the lower part of the body is drawn up towarks the chest in climbing.

The lineæ transversæ, which are the remnants of the septa which divirle the muscular structure at intervals in the lower rertebrates, and which in the erororlile form the abdominal rils, have had rarious uses asigned to them. In the first place, they will tend to keep the muscular fibres in their proper place, and prevent them from being separated so as to allow of rentral hernia. Secondly, they will enable the muscle to act not only upon the points of bone which form its ilirert attachment, but, by means of their connection with the sheath of the musche and the aponeuroses of which it is formed, they will in some measure diffuse the action of the muscle orer the lower ribs and the erest of the ilimm. Thirdly, they will enable one part of the muscle to act independently, as for example when the lower part exercises some pressure upon the blatder in micturition. Fourthly, they frevent extensive separation when the muscle is injured. On acromnt of the serere strain to which the muscle is exposed, it is sometimes ruptured. If the muscular fibres extended without interruption from the pulus to the rnsiform cartilaye, such a rupture would oecasion a much willer separatiom, and comsenuently much greater disahlement than is now found to be the case.

Relations. - Superficially, the front layer of its sheath above. and helorr the pyramidalis; deeply, it is separated from the transrersalis fascia and peritonum in the greater part of its course hy the posterior layer of its slreatli; in its lower fourth it is in contact with the transversilis fascia; and alores. it lies on the eartilages of the fifth to the ninth ribs, and corers the interesstal museles which lie between them. The deep apigastric artery asomels herhind the muscle to join with the superior epigastric branch of the interinal mimmancy. 
Variations.-The rectus may be inserted as high as the fourth or even the third rih. A lateral rectus is sometimes found between the external and intemal oblinue muscles, extending from the tenth rib to the iliac erest.

\section{Trinsperse and Oblique Múches}

This group ensists of three muscles-the obliquus externus, the obliquus internus, and the transtersalis-which lie in successive strata in the abdominal wall.

\section{OBLIQUUS EXTERNLS}

The obliquus externus abdominis-named from its position and directionis a broal eurvel sheet, partly muscle and partly aponeurosis, of an irregularly quadilateral shape.

Origin. - The outer surface of the eight lower ribs about their middle by a series of nearly horizontal lines which, after crossing each rib obliquely downwards and backwards, extend for a short distance along their lower borders.

Insertion.-(1) By a strong aponeurosis along the whole of the linea alba; (2) the front of the os pubis close to the symphysis; (3) the spine of the pubes and the adjacent part of the ilio-pectineal line; (4) the deep fascia of the thigh in a thickened band which stretches from the spine of the pubes to the anterior superior spine of the ilium: (5) the anterior half of the outer lip of the crest of the ilium.

Structure.- At their origin the muscular fibres form a series of teeth which interligitate in the upper part of the muscle with the scrratus magnus, and in the lower with the latissinus dorsi. The general direction of the origin is an oblique line somewhat curved upon itself so as be convex upwards and backwards. Above and below, the origin is nearer to the anterior extremities of the ribs. From this origin the fleshy fibres pass downwards and forwards, and at the same time diverge fanwise, at first lying upon the ribs and their cartilages, and then without any bony support as part of the muscular wall of the abdomen. The change from fleshy to tendinous fibres takes place at some distance from the outer border of the rectus muscle, in such a way that the fleshy mass teminates rather aloruptly in a right angle situated in the iliae region of the abdomen. This angle is formed in front by a vertical line, which passes downwards from the tip of the ninth costal cartilage; and below by a horizontal line passing forwards from a point upon the crest of the ilium an inch or two $(2.5$ to $5 \mathrm{~cm}$.) behind the anterior superior spine. This abrupt limitation of the muscular fibres gives rise to a projection which is distinctly visible through the skin in a muscular subject. The aponeurosis thus formed blends in nearly the whole of its extent with that of the suljacent muscle, the ohliquus internus, and in the middle line it unites at the linea alba with that of the opposite sirle. Above, it extends upwarls as high as the insertion of the rectus muscle, of which it forms part of the sheath, and in this locality it gives origin to a part of the pectoralis major.

The insertion into the pubic bone of the same sicle is interrupted by an interval corresponding to the crest of the pubes, and forms the external abdominal ring. From the spine of the pubes to the anterior superior spine of the ilimm, the aponeurosis forms a thickened hand slightly convex downwards, which blends with the fascia lata, and is callerl Poupart's ligament. The rest of the insertion into the out('r lip) of the ("rest of the ilimm is by short tendinous fibres.

The insertion of the lower edge of the aponeurosis is also earried backwaris and outwarls from the spine of the pubes along the imner part of the ilio-pectineal line ly a horizontal triangle of fatciat allol Gimbernat's ligament. This liganent is attached to the lower enel of Poupart's ligament in front, and it presents a cencave surface upwark, upon which lie the structures which emerge through the external ablominal ring. The filores of (imbernat's ligament are continued upwarls and inwarls berond the ilionectineal line to the front of the rectus and the linea alla hy a laper called the trimgner fosciu, which lies behind the inguinal camal and the external aldominal ring. 
The external abdominal ring (nig. 2S5) is an olliquely directed slit or marrow triangular aperture in the aponeurosis of the obliquus externus, which transmits the

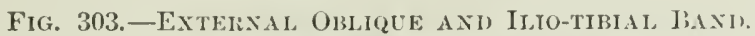

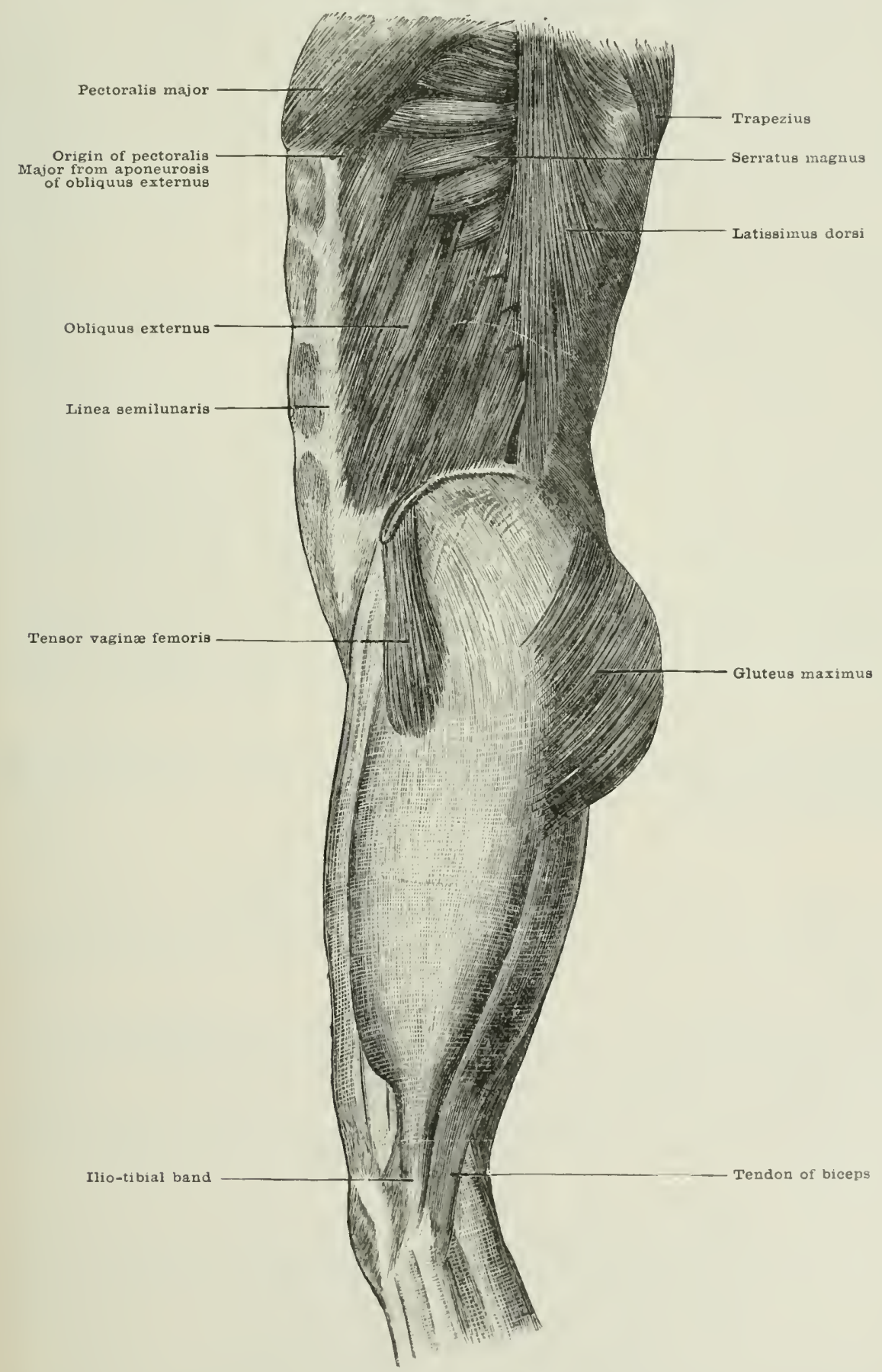

spermatic corl in the male, and the round liganent of the uterus in the female. The

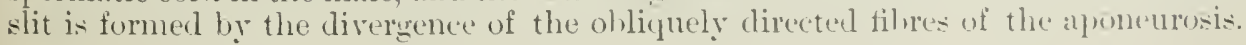


Those above, which form the inner pillar, as it is called, of the ring, run downwards and inwards to be attached to the front of the symphysis pubis; these leclow, which form the external pillar of the ring, form a thin edge at first, but thicken just before their attachment to the suine of the pubes and the inner extremity of the ilio-pectineal line, lor at this point the extermal pillar is iclentical with l'ompart's ligament. I pon the surface of the obliguus externus, close to the "xternal aldelominal ring, the obliegue fibes of the aponeurosis anc fastened together ly some transrersely directed filores, the intercolumnar fibres, which run upwards and inwards from Poupart's ligament, liniting and rounding off the upper and outere end of the extemal abelominal ring. A thin membrane, the intercolumnar fascia, is prolonged from the elges of this opening over the spermatic cord and round ligament, of which it forms the external envelope.

Nerve-supply.-From the anterior branches of the lower thoracic nerves by means of numerous filaments which, passing through the internal oblique, enter the muscle on its derp surfare.

Action.-(1) The curved muscular fibres in their contraction tend to become straight and so mompress the viscera which lie in their concarity; they act in defecation, micturition, parturition, and all expiratory efforts; (2) the two obliqui externi acting together will draw upwards the front part of the pelvis, and so flex it upon the thorix; (3) the muscle of one side, acting alone or in conjunction with the internal oblique of the opposite sicle, will rotate the pelvis and the lower part of the body to the same side; (4) it will tend by its posterior fibres to draw the crest of the ilimm upwards towards the lower ribs, and will thus act as a lateral flexor of the pelyis upon the thorax; (5) acting from below, the muscles of the two sides will draw the thorax downwards and forwards and flex the lumbar and lower part of the thoracie spine; (6) it will rotate the thorax upon the pelvis so as to turn the thorax and the upper part of the body to the opposite side; (7) the posterior fibres will flex the thorax laterally.

Relations.- Superficially, the integuments, and for a short space behind the latissimus dorsi; deeply, the lower ribs, their eartilages, the intercostal muscles between them, and the internal oblique; and below, the spermatie cort or round ligament in the inguinal canal.

Variations.-The oblique externus may rise from more or fewer ribs. Occasionally a deeper plane is separated from the rest of the muscle. In one case, the anterior part of the aponeurosis wals ubserved to be wanting.

\section{OBLIQULS INTERNES ABDOMINIS}

The obliquus internus abdominis (fig. 266)-named from its relation to the precerling musele and the direction of its fibres-is an irregular quadrilateral curved sheet, partly fleshy and partly aponcurotic.

Origin.-(1) The outer half of Poupart's ligament; (2) the anterior two-thirds of the space intervening between the inner and onter lips of the crest of the ilimm; (3) the outer and posterior aspect of the aponeurosis of the transversalis abdominis (which aponetrosis is also called the lumbar fascia).

Insertion.-(1) Fol ahout one inch $(2 \% \mathrm{~cm}$.) into the inner extremity of the ilio-pectineal line; (2) the anterior horler of the crest of the pubes; (i) the whole length of the linea allar; (4) the lower borders of the cartilages of the last throe rils.

Structure.-Arising hy fleshy and short tendinous fibres intermingled, a fleshy sheet is soon formed, the filmes of which diverge; the anterior pasing formaris and downwrels, the middle forwards and upwards, and the posterior directly mwards to their insertion, which is hy means of a hroad aponeurosis. At the fronit of the lower interesstal spares the fibres rum parallel to, and in the same plane with, the internal interecstals. The position of the change from fleshy to aponeurotic filores may he inclieated by two lines at right angles to each other; one fassing upwards and a little outwarls from the midllle of Poupart's licament, the

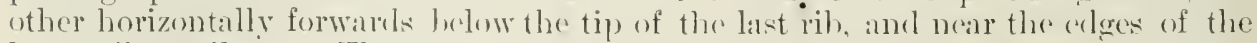
lower rib cartilages. The aponeurosis is blended with that of the external olsigue, 
and in its upper three-fourths it divides into an anterior and a posterior plane which together form the sheath of the rectus muscle. In the lower fourth of the ablomen the whole of the aponeurosis passes in front of this muscle. The line of division of the aponcurosis of the internal oblinge is indicaterl on the surface of the ahelonem by a furrow ealled the linea semilunaris, which lies between the fleshy part of the muscle and the outer horder of the rectus muscle, and forms a curve. concive inwarls, which extends from the cartilage of the ninth rib above to the vicinity of the pubes below.

The plica semilunaris, or fold of Douglas, on the other hand, is the name given to the lower extge of the pesterior sheath of the rectus, when that muscle pierees the aponempses so as to lie behind all of them in the lower fourth of its course. The lowest portion of the aponemosis of insertion of the obliguns internus is closely blenderl with that of the transwersalis abdominis, and is ealled the conjoined tendon.

Nerve-supply.-From the anterior primary branches of the lower thoracic nerves, and from the first nerve of the lumbar plexus by means of the ilio-inguinal and ilio-hypogastric nerves. The main branches of these nerves run forwards between this muscle and the transversalis abdominis, and give off their filaments to the internal surface of the muscle; some also are distributed to the muscle by the branches which perforate it in order to supply the extemal oblique.

Action.-(1) The fibres of the muscle being eurved tend to flatten upon their contraction and so to compress the viscem contained within their concavity; they will therefore help in defecation, micturition, parturition, and all expiratory efforts. (2) It will also assist expiration by drawing the lower ribs downwards. (3) When hoth muscles act together, they flex the thorax upon the pelvis. They will also flex the lumbar and lower thoraciespine. (4) When the muscle of one side acts alone, or in conjunction with the obliquus extcrnus of the other side, it will rotate the thorax to its own side. (5) The posterior fibres of the muscle will draw down the side of the thorax; it will therefore he a lateral flexor of the thorax and of the lumbar and lower clorsal spine. (6) Acting from the thorax, this muscle will flex the pelvis, rotate it to the opposite side, and by means of its posterior tibres it will act as a lateral flexor of the pelris.

Relations.- Superficially, the external ollique and latissimus dorsi; deeply, the transversalis abdominis. Its lower margin lies for a short distance in front of the inguinal canal, containing the spermatic cord in the male, and the round ligament in the female. The conjoined tencon lies internally beneath these structures. The aponeurosis of the internal ob]ique is also in relation with the rectus muscle, of which it forms the sheath in the upper three-fourths of its extent.

Variations.- Sometimes the muscle is crossed elose to its insertion intu the ribs by tendinous intersections, which probably represent ribs.

\section{Cremaster}

The cremaster (fig. 285) — named from its action as a suspender of the testide

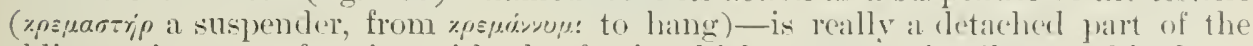
cobliquus internus, forming with the fascia which comects its fibres a thin loopshaped land, which in the male envelopes the lower part and front of the testicle and spermatic cord. In the female it is either entirely absent, or a few filores 11 wn the front of the romel ligament take its place.

Origin.-The upper and deepsurface of Poupart's ligament about its midhle point.

Insertion.-(1) The spine, and crest of the pulic hone; (2) the front of the fascia propria or infundibuliform fascia, which (urvelopes the testicle and spermaltic (o) rel.

Structure.-The fibres, which differ from all wther musels in therin seattered and separate character, spring fleshy from the concavity of Poupart's ligament on the leep aspect of the aponeurosis of the olliguns externus. in continuation of the origin of the obliguts intepnus. Throw main clivisions way he noterl:- 1 ) A series of loops which pass from this origin at difterent heights in front of the corre 
and testicle, with their convexities directed lownwarls and elosely connected with the faseia propmia of the testicle; finally, they collect into a narrow tendinoms band, which is attached to the spine and crest of the pubes. (.) A group of divergent deshy fibres, which pass from the origin downards and inwarls to be lost upon the fascia propria. (3) I smaller gromp, which desecurl from the tendinous insertion to be lost in a similar manner ipon the front of the fascia propria.

Between these fleshy fihres, which are often thin and diflicult to recognise, there is a layer of connective tissue, called the cremasterie fascia, which unites them and forms one of the coverings of the testicle and cord.

Nerve-supply.-The genital branch of the genito-crural, from the first and second lumbar nerves, gives off numerous filments whieh rnter the muscle mon its deep and posterior aspect.

Action.-To raise the testicle, and draw it upwarks towarts the extermal abdominal ring. This action is involuntary, and is usually of a reflex character, being readily excited by any irritation of the adjacent skin either of the scrotum or thigh.

Relations.-Superficially, the external oblique aponeurosis above, the intercolummar fascia, dartos, and integuments below; deeply, the spematic cord and testicle with its fascia propria.

\section{TRAMEVERSAIIS ABDOMINIS}

The transversalis abdominis-named from the general direction of its fibresis an irregularly quadrilateral eurved sheet, partly muscular, partly aponeurotic.

Origin.-(1) The inner surface of the cartilages of the last six rils, close to their junction with the ribs, by teeth which interdigitate with the attachments of the diaphragm; (2) the strong aponeurosis called the lumbar fascia, which arises (a) by its anterior layer from the front of the transverse processes of the five lumbar vertelore, $(b)$ hy its middle layer from the tips of the transwerse processes of the five lumbar vertebre, $(c)$ by its posterior layer from the general vertebral aponeurosis which is attached to the spines of the thoraeic, lumbar, and sacral rertebra; (3) the anterior two-thirds of the inner lip of the crest of the ilium; (4) the outer third of Poupart's ligament.

Insertion.-(1) The whole length of the linea alba; (2) the anterior border of the crest of the pubes; (3) the inner end of the ilio-pectineal line for about one inch and a half $(4 \mathrm{~cm}$. ).

Structure.- Arising by short tendinous intermixed with fleshy fibres, the muscle passes transversely forwards, diverging slightly to its insertion. "The change from Heshy to aponemrotie fibres is in a curved line, the upper and lower extremities of which approach the linea alba more closely than in the eentral part of the muscle. In the upper part the fleshy fibres are orerlapped in front by the rectus muscle; and at the lower border of the musele where it terminates in a small arch, passing over the spermatic cord or romd ligament, the fleshy fibres cease just above thr midclle of Poupart's ligament. The muscles of the two sides, joined as they are by the central aponeurosis, may be looked upon as a single muscle with a central aponeurosis, like the diaphrigun.

In its mper three-fourth the anterior aponeurosis is closely hlended with the posterior division of the aponemosis of the internal ollique muscle, and forms the hincler part of the sheath of the rectus in this region. In the lower fourth, the anterior aponeurosis is blended with the undivided aponeurosis of the internal ohligure and passes in front of the rectus muscle and the prramidalis.

The posterior aponeurosis, or lumbar fascia, (consists of strong transwerse filores. The milllle layor is the strongest, and has in its substance fibrous lands passing ontwards from the tips of the transverse processes of the lumbar vertebre, and continume the series of the ribs connceted with the dorsal transwerse proceses. Botween this midlle laver and the anterior layes which springs from the front of the tips of the transirese processes is placed the quatratus lumbormm: and a thickening of this antrior layer pasing from the tips of the transwerse processes of the first and secomel lumbliar rertehre to the lowest rib, called the ligumentum 
arcuatum externum, gives origin to a part of the diaphragm. Between the micllle and posterior layers is placed the ereetor spinde muscle. This posterior layer blemels with the vertebral aponeurosis, and gives origin to the latissinus dorsi, the serratus posticus inferior, and other muscles.

Nerve-supply.-The anterior primary branches of the lower thoracic nerves and the ilio-1 ypogastric and ilio-inguinal branches of the first nerve of the lumbar plexus. The nerves as they run forward between this muscle and the obliquus internus distribute filaments to its outer surface.

Action.-The muscles of the two sides with their intervening aponeurosis form a strong girth round the aldeminal viscera, and by their contraction compress most powerfully the contents of the abdomen.

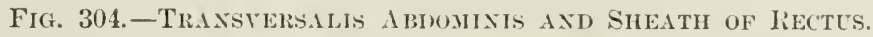

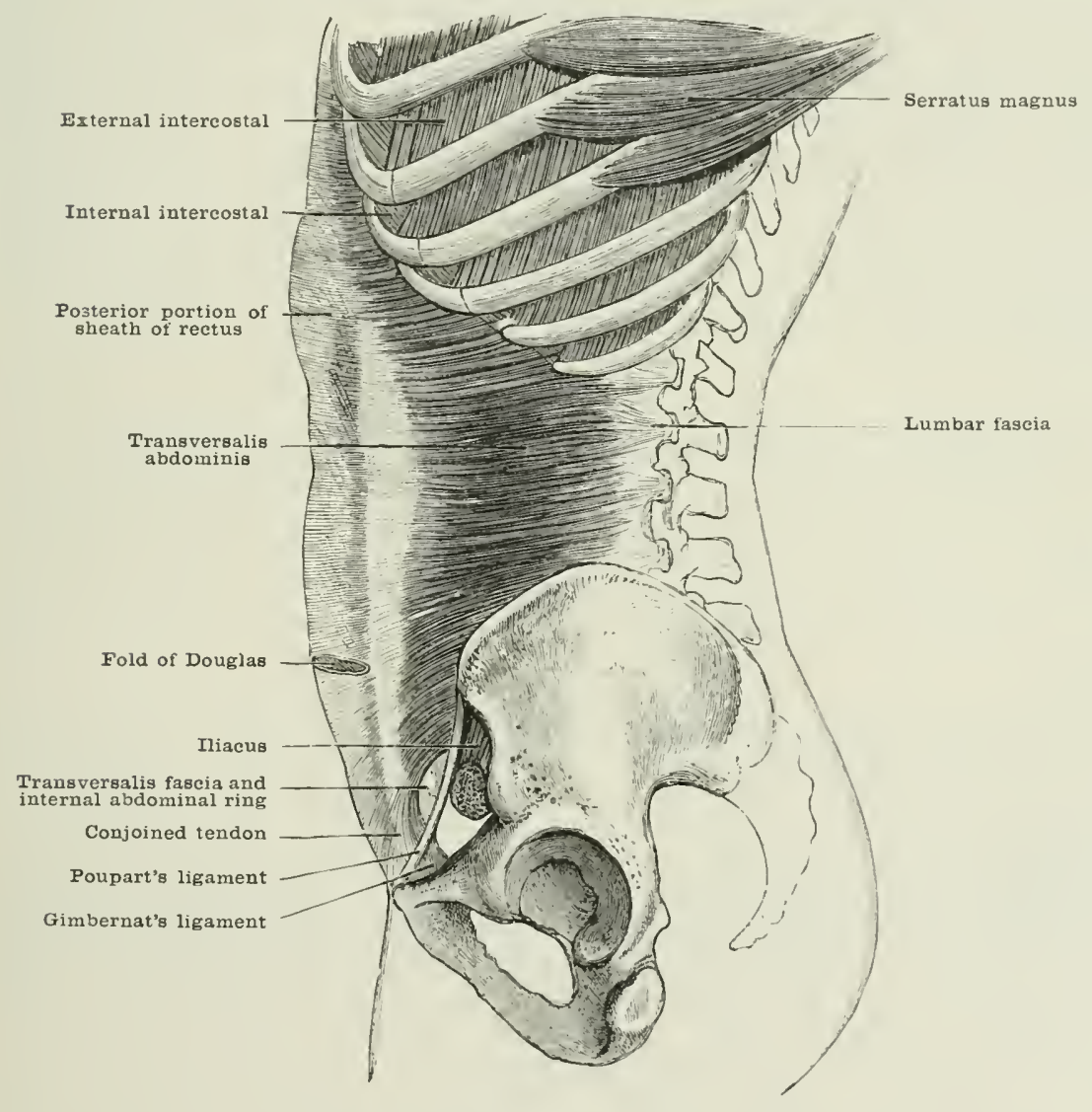

It will thus be seen that the three layers of the transverse muscle in the abdominal wall cross one another at various angles, one pair passing transeresely forwards, a second forwards and upwards, and a third forwards and downardi. The following objects are ganeel by this arrangement: (1) the wall is rendered much stronger, and the probability of a hemial protrusion of any portion of the viscera between the separated fibres of the muscles is diminished; (2) contraction of the wall is permitted in every direction; (3) greater alpuroxination of the moriable boundaries of the abdominal wall is: obtamed by means of the obliguity of the muscles which effect this morement. For cxample two parallel hones can have the distance between them diminished only by one lalf, supposing that the muscular fibres producing this morement run perjendienlarly from one bume to the other: but if the fibres cross one another ohliguely, like these of the external and internal 
oblinue muscles, in pasing from the crest of the ilium to the lower ribs, a much mere complete alproxination of the homes is effected.

Relations. - Fuperficially, the ollipuus internus. the eartilages of the lower ribs, some small ressels. ant the lower interenstal nerve; above, it is eontinuous with the bover borter of the triangularis stemi; below, it lies above the spermatic cord or round ligament, and its conjoined tendon lies for a short distance beneath these structures; decply, the transersalis fascia which separates it from the peritonemin.

The sheath of the rectus is former by the aponeuroses of the three preceling museles. "That of the obliquus internus divides into an anterior and posterior" layer. The anterior layer blenderl with the aponeurosis of the obliquus externus forms the front portion of the sheath. Mbove, it is attached to the cartilages of the fifth, sixth, and serenth rihs; and internally it blends with the posterior portion of the sheath along the linea alba. The posterior portion of the sheath is formed by the posterior layer of the aponeurosis of the obliquus internus. Which is blended with the aponeurosis of the transversalis. Above, it is attached to the lower edge of the cartilages of the seventh and eighth ribs, and to the ensiform cartilige. Internally it blends with the front portion of the sheath along the linea alba. Rather nearer the umbilicus than the pubes, the posterior portion of the sheath becomes suddenly much thinner and weaker at the fold of Douglas, which is a transverse line indicating that the fibres of the abdominal aponemroses which have down to this level formed the posterior portion of the sheath, now pass to its front wall. Below this level the posterior portion of the sheath is formed by a thickening of the transversalis fascia (page 411).

\section{POSTERIOR VERTICAL IIUSCLE-QUADRATUS LUMBORUM}

The quadratus lumborum (fig. 286) -named from its approximately square shape and its position in the region of the loins-is a thick quadrilateral sheet.

Origin.-(1) About two inches (5 cm.) of the inner lip of the crest of the ilimm at the junction of its middle and posterior thirds; (2) the ilio-lumbar ligament; (3) the tips of the transrerse processes of the three or four lower lumbar rertebrie.

Insertion.-(1) The inner half of the lower border of the last rib; (2) the tips of the transverse processes of the upper three or four lumbar vertebre; and (3) the fibrous continuations which pass out from these transrerse processes in the substance of the midclle portion of the lumbar fascia, and which represent the abdominal ribs.

Structure.-This muscle varies consiclerably in its structure and arrangement, the origins from, and insertions into the transverse processes differing much in different subjects. Its origin is usually by short tendinous intermixed with fleshy fibres, and extends at its lower part all along the ilio-lumbar ligament, and behind the attachment of this ligament from the inner lip of the erest of the ilium. The fibres converge somewhat as they ascend; the outermost, passing upwards and inwards to the midelle print of the lower horder of the last rib, white the inner fibres pass vertically upwards along the tips of the transverse processes of the lumbar vertshre, from which they receive short tendons, and they sometimes give tentinous slips to these proceses. On the anterior and posterior surfaces of the nuscle are often secen asending fibres from the transverse processes, which diverge slightly hofore they are inserted into the lower border of the last rib.

Nerve-supply.-From the twelfth thoracic and upper lumhar nerves, by filaments which enter the muscle upon its anterior surface near its inner border.

Action.-(1) It will draw downwals the last rib, and will therefore act as a lateral fiexor of the therax as woll as of the lower thoracie and the lumbar spine; $(\bullet)$ it will assist in exprimtion by drawing ${ }^{\bullet}$ lown the last rib; (3) taking its fixed point from the last rib, it will draw upwark the erest of the ilium, and so act as a lateral flexor of the polvis upon the thorax.

Relations.-In front lie the kidney, the colon, the psoas, the lumbar arteries and newes, separated from it hy the anterior hace of the lumbar fascia. Behind, 
the mildle layer of the lumbar fascia separates it from the erector spina, and along its inner border are placed the intertransversales.

The transversalis fascia, which lines the interior of the muscular portion of the ablominal parietes, is a thin layer of connective tissue. It is best marked in the lower part of the front of the aldomen, where some of the muscular and aponeurotic layers are deficient. Below; it is attached to the inner border of the whole length of the crest of the ilium, and to the outer half of Poupart's ligament, where it blends with the iliae fascia corering the iliacus muscle. Beneath the inner latf of Poupart's ligament it is somewhat thickened, and ealled the deep crural arch. This is but loosely attached to l'oupart's ligament, and the fascia is continued into the thigh, where it forms the front of the sheath of the femoral vessels. Internally to this, it is attached to the free margin of Gimbernat's liganent. and the inner end of the ilio-pectineal line. Further inwards it is inserterl along the posterior border of the crest of the pubes. At the back of the linea alba it is continuous with the fascia of the opposite side. Behind the lower part of the rectus muscle it is thickened, and takes the place of the posterior portion of the sheath from the pubes to the fold of Douglas. Above, it becomes thin and blends with the faseia covering the under surface of the diaphragm; and behind, it is lost in the loose fat which covers the posterior surface of the kidneys, together with the back of the aseending and descending colon.

About half an inch $(1.2 \mathrm{~cm}$.) above Poupart's ligament, half way between the anterior superior spine and the symphysis pubis, it is perforated by the spermatic cord in the male, and the round ligament in the female. To the margins of the opening, which is called the internal abdominal ring, is attachert a tubular prolongation, the infundibuliform fascia, which invests the cord or round ligament. The comnection of this tube to the rest of the fascia may be compared to the attaehment of the sleeve to a coat. No opening is therefore visible from the exterior until the sleeve-like tube has been divided.

\section{MUSCLES OF THE BACK}

The first and second layers have already been descrilued, as they belong to the groups of museles whieh pass from the thorax to the bones of the upper extremity. The third layer consists of muscles whieh stretch in a nearly transyerse direction from the spinous processes of the vertebre to the back of the ribs, viz. the serratus posticus superior and the serratus posticus inferior.

\section{TIIIRD LAYER}

\section{SERRATLS POSTICLS SLPERIOR}

The serratus posticus superior-namel from its saw-like edge and its relation to the other serrati-is a quadrilateral sheet with a touthed outer margin.

Origin.-(1) The outer surface of the lower part of the ligamentum nucha near its posterior edge; (2) the spines of the last cervical and first two thoneic vertebre, and the supraspinous ligament eonneeting them.

Insertion.-The upper borders and outer surfaces of the seennd to the fifth ribs. extermal to their angles.

Structure.-The inner half is a tendinous sheet, the fibres of which rum downwarks and outwards, and when they have passed heyond the line of the transwerse proesses they heeome fleshy and are inserted into the ribs by the lower lorders of the four teeth into which the muscle divides. 
Nerve-supply.-From the second and third intercostals by fine filaments which enter the outer part of its deep surface.

Fig. 305.-The THird AND Folrth LaYers of the Miscles of the bick.

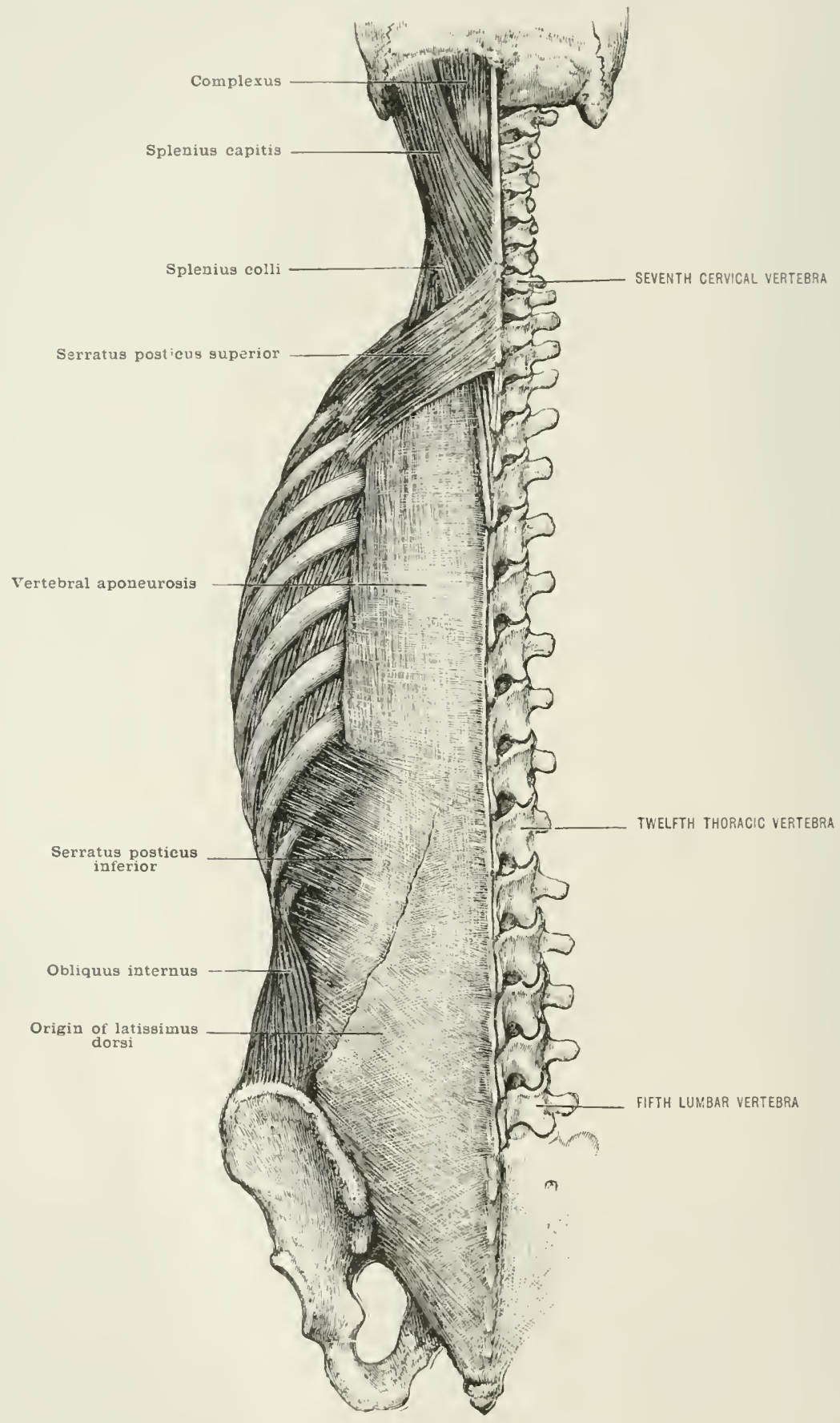

Action. -To raise the rils into which it is inserted; and therefore to assist in inspuration. 
Relations.-Superficially, the trapezius, levator anruli scapula, rhomboidens minor and major; deeply, the rertehral aponeuresis which separates it from the splenius and the more superficial spinal muscles; farther outwards the muscle covers part of the external intereostals.

Variations.-The slips vary in number. Sometimes it gives off a slip from its upper borter or posterior surface which goes to the levator anguli scapule, the mistoid lnocess, or the superior nuehal line.

\section{SERRATLS POSTICLS INFERIOR}

The serratus posticus inferior-named also from its outer saw-like margin, and its position-is a quadrilateral shect.

Origin.-The spines of the two lower thoracic and two upper lumbar vertebra.

Insertion. - The lower borders of the last fom or five rils external to their angles, except in the case of the last rib which has no angle; and as far forwards as the costal origins of the latissimus dorsi.

Structure.-More than half of the muscle is aponeurosis, which is blended with that of the latissimus dorsi on its superficial, and of the erector spine on its deep aspect, and forms a part of the vertebral aponeurosis, which blends with the posterior layer of the lumbar fascia. The fleshy fibres are directed upwards and outwards from this aponeurosis, arising in an oblique line which is nearer the spine above than below, and inserted directly, or with small tendinous attachments into the ribs. Each succeeding tooth slightly overlaps, and extends farther forwards than the one below. The middle teeth are the largest.

Nerve-supply.-Filaments from the tenth and eleventh intercostals which enter the deep surface of the outer part of the muscle.

Action.-(1) To depress the lower ribs; (2) to fix them, so as to enable the diaphragm to contract. It is therefore in this respect a muscle of inspiration.

Relations.- Superficially, the latissimus dorsi; deeply, the erector spinæ with its upward continuations, also the levatores costarum, and the external intercostal muscles.

\section{GENERAL ARRANGEMENT OF THE MLSCLES AC'TING UPON THE SPINAL COLUMN}

\section{THE VERTEBRAL APONELROSIS}

Beneath the serrati postici are arranged what may be called the muscles of the back proper, viz. those which move the vertebral column and act chiefly upon the spines and transverse processes of the vertebre and the parts of the skull which are serially continuous with them. They lie for the most part in the groore on either side of the spines of the rertehre, and they are hound down and protected ly the strong vertebral aponeurosis which is blended below with the tendinons origin of the latissimus dorsi, the serratus posticus inferior, and the erector spina. Laterally, it is attached to the angles of the ribs; and internally, to the spines of the vertehrie and the supra-spinous ligament. Above, it passes beneath the tendon of the serratus posticus superior, and is then lost in the thin fascia corering the splenii.

The back muscles proper may be arranged aceording to their clirection into two great divisions, each of which contuins two class's. The vertical division consists of muscles which run hetweon similar points of bone, and it: two claseres will contain the spinales, which comnert the spines of the vertehre with one another and with the mesial portion of the necipital bone; the tronsersales. which connect the transverse processes of the sacral and lumbar regions with the trmsverse processes and the adjacent portions of the ribs in the thorar is region. the articular and transwerse processes in the cervical region. and the mastoid process at the upper end of the spinal colmmn. The oblique division eonsists of musces whith rum ohliguely, and contains two classes: the spinn-tidnsersules, which run upwards and outwardis from spine to transwerse process, or to a joint of bone which enresponds 
to a trinsverse process, e.g. the mastoid process: and the transcerso-spinules. which run upwards and inwards from transwerse process to spine.

The action of these muscles will be easily asertained hy ohserving to which class they belong. The spinales will simply extemel. while the transersales will promluee lateral flexion as well as extension. The oblique. in arddition to extension and lateral flexion, will also prolnce rotation whererer the ligaments and processes of the vertehre permit of this morement.

\section{Focrth LaY'er}

The fourth laver of the muscles of the lack consists of two muscles. which are closely connected with each other, and belong to the spino-tianscersulis class of the oblique division.

\section{AND 2. SPLENILS}

The splenius (fig. 30.5) - named from $\sigma$ aiviru, a bandage or compress, probal)ly on account of the way in which it erosses orer and binds down the complexus and other muscles - is a broad four-sided sheet, divided into two parts at its insertion: the one part being the splenius capitis, and the other the splenius colli.

\section{(1) Splexil's Capitis}

Origin.-(1) The lower two-thirds of the ligamentum nuchr; (2) the spines of the seventh cervical and upper two thoracic vertebræ, and the interspinous ligaments between them.

Insertion.-The outer third of the middle nuchal line of the occipital bone, and the back part of the outer surface of the mastoid process of the temporal bone.

Structure.-Arising by a short tendinous aponeurosis, the fleshy fibres pass upwards and outwards parallel to each other, and are inserted by short tendinous filnes, except along the anterior border, where the tendon of insertion extends more than an inch $(2.5 \mathrm{~cm}$. ) downwards.

Nerve-supply.- The external branches of the posterior primary divisions of the middle cerrical nerves which enter the outer part of the deep surface of the musele.

Action.-(1) To extend the head and neck; (2) to flex them laterally; (3) to rotate the face to the same side.

\section{(2) SPlexit's Colli}

Origin.-The spines of the thind to the sixth thoracie vertebræ, ant the interspinous ligaments between them.

Insertion. - The back of the posturior tubercles of the transverse processes of three or four upjer cervieal vertehrat.

Structure.-Of parallel fleshy fibres with a short aponemotic origin, and inserted by small tentons, the highest of which is the largest.

Nerve-supply.-The external branchas of the posterior dirisions of the lower cervical nerves:

Action.-(1) To extend the upper part of the nerek; (2) to flex it laterally; (3) to rotate it to the same sirte.

Relations of the splenius. - Superficially, the stcrno-mastoirl, trapezius, scrratus posticus superior, and the levator anguli scapula which conceals the splenius colli in the posterior triangle of the norek. limenth lie the complexus, trachelomatoid, cervicalis ascentens, and transversalis colli.

Variations.-The number of the thoracic vertelore from which the splenii arise varies. The splenius colli may he alsent. The slip mentioned in the variations of the serratus posticus superior may be considered to be a variation of the splenii. 


\section{FHTH LAYER}

The fifth laver consists of vertical muscles, and contains both spinales and transversales. To the latter class belong the greater part of the erector spine ancl the seren muscles which either spring from it or are serially continum with it: viz. the ilio-costalis, accessorius ad ilio-costalem, crevicalis ascendens, longisimus dorsi, transversalis colli, trachelo-mastoid, and the spinalis dorsi.

\section{ERECTOR SPIYE}

The erector spinæ-named from its function-is a lroad and rery strong membranous sheet of a triangular shape, with a larer of fleshy fibres umon its deep surface, and it divides in the lumbar region into three longitudinal series of muscles which fill the greater part of the vertebral groove.

Origin.-(1) The spines of the two last thoracic, all the lumbar, and the four upper sacral vertebre; (2) the back of the sicle portion of the fourth sacral vertebra; (3) the posterior sacro-iliac ligament, a few of these fibres heing continuous with the origin of the gluteus maximus; (4) the upper part of the posterior superior spine of the ilium, and the posterior fifth of the iliac erest.

Insertion.-It is continuous with the spinalis dorsi. longissimus dorsi, and ilio-costalis.

Structure.-A strong membranous sheet, everyhere continuous except at the origin from the lower thoracic and upper lumbar spines. where it is partly divided into separate tendons.

It breaks up into fleshy fibres in a line which stretches obliquely upwards and inwards from the front of the iliac origin to the last thoracic spines. Fleshy fibres also arise upon its deeper surface at a lower level, and some arise directly from the posterior superior iliac spine and the erest under cover of the tendinous origin.

Nerve-supply.-The external branches of the posterior divisions of the lumbar nerves which enter its deep surface.

Action.-Generally, that of extension of the lumbar spine on the pelvis; but a full account will be given with the description of the succeeding muscles.

Relations.- Superficially, the rertebral aponeurosis, with whieh it is blenderl at its origin and for the first two inches ( $5 \mathrm{~cm}$.) of its course. Br this aponeurosis it therefore enters into a close relation with the lower part of the tendons of the latissimus dorsi and serratus posticus inferior. Deeply, the multifidus spine, some of the fibres of which arise from it.

The outer division extends upwards along the angles of the ribs and the transverse processes of the lower cervieal rertebre, and eonsists of the ilio-eostalis. accessorius ad ilio-costalem, and the cervicalis ascendens. It is seprarated from the middle dirision by the external branches of the posterior divisions of the spinal nerves.

\section{Oeter Divisios}

\section{ILIO-COSTALIS}

The ilio-costalis, or sacro-lumbalis-named from it. attar.hment to the ilimm and ribs-is an elongated muscular shert. with a serrated outer border formed by the insertion of its tentons into the lower rils.

Origin.-The onter portion of the erector spince.

Insertion.-(1) The angles of all the lihe flom the sixth to the eleventh; (2) the lower border of the last rib: (3) the tips of the transwerse proceses of the lumbar vertebre. and the fibrous processes which extend outwarts from the tips of the transwerse processes of the upper lumbar rertehre into the lumbar fascia. 
Fig. 306.-Tile Fiftil Layer of tie Miscles of the Bick.

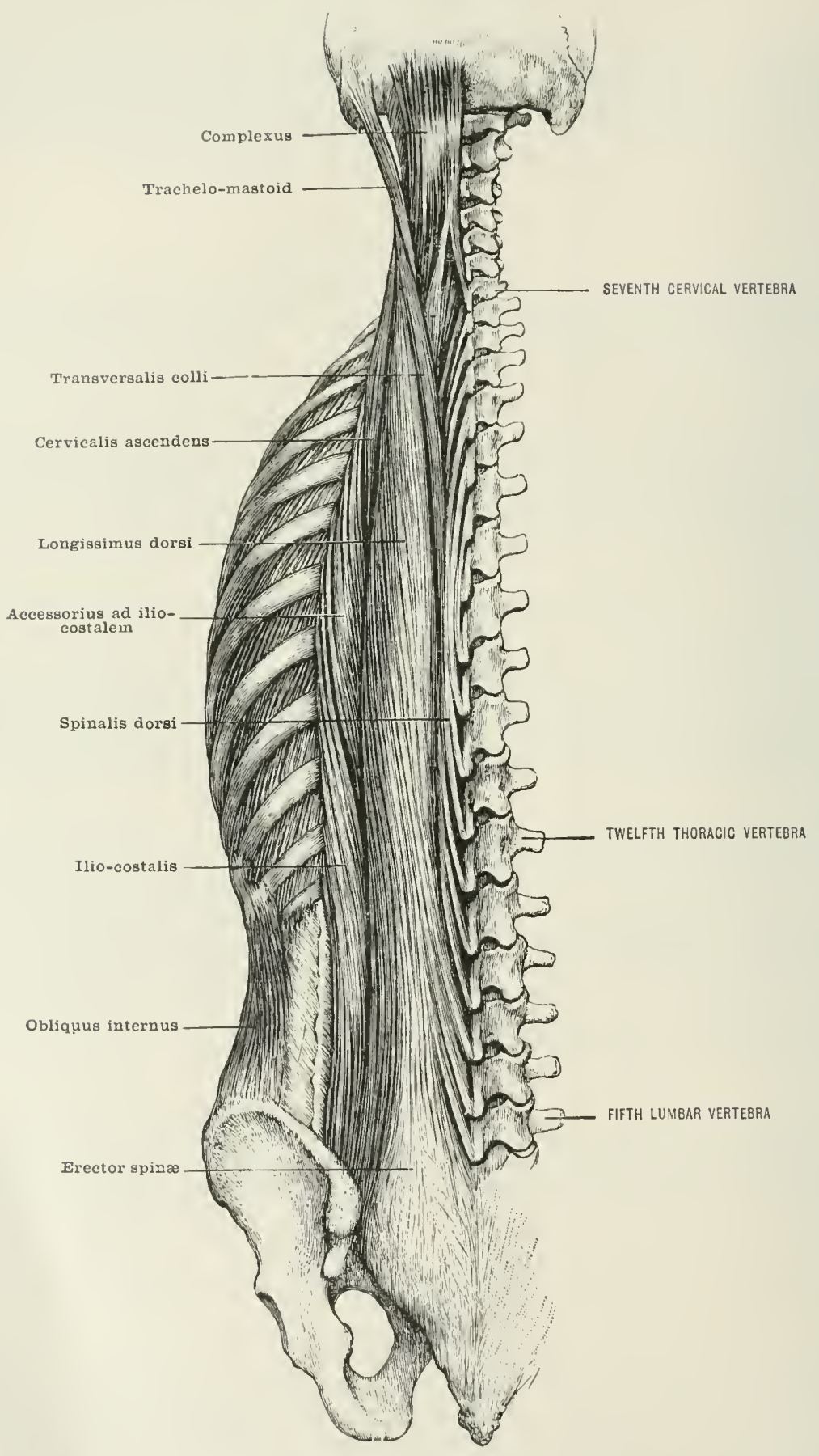

3. ICCESLORITS AD ILIO-COSTALEN

Thr accessorius ad ilio-costalem or ad sacro-lumbalem-named from its hrong an ancessory or arlition to the ilio-costalis-is a narow museulo-tendinous hamel with a serrated margin on either side. 
Origin.-The upper borders of the angles of the seventh to the eleventh ribs and the back of the last rib.

Insertion. - The back of the transerse process of the seventh cervical rertehra, the first rib just external to its tuberche, and the angles of the second to the fifth rils.

\section{CERTICALIS ASCENDENS}

The cervicalis ascendens-named from its position in the neek and its direction-is a still thinner musculo-tendinous band with serrated margins.

Origin.-The hack of the four or five upler ribs just internal to the insertion of the precerling muscle.

Insertion.- The back of the transverse processes of the fourth, fifth, and sixth cervical vertebre.

Structure.-These three sections form a compound muscle, composed for the most part of fusiform bellies with tendinous origins and insertions, placed in series so that the origins of the higher slips are on a level with the insertions of those that arise six or seven vertebre or ribs lower down. The lowest of the series arise directly from the muscular mass of the erector spine; and the insertions of these Jower slips, especially those into the lumbar fascia and last rib, are fleshy. A part of the tendinous origin of the slips of muscle is so closely blended that a complete separation of the muscle into its component parts is impossible. There is a gradual diminution of the size of each component musele and its tendons as we trace the compound mass upwards.

Nerve-supply.-The extemal branches of the posterior divisions of the spinal nerves from the lower cervical nerves to the last thoracic.

Action.-(1) To extend the vertebral column, in the lower cervieal, thoracic, and upper lumbar regions; (2) to flex it laterally in these regions; (3) to depress the ribs, and so help in expiration.

Relations.- Superficially, the trapezius, rhomboirlei, latissimus dorsi, the serratus posticus superior and inferior, and the two sylenii; deeply, the intercostal muscles and the levatores costarum; internally, the museles of the middle division, and the external divisions of the posterior spinal nerves.

\section{Midple Division}

The middle division extends along the back of the transverse processes of the lumbar and thoracic vertebre, the articular processes, and adjacent prirt of the transrerse processes of the cervical vertebre, and ends at the mastoid process of the temporal bone. It consists of the longissinus dorsi, transrersalis colli, and trachelo-mastoid.

\section{LONGISSIMILS DORSI}

The longissimus dorsi-named from its great length and its position in the dorsal region-is a compound muscle forming a long band. with its surfaces directed outwarels and inwards, and an anterior margin provided with an outer and inner row of teeth by which it is inserted.

Origin.-(1) The miklle part of the erector spina; and (2) the transwerse processes of some of the lower thoracie vertebre.

Insertion.-Externally: (1) the lower border of the back of the transworse processus of the upper lumbar vertebra; (2) the lower borker of the ribs just exturnal to thrir tuhercles. Internally: (1) The acessory tulereles of the upruer lumbar and lower thoracie rerteh)rax; and (2) the back of the transwerse processes of the rest of the thoracic rertelore. 
FIG. 30\%, - THE FIFTI LAYER OF THE MUSClEN OF THE BACK, AFTER SEPARATIAG TIIE UUTER AXD MIDLLE DIVISIONS.

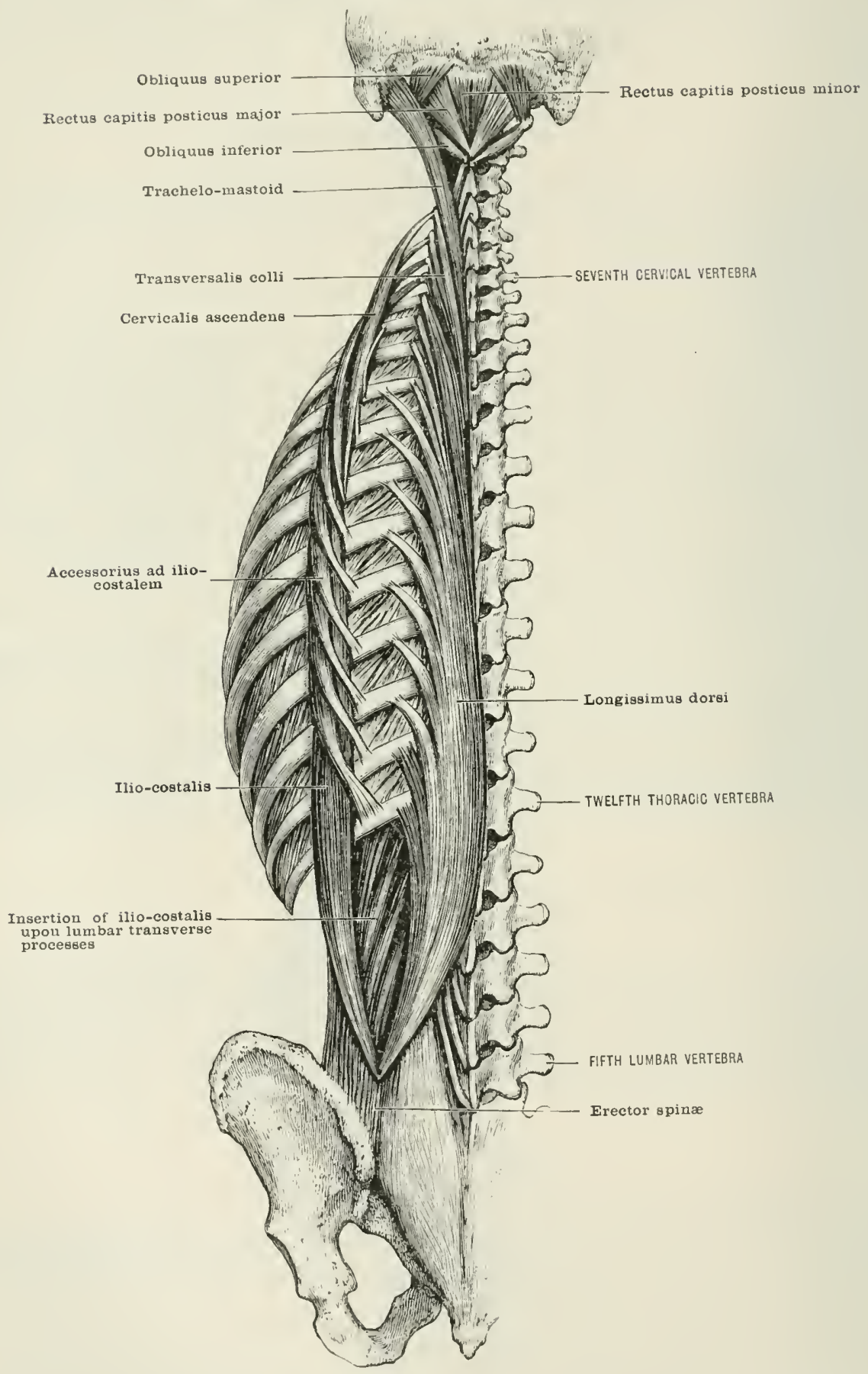

\section{TRANGYERAALIS COLLI}

The transversalis colli-namel from its attachment to the transverse processes and its insertion in the neck-is a similar hut narrower musenlo-tendinous band. 
Origin.-The back of the transverse processes of the five or six upper thoracic vertehra, internal to the insertion of the preceding muscle.

Insertion. - The postrior tubercles of the transverse processes of the second to the sixth cervical rertebrae.

\section{TRACHELO-MLASTOID}

The trachelo-mastoid-named from its origin, part of which is in the neck (spriygins), and its insertion upon the mastoid process-is a similar but smaller musculo-tendinous band.

Origin.-(1) The back of the articular processes of the lower three or four cervical rertehre; (2) the back of the transrerse processes of the four or five upper thoracic vertebre.

Insertion.-The posterior border of the mastoid process.

Structure of the middle division.-The three parts of this clivision have a close connection with one another, and a long tendinous expansion which covers the inner and back part of the longissimus dorsi, is common to it and the spinalis dorsi.

The association of the two upper portions of the livision is so close that they are sometimes described together muler the name transversalis, the trachelo-mastoid being called the transversalis capitis to distinguish it from that part of the muscle which is inserted into the neck. All the upper lements of this long compound muscle have tendinous origins and insertions.

The trachelo-mastoid portion is often found to have a tendinous intersection crossing its fleshy fibres.

Nerve-supply.-The external division of the posterior branches of the lower cervical, all the thoracie, and the upper lumbar nerves.

Action.-(1) To extend the cerrical, thoracic, and lumbar spine; (2) to flex it laterally; (3) to extend and laterally flex the head, rotating the face to the same sicke.

Relations.-Superficially, it is covered by the latissimus dorsi, trapezius, rhomboidei, serratus posticus inferior and superior, and the two splenii; upon its inner border lie the spinalis dorsi and complexus. Tpon its outer lie the muscles of the outer division and the external divisions of the posterior branches of the spinal nerves. Beneath lie the multifidus spince and the semispinales dorsi et colli.

\section{Trxer Divisiox}

The inner division consists usually of a single muscle the spinalis dorsi; but sometimes a small muscle, the spinalis colli, continues the series into the neck.

\section{SPINALIS DORSI}

The spinalis dorsi-named from its attachment to the spines in the dorsal region-is a musculo-tendinous band closely connected below with the anoneurosis on the back of the lomeissimus dorsi.

Origin.-The erector spine, and especially that part which is attached to the two or three lower thomeie and the upper lumbar spines.

Insertion.-The spines of the upper thoracie rertebre.

Structure.- Cpon its posterior surface it is coverel by a thick aponeurosis, from the upper edge and anterior surface of which fleshy fibres pass almust directly upwark, and are then inserted hy means of four to cight tenchus into as many of the upper thoracic spines. They are closely blented with the tendons of the semispinalis dorsi at their insertion.

Nerve-supply.-The posterior hranches of the thoracic nerres.

Action.-To extent the thoracic spine. 
Relations.-Fiperficially, the two serrati postici, the latissimus dorsi, the rhomboidei and splenii; externally, the longissinus dorsi; deeply the semispinalis dorsi and complexus.

Variations of the erector spinæe and its divisions.-The number of ribs or vertebra from which the varions parts of these divisions arise, or into which they are inserted, varies much. The insertions upon the lumbar vertelnae are often less numerous than those described. Ocealsionally the lonerisimus dorsi receives accessory filnes from the lower ribs. Sometimes the purtion of the longissimus dorsi, which arises from the transrerse processes of the lower thoracie vertebra, is separate flom the rest of the muscle, and is inserted into the transverse processes of some of the upper thoracic vertebrie.

\section{SIXTH LAYER}

The sixth laver, or rather group, consists of four strata of oblique muscles belonging to the class of transverso-spinales; the deepest stratum being forned by a siries of smail muscles which run upwards and inwards from the back of one vertehra to that of the next above it; while the other strata run in the same dircetion but less oblicpuely, so as to cross over the backs of several vertebre before reaching their insertion.

\section{COMPLEXLS}

The complexus, or semispinalis capitis (fig. 306)-named from the complex or complicated arrangement of the museular bundles which were formerly inchuded moler this designation, viz. the complexus, trachelo-mastoid, fe.-is a musculotendinous band somewhat constricted about its middle.

Origin.-(1) The hack of the articular processes of the cervical vertebra from the third to the sixth; (2) the back of the transwerse processes of the seventh cervical and the six upper thoracic vertebra; (3) generally also by an inner head from the spine of the seventh cervical vertebra.

Insertion.-The under surface of the occipital bone between the middle and inferior muchal lines from the middle line for nearly two inches ( $5 \mathrm{~cm}$.) outwards.

Structure.-A rising by tendinons slips, the fleshy fibres pass upwards and slightly inwards, and are inserted either directly into the occiput or by a short aponeurosis which covers the thick part of the nuscle near its outer border. On their way, the innermost fibres are intersected by a transverse tendinous band opposite the sixth cervical spine, and this part of the muscle, being thus divided, is often called the biventer cervicis. There is usually also a smaller tendinous intersection across the posterior surface of the muscle at a higher level.

Nerve-supply.-From the suboceipital and great occipital nerres, and from the internal divisions of the posterior branches of the three or four following cervical nerves which enter the deep surface of the muscle.

Action.-To extend the head, to flex it laterally, and to rotate the face slightly to the opposite side.

Relations.- It is covered by the trapezius and the two splenii, and it lis upon the muscles of the suboceipital triangle and the somispinalis colli, the rertebral artery and the anastomosis between the arteria prineeps cervicis and the arteria profunda aervieis. It is piereed by the great ocoipital nerve. Internally it lies elose to the ligamentum nuche; and externally, to the trachelo-mastoid and transversalis colli.

Variations. - The imner head may arise from several of the thoracie spines as well as that of the seventh rervieal vertehra. Sometimes a secoml and smaller complexus runs beneath the normal inusele from the upper thoracic vertetrae to the head.

\section{SEMISPINAIIS DORAI}

The semispinalis dorsi-named from the fact that the inner half only of the muscle, i.e. its insertion, is attarehed to the spines of the vertehre, and from its situation in the dorsal rexion-is a rather feehle compound musele, consisting of a series of small muscles with tendinous axtremities. 
Origin.-The back of the transverse processes of the sixth to the tenth thoracic vertebrie.

Fig. 308.-The Sixth LAYer of the Mitscles of the Back.

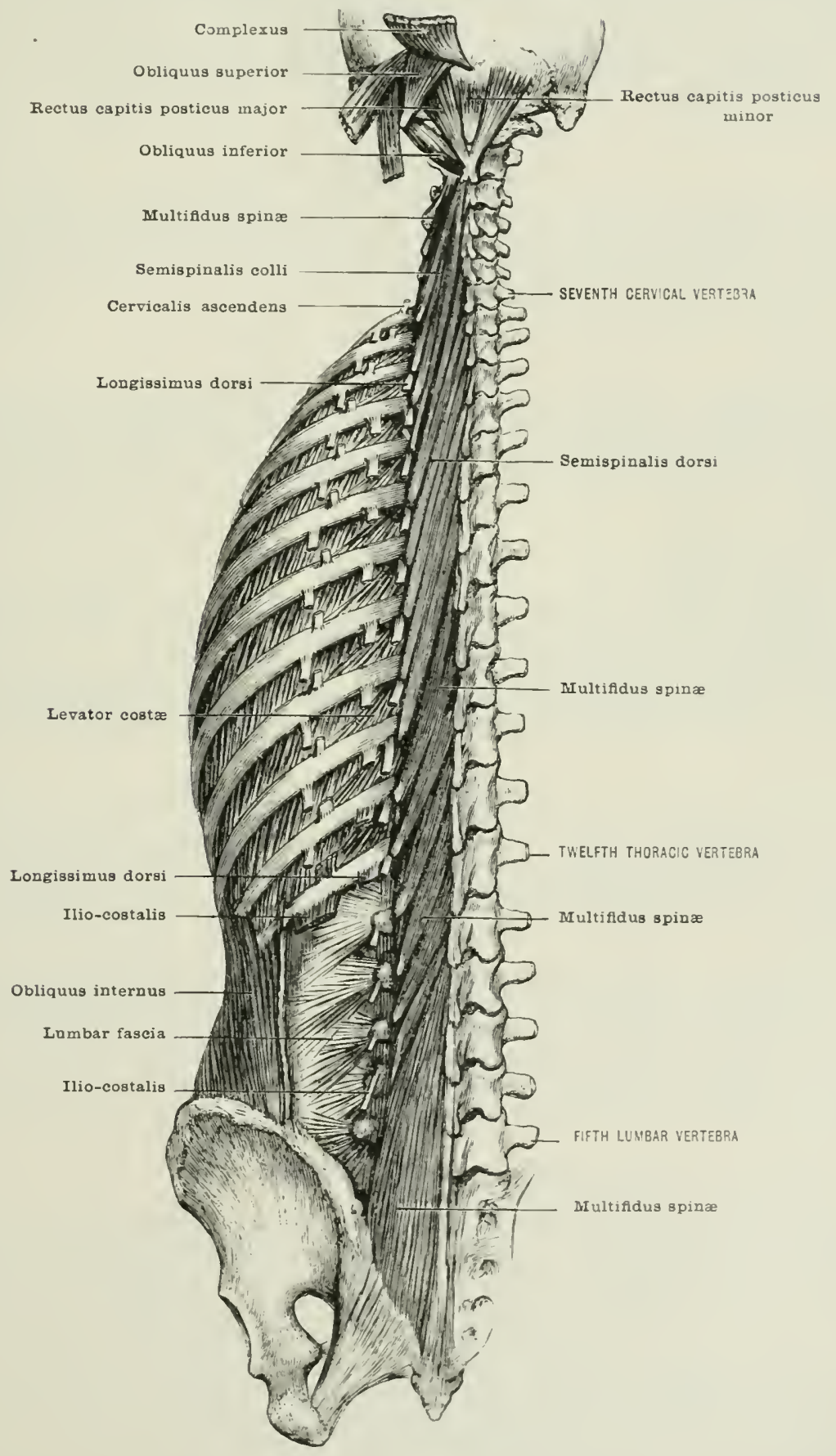

Insertion. - The spines of the last two cervical, and first four thoracic vertehra. Structure.-Arising ly long slender tendons, the fleshy filmes form at thin sheet 
which runs upwards and inwards, and then breaks up again into short tendons of insertion. Eisch muscle bridges orer six or seren vertehrax.

Nerve-supply. - The internal elivisions of the posterior branches of the thoracic spinal nerves.

Action.-To extend and laterally tlex the lower cervical and upper thoracic portions of the spinal column. The upuermost tendons will also assist in rotating the lower part of the neck to the "ruposite side.

Relations.-superficially, the spinalis and longissimus dorsi; deeply, the multificlus spina.

\section{SEMISPINALIS COLLI}

The semispinalis colli-named from the attachment of one-half the muscle, i.e. the insertion, to the spines of the cervical vertehre-is a somewhat triangular sheet, with a serrated base placed vertically along the transverse processes, and the apex at the spine of the second cervical rertebra.

Origin.-The back of the transverse processes of the five or six upper thoracic vertebrie.

Insertion.-The spines of the seeond to the fifth cervical vertebre.

Structure.-Arising by short tendons, the fleshy fibres pass upwards and inwards, bridging over in their course five or six vertebre, and are inserted by still shorter tendons into the spines of the cerrieal rertebre. The highest is by far the largest.

Nerve-supply. - The intemal divisions of the posterior branches of the lower cervical nerves, the upper ones entering the muscle on its superficial, and the lower on its deep aspect.

Action.-(1) To extenri; (2) to flex laterally; (3) to rotate to the opposite side. the second and following cervical vertebre.

Relations.- - iuperficially, the complexus, from which it is separated hy branches of the posterior cerrical nerves and the anastomosis of the arteria profunda cervicis with the arteria prineefs cervicis; deeply, the nultifidus spinx.

\section{MULTIFIDUS SPINE}

The multifidus spinæ-named from its many divisions (multus, many; findo, to eleare) -is a compound muscle, fleshy and thick in the sacral and lumbar regions, but beeoming thin and more aponeurotic in the thoracic and cervical regions.

Origin.-(1) The groove in the back of the sacrum, hetween the spines and the elevations which represent articular processes, the posterior saero-iliae ligaments, and the deep surface of the tendon of the erector spina; (2) the mammillary processes of the lumbar vertebre; (3) the back of the transverse processes of all the thoracic vertebre; (4) the articular processes of the fourth to the sixth cervical vertebre, and the back of the transverse process of the seventh cervical vertebra.

Insertion.-The lower horders of the spines of the vertebre from the last lumbar to the second cervical.

Structure.-Arising hy tendinous fibres superficially, but by fleshy filores decply, the bundles of ach rlement of the muscle diverge, the nore sujuerficial ones running obliquely upwards and inwards so as to bridge three vertebre. while the deeper ones pass more transversely to the third. second, and in the neck, the next rertebra above. Consequently, the more superficial fibres from one vertebra overlap the deeper ones from somse of the vertebra above.

Nerve-supply.- The internal livisions of the posterior branches of the spinal nerves from the second cervieal to the third sacral.

Action.-To exteme laterally flex, and to rotate to the opposite side, the various parts of the spinal columin.

Relations.—-Cuperficially, the erector spine, longissimus and spmalis dorsi, the remispinalis dorsi and colli; deeply, the rotatores spine. 


\section{ROTATORES SPINE}

The rotatores spinæ-named from the rotatory action which they impress upon the spine-are small rhomboidal sheets, chiefly found in the thoracic region, where they form a series of eleven pairs, but occasionally found also in the upper lumbar and the lower cervical regions.

Origin.-The back and upper border of the transverse process.

Insertion.-The lower boreler of the lamina of the next vertebra above.

Structure.-Sheets of parallel fibres, almost entirely fleshy, which run upwards and inwards.

Nerve-supply.-The internal divisions of the posterior mimary branches.

Action.-To rotate to the opposite side, and also to extend and laterally flex, the rertebra which receives its insertion.

Relations.-Superficially, the multifidus spinæ; deeply, the ligamenta subflava.

\section{SEvesth LAYER}

The serenth group consists of short rertical muscles, the interspinales and intertransversales, which lie on a deep plane internal and external to the transversospinales, and under cover of the longer vertical muscles which form the fifth layer of the back.

\section{INTERSPINALES}

The interspinales-named from their position-are small ribbon-like muscles which run vertically between the spines, especially in the cerrical and lumbar regions.

Origin.-The upper surface of the spine of the vertebra, near its tip.

Insertion.-The posterior part of the lower surface of the spine of the rertebra above.

Structure.- In the neck the bundles are attached to the two parts of the bifid extremities of the spines from the axis downwards. In the lumbar region they form broader bands attached to the whole length of the spines, and separated by the interspinous ligaments.

Nerve-supply.-The internal divisions of the posterior branches of the spinal nerres.

Action.-To extend the vertebra next above.

Relations.-Behind, the spinales and complexus; internally, the interspinous ligaments; extemally, the multifidus spine.

Variations.-Oceasionally they pass over one spine to be inserted upon the next but one. The spinalis colli, when present, may be looked upon as a still greater extension of this variation.

\section{INTERTRANSTERSALES}

The intertransversales-named from their position between the transrerse processes-are small rertical bands, also found chiefty in the cervieal and lumlur regrions.

In the neck (fig. 316) they are doulle, the anterior band connecting the anterior tubereses of the transverse procesies of the cervical rertebre, and the posterior the posterior tubereles.

In the lumbar region they are also doulbe, an outer set connecting the adjacent surfaces of the ends of the transverse processes, and an inner connecting the aceessory tubercle of one vertehra to the mammillary tuherele of the noxt rertolia helow. A few similar pairs of museles may also be found in the lower part of the thoracic region.

Structure.-Fleshy, with parallel filures. 
Nerve-supply. - The spinal nerves as they emerge from the intervertebral foraminil.

Action.-To flex laterally the spinal column.

Relations.-In the neck, the anterior primary branches of the nerves come out between the anterior and posterior intertransversales, and the posterior primary branches emerge at the inner borters of the posterior intertransversales. They are hidelen from view hy the mass of museles attached to the transwerse processes. In the lumbar region they lie muder cover of the erector spina and its divisions, and they are covered in front by the psoas (fig. 286 ).

\section{THE SUBOCCIPITAL MUSCLES}

The suboccipital group consists of short muscles, situated in the same plane as the preceding. but somewhat altered in their arrangement on account of the peculiar morements of the region. They are the rectus eapitis posticus major and minor, the obliquns capitis inferior and superior, the rectus capitis lateralis.

\section{RECTLS CAPITIS POSTICLS MAJOR}

The rectus capitis posticus major (fig. 308)-somewhat incorrectly named from the direction of its fibres, its position, and size-is a triangular sheet.

Origin.-The upper surface of the spine of the axis along its side and one-half of its bifid tip.

Insertion.-The middle third of the inferior nuchal line of the occipital bone.

Structure.-From a narrow tendinous origin the fleshy fibres diverge as they run upwards and outwards to a broad insertion.

Nerve-supply. - A branch of the suboceipital which enters the middle of its superficial surface.

Action.-To extend the head upon the neck; and to rotate the head to the same side.

Relations.-Behind, the complexus and obliquus superior; in front, the succeeding muscle.

\section{RECTUS CAPITIS POSTICUS MINOR}

The rectus capitis posticus minor (fig. 308) - named from its direction, size, and position-is also flat and triangular.

Origin.-The upper part of one-half of the posterior tubercle of the atlas.

Insertion.-The inner third of the inferior nuchal line of the occipital bone, and the space immediately in front of it.

Structure.-Fleshy, and consisting of fibres which diverge in fan shape as they jass upwards and outwards.

Nerve-supply.-Branches of the suboccipital nerve which enter the outer part of its superficial surface.

Action.-To extend the head on the neck.

Relations.-Behind, the preceding muscle and complexus; in front, the posterior oceipito-athantal ligament.

\section{OBLIQLES CAPITIS INFERIOR}

The obliquus capitis inferior (fig. 308)-namer from its direction and position-is a fusiform sheet.

Origin.-The upper part of the sidr of the spine of the axis.

Insertion.- The low part of the tip of the transverse process of the atlas.

Structure.-Ftrong and fleshy, with pointed extremities, and a general direction upwards and outwards. 
Nerve-supply.-The suboceipital, which sends branches to its upper horker.

Action.-Chiefly to rotate the atlas, and with it the head, to the same side. It will also help in extension and lateral flexion of the atlas upon the axis.

Relations.-Behind, the complexus and the great ocuipital nerve, which winds round its lower border; in front, the posterior atlanto-axial ligament and rertebral artery.

\section{OBLIQUUS CAPITIS SUPERIOR}

The obliquus capitis superior (fig. 308) - named from its direction and position -is flat and triangular.

Origin.-The back of the upper surface of the transverse process of the atlas.

Insertion.-The impression immediately behind the outer half of the inferior nuchal line of the occipital bone.

Structure.-Of fleshy fibres which diverge fanwise upwards and inwards.

Nerve-supply.-The suboccipital, which supplies it at the inner part of its deep surface.

Action.-To extend and slightly to flex laterally the head.

Relations.-Behind, the complexus and splenius eapitis; in front, the rectus capitis posticus major, vertebral artery, and posterior occipito-atlantal ligament.

\section{RECTUS CAPITIS LATERALIS}

The rectus capitis lateralis (fig. 316)-named from its direction and position -is a quadrilateral sheet, and corresponds to the intertransversales posteriores of the rertebra below.

Origin.- The front of the upper surface of the lateral mass of the atlas.

Insertion.-The under surface of the jugular process of the occipital bone.

Structure.-Fleshy, with parallel vertical filnes.

Nerve-supply. - The anterior branch of the first cervical nerve which passes out internal to it, and supplies it from the front.

Action.-To flex the head laterally.

Relations.- In front, the anterior primary branch of the first cerrical nerve, and the internal jugular rein; behind, the obliquus superior and the trachelomastoid.

Variations.-Occasionally the short muscles of this group are double. Small slips of muscle have been observed, running from the spines of the lower cervical rertebre, or the ligamentum nuchre to the occipital bone.

\section{MIUSCLES OF THE HEAD AND TECK}

The superficial laver in this region is peculiar in that it consists of numerous muscles contained in the connective tissuc outsicle the drep fascia. This connective tissue, the superficial fascia, is moderately provided with fat, and extends without any deep connection to the arljacent regions of the thorax, arm, and back. In the scilp it is firm and difficult to dissect on account of numerous septa which pass through it to unite the skin to the suljacent muscular aponeurosis. In this situation the superficial fascia is richly provided with blood by vessels which run within it instear of beneath the deep fascia, which is their usual position in other parts of the body.

Besides the peculiarity of their position outside the leep fiscial, these musclis are all associated in their function, viz. to produce the various morements of the features by which the expression of the emotions is effecterl. They are also 
peeuliar in the fact that many of them decussate with one austher on the way to their insertion in the skin; and they are all supplied by the seventh pair of crimial nerves.

\section{SUPERFICIA, MLSCLES OF NECK AND SCALP}

\section{PLATYNAL MYOLES}

The platysma myoides-named from its flat expanse (platysma, a plate) and its smilarity to musche (myoides, like muscle, for the older anatomists considered it to be only a nembrane)-is a quaclrilateral sheet with a somewhat toothed posterior border.

Origin.-(1) The deep fascia of the upper part of the front of the chest and the shonlder, and the deep cervieal fascia covering the sterno-mastoid.

Insertion.-(1) The outer surface of the lower horder of the body of the mandible, both on the same and the opposite side; (2) the deep surface of the skin from the concr of the mouth to the anterior border of the masseter muscle.

Structure.-Arising by slender bundles from the fascia covering the pectoralis major and deltoid, in a line from the second costal cartilage to the tip of the acromial process, the pale muscular fibres at first converge slightly until they have crossed the clavicle. They then run parallel to one another upwards and forwards, receiving at the posterior border of the muscle small teeth from the deep fascia forming the sheath of the stemo-mastoid. The anterior fibres cross the middle line half-way between the hyoid bone and the smmphrsis, and are inserted into the lower border of the body of the mandible upon the opposite side of the neck. The greater part of the rest are inserted into the outer surface of the lower border of the mandible on the same side, but some are continued upwards and join with the depressor labii inferioris. Still furtler back, a few fibres pass upwards over the lower part of the masseter, and are inserted into the deep surface of the skin just outsicle the angle of the month. A strong bundle of these fibres which runs nearly transversely forwards to the comer of the mouth will be described later as the risorins miscle. In its whole extent, the muscle is closely connected with the deep surface of the skin.

Nerve-supply.- The seventh cranial nerve, ly means of the inframandibular branch of the cervico-facial division, which supplies it from beneath at a point a little below the angle of the mandible.

Action.-(1) To draw downwards and outwards the lower lip, by means of the filmes which are continued upwards into the depressor labii inferioris. In transverse wounds below the mandilsle, the division of this muscle often impairs this movement. Durhenne has shown how important a part this depression of the lower lip discharges in the expression of horror or extreme surprise. (2) To draw outwards the soft parts of the sisle of the neck, so as to diminish pressure upon the veins during strong inspiratory efforts. Is the muscle is arched in its prissage from the clavicle to the mandible, with the concavity directed ontwalds, it is plain that its contration will flatten the arch and tend to lift the skin and fiscia off the ressels, in exartly the opposite manner to that hy which preseure is exerted when the concarity is upon the drep surface of a muscle. (3) It may assist feebly in depression of the mandihle: and, if that le fixed, in flexion of the hear and rotation towards the sime silc. This musele covers all the front of the neck with the exception of a narrow triangular interval, the base of which is formed by the mpper border of the sternum and the adjacent sterno-clavieular joints.

Relations.-It lies immerliately bencith the skin and superficial fascia, and in a lean neck the hundles are often distinctly visible through the skin, especially when an effort is mache to depress the lower lip while the teoth are clencherl. A thin hand derived from the anterior part of the depressor anguli oris usually crosses it superficially burath the chin (jage fos). Upon its deep surface live the deep cervical fascial, the "xtermal jugular vein, the glandulae concatenatse of the neck, the parotid and smbmaxillary glands, and the superticial branches of the 
cervical plexus, together with the masseter, and buccinator, the muscles of the front and side of the neek, and the pectoralis major and deltoid. 'Its anterior horder lies externally to the sterno-clavieular joint, and is often conspicuous in the aged, in whom the two muscles may be seen to hang, like a dewlap, heneath the chin, and then to divide into the two separate folds formed by their intemal border's, which run outwards and downwards towards the clavicles.

Variations. - The anterior border of the muscle may be placed as far backwards as the middle of the elavicle, and in some eases the muscle has been entirely alsent. Slips have been seen going to the side of the thyroid cartilage, the aluricle or the mastuid process.

Fig. 309.-The Superitcial Mescles of the Head ard Neck.

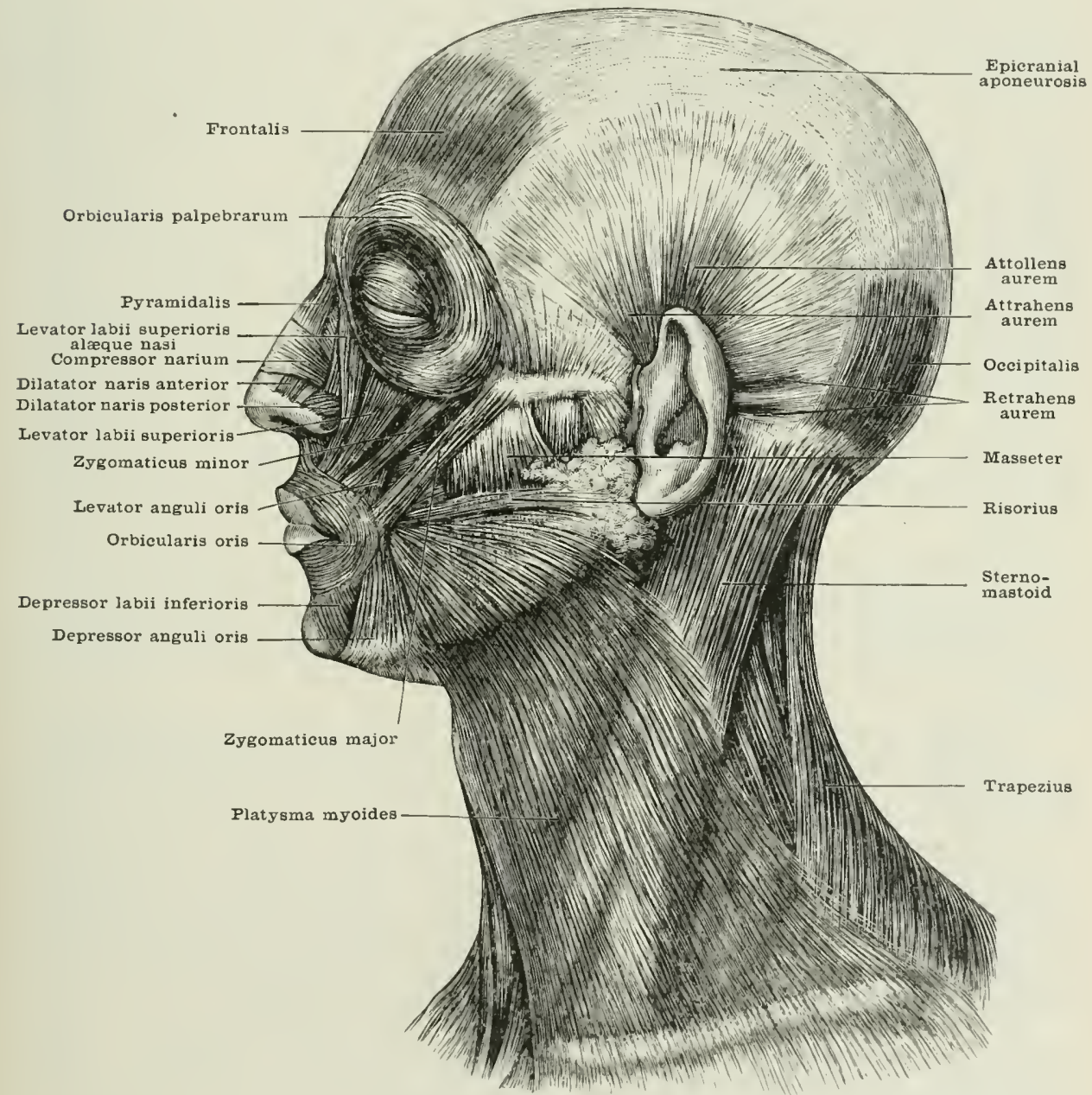

\section{OCCIPITO-FRONTALIS}

The occipito-frontalis-named from its two muscular bellies. which cover parts of the oceipital and frontal lones-comsists of two curved muscular sheets mited by a strong aponeurosis, and is lest describer in three parts-riz. the occipitalis and frontalis muscles and the epicranial aponeurosis.

(1) The occipitalis is a small quadrilateral sheet.

Origin.-(1) The outer two-thirks of the superior nuchal line of the occipital bone, and () a lidge upon the mastoid process. 
Insertion.-The posterior borter of the picranial aponeurosis, about one inch and a half $(3.7 \mathrm{~cm}$.) above the superior nuchal line of the oecipital bone.

(2) The frontalis - a curved sheet of somewhat quarlrilateral shape, with a convex upper. and a concave lower border.

Origin.-The epieranial aponeurosis, about half-way between the coronal suture and the orlital areh.

Insertion.-The theep surface of the skin of the eyebrow and of that which occupies the space at the root of the nose between the evebrow and the middle line.

(3) The epicranial aponeurosis forms the central tendon of the oecipitofrontalis, and its attachments will be described with the strueture of the muscle.

Structure.-The occipitalis is thin and pale, and arises by short tendinous interminglet with muscular fibres, and, after passing in parallel lines for about one inch and a half $(3.7 \mathrm{~cm}$.) upwards, it is inserted into the epicranial aponeurosis, a strong eurved sheet, which occupies the whole of the surface of the skull from the superior nuehal lines behind to the eyebrows in front, and is eontinued laterally over the temporal fascia of either sicle to ahout the level of the external auditory meatus. Abore, it is tendinous, and composed of fibres which run from behind forwards. It is thin in front and behind, where it forms a sort of sheath to the oceipitalis and frontalis muscles; but near the median line behind, it is thick where it fills up the interval between the occipitales. Laterally, it becomes rery thin, and is lost in the loose connective tissue superficial to the temporal fascia after having given origin to the attrahens and attollens aurem museles. In front, a narrow triangular slip, with the base upwards and the apex between the evebrows, is left between the frontales. which are larger and somewhat thicker than the occipitales. The fibres of the frontales run in p:arallel bundles downwards and slightly inwards, and are lost in the subcutaneous fat of the eyebrows; while near the middle line a small shp is continued upon the bidge of the nose as the pyramidalis, after entering into elose relation with the deep surface of the skin at the junetion of the forehead and nose.

Nerve-supply.-The occipitalis receives one of the divisions of the posterior auricular branch from the facial or seventh cranial nerve. Its filaments unter the deep surface of the muscle close to the outer border.

The frontalis is supplied hy the temporal branch of the temporo-facial division of the facial nerve which is distributed to the deep surface near its onter border.

Action.-The occipitales draw back the epicranial aponeurosis, and with it the scalp, which is intimately attached to its superficial aspect. Aeting from behind, the frontales raise the erebrows. If these are fixed by the contraction of the ortienlaris palpelsarum, the frontalis will draw forwards the epieranial aponeurosis and scalp. When both occipitales and frontales contract, they raise the eyelorows to the utmost extent, and throw the skin of the forehead into transierse wrinkles, as in the expression of surprise or horror. At the same time, on aceount of the direction of the hair-bulbs, which lie with a forward slant hehind and a backward slant in front, there will be a tendency to lift the hair shafts, and to make them 'stand on end, like quills upon the fretful por'eupine.'

When the frontalis alone contracts, talking its fixed point from above, a slight elevation of the eychrow is produced, as in the expression of attention. This is also accompanied by a transverse wrinkling of the forehead.

Relations.- Superficially, the epieranial aponeurosis and its muscles are in very close connection with the skin of the scalp and forehead, being only separated from it hy granular fat which is contained in small compartments formed by fibrous septa extending from the aponemrosis to the deep surface of the skin. In the fat lie the hair-hulls and blond-ressels of the salp. Beneath. it is separated from the perieranium and temporal fascia by very loose connective tissue.

Variations. - The nceipitalis may be enntinuous with the retrahens aurem. The froutalis may have insertions into the external or internal angle of the frontal bone, the nasal process of the maxilla, or the nasal bone. 


\section{THE IIUSCLES OF THE EYELIDS AND EYEBROWS}

These are four in number-viz. the orbicularis palpebrarum, the tensor tarsi, the corrugator supercilii, and the levator palpebre superioris. To these may be added a fifth, the frontalis, which has been described. The levator palpebre superioris will be described with the ortital muscles. The only part of it which is visible in a dissection of the face is its hroad expansion, which is intimately blended with the front of the crescentic plate of condensed fibrous tissue called the upper tarsal cartilage.

\section{ORBICLLARIS PALPEBRARLII}

The orbicularis palpebrarum-named from the rounded shape of the majority of its fibres (orbiculus, a little circle) and its relation to the erelicls-is an oral sheet with a long transverse dianter and so curved as to fit the prominences and depressions of the eyelids and the margin of the orbit.

It consists of a marginal and a central division: the former stronger and called the orbital portion; the latter thin and pale, and called the palpebral portion. Both have attachments to the tarsal ligaments, by which the so-called tarsal cartilages are fastened to the margins of the orbit. The internal tarsal ligament, or tendo oculi, is a strong flat band of fibrous tissue about a sixth of an inch $(4 \mathrm{~mm}$.) long with surfaces which look upwards and downwards. It arises from a projection upon the crest of the nasal process of the maxilla, and passes transversely outwards and somewhat upwards in front of the lachrymal sac, to which it gives off an aponeurotic covering. It then bifurcates into an upper and a lower division, which diverge to be attached to the inner extremities of the tarsi, here separated by the caruncula lachrymalis. The external tarsal ligament is undivided; it passes from the margin of the frontal process of the malar bone transversely inwards to the extremities of the tarsi, which at the outer commissure of the eyelids are in close contact.

The orbital portion of the orbicularis palpebrarum consists of a series of concentric oral loops which are attached only at the inner side of the orbit.

Origin and insertion.-(1) The lower part of the internal angular process of the frontal bone; $(2)$ the posterior half of the outer surface of the nasal process of the maxilla; (3) the upper and lower surfaces of the inner half of the internal tarsal ligament.

The palpebral portion consists of paler and shorter semielliptical fibres.

Origin.-The upper and lower surfaces of the outer half of the internal tarsal ligament, together with the adjacent part of the aponeurosis corering the lachrymal sac.

Insertion.-The upper and lower surfaces of the external tarsal ligament.

Structure.-Both portions of the muscle are entirely composed of fleshy fibres. In addition to the origin of the orbital portion at the inner part of the orhit, it gives off processes from its circumference which blend with the adjacent muscles, such as the frontalis and the elevator of the upper lip. Noreover, some of the deeper fibres of the muscle decussate with the fibres of those adjacent muscles which lie uncler cover of the outer loops.

The innermost fibres of the palpebral portion are shorter than the rest and. instead of extending across the whole length of the tarsi, they teminate upon their free margins, between the attachment of the eyelashes and the orifies of certain glands which line the inner surface of the tarsi.

Nerve-supply.- The temporal and malar branches of the temporo-facial division of the facial nerve, which enter the outer part of the muscle upon it: deep surface.

Action.-(1) The orlital portion hy its contraction clraws the soft parts around the opening of the orhit inwards and towards the palpehral aperture, raising a ridge which deepens the socket of the eye so as to protect the ryehall from injury, e.g. from the blow of a fist: (2) Its upper part will lower the erebrow, as when the face is exposed to a strong light, or when the mind is wrapt in thought. 
The palpebral portion will lower the upleer and raise the lower eyelid, in closure of the cye. (4) The firm contraction of the whole muscle presses upon the ereball, and supports it from the eril effecet of a strong expiratory effort, which by the rush of hlood into the interior of the ereball might burst its thin-walled ressels, and do scrious harm to the delicate structures within. Thus it will be noticed that in shouting, sneezing, or violent coughing the eyes are tightly closed. (5) By pressure upon the lachromal gland it is probable that the muscle influences the secretion of teass: hence thire flow during violent coughing or laughter. It will also draw outwarls and forwards the covering of the lachrymal sae, and so produce a suction of the tears through the canaliculi into the sac.

Relations. - Fuperficially, the skin; upon its deep surface the tarsal cartilages and their ligaments, the palpebral ligaments and the expansion of the tendon of the levator palpebre superioris; the bones which hound the opening of the orbit, the frontalis and corrugator supercilii muscles above; the temporal fascia externally; the zromaticus minor, levator lahii superioris, and levator labii superioris alxque nasi, helow; also the supraorlital ressels and nerve, the supratrochlear nerve, the terminal portion of the facial artery, and the palpebral branches of the infraorbital ressels and nerre.

\section{TENSOR TAREI}

The tensor tarsi-named from its supposed artion upon the tarsus-is a small muscle composed of two that slips, which are closely comnected with the preceding muscle.

Fig, 310. -The Texsor TArei Axi Corregator Supercilit.

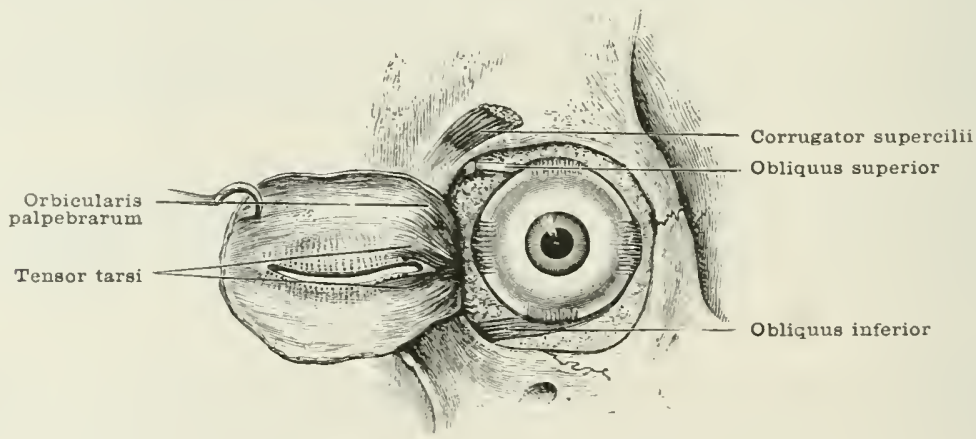

Origin.-The crest of the lachrymal bone.

Insertion.-The posterior aspect of the inner end of the tarsi.

Structure.-Arising as a thin muscular sheet, at the back of, and in close contact with, the outer surface of the lachrymal sac, the muscle divides into two slips which rm behind the canaliculi, and are inserted into the edge of the eyelick near the puncta lachrymalia.

Nerve-supply.-From the infraorbital hranch of the upper division of the facial nerve, by small slips which enter the muscle near its lower border.

Action.- To compress the lachrymal sac ly drawing inwarls and backwards the outer part of the tenclo oculi and the inner encls of the tarsi.

Relations.-Internally and in front, the lachrrmal sac; externally and hehind, the orbital fat from which it is separated by the capsule of 'Tenon.

\section{CORRLGATOR SIPERCTLII}

The corrugator supercilii-named from its action, the wrinkling of the browis a short ribhon-shaperl muscle.

Origin.-The inner extremity of the supereiliary rislge of the frontal hone. 
Insertion.-The deep surfice of the skin at the midclle of the eyclorow.

Structure.- I small wisp of fleshy tibres, dosely comected with the orbital portion of the orbicularis palpeloram. It passes outwarls, and at the same time slightly upwards and forwards, to the under surface of this muscle, and, diverging slightly, its fibres pass hetween the interlacing fibres of the orlicularis and frontalis to their insertion into the skin.

Nerve-supply.-The temporal branch of the upper clivision of the facial nerve. which enters its (leep) surface from the outer sicle.

Action.-To draw the middle of the eyehrow inwards and slightly downwards. In the adult this causes vertical wrinkles to form between the eyelrows, and gives a frowning aspect to the face, as when a difficulty occurs either in thought or action. In the crving infant, the effect of its contraction is to cause dimples about the centre of the eyebrows, which may usually be observed just before the orbiculare palpebrartum close the eyes.

Relations.-Superficially, the orbicularis palpebrarm; deeply, the frontal bone. For The Muscles of the Eye, see pages 854-7.

\section{THE EXTRINSIC MUSCLES OF THE ATRICLE}

The extrinsic muscles of the auricle (fig. 309)-viz. the attollens aurem, the attrahens aurem, and the retrahens aurem-are feeble, and ahmost restigial in man. They are elosely connected with the occipito-frontalis. The largest of the three is the attollens aurem.

\section{ATTOLLENS AUREM}

The attollens aurem-named from its action as an elevator of the auricle-is a thin triangular sheet.

Origin.-The epieranial aponeurosis, a short distance below the top of the temporal ricke.

Insertion.-The inner surface of the pinna of the auricle, over a space which corresponds to the fossa of the antihelix upon its outer surface.

Structure.-A thin, fan-shaped sheet, consisting of muscular fibres and bands of connective tissue, which all converge from above upon a flat tendon just above the point of insertion.

Nerve-supply.-The temporal branch of the upper division of the facial nerve. by filaments which enter the front of the deep surface.

Action.-To draw upwards the auricle.

Relations.- Superficially, the skin; deeply, the temporal fascia and auriculotemporal nerve.

\section{ATTRAHENS AUREM}

The attrahens aurem-namerl from its action in drawing forwards the anrichis a smaller and very thin triangular sheet.

Origin.- The lateral horder of the epicranial aponeurosis in front of and behw the kevel of the preceding, with which it is nsually continuous.

Insertion.- The front of the inner surface of the helix.

Structure. - It consists of a thin stratum of muscular fibres, intermingled with connective tissue, lying upon the temporal fiscia, and converging hackwards and downwarks upon a feeble that temiton.

Nerve-supply.-The same as the freceling.

Action.-To draw forwarks and upwards the auricle.

Relations. Superficially, the skin; deeply, the temporal fascia, temporal artery, and auriculo-temporil nerre. 


\section{RETRAFENS ALREM}

The retrahens aurem-named from its action of drawing back the auricleconsists of two muscular baurls, which narrow slightly as they pass forwards to the ear.

Origin.-The upper part of the outer surface of the mastoid process of the tempriral hone.

Insertion.-The immer surface of the concha.

Structure.-It consists usually of darker and more distinctly fleshy hands than the two preeeling muscles. They arise, one above the other, by short tendinous fibres from the mastuid process, and pass transversely forwards to their tendinous insertion.

Nerve-supply.-The posterior auricular branch of the facial, which sends filaments to the luwer yart of its deep surface.

Action.-To draw back the auricle.

Relations.- Superficially, the skin; deeply, the posterior auricular artery, part of the great amricular and the posterior amicular nerves.

\section{THE MUSCLES OF THE NOSE}

The chief muscles of the nose are three in number: viz. the prramidalis nasi and compresor narium, which consist of muscular fibres which pass upwards and outwards from an aponeurosis, covering the cartilaginous part of the ridge of the nose, and intimately connected with the under surface of the skin; and the depressor alie nasi. $\Lambda$ small slip from the levator labii superioris alæque nasi is also attached to the ala nasi; and tro little muscles may sometimes be found in the subeutaneous tissue upon the outer surface of the nostril: viz. the dilatator naris anterior and posterior.

\section{PYRAMIDALIS}

The pyramidalis (figs. 309 and 311) -named from its triangular shape, which is like the side of a prramicl-is a thin sheet.

Origin.--The ipper border of the nasal aponeurosis over the junction of the cartilage with the lower border of the nasal bone.

Insertion.-The deep surface of the skin between the eyebrows, being at this point continuous with the inner fibres of the frontalis.

Structure.-The muscular fibres form a slightly curved sheet, which wraps round the anterior surface of the nasal bone, and is continuous with the corresponding muscle of the other side. They converge as they pass upwark, and the outer ones run slightly inwards as well as upwards, to their insertion.

Nerve-supply.-The infraorbital branch of the upper division of the facial, which enters the outer part of its deep surface.

Action.-To draw downwards the skin between the eyebrows, so as to throw it forwarls into a fold, and at the same time to produce a transverse groove above the bridge of the nose. This gives to the face a stern, aggressive, or fierce expression.

Relations.- Auperficially, the skin; and deeply, the nasal bone.

Variation.-This muscle is sometimes absent.

\section{COMPRENAOR NARIUM}

The compressor narium (figs. 309 and 311) - named from its supposed action as a compressor of the nostrils-is a triangular sheet, the base of which is attached to the nasal aponeurosis abore mentioned. 
Origin.-The sides of the nasal aponeurosis.

Insertion.-(1) The lower and front part of the canine fossa of the maxilla; (2) part of its fibres are continued into those of adjacent muscles, especially the levator labii superioris aliegue nasi, and the lerator anguli oris.

Structure.-Arising from the side of the aponeurosis in a rertical line ahout half an inch $(1 \cdot 2 \mathrm{~cm}$.) from the ridge of the nose. the filores of the muscular shecet converge as they pass hackwards, outwards and downwarts to a narrow hand just above and behind the ala nasi. Here they are partly attached to the maxilla, and partly they pass into the adjacent muscles.

Nerve-supply.-The infraorlital branch of the upper division of the facial nerve, which sencls filanents to the deep surface of the muscle near its upper border.

Action.-(1) To depress slightly the cartilaginous ridge of the nose; (2) to throw into rertical wrinkles the side of the nose, as when a bad smell is perceived; (3) to assist the adjacent muscles in dilating the nostril and drawing up parts of the upper lip.

Relations.-Superficially, the skin and levator labii superioris alsque nasi; deeply, the cartilages of the nose.

\section{DEPRESSOR ALE NASI}

The depressor alæ nasi (fig. 311) -named from its action upon the cartilage of the nostril-is a small triangular sheet.

Origin.-The incisive fossa of the maxilla.

Insertion.-(1) The lower and back part of the cartilage of the ala nasi; (2) the arljacent part of the lower border of the cartilaginous septum nasi.

Structure.-Its muscular fibres diverge upwards and outwards from their origin.

Nerve-supply. - Small filaments from the buceal branch of the lower division of the facial nerve, which enter the muscle near its outer border.

Action.--To draw downwards and inwarls the alar cartilage.

Relations.-Superficially, the orhicularis oris; deeply, the maxilla. It is also closely connected with the fibres of the previous muscle and the elevators of the upper lip.

\section{LEVATOR LABII SLPERIORIS ALEQUE NASI}

This muscle will be described with the Muscles of the Movtr.

\section{DILATATOR NARIS ANTERIOR}

The dilatator naris anterior (fig. 309) - named from its action and positionis a small quarhilateral sheet.

Origin.-The lower edge of the lateral cartilage of the nose.

Insertion.-The deep surface of the skin covering the ala nasi.

Structure. - A thin stratum of muscle, which may occasionally be found passing lownwards upon the upper part of the alar curtilage.

Nerve-supply.-The infraorlital branch of the upper division of the facial nerve.

Action.-To dilate the nostril, c.g. in the expression of anger, or in hart breathing.

Relations.- Superficially, the skin below and the compressor narim abore: deeply, the cartilages of the ala.

\section{DILATATOR NARIS POATERIOR}

The dilatator naris posterior (fig. 309) - named from its action and position -is a similar sheet of somewhat quadrilateral shape.

Origin.-(1) The erlge of the nasal aprerture of the maxilla; and (-2) the outer suriace of the sesamoid cartilnges of the nose. 
Insertion.-The skin orer the posterior and lower part of the alar cartilage.

Structure.-I thin stratum of parallel muscular fibres rumning forwards and downwards.

Nerve-supply.-The infraorbital branch of the upper division of the facial nerve.

Action.-To lilate the nostril.

Relations.-Superficially, the skin and levator labii superioris alieque nasi; decply, the sesmoid cartilages.

\section{MUSCLES OF THE MOUTH}

The muscles of the mouth consist, first, of the orlicularis oris, which is the sphincter surrounding the aperture; and secondly, of the bands which radiate from this, as a centre, to their origin upon the adjacent facial bones. These may be gromped into three sets: riz. (1) the transverse series, which rarliate transversely. This consists of only one pair of muscles, the buccinators. (2) The angular serice, which pass from above or below to the corner of the mouth. (3) The labial series, which pass nearly rertically either downwards or upwarks to the lips, and chiefly to their inner haif.

A fourth series may be added, which have no special connection with the mouth. viz. two nearly rertical muscles close to the middle line, which racliate from an origin close to the mouth. Of these, one has already been clescribed, the depressor alre nasi; the other arises from the lower jaw, the levator menti.

The muscles might also be arranged according to their stratification, for they form two, and, in some parts, three layers over the greater part of this region.

\section{ORBICULARIS ORIS}

The orbicularis oris - an unpaired muscle, named from its shape and situation -is an oral sheet with the long axis placed transwersely, and its fibres arranged round a transwerse central aperture. Like the orbicularis oculi, the muscle may be divided into an intemal or labial portion, and an external or facial. The first part, which is superficial, has no bony comnection, exeept through the medium of the adjacent muscles with which it is closely blended. The second, which is deep and which forms part of the third layer of the facial muscles, has the following small attachments to bone and cartilage.

Attachments to bone and cartilage.-(1) Naso-labial slips from the back of the lower part of the cartilage of the septum of the nose; (2) the incisive fossa of the maxilla just above the socket of the lateral incisor tooth; (3) the incisive fossa of the mandible, below the sockets of the lateral incisor and canine teeth.

Structure.-The orbicularis oris consists of three sets of fibres, which are in their direction approximately transverse, vertical, and sagittal or anteroposterior. The transverse set form the most conspicuous part of the muscle; they are continuous on either sick with the fibres of the buccinator, and they constitute the greater part of the fine smonth huncles which lie leneath the red skin of the prolabium, and are callecl the labial portion of the muscle. The vertical fibres are clerived from the elevators and clepressors of the lips, including the zygomatici; they form the superficial part of the facial portion, and they interlace with the transverse filnes. Nany of them pass round the corners of the mouth and become transwerse; those arising from the maxilla and its ricinity passing to the lower lip, while those from the mandible go to the upper. The sagittal or anteroposterior fibres pass directly or somewhat obliquely from before hackwards between the transwrse fibres, ancl unite the skin to the mueous membrane. They are found chicfly in the labial portion of the muscle. The two naso-labial slips pass side by side vertically downwards to the upper part of the muscle, their position being indicated upou the surface hy two small rertical ridges which deseend from the columna nasi on either sile of the median groove of the upper lip. The 
fleshy slips from the maxilla and mandible-the musculi incisivi, as they are eallerl-pass outwards and forwards to join the deep surface of the transverse fibres near the corners of the nouth.

Nerve-supply.-The huceal and supramaxillary bunches of the lower division of the facial. which enter the facial part of the muscle near its outer border.

Action.-(1) To bring together the lips and to oppese all the other muscles which converge upon the mouth, and tend to draw it open in various directions. It thus aets negatively, and prevents the expression of any emotion, as when the lips are pursed up. If the upper fibres alone act, the upper lip will be drawn

Fig. 311.-The Deeper Lajer of the Mlescles of the Face axd Neck.

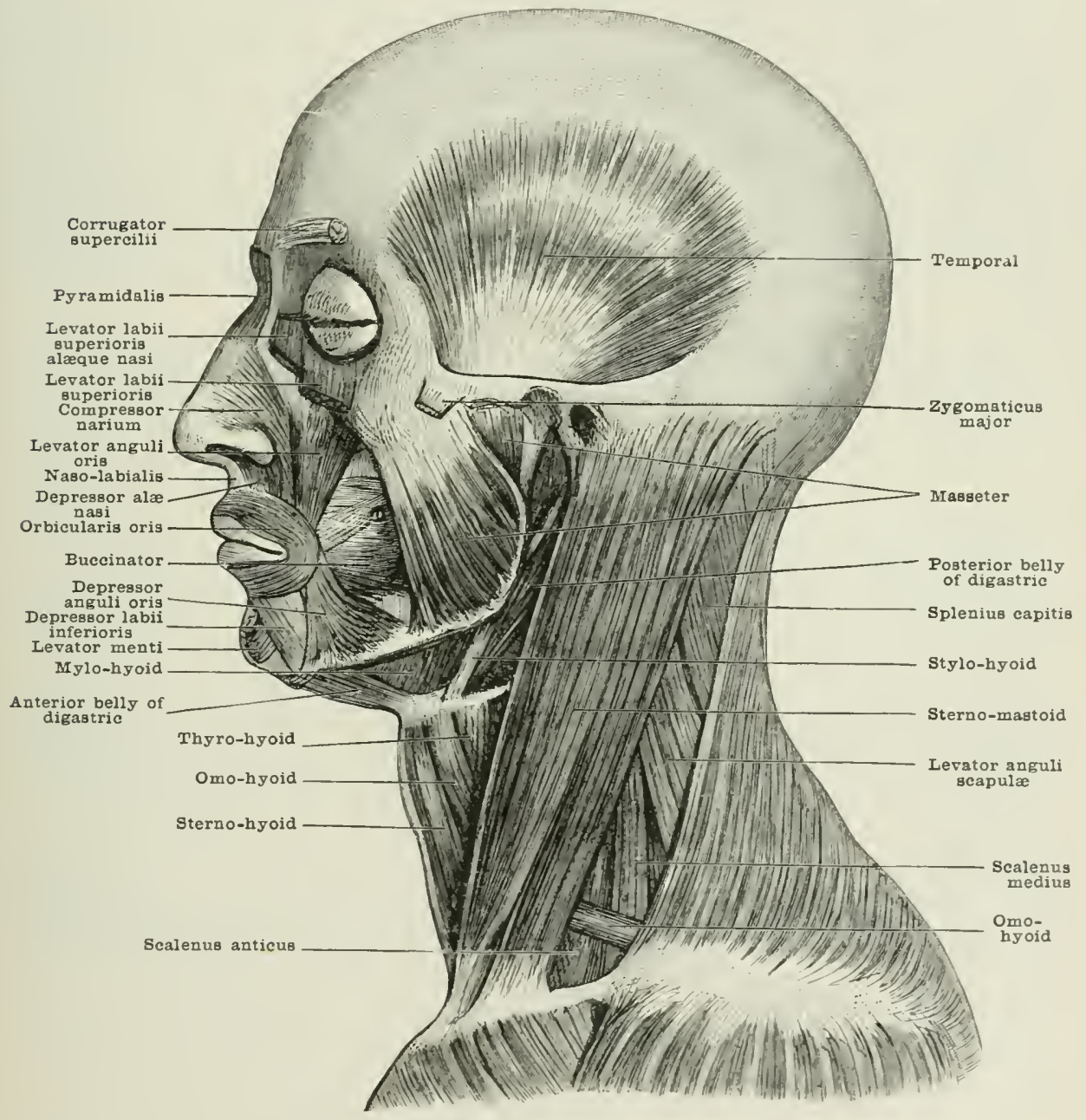

downwards; if the lower, the lower lip will he drawn upwards. If the filores of the labial portion contract strongly, the corners of the nouth are alporoximated. (2) To shoot out the lips: this will chiefly depend upon the contraction of the facial portion and the musculi incisivi. (3) To press the lips against the teeth: the plane of the muscle being eurved, with the concavity against the arches formed by the front tecth, its contraction will carry the fool hackwarils into the oral cavity.

Relations.- In front of the lahial portion is the bright red skin of the prolahium; and in front of the facial portion lie the angular and labial series of muscles, together with some subcutaneous fat. 
Cpon the deep surfare lies the mucous membrane of the mouth, separated from the muscular filnes ly the mueous and small salivary glands, together with the superior and inferior cornany arterics.

\section{Traxsyerse Muscles of tile Mouth}

This group comprises only the buceinator.

\section{BLCCINATOR}

The buccinator-named from its action, as it is the muscle used by the trumpeter (buccinctor) - is a somewhat oval sheet of museular fibre, distinet in its origin, but blending in front with the orbicularis oris. It forms a part of the third stratum of the facial museles.

Origin.-(1) The outer surface of the alveolar process of the maxilla ahove the molar teeth; (2) the anterior border of the pterygo-maxillary ligament, a filrous band or raphé extending from the hamular process of the internal pterygoid plate of the sphenoid bone to the back of the mylo-hyoid ridge of the manchible; (3) the outer surface of the alveolar process of the mandible below the molar teeth.

Insertion.-The outer part of the orbicularis oris.

Structure.- It rises by fleshy fibres which run forwards in four sets. The upper set pass directly into the facial portion of the orbicularis oris which belongs to the mperer lip; the next pass downwards and forwards to that which belongs to the lower lip; the third upwards and forwards, decussating with the second set to join the lower part of the orbicularis in the upper lip. Finally, a fourth set which pass from the mandille to the lower part of the facial portion of the orlicularis oris belonging to the lower lip.

Nerve-supply.-The buccal branch of the lower division of the facial, which sends filaments into the back part of its outer surface; it is also pierced by the buccal branch of the inferior maxillary division of the fifth nerve on its way to supply the mucous membrane lining the cheek.

Action.--(1) To draw outwards the comer of the mouth, widening it and pressing the lips against the teeth; (2) to diminish the concavity of the cheek, compressing the air contained in it, as in using the blowpipe or playing the comet; or forcing inwards the food when, in mastication, any portion of it has escaped into that part of the mouth which is external to the bicuspids and molar teeth.

Relations.-Superficially, the skin, subcutaneous fat, Stenson's duct, the zygomaticus major, risorius, a large mass of fat (the buccal fat-pad) which separates the buccinator from the masseter, and a laver of deep fascia continuous with that which covers the upper part of the pharynx; deeply, the mucous membrane of the mouth. The upper part of the muscle is perforated ly Stenson's duct. The buccinator is almost continuous behind with the superior constrictor, from which it is only separated by the tendinous intersection of the pterygo-maxillary liganent.

\section{Axgular Muscless of the Moutil}

The angular series are four in number: viz. the zyomaticus major, levator anguli oris, risorius, and depressor anguli oris. Two deseend to the corner of the month ololiguely from above, one rums almost horizontally forwards, and one ascends from below. They bend at the cornor of the month, and form there a thick muscular mass, behinel which is a clepression filled up with the fat covering the buecinator. In a lean face this depresion is often rery conspicuous, and in some faces its position is indicated by a dimple when the zygomaticus major contracts. 


\section{ZYGOMATICLS MAJOR}

The zygomaticus major-named from its origin from the zygoma and its size -is ribhon-shaped, and belongs to the first layer of the muscles.

Origin.-The outer surface of the malar bone near the zyomatic suture.

Insertion.-The deep surface of the skin, and the subcutaneous tissue at the outer extremity of the upjer lip, and just external to the commissure of the lips.

Structure.-Arising ly short tendinous fibres, the muscle forms a fleshy band which passes downwards and forwards to the meeting-point of the angular muscles at and external to the angle of the mouth, where it blends with the orbicularis oris and the other angular muscles, its outermost fibres passing into the outer fibres of the depressor anguli oris.

Nerve-supply.-The infraorbital branch of the upper division of the facial nerve, which enters the middle of its deep surface.

Action.-To draw upwards and ontwards the corners of the mouth, as in smiling or laughter. When it is strongly contracted, it throws into prominence the soft parts of the cheek in front of the malar bone, raises the lower eyelid, and produces 'crow's fect.' as the wrinkles are called which radiate ontwards from the outer canthus. When both muscles act together, the mouth is widened, and the upper lip raised so as to show the upper teeth, in what is ealled a 'broad grin.'

Relations.-Superficially, the skin; deeply, the buccinator and facial part of the orlieularis oris, the facial and transverse facial arteries, the facial vein, and some branches of the facial nerve.

\section{LEVATOR ANGLLI ORIS}

The levator anguli oris-named from its action upon the corner of the mouth -is a triangular sheet and belongs to the second stratum of the facial muscles.

Origin.-The canine fossa of the maxilla.

Insertion.-The deep surface of the skin, and the subentaneous tissue, close to the corner of the mouth.

Structure.-Arising muscular from its loroad origin ahove the canine and bicuspid teeth, the fibres converge in a downward and outward direction, and blend with the other angular muscles outsirle the corner of the moutl.

Nerve-supply.-The infraorlital branch of the upper division of the facial at the outer part of the anterior surface.

Action.-To raise the corner of the mouth, but at the same time to draw it inwards.

Relations.-Superficially, the zygomaticus minor and levator labii superioris, the infraorbital vessels and nerves; ileeply, the facial portion of the orbicularis oris.

\section{RISORILS}

The risorius-named from its supposed action in laughter-is flat and ribbonshaped, and belongs to the superficial layer of muscles, being a pirt of the platysma myoides, and often very small and ill-eleveloped.

Origin.-The subcutaneous tissue overlying the deep fascia which covers the masseter and parotid glanel.

Insertion.-The subeutaneous and muscular tissue cxtrmal to the angle of the mouth.

Structure.-It. is a land of parallel fibres which runs transwersely forwards from the upper and posterior part of the platysma to the cormer of the nimuth.

Nerve-supply.-The huecal branch of the lower division of the facial nerve which enters it from beneath.

Action.-To widen the mouth by drawing its corner directly outwials. It is: not nsed in the expression of pleasure like the zyomaticus major. hut it gives a 
strained painful expression to the features, such as is seen in tetanus, and called the 'risus sardonicus.'

Relations._- inerficially, the skin and subentaneous fat; deeply, the masseter and buecinator, the facial artery and rein, and branches of the facial nerve.

\section{DEPRESSOR ANGLII ORIS}

The depressor anguli oris-named from its action upon the corner of the mouth-is a triangular sheet, and belongs to the superficial layer of facial muscles.

Origin.-The outer aspect of the lower border of the hody of the mandible and the external oblique line below the canine, bicuspid, and first molar teeth.

Insertion.- The subcutaneous comective tissue, and the muscular mass external to the cormer of the mouth.

Structure.-Its fibres, arising fleshy, converge upwards and inwards, and, having diminished to a narrow band, join the general muscular mass at the corner of the mouth, some of them being continued upwarls into the levator anguli oris, and the most external into the zygomaticus major.

The fibres which form the imner border of the muscle are often continued downwards below the mandible, and form with those of the other side a band, partly muscular and partly fibrous, which, lying heneath the platysma myoides, supports and compresses the subeutaneous fat helow and behind the prominence of the chin. When there is much subcutaneous fat, the ahsence of this support gives rise to a considerable prominence behind this band, producing the so-called 'double chin.'

Nerve-supply.-The supramandibular branch of the lower division of the facial nerve, which sends filaments to the back part of its deep surface.

Action. - To draw downwards and somewhat outwards the angle of the mouth, giving an expression of sorrow to the face, and making the indiridual look 'down in the mouth.'

Relations.-The skin superficially; and deeply, the depressor labii inferioris and inferior coronary artery.

\section{Labial Group of Muscles}

The labial group consists of three muscles which pass downwards from the maxilla, and form a continuous sheet which might fairly be included under one name; and a fourth muscle which passes upwarls fron the mandible. All the muscles are inserted into the lips, and especially into that part of them which intervenes between the middle line and a point half way between this and the corner of the mouth.

The upper set is formed by the levator labii superioris alzerue nasi, the levator labii superioris, and the zygomaticus minor; the lower muscle is the depressor labii inferioris.

\section{LEVATOR LABII SUPERIORIS ALEQUE NASI}

The levator labii superioris alæque nasi-named from its action as an elevator of the upper lip and the nostril-is a somewhat triangular shert, bifurcating below at the hase which corresponds to the insertion of the muscle. It betomes to the superficial layer of facial muscles.

Origin.-The anterior half of the outer surface of the nasal process of the maxilla.

Insertion.-(1) The decp surface of the skin which envers the lower part of the ala nasi; (2) the deep surfare of the skin and the general muscular mass, of the immer half of the 11 p)

Structure.- Mrising lleshy, its fibes diverge somewhat as they pass downwards; they then decussate with those of the orbicularis oris elose to the probabim. 
Nerve-supply. - The infratorbital branch of the upler division of the facial nerve, which sends filaments to the outer part of the deep surface of the muscle.

Action.-(1) To raise and dilate the nostril; (2) to raise the inner half of the upper lip.

Relations.-Superficially, the skin and orbieularis palpebrarum; deeply, the compressor narium and levator anguli oris.

\section{LEVATOR LABII SUPERIORIS}

The levator labii superioris-named from its action-is a nearly square sheet, anr it belongs to the superficial layer of muscles.

Origin. - The front of the maxilla just below the margin of the orbit, and from the arljacent part of the malar bone.

Insertion.-The deep surface of the skin and the subjacent muscular tissue near the upper edge of the inner half of the upper prolabium.

Structure.-Its fibres, arising theshy, descend parallel to one another and almost rertically to their insertion, where they interlace with the fibres of the orbicularis oris. It frequently receives at its outer border some bundles of fibres from the orbicularis palpebrarum.

Nerve-supply. - The infraorlital branch of the upper division of the facial nerve, which sends filaments to the outer part of its deep surface.

Action.-To raise the inner half of the upper lip. This muscle, with its two follows, the preceding and following, is especially used in the expression of grief, and to some extent of anger also, as when the lip is raised and somewhat everted so as to show the canine tooth. In crying, the action of these muscles is strongly displayed, for when the eyes are closed hy the orbiculares palpehrarum, at the same time the mouth is made square by the elevation of the inner half of the lip. while the outer half is drawn down hy the depressor anguli oris.

Relations.- Superficially, the skin and orbicularis palpebrarum; deeply, the levator anguli oris, the infraorbital vessels and nerve.

\section{ZYGOMATICUS MINOR}

The zygomaticus minor-named from its association with the zygomaticus major and its smaller size-is a small ribbon-shaped band, often absent, and belonging to the superficial layer of facial muscles.

Origin.--The lower part of the front of the malar bone close to its junction with the maxilla.

Insertion.-The deep surface of the skin and the suljacent muscular tissue at a point upon the upper border of the prolabium of the upper lip abont miclway between the middle line and the outer comer of the mouth.

Structure.-Arising fleshy, the small band of parallel fibres which is upon its inner margin elosely connected with the preceding muscle, passes downwards and inwards to its insertion, which interlaces with the fibres of the orbicularis oris.

Nerve-supply.- The infraorlital branch of the upper division of the facial nerve, which sends filaments to the deep surface of the muscle.

Action.-To raise and somewhat evert the part of the upper lip to which it is attached.

Relations.- Superficially, the skin and orlicularis palpebrarm; deeply, the I'vator anguli oris, facial portion of the orbicularis oris, and the infraorhital lianch of the facial nerve.

\section{DEPRESSOR LABII INFERIORIS}

The depressor labii inferioris, or quadratus menti-named from its action, or shape, and its commection with the lower lip and (hin (mentum) - is a nearly square sheet, and belongs to the socond layer of the facial muscles.

Origin.-The outer aspect of the lower borter of the body of the mandible below the canine and bicuspicl tecth. 
Insertion.-The deep surface of the skin and the subjacent muscular mass along the lower extge of the prolabium of the lower lip.

Structure.-It consists of parallel muscular fibres, many of them continuous with those of the platysula myoles, which pass upwards and inwards to interlace with the fibres of the orbicularis oris along the line above mentioned. The inner margins of the muscles of the two sides meet above in the middle line.

Nerve-supply.- The supranandibular branch of the lower division of the ficial nerve, which sends filaments to its deep surface near its outer border.

Action.-To draw fown and somewhat evert the lower lip.

Relations.-Superficially, the skin and the depressor anguli oris; deeply, the facial portion of the orbicularis oris, the mental ressels, and nerve.

\section{Muscles Raditisg From THE Mouth}

The two muscles which radiate from the mouth are the depressor alre nasi and the levator menti.

\section{DEPRESSOR NLE NASI}

The depressor alie nasi has been described with the muscles of the nose.

\section{LEVATOR MENTI}

The levator menti, or levator labii inferioris-named from its action-is a short, thick, and somewhat fan-shaped muscle, belonging to the seeond layer.

Origin.- The incisive fossa of the mandible, helow and a little internal to the attachment of the incisivus inferior of the orbicularis oris.

Insertion.-The subcutaneous tissue just above the point of the chin.

Structure.-Arising fleshy, its fibres diverge slightly as they pass downwards and inwards to meet in the millle line with those of the opposite side just below a pellet of fat which lies beneath the skin at a short distance above the point of the chin.

Nerve-supply. - The supramandibular branch of the lower division of the facial nerve, which terminates in this muscle.

Action.-To draw upwards the skin covering the prominence of the chin, and to elevate and shoot out the lower lip. It has been sometimes called the musculus superbus, from the haughty and contemptnous expression which it produces when it acts at the same time with the depressor anguli oris. A slighter contraction, however, gives the month an expression of firmmess and decision.

Relations. - Superficially, the mucons membrane of the mouth and the facial portion of the orbicularis oris above, the subcutancous fat below; deeply, the mandible.

\section{MIUSCLES OF MLISTICATION}

The muscles of mastication form an independent group, four in number, occupying the bark part of the side of the face, and the temporal and zygomatic fossae, and consisting of the masseter, the temporal, with the external and internal pterygoid muscles. The temporal muscle is covered hy a strong membrame, the temporal fascia, which, arising from the temporal ridge, is attached below to the upuer borker of the zycoma, after first dividing into two lamina which go to the outer and inner aspects of this bereler, and eontain between them a small yuantity of fat. From the zyomat cownwarels, the masseteric fascia is continued to the posterior and inferior borders of the ramus of the mandible, chveloping the masseter muscle. Closely commereded with this is the parotid fascia which envolops the parotid gland, cxtending hackwards from the masseterie fascial to that part of the dere cervical fiscial which covers the uplere portion of the stemo-nmastoid 
muscle; covering also the deep surface of the gland, and giving off a process called the stylo-muxillary ligament, which, rumning from the styloid process to the angle of the mandible, separates the parotid and submaxillary glands.

\section{MASSETER}

The masseter (fig. 311) -named from the Greek word rafoumat, to chew-is a strong quadrate sheet, consisting of two layers.

Origin.-The superficial layer, from the lower border of the malar bone, and the lower border of the anterior two-thirds of the zygomatic arch; the deep layer, from the lower border of the posterior third of the zrgomatie arch, and the whole of its inner surface.

Insertion.-The superficial layer, into the lower half of the outer surface of the ramus of the mandible; the deep layer, partly with the superficial layer, and partly into the upper half of the onter surface of the ramus of the mandible.

Structure.-The origin and insertion are by tendinous bands intermingled in multipenniform fashion with fleshy fibres. The fibres of the superficial sheet are directed obliquely downwards and backwards; those of the deep sheet almost vertically downwards, and they are much shorter than the superficial fibres. The two sheets blend closely in front, but are separate hehind, where the muscle forms a sort of pocket closed above at the origin and below at the insertion, as well as in front, but open behind.

Nerve-supply.-The masseteric branch of the motor portion of the mandibular division of the fifth nerve, which enters the deep surface of the muscle just below the zygoma.

Action.-To close the jaw, and by its superficial layer to draw it slightly forwards. In closing the jaw it acts with less mechanical disarlvantage than is usual with muscles. When the pressure to be overcome is exerted upon the back teeth, the arm of the lever upon which the power acts is almost as long as that which intervenes between these teeth and the fulcrum. This fulcrum is not at the temporo-mandibular joint, but at a point below the neck of the mandible, corresponding very nearly to the lower attachment of the internal lateral ligament. Moreover, the resultant force of the muscle, acting as it does upwards and forwards, is perpendicular to the lever, which may be roughy described as a bar extending downwards and forwards from the neck of the mandible to the point of the chin.

Relations.- Superficially, the parotid gland and its duct, the platysma myoides, the risorius and the masseteric fascia, the transverse facial ressels, the ficial vein, the upper and lower divisions of the facial nerve; teeply, the buccal fat-pad which separates it from the buccinator and a small part of the temporal muscle.

\section{THE TEMPORAL MUSCLE}

The temporal muscle-named from its attachment to the temple (=tempms) -is a thick, somewhat triangular sheet; more correctly it may be described as forming the quadrant of a circle.

Origin.-(1) The whole of the temporal fossa, from the temporal to the pterygoid riclge, with the exception of a small part close to the outer wall of the orluit. which is occupied by fat; (2) the inner surface of the temporal fascia down to its lower attachment to the zyomatic process, from the inner surface of which some of its fibres also sometimes arise.

Insertion.-The point, posterior horder, and the whole of the inner surface of the coronoid process of the mandible, down to the last molar tooth.

Structure.-The bones of the temporal fossa and the temporal fascia form a pouch, open downwats, from which the fleshy fibres of the muscese comrerese, the middle fibres ruming downwards, the anterior downwarts and backwarts, thr. posterior almost transversely forwards. to he inserten below wum both faces of a tlat tendon which, hecoming free of Hesh on the outer surface first, embraces the point and borders of the coronoid proces:s. 
Nerve-supply.-The two or three deep temporal hranches of the motor portion of the manclibular division of the fifth nerve, which enter the lower part of its deep sllrfice.

Action.-To close the jaw: its posterior fihres will also draw it backwards after the other muscles have protrurled it. This muscle, like the masseter, has to contend with very little mechanical disadvantage, power being of more importance in mastication than speed.

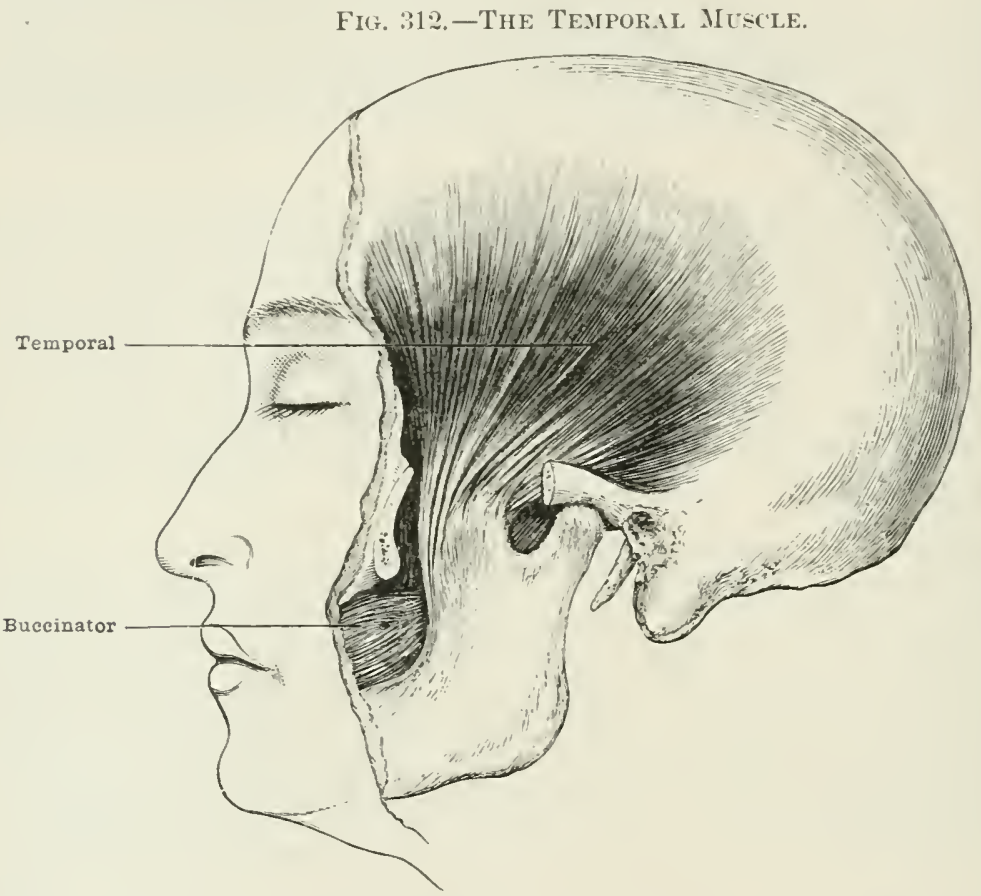

Relations.-Superficially, the temporal fascia which separates it from some of the auricular muscles, the sicles of the epicranial aponeurosis, the auriculo-temporal nerve, and the upper hranches of the facial nerve; the zygoma and a small part of the masseter. Deeply, the temporal fossa, and the external pteryoid muscle.

At its posterior border it is crossed by the masseteric nerve and ressels.

\section{PTERTGOIDELS EXTERNUS}

The pterygoideus externus-named from its attachment to the pteryoid process of the sphenoid lone, and its relation to the companion muscle-consists of two thick triangular shects, the one lying in a horizontal, and the other in a rertical plane.

Origin.-Upper head: the under surface of the great wing of the sphenoid hone, internal to the pteryoid ridge, and external to the foramen ovale and foramen spinosum. Lower head: All the outer surface of the external pterygoid plate.

Insertion.-Upper head: (1) The front of the interarticular filco-eartilage of the temporo-nandihular joint; (2) the adjacent portion of the capsular liganent; (3) the upper lart of the front of the nerk of the condyle of the mandible. Lower head: The pit in the front of the neck of the condyle.

Structure.-Aring by fleshy fibres, which are closely connected at the pterygoid riclec with part of the temporal muscle. the upper heach forms a fan-shaped sheet and prases hackwards and slightly outwards to its insertion, which is by short tendinous fibres blencling helow with those of the lower head. The lower 
and much stronger head is at first separated from the upper by a small chink. which may give passage to the internal maxillary vessels. It arises fleshy, converges backwark, outwards, and somewhat upwards, and is inserted by short tendinous fibres.

Nerve-supply.-The external pteryoid branch of the motor portion of the mandibular division of the fifth nerve, which divides into filanents entering its deep surface.

Action.-(1) To draw forwards the ramus of the mandible, and the interarticular fibro-eartilage; ( 2 ) to draw them inwards. The combination of these two movements produces the oflique movement of the lower molar teeth of one side forwarls and inwards with respect to the upper molars which are their opponents. It should be observed also that this inward movement of one sicle is the action by which the ramus of the opuosite side is moved outwards. (3) To assist in opening the mouth br depression of the lower jaw. As the transwerse axis of this morement passes through the mandible at two points situated below

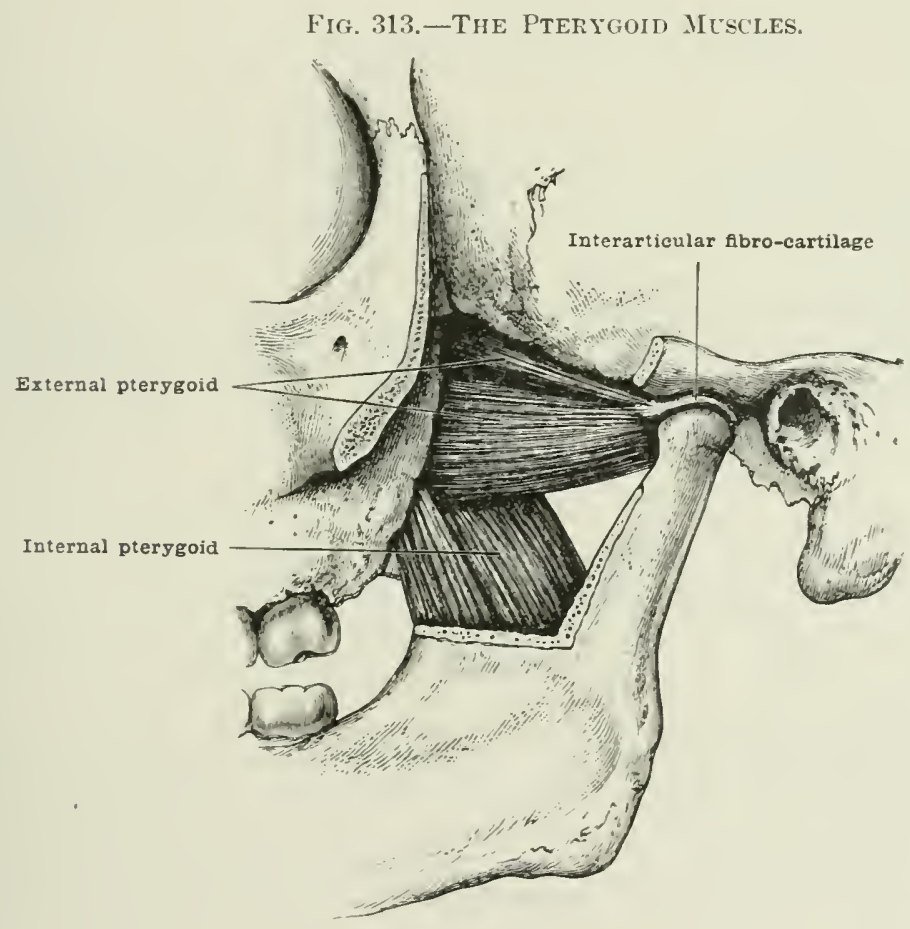

the necks of the rami, it follows that a forwarl morement of the conclyles and necks will assist in the backwarl movement of the angles and body which acconpanies the depression of the mandible.

Relations.- Superficially, the anterior fibres of the internal pterreroid, the temporal muscle, and, at a little clistance, a small part of the masiceter; deeply, the internal pteryoid muscle, the internal maxillary vessels (unless, as smmetimes, they pass across the outer surface of the lower head), the middle meningeal amd inferior dental ressels, with the masseteric and posterior deep temporal nerres passing behind or through the attachment of the upler head; the hurcal amd antrrior deep temporal nerves ruming hetween the two heads; the lingual gustatory and inferior dental nerves beneath the lower head.

Variations.-Nuscular fibres are frerpently found upon the deep surface of the external pterygoirl, rumning from the back of the external litcrygoid plate to the spine of the sphenoid, or the vaginal process of the temporal bone. 


\section{PTERYGOIDELS INTERNLS}

The pterygoideus internus-named from its origin and relative position-is a thick quadriliteral sheet.

Origin.-(1) The whole of the inner surface of the external pteryoid plate and the adjacent part of the tuberosity of the palate bone. (2) A suall triangular area. consisting of the outer surface of the tuberosity of the palate bone, and a small strip in front belonging to the maxilla.

Insertion.-The lower half of the internal surface of the ramus of the mandible, including the adjacent parts of its lower and posterior borders, and extending as high as the mylo-hyoid ridge and inferior dental canal.

Structure.- Arising fleshy, the filores rm varallel to one another, downwards, backwards, and outwards, to be inserted partly into the mandihle, and partly in multipenniform fashion, like those of the masseter, into the tips and sides of fibrous septa, which, passing upwards from the periosteum of the mandible. separate the muscular hundles from one another.

Nerve-supply.- The internal ptergoid branch of the motor portion of the manclibular division of the fifth nerve, which enters the deep surface near its posterior border.

Action.-(1) To close the jaw. The same remarks which were made with respect to the very small loss of mechanical advantage in the masseter muscle apply to this muscle. (2) When closed it will draw the jaw forwards; and also (3) it will help the external pteryoid in drawing the ramus of its own side towards the middle line.

Relations.-Superficially, the external pterygoid muscle, the internal lateral ligament, the internal maxillary ressels, the inferior dental and lingual nerves; deeply, the tensor palati and superior constrictor of the pharyx, the stylo-hyoid muscle and the posterior belly of the rigastric, the submaxillary gland.

\section{THE MUSCLES AND FASCIE OF THE FRONT OF THE NECK}

The platysma myoides has been already described (page 426) with the muscles of expression.

The musches of the neck which lie beneath it are surrounded by a layer of deep fascia, ealled the cervical fascia. This is a strong tubular membrane, attached above to the lower border of the mandible, the parotid fascia, the upper part of the mastoid process, and the superior nuchal line. At the hack of the neck it is continuous with the deep fascia which gives a thin investment to the trapezius muscle. In front, it is attached to the lower border of the body and great cornu of the hyoid bone. Below, it ends upon the front surface of the presternum and the clavicle. The deep luyer of the cervical fascia separates from it just helow the hyoid bone, and runs downwards in elose proximity to the stemo-hyoid muscles and the other depressors of the hyoid hone, to the upper part of the posterior surface of the stemum, and the posterior surface of the clavicle. Laterally, it hlends with and completes the sheath of the stemo-mastoid muscle, which is partly formed by the superficial layer of the cerrical fascia; it also binds down the posterior belly of the omo-hroid to the clavicle and first rib. Below its attachment to the sternum and clavicle it is continned downwards in front of the trachea and great ressels at the root of the neck into the superior mediastimm, and it finally joins the pericarclium. Behind, it gives an investment to the depressors of the hyoid lione. Between this deep layer of the cervical fascia and the superficial layer is a small spare containing a jart of the course of the anterior jugular vein, a lymphatic gland, some fat and loose connective tiscue.

A still rleeper fibrous layer, the prevertebral fascia, stretches across the neck and divides the eylindrical tube formed hy the eervical fascia into a posterior and anterior compartment. Its surfaces are directed forwards and hackwarls. Behind, 
it rests in the middle line upon the ligaments covering the front of the bodies of the cervical vertebre. Laterally, it covers in the prevertehral muscles, and is attached to the deep, surface of the superficial layer of the eerrieal fascia between the sterno-mastoid and trapezius muscles.

In the compartment formed between the decp layer of the eervical fascia as it invests the depressors of the In yoid hone, and the prevertebral fascia, processes are given off which form the sheath of the erreat ressels of the nock, and invest the throid gland, the trachea, and pharyn.

The museles of the front of the neek may be divided into three groups: the first group consisting of one muscle which ascends from the stemum and clavicle to the head, the stemo-cleido-mastoideus; the seeond, of those which ascend from the stemum, clavicle, and shoulder-blade to the hyoid bone and thrroid cartilage; the third, of those which are attached to the hyoid bone below, and the skull and lower jaw above.

\section{Finst Groce}

\section{STERTO-CLEIDO-MASTOID}

The sterno-cleido-mastoid, or sterno-mastoid muscle-named from its attachments (xis:s=a key, being the equiralent of claricle)-is a strong ribbonshaped band, bifurcated below, and somewhat constricted in its middle third.

Origin.-Sternal head: the front of the manubrium (or presternum) between the notches, the middle line, and for the clavicle and first rib. Clavicular head: The upper part of the anterior surface of the inner third of the clavicle.

Insertion.-(1) Along the anterior border and the outer surface of the mastoid process of the temporal bone; (2) the outer half of the superior nuchal line of the oecipital bone.

Structure.-The stemal head is a rounded but flat tendon; the elavieular is partly Heshy and partly tendinous. After a course of about an inch $(2.5 \mathrm{~cm}$. ), the sternal head expands into a flat muscle, which eonceals the greater part of the claricular portion, ancl, passing upwards, outwards, and backwards. is sprearl over the whole line of the upper attachment. Frequently it is so separate from the elavicular head, that they might rery fairly be considered to form two muscles. The clavicular head soon becomes entircly fleshy and ascends more directly. At first it is separated by a small interval from the sternal head, corresponding to a part of the sterno-clavicular joint, from which it sometimes receives a few filmes of origin; when they have joined, it passes beneath the stemal head to its insertion, which is chiefly the lower part of the cuter surface of the mastoid process. The whole insertion in front is composed of short tendinous fihres, and behind of a thin aponeurosis. As the whole muscle has a rery wide range of action. nearly the whole length of its fibres is fleshy. The sternal head is a little longrer than the other, but has little if any more range of movement. Hence it is tendinous.

Nerve-supply.-(1) The spinal accessory nerve, which, while traversing the d(eep) surface of the muscle at the junction of its upper and midlle thirds. sends filaments to it; (2) the cervieal plexus through the anterior primary hranches of the second and third cervieal nerres, which enter the upper part of its deer surface.

Action.-(1) To flex laterally the head and neek, so as to draw the side of the hearl towards the shoulder. (2) To rotate the face towards the opposite sirle. Of the two parts of the muscle, the cleido-mastoid portion is more concenened in lateral Hexion. the stemo-mastuid in rotation. The combination of all these morements may be very well seen in a cas of wryeck, which results from the premanent contraction of this muscle. (3) When both muscles act, to flex the hearl and neck upon the thorax. at the same time rasing slightly the chin. which is therefore carried horizontally forwards. (4) To rase the sternum and inner end of the clavicle. This action may sometimes be seen in patients with paralysis of all the parts bencath the cerrical region, when the only nerves available for re-piratory 
movements are the phrenic and those which sulply certain of the muscles of the neck. (5) If the head he much thrown back, the two sterno-mastoids may be used to inerease the extension.

Relations.-Fuperficially, the deep cervical fascia and integuments, the platrsma myoides, external jugular vein, and nany of the superficial branches of the cervical plexus, and the glandulix coneatenate; deeply, the reetus eapitis anticus major, omo-hyoid, sterno-hyoid and stemo-thyroid, the posterior belly of the digastrie, the splenius apitis, levator anguli seapula, and three sealene muscles; the common, external, and internal carotid and subclavian arteries, with several

Fig. 314.-ANterior axd Lateral Cervical Muscles.

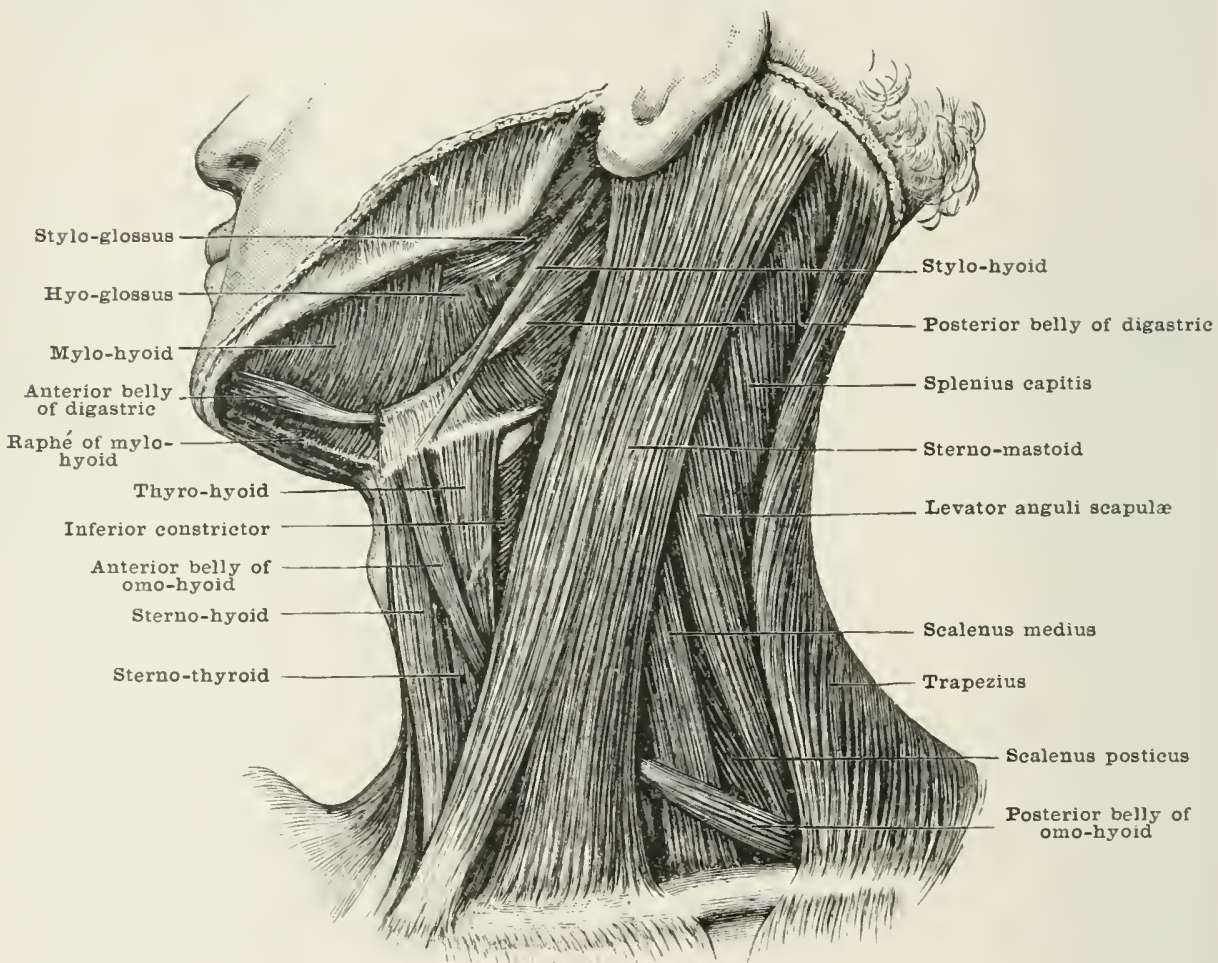

branches of the extemal carotid, the internal jugular, facial, thyroid, anterior jugular, and other veins; the spinal accessory and hypoglossal nerves, the cervical and upper part of the brachial plexuses with many of their branches, the paroticl gland, the lateral lobe of the thyroid gland, and numerous deep cervical lymphatic glands.

Variations.-The clavicular origin may extend farther outwards upon the collar lone. Besides its insertion into the mastoid process, this head may have an attachment to the superior muchal line, callerl the cleilo-occipitul. An extension of the sternal hearl has been olserved arising from the costal cartilages as low as that of the fifth rib. Silips sometimes pass from the upper part of the innsele to the angle of the jaw, the pharynx, the auricle, or the upuer attachment of the trapezius. 


\section{THE INFRA-HYOID MISCLES}

The infra-hyoid muscles form a group of four long flat muscles. arranged in two layers, and enveloped by the deep layer of the cervical fascia.

\section{Superficial LAYER}

This consists of two muscles-the sterno-hyoid and omo-hroid.

\section{STERNO-HYOID}

The sterno-hyoid (figs. 301 and 314 )-named from its two attachments-is long and ribbon-shaped.

Origin.-(1) The back of the manubrium (presternum) just internal to the notches for the clavicle and first rib; $(2)$ the lack of the posterior stemo-clavicular lixament; (3) the back of the inner end of the clavicle external to the facet for the first costal cartilage.

Insertion.-The lower border of the body of the hyord bone, close to the midlle line.

Structure.-It arises fleshy, and forms a bankl of parallel fibres. which approach the middle line as they ascend, and are inserted by a short tendon.

Nerve-supply.-From the first three cervical nerves through the descendens and communicantes hypoglossi, which send filaments to its deep surface near its upper end.

Action.-To draw down the body of the hyoid hone. e.g. after it has been raised in swallowing; also to fix it when the muscles which pass upwards from it are llepressing the tongue, as in suction.

Relations. - Superficially, the deep cervical fascia, sterno-mastoid, stemoclavicular joint, anterior jugular vein; deeply, the sterno-thyroid, crico-thyroid. thyroid and cricoid cartilages, the trachea, thyroid isthmus, and the inferior thyroid vein.

Variations.-The sterno-hyoid may arise from the clavicle alone, and occasionally eren from the middle of that boue. It may be absent or double. A tendinous intersection sometime: crosses it.

\section{OMO-HYOID}

The omo-hyoid ( $\tilde{w}_{\mu \circ}=$ shoulder) - named from its attachment to the shoulderblade and the hyoid bone-is ribbon-shaped with a tendinous constriction in the middle which divides it into two fleshy bellies.

Origin.-(1) The upper borler of the seapula for about an inch $(2.5 \mathrm{~cm}$. behind the suprascapular notch; (2) oceasionally, the upper horder of the transverse ligament which crosses the notch.

Insertion.-The lower border of the hody of the hyoid hone just extemal to the preceling muscle, which it also slightly overlaps.

Structure.-Arising fleshy and broad, the muscle contrarts slightly as it passes forwards, and a little upwarls, across the posterior triangle of the neck ahove the clavicle. Beneath the stemo-mastoid, and orer the great ressels of the neck, it becomes tendinous for a short distance; and then, changing its direction, it asain expands to a fleshy band which runs upwards and slightly forwards and inwarts to its insertion, which is by short tendinous, intermingled with fleshy filmes. In obtuse angle is formed between the two bellies, the lower portion of the muscle and its tendon being held down by as strong yrows of the derpl layer of the cervical fascia, which, forming a loop itround them. prases dewmards to be attachert to the posterior surface of the clavicle and to the first rit.

Nerve-supply.- The anterior belly is supplienl hy a branch from the rlecendens hypoglosit, which enters the back of its deep surfice. while the posterior receives 
a branch from the loop of communieation between this nerve and the communicanter hyloglosi which enters the deep surface of the muscle close to its junction witl the tendon.

Action.-(1) To draw down the lygoid hone; (2) very slightly to help in raising the solpula; (3) to make tense the lower part of the cervical fascia. In this way it assists the platysma myoides in diminishing the inward suction of the soft parts, which tends to compress the great vessels and the apices of the lungs during prolonged insuriratory efforts. The part of the muscle between the stemo-mastoid and the carotid sheath, being tendinons, will not rary in thickness, otherwise during contrattion it might tend to obstruct the ressels beneath.

Relations.- Superticially, the deep cervical fiscia, stemo-mastoid, clavicle, subclavins and trapezins, the extemal jugular vein, and the descending branches of the superficial cervical plexus; deeply, the thyro-hyoid, sterno-thyroid, scaleni, and the first digitation of the serratus magnus, the sheath of the common carotid artery and internal jugular vein, the upper part of the brachial plexus, often the third part of the subclavian artery with the transversalis colli and suprascapular ressels and the suprascapular nerve.

Variations.-These are very frequent. It may be absent or double. The posterior belly may he attached to the clavicle and seapula, or to the elaviele alone. It may reeeive a slip from the manubrium. The anterior belly may blend with the sterno-hyoid, and it may send a slip to the thyroid cartilage or the mandible.

\section{SECOND LAYER OF INFRA-HIYOID Muscles}

This consists of two muscles-the sterno-thyroid and thyro-hyoid.

\section{STERNO-THYROID}

The sterno-thyroid (figs. 301 and 314 ) -named from its attachment to the sternum and thyroid cartilages-is flat and ribbon-shaped.

Origin.-(1) The lower part and side of the back of the manubrium (presternum ), from the middle line to the noteh for the first rib cartilage; (2) the back of the first rib cartilage, and oceasionally that of the second; and (3) occasionally from the back of the clavicle near the facet for the first costal cartilage.

Insertion.-The oblique line on the outer surface of the ala of the thyroid cartilate.

Structure.-Arising fleshy, the two muscles form broad bands of parallel fibres, which at first lie close to one another, and afterwards diverge slightly as they ascend. Finally, they are inserted by short tendinous fibres into the thyroid cartilage. Oecasionally, the musele is erossed by a tendinous intersection.

Nerve-supply.-Branches from the loop between the descendens and the commumiantes hypoglossi which enter the onter part of the deep surface of the musele.

Action.-(1) To draw down the thyroid cartilage, e.g. after swallowing; (2) in conjunction with the thro-lyyoid it will depress the hyoid bone.

Relations.-Cuperficially, the cervical fascia, the anterior jugular vein, the sterao-matoid and stemo-hyoid and omo-hyoid muscles; deeply, the inferior constrictor, the criend artilage, crico-thyroid nuscle, thrroid gland, inferior thyroid reins and trachea, the common carotid artery and left innominate rein.

Variations.-This muscle may be absent or double; the muscles of the two sitles may be united. It may send a slip to the carotid sheath.

\section{THYRO-HYOID}

The thyro-hyoid-named from its attachment to the thyroid cartilage and hyorid hone-is a yuabrilateral sheet.

Origin.- The oblique line on the outer surface of the ala of the thyroid cartilage. 
Insertion.-The lower horder of (1) the outer third of the body of the hyoid bone; and of (2) the inner half of the greater cornu.

Structure.-This muscle is a continuation upwards of the preceling muscle, many of its fibres being deriver from those of the sterno-thyroil without any attachment to the eartilage. It comsists of parallel fleslyy fibres which run nearly vertically upwards to their insertion into the hyoid lwone.

Nerve-supply.-A special hranch of the hypoglosial nerve which enters the deep surface of the muscle near its posterior border.

Action.-(1) To draw up the thyloid cartilage, as in swallowing, or in the production of a high note in singing; (2) in association with the stemo-thyroid to draw lown the hyoid bone.

Relations.-Superficially, the stemo-hyoid, omo-hyoid, and stemo-mastoil; deeply, the thyro-hyoid meinbrane, the thyro-hyoid bursa, the superior laryngeal ressels and nerve.

Variations.-Slips are occasionally seen passing from the cricoid cartilage to the hyoid bone, or between the upper border of the thyroid cartilage in front and the body of the hyoid bone.

\section{THE SUPRA-HYOID MLSCLES}

These consist of four muscles arranged in three layers: the first containing the digastric and stylo-hyoid, the second the mylo-hyoid, and the third the genio-hyoid.

\section{DIGASTRIC}

The digastric-named from its two bellies (yactrip, the belly) -is composed of two flattened and somewhat spindle-shaped bellies united by a tendon.

Origin.-(1) Of posterior belly, the digastric fossa of the temporal bone; (2) of anterior belly, the lower border of the body of the mandible just external to the sympliysis.

Insertion.- $\mathrm{By}$ its central tendon, which is attached to the outer part of the lower border of the body of the hyoid hone and the adjacent part of the great cornu.

Structure. - The posterior belly at its origin consists of short tendinous fibres, which soon form a laterally conpressed muscle. This passes downwards, forwards and inwards, and converges upon a laterally flattened rounder tendon about half an inch $(1 \cdot 2 \mathrm{~cm}$.$) above the tip of the great cornu of the hyoid bone.$

The anterior belly arises by short tendinous fibres, and forms a muscle flattened from before backwards and from above downwards, which is shorter and smaller than the posterior helly. Its fihres converge as they jass backwards and slightly downwards and outwards, to end in the flattened tendon a quarter of an inch (6 1mm.) above the junction of the body and great cornu of the hroid hone. The central tendon is hound down to its insertion upon the hyoid bone, chiefly by a fibrous expansion given off from its lower border, and to i very small degree also by the oblique arch over it formed by the division of the stylo-hyoid muscle. Often, a part of this expansion passes inwards across the middle line and, miting with it:fellow, forms a membranous covering to the deeper structures, and unites the inner horkers of the two anterior hellies.

Nerve-supply.-The posterior belly, which is really a distinet muscle, belonging to a deeper stratum of the muscular planes, receives a special branch from the facial nerve which enters the upper part of its deep surface. Perhays this may he due to the fact that this part of the muscle assists in swallowing; for the facial nerve, by means of the Vidian and the relations which through the lesser superficial petrosal nerve it has with the otic ganglion, may be comsilered to take jart in this function, as well as in the expresion of emotions.

The anterior helly receives at the outer part of its deep surface the terminal filaments of the mylo-hyoid twig from the inferior dental (or mandibular) branch of the mandibular division of the fifth nerve. 
Action.-(1) The posterior belly draws upwards and backwards the hyoid bone, as in the elevation of the larvinx in the second part of deglutition; (2) the anterior helly, acting from above, draws upwards and forwards the hyoid hone; and, acting in the opposite direction, (3) it assists in the depression of the lower jaw and in opening the mouth. Although a comparatively weak muscle, it acts with considerahle power in this morement, for it is inserted at the end of the lever of the second order formed by the mandible, while the resistance which it has to overeome is exerted by muscles acting much nearer to the fulcrum. Morcover, its direction downwards and backwards is at a considerable angle with the line of the lever, viz. that which joins the prominence of the chin to a point a little above the inferior dental foramen. (4) If the mandible be fixed and both bellies act, the hyoid bone will be drawn directly upwirds. By this action the muscle is of great importance in the elevation of the tongue, which rests upon the upper surface of the hyoid hone. It will therefore help in the first part of deglutition, in which the back of the tongue is pressed against the hard palate.

Relations.-The posterior belly lies beneath the mastoid process, the sternomastoil, splenius, and trachelo-mastoid muscles, the facial rein, and the parotid gland; in front lies the stylo-hyoid muscle; deeply, the midlle constrictor of the pharynx, the hyo-glossus, the external and internal carotid arteries, and some of the branches of the external carotid, the internal jugular vein, the hypoglossal and superior laryngeal nerves.

The tendon lies beneath the deep cervical fascia, platysma myoides, and part of the stylo-hyoid muscle. Above is the submaxillary gland. On its deep surface is the rest of the stylo-hyoid muscle, the mylo-hyoid, the hyo-glossus, and the hypoglossal nerve.

The anterior belly is covered by the deep cervical fascia and platysma myoides, and it lies upon the mylo-hyoid inusele.

Variations.-A second posterior belly may arise in front of the angle of the mandible; slips may also arise from the styloid process, or the pharynx. The anterior belly may be absent; it may be partly or' entirely united with that of the opposite side, or may send a slip to the median raphe of the mylo-hyoid.

\section{STYLO-HYOID}

The stylo-hyoid-named from its attachments-is a slender fusiform muscle with a bifurcated lower extremity.

Origin.-The back and outer surface of the styloid process of the temporal bone near its loase.

Insertion.-The lower border of the body of the hyoid bone at the point of union with the great comu.

Structure.-Arising by a short tendon, its fibres soon become fleshy and pass downwards and forwards. Just before its insertion they divide into two bundles, which form an obliquely directed areh bridging over the tendon of the digastric muscle.

Nerve-supply. - A special branch of the facial nerve, which enters its deep surface from behind.

Action.-The same as that of the posterior belly of the digastric, viz. to draw the hyvid bone backwarls and upwards.

Relations.- Superficially, the parotid gland and deep cervical fascia; in front, the submaxillary gland; hehind, the posterior belly of the digastric; deeply, the middle constrietor and hyo-glossus and the external carotid artery.

Variations.-The stylo-hyoid may arise in part from the eartilage of the external auditory meatus. It may be absent, or its insertion may be undivided, in which case it may pass to the imner or outer sile of the digastric tendon. A second stylo-hyoid may run beneath the hyo-glossus to the lesser cornu of the lyyoid bone.

\section{MYLO-HYOID}

The mylo-hyoid-named from its attachment to the lower jaw ( $\mu \dot{u}^{\prime} \gamma_{\mathrm{y}}=$ a mill and the jaw) and to the hyoid bone-is a triangular and somewhat eurved sheet. 
Origin.-The whole length of the mylo-hyoirl rielge on the inner surface of the body of the mandible.

Insertion.-(1) The lower edge of the anterior surface of the body of the livoid bone; (2) a median raphe extending from the mirldle of the lower border of the body of the lyoid bone to the back of the symphysis of the mandible immerliately below the genial tubercles.

Structure.-Arising by fleshy and short tendinous fibres intemingled, the musele passes inwards and slightly downwards to its insertion by short tendinous fibres into the median raphe and hyoil bone. Sometimes the fleshy fibres are here and there continuous with those of the other sicle. Each of them is somewhat arched, so that the whole sheet has a slight downward convexity. The muscles of the two sides together form a curved diaphragm which stretches across the angle contained between the two portions of the mandible.

Nerve-supply.-From the third (or mandibular) division of the fifth cranial nerve, by the mylo-hroid branch of the inferior dental which enters the uncler surface of the muscle by several filaments.

Action.- (1) To raise the tongue, the floor of the mouth, and the hyoid bone, as in mastication and the first part of swallowing. By its elevation of the hyoid bone it will also exert some influence on the larynx and lower part of the pharynx. These actions will be most efficiently carried out when the jaw is closed. (2) Acting from below, it will help in the depression of the lower jaw and in opening the mouth.

Relations.-Upon its under surface lie the superficial portion of the submaxillary gland, the submental artery, and the anterior belly of the digastric muscle. Above, it is in contact with the genio-hyoid and hyo-glossus, the sublingual gland, the deep portion of the submaxillary gland, and the hypoglossal nerve.

Variations.-The mylo-hyoid may be closely connected with the anterior belly of the digastric. Openings are sometimes found in the muscular sheet, containing lobules of the submaxillary gland.

\section{GENIO-HYOID}

The genio-hyoid-named from its attachment to the chin ( $\gamma$ sisenis) and the hyoid bone-is somewhat fusiform, but flattened from above downwards behind, and from side to side in front.

Origin.-The lower genial tubercle.

Insertion.-The anterior surface of the hody of the hyoid hone.

Structure.-Arising by a short tendon, its fibres pass backwards and slightly downwards, close to those of the corresponding muscle of the other side. Near the hyoid bone they spread out laterally, and occupy nearly the whole of the upper and anterior surface of the body, sometimes even a small portion of the greater cornu.

Nerve-supply.-The hypoghossal nerve, which sends filaments to the deep surface.

Action.-(1) To raise and draw forwards the hyoill bone; (2) to draw down the mandible. In its direction and action it is closely related to the anterior belly of the digastric.

Relations.-Superficially, the mylo-hyoid musele; deejly. the genio-hyoglossus; on its median surface, the corresponding muscle of the other side.

Variations.-The genio-hyoid may be double, or it may form one muscle with its fellow of the opposite side.

\section{THE EXTRINSIC MUTSLES OF TIIE TONGLE}

The tongue consists chiefly of muscular tissue. part of which arises from the adjacent bones, while the rest is made up of bands of fibre which frass in various directions in its substance, and have no external attaclment. The latter or intrinsic 
muscles will he describet later; the former or extrinsic muscles constitute a group which is nearly related to those which have been just described. It consists of four muscle-viz, the genio-hyo-glossus, the hyo-glossus, the stylo-glossus, and the palato-glossus.

\section{GENIO-HYO-GLOSSLS}

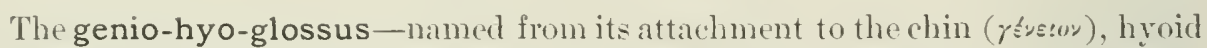
bone, and tongue (riwosor), is a flat sheet forming the quadrant or, more correctly, the sector of a circle, and separated from its fellow by a thin stratum of connective tissue, the splum of the tongue.

Origin.-The upper genial tubercle.

Insertion.-(1) The whole length of the tongue in the submucons tissue just extemal to the median plane, from the tip along the dorsum to the root; (2) the upper part of the anterior surface of the body of the hyoid bone; (3) by a few fibres into the sicle of the pharynx.

Structure.-Its origin is by a short tendon, from which its fleshy fibres diverge in a fan-shaped sheet to their extensive insertion.

Nerve-supply.-The hypoglossal, by filaments which enter its outer surface.

Action.-(1) To draw downwards and forwards the mesial portion of the tongue so as to make its dorsum concave upwards in a transverse direction; (2) by its anterior fibres to draw back the tip of the protruded tongue; (3) by fibres which pass to the back part of the elorsum of the tongue to draw it forwards, and protrucle the tongue; (4) by its lowest fibres to draw upwards and forwards the hyoid bone, and so help the genio-hyoid and anterior belly of the digastrie in raising the tongue; (5) acting from below, its hyoid portion will help in depressing the lower jaw.

Relations.-Extemally, the inferior lingualis, hyo-glossus, and stylo-ghossus muscles, the ranine artery, the terminal branches of the hypoglossal and lingual gustatory nerves, the mucous membrane of the floor of the mouth, the sublingual gland, and Wharton's duct; internally, the fellow muscle and septum lingure; along its lower border, the genio-hyoid muscle.

\section{HYO-GLOSSLS}

The hyo-glossus-named from its attachments to the lyoid bone and tongue (riciara)-is a thin square sheet.

Origin.-(1) From the front of the hyoid bone near the upper border of the outer third of its body; (2) from the upper border of all its great cormu; (3) by a small ship from the lesser cormu.

Insertion. - The submucous tissue and adjacent museular mass of the posterior half of the tongue external to the preceling muscle.

Structure.-The fleshy fibres arise directly from the bone in a thin sheet, and ascend nearly parallel to one another. The anterios fibres, howerer, diverge slightly forwards, and they all, having reached the upper surface of the sides of the tongue, course inwarls, interlacing with the fibres of the palato-glossus and superficial lingualis to form a sulmucous cover to the tongue.

Those which arise from the lesser cornu are often ileseribed as a distinct muscle, the chondro-glosses, which is separated from the rest of the muscle by some bundles which pass from the lower part of the genio-hyo-glossus to the superior constrictor.

Nerve-supply. - The lypoglossal nerve, which sends filaments into its outer surface.

Action.-(1) To draw downwards the sides of the tongue, increasing its transverse convexity; ( 2 ) to draw hackwards the protruded tongue.

Relations.-Extemally, the mylo-hyoid, digastrie, stylo-hyoid, and styloglossus muscles, the lingual vein, lingual gustatory and hypoghossal nerves, the sulmaxillary crland and Wharton's duct; deeply, the inferior lingualis, genio-hyoglossus, middle constrictor, and part of the origin of the superior constrictor, the lingual artery, and glosso-pharyngeal nerve. 


\section{STYLO-GLOSETS}

The stylo-glossus-named from its attachments to the styloid process and

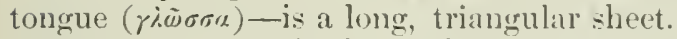

Origin.-(1) The front of the lower part and tip of the styloid process of the temporal bone; (2) the upper part of the stylo-mandibular liganent.

Insertion.- The submueous tissue and subjacent muscular strata of the side of the tongue and the adjacent parts of its under surface.

Structure.-Arising by short tendinous fibres, the muscle soon develops into a long, fan-shaped, laterally-compressed sheet, which passes in a long curve, with an upward concarity, forwards and slightly downwards and inwards to the side of the tongue, where it partly overkaps and partly interlaces with the hyo-glossus musele, forming with this muscle and some of the fibres of the palato-glossus a thin superficial stratum which is continued forwarls to the tip of the tongue.

Nerve-supply.-From the hyporlossal nerve, by filaments which enter its external surface.

Fig. 315. -SIDE View of the Ml'scles of the Toxgle.

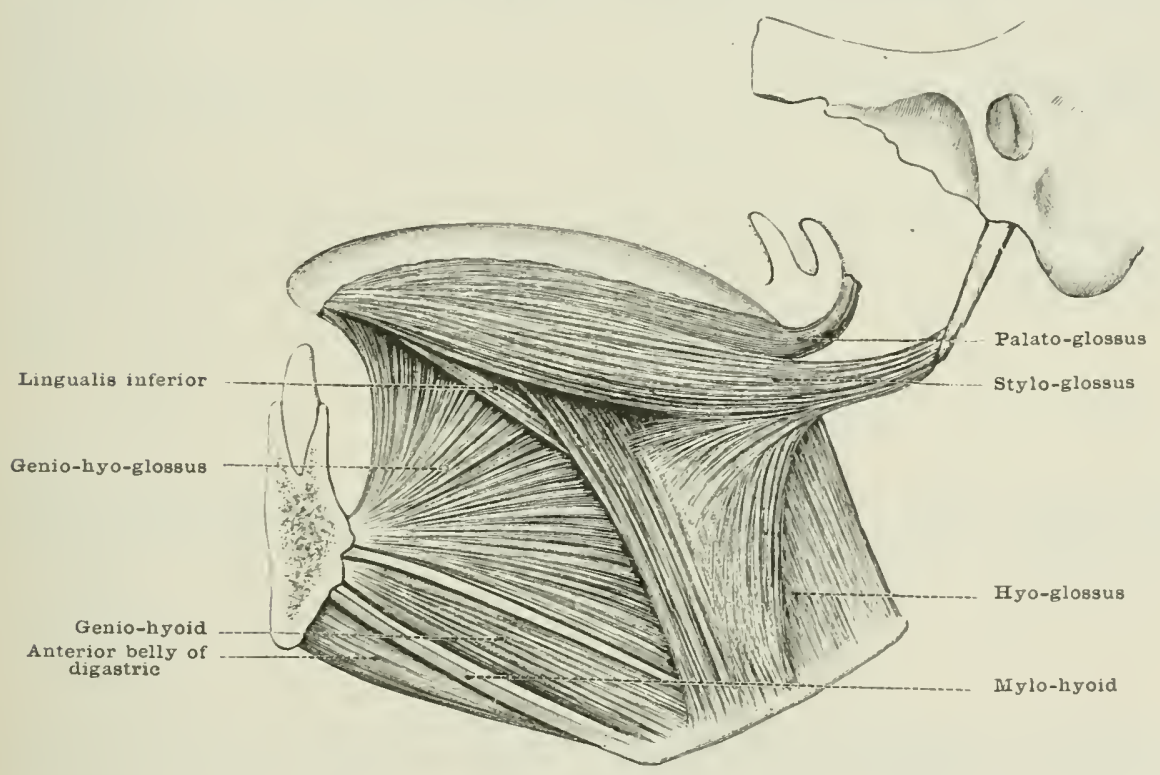

Action.-(1) To draw back the tongue-for this purpose it arises from the styloid process as low as possible and below the level at which the two other styloid muscles arise; (2) to draw upwards the sides of the tongue, so as to help the geniohyo-rglossi and some of the intrinsic muscles in making its upper surface concare from side to side.

Relations.-Superficially, the internal pterygoid, the praroticl gland, lingual gustatory nerve, and the mueous membrane of the side of the tongue; detply, the stylo-pharyngeus, hyo-glossus, inferior lingualis and genio-hyo-glossus, with the glosso-pharyngeal nerve.

\section{PALATO-GLOSSLS}

The palato-glossus-named from its attachment to the soft palate and tongue (yicosra) -is a somewhat cylindrical muscle which expands at either end into a thin sheet.

Origin.-The under surface of the aponeurosis of the suft palate: and at the middle line its fibres are continuous with those of its fellow of the oprosite side. 
Insertion.-(1) The superficial museular stratum which rovers the side and adjacent part of the muler surface of the tongue; $(2)$ it is partly continuous with the deep transrerse lingualis muscle.

Structure.- Arising in a thin muscular sheet, its fihres form as they pass ontwards a small cylindrical bundle which, lying in front of the tonsil and against the wall of the pharyux, ronstitutes the anterior pillat of the fauces. This bundle runs downards and forwards till it reaches the sirle of the tongue at the junction of its middle and posterior thirds. Here some of the fibres pass forwards and downwards to join the superficial stratum formerl by the stylo-glossus and hyoglossus. The rest pass inwards towarls the middle line, being continued into the deep transverse lingualis musele. This part of the two museles, together with the associated portion of the lingualis transversus, forms a sphincter muscle round the front part of the fancial opening.

Nerve-supply.-Filaments from the pharyngeal plexus.

Action.-(1) To draw downwards the sides of the soft palate; (2) to draw upwards and backwards the sides of the tongue. The combination of these two actions eloses the front part of the fancial opening, as in the seeond part of swallowing, when the back of the tongue comes into enntact with the soft palate, and prevents the return of the food which is being grasped by the constrictors. It should be remembered, however, that the elevation of the tongue is chiefly due to the musdes which raise the hroid bone.

Relations.- Superficially, it is covered by the mueous membrane of the soft palate and the side of the tongue; deeply, it is in contact with the aponemrosis of the soft palate, the superior constrictor of the pharrnx, and the hyo-glossus; behind it lies the tonsil.

For Museles of the Palate see page 944. For Muscles of the Pharynx see pages $950-952$.

\section{THE DEEP MLSCLES OF THE FRONT OF THE NECK}

The deep muscles of the front of the neek consist of an inmer and an outer group, separated from one another by the line of the anterior tubercles of the cerrical vertebræ. Both groups are covered in front by the prevertebral fascia.

\section{Outer Group}

The outer group is formed by the three sealeni, which pass from the first two ribs upwards and inwards to the transverse proeesses.

\section{SCALENLS ANTICLS}

The scalenus anticus-named from its shape (scaleme = of unequal sides, being a term applied to rertain triangles in geometry) and its relation to its fellows -is a thick triangular sheet.

Origin.- The scalene tubercle near the inner horder of the upper surface of the first ril).

Insertion.-The anterior tuhereles of the third, fourth, fifth, and sixth eervieal vertebrie.

Structure.-Arising by a short, somewhat flattened tendon, which is continued upwards for a short distance upon the front and onter surface of the muscle, the fleshy fibres diverge as they bass upwards and slightly backwards and inwards to be inserted by four short tenclons into the transverse processes.

Nerve-supply.-From the anterior primary hrinehes of the fourth, fifth, and sixth cervicil nerves elose to their points of emergenee.

Action.-(1) The rib baing fixed, it will help to flex the neek both forwards 
and laterally, and to rotate it so as to turn the face to the opposite side; (2) it will raise the first rib, especially in forced inspiration.

Relations.- In front lie the sterno-mastoid, omo-hyoid, and subclarius, the internal jugular vein, the subclavian vein and phrenic nerve; on the inner side are the rectus capitis anticus major, longus colli, the vertebral vessels, and the sympathetic cord; on the outer side and behind emerge the anterior primary branches of the cervical nerves separating it from the scalenus nedius; and lower down it crosses in front of the second part of the subclavian artery and the pleura.

\section{SCALENUS MEDIUS}

The scalenus medius-named from its shape and position-is an elongated triangular sheet.

Origin.-The upper surface of the first rib between the tuberosity and the groove for the subclavian artery.

Insertion.-The front of the posterior tubercles of the six lower cervical vertebræ, and frequently also the lower part of the lateral mass of the atlas.

Structure.-Arising by a broad band, tendinous in front and muscular behind, the fleshy fibres form a thick sheet of slightly divergent fibres, which run upwards and inwards to end upon the vertebre in six short tendons.

Nerve-supply. - The anterior primary branches of the cervical nerves as soon as they emerge supply numerous filaments to the inner part of its anterior surface.

Action.-Acting from below, to flex the neck laterally; acting from above, to raise the first rib as in forced inspiration, or to fix it in ordinary inspiration.

Relations.-In front lie the sterno-mastoid, omo-hyoid, and trapezins, the subclavian artery, cervical and brachial plexuses; behind, it is in contact with the levator anguli scapule and scalenus posticus.

\section{SCALENLS POSTICLS} sheet.

The scalenus posticus-named from its form and position-is a triangular

Origin.-The upper part of the outer surface of the second rib liehind the rough prominence for the serratus magnus.

Insertion.-The lower surface of the posterior tubercles of the two or three lowest cervical vertebræe.

Structure.-Arising partly directly from the bone, and partly by a short aponeurosis which covers the outer and posterior part of the origin, its fleshy filres converge and are inserted by three short tendons.

Nerve-supply. - Small filaments which come from the lower three cervical nerves at their points of emergence, and, after passing through the scalenus modius, enter the front service of the muscle.

Action.-When the rib is fixed, to flex the lower part of the neck laterally, and acting from above, to raise the second rib, especially in forced inspiration.

Relations.- In front lies the scalenus medius; behind, the levator anguli scapulie.

Variations of the scaleni.-The scalenus posticus may be absent. The sealenus medius may arise as low as the third rib. A portion of the scalenus anticus may be separate firm the rest, and pass behind the subclavian artery. 


\section{IXYer Grolp}

The inner or precertebral group consists of the greater and lesser rectus capitis anticus and the longus colli.

\section{RECTLS CAPITIS ANTICUS MAJOR}

The rectus capitis anticus major-named from its direction, position, and size-is a thick, irregular, quadrilateral sheet.

Origin.- The front of the anterior tubercles of the thind, fourth, fifth, and sixth cervical rertebre.

Fig. 316. -The Mlecles of the Frovt of the Neck.

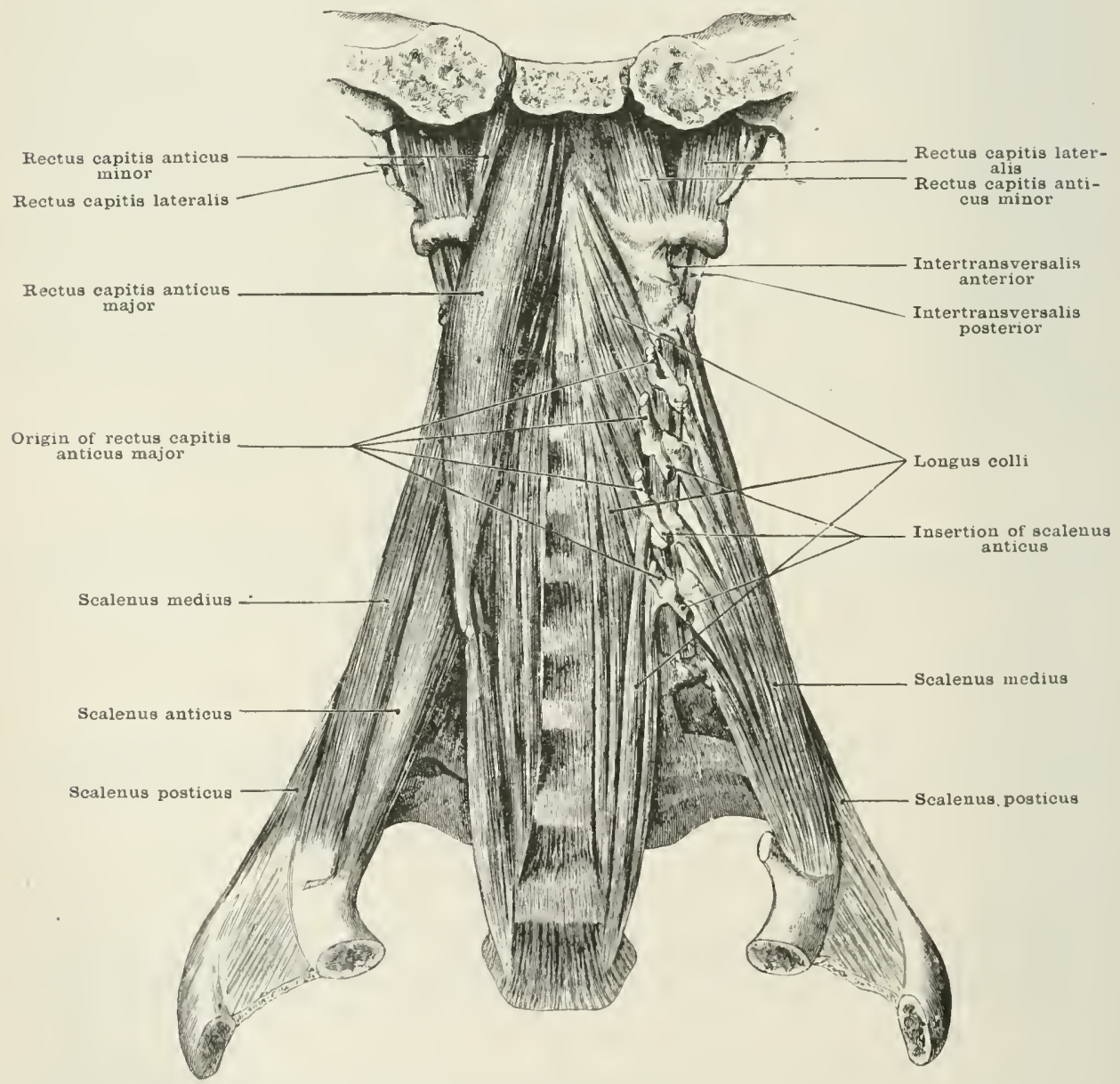

Insertion. - A transverse impression upon the under surface of the basilar process of the ocripital hone, extending from just behind the pharyngeal tubercle outwards and somewhat forwards.

Structure.-Arising hy four tendinous teeth, the parallel fleshy filores run upwards and inwarks to be inserted directly upon the oceipital bone. An incomplete tendinous intersection crosses its anterior surface.

Nerve-supply.- Internal branches from the first and second cervical nerves enter the upper part of its front surface. 
Action.-To flex the hearl, and slightly to rotate it to the same side.

Relations.- In front, the internal and common carotid artery, the internal jugular vein, the pnemogastric and sympathetic nerves, and the upper part of the pharynx; behind, the rectus capitis anticus minor, and part of the longus colli.

\section{RECTUS CAPITIS ANTICUS MINOR}

The rectus capitis anticus minor-named from its direction, position, and size-is thick and riblon-shaped, and continues the series of the anterior intertransversales.

Origin.-The upper surface of the lateral mass of the atlas in front of the articular process.

Insertion. - The under surface of the basilar portion of the occipital bone in front of the foramen magnum, but not as far inwards as the preceding muscle.

Structure.-Parallel or slightly divergent fleshy fibres which run upwards and inwards.

Nerve-supply.-The first cervical nerve, which sends a filament to its front surface.

Action.-To flex the head.

Relations.-In front, the rectus capitis anticus major; behind, the anterior occipito-axial ligament.

\section{LONGL'S COLLI}

The longus colli-named from its length and the region in which it lies-is a compound muscle, and forms an elongated triangular sheet with the hase running vertically along the outer border of the anterior common ligament, and the obtuse apex directed ontwards. It consists of three portions: one mesial, the rerticul; and two lateral, the upper and lower oblique portions.

\section{Vertical portion:-}

Origin.-Lateral part of front of bodies of last two cervical and first three thoracic vertebre, external to the anterior common ligament.

Insertion.-Lateral part of front of bodies of second, third, and fourth cervical vertebrie.

Lower oblique portion :-

Origin.- Lateral part of front of bodies of the first three thoracic vertehre.

Insertion.- The front of the anterior tubercles of the transwerse processes of the fifth and sixth cervical vertebre.

\section{Upper oblique portion :-}

Origin.--The front of the anterior tubercles of the transverse processes of the third, fourth and fifth cervical vertebræ.

Insertion.-The under surface and sirle of the antrrior tubercle of the atkas.

Structure.-All three portions arise by short tendons, then becone fleshy, and are inserted by short tendons, with the exception of the superior ollique portion, which has a fleshy attachment to the tubercle of the athis.

Nerve-supply.- The anterior branches from the cerrical nerres soon after their emergence.

Action.--To flex the neck; and also by its ohlique portions slightly to rotate and laterally flex it.

Relations.- In front, the pharynx, osophagus, great vessels of the neek, the inferior thyroid artery, the sympathetic cord, the fmemogastric nerve. and the recurrent laryngeal nerve; liehind, the vertebril column, and, under cover of the lower oblique portion, the vertebral artery. 


\title{
ABNORMAL MUSCLES
}

\author{
BY J. BLAND SUTTON, F.R.C.S.
}

ASSISTANT SLRGEON TO THE MIDDLESEX HOSPITAL, AND SURGEON TO THE CHELSEA HOSPITAL FOR WOMEN

REVISEN AND ADDED TO BY ARTHUR ROBINSON, M.D., LECTLRER ON AXATOMY AT THE MidDLESEx Hospital,

The abductor ossis metatarsi quinti arises from the onter tubercle of the calcaneum.

It is inserted into the tuberosity at the base of the fifth metatarsal bone. The origin and insertion are marked in fig. 167. It is present in two out of every three subjects, and when not represented by unsele filres its place is occupied by a band of fibrous tissue.

Agitator caudx is a small slip of muscles which arises from the last piece of the sacrum or from the side of the cocryx. It is inserted into the femur below the glutens maximus.

Amygdalo-glossus.- A small muscle which arises from the side of the tongue and is inserted into the outer surface of the tonsil.

The anomalus arises from the nasil process of the maxilla, beneath the levator labui superioris "luque musi. It is inserted into the maxilla close to the origin of the compressor naris.

The atlanto-mastoid arises from the transverse process of the atlas, between the superior coblique and the rectus capitis lateralis. It is inserted into the posterior part of the mastoid process.

Azygos pharyngis.-This musele arises from the pharyngeal tubercle on the under surface of the body of the occipital bone.

It is inserted into the raphe of the pharynx superficial to the insertion of the superior and middle constrictor muscles. It may blend with the ascending fibres of the middle constrictor. It is often represented by a fibrous band. [For figure, see Macalister, Proc. Royal Irish Acadenu, rol. ix.]

'The chondro-epitrochlearis arises from the cartilages of one or two ribs (usually the seventh), or from the aponeurosis of the external obliyue wuscle.

It is inserted. into the faseia on the inner sile of the arm, or into the intermuscular septum, and sometimes into the internal condyle of the humerus. [For figure, see Perrin, Journ. of Anat. anel Pliys, vol. v. plate ix.]

The cleido-hyoid arises from the clavicle near the outer border of the sterno-hyoid.

It is inserted into the body of the hyoid surerficial to the stemo-hyoid.

The cleido-occipitalis arises from the elavicle posterior to the stemo-mastoid and anterior or external to the cleido-mastoid. It runs upwards parillel with the posterior border of the stermo-mastoid to be inserted into the superior nuchal line of the occipital bone anterior to the (1)igin of the trapezius. [Perrin; a good figure in Jomm. of Anat. and. Plys. vol. v. 1). 253.]

The costo-coracoideus arises from one or nore ribs, between the pecturalis major and the latisimus dorsi, and is inserted into the coracoid process.

The costo-fascialis is a muscular slip given off from the outer border of the sterno-thyroid near its origin.

It is inserted into the sheath of the carotid ressels, and sometimes reaches as high as the level of the thyroid curtilage.

The curvator coccygis arises from the anterior surface of the fifth piece of the sacrum.

It is inserted into the anterior surface of the coceyx. [For figure, see MI. Watson, eJoum. of Auret. amel Pliys. vol. xiv. 1. 40\%.]

The depressor thyroidea rexises from the lower border of the first ring of the trachea quite elose to the middle line.

It passes vertically upwards to be inserted into the lower border of the thyroid cartilage internal to the crico-thymid. [The muscle is figured by Messenger Bradley in . Iomm. of Anat. and Pliys. vol. vi. p. 420.$]$

'The dorso-epitrochlearis is a muscular slip giren off by the tendon of the latissimus dorsi at the axilla. Sometimes it is directly continuous witl a chomiro-epiteochlemris musele.

It is imserted into the long head of the trieeps, or into the fascia of the arm, and sometimes into the internal intermuscular septum. [For figure, see Perrin, Joum. of Anat. amd Phys. vol. v. plate $x$.]

The epitrochleo-anconeus is a small muscle crising fiom the back of the internal condyle of the humerus, and passing uver the ulnar nerve is imserted into the inner side of the olecranon. 
This is the most frequent of all the muscles to which the term 'abnornal' is appliecl. [For figure, sce Wood, Pinc. lioy. Sioc. vol. xv. p. 521.]

The extensor annularis rerises from the posterior surface of the ulnar shaft below the extensor indicis. When an extensor medius is also present, it will arise in eormmon with the ammularis.

The tendon passes under the annular ligament with the common extensor, and is inserted into the tendun of the ring (fourth) finger.

The extensor brevis digitorum manus arises from the ligamentous tissues on the back of the carpus, or from one of the bones of the furearm, or from the posterior anmular ligament. It pissies under the pusterior annular ligament, and gives off three slipis which blend with the tendons of the third, fourth, and fifth digits.

The extensor carpi radialis accessorius arises fiom the humerus below the extensor earji ratdialis longior.

It is inserted into the metacarpal bone of the thumb, or into the abductor pollicis, or into the first dorsal interosseous muscle.

Extensor carpi radialis intermedius. - This muscle usually arises from one or both the ratial extensors of the carpus, and more rarely from the humerus. It is inserted into the second or third metacarpal bone.

The extensor coccygis arises from the posterior surface of the last piece of the sacrum.

It is inserterl into the posterior surfice of the coccyx.

The extensor medii digiti arises from the ulna below the extensor indieis, or from the nosterior annular ligament. It is insertul into the extensor ex pansion of the middle finger.

The extensor ossis metatarsi hallucis crises as a slip from the extensor proprius leullucis or from the extensor conmm is digitornn, or from the tibiulis anticus. It maty arise as a separate muscle close to the extensor proprius.

It is inserterl into the metatarsal bone of the hallux.

The extensor primi internodii hallucis longus is usually an offset from the extensor proprins, but it may arise separately from the fibula and interosseous membrane or from the tibialis anticus.

It is inserted into the inner part of the base of the first phalanx of the hallux. [See Wood, Proce. Roy. Sorc. vol. xr. p. 535.]

The flexor accessorius longus arises from the fiscia over the flexor tongus lallucis, or from the fibula or tibia; it passes with the tendon of this muscle beneath the internal annular ligament; and ends in a tendon which erosses the long plantar ligament oblinuely, to be inserted into the sesamoid bune in the tendon of the peronens longres, or it joins the long flexor or the accessorius.

When this umacle is present, the accessorius is sometimes absent. [For figure, see Thane, Proc. Arut. Soc. of Gt. Britnin and Treland, May 1891.]

The flexor carpi radialis brevis vel profundus arises from the front surface of the radius near the anterior border, above the pronator quadratus, but below the flexor longus pollicis.

The insertion is very variable: in some cases it only reaches the annular ligament, whilst in others it passen under this structure to be inserted into the trapezium, magnum, or the base of the seend or third metacarpal bones. [For figure, see Wood, Journ. of Anut. and Phys. rul, i. 1. 57.]

The gluteo-perinealis arises from the fascia at the lower border of the gluteus maximus. It joins the transcersus perinei or is inserted into the triangular ligament.

'The gluteus quartus arises from the anterior part of the inferior gluteal ridge of the ilium; it lies in close contact with the capsular ligament of the hip-joint.

It is inserted into the top of the great trochanter of the fimur anterior to the insertion of the gluteus minimus. [For gooul figure, see Gruber, Virchou Arch. brl. crii. s. 480.]

Hyo-epiglottideus. - This muscle arises from the midule of the ridge on the lingual aspect of the epiglotti:

It is inserted into the median tubercle on the body of the hyoid bone. It is often represented by al fibrous band. [See Jomrn. of Amrt. and Phys. vol. xxiii. 1. 2ifi.]

The iliacus minor, or ilio-capsularis, erises from the anterior inferior spine of the ilium.

It is inserted into the lower pall of the anterior intert rochanteric line, or into the ilio-femoral portion of the cilpsule.

The interclavicular muscle usnally consists of two fleshy bellies with a stont intermethate tendon. It arises from the clivicle, anterior to the attachment of the rhomboid ligament and from the ligament itself.

It is inserted into a corresponding position on the opposite clavicle, and fills up the gap between the stemal ends of the clavicles. [Lane, Jomrie. of Anat. and Phys. vol. xx. 1. 5tt.]

The interosseus primus volaris is a slender muscle arising from the ulnar side of the basee of the first metacarnal lone.

It is inserted into the side of the base of the first phalanx of the thumb in common with the adiluetor pollieis.

Its origin and insertion are market in fị̣. $135,1 \% .130$.

The ischio-aponeuroticus, or tensor fasciæ cruralis, arises from one of the hanstring musce-. and is insertecl into the fascia un the back of the leg.

Kerato-thyroid.-A short, slender muscle arising from the luwer border of the ericoirl sartilage behind the articular licet.

It is inserted intu the inferior cornu of the thymit cartilage. 
The levator clavicula arises from the trimsvejse processes of the first and second eervical

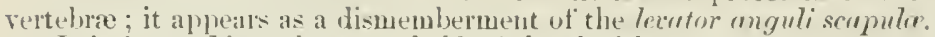

It is inserted inte the outer half of the claviole.

Levator glandulæ thyroideæ. -This muscle arises from the istlimus, but more frequently from the pyramidal process of the thyroid body.

It is inserted into the anterior surfice of the bouly of the hyoid bone. Frequently it is connecterl with the tlyoro-hyoid muscle, and oceasionally with the stemo-thyroid.

The mento-hyoideus is a slip of muscle which arises from the body of the hyoid bone. Sometimes it consists of two parallel slips.

It is inserterl into the symplysis superficial to the mylo-hyoid muscle.

The mylo-glossus, a small accessory slip of the stylo-glossus, arises from the angle of the mandible, or from the stylo-maxillary ligament.

It is inserted into the side of the tongue between the stylo- and hyo-glossus muscles. [For figure, see ITood, Pioc. Roy. Soc. vol. xv. p. 523.]

Obliquus inferior accessorius. - A small muscular slip which passes from the inferior reetus to the inferior oblique muscle.

The occipitalis minor arises from the fascia over the occipital origin of the trapezius and terminates in the fascia over the insertion of the sterno-mastoid.

The occipito-hyoid arises from the mastoid process of the temporal bone and adjacent portion of the superior nuchal line. It passes superficially across the sterno-mastoid near its virigin, to be inserted into the hyoil bowe near the junction of the cornua with the basi-hyoid, and in close association with the posterior belly of the digastric. [Perrin : good figures in Joum. of Anat. and Phys. vol. v. pp. 25l-3.]

The occipito-scapular, or rhomboideus occipitalis, arises from the occipital bone on a lerel with the splenins capitis under cover of the trapezius. It passes downwards to be iuserted into the pusterior border of the seapula at the base of the spine. [For figure, see Wood, $P$ ioc. Roy. Noc. vol. xv. 13. 521.]

The opponens hallucis arises from the oblique adductor of the great toe, and is inserted into the first metatarsal bone.

The opponens minimi digiti pedis arises from the flexor brevis minimi digiti and is inserted into the fitth metatarsal bone.

Pectoralis minimus.- A rare muscle which arises from the eartilage of the first rib, and is inserted into the coracoid process.

The peroneo-calcaneus internus arises from the lower part of the flexor (posterior) surface of the fibula, external to the origin of the flexur longus hallucis. Its tendon passes beneath the internal annular ligament with the tendon of the flexor longus hallucis, to be inserted into the fore part of the inner' surface of the caleancum. [For figure and reference, sce 'Thane, Proc. Anit. Ninc. of Git. Britain and Ireland, May 1891.]

The peroneo-tibialis urises from the imer side of the head of the fibula. liteus.

It is insoted into the upper extremity of the oblique line of the tibia bencath the pop)-

'The peroneus accessorius arises from the fibula, between the peroneus longus and the peroneus lorevis, and joins the tenilon of the longus in the sole of the foot.

The peroneus quartus arises from the flexor surface of the fibula between the peroneus bieris and flexor longus hallucis.

It is inserted into the ridge of the cuboid, neroneo-euboideus, or into the peroneal tubercle of the calcanewn, peroneo-calcaneus externus.

The peroneus quinti digiti arises from the lower fourth of the fibula under cover of the jeroneus brevis.

It is inserted into the aponeurosis on the extensur surface of the little toe. [Wenzel Gruber has deroted a monograph to this muscle, entitled Musculus Peronei Digiti T. Berlin, 18s6.]

The petro-pharyngeus arises from the raginal process of the temporal bone and is inserted into the pharyux.

The pharyngo-mastoideus arises from the mastoid process and is inserted into the pharynx.

The pisi-annularis arises from the pisiform bone and is imserted into the anmular ligament.

The pisi-metacarpeus arises from the pisiform bone and is inserted into the fifth metacarpal. It freruently forms part of the abductor minimi digiti. forils.

The pisi-uncinatus arises from the pisiform bone and is inserted into the hook of the unci-

The popliteus minor arises from the femur to the inner side of the plantaris.

It is inserted into the posterior ligament of the knec-joint.

The psoas parvus arises from the bodies of the list thoracic and first lumbar vertebre and from the lisc letween them.

It is inserted by means of a thin flat tendon into the ifio-pectineal line. This muscle is fiequently present.

'The pterygoideus proprius arises from the erest on the greater wing of the sphenoid.

It is inserted intu the posterior burder of the external pterygoid plate, and occasionally into the tuberusity of the maxilla. [For figure, see Wagstaffe, Journ. of Anat. imul Phys. vol. v. p. 23.7

The pterygo-pharyngeus externus arises from the haumlar process of the splienoid bone and is inserted into the pharyux. 
The pterygo-spinous arises frou the alar spine of the sphenoid.

It is inserted into the posterior margin of the external pterygoid plate. This muscle is sometimes replaced by ligament.

The pubo-transversalis arises from the ilio-pectineal line behind the conjoinerl tendon, and is inserted into the transtersalis fiscia, the aponeurosis of the transversalis muscle or the outer end of the semilunar fold of Douglas.

Rectus abdominis lateralis.-This muscle consists of rertical filures passing from the lower ribs to the upper part of the ilium between the oblique abduminal muscles.

The rectus capitis anticus medius arises from the middle of the anterior surface of the body: of the axis near its lower border by means of a tendon. As it passes rertically uj,warls, it bifurcates, ench fleshy belly being inserted into the basilar process of the occipital bone immediately in front of the foramen magnum, posterior to the insertion of the rertus calitis anticus major, and internal to that of the rectus eapitis anticus minor. [Walsham, Journ. of Anut. and Phys. vol. xriii. p. 461.$]$

The rhombo-atloideus arises from the lower cervical or upper dorsal spines, superficial to the serratus posticus: superior, and is inserted into the transverse process of the atlas.

The rotator humeri cirises from the under surface and outer border of the coracoid process of the scapulit.

It jasies across the tendon of the sulseapularis, to be inserted into the neck of the humerus, below the lesser tuberosity, and between the insertions of the subscapularis and the conjoined teudons of the latissimus dorsi and teres major muscles.

The rotator humeri is a part of the coraco-brachialis muscle, and is often referred to as the coracu-brachialis superior vel brevis. [For figure, see Wood, Journ. of Anat. amed Phys. vu]. i. p. 47.] The insertion of this muscle is indicated in fig. 125.

The spheno-pharyngeus arises from the spine of the sphenoid and is insented into the wall of the pharynx.

'The spinalis cervicis arises from the ligamentum nuchæ and the first dorsal spine. It is inserted into the spine of the axis, and occasionally into the spines of the third and fourth cervical vertebræe.

The sternalis muscle (rectus sternalis) arises from the sheath of the rectus aldominis, or from the tissues covering the fifth and sirth costal cartilages.

The direction of the fibres is very variable. In some eases they are directed obliquely outwards; in others, they pass vertically upwards to be inserted into the fascia covering the origin of the sterno-mastoirl, or into the aponeurosis of the peetoralis major, or into the upper part of the manubrium of the sternum. A sternalis may be present on each side. In some instances they are entirely muscular; in others, furnished with terminal tendons. [See Jouriz. of Anat. and Phys. vols. i. 246 , xviii. p. 208, xix. p. 311.]

The sterno-clavicularis urises from the front of the manubrium stervi, and is insirted intu the clavicle, between the pectoralis major and the custo-coracoid membrane.

The stylo-auricularis arises from the cartilage of the external auditory meatis and is insertal into the styloid process of the stylo-glossus muscle.

The subscapularis minor arises fiom the axillary border of the scapula and is inserted into the capsular licament or the adjacent part of the inner margin of the bicipital groove.

The supraclavicularis arises by a slender tendon from the upper border of the maubrium of the sternum. It passes outwards, above the sterno-clavicular joint, behind the sterni-mastoid muscle, to be inserted into the clavicle. When present in both sides, the muscle sometimes fuses in the middle line.

Supracostalis. - When this musele is present it extends from the anterior enci of the first to the anterior euds of the third or fuurth ribs. It may be connected also with the deep fascit of the neck or the scalene unuscles.

The syndesmo-pharyngeus arises from the lateral thyro-hyoid ligament and is inserted into the middle constrictor.

The tibialis secundus arises from the back of the tibia below the flexor longus digitorum and is inserted into the back of the calpsule of the ankle-joint or into the anmular ligament.

The tibio-fascialis anticus arises from the lower third of the anterior border of the tibia.

It is inserted into the annular ligament and ileej) fiscia.

Transversus menti. A muscular band extending between the adjacent borders of the depressor muscles of the lower lip.

The transversus nuchæ arises from the external occipital protuberance and is inserted into the fisscia of the sterno-mastoid.

The triticeo-glossus arises from the cartilago triticea in the thyro-hyoil ligament.

It is inserted into the side of the tongue, blending with the posterior fibres of the hyoglosius.

The ulnaris quinti digiti arises from the lower part of the uhna or from the extensor carli ulnaris. It is inserted into the metacarpal bone of the little finger or it may join the tendon of the extensur minimi digiti. 


\title{
SECTION IV
}

\section{ARTERIES, VEINS, AND LYMPHATICS}

\author{
BY W. J. WALSHAM, F.R.C.S.
}

SURGEON TO ST. BARTHOLOMEW'S HOSPITAL; LECTERER OY SLRGERY; LATE LECTURER ON ADVANCED ANATOMY IN ST, BARTHOLOMEW'S IIOSPITAL MEDICAL SCIFUUL, ETC., ETC.

\section{THE ARTERIES}

$\mathrm{T}^{\mathrm{w}}$

THE arteries are divided into the pulmonary and the systemic. The pulmonary eonvey the blood from the right rentricle of the heart to the lungs, whence it is returned, when aërated, by the pulmonary veins to the left auricle, and through that cavity into the left rentricle. The systemic arteries arry the blood from the left rentricle all over the body, whence it is returned by the vense care to the right amicle, and through it to the right rentricle. The hmgs also receive blood from the srstenic arteries-the bronchial. This blood which serves for the nourishment of the larger and sunaller branches of the bronchial tubes and the lung substance is returned, in part by the bronchial veins to the general renouscirculation, and thence to the right side of the heart; and in part by the pulnonary veins, along with the aërated blood, to the left side of the heart.

\section{THE PULIONARY ARTERY}

The pulmonary artery (fig. 317) passes from the right rentricle to the lungs. It cliffers from all other arteries in the body in that it contains venons hlond. It arises as a short, thick trunk from the upjer and front part of the right rentricle known as the conus arteriosus, and, after a course of about two inches within the pericarlimm-the serous layer of which mentrane forms a common sheath for it and the aorta-divides into a right and a left branch. These hranches pierce the perieardium, and pass to the right and loft lung respectively.

The trunk of the pulmonary artery at its origin (iig. 319) is on a plane anterior to the first portion of the arch of the aorta, and shightly overlaps that vessel. Thenee it passes upwark, backwards, and to the left, forming a slight curve round the front and left siche of the ascending portion of the aorta (fig. 321); and, having reached the concavity of the transwerse portion of the aortic arch, on a level with the fifth thoracic rertehra, and on a plane posterior to the ascending aorta, it divides into its right and left branches, which diverge from each other at an angle of about $130^{\circ}$. 
In the fortus, the pulnonary artery (fig. 318) continues its course upwarls. backwarels, and to the left, moler the name of the ductus arteriosus, or ductus Botalli, and opens into the descenting aorta just helow the origin of the left subclavian artery. After birth, that portion of the pulmonary artery which extends to the aorta becomes obliterated, and remains merely as a fibrous cord.

The trunk of the artery with the ductus Botalli was originally the left fifth aortic arch, and the recurrent laryngeal mere in early foetal life passed below it direct to the larynx. As in the process of development the heart descends into the thorax, and the fifth arch assunes a more rertical direction, it comes to pass that the nerve winds round the transverse portion of the aorta, the fourth aortic arch,

Fig. 317.-Axterior View of tile Heart with the Labge Arteilfes axi Veixi.

(By permision. Royal College of Surgeons Museum.)

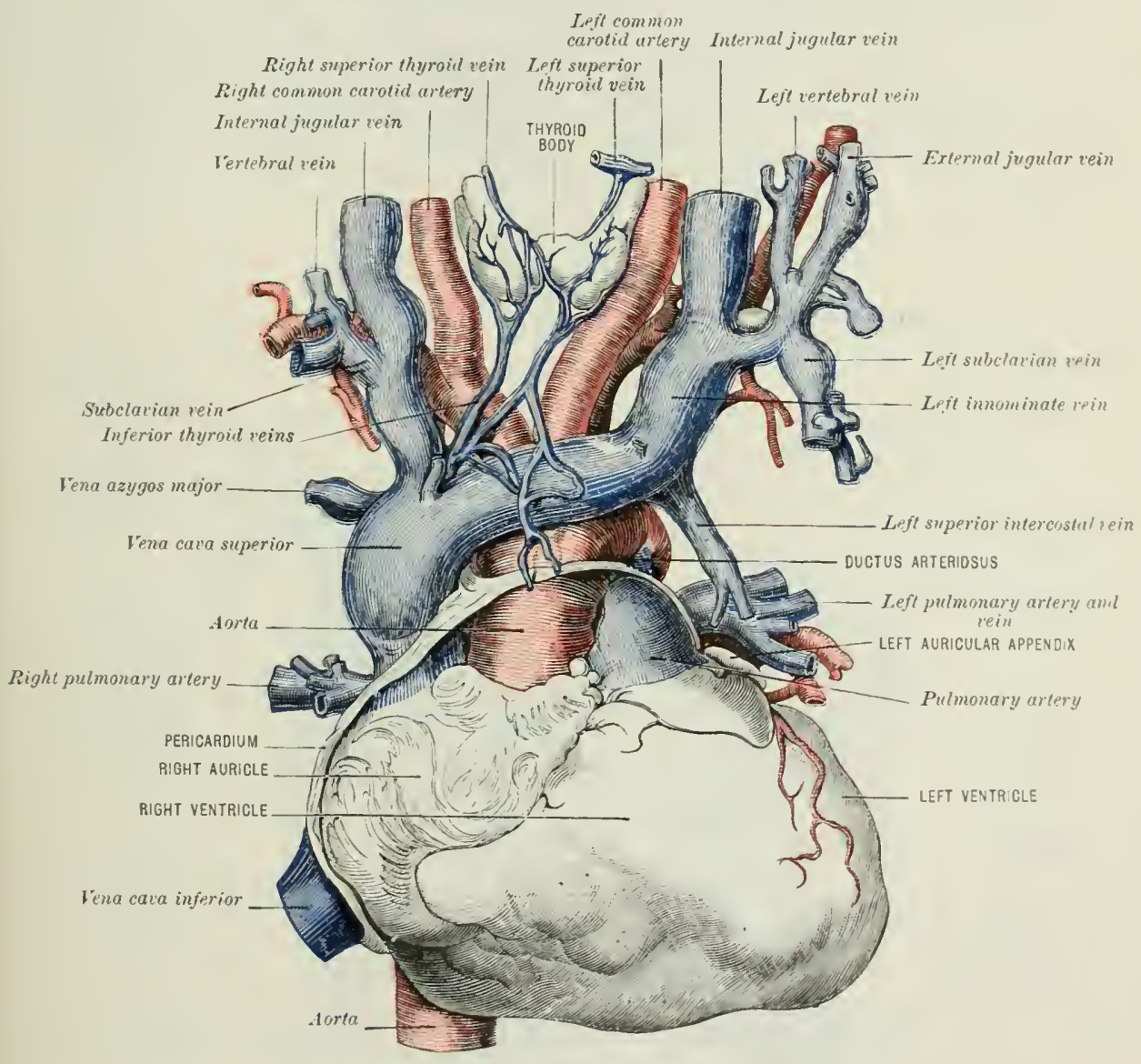

and consequently external to the ductus arteriosus (fig. 321). In arlult life the corr formed by the obliterated ductus arteriosus arises a little to the left of the lifuriation of the pulmonary artery, and resives a slight reflexion from the pericarlium as it pierees that membrane. It oceasionally remains partially umohliterated.

Relations.-In front, the trunk of the pulmonary artery is coremed by the seeond bone of the sternmun, the remains of the thrmus gland, and the periendimn (fig. 319), and at its commencenent lies immediately behind the anterior extremity of the seeond interesstal space, the left lung and pleura intervening.

Behind, it lies suceessively upen the ascending part of the areh of the acortat and the left auriele. 
To the right are the ascenting aorta, the right amricular appendix, the right coromary artery, and the cardiac nerves.

To the left are the pericarlium, the left pleura and lung, the left auricular appenclix, the left coronary artery, and the cardiac nerves.

Fi(ł. 318.-The HeArt, With the Arch of the Aorta, the Pllifusary Artery, the Ductes Arterlost's, AND the Vessels concensed in the Fotal Circulation.

(From a preparation of a fetus in the Museum of St. Bartholomew's Hospital.)

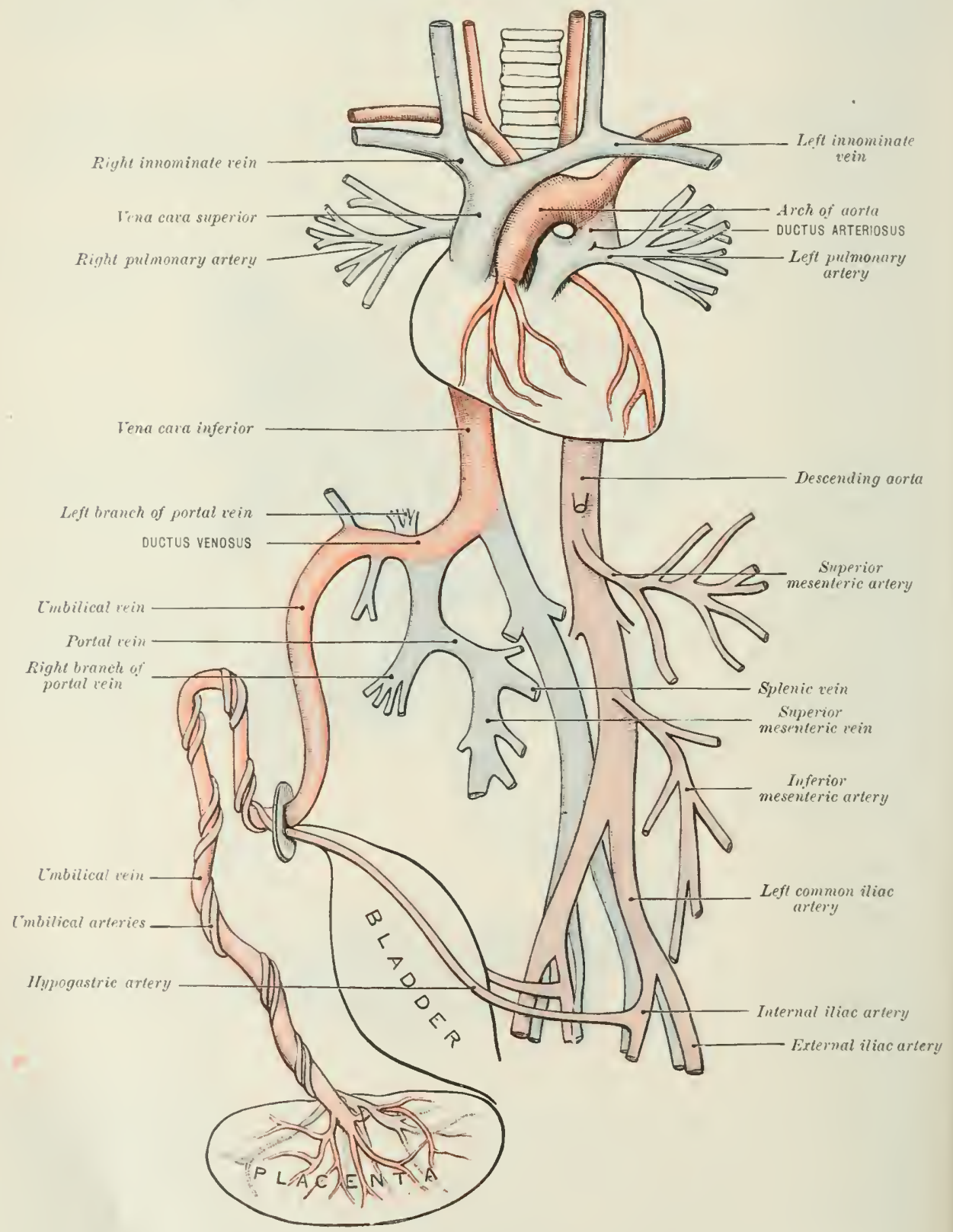

THE RIGHT PULMONARY ARTERY

The right pulmonary artery (figs. 319 and 320 ), longer than the left, passes almost horizontally outwards under the arch of the aorta to the root of the right 


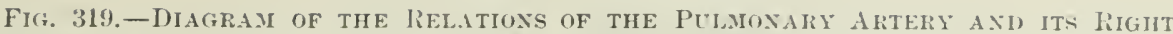
ANI LEFT BRANCHES. (Walshan.)

IIICIIT P.IEIMOGASTRIT IEIVE

Tena azygos major

RIGHT BRONCHUS

Right pulmonory artery

RIGIIT PHREVIC NERIE

lena cara superior

PERICARDIUM

R!GHT AURICULAP APPENOIX

Right curanary urtery
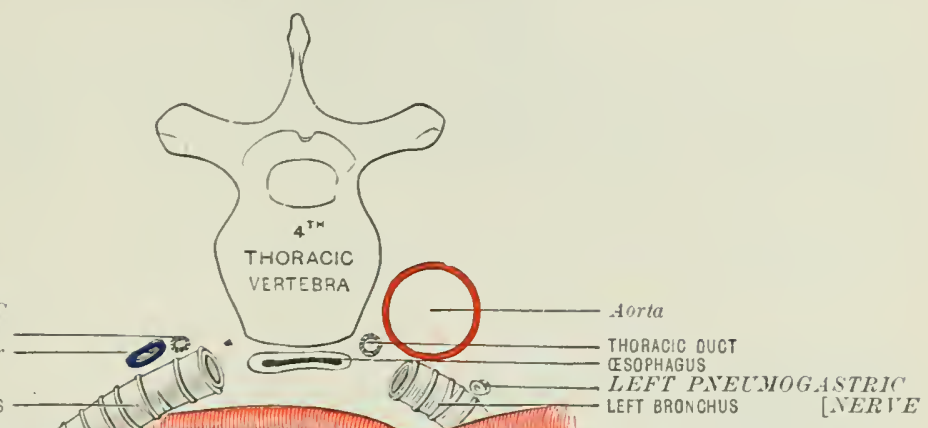

RIGHT PLEURA AND LUNG

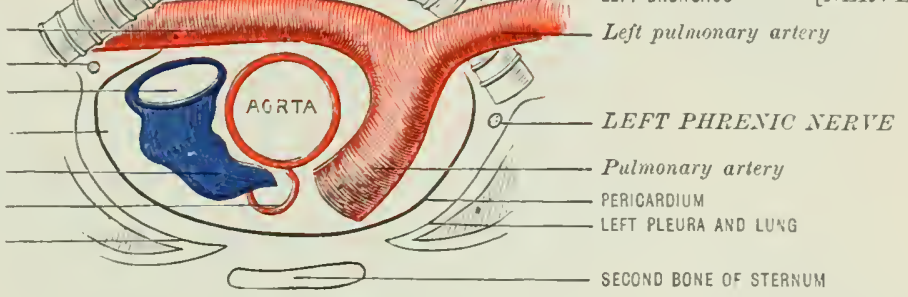

Fig. 320.-Posterior View of Heart axid Greatej: Vessels.

(By permission. Royal College of Surgeons Musenm.)

Lefl common carotid artery

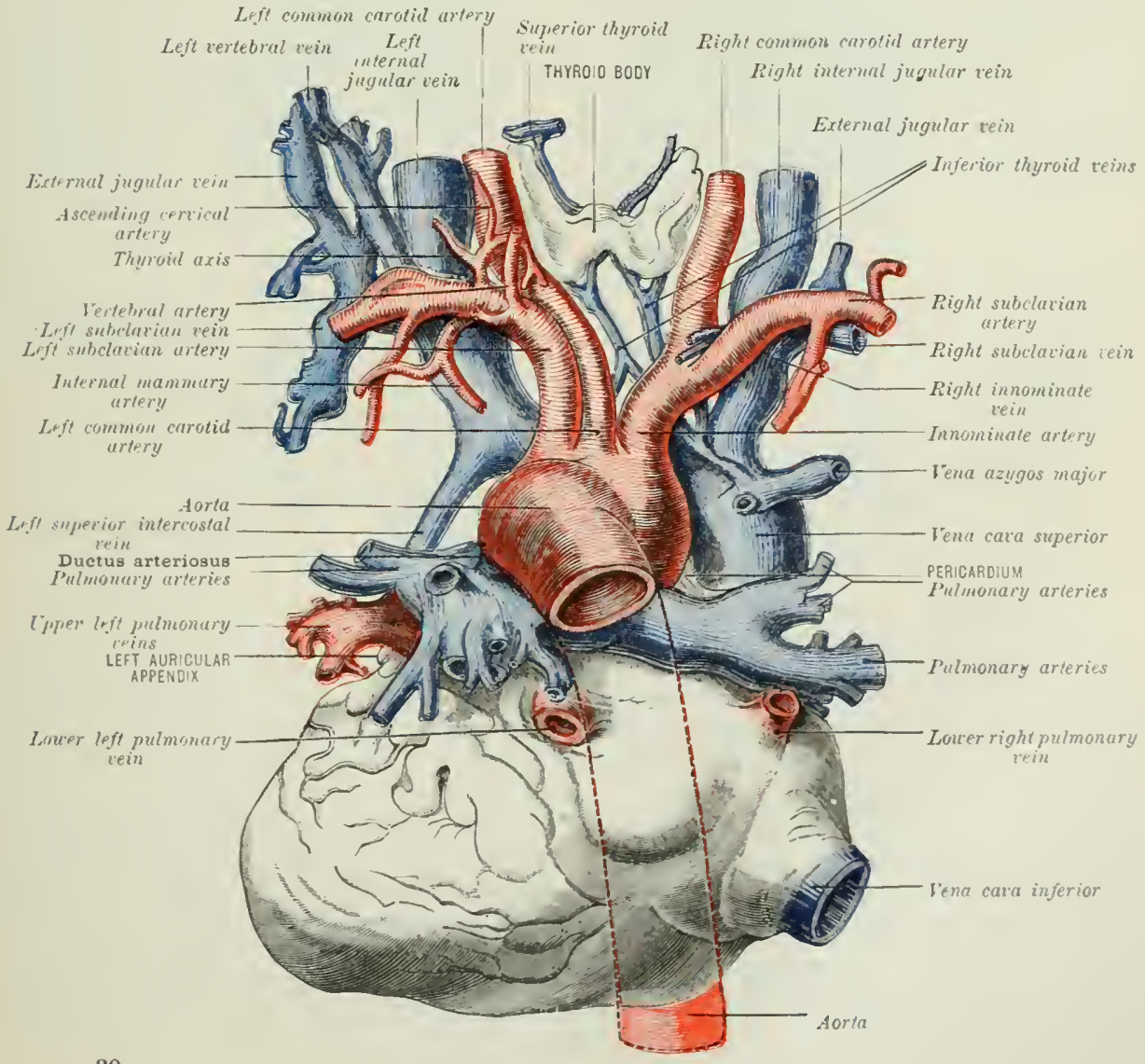


Iung, where it divides into a larger upper branch, which supplies the upper lobe and gives off a descending loranch to the midelle or third lobe. and into a smaller inferior branch for the supply of the inferior lobe. These manches follow the "ourse of the bronchi, dividing and subdividing for the suply of the lobules of the lung. The terminal hranches do not anastomose with each other.

Relations.- In its course to the lung it has in front of it (fig. :319) the aseending aorta, the vena cava smperior, the phrenic nerve, the anterior pulnonary plexus, and the reflexion of the pleura. Behind are the right bronchus and the temination of the rena azygos major. Above is the transwerse portion of the areh of the aorta, and below are the left auricle and the upper right pulmonary vein.

At the root of the lung it has the right bronchus above and behind it; the julmonary veins below and in front. Crossing in front of it and the other strueture forming the root of the lung are the phrenic nerve and the anterior pulmonary plexus; behind are the rena azygos major, the pnemogastric nerve, and the posterior pulmonary plexus (fig. 324).

\section{THE LEFT PLLMONARY ARTERY}

The left pulmonary artery, shorter and slightly smaller than the right, passes in front of the descending aorta to the root of the left lung, where it divides into two branches for the supply of the upper and lower lobes respectively. These divide and subdivide as on the right side (fig. 319).

Relations.-At the root of the lung it has the left bronchus behind and also below it in consequence of the more vertical direction taken by the left bronehus than hy the right. Below and in front are the pulmonary reins, while between the artery and the upper left pumonary vein the vestigial fold of Marshall is to be seen. Crossing in front of it and the other structures forming the root of the lung are the phrenic nerre, the anterior pulmonary plexus, and the reflexion of the left pleura; crossing behind, are the lescending antal, the left pnemogastric nerve, and the posterior pulmonary plexus (fig. 32t).

\section{THE STTENIC ARTERTES}

\section{THE AORTA}

The aorta is the main srstemic arterial trunk, and from it all the srstenic arteries are lerivesl. It begins at the left ventricle of the hourt. and, after rumning a short clistance mpwark and to the right. tums backwards and to the left, and then clownwarls, forming the arch of the aorta. It is thence continued through the thorax as the thoracic aorta, and finally enters the aldomen at the aortic opening in the diaphragm, and, passing through the abdominal carity under the name of the abdominal aorta, teminates opposite the fourth lumbar vertehra in the right and left (ommon iliac arteries. From the point of hifureation a small resed is eontinued fown the mirldhe line in front of the sacrum and rocerx, and encls in the eocryenl grlomerulus. This resel (known as the middle sacral) is nsually regarder], morphologically, as the sacral and coccygeal aorta; while the corergeal glomerulus is believer to represent the rutiments of the caudal aorta, with probahly a persistent part of the prost-anal gut. 


\section{THE ARCH OF THE AOR'TA}

The arch of the aorta (fig. 321) begins at the upper and lack part of the left ventricle of the leart, behind the sternum, on al level with the lower border of the third left costal cartilage. Thence it passes upmards and slightly formarls and to the right, as high as the level of the upper horder of the second costal cartilage of

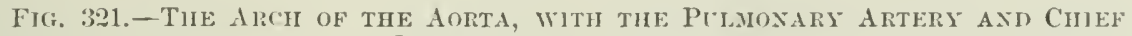
BRANCIIES OF TIIE AORTA.

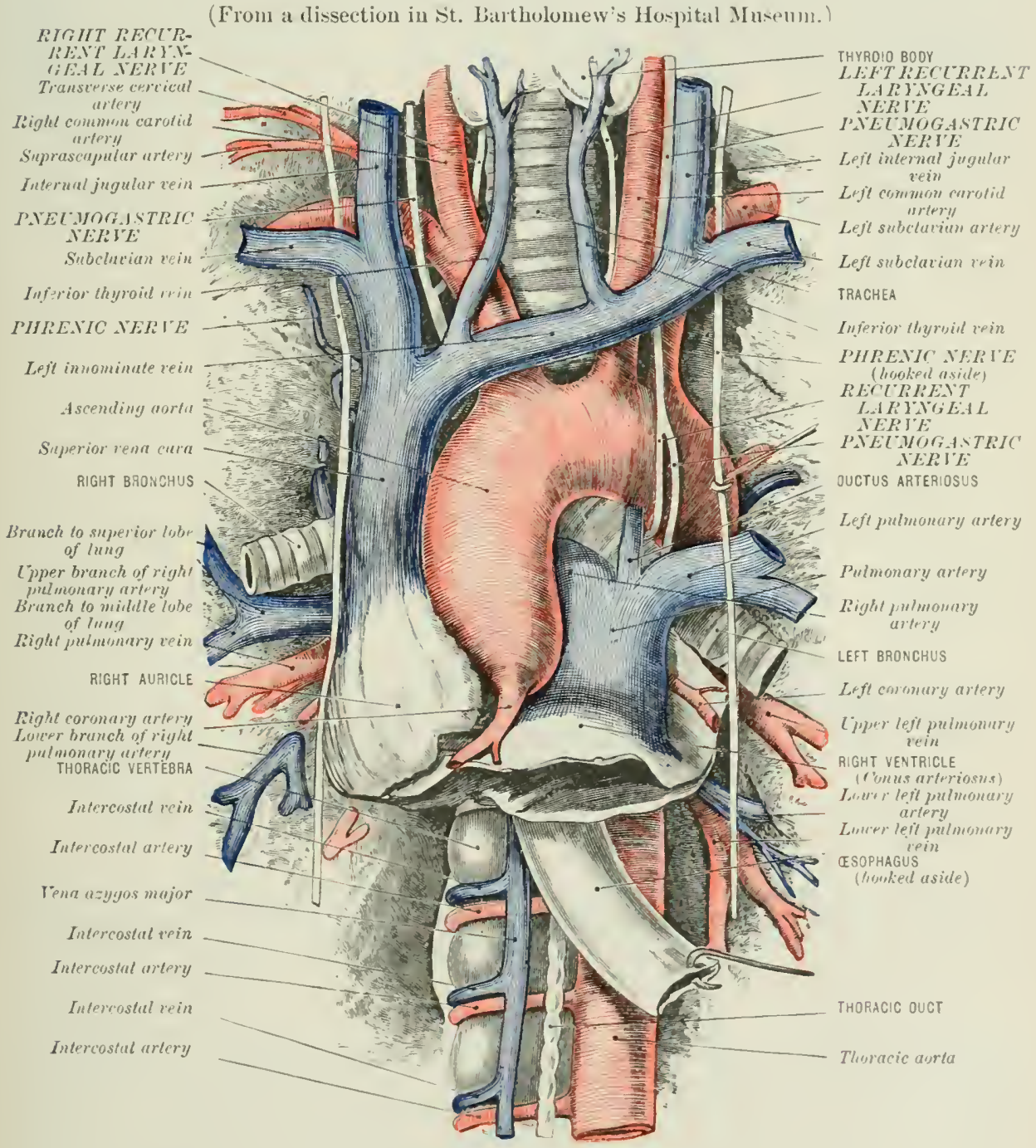

the right side; and then, curving backwards, upwarls, and to the left, crosses behind the sternum at the level of the middle of the manubrimm; and, reaching the l.ft side of the body of the fourth thoracic vertebra, runs downwares on the sicle of the body of that and the fifth thoracic rertebra, at the low re horder of which it terminates in the thoracic aorta. The arch thus formed hats its convexity upwarls: and to the right; in its concavity are situated the left hronehus and the right pulmonary artery. Accurding to its direction. it is somewhat arlitrarily divided into an ascending, transverse, and elescending prart. Morpholorically the ascencling 
purtion is the rentral aorta; the descending portion, part of the left clorsal aorta; and the transierse portion, the fourth left aortic arch. Each portion requires a seplarate description.

\section{The Ascending Portion of the Arch of the Aorta}

The ascending portion or rentral aorta ascends behind the sternum from the upper part of the left rentricle of the heart, on a level with the lower borcler of the third left costal cartilage, to the upper border of the second right costal cartiline at the junction of these eartilages with the strmum. It measures from two to two and a quarter inches $(5.5 \mathrm{~cm}$.). forming, as it ascends, a gentle curve, the most prominent part of which, when the aorta is distended, is situated about a quarter of an inch $(6 \mathrm{~mm}$.) from the sternum. It is enclosed for the greater

Fl(i. 322,-Scheje of the Reldtions of the First Portion of the Arch of tile Aolita. (Walsham.)

I, at origin ; II, a little higher up.
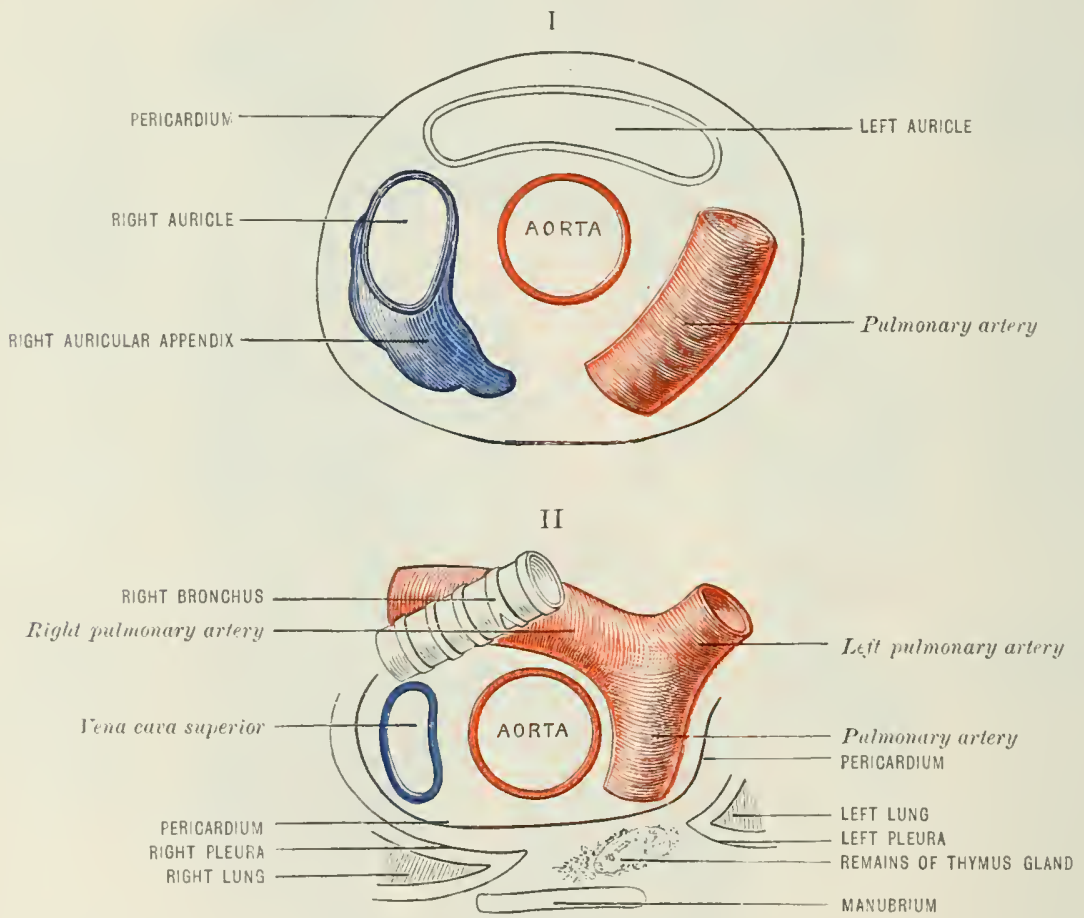

fart of its length in the pericardium, heing invested, together with the julmonary artery, in a common sheath formed by the serous laver of that membrane. i dilatation known as the great sinus of the arch of the aorta is often present along the right sicle. Immediately above the heart the aorta presents three bulgings, known as the sinuses of Valsalva; they are placed, two anteriorly, and one posteriorly. From the anterior are derived the coronary arteries of the heart. (See Healite)

Relations.-In front (fig. 322 ), it is overlapperl at its commencement hy the right auricular appentix and the puhmonary artery. Higher up, as the puhnonary artery and aurienlar appendix diverge, it is separated from the manubriun by the prericardium, the remains of the thymus gland, and loy the loose tissue and fat in the superior mediastinum, and is here slightly overlapjed by the right plenra and hy the edge of the right lung in full insprimation. The commencement of the coronary arteries is also in front. 
Behind are the left auricle of the heart, the right pulmonary artery, the right bronchus, and the anterior right deep cardiac nerves.

On the right side it is in contact. below with the right auricle, and above with the superior vena cavia.

On the left side are the pulmonary artery and the branches of the right superficial cardiac nerves.

The Tracielerse Portion of the Arch of the lorta

The transverse portion of the arch of the anta extends in a gentle curve upwards, backwards, and to the left. from the level of the upper border of the second right costal cartilage to the left side of the hody of the fourth thoracic vertebra. Passing uncler the areh are the left bronchis, the right pulmonary artery, and the left recurrent laryogal nerve. It measures ahout one inch anil four-fifths $(4.5 \mathrm{~cm}$. ).

Relations.-In front (fig. 323), it is slightly orerlapped by the right pleura

Fig. 323.-Schese of the Relatioss of the Traxinerae Portion of the ARCH OF THE AORTA. (Walsham.)

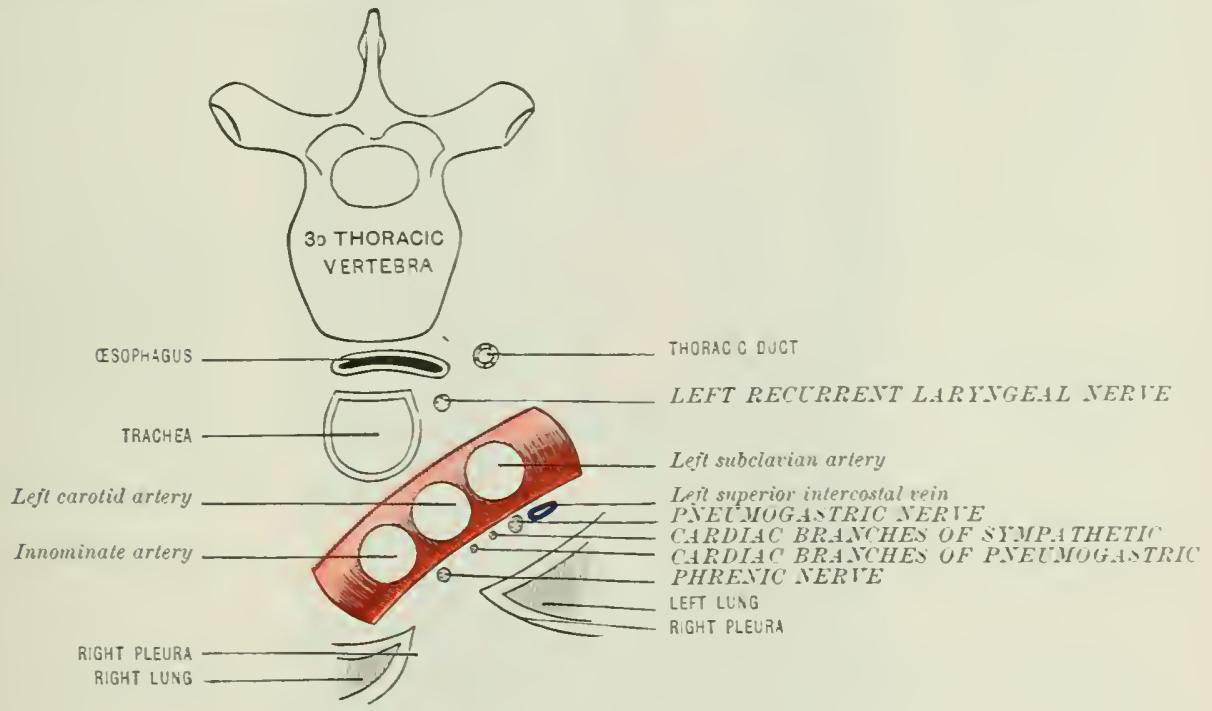

and lung, and to a greater extent by the left pleura and lung. It is crossed in the following order from right to left, by the phrenic nerve, by the cardiac branches of the pneumogastric nerve, the cardiac branches of the sympathetic nerve. by the pneumogastric nerve, and by the left superior intercostal vein as it passes up to the left immominate rein.

Behind it (fig. 323) are the trachea, the asophagus, the thoracic duct, the deep cardiac plexus which is situated on the trachea just abore it: hifurcation, and the left recurrent laryngeal nerve.

Above it (fig. 3:1) are the three chief branches for the heal. neek, and upper extremities, namely, the inmominate, the left carotid and the left subclivian arteries, and the left innominate rein.

Below it-that is. in its concavity-are the bifurcation of the pulmonary artery, the left bronchus. the left recurrent laryngeal nerve. the remains of the ductus arteriosus, the superticial eardiae plexus. two or more hronchial lrmphatic glands (fig. $3: 1$ ), and the reflexion of the pericardium. 
The Descending Portion of the Arci of the Aorta

The descenting portion of the arch of the aorta, morphologieally a part of the primitive dorsal aorta, eleccends by the left side of the body of the fourth and fifth thoracic rertebre, and end at the lower border of the latter in the thoracic aorta.

Just below the spot where the ductus arteriosus (the fifth left areh) joins the aorta, a constriction (the aortic isthmus) is at times met with, and below this again a dilatation of a fusiform shape (the aortic spindle).

Relations.-In front, it is in contact with the reflexion of the left pleura and the root of the left lung (tig. 32.5$)$.

Fig. 324. - The Heart Axd Great Vesells, with the Root of the Luxgs, SEEX FRon behIXD. (St. Bartholomew's Hospital MIuseum.)

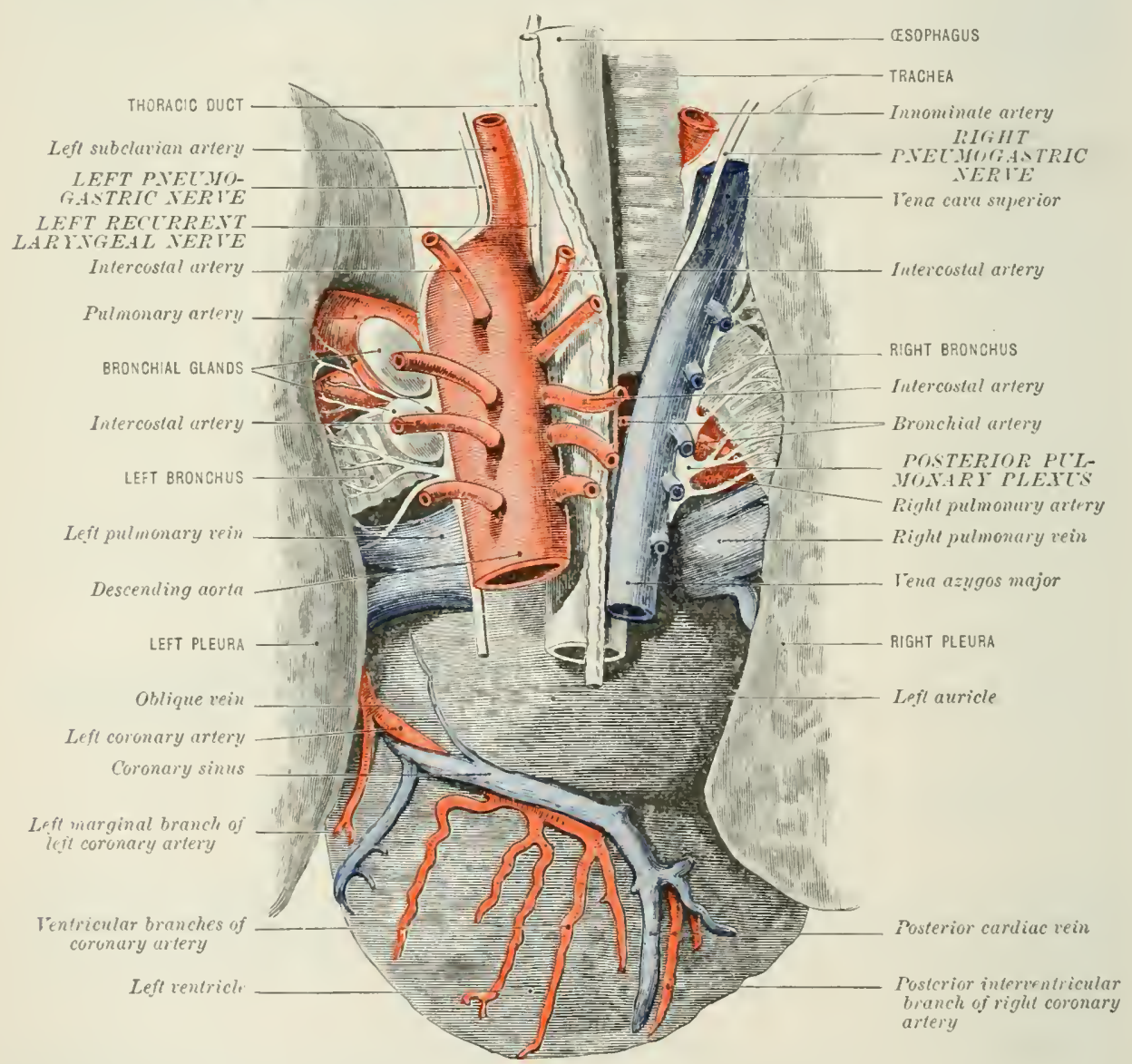

Behind, it is in relation with the left side of the bodies of the fourth and fifth thoracic vertebre and the pleura.

To the right side are the resophagus and thoracic duct, and tlie fourth and fifth thoracic vertehrie.

To the left side are the left pleura ant lung.

\section{Tariations in the Arch of the Aorta}

The variations that have been met with in the aurtic arch are very numernus. Only the chicf ean be here mentionel. They may he divided into:-1. Variations in the arch itself; and 2. Variations in the number and arrangement of the three chief branches. The vilriatiuns in the coronary arteries are deseriberl under Conoxary ARTERIEs, fage 473. 


\section{(1) Turiations in the Aortic Arch itself}

The variations in the aortic arch itself may for the most part be traced to alsnormalities in development of the embryonic structures from which the three portions of the arch and the pulmonary arteries and ductus arteriosus are derived, i.e. (a) the primitive ventral aortic stem; (b) the fourth and fifth branchial arches; and $(c)$ the dorsal aurtic stems.

\section{(a) Variations depending on Alurmmalities in Dcrelopment of the Tentral Aortic Stem}

These rariations are closely associated with abnormalities of the pulmonary artery and heart. They depend upon deficient development of the septum which normally divides the anterion stem into the first portion of the antil and the pulnonary artery. The following are some of the chief rariations:-

(1) The arrta and pulmonary artery may arise as a single stem from a simple heart. The septum here is completely absent. The condition resembles the normal state in fishes.

(2) The aorta and pulmonary artery may lie more or less conjoined, and the septum of the heart incomplete. This is analogous to the nomal condition in repitiles.

(3) The aorta and pulmonary artery may be transposerl.

(4) The aorta or puhmonary artery may be in part obliteraterl. and the blood carried into the remainder of the affected ressel through an abnormal opening leyond the obliterated part.

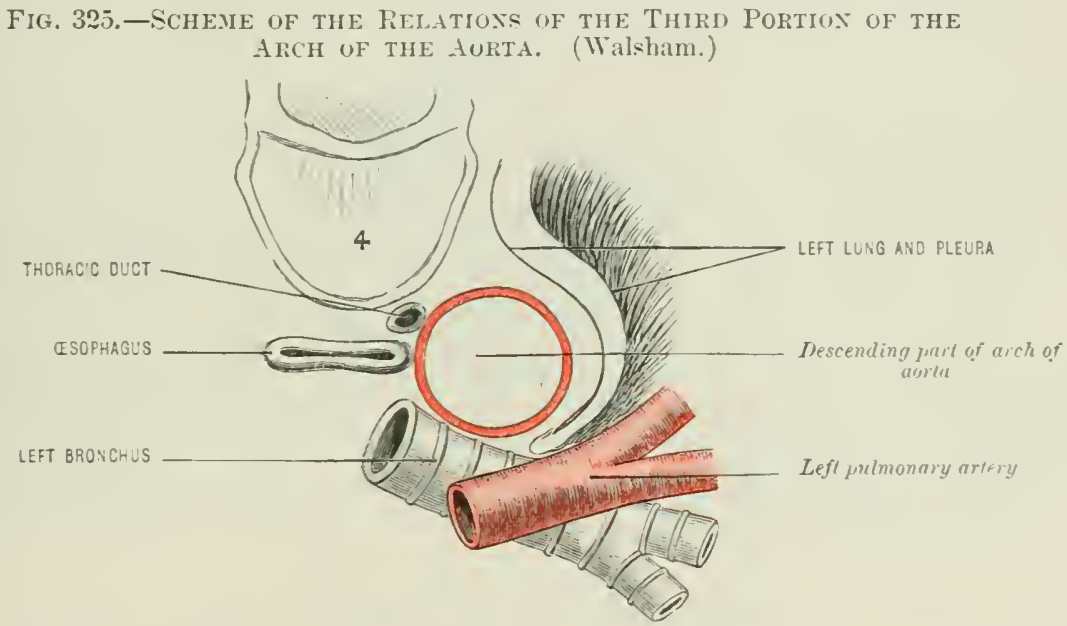

\section{(b) Tariations dependiury on Abrormalities in Develnpment of the Fourth and} Fifth Arrtic or Branchial Arches

(1) The aortir may be double, the normal condition in amphilians, each arch griving off a corresponding earoticl and subelavian artery. This abnormality is explainel lyy the persistence of the right fourth aortic arch and right descending aortic stem, as well as the corresponding parts (nI the left side. The trachea and cesuphagus pas through the arterial circle thus formed.

(2) The aortic arch may turn orer the right bronchus insteinl of orer' the left. 'This is the normal condition in birds, and is explained by the persistence of the right fourth aortic arch and right descending aortic stem and the obliteration of the corresponding jarts on the left side.

(3) The pulmonary artery may be given off from the aorta. This comlition is due to the (nbliteration of the anterior part of the fifth brinchial arch and the persistence of the posterior part which normally constitutes the ductus arteriosus.

\section{(c) Trariations depending on Alnormalities in Developmont of the Dorsal Aortic Stems}

The right subclavian may arise from the third part of the arch of the aorta. It then lasen behind the trachea and cesophagus, and in front of the rertebral column. to gain the interral betwen the right scalene muscles. The explanation of this abmormality is that the right fourth areh, from which the right subclavian is normally developed, is obliterated, whil-t the right posterior alortic stem remains pervious as far as the spot where it normally joins the right fourth arch. the blood thus passing through the aortic stem insteal of the arch. The recurrent larygeal nerve in these cases runs straight to the larvix, since, the fourth arch being obliterated, the nerte is no lunger hooked down by it. liudments of the right aortic stem freipently persist as the aberans branch of the superior intercostal artery and thoracic aurta. 
In addition to the above variations, the arch of the aorta may be higher or lower in the thorax than normal. In the former calse it may eross the first bone of the sternum, just below, or eren a little above, the steruat notch, and reach the side of the second or third thoracic vertebra instead of the fourth. In the latter case, that is, when it is situated lower in the thorax than normal, it mat cross the sternum below the level of the manubrium, and come into eontact with the spine on a level with the fifth or sixth thoracic vertebra.

\section{The Chief Fariations in the Three Primury Brrenches of the Transcerse Portions of
the Aortic Arch}

(1) All may arise from a common stem : a eondition explained on the supposition that the auterior aortic roots hare become fused, and have so collected all the branehes tugether. A similar condition is normal in the horse. This variation is rare.

(2) They may arise as two stems: ( $a$ ) One stem may be common to the right subelarian, right carotid, and left carotid, the other stem being the left subclavian. This is one of the commonest variations in the arrangement of the primary branches. It is the normal eondition in nuny mammals, and was formerly described as the normal condition in man. It is of some surgical interest, in that the left carotid when thus given off way eross in front of the trachea. (b) Ore stem may be common to the left subclavian, left carotid, and right earotid, the other stem being the right subclavian. In this variety the right earotid passes in front of the trachea. (c) There may be two innominate arteries, one stem forming the right, the other a left innominate artery as in bircls. (d) One stem may be common to the right and left carotid arteries, the other stem being the left subclavian - the right subclavian in this case coming from the thoracic aorta.

(3) They may arise as three stems: but, in plice of being given off in the normal way, (a) the right and left subclavian may come off separately, and the earotids arise by a common stem between the subclaviaus. This is the normal condition in some cetaceans. (b) The right sub(-lavian and right carotid may arise separately, the left carotid and left subclavian forming a left immominate stem. (c) The innominate may give off the left carotid, the left vertebral, and left suluclaviau, the other two ressels arising from the areh.

(4) They way arise as four stems, which may be given off in the following order : $(a)$ inmominate, left carotid, left vertebral, left subclavian (the commonest conditiou) : (b) right earotid, left carotid, left subelavian, right subclavian; $(c)$ right subclavian, right carotid, left earotid, left subclavian-the normal condition in the walrus and wombat.

(5) They may arise as five stems, the fire branches being given off in the following order : (a) light subclavian, right carotid, left carotid, left vertebral, left subclavian ; (b) jight earotid, left carotid, left vertebral, left subclavian, right subclavian; $(c)$ right carotid, left earotid, left subclavian, left vertebral, right subelavian; $(d)$ right subclavian, right external carotid, right internal carotid, left common carotid, left subelavian; $(e)$ imnomiuate, right vertebral, left carotid, left rertebral, left subelavian.

(6) They may arise as six stems, given off as follows: light subelavian, right vertebral, right earotid, left carotid, left vertebral, left subclaviau.

\section{Braxches of tile AreII OF tIIE AORTA}

1. The ascending portion gives off-(1) Right coronary: (2) left coronary.

2. The transverse portion gives off-(1) Innominate; (2) left common caroticl; (3) left subclavian.

3. The descending portion gives off no branch.

I. The branches of the first, or ascending, portion of the arch of the arta are the right and left coronary for the supply of the tissues of the heart. They come wff from the aorta, immerliately ahove the aortic valves, from two of the dilatations known as the sinuses of Talsalva.

\section{TIHE RIGHT CORONARY ARTERT}

The right coronary artery (figs. 321 and 326 ) arises from the right anterior sinus of Valsalva, and, passing forwards and to the right between the riglit auricular appentix and the pulnonary artery, turns to the right, and courser in the right anriculo-ventricular groove to the back of the heart, where it follows the posterior interventricular groove to the apex of the ventricles, giving off, howerer, a small transverse liranch. which continues in the groove between the left auricle and rentricle to anastomose with the terminal branch of the left coronary artery. In this (o)tre it gives off the following branches: (a) A right auricular branch (fig. 326), which turns backwards and upwards between the right auricle and the aorta, 
supplying the structures between which it runs and the auricular scptum; (b) a preventricular branch (fig. 326), which runs down the front of the right ventricle, sulplying its walls; (c) a right marginal branch (fig. :326), which courses down the right margin of the right ventricle; (d) a posterior interventricular branch, or the continuation of the coronary trunk, which passes down the posterior interventricular groove, giving twigs to each ventricle and the interventricular septum, and anastomosing at the alpex of the heart with the anterior interventricular liranch of the left coronary artery; and $(e)$ the transverse branch, which runs in the left aturiculo-ventricular groove to anastomose with the terminal hranch of the left colonary (fig. 326 ).

\section{THE LEFT CORONARY ARTERY}

The left coronary artery (figs. 321 and 326 ), a little larger than the right, arises from the left anterior sinus of Valsalva, and, passing forwards and to the left between the pulmonary artery and left auricular appendix, courses round the heart

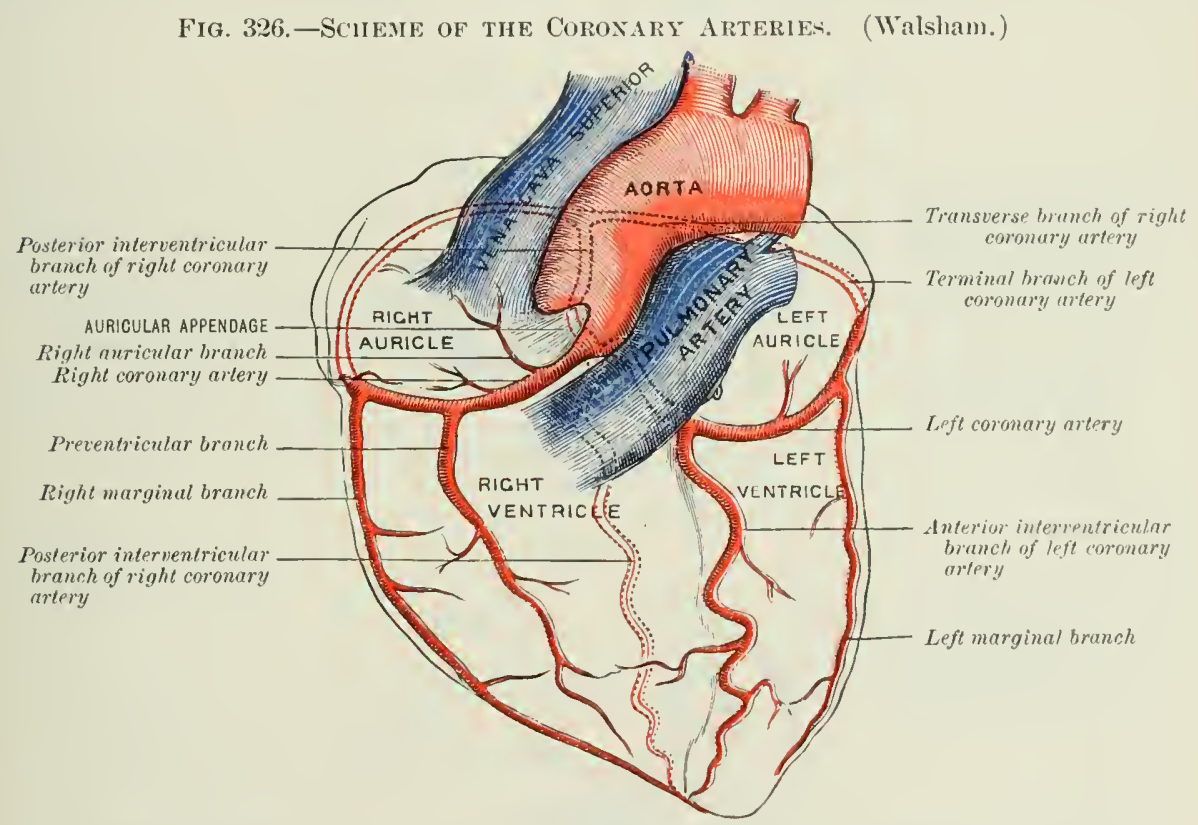

in the left auriculo-ventricular groove to anastomose with the transverse hranch of the right eoronary artery. It gives off the following branches: $(a)$ A left auricular branch, which supplies the left auricle, the puhnonary artery, and the commencement of the aorta. (b) A large anterior interventricular branch, which is larger than the continuation of the vessel between the auricle and rentricle. and is regarded by some as the main trunk of the left coronary artery. It courses downwarts in the anterior interventricular groove to the apex of the heart, where it forms a slight anastomosis with the posterior interventricular branch of the right vessel (fig. 324). It supplies both ventricles and the interventricular septum. (c) A left marginal branch, which runs chwn the loft margin of the heart, sulpulying loranches to the walls of the ventricle. (d) The terminal branch, the continuition of the ressel, anastomoses with the transverse branch of the right coromary artery.

\section{Variations in the Comary Arteries}

(a) They may arise as a common trunk. (b) They may buth arise from the same sinus of Valsalva. $(c)$ The interventricular and terminal branches of the left coronary may arise separately from the simus of Valsalva. (d) One coronary artery may be larger than nimal; 
the other vessel is then correspondingly small. $(e)$. In extra coronary artery may arise from the pulnunary artery.

II. From the transverse part of the aortic arch are given off the innominate, the left common carotid, and the left subclavian arteries. The inmominate and left carotid arise close together-indeed, so close that, when seen from the interior of the aorta, the orifices appear merely separated by a thin septum. The left subclarian arises a little less close to the left carotid.

\section{THE INNONINATE ARTERY}

The innominate or brachio-cephalic artery (fig. 321), the largest branch of the arch of the aorta, extends from near the commencement of the transverse por-

Fig, 32\%.-SChene of the Relations of tire Ixxominate Artery. (Walsham.)

I, a little above origin; II, a little below bifurcation.

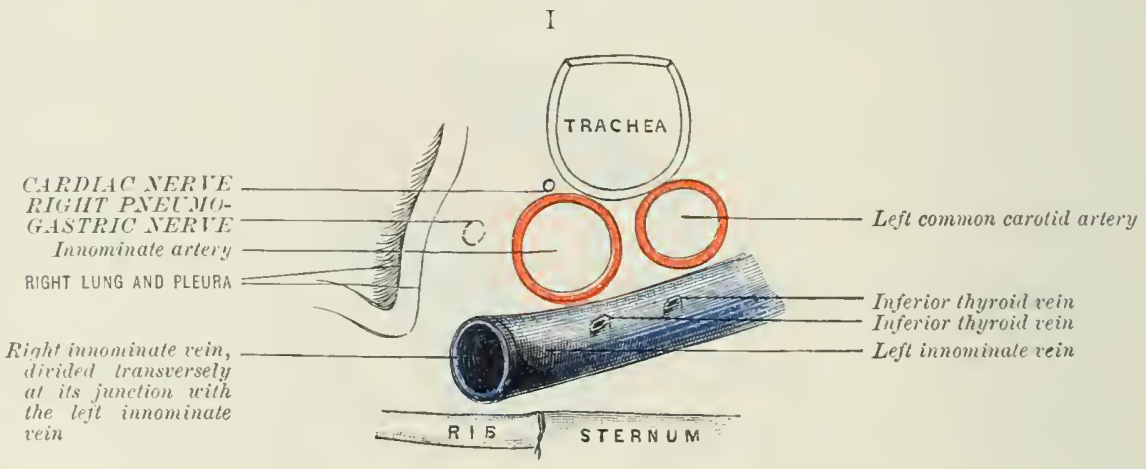

II

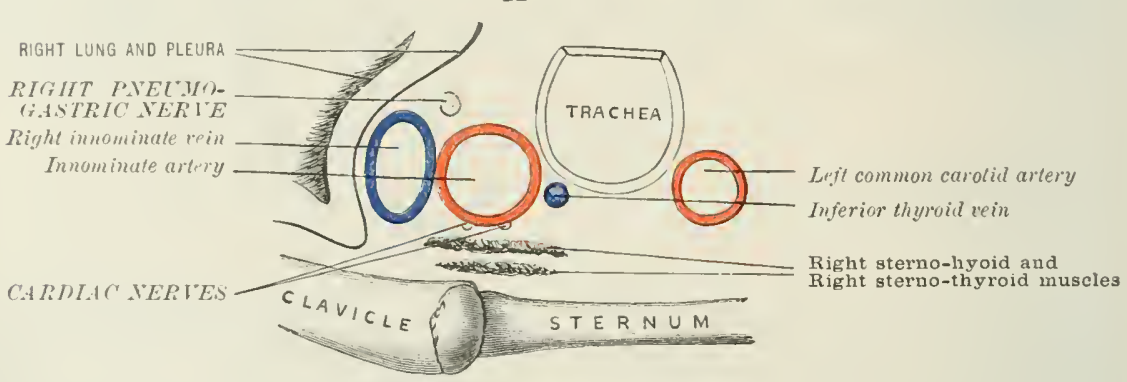

tion, upwards and a little forwards and to the right, as high as the upper limit of the right sterno-clavieular joint where it bifureates into the right common carotid and right subdavian arteries. It lies obliquely in front of the trachea, and meatsures from an inch and a half to two inches in length (about 4 cm.).

Relations.-In front of the artery (fig. 327) are the manulurum, the origins of the sterno-hyvicl and sterno-thyroid muscles, the right sterno-clavicular joint and the remains of the thrmus gland. The left innominate rein crosses the root of the vessel, and the inferior thyroid veins descend obliquely over it to end in the left innominate vein. The inferior ecrrical cardiac branches of the right pmemogastric pass in front of it on their way to the leep eardiac plexus.

Behind, it lies on the trachea, crossing that tuhe obliquely from left to right, and coming into contact ahove with the right pleura.

To the right side are the right immominate vein, the right pnemogastric nerve, and the plenra. 
To the left side are the left common carotirl, the remains of the thrmus gland, the inferior thyroid reins; and higher, the trachea.

\section{Variations in the Innominate Artery}

The variations in the innominate artery are of surgical interest. (a) It may divide lower than normal, thus decreasing the available space for the applieation of a ligature to it, but at the same time increasing the length of the first portion of the right sublavian artery. (b) It way divide higher than usual, and may then incline almormally to the left, mounting in front of the trachea above the sternum. Under these circumstances it is in danger in the low operation of tracheotomy. $(c)$ When abmormally long and inclining to the left, it may pass behind the tracheal or the œesophagus to gain the right side. (d) It nlay give off the thyroidea ima artery, and, more rarely the vertehral, the internal mammary or a smaller twig, as a bronchial, thymic, pericardiac, or tracheal branch.

The branches of the innominate artery are: (1) The right common carotid; and (2) the right subclavian. These are terminal branehes. There are usually no collateral branches from this ressel, but at times the thyroidea ima may arise from it.

\section{THE COMMON CAROTID ARTERIES}

The common carotid arteries pass up deeply from the thorax on either side of the neck to about the level of the upper horcler of the thyroid cartilage, where they divide into the external and internal carotid arteries. The external carotid supplies the structures at the upper part of the front and side of the neck, the larrnx, pharynx, tongue, face, the upper part of the back of the neck, the structures in the pteryoid region, the scalp, and in chief part the membranes of the brain. The internal carotid gives off no branch in the neck, but enters the cranium and supplies the greater part of the brain, the structures contained in the orbit, and portions of the membranes of the brain.

The common caroticl artery on the right side arises from the bifureation of the innominate behind the sterno-clavieular joint; on the left side from the arch of the aorta a little to the left of the imnominate arterr, and on a somewhat posterior plane to that ressel (fig. 321). The portion of the left common carotid artery which extems from the arch of the aorta to the level of the sternoclavicular articulation lies deeply in the chest, and requires a separate clescription; but above the level of the sterno-clavicular joint the relations of the right and left carotids are practically the same, and are given under the account of the right common caroticl.

\section{THIORACIC PORTION OF THE LEFT COMIION CAROTID ARTERY}

Within the thorax the left common carotid is deeply placed belind the first bones of the sternum, and is overlapped hy the left lung and pleura. It arises from the mirldle of the transverse portion of the aortic arch, dose to the left side of the inmominate artery, and a little posterior to that ressel, and ascends ohliguely in front of the trachea to the left strmo-clavicular artieulation, above which its relations are similar to those of the right common carotid.

Relations.-In front, but at some little distance, are the manubrium and the origins of the left stemo-hyoid and sterno-thyroid muscles; whilst in montact with it are the remains of the thrmus gland, and the loose sonnective tissue and fat of the superior mediastinum. Crossing its root is the left innominate vein.

Behind, it lies successively upon the trachea, the asoplagus (which here inclines a little to the left), the thoracic duct, and the left recurrent laryngeral nerve.

To its right side is the root of the innominate artery, and higher ul are the traehea and the inferior thyroid reins.

To its left side, but on a posterior plane, are the left subclavian artery and the 
left pneumogastric nerve; and, slightly overlapping it, the edge of the left pleura and lung (fig. 3:3).

The variations in the origin of the left common carotid are given under VARIATIONS OF THE ARCH OF TIIE AORTA (page 471 ).

\section{THE COMION CAROTID ARTERY IN THE NECK}

The common carotid artery in the neck extends from the sterno-clavicular articulation to the upper border of the thrroid cartilage on a level with the fourth cervical vertebra where it divides into the external and internal carotid arteries. A line dram from the sterno-clavicular joint to the interval between the mastoid process and the angle of the jaw would indicate its course. The artery is at first

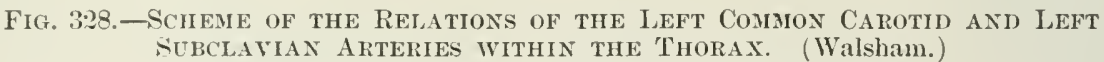

I, just above origin ; II, just below level of sterno-clavicular joint.

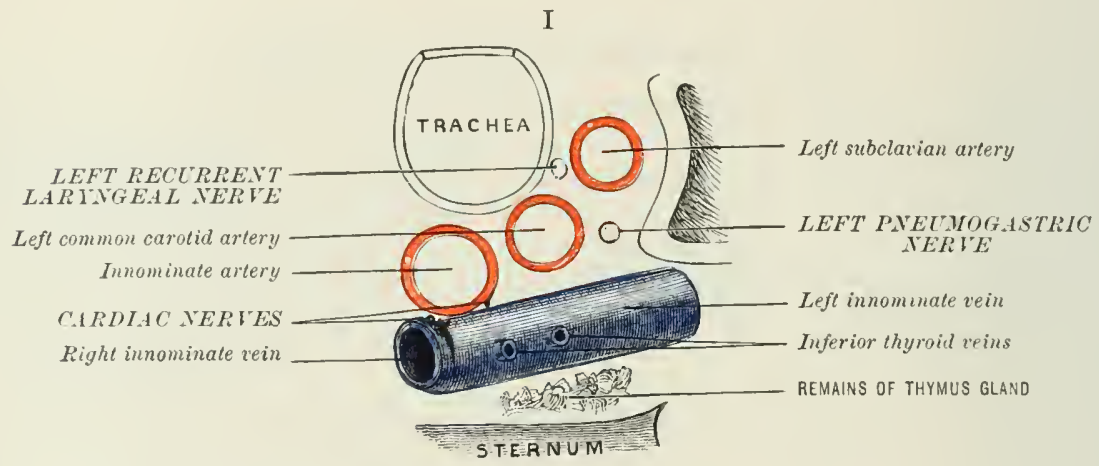

II

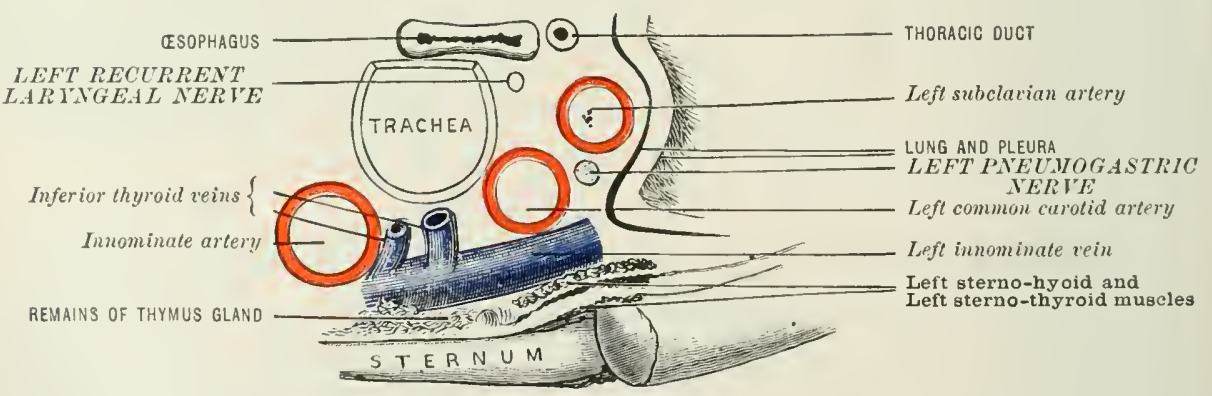

deeply placed beneath the sterno-mastoid, sterno-hyoid, and sterno-thyroid muscles, and at the level of the top of the sternum is only three-quarters of an inch (2 cm.) distant from its fellow of the opposite side, and merely separated from it by the trachea. As the carotid arteries rum up the neck, however, they diverge in the form of $a \mathrm{~V}$ and become more superficial, though on a plane posterior to that in which they lie at the root of the neck, and are separated from each other by the larynx and pharynx. At their bifureation they are about two inches and a quarter (6 cm.) apart. The common carotid is contained in a sheath of fascia common to it and the internal jugular vein and pnemmogastric nerve. The artery, vein, and nerve, however, are not in eontact, but separated from one another hy fibrous septa, which diride the common sheath into three compartments: one for the artery, one for the rein, and one for the nerve. The vein, which is larger than the artery, lies to the outer side, and somewhat overlays the artery. The pnemmo- 
gastric nerve lies behind and between the two vessels. The artery on the right side measures about three and three-quarter inches $(9.5 \mathrm{~cm}$.); on the left side about four and three-quarter inches $(12 \mathrm{~cm}$.$) .$

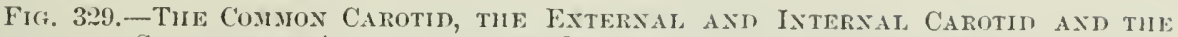

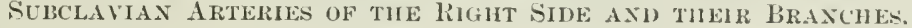

(From a dissection by Dr. Alder Smith in the Iusem of St. Bartholomew 's Hospital.)

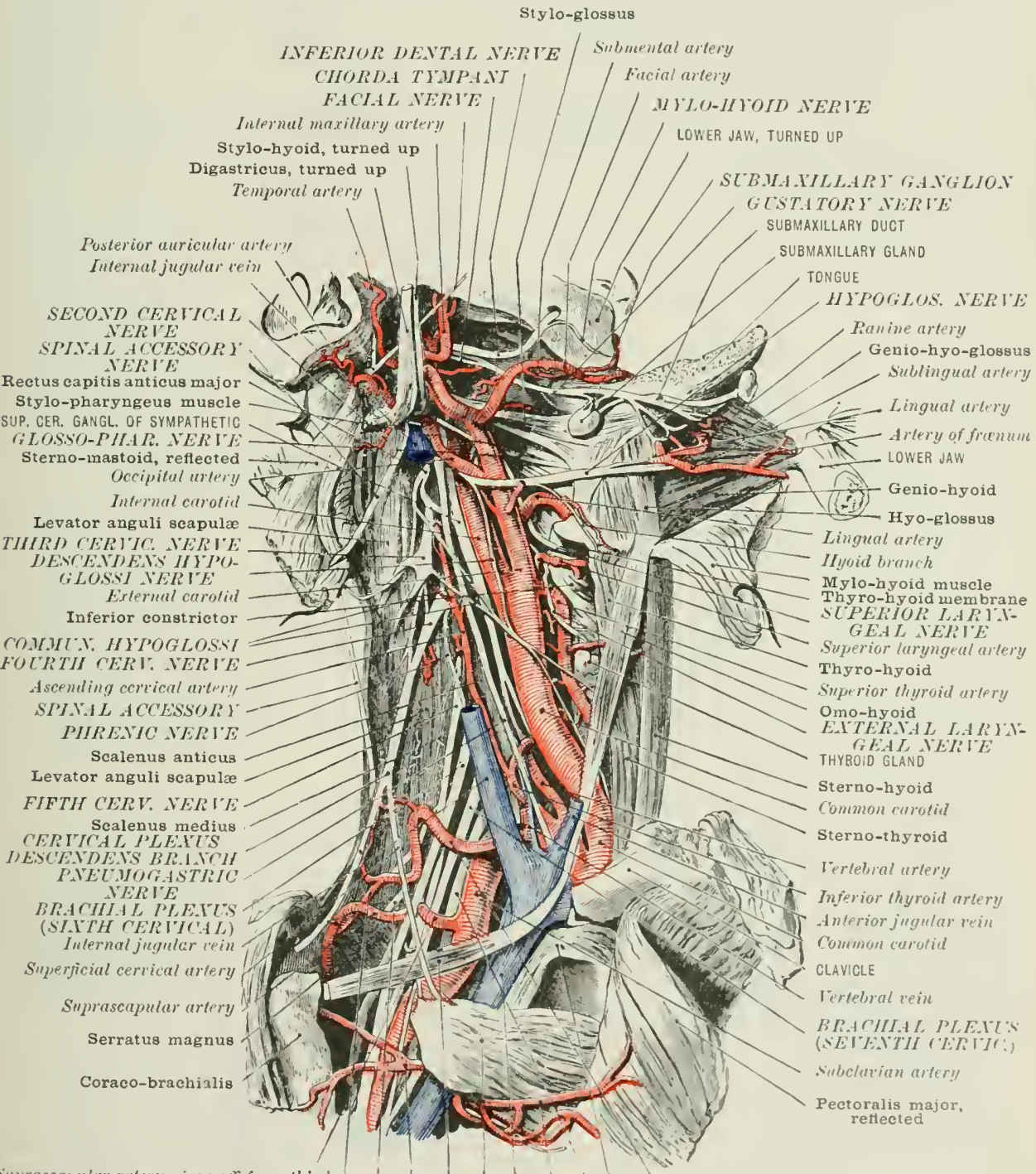

Ninjrascapular arlery given off from lhiral petrl of subclarian

I'tsiterior scapular arlery

SLPRASCA PLLAR NERIE

Humeral thoracic artery

Posterior belly of omo-hyoid, drawn down

Transierse cemical artery

Subclavius, reflected

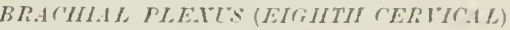
I'ctoral branch of acromial thoracic artery

Suliclatian tein

Pectoralis minor

Relations.-In front the artery is covererl by the skin. superficial filscia, platysma, and deep fascia, and is more or less overlapperl hy the sterno-mastoid muscle. At the lower part of the neek it is covered in addition hy the sterno-hyoid and 
stcmo-thyrut muscles, and is crossed by the anterior jugnlar vein, and is often overlapped hy the throvd body. Opposite the cricoid eartilage it is crossed obliquely he the omo-hroid muscle: and above this spot by the middle and superior thyroid,

Fig. 3:30.-The Collateral Circllation after Ligatere of the Comion Carotid Axd SUBCLATIAX ARTERIES.

(A ligature is placed on the common carotid and on the third portion of the subelavian artery.)

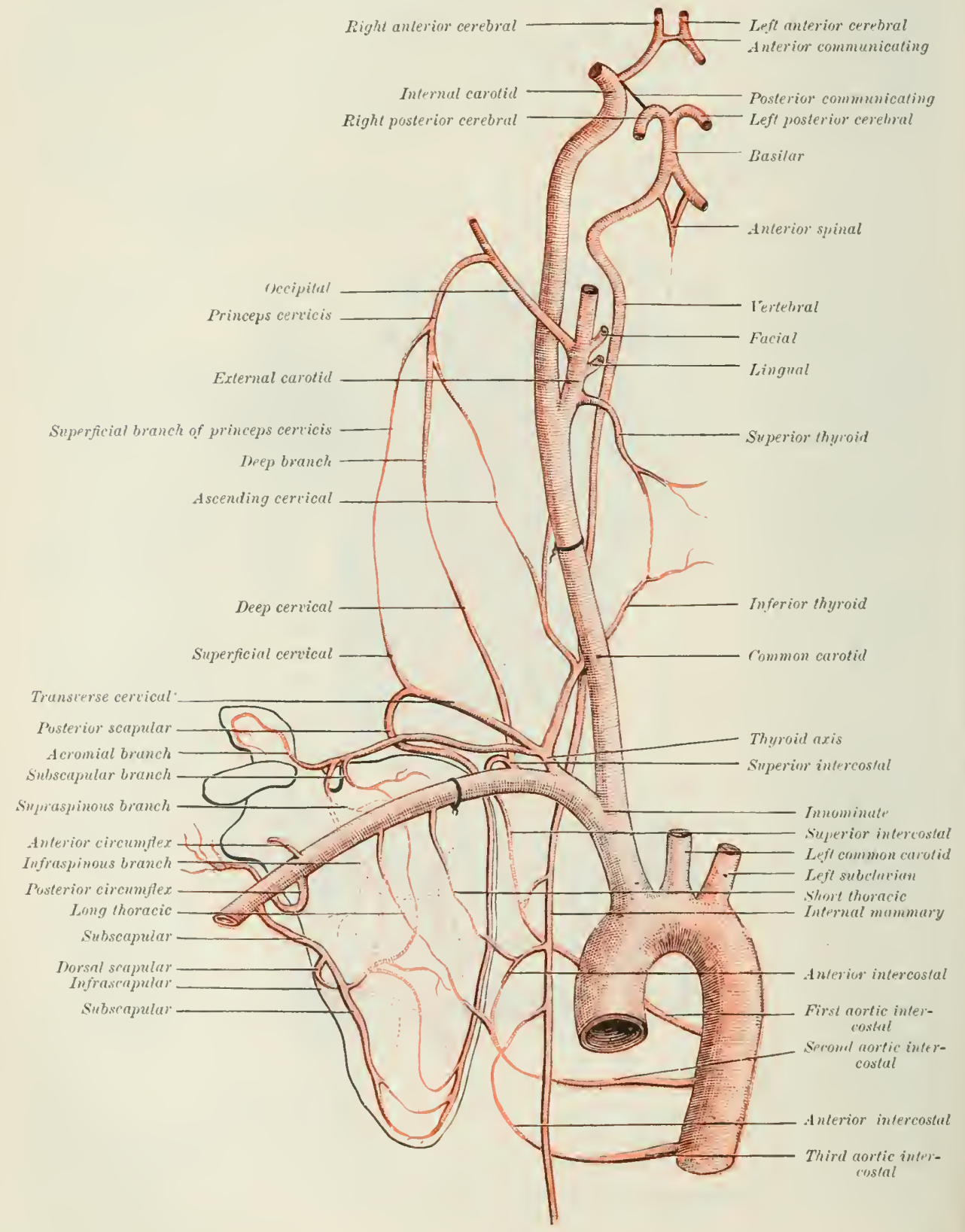

the lingual, and gencerally the facial veins in their course to the internal jugular, and by the midelesterno-mastoid artery as it passes from the superior thyoded artery, its ustal sourer, on its way down to the stemo-nastodel muscle. Along the anterior 
border of the sterno-mastoid there is a communicating vein between the faciol and anterior jugular veins, which, as it crosses the line of the carotid artery, is in ranger

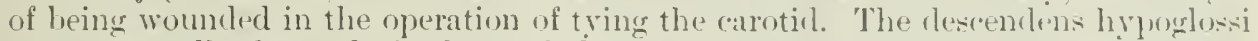
nerve generally descends in front of the carotid sheath, being there juined hy the communicantes hypoglosi, one or two small hanches of the serond and thirl (ervical nerves. At times this nerve mus within the sheath. There are usually two lymphatic glands alout the bifurcation of the artery. These are often founil enlargerl and infiltrated in cancer of the lip and tongue.

Behind, the common carotid lies on the longus colli and scalenus anticus below; and rectus capitis anticus major above. Posterior to the artery, but in the sane sheath, is the pneumogastrie nerve; and posterior to the sheath, the chain of the sympathetic and the cervical cardiac branches of the srmpathetic and pnemmogastric nerres. At the lower part of the neck the inferior thymid artery courses obliquely behind the carotirl, as does likewise the recurrent laryngeal nerve.

Internally, from below upwards, are the trachera and cosophagus. with the recurrent laryngeal nerve in the groove between them, and the terminal branches of the inferion throid artery, the lateral lobe of the thyroid body, the cricoid eartilage, the throid cartilage, and the lower part of the pharynx. At the angle of bifurcation is a vascular structure kmown as the ganglion intercaroticum or the carotid gland.

Externally are the internal jugular vein and the pneumogastrie nerve. On the right side, at the root of the neck, the rein diverges somewhat from the artery, learing a spare in which the pneumogastric nerve and vertebral artery are "xposit. On the left side the vein approaches and somewhat overlaps the artery, thus learing no interval corresponding to that on the right side.

The ericoid cartilage is as a rule taken as the centre of the incision in the operation for ligature of the common carotid artery. The incision is made in the line of the vessel parallel to the anterior margin of the stemo-mastoid muscle. The omohyoid forms one of the chief rallying points in the course of the operation for ligature of the artery above that muscle, the usual situation. The artery is found beating at the angle formed by the omo-hyoid with the stemo-mastoid.

Branches.-(1) External and (2) internal carotid arteries. The conmon carotid gives off no lateral braneh, and consequently does not dininish in size as it runs up the neck. It is often a little swollen just below its lifureation, a condition that should not be mistaken for an aneurismal dilatation.

\section{Tiurutions of the Common Carotid Aiteries}

The variations in the origin of the common carotid have been already mentioned under Variations of the Chief Braxches of the Aortic Arci (page 4:2).

The following variations are of surgical interest:-

(A) The artery may cruss obliquely the luwer part of the trachea abore the level of the sternum. 'This may uccur on the right side: (a) when the imnominate is situaterl abmormally to the left of the middle line; $(b)$ when the right common earotid arises as the second branch of the anrtic arch; and $(c)$ when the right and left common carotids arise as a common stem from the aorta. On the left side: when the left common carotid arises from the inmoninate.

(B) The right common carotid mas, when arising from the arrtal, run behind the trachea and asophagus to the right side of the neck.

(C) The commencement of the right common carotil may be above or below the natual spot, aceorling as the innominate bifureates hirher or lower thin usual. A low bifureation of the innominate is somewhat the more common abmomality.

(D) The common carotid may run in a very tortuous manner, formung one or more listinct loojs in its course up the neck.

(E) The artery may bifureate higher or lower than normal. A high lifureation is the more common. The bifureation may oreur as high as the hyoid bone, or eren styloid process; on as luw as the cricoid cartilage, or within an inch and a half of its origin.

(F) The artery may not hifureate, but give off the branches usially deriverl fiom the exterual division as it ascends in the neck.

(G) The comumn earutid way be absent, the axternal and internal carutids ari-ing direetly from the aorta.

(H) It may give off one or more of the branches usually derived from the external carotid.

(I) It may give off a thyroilea ima.

(J) The pineumogastric nerve may run in front of the artery instead of hehind it

The collateral circulation (fig. 3:30), after ligature of the ermmon carntid. is carricel on chicfly 
los the anistomnsis of the internal carntid with the internal carotid of the opposite side through the circle of Willis; by the vertebral with the opposite vertebral ; by the inferior thyroid with the superior thyroid; by the deep cervical branch of the superior intercostal with the princens cervicis of the occipital ; hy the superior thyroid, lingual, facial, occipital and temporal. with the corresponding arteries of the opposite side, and by the ophthahmic with the angular. The anastomosis between the deep cervical branch of the superior intercostal with the princeps cervicis of the occipital is an important one and is situated deeply at the back of the neck, and is to be found lying between the cmplexus and semi-spinalis colli muscles.

\section{THE EXTERNAL CAROTID ARTERY}

The external carotid artery, the smaller of the two branches into which the common circotid divides at the upper border of the thrord cartilage, is distrihuted to the anterior part of the neek, the face, and the side of the skull both soft parts and bones. the integuments externally, and dura mater internally. It is derelopmentally derived from the third aortic arch. and supplies the oral and post-oral visceral branches. It is at first situated internal to the internal carotid; lut as it ascencls in the neck it forms a gentle curve, with its convexity forwards and, rumning slightly backwards as well as upwards, terminates opposite the neck of the lower jaw just below the condyle, by dividing into the internal maxillary and superticial temporal arteries. It here lies superficial to the internal carotid. from which it is separated by a portion of the parotid gland. At its origin it is overlapped by the anterior margin of the sterno-mastoid, and is covered by the superficial fascia, platrsma, and deep fascia. Higher up the neck it passes beneath the strlo-hroil muscle. the posterior belly of the digastric musele, and the hypoglosil nerve; and. entering the parotid gland, is situated deeply in that structure at its division into its terminal branches. It is separated from the intemal carotid artury posteriorly by the stylo-pharyngeus and stylo-glossus muscles, the glossopharyngeal nerve, the pharyngeal branch of the premogastric nerve, a portion of the jalrotid gland. and the stylo-hyoid ligament; or, if the styloid process is ahnormally long. hy that process itself. It measures about two and a half inches (6.5 (m).).

Relations (fig. 329).-In front, in addition to the skin, superficial fascia. platyma. and leep fascia, it has the hypoglossal nerve. the lingual and facial veins, the posterior belly of the dignstricus and stylo-hyoid muscles, the temporomaxillary rein, the superior cervical lymphatic glands, branches of the facial nerve, anel the parotid glanel. The stemo-mastoid also overlaps it in the natural state of the parts.

Behind, it is in relation with the internal carotid. from which it is separated hy the stylo-glossus and stylo-pharygens muscles, the glosso-pharygeal nerve, the pharyeal branch of the pnemogastric nerve, the stylo-hroid ligament, and the parotid ghamd. The superior laryngeal nerve crosses behind both the external and internal caroticl arteries.

Internally, it is in relation with the hyoir bone, the pharygeal wall, the ramus of the jaw. the stylo-maxillary ligament which separates it from the submaxillary gland, and the parotid glanil.

Externally, in the first part of its course, it is in contact with the internal carotid artery.

\section{Chief Tariations of the External C'arotid Artery}

The variations of the external carotid artery are not of much smrgical importance. The variations in its origin have been discussed under YaRIATIOSS OF THE Coymon CAROTID.

(A) It may be absent, the liranches usually derived from it coming off from the upward continuation of the common trumk.

(B) It may run superficial to the stylo-hyoid muscle.

(C) Its branches may come off irregularly; or may le diminished or increased in number either by two or more arising as a common stem, or by its giving origin to branches not vsually deriven from it, as the sterno-matsoid banch of either the superior thyroid or oceipital artery.

(D) At times all its branches come off elose together just above its origin.

The branches of the external carotid are usually given off in the following order, from below upwards:- 
1. Ascenrling pharyngeal . . . A-cending set.

2. Superior thyruil . . . . . . )

3. I.ingual . . . . . . Anterior sct.

4. Facial . . . . . . . I

5. Oecipital . . . . . . . ! Posterior sot.

6. Posterior auricular . . : Posterior set.

¡. Temporal . . . . . . I Teminal set.

s. Internal maxillary . . . . . T Teminal set.

\section{THE ASCENDING PHARYNGEAL ARTERY}

The ascending pharyngeal artery is msually the first or second branch of the external caroticl. Ucasionally it comes off at the bifureation of the common

Fig. 331.-Scheye of Rigit Asceximg Pharygedl Artery. (Walsham.)

The internal carotid artery is hooked aside.

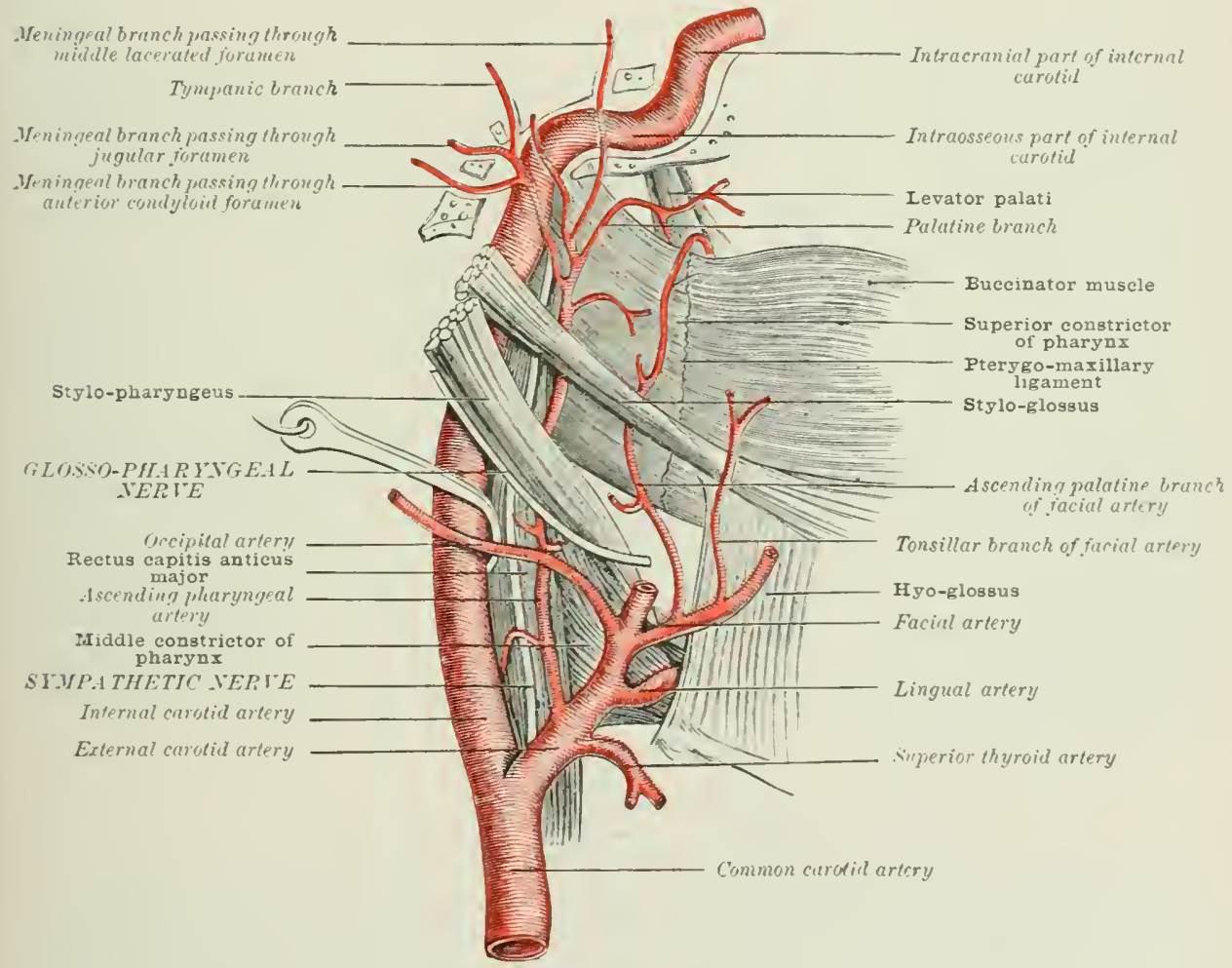

carotid from the common carotid itself. It is a long slender ressel, the smallest named branch of the external carotid, and runs deeply sated up the neek to the bass of the skull, having the walls of the pharyx and the tonil internally, the internal carotil artery externally, and the rertebral column, the rectus eapitis antieus major, and the smmpatheti. nerve posteriorly. In front it is crosecl hy the stylo-glosis (see fig. 331) and stylo-pharyngens muscles and the glosso-pharygeal nerve.

\section{Branches of the Ascendixg Pilarygenl Artery}

The ascending pharyngeal artery tres off the following branches:-(1) Prerertcbral: (2) pharyngeal; (3) palatinu; (4) tympanic; (5) meningeal.

(1) The prevertebral are distrihuted to the recti muscles, the fascia in front of 31 
the vertebral column, and to the sympathetic nerve and lymphatic glands. These branches anastomose with branches of the ascending cervical. (2) The pharyngeal supply the sulerior and middle constrictor muscles and the nucous membrane lining them. These ressels anastomose with branches of the superior thrroid. (3) The palatine passes orer the upper edge of the superior constrictor to the soft palate and its muscles. This hranch follows a comrse sinilar to that taken by the ascencling palatine artery, and when the latter is small may take its place. It generally gives off small twigs to the Eustachian tube and tonsil. (4) The tympanic accompanies the tympanie branch of the glosso-plarygeal nerve through the trmpanic canaliculus into the trmpanum, and anastonioses with the other tympanic arteries. (5) The meningeal are distributed to the membranes of the brain. Some of these pass with the jugular vein through the jugular foramen into the cranium, and supply the dura mater in the posterior fossa of the skull. Others occasionally reach the same fossa through the anterior condyloil formen in company with the hypoglossal nerve; while others pass through the cartikge of the midlile lacerated foramen and supply the middle fossa of the skiull.

\section{THE SUPERIOR THYROID ARTERY}

The superior thyroid artery arises from the front of the external carotid a little abore the origin of that ressel, and, comrsing forwarks, inwards, and then downards, in a tortuous manner, supplies the depressor muscles of the hyoid bone, the larynx, the throirl body, and the lower part of the pharynx. The artery at first runs forwarls and a little upwards, just beneath the greater cornu of the hyoid bone. In this part of its comrse it lies in the superior carotid triangle, and is quite superficial, being covered only with the integument, fascia, and platrsma. It next turns downwards, and passes beneath the omo-hroid. sterno-hyoid, and sterno-thyroid muscles, and ends at the upper jart of the thyroid body by breaking up into branches, some of which pass downwards in front, and others behind the literal lobe of that structure to anastomose with ascenting branehes from the inferior thyroid; whilst others, again, but much smaller in size, pass in the substance of the isthmus across the front of the trachea to anastomose with the superior thyroid artery of the opposite side. These vessels, however, are so small, that if the isthmus is dividerl accurately in the mirdle line, there is practically no arterial hrmorrhage. From the branch to the thyroid bock twige are given off to the inferior constrictor and the upper part of the osophagus. Thes anastomose with branches from the inferior thyroil. The superior thyroid vein passes bencath the artery on its way to the internal jugular vein. The superior thrroid is the artery most commonly divided in cases of suicidal wounds of the throat.

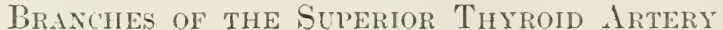

The named branches of the superior thyroid artery are:-(1) The hyoid; (2) the sterno-mastoid; (3) the superior laryngeal; and (4) the crico-thyroid.

(1) The hyoid-or infra-hyoid branch as it is sometimeseallerl, usually a small twig-passes along the lower border of the hyoid bone, lying on the throhyoid membrane under cover of the thro-hyoid and sterno-hvoid muscles." It supplies the infra-hyoid huma, and the thyo-hyoid musele, and anastomoses with its fellow of the opposite side, and with the supra-hyoid brandh of the lingual. When the latter artery is small, the infra-hyoid is msully comparatively large, and vice versa.

(2) The sterno-mastoid (fig. 392) - or middle mastoid artery as it is occasionally called-conrses downwark and hackwards across the carotid sheath, and entering the strmo-mastoid supplies the middle portion of that musede. It gives off slender twigs to the thyo-hyoid, stemo-hroid, and omo-hyoid museles, and the platysua and integmments covering it. At tines the vessel arises directly from the external carotid. It lies usually somewhere in the upper part of the incision for tring the commom arotid above the omo-hyoid muscle.

(3) The superior laryngeal (tig. 329 ) passes inwards and forwards beneath 
the thrro-hyoid muscle, and, perforating the thyro-hyoid membrane along with the superior laryngeal nerve, supplies the intrinsid musces and mucous lining of the larynx. Its further distribution within the larynx is given with the description of that organ. This branch sonetimes arises from the external carotid rirect. It may enter the larym by jassing through a foramen in the thyoid cartilage.

(4) The crico-thyroid-or inferior laryngeal branch as it is sometime called, usually insignificant in size-passes aeross the crico-thyroid nuembrane immediately beneath the lower borler of the throid cartilage. It anastomosis with its fellow of the opposite side, and usually sends a small branch through the membrane into the interior of the laryx. Occasionally a considerable twig descends over the cricoid cartilage to enter the isthmus of the thyroid gland. The erico-thyroid has, however, frequently been seen of comparatively large sizeonce as large as the radial, and crossing the membrane obliquely. In order to

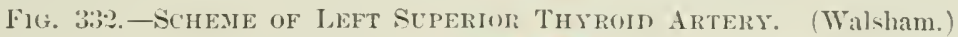

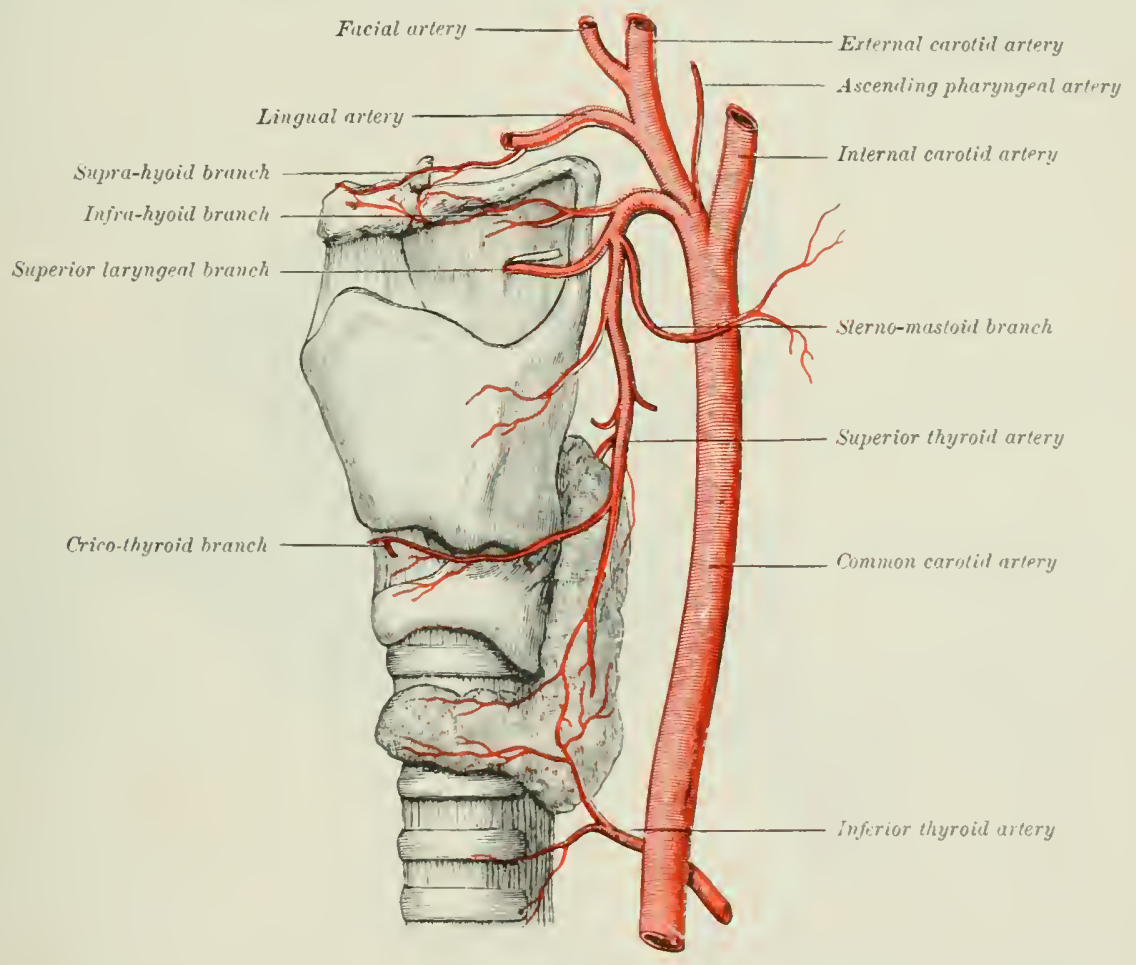

aroid injuring the crico-thyroid artery in the operation of larverotomy, it is usual, if the operation has to he flone in a hurry, to make the incision throngh the crico-thyroid membrane in a transwerse direction, and as near to thre crieobil cartilage as jossible.

\section{THE LINGLAL ARTERI}

The lingual artery (fig. 33.3) arises from the front of the exterial caroticl, between the superior thrreicl and fincial arteries, often, as a rommon trunk with the latter vessel, and nearly opposite or a little below the greater andu of the liverd bone. It may, for purposes of description, he divided into three mertions: the first,

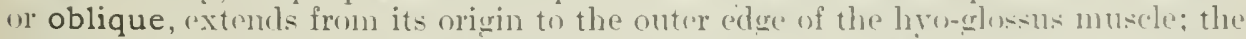
second, or horizontal, lies beneath the hyo-glossus: the third, or ascending, beneath the tongue. The first or oblique portion is situatel in the supurior carotid triangle, and is superficial, being corered merely by the integuments, 
platrsma, and deep fascia. Here it lies on the middle constrictor muscle and superior larvngeal nerve. After ascending a short distance, it enres downwards and forwards beneath the hypoglosial nerve, and, in the second part of its course, runs horizontally along the mpper border of the hyoil bone, beneath the hro-slosus, by which it is separated from the hypoglossil nerve, the posterior belly of the digastrieus and the strlo-hyoid musces, and the lingual vein. In this part of its course it lies successively on the mirllle constrictor of the pharynx and the genio-hyo-glessus muscle, and crosses a small triangular space known as 'Lesser"s trimgle, the sides of which are formed by the tendons of the digastric, the hase by the hypoglossal nerve, and the floor by the hyo-glossus muscle, in which situation it is usually tied. In the third part of its course it ascends tortuonsly, usually beneath the anterior margin of the hyo-glossus, to the under surface of the tongme, and is thence continued to the tip of that structure lying hetween the lingualis and the genio-hyo-glossus mus les. From the anterior eelge of the hro-glosins to its termination, it is only covered hy the mucous membrane of the inder surface of the tongue. This part of the vessel is sometimes called the ramine artery.

Fig. 333.-Schene of tile Right Lingull Artery. (Walsham.)

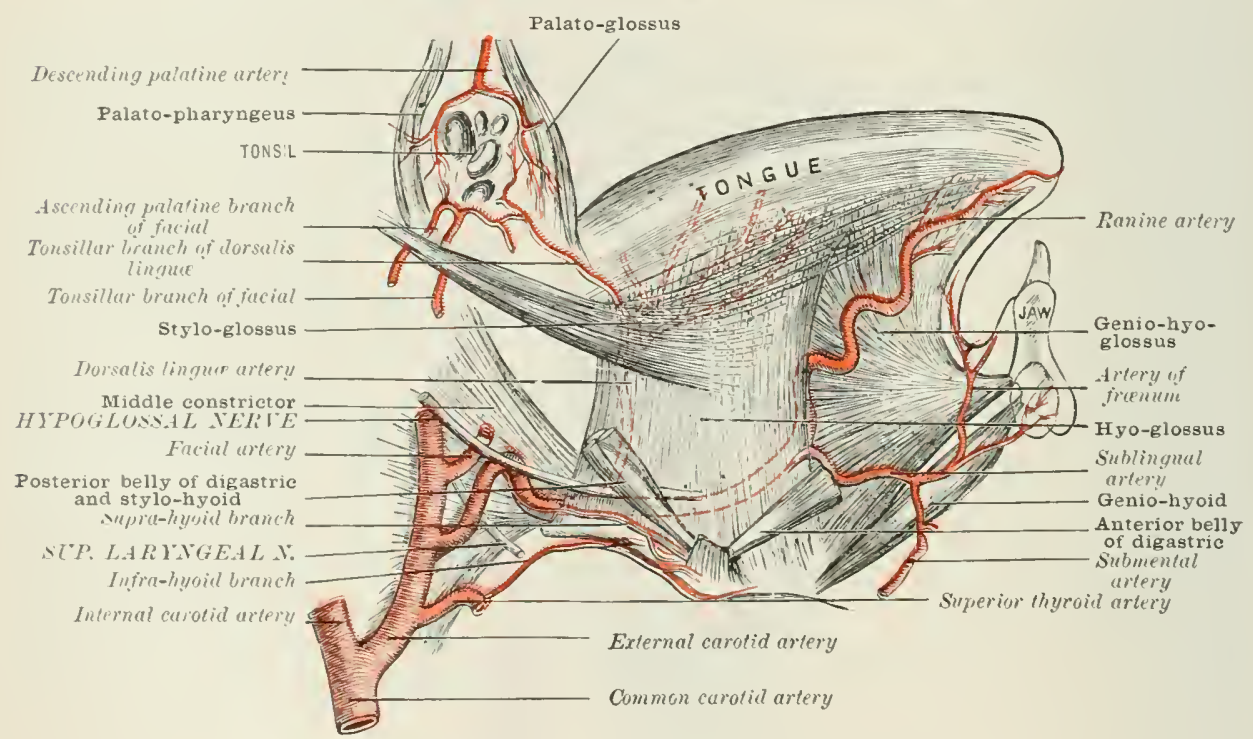

Braxches of the LANGt.ll ARTERY

The named branches of the lingual artery are:-(1) The hyoid; (2) the dorsalis lingure; (:3) the suhlingual: and (4) the lanine.

(1) The hyoid, or supra-hyoid (fig. 333 ), is a small ressel which arises from the first part of the lingual, and courses along the upper border of the hyoid bone, superficial to the hyo-grosus. but beneath the insertion of the posterior belly of the digastrieus and stylo-hyoid. It anastomoses with its fellow of the opposite side, and with the infra-hyoil, a branch of the superior thyroid artery, and supplies the contiguous muscles.

(2) The dorsalis linguæ (fig. 333 ) arises from the second portion of the lingual artery. manlly under cover of the posterior edge of the hro-ghosus muscle. It ascencls to the lack of the dorsum of the tongue, and, dividing into branches, supplies the mucous membrane on each side of the $V$ formed by the circumvallate pkipilla. It also supplies the pillars of the fauces and the tomsil, where it anastomoses with the other faucial and tonsillar arteries. Instead of a single artery, as above desorilved, there may he several small ressels running directly to the jarts mentioned. The artery anastomoses in the mucous membrane by rey small 
branches with the ressel of the olpmite side; but the anastomoris is so minute that when one lingual artery is injected, the injection merely passes across to the opposite sicte at the tip of the tongue; and when the tongue is divided accurately in the middle line, as in the remoral of one-half of that organ, practically no hemorrhage occurs.

(3) The sublingual artery (fig. 333 ) usually comes off from the lingual at the anterior margin of the hyo-glossus. It passes beneath the mylo-hyoid to the sublingual gland, which it supplies, and, perforating the muscle, anastomoses with the sulmental artery, a branch of the facial. It also supplies branches to the side of the tongue, and gives off a terminal twig, which anastomoses beneath the mucous membrane of the floor of the mouth (to which it also gives twigs) with the artery of the opposite sitle. The artery of the frænum is usually derived from this ressel (fig. 333 ).

(4) The ranine artery, the termination of the lingual, courses formark beneath the mucous membrane, on the under surface of the tongue, to the tip. It lies external to the genio-hyo-glosisus, between that muscle and the inferior lingualis, and is accompanied by the ranine rein and terminal branch of the gustatory nerve. It follows a very tortuous course, so that it is not stretehed when the tongue is protruded. Branches are given off from it to the contiguous muscles and mucous membrane. Near the tip of the tongue it communicates with its fellow of the opposite side, as shown by the fact that when the lingual artery of one sicke is injected the injection fluid passes into the branches of the artery of the other side.

\section{THE FACIAI, ARTERY}

The facial artery (fig. 334) —also called the external maxillary-arises immediately above the lingual from the fore part of the extemal caroticl, at times as a common trunk with the lingual. It courses forwards and upwards in a tortuous mamer to the lower jaw, and, passing over the body of this bone at the anterior chlge of the masseter muscle, winds obliquely upwards and forwards over the fice to the inner canthus of the eye, where it inosculates, under the name of the angular artery, with the nasal braneh of the ophthalmic. It is usually divided into two portions-the cervical and the facial.

The cervical portion (fig. 334) ascends tortuously from its origin from the external carotid upwards and forwards beneath the posterior belly of the digastric and stylo-hyoid musches. and usually alio beneath the hypoglossal nerve, and then making a turn runs horizontally forwark for a short way leneath the jaw. either imbedded in or lying under the submaxillary gland. It has here the mylo-hyorit and stylo-glossus beneath it. On leaving the cover of the gland it forms a lon] passing first downwards and then upwards over the lower horder of the jaw immediately in front of the masseter muscle, where it is superficial, being merely covered by the integument and platysma. Here it can be felt beating, and can be rearlily compressed. In the above course it lies in the posterior part of the submaxillary triangle. and, in adrlition to the structures already mentioned as crossing it. is covered by the skin, superficial fascia, and platysma, and by one or two submaxillary lymphatic glands. The vein is separater from the artery liv the submaxillary gland, the posterior belly of the digastric muscle, the stylo-hyoid muscle, and the hypoglossal nerve.

The facial portion (fig. 334) of the facial artery ascends tortuously forwarts towards the angle of the mouth. passing under the plat ysma (risorius) and zromatic muscles and the supramaxillary and huceal branches of the facial nerve. It here lies upon the jaw and the bucinator muscle. Thence it couses upwards hy the side of the nose towards the inner canthus of the eve, heing covered by the levator lahii superioris, levator lahii superioris alieyue nasi, and infraorlital branches of the facial nere, and lving on the levator anguli oris (smetimes on the levator labii superioris. instear of helow it) and the infraorbital branches of the fifth nerve. The facial rein takes a much straighter course than the artery, is separated from it by the zygomatic muscles, and lies to its outer sicle. 


\section{Braxches of the F.tcill Alitery in the Neck}

The branches of the facial artery in the neck are:-(1) The ascending, or inferior palatine; (2) the tonsillar; (3) the glandular; (4) the muscular; (i) the sulmental.

(1) The ascending, or inferior palatine (figs. $39: 3,3.34$ ) - the first branch of the facial, but often a distinct branch of the external carotid-ascends between the

Fig. 334.-Schene of tile Right Facill Artery. (Walsham.)

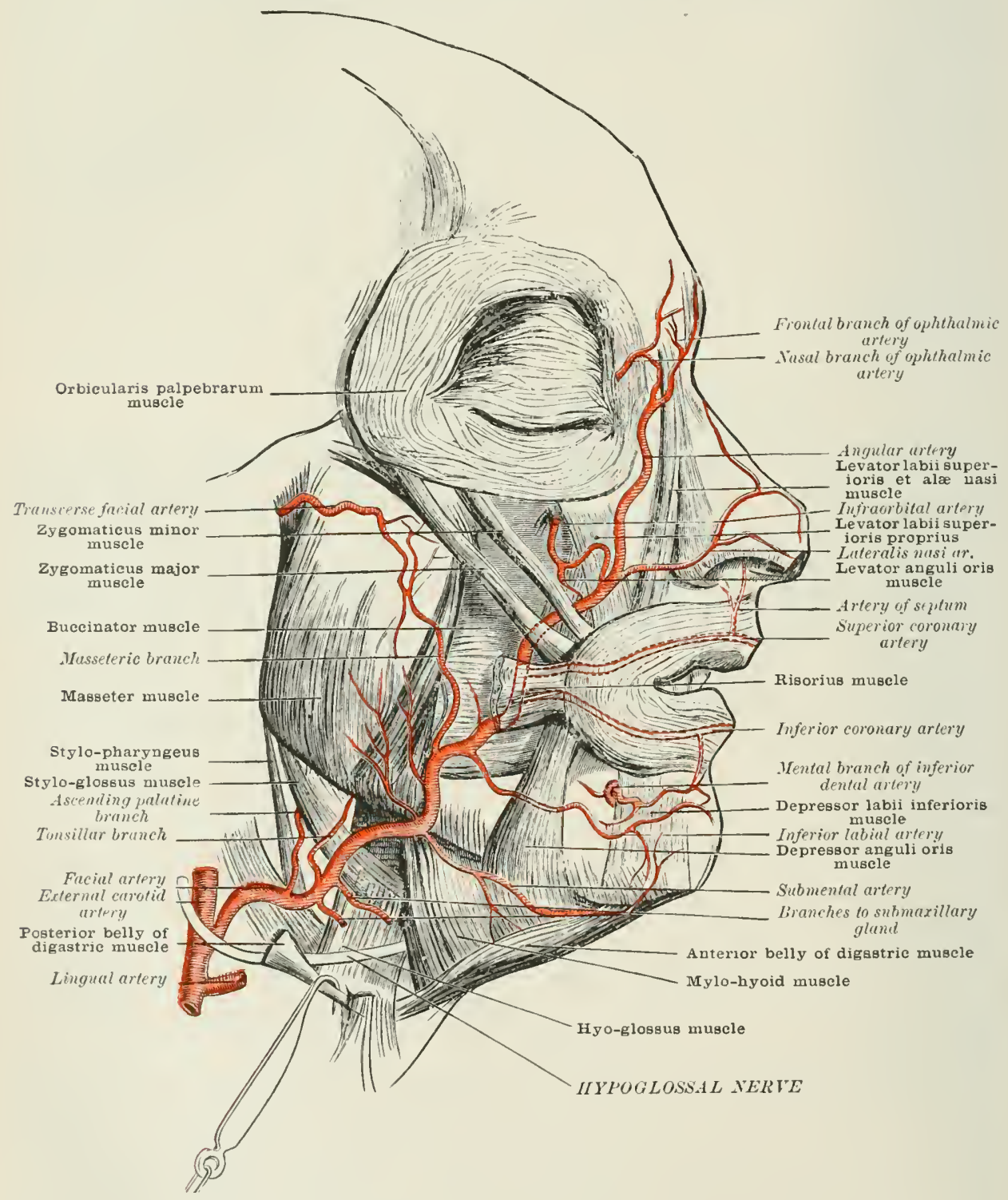

internal and external carotids, and then between the stylo-ghosiss and stylopharyngeus muscles, and on reaching the wall of the pharyix is continued upwards lotween the superior constrictor and internal pteryoid muscles towarls the base of theskull as high as the levator palati, where it divides into two luranches, a palatine and a tonsillar. One of these branches, the palatine, passes with the levator palati 
over the eurved upper margin of the superior constrictor to the soft palate, where it is distributed to the tissues comstituting that structure, and anastonuses with its fellow of the opposite side and with the elescending palatine branch of the internal maxillary, and the ascending pharyngeal, which vessel often to a great extent sulplies the place of this artery. The other branch, the tonsillar, supplies the tonsil and the Eustachion tube, anastomosing with the tonsillar branch of the facial and ascending pharyngeal arteries. The ascending falatine artery supplies the muscles between which it runs on its way to the palate.

(2) The tonsillar branch (fig. 3i3t) ascends between the stylo-glossus and internal pterygoid mu-cles to the level of the tonsil, where it perforates thesuprior constrictor nuscle of the pharynx, and ends in the tonsil, anastomosing with the tonsillar branch of the ascending palatine and with the other tonsillar arteries (fig. $339)$. It gives hranches also to the root of the tongue.

(3) The glandular or submaxillary branches are distributed to the submaxillary gland as the artery is jussing through or beneath that structure. A small twig from one of these liranches usually supplies Wharton's duct.

(4) The muscular branches are small twigs given off irregularly to the contigmus muscles, riz. the posterior belly of the digastric, the stylo-hyoud, the styloglosis, and the mylo-hyoid muscles.

(5) The submental branch (fig. 334) comes off from the facial as the latter res-et lies uncler cover of the submaxillary gland, and, passing forwards on the mylo-hyoir mucle letween the base of the jaw and the anterior belly of the digastricus, supplies these structures and the orerlying platyma and integuments. It gives off the following small branches:-(a) muscular, to the muscles hetween which it runs: (b) perforating, which jasses through the mylo-hyoid to anastomose with the sublingual; (c) cutaneous, to the integuments covering it; $(d)$ mental, which turns over the border of the lower jaw near the symphysis, and. after supplying a branch to the depresor latii inferioris, the levator menti, and the other adjacent soft tissues forming the chin and lip, anastomoses with the mental branch of the inferior dental, the inferior labial, and the artery of the opposite side.

\section{Braxches of the Facial Artery on the Fare}

From the outer or concave side of the artery are given off:- (1) masseteric branches which ascend over the masseter to anastonose with the masseteric branch of the internal maxillary artery and the transwerse facial artery; and (2) buccal, which yas: upwarks over the buccinator and anastomose with the buecal branch of the intemal maxillary, the transverse facial, and the infraobital arteries.

From the inner or convex side the following larer and named ressels are given off:-(1) The inferior labial: (2) the inferior coronary; (3) the superior coronary; (4) the lateralis nasi; and (5) the angular.

(1) The inferior labial artery arises either separately from the facial artery, or in common with the next branch-the inferior coronary. It courses forwarts heneath the depressor anguli oris, and over the depressor labii inferioris, and, after sulplying the contiguous muscles and integuments, anastomoss below with the sulmental, above with the inferior coronary, and between the wo with the mental hranch of the inferior dental which esapes from the mental foramen.

(2) The inferior coronary artery arising from the facial a little ahove the inferior labial, or in common with it, passes forwarks beneath the deprescor anguli oris towards the angle of the month, thence skirts along the lower lip, between the mucous membrane and orlicularis oris, about a quarter to half an inch from the junction of the skin and mucous membrane, and anastomoses with its fellow of the opposite side. It can readily be felt beating during life hy pressing the lip between finger and thumb. It gives off descending liranches which antastomose with the inferior labial and the nental branch of the inferior dental (or mandibular ) artery.

(3) The superior coronary artery, arising from the facial a little higher than the inferior coronary, passes forwarls bencath the zyomaticus major. and then. like the inferior coronary, courses tortuously along the lower maroin of the upper lip between the orbicularis oris and the inueous membrane about half an inch 
from the junction of the muenus membrane and the skin. It is usually larger than the inferior cononary. The superior coronary anastomoses with its fellow of the opposite sicle, and gives off a small artery to the septum-arteria septi nasi. Compresion of this ressel will sometimes control hamorrhage from the nose.

In the operation for hare lip, the pin or suture should he passed sufticiently deep to transfix the divided comnary artery, or hemorrhage may continue into the mouth. Blecting from either coronary ressel cam be readily controlled by the thumb and forefinger grasuing the lip.

(4) The lateral nasal artery (fig. 334 ) is a small twig or twigs given off from the farial opposite the ala of the nose. It passes forwarls over the ala and lower part of the nose, supplying the integuments, muscles, and cartilages, and anastomuses with the artery of the septum, the ressel of the opposite side, and the nasal branches of the ophthalmie.

(i) The angular artery (fig. 334) is the name given to the termination of the facial artery. It anastomoses at the imner canthus of the eye with the nasal linanch of the ophthahmic. It is accompanied by the anterior descending vein from the scalp. It lies to the immer side of the lachrymal sac, and supplies that structure and the lower part of the orbicularis oculi, beneath which a branch anastomoses with the infraorbital artery. The situation of the artery to the inner side of the lachrymal sac should be borne in mind in opening a lachrymal ahscess.

\section{THE OCCIPITAL ARTERY}

The occipital artery (fig. 33.5) is usually a ressel of considerable size. It comes off from the posterior part of the external carotid opposite the facial, or else a little higher than that ressel. It then winds upwarls and hackwards to the interval between the mastoid process of the temporal bone and transverse proces: of the atlas, and, after ruming horizontally backwards in the oceipital groove on the mastoid portion of the temporal bone, again turns upwards, and ends by ramifying in the scalp over the back of the skull, extending as far forwards as the rertex.

The ressel may be divided into three parts-riz. that internal to the sternomastoil muscle; that beneath the stemo-mastoid; and that extemal to the stemomastoid.

In the first part of its course the occipital artery is covered by the integuments and fascia, and is more or less overlapped by the posterior belly of the digastric muscle, the parotid gland, and temporo-maxillary rein. It is crossed hy the hypo-glossal nerve as the latter winds forwarls over the carotid ressels to reach the tongue. It suceessively crosses in front of the intemal carotid artery, the hypoglossal nerve, the pnemogastric nerve, the internal jugular vein, and the spinal accessory nerve.

In the second part of its course it sinks deeply beneath the digastric muscle into the interval between the mastoil proeess of the temporal bone and the transverse process of the atlas. It is here covered by the stemo-mastoid, splenins eapitis, and trachelo-mastoid muscles and by the origin of the digastricus; and lies, first on the rectus capitis lateralis, which separates it from the vertebral artery, then in the occipital groove on the mastoid portion of the temporal bone, and then on the insertion of the superior oblinue muscle.

In the third part of its course it enters the triangular interval formed by the diverging borders of the splenii cantitis and the superior emverl line of the occipital bone. Here it lies beneath the integuments and the aponemosis miting the oceipital attichments of the sterno-mastoil and trapezius, and rests upon the complexus just before the insertion of that muscle into the oreipital hone. In company with the great occipital nerve, it porforates cither this aponeurosis, or less often the posterior belly of the ocripito-frontalis, and follows ronghly, but in a tortunus course, the line of the lambdois suture lying lotween the integument and the cranial aponeurosis. In the scalp it cliviles into several large branches, which ramify over the back of the skull and reach as far formards as the vertex. They 
anastomose with the corresponding branches of the opposite side, and with the posterior auricular, and the superficial temporal arteries.

\section{Braxches of tile OCcIPlTAL Artery}

The branches of the occipital artery are:-(1) The sterno-mastoid; (2) the posterior meningal; (3) the aurioular; (4) the mastoid; (5) the princeps cervicis; (6) the communieating; ( 7 ) the musenlar; and (S) the teminal. The stemomastoirl, posterior meningeal, auricular, and princeps cervicis are the four ressels usually named amongst the above branches.

F1\%. 335. - Schene of Right Occipital axn Posterior Avricular Arteries. (Walsham.)

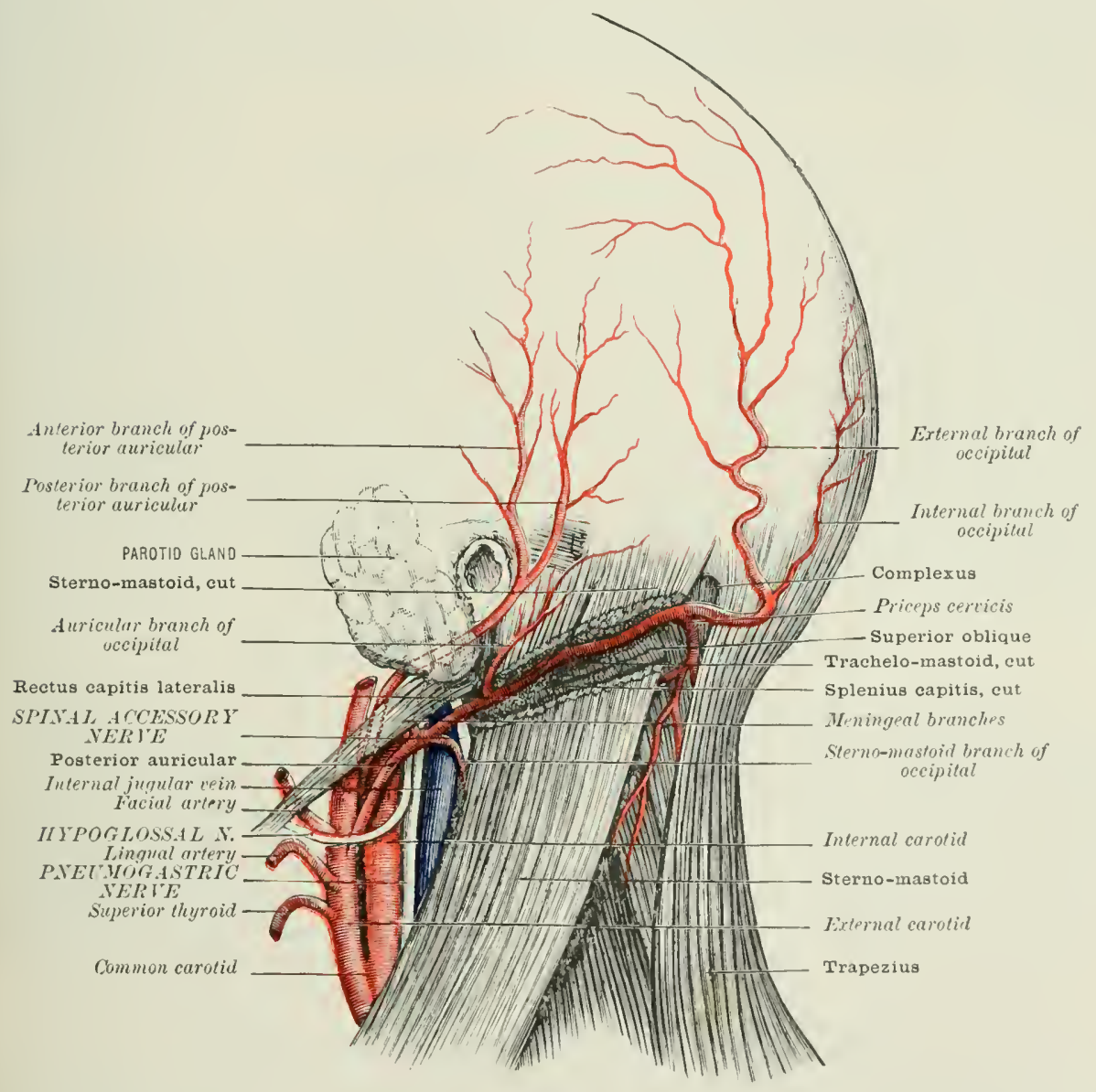

(1) The sterno-mastoid branch (fig. 335) usually comes off from the oceipital just after its origin from the carotirl, and. pasing downwards and hatelward- wer the loop of the hypoglossal nerve, enters the sterno-nustoil muscle in comprny with the spinal accessory nerve. At times this artery is a distinct branch of the external carotid. The hypoglossal nerve then as a rule loops round it instead of round the occipital.

(2) The posterior meningeal branches (fig. 335), one or more in number, are long slender vessels which leave the oecipital artery ats it rosses the internal jugular rein, and, ascending along that vesere pas with it through the jugular formen, and are distributed to the dura mater lining the posterior fossa of the skull. 
(3) The auricular branch ascends over the mastoid process to the back of the ear. and supplies the pinna and concha. It sometimes takes the place of the posterior anticular artery (fig. 33.5).

(4) The mastoid branch is a small twig that passes into the sliull through the mastoid foramen. supplying the dura mater, the diploë, the wialls of the lateral sinus and the mastoid cells.

(.) The princeps cervicis (fig. 335), the largest of the branches of the occipital, arises from that artery just before it emerges from beneath the splenius, and, descending for a short distance between the splenius and complexus, divides into a superficial and a deep branch. The superficial branch perforates the splenius, supplies branches to the trapezius, and anastomoses with the superficial cervical, a branch of the transverse cervical artery. The deep branch passes downards between the complexus and semispinalis colli, and anastomoses with the deep cervical hranch of the superior intercostal and with branches of the rertebral (fig. 338). The anastomoses between the above-mentioned arteries form important collateral channels after ligature of the common carotid and subclavian arteries (fig. 330 ).

(6) The communicating branches run deeply into the triangle formed hy the superior oblique, inferior oblique, and rectus capitis posticus major muscles, and there anastomose with branches of the rertebral.

(7) Muscular branches throughout the course of the occipital artery are distributed to the contiguous muscles-viz. in ardition to the stemo-mastoid which receives a named branch, to the digastricus, stylo-hyoid, splenius, trachelo-mastoid, trapezius. the small muscles forming the suboccipital triangle, and the posterior belly of the occipito-frontalis.

(S) The terminal or superficial branches (fig. 33.5), usually two in number, namer from their position internal and external, ramify orer the scalp, and have already heen described. The internal branch generally gives off a twig which enters the parietal formen (parietal artery) and is distributed to the dura mater. The occipital artery may also give off the stylo-mastoid, the posterior auricular, or the ascending pharyngeal arteries.

\section{TIIE POSTERIOR ALRICLLAR ARTERY}

The posterior auricular artery (fig. 335 ) arises from the posterior part of the external carotid artery, usually immediately above the posterior belly of the digastric, about the level of the tip of the styloid process. Occasionally it arisos under corer of the digastric, quite close to, or as a common trumk with. or as a Jranch of, the occipital. It courses upwards and backwards in the parotid gland to the notch between the marerin of the external auditory meatus and the mastoid process, where it divides into two branches, an anterior or auricular, and a posterior or mastoid. In this course it rests on the styloirl process, crosses the spinal accessory nerve, and is crossed itself by the facial nerve.

\section{Bratches of the Posterior Avricular Artery}

The branches of the posterior auricular artery are:-(1) The parotid; (2) the unuscular; (3) the stylo-mastoid; (4) the anterior terminal, or auricular; (5) the posterior terminal, or mastoil (fig. 33.5 ).

(1) The parotid branches are distributed to the lower portion of the parotid gland, and anistomose with the other parotid arteries.

(2) The muscular branches suply y the posterior belly of the digastricus, the stylo-hyrid, and retrahens aurem muscles.

(3) The stylo-mastoid branch comes off from the posterior auricular artery just before it reaches the notch hetween the margin of the external auditory meatus and the mastoicl process, and, following the facial nore upwards, enters the stylomastoid foramen in the temporal hone. In the aqueduct of Fallopius it gives of the following namerl twigs:-( 1 ) meatal, to the external auditory meatus; (b) mastoid, to the mastoid cells and mastoid antrum; (c) stapedic, which runs for- 
wards to the stapedius muscle; (d) tympanic, which anastomoses with the trmpanir branch of the internal maxillary, forming with it in the fortus a rascular circle around the membrana trmpani; (e) vestibular, to the restilule and semincircular eanals; and $(\dot{f})$ terminal, a small twig which enters the hiatus Fallopii with the great superfieial petrosil nerve, and anastmoses with the petrosal hranch of the large middle meningeal artery.

(4) The anterior terminal or auricular branch passes upwarls bohind the ear and beneath the retrahens aurem, supplying the back of the finna and neighbouring integuments. It anastomoses with the posterior branch of the superficial temporal artery. The branches to the pinna not only supply the back of that structure. hut some perforate the eartilage, and others tum over its free margin to supply the front surface; there they anastomose with the anterior auricular branches from the temporal.

(5) The posterior terminal, or mastoid or occipital branch, passes upwarts and backwards. crosing the aponeurotic insertion of thesterno-mastoid muscle. It gives a branch to the posterior belly of the oceipito-frontalis, and anastomoses with the occipital artery.

\section{THE TEMPORAL APTERY}

The temporal artery, or superficial temporal artery-the smaller of the twi terminal clivisions of the external carotid, though apparently the clirect continuation of that resse]-arises opposite the neek of the lower jaw and. under corer of the parotid gland, passes upwarls in the interral between the condyle and the external auclitory meatus to the zrgoma, lying on the capsule of the joint. Thence it ascends over the posterior root of that process and the temporal aponeurosis for about an inch and a half to two inches $(4 \mathrm{~cm}$.), and there divides into an anterior and a posterior lraneh. It is surrounded by a dense plexus of sympathetic nerves, and is arcompanierl by the aurienlo-temporal nerve, which lies bemeath and genemally a little behind it. It is crossed by the temporo-facial division of the facial nerie. and by the attrahens aurem muscle. As it crosses the zygoma it can be readily felt pulsating immerliately in front of the ear, and in this situation can be compressed against the bone. It is here quite superficial, being merely covered ly the integuments and a delicate prolongation from the cerrical fascia.

\section{Branches of the Temporal Artery}

The branches of the temporal artery are:-(1) The paroticl; (2) the articular; (3) the masseteric; (4) the auricular, or anterior aurienlar; (5) the transverse faeial; (6) the middle temporal; (7) the orbital; ( 8 ) the anterion terminal; (9) the posterior terminal.

(1) The parotid branches are small twigs giren off in the substance of the paroticl gland to that strueture.

(2) The articular branches supply the temporo-maxillary joint.

(3) The masseteric are one or two small hranches to the masseter musele.

(4) The auricular or anterior auricular branches sulply the tragus, the pinna, and the lobule of the ear, and to some extent the external auditory meatus.

(5) The transverse facial is the largest branch of the temporal. It sometime arises from the external earotid as a common trunk with the temporal. It is at first deeply scated in the substance of the parotirl gland. hut, soon emerging from under that part of the gland known as the socia parotidis, courses transweredy aeross the masseter muscle ahout a finger's hreadth helow the zycroma. Stemo"s duet runs below it, and the infraorbital branches of the facial nerve above it. It supplies the parotid gland, the masseter musele, and the skin of the fice, and anastomoses with the infraorbital, the luceal, and the facial arteries.

(6) The middle temporal branch, or middle deep temporal artery (fig. 336 ). arises just above the zygoma, and, perforating the temporal aponeurosis ancl temporal muscle. ascendis on the spuamous pertion of the trmporal hone, anel anastomoses with the posterior deep temumal artery.

( 7 ) The orbital or zygomatico-orbital branch (fig. 336 ), as it is sometimes 
called-at times a branch of the deep temporal-passes forwards along the upper border of the zyoma in the fat between the superficial and deep lavers of the temporal aponeurosis, and, after griving branches to the orbicularis orili, sends one or more twigs into the orbit through the orbital foramina in the malar bone to anastomose with the lachrymal and palpebral branches of the ophthahnic.

(s) The anterior terminal branch ramities tortuously in an upward and forward direction orer the front part of the skull. It lies, first between the skin and temporal fiscia, and then between the skin and occipito-frontalis aponemrosis. It supplies the anterior belly of the oceipito-frontalis and the orbicularis oculi muscles, and anastomoses with the supraorbital, supratrochlear, and frontal branches of the ophthahmic, and with the corresponding artery of the opposite side. The secondary branches given off from this ressel to the scalp run from hefore backwark.

(9) The posterior terminal branch ramifies on the side of the head between the skin and temporal fascia. Its branches anastomose, in front with the anterior terminal hranch; behind, with the posterior auricular and occipital arteries; and above, across the rertex of the skull, with the corresponding artery of the opposite side.

\section{S. THE INTERAAL MAXILLARY ARTERY}

The internal maxillary artery (fig. 336 ) is the larger of the two terminal divisions of the external carotid. It arises opposite the neck of the jaw in the substance of the parotid gland, and, passing first between the neck of the jaw and the spheno-mandibular ligament-the so-called internal lateral ligament of the lower jaw-and then between the external and internal pterygoid muscles, sinks deeply into the spheno-maxillary fossa, and there breaks up into its terminal branches. It is divided into three portions: a maxillary, a pteryoid, and a sphenomaxillary.

(1) In the first part of its course (the maxillary portion) the artery lies lretween the neck of the jaw and the spheno-mantibular ligament, taking a horizontal course forwards and inwards parallel to and a little below the auriculotemporal nerve and the external pterygoid muscle. It is here embedded in the deep portion of the parotid gland, and usually crosses in front of the mandibular (inferior dental) nerve.

(2) In the second part of its course (the pterygoid portion) the artery lies either hetween the two pterygoid muscles and the ramus of the jaw, and then turns upwards over the outer surface of the external pterycoid, heneath the temporal muscle to gain the two heads of the external pterygoid, between which it sinks into the spheno-maxillary fossa; or it passes behind and intemal to the extemal pterygoid, and is covered by that muscle till it reaches the interval between its two heads, where it then often forms a projecting loop as it turns into the sphenomaxillary fossa.

(3) In the third part of its course (the spheno-maxillary portion) the artery lies in the spheno-maxillary fossa beneath the maxillary division of the fifth nerve, and in close relationship with Neckel's ganglion, and there breaks up into its terminal branches.

\section{Braxcies of the Ixtersal Maxillary Artery}

The branches of the internal maxillary artery are:-

(A) From the first part :-(1) The leep auricular; (2) the tympanic; (3) the large midlle meningeal; (4) the mandibular (inferior dental); (5) the small mildle meningeal (sometimes). All these ressels pass through bony or cartilaginous canals.

(B) From the second part:-(1) The masseteric; (2) the posterior deel temporal; (3) the intemal pterygoid; (4) the extemal pterygoid; (5) the buccal; and (6) the anterior decp temporal. All these branches supply musches.

(C) From the third part:-(1) The posterior dental, or alveolar; (2) the infra-orbital; (3) the posterior, or descending palatine; (4) the Vidian; (5) the 
pterygo-palatine; and (6) the naso- or spheno-palatine. All these liranches pass through bomy anals.

Bronches of the First Part of the Internal. Mrexillury strtery-(1) The deep auricular (fig. 336) passes upwards in the substance of the parotid gland behind the eapsule of the temporo-maxillary joint, and, perforating the bony or cartilacinous wall of the external auditory meatus, supplies the skin of that passage anul the membrama tympani. It at times gives a branch to the joint as it prasses behinel the temporo-maxillary calpsule.

(2) The tympanic branch, or Glaserian artery, is a long slender vessel, which runs upwards behind the condyle of the jaw to the (ilascrian fiscure, through which it passes to the interior of the trmpanmm. Here it supplies the lining memhrane. of that eavity and the laxator trmpani muscle, and anastomoses with the other tympanic arteries, forming with the tympanic branch of the stylo-mastoid artery a

Fig. 336. - Scheye of Left Ixtersal Maxil.tary Artery. (Walsham.)

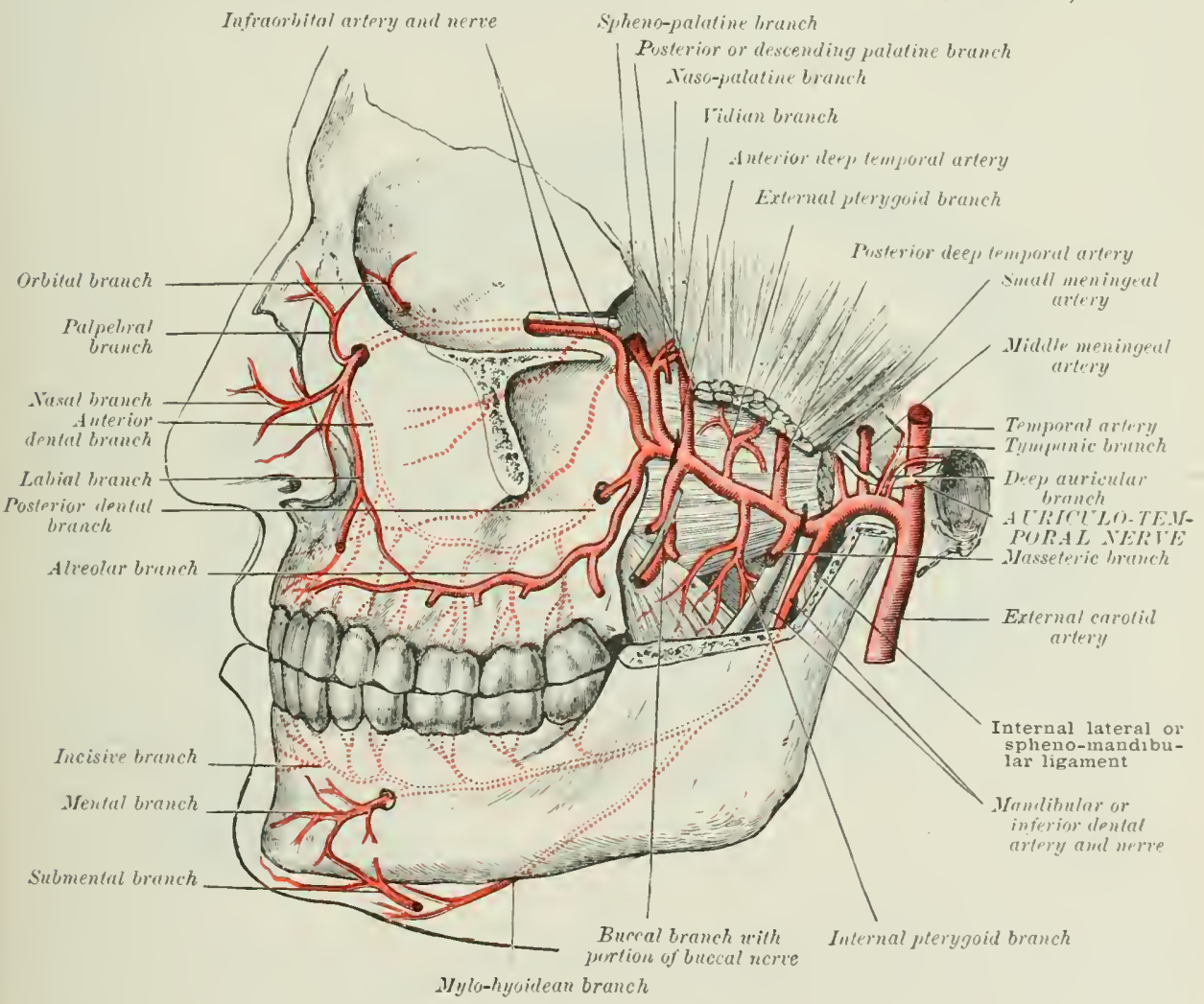

vascular circle around the membrana tympani. This circle is more histinct in the fertus than in the alult.

(3) The large middle meningeal is the largest branch of the intermal maxillary artery. It comes off from that vessel as it lies letween the sheno-mandihular ligilment and the ramus of the jaw, and under cover of the extemal piterresend pasieses directly upwards to the foramen spinosum, through which it enter's the interior of the cranium. In this part of its course it is crosserl by the chordal trompani nerve; and just hefore it enters the foramen is embraced be the two heals of orierin of the auriculo-temporal nerve (fig. 3336 ).

The trunk of the mandibular division of the fifth nerre, as the latter emareres through the foramen ovale, lies in front of the artery. Ls the artery passes upwares it is surrounded by filaments of the smmpathetic nerve, and is acempanied hy two veins which olen into the intemal maxillary vein. On whering the skull it ramifies 
between the bone and dura mater, supplying both structures. It at first ascends for a shert distance in a groove on the greater wing of the sphenoid, and then divides into two branches, an anterior and a posterior.

The anterior branch jakses upwards, in the groove on the greater wing of the sphenoid, on to the parietal bone at its anterior and inferior angle; at this spot the groove beconses deepened and often bridged orer by a thin plate of bone, being eonverted for a yuarter to half an inch or more into a clistinct camal. The situation of the artery is here indicated on the exterior of the skull by a spot an inch and a half behind, and about an inch above, the external angular process of the orbit. The anterior branch is continued along the anterior border of the parietal bone nearly as far as the superior longituclinal sinus, and gives off in its comrse, lut especially posteriorly, large branches which ranify in an upward and backward direction in grooves on the parietal hone (fig. 397).

The posterior branch passes hackwarls over the squamous portion of the temporal bone; and thence on to the parietal bone, behind the anterior hranch.

Fig. 33\%.-The Minde Mexingenl, ARtery Withix the Sklll.

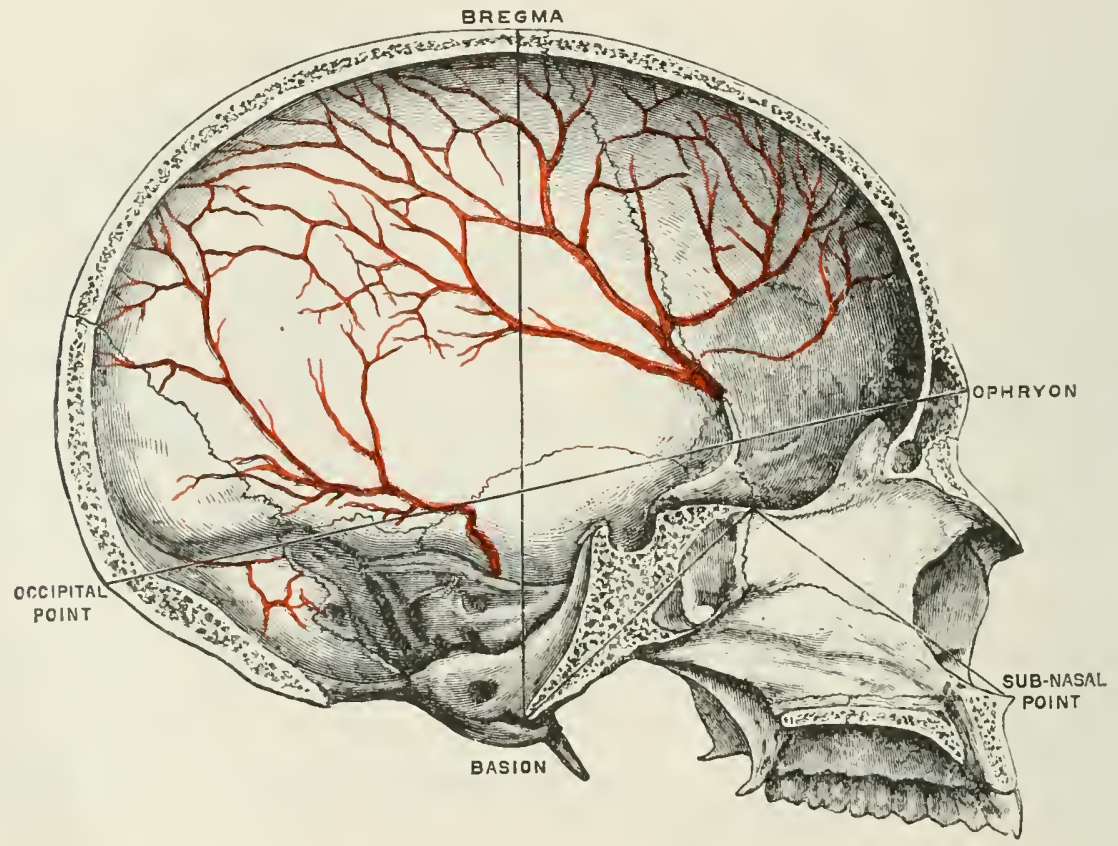

This branch and its collaterals extend upwards as far as the longitudinal sinus, and backwards as far as the lateral sinus.

In addition to its terninal anterior, and terminal posterior branches, the middle meningeal gives off:- (a) Gasserian branches to the Gasserian ganglion and Meckel's space. (b) A petrosal branch, which 'nters the hiatus Fallopii in company with the larese superficial petrosal nerve and anastomoses with the terminal liranch of the stryo-mastoid artery. (c) I tympanic branch, which entors the canal for the tensor tympani, and supplies that muscle. (d) An orbital or lachrymal branch, which enters the orlyit at the outermost part of the sphenoival fisture, or sometimes through a minute formen, just extemal to that fissure, and andastomoses with the lachrymal branch of the ophthalmic. (e) Anastomotic or perforating branches which pierce the greater wing of the sphenoid bone, and anastmose with the deep temporal arteries.

(4) The mandibular (inferior dental) artery (fig. 336), arising from the internal maxillary as it lies between the spheno-mandibular ligament and neck of the jaw, courses downwards to the mandilutur foramen, which it enters in company 
with, and a little behind and external to, the mandihular nerve. It them pasises along the canal in the interior of the bone, giving off branches to the molar, hicuspiel, and canine teeth. On reaching the mental foramen it divides into two branches, the incisive and the nuental. The incisive continues its course in the lone, and supplies branches to the incisor terth, and andstomoses with the artery of the oppesite sile. The mental passes through the mental formen in complny with the mental branch of the mandibular (inferior dental) nerve, and enerose on the chin umber cover of the deperessor labii inferioris. It anastomosen abere with the inferior coronary, and below with the submental, and also with the inferiou labial. Near its origin the artery gives off ( $($ ) a lingual or gustatory branch, which accompanies and supplies the lingual nerve, and ends in the nucous memlnrane of the mouth; and, just before it enters the dental foranen in the lower jaw, (b) a mylo-hyoidean branch, which accompanies the nerve of that name along the growe in the lower jaw, anc, after supplying the mylo-hyoid muscle, anastomoses with the sublingual and submental arteries.

(5) The small meningeal arises either from the internal maxillary a little in front of the large middle meningeal, or as a branch of that ressel. It pasies upwarks along the course of the mandibular division of the fifth nerve, and, entrering the skull through the foramen ovale, is distributed to the Gasserian ganglion, and to the walls of the cavernous sinus and the dura mater in the neighbourloox.

Brunches of the Second Purt of the Internal Maxillary Artery. - The branches of the second portion of the internal maxillary all supply muscles. They are:-(1) The nuasseteric; (2) the posterior deep temporal; (3) the internal pterygoid ; (4) the extemal pteryoid; (5) the buccal; and (6) the anterior deep temporal.

(1) The masseteric branch comes off from the internal maxillary as the latter is passing from between the neck of the jaw and the spheno-mandibular liganent. It is directed outwards along with the masseteric nerve, and, passing through the sigmoirt notch in the lower jaw, supplies the masseter muscle. Some filaments perforate the muscle and anastomose with the transverse facial and with the masseteric branches of the facial itself.

(2) The posterior deep temporal arises, as a rule, from the internal maxillary in common with the masseteric or a little beyond that branch. It passes upwarls bencath the tempral muscle in a slight groove on the anterior margin of the stuamous portion of the temporal bone, supplying the temporal muscle, the pricranimm, and the external layer of the bone. It anastonoses with the anterion (leep temporal and the other temporal arteries.

(3) The internal pterygoid branches are short trunks which pass into and sujply the internal pterrgoid muscle.

(4) The external pterygoid branches supply the external pterygoid muscle, and, like the internal pteryoid branches, are short trunks, and rery imegular in their number, origin, and distribution.

(5) The buccal branch (fig. $: 336$ ) courses forwards and downwards with the bueal nerve to the buccinator muscle, lying in close contact with the imner sirle anct anterion margin of the tenton of the temporal muscle and cononoid process of the lower jaw. It supplies the buccinator nuscle and mucous membrane of the mouth, and anastomoses with the facial, transwerse facial, and infrarthital arteries.

(6) The anterior deep temporal branch aseends beneath the temporal muscle in a slight groove on the greatre wing of the splonoid lome. It supplice the muscke, fericranium, and subjacent bone, and gives off small branches which pass through minute formina in the malar bouse. Some of these last branches rnter the orthit and anastomose with the lachrmal artery; others energe on the face and anastonnose with the transverse facial artery.

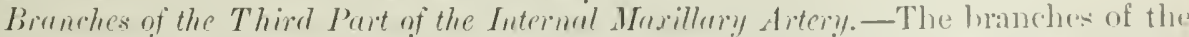
third part of the internal maxillary artery, like those of the first part, all pass them bomy cunals. They are the following:-(1) The posterior dental, or alrenlar ; (2) the infraorbital; (3) the posterior, or descending palatine; (4) the Viclian; (i) the pteryo-palatine; and (6) the naso-palatine, or splume-patatine

(1) The posterior dental ol alveolar branch arise from the internal maxillary

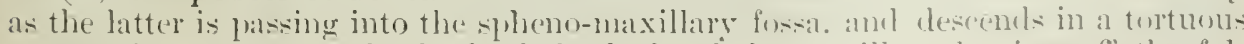
manner in at gloove on the hack of the body of the maxilla. It grives off the fol- 
lowing hranches:-(u) Antral, which plass through small foramina into the antrum; (b) dental, which pass into hony eanals to supply the molar and hicuspid tecth; (c) alveolar, or gingival, which supply the gums; and (d) buccal, which are distributed to the buc inator muscle.

(-) The infraorbital branch arises from the internal maxillary, generally as a common trunk with the pusterior dental. It passes forwards and a little mowards throngh the spheno-maxillary fossa then forwards in company with the maxillary divjion of the fifth nerve, first along the groove, and then through the eanal in the orlital plate of the maxilla; and finally, emerging on the face at the infraorloital foramen, under cover of the levator labii superioris proprius, is distributed to the structures forming the mper lip, the lower evelid, the lachrymal sac, and the sicle of the nose. It anastomoses with the superior coronary and angular branches of the facial. with the nasal and lachrymal branches of the ophthalnic, and with the transverse facial. It gives off the following small branches:- $(a)$ Orbital, to the fit of the orbit and to the inferior rectus and inferior oblique muscles; $(b)$ an anterior dental branch, which passes downwards through a groove in the anterior wall of the superior maxilla, together with the anterior dental branch of the infraorhital nerve, and,supplies branches to the incisor and eanine teeth and the mucous membrane of the antrum; and $(c)$ nasal branches, which pass through the foramina in the nasal process of the superior maxilla (sutura notha).

(3) The posterior or descending palatine branch descends in the posterior palatine canal with the great or anterior palatine branch of Meckel's ganglion. On emerging on the palate at the posterior palatine foramen, it divides into the following branches:-( 1 ) An anterior branch, which courses forwards in the mucoperiostem at the junction of the hard palate with the alveolar process as far as the anterior palatine foramen, where it anastomoses with the naso-palatine artery; and (b) posterior branches, which pass backwards and downwards into the soft palate, contributing to the supply of that structure, and anastonosing with the ascending palatine artery. After the operation for cheft palate, serious hemorrhage occasionally occurs from the descending palatine artery. It may be stopped by compresing the artery by means of a plug inserted in the posterior palatine foramen. The foramen is situated a little behind, and internal to, the last molar tooth, and almost immediately in front of the hamular process.

(4) The Vidian artery is a long slender branch which passes backwards through the Vidian canal in company with the Vidian nerve into the cartilage of the middle lacerated foramen. It gives off the following branches:- $(a)$ Pharyngeal, which contributes to the supply of the roof of the pharynx, and anastomoses with the ascending pharyngeal and pterrgo-palatine arteries: (b) Eustachian, which is distributed to the Eustachian tuie; and (c) tympanic, which enters the tymupanum, and anastomoses with the other tympanic arteries.

(5) The pterygo-palatine artery, or pterygo-pharyngeal as it is sometimes callect, a still more slender hranch than the Vidlan, jasses backwards through the ptrygo-palatine foranen with the pharyngeal nerve, a hranch of Meckel's ganglion. It divicles into three hranches:- (a) Pharyngeal, to the roof of the pharrinx; (b) Eustachian, to the Eustachian tuhe; and $(c)$ sphenoidal, to the sphenoidal cells. The pteryo-palatine sometimes arises from the spheno-palatine.

(i) The spheno-palatine or naso-palatine artery, the terminal branch of the internal maxillary, passes with the spheno-palatine branch of Neckel's ganglion from the spheno-maxillary fossa into the nose through the spheno-palatine formmen. Crossing the roof of the nose in the muco-periostemm, it passes on to the septum, and then rums forwards and downards in a groove on the vomer (under the name of the naso-palatine, or artery of the septum) towards the anterior jalatine foramen, where it anastomoses with the antrior palatine artery, which enters the nowe thromen the lateral compratument of that foramen (the canal of stenson). In this course it gives off the following branches:-( (1) A pharyngeal branch (or descending pharyngeal branch, as it is sometines callecl), which is distributerl to the roof and contiguous portions of the pharynx. (b) A sphenoidal branch, which supplies the sphenoidal (e)ls. (c) Nasal branches, which ramify over the turlinal bones and lateral walls of the nose, and give twigs to the ethmoidal and frontal sinuses and lining membrane of the antrum.

(d) Ascending septal 
branches, which run upwarls and forwards, giving small twigs to the mucous nembrane covering the upler part of the septum, and which pass through the cribrifom plate of the ethmoid, and anastomose with the ethmoidal arteries (perforating or meningeal branches).

\section{THE INTERINA CAROTID ARTERI}

The internal carotid (fig. 338 ) arises with the external carotid at the hifurcation of the common caretid, opposite the uplere horder of the throvirl cartilage, on a level with the fourth cervical vertebrat. It is at first placeel a little external to the

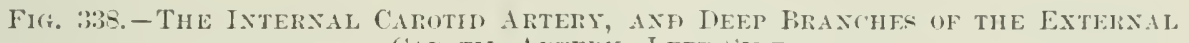
CARUTID AlTEIS, LEFT SIHE.

(From a dissection in the Hunterian Musemm.)

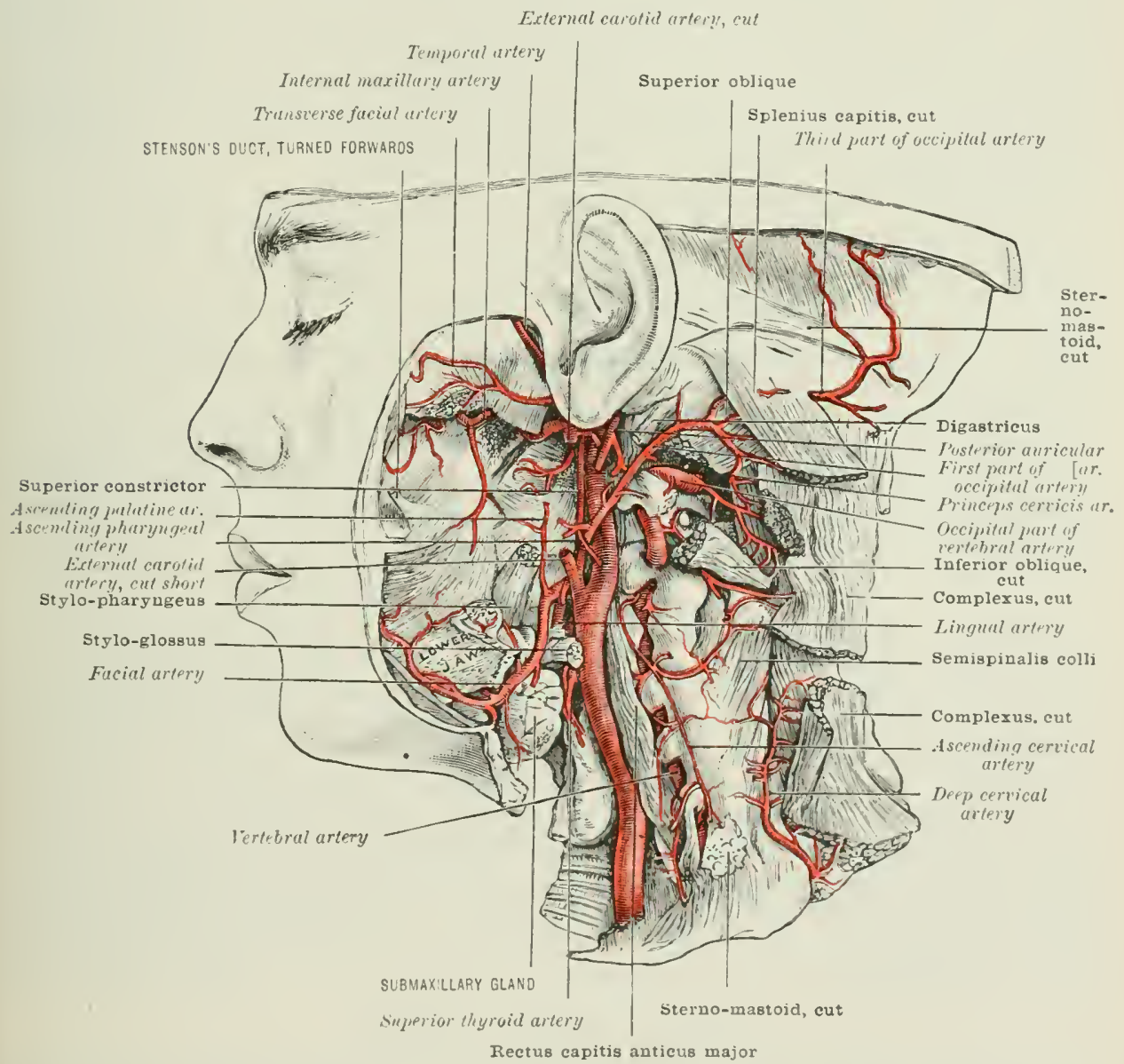

external carotid, but as it ascends in the neek the external carotid hecomes more superticial and in front of the internal. The internal anotil passes up) the neeck, in front of the transverse processes of the upper arvieal rertebrat lying mon the rectus capitis anticus major to the canotid foramen. thenese throush the carotid canal in the petrons portion of the temporal bome, making at first a tum forwarts and inwarks and then a secomel turn upwarls, and enters the cramium though

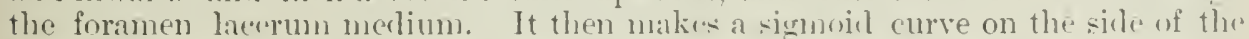

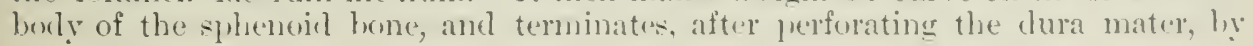


dividing opposite the antrior clinoid processes in the fissure of Sylvius, into the anterior and michle cerebral arteries.

In its course up the neck it often forms one or more curves, especially in old people. Between the internal and the external carotids, at their angle of divereence, is situated the intercaroticl body, or ganglion interearoticum.

The internal carotid is the continuation upwards of the primitive clorsal aorta. and supplies the greater part of the brain, the contents of the orbit, and parts of the internal ear, forehead, and nose. It is clivided into three portions:-1. a cervical; 2. an intraosseous, or petrosal; and 3. an intracranial.

\section{The Cervical Portion}

Relations.-In the neck the artery is at first comparatively superficial, having in front of it, as it lies in the superior carotid triangle, the skin. superficial fascia, platysma and (leep fascia, and the orerlapping edge of the sterno-mastoid muscle. Higher up, as it sinks beneath the parotid gland (fig. 329), it becomes deeply placed, and is crossed by the posterior belly of the digastric and stylo-hyoicl muscles, the hypoglossal nerve, and the occipital and posterior auricular arteries; whilst still higher it is separated from the external carotid artery, which here get: in front of it, by the stylo-glossus and stylo-pharyngeus muscles, the gloseopharyngeal nerve, the pharyngeal branch of the pneumogastric nerve, and by the stylo-hyoid ligament.

Behind, it lies upon the rectus capitis anticus major, which separates it from the transverse processes of the three upper cervical vertebræ, on the superior cervical ganglion of the srmpathetic nerve, and on the pneumogastric nerve. Near the base of the skull, the hypoglossal, pmemogastric, glosso-pharyngeal, and spinal accessory nerves cross obliquely behind it, separating it at this spot from the internal jugular rein, which, as the artery is ahout to enter the carotid canal, also forms one of its posterior relations.

On its outer side are the intemal jugular vein and pmeumogastric nerve.

On its inner side it is in relation with the pharynx, the superior constrictor muscle separating it from the tonsil. The ascending pharyngeal and ascending palatine arteries, and at the base of the skull the Eustachian tube and levator palati inuscle are also internal to it.

\section{The Intraosseos or Petrosal Portion}

The intraosseous portion (fig. 331) is situated in the carotid (anal in the petrons portion of the temporal bone. It is here separated from the walls of the canal by a prolongation downwards of the dura mater. In this part of its course it first ascends in front of the trmpanum and cochlea of the internal ear; it then turns forwards and inwards, lying a little internal to and behind the Eustachian tube, and enters the cranial cavity by turning upwards through the formen lacerum medium, lying upon the lingula of the sphenoid bone. In this part of its course it is accompanied by the ascending branches from the superior cervical ganglion of the sympathetic. These form a plexus about the artery, hut are situated chiefly on its outer side. It is also surrounded by a number of small reins, which receive tributaries from the tympanmm, and open into the cavernous sinus and internal jugular vein.

\section{The Ixtracranial Portion}

On entering the cranium through the formmen lacerum medium, the internal caroticl first ascends towards the posterior clinoid process. Wut soon rhanging its direction, it curves forwards and slightly downards hy the side of the body of the sphenoid bone on the inner wall of the cavernous sinus. Here it has the sixth nerve immerliately external to it, and is covered by the lining membrane of the sinus. Again turning upwards, it pieres the dura mater on the inner side of the anterior clineid proecss, and, passing between the second and third nerves to the antrior perforated spot at the inner enel of the sylvian fissure, divides into its two terminal branches, the anterior and midlle cerehral. After it has perforated the dura mater, 
it is describer by sone anatumists as a fourth portion-the intracerebral (fig. 3si). As it lies in the foranen lacerum medium the artery is crossed on its outer side hy the great superficial petrosil norve as the latter goes to join the great reep pwtrosil from the carotid plexus to form the Vidian nerve.

\section{Blixumes of tife Ixterial Carotid Artery}

The cervical portion gives off no branch. The intraosseous portion gives off:-(1) Tympanic; (2) Virlian. The intracranial portion gives off:-(1) Arteria recciptaculi; (2) pituitary; (3) Gasserian; (4) meningeal; (5) ophthalmic; (6) posterior communicating; ( 7 ) anterior choroid; (S) anterior cerebral; (9) midule cerebral.

Branches of the Intraossons. Portion.-(1) The tympanic enter's the tympanum through a small foramen in the busterior wall of the carotid canal, and contributes its quota to the blood-supply of that carvity. It anastomoses with the tympanie branches of the stro-mastoid and internal maxillary arteries. (2) A Vidian branch is also described, and is said to anastomose with the Virlian artery.

Birnches of the Intorerminl Pontion. - As the internal carotid artery lies on the inner side of the cavernous sinus. it gives off the following branches:-(1) Arteria receptaculi, small hranches to the walls of the cavernous sinus; (2) pituitary branches to the pituitary borly; (3) Gasserian or ganglionic branches to the (iascerian ganglion: (t) meningeal or anterior meningeal branches to the dura mater; these anastomose with anterior branches of the middle meningeal.

\section{(.) THE OPHTHALMIC ARTERY}

The ophthalmic artery (fig. 339) comes off from the internal carotid immediately below the anterior clinoid process just as the latter vessel is passing through the lura mater. Entering the orbit through the optic foramen betow and extemal to the optic nerve, it at once perforates the sheath of dura mater which is prolonged through the optic foramen on both artery and nerre. It then runs in a gentle curve with its convexity outwards below the optie nerve and external rectus, being here crossed hy the nasal nerve, and turning forwards, inwards, and upwards passes wer the optic nerve, round which it thus forms a loop (fig. 339) to the inner sicle of the orbit. Thence it runs olliquely beneath the superior rectus in front of the nasal nerve under the lower border of the superior oblique, but above the internal rectus, and continues its course under the pulley for the superior oblique and reflecterl tendon of that muscle to the internal angular process of the orbit, where it divides into the frontal and nasal branches.

\section{Brinches of the Ophtildlaic Artery}

The branches of the ophthalmic artery are:-( 1 ) the lachrymal; (b) the supra-urbital; (c) the eentral artery of the retina; (d) the musenlar; (e) the ciliary; $(f)$ the josterior cthmoidal; (y) the anterior ethmoidal; $(h)$ the palpehral; (i) the frontal; and (li) the nasal.

\section{(a) The LAciryal Artery}

The lachrymal artery is usually the first and at times the larges branch of the ophthalmic. It arises between the superior and external reetus on the outer side of the optic nerve from the ophthalmic soun after that ressel has enteres the orlit. At times it is given off from the ophthalmic outsiele the orbit, and then wsually passes into that cavity through the sphenoidal fissure. It runs forwards along the outer wall of the orhit with the lachrymal nerve ahove the upper horcher of the external rectus to the lachromal gland. which it supplies. In this course it furnishes the following branches:- (i) Recurrent lachrymal, one or more hranches which pass hackwards thromg the sphennidal fissure, and anastomoses with the lachrymal branch of the large midelle meningeal artery. The anastomosis is some- 
times of large size, and takes the chief share in the formation of the lachrymal artery. (ii) Muscular branches, distributed chiefly to the externit rectus. Malar branches-small twiors. which pass through the malar wals, and anastomose with the orhital hanch of the middle tempral, and with the transterse facial on the cherk. (iv) Palpebral branches, which are distributed to the upler and lower erolicls and to the conjunctiva. (V) Ciliary. See Cillur Aliteries, lain: 501 .

\section{(b) The Supragrital Arteri}

The supraorbital artery usmally arises from the ophthalmic as the latter vessel is alout to cross orer the optic nerve. Passing upwarls to the inner sicle of the superior rectus and levator palpelora, it runs along the upper surface of the latter musce with the frontal nerve in the orbital fat, but beneath the periostem to the supracrbital notch. On emerging on the forehead beneath the orbicularis palpe-

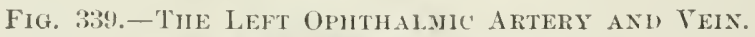

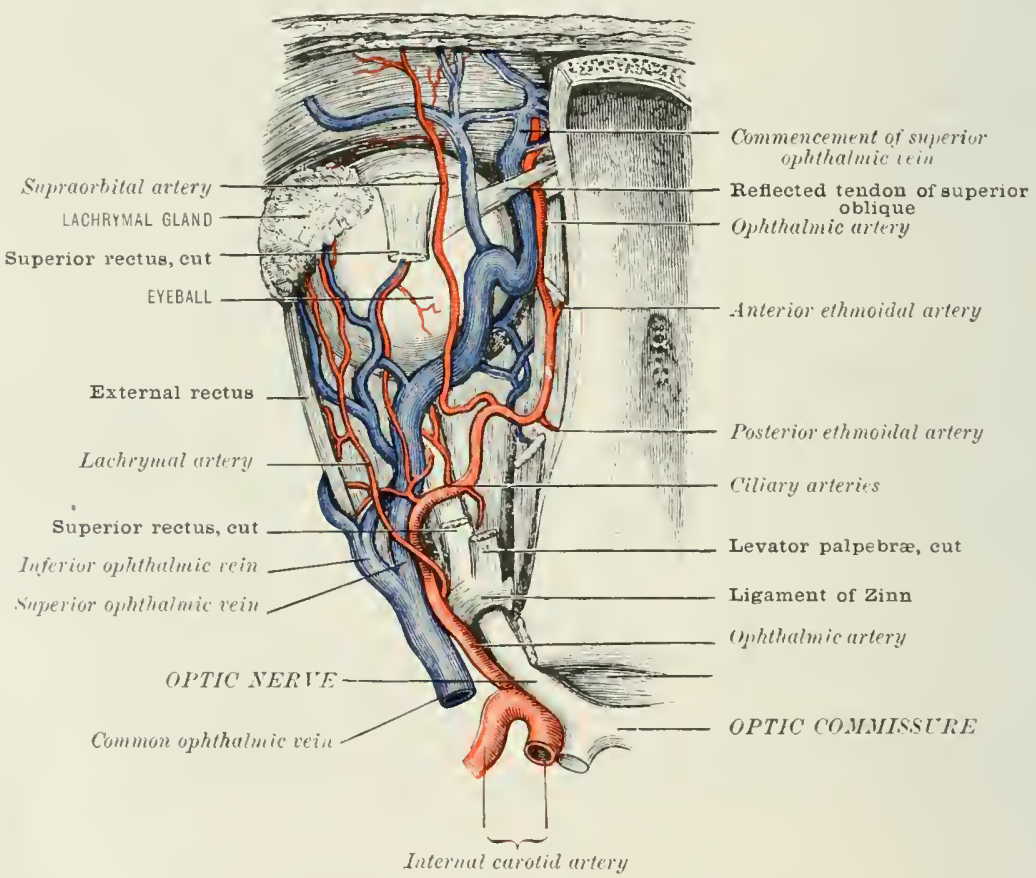

hrarum, it diviles into a superficial and decp lnanch; the former ramifies betwern the skin and oceipito-frontalis, the latter between the occipito-frontalis and the pericratum. Both hanches anastomose with the antrior hranches of the superficial temporal, the angular hranch of the facial, and the transverse facial artery. The hranches of the sulparorhital are:-(i) Periosteal, to the periostemen of the roof of

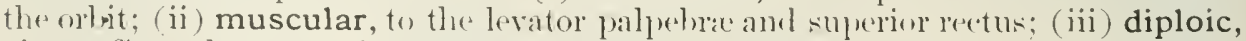
given off as the artery is passing through the suprabrital notch and entering a minute formmen at the bottom of the notch is distributerl to the diplö and frontal sinuse; (iv) trochlear, to the pulley of the superior ollitigue: (v) palpebral, to the "lyper eyeliel.

\section{(c) Tul: cestral Artery of tue Retixi}

The arteria centralis retinæ, a small lut constant hranch, comes off from the ophthalmic close to the optic foramen, and, perforating the optic nerve about a puarter of an inch behind the grlobe, rums forwats in the sulstance of the nerve to the eyelall, suply lying the letina. The fact that this artery penetrates the substanee of the optic nerve is of arelopmental interest, as it inclieates the spot where the 
mesenchyma invaginated the primary optic vesicle on its ventral aspect to form the vitreous. Its further description is given in the Ax.Tomy of THE EYE.

\section{(1) Tue Mestudar Branihes}

The muscular branches are very variahle in their origin and distrihution. They may be roughly divirled into simperior and inferior sets. The superior or smaller set supply the superior oblinue, the levator palpebra, and superion rectus. The inferior pass forward between the optic nerre and the inferior reetus. supplying that muscle, the internal rectus, and the inferior obligue. From the muscular lranches are given off the anterior ciliary arteries. (See ('illary Arteries.)

\section{(e) Tile Cifling Arteries}

The ciliary arteries are divicled into three sets:- The short posterior, the long posterior, and the anterior. (i) The short posterior, five to six in mumber, rome off chictly from the ophthalmie as it is crosing the optic nerve. They run forwards about the nerve, dividing into twelve or fifteen small vessels, which prerforate the sclerotic around the entrance of the optic nerve, and are clistributed to the choroid coat. (ii) The long posterior ciliary arteries, usually two in number, come off from the ophthalnic on either side of the optie nerve, and run formals with the short ciliary to the selerotic. On piercing the sclerotic, they course forrwards, one on cither side in the equatorial line, between that coat and the choroicl to the eiliary processes and iris. Their further distribution is given under the AxATonY of THE EYE. (iii) The anterior ciliary are clerived from the museular limeles and from the lachrymal. They rum to the globe along the tendons of the rexti, forming a zone of radiating vessels beneath the conjunctiva. They perforate the sclerotic about a quarter of an inch $(6 \mathrm{~mm}$.) behind the cornea, and supply the iris and ciliary processes. It is these vessels that are collargerl and congesterl in iritis, forming the circumcorneal zone of redness so eharacteristic of that diserase. They then differ from the tortuous ressels of the conjunctiva in that they are straight and parallel.

\section{(f) The Posterior Ethioidal Artery}

Tne posterior ethmoidal rums inwarks between the superior oblique and internal rectus, and, leaving the orhit by the posterior ethmoidal canal, together with the spheno-ethmoidal branch of the nasal nerve, enters the josterior ethmoidal ceels, whence it passes through a transwerse slit-like aperture between the sphenoid lone and cribrifom plate of the ethmoid bone into the cranimus. It gives oft' (i) ethmoidal branches to the posterior ethmoilal cells; (ii) meningeal branches to the dura mater lining the cribriform plate; and (iii) nasal branches, which pats through the eribriform plate to the superior meatus and upler spongy bumes of the nose, and anastomose with the nasal hranches of the spheno-palatine artery.

\section{(g) The Mnterior Etmionda Artery}

The anterior ethmoidal (figs. 389). 397), a larger liranch than the posterior

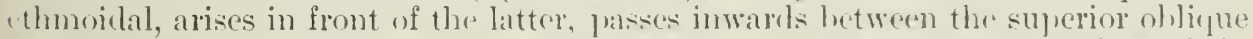
and internal rectus, ant, leaving the orthit through the anterior cthmoidal eamal, in rompany with the nasal nerve, onters the cranial cavity. After rumning a short distance beneatl the dura mater on the erihriform plate of the ethmoid bone it passes inte the nose througle the horizontal slit-like aperture lye the side of the rrista galli. Its terminal branch passes along the groose on the umber surface of the nasal bone, and enereses on the nose between the lome amel lateral cartilasere, terminating in the skin of that organ. It gives off the following luandhes in it: course:-(i) Ethmoidal, to the anterior ethmoidal (ells; (ii) meningeal, to the dura mater of the anterior fossa; (iii) nasal, to the millile meatus amel anterior part of the nose; (iv) frontal, to the frontal sinuses; (v) cutaneous, or terminal, to the skin of the nose. 


\section{(h) The Palpebral Pranches}

The palpebral branches arise either selarately or by a common trunk from the ophthalmic artery opposite the pulley for the superior ollique. just as the latter ressel is about to divide into its teminal hranches. They pass, one above and one below the internal tarsal ligament or temelo oculi, and then skirt along the upper and lower eyelids respectively, near the free margin letween the tarsal cartilages and the orbicularis muscle, and form a superior and inferior palpebral anch by anastomosing with the palpebral branches of the lachrymal. The mpere also anastomoses with the supraorbital artery and orbital branch of the temporal artery; the lower with the infraorbital, the angular branch of the facial, and the transverse facial arteries. A branch from the lower palpehral passes with the nasal duct as far as the inferior meatus. Small twigs are also given to the caruncle and conjumetiva.

\section{(i) The Frojtal Braxeh}

The frontal branch, the upper of the terminal hranches of the ophthalmic, pierces the tarsal membrane at the inner angle of the urbit. passes uprards orer the frontal bone, beneath the orbicularis palpebrarum and corrugator supercilii. supplies the structures in its neighbourhood. and anastomoses with its fellow of the opposite side, with the supraorhital, and with the anterior division of the superficial temporal artery.

\section{(k) The Nasal Braxch}

The nasal, the lower of the terminal branches of the ophthalnic. leares the orbit at the inner canthus by perforating the tarsal membrane above the tenclo oculi. It then descends along the dorsm of the nose, beneath the integuments; and anastomoses with the angular and lateral nasal hranches of the facial. It gives off a lachrymal branch as it crosses the lachrymal sac. ancl a transverse nasal branch as it crosses the root of the now: the lattrer vosel anastomoses with its fellow of the opposite side.

\section{(6) THE POSTEPIOR COMILNICATING ARTERY}

The posterior communicating artery (fig. 340 ) is given off from the internal carotid just before the division of that ressel into the anterior and midclle cerehral arteries; occasionally it arises from the middle cerebral itself. It is as a rule a slenter vessel which runs backwards over the optic tract and crus cerebri along the sicle of the uncinate convolution to join the posterior cerebral. At times, howerer, it is of considerable size, and contributes chiefly to form the posterior ceretral, the jortion of the latter vessel between the basilar and posterior communicating being then as a rule reduced to a mere rudiment. It gives off the following branches:(11) the uncinate, to the convolution of that name; and (b) the middle thalamic, (1) the optic thalamus.

\section{(}

The anterior choroid is a small but ennstant vessel, which arises as a rule from the bark part of the intemal caroticl just external to the origin of the posterior communicating. It passes hackwarks on the optic tract and the erus cerehri, at first lying parallel and a little external to the posterior communicating artery, and then, turning slightly outwark, rips moler the erge of the monate eronvolution, and. entering the transwerse firsure at the lower end of the desending ormu of the lateral rentricle. ends in the choroid plexus and supplies the hipho(ampus major anel corpus fimbriatum. 


\section{(S) THE ANTERIOR CEREBRAL ARTERY}

The anterior cerebral artery (fig. 340)-one of the terninal branches into which the intemal carotid divicles in the fissure of sylvins-passes at first forwarls and inwards across the anterior perforated space between the olfactory and ofitic nerves to the longitudinal fissure where it approaches its fellow of the opinosite side, and communicates with it by a short transverse trunk, about two lines long, known as the anterior communicating artery. Onwards from this slot it runs side hy side with its fellow in the longitudinal fissure round the genu of the corpuis callosum; then, turning backwards, it continues along the upper surface of that commissure, and, after giving off large branches to the frontal and parietal lobules, anastomoses with the posterior cerebral artery.

The branches of the anterior cerebral are:-( $a)$ Communicating; $(b)$ ganglionic, or central; (c) commissural; (d) hemispheral, or cortical.

(a) Communicating.-The anterior communicating is a transverse trunk about two lines in length, connecting the right and left anterior cerelural arteries. It lies immediately in front of the optic commissure across the lamina cinerea. It gives off some of the antero-median branches which pass from the anterior cerebral to the fore end of the caudate nuclens. Sometimes the anterior cerebral arteries, instead of communicating by a transverse trunk, coalesce for a short distance and then again divide. Upon this short trunk the terminal filaments of the carotid plexus of the sympathetic of either side meet in a small gangliform enlargement linomn as the 'ganglion of Ribes.'

(b) Ganglionic, or central.- The antero-median group, together with the antero-median branches of the anterior communieating, pass through the lamina cincrea and supply the fore end of the caudate nuclens.

(c) Commissural.-These supply the colpus callosum.

(d) The hemispheral or cortical branches.-(i) The orbital, three or four in number, supply the inferior surface of the first frontal convolution, and give off small trigs to the olfactory bulb. (ii) The margino-frontal arise from the artery as it lies on the corpus callosum, and, after supplying the marginal convolution, pass on to the convex surface of the hemisphere and further supply the first and second frontal convolutions and the upper part of the ascending frontal convolution. (iii) The calloso-marginal supplies the callosal convolution and the upper part of the marginal convolution. (iv) The quadrate is a branch to the convolution of that name.

\section{(9) THE MIDDLE CEREBRAL ARTERY}

The middle cerebral artery (fig. 3 40 ) - the larger of the two terminal divisions of the internal carotid-passes obliquely upwards and outwards into the fissure of sylvius, and opposite the insula or island of Reil divides into its hemispheral or cortical branches.

The branches of the middle cerebral are:-(a) Ganglionic, or central; and (b) hemispheral, or cortical.

(a) Ganglionic, or central.-(i) The caudate are two or three small branches, which arise from the imer aspect of the artery and pass through the inner part of the floor of the fissure of Srlvius to the head of the caudate nuclens. (ii) The antero-lateral are numerous small arteries, which pass through the anterior perforated space and supply the caudate nucleus (except its hearl), the internal capsule, and part of the ojtic thalamus. (iii) The lenticulo-striate, a larger branch of the antero-lateral set, passes through a separate hole in the outer part of the anterior perforated space, runs upwards between the lenticular mucleus (which it supplies) and the external capsule, perforates the internal (apsule, and terninates in the caudate nueleus. It has been so frequently fommel ruptured in apoplexy, that it is called by Chareot the 'artery of cerebral hamorrhage.' (iv) sonetimes a more or less distinct branch, called lenticulo-optic, is distributed to the outer and hinder portion of the lenticular nucleus and the extemal portion of the thalamus opticus. 
(b) The hemispheral or cortical branches come off from the midlle cerebral opposite the insula. They are four in number:-(i) The inferior, or orbitofrontal, to the inferior frontal convolutions. (ii) The ascending frontal, to the lower part of the asending frontal convolution, the mper part being supplied by the margino-frontal, a branch of the anterior cereloral. (iii) The parietal, to the whole of the ascenting parietal and the adjacent part of the inferior parietal convolution. (iv) The parieto-temporal, to the convolutions around the posterior limb of the fissure of sylvius-riz. the supra-marginal, the angular, and the posterior part of the inferior parietal above, and the first and the greater part of the second and third temporal below.

\section{The CiRCle of Millis}

The anastomosis of the hranches of the intemal carotid and vertebral arteries at the base of the brain is known as the circle of Willis (fig. 340). This so-called

Fig. 340.-THE ARTERIEs of THE BrAIs.

(The posterior part of the cerehrum on the left side has been cut away to show the cerelsellum. From a preparation in the Museum of St. Bartholomew's Hospital.)

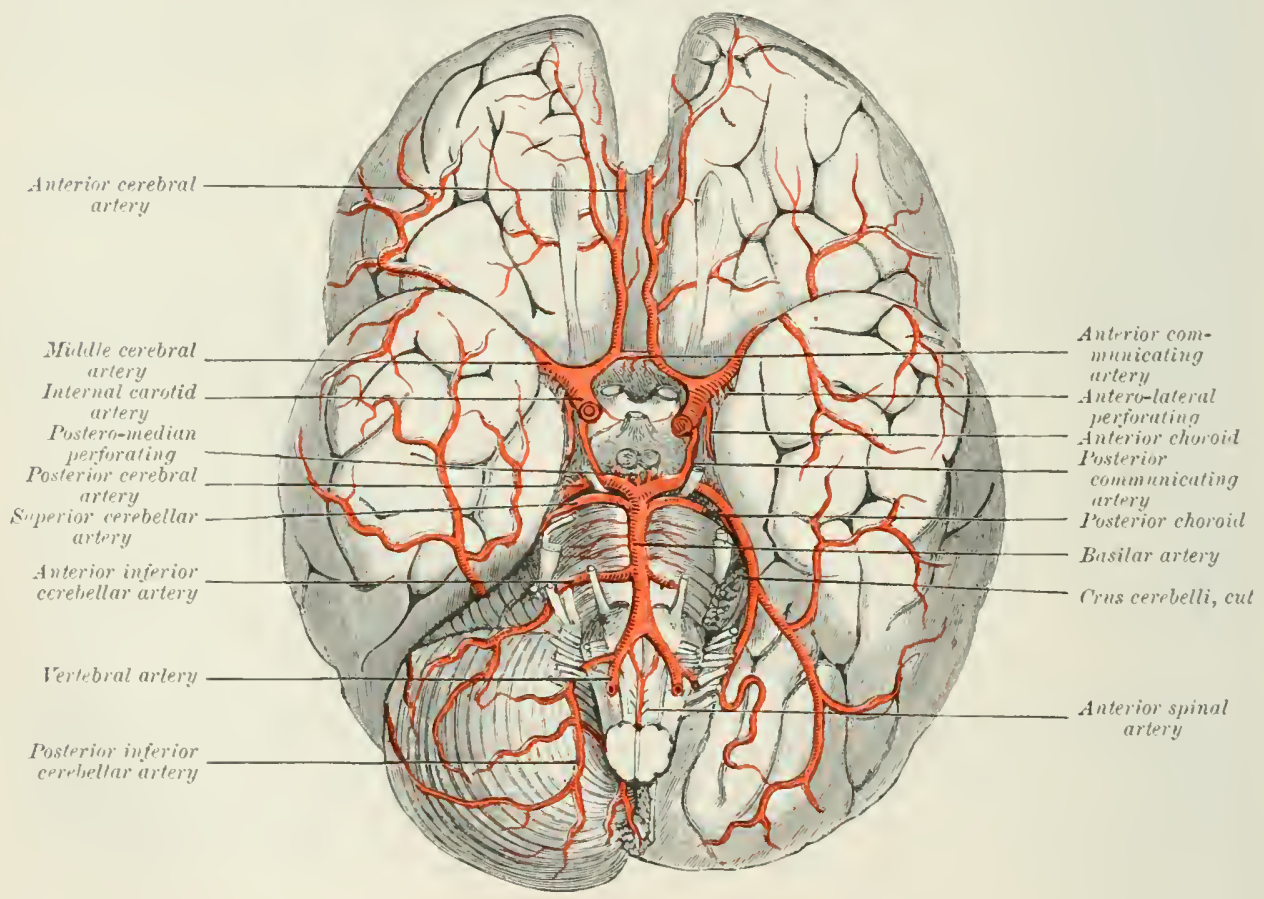

circle, which has really the form of a heptagon, is formed, in front, by the anterior communicating artery uniting the anterior cerebral arteries of opposite sides; laterally, by the trunk of the internal carntid and the posterior communicating arteries stretching between it and the posterior cerehral; behind, by the two po-terior (cerebrals direrering from the hifureation of the basilar artery (jage 543). This free anastomosis between the two internal carotid and the two vertebral arteries serves to equalise the flow of blood to the sarious portions of the brain; and, should one or more of the arteries entering into the formation of the circle be temporarily or permanently obstructerl, it ensures a flow of hlood to the otherwise deprived part through some of the collateral arteries. Thus, if one carotid or one vertebral is obstructed, the parts supplied by that ressel receive their blood through the eircle from the remaining pervions rescels. Indeed, one vertehral artery alone has been found equal to the tatk of carring suflicient hlood for the supply of the 
brain after ligature of both the carotids and the other rortebral arters. Further, the circle of Willis is the only merlium of anmmunication between the ganglionic or central and the hemispheral or cortical branches of the ererobal arteries, and between the various ganerionic branches themselres. The ranglionic and the cortical branches form separate and distinet systems, and do not anastomose with wach other; and the ganglionic, moreorer, are so-ralled end-ressels, and do not anastomose with the neighbouring ganglionic branches.

\section{THE SLBCLAIIAY ARTERY}

The subclavian artery on the right side arises at the lifurcation of the immominate buhind the right stemo-clavicular articulation. On the left side it arises from the arch of the aorta, and as far as the inner border of the scalenus anticus is situated reeply in the chest. The first portion of the left subclavian artery is described seprarately.

Berond the inner border of the scalenus anticus the artery has the same relat tions on hoth sides. It courses from this point heneath the clavicle in a sight rurve across the root of the neck to the outer borter of the first rib. there to mul in the axillary artery. Thus the course of the artery in the neck will he indicated by a line rlawn from the stemo-claricular joint in a curve with its convexity upwardto the middle of the clavicle. The height the artery rises in the neck varies. It $i=$ perhaps most commonly about half an inch alwre the clavicle. If the curvel line above mentioned is drawn to represent part of the circumference of a circle having its centre at a point on the lower margin of the clavicle an inch and a half from the sternal end of that bone, the line of the artery will be sufficiently well indicated for all practiral purposes. In its comrse the artery arches over the rome of the Jewra and gains the groove on the upper surface of the first rib by jassing between the scalenus anticus and medius muscles. The artery is accompanierl by the subclarian rein, the latter vessel lying in front of the scalenus anticus. anterior to the artery, and on a slightly lower plane.

The subclurian artery is divided into three protions-as it lis internal to, helinel. or extemal to, the scalenus anticus muscle.

\section{THE FIRST OR THORACIC PORTION OF THE LEFT SLBCLATIAN IPTERY}

The left subclavian artery (fig. 328 ) arises from the termination of the transverse portion of the areh of the aurta. The first part of the left subelavian is conseruently longer than the first part of the right. which arises at the hifureation of the innominate opposite the right sterno-clavicular joint. The artery at its origin is situated deeply in the thorax, and as it arises from the aorta is on a plane pusterior to and a little to the left of the thoracic portion of the left common arritil. It first ascenels almost rertically out of the rhest. and at the root of the neer curves outwards over the apex of the left pleura and lung to the interval leetwen the anterior and midlle scalene muscles. Berond the inner lurder of the sealenus anticus-that is, in the second and third portions of its course-its retations are similar to those of the right subchisian artery.

Relations. - In front it is coverel by the left jleura and lung. whil-t more superficial are the stemo-thyoirl, stemo-hyoid, and stermo-mastoil muster. It is (rosicel a little ahove its origin he the left innominate win, amd higher in the neek near the scalenus anticus by the internal jugular, vertebral, and suludarian reins. The phrenie nerve crosses the artrery immediatrly internal to the soilenus anticus, and then deseends parallel to it hit on an anterior plane to cross the areh of the 
aorta. The pnemogastric nerve descends parallel to the artery between it and the left common carotid, coming into contat with its anterior surface just before crossing the arch of the aorta. The left cervieal carcliae nerves of the sympathetic also desend in front of it on their way to the earliac plexus. The left common carotid is situated anteriorly and to its right. The thoracic duct arches orer the artery just internal to the scalenus anticus, to empty its contents into the confluence of the intemal jugular and subclarian veins (fig. S6to).

Behind and somewhat internal to it are the asophagus, thoracic duct, inferior cervical ganglion of the sympathetic, longus colli muscle, and rertebral column. To some extent it is overlapped posteriorly by the left pleura and lung (fig. :28 ).

On its right side are the trachea and the recurrent laryngeal nerve, and, higher up, the (esophagus and thoracic duct.

On its left side are the left pleura and lung.

The chief variations in the origin of the left subclaviau artery are given under VAatations OF THE IRCH OF THE JORTA (page ti2).

\section{THE FIRST PORTION OF THE RIGHT SLBCLAVIAN ARTERY}

The first portion of the right subclavian artery extends from its origin at the bifurcation of the innominate, behind the upper margin of the right sternoclavicular joint, upwards and outwards in a gentle curve orer the apex of the right lung and pleura to the inner border of the scalenus anticus. It neasures about one inch and a quarter in length (3 (mo.). In this course it ascends in the neck a variable distance above the clavicle, but is so deeply placed, so surrounded by important structures. and gives off so many large branches, that it is now seldom or never selected for the application of a ligature.

Relations.-In front it is covered by the integmments, the superficial fascia, the platysma, the anterior layer of the deep fascia, the clavicular origin of the stemo-mastoid, the stemo-hyoid and stemo-thrroid muscles, and the deep cervical fascia. It is crossed by the commencement of the immominate, by the internal jugular, and by the vertebral reins: and from within outwards by the pnemmogastric and phrenic nerves, and the superior cardiac branches of the sympathetic nerve. A loop of the sympathetic nerve itself also crosses the artery, and forms with the trunk of the sympathetic a ring around the resel known as the ammulus of Tieusens.

Behind, hut separated from the artery by a cellular interval, are the longus colli muscle, the transverse process of the seventh cervical or first thoracie vertebra, the main rhain of the sympathetic nerve, the inferior cardiac nerves, the recurrent larymeal nerve and the apex of the right lung and plenra.

Below, it is in contact with the pleura and lung and the loop of the recurrent laryngeal nerve. which winds round the artery from the pneumngastric and ascends behind it to the laryn. The subclavian vein is below the artery and on an anterior plane.

Branches.- The rertehral, internal mammary, and thyroicl axis arise from this piat of the resed. Not meommonly a small aberrant artery also takes origin from this protion of the artery and descends to the Ioft behind the osophagus to join : branch of the aorta opposite the third or fourth thoracic rertebra. This ressel is probably the remains of the right aortic root.

\section{THE SECOND PORTION OF THE SUBCLAYIAN ARTERY}

The second portion of the subclavian artery lics behind the salenus anticus muscle. It measures ahout threre-fuirters of an inch in length ( 2 cm.), and here reaches highest in the neck. The subclavian vein is separated from the artery by the sealenus anticus, and lies on a lower and anterior plane.

Relations. - In front it is corered by the skim, smperficial fascia, platysma, anterior layer of deep fascial, the clavicular origin of the stemo-mastoid, posterior 
layer of dere fascia, and by the scalenus anticus. The phrenie nerremhich, in consequence of its oblique course downwards and inwarks, crosses a portion of both the first and second part of the subelavian-is separater from the second portion by the scalenus antieus muscle as is also the subdavian vein which courass on a somewhat lower plane.

Behind the artery are the apex of the plemra and lumg, and a prortion of the scalenus medius; also the structure known as Sibson's fascia.

Above is the brachial plexus.

Below are the pleura and lung.

One branch only-the superior intereostal -is, as a rule, given off from this portion of the subelavian; oceasionally the posterior scapular artery arises from it.

\section{THE THIRD PORTION OF THE SUBCLAVIAN ARTERY}

The third portion of the subclavian artery extends from the outer margin of the scalenus anticus muscle, downwards and outwards to the outer border of the

Fig. 341.-The Right Subchirix Artery.

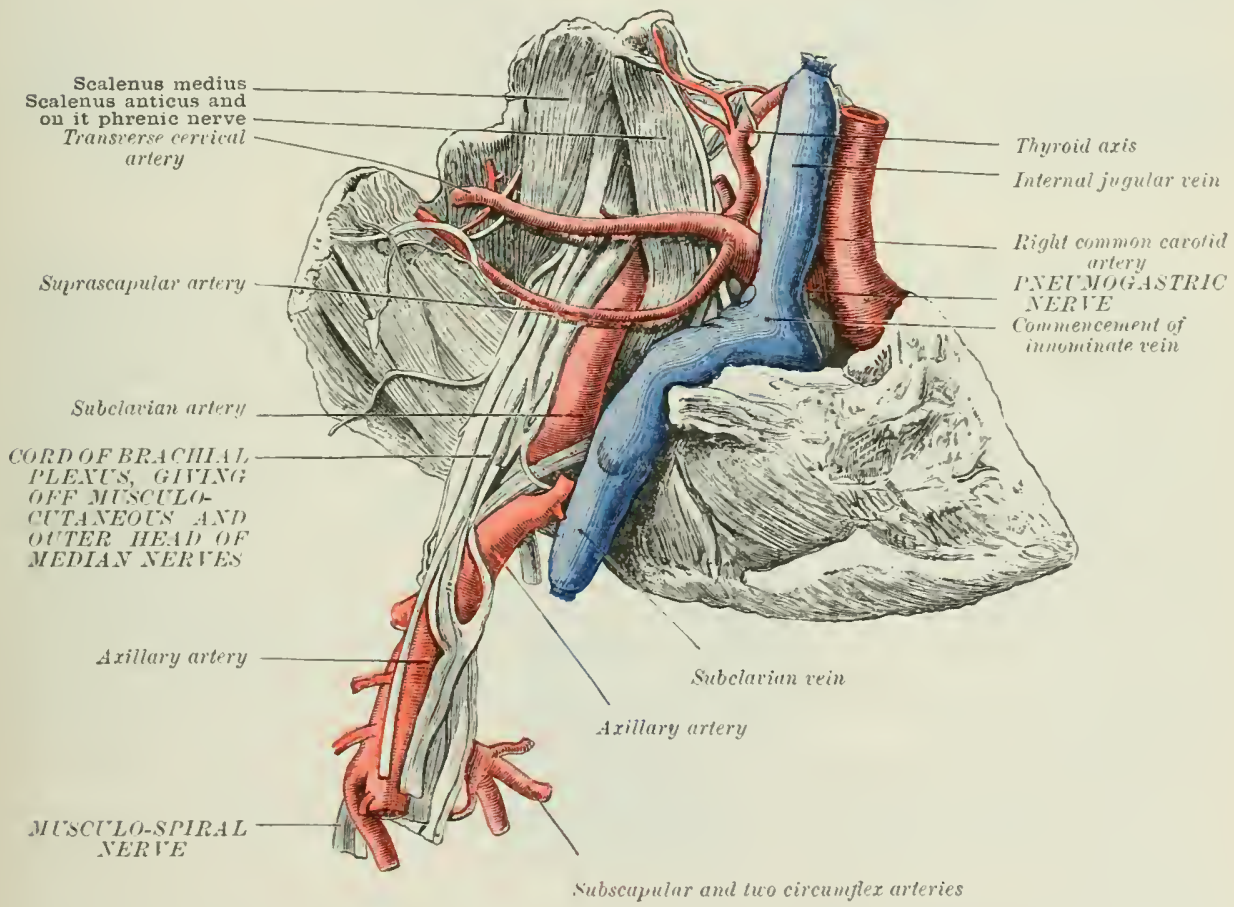

first rih. It is more superficial than either the first or second portions: it is in relattion with less important structures, and as a rule gives off no loranch, and for there reasons is the part selecterl when practicable for the application of a ligature. It is the longest of the three portions of the subelavian artery, and lies in a triangle-the subdavian triangle- houmeded by the sterno-mastoid, the onno-hyoid. and the clavicle.

Relations. - In front it is covered by the skin, superficial fascia, platysma, clat vieular branches of the descending portion of the superficial cervical plexus of nerre: anterior layer of deep fascia which desends from the omo-hyoid to the clatrich: ame the posterior laver of deep fascia which descends from the omo-hroirl to the first rib and is prolonged inwards orer the scalenus anticus and phrenie nerve. Betwern the two layers of faseia is a variable amount of edlular tissue and fit, and 
ruming in this is the suprascapular artery. The subclavian is crossed by this artery unless the arm is drawn well downwards. Hence one of the reasons for depressing the shoulder, and thus avoiding the supraseapular artery, in the operation of ligaturing the subclavian. Cluse to the outer margin of the sterno-mastoid, the external jugular vein pierces the fascia, and "rosses the subclavian artery to open into the subelavian vein. As this rein lies between the two layers of fascia, it receives on its external side the suprascapular, transverse cervical, and other reins of the neck, which together form a plexus of large veins in front of the artery. The nerve to the subclavius, and when present the accessory branch from this nerve to the phrenic, also here cross in front of the artery. In very muscular subjects the sterno-mastoid may extend further outwards along the clavicle than usual, and in such a case will form one of the coverings of the artery.

Behind, the artery is in contact with the scalenus medius, and with the enrd of the brachial plexus formed by the mion of the eighth cervical and first dorsal nerve.

Below, the artery rests in the josterior of the two grooves on the upper surface of the first rib.

Above is the brachial plexus of nerves am the posterior belly of the omo-hyoid muscle. The cord formed by the fifth and sixth cervical nerves is also above the artery. but on a somewhat anterior plane. It is close to the ressel, and has been mistaken for the artery in the application of a ligature.

As a rule there is no branch given off from the thirel portion of the subchavian. At times, however, the supraseapular (fig. 329) or the posterior seapular artery may arise from the third portion of the subelavian, instead of from the thyroid axis and from the transrerse cervical respectively as here described.

\section{Chief Iariations in the Subclavian Artery}

(A) The right subelavian artery may arise directly from the arch of the aorta, and then come off as the first, second, third or fourth branch of that vessel. W' hen it arises as the first branch, it takes the place usually oceupied by the inmominate; when it arises as the last branch, it cumres behind the trachea and oesophagus to gain the groove on the first rib. As the second or thirl branch of the aortic arch it is very rare; in both instances it then runs behind the right common carotid. The explanation of the right subclavian arising as the last braneh of the areh of the aurta, is that the right aortic arch has remained pervious, whilst the normal root of the subclavian artery has become obliterated. An arteria aberrans, given off from the right subclavian or fion the superior intercostal, ean generally be traced to the third thoracic vertebra behind the cesophagus, and in a number of such cases can be followed acruss the spine to anastomose with a branch of the thoracic aorta given off below the ductus arteriosus. It is the enlargement of this anastomusis-which is itself the remains of what was the primitive right dorsal aorta in the embryo-that gives rise to the alonormality in question. The inferior laryngeal nerve in such cases, in consequence of the right fourth arch which forms the first portion of the subchivian being obliterated, follows a direct course to the larynx instead of winding recurrently round the subclavian artery.

(B) The right subclarian may arise higher or lower in the neck than usual, aceording as the innominate divides above or below the normal sitnation.

(C) It may perforate the scalenus anticus or pass in front of that muscle.

(D) It way ascend as high as an inch and a half above the clavicle, or remain below the level of that bone.

(E) The third part of the artery may be covered by the trapezius or sterno-mastoid, or by a clavicular origin of the omo-hyoid.

(F) The snbelavian vein may acempany the artery behind the sealenus anticus.

\section{Brinches of the Subetayia Artery}

From the first portion of the sulularian artery are given off: from the upper and back part and ahout three-quarters of an inch (2) cm.) from its origin, the vertebral; a little further outwards, from the front part, the thyroid axis ; and from the lower part-usually opposite the thyoid axis, or else between the thyroid axis and the vertebral-the internal mammary.

From the second portion arises, from the hack of the ressel, the superior intercostal.

The third portion as a rule, gives oft' no branch. 


\section{Braxches of the First Part of the subchatex Artery}

\section{TIE VERTEBRAL ARTEIT}

The vertebral artery, the first and largest branch, arises from the upper and posterior part of the first portion of the subclavian, on the right sicle about three-ruarters of an inch ( 2 com.) from the origin of the latter vessel from the innominate, on the left side, from the most prominent part of the arch of the subclavian, close to the inner edge of the scalenus anticus nuscle. It first ascends to the foramen in the costo-transverse proeess of the sixth cervical vertebra, and, having bassed through that formuen and those of the next succeeding cervical rertebre as high as the axis, it turns ontwards and then upwards to reach the foramen in the

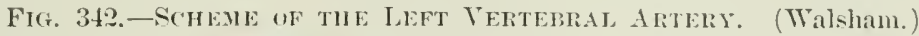

The internal jugular and vertebral veins are hooked aside to expose the artery.

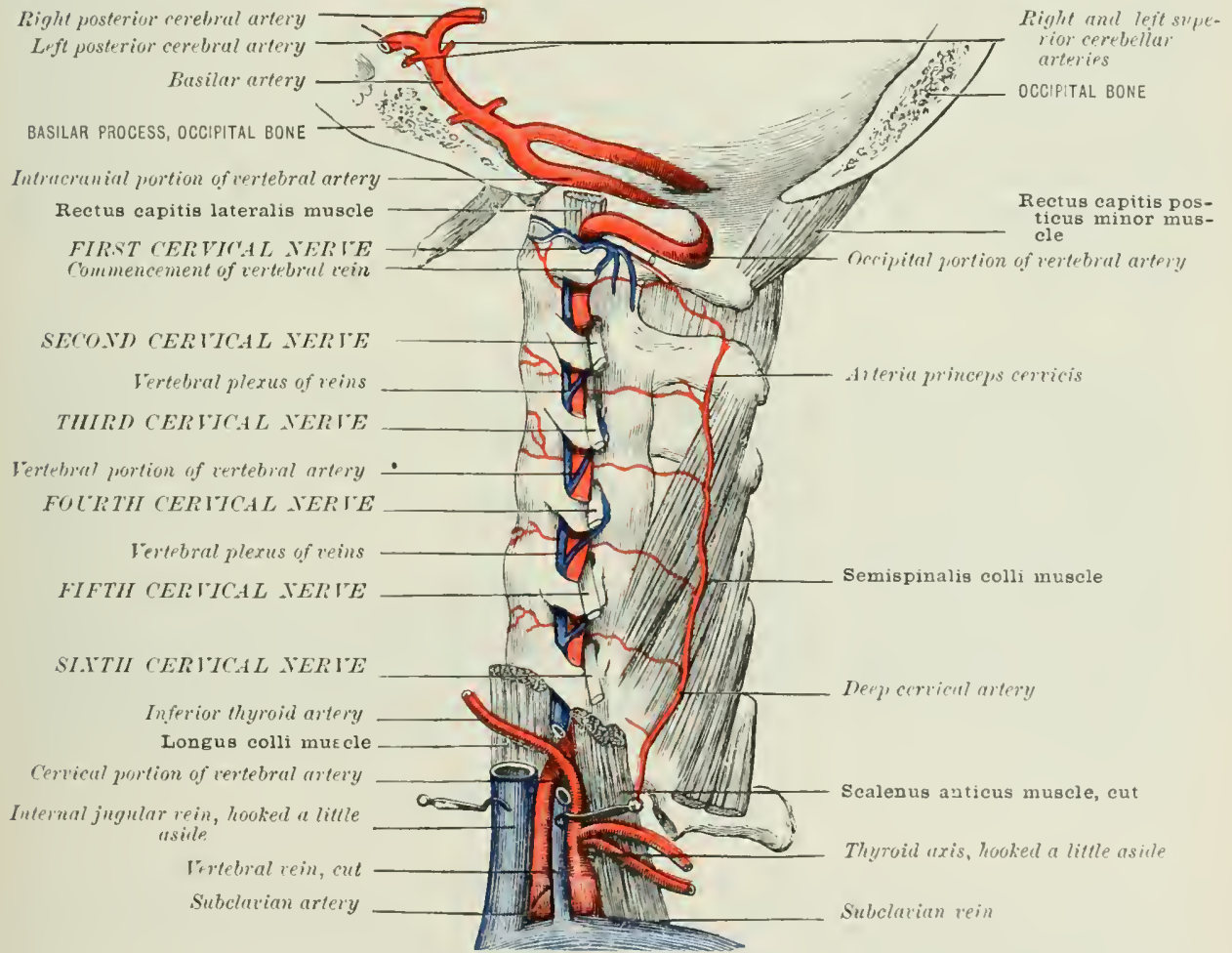

transverse process of the atlas; after passing through that foramen it turns backwards behind the articular proms lying in the groure on the posterior areh of the atlas. It next pierces the posterior occipito-atoid liganent and the chra mater, and enters the cranium through the formen magmum. Here it passes wowrls, at first lying by the side of the medullis, then in front of that structure, and teminates at the lower portion of the pons ly inosulating with the vertebral of the olpusite sile to form the hasilar.

The vertehal artery may be divicted for purposes of rescription into four parts: the first, or cervical, extending from its origin to the transwerse lreeces of the sixth cervicul vertehra: the second, or vertebral, situatel in the intervertebral foramina: the third, or occipital, contained in the suluecipital triangle: and the fourth, or intracranial, within the craniun.

The first or cervical portion.-The artery lere lies between the sealenus 
anticus and longus colli museles. In front it is covered by the vertebral and internal jugular reins, and is crossed by the inferior throid astery: and on the left side. in addition, by the thoracie duct, which runs over it from within outwards. Behind, the artery lies on the transverse process of the seventh cervical vertebra and the smompathetic nerve. To its inner side is the longus colli. To it outer side is the scalenus anticus. It gives off as a rule no branch in this part of its course. Oceasionally, however, a small branch passes into the foranen of the transwerse process of the seventh cervical vertelura.

The second or vertebral portion.-As the artery passes through the intervertebral formina, it is surrounded by a plexus of veins and by hranches of the sympathetic nerve. The cervical nerves lie behind it. Between the transworse processes it is in contact with the intertransverse muscles.

The third or occipital portion.-The artery here lies in the suboceipital triangle, bounded by the superior oblique, inferior oblique, and rectus calpitis posticus major muscles. As it winds round the groore on the atlas, it has the rectus capitis lateralis. the articular process, and the occipito-atloid ligament in front of it; the superior ohlique, the rectus capitis posticus major and the complexus behind it. Separating it from the arch of the atlas. is the first cervical or suboccipital nerve.

The fourth or intracranial portion extends from the aperture in the dura mater to the lower border of the pons, where it unites with its fellow to form the basilar artery. It here winds round from the side to the front of the medulla, lying in the vertebral groove on the basilar process of the occipital hone. In this course it passes beneath the first process of the ligamentum dentatum, and between the hypoglossal nerve in front, and the anterior roots of the subocipital nerve behind.

\section{Chief Tariations of the Iertebral Artery}

(A) The right vertebral artery may arise from the first part of the subchavian, either nearer to the innominate, or nearer to the anterior scalene muscle than normal.

(B) It may come off from the arch of the aorta direet. (See Variations in tue CuIfF BRANCHES OF THE ARCH OF THE AORTA.)

(C) It may urise from the right common carotid when the right subclavian is given off from the aorta beyond the left subelavian.

(D) It may pass behind the œesophagus.

(E) The left vertebral artery may also arise from the arch of the aorta direct, or from the left common carotid. (See Variations in the Cinef Branches of tile Aorta.)

(F) Either vertebral may enter the foramen in the seventh cervical vertebra, or in that of the fifth, fourth, third, or seeond. When entering one of the higher vertebral foramina, it may lie behind the common earotid and cause some embarrassment in the ligature of the latter vessel.

(G) Either vertebral may give off the inferior thyroid, superior intercostal, deep cervical, or vecipital artery.

(H) One or other artery may be much increased or diminished in size.

\section{Braxches of the Vertebral Artery}

A. Cervical portion.-No branch.

B. Vertebral portion.-1. Lateral spinal; '2. musenlar.

(. Occipital portion.-1. Muscular; 2. anastomotic.

D. Cranial portion.-1. Posterior meningeal; 2. posterior spiual; 3. anterior spinil; t. posterior cerebellar.

\section{Braxches of the Second or Vertebril Portion}

1. The lateral spinal branches run through the intervertelinl formina into the vertebral canal. and there clivide inte two branches: (a) The spinal, which ramifies on the backs of the bodies of the cervical vertebra: and (b) the medullary, which runs along the spinal nerves. supplies the cort and its membanes and anditomoses with the arteries above and below. 2. The muscular branches sulply the deep muscles of the neck, and anastomose with the ascending cervical, occipital, and leep cervieal anteries. 


\section{Braxines of the: Thlil) or Oecipital P'orten}

1. Muscular, to the muscles forming the suboceipital triangle; 2. anastomotic, to the branches of the oecipital artery.

\section{Braxches of the Folrtil or Cranial Portion}

1. The posterior meningeal is a small hauch griven oft as the vertelubl artury pierces the ilura mater to enter the cranium. It supplies the bone and dura matcr of the posterior fosisa of the skull, and anastomoses with the posterion meningeral branches derivel from the oceipital and ascending pharyent arteries. It gives brilnches to the falx cerehelli (tig. 385 ).

2. The posterior spinal artery runs clownards oblipuely alomg the side of the medulla to the back of the cord. down which it jasses bohind the rowe of the spinal nerves, being reinforeed by lateral branches running inwards along these nerves, in the neck from the vertehral. in the dorsal region from the intercostal.; and in the lumbar region from the lumbar arteries. It can be traced as low as the end of the spinal cord.

3. The anterior spinal artery comes off from the vertehal a little helow it: termination in the basilar artery. Descending obliquely inwards in front of the merlular, it unites on a level with the foramen magnmm with its fellow of the opposite side. The single ressel thus formed runs downwards in front of the spinal cord beneath the pia nater as far as the temination of the cord, being reinforred by the lateral spinal branches the whole way down (fig. 35T). The spinal arteries are described in detail with the anatomy of the spinal cort.

4. The posterior inferior cerebellar (fig. 340 ) - the largest bram of the vertchral-arises from that vessel just before it joins its fellow to form the basilar artery. At times it may come off from the basilar itself. It runs, at first outwarls across the restiform body between the origin of the pmemogastric and hyjoghesal nerves, and, descending towards the vallecula, there divicles into two hranches, an internal and extemal. (a) The internal or inferior vermiform branch lums backwards between the verniform process and the lateral hemisphere of the rerelxllum. It supplies the rermiform process, and anastomoses with the artery of the opposite side, and with the superior vermiform branch of the superior cerebellar. (b) The external or hemispheral branch runs outwards. and, ramifyiler over the morler surface of the cereluellar hemisphere, supplies its cortex and anastomoses along its outer margin with the superior rerebellar arteries.

From the undivided trunk of the posterior inferior cerebellar artery branches are given to the choroidal plexus and the fourth rentricle.

\section{THE BASILAP ARTERY}

The basilar artery is formed by the eonfluenee of the right and left vertelural arteries, which mect at an acute angle at the lower horder of the pons varolii. It runs forwards and upwarls in a slight groowe in the mirldle line of the prous. anol divides at the uperer lumere of that structure at the level of the pretentorial opening into the two posterior cerebral arteries.

\section{Branciles of the B.inllar ARTERY}

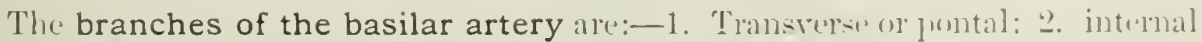

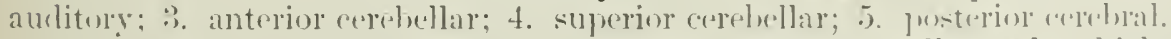

1. The transverse or pontal arteries are numerous small vests whith rme

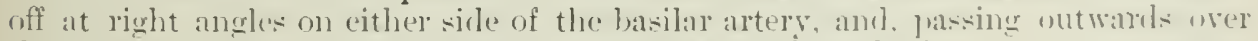
the pons. supply that structure and adjacent parts of the brain.

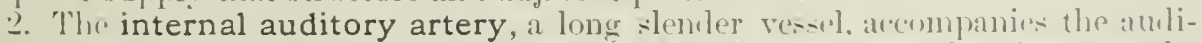

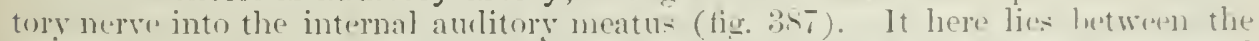
fardial and aurlitory nerves, and at the botton of the meatus paseses into the internal ear, and anastomoses with the other auditory arteries. (Ser l xtraxid. E.dr.) 
$\therefore$ The anterior cerebellar-or anterior inferior cerebellar artery, as it is sometimes called-alrises from the basilar soon after its origin, passes outwards and backwards across the pons. and then over the crus cerebelli to the front part of the under surface of the cerebellum. It anastomoses with the posterior inferior cerebellar antery (fig. :340).

4. The superior cerebellar comes off from the basilar immediately behind its bifureation into the posterior cerebral arteries. It courses outwards and backwards over the pons, in a curve roughly corresponding to that of the posterior cerebral artery. from which it is separated by the third cranial nerve; but, soon sinking into the groove between the pons and the crus cerebri, it curres round the latter structure on to the upper surface of the cerebellum, lying nearly parallel to the fourth nerve. Here it diviles into two branches, an intemal and external. (a) The internal or superior vermiform branch courses backwards along the superior rermiform process. anstomosing with its fellow of the opposite side, and at the posterior notch of the cerebellum with the inferior vermiform branch of the posterior inferior cerebellar artery. (b) The external or hemispheral branch rums ontwards to the circumference of the cerebellum, anastomosing with the external branch of the inferior posterior cerebellar artery.

Banches are given off from the main trunk of the superior cerebellar artery. or from its internal branch to the valve of Vieussens, the optic lobes. the pineal gland, and the choroid plexus.

$\therefore$ The posterior cerebral arteries are the two terminal branches into which the hasilar bifurates at the wper border of the pons immediately behind the posterior perforated space. Each artery runs at first outwards and a little forwards acros the crus cerehri immediately in front of the third nerve, which separates it from the superior cerebellar artery. After receiving the posterior communicating artery, which runs backwards from the internal carotid, the posterior cerebral turns hackwarls on to the under surface of the cerebral hemisphere, where it lreaks up into branches for the supply of the temporo-sphenoidal and occipital lobes.

The branches of the posterior cerebral artery may be divided into the ganglionic or "entral, and the cortical or hemisuheral.

(i) The ganglionic or central branches, are divided into the postero-median; the ponterior choroirl; and the postero-lateral. (i) The postero-median branches come off from the posterior cereloral near its origin, and, pasing through the cerehral substance forming the posterior perforated spot, supply the inner part of the optic thalamus and the walls of the thirel rentricke; (ii) the posterior choroid branch pases through the transverse fiswre to the relum interforitum and choroid plexus; (iii) the postero-lateral branches arise extermal to the spot where the posterior ceretral artery is joined by the posterior communicating. They run to the posterior part of the optic thalamus and give branches to the cus ereluri and optic lobes or corpora yuadrigemina.

(b) The cortical or hemispheral branches are distributed as follows:- (i) the uncinate, a branch to the anterior part of the uncinate convolution; (ii) the temporal, a lianch to the inferior part of the temporal lobe; and (iii) the temporo-occipital, a branch to the cuneus, lingual convolution, and outer surface of the oreipital leole.

Here it nuay he stated, not only in reference to the branches of the posterior cereloral artery. lut also with reseect to the branches of the anterior and middle cererral arteries, which are described with the internal carotid (page 50:3), that there is no anastomosis between the cortical and central branches. The cortical and the central form two distincet and separate sistems. The cortical may or may not. anastomose with each other, but the communication between the neighbouring cortical branches is selklom sufficient to maintain the nutrition of an area when the rescel that nomally supplies it is olstructed. The central branches are so-called end-resicels and do not anastomose with earh other. Hence obstruetion of the midclle cretoral or sylvian artery leads to softening of the area supplied hy its central lormelyes. But not always to softening of the region supplied hy its cortical branches. Indeed the cortical region mav coca]e completely, although the eentral area is irreparably disoramised. The gloss anastomosis of the posterior eerebral 
with the anterion and mindle cerelmal arteries through the circle of Willis is: described with the luanches of the internal caroticl (page j04).

\section{SLMMARY OF THE DISTRIBLTION OF THE CEREBRAL ARTERIE-}

Here it may be of advantage to give a hricf smmmary of the distribution of the anterior, micklle, and posterior cerebral arteries, the branches of which have alrearly heen described in detail. The branches of each are divided into the central ir ganglionic, and the eortical or hemispheral. The central hranches ariee at the (onmmencement of the cerebral arteries about the circle of Willis, whilst the cortic:all are drover ehiefly from the termination of these ressels.

(A) The central branches are clivided into six sets-two median and form lateral. 1. The two median are-(1) The antero-median, which arist from the anterior cereloral and the anterior communicating. and sulply the fore end of the caurlate uucleus, and (2) the postero-median, which arise from the posterior cerebral, and supply the inner part of the optic thalamus and neighbouring wall of the third ventricle. 2. The four lateral, two on rach side, are also divided into intero-litteral, and postero-lateral. (1) The antero-lateral arise from the middle cerebral, and, passing through the anterior perforated spot, supply the lenticular nucleus, the posterior part of the caudate nucleus, the internal and external (apsules, and the outer part of the optic thalamus. (2) The postero-lateral arice from the posterior cerebral, and supply the hinder part of the optic thalamus, the (rus, and the optic lobes or corpora quadrigemina.

(B) The cortical branches ramify in the pia mater, giving off branches to the cortical sulstance, some of which extend through it to the mrlerlying white $-\mathrm{hl}_{1}$ stance. The cortical branches of the anterior cerebral, roughly sjeaking: sulply the median surface of the frontal lobe as far as the precuneus. the immer part of its orlital surface, and part of its convex surface, riz. the highest part of the ascendine frontal and the first and most of the second frontal convolutions. The cortical hranches of the middle cerebral-or Sylvian artery as it is often called, becau-e of its relation to the Sylvian fissure-supply the most important area, namely, the motor convolutions; and also the largest, namely, the inferior frontal, the ascending parietal, part of the inferior prietal, the supramarginal and angular, the posterior frart of the superior parietal, the first temporal, and the anterior part of the second and third temporal convolutions. The cortical branches of the posterior cerebral $\therefore$ ulply the occipital lobe, and the inferior asprect of the temporal lobe.

It will be seen, therefore. that the middle ceretral supjolies the motor regrom, both central and cortical, exerent a part of the leg centre. It also sulplies the region of the cortux that subserves "utaneous sensilility, the cortical anditory centre, and in part the higher visual centre. It likewise supplies all the cortical recrims concerned in speech processes in the left hemisphere. The anterior corebral supplies only a small part of the motor region-namely, the part of the lece centre that oceupies the paraerentral lobule and the highest part of the ascending frontal convolution. The posterior cereloral supplies the risual path from the middle of the tract hackwarks. and the lalf vision centre in the oceipital lobe. It supplies also the corpora quarlrigemina and the sensery jart of the internal calsule.

\section{THE THYROID ANI}

The thyroid axis arises from the upper and front part of the suluclavian artery. usnatly oplosite the intemal mammary, and at litte internal to the inmer lourder of the sealenus antieus. It is a short thick trunk, and thivdes almust immerliately into three radiating branches-namely, the inferior thyroid, the suprascapular, and the transverse cervical (tig. 330 ).

Oceasionally the posteriur sapular branch of the transwerse cervical arises from the third portion of the subchiam; the smperficial revieal, the other luranch into which the transverse cervical divides, then commonly acoutes off from the axis. 


\section{THE INFELIOR 'THYROID AR'TERT'}

The inferior thyroid, the largest of the three branches into which the throid axis divides, ascends tortnously upwards and inwards in front of the rertebral artery, the recurrent laryngeal herve, and the longus colli muscle, and hehind the common carotid, and the srmpathetic nerve or its middle cervical ganerlion, to the thrroid body, where it anastonoses with the superior throid artery and the artery of the opposite side. It gives off the following hranches:-(1) Muscular; (2) ascending cervical; (3) resophageal; (4) tracheal; and (5) inferior larrngeal.

(1) The muscular branches supply the scalenus anticus, longus colli, sternohyoid, stemo-thyroid, and omm-lyyoid muscles, and the inferior constrictor muscle of the pharynx.

(2) The ascending cervical (fig. 329) is given oft from the inferior throin as that ressel is jassing heneath the carotid sheath. It asends between the salenus anticus and the rectus capitis anticus major, lying parallel and a little internal to the phrenie nerve and bethind the intemal jugular vein. It anastomoses with the vertelural, ascencling pharyngeal, and occipital arteries, and supplies the following loranches:-( (a) Muscular, to the deep muscles of the neck; (b) spinal, which enter the spinal canal with spinal hranches of the verteloral artery; and $(e)$ phrenic, to the phrenic nerve. Two veins accompany the ascending cervical artery, and cul in the innominate vin.

(3) The œsophageal branches of the inferior thyroicl artery sulply the asophagus, and anastomse with the other arteries supplying that tulue.

(4) The tracheal branches ramify on the trachea, where they anastomose with the tracheal branches of the superior thrroid and hronchial arteries.

(5) The inferior laryngeal branch passes along the traclea to the hack of the cricoid cartilage in company with the recurrent laryngeal nerve. It anters the larynx beneath the inferior constrictor. Its further distribution in that organ is described under LanYix.

\section{TIE SLPRASCAPTLAR ARTERY}

The suprascapular, or transversalis humeri, passes more or less transwrely ontwards across the root of the neck, lying first heneath the stermo-nastoid, and then in the subclarian triangle behind the clavicle and subclavius muscle. At the external angle of this space it is joined by the suprasuapular nerve, sinks beneath the posterior belly of the omo-hyoid, and passes over the ligament bridging the scapular notch, the nerve pasing through the notch (fig. 343 ). It then ramities in the supraspinous fossa of the scapula, and, winding downwards round the base of the spine over the neck of the scapula, enters the infraspinous fossat, and terminates by anastomosing with the dorsal seapular and posterior scapular arteries. As it lies under cover of the sterno-mastoid muscle, it crosses the phrenic nerve and the sealenus anticus; and as it conrses through the subclarian triangle, it is separated by the eervical fitwia which deseends from the omo-hyoid to the first rib, from the sulderian artery and lorachial plexus of nerves. If this artery is seen in tring the subelavian it sliould not be injured, as it is one of the (hief ressels lye which the collateral circulation is carried on after ligature of the sulchavian in the third part of its course. At the outer part of the subelarian triangle it is covered by the trapezius, and after passing over the seapular ligament it pierces the supraspinous fascia and passes bencatl the supra-spinatus muse, and ramifies between it and the lone. In the infraspinous fossa it lies hetween the infrat-spinatus and the bone. The artery is areompanied be two vins.

The branches of the suprascapular are:-(1) The inferior stemo-mastoirl, given off to that musele as the vessel crosics behind it; (2) the suludavicular to the subclavins muscle; (:3) the nutrient. to the claviche; (t) the suprastemal, which passes orer the strinal end of the chavele to the skin of the upler part of the chest; (5) the acomial, to the arterial rete of plexus on the aromial process, to reach which it pierces the trapezius; (6) the articular, to the acromio-edavirular 
joint and shoulder-joint; $(\bar{T})$ the subseapular, given off as the artery is pas-ing over the sufuraseapular liganent, deseends to the subscalpular fossal between the sulseapularis and the bone, and andstomoses with the infraseapular hranch of the dorsal scapular artery, and with the subscapular and posterior scapular arteries; (S) the supraspinous branches, which ramify in the supraspinous fossa, and supply the supra-spinatus musele and the periostemu and the nutrient arterr to the bone; (9) the infrappinoms brancher, which ranify in a similar way in the infraspinous fossi, giving off like twigs to the infra-spinatus muscle, the periostemm, and the lione.

\section{THE TRANSTERSE CERVICAL ARTERY}

The transverse cervical or transversalis colli artery-some what larger than the supraseapular artery-rums like the latter vesel transwersely outwals acros the root of the neck. biat on a slightly higher plane, and a little above the claviche.

Fig. 343. - SCheye of Axastoyoses of the Right SCApulak ARteries. (Walsham.)

Sicbscapular branch of summascayniar artery

Supraspinous branch of suprascapular artery

Iustrrior scapular artery

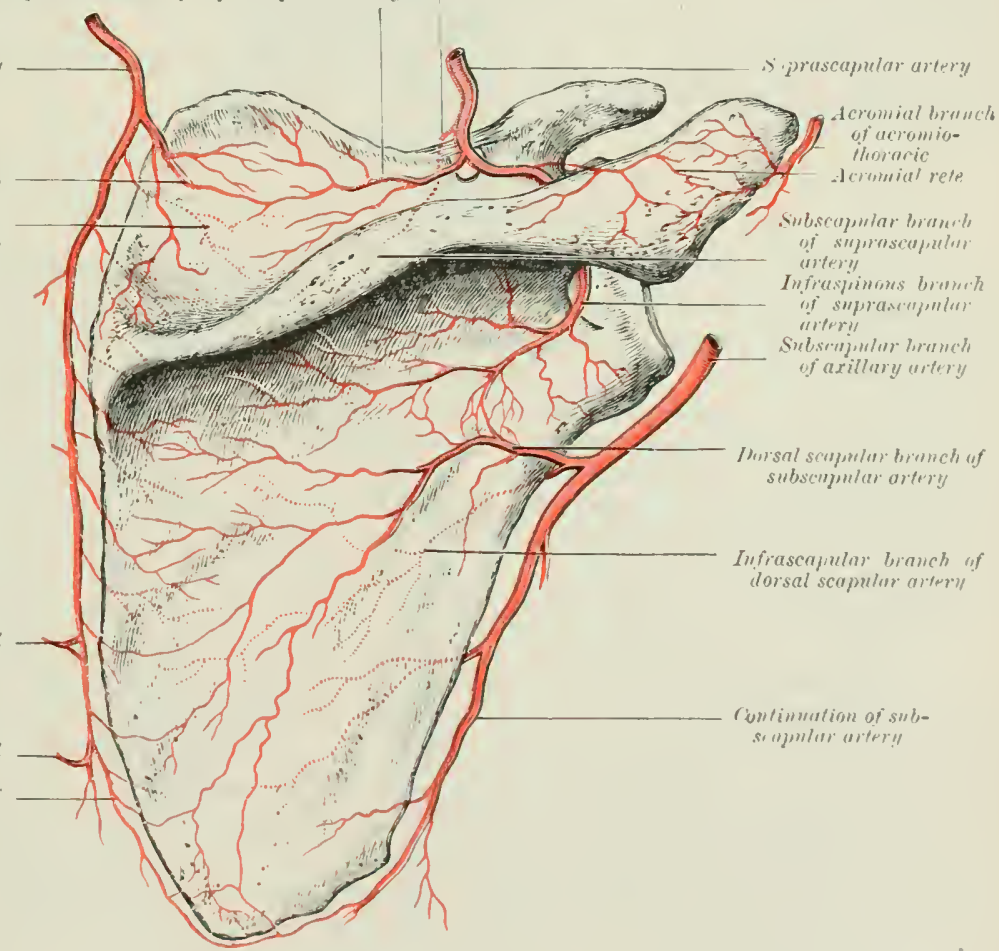

At its origin from the throid axis it lies under the sterno-mastoid; on learing the wover of this musele, it erosses the upper part of the subelavian triangle, lying here only beneath the platyma and erevieal fascia; further outwarls, it palsos beneath the anterior marcin of the trapezius and omo-hyoud muscle, and at the onter margin of the levitor anguli seapule divirles into the posterior seapulat and superfieial cervical arteries. In this eourse it aroses the phronic nerve. the scalenus anticus. the brachial plexus, and the sealenus medius. At times it pas as betweren the eords uf the brachial plexus.

The terminal branches of the transverse cervical artery are:-(1) The posterior scapular; and (ㄹ) the superficial cervical. 'The posterior scapular reatsionally arises from the third portion of the subelatian artery. 
(1) The posterior scapular-the alparent continuation of the transrerse cervical artery-inegins at the outer border of the levator anguli scalpulas, and, continuing its comrse bencath this muscle to the uplere and josterior angle of the s:apula, turns downwards and skirts along the posterior border of the scapula, leetreen the serratus magnus in front and the levator anguli satpula and rhomlwileus minor and major behind, to the inferior angle, where it anastonoses with the sulseapular artery. It gives off the following branches:- ( 1 ) Supraspinous, which ramifies between the supraspinous muscle and the trapezins, and sends branches through the musche into the fossa, to anastomose with the supraseapular artery. (b) Infraspinous branches, one or more of which enter the infraspinous fossi, and anastomose with the dorsal scapular. (1) Subscapular branches, which enter the sulscapular fossa, and anastomos: with the supurasapular, infrascapular, and subscapular arteries. (d) Muscular branches, to the muscles between which it runs and to the latissinus dorsi. These branches anastomose with the posterior divisions of the intereostal arteries.

(2) The superficial cervical artery, smiller than the posterior scapular, asecnds muler cover of the anterior margin of the trapezins, lying upon the levator anguli scapule and splenius muscles. It supplies hranches to the trapezius, levator anguli scapulat, and splenius muscles, and the posterior wain of lymphatic glands. It anastonoses with the superficial branch of the princeps cervicis which descends from the necipital between the splenius and complexus. It is accompanied by two reins. This artery may arise directly from the thyroid axis, or from the third part of the subclarian artery.

\section{THE INTERNAL MAMMARY ARTERY}

The internal mammary artery (fig. 34t) (omes off from the lower part of the first jumtion of the subclayian, usually opposite the thyroid axis. elose to the imner rlge of the scalenus anticus, occisionally opposite the rertebral, or at a spot letween these two vessels. It deseends with a slight inclination forwards and inwards, moler corer of the clavicle, and enters the thorax bohind the cartilage of the first ril, and thence passes down behind the cartilages of the next succeeding rihs, about half an inch from the external margin of the sternmm, to the sixth intersace, where it livicles into the superior epigastric and musculo-phrenic. It is accompranied by two reins, which unite into one trumk behind the first intereostal muscle, and pass to the imner sicle of the artery into the corresponding rena imominata; occasionally on the right side into the vena cava superior direct. The artery may lee divided into two portions, the cervical and the thoracie.

The cervical portion is covered by the sternomastoid muscle, subclavian rein, and internal jugular vein, and is crossed ollicuely, from without inwards. hy the phrenic nerve. It rests upon the pleura and courses round the upper part of the innominate vein. There is no branch from this part of the artery.

The thoracic portion lies behind the cartilages of the six inpere ribs, and in the interspace between the ribs has in front of it the pectoralis major and the internal intereostal muscles and the external intereostal memhrane. Behind, it is. in contact above with the pleura, but it is separated from it lower down by sijs of the triangularis sterni. On the left side the artery between the fourth and sixth ribs may be said to he in the anterior neeliastinum, the pleura here forming a moteh for the heart. In the first, second, and third spaces the artery, if womnded, am he assily tied; but in the fourth space the operation is attended with more diflieulty. The remaining suaces are so narrow that a portion of the cartilage would have to be removel to exjose the vessel.

The branches of the internal mammary artery are:-(1) The superior phrenic; (2) the modiastinal, or thymic; (3) the pericardiac; (4) the stemal; (5) the anterior intcrentals; (6) the perforating; (7) the lateral infracostal; (8) the suluror epigastric; and (9) the musculo-phrenic.

(1) The superior phrenic, or comes nervi phrenici, is a long slender vessel which comes off from the internal mammary just after it has entered the chest, and desconds with the phrenic nerve, at first between the plenra and innominate vein; 
then Jetween the pleura and the vena cara suferior; and lastly, between the pleura amel the perieardium to the diaphragm, where it anastomoses with the other diaphragmatic arteries. It gives hranches both to the plema and pericardiun.

(2) The mediastinal or thymic branches come off irregularly from the internal mammary. They are of small size, and supply the comnective tissue, fat, and lymphatics in the superior and anterior mediastina and the remains of the thymus glant.

(3) The pericardiac branches are distributed to the anterior surface of the pericartium.

(4) The sternal branches enter the nutrient foranima in the sternum, and also) sup'ply the triangularis sterni.

Fig. 344. - Scheme of the Rigit Intersal Mammary Arteri. (Walsham.)

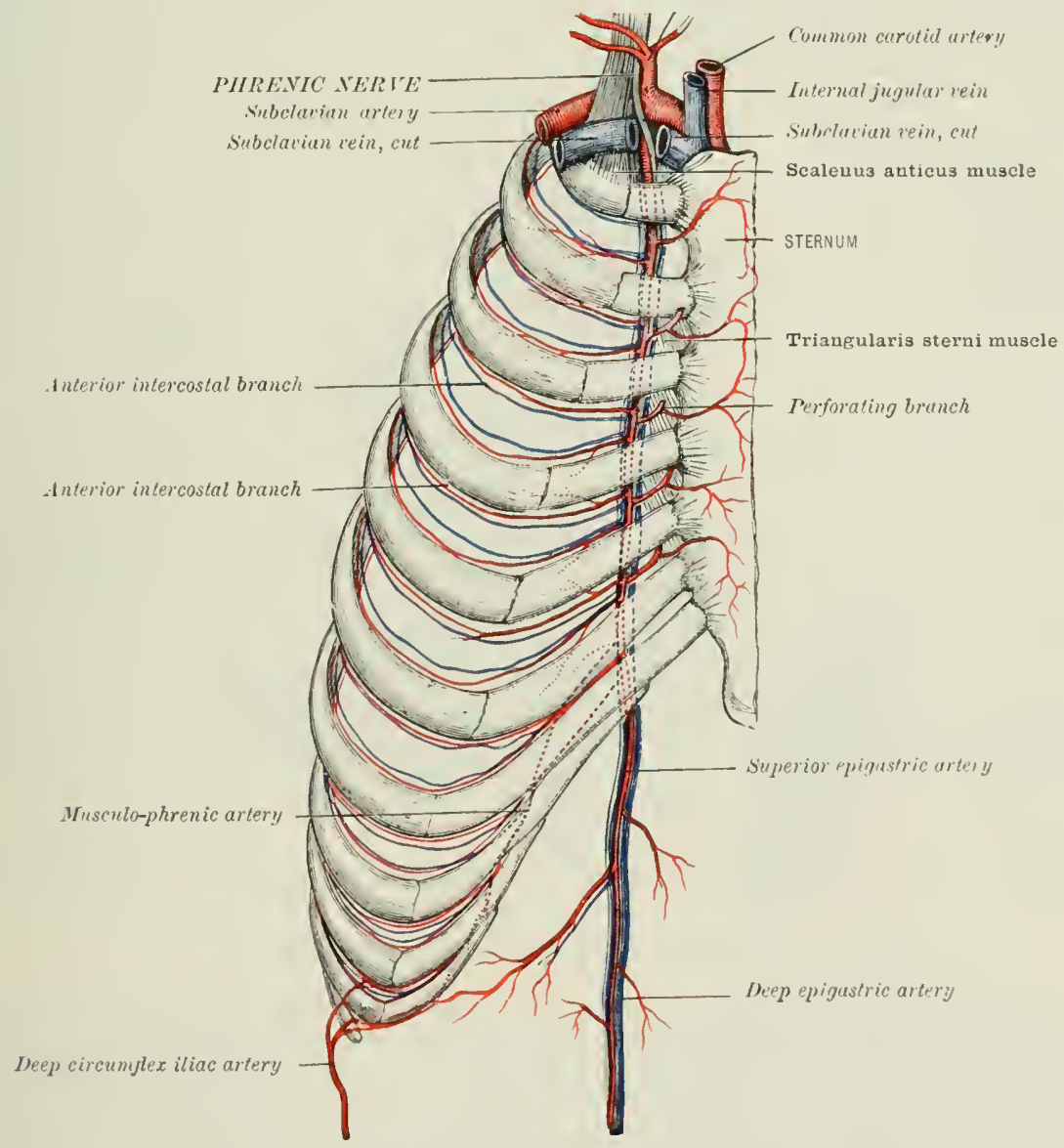

(5) The anterior intercostal arteries (fig. 34t) - two in each of the fire or six upper intercostal spaces-run outwarts from the intemal mammary artery, along the lower border of the rils abose and the upper border of the rit, betow, and anastomose with the corresponding upper and lower hanches of the aortic intercostals. Each pair of branehes sometimes arises by a common trunk from the intemal mammary, which in this case som divides into an uplere and a lower branch. as above described. Ther lie at first between the internal interestal museles and the pleura; afterwards hetween the external and internal interostal muscles. They supply the contiguous muscles, the pectoralis major, and the rihs.

(i) The perforating or anterior perforating branches-five or six in number, one corresponding to each of the fire or six uluer slyaces-come off from the front 
of the internal mammary, between the superior and inferior anterior intereostals, and, perforating the internal intercostal muscles, jass forwards hetween the costal atrilages to the peetoralis major, which they supply. The teminal twigs perforate that muscle cluse to the stemmo, and are distributed to the integment. The second, third, and fourth perforating supply the inner and tleep surface of the mammary gland, and becone greatly enlarged during latetation. 'They frepuently reyuire ligation in t'xeision of the breast.

(7) The lateral infracostal artery (Macalister) is given off close to the first rib, and deseends behind the ribs just external to the enstal cartilayes. It anastomoses with the uprer intercostal arteries. This ressel is often of insignificant size, or abeent.

(s) The superior epigastric artery (fig. 844 ), or internal terminal branch of the internal mammary artery, leaves the thorax behind the seventh costal eartilage by passing through the costo-xiphoid space in the diaphagn. It is the direct prolongation of the internal manmary downwards. In the abromen it desends behind the rectus muscle, between its posterior surface and its sheath, and, lower, entering the substance of the muscle, anastomoses with the deep eprigastric. a bunch of the external iliac. It gives off the following small branches:- (a) The phrenic, to the thaphragm; (b) the xiphoid, which erosses in front of the ensiform cartilage, and anastonoses with the antery of the opposite side; (c) the cutaneous, which perforate the anterior layer of the sheath of the reetus and sulprly the integuments; (d) the muscular, to the rectus muscle, some of which perforate the rectus sheath laterally, and are distributed to the ohlique muscles; $(e)$ the hepatic (on the right side only), which pass along the falciform ligament to the liver, and anastomose with the hepatic artery; $\left(f^{\prime}\right)$ the peritoneal which perforate the prosterior layer of the sheath of the rectus, and ramify on the peritoneum.

(9) The musculo-phrenic, or external terminal branch of the internal mammary artery, skirts outwals and downwarks bolind the costal cartilages of the false rihs"along the costal attachments of the diaphragn, which it perforates opposite the ninth rib. It terminates, muth redued in size, at the tenth or eleventh intercostal space by anastomosing with the ascenting branch of the deep circumflex iliac artery. It gives off in its course the following small branches:-(a) The phrenic for the slpply of the diaphragn; (b) the anterior intercostals, two in number for ach of the lower tive or six intercostal spares, are distributed like those to the upper spaces, alrealy deseribed, and anastomose like them with the correspending branches of the lower antic intercostals; (c) the muscular for the supply of the oblique muscles of the abdomen.

\section{Braxches of the seconil Part of the subch thax Artery}

\section{THE STPERIOR INTERC(N'TAL ARTERY}

1. The superior intercostal artery (fig. 34.) usully arises from the hack part of the second portion of the subelarian artery, behind the scalemes anticus on the right side, but sometimes just internal to that muscle on the left side. It at first rums hackwards and a little upwards above the apex of the pleura, and then turns lownwarls and enters the thorax in front of the neck of the first rib. It terminates in a branch which runs forwards in the first intereostal space. Frepuently, and especially on the right sirle, it is continued in front of the neek of the second rib, and supplies a branch to the second interenstal space. This luanch may then be reinforeed by an intercostal from the aorta, which supplies the space when the branch is not present. As the superior intercostal crosses the necele of the first rib, it lies internal to the anterior branch of the first dorsal nerve, and external to the superior thorare canglion of the symputhetic. That part of the superior intereostal which intervenes hetween its origin from the subclavian and its first branch, is sometimes talled the costo-cervical artery.

Branches.-The superior interestal gives off:-(1) The deep cervieal; (2) the first intereostal; and (3) the arteria alyerans.

(1) The deep cervical branch is given off from the sulerior intercostal just 
before the latter enters the thorax. It passes directly hackwards, first leetween the seventh and eightl cervieal nerves, and then hetween the transwerse process of the seventh cervieal vertebra and the neek of the first rib, having the body of the seventh cervical vertebra to its inner sicke, and the intertransrerse muscle to its outer side. It then turns upwards in the groose between the transwerse and spinous processes of the exvieal vertebre lying $u p$ on the semispinatis colli. It is coverect ly the complexus. Between these muscles, near the axis, it anastomoses with the deep branch of the princeps cervicis of the oceipital artery. The deep cervical is homologous in its course to the posterior branch of an aurtice interesital, lueing morphologically the posterior branch of the intercostal artery for the serwhth cervical space. It grives off the following small branche:-(a) Muscular, to the semispinalis colli and complexus; (b) anastomotic, which andstomose with branches of the verteliral, aseending cervical and prince js cervicis arteries; and (c) vertebral or spinal,

Fit. 345. - SCHEME of the Rinht SUPERluR INtercostal, ARtekr. (Walsham.)

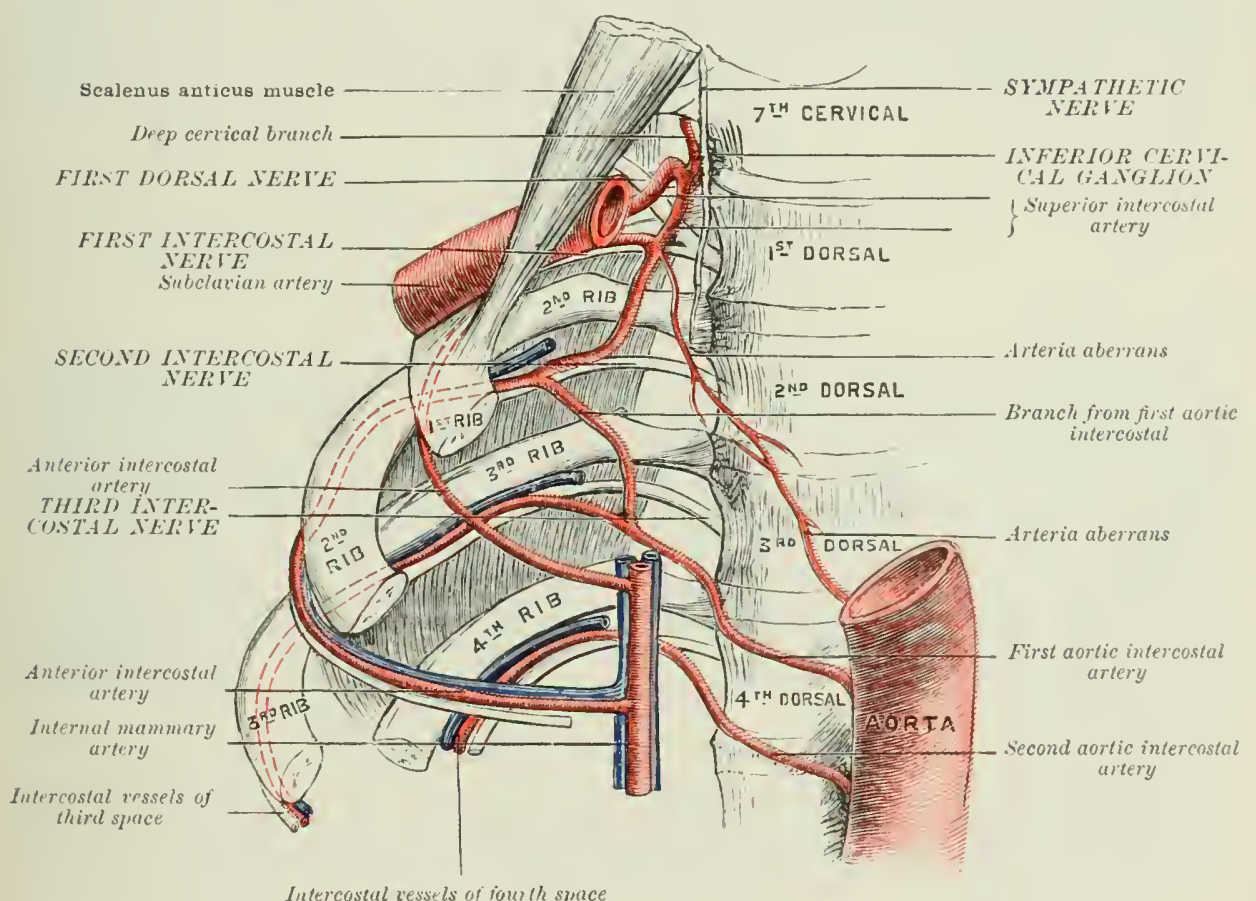

Intercostal ressels of fouth space

which enters the spinal canal through the intervertel,ral foramen with the eighth eervical nerve.

(2) The first intercostal branch runs forwards in the first interestal slace. and, like the second intercostal branch, which, when precunt. runs to the second space on the right side, resembles in its course and distribution the succeding

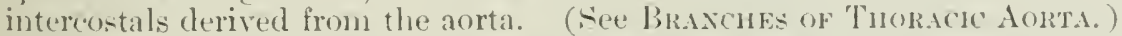

(3) The arteria aberrans, when present, comes off from the imer sille of the right superior intercostal, and occasionally from the risht sulvelavian itself. (See lage 506.) It descends as a delicate vessel into the thorax. jassing hatekards and inwards behind the osophagus as far as the thim or fourth thoracic vertelorit, where in some cases it is found to anastomose with a similar delieate liranch coming off from the aorta below the ductus arturiosus. This anastomosis, which represents the remains of the right dorsal aortic stem, may become enlargerl, and the suliclavian artery on the right sicte be derived from the arch of the acrta. This accounts for the subclavian in sueh circunstances fassing behind the asophagus. (See Varlations of the Alich (IF the AORTA.) 


\section{THE AYILLARY ARTERY}

The term axillary is alphlied to that portion of the main arterial stem of the upper limb that passes through the axilla. The axillary artery therefore is contintous with the subclavian above and with the brachial below. It extends from the outer horder of the first rib to the lower elge of the teres major muscle, and has the shoulder-joint and the neck of the humerus to its outer side. When the arm is placed close to the sicle of the bocly, the artery forms a gentle curve with its convexity upwards; but when the arm is carried out from the side at right angles to the trunk in the ortinary dissecting position, the ressel takes a nearly straight course, which will then be indicated by a line drawn from the middle of the claricle to a spot midway between the condyles of the humerus. The axillary artery is at first deeply placed heneath the pectoral muscles, but in its lower third is sujerficial, being corered only by the skin and the superficial fascia and derp fascia. It is divided into three parts-first, second, and third, according as it lies respectively alove, beneath, or helow the pectoralis minor.

\section{The First Part of tie Axillary Artery}

The first part of the axillary artery extends from the outer border of the first rib to the upper border of the pectoralis minor. It measures about an inch in length $(2.5 \mathrm{~cm}$.$) .$

Relations.-In front it is covered by the skin, superficial fascia, the origin of the platysma, the deep fascia, the pectoralis major, the costo-coracoid nembrane. the subclavius musele and the clavicle when the arm hangs down by the side. The cephalic and acromio-thoracic veins, the external anterior thoracic nerve, and the axillary lymphatic trunk, cross over it. A layer of the deep cervical fascia which has passed under the clavicle also descends in front of it.

Behind, it rests upon the first intercostal space and first intercostal muscle, the first digitation and sometimes a portion of the second digitation of the serratus magnus muscle, and a part of the second rib. The posterior or extemal respiratory nerve of Bell, on its way to the serratus magnus muscle, passes behind it.

To its outer side, and somewhat on a higher plane, are the cords of the brachial plexus.

To its inner side, and on a slightly anterior plane, is the axillary rein. The anterior internal thoracic nerve courses hetween the vein and the artery.

\section{The Second Part of tile Axillary Artery}

The second part of the axillary artery (fig. 346 ) lics bencath the pectoralis minor deep in the axilla. It measures a little more than an inch in length (") im.).

Relations.-In front, in addition to the pectoralis minor, it is errered by the perturalis major ant the integuments.

Behind, it is separated by a considerable interval containing loose connective tissue and fat from the subseapularis muscle; whilst behind, and in contact with it, is the posterior cord of the brachial plexus.

To the inner side, but separated from the artery ly the inner cord of the brachial plexus, is the axillary vein.

To the outer side is the vuter cord of the limehial plexus, and at some little distance the coracoisl procers.

It is thus seen that the seend portion of the axillary artery is surounded on three sides by the cords of the hrachial plexus-one hehind, one internal, and one external. 


\section{The Third Part of the Axillary Artery}

The third part of the axillary artery (fig. 346 ) extends from the lower border of the pectoralis minor to the lower borter of the teres major. Its upurer half lins deeply placed within the axilla, beneatl the lower erlge of the pectoralis major muscle, but its lower half is in the arm external to the axilla, and is uncovered hy muscle. It measures about three inches in length $(7 \cdot 5 \mathrm{~cm}$.$) .$

Relations.-In front it has, in addition to the skin and superficial fascia, the pectoralis major above, and lower down the deep fascia of the arm. It is rossed obliquely by the imner root of the median nerve and by the outer brachial vena comes.

Behind, it lies successively upon the subscajularis, the latissimus dorsi, and teres major muscles. From the first-named muscle it is separated at first by a tonsiderable mass of fat and cellular tissue. The museulo-spiral and circuntlex nerves intervene between the artery and the muscles.

On its outer side it is separated from the bone by the coraco-brachialis, loy which it is partly overlapped, this muscle and the short head of the biceps serving as a guide to the artery in ligature. For a part of its course it has also the musctiocutaneous nerve and the outer root of the median nerve to its outer side.

To its inner side it has the axillary rein, the ulnar nerve, the internal cutaneous nerve, the lesser internal cutancous nerve, and the inner ront of the median nerve. The ulnar nerve is between the artery and the vein. The internal cutaneous nerve is a little in front of the artery as well as internal to it.

\section{Tariations in the Axillary Artery}

The chief variations in the axillary artery are:-( $a)$ It may give off the radial artery: (b) more rarely, the ulnar artery; $(c)$ still more rarely, the internsseous artery, or a vas aberrans; (d) it may give off a common trunk, from which may arise the subscapular, the anterior and posterior circumflex, and the superior and inferior profunda arteries. The branches of the brachial plexus usually surround this common trunk, and not what is appareutly the main brachial artery. The latter vessel indeed would seem in many of these instances to be really an enlarged vas aberrans, and the common trunk the main brachial artery, the lower portion of which has been obliterated, i.e. obliterated from the last branch given off from the common trunk to the spot where it is again joined by the vas aberrans. (e) The axillary artery may be covered in the third part of its course by a muscular slip (the dorsi axillaris), dericed from the upner part of the tendon of the latissimus dorsi, and always present in early foetal life, though is a rule atrophied later.

\section{Branches of the AxIllary Artery}

The first part gives oft:--(1) The superior thoracic; and (2) the acromiothoracic.

The second part gives off:-(1) The long thoracio: and (2) the alar thoracie:

The third part gives off:-(1) The subseapular: (2) the anterior circumflex; and (3) the posterior circumtlex.

\section{Braxches of the First Part of the Axilladry Arteiry}

1. The superior or short thoracic is variously given off from the axillary artery, usually either as a common trunk with the next branch, the acromial thoracic, or a little above. It passes behind the axillary vein across the first intercostal space, supplying the intercostal muscles and the upper portion of the sorratus magnus, and anastomoses with the interrostal arteries. At times it sonds a branch between the peetoralis major and minor, which then, as a rule, more or lese takes the place of the pectoral branch of the acromial thoracic.

2. The acromio-thoracic, or thoracic axis, arises from the front part of the axillary just above the upper horler of the pectoralis minor. It is a short trunk. and coming off from the front of the artery pieres the costo-coraceid membrane, and then civides into three or four small branches, named from their direction:( 1 ) the acromial, or thoracica acromialis; (b) the humeral. or thoracica humeralis; (c) the pectoral, or short thoracic of some authors; and (d) the claricular. 
Fig. 346. - The Lower Part of the Axillary, the Brachial, axd the Radil axp UlNAR ARTERIES, Right SIDE.

(From a dissection in the Museum of the Royal College of Surgeons of England.)

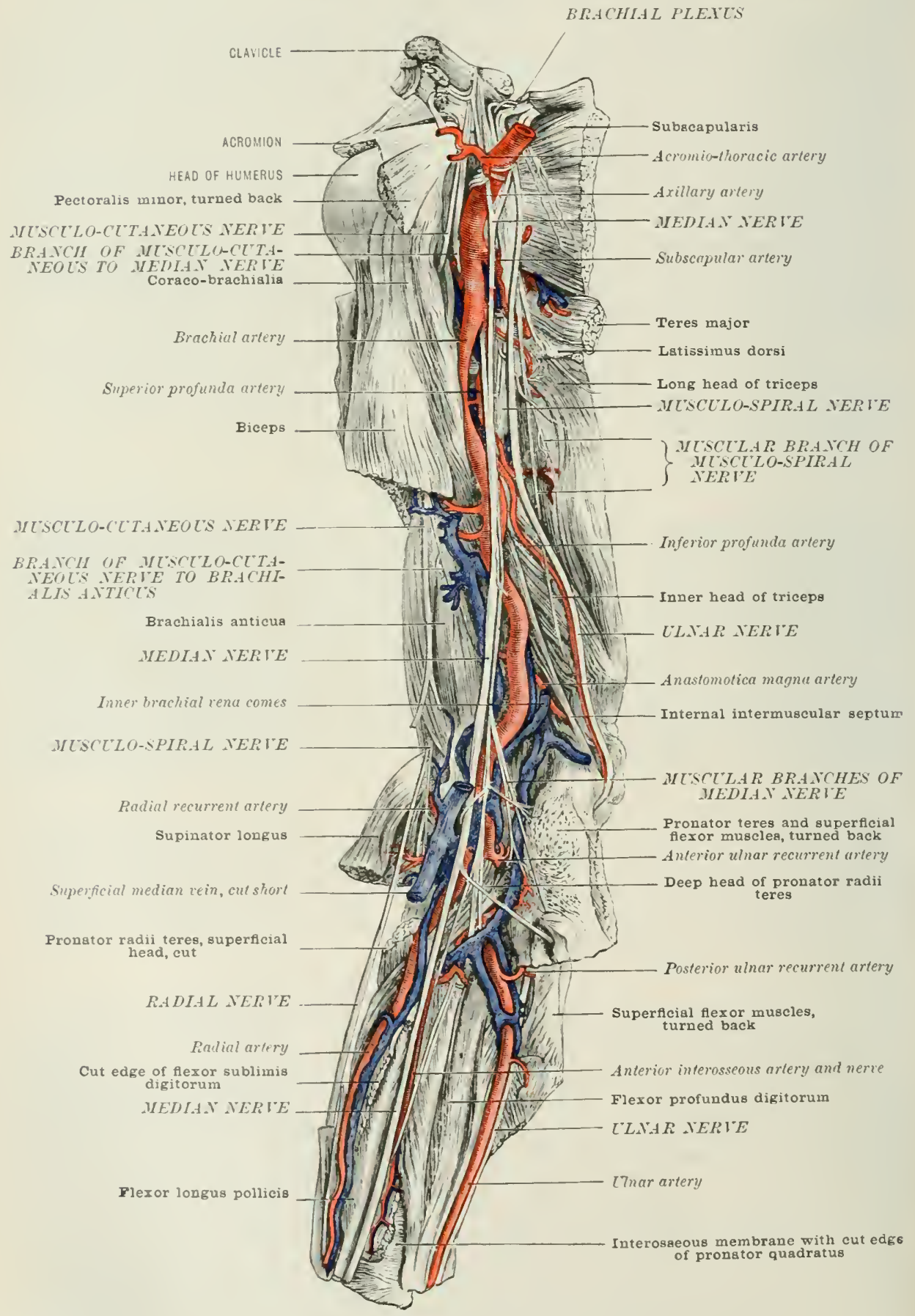


(a) The acromial branch or branches pass outwards across the coracoid process; frerguntly through the deltoirl muscle, which they in part supply, to the acromion, where they form, br anastomosing with the anterior and posterior circumflex and suprascapular arteries, the so-called acromial rete, or plexus of ressels on the surface of that process.

(b) The humeral branch - the descending branch of some authors- mus downwards with the cephalic rein in the interval between the pectoralis major and the deltoid, ant, supplying lateral oftsets to these muscles and the adjacent integuments, anastonoses with the anterior and posterior circumflex arteries.

(c) The pectoral branch passe's between the peetoralis major and minor mus-

Firi. 347.-Tine Dorsal SCApular Artery, Right Silie.

(From a dissection in the Museum of the Royal College of Surgeons.)

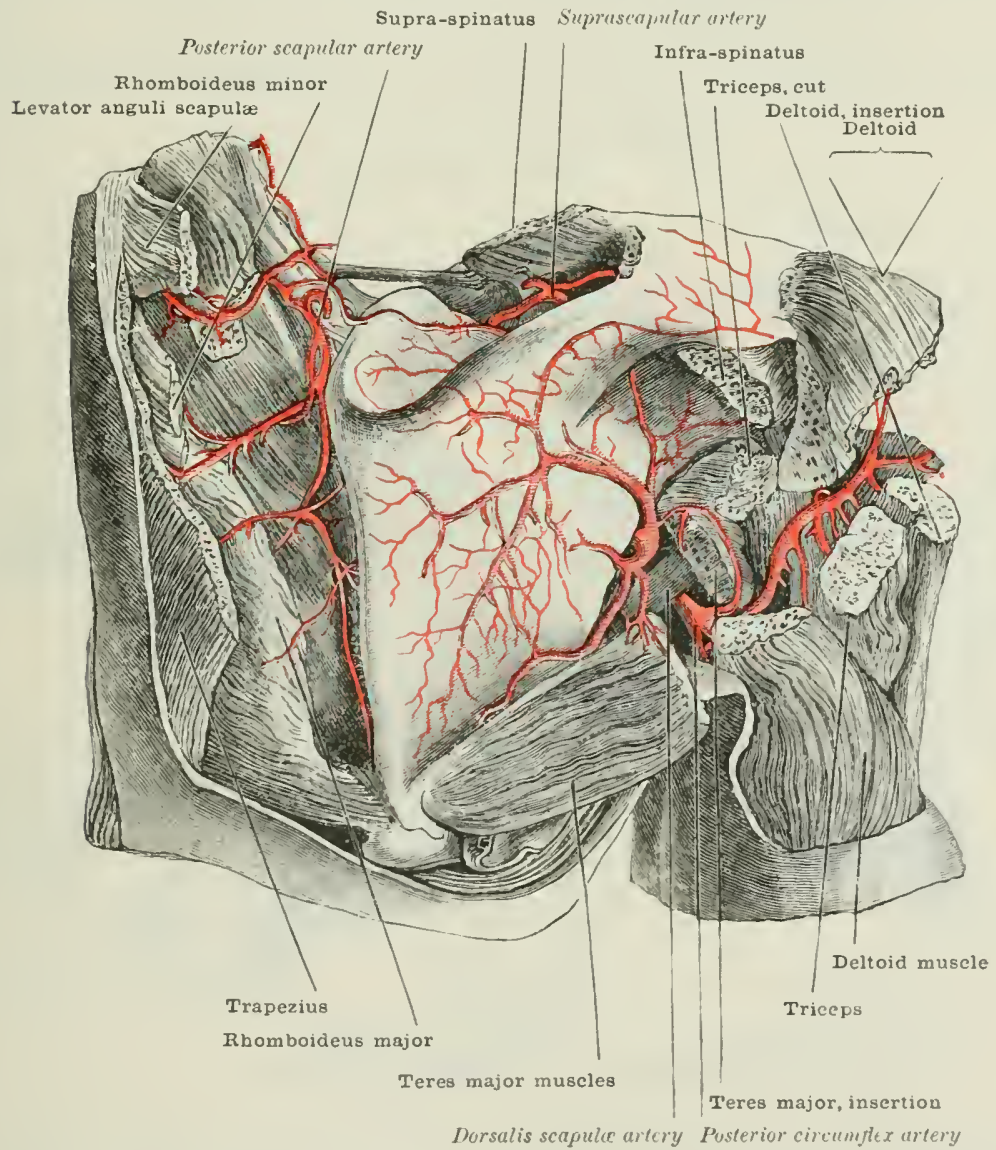

eles. both of which it supplies, and the superimposed mammary gland. In the fenale, one or more of these branches which perforate the pectoralis major are often of large size.

(il) The clavicular branch jasse's upwards heneath the claricle and supplies the subclavius muscle, and anastomoses with the supraseapular artery.

\section{Braxches of the Secoxd Part of the Axillary Artery}

1. The long thoracic artery-also called the external mammary-descends along the lower border of the pectoralis minor, uneler cover of the pectoralis major, to the walls of the chest. It supplies both pectoral nuscles and the serratus 
magnus, sends branches round the lower horder of the pectoralis major to the mammary gland, and temninates in the intercostal muscles by anastomosing with the aortic intercostals and the internal mammary. It alss furnishes branches to the glands of the axilla. The branches to the niammary gland in the female are often of large size.

2. The alar thoracic are small branches given off either directly from the axillary artery to the lymphatic glands in the axila, or from some of the other branches of the first or secund part of the axillary artery.

\section{Braxches of jhe Third Part of the Axillary Artery}

1. The subscapular artery is the largest braneh of the axillary. It arises (opposite the lower border of the subscapularis, and runs downwards and inwards

Fig. 34R.-The Right Posterior Circumfex Artery.

(From a dissection by Mr. Horner in the Museum of St. Bartholomew's Hospital.)

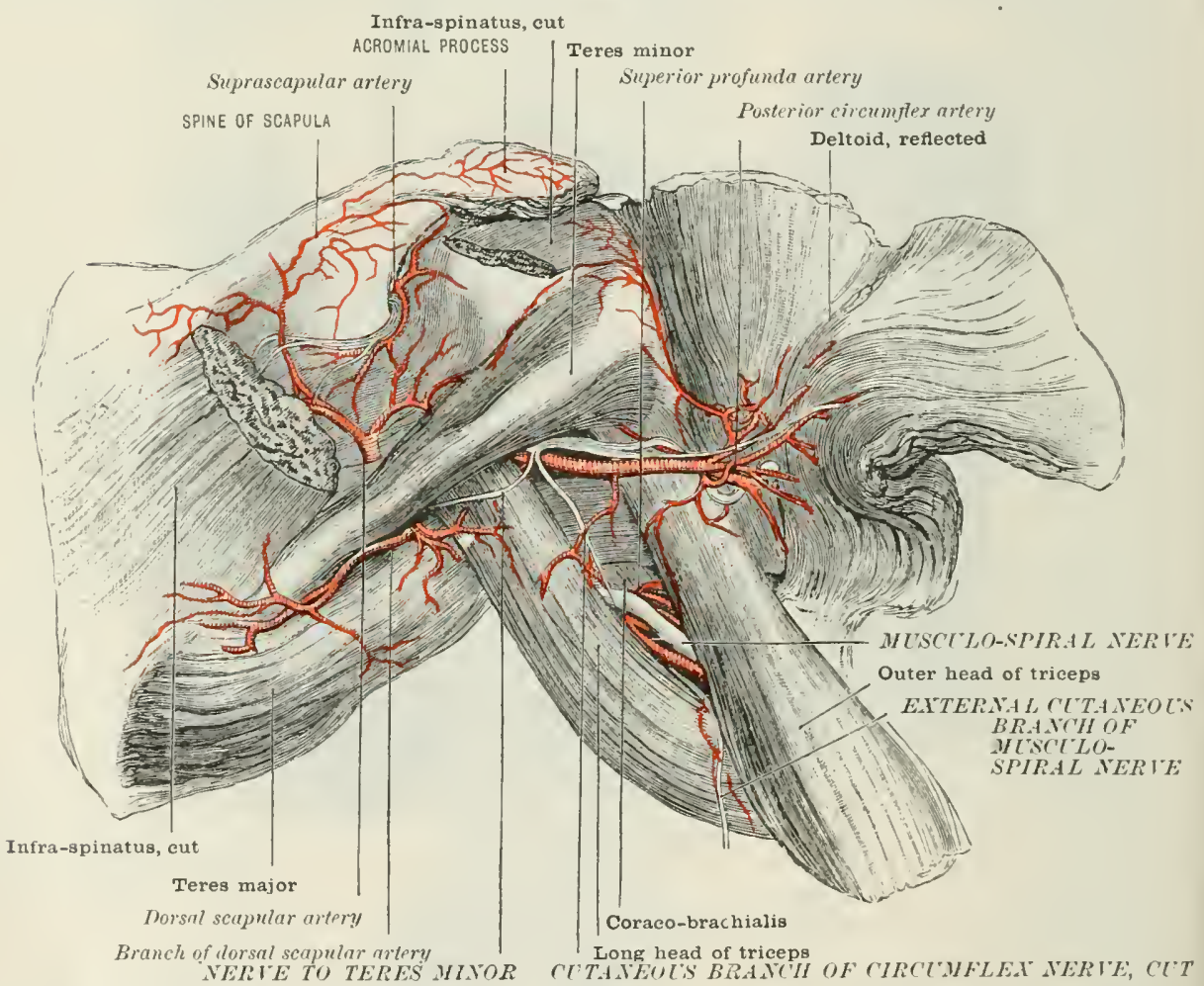

along the anterior border of that musele under covel of the latissimus dorsi as far as the angle of the seapula, where it anastomoses with the dorsal seapular, posterior seapular, long thoracie, infraseapular, and the intereostal arteries. The long subseapular nerve areompanies it. It supplics the subscapularis, teres major, latissimus dorsi, and scrratus magnus muscles, and gives branches to the glands in the axillary space. The course of this large vessel along the posterior border of the axilla shoub be remembered in opening absesses in the axilla, and in removing enlarged glands from this space. It is aceompanied by two veins, which usually unite and then receive the dorsal sapular vein, and open as a single vein of large size either into the axillary or at the eonfluence of the immer brachial rena comes with the basilic rein.

Ahont an inch to an inch and a half from its origin, the subscapular artery gives off the following large branch:- 
The dorsal scapular, arising from the subseapular, usually at the abovemontioned spot, bakses hackwards through the triangular space hounded by the subseapularis alove, the teres major below, and the long head of the triceps externally, and then between the teres minor and the axillary border of the seapula, which it commonly grooves. It thus reaches the infraspinous fossa, where, uncter cover of the infraspinatus, it anatomoses with the suprascapular and posterior scapular arteries (tig. 347 ). As it passes through the triangular slace, it gives oft a ventral branch, sometimes called the infrascapular, which ranities between the sulsocalumlaris and the hone, supplying branches to the subscapularis, to the scapula, and to the shoulder-joint. I second branch is often given off near the triangular spate and passes downwards between the teres major and teres minor. supplying both 1uluscles (fig. 348).

The chief variations in the subscapular artery are:-(a) It may eome off with the posterior circumflex; $(b)$ it may arise from at trunk common to several other of the branches of the third

\section{Fig. 349.-THE AxAstomoses ABOUT THE SCAPLLA.}

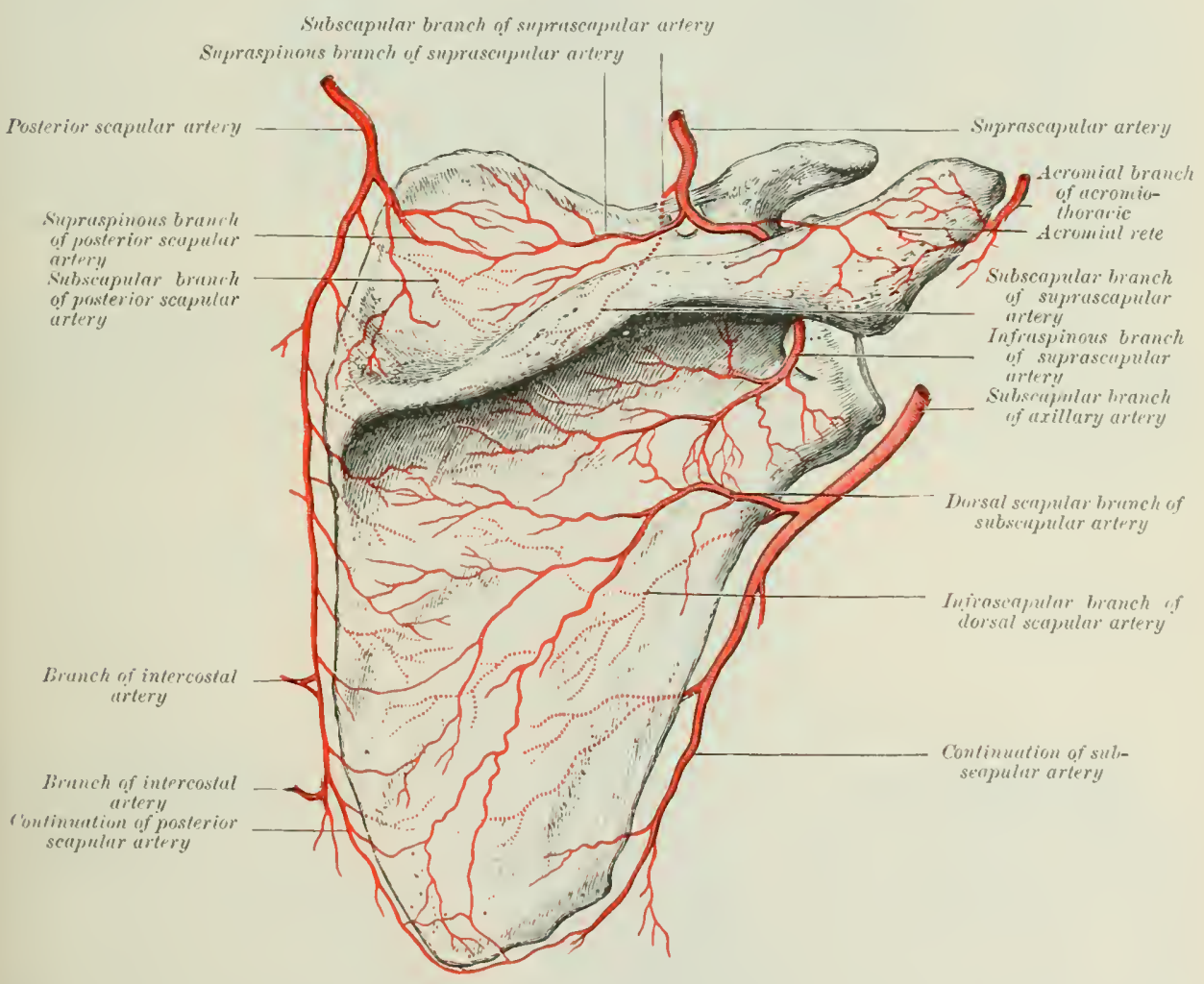

fart of the axillary artery and upper part of the brachial artery: and $(c)$ its dorsal scapular branch may arise fiom the axillary direct.

2. The anterior circumflex, usually quite a small vescel. comes off from the suter sille of the axillary artery. aenerally opposite the pusterior aireumflex. It passes beneath the coraco-hrachialis and short and long heads of the hiceps. wincling transersely round the front of the surgieal neck of the humerus, acrose the bicipital groove, and anastomoses with the posterior circumitex and arromial thoracic arteries. It gives off the following small branche: ( 1 ) the bicipital or ascending, which runs up the bicipital grome to supply the bong tendon of the liceps and the shonlere-joint: and (b) a pectoral or desending hranch. which runs downwarks along the insertion of the pectoralis major. and silpylies the tendon of that muscle. The anterior ciremuftex artery; in conserpuene of its being close 
to the bone, is sonetimes difficult to secure in the operation for excision of the shoulder-joint.

Chief variations. - ( $t$ ) The anterior circumflex may be given off from the posterior cireumflex; or (b) firom a stem common to it and sereral other vessels. (See Vartatioss is the AXILLARY ARTERY, fage 5:21.)

3. The posterior circumflex artery (fig. 348) arises from the hinder part of the axillary, just below the lower burtcr of the sulseapularis muscle. It passes through the quadrilateral space, bounderl by the teres minor above, the latissimus Iorsi and teres major below, the humerus externally, and the long head of the triceps internally, and, winding round the back of the humerns beneath the deltoid, breaks up uncler cover of that muscle into a leash of branches. which for the most part enter it: substance. The circumflex nerve and two rene comites run with it. It anastomoses with the anterior circumflex, the arteries on the acromion, and the superior profumcla artery.

In adrlition to the leash of ressels to the deltoid, it gives off the following small branches:--(a) nutrient, to the greater tuberosity of the humerus; (b) articular, to the back of the shoulder-joint; (e) acromial, to the plexus on the acromion; and (d) muscular, to the teres minor and long and short heads of the triceps. One or more of these branches to the triceps (the tricipital) descend either between the weter and long head, or in the substance of that muscle to anastomose with an ascending branch from the superior profunda artery. It is by means of this anastomosis that the collateral circulation is chiefly carried on when the axillary or the brachial artery is tien between the origins of the posterior circumflex and superior profunda arteries (fig 330 ).

The chief variations in the posterior circumflex are:-(a) It may arise with the subscapular artery as a common trunk. (b) It may come off from the brachial, and run up behind the teres major to the quadrilateral space. (c) It may give off the inferior profunda, the anterior circumflex, or the dorsal scanular. (d) It may be double. (e) It may form one of the vessels arising fiom a trouk common to sereral branches of the axillary and brachial arteries. (See VARLATiosis iN the AXIllary ARTerr, mage 5:2l.

\section{THE BRACHIAL ARTERY}

The brachial artery, the continuation of the axillary, extents from the lower borker of the teres major to a little below the eentre of the crease at the bent of the dhow, where it divides, opposite the junction of the head with the neck of the racius, into the ralial and unar arteriss. The artery is situated at first internal to the humerus; but as it passes down the arm it gradually gets in front of the mone, and at the bend of the elbow lies midway betwern the two condrles (fig. 350 ). Hence, in controlling hemorrhage. the artery should be compresised outwarls against the bone in its uyer third, outwards and backwards in its midhle third, and dircetly hackwards in its lower third. Throughout the greater part of its course the artery is superficial, heing merely overlapped slightly on its outer side hy the coraco-buchialis and hicos muscles: but at the bent of the elbow it sinks teeply beneath the semilumar fiscia of the biceps into the triangular interval (anterubital space), bounderl on either sirle by the supinator longus and pronator rarlii teres, and at its bifureation is more or les under arover of these museles (fig. 851). The sheath of the brachial artery is clesely incorporated with the fascial covering the biceps muscle, and it is for this reason that in the operation for ligaturing, the vessed is apt to be retracted with the muscle. A line drawn from midway hetweren the folds of the axilla at the outer side of that suace to midway between the condyles of the humerus, will inclieate its course. It is accompanied by two veins which frequently communicate across the artery. 
Relations.--In front, the artery is covered by the integument and superficial and deep fascie, and at the bend of the elhow by the semilunar fascia of the bicepsis and in muscular subjects hy the orerlapping margins of the supinator longus and

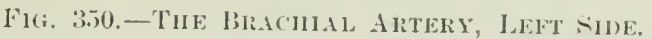

(From a dissection in the Murem of the Royal College of singeons.)

suproscupulur urtery aul nerve

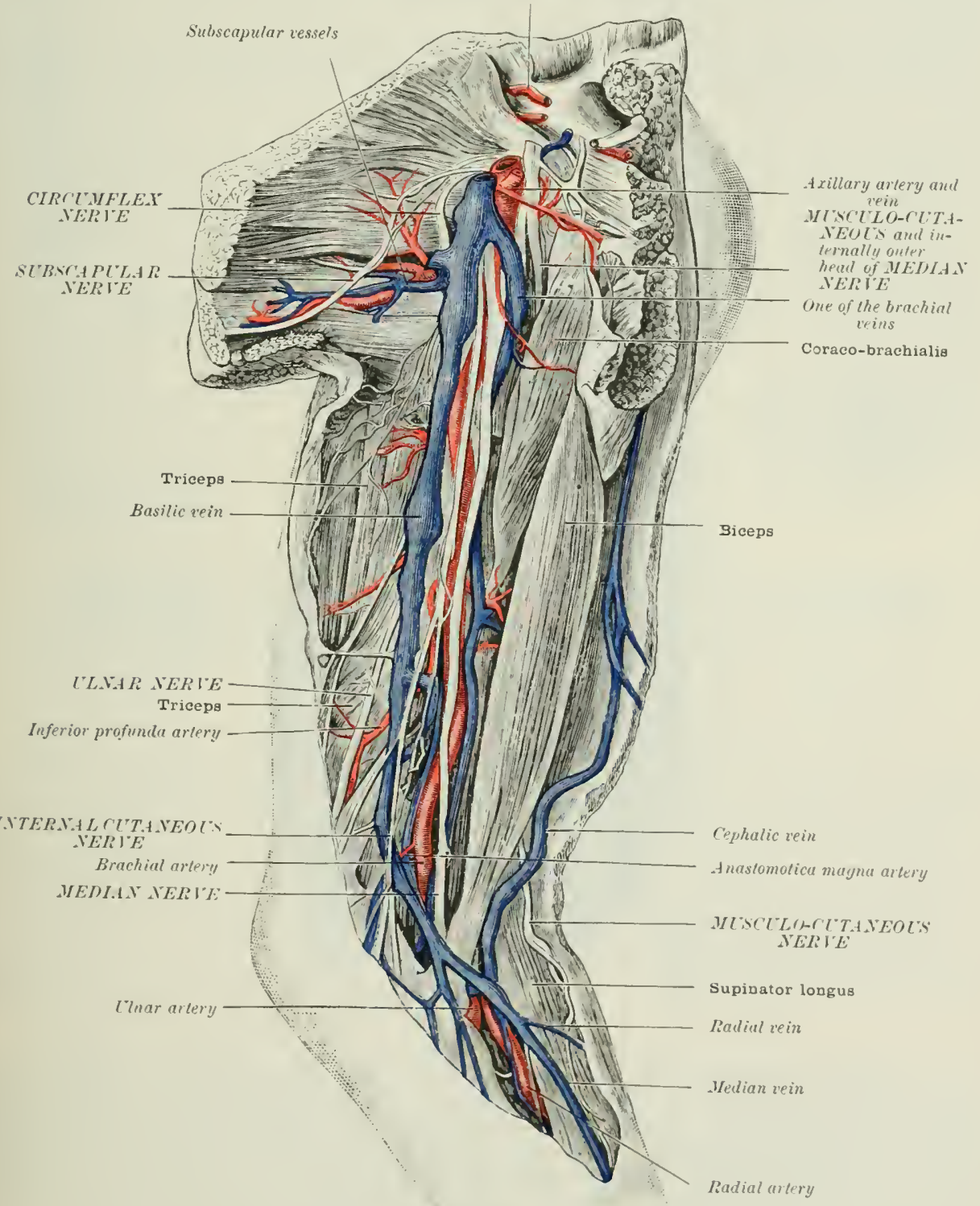

pronator ratii teres. In the mithlle third of the arm it is crosed obliquely from without inwards ly the median nerves and at the bend of the elhow by the meelian basilic vein, the hicipital fascia intervening (tig. 3.5, ). 
Behind, it lies snecesively on the long head of the trieeps (from which it is seprated by the musculo-spiral nerve and superior profunda artery), on the imner head of the tricess, on the insertion of the coraco-brachialis, and thence to its bifureation on the brachialis anticus muscle.

External to the artery is the coraco-brachialis ahove, and the muscular belly of the bicems below, both of which slightly overlap the vessel, and at the bend of the How the tendon of the biceps. The external venta comes is also to its outer side. The merlian nerve is in anse (ontact with the onter side of the artery in the upper thirl of its comse, but in the minlle third crosses the artery obliquely to gain the inmer sirke.

Internal to the artery in the upper part of its course are the internal cutaneous and the uhat nerves; the latter nerve, however, leares the artery about the origin

Fig. 351.-The Bharhile Artery at the Benn of the Elbow, Left Side, Front View.

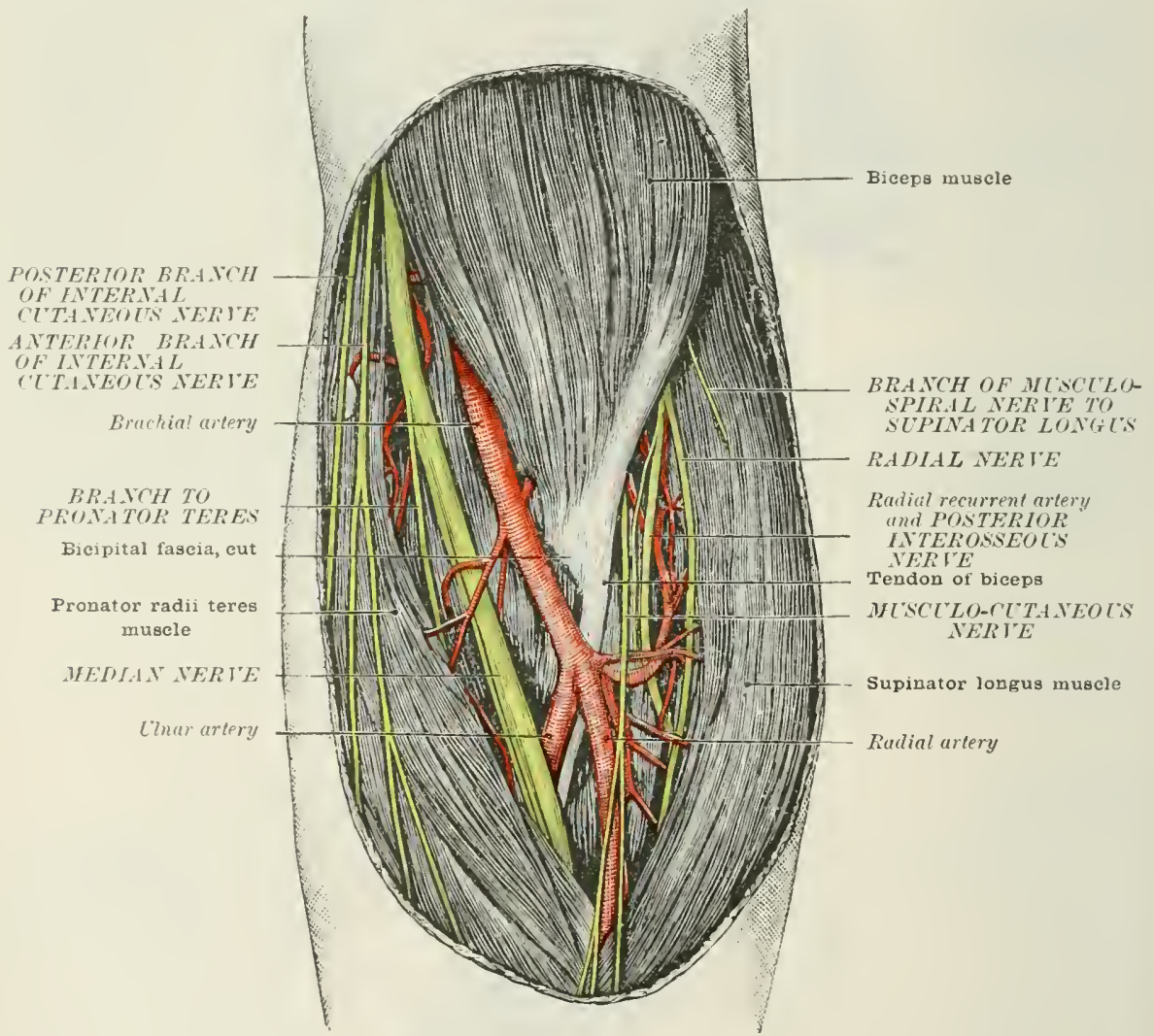

of the inferior mrofumda branch, to make, with that vessel. for the internal condyle. Lower down, the internal cutaneons nerve also leaves the artery, by piereing the deep farcia. The median nerve is in close contact with the inner side of the artery in its lower third and at the bensl of the elbow. The hasilie vein is superficial to it, and a little to its inner side in the erreater part of its course, but separated from it hy the deep fiscia. The internal vena comes rums aloner its inner sirle.

\section{The lurintions in the Brathinl Aitery}

The chief variations in the brachial artery are:-(1) A high division into its terminal branches. 'The high division may oecur at any spot in the normal antre of the vessed, but is most common in the mper third of the arm, anil least enmmon in the middle third. The two vessels into which the brachial then divides as a rule run parallel to each other to the bend of the 
elkow in the usual sitmation of the lrachial. whence ome follows the mormal comse of the radial artery throngh the forearm, and the other takes the normal "omre of the nhas artery, giving off as nenal the common interosseons artery. This arrangement may be "omsilerent a simple high division of the brachial. At uther times the alisposition of the two vessels is alfferent : these (i) the two arteries may communicate at the elbow by a cross branch, or remite, and then again divide in the nsual mamer. (ii) One vessel may fiollow the eourse of the ulnar artery in the forearn, and the other divisle into the radial and eommon interosens. This condition is spoken of as a high origin of the uhar: (iii) One artery way divide into the radial and uhar as monal, and the other take the course of the common interosseous and divide inte the anterior and pusterior interossenus arteries; or, much more rarely take the course of the pusterior interosseons

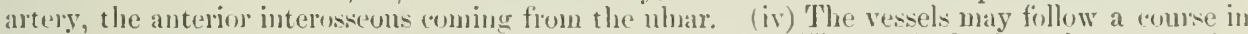
the uluer arm different from that of the nommal brachial. Thus (A) the buanch rejuresenting the raclial may ( $(1)$ eross over or moter the other hranch; (b) perforate the deep fascia above the ellow, and run beneath the skin to its place in the forearn; or (c) lass behind the temlon of the? biceps. (B) The loranch representing the uluar may (a) run to the front of the imner condyle with the median nerve, and thenee reach its usual situation by descending fiom within outwards hereath the fiscial and pronator teres, or, more rarely, beneath some of the flexor muscles or merely beneath the skin: or (b) it may run with the uluar nerve hehind the innes condyle, and thence beneatls the muscles to its unal place in the forcarm. (2) An enlarged vas aberrans may be present. This is a long slemeler vessel, which arises from the brachial nsually near the origin of the smierior protundil, and joins must commonly the radial artery, or, more rarely, one of its bramedies, or the ulnar. It is said to be nsually present, thongh not admitting of complete injection, and to deseend over the median nerve to the biceps muscle. At times this ressel takes the placer of the brachial ; the median uerve will then be found behind the arterg. (3) The lurachial may rum with the median nerve towards the immer condyle, where it then usually turns romm a wipraconlyloid process after the course normally taken by the artery in the Felidae. in which it rums through a supracondyloid foramen. Thence it descends to its normal situation beneath the pronator teres, which then usually arises from a fibrous expansion from the provers. (4) The braehial may be eovered by varims muscular slips derived from the adjacent muscles. (5) Certain abourmalities in the giving off of its collateral branches. These are referred to under each branch.

Braxches of the Brachlal Artery

The branches of the brachial artery are:-(1) The superior profunda; (2) the inferior profunda; (3) the anastomotica magna; (4) the nutrient; (5) the muscular; and (b) the terminal branches-the radial and ulnar arteries.

\section{(1) The siterior Profuird Artery}

The superior profunda is the largest of the branches of the brachial. It arises from the inner and hinder aspect of that artery. a little below the inferior borker of the tendom of the treses major. It at first lies to the inmer side of the brachial, lut sour pases lwhind that resecel, and, sinking letween the inner and long heads of the triceps with the musculo-spiral nerve, curves round the humerus in the musculospiral groose. lring in contact with the home between the inmer and outer hears of the triceps. On reaching the extemal supraeondyloid ridge of the humerus. it furforates the external intermuseular septum, and. ontinuing forward hetwen ihe supinator longus and Inachialis antiens to the fromt of the external eondyle, (ends hy anastomosing with the radial recurrent artery.

It gives off the following lianche:-

(r) The ascending branch, which runs mowark behind the tendom of the teres major in the substance of the trinels, or lutweren the outer and inner hearls of that muscle, to anastomose with the tricipital hraned of the posterior circumflex artery. The importane of this anastomosis in carrying on the rollateral rinculation after ligature of the third part of the axillary artery below the ciremullex. or the brachial alove the profumla. has already heen mentioned (page .i2(i).

(b) The cutaneous branch, which rums with the extemal rutanenus hanch of the museulo-spiral nerve to supply the skin of the outer side of the arne.

(c) The articular branch, which is often latere than the (ontinuert trunk of the superior profunda itself, is given off from the artery just hefore it prerforates the

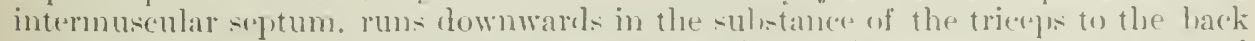

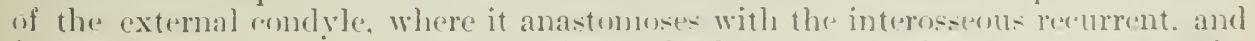
forms an arterial areh by anastomosing with the anatomotica magma across the 
back of the lower end of the humerus immerliately alwow the olectanon fossia. From this arch or rete snall twigs enter and supply the elbow-joint.

(d) I nutrient artery is sometimes given to the upper end of the humerus.

(e) Muscular branches to the triceps.

Chief variations. - The superior profunda may arise (a) from the axillary artery in cummon with one or more branehes of that vessel; or (b) as a common trunk with the inferior profunda. (c) It may give off the posterior circumflex, which then runs upwards behind the teres major to reach the batek of the shunlder.

\section{(2) The Inferior Proflyda Artery}

The inferior profunda arises from the imner sicle of the brachial, usually ahout the level of the insertion of the coraco-brachialis, at times as a common trunk with the superior profunda. It passes with the ulnar nerve olliquely downwads and inwards through the internal intermuscular septum, and then along the inner hearl of the triceps to the back of the internal condyle where, under cover of the deep fiscia and the origin of the flexor carpi ulnaris from the olecranon and internal condyle, it anastomoses with the posterior ulnar recurrent and anastomotica magna arteries. It frequently supplies the nutrient artery to the humerus. It gives branches to the tricejs, to the elbow-joint, and a branch which passes in front of the internal condyle to anastomose with the anterior uhar recurrent.

Chief variations.-(1) The inferior profunda may arise $(a)$ with the superior profunda ; (b) from a trunk common to several other branches of the axillary and brachial arteries. (2) It may be absent, its place being taken by the anastomotica magna.

\section{(3) The An.htomotica M.agna Artery}

The anastomotica magna arises from the inner side of the brachial, about two inches above its bifurcation into the radial and ulnar arteries, and, rumning downwards and inwards across the brachialis anticus, divides into two hranehes, a posterior and an anterior. The posterior pierces the internal intermuscular septum. wint:romel the internal contyloid ridge of the limerus, and pierces the triceps. betwen which and the hone it anastomoses with the articular branch of the superior yrofuncla artery, and to a lesser extent with the interosseous recurrent, forming an arterial arch or rete mund the upper border of the olecramon fossa. The anterior hranch passes downwards and inwards between the brachialis anticus and pronator teres, and anastomoses in front of the internal condyle, but beneath the pronator teres, with the anterior ulnar recurrent. From this branch a small ressel pasies lown behind the internal condyle to anastomose with the posterior ulnar recurrent and inferior profunda arteries.

Chief variations.-(a) The anastomotica magna may take the place of the inferior profunda. (b) It may be very small, the inferior profunda taking its place.

\section{(4) Tire Nutrient Arter of tie Humerus}

The nutrient artery of the humerus comes off from the brachial alout the level of the insertion of the coraco-brachialis, or from the inferior profunda, or from one of the muscular branches. It passes obliguely downwark through the nutrient formusen, and on entering the medullary canal of the humerus divides into an ascenking and a descending branch, of which the latter is the larger.

\section{(5) The Muscular Branihes of the Brichial.}

The muscular branches are irregular in their number, origin, and distribution. They vary from about five to eight, usually eome off from the outer part of the artery, and are distributed to the cormeo-brachialis, biceps, and brachialis anticus muscles. The nutrient artery of the humerus frequently arises from the uppermost nulsecular branch. 


\section{TIIE ULNAR ARTERY}

The ulnar artery, the larere of the two terminal branches of the brachial, begins opposite the lower border of the hear of the radius in the middle line of the forearm. Thence through the upper half of the forearm it rums in a slight curre, with its convexity inwards, deeply beneath the pronator teres and superficial flexor museles, and, having reached the unar side of the limb ahout midway between the elbow and the wrist, it passes directly downwards, being merely overlapped by the flexor carpi ulnaris. Crossing the annular liganent immediately to the ractial side of the pisiform bone, it enters the palm, where it divides into two branches, which enter respectively into the formation of the superficial and deep palmar arches. The artery is accompanied by two veins, which anastomose with each other by frequent eross branches, and nsually terminate in the hrachial renae comites; or sometimes the inner vena comes ends in the inner brachial vein, the outer vena comes in the median profuncla rein. The ulnar nerve is at first some distance from the artery, but approaches the vessel at the junction of its upper and midcle thirds, and then lies close to its immer or ulnar side. The comrer of the artery in the lower two-thirds of the forearm is indicated by a line drawn from the front of the internal condrle to the radial side of the pisiform bone; and in the upper third of the forearm by a line drawn in a gentle curve with its convexity inwards from an inch below the centre of the bend of the elbow to a point in the former line at the jumetion of its upper with its middle third. The artery throughout its course is best reached through the innemost intemuscular septum, i.e. the interval hetween the flexor carpi ulnaris and the flexor sublimis digitorum.

The relations of the artery will be given in detail-as it lies in the forearm, at the wrist, and in the palm of the hand.

\section{Relation of the Ithar Artery in the Forearm}

In front.- In the upper half of the forearm the nlnar artery is deeply vlaced beneath the pronator teres, the flexor carpi radialis, the palmaris longus, and the Hexor sublinis digitormm. In the lower half it is comparatively sunerficial, being merely overlapped above by the tendon of the Hexor earpi uharis, whilst the last inch or so of the vessel is only covered as a rule by the skin and superficial and deep fitscia. As the artery lies beneath the pronator teres. it is crosicel from within ontwarks by the median nerve, the dee head of origin of the musche usually separating the nerve from the artery. The lower part of the artery is crossed by the palunar cutaneous branch of the uhnar nerve.

Behind.-For ahout an inch of its course the artery lies upon the brachialis anticus; but thence, as far as the anterion annular ligament of the wrist, upon the flexor profundus digitorum, which separates it above from the interesseous menshrane and bone, and at the wrist from the pronator quadratus. The artery is bound down to the Hexor profundus digitorm by lrands of fisciat.

To the outer side in the lower two-thirds of its course is the thexor suldimis digitorum.

To the inner side in the lower two-thirds is the flexor arpoi unaris, the guide to the vessel. The ulnar nerve, as it enters the foream from hehind the immer conclyle, is at first some distanee from the artery, heing separater from it in it: upper third hy the flexne suhlimis sligitormm, but in its lower two-thirels is in close contact with the ressel and on its uhar side.

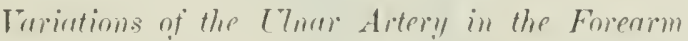

The principal variations of the ulnar artery in the forearm are: (A) It may arise from the brachial atowe the usual puint of division or from the axillawy in which ease it istally runs over

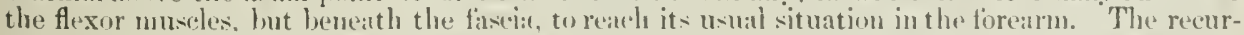
rent arteries and the commun interossens are then watly derived from the trunk veson from 


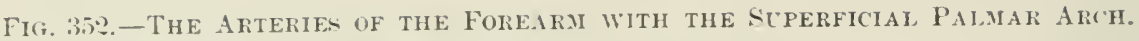

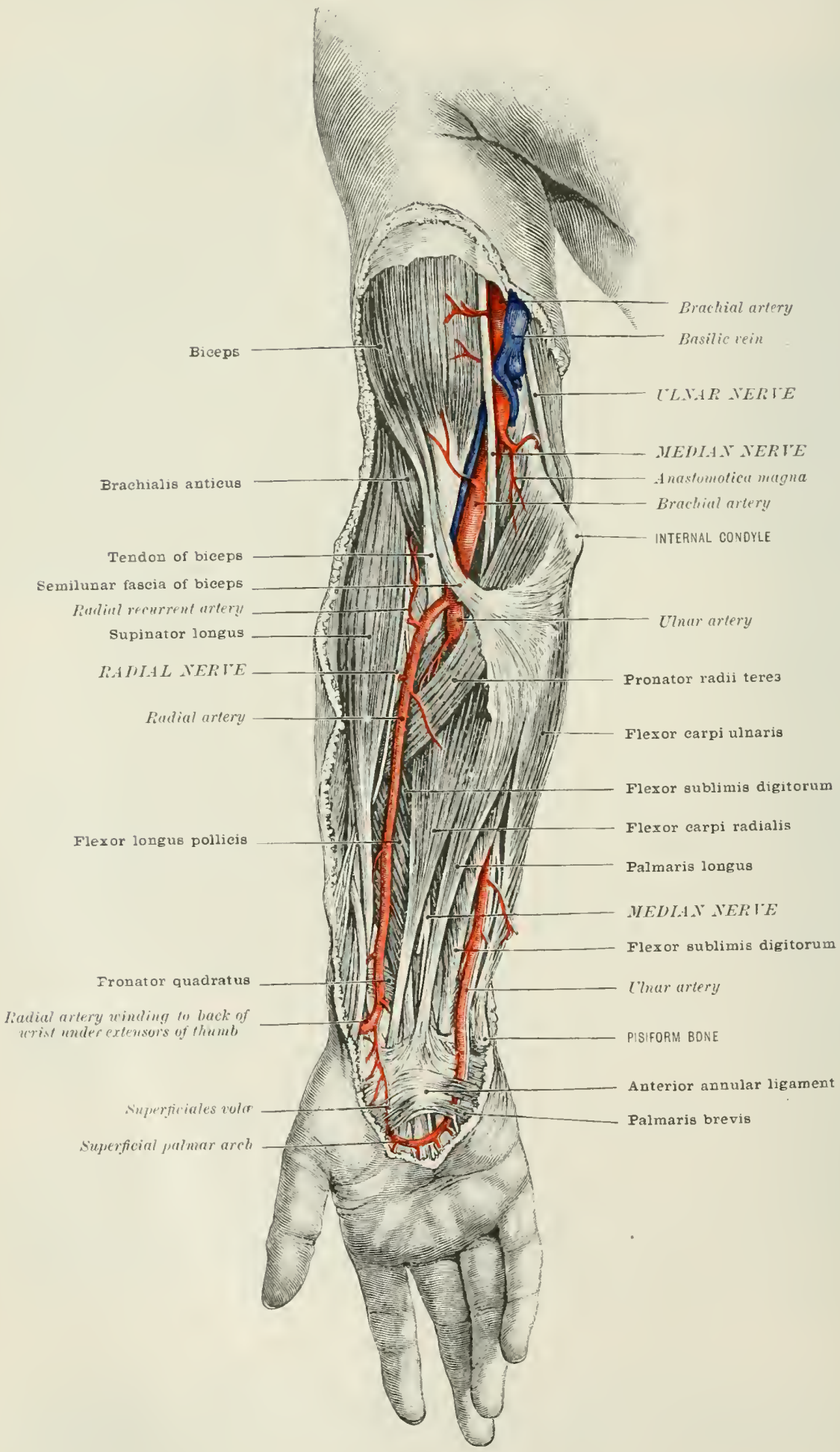


which the uhnar is given off. At times it rums beneath the muscles, or merely beneath the skin. (B) It may in some casess of high division of the brachial run beneath the fascia throughout it. whole extent in the forearm. (C) In sume cases of normal origin from the brachial it takes a superficial course in the forearm, being merely eovered by the faseia, the recurrent branches aml the common interosseous then arising from the radial.

The branches of the ulnar artery in the forearm are:-1. The anterior ulnar recurrent. 2. The posterior ulnar recurrent. 3. The interosseous or common interosseous: (a) anterior interosseons-(i) arteria comes nervi mediani, (ii) muscular. (iii) medullary, (iv) anterior communicating; (b) posterior interosstous-(i) interosseous recurrent. (ii) muscular, (iii) articular. 4. Muscular. .). Nutrient. 6. Posterior ulnar carpal. -. Anterior ulnar carpal.

1. The anterior ulnar recurrent is a small branch which leaves the inner sille of the ulnar artery soon after its origin, and, rumning upwards and inwards between the outer edge of the pronator teres and the brachialis anticus. anastomoses in front of the internal condyle with the anastomotica magna and a branch of the inferior profunda artery. "It supplies branches to the muscles between which it runs.

2. The posterior ulnar recurrent, larger than the anterior ulnar recurrent. comes off from the inner side of the ulnar artery, either a little below the latter branch, or else as a common trunk with it, and, passing inwards betreen the flexor sublimis and flexor profundus digitorum, turns upwards to the back of the internal condyle, where it lies with the ulnar nerve between the two heards of origin of the flexor carpi ulnaris. It supplies the contiguous muscles-the flexor carpi ulnaris. the palmaris longus, and the Hexor sublimis and profundus digitorum-the elbowjoint and the ulnar nerve, and anastomoses with the inferior profunda. with the amastomotica magna, and with the interosseons recurrent, forming the so-called rete olecrani.

3. The interosseous or common interosseous artery, is a short thick trunk half an inch or so in length, which comes off from the outer and back part of the ulnar artery about an inch from its orion, and just before that artery is erossed by the median nerve. It passes backwards and downwards between the Hexor longus: pollieis and the flexor profundus digitorum, towards the triangular interval hounded by the upper border of the interosseous membrane, the oblique ligament. and the outer border of the ulna. where it divides into the anterior and posterior interosseous arteries.

(a) The anterior interosseous artery, smaller than the posterior, but apparently the direct continuation of the common trunk, courses downwards in front of the interosseous membrane, upon which it lies under cover of the overlapping edges of the flexor profundus digitorm and Hexor longus pollicis, to the upper border of the pronator "fuadratus, where it terminates in two branches. an anterior terminal and a posterior terminal.

The anterior interosscous artery is accompanied by two reins and by the deep branch of the median nerve which lies to its radial side. The artery is hound down to the interuscons memlirane by aponeurotic fibres.

The branches of the anterior interosseous artery are:-(1) The arteria comes nervi mediani-or the median artery as it is sometimes shortly called-is a long slenrler vessel, which arises from the anterior interosseous immediately after the latter is given off from the common trunk. It prasses forwards between the Hexor profundus digitorm and the flexor longus pollicis to the median nerve. with which it descends beneath the ammlar ligament into the palm, and when of large size sometimes enters into the formation of the superficial palmar areh. It times: the artery arises from the common internseous before its division. (ii) Muscular branches supply the flexor longus pollicis, flexor profundus digitorum, and pronator quadratus, and the extrisor muscles of the thumb, which they reach liy passing backwards through the interossous nembrane. (iii) This nutrient arteries of the radius and ulna are usubly derived from this vessel. (iv) The anterior terminal and smaller division of the anterior interossous artery. sommtimes called the anterior communicating. passes either in fromt of or lrehind the pronator quadratus. liut in either case in front of the interessersts membrane. and anastonoses with the anterior carpal hranches of the radial and ulnar arteries, and 
with the recurrent hranches from the deep palmar arch, forming the so-called anterior carpal rete. (v) The posterior terminal and larger division pierces the interossous membrane, and continues its eourse downards behind the interastens nembrane, under cover of the extensor muscles, to the back of the wrist, where it ends by anastomosing with the posterior carpal branches of the radial and

Fig. 353.-The Fack of the Left Foreari, with the Posterlok Ixterosseot's Artery ANI BRANCHES OF THE RADIA, AT TIE BACK OF TIE: WRIST.

(From a dissection in the Hunterian Museum.)

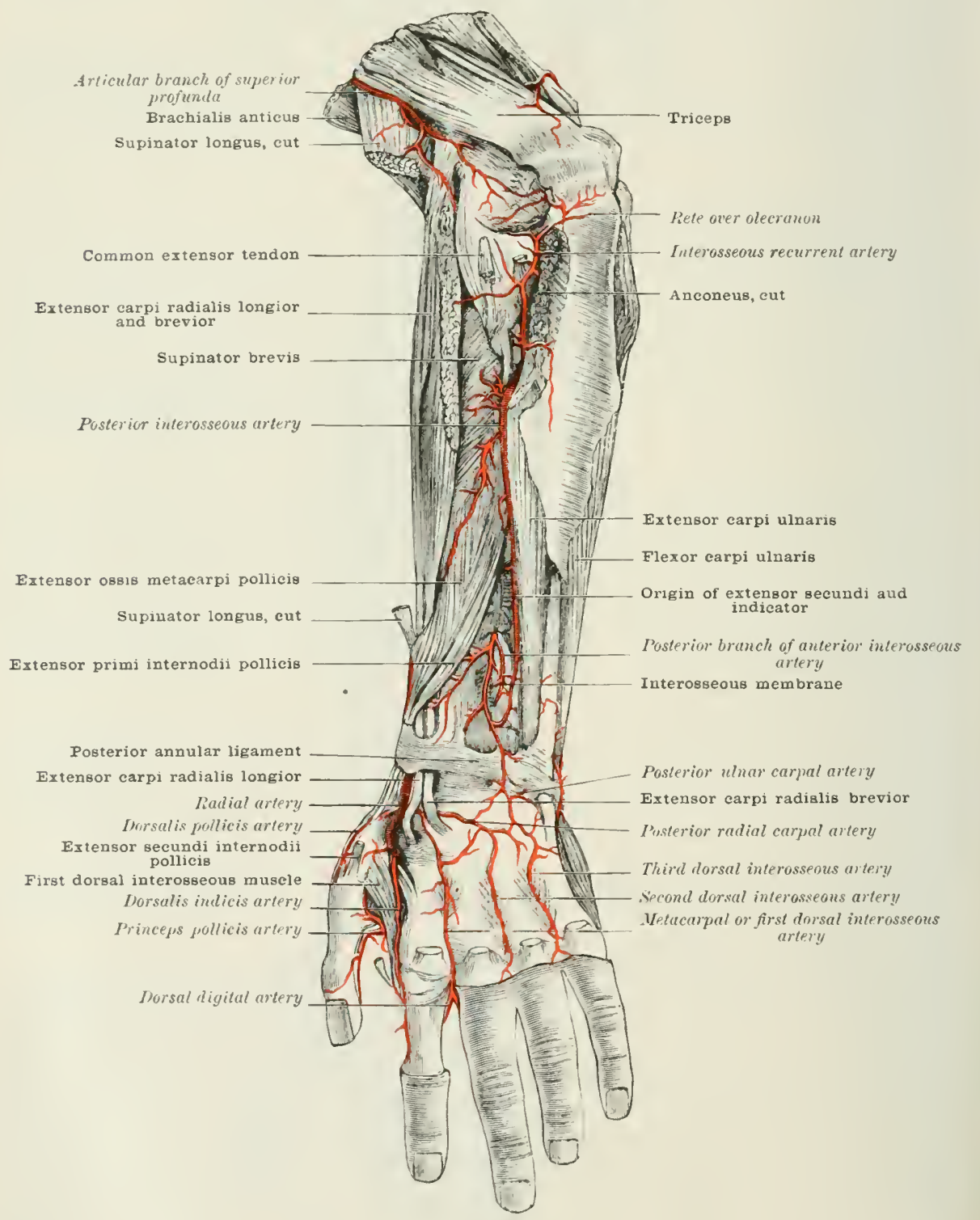

ulnar arteries, forming the so-ealled posterior carpal rete. This branch andstomoses, as som as it pierces the interosseous nembrane, with the posterior interosscous artery.

(b) The posterior interosseous artery, the larger division of the common interesseous, tums backwards through the triangular interval bounded by the 
interosseous membrane helow, the ublique liganent alwe, and the uha internally, and, emerging at the back of the forearm botween the extensor oscis metacarif polliars and the suphinater hrevis, muler cover of the superfiedial extensons of the forearm, descends hetween the superficial and the dere muscles, corsing in this (a) me the extensor ossis metarpi pollicis, the extensor primi internodii pollicis, the extensor secundi internorlii prollicis, and the inclieator (fig. 353). It anastumoses at the lower border of this muscle with the anterior interosseous, or with the fusterior branch of the anterior interosseous which here, as alove describer, has perforated the interosseons memlirane. It is separated from the nerve of the same name at first by the ratius and supinator brevis and on the back of the forearn hy the extrnsores seemeli internorlii pollicis and indieis.

It gives off the following branches:-(i) The interosseous recurrent, or posterior interosseous recurrent (fig. 358), arises from the posterior interossents as the latter emerges from leneath the supinator brevis. It runs upwards betwen the anconeus and supinator brevis, usually under cover of the former, to the interval leetween the external condyle and the olecranon, where it anastomoses with the sljerior profuncla, anastomotica magna, radial recurrent, and posterior uhar recurrent arteries, and gives inanches to the retiform plexus over the olecramon-the rete olecrani. (ii) Muscular branches are griven off to the superficial :mit lecp extensor muscles. (iii) Articular branches enter the back of the wrist-joint.

4. The muscular branches of the ulnar artery supuly the contiguous muscles and are variable in number, origin, and distribution.

5 . The nutrient artery of the ulna may be given off from the main trunk of the ulnar artery, or from one of its nuscular branches, or from the anterior inter(1)

6. The posterior ulnar carpal comes off from the uhar artery a little ahove the anterior annular ligament, and, winding inwards round the end of the uma (1) the intermal lateral ligament of the wrist, beneath the flexor carpi ulnaris. ramifies on the hack of the carpus beneath the extensor tendons. It forms hy its anastomosis with the posterior raclial carpal and with the posterior luanch of the anterior interossous and with the posterior interosseous arteries, a plexus or rete, the so-called posterior carpal arch. The hranches griven off from this plexus or arch are described with the posterior carpal banch of the radial artery (1)age iti).

7. The anterior ulnar carpal is a small branch given off from the uhar artery "pposite the carpus. It passes heneath the flexor profundus digitorum to anastomose with the anterior ractial carpal, with terminal twigs of the anterior branch of the anterior interossons, and with recurrent branches from the deep palmar arch, forming an anastomotic areh across the front of the carpus-the so-called anterior carpal arch wr rete.

\section{Relations of the t'lisir Artery at the Wrist}

The ulnar artery at the wrist may he said to extend from the upper to the lower border of the anterior ammular ligament. It here lics immerliately to the ractial silte of the pisiform bone, and to the uhner side of the hook of the unciform, the two bones forming for the resel a protecting chamel, which is further comverted into a short eanal by the expansom of the flexor carpi ulnaris passing from the pisiform to the hook of the unriform. The uhar norve in this situation is immeliately to the nlmar side of the artery.

Relations.- In front it has. in addition to the expansion alove mentioned. the skin and superficial fascia; below, it rests om the ammlar ligament; internally are the ulnar nerve and pisiform home: externally, the hook of the uncifirlul.

The unar artery gives off no named branch in this part of its course. 


\section{Relations of the Chane Arteri in the Paly

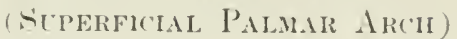

The ulnar artery, on entering the palm, livides into two hanches, the superficial and deep.

The superficial branch (fig. 3ist), the direct continuation of the vessel, anastomoses with the superficial volar, a lranch of the radial, forming what is then known

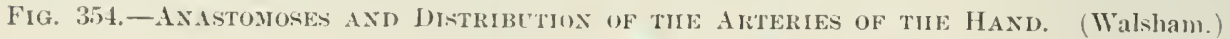

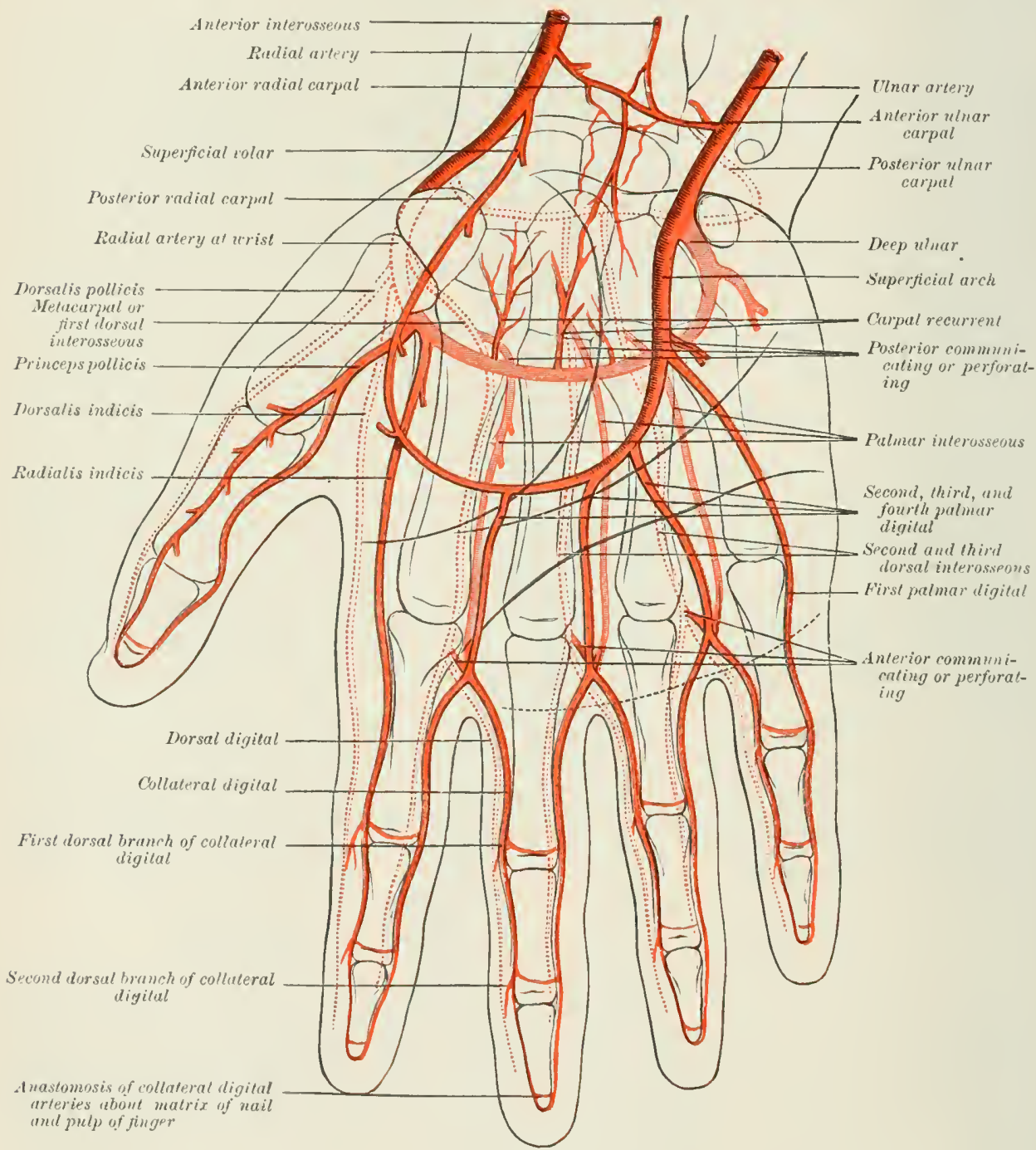

as the superficial palmar arch. After descending a short distanes towarls the reft betwern the fourth and fifth fingers, it turns outwards towards the thumb, forming a enrve with jts (onvexity towards the fingers amd its concavity towarls the muscles of the thumb, and anastomoses opprosite the cleft between the index and misklle fincers, at the junction of the upper with the midlle thind of the palm, with the superficial rolar branch of the radial artery to complete the areh. $A$ line drawn acrosis the palm on a level with the thumb at a right angle to the hand will roughly indieate the situation of the arch. 
Relations.-In front: in addition to the skin and superficial fascia, the reised is crossed successively, from within ontwards, hy the pulnaris brevis, the painsar branch of the uhar nerve, the pahnar fascia, and the palmar baneh of the median nerve.

Behind, it rests upon, from within outwarts, the short muscles of the little finger, the digital hranches of the ulnar nerve, the flexor tendons, and the digital branches of the median nerve.

Fig. 35i. - The Alteries of the Right Foreakm and the Deep Palmar areh.

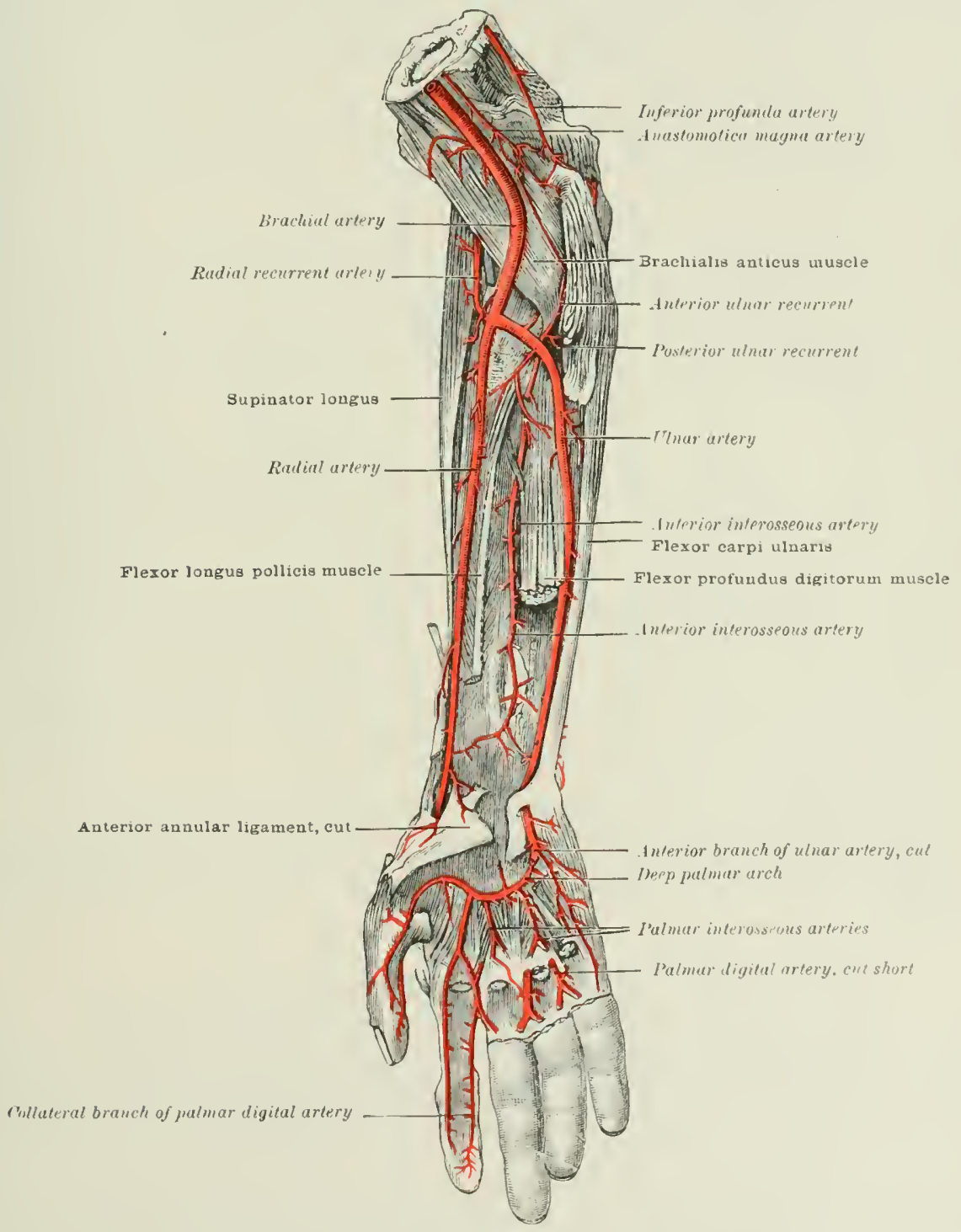

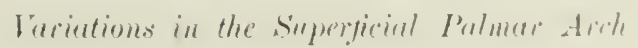

The superficial palmar arch is very subject to variations. (1) It may be formed by the superticial branch of the uluar anastomosine with the radialis indieis, or with the radial in the palun insteat of with the superficial volar branch of the ratdial. (B) The superficial volin may be larger than usual, and take a greater share than the uhar in the finmation of the arch. (C) The arch may be reinforced by a large median artery, or by an enlarged interesentens artery. (I) The arch may be double, both the superticial braneh of the ulnar and the superficial velar dividing 
into two branches which anastomose across the palm. (F) The arteries of the thumb and radial side of the index finger may be given off from the arch. (F) The arch may be ineomplete, the imner digital branches coming off from the ulnar, and the outer from the superficial volar, the radial in the palm or an enlarged median artery. (G) 'The arch may be absent, the lateral digital arteries being then given off from enlarged interosceous arteries from the deep arch, or from enlarged dursal interosseuus arteries.

The branches of the superficial palmar arch are:-(1) The four clicital arteries; (2) the muscular; and (3) the cutaneous.

(1) The digital arteries, nsulally four in number. are given off from the convexity of the superficial arch and, rumning downwards through the pralne suply hoth sides of the little. ring, and middle fingers, and the ulnar side of the index finger. The radial side of the index finger and the thumb are supplied respectively hy the radialis indicis and princeps pollieis, branches of the radial artery. The ligital anteries are named, from within outwards-first, second, third, and fourth. The first digital artery runs downwards and inwards over the muscles on the inner side of the pralm, and thence along the ulnar side of the little finger. It gives branches to the abductor. flexor brevis, and opponens minimi digiti muscles. This branch sometimes comes from the deep branch of the ulnar artery. The second, third, and fourth digital arteries run downwards in the interspace between the little and ring, the ring and middle, and the niddle and index fingers respectively, to within about a quarter of an inch of the clefts letween the fingers, where they divide into two branches (collateral digital) for the supply of the sides of the contiguous fingers. As the digital arteries pass through the palm, they lie hetreen the flexor tendons, on the digital nerves and lumbrical muscles, and beneath the palmar fascia. Just before bifurcating they pass under the superficial transverse ligament, and are joined by the palmar interosseous branches from the deep palmar arch (fig. 354). At this spot they also receive the anterior perforating branches from the clorsal interosseous ressels. On the sides of the fingers the collateral digital arteries lie between the palmar and dorsal digital nerres. They anastomose hy small hranches, forming an arch across the front of the bones on the proximal side of each interphalangeal joint. They supply the flexor tendons and the integument.. and terminate in a plexiform manner beneath the pulp of the finger and around the matrix of the nail. A dorsal digital branch is given off to the back of the fingers about the level of the middle of the first phalanx, and a second but smaller dorsal digital branch about the level of the middle of the second phalanx.

(2) The muscular branches from the superficial arch are very small and suplly the superficial muscles.

(3) The cutaneous branches supply the integuments of the palm.

The deep branch of the ulnar artery, also called the communicating artery, sinks deeply into the palm hetween the abductor and flexor brevis minimi digiti. and joins the radial to form the deep palmar arch. (See The RAdial ArtenY. page 543.)

\section{THE RADLAL ARTERY}

The radial artery-the smaller of the two arteries into which the lirachial divides at the bend of the elbow-appears as the direct continuation of the brachial. It runs downwarts and outwards along the radial side of the forearm as far as the styloid process, then. coiling over the external lateral ligament and outer and back part of the wrist, enters the palm of the liand from hehind between the first and second metacarpal hones, and ends by anastomosing with the deep branch of the uhar to form the deep ralmar arch. Hence the artery is divisible into three parts: that in the forearm, that at the wrist, and that in the palm of the hand. The course of the artery is inclieated by a line drawn from a point one inch below the ("ntre of the elbow to a point situated half an inch internal to the styloid process of the radins.

\section{The Radial Artery ix the Foreary}

In its course through the forearm (fig. 351) the radial artery is found in the outermost intermuscular space, and it is only necessary to divide the skin, super- 
ficial and rleep fascia, to expose the vessel, and in addition in the upper third to separate the supinator longus (humero-radialis) from the pronator ladii teres.

In front, the artery is at first overlapued by the supinator longus. but for the rest of its course it is merely covered by the skin, superficial and deep fascise, hy some eutaneous reins, and by eutaneous branches of the musculo-cutaneous nerve.

Behind, it lies sucessively from aboxe downwards on the tendon of the liceps. the supinator lirevis, from which it is separated by a laver of fat, the insertion of the pronator ralii teres, the raclial origin of the flexor sublimis digitorum, the flexur

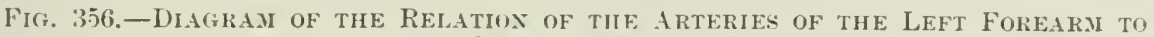
THE BurEs. (Walsham.)

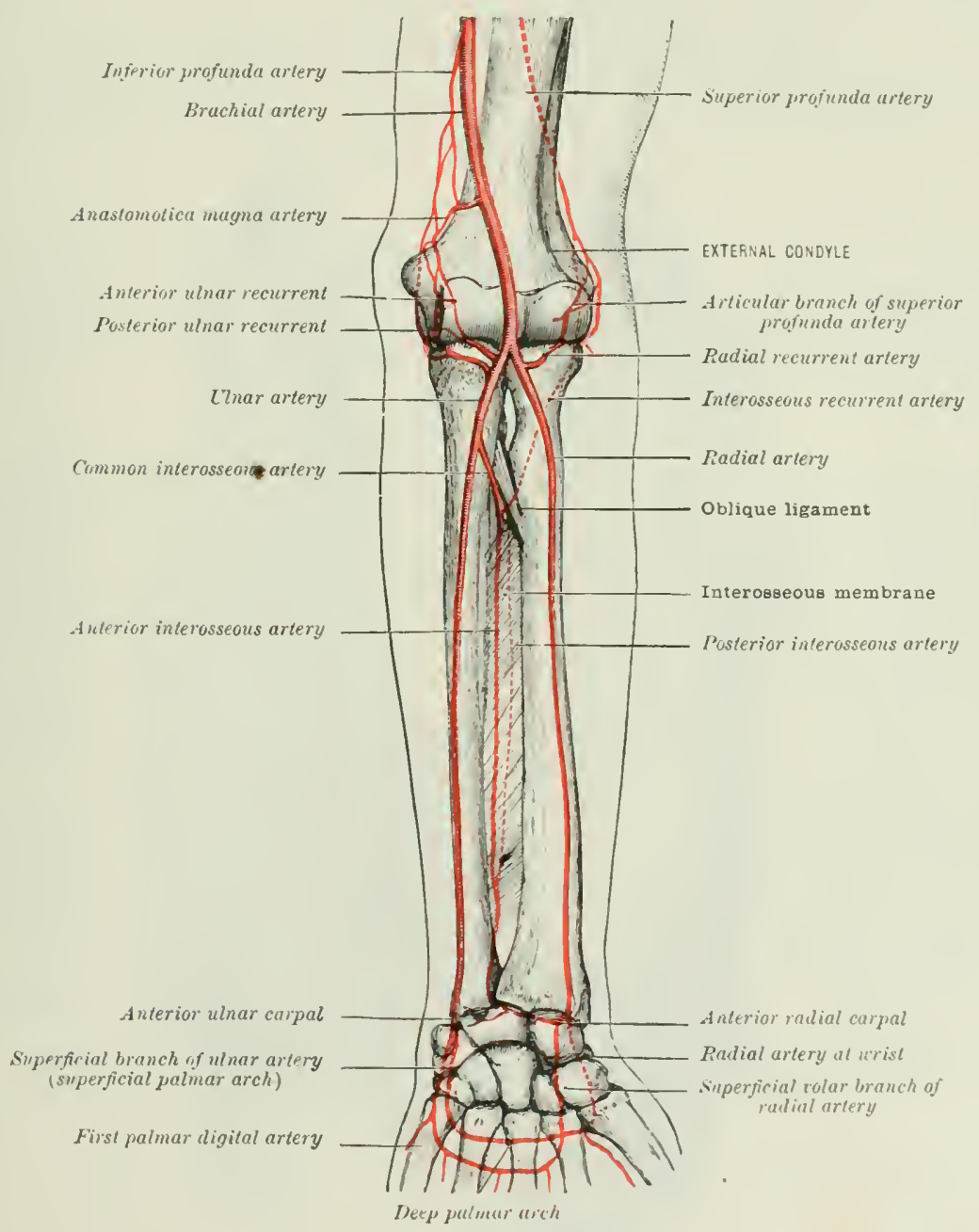

longus pollicis, the pronator quadratus. and the front surface of the lower end of the rarlius. It is in this last situation, where the artery lies upon the bone and can therefore he easily pressed against it, that the pulse is usually folt.

On its outer side it has, throughout the whole of its course, the supinator longus or humero-rarlialis muscle, the guide to the artery in ligature and the external vena comes; in its middle third. the radial nerve as well. In its lower third the radial nerve is to its outer side. but separated from it hy the supinator longus and fascia.

On its inner side, in the upper thirt is the pronator radii teres, in the lower 
thirel the tendon of the flexor carpi radialis, and throughout the whole of its course the internal vena comes.

\section{Variations in the Radial Aitery in the Forearm}

(A) The radial artery may be given off from the brachial higher than usual, or from the axillary artery. (B) It may arise from the brachial lower than the bend of the elbow, but a low division of the brachial is rare. (C) It may run superficial to the fiscia of the forearm. (D) It may" cross over, instead of under, the extensors of the thumb. (E) It may terminate in the foream or be absent, its place in the forearm and hand being then supplied by the ulnar, the anterion interosseous, or an enlarged median artery. (F) It may be joined by a vas aberrans rrom the brachial or axillary artery.

\section{Fig. 35\%.-Tile Bexd of the Eibow, Left Side.}

(From a dissection hy Dr. Alder Smith in the Mreum of 'St. liartholomew's Hospital.)

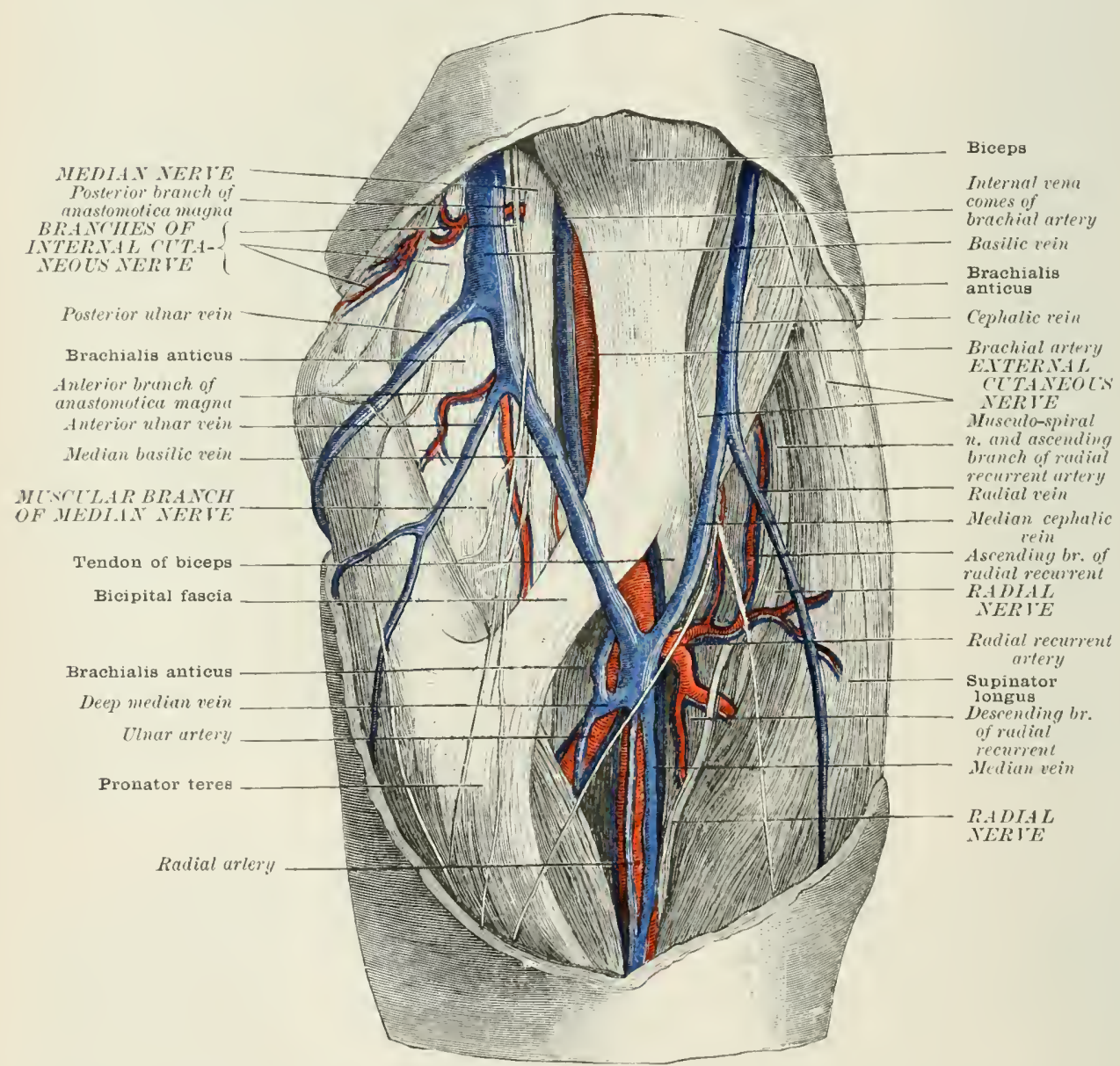

The branches of the radial artery in the forearm are:-(1) The radial recurrent; (2) the muscular; (3) the anterior radial carpal; (4) the sujertielal rolar.

(1) The radial recurrent usually arises from the onter side of the radial just below its origin from the brachial. It at first runs outwards on the supinator frevis, and then divides inte three (hief hranchess (fig. 357). One of these runs tramsversely ontwarls througl the filores of the musento-spiral nerve, or between the radial and gosterior interosseous nerves when the musenlo-spiral divides higher 
than usual, inte the supinator longus and extensor carpi raclialis longior and hrevior, and anastomoses with the introssous recurrent. $\lambda$ second aseends between the brachialis anticus and supinator longus, with the musculo-spiral nerve, and anastonoses with the superior profunda artery. A third desends with the radial nerve under cover of the supinator longus supphying that muscle. The radial reeurrent also gives off hanches to the elhow-joint.

(2) The muscular branches of the radial artery come off irregularly to sulply the contiguous muscles w the outer sicle of the forearm.

(3) The anterior radial carpal arises from the inner side of the radial artery about the level of the lower horder of the pronator quadratus. It crosses the front of the radius beneath the flexor muscles, and andstomoses with the anterior carpal hranch of the ulnar, forming what is sometimes called the anterior carpal arch; or what is more properly speaking, an arterial plexus or rete-the anterior carpal rete. This plexus is joined above hy small twigs from the anterior interosseons artery, and helow by recurrent brancles from the deep palmar areh. It supplies Lranches to the lowere end of the radius, and to the wrist and carpal joints.

(4) The superficial volar leares the radial artery as the latter ressel is alont to turn over the external lateral ligament to the back of the wrist. It coursw forwarls orer the short muscles of the ball of the thumb, and anastomoses with the superficial branch of the ulnar artery to complete the superficial palmar ared. It supplies small branches to the muscles of the hall of the thumb, and at times trminates in these muscles without joining the arch. Ocrasionally it passes bencath the aldrluctor pollicis. This branch is often small and ends in the muscles of the thimil).

\section{The Radial artery at the Wrist}

The radial artery at the wrist winds over the onter side of the carpus, uncler the extensor trindons of the thumb, from a spot a little below and internal to the stroid process of the ladius to the base of the first interossous space. where it sinks between the two heads of the abductor indicis into the paln, to form, by anastomosing with the deep branch of the ulnar artery, the deep palmar arch. A line drawn from half an inch internal to the styloid jrocess to the hase of the first interuseous space, which can be distinctly felt on the back of the hand, will roughly indicate the course of the artery.

Relations.-The artery is covered sucessirely by the extensor ossis metacarpi follicis and extensor prim internodii pollicis, by branches of the radial nerve and superficial radial veins, and, just hefore it sinks letween the two heads of the abductor indicis, by the tendon of the extensor sceundi internodii pollicis. The hranches of the radial nerve to the thumb and index finger cross it. It is at first somewhat deeply placel beneath the first-mentioned extensor muscles of the thmul; but subsecpuently it lies quite superficial, and can be felt pulsating in a little trianrrular depression bounded on rither sirle by the extensor primi and extensorsecundi internorlii pollicis, and above by the lower end of the radius. The antery lies sucecsively on the extemal lateral ligament of the wrist. on the seaphoil, the trapezium, the base of the first metalearpal hone, and on the dorsal ligaments uniting these bones. It has usually with it two companion reins, and a few hranches of the musculo-cutaneous norve.

The branches of the radial artery at the wrist are:-(1) The postrion radial carpal: (2) the metacarpal, or the first dorsal interossons: (3) the dorsalis pullicis.

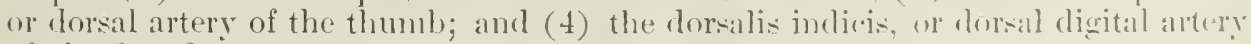
of the first finger.

(1) The posterior radial carpal arises from the raclial as the latter versel passes under the extensor ossis metacarpi pollicis, and runs inwarks heneath the extensor carpi rathalis longior and hrevior, and the extensor sordmeli intermolii pollicis, across the hack of the earpus, to anastomose with the fosterior uhan (a) and with the terminal twigs of the pesterior hrameh of the anterior interesserneartiry. This anastomosis is called the posterior carpal areh. or posterior carpal rete. The two following namerl hranches are given off from this areh on rete:(a) The second and (b) the third dorsal interosseous arteries to the thim and fourth spaces respectively. These vesels run downwals on the dorsal inter- 
osimous muscles as far as the flexure of the fingers, and there divide into two hranches (dorsal digital), which run along the sides of the contiguous fingers on their ctorsal aspect. Near their proximal end they anastomose with the posterior perforating branches of the deep palmar arch. Distally they are connected by anterior perforating branches with the digital arteries of the corresponding spaces.

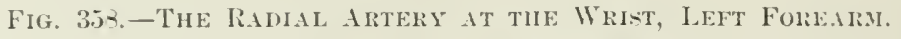

(From a dissection in the Hunterian Museum.)

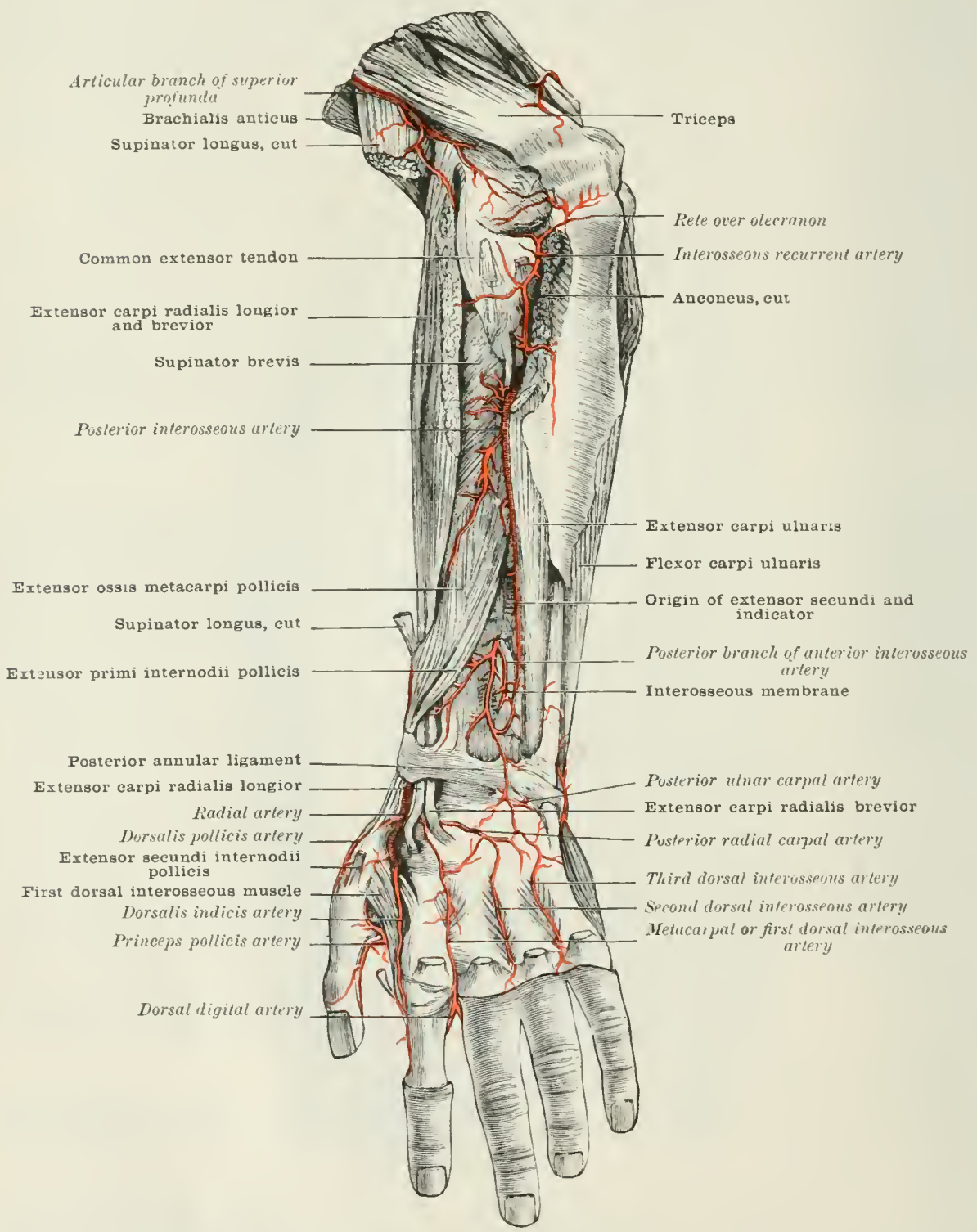

The branches which rm along the backs of the fingers anastomose with the dorwal branches of the colliteral digital arteries derived from the palnar digital vessels (fig. 3.59$)$.

(2) The metacarpal or first dorsal interosseous artery (figs. 3.58, 3.59) arises from the radial artery beneath the extensor scomeli internodii pollicis, and, crossing the second metacarpal bone, jakses downwards on the second dorsal 
interosseous muscle betwern the extmsor tendons to the lerel of the metacirpuphalangeal joint, where it divides into two small branches, like the other dorsal interosseous arteries, for the supply of the sides of the contiguous fingers on their dorsal aspect. At the hase of the second interoseons space it communicates with the posterior perforating branch of the deep arch, which here runs hackwarls between the heads of the second dorsal interosseous muscle, and at the fore part of the space it anastomoses through the anterior perforating branch with the fourth digital artery.

The dorsal digital arteries, the teminations of the metacarpal artery ancl dorsal interossous arteries, extend along the sides of the fingers as far as the first inturphalangeal joint, where they anastomose with the dorsal branches of the collateral digital arteries.

(3) The dorsalis pollicis arises from the radial just before it sinks betweer the two heads of the first dorsal interosseous muscle. It runs downwarls on the uhar side of the extensor secundi internodii pollicis, along the metacarpal bone, and divides into two branches for the supply of the radial and uhar side of the thumb on its dorsal aspect. These branches sometimes come off separately from the radial artery.

(4) The dorsalis indicis arises from the radial just as that artery sinks between the two heads of the first dorsal interosseous muscle, usually below the origin of the clorsalis pollicis, but sonetimes as a common trunk with the latter resel. It runs downwards along the radial side of the metacarpal bone of the inclex finger, and can be traced along the radial side of that finger as far as the first interphalangeal joint, where it anastomoses with the dorsal branch of the raclialis indicis.

\section{The Radil Artery in the Palil (the Deep Palmar Aroh)}

The radial artery enters the palm between the first and second metacarpal bones at the base of the first interosseous space, by passing between the two lieads of the first dorsal interosseous muscle. It then runs inwards between the adductor pollicis and inner head of the Hexor brevis pollicis, and continuing its course in a slight curve with the convexity forwarls, across the base of the metacarpal bones ancl interosseous muscles, it anastomoses with the deep branch of the ulnar, forming the deep palmar arch. The arch thus formed may be said to extend from the fir:t interosseous space to the base of the metacarpal hone of the little finger, and is a finger's breadth nearer the wrist than the superficial arch. It is coremel hy the superficial and deep Hexor tendons, by the inner hearl of the Hexor brevis pollicis, and by part of the flexor brevis minimi diciti. It is accompanied by the deep lianch of the ulnar nerve, and two small venæ comites.

\section{luriations in the Deep Palmar Arch}

(A) The deep palmar arch may be larger than usual, and its interosseous branches supply the place of one or more of the digital arteries by dividing at the cleft of the fingers into collateral digital branches. (B) It may be reinforced by enlarget posterior perforating branches from the radial and its branches on the back of the hand, or ly a latge anterior interosseuns. (C) The radial may join the deep areh by passing through the sceoml instead of the first interosseous smace. (D) The princeps pollicis and radialis indicis may come off from the superficial arch or from the -uperfieial volar, or from a separate branch of the radial which passes through the first interosseous -jace.

The branches of the deep palmar arch are:-(1) The princeps pollicis; ( 2 ) the radialis indicis; (3) the palmar interossens (three in number); (4) the recurrent carpal; (5) the posterior perforating. The first two are usually spoken of as coming off from the radial artery in the palm: the last three from the des pralman arch.

(1) The princeps pollicis arises from the radial artery as it cuters the falm, between the two heads of the aluluctor indiris. It passes downards betwen the adductor transversus pollicis and abluctor indicis, parallel to the metacarpal bone, and hetreen the two portions of the flexor brevis pollicis under corer of the flexing 
loneru- pollicis. Opposite the metacarpo-phalangeal joint it usually divides into two branches, one of which is distributed to each side of the thumb on its palnuar aspect. These ressels anastomose with each other at the end of the thumb, like the other collateral digital arteries.

(2) The radialis indicis comes off from the radial artery a little lower than the former vesset. or as a common trunk with it, and passes forwards between the abductor indicis and adductor transversus pollicis, parallel to the radial side of the

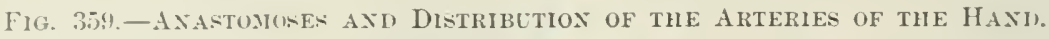

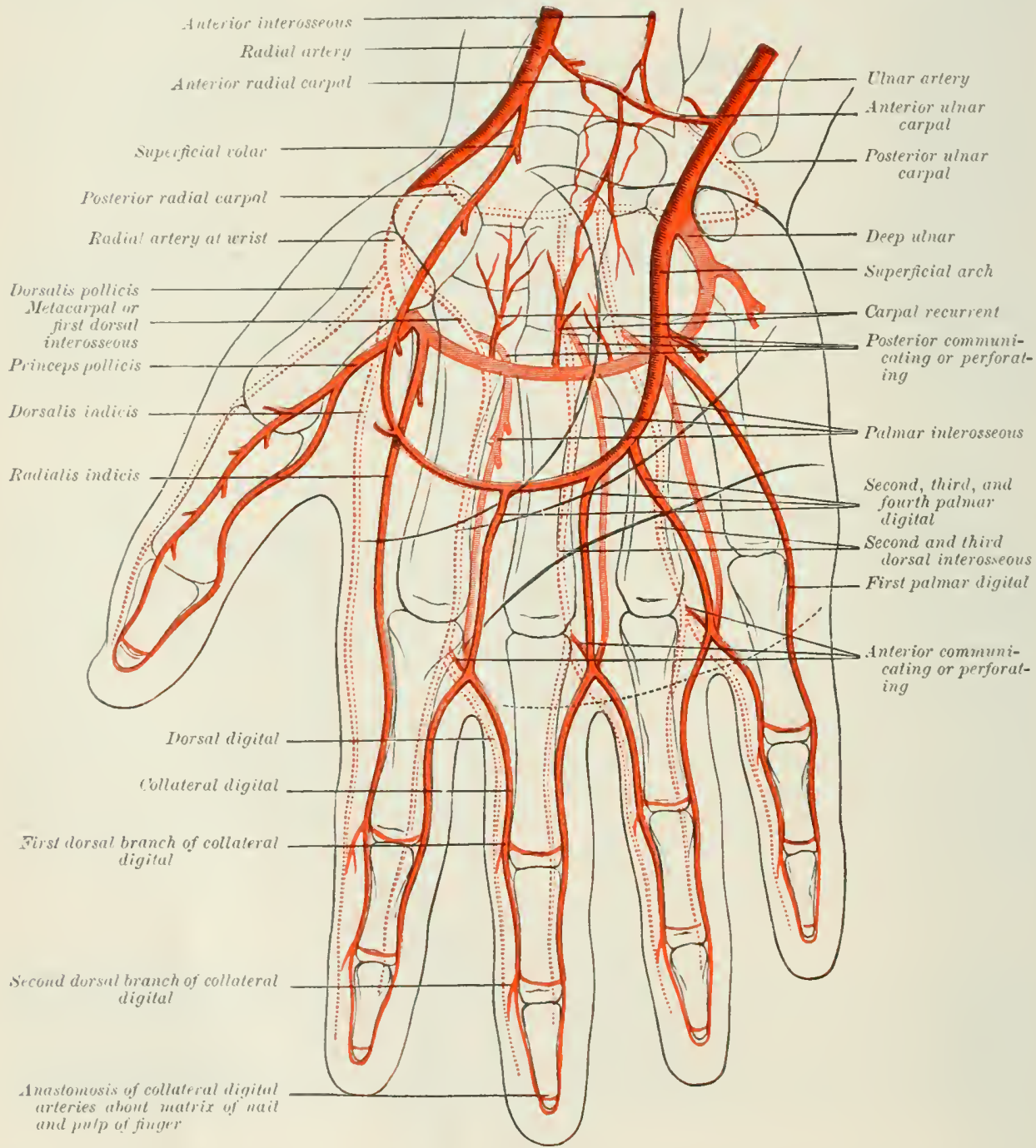

second metacarpal bone. After emerging from beneath the adduetor transerersus pollicis, it continues its comrse along the ratial sicle of the inclex finger, on its Jahmar aspect, as for as the tip, anastomosing in this course with the collateral digital artery on the opuosite side of the finger in a way similar to that of the other (o)liateral digital arteries. It frepuently communicates, at the lower horder of the achluctor pollicis, with the superficial pahmar areh and princeps pollicis. It gives uff a dorsal branch, which anastomoses with the torsalis inclicis.

(3) The palmar interosseous arteries, three in number, come off from the 
convexity of the deep arch, and, coursing downwarks in the centre of the second, third, and fourth interoseous spaces on the internseous muscles. terminate near the clefts of the fingers ly anastomosing with the digital arteries form the superficial arch. These vessels supply the interosseous muscles and the bones, and the second, thirel, and fourth lumbricales.

(4) The recurrent branches come off from the concavity of the arch, and consist of two or three small vessels which run upwards towards the wrist, and anastomose above with the anterior lianch of the anterior interoseous. and laterally with the anterior radial and ulnar carpal arteries, forming the so-called anterior carpal rete (fig. 359 ).

(5) The posterior, communicating, or perforating, also usually three in number, pass from the arch directly through the second, third, and fourth interosseous spaces between the two heads of the corresponding dorsal interosseous muscle, and join the proxinal ends of the metacarpal artery (first dorsal interosseons), and the second and third dorsal interosseous arteries respectively.

\section{THE DESCENDING, OR THORACIC AORTA}

The thoracic aorta (fig. 360 ) extends from the termination of the aortic arch at the low"er horder of the body of the fifth thoracic vertebra to the lower border of the body of the twelfth thoracic rertebra, where it passes through the aortic opening in the diaphragm, and is thence continued under the name of the abdominal anrta. It is at first situated a little to the left of the rertebral column, but as it descends approaches the front of the column, at the same time following the backward curve of the spine, and at its passage through the diaphragm is almost in the middle line. It lies in the posterior medinstinum, having the osophagus at first a little to the right of it, then in front of it, and just above the tenth thoracic vertehra, where this tube pierces the diaphragm, a little to its left side.

Relations. - In front it is crossed from above downwards br the root of the left lung, hy the asophagus, which separates it from the pericardium and heart, and by the cliaphragn.

Behind, it lies upon the lower seren thoracic vertebræ, and is crossed obliquely opposite the serenth or eighth thoracie vertebra by the rena azygos minor, and oplusite the fifth or sixth vertebra by the third azyos vein, or by one or more of the left interestal veins.

On the right side it has, alove. the nsophagus, and lower clown the right pleura and lung. The vena azyos nuajor and thoracic duct also lie to the right, liut on a somewhat postrior pliane.

(n) the left side it has the left lung and plenra above. and the asophagus lodow. The rena azygos minor and the third azygos rein are also to the left, but on a posterior plane.

\section{Brixches of the THor.cic Aort.}

The branches of the thoracic aorta may be dividerl into the visceral and the parietal. The visceral are:-(1) The pericarliac; (2) the hronchial: ancl (3) the resophageal. The parietal are:-(1) The interostal; (2) the subcostal; (3) the diaphragmatic; and ( 4 ) the arteria aberrans.

\section{Iت̈sseren! Biminchess}

(1) The pericardiac-two or three small hranches. irregular in their orimin, course, and rlistribution- pass to the posterior surface of the perieardium to supply that structure, and anastomose with the other periearliac liranches. They give small twigs to the posturior mediastinal glames.

(2) The bronchial arteries (fig. 324) supply the bronchi and the lung substance. They vary comsirlerably in their origin. course, and distribution; they are usually three in number-one on the right sile. and two on the left.

(a) The right bronchial generally arises either from the first right aortic inter35 
costal, or else as a common trunk with the left upper bronchial from the front of the thoracic aorta just below the level of the bifurcation of the trachea. It passes outwards on the back of the right bronchus, and is distributed to the bronchi and lung substance. (b) The left upper bronchial arises from the front of the thoracic aorta just below the bifurcation of the trachea, or as a common trunk with

Fig. 360,-The Arch of the Aorta, the Tiloracic Aorta, AxD the Abdomixal Aorta, WITH THE SUPERIOR AND INFERIOR VENA CAYA AXD THE INNOMNATE AXD AZYgos VeINS.

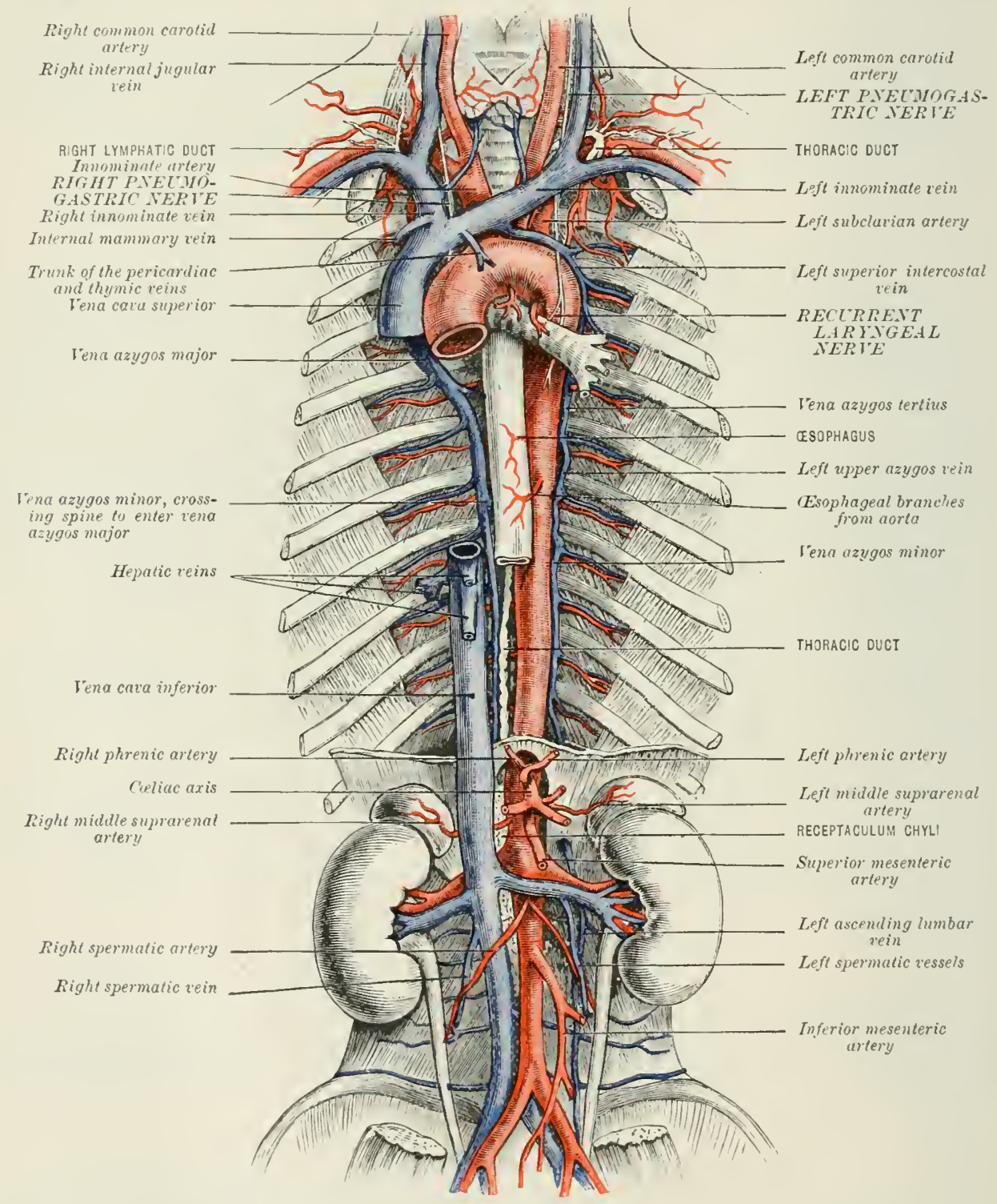

the right bronchial. (c) The left lower bronchial arises from the front of the thoracic aorta just below the level of the left bronchus. Like the corresponding artery on the right side, the left hronchial arteries run outwards on the left bronchus, and, after dividing and sublividing on the hack of the hronchi, supply the bronchi themselves and the lung sulstance. Small twigs are given off from the bronchial arteries to the bronchial glands and to the oesophagus. 
Fig. 361.- Schase of the Thoracic Aorta. (Walsham.)

1. At level of fifth thoracic vertebra

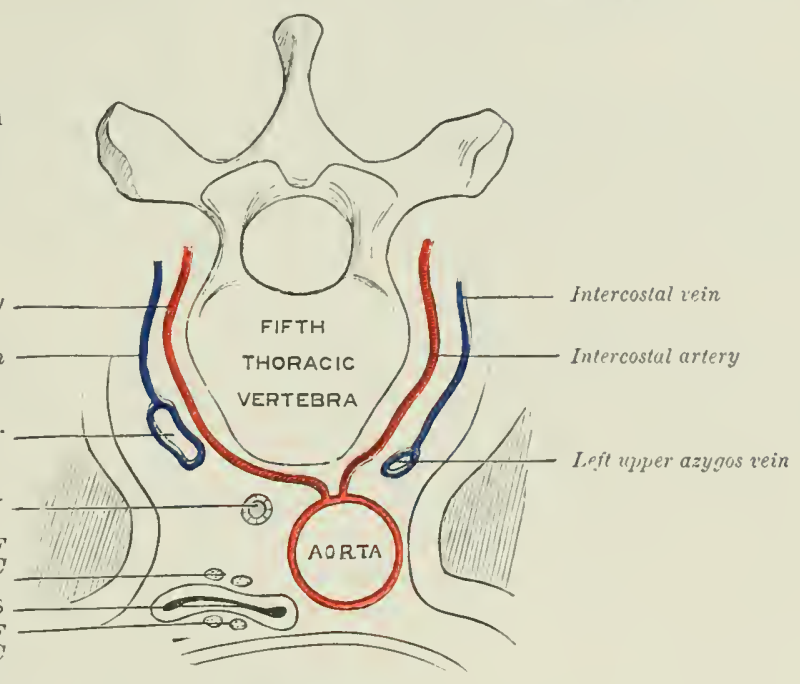

QESOPHAGEAL PLETLSOF EEFT PNEL IOFASTRIC NERIE

2. At level of seventh thoracic vertebra.

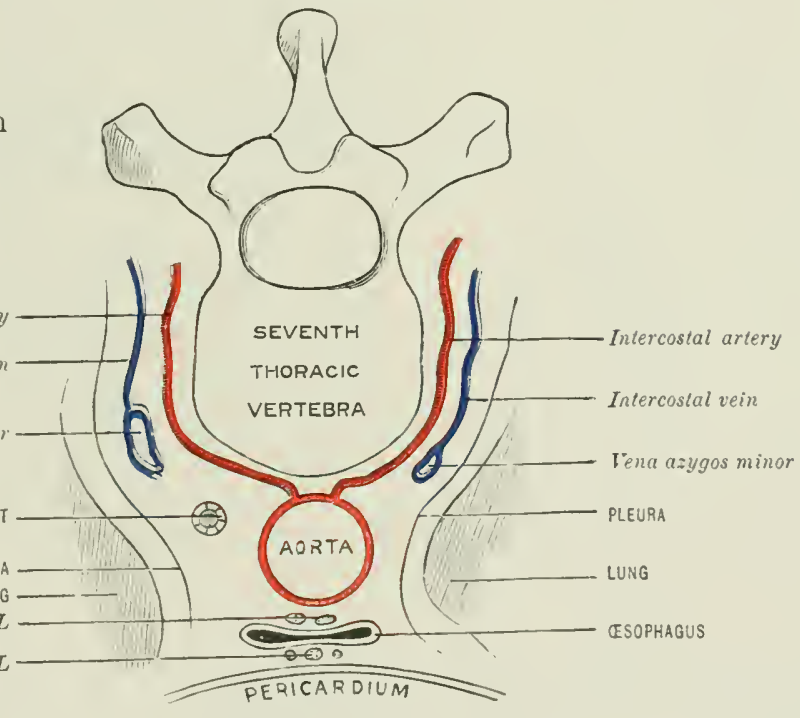

3. At level of ninth thoracic vertebra.

RIGHT ESOPHA
PLEITS LEFT WEOPH.A GE.1L PLEIT'S

THORACIC DUCT PLEUR

LUNG

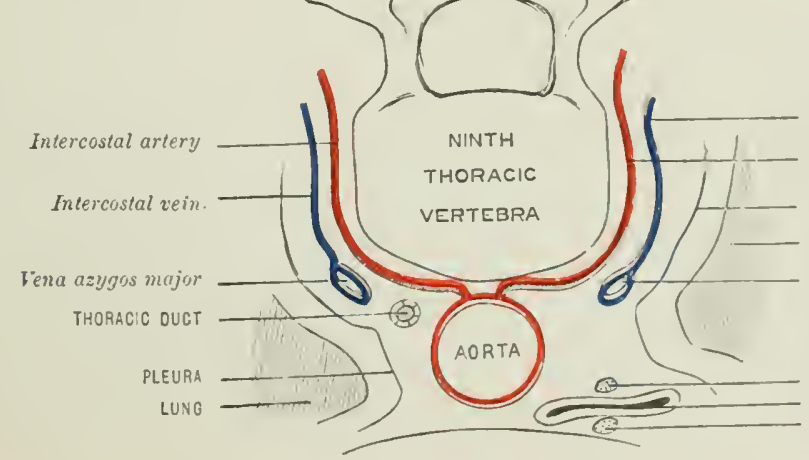

Intercostal vein Intercostul artery PLEURA 
(3) The œsophageal arteries, four or sometimes five in number, arise at intervals from the front of the thermeic aorta, the first coming off just below the left lower bronchial. They usually increase in size from above downwards, the upper coming oft more towarls the right side of the aorta, the lower more towards the left side. Ther pass forwards to the osophagus, supplying that tube and anastomosing with each other and with the descending esophageal branches of the inferior throid abore, and with the ascending asophageal hranches of the phrenic and gastric arteries below, this forming a chain of anastomoses along the whole length of the tube.

\section{B. Parietal Branches}

(1) The aortic intercostal arteries, usually ten in number on each side, supply the lower interostal spaces, the two upper spaces being supplied hy the superior intercostal branch of the subclarian artery. The tenth artery rums along the lower horder of the last rih, and would be better called the subcostal artery; it is similar in its distribution to the other intercostals, but is described separately.

The aortic intereostals arise in pairs from the back part of the thoracic aorta, and at once turning, the one to the right, the other to the left, wind backwards over the front and sides of the rertebral bodies to reach the intercostal spaces, which they follow, and anastomose in front with the anterior intercostals given off from the internal mammary and musculo-phrenic arteries respectively. In fortal life these arteries run almost transversely backwards, or even with a slight inclination downmarck, to the intercostal spaces; but after the first year, in conscquence of the disproportionate growth of the aorta and rertebral columm, the upper intercostals have to ascend to reach their respective spaces. For convenience of description the intereostal arteries may be divided into two portions-the vertebral, which lies upon the bodies of the rertebrx; and the intercostal, which lies in the intercostal spaces.

The vertebral portion.-The arteries in their course round the vertebre differ on the two sides of the hody. On the right side the arteries-and especially the upper, in consequence of the aorta lying a little to the left sicle of the spine in the upper part of its course-are longer than the left. They wind over the front and right sile of the rertebre, being crossed hy the thoracic duct and rena azygos niajor, and corered by the right pleura and ling. The upper are also crossed by the resophagus. They give off small branches to the bodies of the rertelore and anterior common ligament. On the left side, as the intercostals wind round the silles of the bodies of the rertebra, the lower are crossed by the vena azy ros minor, the two upper by the left superior intercostal vein, and the two next by the third azygos vein when this is present. They are all covered by the left plema and lime.

The intercostal portion.-In their course through the intercostal spaces the arteries are alike on both sides. They at first cross the intercostal spaces obliquely, in consequence of the downward direction of the rilss, towards the angle of the rib ahove, and thence are continued forward in the subcostal groove, and anastomose with the superior branches of the anterior intereostals from the internal mammary in the upper spaces, and from the musculo-phrenic in the lower spaces. They lic: at first on the external intercostal muscles, being covered in front by the plemra and lung, the endothoracic fascia and the infra-costales muscles. Opposite the heads of the rils they are crossed by the sympathetic nerve. At the angle of the ribs they fass unier corer of the internal interestal muscles, and thence to their temination lie between the two intercostal muscles. Their situation in the midspace as fur as the angle of the rib should be remenbered in performing paracentesis thomeis. To aroid the risk of injuring the ressels, the puncture should not be made further back than the angle of the rils. They are acompaniect by an intercostal nerve and vein, the vein lying above and the nerve below, except in the upper spaces where the artery, having to ascond to reach the space, at first lics below the nerve which passes transrersely outwards. The uppermost artic intereostal artery anastomoses with the superior intercostal from the subclavian, and at times supplies almost entirely the second intercostal space. The arteries to the tonth and derenth spaces on reaching the end of their respective ribs pass between the 
abchminal muscles, and anastomose with the deep argastric artery from the external iliac, and with the lumbar arteries from the abdoninal aorta.

The intercostal arteries give oft the following branches:-

(a) The dorsal branch.-This large branch is given off from the intercostals opposite the guadrilateral space bounded by the transrerse process of the rertebra above, the neck of the rib below, the body of the vertebra internally, and the superior costo-transverse ligament externally. l'assing backwarels towards this space with the dorsal branch of the corresponding intereostal nerve, the dorsal branch divides opposite the interertebral foramen into a spinal and a muscular branch. (i) The spinal branch enters the intervertebral foramen along with the undivided trunk of the intercostal nerve, and subdivides into three branches:-(") an anterior. or preneural. which ramifies on the back of the hody of the rertebra and anastomoses with the corresponding ressels above and below; $(\xi)$ a posterior, or retro-

Fig. 362.-SCHEME of Iñtercostal Artery. (Walsham.)

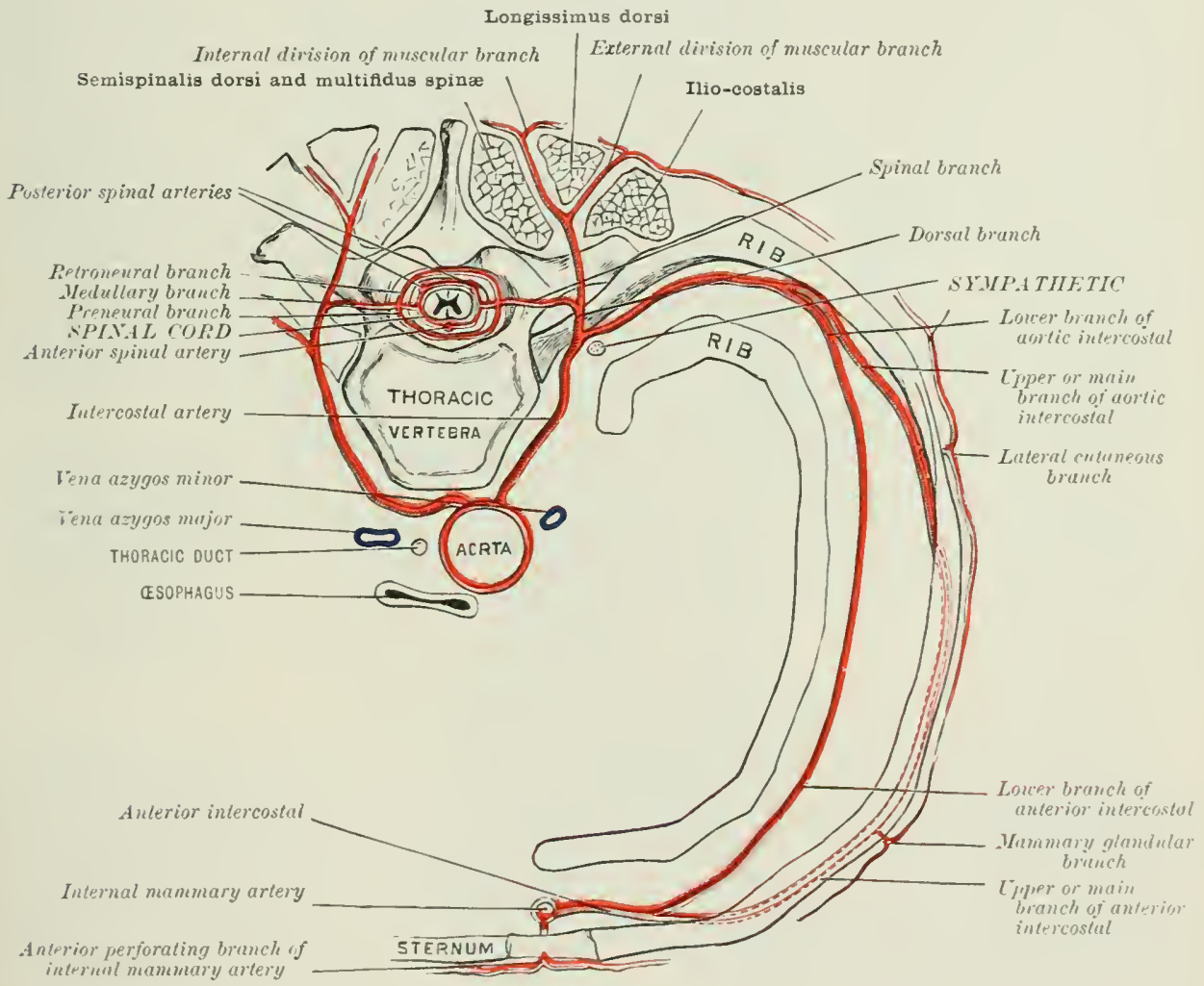

neural, which ramifies orer the back of the spinal canal and also anastomeses with the like artery abore and below; and (r) a middle or medullary, which. passing inwards in the sheath of dura mater to the spinal eord, anastomoses with the anterior spinal artery in front, and with the posterior spinal artery tuhind. (ii) The muscular branch passes backwards through the quadrilateral space, anel sonn subdivides into an external and internal hanch. The former passes between the longissinus dorsi and ilio-costalis, and, after supplying these muscles gires cutaneous offisets to the integuments. The latter or intermal liranch pierces the multifidus spinx, and, emerging between the longisimns dorsi and semispinalis dorsi near the spinous processes. gires cutaneous offsets to the skin. It supplies the muscles in its course.

(b) The collateral intercostal branch comes off from the interenstal artery near the angle of the rib above. and descends to the uprer border uf the rib helow, 
along which it runs between the intereostal muscles to anastomose with the inferior division of the anterior intereostal branch of the internal mammary artery. It is much smaller than the main intereostal artery, and helps to supply the structures in the intercostal space and neighbouring parts.

(c) The pleural branches ramify beneath the pleura, forming a plexus by anastomosing with like branches above and below.

(d) The muscular branches supply the intercostals, serratus magnus, and pectoralis major and minor, and anastomose with the long and short thoracic branches of the axillary artery.

(e) The lateral cutaneous branches run with the lateral cutaneous branches of the intercostal nerves to the skin.

(f) The mammary glandular branches are giren off from the intereostal arteries in the third, fourth, and fifth intereostal spaces, and supply the mammary gland. They are of large size during lactation, and generally require a ligature in the remoral of the breast.

(2) The subcostal artery, or the twelfth dorsal as it is sometimes called, follows the same course as the intercostals as far as the head of the twelfth rib. It then passes in company with the twelfth dorsal nerve along the lower border of the twelfth rib, lying in front of the quadratus lumborum muscle, behind the fascia transversalis. Crossing in front of it is the thickened upper bridge-like margin of this fascia, which stretches across the quadratus and gives origin to some of the fibres of the diaphragm, and is known as the ligamentum arenatum externum. The subcostal artery anastomoses with the lumbar arteries and external circumflex iliac artery. At the onter edge of the quadratus lumborum it passes between the abdominal muscles, and is distributed in a manner similar to that of the lumbar arteries.

(3) The diaphragmatic branches are small twigs coming off from the thoracic aorta immediately above the diaphragm. They are distributed to the vertebral portion of the diaphragm on its upper surface.

(4) The aberrans artery is a small twig which, arising from the thoracic aorta near the right bronchial artery, passes upwarls and to the right behind the œsophagus and trachea, and is occasionally found to anastomose on the nesophagus with the arteria aberrans of the superior intercostal artery. It is regarded as the remains of the right aortic dorsal stem (fig. 345 ).

\section{THE ABDOMINAL AORTA}

The abdominal aorta (fig. 363 ), the continuation of the descending or thoracic aorta, begins at the aortic opening in the diaphragm opposite the lower border of the twelfth thoracic vertebra, and ends opposite the midclle of the body of the fourth lumbar vertebra on its left side, by clividing into the right and left common iliac arteries. It is at first centrally placed between the pillars of the diaphragm, but as it descends in front of the lumbar vertebra it leaves the micldle line, and, at its bifurcation, lies a little to the left side of the spine. The spot at which the aorta bifurcates is, for all practical purposes, roughly indicated on the surface of the abdomen by a point about half an inch helow and a little to the left of the mmhilicus. But the level of its bifurcation may be more aceurately determined by a line drawn across the front of the abdomen from the highest point of one iliac crest to the highest point of the other.

The vena cara inferior, which accompanies the abrominal aorta, lies to its right side. Below, the vein is in contact with the artery and on a somewhat posterior plane; but above, it is separated from the aorta by the right erus of the diaphragm, and in consequence of the caral opening in the diaphragm heing placed further forwarl than the opening for the aorta, is on an anterior plane.

Relations.- In front (fig. 364), the arrta is successirely crossed from ahore downwarls by the right lohe of the liver, the solar plexus, the lisser omentum, the termination of the cesophagus in the stomach, the ascencling layer of the transverse meso-colon, the splenic vein or commencement of the vona porta, the pancreas, the left renal vein, the third portion of the duodenum, the mesentery, the 
aortic plexus of the sympathetic nerve, the spermatic or ovarian arteries, the inferior mesenterie artery, the median lumbar lymphatic glands and lymphatic ressels, and the small intestines.

Of these struetures the solar plexus, the aortic plexus, the splenic vein or the commencement of the vena porta, the pancreas, the left renal vein, the duodenum, the lymphatics, the spermatic or orarian arteries, and the peritoneal reflexions are in eontact with the aorta.

Behind, the aorta lies upon the boties of the lumbar vertebra and intervening

Fig. 363.-The AmDomixal, dorta ANl its Branches, With the Ixferior VENA CAYA AND ITS TRIBCTARILA.

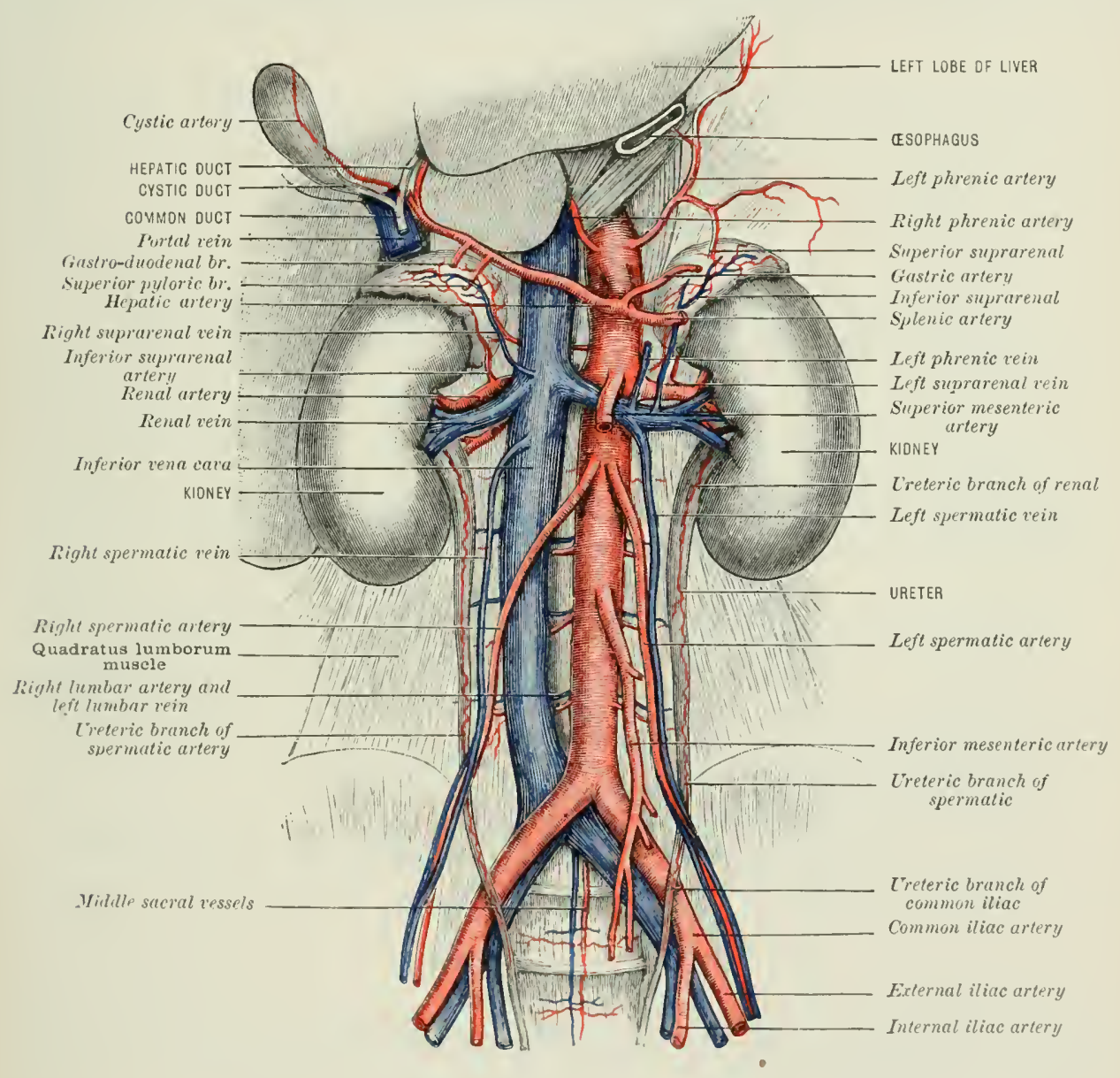

intervertebral cartilages, the anterior common liganent, the origin of the left crus of the diaphragm, and the left lumbir veins,

On the right side from ahove downwals are the right crus of the eliaphragm, the great splanchnic nerve, the spigelian lobe of the liver, the receptaculum chrli and beginning of the thoracie duct (the two latter structures are on a posterior plane), the right semilunar ganglion, and the renal cava inferior.

On the left side are the loft "rus of the diaphragun, the left splanchnie nerve, and the left semilunar ganglion. The panceas is also in eontact with the arta on the left side, as are, too, the small intestines, but selarated from it by peritoneun. 


\section{Fariutions in the Abdominal Aorta}

Variations in the abdominal aorta, except as regards its place of division and some irregularity in the origin and number of its branehes, are not common. Aceorling to Quain, in ten out of every thinteen subjects examined, the bifurcation trok place within half an inch above or below the level of the highest part of the crest of the ilinm. The eommonest situation for its bifureation with reference to the vertebre is perhaps opposite the lower border of the body of the fourtli lumbar, but it may divide opmosite the disc between the fourth and fifth lumbar, or rarely oplnosite the fifth lumbar. A higher division than at the usual snot is less common. 'I'he artery, however, has been found in exeeptional instances dividing as high as the origin of the renal arteries, or eren as high as the second lumbar vertebra.

The following rare variations have been met with:-(A) The aorta passing through the asophageal opening in the diaphragm. (B) The aorta lying on the right side of the vena cava; the vein then passes over the upper part of the anrta to gain the caval opening. (C) 'The aorta with a vena eara on each side, the left vein passing across the upper part of the artery to open

Fig. 364.-SCHEME of THE ABDomixal AortA. (Walsham.)

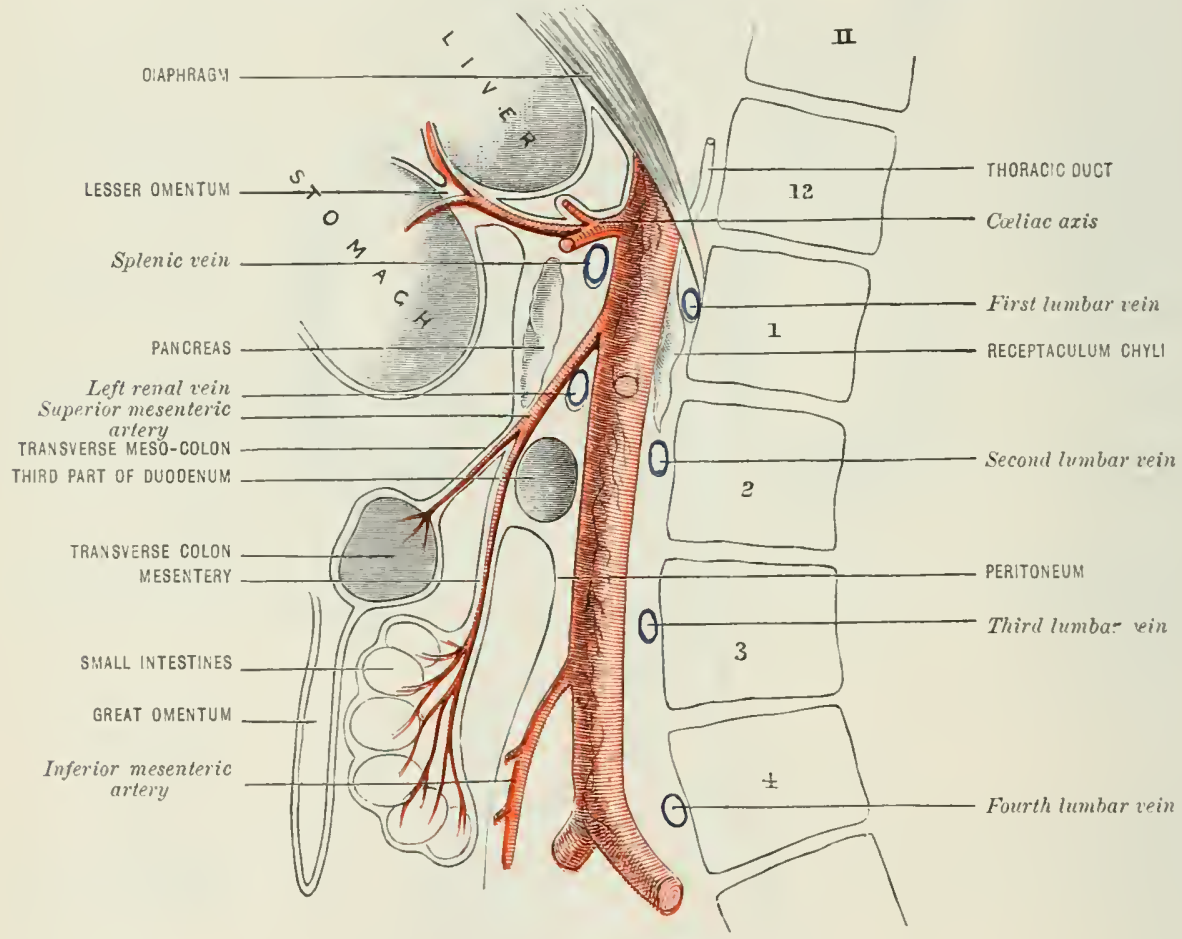

intu the right vein just below the caval opening. (D) The aorta giving off a pulmonary branch close to the origin of the eoliae axis, the abnormal ressel then passing through the oesuphageal opening, and supplying a branch to the lower lobe of each lung.

The variations in the branches of the aorta are described under each branch.

\section{BRANCHES OF THE ABDOMINAL AORTA}

The branches of the abdominal aorta are given off in the following order from above lownwards (fig. 363):-

(1) Right and left phrenic; (2) coeliac axis; (3) richt and left suprarenal or capsular; (4) right and left first lumbar; (5) superior mesenteric; (6) right and left renal; (7) right and loft spermatic; (S) right and left second lumbar: (9) inferior mesenteric; (10) right and left third lumbar: (11) right and loft fourth lumbar; (12) right and left common iliac; (13) midlle sacral.

The above branches may he divided into the parietal, the risceral, and the terminal. 
The parietal branches are listriluted to the alolominal walls. They are the right and left phrenics. and the four right and left lumbars.

The visceral branches supply the viscera. Three of these are given of singly from the front of the aorta. namely, the "roliac axis, the superior nesenterice and the inferior mesenteric; and thee are given off in lairs, namely, the two suprarenals, the two renals, and the two spermatics.

The terminal branches are the middle sacral and the right and left common iliac arteries.

\section{A. The Parietal Braxches of the Abdomixal Aorta}

\section{THE PHRENIC ARTERIES}

The right and left phrenic arteries-sometimes called the inferior phrenic to distinguish them from the diaphragmatic branches of the internal mammary and thoracie aorta-msually arise from the aorta as it jasses between the crura of the diaphragm either as a common trunk or as separate ressels. At times they cone off as a common trunk from the coliac axis; or either the right or left ressel may come from this artery, or from other of the upper branches of the abdominal aorta.

The right phrenic passes (fig. 363 ) over the right crus of the diaphragm behind the vena cava, and then upwards and to the right hetween the central and right leaflets of the central tendon of the muscle, where it divides into an anterior and a posterior branch. The former courses forwards and inwards. and anastomoses with the anterior branch of the left phrenie, with the musculo-phrenic branches of the internal mammary, and with the superior plnenic arteries; the latter passes outwards and backwards towards the rils, and anastomoses with the interenstal arteries. Besides the two terminal branches and branches for the supply of the diaphragm itself, the right phrenic gives off the following:-(1) Right superior suprarenal, to the right suprarenal capsule; (2) caval, to the rena cara; (3) hepatic, to the liver; and (4) pericardiac, to the pericardium.

The left phrenic crosses the left crus of the diaphragm hehind the asophagus. ant then runs between the left and central leaflets of the tendon, dividing like the right into an anterior and a posterior branch. The former runs forwards and inwarls, and anastomoses with the anterior branch of the right phrenic, the left musculo-phrenic from the internal mammary, and the superior phrenic artery. The latter courses outwards and backwarls towards the ribs, and anastomoses with the interesstal arteries. In arldition to the terminal hranches, and branches to the dinphragm itself, the left phrenic gives oft:-(1) CEsophageal branches to the (1sophagus. where they anastomose with the other wesphageal branches; (2) left superior suprarenal, to the left suprarenal holy; (3) splenic, to the spleen: and (4) pericardiac, which perforate the diaphragin and anastomose with the other pericardiac arteries.

The variations in the origin of the phrenic arteries are very nuncrus. The chief lave been alluded to in the general deseripition of the ressels.

\section{THE TLYMB.AR ARTERIER}

The lumbar arteries (figs. 360. 3693), usually aight in number, four on carti

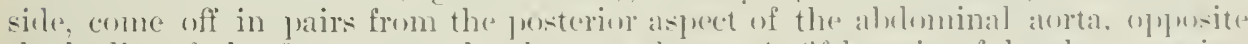

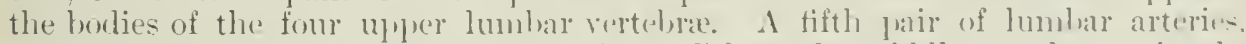

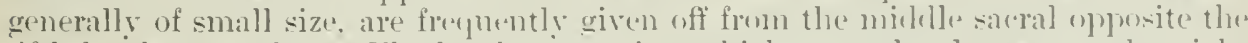
fifth lumbar rertebra. The lumbar arteries, whel are rather longer on the riglit than on the left sicle, in concerpuence of the aorta lying a little to the left of the

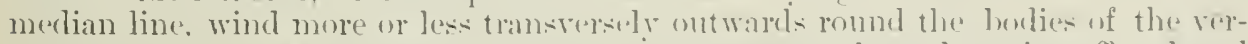

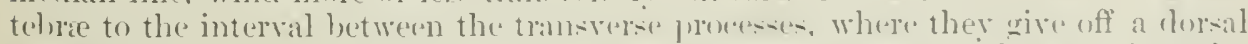

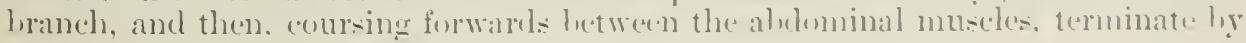


andstomosing with the other arteries of the abdominal wall. As they wind romel the bolies of the vertehrat they lass beneath the chain of the sympathetic nerve, and the upper two beneath the right crus of the diaphragm on the right sicle, and the left crus on the left sile. The right arteries also pass beneath the vena cava inferior. and the two uprer on that sirle beneath the rexeptaculum chrli. The anteries on both sides then dip beneath the tendinous arch thrown across the sides of the bulies of the vartebre hy the psoas, and continue beneath this muscle until they arrive at the interval between the transrerse processes of the rertebra and the imner eelge of the tuadratus lumhorum. Whilst under cover of the psoas they are acennpmied hy tro sleneler filaments of the sympathetic nerve and by the lumbar reins. A little anterior to the transverse processes they are crossed by branches of the lumbar plexus, and here usually cross in front of the ascending lumbar vein. They now pasis behind the quarlatus lumborm, with the exception usually of the first, and sometimes of the last, which may pass in front of the muscle. At the onter edge of the quadratus they run between the transversalis and the intemal olligue, and then, perforating the internal oblique, between the internal and external oblique. Finally, much climinished in size, they enter the rectus, and give off one or more anterior cutaneous branches, which accompany the last dorsal and the ilio-hypogastric nerves to the skin. They anastomose with the lower intercostals, ilio-lumbar, deep circumflex iliac, and deep epigastric arteries.

The lumbar arteries give off the following branches:-

(1!) Vertebral branches which supply the bodies of the vertebræ and their connecting ligaments.

(b) Muscular branches to the psoas, quadratus lumborum, and oblique muscles of the abdomen.

(c) The dorsal branch. This is of large size, and passes backwards in company with the dorsal nerve between the transverse processes above and below, the intertransversalis internally, and the quadratus lumborm externally, to the muccles of the back. On reaching the interval between the longissimus dorsi and multifidus spine, it divides into an external and internal hranch. The former ents in the multifidus, the latter and larger supplies the erector spine, and gives luanches which accompany the termination of the dorsal nerves to the skin. Just hefore the artery passes between the transrerse processes it gives off a spinal branch, which accompanies the lumbar nerve through the intervertebral foramen into the spinal canal. Here the spinal branch divides into three twigs, one of which passes thromgh the sheath of the dura mater to the termination of the spinal cord and cauda eruina; the other two are clistributed to the walls of the spinal canal after the way described in the case of the intercostals.

(d) Renal branches of small size pass forwards in front of the quadratus lumhorm to the capsule of the kitney. They anastomose with the'renal artery. A commmnication is thus established between the renal arteries and the arteries sujplying the lumbar region.

The fifth pair of lumbar arteries, when present, usually come off from the mildle sacral artery. Each courses outwards, heneath the common iliac artery and rein; and, after giving off a dorsal branch, ramifies over the lateral mass of the sacrum, and ends in the iliacus muscle by anastomosing with the circmnflex iliac artery. The dorsal branch passes to the back between the last lumbar vertebra and the sacrum and ramifies in the gluteus maximus, anastomosing with the lumbar arteries abore, and with the gluteal artery below.

The variations in the hmbar arteries are not of great importance. (A) One or more pairs may arise as a (4)mmon stem from the back of the aurta. (B) The first lumbar may be joined at its onigin with the subcostal artery ; or the third and fourth lumbar, or less often the second and third lumbar, may arise firm the antil as a $(\bullet) m m o n$ stem. (C) The fifth pair may sometimes:

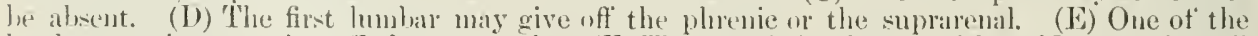
humbar arteries may give off the spermatie. (F) 'The fimrth lumbar on either side may give off the midllle sacral, or both arteries may arise as a common stem with the midlle sacral. 


\section{B. The Visceral Branches of the Abmumal Aorta}

\section{THE COELIAC ARTERT}

The cœliac artery-or cœliac axis as it is commonly called, beeause it breaks up simultaneously into three branches which racliate from it like the spokes of a wheel from the axle-is a short thick trunk given off from the front of the aorta between the crura of the diaphragm a little below the aortic opening. It passes horizontally forwards above the upper margin of the panereas for aloout half an inch, and then breaks up into three branches for the supply of the stonach, duodenum, spleen, pancreas, liver, and gall-bladder (fig. 365).

Relations.-In front is the lesser omentum; behind, the aorta; above, the right lobe of the liver; below, the panereas; to the right, the right seluilunar

Fig. 365.-The Coldac Artery axt its Braxcines.

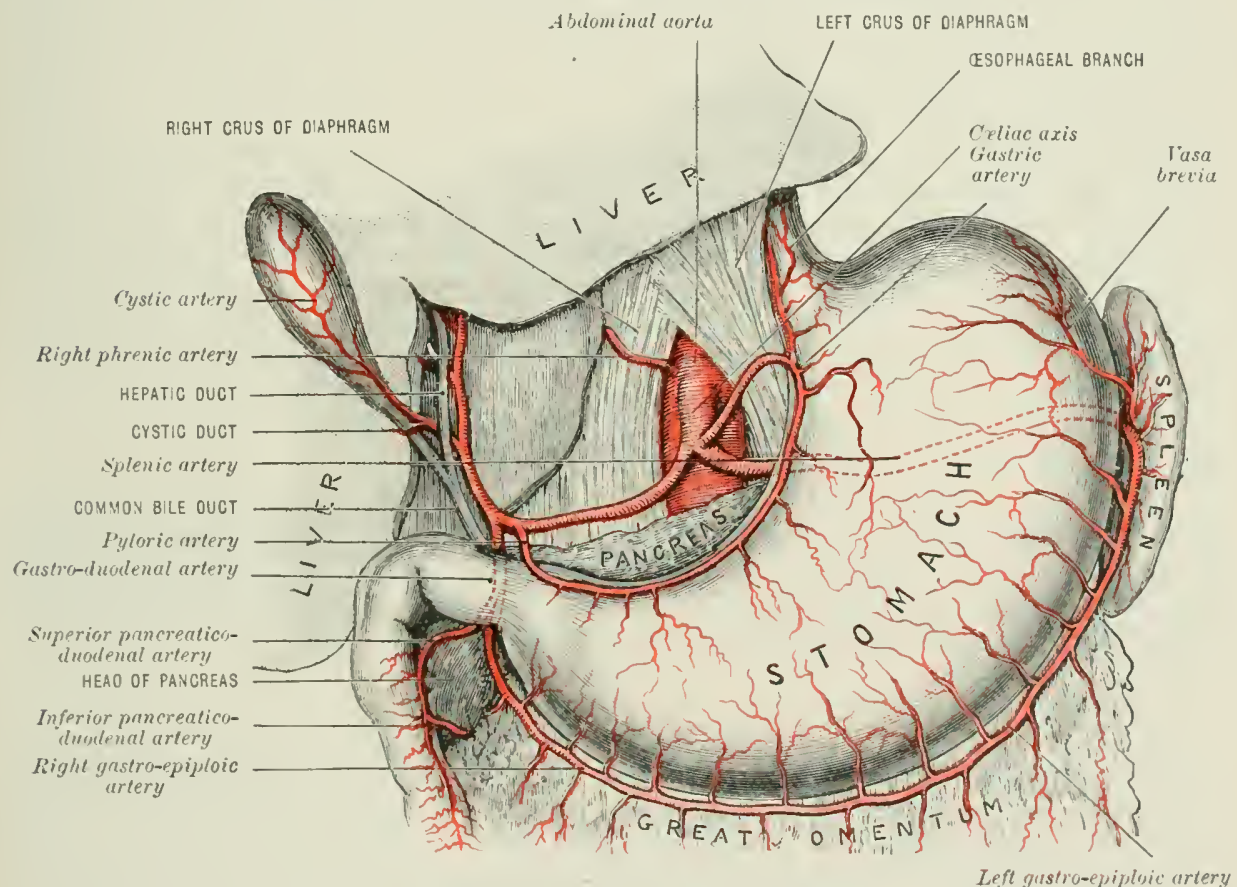

ganglion and lobulus Spigelii of the liver; to the left, the left semilunar ganglion and the cardiac end of the stomach. It is closely surrounded by the dense solin plexus of sympathetic nerres.

Variations.-(1) The coliace axis may le alsent ; the branches usually arising from it then

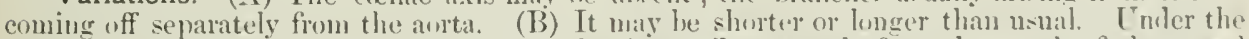
latter circumstance the bramches are commonly given off soparately from the trunk of the resiel insteal of radiating from one spot. (C) It may give off two hranches only : these are nomally the splenie and hepatic, more rarely the gaintric and the splenie. (D) It may grive off more than three hrauches, the adklitional branch being one of the phrenies; a trunk common to the two phrenics; a gastro-duodenal; a seeond gastric or splenie artery, or the superiur mesenterie the median colie or the panereatica magna. (E) One or other of the branches nomal to the coliae axis may be absent, or replaced by a stem emmmen to the phrenies, or by the risht suprarenal and the rielit gastro-epiploie, or more rarely by sume other branch.

Branches of the coliac artery.-The coliac axis gives off the grastric, hepatic, and splenic arteries. 


\section{THE GASTRIC ARTERY}

The gastric or coronary artery (fig. 36.5), the smallest of the three luanches into which the coeliac axis diviles, courses at first upwards and to the left towards the cardiace end of the stomach, where it turns sharply round, and then, coasting along the lesser curvature of the stomach, descends from left to right towards the wlorus. It anastomoses with the superion ploric branch of the hepatic artery, which has proceeded from the opposite direction. the two branches thus forming a continuous arterial arch corresponding to the lesser curvature of the stonach. The artery at first lies behind the posterior layer of the lesser omental sac of peritomenn (fig. 36t), but on reaching the cardiac end of the stomach it passes through the so-called pancreatico-gastric fold of peritoneum into the lesser omentum, between which it then runs to its terminal anastomosis with the pyloric. It is surrounded by the coronary plexus of sympathetic nerves.

The branches of the gastric artery are:-(1) The osophageal; (2) the carhiac; (3) the gastric; and (4) the hepatic.

(1) The œsophageal branches, given off where the artery makes its bend on to the stomach, ascend on the asophagus, and, passing through the asophageal opening of the diaphragm, anastomose with. the thoracic oesophageal branches and the branches from the left phrenic.

(2) The cardiac branches, two or nore in number, are given off for the supply of the cardiac end of the stomach, around which they form an anastomotic circle.

(3) The gastric branches come off from the artery as it lies between the layers of the lesser omentum, and are distributed to the front and back of the stomach (the lesser anterior and posterior gastric branches), over which they ramify; anastomosing with branches ascending from the right and left gastro-epiploic on the greater curvature. One of these branches of larger size ramifies over the front of the great cul-de-suc, the greater anterior gastric (Macalister), and anastomoses with the vasa brevia and left gastro-epiploic from the splenic.

(4) The hepatic branch is a constant small wig passing to the left lobe of the liver, where it anastomoses with the left hepatic artery.

Chief variations.-(A) The gastric may arise directly from the aorta, and may then give off one of the phrenics, or both, or a trunk common to the two. (B) There may le two gastric arteries instead of one. (C) The gastric may give off the lef't branch of the hepatic artery. This appears to be due to the enlargement of the constantly present small hepatic branch, and the obliteration of part of the normal left branch of the hepatic artery.

\section{The Hepatic Artery}

The hepatic artery, the largest branch of the coliac axis in the foetus, but intermediate in the adult between the gastric and the splenic, comes off on the right side of the coliac axis. and, winding upwards and to the right to the transverse or portal fissure of the liver. there breaks up into two chief branches for the suply of the right and left lobe of that organ. It at first courses forwards and to the right along the upper borter of the head of the pancreas, behind the posterior layer of the lesser onental sac of peritoneum, to the upper margin of the duodenum, where, at the hase of the so-called right pancreatico-gastric fold, it passes hetween the two layers of the lesser omentum, and thus asends along with the hepatic duct which lies to its right, and with the portal rein which lies behind it, to the transerese or portal fisure of the liver. As it lies with the hepatic duct and portal rein between the layers of the lesser omentum, it is in front of the so-ralled foranen of Winslow.

The branches of the hepatic artery are:-(1) The pancreatic; (2) the superior lyloric; (3) the gastro-duodenal: (4) the right terminal; and (j) the left terminal.

(1) The pancreatic, or lesser pancreatic branches as they are often called. come off from the hepatic as it rums along the upper margin of "the pancreas, ancl suply) that organ.

(2) The superior pyloric comes off from the hepatic just as the latter vessel enters the leser omentmm, and. Alecending hetween the two layers of that fold of peritoneme to the pylorus, there turns leftwards, and, ascennling from right to left, 
anastomoses along the lesser curvature of the stomach, as already mentioned, with the gastric artery, which deseends from the oplosite direction.

(3) The gastro-duodenal arises from the hepatic a little heyond the prlorice It desends behind the ascending jortion of the duodenum to the lower herder of the pylorus, where it diviles into the right gastro-epiploic and the superior pancreatico-duodenal. It varies from half an inch to an inch in length. In addition to the above branches, it may give of the inferior pyloric artery.

(a) The right gastro-epiploic, entering the anterior fold of the great omentum, coasts from right to left along the erreater curvature of the stomach, and anastonose's with the left gastro-epiploic branch of the splenic, which descends from left to right also along the greater curvature to meet it. From this anastonotic arch are giren off:-(i) Ascending or gastric branches, which supply the anterior and posterior surfaces of the stomach, and anastomose with the descending gastric branches of the arteries along the lesser curvature. (ii) Epiploic or omental branches-long slender vessels, which descend between the two anterior lavers of the great omentum, and then, looping upwards, anastomose with similar slender branches given off from the middle and left colic, and passing down in like mamner between the two posterior layers of the great onentum.

(b) The superior pancreatico-duodenal-the smaller division of the gastroduodenal-arises from that ressol as it passes behind the first portion of the duorlenum, and courses downwards hehind the peritoneum, in the anterior groore between the second portion of the duodenum and the pancreas, to anastomose with the inferior pancreatico-cluolenal, a branch of the superior mesenteric. which rums upwards between the contiguous borders of the pancreas and duodenum. Both the inferior and superior pancreatico-duodenal give off branches to the duodenum and the pancreas.

(c) The inferior pyloric arises either from the gastro-duodenal or from the right gastro-epip]oic; it supplies the pyloric end of the stomach, and anastomoses with the other arteries in that situation.

(t) The right terminal branch of the hepatic artery is given off at the portal fis-ure of the liver, and runs to the right towards the end of that fissure, either hehind the hepatic and cystic ducts, or between these structures. At the right end of the portal fissure it divides into two or more branches, which again subdivide as they chter the liver substance for the supply of the right lobe. As it crosses the crstic duct it gives off the crstic artery.

(a) The cystic artery courses forwards and downarls through the angle formed hy the union of the hepatic and crstic ducts, and just before it reaches the rall-bladder divides into a superficial and deep branch. The former breaks up into a number of small ressels, which ranify over the free surface of the gall-bladder beneath the peritoneal covering, ancl furnish branches to the muscular and mucous coats. The deep branch ramifies between the gall-bladder and the liver-substance, supplying each, and anastomosing with the sulerficial branch.

(5) The left terminal branch, the maller division of the hepatic artery, runs inwards towards the left end of the portal fissure, and, after giving oft a distinct branch to the singelian lobe, enters the left lobe of the liver.

Chief variations.-(A) The hepatic artery may arise directly from the aorta, or from the gantrie, the superior mesenteric, or the right remal artery. (B) Tugether witl a normal artery there may lie an aecessory hepatic from one or other of the above-named or neighbouring hanches. (C) The hepatic artery may be altogether wanting, and its place supplied ly one or more acessory arteries derived from one or uther of the abore-naned sonres. This raviation is explainet by Hyrtl on the supposition that there has been whliteration of the nomal hepatie, with enlargement of one or nore of the minute branches which normally proceed from the aorta and the above-named branches to the eapsule of the liver.

\section{The ज्ptexic Artert}

The splenic artery-the larest hranch of the coliac axis-arise from the left sicli of the temmation of that vescel helow the gastric, and passes along the uplere horder of the pancreas in a tortuous manner to the splecen. It at first liss hehind the ascending layer of the transverse meso-colon, but on nearing the splieen enters 
the lieno-renal ligament, and there hreaks up into numerous branches. which enter the hilum and supply the organ. In this course it crosses in front of the left (rus of the diaphragm and the upper end of the left kidney and is placed above the splenic rein.

The branches of the splenic artery are:-(1) The smaller pancreativ; (2) the larere pancreatic; (3) the left gastro-epiploica; (4) the vasa brevia; and (5) the terminal.

(1) The smaller pancreatic branches come off from the splenic at rarring intervals, as that ressel courses along the upper margin of the pancreas. They enter and supply the organ.

(2) The larger pancreatic branch usually arises from the splenic about the junction of its midlle with its left third. Entering the pancreas obliquely, it runs from left to right, commonly above, and a little behind, the panereatic dlict, which it suplies together with the substanee of the organ.

(3) The left gastro-epiploic arises from the splenic behind the great cul-de-sac of the stomach, and, passing between the anterior layers of the great omentum, descends along the greater eurvature of the stomach from left to right. and anastomoses with the right gastro-epiploic. Like that vessel, it gives off ascending or gastric branches to the anterior and posterior surfaces of the stomaeh respectirely, and lone slender descending epiploic or omental branches to the great omentum which anastomose with like branches from the right and left colic arteries.

(4) The vasa brevia come off from the splenic just before it divicles into its teminal branches, oftentimes from some of these teminal hranches themselves. Passing from between the folds of the lieno-renal ligament into those of the gastrosplenie, they thus reach the greater cul-de-sar of the stomach, where, ramifring over both its anterior and posterior surfaces, they anastomose with the gastric and left gastro-epiploiea arteries.

(5) The terminal branches, fire to eight or more in number, are given off from the splenic as it lies in the lieno-renal ligament, and, entering the spleen at the hilum, are distributed in the way mentioned in the description of that organ.

The variations of the splenic artery are neither numerous nor important. (A) It may divide into two branches which remite, the splenic rein running through the loop thus formenl. (B) It may sumetimes give off branches normally derived from other vessels, such as the gastric, the middle colic, and the left hepatic. (C) The variations in its origin are mentioned under TARLAtions of the Celiad Axis (page 555).

\section{THE SCPERIOR MENENTERIC ARTERY}

The superior mesenteric artery is given off from the front of the aorta a little helow the eoliae axis, which it nearly equals in size; sometimes as a common trunk with the axis. Lying at first behind the pancreas and splenie vein, it soon passes forwards between the lower border of that gland and the upper border of the third portion of the duodenum, and, crossing in front of the duodenum, enters the mesentery, in which it runs from left to right, in the form of a eurve with its (onrexity to the left, to the cacm, where it anastomoses with its ileo-colic branch. Its rein lies to its right sirle abore, having previously crossed obliquely in front of the artery from left to right. It is smroumded by the mesenteric plexus of nerves. The accessory jortion of the heact of the pancreas dips in behind the ressel.

From the concare side of the artery branches are given off to the duolenum and the colon. viz: :-

(1) The infrrior pancreatico-duokenal; (2) the midlle colic; (3) the right colic; and (4) the ileo-colic:

From the convex side hranches are giren off to the small intestines, viz. :-

(5) The vasa intestini temis.

It will thus be seen that the superior mesenteric artery supplies, with the exception of the upper third of the lnokenum, the whole of the small intestine and half the large.

(1) The inferior pancreatico-duodenal arises either from the sulerior mesen- 
teric as that vessel emerges from the contiguous margins of the pancreas and transverse duodenum or from its first intestinal branch, and, crossing behind the superior mesenteric vein, courses upwards and to the right between the head of the pancreas and the duodenum, beneath the asconding layer of the transwerse meso-eolon, to anastomose with the superior pancreation-duodenal, which is givin off from the gastro-duodenal, and descends in a like situation beneath the ascencling layer of the transverse meso-colon.

(2) The middle colic, arising from the concarity of the superior mesenteric a little below the pancreas, enters the transwerse meso-colon, and divides into two branches-one of which passes to the left and anastomoses with the ascending

Fig. 366.-The Superior Mesexteric Artery Axil Veix.

(The colon is turned up, and the small intestines are drawn orer to the left sirle.)

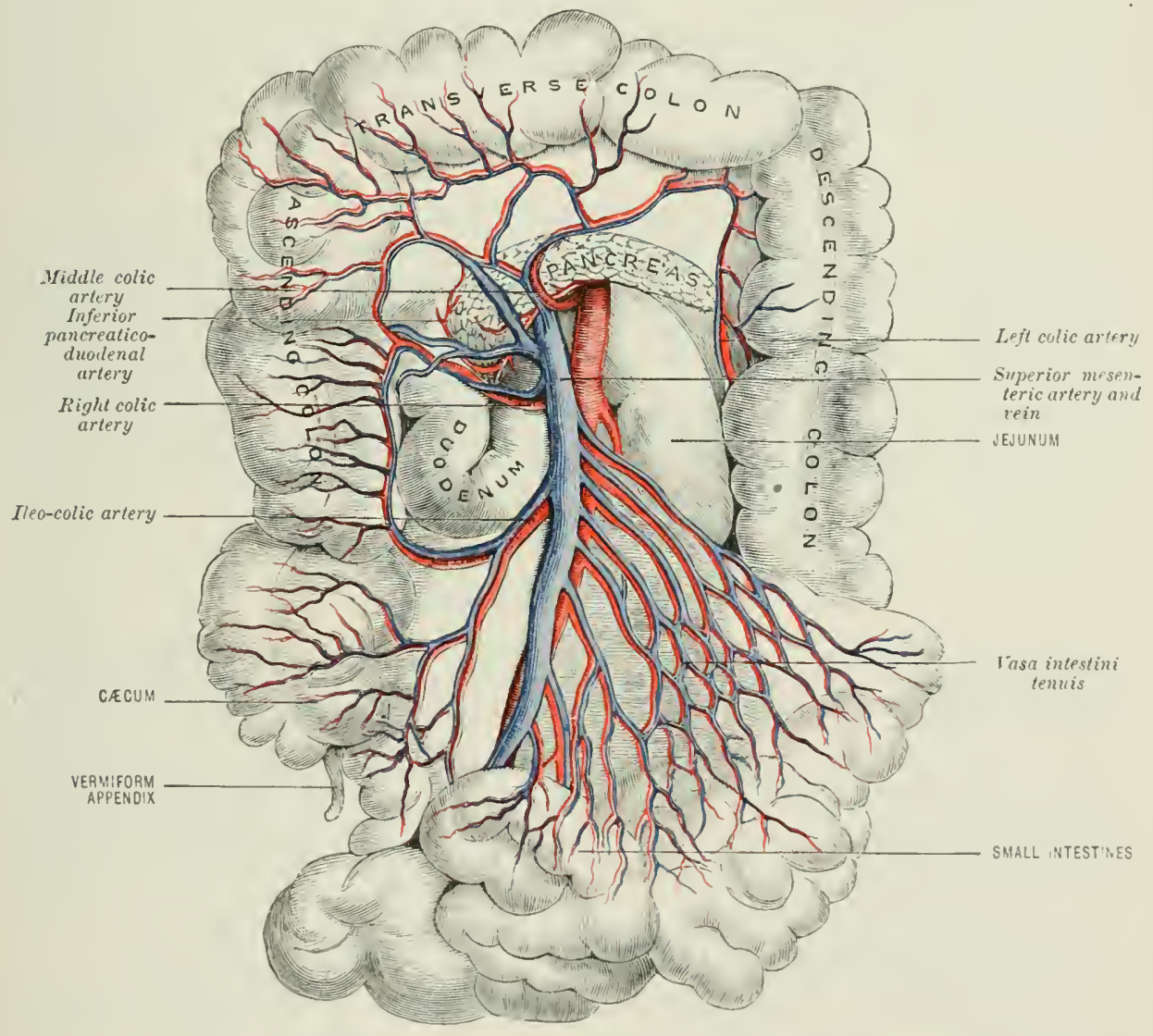

branch of the left colie; the other, wincling downwards anct to the right. anastomoses with the ascending branch of the right orolic.

(3) The right colic-sometimes given off as a common trunk either with the former branch or with the ileo-colic-passes to the right luhinel the peritonem to the back of the ascencling colon. where it divicles into an asconding branch, which anastomoses with the descemling branch of the midtele colic, and a descending branch which anastomoses with the asernding or eolie lianch of the ilon-colic.

(4) The ileo-colic descends behind the pritonem towarts the easum. where it divides into a colic branch which tracks upwarls bencatle the peritomem to anastomose with the descencling branch of the right (onlic: and into an ilear hranch which passes between the layers of the mesentery and andstomoses with the termination of the superior mesenteric artery. 
From the anastomotic loops formed between the termination of the superior mesenteric, the ilow-colic, the right colic, and the middle colic arteries, secondary loops are derived whrnce hranches pass to the termination of the ileun, the exeun, the remiform appendix, the ascending colon, and half the transverse colon. These branches on reaching the intestine divide into two, one of which passes in front, and the other behind the intestine, and, after encircling it, anastomose with each other and with the neighlrouring circlets above and below.

(5) The intestinal branches, or vasa intestini tenuis, arise from the convex sicte of the superior mesenteric, and, rarring from twelve to sixteen in number, racliate in the mesentery, where each diviches into two branches, which inosculate with similar branches given off from the branch above and below. From the primary loops thus formed, secondary loops are derived in like manner, and from these tertiary, and at times quaternary, or even quinary loops. From the ultimate loops terminal branches pass on to the intestine through the triangular interval left at the spot where the mesentery is reflected on to the muscular coat of the gut. On reaching the wall of the gut these terminal ressels bifurcate, the two branches encircling the intestine, and thus forming with those above and below a series of vascular rings surrounding the suall intestine throughout its whole length. These branches of the superior mesenteric in their course to the intestine also supply the mesentery and the mesenteric glands.

The variations in the superior mesenteric artery are numerous. (A) It may be double. (B) It may give off accessory branches to the liver, stomach, pancreas, spleen, and gall-bladder. (C) It may give off branches normally derived fiom other sources, namely, the hepatic or its riglit or left lmanch, the cystic, the gastro-ruorlenal or its right gastro-epiploie branch, the gastrie or the pancreatica magna. (D) It may give off the left colic and superior laemorrhoidal, thus takiug the place in whole or in part of the inferior mesenteric. (E) Its colic and intestinal branches may vary considerably in their origin and course, and in the mumber of primary and secondary loops that they form. (F) A rare abnormality described by Hyrtl is the persistence of au omphalo-mesenteric artery running to the neighbourhood of the umbilicus and giving off a branch to the urachus, or a branch to the liver through the falciform ligament, or a branch to the rectus anistomosing with the epigastric.

\section{THE RENAL ARTERIES}

The renal arteries come off one on each side of the abctominal aorta, a little below the superior mesenteric and first lumbar arteries, on a level with the first lumbar vertebra. They pass transversely outwards across the crura of the cliaphragm to the kidneys, the right being on a slightly lower plane and somewhat longer than the left, and passing behind the inferior vena cava. In front of each is the corresponding renal vein. Behind each at the hilum of the kidney is the contmencement of the ureter. Before entering the kidney they break up into three or four terminal branches. The distribution of the arteries in the kidney is described uncler the anatomy of that orom.

Each renal artery gives off the following branches:-

(a) The inferior suprarenal, which ascends to the suprarenal hody.

(b) The capsular or peri-renal branches to the (:ip)sule of the kidney and peri-renal fat.

\section{(c) The ureteral branch to the uppere end of the ureter.}

Variations in the renal arteries are common. (A) The right and left renal may arise from the aorta by a common stem. (13) They may arise fiom the aorta lower than usual; the kidneys thrn being also below their usual situation. (C) 'There may he several remal arteries on each side, w the renal artery may divide elose to its origin into several branches. (1)) The renal artery on one or both siles may arise from the bifureation of the anta. from the common iliac, the interual iliac, the inferior mesenteric, or the midule sateral artery. (F) The right artery may cross in front of, insteal of Jehiud, the vena cava. (F) The bramehes of the renal artery may perforate the substance of the kidney instear of entering at the hilum. (G) The remal artery may give urigin to Inanches nomally derived fiom other vessels, as the phronic, the hepatic or its right branch from the right renal, the midlle suprarenal, some of the colic arteries, the spermatic, one or more of the lumbar arteries, or the greater pancreatic altery. (II) Acessony renal arteries, varying in size and generally derived from the aorta, are common. 'I'he'y matenter the kidney at almost ally jart of the orgau. 


\section{THE SUPRARENAL ARTERIF}

The capsular or suprarenal arteries are deriverl from three sources, and are named as follows:-(1) Superior suprarenal; (2) middle suprarenal; and (3) inferior suprarenal.

(1) The superior suprarenals, one on each side, are usually derived from the phrenies, and descend to the suprarenal bodies.

(2) The middle suprarenals, or suprarenals proper, come off one on earh side from the aorta, just above the first lumbar artery, and pass transversely ontwarels to the suprarenal bodies, across the crura of the diaphragm a little ahove the renal arturies. In the foetus they equal the renals in size. In the adult they are much sinaller.

(3) The inferior suprarenals are branches of the renals. They ascend, one on each side, to the suprarenal bodies.

The suprarenal veins, usually one on each side, terminate as a rule on the left sicle in the left renal; on the right side, in the inferior vena cava.

For the distribution of the suprarenal ressels within the suprarenal capsules, see page 1014.

\section{THE SPERMATIC ARTERIES}

The spermatic arteries come off from the front of the abdominal aorta. Thery direrge from each other as they descend over the aorta and psoas muscle to the deep or internal abdominal ring, where they are joined by the vas deferen.; and, passing with it through the inguinal canal and ont of the external or superficial abdominal ring, run downwards into the scrotum in a tortuous course to the testicle. They terminate in branches to the epididymis and body of that organ. Within the abdomen they lie beneath the peritoneum, and cross in their descent over the ureter and distal end of the external iliac artery; the right being superficial to the rena cara, and behind the termination of the ileum; and the left beneath the sigmoicl flexure of the colon. In the inguinal canal and in the scrotum the spermatic reins lie in front of the artery, and the vas deferens lies behind it.

In the fotus these ressels pass transversely outrards to the testicle, which in early foetal life lies in the loin in front of the kidner; but as the testieles descend to the scrotum, the ressels become elongated, and are drawn with the testicle into the scrotum.

The spermatic arteries give of the following branches:-(1) Creteral; (2) cremasteric; (3) epididymal; and (4) testicular.

(1) The ureteral are small branches given off to the ureter as the spermatic artery crosses it. They anastomose with the other ureteral branches derived from the renal, eommon iliac, and resical arteries.

(2) The cremasteric are small branches given off to the cremaster muscle; they anastomose with the cremasteric branch of the deep epigastric.

(3) The epididymal are distributed to the epididynis, and anastomose with the artery of the ras.

(4) The testicular are the terminal branches of the spermatic: they perforate the tunica albuginea posteriorly, and are clistributed to the body of the organ in the way mentioned in the section on the Testicte.

Chief variations in the spermatic arteries. - (A) One or both may be ranting, the testiche being then supplied by branehes from the vesical or prostatie arteries jassing under the arch of the pubis. (B) One or both may arise from the renal, wore rarely from the suprarenal. (C) One may eome off higher than the uther. (D) They may eome off from a common stem. (E) One or both may be double in the whole or part of their eourse. (F) The right spermatie may. lun behind instead of in front of the inferior rena cara. 


\section{THE OYARIAN ARTERIE-}

The ovarian arteries are the homologues of the spermatic arteries in the male, and conrespond in their relations in the mper part of their course. They diverge somewhat less howerer, and on reaching the ferel of the common iliac artery tum inwards over that ressel and descend tortmously into the pelvis between the folds of the broad liganent to the ovaries. In the broad ligament the ovarian artery lies below the Fallopian tube, and on reaching the ovary tums backwarls and supplies that organ (fig. 370 ).

They give off the following branches:-(1) Lreteral; (2) Fallopian; (3) uterine; and (4) ligamentous.

(1) The ureteral is clintributed, as in the male, to the ureter.

(2) The Fallopian supplies the i-thmus and ampulla of the Fallopian tulse and its fimbriated extremity.

(3) The uterine runs along the Fallopian tube to the superior cornu of the uterus, which it supplies, together with the upper part of the funclus uteri, and anastomoses with the uterine arteries from the internal ilia..

(4) The ligamentous is distributed to the romnd ligament, passing with that structure through the inguinal canal, ant amastomosing with the cremasteric and superficial external pudie arteries.

Like the spermatic the orarian arteries in the fortus come off at right angles to the aorta, and pass transwersely ontwards to the oraries, which are formed, as are the testicles. in the right and left loin in front of the kidners. Ther elongate as the ovaries descend into the pelvis. During pregnaney these arteries indergo great enlargement.

\section{THE INFERIOR MESENTERTC ARTERY}

The inferior mesenteric artery, smaller than the superior, arises from the front of the aldominal anrta about an inch and a half abore the lifurcation of that vesel. It runs obliquely downards and to the left, across the lower part of the abchminal aorta and then orer the left psoas muscle and left common iliac artery. deseends into the pelvis between the larers of the nuso-rectum, and terminates on the rectum in the superior hamorrhoilal or superior lectal artery. It at first lies behind the peritoneum, or in the left lumbar mesn-colom when that strueture is present. It supplies the lower half of the large intestine. Its vein lies at first close to the left side, but soon paswes upwards on the psoas, away from the artery, to (1) in the splenic vein (fig. $36 \overline{6}$ ).

The branches of the inferior mesenteric ar":-(1) The left colic; (2) the sigmoid: and (3) the superior hemorrhoilal.

(1) The left colic runs transiersely out wards and to the left, heneath the peritomemn, and divides into two branches, one of which, entering the transwerse mesocolon, ascends upwards and to the right, to anastomose with the midlle colic. The other descends, and, entering the sigmoid meso-colon, anastomoses with the ascemeling branch of the sigmoid artery.

The distribution of this artery and the next to the colon is similar to that of the colic branches of the superior mesenteric, and does not require a separate description. (Se Superior Mesexteric Artery, pages 5.59, 560.)

$(2)$ The sigmoid artery rums downwarls and to the left over the psoas musche. and, entering the sigmoid neso-colon, livides into two branches; the ulper anastomosing with the left eolic, the lower with the superior hamorrhoidis.

(3) The superior hæmorrhoidal is the continmed trunk of the inferior mesenteric. It descends into the pelvis, behint the rectmm, between the larers of the meso-rectum. On reaching the wall of the howel it hifureates, one lomeh proceeding on either sirle of the gut, to within fom or tive inches of the anus. Here each adrain clivides, and the lianches, piereing the muscular coat, descend hetween that eoat and the mucous membrane, forming with each other, and with the midrlle hamoryoblal anteries-ilerived from the internal iliac-a sories of small ressels, ruming longitudinally to the rectum, and parallel to each other as far as the level 
of the internal sphincter, where ly their anastomosis, they form a series of loups aromel the lower part of the rectum.

The chief variations in the inferior mesenteric are:-(1) Its place may be -npplied lyy the superior mesenterice. (B) It may give branches to the liver or kidney. (C) It may give uff the

Fui, 367.-The Ixflior Mesextenic Artery axi, Vers.

(The colon is turned up, and the small intestines are drawn to the right side.)

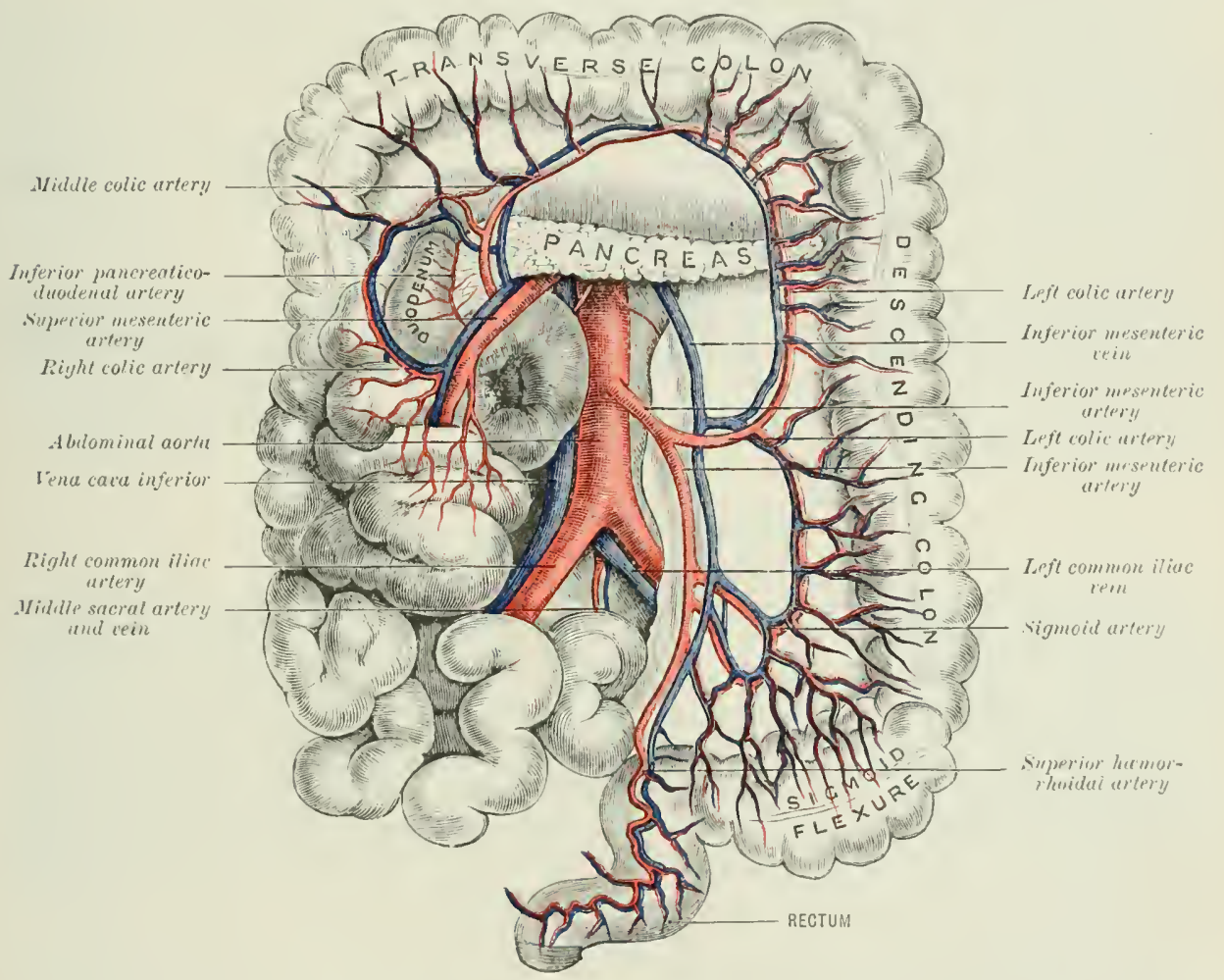

middle colic. (D) It may wive off a stem to luth umbilieal arteries. (E) The ana-tumn-is between the mishlle and left colie arteries may be wanting-the normal condition in the ruminamts and the poretupines.

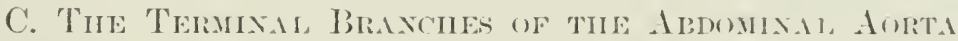

\section{THE MLDLE SACRAL ARTERY}

The middle sacral artery is, anatomically, the continuation of the aortit, and is generally hut not universally held to be the homologne of the salcral and coecreal

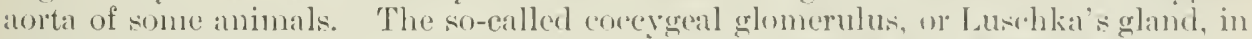
which it terminates, is believed to contain the rudiments of the aludal aortal, of artery of the tail. 'The artery is mesially placerl, amb extruls from the lifureation

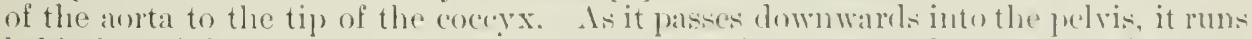

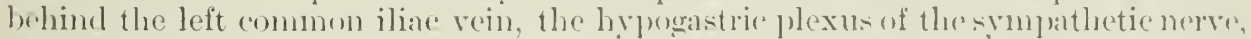
and the layer of peritonem that deseends from the mesentery into the prelvis to become the meso-rectum. It lies sucessively upon the intervitatial disc between the fourth and fifth lumbar vertebre, the fifth lumbar vertebra, the intervertebral disc between that vertehra and the sacrum, and lower down upon the middle of the anterior surfiace of the sacrum and concers. 
Branches.- The mirldle sieral gires off:-

(1) The fifth pair of lumbar arteries (sometimes). These are described with the lumbar arteries.

(2) Lateral sacral branches, usually four in number. These are serially homologous with the intereustal and lumbar arteries griven off by the aorta. They run more or less transversely outwards, and amastomose with the lateral sacril lianches of the internal iliac artery. Ther give off small spinal branches, which frass through the sacral formmina, and supply the sacral canal and back of the Silclilm.

(3) Rectal or hæmorrhoidal branches pass forwarls in the layers of the mesorectum, to the rectum which they help to supply, and anastomose with the other hamorrhoidal or rectal arteries.

On the lower part of the middle sacral artery-the coeergeal part-there are often found small pouches or varicosities, which are believed by some to represent the rudiments of lateral coceygeal arteries, homologous to the intercostal, lumbar, and sacral arteries, given off from the aorta in these regions.

The variations of this ressel are unimportant. (A) The most frequent perhaps is for it to come off from the back of the aorta a little above the bifureation; or (B) from one or other of the common iliacs; or (C) as a common trunk with what are usually its branches, the fifth frair of lumbar arteries. (D) It sometimes gives off an accessory renal artery-al fact of interest, in that the kidueys occuly a lower position in the abtomen in some animals than in man.

\section{THE COMIION ILIAC IRTERIES}

The common iliac arteries must be regarded as the terminal luanches of the abdominal aorta. unless the midlle sacral and the artery of the tail in the lower animals are regarded as the continuation of the abdominal aorta. The eommon iliacs arise opposite the left side of the middle of the lrody of the fourth lumbar rertebra, at the hifureation of the abdominal aorta, and, diverging from each other in the male at about an angle of $60^{\circ}$, and in the female at an angle of $68^{\circ}$, terminate opposite the lumbo-sacral articulation hy lifureating into the external iliae, which is continued along the brim of the pelvis to the lower limb, and into the internal iliar. Which passes orer the brim of the pelvis and descends into that caritr. Both arteries lie on the fifth lumbar rertebra, are corered by the peritonemm, and are crossed by the ureter, and in the female, in addition, by the ovarian arteries.

The relations of the arteries differ slightly on the two sides, and may be consiclererl separately.

\section{The Right Commox Iliac artery}

The right common iliac measures about two inches in lencth ( $5 \mathrm{ens}$.), and is: rather longer than the left, in consequence of the aorta lifureating a little to the left of the median line.

Relations. - In front it is covered by the peritonemm, and is crossed by the right meter a little before its lifurcation, lus the ovarian artery in the female, by the termination of the ileum, by the terminal hranches of the superior mesenterie artry and by branches of the sympathetic nerve desending to the hypogistric plexils.

Behind, it lies on the right eommon iliar vein, the end of the left eommon iliac rein, and the commencement of the inferior vena cava, which separate it from the fourth and fifth lumbar vertehre and their intervening disc. the psos muscle, and

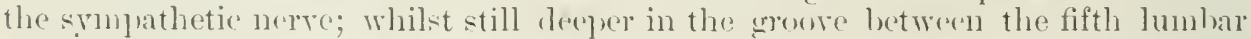
reptebra and the poas are the lumbo-saclal cord, the obturator nerve, and the iliolumbir artery.

To the right side are the heginning of the inferior vena cava, the end of the right common iliac rein. and the psoas muscle, which, howerer, is separated from the artery by the inferion vena cara at its upper part.

To the left side are the right eonmon iliac rein, the termination of the left common iliae vin, and the hypogastrie plexus. 
It will be thus seen that the right common iliac artery erosses both common ilias: veins, and that its own vein, the right, is at first a little to the left side, lut, as it ascencls, lisses beneath it, and gets a little to the right side. Sinee the bifurcation of the rena cava is a little below and to the right sicle of the bifureation of the anrta, it follows that the right common iliac artery lies on the conmencement of the venal calsa.

\section{The Left Common Iliac Arteri}

The left common iliac artery, one inch and three-quarters in length $(4 \mathrm{~cm}$.$) ,$ is a little shorter and thicker than the right.

Relations. - In front it is corered ly the peritoneum, which separates it from the intestines, and is crossed by the ureter, the ovarian artery in the female. branches of the srmpathetic nerve lesending to the hypogastric plexus the temination of the inferior mesenteric artery, the sigmoid flexure, and the sigmoid mesio-colon.

Behind are the lower border of the hody of the fourth lumbar vertelsa, the dise between the fourth and fifth lumbar vertebre, the body of the fifth lumbar vertebra, and the disc between it and the sacrum. Crosing deeply behind the artery between the fifth lumbar vertebra and the psoas, is the obturator nerve, the lumbo-sacral cord, and the ilio-lumbar artery.

To the left side is the psoas muscle.

To the right side are the left common iliac rein, the hypogastric plexus, and the miclle sacral artery.

\section{Tariations in the Common Ilien Aiteries}

(A) The common iliae arteries may be longer or shorter than here described. They have been firund as short as half an inch, or as long as four and a halt inches, but the nsual limit is something between one and a half to three inclies. This variation in the length of the vessels may lepend upon the aorta bifureating alwe or below the usial spot, or upon the common iliae arteries dividing ligher or lower than usual. A low bifurcation of the aorta is somewhat more common than a high bifureation, as is also the case with the common iliacs. (B) The common iliacs may be absent, the external and interual iliacs then arising together from the end of the aorta. (C) Either artery may give off a large branch, such as the ilio-lumbar, the lateral or the middle saeral, sometimes a lumbar, or oceasionally au atecessory renal artery.

\section{Collateral Circulution}

The collateral circulation after oh-truction or ligature of the common iliac artery is earried on chiefly (figr. $3 \bar{T}-$ ) by the antastomusis of the middle sacral with the lateral sacral; the internal mammary with the epigastrie; the lumbar arteries of the aorta with the ilio-lumbar and deep circumflex iliate the pulsic branch of the ej, igastric with the pubic branch of the oliturator; the posterior branches of the sacral arteries with the rluteal ; the smperior hamorrhoidal fom the superior mesenterie, with the hemorrhoidil branches of the internal iliac and pudic; the ovarian arteries from the aorta with the uterine branches of the interual iliac; and loy the anastomo:is across the mirldle line of the pubic branch of the obturator with the like resicel of the opposite side ; the lateral saeral with the opposite lateral saeral; and the resical, hamorrhoilal, uterine, and vaginal branches of the intermal iliae with the corresponding branther- of the vpluvite interual iliae.

\section{Braxthes of the Compox Ihal A RTERT}

The branches of the common iliac artery are:-(1) Peritoneal and sulperitoneal; (2) ureteral; (B) internal iliac; and (4) external iliar.

(1) The peritoneal and subperitoneal are rlistributorl to the peritomemn and suhperitoneal fat. They anastomose with like rescels given off from the lumbar, phrenic, and renal arteries, forming a sulpreritoneal arterial anastomosis. They are very small and unimportant.

(2) The ureteral are small insignificant twigs given nft to the ureter as that duct croses the artery. They anastomose with the ureteral arteries given oft from the spermatic alove, and with these lerived from the vescal arteries lelow. 


\section{(3) THE INTERNAL ILIAC ARTERY}

The internal iliac artery arises at the bifurcation of the common iliac opposite the lumbo-sacral articulation. It descencls into the pelris for aluout an incle and a (quarter $(B$ cm. ), and then divides, opposite the upper margin of the great sacrosciatic foramen, into an anterior and a posterior loranch.

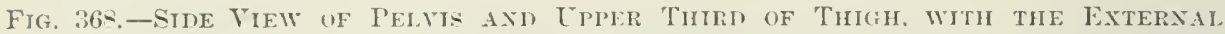

Iliac, Ixtersal Iliac, axi Femoral, Artertes axd tieir braxches, Left Sine.

(From a dissection by W. J. Walsham in the Musenm of St. Bartholonew's Hospital.)

The hadder is hooked over to expose back of pelvis.

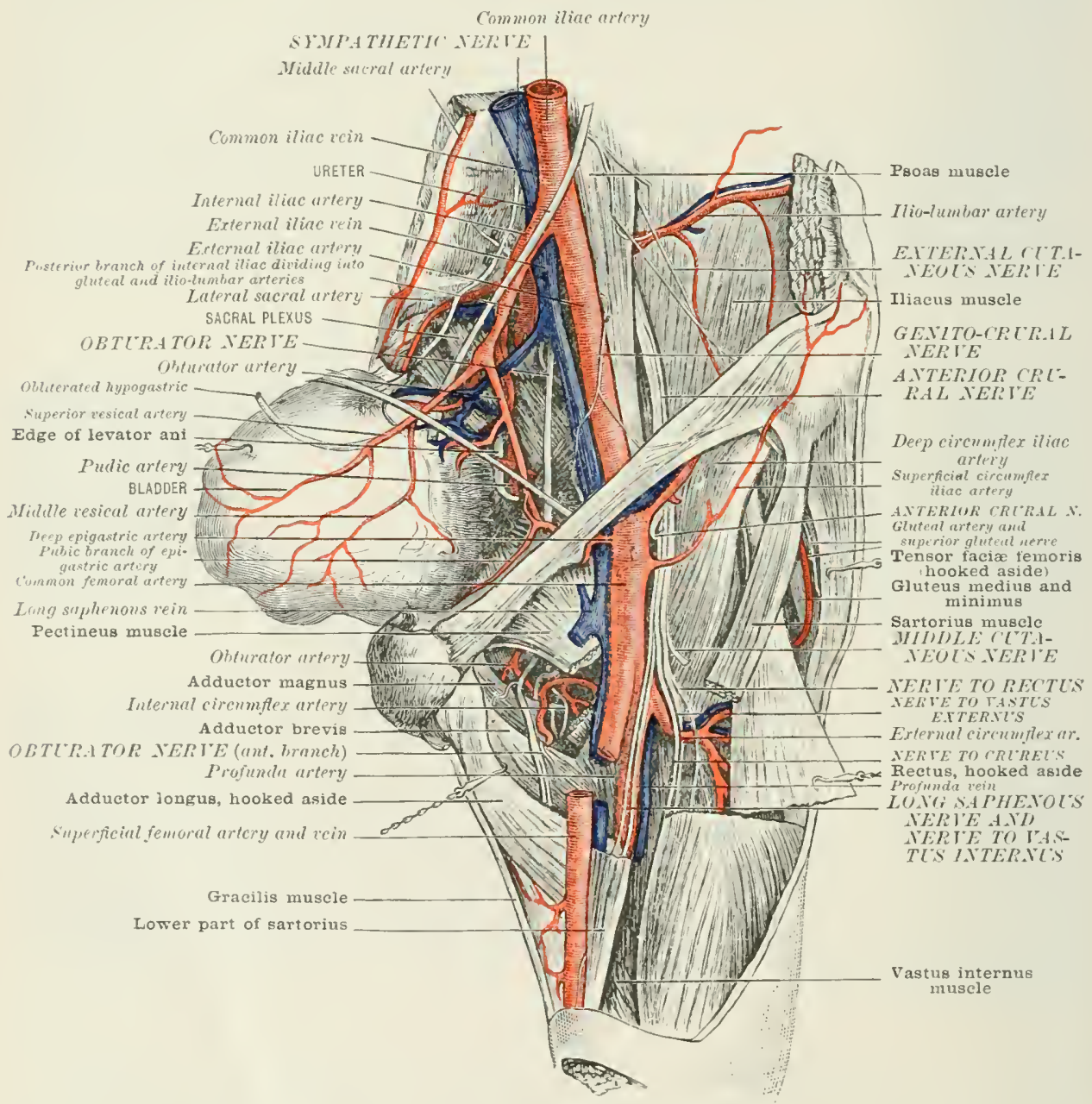

Relations.--Behind, it rests on the termination of the extemal iliac vein, the internal iliac rein, the immer margin of the poos muscle, the lumbo-sacral cord, the ol,turater nerve, and the sacrum.

In front it is coveres hy the peritonem, and is crossed hy the ureter.

In the adult the internal iliae is smaller than the "xternal ilian'; lut in the foetus the internal is much lirerer than the external, and is, together with its anterior branch, the ressul hy which the libor is returned to the placenta. In carly fortal 
life it does not descenel into the pelvis, hut coures ahere the pelvic lrim by the sicte of the allantois, and later by the side of the blackler and uraches, to the minbilicus, moler the name of the hyjogastric artery. At the mulilicus it is joined by the umbilical rein, and by the hypogastric artery of the opposite sile. The two arteries, now known as the umbilical, coil spirally round the rein on their way to the placenta. forming the umbilical cord (fig. 36 sis). After hirth the hypogastric artery (eatses to be pervious beyond the superior resical buanch, and is converted inte a fibroms cord, the olbliterated hypogastric artery.

Variations.-( $(1)$ The internal iliac may be longer or shorter than usual. It is scklom lets than in inch in length, but has been met with as short as lialf an inch, and as long as three inches. The variation in length grenerally depends upun the length of the common iliac; when this bifureates higher than unal, the intemal iliac is then longer, and may lie at first above the brim of the pelvis; but the length may also depend upon the artery itself dividing higher or lower than usual into its branches. This division may occur anywhere between the brim of the pelvis and the upper border of the sacro-sciatic foramen. (B) It: branches may be given off without the artery diriding into an anterior and a posterior division, or one or more branches may arive above the division.

The branches of the posterior division of the internal iliac are:-(1) The ilio-lumbar; (2) the lateral sacral: and (3) the gluteal.

The branches of the anterior division are:-(1) The hypogastric; (2) the superior, middle, and inferior vesical: (3) the middle hremorrhoidal; (4) the utcrine; (5) the raginal; (6) the obturator; ( 7 ) the satic; and (S) the internal purlic.

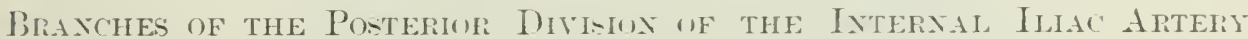

\section{THE ILIO-LCMBAP ARTEFY}

The ilio-lumbar artery-a short vesel coming off from the posterior part of the internal iliac artery-runs upwards and outward: leneath the common ilian artery, first between the lumbu-sactal cord and oluturator nerve, and then betwern the firos muscle and the vertebral column. On reaching the brim of the pelris it divides into two branches. an iliae and a lumbar. The iliac branch passes ontwatris beneath the poos and anterior crural nerve ancl. perforating the iliacus. ranifies in the iliac fossa between that muscle and the bune. It supplies a nutrient artery to the hone, and then breaks up into several hanches which radiate from the parent trunk, upwards towark the sacro-iliac synchendrosis, outwards toward: the crest of the ilium, clownards towarls the anterior superior spine, and inwards towards the pelvic carity. The first amastomoses with the last lumbar; the weenel with the external eircumflex and gluteal; the thirk with the deep circumflex iliar. from the external iliac: the fourth with the iliac branch of the obturater. The lumbar branch ascencls leneath the proas. and. supplying that muscle and the puarlatus lumborum, anastromeses with the last lumbar artery. It sends a lianch into the spinal canal thromer the intervertedral foranem lwetween the last lumbar vertebra and the sacrum. which anastomoses with the other spinal arteries. The ilio-lumbar artery is serially homoloments with the lumbar arteries. Hence the similarity in its crourse and distrilutiom.

\section{THE LATEIAL, SACRAL, ARTERIE}

The lateral sacral arteries, usually two in numbers, arios from the fonsterion rivision of the internal ilias. The superior artery, when two are present, runs

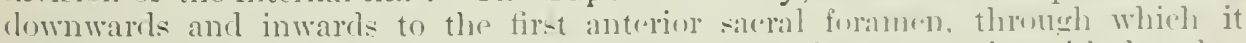

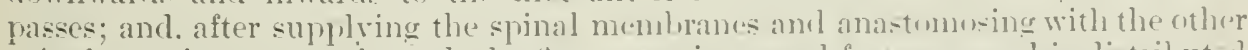
spinal arteries, pasces through the first josterior sacral formen. and is distriluter to the skin over the hark of thr sarem, there andstomoing with luanches of the gluteal and sciatic arteries. The inferior lateral sacral ifwencls: on the sire of 
the sacrum, external to the sacral chain of the sympathetic, and internal to the anterior sacral foramina. crossing in its course the slips of origin of the prriformis muscle and the first anterior sacral nerve. On reaching the coccyx it anastomoses in front of that hone with the middle sacral artery, and with the inferior lateral sacral of the opposite side. In this course it gives off:-Posterior or spinal branches, which enter the second, third, and fourth anterior sacral foramina, ant, after supplying the spinal membranes and anastomosing with each other, leave the spinal canal hy the corresponding posterior sacral foramina, and are distributed to

Fig. 369.-The Gleteal, Region, With the Gltteal, Sciatic, axd Pcic diteries.

(From a rlissection hy W. J. Walsham in St. Bartholomew's Hospital Museum.)

The inferior gluteal branch of the sciatic artery bas been drawn inwards over the tuber ischii with the reflected origin of the glateus maximus musele.

Gluteus medius, turned up

INFERIOR FLTTE.IL FERTE | Gluteus minimus

Gluteus maximus, cut | | Muscular branches of sciatic artery

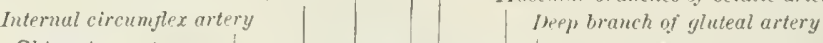

Obturator exterus $\quad$ SLPERIOR GLLTEAL NEIIE

Insertion of gluteus medius
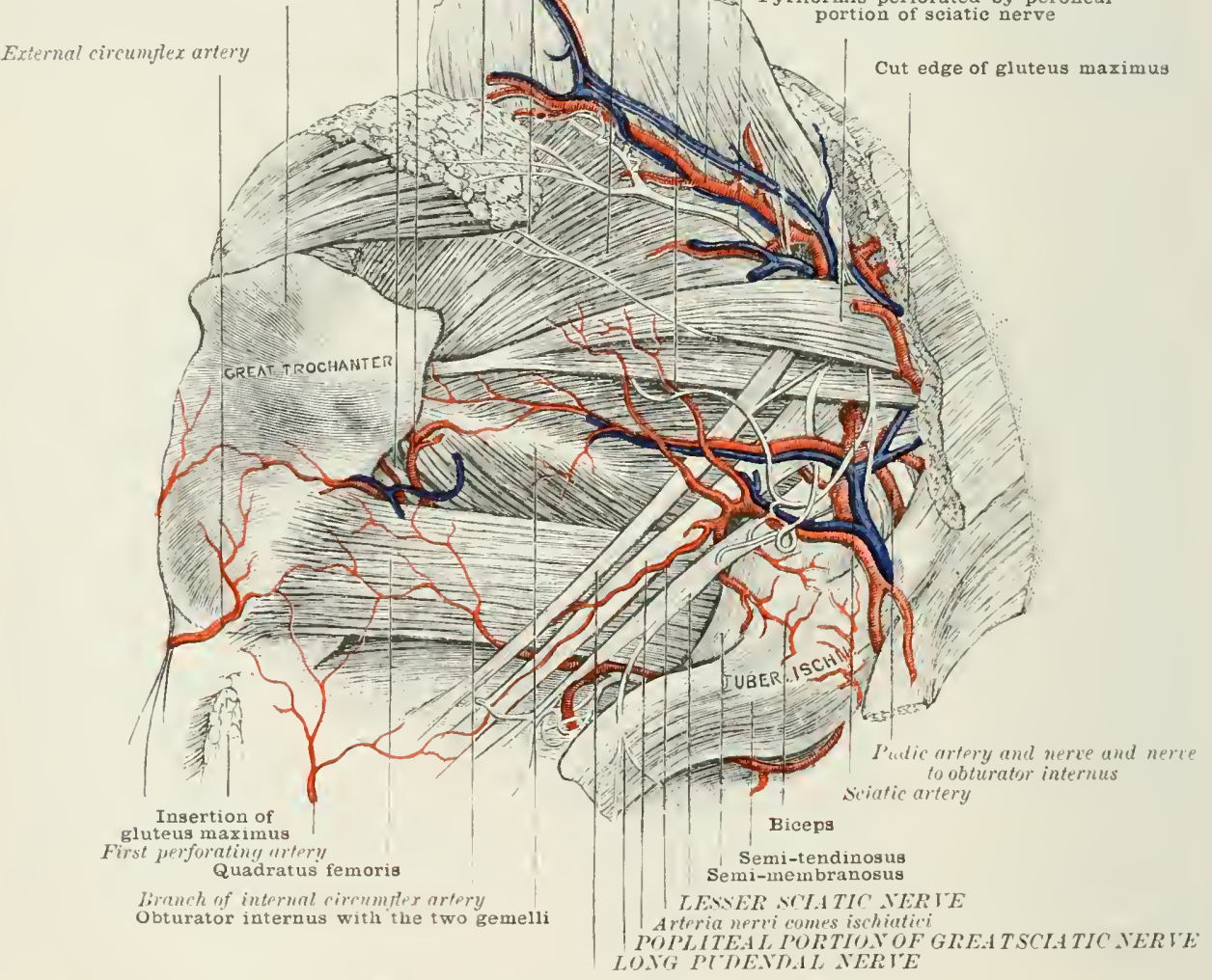

PERONEAL PORTIOY OF GRE.1T SCI.ITIC NERIE

the muscles and skin orer the back of the sacrum; anterior or rectal branches which run forward to the rectum; external branches which are distributed to the pyriformis, coceygeus, and the sacral nerres; and internal branches which pass inwarls across the sicpum to anastomose with branches of the midlle sacral artery.

It times the lateral sarcral arteries are excedingly small, the spinal hranclies then coming chiefly from the milllle sacral. The anastomosing branches botween the lateral sacral and mirlille sileral are neually recarded as sacral arteries dininished in size, and serially homologous with the humbar and intereostal arteries. 


\section{THE GILTEAL ARTERY}

The gluteal artery, the largest branch of the posterior division of the internal iliac, connes off as a short, thiek trunk from the outer and back part of that resicel, of which indeed it may be regarded as the enntintuation. Pascing barkwarls letween the first sacral nerve and the lumbo-sacral cord through an osien-tendinous: arch formed by the matrin of the bone and the upper erlge of the pelvic fiscria, it leaves the pelvis through the great sacro-satic foramen alove the priformis muscle in company with its vein and the superior gluteal nerve. At its exit posteriorly from the great sciatic foramen it lies under cover of the ghutens maximus anit beneath the gluteal rein, and in front of the superior gluteal nerve. It here lneaks: up into two ehief hranches, a superficial and a deep. Its emergence from the felvis is indicaterl on the surface by a point situated at the junction of the postrior with the middle third of a line drawn from the anterior superior to the posterior superior spine of the ilimm.

Branches of the gluteal artery:-

(a) Within the pelvis, branches are distributed to the obturator internus, the prriformis, the levator ani, the coccrgeus, and the pelvic bones.

(b) External to the pelvis, the artery divides into a superficial and deep iranch.

(i) The superficial branch Jreaks up into a number of large ressels for the supply of the upper portion of the gluteus maximus, some of them pierring the murele and supplying the skin over it, and anastomosing with the posterior hranches of the lateral sacral arteries; whilst one of larer size, emerging from the nucre near the iliac crest, anastomoses with the deep circumflex iliac arterr. The lower branches to the muscle anastomose with branches of the sciatic.

(ii) The deep branch subdivirles into a superior and an inferior branch. (1) The superior skirts along the line of origin of the gluteus minimus, between the shlten:

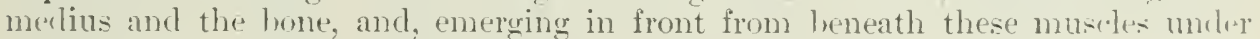
corer of the tensor fascire femoris (fig. 368), anastomoses with the ascending hranch of the extemal circumflex and deep circumflex iliac arteries. ( $\xi$ ) The inferior branch passes forwards between the gluteus nedius and minimus. aceompanierl hy the liranch to the tensor fascia femoris of the inferior livision of the superior glutal nerve trimards the great trochanter, where it anastomoses with the a-connline branch of the external circumflex. It supplies branches to the contiguous muscles and to the hije-joint. ilimm.

The deep branch before its division gives off the cxternal nutrient artery of the

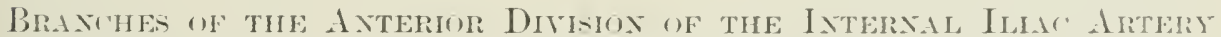

\section{THE HYPOGASTRIC ARTERY}

The hypogastric artery, the main trunk of the internal iliae in the fortus is the apparent continuation of the anterior lorancle of the internal iliac. I'as-ing forwards along the sile of the pelvis, it enters the lateral false ligament of the harkler, where, after giving off one or more vesical branches. it ceases to be previnus as it passes on to the sicke and upjer part of the bladeler. Thence it ascends, monder cover of the anterior fake ligament, as a fibrous cord. to the umbilicus. where it is joined hy its fellow of the opposite siche. Is it lies in the lateral false ligament it is erossed by the vas deferens.

\section{THE VESICAL APTERIES}

The vesical arteries are divided into the superinr, midlle, and inferior.

(1) The superior vesical artery-though usually rwatibed as a hrameh of the intemal iliae, inasmuch as it is alyarently given oft from the anterior division of 
that vesel-is really a branch of the unobliterated portion of what, in the fortus, was the hypogastric artery. It ramifies over the upper fundus of the blakler, anastomosing with the artery of the oplosite sicle and with the middle and inferion vesical below. It gives off the following hranche:- - (a) The deferential, or artery of the vas deferens, arises from the sujerior resical near the s]ot where the vas crosises the obliterated hypogastric artery, and. having reached the ras, divides into an asemeling and a desending branch. The ascending branch follows the vas through the inguinal canal to the testicle, where it anastomoses with the sprematic artery. The descending hranch passes clownwards to the dilated portion of the ras and resicule seminales. (b) The uracheric branch passes mpwarks along the uradius. (c) The ureteric branches pass to the lower end of the ureter, which they suply. and anastomose with the other ureteric arteries. (d) The middle vesical (rometimes).

(2) The middle vesical is a branch either of the superior resical, or of the mohliturated portion of the hypogastric artery. In the latter ease it is given off lefore the superior vesical. It is distributed to the sides and base of the bladkler. and anastmoses with the other vesical arteries.

(3) The inferior vesical arises from the anterior division of the intemal iliac, frecutently in common with the middle hemorthoidal, and passes downwards and invares to the base of the bladeler, where it breaks up into branches which ramify over the lower part of the viscus. It gives off:- (a) Branches to the prostate. which supply that orean and anastomose with the arteries of the opposite side by means of descending arteries which pass through the prostatic plexus of reins. but ontsicle the capsule of the prostate, and with the inferior hrmornoidal branches of the internal pudic. It times one of these prostatic branches is of large size. and supplies certain of the parts normally supplied hy the intemal pudic. It is then known as the accessory pudic, and then most commonly teminates as the clorsal artery of the penis. (b) Branches to the vesiculae scminales; and (c) branches (in the fomale) to the vagina. (Nee VAGINAL A RTERY.) The artery of the ras deferens sometimes arises from the inferior resical. instead of from the superior resical.

\section{THE MIDILE H.EMORRHOIDAL ARTERY}

The middle hæmorrhoidal or the middle rectal artery, variahle in its origin. lerhaps most commonly arises from the anterior division of the internaliliac alone with the inferior resicul. It runs inwards to the sides of the middle portion of the rectum, dividing into branches which anastomose above with the superior hrenorrhoidal derived from the inferior mesenteric, and below with the inferior hremorrhoidal derived from hranches of the pulic. Its corresponding vein teminates in the inferior mesenteric vein.

\section{THE LTERINE ARTERY}

The uterine artery arises from the anterior branch of the internal iliac close to or in conjunction with the middle hemorthoidal or inferios vesical. It rums downwark and inwards through the pelvic connective tissue in the so-ealled infundibulepelvic lisament, crossing the ureter about half an inch from the cervix uteri. It then tums upwards and aseends between the layers of the broad ligament on the side of the uterus in a coiled and tortuous manner, and, after giving off a number of tortuous branches which rannify in a horizontal mames over the front and hack of the uterus, sulphying its substance, anastomoses with the uterine branch of the orarian artery. 'The distribution of the vessel in the uterus will he describul with that organ. The branches of the uterine artery are:-(1) Cervical.-This

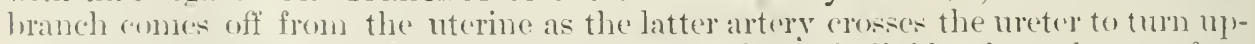
warks an to the uterus. It runs directly inwarls, and diviles into three or four hranches which poss on to the cervix at right angles to it; one hranch anastomosing with its fellow of the olposite side in front and behind the neck, forming the so-callect colonary artery of the cervix. (2) Vaginal azygos. -4 second banch descends 
both in front and behind in the middle line of the cervix on to the vargina, and forms, with branches of the vaginal arteries, the so-called azygos artery of the vagina.

\section{THE TAGINAL AR'TEIIES}

The vaginal arteries come off separately from the anterior division of the internal iliac, or one or more of them may arise in common with the inferior resical, uterine, or middle hamorrhoidal arteries. They are uswally two or three in number. They pass through the pelvic connective tissue to the side of the ragina. supplying its walls, and anastomosing with the corresponding arteries of the oplposite side, with each other, and with tortuous branches from the artery of the cervix. a branch of the uterine. With this ressel they form a more or less vertical trunk in the median line of the vagina, both back and front. This ressel is known as the

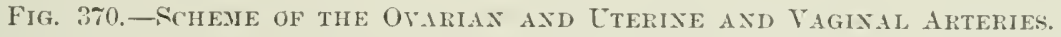

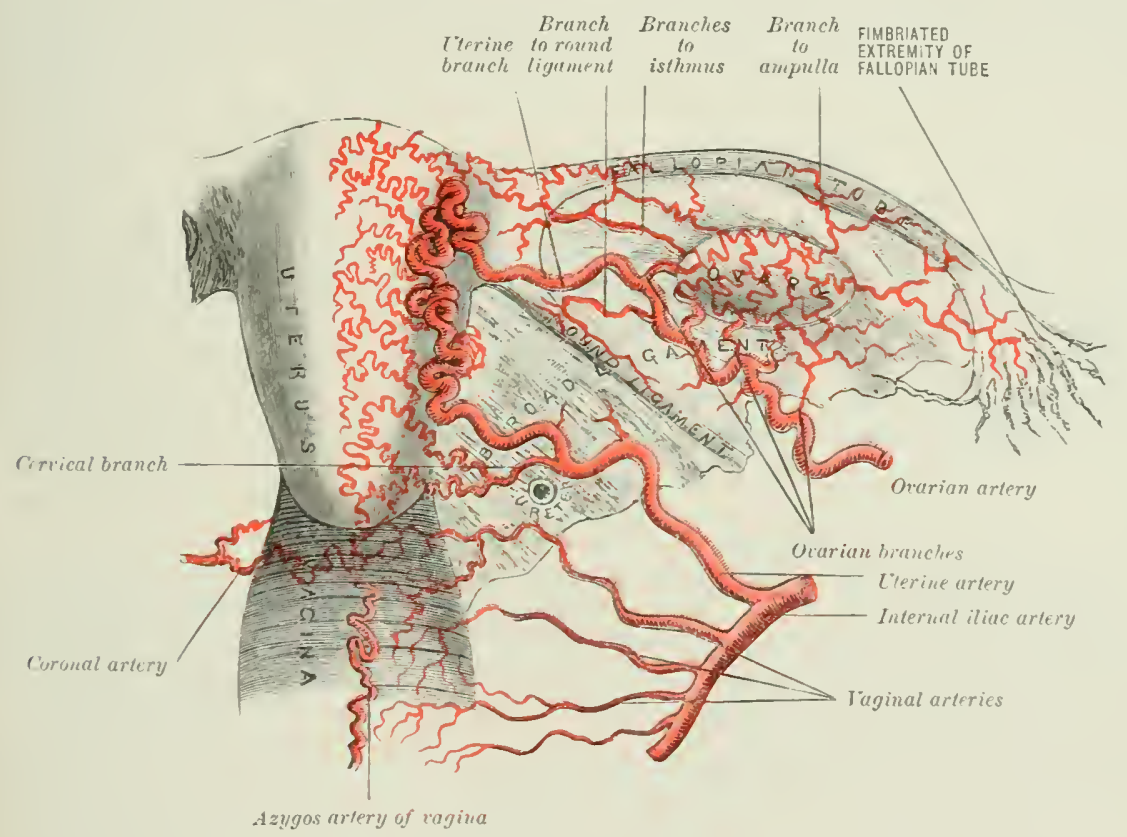

azygos artery of the vagina. The lewer vaginal arteries extent to the hull, of the vestibule, where they conmunieate with the bulbar branch of the internal purlic. small liranches extend also on to the rectun.

\section{THE OBTURATOR ARTERY}

The obturator artery comes off from the anterior division of the internal iliac at about the same spot as the hypocastric. Oceasionally it arises from the posterior division. It runs forward and downwards a little botow the lrim of the pelvis, having the oliturator nerse alove, and the obturator vein below. It here lies botween the peritoneum and the pelvic fascia, but pieres the faseia to gain the ohturator canal, the aperture in the upper and outer part of the obturator memhranc. In this course it is eroserl ho the ras deferens. On cuncrging from the olturator canal, the artery divides into two branches. an external and an internal, which wind round the margin of the thyoid formen beneath the oliturator externus muscle. 
Within the pelvis the artery gives off:-(1) An iliac or nutrient branch; (2) a resieal branch; and (3) a pubie branch. Without the pelvis, it divides into:(1) An external branch; and (2) an internal branch.

1. Intre-pelvic branches.-(1) The iliac or nutrient branch ascends to the iliae fosw, passing hetween the iliacus muscle and the bone. It supplies a nutrient ressel to the ilium, and anastomoses with the internal branch of the iliac division of the ilio-lumbar artery.

(2) The vesical branch or branches are small ressels which run in the lateral false ligament of the bladder to that organ, where they anastomose with the other resical arteries.

(3) The pubic branch comes off from the obturator as that ressel is learing the pelvis by the obturator canal. It runs mpwards and inwards behind the pubes, anastomosing with its fellow of the opposite side of the hody, and with the pubic lianch of the deep epigastric artery. One of the anastomosing channels between the pubic branch of the olsturator and pubic hranch of the deep epigastric arteries is sometimes of large size, a fact of surgical interest in that the enlarged vessel may then run round the inner side of the femoral ring (1age 579).

B. Extra-pelic branches.-(1) The external branch slirts the external margin of the thyroid foramen, lying between the obturator cxtemus and the obturator membrane. At the lowernargin of the foramen it divides into two branches. One lranch continues its course round the lower nargin of the foramen, and anastomoses with the internal branch of the oloturator and with the internal diremnflex. The other branch turns ontwards below the acetabulum, and ends in the muscles arising from the tuberosity of the ischium. It anastomoses with the sciatic artery. This branch gives off a small twig which passes under the transverse ligmment into the hip-joint, where it supplies the srnovial membrane, the ligamentum teres, and the fat in the fossa at the bottom of the acetabulum.

(2) The internal branch runs round the immer margin of the thyroid foramen, and anastomoses with the immer division of the external branch and with the internal circumflex artery. It supplies branches to the oliturator and adductor muscles.

\section{THE SCIATIC ARTERY}

The sciatic artery-the larger of the terminal branches of the anterior division of the internal iliac-passes over the sacral plexus and prrifomis muscle to the lower part of the great sciatic foramen, where it leares the pelvis with the pudic artery, behind and external to which it lies, by passing between the prriformis and cuccrgeus muscles. On emerging from the great sciatic foranen in the gluteal region muler cover of the gluteus maximus, it descends to the immer side of the great sciatic nerve, lying midway between the tuherosity of the ischium and the great trochanter on the gemellus superior, obturator internus, gemellus inferior, quadratus femoris, and upper part of the adductor magnus muscles. It anastomoses with the internal circumflex artery, and superior perforating branch of the profundal. The branches of the sciatic artery are divided into the intra- and extra-pelric.

The intra-pelvic branches are small and mimportant, and irregular in their origin and clistribution. They are given off to the levator ani, cocergens, and pyriformis muscles, the rectum, bladder, prostate gland, and resicule siminales.

The extra-pelvic branches are: (1) The cocergeal; (2) inferior ghtuteal; (3) muscular; (4) anastomotic; (5) articular; (6) rutaneons; and (7) comes nervi ischiativi.

(1) The coccygeal is a small branch which passes inwards, and, piereing the great sacro-sciatic ligament and the glutens maximus, is lost in the integment orer the lower part of the sacrum and cocera. It gires several branches to the lorrer and internal part of the glutens maximus as it passes through it.

$(2)$ The inferior gluteal is a fairly large braneh which arises from the seiatic just helow the coreygeal, and, turning mowals and inwarks into the deep surface of the glutens maximus along with the inferior gluteal nerve, supplies that muscle, and anastomoses with the gluteal artery.

(3) The muscular branches, valialle in their number and origin, pass to the 
pyriformis, ohturator internus, and gemelli muscles, anastomosing with the puelic, the internal eireminflex, and the obturator arteries.

(4) The anastomotic branch crosses the external rotator muscles cither over or under the great sciatic nerve, and contributes to the formation of the soreallerl crucial anastomosis by anastomosing with the first perforating below, the ternination of the internal ciremflex intemally, and the trunserse braneh of the external circumflex externally (fig. 369 ).

(5) The articular branches pass beneath the rxternal motator muscles with the nerve to the quadratus femoris, and send several filaments into the posterior part of the capsule of the hip-joint.

(6) The cutaneous branches turn round the lower borter of the gluteus maximus, along with branches of the small sciatic nerve, and supply the integument of that region.

( 7 ) The comes nervi ischiatici is a long slender vessel which passes down the lack of the thigh with the great sciatic nerve, to which it semels numerous branches. It anastonoses with the internal ciremmflex, and with the first, seconcl, and third perforating arteries, and with the termination of the profunda, or fourth perforating. After ligature of the femoral in Searpa's triangle this artery becomes greatly enlarged, and contributes through its anastomosis with the above-mentionerl arteries to the supply of the parts below the ligature.

\section{s. THE INTERNAL PLDIC ARTERY}

The internal pudic artery-the smaller of the two terminal branches of the anterior division of the internal iliac artery-comes off with the sciatic, the other terminal branch, either separately or as a common trunk, opposite the prriformis muscle. It descends with the sciatic over the prriformis and sacral plexus of nerves, lying anterior and internal to the latter artery as far as the lower border of the great sciatic foramen, where it passes out of the pelvis between the prriformis: and coreygens muscles. It then winds over the onter surface of the spine of the ischimn under corer of the gluteus maximus, and re-enters the pelvis through the lesser sciatic notch. Rumning forwards over the obturator internus muscle, it passes through the base of the triangular ligament, and, continuing its coulsw along the ramus of the pubes, gives off between the two layers of the triangular ligament the artery of the crus and the artery of the bulb, and is continued through the anterior layer of the ligament as the dorsal artery of the penis.

The relations of the artery may be consiclered:-(1) 1 s it lies within the pelvis; (2) as it croseses the spine of the ischimm; (3) as it lies on the obturator internus muscle, in the outer wall of the ischio-rectal fossa; and (4) as it liss between the two layers of the triangular ligament.

(1) Within the pelvis the artery crosses the prriformis muscle and sacral plexus of nerres. lying somewhat anterior and intemal to the siatic artery, which is usually given off from the intemal iliac along with it. At the lower boreler of the sciatic foramen it leaves the pelvis hy passing between the proriformis and cocergeus muscles along with the sciatic artery, the pulic nere, the greater and lesser sciatic nerves, and the nerve to the obturator internus.

(2) As it crosses the spine of the ischium it has a companion rein on either side, the pulic nerve on its inner side, and the nerve to the oliturator intornus on its onter side. It is covered by the glutens maximus musele, and more or less liy the overlapping edge of the great sacro-sciatic ligament. In a thin subject it cain be felt pulsating as it croses the ischial sine. A surt taken at the junction of the imner with the outer two-thirds of a line drawn from the top of the great trochanter with the fomur rotated inwards to the base of the cocerx. inclicales externally the situation of the artery as it croses the ischial spine. In this situlation it may, in a thin sulject, be compreserl. The branches of the artery in this part of its course are: (a) Small twigrs to the gluteus maximus: (b) a small branch to the obturator internus which accompanies the nerve to that muscle; (r) a sarelat branch which jierces the great sciatic ligament and anastonnses with the sciatic artely. 
(3) In the third part of its course, as it lies on the obturator internus muscle, in the outer wall of the ischio-rectal fossa, it is placed about an inch and a half $(3.5 \mathrm{~cm}$.) above the lower margin of the tuberosity of the ischimm. It is here hound down to the muscle by a strong sheath of the obturator layer of the pelvic fascia (Alcock's canal). In this part of its course the dorsal nerve of the penis and the superficial perinaal nerve, into which the pudic nerve divides about this situation, lie respectively ahove and below the artery.

The branches of the pudic artery in the third part of its course are:- $(a)$ The external or inferior hamorrhoidal; and $(b)$ the superficial perinxal.

(i) The external or inferior hæmorrhoidal branches (inferior or posterior anal) are given off from the pudic at the posterior part of the ischio-rectal fossa, just after it enters the outer wall of that cavity through the lesser sciatic foramen. They perforate the sheath of obturator fascia binding the pudic artery to the

Fig. 370A.-The ARteries of the Perix.eum.

On the right side Colles's fascia has been turned back to show the superficial ressels. On the left side the superficial vessels have been cut away with the anterior layer of the triangular ligament to show the deep ressels.

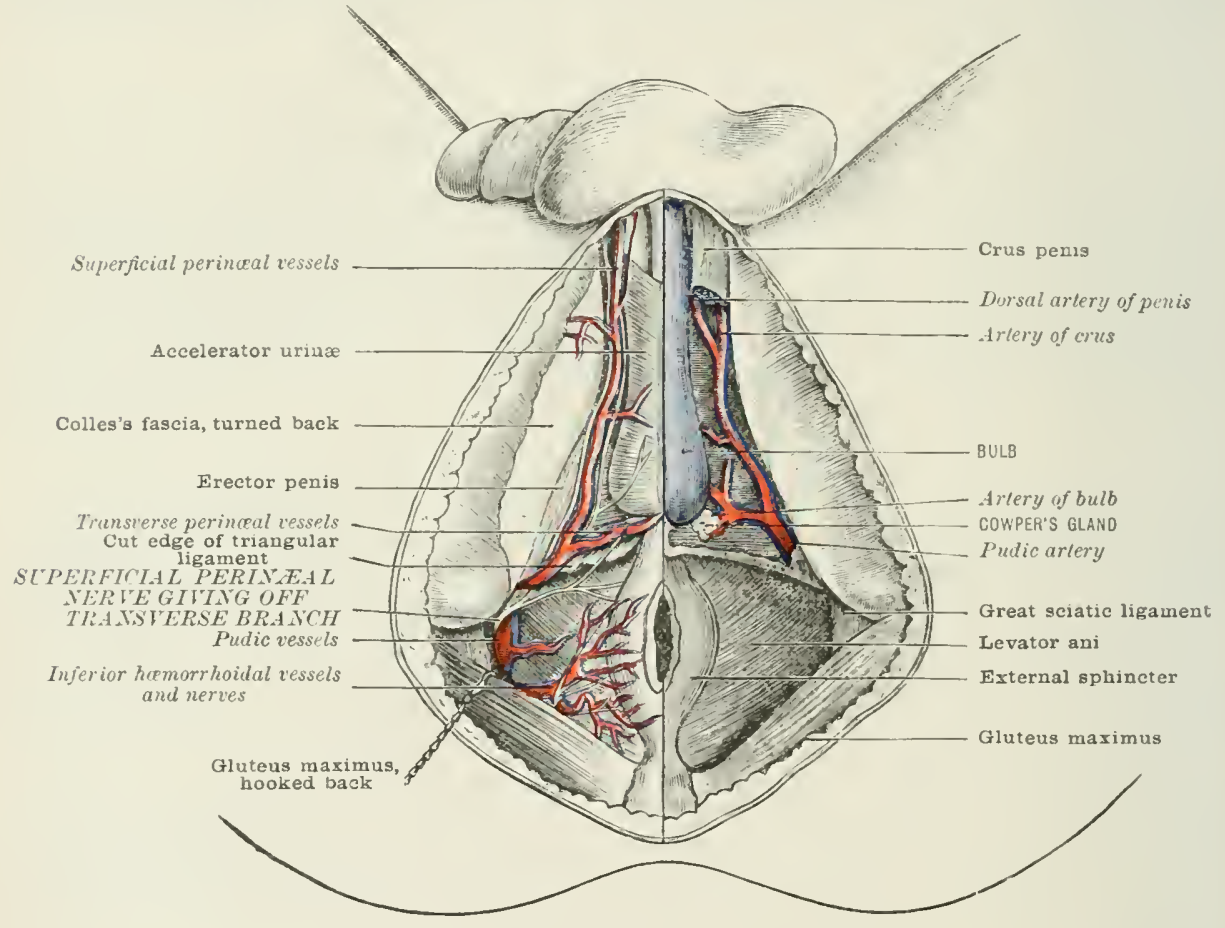

ohturator internus, and course transversely through the fat of the ischin-rectal fossa, inwards to the anus, where they supply the sphincter muscle and levator ani, amd anastomose with the superior and niddle hamorrhoidal arteries. Twigs are given off from them to the skin covering the anal triangle of the perineum; other brinches supply the gluteus maximus and wind over the posterior fold of that muscle to the integuments; whilst others again run forwards and anastomose with the transverse and superficial perineal arteries (fig. $370 \mathrm{~A}$ ).

(b) The superficial perinæal branch aries from the pudic at the front of the ischio-rectal fossa, just hefore that vessel pierces the posterior layer of the tritngular ligament. It passes through the deej layer of the superficial fascia of the perinewm (Colles's fascia), where that structure is continued into the anterior layer of the triangular ligament round the transverse fuerinas muscle. It then erosses in front of (occasionally behind) that muscle, and enters the perineal triangle, the 
space between Colles's faseia and the anterior layer of the triangular ligament, bounded by the erector penis externally, the acoleratur urina internally, and the transverse perinat inuccle below. On nearing the alex of this triancrle it diviles into long slender branches, which are continued along the back of the scrotum, anastomosing with the superficial extemal pulic hranch of the common fonmral. In this course it is acompanied by the superficial perineal nerve. It supplies the contiguous nuscles and the integuments of the scrotum. As a rule it gives off the following branch:-

The transverse perinæal artery usuilly arises from the lefore-mentionem artery. Occasionally it is a direct branch from the pulic trunk. It courses transversely inwards, on the transverse perineal inuscle, towards the central tendon of the perin:oum, supplying the muscles and integuments of the perinatum, anel anastomosing with its fellow of the opposite side.

(4) In the fourth part of its course the pudic artery lies between the two layers of the triangular ligament, close to the ramus of the jubes, in the sulstance of the compressor methre muscle, having the anterior layer of the triangular ligament in front and the posterior layer behind. In this situation it gives off the artery of the bulh and the artery of the crus penis, and then continues its conurse

Fig. 371.- Cideme of the Plid Artery ani its Braxches.

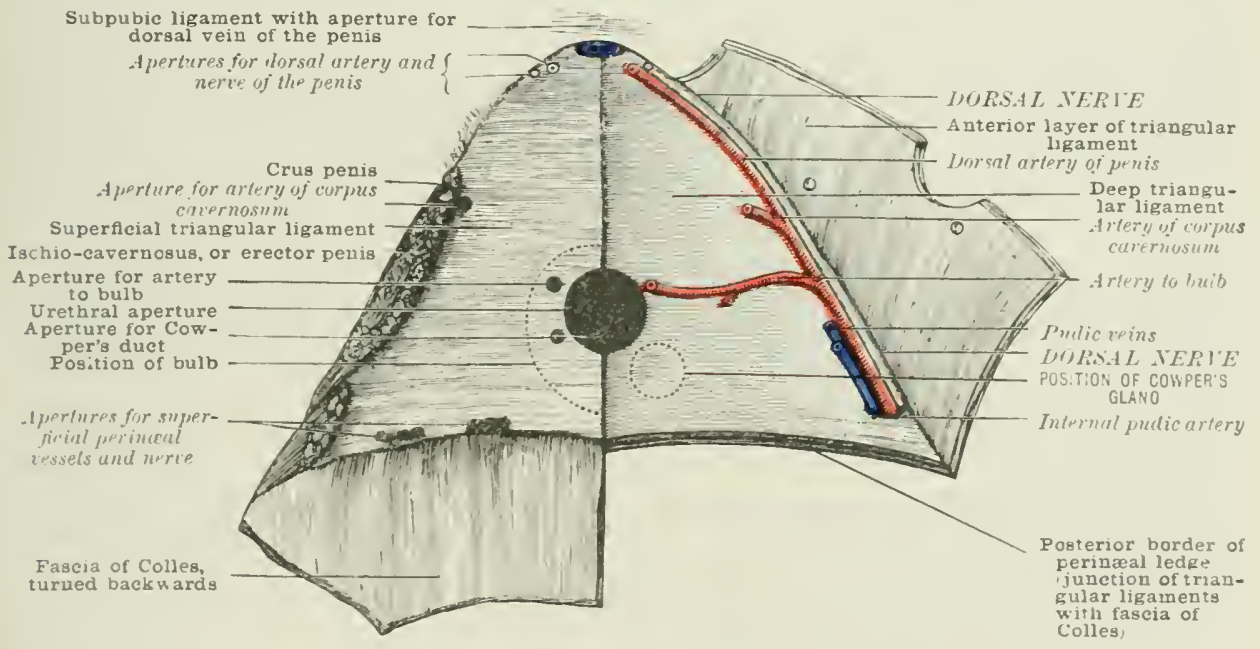

forwarks through the anterior layer of the triangular ligament under the name of the dorsal artery of the penis.

The branches of the pudic artery in the fourth part of its course are:- ( 1 ) The artery of the bull); $(b)$ the artery of the arus; and $(c)$ the dorsal artery of the jenis.

(a) The artery of the bulb, often of limge sizt. (rmmes off from the puclie soon after that vessel has pased hetween the two layers of the triangular ligament. It runs inwards and slightly upwarls behind the anterior layer of the triangular lietiment, ambedded more or less in the substanes of the compressor urethre muscle. On nearing the urethra, it prases forwarts through a hole in the anterior lareer of the triangular liganent (tigr. 371 ). ly the side of the opening ion the urethra, and. "ntering the bulh, supplies the ereetile tisene of the hull, and corpus spongiosum in the way describel molere the anatomy of the wrethra. It erives off a branch. just hufore piereing the anterior layer of the triangular ligament, to (omper's glands (fig. 370.1 ).

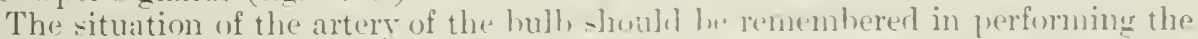
operation of lateral lithotomy. As a rule. the artery is well above the central tendun of the perineum. If the point of the knife is enteresl below this spest, and care is taken not to elirect its point subsequently too much upwards so that the deepere part 
of the incision is not made higher than the superficial. the artery will not be endangered. At times, howerer, the artery is given off from the pudic lower than normal. Its division may then be mavoidable.

When the artery is given off, as it occasionally is, from the accessory pulic, it pierees the anterior layer of the triangular ligament higher up, and is out of elanger in the ordinary low opreration of latreral lithotomy. Further, the artery of the bulh may be absent on one side, smaller than usual, or double.

In the female, the artery of the hulb, smaller than in the male, ends in the luall of the vestibule.

(b) The artery of the crus is usually given off from the pudic a little higher than the artery of the bulb. It makes at once for the ramus of the pubes, perforates the anterior layer of the triangular ligament close to the bone, and enters the crus penis (figs. $370 ., 371$ ). This artery has to be divided in the operation for the removal of the whole of the penis by dissecting off the crura from the rami of the pubis and ischium. Its situation close to the bone at times gives rise to some little trouble in securing it. A small additional artery to the corpus spongiosum is occasionally given off from this branch and then contributes to the supply of that structure and inosculates with branches from the artery to the bulb.

In the female, the artery ends in the crus clitoridis.

(c) The dorsal artery of the penis (fig. 371), the termination of the pudic, latsic's upwards between the two layers of the triangular ligament in the substance of the compressor urethre muscle; then, turning forwards, perforates the anterior layer of the triangular ligament, near its apex, a little to one side of the central apical opening for the dorsal vein. It then passes betwcen the two layers of the suspensory ligament of the penis, and descends along the dorsum of that organ, the single centrally placed dorsal vein separating it from the artery of the opposite side. The dorsil nerve lies to the outer side of the artery, and, still more external, the deep external pudic branch of the common femoral artery. At the glans the dorsal artery forms an anastomotic chain around the corona with the ressel of the opposite side. The superficial external pudie branch of the femoral at times may take the place of the dorsal artery. Occasionally the dorsal artery is found to arise from the inferior vaginal; that is, from an enlarged branch of the vessel known as the accessory pudic (see page 570 ).

In the female, the temination of the pudic is called the dorsal artery of the clitoris.

The dorsal artery gives branches to- $(a)$ The corpus avernosum; (b) the skin of the penis; (c) the glans penis; and in the female, $(d)$ the glans and prepuce of the clitoris.

\section{THE EXTERNAL ILIAC ARTERY}

The external iliac artery-the larger in the adult of the two vessels into which the common iliac divides opposite the lumbo-sacral articulation-extends from this spot along the brim of the pelvis, lying upon the inner border of the psoas muscle, to the lower margin of Poupart's ligament, where, midway between the anterior superior spine of the ilium and the symphysis pubis, it passes into the thigh, and takes the name of the femoral.

It measures three and a half to four inches $(10 \mathrm{~cm}$.) in length. The course of the rossel is indicated by a line drawn from half an inch below and a little to the left of the umbilicus, to a point a little internal to the centre of l'oupart's ligament, that is, to a spot midway between the symphysis pubis and the anterior superior spine of the ilimm. If this line is divided into thirds, the lower two thirds indieate the situation of the external iliac, the upper third the common iliac. The external iliac vein, the continuation upwards of the femoral rein from the thigh, lies to the immer side of the artery, hut on a slightly lower plane, and just before its termination grets a little behind the artery on the right side.

Relations. - In front, the artery together with the vein is covered by the parietal peritoneum descending from the abdomen into the pelvis, and by a layer of condensed subperitoneal tissue, known as Abemethy's fascia. It is crossed by the termination of the ileum on the right side, and hy the signoid flexure on the 
left. The genital branch of the genito-crumal nerve runs olliguely oxer its lower third, and just hefore its temination it is arosed transwersely by the deep cireunflex iliac vein. The spermatic vessels lie for a short distance on the lower part of the artery, and the vas deferens in the male and the ovarian vessels in the fomale eurve ovel it to descent to the pelvis. It is sometimes erossed at its origin by the ureter. The external iliac lymplatic glands lie along the course of the artery. The commeneement of its deep epigastric hranch is also in front.

Behind.- It first the artery lies partly upon its own rein; lower down upon the imner horder of the psoas; and just before it passes through the lacuna vasculosia, beneath Poupart's ligament, upon the tendon of the psoas. The continuation of the iliac into the polvic fascia is also below it.

To its inner side is the extemal iliae rein, the preritoneum, the descending layer of fascia, and the vas deferens in the male, and ovarian ressels in the female.

To its outer side is the psoas musele and the iliac fascia.

Variations.-(A) The external iliae may be longer or shorter than usual, aceording as the common iliac bifureates above or below the nunal spot. When longer it often takes a very tortuons course, making a partial hop or bend which may dip down below the brim of the pelvis. (B) It may be much smaller in size than usual; this is especially the ease in those instances in which the femoral or main vessel of the lower limb arises from the sciatic or other branch of the internal iliac. It then often ends in the profunda. (C) It may give off a large branch, as the deep circumflex iliac or deep epigastrie, higher than usual.

The collateral circulation is carried on (fig. 372), when the external iliae is tied, by the anastomosis of the ilio-lumbar and lumbar arteries with the circumflex iliac; the internal mammary with the deep epigastrie; the obturator with the internal circumflex; the seiatic with the internal (iremuflex and superior perforating; the gluteal with the external eireumflex; the arteria comres nervi ischiatici fom the sciatic, with the perforating branches of the profinda; the external pudic with the internal pudic; the pulsic branch of the obturator with the pubie branch of the epigastric.

The branches of the external iliac artery are:-(1) The deep epigastrie; (2) the drele ciremuflex iliac; and (3) several small and insignificant twigs to the neighbouring psoas muscle and lymphatic glands.

\section{(1) The Deep Epigatste Artery}

The deep epigastric artery usually eomes off from the external ilian just abore Poupart's ligament. Immediately after its origin, the ras deferens in the mate. and the round ligament in the female, loop round it on their way to the pelvis, drawing, as it were, the artery slightly inwards and downwards. It here lies intemal to the imner matrin of the derp or internal ablominal ring hehind the inguinal camal, and a little to the upleer and outer side of the femoral ring. Thence it passes upwards and inwarks, above and to the outer side of the superficial or external abdominal ring, lying between the fascia transversalis and the peritonemm to the lower margin of the posterior layer of the sheath of the rectus (fold of I)ouglas). Having piereed the fascia transersalis at this point, it passes in front of bouglas' fold and turns upwarls between the retus and its sheath, lying here about midway between the outer and imere edge of the musele. Higlere, it enters the substance of the musele, and anastomoses with the superior epigastrie, descending in the rectus from the internal mammary.

The situation of the artery between the two abdominal rings should be borme in mind in the operation for strangulated inguinal hernia, and its near proximity to the upper and outer side of the femoral ringshould wot be foreotten in the operation for femoral hernia. The artery is accompanionl hy two veins, of which the inmer is the larger. They end in a single trumk lefore opening into the external iliace rein.

The deep epierastric gives off the following sulall liranche:-(a) The cremasteric, which runs with the vas through the inguinal canal. supplies the cremaltere nuscle, and anastomoses with the spermatic, inferior external purlice and sujerficial perineal arteries. (b) The pubic, which jasses helow, or sometimes alwere, the femoral ring to the back of the pubes, where it amasomotes with the pubic branch 
of the olsturator and the corresponding ressel of the opposite side. This branch, though usually small, is oecasionally considerally chlargerl, when its exact course beeomes of great interest to the surgeon. Thus it may descent immerliately internal to the vein, and therefore externat to the femoral ring, or it nuty pass inwards in front of the fomoral ring and turn downwads either behind the os puhis or inmeriately behind the free edge of Gimbernat's ligament, in which situation it would be exposed to injury in the operation for the relief of a strangulated femoral hemia. (c) The muscular, which "supply the rectus and the oblipue and thansverse muscles of the abdomen, and andstomose with the lower intereostal and the lumbar arteries. (d) The cutaneous, which pierce the rectus, and supply the skin, anastomosing with branches of the superficial epigastric. And (e) the terminal, which anastomose above the umbilicus with the superior epigastric branch of the internal mammary.

Variations.-(A) The epigastric may come off from the external iliac higher than usual; it has been met with arising as much as two inches and a half above Poupart's ligament. (B) It may arise from the femoral below Poulart's ligament, or eveu from the mrotunda. (C) It may arise as a common trunk with the circumflex iliac. (D) It is sometimes double. (E) It may arise from the obturator, or conversely it may give off the obturator artery. This variation is due to the enlargement of the normal anastomosis of the epigastric and obturator through their pubic branches. It is of emsiderable importance to the surgeon, since the obturator artery, when given off from the epigastric, may rmm either external or internal to the femoral ring to reach the obtnuator foramen. This abnormalorigin of the obturator is sairl to occur once in every three subjects and a half; but the abnormal artery mily courses round the inner side of the ringin which situation it is liable to injury in the operation for femoral hernia-in exceptional cases. According to Langton (Holden's 'Anatomy'), the chances are about seventy to one against this vecurring. But even when it takes the abuormal course, it lies a line and a half or so from the margin of the ring, and will probably escape injury in the division of the stricture if several shurt notches are made in place of a single and longer incision.

\section{(2) The Deep Circumfex Iliac Artery}

The deep circumflex iliac arises from the outer side of the external iliac artery, either opposite the epigastric or a little below the origin of that vessel. It courses upwards and outwards just above the lower margin of Poupart's ligament, lying between the fascia transversalis and the peritonem, or at times in a fibrous eanal formed by the union of the fascia transversalis with the iliac fascia. Near the anterior superior spine of the ilimm, it perforates the transversilis, and then comses between that muscle and the internal oblique, along and a little above the erest of the ilimm. It finally divides into an ascending branch, which anastomoses with the lumbar and lower intereostal arteries, and a marginal braneh which rums backwarls to anastomose with the ilio-lumbar artery. It is accompanied by two reins. These unite into one trunk, which then crosses the extemal iliac artery to join the extemal iliac vein.

The deep circumflex iliac artery gives off the following branches:- $(a)$ Muscular branches, which supply the psoas, iliaeus, sartorius, tensol fascie femoris, and the oblique and transverse muscles of the abdomen. One of these branehes. larger than the rest. usually arises about an inch behind the anterior superior spine of the ilium and ascends perpendicularly between the transwersalis muscle and the intemal oblique. It has receired no nime but is important to the surgeon, as it indicates the intermuscular plane between the two mmscles. (b) Cutaneous branches, which supply the skin orer the course of the ressel, and anastomose with the superficial circumflex iliae, the gluteal, and the aseending branch of the external cireunflex.

Variations.-(A) The circumflex iliac, like the epigastric, may be given off fiom the external iliac higher than mormal, thongh seldom if ever as high as the fatter. (B) Jores rarely it may come off from the femolal helow Pompart's ligament. (C) It may arise as a common trink with the epigastric. (D) It may be cloubls. 


\section{THE FEMORAL ARTERY}

The femoral artery (fig. 372 ) is the continuation of the external iliac, and extends from the lower horder of Poupart's ligament, down the front and inner part of the thigh, to the tendinous opening in the arductor magme, through which it passes into the popliteal space, and is then known as the popliteal. The fenoral artery is at first quite superficial, being merely covered by the skin, and superficial and deep fiscia; but, after thus passing about tive inches ( $13 \mathrm{~cm}$.) in a direction downwards and inwards through the space linown as scarpa's triangle, it sinks at the apex of that triangle beneath the sartorius muscle, and thence to its termination continues beneath the sartorius, comsing deeply between the vastus interms. and adductor muscles in the space known as Hunter's canal. It at first rests upon the brim of the pelvis and head of the thigh bone, from which it is merely separated by the capsule of the hip-joint and the tendon of the psoas. Here it can be readily compressed. Owing to the obliquity of the neck of the femur and the direct course taken by the artery, it lies lower down only on muscles, at some little distance from the bone (fig. 373). At its termination, in consecunence of the shaft of the femur inclining towards the mildle line of the body, the antery lies close to the bone, but to the inner side. The course of the vessel when the thigh is slightly fiexel and abducted-the position in which the limb is placed when the ressel is ligatured-is indicated by a line drawn from a spot midway between the anterior superior spine of the ilium and the symphysis pubis to the adductor tubercle. When the thigh is in the extended position and parallel to its fellow, the course of the artery will correspond to a line drawn from the spot above-mentioned to the inner border of the patella.

The artery for about the first inch and a half to two inches ( 4 to $5 \mathrm{~cm}$.) is known as the common femoral, but at this distance from Poupart's ligament it gives off a large branch ealled the profunda, or deep femoral. For the rest of its course it is known as the superficial femoral. The superficial femoral is only superficial where it lies in Scarpa's triangle-that is, for about three and a half inches $(9 \mathrm{~cm}$.$) of its$ course; the remainder of the artery being deeply placed in Hunter's canal, though less deeply than the profunda, or deep femoral. The details of the anatomy of the femoral will perhaps best be studied by considering the relations of (1) the common femoral; (2) the superficial femoral as it lies in Scarpa's triangle; and (3) the superficial femoral as it lies in Hunter's canal.

(1) The relations of the common femoral artery.-In front, the common femoral (fig. $37 \cdot 2$ ) is eovered by the skin, the superficial fascia, the iliac portion of the fascia lata, the crural branch of the genito-crural nerve, the superficial ciremntiex iliac vein, and sometimes the superficial epigastric vein. The fascia transiersalis, which is eontinued downwards into the thigh beneath Poupart's ligament, is also one of its anterior relations, but soon becomes indistinguishable from the sheath of the ressel.

Behind, the artery lests upon the tendon of the psoas muscle, which separates it from the brim of the pelvis and capsule of the hip-joint, and, a little lower, on the pectineus, more or less loose fat and cellular tissue intervening. The branches of the anterior crural nerve to the pertinems musche also pass behind it.

A similar prolongation to that derived from the fascia transtersalis in front desends behind the vessel from the iliae fascia; but, like the anterior prolongation of fascia, soon blends with the sheath of the ressels.

To the inner side is the femoral vein, but separated from the artery in the upper part of its eourse by a thin layer of fascia pasing from the continuation of the iliac fascia behind the vessels, to the eontinuation of the fascia transrersalis in front of the ressels.

'To the outer side is the leash of nerves known as the antorior crural. These are, however, separated from the artrery by a few filmes of the proas muscle.

(2) The relations of the superficial femoral artery in Scarpa's triangle (fig. 320 ). - In front, the artery is covered hy the skin and by the superficial and deep fascia, and is crossed at the lower part of scarya striangle ly a hranch of the internal cutaneous nerve. The crural branch of the genito-crural nerve 
is superficial to it, hut is separated from this part of the femoral artery by the reep fascia.

Behind, the artery lies on the pectincus, from which it is separated by the femoral rein and the profunda vein and antery. Lower down, it lies on the upper portion of the adcluctor longus muscle.

To its outer side is the long silphenous nerve and the nerve to the vastus internus, the anterior crural nerve having in this situation more or less broken uj into its (ompenents.

Fig. 372,-The Femoral, Altery ix Scarpa's Triaxgle.

(From a dissection by Wr. J. Walsham in St. Bartholomew's Hospital Museum.)

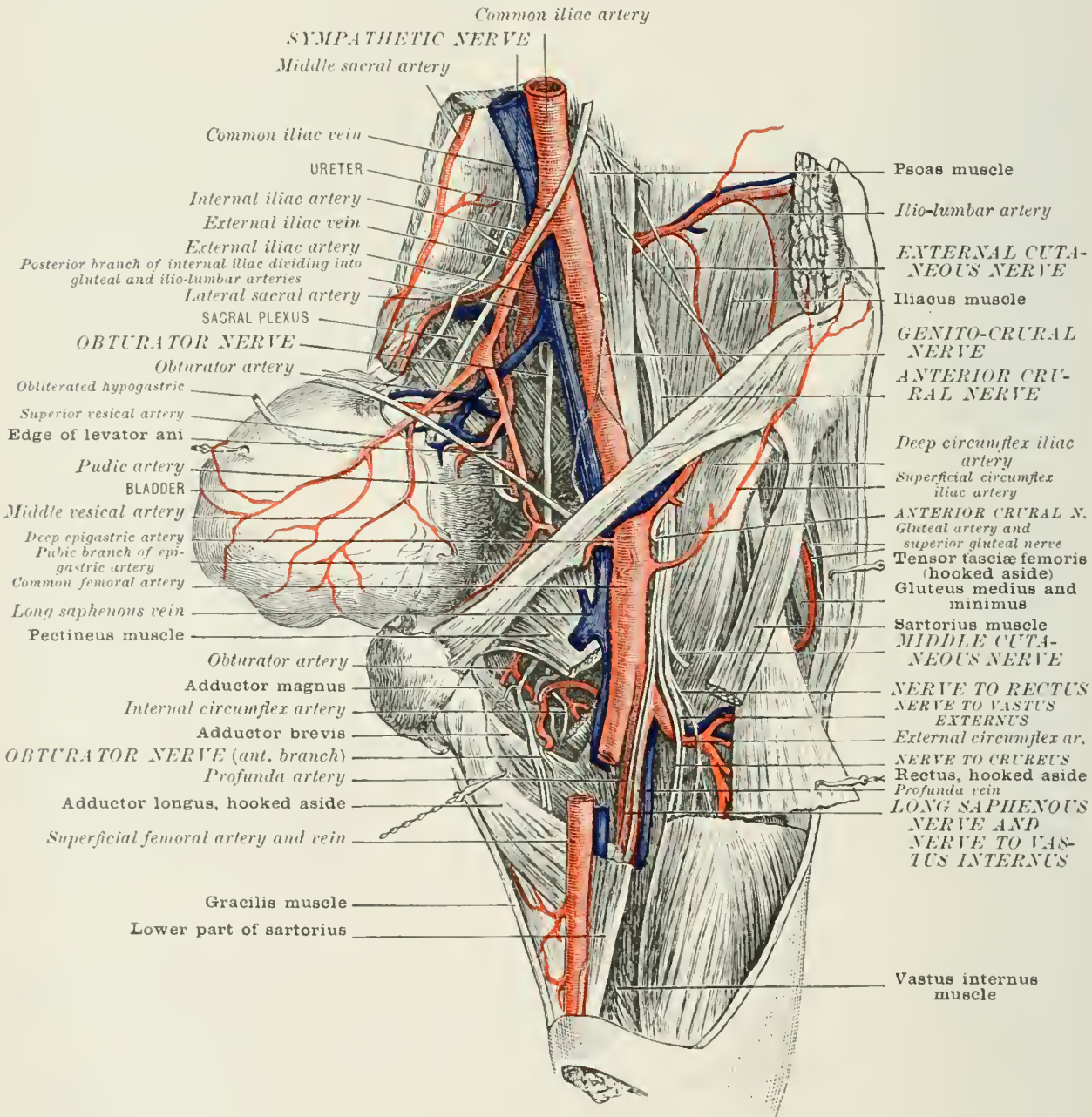

To its inner side is the fenoral vein, which, howerer, at the apex of Searpa's triangle, is getting somewhat behind the artery.

The superfecial femoral varies in leneth aceording to the distance that the profuncla is given off from the emmmon femoral below loupart's ligament. As a rule, it measures there inches and a half (! cm. ), the enmmon an inch and a half $(4 \mathrm{~cm}$.). But the profunda may come off two or more indere hedow Poupart's ligament, in which case the superficial femoral will he shorter to this extent; or it may come off less than an inch and a half hrow l'oupalt's ligament, or ewon from the extemal iliax alove l'oupart's ligament, when the sunerticial will be longer than normal. The 
practical point to remember is that it is more nsual to moet with a short than with a long common femoral, and that, if the sulperticial fomoral is tied at the alpex of Scarpa's triangle-i.e. the spot where the inner edge of the sirtorius ames into contact with the adductor longus-there is nearly always as sullieient length of that vestol above the ligature to ensure a fim intemal clot, and comseruently, ats far as this point is concemed, a sucesisful result.

(:) The relations of the superficial femoral artery in Hunter's canal.IInnter's canal is the somewhat triangularly shapeel spare boumleel ly the rastus internus on the outer side, the arlductors longus and nuagnus on the inner sile, and he an aponeurosis thrown aleress from the adluctors to the vastus in front. Below, the canal terminates at the opening in the adductor magnus; above, its limit is less well defined, as here the aponeurosis between the muscles becomes lesit tenclinous, and gradually fades away into the perimuscular fascia. The transverse direction of the fibres of the aponeurotic covering at the lower two-thirts of the canal is characteristic, and serves as a rallying point in tying the artery in this part of its course. Lying sunerficial to the aponenrois is the sartorins muscle. The superficial fomoral artery as it lies in this canal has the following relations:-

In front, in addition to the skin, superficial and deep fascia, are the sartorius muscle and the aponeurotic filmes of the canal. The internal saphenous merve closses the artery from without inwards, lying in the wall of thr canall.

Behind is the angle of meeting of the vastus internus and the adductors.

The femoral vein lies behind the artery, hut gets a little extemal to it at the lower part of the canal. It is here very firmly and closely attacher to the artery, embracing it as it were on its posterior and external aspect. Hence it is very lialile to be punctured on ligaturing the artery in this part of its course. Such an areident is best avoided by opening the sheath of the vessels woll to the inner side of the front of the artery, and by keeping the point of the anemrsm neetle closely applied to the ressel in passing it from without inwards between the vein and the artery. There are sometimes two veins, which then more or less surround the arteris.

'To its inner side is the adductor longus above and the adductor magnus beluw.

To its outer side is the vastus internus, the nerve to the vastus internus, and at the lower part of the canal the femoral vein.

\section{Turintions in the Femoral Artery}

The most important variations in the femoral artery are:-(A) The femoral arising from the sciatic or internal iliac, ambl passing out of the pelvis and down the back of the thigh with the great sciatic nerve to the popliteal space; the external iliac under these cireumstinces ending in the profunda or external cir'umflex, or some other branch of the feusoral. (B) A dimble eonlition of the femoral artery beluw the origin of the profumlat ; the resset re-uniting lower down the thigh. (C) A vas aberrans given off from the immer sile of the enmmon femoral or external iliac, and joining the femoral lower down. (D) The vein may remain to the inner sile of the artery its whole distance through the thigh, or it may be double, especially in Hunter's canal. 'There is often a plexiform arrangement of the vein arouml the artery in this situation. (E) The variations in the origin of the unofunda have been alrearly mentioned.

\section{Brixches of the Fenoril Artery}

The femoral artery gives off the following branches:-

A. From the eommon femoral:-(1) The superficial epigastric; (2) the superficial circumflex iliae; (3) the superficial external puclie; (4) the deen cxternal pudic; and (5) the profunda.

B. From the superficial femoral in Searpa's triangle:-(1) Muscular hranches; and (2) the saphenous branch.

C. From the superficial femoral in IIunter's canal:-(1) Muscular brancher; and (2) the anastomotica magnia. 


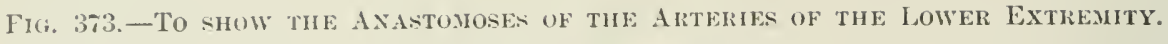

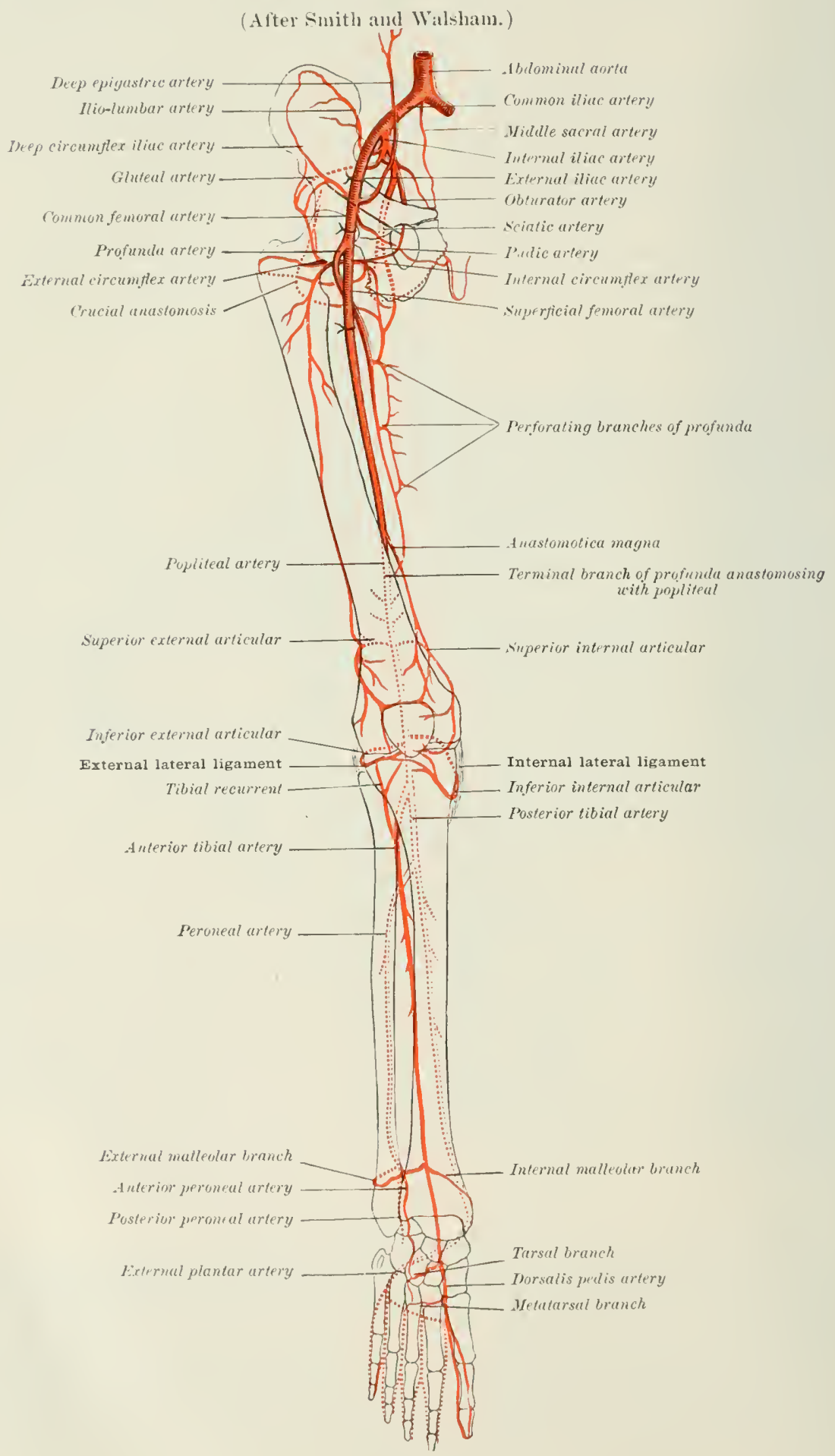




\section{A. Branches of the Cimmon Femoral}

(1) The superficial epigastric artery eomes off from the fromoral allout half an inch below Poupart's ligament. At its origin it is beneath the fascia lata, hut almost at once passes through this fascia, or else through the saphenons opening, and comrses upwards and inwards in front of the external oblique muscle alnost as far as the umbilicus. It ends in numerous small twigs, which anastomose with the cutanenus branches from the deep epigastric and internal manmary. In its conrse it gives off small branches to the inguinal glands and to the skin and superficial fascia. Ruming with it is the superficial eprigastric rein, which ends in the long saphenous just before the latter passes through the saphenous opening.

$(\cdot 2)$ The superficial circumflex iliac artery (fig. 37.2), uswally smaller than the superficial epigastric, arises either in common with that vessel, or else as a separate branch from the femoral. It passes upwards and outwards orer the iliacus, and, soon perforating the fascia lata a little to the outer sicle of the salphenous opening, rums more or less parallel to Poupart's ligament alout as far as the rest of the ilium, where it ends in branches which anastomose with the deep rircumflex iliac artery. In its course it gives off branches to the iliacus and sartorius muscles, to the inguinal glands, and to the fascia and skin. Its companion rein, the superficial ciremmflex iliac, ends in the long saphenous rein just before the latter passes through the saphenous opening.

(3) The superficial or superior external pudic artery arises from the inner sicl of the femoral, either a little above or else in common with the deep or inforior external pudic. It passes either through the fascia lata, or else through the cribriform fascia covering the saphenous opening, ascends upwards and inwards over the sfermatic cord in the male, or round ligament in the female, and divides into branches, one of which supplies the integuments above the pubes, while another Irserends along the penis "xternal to the dorsal artery, with which, and with the correpunding artery of the opposite side, it anastomoses at the corona. In the t'male, this branch terminates in the preputium clitoridis, anastomosing with the derwal artery of that orean. Small branches aleo dercend to the scrotum and lithium respectively. As it crosses the corr it anastomoses with the cremasteric hranch of the deep epigastric. It is accompanied by two small veins, which usutlly join to form a single rein opening into the upper end of the long alphrnous.

(4) The deep or inferior external pudic artery arises from the inner side of the fomoral artery, either in common with the preceding branch or a little lower down. It runs inwarls heneath the deep fiscia, across the pectineus and adductor lomers muscles. and, perforating the fascia close to the ramus of the puhes, supplies the skin of the scrotun or the corresponding part, the labimm majus, in the female, anastomosing with the superficial perinaal branch of the intemal pudic. It supplies small twigs to the petineus and adductor muscles as it crosses them. Its (ompanion veins teminate as a single trunk in the long saphenous.

(5) The profunda or deep femoral artery (figs. 372,373 ) is the ehief mutrient versel of the thigh. It is nsullly given off from the back and outer part of the (ommmon femoral, about an inch and a half $(t \mathrm{~cm}$.) below Poupart s ligament. At first it is a little (xternal to the femoral, hent as it runs downware and hackwarls it gets behind that artery and coloser to the bume. On reaching the upper boreler of the adductor longus musele, it leaves the femoral, ame, pasing leneath the musele, pieres the adductor magnus, and finally, moch reduced in size, ends in the hamstring muscles.

Relations.-Behind, the artery lies sucessively upon the iliaens, the pectinens. the adductor hrevis, and adluetor magnus muscles. In front, at first it is superfircial, heing merely corered by the skin, superficial and deep fasciec, and hranches of the anterior crural nese; lut as it sinks behind the femoral artery, it has in front of it both the femeral and the profumda reins, and lower down the alductor longus muscle. Externally is the femure at the angle of mion of the adeluctors longus and brevis. Internally is the pectineus at the upper part of its course.

Branches of the profunda.-The profuncla gives iff the following hranches: -(a) The external eircuntex; (b) the internal circunflex: and (c) the three per- 
forating. The termination of the artery is sometimes called the fourth perlorating liranch.

(11) The external circumflex, a short trunk, hut the largest in diameter of the branches of the artery, arises from the outer sick of the profundal as it lies on the iliacus muscle, about three-pguaters of an inch (2) (mo.) below the origin of that ressel from the femoral. It passes transersely outwards over the iliatens, under the sartorius and rectus, and between the branches of the anterior crural nerve. In this course it gives oft' hranches to the rectus and crumeus, and then divides into three chief sets of branches-an ascending, transrerses, and decending.

(i) The ascending branch, consisting of one or more separate vessols, rums. upwarls beneath the surtorius; then, sinking deeply heneath the tomsor fanciax fenoris on the outer sirte, and the glutens medius and minimus on the inner side. andstomoses with the superior ghteal and the dere circumflex iliale arteries. This branch also supplies a twig which runs upwards under the rectus to the hip-joint.

(ii) The transverse branch, or branches, run transversely outwarks, and, winding over the rureus and piereing the vastus externus, anastomose towards the back of the thigh with the superior perforating branch of the profuncla, the sciatice, and internal ciremmflex arteries. These branches will usually be found a little loklow the great trochanter.

(iii) The descending branches run directly downwards along with the nerve to the vastus externus muscle. They lie beneath the rectus muscle and on the crumens or vastus externus, some of them heing just under eorer of the anterior edge of the latter muscle. They are distribnted to the rastus externus, crurem. and rectus, one branch usually ruming along the anterior border of the rastus extemus as far as the knee-joint, where it anastomoses with the superior external articular branch of the popliteal (fig. 376); another, entering the crureus, anastomoses with the lower perforating branch of the profumcla and with the anastomotical magna.

Variations of the external circumflex.-(A) It may mome off from the femoral alove the profunda. (B) It may be double, one branch coming off from the femoral, and one from the inofunda, m both fiom the profimia, or both from the femoral above the jrofunda.

(b) The internal circumflex artery comes off from the back and inmer part of the profunda artery on ahout the same level as the external circumflex; sometimes as a common trunk with that ressel. As it winds round the inner sirle of the femur to reach the region of the trochanters, it lies sucessively, first, between the psoas and peetineus, then between the obturator externus and arlincetor herev; finally, between the adductor magnus and quadratus femoris, where it anastomoses with the external circunflex extemally, with the soitic alose, and with the superior perforating below, forming the so-called crucial anastomosis. As it passe betwern the obturator externus and adduetor brevis, it gives off two (1] nure hranches to the adductor bongus, the adductor brevis, the gracilis, and the ohturator externus, and anastomoses with the ohturator artery. Another small hranch

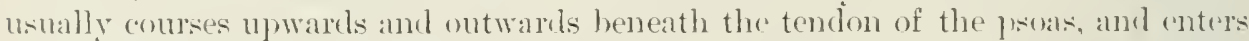
the hip-joint bencath the transwerse ligament, and, together with the articular hranch of the obturator. supplies the fatty tissue in the acetabulum, and sends branches to the symovial membrane. As it lies beneath the adductor brevis, it gives off a descending branch to the adductor magnus and brevis. This branch is generally accompanied by the postrom division of the oloturator nerve. Before passing hetween the quadratus fenolis and adductor magnus, a small branch runs upwards beneath the quadratus femoris to supply the hack of the hip-joint, and anastomoses with the gluteal and sciatic arteriss. Its compranion rejus join the profumbla vein.

Variations of the internal circumflex.-(A) It may come off from the profumla artery befine the external circumflex. (B) It may arise from the femoral artery; or (C) fiom the extermal iliat ur one of its branches.

(r) The perforating arteries of the profunda are so called hecause they frer-

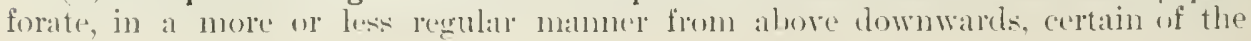


actuctor muscles. They form a series of lowps hy anastomosing with one another (fig. 373), and with the grluteal, internal cireuniflex, and seiatic arteries above. and with the muscular and articular branches of the pupliteal below. They are distributed ehiefly to the hamstring museles, but send twigs along the extemal intermuscular septum to supply the integuments at the back and outer parts of the thigh. Other branches perforate the external intermusaluar septum and the short head of the biceps, and, entering the (rurens and vastus externus, anastomose with the descending bramch of the external cirmutlex. All the perforating arteries, moreover, contribute to reinforec the artery of the sciatic nerve, a branch of the sciatic artery. They are each acempanied by two veins which terminate in the profunda.

(i) The superior or first perforating is given off from the profunda as that ressel sinks beneath the alductor longus. It cither pierces the adductor brevis. or else runs between the pectineus and adductor brevis, and then passes through a small aponeurotic opening in the adductor magnus close to the inner hip of the linea aspera. In this course it supplies branches to the adductors, and, after perforating the adduetor magnus, is distributed to the lower part of the glutens maximus and the hamstring muscles, one branch commonly running upwarts beneath the gluteus maximus to anastomose with the extemal ciremflix, internal cireunflex, and sciatic arteries, forming the crucial anastomosis at the junction of the neck of the femur with the great trochanter (fig. 373). A second branch descends to anastomose with the ascending branch of the midklle perforating.

(ii) The middle or second perforating, which is given off from the profuncta as it lies behind the adductor longus, pierces the adductor brevis, and then pasess through a second aponeurotic opening in the adductor magnus a little below that for the first perforating artery, and also close to the linea aspera. It supplies the hamstring museles, sends a branch upwards to anastomose with the descending branch of the superior perforating, and another downwark to anastomose in like manner with the ascending branch of the third perforating. It usually supplies the chief nutrient branch to the femur. At times, however, this comes from the third jerforating.

(iii) The inferior or third perforating also arises from the profunda as it lies under the adductor longus, usually about the level of the lower border of the adductor brevis. It turns beneath this border, and then, like the first and second perforating, passes through an aponeurotic opening in the adeluctor magnus clise to the linea aspera. It also supplies the hamstring nulseles, and divides into two hranches, which anastomose above with the second perforating, and ludow with the temination of the profunda or the fourth perforating.

(iv) The fourth perforating is the continuation of the profundia. It pasios through an aponeurotic opening in the alluctor magnus just alone the oluming for the femoral artery. It anastomoses, above with the thiril preforating, and betw with the superior museular and articular branches of the popliteal. It supplies chiefly the short head of the biceps.

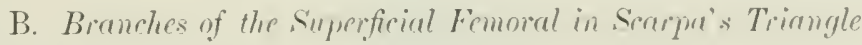

The branches given off hy the superfecial femolal in sorpa : triangle are usually small and insignificant. They are:-(1) Muscular, to the saltorius and rectus: anil (2) saphenous, to the region of the lomgraphenous vein and femoral lymphaties in the neighbourhood of the rein.

\section{Branches of the sinperficial Femoral in Hunter"s Camal}

The branches in Hunter's canal are:-(1) Yuscular: and (2) the anastomotica magna.

(1) The muscular branches supply the surtorius, the rectus, the vastus internus, the crurcus, and the adductor muscles. They are ksually larger than the museular lianches given off in Searpa's triangle.

(2) The anastomotica magna arises from the front and inner sille of the 
femoral just before the latter perforates the adductor magnus muscle, and almost immediately dirides into two branches, ( $(1)$ a sujerficial and $(b)$ a deep. These branches mily sometimes come off separately from the femoral.

(i) The superficial branch piere's the aponeurotic covering of Hunter's canal, passes between the sartorius and gracilis muscles along with the internal saphenous nerve, and, perforating the deep fascia, supplies the skin of the upper and inner sille of the leg and anastomoses with the inferior internal articular branch of the popliteal and the other ressels forming the plexus or rete at the inner side of the knee. In its comrse it gives twigs to the lower part of the sartorius and gracilis muscles.

(b) The deep branch runs downwards in front of the adductor magnus tendon, burrowing amongst the fibres of the vastus internus as far as the internal condyle, where it passes into the plexus or rute on the inner sicle of the knee-joint, anastomosing with the internal inferior articular branch of the popliteal, the anterior tibial recurrent, and the external superior articular branch of the popliteal across the front of the femir just above the articular surface of the knee-joint. In common with the rest of the rete it sends hranches into the knee-joint. It also supplies branches to the vastus internus and crureus muscles.

\section{THE POPLITEAL ARTERY}

The popliteal artery (fig. 375) runs through the popliteal space or ham. It is at continuation of the femoral, and extends from the aponeurotic opening in the adductor magnus at the junction of the middle with the lower third of the thigh to the lower border of the popliteus muscle, where it terminates by dividing into the posterior and anterior tibial arteries. This division is on a level with the lower horder of the tubercle of the tibia. As the artery passes through the opening in the adductor magnus, it is accompanied by the popliteal rein, and at times by the branch of the obturator nerve to the knee-joint. The rein throughout is behind the artery, at first lying a little external to it, but as the vessels pass through the popliteal space the rein crosses obliquely orer the artery, and at the termination of the artery lies a little to its inner side. The internal popliteal nerve is superficial to both artery and rein. As it enters the space it is well to the outer side of the ressels, hut as it descends it gradually approaches them, crosses behind them, and at the lower part of the space lies to their inner side. The artery in the whole of its course is deeply placed and covered by a considerable amount of fat and cellular tissue.

Relations (fig. 374).-In front, the artery lies successively on the popliteal surface of the femur (from which it is separated by a little fat and sometimes one or two small glands); on the posterior ligament of the knee; on the hinder edge of the articular surface of the head of the tibia; and on the popliteus muscle. From the latter muscle it is separated by the expansion from the semi-membranosus which corers the muscle, and is attached to the oblique line on the tibia.

Behind, the artery is covered, above by the semi-membranosus; in the centre of the space by the skin, superficial and deep fascia; and below by the immer head of the gastrocnemius. The popliteal vein is behind it in the whole of its course. The internal popliteal nerve crosses behind it ol,liguely from without inwards, about the centre of the space. As the artery divides into the anterior and posterior tibial, it is crossed by the aponeurotic areh of the soleus which stretches between the tibial and fibular origins of that muscle.

To the inner side are the semi-membranosus above, and the inner head of the gastrocnenius and the internal pophiteal nerve below.

To the outer side are the bicess and the internal popliteal nerve above, and the onter head of the gastmenemius and the plantaris below.

Principal variations in the popliteal.-(A) It may divide higher. or more rarely lower than usual. (B) It may divile into the anterior tibial and peroneal. (C) The vein may be deeper than the artery, or separated firom it by a slip of the gastrocuemins. 
Braxches of tile l'OPLITE.L ARTERY

The branches of the popliteal may le divided into-(1) The cutaneous; (2) the muscular or sural; (3) the articular; aml (4) the terminal.

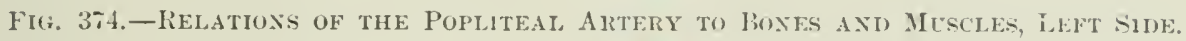

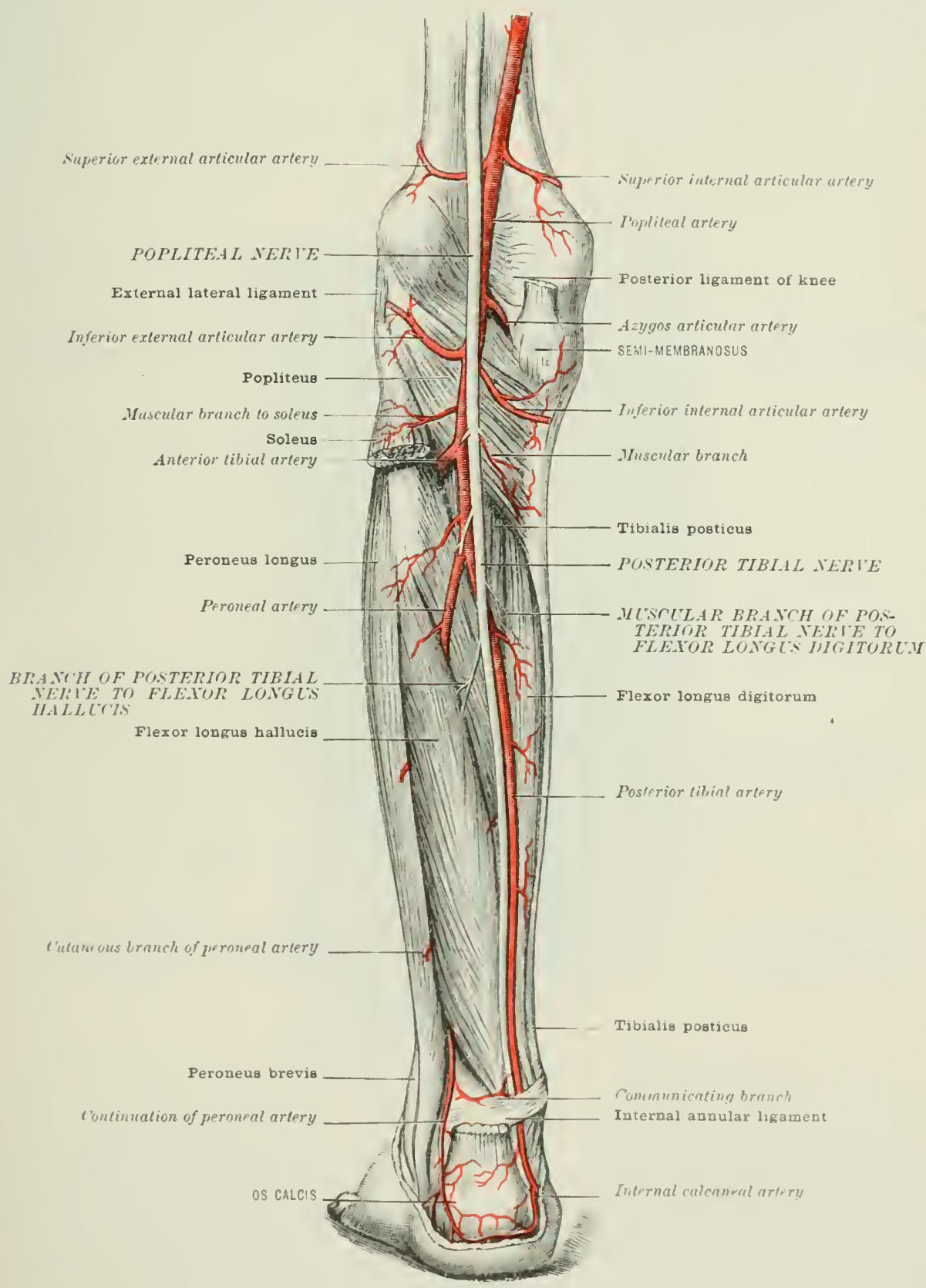

(1) The cutaneous branches - very irrernlar in their origin, number, and distrihution-arise either from the main trunk or from one of the inferior muscular branches, pass downwards between the two heads of the gastronemius, and, per- 
forating the deep fascia, supply the skin and fascia of the calf. A branch, nsually of moderate size accompanies the short or extermal saphenous rem, and is sometimes called the pesterior saphenous artery.

(2) The muscular or sural branches are commonly divided into the superior and inferior. Ther arise from the upper and lower portions of the popliteal respectively; the former supply the muscles forming the boundaries of the upper half of the popliteal space; the latter. the muscles of the calf.

( $(1)$ The upper muscular branches-()r superior sural, as ther are sometimes called-are distributed to the hamstring muscles and lower part of the adductor

Fig. 3\%5.-Sine View of The Right Poplatear, Alitery.

(From a dissection in the Hunterian Musenm.)

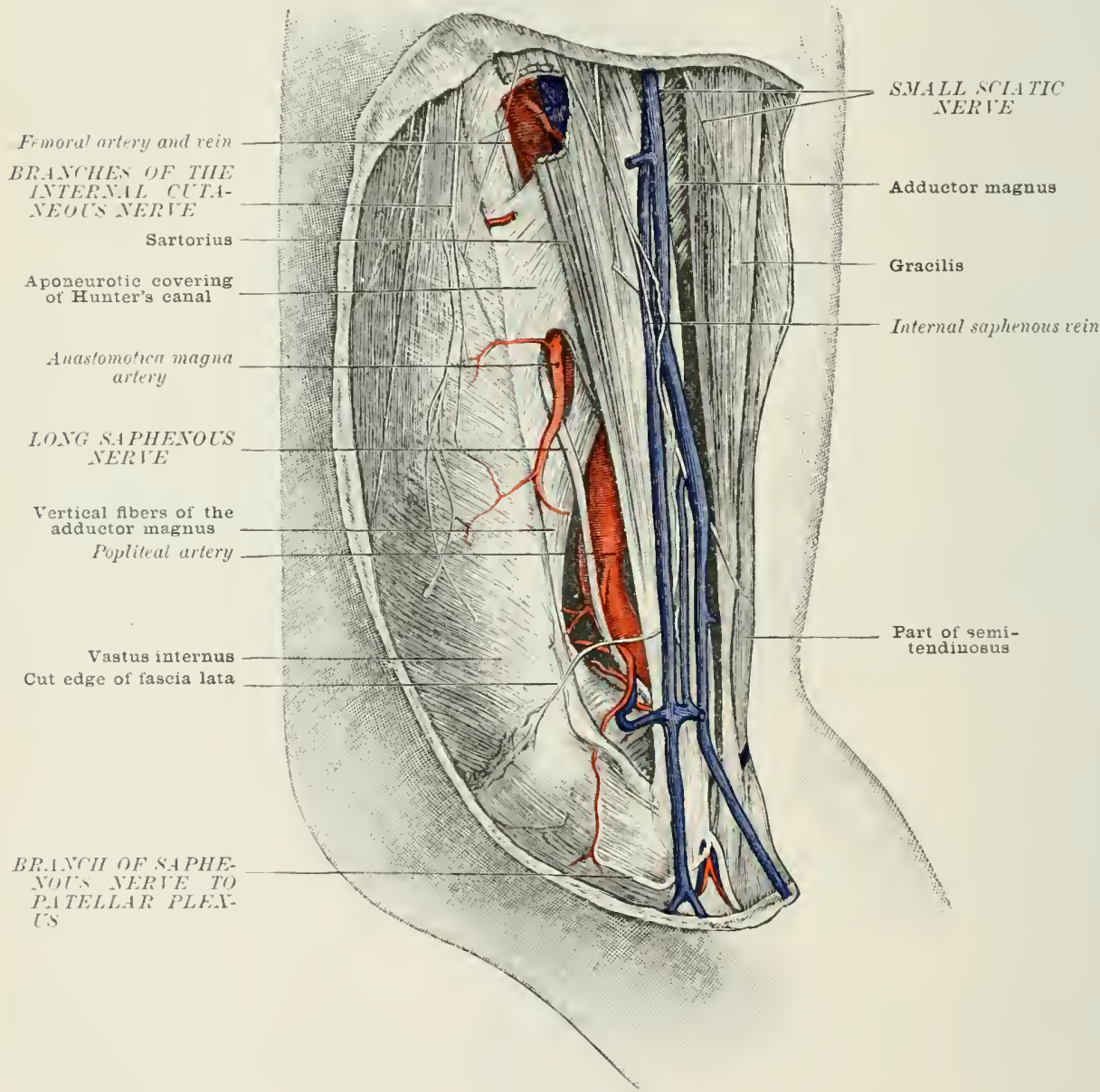

magnus. They anastomose wh the superior articular arteries, and with the termination of the profuncla. (b) The inferior muscular or sural branches, usually two in number and of lalge size, come off from the popliteal just as it passes under cover of the inner head of the gastroenemius. They at first deseend between the two heads of the latter muscle, one brameh then chitering the outer, and one the imner heat. They also supply branches to the soleus and plantaris muscles.

(3) The articular, five in number, are divided into two superior (internal and external), two inferior (internal and external), and the azyes, or anterior. The superior and inferior come off transwersely in pairs from either side of the popliteal, 
the superior above, the inferior below the joint, and, winding round the bones to the front of the knee, form-hy anastomosing with each other and with the anistomotica magna, the termination of the juofmedis, the desending branch of the external cireminflex, and the anterion tilial recurrent-a superficial and deep, arterial rete (fig. 376 ). The superficial anastomosis or rete lies between the skin and fascia round alout the patella (patellar rete), which it supplies, the larger branches entering it from above. The decp anastomesis or rete lies on the surface of the bones around the articular surfaces of the femmer and tilnia, supplying branches to the contiguous bones and to the joints. The azygos articular is a single short trunk coming off from the deep surface of the popliteal artery. It at once passess through the josterior ligament into the joint.

(i) The superior external articular, the larger of the two superior articular

Fig. 376.-The Axastonosis abort tile LeFt KNeE-JolNt. (Walsham.)

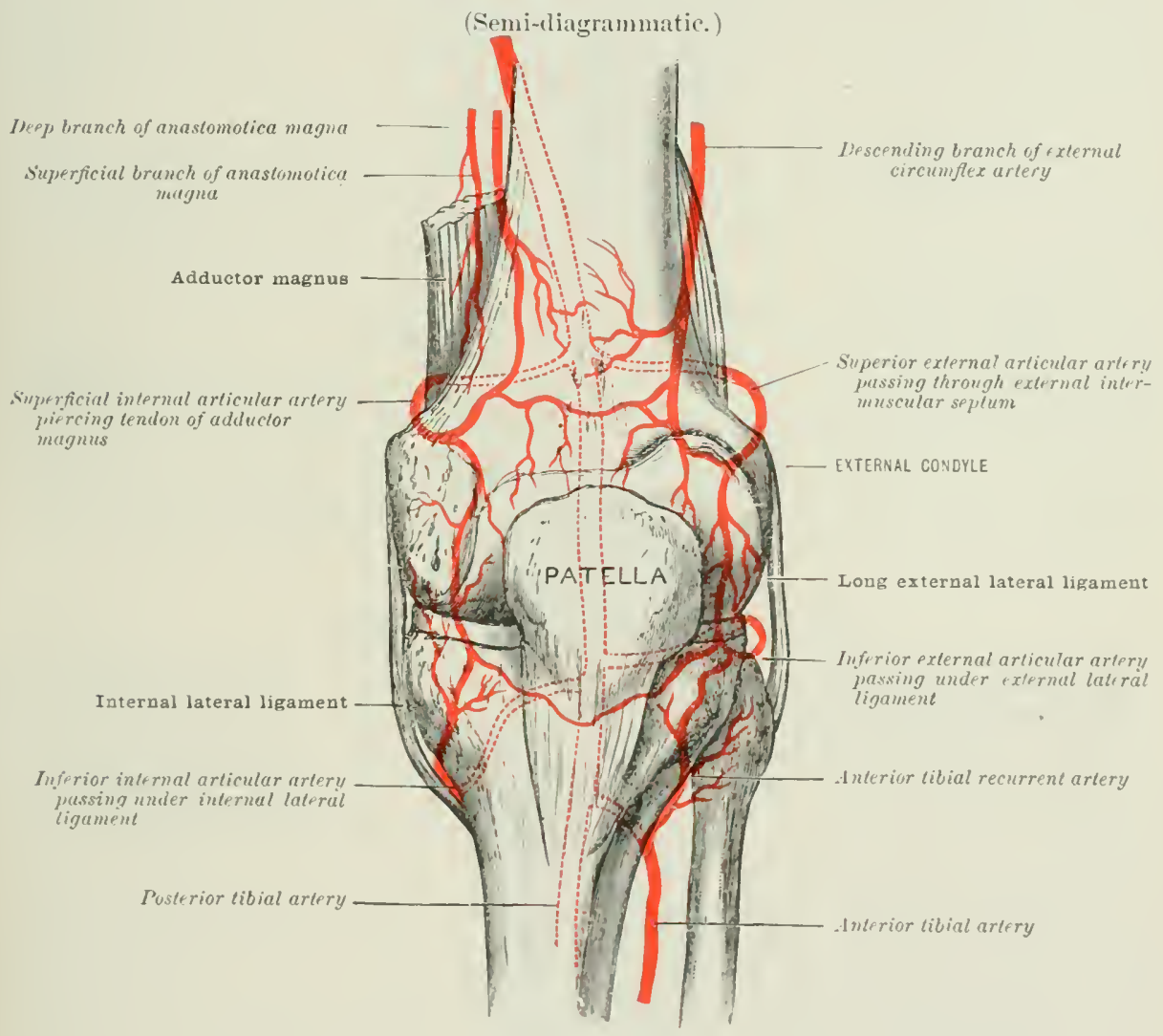

branches. runs transversely outwards above the extcrual head of the gastromemins,

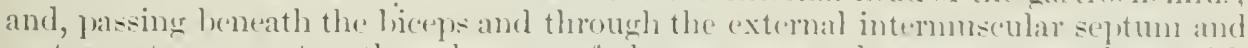
vastus externus, enters the substance of the crurens, and andstomoses. above with the desending branch of the external circumflex, helow with the inferior ("xternal articular, and across the front of the frmur with the sujerior internal articular. the anastomotica magna, and tomination of the forofunda, forming with them, as already described, the reep periarticular rete. Branches are given off to the patella, to the upper and outer part of the joint, to the bone, and to the continuons muscles.

(b) The superior internal articular (tiw. 3it) mus transtersely inwarls just above the inner hearl of the gastrocnemius. hencath the semi-meminancisus. ant. after perforating the tendon of the alduetor lisanus, miters the substance of the 
vastus internus, where it anastomoses (fig. 376 ) with the deep branch of the anastomotica magna and termination of the profunda above, with the inferior internal articular below, and with the superior external articular arross the front of the femur. It supplies small branches to the contiguons muscles, to the femur, to the patella, and to the joint.

(c) The inferior internal articular, the larger of the two inferior articular arteries, passes ohliquely downwards and inwarts across the poplitens, below the internal tuberosity of the tibia, and beneath the internal lateral ligament to the front and inner sicle of the knee-joint, where it anastonnoses (fig. 376), above with the superior internal articular and the superficial branch of the anastomotica magna, and across the front of the tibia with the inferior external articular. It supplies branches to the lower and imner part of the joint.

(d) The inferior external articular (fig. 376) passes outwards above the head of the fibula, along the tendon of the poplitens muscle, beneath the external head of the gastroenemius, and then under the tendon of the biceps, and betreen the long and short external lateral ligaments. Then winding to the front of the joint, it anastomoses above with the superior external articular, below with the anterior tibial recurrent, and across the front of the tibia with the internal inferior artieular. It also supplies branches to the outer and lower part of the joint.

(e) The azygos articular arises from the deep surface of the popliteal artery, and passes, with the articular branch of the obturator nerve, through the posterior ligament, directly into the knee-joint, where it supplies the crucial ligaments, and the ligamenta mucosa and alaria. It anastomoses with the intrinsic branches of the other articular arteries.

(4) The terminal branches of the popliteal are the posterior and anterior tibial arteries. The former appears to be a direct continuation of the ressel, and passes down the back of the leg to the inner ankle, where, on entering the sole of the foot, it clivides into the intemal and extemal plantar. The anterior tibial tums forwards, and, passing through the interosseous membrane, descends along the front of the leg, and ends, under the name of the clorsal artery of the foot, by anastomosing, through the first interosseous space, with the external plantar artery in the sole.

\section{THE POSTERIOR TIBIAL ARTERY}

The posterior tibial artery (fig. 377), the larger of the two branches into which the popliteal divides at the lower borkler of the popliteus muscle, runs downwards on the flexor aspect of the leg between the superficial and deep museles to the back of the inner ankle, where, midway between the tip of the internal malleolus and os calcis, and under cover of the origin of the abductor hallucis as it arises from the internal annular ligament, it divides into the internal and external plantar arteries.

The artery is first situated midway between the tibia and fibula, and is leeply placed beneath the muscles of the ealf. As it passes downwards it inclines inwards, and at the lower third of the leg is smperficial, being only covered by the skin and fascix. At the ankle it lies heneath the internal annular ligament, and at its bifmrcation also beneath the abductor hallucis. A line drawn from the centre of the popliteal space to a spot miclway between the internal malleolus and point of the heel will indicate its comrse.

Relations.-Anteriorly, from above downwards, it lies suecessively on the tibialis posticus, the flexor longus cligitorum, the posterior surface of the tibia, and the internal lateral ligament of the ankle-joint.

Posteriorly, it is covered by the skin and fiscia, the gastrocnemius and solens, and the deep or intrinuscular fascia of the leg, by which it is tightly bound down to the underlying muscles. It is crossed hy the prosterior tibial nerve alout an inch and a half below its origin and after it has given off its peroneal branch, the nerve first being on the inner, and for the rest of its comrse on the outer side of the vessel (fig. 374). It is aecompanied by two veins, which send numerous anastomosing branches across it. In the lower thirl of the leg the artery is superfieial, being only covered by the slin and by the smperticial and deep fascia. 
At the inner ankle it lies beneath the internal ammular ligament and alductor hallueis upon the internal lateral ligament of the ankle-joint. Here it has the tibialis postieus and flexor longus digitormm in front of it, and the posterior tibial nerve and the flexor longus hallucis behind and to its outer side.

At times the posterior tibial nerve clivicles higher than usual, when one loranch lies on the inner side of the artery, and the other hranch on the outer side.

The branches of the posterior tibial artery are:-(1) The peroncal; (2) the

Fig. 377.-The Popliteal, tie Posteriol Tibial, axn the Peionedi Artery, RIIIIT NIIIE.

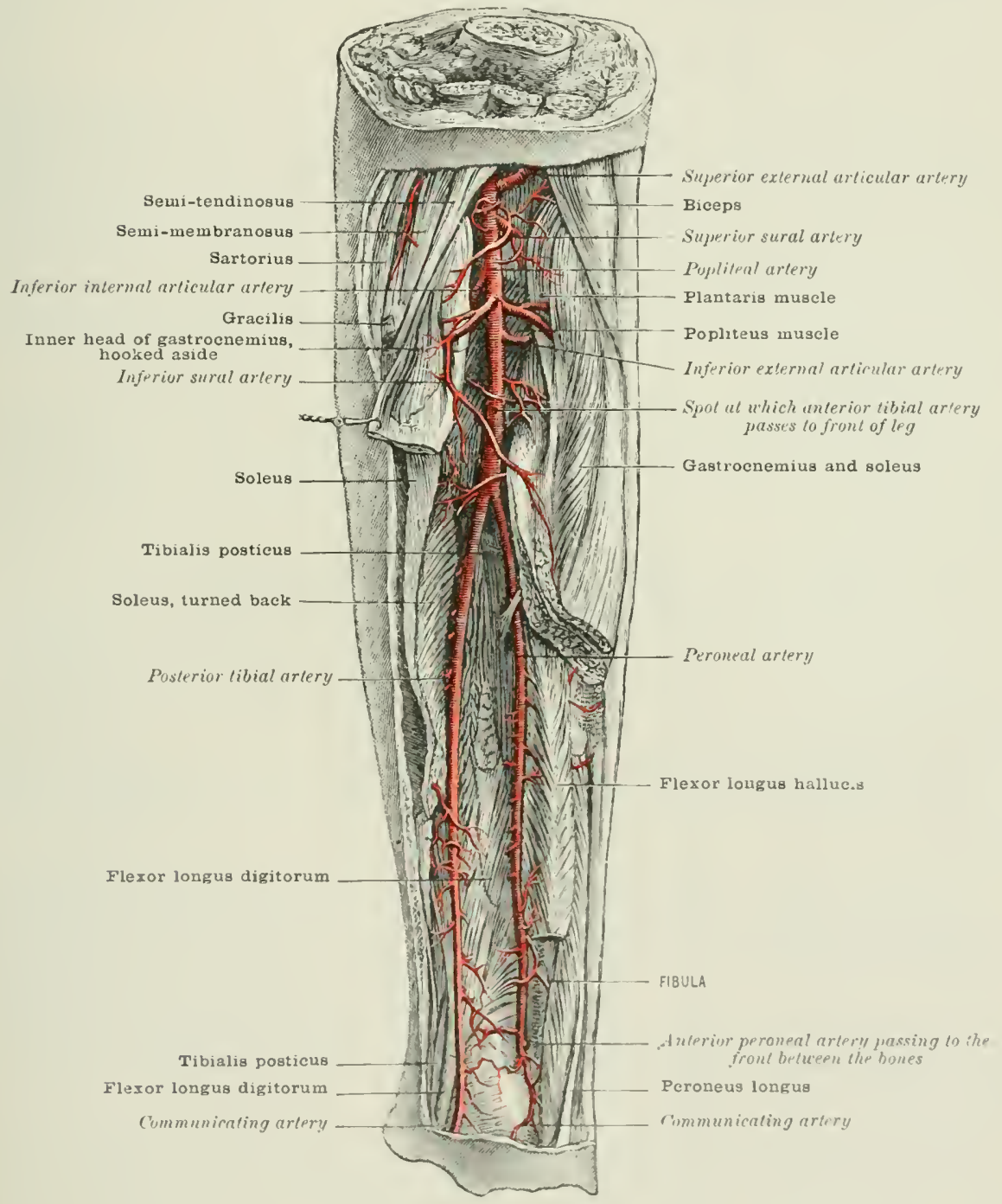

museular; (3) the medullary; (4) the cutaneous; (j) the communicating; (6) the malleolar: (T) the calcanean, or internal calcanean; and (S) the terninal. i.e. the extermal and intermal plantar arteries.

(1) The peroneal artery (figs. $37.4,37 T$ ) ariss from the posterior tihial almut one inch below the lower borker of the poplitens numele. At lirst forming a ande curve with the (onvexity outwards, it approasches the fibula, and continues itsonurse downwards close to that bone as far as the lowerent of the interosseous membrame, 
where it gives off a lare hranch. the anterior peroneal, and then, passing over the lack of the inferior tilio-fibular joint, terminates $w$ breaking up into a network, which is distributed ower the back of the external malleolus and outer surface of the calcanemm (fig. 381). It is aceompanied lw two vena comites.

Relations. - At its upper part it is deeply placed between the tibialis posticus and soleus muscles, and beneath the deep or intermuscular fascia. For the rest of its course to the ankle it lies bencath, or sometimes in the substance of the flexor longus hallucis in the angle between the fibula and interoseons membrane. After giving off the anterior peroneal, it is only covered, as it lies behind the tibio-fibular articulation, hy the integuments and deep fascia, and in this part of its course is sometimes called the posterior peroneal.

The branches of the peroneal artery are:-(a) The anterior peroneal; $(b)$ the muscular; (c) the mechllary; $(d)$ the communicating; $(e)$ the cutaneous; $(f)$ the extemal ealcanean; and $(g)$ the terminal.

(ii) The anterior peroneal artery arises from the front of the peroneal artery at the lower part of the interosseous space, and, passing through the interosseous membrane, runs downwards over the front of the inferior tibio-filular joint, beneath the peroneus tertius. and supplics this muscle and the inferior tibio-fibular joint. It anastomoses with the tarsal. netatarsal, and external malleolar branches of the anterior tibial artery, and with the external plantar artery on the outer side of the fout, forming a plexus over the outer ankle (fig. 380).

(b) The muscular branches of the peroneal artery are distributed to the contiguous muscles. namely: the flexor longus hallucis, the tibialis posticus, the peronei, and the soleus.

(c) The medullary enters the nutrient foramen of the fibula.

(d) The communicating branches pass transversely inwards in front of the tendo Achillis to anastomose with the communicating branch of the posterior tibial. The usual situation of this communication is from one to two inches above the ankle-joint.

(e) The cutaneous branches run outwards between the flexor longus hallucis and soleus to supply the integuments on the outer side of the leg.

$(f)$ The external calcanean comes off from the peroneal helow the point at which the anterior peroneal is given off, and is distributed over the outer surface of the os alcis.

(y) The terminal branch or posterior peroneal, the continuation of the permeal artery, anastomoses with the other arteries distributed to the external malleolus and heel.

(2) The muscular branches of the posterior tibial artery are distributed to the contiguous muscles, namely: the tibialis posticus, flexor longus digitorum, and soleus.

(3) The medullary artery, a ressel of large size, leaves the posterior tibial at its upper part, pierees the tibialis posticus, and enters the medullary foramen in the upper third of the posterior surface of the tibia. In the interior of the bone it divides into two branches: an ascending or smaller, which runs upwards towards the head of the bone; and a descending or larger, which courses downards towards the lower end. It gives off two or three muscular twigs to the tibialis posticus before it enters the foramen. The medullary artery of the tibia is the largest nutrient artery of hone in the body, and is accompanied by a nerve given oft by the nerve to the popliteus.

(4) The cutaneous branches pass inwards to the integuments on the inner side of the leg. They run in the collukar planes between the deep and superticial muscles, and serve as useful guides to the ressel when ligaturing the posterior tibial through the lateral incision.

(5) The communicating branch arises from the posterior tihial ahout two inchess above the imner malleolus. and, passing transversely outwarks acose the tilia heneath the flexor longus halluris and tendo Achillis, anastomoses with the communicating branch of the peroneal.

Frequently an inferior communionting branch between the posterior tibial and peroncal arteries is likewise present in the louse comnective tissue beneath or behind the tenrlo Achillis: (tigr. 374). 
(6) The malleolar or internal malleolar branches are distributcel, as the name implies, orer the intermal malleolus, andsemesing with the other arteries entering into the retifom plexus of vessels over that portion of bone. In their eourse to the malleolus, they rom beneath the flexor longus digitorum and tibialis posticus muscles.

(7) The calcanean or internal calcanean branch is distributed to the soft parts orer the imner sicle of the "aleaneum. This branch-or, as is frequently the case, branches-comes off from the posterior tibial just lrefore its lifureation, and anastomoses with the internal malleolar and peroneal arteries (fig. :37!) ).

(8) The terminal branches are the extemal and intermal plantar arteries.

\section{THE ENTERNAL PLANTAR ARTEIIY}

The external plantar artery-the larger of the two branches into which the posterior tibial divides beneath the intemal ammular ligament-jasses at first obliquely forwards and outwards across the sole of the foot to the base of the fifth metatarsal bone. where it makes a bend forwards and inwards, and, sinking deeply into the foot, teminates at the proximal end of the first interossens spare liv anastomosing with the communicating branch of the dorsal artery of the foot. In its course to the fifth metatarsal bone the artery runs in a more or less straight line whinuely across the foot; whilst its deep portion, extending from the fifth metatarsal hone to the proximal end of the first interosseous space. forms a slight curve with the ronvexity forwards, and is known as the plantar arch. The plantar arch is (omparable to the deep palmar arch formed by the deep branch of the ulnar anastomosing with the radial through the first interosseous space. This homology is at times nore complete in that the communicating branch of the dorsalis perlis, the honologue of the rarlial in the upper limb, takes the chief share in forming the arrh. The extemal plantar artery is accompanied by two veins. The course of the artery is indieated by a line drawn across the sole of the foot from a point midway between the tip of the internal mallenlus and the greater tubercle of the calcancum to the base of the fifth metatarsal bone. and thence forwards and inwarls to the posterior part of the ball of the great toe.

Relations. - In the first part of its course from the inner ankle to the base of the fith metatarsal hone, the artery is covered successirely ly the abluctor lallucis and the Hexor brevis digitorum, by which it is separated from the plantar fascia, and may he slightly overlapped in muscular subjects by the abeluetor minimi digiti. Is it approaches the base of the fifth metatarsal bone, it lies, as it turns: forwards and inwards before sinking into the fort, in the interspace between the Hexor brevis digitorum and the abeluetor minimi digiti. and is here only corered hy the skin and superficial fascia, and the plantar fascia. It lies upoin the calaineum. the flexor accessorius. and the flexor brevis minimi digiti. It is acemmpanied hy the external plantar nerve, the smaller of the twe divisions into which the posterior tihial nerve divides. In this part of its course it gives off small branches to the eontiguous muscles and to the herel.

In the second part of its course the artery. which is here known as the blantar arch, sinks into the sole, and is covered, in adelition to the skin. sujerticial fascia, plantar fascia, and flexor brevis digitorum, hy the temelon of the flexor longus digitorum, the lombricales. branches of the internal plantar nerve, and the adductor hallueis. It lies upon the proximal ands of the soromel, thirel, and fourth metatarsal bones and the corresponding interwsente muscles.

The branches of the external plantar artery are:-( i, Mlisular: (2) (alcancal; (3) cutaneous: (4) anastomotic: (5) articular; ( (i) pusterior perforatiug; and $(7)$ digital.

(1) The: muscular branches of the external plantar are distributed to the contigums muscles: in the first part of its course to the flexor lurevis digitomm,

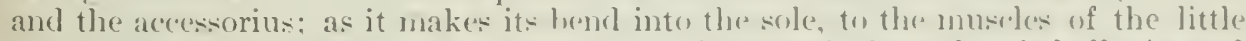
toe; and, as it forms the plantar aroh, to the interosser. Hexor hrevis hallueds. and adductor hallucis.

(2) The calcanean are two or three small hamelus which are li-trilunted orer 38 
the inner surface of the ealcaneum, and anastomose with the internal caleanean branch of the posterior tibial artery (fig. 379).

(3) The cutaneous pass between the abductor minimi digiti and flexor brevis ligitorum, and through the interval between the middle and outer portions of the plantar fascia, to the skin.

(4) The anastomotic turn orer the outer border of the foot, and anastomose with the tarsal and metatarsal branches of the dorsalis pedis (fig. 381).

(5) The articular come off from the eoncarity of the arch, and, running backwards and upwards, are distributed to the articulations of the tarsus. They are

\section{Fig. 378. - The Plantar Arteries, Left Foot.}

(From a dissection in the Museum of St. Bartholomew's Hospital.)

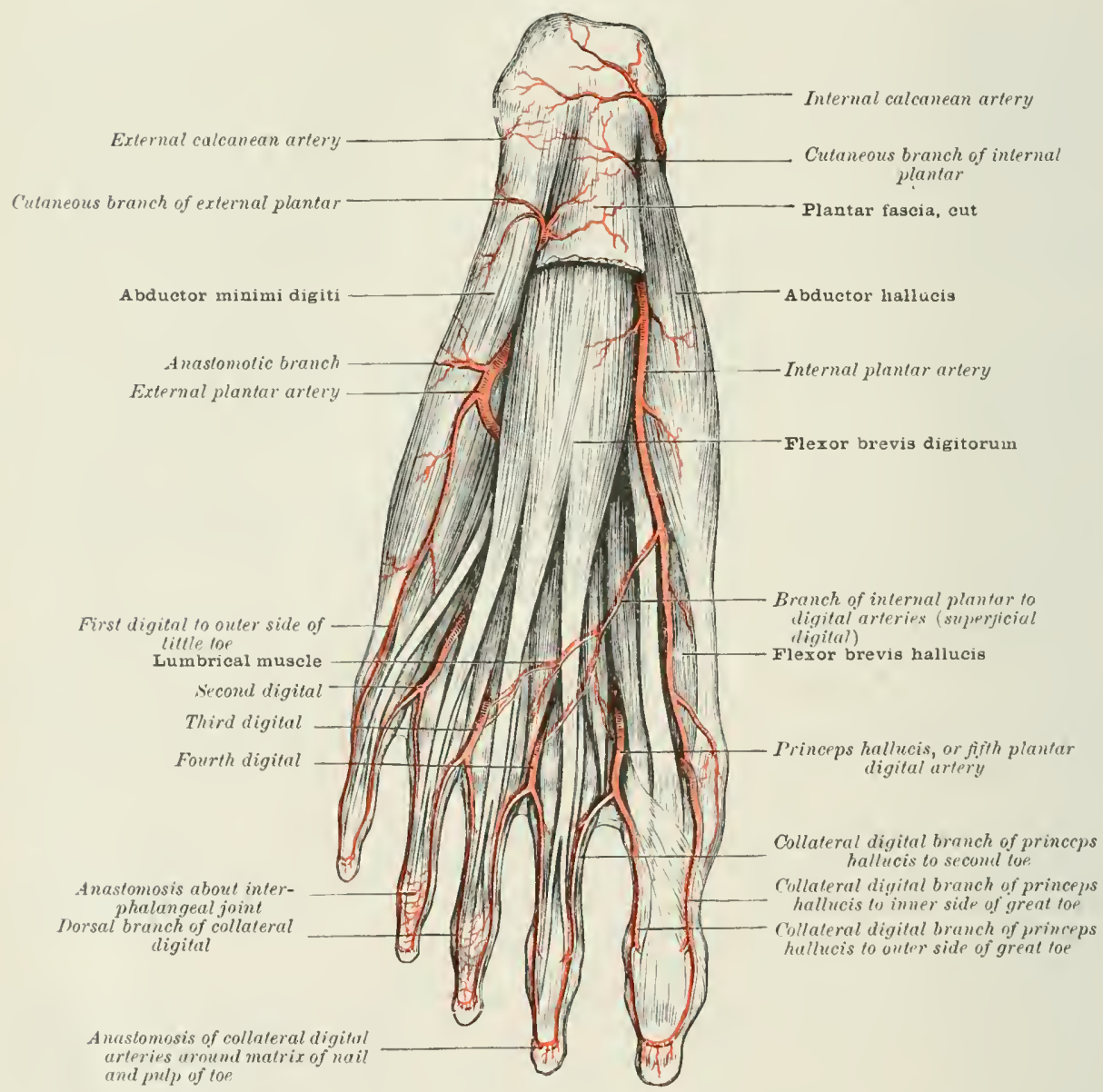

homologous to the reeurrent branches of the deep palmar arch in the hand, and, like the latter, are usually three in number.

(6) The posterior perforating, also three in number, ascend through the proximal end of the second, third, and fourth spaces, between the two heads of the eorrespondingly named dorsal interosseous muscles, and communicate with the proximal ends of the first, seeond, and third interosseous arteries (fig. 351).

(7) The digital or plantar digital arteries are usually four in number, and are distributed to the imner and outer sides of the third. fourth, and fifth toes, and to the outer side of the second toe. Ther are named first, second, third, and fourth as they come off from the arch from without inwards, and not aceording to 
the interosseous space in which they run. The first comes off from the outermost part of the plantar arch, and courses forwards along the outer side of the little tor. (figs. $378,379,381$ ), over the fifth metatarsal bone and the abduetor and flexor brevis minimi digiti muscles. The second, third, and fourth digitals run forwards in the centre of the interosseous spaces on the therein contained interosseous muscles, under cover of the contiguous lumbrical, the short and long flexor tendons, and the transversalis vedis muscle. Near the cleft of the toes they become superficial, and bifureate for the supply of the contiguous sides of the tous: the second supplying the inner side of the fifth and the outer side of the fourth toe; the third the inner side of the fourth and the outer side of the third toe; and the fourth the inmer side of the third and the outer side of the second toe. The supply

Fig. 379.-Right Plantar ARtekies (DeÉ).

(From a dissection in the Hunterian Musenm.)

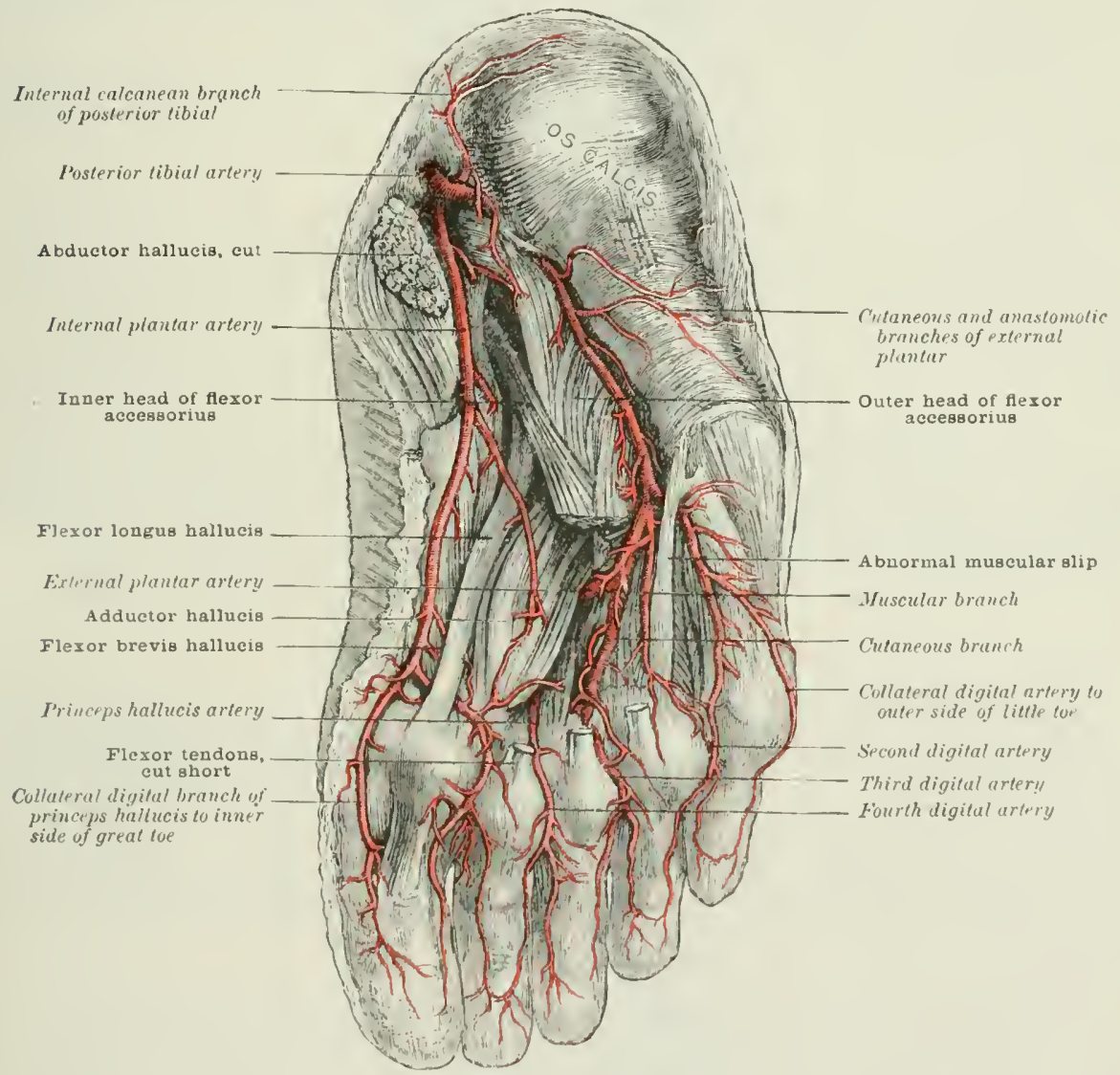

of the inner side of the second and both sides of the great toe is derived from the dorsalis pedis through its communicating branch to the plantar areh. The digital arteries, immediately before they lifurcate, send upwards on to the torsum of the foot a communicating branch (the anterior perforating artery) to the corresponding dorsal interosseous arteries. On the sicle of the toes the disital anteries-here sometimes called the collateral digital arteries-furnish numerous small hranches to the integuments and the flexol troluns and their sheaths. They anastomose hy many small twigs with the dorsal interosisens arteries, which alsil rmo along thir sides of the toes, hut more towards the dorsal aspect. Immediately above each phalangeal joint the collateral digital vessels communicate ly eross hranches, forming a rete for the supply of the articular end of the plablanges and the con- 
tignoms joints. At the distal (nd of the toes they also freely anastomose with each other, forming a rete bencath the pulp and around the matrix of the mail. The digital arteries are ach accompanied by two small reins.

\section{THE INTERNAL PIANTAR ARTERY}

The internal plantar artery (firs. 37s, 379)-the smaller of the two divisions: into which the posterior tibial divides at the inner ankle-passes forwards along the inner side of the sole of the foot usually to the first interosseous space, where it ends by anastomosing either with the fifth plantar digital artery (princeps hallucis) derived from the communicating branch of the dorsalis pedis, or with the branch griven off by the fifth plantar digital to the inner side of the great toe (figs. 378,379 ).

Relations. - The artery is at first under cover of the abductor hallucis, but afterwards lies in the interval between that muscle and the flexor brevis digitorm. It is covered by the skin and superficial fascia, but not by the plantar fascia, since it lies between the middle and inner portions of that structure.

The branches of the internal plantar are small and irregular in their origin, course, and distribution. The following are described:-

(1) The muscular branches supply the abductor hallucis, and flexor hrevis (ligitorum.

(2) The cutaneous branches supply the skin over the course of the ressel.

(3) The articular sink deeply into the sole, and supply the articulations on the inner side of the foot, and anastomose with branches of the external plantar arters.

(4) The anastomotic run beneath the abductor hallucis and round the inner side of the foot. to anastomose with the internal tarsal branch of the dorsalis perlis.

(5) The superficial digital are very small twigs which accompany the digital branches of the internal plantar nerves, and anastomose with the plantar digital arteries in the first, second, and third spaces. At times a twig from one of these hranches joins the external plantar artery to form a superficial plantar arch.

\section{THE ANTERIOR TIBIAL ARTERY}

The anterior tibial artery (fig. 380) - the smaller of the two branches into which the popliteal artery divides at the lower border of the popliteus muscle-at first courses forwards hetween the two heads of origin of the tibialis posticus, and, after bassing between the tibia and filula above the upper part of the interosseous membrane, runs downwards on the front and outer aspect of the leg, between the anterior muscles, as far as the front of the ankle-joint (fig. 380). Below this spot it is known as the dorsalis pedis. The course of the vessel is indicated by a line drawn from the front of the head of the fibula to a point midway between the two malleoli.

The artery is aceompanied hy two veins which communicate with each other at frequent intervals across it. It is also aceommanied in the lower three-fourths of its course hy the anterior tibial nerve. The nerve, which winds romnd the head of the fibula, and pierces the extensor longus digitormm, first eomes into eontact with the onter side of the artery somewhere about the upper third of the leg; then, in the middle third of the leg, it gets a little in front of the artery, and in the lower third again lies to its outer sille.

Relations. - The artery at first lies in the triangle formed by the two heals of the tibialis posticus and the popliteus muscle; and, as it passes through the hole in the interosseons membrane, it has the tilia on one side and the fibula on the other. It is separated from the anterior tibial nerve at its commencement by the neck of the filula and the extensor longus digitorum. This arrangenent is homologons with that met with in the foream in the ease of the posterior interosseous artery and nerve.

Posteriorly in its course down the leg it lies in its upper two-thirts upon the 
interosseous membrane, to which it is closely bound hy fibrous hands; and in its lower third upon the front of the tibia and the ankle-joint.

Fig. 380.-The Axterior Tibid, Artery, Dorsai, Artery of tife Foot, Axd Axterioli PERONEAL, ARTERY, ANI) TIEIR BRANCHES, I,EF SIIE.

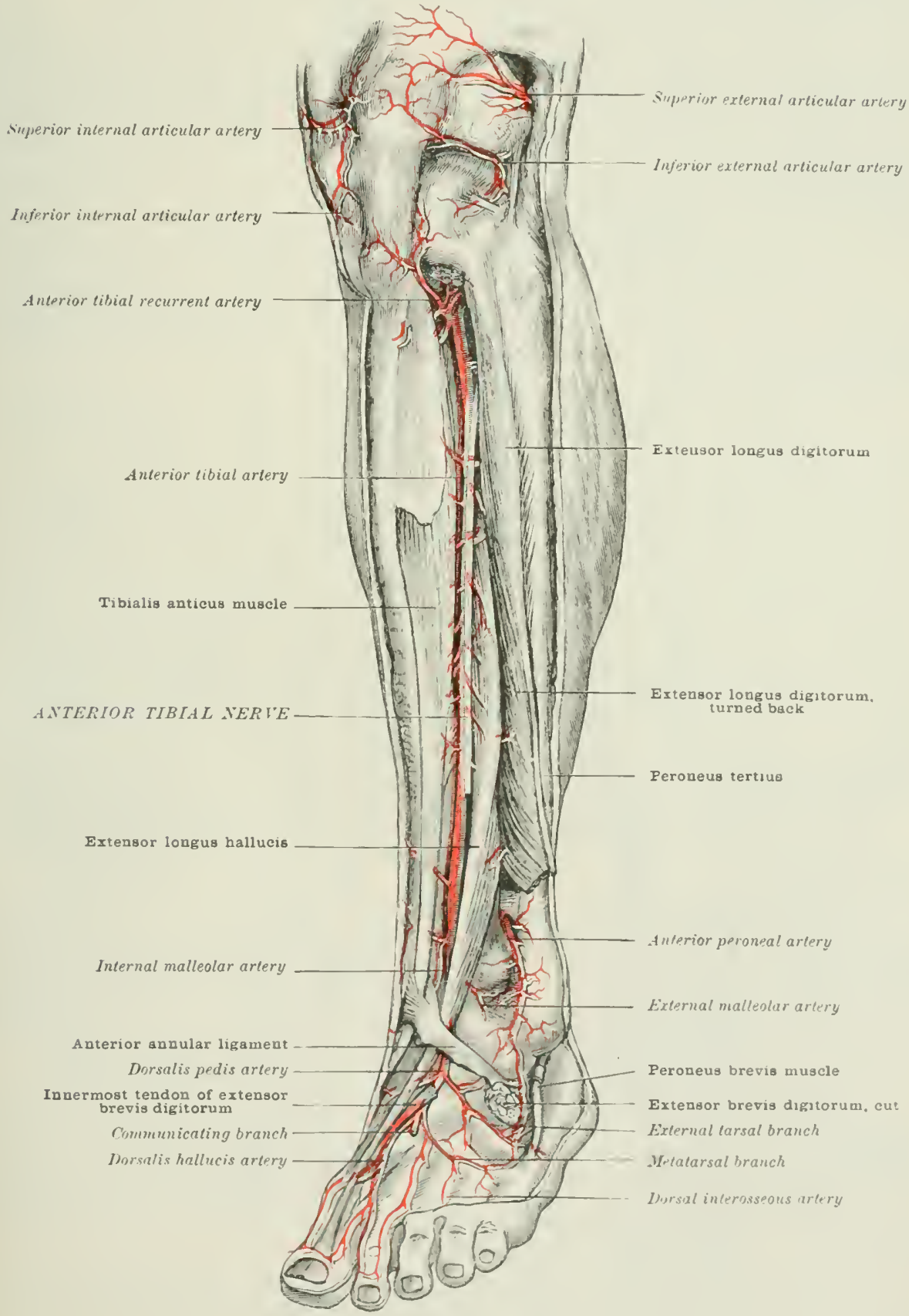

To its inner side along its upper two-thirds is the tihialis anticus muste: liut at the lower third it is crosed by the tendon of the extensor proprius hallucis, and then for the rest of its course has this tendon overlapping it or to its inner side. 
On its outer side it is in contact in its upper third with the extensor longus digitorum muscle; in its middle third with the extensor mroprius hallucis: but, as this muscle crosses to the inner side of the artery, the vessel usually for a very short part of its course comes again into contact with the extensor longus digitorum. At the upper and lower thirds of its course on the front of the leg the artery has the anterior tibial nerve to its onter side.

In front the artery is covered by the skin. superficial and deep fascia. In its upper two-thirds it is deeply placed in the cellular interval between the tibialis anticus on the inner side, and the extensor longus digitorum and extensor proprius hallucis on its outer side; and in its lower third it is erossed fron without inwards by the tendon of the extensor proprius hallucis, and lies beneath the anterior annular ligament of the ankle-joint. The anterior tibial nerve is usually in front of the artery in the middle third of the leg.

The branches of the anterior tibial artery are:-(1) The posterior tibial recurrent; (2) the superior fibular; (3) the anterior tibial recurrent; (4) the mus(ular; (5) the internal malleolar; and (6) the external malleolar.

(1) The posterior tibial recurrent is oceasionally absent. It ascends between the popliteus muscle and the posterior ligament of the knee-joint supplying these structures and the superior tibio-fibular joint. It anastomoses with the inferior external articular branch of the popliteal, and to a less extent with the inferior internal articular branch.

(2) The superior fibular is a branch of small size which arises from the main trunk just before it passes through the interosseous space. It winds round the neck of the fibula, pierces the attachment of the soleus and is distributed to that muscle and to the skin.

(3) The anterior tibial recurrent is given off from the anterior tibial artery immediately after that ressel has passed through the interosseous membrane. It winds tortuously through the substance of the tibialis antiens muscle, over the onter tuberosity of the tibia close to the bone; and, perforating the deep fascia, ramifies on the lower and outer part of the capsule of the knee-joint. It anastomoses with the inferior and superior external articular loranches of the popliteal, with the descending branch of the external circumflex, and somewhat less freely with the internal articular branches of the popliteal and with the anastomotica magna. It gives off small branches to the tibjalis anticus, the extensor longus rligitorum, the knee-joint, and the contiguous fascia and skin. It forms one of the collateral channels by which the hood is carried to the limb below in obstruction of the popliteal artery (fig. 376 ).

(4) The muscular branches, some ten or twelve in number. arise irregularly from either side of the artery as it courses down the limb, and supply the contiguous muscles.

(5) The internal malleolar, the smaller of the two malleolar branches, arises from the lower part of the anterior tibial artery a little higher than the external, usually about the spot where the tendon of the extensor longus hallucis crosses the anterior tibial artery. It winds inwards over the internal malleolus, passing beneath the tibialis anticus, and forms an internal malleolar plexus or rete about the inner ankle over the lower end of the tihia by anastomosing with branches from the posterior tihial, internal plantar, and internal calcanean arteries.

(6) The external malleolar, larger than the internal, arises from the outer side of the anterior tibial artery. usually on a lower level than the internal malleolar. It winds in an outwaid and downward direction romel the external malleolus, passing beneath the extensor longus digitorum and peroneus tertius, and forms the external malleolar plexus or rete hy anastomosing with the anterior peroneal. the termination of the peroneal, the external plantar, and the external tarsal branch of the dorsalis pedis (fig. 381 ).

The anastomosis between the external malleolar and anterior peroneal is sometimes of considerable size, supplying the bloorl to the dorsal artery of the foot; the anterior tibial, then much reduexl in size, usually ends at the spot where the external malleolar is usually given off. 
FI( 381.- SCHEME (IF THE DISTRHBLTION AND ANASTUMOSES OF THE ARTERIES OF THE Rirint Fuot. (Wilsham.)

(The plantar arteries are shown in dotted outline; the dorsal in solid renl.)

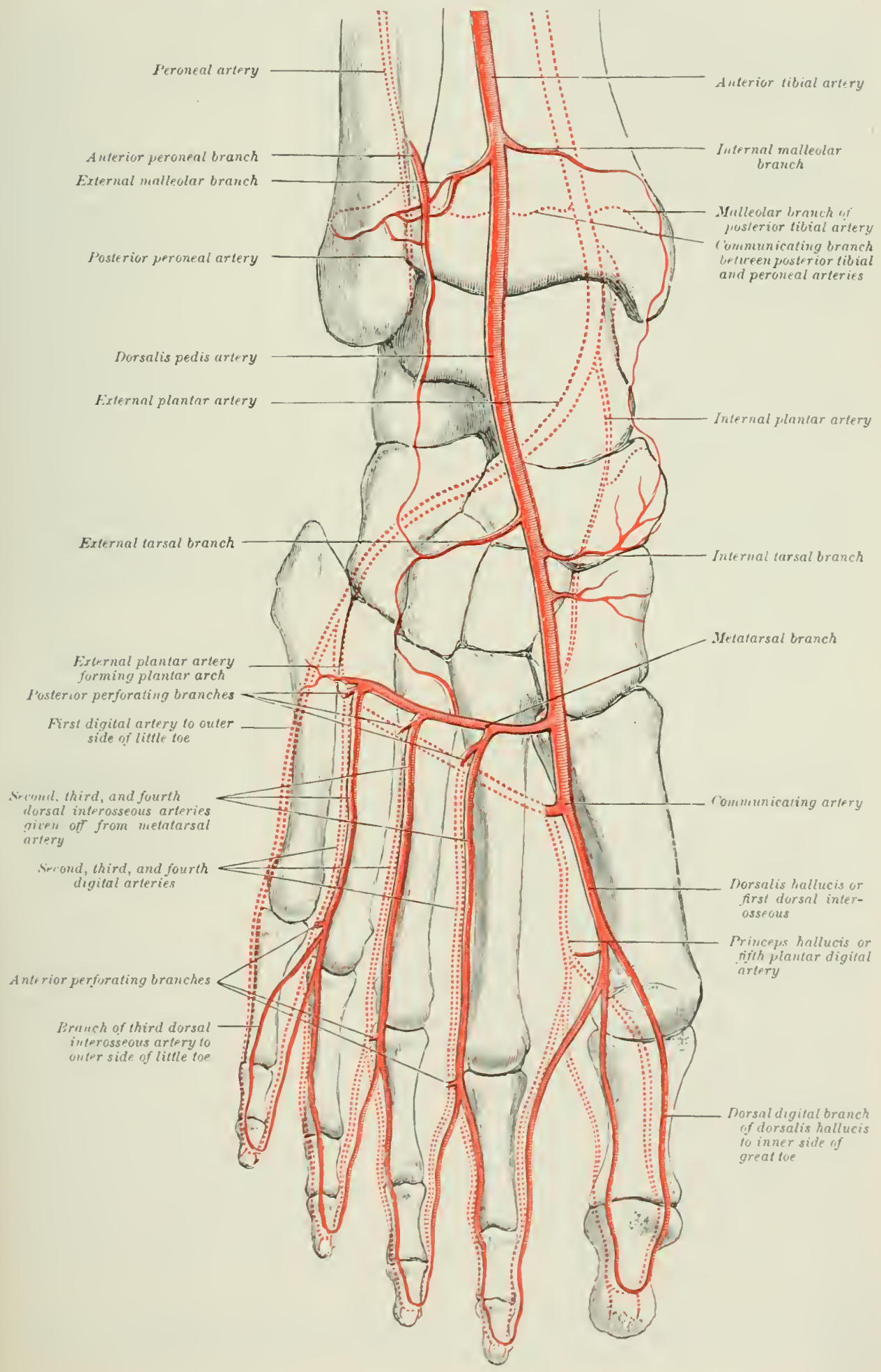




\section{THE DORALALIS PEDIS ARTERY}

The dorsalis pedis artery is a continuation of the anterior tihial. It extenls: from the front of the ankle-joint to the proximal end of the first interosseous space where it dips into the sole to join the external plantar artery and complete the plantar arch. The course of the artery is indicated hy a line drawn from a point midway between the two malleoli to the proximal end of the first metatarsal space.

Relations.-Behind, the artery from above downwards lies suceessively on the astragalus, scaphoid, middle cunciform, and the bast of the seeond metatisal bones, and the ligaments uniting these hones. As it sinks into the sole, under the name of the communicating artery, it lies between the two heads of origin of the first dorsal interosseous muscle. At times it takes a course a little more outwarks, then lying either partly on the middle cumeiform bone, or on the dorsal ligaments uniting the middle cuneiform to the internal cumeiform. It is more or less bound down to the bones by aponeurotic fibres derived from the deep fascia.

In front, the artery is covered by the anterior amular ligament, sometimes by the extensor longus hallucis, hy the skin, the superficial and deep fascia, and, just before it sinks into the sole, hy the innermost tendon of the extensor brevis digitormm. The angle formed by this tendon with the extensor longus hallucis is the best guide to finding the artery in the process of ligature (fig. 380 ).

To its outer side is the innermost tendon of the extensor longus digitorum, and lower down the immermost tendon of the extensor luevis digitorum. The anterior tibial nerve is also to its outer side. as is also the outermost of its renx eomites.

To its inner side is the 'xtensor longus hallucis, except at times for aloout half an inch below, where the innermost tendon of the extensor brevis digitorum, having crossed the artery, may lie between it and this tendon. The innernost of the vena comites is also to the immer side. Branches between the renze comites at intervals cross the ressel.

The branches of the dorsalis pedis artery are:-(1) The tarsal; (2) the metatarsal; (3) the dorsalis hallucis; and (4) the communieating, or plantar digital.

(1) The tarsal branches may be divided into (a) the external, and (b) the internal. (a) The external tarsal runs outwards orer the scaphoid and culnid bones, beneath the extensor brevis digitorum. It supplies hranches to that muscle, and to the bones and the articulations between them, and anastomoses above with the extemal malleolar and anterior peroneal, below with the metataral, and extemally over the outer border of the foot with the anastomotic branches of the externil plantar artery. (b) The internal tarsal consists of a few small branches which run over the immer side of the foot, supplying the skin and articulations, and anastomose with the internal malleolar.

(2) The metatarsal artery (figs. 3S0, 3S1) rums outwarls across the foot, in is slight curve with the convexity forwards, over the bases of the metatarsal bones, and beneath the extensor tendons and the extensor brevis digitorum. At the outrer border of the foot it anastomoses, above with the extemal taral, and extemally with the anastomotic branches of the external plantar. From the convexity of the arch it gives off three dorsal interosseous arteries, which run forwards on the dorsal interosseous museles in the centre of the seeond, third, and fourth intrrosseous spaces to the eleft of the toes, where they bifurcate for the supply of the contirnous sides of the second and third toes, the third and fourth toes, and the fourth and fifth toes. The outermost of the interosseous branches gives off a small res:sel for the supply of the outer sirle of the little toe. At the proximal end of the second, third, and fourth interosseous spaces each artery receives a branch of communisition from the external plantar artery (posterior perforating), and immediately before they bifurcate a second communicating artery through the distal end of the interosseous space from the eorresponding digital vessel (anterior perforating artery).

The little dorsal digital vessels, into which the dorsal interosseous arteries divide at the eleft of the tors, run along the side of each toe towards the dorsal aspect, anastomosing with each other across the dorsum of the toes and by frequent 
lanches with the eollateral digital branches of the digital arteries, which also run along the silles of the toes hut nearer the plantar surfice. At the enel of the toes they anastomose with ach other aromel the quick of the nail.

(B) The dorsalis hallucis-or first dersal interosients artery. as it is somptimes callex-is the aplatrent continuation of the clorsalis peclis. like the other dorsal interosseons arteries, it passes forwarls, in the centre of the first interosinens space, con the first dorsal interesseons muscle. At the cleft of the toes it cliviles into two dorsal digital branches - the one for the suplyly of the outer sille of the great toe, the other for the immer side of the second toe. Before its bifureation the dersilis hallueis gives off a small hranch, which runs inwards, uncler the extensor longus hallucis, for the supuly of the inner side of the great toe; hut this hranch is sometimes absent. At the front of the suace, immediately before its hifuration, the dorsalis ballucis communieates with the fifth plantar digital artery, or princeps hallucis, through an anterior perforating artery (fig. 381).

(4) The communicating - first interosseous perforating, or plantar digital artery, as it is variously ealled-ames off from the dorsalis perlis with the dorsalis hallucis (into which arteries inderel the dorsalis pedis may be said to divide). It the hack of the first interosieous space it dips into the sole hetween the two head: of the first dorsal interosseons muscle, and communicates with the termination of the "xternal plantar artery, completing the plantar arch. in a manner sinular te that in which the raclial artery, passing through the first dorsal interosemus musche in the hancl. completes by inosculating with the ulnar the deep lalmar arch. It the spot where it joins the external plantar it gives off the fifth plantar digital artery, or princeps hallucis, which runs forwark in the centre of the first interuseous suace to the cleft between the first and second toe, where it clivides into rollateral branches for the adjacent sicle of each. Bofore bifureating, it supplies a hranch to the inner sile of the great toe. and receives the anterior communisating artery from the dorsalis hallucis. 


\section{THE VEINS}

$\mathrm{T}^{\prime \prime}$

HE veins, like the arteries, are divided into the pulmonary and the systemic.

The pulmonary return the aërated blood from the lungs to the left side of the heart, and are the only veins that contain arterial blood. The systemic veins bring back to the right side of the heart the impure renous blood from the rest of the body. All the systemic reins terminate ultimately either in the superior or inferior vena cava, except the cardiac veins, which return the blood from the heart's substance, and open directly into the right auricle.

The reins from the stomach and intestines, the spleen, and the pancreas, before opening into the inferior vena eava, are collected into a large trunk rein called the portal vein, which breaks up, like an artery, into capillaries in the substance of the liver. From these capillaries the blood is again collected by the hepatic reins, which finally open, as two or more large-sized ressels, into the inferior vena cava.

The veins are described under the heads of:-1. The veins of the thorax; 2. the veins of the head and neck; 3 . the veins of the spine; 4 . the veins of the abdomen; 5. the veins of the upper extremity; and 6 . the veins of the lower extremity.

\section{THE VEINS OF THE THORAY}

The veins of the thorax are: the pulmonary, which arry the blowl from the lum gr to the left side of the heart; and the superior vena cava and its tributaries, which return the venous blood from the head and neck, the upper extremities, and the walls of the thorax, to the right side of the heart. The inferior vena cara, which brings back the blood from the abdomen and pelvis and lower extremities, is described with the reins of the abdomen, in which cavity it lies throughout by far the greater part of its course, somewhat less than half an inch of its upper end only being situated in the thorax.

The pulmonary reins are contained in the middle mediastinum. The superior vena cara and the right and left innominate veins course through the superior inediastinum. The azygos veins, the larger of which opens into the superior vena cava, lie on either side of the thoracic vertebra in the posterior mediastinum. They receive the intercostal, the bronchial, and the cesophageal veins.

\section{THE PLIMONARY VEINS}

The pulmonary veins (fig. 320 ) return the aerated blood from the lungs to the heart. They are usually four in number, two right and two left. Occasionally, however, there are three pulnonary veins on the right side, the result of the vein 
from the middle lobe of the right lung opening separately into the left auricle instead of joining as usual the upper of the two right pulmonary veins. The relations of the pulmonary reins to the pulmonary arteries and loronchi in the lumgs are given with the Axatomy of the Lcisgs. At the root of the lung the pulmonary veins on both sides are arranged as an upper and a lower branch, an anterior descending branch of the bronchus passing between them. The upjer vein on the right side is larger than the lower, and usually receives the vein from the middle lobe of the right lung. The lower rein on the left side is larger than the upper. Both the upper and lower veins lie in front of the pulmonary artry and on a lower plane, and rum almost horizontally inwards and forwards to the left auricle. As they pierce the pericardium they receive a reflexion from the serous layer of that membrane. Their relations within the pericardium are given with the Axatom of the Heart. At the root of the lung their relations to the surrounding structures are similar to those of the pulmonary artery (page 466). A separate description is not required.

\section{THE YENA CAVA SUPERIOR}

The superior or descending vena cava (fig. 381A) carries to the heart the blood returned from the head and neck and upper extremities through the right and left innominate veins, and from the walls of the thorax, either directly through the greater azygos vein, or indirectly through the imnominate reins. It is formed (fig. 381A) by the confluence of the right and left innominate reins at the lower border of the first right costal cartilage close to the sternum, and, descending from this spot in a gentle curve with its convexity to the right and in a direction slightly backwards and outwards behind the sternal end of the first and second intercostal spaces and second costal cartilage, terminates in the right auricle of the heart on a level with the third right costal cartilage in front and the serenth thoracic vertebra behind. It measures about three inches in length $(7-8 \mathrm{~cm}$.$) .$ A little more than its lower half $(t \mathrm{~cm}$.) is contained within the pericardium, the serous layer of that membrane being reflected obliquely over it immediately below the spot where it is joined by the rena azygos major, and on a lower level than the reflexion of the pericardium on the aorta. The vena cava superior contains no valve.

Relations.-In front (fig. 322), in addition to the first and seeond intercostal spaces and the second costal cartilage, it is covered by the remains of the thrmus gland, the interthoracic fascia, and the pericardium, and is overlapped by the right pleura and lung.

Behind (fig. 324) are the vena azygos major, the right bronchus, the right pulmonary artery, and the superior right pulmonary rein; and helow; the fihrous layer of the pericardium. The serous layer is reflected over the front and sides of the vessel, but not over its posterior part.

To the right side are the right lung and pleura, and the phrenic nerve.

To the left side are the innominate artery and the first or ascending portion of the arch of the aorta.

Tributaries.-In addition to the right and left imnominate reins and the rena azygos major, it receives small reins from the mediastinum and pericarlium.

\section{THE INYOMINATE OR BRACHIO-CEPHAIAC VEINS}

The innominate veins return the blood from the head and neck and upper extremity. They are formed on each side by the confluence of the internal jugular and subclavian reins behind the sternal end of the clavicle. They terminate at the lower border of the first costal cartilage on the right side by uniting to form the superior vena cava. The innominate reins have no valves.

The right innominate vein (fig. 3.92) measures ahout one to one and a half inches in length $(2-3 \mathrm{~cm}$.), and descends from its origin behind the sternal end of the clavicle, very slightly forwards and inwards, superficial to, and to the right of. the 
sulsclavian and inmominate arteries. to its junction with the loft rein frehind the first enstal cartilage close to the sternum.

Relations. - In front (fig. 327 ) are the origins of the stemo-hyoid and sternothrovid muscles, the clavicle, the first costal cartilage, and the remains of the thimus gland.

Behind are the pleurat and lung.

To the right are the right pleura and lung, and the phrenic nerve.

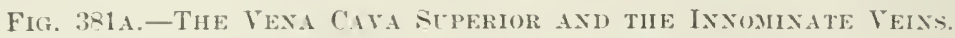

From a dissection in st. Batthulomew"s Hospital Musenm.)

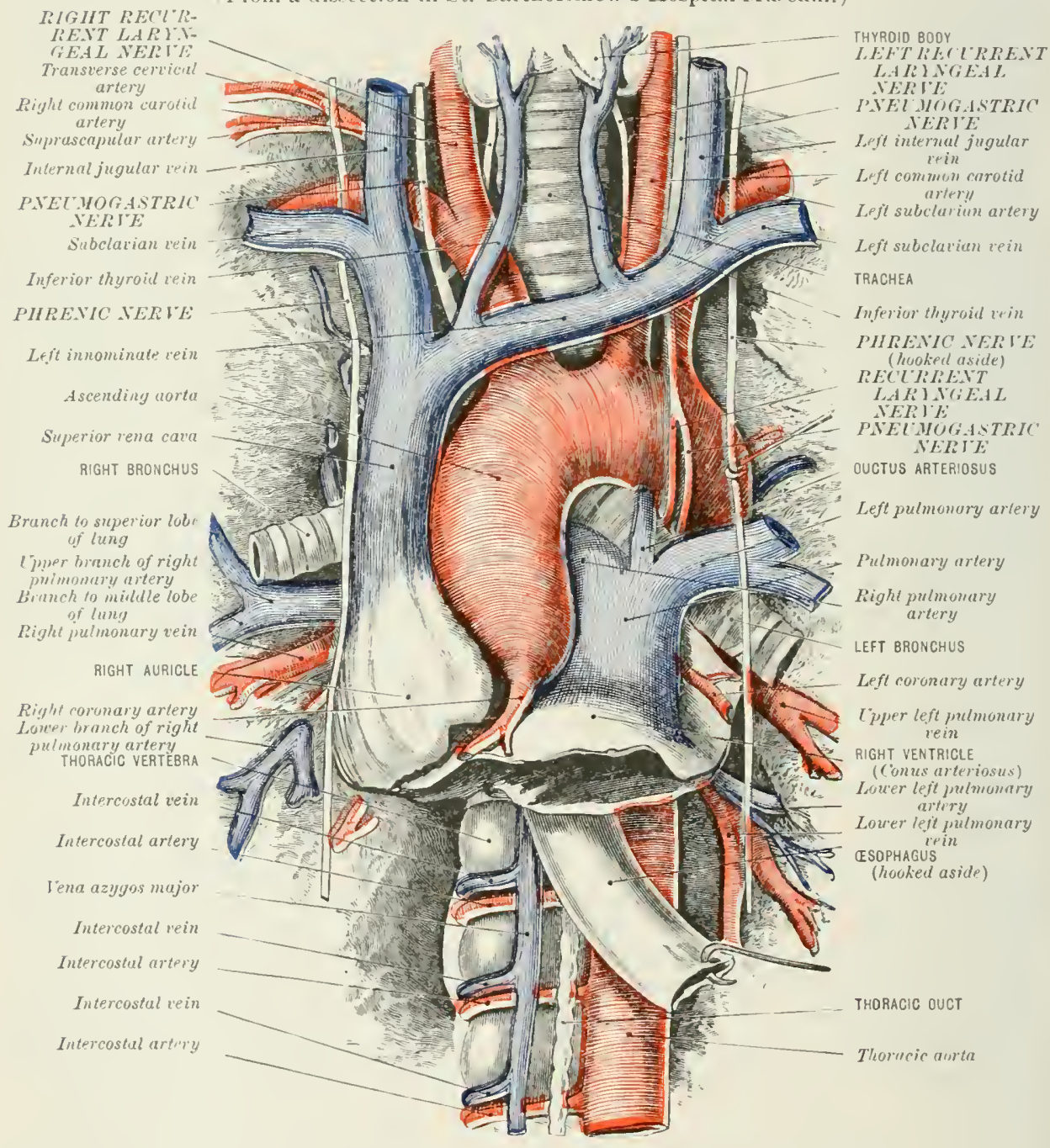

To the left (fig. $391 \mathrm{~A}$ ) are the right subclavian artery, the immominate artery, the right pneumogastric nerve, and the trachea.

The left innominate vein (tig. 381. ) measures two and a half to three inches in length ( $6-7 \mathrm{~cm}$.), and extends from its origin behind the sternal end of the left (davicle obliquely acess the three main branches of the areh of the andta to unitr with the right inmominate vein at the lower border of the cartilage of the first rib close to the sternum to form the vena cara superior. In this course it runs from left to right with an inclination downwards and slightly backwark. A line llawn obliquely a(ross the upper half of the mamulnium of the stermum, from the sterno- 
clavieular articulation on the left silk to the lower horder of the first costal cartilage at its junction with the strenum on the right sids, will indicate its course. The left imominate rein is on a lexel with the top of the sternum at hirth.

Relations.-In front, in aclelition to the manuluriun of the sternum, it has the origins of the stermo-hyoid ambl stemo-thyoid museles and the remains of the thymus gland, the sternal end of the left chavele, and the sterno-clavicular anticulation (figr. $328,3-1 \mathrm{~A}$ ).

Behind, are the three ehief arteries ariong from the areh of the aorta tles trachea, and the left phrenic and left ponemmongtrice nerves.

Below it is the transwerse portion of the areh of the antal.

Above it are the eervieal fascia and inforior throbil veins.

Tributaries.-In adclition to the internal jugular and subclavian reins, by the confluence of which the inmoninate reins are formerl, each rein receives on itmpler asperet the rertebral, the deep cervical and inferior throbid reins; and on its lower aspect the internal mammary vem. The left rem, moreorer, is joined ly the left superior intreostal. and by the thymic. mediatstinal, and pericaldiac verins. At the confluence of the internal jugnhar and sublavian reins on the right side. the right lymphatic duct opens; on the left side the thoracic duct. The vertelral, the deep cervical, and the inferior thyoid veins are described with the deep roins: of the hearl and neck (page 628 ).

The internal mammary veins (fig. $3+4$ ) are fomed hy the unim of the vente comites of the superior epigastric and musculo-phrenie branches of the internal mammary artery. They receive in their course through the chest collateril tributaries corresponding to the branches of the intemal nammary artery. Just lecore reaching the innominate rein they unite behind the first intercostal slare to form a single trunk which opens into the innoninate vein on the inner side of the internal mammary artery. They contain many valyes.

The left superior intercostal vein-or, more correctly speaking, the lower left superior intercostal rein-longer than the right. which is described as a tributary of the rena azyos major, receives the intercostal veins from the three or four uplur loft intercostal spaces except from the first space, and, ascending orer the arch of the arta, oprens into the left inmominate rein. It nsually receives the left hronchial rein, and communicates with the uper left azyos rein. (Nore Ixter("NT.1L VeINS, Jage 608.)

Thr mediastinal, pericardiac, and thymic veins are small vessels, corresponding to the arteries of those names given off by the internal mammary. Ther io not, howerel, as a rule, join the internal mammary vein, lut unite into a single trunk (tigs. 317, 35.2), which passes orer the transwerse part of the arch of the aorta. and opens into the lower and anterior part of the left innominate rein.

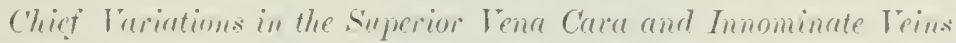

The variations in the vena cava and imominate veins defrend upon certain alnormalities in the levelopment of the great veins from the ducts of Cuvier and the primitive jugular reins. and can here receive only a brief mention. 'They may be classified as fullows:-

\section{(1) Vurintions the to the Persistence of the Left Duct of Curior}

(a) The left subclavian may join the left internal jugular vein to form a trunk which is contimed almost vertically lownwards over the arreh ut the aorta in front of the root of the left hung, to upen into the coronary sinus of the heart. This variety is known is the persistent left supering vena cava, and is the mormal arrangement of the great anterior veins in sme animals. The ruli-

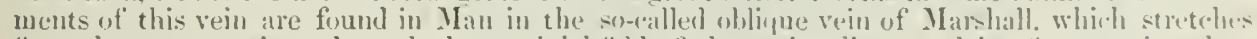

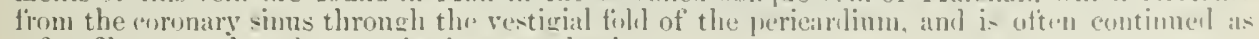
a fine fibums cord to the smerior interestal rein.

When the so-called left superior vena cava is present, the mper left azygur vein (the remans of the left primitive (ardinal rein) may open into it ly arching over the lont of the leot lune in a way similar to that in which the erreater azyon (the riglit primitive carlinal rein) npens into

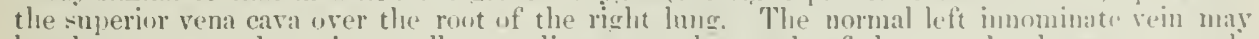

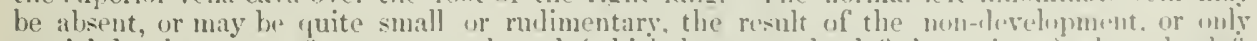
partial development, of a transverse l,ranch (which becomes the left inmminate) when the left part of the sinus venosis and the left duet of C'uvier are transformed intu the comonary simus, the oblique vein of IIarshall, aml the upper portion of the left sujerior intereotial rein. 
(b) A vein may run from the left innominate, or left superior intercostal rein, thromgh the vestigial fold of the pericardium to the coronary sinns, the left innominate vein being itself normal. This abnormality is similar in kind, but minor in degree, to the former, described under (a).

\section{(2) Turiations due to Persistence of the Left and Suppression of the Right Duct of Curier}

(a) The right innominate vein may cross the arch of the aorta to join a vertical left imnominate vein, and thus form a left superior vena cava, the nomnal right smperior cava being absent. 'The arrangement of the azygos veins under this condition may be reversed, there being a left vena azygos major opening over the root of the left lung into the left superior cava, and an upper and lower riglit azygos vein arranged after the manner of the normal left azygos veins. This arrangement of the veins may occur independently of any general transposition of the viseera.

(b) There are many other varieties, depending upon abnormalities in the normal development of the great veins from the Cuvierian ducts and from the primitive jugular and eartinal reins; but these cannot be discussed here.

\section{THE AZYGIOS VEINS}

The azygos veins (fig. 382) are three in number. They collect the blood returned from the eleven intercostal spaces on the right side, and from the seven or eight lower intercostal spaces on the left side. They lie on each side of the front of the bodies of the thoracic vertebræ, and establish a communication between the superior and inferior venæe caræ through the ascending lumbar reins.

The vena azygos major begins in the aldomen, where it may be looked upon as a continuation upwards of the ascending lumbar vein (page 633). It passes through the aortic opening of the diaphragm, runs up through the posterior mediastinum on the right side of the front of the bodies of the thoracic vertebre as high as the fourth thoracic vertebra; then curves forwards over the root of the right lung, and opens into the superior vena cara immediately before the latter pierces the pericardium.

Relations.-(1) In the abdomen, the vena azygos major lies to the right of the aorta and thoracic duct, under cover of the right crus of the diaphragm, "1pon the first. sometimes upon the second, lumbar rertebra. At this spot it receives the right subcostal rein, and is continued helow into the ascending lumbar rein; or, if the lower part of this rein is small, it may appear to begin in one of the lumbar veins, or in the rena cava, or where the portion of the ascending lumbar rein which communicates with the renal is enlarged, in the renal rein. Through this intermediation of the ascending lumbar rein, a communication is establisher between the iliac veins and the rena azygos. In obstruction of the inferior vena "ava much of the hlood from the lower extremities and abdominal wall is returned hy the vena azygos major and its continuation, the ascending lumbar vein, in the abdomen, to the vena cava superior. (See Ascexding Lcumar VEL, page 63:)

(2) It the aortic opening the vena azyos major lies to the right of the aorta and thoracic duct, hetween the cruma of the diaphragm.

(3) In the posterior mediastinum, as it courses mywards on the right side of the bodies of the thoracic vertebre, the vena azrgos major croses in front of the lower riglit intercostal arteries, having on its left side the descending aorta and thoracic duct, in front the root of the right lung and lower down the plenra, and on its right side the right pleura and lung.

(4) Is it curls over the root of the right lung, the vena azygos major is in contact with the right hronchus, the puenungastric nerve passing obliquely between them (fig. 324).

It usually contains an imperfect pair of valyes at the spot where it turns forwards from the fourth thoracic vertebra to areh over the root of the lung; and still more imperfect valves alre found at varying intervals lower down the rein.

Tributaries.-(1) The vena azyos minor; (2) the vena hemiazyos acessoria, or one or more of the left intercostal reins; (品) the lower end of the lower superior interestal vein of the left side (sometimes); (4) the lower right asophageal veins; (i) a few right mectiastinal veins; (6) the right loronchial vein; ( 7 ) the lower right 
superior intercostal rein; ( 8 ) the nine lower right intercostal veins; and (9) the right subcostal vein.

The vena azygos minor-also called the lower left azygos and vena hemiazygos-begins in the abdomen by communicating, like the vena azygos major. with the ascending lumbar vein of the left side. Through this rein it communi-

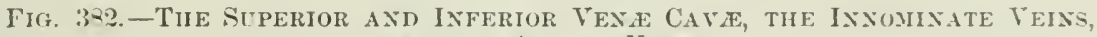
ASD TIE AZYGOS VEIS:

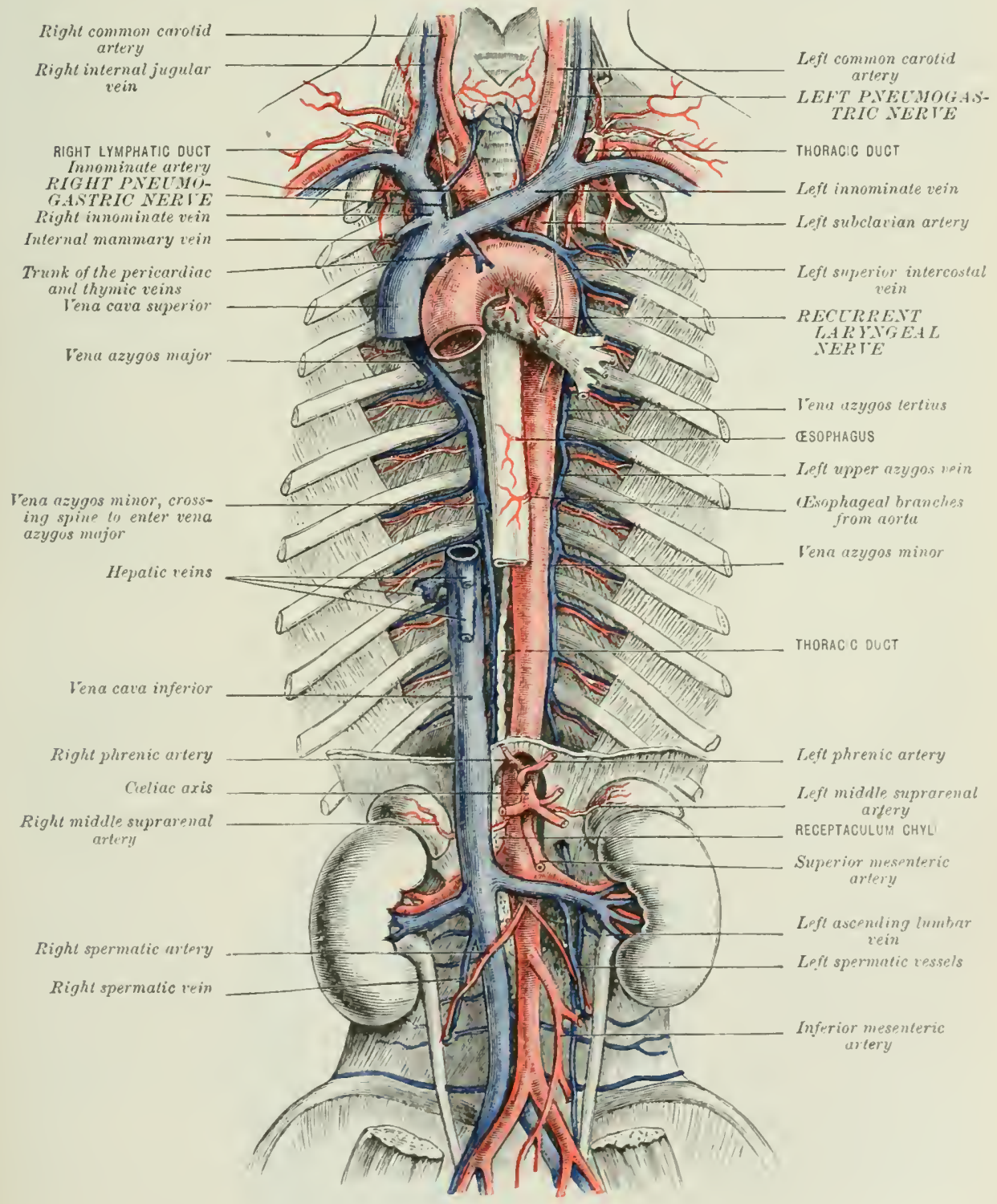

cates with the lumbar veins, the remal, and the iliac reins, and, according an-one or other portion of the ascendling lumbar is enlared and other portions are climini:her in size or obliterated, so may the vena azyos minor appear to hegin in the venar cara inferior or in a lumbar, the renal, or cone of the iliac reins. The rena azyous minnr, after receiving the left subeostal rein, passes through the left crus of the diaphragm, and courses up the posterior mediastinum to the left of the horlies of 
the lower thoracic vertehre as high as the eighth, where it turns obliquely to the right, and. crossing in front of the spinal column behind the aorta and the ixesphagus, opens into the rena azygos major. In its course it crosses over three or four of the lower left intereostal arteries, and is eovered hy the pletura.

Tributaries.-(1) The lower four left intercostal reins; (2) the left subcostal vein; (3) the lower ent of the third azyos vein (sometimes); (4) small left merliastinal rins; and (5) the lower left eesophageal reins.

The vena azygos tertia (also called the upper left azygos and vena hemiazygos accessoria) varies considerably in size, position, and arrangement, and is often ahsent. It lies in the posterior mediastinum by the left side of the bodies of the fifth, sixth, and seventh thoracic vertebræe, and is more or less rertical in direction. It is continued above into the lower left superior intercostal rein, and helow either joins the vena azygos minor, or passes obliquely across the sixth or seventh thoracic rertebra to join the vena azygos major. "The intercostal veins intervening between it and the vena azygos minor then open directly across the spine into the rena azygos nujor. It crosses the corresponding left intercostal arteries, and is corered by the pleura.

Tributaries.-(1) The fifth, sixth, and sometimes the seventh intreostal reins; (2) the lower end of the lower left superior intercostal vein; (3) the upper end of the rena azrgos minor (sometimes); and (4) the left bronchial vein.

The intercostal veins.-The intereostal veins are eleven in number on each sirke, and correspond with the intercostal arteries. The last thoracic vein is here walled the subcostal, and is described separately (page 609). There is one rein to each intercostal artery, the vein lying above the artery whilst in the intercostal space. Each rein is joined by a dorsal tributary which runs with the dorsal hranch of the intercostal artery between the transverse process of the vertebre and the neck of the rib. The dorsal tributaries return the blood from the muscles of the bark, and receive communicating branches from the dorsal spinal plexus and from the spinal veins through the intervertebral formina. The intereostal veins also receive small tributaries from the bodies of the vertebræ. The termination of the intercostal veins is different on the two sides, and is seldom alike in any two consecutive subjects.

On the right side.-The first intercostal vein (the upper right superior intercostal vein) ascends with the superior intercostal artery, a branch of the suluclarian, to end either in the vertebral vein just before the latter joins the right innominate vein, or in the right inmominate direct. The sceond intercostal vein either joins with the first, and opens with it as a common trunk into the rertebral or innominate vein, or it joins with the third or with the third and fourth to open into the rena azygos major as the latter is arching over the root of the right lung. This vein is known as the lower right superior intercostal vein. The fifth, sixth, seventh, eighth, ninth, tenth, and cleventh right intercostal reins join the rena azygos major. The upper of these have well-marlied ralves where they join the azygos vein. In the lower veins these valves are imperfect. All the intercostal reins are provided with valves in their eourse between the muscles.

On the left side the first intercostal vein also follows the superior intercostal artery from the subclavian, and ascends to join the left vertehral or left immominate rein, and is known as the upper left superior intercostal vein. The second intercostal vein either joins the first, and opens with it as a common trunk into the lift vertebral or left innominate vein, or joins the third and fourth, as described below, to form the lower left superior intercostal vein. The third and fourth, and sometimes the second, intercostal reins mite to form a single trunk, the lower left superior intercostal vein, which passes upwards across the areh of the aorta, and opens into the left innominate vein. This rein usually communicates at its lower end with the third azyos rein, but at times crosses the spine, and enters direstly the vena azygos major. A fibrous cord can frequently be traced from it through the restigial fold of the pericardium to the obligne vein of Marshall (page 605). The fifth and sixth, and sometimes the seventh, intercostal veins "ither end in the third azygos vein, or, if this is absent, cross the spine, and open lirectly into the rena azyos major. The eighth, ninth, tenth, and eleventh, and sometimes the seventh, intercostal reins join the rena azygos minor. 
The subcostal vein, or twelfth thoracic vein, lies bencath the last rib, and accompanies the twelfth dorsal or subeostal artery. It receives tributaries corresponding to the branches of the subeostal artery, and opens on the right side into the vena azygos major, and on the left side into the vena azygos minor.

The bronchial veins correspond to the hronchial arteries, but do not return the whole of the blood carried to the lungs by those vessels-that part which is chistributed to the smalker bronchial tubes and the alveolæ being lorought back by the pulnonary veins. The bronchial veins issue from the lung substance behind the structures forming the root of the lung. The right rein generally joins the vena azygos major just before the latter vein enters the superior vena cava. The loft vein opens into the lower left superior intereostal vein, or into the upper left azygos vein. The bronchial veins at the root of the lung receive small tributaries from the bronchial glands, from the trachea, and from the posterior mediastinum.

The œsophageal veins from the thoracic portion of the cesophagus end in part in the rena azygos major, and in part in the rena azygos minor.

\section{THE IEINS OF THE HEART}

The cardiac or coronary veins return the blood from the substance of the heart. They accompany the corresponding coronary arteries, and terminate for the most part in a dilated vein known as the coronary sinus. This opens directly into

Fig. 383.-The Coronary Sinus.

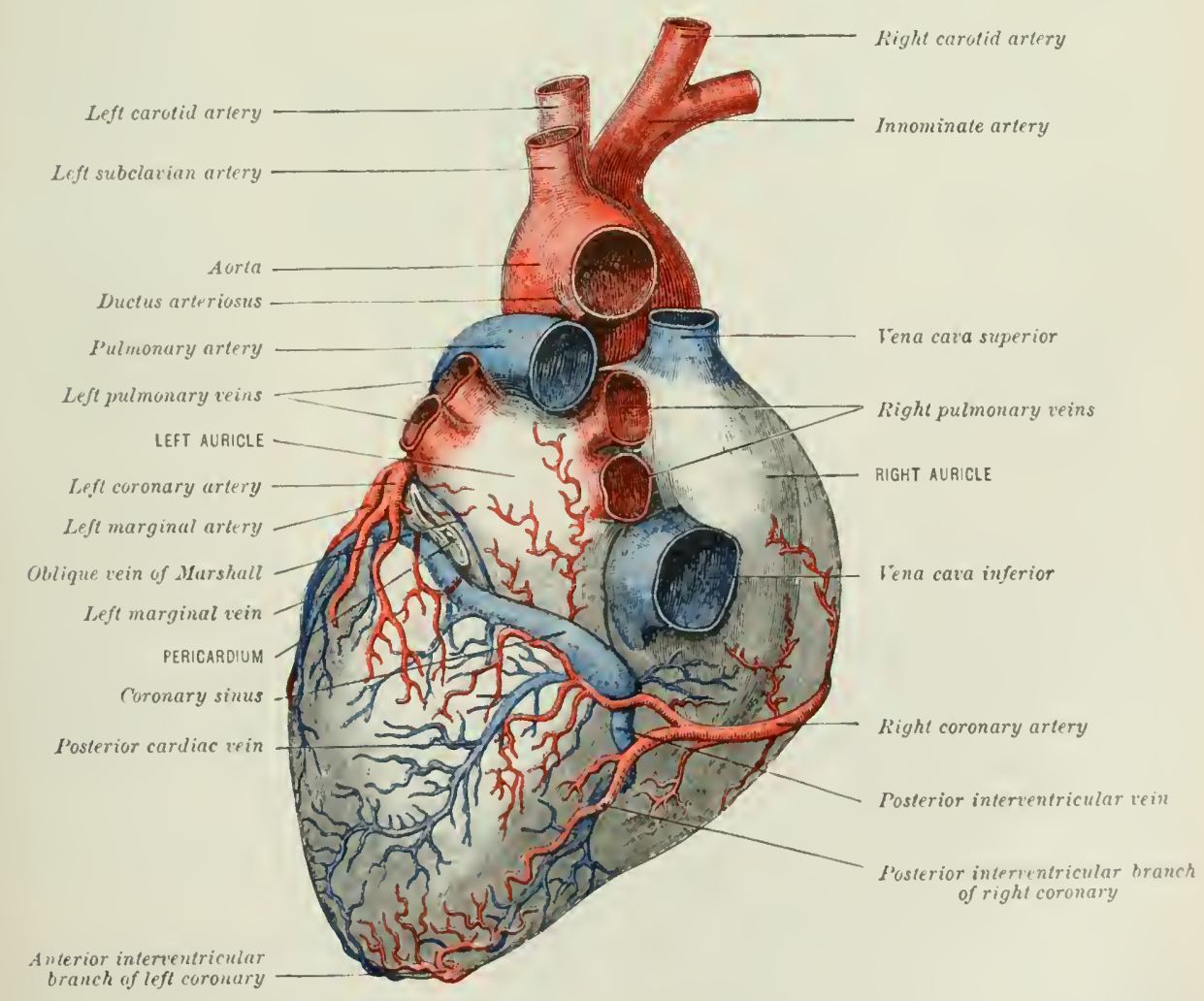

the right anricle of the heart, between the tricuspid ofening and the opening of the inferior vena cava. Some smaller veins from the heart's substance (venæ minima cordis) open separately and directly into the right auricle at the bottom of some of the small depressions known as the foramina Thehesii. 
The coronary sinus is situated at the back of the heart, in the groove hetween the left auricle and left ventricle. It measures about an inch in length. Its upening into the auricle is guarded hy the so-called Thebesian or eoronary valve. It receives the following tributaries: (1) The great coronary or cardiac vein, of which it appears to be the large and dilated end; (2) the posterior cardiac or posterior interventricular vein; (3) the right auricular vein; and (4) the oblique vein.

(1) The great coronary or cardiac vein is formed by the union of $(a)$ the anterior interventricular vein, which runs upwards from the apex of the heart, in the gronve between the right and left rentricles, in company with the artery of that name; with (b) the left auricular vein, which returns the blood from the left auricle. The vein thus formed then runs round the left side of the heart. in the groove between the left auricle and left ventricle, and terminates in the coronary sinus at the spot where the latter is joined by the oblique vein. Its entrance into the sinus is guarded by a double valve. It receives $(c)$ the left marginal vein or veins, and branches from both ventricles, especially the left.

The left marginal vein runs with the artery of that name over the surface of

Fig. 394.-SCheye of the Coronary Veins. (Walsham.)

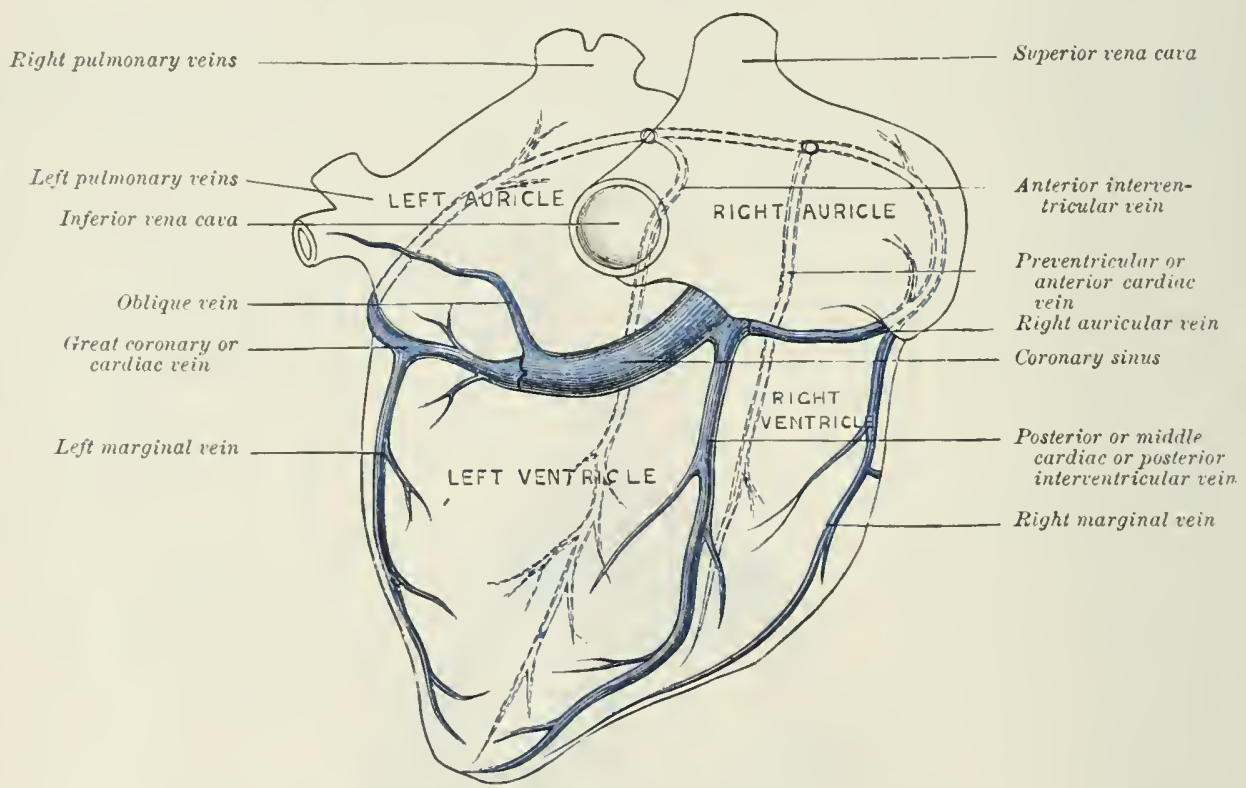

the left ventricle, along the left margin of the heart. It receives tributaries frum the left ventricle, and teminates in the great comary vein.

(2) The posterior cardiac, middle cardiac, or posterior interventricular vein accompanies the posterior interventricular artery upwards, from the apex of the heart in the posterior interventricular groove. It ends in the coronary sinus, just before the termination of the latter in the right auriele. It receives tributaries from the posterior surface of hoth ventricles, and is guarled by a ralve where it joins the coronary sinus. Two or three small veins (posterior eardiae, or smallor posterior carliac) run upwards from the back of the left rentricle, and open into the corouary sinus by separate oritices guarled by valves.

(3) The right auricular, right coronary, or small coronary vein, runs in the right auriculo-ventricular gronve, and terminates in the coronary sinus just before the entrance of that sinus into the auricke. It is joined by the right marginal vein and by the preventricular or smaller anterior carliac vein or veins.

(4) The oblique vein - the greater part of which is often represented merely by a delicate fibrous (a)rd-runs across the hack part of the left auricke, in the vestigial fold of the pericardium to the coronary sinus. This rein, with the coronary sinus, 
its dilated portion, represents what was the left duct of cuvier and part of the sinus venosus in the fortus. Asstated at pange 60.5, it is oceasionally found pervious, and may be greatly enlarged, and help to form the so-ealled left sinjerior vena caral. There is, as might be gathereel from the comsicleration of its morphologr, no valve where the oblique vein is continued into the coronary sinus.

The right marginal vein - sometimes called the anterior cardiac vein, or vein of Galen-runs over the right ventricle, along the right margin of the heart, and opens either into the right auricular vein or separately into the lower part of the right auricle, its orifiee, known as the foramen of (ialen, being situater immediately helow the opening of the superior vena cala. Othes sulall veins-the smaller anterior cardiac veins (venæ cordis parvæ, or preventricular veins)-ahso track up, from the anterior surface of the right ventricke, and open either inte the right marginal vein or separately into the right auricle.

\section{THE VEINS OF THE HEAD ATD IECK}

The veins of the head and neck may be divided for purposes of description into the superficial, which return the blood from the external parts of the head and neck; and into the deep, which return the blood from the dreper structures. The superficial may be again subdivided, according to the region from which they carry the blood, into (1) 'The veins of the scalp and face; and (2) the reins of the neck. The deep veins -into which, moreover, some of the superficial open-may be subdivided into:-(1) The veins of the diploë; (2) the renous sinuses; (3) the veins of the brain; (4) the veins of the nasal cavities; (5) the reins of the ear; (6) the veins of the orbit; $(7)$ the veins of the pharynx and larynx; and ( 8 ) the deep veins of the neck. All the veins, whether superficial or deep, sooner or later terminate in the internal jugular, the external jugular, the vertebral, or the derp cervical vein-chiefly the two former; and these veins open direetly or indirectly into the innominate veins at the root of the neck, through which all the blood from the head and neck ultimately passes on its way to the heart. 'The external jugular rein is quite superficial; it is formed by the confluence of the reins corresponding to the upper branches of the external carotid artery, and, after receiving tributaries from the superficial parts of the neck and from the shoulder, terminates just above the clavicle in the subclavian vein. The internal jugular vein is deeply placed by the site of the common and internal carotid arteries. It begins in the jugular fossa, where it is continuous with the lateral sinus, and, after receiving tributaries corresponding to the lower branches of the external carotid artery. teminates at the root of the neck in the immominate rein. The vertebral vein acemmpanies the vertehral artery through the formana in the transerse procestes of the cervical vertebre. It hegins in the suboceipital triangle by the confluence of small reins from the deep museles at the lack of the oceijunt, and, aftrie receiving tributarias from the cervical spine and teep muscles of the nere, encls in the innominate rein. The deep eervical reerives the oceipital rein. eomses downwards amongst the deep museles at the back of the neck, and ands in the innmminate rein.

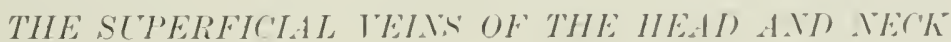

\section{THE SUPERFICIA VEINA OF 'THE SCAIP ANI) FACE}

The blook from the sealp is retmoned by three main channels-viz. an anterior, which passes over the forehead and faci2; a posterior, which desemels orer the oceipital bone; and a lateral, formed by the confluenese of two smaller weins which descend orer the parietal and temporal hones respectively-one in front, and one behind the ear. 
The Axterior superficial Vein of the Scalp axd Face

The anterior vein descends near the middle line, over the frontal bone, to the inner angle of the orbit; continues its course by the side of the nose to the check, which it crosses obliquely, to the anterior edge of the masseter muscle, and thence passes through the digastric triangle to the upper border of the hyoid bone, where it terminates in the intemal jugular rein. In this course it is reinforced hy numerous collateral veins, and gradnally increases in size. It has, moreover, nimerous communications with the deep reins.

Fig. 3-5.-Thl: Slperficial Veins axd Lyuplitics of the Scalp, Fate, axd Neck. (Walsham.)

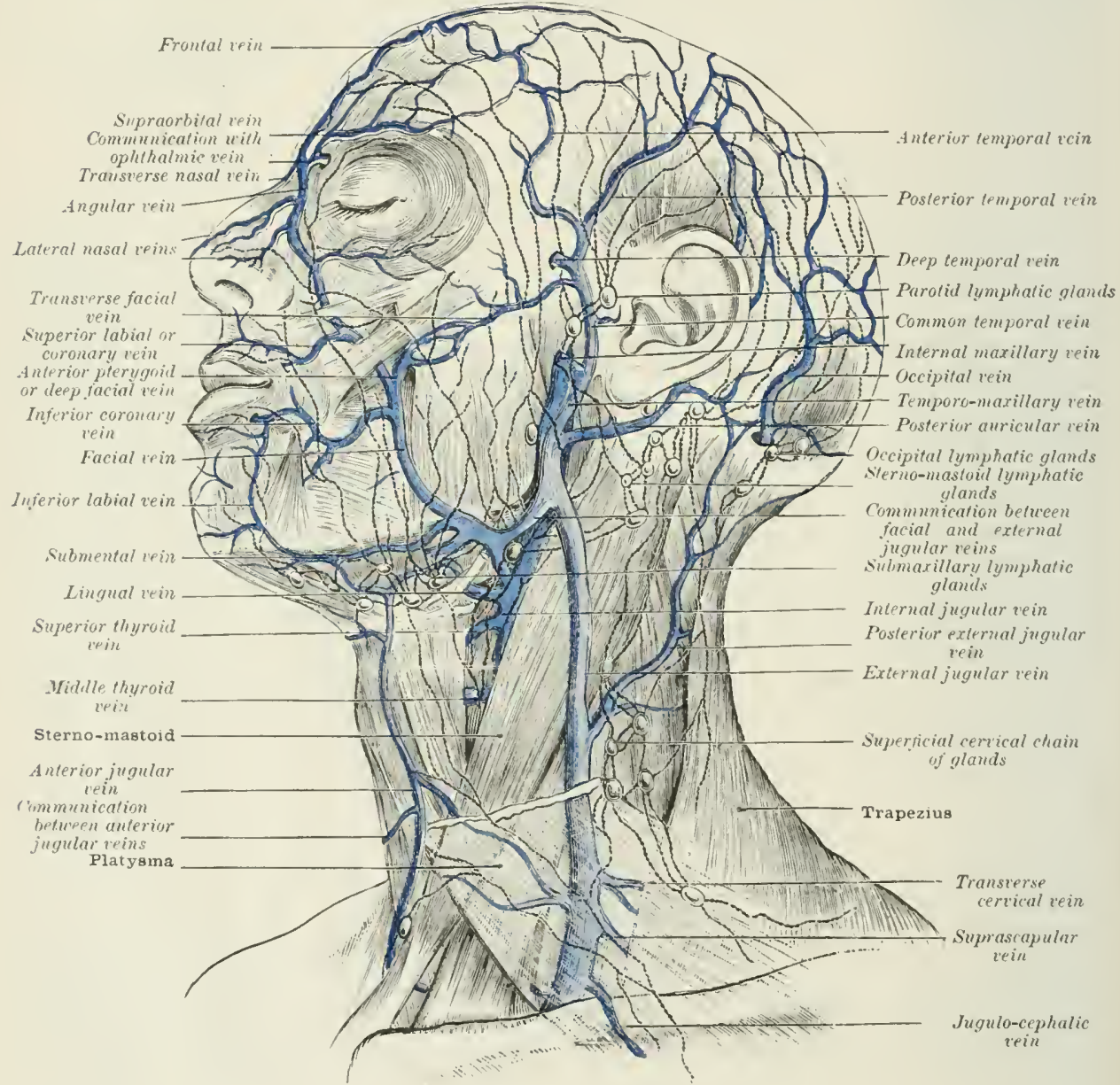

This long continuous trunk vein is variously named according to the reuion in which it lies. Thus, as it descends over the frontal hone it is kuown as the frontal vein; as it lies by the side of the nose it is called the angular vein; whilst in the remainder of its course over the face and neck it is spoken of as the facial vein.

(1) The frontal vein begins ahout the level of the coronal suture in a renous plexus which communicates with the anterior division of the temporal vein. Soon forming a single trunk, it passes vertically downwards over the frontal bone, a short distance from the middle line and parallel to its fellow of the opposite side, to the inner canthus of the eyelids, where it takes the name of the angular rein (fig. 385).

Tributaries. - In its course it receives numerous tributaric from the forehead, 
and communicates freely with the vin of the opposite sille, across the glalerlla of ront of the nose, by a transrerse hranch sonetimes callerl the transverse nasal vein. Just before its temination it resives the sup raorhital vein. The transterse nasal rein usually receives the dorsal reins of the nose.

The supraorbital vein begins over the frontal enineners by intrenmunicattions with the anterior banch of the superficial temporal vein. It receives tributaries from the forehear and eyehrow, and, ruming ohliquely downwads amel inwards, opens into the temmation of the frontal vein. It communiontes with the ophthahnic vein, and receives the frontal rein of the diploë as the latter vein issues from the bone at the bottom of the silpmorbital notch.

(2) The angular vein, the continuation of the frontal voin clownwark, cxtemls from the junction of the frontal and suj,raorbital veins a littlo helow the lerel of the eyebrow, to the level of the lower margin of the orbit, where it becones the facial vein. In this short course it skirts round the immer margin of the orbit, lying with the angular artery on the nasal process of the superior maxillary bone a little internal to the lachrymal sac. Branches pass from the posterior part of the angular vein into the orbit to join the ophthalmice.

The angular, the facial, and the ophthalmic reins contain no valves. The bloxk, therefore, can pass either forward from the ophthalmic into the angular, or hackwark through the facial and angular into the ophthalmic, and so on to thes cavemous and other venous sinuses of the cranium. Hence in certain tumours in the orbit and renuium, the congestion of the angular and facial vins; and the danger in facial carbuncle and anthrax of septic thrombi spreading backwards through the angular and ophthahnic veins to the cranial sinuses.

Tributaries.-(a) The superior lateral nasil; and $(b)$ the palpehral reins.

(a) The superior lateral nasal veins ascend from the ala and the side of the nose to join the imner side of the angular rein (fig. 355 ).

(b) The palpebral veins proeced from the upper and lower eyelids, and open into the outer side of the angular vein, either separately of by a rommon trunk. Several branches of the inferior palpebral vein open into the facial vein (figr. $: 385$ ).

(3) The facial vein, the continuation of the angular, hegins at the lower margin of the orlit, and, crossing the faere obliquely rlownarls and outwarks, passes at the anterior edge of the masseter muscle over the body of the lower jaw, and thenc. downwards and backwards across the digastric and superior carotirl triangles to join the internal jugular vein about the level of the hyojel bone. It rums in a more or less direct lim hehinel it: corresponding artery, the facial, which itself pursues a tortuons course. It usually passes beneath the zyomatie miseles and beneath the platysma, lut alove the other muscles. It the antrior edge of the maswerer it meres the farial artery. lying immediately posterior to it. In the neck it liebrucath the platysma and cervical fascia, and is usually separaterl from the facial artery by the sulmaxillary gland and the stylo-loyoirl, and the posterior belly of the rigastricus monses, letow which it frequently recoives a rommmicating hranch from the external jugular voin. That portion of the rein from the spot where it receives the communiating branch to its tamination in the internal jugular is sometimes alled the common facial vein; anrl the eommminting hranch, thr" anterior division of the temporo-maxillary vein. (S.e TEMPOR(-MAXILLARY Vess, page 616.)

Tributaries.-It receives on its inner side, from above dowmarls:-( inferior lateral nasal veins; (b) the superior labial vein; (r) the inferior labial reins:; (d) the sulomental vem; (b) the sulmuxillary veins. On it: outer side :- $(a)$ thes inferior balpeloral reins; (b) the anterior internal maxillary vein; (c) the huecal rein; (d) the anterior parotid rein; (e) the masseteric roin; and (f) the inferior palatine vein.

Communications. - It commmicates with the infranthital vein, the pitregoid plexus of veins, the anterior jugular vein, ancl the external jugular vein.

Tributuries on the Inner sille.- $(a)$ The inferior lateral nasal vein is a small branch which corresponds with the latralis mas artery. It joins the farial on al level with the ala of the nose.

(b) The superior labial or coronary vein hemins as a plexu- in the orliculatis 
oris muscle of the upper lip, and passes with the superior coronary artery outwards, and joins the facial vein a little below the level of the ala of the nose.

(c) The inferior labial veins. - A small branch (inferior coronary) usually opens into the facial a little below the superior labial vein; but the rhief branch from the lower lip descends as a rule orer the chin to the submental vein, and thus only opens indireetly into the facial rein. It may open into the anterior jugular vein.

(d) The submental vein lies on the mylo-hyoid muscle superficial to the sul-mental artery. It begins below the chin, and, rumning backwarls in the rligastric triangle, joins the facial vein just after the latter has passed orer the body of the lower jaw. It receives branches from the inferior labial plexus and the neighlouring muscles, and communicates with the anterior jugular rein.

(e) The submaxillary or glandular veins ojen into the facial as it crosses the sulmaxillary gland. But some branches from the gland often open into the submental vein.

Tibutaries on the Outer Side.-(a) The inferior palpebral veins.-Several branches pass downwards to the facial vein; others, as hefore stated, pass inwards to the angular vein (page 613). Through one or more of these branches a communication is formed with the infraorbital vein.

(b) The anterior internal maxillary vein, sometimes known as the deep facial, passes downwards and forwards from the pterygoid plexus of reins between the buccinator and masseter muscles, and opens into the outer side of the facial rein under corer of the zrgomaticus major muscle.

(c) The buccal vein is a small branch from the buccinator muscle.

(d) The anterior parotid branch descends from the glandula socia parotidis forwards to the facial.

(e) The masseteric is a small branch from the masseter muscle.

$\left(f^{\prime}\right)$ The inferior or descending palatine vein accompanies the ascencling palatine or tonsillar artery from the renous plexus about the tonsil and soft palate, and joins the facial rein just below the body of the lower jaw.

The communicating branch between the external jugular and facial veinssometimes known as the anterior division of the temporo-maxillary vein-rums obliquely downwards and inwards from the external jugular vein from near the spot where the latter is continuous with the temporo-maxillary trunk. It joins the facial rein deeply just behind the angle of the jaw.

The chief variations in the facial vein are:-(1) It may run over the stemn-mastoid and open into the external jugular vein ; (2) it may open into the anterior jugular rein ; (3) it may run beneath the posterior belly of the digastricus and stylo-hyoid muscles; $(4)$ it may receive the lingual vein, the pharyngeal vein, or both of these veins.

\section{The Posterior Superficial Vein of the Scalp}

The posterior vein descends over the occipital bone, and then deeply amongst the muscles at the back of the neck. It ends in the immominate vein. The first or superficial portion of this trunk is known as the occipital vein; the second or deeper portion as the deep cervical vein (fig. 385 ).

The occipital vein hegins at the back of the skull in a renous plexus which anastomoses with the posterior auricular and posterior branch of the sujerficial temporal reins. It passes downwards over the occipital bone, and, perforating the trapezius with the occipital artery, sinks deeply into the suboc(ipital triangle, where it terminates in the deep cervical rein. At times it takes a more superficial course, and, joining the posterior auricular, mases with this into the extemal jugrular vein. One of its branches-usually the ontermost-receives an emissary rein issuing through the mastoid foramen of the temporal bone, and in this way forms a communication with the latrral sinns.

The deep cervical vein begins as a plexus of subll veins in the subocipital triangle. After recoiving, as a rule, the oceipital rein, it passes downwards lietween the complexus and the semispinalis colli, in company, first with the princeps cerrieis branch of the occipital artery, and afterwards with the deep cervical branch of the 
superior intercostal artery. On reaching the transverse process of the serenth cervical vertelora, it turns forwards between that proces: and the neek of the first rib, and opens either directly into the innominate vein or into the rertebral inmediately hefore that vein joins the immoninate.

Tributaries. - It receives branches from the muscles anongst which it runs.

\section{The Lateral, Superfichal Vems of the Scalp}

The lateral veins descend, one in front and one behind the ear, and mite about the level of the angle of the jan to form a single trunk-the external jugular vein.

The anterior vein, the larger of the two, is known as far as the zygoma as the superficial temporal vein. There it is joined $b$ a deep vein from the temporil fossa-the middle temporal vein; and the uniterl trunk, now called the common temporal vein, passes orer the zygoma into the parotid gland. Opposite the neek of the lower jaw it receives the large internal maxillary vein, and takes the mame of the temporo-maxillary vein. This emerges from the lower border of the parotid gland, and joins the posterior lateral vein, which is known as the posterior auricular, to form the external jugular vein.

The Anterior Laterul I'eins.-The superficial temporal vein retums the hloxl from the parietal region of the sealp. It is formed by the union of an anterior and a posterior branch: the former communicates with the sumporbital and frontal reins: the latter with the posterior auricular and occipital veins and the tomporal rein of the opposite side. These branches lie superficial to the corresponding branches of the superficial temporal artery, which they roughly though not accurately follow. Like the artery, they lie between the skin and the eranial aponeurosis, and descend over the temporal fascia to unite a little above the zyoma, and just in front of the pimal of the ear, to form the smperficial temporal trunk. The rein thus formed continues its course downwarls with the trunk of the temporal artery, and oyposite the zyoma is joined by the midclle temporal rein to form the common temporal vein.

The middle temporal vein corresponds with the middle temporal artery. It begins in a plexus in the temporal fossa, and then runs backwads loween the layers of the temporal fascia, the outer layer of which it perforates near the mgoma, to join the superficial temporal rein. It receives an orbital branch, which corresponds with the orbital branch of the temporal artery, and communicates in front with the oplithalmic rein, the extemal palpebral veins. and the infratorital voins, and then runs backwards between the layers of the temporal fascia to join the middle temporal trunk or plexus. The nidille temporal vein conmunicates with the deep tempomal reins, and through them with the pterrgoid renoms plexus.

The common temporal vein, formed by the confluence of the superticial and micllle temporal veins, descrends over the zyoma just in front of the pinna of the "ar, lying a little superficial to the temporal artery. Then, jassing derply into the parotid ghand, between the extemal auditory meatus and the angle of the jaw, it is joined almost at a right angle by the internal maxillary vein, and becomes the temporo-maxillary vein.

Tributaries. - It receives $(a)$ the transverse facial vein, which corresumes to the transverse facial artery; $(b)$ articular veins from the plexus around the temporo-mandibular joint - this plexus receives the tympanic vein, which, texwether with its corresponding artery, basses through the fisture of (iliser: (c) parotid veins, from the substane of the pratiel gland; $(d)$ masseteric veins, from the milsieter muscle; and $(r)$ anterior auricular veins, from the pimna of the ene.

The internal maxillary vein acempanies the first palt of the intermal maxillary artery between the internal lateral or splueno-mamelibular ligament and the nex $k$ of the lower jaw. It hegins at the posterior contluenes of the veins forming the pterygoid plexus, and enels by uniting with the (1) munom temporal vein to form the temporo-maxillary trunk.

The pterygoid plexus is formed hy the vins which arrespond to the handhes of the internal maxillary artery. It is situated, partly on the inner surface of the

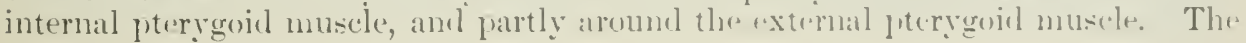


veins entering into this plexus are:- the two middle meningeal, which accompany the artery of that name; the posterior dental vein; the mandibular (inferior dental); the masseteric; the buccal; the pterygoid veins from the pterygoid muscles; the deep temporal, by which the plexus communicates with the temporal plexus; the spheno-palatine vein; the infraorbital; the superior palatine; the lower branch of the ophthalmic vein, which courses through the sphenomaxillary fissure from the orlit; and the Vesalian vein, through which the plexus comunicates with the caremous sinus. The plexus ends posteriorly in the internal maxillary vein which joins the common temporal vein, and anteriorly in the anterior internal maxillary or deep facial vein, which passes forwards and downwards hetween the buccinator and masseter muscles to join the facial rein.

The above-mentioned veins, forming by their confluence the pterygoid plexus. correspond in their course so nearly with that of their companion arteries, that a detailed description is not necessary. Although deeply placed, they are for convenience described with the superficial veins.

The temporo-maxillary vein is formed by the union of the common temporal rein and internal maxillary vein in the substance of the parotid gland. It usually joins about the angle of the jaw the posterior auricular vein to form the external jugular. At other times it divides into two branches, an anterior and a posterior. The anterior division runs forwards and downwards, and joins the facial vein (see Fardal Vers). The posterior division rums backwards over the stemo-mastoid and joins the posterior auricular to form the external jugular. When the temporomaxillary trunk without dividing joins the posterior auricular to form the extemal jugular vein, the anterior branch is represented by the communicating branch between the external jugular and facial reins.

The Posterior Lateral Veins. - The posterior auricular vein begins in a venous 1) lexus on the posterior part of the parietal bone. This plexus communicates with the vein of the opposite side, across the sagittal suture, and with the posterior branch of the superficial temporal vein in front, and with the occipital vein behind. It descends over the back part of the parietal bone and the mastoid process of the temporal bone. lying with its artery behind the ear. It then leaves the artery, and passing over the upper part of the stemo-mastoid muscle obliquely forwards and lownwards, joins the temporo-mandibular vein about the level of the angle of the lower jaw, forming the external jugular rein (fig. 385).

Tributaries.-(a) Auricular veins from the back of the pinna: and $(b)$ the stylo-mastoid vein, corresponding to the little stylo-mastoid artery. The latter vein opens into the posterior auricular vein, as a rule, as the latter leaves the mastoid process.

\section{THE SLPERFICIAL VEIXS OF THE NECK}

The external jugular vein is formed by the confluence of the posterior auricular and temporo-maxillary veins near the angle of the lower jaw. It rums obliquely downwards and hackwards across the stemo-mastoid muscle to a spot opposite the midrle of the clavide, where it terminates as a rule in the subclavian rein. I line drawn from a point midway hetween the mastoid proeess and angle of the jaw to the midrlle of the clavicle will indicate its course. It is covererl by the skin, superficial fascia, and platysma, and is crossed by a few branches of the cervical plexus, the great auricular nerve rumning parallel to it at the upper part of the neck. It at first crosses the sterno-mastoid obliquely, then runs nearly parallel to the posterior border of that muscle, from which it is separated throughout its course by the anterior layer of the deep cervical fascia.

Just ahove the clavicle it perforates the cervical faseia, by which it is prevented from readily collapsing, thr fiscia heing attached to its walls. It then opens into the subclavian vein; occasionally into the internal jugular, or into the confluence of the subclavian and internal jugular veins. It eontains a pair of valves ahout one inch to two inches above the clavicle, and a second pair where it "nters the subclavian vein. Both of these valves were shown by sir James Struthers not to prevent the hlood regurgitating, or injections passing from the larger rein into the external jugular. 
Some anatomists iescribe the external jugular rein as beine former by the junction of the posterior auricular and oceipital veins. The rein here rexalded as the upler part of the trunk of the extemal jugular is losked mon be them merely as a branch of conmunieation between the external jugular and temjorm-maxillary vein.

The chief variations of the external jugular vein are:-(1) It way he very mall, wr much -maller or much larger than the uppusite reiu; (2) it may be wanting on one or huth sides, the vins which nomally form it then wpening into the internal jugular; (3) it may be formed merely by the pusterior auricular rein; $(4)$ it may be perforated by the superficialis $(\cdot$, lli nerve; $(5)$ it maly receive the facial, the lingual, and the cephalic veins; (ij) it may pass urer the claviche and open into the eephalic or subclavian vein.

Tributaries and communications.-From above dowmarls, the extermal jugular receives a lranch from the intemal jugular rein; the posterior external jugular, which in the fortus was part of the primitive jugular vein; a large liranch connecting it with the facial vein; one or two small linanches of ermmuni(ation from the anterior jugular rein; near its temination, the transverse cervical and suprascapular veins; and sometimes the anterior jugular vein at the lusterior border and hinder surface of the stemo-mastoid. At times the occipital rein opens into the external jugular, and is by some anatomists regarded as the nurmal termination of the former vein.

The posterior external jugular vein descends from the upper and hack part of the neck, receiving small tributaries from the superficial structures and nu-c.les. It tines it rommunicates with the occipital, or may aplear as a continuation uf that rein. It opens into the external jugular as the latter vein is leaving the stema-mastoid muscle. In the fotus this rein returns the hlool from the interion of the cranim through the post-glenoid foramen. Vestiges of the foetal trunk are said to remain in the mastoid rein.

Thr suprascapular veins, two in number, correspond to the suprasenpular artery. They usually form one trumk before they open into the external jugular roin. Ther contain irell-marked valves.

The transverse cervical veins-or vena comites of the transrelso rervical artery-accompany that vessel and open with the supuacapular vein into the extrinal jugular close to the spot where the latter vein joins the suleclavian.

The anterior jugular vein begins below the chin by ammuniating with the mental. sulmental, inferior labial, and inferior hyoid reins. It descents a littl. extronal to the niddle line, receiving branches from the superficial structures at the front and sirle of the neck, and occasionally a branell from the laryox and thyour

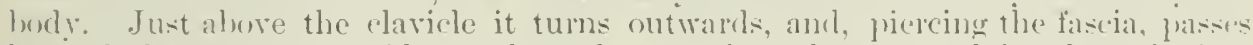
hereath the stemo-mastoid musele and opens into the extemal jugular vein just lufore the latter joins the subclavian; at times it "grens into the sulelavian rim itself. In its course down the neck it communicates with the external jugular; and,

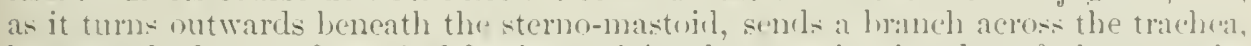
between the layers of cervical fascia, to join the anterior jugular of the mpurite sille. This communicating rein may be dividerl in the operation of trathentemey and

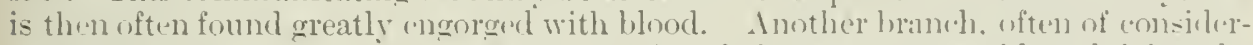
able size. courses along the anterior margin of the sternom-mastoill and joins the far.jal vin. When the anterior jugular vein is large, the exterual jugular is - mulll,

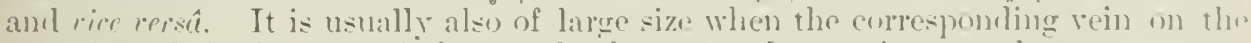

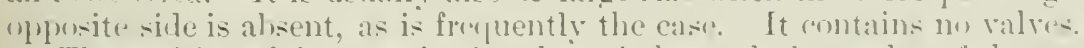

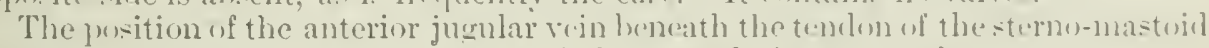
should be borme in mind in tenotomy of that muscle for wry-meck.

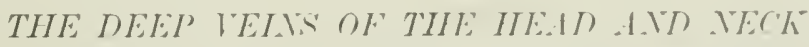

The deep veins of the head and neck ma! be livisul intu-1. the voin- of

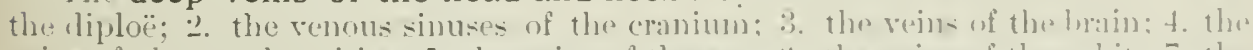

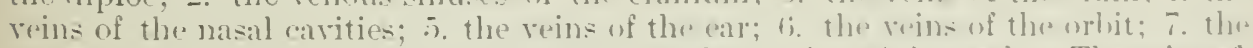

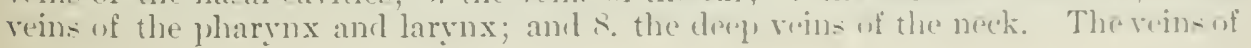


the diplä terminate partly in the superficial veins already described. partly in the renous sinuses of the crinium, and partly in the decp veins of the neck. The ranus sinuses open into the deap reins of the neck. The reins of the brain terminate in the renous sinuses. The reins of the nasal carities teminate partly in the deep, and to some extent in the superficial veins. The veins of the ear join both the superficial and deep reins and the renous sinuses. The veins of the orbit terminate partly in the superficial reins, but chiefly in the renous sinuses. The reins of the pharynx and laryux enter the deep reins of the neck.

\section{THE VEINS OF THE DIPLOË}

The veins of the diploë are contained in bony channels in the cancellous tissue between the external and internal tables of the skull. Ther are of comparatively large size. with rery thin and imperfect walls, and form irregular communicating ehamnels. They have no valves. They can only be seen on removing the external

Fig. 3-6.-The VeIss of TIE DIPLö.

(From a specimen in St. Bartholomew's Hospital Iuseum.)

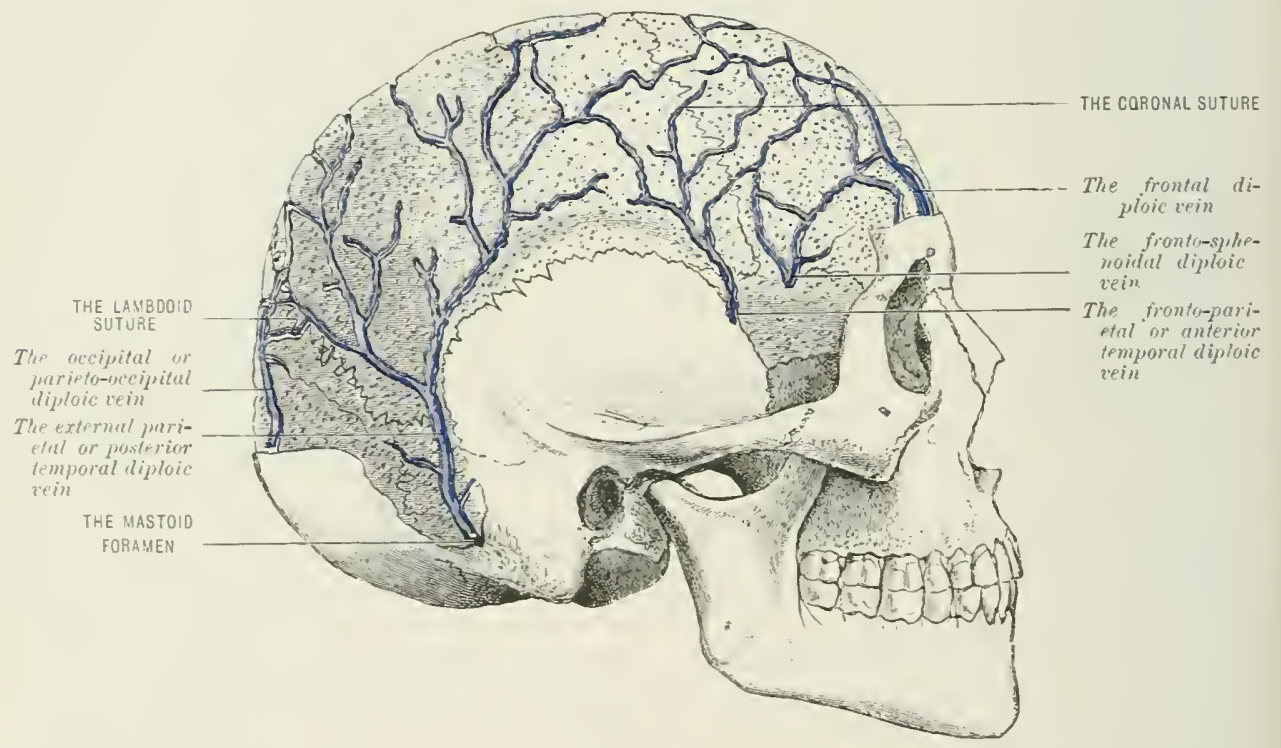

table of the skull with a file or chisel. They terminate in four or five main and decending chamnels, which open, some outwark through the external tahle of the skull into some of the superfieial and deel veins of the heach and ficce, and some inwarks through the internal table into the renous sinuses. Ther are divided into the fromtal. fronto-s phenoidal. fronto-parietal or anterior temporal, external farietal or pristerior temporal. and oceipital or paricto-occipital.

The frontal are contained in the anteriol gart of the frontal bone. Ther eonverer anteriorly to a single voin which passes downwards, perforates the cxtemal table through a small alferture in the roof of the supraorlital notch, and terminates in the smpratorbital rein.

The fronto-sphenoidal are containex in the latcral parts of the fromtal hone, anc. ruming into the sphemoirl bone, teminate in the sinus ala prove.

The fronto-parietal, or anterior temporal, are (ontainest in the posterior part of the frontal and in the anterior part of the parietal bone. They pass downwarts, and end. partly in the deep temporal veins by perforating the greater wing of the sphenoirl bone. and party in the superior petrosal sinus.

The external parietal, or posterior temporal, ramifies in the parietal bone, 
and, coursing downards to the posterior inferior angle of that lone, pasces either through a foramen in its immer table, or through the mastoid foramen inte) the lateral sinus.

The occipital, or parieto-occipital, ramifies chiefly in the oecipital bone, anel opens into the recipital rein or into the lateral sinus.

The diploic reins freely anastomose with one another in the adult; lut in the: fortus, before the bones have united, cach srstem of reins is distinct.

\section{THE VENOLS SINLSES OF THE CRANITM}

The venous sinuses of the cranium are endothelially lined hlord-spaces situated between the periosteal and meningeal layers of the dira mater. They are thes channels by which the hlool is convered from the cerelnal veins, and finn some of the veins of the meninges and diploë, into the reins of the neck. The sinuses of the base of the skull also carry the chief part of the blood from the orbit and ereball to the jugular veins. At certain spots the sinuses communicate witl the superticial reins by small ressels known as the enissary veins, which run through foramina. in the cranial bones.

The renous sinuses are eighteen in number: six being disposed medianly and singly; six laterally and in pairs. The median and single sinuses are:-(1) the superior longitudinal; (2) the inferior longitudinal; (3) the straight; (4) the occipital; (5) the circular; and (6) the transverse or basilar. The lateral and paired sinuses are:- $(\overline{7})$ the two lateral; (8) the two superior petrosal; (9) the two inferior petrosal; (10) the two cavernous; (11) the two spheno-parietal (sinus alie jarve), and (12) the two sigmoid-which latter, however, are usually described as jart of the lateral. Occasionally there are two additional sinuses (the two petrosquamous), due to the persistence in the adult of what in the foetus was the continuation of the lateral sinus.

(1) The superior longitudinal sinus, or superior sagittal sinus (fig. 3\&8), lins in the median growe on the inner surface of the calvarium along the attarberl margin of the falx (erebri. It extends from the foramen execum to the internal occipital protuluerance. It grooves from hefore backwarls the frontal hone, the (ontigunus sagittal margin of the parietal bones, and the squamous jortion of the oceipital bone. In the fortus it communicates, though the foramen cxemm, with the nasal reins, and generally throughout life with the superficial temporal rein through the parietal formune. It is triangular on section, the base of the triangle (a)responeling to the lone. Crosing it are a number of fibrous banels known ats

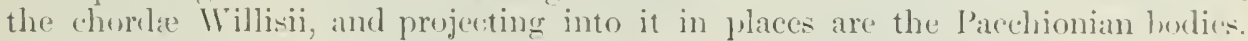
In front the sinns is quite small, lut it increases creatly in culihre as it rmo backwards. It receives at intervals the superior entieal cerehral veins ancl the reins from the falx. The former, for the most part, open into it in the elirection opposite to that in which the blowe is flowing in the sinus. They prass for some distance in the walls of the sinm before opening into it. Posteriorly, at the internal oreipital protuberanes, the superiol longitulinal sinus usually tums sharply to the right, and ends in the right lateral sinus; the straight sinus then usually teminates in the left lateral sinus, and the right and loft lateral sinuses commmicate with carch other across the occipital protuberanee. Oceasionally. howerer, the sulnerior longitudinal sinus ends in the left lateral sinus. the straight then passing inte the right. At other times the posterior end of the superior longiturlinal sinus at the internal oceipital protuberanes beromes slightly dilated. forming what is callow the torcular Herophili, or confluence of the sinuse. When this dilatation exist:the straiglit sinus usually opens into it in front. the two lateral sinuses on either side, the superior longitudinal abere, the ordipital sinus or simms's. when two are present, betow. The toreular may communicate with the oreipital rein thengh the occipital emissary vein. which, when bresent, passes through a minnte foranum in the occipital ptotuluerance.

(2) The inferior longitudinal or inferior sagittal sinus (fig. 3s.5) is situatred at the free margin of the falx cerebri. Buerinning aluut the junction of the anturior with the middle third of the falx, it is continued hackwards aloner the concave or 
lower margin of that process to the junction of the falx with the tentorium, where it ends in the straight sinus. The sinus is cylindrieal in shape and of small size, and receives some of the inferior frontal veins of the brain, some of the veins from the median surface of the brain, and some of the veins of the falx.

(:3) The straight sinus, or sinus rectus (fig. 388)-also variously ("alled the sinus tentorii, perpendicularis, and ohliquns-lies along the junction of the falx cerebri with the tentorium cerebelli. It is formed by the union of the great rein of Galen, from the velum interpositum, and the inferior longitudinal sinus. It receives in its course hranches from the tentorium cerebelli and from the uprer surface of the cerebellum. It runs downwarls and backwards to the intemal occipital nrotuherance, where it ends in the left lateral sinus, at times in the right lateral sinus, or in the toreular Herophili when that blood-space is present. On section it is triangular in shape, with its apex upwards.

Fig. 387.-The Vexols Sinuses.

(From a (lissection by W. J. Walsham in st. Bartholomew's Hospital Museum.)

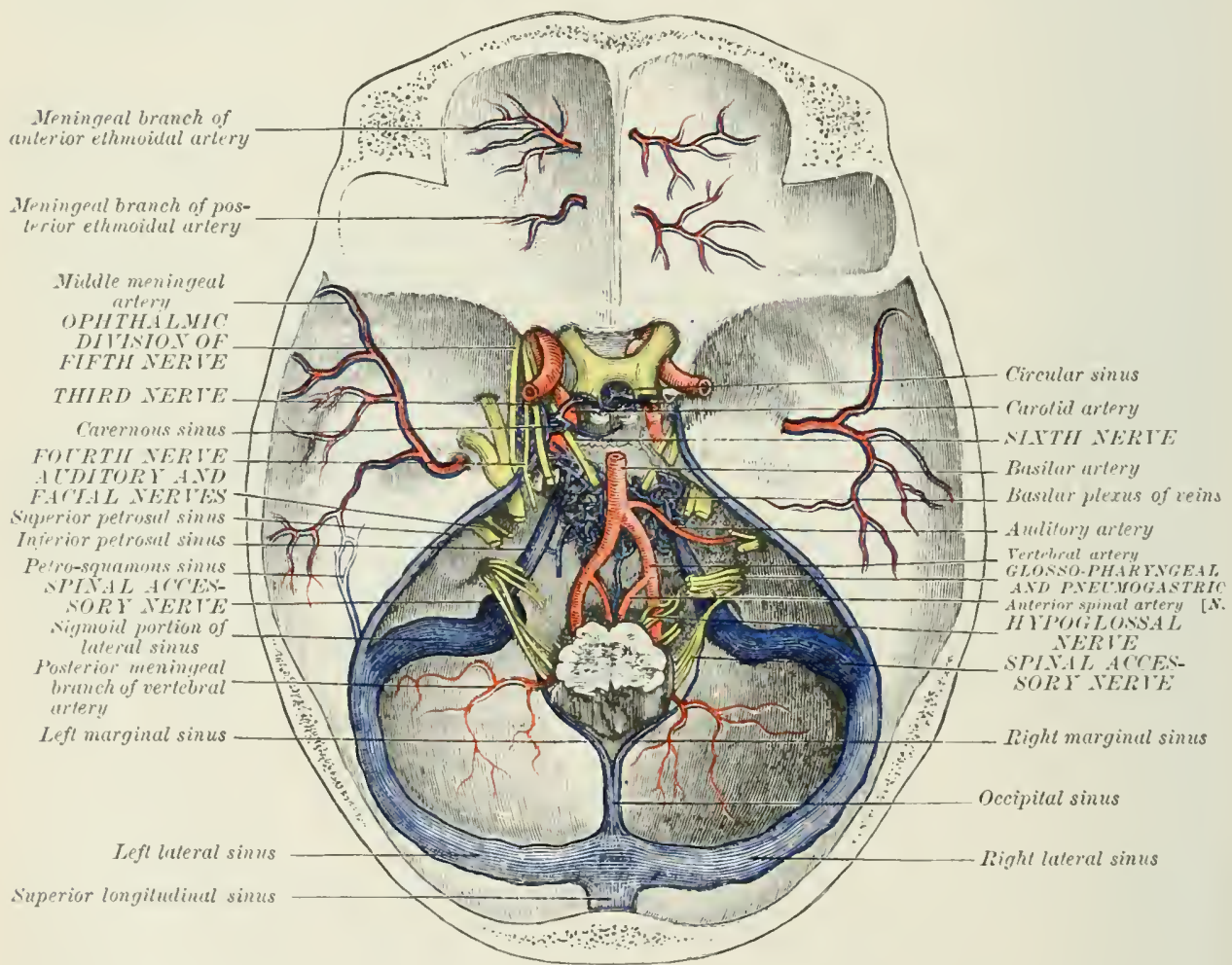

(4) The occipital sinus (fig. 3ST) ascends mesially at the attacherl margin of the falx cerebelli, along the lower half of the squanoms portion of the ocripital bons from near the posterior margin of the foramen magnum to the internal occipital protulerance. It wsully begins in a right and a left branch, known as the marginal sinuses. These proceed from the termination of each lateral sinus, run round the foramen maguum, where they communicate with the posterior spinal veins, and unite at a variable distanee from the internal oceipital protuluerance to form the single occipital sinus. Sometimes they remain separate as far as the occipital protuherance, then forming two oreipital sinuses. One or other of the marginal sinuses may be much smaller than the other, or be entirely absent. At the point where the marginal sinuses unite to form the single ocripital sinus, there is a communication with the posterior spinal veins. The oreipital sinus ends either in one of the lateral sinuses, in the straight sinus, or in the toreular 
Herophili when this is present. It receives in its anure reins from the tentorium cerebelli, and from the inferior surface of the cerebellum. It communicates through the plexus of reins which surrounds the hypoglossal nerve in the anterior condyloid foramen with the vertehral vein and veins of the anterior spinal plexus.

(5) The circular sinus, so called (fig. 385 ), is a venous plexus endireling the hypophysis cerebri, and comnerting the right and left eavernous sinuses. The more distinet channels are found, one in front of the sellat turcica, one behind, and one on its floor, and are sometimes "alled the anterior, posterior, and inferior intercavernous sinus, the last being also known as the inferior circular sinus of Winslow.

(6) The transverse or basilar sinus (tig. 35i) is a venous plexus in the suhstance of the dura mater over the basilar process of the oceipital hone. It extends from the cavernous sinus to the margin of the foramen magnum below. It

Fig. 388.-The Vexous Sinuses. (Longitudinal section.)

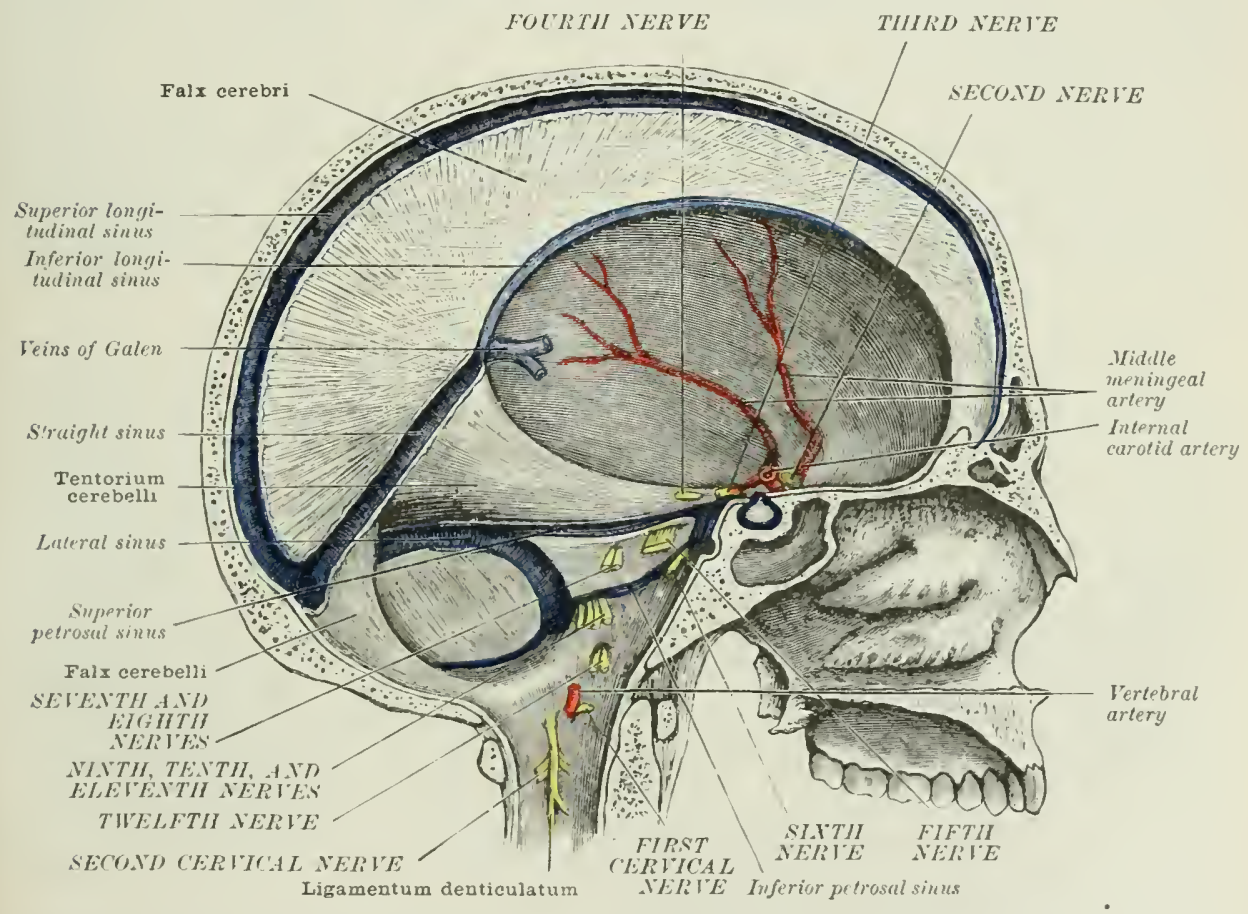

communicates laterally with the inferior petrosal sinus, and inferiorly with the anterior spinal reins." Through this sinus passes the sixth norve. One of the larger of the irregular venous elannels forming the sinus passes transversely from one inferior petrosal sinus to the other. It is this portion to which the description of the transverse sinus given by some authors appears to apply. This venous plexus on the basilar proess is serially homolocous with the anterior sfunal plexus of veins on the posterior surface of the bodies of the vertehrae.

(7) The lateral sinus (fig. 387) extends from the internal oc(ipital protuberance to the jugular foramen. In this eourse it lies in the groove (which has been named after it) along the squamous portion of the necipital home. the posterior inferior angle of the parietal bone, the mastoid portion of the temporal hone, and the jugular process of the oecipital bone. It at first runs horizontally outwards and forwards between the two lavers of the tentorium eerelwlli. following the enrve of the groove on the oceipital and the posterior inferior angle of the parietal bones. In this part of its course it is sometines known as the transverse sinus, or lateral sinus proper, but on reaching the groove in the mastoid portion of the tem- 
poral bone it leaves the tentorium and curves clownwards and inwards and then forwards over the jugular process of the occipital bone, and ends in the posterior compartment of the jugular fossa in the sinus jugularis or bulb of the intemal jugular vein. The S-shaped part of the sinus which lies on the mastoid portion of the temporal and jugular portion of the occipital bone is sometimes known as the sigmoid sinus. The lateral sinus receives the reins from the temporosphenoidal lobe of the cerebrum, some of the superior and inferior cerebellar reins, some of the reins of the medulla and pons, the occipital and the external parietal reins of the diploë, and at the spot where it leaves the tentorium the superior petrosal sinus and, when present, the petro-squanous sinus. It communicates with the occipital and rertehral veins through the mastoid and posterior confyloid foramina by means of emissary veins. As the lateral sinus lies between the layers of the tentorium it is on section prismatic in shape. The sigmoid portion is semicylindrical.

The right lateral sinus is usually the larger and the direct continuation of the superior longitudinal sinus, and lience convers the chief part of the blood from the cortical surface of the brain and rault of the skull. The left lateral sinus is usually the smaller and the direct continuation of the straight sinus, and henee returns the chief part of the blood from the central ganglia of the brain.

The relation of the lateral sinus to the outside of the skull, especially to the mastoid process of the temporal bone, is of importance with reference to the operations of trephining the mastoid cells. opening the tympanmm, and exposing the sinus itself, in septic thrombosis, \&c. The course of the sinus corresponds to a line drawn from the external occipital protuberance to the base of the mastoid process, or to the asterion, and thence orer the back of the mastoid process in a curved line towards its apex.

(8) The superior petrosal sinus (figs. 357, 385) runs at the attached margin of the tentorium cerebelli, along the upper border of the petrous portion of the temporal bone. It connects the cavernous with the lateral sinus. Leaving the outer and back part of the cavernous sinus just below the fourth nerve, it crosses the fifth nerve, and, after grooving the petrous bone, ends in the lateral sinus as the latter turns downwards on the mastoid portion of the temporal bone. It receives reins from the temporo-sphenoidal lobe of the cerebrum, reins from the cerebellum, veins from the tympanum through the squamo-petrosal fissure, and sometimes the fronto-parietal veins of the diploë.

(9) The inferior petrosal sinus (figs. 385, 385) runs along the line of the petro-occipital suture, and connects the cavernous sinus with the commencement of the internal jugular vein. It is shorter than the superior petrosal, but consiclerably wider. As it crosses the anterior compartment of the jugular formen, it separates the ghosso-pharyngeal from the pnemogastric and spinal accessory nerves. It receives veins from the inferior surface of the cerebellum, from the merlulla and pons, and from the internal ear. The last issue through the aqueductus restibuli and aqueductus cochleæ.

(10) The cavernous sinus (fig. $38 \%$ ) is an irregular shaped renous space situated between the meningeal and periosteal layers of the dura mater on the side of the body of the sphenoid bone. It extends from the central end of the sphenoidal fissure in front to the apex of the potrous hone hehind. Its outer wall is the more distinct, and contains in it, but separated from the blood by the lining memhrane of the sinus, the third and fourth nerves, and the ophthalmic division of the fifth nerve, the nerves lying in the above-nentioned order from above downwards, and from within outwards. The internal carotid artery and the sixth nerve also pass through the sinus, being separated from the hood by the endothelial lining. The inner wall is practically absent, the blood-space communicating acros the millle line with the opposite sinus in front. behind, and below the pituitary body or hypophysis cerebri. (See C'IRctlar sixts.) The caremous sinus is traversed hy numerous trabeculie or fibrous bands, so that there is no central space, but rather a number of endothelially-lined irregular lacunar cavities communicating with ach other. Hence its name (avernous, from its resemblance to cavernous tissue. In front it receives the ophthalmic rein, with which it is practically continuous, and just above the third nerve the sinus ala parra. 
Internally it communicates with the oppositesinus, and posteriorly it and- in the superior and inferior petrosal sinuses. It also receives veins from the inferior surface of the frontal lobe of the lrain, and some of the mikdle cereloral veins. Through the V'esalian vein, which runs in a minute foramen in the spinous jorscess of the sphenoid bone, the sinus commminates with the poteryerol plexus of reins; through the venous plexus around the intrasseous portion of the internal carotid, with the internal jugular vein; and through small roins which leave the cranium by the formen orale and formen lacerum mextium, with the pteryoid and pharygeal plexuses.

(11) The spheno-parietal sinus, or sinus alæ parvæ, runs in a slight groove on the under surface of the lesser wing of the sphenoid bone. It originates in one of the meningeal veins near the apex of the lesser wing, and, ruming inwards, passes through the sphenoidal fold of dura mater above the third nerve into the front part of the cavernous sinus. It generally receives the fronto-sphenoidal reins from the liploë.

The petro-squamous sinus is oceasionally present. It lies in a groore along the junction of the petrous and squamous portions of the temporal bone. It opens posteriorly into the lateral sinus at the spot where the latter enters on its sigmoid course. In front it sometimes, though very rarely, passes through a foramen in the squamous portion of the temporal bone between the glenoid cavity and the external auditory meatus into the temporal vein. This sinus is the rudiment of what in early footal life, before the kevelopment of the intemal jugular vein, was the continuation of the lateral sinus, the blood from the interior of the skull at this period passing through the above-mentioned foramen into the primitive jugular vein.

\section{THE VEINS OF THE BRAIN}

The veins of the brain present the following peculiarities:-(a) They do not accompany the cerebral arteries. (b) Ascending veins do not as in other situations run with ilescending arteries, but with ascending arteries, and vire versit. (c) The deep veins do not freely communicate. (d) The veins have very thin walls, no muscular coat, and no valves. (e) The veins opening into the longitudinal, and some of those opening into the lateral sinus pour in their blood in a direction opposite to the current in the sinuses, so impeding the flow in both rein and sinns.

$(f)$ The flow of blood in the sinuses is further retarded by the trabeculas stretehing aeross their lumen, and in the longitudinal sinus by the blood having to ascend, when the hody is erect, through the anterior half of its course.

The reins of the brain may be divided into the cerebral and the cerebellar.

\section{The Cemebril Velis}

The cerebral veins, like the cerebral arteries, may be divided into the cortical or hemispheral, ant the central or ganglionic.

The cortical, hemispheral or superficial veins ramify on the surface of the brain and return the blond from the cortieal sulstanee into the venous sinuses. They lie for the most part in the suldei luetwern the convolutions. hut some pass over the convolutions from one suleus to another. They consist of two sets: a superior and an inferior.

(1) The superior cortical veins, some eight to twelve in number on rach siche. are formed by the union of hranches from the anver and median surfices of the cerelorum. Those from the convex surface pass forwarls and inwarts tomalds the longiturtinal fissure, where they are joined by the brandhes enming from the merlian surface. After receiving a sheath from the arachnoisl. they (niter ohligurly into the superior longitudinal sinus, ruming for some distance in its walls. Thers vins freely eommunicate with each other, thus cliffering from the onrtical arteries. They

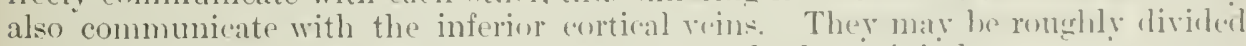

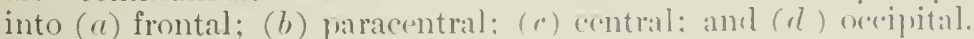

(2) The inferior cortical veins monify un the hase of the hemisphere and the lower part of its outer surface. Those on the inferior surface of the frontal lolu 
pass. in part into the inferior longitudinal sinus, and in part into the carernous sinus. Those on the temporo-sphenoidal lobe enter in part into the superior petrosal sinus, and in part into the lateral sinus, passing into the latter from before backwards. A large vein from the oceipital lobe winds over the crus ceretri and joins the great rein of Galen just before the latter entrs the straight sinus. One of the inferior cortical reins is sometimes called the middle cerebral rein; another the great anastomosing vein of Trolard; another the posterior anastomosing rein of Labbé. The first ramifies orer the under surface of the frontal and temporosphenoidal lobes, and at the anterior and lower part of the fissure of sylvius opens into the caremous sinus. The second establishes a communication betreen the superior longitudinal and cavernous sinuses by anastomosing with the middle cerebral and one of the superior cortical reins. "The third passes from the middle cerehral rein orer the temporo-sphenoidal lobe to the lateral sinus.

The central, ganglionic, or deep cerebral veins are collected into two large renous trunks. the venze Galeni, which leave the brain at the great transierse fissure. that is, between the splenium of the corpus callosum and the optic lobes. At this spot they mnite to form a single rein, the vena magna Galeni, which opens into the anterior end of the straight sinus. The venæ Galeni are formed by the union of the choroid vein with the vena corporis striati near the foramen of Ionro. From this spot they rum backwards parallel to each other between the layers of the relum interpositum, and terminate in the way above mentioned.

Tributaries of the veins of Galen.-The choroid rein, the vein of the corpus striatum, the basilar vein, the veins of the optic thalamus, the rein of the choroid plexus of the third rentriele, and reins from the corpus callosmon, the pineal bodr, the optic lobes, and posterior horn of the lateral rentricle. The united trunk, or great rein of Galen, receives reins from the upper surface of the cerebellum, and one of the posterior inferior cerebral reins.

The choroid vein runs with the choroid plexus. It begins in the inferior cornu of the lateral ventricle, and ascends on the outer side of the choroid plexus along the margin of the velum interpositum to the foramen of Monro, where it unites with the rein of the corpus striatum to form the rein of Galen. It receives tributaries from the hippocampus major, corpus callosum, and fornix.

The vena corporis striati, formed by veins from the corpus striatum and optic thalamms, rmms forwards in the groore between those structures, passing in its course beneath the trenia senicircularis, and joins the vein of Galen at the formen of Momro. Tributaries. - It receives, in addition to the veins from the corpus striatum and optic thalamus, small reins from the fornix, septum lucidum, and anterior cornu of the lateral rentricle.

The basilar vein, formed by the confluence of the deep Sylvian rein, the inferior striate reins, and some small anterior cerebral veins, runs backwards over the crus cerebri, and enters the rein of Galen near the union of that ressel with the vein of the opposite side. Tributaries. - The deep sylvian vein from the insula and surrounding convolutions; the inferior striate veins from the corpus striatum, which they leave through the anterior perforated space; anterior cerebral reins from the front of the corpus callosum; interperluncular veins from the structures in the interpeduncular space; rentricular veins from the middle cornu of the lateral ventricle; and mesencephalic reins from the mid-hrain.

\section{The Cerebellar Velis}

The cerebellar veins are divided into the superior and inferior.

The superior ramify on the upper surface of the cerebellum; some of them run inwards over the superior vermiform process to join the straight sinus and great rein of Galen; others run outwards to the lateral and superior petrosal sinuses.

The inferior, larger than the superior, run, some forwards and outwards to the inferior petrosal and lateral sinuses, and others directly backwards to the occipital sinuses. 


\section{The Teiss of the Medellat axi) Poxs}

The reins from the medulla oblongata and the pons terminate in the inferior petrosal and lateral sinuses.

\section{THE VEINS OF THE NASAL CAVITIE-}

The renous plexuses on the inferior turbinated bone and back of the septum are described with the Noss. The veins leaving the nasal cavities follow roughly the course of their corresponding arteries. Thus the spheno-palatine veins pass through the spheno-palatine formen into the pterygoid plexus; the anterior and posterior ethmoidal reins join the ophthalmic. Small reins accompany branches of the facial artery through the nasal bones and nasal processes of the superior maxillary bones, and end in the angular and facial veins; and other small veins pass from the nose anteriorly into the superior labial, and thence to the facial.

\section{THE VEINS OF THE EAR}

The veins from the external ear and external auditory meatus join the temporal and posterior aurieular veins. The reins from the trmpanum open into the superior petrosal sinus and temporo-maxillary vein. The blood from the labyrinth flows chiefly through the internal auditory reins which lie with the internal anditory artery in the internal auditory meatus, and enters the inferior petrosal or lateral sinus. Some of the blood from the labyrinth, however, passes through the vestibular vein which lies in the aqueductus restibuli, into the inferior petrosal sinus, and some through the aqueductus cochlere, into the commencement of the internal jugular vein.

\section{THE VEINS OF THE ORBIT}

The hlood from the eveball and orbit is returned by the ophthalnic rein into the cavernous sinus. This vein and its tributaries have no valves, and communi(ate in front with the frontal, supraorbital, and other reins. Hence under certain conclitions, as from pressure on the cavemous sinus, the blood may flow in the contrary direction to the normal-i.e. from behind forwards into the frontal and supraorbital, and thence through the angular vem into the facial. In this way pressure on the retinal reins is quickly relieved, and little or no distension occurs in eases of obstruction in the cavernous sinus.

The ophthalmic vein, or common ophthalmic vein, is formed by the confluence at the back of the orbit of the superior and inferior ophthalmic ieins. It is a short thick trunk, and jasses backwards between the two hearts of the external rectus muscle below the sixth nerve, and at the inner part of the sphenoirlal fissure leaves the orbit and enters the front part of the cavernous sinus.

A. The superior ophthalmic vein, larger than the inferior, begins at the inner canthus of the eyelid by a free communication with the frontal, supraorlital. and angular veins, and thence runs backwards and outwards with the ophthalmic artery across the optic nerve to the imner end of the sphenoidal fissure, where it joins the inferior ophthalmic vein to form the common ophthalmic trunk. In this course it lies anterior and superficial to the ophthalmic artery.

Tributaries.-(1) The superior muscular veins; (2) the ciliary veins: (3) the anterior and posterior ethmoidal veins; (4) the lachrymal vein; and (5) the central rein of the retina.

(1) The superior muscular branches are derived from the levator palpetrre, superior rectus, superior oblique, and internal rectus.

(2) The ciliary veins are cliviled into two sets: an anterior, which emerge from the eyeball with the anterior ciliary arteries, and open into the muscular veins returning the blood from the four recti; and a posterior set, know as the venæ ror- 
ticose, which latye the glube midway hetween the cornea and entrance of the optic nerve. The latter veins are four or five in number, the upper ending in the superior, the lower in the inferior ophthalmic rein (page 852 ).

(3) The anterior and posterior ethmoidal veins correspond in their course with the arteries of the same name. They enter the orbit through the anterior and posterior ethmoidal formina, and join either the ophthalmic direct, or one or other of the superior muscular branches.

(4) The lachrymal vein returns the blood from the lachrymal gland, and corresponds in its course to the lachrymal artery.

(5) The central vein of the retina runs with the central artery in the optic nerve. It joins the superior ophthamic at the back of the ortit.

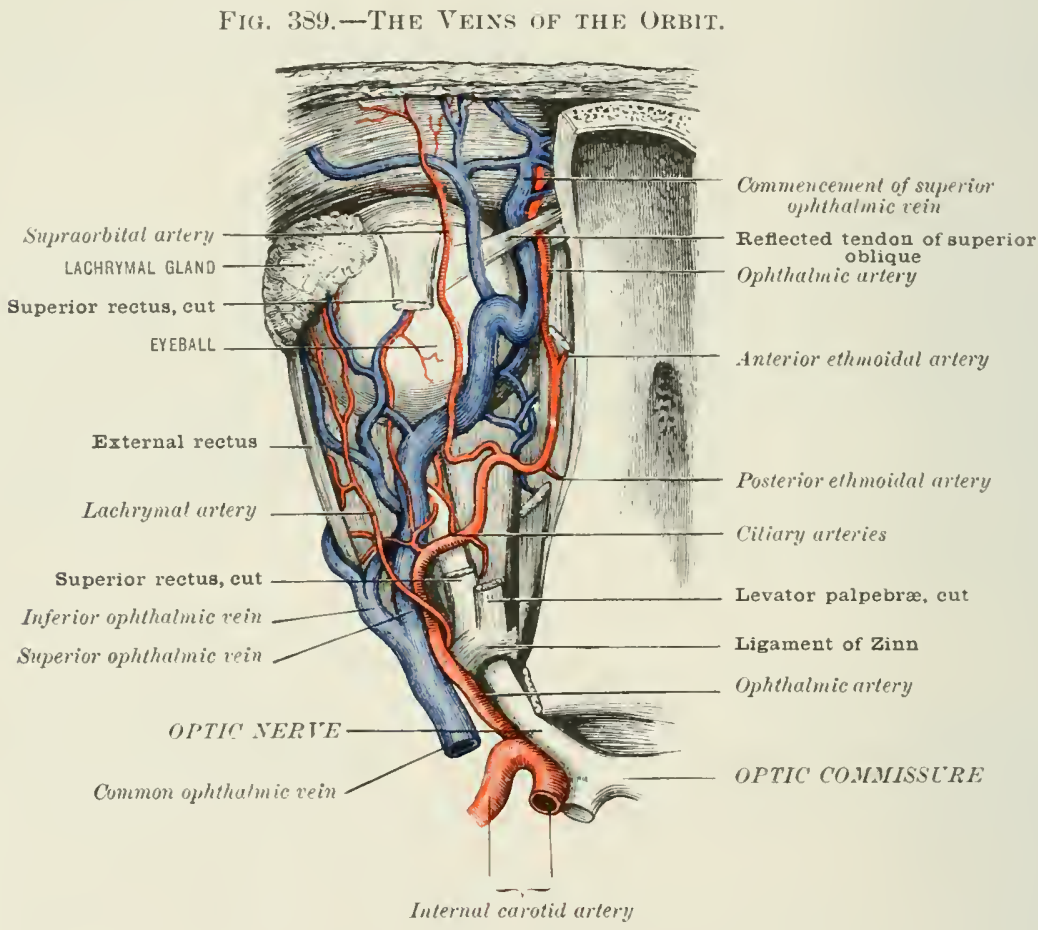

B. The inferior ophthalmic vein, smaller than the superior, is formed near the front of the orbit hy the confluence of the inferior muscular with the lower posterior ciliary veins. It runs backwards below the optic nerve, along the floor of the orbit, and either joins the superior ophthalmic vein to form the common ophthalmic trunk, or clse opens separately into the carernous sinus. A large communicating branch passes downards through the spheno-maxillary fissure to join the pteryoid plexus of veins.

Tributaries.-(1) The inferior muscular, which are derived from the inferior oblique, inferior rectus, and external rectus; and (2) the lower posterior ciliary veins.

\section{THE VEING OF THE PHARYXX IND TARIXX}

The veins of the pharynx are arrangerl in the form of a plexus. between the constrictor muscles and the pharvngeal or prevertebral fascia. The plexus receives branches from the murons membrane, from the soft jalate, the Eustachian tuhe, and the anterior recti aml longus (o)lli muscles. Above, it communicates with the 
pterygoid plexus of reins; below, either with the lower end of the facial rein, or with the internal jugular vein.

The veins of the larynx end partly in the superior, and partly in the inferior thyroid reins.

\section{S. THE DEEP VEINS OF THE NECK}

The deep veins of the neck are the internal jugular vein, the vertebral vein, and the deep cervical rein and their respective tributaries.

\section{The Ixtersal J Jugular I'ein}

The internal jugular vein begins at the jugular fossa, and is the continuation of the lateral sinus. It passes down the neck in company first with the internal carotid artery, and then with the common carotid artery to a spot a little external to the sterno-clavicular articulation, where it joins the subclavian to form the innominate rein. At its commencement in the larger, and posterior and external part of the jugular foramen, it is somewhat dilated, forming the so-called bulb or sinus of the internal jugular vein. This dilated part of the internal jugular rein lies in the jugular fossia of the temporal bone and is therefore in immediate relation to the floor of the trmpanum. At first the internal jugular lies in front of the rectus capitis lateralis, and behind the internal carotid artery, from which it is separated by the hypoglossal, glosso-pharyngeal, and pneumogastric nerres, and by the carotid plexus of the sympathetic. But as it descends it passes gradually to the outer side of that ressel, and retains this relation as far as the upper hordir of the thyroid cartilage. Thence it runs to its termination along the outer side of the common rarotid artery, being contained in the same sheath with it and the pnemogastric nerve, but separated from these structures by a distinct septum. The vein generally orerlaps the artery in front; hence the importance in tring the carotid of opening the sheath well to the immer side of that vessel. in order to avoid the vein. About an inch above its termination it contains a pair of imperfect valves.

Tributaries.-It the bulb or sinus the internal jugular rein receires the inferior petrosal sinus; opposite the angle of the jaw reins from the pharyngeal plexus, and often a communicating branch from the external jugular vein; opposite the bifurcation of the carotid it is joined by the facial. and a little lower down $h \mathrm{w}$ the lingual and the superior thyroid vein, and at the level of the cricoid cartilage by the middle thrroid vein.

The inferior petrosal sinus is described with the other sinuses of the brain (page 622 ); the pharyngeal plexus with the veins of the pharyx (see above); and the facial rein with the superficial reins of the scalp and face (pagre 613).

The lingual vein begins near the tip of the tongue, under the name of thr. ranine. It lies at first dos to the hypoglossal nerve and beneath the mucous membrane covering the under surface if the tongue. It then passes barkwarls across the hyo-glossus where this muscle forms the floor of Lesser's triangle, the latter musele intervening between it and the lingual artery. After receiving the sublingual vein and the dorsalis lingue reins which roughly enrrespond to their respective arteries, and the two small veins (vente comites) which frepuently accompany the lingual artery beneath the hro-glossus, the mited trunk crosies the common carotid artery and opens into the internal jugular vein. At times these tributaries open separately into the internal jugular vein or into the facial vein.

The superior thyroid vein emerges from the upler part of the thyroid bedy: in which it freety anastomoses with the other thyord reins, both in the substance of the organ, and on its surface beneath the cajisule. Thence it passes upwards and outrards into the internal jugular vein, crosing the common carotid artery in its courws. It times it forms a common trunk with the facial vein. Its tributaries are the sterno-hyoid. sterno-thyroid. and thyro-hyoid reins from the muscles bearing those names: and the crien-throvid and superior larrongeal rein, which correspond with the crico-thyroid and superior laryneral arteries repectively. These require no special description.

The middle thyroid vein passes out from the cilpsule of the thyroir gland 
near the lower part of the lateral lobe of that boly, crosses the common carotid olliguely downwards and outwarks, and opens into the internal jugular rein a little below the cricoid cartilage.

\section{The Ixferior Thyoid Veins}

The inferior thyroid veins descend from the lower part of the thyroid body obliquely outwards to the innominate veins. The right vein crosses the innomiinate artery just before its bifurcation, and ends in the right immominate vein a little above the superior vena cava. It receives inferior laryngeal reins and reins from the trachea, and has valves at its termination in the inmominate. The left vein passes obliquely over the trachea behind the sterno-thyroid muscle. and opens into the left innominate vein. It also receives laryngeal and tracheal reins, and is guarded by ralves where it opens into the imnominate trunk. The inferior thrroid reins communieate across the trachea by transverse branches. Not unfrequently the inferior thyroid reins (right and left) unite to form a single trunk which joins the left innominate vein.

\section{The Vertebral Veins}

The vertebral vein (fig. 3.2) does not accomlany the vertehral artery in its fourth stage, that is, within the skull, but begins as a plexus of small veins in the suboccipital triangle. It then enters the foramen in the transverse process of the atlas. and passes with the rertebral artery through the foramina in the transrerse processes of the cervical vertebre, forming a plexus around the artery. On learing the transverse process of the sixth cervical rertelora it crosses in front of the subclavian artery and opens into the innominate vein. It has one or two semilunar valses at its entrance into the innominate vein. In the suboccipital triangle it communicates with the intraspinal, deep cervical, and occipital reins, and is joined by reins from the recti and oblique muscles and the pericranium. Tributaries.-As it passes down the neck it receives (1) lateral spinal reins, which issue along with the cervical nerves and lateral spinal arteries from the spinal eanal; (2) branches from the renous plexus about the bodies of the cervicul rertebre and their transverse processes; (3) branches from the deep cervical muscles: and $(4)$ branches from the cerrical dorsal spinal veins. Just before it teminate: in the innominate it is joined by (5) the deep cervical vein (sometimes): (6) the anterior rertebral rein; and ( 7 ) the upper superior intercostal rein (sometimes).

The anterior vertebral vein begins in a plexus in front of the bodies of the cervical vertebre, and, running downwards with the ascending cervical artery between the scalenus anticus and longus colli muscles, opens into the rertebral rein just before the latter ends in the innominate. It receives tributaries from the scaleni, longus colli, and rectus capitis anticus muscles.

The deep cervical vein, which is really a part of the posterior superficial vein of the soalp, is described with that rein (page 614 ).

\section{THE SPINAL, I'EINS}

The spinal veins, which form plexuses aromel and within the spinal eanal from the cranium to the sacrum, may he divided into the extra- and intraspinal veins. The extraspinal fom a plexus hoth in front of the bodies of the vertebræ (the anterior spinal plexus), and in the spinal groove between the transverse and spinous processes-the dorsal plexus, or dorsal spinal plexus as it is often called. The intraspinal veins, or those within the spinal canal, may be divided 
into the meningeal and the medullary. The meningeal form an anterior and a posterior spinal plexus between the dura mater and the walls of the slinal canal, and are generally known as the meningo-rachidean veins. They reerire the veins from the bodies of the vertebre. The medullary set are situated within the durat mater; they return the blood from the spinal cord, and are known as the medullispinal veins.

1. The extraspinal veins.-( $($ ) The veins of the anterior spinal plexus ramify in front of the bodies of the vertelure. They are of small size and most distinct in the eervical region (fig. 390 ). They open into the neighbouring veins.

(b) The veins of the posterior spinal or dorsal spinal plexus are situated around the spinous processes, the lamince, and the articular and transverse processes of the vertebre, the larger veins of the plexus rumning horizontally forwards along the interspinous ligaments. The plexus is formed chiefly by the mion of tributaries proceeding from the integuments of the back and the spinal muscles.

Fig. 390.-The SPINaL Veiss.

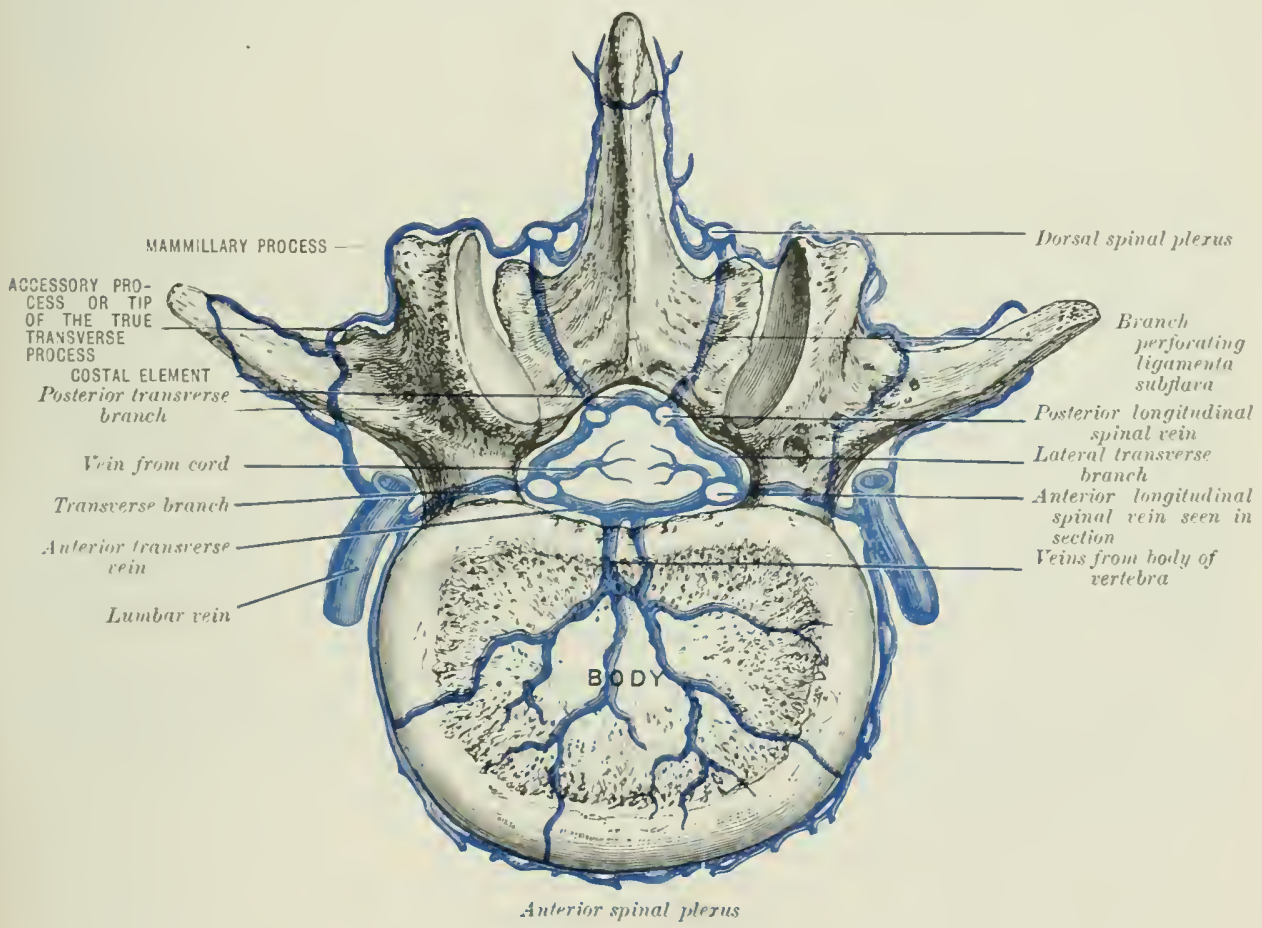

Communications take place hetween the veins of atach rortchral segment he rertical hranches rumning upwards and downwards to the plexus above and helow respectively near the hase of the transverse procesers. Branches are also sent through the ligannenta subflava between the lamina of the several vertebrix to the posterior plexus of the intraspinal reins. and also forwards hetween the transwerse processes of the rertebre to join the vertebral voin in the neck. the dorsal hranch of the intercostal veins in the thorax, the lumbar voins in the lumbar region, and the lateral sarral veins in the sacral region.

2. The intraspinal veins are livided into ( 1 ) the meningeal; and (b) the medullary, or medulli-spinal.

(1) Th" meningeal extra-medullary or meningo-rachidian veins lis in the fatty tissue between the walls of the vertebral eanal and the dura mater or theea vertebralis. They are arrangerl in four longiturlinal rhameds. two of which are anterior and two posterior, united hy transrerse branches enresponding in number to the vertel)ral segments (fig. 3!) 
The anterior longitudinal spinal veins extend from the formen magnum to the cocerx as two tortuous plexiform vesiels, one heing placed on each side of the hack of the bodies of the vertehre behind the posterior common ligament. Opposite the body of each vertebra they commmicate ly a transwrse branch, which passes between the borty of the rertehra and posterior common ligannent, an arrangement which is sometimes spoken of as the spinal venous latder. Each transverse bramch as it lies under cover of the posterior common liganent reccives the reins from the bodies of the vertebre (the venæ basis vertebræ). At the spot where each longitudinal rein is joined hy the transire linunch, the ressel becomes considerably dilated. From the longitulinal vein luancles run barkwards to join the posterior" longitudinal reins, and opposite the intervertetral foranina a transverse branch runs outwards to join the vertehral vein, the interecstal veins, the lumbar veins, and the sacral veins, aceording to the region of the spine in which the vertebra is situated. Above, the anterior spinal veins communicate with the hasilar plexus at the front of the foramen magnum.

The posterior longitudinal spinal veins, smaller than the anterior longitudinal reins, likewise extend from the cranim to the acrax. They lie hetween the posterior wall of the spinal canal and the dura mater. Like the anterior, ther eommunicate by transverse branches, which receive reins through the liganenta subflava from the dorsal spinal plexus. They also communicate with the anterior longitudinal veins by lateral transwerse branches.

It will be thius seen (fig. 390) that in the intrrior of the rertehral canal, opposite each rertebral scgment, there is a renous ring between the bony wall of the canal and the sheath of the dura mater, the ring being formed in front by the anterior transverse rein; on each sicle by the dilated portion of the trunk of the anterion longitudinal spinal vein, and the lateral transverse hranch; and behind, by the trunk of the posterior longitudinal rein and the posterion transverse branch. This venous ring receives veins from the body of the vertelira, from the spinal cord, and from the meninges, and pours its blood, in part through the lateral reins lying in the intervertebral foramina into the rertebral, intercostal, lumbar, or sacral veins; and in part through the branch which perforates the ligmenta subflara into the dorsal spinal plexus. Above, the posterior longitudinal veins communicate at the back of the foramen magnum with the oceipital simuses. Around the foramen nagnum a distinet renous ring or plexus is formed by the communieation between the oceipital and marginal sinuses and the posterior and anterior spinal veins.

(b) The medullary or medulli-spinal veins, or veins of the spinal cord, are of small size, and run in the pia mater in a tortuous course along the spinal cort. They join the renous ring corresponding to each rertebral segment by passing along the sheath of dura mater reflected round the spinal nerres.

\section{THE T'EINS OF THE ABDOMEN AND PELITS}

All the veins of the abdomen and pelvis-with the exception of the superior epigastric rein and ascending lombar voin. which open ultimatey into the superior rena cava-enter directly or indirectly inter the inferior rena eava. The reins corresponding to the parietal hranches of the ablominal aorta, except the midelle sacral vein, open directly into the inferior vena rava; the middle sacral rein only inclirectly through the left eommon iliae vein. (of the viscral veins correspomding to the visceral branches of the abdominal anta. those which return the blood from the stomach, intestines, and pancreas (the rhylopoetic riscera), and from the spleen, end in a common trumk (the portal vein). The portal rein enters the liver, and breaks up in the liver substance into capillaries like an artery, and from 
these capillaries arise the hepatic veins which open into the inferior vena caval as that ressel grooves the under surtace of the liver.

Of the wther visceral veins, hoth renals, the right caljsular, and the right spermatic or ovarian ofen directly into the inforior vena caval; whilst the left eapsular and left spermatic or ovarian only join that vessel indirectly through the left renal.

Two of the superficial veins of the lower part of the anterior albelominal wall, the superficial epigastric and superficial 'in'unflex iliac, enter the long saphenons rein; and two of the deep reins from the like situation, the deep epigastrie and deep circumflex iliae, enter the external iliac vein. The blood in these ressels, however, can flow upwards as well as in the nomblly downward direction. In obstruction of the inferior vena cava they become greatly enlarged, and form, with the superior epigastric vein and with other superficial veins of the thorax with which they anastomose, one of the chicf chamels for the rutum of the blood from the lower limbs.

The reins of the pelvis, which reeeive the veins from the peringem and ghuteal region, join the internal iliac vein.

\section{THE INFERIOR VENA CAYA}

The inferior or ascending vena cava (fig. 3911) is the large vessel which returns the blood from the lower extremities and the abdomen and pelvis. It is fommer by the confluence of the right and left common iliac veins oplusite the body of the fifth lumbar vertebra, ascends in front of the lumbar vertebre to the right of the abdominal aorta, passes through the eaval opening in the diaphragm, and conds in the lower and back part of the right auricle of the heart on a level with thr lower border of the ninth thoracic vertebra. At its origin it lies behind the right common iliae artery on a plane posterior to the aorta, but as it ascends it paises slightly forward and to the right, getting on a plane anterior to the aorta, and becoming separated from that artery by the right crus of the diaphragm and the bohulus sigelii of the liver. Whilst in contact with the liver it lies in a cleep gromes on the hinder surface of that organ, the groove being often eonverted into a listinct eanal by a thin portion of the hepatic substance hridging across the groove. As it passes through the diaphragm its walls are attached to the tendinous margins of the eaval opening, and are thus held apart when the muscle contrats. On the thoracie side of the diaphragm it lies for about half an inch within the fericardium, the serous layer of that membrane being reflected over it.

Relations. - In front it is covered by the peritonemu, and crosised ly the right spermatic artery, branches of the aortic plexus of the srmuathetic, the transerere colon, the root of the mesentery, the duolenum, the heal of the pancreas. the portal vein, and the liver. The median eroup of the hunbar lymphatic glands are also in front of it below, and at its commeneement the right common iliac artery rests upon it.

Behind, it lies on the lumbar vertehrar, the right lumbar arteries, the right renal artery, the right semilunar angliom, and the right arus of the diapleragm.

To the right are the peritomenm, liver, ant pisoas musele.

To the left is the aorta, and higher" up the pight ('us of the diaphragm.

Tributaries. -The inferior rema earal reerives the following veins:-(1) the renal reins; ( $(2)$ the right suprarenal wein: (B) the right spermatic or $(4)$ the right ovarian rein; (.j) the humbar roins; (b) the inferior phrenie roins: (i) the hepatic veins; and (s) the right and left commen iliar reins.

(1) The renal or emulgent veins return the lolowe from the kidneys. They are short but thick trunks, and open into the rema rava neally at licht angles in that ressel. The rein on the left sirle, like the kirhery, is a little higher than on the riglit, and is also longer, in ("unsequence of its having to cross the alortal. The (omparative shortness of the right remal rein should he home in mind in the operation of nephrectomy, sines. if tom much traction is marle on the porlicele. not only the vein, but a portion of the rena rava may he dratro into the licature. as

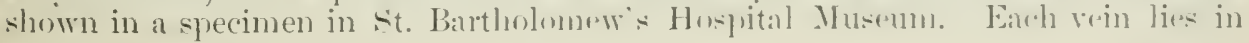


front of its corresponfling artery. The left rein crosses in front of the aorta, just below the origin of the superior mesenteric artery. It is covered by the third portion of the duorenum, and receires the left spermatic, or the left orarian in the female, and usually the left suprarenal, and sometimes the left phrenic. There are rudiments of valves in ach rein where it joins the vena eara. Those on the right sikle, however, are less well marked.

(2) The suprarenal veins.-There is usually only one suprarenal vein on each side to return the blood brought to the suprarenal body by the three suprarenal arteries. On the right side the rein opens into the vena cava clirect above the opening of the right renal rein. On the left side, it opens into the left renal.

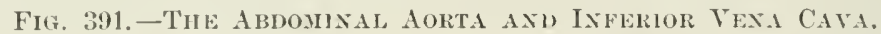

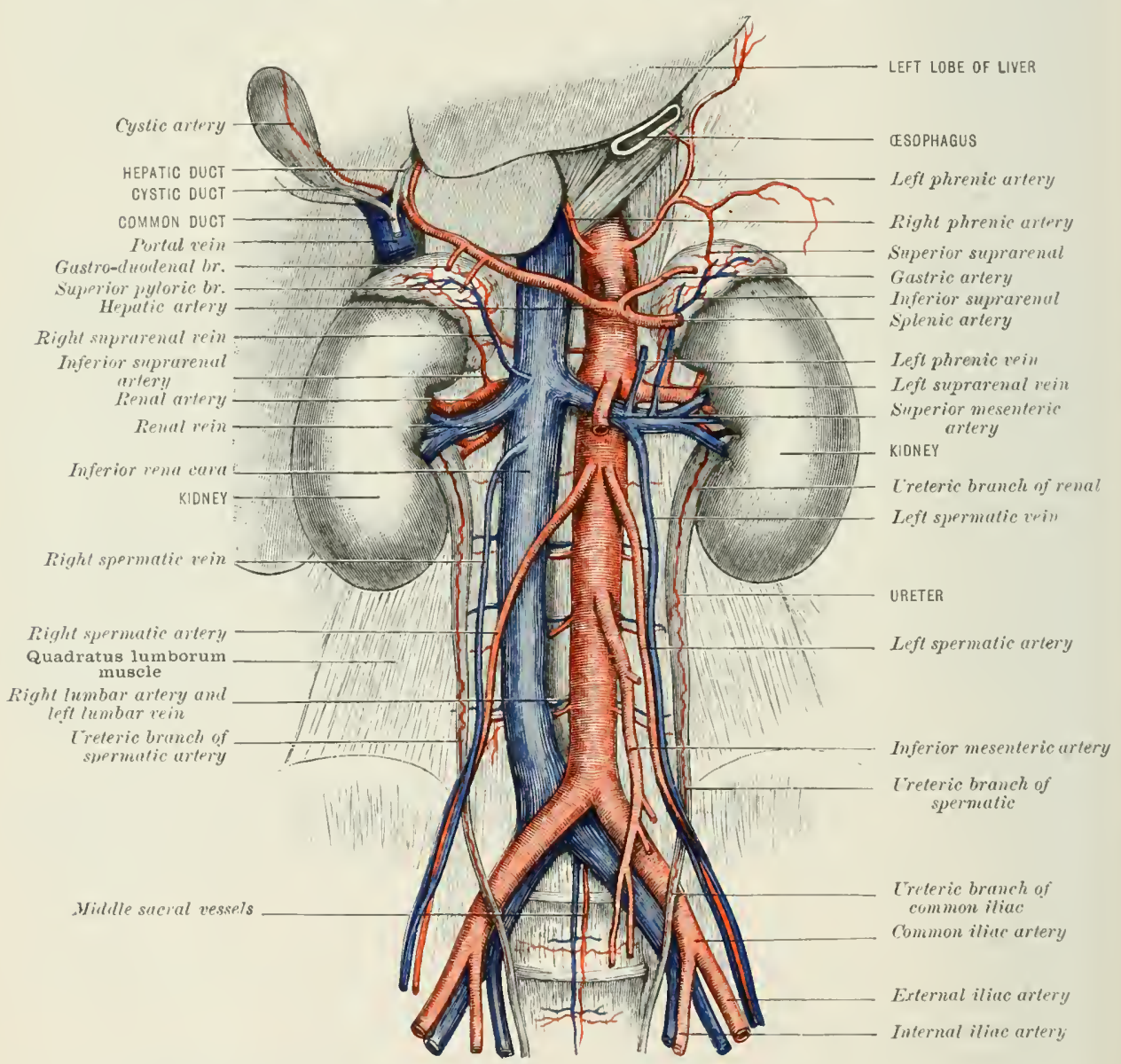

(3) The spermatic veins return the bloor from the testicle. They begin by the eonfluence of small branches from the body of the testicle and epididymis, and as they proeed up the spermatic cord, in front of the spermatic artery and vas deferens, become dilated and plexiform, constituting the so-called pampiniform plexus. Ifter passing through the external abdominal ring, the inguinal eanal, and the internal abelominal ring, the plexus merges into two reins, which lie one on each side of the spermatie artery. Along with the artery the veins pass up beneath the peritonemo, and on the left side also beneath the sigmoid flexure of the colon, across the psoals muscle and ureter, to end as a single trunk, on the right side in the inferior rena cava, and on the left side in the left renal vein. There are commonly a number of imperfect valves in the spermatic plexus and a 
perfect pair at the termination of each spermatic vein. On the left sicle. however, the teminal valve may be wantine.

(4) The ovarian veins begin as the pmpliniform plexus neal the crary, between the layes of the hroal ligament. This plexus communicates freoly with

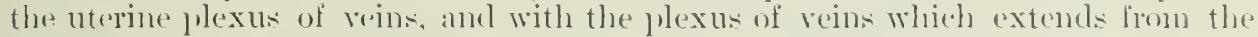
hilum of the ovary inte the orarian liganent (the ovarian bulb). After latsing from between the layers of the lovad liganent, the plexus unites to form at first two and then a single vested, which accompranise the ovarian artery, following a similar conrse to the spermatic veins in the male. The right ovarian vein opens into the inferior venal caral the left into the left renal. Ther usually contain imperfeet valves in their plexiform part, and a perfect valve where they join the rena cara and lenal rein respectively.

(5) The lumbar veins. -There are usully four lumbar veins on each side corresponting to the lumbar arteries. The main trunks of these veins, which lie beside the bodies of the lumbar vertebre, are formed ly the mion beneath the poas of anterior and posterior branches. The anterior branches collect the hood from the front and lateral walls of the aldomen. They communicate in front with the internal mammary and epigastric reins, and then rom batekrards between the abdominal musces in compan with the anterior hanches of the lumbar arteries to their confluener with the posterior banches. The posterior branches wilect the blond from the loins and muscles of the back, and correspond to the pusterior or dorsal division of the lumbar arteries. They receive communirating branches from the dorwal spinal plexus and from the vertehral camal, and jass forwark between the transwerse processes to join the anterior branches. The trunk lumbar voins are connected beneath the jwos muscle ly rertical hranches, which crose in front of the transerse processes. The last lumb rein is rariously joined below by a vertial branch to the rommon iliac, internal iliac, lateral sacral or ilin-lunbar voin, and the first lumblar vein is similarly comnected aloove with the commencenent of the vena azyos major on the right, and the rena azyous minor (m) the left side. The rertical vein thus formerl is known as the ascending lumbar vein, ancl is rexarderl by some morphologists as the remains of the primitive or carlital vein of the embryo. The trunk lmmbar vems rum up beneatl the tendin-

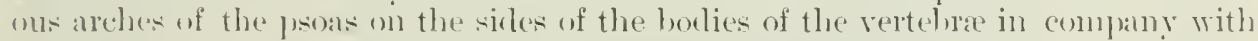
the lumbar arteries and branches of the sympathetie norre. and end in the inferior

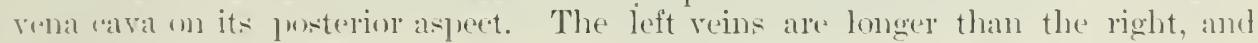
batsis behind the atorta.

(i) The phrenic veins, or inferior phrenic veins as they are smuetimes (allert, follow the eourse of the phernic arteries: the right opens into the vena caral direcet; the left into the sulurarenal, the left remal, or the rena caval.

(7) The hepatic veins, the largest trihutaries of the rena cara, return the blook from the liver. Commeneing in the sulstance of the liver (sor Lavers). they

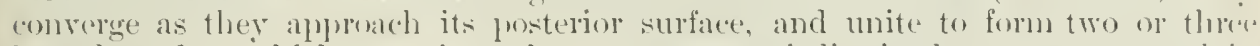
large hranches, which open into the vena caras as it lies in the groove or canal in that organ. Some smaller vessels from the lolmlus Fivelii, and other parts of the

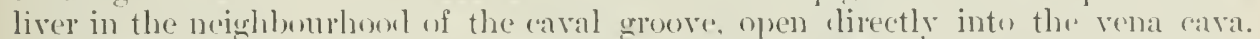
The hepatic veins contain no valves, lut, in consergence of those from the right and left hobe of the liver opening oblipuety into the venal caval. fresent a somilumar fold at the lower marerins of their orifiees.

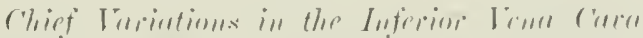

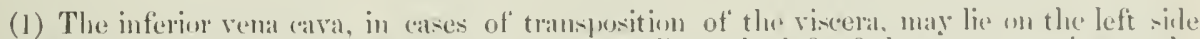

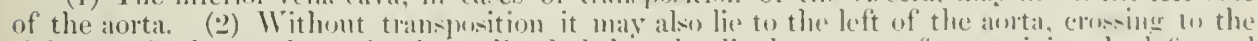

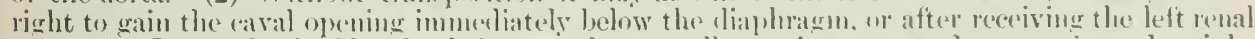

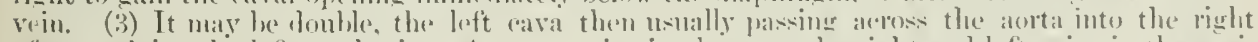
after receiving the left renal vein. I commmination hetweren the right and left veins in the prostion of the normal left common iliare vein may or maty mot then exist. (4) The inferior vental (ava

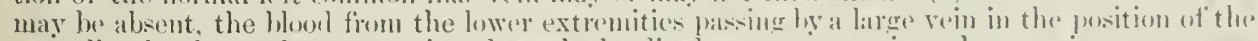

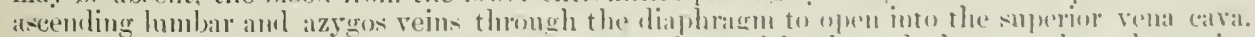
The hepatic reins then open directly into the right anriele thomeh the mermal caval opering

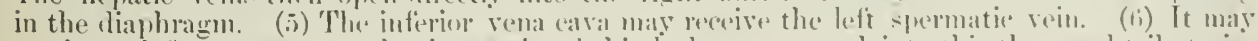
receive a left accessory renal vein passing behind the aorta, and inte this the usmal tributaries 
of the left renal vein may ofen. ( $\bar{c}$ It may receive several aceessory renal veins; as many as even on each side have been met with. (s) The lumbar veins may enter it on one on both sides als al (*)mmon trunk.

\section{(s) THE COMMON ILIAC VEINS}

The common iliac veins are formed opposite the saeru-iliac sychomdrosis by the conflunee of the extemal iliac and internal iliac veins. Ther converge as they ascencl. and unite opposite the upper border of the fifth lumbar rertelora to form the rena cava inferior a little to the right of the median line.

The right vein, shorter and nore vertical in direction than the left, passes ohliguely behind the right common iliac artery to its outer side, where it is joined ly the left common iliac rein.

The left vein lies to the inner side of the left common iliac artery, and, after crosing in front of the promontory of the saermm and fifth lumbar vertelura below the hifurcation of the anta, passes beneath the right common iliac artery to join the light rein and form the inferior vena eava. The left rein mar contain an imprerfect valve.

Tributaries. - The ilio-lumbar reins may enter the lower yart of the common iliac. or open into the internal iliae vein. The left vein receives the midclle sacral rins.

(11) The ilio-lumbar veins follow the course of the ilio-lumbrartery, and end either in the common iliae or in the internal iliac vein.

(b) The middle sacral veins ascend on either sicle of the mirldle sacral artery in front of the sicrum, to open usually by a single trunk into the left common iliac vein. Ther communicate with the lateral sacral veins, forming the so-caller presacral plexis. Below, the middle sacral reins communicate with the hemorrhoidal rins.

\section{('heict Toriations in the Common Iline Veins}

(1) Either common iliac vein way be clouble, or double only for a portion of its extent. (2) One may be absent, - the external and internal iliac veins joining the opposite common iliac to form the vena cava. (3) The right and left internal iliae veins may unite and open as a common trunk at the confluence of the right and left external iliac veins to form the vena cara. (4) The midfle sacral trunk vein may divile. and one branch onen into the right, and the other into the left comm iliac rein.

\section{THE IORTAL VEIY AND ITS TRIBTTARIE-}

The reins arresumeling to the inferior mesenteric, the sumerior mesenteric, and the lnanches of the creliac artery, with the exception of the terminal branches of the herbatic arterv, do not join the inferior vena cava direct, but unite to form a (onmmon trunk - the portal vein.

This vein enters the lirer. and breaks up in its sulstance into capillaries like an artery, from which the blool is again ultimately collected hy the hepatic reins, ank (arrixl hy them into the inferior rona eava. The terminal branches of the lematic artery also break mp in the liver into eapillaries, and from them the blood likewise finds its war finally into the hepatie reins, and thence into the inferior rana (ava. Thus the arterial hlook. leaving the aorta for the supply of the stomandh, the intestines, the pancreas (the so-ealled ehrloportie visera), and the spleen, parses, before it reaches the vena cava, throngh two sots of eapillarics: viz. the "apillaries of the risecra and the eapillaries of the liver. Henee the prortal systen of reins may bre sait to terminate in capillaries at each end; to hegin, like other voins, in eapillaries in the viscera; hut. unlike other veins, to end in eapillaries like an artery, insteacl of in a langer and larger vein till the auriele is reathere. The wortal rein and its trihutaris have no valyes.

The portal vein is a thick trunk about three inches in length (7-S cm.). It is formerl behind the pandreas. opposite the right sicle of the hody of the second lumbar yertelua, by the mion of the smurior mesenterie with the splenie vein. After pasing behind the first part of the luolenum, and then between the layers 
of the lesser comentum in company with the hepatic artery and the hepatic dure. it enters the transverse or portal fissure of the liver, and there divides into a right and a left branch. In this course it passes upwards and to the right, having luth the heyatic artery and the common bile duct in front, the former to the left, the latter to the right. It is surrounderl by branches of the hepatic plexus of the symfathetic nerve, and by numerous lymphatic vests and some glands. Tlur exmnective tissue sheath enclosing these structures is called the eapsule of (ilis-on). Iust before it divides it is somewhat dilated, the dilated portion being ealled the sinus of the portal vein. The division into right and left lianches takes places towards the right end of the transierse fissure of the liver. The right branch is shorter and thicker than the left, and supplies the right lobe of the liver and a

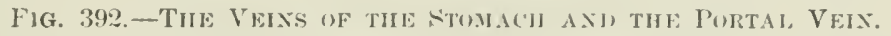

(From a dissection hy W. J. Witlsh:ı.)

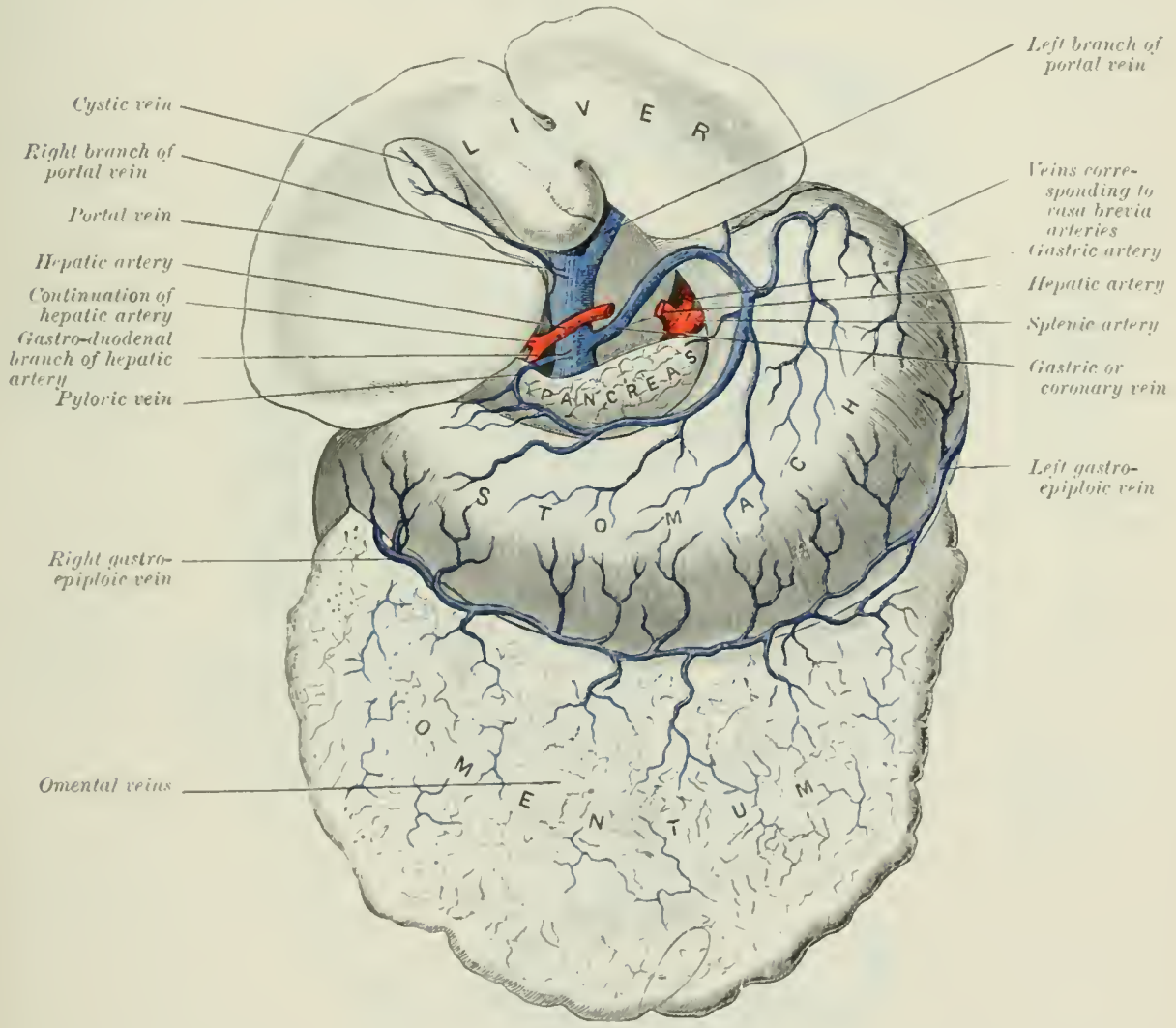

branch to the quadrate lobe. The left branch is longer and smaller than the right. and supplies the left lobe, and gives a braneh to the spigelian and yuadrate lobes. It is joined, as it arosses the longiturlinal fissure, by a fibrous eorrl. knuwn as the round ligament of the liver or the olliterated umbilieal vein, and posteriorly ly a

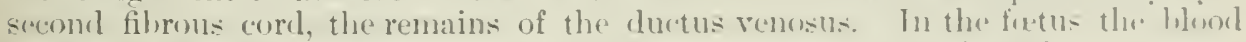
pases through the umbilieal rein and durtus venosus directly inte the venat rava. a rery small quantity only tuming to the right and left into the hranelese of the portal vein. Before birth, the blood in that part of the left hamen of the purtal rein which lies between the trunk of the vena porta and the mombilical vein travels from left to right: but after lirth, as the portal rireulation lecomes froly established and the umbilical rein and ductus venosus are olditeraterl, in the (1) prosite direction, i.e. from right to left. 
Tributaries.-The pyloric, the gastric, the eystic (which latter usually enters the right branch), the superior mesenteric, and the splenic.

The pyloric vein begins near the pylorms in the lesser curve of the stomarh, and, ruming from left to right with the superior pyloric artery, opens directly into the lower part of the portal rein. It receires branches from the pancreas and duodenum.

The gastric or coronary vein rums with the gastric artery at first from light to left, along the lesser erurve of the stomach, towards the cardiae end, and then, turning to the right, passes across the spine from left to right to end in the portal trunk a little higher than the pylorie vein (fig. 392). At the cardiac end of the stomach it receives small branches from the asopliagus.

Fig. 393.-The SUperior Mesexteric Veix.

(The colon is turner up, and the small intestines are drawn orer to the left side.)

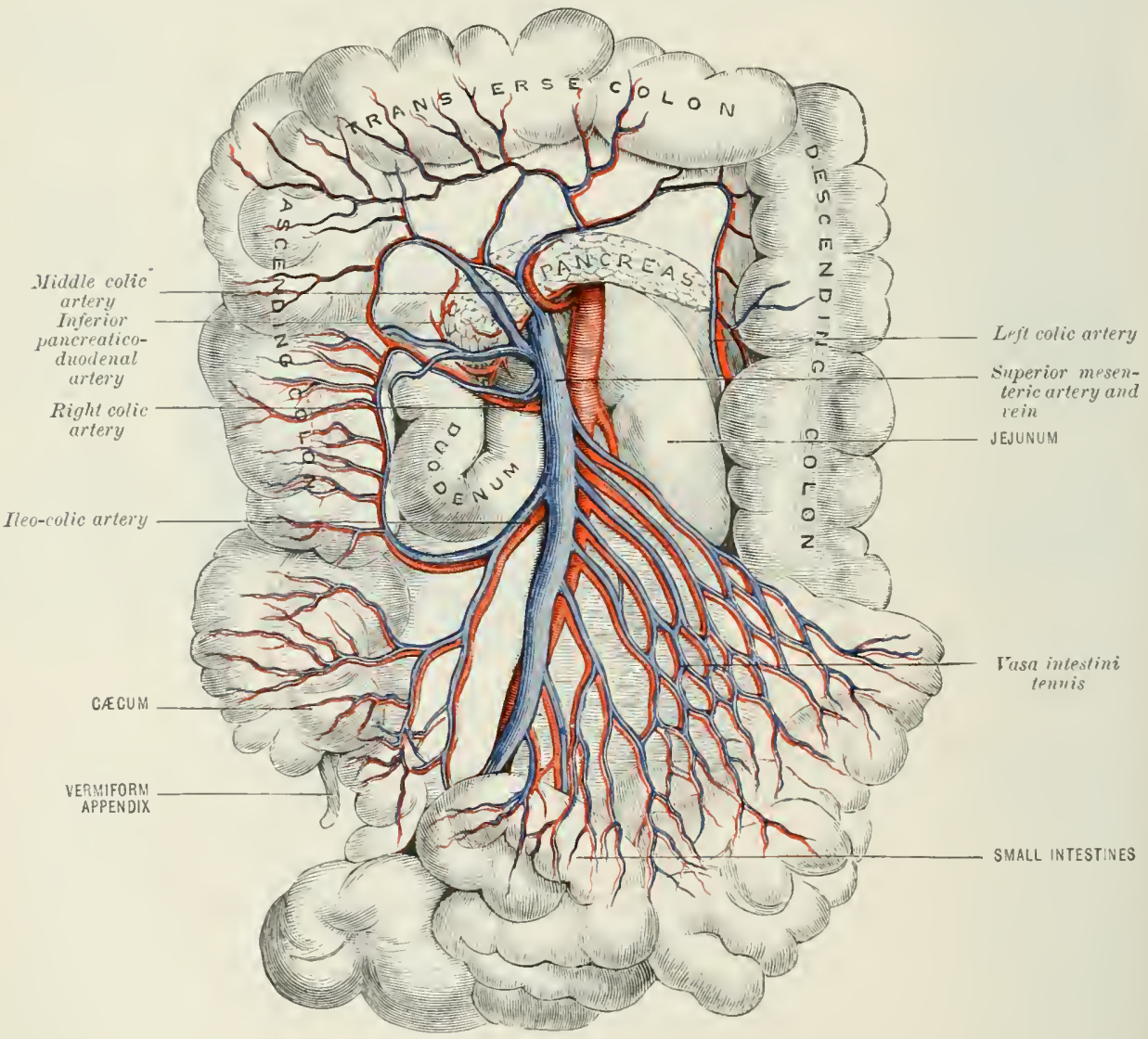

The cystic vein returns the blood from the gall-bladder. It usually opens into the right branch of the portal rein.

The superior mesenteric vein hegins in tributaries which correspond with the branches of the superior mesenteric artery. It eourses upwards a little, in front and to the right of the artery, passing with that vessel from between the layers of the mesentery in front of the duolenum, and behind the pancreas, where it joins the splenic vein to form the portal trunk.

Tributaries.- In addition to the tributaries corresponding to the branches of the superior mesenteric artery-riz. the ileo-colic. right colic, midlle colic, and small intestinal veins (fig. 393 ) -it receives the right gastro-epiploic and the pancreatico-duodenal veins just before its termination in the portal rein. 
The right gastro-epiploic vein accompranies the artery of that nam?. It runs from left to right along the gleater curvature of the stomach, receiving branches from the anterior and posterior surfaces of that viscus, and from the great omentun, and, pasing behind the first portion of the duodenum, ends in the superior neserenteric vein just before that vessel joins the jortal trunk.

The pancreatico-duodenal vein runs with the corresjonding arteries hetwe(n) the head of the pancreas and the second portion of the duodenum, and ends in the superior mesenteric vein a little below the spot where that vesece is joined by the right gastro-epiploic rein.

The splenic vein issues as several large branches from the hilum of the spleen. These som unite to form a large trunk, which passes across the aorta and spine in company with the splenic artery. helw which it lies, to join at nearly a right angle

FiG. 394.-The Ixferiur Mesexteric Veis.

(The colon is turned up, and the small intestines are drawn to the right side.)

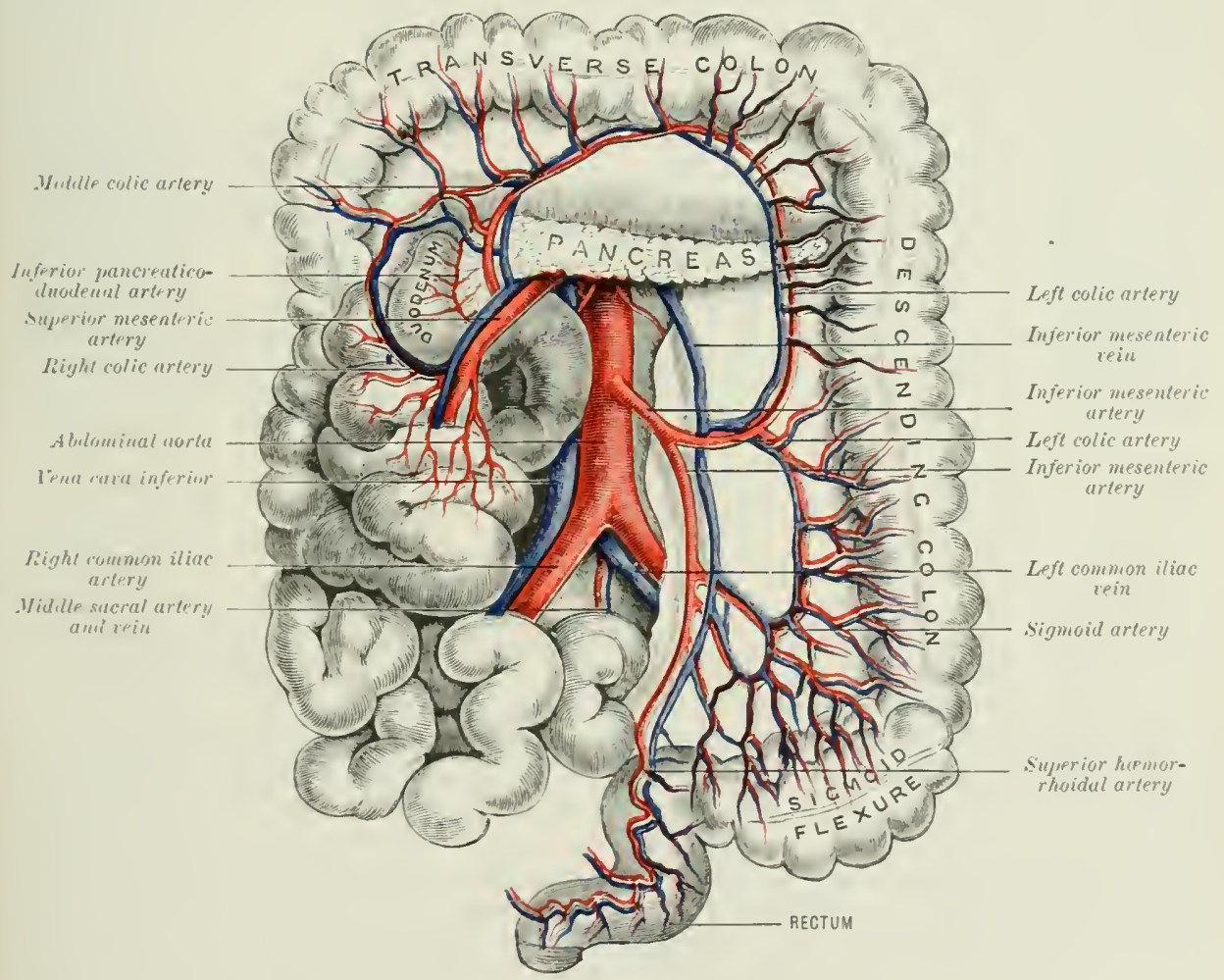

the superior mesenteric rein. In this course it lies behind the pancreas; and at its union with the superior mesenteric to form the vena porta, in front of the inferior vena cava.

Tributaries. - It receives veins corresponding to the vasa brevia arteries from the cardiac end of the stomach, the left gastro-epiploic vein, reins from the pancreas, and the inferior mesenteric vein.

The left gastro-epiploic vein accompanies the loft gastro-epiploic artery. It runs from right to left along the greater curvature of the stomach. receives branches from the stomach and omentum, and opens into the commencenent of the spilenic vein.

The inferior mesenteric vein begins at the rectum in the superior and midrle hremorrhoidal veins. It passes out of the pelvis with the inferior mesenteric artery; but. after receiving the veins corresponding with the sigmoid and left colic branches 
of that ressel, it leaves the artery and rums upwards on the proas to the left of the ancta and behind the peritonemi. On approaching the pancreas it turns slightly inwards, and passes ohliguely behind that gland to join the splenic rein just before the latter unites with the superior mesenteric to form the vena prorta.

\section{THE TEISS OF THE PELITS}

The veins of the pelvis, with the exception of the middle sacral rein, which terminates in the left common iliae rein, open into the internal iliac rein. Lnder the hearl of pelvic reins are included all of those corresponcling to the branches of the internal iliac artery except the hypogastric branch, although some of these reins do not return the hlood from the pelicie walls or viscria.

The internal iliac vein is formed by the confluence of the veins (except the umbilical) (orresponeling to the Jranches of the internal iliae artery. It varies comsiderably in length, but is usually quite a short trunk, extending from the upper part of the great sacro-sciatic foramen to the sacro-iliae symchondrosis, where it join: the external iliae to form the common iliae rein. It lies behind and a little internal to the internal iliae artery. It contains no valve.

Tributaries.-.The internal iliae rein receives directly or indireetly the following branches: the gluteal, ilio-lumbar, lateral sacral, olsturator, sciatic, pudic, dorsal penile. prostatic, resical, and hemorrhoidal reins. The single umbilical vein-the rein corresponding to the right and left hypogastric arteries and their continuation, the umbilical arteries-does not enter the pelvis. but, leaving the umbilical arteries at the navel, passes along the falciform ligament to the liver. After birth it is converted into a fibrous cond. (See Pontal Ves, page 634.)

The gluteal veins accompany the gluteal artcry, and, passing through the upper purt of the great sciatic formen, open into the internal iliac vein near its termination, either separately or as a single trumk.

The ilio-lumbar veins open into the internal iliac a little higher than the yluteal. At times they join the common iliac vein.

The lateral sacral veins join the gluteal or the internal iliae at or about the sance situation as the gluteal. They form with the midcle sacral reins a plexus in front of the sacrum, and receive branches from the sacral canal.

The obturator vein, which lies below the obturator artery as it cresses the sicle of the prelvis, opens into the front of the internal iliae vein a little below the gluteal. Its branches correspond to those of the artery.

The sciatic veins accompany the sciatic artery, and, as a rule, unite to form a single trunk before joining the internal iliac a little below the olsturator rein.

All the ahore veins so closely follow the ramifications of their respective arteries, that no further special description of them is required. They all contain valyes.

The pudic vein does not begin as the dorsal rein of the penis, but issues from the corpus cavernosum with the artery of that body. It communicates, howerer, with the clorsal rein before the latter pierees the triangular ligament. In the rest of its course it rums with the pulic artery, receiving tributarics corresponding to the branches of that reserel. It terminates in the lower part of the internal iliac: vein.

The dorsal vein of the penis begins in a plexus around the eorona glantis, then rums alenge the centre of the dorsum of the penis between the two pulic: arteries. In this course it receires large tributaries from the interior of the oroun, which, concrging for the most part between the corpus spongiosum and corpus cavernosim, wind obliquely over the outer surface of the latter structure to the Arorsum of the penis to ent in the dorsal rein. At the root of the penis the dorsal vein leaves the dorsal arteries. and, passing straight backwards between the two layers of the suspensory ligament, and then through either the subpubie ligament or the upper part of the triangular ligament of the pelvis (fig. 371) lifurcates, each branch passing backwarts and downwards to the prostatico-resical plexus of veins. At times the dorsal vein begins as two branches, which rum between the dorwal arteries and only unite to form a single trunk about an inch anch a half from the 
triangular ligament. Before passing through the triangular ligament, it communicates on cach side with the primary raticals of the purlic voin. After dividing inte a right and a beft branch within the pelvis, each vessol gemerally (oommumicates with the obturator vein by a branch passing orer the back of the pubes to the obturatus foranen.

The prostatico-vesical plexus surromels the prostate and the neek and lower fundus of the blarkler. It receives in fromt the right and left divisions of the dorsal vein of the penis, and communicates josteriorly with the hamorrhoidal plexus. The prostatic reins and the resical plexus inen into it. The vins forming the plexus are of large size, especially in old mon, in whom they often beeome varieose, and eontain phleholiths, or vein-stones. The plexus is surrombled by a kind of capsule formed by the recto-resical process of the pelvic farcia. It terminates in a single stem on each side which opkens into the internal iliat vein.

The vesical plexus surrounds the ulver fundus, the sides, and the anterior and posterior surfaces of the bladder. It is situated between the muscular coat and the peritonem, and where the bladder is uncovered hy peritonem extemal to the muscular coat in the pelvic cellular tissue. It opens into the prostaticu-resical plexus.

The hæmorrhoidal plexus of veins surrounds the rectum, and is situated at the lower part of that tuhe between the muscular and mueous coats. The reins of this plexus terminate in the inferior, middle, and superior hremorrhoidal vein-.

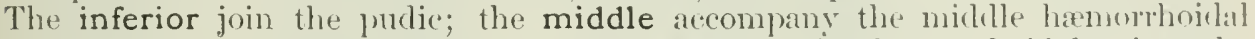
arteries, and open into the internal iliae and superior hemorhoidal reins; the superior form the commencement of the inferior mesenteric rein, and through this the blood gains the portal rein. None of these veins have any valves, hence the entargement of the inferior hemorhoidal veins, a condition known as piles, when the portal rein is olstructed, as from compression of its captillaries in cirrhosis of the liver. Through the hamorrhoidal reins a free communication is established between the systemic and portal system of reins.

\section{THE IFISS OF THE LPPER EITREUTT}

The veins of the upper limb consist of two sots-al superficial and a deep.

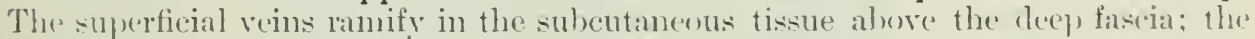
derp aceonmany the arteries, and have practieally the same relations as those

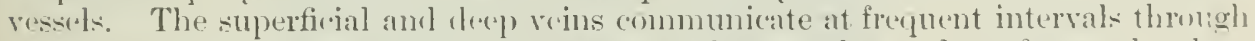

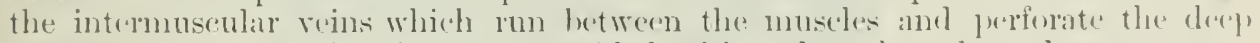
fascial. Both sets of veins are provided with valves, lunt the valves ane mone numerous in the dece than in the sujerficial. There is moually a valse where the derep reins join the supurfieial. The superficial veins are larger than the deren, and take tle greater share in returning the blowl.

\section{THE STPLRFITA, IELS OF THE LPIER EATREMITY}

The superficial veins hegin in two irregular renoms plexuse- one situatew on the hack of the lamel, and the enther on the front of the wrist. Fond the ratial sicle of the dorsal plexus, a single rein, the superficial radial, runs up, the forman as far as the ellow. From the ulnar side of the plexus, two veins (a) urse up the inner side of the foream-the anterior and posterior superficial ulnar veinsand. joining together a little helow the henel of the clbow. furm a single superficial ulnar vein. From the anterior plexus a vein runs up the middle of the fromt of the forealu-the superficial median vein-anch, after recoivine a branch from the deep veins at the hend of the ellow (the deep median), divictes into an outer 
hranch (the median ephalic) and an inner branch (the median basilic). The median cephalic rums upwards and outwards to join the superficial radial vein. The united trunk, then known as the cephalic, continues up the outer side of the arm, and opens into the axillary rein. The median basilic runs upwards and inwark to join the superficial ulnar vein. The trunk thus formed (the basilic) courses up the inner sille of the arm to juin the inner brachial vena comes and form the axillary vein.

The dorsal venous plexus, which is situated on the back of the hand, sometimes takes the form of an irregular arch, stretching across from the radial to the

Fig. 395. - Tile Bexi of tire Elbow With the Superficial Veiss, Left Side.

(From a dissection by Dr. Alder smith in the Museum of St. Bartholomew's Hospital.)

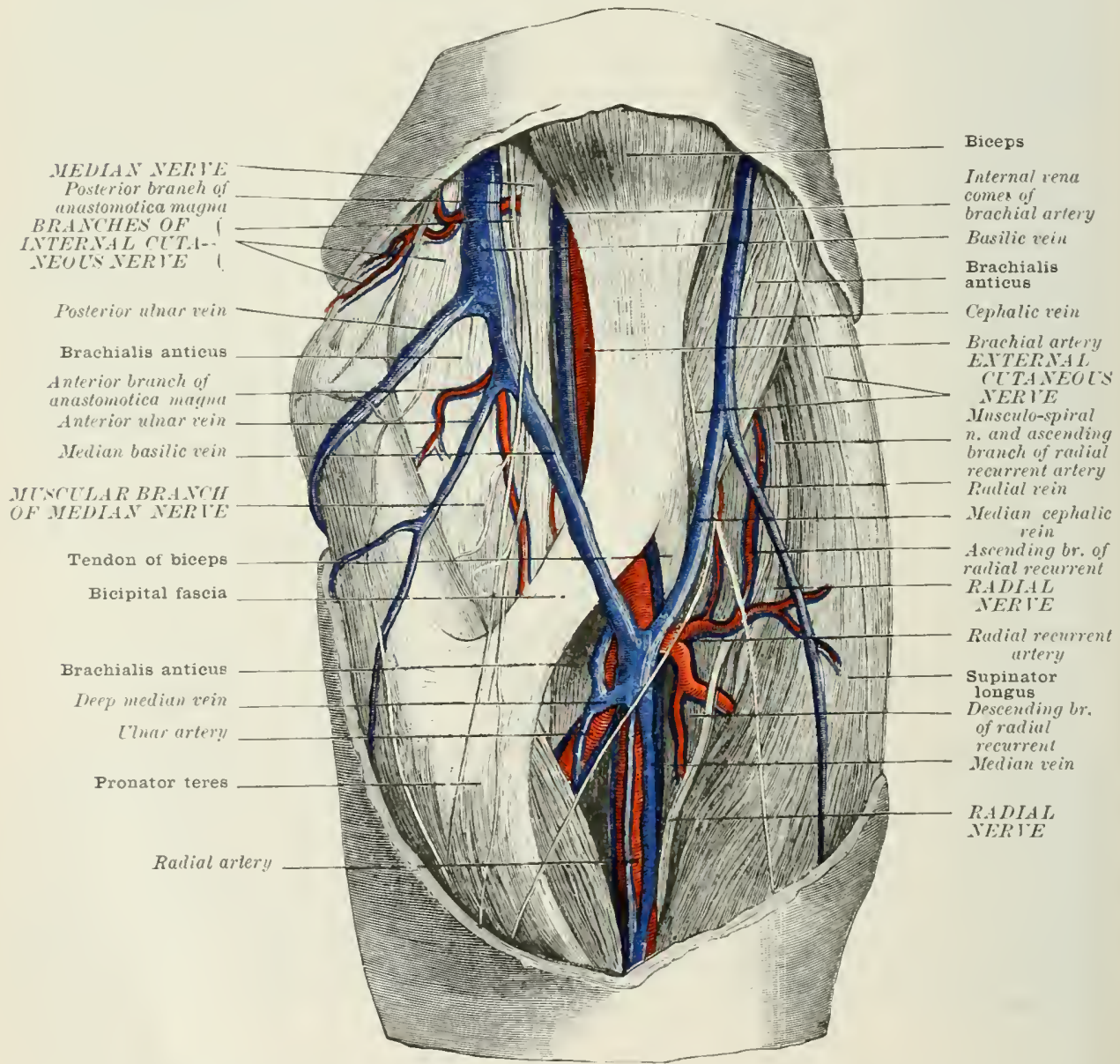

ulnar side; at other times, the form of two more or less distinet plexuses, a ratial clorsal and an ulnar dorsal; but an exactly similar arrangement is seldom met with in any two consecutive bodies.

'The distal part of the arch or plexus reeeives the digital veins from the fingers. These digital veins, two to each finger, start fron a minnte plexus about the nail, run along the finger, wne on either sicle. to the cleft. Where each unites with the vein from the contiguous side of the neighbouring finger. and so form single trunks which procect upwards to the arch. The reins of the fingers communicate at frequent intervals hy eross branches above and below the interphalangeal joints.

Here it may be noted, that whilst the veins which retum the chice part of the 
blood from the fingers are superficial and thersally placed, the arteries are deep and situaterl towarls the pahmar surface. Alinute vene comites, however, lie on asch sicle of the digital arteries.

The anterior median plexus is situaterl on the fore part of the wrist. It is very irregular in its arrangement, and receives a fer small branches from the jalm and from the outer and front part of the thumb.

The superficial radial vein begins at the raclial and of the dlorsal venous plexus or arch, and, atter receiving veins from the thumb and communicating with the deep reins accompranying the radial artery, (onress up the malial sicle of the foreami along with the musculu-cutaneous nerve. It receives numereus hranches from the front and onter surface of the forearm, and a little above the bend of the ellow, in the slight suleus at the onter sicle of the licipital prominence, mites with the median cephalie rein to form the cephalic rein (figs. 395,396 ). It contains from four to six valves.

The anterior superficial ulnar vein brgins on the inner and front surface of the wrist, runs up the inner sicle of the foream. and joins the postcrior ulnar rim just below the hend of the elbow; or it may unite directly with the median basilio: to form the basilic rein. In the latter case the posterior superficial ulnar vein joins the basilic (fig. 39.5). The anterior uhar rein is accompanied by the anterior branch of the internal cutaneous nerve. It contains about four valves.

The posterior superficial ulnar vein, larger than the anterior, begins at the ulnar side of the dorsal plexus. It receives the vena salvatella, or vein of the little finger, and commumientes with the deep ulnar reins by means of an intermuscular liranch which passes beneath the abductor minimi digiti. As it courses upwards on the posterior aspect of the forearm it receives numerous cutantous branches, and near the bend of the elbow joins the anterior superficial uhnar vein. Just below the internal condyle the united trunk turns forwards to mite with the median basilic to form the basilic vein. When the basilic is formed by the mion of the anterior nlnar and median hasilic (fir. 39.5), the posterior unar vein may *nel in the hasilic vein direct. It contains alunt four valyes.

The superficial median vein begins in the anterior plexus in front of the wrist, and passes up the centre of the front of the foream, receiving numerous "utaneous hranches, and communicating on each sille with the superfirial ulnar and rartial veins. At the bend of the elbow it receives the deep median vein, which is formed liv the union of the outer vena fomes of the ulnar artery with the muscular and raclial recurrent veins. The short trunk pieres the deep farcia to join the merlian rein. which immediately afterwarls hifurcates into the median basilic and merlian rephalic.

The median cephalic vein, the smaller branch of the median, runs upwarks and ontwarks in the sulens hetween the hicess and supinatus longus, and. joining the superficial radial vein immediately ahore the bemel of the elhow, forms the rephaliv rein. The musculn-cutaneous nerve passes beneath it, a fer fibres of the nerve lying superficial to it.

The median basilic vein, the larger of the two divisons of the median rein, runs upwarls and inwarks alcuss the semilunar fascia of the bieeps, by which it is separated from the hrachial artery, to the internal hicipital sulews, where it juins one of the superficial unar veins or their united trunk to form the hasilic. Fibres of the internal eutaneous nerve pass buth in front and lechind it. This rein is "specially prominent at the hend of the elluw; and. on arecomt of its larger size and superficial position. was usually chesen in renesertion when this operation was

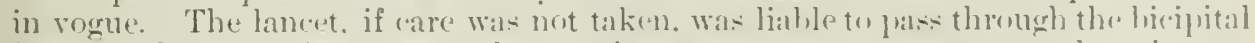
fascia and injure the artery. When vareose anemysm or anemrymal varix was a conmon result.

The cephalic vein, formed hy the mion of the molian wephalic with the sulpuficial radial vein, courses upwards first in the "xternal licoipital sulcus, and then in the interval hetreen the pectoralis major and the deltuid. perforates the costocoracoil memlirane, and. crossing the first part of the axillary artery, "lene into the axillary vein. It contains a pair of valves where it joins the axillary vein.

The basilic vein-formet hy the union of the median hasilie and one of the superficial uhar veins or their united trunk-parses up the inner sicle of the arm 
a little internal to the biceps. and nearly over the course of the brachial artery. At the junction of the mildle with the lower third of the arm it pierces the

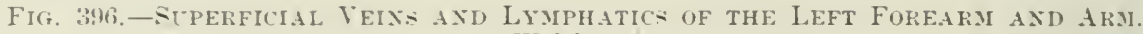
(Walsham.)

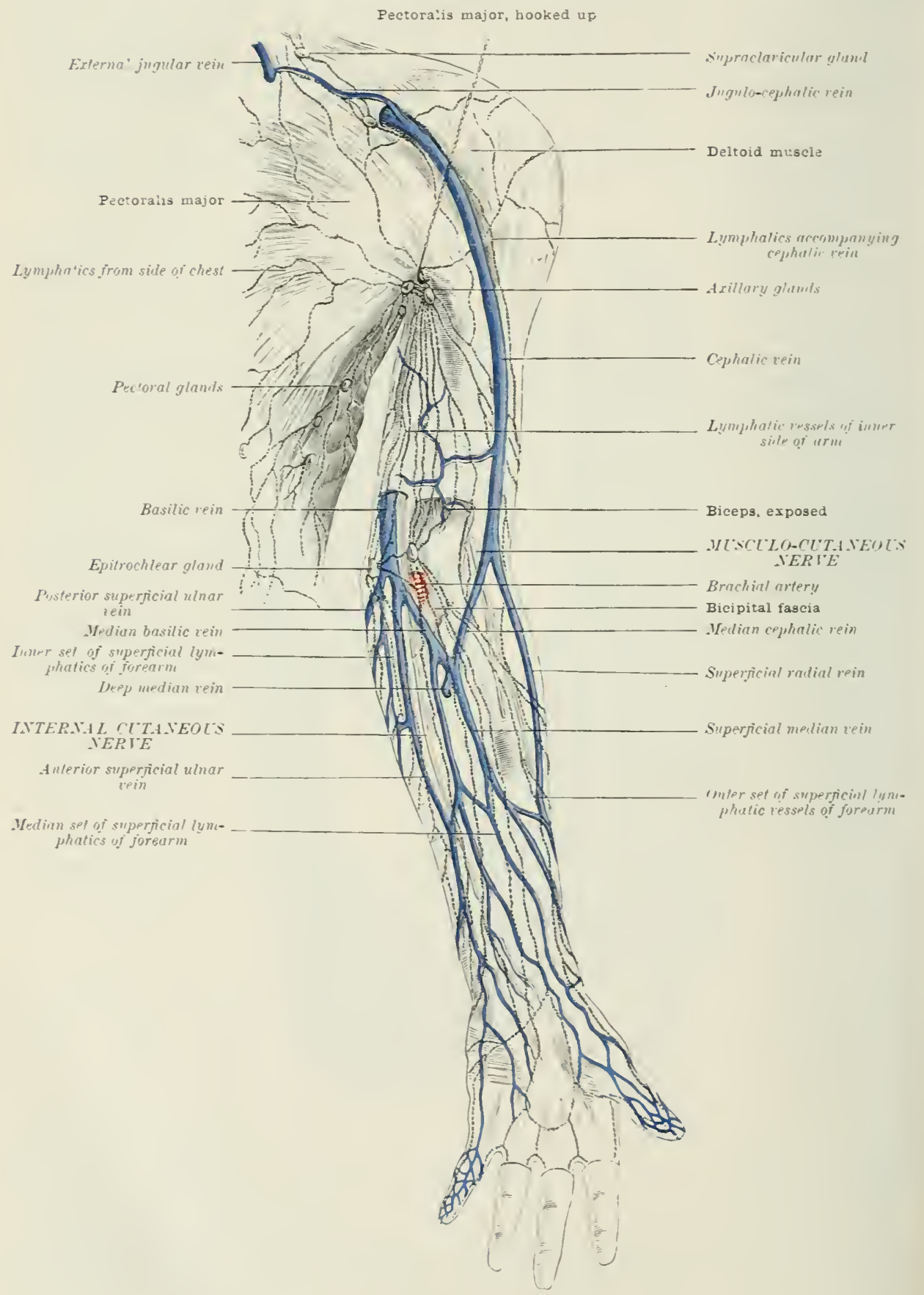

depl fascia, and ends by uniting with the inner brachial vena comes to form the axillary rein. 


\section{THE DEEP VEINS OF THE LPPER ENTREIITY}

The deep veins of the upper extremity accompany their corresponding arteries and consequently require no detailed description. There are two veins to each artery below the level of the axilla, known as the companion veins or vena comites. In the leg, as will be afterwards noticed, the vene comites of the main arteries extend as far as the knee only. The deep reins all contain numerous valves, and communicate at frequent intervals through intermuscular veins with the superficial.

Beginning at the fingers, two ninute veins accomprany each digital artery along the sides of the fingers, and, uniting at the cleft, form interdigital veins which join the vena comites of the arteries, forming the superficial palmar arch. In like manner the veins accompanying the arteries forming the deep arch receive tributaries corresponding to the branches of that arch. The renx comites from the uhnar side of the superficial and deep arches unite at the spot where the uhar artery divides into the superficial and deep branch to form two ulnar venæ comites; whilst those on the radial side of the superficial and deep arch accompany the superfieial volar artery and the termination of the radial artery respectively, and unite at the spot where the superficial volar is given off from the radial artery, to form the radial venx comites. The ulnar and ratial venæ comites thus formed course up the forearm with their respective arteries, receiving numerous tributaries from the muscles amongst which they run, and giving frequent communications to the superficial veins. They finally unite at the bend of the elbow to form the brachial vena comites. The uhnar vene comites receive, before joining the radial, the companion veins of the interossenus arteries. At the bend of the elbow the deep veins are conneeted with the superficial median vein by a short, thick trunk, the deep median vein.

The brachial venæ comites accompany the brachial artery, the immer vein receiving at the lower border of either the teres major or subscapularis muscle the outer vein and the basilic vein, to form a single axillary vrin.

The vense comites of the arteries of the arm anastomose with one another by frequent eross branches.

The axillary vein is formed by the junction of the inner brachial vena comes with the basilic vein at the lower border of either the teres major or subscapularis muscle. It is a vessel of large size, conveying as it does nearly the whole of the returned blood from the upper extremity. It accompanies the axillary artery through the axilla, lying to its inner side and at the upper part of the space on a slinhtly lower plane. At the outer border of the first rib it changes its mame to the subelavian. It las one or two axillary glands in dose connection with it, and is liable, if eare is not taken, to be wounded in removing these glands when infiltrated with cancer secondary to cancer of the breast. The vein contains a pair of valves, ustualy placed near the lower borter of the subscapularis muscle. It receives in its course through the axilla:-(1) 'The subseapular veins which accompany the sulseapular artery; (2) the ciremuflex veins areompanying the eireumflex arteries; (3) the long thoracic veins accompanying the long thoracic artery; (4) numerous small veins returning the blood from the axillary glands; (5) the veins corresponding to the branches of the thoracic axis; and $(\dot{6})$ the cephalic vein.

The subclavian vein (fig. 329 ) is the continuation of the axillary. It begins at the outer borler of the first rih, and teminates by joining the internal jugular to form the imnominate vein opposite the outer part of the steme-clavicular articulation. It lies anterior to the subelavian artery and on a lower plane, and is separated from the artery in the second part of its arise by the scalenus antians musele. The subclavian vin, just before the spot where it is joined hy the external jugular, contains a pail of valves.

Tributaries. - Near the outer border of the sterno-mastoid muscle it recuives the external jugular vein. Occasionally the cephalic vein, or al lameh from the cephalic (the jugulo-cephalic), passes over the clavicle to the suludian (fig. 3965 ).

Chief variations.-(1) The subclavian vein may run on a higher plane than usual, lying 
even above the artery. (2) It may pass with the artery behind the sealenus anticus. (3) It may run behind the scalenus anticus and the artery in tront of that muscle. (4) It may split and encluse the sealenus anticus. (5) It may pass between the clavicle and the subelavius. (6) It may receive directly the transverse cervical, the sujrascapular, the anterior jugular, or the cephalic rein, or the vene comites of the brachial artery.

\section{THE VEITS OF THE LOIIER EITREIITY}

The veins of the lower extremity are divided into the superficial and the deep. The superficial veins lie in the subeutaneous tissue superficial to the deep fascia, through which they receive numerous communicating branches from the deep reins. Ther are collected chiefly into two main trunks, which, begimning on the foot, extend upwards, one lying antero-intemally, and the other posteroexternally. The former finally joins the femoral vein by passing through the deep fascia at the groin; the latter the popliteal by perforating the fascia at the han. The deep veins, on the other hand, accompany their corresponding arterics. Below the linee there are two veins to each artery; above it, excepting at the back of the thigh, there is only one vein to each artery. All the reins of the lower limb have valves which are more numerous than in the veins of the upper extremity, and in the deep than in the superficial veins.

\section{THE SLPERFICIAL IEEIS OF THE LOIVER EXTREMITY}

The superficial veins of the lower limb are collected into two main trunks. One. the long or internal saphenous, which is placed antero-internally; the other, the short or external saphenous, which is placed postero-externally. These reins commence on the dorsum of the foot in an irregular areh, which stretehes across the instep with its convexity towarls the toes. The arch receives branches from the four outer toes and dorsum of the foot, and one branch of somewhat larger size than the rest from the inner side of the great toe. It also communicates with the vense comites accompanying the dorsal artery of the foot (fig. 397).

The long or internal saphenous vein commences on the inner side of the font at the inner end of the above described venous arch, and, after reeciving branches from the sole which join it by turning over the inner border of the foot, passes upwarks in front of the inner ankle, and then olliquely upwards and backwards about a finger's brath from the posterior horder of the tibia in company with the internal saphenous nerve, which becomes superficial just below the knee. Continuing its course upwarks, it passes behind the internal condyle, and then runs upwards and somewhat outwards on the inner side of the front of the thigh to about an inch and a half below Poupart's ligmment, where, after receiving the superfi“ial circumflex iliae, superficial epigastric, and superficial external pudie veins, it dips through the saphenous opening in the fascia lata, and ends in the femoral vein. In its course up the lear and thigh it receives numerous unnamed cutaneous branches, and at variable intervals communicates with the deep veins. Just before it passes through the saplienous opening, it often receives a large vein (external femoral cutaneous) formerl by the union of several of the eutaneous reins on the upper and outer part of the thigh, and a second vein (the internal femoral cutaneous) formed by the union of the cutaneous veins from the inner and back part of the thigh. The long saphenous vein contains from ten to twenty valves.

The short or external saphenous vein begins at the outer end of the renous arch, or plexus, on the lorsum of the fort. After receiving branches from the sole, which turn over the outer border of the foot. it passes behind the outer ankle, and then upwards and inwards, lying at first along the outer side of the tendo Achillis, 


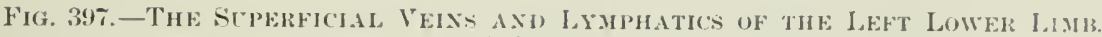
(IVilshim.)

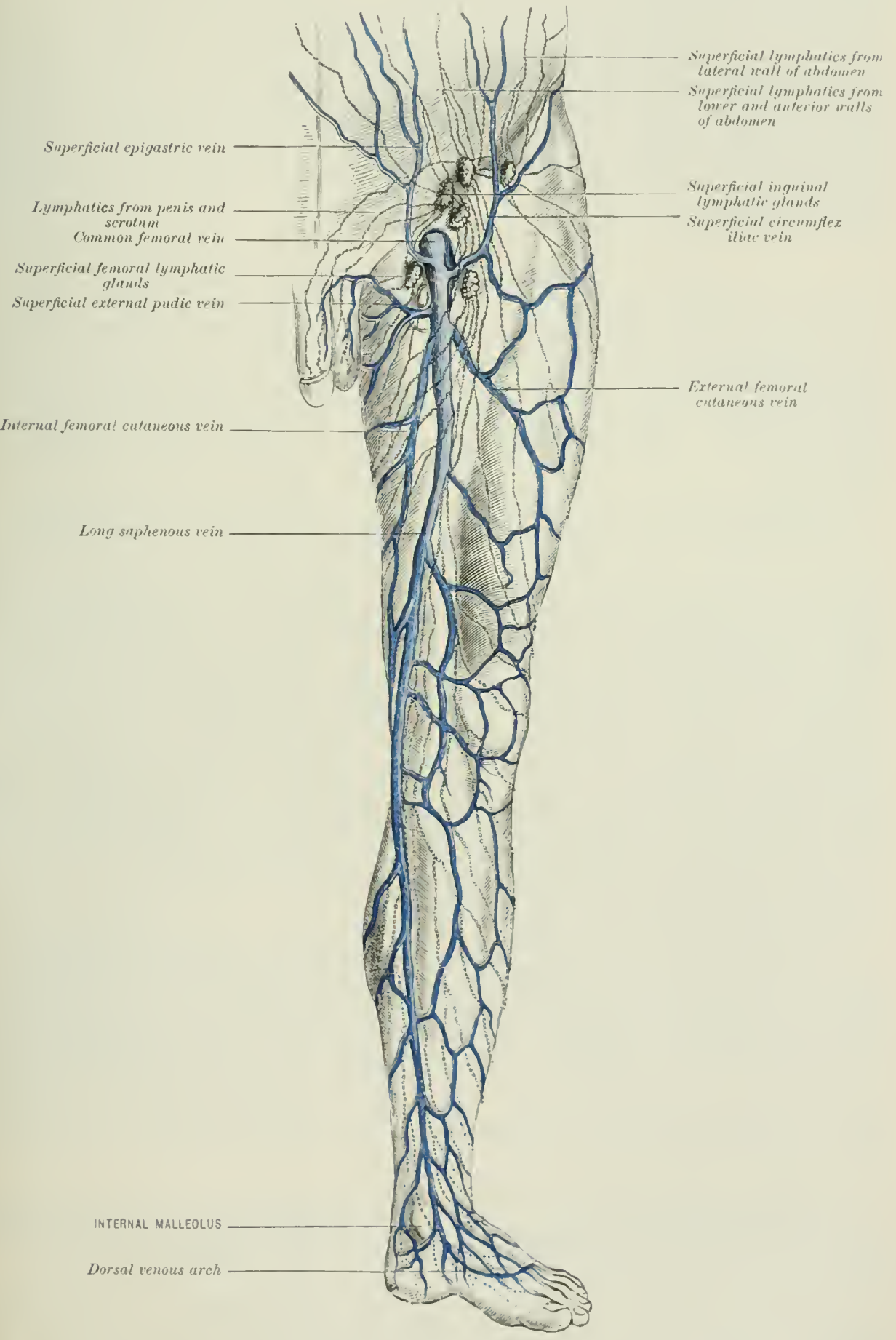


afterwards along the back of the calf, in company with the external or short saphenerus nerve to about the lower part of the centre of the popiiteal space, where it perforates the dee fascial, and, sinking between the two heads of the gastroenemius, opens into the popliteal vein. As it passes up the calf between the superficial and deep faseia, it receives numerons eutaneous reins from the heel, and the outer side and hack part of the leg, and communicates at intervals, through transverse or intermuscular branches, with the deep veins (vene comites) aecomfranying the peroneal artery. Just before perforating the deep finscia, it receives a large descencling liranch from the lower and batek part of the thigh, and semels mpwards and inwards a communitating vein to the long saphenous. $A$ small offshoot from the inferior sural branch of the popliteal artery aceompanies the vein for a short distance down the back of the calf. The short saphenous rein contains from nine to twelve villy's.

\section{THE DEEP IEIVS OF THE LOUER EXTREIITY}

The deep veins of the lower extremity accompany the arteries, and have received corresponding names. From the foot to the knee there are two veins to each artery. These veins run on either side of the eorresponding artery, and communicate at frequent intervals with each other across it. They are known as the venxe comites. From the knee upwards there is a single vein to each artery, except at the back of the thigh and in the gluteal region, where there are commonly two.

The veins of the foot and leg.-The vems comites of the internal and external plantar arteries, after receiving small veins corresponding to the branches of these vessels, unite beneath the abductor hallucis muscle to form the venx comites of the posterior tibial artery. These, again, receive, at the spot where the peroneal artery is giren off from the posteriol tibial, the venre comites of the peroneal artery, which are formed in like mamner by the confluence of the rarious veins corresponding to the branches of that ressel. Opposite the lower border of the popliteus muscle, the posterior tibial reins unite with the anterior tibial veins, which pass through the upper part of the interossous membrane with the anterior tilial artery, to form the popliteal. The anterior tibial veins are the eontinuation of the renze comites of the dorsal artery of the foot, which, in their tum, are formed by the confluence of the veins acompanying its various branches. The anterior tibial renæe comites thus formed run with the anterior tibial artery up the front of the leg, and, after passing through the interoseous membrane along with the artery, join the posterior tibial veins to form a single popliteal.

All these veins contain numerous valves, and communicate, by means of intermuseular branches, with the superticial reins.

The popliteal vein is formed by the confluence of the venxe eomites of the anterior and posterior tibial arteries at the lowe border of the popliteus, and extents upwarts to the opening in the adduetor magnus at the junetion of the midclle and lower third of the thigh, where it changes its name to femoral. It accompanies the popliteal artery, lying superficial to it in the whole of its course, and tightly bound down to it by its fascial sheath. At the lower nart of the space it is a little interual to the artery, but, erosing the ressel obliquely as it aseends, lies a little extemal to it at the upper part of the space. The internal popliteal nerve lies superficial to the vein, being external to it above, then on it, and then a little to its inner side. The peppliteal vein contains two or three valves.

The chief variations of the popliteal are:-(1) It may lie between the artery and the bone. (2) It may be double through a part or the whole of the popliteal space. (3) Two veins by frequently uniting in front and behind the artery may form a kind of plexus around the vesiel. (4) It may be shorter than usual in conseguence of a highl union of the tibial vena conites.

The femoral vein, the continuation of the popliteal upwark, extends from the tendinous oprening in the adductor magnes to an inch anel a half below Poupart's lisament where it joins the profunda vein to form the common fenoral vein. In this course its relations are similar to those of the superfieial femoral artery. As 


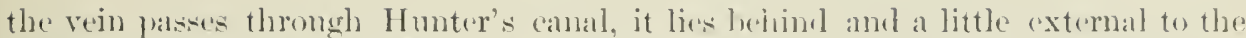
artery. At the alex of scarpa's triangle it is still postrior to the artery, hut gradually passes to the inner side as it aserends through that space. It contains three pairs of valves. The close eonnection of the vein to the artery shenlel be remembered in the operation of ligature. The sheath should he opened on its imner side, that is, well over the artery, and the point of the ameurysumede nept closely applied to the artery lest it perforate the overdapying rein.

Tributaries. - (1) The rene contites of the anastomotica magna artery; (2) the vene comites correspondling to the musenlar hranches of the fenoral.

The profunda or deep femoral vein aceompanies the profunda or deep femoral artery, and receives the rena contes eorresponding to its various branches. Enlike the other rems of the lower extremity, it lics in front of its companion artery, and is at first a little intermal to it. It terminates by joining the superficial femoral vein about an inch and a lialf lesew Poupart's ligament in the angle betwern the femoral and profunda arteries. It contains five ralves.

The common femoral vein is a short thick trunk corresponding to the common femoral artery. It is formed by the comfluence of the superficial femoral anel profunda veins about an inch and a half below Pompart's liganuent, and is continued upwarks to the lower borker of that strueture, where it takes the name of external iliac. It lies on the same plane as the common femoral artery, but internal to that vessel, from which it is separated by a delicate prolongation of fascia stretching between the front and back layers of the femoral slueath. Internally, it is separated by a similar septum of fascia from the crural canal. It usually contains two valves: one just above the junction with the profunda vein, the wher just below Poupart's ligament (fig. 372).

Tributary. - The long saphenous rein which reaches it by passing through the salphenous opening in the deep fascia.

Chief variations. - (1) The femoral vein may be double in part or in the whole of its length. (2) It may split into two and embrace the femoral artery. (3) It may pass through the aldnctor magnus above the femoral artery and rum sefrarate from the artery until it joins the frofunda vein to form the common fenoral vein. (4) It may run with the sciatic nerve and pieree the aldnctur magnus at the level of the lesser trochanter. When this occurs the femoral artery is usmally very small, and the sciatic artery is the chief nutrient vessel of the thigh.

The external iliac vein is the continuation upwark of the common femoral. Beginning at the lower border of Poupart's liganent it accomplanies the external iliac artery upwards and inwards along the brim of the pelvis, lying at first on the lurizontal ramus of the pubes, and then on the jooas muscle. It teminates in the (ommon iliae vein by joining the internal iliae vein belind the internal iliac artery (1) w site the lower borker of the sacro-iliac synchondrosis. It lies at first internal to the external iliac artery, and on the left side lemains internal to the artery throughout its eourse. On the right side, howeres, as it aseends, it gradually gets a little behind the artery. It contains one or two valyes.

Tributaries.-(1) The deep epigastric vein, formed hy the mion of the vente (onnites of the deep epigastric artery, joins the external iliac jus above Poupart's ligament. (2) The deep circumflex iliac vein, which is formed in the same waty by the confluence of the rense comites of the deen circmutlex iliac artery, joins the external iliac vein a little hisher. 


\section{THE LTMPHATIC'S}

$\mathrm{T}^{\mathrm{H}}$ E lymphatics consist of lymphatic ressels and lymphatic glands. The lymphatic ressels carry lymph, and the lymphatics of the intestine chyle as well whilst digestion is going on. The chyle-carrying lymphatics are generally known as lacteals. The lymphatic glands are situated at certain spots in the course of the lymphatic vessels. The lymphatic vessels ultimately teminate either in the left or right lymphatic duct. "The former, some eighteen inches in length, known as the thoracic duct, begins at the confluence of certain lymphatics in the abdomen, passes through the thorax, and terminates in the left imominate vein at the confluence of the left internal jugular and subchavian veins. It receives the lymphatics of both lower extremities, the lymphatics of the abdomen. except those from the convex surface of the liver, the lymphatics from the left half of the thorax, the left half of the head and neck, and the left upler extremity. The right lrmphatic luct is a short vessel a little less than an inch in length. It receives the lymphatics from the convex surface of the liver, the right half of the thorax, the right side of the head and neck, and the right upper extremity. It ends in the right immominate rein at the confluence of the right intemal jugular and subclivian reins.

The thoracie duct, or left lymphatic duct, is described with the Lrmphatics of THE Thorax; the right lymphatic duct with the Lruphatics of the Head ANd Neck.

\section{THE LYUPHATICS OF THE HEAD AND NEC'}

The lymphatics of the head and neck are lividerl into the superficial and the deep. The superficial roughly follow the course of the sulperficial reins. Streaming down the scalp and face, they entre the neck through corresponding groups of superficial glands, and then converge to join the superficial corvical chain and in part the deep cervieal chain of glands which are situated along the course of the external and internal jugular veins respectively. The deep lymphaties of the head and neck follow roughly the course of the deep arteries. They include the lrmphatics from the interior of the craninm; from the orbit; from the interior of the nose and mouth; from the tongue; from the pharrnx, laryx, and mpler part of the trachea and osophagus, and from the thyord gland. After passing through certain glands in their comrse, they terminate ehiefly in the deep corvinal

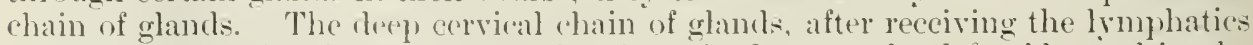
from the superficial chain, ends in the thoracic duct on the left side, and in the right lymplatic duct on the right side. 


\section{THE SLPERFICIAL I YMPIITTC IESSELS AND GLANDS OF THE HEAD AND NECK}

\section{A. The siperfictal Lymphatic Vessels}

The superficial lymphatic vessels may be subdivided into the superficial lymphatics of the scalp, the fice, and the neck (fig. 39s).

1. The superficial lymphatic vessels of the scalp follow roughly the course of the superficial veins. Thus there is (1) a posterior or occipital set, which course downwards over the occipital bone to the occipital, or suboceipital glands as they are sometimes called; (2) a posteru-lateral or josterior aurieular set, which course downards behind the arar, and end in the posterior auricular or sterno-mastoid glands; (3) an antero-lateral or temporal set, which accompany the superficial tempral vein in front of the ear, and end in the parotid lymphatic glands; and (4) an anterior or frontal set, which course dornwards over the frontal bone and end in the facial lymphatics.

2. The superficial lymphatic vessels of the face-continuous at the root of the nose with the frontal set of lymphaties descending from the scalp-course downwards and backwards with the facial vein, receiving tributaries from the inner half of the eyelicls, the side of the nose, the contiguous portions of the cheek, and the upper and lower lips. They end in the submaxillary lymphatic glands beneath the lower jaw. The lymphatics from the outer part of the evelicls and the outer part of the cheek run backwards and slightly downwards to the parotid lymphatic glands.

3. The superficial lymphatic vessels of the neck form a plexus in the sul,cutanens tissues of the neck. They communicate with the superficial lrmphaties of the scalp and face, and with some of the superficial lymphatics of the upper part of the thorax. They end in the superficial cervical chain of lymphatic glands.

\section{B. The sepenficial Limphatic Glatios}

The superficial lymphatic glands of the head and neck may be divided into two scts, a trinsverse and a vertical (fig. 39S).

1. The transverse occur in groups in the course of a line drawn from the ceciput to the mastoid process, and thence along the zyoma and beneath the body of the lower jaw to the symphysis. They receive as afferent vessels the lymphatios of the sealp and face. Their efferent vessels pass into the superficial and deep (ervieal rhains.

They are named:-(1) The occipital, or suboceipital; (2) the posterior auricular, or stemo-mastoid; (3) the parotid; (4) the buceal; and (5) the submaxillary.

(1) The occipital or suboccipital glands are situated at the hack of the head. beneath the skin, just below the superior eurved line of the occipital bone and orer the insertion of the complexus muscle. They receive the lymplatic rescols from the back of the head. Their efferent vessek discharge into the superficial lymplatic

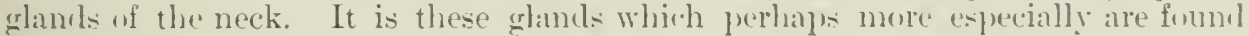
enlarged in secondary sryhilis.

(2) The posterior auricular or sterno-mastoid glands, situater orel the insertion of the sterno-mastoid muscle lehind the ar, receive the posterior anricular lymphatics. Their efferent rescels discharge into the sulerficial corvical lymphlatices.

(3) The parotid lymphatic glands are situater just in front of the war wer the parotid salivary gland, in the sulstance of which one or more are emherfled. They receive the temporal set of lymphatic ressels. and the lymphatios from the external parts of the eyelid and pusterior and greater part of the cheek. They discharge, partly into the submaxillary grands, and partly into the superficial cervical chain.

(4) The buccal lymphatic glands are situated on the surface of the buecinatror. 
Some of the facial lymphaties pass through these on their way to the submaxillary glands.

(5) The submaxillary lymphatic glands are situated in the ligastric triangle, bencath the body of the lower jaw. They vary from eight to twelve in number. They receive some of the Irmphatics from the face, i.e. from the upler and lower lips and side of the nose; the lymphaties from the floor of the mouth, from the front part of the tongue, and from the sublingual and subnaxillary salivary glands, and the anterior efferent vessels from the parotid lymphatic glands. Their efferent ressels terminate partly in the deep, and partly in the superficial cervical lymphatic glamels. Two or three glamds situater in the middle line luetween the anterior bellies

Fig. 398. - Tile Superficial Lyuphatics of the Scalp, Face, Axn Neck. (Walsham.)

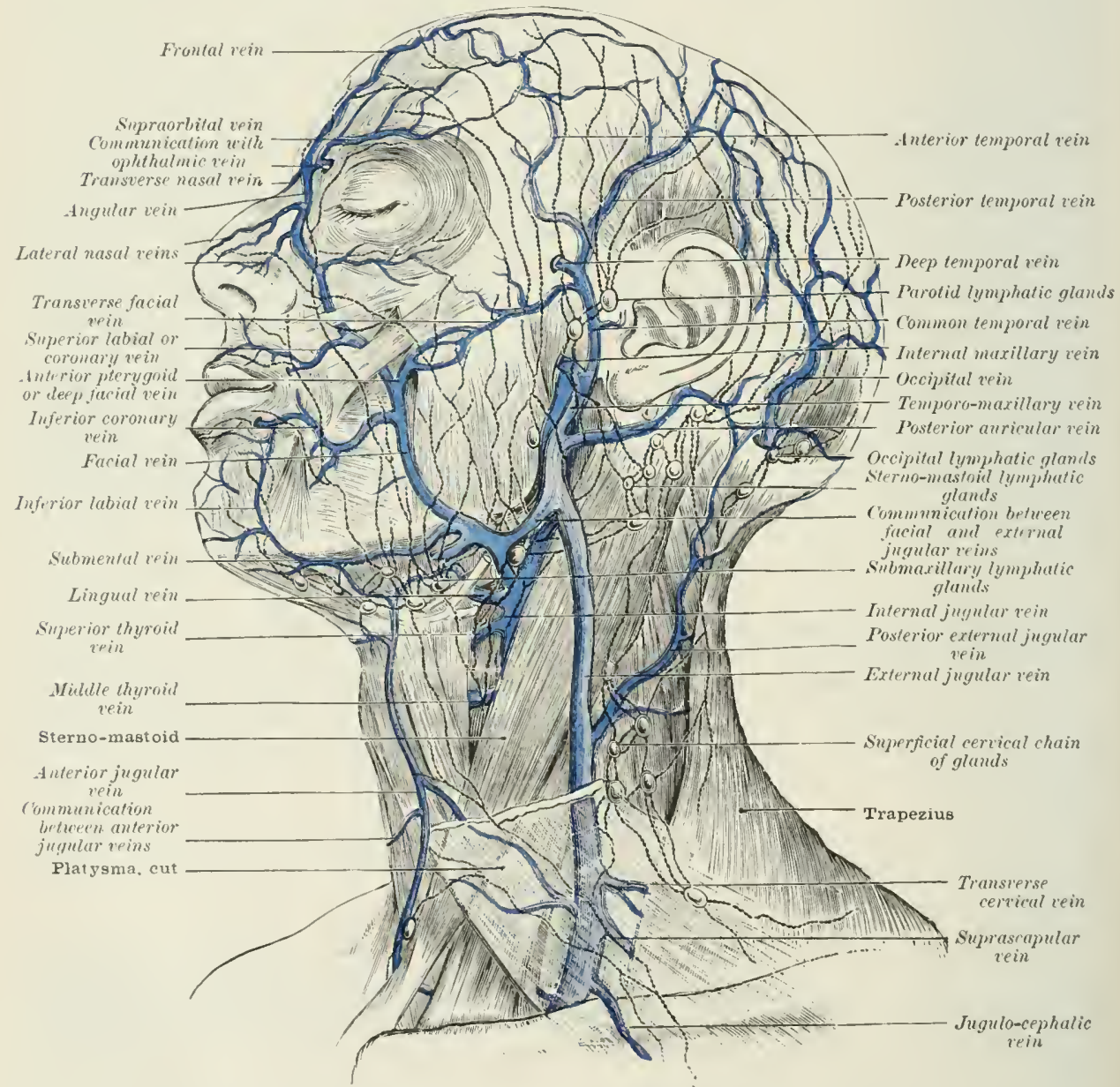

of the digastric museles are sometimes distinguished as the suprahyoid lymphatic glands.

2. The vertical set of superficial glands of the neck - four to six in number, known as the superficial cervical chain-are situated chicfly in the posterior triangle of the neck, along the course of the external jugnlar vein, between the platrsma and the deep fascia. Small superficial glands are also fomd in the front of the neck between the hyoid lone and the sternum, and posteriorly over the trapezins musce. The superficial cervical glands recejve the vesseds from the orcipital glands, and frons the posterior auricular glands, and part of those from the parotid and submaxillary glands. They also receive the lymphatics from the 
integuments of the neek and from the external ear. Thrir efferent vessels open into the deep chain of ecrical glands.

\section{THE DEEP LYUPHATIC I'ESSELS AND GLANDS OF THE HEAI) AND NEC'K}

\section{A. The Deep Lymphatic lessels of the Head and Neck}

The deep lymphatic vessels of the head and neck may be divided into the lymphaties of the cranium, the orbit, the temporal and zygomatic fossa, the nose, the mouth and tongue, the pharynx, the larynx, the upuer part of the cesophagus and trachea, and the thyroid body. They roughly follow the course of the deep arteries, and terminate in the deep cervical chain of lymphatie glands which accompany the common carotid artery and internal jugular voin.

1. The lymphatics from the interior of the cranium are divided into the

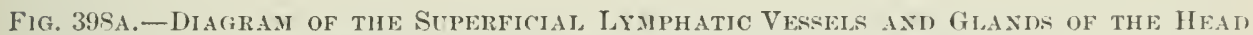
A NI) Nerk. (After Irawing hy Dr. Francis R. Sherwood.)

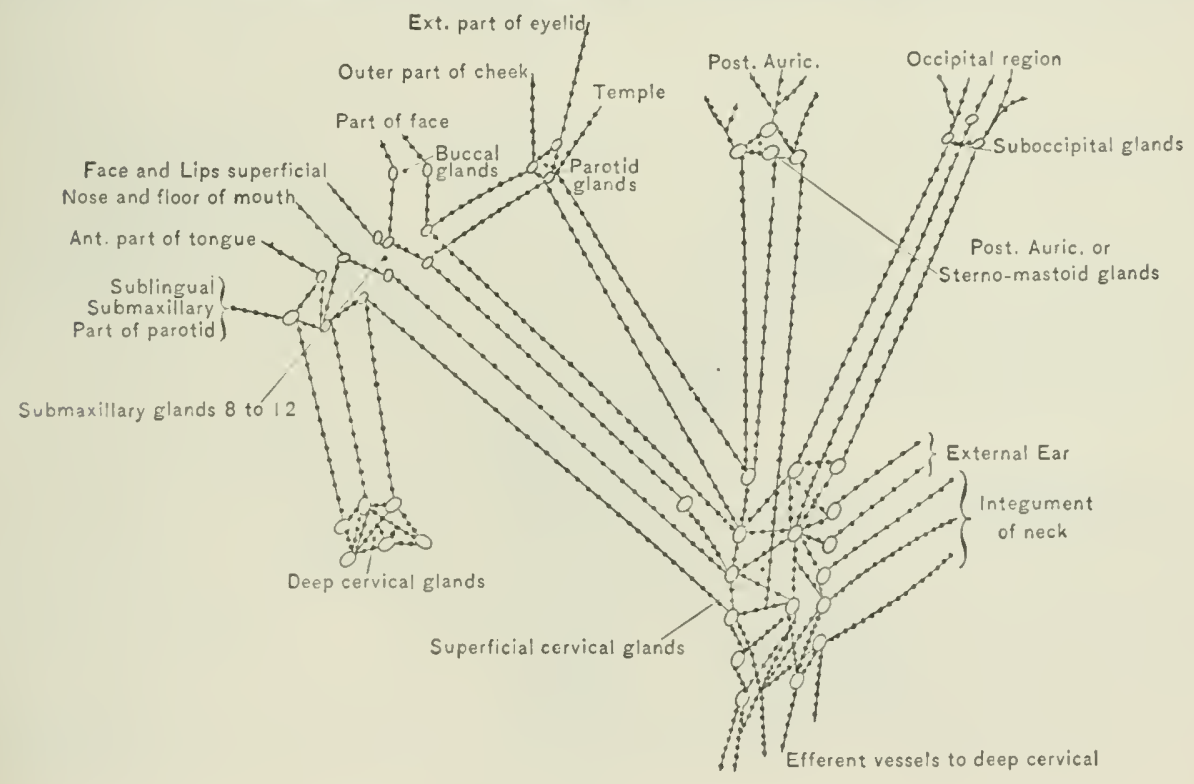

meningeal and the cerebral. The meningeal aceompany the meningeal arteries through the various foramina in the base of the skull, and terminate in the deep ecrvical chain. The cerebral lymphatics pass in like manner with the eerebral vessels (the internal earoticl and vertebral arteries, and the internal jugular rein). through the eorresponding foramina in the base of the skull, and join the decep lymphatic ehain. The origin of the eerebral lymphaties and the lymphaties from

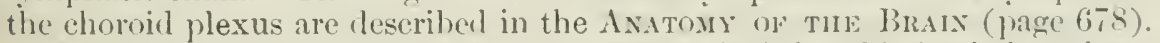

2 . The lymphatics of the orbit pass with the infarorbital vein into the shemomaxillary fossa, and thence with the intemal maxillary vein into the internal maxillary and deep parotid grands. (For deseription of the lymplatios of the eyeball, see page 852 .)

3. The lymphatics from the temporal and zygomatic fossæ run with the arteries in these situations, and, after passing through the internal maxillary glinds, join the deep cerrical chain.

4. The lymphatics from the interior of the nose acompany the artric's supplying that eavity, and terminate, in lart in the lymplatics of the pharyen, lout chiefly in the deep cervieal chain. They communicate, through the lymphatic 
spaces which surround the olfactory nerres, with the subdural and subarachnoid lymph-spaces of the cranium.

5. The lymphatics of the mouth and tongue.-The lymphaties from the floor of the mouth pass through the mylo-hyoid muscle into the submaxillary lymphatic glands. The lymphatics of the lips jass with the superfieial lymphaties, partly into the submaxillary glands, and partly into the deep cervical chain. The lymphatics of the deep surface of the cheek and of the roof of the mouth join the intemal maxillary lymphatic glands. The lymphaties of the tongue run backwards with the ranine rein, and, after passing through several small lingual glands on the hyo-ylossus muscle, join the deep cervical chain. The lymphatics of the front part of the tongue pass with the lymphatics of the floor of the mouth, through the mylo-hyoidean muscles into the submaxillary glands.

6. The lymphatics of the pharynx run along the course of the pharyngeal arteries and enter the upper set of cleep cervical glands. Those from the upper part of the pharyx pass through the post-pharyngeal gland. The lymphatics of the tonsil open into the submaxillary glands near the angle of the jaw.

Fig. 393B,-Diagrair of the Defp Lymphatic Vessels and Glands of tile HeAD AND Neck. (After Drawing by Dr. Francis R. Sherwood.)

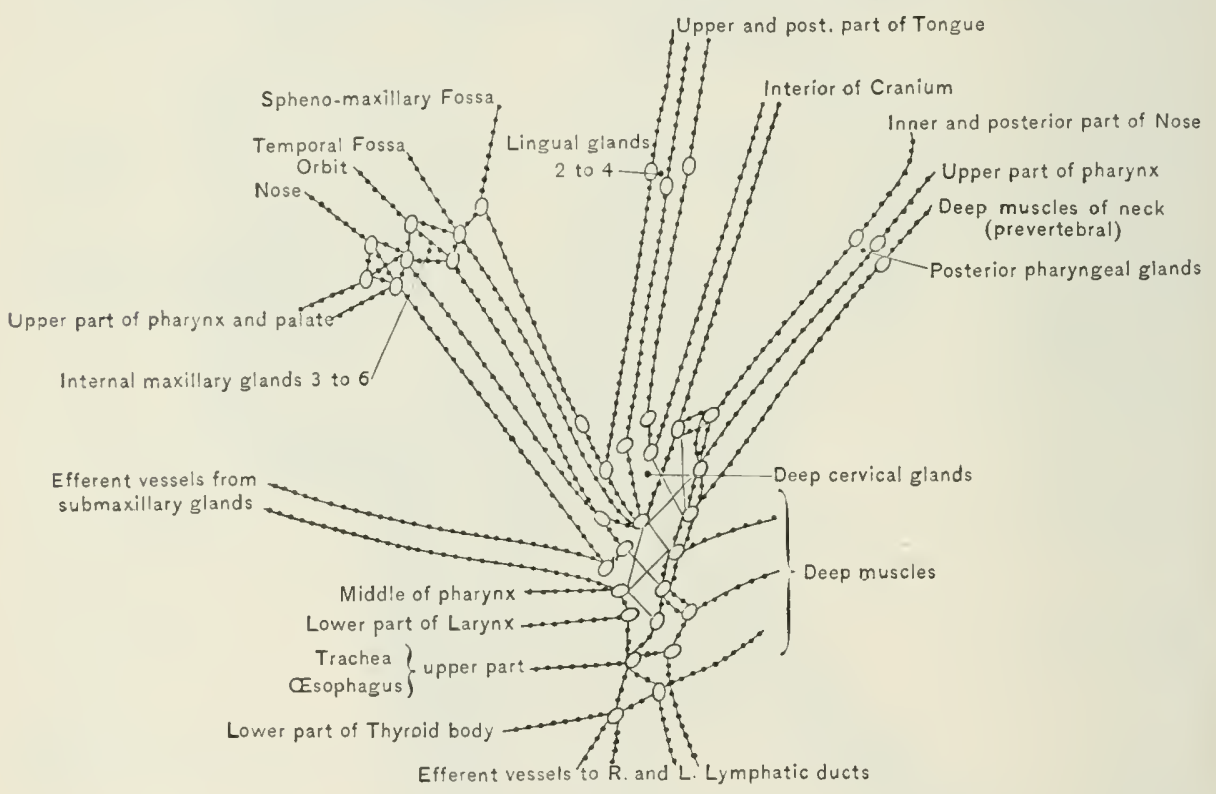

7. The lymphatics of the larynx join the deep cervical glands. Those above the glottis pierce the thyro-hyoid membrane, and end in the upper set of the deep cervical glands; those below the glottis perforate the crico-thyroid membrane, and, after passing through one or more small laryngeal glands at the lower part of the larynx on its anterior or lateral aspect, enter the lower set of the deep cervical glands.

8. The lymphatics of the upper part of the œsophagus and trachea join the lower glands of the deep cervical chain.

9. The lymphatics of the thyroid body aecompany the thrroirl arteries, and end in part in the upuer and in part in the lower glands of the deep cervical chain.

\section{B. The Deep I ymphatic Glands of the Head and Neck}

1. The deep lymphatic glands of the head are few in number. They are the lingual, the internal maxillary, and the post-pharyngeal.

(1) The lingual, two to four in number, are situated on the outer surface of 
the hyo-glossus and genio-hyo-glossus muscles. They reecive lymphatios from the upler surface and posterior part of the sulstanes of the tongue. Their efferent vessels terminate in the superior glands of the teap cervical chain.

(2) 'The internal maxillary or deep facial glands, three to six in number, are situated hy the side of the pharymx immerliately behind the luxcenator musede. They receive the lymphaties foril the orhit, the nose, the temporal and spluenomaxillary fossae, the upler jaw, the palate, and the pharynx. Their efferent vessels join the superior glands of the dere cervieal chain.

(3) The post-pharyngeal gland is situated behind the pharynx on the rectus eapitis antieus major near the base of the skull. It receives lymphaties from the upper part of the pharynx, from the nose, and from the dere prevertebral muscles.

2. The deep lymphatic glands of the neck are divided into the upper and the lower.

The upper set extend along the course of the internal jugular vein from the base of the skull to about the lovel of the thyroid cartilage. Ther receive the lymphaties from the interior of the cranium above; the lymplatics from the deep nimseles of the upper part of the neck behind; and the lymphaties from the internal maxillary glands, the posterior half of the tongue, the middle portion of the pharynx, the upper part of the larynx, the upper part of the throid hody, and some of the efferent ressels from the submaxillary lrmphatic glands in front and intemally. Their efferent ressels pass downwaids to the lower deep cervical glancls.

The lower deep cervical glands follow the course of the internal jugular vein from the throoid artilage to near the clavicle. Ther receive the lymplatics from the lower jart of the neck, the efferent vessels from the superior set of doep cervical glands, the lymphatice from the lower part of the larynx, the lower part of the throid looty, the uplere part of the trachea and osoplagus, and the efferent ressels from the superficial cervieal glands. Their efferent vessels end in the jugular lrmphatic trunk, which unites with the suliclavian lymphatic trunk, on the right sille to form the right lrmphatic duct, and on the left side to and in the thoracie duct. The right jugular trunk may also receive the lymphatics coming from the riglit half of the superior and anterior mediastina.

The right lymphatic duct.-The right lymphatic duct is a short resiol from half to threesuarters of an inch long. It receives the lymphatics from the right side of the hear and neck, from the right upler extremity, most of the lymphaties from the right sisle of the thorax, the right lung and pleura and form the right side of the heart and part of the lymphatics from the convex surface of the liver. It passes clownwards and inwards from its formation al the uniom of the subelavian and jugnlar lymphatic trunks, and ends at the confluence of the right internal jugular and subclavian veins. Its entrance is guarderl by a double valve.

\section{THE LYMPHATRS OF THE LPPER ESTREMTY}

The lymphatics of the upper extremity-omsinting of luth lymplative ves-

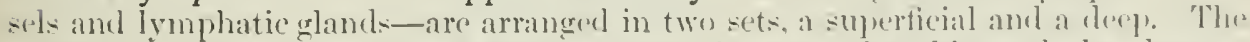

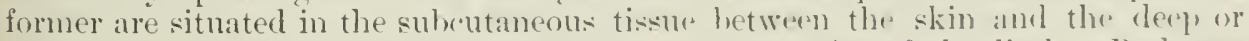
muscular fascia, the latter along the comse of the arteries of the limb. Both sets convere as they approach the axilla, and unite in the axillary glanels. The efferent ressels of these glands form one or more trunks, which ojem. on the left side, into the thoracic luet, and, on the right side. into the right lymplatic duct. 


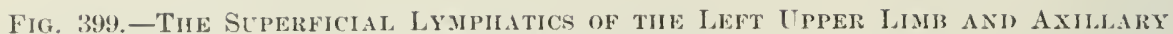
Gisxis. (Walshim.)

Pectoralis major, hooked up

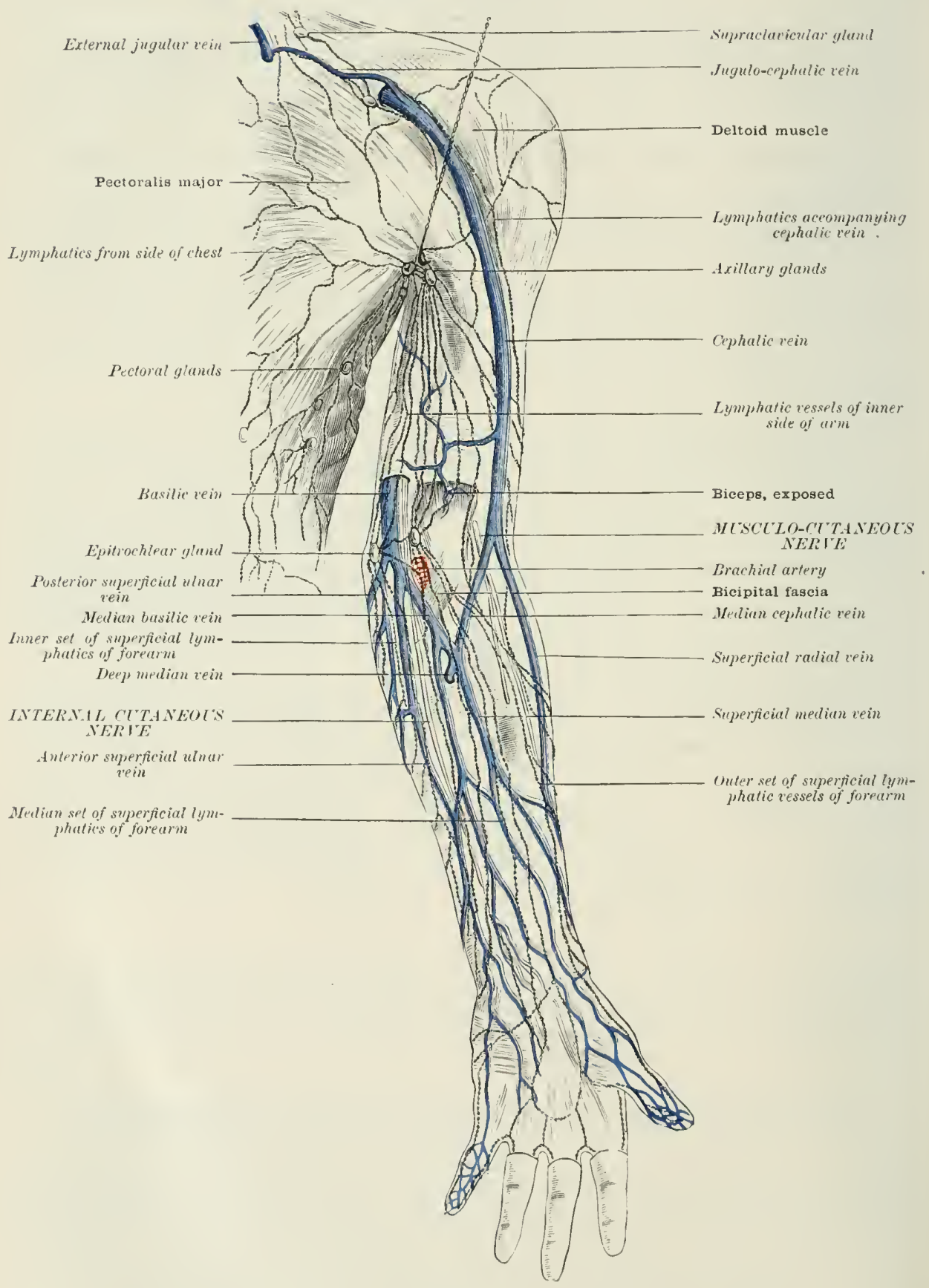




\section{THE SLPERFICIAL LYMPHATIC VESSELS AND GLANDS OF TIIE LPPER EXTREMIITY}

1. The superficial lymphatic vessels begin around the matrix of the nail and in the pulp of the finerer. 'Thener they run upwarks, in the form of fourmain channels, along the side of the finger-two on the dorsil and two on the palnar asisecet.

The palmar set end on the convexity of a lymphatie pahmar are. From the areh, lymplnatic vessels rm up) the forearm, more or less in two sets-an outer anel an inner-roughly following the course of the superficial veins; a third or median set, starting as a plexiform arrangement in front of the wrist, runs up between the other two. The communication, however, between the theremain sets of vessels is so flee that, when they are minutely injected, the front of the foream alppears covered with a dense plexus of lymplostics (fig. 3!99).

The dorsal set of digital lymphaties ends in a plexus on the back of the hand. From this plexus numerous lymphatic ressels stream up the back of the forearm, ancl, winding round the inner and onter borders respectively of the limb, join the lymplaties on the anterior aspect.

From the bend of the elbow the lympluatics run up the arm, the greater number following the course of the basilic vein, and, dipping beneath the pectoratis major, converge to end in the axillary ghands. The lymphatics from the outer side of the arm run in chief part obliquely across the biceps, towark the axilla; but a few accompany the cephalic vein to the infraclavicular lymphatic glands. The lymphaticsover the deltoid also manly end in these glands.

2. The superficial lymphatic glands are few in number. There are none, as a rule, below the bend of the elbow. Oceasionally there is one at the hend of the ellow, and eonstantly two or three are found alowe the internal condyle (epitrochlear glands), in the course of the lymphatie ressels running with the hasilie rein.

\section{TIE DEEP LYMPHATIC TESSELS AND GLANDS OF THE LPPER ETTREIITT'}

1. The deep lymphatic vessels accompany the arteries of the upper extremity. Hence in the forearm they are found along the course of the radial, the ulnar, the anterior interosseons, and the posterior interosseons arteries. At the bend of the ethow they converge, and follow the andur of the brachial and axillary arteries to the axilla, and there end, together with the superficial lympluaties of the upler extremity and the superficial lymphaties from the side of the chest and hack of the shoulder, in the axillary lymphatic glands. They communicate with the superficial lymphaties at the wrist.

2. The deep lymphatic glands. - i few small ghands are oceasionally found in the course of the lympluatie ressels acemmpanging the arteries of the forearm, and, more often, a few in the course of those acromplanying the hraldial antery. But the first important set of deep glands is met with in the axillal.

The axillary glands are mumerous and of large size. They are ahout twelve

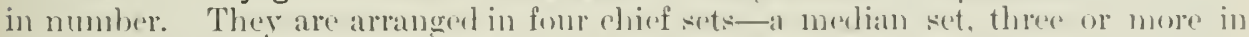
number, situated along the eourse of the axillary alrtery and rein (axillary glands proper); an imner or anterior set, four or five in mumber, situated helow the greater pretoral museles in the course of the lomer thorate artery, on the outere surfice of the serratus magnus (pectoral glands); a posterior or ixtermal set, us:lally two in

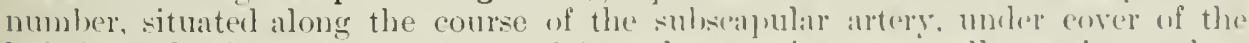
latissimus dorsi (subscapular glands); and a sluperior sot, lisually two in number.

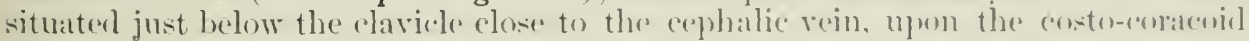
membrane in the fossa leneath the pectoralis major and deltoirl (subclavian or infraclavicular glands).

The axillary glands projer, or the grlands aloug the course of the axillary artery and vein, receive the latger number of lymphatics from the amm. The jectoral 
glands receive the lymphatics from the mammary gland, the side of the chest, and the integument of the upper portion of the abdominal wall. The subscapular glands receive the lymphatics from the integuments of the back. The infraclavicular glands receive the lymphatics from the outer part of the arm and integuments covering the deltoid. They communicate, above with the cervical lympluatics, and below with the other glands in the axilla. The efferent ressels from ail these whands run upwards along the subclavian vein, and enter the neek either as four distinct trunks, or as a single trunk (the axillary lymphatic trunk), and terminate on the left sicle in the thoracie duct, and on the right side in the right lymphatic duet.

The communication between the glands in the axilla is very free. Thus, in secondary infiltration following carcinoma of the hreast, although the pectoral glands may at first be alone affected, the remaining sets generally become also involved.

\section{THE LYIPHATICS OF THE THORAX}

The lymphatics of the thorax may be divided into the parietal, which ramify in the thoracic walls; and the riseeral, which receive the lymph from the thoracie viscera. The thoracic luct, which convers the lymph from the lower extremities and from the greater yart of the abdomen, passes through the posterior mediastinum on it: way to the confluence of the left internal jugular and subclavian veins at the root of the neck, and is described here with the lymphatics of the thorax.

\section{THE PARIETAL LYIPHATIC TESSELS AND GLANDS OF THE THORAT}

1. The parietal lymphatic vessels are divided into the superficial and the (leter).

The superficial parietal lymphatics ramify beneath the integuments, over the pectoralis major in front, the serratus magnus laterally, and the trapezius and latissimus dorsi hehind. Ther all converge towards the axilla, and end in the axillary glands. The lymphatics of the mammary gland end for the most part in the pectoral set of the axillary glands, but those from the inner portion of the gland pass through the second, third, and fourth intercostal spaces into the internal mammary lymphatic chain of glands, and thus open into the thoracie duet on the left, and the right lymphatic duct on the right side. Aceording to Macalister, the lymphatics from the nipple and areola pass more deeply into the axilla, and end in one of the axillary glands, placed nearer to the clavicle than the pectoral set.

The deep parietal lymphatics are subdivided into (1) the intercostal and (2) the diaphragmatic.

(1) The intercostal lymphatics accompany the intercostal arteries and receive the lrmph from the intereostal museles and the parietal pleura. Those in the anterior part of the intereostal space run forwards and end in the internal mammary or anterior intereostal Jymphatie glands. Those in the posterior part of the space run backwards, and-after receiving the dorsal Irmphatic ressels which accompany the dorsal branches of the intercostal arteries between the transwerse processes of the vertehre, and return the lymph from the muscles of the back and from the spinal canal-end in the intercostal or posterior interestal lymplatic glands.

(2) The diaphragmatic lymphatics follow the vessels of the diaphragm. They terminate, anteriorly in the internal mammary and anterior mediastinal lymphatic glands; postero-laterally in the lower intereostal lymphaties and in the lymphaties accompanying the museulo-phrenic artery; and posteriorly in the pos- 
teriol mediastinal glands. The lymphaties from the vertebral portion of the diaphragm end in the lumbar glands (see Lrimpiates of ABnomex, page 661). Some of the lymphaties from the right side join the hepatic lymphatic's. de(l).

2. The parietal lymphatic glands are also divided into the superficial and the

The superficial parietal glands.-The three or four glands along the lower border of the pectoralis major, deseribed here as the pectural set of the axillary glands, are by some anthors classed as superficial thoracic glands. They receive the lymphaties from the front of the chest, and some of the lymphatic's of the mammary gland. There is also occasionally a superficial gland a little below the ensiform cartilage called the epigastric gland. It receives, when present, some of the lymphatics from the lower anterior chest walls and upper part of the abdomen.

The deep parietal glands are:-(1) The internal manmary, sternal, or anterior intercostal; and (2) the intercostal or posterior intereostal.

(1) The internal mammary, sternal, or anterior intercostal glands lie along the course of the internal mammary artery behind the costal cartilages of the true

Frg. 399A.-Diafrail of tile Superfictal and Deep Lymphatic Vessels axd Gilaxis of THE UPPER EXTREMTY IXCLCDING THE SLPERFICIAL LYMPHATIC VESEES OF THE BAC AxD Chest. (After Irawing by Dr. Francis R. Sherwood.)

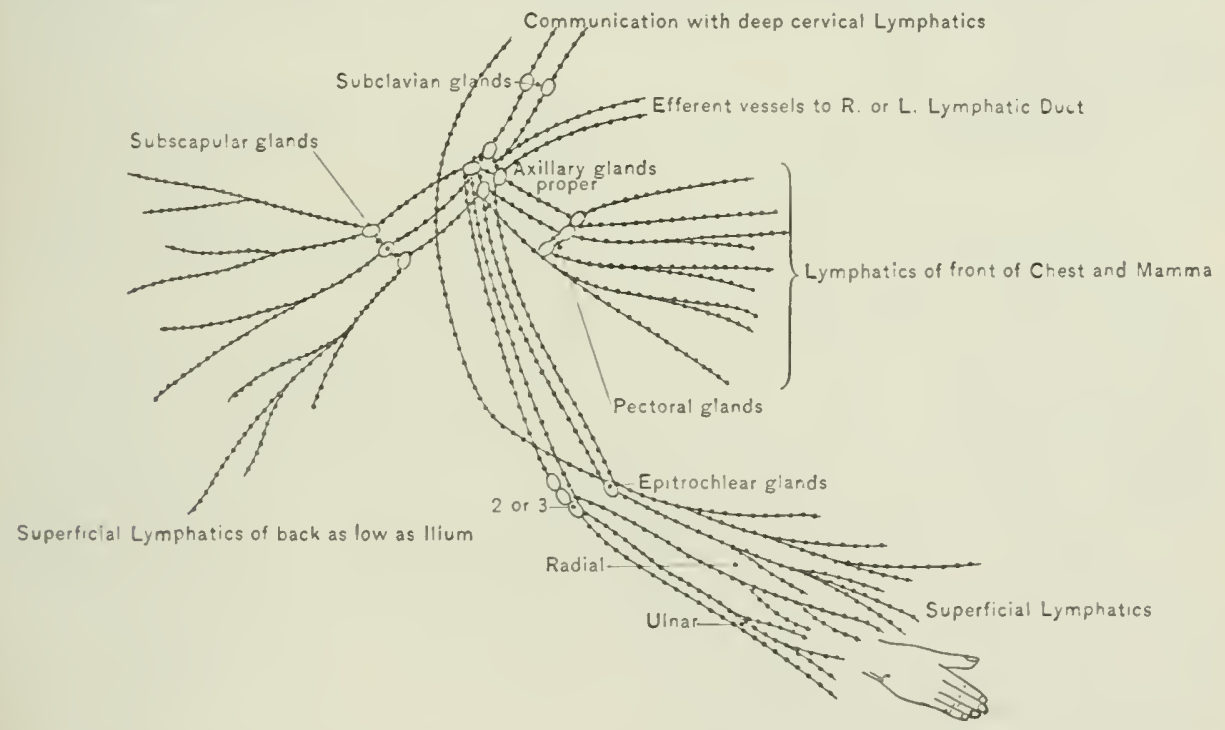

ribs. There is usually one grand corresponding to each interestal space. These glands receive the lympliaties from the anterior part of the intereostal splaces. the lymphatics ascending with the superior epigastric artery from the abrominal walls. the lympluatics acompanying the museulo-phrenic artery from the diaphragm and lower interestal spaces and the lymphaties from the inner portion of the mammary grand. The efferent vessels from the uplermost glands join the thoracie and right lymphatic ducts respectively, but some of the offerent vessels of the lower glands join the anterior mediastinal glands.

(2) The intercostal or posterior intercostal lymphatic glands lie in the ju:terior end of each intereostal space about the level of the hearls of the ribs. They receive the lymphaties accompanying the interestal vesels from the posterior part: of the interostal spaces. and the lymphatics from the dee muscles of the lack, and from the spinal canal. The lowemost also reerive some of the lymphatio from the diaphragm. On the left side their efferent vessels open into the thoracic duct. On the right side the efferent vesicels from the luwer glands also join the therar.ic duct, but the ressels from the upper crlands may join the efferent vessils from the hronchial glands (the bronchio-mediastinal trunk and open into the right lyonphatie duct. 


\section{THE ITSCERAL IYHPHATIC IESSELS AND GLANDS OF THE THORAI}

1. The visceral lymphatics of the thorax include those from the heart and pericardimu, the lungs and visceral pleura, the oxsophagus and the thymus gland, with the ghands into which these lymphaties respetively open-namely, the anterior mediastinal, the supurior mediastinal, the posterior mediastinal, and the bronchial.

The lymphatics of the pericardium end in front in the anterior mediastinal and superior meliastinal glands, and behind in the posterior mediastinal glands.

The lymphatics of the heart hegin at the apex, and follow the coronary vessels to the base, where they leave the pericardium, and mite to form a right and a left trunk. The former passes orer the arch of the aorta, then through one of the superior mediastinal or cardiac glands, and thence backwards to the trachea, on which it runs to join the right lymphatic duct at the root of the neek. The left trunk courses along the pulmonary artery, and, at the bifurcation of that vessel, passes through one of the posterior mediastinal glands behind the arch of the aorti, and thence runs up the left side of the trachea to end in the thoracic duct.

The lymphatics of the visceral pleura and lung fom a superficial set beneath the pleura, and a deep set which accompanies the pulmonary ressels and bronchial tubes. At the root of the lung the superficial join the deep, which then enter the bronchial glands.

The lymphatics of the thoracic portion of the œsophagus begin as a plexus between the mucous membrane and the muscular coat, perforate the latter, and terminate in the posterior mediastinal glands.

The lymphatics of the thymus terminate in the superior mediastinal glands.

2 . The visceral lymphatic glands are the anterior mediastinal, the superior mediatinal, the posterior mediastinal, and the bronchial.

The anterior mediastinal or sternal glands lie in front of the pericardium behind the sternmm in the loose tissue of the anterior mediastinum. They receive the lymplatics from the antero-median portion of the diapluragm, the front of the pericardium and heart, some of the cfferent vessels from the lower internal mammary lymphatic glands, and the lymphatics from the convex surface of the right lolse of the liver. Their efferent ressels pass upwards to the superior mediastinal glands.

The superior mediastinal or cardiac glands lie in front of the upper part of the pericardium, the areh of the aorta, and left immominate rein. They receive the lymphaties from the anterior mediastinal glands, from the upper and front part of the pericardium and right side of the heart, and from the thymus ghand. Their efferent vessels rum up the siles of the trachea to join the thoracie eluct and right lymphatic duct respectively.

The posterior mediastinal glands are situated in the posterior mediastinum along the course of the aorta and asophagus. They receive lymphaties from the back of the pericardium and left side of the heart, from the asophagus, from the posterior part of the diaphragm, and a few from the right borker of the liver. Their efferent ressels pass chicelly into the thoracie duct; a few into the bronchial mimels.

The bronchial glands are placer between the divisions of the bronchi at the root of the lumg (pulmonary glands), and about the bifurcation of the trachea (tracheal glands). The larger glancls, situated at the hifureation of the trachear, are twenty or thirty in number. They receive the lymphatics from the lung and viceral pileura; also some of the lyujulaties from the trachea and from the back of the heart and pericantimm, and a few of the efferent vessels of the posterion mediastinal glamb. Their efferent ressels, with the efferent ressels of the sujerior moliatinal or "alrliac glands, pass up the sides of the trachea, and on the right sisc oither terminate direstly in the right lymphatic duet, or join with the efferent verists of the interenstal glinels to form a common trunk, the broncho-mediastinal trunk, and thus open into the right lymphatic duct. On the left side they open directly into the thoracic duct, or first form, as on the right sicke, a bronchonediastinal trunk. 
In early life they are of a pinkish colour, but as life andrances they herme bluish, and later alnost black, from the degesit of pignent arrestem in them in its passage from the lungs.

\section{THE THORICIC DL'CT}

The thoracic duct begins in the abtomen at the receptaculum chyli opposite the first or second lumbar vertebra, enters the thorax through the ardite olrening of the diaphragm, runs up the porterior mediastimm to the right of thr anta, crosses behind the atortic areh, and, leaving the thorax at the superion opening. ascents on the left side of the neck as high as the serenth relvical rertebrat and, finally curving orer the apex of the left plema and subclavian artery, ends in the confluence of the left internal jugular and subelavian veins.

The duct is about eighteen inches long, and pursues a tortuous course. It conltains many double valves which, when the duet is dilated, cause it to be (o)nstricted at intervals, and give it somewhat the appearance of a string of beals. The valves are more numerous in the upper than in the lower part of the duet. At its entrance into the innominate rein there are two perfect valves, which effectually prevent any regurgitation of lymph or entrance of blood. The ealibre of the duct usually decreases as it ascends through the thorax, but increases again at its upper part. It is least at or ahout the fifth thoracie vertebra. The thoracic duct eonveys the lymph from the lower extremities, the lymph and chyle from the abdomen (exrept some of the lymph from the convex surface of the liver), the lymph from the lett side of the thorax, and some of that from the right side, and the lymple from the left upper extremity and the left sicle of the head and neek.

The relations of the thoracic duct in the aldomen, thethorax, and at the root of the noek, nay be consiclered separately.

1. The abdominal portion of the thoracic duct lies deeply placed helind and hetween the aorta and the right crus of the diaphragm on the front of the boty of the second lumbar vertelisi. This part of the duet is dilated into an irregular, silceulated, and fusiform sae, known as the receptaculum chyli, or cistern of Pecquet. It receives the efferent ressels of the lumbar glands, the intestinil lymphatie trunk, and sometimes some of the hepatic and gastrielrmplatics. It is thin-walled and contains no valves, and is about an inch and a half long ( $38 \mathrm{~mm}$.) and about a quarter of an inch in cliameter at its widest part ( 7 mm. ). As the durt passes through the aortic opening of the diaphragm, it still lies to the right of the aorta, and has the vena azyeses major to its right side.

2. The thoracic portion of the thoracic duct lies at first in the posterior mediastinum between the arorta and the rena axyos major, in front of the siren lower thoracic vertebrac; but at the level of the fifth thoracie vertehra it passes to the left behind the resophagus and antic arch, and enters the superior nediastinmm, whence it excapes thromgh the upler aperture of the thorax into the root of the neck. This portion of the luet is not of epual calihre throughout; as a rule, it icontracted in some places amb dilated at others. The constrictions indicate the situation of the valves.

In the posterior mediastinum it has in front of it, from helow upwards, the

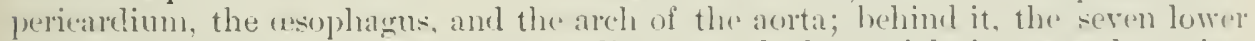
theracie rertabre, the anterior rommon liganent, the lower right interestal arteries. the vena azyoge minor, and at timses one or more of the mid left interental voins. ami the renal axgos tertia. To its left is the thoracie aorta, amb to its right the rena aygos major and the right plema. In the superior mediastinum it aseends.

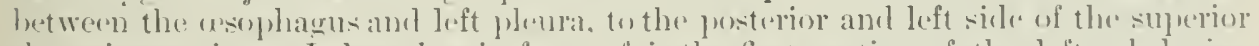
theracic opening. It here has in fromt of it the first portion of the left suldelavian

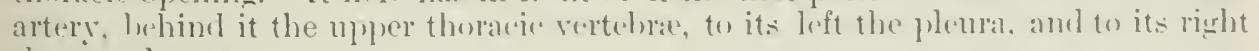
the trimphatgus.

Opening into the thorarie portion of the duct are:-the lymphaties from the.

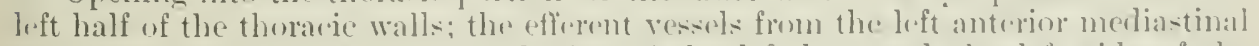
and interesstal glands; the lymplaties of the left lung and the left sille of the leart; the lymphaties of the tratheal amel exenphages. and the right lower intermal mammary lymphaties. 
3 . The cervical portion of the thoracic duct ascends as high as the level of the seventh cervical vertelin, and then eurves, downmards and forwards, over the apex of the pleura in front of the subclavian artery, scalenus anticus muscle, and rertehal rein, behind the left intemal jugular vein, and behind and subsequently external to the left common carotid artery, and, having received the left jugular lymphatic trunk, opens into the left innominate vein at the confluenee of the internal jugular and subchiam veins. The cervical portion receives the lymplatics from the left mpper extremity and left side of the head and neck.

The chief variations in the thoracic duct.-(1) The thoracic duct may be double; when this is the case, the left duct may end normally in the left innominate vein, and the right in the corresponding situation on the right sile; or the two ducts may unite at the root of the neck, and open into the left innominate vein. (2) The reduplication may be incomplete. 'Thus : (a) The duct nlay at first be single, but divide into two seprarate ressels at a variable distance from its termination, and then (i) one branch of the duct may enter the left confluence of reins at the root of the neek: the other the right confluence, a normal condition in some animals; or one may enter the confluence of veins in the normal manner, the other either the subclaviau or internal jugular vein ; or (ii) the two branches may reunite--this is a frequent variety, and is regarded as a normal condition by some anatomists. (b) It may break up into several branches in its course through the thorix, forming a plexus of ressels, which subsequently reunite into a single duct. (3) The thoracic duct may lie altogether to the left side of the aorta, and terminate as normal. (4) The duct may open into the eonfluence of the subclarian and internal jugular veins on the right side, an abnormal arrangement which may oecur under the following conditions :(a) when the viscera are transposed; $(b)$ when there is a right aortic arch without transposition of viscera; and $(c)$ when the ressels and viscera are normal. (5) The duct may end in the vena azygos major.

\section{THE L YIPHATICS OF THE ABDOMEN AND PELIIS}

The lymphatics of the abdomen and pelvis may be divided into the parietal, which ramify in the abdominal and pelvic walls; and the visceral, which receive the lymph from the pelvic viscera, and the lymph and chyle from the abdominal viscera.

\section{THE PARIETAL LYMPHATIC IESSELS AND GLANDS OF THE ABDOMEN AND PELITS}

1. The parietal lymphatic vessels may be sululivided into the superficial, which ramify bencath the skin in the subcutaneous tissue, and include the lymplatics of the skin of the penis and scrotum and of the external grenital organs in the female; and into the deep, which accompany the deep arteries of the abchminal and pelvic walls. The former for the most part end in the superficial inguinal glands; the latter in the lumbar glands.

(1) The superficial parietal lymphatics. - The superficial parictal limplatics of the abdominal walls are situated between the skin and the abdominal muscles. Those from the front of the ablomen, below the level of the mmbilicus, pass downwarks along the course of the superficial epigastric artery and reins, and end in the superficial inguinal glands. The lymphatics from the upper frart of the front of the ahdomen, above the level of the umbilicus, pass upwards and outwards with the lymphatics from the front and sicle of the chest to the axillary glands. The lymphatics from the lateral abdominal walls rum, in part over the crest of the ilium, in the course of the superficial circumflex iliac artery and veins, into the nuter superfieial inguinal glands, and in part follow the course of the lumbar and ilio-lumbar arteries, and, after perforating the abdominal muscles, end in the lateral lunbar glands. The superficial lymphatics from the lower part of the back and from the gluteal region for the most part pass outwards over the gluteal muscles to end in the outermost superficial inguinal glands; but those from the region of 
the anus follow the course of the perinual lymphatics through the fork to the immermost superficial inguinal glands.

'The superficial lymphatics of the penis begin in the prepuce, and thence pass backwards to the coronal glandis, where they form a ring around the glans. This ring receives the superficial lymphatics from the grans, and the lymphatics from the anterior two-thirds of the urethra which run from behind forwirds. From the glans three main lymphatic chamels run backwards under the integunents of the penis, one on the dorsum, and one on each side of the organ. At the root of the penis the dorsal lymphatic ressel divides into a right and a loft luanch, wach branch passing with the lateral lymphatic ressel of the corresponding side to the superficial inguinal glands. The deep lymphatics of the penis pass with the dor:al rein into the pelvis, where they join the lymphatic glands ahout the internal iliae artery

The lymphatics of the scrotum in the male, and of the parts corresponding thereto in the female, and the lymplotice of the other extemal generative organs in the female, rum with the suporficial extemal pudie arteries to the superficial inguinal glands. It will be-noted that the lymphatics of the testicle pass with the spermatic artery to the lumbar glands.

The superficial lymphatics of the perinæum run upwards over the adductor muscles, through the fork between the thighs, and join the superficial inguinal glamkls.

() The deep parietal lymphatics.-Whe deep lymphatics of the anterior and lateral abdominal walls accompany the parictal ressels to the back of the abdomen, where they end in the deep glands. Thus some follow the deep epigastric artery to the external iliac glands; others the deep eircumflex iliac artery also to the extermal iliac glands; and others, again, the ilio-lumbar and lumbar arteries to the lateral lumbar glands. The last are also joined by the lymphaties from the muscles of the back and from the spinal cord. The deep lymphaties from the upper part of the abdoninal wall pass, with the superior epigastric artery, into the thorax, where they end in the internal mammary Iymphatic glands.

The deep lymphatics of the pelvic walls accompany the parietal ressche and hemese are found with the obturator, sciatic, gluteal, pudic, and sacral arteries. 'They end in the glands surrounding the internal iliac artery, and in the sacral glands.

2. The parietal lymphatic glands lie, for the most part, along the back of the ablomen and pelvis, and are known, from their position, as the external iliac, intemal iliac, sacral, lumbar, and cueliac glands.

The external iliac lymphatic glands lie along the course of the external iliae and erommons iliac arteries and veins. They are three to five or more in number. They receive the lymphatics from the inguinal glands and femoral glands, and the drep lymphatic ressels acompanying the deep epigastric and deep eiremmHex iliar: arteries and veins from the antrior and lower abdominal walls. Their efferent ressels join the lumbar glands. They communicate with the internal iliace grlands.

The internal iliac glands are situaterl in the curse of the internal iliac artery and its branches. They vary from nine to twelve or more in number, the laresest being situated at the upper part of the great sciatic foramen. They receire the lymplatics from the muscles of the pelvis and the lymphatice corresponding to the branches of the internal iliac artery. Thus the greater number of the lymplotics from the pelvic viscera, from the deeper parts of the perinsem, and from the hinder and deeper parts of the sorotum or labia majora, the deep lymphatics of the penis and josterior part of the urethra. the deep lymphatics from the wluteal region, and some of the lymphatics from the arlunctrin musles of the mper part of the thigh, join these glands. Their efferent vesorls pass to the lumbar glands.

The sacral glands are situated in the hollow of the sacrum, four or five heing placed in the meso-rectal folds oplosite its jomontory. They recrive the lymphatics from the rectum and the hinder walls of the pelis. Thery join the lumitra glands.

The lumbar glands lie beneath the peritomeum, at the back of the abomom, on the front and sides of the lumbir vertehre. They are usually divided into three gromp. a median and two lateral; but these freely communicate with one another across the aortil and rena cava. 
The median group (aortic lumbar glands) consists of ahout six large glands placed along the abdominal aorta and rena cava. They extend from the hifureation of the dorta to the second lumbar vertelinis.

The median group receive the efferent ressels of the external and internal iliac and sacral grands, the lymphatics aceompanying the suernatio or ovarian vesseds from the testicle or ovarian plexus respectirely, and the lymplaties of the kidners. smprarenal bodies, and hinder portion of the diaphragun. They also receive must of the efferent vessels from the lateral sets. Their efferent vessels commonly mite aliout the level of the second lumbar vertebra to form a risht and a left lumbar lymphatic trunk, which open, with some small ressels from the lateral sets, into the receptaculum chyli. The left lumbar trunk also receives the lymphaties of the descending colon and sigmoid Hexure.

The lateral lumbar glands, transverse lumbar or psoas glands, are situited behind the psoas between the transrerse processes of the lumbar rertelne. They are twenty or thirty in number, and smaller than the glands of the central gromp. The lateral glands receive the lymphatics accompranving the lumbar arteries, the lymphatics from the muscles of the back, the spinal canal, and from the deeper part: of the parietes of the posterior abchminal walls. Their efferent ressels open, in part into the median set, and in part, as separate ressels, into the receptaculum chvli.

The coliac glands, sixteen to twenty in number, are grouped around the coliac axis in front of the aorta. above the origin of the superior nesenteric artery. At the back of the transverse meso-colon they receive the efferent ressels from some of the hepatic glands, the superior gastrie glands, the inferior gastric glands, the splenic and the panereatic glands. Their efferent ressels join the intestinal lymplatic trunk, and open into the receptaculum chyli.

\section{THE VISCERAL LYUPHATIC IESSELS AVD GLANDS OF THE ABDOLEN AWD PELYIS}

The lymphaties of the pelvic and abdominal viscera are considered separately.

1. The lymphatics of the pelvic viscera.-The lymphatics of the bladder pass partly hackwards, beneath the peritonemm, to join the rectal lymphatics, or the lympliatics of the uterus and vagina in the female: and partly forwards, to join the prostatic lymphatics and the lymphatics of the resicula seminales. These anterior sets of lymphatios together with those from the prostate and resicula seminales, pass through the anterior true ligaments of the bladder, in which there is a small sland. into the internal iliac lymphatics.

The lymphatics of the rectum run backwards between the two layers of the mestrectmm, in which there are four or five glands, through the sicral to the lumbar glands. At the lower part of the rectum the lymplatics become continuous with the cutaneous lrmplatic's round the anus, and for this reason disease of the lower part of the howel involves the inguinal glands.

The lymphatics of the uterus, vagina, ovaries, and Fallopian tubes.The superficial lymphaties of the uterus, which lie beneath the peritoneum, pass, trigether with those of the substanee of the fundus and upler prart of the hody of the organ. outwards, in the broad ligament, where they join the lymphaties fiom the ovaries and Fallopian tuhes, and pass ul, with the ovarian ressels, to the lumbar glands. The lymphaties from the lower yart of the boty and from the cervix of the uterus run, together with most of the lymphaties of the vigina, along the course of the utrerine and vaginal vessels, and teminate in the internal iliac grands. The lympluaties from the lower part of the vagina join the superficial inguinal glanels.

The lymphatics of the testicle accompany the spermatic vessels, and terminate in the lumbar grands situated immediatcly bow the ronal arteries. Hence in "arcinoma of the testicle the lumbar glands are those which first become emlarged, the inguinal not leeing affected until the skin of the serotum becomes involved in the disease.

2. The lymphatics of the abdominal viscera are divided into-(1) The 
lymphaties of the stomach; (2) the intestines; (3) the liver; (4) the syluen: (5) the panereas; (6) the kidneys; (7) the ureters; and (s) the suprarenal capsules.

(1) The lymphatics of the stomach begin in the mucous and sulkerous coat. and thence follow the course of the blorel-resels. Thus some rum upwards to the lesser curve of the stomach, others downwards to the greater curve, and others leftwards to the greater ('nd. In this way, three chief sets are formed-the superior gastric, the inferior galstrie, and the left gastric lymphatics. (11) The superior gastric follow the course of the coronary vein along the lesere curvature towards the eardiac end of the stomach, lying between the layers of the lesere omentum. They pass on their way through fire or six small (superior gastric) lymphatic glands. Reaching the cardia, they turn downwards, and, laving been joined by some of

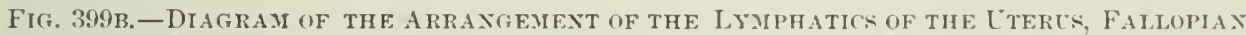

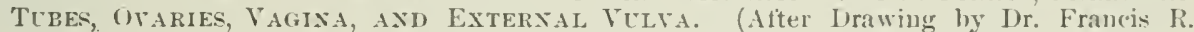
Sherwood.)

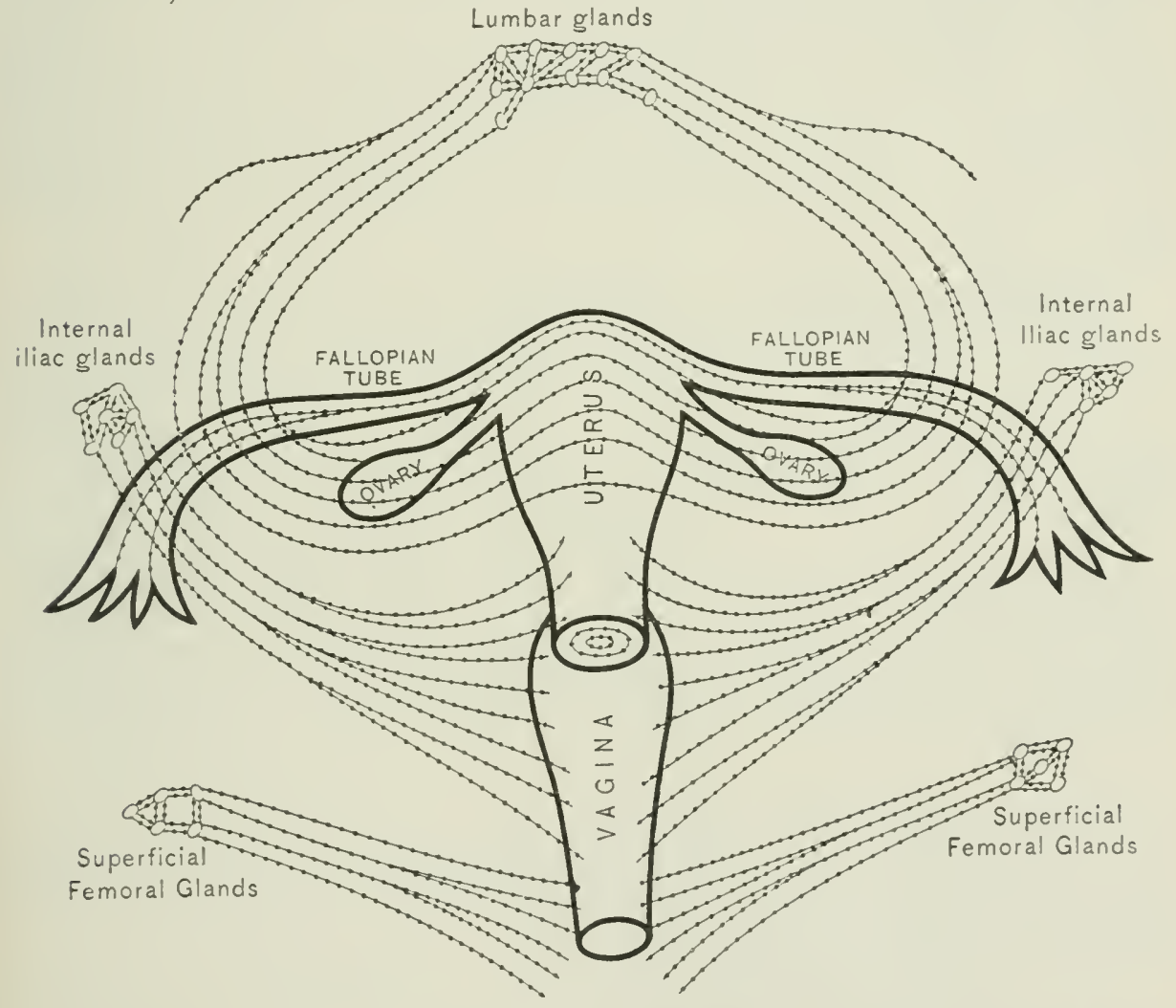

the lymphaties from the left lobe of the liver, enter the upper celiac glands. (b) The inferior gastric lymphatics follow the course of the right gastro-epiploic ressels towards the whorus, along the greater eurvature of the stomach, between the larers of the greater omentum. After pasing through six or eight small glands (inferior gastric), they are joined by the lymphatios from the upper part of the chodenum, and rum between the prorus and panereas to the ereliac glands. (c) The left gastric lymphatics run with the vasa hrevia, between the folds of the gastrosplenic omentum, to the splenic lymphatic glands.

The lymphatic glands of the stomach are the suluerior and inferior gastric glands.

The superior gastric glands, five or six in number. are situated along the lesser curve between the lavers of the gastro-hepatic omentum. They recere the superior gastric lymphaties; their efferent lucts jass first upwarls towarls the 
aesophagus, and then, after receiving the lymphatics from the upuer and left portion of the left lobe of the liver, turn downwards behind the pancreas to join the corliac glimds.

The inferior gastric $\omega^{\circ}$ gastro-epiploic glands, six or eight in number, lie alomg the greater curve of the stomach between the layers of the great omentum. They recove the inferior gastric lymphatics and the lymplatics of the great omentum. Their efferent ressels pass with the lymphatics from the upper part of the duodenum into the coliac glands.

(2) The lymphatic vessels of the intestine are divided into the lymphaties of the small intestine and the lymphatics of the large intestine.

The lymphatics of the small intestine are called the lacteals, because thry "arry the chyle as well as the lymph from the intestinal walls. Beginning party heneath the peritoneal coat-but chiefly in two plexuses, one between the muscular coats, and one beneath the mucous membrane-they pass round the intestine with the blood-ressels to the mesenteric attachment, and thence between the layers of the mescutery to the mesenteric glands.

The lymphatics of the large intestine are disposed of as follows:- $(a)$ Those from the ciecum and ascending colon pass between the laver's of the meso-colon to the meso-colic glands. (b) Those from the transverse colon and upper half of the descenting colon pass with the middle colic artery between the layers of the mesocolom, also to the meso-colic glands. (c) Those from the lower half of the descending colon and sigmoid flexure pass into the left lymphatic trunk of the lumbar glands. The lymphatics of the rectum are deseribed with the lymphatics of the jelvis (page 662 ).

The lymphatic glands of the intestines are the mesenteric and meso-colic.

The mesenteric glands, some one hundred and fifty to two humbled in number. lie between the layers of the mesentery. They are arranged roughly in three set:: (a) A prinary set, about two inches from the intestinal margin of the mesentery, receive the lymphatics from the intestine. The efferent ressels from these glands pass into the next or secondary set. (b) The secondary set are situated about the primary loops of the superior mesenteric artery; they are more numerous than the primary set, and receive the efferent vessels of the latter. Their efferent ressels end in the tertiary set. (c) The tertiary set of glands lie along the course of the trunk of the superior mesenteric artery. They are larger than the secondary set, and closer together. Their efferent vessels mite to form three or four trunks, or perhays more often a single trunk (the intestinal lymphatic trunk) which, after receiving the efferent ressels from the meso-colic glands, opens, either separately, or together with the efferent ducts of the coliac glands, into the receptaculum chyli.

The glands and lacteals of the jejunum are more numerous than those of the ileum.

The meso-colic glands, twenty to thirty in number, are placel between the layers of the meso-colon. They receive the lymphatics from the cacmu, ascending and transwerse colon, and from part of the descending colon. Their efferent ressels join the ufferent ressels from the tertiary set of meschteric glands. and open with them into the receptaculum chyli.

(3) The lymphatics of the liver consist of a superficial and deep set. The former are arranged in a plexus beneath the peritoneal covering; the latter accompany the blockl-vessels in the sulustance of the organ.

(i) The superficial set of lymphatics form groups, and rum in various direetions. Thos on the upper or convex surface of the liver are disposed of as follows:- (i) The lymphatios of the left half of the right lobe, and of the right half of the left lobe, converge towards the falciform ligament, up which they run to the diaphlagme. They then pass through the costo-xiphoid space, and enter the anterior mediastinal chain of glands, and thes open in part into the right lymphatie duct. (ii) The lymphatics on the anterior part of the convex surface pass over the anterior margin, and along the course of the longitulinal fissure to the hepatic glands in the gastro-hepatic omentmm. (iii) The lymplatics along the posterior margin of the liver pass between the layers of the coronary ligament to the diaphragm, which they perforate, and end in small glands alwit the upper part of the vena cava (Quain). (iv) A group from the right half of the right lobe pass out- 
wards and backwards to the right lateral ligament, where they either perforate the diaphragm and end in the anterior mexliastinal glands, or cross its crus and open into the coliac grands or reeeptaculun chyli. (v) $A$ group from the left half of the left lobe pass through the left lateral ligament. and join the asophageal lymphaties at the esophayeal opening of the diaphragm, or pass with the superior gastric lymphatics behind the pancreas to the coeliac glands. Or they may fieree the diaphragm and enter the glands in the anterior mediastinum.

The superficial lymphatics on the under surface of the liver are arranged as follows:-(i) The areater number converge to the transverse fissure, and thence pass with the deep lymphaties to the hepatic glands in the gastro-hepatic omentum; (ii) a group from the back of the right lobe pass to the lumbar glands; (iii) a group) from the back of the left lobe join the esoplatgeal lymphatics or superior gastric lymphaties, and end with them in the coeliac glands; (iv) the lymphatics of the gall-hladder rum with the hepatic artery to the hepatic glands in the gastro-hejatic omentum.

(b) The deep set of lymphatics run, in part with the portal vein, and in part with the hepatic vein. (i) The portal set emerge at the transverse fissure, and pass with the blood-ressels to the hepatic glands in the gastro-hepatic omentun. (ii) 'The hepatic set perforate the diaphragm with the inferior vena cava, and, having passed throthgh some small glands round the uplere part of that vessel, join the superficial lymphatics from the posterior margin of the liver, and with them rum down the thoracic surface of the vertebral portion of the diaphragm to the commencement of the thoracic duct or receptaculum chyli.

The hepatic glands are situated in front of the portal vein between the layers of the gastro-hepatic omentum. They receive the deep portal set of lymphatics. the anterior group of the superficial lymphaties from the convex surface of the liver, most of the superficial lymphaties from the under surface of the liver, and the lymphaties from the gall-biladder. Their efferent vessels proceed to the coeliac glands.

(4) The lymphatics of the spleen.-The splenic lymphatics are arranged in a superficial set which ramify beneath the peritoneal covering; and in a deep sot, which run with the ressels in the parenchyma of the organ. Both sets unite at the hilmm, and terminate in the splenic glands.

The splenic glands, eight to ten in number, are situated in the hilum of the. spleen, and along the course of the splenic artery and rein. They receive thr. superticial and deep lymphaties of the spleen, and the left gastric lymphatics which run with the vasa brevia in the gastro-splenic omentum from the greater end of the stomach. The efferent vessels run behind the peritonemu and pancreas with the splenie artery to the coliae glands. They are joined on the way hy the lymphatics of the pancreas.

(5) The lymphatics of the pancreas consist of a douhle set, a superficial and a deep. They leave the pancreas along with the ressels rorived from the splenic artery, and, joining the lymphatics of the spleen, end in the coliac glands.

(6) The lymphatics of the kidneys ramify, martly on the surface, and partly in the substance of the organ. They unite at the hilum, and run inwards to the central set of lumbar glands, situated immediately in front of the rensal ressels. Ther receive the lymphatics from the suprarenal bodies and from the mper part of the ureters.

( 7 ) The lymphatics of the ureters end chiefly in the renal lymphatics. Those from the lower part join the posterior resical set of lymplutics.

(8) The suprarenal lymphatics leave the suprarenal hodies with the supratremal veins, and join for the most part the renal lymphatios in the hilum of the kidneys. A few pass direct into the central lumbar chain of glands. 
Fig, 400.-The Superficial Lyaphatics of the Left Lower Lini. (Walsham.)

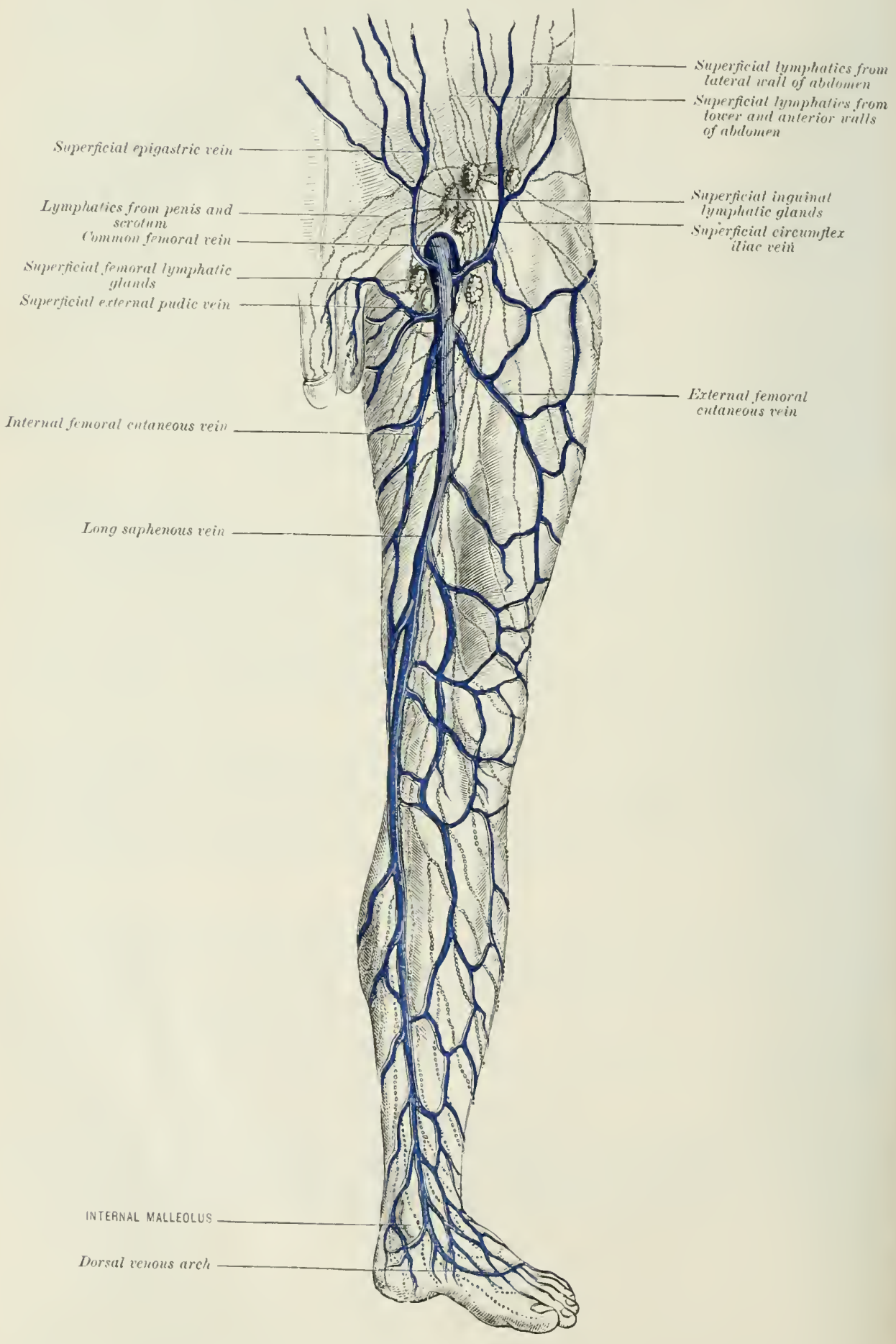




\section{THE LYIPHATICS OF THE LOWER EITREMTY}

The lymphatics of the lower extremity, like those of the upper, may he divided into the superficial and the deep. The former run in the subeutancous tissue with the superfieial veins, the latter along the course of the deep arteris. At the groin the superficial end in the deep, which then pass under Poupart's ligament into the abdomen.

\section{THE SUPERFICIAL LYIPHATIC TESSELS AND GLANDS OF THE LOI'ER EITREIITTY}

The superficial lymphatic vessels follow in chief part the long and short saphenous veins. Passing from the toes to a plexus on the dorsum and sole of the foot respectively, they thence run up the leg, forming two chice sets of lymphatic vessels, an imner and an outer. The inner and larger accompanies the long saphenous vein in front of the ankle, hehind the inner side of the knee, and then up the inner and front part of the thigh to the inguinal glands. The onter set, beginning on the outer side of the foot, run up the outer side of the leg, somm passing round the front of the tibia to end in the inner set below the knee; other passing over the popliteal space to join the inner set higher in the limb; and others, again, perforating the deep fascia along with the short saphenous vein to end in the popliteal glands.

The lymphatics of the gluteal region wind, in part round the inner sicke of the thigh, over the upper portion of the adduetors, to join the immermost inguinal glands; and in part over the erest of the ilium to join the ontermost inguinal glands. On this aceount it is not uneommon to find that an abrasion caused by wearing an ill-fitting truss results in an abscess in the inguinal region.

The superficial lymphatic glands. - There are no superficial glands below the inguinal.

The inguinal glands, six to twelve in number, are situated in the inguinal region. They may be subrlivided into the oblique, or inguinal proper, which are grouped along the course of Poupart's ligament; and the rertical, or femoral, or saphenous, which surround the saphenous opening.

The oblique or inguinal glands proper, which are sitnated on a higher level than the vertical set, receive the lymphatics from the integuments of the penis and scrotum, and the skin of the pudenda and lower part of the vagina in the female. They also receive the lymphaties from the integuments of the lower part of the abdomen, and that covering the prinal and gluteal regions. Their efferent resels in part pass through the saphenous opening, and in part perforate the deep farcia to end in the deep inguinal and, to some extent, in the lumbar glands. It is these superficial inguinal glands which heome enlarged in vencreal disease, in chancres: and epithelioma of the penis and scrotum, or labia in the fomale, and in boils or other sources of irritation about the anus, crluteal region, and perinsemn.

'The vertical set, or saphenous or superficial femoral glands, receive ther superficial lymphatics from the lower limls. They are found enlarged in sores on the heel, malignant clisease of the skin, ete.

\section{THE DEEP LYUPHATIC TESSELS AND GLANDS OF THE LO ITER EXTREMITT}

The deep lymphatic vessels of the lower limb follow the course of the deere arteries and veins. Thus they aceompany the internal and external jlantay arteries in the sole, and the dorsalis pedis artery on the dorsum of the fout. In the leg they are found following the posterior tibial, anterior tihial, and proneal arteries, and, after passing through the lymphatic glands in the popliteal sprace, atecomplany, 
first, the popliteal, and then the foumsal artery up the thigh to the deep inguinal or deep femoral glanrls. Deep lymphatics alsi run with the profunda artery. These also join the deep fenoral lymphatic glanrls. Others accompany the gluteal and ischiatic artery, and end in the lymphatic glands of the same name at the great sciatic foramen.

The deep lymphatic glands of the lower extremity are met with chiefly in the popliteal space and in the inguinal region. One, or sometimes two, small glanels, however, may be found in the upper jart of the front of the leg. lying on the interosseous monibrane along the course of the anterior tibial artery.

The popliteal glands are placed deep in the popliteal space around the popliteal

Fig. 400A. -Diagray of the Superfictal axd Deep Lyyphatic Tessels asd Glasis of TIE LOWER EXTREMTY, IXCLUDING THE SLPERFICIAL LYMPHATICS OF THE FXTERXAL Gexitals and the Lyuphatics of the Gluteal axi) Ischial Regioss. (After Drawing by T)r. Francis li. sherworl.)

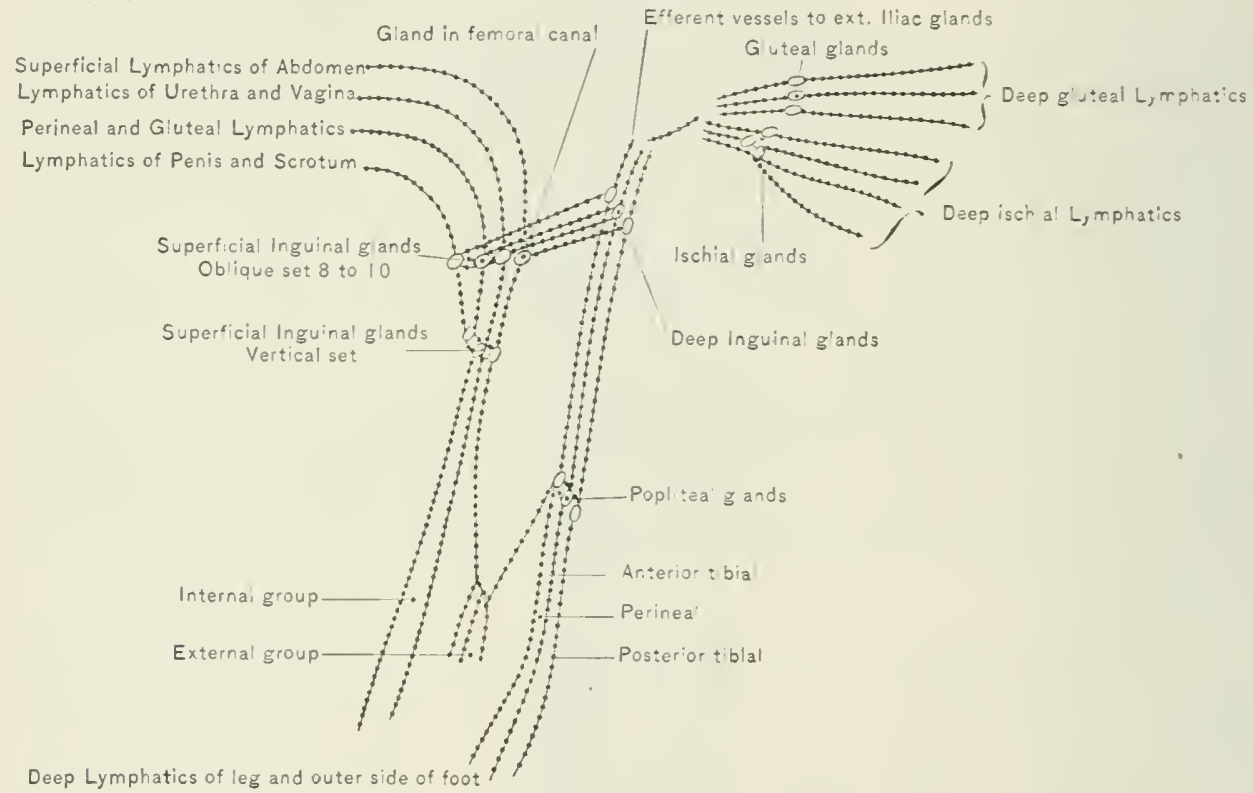

artery and rein, and are about fire in number. They receive the deep lrmplatics from the leg, and those of the superficial which perforate the deep filscia along with the external saphenous rein. Their efferent ressels accompan the popliteal and the femoral ressels to the deep inguinal or femoral glands.

The deep inguinal or deep femoral glands surround the upper part of the femoral ressels. One or more are constantly found in the femoral canal. They receive the deep lrmphatics acompanying the femoral artery, and a few of the efferent ressels from the superficial inguinal glands. Their efferent ressels pass. in part along the course of the femoral vessels, and in part through the femoral ring to join the glands along the enmse of the external iliac arterr. 


\section{SECTION T \\ THE NERTOCS SYSTEM}

BY H. ST. JOHN BROOKS, M.D., B.Cu., D.Sc., B.А.

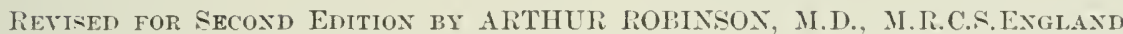

LECTLRER ON ANATOMY IN THE MDDLESEX HOSPITAL MEDICAL SCHOOL; EXAMIXER IX ANATOMY FOR THE CONJOINT ROARD OF ENGLAND

\section{TECROLOG Y}

$\mathrm{N}$

EUROLOGY is that branch of Anatomy which deals with the nerrous system. It treats of the brain and spinal cord, constituting the cerebro-spinal axis or central nervous system; the cranial and spinal nerves, or peripheral nervous system, and the sympathetic system, which is intimately connected with the two former and closely associated with the vessels, viscera, and glands. The study of the nervous system (of the brain in particular) is greatly facilitated hy a knowledge of its mode of development and by Comparative Anatomy. It

Fig. 401.-Dighamyatic Sagittal Section of a Tertebrate Braix. (After Huxley.)

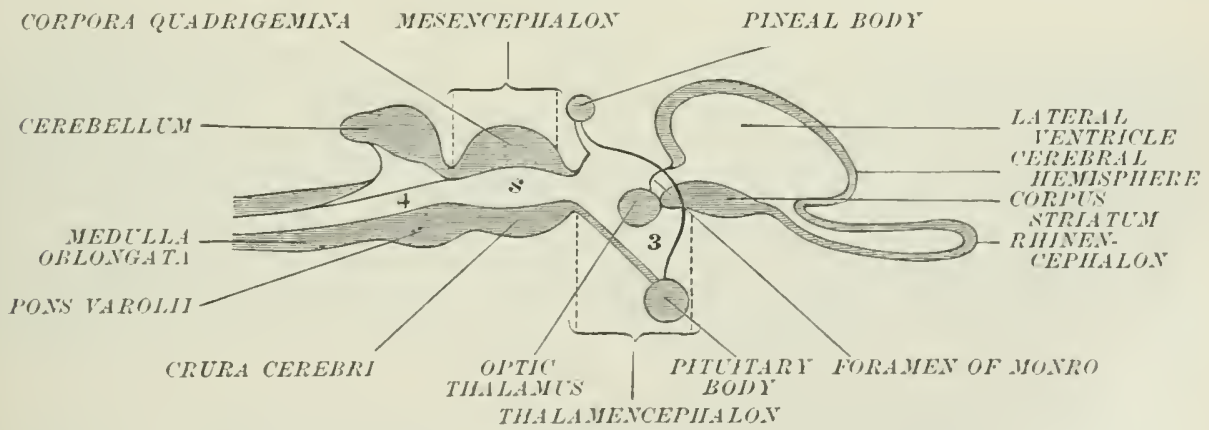

4. fourth ventricle; s, aqueduct of Sylvius ; 3 , third vent ricle.

is not our purpose to enter into these sulijects here; lut an examination of the two diagrams (figs. 401 and 402 ). which are hased upon Embryologes and Comparative Anatomy, will familiarise the stuclent with the plan upun which the brain is laid down, and form a key to the complicated structure of the arlult hmman brain.

At an early period of embryonic life the cerebro-spinal axis consists simply of a thin walled tube, the neural tube, which hecomes enlargerl at the c'phalic end of the body. Constrictions appear on this enlarged cephalic end, dividing it into three 
resicles, an anterior, a middle, and a posterior. The ventricles of the brain are afterwards developed from these three corebral vesicles, and the remainder of the neural tube forms the central canal of the spinal cord. The sulstance of the brain and cord is formerl by thickenings of the wall of this neural tube. The terminal or anterior cerebral vesicle becomes divided into an antrior and a posterior division; the latter persists as the third ventricle, which, with the parts around it, constitutes the thalamencephalon. The anterior clivision is afterwards clifferentiated into the cerebral hemispheres or prosencephalon. It becomes at first indented in the middle line, and then completely bilobed. In this way two symmetrical cavities, the right and left lateral ventricles, are formed.

The anterior part of the wall of the cerebral resicle hetween the two hemispheres, thus mapred out, is ealled the lamina terminalis. The lamina teminalis is earried backwarks so as to bound the third rentricle in front, and the aperture of communication (foramen commune anterius), connecting the thire with the lateral ventricles, hecomes narrowed. The eavity of the middle cerebral vesicle becomes the aqueduct of Sylvius, and the parts developed around it constitute the mid-brain or mesencephalon. The carity of the posterior cerebral resicle becomes the fourth ventricle, and its walls are differentiated into the cerebellum and pons Varolii (epencephalon), and into the medulla oblongata (metencephalon).

The walls of the lateral rentricles become greatly thickened and form the cerebral hemisplieres, constituting the greater part of the mass of the brain. They

Fig. 402.-Diagramitic Horizontal Section of a Vertebrate Badix. (After Huxley.)

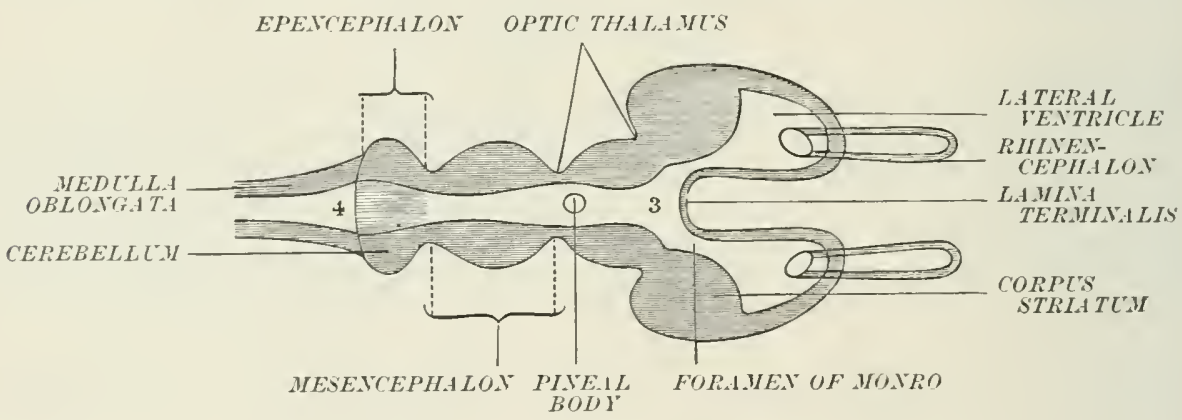

grow backwards from the position represented in the diagram (fig. 401), and cover the midl- and hind-brain. In front of the lamina terminalis the walls of the lateral rentricles remain thin, and approximate so as to enclose a narrow space, the fifth ventricle. Thus the fifth rentricle differs entirely in its mature from the other ventricles of the brain: it is a separated portion of the interhemispheric or great longitudinal fissure, and has nothing to do with the true ventricular cavities; according to Testut it is lined by a rudimentary layer of pia mater. Later on, a grat transrerse commiscure (corpus callosum), which passes from one hemisphere to the other, is developed. It commences in front of the fifth rentricle in the secondarity fused portions of the cerebral walls, and afterwards extends backwards as the hemispheres grow over the mesencephalon.

The oldest portion of the rerebral hemisphere, both in the series of rertelorates and in the development of the individual, is the island of Reil with the grey masses which lie subjacent to it (nucleus caudatus and nucleus lentieularis of the empus striatum). These structures constitute a central portion (Stammtheil of solnwalle) which is almost completely invested by the remaining larger part of the hemisphere. The latter forms the less massive part of the wall of the lateral ventricle, and may be callul the mantle-wall (Manteltheil of Schwalbe).

The rentricular carities of the brain and the central canal of the spinal cord are lined hy a liver of epithelial cells, inmediately outside which is a stratum of neuroglia, free from nerre-cells, which is called ependyma. The ependrma around the ecentral canal of the cord is often termed substantia gelatinosa centralis. 
Neuroglia is the name given to the peeuliar intretitial tis-ue of the hrain and corrl. It is continuous with processes of pia mater which lij, in from the surfact.

Nerve-fibres are processes or outgrowthe of the nedre-cells of the central nervous system, from which they pass to be distrihuterl to erery jalt of the lonly. They are elassed hy physiologrists into efferent and afferent filores. Efforent in centrifugal nerve-fibres convey inpulses from the nerve-centres they amplise motor nerves to museles, secreto-motor nerves to glands and vaso-motne nerres. Afferent or eentripetal nerves convey impulses towald the nerveredetre; they comprise sensory nerves and other nerves conveying impulsts. which under ordinary

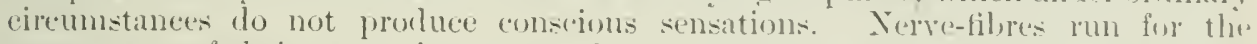
greater part of their course in compact bundles of various sizes, and thase foundles are called nerves in the most general use of the term. Verves are ustally mixerl (i.e. contain both efferent and afferent fibres). Most nerves are of a whitish colour cwing to a medullary sheath which invests the "sential parts (axis-erlinders) of the individual fibres. Others (chiefly visceral nerves) ate of a pearly-grey colour owing to the alsence of the merlullary sheath in the majority of the tibres which make up the nerve.

The fibres of sensory nerves are outgrowths from nerve-cells contained in ganglia, such ats the Gasserian ganglion and the ganglia on the posterior toots of the spinal nerves. Thiere ganglia, although appearing to belong to the peripheral nervous system in the adult, were (in early embryonic life) in continuity with the general epiblast of the neural canal.

Certain terms which are in frequent use, such as coronal, sagittal, and horizontal, may be lefined here. A coronal section is a rertical section passing through or parallel to the eoronal suture. in other word: a transierse vertical section. A sagittal section is a rertical section taken at right angles to a cornal section-an antero-posterior rertical section. A horizontal section is a section taken at right angles to the perpendicular axis of thr hody. Structures which lis in the planes of these sections are sometimes spoken of as coronally placrel, sigittally directed, ete.

\section{THE MENTACES}

The brain and spinal cord are invested by three membranes, termed the meninges, which aftord protection and stupert to the delicate nervous structures and also furnish a convenient medium in which the blood-rescels ean ramify. The outer of these is thick and tough, and is termed the dura mater. The intermurliate amel inner membranes (arachnoid and pia mater) are thin and delieate. There membranes present differenees in the regions of the brain and spinal cord rejertively. The membranes of the brain will lw tirst consisleresl, and the ditforences met with in relation to the spinal cord will be dealt with in the description of that region.

Dissection. - The first step in the examination of the meninges is the removal of the luain. The calvaria should be remored as follows:-The lone havine been laill hare, a string should he

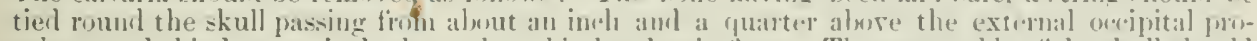
tuberane behind, to an inch alose the orbital arehes in front. The vuter table of the skull shomle]

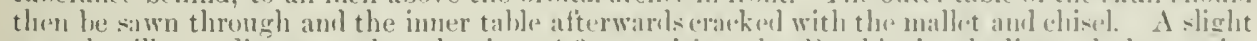
wrench will now disengage the calraria. After noticing the l'andhinnian bodius and the menin-

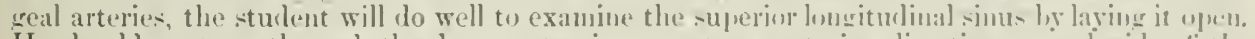

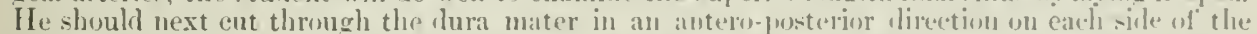
sinus, and then make in isions directed transwersely ontwarls from the central jwins of the two

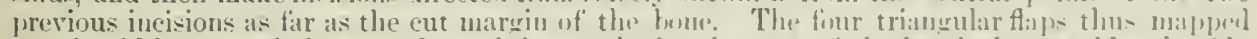

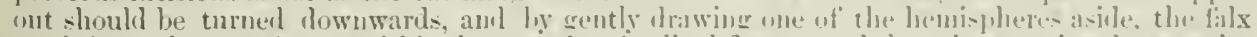

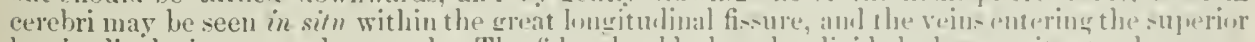

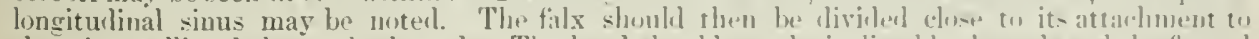
the erista galli and thrown backwards. The head should next be inelines hatekwarls anil the frontal 
lobes of the brain gently raised. The following structures will then come into view, viz. the alfactury bulls, the second, third, and fourth nerves, the infundibulum, and the internal carotid arteries. The olfactory bulbs will come away with the brain, but the other structures will require to be divided with scissors, as the nerves are frequently torn awiy fiom their comnections by using a scilpel for this purpose. The head should next be gently inclined towards the right side, and the tentorium divided elose to its attachment to the bone. 'The sixth, seventh, aud eighth nerves should be eut at the same time. This dissection should be repeated on the opposite side. The head should then be tilted backwards, and the remaining eranial nerves, the vertebral arteries, and the commencement of the spinal cord cut through. The latter should be divided as low (lown as it can be reached with the scalpel. The brain ean now be removed from the eranial cavity, the veins of Galen being ruptured by this process.

The DURA MATER is a tough fibrous membrane of a bluish-white colour presenting extemally a rough appearance, but internally smooth and shining. It performs the double function of an endostem to the interior of the skull and of afforling support and protection to the brain. In correspondence with this double function it may be regarded as consisting of two layers, an outer or periosteal lamina, and an inner or supporting lamina. These layers are inseparable for the creater yart of their extent, but along certain lines the inner lamina leaves the periosteal lamina and forms shelf-like projections (of which the falx cerehri and the tontorium cerebelli are examples) into the eranial cavity. Along the lines where these layers divaricate spaces occur which form cranial sinuses. A cranial sinus may be defined as a space formed by the cleavage of the dura mater, lined by a prolongation of the lining membrane of a vein and eonvering venous blood. Some of the sinuses are placed between the periosteal and supporting layers of the dura mater-the lateral sinus is a good example of this class. Others (as the straight sinus) are bounded wholly by the inner or supporting layer.

The cranial sinuses form two principal systems, which, however, communicate with each other. 'The following is a list of the sinuses which mite to form the larger of these two systems :- superior longitudinal, inferior longitudinal, straight, occipital, superior petrosal. These form a system which converges at the torcular Herophili, a dilated blood-space situated on the right side (rarely on the left) of the internal occipital protuberance. The blood from the torcular is drained away by the lateral sinuses (more particularly by the right sinus). which also receive blood from the cavernous sinuses by the superior petrosal sinuses, and it leaves the cranium through the posterior compartment of the jugular foramen. 'The straight sinus usually passes into the left lateral sinus. The smaller system cumprises the spheno-parietal, cavernous, circular, transverse, and inferior petrosal sinuses. The lolool from this system passes into the internal jugular vein by the inferior petrosal sinus through the anterior compartment of the jugular furamen.

Emissary veins.-These veins are possibly extracranial tributaries of the cranial sinuses undel. normal conditions, but, in cases of engorgement of the sinuses, permit the flow of blood in the opposite direction, and become, in accordance with their name, emissary. The mastoid emissary is the most important of these veins; it passes through the mastoid foramen to enter the lateral sinus, and explains the value of applying leeches behind the ears in cases of cerebral congestion. Threc small emissaries enter the superior longitudinal sinus, one of these passes through the foramen creeum : the others traverse the parietal foramina. An additional vein occasionally mases to the torcular Herophili through a foramen in the occipital bone near the external occipital protuberance. Emissary veins pass through the forawen ovale and foramen of $V^{r}$ esalius, and place the cavernous sinus in communication with the pterygoid venous plexus; others traverse the cartilage which occupies the foramen lacerum medium. Small veins enter the lateral sinuses through the anterior and postcrior condyloid foramina. A mimute venous plexus, which acempanios the internal carotid artery through the carotid eanal, establishes a communication betwecn the cavernous simus and the internal jugnlar vein. (Rektorzik.)

The dura mater of the brain is continuous through the foramen magnum with the dura mater of the cord. It is also continuous, through the various for:umina in the cranium, with the exterual periostemm of the skull. This is most casily ohserved at the sphenoidal fissure, hut may be made out with orlinary care at any of the other foramina. It sends a strong prolongation through the optic foramen which splits into two layers, one of which forms the sheath of the optic: nerve, and the other is continued into the periostem of the orbit. On account of the number of formina at the base of the skull, it follows that the dura mater is more firmly eomnecterl to the bone here than at the roof and sides. In the region of the hasilar process of the oceipital bone, the dura mater splits into supporting and periosteal layers. The supporting layer passes througl the foramen magnum to become 


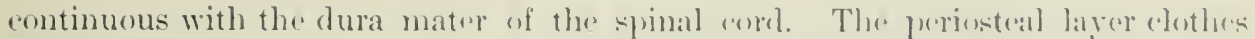

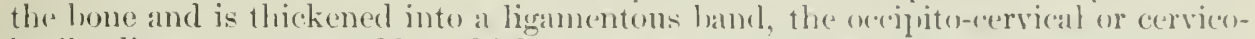
basibar ligament (page 1S8), which passes through the foranem magnum to join the posterior common ligament of the rertebre and to gain attachunent to the body of the axis. Thus a comection is estahlished between the dura mater and the feriostem of the vertehre. At the lack and siles of the formen magnum the duma mater does not split inte periosteal and supporting layers mutil it reaches the marcin of that opening, where its layers divaricate, the one to become continuous with the "xternal periostem of the skull, the other to be continued into the simal elurat mater. In the midelle fossa of the skull there is a separation of the periosteal and supporting layers to form the carernous sinus; on the inner sicle of this the suf forting layer is monlded round the pituitary boly and then folds on itself to form the diaphragma sellæe which roofs in the pituitary forsa. Extemal to the "alvernous sinus the two layers remain separate for somie listance, forming a space (Meckel's space), which enckses the (iassorian ganglions. The vuter surface of

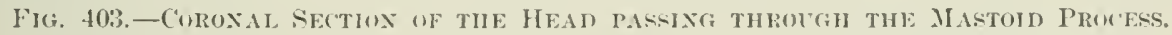

(From a monnted sperimen in the Anatomical Department of Trinity College, Dnblin.)

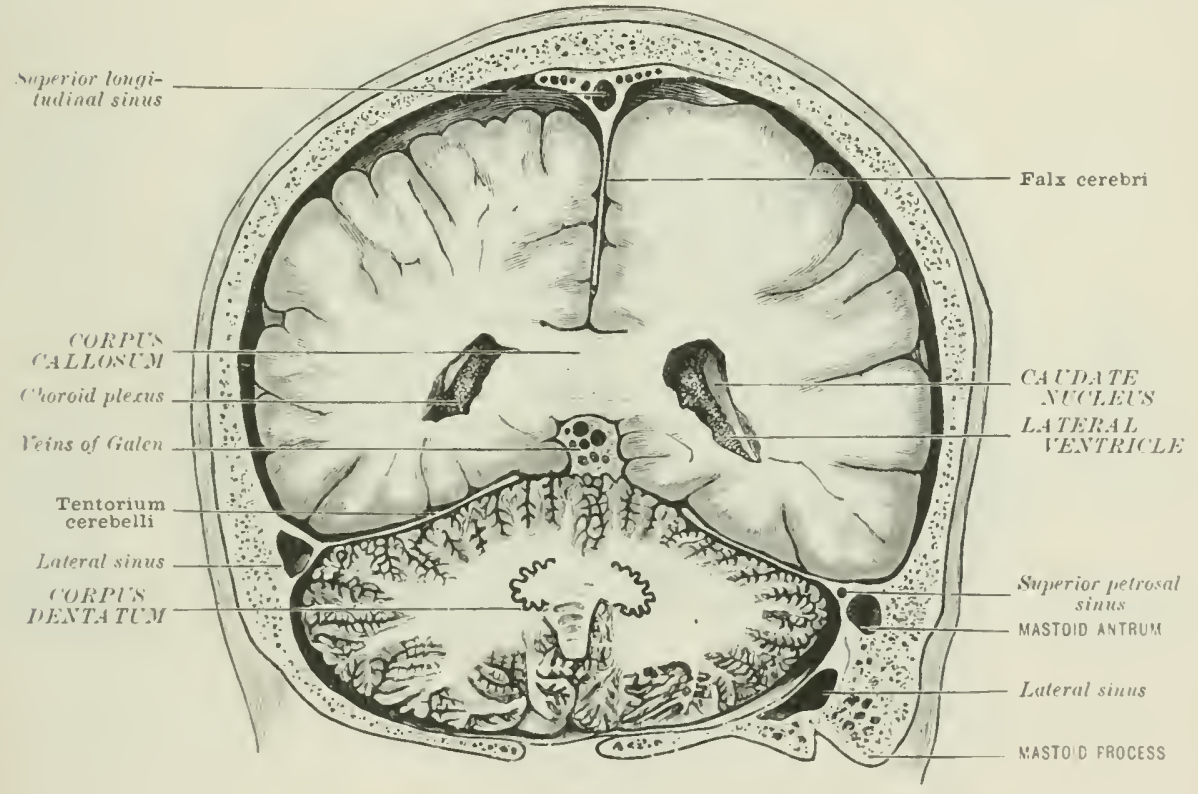

the dura mater is covered with a number of arteries. which ramify between it and the inner tal)le of the skull. These vesiels hreak up into small twigs which fenetrate the bone. The term meningeal, alplied to the arteries in cuction, is somewhat mislearling, inasmuch as they do not supply any of the meninges, exeryt the dura mater, being chicfly destined for the nutrition of the ermial hones. These

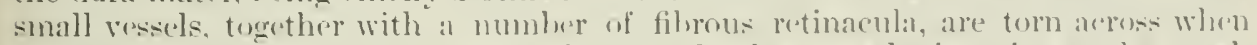

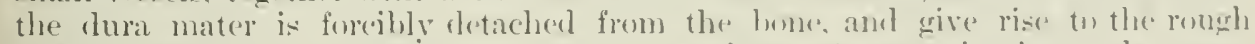
appearance which is presented hy its outer surface. An examination moler water will, however, reveal smooth spots interspersod among the hundles of rujetured vesseds; these are subperiosteal lymph-spaces.

Meningeal arteries.-The middle or great meningeal artery, which cutcrs the midlle eranial fossa through the foramen spinosum. smpplies the durn mater which line the vant of the cranum. In addition to this there ane menimgeal anteries, mostly of surall size. which are limiter? in their distribution to the base of the cramm. In the anterior cranial fissin there are anterior meningeal branches of the anterior and pusterior ethmoidal arteries, which enter the crauium through the anterior and posterior interwal urbital canals; also twigs frum the millle meningeal 
which usually pierce the great wing of the sphenoid near the outer angle of the sphenoidal fi-sure. In the middle cranial fuss the following arteries are met with: a branch of the ascending pharvigeal which perforates the cartilage which vecupies the foramen lacermm medinm; the meningea parva which enter the cranium throngh the foramen oviale; the meningeal branch of the interual carotit, and twigs fjom the mithle meningeal. In the posterior cranial fossi. two meningeal branches, deriven from the oceipital and ascending pharyngeal, enter through the justerior compartment of the jugular formen, another twig from the oreipital passes through the mantoid finamen, and a twig from the asending pharygeal makes its way through the anterior comlyluil foramen. A meningeal branch of the vertebral is civen off from that artery, in the interval between the occipital bone and the pusterior arch of the atlis, and enters the skull throngh the foramen mannmu.

A brameh of the oecipital artery (ramus parietalis, Cruveilhier) oceasionally passes through the parietal foramen to the tura mater lining the calvaria.

The following are the infoldings formed hy the inner or supporting layer of the dura mater, taken in their order of magnitude: the falx cerebri, the tentorium

Fig, 404.-Coronal Section of the Head PAssixg throlgh the Pusteriok Horss of the Lateral Vextricles.

(From a mounted speeimen in the Anatomical Department of Trinity College, Dublin.)

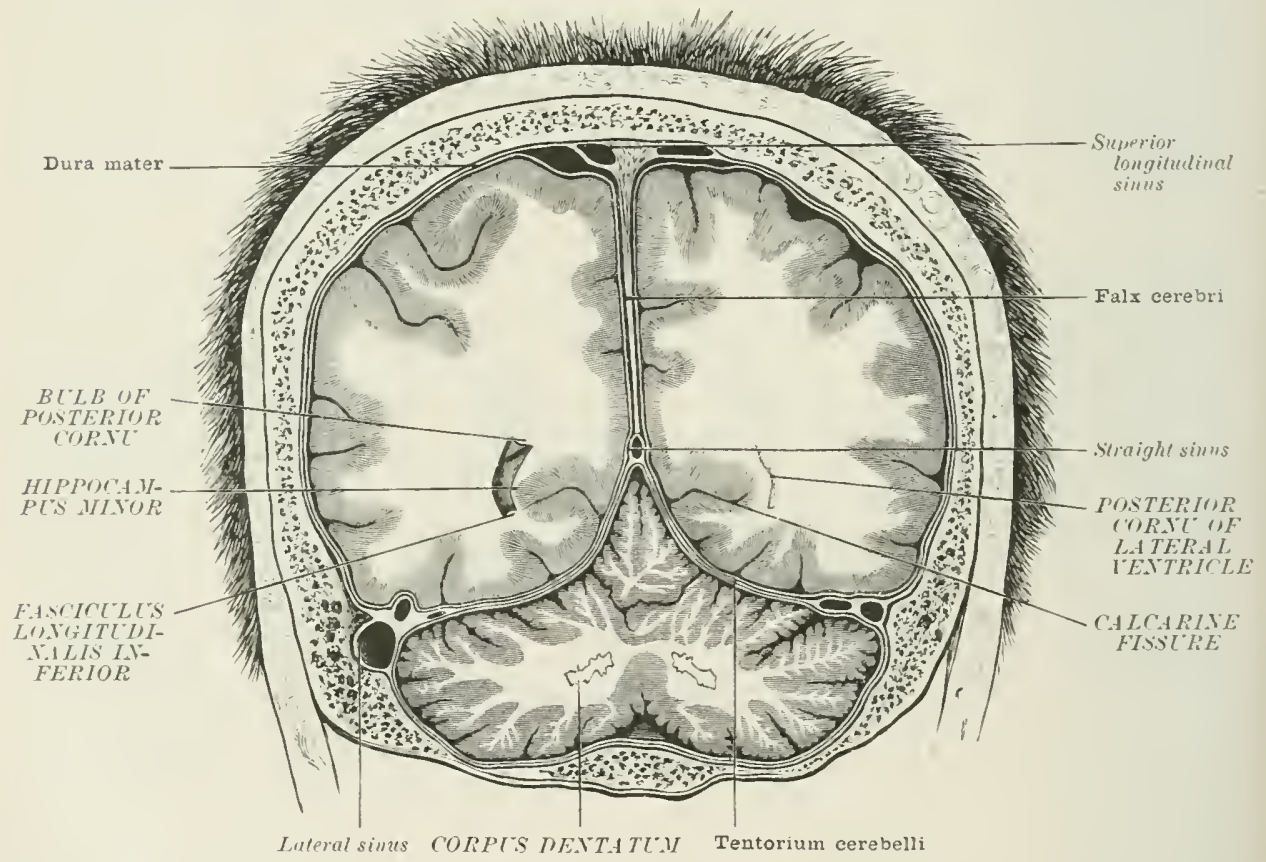

cerebelli, the falx cerebelli, and the diaphragma sella. There are also two smaller paired folds: viz. the folds which project from the lesser wings of the sphenoil hone into the sylvian fissures of the brain, and the crescentic folds which are placed orer the optic nerves at the mper margin of the optir formina.

The Falx Cerebri is a large sickle-shaped process, deeper hehinel than in front. which is placed in the great longitulinal fissure of the brain. It is attached by its hase to the tentorium cerebelli, in the millile line, and maintains hy its tension the vaulted character of the latter. The straight sinus follows this line of attachment. Its aly'x is firmly fixed to the prista galli of the ethmoirl, amel has also an attachment to the ethmoidal spime of the sphenoid bone. Its convex or upper maryin moresponds to the superior longituclinal sinus. and is attached to the periosteal layer opposite to the exlges of the groove for that sinus in the frontal, the two parietal, and the oreipital lones. The inferior longiturlinal sinus courses along

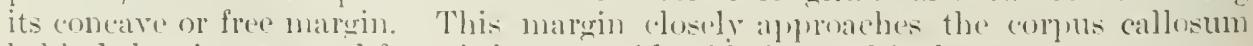
behind, hut is separated from it hy a consideralile interval in front. 
The Tentorium Cerebelli oreupies the interval hetwern the corrolum and

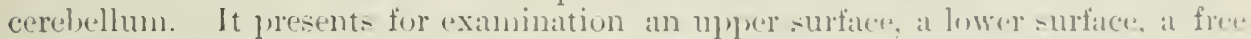
or concare loreter, and an attareher or convex lurder. The upper surface is in contaret with the occipital and temporal lobes of the cerehrum, and is strongly comvex upwarls, forming a ronf-like structure, to the ridge of which the lase of the falx cerelsi is attached. This ridge alow slopes upwards and forwards, on that its highest point is situated at the free borker. The under surface is in appostion to the cerebellum. The free border bounds an opening usully described as oval, leut which is more properly trimerular with curved sicks, the ajex of the triangle leeing turnerl backwards, and correponding to the point where the reins of (ialen renter the straight sinus. This opening transmits the crura corebri and thr. smperior peduncles of the cerebellum, these parts forming an istlmus connecting the masses of brain substance above and below the tentorium; the basilar artery and the third pair of cranial nerves also pass upwards through it. Followed

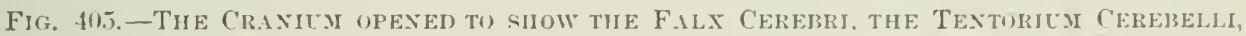

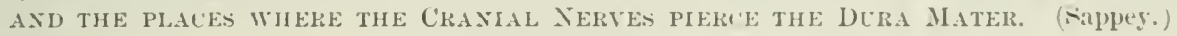

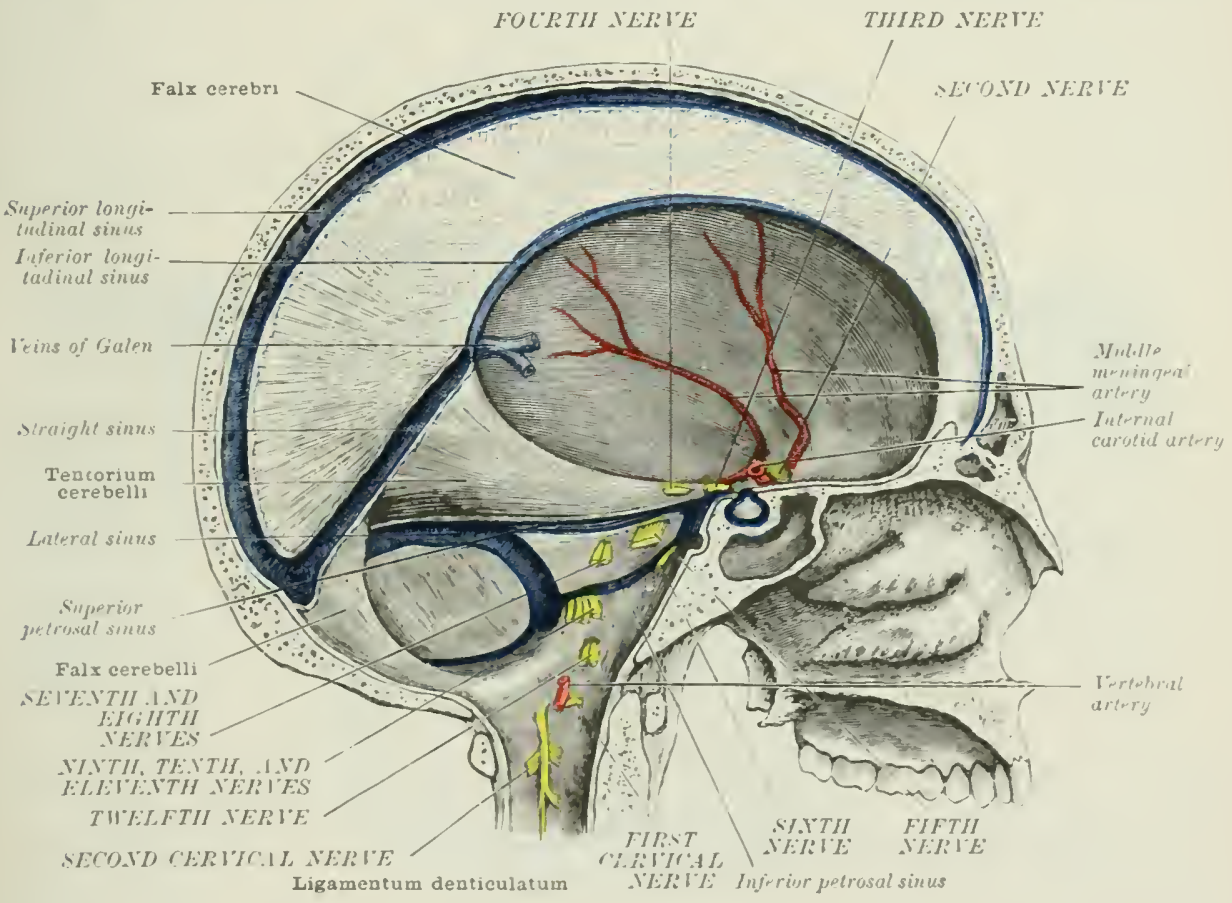

forwarls, the free border is seen to be attached to the anterior clinoid promese of the sphenoid bone. The attached border follows the latrall sinus alunes the oceipital and parietal hones, amel then corresponds to the supurior petrosial sinualong the superior border of the petrous portion of the tomproral. and finally dips

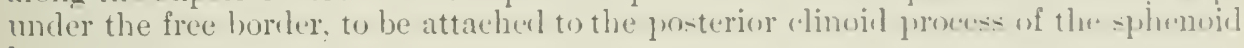
bone.

The Falx Cerebelli is a small prominent fold, which is bland lwetwen the

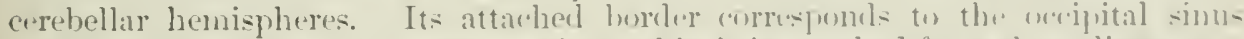

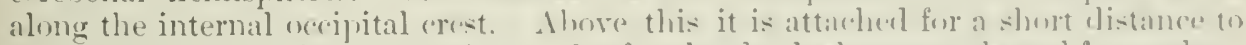

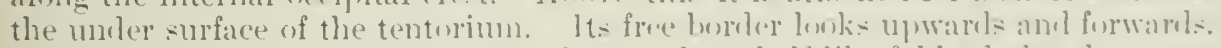

The diaphragma sellæ is a small, ammular, shelf-like folel of the dura mater which roofs in the pituitary for-al. leaving a small aperture in the contre, which transmits the infundibulum.

The subdural space is a narrow lymple-suace lutwern the luma mater ind

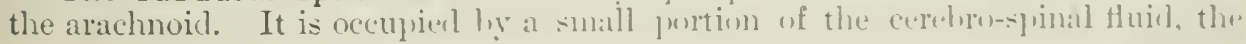


greater part of which, however, is lodged in the meshes of the subarachnoid tissue, and in the ventricles of the hrain (page 678 ). This space separates the arachnoid from the dura mater, except where it is crossed by the reins of the brain passing to the cranial sinuses. by the Pacchionian bodies, and by the cranial nerves at their fuints of exit from the skull.

The ARACHNOID is a thin delicate membrane, which presents a well-defined limiting surface towards the dura mater. but on its deep or pia-matral surface jasses insensibly into the subarachnoid tissue. The arachnoid does not dip into the fissures of the cerebrum and cerebellum, with the exception of those fissures which contain processes of dura mater. Thus it is carried into the great longitudinal fissure for a depth corresponding to the falx cerebri, and it passes for a short distance into the fissure of sylyins around the fold of dura mater which projects from the lesser wing of the sphenoid.

On each side of the superior longitudinal sinus groups of small lohulated bodies, the so-called Pacchionian glands, project from the surface of the arachmoid; these are enlargements of the normal villi of that membrane which perforate the dura mater and cause absorption of the bone in their vicinity. Most of these bodies are

Fif. 406.-Coronal Section throggh the Great Loxgitudish Fissure, showisg the IExixges. (Key and Retzius.)

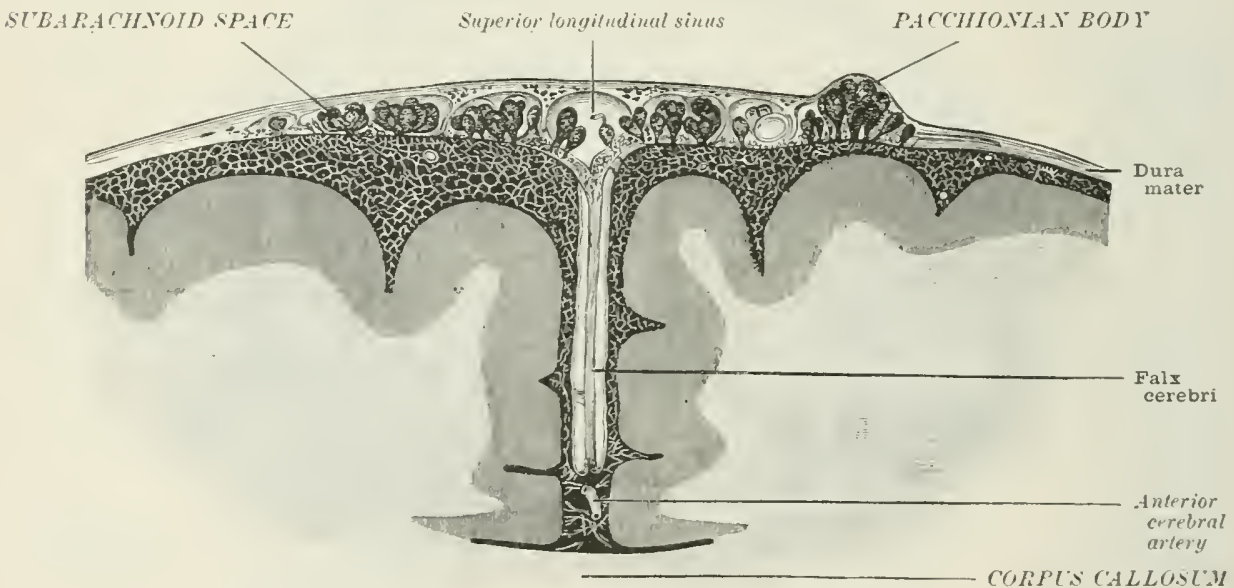

lodged in irregular pits in the calvaria; others project into the superior longitudinal sinus. They mar also oceur in other situations.

The subarachnoid tissue consists of very fine trabeculæ, clothed with endothelial cells, which pass from the arachnoid to the pia mater. 'Thus, a subarachnoid space, in the proper sense of the word, does not exist; it is convenient, however, to retain the term to designate the region which is occupied by the subarachnoid tissue, and to speak of the accumulations of this tissue which are formed in regions where the distance between the arachnoid and pia mater is increased as subarachnoid spaces. It should be molerstood, however. that in these larger smaces the subarachnoil tissue is less abundant and the meshes are larger than in the regions where the arachnoid and the pia mater are more approximated.

The largest of these spaces is the cisterna magna, which is a continuation of the posterior subarachnoril space of the spinal cord. This space appears triangular in sagittal section. It is bounded in front by the laver of pia mater (tela choroidea inferior, page 718) which eloses in the lower part of the roof of the fourth ventricle, and above by the inferior vermiform process of the cerebellum. It extencls laterally as far as the outer margins of the tonsillar lobes. It communicates with the fourth ventricle hy means of three small openings; the principal of these (foramen of Majendie) is in the midclle line of the tela choroidea inferior immediately abov the obex (jage 715). The two others (formina of Key and 
Retzius) are at the rxtremities of the recesus laterales of the fourth ventriche,

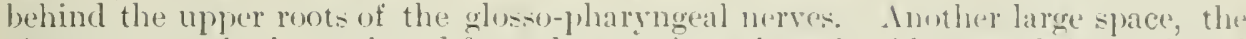
cisterna pontis, is continued from the anterior subarahnogl spaes of the cord, and extends forwark as far as the commencement of the great longitulinal fiscure, and laterally to the inner margins of the tenuporo-sphenoidal lobes. The hasilan artery and the circle of $W$ illis are placed in this space. The cisternal pontis communicates freely around the medulla oblongata with the cistema magna-thus the medulla is encircled by a wide subarachnoid space.

A large space is also to he found hetween the lower exlge of the fals ererbri (where the arachnoid passes across from one corehral hemisphere to the other) and the upper surface of the corpus callo:mm. This space contains the trunks and larger branches of the anterior corohral arteries. Anothro considerahle space

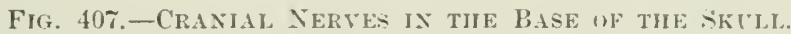

(On the left side the dura mater has been removed in the mildle forsit.)

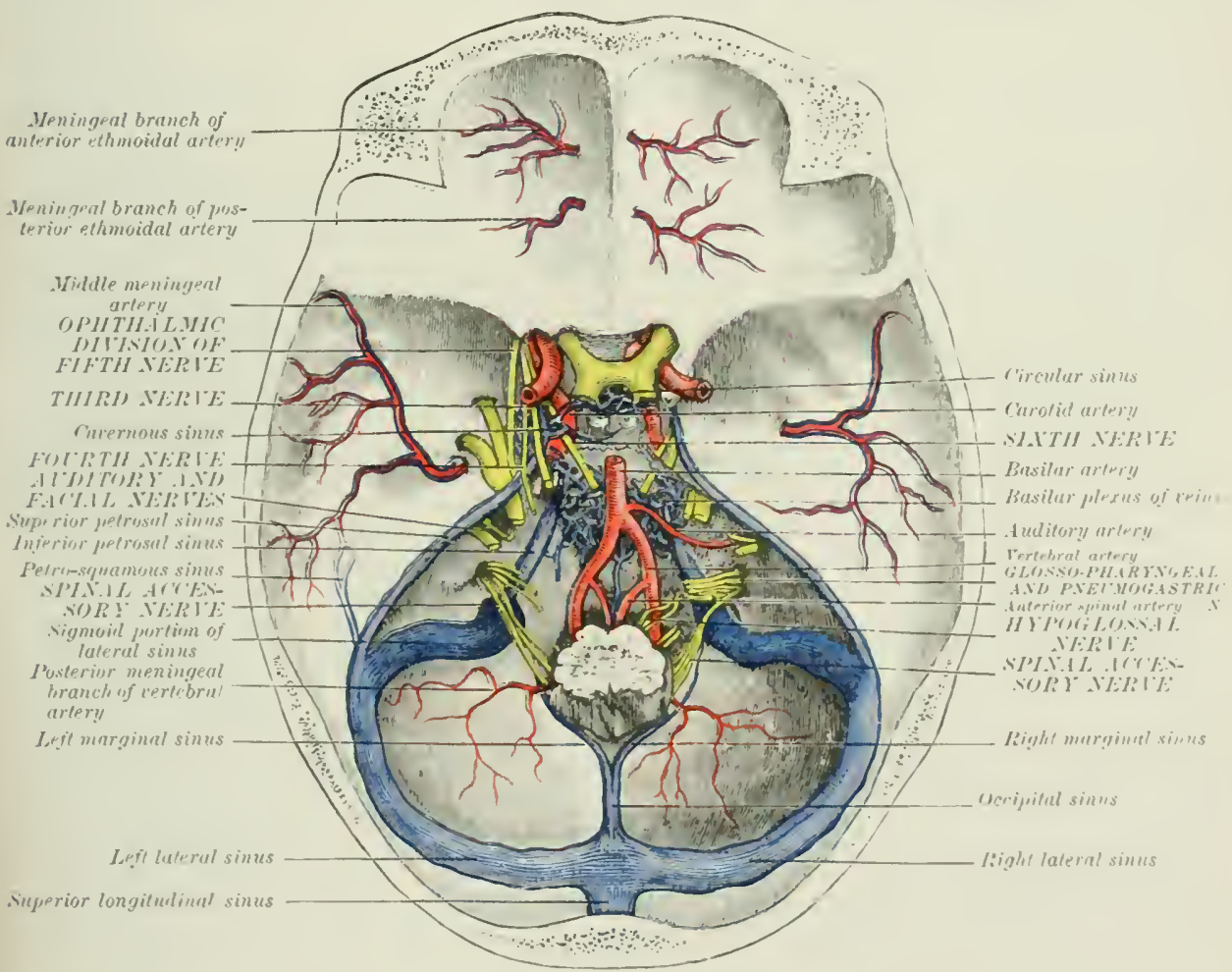

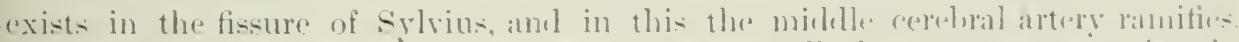
Thus, with the exeeption of the ei-terna magna. all the-e spatees serve for the areommorlation of large arteries. There is also a space letween the corpora pulatrigremina and the anterior extremity of the superier vermiform fromes of the cerehellum, and through this the vein- of Galen pass to terminate in the straight sinu-.

The PIA MATER is a delicate vasular memhrame which elusely invests the nerrous substance. It follows areurately the contour of the surfan of the lirain.

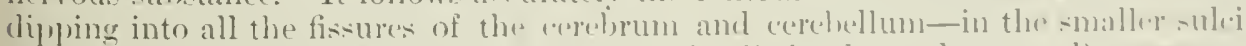

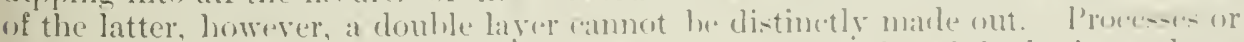
folds of this nembrane project into some of the rentricles of the hrain, and are separatel from the rentrieular cavitio only hy a laye of cpithelimu. These folds form the velum interpositum and chorvid jlexusis. which will les descrihert 
with the anatomy of the rentricles. The blowd-ressels, which divide freely in the sulnatanoid tissue, sulvlivide into the pia nater, forming by their inosenlations: fine networks fron which innumerable minute ressels proceed to penctrate the nervous sulstance.

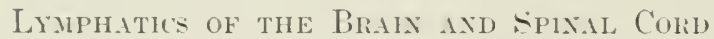

The lymphatics of the brain and spinal cord are preeuliar, inasunch as they open into the subarachnoid sprace, and are only indirectly connected with the general lymphatic aur venous systelus. The communications with the renous srstem are effected ly the Palcchionian bodies. The lymphatics of the peripheral nerves are in the form of tubular sibees placed between the lamella of the perineural sheaths. These tubular channels open into the subchal and subarachnoid spaces.

The subdural space is a very narrow interval between the dura mater and arachooid (page 675). It normally contains only sufficient fluid to mosten its surfaces. It is in communication with the lymphatics of the neck and also of the back and loins. It also communicates with the perineural spaces around the nerves, and with the lymph spaces which surround the olfactory, uptic, and auditory nerves. It sends prolongations around the Pacchionian bodies. It does not communicate with the subarachuoid space.

The subarachnoid space contains the greater part of the cerebro-spinal fluid, the fluid oceupying the meshes of the subarachnoid tissue. The lymphatics of the brain and cord and also the perineural spaces of the nerves open into this space. It is also in communication with the rentricular system of the brain by means of the foranen of Majendie and the foramina of Key and Retzins. Slit-like communications between the subarachnoid space and the dercending horn of the lateral ventricle have also heen described (Merkel and Mierzejersky). It also communicates with the perilymph spaces of the internal ear and with the lymphatics of the mucous membrane of the nuse. It sends prolongations around the optic and anditory nerves.

The lymphatic vessels of the brain and cord surround the arteries, and are hence called perivascular lymphatics. As each artery dips into the nervons substance it carries with it a tubular jrocess of the pia mater. This tubular process is lined ly encluthelial cells and a similar layer covers the coat of the artery. In this mamer the lympl space is bounded. The perivascular lymphatic follows the artery as far as it- capillary ramifications.

There is a lymph-space between the two lavers of the spinal pia mater. Lrimph-spaces between the outer and middle coats of the cerebral arteries (Virchow-Robin space) and others around the individual nerve-cells of the brain have been described, but these are very generally helieved to be artificial, being dne to shrinking from the action of reagents. According to Obersteiner, however, the existence of the pericellular spraces 'is proved by the presence within them of lymphatic cells.' The so-called epicerebral and epispinal spaces, situated between the deep surface of the pia mater and the nervous substance, are also artificial.

Structure of a Pacchionian body.-A Picchionian body consists of $(a)$ a central (core of sul)arachnoid tissue which is joined to the general subarachnoid tisse by a comparatively narrow stalk. This is limiter by $(b)$ a layer of arachnoid; around which is $(c)$ a prolongation of the subdural space. Boumding this space is $(d)$ a very thin layer of membrane derived from the imer layer of the dura mater. It has been shww experimentally that injections thrown into the subarachnoid space permeate the Pacchionian bodies and pass into the venous sinuses into which these bodies project. In this course the injection distends the subdural slace of the Pacchionian borly, but does not enter the general subdural space. It should be mentioned, however, that anatmical pores by which the injection conld pass do not exist. It is probable from these (xperiments that an ontlet fir the cerebro-spinal fluid is provided by the Pacehionian hodies.

Cerebro-spinal fluid,-The cerebro-spinal fluid occupies the suldural and subarachuoid spaces of the buain and cord and alsu the rentricular cavities of the brain. The average ruantity is about two ounces (Labilois and Stirling). Its splecific gravity is alont 1010 . It is of a very pale yellow colsor, and presents many of the chalacters of ordinary lymph. but differs firm lymph in not being coagulable, as it ches not contain either fibriu factors or fibrin ferment. It contains a substance which acts on Fehling's solution like dextrose, lut which is not a sngar (Fister).

The cereloro-spinal fluid is alerivel in part from the lymphatic vessels which open into the subarachnoil and sublural spares, but is also believed to be secreted ly the epithelial (olls: which (over the chorrid plexuses. These cells are conbical in form, and resemble secreting cells; a puress of the choroid plexus covered by these cells has been aptly compared hy Foster to "an everted alveolus of a secreting gland, with the epithelium outsile and the blood-resinels within.' 


\section{THE EMCEIMALON}

The encephalon, or brain, is the portion of the "rethe-s pinal axis which is: lexlged within the cranial cavity and constitutes (hy weight) alout 98 per crent. of the whole. It eomsists of the erelum, the cereludlum, the pons Varolii, and the medulla oblongata. The medulla is eontinuous with the sumal corrl at the derenssition of the pyramils. The encephalon, taken as a whole, i- dliperidal on ovoirlal in form, presenting above a tolerahly even convexity formed he the cereliral henispheres, but below a more irregular surface corresueneling to the fosse in the lase of

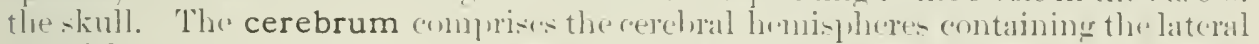
rentricles (prosencephalon), the (1)tic thalanij with the third rentricle letween then (thalamencephalon), and the mesencephalon. It oceupies the upver compartment of the cranial cavity, resting on a flow formed ley the anterior and

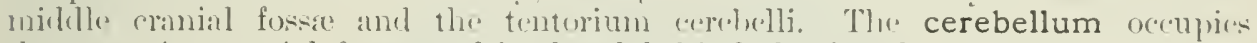

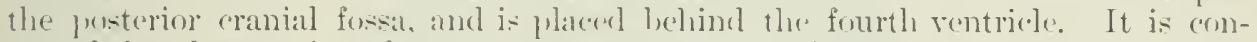
necterl he three pairs of peduncles of crura to the corelmum, pons, and the

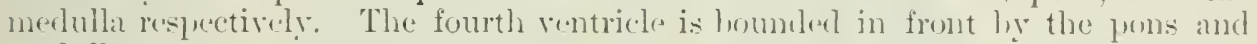
merlulla.

In every part of the encephalon two distinct kinds of nervous substance are to be met with, termed grey and white matter. The grey matter is chiefly dispmed upon the surfice, is in the (onrolutions of the cerebrum and cerebellum; but it is also met with in detacherl or partially detached masses or muclei, such as the corjurat striata and optic thalami in the cerebrum, the nuclei of the medulla and pons, and the corpus dentatum of the cerebellum. It is composent of groups of ganglion cells, which posess the pwirer of originating nervons implulses; or of recoiving impulses porheed by the action of externat stimuli on the end-organs of nerves; or of morlifying and redirecting such iupulses. The white matter oweurs in the greatest guantity in the

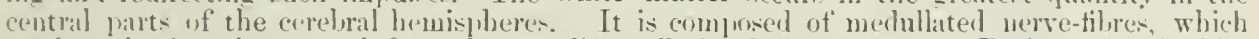
conduct the impmlses to and from the ganclion cells in the grey matter. Buth grey and white matter are supportet liy a delicate interstitial tiswe termed neuroglia.

\section{B.LE: UF THE BrilN}

Dissection.-The stmulent is recomunended to conmence the disection of the brain ly a ircucral "xamuination of the strurtures forming the base of that organ. He should carefiblly remere the remains of the membranes from the base, and after studying that region should proceed in a similar manner to remove the membranes fimu the superior and lateral surfices of the cereliral hemispheres.

The base of the brain presents fin eximnination the inferior surfaces of the froutal

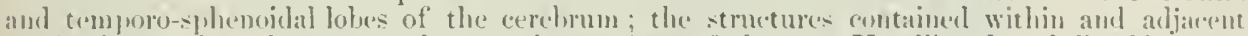
(1) the interpeduncular space: the anterior surfices of the puss Varolii and nedullat oblumgata, the inferior surfices of the lateral hemi-pheres of the cerebellum : and the superficial orienis: of the eranial nerves. In firut, the orhital surfices of the frontal lobes are seen selparated

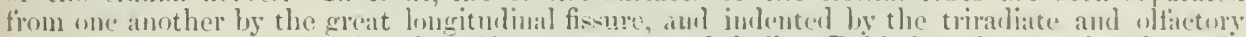

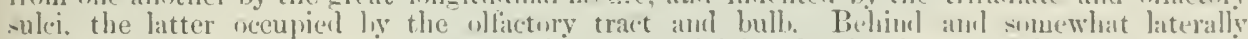

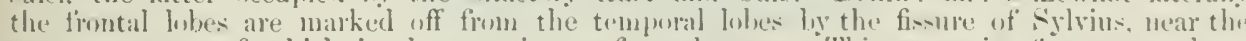

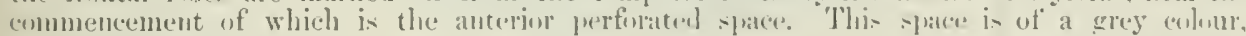

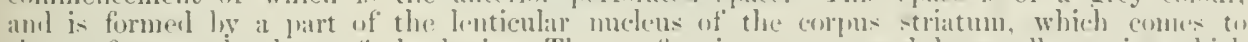

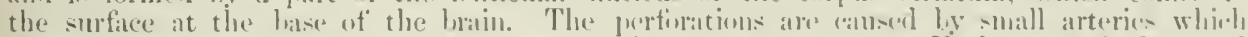

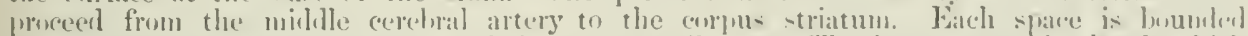

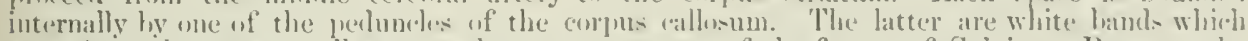

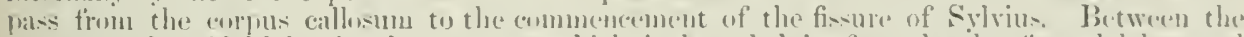

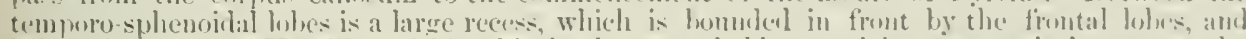
behim by the gems Varolii ; within this is the rematkable arterial anastomosis known is the

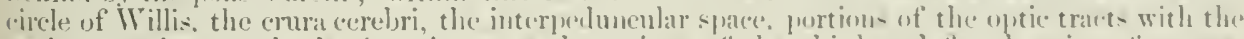

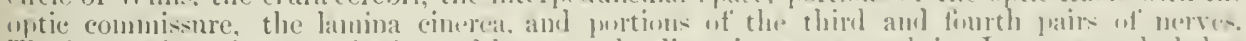

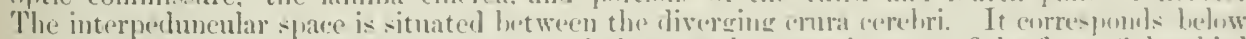

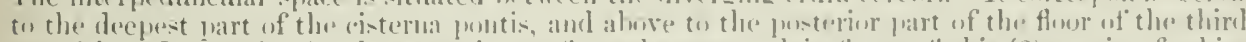

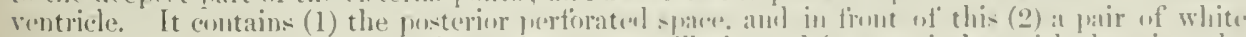

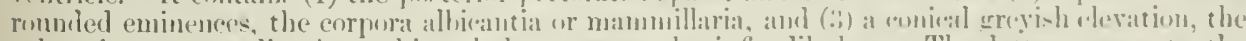

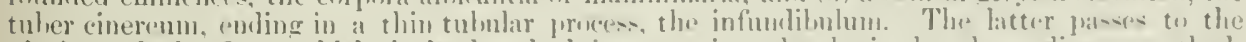
pituitary body, from which it is detached in remuring the lirain lye the ordintary methosl.

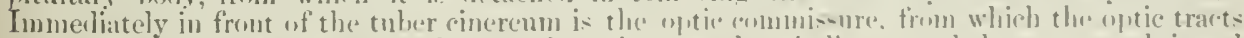

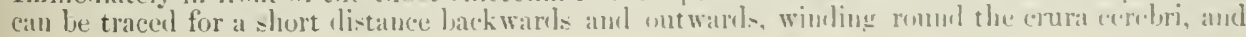


finally disappearing under cover of the temporal lobes. A thin grey lamina, the lamina cinerea, passes from the anterior border of the optic commissure to the commencement of the great longitudinal fissure, where it gains an attachment to the rostrum of the corpus callosum. 'The erura cerebri appear as two strong flattened bundles of white fibres, which emerge from the superior border of the pons, and, diverging from one another, pass under cover of the temporal lobes, and are soon lost to view. On each side the third uerve is seen passing between the posterior cerebral and superior cerebellar arteries, it surings by a row of filaments from a groove at the inner margin of the erus. The fourth nerve, a slenter romited fisciculus, winds romul the outer side of the erus. The pons Varolii appears immediately behind the enura as a broad band of white fibres directed transversely, and passing from one cerebellar hemisphere to the other. It narrows on each side as it passes into the eerehellum. It is marked by a shallow groove in the middle line in which the basilar artery rests. The fitth nerve is seen piercing the side of the pons near its upper borter in the form of two bundles, a large posterior or sensory root, and a small anterior or motor root, separated from the former by some of the transverse

Fig. 40R.-VIEW OF THE Base of THE BRAIx. (After Beaunis.)

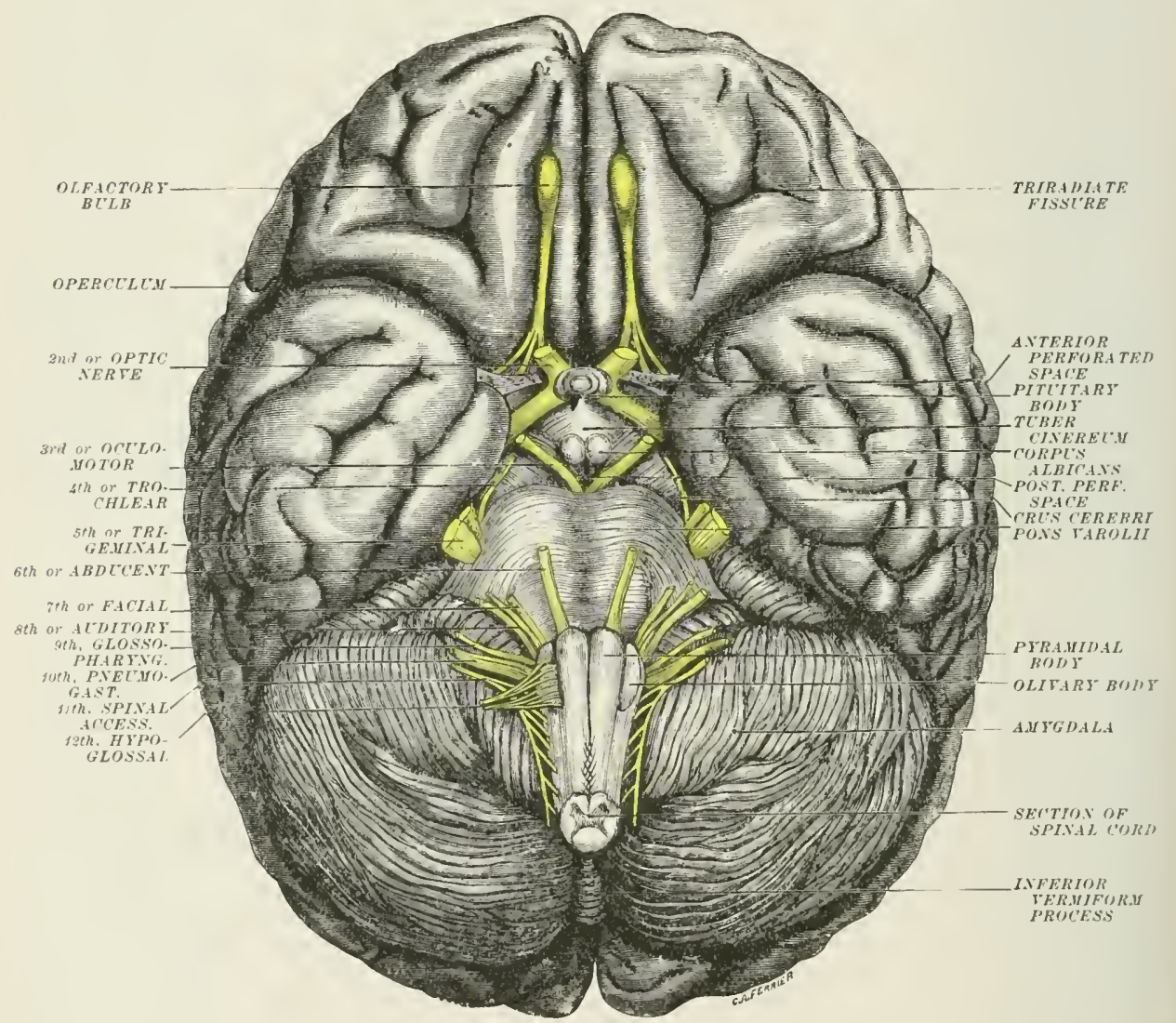

fibres of the pons. The sixth nerves are seen at the lower borter of the pons in the groove between it and the medulla, emerging from the latter close to the outer side of the pyramidal bodies on between the filores of these bodies. 'The prramidal and olivary bodies can readily be made out on the medulla, and a portion of the restifirm body can also losesen without disturbing the parts. The twelfth or hypogloswal nerve emerges by a row of filaments from the groove hetween the olivary and pyramidal bodies. The ninth, tenth, and eleventh nerves, which apporar in numerical order fiom above downwards, arise from the groove between the olivary and restiform ludies; the origin of the eleventh or spinal accessory nerve being contimed down the lateral column of the eord. The seventh and eighth nerves are close to the edge of the pons in the angle between the latter and the cerebellum. 'The cerebellar hemispheres are placed one on each side of the medulla and conceal the oreipital lobes of the cerebrmm when viewed from the base.

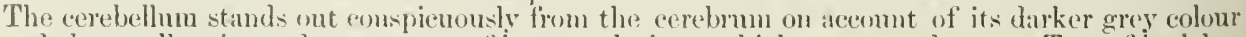
and the smaller size and narrowness of its conwolntions, which are termed folia. Two of its lobes are more prominent than the rest, viz. the amygdalæ or tonsils, which are placed clowe to the medullit, one on each side; and the flocculi, which lie clowe to the pons above the tenth or phemogastric nerves. 


\section{THE CEREBRAL HEMLSPHERLS}

The cerebral hemispheres constitute abuut 85.5 jur cent. of the entire hrain, and viewed from above, present an ovate form, broader behind than in front. They contain the lateral rentrieles in their interior. They are sejarated from one another ly the great longitudinal fissure, the floor of which is formed ly the (orpers eallosum, a great commissure which comnects uach hemisphere with its follow. Each henisplere presents for examination four surfaces, supero-external, inferior, internal, and tentorial, and two extremities or poles, an anterior and a posterior; the anterior pole presenting an edge flattened intermally and bevelled externally; the posterior forming a blunt rounded point which is lirecterl hackwards with an inclination downards. With the exception of a small portion of the inferiorsurfare, the ecrebral hemispheres are entirely arered with fissures or sulci, which mark off intervening elongated clevations terned convolutions or gyri. By this means the surface area of the hrain and consequently the poportion of grey to white matter is very greatly increased. The general arrangenent of the convolutions in the two hemispheres of the same hrain is tolerably symmetrical, but minor differences always oceur. These differenees are more particularly seen when there is any

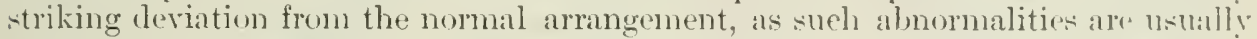
confined to one hemispliere. The supero-external surface is convex. presenting a sharper curve in the transwerwe than in the antero-posterior diretion. It is marked off from the intemal surface at the great longitudinal fisture he a welldefined erlge. It is divided for alout its middle third into a superior and an inferion segnent hy the horizontal limb of the fissure of sylvius which lies above the temporo-sphenoidal lobe. The internal surface is flattemed, and is serbatited form the opposite hemisphere by the falx cerelni and the sularachoid space. The inferior surface is dividerl into two parts by the stem of the fisture of srlvius: the pusterior part is formed by the anterior end of the temporal lobe which is romeled and prominent, comstituting the temporal pole. In front of the sivlvian fisture is the orlital area of the fontal lole. Which is comeave and arlapterl to the orlital plate. of the forntal bune. The tentorial surface is direxted downwards and inwalls: it is conceive and rests upkn the tentorium cerebelli.

Fissures. - Ender this term are included: (a) narrow intervals formal ly the. apporamation of parts primitively widely separated, and (b) fir-ures due to infoldings of the ventricular wall for a gart or the whole of its thicknes. ()nly two fissures are includerl in the former eategory, viz. the great longiturlinal ame thr. Ereat transerse fiscures of the erehrum. (ii) The great longitudinal fissure

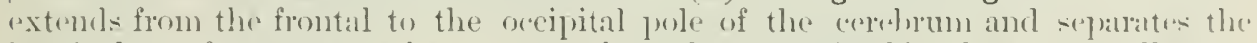
hemispheres from one another, except where they are joinesl hy the rorpus allowim.

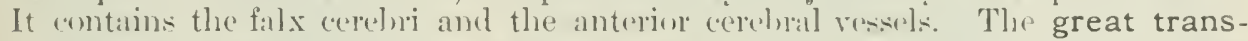
verse fissure will be described with the anatomy of the bateral and thirel ventriclec. (b) The remaining fissures prenent a very distinct division into complete and incomplete. The amplete fissures ate forned by an infolding of the entire think-

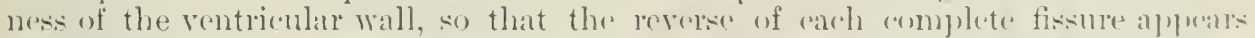
ats a bulging into the cavity of the ventrieles. The eomplete fissures amplise

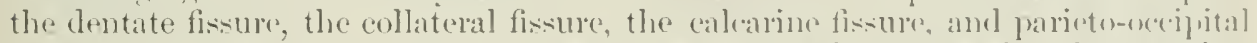

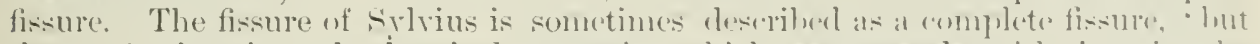
the projection into the henisphere cavity which corresponds with it (viz. the (")rpens striatum) is not formed by an infolding of the mantle wall, lout ats an

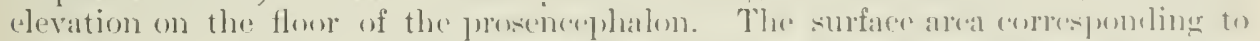
this internal projection does not liece pare with the mantle, as the latter wrows:

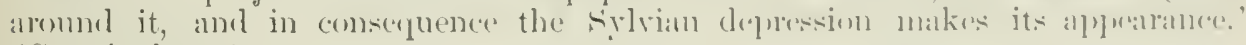
(Cumlningham.)

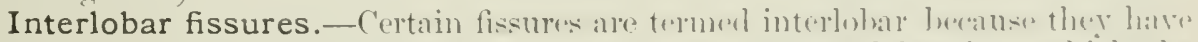
been selecterl to detemine the houndaries of the various lobes into whide the hemispheres have been (somewhat artificially) dividul. These ale the parictooccipital fissure and the firsures of sylvius anil of liolanelo.

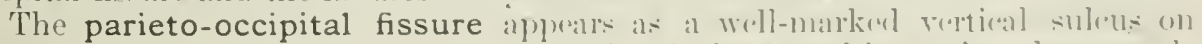
the posterior gart of the inner face of the hemisphere, and is continued ontwants 
for a short distance on to the convex surface. The portion on the mesial surface is distinguished as the internal parieto-occipital or internal perpendicular fissure. It will be more partioularly describel with the fissules and ("omvolutions of the inner surface of the hemisphere. The jortion which apperas on the convex surface is distinguisher as the external parieto-occipital fissure.

The fissure of Sylvius is situated partly on the base and partly on the external surface of the hemisphere, and is, with the exception of the great lomgitudinal fissure, the most conspicums suleus in the brain. It commenees at the outer angle of a depresiom callerl the vallerula sylvio, in which the anterior prerforated space is situaterl. It passes ontwarts and imwards with an inclination backwards, and divies into three bramches or limbs, a posterior, an ascending, and an anterior. The posterior limb is hy far the lareset, and is to be regareled as the continuation of the

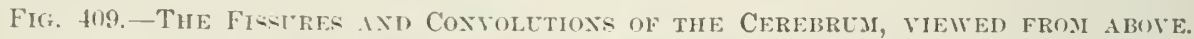

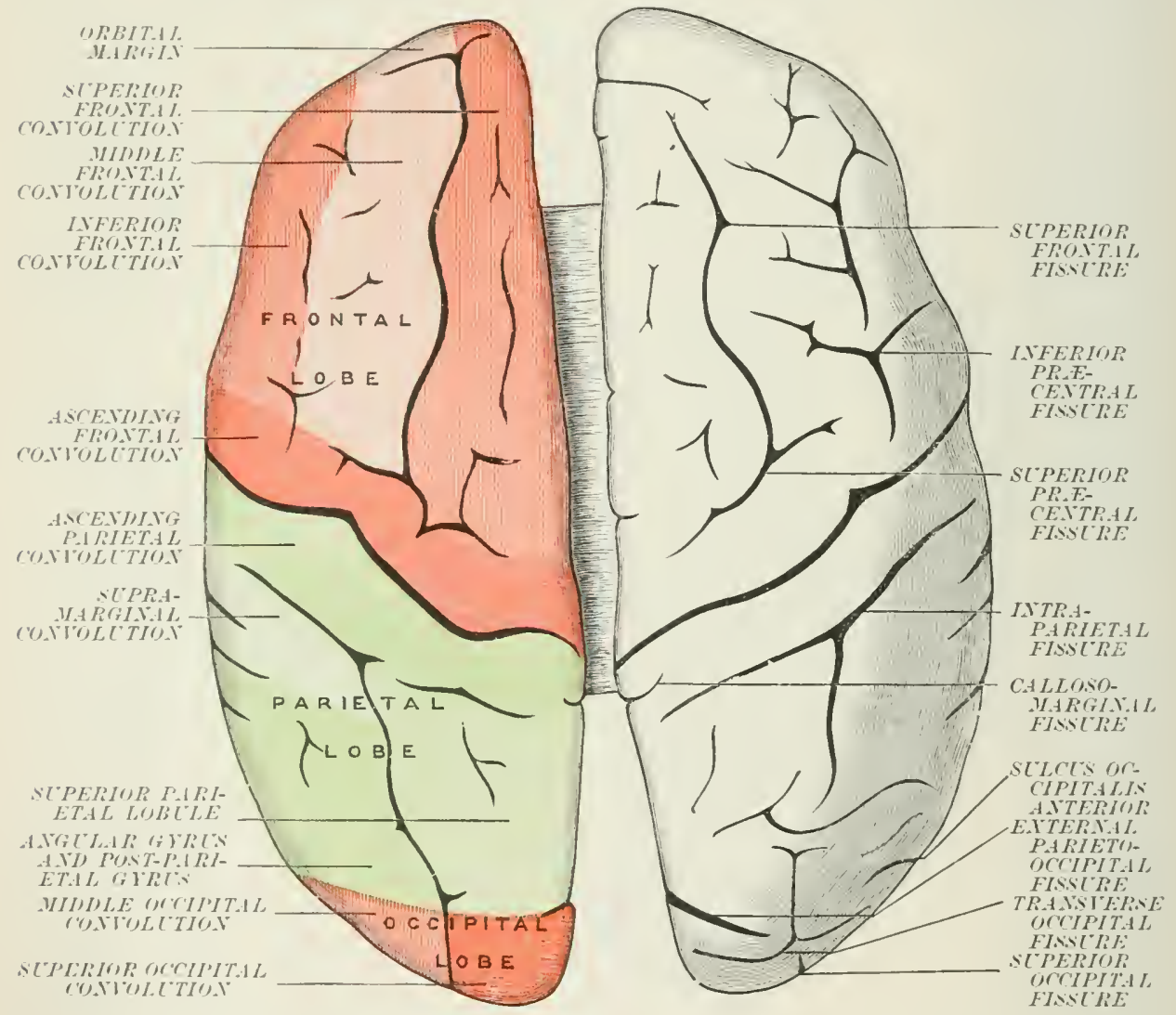

main fissure; it passes backwards and slightly upwards, separating the tempromsphenoirlal from the frontal anel prietal lobes, and finally, taking a more urwarl clirection, encls in the parietal lohe. The ascending limb is short and pases: vertically murarls; the inferior frontal convolution arches aromel it. The anterior limb is about the same leneth as the ascending; it passes directly forwards into the sulsitance of the inferior frontal anvolution.

The convolutions which surromel the fissure of Sylvins orver in and conceal the econtral lolw and are therefore called the operenla. The oprerenla are four in number-the temperal, the fromto-parietal, the frontal, and the orlital. The temporal operculum is fomerl liy the mper tempon-sphemoirlal anvolution, the fronto-parietal operculum hy the lower encls of the aserenting frontal and garietal convolutions and the posterior and of the inferior frontal convolution. 
The frontal operculum is the small part of the inferior frontal convolution inclosed betwern the ascenting and the anterior horizontal limbs of the sivlvian fissure and the orbital operculum is the part of the inferior frontal convolution leneath the latter limb.

The fissure of Rolando, or central sulcus, serves as a line of remareation between the frontal and parietal lobes. It is, next to the fiscure of sylvius, tho most important of the incomplete fissures of the lran. It extends from the great longitudinal fissure to the sylvian fissure, and may communicate with the latter (19 per cent., Cumningham), but the communication is alwars shallow. At its upper end it usually (60) per cent., ('mningham) passes into the great longitudinal fisture and alpliars on the mesial surface of the hemispluere, where it ends by bending backwarls for abont a quarter of an inch. The fissure of liolancto is directed downwards and forwards so that the fissures of the two sirles taken togrether form an angle of about $143^{\circ}$, open in fromt. The fissure does not pursue a perfectly straight course, but is somewhat sinuous, and two of its bends, more

Fig. 410,-Lateral View of the Fisstres axi Coxyolutioss of the Cerebrey.

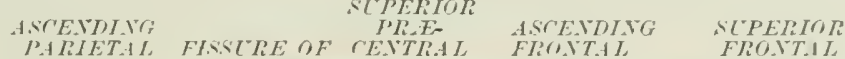

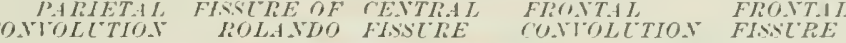

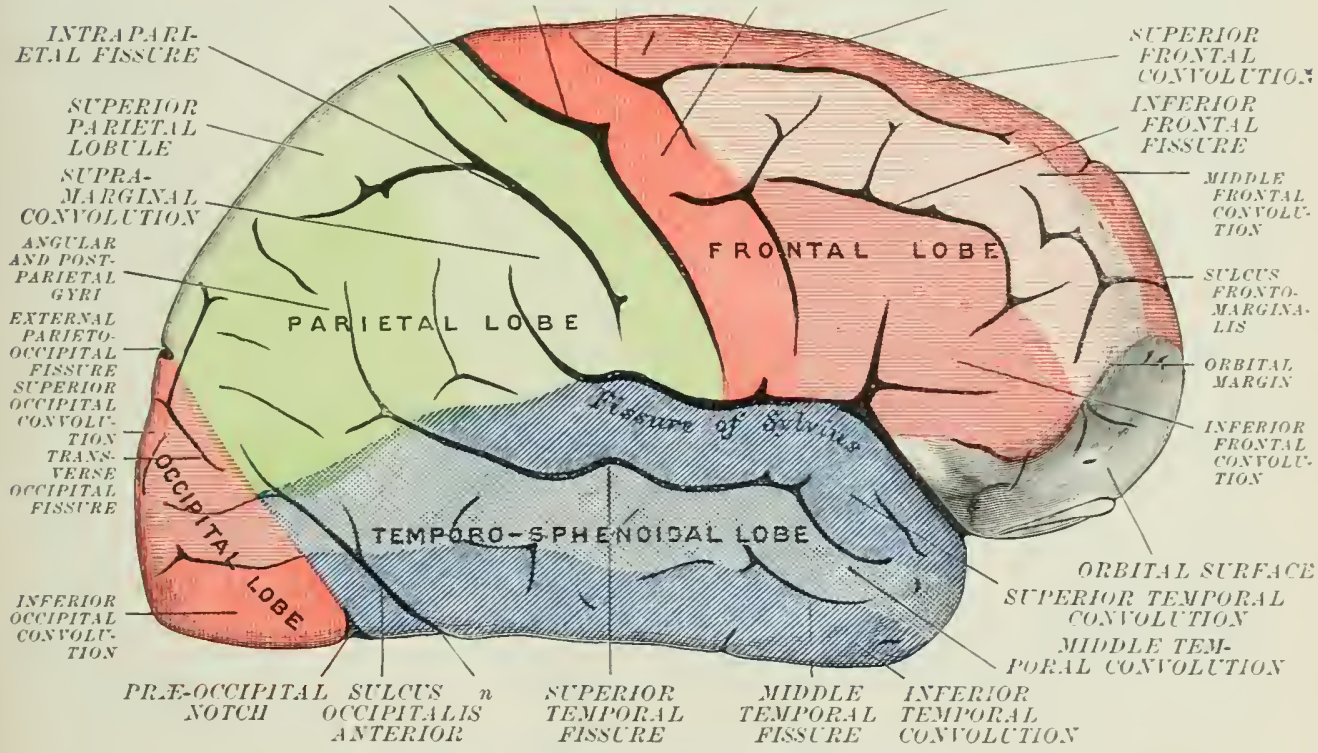

conspicuous and constant than the others, have been described as the superior and inferior genua. These genua mark off the fissure into three aproximately equal parts. The superior genu is directed haekwarls. The inferior genu looks forwards; it is more eonstant and much more strongly marked than the superior genu. In rare cases the fissure of Polando may eommunicate with the precentral or intraparictal sulci, but as a rule it pursues an isolated course across the convex surface.

It has been very generally taught that the fisure of Rolando is causerl by the jressure of a vein which passes during foetal life (from the fourth to the sixth month) from the widlle cerebral vein to the superior longitulinal sinus. This view has been recently disprered, as it his been slown that the fissure develops in two segments, an upper and a lower, and the fiscure is afterwards eompleted by the sinking down of the central portion. The remains of this contral elevatim can always be seen on opening the fissure of Rulandu ats a deeply placed annectunt or bridging conwolution at the level of the superior genu. (Cmuninghan.)

The fissure of Rolanch is one of the earliest of the incomplete fissures to appear, and is usually developerl during the last week or ten days of the fifth month of intra-nterme life. By its transverse direction it interrup,ts the lungitudinal cuurse of the wajurity of the (cerebral fis:ures; 
this peculiarity is shared, however (but not so constantly), hy the pracentral sulcus and by the vertical part of the intraparietal fissure. It is one of the most important landmarks on the cerebral surfice, as the principal motor ceutres of the cortex are situated around it.

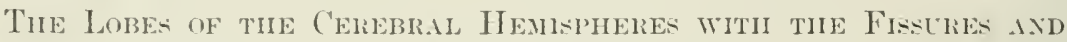 Convolutions}

Eich cereloral hemisphere is divided into five lobes, viz. the frontal, parietal, occipital, temporo-sphenoidal, and the eentral lobe or island of Reil. Four of these Inhes are visible on the peripheral part of the hemispleres; the fiftl, or istand of Ricil, is deeply placed and is concealed by the operenlum.

Two other lobes, the limbic and the olfactory lobe, are also described.

The FRONTAL LOBE oceupins the fore part of the hemisplicre and presents three surfaces: a convex supero-external or frontal, an inferior or orbital, and an internal or mesial. The convolutions and fissures on the mesial and tentorial surfaces of the hemisphere will be described separately. The frontal lobe is bounder hohind by the fissure of Rolando, and below, for about its posterior half, by the stem and posterior linb of the fissure of Sylvius. It is limited internally by the callosomarginal fissure.

The frontal surface is separated from the orbital by a well-marked angle which may be alled the orbital margin. This margin is usually destitute of fissures. and forms a curve concentric with the orbital areh of the frontal bone. The fissures on the frontal surface require description: one of these, rumning in a transverse direction, is temed the pracentral, the other two, which run parallel to the great longitudinal fissure, are named superior and inferior frontal.

The præcentral sulcus is placed in front of and parallel to the fissure of Rolando, and is usually divided by a sagitally-placed convolution into two parts, a superior and an inferior precentral; the former is usually continuous with the superior frontal fissure.

The superior frontal fissure is sometines discontinuous with the precentral. It its orhital end it often passes into a cormally placed, curved fissure, termed the sulcus fronto-marginalis. The latter is situated just above the orbital margin of the frontal lolse.

The inferior frontal fissure may be continuous with the pricentral, but a namow grms usully separates the two fissures.

The convolutions on the frontal surface are four in number: one directed transversely to the long axis of the corebrum, the ascending frontal; and three lying in an antrio-posterior direction, named stuperior, middle, and inferior frontal.

The ascending frontal convolution bounds the fissure of Rolando in front, and is placed between that fissure and the precentral suleus. It is connected at the lower ent of the fissure of Rolando with the ascending parietal eonvolution, and fusses into the paracentral lobule on the inner face of the hemisphere.

The superior, midkle, and inferior frontal convolutions oecupy the remainder of the frontal surface, and are matked off by the sulerior and inferior frontal sulei. They pass forwards, and become continuous with the convolutions on the orlital surface. They are not simple, but are traversed luth in a coronal and sagittal direction he tirtiary fissures.

The superior frontal convolution is continumes helinel with the ascending fromtal, and passes in front into the grous reetur and inte the intromal and anterior

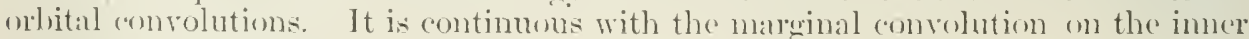
face of the hemisphere.

The middle frontal convolution is entinuous behind with the ascending frontal when the stuperior and inferion presentral fistures are discontinuous. It passes in front into the anterior orbital gyrus. It is alnost invariably continuous with the superior and inferion frontal convolutions at the orbital margin of the frontal lobe, and is often eomnerefer to these comvolutions hy secondary gyri passing arens the superior and inferior frontal fistures.

The inferior frontal convolution is continuous behind with the asecunding frontal, and joins the external orbital grrus anound the orbital margin. The 
ascending and anterior limbs of the fissure of sylvius eut into the substance of this convolution, and divide it posteriorly into three parts, viz. pars orbitalis, pars triangularis, and pars hasilaris. The pars orbitalis is situated below the anterior limb of the sylvian fissure. The pars triangularis is included between the aserendiner and anterior limbs of the fissure. The pars basilaris is platerl behind the ascending limb of the sylvian fissure between the latter and the inferior wrecentral sulcus.

This convolution is of great physiological interest, as the faculty of articulate speech is lncalised in its posterior part (Bruca's convolution). Disease of this limited portion of hrain substance on the left side produces aphasia, except in left-handed prersons, in whom the speech-centre is placed in the eorresponding position on the right side. The sneech-centre is linited to the pars basilaris. Aceording to Ferrier, the speech-centre includes (in addition to the above) the inferion extrenity of the ascending frontal convolution and a small part of the ascending parietal immediately behind the lower end of the fissure of Rolande.

The orbital surface of the frontal lobe appears flattened in hrains hardened in the ortinary manner; but when the brain is hardened in situ (fig. 410 ) it pressents a very characteristic concavity, being moulded on the orbital plate of the frontal bone. The outer half of the orbital surface looks directly downwards, but the inner half, following the eurve of the orbital plate, looks much more outwarls than downwarls, and forms a tolerably sharp edge where it meets the intemal surface. Two fissures are situated on this surface, viz. the triradiate and the olfactory.

The triradiate fissure, as its name implies, is formed by three lranches, which racliate from a common point. One branch is directed forwards. another hackwards and inwards, and the third outwarks. Another branch frequently surings from the external division near its centre, and in such cases the triradiate fissure assmes an $\mathrm{H}$-shaped outline.

The olfactory or straight sulcus is placed a short distance external to the great longituclinal fissure, and lockes the olfactury tract and hull.

'The convolutions on the orbital surface comprise the three orbital convolutions and the straight convolution.

The orbital convolutions are wedge-shaped masses placed between the limbs of the trirarliate fiscure. They are called, from their position, internal, anterior, and posterior. They are continnous with the superior, middle, and inferior frontal convolutions resectively.

The straight convolution, or gyrus rectus, is situated between the suleus of the same name and the margin of the great longiturlinal fissure. It is continuous in front with the superior frontal convolution, and on the inner margin of the hemisplere with the marginal gryus. It is sometimes described as a part of the internal orbital convolution.

The convolutions on the intermal surface of the frontal lobe are the marginal and the paracentral. The student is recommended to defer the study of these till a later period (page $690)$.

The PARIETAL LOBE occupies the portion of the convex surface between the frontal and occipital lobes and ahore the temporo-sphenojolal lobe. It is hounderl in front by the fissure of Polando. Internally it is continued into the mesial surface of the hemisphere, where it is marked off from the adjacent lobes by the upturmer enct of the callosn-marginal fissure in front, by the internal parieto-ricripital fissure behind, and nore obsemrely betow by the variable sulcus subparietalis. (On the convex surface of the hemisphere the posterior limits of the parietal holos are in a great measure artificial. The external paricto-occipital fissure marks it off for a short distance, and the boundary is then crossed by convolutions temerl annectant grri, which run in a sagital direction and so bring the parietal and oceipital bohes into direct continuity. There is, however, a notch, the prip-orcipital notch (fig. 410 ), placed at the lower margin of the hemisphere between the oeripital and temural lobes, and if a line he drawn from the extremity of the external parieto-ocoijital fissure to this notrh, the upper yart of the line, together with the rixtrinal parietooccipital fissure, scyarates the parietal from the occipital lobe. The parietal lobe 
is limited below by the posterion limb of the sylvian fissure in the horizontal part of its course, and lehind this its lower limits are artificially malped out by producine the horizontal part of the sylvian fissure backwards to meet the posterior boundary. The palietal lobe contains one fissure of inportance - the intraparietal.

The intraparietal fissure is a systrm of three fissures, viz. a superion and an inferior rertial, placed prarallel to the fissure of lolando; and a horizontal placed at right angles to the other two. These parts may in rale calses remain selarate, lout most commonly are united with one another, forming a $T$-shapeel figure. Moreover, the horizontal fart may mite with a fourth grart, the ramus occipitalis, which extench into the occipital lobe.

The intraluarietal fissure has been hitherto reganded as consisting of an ascending and a herizontal part; the upper rertical limb (postcentral sulcus) being iletacherd. This is a common variety of the fissure, but it has recently been shown that the T-shaped form is the commonest or normal arrangement. (C'unninghami.)

The convolutions of the parietal lobe are: an ascending parietal, bounding the fissure of Rolando posteriorly and placed between that fissure and the intraparietal sulcus; and two parietal lobules, a superior and an inferior, placed above and below the lorizontal limb of that fissure. The inferior parietal lobule is further subdividerl into an anterior part called the supramarginal convolution, a midrlle, termed the angular grrus, and a posterior part, the post-parietal convolution.

The ascending parietal convolution extencls from the postorior limb of the Sylvian to the great longitudinal fissure, and is hounded in front by the fissure of Rolando, and behind by the intraparietal sulcus. It is continuous with the supramarginal convolution below the intraparietal fissure, and at its upper end is continued into the paracentral lobule on the imer surface of the hemisphere.

The superior parietal lobule is a squarish mass inctented on the surface by tertinry fissures. It is limited internally by the margin of the great longitudinal fissure where it hecomes continume with the precuneus. The anterior end of the ramus vecipitalis of the intrapurietal fissure temmates in this lolule when it is not continuous with the remainder of the intraparietal fissure, and, in such cases, the superion and inferior parietal lobules are continuous posteriorly. The superior parietal lobule is joined in front, hy a comvolution of variable lireadth, with the

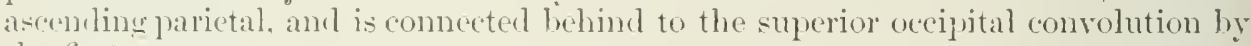
the fin'st annectant gyrus.

The supramarginal convolution is the anterior part of the inferior parietal lobule. It arches around the uptumed extremity of the posterior limb of the fisture of sylvius. It is continuous in front with the ascending parietal comvolution, behind with the superior temporal gyrus and also with the angular gras. It is often very obscurely marked off from the latter.

The angular gyrus is placed hehind the preceding and embraces the extrenity of the parallel fissure. It is ontinuous behind with the middle temporal convolution. It is also usually connected to the middle occipital convolution by the third anneretant gryus.

The post-parietal convolution forms the posterior part of the inferior parietal lobule. It curves round the second temporal suleus and joins the third temporal ("onvolution.

The OCCIPITAL LOBE occupis, approximately, the portion of the cranial cavity which is interposed between the superior fosse of the ordipital bone and the tentorimu cerehelli. It presents three pery distinct surfaces: a convex supero-(x)emal, a mesial or intrmil, and a tentorial. The latter looks downwards and slightly inwards. These three surfaces meet at the oreipital pole. It is shamply markeit off on the mesial surface hy the internal parieto-oreipital fissure. On the conrex surface the line of demarcation (as already described in treating of the parietal lohe is mate by drawing a line from the extrenity of the "xternal parieto-oceipital fissure to the primecipital notch (fig. 410). This line separates the occipital from the parietal and tempural hobes.

The præoccipital notch (fig. 410 ) is prorlucel by the impression of the reins which enter the lateral sinus. Inother impression (fig. 410, n), which is produced 
by the superior borler of the petrous portion of the temporal bone, has been sometimes described as the preoceipital notch.

It is generally stated that the occipital lobe passes into the temporal lobe on the tentorial surface without any line of demareation. A mumber of methorls of mirking off the occipital lole have been proposed by different authors. These are all largely artificial. 'The occipital lobe is due to a backward growth common to the parietal and temporal lokes. That growth earries with it a prolongation of the lateral ventricle, forming the posterior coruu. The vecipital lube is therefore that lart of the hemisphere which contains the posterior corvu. It may be markerl off on the tentorial surface by a line drawn fiom the preoceipital notch to the extremity of the parietooccipital fissure at the isthmus of the gyrus formicatus (fig. 411). 'The remaining bonmlaries will be the parieto-occipital fissure for its entire length and (as before) a line drawn fiom the extremity of the external parieto-occipital fissure to the præoccipital notch.

The fissures on the convex surface of the occipital lobe are the superior, mindle, and inferior oceipital fissures; to these may be added the ramus oceipitalis of the intraparietal fissure with its appendage the transverse occipital fissure.

The superior occipital fissure may be represented by a direct continuation of the intraparietal fissure to the occipital pole of the cerebrum. Hore commonly, howerer, it is limited to the posterior part of the oreipital lobe (fig. 409, right sicle), and is not continuous with the intraparictal fissure. The ramus occipitalis of the intraparietal fissure may be directly continued into the occipital lobe from the horizontal limb of the main fissure, or it may commence in the superior parietal lobule. In either case it passes backwards into the oecipital lobe between the first and second annectant gyri, and usually terminates a short distance behind the external parieto-occipital fissure by dividing into two branches which extend upwards anct downwards at right angles to the main fissure, and together constitute the transverse occipital fissure.

The middle occipital fissure is often feebly rleveloped. It is directerl from lufore hackwards and meets the superior oecipital fissure at the occipital pole.

The inferior occipital fissure is jlaced along the margin which separates the conver surface from the tentorial surface of the hemisphere. It may extend in a tortuous manner from the preoccipital notch to the occipital pole of the hemisphere but is often broken up by one or more convolutions crosing it.

The convolutions on the convex surface are three in number, and are imperfectly marked off from one another by the fissures above described. They pass from before hackwarls and become conlluent at the occipital pole.

The superior occipital convolution is placed between the superior ocripital fissure and the margin of the great longitudinal fissure. It is continuous with the cuneus on the inner surface of the hemisphere, and is joined in front by the first annectant grrus to the superior parietal lobule.

The middle occipital convolution is situaterl between the superior and middl, occipital fissures, and is united in front to the post-parietal by the second and third annectant gyri.

The inferior occipital convolution occupies the interval between the middle and inferior occipital fissures, and may be connected to the middle temporal convolution by a fourth amectant gyrus.

The annectant gyri are four small sagittally-directed convolutions which cross the boundary line which separates the occipital from the parietal and temporal lobes. They are numbered from alove downwards. The first and serond of these are the most eonstant and are placed one on earch sicle of the ramus occipitalis of the intraparietal fissure. The third and fouth are not infieifuently absent as they may be ent through by a fisinre, the sulcus occipitalis anterior.

The sulcus occipitalis anterior is an inconstant fissure which is parallel to, and placed a little in front of, the anterior boundary of the occipital lobe on the convex surface of the hemisplinere.

The TEMPORAL LOBE (temporo-sphemoidal lobe) is sharply marked off in front by the sylvian fissure, but, as we have already seen, it passes hehind without any surface line of demareation into the parietal and occipital lobes. Its anterior extremity forms a bold prominence directed downwards and forwards (the temporal pole of Broca). It has four surfaces: an extrual, forming part of the general conrexity of the hemisphere; an inferior, whinh rests on the great wing of the sphenoid and the adjacent part of the jetrous portion of the temporal bone; a tentorial. 
and a superior, which is -ituated within the sylvian fissure and can be clisplayed by pulling up the oprerulum.

The boundaries of the temporal lobe have been already indieated in the deseription of the other lobes, but may be recapitulaterl as follows. It is bounderl belind hy the lower part of the line drawn from the external parieto-oecipital fissure to the preoceipital noteh. Above, it is limiter ly the horizontal part of the posterior limb of the Sylvian fissure and by a line continuing the lorizontal direction backwarls to meet the posterior boundary. Its tentorial surface may be marked off from the occipital lobe by a line drawn fiom the praeoccipital notch to the isthmus of the gyrus fornicatus.

Thros fistures traverse the temporal lohe in a direction parallel to its long axis. The first of these, the superior temporal or parallel fissure, is one of the most comstant of the incomplete fissures of the cerebrum. The other two, termed midile and inferior temporal, seldom appear as well-marked sulci, being as a rule broken up, by fissures and grid erossing at right angles to their direction.

The collateral fissure on the tentorial surface is approximately parallel to the three temporal sulci; it marks off the temporal from the falciform lobe.

The parallel fissure commences a short distance behind the apex of the lolve, and taks a course parallel to the posterior limb of the fissure of sylvius. Its uptumed extrenity ends in the parietal lobe, where it is embraced by the angular gy'mis.

The middle temporal fissure runs in the same general direction as the parailed fir-ure but is placed at a lower level. It may communicate behind with the sulcus accipitalis anterior.

The inferior temporal fissure is placed on the under surface near the lateral margin of the hemisphere. It is in a line with the inferion occipital fissure.

Three convolutions are present on the outer surface, running in an anteroposterior direction. They are termed the superior, middle, and inferior temuoral convolutions. They become confluent with one another at the apex of the lobe.

The superior temporal or inframarginal convolution lies between the Sylvian and parblel fissures. It is comtinuous alove with the supramarginal and angular erviti.

The middle temporal convolution, placed hetween the parallel and the mirldle tempural fiscures, is continuous behind with the angular gyrus and the post-parietal convolution. It is usually joined to the inferior occipital hy the fourth amnectant gyrus.

The inferior temporal convolution is situated on the lateral margin of the hemisphere. It may be comnected to the inferior oeciputal eomvolution by a fifth annectant grvus.

The superior surface of the temporal lohe is in contact with the operculum. It is asced hy two or three (sometimes four) transverse temporal convolutions. (Hesclil.)

Dissection.-The student shuuld now raise the opereulum and at the same time draw the temporal lobe downwards in order to hring the island of Reil into view. 'The large branches of the midlle cerebral artery which lie among the convolutions of the island should be removerl, together with the allherent yia mater.

The CENTRAL LOBE or ISLAND OF REIL corresponds to the floor of the embryonic: fossa Sylvii, and is placerl extemal to the clanstrum. Its form is triangular; the hase of the triangle is placerl upwarks and inwarks, the apex forms a prominence, the limen insulde, which separates the vallocula sylvii from the fissure of the same name. It is hidrlen by the opercula and is surrounded, except at the limen, by a curved furrow, the sulcus circularis Reilii (Schwalbr). From five to seven convolutions, the gyri operti, rarliate from the limen insula. The island is divided into a larger anterior part (pars frontalis), and a smaller posterior part (pars parieto-falciformis) hy a constant fisknre, the sulcus centralis insulæ (Hefftler and Eherstaller), which has the same dircetion, and is in the same plane, as the fissure of liolando. 
The pars parieto-falcitormis is usually termed pars temporo-parietalis ; a -tudy of the develomment of this part of the island has shown, hewever, that it is connected with the falciform and not with the temporal lobe. (C'muinghan.)

Dissection.-The student is recommended to defer the study of the convolutions on the mesial and tentorial surfaces of the hemisphere until the dissection of the corpus callosum is completed, and to proceed as follows. He should make a horizontal section through the uppermost part of the crebral hemispheres; this will display the eentral core of white matter (centrum ovale minus) surrounded he a convoluted border of grey matter. Within the white matter a number "If minutr vessels will be seen which alnear as ljeeding points in a fresh brain (the puncta vasculosa vel cruenta). He may then remove successive thin sections until he reaches the level of the corpus callosum, the fibres of which, spreading out into the hemisphere, form an extensive white laver eallerl the centrum ovale majus. A far more instructive disection, however, ean be made h,y cautiously tearing the brain substance in a direction from within outwards until the callowal fi-snre is reached. By the latter method the following foints ean be made wut in an ordinary well-harlened brain: (1) The white filses entering each convolution sprealing ont so as to end jernemlicularly to the surface. (2) The fibres from the body of the cor']ns eallusum passing at frist lorizontally outwards into the hemisphere and then diverging, sme sweeping upwards to the parietal and frontal lubes, others hending downwards into the temporal lobe and following the long axis of that lobe. At the point where they lend dowuwards they readily break, as they are here intersected by fibres passing upwards from the inner capsule. (3) The fibres from the anteror and posterior extremities of the eorjus callosm rassing in a curver manner into the frontal and acipital lobes respectively, forming the forceps minor and the forceps major. (4) A set of fibres, known as the cingulum, which run within the gyrus fornicatus, forming a sagittallydirected arch. The dissector shond next study the corpus callosum and the convolutions on the inner fice of the hemisphere. The eonvolutions on the tentorial surface may be learned from a mounted specimen, or better still from a cast of a cerebral hemisphere, and the actual convolutions can be examined when the hemispheres are cut away from the mesencephalon at a later stage.

Mesial and tentorial surfaces of the hemisphere.-The mesial surface of the hemisphere is narked off from both the convex supero-external and the tentorial surtace ly the margin of the great longitudinal fissure. This margin follows a curved course as a well-defined horder from the posterior extremity of the gyrus reetus as far as the occipital pole of the cerelorm. From this point it passes forwards and pursues a slightly curvel course to the splenimm of the corpus callosmu inmediately beneath which it ends. The latter part is termed by schwalle the internal occipital border; it is only seen in carefully-hardened brains, and appears as a rounded margin crosing the bilutus lingualis, and in front of this marking the crus fornieatus inmediately above its isthmus (fig. 411). The tentorial surface is marked off from the supern-external surface by a well-rlefinct border which extends from the occipital pole to the extremity of the temporo-sphenoidal kohe. forming a slight curve with the convexity upwards. The fissural system of the inesial and tentorial surfaces is of considerable importance and interest, as all the complete fissures of the cerebrum appear on these surfaces. These fiscures are, ats already mentioned. the internal parietn-occipital. the calcarine, the dentate, and the collateral. The calloso-marginal, a constant and important incomplete fis:ure, is also to be seen on the mesial surface.

The calloso-marginal fissure commenees below the genu of the corpus callosm and pursues a curved course parallel to the corpus callosum until it reaches a jwint a short distance behind the upper extremity of the fissure of Rolando. It then hends upwarls and extends on to the comvex surface for a short clistance, where it indents the upper end of the ascending parietal convolution. Two branches which pass from this fisure deserve special mention as. although not constantly present, they form useful lines of demaration. One of these, the sulcus paracentralis, passes upwarls between the paracentral and the marcinal crompolutions. Another, the post-limbic or sulcus subparietalis, pass's backwards from the hend of the main fissure and separates the jurecuneus from the gyrus fornicatus.

The parieto-occipital fissure commenew at the isthmus of the groms fornicatus, and passes at first backwarls and upwards. and then almost vertically upwards to reach the margin of the hemisphere, where it bends outwards and ends as the extrornal parieto-occipital fisiure.

The calcarine fissure rommences by a hificl extremity near the occipital poie. and passes horizontally forwarls with a slightly curved course to become confluent with the parieto-ocripital fissure. 
From what has been sajel, it folluws that the internal parieto-occipital and calcarine fis-sures form by their union a $Y$-shapeel figure. The hinder part of the stem of the $Y$ and the fore loat of the calcarine tissure probuce an rlevation within the posterior cornu of the lateral ventricle known as the hippocampus minor. It has been recently shown that in its derelopment the stem of the $Y$ may belong to the parieto-oceipital fissure alone, or to the calcarine alune, or may be common to both. (Cumuinghan.)

The callosal fissure is a deep furrow which follows the curve of the corpus callosum, being placed between that body and the gyrus fornicatus. It commences below the rostrum of the corpus callosum and terminates behind the splenium, where it becomes continuous with the lentate fissure.

The dentate or hippocampal fissure extends from the splenium of the corpus (allosum to the hooked extrenity (uncus) of the uncinate graus. It produces an elevation in the descending cornu of the lateral rentricle, which is termed the hippocampus major.

The collateral fissure is common to the oceipital and temporal lobes. It passes

Fig. 411.-Convolutions and Fissures on the Mesial and Textorial Strfaces of the HeJispliere.

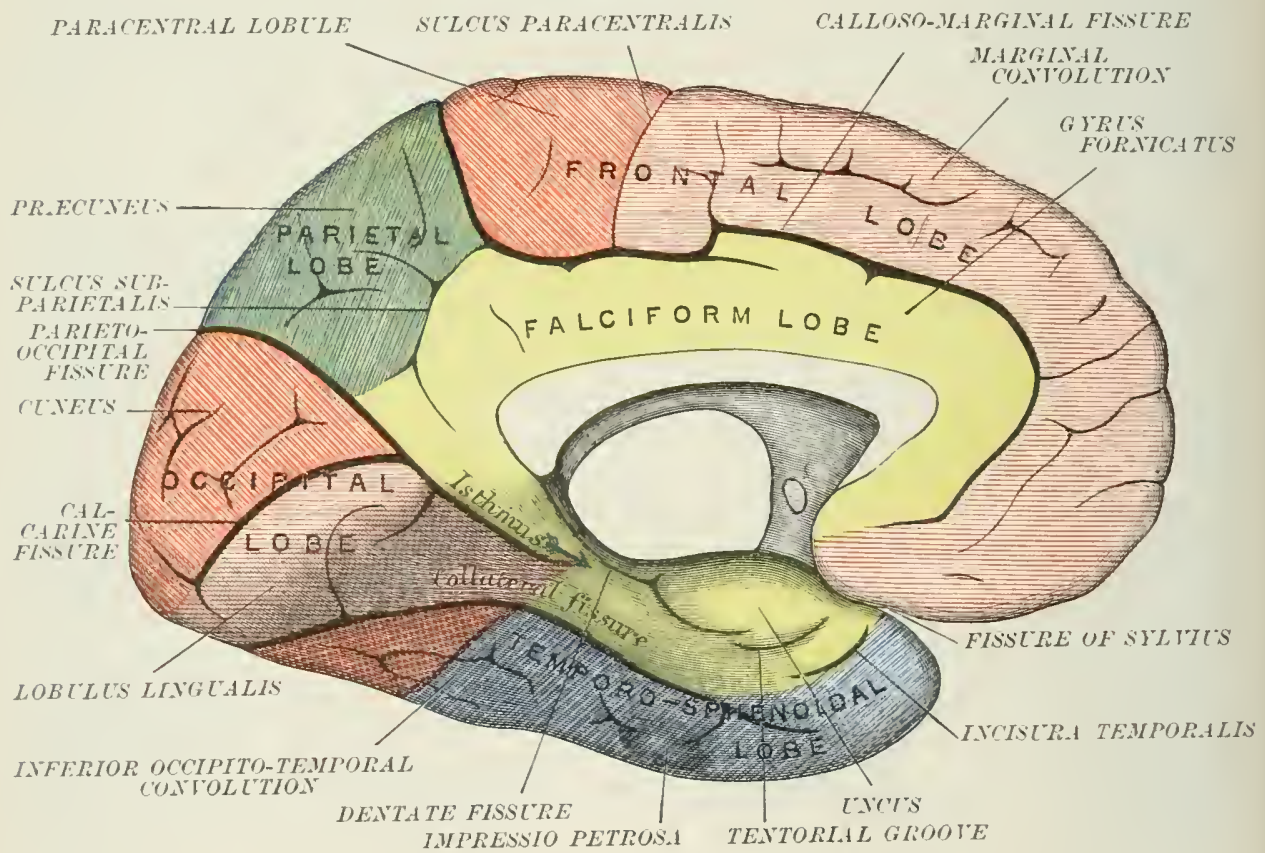

from a point on the unfler surface of the temporal lobe, near its apex, to the occipital pole of the hemi-phere. The reverse of this fiscure appears as an elevation (the eminentia collateralis) in the descenting cornu of the lateral ventricle.

The following convolutions appear on the mesial and tentorial surfaces:-

The marginal convolution eommences below the rostrum of the corpus callosm and oceupies the area of the mesial surface between the calloso-marginal fissure and the margin of the hemisphere as far as the paracentral suleus. The latter separates it from the paracentral lobule. It is continuous around the margin of the hemisphere with the gyrus rectus, the internal orbital, and the superior frontal convolutions. It is marked by tertiary fissures along its whole course, in larticular by a tissure which rums for some listane parallel to the calloso-marginal suleus.

The paracentral lobule is bomeled in front by the palatentral suleus; below and hehine by the eallosis-marginal fissure. It is continnous aromed the margin of the hemisphere with the aseemeling frontal and ascemeling parietal convolutions; but as it is comnected with the former ly a much broater hamel than with the latter. 
When the typical backward turn of the upper extremity of the fissure of fiolindo is jnesent. it hooks balekwarks into the forward lend formed by the upper extremity of the calloso-marginal fissure, and thus the frontal and parietal lobes are only connected by a narrow isthmus between the two fissures.

The gyrus fornicatus, or gyrus cinguli, which forms part of the limbic lobe. commences hetween the rostrum of the corpus callosun and the extremity of the marginal convolution, and, pursuing an archerl course prallel to the corpus callosum, ends in a narrow convolution, the isthmus, which commets it to the uncinate grrus. It is placed between the calloso-marginal and callosal fissures, and is thus clearly marked off from adjacent structures in the greater part of it: extent, lut is often very imperfectly separated from the superior parictal lobule. It may also be connected to the hinder end of the marginal convolution by a small iryus crossing the calloso-marwinal fissure.

The præcuneus, or quadrate lobule, is a squarish mass of small grri which is continuous around the margin of the hemisphere with the superior parietal lobule. It is bounded, in front by the upturned end of the calloso-marginal fissure; behind, by the parieto-occipital fissure; and it may be marked off below, from the grrus fornicatus, by the sulcus subparietalis.

The cuneus, or cuneate lobule, is a werge-shaped mass oceupring the interval between the intemal paricto-oceipital and calcarine fissures. It is continuous around the margin of the hemisphere with the superior occipital eonvolution. In a properly hardened right hemisphere it shows a distinet bevelling near the margin. This is produced by the impression of the superior longitudinal sinus. This bevelling can be traced downwards to the extremity of the lobulus lingualis, and les:distinctly forwards to the precuneus. In rare instances it may be seen in the left hemisphere instead of the right.

Two sagittally directed convolutions are situated on the tentorial surface. They are termed the superior and inferior occipito-temporal convolutions. The superior of these is divided into an anterior part called the uncinate grrus, and a posterior part which is known as the lobulus lingualis.

The uncinate convolution commences behind at the isthmus, by which it is continums with the grrus fornicatus, and ends immediately behind the anterior perforated space in a hook-like elevation, the uncus. It is separated from the dentate convolution by the rlentate fissure, it is marked off from the inferior occipito-teniporal convolution by the collateral fissure and, in front of this, by the incisura temporalis, it forms part of the limbic lobe. The outer part of the anterior end is marked by a distinct groove, which, as it is producerl by the free edge of the tentorium cerebelli, may be ealled the tentorial groove (fig. 411).

The uncinate convolution is covered mith a peculiar fine network of white filres, the substantia reticularis alba. These fibres are derived fiom the stria longitudinales laterales which jass from the splenium of the corpus callosum on to the isthmus, and from thence to the uncinate gyrus.

The dentate convolution or fascia dentata will be more conveniently described with the anatomy of the lateral ventricle, as it is usually dissected in connection with that carity.

The lobulus lingualis is the prosterior part of the superior oecipito-temporal convolution. It is bounded by the calcarine and parieto-oceipital fissures above, and by the collateral fissure below. As the internal occipital border crosses this lobule it divides it into two parts, an upper part which appears on the nesial surface, and a larger lower portion situated on the tentorial surface.

The inferior occipito-temporal convolution extends from the alex of the temporal lobe to the occipital pole of the hemisphere. It is hounder ahove by the collateral fissure, and betow by the inferior temporal and inferior occipital fisures. It is marked by the impressio petrosa at the junction of its anterior and middle thirds.

Three distinct impressions, which lie in a line with one another, are prorlueed on the brain ly the petrous portion of the temporal bone. One of these (fig. $410, n$ ) corresponds to the portion of bone opposite the confluence of the superior petrosal with the lateral sinus. Another, the impressio petrosa, which may be large and cunspicuus, is caused by the prominence of the 
superior scuicirendar canal. The third impression (incisura temporalis) is situated near the vallecula sylvii, about one-thiml of an incel extemal to the tentorial gronve.

The LIMBIC LOBE lies on the mesial and tentorial surfaces of the cerebrim. It is lesunded extemally by the calloso-marginal sulcus, the subparietal or post-limbic sulcus, the stem of the alcarine fisture, and the collateral fissure. It consists of an outer part formed by the callosal comvolution, the isthmus and the uncinate errus, and an inner part in which are included the fornix, the septum lucidum. the stria longitudinales mediales and laterales, and the fascia dentata, all of which will be subsequently described.

THE OLFACTORY LOBE.-The olfactory lobe attains a considerable size in some of the lower mammals, and in them it may contain a prolongation of the lateral rentricle in its interior; in seals it is small, in cetacea it is absent, and in monkeys and men it is rudimentary. Its anterior part is developed as an outgrowth of the corebral resicle, but the cavity, which is present at first, soon disippears in man, though its position is indieated, even in the adult, by the remains of the ependyma which lined it.

The olfactory lobe is divided into two lotules-the anterior and the posterior. The constituent parts of the anterior olfactory lobule are the bulb, the tract, the trigonum olfactorimm, and the olfatery area of Broca. It is sriarated from the posterior olfactory area hy a curved fissure, fissura prima, which rums outwards fron the great longitudinal fissure in front of the anterior perforated space.

The olfactory bulb is an ovoid mass of gray and white matter a little more than a third of an inch long $(1 \mathrm{~cm}$.) and about a sixth of an inch ( $4 \mathrm{~mm}$.) wirle. It rests below on the cribriform plate of the ethmoid hone, and is lodged alove in the olfactory sulcus on the orbital surface of the frontal lobe. Ahout twenty olfactory nerves spring from its lower surface and pass through the foramina in the cribriform plate.

The olfactory tract is a triangular hand of white matter which extends hackwarls from the posterior extremity of the bulb. It is about three-quarters of an inch long (2 cm.) and one-tenth of an inch broad (2.5 $\mathrm{mm}$.). Its apex is Fmbeded in the olfactory sulcus and its lower surfice rests on the presplienoid hone (jugum sphenoidale). Posteriorly it terminates in two roots, the mesial and lateral. which enclose the trigonum olficturimm. The lateral root passes outwards and backwards across the anterior perforated space to the anterior end of the uncinate grus; the mesial root curves inwards behind Broca's olfactory area and hromes continuous with the lower end of the callosal grus. The anterior olfactory lobule is, therefore. intimately comnected with the anterior part of the limbic libe, the two toguther forming the rhinenerphalon, or racepuet-shaped lobe of Broca.

The trigonum olfactorium is a small triangular area of glay matter enclosed hetween the two roots of the olfactory tract and bounded behind by the fissura juima.

Broca's olfactory area is a small part of the posterior end of the gyrus rectus separated off from the remainder by a small oblique sulcus anlled the fisina serotina and bomeled posteriorly and extemally ly the mesial root of the olfactory tract.

The posterior olfactory lobule is that portion of the gray cortex which forms the anterior perforated space. It is lounder internally by the perluncle of the corpur callosm, anteriorly hy the fistura prina which seprates it from the anterior olfartory lobule, and it extruds extemally into the vallecula sylvii, being crosicel hy the latreal root of the olfactory tract.

THe Cokple Caldosum is a great white transrerse commissure which unites the cerebral hemispheres. Its form can be well studied in a mexial sertion of the hrain (fig. 412), in which it appears as a lomeiturlinal areh with romoled anterior and pesterior extremities. The posterior extremity is called the splenium; it is

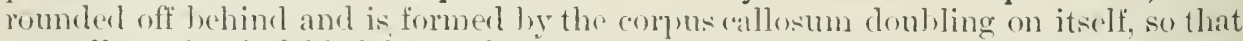
a small portion is folded forwards inder, and in close oplosition to, the larger part (fig. 413). The anterior extremity or genu is les sharply bent than the posterior end. It is continued clownwals and batewads inte a portion which appears 
Fig. 4i:-Masial. Sectiox of Exthe Brin. (After Henle.)

The (*) points to the anterior extremity of the gyrus fornicatus; ahove it is the basal white commissure.

POSTERIOR NTLCESOF MHDPLE FORAMUSY

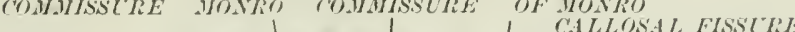

MTAAL BOD

CPRLENICY OF

LAt MISHA

QLAIIIIEEMINA

I UEIDLCT UF SHJ TH

ITH TE OF
IIETSSEXS

CEREBELLLW

FOIRTII IENTRICLE

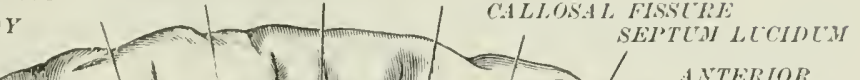
$M$
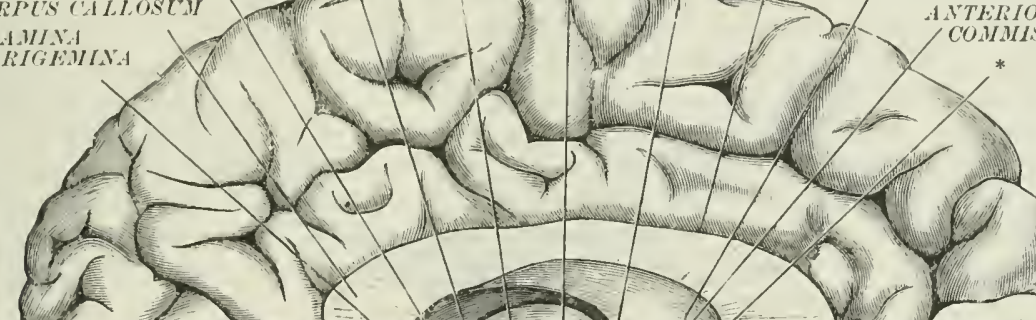
wointed in section and is ealled the rostrum. The rostrum is connected to the mminal cinerea ly a thin larer of white substance, the basal white commissure. The portion which intervenes between the splenimm and restrum, and which eon-

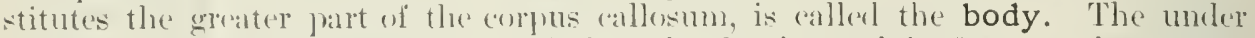
surtace of the luxty is adherent behinet to the formix, and in front to the septem

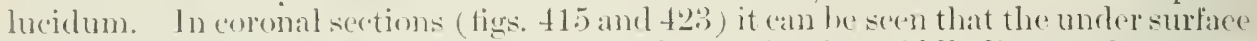
is free for sonte distance, except at its attachment in the midtle line to the fornix and soptum lucislum. This free portion forms the roof of the lateral rentricles. The upper surface lemains free for a shorter distance than the lower, and ends at the fluor of the ablosil tissure, where the filres of the corpus callosum enter the substance of the hemisphere. It forms in the transwerse direction a gentle curve with the concavity directed upwards. Viewed from above, the corpus callosum is scen to present a transverse striation, this being an indication of the lumblles of fibres frasing from hemisphere to hemisphere. These transverws striations are crossed superficially by narow longitudinal lands, the strixe longitudinales mediales and the stria longitulinales laterales or tienia tecte.

The striæ longitudinales mediales are pliced one on each siche of the middle line, and lie very close together, leaving a narrow interval between them which is alled the raphe. Traced forwards, they slightly diverge and pass round the genu to the rostrum; here ther separate more widely, and pass along the inner margin of the anterior perforated space, under the name of the peduncles of the corpus eallosum, and are lost at the commeneement of the fissure of sylyius. Traced hackwards each medial stria is found to be continuous at the splenium of the corpus callosmm with the fasciola cinerea. This turns round the splenium and is continuous beneath it with the fascia dentata.

The tæniæ tectæ, or striæ longitudinales laterales, lie on the mper surface of the corpus callosmm under cover of the callosal grrus. Ther also can be traced backwards romd the splenium into continuity witls the fasciola cinerea. The medial and lateral strice together represent the free margin of the gray matter on the inner surface of the bran, in the same way that the liscia dentata represents it on the tentorial surface, and they constitute the remains of a degenerated supra(allosial gyrus.

The fibres of the corpus callosum after entering the cerehral substance spread out to every frart of the hemispheres (with the exception of small portions of the temporal lobes) in the fullowing sets:-

'The fibres from the genu pass forwards and outwards into the anterior pant of the fiontal lithe, and then sweep inwarls forming the forceps minor.

The fibres from the body have the following distribution :-The uppermost fibres pass outwards and then upwards, and finally curve inwarils to the upper and mesial surtiees of the fiontal amt parietal lobes. The intermediate fibres pass transversely outwards to the same lobes. 'The lowest fibres form the roof of the lateral ventricle, and ate separated from that cavity only by the ependyma and epithelium, and livide into anterior and posterior rets which are differently llistributed. The anterior set ends in the opercula. The posterior set forms a hayer alled the tapetum which fillows the dexcending and posterior connua of the lateral ventriele, ronfing over ankl bounding these cormua externatly. The part which finllows the descending cornu is destined for the temporal lohe. The prortion which accompanies the posterior cormu gasses to the under part of the vecipital lobe.

'The fibres from the splenium, and fiom the part which is folded below it, pass lack wards and outwards, and then sweep inwarls forming the forceps major, the fibres of which pass to the josterior and upuer parts of the oceipital lobe.

Dissection.-Having compluted the examination of the corjuns callosmm and of the mesial smeface of the hemisphere, the student should next tum his attention to the tateral ventricles. 'The remaining fibres of the body of the cortus callowm should be divided al little to the right

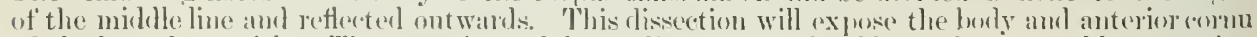
of the lateral ventricle. 'Tlhe pusterion and descending comma shomlel next be exposed ly remoring their vuter walls.

The Laterat Vextreles are eavities in the erebril hemispheres which are continuous with the thirl rentride and with one another, through the formon

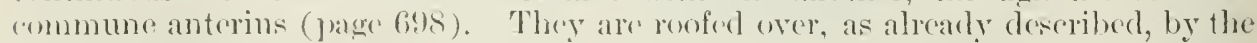
corpus eallosum, and are lined throughout by enthelime, which is reflected over the chorotel plexuses, and is not continuons with the lining of the third rentriele except at the formina of Momro. This epithelial lining forms the ventriendar wall in 
the region of the so-called transverse fissure, through which the choroid plexus projects. This fissure is therefore not a breach in the ventricle, but simply a thin part of the wall through which the locally thickened pia mater (choroid plexus)

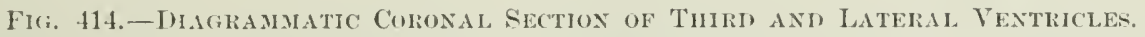

(From S(hwalbe, slightly modified.) LATERAL VENTRICLE

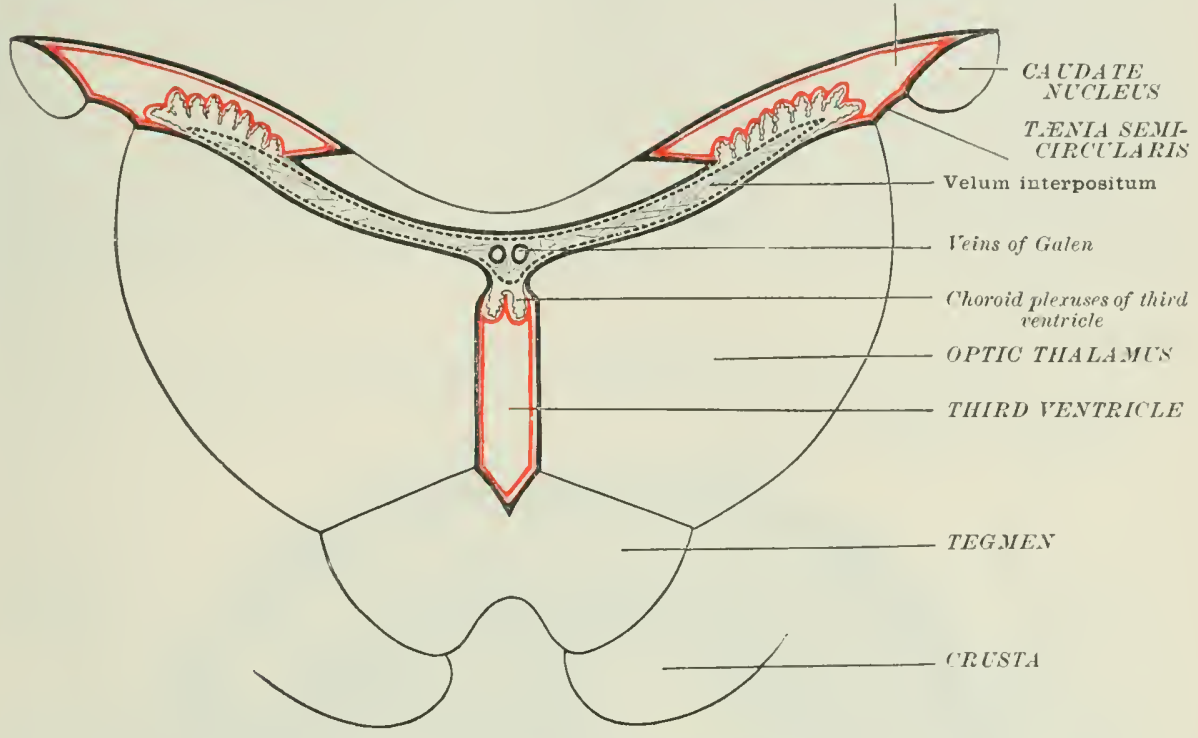

The red lines indicate the epithelium.

Fit: 415.-CORONAL SECTION OF TIE HEMISPHERES PASSING THROtGif THE ANTERIOR CoRNua of the Lateral Ventricles.

(From a monnted specinen in the Anatomical Department of Trinity College, Dublin.)

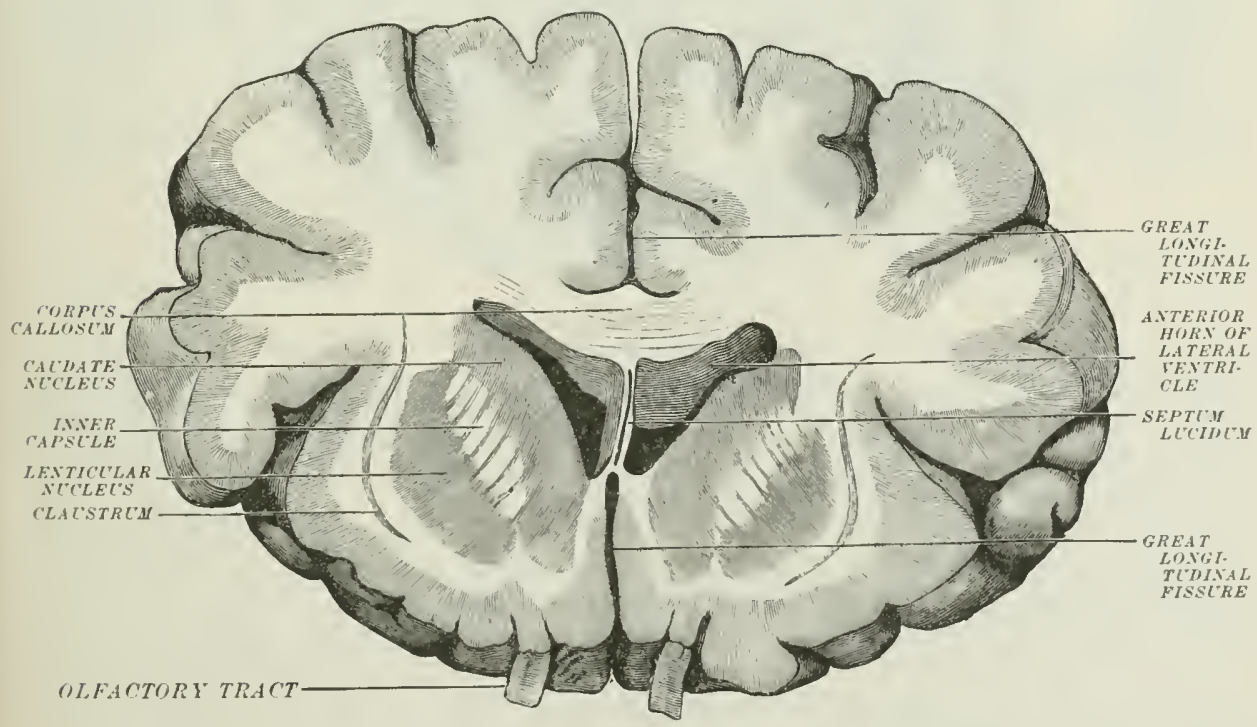

can he secu. Each lateral ventricle consists of a central part or hody and three cornua: an anterior, an inferior or descending, and a posterior.

The body may be defined as the portion of the rentricle which extends from 
the foranes of $M$ omm to the groint where the "arity hifureates into its porterior and descending comma. It corresponds almost "xactly in length to the portion wi the optic thalamus which lies fore within the rentricular earity. It is greatert in its antero-posterior, and -mallest in its rertical riameter. It is linited on the inner sicle by the attathment of the fornix to the corpus callosum, and by the narow posterior part of the septum lucidum. On the outer sicle it is bounded by the filores of the corpus callosum entering the substance of the hemisphere. Its floor looks upwards and slightly inwarls, as can be well seen in coronal sections, and is formed ly a series of structures which trend forwards with an inclination inwards. These structures are placed in the following order from without inwark:- the caudate nuclens of the corpus striatum, the temia semicircularis and lamina cornea, the optic thalamus, the (homolel plexus and the fornix (figs. 414 and 419 ).

The anterior cornu is directed forwards, downwards, and outwarls. It appears cresentic in outline both in coronal and horizontal section. The concavity of the cresent looks downwards and ontwards, and is caused by the projection of the

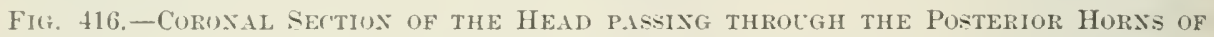
THE LATERAL Yextricles.

(From a mounted specimen in the Anatomical Department of Trinity College, Dublin.)

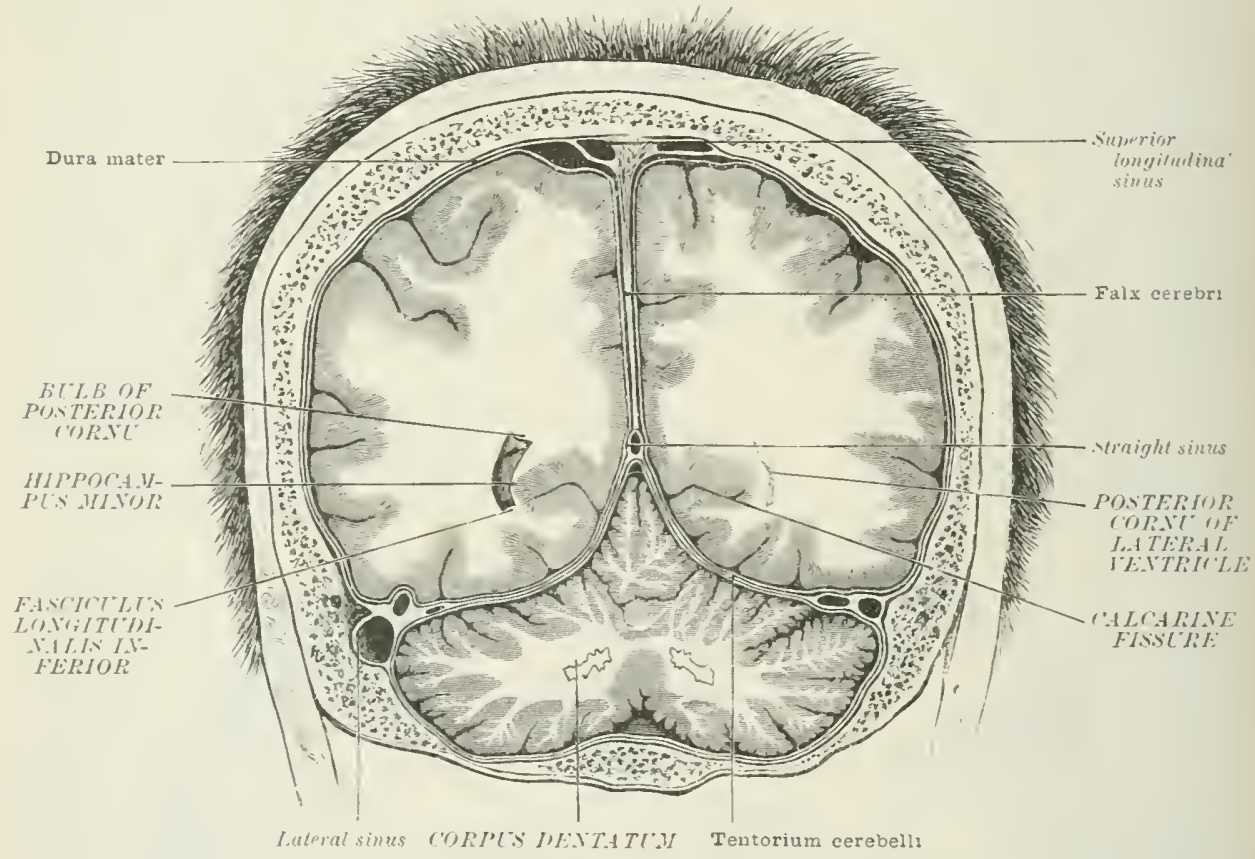

caudate nucleus into the carity. The anterior cormu is bounded internally by the septum lucidum, which forms a thin rertical partition between the anterior comma of epposite sidess albore and in front by the corpus callosum, and behind and externally by the hearl of the camblate nuelens.

The posterior cornu is horizontal in its whole comrse. and is lirected at first backwarls and outwank, and afterwarls hackwarks and inwarls. It presents on it: inner will a curved prominenes, the hippocampus minor or calcar avis ; anel above this a serend prominenee. the bulb of the cornu, which is calused by a part

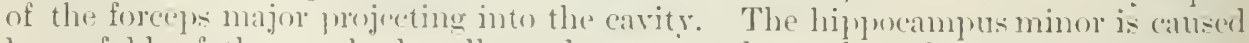
by a fold of the eerebral wall. and corresiomels to the walearine fissure on the

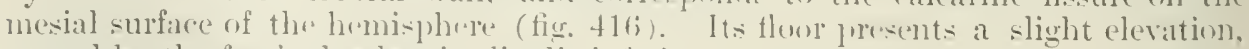
caused hy the fasciculus longitudinalis inforior.

Dissection.-The oprerulum should next he pulled npwarls, when the small portion of sulstance still attaching it to the hrain will be broken through. A complete view of the inland of 
Reil is then obtained. Lastly, the stuctent should make a series of thin sagittal sections through the island of Reil and the frontal lobe until the great transrerse fissure and its relation to the descending cornu of the lateral ventricle is seen (fig. 417 ). The sections will pass through the lenticular and caudate nuclei of the corpus striatum and through the optic thalamus.

The inferior or descending cornu pursues a more curved and complicated course than the other two comua. It is directed at first outwards and backwirds. and then hends somewhat sharply clownards; lastly, it sweeps forwards with an inchination inwards, following the long axis of the temporo-sphenoidal lobe. In transverse section it is seen to be smmewhat triangular, presenting a flowr, an immer wall, and a curved loof which bounds the cavity ahore and externally. The floor is former hy the eminentia collateralis. The following structures appear on the inner wall:- the hippocimpus major, ending in the pes hippocampi; the cor]ur fimbriatum; and the ehoroid plexus, the latter apparenty passing through a fissur. (the erreat transwerse fissure). The roof is formed from within outwards by the tienia semicircularis, by the narrow posterior prolongation of the caludate nucleus

Fig. 417.-A Dissection of tire Descexdiyg Corye of the IAteral Vextricle, WITH A SAGITTAL SECTION THROUGH THE BASAL GAXGLIA.

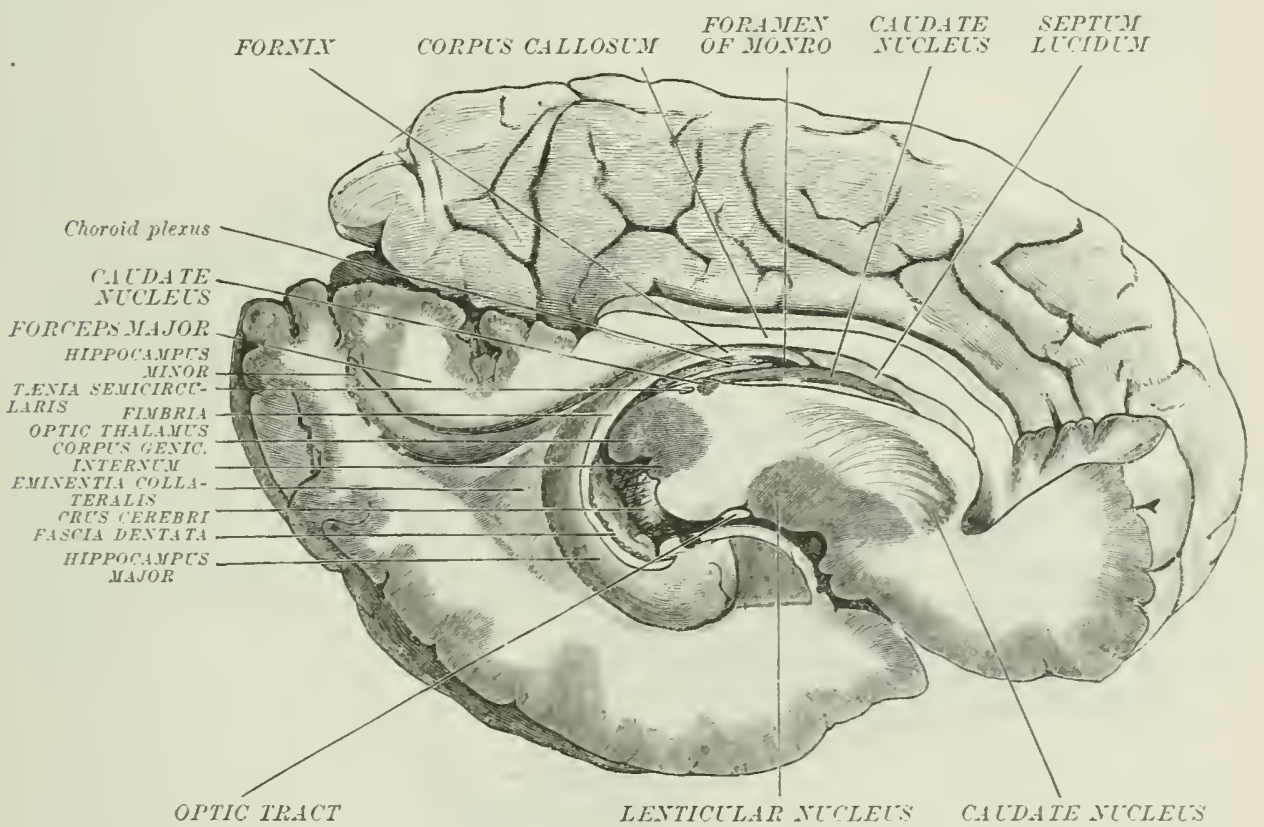

of the corpus striatum, and hy the tapetum. At the extremity of the cormu the

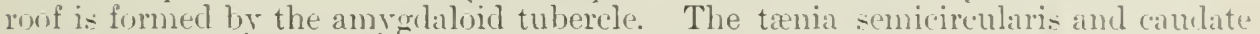
nuclus may be traced to this tubercle.

The eminentia collateralis is a smooth triangular elevation, which conmenes. in the interval between the hippocampus major and minor, and extends, mamowing as it proceeds, nearly to the extrenity of the descending comu. It is the inclentation of the ventrieular wall proluced by the collateral fis-sure.

The hippocampus major, or cornu Ammonis, is a curved white borly whirh ends in a blunt extremity (pes hippocampi), on which are small inclentations. giving it an obscure resemblance to the paw of an animal. It corresponds to the dentate fis:-ure.

The corpus fimbriatum, tænia hippocampi, or fimbria, is a narnw -trip of white matter with a somewhat way appearance, which is placed along the concave side of the hippocmpus major. It is formed hy a portion of the filure of the fornix continued into the descending comu, and present- applarently a free alge towards the transverse fissure, but is in reality continuel into the epitheliun which 
covers the choroid plexus. When this epithelium is torn through and the ehoroid plexus pushed forwards, the fascia dentata is exposed; the latter structure is placed above the dentate fissure, hetween the fimbria and the uncinate gyrus.

The choroid plexuses are vaseular fringes formed ly an infolding of the pia mater in the region of the so-called great transverse fissure. They extend from the termination of the descending cornua to the foramina of Monro, through which they disappear. The epithelial lining of the rentricle passes from the thin (ally:lrently free) edge of the fimbria over the choroid plexus to the trenia senicireularis. This epithelium, which is the morphologieal wall of the comu, excludes the choroid plexus (strictly speaking) from the rentricular (avity.

The foramina of Monro are the apertures through which the lateral rentrieles communicate with the third rentricle, forming at their communication a Y-shaped passage, the foramen commune anterius, by means of which the lateral ventricles

Fig. 418,-A Dissection silowixg tile Free or Ixtraventricular Portion of the Cal-

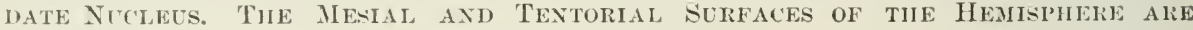
ALsO SHOWN.

(From a monnted specinsen in the Anatomical Department of Trinity College, Dublin.)

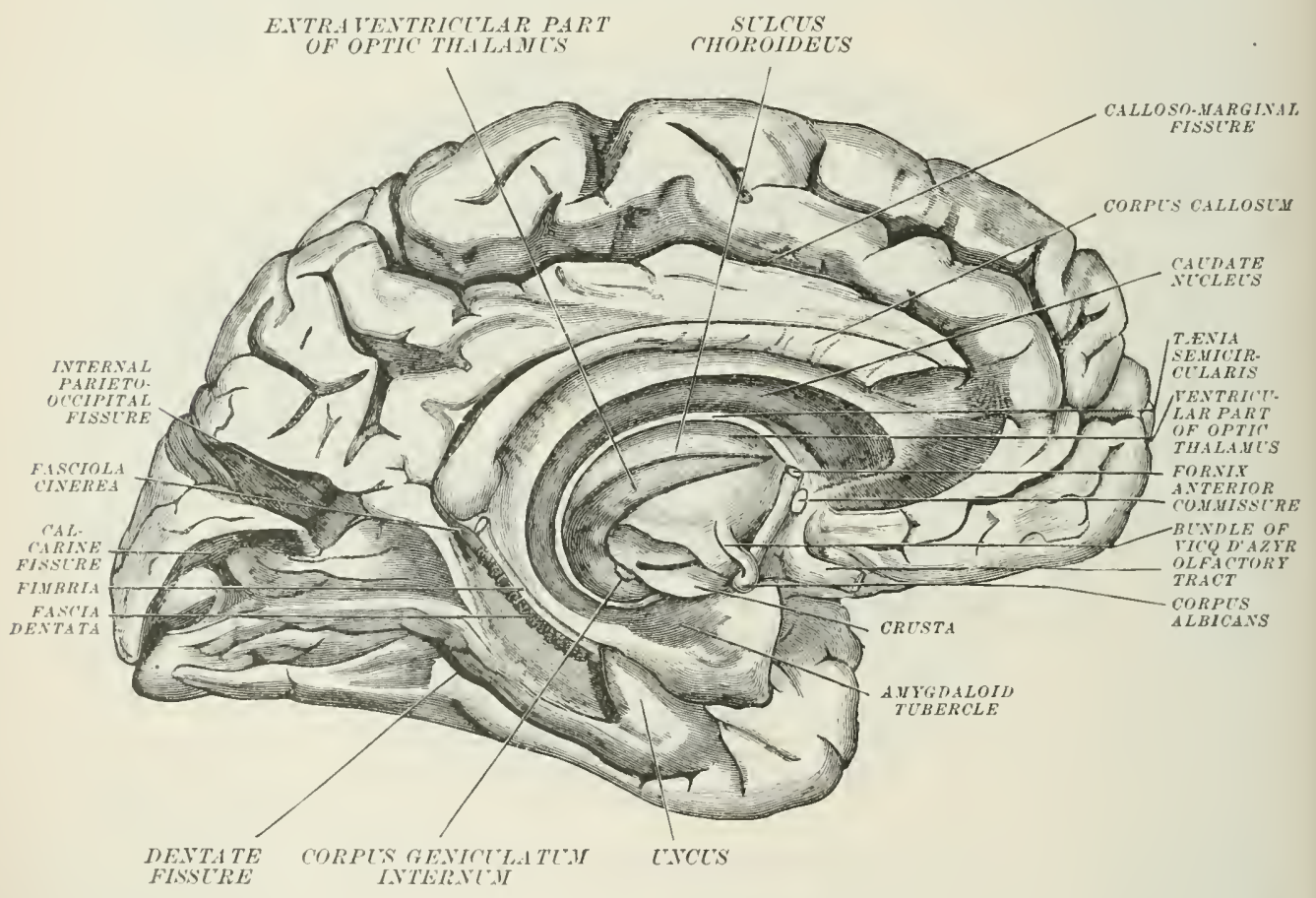

of opposite sides communicate with one another. The choroid plexuses of the 'ateral ventricles are continuous with one another through this passage. Each foramen of Ionro is crescentic in outline, and is hounded in front and above $\mathrm{Ww}$ the anterior pillars of the fornix; helow and behind by the anterior extremity of the optic thalamus; and behind hy the reflexions of epithelium from the fornix and optic thalamus on to the choroicl plexus.

The fascia dentata, or dentate convolution, is the free edge of the grey matter of the hemisphere, and dorives its name from its ehameteristically notehed or indented appearance. It is placed alowe the dentate fissure, and follows this fissure upwards towarts the splenium of the eorpus callosum, where it lerenes continuous with the fasciola cinerea. The fasciola cinerea is a grey lamina resmbling the fascia dentata but with a smootl nuapin. It ends just above the splenium of the corpus callosum. 
Dissection.-The student should slice away the left hemisphere and expose the lateral rentricle of that side, leaving the central portion of the corpus eallosum in situ for the present. He should then make a series of horizontal sections through the island of Reil and corpus striatum of the left side. If he has carried ont the dissection as recommended on the right side, he will now be in a position to sturly the corpus striatmm buth in horizontal and vertical section, and at the same time to exanine its intraventricular part more fully. The horizontal sections will pass through both noclei of the corpus striatmon with the inner and outer capsules, the claustrum, and a portion of the optic thalamus (fig. 419).

\section{Basil Gaxgla of the Hemispheres}

A series of ganglionic masses is placerl in the base of each cerebral hemisphere. They are subjacent (with the exception of the amygdaloid nuclens) to the island of Reil and form, with that lolse, the oldest part of the hemisphere; that is to say, they constitute the portion which is (as already mentioned) the first to appear both in the rertebrate series and also in the development of the individual. They are all semi-detached local thickenings of the grey cortex, and may be enmmerated as follows:-the corpora striata, each composed of two nuclei, the nuclens caudatus and the nucleus lenticularis; the claustra, and the amygdaloid nuclei. The optic thalami are in close proximity to the corpora striata, but belong to the thalamencephalon. Certain important fasciculi of white matter are intimately relater to the corpora striata. The chief of these white fasciculi are the inner and outer (alpules, the anterior commissure, and the tronia semicircularis.

The nucleus caudatus is an elongated mass of grey matter somewhat reseml, ling a pear with a long curved stalk. It presents a free, or rentricular, surface. and a surface which is embedded in the hemisphere. It is thickest at the anterior end. or head. The free surface of the anterior thickened portion looks upwards and inwards, and bulges into the anterior horn of the lateral rentricle. Thence it ascencts with an inclination outwards to the body of the ventricle, where it forms the outemost constituent of the floor of that carity, and narrows into the commencement of the tail. In this situation it is serarated from the optic thalamus by the limina comea and tænia semicircularis. The tail of the nucleus caudatus then passes into the descending cornu. It is placed at first in front of the comu, afterwards forms part of the roof of that eavity, and ends at the amyglaloid tubercle. The deep surface of the caulate nucleus is separated from the nucleus lenticularis by a layer of white matter called the inner capsule. The two nuclei are, howerer. connected by bands of grey matter which intersect the fibres of the anterior limh of the inner capsule, and they are directly continuous for a short distance in front.

The nucleus lenticularis is emberded in the substance of the hemisphere except at the lase of the brain, where it comes to the surface for a small part of its extent at the anterior perforated space. Here it is continuous externally with the claustrum and, as hefore stated, with the nucleus caudatus. In horizontal section it appears like a bi-convex lens, with its surface directed outwards and inwards, the outer surface forming a curve of larger radius than the immer. In sagittal section the lenticular nucleus is also somewhat lens-shaped in outline (fig. 417). In coronal sections through the anterior part it appears crescentic, with the convexity turned downwards and outwark (fig. 415): hut in successive sections taken from before backwards the crescentic gives place to a triangular or wedge-shaped outline (fig. 421). In fresh brains this grey mass can be seen to be traversed by thin white intersections, the internal and external medullary laminæ, which divide it into three zones. The mirllle and inner zones are of a rellowish grey colour, and constitute the globus pallidus. The outer zone is of a darker reddish grey. and is traversed with fine white strice. It is called the putamen.

The putamen is the longest part of the lenticular nucleus, and is the only portion of that borly which is continuous with the caudate nuclens.

The above agrees substantially with the aceount which is given hy Schwalloe; this anatomist, howerer, describes the amygdaloid mucleus as discontinuous with the tail of the caudate nucleus. Accorling to Foster and Sherrington, the glolus pallidus of the lenticular nucleus as well as the putamen is continuous with the eandati nuclens.

A hand of white fibres, the ansa lenticularis, jasses inwards below the inner capsule. It emerges from the under surface of the lenticular nucleus, being continued from the mednllary 
lamina. It also receives fibres from the inner segment of the globus pallidus. The ansa lenticulin's enters the subthalanic region and passes beneath the red nueleus, where it becomes indistinct.

The claustrum is a thin hand of grey matter which is placed, nearly vertically, external to the lenticular nuelesw, and separated from the latter, exeept at its lower part, hy the outer capsule. It is separated from the gres matter of the island of Reil by a layer of white matter, into which it sends small pointed processes corresponding to the grri operti of the island. It is fused at its anterior end with the amygdaloil nucleus. (Hill.)

Fig. 419.-Horizoxtal Section of the Cerebriy.

(After Lamiois and Stirling.)

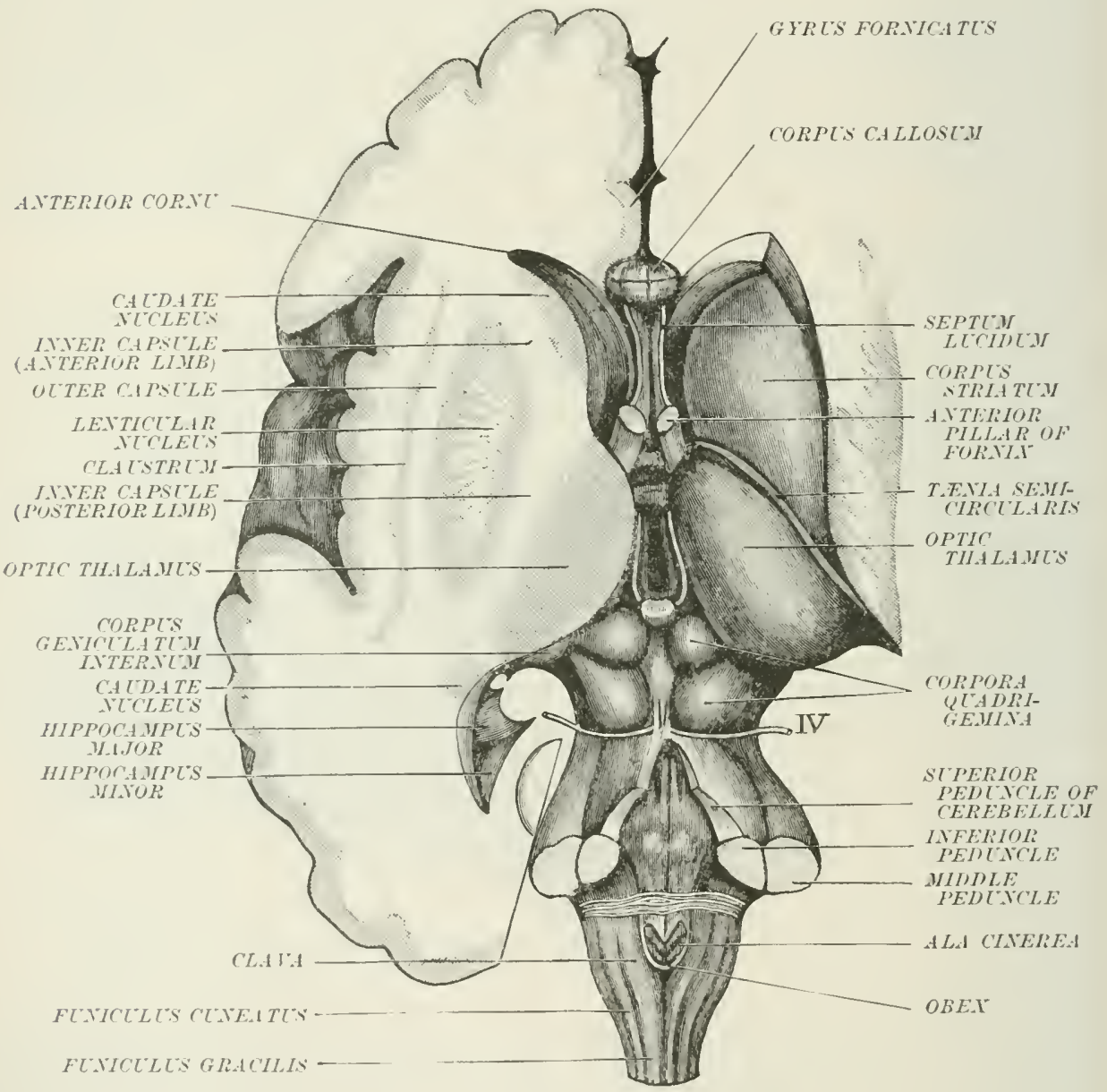

The amygdaloid nucleus is a thickening of the errey cortex of the apex of the

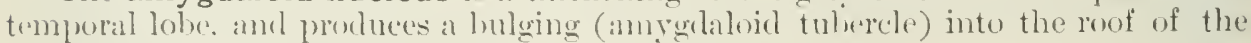
extrenity of the descending cornu of the kiteral ventricle.

The tænia semicircularis, or stria terminalis, is a hand of fibres whirh passes upwarks and hatkwarks from the anterior pillar of the fornix, traversing the groove between the candate nuclens and the optic thalamms. It acrompanies the

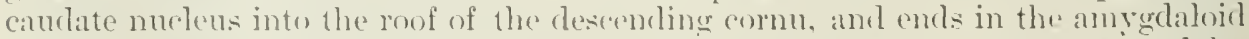
nucleus. In its course along the grouve aluse montioned it is partly eorered by the rein of the corpus striatum and hy a thickented ham of ependyma, the lamina cornea, which also covers the vein. 
The inner capsule is a broad band of white filmes which is placed on the immer sicke of the nucleus lenticularis. In loorizontal section it presents an anterior limb between the two nuclei of the corpus striatum, and a posterior limb which separates the nucleus lenticularis from the optic thalamus. These two limbs neet at an angle salient inwarls. This angle is called the genu, and is placed adjacent to the tania senicircularis.

In vertical section the inner capsule presents a beautiful arched arrmgement of radiating white fibres (tig. 417).

The outer capsule, much narrower than the inner, is a band of white fibres which intervenes between the claustrum and the nucleus lenticularis.

In a horizontal section through the basal ganglia of the hemisphere and adjacent prart of the thalamencephalon, an alternation of grey and white layers is seen in the following order from without inwards:-(1) the grey matter of the island of Reil ; (2) the white matter of the same lobe; (3) the clanstrum; (4) the outer capsule; (5) the nucleus lenticularis; (6) the imner capsule; ( $\overline{7}$ ) the nucleus caudatus and uptic thalamus: separated from one another by the trenia semicircularis (fig. 419 ).

The anterior commissure bounds the third ventricle in front, but belongs to the ecrebral hemispheres, as it is developed in connection with the lamina terninalis. It presents a cylindrical free surface towards the thircl rentricle, where it appear: like a small transverse har in the interval between the anterior pillars of the fornix. It passes outwards in front of the fornix, and traverses the cereloral sulstance below the lenticular nucleus on each side (fig. 4:21), the fibres inclining hackwirds and assuming a twisted arrangement as it proceeds. It ends in the teunporal lobe.

Dissection.-The student should cut through the remaining part of the corpus callosum abont the middle, raise the posterior portion, carefully detaching it from the sul iqacent forvix, and throw it backwards. This dissection will reveal the body and the diverging josterior pillars of the fornix. He should then raise the anterior portion of the corpus callosum, and snip through the septum lucidum with a sharp pair of scissors. The slit-like fifth ventricle will now lue visible, or may be brought into view hy gently separating the lamina of the seftum lucidum with the point of the scalpel. The firnix should next be examined and then disided by cutting through its borly and throwing the parts backwards and forwards. By this dissection the su-called tranyverse fisture will be olened up and the velum interpositum exposed.

The FORNIX is a longitudinally-arehed bundle of fihres composed of two srmmetrical halves which are united toguther at the central prart. forming the hody. hut diverge in front and behind, constituting the anterior and posterior pillars. The body forms a curve parallel to the corpus callosum, to the under surface of which it is allerent.

It is narrowest and thickest in front. widest and thinnest behind. It lies on the rolum interpositum, which separates it from the third rentricle and from the optic thalami. The onter portions of its upper surface are placed in the body of the. lateral ventricles, corered by the cpithelium which passes at the thin outer margin of the fornix into the epithelial covering of the choroid plexuses. The posterior pillars diverge from the body, passing backwards and outwards. In the interval lutween them the splenium of the corpus callosum can be seen if vicwed from below. This is marked by faint longitudinal, transerse, and oblique lines, and is described as the lyre. The posterior pillars expand as they pass outwards and enter the descending cornua of the lateral rentricles. A consiruous bundle of fornix fibres passes along the concave horder of the hippormpus major as the fimbria, which (an be traced to the uncus. Other fibres arescattered over the hipuncampus major and the eminentia collateralis. The anterior pillars sweep clownards with a sharper curve than the corpus callusmm, and so divere from it, leaving an interval which is necupiex liy the septum lucidum. They descend. in the form of two rounded slightly-rliverging hundles, immerliately liehind the anterior commissure. Here they are joined by the trenia semicirculares, and receive filmes from the perluncles of the pineal borly and from the septum lucidum. In this situation they present a fres: surface, excejit in front, where they give attachment to the septum 
lucidum. Having reached the hase of the brain, they end in the grey nuclei of the corpora albieantia.

The anterior pillars of the fornix were formerly deseribed as twisting on themselves to form bents or loops in the base of the brain, the corpora albicantia, the fibres atter forming the bend heing continuel upwards on the innere sides of the descending anterior pillans ats the bundles of Vicq d'Azyr. 'This deseription is borne out by naked eye discection, but it lais been slown that the buntles of Tieq d'Azyr are rliscontmuons with the fornix fibres. (Forel and Gudden.)

The septum lucidum is formed hy thin portions of the hemisplure walls, which have become alpuroximated and in part fused, but are separaterl in the greater part of their extent hy the fiftl rentricle. It appears as two elosely alproximated thin vertieal lamine, sejarating the anterior comual of the lateral ventricles of opposite sides. It is attached abore and in front to the under surface of the body and back of the genu of the corpus allosum, below to the rostrum and to the basal white comminsure, and hehind to the anterior pillars of the fornix. Viewed from the sile, it is triangular in outline, with an acute angle directed backwards and oceupying the narrow interval between the front of the body of the fornix and the corpus callosum (fig. 412 ).

Each of the two lamine which constitute the septum lncidum contains three lavers: a layer of ependyma and epithelium next the lateral ventricle, a middle layer of white fibres, and a liyer of rudimentary grey matter next the fifth ventricle. A layer of commective tissue immediately boumding the fifth ventricle (nudinentary pia-matral layer) is deseribed by Testut.

The fifth or Sylvian ventricle is a narrow, sagittally-directed, slit-like cavity which originally formed a jart of the great longitulinal fissure. It lies between the layers of the septum lueidum and it does not communicate with any of the true rentrieles of the brain.

The great transverse fissure of the cerebrum is of a horse-shoe shape, and extends from the foramen of Monro on each side to the temmination of the descending cormu of the lateral ventricle. It is not a fissure in the sense of forming a communication between the ventricles and the exterior of the brain, but it may be considered as a fissure in the same sense that we use the term 'complete fissure.' If we compare it with the adjacent rentate fissure, we find that the latter produces a bulging (the hippocampus major) into the ventricular eavity. This bulging contains an inner layer of white and an outer layer of grey matter, and is simply at fold of the ventricular wall, which is here thinner than elsewhere. The floor of the dentate fissure is occupied by pia mater. Now if we suppuse the substance of the himpreanums thiment away until only the epithelial lining of the ventricle wats left, this epithelium would come in contact with the external pia mater, and an arrangement resembling the choroil plexus, eoming through a fissure, the hippocampal fissure, wumld be produced. The choroid plexus is therefore an internal convolution reduced to a layer of epithelium forming the morphological wall of the ventricle, and produced by a fissure, the great transverse fissure, which is oceupied by a speecialised and highly vascular part of the pia mater. In complaring the great transverse fissure with the complete fissures of the cerebral henispleres, however, we must not lose sight of the fict that it is not limited to the hemisphere wall (except at its extremities in the temporal iobes), but is produced, for the greater yart of its extent. by the follting of the moseneephalon over the thalamencephalon (page 670). Areorling to Nerkel and II ierzejewsky, small slit-like aprertures are found in the region of the transverse fissure near the termination of the desernding hom of the lateral ventricle. These place the eavity of the lateral ventricle in communieation with the subarachnoil space.

The velum interpositum, or tela choroidea superior, is a large triangular fold of pia mater which overlies the third ventriele. The hody and posterior pillars of the fornix and the splenimm of the (orpus callosum rest on its upper surface. It is continuous laterally with the choroid plexuses of the lateral ventrieles, which are simply the convoluteil and highly vascular margins of the fold. Tracerl hackwards, the livers are seme to divaricate and to become continuous with the pia mater cosering the tentorial surface of the oceipital lobes and the upper surfice of the rerellum. Two large reins, the veins of Galen, commence at the anterior extrenity of the relum interpositum. The veins of Galen are chicfly formed by the vesins of the corpora striata, and are continued backwards in the middle line to encl in the straight sinus. In this course they lie in a prolongation of the subarahomid space between the two layers of pia mater which form the velum interpositum, and usually unite into one vein before entering the straight sinus. 
The under surface of the velum interpositum rests on the inner parts of the optic thalami, and hetween the latter it is placed directly over the third rontricle, where it is covered by a layer of epithelim continuous with the lining of that cavity, but disentinuow with the epithelium of the lateral rentricles, except at the forminin of Monro.

The choroid plexuses extend from the extremity of the descending emmu of each side to the foramen of Monro where they become continuous with one another through the formen commune anterius. From the junction of the two plexuses a pair of small vaseular fringes pass backwards on the uncler surface of the relum interpositum in the middle line, and depend into the cavity of the third rentriele,

Fig. 420.- Horizoxtal Sectiox of the Cerebral Heyispheres.

(From a momnted specimen in the Anatomical Department of Trinity College, Dublin.)

(The fornix has been reflected to show the velum interpositum.)

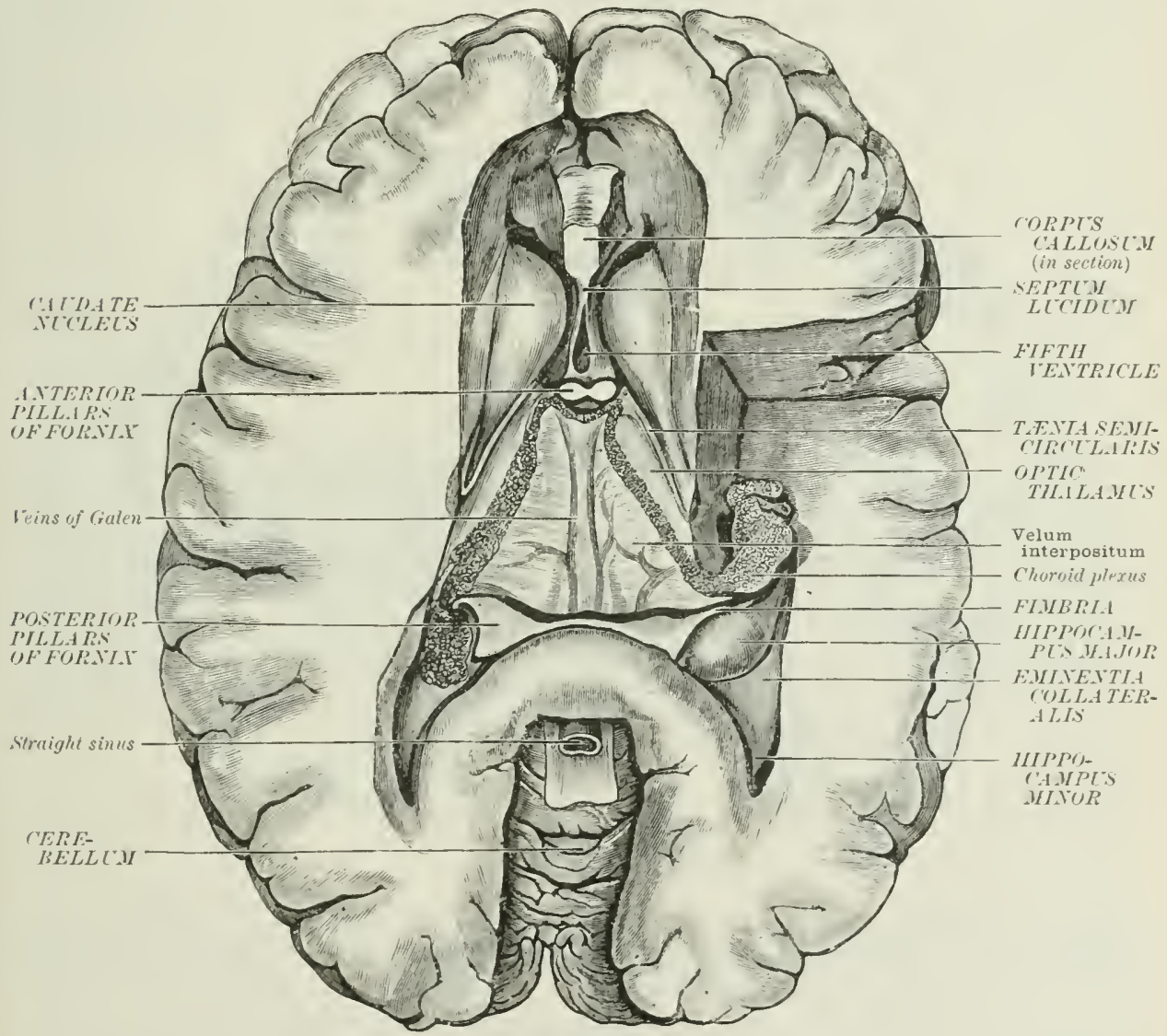

constituting the choroid plexuses of that cavity (fig. 414). The antcrior chorois artery enters the choroid plexus at the termination of the dezcending comn; other smaller arteries are supplied to the plexus from behind, and are derived from the posterior cerebral artery.

Dissection.-The student should divide the spleninm of the corpus callosum in the middle line, and remove the portions of the hemispleres which lie posterior to the great transverse fissure; they will readily separate at the fisure, and hreak off at the extremities of the tempural lobes. This operation should be comlucted with gentleness, as the walls of the third rentricle are very prone to become unduly divariated by this dissection. The part removed shoukl be re-examined, as the relations between the fisures anl hipposmpi can be studied to great advantage at this stage. The cavity of the third rentricle may now be displayed by raising the 
rehm interpositum, and reflecting it backwarks. This must be done cautionsly, as the pineal berly is chosely enfolded in the josterior part of the under layer of that membane, and an attempt should be make to retain it in its proper place. The dissector shoukl thoroughly examine the cavity and flow of the third ventricle and the free surfices of the optic thalani, hut he is recommended to dissect the deep surfices of the latter bodies in connection with the mesenerphialon.

\section{TIIE TH.MLAMENCEPHALON}

The THIRD VENTRICLE is a narrow cavity whose lateral walls are so closely afproximaterl that in coronal sections it appears as a vertical slit. It communiaates in front with the lateral ventricles by the foramina of Monro. Behind, it is continuous with the fourth rentricle through a namow pasiage, the aqueduct of sylvins. The opening into the aqueduct is bounded above by a transverse white bundle of tibres, the posterior commissure; and, above this, a prolongation of the

Fig. 421.-Corosil section tirotgh tue Anterior Part of the Thirn Ventricle.

(From a mounted specimen in the Anatomical Department of 'Trinity College, Dublin.)

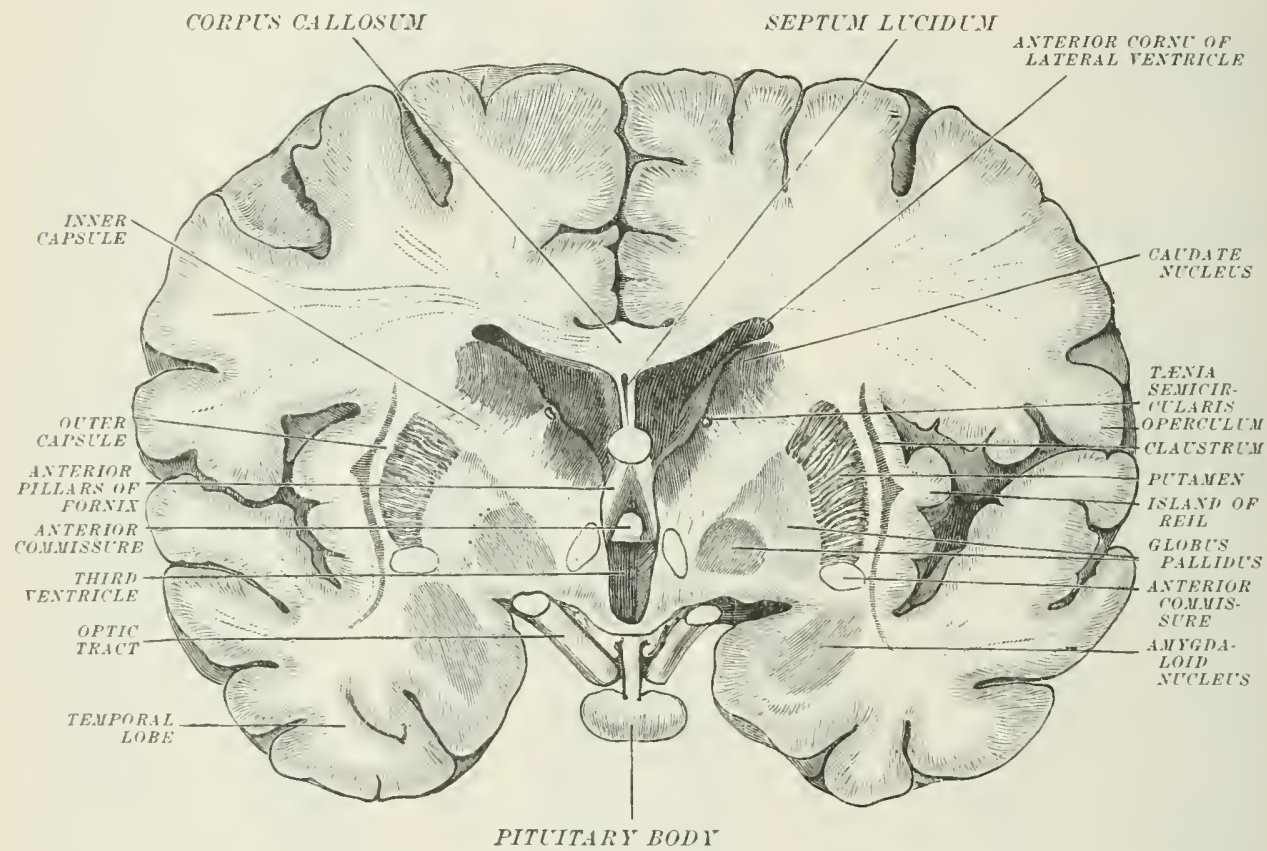

ventricular earity extends into the stalk of the pineal boly, in which it ends hlindly. The third rentricle is covered by the corpus callosmin, the fornix, and the velum interpositum; its true roof, however, is formed by the epithelium lining the under surface of the last-1umed structure. The central part of its carity is crossed transwerely he the middle or grey commissure. It is bounded, laterally ly the optic thalami, and in front by the anterior pillars of the fornix and by the anterior commissure. It is limited behind by the commenecment of the aquerluct of sylvius, hy the posterior commissure, and hy the reflexion of epithelium from the uppres surfare of the pincul body on to the under surface of the velum interpositum. In the anterior part of the ventricle the flow is marked off from the lateral walls hy the anterior pillars of the fornix, which, after forming part of the anterior houndary, sweep lackwards with an inclination downwards: in this situation ther are covered by a thin layer of the central grey substance of the ventricle, and juoject as shight ridges. The third rentricle is relatively slallow for about the posterior thirel of its extent, but in its anterior two-thirds it presents a deep recess which is divided into an anterior and a posterior fart by a proninent rielge. This 
ridge is formed by the junction of the tuber cinereum and the lamina cinerea alove the optic commissure. The floor is formed by the following structures:behind, by the tegnental portion of the diverging crura cerebri, and between them by the posterior perforated space; in front of this by the corpora albicantia, the tuber cinereum with the infundibulum and the lamina einerea. The latter slopes upwarls to the anterior commissure, and is relegated by some anatomists to the anterior wall instead of to the floor.

The central grey matter of the third ventricle is continuous behind with the grey matter of the arqueduct of Sylvius, and passes in fiont into the basal grey commissure. It also covers the luwer parts of the internal surfices of the optic thalami, and gives at thin covering to the anterior pillars of the fornix and to the bundles of Vicq d'Azyr.

The optic thalami are a pair of large ganglia placed one on each side of the third ventricle. Each optic thalamus is a short prismatic body whose long axis is directed forwards and inwards. This axis is not straight, but is slightly curved with its convexity upwards. The thalamus presents an anterior and a posterior extremity or tubercle, and four surfaces: a superior and an internal which are free, and an inferior and an external which are imbedded in the cerebral substance. The anterior tubercle is a blunt rounded point which forms the posterior boundary of the foramen of Monro. The posterior tubercle, or pulvinar, is broader than the anterior, and is compressed from above downwards. It is directed backwards and downwards; it is continued externally into the outer geniculate body, and overhangs the inner geniculate body. It is placed above and in front of the descending cornu of the lateral ventricle, but is separated from the cavity of the latter by the choroid plexus. The superior surface shows a slight convexity, more pronounced in the antero-posterior than in the transverse direction. It is covered with a layer of white fibres. It presents a groove, the sulcus choroideus, which underlies the free edge of the fornix, separated from the latter only by the velum interpositum. This groove marks off an antero-external area, wider in front than behind, which ends in the anterior tubercle and which forms part of the floor of the lateral ventricle. Internal to the sulcus choroideus is a larger area, which is covered by the fornix and velum interpositum. This area is limited internally for about its anterior half by the stria pinealis, or peduncle of the pineal body, a white bundle of fibres which runs along the sharp edge which separates the superior from the median surface. The posterior part of this area slopes gradually into the pulvinar. Between the superior surface and the posterior part of the stria pinealis is a small triangular area, the trigonum habenulæ, which is sunk below the level of the adjacent part of the thalamus. The internal surface is nearly flat and bounds the cavity of the third ventricle, towards which it presents a slight convexity. It is of a pale-grey colour owing to a thick layer of ependyma covering the ganglionic substance, and is united to its fellow of the opposite side by a broad band of grey matter, the middle or grey commissure (commissura mollis). It is crossed at its lower margin by a groove, the sulcus of Momro, which passes from the foramen of Monro to the commencement of the aqueduct of Sylvius. The external surface rests against the fibres of the inner capsule behind the genu, being separated from the nucleus lenticularis by the inner capsule. The inferior surface is placed over the crus cerebri, on the tegmental part of which it rests.

In coronal sections through the posterior part of the thalamus, the external surface is seen to be separated from the inferiur surface by a distinct angle; but in similar sections through the anterior part the two surfaces pass into one another, the angle being rounded off. The grey substance of the thalamus is indistinctly marked off into three nuclei : an antero-superior, an external, and an internal. The largest part of the antero-superior nucleus forms the anterior tubercle; the thinner portion passes backwards above and between the other two nuclei; its shape has been not inaptly compared to that of the caudate nucleus. A remarkable bundle of white fibres, the ansa lenticularis, passes below the optic thalamus and inmer capsule from the lenticular nucleus of the corpus striatum.

The pineal body (epiphysis cerebri or conarium) is a reddish-grey body about the size of a cherry-stone. It has the form of a flattened cone, compressed from above downwards. Its long axis is directed forwards and slightly upwards. Its base is directed forwards and passes into a bilaminar stalk. Its superior surface is 
enverel ly epithelium for the anterior two-thirds or therefourths of its extent. and hounds in part the carity of the third rentricese. Its inferior surface rests in the mesial eroove betwen the superior yuabrigeminal bodies, separated from the latter ly a fold of pia mater. The stalk of the pineal body is continuous by its lower limina with the pustiolior commisime. Its upuer lamina passes into the peduncle or stria pinealis, which passes at first outwarks, and then forwards, along the margin of the optie thatamus which separates the upper and mesial surfaces of that body; it then (rossis the floor of the formen of Monro and joins the anterior pillars of the fornix.

The recessus pinealis is a diverticulum from the cavity of the third ventricle, which extends into the stalk and a short distance into the body of the conarium. Within the pineal body, aud in the auljacent part of the relum interpusitum, a number of gritty particles (acervulus cerebri, brain sand) are fouml. There particles consist chiefly of phosphate and carbonate of calcium. The pineal body was formerly described as a gland (pineal gland) but is now known to be a rudimentary unpaired eye. This pineal eye lies close to the surface in some of the luwer verte-

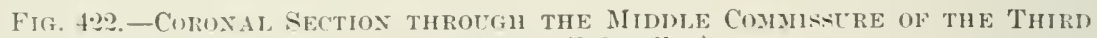
Ventricle. (Schwalhe.)

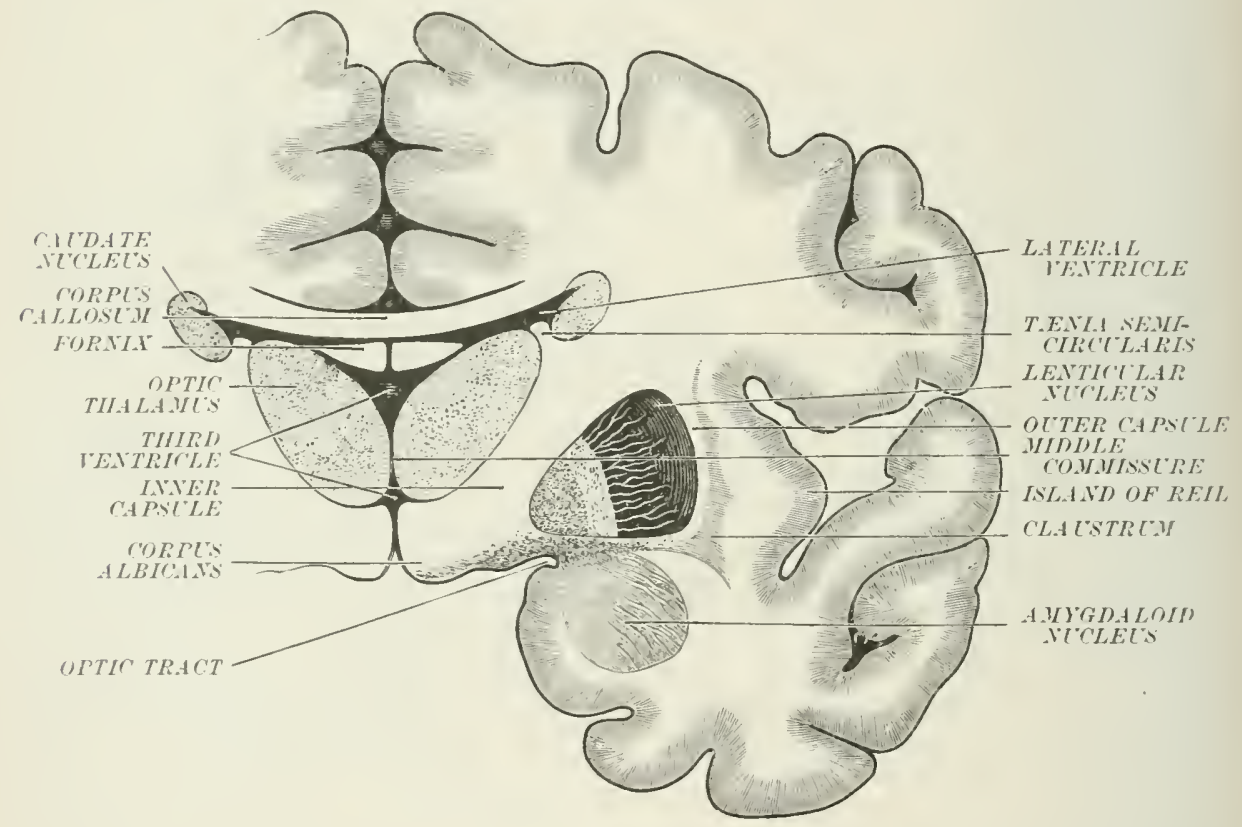

hrates, aml was probably functional at al former perior. A great parictal foramen in the extinct reptile Ichthyosiarns is strongly suggestive of a functional pineal eye.

The posterior commissure is a transverse band of fibres which projects into the posterior part of the cavity of the third ventricle (page 708).

The subthatanic tegmental region and the corpora geniculata will be wore conveniently described with the meseneephalun.

The basal grey commissure is a continuous plate of grey matter which is formed from lohinel ferwark hy the posterior perforated space, the tuber cinerem, ancl the lamina eincrea.

The posterior perforated space is a stratum of grey matter which is perforited by a number of small vessels deriverl flom the enmmenements of the posterior ecrethal and superior cerebellar arteries. It oceupies the back part of the interperluncular space and extends for a short distance moleperer of the pons, where it founds a recess, the foramen cæcum anterius. It is continuous literally with the 
grey matter of the tegmenta of the crura cerebri, and is attacher in front to the corpora allicantia. The portion of the slace which is situated in front of the exit of the third nerve forms part of the floor of the third rentricle; the posterior part belongs to the mesenceplialon.

The corpora albicantia alprear as a pair of white knols in the hase of the hrain. Each contains in its interior a grey nucleus. This nucleus is joined by the anterior pillar of the fornix and the hundle of Vicy d'Azyr of the same side. The bundle of Vicq d'Azyr passes mwards and forwards through the grey matter of the optic thalamus to the anterior tubercle of that botly.

The tuber cinereum is a grey elevation placed immerliately behind the optic commissure. It is the largest part of the hasal grey commissure, and is continuous: laterally, above the optic tracts, with the grey cortex of the temporal lobes (fig. 421). In front it passes over the optio commissure into the lanina cinerea. It is continum below into a conical process, the infundibulum, which is directed downwills and slightly forwards, through the central opening in the diaphragma sellie to end in the posterior lole of the pituitary body. The upper part of the infundibulum is hollowed out by a diverticulum of the third rentricle, the recessus

Fig. 4?3.-Corosal Section throcgit tire ThIRd Vextricle behixd the Midde Commistre. (Gegenbaur.)

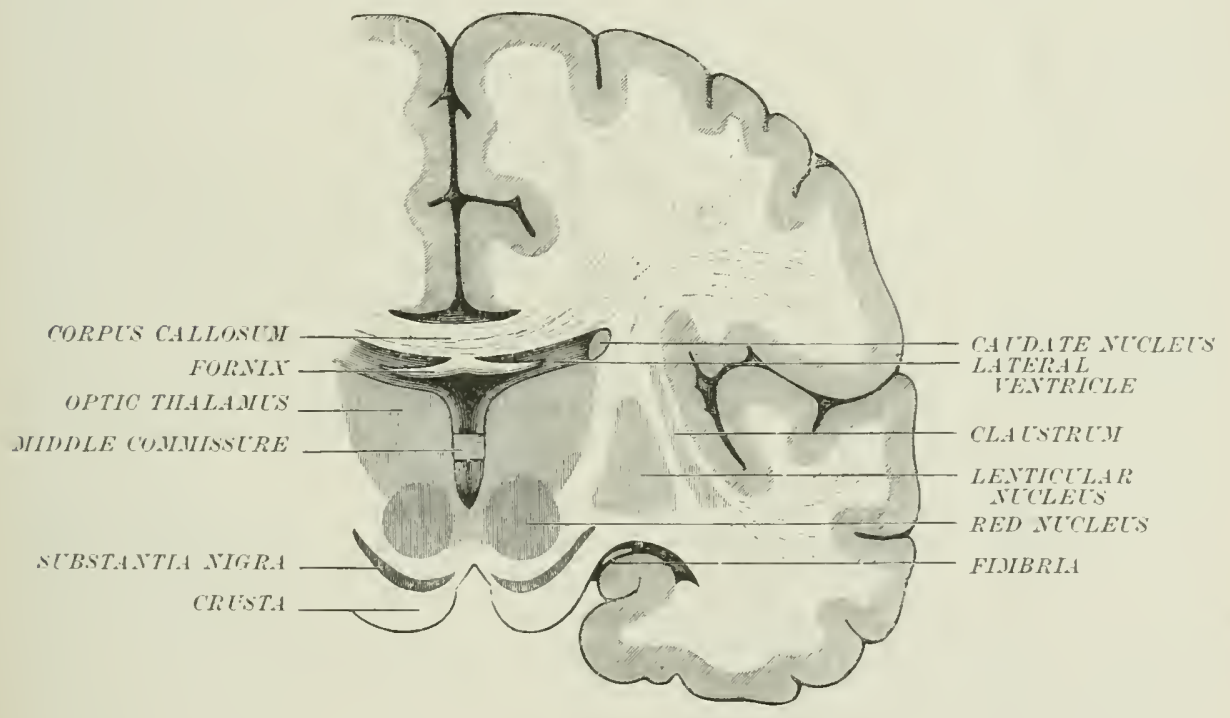

infundibuli. The tuher cinereum and infundibulum correspond to the median recess in the floor of the third rentricke.

The pituitary body, or hypophysis cerebri, is a small elliproidal borly which is lodged in the pituitary fossil of the splienoid bone. Its long axis is ilirecterl transversely, and its antero-posterior and vertical diameters are alout equal.

The pituitary body consists of two distinct lobes, an anterior and a pusterion. The anterior lobe is of a reddish-grey colour, and is considerably larger than the posterior lobe, which it partially embraces. The posterior lobe, of a yellowish-grey colour, is lodged in a recess in the anterion. lobe, and is the only part connected with the infundibulum.

This boty was formerly describerl as the pituitary gland, becanse it was supposed to secrete the pituita, or mucus of the nose. A ceorling to Gaskell's ingenious theory, the infindibulum is the month of an arehaie alimentary canal. The ventricular system of the brain is the miment of the eephalic stomach as foumd in Arthropods. The central canal of the spinal cord is the atchitic intestine, and the neuro-enteric canal (an embryonic communication between the neural tube and the intestine) connects this archilic intestine with the ann-rectal region. This pitnitary borly is of great interest in the light of this theory, as it hrings the archicic month to the surfice. The posterior lobe is deseloped in connection witl the brain. but the anterior lobe is formed independently. It originates as an mpward growth of the epiblantic invagination which forms the mouth, and is afterwards cut off by the chondrifieation and subserpent ossification of the skull. 
The optic commissure is formed by the miom and partial decussation of the optic tracts of oplosite sides. Eareh optic tract may be traced backwards from the conmissure, around the crus cerebri, to the region of the corpora geniculata (jage 710 ).

The lamina cinerea is a thin plate of grey matter which may be seen from the base of the brain hy pulling the optic conmissure slightly backwards. It is continuous in front with the grey matter of the olfactory convolutions of the frontal lobes, and between the latter it is comnected to the rostrum of the corpus callosum by the basal white commissure. laterally, it is continuous with the anterior perforated space. It forms the anterior sloping part of the floor of the thirel ventricle.

Nerve-tracts in the substance of the thalamencephalon and prosencephalon.-The systems of fibres which are eonnected with the optic thalanus may be first consilered; the principal of these are: (a) The posterior commissure; (b) the corona radiata of the optic thalanus; and (c) the bundle of Vica d'Azyr.

(ii) The posterior commissure contains a tract of fibres which passes from the optic thalamus to the tegmental region of the mesencephalon on the opposite side; but beyond this, nothing is known with any degree of certainty. It is said to transmit fibres from the fillet and from the posterior longitudinal bundle to the opposite side. Fibres are also said to proceed via this commissure from the ganglion hahenula and the pineal body to the oculo-motor nueleus of the opposite side. It is therefore a bundle of decussating fibres derived from virious sources, and probably does not contain any true commissural fibres.

(b) The corona radiata of the optic thalamus is formed of a system of fibres which converge to the thalamus from the cortex of the frontal, parietal, occipital, and temporal lobes, and it also receives a small bundle from the cortical part of the olfactory tract. Portions of this system, namely, the fibres from the occipital tolre (posterior peduncle of the thalamus), and from the temporal lobe (inferior peduncle), require special notice. The posterior peduncle of the thalamus (optic radiation) passes backwards in the white matter of the hemisphere in company with a great bundle of sensory fibres to the occipital lobe. It is further described in connection with the optic nerve (page 746). The inferior peduncle may, for the sake of simplicity, be described with the ansa peduncularis, as it forms an important constituent of that body.

The ansa peduncularis may be exposed from the base of the brain by dissecting the optic tract from the surface of the crus cerebri. It is a band of fibres which winds round the ventral surface of the crusta just at the transition of the latter into the inner capsule. Its principal constituents are the ansa lenticularis and the inferior peduncle of the thalamus. The ansa lenticularis proceeds from the medullary laning of the lenticular nucleus and passes transversely inwards immediately below the globus pallidus. It then enters the subthalanic region, and without doubt passes into the mesencephalon, but its exact comse camnot be followed with certanty. The inferior peduncle of the thalamus is partly formed hy a sagittally-rlirected bundle which passes hackwards through the substance of the thalamus between the anterior pillar of the fornix and the bundle of Vicg i'Azyr. This bundle is joined by fibres from the superior surface of the thalamus (stratim zonale). The filores from the stratum zonale pass from the superior to the internal surface of the thalamus, and finally, reaching the inferior surface of that body, join the sagittal bundle first mentioned to form the inferior peduncle; the latter now passes outwards helow the ansa lenticularis and ends in the cortex of the tenporal lobe.

(c) The bundle of Vicq d'Azyr passes from the anterior tubercle of the thalamus to the nucleus of the corpus albicans. It might he regarderl as a constituent of the corona radiata-the nucleus of the corpus allicans being considered as modified cortex.

The white mattre of the cerebral hemispheres contains the following systems of fibres: (a) The corona radiata; (b) commissural or interhemispheric fibres; (c) association or intrahenispherie fibres. These three systems of fibres are clisposed in more or less defined tracts which can be unravelled by dissection, but in certain 
situations where the different tracts eross one another the arrangement becomes more complicated. This is notably the case in the region where the fibres of the corpus callosum intersect the fibres of the inner eapsule.

The corona radiata is the name given to the prolongation of the fibres of the imner capsule into the hemisphere. It is continued upwarts from the inner capsule as a somewhat narrew band (pecluncle of the corona radiata), but the fibres soon spread out like a fan and proceed to the cerebral cortex. It will be well at this stage to re-exanine the constitution of the inner capsule; the latter contains three sets of filnes, namely: (a) Fibres which pass from the crusta of the crus (erebri directly into the corona radiata without the intervention of nerve-cells; $(b)$ filnes passing from the mesencephalon into the optic thalanus and corpus striatum; and (c) filores from the thalamus (part of the corona radiata of that body); and from the corpus striatum to the cerebral cortex. We have already seen (page 701) that the inner apsule shows in horizontal section an anterior limb, a posterior limb and a genu. The fibres which oceupy the most anterior part of the anterior limb belong to the corona racliata of the optic thalamus. Behind these fibres is a tract which extends nearly to the genu; this tract is formed by fibres which are derived from the frontal lobe, and although their function is not accurately known they are supposed to be associated with the higher intellectual functions. Traced downwards, this bundle passes into the crusta, forming rather more than the imer fifth of that borly, and from thenee enters the pons, where a part of it seems to terminate (frontal pontine tract). Its further course is unknown. The portion of the inner calpsule immediately in front of the genu is intinately associated with the faculty of speech; it passes in the crusta immediately extemal to the frontal pontine tracts. The genu conveys fibres from the cortex cerebri to some of the motor cranial nerves. These fibres pass immediately external to the preceding (aphasia) bundle, and probably decussate in the pons to become commected to the nuclei of the facial and hypoglissal nerves, and to the motor nucleus of the trigeninal. The anterior twothirds of the posterior limb of the imner capsule is formed by the pyamidal tract which is described elsewhere (page 741). The posterior third of the posterior limb) of the inner capsule is formed by sensory fibres comprising the optic racliation; the latter proceeds exclusively from the oceipital lobe. The remaining sensory filsres are derived from the oceipital and temporal, and to a certain extent from the parietal, lobes. They descend in the crusta, occupying the outer third of that body. As this sensory tract traverses the crusta, its outermost part is formed by filpes derivel from the fillet.

The commissural system, consisting of the corpus callosum and the anterior conmissure, has been already described (pages 692, 701).

The intrahemispheric or association fibres unite different portions of the cortex of the same hemisphere to one another. These fibres are in two sets-a long and a short. The short fibres (fibræ arcuatæ seu propriæ) unite two adjacent convolutions, the fibres passing round beneath the fissure which separates the two convolutions. The long fibres are clisposed in several nore or less well-defined tracts, namely: the cingulum, the fascieulus arcuatus, the fasciculus uncinatus, the perpendicular occipital fasciculus, and the fasciculus longitudinalis inferior. The cingulum is a well-defined band, which oceupies the core of the grrus fornicatus. Year the splenium of the corpus callosum it receires an accssion of fibres from the occipital lobe. The fasciculus arcuatus passes from the cortex of the frontal to the occipital lobe; it also sends some fibres into the temporal lohe. The fasciculus uncinatus springs from the orbital gyri and from the inferior frontal convolution, and, after traversing the lower part of the claustrum, ends in the cortex of the temporal lole near the anygdaloid nucleus. The perpendicular occipital fasciculus passes from the inferior parietal lobule to the inferior occipito-temporal convolution. The fasciculus longitudinalis inferior is an extremely well-defined humlle which passes from the ocripital to the temporal lohe.

The external capsule also belongs to the association system, as it is chiefly concerned with the conrolutions of the istand of Reil.

Dissection.-The stulent shonld remore the pia mater from the anterior part of the unper surface of the cerebellum, and also any of that membrane which may be still adlerent to the inadrigeminal bodies. The anterior part of the cerebellum should now be gently pushed baek- 
Warck until the ruarligeminal berdies and the lateral parts of the crura cerebri are fully exposed. The valve of Vieusechs and the slemer pair of tourth nerves which spring fiom its upper paut are very liable to injury at this stage. In coulueting this clissection, the stmlent will notice a prair of braid white hands, the smerior gedumeles of the cerebellum, converging towarls the lower jair of quatrigeminal lordies. and a thin white lamina, the valve of lieusens, filling the interespace between them. The mesencerphalon in now fully exposerl, and its fire surface shenld first be examinerl. Directions will be subseguently giren for the examination of its internal st lucture.

\section{The MesexcephaLoN}

The aqueduct of Sylvius is a narrow passage, a little more than half an inch long. which mnites the cavities of the third and fourth rentricles: hence it is sometimes called iter e tertio ad quartum ventriculum. It is roofed by a plate of grey matter, the lamina quadrigemina, which is sumounted by two pairs of elevations, the corpora quadrigemina. Its thor is formed br the tegmenta of the cura cerebri. Its ontine in transverse section varies in different parts of its course. Thus, at its commeneement, under the yosterior commissure, it has the form of an isosceles triangle with the apex directed downwards. Below the anterior qualrigeninal bodies it is heart-shaped, then somewhat shield-shaped. Lower down, on the level of the posterior corpora quadrigemina, it has the form of an crate leaf with the stalk threetel downwards; and finally, at its junction with the fourth ventricle, it is T-shaped in section (fig. 444).

The grey matter of the aqueduct is a thick stratuus which surrounds that eanal, and is con. tinnous with the grey matter of the floor of the fourth rentricle. It is bounded below by the formatio reticularis, ant by the posterior longitulinal bundle (fig. 424). It is continuous al ure with the grey matter of the lamina quadrigemina. Grouls of cells are emberded in this grey snbstance; the must important of these is a long column of nerve-cells which is placed near the middle line beneath the aqueduct close to the formatio reticularis (fig. 424). This is the contimuous nucleus of the third and fourth nerves. It commences near the junction of the third ventricle and the aqueduct, and extends for nearly the whole length of the latter. It is on a line with the nuclei of $t w 0$ nerves (sixth and $t w e l f t h$ ) which arise from the floor of the fourth ventricle. The nucleus of the descending root of the fifth nerve is a groul of cells in the regiom of the upper quadrigeminal borlies, situated above and external to the nucleus of the third nerre; it is limited on its outer side by the white fibres of the nerre-root itself:

'The formatio reticularis will be describerl with the anatomy of the medulla and pons.

The CORPORA QUADRIGEMINA are four grevish elevations which smmount the lamina quatligemina. The superior or anterior pair are termed the nates; the inferior or posterior pair; the testes. The corpora quarlrigemina are marked off ly a cruciform groove, the transverse limb of which is the more distinct. The frortion of the vertical groove which lies botween the nates is also well marked, but the groove between the testes is shallow and is obscured hy a rounded bundle of tibres, the frenulum veli, which passes downwark and spreack out on the valve of Tieussens, immediately below the testes. The corpora quadrigemina consist of grey matter overlaid by a thin sulerficial stratum of white fibres.

The nates are broader and darker in wolour than the testes. and form a yair of owoid revations with their long axes directed upwark and outwark; this direction is continued into the corresponling hrachia.

The brachia of the nates, or superior brachia, are slightly-raised white bands which pass on earh sicle from the nates in the intervals letweren the pulvinar of the optio thalani anel the corpora genirulata interna. They are sharply marked off from the latter, but less clistinctly from the thalani. Each hrachim is continued below the corpus geniculatum externum of its own side directly into the optic tract.

The testes are lighter in enlour, and form more promouncerl elevations than the nates. Each testis is a smmewhat pear-shaperl lemly, the narrow enel of which is continuerl into the luachium of its own siele.

The brachia of the testes, or inferior brachia, are narrower ant more prominent than the hrachia of the nates, and rm parallel to the latter. Each brachimm passes below the (onplus greniculatum intermun of its own side and disalplears from the surface.

The corpus geniculatum internum is an wal elevation which is placed behind 
the lateral groove of the mesencephalon under cover of the pulvinar. Its long axis is directed transwersely. A band of white fibres is prolongert from its outcre end into the optic tract. "This passes as the hindemost layer" of fibres in the optic commissure into the corresponding bundle of the opposite side. It is therefore commissural in nature. It does not contribute any fibres to the optic nerve.

The corpus geniculatum externum is a slight elevation at the outer sirle of the pulvinar. It is directly continuous with the optic traet.

The remainder of the mesencephalon is formed by the crura cerebri, each of which is divided into three distinct parts asily lecognised in transverse section (fig.

\section{Fig, 424.-DeEP ORIGIN of THE THIRD Nerve. (Alter krause)}

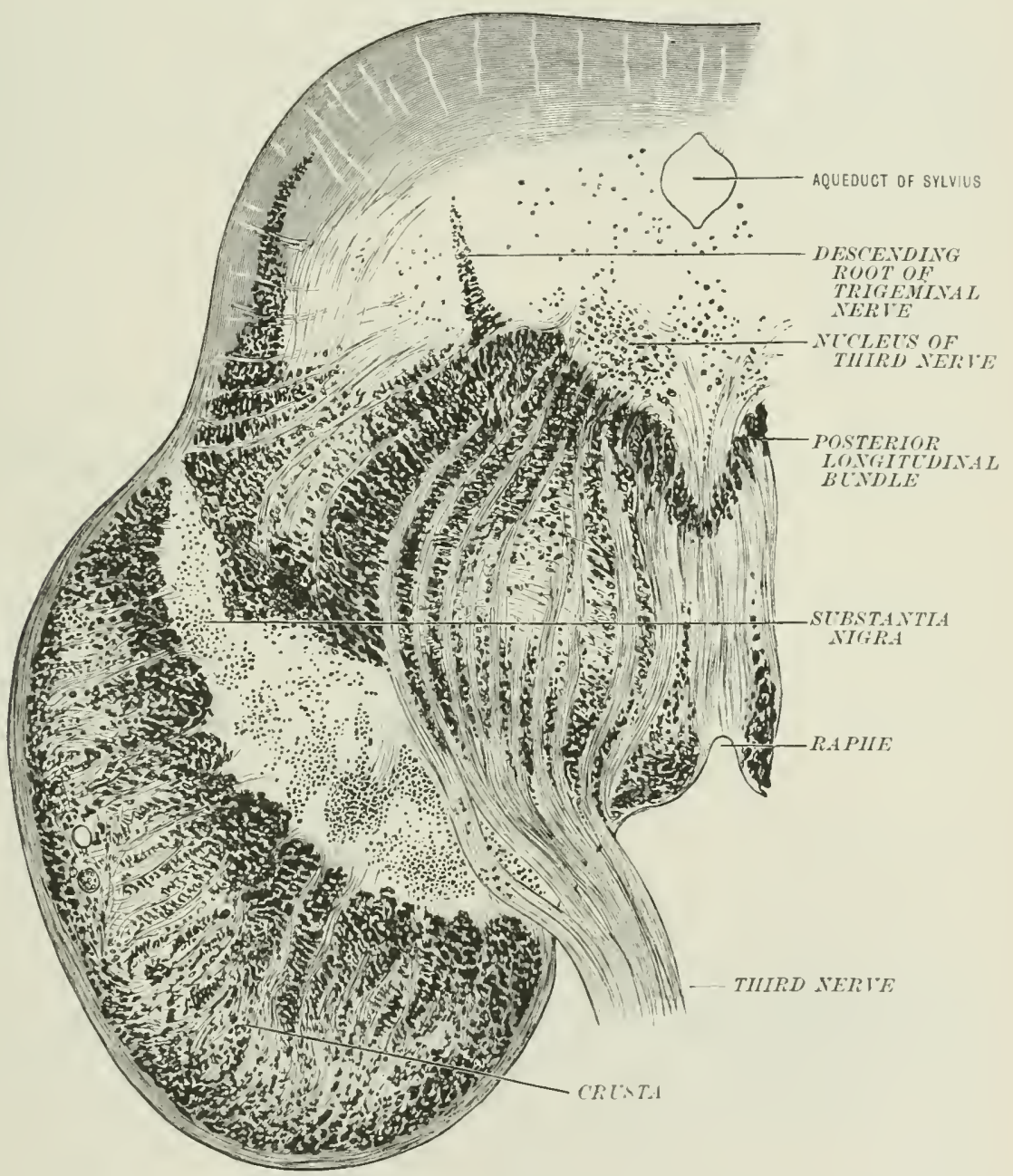

424). These are (1) a greyish upper portion, the tegmen; (2) a hand of almost black substance, the substantia nigra; and (3) a low white portion, the crusta, which appears at the base of the hrain. The tegmen is al:o marked off superficially from the crusta by two gronves, the oculo-motor and the lateral groove, whirh may be seen in section to eorrespond with the inner and outer extremities of the substantia nigra. The oculo-motor crroore derives its name from the third ol oculnmotor nerve, the filaments of which reach the surfare along this furrow. The lateral groove of the mesencephalon is best marked near the upper border of the pons, where it is bounded below by the superficial fibres of the crusta; and above 
by a triangular band of fibres, the fillet, which disappears under the testis and its brichinm.

The crusta, or pes, is a large flattened band of white fibres which is erescentic in section, with the concavity directed backwards and inwards, and in contact with the substantia nigra. Its antero-inferior, inner, and outer surfaces are free. These surfaces are marked with ridges indicating the bundles of fibres of which it is composed. These ridges do not rum parallel to the axis of the erus, but take a slightly eurved course, passing at first outwards and then upwards. The crusta is continuous below through the pons with the pyramidal body of the same side, and with the cerebellar hemisphere of the opposite side. It is somewhat constrieted where it emerges from the pons. It is continuous above with the inner capsule.

Dissection.-The student should scrape away the remains of the lenticular nucleus on the left side until the white substance of the inner capsule is exposed. He should then raise the superficial fibres of the under surface of the crus of the same side, and by tearing off these fibres in an npward direction he may readily demonstrate the continuity of the crusta with the inner capsule. The dissector may also follow the fibres of the crusta downwards to the pyramidal bodies ly cutting through the superfieial transverse fibres of the pons, but it is better to clefer this disivection till a later period. The remainder of the mesencephalon with the optic thalami should

Fig. 425.-Lateral View of Mesencephalon, Poxs, and Medilla. (Gegenbaur.)

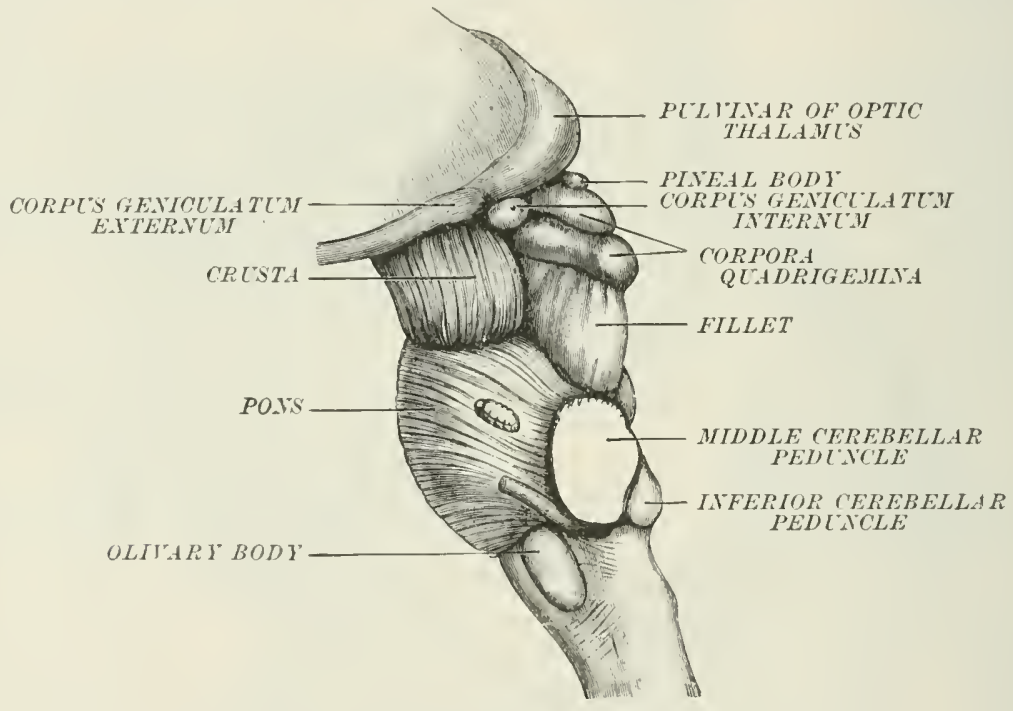

be carefully preserved until the end of the disseetion of the brain, when they should be examined in comnection with the medulla and pons by a series of sections.

The fibres composing the central third of the erusta are derived from the pyramilal bodies and pass into the anterior lalf of the posterior limb of the imer cajsule to the ascending frontal and aseending parietal convolutions. Its outer third is formed by fibres which are partly derived from the cerebellar hemispheres of the opjosite side, and which jass through the josterior half of the posterior limb of the inner eapsule to the temporal and occipital lobes. 'These fibres are considered to he sensory in function. Lastly, the fibres constituting its inner third pass upwarls through the genu and anterior limb of the capsule to the convolutions of the frontal lobe, while below some form communications with the nuelei of the cranial nerves, and others ale distributed to the erebellum in a similar mamer to the filmes of the outer third of the erusta. 'There are other tracts of minor importunce in the crista.

The tegmental portions of the crura eerelori, unlike the erustie, are continuous with one another across the middle line, where they mite in a merlian raple. Each tegmen extends into the thalanencephalon helow the optic thalamus, where it contains a yollowish-grey lenticular hody which is ealled the subthalamic body. The tegmentum contains both grey and white matter, with a continuation of the formatio reticularis of the medulla and pons. The most conspicuous of the collections of grey matter is the tegmental or red nucleus, a nitss of brownish-grey 
matter which is placed helow the optic thalamms, and "xtemels batewarts inter the

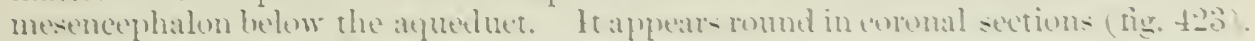

The best marked of the white strands are the stuperion peelumeles of the cere-

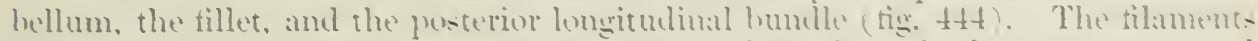

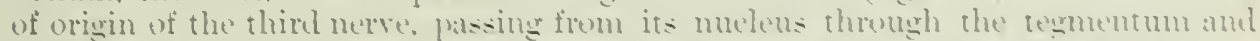

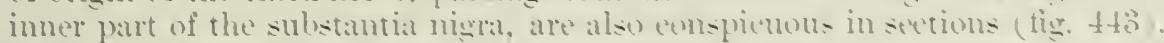

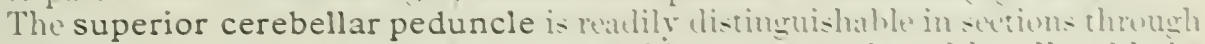
the lowest part of the mesencephalon as a white, aresent-shaped humble with it:

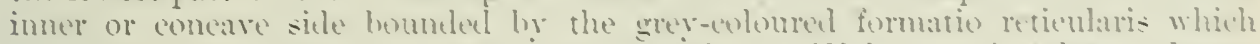

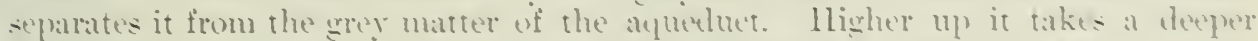

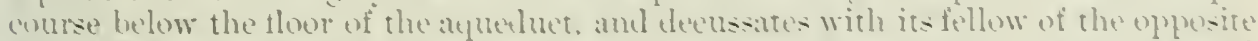
side. It then passes into the subthalamie revion, amb separates inte an inner amel an outer division. The inner division pases internal te the red nutelus and enter the under surface of the optio thatamus. The outer division pases extermal to the red nueleus and prohably enters the gholus pallidus of the lentioular mudem.

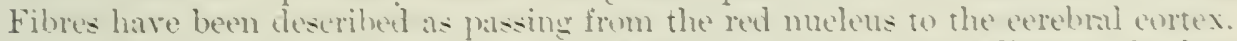

The fillet appears at the level of the lowere quatrigeminate hodies as a that hami of longitulinal fibres in the rentral part of the regmentum, inte which it hats

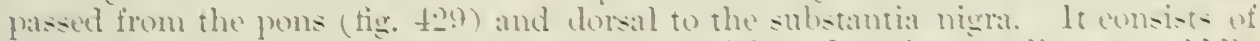
there parts, an onter or litteral, internal or mesial, and am intermediate or midule

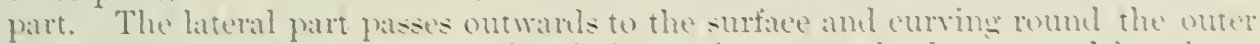

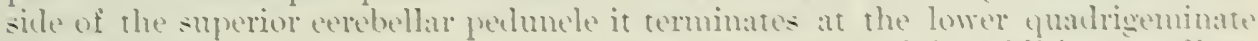
huly (tig. f.0.7). It is also known as the lower fillet, and in ahlition to fiber cheried frem the asernding antero-lateral trate by the superiog medullary velum

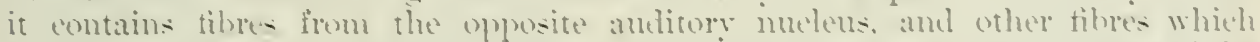

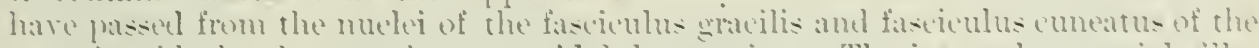

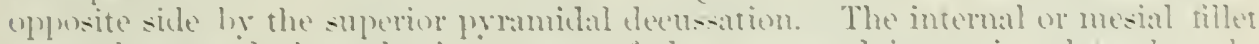

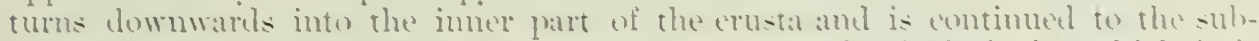
thalamic tenmental rewion, where it enters the ansal lentieularis. by which it is

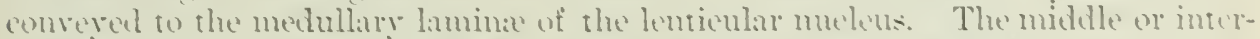

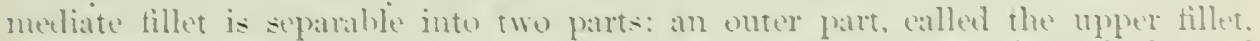
which teminates in the white matter of the superior qualrigeminate buty, ame a remaining portion which passes mpards inte the subthalamie tegmental revion.

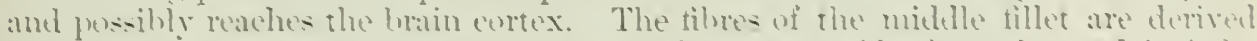

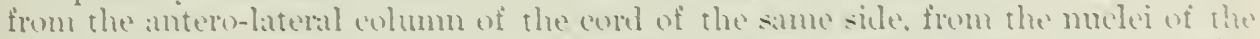

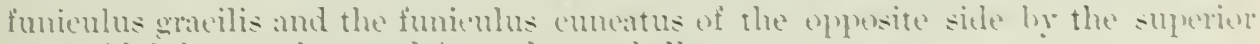
pramilal ilensition, and trom the cerehellum.

"The posterior longitudinal bundle is a strame of large white tilures which lies

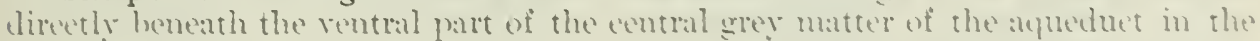

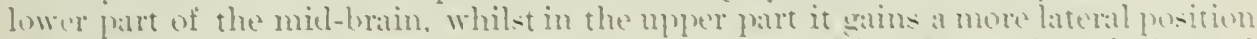

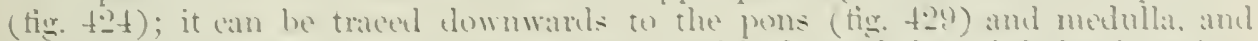

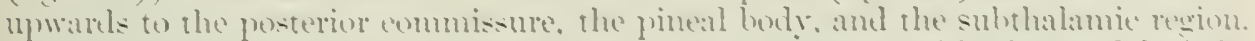

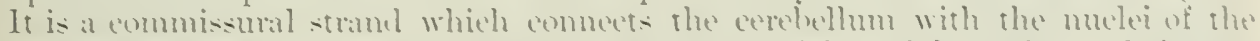

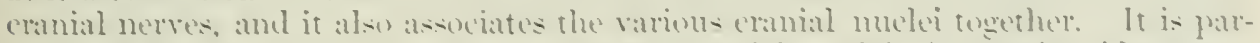

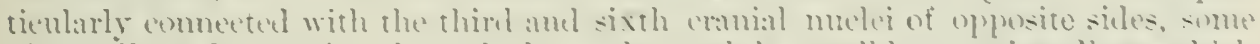

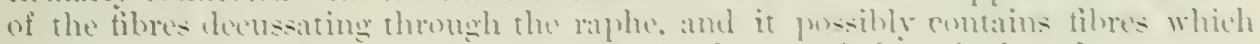

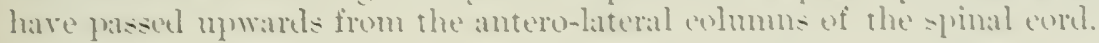

\section{TH: EDENGPHALO}

Dissection. - The pia mater should be remaresl from the superior and interior surtius of the

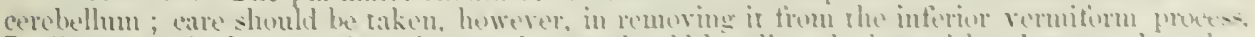

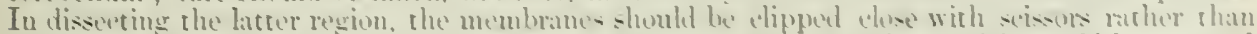

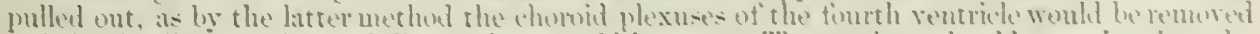

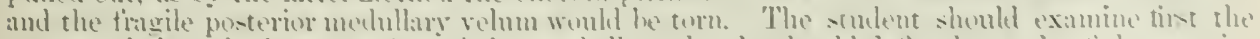

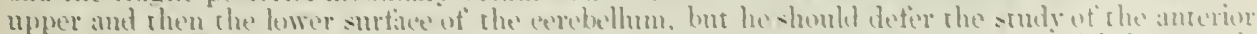

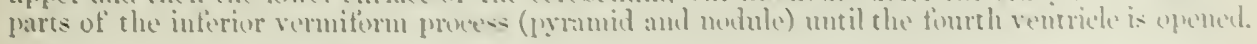

The CEREBELLUM ematsts of twe literal masses, the hemispheres. which are

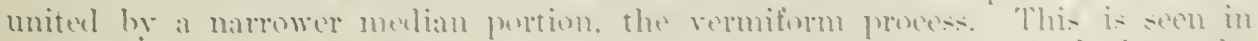

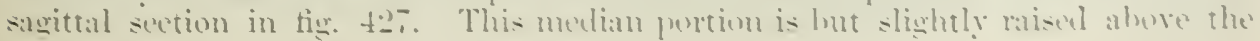


level of the hemispheres as sen flom albove, where it constitutes the superior vermiform process (fig. $42-i$ ); hut, as seen from helow (inferior vermiform process), it forms the root uf a deep reers hetwern the hemispheres, the vallecula, which is oceupied for the most part by the medulla. The vallecula terminates in front at the carity of the fourth rentriele. Behind, it passes into a deep noteh, the incisura marsupialis, whith is ocempied by the fald cerehelli and the cisternat magna of the sulatrachnoid space. The surface of the ecrehellum is corered hy a number of folia, which are curved, with a general direction convex backwarls and outwarts. The folia are much narrower than the cerchal convolutions, and are of a larker srey color than the lattrer. They are separated hy fissures, some of which appear on the surface separating individual folia; others dip in for some distance below the surlace, and within these secondary fissures are developed. In this way the great horizontal fissure and the interlobar fissures are formed. The separation into lohes is somewhat arbitrary, as fissures resembling the interlobar fissures in character traverse the substance of the lobes.

The cerebellum is connected to the adjacent parts of the cerebro-spinal axis by three pairs of peduncles: a superior pair to the cerebrum; a middle pair to the fons: and an inferior pair to the metulla.

The great horizontal fissure is deeper than the interlobar fissures. It commences at the point where the middle perluncle of the cerebellum enters the hemisphere and pursues a curved course around the margin of the hemisphere, inclining first downards, and then eurving stightly upwards, and crossing the midtle line immediately alove the incisura marsupialis, to pursue a similar course on the (n) posite side. On opening up the fissure, mumerous folia are seen to run obliquely within it, some of which eross the Hoor of the fissure so as to connect the upper and lower surfaces which bound the fissure. The great horizontal fissure separates the superior and inferior surfaces of the cerebellum.

The superior surface of the cerebellum has a general inclination backwards and outwarls. This surface is appoximately flat, but shows a slight concavity corresponding to the superjacent occipital lobe of the cerebrum. Mesially the slope of the surface becomes more abrupt, and forms the superior vermiform process. Of the fissures which traverse this surface the most important is the sulcus cerebelli superior, which hranches off from the great horizontal fissure at its commencement and curves over the posterior part of the upper surface to approach the great horizontal fissure again at the smperior vermiform process, where the two fis:-ures are solarated only by a narrow hand, the folimn cacuminis (fig. 427 ). The sulcus cerebelli superior divides the superior surface into a larger anterior part, the quadrate lobe, and a smaller semilunar posterior portion, the posterior superior lobe. Another fissure divides the quadrate lobe into an anterior crescentic and a posterior crescentic portion. The anterior crescentic portion is usually subdivided into two portions by another suleus parallel to the fissure last mentioned.

The superior vermiform process is divided by fissures, continuous with the sulei above described, into parts which are placed in the following order from hefore hackwarks: lobulus centratis, monticulus cerebelli, and folium cacuminis. The lobulus centralis is a small squarish mass which is placed below and behind the testes, separated from the latter by a fold of pia mater. It rests below on the lingula, which separates it from the valve of Vieussens (fig. 426). It expands laterally into a pair of somewhat triangular folds, the alæ (fig. 426), which are entirely orerlapped and hidden hy the quadrate lobes when the cerebellum is viewed from above in its undisturbed josition. The lingula is a small tongue-shaped jortion of the cerebellun which lies on, and is adherent to, the valve of Vienssens. Its basil part is continuous with the lobulus centralis, and it consists of form four to tive transwrse follia. The monticulus cerebelli is tivisled into an antrior elevate? portion, therentmen, and a posterior sloping part, the declive. The culmen connerts the anterior cresutie portions of the quadrate lobes of opposite sides, and is traversed ly the fissures which intersecet these portions. The declive connects the posterior cresentir portions, and consists of about six or seren transwerse folia. The folium cacuminis is a $11: \mathrm{rrow}$ hand which connects the posterior superior lobes of opposite sides. It is not a simple folimm, hut is marked on its superior and inferior surfaces liy trassere furrows. 
The inferior surface of the cerebellum shows a pronounced convexity corresponding to the inferior fosise of the occipital bone on which it rests. It is smoothly rounded off externally and behind, but changes its direction abruptly internally and in front, where it comes in contact with the medulla and pons. It is marked off into lobes, which are arrangerl in the following order from belind forwards: posterior inferior, slender, hiventral, tonsillar, and floculus. The posterior inferior is a narrow crescentic lobe, which bounds the great horizontal fissure inferiorly. The slender (lobulus gracilis) is similar in shape, but nurower, as its nanie implies. The biventral, shorter and thicker than the two last deseribed, is divided hy a well-marked fissure into an anterior and a posterior portion. The tonsillar lobe (amygdala) lies internal and slightly anterior to the biventral, and is partly hidden in the rallecula. The flocculus is a small lobe forming a marked projection in front of the biventral lobe, which it separates from the middle peduncle of the cerebellum.

The inferior vermiform process is formed by the following parts, taken in oreler from behind forwards: tuber valvule, pyramid, urula, and nodule. The tuber valvulæ is a transverse hand, consisting of about seren or eight folia, which commects the posterior inferior and slender lohes with their fellows of the olynsite

Fig. 426.-INFerior ScrFace of tile Cerfibility.

(From a mounted speeinen in the Anatomical Department of Trinity College, Dublin.)

VALV OF ITETSSEXS LOBLLCS CENTRALIS

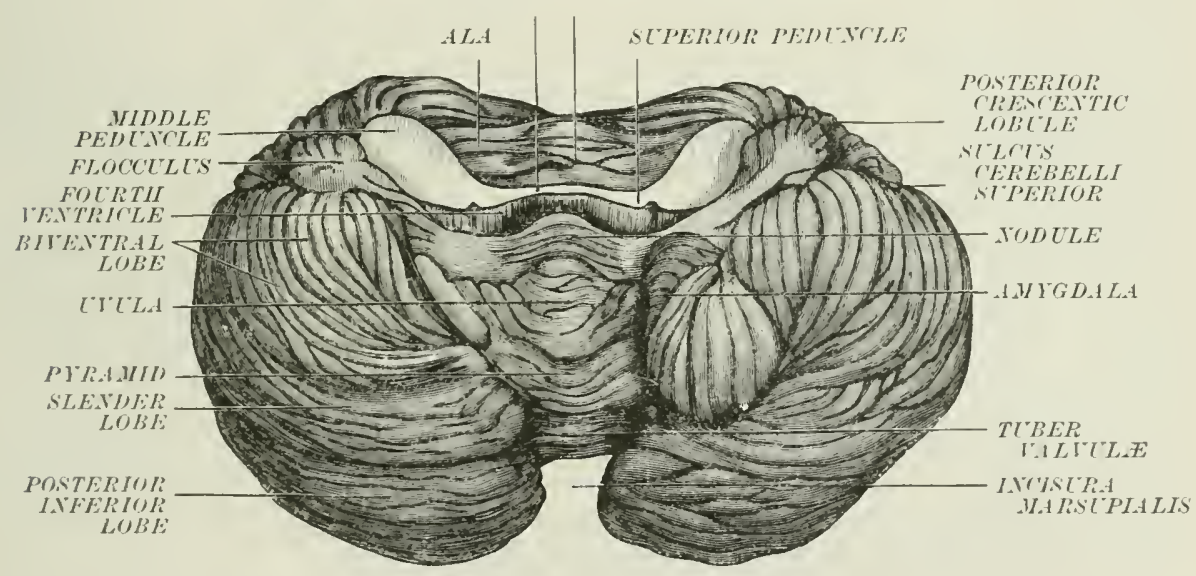

side. The pyramid is the most massive portion of the inferior remiform process, and is comnected to the birentral lobes on each side. It consists of from five to eight folia. The uvula is an clongated portion, compressed laterally, and connecterl to the amygdala on each side by the furrowed band. The nodule, or laminated tubercle, is the prominent anterior extrenity of the inferior vermiform process which projects into the cavity of the fourth ventricle. It is connected to the flocculus on each side by a thin white plate, the inferior medullary velum. The latter will be referred to in connection with the anatomy of the fourth rentricle.

Dissection.-The student should now oltain a view of the principal systems of fibres in the cerebellum by the following dissection, which we shall speak of as Reil's methoul. The great horizontal fissure should be opened up and the portion of the eerebellum which lies superior to that fissure gently torn off the underlying portion. If this proceeding bas been surecesfully accomplished, a large bundle of fibres will be seen passing through a gap between the superion and midlle peduncles of the eerebellum, and passing towards the superior' surface. 'This loundle is formed by the restiform body and by the lower fibres of the pons. The ponstion of the enr jus dentatum will also be noticeable near the middle line, as the white fibres which form the eapsule of that hody are disposed in ridges eorresponding to the plications of grey matter of the nucleus. A more superficial dissection on the opposite side will show the fibres of the abovementioned hundle passing inwards, forming at first curres convex baekwarks, and then sweeping upwards into the folia of the superior rermis. A horizontal section through the corpus dentatum 
on the riglat side will expose the plicated bag of grey matter which constitutes the uucleus, an opening inte which, the lilum, will be seen on the inner and uprer side. If a small portion of the filmes of the superior peduscle of the cerebelhum of the same sile be now raised and torn sently in a downward direction, the fibres are readily traceable into the white eentre of the nutelens.

I horizontal section through the superior vernis will show the smaller nuclei of the cerebellum (nutei fastigii, cmboliformis, and globosus). These are, however, somewhat difficult to fiud.

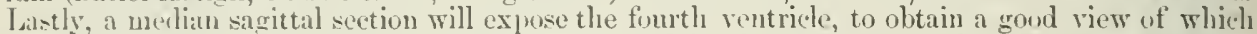
the reminders of the cerebellar hemispheres should be tramn gently aside. In loiug this care should be taken of the inferior medullary velum.

White matter of the cerebellum.-In a mesial sagittal section of the cerebellum (fig. 4.97) the amount of white matter is smaller in proportion to the erey nuatter than in any other section. It presents a characteristically branched appearance which is alled the arbor vitæ. Two main elivisions, the rertical and horizontal hranches, of the arlor vitre are described, and from these secondary lamitications arise. The vertical branch is mainly continued into the culmurn, where it sublivides somewhat freely. It sends forwards usually two hranches into the lomulus centralis, and a slender trig into the lingula. The main axis of the horizontal branch is prolonged into a slender white band, which enters the folium cacminis. From the upper surface of the horizontal branch a stout offset is sent into the declive, and from its lower surface branches are sent into the tulrer valvulie, prramid, and urula. A small oftset enters the nodule, and if this he traced in a lateral direction it will be found to be continued into the inferior medullary velum,

In coronal sections the disposition of the white matter in the hemispheres is well scen. It forms a somewhat oroid mass in each hemisphere, near the centre of which the corpus dentatum is placed (fig. 416). The appearance is very similar in sagittal sections through the centre of a hemisphere. It is not necessary to give a s'prarate description of the divisions of the white matter, as these correspond to the lobulation of the surface.

The grey matter in the interior of the cerebellum consists of four pairs of nuclei, which are everywere separated by white matter from the grey matter of the folia. The largest of these nuclei in each hemisphere is called the corpus dentatum. The smaller, which are placed nearer the middle line, are called the nucleus emboliformis, nucleus globosus, and nucleus fastigii.

The corpus dentatum is a crumpled sheet of grey matter which presents a similar untline in coronal, sagittal, and horizontal sections. This outline is approximately an oral bounded by a way line. This line is broken only on the inner ant anterior sicte, where the white matter of the exterior is continuous with that of the interior through an aperture ealled the hilum.

The nucleus emboliformis is an elongated streak of grey matter, which is plarext on the imner side of the corpus dentatum. It is somewhat enlarged at its anterior extremity, hence it may be described as club-shaped. The nucleus globosus comsists of several spheroidal clumps of grey matter, which are placed on the immer side of the preceding; these clumps are connected with one another, and also with the nucleus cmboliformis and nuclens fastigii. The nucleus fastigii raries somewhat in its minute structure from the three nuelei alore described. It is situated immerliately over the roof of the fourth ventricle, scparated from that eavity, howerer, by a thin stratum of white matter. The nucked of olpusite sides nearly touch one another in the micklle line.

The fibres of the cerebellum may be decribed under the following heads: (a) Filuresterived from the cerelsellar juduncles, and (b) intrinsie filnes. (a) The filures of the mithle pertuncle comneret the cerchellum (1) with the nuclei of the pons on the same side, (2) with the posterior longitudinal hundle and the fillet of the same sirle, and by means of these tracts with the corpora quadrigemina, and the antero-lateral tract of the spinal corrl. (3) with the promiclal tracts of the sime and the oplusite side hy means of which comnections are established with the corpora quarligemina and the corpus striatum. The upper fibres of the pons pass into the lateral parts of the erelelear hemispheres, and ent in the grey cortex. The middle fibres sween, lommarls. forming the ollique fasciculus, and end in the folia of the inferior surface. The lower fibres accomplany the 
restiform body to the superior surface. The restiform body (inferior peluncle) is joined on entering the cerelellum by the inferior fibres of the jons; the two together unite into a distinct round bundle, the inner part of which is formed by the restiform body; the outer by the pons-fibres. This bundle passes through a distinct gap) or interval bounded by the superior peduncle internally, and by the greater part of the middle princle extemally. Its fibres then spread out into a layer, the filre semicireulares of stilling which are disposed in gentle eurres conrex backwards and outwards; these fihres corer the capsule of the corpus dentatum, and finally sweep abruptly upwards into the folia of the superior vernis. Some fibres enter the nucleus fastigii. The fibres of the inferior peduncle are connected with the opposite olivary body, with the fillet and posterior longitudinal bundle of the same side, and with the antero-lateral column of the cord.

The corpus dentatum is eovered by a distinct capsule of fibres (the "fleece" of Stilling) derived from the olivary nucleus of the opposite side. The fibres are probably for the most part interupted in the nerve-cells of the corpus dentatum, and are then (indirectly) continued into the white matter which occupies the interior of that plicated bag of grey matter. From the hilum of the corpus dentatum a hundle of fibres passes out, which is joinerl by fibres from the fleece. and thus the superior cerebellar peduncle is formed. The superior cerethellar peduncle passes upwards and inwarls, and receives a covering on its outer side from the inferior fillet. It disappears from the surface by passing under eorer of the tristis of its own side, and assumes a deeper position in the mesencephalon. passing to the rentral side of the aqueduct of sylvius. The majority of the filores decussate with their fellows of the opposite side, the decussation being most pronounced at the level of the centre of the nates. The decustation being completed, the decussated fibres and those which remain on the same sicle proceed hrainwards as a distinct column. This column of fibres soon encounters the red nueleus, and the fibres pass through the nucleus in small bundles, the cross-section of which gives the punctated aplearance to the red nucleus which is so characteristic of that body when seen in coronal section. Beyond the red nucleus. fibres of the superior peduneles certainly enter the optic thalamus, and probably the globus pallidus and the cortex cereliri.

(b) Sagittally-directed filures are placed within the superior vermis. When traced forwarls these fibres are found to decussate with their fellows of the opposite sirle in front and above the nucleus fastigii; here they are joined by true commissural fibres from its liemisphere, the whole forming the great anterior cerebellar commissure of Stilling.

Filores unite the different folia to one another, constituting a system of fibre: which form the most peripheral part of the arbor vitæ. These fibres, from their general arrangement, are called garland-like fasciculi.

The FOURTH VENTRICLE is a cavity which is widest and most lofty about its cuntre. and narrowed at its anterior and posterior extremities. It communicates with the third rentriele ahove through the aqueduct of Srlvius, and passes helow into the central eanal of the spinal cord. Its long axis is directed upwards and forwarls. The structures which bound it behind are said to constitute it: roof, while the parts bounding it in front are described as its floor. The roof is formed from above downwards by the following structures: the superior peduncles of the cereliellum with the ralve of Vieuswens between them, the white matter of the remiform process of the cerebellum, the inferior medullary vela, and the epithelial lining of the choroid plexuses and tela choroidea inferior. Some snall plates of white matter, the oliex and the ligula, also enter into the formation of the roof. The inferior part of the floor is formed by the medulla and the suprerior lart by the posterior surface of the pons. Some white lines (strice actsticae), which cross the floor transwersely, approximately separate the pontine from the merlullary jortion of the floor.

The valve of Vieussens, or superior medullary velum, is a thin plate of white matter which fills in the angular interval between the superior peduncles of the cerebellum. It is continuous behind with the white matter of the superior vermiform process of the cerebellum. The lingula rests on the posterior part of its 
uplyer surfice. The fibres of the fourth nerve decussite within its substance at its muper jart.

The inferior medullary vela are thin eresentic translucent banks of white matter which extend from the nodule to the floceulus on each side; hence they hive heen ealled commissuræ ad flocculos. Eich velum presents a concave alge, which is apparently free, but which is in reality continued into the epithelium, which corers the choroid plexuses. It is attached to the cerebellum by its convex erlige.

The choroid plexuses of the fourth ventricle are convoluted vascular folds of the pia mater, which project into the cavity of the fourth rentricle, but are exclurled frem the ventricular cavity hy ar layer of epithelimn. They run at first forwards close together on each sile of the middle line, and then turn outwards along the edges of the inferior medullary vela to reach the lateral recesses of the ventricle, where they becone continuous with the general pia mater.

Fig. 427.-Right Half of the Excephalic Penuxele as seen froy the Ixside of A Medias section. (Allen Thomson, after lieichert.)

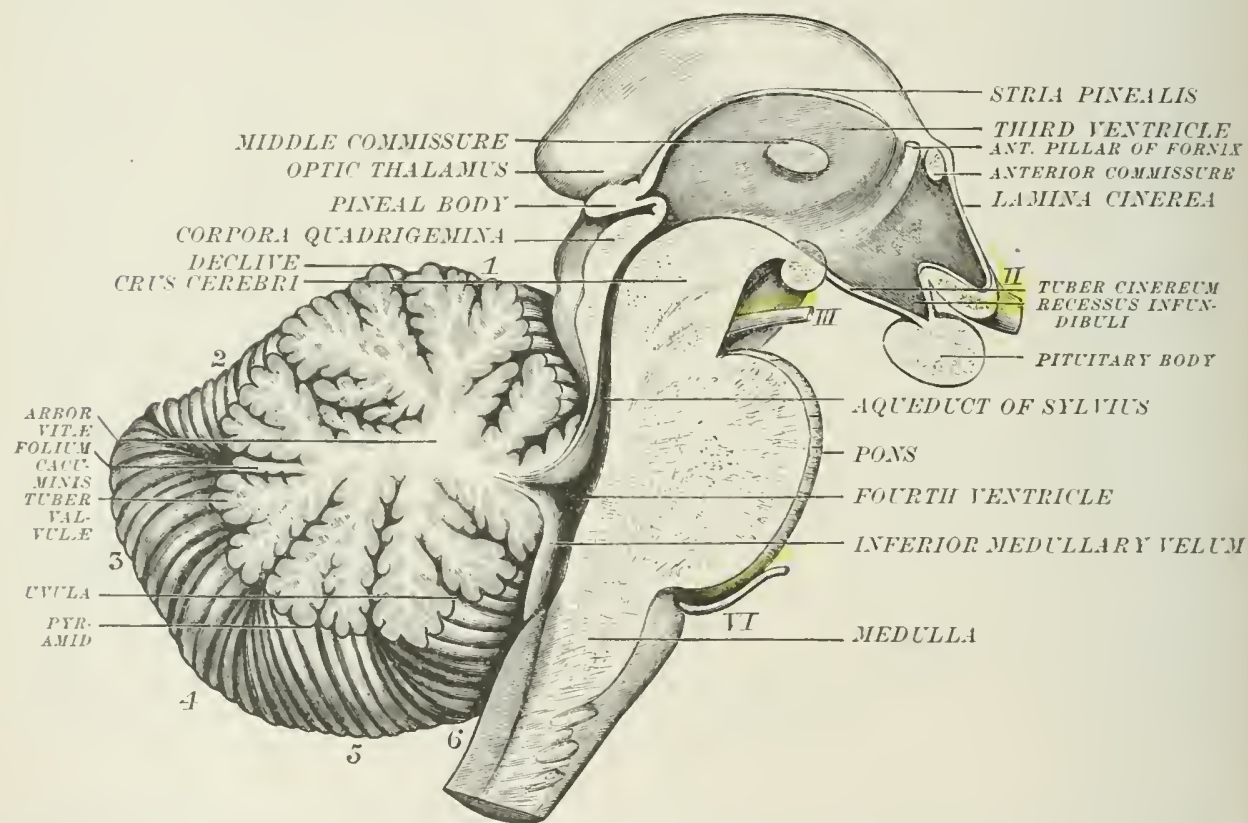

1, culmen ; 2, posterior crescentic lobe ; 3, posterior inferior lobe ; 4, slender lobe ; 5 , biventral lohe; 6 , amygdala.

The tela choroidea inferior is a layer of pia mater which closes in the lower and back part of the fourth rentricle. It extends from the choroid plexuses to the ligula and obex, where it is eontinued into the pia mater which covers the posterior surfare of the lower part of the medulla. As already mentioned in the description of the meninges, it presents three oprenings or defeiencics: one (foramen of Majendie) in the midllle line immoliately above the olex, and two (foramina of Key and Retzius) at the lateral recesses.

The obex is a thin, somewhat triangular plate of white matter, oceupring the angular interval between the two diverging davix. It is not infrequently absent.

The ligulæe are thin narrow strips of white matter, which project from the inner margins of the clave. They rm at first upwarels and forwards, and then turn outwards around the restiform hodies. They may sometimes be traced as far as the floceuli, when they hecome continunus with the inferior medullary vela. Their inner, apparently free, edges are continuous with the epithelial roof of the fourth ventricle. 
The floor of the fourth ventricle is a depressed area, which is rhomboital in outline, the longer diancter of the rhomboid being directerl upward-and forwarts and marked by a very distinct fissure, the sulcus longitudinalis medianus, which is continuous below with the central canal of the spinal corel. The ventriteular flows' is bounded laterally by the clavas and corpora restiformia helow, hy the midelle perluncles of the cerelellum in the middle, and by the suprerior pedundes of the cerebellum abse. Lnder cover of the obex, where the fourth ventricle is about to join the central ranal of the cord, a small ampulla is formerl, termed the ventricle of Arantius. The widest part of the Howr corresponds to the lateral recesses of the ventricle. Close behind the lateral recesses, the floor is crossed by sone white lines, the striæ medullares or striæ acusticæ, which emerge from the sulcus longitulinalis medianus, and pass outwards to the auditory nerve. The strie divite the floor into two approximately equal parts, an inferior and a superior.

The inferior moiety of the floor is inclented $b y$ an angular groove, the fovea inferior or posterior, which marks off a depressed triangular area of a grey colnur, the ala cinerea. The latter corresponds in position to the subjacent nuclei of the ragus and glosso-pharyngeal nerves, and is therefore also termed the trigonum vagi. The apex of the posterior forea is directed forwards. It nearly touches the strixe acustica, and thus two other triangular areas, both of a whitish colour, are marked off in the inferior moicty of the Hoor. The internal of these areas is callerl the trigonum hypoglossi, since it corresponds in prosition to the nucleus of the hypostossal nerre. It is bounded by the inferior forea, the strix arusticat, and the suleus longitudinalis medianus. The outer triangle is bounded by the inferior forea, by the strixe acustica, and by the clave. It forms the inferior part of a prominence or swelling which extends into the pontine portion of the floor. This prominence is called the tuberculum acusticum. It is well marked in the brain of the infant.

The superior moiety of the floor is completely covered by a thin layer of white sulstance. It presents, on each side of the sulcus longitudinalis medianus, a semicylindrieal devation about five millimetres in length, which is called the eminentia teres. It is cansed by an underlying bundle of fibres, the fasciculus teres, which is now known to be a part of the intrapontine course of the fibres of the facial nerve, though possibly it may contain fibres from other sourees. Extemal to the eminentia teres is a cleprescel area, the fovea superior, which is acasionally crossed hy a whitish hand of filores, the conductor sonorus. The conductor sonorus meets the stria modullaris of its own sirle. at the suleus longitudinalimerlianus, at an acute angle. Immediately in front of the foreasuyerior is a bluish spot, the locus cæruleus, which is caused by the substantia ferruginea showing through the white covering of the floor. The substantia ferruginea is an aggregation of clarkly-pigmented cells, which is rery conspicuous in transrerse sections through the upper part of the floor of the fourth rentricle and through the lower part of the aquerluct of sylvius.

The PONS VAROLII is that portion of the epencephalon which lies in front of the proximal part of the fourth rentricle. As seen from the base of the brain, it forms a consirlerable prominence, which narrows on each side as it passes into the micklle wrebral preduncles. At its lower horder the pramidal hodies are seen disappearing into its substance, while at its upper borler the cruba (erel)ri are seen emerging. It restis on the body of the splienoid hone, raching upwards as far as the margin of the dersum sellac. It presents a ventral and at dorsal surface, and a superior and an inferior horder. Lateral surfares have alos been describer, hut these are deteminerl artificially hy dividing the pons proper from the midclle cerebellar peduneles. The bommlary between the pons am the mirlle cerebellar peduncles on each side is arbitrarily mapped out by a line drawn from the exit of the trigeminal nerve to the superficial origin of the facial. (Henle.)

The dorsal surface has been drecribed in connection with the floor of the fourth ventricle.

The ventral surface is broad and prominent, strongly convex from sidle to sicle, and slightly convex from hefore lackwalik. It presents a transiersestriation. ("orresponding to the bundles of commi-sural fibres passing from hemisphere to 
hemisphere of the cerehellum. Mesially, it is marked by a sagittal groove or furrow, which usually lodges the basilar artery, hut is in no way caused by the contact with the ressel. On each side of the groore a prominence is formed, where the sagittally-directed fibres of the pyrmidal bodies pass brainwards, under corer of the transierse fibres of the pons.

The superior border is convex forwarks. Its fibres pass directly into the upper horder of the middle pedunche of the cereledlum.

The inferior border is marked off $\mathrm{l}$ a a distinct transerse groove from the medullis. It is formed in its inner part by the lowest fibres of the pons, but these are crossed near the junction of pons and middle peduncle by the oblique fasciculus. The oblique fasciculus is formed by the middle transverse fibres of the pons; which pass clownwards and backwards, intemal to the exit of the trigeminal nerve, on each side, and cross the inferior fibres on their superficial aspect.

Coronal sections through the pons (fig. 429) show that it comprises two very distinct regions-an anterior or ventral region and a dorsal region, which is called tegmental, as most of its constituents are continued into the tegmentum of the mesencephalon. The ventral region consists of transverse and longitudinal fibres, interspersed with small aggregations of grey matter. The transverse fibres are:(a) Fibres which pass from the middle peduncle to the opposite side, where they turn upwards to the brain or clownwards to the cord: $(b)$ fibres which emerge from the cerebeltum by the midelle peduncles, and terminate in connection with the nuclei of the pons on the same side. The longitudinal fibres are the upward continuation of the pyranids. They pass upwards in flattened bundles, separated from one another by some of the transverse tibres of the pons.

In the upper or tegmental region the chicf things to be observed are: the tract of the fillet (which lies next to the ventral region), the fomatio reticularis, the posterior longitudinal bundle, the substantia ferruginea, and the funiculus teres. The superior olivary nucleus, the nuclei of the sixth and seventh cranial nerres, the motor nucleus of the trigeminal, with parts of the ascending and descending roots of the last-named nerve and portions of the nucleus of the auditory nerve, are emhedded in this region of the pons (figs. 429 and 430 ).

The dorsal and rentral parts of the pons are separated by a transverse layer of filures called the trapezium or corpus trapezoides (fig. 430 ), beeause in some manmals it appears on the rentral surface of the pons in a quadrilateral area between the bundles of the pyramidal fibres of the two sides. It consists of fibres crosing from side to side through the raphe many of which, derived from the accessory auditory nuclens, pass through the trapezium to the lateral fillet of the opposite side and by it are conveyed to the lower quadrigeminate body.

Some of the structures mentioned in the preceding paragraph are visible to the unaided eye in ordinary dissecting-room specimens. The nuclei of the cranial nerves will not be further described here, as a full account of them will be given in the section on the cranial nerves.

\section{The Metexcephalox}

The MEDULLA OBLONGATA, or bulb, is the portion of the cerebro-spinal axis which "xtends from the inferior lorder of the pons to the decussation of the lyramids. It presents an anterior, a posterior. and two lateral surfaces. The anterior surface rests upon the hasiar groove of the occipital bone, and extends downards an far as the point where the odontoid process is crossed by the transverse ligament of the atlas (Testut). The bulb has the form of a truneated cone, the base of which is continued into the pons above. while the truncated apex is frolonger into the spinal corrl below. The posterior surface is received into the vallecula, between the cereludlar hemispheres, and forms, hy its upper part, as alrearly deseribed, the lower part of the floor of the frurth rentricle. 'The ninth to the twelfth nerves (with the exception of the spinal part of the spinal accessory) take their superficial origin from its sides. The sixth, seventh, and eighth nerves appear in the transverse groove between the medulla and the pons in numerical order from within ontwards.

The ventricular part of the medulla has been already described; but on the 
extraventricular portion certain fissures, and the elevated portions which these fissures may out, require notice.

Fissures.-C'ommencing in front, we find the anterior fissure (fissura longitudinalis anterion) occupying the middle line. It is shallow below, where it is almost separated from the anterior longitudinal fissure of the cord by the decussation of the lyramids; derper above, where it separates the pyranids of opposite sides. Superiorly, it ancls in a blind recess, under the marcin of the pons, the foramen cæcum posterius, or foramen cæcum of Vicq d'Azyr. External to the anterior fissure, we find the sulcus lateralis ventralis; the latter intervenes between the pyramid and the olive above, and extends downwards inmediatcly in

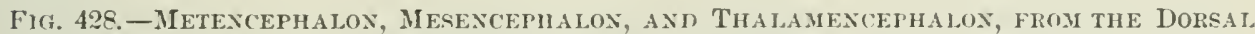
SuRfACE. (After Obersteiner.)

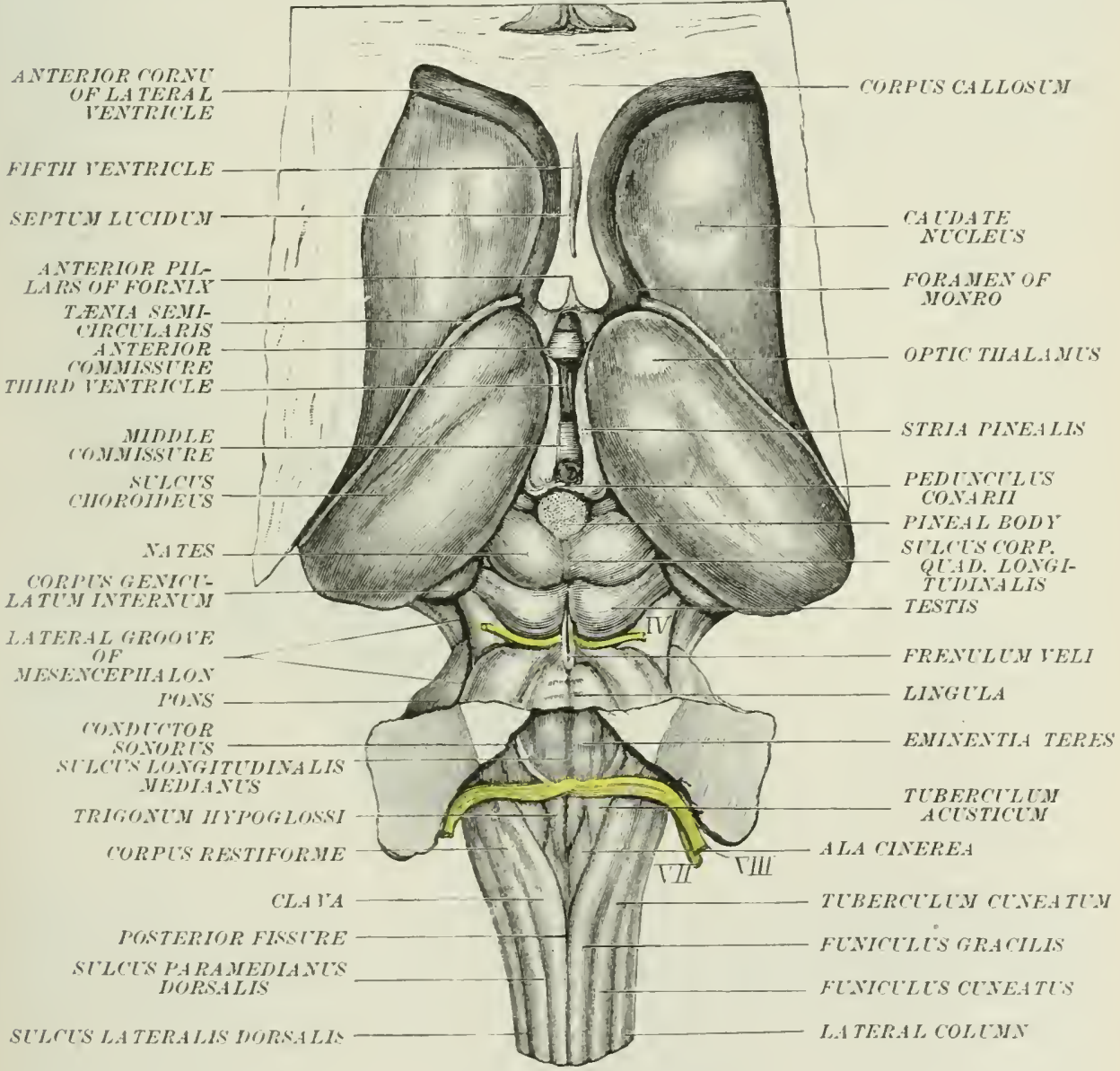

front of the olive and the lateral column. It is joined below the olive by the postolivary sulcus. From its upper part, a fissure (sulcus parapyramidalis) passes downwards and inwards to jnin the anterior fissure.

On the posterior surface of the medulla we find the posterior fissure (fissura longiturlinalis posterior) occupying the middle line. It is continuous below with the posterior fissure of the spinal cord, and ends above at the fourth ventricle. External to this we find the sulcus paramedianus dorsalis, and more extemally the sulcus lateralis dorsalis. The former of these two fissures ends above at the apex of the clava, the latter extends for some distance further upwards. To recapitulate, the fissures of the medulla, taken in order from before backwards, are as 
follows: fissura longitudinalis anterior, suleus parapromidalis, suleus lateralis ventralis, suleus postolivaris, sulens lateralis clorsalis, sulcus parmonelianus dorsalis. fissura longitulinalis posterior. As will he seen fom the provious description, however, this summary applies only to the upper or proximal part of the medulla; in the rlistal part the fissures herome reslued in number owing to some of them becoming anfluent with others. C'ortain of the aloso-nentioned fiscures divirle the medulla into columms or areas corresponding, for the most part, to the colmms of the cord. Thus we have an anterior area hetween the anterior fissme and the suleus lateralis ventralis, al lateral area between the last-named fissure and the suleus lateralis dorsalis, and a pesterior area letween the sulens lateralis dorsalis and the posterior fissure.

The anterior area of the medulla is oceupied, for the greater part of its extent. he the pyramidal bodies. These are a pair of prominemees somewhat pyriform in outline, which hir on each sicle of the anterior median fissure. Their larger ends are directed upwarls and abut against the pons where they become slightly constricted. Latrally, they are markerl off ly the sulci parapyramidales. Their

Fig. 429.-Traxsierse Secton throtgil the Upper Pakt of the Pons. (Schwalbe.)

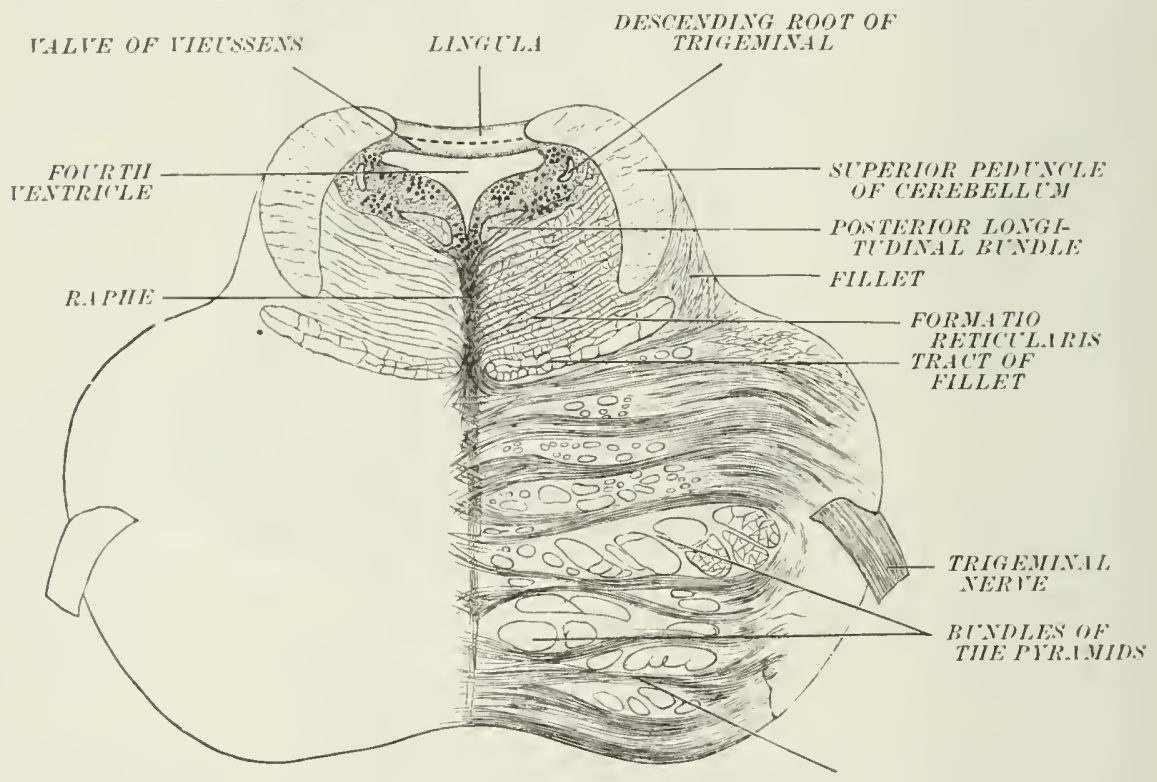

TRANSTERE FIBRES OF PONS

apices are direeted downwards and correspond to the derensiation of the pramids. The greater number of the fibres pass aeross at this point ambl make their way into the lateral columm of the opposite side of the cord (lateral pyramidal tract); a small bunlle, however, of the outermost fibres of each pramid runs downwards in the anterior eolumn of the cord of the same side (anterior pramidal tract).

The remaincler of the anterior colum is ocempied by the funiculus anterior. This is a triangular area of white substance which intervenes between the suleus parapyramirlalis and the sulcus lateralis ventralis. Its base is directed clownwards, and is continuous with the anterior gromed hundle of the anterior colum of the cord. Its apex, directed upwards, is werlged in between the olivary and pyraniclal borlies. The progressive climinution of the tract when traced wpwarls is owing to its fibres receling from the surfice, being orerlapped by the pramidal body.

The lateral area of the medulla is namow below, boung formed hy the continuation of a portion only of the lateral columm of the corl. Higher up) it expands and presents: (a) The olivary boxly and (b) the tuherele of Rolando. The lateral column is a band which passes upwards between the sulens lateralis ventralis and the sulcus lateralis dorsalis. Above, it passes behind the lower part of the olivary 
boily, and here a greyish prominence, the grey tubercle of Rolando, (n)mes to the surface. Bepond this the lateral colum ean be followerl as a narrow band behind the olive as farr as the transverse growe at the lower border of the pons. 'The' olivary body is an oroidal prominence from twelve to sixteen millinetres long, which extencls mpards as fire as the transverse groove at the lower border of the jons. It is separated from the pramidal body by the sulcus lateralis rentralis. and marked off externally by the suldus postolivaris. Its lower end is arosed hy the external areiform filores. The external arciform fibres enerese from thic anterior lomgitulinal fisisure and from the suleus lateralis ventralis, and arch round the pyramidal and olivary bodies to join the restiform borly of the same sicle.

The posterior area of the medulla is oceupied in its lower part ly twoslender fasciculi, each of which expands above into a tubercle. The inner of the two icalled the funiculus gracilis, the onter the funiculus euneatus. The funiculus gracilis is separated from its fellow of the opposite side by the posterior fissure. A. it apploaches the lower extremity of the fourth ventricle, it swells out into a prominence called the clava. The latter diverges from its fellow of the opuosite sille, bounding the fourth ventricle. When traced upwards it gradually tapers off into a fine point. To the inner margins of the diverging portions of the clave we find the obex and ligulie attached, as alroady described (page 718). The funiculus cuneatus is placed between the funieulus last deseribed and the lateral area of thr. medulla. At the level of the clava it swells out into a prominence, the cuneate tubercle. Alowe this point it clisappears from the surface.

The upper part of the posterior area is occupied by the restiform body. The latter alplears at first sight as if it were the continuation upwarls of the funieulus cuneatus and of the lateral tract, and this was formerly deserileed to be the case. It is now known, however, that it is formed by the direct cerelcellar tract (page $7 .+2)$, the extemal arciform fibres, and the deep or intemal arciform fibres. These constituents unite and form a rounded cord which proceeds upwards and then backwarls to the cerebellum, forming the inferior pedunele of that body. In its lower part it is embraced by the roots of the auditory nerve. It then pasies. thromgh a gap or interval hetween the superior and middle cerebellar pedumeles. and ends in the superior rermiform process of the cerebellum in the nucleus fastigii. It is connered by the arcuate fibres with the columns of Goll and Burclach, partly. hy uncrosied and partly ly crossed fibres. The uncrossed fibres have been showin ti take a larger share in the formation of the restiform body than the crossed filmes (barkschewitsch and Freul). The crossed fibres all reach the restiform body as arciform fibres; many of these fibres traverse the olivary nueleus hut without entering into comnection with its nerve-cells (Ellinger); they also traverse the acessury olives and may pierce the ascending root of the trigeminal nerve; ther all decussate at the raphe, and from thence proceed in two groups, superficial and derp areiform filmes. The superficial arciform fibres emerge through the anterior fissure of the medulla, some also through the suleus paramedianus ventrilis, and arch round the prramidal body and olive to join the restiform bodr. In this part of their conrse they pass letween the root-fibres of the ninth, tenth. (leventh, and twelfth nerves. "The deep arciform fibres, after erosing in thr. raphe, traverse the olivary nuelens of the opposite side, and pass thence, through the substaner of the modulla, into the restiform body.

The olivary body also sends fibres to the restiform hody. Filres pass ont of the hilmm and cross in the raphe; they then traverse the olivary body of the opposite sile and join the restiform body.

As already mentioned, the superficial origins of some of the cranial nerves appear on the surface of the medulla. The sixth, seventh, and eighth nerves come to the surface in the transserse groove between the medullat and pons (fig. 411). The twelfth nerve appears by a row of filaments in the groove between the olivary and pratmidal buliss, and in a line with these filaments, opposite the decussition of the praminds, the upper part of the anterior root of the first cervical nerve comes to the surfice. Between the olivary and restiform bodies, the ninth, tenth, and the upper part of the eleventh nerves make their appearanere, and hehind the latter the upper filanents of the posterior root of the first cervieal nerve reach the surface. 
Dissection.- If the student has followed out the dis-ection previously recommended, the brain will now he redneed to the medulla, the pons, the mesenceplialon, and small portions of the hemispheres (chicfly thalamencephalon). He should now tear off the transverse fibres of the puns on one side uf the middle line, so as to bring into view the flattened bundles which form the continuation of the pyramidal borly throngh the pons. By tearing these pyramidal fibres in a siscital direction, the dissector will he able to follow them through the crusta into the imner (anpsule. Iastly the dissector shonld wake a series of transerse sections through the remaining nortim of brain-substance. An inspection of figs. $423,424,429,430$, and 431 will materially aid him in comprehending the somewhat fant indications which le will observe in his sections.

The following are the principal points which can he made out by the unaided eye in an ordinary brain, hardenes in spirit, and treated in the above-mentioned mamer. (In a brain hardened in Miuller's fluid many additional details can be mate out.) In the uppermost sections the tegmental or red nucleus is readily recognised by its romded ontline; it lies below the optic thilkmus, and extends backwards for a consiclerable distance (fig. 423). It the section pass through the external geniculate body, curved bands of white watter intersecting the grey matter can be scen. Sections throurh the upner part of the mesencephalon show the red nuclens in the tegmentum, the substantia nigra, the crusta, and the aqueduct of Sylvius. Lower down, the decussition of the superior yeduncles of the cerebellum forms a conspicuous white centre in the tegmentım; the grey matter surrounding the aqueduct is distinct in colour from the rest of the section, and on the ventral side of this grey matter the posterior longitudinal bundle can be finintly made out. Sections through the inferior corpora quadrigemina show the posterior longitudinal

Fif. 430.-Traxsyerse Section of tie Pons NeAr tile Cextre of tile Fol:Rtil VEXTRICLE. (Sechwalbe.)

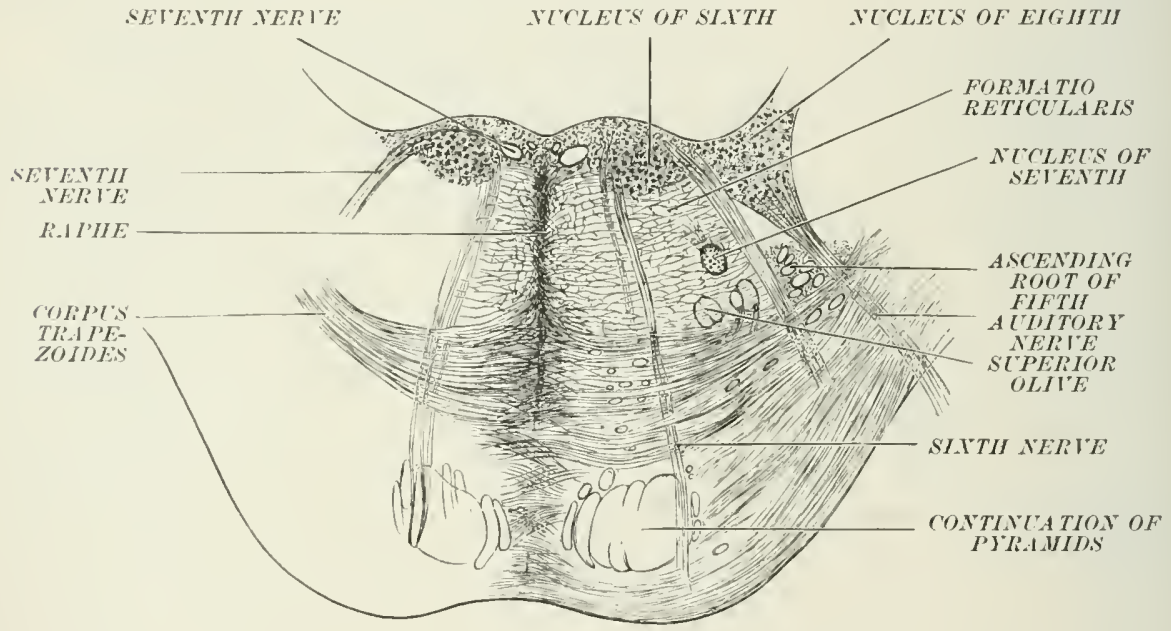

bundle more distinctly; the superior peduncles of the cerebellum lie on the ventral side of the hundle, touching one another at the raphe, but commencing to rise up around the sides of the aqueduct; vential to these the tract of the fillet may be seen as a white hand; and ventrally to the fillet the longitudinal fibres of the pons are woll seen intersecting the transverse fibres. Sections through the valve of Vieussens (fig. 429) show the superior peduncles of the cerebellum in the firm of distinct white crescents placed laterally to the floor of the fourth ventricle. The posterior longitudinal bundle is now very distinct. It appears pear-shaped in eross-section with the narow end pointing outwards and abutting against the substantia ferruginea ; the latter stands out as a conspicuns lark spot. The tract of the fillet is easily recognised as a white flattened oval bumlle. The areal mapper out between the posterior longitudinal bundle, the superior peduncles of the rerebellum, and the tract of the fillet, is ocmpied by the formatio reticularis. In sections distal to this, the posterior longitudinal bundle and the tract of the fillet rapidly lose their distinctness, and in the medulla little can be made ont as a rule except the olivary moleus. 'The latter appears as a thin wavy grey line ocenpying the interior of the olivary body.

Internal structure of the medulla.-Transverse sections of the medulla show that it is composen of symmotrical halves separited by a central raphe. The raphe is cutirely formed by decussating fibres. Each lateral half is composed of both grey and yllite matter. The white matter will be dealt with in common with the tracts of the spinal cort and with the cranial nerves.

The arrangement of the grey matter in the medulla is, for the most part, 
not visible to the unaided eye, and therefore will be dealt with vary liefly here. It is usually classified into two ategories: (a) Representatives of the grey cresecnts of the spinal cork; and (b) nuclei or aggregations of grey matter not represented in the spinal cord. As will be seen on consulting the section on the FPlNAL Cord. the grey matter of the latter consists of a pair of bilaterally symmotrical grey crescents which are united in the middle line by a grey commissure. In the centre of this commissure is the central canal of the cord. The central canal extends upwards into the lower or distal part of the medulla, but, in the upper part of the last-named structure, the posterior columns diverge from one another so that the central canal opens ont and expands into the floor of the fourth ventricle. Therefore the ependyma which surrounds the central canal, together with the grey masses at the bases of both anterior and posterior horns, is sprearl out on the floor

Fig. 431.-Transverse Section of the Medulla a mittle Above the Lower Extremity oF the Folrtil VentRICLE. (After Krause.)

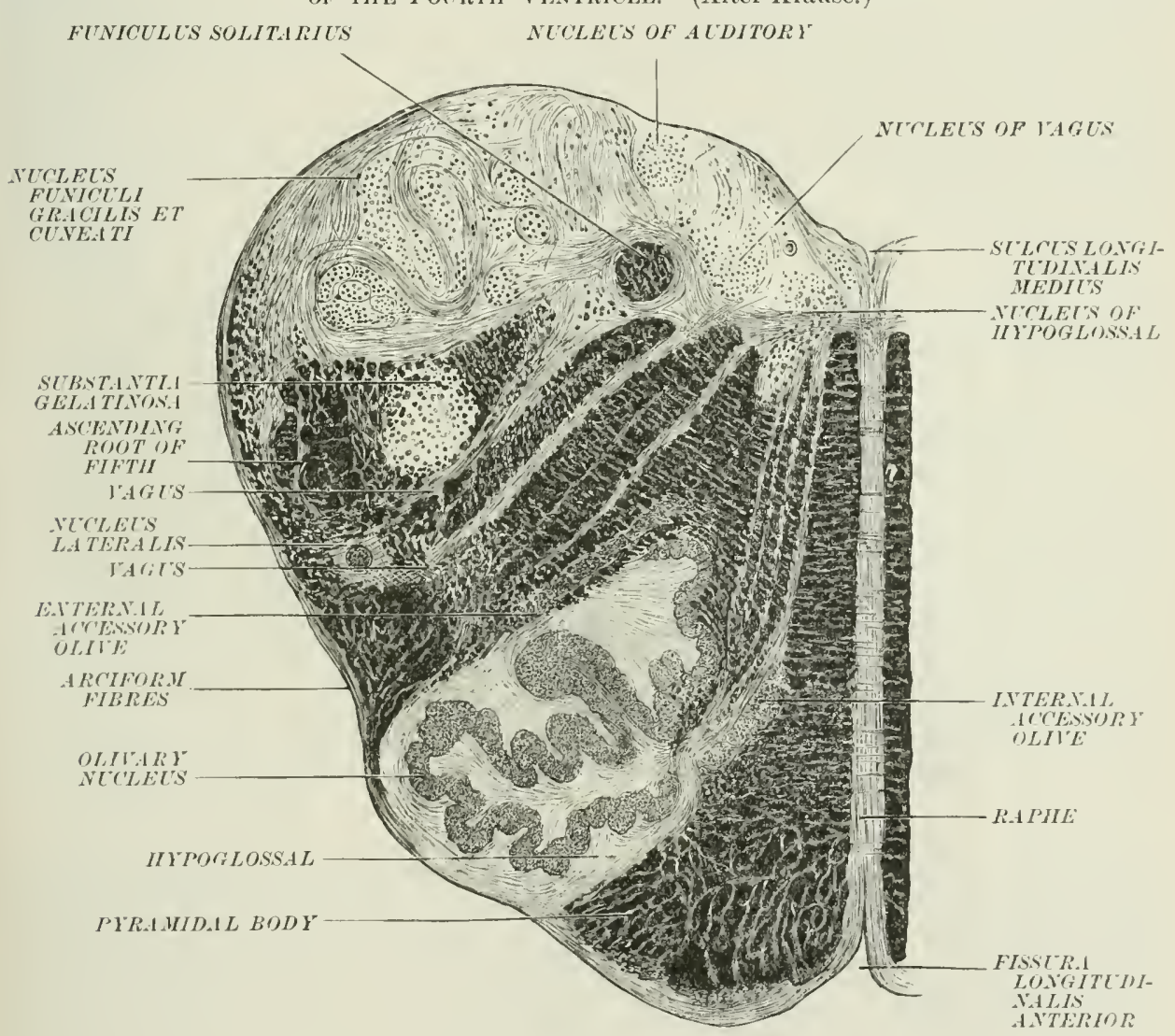

of the fourth ventricle. From the nerve-cells in this grey matter some of the cranial nerves, which take their origin in the medulla, arise. The grey matter of the base of the anterior horn suffers but little displacement, and lies in a column on each side of the sulcus longitudinalis medianus, and from this a motor nerve (the twelfth) arises. The sixth nerve arises in suries with the twelfth in the tegmental region of the pons, and the nuclei of the fourth and thirel nerves continue this motor column of cells hrainwards in the floor of the aqueduct of Sylvius. The grey matter of the hase of the posterior horn is displaced laterally, so that it underlies the surface markings which have been leseribed ahove as ali cinerea and tuberculum acusticum, and from this grey matter the sensory parts of the tenth and ninth nerves and part of the eighth nerve arise. The headof both of the homs of the grey ereseents are also represented in the medulla. At 
the decussation of the promids (fig. 43s) larere lumbles of filmes pass from the lateral columms of the cord to crose over to the opposite sile and alpyear in the anterior columm of the medulla, forming the greater part of the pramich. These homdles of filmes cut thromgh the nocks of the anterior horms so as to completely amputate the heads of the horns. A little higher up each head is thrust into a more lateral position hy the increased size of the prymids, and forms the nucleus lateralis and the muderis anbiguns (fig. 432). The motor nuclei of the portion of the eleventh whieh arises in the medulla, and of the tenth and winth nerves, are regarded as derivatives from the head of the anterior hom, and the series is continued upwards by the nuelens of the seventh (at the junction of the pons and medulla), and in the pons by the motor nuclens of the trigeminal. A little alowe the decussation of the priamids. bundles of fibres, chiefly from the funiculi gracilis and cuneatus, pass forwards and cut through the neck of the posterior horn, and then decussate, forming the sensory or upper pramidal decussation (decussatio lemmisci). The soparated head of the posterior hom (substantia gelatinosa Rolundi) is continued upwards as far as the accessory sensory nuclems of the fifth nerve. This substantia selatinosa is one of the sensory nuclei of the fifth nerve, and is covered extemally by a hand of white fibres, concave inwards, the ascending root of the trigeminal nerve (fig. 432). At one point the substantia gelatinosa approaches very near the surface. and forms the grey tuhercle of Rolando.

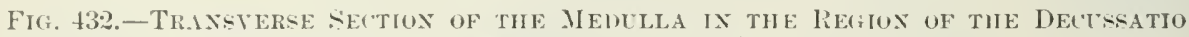
Lemisisci. (Schwalbe.)

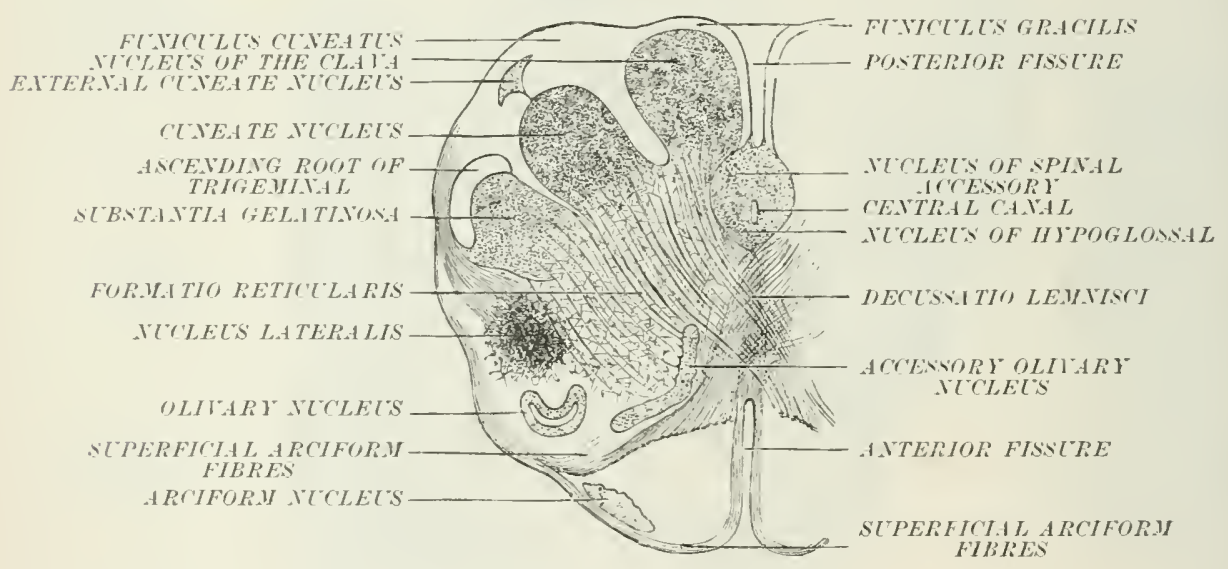

Of the nuclei which are apparently without representatives in the grey matter of the spinal cord. the most important is the olivary nucleus ; this is a crumpled hag of grey matter enelosing white matter and oceupying the interior of the olivary loxly. It can wasily be seen with the unaided eve in cross-sections of the medulla. It presents a marker remblance, in miniature, to the corpus dentatum of the rerebellum, and is often called the corpus dentatum of the olivary body. It presents an opening or hilum which opens downwards and inwards. The nucleus of the clava and the nucleus cuneatus are not directly represented in thr. (ond. hut their comnertion with the prosterior horns "an he seen in sections through the lower part of the meslullat they have probably the same anatomical ralue as a (n)lumn of norve-erlls (clarke's column) in the dorsal region of the spinal cord ('Testut). Other nucles of smaller size are found in the medulla; the mucleus areiformis and the aceroury ulive will serve as examples of these (fig. 432). None of these smaller nuclei are risible to the mainled eye.

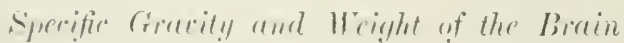

The average specific gravity of the brain is abent [0.36. The white matter is smuewhat more heary (sp. gr. 1040) than the erey mattere (sp. gr. 1034). 
The adult male brain weighs on an average 49.5 ounces; the female braiu is somewhat lighter, and weighs from 5 to $5 \%$ onnces less than the male.

The cerebrum forms about $8 \cdot \cdot 5$ frer cent. of the entire hrain; the cerebelluur about 10.5 per cent.; and the pons and medullit about 2 per cent.

\section{Weight of the sprimal cord}

In the adult, the spinal cord, when all extraneous structures have been removerl, weighs from 1 to $1 \%$ ounces.

For deseription of cranio-cerehral Topography see section X.

\section{THE RELATIONS OF THE BRAIN TO THE WALL OF THE C'RANIAL CAYITY'}

In this section the sulject of cranio-cerebral toporraphy will be dealt with from a purely anatomital standpoint, for the precise methorls liy which the exact positions of the more important fissures. sulci. convolutions. and areas can he ascertained and mapped out on the surface of the head in the living sulject are fully described in section $\mathrm{X}$, whilst here only a very general survey of the relations of the brain to the cranial bones will be given.

The parts of the brain which lie in close relation with the walls of the cranial mavy are the olfactory bub and tract, the inferior and outer surfaces of the cerebral hemispheres, the lower surfaces of the lateral lohes of the cerebellum. the anterior surfaces of the medulla and pons, and the pituitary body.

('ertain of these portions of the brain lie in relation with the lasi-cranial axis that is, with the hasi-oecipital, the basi-sphenoid, and the ethmoirl bones, -whilst others are seprarated by the membranes only from the sides and rault of the cranial spare. Considering the former portions first, the anterior surface of the medulla ollongata. which is formed ly the anterior pyranids. lies, posteriorly, upon the upper surface of the basi-occipital bone. More anteriorly the anterior surface of the pons rests upon the basi-sphenoid. from which it is partly separated by the lasilar artery and the sixth pair of cranial nerves. In front of the dorsum sella the pituitary body is lodged in the pituitary fossa; still further forwards the olfactory tracts lie in grooves on the upper surface of the presphanoid section of the sphenoid bone; and in front of the sphenoid the olfactory hulls rest upon the cribriform plates of the ethmoid.

Behind and laterally to the posterior part of the foramen magnum the lateral lobes of the cerebellum are in relation with the eranial wall, resting upon the lower part: of the supra-and the posterior parts of the ex-occipital portions of the occipital bone, whilst, anteriorly, each is in relation with the inner surface of the mastoid proress and the posterior surface of the petrous portion of the temporal bone. The area of the skull wall which is in chose relationship with the rerebellar hemispheres may be indicated, on the external surface of the skull. ly a line which commences from the lower part of the external occipital protuberance: thence it runs upwards and outwarls. It crosses the superior curved line a little beyond its centre, and, continuing in the sane direction, it crosses the lower part of the lambloid suture and reaches a point directly above the asterion (the meeting-point of the oceipital. temporal, and parietal bones). whence it descends. just in front of the oeciputomastoid suture, to the tip of the mastoid process; there it tums inwarls to its termination at the margin of the foramen magnum, immerliately lehind the posterior ('nul of the occipital condyle.

The other portions of the brain which lie in dose relation with the cranial walls are the lower and external surfaces of the cerebral hemispheres.

The lower surface of each cerehral hemisphere comsists of two parts, an anterior and a posterior, which are separated by the stem of the sylyan fissure. The anterior part, formed hy the corbital surface of the fromtal lobe, rests upon the uperer 
surfaces of the orbital plate of the frontal hone and the small wing of the splueneriel; it is therefore in close relation with the upper wall of the orbital cavity. The posterior fart, hehind the silvian fissure, is formenl hy the anterior portion of the temporal lobe, incluling its apx. The apex itself projects against the orbital flate of the great wing of the sphenoid hone, and it is in relationship with the posterior part of the outer wall of the orbit. The fower surface of the hemisphere, behind the apex of the temporal lobe, is in contact with the mpler surfaces of the great wing of the sphemoid and the petrous part of the temporal lone.

The external surfaces of the areloral hemispheres have the nost extensive relationships with the crmial wall, and it is more especially to these surfaees that the practieal surgen turns his attention. The general area in whieh the outer surface of ach rerebral hemisphere is in relation with the skull hones is readily indicated by a series of lines which correspont with the positions of its supraciliary, the infero-lateral, and the supero-nesial horders.

The line marking the supraciliary margin of the hemisphere commences at the nasion (the mirl-point of the fronto-nasal suture); it passes outwards above the supraciliary ridge, erosses the temporal ridge, then, tuming hackwards in the temporal fossa, it reaches the parieto-sphenoidal suture, along which it eontinues hackwarls to its posterior extremity.

The line marking out the infero-lateral borker commences at the posterior end of the parieto-sphenoidal suture, whence it passes downwark, in front of the spheno-squamous suture, to the pterygoid ridge (infra-temporal (rest); there it turns lackwards; rumning parallel with and intemal to the zygonatic arch, it crosses the root of the zygoma, and ascending slightly it passes above the external aulitory meatus; continumg lackwards with an inclination upwards it rearhes a foint inmediately alove the asterion; thener it descends, and, crossing the lower fart of the lambioil suture and the superior eurvel line, it passes inwards to the lower part of the extemal oceipital protuleranee.

The supero-mesial border is defined ly a line which runs from the nasion to the ininn; this line should be draw about $5 \mathrm{~mm}$. to the outer sicle of the sagital suture, hecause the mesial area is ocrupied by the superior longitudinal sinus, and it should be further away from the midlle line on the right than on the left sile becallse the sinus tends to lie more to the right side.

The area of the skull wall encherel hy the three lines which mark the positions of the supraciliary, infero-lateral, and the supero-mesial borders of the cerebral hemisphere is formed by the rertical plate of the frontal bone, the parietal bone. thre great wing of the sphenoil, the squamous part of the temproml, and the mpler section of the supra-oecipital segment of the oceipital lone; it covers the outer surfaces of the frontal, prictal, tempolal, and oceipital lobes and the fissures and sulei which hound anct mark them.

The frontal bone covers the superior, niddite, and infurior frontal convolutions, except their posterior extremities, which are beneath the parietal bone (fig. 433 ). The aserending limb of the fisture of Sylvius, which ats inte the posterior part of the inferior frontal convolution, runs parallel with and uneler cover of the lower part of the enomal suture or inmoriately in front of it, and the anterior horizontal limb is parallol with and beneath the upper margin of the great wing of the splhenowit. The parietal lone is in relation with the outer surfaces of four lobes of the brain. speaking very generally, it may be sairl that the anterior thirl corers the posterion part of the frontal lobe, incluling the ascencling frontal convolution and the posterior ents of the superior, millile, and inferior frontal convolutions and the mpler and lowrer precontral sulci, whilst the posterior two-thirds are sujerfiecial to the barietal lobes, the posterion part of the temporal lolue, the anterior part of the oecipital lolse, the posterior part of the horizontal limb of the sylvian fissure the mpure and lower post-contral sulei, the intrapuatietal suleus, the justerior sections of the first and second temporal sulei, and the extermal parieto-ox(ipital fissure. The fiscure of Rolando is bemeath the parietal bone at the junction of its midelle and antrior thirds (tim. 4.33 ).

The upper end of the fissure of Rolando lies jo per cent. of the whole length of the naso-inionie line hehind the nasion: it is 5.5 mm. from the coronal suture in

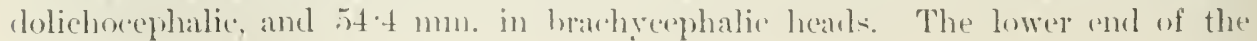


fissure is immediately above the posterior horizontal limb of the fissure of sylvius; it lies lemeath the point of intersection of the auriculo-bregnatie line with a line drawn from the stephanion (the point where the temporal ridge euts the cormal suture) to the asterion (Macalister). In skulls of a sagittal length of $18 \mathrm{em}$. ancl over this proint is 45.5 per eent. of the horizontal are from the glabella to the inion. and in skulls of less than $18 \mathrm{~cm}$. it is 46 per eent. of the same are posterior to the glabella.

Thre position of the posterior horizontal limb of the fissure of Sylvius varies; its posterior part is always under cover of the parietal bone and it terminates either in front of or below the parietal eminence, but the anterior part may be ahove, bemeath, or below the squamo-parictal suture. In the adult the anterior jart of the fissure rums upwards and backwards from the posterior end of the spheno-

Fir. 433.-Drawing of a Cast of the Head of an Adtht Male.

(Prepared by Professor Cunningham to illustrate cranio-cerebral topography.)

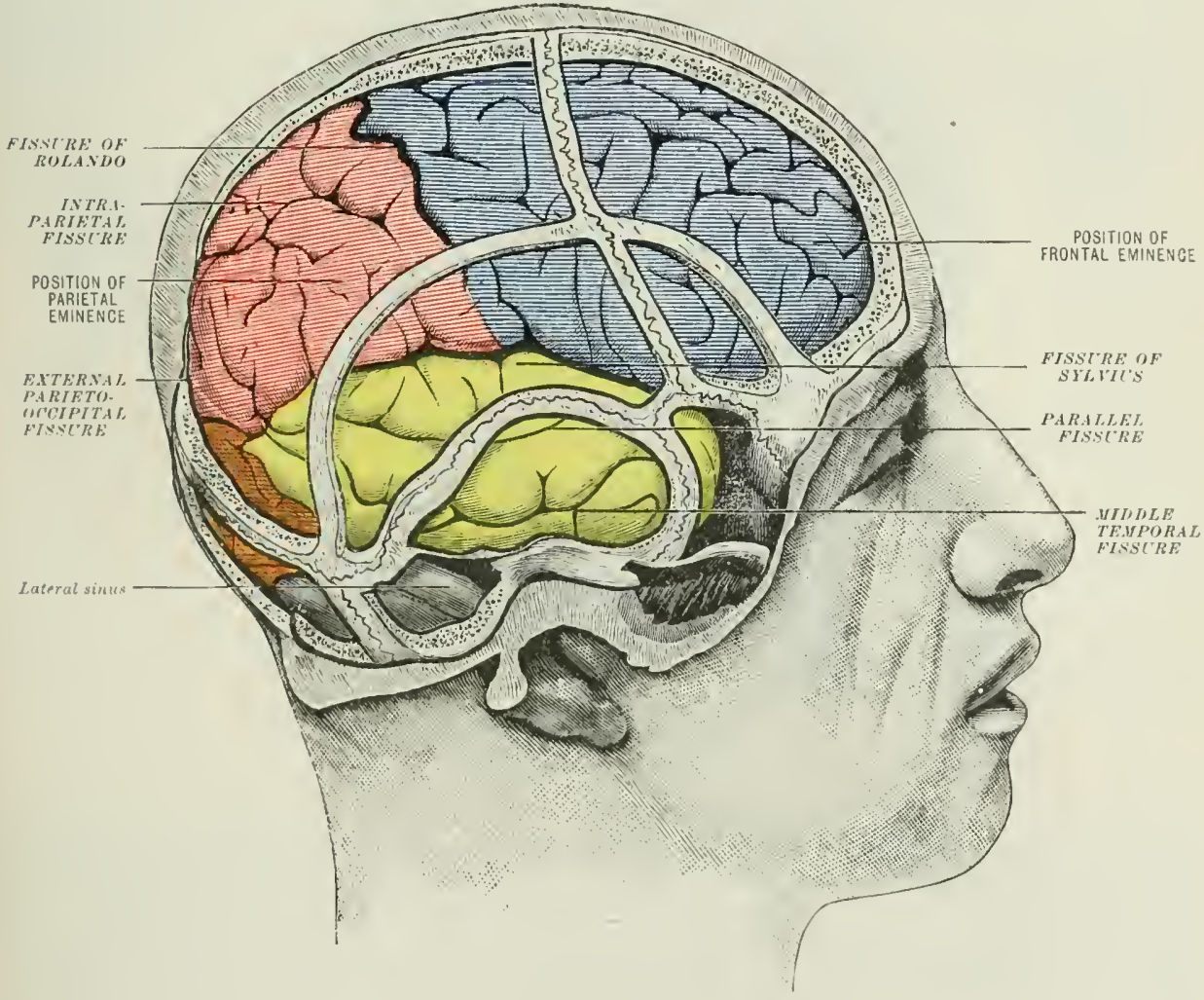

farietal suture along the anterior part of the squano-parietal suture to its highest point; thence it continues in the same direction leneath the parietal bone towards the lamblat, teminating either in front of or below the parietal enninence. In the child. howerer, the firsure is ansiderably above the line of the squano-faridal suturo (fig. 4:) which it grachally apmoaches, attaining its adult position about the nintl year; this change of position, which occurs during the first nine rears, is ine partly to the ascent of the sutural line and partly to the descent of the fissure on the surface of the lorain.

The uyer end of the external parietn-necipital fissure usually lies about 5 nmm. in front of the lambla, and the comrse of the fissure may be indieated by a line drawn from $5 \mathrm{~mm}$. in front of the lambela to a point immediately alvow the asterion, ancl, as the latter point corresponds with the fre-oecipital hoteh on the 
infero-lateral border of the hemisphere, the line in yuestion will indicate the arlja("ent margins of the parietal, temporal, and occipital lobes of the hrain.

The occipital bone is in dose relation with the ccrebellum, as already pointed nut, but it also covers the prosterior part of the outer surface of the occipital lobe of the cerehrum. The great wing of the sphenoid covers the outer surface of the apex of the temporal lobe, and the squamous part of the temporal hone covers the anterior parts of the superior. middle, and inferior temporal convolutions and the sulci which separate them.

In every consideration of the topographical relations of the cerebral convolutions to the walls of the cranial cavity it must be borne in mind that the conditions are

Fis. 434-DRaWixg of a Cast of the Head of a Newly-bord Male Ixfant.

(Prepared by Professor Cunningham to illustrate cranio cerebral topography.)

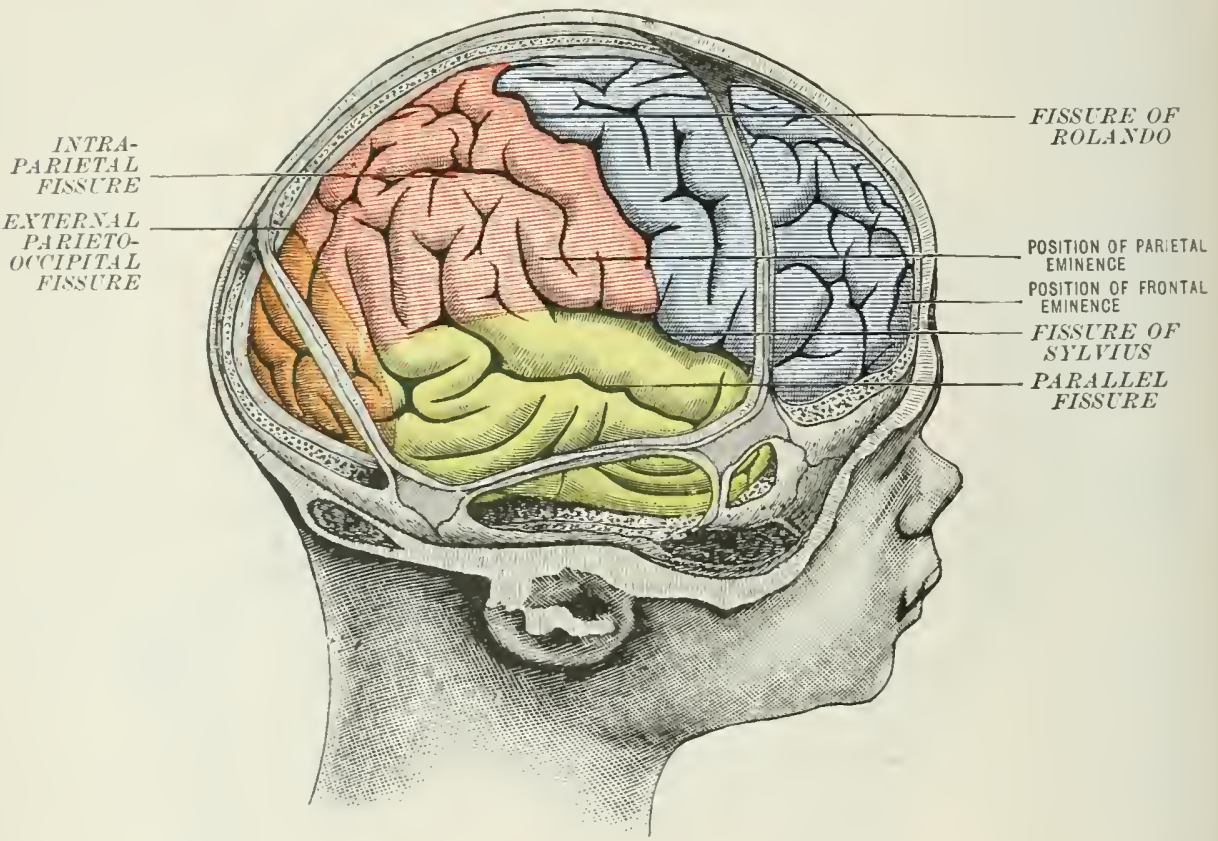

not constant, and that, therefore, the relations are variable. The three main factor: upon which this rariability depends are age, sex, and the shape of the skull. A. (xamples of the variations which oeeur it may be mentioned that the fissure of Sylvius is higher in the child than in the alult (compare figs. 433 and 434 ). The uiper end of the fissure of Rolando is further away from the coronal suture in the female and the child than in the adult male, and in dolichocephalic than in hrachyerphalic heads. The angle formed between the line of the fissure of Rolando and the micl-sigittal plane, which averages about $69^{\circ}$ in the adult, is more acute in rolichocephalic heads, and the external parieto-oceipital fissure is further forwards in the rhilrl, and possibly in the female, than it is in the adult male. 


\section{THE SPINAL CORD}

The spinal cord is the elongated portion of the cerebro-spinal axis which is contained within the spinal canal. It extends from the level of the transwerse ligament of the atlas to the hody of the second lumbar vertebra. Occasionally it only extends as far as the body of the first lumbar rertelora. It is invested, in common with the brain, by three membranes: dura mater, arachnoid. and pia mater. The portions of these membranes which are contained within the cranial cavity, and are therefore in relation to the brain, have been already described (page 671). There are, howerer, certain differenees between the cranial and the spinal meninges; therefore, a short separate description of the latter will be necessary.

Dissection.-The subject being pliced on its face, the neural canal una be laid open in the usual manner by cutting through the pedicles of the vertebre and removing the neural arches of the sacrum. 'The cord and its membranes should be first examined in situ. About three inches of the theea should be ripped up at the junction of the dorsal and lumbar regions for this purpose. The entire eord with the membranes should then be removed by dividing both cord and membranes at the level of the articulation between the atlas and axis and cutting through the nerres

Fig. 435. - Traxsierse Section of the SPIxAl CoRd AND its MeMbraxes. (After Key and Retzius.)

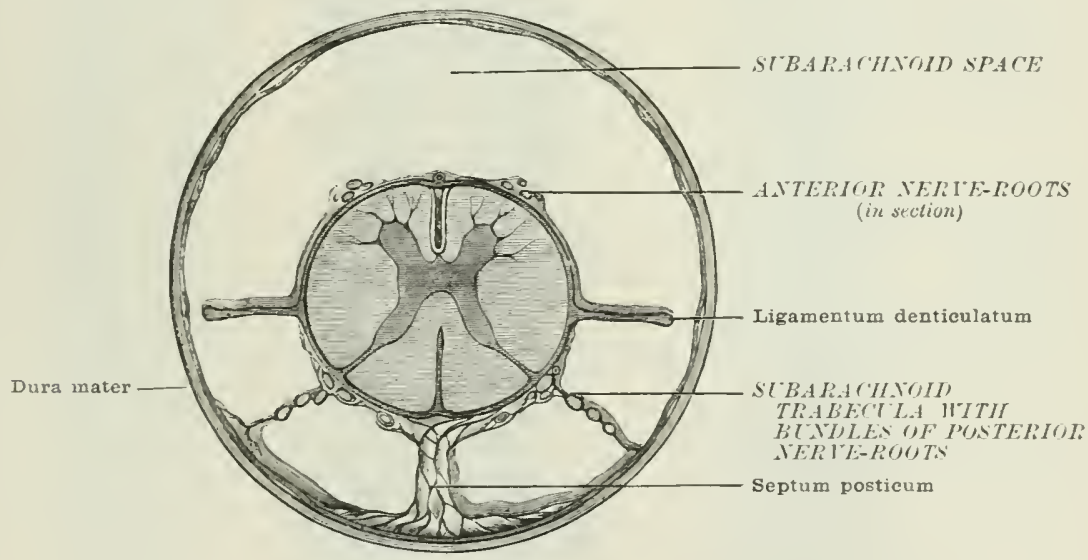

as they enter the intervertebral foramina. Two or three of the lower lumbar or upper sacral nerves shouli be cut sufficiently long to preserve the ganglia on the posterior roots. The cord should now be yinned out with its posterior surface uppermost in a cork-lined tray and dissected under water. On laying open the dura mater by a mesial longitudinal incision, the arachnoid will come into view and will be rendered more evillent by blowing air between it and the pia mater with at blowpipe. (On slittine up the arachnoid some of the coarser strands of the subararhnoid tissue may be male out. The posterior and anterior nerve-roots will also be seen with the ligamentum denticulatum between them. The connection of the latter with the pia mater is well seren under witer. The pia mater appears white and glistening, and when traeed downwards is very obviously continnous with the filum terminale. The list-named structure stands ont conspicuously among the dnller-coloured nerve-ronts which constitnte the cauda erpuna. On the anterior aspect of the rord the linea splendens will be secu. Tastly the student should make a series of transrerse sections throush the cord and compare the disposition of the grey aud white matter in the different regions (fig. 439).

The DURA MATER forms il lonse sheath or theca around the cort. It invests not only the cord but also the elongated nerve-mots. which (under the name of cauda equina) extend beyond the corrl. It invests the cauda equina as far as the second or third sacral vertebra, but at this level it converges so as to form a blunt holluw cone, and is representerl lower down only by the sheath of the filum terminale. By means of this sheath it is attached to the hase of the cocerx. Its outer surface is 
rough and is loosely connected by fatty tissue to the ligaments and periosteum whirh line the neural canal. Fone stronger retinacula comect it to the posterior common ligament. Its inner surfare, smooth and shining, is separated from the arachnoid by a narrow sublural space. It is connected to the cord by a special development of the pia mater-the liganentum denticulatum. It is continuous through the foramen magnum with the supporting layer of the clura mater of the liain. It sends tubular prolongations around the spinal nerves. These prolongations gradually merge into the connective tissue sheaths (epineurium) of the nerres. Eareh tube is divided by a septum into two compartments, one for the anterior, and whe for the posterior ront of the spinal nerve.

The differences between the dura mater of the brain and corel may be summarised as follows:-The dura mater of the cord does not send processes or infoldings into the fissures of the cord. It represents only the supporting layer of the dura mater of the brain. The periosteal layer is represented by the periostem of the neural amal, hut is separated from the supporting layer by fatty tissue, and by some venous plexuses. Hence this periostem is only brought into relation

Fig. 436.-View of the Mejiranes of the Spinal Cord. (Ellis.)

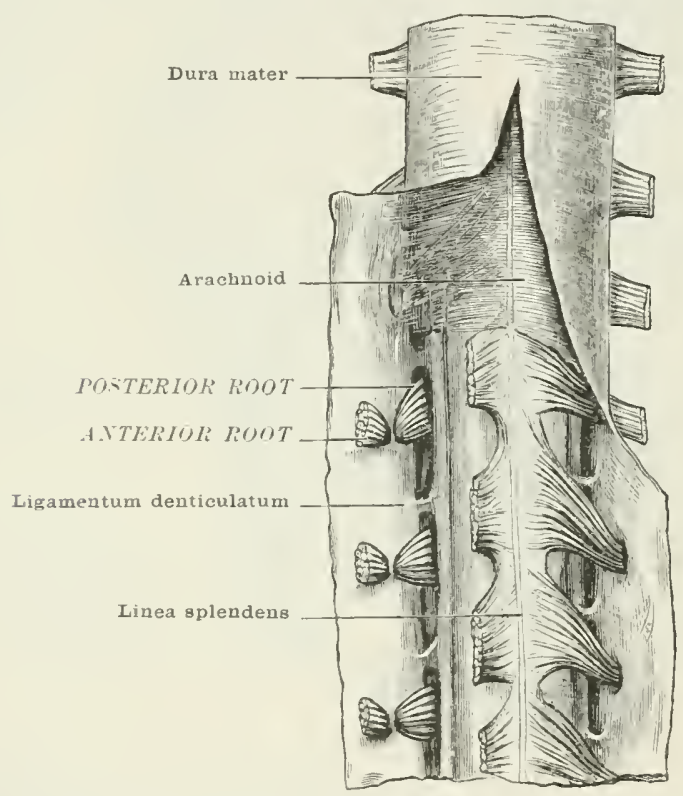

with the dura mater proper by the fact, allealy noticed (page 67:2), that the dura mater of the cranium is direetly continuous by the medium of the posterism oceipito-axial ligament with the periosteum of the nemal canal.

The ARACHNOID is separated from the dura mater by a narrow sublural space, and is comnected to the dura nuter only opposite the attachments of the ligamentum denticulatum, to be presently described. It is a thin membrane rescmbling the cerebral arachnoid, with which it is continuous. It sends tubular investments along the nerve-roots. These investments eventually become continuous with the perineural sheaths of the nerves. It extends downwards within the theea as fir as the serond or third sacral vertebra, forming a common investment to the bundle of nereroots constituting the cauta equina.

The subarachnoid tissue is much less ahmolant in the spinal portion than in the cerebral part of the subarachnoid space. It passes from araehoid to pia mater in the form of delicate threads, which are separated from oue another by comparatively wicle intervals. It alse gives support to the merve-poots as they eross the subirachnoil space (fig. 435)). An incomplote membranous septum, the septum posticum (Kry and liatzius), passes from arachoid to pia mater opposite the 
posterior septum of the spinal cord, and sorves to conduct blood-ressels to the cord. The space is also partially divided into a posterior and an anterior conpartment by the ligamentum denticulatum.

The PIA MATER of the cord consists of two layers, an outer and an immer, the latter of which represents, and is continuous with, the pia mater of the brain. Both layers dip into the anterior fissure of the cord, and the inner layer is continnous with the posterior septum. The outer layer is strong and fibrous, and

Fig. 43\%.-Posterior View of THE MedulaA Oblongata AND OF the SPIAAl, Cord, WIII ITs Coverings Axd the lioots of the Nerves. (Hirschteld and Leveillé.)

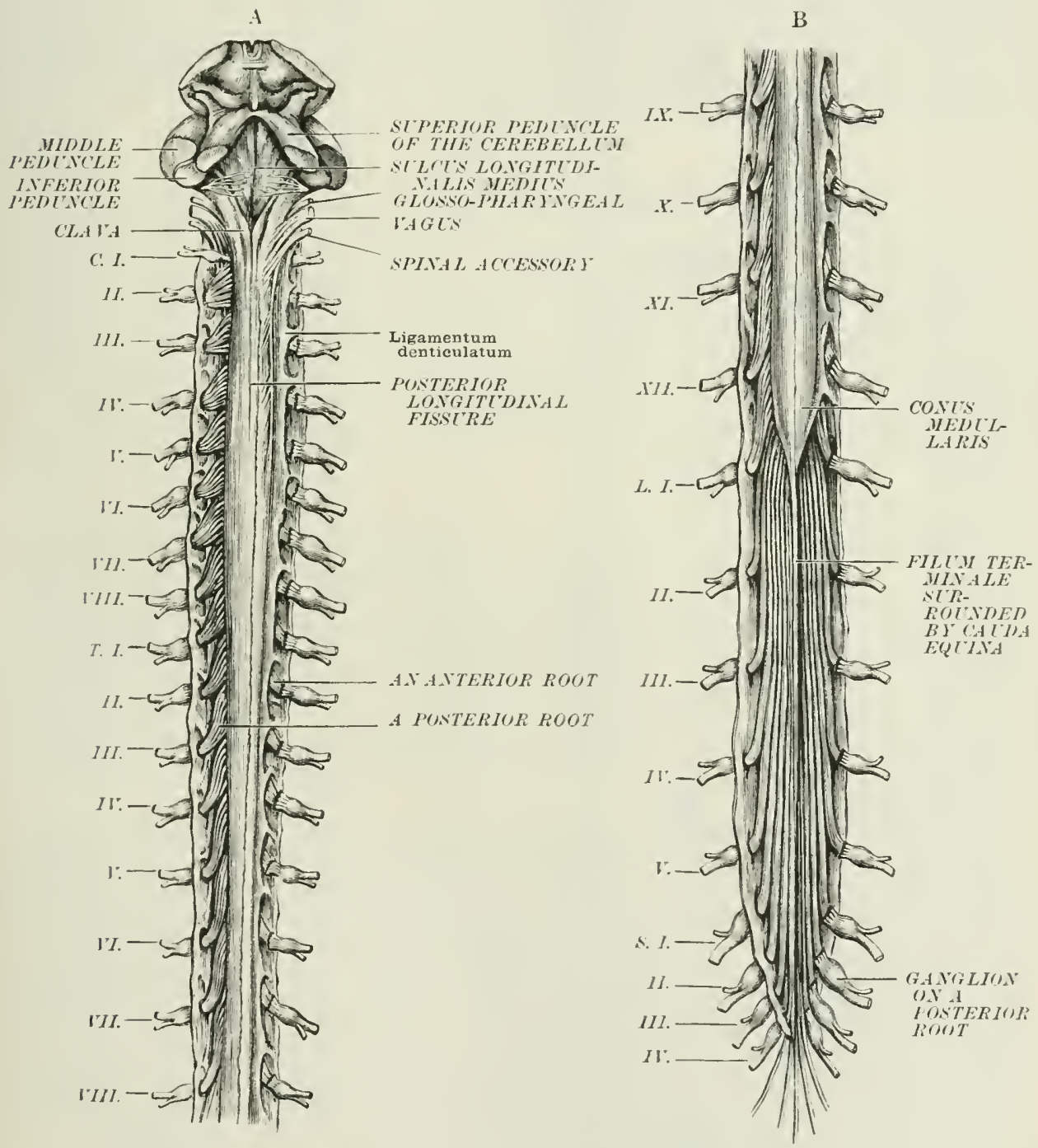

presents certain localised thickenings which require separate description; these are the ligamentum denticulatum and the linea splendens. The filum terminale may be conveniently deseribed along with these.

The ligamentum denticulatum is a fibrous band which is attached on ealch side of the cord about midway between the anterior and posterior nerve-roots. It is continuous by its inner margin with the pia mater. Its outer margin is characteristically scalloped or denticulated. and presents about twenty-one pointed processes by which it is attached to the clura mater. These processes do not pierce the 
arachnoid, but receive fummel-shaped sheaths from it (Key and Retzius). The highest of these processes is at the level of the formen magnum, and is placed between the hypoglosial nerve and the vertebral artery. In the upper region of the cord one denticulation is regularly placed botween the point of exit of each nerve and the next nerve below; lower lown the arrangement becomes less regular. It is continuous below with the filum terminale. The linea splendens (Haller) is a conspicuous linear thickening which is placed in the middle line in front of the cord. It presents a silvery white appearance. It is continuous below with the filum trminale. The filum terminale is the continuation of the pia-matral sheath of the cord, and contains but little nervous matter in its interior. It is easily distinguished by its shining white appearance from the nerve-roots anong which it lies. It is a slender strand which extends from the pointed lower extremity of the spinal cord to the lower end of the sacrum, or first picee of the cocerx, opposite which it is attached to the bone. As already mentioned, it receives a sheath from the lura mater in the lower part of its course.

\section{ENTERNAL CHARACTERS OF THE SPINAL CORD}

The spinal cord is about eighteen inches in length, and forms (ly weight) about two per cent. of the cerebro-spinal axi. It is cylindrical in form, and is slightly compressed from before barkwards, so that the transverse exceeds the anteroposterior diameter. It is continuous with the medulla oblongata above at the decussation of the pyramids; below it tapers off into a cone, the conus medullaris, the apex of which is continued downwarls by the film terminale. It follows the curvatures of the eamal in which it is placed, and therefore describes two curves, the upper or cervical convex forwards, and the lower or dorsal concare forwarls.

In two regions of the eord distinet enlargements are visible: these are callecl the cervical and the lumbrom argements. The large size of the nerves which are given off to supply the limbs, forming the brachial and lumbo-sacral plexuses, obviously account for these enlargements of the cord. The increase in size is almost entirely produced by an increase in the transwerse diameter. The cervical enlargement is more pronounced than the lumbar swelling. It commences at the level of the third cervical vertebra, and ends at the second dorsal. It is at its maximum at the level of the sixth cervical rertelya. The lumbar enlargement commences at the level of the ninth dorsal vertebra, and reaches its maximum at the twelfth rlorsal; below this point it rapidly diminishes and passes into the conus medullaris.

The spinal cord is bilaterally symmetrical, the two halves being defined by an anterior fissure and a posterior septum. From the antero-lateral and posterolateral aspects of the cord the anterior and posterior nerr-roots emerge, forming two parallel series of fascieuli which extend throughout the entire length of the cord. In the upper ecrvical region the intrathecal course of the nerve-roots is very short, and the direction taken by the roots is nearly transverse. As the roots are traeed downwards in the dorsal and lumbar regions, they become progressively longer, and descend with an incrasing degree of obliquity. Hence the lumbar and sarral nerveroots have a rory long intratheeal course. They extend beyond the temunation of the cord (which, it will be remembered, ends at the body of the seond lumbrertohra), and lie within the thea in a sheaf somewhat resumbling a hors's tail, and therefore called the cauda equina.

The cord is dividerl into definite macroscopical areas hy one fissure, two sulci, thres septa, and the exits of the anterior nerve-roots.

The fissure.-The anterior fissure separates the cord into two lateral areas anteriorly (fig. 4:39). It is relatively wide and extends from the surface to the anterior white commissure, attaining a depth equal to about one-third the anteroposterior diameter of the cord. It contains a fold of pia mater and hranches of the anterior spinal ressels. It is continued above along the anterior surface of the medulla, being partially interrupterl by the decussation of the pyramids, and it teminates at the formencon caecum just below the pons (fig. 441). 
Fig. 438. - Axterior AxD Posterior View of the Spinal Curd.

(Modified from Quain.)

I represents the filum terminale.
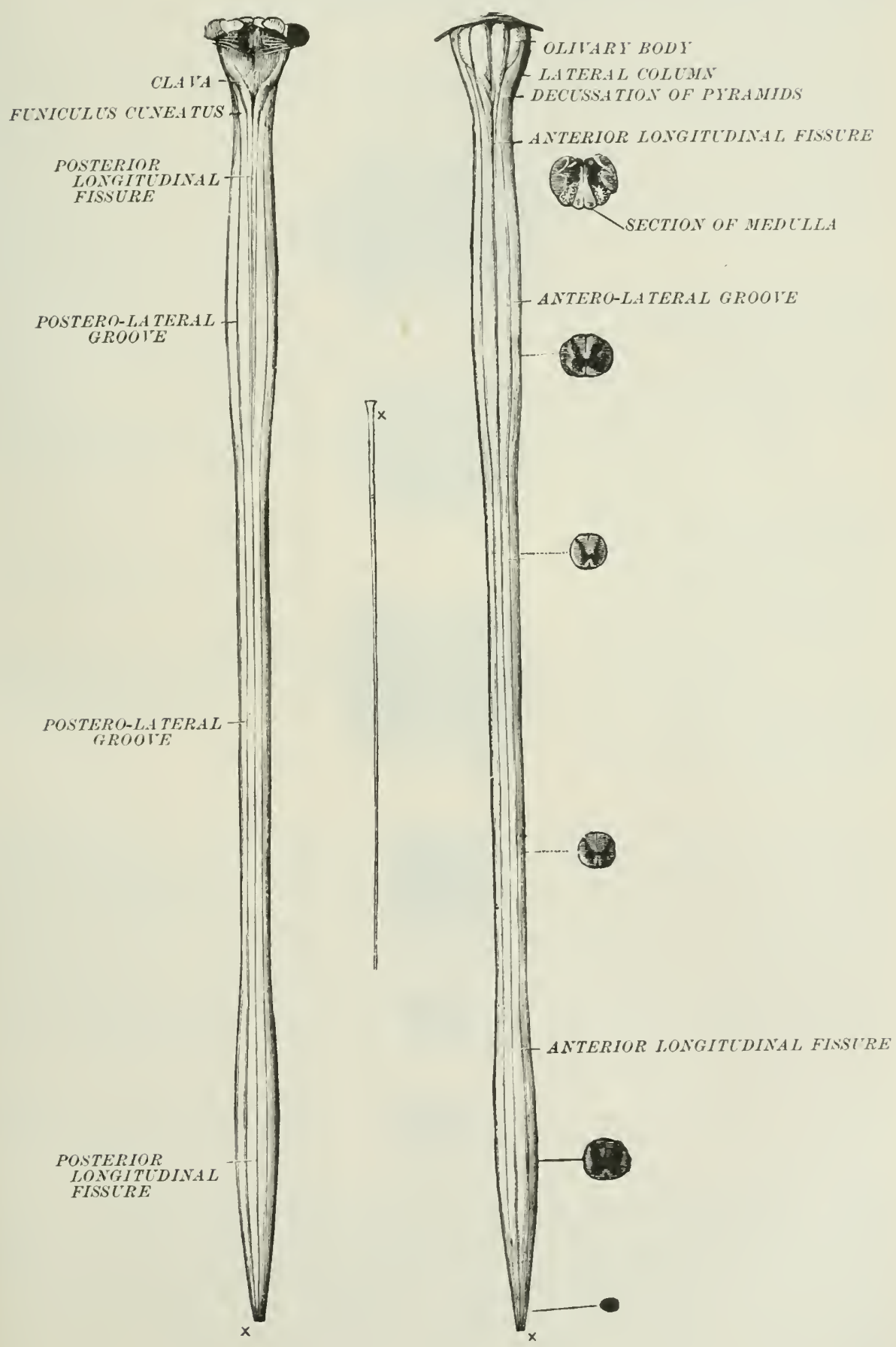
The two whlej are placed dorso-laterally (fig. t35) and the posterior nerveroots ennerge from them. They serve to divide each half of the cord into a posterior and an antero-lateral area or colmm (fig. 439 ).

The anterior nerve-roots (merge from the antero-lateral aspects of the cord, not from grooves or sulei, but in a relatively seattered mamer. Ther divide the anterolateral columms into anterior and lateral portions (fig. 439).

The three septa lie in the clorsal part of the cord; they are a median and two

Fit, 439. - Sections throcgh Different Regions of the śpinal Cori). (After sicliwalbe.)
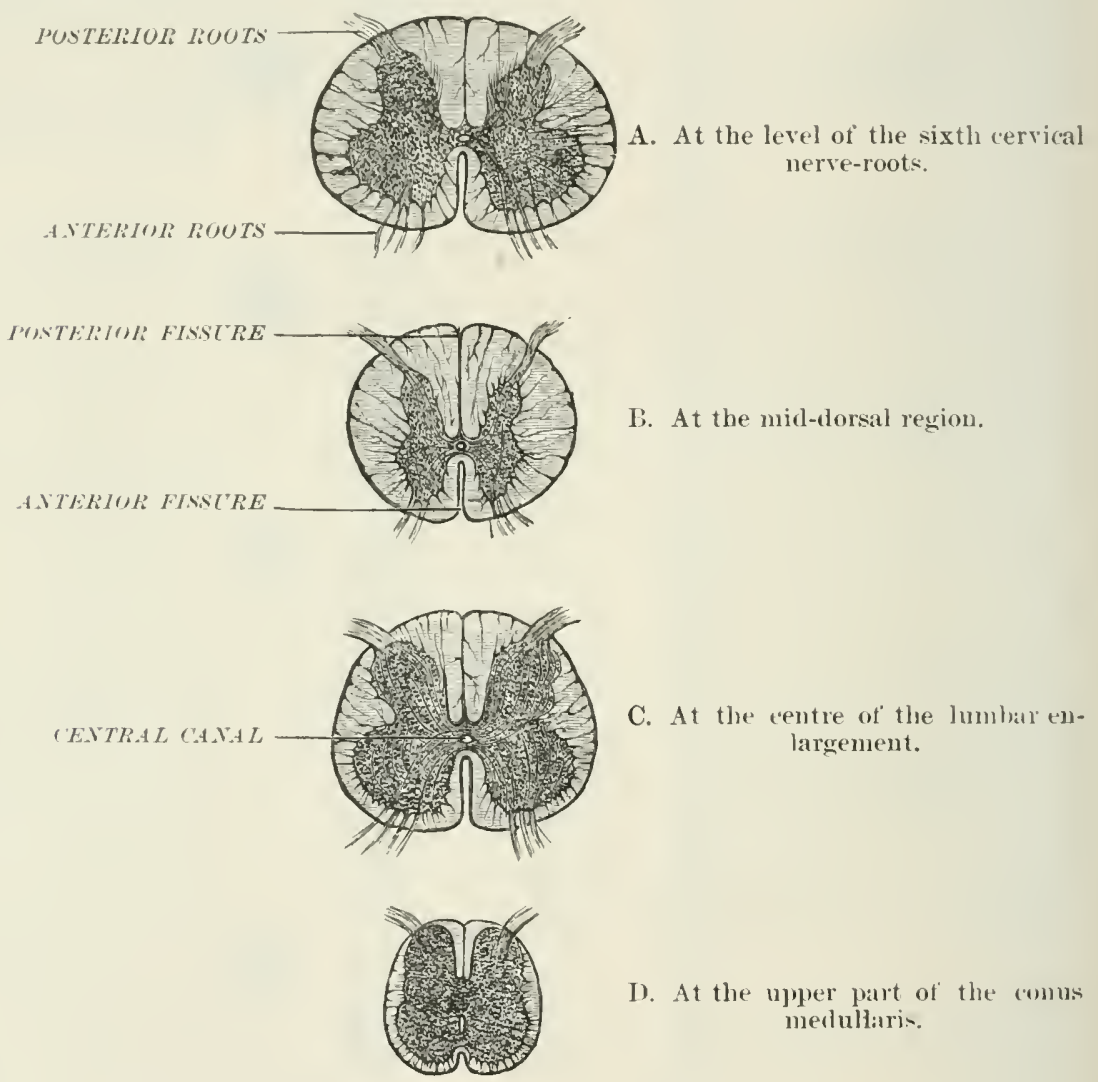

I). At the upper part of the (om) us medultaris.

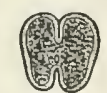

E. At the level of the fith sacral nerve-roots.

lateral. The postero-median septum axtends thromghout the whole lingth of the (o)rel, separating it into lateral halves dorsally (figr. 439)). It consists of neuroglial tissue containing branches of the posterior spinal vessels, and it passes from the pia mater to the posterior, or grey, commissure. The postero-lateral septa are only seen in the forsal and cervical regions. They extend from the pia mater inte the posterior columm, dividing it into postero-median and posterolatrral parts. 


\section{INTERAAL STRLCTLRE OF THE SPIXAL CORD}

In transverse section, each lateral half of the cord is seen to be composecl of both grey and white matter, the latter being disposed on the surface. The grey matter is in the form of a crescent, which has been not inaptly compared (by Testut) to a large comma (6). The head of the comma looks forwards and constitutes the anterior horn of grey matter; the tail forms the posterior hom, and the convexity looks inwards and is united to the grey crescent of the opposite side by the grey commissure. The two crescents, with the commissure, form a figure resembling a apital $H$. Within the grey commissure is the central canal of the cord, and in frout of the grey commissure, oecupying the floor of the anterior longitudinal fissure, is the anterior white commissure. Medullated fibres cross the middle line hoth in the white and in the grey commissure. The term commissure is somewhat mislearling, as the majority of the nerve-fibres which pass from sirle to side are not ('onmissural but decussating fibres.

The grey matter of the cord consists of two varicties: (a) Substantia gelatinosit, and (b) substantia spongiosa. The former (a) covers the head of the posterior horn like a cap (substantia gelatinosa Rolandi), and is also found around the central canal (substantia gelatinosa centralis). The latter is continued into the ependyma of the cerebral ventricles. (b) The substantia spongiosa is much more extensive than the substantia gelatinosa, and contains large nerve-cells. Thes. cells are arranged in clefinite groups. forming columns in the grey matter.

The cell columms in the anterior cornua are arranget as followis:
[)(orso-mesial.
II sial (fig. $+40 \mathrm{~A}$ ).
Ventro-mesial.
Lateral (tig. $+40 . \mathrm{A}) \cdot\left\{\begin{array}{l}\text { Dorso-latmal. } \\ \text { Ventru-lateral. }\end{array}\left\{\begin{array}{l}\text { Latteral. } \\ \text { Mesial. }\end{array}\right.\right.$
C'These colum are the most constant in all situation:. and are believed to supply. the spinal muscles.
Best marked opmosite the limb nerves to which they give origin.
In cervical region, sives origin to spinal accessory.
In crrvical region, gives wigin to phrenic nerve.

The cells of the posterior cornu.-The cells of the posterior cornu are less regular than those of the antorior corm in arrangement, hut several groups are described. They are (1) peripheral colls, some of which possess long, curved fro(csics, and hence are callexl compt cells; (2) central cells: (3) basal cells; (4) the (colls of the substantia gelatinosa; and (5) solitary cells, which are scattered irregularly and which vary in size. The protoplasmic or dendritic processes of the cell: of the posterior cornu permeate the gray matter of the eormu; their axis-cylinder procesises or axoms lum in various directions, and their teminations are for the most part unknown; some of them, however, fass to the anterior cornu and to the anterion commissure, and these are believed to isine from the cord as the sinall filses of the anterior nerve-ronts.

Clarke's column of cells (fig. $440 \mathrm{~A}$ ). - This column of cells lies at the late of the posterior cormu internally. It consists of large ovoid cells whose long axes ar. parallel with the axis of the cord. The onlumn is limited to the dorsal regiom. but ecels of similar nature, ocenpying a sinnilar position, are found in the lumbar region of the cord opposite the serond and third sacral nerves. where they form stilling's nueleus. Others are recognisable in the revival region, and they are probably represented in the medulla by the cells of the muderts gracilis and the nucleus cuneatus. Nany of the axoms of the (c)ls of this (o)lumn frass up wards to)

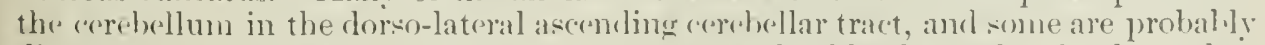

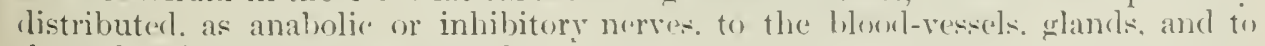
the walls of the alimentary canal.

The intermedio-lateral tract.-The internerlio-lateral tract w rolumn of 
nere-cells lies at the base of the anterior comu externally; it is limited to the (borsal lenion, but cells ocempring relatively similar positions are found in the cervical and lumbal regioms also. The axons of its colls probalily constitute the katabolic w nutor nerve-filses of the muscles of the glandular and vascular systems.

A middle column of cells call be recognised in the centre of the grey matter at the junction of the anterior and posterior comua. It is more or less distinct thronghout the whole length of the cord, and its function is unkuown.

The term processus reticularis is applied to a number of strands of grey matter which project into the white natter and anastonose together on the outer sich of the hase of the posterior cornu.

The central canal of the cord is lined hr colummar epithelium; it is "ontinued into the filum teminale for alout half the length of the latter, and is here somewhat dilated; a fow nervefibres accompany the canal into the film terminale, and are supposel to be rudimentary cocegeal nerves. The canal is dilated in the conus medullaris, forming an irregular cavity, the sinus rhomboidalis inferior, or ventriculus terminalis.

In transverse sections through the spinal cord made in the dissecting room the general arrangement of the grey and white matter can be made out, and sections from the different regions of the cord can be distinguished from one another in fresh specimens, especially with the aid of a porket lens.

In the upper cervical region (at the level of the second or third cervical nerres) the grey matter forms an $\mathrm{H}$-shaped outline bearing a great resemblance to the outline in the dorsal region (fig, 439, B). Sections through this region are very difficult to distinguish from sections of the dorsal corl with the naked eye. The microscope, howerer, reveals the absence of Clarke's column and the presence, in sume cases, of root-fibres of the spinal accessory nerve.

In the lower cervical region (fig. $439, \mathrm{~A}$ ) the cord is elliptical in ontline and the anterior horms of the grey crescents are very large; the section shows a certain similarity to a section through the lumbar region (fig. $439, \mathrm{C}$ ). In the latter. however, the anterior horns are more evenly rounded, the general outline approaches more nearly to a circle, and the proportion of gley to white matter has greatly increased.

Sections of the dorsal region can be easily recognised with the microscone by the presence of Clarke's column, which is confined to the dorsal, lowest fart of the eervical, and the uppermost part of the lumbar regions.

Sections through the part of the cord from which the sacral nerves arise show a great preponderance of grey matter. This feature becomes more marked as the termination of the cord is approached (fig. $439, \mathrm{D}, \mathrm{E}$, and F).

\section{THE DEEP CONNECTIONS AND ASSOCIATIONS OF THE SPINAL NERIES}

But little information can be gained from a mere macroscopical or microseopical eximnination of the adult cord concerning the course of the fibres of the nerve-roots within it, and the facts detailed here have been chiefly ascertained by embryological and pathological resenrch. The suceess of the embryological method depends upom the farct that certain tracts or groups of filores myelinate (or acepuire their medullary sheath) at an earlier period than others, and therefore these tracts of medullated fibres can he followed and reegnised through a series of sections. The pathological method rests upon the influence which nerve-cells exert upon nervefilses: this so-called trophic influence depends unon the fact that every nerve-fibre is a process of a nerve-cell and can mly exist and retain its functions as long as it remains commected with the coll. The trophic cell, therefore, of erery nerve-filore is that cell from which the tihre arises and with which it is in direet structural continuity. If the trophine cell is destroyed the nerve-fibre dies, or if the structural continuty of the cell and fibre is interrupted by section, then the fibre decenerates and dies beyoud the point of interruption, and the dexeneration and death ondur

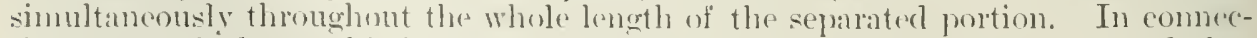
tion also with the troplite influenere of nerve-cells it must be horne in minel that "rory nervecell with its proxesses eonstitutes a distinct entity, alled a neuron, which has dose associative pelations with other nervecells and with rarions tistues of the body by means of its processes, but it is alsolutely devoid of structural 


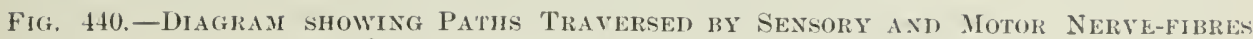
AND TIEIR COUKSE TO AXD FROM THE CORTEX OF THE BRAIN.

(Sensory fibres blue; motor fibres red.)
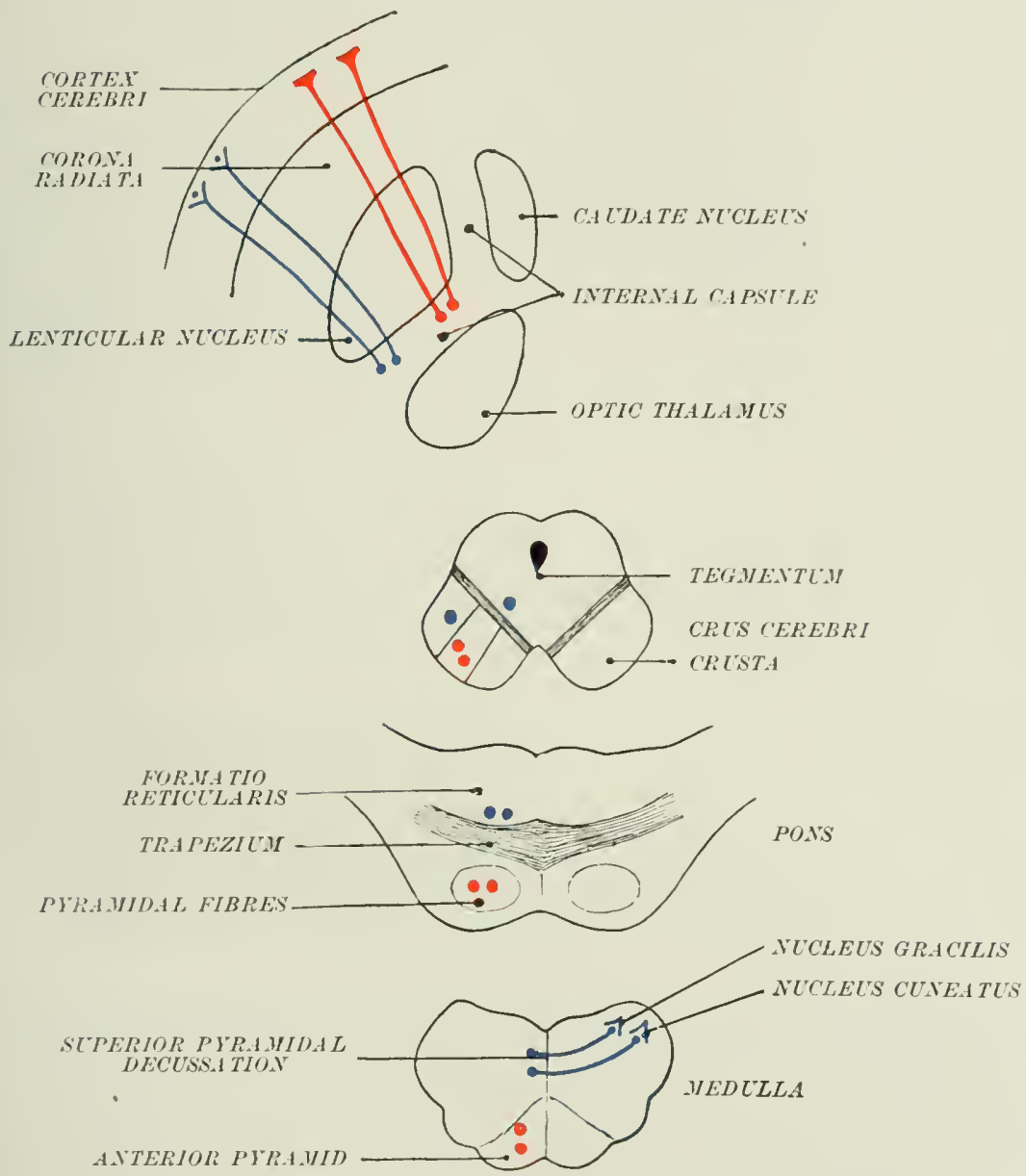

POSTERIOR PIRAMID

POSTERIOR CORST

DECLSSATION OF PIRA,MIDS

ANTERIOR CORNT

ANTERIOR PYRALID

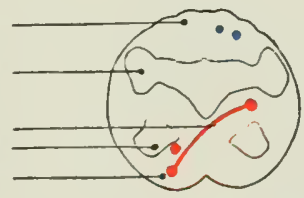

LOWER PART OF MEDLLLA

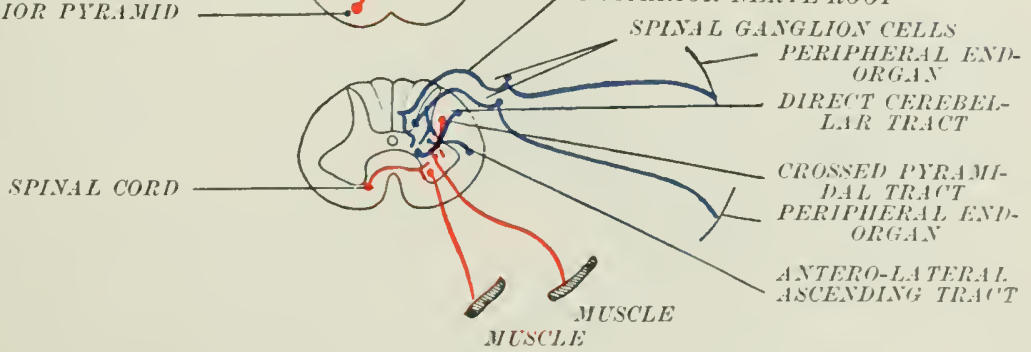


continuity with them. The centre of the neuron is the body of the cell. The procrses of the neuron form two sets, the protoplasmic, dendritic or afferent, and the axis-cylinder process, which is termed the axon or efferent process. The dendritic processes of the neurons of the brain and spinal cord are usually short, relatively numerous, and profusely branched, but the dendritic or afferent process of a spinal gamglion cell frequently runs a long distance before dividing into its terminal ramifications. The terminal filaments of the dendrites may be associated either with the arborisations of the axons and clendrites of other cells or with sperialised end organs. The axoms may be short or long; those of the cord and brain terminate either in ramifications round other nerve-cells or in association with sprecial end organs. The axons of the spinal ganglia enter the cord and clivide into an ascending and a descending branch, both of which give off numerous collaterals, and they terminate in ramifications around other nerve-cells.

The knowledge of the above facts, and the careful study of the degenerations resulting from the section of nerve-roots and the clestruction of nerve-cells, combined with repeated observations on the phenomena observable during the development of the nerve-roots and the spinal cord, have led to the formation of the following conclusions concerning the deep connections of the spinal nerve-roots.

The anterior roots.- The majority of the fibres in the anterior nerve-roots are axons of the cells of the anterior cornua, but some of the smaller fibres are derived from the eells of the posterior cornua, and from the cells of Clarke's column and the intermedio-lateral tract, whilst others which pass to the roots from the white columns are believed to be processes of some of the nerve-cells of the cerebellum; therefore if the nerve-cells in the regions mentioned are destroyed, or if the anterior nerve-roots are divided beyond their exits from the cord, the nerve-fibres which form them degenerate to their peripheral terminations.

The posterior roots.- The fibres of the pusterior nerve-roots are processes of the cells in the posterior root ganglia. The filores in each root external to the ganglion are the afferent or dendritic processes, and the fibres in the internal portion of the root are the axons or efferent processes, which pass into the cord; therefure if the posterior nerve-root is divided external to the ganglion the peripheral portion undergoes degeneration, but if the division is made intemal to the ganglion then the central part degenerates and the positions of its fibres in the substance of the eord become recognisable.

Two groups of fibres are distinguishable in each posterior root as it enters the cord, an outer or lateral group of small fibres, and an inner group of large fibres intermixed with some small fibres. The fibres of the outer group enter the cord over the apex of the posterior eornu and turning upwards they form a small column called the marginal bundle or Lissauer's colmmn (fig. 440A), in which they run for a short distance hefore entering the substantia gelatinosa Rolandi. The inner group passes into the outer part of the posterior column, and it is possible that some of its fibres terminate in Clarke's column, but the majority, if not all, divide into two branches, one of which passes upwards and the other clownwards; both the main fibre and its two terminal branches give off numerous collateral branches which enter the grey matter and ramify round the cells of Clarke's column and the cells of the prosterior and anterior cornua of the same side, and some pass through the grey commissure to the grey matter of the opposite side. The terminations of the descending hranches of the posterior root-fibres are not definitely known, but they are believed to be in the grey matter of the lower segments of the cord. The ascending hranehes pass upwards to the medulla, gradually nearing the postero-median septum as they iscend, and they triminate in arborisations round the cells of the nucleus gracilis and the nucleus euneatus in the medulla oblongata.

Tracts of the spinal cord.- The fibres which form the white columms of the spinal cort are the axons of nerve-cels of the cord, brain, or ganglia, which are passing upwards or downwarls in the eord to terminate at a higher or lower level; the formere are called ascending fibres, the latter deseending, and the degenerations which oceur in them are temed ascending and descending degenerations respectively.

Both the ascending and desceneling fibres are groupeel in tracts, but it must he 
clearly understerod that these tracts or columms are only reeognisable during their development or when affected with disease or degeneration.

The following tracts are recognised in the posterior eolumns:-
Ascending $\left\{\begin{array}{l}\text { The postero-lateral, or Burdach's columm. } \\ \text { The postero-mesial, or Goll's columm. }\end{array}\right.$
Descending $\{$ The comma-shaped tract.
(fig. $440 \mathrm{~A}$ ).

The two ascending columns are not distinguishable from each other betow the mid-dorsal region, but above that level they are partially separated by a septum of neuroglia called the postero-lateral septum. The fibres of Goll's column are small and those of Burdach's colmmn are large, but both are derived from the posterior nerve-roots, and as they pass upwarls they give off collaterals which enter the grey mattrer.

Some of the fibres of the posterior ascending columns terminate in arborisations. round the cells of the grey matter of the cord, but others pass upwards to the medulla oblongata, where the fibres of Goll's column ramify round the cells of the nuclens gracilis, and the fibres of Burdach's columm arhorise round the cells of the mucleus cuneatus.

The descending or comma-shaped tract is small, often ill-clefined, and it lies in the midst of the postero-lateral ascending tract. It consists of fibres from the posterior roots which are passing downwards to lower segments of the cord.

The tracts which have been defined in the antero-lateral columm are the following:-
Descending $\left\{\begin{array}{l}\text { Crossed pyrmidal. } \\ \text { Direct pramidal. } \\ \text { Antero-lateral descending cerebellar. }\end{array}\right.$
Ascending $\left\{\begin{array}{l}\text { Dorso-lateral, or direct cerebellar. } \\ \text { Antero-lateral aseending cerebellar: } \\ \text { Lissauer's column, or the marginal bundle. }\end{array}\right.$
(fig. $440 \mathrm{~A}$ ).
Antero-lateral ground bundle.

The descending tracts of the antero-lateral column.-Tho crossed pyramidal tract is a somewhat triangulat hundle of nerve-fihres lying in thr. (orsal part of the antero-lateral columm, in front of and somewhat cxtermal to the posterior cornu. It is separated from the surface, except in the lowere part of it: extent, by the direct cerebellar tract (fig. 440..). Its fibes are the axons of nervecolls in the cortex of the opposite side of the bain; they pass downards through the corona racliata, the internal apsule, the cruma cerebri, the pyramidal hundles of the anterior pyramid of the medulta te the decussation of the promids:; there they eross the middle line and continue their elesecut in the ofposite antero-lateral colimn; finally they leave the antero-lateral column and pass into the sulstance of the anterior cormu, where they terminate in ramifications round the motor cell: (fig. 440. ).

The direct pyramidal tract is a small quarlrilateral humlle of nerre-filures situated at the side of the anterior fissure. It camnot be traced downtards beyond the midedorsal region. Its fibres are the axoms of the nerve-cells of the limin rortex of the sanne side. which have taken the course desculled in commection with the crossed pyramidal fibres as far as the medulla; then, instead of erosing to the opposite side, they have descented in the anterine column of the same side; ultimately, howerer, they reach the opposite sicle hy passing through the anterion white commissure, and they terminate in ramifications round the motor cells of the anterior cormu.

The descending antero-lateral column is situater peripherally. It extruls: forwarls from the crossed prramidal and direct creliellar tracts to the hase of the direct prramidal tract, but it is broakler dorsally than rentrally, and its filores are more or less mixed with those of the antero-lateral ascending cerdullar tratet 
(fig. 440A). Its fibres are processes of nervecells situated in the rermiform process and the lateral lobe of the cerebellum: they alescent to the cord through the middle perlunele of the cerebellum. and through the restiform body.

The ascending tracts of the antero-lateral column.-The dorso-lateral or direct cerebellar tract occupies the dorsal part of the periphery of the cord on the onter sifle of the crossed prramidal tract, extending from the tip of the posterior colnu to the antero-lateral ascending and hescending traets (fig. $440 \mathrm{~A}$ ). It scharates the crossed pyramidal tract from the surface, excent in the lower dorsal region, where the pyamidal fibres intervene between it and Lissauer's column. Its fibres are processes of some of the cells of Clarke's columm, and they terminate in ramifications in the cerebellum, to which they pass by the restiform body.

The antero-lateral ascending cerebellar tract occupies an area in front of the crossed pramiclal tract extending forwarls to the region of the anterior nerve-roots. Its fibres are mingled with those of the elweending antero-lateral tract,

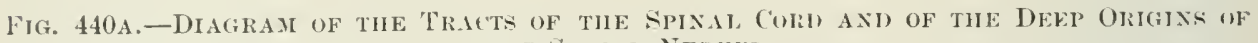
THE SPINAL NERVES.

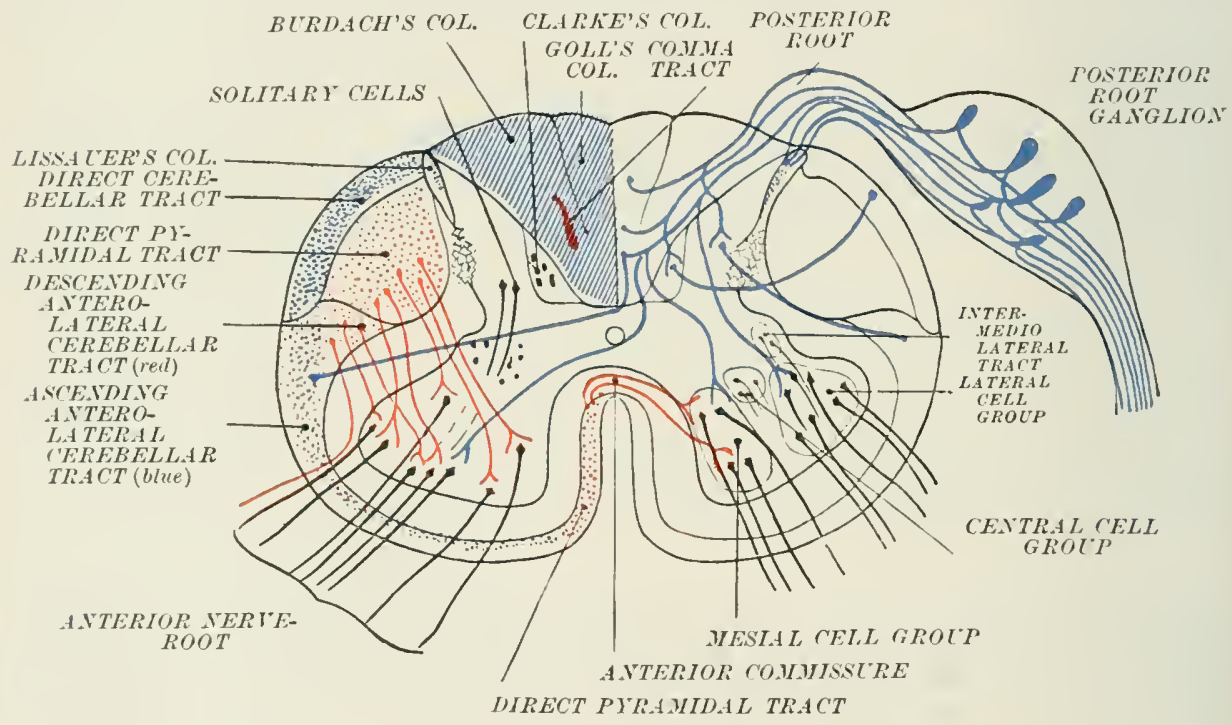

but they have a more limited anterior extension and ther occupr a broader area posteriorly; they are processes of nerve-cells of the eord and possibly of the cells of the posterior comu. They pass upwarls through the reticular formation of the medulla and pons; some reach the cerebellum hy the superior peduncle and others join the fillet.

Lissauer's column is a small bundle of small filres situated at the apex of the posterior cornu dorsal to the crossed prrmidal and direct eerehellar tracts. It consists of the small filures from the lateral parts of the posterior nerve-roots which are passing upwarks to torninate in the grey matter of higher segments of the rord.

The antero-lateral ground bundle embraces the anterior cornu and the outer side of the hase of the pesterior comu (fig. $440 \mathrm{~A}$ ); it rejresents all the antern-lateral columm not included in the previously mentioned tracts, and it consists of ascenting and descending commissural fibres passing between different segments of the corrl. 


\section{THE PERIPIIERAL NERTOLS SYSTEM}

The cerebro-spinal nerves, together with the end-organs of these nerves, the sympathetic system and the ganglia which are connected to both the cereloro-spinal and the sympathetic nerves, make up the peripheral nervous system. The cerchrospinal nerves are invariably paired, and, with a few exceptions (notably the ragus), are srmmetrical in their origin, course, and clistribution on the two sides of the body. The cranial nerves arise direetly from the brain and pass out from the skull through formmina in the cranial wall. "The spinal nerves arise by anterior and posterior roots from the spinal cord, and leave the spinal canal hy passing through the intervertebral foramina. The first spinal nerve is somewhat exeptional, as its origin is partly from the merlulla, and, moreorer, it leares the spinal canal by passing between the occipital bone and the atlas.

\section{THE CRANIAL NERYES}

The cranial nerves are classified into nine pairs by Willis, and into twelve pairs by Soemmerring. W'illis's classification depends upon the mamner in which the nerves piecce the dura mater; for example, the glosso-pharyngeal, ragus, and spinal accessory nerves all pierce that membrane opposite the jugular foramen, lence they collectively form a cranial nerve (the eighth) of Willis. In Soemmerring's classification each nerve-trunk is considered separately. Willis's classification was formerly in use; it is now, however, generally discarded in faror of soemmerring's elassification. The latter will be followed in this work.

The following table will explain the relation of Willis's to soemmerring's dassification:-

\section{Willis}

First pair of nerves

Sereond

'Thirol

Furtl

Fifth

Sixth

Seventh

Fight

Sinth soemmerring

First jair of nerves

second

Third

Fourth

Fifth

Sixth

(Portio dural Seventh

(Portio mollis Fighth

(Nintlı

- 'Tentlı

( Flereuth
T'welfitl

.,
,
",
",
",
,

Names

\begin{tabular}{|c|}
\hline 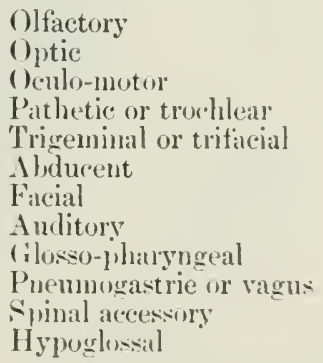 \\
\hline
\end{tabular}

It will be well to notice here that the olfactory bulb and tract and optic nerves are not serially homologous with the other cranial nerre, hut are rather outerowths of the cerebril substance itself. The 'filmuents of the olfactory nerve, which piere the cribriform plate of the rthmoid bone, eorrespond collectively to a cranial norve. In the ease of the optic nerve, the retina, as a sturly of its derelopment shows, is a portion of the brain extruded berond the eranial wall, and the ganglionic layer of the retina in all probability corresponcls to the 'nucleus of origin' of an ordinary cranial nerve. The nervous elements which intervene between the wanglionic layer of the retina and the rows and cones therefore represent the true optic nerves.

Superficial and deep origins. - The point at which a eranial nerve emerocs from the substance of the brain is eallerl its superficial origin; while the collowtion of nerve-cells to which its fibres ean be followed is ealled its deep origin. It must be clearly understood. howerer, that the deep origin is only the proximate origin of the nerve, the real origin is in the cerebral cortex. For example, injuries to the lower portions of the ascending parictal and ascending frontal convolutions almost 
as surely paralye the facial and hypughosial nerves as if the nuclei of these nerves had becin destringed in the medullia.

General distribution.-The olfactory, optic, and auditory nerves are exclusively nerves of special sense, and are distributed to the nose, the eye, and the ear, respretively, Of the remaining nerves, some are motor, others are mixerl. The motor nerves are: the third, fourth, and sixth to the oeular muscles, the seventh (o) the platysma and to the superficial muscles of the face and sealp, and the twelfth to the muscles of the tongue. The mixed are the fifth, which is chiefly sensory to the face, teeth, eve, external anr, and fore palt of the sealp, but also notor to the muscles of mastication; the ninth, which comtanis fihres for the special sense of

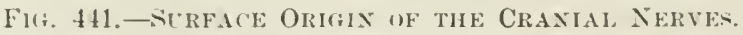

(Ater Allen Thomson.-(guain.)

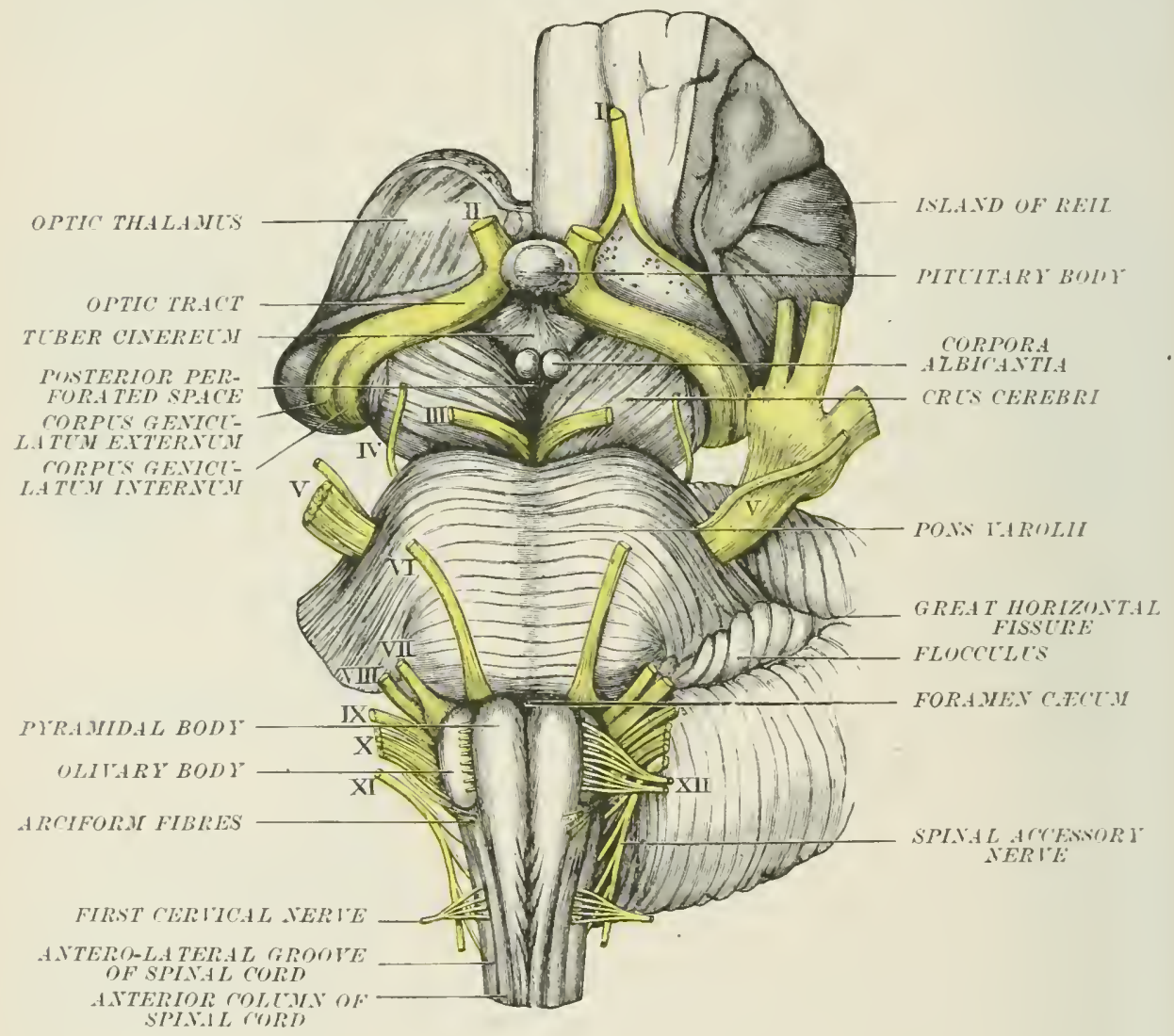

taste, also ordinary sensory and nuntor fibres; the tenth, which convers semsory fibres to the extemal ear, and both motor and sensory fibres to the pharyix, laryix, heart, lungs, trachea, asophagus, and stomach; and the eleventh, which dividus into a spinal part, wholly motor, destined for the stemo-mastoid and trapezius musches, and a mixed or aecessory part which joins the tentl.

In the following pages the comrse of each nerve is deseribed in order from its so-called deep origin to its peripheral distribution; the ultimate commection with the eortex is described in the anatomy of the brain. An exception is made, howcrer, in the case of the olfartory and optic nerres, the cerebral connertions of which are described with the norves. 


\section{FIRST OR OLFACTORY NERIEN}

The olfactory nerves are twenty to thirty in number on atach sides. There rises from the lower surfaces of the olfatory bulbs, and are grey filaments deveid of white sheaths. They pass in two rows, imner and outer, through the formmina in the cribriform plate of the ethmoid. Entering the olfactory nucous membrame they anastomose tugether and afterwarels break up into filaments. The filanents. of the outer group are distributed over the upper and middle turbinal bones in the upper fifth of the outer wall of the nasal eavity, and those of the immer group orer a similar extent of the upler part of the seytum.

The olfactory nerve-fibres are processes of special olfactory cells in the upper parts of the nasal mucous membrane. They teminate in the olfactory hulh in ramifieations which are interwoven with the denclrites of the mitral colls of the bulb forming with them the olfactory glomeruli. From the mitral cells filores pass

Fig. 14\%.-Nerves of the Nasil Caritr.

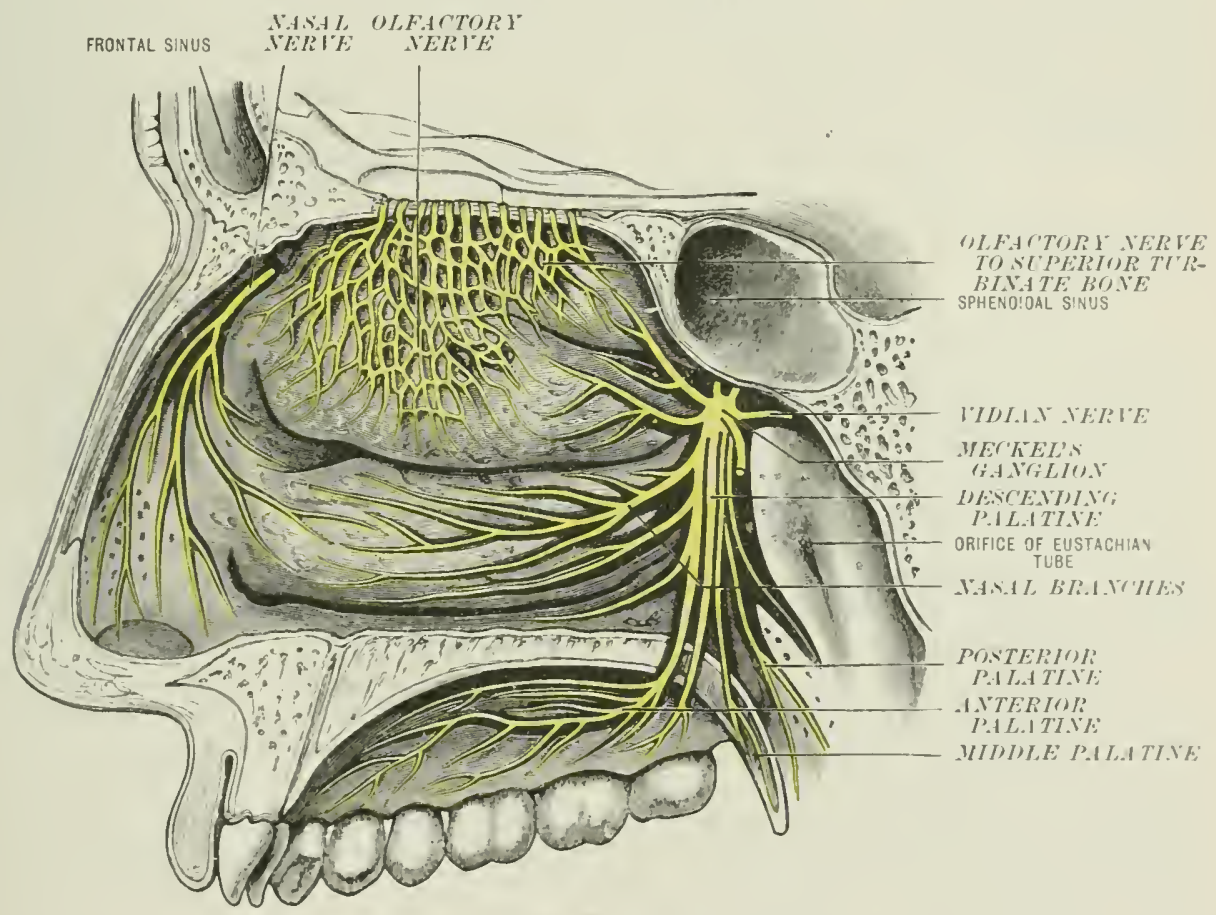

backwarls: into the olfactory tract. These may lu alasified into two groups, namely:-(a) Fibres which enter the cortux of the tract: and (l, fibres which pals: through the white matter to other garts of the hrain without hecoming ("endureter to the cortex of the tract. (11) From the cortex of the tract some filmes palsin rii the external white root to the aortex of the temporal lobe. ()thers anter the anterior anmmissure, and proceed to the cerelural cortex of the olpmesite side. (b) (of the fibres which pass directly through the tract. some gass hy the external white root to the temporal lobe; others pass as a slender trant inte the moler border of the internal eapsule, and so reach the front of the optie thalimus (Obersteinur. A rommissural bundle of fibres, which pasces fon one olfartory tract to it follow of the opposite sirle, ria the anterior ammisure, is also described.

As thry pass through the formuna in the rribrifom plate. the olfactory nervefibres are invested he sheaths deriverl from the dura nuater. 


\section{SECOND OR OP'TI MEIIVES}

The optic nerves appear at the base of the brain as a pair of round white cords, which arise from the optic chiasma. From the posterior aspert of the latter structure, two somewhat similar corts, the optic tracts, pass hackwards and outwarks. Each optic nerve is continuous, through the chiasma, with both optic tracts. It will be convenient to trace first the central comnections of the optic nerves through the optic tracts, and afterwards to follow the nerves forwarls from the optie (liakma to the eyehall.

The optic chiasma or commissure rests upon the optie groore, on the superior surface of the sphenoid hone. It is in relation above with the third rentricle, heing separated only by a thin layer of grey matter from that cavity. The internal earoticl arteries are close to its onter sides, behind it is the tuber cineremn, and in front the lamina cinerea, the anterior cerebral and the anterior communicating arteries.

Constitution of the optic chiasma.-Three sets of filores are described in the optic chiasma, namely: (a) Fibres from one optic tract to the optic nerve of the same side; (b) fibres from one optic tract to the optic nerve of the opposite side; (a) commissural fibres passing from one optic tract to its fellow of the opposite sicle. (a) The uncrossed fibres proceed from the lateral or temporal half of the retina of the same side. They oceupy the outer part of the chiasma. (b) The crossed fibres, which form the largest constituent of the chiasma, are derived from the mesial or nasal half of the retina, and pass into the optie tract of the opposite side. (c) The commissural fibres oceup the hack part of the chiasma. They have nothing to do with vision. Two sets are described under the names of Gudden's and Mernert's commissures.

The optic tract mases backwards and ontwards between the outer side of the tuber cinereum and the anterior perforated space, then it passes under corer of the temporal lobe, winding around the crus cerebri. As it applies itself to the latter, it adheres to it, and becomes flattened from above downwards. It next inclines upwards, and divides into an external and an internal root. These roots proceer towards the external and internal geniculate boties, respectively. The internal root contains the fibres of Gudden's commissure.

A portion of the external root hecomes connected with the nerve-cells in the external geniculate body; another part enters the pulvinar of the optic thalamus, while a third part passes in the supcrior brachimm to the superior quadrigeminal body of the same side.

The fibres of the optie nerve terminate therefore anidst or in the ganglion cells of the external geniculate body, the pulvinar of the optie thalamus, and the superior quadrigeninal body; hence, these three bodies have been said to contain the nuelei of origin of the optic nerve. Other filores, howerer, collectively temed the optic radiation, emerge from these three hodies, and pass through the most posterior part of the inner apsule to the oceipital lobe, and thus the cortical origin of the optic nerve is established. The exact area of the cortex devoted to the sense of sight is still a matter of dispute, but the weight of eridence seems to he in firsour of the cuneus being the cerebral centre of vision.

Other ronts of the optic nerve are described, of which the direct corticul root (Wrinicke and crulden) is perhaps the most important. This root leaves the optic trat as the latter is crossing the crus cerelni, and runs upwards in the inner (alpsule to join the optic radiation. Another root is described which jasses from the optic chiasma into the central grer matter of the third rentricle. The lescending root (Stilling) enters the erus and is variously distributed; a portion of its fibres become connected with the oculo-notor nucleus, and thus a path for reflex movements of the iris and ciliary musele is probahly established.

Gudden's commissure.-Filres emerge from the posterior quadrigeminal horly, constituting its hrachimm, and enter the intemal genieulate holy. After partial interruption in the nerve-cells of the latter, these fibres are continued into the optic tract and pass across to the opposite side, forming the lack part of the (p)tic chiasma, to enter into a similar relation to the intermal geniculate and posterior yuarlrigeminal hodies of the opposite sirle. 
Meynert's commissure.-From the grer matter of the tuber cincemun fibres arise which crosis the middle line hehind fudklen's eommissure and enter the aruta on the opposite side, from whener they are saicl to lass into the sulthalanile body.

The optic nerve passes forwards and outwarls from the chiasma and enters the orthit through the optic formen, areompanied he the ophthalmic artery, the vesel lwing extemal to and slightly helow the neres. It then slightly changes it: direction and passes almost diresely forwards to enter the lack of the creball about three millimetres internal to and sightly below the prostrior "xtremity" of the optic: axis; having enined the interior of the eyeloll its filues sprearl out in the retina. In its eourse through the orbit it is surrounded by the ciliary arteries and uerves; its upper surface is crossed obliguely by the ophthatmic artery and the nasal nerve, and the lenticular ganerlion is in contact with its outer surface. Year the optic foramen it is surrounded liy, and in close relation to, the four reeti museles; hut further forwards it is separated from the muscles ly an interval containing fat. The arteria centralis retine pierces the under surface of the optic nerve near the midcle foint of the intranbital part of its course and thence runs into the eyelall in the axis of the norve. Very distinct prolongations of the cerebral membranes aetompany the optic nerve. The dura mater, having entered the orbit through the optic formen, delaminates into the orhital periostem and the sheath of the optic nerve; the latter is tough and strong, and becomes continuous with the selerotic of the evehall. Within the dura mater is a narrow sublural space, then the arachnoid and it (omplaratively wide subarachnoid space, the inmer boundary of which is formerl hy the pia mater, which invests the bundles of nerve-fibres.

\section{THIRD OR OCTLO-IIOTOR NERTE}

The third or oculo-motor nerve arises from a column of nerve-cells which is placed in the grey matter beneath the floor of the aqueduct of Sylvius immecliately dorsal to the posterior longitudinal bundle. This nucleus extends from the level of the posterior commissure to a point corresponding to the interval between the nates and test's, where it is imperfectly separated from the nucleus of the fourth nerve. The fibres arising from it pass flownwarts and forwards in a series of fasciculi, which traverse the posterior longitudinal bundle, the red nuclens, and the inner part of the substantia nigra, and they amerge (superficial origin) in a row of ahout nine fasciculi from the oculo-motor groove at the inner side of the crus in the prosterior fosia of the skull.

The third nerve passes between the superior cerebellar and posterior cerebral arteries, traverses the aperture in the tentorimm. enters the middle fossa of the skull, and then pieres the dura mater ahout midway hetween the anterior and posterior clinoid processes of the sphenoid bone in the centre of a little triangular space which has the following boundaries: externally, the free margin of the tentorim cerehelli, posteriorly the attached margin of the tentorimm. and internally a ridge of llura mater which extends fon the posterior to the antrios elinoil process. It then enters the outer wall of the eavernous sinus and runs forwarts to the sphenoidal fissure, orenpying, at first, a position superior and internal to the fonth nerve. Behind the sphenoidal fissure it divides into a superior and an inferior division. These divisions, as they enter the orhit through the sphenoidal

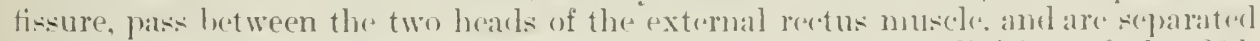
from one another by the nasal branch of the ophthalmic division of the fifth nerve.

The superior division supplies the superior reetus. It enters that muscle on itsoneular surface and sends a branch past its immer border to sulply the levitur lalpebre superioris.

The inferior division, considerab]y larger than the superior, flivides into there branches: two of these, the nerves to the internal and inferior recti muscles. pierce the ocular surfaces of the muscles which they supply. The third branch, the nerve to the inferior oblipue, is considerably longer than the other two. It runs forwards in the interval between the inferior and external pectus muscles, and pierees 
the posterior horder of the inferior oblique. Near its commencement it gives off the short or motor root to the lenticular ganglion.

The third nerve supplies all the orbital muscles, with the exception of the

Fig. 443.-Deep Origix of the ThiRn Nerve. (After Krause.)

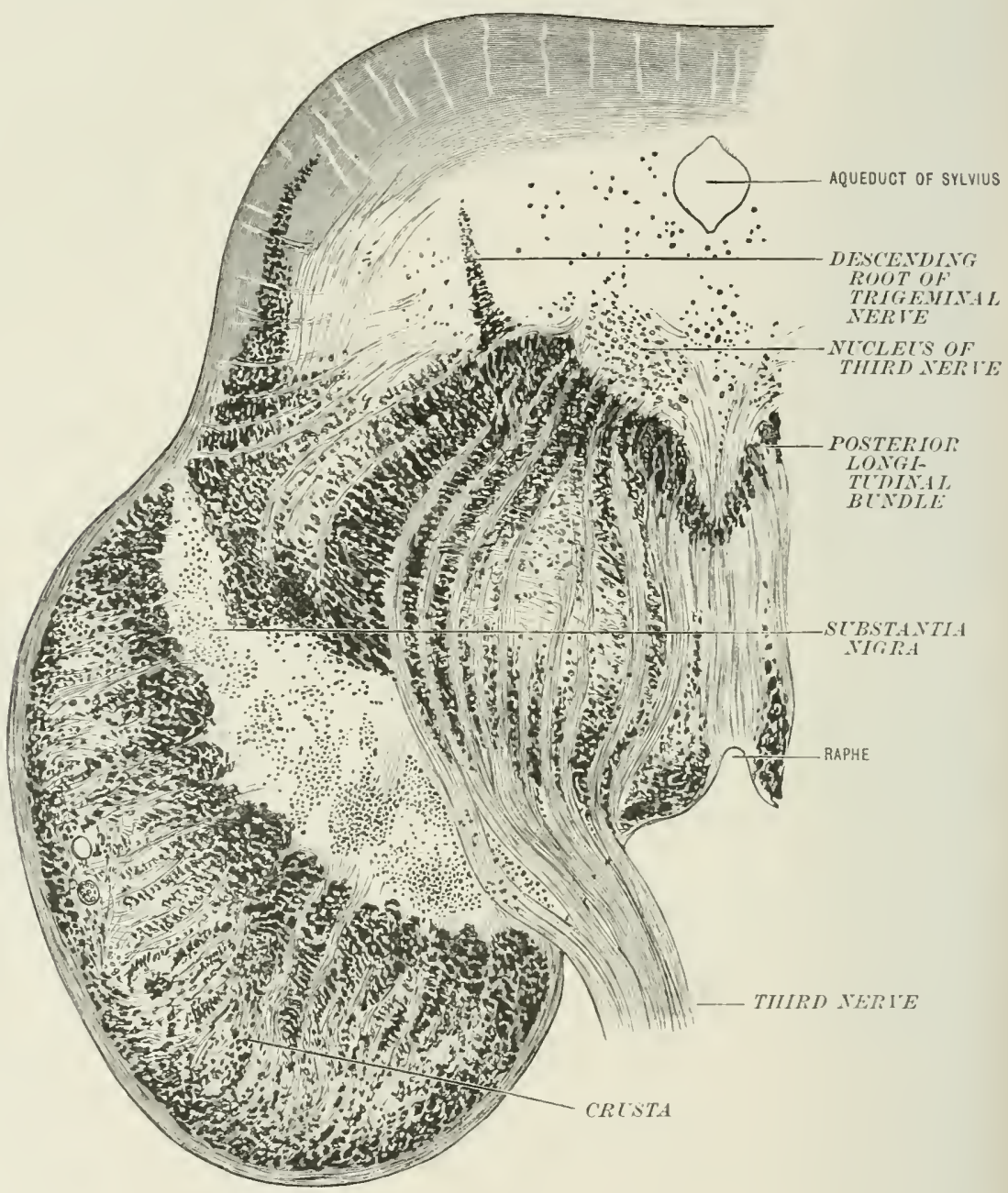

"xternal rectus and the superior oblique. It also supplies (through the lenticular ganglion) the ciliary muscle and the circular fibres of the iris (sphincter iridis).

In the wall of the cavernous sinus it is eomneeted with the "arernous plexus of the sympathetic and with the ophthalmic division of the fifth.

\section{FOURTH OR TROCHLEAR NERYE}

The fourth or trochlear nerve arises from a column of nerve-cells which is continuous with the nurleus of the third nerve. This colum of cells is emberded in the central grey matter bus the aqueduct, and extends from the level of the interval between the nates and testes to the lower margin of the latter hodies. The nerve-fibres issuing from this elongated nucleus form two or three rounded hmulles, which run downwards. backwards, and slightly outwards along the outer side of the nucleus, and then incline inwints to reach the vilve of Vieussens, in 
the substance of which they dectussate with their fellows of the opposite side and become collected into a single bundle (fig. 444). 'This bundle emerges as a slenrler rounded fasciculus (superficial origin) from the valve of Vienssens, elose to the frentum veli, immediately below the testes, and winds romel the crus cerebri to appear at the base of the brain nar the anterior margin of the pons. The right nerve, therefore, arises from the left nucleus and vice versit.

The fourth nerve pierces the dura mater at a point a little behind and extemal to the posterior clinoid process of the sphenoid hone in the posterior fossa of thr skull. It runs forwards in the outer wall of the cavernous sinus, being placed between the third nerve, which is above and internal to it, and the ophthalmic

Fig. 44.- Sectons throvoir the Orgix of the Fourth Nerve. (Stilling.)

(The upper figure is an oblique section. the lower is a coronal section.)

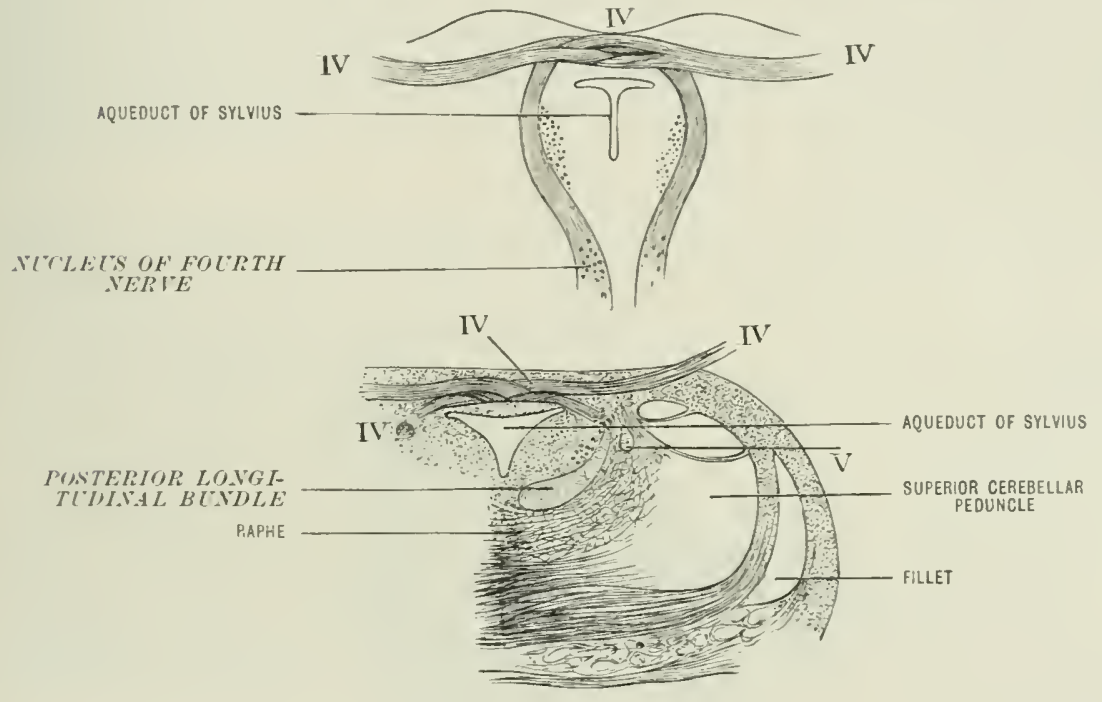

rivision of the fifth nerve, which is situated below and to its outer side. As it alproaches the sphenoidal fissure it bends upwards, crosses on the outer side of the third nerve, and passes through the innermost part of the sphenoidal fissure. As it passes through the fissure it is placed above and internal to the frontal nerve. It then passes inwards above the origin of the levator palpebra superioris muscle, and pierces the orbital surface of the superior oblique muscle, in which it ends.

The fourth nerve is the smallest of the cranial nerves. It is remarkable for the length of its intracranial course and for its mode of decussation. Whilst in the wall of the cavernous sinus it is connected with the ophthalmic branch of the fifth nerve and with the cavemous plexus of the sympathetic.

\section{FIFTH OR TRIGEMINAI, NERVE}

The fifth or trigeminal nerve consists of two parts, a larese sensory ront (jortio major) and a small motor root (pertio minor). The portio major plasses intu a ganglion (Casserian ganglion) which has been cenupared to the ganglion on the posterior root of a spinal nerve, which it probably resembles in exercising a trophic influence on the nerve-fibres, though this has not heen experimentally proved. The "superficial origin" of the nerve is from the sicle of the pons near its uppur borler. The deep origin of the portio major is chiefly hy the ascending root, a long tract of fibr's which runs for a considerable distance within the cerehru-spinal axis. The. portio major has, however, in addition to this, several supplementary rorigins. The portio minor arises principally from a nucleus which is emberlded in the errey 
matter of the floor of the fourth rentricle, but it also receives the whole or the greater part of a long tract of fibres, which passes downmards from the mesencephatum, and which is termerl the descending root.

The majority of the fibres of the portio major spring from the nerve-rells of the Gatserian ganglion; they enter the pons at the base of the middle peduncle and near its upper border. In the sulstance of the pons they pass backwards and downwarls, and the smaller number terminate in artorisations around the cells of the upper sensory nucleus of the fifth nerve, an ovoid group of nerve-cells situated in the upper and lateral part of the floor of the fourth ventricle external to the motor nucleus and continuous below with the substantia gelatinosa Rolandi, which is called the lower sensory nucleus. The greater number of the fibres of the portio major pass downwards in the pons, medulla, and spinal cort, fomning a crescentic bundle, known as the ascending root of the fifth nerve, which lies external to the sulstantia gelatinosa of Rolando. It dininishes in size as it descends, and it finally terminates in the upper part of the ervical region of the cord. Its fibres palss into the sulstantia gelatinosia and probably teminate in arhorisations. In the pons the ascenting root of the fifth nerve is deeply placed between the auditory and facial nerve-poots (fig. 430), and in the upper part of the medulla it is covered by the restiform body (fig. 432), but in the lower part of the medulla and the upper part of the cord it lies close beneath the surface.

The descending root arises from a columm of nerve-cells which is embedded in the grey matter of the arqueduct above and external to the nucleus of the third nerve. The root eommences at the level of the upper part of the nates, and increases in size as it descends, forming a white bundle of fibres crescentic in section, some of these fibres being comnected with the nerve-cells which are placed on their inmer sile (fig. $444, \mathrm{r}$ ). It passes through the grey matter of the upper part of the floor of the fourth ventricle, close to the outer side of the substantia ferrugineal, and reaches the upper part of the motor nurleus of the fifth nerve. Here it is joined hy the principal part of the motor root, which arises from the motor nucleus, and hy a few fibres from the motor nueleus of the opposite side. It then passes downwards and forwards through the pons to emerge as the portio minor of the fifth nerve. At its emergence it is placed a little in front of the sensory portion, and is separated from the latter by some of the transverse fibres of the pons. The motor nucleus is an oroid mass of cells considerably shorter than the accessory sensory nucleus, on the immer side of which it is placed. It is on the same line as the nucleus of the faeial nerve, and is immediately in front of that nueleus.

According to some observers some fibres of the descenting rout enter the sensory root and are saicl to erentually pass into the ophthalmic division.

The sensory and motor roots of the nerve pass downwards and forwards towards an aperture in the dura mater which is placed under cover of the tentorium cerebelli, a little extemal to the apex of the petrous portion of the temporal bone in the posterior fossa of the skull. In this course the motor root takes a halfspiral turn around the sensory root, passing first to the inner side, and then below the latter. Both roots then pass through the aperture above mentioned to enter Meckel's space in the middle fossa, betwern the supporting and periosteal layers of the dura mater. The motor root passes out of the skull through the foramen ovale, accompanied by a larger sensory bundle from the Gasserian ganglion. and joins with the latter outside the skull to form the mandibular (or inferior maxillary) division of the fifth nerve. The sensory root spreads out into a flattenerl, somewhat fan-shaped, plexiform hundle, and enters the Gasicrian ganglion.

The Gasserian ganglion is a reddish-grey band of ganglionic matter, with its long axes slightly curved so ats to present a convexity forwards and outwarks. The upper and lower surfaes of the ganglion are also slightly convex and are somewhat allherent to the clura mater, the upper surface heing more firmly attached than the lower. It rests in a depressiom on the petrous bone and, in front of this, on the cartilage which oxapies the formen lacerum medium. From the convex antero-extemal border of the eanglion, three large bumbles of nerve-fibres arise. The first or ophthalmic division enters the orbit through the sphenoidal fissure. The second or maxillary (superior maxilary) division leaves the skull through the 
foramen rotumdum. The thiml division passes through the foramen ovale in fromt of the motor root of the fifth nerve, with which it unites, as already describerl, to form the mandibular (inferior maxillary) division. The (rasserian ganglion

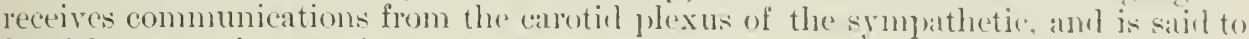
fumish some minute trigs to the dura mater.

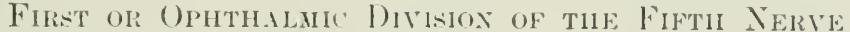

The ophthalmic is the smallest of the three divisums of the fifth, and is antimety sensory in function. It passes forwares and inwards in the outer wall of the (avernous simus, where it is placed below and external to the fourth nerve. Behinel the sphenoilal fissure it dirides into thre branches. These branches pass through the sphenoidal fissure, piereing the fibrous derivative of the dura mater which coss's it. 'T'wo of them, the frontal and the lachrymal, enter the orbit above the external rectus muscle. The renaining branch, the nasal, passes between the two heacls of that muscle. In its course in the outer wall of the cavernous sinus the ophthalnic. division receives eommmnications from the carotid plexus of the srmpathetic, and gives off a tentorial branch (nervus lecurrens rami primi, luschka) which runs larkwards for a short distance within the sheath of the fourth ner've, and is distriluted

Fig. 445.-NERVES OF THE ORHIT, FRoM THE OLTER SIDE.

(From siapler, atter Hirschfeld and Leveillé.)

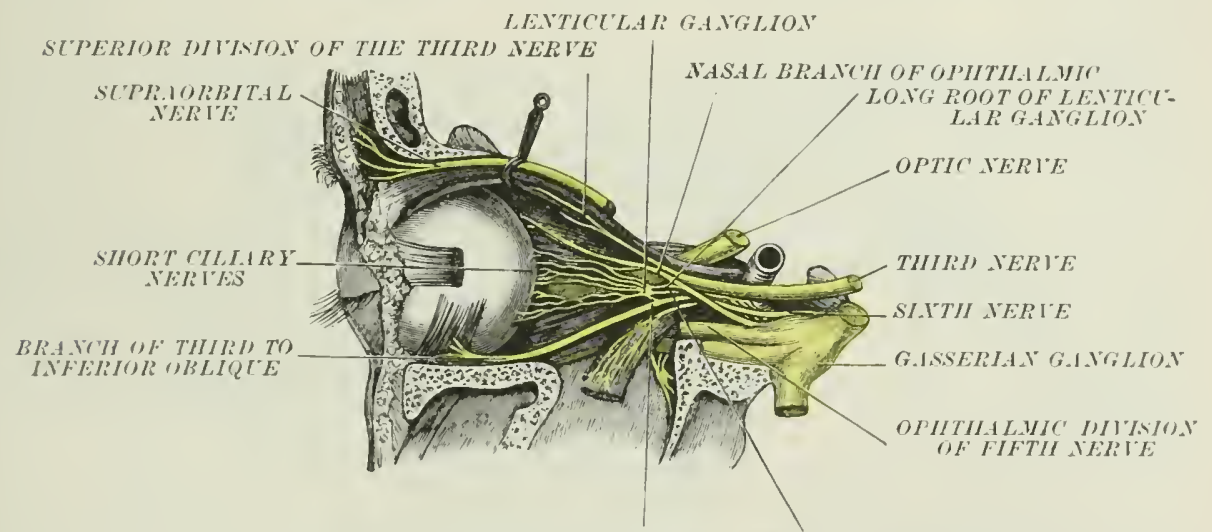

SHORT ROOT OF

SVMPATHETIR ROOT OF LESTIRT'LAI LEVTIRTLIR GANGLION

GANGI,ION

between the lavers of the tentorium cerebelli. It also gives communicating hranches to the third, fourth, and sixtlo nerves. The orhital museles receive their sensory supply through these communications.

(1) The frontal nerve is the laresest branch of the ophthamic division. It passes forwarls and upwards on the inner sicle of the third nerve, and enters the orbit immediately external to, and a little below, the fourth nerve. It passes forwards between the periosteum of the orbit and the levator palpebre suprerioris muscle, and, a little behind the middile of the orhit, flivides into two hranches. termed the supraorbital and supratrochlear.

(2) The supraorbital nerve leave's the orhit hy passing through the supraorlital noteh or formen, where it gives twigs to the upper evelirl, and turns upwarks on the frontal bone, aceompanied by the supranrhital artery. It divides into two branches. an external and an internal. Juth these loranches divide into soveral twigs, which pass very oblicuely through the anterior helly of the oreipito-frontalis: muscle, and supply the integrment of the forehearl and fore part of the seally. The external branch, which is comsikeraluly larew than the intermal, may be traced backwards nearly as far as the lambeloilal suture.

(3) The supratrochlear nerve is lireted forwams and inwards ahwe the pulley of the smperior oblique muscle. It communieates with the infratrochlear 
branch of the nasal nerve and turns upwarts on the foreheat, aceompanied by the frontal artery. It is much smaller than the supraorlital nerve, and it is distributed to a small area of integmment around the glabella. It gives twigs to the inner part of the upper erelicl.

(4) The lachrymal nerve is the smallest of the three branches of the ophthalmie division. It passes through the sphenoidal fissure external to and slightly below the frontal nerve, and is directed forwards and outwards along the upper border of the external rectus musele to the laehrymal gland. Immediately behind the lachrymal gland it communicates with the temporal branch of the orbital nerve, forming a loop convex forwards; from this loop and from the adjacent part of the trunk of the nerve a number of twigs pass into the gland substance. A small twig passes beyond the gland and is distributed to the integument and conjunctiva at the outer canthus of the eye.

(5) The nasal nerve enters the orbit by passing forwards between the superior and inferior divisions of the third nerve, and takes an oblique course forwards and inwards to reach the inner wall of the orbit. In this course it passes between the optic nerve and the superior rectus musele. It then passes between the superior oblique and the internal reetus, traverses the anterior internal orbital canal, accompanied by the anterior ethmoidal ressels, enters the anterior fossa of the skull, crosses the cribriform plate of the ethmoid bone under cover of the clura mater, and enters the nasal fossa through a slit-like aperture at the side of the crista galli (the ethmoidal fissure). It terminates within the nasal fossa by dividing into three branches: an internal, or septal; an external; and an anterior, or terminal.

Branches.-The long root to the lenticular ganglion is given oft at the sphenoidal fissure. It is a slender filament which passes forwards to join the upper and back part of the ganglion. The long ciliary nerves, usually two in number, arise from the nasal trunk as the latter is crossing the optic nerve. They are directed forwarls along the imner side of the optic nerve, and join the lower set of short ciliary nerves after they pierce the sclerotic (page 851). The infratrochlear nerve is given off by the nasal just before the latter enters the anterior internal orbital cancl. It passes forwards beneath the pulley of the superior oblique muscle, and supplies the skin and conjunctiva around the inner canthus of the eye and the integument of the upper part of the nose. It also supplies the lachrymal sac and caruncle. It communicates with the supratrochlear nerve in front of (sometimes behind) the pulley.

The internal or septal branch of the nasal nerve runs downwards and forwarks on the upper and front part of the nasal septum.

The external branch gives two or three twigs to the anterior extremities of the superior and middle turbinated bones, and to the mucous membrane of the outer wall of the nose.

The terminal or anterior branch runs downwards in a groove on the inner surface of the nasal bone. It pierees the wall of the nose between the nasal bone and the lateral eartilage, and supplies the integument of the lower part of the dorsum of the nose as far as the tip of that organ.

\section{Lextic that Gaxglion}

The lenticular, ciliary, or ophthalmic ganglion is a small redelish-grey boly: about the size of a pin's head. It is quadrilateral in outline, and its outer and inner surfaces are slightly convex. It is placed between the optie nerve and the external reetus musele, about a quarter of an inch in front of the sphenoidal fissure. Following the general rule applying to the sporatic ganglia which are connecter with the fifth nerve, it is provided with three roots, a motor, a sensory, and a sympathetic. The motor or short root is derived from the branch of the oculonotor to the inferior oblique musele; it enter's the posterior inferior angle of the ganglion. The sensory or long root is a branch of the nasal nerve; it passes along the outur side of the optic nerve, and enters the upper and hack part of the ganglion. The sympathetic root is deriverl from the cavernous plexus of the sympathetic; it may renter the back part of the ganglion in the form of fine twigs, 
but wasuly reaches the gandion for the mest fart through the third and nateit nerves, being incorpromated with the motor and semsory monts.

From the antrior border of the ganglion about six short ciliary nerves arise; these subdivide and eommunicate with the loner ciliary nerves, forning about twenty

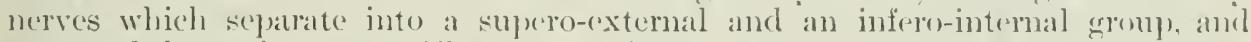
surround the optie nerve. The nerves pierese the selerotic in a circle around the entrance of the optie nerve inte the eyeball, and pass forwarls between the selerotic and choroid coats of the eye. They sil]ply nerves of ordinary somsation and trophic: nerves to the creball (derived from the nasal): the larliating fibres of the iris (derived from the sympathetic): and the ciliary muscle and splineter of the pupil (derived from the oculomotor) ( page s.50).

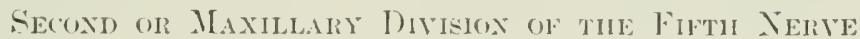

The maxillary (superior maxillary) division of the fifth nerve is intermediate: in size between the mandibular (inferior naxillary) and (n)hthalnie divisions, anrl, lik. the latter, it is entirely sensory in function. It proceeds forwards from thes

Fic. 446. - The Maxillari Nerve seex flom Witurto. (Beannik.)

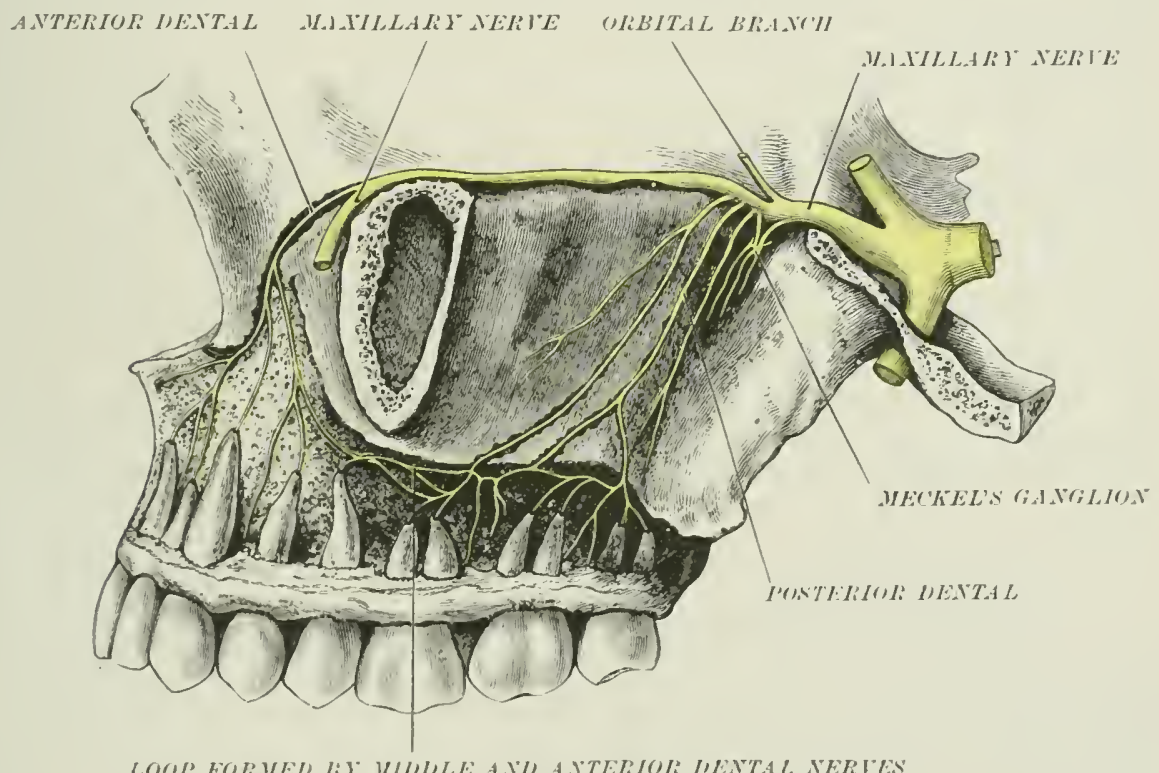

LOOP FORWED IY WHDILE AND ANTERIOR IIENTA L NERITS

Casserian ganglion for abut one-thiml of an inch within the skull, and then passe through the foramen lotumclum. It traverses the upper part of the sphenomaxillary fossa, and. inclining mpards, passes into the orbit through the sphenomaxillary tisture. It then courses forwarks along the infrablital foove, acen-

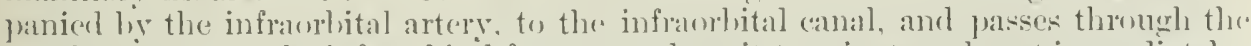

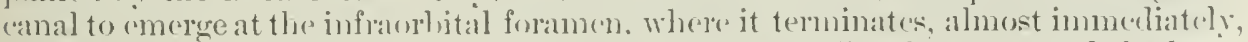

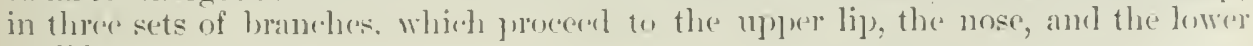
erelicl.

Branches. - The brandhes of the maxillary divisom may be alasified into fome scts, namely:-(1) Intrareanial hranches: (2) hranches which are given off in the

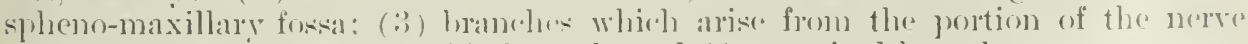
which is placest in the infractital ramal: and (4) terminal hranches.

The first sot (1) consists of one ar two recurrent twigs to the duria mather. which form lowes with the recurrent hanch of the manclihular (inferior maxillary division. The second set (2) compuris"s the orbital nerve, the spheno-palatine nerves, and the posterior superior dental nerves. (:i) Th. middle and anterior 
superior dental nerves constitute the third set. (f) The terminal branches fall into three wrougs, which are termed labial. nawal, and palpeloral hranches.

The orbital or temporo-malar nerve passes upwarls and forwarls through the spheno-maxillary fisture by whel it enters the orbit, and terminates hy dividing into two luanches, temporal and malar. The temporal branch communicates with the lachrymal nerve, and then rums forwards through the periostem on the outer wall of the orhit, and traverses the spheno-malar foramen. It enters the temporal fossa and pierces the deeper of the two lamelle of the temporal fascial. It runs ontwards for about a quarter of an inch in the fat between the two lamellar of the fastia, and pierees the superficial lamella alyout an inch alove the superior borcter of the zygoma; here it forms a well-marked communieation with the temporal branch of the facial neve, and then ramities in the integment of the antrion temporal region. The malar branch (ramus subcutaneous malæ) runs forwards in the loose fatty tissure of the orbit, and passes through the malar formen. It pierces the orbicularis palpelsarum and supplies a small area of skin orer the prominence of the cheek. It communieates with the malar hranth of the facial nerve.

The spheno-palatine nerves are two stout twigs which pass dowmards to Meckel's ganglion, of which they form the sensory roots; most of the nervefibres pass on the inner side of the ganglion without traversing the ganglionic substance, but it is more convenient to trace these nerves with the branches of the gamglion.

The posterior superior dental nerves, wsully two in mumber, lass downwarls and outwards through the pterygo-maxilary fissure. They furnish sereral twigs to the gums (nervuli gingivales) and adjacent part of the nineons membrane of the eheek. They then enter foramina in the maxilla, follow the eurve of the alveolar arch through minute canals in the bone above the roots of the molar teeth, and end by communicating in a plexiform manner with the middle dental nerve. Ther give off minute branches to the mucous memlnane of the antrum, and furnish three twigs to aach of the molar teeth. These twigs enter the formina at the tijs of the fangs of the teeth and ramify in the pulp.

The middle and anterior superior dental nerves are small branches which pass through eanals in the substance of the maxillat te supply the incisor, amine, and licuspid teeth and the corresponding regions of the gums. In the 11 ) more particularly in the lower, parts of these canals the nerves are surroundecl on all siles by thick bone; but in the middle part, where they are traversing the anterior wall of the antrum, they are surrounded by a mere shell of bone, which is not infrequently deficient on the deep surface, so that the nerves may lie in grooves in the anterior wall of the antrum between the bone and mucous membrane. In this situation the nerves furnish twigs to the antrum. The middle dental nerve enter's a formen at the posterior part of the infraorbital canal. It supplics the licuspirl teeth, and commmicates with the anterior and posterior dental nerver. It may be wanting. The anterior dental nerve enters a eanal elose to the infraorbital foramen, and supplies the incisor and canine teetl. It gives off a nasal branch, which passes through a minute canal in the bone and enters the anterior. part of the inferior meatus. Here it ramifies in the mucous membrane, and communicates with the naso-palatine nerve from Meckel's ganglion. It communicates with the midlle dental nerve.

Two small gangliform enlargements are oceasionally found on the plexiform arch formed by the dental verves. One of these, the ganglion of Valentin, is situated above the root of the secomd bieuspid at the junction of the mildile and posterior dental nerves. The other, the ganglion of Bochdalek, is placed on the junction of the anterior and middle dental nerves.

The labial branches, usually four in number, are the largest of the three terminal divisions of the maxillary nerve. They pass downwards, spreading out as they descend, undere cover of the levator labii siperioris muscle, and ranify in the structures forming the upper lip, very large twigs being supplied to the inuens membrame.

The nasal branches, three or fomr in number, are intermediate in size. They pass inwards under cover of the levator labii superioris alaeque masi, and supply the integument on the lateral aspect of the nose. 
The palpebral branches, the smallest of the terminal divisions of the nerve, pieree the origin of the levator labii superioris, and turn upwarts aromel the lower hordes of the orbieularis galpobrarum. They are ustully two in number, atu external and an internal; they ramify in the integinent of the lower cyelicl.

The terminal hranches of the maxillary division communicate frecely with the? infratolytal branch of the factal, forming the infraorbital plexus. The plexus is placed under cover of the levator laliii superioris.

\section{MECKEL'S GINGLION}

The spheno-palatine, nasal, or Meckel's ganglion is a small rectelish-grey body which is situated in the spheno-maxillary fosis. It is triangular in form, flattened at the sides, and measures about one-fifth of an inch in its longest diameter. It is provided with three roots, a motor and a sympathetic, which reach it through the Virlian nerve, and a sensory root from the maxillary nerve. The latter root is in the form of two stout twigs, which are describerl as the spheno-palatine nerves.

Roots. - The great superficial petrosal nerve is the notor root of the ganglion. It alises from the geniculate ganglion of the facial nerve within the aqueduct of Fallopius, and enters the eranial cavity by trarersing the hiatus Fallopii. It then runs forwarls and inwards in a groove in the petrous portion of the temporal bone, and, after passing under the Gasserian ganglion, enters an ohlique canal in the cartilage which oceupies the foramen lacerm medium. Javing reached the pesterior opening of the Vidian canal, it unites with the great drep petrosal nerve to form the Vitlian nerve.

The great deep petrosal nerve is of a grey colour and is soft in consistener. It arises from the carotid plexus of the sympathetic close to the intracranial termination of the carotid canal. traverses a canal in the cartilage, which oceupics the formmen lacerum medium, and joins the Vidian nerve.

The Vidian nerve runs forwards through the canal of the same name, acconpanied by the Vidian artery, and enters the spheno-maxillary fossa, where it enck in the pristerior angle of Meckel's ganglion. While within the canal the Vidian nerve furnishes nasal twigs to the mucous membrane of the prosterior part of the roof of the nose. They may be regarded as superior nasal nerves, which, after leaving Neckel's ganglion, have become associated with the Viclian nerve for a part of their (o)urse.

Branches.-The branches of Neckel's ganglion are classificl into (1) ascending, to the orluit; (2) internal, to the mueous membrane of the nose; (3) descending, to the hard and soft palate; and (4) posterior, to the pharynx.

(1) Ascending branches.-The ascending or orbital branches are two or thrers suall twigs which enter the orbit through the spheno-maxillary fissure, and proceed within the periosteum to the inner wall of the orhit, where they pass through thro posterior internal orbital canal and thromgh the formina in the suture behine that canal to be distributed to the mueous nembrane which lines the posterior ethmoislat cells and the sphenoilal sinus.

(2) Internal branches.-The internal branches are derived in part from the

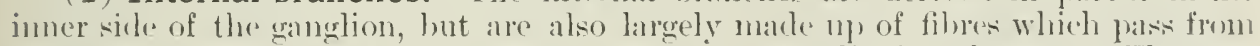
the spheno-palatine nores without traversing the ganglionic substanee. They are disposed in two sets, the superior nawal and the septal.

The superior nasal are six of seren small twigs which fass through the spluenopalatine formone and are distributed to the muens membrane covering the posterior parts of the superior and nithlle turbinated bones. They also furnish twigs to the lining mombrane of the posterior ethmoislal cells.

The septal branches are two or three in number, and priss inwarks through

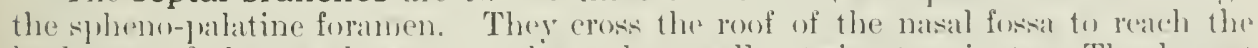
balck part of the nasal septum, where the smaller twigs terminate. The latrest nerve of the sit, naso-palatine nerve, or nerve of Cotunnius, runs lowmats: and forwards in a growe in the vomer between the periostemm and the murous membrane to the anterior palatine canal. Here it commmicates with the natsal branch of the anterior superior dental nerve. The two naso-palatine nerves then fars through the foranina of searya in the intermaxillary suture, the left nerve 
pas-ing through the anterion of the two foranina. In the lower part of the anterior palatine canal the two nerves form a plexiform communication (formerly deseribed as ('lopuet's ganglion) and furnish twigs to the anterior part of the hard palate. In this situation they conmmunieate with the anterior palatine nerves.

(i) Descending branches. - The descending luranches are the great or anterior. the posterior, and the external palatine nerves. like the internal set of branches, thes are in part derived from the ganglion and in fart directly continuous with the spheno-pralatine nerves.

The great or anterior palatine nerve arises from the inferior angle of Ileckel's ganglion, and pases downwards through the posterior palatine canal. accompaniced hy the descending palatine artery. Energing from the canal, it divides into two ir three branches, which pass forwards in grooves in the hard palate and supply the glands and mucous membrane of the hard palate and the gums on the inner atprect of the alveolar border of the upper jaw. During its eourse through the pusterior palatine canal, the anterior palatine nerve gives off, usually two, inferior nasal nerves. These nerves pass through small openings in the perpendienlar plate of the palate bone to supply the mucous membrane covering the back parts of the inferior turbinated bone and lining the middle and inferior motuses of the nose.

The posterior or small palatine nerve passes downwards through the acerssory matine canal, and enters the soft palate, distributing branches to that organ. to the urula, and to the tonsil. It was formerly believed to convey notor fibres from the facial nerve to the levator palati and azyos urula muscles, but these nuscles are now known to be supplied ly the spinal aecessory nerve, through the pharygreal plexus.

The external palatine nerve, the smallest of the three, traverses the external palatine canal, and supplies twigs to the tonsil and to the arljacent part of the solt jalate.

(4) Posterior branch.-The Vidian is considered by some anatomists to he a hranch, in which case it would be classerl here. We have, however, regarded it as the united motor and sympathetic root of the ganglion; therefore, the pharyngeal branch only remains to he described.

The pharyngeal branch is of small size, and passes backwards and somewhat inwarls through the pteryo-palatine canal, accompanieal by the pterygo-palatine artery. It is distributed to the mucous membrane of the uppermost part of the fharynx, to the upper part of the posterior nares, to the opening of the Eustaclian tube. and to the lining of the spleneidal sinus.

\section{Thiri) or Manibllak Divisiox of tife Fiftu Nerie}

The mandibular (inferior maxillary) division is the largest of the three divisions of the fifth nerve, and is formed, as hefore stated, hy the union of two distinct parts, namely, the mire motor root of the fifth nerve and a large bundle of tibres derived from the sensory root and traversing the Casserian ganglion. These two parts pass through the formen ovale and mite immediately outside the skull to form a large trumk which terminates almost directly after its formation ly dividing into a smaller anterior and a larger posterior portion. The anterior portion is chiefly motor, and the posterior division mainly sensory in function. Previous to its thision, two branehes arise from the trunk of the nerve, namely, the recurrent nerve and the nerve to the internal piteregoisl.

(1) The recurrent nerve enters the cranium through the formen sjinosum, acompanying the midlle meningeal artery, and divides into an anterior and a prsterior branch. The antrior branch rommunicates with the mening(al branch of the maxillary division of the fifth nerve, furnishes filaments to the dura mater, and curls in the reseous substance of the great wing of the sphenoid. The pesterior hrancle traverses the petro-spuamous suture and ends in the lining nembrane of the mastoirl cells.

(2) The nerve to the internal pterygoid passes under eover of a clense layer of fascia derived from an expansion of the ligamentum pitrygo-sjinosum, and cuters the deep surface of the muscle. Near its commenement this nerve furnishes a motor root to the otice ganglion. 
The ANTERIOR PORTION of the mandihular division of the fifth nerve supplies the temporal, masseter, and external pterygoid nuseles, and gives oft a sensory branch, the long buecal norve; the latter is accompanied, in the first part of its course, by a small stramel of motor fibres which leaves it te and in the anterior fart of the teinporal muscke.

(1) The temporal nerves, wisully two in mumber, pass hetween the bome and the upper border of the extemal pterygoid muscle, and turn upwards around the infra-temporal crest of the sphenoid bume to end in the deeps surface of the temporal muscle. The posterior of these two nerves may arise in common with the masseteric nerve.

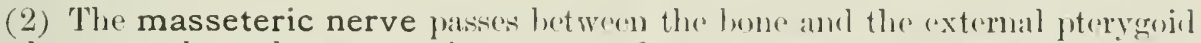
muscle external to the temporal nerves, and alcompanios tho massoteric artory through the sigmoid noteh of the mandible to he distributed to the masseter. It

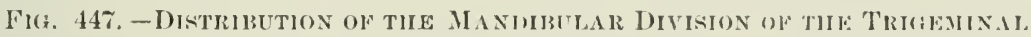
Sinve. (Henle.)

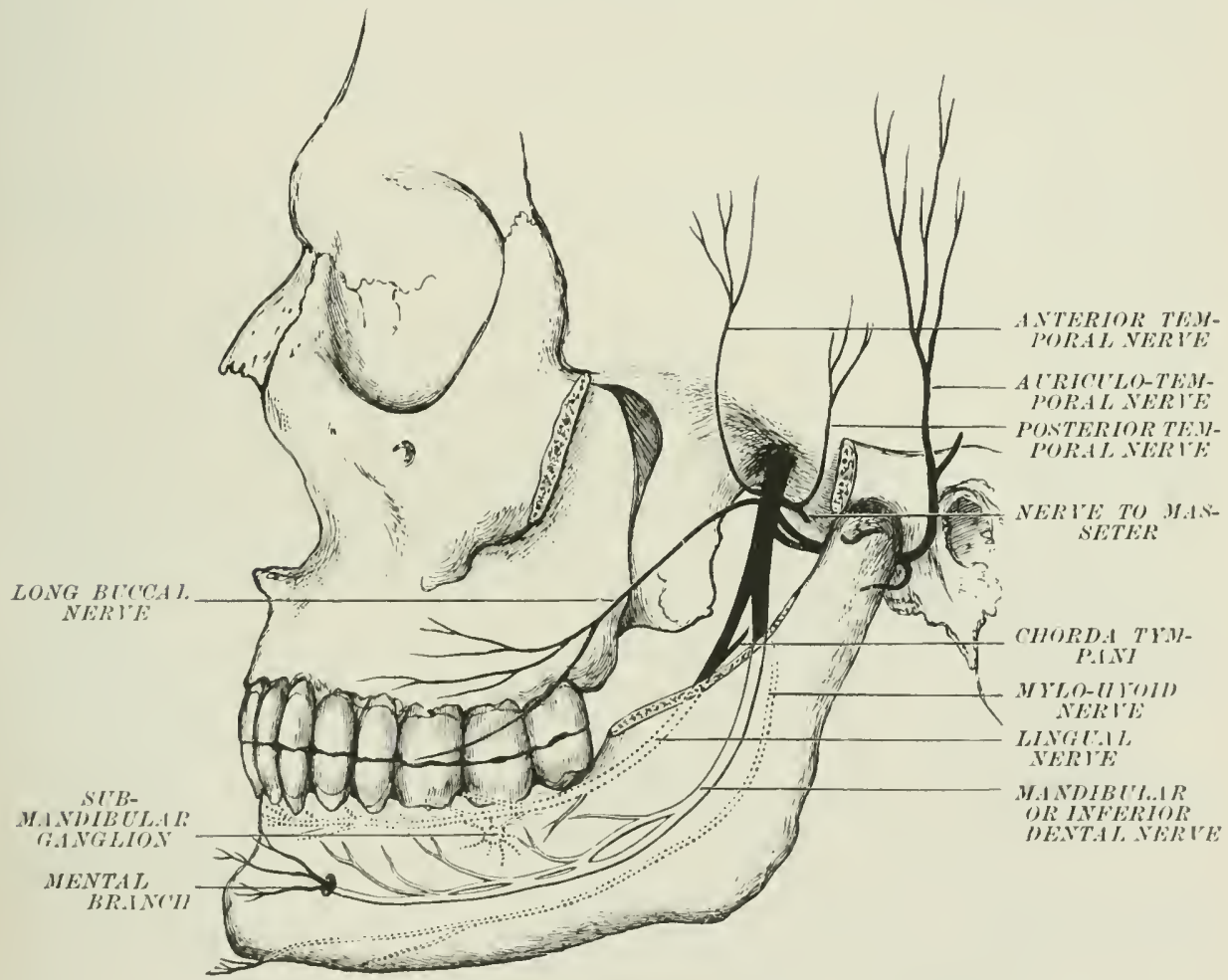

maly be realily traned through the deeper fibres of the masseter nearly to the anterior border of that muscle. As it emerges from under anere of the cxtemal pterygoirl it gives a twig to the temporo-mandibular articulation.

(i) The nerve to the external pterygoid, after a course of alout an eighth of an inch, divides into twigs which enter the deep surface of the two heads of the muscle. It is usually adherent at its origin to the long huceal norve.

(4) The long buccal nerve pakses hetween the two heads of the exterual poterygoid muscle, and then turns forwards and emerges from under coser of the temporial and masseter museles at the anterior border of the latter. It rums forwards and commmnicates with the buecal branch of the farcal, being in this situation corerenl only by the integument and fascial, to which it gives branches; then it pioress the. huceinator muscle and ramifies in the mucous nemulame lining the eherek, its terminal twiess reaching as far forwards as the angle of thr mouth. As it emerges 
from between the head- of the external pterygoid, it gives off a stender twier to the temporal muscle.

The POSTERIOR PORTION of the mandilular division of the fifth nerve divides into three large branches: two of these. the auriculo-temporal and the lingual, are "xchsively semsory: the remaining hranch, mandibular (inferior dental), contains at strand of motor fibres-the mrlo-hroid nerre.

(1) The auriculo-temporal nerve arises by two roots, which usually eubrace the midule meningeal artery, and pases backwads and outwards betwen the internal lateral liganent of the temporo-mandibular articulation and the condrle of the mandible, closely embraxing the capsular ligaments of the joint. It then ascends under cover of the parotid gland and traverses the glandular substance as it crosses the root of the zyoma. It aceompanies the temporal artery, being placed under eover of and slightly behind that ressel, and terminates at the level of the tragus of the ear by divilling into auricular and temporal branches. As it passes through the parotid gland it communicates with the temporo-farial division of the facial nerve by two stunt twigs, which may surroumd the temporal artery. The auriculo-temporal nerve receives communicating twigs from the otic ganglion, and gives off the articular branch, the nerves to the meatus, and the parotid branches. It terminates in the anterior auricular and superficial temporal branches.

(a) The communicating twigs from the otic ganglion join the nerve close to it: commeneement in the form of several fine filaments.

These filaments have been shown by physiological experiments to be derived from the glussi). 1.haryngeal nerve through the lesser superficial petrosal. They run for a short distance in the trunk of the aurieulo-temporal, and leave it uncler the name of parotid branches. They are the -ecretu-motor fibres of the parotid gland.

(b) The articular branch is supplied to the temporo-mandibular articulation as the auriculo-temporal nerve is passing between the capsular ligament and the parotid gland.

(c) The nerves to the meatus, two in number, pass between the bony and (artilaginous parts of the external auditory meatus and supply the skin lining the meatus. The upper of the two nerves fumishes a filament to the upper and anterior part of the membrana trompani. The lower nerve gives twigs to the lobule of the ear. Occasionally only the upper nerve is present, the lower being replaced by a twig from the great anricular. (Henle.)

(d) The parotid branches are a variable number of fine twigs which arise either wirectly from the auriculo-temporal nerve or from the loops of communication lwe ween it and the facial. As above mentioned, they supply the glandular substance.

(e) The anterior auricular branches, two in number, are supplied to the upler part of the pinna. and are chicfly distriluted to the integunent which covers the anterior aspect of the tragus and helix.

$\left(f^{\prime}\right)$ The superficial temporal branches divide at acute angles and ramify wre the integument which covers the temporal fascia. The largest twig acenipanies the posterior linanch of the temporal artery. The anterior twigs communicate with the temporal hranches of the facial nerve.

(2) The mandibular (inferior dental) nerve is the largest branch of the mandilular division. It passes downwards under cover of the external pteryoid muscle to reach the interval hetween the ramus of the lower jaw and the sphemomandibular ligament. In this situation it is placed on the outer side of and somewhat hehind the lingual nerve, and is commected to the latter by a transwerse commumicating hranch. It then enters the mandiloular canal accompanied hy the manclibular artery, and lies at first hehind and then below that ressel as it follows the course of the canal. Opposite the mental formen it teminates by dividing into an incisive and a montal branch. The branches of the inferior dental nerve arr the mrlo-hroid, thr alveolar, the incisive, and the mental.

(a) The mylo-hyoid is given off from the mandilunlar nervo immerliately hefore the latter enters the dental canal. It rums dowmards and forwards in the mylo-hyoirl groove of the mandible hetween the bone and the internal pterggoid miscle. In this course it is aceompanied by the mylo-hyoid artery. It then rums forwards on the inferior surface of the mylo-hyoid inuscle, under cover of the sub- 


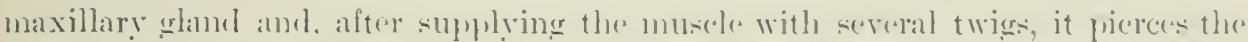
anterion helly of the ligastrie. in the sulstandere of whith it encls.

(b) The alveolar branches ale a

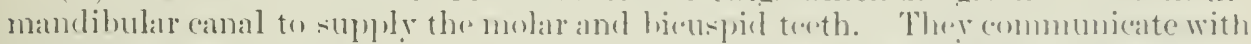
one another within the bone. forming a fine plexus. Fom this plexus twigs ane given off corresponding in mumber to the fances of the teeth; they unter the minute apertures at the tips of the fange and enel in the pulp. Twigs are also given to the aljacent part of the gums (nervi gingivales).

(c) The incisive branch, the smaller of the two terminal divisions. is continued

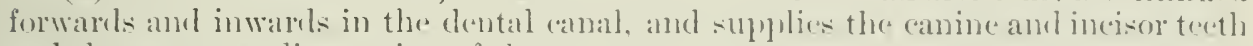
and the corresponding recrion of the gumlls.

(d) Thr mental branch is a nerve of consielerahle size which onureres through the mental formen. It communicates, near its exit, with the supamandilular branch of the facial nerve, and then divides into three branches. The smallest hameh turns clownwarels to supply the ehin. The other two pass mpards diveroring as they ascenel, and thive into a mumber of twigs. The stoutest twigs ranify. upen the inucous nemblane which lines the bower lip. Other twigs are distributed to the integument and fascia of the lip and (hin.

(3) The lingual (formerly (alled gustatory) nerve is slightly smaller than the mandibular nerve, and is placed at first in front of and clese to the inner sicle of the latter moler corer of the external potergoid muscle. In this -ituation it is: joined by the chondat tympani nerre; the latter enters the lingulal on its outer side. the two nerves miting at an acute angle. The lingual then esajes from under. (o) hy a transwerse communicating branch. It then fasces between the ramms of the manrlible and the internal pterrgoid musele. and is continued forwards loetween the murous membrame of the mouth and the mylo-hyoid muscles and lies on the origin of this muscle elose to the bome. In this pant of its course it can he easidy divided lye an meision through the mueous membrane at the lewel of the second lower nimlar towth. It then runs between the mylo-hroid and hro-ghesus muscles.

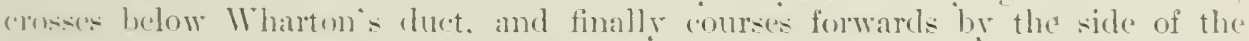
tomerne, so ats to reach the tip of that organ. As it cosses the hyo-shosus muscle it forms a curve with the comrexity directed clownwards. and is comected at the

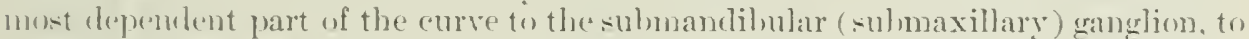
which it furnishes sensory roots. [mmediatry heyond the ganglion it eommuni-

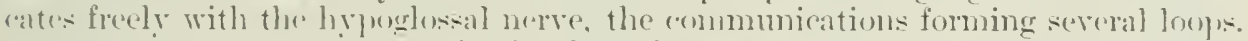

Branches.-(a) (ommmicating bunches are griven to the mandihular merve. to the submaxillary gameriom, and to the hypoglosil nerve. These have alrealy

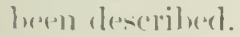

(b) Twigs are distriluterl to the interval hetweren the tongue and grums, and ramify in the mucous membrane of the flowe of the month.

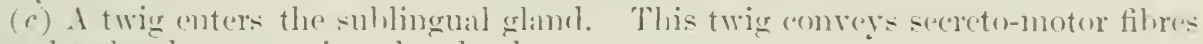
from the rherda trmulani to the erland.

(d) The lingual hranches are a series of twigs which are given off hy the lingual nore in the last stage of its comrse as it is pasing forwarls towamls the tip of the

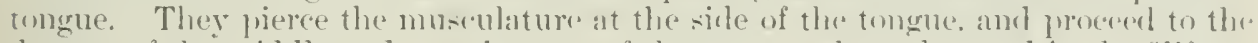
dersum of the midelle and anterior part of that organ, where they enet in the filiform amel fumcriform papillice.

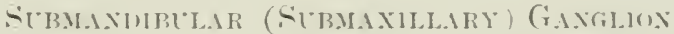

The submandibular ganglion is a small rerklish furiform holly which is placed

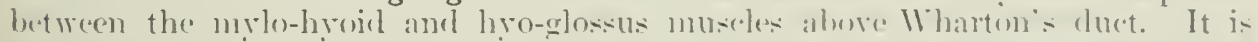

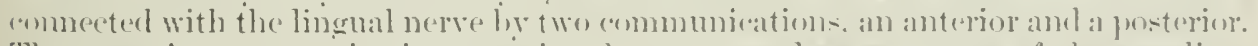

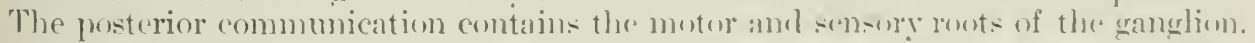
The anterior communiontion repurents a brand pas-ing from the ganglion to the

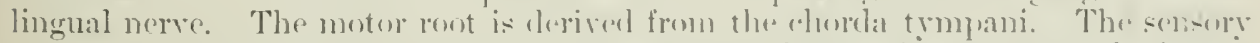

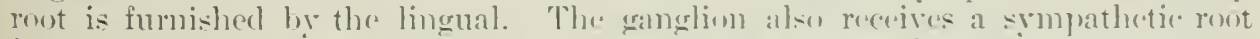
from the plexus of the srmpathetic which aremplanies the farial artery.

Branches.-The ganglion fumi-he tive or six twigs to the sulmamtihular 
(submaxillary) glamd, and give's minute twigs to Wharton's duct, which accompany the duct to its termination. From the fore part of the ganglion a branch passes to the lingual nerve, and threugh this branch fibres from the chorda tympani are conveyed to the sublingual glimel and to the tongue.

Sublingual ganglion. - I snall ganglion has been described hy Blamlin ant others on the twig to the sublingual gland. Aceording to Bose, it is not constant.

\section{OTI" GANGLION}

The otic ganglion, or ganglion of Arnold, is a small reddish-grey hody which is placed immediately below the formen ovale, internal to the mandibular division of the trigeminal nerve. The artilage of the Eustachian tulse and the tensor tympani muscle are placed cluse to its inner side, and the middle meningeal artery is behind it. The ganglion is oral in form, and compressed in its coronal diameter. It is greatest in its sagittal dianeter. which is about four millimetres.

Roots.-The mandibular division of the trigeminal nerve supplies one or mor' roots to the otie ganglion; these roots probably contain both sensory and motor fibres, and are associated with the nerve to the internal pterygoid. The lesser superficial petrosal nerve enters the ganglion, being a motor root. The ganglion receives a sympathetic root from the plexus which surrounds the middle. meningeal artery.

Branches.- The otie ganglion furnishes muscular twigs to the tensor palati and tensor tympani; these twigs, ispecially the former, pass for the most part from the mandibular division of the fifth nerve to the muscles without interruption in the nerve-cells of the ganglion. It also gives communicating branches to the aurieulotemporal, the ehorda tympani. and to the Vidian nerves.

\section{SIXTH OR IBIICENT YELIE}

The sixth or abducent nerve arises from an approximately splierical cluster of nerve-cells which is placed between the grey matter of the floor of the fourth ventricle and the formatio reticularis. This nucleus is situated near the middl. line, a little in front of the striæ acusticæ, and corresponds to the eminentia teres. It is on a line with the nuclei of the third and fourth nerves. The fibres which allise from it plunge forwards and downwards through the substance of the pons. and emerge at the lower border of the latter strueture (superficial origin). Some of the fibres pass through the pranidal boly; others pass out in the interval between the latter and the olivary body.

The sixth nerve was formerly deseribed as giving fibres of origin to the facial, but Gudden and Gowers have shown that this is not the case. A remarkable strand of fibres passes from the abducens nucleus to the posterior longitudinal bundle. It runs brainwards, forming the inner border of the lundle, and deeussates below the corporis quadrigemina with its fellow of the opposite side; it then joins the third nerve, and passes eventually into the internal reetus muscle. 'Thus the eyes earn be directed to the right or left, as the case may be, by the action of a single nuclens, e. g. in turning the eves to the right, the right external rectus and the left internil rectus are used, anct these are both supplied by the right aldueens nneleus.

The sixth nerve pieres the lura mater at a point a little above the junction of the basilar proess of the occipital bone with the sphenoid. It rums upmarks between the pons and the borly of the sphenoid and at the side of the basilar artery, and turns forwards in the interval between the apex of the petrous portion of tie temporal bone and the posterior clinoirl process of the sphenoid, passing in this situation under cover of a ligament which connects the ostous prominences above mentionect. It enters the floor of the carernous sinus, and passes on to the outer side of the internal carotid artery. In this situation it receives serral communications from the earotid plexns of the sympathetic. It enters the orbit througli the sphenoidal fisture, passing letween the inferior division of the thind nerve and the ophthalnie vein, in the interval between the two heads of the external rectus muscle, and ends by piereing the ocular surface of that musele. 


\section{SEVESTH OR FACLAL NELIE}

The seventh or facial nerve is formed hy two distinct parts-the main trunk,

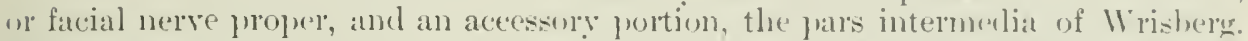
The facial nerve proper arises from an elongated nucleus which is depply plater in the reticular formation of the pons below the floor of the fourth rentricle. This nucleus (ommences at the level of the strixe acustica, and extends bramwarls for about four millimetres. The fibres which arise from it pursue a remarkably tortuents enurere within the substance of the pons. At first they pass lackwands and inwarks (1) as to approach the ependyma of the Hoor of the fourth rentricle clese to the sulas longiturlinalis medianus (crus of origin). They then run upwards and forwarks in a compact bundle (fasciculus teres, or ascending crus), which produces an waration (eminentia teres) on the floor of the fourth rentricle inmediately external to the median fissure. The bundle of fibres then hends, and is directer at right angles to its former course; it arehes outwards orer the nuelens of the sixth nerve, and paseses forwards, outwards, and downwals (issuing crus). In this part of its coulse it passes to the outer side of its om nucleus, leetween the litter and the ascenrling root of the fifth nerve. Finally it emerges at the lower horder of the pons in the interval between the olivary and restiform borlis (-11)erficial origin).

From the above description, it will be seen that the facial nerve anbares the

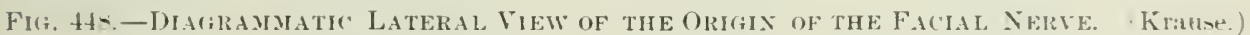

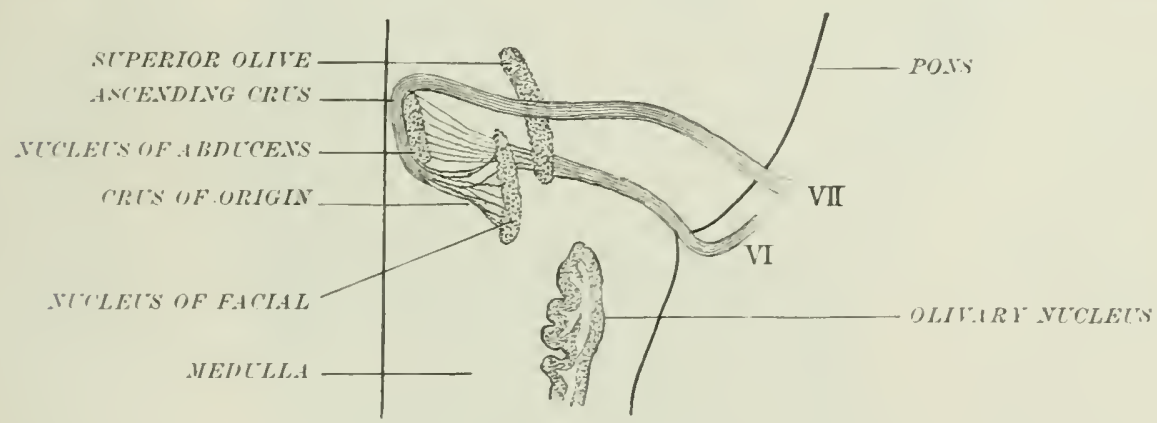

nurlas of the alducens: the term genu nervi facialis internus is alpulind to the nerve in this part of its (ourse. Within the substance of the pons the is:uing lout of the facial nerve is joined hy fibres from the oculo-motere and hypoglosial nucled which pass to it ly moms of the posterior longitudinal bumdle. The filnes from

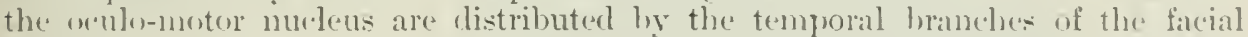
nerve to the (orrugator supereilii, the upper part of thenthenlaris palpwharum and

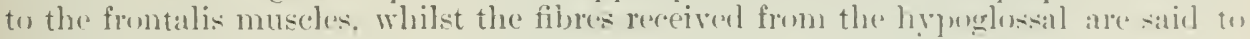
silply the orlic ularis oris.

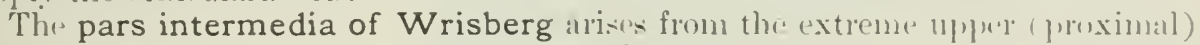

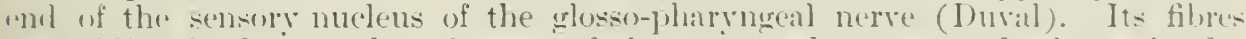
jus: obliquely thougth the substanee of the pons, and emerge at the lower burdur

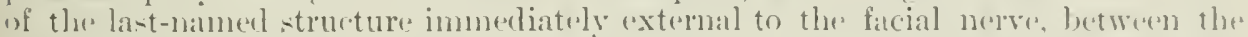
latter and the auditory nerve (superficial orieriu). Thence the nerve jasiss. in thes form of a smatl compict bundle, and (d)ter's the intermal aluditory meatus. In this situation it lies on the upper surface of the auclitory merve, while the fareisl is

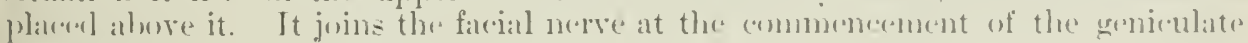
gameliont.

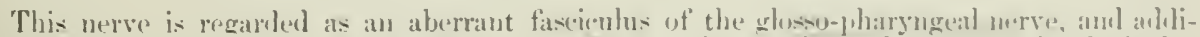

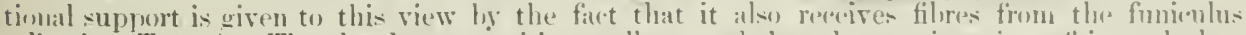

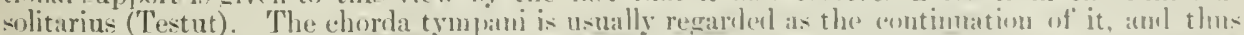
the anterior part of the tomgue receives fibres from the elomo-phargmeal through the churda 


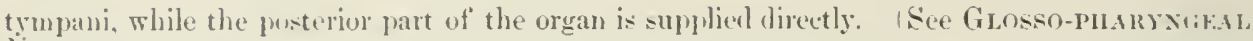
IERTE.)

It its superficial origin the facial nerve is placerl immediately internal to the auditory nerve. the pars intromedia of Wrishere intervening between them. As the facial nerve enters the internal auditory motus, it is placed above the anditore nerve. It then parts conmany with the auditory nerse by entering the andeduct of Fallopius. While traversing the aqueduet, it necessally follows the windings: of that canal. It patses at first outwards and forwards through the lone above and between the cochlea and the vestibule. It then makes a sharpluend, and runslackwards and slightly downords, being separated from the trumpanum in thispart of its comre only ly a very thin sale of lome and hy the number membrane. lining the cavity. Lastly, it runs directly downwards, and emerges at the stylumatstoid foramen. The portion of the nerve corresponding to the first hend is consirlerably thickenel, and contains some nerverells: it is called the geniculate ganglion. The ganglionic substance forms a little conical cap on the benel of the newe, the apex of the cone being directed towards the hiatus Fallopii.

After its emergence from the stylo-mastoid foramen, the facial norve rums downwards and forwards within the substance of the parotid gland, and tirminites by diviling into two divisions-an upper or temporo-facial, and a lower or cervi(n)facial.

The branches of the facial nerve may he classified into three sets:-(1) Branches given off within the aqueduct of Fallopius; (2) hranches from the extracranial portion of the nerve before its terminal division; (3) branches of the temporo-ficial and cervico-facial divisions.

(1) Six branches are given off within the arpueduct: viz. three from the greniculate ganchion, the great, the lesser, and the extemal superficial petrosal nerves; and three from the facial nerve in the descending fart of its course-riz. the nerve to the stapedius, the chorda trmpani, and a communicating twig to the penemu(ralstric.

(a) The great superficial petrosal nerve receives a communicating filament from the trmpanic branch of the glosso-pharygeal, and leaves the anuerluct by fassing through the hiatus Fallopii. It runs forwards and inwards in al grovere on the petrous portion of the temporal hone under corer of the rlura mater. It passes heneath the Gasserian ganglion. and pierces ohliquely the cartiliginous sulsitance which occupies the foramen lacerum medium: here it is joined by the great deep petrosal nerve, and forms, with the latter, the Vidian norve as alrearly described.

(b) The lesser superficial petrosal nerve arises from the geniculate ganglion external to the preceding. It receives a relatively large communication from the tympanic branch of the glosso-pharyngeal. This communication is often considered to be the main root of the nerve (Schwalbe and others). It leaves the andueduct through a canal which is placed extemal to the hiatus Fallopii, and pasises forwards for a short distance, lying in a groove in the bone, under cover of the dura mater. It escapes from the eranium through a small foramen situated between the formen orale and the foramen spinosum (canalis innominatus), and enters the otic ganglinn. Ocusionally it leaves the skull by traversing the suture between the great wing of the sphenoid and the petrous portion of the temporal hone. or by pasing throngh the foramen ovale.

(c) The external superficial petrosal is the smallest of the three petrosil] norves. It passes through a minute canal in the temporal bone immediately external to the point of emergence of the lesser superficial norve. It then runs forminti: under corer of the llura mater. and joins the plexus of the sympathetic on the midclie meningeal artery elese to the foramen spinosum.

(d) The nerve to the stapedius is a minute twig which is given off ly the fictial nerve immerliately below the second bend which the nerve forms within the anneduct. It passes through a small eanal leading from the aqueduct to the interion of the pyramil, and ends in the muscular sulstance of the stapedius.

(e) The chorda tympani arises from the facial nerve about fire millimetres

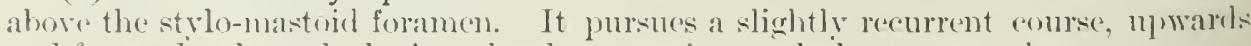
and forwards. through the iter chorda posterius and thus enters the trmipanum. 
It crosses the membrana truphani at the junetion of the upper and middle thinds of that membrame. In this frart of its course it runs forwarels betweren the fibous and

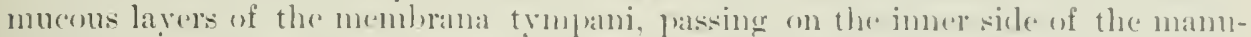

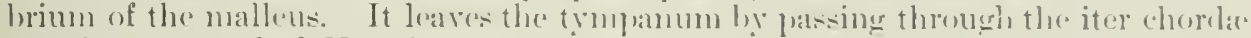

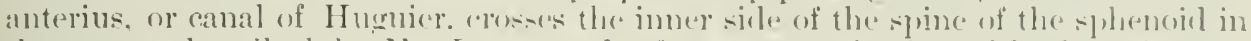
the groove described by $11 \mathrm{r}$. Lucas, and, after communicating with the otic gan-

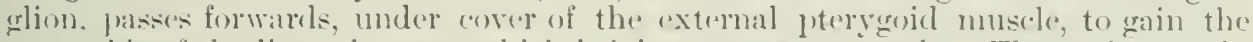
outer sicke of the lingual nerve, which it joins at an aceute angle. Thence it runs in the sheath of the lingual nerve, a portion of its fibres, as already describer (see Lisidal Nerve), gassing into the submindibular ganglion. Other fibres reach the sulilingual grland, and the dorsum of the tongue.

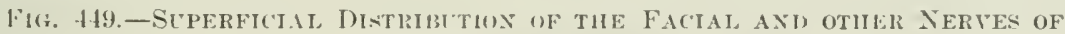
TIL HE.AD. (After Hirschfeld and Leveillé.)

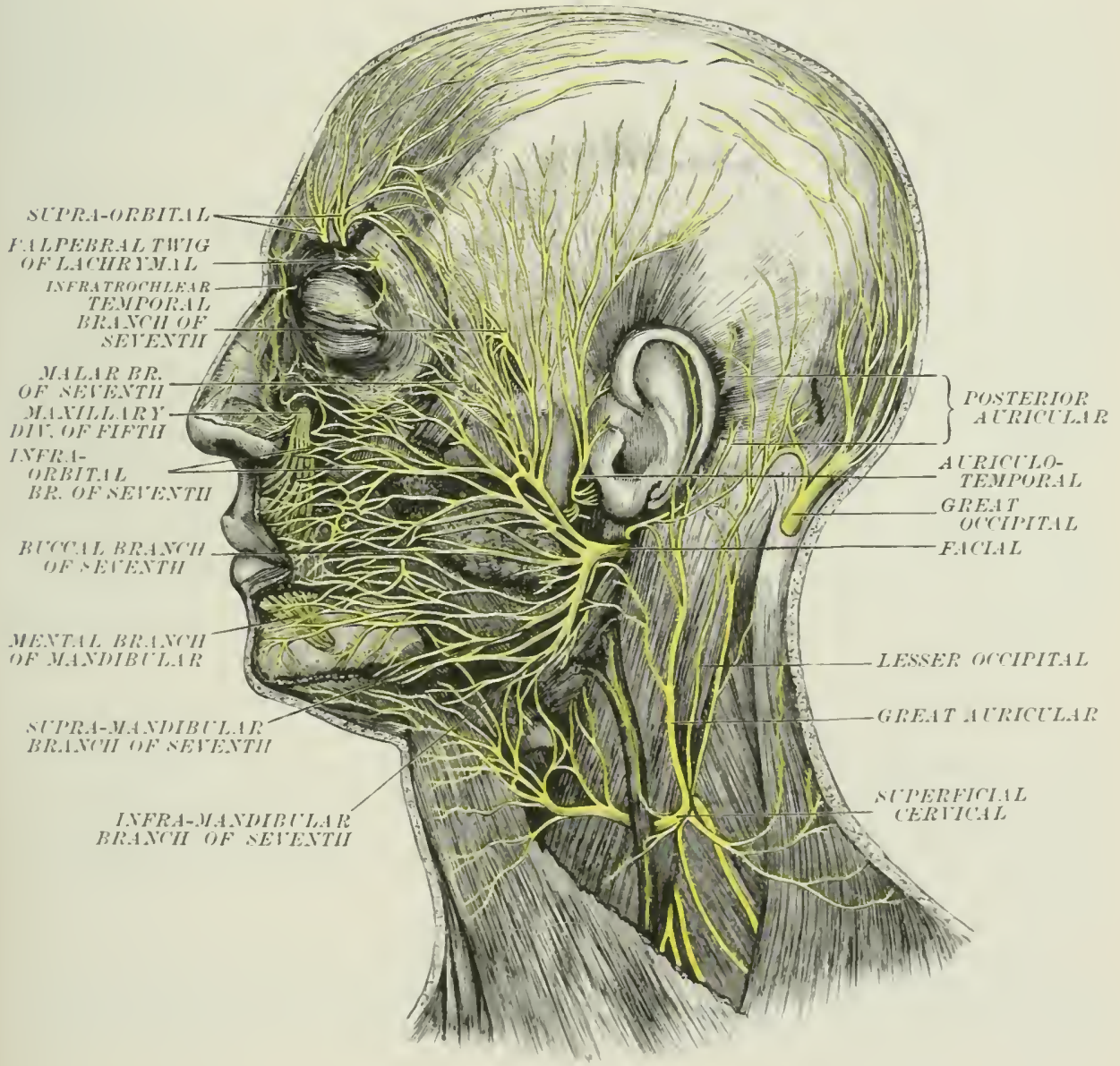

$(f)$ 'The communicating twig to the pneumogastric is giv'll off at the same

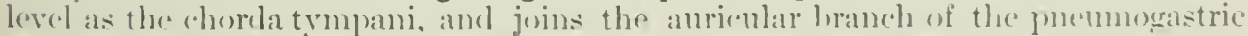
while the latter is traversing the sulstanee of the temporal home.

(2) The branches which arise from the facial nerve between the stylo-mastnicl foranen and the terminal hifureation are the pusterior andicular and the nerves to the posterior helly of the digastrie and to thestrlo-hoverel muscles. A lingual branch is alson described.

(a) The posterior auricular nerve is the first hanch of the extracranial jor-

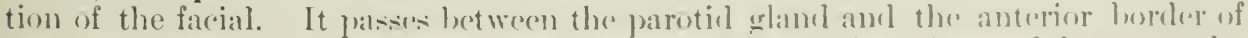
the sterno-matstoid muscle, and runs upwarls in the derp interval luetween the 
external auditory neatus and the mastoid process. In this situation it communicates with the aurieular branch of the pnemogastric. It supplies the retrahens aurem, and sends a slender twig upwards to the attollens aurem, and ends in a long slender branch, which passes backwards to supply the posterior belly of the occipitofrontalis. It also receives filaments from the small occipital and posterior auricular nerves, and supplies the ohlique and transworse museles on the inner surface of the pinna.

(b) The nerve to the posterior belly of the digastric arises from the facial nerve close to the strlo-mastoid formen, and enters the digastric near the centre of that muscle, or sometimes near its origin. It frequently communicates with the glosso-pharygeal nerve.

(c) The nerve to the stylo-hyoid arises at the same level as the preceding nerve, the two nerres sometimes forming a common trunk. It ends in the upper part of the muscle for which it is destined.

The lingual branch is remarkable for its long course. It arises close to the two small muscular nerves above described. It passes on the unter side of the stylo-pharyngeus muscle, and gains the side of the pharynx. In this situation it is joined by filaments from the glusso-pharyngeal. It then passes between the palato-glossus muscle and the tonsil, and reaches the base of the tongue, where it ends in filaments to the mueous membrane and in twigs to the palato-glosiss and stylo-glossus muscles. (Testut.)

(3) Six branches are given off from the two terminal divisions of the facial nerve. These branches traverse the substance of the parotid gland, and emerge at its margin. At their emergence they range from a point on the zygoma, a little in front of the spot where the temporal artery crosses the bone, to the angle of the lower jaw. These branches proceed forwards over the face and front of the neck. and by frequently communicating with one another form a great expanded plexus which is alled the pes anserinus. Taken in order from above downwards, the temporo-facial division gives off the following branches: temporal, malar, and infraorbital. The cervico-facial division divides into buccal. supra-mandibular and infra-mandibular branches.

The TEMPORO-FACIAL DIVISION of the facial nerve runs ohliquely upwards and forwarts through the substance of the parotid gland, crosses the exterinal carotid artery and the temporo-maxillary vein on the superficial aspect of those ressels. and terminates, as above described, in three branches.

In this course it receives communications from the auriculo-temporal nerve, as mentioned in the description of the fifth nerve.

(a) The temporal branch passes upwards throngh the parotid glamel, and emerges at the upper horder of the gland at a point a little in front of the temporal artery. It divides into several branches, which communicate with one another and with the nalar branch. It also communieates with the temporal branch of the orbital, and with the supraorbital nerve. Its largest branches are distributed to the upper part of the orbicularis palpebrarum, and to the anterior belly of the occipitofrontalis. It also supplies the attrahens aurem, the corrugator supercilii, and, occasionally, the attollens aurem.

The fibres which run in the facial nerve to end in the orbicularis palpebrarum, the corrugator supercilii, and the frontalis museles are probably derived from the oculo-motor nucleus of the same side, and pass downwards in the posterior longitudinal bundle to join the genu nervi facialis. (Menclel.)

(b) The malar branch is a smaller nerve than the preceding. It is directed upwarls and forwarls to reach the nost prominent part of the malar bone; it supplice the lower part of the orhicularis palpebrarum. It also gives twigs to hoth ereliwl:; it communicates with the malar branch of the orthital, with the supraorbital and lachrymal branches of the ophthalmie, with the palpeboul twigs derived from the superior maxillary division of the fifth, and with the temporal and infratorlutil branches of the facial.

(4) The infraorbital is the laryost of the nerves which enter into the pes anserinus. It escapes from the parotid glamel ahove stenson's duct, and divides into several branches. These branches commmunicate freely with one another, and pass 
inwards on the derel surface of the zyenmatire and the levator lathi superioris Enrler eover of the latter muscle they communiente with the teminal hranches of the superion maxillary division of the tifth nerve, forming the infraorbital plexus; thence twigs extend to the nose, and communieate with the masal branch of the (1) hothalmic nerve. The infratorbital hranch also forms communieations with otlur branches of the facial, namely with the malar above and with the lenecal below. It supplies the zyomatici, the levator labii superioris, the lexator labii superioris alaeque nasi, the levator angruli oris, the promidalis nasi, the compleresor nasi, and the depressor alie nasi. It also gives twigs to the buccinator and to the orbicularis oris.

The CERVICO-FACIAL DIVISION of the facial nerve is directed forwards anci downwards through the parotid gland, and, like the temporo-facial division, it crosises on the outer side of the external carotid artery. As it traverses the glandular substance it communicates with the facial branches of the great auricular nerve. As above described, it terminates in three branches: the buccal, the supra-mandilular, and the infra-mandibular.

(ii) The buccal branch is of small size, and is the highest of the three branches of the cerrico-facial division. It is placed between the infraorhital and supmermondibular branches of the facial, and communicats with both these branches. It emerges from the parotid gland below Stenson's duct, and erosses the masseter musele. In front of the anterior boriler of the masseter, it communicates with the long buceal branch of the fifth, and then breaks into twigs, which end in the buecinator and orbicularis oris.

(b) The supra-mandibular branch, after escaping from the parotid crlancl. crosices the lower part of the masseter musele, a little way above the angle of the lower jaw, and passes forwards, under cover of the risorius and the depressors of the hwer lip, as far as the middle line. It communieates with the buecal and infra-mandibular branches of the facial, and with the mental branch of the mandihular nerve. It supplies the risorius, the depressor anguli oris, the depressor labii inferioris, and the levator menti.

(c) The infra-mandibular branch lecomes superficial at the lower margin of the parotid gland, and runs oblingely downwards and forwards, under cover of the platysma, across the sicle and front of the nrek. It forms one or more communicating loops. near its commenoment, with the great auricular nerve, and longur lonp. lower down, with the superficial cervical nerve. It supplies the platysua myoirlis.

\section{EIGIITH OR ATDITORY NERIE}

The auditory nerve appears at the lower lorrler of the pons (superficial origin), inmediately external to the facial nerve. It arises ly two roots, a lateral and a mesial. These roots embrace the restiform body, the lateral ront being axternal. and the mesial root internal to that holy (fig. 450 ). The lateral root (superficial. clorsal, inferior, or posterior mot) is continuous with the cochlear norve, and is the true nerve of hearing; while the mesial root (deep, rentral, superior, ar anterior root) is continuel into the vestibular nerve. and is concerned in the maintenaner of equilibrium. The nuclei in comnection with these roots will be first alcsoriberl.

The small-celled or chief nucleus is superficially placerl in the floor of the fourtl rentricle. It is largest in the region of the strige melullares. in which situation it appears in coronal sertions as a triangular grey mass, which reaches the midclle line. It extends formark from this point as far as the abdurems nuelens and backwards for about an equal distance. Both in front and luhind it reeceles from the midlle line. The nerve-rells forming this nucleus are all of small sime.

The large-celled or Deiters' nucleus is placel close to the inmersen of the restiform lody. It is about the sime length as the small-collerl nuclets. hut oceupies a position derpor and further forwards than the latter. The cells of this nueleus are of large size, and are most numerous at the anterior part. It deerene-

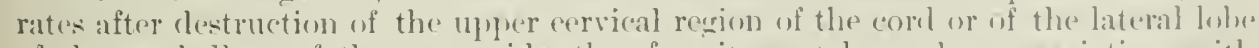
of the cerebellum of the same side. the lefore it must have mase assuriations with these parts, hut it is probably uncmnected with the anditory nerre. 
The accessory nucleus (lateral or rentral nucleus) is a group of cells chicefly contained within the lateral root, but also occupying the angular intersace between the lateral and the mesial roots. It presents marked athinities to a spinal nerveganglion, particularly in the character of the nerve-cells in its anterior (superior) part. Some of the fibres which spring from it pass through the trapezium to the tillet of the opposite side, hy means of which they reach the posterior quadrigeminate body, whilst others terininate in the upper olive of the sime and the opposite sides.

Lateral root.--The lateral root arises chiefly from the cells of the acessory nucleus, but a certain number of fibres are believed to pass by that nucleus without interruption. Both sets of tibres travel in a tolerably compact bundle aromel the outer sicle of the restiform boly. A certain number take origin in the cells of the tuberculum acusticum, the others cross the floor of the fourth ventricle, as strie merlullares, and, having crossed the middle line, take origin partly in the so-called nucleus funieuli teretis of the opposite side, and pass partly into the conductor sonorus. The origin of the conductor sonorus is unknown; its conre has heen noticel in the description of the fourth ventricle (page 719 ).

Mesial root.- This root passes to the inner side of the restiform body and has

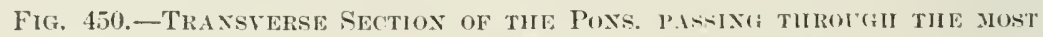
I)ITAL OF TIIE NTRI.E MEDILIARES. (Krause.)

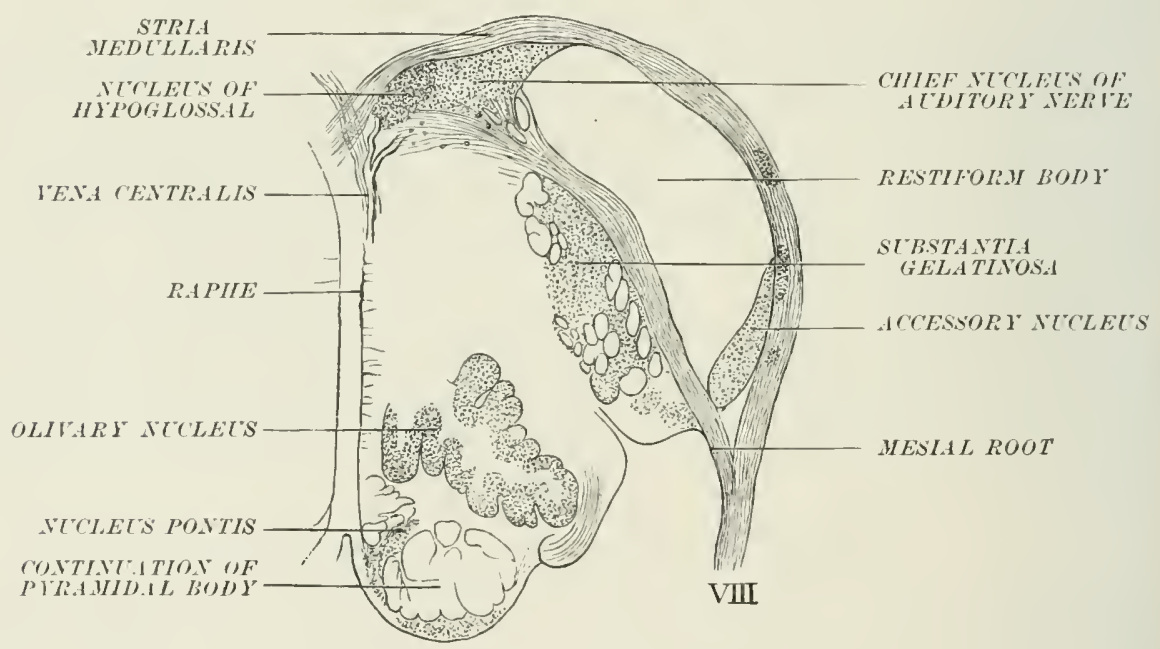

no connection with the rentral nucleus; most of its fibres terminate in the smallcelled, chief, or torsal nucleas, but sone probably pass directly to the cereledlum.

There appears to be but little doubt that the superior temporal convolution is the cortical centre for hearing (Ferrier). Aceording to Obersteiner, the probable links between the nerves of hearing and the cortical acoustic field are as follow: lateral root, accessory nucleus, superior olive, lateral fillet, posterior quadrigeminal body, internal geniculate body, temporal lobe.

The two roots unite at the ventral horder of the restiform body, and the merve thus formed, proceeding upwards, ontwards, and forwards, enters the internal anditory meitus, near the outer and of which it divides into an anterior or upper, and a pesterior or lower bunch. In its course through the meatus, it is accompanied by the facial nerve, the pars intermedia, and the internal auditory artery. These structures are all contained in a common sheath of arachnoil. Within the meatus the anclitory nerve becomes Hattened, and it is eurved in such a mamner as to form a half-erlinder, open above. The pars intermedia lies in the concavity of this halfcrlinder, and above this is the facial nerve, the three nerves being connected by a lax eonnective tissue. This connertive tissue has often been mistaken for norvous communications. ('Testut.) 


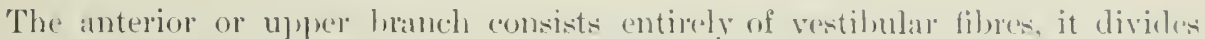
into three parts which pass above the crista falciformis, through the areal cribusil superior, and are elistributed to the ntricle, and to the anpullax of the salperione and external somicireular camals. Cianglionic nerve-cells are found in this part of the merve.

The lower or posterior hranch contains hoth vestilular and cochlear filmes. It gives off the fomer in two twigs which contain ganglion alls, one passes through the area cribresa media to the sirecule, and the other through the foramen singulare to the ampulla of the posterior rertical sinicireular camal. The remaning and larere part of the lower branch comsists of cochlour filnes whing pass through the tractus spiralis forminulentus of the inferior criluriform area into the exintral anal of the modilus and the spiral limmina of the corhlea. They are commerest with the nervecells of the spriral ganglion of the cochlea, and they teminate in the organ of Corti.

\section{NINTH OR GLOSSO-PHARYYGEAL NERY'}

The glosso-pharyngeal nerve is made up of filues dived from three rifferent sourecs. Two of these sets of fibres arise from distinct grougs of cells, and represent the motor part of the nerve and the portion devoted to the special sense of taste. The third set of fibres takes the form of an ascending root (fumiculus solitarius); the round cross-section of which forms a comspicuous object in sections thromgh the lower part of the medulla. The filores fom these three sources amerer in the form of several fascieuli (superficial origin) in the groove between the olivary and restiform bodies, near the lower border of the pons, in series with the roots of the vagus nerve.

The two principal nuclei are called the small-celled and the large-eelled nuclei, and are absolutely continuous with the muclei of the ragus and of the accessory fart of the spinal acessory nerve.

The small-celled nucleus (sensory, or acessorio-rago-glosso-pharvilgeal uncleus ) corresponch for the most part to the ala rinerea in the Hoor of the fourth ventricle. In this situation it lies immerliately extemal to the chiof nurdens of the hypo-glussal nerve. Higher up, it reedes from the middle line, and is more derply phaned. being areared by the chief nuclens of the auditory nerve. It is form this decper (upler) part that the glossis-pharyngeal fihres take origin and these fibres are rexarlerl as the concluetors of the special sense of taste.

The large-celled nucleus (motor moleus, nuclens ambiguus) contains (edls resimbling the motor cells in the anterior herm of the spinal cord, and is regarederl as a portion of the head of that horn which has been anjutated from the neck by the decussation of the pyramids. It is more decply placed than the small-cellat nucleus. It is placed between the molens literalis and external acecsorr olive, and somewhat dorsally to both. It rextends in a sagital direction from the level of the stria merlullares downwarls to a point a little lowow the fourth ventriele. From the upper end of this nueleus fibes pass dorwally and then areh outwards to join

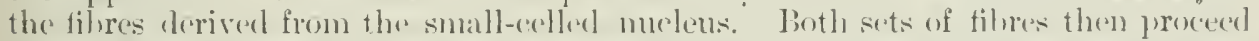
forwards and outwards, juereing the asemeling leot of the trigeminal, and emerge at the rentral nuarein of the restiform locly.

'The ascending root (funculus solitalius) (ommences at at point inmerliately above the level of the deenssation of the pramils. It passes nuwarls in the form

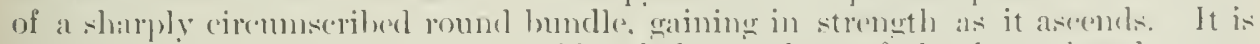
placed at first elose to the outer sirke of the nurleus of the hypeglessal merve:

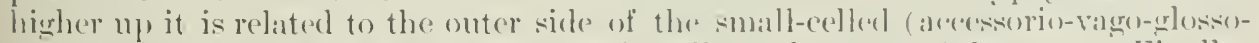

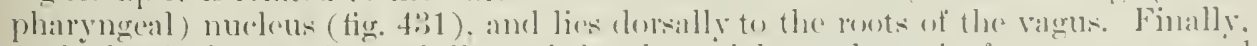
at the level of the striae merlullares, it lemels at right angles fo its formere courese, and rums forwards and outwards, traversing the sulstantial gelatinesil and the asoweling

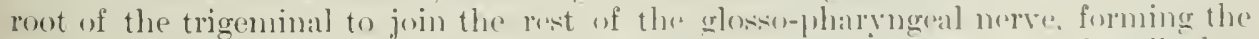

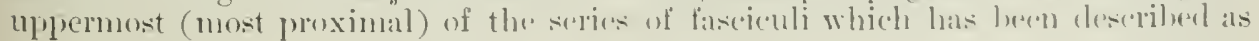
the superficial origin of that nerve. 
The term ascending as applied to the fibres of the glosso-pharyngeal nerve which lie in the funiculus solitarius is unjustifiable. In reality the funiculus consists of fibres of the glossoplarymeal and vigus nerves, derived from the ganglion cells of these nerves, which are jassing downwards to lower levels of the merlulla, and which correspond, therefore, to a certain extent, with the fibres of the desecending eomma-shaped tract of the spinal cort.

From its superficial origin the glosso-pharyngeal nerve proceeds outwards and slightly forwards, below and in front of the theculus, to reach the nirklle compartmont of the jugular formen, which it traverses in common with the vagus and spinal aceessory nerves. As it passes through the foramen it is placed in front of. and a little internal to, the vagus and spinal accessory nerves, but nceupies a separate compartment in the dura mater, and is lodger in a groove on the lower border of the petrous portion of the temporal bone. Having emerged at the hase of the skull, it lirs at first in contact with the vagus, but leaves the latter almost immerliately and passes forwards and inwards between the internal jugular vein and the internal carotid artery and curves round the outer side of the latter vessel between it and the external cirotid. In this part of its course it is placed under cover of the stylo-pharrngeus muscle. It then winds round the lower border of that muscle, and finally passes upwards in front of it and gains the deep surface of the hyoglossus, where it breaks up into its terminal or lingual branches. In the course above described, the glosso-pharyngeal deseribes al curve with the convexity directed downwards and hackwards.

In its course through the jugular foramen, two ganglia are formed upon the trunk of the nerve, the lower of these bodies (petrous ganglion) is the more "onstant. the upper or jugular ganglion being generally regarderl as a segmentation from the petrous ganglion. The two ganglia taken together are generally assumed to be equivalent to the ganglion on the posterior root of a spinal nerve.

The jugular ganglion (ganglion of Ehrenritter) is a small greyish body which involves only the lack part of the nerve. It is lodgerl in the upper part of the groove in the temporal bone through which the norve passes. This ganglion does not give off any branches.

The petrous ganglion (ganglion of Andersch) is an ovoin grevish body which probahly involves all the fihes of the nerve. Its long axis coincides with the axis of the nerve, and measures two or three millimetres. It is placed in the lower part of the jugular fossa. The nerve of Jamolson and some communicating branches arise from it.

Branches.-The following branches are given off by the glosso-pharyngeal nerve:-(1) meningeal; (2) tympanic; (3) communicatiog; (4) muscular; (5) pharyngeal: (6) tonsillar; and (7) lingual.

(1) The meningeal branches are slender twigs which are given off within the cranium, and are distrilsuted to the pia mater and arachnoid. (Bochdislek.)

(2) The tympanic branch, or nerve of Jacohson, is a small twig which arises from the petrous ganglion. It enter's a minute canal (the tympanic canaliculus), which commences bolow on the ridge between the jugulat fossa and the inferior opening of the carotid canal, and ends above, in the tympanic cavity, immediately helow the promontory. The nerve, having traversed this canal, lamifies on the promontory, grooving the bone, and forming the tympanic plexus. The following branches arise from the nerve within the tympanmm: (a) a communicating twig to the great superficial petrosal; $(b)$ a twig to the lesser superficial petrosal, which is eonsidered by some anatomists to be the main root of the nerve; $(r)$ a twig to the mucous memlrane surrounding the fenestra ovalis; $(d)$ a twig to the fenestra rotunda; (e) a twig to the lining membrane of the Eustachian tube; $\left(f^{\prime}\right)$ a twig which passes thromgh the carotico-tympanic canal to join the carotid plexus of the sympathetic.

(3) The communicating branches arise from the petrous ganglion. One joins the superior cervical ganglion of the sympathetie; another forms a loop with the aurieular branch of the vagus; while a third, less constant than the other two, joins the ganglion of the root of the valgus. Immediately betow the petrous ganglion a twig is given off which joins the lingual branch of the facial as ahove described (page 764). 
(4) The muscular branch is distributed to the stylo-pharyngens muscle. This hranch receives a communication form the facial.

According to Testut, the glosso-pharyngeal gives off' carotid branches whicd join the carotid plexus of the sympathetic and also museular twigs to the digantrie, stylo-hyoid, and styleglossus muscles.

(5) The pharyngeal branches may he two or three in mmber, and arise from the nerve a short distance helow the jetrous ganglion. The jorincipal and most constant of these nerves palsises on the outer side of the intemal carotid artery, and after a very short independent course joins the pharyngaal branch of the vagus to form the jharyngeal plexus with that nerve, and with hranches of the superior cervical ganglion.

(6) The tonsillar branches atre a number of small twigs which arise under cover of the hyo-glosisus muscle; these proced to the tomsil, around which ther form a plexus. From this plexus fine twigs proeced to the pillars of the fances and to the soft palate.

(7) The lingual branches arise from the termination of the nerve and procere to the dorsum of the tongue, where they are chiefly distributed to the circumvallate papillse. Some small twigs pass backwards to the follicular glands of the tongue. and to the anterior surface of its epiglottis. Other twigs are distributed around the formen caecum, where they communicats with the corresponding twigs of the mprosite sirle.

\section{TENTH OR PNELMOGASTRIC NERVE}

The pneumogastric or vagus nerve is the longest of the cranial nerves. It is remarkable for its extensive distribution, for the asymmetry which it show in certain parts of its course and distribution, and for the ahmost vertical course which it pursues. It supplins, as its name implies, the lungs and the stomach, but also furnishes branches to the external aar, the pharynx, larynx, osophagus, trachea. heart, and alklominal viscera.

The pnemogratric nerve arises in the medulla in a mamer nearly identieal with the glosiso-pharyngeal nerve, the roots of the former nerve beine a serial contimuation of the roots of the latter. Thus we find that sensory roots arise from the small-celled nucleus (in a position corresponding to the ala einerai in the floor of the fourth rentricle), and motor roots arise from the nucleus ambiguns. The. latter arel round to join the sensory roots. The vagus is also said to le emmected by a few fin filaments with the funiculns solitarius. The roots from these difforent someres unite and pass forwarls and outwards to (merge (superficial origin) in the form of from ten to fifteen fascieuli, lectreen the restiform horly and the lateral column of the medulla. This row of fascienli is in sories above with the

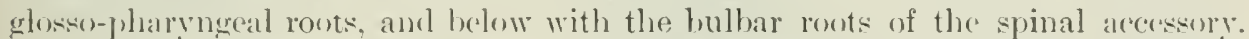
The roots of these three nerves annot he distinguisherl from one another either at their superficial origin, or at the points where they spring from their nuclei in the medulla, unless the connection of the roots with thrir respective trunks has leren preserved.

From its supurficial origin the vagus nerve procerds outwards and slightly upwards and forwarls beneath the floculus to reach tho jugnlar foramen. It traverses the mirldle complatment of the foramen aceompanied by the spinal aceswory and glosso-pharyngeal nerves. The former nerve oceupies the same (ompartment in the clura mater as the vagus. The glosso-pharygeal is provided with a separate sheath, and is in front of and somerhat internal to the other two nerves. As the vagus traverses the jugular foramure it bends at a riglit angle to its former course, and proceeds vertically downwards. In its anuse down the neck it is placed in front of the rectus capitis anticus major and longus colli muscles, but separated from them by the prevertebral layer of the cervical fascoia. In the mpere part of the neck it is placed hetween and on a plane pesterion to the internal jugrular vein and the internal carotid artery. In the lower part of the neck it oeempies at similar position in regard to the internal jugular vein and common carotid artery. the vein being in front and external. and the artery in front and internal to the 
nerve. The threse structures are emelesed in a common sheath derived from the deeplervical fiscoia.

In their course through the tholax the nerves of the left and right sides differ in some respects from each other.

Fig. 451.-Distribetion of the Pnecyogastric Nerve, viewed flodi liemind. (Kraluse.)

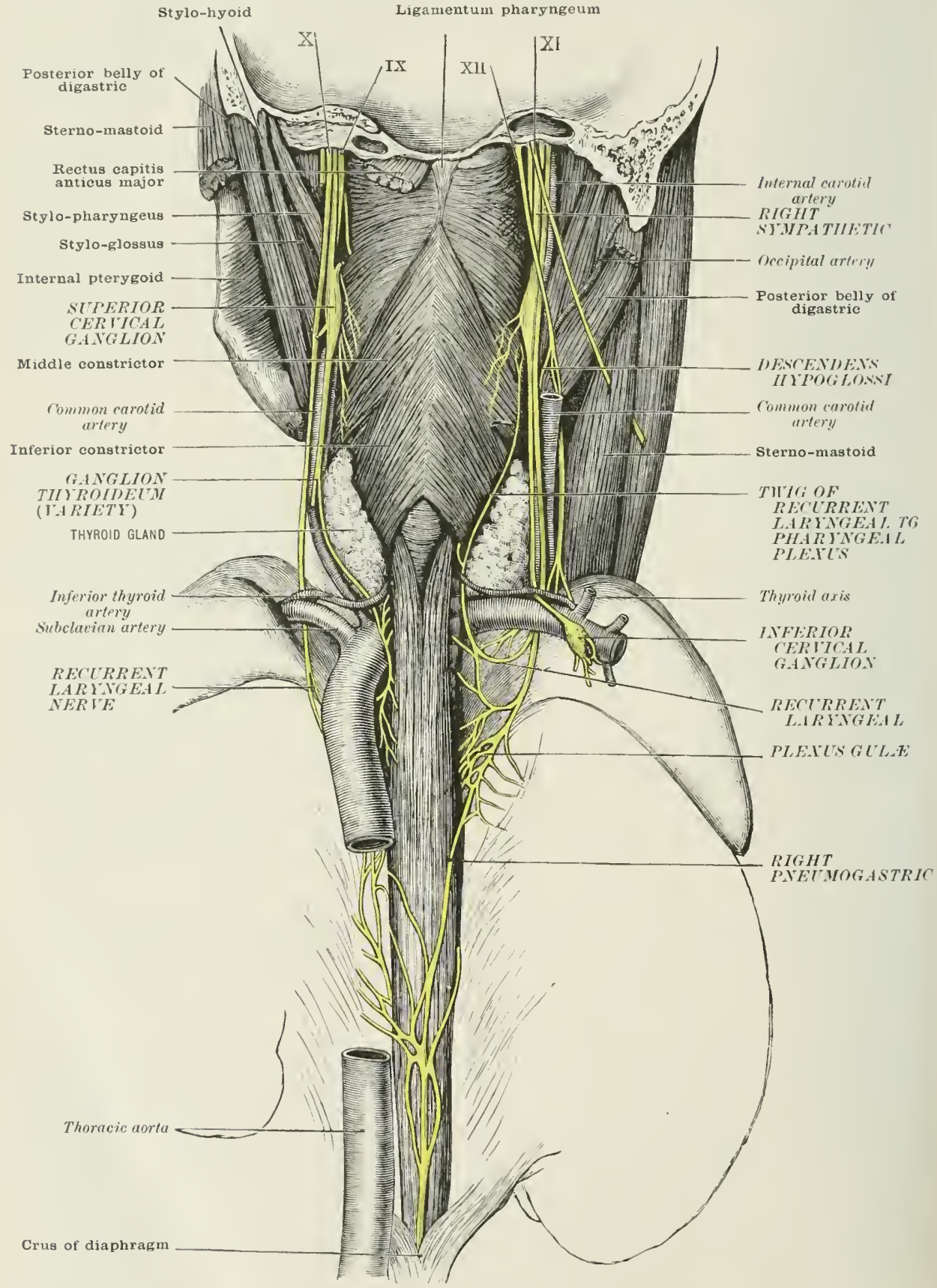

The right vagus nerve passes in front of the first stage of the subchivin artery between the latter and the right innominate vein, ancl then, inclining backwards, 
runs downwards on the side of the trachea, posterior to the right imnominate vein and the superior vena cava, to reach the posterior aspect of the right bronchus. Behind the hronchus it expands into a great, flat, plexiform band, from which the posterior pulmonary plexus proceds. The vagus then inclines inwards in the form of two eords, and conmmunicates with the pnemogastric of the opposite sicle both in front and behind the asoplagus to form the asophageal plexus (plexus gula). Having interehanged a considerable number of filmes with the other nerve, the right vagus then descends (having regained the form of one nerve) behind the orsephagus through the resophageal opening of the diaphragne, and spreads out on the posterior surface of the stomach.

The left vagus nerve enters the thorax behind the left common carotid artery leetwen the lattere and the loft sulvelavian artery. $A$ s it approaches the arch of the arorta it bends suddenly backwards, and crosises the root of the subclavian artery on the left siche of that vessel, immediately under cover of the pleura. It then crosises the left side (in front) of the areh of the aorta, and bends barckwards te reach the posterior aspect of the left hronchus, where it spreach out in a similar manner to the nerve of the right side. It then descends on the asophagus, entering into the plexus gula, and on reaching the diaphragm passes in the form of a single trunk in front of the nesophlagus into the abdominal cavity, and spreats out on the anterior surface of the stomach.

At the base of the skull the vagus presents two ganglia: an upper ganglion, or ganglion of the root; and a lower, or ganglion of the trunk.

The ganglion of the root is placed within the jugular formen opprosite the. jugular ganglion of the glosso-pharyngeal. It is an irregular greyish swelling of from four to six millimetres in length. It is usually regarded as corresponding to at spinal ganglion.

The ganglion of the trunk, situated a little below the preceding, is a fusiform ('nlargenent of the nerve about twenty millinetres in length, and four to five millimotres in transverse climeter at its thickest part. The hypoglossal nerve is firmly attached to it by (onnective tissue and encloses it in a spiral turn, being placed at first to the inner side of the vagus, then passing behind, then to its outer sicle, and finally rosing it in front. The superior cervical ganghion of the sympathetic is lrehind and a little external to the vagus; the glosso-pharyngeal is in front of it. 'The acestory portion of the spinal acessory nerve joins the ganglion of the trunk; some of the filmes running orer the ganglion into the pharyngeal and superion larvengeal branches.

Branches. - The branches of the vagus may be classified into (1) communicatingr Jrimches; and (2) branches of distribution.

(1) Communicating branches.-The ragus communicates with the following neres:- $(a)$ the glosso-pharyngeal to the auricular branch of the pneumogastric'; (b) the spinal acessory; (c) the hypoglossal; (d) the sympathetic; and (e) the upper two spinal nerves.

(a) Besicles the communicating branch to the vagus just referred to, a eonimumicating twig is given off from the pmemogastric, close to the base of the skull, which joins the glosso-pharyngeal nerve immediately below the petrous ganglion.

(b) The spinal accessory gives some fine filments to the ganglion of the root of the vagus within the jugular formmen. Lower down, the remainder of the accessory portion joins the ganglion of the trunk.

(c) The hypoglossal furnishes two or three fine filaments to the ganglion of the trunk of the vagus. 'These filaments are given off by the hypoglossal as it winds round the ganglion.

(d) 'T'wo or three twigs from the superior cervical ganglion of the sympathetic join the ganglia of the trunk and root. Lower down the branches of distribution of the vagus communieate extensively with the sympathetie.

(e) A twig passes from the loop formed by the anterior primary divisions of the upper two spinal nerves to the ganglion of the trunk of the vagus. This (ontmunication is not constant.

(2) Branches of distribution.-These are (a) the meningeal; (b) aturieular; (r) pharỵngeal; (d) superior largngeal; (e) inferior laryngeal; (f) cardiac; (g) pulnonary; (h) astophageil; and (i) abdominal hranches. 
(a) The meningeal "rr recurrent branch is a slender filament which is given off from the ganglion of the root. It takes a recurrent course through the jugular formen, and is distriluted to the dura mater around the lateral sinus.

(b) The auricular branch, or nerve of Arnold, arises from the ganglion of the root in the jugular formen. It traverses the hone, passing to the inmer side of the anueduct of Fallopins; forming a conmmmication with the facial nerve, and emerges behind the pinna, where it divides into two branches, one of which joins the posterior auricular branch of the facial while the other supplies the posterior and inferior part of the external auditory meatus and the back of the pinna. It also supplies twigs to the asseons part of the external anditory meatus and to the lower lart of the outer surface of the membrana tympani.

(c) The pharyngeal branches may be two or three in number. The principal of these joins the pharyngeal lrameh of the glosso-pharyngeal in front of the internal carotid artery, and passes with the latter behind the external carotid artery lownwards and inwarls to reach the posterior aspect of the pharynx. Here the two nerves are joined by branches from the superior cervical ganglion of the sympathetic, and form, with the latter, the pharyngeal plexus.

(d) The superior laryngeal nerve arises from the lower part of the ganglion of the trmk, and passes olliquely downwards and inwards behind and internal to both internal and extemal carotid arteries towards the larynx. In this course it describes a curve with the convexity downwards and outwards, and rlivides into (i) a larger internal and (ii) a smaller extemal branch. Before its division it is joinel by communications from the sympathetic and from the pharyngeal plexus.

(i) The internal branch accompanies the superior laryngeal artery to the interval between the upper border of the thyroid cartilage and the great cornu of the hyoid bone. It passes under cover of the thyro-hyoid muscle and pierces the thyro-hyoid nuembrane to gain the interior of the larynx; here it rlivides into a number of diverging branches. The ascending branches supply the mucous membrane on both surfaces of the epiglottis. The descending branches ramify in the mucous membrane lining the larynx, communicate with the recurrent laryngeal nerve, and supply the mueous membrane which covers the back of the ericoid cartilage.

(ii) The external laryngeal branch runs downwards towards the lower horder of the thyroid cartilage. It pierees the lower filues of the inferior constrictor of the pharyx, and ends for the most part in the crico-thyroid muscle. A few filaments pierce the crico-thyroid membrame, and are distributed to the lining memlirane of the larynx. It gives off a cardiac branch which joins one of the carliac hanches of the sympathetic; it also furnishes twigs to the inferior constrictor and (ommunicating twigs to the pharyngeal plexus, and it receives a communication from the superior cervical ganglion of the sympathetic.

(e) The inferior or recurrent laryngeal nerve of the right side arises at the root of the neck in front of the first stage of the right subclavian artery. It hooks romel the artery, passing below and then behind that ressel, and runs upwarks and slightly inwards, crossing obliquely behind the common carotid artery. Ilaving gamed the sids of the trathea, it runs upwards in the groove between that eamal and the asophagns, accompanied by the inferior thyroid artery, and enters the larynx by passing under cover of the lower burter of the inferior constrictor of the pharynx. It then loreaks up into branches, which are distributed to all the intrinsic muscles of the larynx with the exception of the crico-thyroid, and it commmnicates, as above montioned, with the superior laryngeal nerve. Near its commencement it ustally gives off a eardiac bunch.

In its course between the asophagus and trachea it gives numerous twigs to these strustures, and near the temination it furnishes one or two twigs to the inferior constrictor of the pharynx.

On the left side the nerve arises in front of the aortic arch, and winds roumd the concarity of the arch just hehind the obliterated ductus arteriosus. It crosices obliquely behind the root of the left common arotid artery, gains the angular interval hetween the asophagus and trachea, and corresponds to the nerve of the right side for the remainder of its course and distribution.

( f ) Cardiac branches.- These are named (from the different levels at which 
they take origin) cervical and thoracic, and form altogether three or four pairs of nerves. These all proceed to the deep carliac plexus, with one exception, the inferior cervical cardiate of the loft sicte, which joins the superticial cardiate plexus.

(i) The superior cervical cardiac nerves, we or two in number, join the corresponding branches from the sympathetic. A full account of these nerves will he given in the description of the eardiac plexus. (See SrMpatnetic Srstem.)

(ii) The inferior cervical cardiac nerve of the left side passes downwards on the left sicle of the artic arch between the latter and the pleura. and joins the superficial cardiac plexus. As it crosses the areh the plurenic nerve is in front of it, and the left upprer cervical eardiac of the sympathetic is behind it. 'The right inferior cervical cardiac passes downwarks on the side of the trachea to join the deep cardiac plexus.

(iii) The thoracic cardiac branches usually arise close to and in connection with the recurrent laryngeal nerves; conseguently the nerves on the left sicle arise a little lower than the right. They are directed inwards to the front of the lower end of the trachea to teminate in the deep cardiac plexus.

(g) The anterior pulmonary branches are one or two small twigs, which arise at the upper horder of the root of the lung and pass forwards to gain the anterior aspert of the bronchus, where they communicate with the svmpathetic and form the anterior pulmonary plexus, whence fine twigs pass along the loronchus into the lung.

The posterior pulmonary plexus is formed by a great flattened expansion of the pneumogastric nerve on the posterior aspect of the bronchus. From this several stout twigs proceed, which communicate with twigs from the second, third, and fourth thoracic ganglia of the sympathetic, and pass into the lung, and it anastomoses with the corresponding plexus of the opposite side.

(h) Esophageal branches. - Numerous twigs are given off from the plexus gula as it encircles the osophagus, and are distributed to the muscular and mucous (o)ats of that canal.

(i) Abdominal branches.-The termination of the left vagus nerve passes through the cesophageal opening in the diaphragm on the antrior aspect of the (esophagus, and is distributed over the anterior surface of the stomach. The strongest branches accompany the coronary artery along the lesser curvature of the stomach, and, from these, twigs pass on to the hepatic artery and join the hepatic plexus. The termination of the right vagus is distributed upon the posterior surface of the stonach, and gives twigs: to the coliac, splenie, and left renal plexuses.

\section{ELEVENTH OR SPINAL ACCESSORY NERYE}

The spinal accessory nerve consists of two distinct parts, which are usually known as the spinal and the accessory portions of the nerve. The former of these (spinal portion) is a purely motor nerve which arises from the nerve-cells in the ventro-lateral group of the anterior cornu of the cervieal portion of the spinal cort. The accessory portion, on the other hand, arises ly a series of roots from the distal parts of both the motor and sensory accessorio-vago-glosso-pharyngeal nucled in the medulla, and would be more properly deseribed as the most distal valgal roots (Obersteiner) than as a separate nerve.

The accessory portion (distal vagal roots, or bulbar accessory) consists of four or five fascieuli which arise in a precisely similar manner to the roots of the vagus with which they are in series. Shortly after their emergence from the meclulla they join the spinal portion and acemplany the latter through the jugular foramen. Having gained the exterior of the skull, the hulbar accessory leaves the nerve with which it has been associated in part of its course, and joins the ganglion of the root of the vagus; some of its fibres pass into the pharyngeal and superior laryngeal nerves as already deseriberl.

The spinal portion arises from the rentro-lateral group of nerro-cells in the anterior cornu of the eerrical portion of the spinal cort. Some of the tilires run longitudinally for a short distanee and join other more direet fibres, which arch backwards and outwarks to cmerere from the lateral column of the cord between the 
pristerior nerve roots and the attachment of the liganentum denticulatum. The superficial origin of the nerve is thus constituted hy a row of filaments which extend from the fifth or sixth (ranely the seventh) to the first arvical nerve. The lowest of this series of roots is close to the ligamentum denticulatum; the highest is near to the point of emergence of the posterior roots of the first eervical nerve. The roots mite to form a romeded cord which comres mpwals, increasing in size as it ascenck, and enters the cranial cavity by pasing through the formen mannmm. Here it is joined, for the time being. liy the accessory portion, and passes with the latter, in the form of a single trunk, through the midille compartment of the juenlar foramen. At the base of the skull it runs downwards, outwards, and lack karels hetween the oecipital artery and the internal jugular vem, to pass under cover of the sterno-mastoid musche; it pierees the elavicular filues of the nuscle and communicates with a branch derived from the second cervieal nerve. From the plexus so formed the stemo-mastoid is supplied. The nerve then emerges at the posterior lurder of the muscle, arosws the floor of the posterior triangle of the neck whliquely, and passes under cover of the trapezius; on the derp surface of that muscle the spinal accessory is joined by branches from the thirl and fourth cervical nerves, and forms with them the subtrapezial plexus, from which the trapezius is supplied.

\section{TWELFTH OR HYPOGLOSAAL NERYE}

The hypoglossal nerve arises from an elongated column of nerve-cells which extends from the strice medullares in the floor of the fourth ventricle downwards to the level of the lower end of the olivary body. This colum contains nerve-cells of large size. It represents the neck of the anterior horn of the grey crescent in the spinal cord, and is continued into that structure below. In its lower part the (o)lumn is placed ventro-laterally to the central canal, but, as the central canal expands into the floor of the fourth ventricle, the grey colum is displacerl laterally, and thus apparently occupies a more dorsal position. It corresponds to the area described as the trigonum hypoglossi, and is separated from the ependyma of the ventricle only by a thin laver of medullated fibres. From the cells embedded in this grey columin the nerve-fibres arise. These fibres pass in lumdles which are clirected ventrally and outwards, internal to the olivary nucleus, between the latter and the internal accessory olive. Finally they energe in a row of from tem to twolve filaments in the furrow hetween the olivary and pyramidal borlies, constituting the superficial origin of the hypoglossai nerve.

An aecessury nucleus is also described which is placed ventro-laterally to the above described (or chief) nucleus. This accessory nucleus represents a portion of the head of the anterior horn.

Fibres pass from the inner side of the hypoglossal mucleus, and cross in the raphe fiom where they aseend brainwards to establish the cortieal origin of the nerve.

The filaments unite to form two fasciculi, each of which pierces the dura mater sparately at a point opposite to the anterior condyloid foramen. As these fasciculi traverse the foramen, they mite to form a single trunk, which is placed at first on the inner side of the pmeumogastric, but then winds spirally round the ganglion of the trunk of the latter nerve, massing behind, external to, and finally in front of the ganglion. In this situation the hypoglossil reeeives two or three communitating loranches from the first and second cervical nerves, and some minute twigs from the varus and sympathetic. The hypoglossal then rums forwards and inwarls, describing a curve, the comvexity of which looks downwards and outwarls. It the commencement of this part of its course it erosses the internal carotid artery and hooks round the oceipital artery, passing immerliately below that ressel. It then crosses external to the extemal carotid artery, the lingual artery, the midclle (x)mstrictor of the pharynx, and the hyo-glosisus nuscle, and, passing under cower of the mylo-hyoid, breaks up into its terminal branches. As it lies on the midelle. constrietor the great anm of the hyoil hone is below it and the tenden of the digastric muscle is above it. As it passes on to the hyo-glossus it is crosed on its superficial surface by the digastrice and stylo-hyoid muscles. It is also orerlapped in this situation ly the submaxillary gland. 
Branches. - The meningeal branch (Luschka) is given off hy the hrpoglossal as it is traversing the anterion condroid formen, and takes a recurrent conrse into the cranial eavity, where it is distrifuted to the dura mater. It is probably derived from the communieating branche's of the punemogastrie or from the first cervical nerve.

The remaining hranches of the hrpeghesal may he rlassifierl into loranches of the cervical plexus which are simply adherent for the time lexing to the cranial norve, and true hypoglossal hranche; the latter are exclusively distributerl to the muscles of the tongue and the genio-hyoid.

The BRANCHES DERIVED FROM THE CERVICAL PLEXUS are the descendens hronglossi, and the muscular twig to the thyro-hroid muscle.

The descendens hypoglossi parts eompany with the hypoglossal at the point where the latter hooks round the occipital arteri. It runs downwards amel slightly inwards on the sheath of the great vessels (ocrasionally within the sheath), and is joined at a variable level by the eommunicantes hypoglusi from the scerond and third cervical nerves, forming a loop, the ansa hypoglossi. The ansa hypoglossi may be placed at any level from a point immediately below the oweipital artery to about an inch and a half above the stcrnum. A twig to the anterior belly of the omo-hyoid arises from the descendens hypoglossi in the upper part of its course. The nerves which supply the sterno-hyoid, stemo-thyroid, and posterior belly of the omo-hyoid are given off by the ansa hypoglossi. Twigs from the first two nerves pass in the muscles behind the manubrimm stemi and in rare cases communicate with the phrenic within the thorax. The nerve to the posterior belly of the onn-hyoid rums in a loop of the cervical fascia below the central tenton of the muscle.

The nerve to the thyro-hyoid is given off near the tip of the great cornu of the hyoid bone, and runs obliquely downwards and inwards to reach the muscle.

The TRUE HYPOGLOSSAL BRANCHES supply the stylo-glossus, hyo-glossus, grmio-hyo-glossus, the genio-hyoid, and the intrinsic muscular fibres of the tolngue.

The nerve to the stylo-glossus is given off near the outer borler of the hyo-glossus. It pierces the stylo-glossus, and its fibres pursue a more or less rexurent course within the muscle.

The nerves to the hyo-glossus are several twigs which are supplied to the unscle as the hypoglossal nerve crosses it.

The nerves to the genio-hyo-glossus and genio-hyoid arise under cover of the mylo-hyoid in common with the terminal branches to the intrinsic muscles of the tringue. They communicate freely with branches of the lingual, forming long loops which lie on the hyo-glossus muscle. From these loops twigs pass into the genio-hyo-glossus and into the muscular substance of the tongue. 


\section{SPINAL NERIES'}

The spinal nerves spring from the spinal comel by four long series of routs, namely, an anterior and a posterior series on each sich of the cord. These origins correspond with the superticial origins of the eranial nerves, being the points at which the nerve-fibres emerge from the rerelno-spinal axis. Like the cranial nerves, the spinal nerves luave also a deep origin. 'This is situated in the anterior ant posterior homs of the grey crescents and has been already described (page 738). The spinal nerves also resemble the cranial nerves, inasmuch as this 'deep' origin is only a preliminary interuption in nerve-cells or in plexuses in the grey matter, and from the decp origin tracts of fibres pass upwards to establish a connection with the cerchral cortex. They differ from the cranial nerves inasmuch as they arise from the spinal cord instead of from the encephalon, in their mode of origin by an anterior motor and posterior semsory root, and by the derelopment, on each of the posterior roots. of a ganglion (the spinal gangtion). C'ertain of the cranial nerves resemble the spinal nerves in the two latter respects; for example, the ragus arises from the large-celled (motor nucleus), a derivative of the anterior horn, and from the small-cellert (sensory nuclens) derived from the basal part of the posterior horn; the roots from these two sources have, however, united before the newr has reached the surface of the medulla. The ganglion of the root of the ragus and the ganglion on the sensory root of the trigeminal (Ciasserian ganglion) are clearly homologous to the ganglia on the posterior roots of the spinal nerves. The hypoglossal nerve is, in rare cases, joined by a small posteriol root on which a ganglion is developed, and, on the other hand, cass's are recorded in which the prosterior root of the first spinal nerve was devoid of a ganglion.

The anterior roots stand out in marked contrast to the posterior roots in regard to their function, being motor, whereas the posterior loots are sensory. They also differ from the posterior roots in sereral anatomical points. The anterior roots (with the single exception of the first) are smaller than the posterior; they arise ly four to six fasciculi, and their origins do not form a linear series. but map out is longitudinal area of one to two nnillimetres in breadth on the surface of the cord. The posterior roots are larger than the anterior, ther arise by six to eight fasciculi, are placed in a strictly lincar series, and, as each root is traverwing the corresponding intervertebral foramen, it enters into a spinal ganglion, a structure with which the motor root has no comnection whatever.

The posterior roots are from one and a half to three times as laree as the anterior, the ratio being-

1 to $1 \cdot 5$ in the thoracic: nerves.

1 to 2 in the lumbar nerves.

1 to 3 in the cervical ne'ves.

Course and direction.-From their superficial origin, both anterior and posterior ronts proceed towards the interverteloral formina, and unite near thr outer limits of the foramina into single trunks. The ganglia on the posterior roots are placed, in the case of the majority of the nerves, within the formmina immediately internal to the point of junction of the two roots. The ganglia of the first and second cervical nerves are placed on the lamina of the atlas and axis. The ganglia of the sacral and eocergeal nerves are placed within the spinal eanal. Each spinal gangtion is an oroid grevish hody, the long axis of which corresponds to the axis of the nerve with which it is incorporated. It is somewhat adherent to its meningeal sheath.

The roots of the first spinal nerve ascend slightly to reach the interval between the atlas and the oceipital bone. The second and third nerves gass horizontally outwards, the fourth passes obliquely downwards and ontwards, and the remaining norves pass out with increasing degrees of obliquity, the intraspinal conrse of the nerve-roots increasing in length as the series is followed downwarls. It follow: from the above statement that the lower nerve-roots are directed almost rertically downwards, and as the spinal cord ends at the level of the second lumbar vertebrai, while the series of intervertebral formina is continuer to the lower end of the 
sacrum, the nerve-roots jassing within the vertebral canal hevond the cord form a Ereat sheaf of fibres, the cauda equina (fig. 4:37). The distance of the puints of mergence (superficial origins) of certain of the nerves from the corresponding intervertebral formmina is given in the following table. This table gives the measurements made hy Testut in a sulject of eighteen years. The length of the spinal cord was in this case forty-one centimetres.

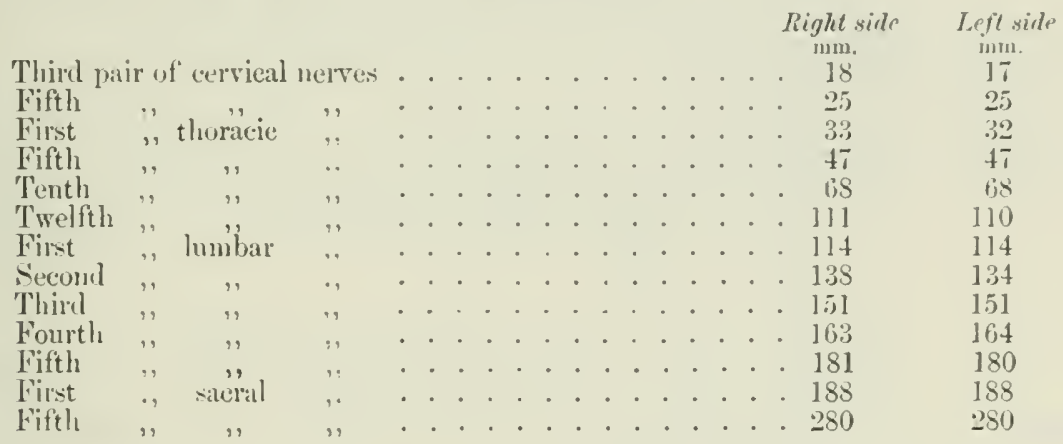

Each spinal nerve, as it enters the intervertebral foramen, is enclosed in a strong tuhular sleath formed by the dura mater. This sheath is at first divided hy a partition into two compartments, one for the anterior and the other for the pusterion ront. The septum soon clisappears and allows the posterior and anterior roots to interningle their tibres. Immediately beyond the ganglion on the posterior rout the sheath thins awa into the epineurium and perineurium of the nerve. The arathoid and pia mater also send tubular proceses around the nerves: these herome continuous with the perineurium, and a comnection is thus established between the lymph spaces around the nerves and the subdural and subarachmoil spaces.

Topography.-The relation of the superficial origins of the spinal nerves to the spinuus frocesses of the vertebre has been investigated hy Nuhn, and more recently by Roirl. In the following table, which is given by the latter anatomist, 1 signifies the highest print of origin; $B$ the lowest point of origin; it gives the extrence limits of origin as olbserved in six subjects. For example, the origin of the sixth thoracic nerve may extend as high as the lower border of the spine of the secomi thoracic vertebra, or as low as the upper horder of the spine of the fifth. but it rlus: not necessillily "xtend either as high or as low as the points inclicated.

Neress

Secoml cervical (A) I little above the posterior arell of atlas.

(B) Midway between posteriur areh of atlis and spine of axis.

Third ., (A) 1 little below posterior arch of atlas.

Fourth $\quad$ (B) Junction of upper two-thirds and lower thir

(B) Yiddle of spine of thirt cervical vertebra.

Fifth " $\quad$ (A) Just below lower border of spine of axis.

(B) Just below lower border of spine of fourtl cervieal rertebra.

Sixth ." (1) Lower border of spine of thiril cervieal vertebra.

$\begin{array}{ll}\text { Seventh ., } & \text { (A) Juwer border of spine of fiftl cervical vertebra. }\end{array}$

(B) Just above lower horder of spine of "ixth cervieal vertehrat.

Figlith ., (A) Epper border of spine of fifth mervical restebra.

First thuracic (A) Yistway hetween spine of fifth cervical and sixth cervieal certebra.

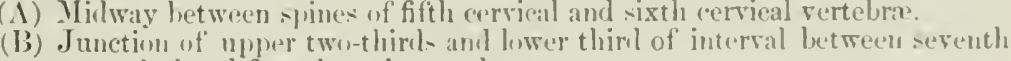
cervical and first thoracie vertelinat.

Second .. (1) Luwer border of spitue of sixtl cerrical rertebra.

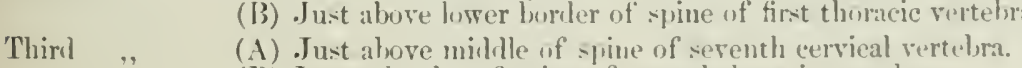

(B) Luwer border of spine of second thoracic vertebra. 
Terces

Fourth thoracic (A) . Just below upper borter of spine of first thoracic vertebra.

(B) Junction of upper thire and lower two-thirds of spine of thirt thoracic vertebra.

Fifth .. $\quad$ (A) Tpper border of spine of second thoracic vertebra.

(B) Junction of upper quarter and lower three-ruarters of spine of fourth thoracic vertebra.

Sixth , (A) Lower border of spine of second thoracic vertebra.

(B) Just below upper border of sjome of fifth thoracic vertebra.

seventh , $\quad$ (A) Junction of upper third and lower two-thirks of spine of fourth thoracic vertebra.

(B) Just above lower border of sjine of fifth thoracic vertebra.

Fighth ,, (A) Junction of upper two-thirds and lower third of interval between spines of fourth thoracic and fifth thoracic vertebre.

(B) Junction of upper quarter and lower three-quarters of spine of sixth thoracic rertebra.

Ninth ., (A) Midway between spines of fifth thoracic and sixth thoracic vertebra.

(B) Upper border of spine of seventh thoracic vertebra.

Tenth ,. (A) Midway between spines of sixth thoracic and seventh thoracic vertebra.

(B) Middle of spine of eighth thoracic vertebra.

Eleventh,, (A) Junction of mper quarter and lower three-quarters of spine of seventh thoracic vertebra.

(B) Just above spine of ninth thoracic rertebra.

Trelfth , $\quad$ (A) Junction of upper quarter and lower three-quarters of spine of eighth thoracic vertebra.

(B) Just below spine of ninth thoracic vertebra.

First lumbar (A) Midway between spines of eighth thoracie and ninth thoracic vertebre.

(B) Lower border of spine of tenth thoracic vertebra.

Second ., (A) Middle of spine of ninth thoracic vertebra.

(B) Junction of upper third and lower two-thirds of spine of eleventh thoracic vertebra.

Third .. $\quad$ (A) Midale of spine of tenth thoracic vertebra.

(B) Just below spine of elerenth thoracic vertebra.

Fourth ., (A) . Just below spine of tenth thoracie rertebra.

(B) Junction of upper quarter and lower three-quarters of spine of twelfth thoracic vertebra.

Fifth ., (A) Junction of upper third and lower two-thirds of spine of eleventh thoracic vertebra.

(B) Middle of spine of twelfth thoracic vertebra.

First sacral (A) Just above lower borker of spine of eleventh thoracic vertebra.

Fifth , $\quad$ (B) Lower border of spine of first lumbar vertebra.

Coccygeal (A) Jower border of spine of first lumbar vertebra.

(B) Just below upjer border of spine of seeond lumbar vertebra.

Classification and number.-There are thirty-one pairs of spinal nerves, viz. eight cervical, twelve thoracie, five lumbar, five sacral, and one coccygeal nerve. 'The cervical nerves are named from the vertebre helow then; the thoracic, lumbar, sacral and cocergeal nerves from the vertebre above them. The first cervical or suboceipital nerve escapes through the interval between the occipital bone and the atlas; the eighth cervical passes through the intervertebral foramen between the seventh cervical and first thoracic vertebre.

General distribution.-Each spinal nerve, at its exit from the intervertehral foramen, gives a small recurrent branch (Luschka), which receives a communicating twig from the srmpathetic, and re-enters the neural canal to he distributed to the meninges and blood-vessels within the canal. Immediately after its exit each nerve divides into an anterior and a posterior primary division. Both the anterior and posterior primary divisions are mixed nerves, containing fibres derived from both the anterior and the posterior roots.

The posterior primary divisions are, with two exceptions, smaller than the anterior divisions. The posterior divisions of the first and second cervical nerve's are larger than the anterior; that of the second ecrvical nerve heing three or four times as large as the anterior division. In the regions of the great plexuses (hrachial, lumbar, and sarral) the anterior division is very nuch larger than the 
posterior, particularly in the case of the upper sacral nervos. The posterior prinary divisions are distributed to the interument of the oceiput, posterior aspect of the nerk, of the back, and of the greater part of the gluteal region. They also sulphly the muscles of the posterior part of the neck and the muscles of the hack, with the exception of such of the posterior cervical and dorsal muscles as are comnected with the superior extremity, the serrati postici, and the levatores costarum.

The anterior primary divisions may be broadly stated to supply the anterior surface of the body from the level of the chin downwards, and also the limbs. Each anterior division is connected with the sympathetic system by rami communicantes. The anterior divisions contrast forcibly with the posterior divisions in the great size that they attain to in the lower cervical and lumbo-sacral regions. In these regions ther communicate with one another to form plexuses, from which a number of branches are given off to supply the limbs.

\section{POSTERIOR PRIMARY DIVISIONS}

The posterior primary divisions of the spinal nerves are, with the exception of the first and second cervical nerves, smaller than the anterior divisions. With the exception of the first rervical, the fourth and fifth sacral and the cocergeal nerves, each nerve divides shortly after its commencement into an internal and an external branch.

CERVICAL NERVES.-The posterior divisions of the first and second cervical recuire separate description. The third, fourth, and fifth cervical nerves ar of small size. They pass backwards at the outer border of the ecmispinatis colli. and divide into internal and external branches.

The internal branches pass between the semispinalis colli and the complexus, giving twigs to both these muscles and to the multifidus spinat. They then pass between the complexus muscle and the liganentum nuchr, jierce the origin of the trapezius, and are distributed to the integument of the hack of the neck. As they enter the fasciae they are directed upwards and outwards. The hranch from the thirl nerve is directed nearly vertically upwards, and is called the third or smallest occipital nerve. It communicutes with the great occipital nerve and reaches the integument of the occiput.

The external branches are distriluterl to the trachelo-mastoirl, the cervicalis ascenclens. the transtersalis colli, and to the splenius.

The internal branches of the sixth, serenth, and eighth cervical nerves pass uncler cover of the semispinalis colli, and end in that muscle and in the ardjacent part of the multifidus spina. The external branches are distributed to the complexus, splenius, cervicalis ascenclens, and transversalis colli muscles.

The posterior primary division of the first cervical nerve passes hatkwards: between the posterior arch of the atlats and the vertebral artery, and traverses the fatty tissue which occupies the triangular space bounded hy the ohliguns superior, the obliguus inferior, and the rectus capitis josticus major. It gives a loranch to each of these three muscles, and a twig which crosses the superficial surface of the rectus capitis posticus major to reach the rectus eapitis posticus minor. Another twig forns a communicating lowp with the great occipital nerve on the posterior surfare of the obliguus inferior. A hrancle is also furnished to the romplexus. In a few cases it gives a cutaneous twig to the back of the aceiput.

The posterior division of the second cervical nerve divill's into a sull external and a very large internal branch. The "xternal lianch gives a twig to the obliguus inforior, and (onds in the (omplexus and trachelo-mastoid muscles. The internal branch is the great occipital nerve. It gives off communicating liranches which pass upwards and downwards, forming loops with the first and third corvical nerves. In this manner a small plexus (posterion (orvical plexus of Cruverilhier) is formed. The great occipital nerve is then clirested upwards. arosing the triangular space described in commection with the first nerve, and being covered by the complexus. It gives one or two twigs to the latter musche, and then pierces it to reach the deep sturface of the trapezius. It priceses the outer lorder of the trape- 
zius immediately lolow the superior curved line, and divides at acute angles into a number of lranches, which ramify in the scalp). These branches communicate treely with the lesser oceipital nerve, and rum in the subcutaneous fat between the skin and the occipito-frontalis. In this situation they are accomplanied by hranches

Fic. 45:- Distribetion of the Posterior Primary Divislosis of THE SPINAL NERVE. (Henle.)

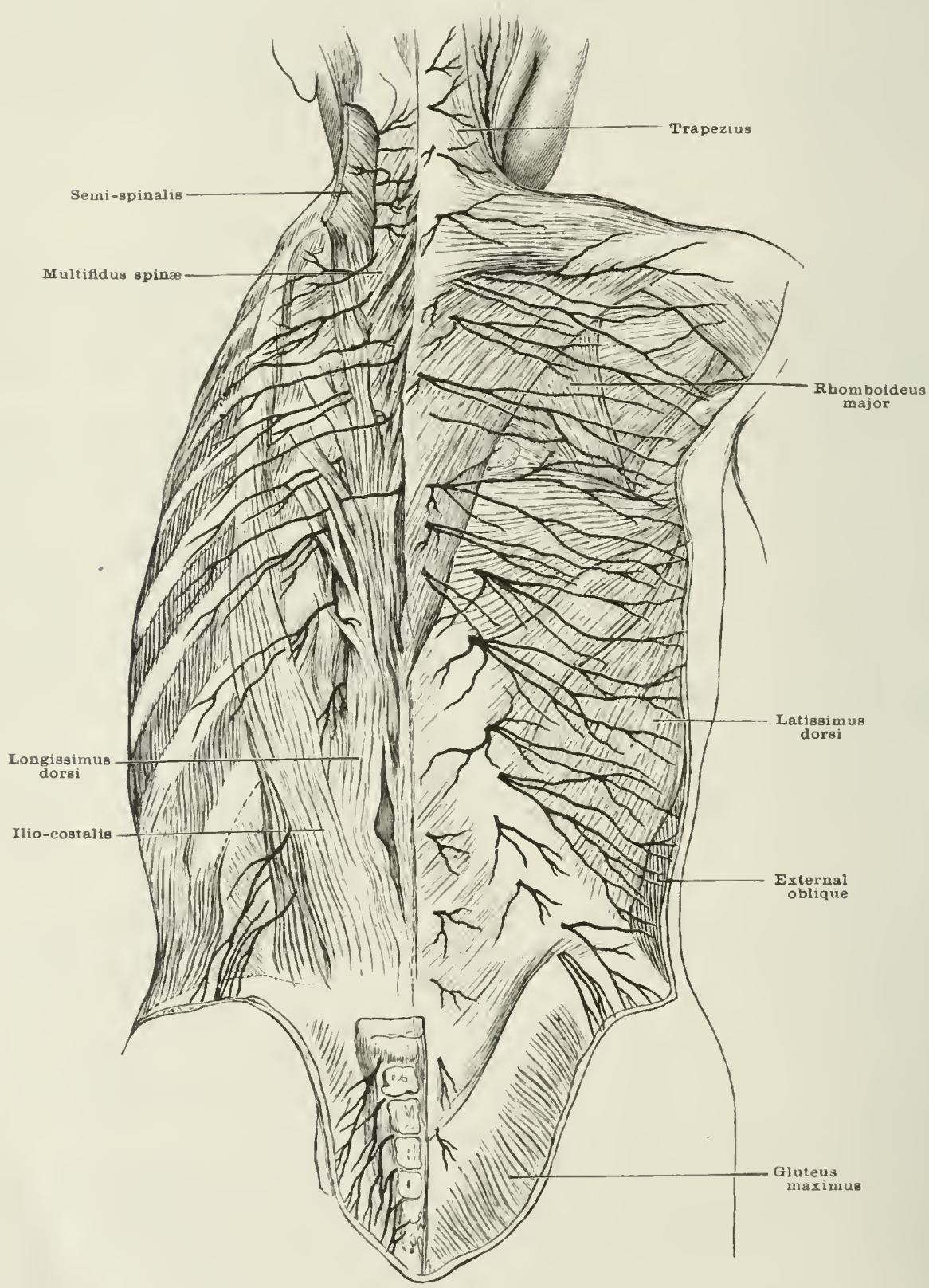

of the occipital artery. They supply the integument which covers the portion of the oceipital bone above the superior eurved line, and the posterior part of the parictal bone. One of them occasionally reaches the pima and supplies the skin on the upper part of its inner aspeet. 
THORACIC NERVES. - The posterior prinary divisons of the thoracie nerves pass backwards between the transverse processes of the thoracic vertebre, and divide into intemal and external hrandese. The internal branches become progressively smaller from the seeond to the last of the series. The external branches show a reciurocal increase in size.

The internal branches pass to the inner side of the longissimus dorsi, giving brameles to that muscle and to the spinalis dorsi, semispinalis, multificlus spinae. rotators spina, intertransversales, and interspinales. Large branches from the upper six or seven nerves reach the surface by piereing the origin of the trapezius close to the spinous processes of the vertebre. They run outwarks in the superti(ial fascia, and supply the integument of the back, including the skin orer the imner half of the infrispinous part of the dorsmo scapulat and the integument over the supraspinous fossa. The cutaneous branch of the second nerve is the largest of the series. From the lower five or six nerves small twigs usually reach the surface and berome cutaneous.

The external branches of the upper six or seren nerves end in the accessorius and longissinus dorsi muscles. The lower five or six, after supplying the adjarent muscles, pierce the outer series of insertions of the longissimus dorsi, and appear in the interval between that muscle and the accessorius. They then pierce the latissimus dorsi, and are distributed to the integument on the lower and outer part of the back.

LUMBAR NERVES.- The internal branches of all the lumbar nerves end in the multificlus spinæ.

The external branches of the upper three nerves, after supplying twigs to the arljacent muscles, pierce the posterior layer of the lumbar aponeurosis at the onter border of the erector spine. The three nerves cross the erest of the ilium and or‘upy different planes in the thick superficial fascia which covers the upper fart of the gluteus medius. The branch from the first nerve is comparativety small, and occupies the most superficial plane. The second oceupies an intermidiate position. The branch from the third nerve is the largest of the three, and oreupies the deepest position; it distributes branches orer the gluteus maximus as fal as the great trochanter. The three nerves communicate with one another and also with the cutaneous branches from the posterior divisions of the two ulyer silcral nerves. The external branch of the fourth lumbar nerve is of smill size and ends in the lower part of the erector spine. The external branch of the fifth lumbar is distributed to the erector spine and communicates with the first Nalcral nerve.

SACRAL AND COCCYGEAL NERVES.-The posterior divisions of the uperer four silcral nerves escape from the neural camal hy passing through the pusterior" salchal foramina; the fifth sarral nerve passes between the sacrmu and oocery. The eocrygeal nerve escapes through the termination of the nemal camal. The uppre three silcral norves divide in the ordinary manner into internal and "xternal bianches, the lower two sacral and the acergeal nerves remain undividerl.

The internal branches of the upper thres salcral nerves are of small size. and arr distributed to the multificlus spina. The extemal hranches unite with ome another and with the extemal branch of the last lumbar nerve to form loops on the prosterior surface of the sacrum. From these loops branches proceed to the posterior surface of the erreat sacro-sedatic ligament, where they communisate to form a second series of loops, whence two or three branches are given off. These branches pieres the gluteus maximus and cone to the surface of that muscle in a line between the posterior superior spine of the ilimu and the tip of the rocerx. They are distributed to the integument over the immer part of the gluteus maximus, and communicate, in their eourse through the superficial fascia. with the fosterior branches of the lumbar nerves.

The posterior divisions of the lower two sacral and of the coccygeal nerve unite with one another and with the posterior hranch of the third sacral, and form loops whence twigs pass to the integunent over the lower end of the cocerx. 


\section{ANTERIOR PRIMARY DIYISIONS}

The antrior divisions of the spinal nerves (with the two exceptions alove mentioned) are langer than the posterior divisions, and each is connected ly one or two rami communicantes with the ganglionated cord of the sympathetic. In the cervieal, lumbar, saeral, and cocygeal regions they combine to form plexuses; in the thoracic region each nerve takes for the most part an independent course, and its typical division into a lateral or chorsal, and an anterior or ventral braneh is very obrious. This division, however, is not confined to the dorsal nerves; it is recognisathle, though with more difficulty, in the lower cervical, lumbar, and saleral regions, and it camnot be clearly distinguished in the upper cervical and cocergeal regions.

CERVICAL NERVES.-The anterior primary divisions of the upper four cervical nerves are of molerate size; each is commected by one or two branches with the staperior cervical ganglion of the sympathetic, and they mite with one another to form a looper plexus, the cervical plexus. The anterior primary division of

Fig. 453.-Diagram of tile Cervical pleates.

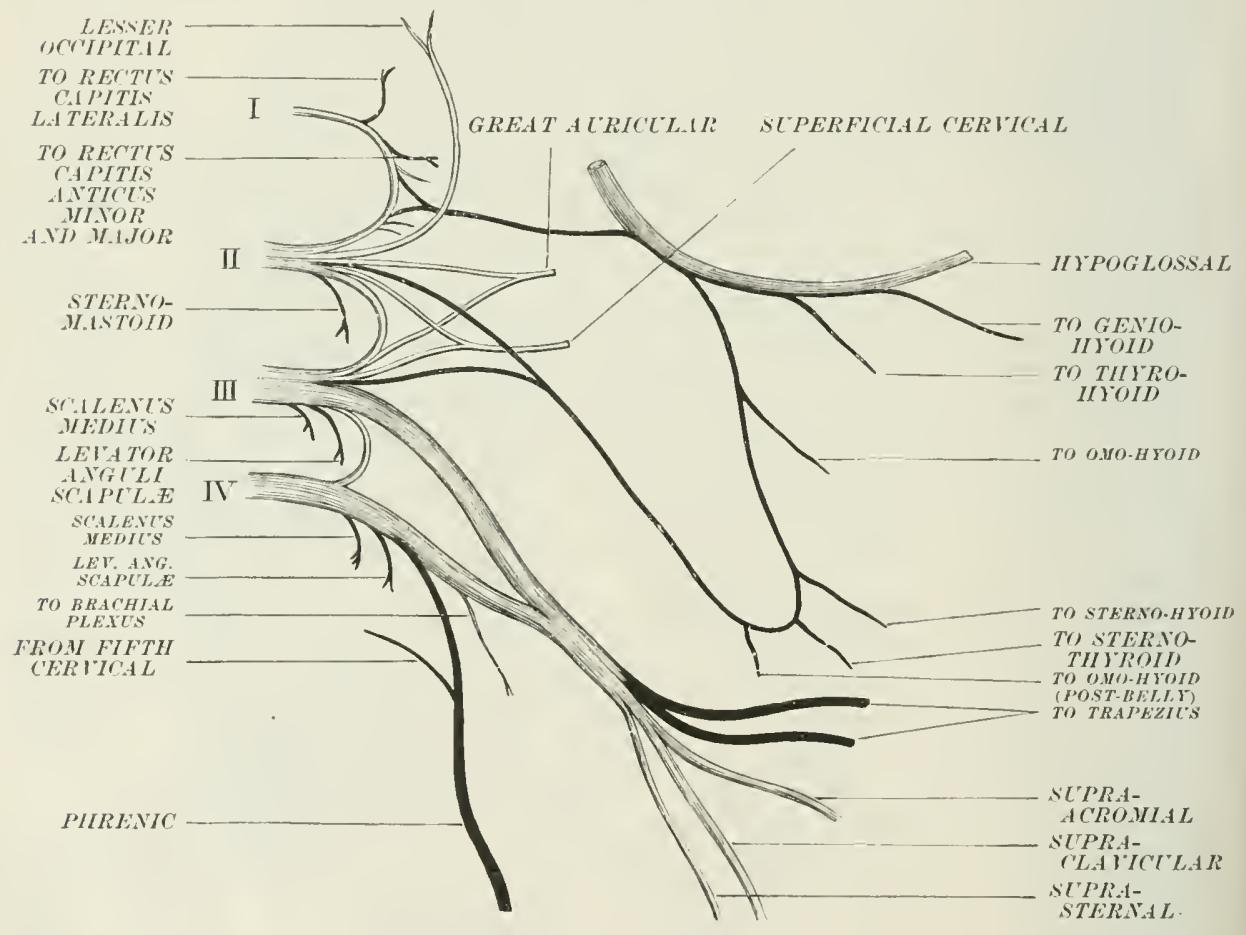

the first cervical nerve, smaller than the posterior division, passes outwards in the groove on the posterior areh of the atlas beneath the vertebral artery, tums forwards hetwen the vertebral artery and the lateral mass of the atlas, and bends downwarls in front of the transverse process of that bone to unite with the second nerve. The anterior division of the second nerve runs outwards behind the superior articular process of the axis, passes behind and to the outer side of the rortebral artery and in front of the seeond posterior intertransverse musele to the interval between the sealenus medius and the reetus wapitis anticus major, where it unites with the first and third nerves. The anterior divisions of the third and fourth nerves, after their exits from the intervertebral foramina, pass behind the vertehral artery and between the anterior and posterior intertranswerse museles to appear in the interspace between the rectus capitis antieus najor and the scalenus 
medius, where the third unites with the second and fourth nerves, completing the plexus.

The lower four cervical nerves increase raljully in size from the fifth to the eighth, and unite with the greater part of the tirst thoracic nerve to form the brachial plexus. Each of these nerves is comnected ly one or two twigs to the cervical sympathetic.

\section{CERYICAT, PLEXCS}

The anterior divisions of the upper four cervical nerves mite to form the cervical plexus in the following manner: the second and third nerves are connecterl by ascending and descending branches with one another, and with the first and fourth nerves. In this way a series of three loops is formed. The fourth nerve is abo comnerted with the brachial plexus by a desending twig. The plexus lios in the upper part of the side of the neck, 11 pon the scilenus medius muscle, and under cover of the upper part of the sterno-mastoir. The lianches of the plexus are classified into a superticial and a deep series. The suprerficial series is subdivided into ascending, transverse, and descemling branches; the deep series into external and internal branches.

\section{Siperfichal Branihes}

Ascending branches.-1. The lesser occipital nerve is derived from the seennl cervical. It passes hackwards and slightly upwards under cover of the sterno-mastoid muscle to reach the posterior border of that muscle. It then ascends, ruming parallel to the posterior border of the musele, being oceasionally overlapyed by it, and passes on to the scalp, where it divides into auricular, mastoid, and occipital branches. (a) The auricular branch runs upwards and slightly forwark to reach the integument on the posterior and upper fart of the pinna, and is distributed there. (b) The mastoid branch is distributed to the skin cowring the hase of the mastoil process. (c) The occipital branches ramify over the occipitalis muscle, and are distrihuted to the skin of the sealp; they communicate with one another and with the great owipital nerve. The branches of the small occipital nerve anastomose with twigs of the posterior auricular, great auricular, and great oecipital nerves.

2. The great auricular nerve arises by two roots, one from the serond, and the other from the third cervical nuve. It accomplanies the lesser oceiprital nerve as far as the posterior horder of the stemo-mastoid. and then wimb round that muscle, and crosses it oldipuely. In this course it runs upwards and forwards towards the tip of the matoid process, and is covered by the skin, superficial fascia, and platysma. At a puint ahout the rentre of its course across the sterno-mastojil muscle, it begins to divide into branches, which diverge from one another as they approach the level of the natstoid process, forming mastoid, amricular, and facial branches. (a) The mastoid branch is small, and is distributed to the integument covering the mastoid process. It anastomoses with the posterior auricular and small oceipital nerves. (b) The auricular branches are thee or four stout twig:which anastomose with the branches of the posterior anricular nerve; they crosic the superficial sufface of the posterior aturicular branch of the facial, and are distributed to the skin on the hack of the pinna with the exception of its uplermost part. One or two twigs pass through fissures in the cartilage of the car, and are distributed to the integument on the onter surface of the lobule and the outce surfice of the lower part of the helix and antihelix. (o) The facial hranches pass upwards and forwards among the superficial lohules of the paroticl and supply the skin over that gland and immerliately in front of it, and they anastomose in the substance of the gland with the cervico-facial division of the facial nerve. In some cases fine twigs may be tracerl forwards nearly to the angle of the mouth.

Transverse branch.- Tht superficial cervical nerve arises from the second and third nerves, and appears at the posterior horler of the stemo-mastoid, a little below the great auricular nerre. It passes transersely across the stemnmastoid under cover of the integuments, ylatysua, and external jugular vein. It 
divides into a number of twigs which spread out after the manner of a fan, and extend, as they approach the middle line, from the chin to the sternum. The upper two or three of these twigs unite, beneath the platysma, with the infra-mandibular branch of the facial, and thus form loops. From the terminal branches of the nerve numerous twigs pierce the platysma to end in the skin of the front part of the neck.

Descending branches.-These are derived from the third and fourth cervical nerves, and arise under cover of the stemo-mastoid. At their commencement they are usually united with the museular branches destined for the trapezius. They

Fi(x. 454. - Superficial Braxches of the Cervical Plexus.

(After Hirschfeld and Leveillé.)

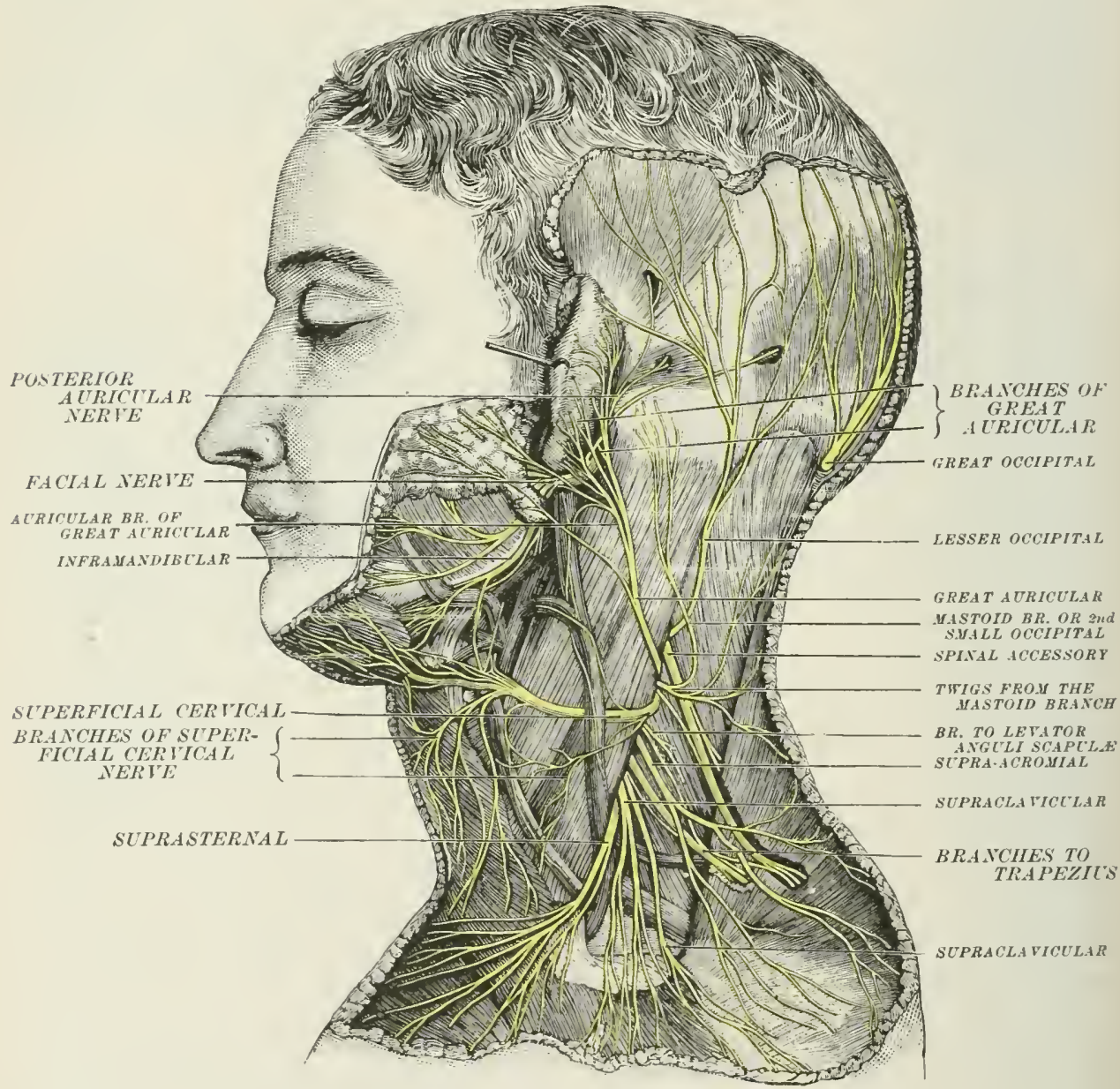

become superficial at the posterior horder of the sterno-mastoid, ahout the centre of that muscle, and are termed supra-sternal, supra-elavieular, and supra-acromial nerves. (1) The supra-sternal twigs are small, and cross over the clavicular origin of the stemo-nastoid to reach the integument wer the upper part of the manubrium sterni. They also supply the sterno-clavieular joint. (2) The supraclavicular nerves, of considerable size, cross in front of the middle third of the claviele under eover of the platysma, and are distributed to the skin, eovering the upper part of the pectoralis major as low as the third rib. (3) The supraacromial branches eross the clavieular insertion of the trapezius and the acromion 
process, and are distributed to the skin which invests the mpere two-thires of the cleltoid muscle. They supply the acromio-clavicular joint.

\section{DEEP' BRAN'HES}

External branches. - Thes's (omsist of communicating branches from the second and third cervical nerves to the spinal accessory, and of muscular branches which supply the sterno-mastoid, scalenus medius, levitor anguli scupula, and traperius.

1. The nerve to the sterno-mastoid arises from the second cervical nerve. It pierces the deep surface of the sterno-mastoid, and (ommunicates within the musche. with the spinal accessory nerve.

2. The nerves to the scalenus medius are derived from the thirel and fourth eervical nerves elose to their exit from the intervertebral formmina.

3. The nerves to the levator anguli scapulæe are clerived from the third and fourth nerves. and occasionally from the second. They pierce the sujerficial surface of the levator anguli, and supply the upper three divisions of that muscle.

4. The branches to the trapezius are usually in the form of two stout twigs: which are given off by the third and fourth cervical nerves. They emerge at the posterior border of the sterno-mastoid, and cross the posterior superior triangle of the neck at a lower level than the spinal accessory nerve. Ther pass under cover of the trapezius in company with the last-named nerve, and communicate with it to form the subtrapezial plexus, from which the trapezius is supplied.

Internal branches.- The internal set of deep branches comprise communicating branches and muscular branches. 1. The communicating branches pats to the ragus and hypoglossal nerves, from the loop formed by the first and seront nerves, and to the sympathetic from all of the four nerves which enter into the (ervical plexus. The muscular branches are distributed to the rectus capitis lateralis, to the reeti eapitis antici major and minor, to the longus colli, to thes lipressors of the hyoid bone (communieantes hypoglossi), and to the diaphragn (phrenic nerve).

2. The branch to the rectus capitis lateralis is furnished to that muscle l,y the first nerve as it crosses the deep surface of the muscle.

8. The nerve to the rectus capitis anticus minor is given off ly the first nerve at the upper part of the luop in front of the transverse process of the atlas.

4. The rectus capitis anticus major receives twigs from the upler four cervi(a) nerves.

5. The longus colli receives hranches from the second, third, and fourth cervieal nerves, and additional branches also from the fifth and sixth nerves.

(i. The communicantes hypoglossi are given off by the second and thirr? cervical nerves, and run ohliquely downwards and inwards in front of the great ressels of the neek to form a loop, the ansa hypoglossi, with the so-called clescerndens hypoglossi. They smply the depressor muscles of the hyoid hone. (sere Hypoglossal Nerte.)

7. The PHRENIC NERVE may arise hy one, two, or three roots, the strongest. and oceasionally the only, rost lecing derived from the fourth eervical nerve. A rout from the fifth is commonly present, and is usually associated either with the nerve to the subchavius or with the communicating branch which passes from the cervical to the brachial plexus. A sender ront from the thind nerve is occasionally present. The ecrical sympathetie also furnishes a communicating twig. The phrenic nerve passes downwards and inwards under corer of the sterno-mastoid. crossing obliquely in front of the sealenus antieus muscle. It is crossed by the transverse cervical and suprascapular arteries, and also hy the onio-hyoid muscle. It passes behind the subclavian vein. and enters the thorix. In this situation it crosses in front of or behind the commeneement of the internal mammary artery and is eommonly joined at this joint hy a commmicating twig from the nerve to the sul,rlavius muscle. On the left sirle it is erossed, in arldition, ly the terminal part of the thoracie duet.

The further course of the phrenic differs on the two sides. On the right side the nerve passes downwards, rmning on the outer side of the right immominate vein, the superior vena cava, and the pericardium, hetween these struetures and 
the pleura. In its course between the perieardium and pleura it crosses in front of the root of the lung. It then pierces the diaphragm immediately on the. feft siche of the opening for the rena eava inferior, and is distributed to the dialphragn, the branches entering the nuscle on its lower surface. On the left

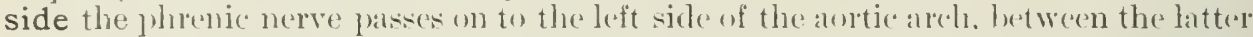
and the plenrat, and in frent of the inferiore crvical cardiate branch of the vagus. It then runs downands betwen the pericardimm and the plemal in front of the root of the lung, taking a longer comse than on the right side in conseyuenee of the inclination of the heart to the left siele, and also on aceount of the lower level of the left "upola of the diaphragm. It pierces the diapluragm immediately to the left of the attachment of the pericatrimm to that musche, and is distributed to its abdominal surface in a similar namer to the nerve min the right side.

Branches. - Minute twigs are supplied (a) to the pleura; and (b) to the pericarlium. (On the right side the nerve communicates with the diaphragmatic plixus of the sympathetic, forming a small ganglion (ganglion diaphragmaticum).

\section{BRICHIAL PLEXIS}

The BRACHIAL PLEXUS is formed by the anterior primary divisions of the four lower cervical nerves and the greater fart of the first thoracic nerve; it is usually joinecl by small communicating twigs from the fourth cervical and second thoracic nerves. The four lower cervieal nerves emerge in the interval

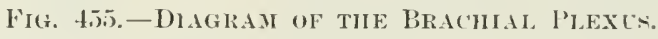

The posterior cord of the plexus is darkly shated.

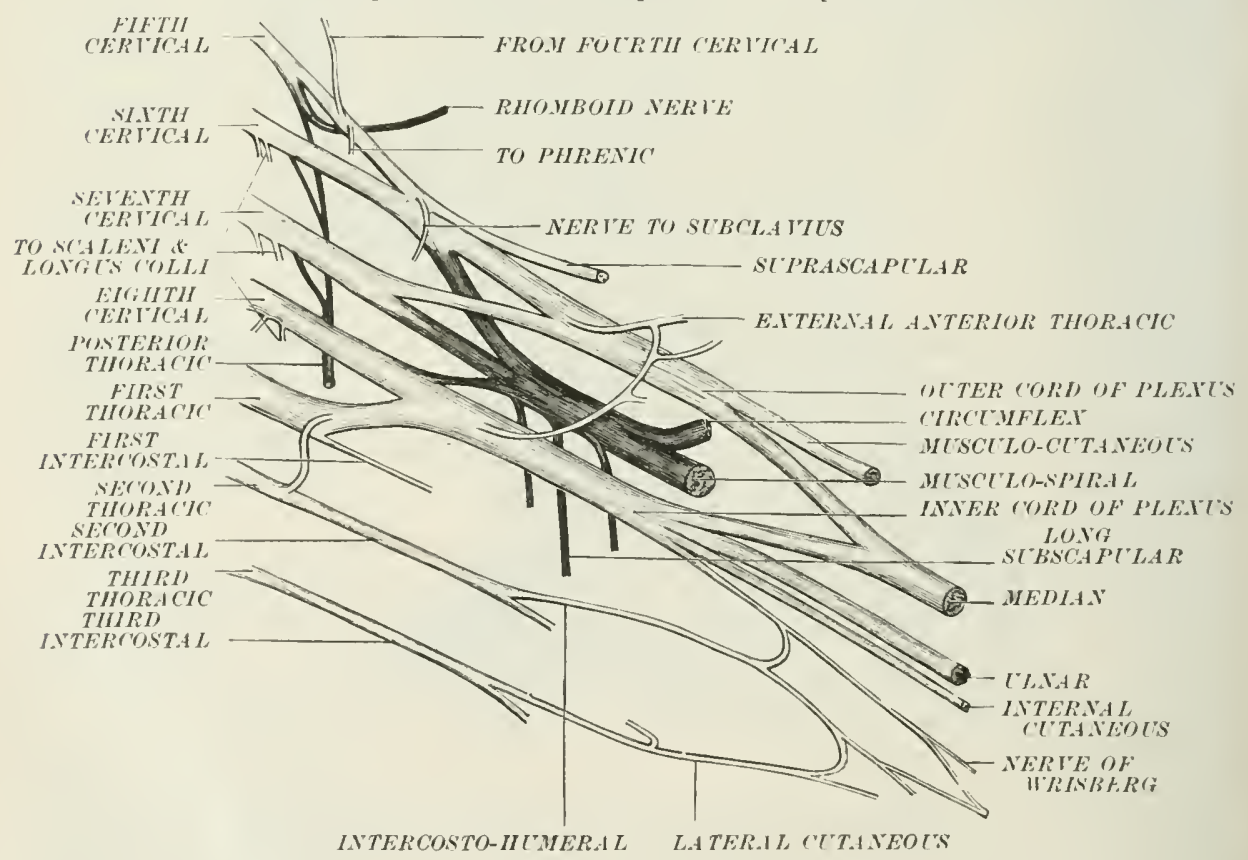

between the anterior and midclle scaleni muscles. The first thoracic nerve, after traversing the intervertebral foramen between the first and second thoracie vertebrar. alpears in the first intercostal space and, after giving off the small first intereostal norve crosses the imner margin and upper surface of the first rib olliquely, and joins the eighth cervieal nerve.

The brachial plexus is divisible into four distinct stages. In the first stage all 
the component nervers alre separate from ealch other. In the secomel stage the nerres unite with one another to form three trunks. In the third stane the trunks divide into anterior and posterior divisions. In the fourth stage the six divisions lecome collerted into threw roumled humlles. which are termerl cords.

The fifth and sixth, and u-ually a communicating twig from the fourth, (crvieal merves unite to form the upper trunk; the serenth remains independent and forms the middle trunk; the eirhth cervicall and first thoracic, with oreasionally a romlmunieating twig from the second theracic, unite to form the lower trunk. Each of these trunks divides into an anterior ame a jesterior clivision. Tlar anterior and posterior divisions of the upper and midllle trunks are albont expual in size. The anterior division of the lower trunk is very und lanerer than the pusterior division. The three posterior divisions unite to form the posterior cord. The anterior divisions of the upper and middlotrunks join to form the outer cord. The anterior division of the lower trunk is continued into the inner cord.

The first stage of the plexus is situaterl upon the midrlle sealene in the posterior triangla of the neek. The second stage is placed in the pusterior inferion triangle of the neck, the lower trunk of the plexus lecing behind the third stage of the sulucharian artery and the upper and middle trunks ahove and on a plane posterior to that resisel. When a posterior sopular artery arises from the third state of the subclavian, it passes hackwards letween the trunks of the plexus. In its third stage the plexus lies moler cover of the claviele and subelavius nuscle. and is placed above, external, and on a plane posterior to the axillary artery. In its fourth stage the plexus is situated under cover of the pectoral muscese and the orrls surround the seond stage of the axillary artery, oceuping the positions indicated by their names, the extemal cord heing in contact with the outer side of the artery, the internal cord on the inner side, and the posterior cord behind the ressel. I little extermal to the outer border of the pectoralis minor. the plexus: terminates by dividing into large nerves, which surround the third stage of the axillary artery.

Thi branches of the brachial plexus are classified into branches which arise alwore the claviele, and branches which are given off below that bone. The branches which arise below the clavicle may he conveniently subdivided into short hranclies which cul in the axilla, and long hranches which arise from the terminations of the thres eords and are destined to supply the shoulder, arm, forearm, and hand.

\section{BR.NTIES GIVEX OFF AHOVE TIIE CLAVICLE}

These are all nuscular branches, and (enuprise the following nerve:- 1 ) supra-apular; (2) rhomhois; (3) pusterior thoracic: (4) communieating to the phrenic; nerves to (i) the subclivius, (6) scaleni, and (7) lonerus colli.

(1) The suprascapular nerve arises from the mpper trunk of the plexus, and therefore contains fibres derivel from the fifth and sixth, and in some cases from the fourth, ("rvicul nerves. It runs dromwards and outwards. "rosses internal to the posterior belly of the omo-ly yoid muscle, and jasses under cover of the trapezius to reach the supriseapular notch; here it rosics the supraseapular artery, and takes a lower pusition than that ressel. It then passes through the supraseaipular noteh beneath the transiorse ligament, and, after fumishing a twig to the shoulder joint. divides into a supraspinnus and an infraspinous branch. The supratspinous brandh inclines inwards and encls in the supraspinatus musele. The infraspinous branch las-ses through the great scapular noteh under (over of the spinu-glanoid ligament, and terminates in the infraspinatus muscrele.

(2) The nerve to the rhomboids ariws from the fifth corvical nerve shortly after its exit from the intervertebral foramen. It arises in common with the upur root of the gonsterior thoracie nerve. and passes hackwards and routwards through the fibres of the scalemus merlins. It then usually rliviles in a julexiform mamme into sereral branches, the strongest of which passes below the lerator anguli scapulae, while the others traverse the lowest division of that muscle and supjuly it with one or more twigs. In the onlular interval betweren the levator and the rhomboideus minor, the twigs reunite to form mo norre, which pass's th the dlecp surface of the two rhombid numseles and supplies thent. 
(3) The posterior thoracic nerve (external respiratory of Bell) arises, by three loots, from the tifth, sixth, and seventh cervical nerves. The upper two roots traverse the substance of the scalenus medius; the root from the serenth passes in front of that muscle. Trigs are fumished to the superior portion of the serratus magnus by the upper two roots; lower lown they unite and are sulsequently joined by the root from the seventh. The nerve now pasises downwards behind the brachial ploxus and the first stage of the axillary artery, and runs along the axillary surface of the serratus magnus, supplying twigs to each of the digitations of that imuscle.

(4) The communicating twig to the phrenic arises from the fifth nerve close to the point where the latter nerve receives the communicating twig from the cervical plexus.

(5) The nerve to the subclavius is a small twig which arises from the fifth nerve or from the upper trunk of the plexus. Its fibres are derived from the fifth or in some cases from the fourth cervical nerve through the communicating trig from the cevical plexus. It rum downwards in front of the third stage of the sub"lavian artery and, after giving off a communicating branch to the phrenic, pierces the posterior layer of the costo-coracoid membrane, and enters the subclavius at the lower borker of that muscle.

Variety.- In rure cases the entire phreuic nerre may pass viâ the nerve to the subclavius in front of the third stage of the subclavian artery.

(6) The scaleni and (7) longus colli are supplied by twigs which arise from the lower two or three ecrvical nerves immediately after their exit from the intervertebral foramina.

\section{Brayches GIVEN OFF BELOW THE C'LAYICLE}

The AXILlARY or SHORT BRANCHES are (1) the extemal and (2) internal anterior thoracic, and (3) the three subscapular nerves.

(1) The external anterior thoracic nerve arises from the outer cord of the plexus; it contains fibres from the fifth, sixth and seventh nerves. After communi(ating with the internal anterior thoracic, it pierces the costo-coracoid membrane and ends in branches which supply the pectoralis major.

(2) The internal anterior thoracic nerve arises from the inner cord and passes forwards between the first stage of the axillary artery and the axillary vein. It contains fibres of the eighth cervical and first dorsal nerves, and it gives branches to the pectoralis minor, some of which pass through the latter muscle and end in the wreat pectoral. The nerve then mites with a branch from the external anterior thoracie, and forms a loop which is placed in front of the first stage of the axillary artery. From this loop additional branches are fumished to the greater pectoral muscle.

(3) The subscapular nerves are branches of the posterior corl. They are three in number, are distinguished as upper, middle, and lower, and are distributed to the subscapularis, latissimus dorsi, and teres major muscles.

(a) The upper or short subscapular nerve is derived from the fifth and sixth cervical nerves. It is distributed exchusively to the subscapularis muscle. It is occasionally double.

(b) The middle or long subscapular nerve contains fibres of the serenth "rrvical nerve; it accompanies the subscapular artery along the axillary margin of the subscapularis musele and ends in the latissimus dorsi.

(c) The lower subscapular nerve, carrying fibres of the fifth and sixth cerrieal nerves, passes behind the subscapular artery, below the dorsalis scapula branch, and is distributed to the teres major; fumishing one or two twigs to the subscapularis, which enter the subscapularis near the axillary margin of that muscle.

TERMINAL OR LONG BRANCHES.-These are given off as follows: from the outer cord, the musculo-cutaneous and the outer head of the median; from the inner cord, the imner head of the median, the ulnar, the internal cutancous, and the lesser internal cutaneons; from the posterior cord, the musculo-spiral and the circumflex nerves. The cireumflex, lesser internal eutaneous, intemal cutaneous, 
and musculo-cutancous ane more proximal in their distribution than the merlian, uhar, and musculo-spiral, and may therefore be first describerl.

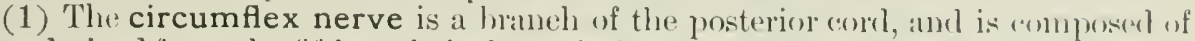
fibres derived from the fifth and sixth cervieal nervess. It aceonumanies the posterior (rirounflex artery through the quadrilateral space bounded by the teres major, long heat of triceps, and subseapularis muscles, and hy the surgieal neek of the humerus, and it divides into a smaller posterior and a larger anterior division. I'perious to its division it furnishes an articular twig to the shoulder joint. This twig pierces the inferior part of the capsular ligament.

(a) The anterior division accompanies the posterior cireumflex artery around the neck of the humerus, and gives off a number of stont twigs which inter the

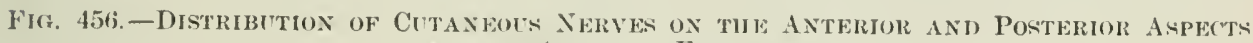
OF THE SUPERIOR ExtREMITY.

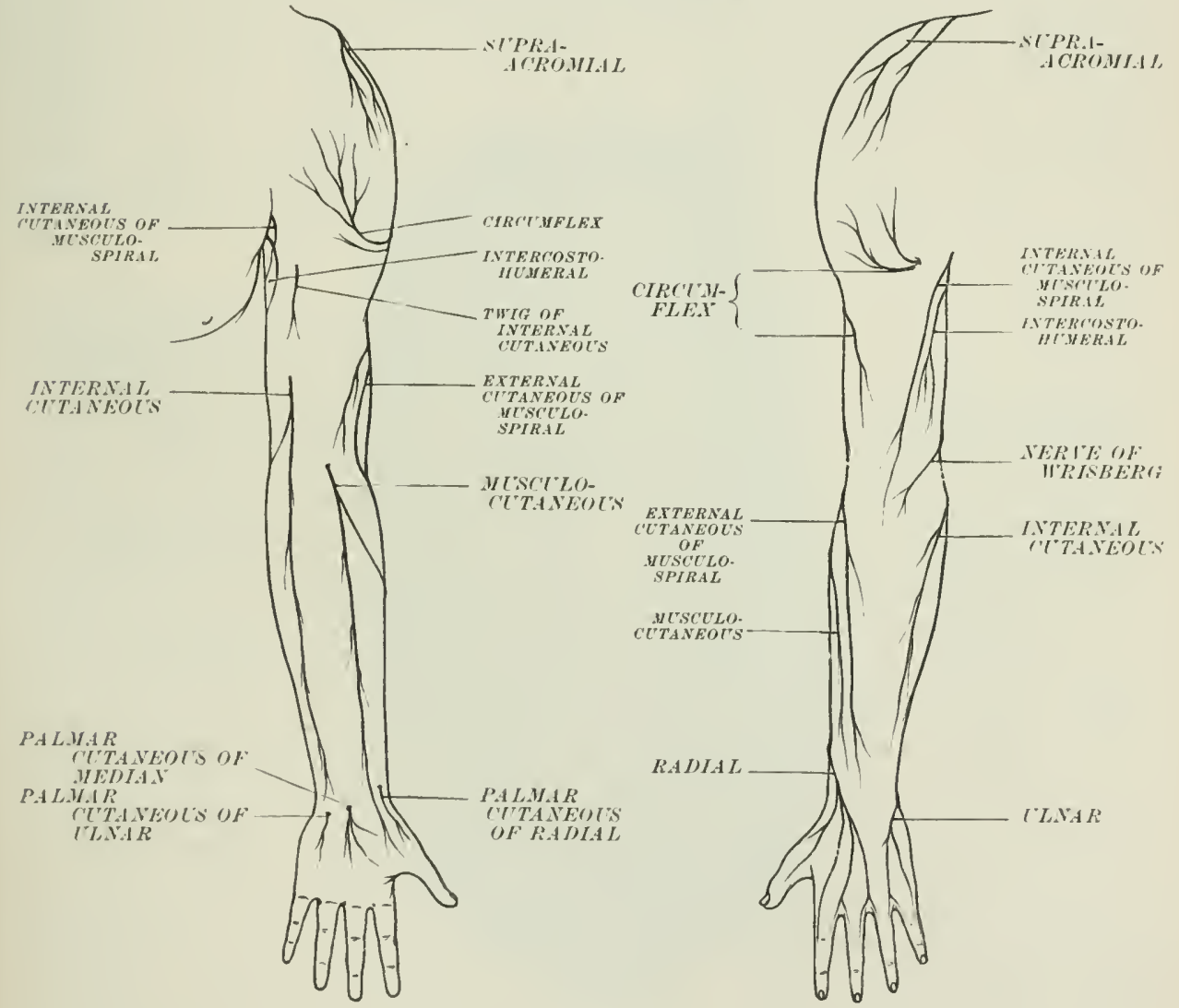

deltoid muscle. A fer fine filaments pierce the deltoid and end in the integument which covers the middle thind of that muscle.

(b) The posterior division divides into entaneous and museulal hranches. The cutaneous branch supplies the skin covering the lower third of the deltoid and a small area of integument below the insertion of that muscle. One nuscular branch is distributed to the teres minor; it swells out into an oroid or fusiforn reddish gangliform enlargement hefore entering the musede, other's suplyly the? lower and posterior part of the deltoid.

(2) The lesser internal cutaneous nerve, or nerve of Wrisberg, arises from the imer cord of the brachial plexus, and is formed of tibres derived from the eighth cervical and first thoracic nerves or from the first thorace nerve alone. It muns downards on the inner side of the axillary rein, heing separited by that 
vessel from the ulnar nerve. It passes downwards with a slight inclination backwarls under (onver of the deep fiascia on the immer side of the arm. At the midelle of the arm it piceces the fascia, and neas the bend of the cllbow it turns somewhat sharply backwards to supply the integument which covers the olecranon process. As it traverses the axilla the nerve of IV risberg communicates with the interestohemeral nerve forming one or sometines two loys. In its course fown the arm it gives a few fine twigs to the integument.

(3) The internal cutaneous is a branch of the inmer corrl, its fibres being ultimately derived from the eighth ecrvical and first thoracie nerves. At its origin it lins on the inner sille of the axillary artery, but it soon passes forwards and lies in the groove botween the artery and the rein anteriorly. In the ulper two-thirds of the arm it lies in front and to the inner side of the lirachial artery.

It then pieres the deep fascia in company with the hasilic rein, and divides into an anterior amel a posterior brancls. Previons to its division it gives off a twig which pieres the deep fascin, ame supplies the intexument of the upper and immer part of the arm. (11) The anterior branch is larger than the posterior, and divicles at acute angles into several twigs, some of which pass in front of and some hehind the median basilic vein, and then run down the forearm to supply the integuments covering its anterior and internal aspect as far as the wrist, anastoumsing with the branches of the ulnar nerve. (b) The posterior branch passes downwals and backwards in front of the intemal endyle of the humerus, and divicles into branches which supply the slin on the postero-intrual aspect of the forearm. It anastomoses with the inferior extemal cutaneous branch of the musculo-spinal nerve and the dorsal branch of the ulnar nerve.

(4) The musculo-cutaneous nerve is a branch of the onter corrl of the brachial plexus. It is composed of fibres which are derived from the fifth, sixth, and serenth cerrical nerves. It is placed at first close to the outer side of the brachial artery, but soon leaves that ressel and pierces the coraco-hrachialis muscle in a direction ohliquely downwards and outwards. Continuing this oblique directiom, it passes between the biceps and brachialis anticus museles, and becomes superfirial at the outer border of the former muscle, a little above the bend of the elbow. It then passes on the deep surface of the median cephalic rein, and divides into an anterior and a posterior branch. P'revious to its division, the museulo-cutaneous nerve supplies three muscles, viz. the coraco-lorarhalis, the biceps, and the brachinlis "mitirus. It also supplies twigs to the humerus, the mutrient artery, and the elbowjuint. The nerve to the coraco-brachialis consists of two or three twigs which are given off from the nerve elose to its origin, and before it has traversed the muscle. In the child this branch rises separately from the seventh cervical nerve. The nerves to the biceps and brachialis anticus muscles arise from the musculo-("utaneous nerve as it is pasing lewwern these muscies. There is a s(p)arate branch for each head of the liecps. The posterior terminal branch is small, and is rlirected downwarls and barliwarls in front of the external condyle of the humerus to he listributed to the skin on the outer and posterior aspect of the foream as low as the wrist. It anastonoses with the radial nerve and with the inferior external cutanenus branch of the musculo-spiral nerve. The anterior branch runs downwals on the outer and anterior part of the forearm, supplying the integment of that region, and hatring communicated near the wrist with the raclial newe, it somets a branel through the deep fascia which arcompanies the raclial artery to the hack of the wrist; it tominates in the skin eovering the midelle piat of the theman' "mineme's

(i) The median nerve is formed by filmes derived foom the fifth, sixth,

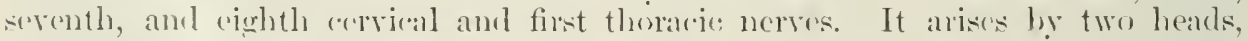

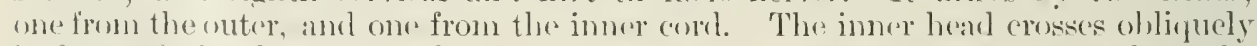
in front of the thimd stage of the axillary artery, and joins the outer head on the external side of that ressel. The median nero runs alnost vertically down the arm uneler eorer of the skin and fascia, and is partially oscrlapped hy the biecps. In the upper part of the arm it is placed on the onter side of the brachial artery. thout the midelle of the arm it resses in front of that ressel, and then rums down on the inner sicle of the artery to the bend of the elbow. It then passes between the two hads of the ponator raclii terese and is separated form the ulnar artery in 
this situation hy the deep head of the musede. It continues vertically downwats: in the midelle line of the forearm between the flexor sublinis and Hexer profundus digitorum; in this part of its course it is aceompanted by a companion artery, the comes nervi meeliani. At the upper borler of the ammula ligament it is julaced between the tendons of the Hexor carpi radialis extemally and the palmanis bongus and flexor sublimis digitorum muscle internally. It passos under cover of the anterior anmular ligament, on the superfielal surface of the flexor tendons, and, at the lower border of the ligament, it enlarwes, and bifureates into two terminal divisions, an immer larger, and an outer smallere.

Branches.-Fhe median nerve does not supply any part of the upere arm. In front of the ellow-joint it furnishes one or two filanents to the articulation. In

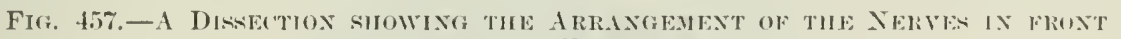
OF TIE ELBOW.

(From a mounted specimen in the Auatomical Department of Trinity College Duhliu.)

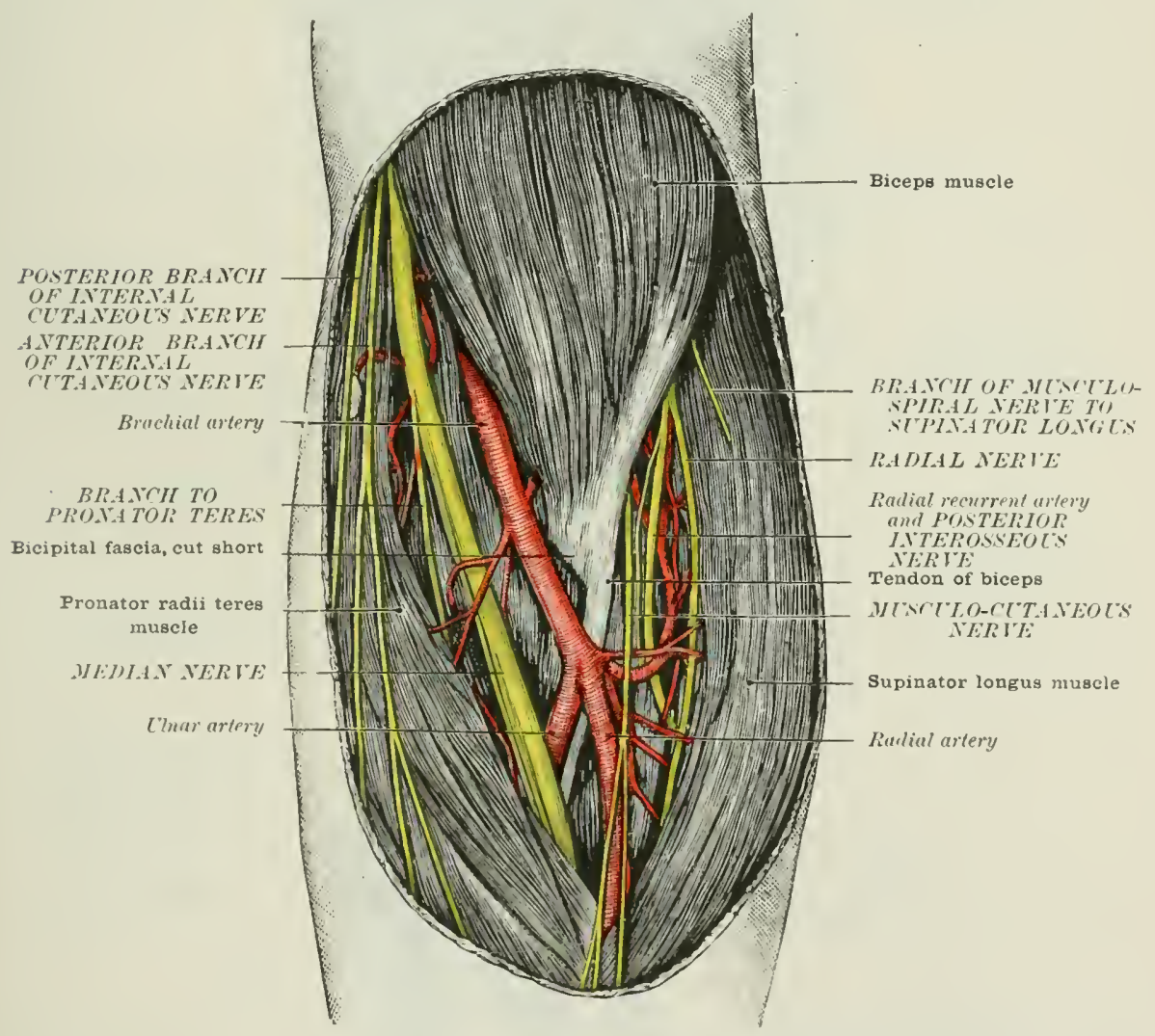

the forearm it supplies all the superficial anterior muscles (with the exception of the Hexor carpi ulnaris) directly from its trunk, and supplies the deep museles (with the exception of the immer half of the flexor profunchs) he its anterior interosseous branch. In the hand it supplies the group of short musches of the thmmb (with the "xception of those which are placed on the uhnar sile of the tendon of the flexor longus pollieis). the two onter lumbrientes. the integument enering the central part of the palm and inner part of the thenar eminenere and the pahmar asperet of the thumb, index, midcle, and raclial half of the ring fingers. It also sends twigs to the dorsal aspeet of these lierits.

(i) The nerve to the pronator radii teres alis's a little atore the luml of the elbow, and pierees the oriter berder of that nutlicke. 
(b) The nerves to the flexor carpi radialis, palmaris longus, and flexor sublimis digitorum arise a little lower down, and pierce the pronator-flexor mass of muscles, to end in the respective members of the group for which they are lestined.

(c) The anterior interosseous nerve arises from the median at the level of the hicipital tuberele of the ratius and run downwards on the interosseous membrane

Fig. 457̈A.-Dissectiox of the LeFt ARy Froy tile Froxt, Sirowisg Portioxs of the

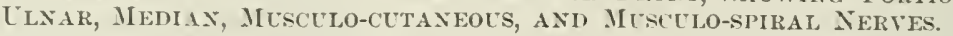

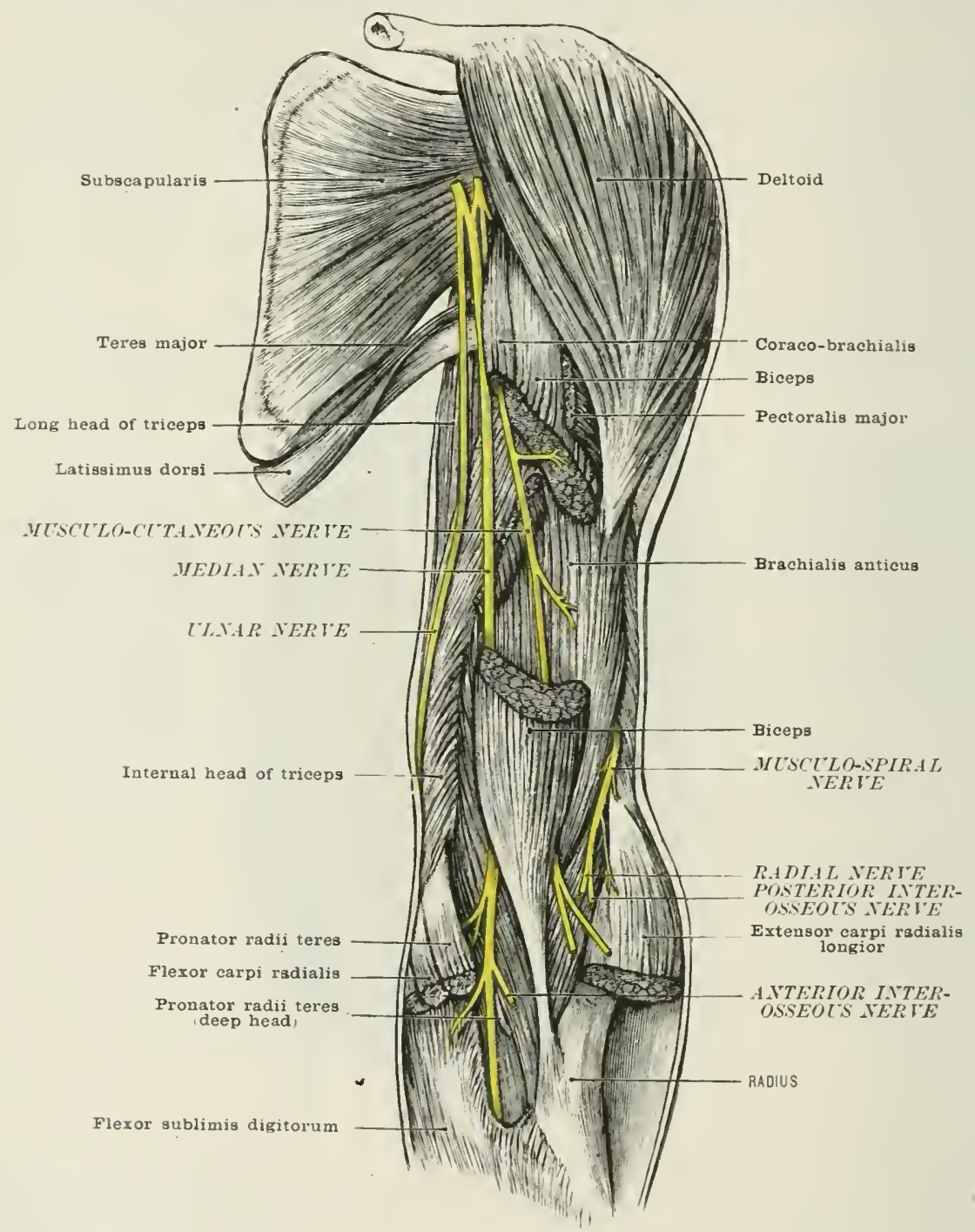

acempanied hy the anterior interosseous artery. It passes under cover of the pronator quadratus, and pierees the deej surface of that musele. The anterior interosseous nerve also furmishes a twig to the front of the wrist-joint and supplies the flexor profundus digitorum and the flexor longus pollicis. The nerve to the former muscle arises from the anterior interosseous near its eommencement and supplies the outer two divisions of the muscle, and communieates within its substance with twigs deriverl from the ulnar nerve. 
It also supplies a branch to the interossenus menthrane which runs downwards upon, or in, the memhrane supplying it ame gring branches to the anterior inter(1)sens and medullary arteries ancl to the periostemon of the ratlius and uhne.

(d) The palmar cutaneous branch arises immediately alowe the anteriol ammlar ligament and passes hetween the tendons of the flexor carpi radialis and the palmaris longus. It then crosies the superficial surface of the ammular ligament, is distributed to the intergment and fascia on the central depressed surfice of the palm, and supplies a few twigs to the inner horder of the themar eminence; these twigs conmunicate with the musculo-cutaneous and radial nerres.

(e) The external terminal division gives off a branch which supplies the. abductor, the opjonens, and the superficial head of the Hexor brevis pullicis muscles, then it divides into two mranches. The outer branch gasses olliquely across the long thexor tendon of the thumb, and runs along the ratial borter of the

Fig. 4ist. Superfictal Nerves of tile Palis. (Ellis.)

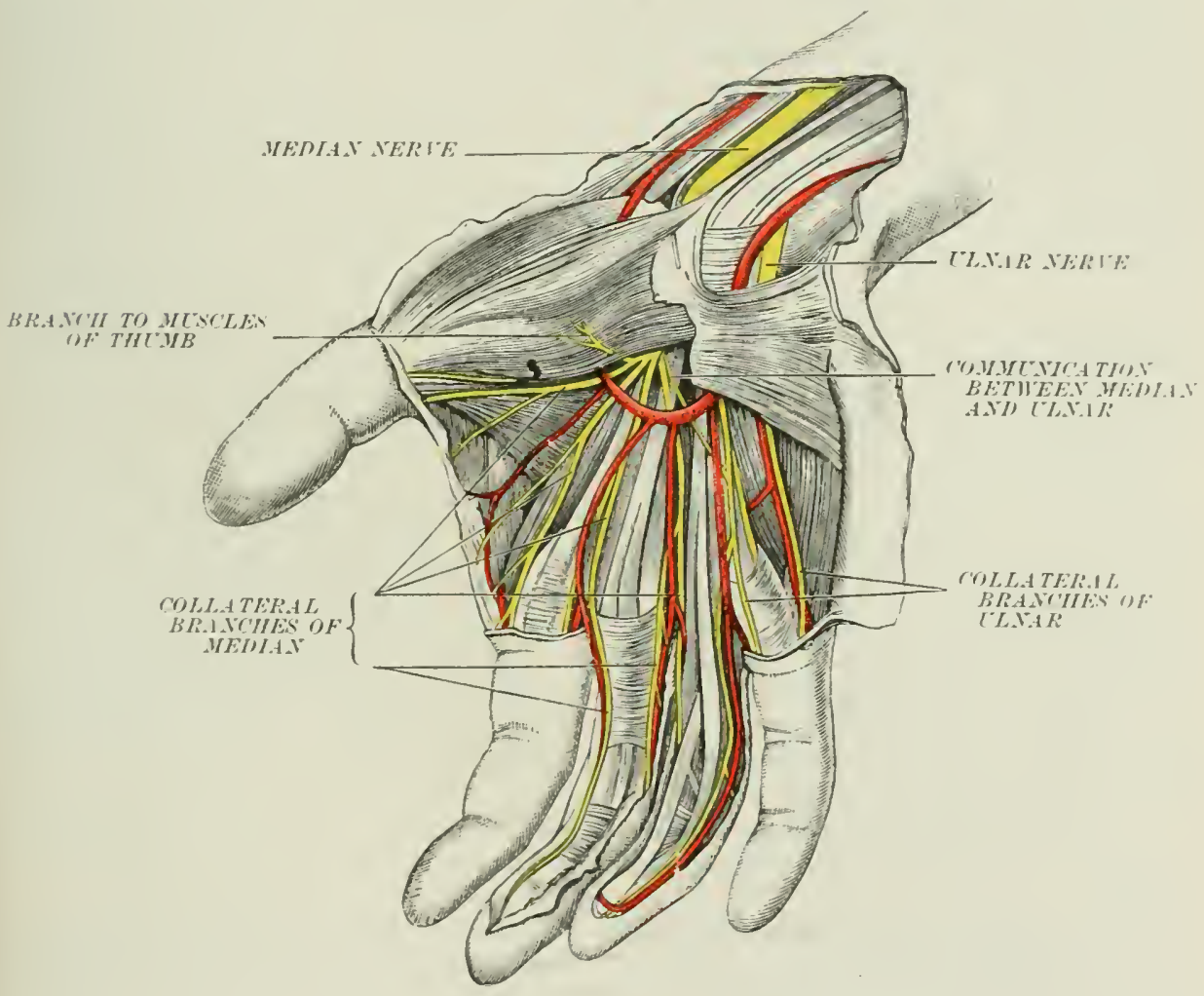

thumb as far as its extrenity. It gives numerous branches to the pulp of the thumb, and a strong twig which passes on to the dorsun to supply the matrix of the nail. The inner branch, after ruming a course varying from an (ightlo to it half an inch, divides into two digital collateral branches. The outer erollateral branch supplies the ulnar side of the volar aspect of the thumb, and gives off al twig to the matrix of the thumb nail. The inner collateral hranch is distributed in a similar manner to the radial side of the index tinger. It gives off a twier (1) supply the first lumbrical muscle.

$(f)$ The internal terminal division divides into an outer and an inner branchl. The outer branch gives a twig to supply the second lumbrieal musche, and divilis a little above the metacarpo-phalangeal artieulation into collateral hranches, which supply the adjacent sides of the index and midlle fingers. and also grive twigs te) the dorsum of each of these digits. These dorsal twigs will he nure particularly 
deseribed later on (1)age 797). The inner branch communicates with the ulnar norve and divides to suply) the adjacent sides of the niddle and ring fingers.

As the branches of the median nerve pass downwarls in the palm of the ham they cross the deep or posterior surface of the superficial palman arch. This relition to the anteries is reversed in the fingers, where the digital arteries are placed behind the nerves. As each digital nerve pursues its course along the margin of the corresponting finger, it gives off twigs to the dorsum of the finger, which supply the skin on the dorsum of the seemd and third phalanges, particularly stout twigs passing to supply the matrix of the mail. Wach nerve terminates in branches to the pulp of the fuger, and on these terminal branches as well as on the more proximal twigs to the volar aspert of the fingers, ovoid bodies, about the size of millet seeds, are developed. These borlies are ealled Pacinian corpuscles, and are one of the forms of sensory nerve-terminations.

(6) The ulnar nerve is the largest hanch of the inner cort of the brachial plexus, and is derived from the eighth corvical and first thoracie nerves. It runs lownwards between the axillary artery and the vein, posteriorly, and preserves the same relation to the brachial artery for the upper third of the arm. It then direrges from the brachial artery at an acute angle, and accompanies the inferior profunda artery through the internal muscular septum and downwards upon the inner hear of the tricegs to the interval between the intemal condyle of the humerus and the olceranon processes of the mha. In this course it in placed under cover of the deep fascia. It then passes between the two heads of the flexor earpi uhnaris, comes into relation with the posterior uhar recurrent artery, and runs downwards moler cover of the flexor earpi ulnaris muscle, hetween it and the flexor profundus cligitorum, to reach the wrist. At the junetion of the upper and middle thirds of the forearn it is joined, at an acute angle, by the ulnar arters, and runs farallel to the inner side of that ressel in the middle and low $r$ two-thirds of the forearm muler cover of the flexor carpi ulnaris, and between that muscle and the flexor sublinis digitorum. Just above the wrist it pierces the decp fascia, enters the hand by crossing the superficial surface of the anterior annular ligament close to the ratial horder of the pisiform bone, and teminates ly hifurcating into a superficial and a deep division.

Branches.-The ulnar resembles the median nerve in not furnishing any hranches to the upper arm. As it passes between the oleeramon process and the internal condyle, it gives off two or three fine filaments to the ellow-joint. In the forearm it supplies the flexor carpi ulnaris and the inner portion of the flexor profundus digitorum, and gives off the three eutancous branches. In the hand it supplies the integmment of the hypothenar eminence, the little finger and half of the ring finger and part of the dorsum; it also gives twigs to the palm and supplixs the short intrinsic muscles of the hand with the exception of the abductor, the opponens, the outer head of the flexor brevis pollicis, and the two outer lumbrirales.

(a) The nerves to the flexor carpi ulnaris and to the immer two divisions of the flexor profundus digitorum arise from the unar in the upper thirel of the furearm.

(b) The Palmar Cutaneous Branch.- Whout the midlle of the forearm it gives off two eutaneous branches; one pierees the faseia and anastomoses with the anterior branch of the internal cutaneous nerve, and the other, the palmar cutameous branch, runs downwards in front of the ulnar artery, and is conducted by the vessed into the paim. It furnishes some filaments to the vessol, and ends in the integrment corroring the central depressed surface of the palm and supplies a fer twigs to the skin of the hypothenar eminence.

(r) The dorsal or posterior cutaneous branch ari-es about two incles above the wrist-joint, and passes backwards under cover of the flexor carpi ulnaris to reach the dorwal asperet of the wrist. It crosses superficial to the tendon of the extensor carpi ulnaris immerliately below the lower end of the uha, and, after griving off twigs to smpply the skin of the dorsum of the hand, elivides inte three Granches, namely: a hranch to the inncre bordor of the little finger; a branch which divides to supply the contiguous borrols of the ling and little fingers, and a branch which enmmunicates with the ralial and participates in the sujply of the adjacent borclers of the ring and middle fingers.

(d) The superficial terminal branch of the ulnar nerve gives off a branch to 
supply the palmaris hrevis muscle, several twigs. which are distributed to the skin (overing the hyputhenar cminemee, and then it divides into two brancher, an innere and an outer. "The inner branch is distributed to the imner side of the little tingere (m) its volar aspect. The outer branch (ommunuieates with the melian merve. and then divides to sulphly the contiguous numgins of the ring and little fingers. "The distribution of these branches to the fingers resembles that of the digital branches of the merlian nerve, which has been alreacty described.

(e) 'The deep branch of the ulnar nerve accompunics the deep branch of the ulnar artery into the interval between the aluluctor and flexor horevis minini rligiti

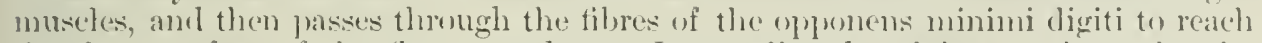
the deep surface of the flexor tendons. It supplies the abluctor, flexor brevis, and opponens minini digiti, the two imer lmbricales, all the interossei, the achluctors, and the inner head of the flexor brevis jollicis. Occasionally it also gives a twig to the outer heal of the flexor hrevis pollicis.

(7) The musculo-spiral nerve is the largest hranch of the liachial plexus It arises from the posterior cord, and contains filmes derived from the fifth, sixth. seventh, and eighth eervical nerves. It is placed at first behind the thirl stage of the axillary artery; lower lown it has a similar relation to the upuer part of the lorachial artery. It soon laves the latter vessel and accompanies the superion profumcla artery into the interral between the immer and outer heads of the triceps. Having followed the spiral groove around the hmmerus, it pierces the external inter-museular septum and runs downwark in the interval betwen the supinator lemgus (brachio-radialis) and the brachiahis anticus museles. A little above the bencl of the elhow it terminates by dividing into the radial and the fosterior interostrulus nerve's.

Branches.-The musculo-spiral nerve gives off three eutanenus branches. nue intrmal and two external, and suppties the following muscles: triceps, anconens. brachialis anticus in part, supinator longus, and extenson carpi radialis longior.

(a) The internal cutaneous branch arises within the axilla, usually in (onmmon with the branch to the long hearl of the triceps. It crosses the tendin of the latis:imus dorsi musele and passes hehind the intereosto-humeral norve to the back of the arm, supplying a strip of integment in the midalle of the dorsal surface extending nearly down to the elhow, and placed between the areas of distribution of the rireumflex and intercosto-humeral nerves.

(b) The external cutaneous branches are distinguished as mper and lower. The upper branch, much the smaller, pierces the deep fascial in the line of the external intermuseular septum; it accompanies the lower prart of the cephalic vein ancl supplies the skin orer the lower half of the outer and anterion asperet of the arm. The lower branch is of rensillerable size. It piores the deep fascia a little. hedow the uppre branch, runs behind the external condyle, and supplies the skin of the mirllle of the back of the forearm as far as the wrist. anastonosing with the intronal eutaneous and musculo-eutanens nerves.

(i) Muscular Branches.-Muscular hranches are givou off in the axillat to the loug and internal heads of the triceps; one of the latter is a long filament which acrompanjes the ulnar neve and is known as the unar collateral. At the balek of the humerus museular luranches are given to the outer and inner heaels of the tri-

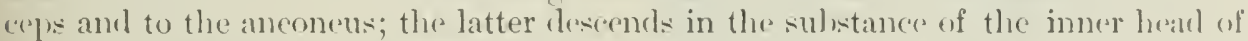
the triceps acompanied hy a hranch of the superior profunda artery. At the outer sirle of the limmerus branches are supplied to the supinater longus, the extensole carpi radialis loneror, and to a seetion of the luachialis anticus; from one of these an articular twig is given off to the ellow-joint.

(d) The posterior interosseous nerve passes clownwarls in the interval

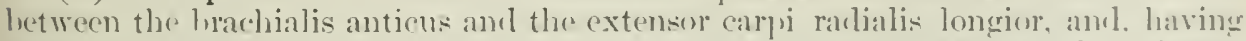
given off liranches to supply the extensor earpi rarlialis hrevior and supunator

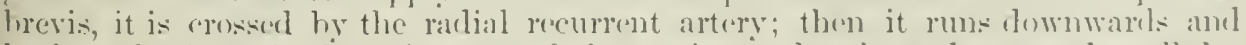
backwarls through the substance of the smpinator lorevis, and enters the collular interval betwen the superfieial and deep layers of muscles at the back of the forrearm; here it cones inte relation with the josterior interoseness artery. which it

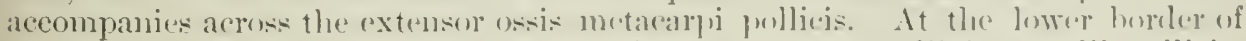

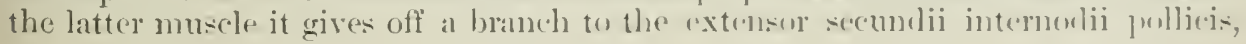


and another which erose the secundii internodii pollicis to reach the extensor indicis: then. leaving the pusterior interoseous artery it dips beneath the exten-or secundii internodii pollicis and comes into relation with the anterior interosens artery, which it accompanies upon the interoseous membrane and the back of the radius. passing through the groove for the extensor communis digitorum and the extensor indicis. to the hack of the wrist. where it terminates in a gangliform enlargement. from which branches are given to the carpal articulations. The muscles -upplied hy the posterior interosseous nerve are the extensor carpi radialis hrevior,

Fig. 459.-A DISSECTIOX OF THE CtTANEOT NERTES ON THE DURSAL ASPECT OF THE HAND AND FINGERS. H. St. J. B.)

The branches of the median nerre are shown in black.

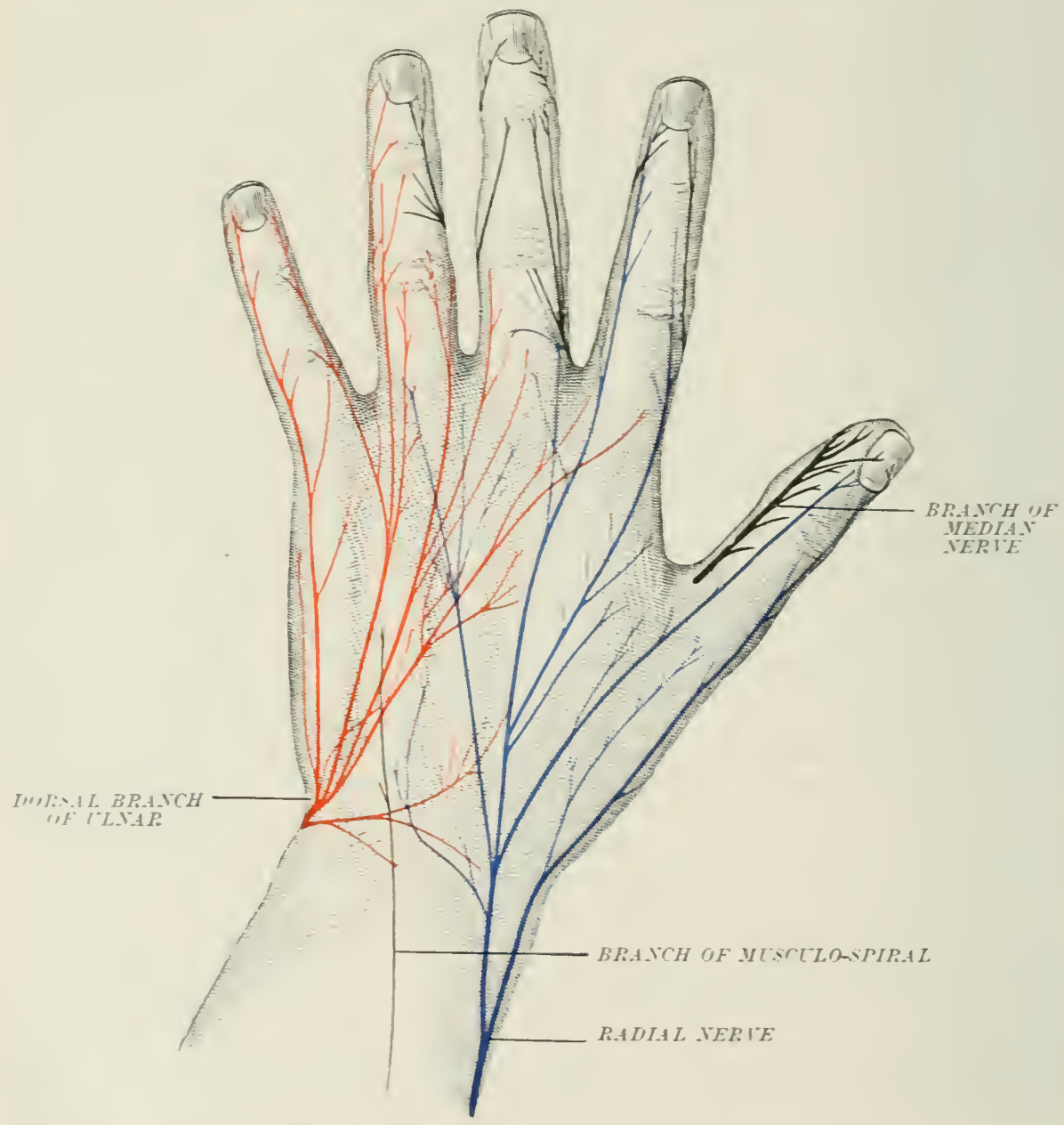

the supinator brevis. the extensor communis digitorum, extensor minimi digiti. extensur carpi ulnaris, the three extensor muscles of the thumb, and the extensor indicis. The supinator brevis receives two twigs. one of which is given uff before the merve pierce the muscle, and the other while it is traversing the muscular $=$ ulbitance.

(i) The radial nerve is somewhat smaller than the po-terior interoseous, and is a furely cutanenus nerve. It runs downwards uncler cover of the supinator longus, crowing the radial recurrent artery and the supinator brevis: it approaches the radial artery at an acute angle. and runs parallel to the outerside of that ressel 
in the middle third of the forearm, crosing the pronator radii teres. It then parts company with the artery by bending backwards on the dexp surface of the tendom of the supinator longus. It pierces the deer fascia in the lower third of the forearm and is directed towards the back of the wrist. where it divides into its terminal branches. One of these, the yahmar eutaneous of the radial nerve, supplies the outer part of the thenar eminence; two other'supply the dorsum of the thumb, a fourth branch runs along the radial side of the index finger, a fifth rivides to supply the adjacent side of the index and middle fingers, and a sixth hranch eommunicates with the dorsal branch of the ulnar nerve to supply the adjacent side of the midille and ring fingers.

Nerve-supply of the dorsal integument to the hand.- It will be seen, by the foregoing description of the ralial and ulnar nerves, that the thumb, index, and half the nithle finger are supplied by the radial; the little and half the ring finger by the uluar; ant the adjacent sicles of the ring and niddle fingers by both radial and uluar nerves. The distance to which these nerves extend on the digits is somewhat variable, but the following is the average condition:-The ralial nerve extends to the base of the thumb nail, to the listal interphalangeal joint of the index, and not quite to the proximal interphalangeal joint of the middle finger, and sends a fine twig in sout cases to the skin covering the metaphalangeal articulation of the ring finger. The ulnur nerve extends to the nail of the little finger, to the distal interphalangeal joint of the ring, aum in some cases to the integument covering the proximal interphalangeal joint of the middle, and the metacapo-phalangeal articulation of the index finger. The distal parts of the dorsum of the fugers are supplied by twigs firm the palmar collateral branches of the median and ulnar nerves, alumst the whole of the middle finger being supplied in this way, and the other digits to a less degree. 'The matrix of the thumb nail is supplied by twigs fiom the palmar branches of the median. A considerable part of the dorsum of the hand is usually supplied by twigs from both the radial and the ulnar nerves, as these nerves overlap one another in their distribution (fig. 459). Ocrasionally two other nerves, the musculo-entaneous and the lower external cutaneous branch of the musculo-spiral, take part in the supply of the back of the hand.

Table finowixg Refation of Cervical axd Dorsal Nerves to Braxches of Brachlal, Plexts

Nerve lioots.

$\therefore$ C.

5 and $6 \mathrm{C}$.
Nerves.

$\{$ Nerve to rhomboids subclavius

Suprascapular

Nerve to subclavius

Upper subscapular

Lower

Circumflex

Posterior thoracic

Extemal anterior thoracic

Musculo-cutaneous

Musculo-spiral

Median

Micldle subscapular

Internal anterior thoracic

Ulnar

( Internal cutaneous

$1 \mathrm{D}$.

Lesser intemal cutancous 


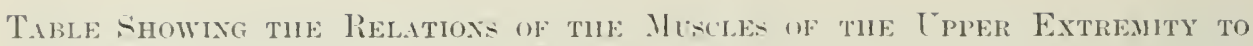
THe C'ERTIL NeRTE-

NERYE ROOTS.

11 th cranial, 2 C'. $3,4 c$.

3 incl + C. . . Levator anguli seapule

Subclavius

Supraspinatus

Infraspinatus

Subscapularis

j) and $6 \mathrm{C}$.

6 $\mathrm{C}$

li and 7 C...... .

5. 6 , and $7 \mathrm{C}$. .

and S C. $\quad \begin{aligned} & \text { Latissimus dorsi } \\ & \text { Triceps }\end{aligned}$

Anconets

$5,6,7$, and $\mathrm{S}$ C. Pectoralis major

Dorsal inteross.

Palmar

Obliq. add" pollicis

Trans. ,, ,

Flex. brev. (deep)

7. SC. and 1 D. $\left\{\begin{array}{l}\text { Peetoralis minor } \\ \text { Flex. subl dicit }\end{array}\right.$

Lumbricals

(Flex. carpi ulnaris

S C. and 1 D. . . , , prof. digit.

, long. pollicis

Pronator quarlratus
Nerves.

spinal acessory

3 alnd + C.

Nerve to subclarius

\} suprascapular

¿pper and lower subscapular

Lower sulscapular

\} ('ircemplex

Musculo-cutaneous

M[usculo-spiral

Posterior interosseruls

Median

,

Mrüculo-spiral

losterior interosseous

Merlian

,

,

Posterior thoracic

Ifusculo-cutaneous

Posterior interosseous

Longe subscalpular

Musculu-spirial

Ext. and int. ant. thoracic

[lllill"

,.

$:$

,

Int. ant. thoracio

Merliam

, and ulnar

Illor

Merian 


\section{TIIORACIC NERTES}

The smaller gart of the first theracie nerve and the seend to the eleventh theracic nerves follow the eontenr of the lody wall in the intervals betwern the ribs, and are therefore termol intercostal nerves. The twelfth thoracic nerre pursues a parallel comse to the others, below the twelfth rih. Fach of the inter-

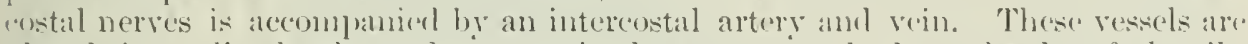
placed, immorliately abose the nerve, in the grome at the lower border of the ril. The twolfth thoracic nerve is accompanied by the first lumbar artery. Eacle thoracie nerve is joined, near the lwal of the rih, by two rami communicantes from the gangliaterl cord of the sympathetic. The first and last thoracie nervess repuire separate description. The iemaning ten norves fall natmally into an uper and a lower group. The members of the upper group (the secomel to the sixth) run between the rihs as far as the margin of the stermum. The members of the lower group (seventh to eleventh nerves) lie for al part of their comre hetwen the layers of the ahdominal wall, the extent of the alulominal distribution increasing from the lighest to the lowest member of the series.

1. First thoracic nerve.-The greater part of the first thoracic nerve arosises the neck of the first ril, to join the brachial plexus as already deseribed. The smaller part, about one-fifth of the entire nerve. russ for about two inches in contact with the under surface of the first rib letween the bone and the pleura, and then entres the cellular interval between the extemal and internal interenstal muscles. For the remainder of its eourse it corresponds to the upper intereostal merves in its distribution, but it loes not usually give a lateral or an anterion cutameous brameh.

Variety.-In some eases a literal cutaneons nerve arises from the first intereostal nerve. may he of small size, but is sometimes as large as an ordinary intercusto-humeral nerve. It conmunieates with the intereosto-humeral nerve and with the nerve of Wrisberg.

B. Upper intercostal nerves.-The second, third, fourth, fifth, and sixth interconstal nurves, after receiving commmnications from the sympathetic, are directul outwarks in the intercostal spaces in frout of the posteriog intercostal membranc. hetween that membrane and the plemas. They then enter the interval between the pxtemal and internal intercostal muscles, and follow the curve of the theracie wall hetween these nuscles as far as the mid-axillary line, and then, taking a deepere pexition, they run through the filues of the intermal interenstals as far as the junction of the bony jarts of the ribs with their cartilages. Hence they pass forwards on the drep surface of the intemal interenstal museles, lying on the jileura amel on the slips of the triangularis sterni, and cross in front of the intemal mammary ressels. lastly, they benel forwarls and pieres the intermal interesstals. the anterior inter(n)tal unembranes and the pectoralis major, and temmate as the antrior cutaneous merves of the thorax. In this cerurse they give off musenlar hranches to the

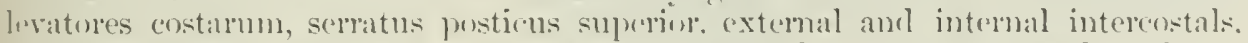
amel triangularis stemi. Eileh nevo also gives off two cutaneous hranehesnammly, the lateral and anterior cutanems nerves of the thorax.

Thi' lateral cutaneous nerves of the thorax pirere the extermal interestal muscles, and divile into anterior and prostringr hranches. These hrandhes pass hetween the digitations of the sorratus magmus, and are separaterl hy an interval of

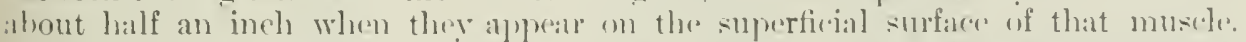
The anterior branches run forwards. crose the lower lowrler of the erreat peeteral.

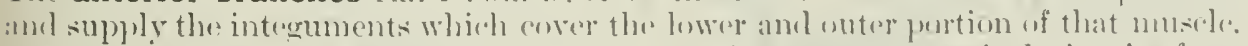
and give twigs to the mammary gland. They increalse peregresirely in size frem above downwals. In the ease of the socomel lateral eutanems nerve. the anterion branch is usually wanting. The posterior branches turn backwards, and suplly" the skin envering the outer part of the latisimus dorsi and the inforion angle if

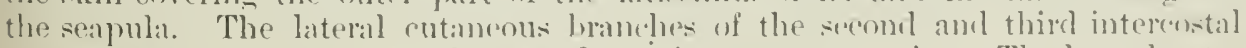
nerves are larger than the others, and recpuire seprate motice. The lateral catil- 


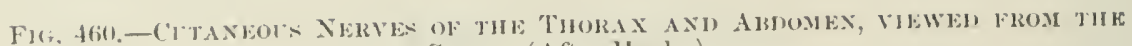
Sill: (After Henle.)

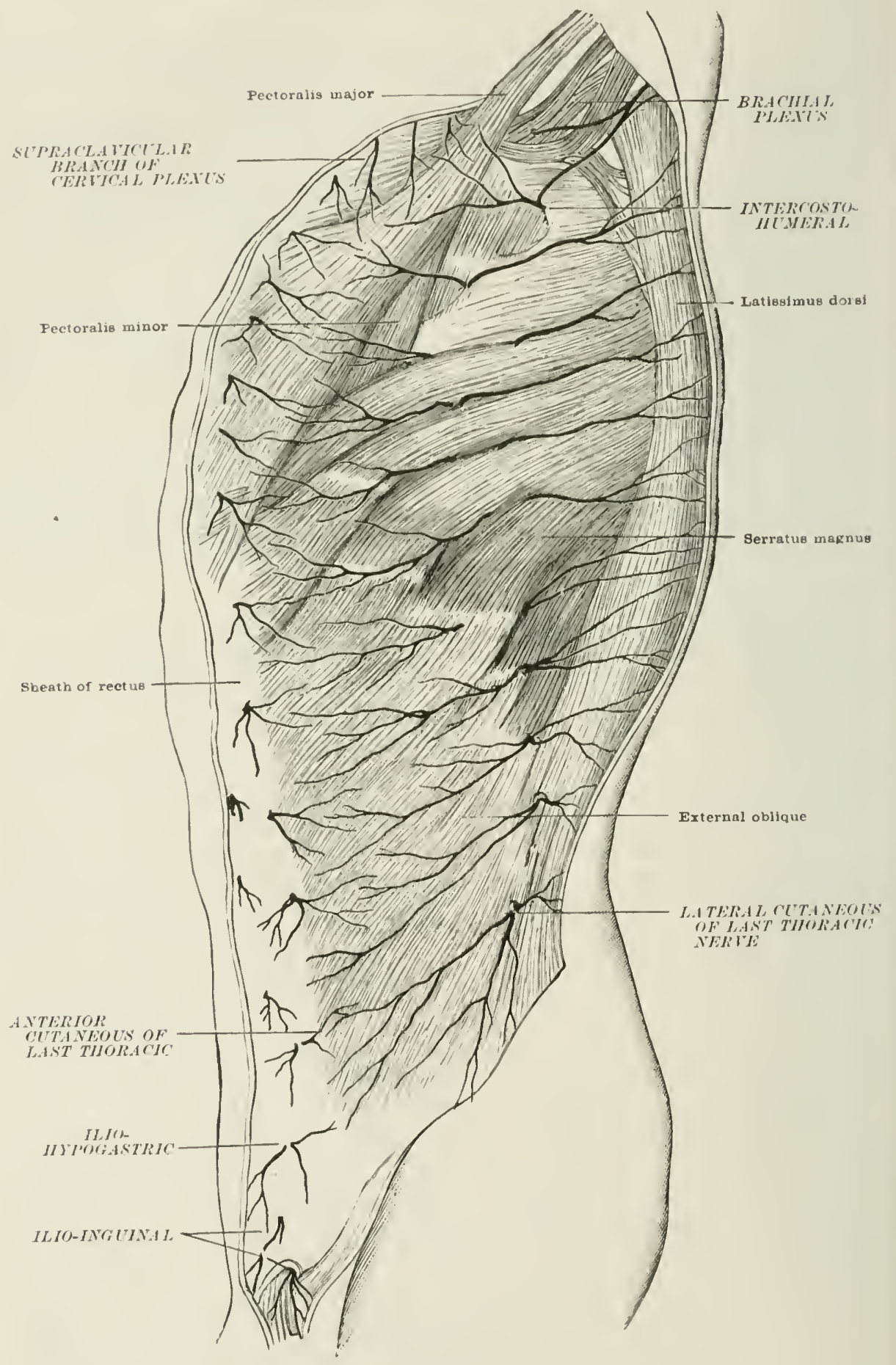


news branch of the seond intercostal nerve is allent the intercosto-humeral nerve. It pases entwarls across the axillary flace. croser the temelon of the lati-sinms dorsi and the internal cutaneous branch of the musculo-spiral nerve to reath the arm. It is distributerl to the interument of the inner and justerior fart of the arm in its upper two-thirels. Within the axilla it communieates with the leser inturnal cutaneous nerve of the lorachial plexus. amel with the lateral cutanewus liranch of the thirel interenstal. The lateral cutaneous branch of the third

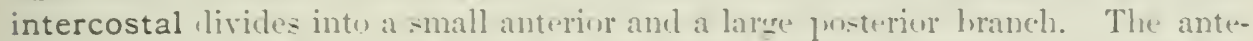
rior branch ends near the malrein of the great jectoral muscle. The prosterior branch communicates with the intereosto-humeral nerve. and then turns round the posterior fold of the axilla. and, after griving a twig to the interument of the arm. "nuls in the skin covering the clur-um of the scapula.

The anterior cutaneous nerves of the thorax are the terminal hranches of the unper intereostal neres. They pierce the pectoralis major in complany with the perforating branches of the internal manmary artery. On reaching the surface of the muscle, they give off minute twigs, which supply the shin over the stemum. and then end in slender branches which are directed nutwards to supply the skin covering the greater part of the pectnralis major. Some twigs from the thirel. fourth, tifth, and sixth nerves are elistributed to the mammary glanel.

C. Lower intercostal nerves.-The serenth, eighth, ninth, tenth, anil weventh interestal newes, in the gart of their comre which lis leetween the rils.

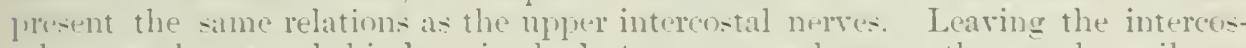
tal spares they pass behind, or in the last two spaces between the costal cartilages. and then forwarls hetween the intemal whligue and transersalis muscles, where they anastomose tosether, in a plexiform manner. Piereing the posterior lamellat

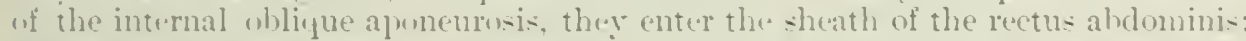
they supply the rectus muccle pass through it. picree the anterior part of it: sheath and terminite as the anterior cutanenus nerves in the skin of the aldomen.

Branches.-The liwer interenstal neros suply the extermal and internal interestal musches the levaturs costarm. the serratus posticus inferior. the internal whligue, the transversalis. the reetus, and from one ur more of them twigs are friven to the costal filores of the diaphram. They alsen give efti lateral cutaneous liranches, hy which the external whlipue is supplicel.

Th. lateral cutaneous nerves of the abdomen are the continuation of the series of the latural entanems nerves of the thorax. Ther divide into anterior and punteriol branches, which pieree the axternal cilligue. The anterior branches

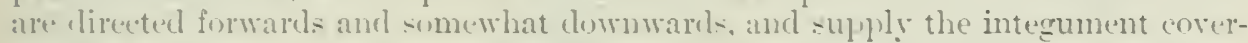
ing the anterior atulominal wall as far as the outer margin of the rectus. Eateh nerve gives uff a muscular twig. which piesees the aljacent digitation of the extr.rnal oblipue muscle on its smpertieial surface. The posterior branches pass back-

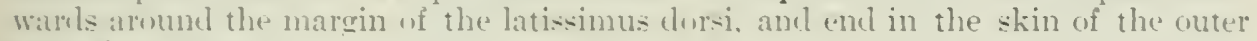
piart of the back.

The anterior cutaneous nerves of the abdomen are the terminal hranches of the lowere interenstal nervers and pieree the anterior part of the sheath of the reetus to smply the sin covering that musele. These nerves are of small size. and sometimes divile before their emeresence, so as to form a double series.

D. Last thoracic nerve.-Thi- nerve gives aff a communicating twig to the first lumbar nerve, and then pase- lemeath the external arewate liganent. and runoutwarls: below the twelfth rib acros the front of the yuadratus lumborum, aceompanied by the fir-t lumbar artery. It pierces the per-terior aponeuresis of the transresalis and follows the curve of the ahelominal wall hetween the transersalis and internal oblinge muscles. In the remainder of its eourse it resemhles a lowe interenstal nerve. After piercing the rectus. however. it sulplies the pramialis: (Griffin). Its lateral cutaneous branch remains undivided, and represents the anterior liviojon of an orlinary lateral cutaneous hranch. On aecount of its di-tribution, it is namerl the iliac lianch. The iliac branch fireres the external

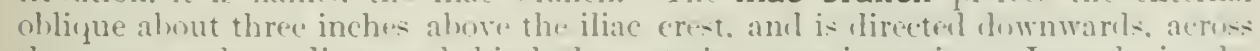
the crest, a short distanep hehind the anterior superior spine. It ends in the integument covering the anterior part of the gluteal region. 


\section{LUMBAR NERIES}

The anterior divisions of the five lumbar nerves increase progressively in size from abore down warls. the first lumbar being about the size of an intercostal nerve. and the fifth a nerve of considerable magnitude. The first. second, thirel, and part of the fourth nerves unite to form the lumbar plexus. The remainder of the fourth unites with the fifth to form the lumbo-sacral cord, which passes to the sacral plextr. Each lumbar nerve is eomnected to the gangliated cord of the srmpathetic by rami communicantes. These rani communicantes reach the lumbar nerves hy accompanying the lumbar arteries through the fibrous arches from which the psoas takes origin.

\section{LUMBAR PLEXUS}

The lumbar plexus is placed among the deeper fibres of the psoas, and is constituted as follors: the first lumbar nerve is joined by a communicating twig from the twelfth thoracic and divides into two branches; one of these is the common origin of the ilio-hrpogastric and ilio-inguinal nerves; the other branch unites with a branch of the second lumbar to form the genito-crural nerve. The second, third, and fourth lumbar nerves divide into anterior and posterior divisions. A part of the anterior division of the second lumbar nerve enters into the eomposition of the genito-crural nerve as above mentioned; the remainder of the anterior division of the second nerve unites with the anterior division of the third and part of the fourth nerve to form the obturator nerve. The remainder of the anterior division of the fourth nerve enters the lumbo-sacral cord. The fourth lumbar nerve, therefore. takes part in the formation of both the lumbar and sacral plexuses; and it is known as the "nervus furcalis." The posterior dirisions of the second. third, and fourth nerves end chiefly in two large nerves-the extemal cutaneous and the anterion crural. The external eutaneous arises from the second and third nerves. The anterior crural springs from the second, third, and fourth nerves. A part of the posterior division of the fourth nerve enters the lumbo-sacral cord. The large terminal branehes above described are given oft within the substance of the peoas: three of these, the ilio-hypogastric, ilio-inguinal, and external cutaneous, appear at the outer border of the psoas. hetween that muscle and the quadratus lumbormm; one, the genito-crural, pierces the anterior fibres of the psoas and appears in front of the muscle; another branch, the obturator. appears at the inner border of the psoas close to the lower margin of the fifth lumbar vertelora; lastly, the anterior crural nerve, the largest branch of the plexus, rums downwards in the interval betwen the psoas and iliacus. Within the psoas small twigs are given off by the lumbar nerves, which end in the muscular substance of the psoas and quadratus lumborum.

Branches.- The nerves to the psoas and quadratus lumbortm from the first and second lumbar nerves arise in the substance of the pioas.

The ilio-hypogastrie and ilio-inguinal nerves are in some cases represented by a common trunk whieh arises from the first lumbar. Nore commonly they exist as two separate nerves, the upper and larger nerve being ilio-hypogastric; the lower and smaller, ilio-inguinal. Taken together they correspond in many respects to a lower intercostal nerve. They run for a considerable part of their comrse betwen the transwersalis and internal ohlique, giving twigs to both these muscles. The ilio-hypogastrie gives off a lateral cutaneous, which is called the iliac branch, and terminates in an anterior cutaneons which is termed the hypogastric branch.

(1) The ilio-hypogastric nerve is a branch of the first lumbar. It allerears at the outer horder of the poas and crosises the quadratus lumborm obliquely to reach the crest of the ilium. In this part of its eourse it is surrounded by the extra-peritoneal fat. It then pieress the transversalis and runs along the crest of the ilium between that musele and the internal oblipue, and, about two and a half inches bohind the anterior superior spine of the iliun, divides into an iliac and 
an hypogastric branch. („1) The iliac branch pierces the internal and exterual oblique muscles and crosses the crest of the ilimm, lying close to the bone. It is directed downwards towards the great trochanter of the fenur; some of its twigs reach as far as that prominence, and supply the integuments corering the fore part of the gluteal region. (b) The hypogastric branch continues the direction of the main trunk, and perforates the internal ollique near the anterior superior spine of the ilimm. In this part of its comse it communicates in a plexiform manner with the ilin-inguinal nerve. It is then directed forwards and inwards under cover of the

Fici. 461.-Diagrai of tile Limbar axd Sacral Plexises. (Modified from Paterson.)

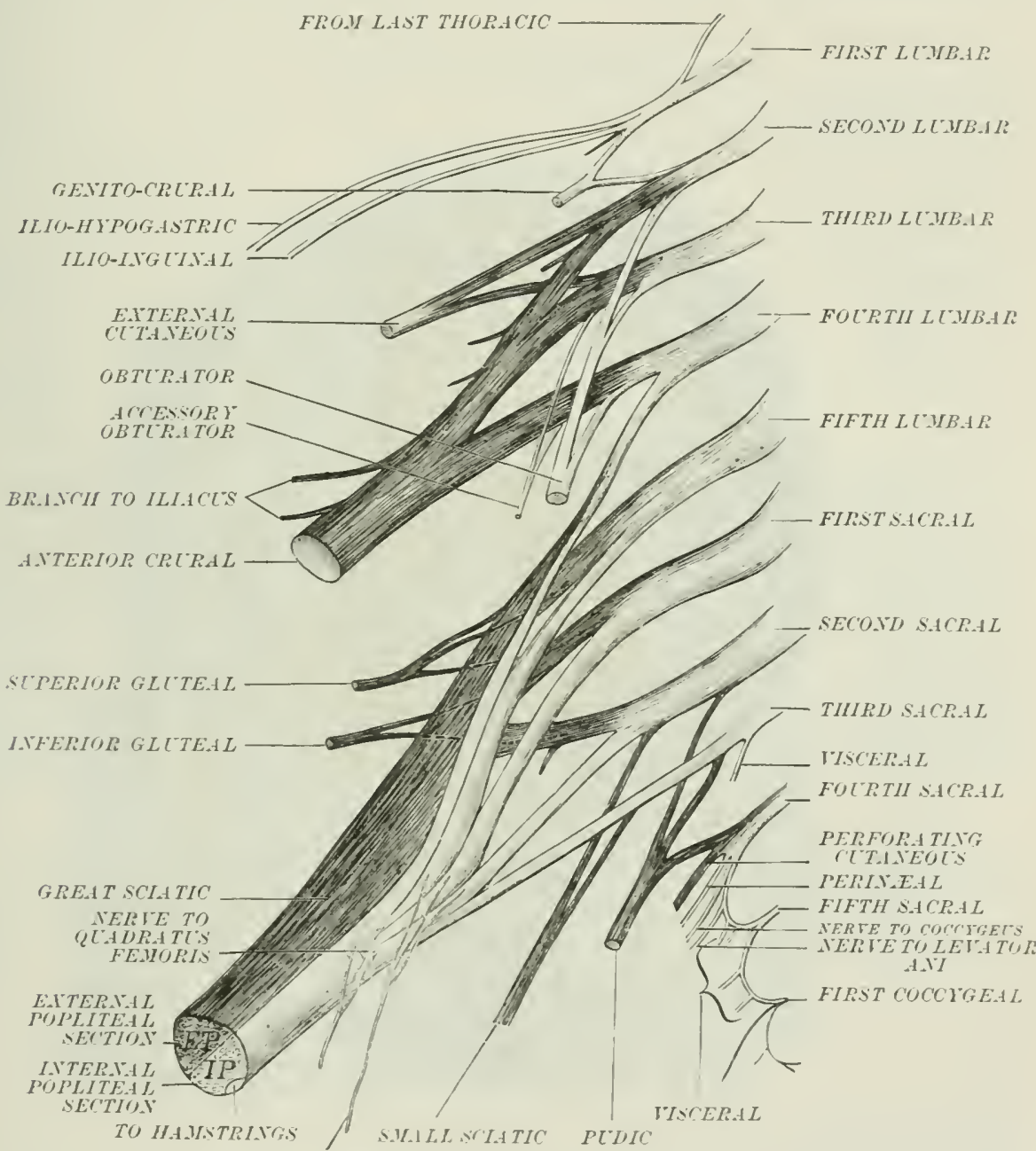

IERIE TO OBTLRITOR INTERITS

aponeurosis of the external whipue. Finally it pieres the aponeurosis outsile the sheath of the rectus at a proint about an inch above the "xternal ahelominal ring. and supplies the skin in that situation. forming a continuation of the series of anterion eutaneous nerves of thr ablomen.

(2) The ilio-inguinal nerve arise from the first lumbar nore in common

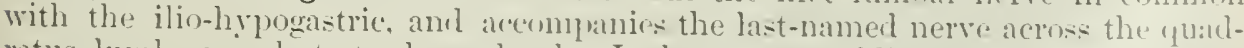
ratus lumbormi, but at a lower lerel. It then passes obliquely across the upled part of the iliacus and pieres the trativersalis muscle. It follows the curve of the crest of the ilimn in company with the ilio-hyposastric, commmnimating with that 
nere in a plexiform manner. It pierees the internal ollique a little in front of the anterior superior spine of the ilium, and rums forwards uncler cover of the aponeurosis of the external oblique immediately above Poupart's ligament, enters the lower part of the inguinal canal and reaches the external ahdominal ring. It then traverses the ring and divides into its terminal hranches, which are distributed to the skin covering the upper part of the adductor longus. the integuments of the scrotum in the male, ancl of the labium majus in the female.

(3) The genito-crural nerve arises from the first and second lumbar nerve by two roots which prass forwards and downwards through the fibres of the psoas, and minite to form a single trunk. The nerve then alpears on the surface of the piseas

Fig. 462.-Braxches of the Lumbar axi SACral Plexts itewein from before.

(After Hirschield and Leveillé.)

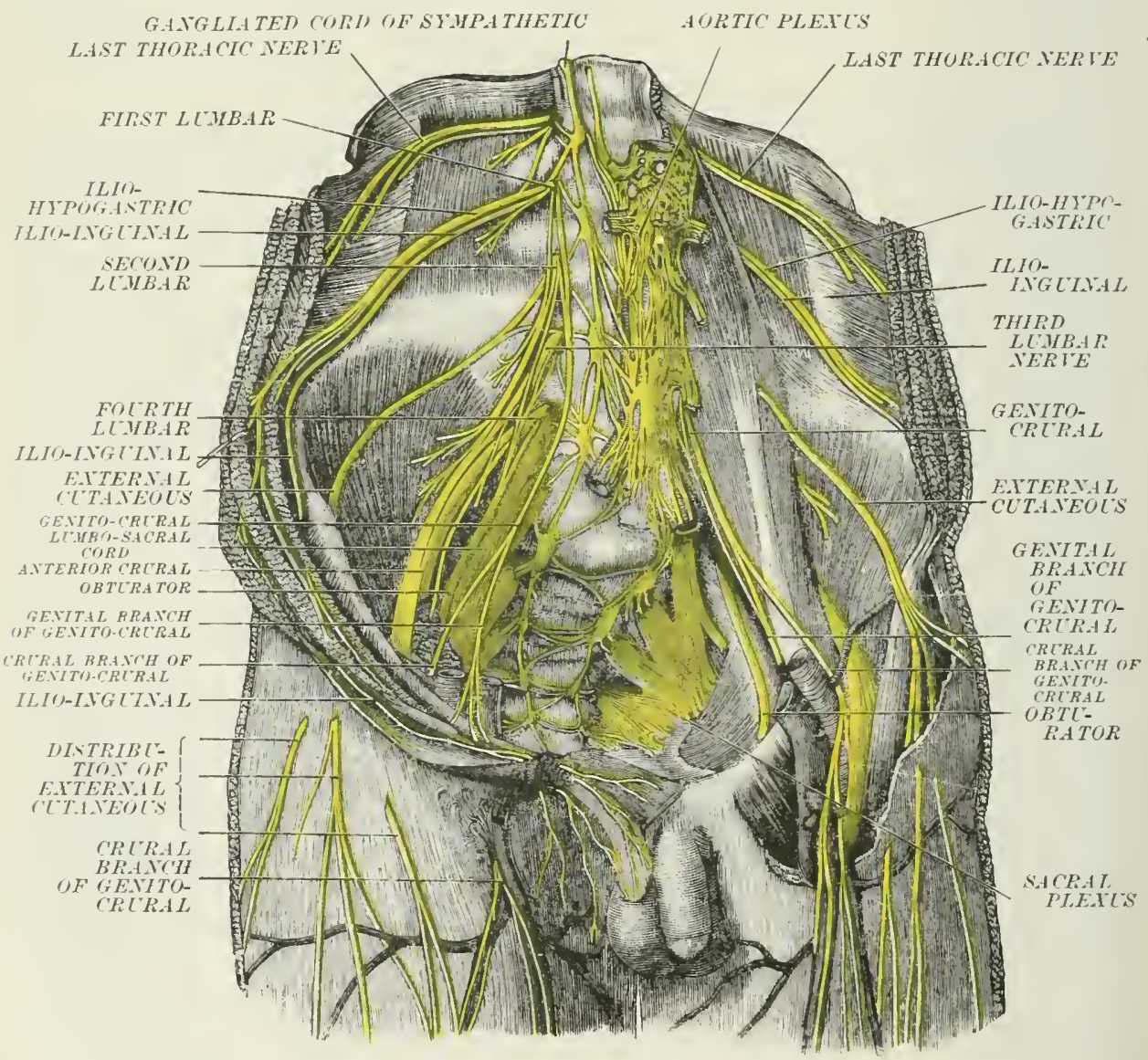

close to the vertebral column, at the level of the third lumbar vertebra and runs downwarls under cover of the peritoneum. After being crosed by the ureter it reaches the outer side of the external iliae artery, where it divides into a genital and a crural branch.

(1) The genital branch accompanies the spermatic vessels through the inguinal canal, and, emerging from the external aldominal ring, pierees the intemal spermatic fascia, and is clistriluted to the cremaster muscle. In the female this branch is rudimentary and accompanies the round ligament.

(b) The crural branch is carried downwards in front of the external iliac and femoral artery into the external eompartment of the femoral sheath. It pierees the femoral sheath and beeomes subentaneous alout two inches below Poupart's liga- 
ment by piercing the fascia lata. It is distributed to the skin covering the uplen and eentral part of the anterior aspect of the thigh.

(4) The obturator nerve arises from the third and fourth lumbar nerves, and in the majority of cases receives an additional root from the second. It prasses betwern the poos nuscle and the body of the fifth lumbar vertebra. It then runs downare and forwards outside the intermal iliac vessels and the ureter, and helow the external iliac ressels to reach the upper margin of the thyroid formen. In this part of it: course it runs parallel to and a little bolow the frim of the pelvis, and is placed in the extra-peritoneal fat between the peritonemu and the parietal pelvic fascia. It is accompanied by the olsmrator ressels which are placed below it. The norve them passes through the defieiency in the obturator nembrane, and divides into two lianches. an anterior and a posterior.

(i) The anterior branch passes aeross the upyer border of the obturator externus, and is directed downwards and inwards between the pectineus and ardlurtor brevis, and divides into the following branches:-(i) A twig for the hipjoint; (ii) a hranch for the adductor longus; (iii) a branch to suply the adductor brevis; (iv) a branch for the gracilis; (v) in rare eases, a twig for the pectineus: (vi) a cutaneous hranch; and (vii) a branch to the femoral artry. The cutaneous branch beennes stperficial hy passing between the adductor longus and adductor brevis, and is then rlirected along the posterior border of the sartorius, where it commmicates with twigs from the long saphenous and from the posterior branch of the internal cutaneous to form the subsartorial plexus.

(b) The posterior branch gives oft branches to suplly the lip-joint and the oloturator externus, and then pierces the upper jart of that muscle and reaches the: interval between the adduetor brevis and adductor magnus. It runs downwards on the anterior surface of the latter muscle, supplying it with twigs, and teminates in an articular twig, the genienlate branch, which is distributed to the knee-joint. (i) The twig to the hip-joint enters the acetabulum by passing through the cotylojid notch. It ramifies in the fat occupring the floor of the acctabulum and in the arljacent synovial membrane. (ii) The branch to the oluturator externus pieres the (leep surface of the muscle. (iii) Sereral large twigs enter the adductor magmns. (iv) The geniculate branch pierces the lower part of the adductor magnus. ancl appears on the posterior surface of that muscle elose to the opening for the popliteil ressels. and descrends on the immer side of (sometimes bohind) the popliteal artery. Having given off a filament which accompanies the superior internal articular artery, it lneaks up into terminal twigs which separately pierce the posterior ligament of the knee-joint.

An accessory obturator nerve is nccasionally present. It arises between the anterior crural and ulsturator nerves from the third and fourth lumbar nerves. It runs along the inner borter of the pisas, and crosses in front of the brin of the pelvis to gain the deep surface of the pectineus. In this situation it breaks up into branches. The largest of these branches joins the olturator nerve, others enter the capsule of the hip-joint, and a branch is furnished to the peetineus.

The branch which joins the obturator nerve may carry filaments for the adductors longus and brevis and the wlicilis.

(5) The external cutaneous nerve arises, by two rots, from the second and thiml lumbar nerves. It emerges at the outer lorder of the peoss and crosese olbliquely in front of the iliacus to reach the interval between the anterior superior. and anterior inferior spines of the ilium. In this course it runs under cover of the fascia iliara. It then passes lwhind Poupart's ligament, crosses in front of the origin of the sartorius, and divides into an anterior and a posterior branch. The posterior branch passes hackwarks and downwark under cover of the fascia lata. and divides into twigs which supply the integument envering the insertion of the gluteus maximus and the upper and outer part of the thigh. The anterior branch is much larger than the posterior. It runs downwards for sereral inches in al canal formed by the fascia lata, and enters the superficial fiscia at the junction of the upper with the miklle thirk of the thigh. It divides into branches which supply the skin of the outer part of the thigh, a few of the terminal twigs reaching as far as the knee and entering into the composition of the plexus patellix. 
(6) The anterior crural nerve is the largest branch of the lumbar julexus. It arises hy three roots. which spring from the secomel, third, and fourth lumbar nerves; these roots traverse the substance of the frons and mite into a single trunk in the deep grove betwen the psoas and iliacus muscles. The nerve then passes under corer of the fascial iliaca, behind Poupart's liqament, into Scarpa's triangle, where it lies external to the femoral sheath and divides into two grouns of temmal branches-the superficial and deep.

In the abdominal part of its course the anterior crumal nerve gives branches to the iliacus, and a twig to the femoral artery.

Fig. 463.-Axterior Creral axp Obtcrator Neries. (Ellis.)

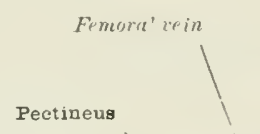

OBTLRATOR (AITERIOR DIV)

OBTLPATOR (POSTERIOR:

UIVISIO.T)

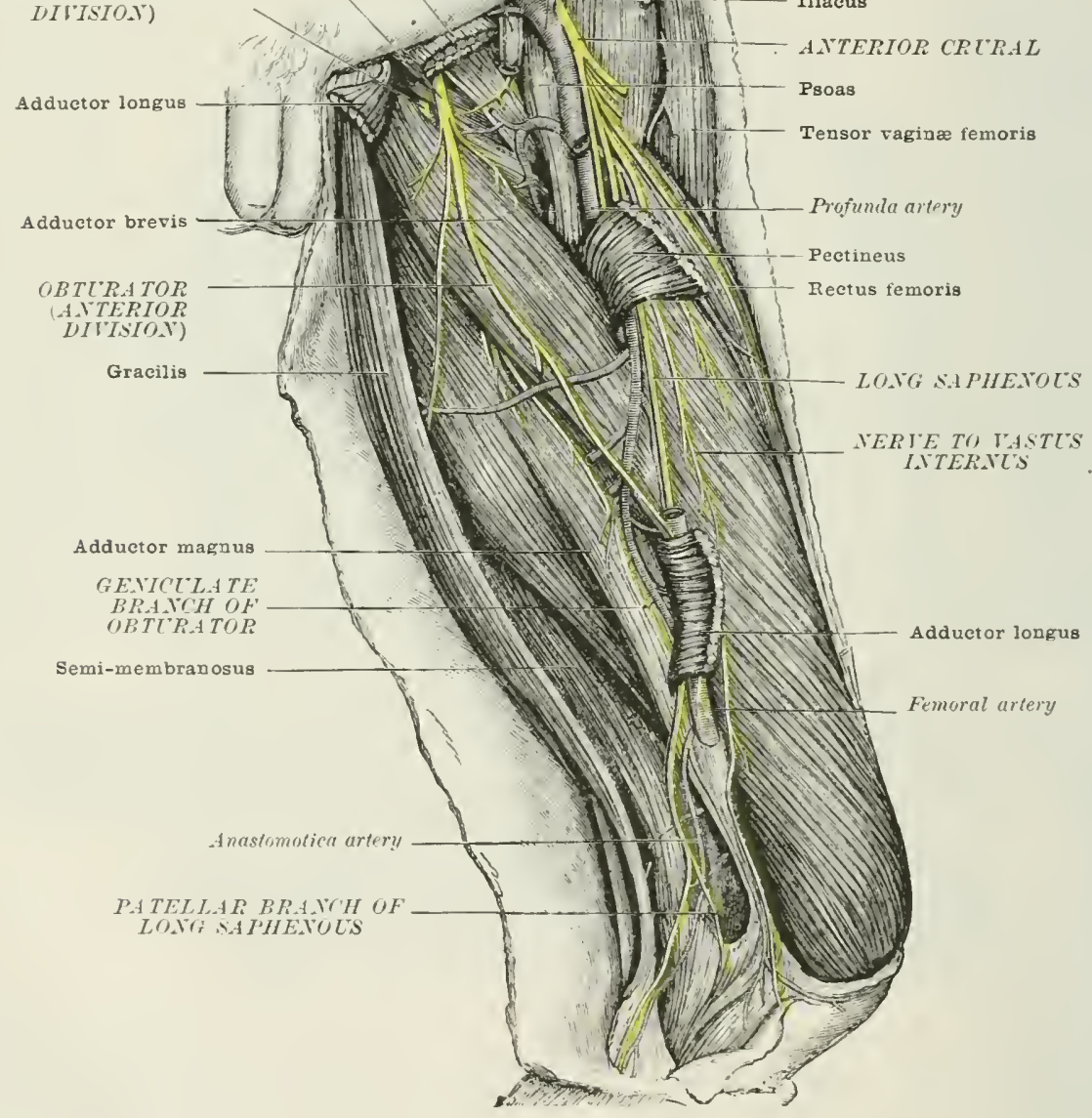

The superficial terminal branches are muscular and cutaneous; they are selrarated from the deep branches by the extrmal ciremflex artery.

The muscular branches of the superficial series contain fibres from the second and third lumbar nerves; they are two in number-one to the pectineus, whith passes lohind the femoral sheath to the anterior surface of the pectineus muscle, and one to the sartorius. The latter usually acempanies one of the two divisions of the milllle cutanems nerve.

The cutaneous branches of the superficial series are the internal and middle 
cutaneous nerves. They also eontain fibres from the second and third lumbr nerves.

The internal cutaneous nerve is directerl dowmwarls along the outer side of the fonoral artery, giving off in this situation two or three cutaneous twigs, which jirere the fascia lata. It then croses obliquely in front of the femoral artery, at the lower angle of Scarpal's triangle, and clivides into an anterior and a posterior hranch. The anterior branch is the larer. It runs downwards, in front of the sartorius. under cover of the fascia lata. It picrees the fascia lata about the misllle of the lower third of the thigh, and, after giving twigs to the skin of that rengon, turns outwards to end in the plexus patella. The posterior branch runs along the posterior border of the sartorius, and, after giving twigs to the sub-

Fig. 464.-Distribetion of Cetaxeors Nerves ox the Posterior Axn Axterior A.PECTS OF THE IXFERIOR EXTREMTY.

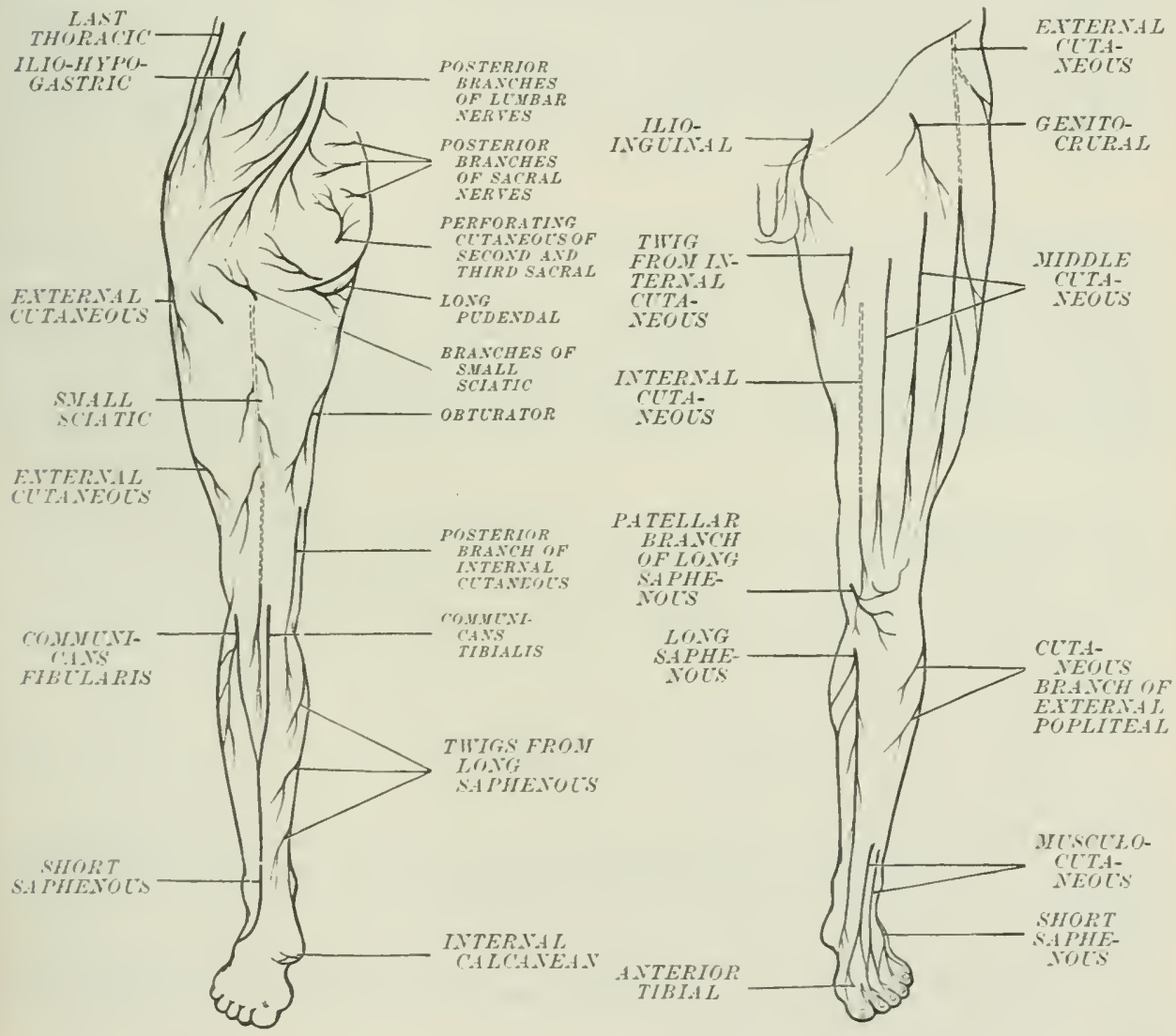

sartorial plexus, runs downwards to the inner aspert of the knee, where it pierers the deep fascia and ends in the integument of the upper and inner part of the calf.

The middle cutaneous nerve usually takes the form of two strong branches. which run a nearly garallel course. One of these hranches usually pierees the sirtorius. while the other croses the superficial surface of that muscle; they pieres the fascia lata a little above the mirdlle of the thigh. They ramify in the superficial fascia. supplying the skin of the anturior jart of the thigh as far as the knee, where they end in the plexus patellice.

The deep branches are six in number-me mitancous (the long saphennus) and five muscular. They are arranged in the following order, from within outwards: the long saphenous nerve, the nerve to the vastus internus, the nerve to the 
subcrureus, the nerve to the crureus, the nerve to the rastus externus, and the nerve to the rectus femoris. They all contain fibres from the third and fourth lumbar nerves.

(g) The long or internal saphenous nerve accompanies the nerve to the vistus internus in its course through Scarpa's triangle, being placed between the litter nerve and the femoral artery. It passes through Hunter's canal with the femoral artery, lying first to the outer side, then in front, and finally to the imner side of that vessel. It the lower end of the canal it joins the superficial branch of the anastomotic artery which it accompanies, hetween the posterior horder of the sartorius muscle and the anterior border of the gracilis tendon, to the inuer sirle of the knee where it becomes superficial. At this point it approaches the long saphenous rein, and accompanies that ressel for the remainder of its comrse. It runs down the anterior and inner jart of the leg, supplying branches to the skin of that region, passes in front of the inner malleolus, and supplies the integument for ahout two inches below that prominence.

As it leares Hunter's canal, the long saphenous norve gives off a patellar branch. This branch pierces the sartorius, and runs, at first rownwards and then outwarks, towards the ligamentum patelle. It gives twigs to the integument covering that ligament, and others which curve upwards to join the plexus patella.

Plexus patellæ.-The skin corering the patella is profusely supplied with nerres which communicate with one another, and are derivel from the external, middle, and interual cutaneous and from the long saphenous.

Subsartorial plexus.- At the posterior border and partly under cover of the sartorius musele, on the roof of Hunter's canal, and a little below the middle of the thigh, branches of the obturator, loug saphenous, and internal cutaneous nerves communicate in a plexiform manner and supply the adjacent skin. The posterior branch of the internal cutaneous has an independent distribution, as already deseribed. Occasionally the eutaneous branch of the obturator is unusually large, and may supply an area of integument covering the lower part of the inner hamstring muscles.

The nerve to the vastus internus accompanies the long saphenous nerve, in Scarpa's triangle, lying to its outer side. At the upper end of Hunter's canal it passes beneath the sartorius, external to the roof of the canal, and enters the imner surface of the vastus internus. It sends down a twig to the knee-joint.

The nerve to the subcrureus frequently rises from the nerve to the erurens. It passes between the rastus internus and the crureus to the lower third of the thigh, where it supplies the subcrureus and sends a branch to the knee-joint.

The nerve to the crureus is represented by two or three branches which finter the upper part of the muscle. One of them frequently sends a twig to the knee-joint.

The nerve to the vastus externus passes downwards heneath the rectus and along the anterior border of the rastus externus, accompanied by the descending branch of the cxternal circumflex artery. It also sends a branch to the kneejoint.

The nerve to the rectus femoris enters the deep surface of that muscle, having previously given off a twig to the hip-joint which accompanies the ascending branch of the external circmuflex artery. 


\section{SACRAL AND COCCYGEAL TERIES}

The anterior primary divisions of the upler four sacral norves escape from the neural canal by passing through the anterior sacral formmina, while the anterion division of the fifth passes forwarls between the sarpum and acrex. The eocergeal nerve escapes from the nemal canal hy passing through the temninal opening. Its anterior primary division pierees the sacro-seiatic liganents and passes forwards. The sacral nerves decrease progressively in size, from the first to the fifth. The first sacral nerve is the langest nerve in the body, while the fifth is very small. Wach samal nerve is connected to the gangliaterl cord of the svmulat thetic hy a gray ramus communicans. The anterior divisions of the first. second, third, and part of the fourth nerves join the sacral plexus: another part of the fourth has an independent distribution. The lower part of the fourth joins the fifth sacral and the cocergeal nerve to form the corecrgeal plexus.

The lianches of the fourth sacral nerve and the corcergeal plexus may be conveniently described first, as their distribution is contined to a limited area in the immediate neighbourbood of the sacral plexus.

\section{FOLRTH SACRAL NERVE}

The fourth sacral nerve, "alled the "nervus ligeminus." gives off an a-cending branch to join the sacral plexus, and a descending twig to the coceygeal plexus. In the interval between these onmmunicating branches several offects arise directly from the fourth sarral without entering into a plexiform arrangenent. Thes. direct ofterts are the perineal branch, and the nuscular nerres to the coecrens ancl to the levator ani.

The perinæal branch of the fourth sacral piesees the pelvic diaphragm. between the contigunus margins of the cocergeus and levator ani, and appents (dose to the tip of the eorecx. It is then directed forwards, and ends in twigs to the external sphincter ani and to the integument of the anus.

The branches to the coccygeus and levator ani enter these musces on their dere] or pelvic surfaces.

\section{SAC'RO-COC'Y'TEAL, R'LENC'}

The anteriol primary division of the fifth satcral nerve divides into arcending and ilesernding branches. The ascending branch unites with the descending hrand $h_{2}$ of the fourth sacral. The desconding branch juins the concergeal nerese. In this: manmer two small loops are formed: these loops constitute the sacro-corergeal plexus. Anterior and prosterior linanches are given of by the plexus. The anterior branches join the hypuastrie plexus (Testut). The posterior branches picere the coccygens muscle, and are distributed to the skin covering the posterior surfince of the coceyx. The coccygeal nerve gives a twig to the cocryeus and (according to Testut) gives oft a hranch which pieres the erreat sacro-sciatic ligament ancl encls in the lower fibres of the gluteus maximus. The plexus is placed in front of the lower part of the sacrum and behind the second part of the rectum.

\section{SACR.AL PLEXT'}

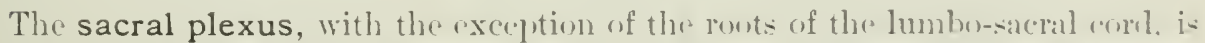

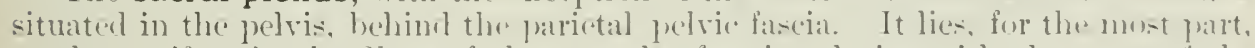
on the priformis. the fibres of that muscle often interlacing with the ronts of the plexus.

It is behind the branches of the internal iliae resels. two wf which, the gluteal and sciatic, pass through its loops. On the left side it is also heluind the first 
part of the rectum, and on the right the lower end of the ileum passes in front of it.

It is formed as follows: a part of the fourth lumbar nerve, " nerrus furcalis." joins the tifth lumbar nerre to form the lumbo-sacral cord; this corel is then joined by the first, second, and third sacral nerves to form a great flattened band, which is directed outwards and downwards towards the lower margin of the great sacrosciatic foramen, and, on crossing that margin, is no longer called the sacral plexus, but takes the name of the great sciatic nerve. A part of the third sacral norve is joined by branches from the second and fourth sacral nerves to form a second or lower hand of relatively small size, which ends in the pudic nerve. Several branches, to be presently enumerated, spring from the plexus; but by far the larger part of the plexus is directly continued into the great sciatic and pudic nerves. The plexus is, therefore, more condensed and more simple in its formation than any other plexus in the body. The two constituents of the lumbo-sacral cord unite to form that structure on, or a little below, the brim of the pelvis. The plexus has the following important vascular relations: the internal iliac ressels are placed a little in front of its upper part; the gluteal artery passes between the lumbo-sacral cord and the first sacral nerve; the sciatic artery passes through the lower part of the plexus (fig. 466).

It has been shown (Paterson) that the anterior primary divisions of the lower four lumbar and the upper two sacral nerves divide into anterior and posterior parts. The branches derived from the interior parts (lightly shaded in fig. 465) always eross in front of the posterior parts and unite to form trunks (e.g. obturator, internal popliteal). which are distributed to what is morphologieally the anterior aspect of the limb. The trunks which are formed from the posterior parts (e.g. external cutaneuns, anterior erural, external popliteal) are distributed to the (morphologically) posterior aspect of the limb; these nerves are darkly shaded in fig. 605 .

The branches of the sacral plexus are classified into collateral and teminal. The collateral branches are the superior gluteal, the inferior gluteal, the nerve to the prriformis, risceral branches, the nerre to the quadratus, the small sciatic, the nerve to the obturator intemus, and the perforating cutaneous nerre. The terminal branches are the great sciatic and the putic nerves.

COLLATERAL BRANCHES.-1. The superior gluteal nerve arises hy two root: one from the lumbo-sacral cord, and the other from the first sacral nerve. The upper root contains fibres derived from the fourth and fiftl lumbar nerves. The nerve accompanies the gluteal ressels through the great sacro-sciatic foramen, passing above the prriformis. It then divides into a smaller up per and a larger lower branch. The upper branch accompanies the upper division of the deep part of the gluteal artery and teminates in the gluteus medius; the lower branch eroses the gluteus minimis with the lower branch of the deep part of the gluteal arterr, supplying filaments to the ghteus medius and minimus and a terminal branch, which passes between their anterior horders, or through the fibres of the minimus, to the tensor fiscia femoris.

2. The inferior gluteal nerve arises from the posterior aspect of the plexus, and contains fibres derived from the fifth lumbar and the first, second, and third sacral nerres. It escapes through the great sacro-sciatic foramen, bew the prriformis, and in this situation is often adherent to the small sciatic norve. It divides into several stout twigs, which enter the deep surface of the gluteus maximus.

3. The nerve to the pyriformis is given off either from the second or from the third sacral nerve before they join the plexus.

4. The visceral branches arise from the third and fourth sacral nerres. They will be lescribed in connection with the srmplathetic.

5 The nerve to the quadratus femoris rises from the fromt of the plexus, olitaining filores from the fourth and fifth lumbar and first sacral nerves. It pasises through the great sacro-sciatic foramen below the prrifomis, and is usually arlherent for some distance to the deep surface of the great sciatio in the part of its contre where it lies between the latter nerve and the bone. It then passes, under cover of the tendon of the obturator internus and the gemelli, and, having supplied the gemellus inferior, encls in the deep or anterior surface of the quadratus femoris, and in the posterior part of the capsule of the hip-joint. 
6. The small sciatic nerve springs from the posterior aspect of the second and third sateral nerves, and, passing rlowmwark, cscapes through the great sacro-sciatic formen by passing below the pyriformis. It then rums downwards on the posterior surface of the great sciatic nerve, under cover of the gluteus maximus muscle, to which it furnishes a branch. This branch is probably a portion of the inferior gluteal nerve, which has adhered in a part of its course to the small sciatic. Fmerging from beneath the gluteus maximus it erosses the biceps, accompranied by a branch of the sciatic artery, and passing down, heneath the deep fascia it enter's

Fig. 465.-Diagay of the Lumbal axn Sacral Plexcses. (Modified from Paterson.)

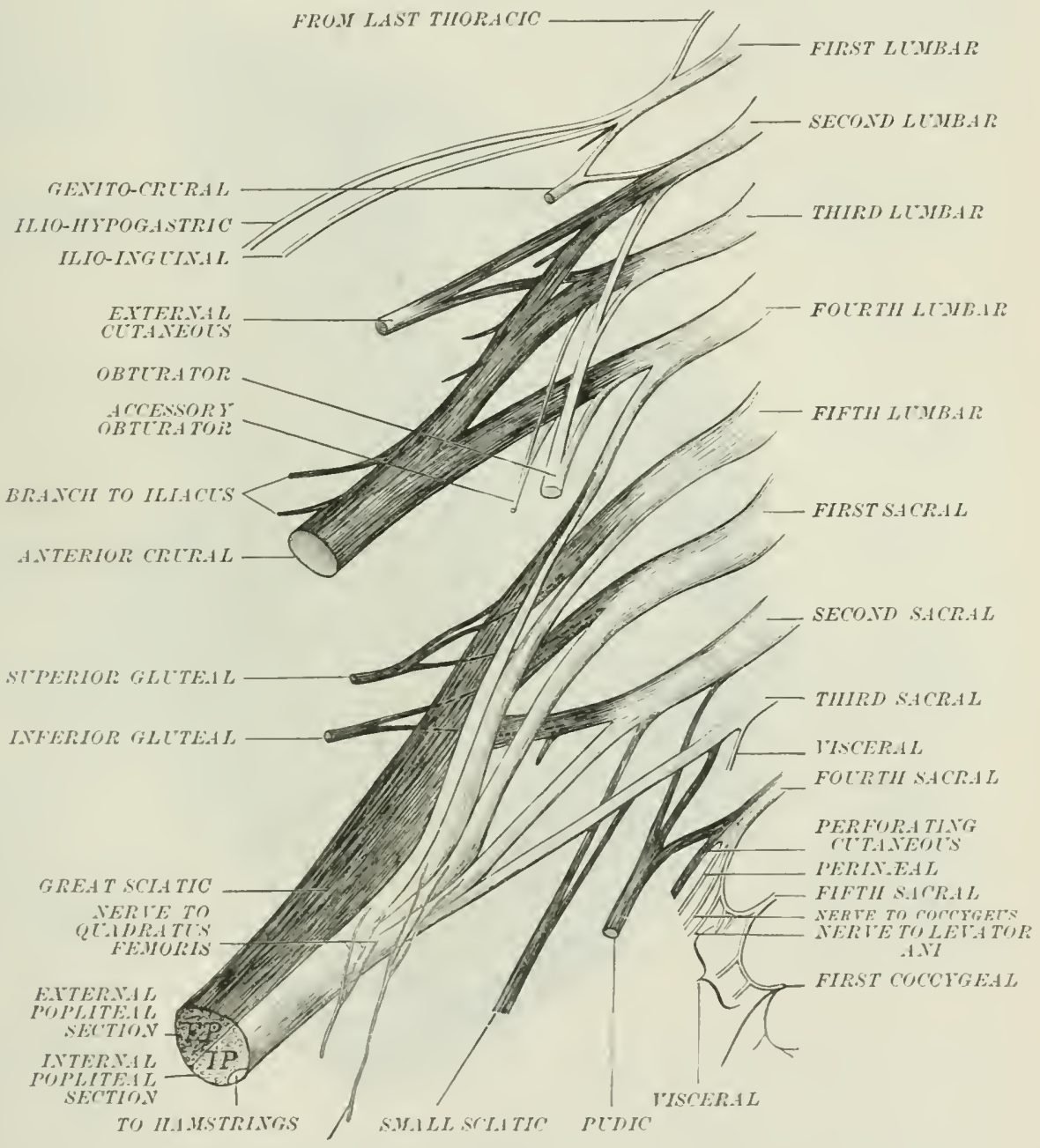

NERTE TO OBTERATUR INTERILS

the popliteal space and picres the deep fascia of the leg a little below the knee, anling in the integument of the mper part of the calf. where it may communicate with the external saphenous nerve. In its course down the thigh it gives off numerous branches, which pieree the fascia lata to supply the skin covering the back of the thigh and the popliteal space. It the lower horder of the gluteus maximus it gives off $(a)$ reflecterl branches, and (b) a large branch termed the long pudendal nerve.

(ii) The reflected branches, three or four in number, wind round the lower 
borter of the gluteus maximus, and, having pierced the decp fascia, supply the intermment covering the lower and outer part of that muscle.

(b) The long pudendal nerve, or nerve of Soemmerring, winds round the origin of the hamstring muscles, just below the ischial tuberosity, giving twigs to the integmment on the immer and upper part of the thigh, and then curves upwards and forwarls towards the external genitals. Having piereed Colles's fascia, it commmicates with the superficial perinceal nerres, and ends in the integument of

Fig. 466. -A Dissection of the Lumbar axd S.cral Plexuses, from behind.

(The anterior crural nerve is placed between the exterual cutaneous and obturator nerves.)

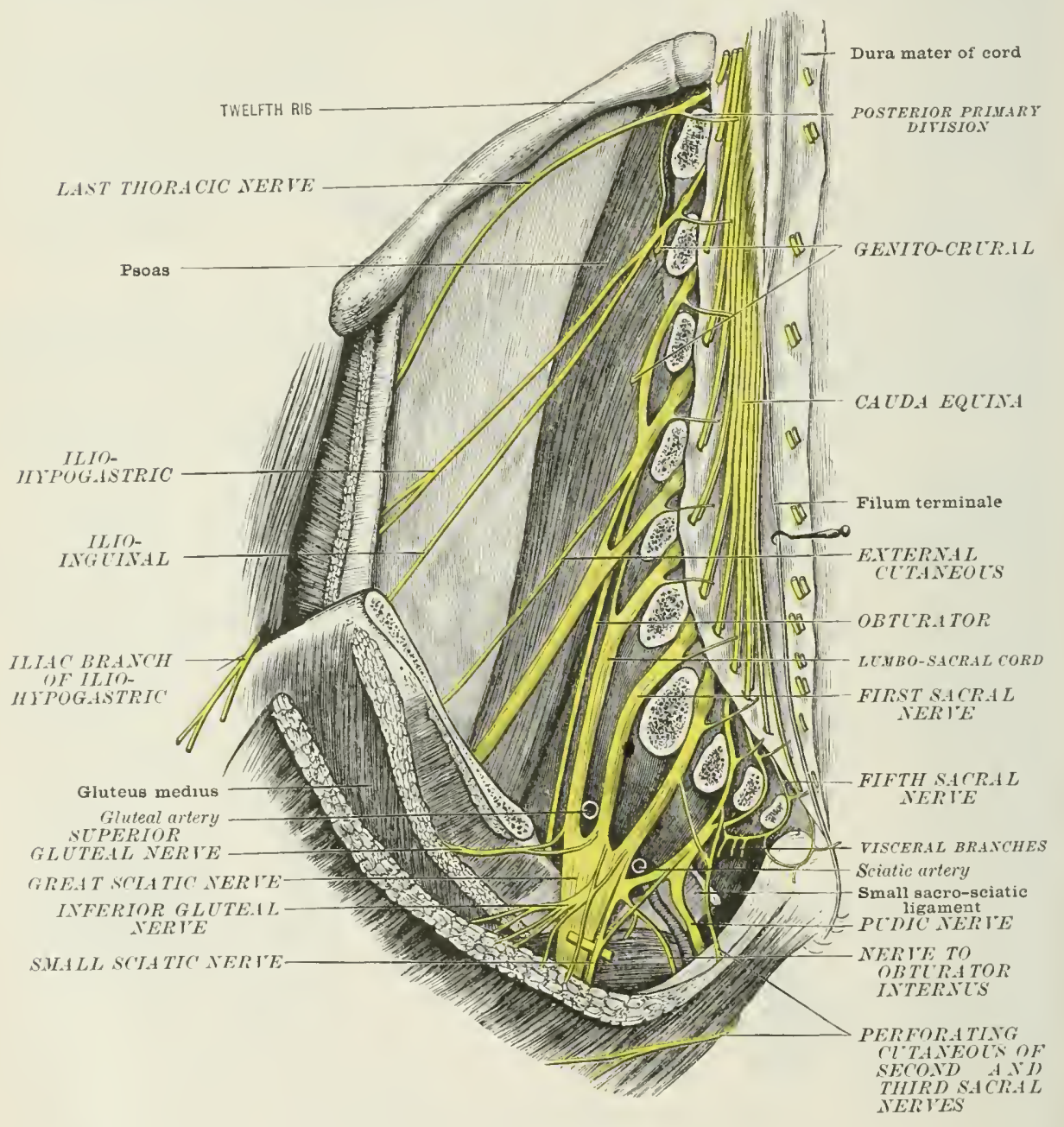

the scrotmm. In the female it is distributed in a similar mamer to the labimn majus.

7 . The nerve to the obturator internus arises from the front of the plexus from the fifth lumbar and the first and second sacral nerves. It passes through the great sacro-sciatic foramen, below the priformis, and crosses the base of the ischial spine, heing placed on the outer sibe of the pudic ressels. Having furnisherl a twig to the superior gemellus, it enters the lesser sacro-sciatic forancm, and ends in the obturator internus.

8. The perforating cutaneous nerve rises from the secomd and third sacral nerves. It runs in the angular interval between the great and lesser sacro-sciatic 
ligaments, and then, perforating the former ligament, runs betwern it and the gluteus maximus. It then winds romel the border of that muscle, helind the ischio-rectal fossa, and supplies the integument covering the lower and inner part of the muscle (figs. 464 and 466 ).

TERMINAL BRANCHES.-1. The pudic nerve arises hy three roots from the anterior divisions of the second, third, and fourtl sacral nelves, and cseapes from the presis by passing through the great sarero-sciatic formen, below the prriformis. It crosses the posterior surface of the small sacresciatic ligament, near the attachment of that ligament to the spine of the ischium, and to the immer side of the pudic ressels. It then accompunies the pudic ressels through the small sacrosciatic foramen, and enters a canal formed by a delamination of the parietal pelvic fascial (Alcock's canal), and, having given off the inferior hamorrhoidal nerve, terminates by dividing into the perincal nerve and the dorsal nerve of the penis. At its origin, the pudic nerve is often connecterl in a plexiform mamner with the nerve to the obturator internus.

Fig. 467.-A Dissection of the Nerves ix the Gleteal Region.

(The gluteus maximus and gluteus medius have been divided near their insertions, anl thrown npward-.)

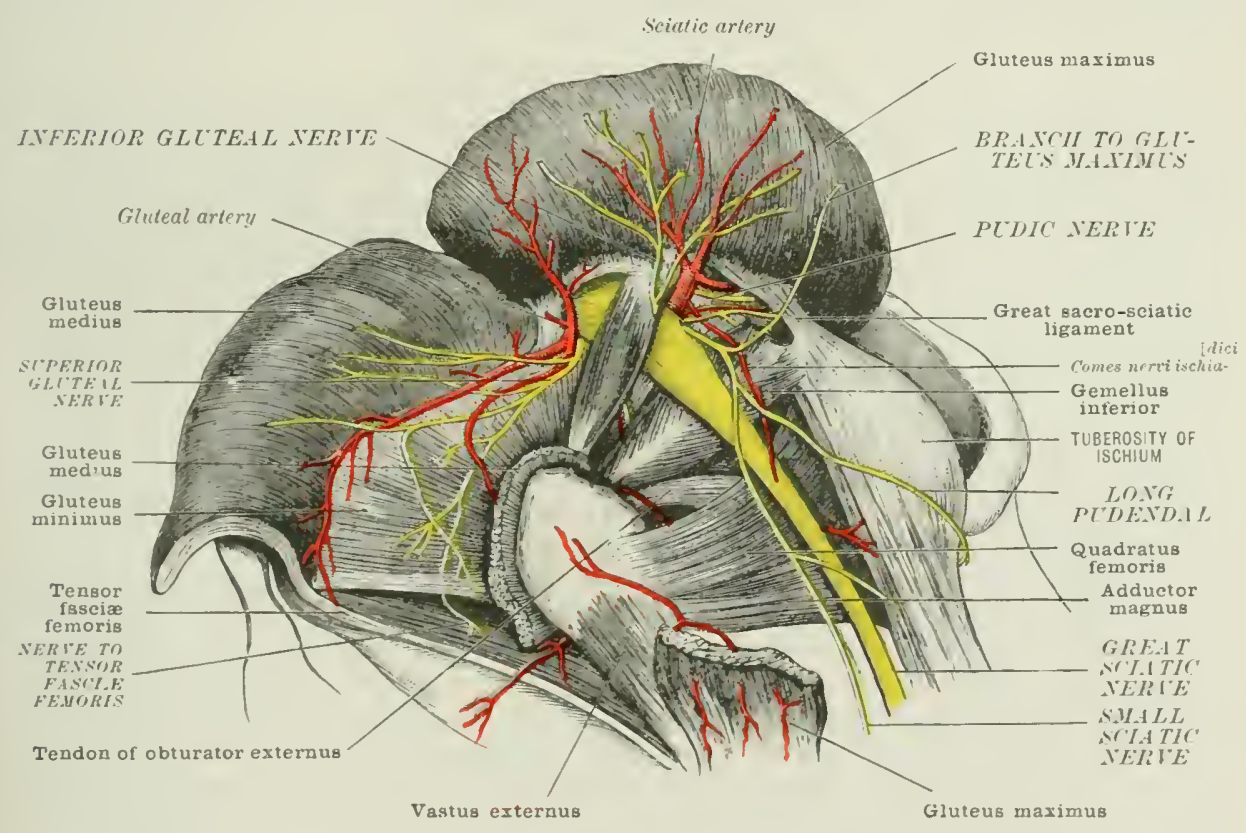

(a) The inferior hæmorrhoidal nerve pierecs the wall of Alecek's camal, and passes inwarls through the fatty tiscue which oceupies the ischin-rectal fosia. It is rleeply placed at the outer part of the fosial, hut becomes superficial as it alpmaclies the anus. It clivirles into teminal twigs, some of which sulply the extemal sphincter ani. while others are clistributed to the adjacent integrment.

(b) The perinæal nerve runs for a short distance in Nleork's canal at a lower level than the pudie ressels, and then divieles inter ('utanenus and muscular divisions. The cutaneous division takes the form of two nerves. which are termed posterior and anterior superficial perinseal nores. The posterior or external superficial perinæal nerve escapes from Alcock's canal at the anterior part of the ischior-retal fossa, fierers the lase of the triangular liganent, winds romel the transwere perinxal muscle, and passes forwards under cover of Colles's fascia. It then divides into several long slender twigs, which rommunieate with the anterior sufurerficial perinaeal and long purlendal nerves, and ('nd in the integrments of the scrotum. In the female they are distributed in a sinilar maner to the lahium majus. The 
anterior or internal superficial perinæal nerve appears a little further forwards than the precoling nerve; it pierees the base of the triangular higanent, and usually passes through the tibres of the transverse perinat muscle. Its terminal oftsets acentumy the branches of the pusterior perinat nerve, and have al similar ristribution. The muscular division of the perinasal nerve is more deeply placed than the cutaneous division. It hreaks u], into the following branches: a twig to the bulb of the urethra, and branches to supply the transiersus perinae erector penis (or clitoridis), aecelerator urina (or sphincter ragina), and compressor urethre muscles.

(c) The dorsal nerve of the penis, which is placed at its origin below the pulic artery, crosses that vessel and courses along above it. It insinuates itself between the layers of the triangular liganent, and lies close to the bone at the outer side of the pudic ressels. It then picrees the anterior layer of the triangular ligament, and, having furnished a branch to the corpus cavernosum, passes between the bone and the crus penis, and is directed downwards between the layers of the suspensory ligament on the dorsum penis external to the dorsal artery. Having given off twigs to the prepuee, it ends in branches to the glans. As it runs on the dorsum penis the nerve is unler cover of a thin strong fascia, and often appears in the form of two or three flattened parallel bundles. The dorsal nerve of the clitoris is clistributed in a similar manner to the clorsal nerve of the penis, but is of much smaller size.

\section{The Great Scintic Nerve}

The GREAT SCIATIC NERVE is the largest nerve in the body. It is, as above mentioned, the main temination of the sacral plexus, and commences at the lower horder of the great sacro-sciatic foramen. It is directed vertically down the thigh, and teminates a little below the middle of the thigh by dividing into the external and internal popliteal nerves. In this course it is covered by the skin and finsciar, the gluteus maximus, the long head of the biceps, and the small sciatic nerve. Its deep or anterior relations are the following, taken in order from above downwards: the ischium, gemellus superior, tendon of obturator internus, gemellus inferior, quarliatus femoris, and adcluctor magnus.

The great sciatic nerve consists of two parts, the extemal and the intermal poplital, which are usually bound together into a single trunk by a connective tissue sheath; sometimes, however, they remain separate, a great sciatic nerve, in the proper sense of the word, heing ahsent.

Ahout the midule of the thigh the external popliteal part supplies a twig containing filaments of the fifth lumbar and the first and second sacral nerves to the short hear of the biceps. At the upper part of the thigh the internal popliteal portion gives branches to the long head of the biceps, the semitendinosus, the semimembranosus, and the adduetor magnus. There are always two branches to the semitendinosus, one to each belly, and they contain filaments of fifth lumbar and the first and second sicral nerves. The branch to the adductor magnus supplies the ischial section of that muscle by filaments derived from the fourth and fifth lumbar nerves, it is usually given oft with the branch to the semimembranosus which also contains fibres of the first sacral nerve. The branch to the long head of the biceps contains fibres from the first, seeond, and third sacral nerves. The EXTERNAL POPLITEAL NERVE, formed of fibres deriverl from the fouth and fifth lumbar and the first and second sacral nerves, enters the superior angle of the popliteal space and runs lownwards anil outwards in eontact with the inner border of the biexps. It leaves the space by passing between the biceps tendon and the outer head of the gastrocnemius, it eroses the popliteus and the inferior external articular artery, then it winds romel the neck of the fibula between the hone and the peroncus longus muscle, and terninates by diviling into the recurrent articular, the musenlo-eutaneous, and the anterior tibial norves.

Branches.-The branches of the extemal popliteal nerve may be classified into articular, reutaneons, and terminal.

(1) The articular branches acempany the superior and inferior extemal articular branches of the popliteal artery, and are clistributed to the knce-joint.

$(2)$ The cutaneous branches are two in number; they often arise by a common 
trunk. One of these, the external cutaneous nerre, which contains filmes from the fifth lumbar and the first and second sacral nerves is distributed to the skin corering the outer and upper jart of the leg. The other branch, the nervus communicans peronei or fibularis, containing fibres from the same ronts, runs downwarl: and inwards beneath the deep fascia, ant joins the nervus communicans tibialis to form the external or short saphenour nerve (page 817 ).

(3) The recurrent articular nerve "nds principally in the upler part of th"

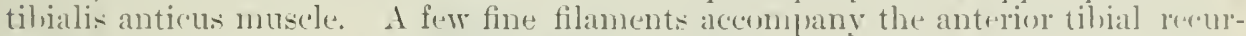
rent artery to the front of the linee-joint. some pass the superior tibio-fibular articulation, anil other's to the head of the tibis.

(4) The musculo-cutaneous nerve, containing filses from the fourth and fifth lumbar and the first sacral nerves. is directed dowawards through the substances of the proneus longus, and is afterwarls placed between the perone ancl extensor longus digitorum. Having given off branches to supply these nuscles, it divides into an external and an internal branch; these branches pierce the deep fascia in the line of the intermuscular septum between the peronei and the extensor group of mucres. The external branch runs clownwarks, in front of the anterior annular liganent. and divides into the following branches: a twig which communicates with the short saphenous; a branch which divides to supply the adjacent sides of the fourth and fifth toes; and a branch which communicates with the internal division of the murulo-cutaneous nerve. The internal branch rosses the anterior anmular ligament ahout an inch to the inner sille of the external branch, and divides into four loranches: the first of these communicates with the extemal branch, forming with it a nerve which bifureates to supply the adjacent sides of the third and fourth tres; the second divides to be distributed to the contiguous sides of the second and third toes; the thirl eommunieates with the internal terminal branch of the anterior tibial at the eleft between the great and second toes; and the fourth supplies the inner borker of the great toe.

In their course across the dorsum of the foot the hranches of the musculocutancous nerve pass beneath the dorsal venous arch. and from the two main divisions of the nerve a number of collateral twigs are given off, which sulply the integunent of the lower part of the front of the leg and the dorsum of the foot.

(5) The anterior tibial nerve, formed from filnes of the fourth and fiftl lumbar and the first sacril nerves, pierces the intermuscular septum between thes peronei and "xtensors, and, having traversed the upuer filures of the extensor longus digitorum, runs lownwards on the interosseous membrane between the last-named muscle and the tibialis antieus; lower down it is placed between the tibialis anticus: and the extensor longus hallucis. It crosses beneath the extensor longus hallucipasses umler cover of the anterior anmular ligament, and teminates in front of the bend of the ankle ly diviling into an external and an intemal branch. In this course it is placed extemal to the anterior tibial artery in the upper third of the ler; it lies on the anterior surface of that ressel in the middle third, and in the remainder of its course it is again external to the artery.

Branches.-In addition to the two terminal branches above mentioned, the anterior tibial nerre gives off an articular twig to the ankle-joint. and branther to supply the tibialis anticus, extensor longus halluris, extensor longus digitorum. and jeroneus tertins. The branches destined for the two latter muscles arise in (onmmon, and take the form of a long slender nerve which runs along the inner siele of the muscles. supplying them with numerous twigs.

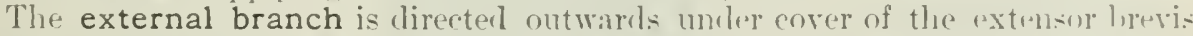
digitorum, ancl. having supplied that muscle, ends in twigs which are distributer to the tarsal articulations. This nerve prosents a gangliform enlargement near its

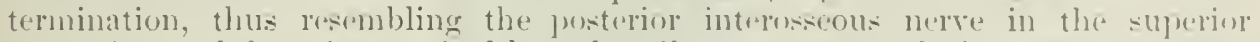

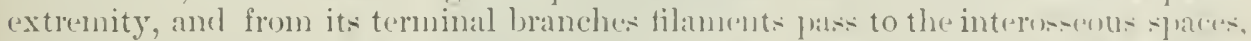
where they anatomose with branches of the extemal plantal nerve and sulply the

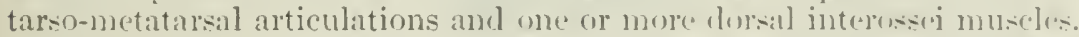

The internal branch is directed forwards towards the interval leetwern the first

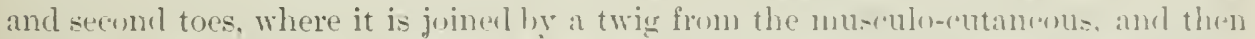

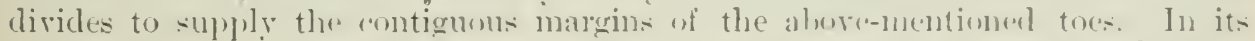
comrse on the dorsum perdis it lies to the outer sile of the dorsal artery of the fort. 
and it is crossed on its superficial surface by the innemust division of the extensor brevis digitorum. In addition to supplying the integment in the area above

Fig. 468.-Distribttion of the Mesclub-cutaxeols axn Axterior Tibial Nerves os THE AXTERIOR ASPECT GF THE LEG AND ON THE DORSTM OF THE FOOT.-(Hirschfeld and Leveillé.)

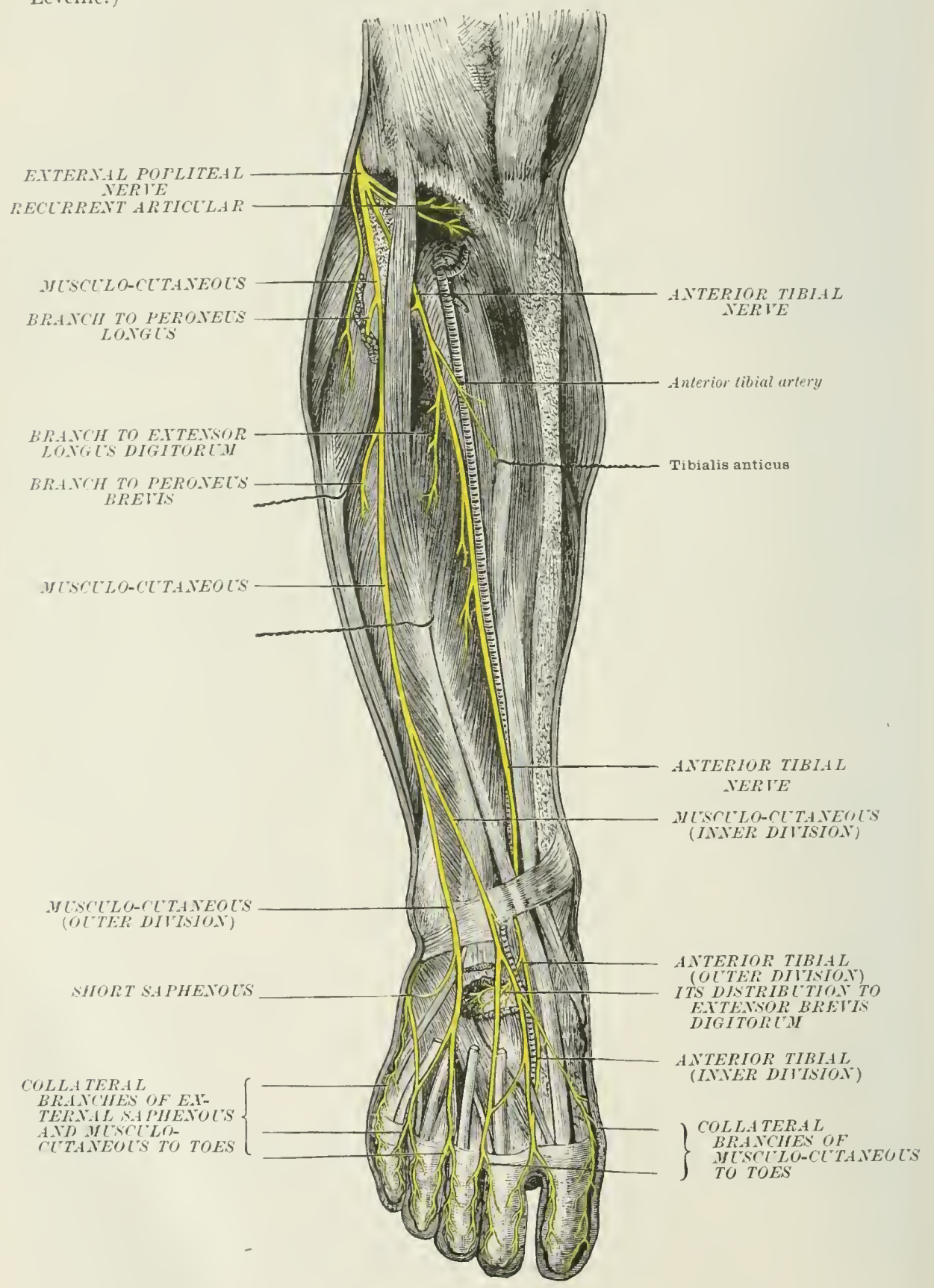

mentioned, it also gives branches to the tarso-motatarsal articulations and to the first dorsal interosseous muscle. 
The INTERNAL POPLITEAL NERVE, formed of filores from the fourth and fifth lumbar and the first, second, and third sacral nerver, is langer than the external fopliteal nerve; it runs downwards, following the same direction as the great sciatie, to reach the lower border of the popliteus muscle, whore it is continued into the posterior tibial nerve. In this course it oceupies the midalle vertical diameter of the popliteal space, ant is the most superficially placed of the important contents of that space. It is overlapperl by the hamstring museles alove and ly the heads of the gastrocnemius below; but is covered only by the skin and fascia for about two inches above the line of the knee-joint. The forpliteal vein intervenes between the internal popliteal nerve and the artery, and the nerve is on a plane superficial to the resseds. In the upper part of the popliteal space the ressels are internal to the nerve; at the level of the knee-joint they are immerliately in front of the nerve; and at the lower part of the space they are placert external to it.

Branches.- The branches of the internal popliteal nerve nua be classified into cutaneous, articular, muscular, and teminal.

(1) The cutaneous branch, the nervus communicans tibialis, containing fibres from the first and serond sacral nerves, arises from the internal popliteal about the centre of the popliteal space, and runs vertically downwards, under corer of the deep fiscia, to reach the interval between the two heads of the grastrocnemitrs; then, inclining a little outwarls, it pierces the deer fascia, and unites with the communicans fibularis to form the short saphenous nerve. The external or short saphenous nerve is formed about the middle of the calf (sometimes higher up or lower down), and runs downards and outwarts, accompanied by the rein of the same name, to reach the interval between the external malleolus and the calcaneum. It crosses superficial to the external annular ligament, and then runs forwards along the outer borker of the foot, supplying numerous twigs to the integument of the region. Having communicated with the external branch of the musculo-cutaneour, it teminates by supplying the integment on the onter side of the little toe.

Varieties.--In a large number of cases the distribution of this nerve is much more extensire. It may supply the fifth and fourth toes and the onter border of the thirl. In some cases the connmunieans fibularis does not join the communicans tibialis, but ends indejendently in the integuments of the calf.

(2) The muscular branches of the intermal popliteal nerve are distributed to the gastroenemius, soleus, plantaris, and popliteus muscles. There is a separate branch for each head of the gastrocnemius, containing fibres from the first and second saeral nerves. The branches to the plantaris and popliteus muscles are formed of fibres from the fourth and fifth lumbar and first sacral nerves. The branch to the popliteus arises lower down than the other loranches. It crosses the superficial surface of the popliteal artery to reach the outer side of that vessel, rums downwards on the posterior surface of the popliteus, and winds round the lower borter of that muscle to gain its deep or anterior surface, where it encls in the muscular substance; hefore it turns round the lower border of the muscle, it gives a branch to the superior tihio-fibular articulation, another to the tibia along the medullary artery, and a long branch to the interossoous membrane; the latter gives twigs to the anterior and posterior tibial arteries and then runs down in the interossonus menbrane and ends in the inferior tibiofilular articulation. The nerve to the soleus is relatively large, it crosses the plantaris to gain the pesterior surface of the soleus carrying fibres of the fifth lumbar and the first and second sacral neres.

(3) The articular branches are three in number, and areompany the stuprior and inferior internal articular and the azyos branches of the popliteal artery, to he distributed to the knee-joint.

The POSTERIOR TIBIAL NERVE contains fibres derived from the fourth and fifth lumbar and the first and sceond sacral nerves; it is the terminal hranch of the internal popliteal, or rather the rlirect continuation of that norve. It rums downWards with an inclination inwards to reach the interval hetween the inner malleolus and the ns calcis, and. having passesl under covere of the origin of the abductor hallucis musele, treminates ly dividinge into the internal and extermal plantar nerves, at a point midway between the tipe of the internal mallewhe and the most

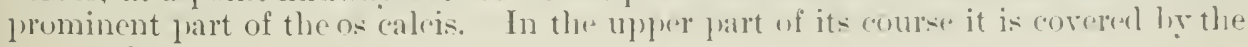


gastrocnemius, plantaris, and soleus muscles, and by the intermuscular part of the deep fascia of the leg. Lower clown, as it approaches the ankle, it is covered only br the skin and fasciax. Its anterior relations are the tibialis posticus in the upler and the flexor longus digitorm and the tibia in the lower fortion of its course. The posterior tihial vesels are placed externally to its upper part; ahove the mirhle of the leg they cross in front of the nerve. and run downwards parallel to its inner side.

Branches. - The posterior tibial nerve supplies the three teep muscles of the

Fig. 469.-Superficial Nertes ix the sule uf the Fuut. (Élitis.)

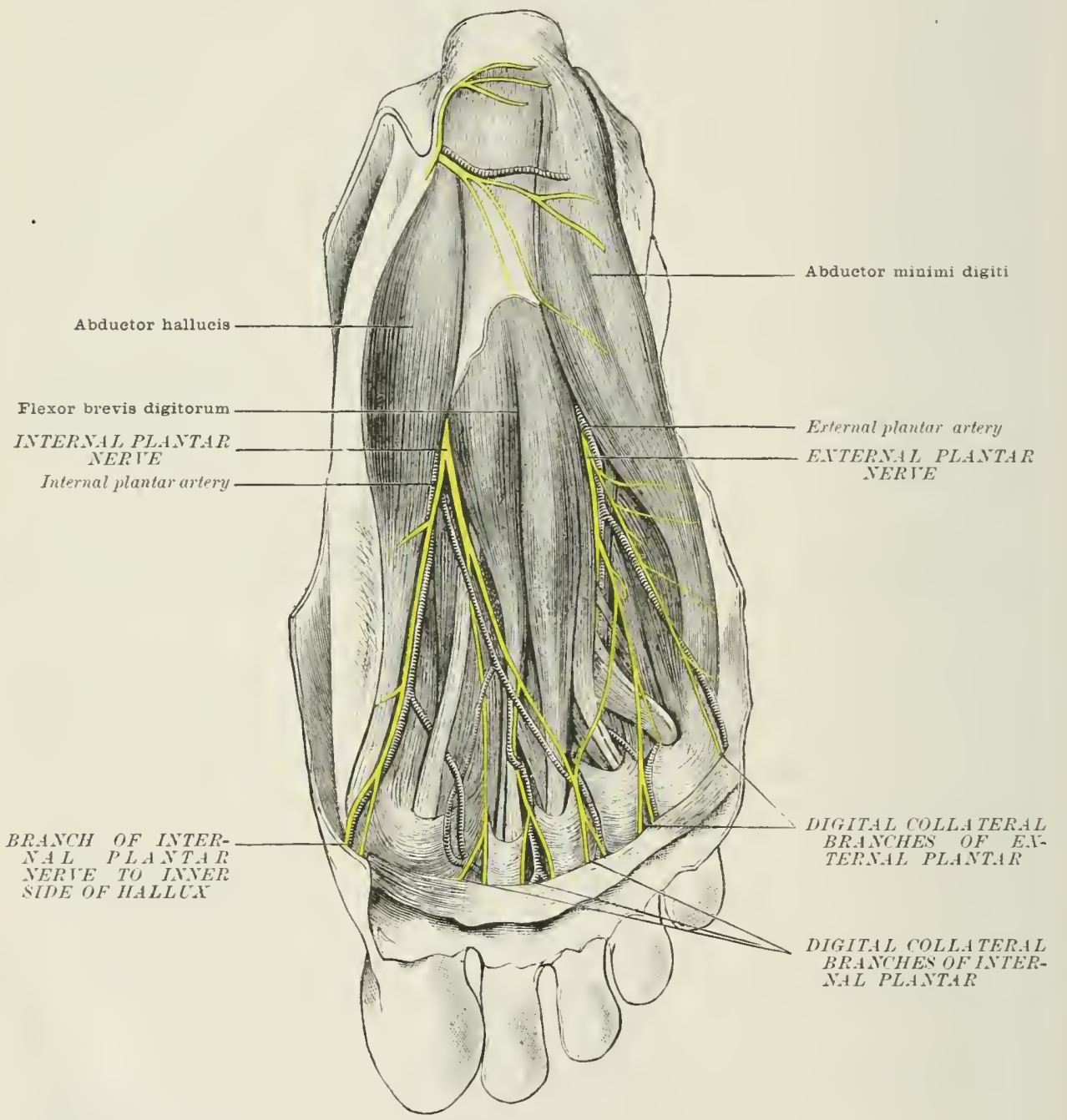

(alf, viz. the tibialis prosticus, flemr lomgns digitomm, and flexor lonyus bullucis, the two former hy twigs from the fifth limbar and the first sacral nerves, whilst the latter receires additional fibres from the second sacral nerve, and it wives a hranch to the soleus. It also furmishes one or two articular filaments to the ankle-joint, and gives off a cutaneous branch, the internal culcanean.

(1) The internal calcanean or calcaneo-plantar cutaneous branch contains: fibres from the first and seend sacral nerves. It arises from the posterior tibial nerve a little above the lerel of the inner mallenlus, and passes under cover of the internal amnular ligament. where it divisles into several branches. These branches 
pierce the internal amular ligament, accompanying the branches of the internal calcanean artery, and are distributed to the thick fascia and interument which covers the heel and adjacent prart of the sole.

(2) The internal plantar nerve is formed of fibres from the fourth and fifth lumbar, and the first and second sacral nerves. It is the lamer of the two terminal branches of the posterior tibial, and corresponds in its distribution tis the median nerre in the hand. It runs forwards in the interval hetween the aldeluctor hallueis and the flexor brevis digritorum; gires oft branches to supply both these muscles. and a number of cutanenus twigs which appear in the interval between the midrle and internal parts of the plantar fascia. It also supplies the astragalo-naricular and the internal intercuneiform joints. Near the level of the tarso-metatarsal articulation it terminates by dividing into four digital branches. The first digital branch gires off a branch to supply the flexor brevis hallucis, and then runs along the inner side of the great toe as far as the extremity of that digit. The second branch gives off a twig to supply the first or innermost lumbrical muscle, and then divides into two collateral branches which supply the adjacent sides of the great and second toes. The third branch divides in a similar manner to sulply the contiguous sides of the second and third toes. The fourth branch communicates with the superficial division of the external plantar, and divides to supply the adjacent sides of the third and fourth toes. The muscular twigs to the flexor brevis hallucis and the first lumbrical muscle contain fibres from the fifth lumbar and first sacial nerves.

(3) The external plantar nerve is formed by fibres of the first and second sacral nerres. It shors many points of resemblance to the distribution of the ulnar nerve in the hand. From its origin, at the termination of the posterior tilinl nerre. it is directed outwarls and forwards between the flexor brevis digitorum and the flexor accessorius. In this part of its course it supplies the accessorius. the abluctor minimi digiti, and the calcaneo-cuboid joint. It is then directed forwards in the interval between the last-named muscle and the flexor brevis digitorum, and trminates at the level of the tarso-metatarsal articulations by divirling into a superficial and a reep division. Previous to its division it gives off sereral cutanents. twigs. which appear in the interval between the middle and external divisions of the plantar fiscia. The superficial division divides into two digital nerres, an external and an internal. The internal branch supplies the interosseous muscles which ocupy the fourth interosscous space, and, having communicated with the internal plantar, divirles into two collateral hranches which supply the contiguous sicle- of fourth and fifth toes. The external branch supplies the flexor brevis minini digiti, and is then directed along the outer border of the little tor to terminate at the extrenity of that digit. The deep division of the external plantar nerve rum: inwards and forwards on the dorsal or deep surface of the flexor tendons, and ramifies in the interval between these tendoms and the internsseous muscles. It supplies the three nuter lumbrical muscles, the internssenus muscles necupring the three inner interosseous spaces, the transwersus pedis, and the adductor hallucis. and it gives branches to the adjacent articulations.

Table silowing Relations of I.tubar ani) Sacral derves to Branches (if

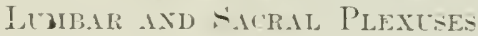

NERE ROoTs.

TERVES.

$1 \mathrm{~L}$.

1 and $2 \mathrm{~L}$.

2 and :? I.

2, 3, ant $+\mathrm{L}$.

4. 5 $\mathrm{L}$... and 1 S.

4 . .) $\mathrm{I}$.., 1 and $2 \mathrm{~s}$.

4 , 5 I., 1, 2. and $3 \therefore$
(Ilio-hypogatstis

i ,, inguinal

Genito-crural

External cutaneous

f Anterior crural

\{ Oloturator

Superior gluteal

Nerve to puarlratus fomoris

(it. sciatic (ext. poplit. part)

(it. sciatic (int. poplit. pilrt) 
Table Show tag Relations of Luabar axi Fieral Nerves to Branches of LCamali AND SACRal Plext'ses. Contimed

NeRVE Riouts.

NERTES.

5 L., 1 and 2......... . . . \{ Inferior gluteal

Serve to obturator intrrmus

1 and 2 s. Nerve to prriformis

2 and 3 s.

2, 3, and $4 .$. . . . . . . Pudic

Table Showixg Relations of Miscles of Lower Extremity to Nerves of Lembar axd sachal Plexuses

NERVE ROOTS.

2 and $3 \mathrm{I}$. . . .

2. 3. and 4 L... $\left\{\begin{array}{l}\text { Gracilis } \\ \text { Adductor brevis }\end{array}\right.$

3 and 4 L. ... . Quadriceps extensor

Adductor magnus

Gluteus medius , minimus

Tensor fase. femoris

Plantaris

Popliteus

Quadratus femoris

Inferior gemellus

Flex. long. digit.

Tibialis posticus

5 L. and $1 \mathrm{s.} \mathrm{.} \mathrm{.}$ Flexor brev. digit.

, ,, hallucis

Abeluctor

First lumbrical

Superior gemellus

Ohturator internus

Gluteus maximus

Semitendinosus

Soleus

Flex. long. hallucis

Pyriformis

Gastrocnemius

Flexor accessorius

Abd. min. digiti

Plantar interossei

Dorsal

Adrl. hallucis trans.

1,2 and 35 ,, , otiliq.

Long head of licep's

Ext. long. hall.

, , , digit.

$\therefore$ brev.

Tibialis anticus

Peromeus tertius

,, longus

, brevis

4, i) L., and 1 .
4, i) L., and $1 . . \quad$ Semimembranosus

Nerves.

Anterior erural

", ",
Obturator "
",
Anterior crural
Obturator

Superior gluteal

and gt. sciatic

Git. sciatic

Internal popliteal

Nerve to quad. fem.

Posterior tibial"

Internal plantar

,,$\quad$,

", $\quad$,

Nerve to obt. int.

Inferior gluteal

Gt. seiatic

Int. poplit. and post. tib.

Posterior tibial

Int. popliteal

Extemal plantar

(it. seiatic

Anterior tibial 


\section{THE DISTRIBLTION OF THE CITANEOLS BRANCHES OF TIIE SENSURY AND MIXED NERYES}

The cutanerous filaments of the semsory and mixed nerves are distriluted to definite regions of the surface of the body which are known as " "utaneous areas." Each cutanens area has one special nerve of supply and the central part of the area receives that nerve alone, but wherever the borders of two areas meet they reciprocally overlap, therefore ach margin of every cutaneous area receires two nerves of supply, its own nerreand that of an adjacent area, and of these sometimes one and sometimes the other preponderates.

\section{The Cetaneol's Areas of the Sicalp}

The limits of the cutaneous areas in the scalp region are indicated in Figs. 469. $469 \mathrm{~B}$, but in general terms it may he said that the skin of the sealp in front of th. pinna is supplied by four cutaneous nurves, the mesial part by the supratrochlear and the supraorbital branches of the first division of the fifth cranial nerre, ans the lateral part by the temporal branch of the second division, and the auriculotemporal branch of the third ilivision of the same nerve.

The portion of the scalp behind the pinna also receives four cutaneous nerves; laterally it is supplied by the great auricular and small occipital branches of the cervical plexus which contain filaments from the second and third cervical nerves. and mesially it receives the great and smallest occipital nerves which are derived from the internal divisions of the posterior primary branches of the second and thirel eervical nerves respectively.

\section{The Cutaneots Areas of the F.de}

With the exception of the skin orer the posterior part of the masseter muscle the whole of the skin of the face is supplied by the branches of the fifth cranial nerve. The nose is supplied mesially by the supratrochlear, the infratrochlear, and the nasal branches of the first division, and laterally by the infraorbital branch of the seeond division. The upper erelid is supplied by the supratrochlear, the supraorbital, and the lachrymal branches of the first division; the lower eyelich by the infratrochlear lranch of the first division and by the infraorbital and the malar branches of the second division. The skin over the upper jaw and the malar bour is supplied by the infraprbital and malar branches of the sceond division, that orer the buccinator muscle by the buccal branch of the third division, and that over the lower jaw. from before backwards, by the mental, huceal, and aurieulo-tramploral hranches of the third division, except a small part near the posterior borter which receives its supjly from the great auricular nerve.

\section{The Cetaneors Areas of the Pixxa}

The upper two-thirls of the nuter surface of the pima are supplierl by the auriculo-temporal branch of the third division of the fifth cranial nerre, and the lower thirel by twigs of the great auricular nerve. The cranial surface of the pimna is supplien in the lower part of its extent hy the great auricular nerve, and in the upper part he the small aecipital nerve. "The josterior surface of the external auditory meatus receives filaments from the aurienlar hranch of the tenth cranial nerve.

\section{The Cetaxeots ARE.AS OF THE NeCK}

The skin over the anterior part of the neck is supplied by the superficial curvienl branch of the corvical plexus, which contains filaments of the ferond and thirel cervical nerves and in the lower part of its extent hy the suprasternal brankh, which comvers twigs of the thirt and fourth ecrvial nerves (fig. 46.9.1). The lateral pant of the neck recerives filaments from the second, thiml, and fourth cervinal nerves: 
hr the great aurieular, small occipital, and supraclavicular hranches of the cervical plexus (fig. 469.). and posteriorly the skin of the neck is supplied by the small cecipital nerve and by the internal branches of the posterior primary divisions of the eervical nerves from the second to the sixth inclusive (fig. $469 \mathrm{~B})$.

Fig, 469A.-Dharam of the Cutaxeous Nerve Areas of the Head axd Neck.

$$
\text { Red-First division of fifth. White-Second division of fifth. }
$$

Blue-Third division of fifth.

Dark sbading-Posterior primary division of eervical nerve.

Oblique shading-Ascending and transverse superfieial branches of cervical plexus.

Transverse shading-Deseending superficial branches of cervical plexus.

It wust be understood the buundaries of each area are not distinct; wherever two areas meet they orerlap.

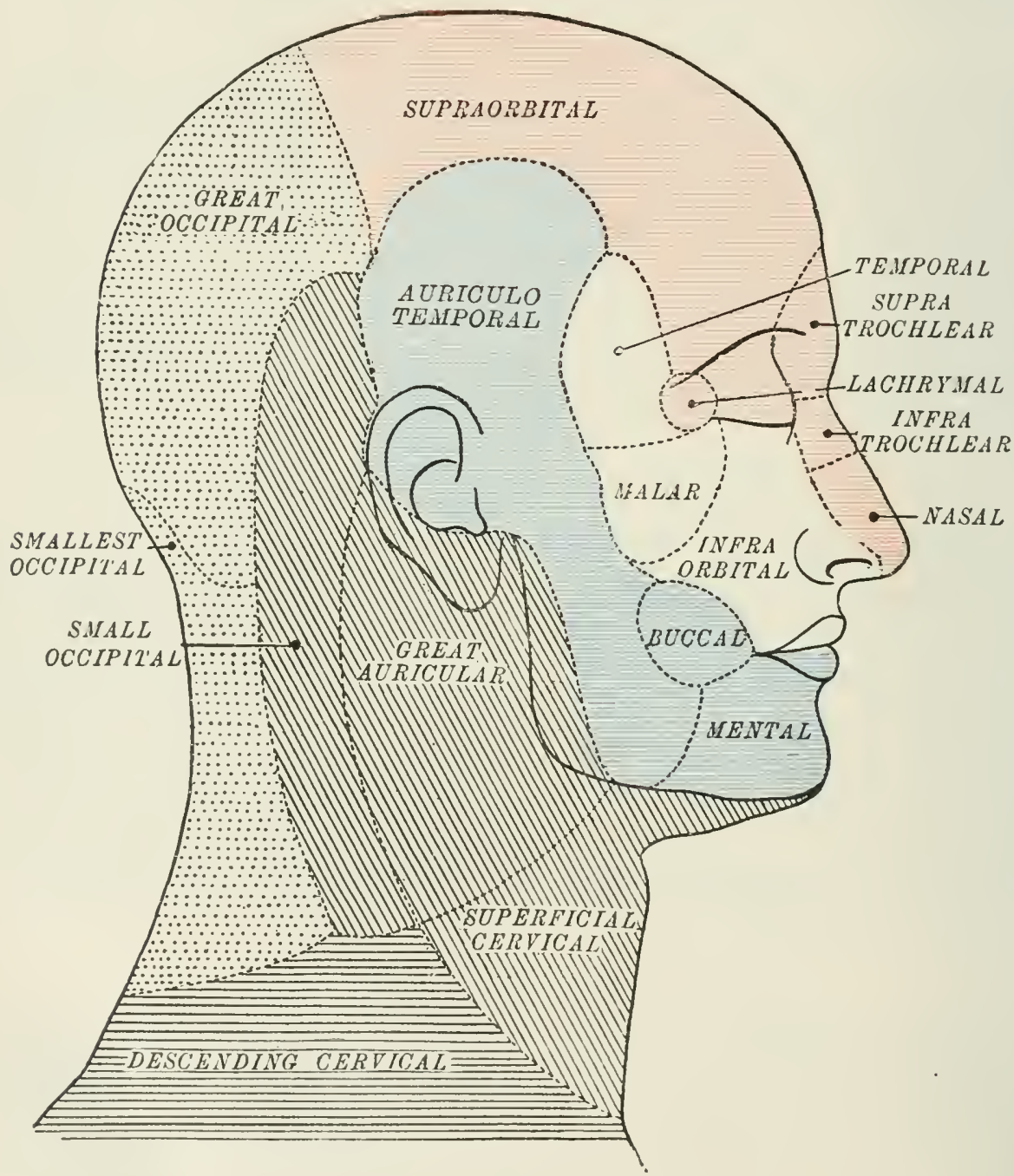

The Cutaneots Areas of the Bony

The skin orer the anterior aspect of the boly as far down as the second rib is supplied by the suprasternal and supraclavicular branches of the cervical plexus, which contain filaments from the third and fourth cervical nerves (fig. $469 \mathrm{~B}$ ); from the second rib to the lower part of the abdominal wall it receives the anterior cutaneous branches, and the anterior divisions of the lateral cutaneous hranches of the dorsal nerves except the first, second, and twelfth (fig. $469 \mathrm{~B}$ ); and the skin over the 
lower and anterior part of the abdominal wall is supplied by the ilio-liypogastric branch of the first lumbar nerve.

The cutaneous supply of the lateral aspect of the body is derived from the lateral branches of the anterior primary divisions of the dorsil nerves from the second to the eleventh, and the skin over the pesterior aspect of the horly is supplierl externally by the posterior divisions of the lateral branches of the forsal nerves from the third to the deventh, and intemally hy the posterior primary divisions of the dorsal nerves (fig. $169 \mathrm{~B}$ ), in the upper half hy their internal branches and in the lower half principally by their external branches.

\section{The Cetaxeots Areas of the T'pper Lamb}

The skin over the upper third of the deltoid muscle is supplied by the supraacromial and supraclavicular l,ranches of the cervical plexus, which contain filaments of the third and fourth cervical nerves, and that over the lower two-thirds by the circumflex nerve, which eonveys fibres of the fifth and sixth cervical nerves (fig. $469 \mathrm{~B}$ ).

The skin over the front of the upper arm is supplied extemally by the circumflex nerve above and by the superior external cutaneous branch of the musculofriml nerve below; the former contains filaments of both the fifth and sixth cervical neres, and the latter filaments of the sixth alone. Internally the skin of the upper arm is supplied by the internal cutaneous nerve with filaments of the eighth cervical and first dorsal nerves, and by the lesser internal cutaneous and intercosto-humeral nerves which are derived from the first and second dorsal nerves. The back of the upper arm is supplied, externally, by the fifth and sixth cervical nerves through the circumflex nerve, and the external cutaneous branches of the musculo-spiral nerve; nseially by the eighth cervical nerve through the internal cutaneous branch of the mu-culo-spiral nerve, and internally by the first and second dorsal nerves through the liser internal cutaneous and intercosto-humeral nerves (fig. 469).

The front of the forearm is divided into two areas, an external, which is suplied by the fifth and sixth cervical nerves through the musculo-cutaneous branch of the brachial plexus, and an internal, supplied by the eighth cervical and first dor:al nerves through the internal cutaneous nerve. On the back of the forearm there are three areas: an extcrnal, supplied by filaments of the fifth and sixth cervical nerves through the musculo-cutaneous nerve; a mildle, which receives filaments of the sixth, seventh, and eighth ecrvical nerves through the inferior external cutaneous liranch of the musculo-spiral nerve; and an internal, which receives the righth cervical and first dorsal nerves through the intemal cutaneous nerve (fig. 469 B).

The front of the hand is supplied by the sixtl, seventh, and eighth cervical nerves and by the first dorsal nerve through the radial branch of the musculo-siral nerve and through the median and ulnar branches of the braclial plexus. The rarlial nerve supplies the radial sicle of the thumb by its jalmar cutaneous branch; the remainder of the palm and the palmar aspects of the fingers are supplied by the median and ulnar nerves througl their palmar cutaneous and digital branches, the median supplying three and a half digits and the ulnar the remaining one and a half (fig. $469 \mathrm{~B}$ ).

The dorsal aspect of the hand is supplied ly the sixth, seventh, and eighth (ervical nerves which reach it through the radial branch of the musculo-spiral nerve and through the median and nlnar nerves. The radial nerve supplies the outer part of the dorsum and the outer three and a half cligits, except the lower farts of the index, midrlle, and half the ring digits which receive twigs from the median nerre, and the ulnar nerve supplies the ulnar half of the dorsum ineluding the inner one and a half digits.

\section{The Cutanents dieas of tile InWER Extremity}

There are six cutaneous areas in the region of the huttork, three upler and three lower. Of the upper areas the external is supplicel by the anterior primary rlivisions of the last clorsal and fir-t lumbar nerresthrough the iliac loranches of the 


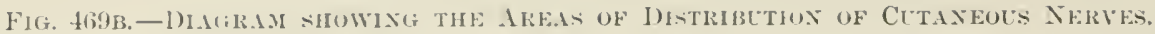
IIEAD:-

Red-First division of fifts. White- Seeond division of fifth. Blue-Third division of fifth. Dark area-Posterior primary divisions of eervical nerves. Oblique and transwerse shading-Branehes of cervical plexus.

BODY AND LAMB:-

Rel-Anterior divisions of anterior vrimary branches. Bluc-Posterior division of anterior primary branches. Two colors in one area indieate that the area is supplied by two sets of uerves, and it should be unlerstoml that wherever two nerve areas approach each other they overlap. The dotteil blue area of suall seiatic inlieates that the nerve eomes from the posterior part of anterior primary divisions of sacral nerves, hut it supplies a thexor area. The area of the perforating entaneous nerve is left unenloured, because its true nature is uneertain. Dark shading-Posterior primary divisions. The uumbers and initial letters refer to the nerve roots from which the nerves are derived.

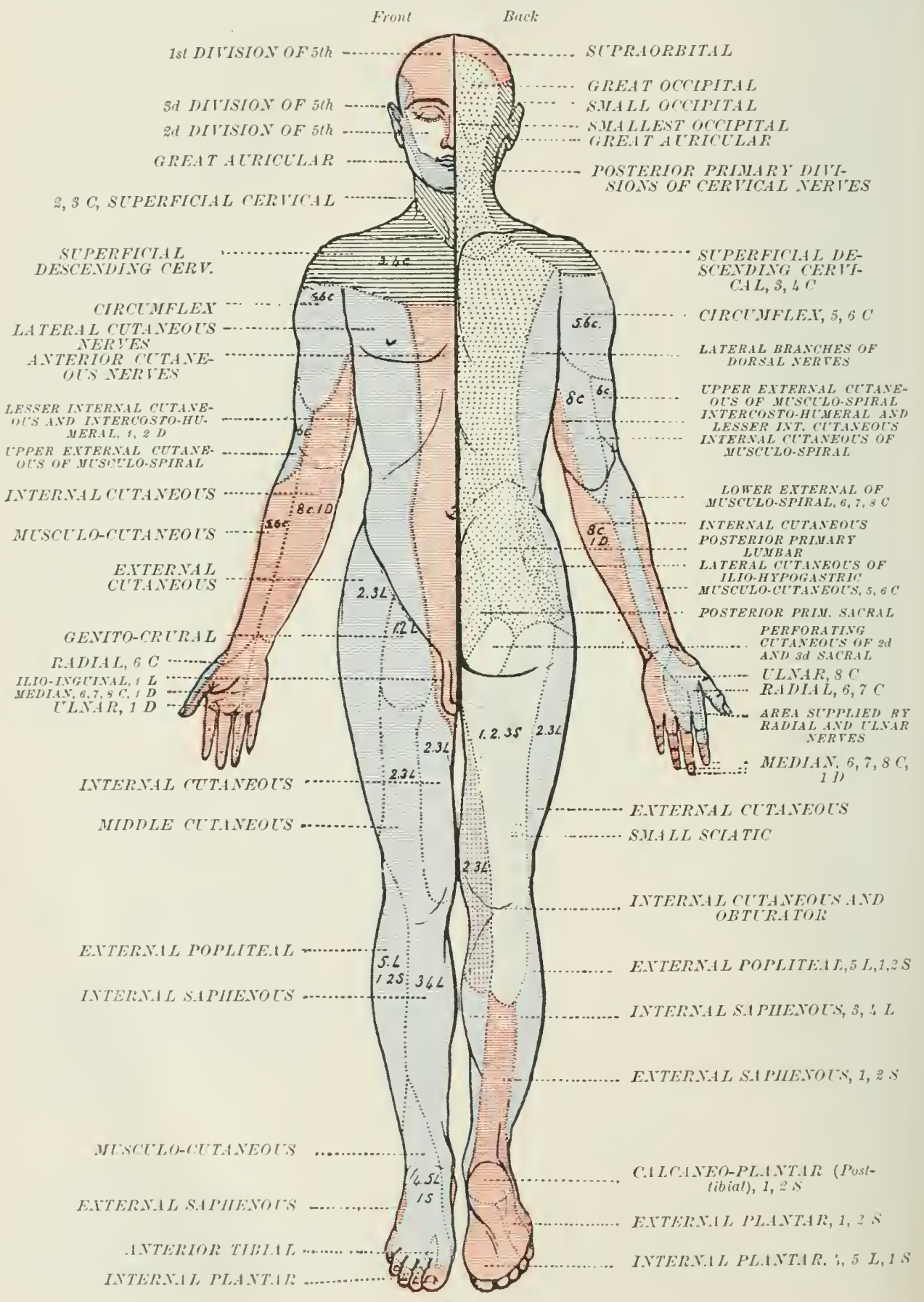




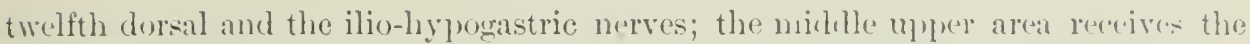
external divisims of the pusterior prinary hamehes of the upper three lumblar nervers, and the inner and upper area is supplied hy twigs from the external divisions of the posterior primary lianches of the uperer two or thres sacral nerves (figr, 46 (b)

()f the lower three areas the outer receives filaments from the secomel and thim lumbar nerves through the external eutaneous branch of the lmmbar plexus the midtle area is supplied lyy the first, second, and third saterall nerves through the stlatl soratic nerve, and the inner area by the second and third sacral norres through the perforating cutaneous branch of the sacral plexus (fig. $469 \mathrm{~B}$ ).

On the back of the thigh there are three areas. The external and the internal aresupplied hy the second and third lumbar nerves, the former through the externil cutancous branch of the lumbar plexus and the latter through the internal cutaneous branch of the anterior crural nerve; the middle area receives twigs from the first, second, and third sacral nerves through the small sciatic brancli of the sacral plexus (fig. $469 \mathrm{~B}$ ).

The front of the thigh is supplied by the first, second, and third lumbar nerves. and there are five cutaneous areas; the outer receives twigs of the second and thim lumbar nerves through the external cutaneous nerve. There are two mesial areats. an upper and a lower. The former is supplied by the crural branch of the genitscrural which convers twigs of the first and sccond lumbar nerves, and the latter receives filaments of the sceond and third lumbar nerves through the mirtlle cutaneous branch of the anterior crural nerve. The small upper and internal area is supplied by the first lumbar nerve through the ilio-inguinal branch of the lumbar plexus, and the lower internal area receives twigs of the second and thiml lumbar nerves through the internal cutaneous branch of the anterior crural nerve (tier. 469313$)$.

The front of the knee is supplied by the second, third, and fourth lunhar nerves through the middle cutancous, the internal cutaneous, and the long sitphen()u- branches of the anterior crural nere (fig. 469B).

The skin orer the regiom of the popliteal space receives filaments internally from seend, third and fourth lumbar nerves through the internal cutaneous branch of the anterior crural nerve and through the superficial division of the ohturator nerve: mesially and extumally it receives twigs of the first three sacral nerves through the small sriatic nerve (fig. 469B).

The skin of the front and immer side of the leg is supplied by the third and fourth lumbar nerres through the long saphenous branch of the anterior crural merve, amk the skin of the front and outer side of the leg receives filaments of the fifth lumbar, and the first and second sacral nerves through the external cutanenus hranch of the external popliteal nerve. The skin of the lower and midlle part of the anterior aspect of the leg is supplied by the musculn-cutaneous nerve which convers filaments of the fourth and fiftl lumbar and the first sacral nerre (fic. $\left.4(j 9)_{B}\right)$

In the skin of the lack of the leg five areas can be distinguished, two internal. upper and fower, two middle, upper and lower, and an external. The upper and imer areic is supplied ly the second, third, and fourth lumbar nerves through the internal cutaneous branch of the anterior crural nerve and the superficial branch of the obturator nerve, the lower internal area receives filaments from the third and fourth lumbar nerves through the long saphenous nere. The upper midlle areal is supplied by the first, second and thire saeral through the small sciatie norre. and the forrer milldle area hy the first and seeond sacral nerves through the externill saphenous nerre. The outer area is supplied ly the fifth lumbar and the fir-t and second sacral nerves through the external cutanenss luanch of the external pupliteal nure (fig. $469 \mathrm{gm})$.

The skin of the dorsum of the font $\mathrm{i}$ s supplial frincipally by the fourth ant fifth lumbar and by the first sareral nerves; the majority of the nerve filamenttravel by the musculo-cutaneous nerve, hut the arljarent sirles of the first ame second tores aresupplied he the anterior cerual nerve, and the outer side of the dorsum of the little toe is supplind hy the first and stemel satcral nerves thromer the external siphenous nerre (fig. $469_{\mathrm{B}}$ ). 
The skin of the region of the heel is supplierl by the firt and second sacral nerves, on the inner surface and inner part of the under surface by means of the calcanco-plantar branch of the posterior tibial nerve, and on its posterior, external, and lower aspects by the external saphenous nerre (fig. 469B).

The sole of the foot in front of the heel receives cutancous filanents from the last two lumbar and the first two sacral nerres, the inner area, which inclucles the inner three and a half digits, being supplied hy the intemal plantar nerre which convers filaments of the fourth and tifth lumbar and the first sacral nerre, and the outer area by the first and second sacral nerves through the extemal plantar nerve.

The immer side of the foot is supplied by the third and fourth lumbar nerres through the long saphenous nerve, and the outer side by the first and second sacral nerves through the external saphenous nerve (fig. 4698).

The skin of the scrotum and penis is supplied by the first lumbar nerre through the ilio-inguinal nerves, and the second and third sacral nerves through the perineal and dorsal penile branches of the pudic nerres (fig. $469 \mathrm{~B}$ ).

\section{SYIIPATHETIC NER VES}

The sympathetic nerves were formerly supposed to be a separate sistem, linkel, it is true, to the cerebro-spinal system by numerous communications, yet possessing, in their ganglia, a certain goreming porrer independent of the cerebrosuinal axis. It is now very generally admitted that the sympathetic nerves are merely the visceral branches of the spinal nerves. but they differ from the somatic nerves in the following respects: $(a)$ in the individual fibres being of smaller calibre than the somatic nerve-fibres; $(b)$ in the great preponderance of non-medullated filnes; $(c)$ in the fibres being interrupted in the nerre-cells, which are contained in a chain of ganglia which is called the gangliated cold of the sympathetic, and often also interrupted in secondary and tertiary ganglia, of which the semilunar ganglia and the nerve-cells in the plexuses of Auerbach and Meissner are examples; and (d) in the tendency that these nerves show to form extensive and closely-meshed plexuses.

The somatic nerves are the nerres which supply the body-mall as distinguisheel from the riscera. They have been described above as the cranial and spinal nerves.

Certain visceral nerves-for example, the visceral branches of the third and fourth sacral nerves-do not join the gangliated cord. While the sympathetic nerves, taken as at whole, can no longer be regarled as a separate system, certain ganglia connected with the sympathetic are capable of automatic action; for example, the ganglia in the heart and in the intestinal walls.

The sympathetic system, as usually described, consists of (u) a pair of gangliated cords which are placed on the front and sides of the rertelinal columm; and $(b)$ three great prevertebral plexuses containing many ganglia; and (c) numerous terminal ganglion cells situated close to or within the varions organs and ressels. ()ne of the plexuses, the carliac plexus, is contained in the thoracic carity. The other two, which are termed the solar and hypogastric plexuses, are placed in the abclominal cavity. The gangliated cords will lie first described.

\section{- G.NGIIATED CORDS OF THE SYMPATHETIC}

The gangliated cords of the sympathetic consist of a series of ganglial united together hy intervening cords. These ganglia are of a reclelish-grey colour, soft in ("onsistence, hut enclosed in tolerably firm investments of connective tiscue. The nerve-cords miting them are pearly grey in colour. Morphologically speaking, there should be thirty-one pairs of ganglia, that is to say, a pair corresponding to 
each pair of spinal nerves. The find, however, owing to the cohesion of curtain ganglia, particularly in the cervicai region, that the number is refuced to from twenty to twenty-three pairs. In the thoracic region the arrangement is the most typical, twolve pairs of ganglia correspending to the twelve thoracie nerves being frequently present. In the thoracic region, also, the arrangenent of the rani communicantes is most easily studied.

Each thoracie ganglion is connected with the anterior primary division of the corresponding spinal nerve by two rami communicantes (fig. $470 \mathrm{~A}$ ), a white and a grev. The white ramus consists of small medullater fibres which leave the spinal cord by the anterior nerve root and pass to the ganglion. Some of the filures of the white ramus pass through the ganglion and leave the vhain directly, or more generally after rumning upwards or downwards for some clistance within it, by the rami efferentes (fig. $470 \mathrm{~A}$ ).

The rami efferentes pass to the jrevertebral plexuses where they may end in artorizations round the cells of the ganglia, or jassing through these ganglionic plexuses they end round the cells of the terminal ganglia, which are situated either close to or within the walls of the ressels and organs. Other fibres of the white rami afferentes terminate round the cells of the vertebral gangha (ganglia of the (hain).

From the cells of the various ganglia, vertelmal, prevertebral, and terminal, non-medullated fibres arise which end in the walls of the viscera, vessels, and glands. Many of the non-medullated fibres which issue from the thoracic vertehral ganglia form the grey rami (fig. 470.1). They pass to the spinal nerves. Some of them turn inwards along the posterior nerve roots to the memlianes of the spinal cord and the walls of the spinal canal; others travel peripherally, with the branches of the nerve; they terminate in the blood ressels, hair muscles, and skin glands. The remaining non-medullated fibres, which issue from the vertebral ganglia, leave in the rami efferentes and pass through the prevertebral plexuses to their terminations (fig. $470 . \mathrm{A}$ ).

In addition to the fibres above mentioned, it is possible that there are also afferent (sensory) filores passing from the viscera, glands, and ressels through the sympathetic ganglial to the posterior nerve roots and thence to the spinal cord.

Cranial portion of the sympathetic.-The small sporadic ganglia (ophthahnic, splleno-palatine, otic, and submaxillary), which have alreaty been described in connection with the trigeminal nerve, are regarded by some anatomists as representing a cranial portion of the gangliated cord, and sympathetie fibres are undoubtedly given off from the ninth, tenth, and eleventh cranial nerres.

\section{CERVICAL PORTION OF THE GANGLIATED CORD}

The cervical portion of the gangliated cord consists of three ganglia united by intervening nerve-cords. Of these the superior cervical ganglion is the largest, and probably represents four coalesed ganglial the midelle cervical ganglion is the smallest, and represents two ganglia; the inferior, internediate in size, is probably formed by the union of two ganglia. The corr takes a vertical eourse clown the neck, and is in contact posteriorly with the prevertehral layer of the cerrical fascia. Behind this fascia it corresponds to the rectus eapitis anticus major abore, and the longus colli below. These muscles and the prevertrbial fascia intervene hetween the corl and the transverse processes of the cervieal vertebre. The intemal carotirl above, and the common carotid artery below, are placed in front of the arangliated cord, and the pneumogastric nerve is externil to it.

\section{Siperior Cervical Gavglow}

The superior cervical ganglion is a furiform body, about one inch to an inch

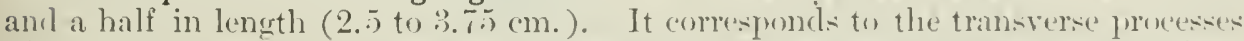
of the second and third (and sometimes the first) cervical vertebre. Alove it is continuer into a stout trunk which is callerl the asceneling hranch. Below, it (nels in a cord which passes dowmards to join the mirldle cervieal granchlion. It is ennnected to the anterior primary divisions of the four upper cervioal nerese hy as 
many grey rami communicantes. Oceasionally the number of rami is increased to tive or six. The ganglion is orcasionally constricted at intervals-these constrictions aftording an indieation of the individual ganglia hy the coalescence of which the superior cervical ganglion is formed.

Branches.--The branches of the superior cervical ganglion are the aseending branch; branches which follow the distribution of the extemal carotid artery (nervi molles); branches of communication to cranial nerves; pharvngeal nerves; the superior cervical cardiac nerve, and branches to the upper cervical vertehre and their ligaments.

1. The ascending branch enters the carotid canal in the temporal hone and clivides into a larger external branch which forms the earotid plexus, and a smaller internal branch which ends in the arernous plexus. These plexuses conmmieate frequently with one another around the artery, and may be regarded as different parts of the same plexus rather than distinct jilexuses.

The carotid plexus is formed by repeatedly communicating branches, which follow the internal carotid artery in the carotid canal, keeping close to the outer sicle of that vessel. The following nerves arise from it: tympanic; great deep petrosal; and a communicating branch to the sixth nerve.

(a) The tympanic branch (small deep petrosal) enters a minute canal (carotico-tympanic canal) in the temporal bone, by which it is conducted to the tympanic plexus (page 768 ).

(b) The great deep petrosal nerve passes forwards and inwards through the cartilage which oceupies the foramen lacerum medium, and unites with the great superficial petrosal to form the Vidian nerve (page 75.5).

(c) The branches to the Gasserian ganglion are given off from the plexus as it emerges from the carotid canal.

(d) The branches to the sixth nerve are very distinct, and can be easily seen when the caremous sinus is opened. They join the abducens as it is rossing the outer side of the internal carotid artery.

The cavernous plexus is placed on the immer side of the internal carotid artery near the pituitary body. Its terminal offsets follow the oplithahmic and cereloril branches of the internal carotid artery. In addition to these it gires off the following branches:-

(a) Communicating branches to the third, fourth, and ophthalmic division of the fifth cranial nerves.

(b) The sympathetic root of the lenticular ganglion. This root is usually in the form of several fine filaments which enter the ganglion at its posterior borker.

(c) Two or three fine twigs enter the pituitary body.

2. The nervi molles are given off from the anterior part of the superior cervical ganghion, and accompany the branches of the external carotid artery. We have alceady noted, in the description of the fifth cranial nerve, that the otic and submaxiliary ganglia receive their sympathetic roots from plexuses of the sympathetic which reach them via the middle meningeal and facial arteries respectively. In addition to these roots to the ganglia, vaso-motor branches, and trigs which enter the parotid gland, are given off. Other twigs, taking a downward direction, enter the interearotic and thyroid borlies; the latter follow the course of the superior thyroid ressels.

3. Communicating branches to cranial nerves.-Brancles of communication arise directly from the ganglion to join the vagus, glosso-pharyngeal, and hypoglossal nerves. Communications are effected with the ganglia of the root and trunk of the ragus, and with the jugular and petrous ganglia of the glosso-pharyngeal.

4. The pharyngeal branches, four or five in number, pass downwards and inwards hehind the extemal and intemal carotid arteries to join the pharyngeal plexus.

5. The superior cervical cardiac nerve arises from the lower part of the ganglion, or oreasionally from the nerve-corl between the superior and middle cervical ganglia. The nerves of the two sides run a corresponding course in the neck, but differ in their arrangement in the thorax. In the neck, each nerve is directed downwarls on the jurerertetoral fascin in front of the longus colli muscle, 
and communieates with the upper cervical carcliac branch of the pnemogastric, with the middle cardiac nerve of the sympathetic, and with the extemal laryngeal and recurrent laryngeal nerves.

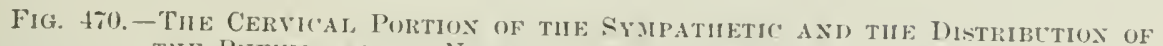

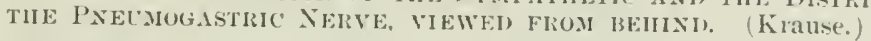

$$
\text { Stylo-hyoid Liganentum pharyngeum }
$$
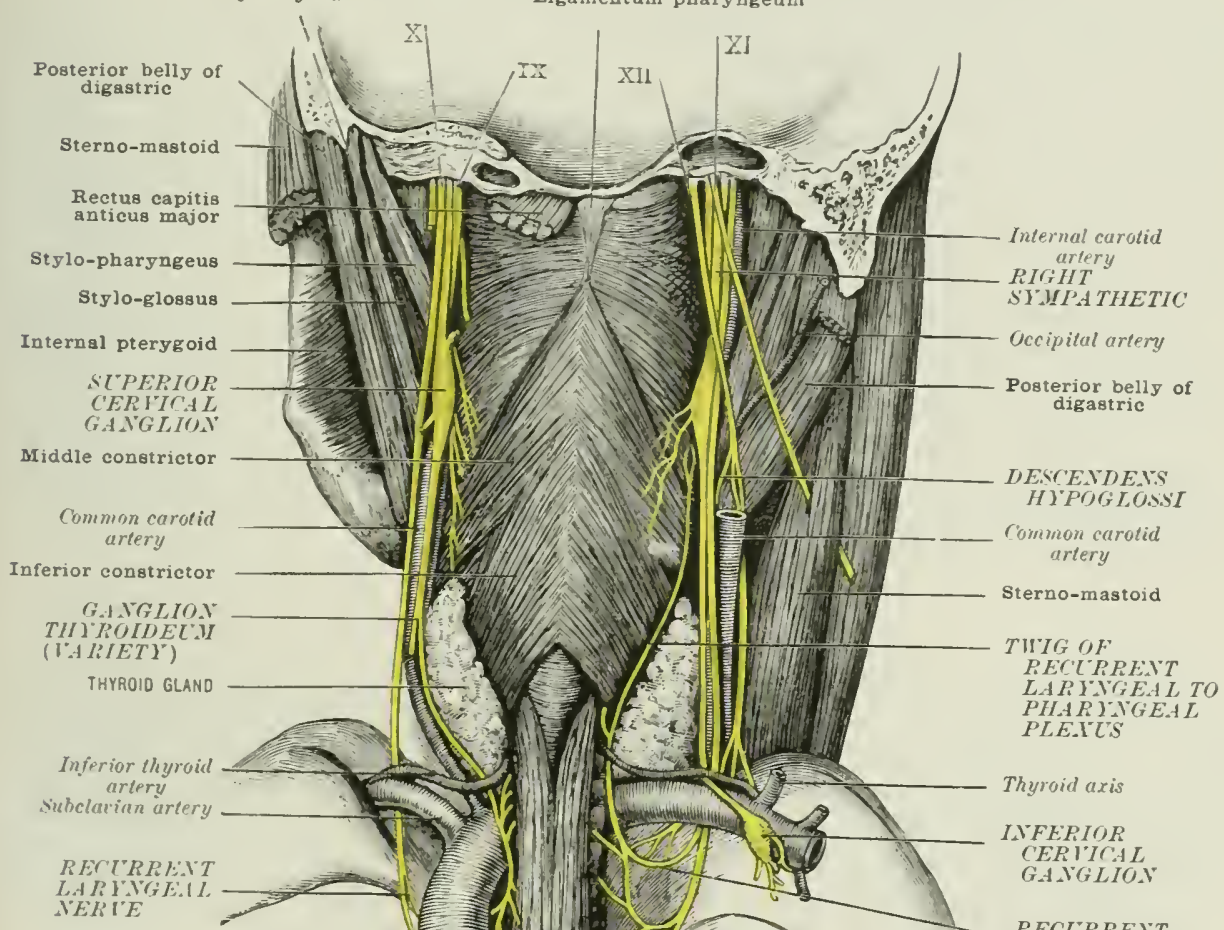
NERTE

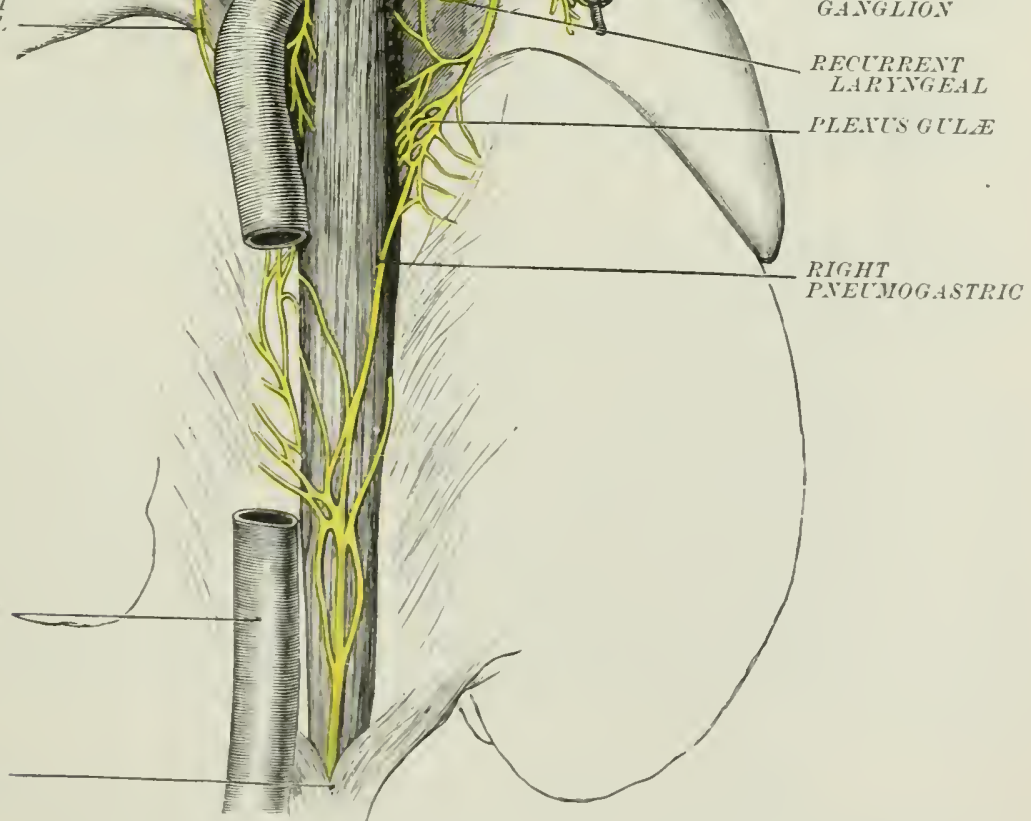

On the right side the nerve passes in front of (oceasimally luhinl) the sul)clavian artery, and is lirecterl along the innominate antery to reascld the bifureation of the trachea, in front of which it terminates in the drep carliac plexus. 
On the left side the nerve is conducted into the thorax in front of the emmon carotil artery, and crosses in front (or rather to the loft side) of the arch of the aorta in the interval betwern the trunk of the vagus and its inferior cervical cardiac branch, and ends in the superficial cartiac plexus.

\section{Midde Cervical Ganglion}

The middle cervical ganglion is a small, somewhat triangular, ganglionic thickening of the cord of the smmpthetic. It is situated at the point where the cord crosses the inferior thyroid artery at the level of the sixth cervical rerteb)ra. It gives grey rami communicantes to the fifth and sixth corvical nerves. It is comnected below to the inferior rervieal ganglion by the main cord of the srmpathetir. which passes behind the subelavian artery, and by one or more nerve-cords which pass in front of that ressel, forming the ansa Vieussenii. The millle cervical ganglion gives off branches to the thyroid body and the middle cardiac nerve.

The branches to the thyroid body communicate with the superior cardiate nerve, and proceed to the grand, following the branches of the inferior thyroid arterv.

The middle cardiac nerve enters the thorax, passing sometimes in front of the suldavian artery, and sometimes behind that ressel. It communicates in the neck with the upper cardiac nerve, and in the thorax with the recurrent larygeal. It terminates in the deep cardiac plexus. On the left side this nerve passes down between the left carotid and subclavian arteries.

\section{INFERIOR CERTICAL GANGLION}

The inferior cervical ganglion is larger than the middle ganglion, and is connected by short grey rami communicantes to the serenth and eighth cervical nerves. It is irregular in form and is deeply placed. being lodged in a depression between the neck of the first rib and the transverse process of the seventh cervical vertebra. In this situation it is concealed by the rertebral artery, the ressel being placed in front of the ganglion. It is mnited to the first thoracic ganglion by one or two stout corls and often by a band of ganglionic sulstance. It gives oft hranches to the vertebral artery and the inferior cardiac nerve.

The branches to the vertebral artery are of considerable size and aceompany the vessel into the arterio-vertebral formina in the transverse processes. The plexus thus formed is continued on the rertebral and basilar to the cerebral arteries.

The inferior cardiac nerve communicates with the midnle carliac and recurrent larrngeal, and passes along the side of the trachea to join the cleep carliac plexus. It occasionally arises from the first dorsal ganglion.

The majority, if not all, of the medullated fibres of the cervical part of the sympathetic cord enter it from the dorsal part, to which they pass by the white rami from the upper dorsal nerves. The destination of many of these filires is unknown, hut some terminate in ramifications pound the cells of the upper cervical ganglion and others in a similar mamner round the cells of the middle and lower ganglia. The fibres which terminate in the upper ganglion are the rasn-motor fibres of the hearl, the secretory fibres of the submaxillary glands, the dilator fibres of the pupil, the motor fibres for the smooth muscle of the eyelicls and orhit, and the pilo-motor fibres (to the muscles of the hairs) of the face and neck. Those which terminate in the midlle and lower cervical ganglia are the cardiac accelerator fibres, and possibly some of the secretory fibres of the sweat glankls of the upper extremity.

\section{THORACIC PORTION OF THE GANGLIATED CORD}

The thoracic portion of the gangliated cord is represented by a chain of twelve pairs of ganglia. In a few cases. on aceount of the coalescence of some of the members of the series, the number may be reduced to eleven or ten pairs. The 
upper ten ganglia lie upon the heads of the corresponding rilse, inmediatcely under corer of the pleura. The lower two are placed further forwards. and lie on the sides of the bodies of the eleventh and wedfth thoracic vertebre between the bones and the diaphragn. The cord is continuous above with the cervical part of the corrl, the first thoracic ganglion being sometimes unitexl across the neck of the fir:t rib with the inferior cervical ganglion. Below, the cord enters the alulominal cavity l,y bassing behind the ligancentum areuatum internum to becone continuous with the lumbar part of the cord. The first thoracic ganglion (ganglion stellatum) is larger than the others, and is of an irregular form. The remainder of the sories are triangular in outline, two of the angles being continued into the intrrganclionic part of the cord, and the other into the rami communicantes. On soms of the lower ganglia a fourth angle makes its appearance, and is continued into one of the roots of the splanclinic nerves.

Branches.-The hranches are classified into external and internal. The external branches are the rami communicantes. A grey and a white ramus (ommunicans comects each ganglion with the corresponding thoracic nerve. Thr internal branches are the rami efferentes, those of the upper four ganglia ar" listributed chiefly to the aorta and lungs. The internal branches of the lower eight ganglia form thre splanchnie nerves which are distributed to the abchominal viscera.

Internal branches.-Upper series.-From the upper four or five ganglia fine twigs arise which are clistributed to the thoracic aorta, mediastinum, lungs: vertrbres, and ligaments.

Internal branches.--Lower series.-These branches, although arising in the thorax, are clestined for the abdominal viscert. The branches from the fifth to the ninth ganglia unite to form the great splanchnic nerve; the lesser splanchnic nerve arises by two roots from the tenth and eleventh ganglia, while the internal branch of the twelfth ganglion forms the smallest splanchnic nerve.

GREAT SPLANCHNIC NERVE.-The fire roots of this nerve run downwarls: ancl inwarks, between the pleura and the bodies of the thoracie rertebrx, and unite within the posterior mediastinum to form a trunk of ensirlerahle size. The nerve thus formed pierces the crus of the diaphragm, and enters the semilunar ganglion of its own side.

The great splanchnic nerve is whitish in colour, owing to a number of medullated filures (ntering into its composition. Occasionally a small ganglion (splamelunic ganglion) is dereloped upon it in the mediastinum. This ganglion is eonstant on the right side. (Cunningham.)

The LESSER SPLANCHNIC NERVE runs a similar courso to the great splanchnic. but at a lower level. It pierces the crus of the diafluagm, or passis through the internal arcuate ligament, and enters the solar and renal plexuses.

The SMALLEST SPLANCHNIC NERVE passes behind the internal arcuate ligilment or through the crus of the diaphragm and enters the renal plexus.

The majority of the sympathetic fibres which pass from the central nervous system enter the dorsal part of the sympathetic chain; some end there, in ramitications around the cells of the ganglia, and others merely pass through on their way to more distant terminations. With regard to those which teminate in the ganglia it has been shown that in the dog and cat many end in the ganglion stellatum. which corresponds with the last cervical and the upper three or four dor-al ganglia in man: amongst these are the sceretory fibres to the sweat glands of the upper limb which emerge from the spinal cord by the lorsal nerves from the sixth to the ninth, and, in the dog, vasn-eonstrietor fibres of the pulnomary blood-ressels which leare the spinal ond by the second to the seventh dorsal nerves. Other fibres which terminate around the thoracic gangrlion eells in the dog and the eat are the raso-constrictor fibres of the upper limbs and some of the raso-constrictur fibres of the lower limb.

Of the fibres which traverse the dorsal part of the sympathetic cord. to gain more distant terminations, some ascend to the cervical region ( 3 . \$ 830 ), others descend to the lumbar region, and many pass by the rani efferentes to the splanchnic nerves.

Amongst those which descend to the lumbar region are pilo-motor fibres, raso- 
motor fibres, and secretory fibres to the lower limb, some vaso-constrictor fibres to the abdominal blood-resisels, motor fibres to the circular, and inhibitory fibres to the longitudinal muscle of the rectum: the latter enter the sympathetic cord by the lower dorsal nerves, they pass by the lumbar efferentes to the aortic plexus and terminate round the cells of the inferior mesenteric ganglion.

The tibres which pass through the dorsal ganglia to the splanchnic nerves are

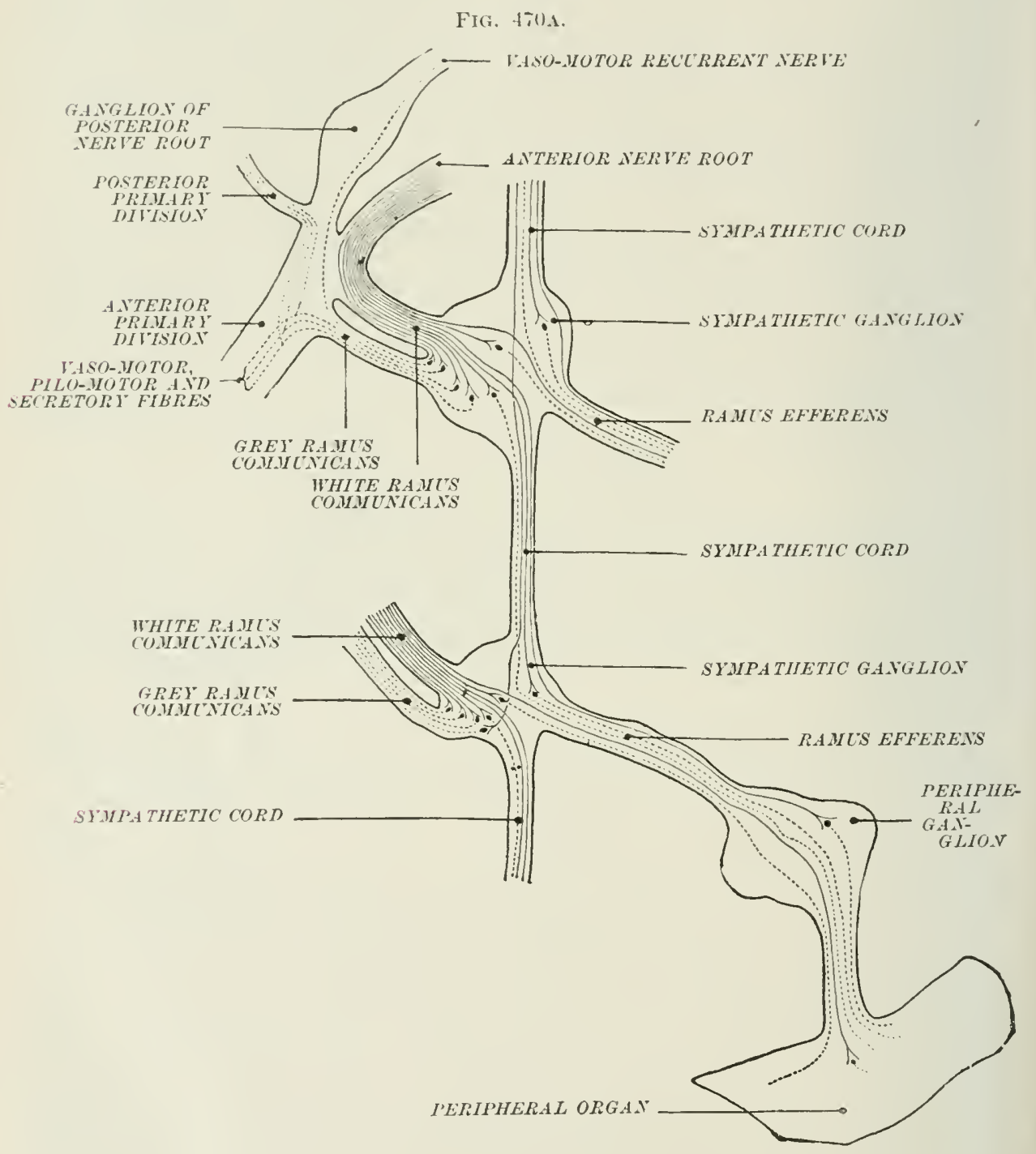

mainly vaso-motor fibres to the ahdominal blood-vessels, the majority of them probably terminate arome the cells of the ganglia in the solar plexus, but those for the renal blood-ressels are said to end in the renal ganglia. In addition to all the above-mentioned fibres there are, in the dorsal part of the sympathetic cord afferent (splanchnic sensory) fibre, passing towards the posterior roots of the dorsal nerve's. 


\section{LEMBAR PORTION OF THE GANGLLTED CORD}

The lumbar part of the gangliated cord consists of a chain of ganglia, un-ually four in number, which are placed in front of the bodies of the vertebre, chese to the anterion horder of the gisoas muscle. On the right sicle the cord is corered by the renal cara, and on the left side it is behind and external to the aorta. Aluser, it is enntinums with the thoracic part of the cord. Below. it is continued into the sacral palt of the cord hy passing behind the common iliac ressels. The rami communicantes are longer in this part of the gangliated cord than in any other region of the budy. [sually two rami pass from each ganglion backwards through the fibrous arches from which the psoas takes origin. and join the lumbar nerves in a smowhat variable mammer. Froquently there is only one ramus communicans and sometimes the numler of rami is increased. The rami communicantes are aceompanied by the lumbar arteries.

Branches. - Come of the branches join the aortic plexus; others pass in front of the common iliac arteries to form the hypogastric plexus, and some terminate in the vertebre and ligaments.

The lumbar portion of the smpathetic corel contains a number of fibres alrealy. ilecribed (p). s:31) which have desecended to it from the dorsal region, but it also whtains other: by the white rami from the lumbar nerres; amongst the latter are adilitional raso-constrictor fibres for the renal blood-ressels, secretory fibres for the rlands of the hind limb, constrictor fibres for the blood-ressels of the lower "xtremity, pilo-motor fibres, motor filmes for the circular. and inhibitory filmes for the longritudinal muscle of the rectum, motor fibres for the uterus. vas deferens and round ligament. motor fibres for the circular and inhibitory fibres for the longitulinal fibres of the liadder, and raso-motor fibres for the penis.

The motor fibres for the bladder and uterus leave the lumbar sympathetic cord by the rami efferentes and pass by the aortic plexus to the inferior mesenteric ganclion. The motor fibre to the vas deferens and spermatic cord enter the genitocrubal nare. Of the vaso-motor fibres of the penis some of the constrictor fitures lain down to the sacral portion of the sympathetic cord where they ramify round the (w) of of the sacral ganglia, the impulses they carry being transmitted by the erey rami of the sacral cranglia to the pudic nerve. Others travel by the inferior mesenteric ganglion, and the latter are accompanied by the vaso-dilator fibres of the penis.

\section{SACR.1L PORTION OF THE GANGLIATED CORD}

The sacral part of the gangliated cord consists of a chain of four small granglia, which is placerl in front of the sacrum internal to the anterior sacral foramina. From the lowest of these ganglia, branches proceed on each sicle and (1)nverge to a median ganglion (ganglion impar) which is situated in front of the last piece of the sacrum or the first piece of the cocerx. The sacral ganglia are connecterl in a somewhat irregular manner to the sacral nerves by short grey rami communicantes.

Branches.-From the upper sacral ganglia branches are given off which join the pelvie plexuses. Others pass across the sacrum to join corresponding branches from the cord of the olposite side. From the ganglion impar twigs pass downwards to enter the coceyeal horly.

There are no white rami from the sacral nerves to the sacral sympathetic ganglia, therefore all the merlullated fibres contained in the sacral sympathetic corel have descendel to it from the torsal and lumbar regions. They include some rasnconstrictor and secretory fibres for the hind limb, jiln-motor fibes for the posterior fart of the body, including. in the cat, the tail, and some vaso-constrictor fibres of the penis.

The white rami of the sacral nerves are representerl hy their viseral hranches. the so-eallerl pelvic splanchunics. These contain motre filores to the Inngiturlinal mu-cle of the bladder, motor fibres for the longritulinal and inhilitory filores for the rircular muscle of the rectum, motor fibres for the uterus. secretriry fibres for the prostate gland, and vaso-dilator fihres for the jeni- 


\section{THE GREAT PREVERTEBRAL PLEXLEES}

The great prevertebral plexuses, as we have alrealy noticed, are the cardiac, solar, and hypogastric. They are formed mainly by branches derived from the gancliated corls, but also receive fibres from the cerebro-spinal nerves; thus the cardiac plexus and solar plexuses are joined by branches of the phemmogatrice, and the hypogastric plexus is joined ly branches of the third and fourth and sometimes the second sacral nerves.

\section{CARDIAC PLEXLS}

As already noted, each pheumogastric nerve gives off two or three cervical cardiac branches, a thoracic cardiac branch, and additional branches may spring from the recurrent laryngeal nerve. There are also three carliac nerves which arise from the cervical sympathetic cord on each sicle. These nerves all procred to the cardiac plexus, but their course and arrangement is extremely varialle. It is rury common to find the upper cervical cardiac branches of the ragus ancl sympathetic uniting to form a common trumk; in other cases the nerves branch and communicate with one another in a plexiform manner. The cardiac plexus, although forming a continuous network of nerves, is for convenience divided into a superficial and a deep plexus. The superficial plexus is situated immediately below the areh of the aorta, internal to the ligamentum ductus arteriosus: it receives the left superior cardiac nerve of the srmpathetic and the left inferior cervical cardiac branch of the pnemogastric. The deep cardiac plexus is placerl in front of the hifurcation of the trachea betreen that structure and the aortic arch; it receives all the other cardiac nerves.

Superficial cardiac plexus.-The superior cardiac branch of the sympathetic and the inferior cervical cardiac branch of the ragns cross the aortic arch on its left sile, being placed between the artery and the left plenra. The nerves then enter the interval hetween the aortic arch and the hifurcation of the pulmonary artery. where they rommunicate with the deep cardiac plexus. A small ganglion (the (ariliac ganglion of $1 \mathrm{~W}$ risberg) is usually dereloped at the point of communimation. Branches are furnisherl to the right coromary plexus and also to the left lung. The latter branches join the anterior pulmonary plexus.

Deep cardiac plexus.-The deep ardiac plexus receives all the right cardiac nerves, and also the cardiac nerves of the left side, with the exception of the superior cervical cardiac of the sympathetic and the inferior cervical cardiac of the ragus. The plexus is placed in front of the bifurcation of the trachea, and gives oft the following branches:- $(a)$ Branches to the anterior pulmonary plexuses of both sides; $(b)$ the left coronary plexus; $(c)$ branches to the right auricle: (d) communicating branches to the superficial cardiac plexus; and (e) branches to the right coronary plexus.

Right coronary plexus.-This plexus is formed by branches from both the superficial and deep cardiac plexuses. It follows the branches of the right coronary artery for a certain distance, bevond which the nerves diverge from the arteries, and run between the pericardium and the muscular substance of the heart. Finally they rnter the muscular substance.

Left coronary plexus.-This plexus is larger than the right. It arises from the d(ep) cardiac plexus, passes forwards between the left anricular appendix and the pulmonary artery, and accompanies the branches of the left coronary artery.

The auricles are supplied ly the lower, and the ventricles, pulnonary artery and aorta by the upper cardiac nerves.

The cardiac plexuses and the network of nerrous structures in the walls of the auricles are the remains of the primitive plexuses found in the embrro which are eallet the bulbar, the intermediate, and the atrial plexuses, terms which sufliciently indicate their relative positions. The hulbar ploxus gives oft the coronary nerves and is transformed into the superficial and part of the deep carliac plexus; the remainter of the deep earlias plexus is formed by the intermediate plexus and the atrial plexus hecomes the aurieular network. 
The fibres which pass to the carliac plexuses are molullated and non-medullated; the former are inhibitory, the latter motor. The inhibitery fibres leave the central nerrous system by the spinal acecsory and ragus nerves, the motor fibres hy the roots of the dorsal nerves.

\section{SOL.IR PLEXTS}

The solar plexus is placed in front of the commencement of the aldominal aorta. It is the largest of the prevertebral plexuses, and is formed by the two semilumar ganglia, and hy a number of interlacing nerve-cords which surround the ganglia. Each semilumar ganglion is placed at the sicle of the coeliac axis. embracing the artery in its concarity. The upper and the lower extremities of the ganglia of opposite sides are connected to one another by nerve-cords, above and below the artery. In this manner the coeliae axis is surrounded by a neuro-ganglionic collar. From this neuro-ganglionic collar a number of branches arise which are joined by branches from the right vagus and by both small splanchnic nerves. and in this manner the solar plexus is formed. From the solar plexus a number of nerres arise which accomprany the abdominal aorta and its liranches, forming seconclary plexuses. which take their names from the arteries ther accompany.

Semilunar ganglia.-These are a pair of reddish-grey. irregularly shaped luchise which rest on the crum of the diaphragm, elose to the roliac axis. The great splanthnic nerve on ach side, after piereing the crus of the diaphragm, enters the outer, or convex, sild of the corresponding ganclion.

Cœliac plexus.-The coliac plexus surrounds the colliac axis, and diviles into splenic, hepatic and coronary plexus:s.

The splenic plexus, after receiving a communication from the right pnemmogatsic nerves accompanies the splenic artery to the spleen. It gires off pancreatic and left gastro-epiploic plexusc.

The hepatic plexus is joined, near the pyloric end of the stomach, hy branches from the left jmeumogastric. and aceompanies the hepatic artery to the liver, where it livicles into right and left hepatic plexuses. Previous to its livision, it gives off pyloric, right gastro-epiploic, and pancreatico-duodenal plexuses. From the right hepatic plexus a cystic plexus is furnished to the gall-lilarder.

The coronary plexus follows the lesser curvature of the stomach, proceeding from left to right. In this course it is joind hy lranches from the left pnemmofartrice and, after giving off numerous twigs to the stomach, encls, near the prorus. iy juming the ploric plexus.

The diaphragmatic plexuses arise from the uppere extremities of the semilunar fanchlia, and arempany the diajplnagmatic arteries to the under surface of the diaphragm. On the right sile a communication is effectert with the phrenic nerve. a small ganglion (ganglion diaphragmaticum) being formed at the print of communication.

The suprarenal plexuses are rerived, in part from the cliaphragmatic. in lant from the solar, and in part from the renal plexuses; ther are distributed (hichly to the medullary portions of the suprarenal horlies.

The renal plexuses are formerl hy hranches of the solar and antic plexuses. and are joined posteriorly by the smallest splanchnic nerves. Each renal plexus surrounds the corresponding renal artery: it contains groups of ganglion cells amel (nters the hilum of the kichey, where it sublivides in the fatty tis-se which oceugives the sinus, and enters the sub-tance of the kidner with the bluod-resecels.

The superior mesenteric plexus is of large size. and is remarkable for the emmaratively white colour of the nerves which compose it. It is derivesl fum the solar plexus, and, after mereving from under corer of the panereas. (elosely sumound the trunk of the supurior mesenteric artery. In thi-ituation a few galnglial (ganglia mesenterica) are formed. Having given nfi luanches. whilh

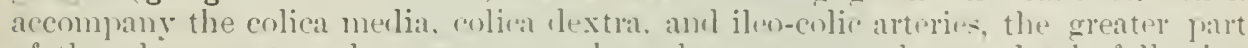
of the plexus enters the mesentery. where the nervenn longer closely following

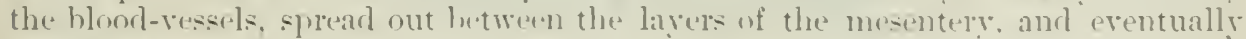
reach the small intestime.

The aortic plexus is in the form of two vast networks of neretes wheh are 


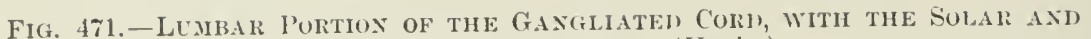
Hopogastic Plexises. (Henle.)

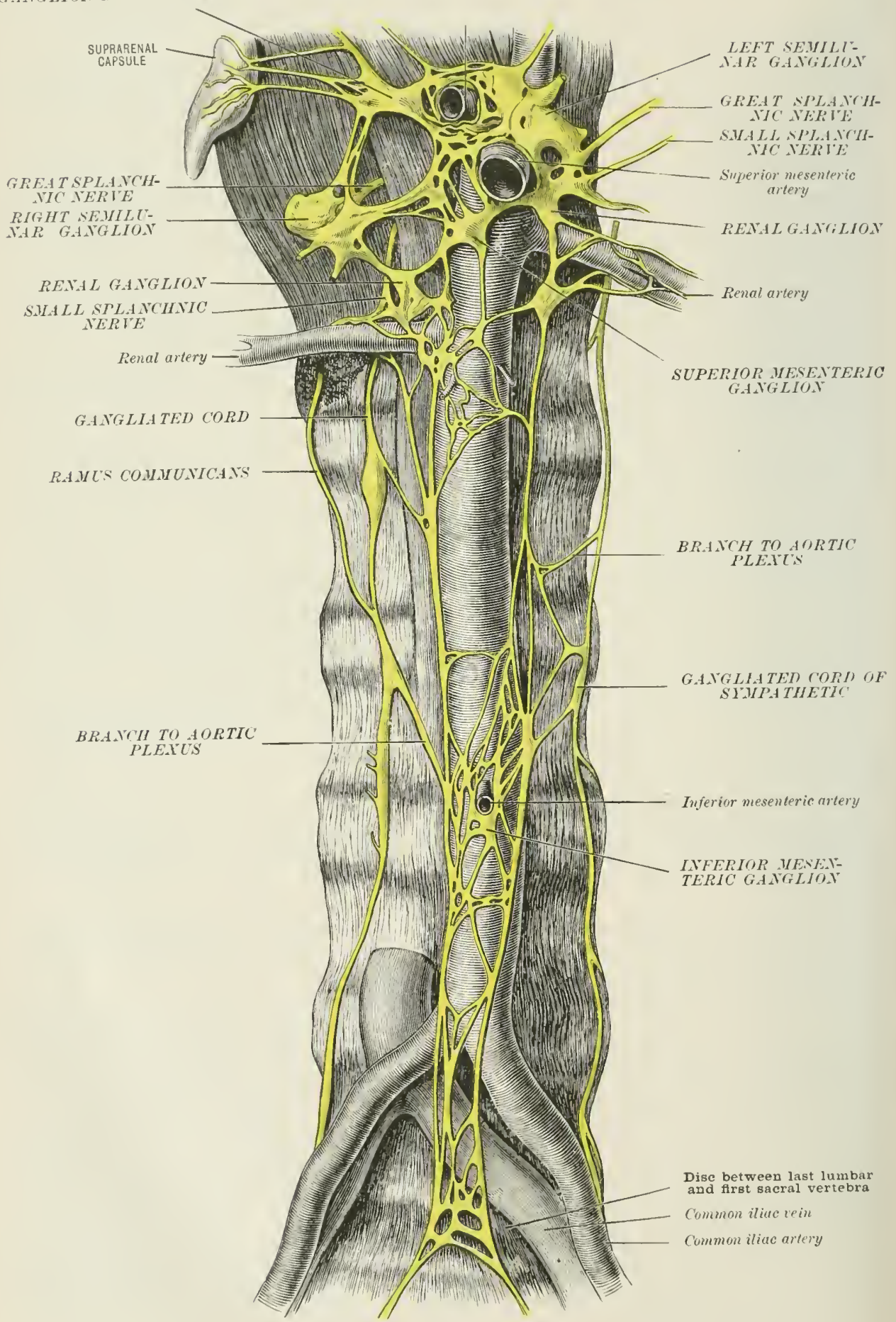


massed along the sides of the abdominal aorta, and are connected by communiating branches which pass across the front of the great vessel. it is formed mainly by the downwarl continuation of the solar plexus, but receives strong reinforcenents from the upper three lumbar ganglia. It gives off the spermatic and inferior mesenteric plexuses, and terminates below in strong branches to the hypogastric plexus.

The inferior mesenteric plexus is much smaller than the superior mesenteric plexus, but, like the latter, is remarkable for its whitish colour. It is rerived from the aortic plexus, and is conveyed by the branches of the inferior mesenteric artery to the descending colon, the sigmoid flexure, and to the upper part of the rectum. In the latter situation it communieates with the pelvic plexuses. It contains the inferior mesenteric ganglion.

The spermatic plexus is derived from the aortic and renal plexuses. It accompanies the spermatic artery as far as the internal abdominal ring, where it is joined ly a fine plexus derived from the pelvic plexus and accompanying the vas deferens. Thus reinforced, it is conducted by the spermatic cord to the testicle.

In the female it accompanies the ovarian vessels to the ovary and uterus.

The more important fibres which pass to the solar plexus have already been described in conneetion with the lumbar and dorsal portions of the sympathetic cord.

\section{HYPOCASTRIC P'LEXUS}

From the lower ganglia of the lumbar sympathetic cord, two or three strong branches froceed which crosis obliquely in front of the common iliac arteries. These nerves are joined by stout offisets from the aortic plexus, and interlace in front of the body of the fifth lumbar vertebra with the corresponding nerves of the opposite side to form a broad flattened band, which is termed the hypogastric plexus. This plexus is remarkable in that it contains little or no ganglionic matter. It soon divides into two lateral portions, the pelvic or inferior hypogastric plexuses.

\section{Pelvic Plexuses}

Each of the two lateral continuations of the hypogastric plexus contains ganglion cells; it passes downwards on the side of the rectum, where it is joined by slemer hranches from the sacral part of the gangliated cord, and by branches from the thirl and fourth (sometimes the second) sacral nerves. In this manner the phic plexuses are formed. Each pelvic plexus gives off branches to the pelvic riscera; these branches, in the greater part of their course, follow the arteries of the prolvis. We distinguish middle hamorrhoidal, resical, prostatic, and (in the female) vaginal and uterine plexuses.

The middle hæmorrhoidal plexuses form a closely-meshed expansion on the silles of the reetum; they communicate above with branches from the inferior mesenteric plexus, and below with the inferior hamorthoidal branches of the pudic nerve.

Thr vesical plexus is chiefly formed hy fibres derived from the third and fourth sacral nerves. The nerves pass forwards on each side of the bladder, and divide into two gronps-a superior group, which supplies the upper two-thirds of the blarlder; and an inferior group, which is distributed to the lower third of that viscus. In the male, branches are given off to the vesicule seminales and vasa deferentia. The nerves to the vas deferens form a slender plexus which accompanies that structure as far as the intemal ablominal ring, where it unites with the spermatic plexus.

The prostatic plexus is placed a little lower down than the resical plexus, of which it is in some measure a continuation. The nerves which pass to it are of relatively large size, and are massed on the sides of the organ, where several ganglionic: massis, from one-eighth to a puarter of an inch in length (ganglia prostatica of Müller), are deweloped. From the prostatic jlexus, offisets are furnisherl to the vesiculde seminales. and alko luranches to the erectile struetures of the penis; the latter hranehes are called carernous nerves. 
The small cavernous nerves are several fine twigs which pierce the layers of the triangular ligament and the muscular structures which surround the membranous portion of the urethra. They enter the corlora carernosia just in front of the subpubic ligament.

The large cavernous nerve takes a similar course through the triangular ligament, and runs forwards on the dorsmm penis as far as the micklle of the organ, where it communicates with the dorsal nerves of the penis. It ends in twigs to the corpus cavernosum.

In the female there are similar nerres, but of much smaller size, distriluted to the clitoris.

The vaginal plexus is formed largely by branches from the sacral nerves. It ramifies on the sides of the vagina, giving off twigs to the erectile substance, and to the mucous membrane. A few fine twigs pass forwards to reach the clitoris.

The uterine plexus accompanies the uterine artery between the layers of the broad ligament, and, having received commmicating twigs from the ovarian plexus, enters the muscular substance. In the gravil uterus this plexus is increased in size, chiefly on account of an hypertrophy of the connective tissue sheaths of the nerres.

The more important fibres passing to the pelvic plexuses are described with the risceral branches of the sacral plexus. 


\title{
SECTION TI \\ ORGANS OF SPECIAL SENSE
}

THE ETE

\author{
BY R. MARCLS GUNX, IIA., F.R.C.S.
}

STRFEOX TO THE ROYAL LONDOX OPHTHALMIC HOSPITAL, MOORFIELDS; OPHTHALMIC SLRGEON TO THF NaTIONAL HOSPITAL

\section{THE EYEBALL AND ITS SLRROUNDINGS}

\section{Gexeral Surface View}

This examination is to be made prior to any disturbance of the parts and is, indeed, best comducted on the living body. A pocket magnifying lens should be at hand for use when retguired.

$\mathrm{T}^{\mathrm{H}}$

HE two eyes are situated nearly in the line where the upper and middle thirds of the face meet; they lie right and left of the ront of the nose. the most prominent part of the front of each globe being about an inch and a quarter from the middle line of the face. Each eye is overshadowed by the corresponding evelurow, and is capable of heing concealed by its evelids. upper and lower.

The orhital margin may he traced all round with the finger. At the junction of the immer and middle thirls of the upyer margin, the suprachital notel can usually lx. felt. and the supraorlital nerve passing through it can sometimes be made to roll from side to side under the finger. The inner margin is the most diflicult to trace in this way, partly hecanse it is more rounded off than the others, partly hecause it is lridged over by a firm fihrous hand (tendo oculi, or inner palpebral ligament), passing inwards from the erolirls; helow this band. howerer, a sharp bony crest is felt, which lies in front of the lachrymal sac. Tote how the eve is pro-

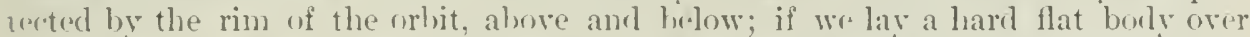
the orbital opening. it will rest upon the upler and lower bong frominences and will not touch the surface of the gloles. Inwark, the eye is protected from injury mainly by the hridge of the nose; outwards it is most readily vulnerable, as here the orbital rim is comparatively low. With one finger placerl over the elosed upper lid, now press the eveluall gently lackwards into the orbit. and observe the elastie resistance met with. due to the fact that the crlobe rests posteriorly on a pard of fat.

The space hetwern the free ederes of the upler and lower lirls is known as the palpebral aperture : it is a mere slit when the lids are closerl; but when they are (1pen its shape is. roughly, that of an almombl lying with its long axis horizontal, and about thirts millimetres in leserth.

When the eyes ar. directrel to an oljoct straight in front of them, this aperture is almut twelve millimetres wiele, but it: wilth ralles with upward and downward 
morements of the ereluall, being greatest on looking stromer ypurards, diminishing gradually as the eve looks progressively lower. The angles formed by the meeting of the lids at each end of the palpebral aperture are named respectively the outer and inner canthus, of which the outer, or temporal, is sharp, while the imer, or masal, is rounded off. On a closer inspection, it will be founcl that, for the last five millimetres or so before reaching the imner canthus, the edges of the lick run an alnost parallel course, and are here devoid of lashes. Through the open palpebral aperture the front of the eveluall comes into view, extending quite to the outer, but not reaching as far as the inner, canthus; just within the latter we find a small reddish prominence, the lachrymal caruncle; and between this and the ereball a fold of conjunctiva known as the plica semilunaris. While the eve is open, press one finger on the skin, a little beyond the outer cantluss, and draw it fimly outwards imom the middle line; observe that the upper lid then falls over the ereball, and that the outline of a firm band already referred to (the tendo oculi) beenmes evident, passing between the inner canthus and the nose. The falling of the lid is caused by our dragging upon a ligament (the outer palpebral) to which the outer end of its tarsus is attached, and so putting the lid itself upon the stretch. If, while the ereball is directed downwards, we place one finger on the outer end of the upper eyelid and chaw it foreibly upwards and outwards. we can usually cause the lower division of the lachrymal gland to present just above the outer canthus.

The upper eyelid is much broader than the lower, extending upwards as far at the eychow. The skin covering it is loosely attached to the suljacent tissues ahove, but inore firmly below, nearer the free margin, where it orerlies a firm filnous tissue called the tarsus. When the eye is open, a fold is present at the upper border of this latter more tightly applied portion of skin, called the superior palpebral fold, and by it the lid is marked off into an upper or orbital, and a lower or tarsal, division. The presence of the tarsus can be readily appreciated on our pinching horizontally the entire thickness of the eyelid below the palpebral fold. The lower eyelid is similarly divided anatomically into a tarsal and an orhital part, but the demarcation is sometimes unrecognisable on the surface, though there is usually here also a fold or groove (the inferior palpebral) visible when the eve is widely opened. There is no precise limit of this lid helow, but it may be regarderl as extending to the level of the lower margin of the orbit. Numerous very fine short hairs are seen on the cutaneous surface of both eyelids. The free margin of each lid has two edges-(a) An onter, or anterior, rounded edge, along which the stiff evelashes, or cilia, are closely placed in sereral rows: and (b) a sharp posterior eilge, which is applied to the surface of the globe. The lashes of both eyelids have their points tumed away from the palpebral aperture, so that the uper ones curve upwards, and the lower downwards; the cilia of the upper lid are the stronger, and those in the middle of each row are longer than those at each end. Between the two edges just described, the lid-margin has a smooth surface. on which we observe a single row of minute apertures, which are the openings of laree modified sebaceour glands (the Meibomian follicles); it is by these glistening. well-hulriated surfaces that the opposite lids come into apposition when they are closed. The sharp) posterior edge of the lirl-margin marks the situation of the transition of skin into mucous membrane. Not far from the inner end of this edge we find a prominence, the lachrymal papilla, on the summit of which is a small hole (lachrymal punctum), the opening of the canaliculus for the passage of tears into the lachrymal sac. The lower punctum is rather larger than the upper, and is placed further from the fimere canthus.

If we now examine the inner surface of the eyelids-e. . of the lower-we observe that it is lined by a soft mucous membrine, the palpebral conjunctiva. Over the tarsil part of the lirl, the eonjunctiva is elosely allherent, but beyond this it is freely movable along with the loose submucous tissue here present. On tracing it hackwards, we find that it covers the whole inner surface of the lidts. and is then continued formats over the front of the eveball, forming the ocular conjunctiva; the bend it makes as it changes its clirection here is called the conjunctival culde-sac, or fornix. Numerons underlying hlook-vessels are visilule through the palpeloral conjunctiva. and heneath the tarsil part of it we can see a series of nearly straight, marallel. light yellow lines, arranged perpendicularly 
to the free margin of the lis-the Meibonian follicles. The conjunctiva over the outer and imner fourths of each lid is not quite so smooth as elsewhere, and is normally of a deeper real colour; we shall finch later that there are glands well developed in these positions.

Whan the eyelids are openerl naturally, we see thromgh the palpebral aperture the following: the greater part of the tramsparent comea, and behind it the coloured iris with the pupil in its contre; white sclerotic to the outer and inner sides of the comea; the semilunar fold and lachrymal caruncle at the inner canthus. The rxtent of the eyelall visible in this way varies according to its position. Thus, with the eyes looking straight forwards, the lower margin of the upluer licl is nearly "lpposite to the top of the cornea, or, more strictly, to a line midway between the top of the comea and the upper border of the pupil, while the lower lid corresponis with the lower comeal margin. When the eyes are directed strongly upwards, the upper lid is relatively on a slightly higher level, as it is simultaneously raised, hut the lower lid now leaves a strip of sclerotic exposed below the comea. On lowking downwarls the upper lid covers the upper part of the comea as low down as the level of the top of the pupil, while the lower lid is about midway between the pupil and the lower eorneal horder.

If we draw the eyelids forcibly apart, we expose the whole cornea, and a zone of sclerotic about eight and a half millimetres in breadth above and below, and ten millinetres in breadth to the outer and inner sides, altogether about one-thirel of

FIG. 47:. - VIEW OF EYEBALL, ITTC, OBTAINED ON WRAWING THE LIDS FOLCHBLY APART. (After Merkel, slightly modified.)

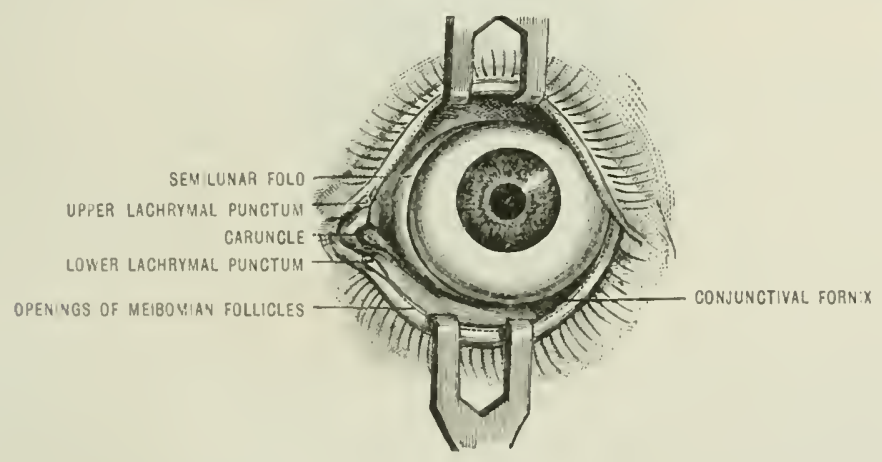

the globe; all the eyehall thus exposed is covererl by the ocular conjunctiva. Orer the sclerotic the conjunctiva is freely movable, and through it we see superticial blocel-ressels that can he made to slip from sicle to side along with it (conjunctival resisels). Occasionally other deeper vessels may also be seen which do not more with the conjunctiva, int are attached to the scierotic (anterior ciliary arteries and prins). Near the comcal border the conjunctiva ceases to be freely movable, and it is closely alherent to the whole anterior surface of the cornea, giving the latter its charateristic bright, refleeting appearance; no blood-ressels are visible through it here in health. (When the lids are shut, the space enclosed between thrir posterior surfaces and the front of the eyetall is thus everywhere covered by conjunxtira, and is known as the conjunctival sac.)

Not infrefuently, the tenclinous insertions of some or all of the recti museles inte the sclerotic may be seen through the conjunctiva, each insertion appearing as a series of whitish parallel lines ruming towarls, but terminating about seren millimetres from the corresponding cormeal border. The cormea appers as a transparent dome, having a curvature ereater than that of the sclerotic: the junction of the two unequally curved surfices is marked by a shallow depresion lmming around the contea, known as the scleral sulcus. In outline the corneas is nearly circular, hut its horizontal diameter is slightly greater than its rejtical. Betweren it and the iris a space "xists, whose depth wis can estinate roughly hy looking at the eye from one side; this sluce, or anterior chamber, is ocenpier ly 
a clear fluid, the aqueous humour. Almost the whole anterior surface of the iris is visible, its extreme periphery only being concealed by sclerotic. In colour the iris viries creatly in different individuals. Tear its centre (really a little up and in) a round hole exists in the iris, the black mpil, whose size varies considerably in different eyes, and in the same eye accorling to temporary eonditions, such as exposure to light, cte.

In examining the surface-markings of the living iris, one of dark colour is to be preferred. Focal illumination will be fonnd useful, for which purpose a second convex lens will be required.

On the surface of the iris we see a number of ridges running more or less raclially; adjoining ones oceasionally unite and interlace to some extent, so as to leave large depressed meshes at intervals. The ridges coming from the edge of the pupil, and those coming from the more peripheral part of the iris, meet in a zigzag elevated ridge, coneentric with the pupil, and by this ridge the iris is roughly marked off into two unequal zones-an outer or ciliary, and an inner or pupillary -of which the inmer is much the narrower. The border next the pupil is edged with small, roundish, bead-like prominences of a dark brown eolour, separated from one another by depressions, so that it presents a finely notehed enntour. Not infrequently, in a light-coloured iris, we may see the sphincter musele through the

Fig. 473.-Left Fundes Oeeli, as seex bi DiRect Opithalioscopic Metion.

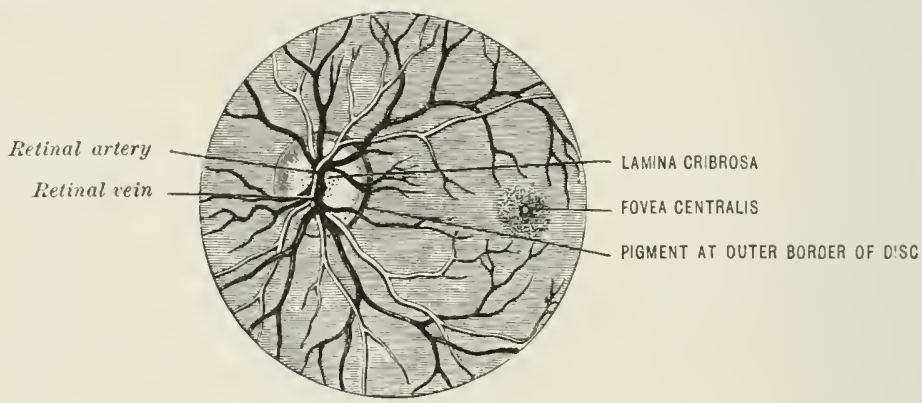

anterior layers, in the form of a ring about one millimetre in breadth around the pupil. The eiliary zone may be deseribed as consisting of three parts: (a) A comparatively smooth zone next the zigzag ridge; (b) a middle area, showing concentric but incompletely circular furrows; $(c)$ a small peripheral darker part, presenting a sieve-like appearance. On the floor of the large depressed meshes, or crypts, parallel radial vessels can be traced, belonging to the iris-stroma. The zigzag line mentioned above corresponds to the position of the circulus arteriosus minor. Oceasionally, especially in a light iris, superficial pigment spots of a rusty brown colour oceur.

If we are examining the living eye, the ophthahmoscope should now be used, so as to gain a view of the fundus. We ean thus study the termination of the optic nerve, the distribution of the larger retinal vessels, ete.

The general red reflex obtained from the fundus is due to the blood in a capillary network (chorio-capillaris) situated in the inner part of the ehoroid. To the nasal side of the centre of the fundus is a paler area of a clise shape corresponding to the intraocular end of the optic nerve, and known as the optic disc, or papilla. This optic disc is nearly circular, hut usually shightly oval vertically; it is of a light orange-pink colour, with a eharacteristic superficial transluceney; its outer third segment is paler than the rest from the nerve-fibres and capillaries here heing fewer. About its centre we often observe a well-marked whitish depression or gap, formed by the dispersion of the nerve-fibres as they sprearl out over the fundus; at the botton of this depression a sicve-like appearance may be seen, due to the presenee of the lamina cribrosa, which consists of a white fibrous 
tissue framework, with small, roundish, light-grey meshes in it, through which latter the nerve-fibre bumlles pass. Also near the eentre of the dise, the retinal blood-vessels tirst come into view, the arteries narrower in size and lighter in colour than the reins; they divide dichotomously as they are distributed over the fundus. The retina proper is so transparent as to be ophthalmoseopieally invisible, but its pigment-epithelium gives a very finely granular or darkly stippled appearanee to the general red reflex. In the centre of the fundus, and therefore to the outer sirle of the clise, the ophthalmoseope often shows a shifting halo of light playing romel a horizontally oval, comparatively dark enelosed area; this latter corresponds to the yellow spot region, and about its centre a small pale spot usually marks the position of the fovea centralis.

Two structures visible at the nasal end of the palpebral aperture have heen previously mentionel, and should now be examined more narrowly. The lachrymal caruncle is in reality an island of modified skin, and fine hairs ean commonly be detected on its surface. On its onter side, separated from it by a narrow groove, is the semilunar fold of conjunctiva; it rests on the eyeball, and is a rudiment of the third eyelid or nictitating membrane, present in birds and well represented in many other rertebrates.

\section{Examination of the Eyeball}

The eyeball of a cadaver should now be removed by snipping with scissors the conjunctiva near the corneal border, then cutting through the ocular museles near their insertion into the grlobe, and finally dividing the optic nerve close to the sclerotic.

The eyeball is almost spherical, but not perfectly so, mainly because its anterior, clear, or corneal segment has a greater curvature than the rest of the eye. considering it as a globe, however, w speak of an anterior and of a posterior pole; the former corresponding to the middle of the front of the cornea, the latter to the micllle of the posterior curvature. An imaginary straight line joining the two poles is called the antero-posterior or sagittal axis of the ereball. The equator of the eye is that part of its surface which lies midway between the two poles. The sagittal axis of the globe is the greatest (about $24.5 \mathrm{~mm}$.), the rertical enuatorial the least (about $23.5 \mathrm{~mm}$.), and the transverse equatorial axis is intermediate in length (about $23 \cdot 9$ ), so that the eyeball is in reality an ellipsoid, flattened slightly from ahove downwarls. Again, if the globe is divided in its antero-pusterior vertical plane, the nasal division will he found to he slightly smaller than the temporal. The optic nerve joins the globe three or four millimetres to the nasial side of the posterior pole.

The shape of the eye depends on, and is preserved by, the outermost tunic, formed ronjointly hy the cornea and sclerotic, the entire outer surfaces of which are now in view. The anterior or comeal part has been alreaty examinnel. All romol the cornea there remains a little adherent conjunctiva; elsewhere. the sclerotic is lireetly exposed, except for some loose comnective tissur which allheres to it, especially around the optic nerve entrance. In front of the equator we see the tendinoms insertions of the four recti muscles. Behind the equator are the insertions of the two oblique muscles-that of the superior oblique tenclinous. and further forwards; that of the inferior more fleshy, and placed between the ontic nerve and the external rectus.

It is difficult to reeggnise the different recti museles by their insertions if we to not know whether the eye examined is a right or a left one. To determine this we shonlu? hold the globe with the optic nerve towarks us, and in the natural yosition with the superior oblinue tenclun uppermost. The inferior oblique tendon will now print to the side to which the eye belongs, and we can consenguently letermine the different recti muscles.

The internal rectus is inserted nearest ( $7 \mathrm{~mm}$. from) the corneal borler; the external reetus commonly, sometimes the superior. is inserted furthes from it (about $S \mathrm{~mm}$.$) . All the recti tendons are broal and thin. lut that of the internal$ is the broadest $(S \mathrm{~mm}$.); those of the extermal and inferiol the narrowest ( $\mathrm{i}$ mm.) 
The greatest interval between two neighbouring tendons is that between the superior and internal reeti (atout $12 \mathrm{~mm}$.); the least is betwen the superior and external $(7 \mathrm{~mm}$.). The form of the lines of insertion of the different tendons varies considerably, the inferior being almost straight, the superior and external convex forwards, the internal further removed from the enneal border below than above.

The insertions of the obliques are at more than double the arerage distance of the insertions of the recti from the corneal border. That of the superior ollique is found on the superior surface of the sclerotic, about sixteen millimetres from the corneal edge, in the form of a line sloping from before backwards and inwards. The inferior oblique has a long fleshy insertion lying between the external rectus and the optic nerve entrance; the posterior end of the insertion, which is also the highest, is only about six millimetres from the optic nerve, and from this point it slopes forwarts, outwards, and slightly downwards.

Several small nerves and two arteries may be seen running forwards and ultimately perforating the sclerotic not far from the entrance of the optic nerve. The two arteries are the long posterior ciliary; they both perforate the globe in the horizontal meridian, one on the outer, the other on the immer side. The short ciliary arteries are too small to be seen in an ordinary examination. The nerves

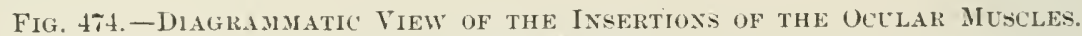
(After Merkel.)
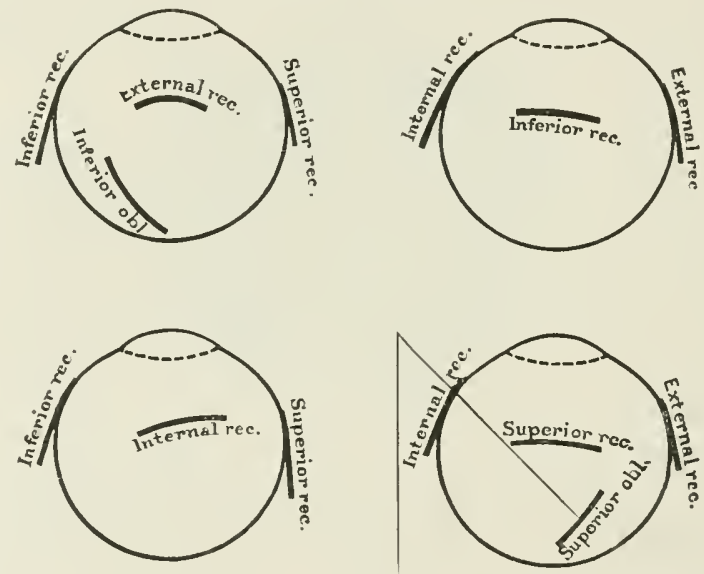

are the long and short ciliary. Nearer the equator, the large venous trunks enserge; they can be traced for some distance in front of their exit as clark lines, rmming antero-posteriorly beneath the solerotic. The optic nerve is seen in section. surrounded loosely by a thick outer sheath; in the centre of the nerve-section a small red spot indicates the position of the central retinal blood-ressels.

For ordinary dissections eyes of the sheep, pig, or lubllock should be obtained. Divite an eyeball into fore and himb halves by cutting through it in the equatorial plane.

1. Posterior hemisphere seen from in front. This is much the same riew that the ophthalmoscope affirds us. Unless the eye be very fresh, however, the retina will have lost its trallsfareney, and will now present the appearance of a thin whitish membrane, detached in finds from the underlying cuats, lut still adberent at the optic dise. The vitreous jelly lying within the retinal cup may be torn away. In the human eye the retina next the posterior pole is stained yellow (macula lutea). On turning the retinil over, a little pigment may be seen athoring to its onter surfice here and there. Cut through the retina close to the opitic dise all rumm anil remove it : note how easily it is torn. We now see al dark lorown surface, consisting of the retinal pigment layer, allherent to the inner surface of the choroid. Brosh off the retinal pigment under water. 'The choroid thus exposed ean fin' the most part be fairly easily torn away from the thick sclerntic, as a lympli-sulace exists between them, but the attichment is firm around the optic nerve entrance, and also where the arteries and herves join the chorosil after penetrating the sclerotic. The chorois is darkly pigmented of a brown colour. with markings on its surfices correspouding to the distribution of its large veins. The inner surfiee of the selerotic 
is of a light brownish colour, mainly fiom the presence of a delicate pigmentenl layen, the membrana suprachoroidea, which allheres prirtly to it, partly to the elorvid, giving to therr adjacent surfices a flecerolent alplearanee when examined number water.

2. Anterior hemisphere viewed fim belind.- The mud openine of the gupil is visibs in

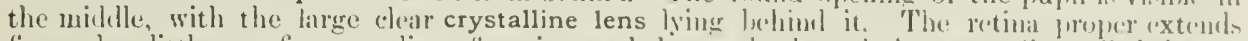

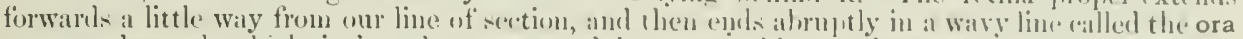
serrata, beyoud which it is ouly representerl by a very thin membine (pars ciliaris retinæe).

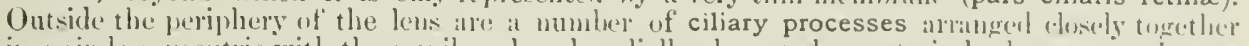

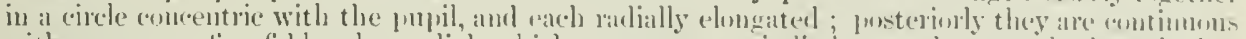

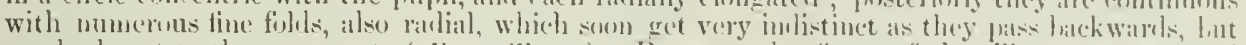

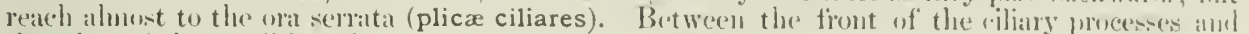
the edge of the punil lies the iris. On remuval ot the retina the imere surfice of all this rearion

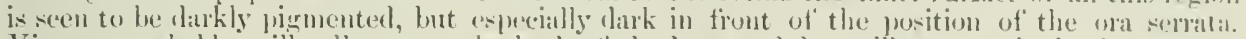

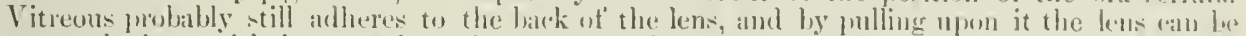

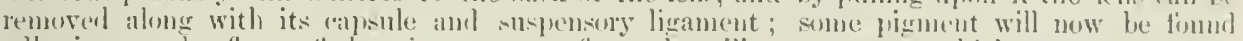

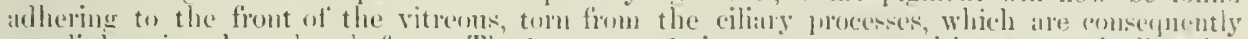
now lighter in colone than hefore. The lens-capsule is trancparent, and has a smonth glistening

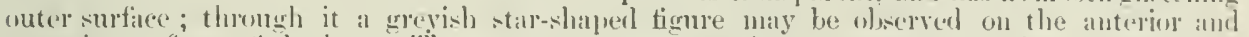
posterior surfaces of the lons. The suspensory ligament is a transparent membrane attacherl to the ealpsule of the lens about its equator, and is best seen by floating the lens in water in al glass vessel placed ou a dark gromd. On opening the eapsule we expose the lens itself, which is superfi lially soft and glutinus to the touch, but becomes firmer as we rub off its outer layers :mil

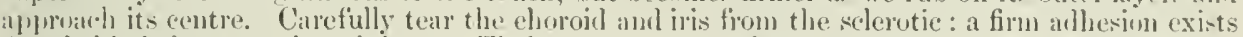
just behiud the corneal periphery. Their outer surfice thus exposed is found to he also rather darkly piguented (as fin forward as the lase of the iris at least), lut it shows a white ring conre- ponding to the adhesion just mentioned, and a pale area behind this ring indicates the position of the ciliary muscle. On this surfice numerns white nerve-cords are visible rumning forwalds.

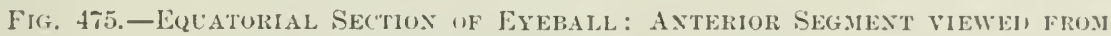
BEHIND. (After IIerkel.)

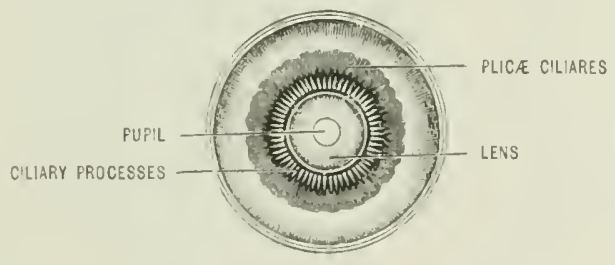

Ob-crve that the iris, the ciliary processes, ete, and the choroid are all different parts of the silne venlar tunic-mere local morlifications of it. Similarly the sclerotic and eorneat are seen tin blent together to firm one suter coat.

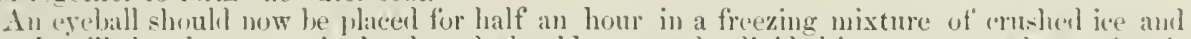
salt. It will thus become guite harr, ame should at once be dividerl into two frart- hy cutting it

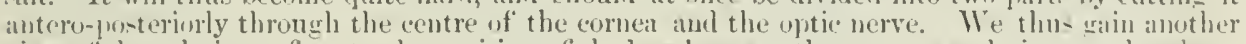
view of the relations of parts, the position of the lens between the agneous and vitreous chanderes, ete. On removing the lens, vitreous, and retina, and brnshing off its pigment, the light mankings curresponding to the choroilal veins (venæ vorticosæ) shouls be noterl, anm their distri-

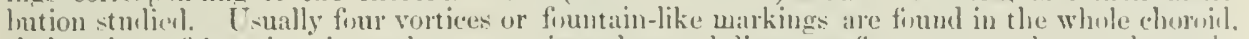
their mints of junction situated at approximately conal distances from one another at almut the line where the porsterior and middle thirds of the grobe meet. 'These seetions should be kept tor reterence while following the further description of the ocular tunics.

1. The outer, fibrous coat of the eye is formed hy the scherotic and cormen.

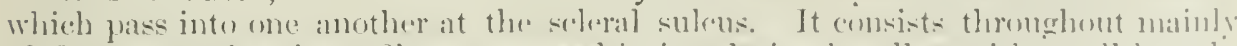
of fine connective-tissue fibres, arrangerl in interlacing bundles, with small lymplispaces at intervals between them. The naked-eye alumeandere of the two divisions

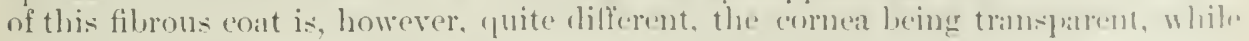
the sclerotic is white and oparue.

The sclerotic encloses the posterior five-sixthes of so of the rewhall, lint there is a hole in it at the entrance of the oftic nerwe (foramen scleræe, only partially

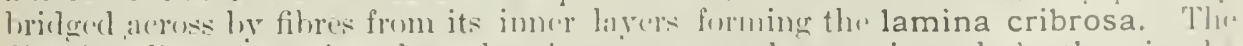

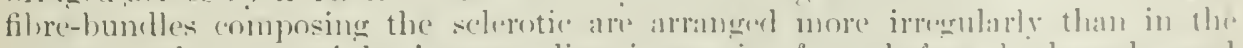
cornea, and run mainly in two directions. vi\% from lefore laickwards, and

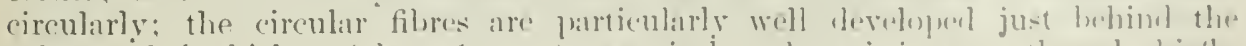

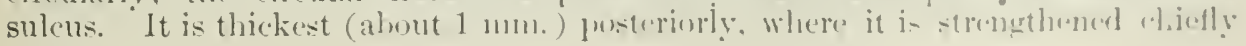


be the outre sheath of the optic nerve, and partly also ly the tiswe surromending the ciliary vesels and nerves. It hecomes glatlually thininer as it passes forwards, up to the line of insertion of the recti muscles, in front of which line it is again reinforeed by their tentinoms fibres becoming incorporated with it. In rhiden the sclerotic is oftens so thin as to allow the underlying choroidal pigment to show through, appearing then of a bluish white. In the aged, acain, it is sometimes rellowish. It always contains a few pigment cells, but these are in the deep lavers, and only hecome visible externally where the sclerotic is piereed hy vessels and nerves going to the choroid. It is itself almost non-raseular, but quite at its anterior enct a large renous sinus (canal of schlemm) runs in its deeper layers cireularty around the cornea. Just in front of this sinus, at the corneal limbus, the sclerotic nerges into the cornea, its deep layers changing first, and finally the superficial ones.

The cornea is thickest at its periphery, and becomes gradually thinmer towards its centre: the curvature of its posterior is consequently greater than that of its anterior surface, but even the latter is more curved than the surface of the sclerotic. In the cornea proper, fibre-bundles are arranged so as to form a series of superposed lamella, each of which is connected here and there to the adjacent ones by fibres passing from one to the other, so that they can only be torn apart with difficulty. The corneal lymph-spaces communicate with one another by very fine canals, and thus not only is a thorough lymph-circulation provided for, buit the protoplasm with which these spaces are partially occupied may be also regarded as continuous throughout. It contains no blood-ressels, with the exception of a rich plexus at its extreme periphery, on which its nutrition is ultimately dependent.

The most superficial part of the true cornea appears homogeneous, even when highly magnified (Bowman's membrane), though there is reason to believe that its structure only differs from that already described in the closeness of its fibrous texture; the two parts are certainly comnected by fine filbres. Anteriorly, the cornea is covered by an extension of the ocular conjunctiva, in the form of an epithelium several layers deep. Posteriorly, the cornea is lined by a firm, thin, grass-like larer (membrane of Descemet, posterior elastic lamina), distinct from the corneal tissue both anatomically and ehemically. At the periphery this membrane break: ul) into a number of fibres, which mainly arch orer to join the base of the iris (ligamentum pectinatum iridis). The intertices between these fibres constitute spaces (spaces of Fontana) freely communicating with the aqueous chamber on the one hand, and indirectly with the canal of Schlemm on the other. Descemet's memhrane is in turn lined by a single layer of flat cells, which are continuous peripherally with cells lining the spaces of Fontana and the anterior surface of the iris. The cornea is richly supplied with nerres, particularly in its most superficial layers.

2. The dark, middle, or vascular coat of the eye, generally known as the uveal tract, is formed by the iris, ciliary boty, and choroid. It is elosely applied to the sclerotic, but actually joins it only at the anterior and posterior limits of their course together, riz. at the scleral sulcus, and around the optic nerve entrance. In front of the sulcus the middle coat no longer lines the outer, leing separated from it (i.e. the iris from the comea) by a considerable space filled with Huid, called the anterior aqueous chamber. The uveal tract has two openings in it; a larger one in front. the pupil, and a smaller one hehind, for the passage of the optic nerve. Its structure is that of a pigmented connective tissue, supporting numerous bloodressels and containing many nerves and two deposits of smooth muscle-filmes.

The choroid forms the posterior part of the ureal tract, and extends, with slowly diminishing thickness, forwards as far as the ora serrata. Its outer and inner surfaces are both former $h y$ non-rascular layers; that covering the outer, the membrana suprachoroidea, is pigmented, arranged in several fine loose lamella, and has been seen in our clissection; that covering the inner surface is a thin, transparent, homogenous mombrane, called the vitreous lamina of the choroid, or the membrane of Bruch. The intervening ehoroidal stromat is rery rich in bloodvessels, which are of largest size next its outer surfice, and hecome progressively smaller as we approach the vitreous lamina, next to which we find a layer of closely 


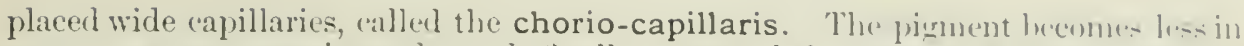
anount as we pass inwards, and finally ceases, being absent cutirely from the chorio-capillaris and vitreous lamina.

In fromt of the ora serrata the ureal cont becomes considerably molificel, and the part reaching from here to the iris may anveniently he termed the abliny resion of the tract, or ciliary body. Its superficial aspects have been alrealy lurefly described. In front, the ciliary processes, about serenty in number, project towarithe interior of the eye, forming the corona ciliaris. Juhind this jart lies the orbiculus ciliaris, whose inner surface is almost smootl. faint radial folds (1)] y being present, three or four of which join ach ciliary jucess. The more minute structure of this ciliary region resembles closely that of the choroicl, except that

Frg. 476. -Diagramatic Horizontal Section of Eyeball axd URit.

(After Fuchs, much modified.)

Periorbita green; muscle-fiscia red; Tenon's cipsule yellow.

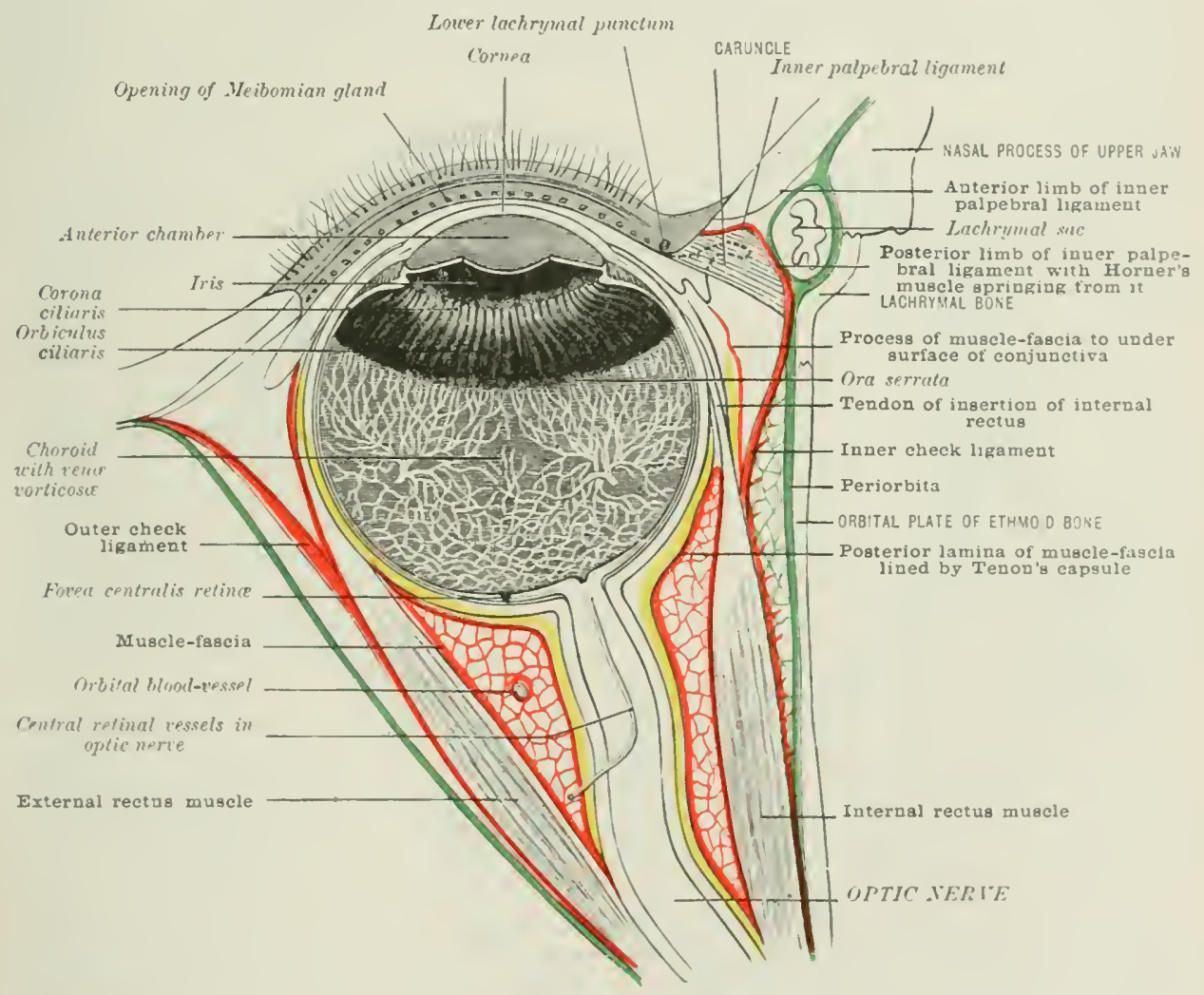

the chorio-capillaris is no longer present, that the stroma is thicker and rieler in

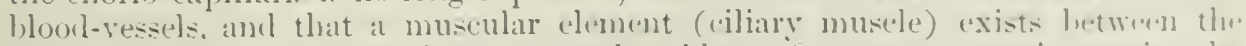
vascular layer and the membrana supratehorojelea. On antero-posterior seetion the ciliary borly is triangular; the shortest sjele looks forwall, and from alumt its minldle the iris arises; the two long siches look respertively inwarls and outwalle. thw inner having the ciliary procesces upon it, while the outer is formed liy the ciliary muscle. This musele pussesses smonth fibres and consists of an outer amb an inmer division; in the outer the fibres run loneritudinally, insertenl inter the onter fitum-

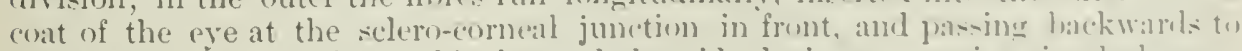
join the outer layers of the orticulus and choroul: the inner contains circularly rum-

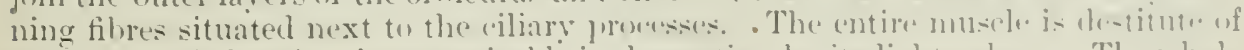
pigment, and therefore is recornisable in the section hy its light colour. The whole 
thickening of the ureal tract in this region, muscle and folds and processes together, is named the ciliary body.

The iris projects into the interior of the front half of the eve in the form of a circular dise perforated in the micklle. The appearance of its anterior surface has already been described. Its posterior surface exhibits numcrous ractial folds running from the ciliary processes to near the pupillary borcler; a thick layer of black pigment covers it and curls round its imner edge. so as to come into view all romnd the pupil as seen from in front. The peripheral or ciliary border of the iris is continuous with the front of the ciliary body, where it also receives fibres from the ligamentum jectinatum iridis; in other respects the iris is quite free, merely resting on the front of the lens-capsule near the pupil. Its stroma is spongy in character, being made up of ressels corered by a thick adventitia, running from the periphery to the pupillary border, with interspaces filled by branching pigment cells, which are particularly abundant near the front surface. Deep in the stroma, rumning round near the pupillary border, we find a broad flat band of smooth muscle fibres, constituting the sphincter iridis. Immediately behind the vascular tissue lies a thin membrane, consisting of fine, straight fibres rumning radially from the ciliary border to just behind the sphincter. The nature of these fibres has long been in dispute, hut they are now accepted as being undoubtedly smooth muscular, a dilator iridis.

The sphincter iridis and the cilinry muscle are supplied by the third nerve, and the dilator iridis by the sympathetic, all by way of the ciliary ganglion.

Quite posteriorly is the pigment already mentioned, really consisting of two layers of pigmented cells, each layer representing the extension forrards of one subdivision of the retina. The front of the iris is covered by a delicate epithelial layer. a continuation of that lining Descemet's membrane. 'The colour of the iris in different individuals depends upon the amount of stromal pigment.

3. The innermost or nervous coat.-The imner surface of the uveal tract is everywhere lined by a layer of pigment of corresponding extent, which usually adheres to it closely on dissection. Developmentally, however, this general pigment lining is quite distinct from the ureal coat, and represents the outer uall of the secondary optic vesicle or embryonic retina: it consists of a single layer of pigmented epithelial cells. The amount of pigment is greatest anteriorly, over the ciliary region and iris, and there is again a small local increase posteriorly, corresponding to the macula lutea and to the edge of the optic foramen. In the ciliary region these cells have recently been described as lining numerous narrow tubular depressions in the inner part of the uveal tract, and they seem here to have a surecial function, viz. that of secreting the intraocular fluids.

From the manner in which the secondary optic vesicle, or optic cup, is formed. its two walls are necessarily continuous in front, at what may be termed the lip of the cul; we have just observed that the outer wall lines the ureal coat everywhere and corresponds in extent; consequently, the lip must be looked for at the edge of the pupil. i.e. at the termination of this coat anteriorly. The imrer wall of the cup, conserpunty, reaches from the lip, or pupillary edge, in front, to the optic stalk or nere behind, and is in close appusition to the jigment-epithelium; unlike the outer, howerer, this wall is represented in the developed eve by tissues rery dissimilar in structure in different parts of its extent. Tracing it hackwards from the pupillary edge, we find that over the whole posterior surface of the iris it exists as a single larer of pigmented epithelium, the developmental changes having here procheed a result similar to what we have found throughout in the outer wall: here, accorclingly. We have a double laver of pigment cells. At the ront of the iris the single inmer layer of cells still exists; but now they become rlestitute of pigment, and this conclition obtains over the entire ciliary region, constitutine what is known as the pars ciliaris retinæ. It the line of the orm serrata the tisue derived from the inner wall abruptly increases in thickness. and rapidly acyuires that complexity of structure characteristic of the retina proper, which extends from here to the optie nerve. It eonsists of sereral larers-nerve-fibes, nerve-cells, and nerve-epitheliumhold together by a supporting fonmework of delicate comnective tissue. The nerveepithelium is on the outer surface, immediately applied to the piement-rpithelium; at the posterior pole of the eye a small spot (fovea centralis) exists, where this is 
the only retinal layer representerl. and where consopuently the retinat is extrentely thin. The nerve-fihres rum on the inner surface of the rrina and are continuous with those of the optie nerre; they constitute the only retinal layor that is (ontinued into the intraocular and of the nerve. The nerverells are found betwern these surface layers. The larger blood-ressels of the retinat run in the inner layer's, and none encroach on the layer of nerve-epithelimm.

Within the coats mentioned, the interior of the eveball is fully oceupied hy erontents, which are dividect into three parts, and differently naned according to their consistence and anatemical form. They are all transparent, as througl them the light has to pass so as to gain the retina. Of these the only no that is sharply and independently outlined is the lens, which is situated in the anterior lalf of the erlelue at the level of the ciliary processes, where it is suspenderl between the other (onstents, which fill respectively the spaer in front of it and the space behind it. The

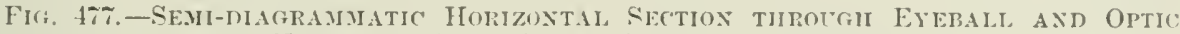
NEIrE. (After Elfinger. lieduced aml altered.)

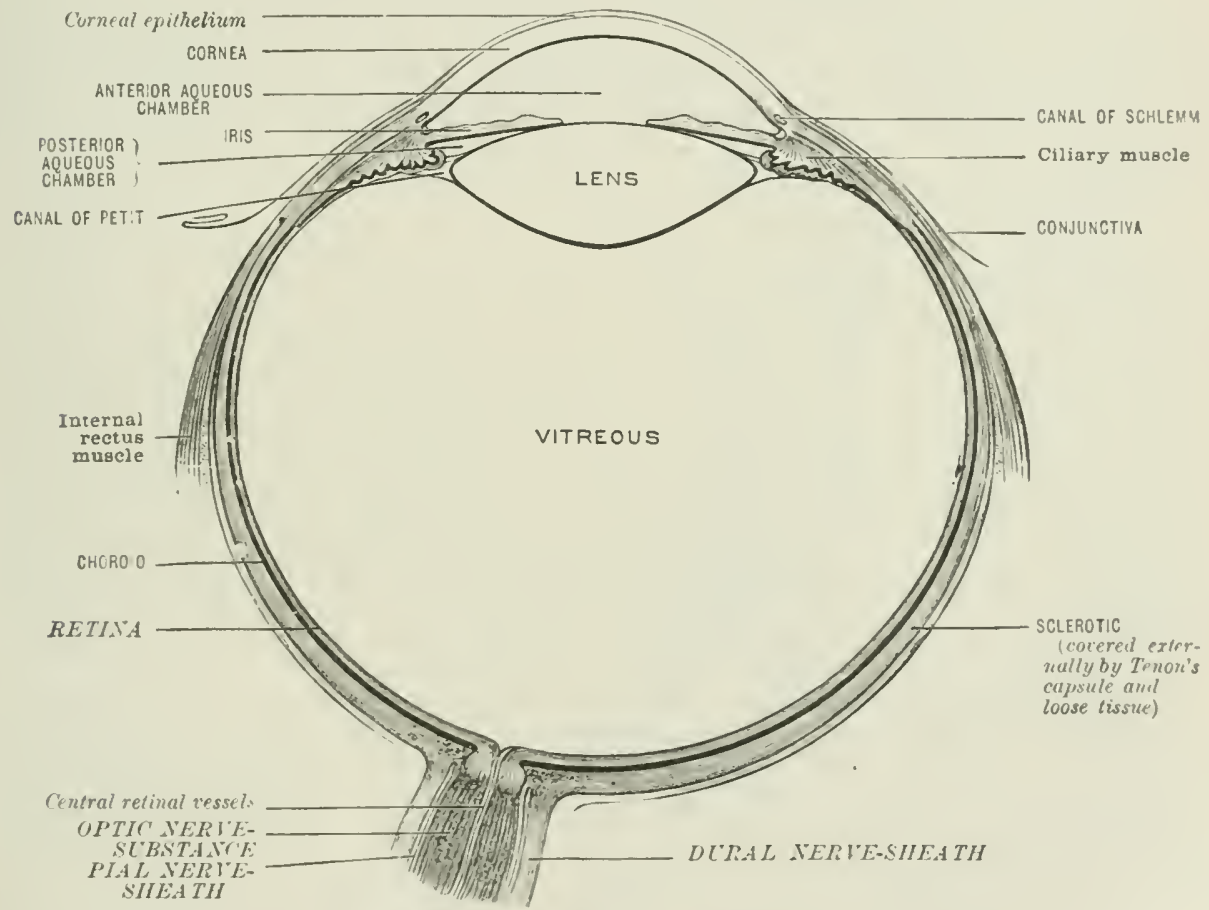

space in front is callet the anterior or auteous chamber; that hehind the lens is the vitreous chamber.

The lens is a bicmlex body. with its surfaces directed anteriorly and posteriorly: these surfaces moet at its rounclerl-oft edge or equator, which is near (lout roes nint touch ) the ciliary processes all round. The postrior is comsiderally more convex than the anterior surface; the central part of each surface is called its pole. "The lens is closely encased in a hraline clastio capsule, thicker orer the anterion than over the posterior surfare. Thus cuclosed, it is held in position in the grobe he a suspensory ligament, attached to its capsule near the equator all romerl, and swing from the ciliary region. Posteriorly, the lens rests in a cup formerl liy the front lart

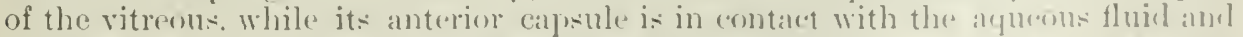
lies alose against the back of the pupillary borker of the iris. IThen in position

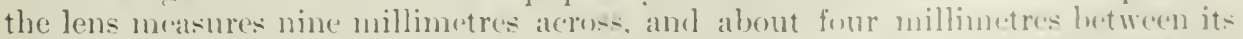

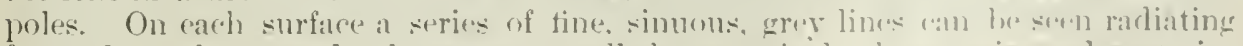
from the pole towards the epuator, callew repentively the anturior and pusterior 
stellate figures. The lines observable on the posterior are always so placed as to be internediate with those on the anterior surface, so that on ricing them through the lens they vceupy a position corresponding to the intervals between the lines on the anterior surface. The lens-capsule is comparatively brittle, and ean he readily eut through when scraped with a sharp-pointed instrument; on doing so the divided edges curl outwards, away from the lenticular substance. When removed from its capsule, the outer portion of the lens is found to he soft and glutinous, but its substance gets progressirely firmer as we approach the contre. This harder central part is known as the nucleus, and the surrounding softer matter as cortex. The cortical part shows a tendency to peel oft in successive layers. It consists of long fibres, the ends of which meet in front and behind at the anterior and posterior stellate tigures.

Histologically the capsule is not in immediate contact with the cortex orer the front surfice of the lens, a single liner of cells intervening, called the subcapsular epithelium.

The suspensory ligament of the lens is formed by a thickening of the anterior part of a membrane enclosing the vitreous, strengthened by numerous fibres derived from the folds of the ciliary region. Its chief attachments to the lens-eapsule are a little in front of and behind the equator, and the space included between the most anterior and most posterior divisions of the ligament is termed the canal of Petit. This space is bridged across by fine intemediate suspensory fibres, and is occupied by fluid.

The vitreous humour is a transparent, eolourless, jelly-like mass, enclosed in a delicate, clear, structureless membrane, called the hyaloid membrane. This latter is elosely applied to the back of the posterior lens-capsule and of the suspensory ligament, and to the inner surface of the pars eiliaris retinæ, retina proper, and optic papilla. Although possessing some degree of firmness, the vitreous humour contains quite 98 per cent. of water, and has no definite structure. Membranes have been deseribed in it, but these are really artificial products. In certain situations spaces exist in the vitreous mass, the most determinate of whieh runs in the form of a canal from the optic papilla to the posterior pole of the lens, corresponding to the position of the foetal hyaloid artery (hyaloid canal, or canal of Cloquet). Other very fine spaces are deseribed running circularly in the peripheral part of the vitreous concentrie with its outer surface. Mieroscopieally, wandering cells are found in the vitreous, which often here assume peculiar forms which the observer ean, not infrequently, study subjectively.

The aqueous humour is a clear, watery fluid, occupying the space between the comea on the one hand, and the ciliary body, suspensory ligament, and lens on the other. The iris, projecting into this space, has both its surfaces bathed in the aqueous; but, as its inner part rests on the lens, it is regarded as dividing the space into two parts, an anterior larger, and a posterior smaller aqueous chamber, which communicate freely through the pupil.

Ciliary nerves of the eyeball.- The long and short ciliary nerves, after perforating the sclerotic, run forward between it and the choroid to the ciliary region, where they form a plexus, from which proceed branches for the ciliary muscle, the iris, and the cornea. The nerves of the iris enter it at its ciliary border, and run towards its pupillary elge, losing their medullary sheath sooner or later, and supplying specially the sphineter muscle. The comeal nerves form an ammular plexus near the limbus, from which a few twigs proceed to the selerotic and conjunetiva, while most of the offects enter and rum radially in the conneal stroma, branching and anastomosing so as to form a plexus. The nerves entering the cornea are about sixty in number, each containing from two to twelve non-medullated nerve-fibres (page 7.53 ).

Blood-vessels of the eyeball.-The ocular tissues receive blood from two sets of ressels, viz. the retinal and the ciliary arteries.

1. The arteria centralis retinæ either comes direct from the ophthalmic artery, or from one of its hranches near the apex of the orbit. Entering the optie nerve twenty millimetres or less lehind the globe, it runs forward in its axis to the end of 
the nerve-trunk, and then divides into branches which run in the inner layer's of the retina, and divide dichotomously as they radiate towards the repuator. The smaller branches lie more deeply in the retina, but none penetrate into the nerve-epithelimm, so that the fovea centralis is non-vasenlar. In the retina, the branches of the central artery do not commmicate with any other arterics, but while still in the optic nerve fine communications take phace between this artery and noighbouring veswes. Thus (a) minute twigs from it, which help to nourish the axial part of the merve, communieate with those ruming in the septa derived from the pial sheath. Again, as the nerve passes through the selerotic, it is surrounded by a vaseular ring (circle

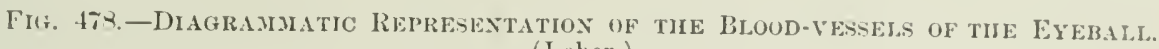
(I,eber.)

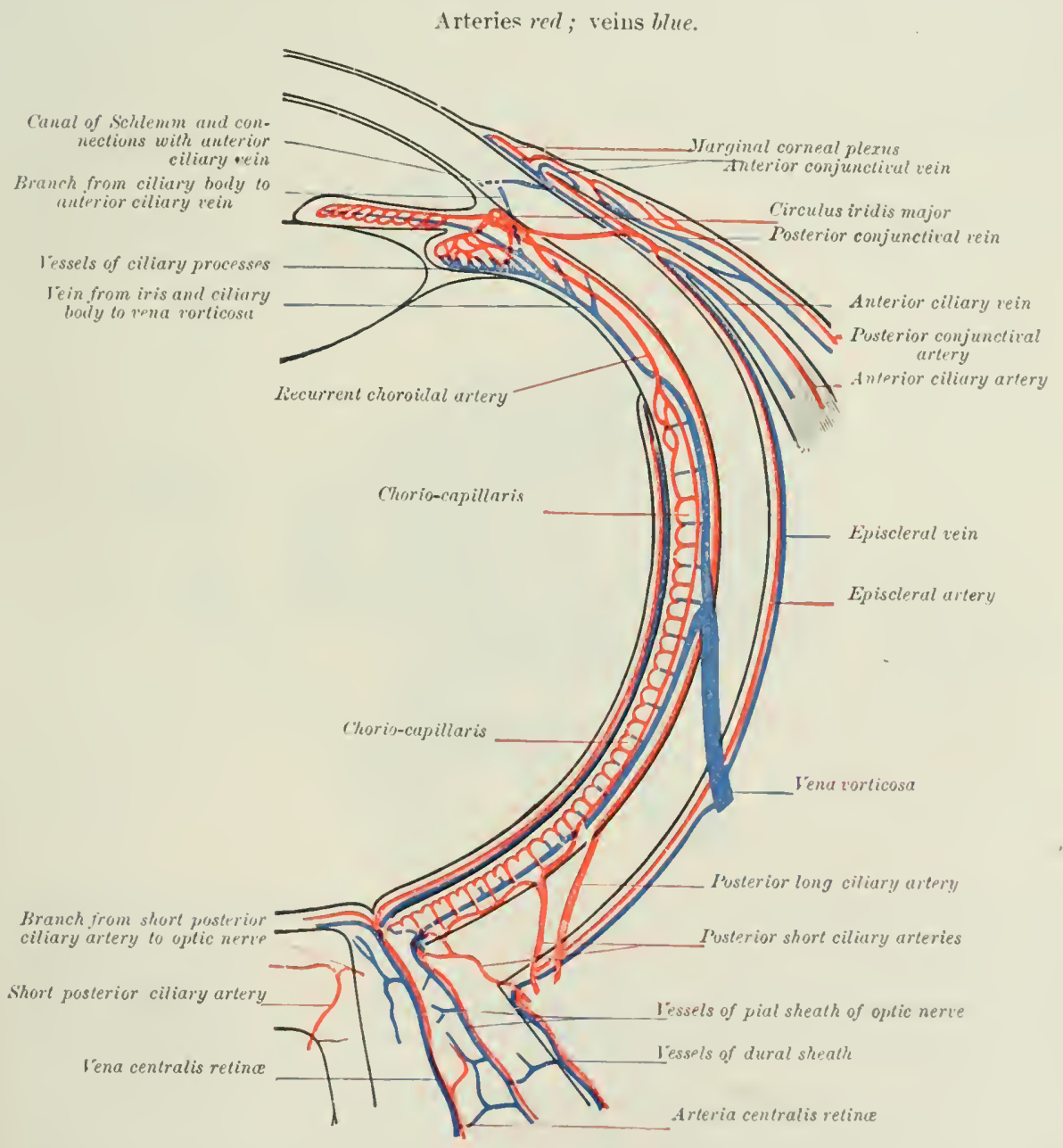

of Haller), formed of fine branches derived from the short pesterior ciliary atrories; fine twigs passing inwards from this ring to the optic nerve, join the bessels of the pial sheath, and (b) an indirect rommunication is thus honght ahout betweren the retinal and ciliary vessels. Finally, as the nerve passes through the cherofid, there is $(r)$ a direct commection hetween these two sets of vesteds, the capillary network of the optic nerve leing here continuous with the chorio-calpil]aris. Not infrepunels]y. a branch from a short posterior ciliary artery ficeres the optic falpilla, and thin courses orer the arljoining retina (a ciliob-retinal artery), supplying the litter in part in place of the central artery. 
The vena centralis retinæ returns the blood of the corresponding artery.

2. The ciliary system of blood-vessels (pages 500, 501, and 625 ). - There are three sets of arteries belonging to this system, all derived directly or indirectly from the ophthalmic artery.

(1) Short posterior ciliary arteries, twelve to twenty in number, pierce the selerotic round the optic nerve entrance, and are distributed in the choroid. Before entering the eyeball, small twigs are given off to the adjoining sclerotic and to the dural sheath of the optic nerve.

(2) Two long posterior ciliary arteries, piercing the sclerotic further from the nerve than the short ciliaries, run horizontally forwards between the selerotic anct choroid, one on each sicle of the globe. On arriving at the ciliary body, they join with the anterior ciliary arteries, forming the circulus iridis major, which sends off branches to the ciliary processes and the iris. The long ciliaries also give twigs to the ciliary muscle, and small recurrent branches run backwards to anastomose with the short ciliary arteries. The arteries of the iris run radially to the pupillary border, anastomosing with one another opposite the outer border of the sphincter so as to form the circulus iridis minor.

(3) The anterior ciliary arteries come from the arteries of the four recti

Fic. 479.-SIRFACE OF CHOROID AND IRIS EXPOSED BY REyoval OF SCLERotic AND Corvea, showixg Distribetion of Blood-vessels axi Nerves.

(Twice natural size. After Zinn.)

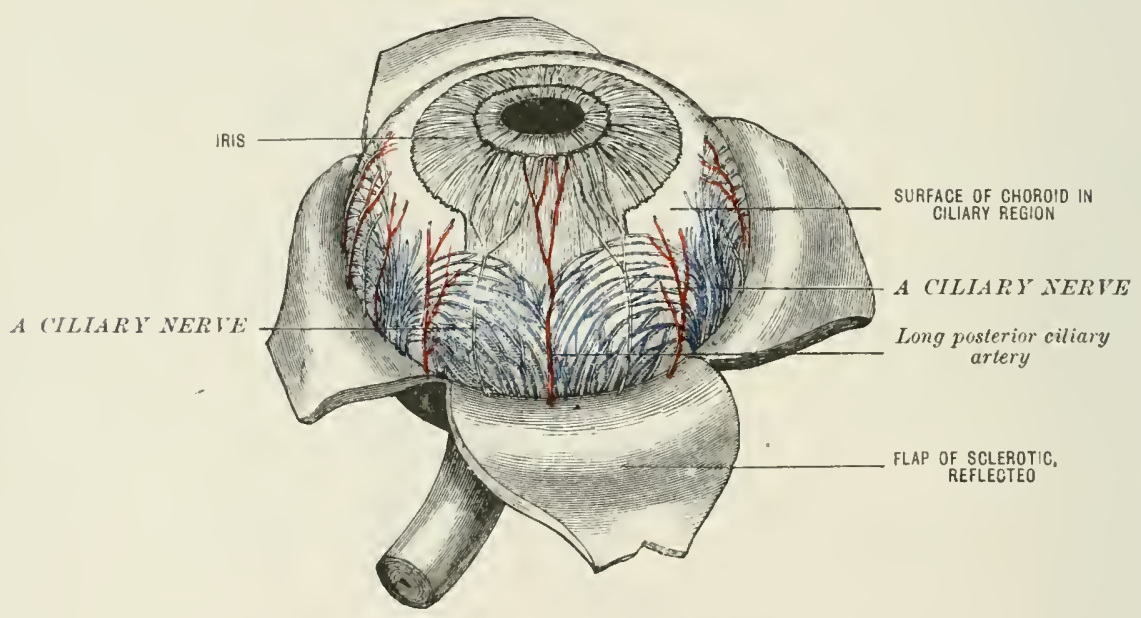

muscles, one or two from each; they run forwards, branching as they go, and finally pierce the sclerotic near the corneal border. Outside the globe they send twigs to the adjoining sclerotic, to the conjunctiva, and to the border of the comea. After passing through the selerotic the arteries enter the ciliary muscle, where they and in twigs to the muscle and to the circulus iriclis major, and recurrent branches to the choroid.

Veins.-The venous bloor from almost the whole uveal tract (choroid, ciliny processes and iris, and part of the ciliary muscle) ultimately leaves the eychall by (1) the venæ vorticosæ, which have been alreaty noticed in describing an anteroposterior section through the globe. One large vein passes hackwards from each vortex, piercing the sclerotic obliquely; it is joined by small episcleral veins when sutside the globe.

(2) The anterior ciliary veins commence by the junction of a few small veins of the ciliary muscle; they pass outwards through the sclerotic near the corncal borter, receiving blood from the veins in connection with Schlemm's canal, and afterwards from episcleral and conjunctival veins, and from the marginal corneal plexus. Finally they join the veins running in the recti muscles.

Lymphatic system of the eyeball. - Npart from those in the conjunctiva 
there are 1 o lymphatic ressels in the eyeball, but the fluid is rontainer in spaces of various sizes. These are usually divided into an anterior and a posterior set.

1. Anteriorly, we have the anterior and posterior ayueous chambers, which communicate freely through the pupil. The aqueous humour is secreted in the posterior of these clambers, from the vessels of the ciliary body and posteriof surface of the iris (see also page 849). The stream passes mainly forwarels through the pupil into the anterior aqueous chamber, whence it escapes slowly by passing through the spaces of Fontana into Schlemm's canal, and thence into the anteriof ciliary veins. Part of the lymph-stream passes from the posterior acjucous chamher backwarls into the canal of Petit, out of which ftuid ean pass into the lens substance, or diffuse itself into the front of the vitreous.

In the cornea the lymph travels in the spaces already mentioned as existing between the fibre-bundles, and in the nerve-chamnels, and at the periphery of the cornea it flows off into the lympluatic vessels of the conjunctiva.

Fig. 480.-TIn Lyuphatics of Tue Eyeball. (Diagrammatic. After Fuchs.)

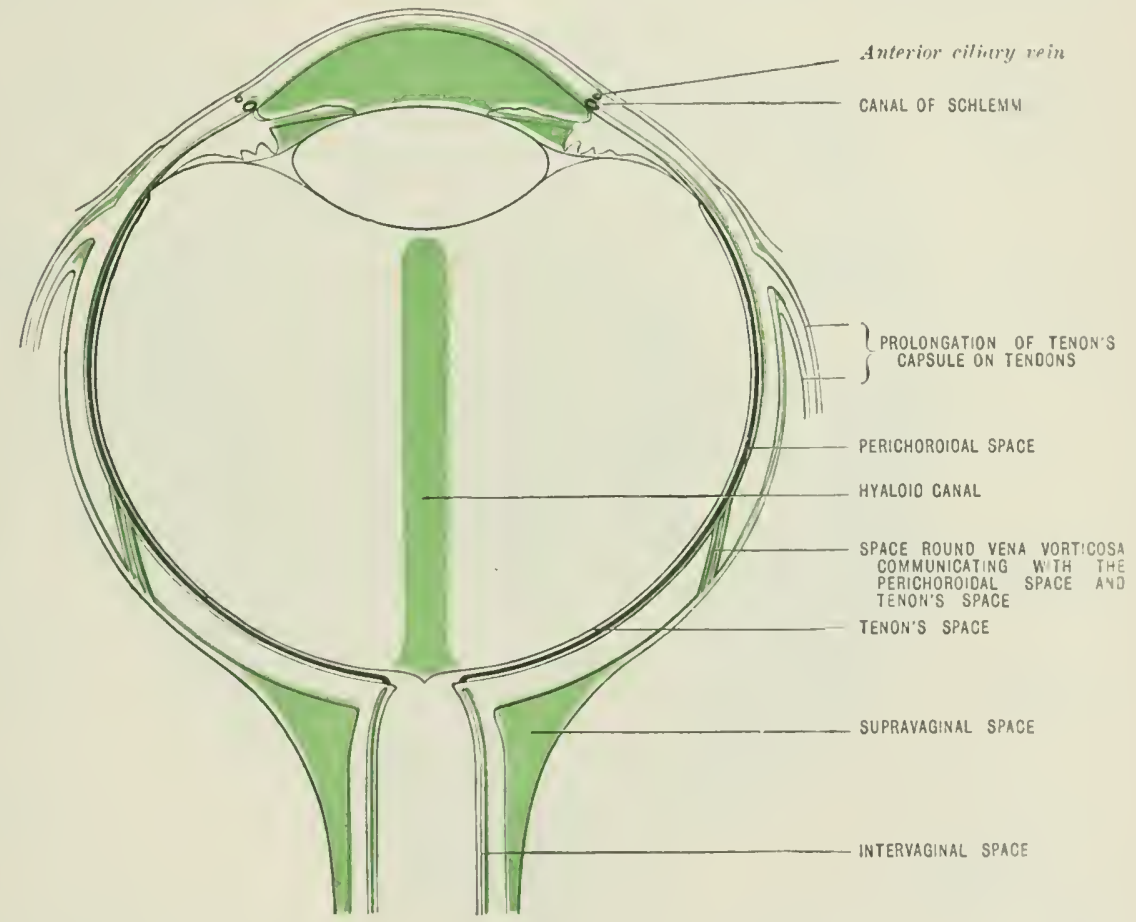

In the iris there is a system of lymphatic spaces opening anteriorly on its free surface by the erypts previously described, and communicating peripherally with the spaces of Fontana.

2. Posteriorly, we have $(a)$ the central or hyaloid canal, hetween the fostrrior pole of the lens and the optic norve entrance, and $(b)$ the perivascular canals of the retina; the lymph from both of these situations flows inte the spaces of the optie nerve, which communicate with the intervaginal space of the nerve and thus with the great intracranial spaces. Further, hetween choroid and solerotie, we have $(c)$ the perichoroidal space, which gets the lymply from the choroin, and communicates with Tenon's space ontside the sclerotic ly the prerforations corresponding to the vasa vorticosa and posterior ciliary arteries, and with the intervilginal space around the optic nerve cutrance. 'Tenon's space, again, is continnoms with the supravaginal space around the optic nerve, which communicates both with the intervaginal spaces, with the lymph spaces of the orbit, and directly with the intracramial spaces at the apex of the ortit. 


\section{CAVITY OF THE ORBIT}

\section{General Arrangeinest of its Contexts}

The anterior wider half of the carity is mainly occupied by the eveball, which lies almost axially, but is rather nearer to the upper and outer than it is to the other walls. The posterior two-thirels of the glolve are in relation with soft parts, chiefly muscles and fat, and its posterior pole is situated midway between the base (or opening) and the apex of the orbital carity. The anterior third of the excball is naturally free, except for a thin covering of the conjunctiva, and projects slightly beyond the opening of the orbit, the degree of prominence varying with the amount of orbital fat, and also to some extent with the length of the globe. A straight line joining the imer and outer orbital margins usually euts the ere behind the cornea-externally behind the ora serrata, nasally further forward, at the junction of the ciliary body and iris. The glohe is held in position by numerous bands of connective tissue. The lachrymal gland lies under the outer part of the

Fig. 421. - Left Eyebal, seen ix its Nonyal Position ix the Orbit, with Vill uF THE OCLLAR Mcscles. (After Merkel, modified.)

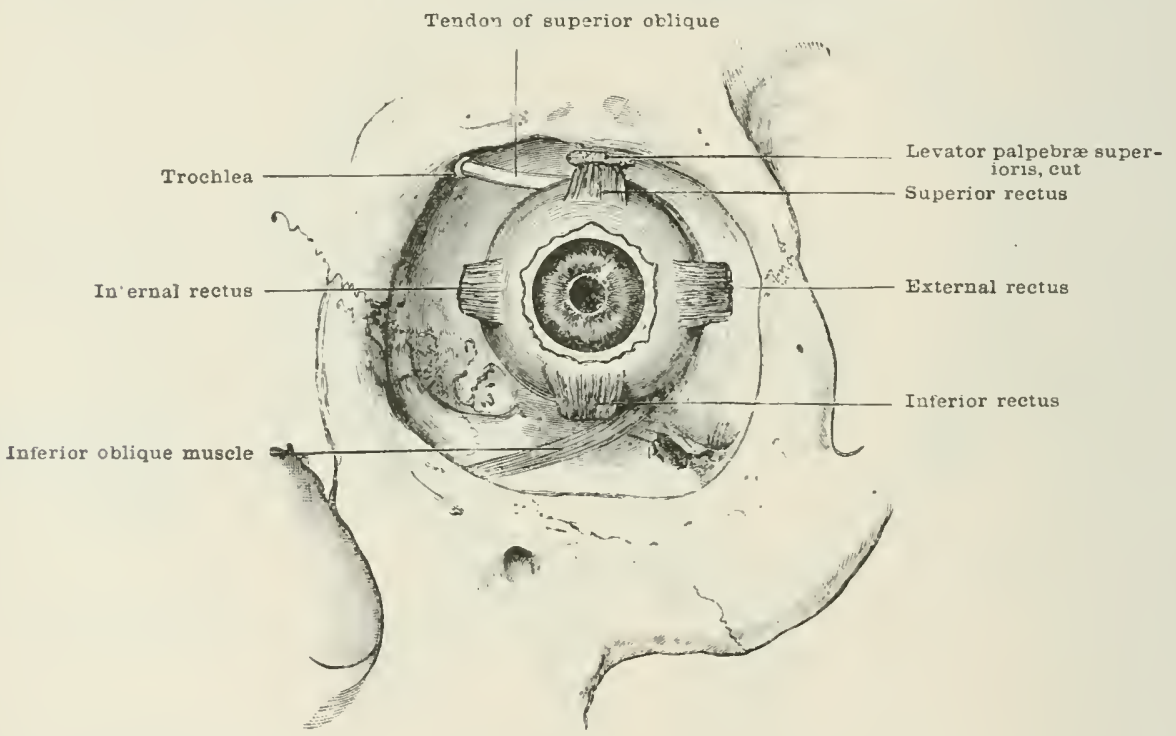

roof of the orbit anteriorly. The orbital fat oceupies the spaces betreen the orlital muscles, and is in greatest amount immediately behind the ereball; it also exists between the muscles and the orbital walls in the anterior half of the carity. Six muscles, viz. the four recti, the superior oblique, and the levatur palpebrie superioris, arise at the apex of the orbit, and diverere as they lass forwards. The recti muscles-superior, inferior, external, and internal-run each near the corresponding orbital wall, but the superior is overlapped in part ly the levator palpelore. The superior ohligue lies about midway between the superior and internal recti. A serenth muscle, the inferior oblique, has a short course entirely in the anterior part of the orbit, coming from its inner wall and passing beneath the ghobe between the termination of the inferior rectus and the orbital floor. The optic nerve with its sheaths passes from the optic foramen to the back of the eyelatl, smounder by the orbital fat, and more immediatrly by a loose commective tisue. Among the contents of the cavity are also to be enumerated many vessels amel nerres, and fibrous tissue septa, while its walls are elothed hy periostem (periorlita).

The muscles of the orbit are seren in number, of which six are ocmlar, i.e. are inserted into the eyehall and rotate it in different directions. These ocular muscles 
are arranged in opponent pairs, viz. superior and inferior recti, superior ind inferior obliques, external and internal recti. With the ax"eption of the short inferior ohlique, they all arise from the hack of the orhit alomer with the serenth orbital musile, the elevator of the upper lid. All these loner nusches take their origin from the periosteum in the virinity of the optic formenen. The four recti muscles arise from a fibrous ring, which arches clese over the uppere and inmer enlere. of the foramen, and extends down and out sil as to embrace fart of the (1)erning of the sphenoidal fissure. Their origins mav he said at first to form a short, common, tendinous tube, from which the individual muscles som separatr, taking the positions indicaterl by their respective names. The external reetus has twe origins from bone, one on either side of the sphenoidal fisture. But in the fresh state the fissure is here bridged across hy fibrous tis-ue, from which this rectus also springs, so that its origin is in reality comtinuous. The part of this filurus

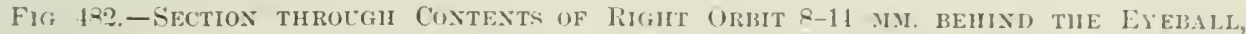
VIEWED FLUM BEHISD. (After Lauge.)

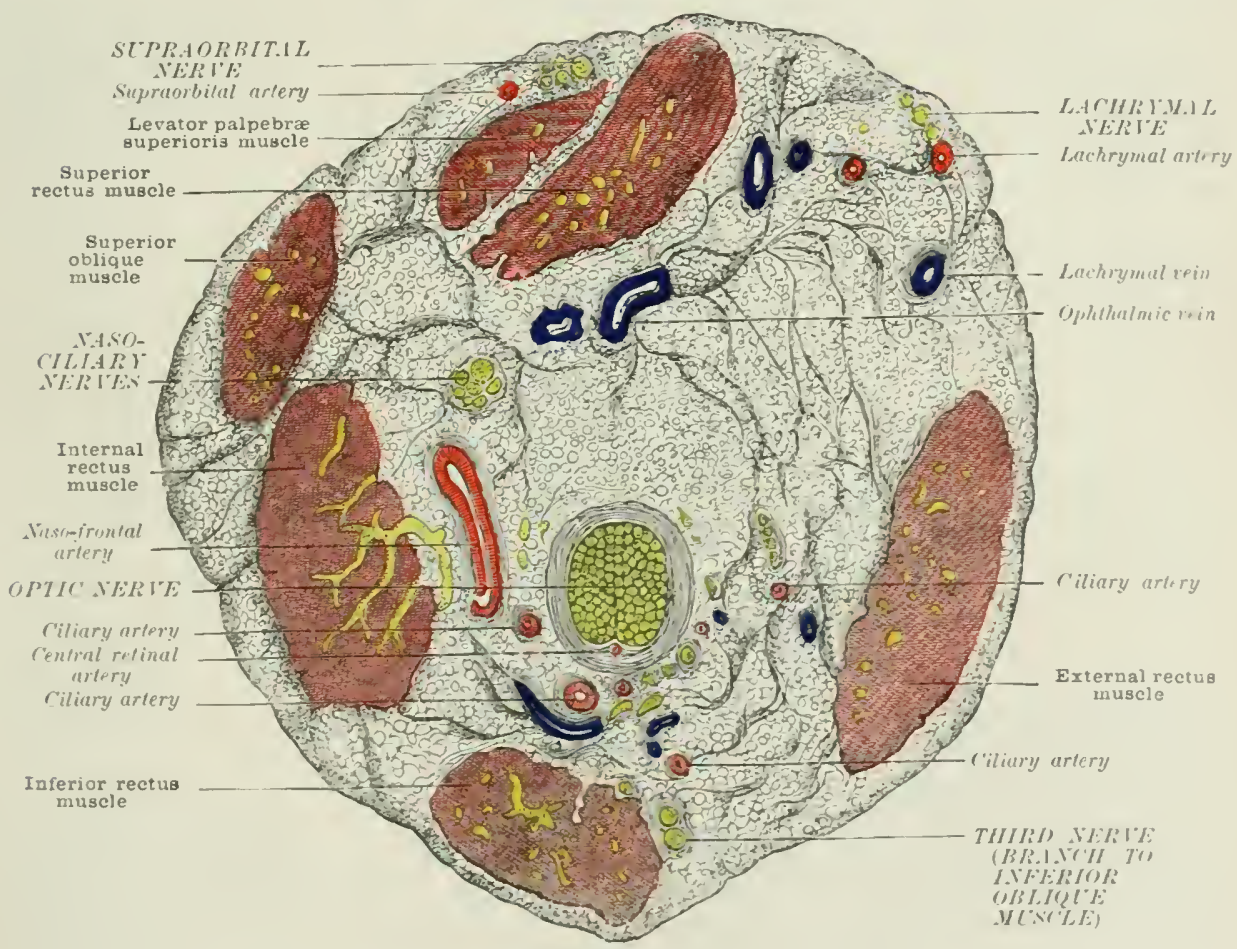

ring nearest the formen (corresponding to the origins of the superior and internal recti) is resely commected with the outer sheath of the ofitie norve. The remaining two long muscles arise just outsile the uppere and imner gart of the aberesunentioned ring, and are often partially united; the levator palpelua tendon is in

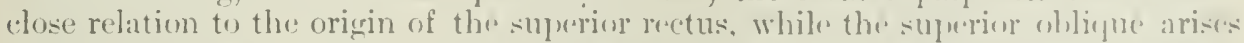
from the periostem of the buly of the sphenoid bone one or two millimetres in front of the origin of the intemal rectus.

The four recti muscles lie rather wuse to the enrresponding orthital wall- for the first half of their course, the superior reetus, however, heine orerlajperl in part hy

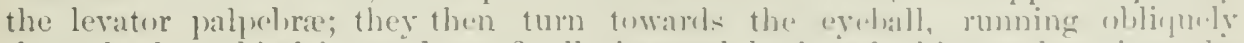
through the orbital fat, and are finally insartet ly brokl, thin temelons inter the sclerotic in front of the equator. The thicket of ther muscles is the intrmal rectus, next the external, then the inferion, and the superior reetus is the thinmest. 
As regards length, the muscular belly of the superior rectus has the longest course, and the others diminish in the order-internal, external, and inferior rectus. The external rectus is supplied by the sixth nerve. The other three recti muscles are all supplied by the third nerve.

The levator palpebra superioris courses along the roof of the orbit close to the periostrum for the greater part of its course, partially overlapping the superior rectus; it finally descends through the orhital fat, and widens out to be inserted into the root of the upper lid. It may be briefly described as being inserted in two distinct layers separated by a horizontal interval. The upper or anterior laver of insertion is fibrous, and passes in front of the tarsus, where it cones into relation with fibres of the orbicularis. The lower layer consists of smooth muscle (Müller's superior palpebral muscle) and is inserted along the upper border of the tarsus. The levator has also connections with the sheath of the superior rectus. These different insertions of the musele will be referred to later along with the description of the orbital fasciæ and of the upper eyelid. It gets its nervous supply from the third nerve, but the smooth muscle developed in its lower laver of insertion is supplied by the sympathetic nerrous system. As its name expresses, its action is to raise the upper lid and to support it while the eye is open.

The superior oblique runs forward close to the inner part of the orbital ronf until it reaches the fossa trochlearis near the internal angular process, where it hecomes tendinous and passes through a fibro-cartilaginous pulley attached to the fossa just named. On passing through this pulley, or trochlea, the tendon bends

Fig, 483.-Diagramatic Represextation of Origiss of OCllar Muscles at thf. Apex OF THE RIGHT ORBIT,

(A ter Schwalbe, slightly altered.)

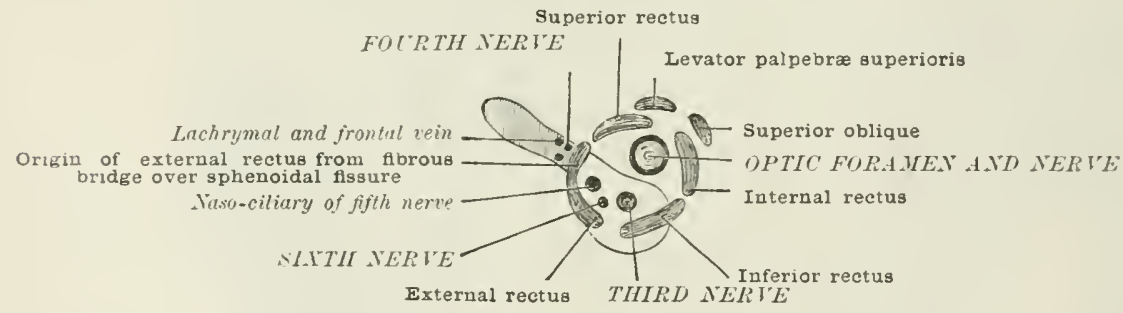

at an angle of $50^{\circ}$, running backwards and outwards under the superior rectus to its insertion into the sclerotic. It is supplied hy the fourth nerve.

The inferior oblique arises from the front of the orbit, about the junction of its immer and lower walls, just external to the lower end of the lachrymal groove. It runs, in a sloping direction, outwards and backwards, lying at first hetween the inferior rectus and the orbital floor, then between the external rectus and the globe; finally it ascends slightly, to be inserted by a short tendon into the sclerotic at the back of the eye. Its nervous supply i. derived from the third nerve. The precise manner of insertion of the different ocular muscles has been described above in our Examination of the Eyebili. (For Mrscles of tife Eyelids and Eyebrows, see laiges 429 and following.)

Action of the ocular muscles. - While rotating the globe so that the comea is turned in different directions. the ocular muscles do not alter the position of the eyeball in the orbit wither laterally, rertically, or antero-posteriorly. In speaking, therefore, of the eye heing moved ipperards, or outuards, etc., it is the altered position of the cornea or front of the cre that we mean to express; it is manifest that, if the cornea moves up, the back of the ryeball must simultancously he depressed, and similarly with other morements. All the morements of the glohe take place by rotation, on axes passing through the centre. Though the possible axes are numerous in combined muscular action, there are three principal axes of rotation of the erehall, and in reference to these the action of individual muscles must be described. 'Two of these axes are horizontal, and one vertical; they all pass through the centre 
of rotation at right angles to one another. By rotation of the eye on its virtial axis the comea is moved outwards (towards the temple), and inwards (towarls the nose): novements called respectively abduction and adduction. In mpwarl anl downwrd movements of the comea, the eye rotates on its horizontal eduatorial axis. The other principal axis of rotation is the sagittal, which we have previous $]_{y}$ described as corresponding to the line joining the anterior and posterior poles of the globe (page 843 ). In rotation of the eye on its sagittal axis, therefore, the ("nrnear may he said to move as a wheel on its axle, for its centre now corresponds to on mul of the axis; in other words, this is a rotation of the cornea. Such moxemonts may, consequently, he expressed with reference to their effect on an innainary spoke of the corneal wheel-e.g. one rumning vertically upwarls from the corment centre. 'Thus we may say 'rotation of the cornea outwards' when this frart of the wheel moves towards the outer canthus, or 'inwards' when towards the nowe.

The only two museles that rotate the eveball merely on one axis are the external rectus and the internal rectus; the former abducting, and the latter arlucting the cornea.

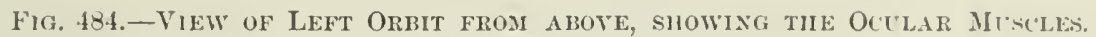
(Froin Hirschfeld anil Leveillé.)

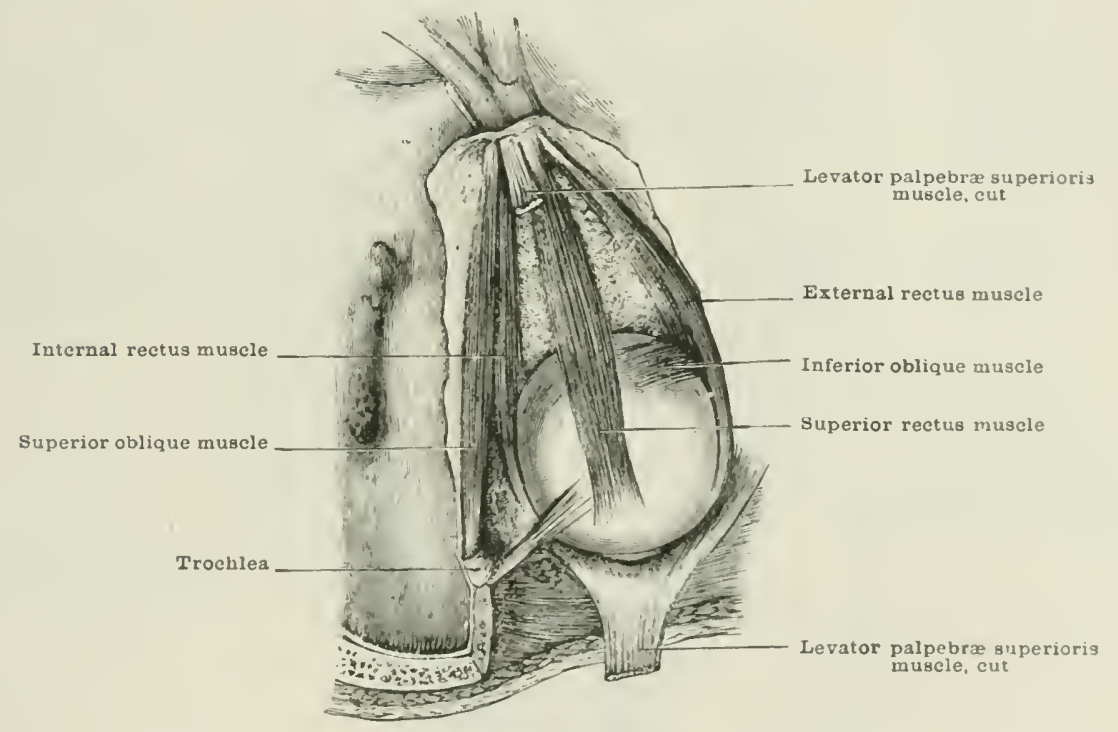

The chicf action of the superior rectus is to draw the cornea upwards, hut at the same time it addurets and rotates the cormea inwards.

The inferior rectus mainly draws the cornea downwards, also adducting it and rotating it outwalls.

The chief action of the superior oblique is to rotate the eornea inwards, also drawing it downwals and slightly ablucting it.

The inferior oblique mainly rotates the comea outwards, also drawing it upwards and slightly abdueting it.

The fascia of the orbit.-The orhital enntents arc bomel tugrother and sup)ported by filorous tissues, which are comnected with each other. fut which may conveniently he regarded as belonging to three systems. These arr: (1) Thuse lining the liony walls; (2) those ensheathing the muscles; and (3) thre ti-sure which partially encapsules the eyclall.

1. The orbital periosteum, or periorbita, is closely apllied to the lum forming the walls of the eavity, but may be stripped nff with compantion ats. It presents openings for the passage of vessels and norves entering and laving the orbit. Posteriorly this tissue is very firm, heing joined by jumesses of the dura mater at the optic canal and sphenoidal tissure; at the optic forancen it is also 
connected with the dural sheath of the optic nerre. $A$ s it covers thesphenomaxillary fissure its fibres are interworen with smooth muscle, forming the orbital muscle of IIüller. From its inner surface processes run into the orbital eavity, sepanting the fat lobules. One inportant process comes from the periorbita about millway along the roof of the orbit, runs forward to the back of the upper division of the lachrymal glanel, and there splits, helping to form the gland-capsule: this eapsule is joined at its inner horder by other periorbital bands coming off near the upper orbital rim. and forming the suspensory ligament of the gland. On the inner sile of the orbit the periorbita sends filmons processes to the trochlea of the superior oblique, which keep it in position. On arriving at the lachrymal groove the periorbita clivides into two layers, a thin posterior one continuing to line the bone forming the floor of the groove, whilst the thicker anterior layer bridges orer

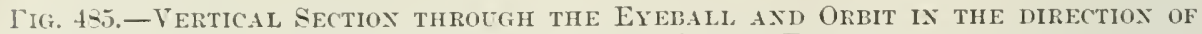 the Orbital Axis, With Closen Ereidid.}

(Semi-diagrammatic. After Schwalbe, modified to show fascix.)

Periorhita green; muscle-fiscia red; Tenon's capsule yellow.

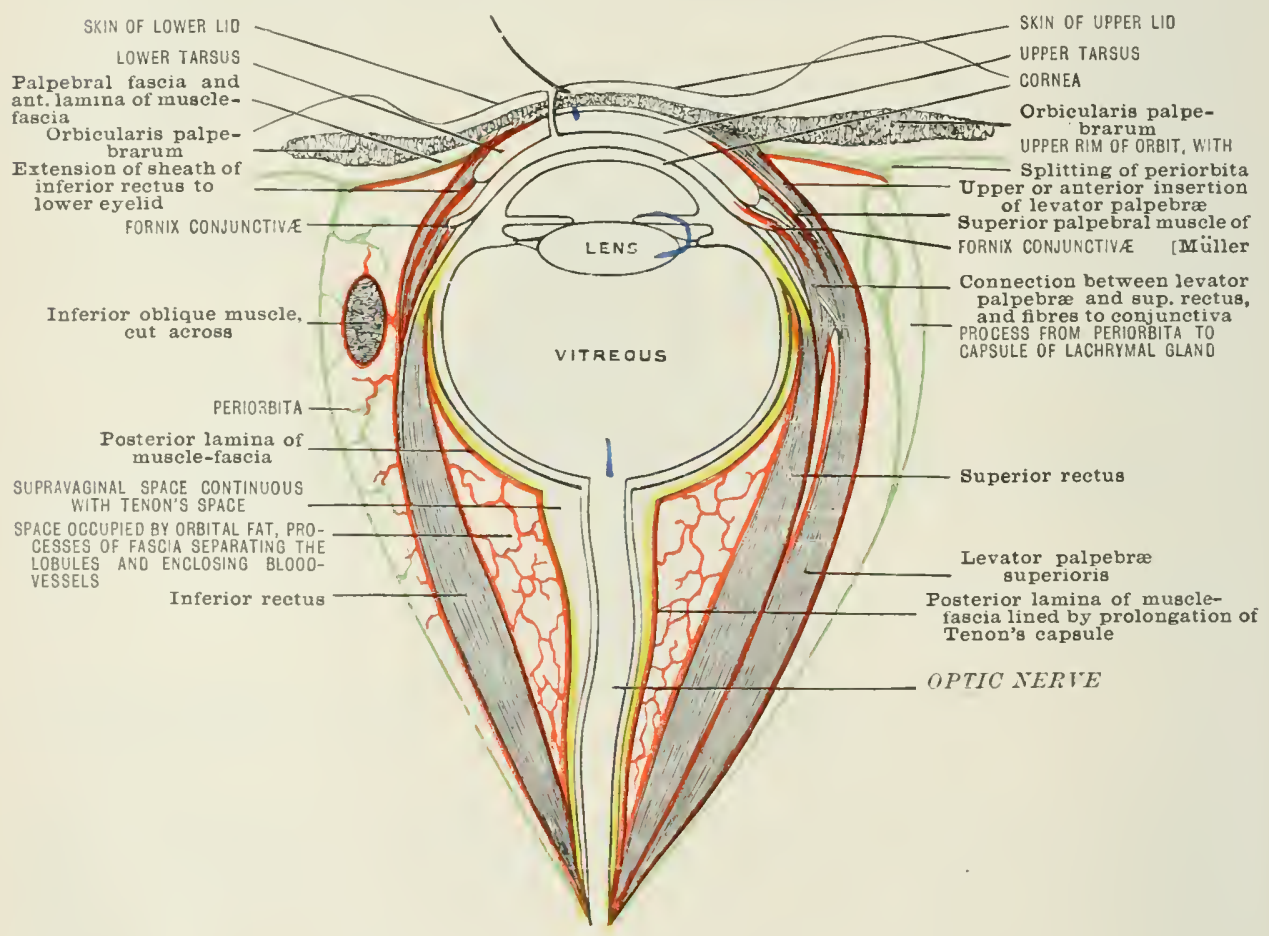

the groove and the sac which lies in it, forming the limbs of the immer palpebril ligament (page $86 \bar{T}$ ).

Quite anteriorly, at the rim of the orbit, the periorbita sends off a membranous mocess which aids in forming the fibrous tissue of the erelids (orbito-tarsal ligament, or palpebral fascia), and is itself continuous with the periosteum of the bomes ontsirle the orbital margin.

2. The orbital muches are connected by a common fascia, which splits at their morders and furnishes a sheath to each. Processes of this fascia give membranous investments for the ressels and nerves (including the optic nerve), splitting similarly to enclose them; these membranous processes also assist in separating the fat lobules. Posteriorly, this finscia is thin and loose, and blends with the periorbita at the origin of the muscles. Anteriorly, it becomes thicker and firmer, accompanies the museles to near the equator of the eyeball, and there clivides into two laminx, 
an anterior and a posterior; the former continues a forwarl course, forming a complete fumel-shaped investment all round, passing ultimately to the evelids and ortital margin-whilst the latter tums hackwarks, covering the hinder third of the glolie.

The anterior lamina is a well-marked membrane everywhere, hut in cortain situations it presents special bands of thickening, corresponding to the direct comtinuation forwards of the sheath of each rectus muscle. Ahere and below, this lamina spreads ont in the form of two large newubranes, which are finally allphlied to the deep surface of the palpebral fascia; the lower nembrane constitintes what has been described as 'the suspensory ligament of the 'yeball.' The? upler nuenbrane refuires a fuller leseription, as its distribution is inodified by the fresence of the levator palpehre muscle.

The upper part of the sheath of the superior rectus (along with the adjuining

Fig. 486.-Horizontal Section Throegh Left Oibit, viewed fruil alove.

(After Von Gerlach. To show check liqaments, etc.)

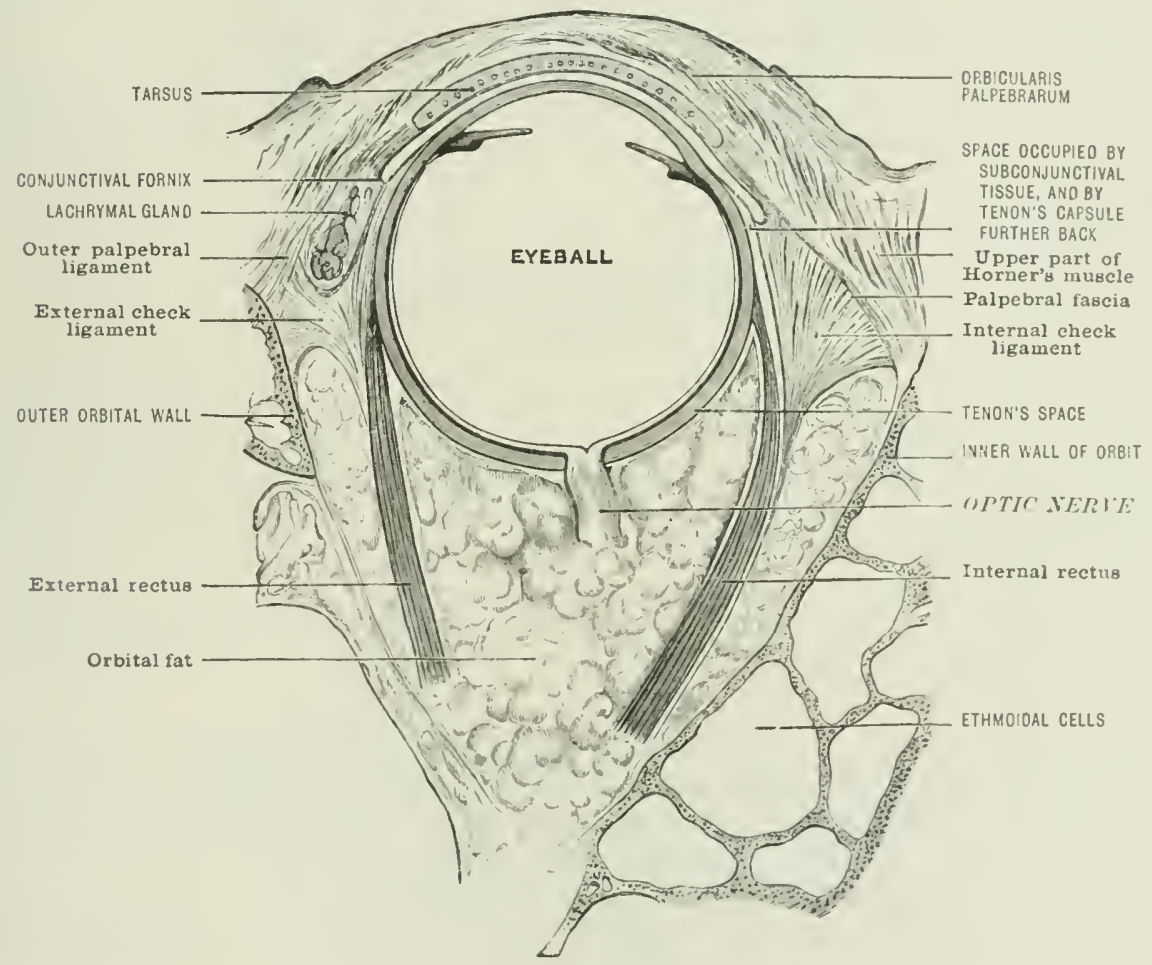

minbrane on each sicle of it) jasses to the deep surface of the levator, to which it c'usely adheres, and completely ensheaths this tendon ly extending round it: bordirs to its upper surface. The lower part of this levator-sheath is applien to the

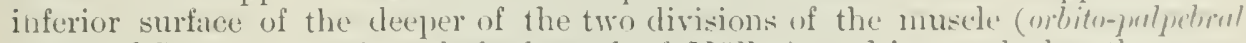
muscle of Sappey, superior pulpebul mack of Mïller), and is attached to the ulyer border of the tarsus of the upper lid, reaching laterally to the outer and immer angle: of the orbit. The upper part of the sheath of the orbite-palpeloralis muscle reathes to the middle of the palpebral fascia, and is mainly continued forward leetween the musele and the fascia to the anterior surface of the tarsus.

The lower memlrane (suspensory ligament of the evehall), joined ly the sheath of the inferior rectus, reaches forwart to the attached (hinder) horder of the tarsus of the lower licl, where it is mainly attacheel, while a part of it extends to the lower palpebral fascia. 
To understand the special bands mentioned above, we must follow the sheath of each rectus muscle forwards, when we find that, while it is rather loosely applied to the muscular belly in its posterior two-thirds, it then suddenly becomes thicker, and is firmly attached to the muscle for some distance before finally leaving it, and is thereafter often accompanied by some muscle-fibres. The best dercloped of these bands, the external check ligament, passes forwards and outwards to the outer angle of the orbit, helping to support the lachrymal gland on its way, and is inserted near the orbital edge immediately behind the external palpelral ligament. The inner band, or internal check ligament, is larger than the outer, but not so thick; it passes forwards and inwards to be inserted into the upper part of the lachrymal crest and just behind it. These two bands, external and internal, come from the sheaths of the corresponding recti muscles. From the sheath of the superior rectus come two thin bands, one from each border. The inner joins the sheath of the tendon of the superior oblique; the outer goes to the external angle of the orbit, assisting in the support of part of the lachrymal gland. The sheath of the inferior rectus is thickened in front, and, on leaving the muscle, goes to the middle of the inferior oblique, splitting to enclose it; it then passes to be inserted into the lower inner angle of the orbit close behind its margin, about midway between the intemal check ligament and the orbital attachment of the inferior oblique.

3. In addition to its partial investment by the muscle-fascia, the eyeball has a special membrane enclosing its hinder two-thirds, usually called Tenon's capsule. This is a thin, transparent tissue, situated immediately beneath the muscle-fascia. It follows the curve of the sclerotic from the insertion of the recti to about $3 \mathrm{~mm}$. from the optic nerve entrance, when it leares the eveball and blends with the posterior lamina of the muscle-fascia; the combined membrane may be traced backwards, enveloping the optic-nerve sheath loosely, approaching it as it nears the optic foramen, but never actually joining it. The interval between it and the nervesheath is called the supravaginal lymph space. Tenon's capsule first comes into relation with the muscles at the point where they are left by their proper sheaths ; it there invests their tendons, forms a small serous bursa on the anterior surface of each, and adheres to the sclerotic in the form of a line rumning round the globe, joining the insertions of the four recti muscles. Between this line and the cormeal border, the conjunctiva is separated from the sclerotic by the subconjunctival tissue, strengthened by a fine expansion of the muscle-fascia.

The inner surface of the capsule is smooth, and is only connected with the sclerotic by a loose, wide-meshed areolar tissue. This interval between the sclerntic and capsule, known as 'Tenon's space, is a lymph cavity, and permits free morements of the eveball within the capsule.

Relation of 'Tenon's Capsule to the Oblique Muscles. - The capsule surrounds the posterior third of the inferior oblique and its tendon, rmming along its ocular surface till it meets the fascial band coming from the inferior rectus (see above), and forming a serous bursa on the superficial surface of the oblique near its insertion. The tendon of the superior oblique for about its last five millimetres is invested solely by 'Tenon's capsule; in front of this, as far as the trochlea, the tendon lies in a membranous tube derived from the muscle-fascia, the inner lining of which is smooth, and may be considered as a prolongation of 'Tenon's capsule.

\section{The Optic Nerve}

The part of this nerve with which we have here to do lies within the orbit, extending from the optic foramen to the eveball. Its course is somewhat S-shaped; thus, on entering the orbit, it describes a curve, with its convexity down and out, and then a second slighter curve, convex inwards. Finally, it runs straight forwards to the globe, which it enters to the inner sicle of its posterior pole Besides curving as just described, the nerve also rotates on its long axis, so that the surface which is below at the foramen becomes trmporal before entering the eyehall.

In its passage through the optic canal the nerve is surounded by a prolongation of the meninges. The dura nater splits at the optic foramen, part of it joining the periorbita, while the remainder continues to surround the 
nerve loosely as its outer or dural sheath. The norve is chesely enveloped by a vatseular covering derived from the pia natrer, named aceordinerly the pial sheath. The space betwern these two sheaths, known as the interenginal sprece, is sublivided by a fine prolongation of the arachnoid (the arachnoidal sheath) int"

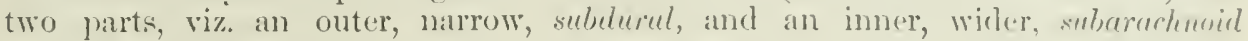

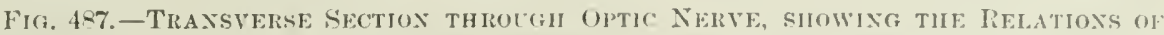

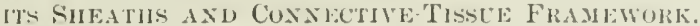

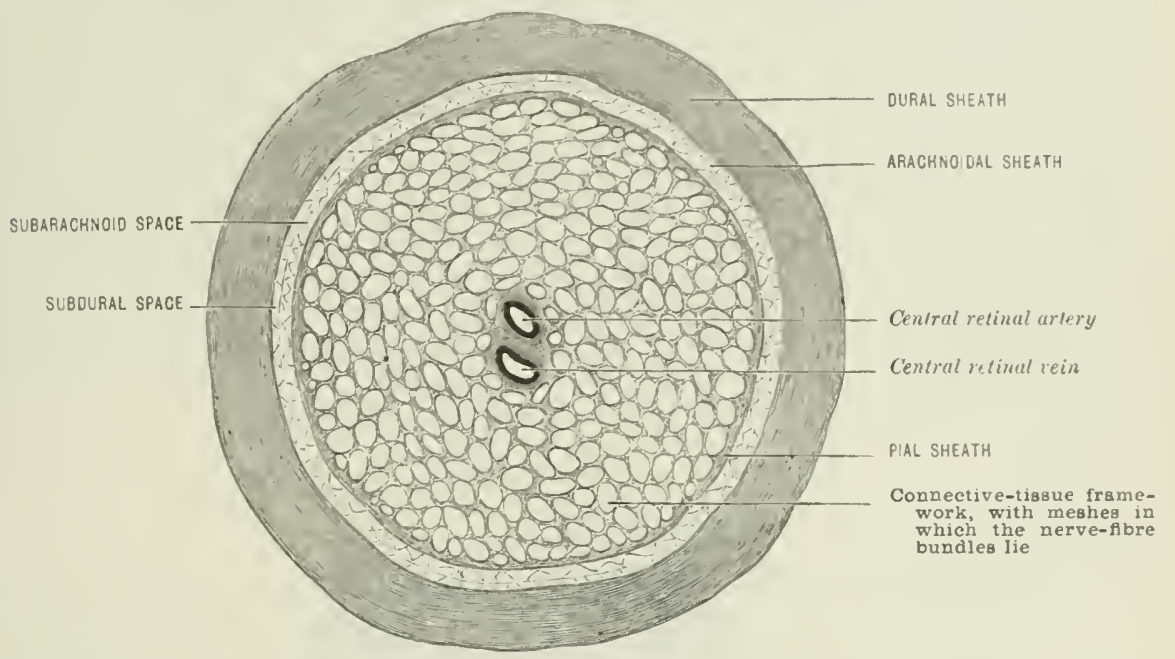

sprece, communicating with the corresponeling intracranial spaces. The arachnoidal sheath is comnected with the sheath on each side of it by numerous fine processes which bridge across the intervening spaces. The pial sheath sends processes inwards, which form a framework separating the bundles of nerve-filses; between the enclosed nerve-filures and each mesh of this framework there is a narrow interval

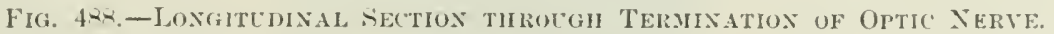

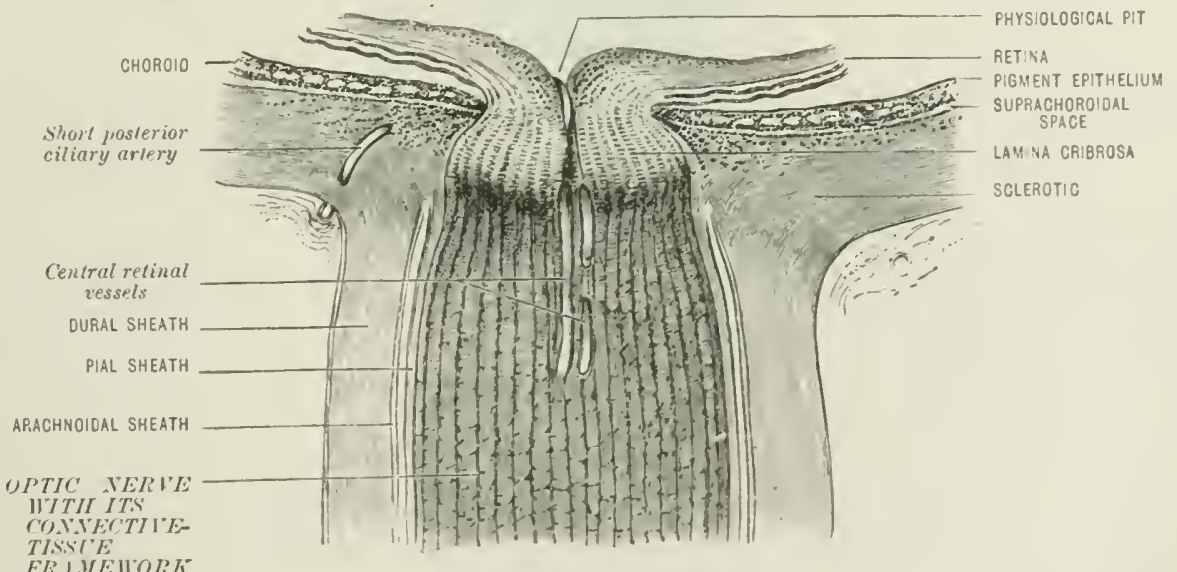

occupied hy lymph. The nerve-filnes are molullated, but have mo printitive shath.

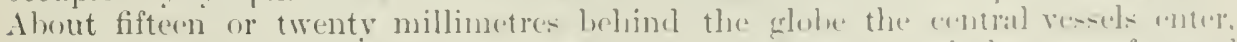
piercing obliquely the fower outer quardrant of the nerve, amel then run forwarl in its axis. They are aremplanierl throughout hy a special fureces of the pial sheath, which forms a fibrous corrl in the centre of the nerve. 
On reaching the eyeball, the dural sheath is joined by the arachnoid, and turns away from the nerve to be continued into the outer two-thirds of the sclerotic. Similarly the pial sheath also here leaves the nerve, its greater part rumning into the inner third of the sclerotie, while a few of its fibres join the choroid; the intervaginal space eonseguently ends abruptly in the selcrotic around the nerve-entrance. In this locality the connective-tissue framework of the nerve becomes thicker and eloser in its neshwork, and has been already alluded to as the lamina cribrosa. It is formed by processes passing out from the central fibrous cord at its termination, and by processes passing inwards from the pial sheath, sckerotic. and choroid. It does not pass straight across the nerve, hut follows the eurve of the surrounding scherotic. heing therefore slightly convex backwards. The nerve-trunk here quickly becomes recluced to one-half its former diameter, the fibres losing their medullary sheath, and being continued henceforward as mere axis cylinders. Apart from the consequent loss of bulk, this histological change may be readily recognised macroscopically in a longitudinal section of the nerve, its aspect here changing from opaque white to semi-translucent grey. The part of the nerve within the lamina cribrosa has already been seen in our ophthalmoscopic examination of the living eye.

The optic nerve is mainly nourished by fine ressels derived from those of the pial sheath, which run into the substance of the nerve in the processes above mentioned. In front of the entrance of the central retinal artery this vessel aids to some extent in the blood-supply of the axial part of the nerve.

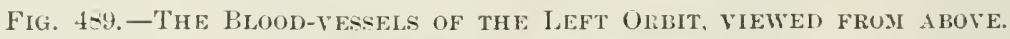

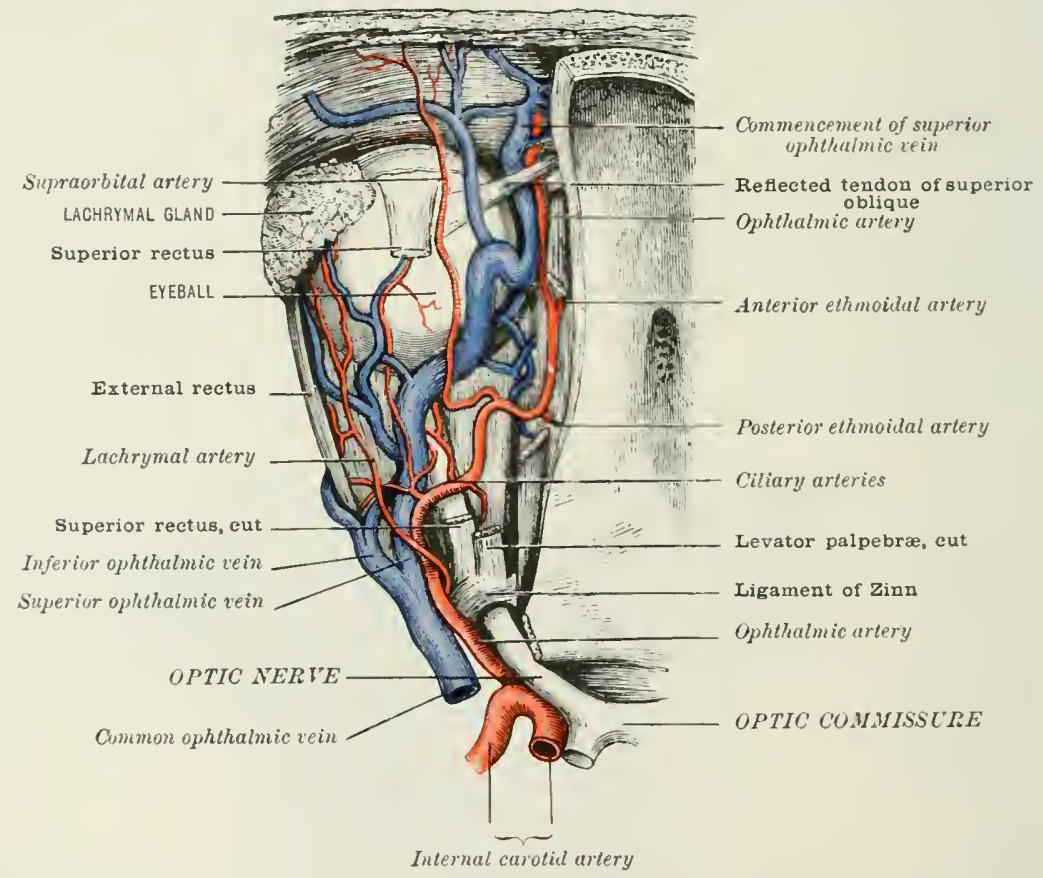

The Blood-yessels Axd Nerves of the Orbit

As these structures will be more particularly described in other sections of this work, a very short general account will suflice here.

Arteries.-The main blood-supply is aftorded by the ophthalmic artery, a branch of the internal carotid, which gains the orhit throngh the optie eanal, where it lies beneath and to the temporal side of the nerve. On entering the orlut it ascends, and passes obliquely over the nptic nerve to the inmer wall of the orlit; in this early part of its course it gives off most of its branches, which rary much in their mimner of origin and also in their course. The arteries of the orbit are 
remarkable for their tortuous course, for their delinate walls, and for thedr lomese attachment to the surromeling tissues. The ophthalmic artery gives off special branches in the orloit to the lachrymal gland, the musches, the retina (through the optic nerve), and the eyeball, as well as to the meningers, the ethmoinlal (alls. and the

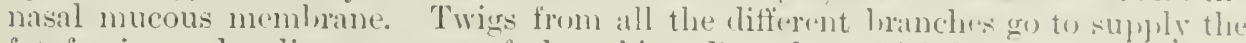
fat, fisciae, and ordinary nerves of the orbit. Branches which have the or hit antrriolly ramify on the forehead and nose, and also go to the sulply of the revelit. and the tear-passages. The ophthalmic artery has numy andastonesses with brancluse

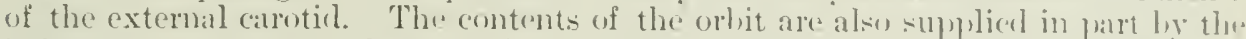
infraorbital artery, a lranch of the intemal maxillary; in particular this artery supplies part of the inferior rectus and inferior oblique muscles in the carity, anil also wives a branch to the lower "relid.

Veins.-Branches, corresponding generally to those of the artery. unite to form the superior and inferior ophthalmic veins, which ultinately, cither sepratty or united into one trunk, jass through the sphenoidal fissure and empty into the

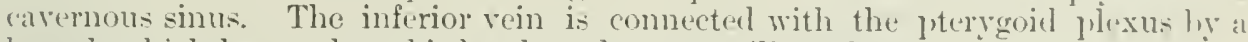
brunch which leaves the orbit hy the spheno-maxillary fisture.

Nerves of the orbit.-These are motor, sensory, and sympathetic, and all enter the orbit by the sphenoidal fissure, with the exception of one small semsisory

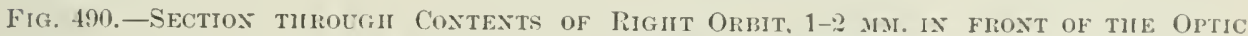
FORAMEN, VIENED FROM BEHIXD. (.lfter Iange.)

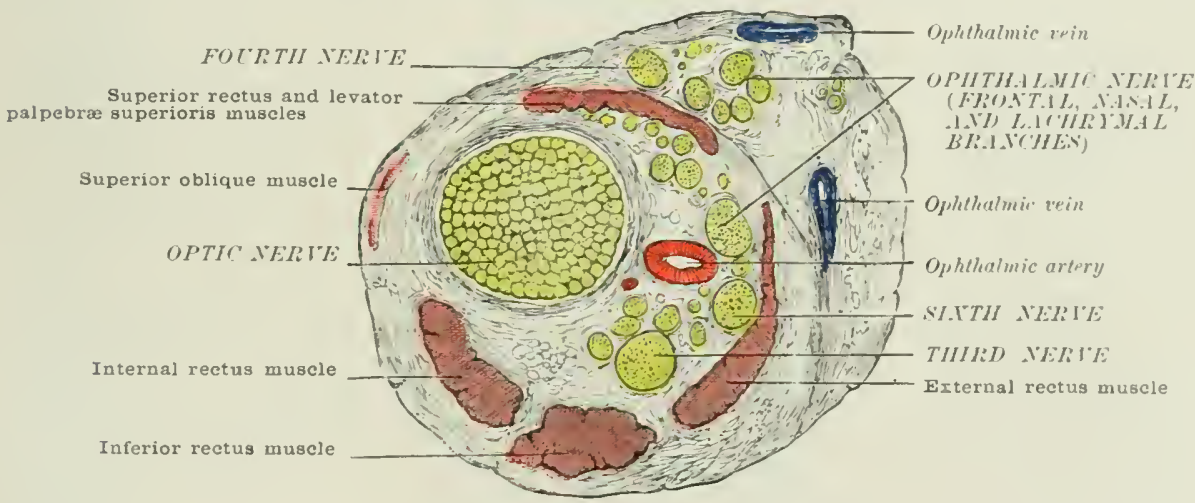

branch passing through the sphenn-maxillary fissure. (The optic nerve has been alrealy described, and is not incluted in this account.)

A. The motor nerves are the third, fourth. and sixth cranial.

1. The third nerve enters the orlyit in two parts, an upper smaller, ancl a lower largar division. The upper dirision gives off two branches: one supplies the superior reetus, entering its lower surface far back; the other branch groes to the levator palpebre, entering its lower surface in its postrerior third. The lower dirixim divides into three branches, of which one supplies the inferior rectus, cutering it: upper surface far back, and another supplies the internal rectus, wntering its inner surface a little behind its midlle. The third hranch of the lower division erives (1) the short root to the ailiar gangliom, and (2) nur or more twigs to the inferior rectus, and the remainder of this hranch then enters the lower surface of the inferior oblique muscle about its micklle.

2. The fourth nerve supplies the superion ololinue muscle, chtering its ullur surface about midway in its inurse.

3. The sixth nerve supplius the extemal rectus. (n)tering its inners surfice alumt the junction of the posterion and middle thirds of the muscle.

As regards the mammer of temination of these motor merves, it is fommel that

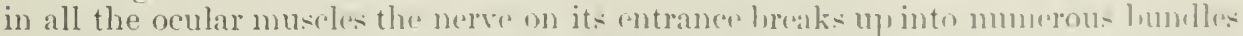

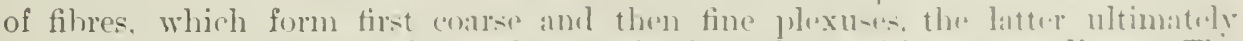

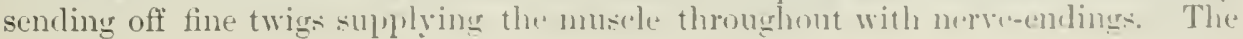


posterion thind of these muscles is, however, comparatively ill supplied with both kinds of plexus and with nerve-endings.

B. The sensory nerves are supplied by the first and second divisions of the fifth cranial nerve. The first division, or ophthalmic nerve, is entirely orbital; while the second, or maxillary, only sends a small branch to the orbit.

1. The ophthalmic division of the fifth nerve enters the orbit in three divisions, namely:-

(1) Frontal, splitting sulsequently into supratrochlear and supraorbital, both passing out of the orbit. It is distributed to the corresponding upper eyelid, and the skin over the root of the nose, the forehead, and the hairy scally as far back as the coronal suture on the same side. It also gires branches to the periostem in this region, and to the frontal sinus.

(2) Lachrymal, supplying the lachrrmal gland, anastomosing with a branch of the superior maxillary in the orbit, and finally piercing the upper eyelid. Outsicle the orbit it is distributed to the outer jart of the upjer lid, the conjunctiva at the external canthus, and the skin between this and the temporal region.

(3) Nasal, giving off $(a)$ a branch to the ciliary ganglion, constituting its long root; (b) two or three long ciliary nertes; and $(c)$ the infratrochlear, passing out of the orbit. The nasal nerve then leaves the orbit, re-entering the cranial carity before being finally distributed to the nose. The infratrochlear branch supplies the eyelick and skin of the side of the nose near the inner canthus, the lachrymal sac, carmele, and plica semilunaris. The nasal nerve, after its second course in the cranial carity, passes through an aperture in the front of the cribriform plate of the ethmoid bone, and is ultimately distributed to the nasal mucous membrane, and to the skin of the side and ridge of the nose near its tip.

2. The maxillary division of the fifth nerve gives a branch, called the orbital nerve, which passes into the orbit through the spheno-maxillary fissure, anastomoses with the lachrymal, and leaves the orbit in two divisions. These are distributed to the skin of the temple and of the prominent part of the cheek.

A few minute twigs from Meckel's ganglion, and sometimes from the maxillary division of the fifth nerve, also pass through the spheno-maxillary fissure to supply the periorbita in this neighbourhood.

C. The sympathetic nerves of the orbit are derived from the plexus on the internal carotid. With the exception of branches accompanying the ophthalmic artery, and of the distinct sympathetic root of the ciliary ganglion, they enter the orbit in the substance of the other nerve-cords. The connections between the ocular nerves and the carotid plexus are recognisable as fibres going to the third, sixth, and ophthalnic nerves; as a rule, the comparatively large twigs going to the sixth join it furthest back, and those to the third furthest forward. Sympathetic comnections with the fourth nerve are very doubtful.

The lenticular or ciliary ganglion is situated between the optic nerve and external rectus far back in the orbit. Its three roots-motor, sensory, and srmpathetic-have been already mentioned. Anteriorly, it gires off three to six small trunks, which subdivicle to form the short ciliary nerves, about twenty in number, piereing the sclerotic around the optic nerve entrance.

The lymphatic system of the orbit.-Although there are no lymphatic cessels or glands in the orhit, the passage of lymph is nevertheless well provicled for. We have already observed the lymph channels within, between, and outside the shaths of the optic nerve, and have seen how these communicate anteriorly with the lymph channels of the evelall, and posteriorly with the intracranial meningeal spaces. In addition, there are lymph-spaces aromnd the blood-ressels, situated between the outer coat and the loose investment furmished by the muscle-fascia. The nerves of the orlit (apart from the optic) are probably similarly surrounderl hy lymph-spaces. In the absence of lynuphatic ressels it is difficult to trace the circulation thoroughly; much of the lymph from the orhital eavity is said to pass into the internal maxillary glands. 


\section{THE FYHLIL:}

The eutaneous and conjunctival surfates of the licls have alrumly ben exannined, and the position of the tarsus has been indicated. Wr. have now to ascertain the nature and relations of the tarsus, and describe the other tistues entering into the formation of the eyelids.

The skin here is thin, bearing fine bairs, and having small solareous and

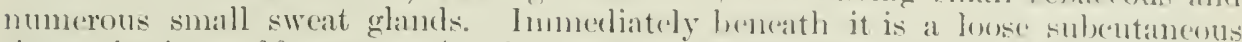
tissue, destitute of fat, selurating the skin from the pal yelural part of the orbicularis

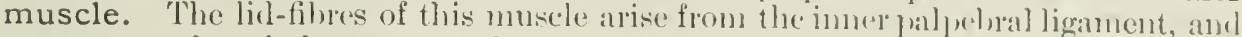
course orer the whole upler and lower eyclids in a stcersion of arches, so as to

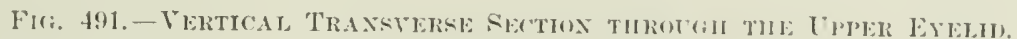
(Atter Waldeyer ami Fuchs.)

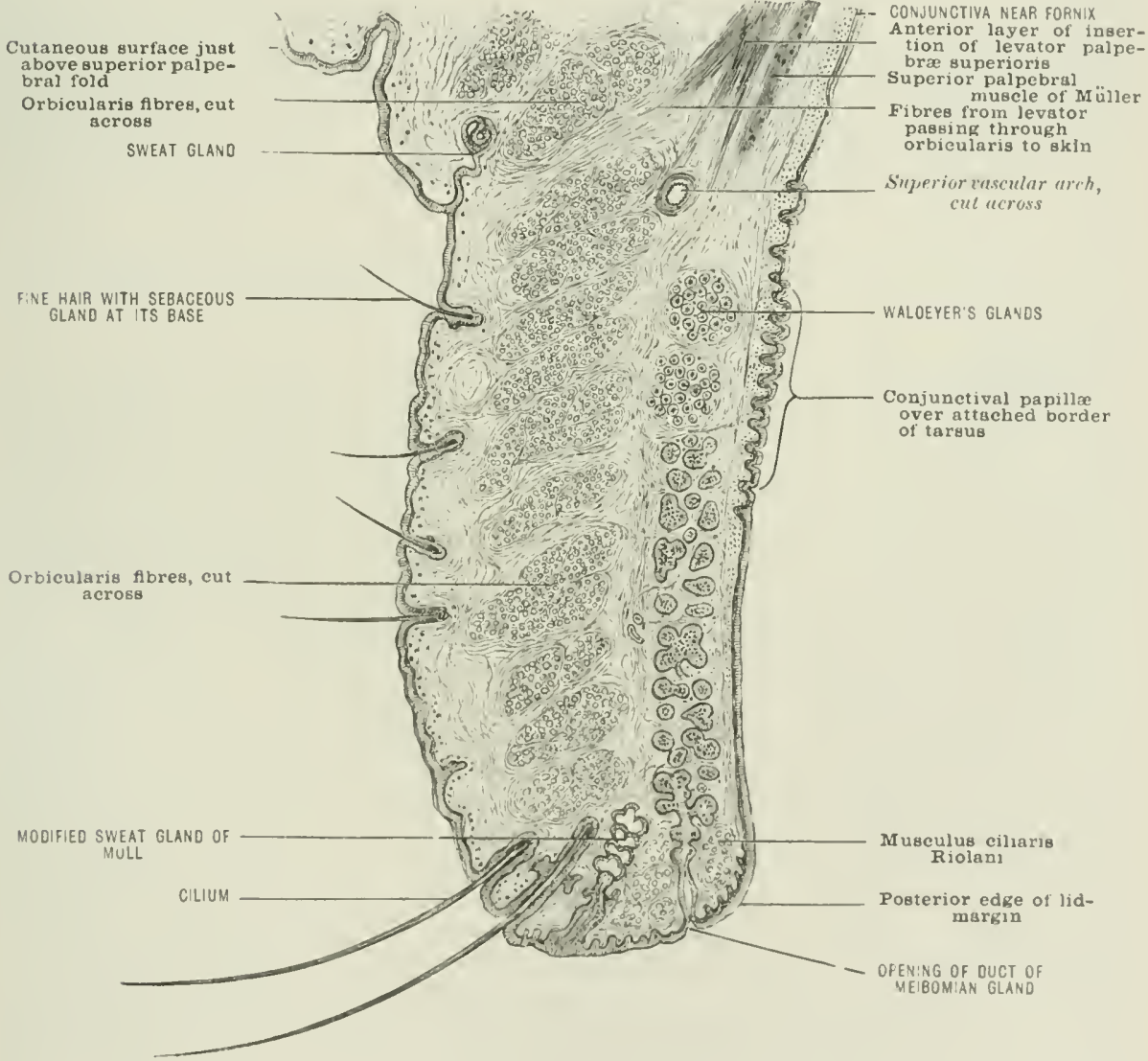

meet again herond the outer eanthus; there they in part join one anothers in part

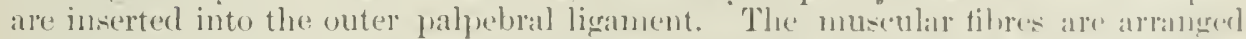
in loose bundles, with spaces between them oreupiod hy esmonetive tissue; in the

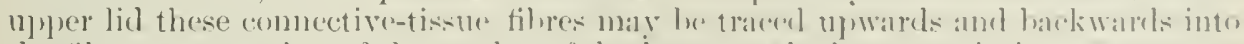
the fibrous expansion of the temelon of the levator palpelore superioris. ()ne stroner bunclle of orbicularis fibres, eallert the musculus ciliaris Riolani, is found netir

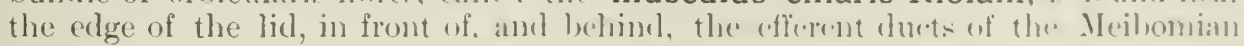
glands.

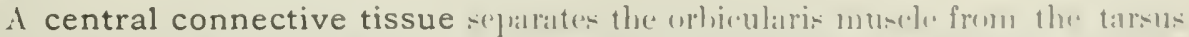
in the tarsal division of the lids. In the uple lid this is to he regarded as mainly.

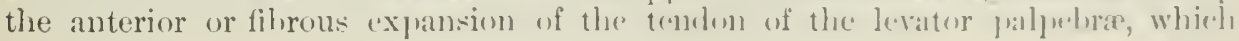


sends connertive-tisure septa between the bundles of the orerlying orbicularis (as just mentionerl) groing to the skin. In the orlutal part of this liel the central conneetive tissue includes als the palpeloral fascial, lying here inmediately beneath the orlicularis muscle; hut this soon thins off and fates inte the more deeply placed levator expansion. This latter is stremethened hy an extension of the sheath of the superior rectus, br which this musche is enalied to influenes the elevation of

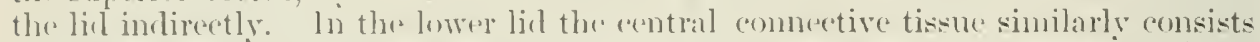
of palpeboul fascia, blendexl with a thin filmous (xtrnsion of the sheath of the inferior rectus. Immediately in front of each tarsus is a little loose connective tis-une. which contains the large bloot-vessels and nerves of the lids.

The tarsus of each licl is a stift plate of close connective tissue, with its surfares directed anteriorly and posteriorly; in its substance the Meibomian grands are mbedrled. One tarsil border is free viz. towark the edge of the linl, the other is attached; the former is straight, while the latter is convex. especially in the upler licl. The length of each tarsus is about twenty millimetres. Its loreatth is createst in the middle of the lid, and becones gradually smaller towards each anthus, where the tarsi are joined to the outer and inner palpebral ligaments. The hrealth of the upper tarsus (10 mm.) is about twice that of the lower. The thickness of each is greatest, and its texture closest, at the middle of its length. thinning off towarls the canthi and towarls both borders. Into the superior anterior borier of the npper tarsus the lower layer of the levator expansion is attached, consisting of smooth muscle-fibres constituting the superior palpebral muscle of Iüller. In like manner, at the inferior border of the lower tarsus, bundles of smonth muscle fibre are inserted (the inferior palpebral muscle of Müller), developerl in what has been regarded as part of the catension of the sheath of the inferior rectus.

The palpebral conjunctiva is firmly adherent to the back of the tarsus: lut in the orhital part of the lid loose subconjunctival tissue interrenes hetween it and Ilüller's palpebral muscle. Arlenoid tissue occurs in the substance of the conjunctivil. especially in its orbital division. Near the upper fornix. the conjunctiva receives expansions of the tendon of the levator palpethre and of the sheath of the superior rectus, and, at the lower fornix, of the sheath of the inferior rectus. The surface of the tarsal conjunctiva shows small elevations or papillæe everwhere: but these are particularly well marked over the attached border of the tarsus.

Glands of the eyelids.-From its mammer of formation the eyelid may he regarded as consisting of two thicknesses of skin, the inner (or posterior) having been cloubled back upon the outer at the edge of the lid; thus the cuticle and corium of the skin proper are represented respectively by the conjunctiva and tarsus of the imner thickness. At the free border of the lid, accortingly, we find glands corresponding to the sebaceous and swoat glands of the skin, viz. large sebacens clands of the cilia (Zeiss's shlands) and Moll's modified sweat glands. Again, in the imner skin-thickness of the lid, the Meibomian glands of the tarsus are selucents. and acino-tubular chands present at the attached border of the tarsus (Walderer's glands) may be reckoned as modified sweat glands. Glands similar in structure to Waldeyer's also occur at the fornix, and are especially abundant near the outer "anthus of the upper liel, close to the efferent ducts of the lachrymal gland; from their structure, and the chararter of their secretion, these acinous or acino-tubular glands have been temed hy Ienle accessory lachrrmal glands.' Other simple tubulay glands (Henle), formed merely ly the depressions between the papillax. are hest dereloper in the inner and nuter fourths of the tarsal conjunctiva of loth lick.

Blood-vessels.-The artrites run in the eentral eonnertive tissue of the lids, mainly in the form of arehes near the horders of the tarsus, from which twigs go to the different palpobal tis-ues. They are suppliesl by the lachrymal and palpoliral branches of the ophthalnice and liy small bionches derived from the temporal artery. The voins are nore numerous and larger than the arteries, and form a chose plexus beneath cach fornix. They empty themselves into the reins of the faee at the inner, and into the orlital veins at the outer eantlus.

The lymphatic vessels of the lids are mumerus, and are principally situated in the conjunctiva. lymph-spates also suround the folliches of the IIeibomian 
glands. The palpebral lymphatic resels manly pass through the preauricular gland; but, sometimes at least, those from the inner half of the lower hid go to the submaxillary lymphatic glands.

Nerves.- $(a)$ Sensory. The upper lid is chietly supplied by luanches of the supraorbital and supratrochlear nerves, the lower lid by one or two branches of the infraorlital. At the inner canthus the infratrochlear nerve also aids in the supply, and, at the outer canthus, the lachrymal. (b) Motor. The jul jeeloral part of the orhicularis is supplied by branches of the facial nerve, which mainly enter it near the outer canthus. Yüller's palpeloral muscles are supplied by the symuthetic nerrous srstem.

The inner palpebral ligament, or tendo oculi, has been referred to preriously: Arising from the frontal process of the maxilla, it extends outwards over the front wall of the lachrymal sac, bends round the outer wall of the sac, and then passes backwards to the posterior crest on the lachrymal bone. It is thus U-shayed, haring its limbs anterior and posterior, embracing the lachrymal sac; the anterior limb lies immediately beneath the skin, and is risible in the living. The palpebral fibres of the orbicularis are inserted into the outer surface of both limbs, thrs. attached to the posterior limb constituting Horner's muscle. The outer palpebral ligament is merely a stronger development of connective tissue in the orbicularis. Both ligaments are connected with the tarsi as already mentioned.

\section{The Lachryilal Apparates}

The tears are secreted by an arinous gland, and flow through fine ducts to the upper outer part of the conjunctival sac, whence they are drained off through the puncta, pass along the canaliculi into the lachrymal sac, and ultimately run dom the nasal duct to gain the inferior meatus of the nose.

The lachrymal gland is situated near the front of the outer part of the roof of the orbit. lying in a depression in the orluital plate of the frontal bone. It consists of two very unequal parts, one placed above and the other beneath the tendinous expansion of the levator palpelra superioris, but small gaps in the expansion permit of connections between these two parts of the gland. The upper and larger subrlivision (superior lachrymal gland) is a firm elongated body. about the size of a small almond; it has a grevish-red colour, and is made up of closely aggregated lohules. The upper surface (next the orbital roof) is convex, and its lower surfare is slightly concare. Anteriorly. the gland almost reaches the upper orbital margin, and it extends backwards for apjroximately one-fourth the depth of the orbit, masuring about twelve millimetres in this direction. The outer border of the gland descends to near the insertion of the fascial expansion of the external rectus, while its inner border almost reaches the outer edge of the superior rectus; its transwerse measurement is about twenty millimetres. It is enveloped in a capsule, which is slung by strong fibrous hands passing to its innor borler from the orbital margin (suspensory ligament of the gland).

The lower sululivision of the gland (inferion larlurymal glamel) is composed of loosely applied lobules, and lies immerliately orer the outer thirel of the upper conjunctival fornix, reaching outwarks as far as the external canthus.

Each subdivision of the gland possesses several excretory ducts, which all open on the outer part of the upper fornix conjunctira, about four millimetres above the upper border of the tarsus. These of the superior gland, three or four in number. pass between the lobules of the lower gland; the outermost duet is the largest, and opens at the level of the external canthus. The ducts of the inferior orland in lart rischarge themselves into those of the ujper, lut there are also sereral fine ducts from this sululivision that run an indegendent course.

Fiar the immer canthus are the two puncta lachrymalia, upper anel lower, each situater at the summit of its papilla. The top of each propilla curves harkwarts towarls the conjunctival sae, so that the puncta are well adapterl for their function of rraining off any thuid collecting there.

The canaliculi lachrymales extend from the puncta to the latehrymal sile. The lumen at the pumetum is horizontally oval, from its lip. leing slightly con- 
pressed antero-posteriorly; the lomen of the lower punctum is somewhat larger than that of the upper. As the lower payilla is a little further from the imner canthus than the upper, the corresponding camaliculus is longer.

On tracing either canaliculus from its origin, we find that at first it runs nearly vertically for a short distance, then bends sharply towards the nose, and finally courses more or less horizontally, converging slightly towards its fellow, and not infrequently joining it before opening into the sac. The calibre varies considerably in this course, being narrowest a short distance from the punctum, and widest at the bend, from which point it again narrows very gradually as it nears the sac. The wall of the canaliculus consists mainly of elastic and white fibrous tissue, lined internally by epithelium, and covered externally by striated muscle (part of the orbicularis). The muscle-fibres rum parallel to the canaliculus in the horizontal part of its course; but they are placed, some in front and sone behind, around the vertical part, acting here as a kind of sphincter. Just hefore their termination, the canaliculi pierce the periosteal thickening that constitutes the posterior limb of the inner palpebral ligament.

The lachrymal sac lies in a depression in the bone at the inner angle of the orbit (the lachrymal fossa). It is rertically clongated, and narrows at its upper and lower ends; the upper extremity or fundus is closed, while the lower is continnous directly with the nasal duct. Laterally, the sac is somewhat compressed. so that its antero-posterior is greater than its transverse diameter. The canaliculi,

Fin. 492.-LACHRYal ApParates. (After Schwalbe.)

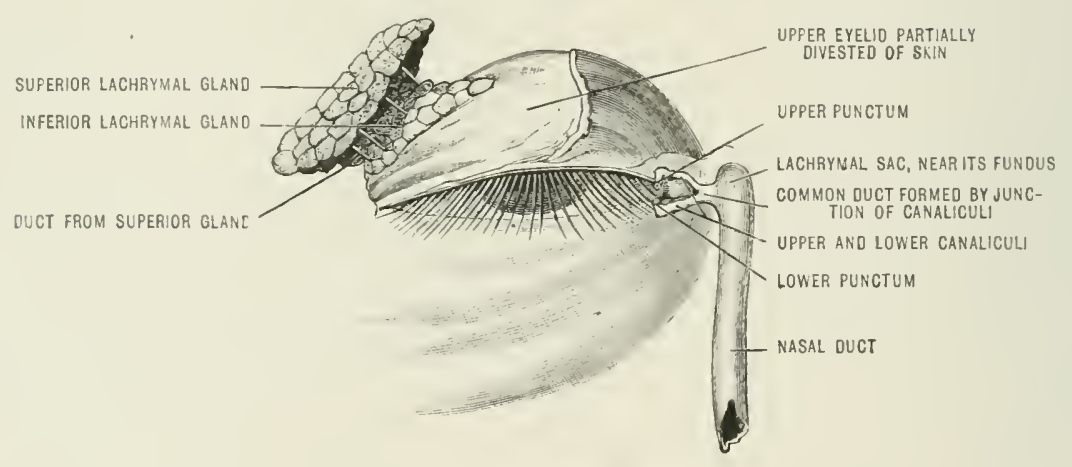

either separately or by a short common tube, open into a bulging on the outer surface of the sac near the fundus. As has previnusly been mentioned, the sac is surrounded by periosteum, but between this and the numcous membrane forming the true sac-wall there is a loose comnective tissue, so that the cavity is capable of consiclerable distension. The relations of the imner palpobral ligament have already been described; it is to be noted that the fundus of the sac extends above this ligament.

The nasal duct reaches from the lower end of the sac to the top of the inferior meatus of the nose, opening into the latter just beneath the adherent borker of the inferior turbinated bone. Traced from ahove. its main direction is downwards, but it hats also a slight inclination backwards and outwards. It lies in a bony canal, whose periosteum forms its outer eovering. Between this and the mucous memhrane of the luct there is a little internediate tissue, in which run veins of considarable size connected with the plexus of the inferior turbinated bone. The duct does not usually open clirectly into the nasal eavity at the lower end of the bony canal, but picrees the nasal inurous mombrane very olliquely, so that a flap of muens membrane covers the lower border of the opening in the bone, upon which thap the tears first trickle after escaping from the luct proper.

The sac and nasal duct together constitute the lachrymal canal, lined throughout by a continuous mueous memhrane. This membrane presents folels in some situations, especially near the opening of the canaliculi, at the junction of the sac 
and duct, and at the lower end of the duct. That at the top of the duct is the most important, as it sometimes interferes with the proper flow of tears out of the sac. The total length of the lachrymal canal is roughly twenty-four millimetres, half of this being sac, and half nasal duct. If, however, we reckon as duct the oblique passage through the nasal mucous membrane, this measurement may occasionally be increased by eight or ten millimetres. The lachrymal sac, when distended, measures about six millimetres from before backwards, by four millimetres transversely. The nasal duct is practically circular, and has a diameter of about three millimetres, rather less at its junction with the sac, where we find the narrowest part of the whole lachrimal canal. 


\title{
THE EAR.
}

\author{
BY ARTHUR HENSMAN, F.R.C.S.
}

REVISED BY ARTHUR ROBINSON, M.D., M.R.C.S.

LFCTCRER ON ANATOMY IN THE MIDDLESEX HOSPITAL MEDICAL SCHOOL. EXAMIXER IX AXATOMY FOR THF COXJOIXT BUARD OF ENGLAXD

The organ of hearing may he divided into three parts:-the EXTERNAL EAR, which inchules the pinna and external auditory meatus; the MIDDLE EAR, or tympanum, with its ventilating shaft the Eustachian tube; and the INTERNAL EAR, which inclukes the osseous labyrinth, within which is placed-the essential jortion of the organ-the membranous labyrinth.

\section{THE EXTERNAL EAR}

The Pinna, or Auricle, is attached to the side of the head, midway hetween the forehead and occiput. Its level is indicated by horizontal lines extenrling backwards from the eyebrows above, and from the tip of the nose below. Somewhat

Fig. 493.-Extraxil View of the Left Alricle.

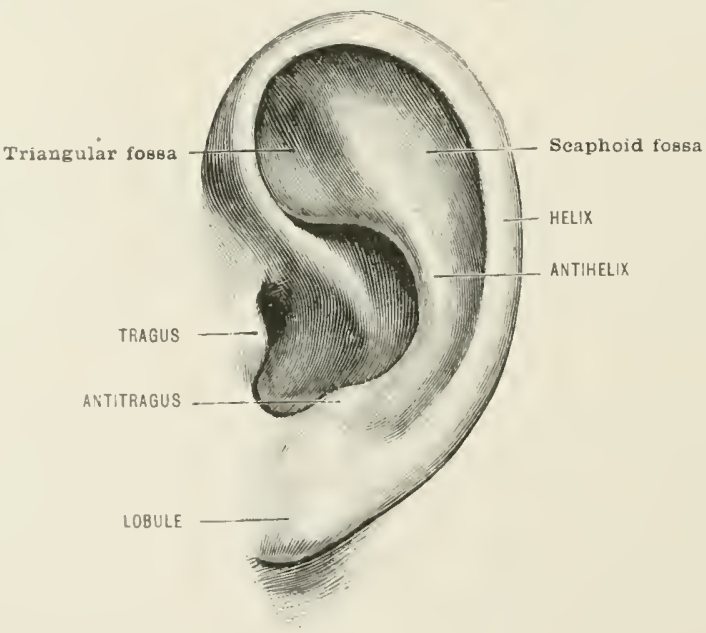

lyriform in shape, its irregular concave outer surface is turnel more or less forwards, but the angle of inclination varies considerably in different suljects. The incurver rim of the ear, whirh diviles its surfaces from each other, commences below in a deep encavity which surmomels, like the mouth of a trumpet, the uxternal anditory meatus. This rim is called the helix, and, traced round the 87() 
ear, ends below at the posterior margin of the lobule. On the upper part of the inverted edge of the helix a little irregular process often exists, which has been regarded as the shrivelled tip of the primitive ear, and anteriorly, where it begins to bend backwards, there is a small projection, the spine of the helix (Fig. 495). The hollow from which the helix starts is called the concha. Within the helix, but separated from it by the scaphoid fossa (fossa of the helix) runs a second curved ridge, the antihelix. It commences below in the little process linown as the antitragus, and bifurcating superiorly bounds a shallow fossa just above the concha, the so-called triangular fossa (fossa of the antihelix). The concha, bounded by the antihelix, is deeply notched below (incisura intertragica). Orerlapping the commencement of the notch before and behind are tro eminences. the anterior and larger, the tragus; the posterior, the antitragus. The anricle varies greatly in different individuals, and the lobule perhaps more than any other part.

The cartilaginous framework of the ear, although it does not enter into all its parts, gires to it the general character and appearance already described. It consists of pliable reticular cartilage of the yellow elastic kind. It roes not enter into the formation of the lobule, which consists entirely of dense connective tissue and fat. Its lower portion is so rolled upon itself as to form a tuhe incomplete above, which tails off as it passes inwards to be attached to the lower third of the external auditory meatus. This attachment is effected by means

Fig. 494.-SEction throlgh the ORIfice of the Right Extersal Alditory Mieates.

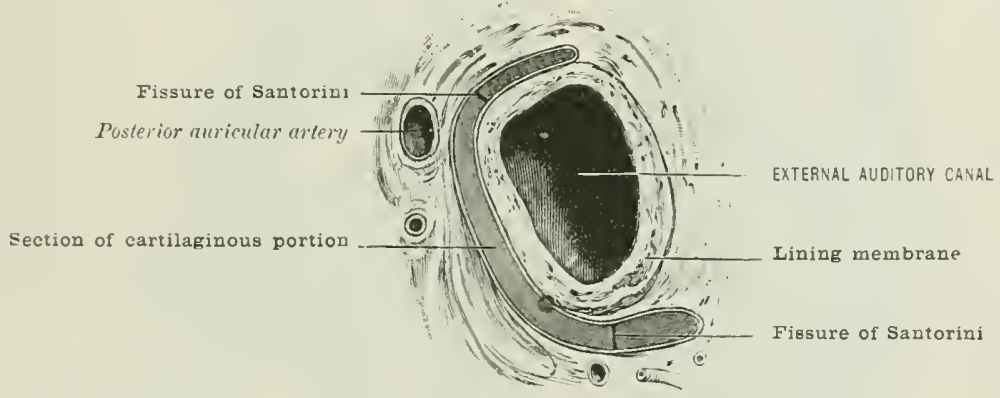

of a dense fibro-elastic tissue which allows considerable shifting on traction of the pinna upwards and backwards. A section passing through the orifice of the meatus shows the cartilage greatly in excess of the fibrous membrane which completes its contour. Deeper sections show the cartilage diminishing more and more until it forms scarcely a third of the lumen of the tube near the hony meatus.

The wall of the channel is traversed by fissures, the fissures of Santorini; but these are not constant in their number, extent, or direction; they are filled with fibrous tissue, and allow the canal to be straightened by traction on the pinna. The lower segment of the cartilaginous meatus is in close contact with the paroticl gland. An abscess in this region may thus hurrow through the fissures and discharge itself through the external meatus. There is also a gap between the helix and the tragus bridgerl over by a band of dense fibrous tissue. Sereral fissures traverse the cartilage, and a deep cleft dividing the antihelix severs the caudate process from the rest of the cartilage below.

Ligaments.-An anterior ligament connects the spine of the helix with the root of the zygoma, and a posterior prasses from the concha to the mastoid process.

A pair of ligaments belong to the cartilage itself, the strong band already described completing the orifice of the meatus, and one less marked passing loetween the concha and the processus caudatus.

Muscles.-The extrinsic muscles, the attollens, attrahens, and retrahens 
aurem, have been described on page 4:31. The special intrinsic museles are six in number. They are diflicult to displiay, and sometimes appear to be absent.

Helicis major is a narrow ship which arises from the spine of the helix and pases upwards along the rim of the helix to near its summit. helix.

Helicis minor is an oblique fasciculus overlying the commencenent of the

The tragicus consists of nearly vertical tibres lying over the outer surface of the tragus.

The antitragicus arises from the outer surface of the antitragus to pass to the cauclate process.

The transversus auris consists of mixed muscular and tendinous fibres which with the following lies on the crinial aspect of the pimma, and traverses the hollow formed between the bulging of the concha and the convexity corresponding to the groove of the helix.

The obliquus auris crusses the hollow between the concha and fossa of the antihelix.

Fig. 495,-Exterixal axd Ixterial Sirface of the Cartilage of the Right PINNA AND ITS MLECLEs, ETC:

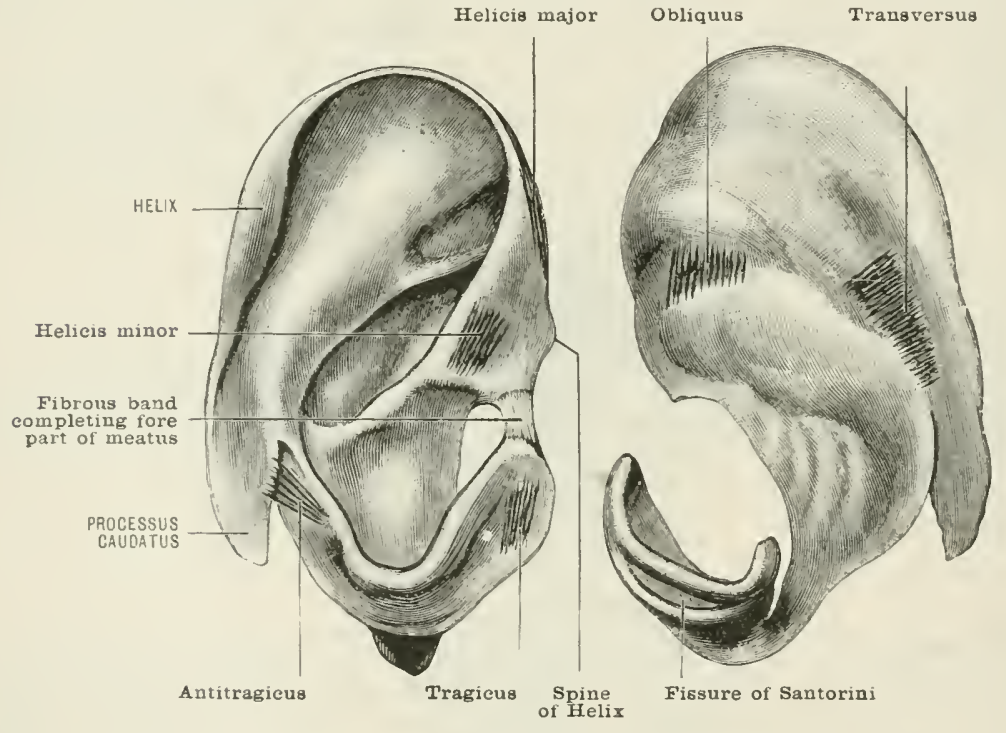

Vessels. - The arteries are the posterior auricular from the external carotid, and the anterior auricular from the temporal.

'The veins enter the posterior auricular' and temporal reins.

Nerves.-The imner surface of the pinma is supplied by three cutaneous nerves, the great auricular, the small occipital and the auricular branch of the vagus. The great auricular supplies the lower three-cuarters, with the exception of a small portion near the meatus which, together with the back of the meatus, is supplicd hy the auricular hranch of the vagus. The small oreipital supplies the upper fourth. Occasionally the great oceipital sends a branch to the uppermost part of the inner surface. The upper two-thirch of the outer surface receive their cutancons supply from the aurieulo-temporal nerve, and the lower third is supplied by the great auricular. The intrinsic museles on the inner surface are supplied by the posterior anricular lianch of the facial and those on the outer surface hy the temporal hranch of the same nerve.

The External Auditory Meatus is about an inch long (25 mm.). It commences at the bottom of the comcha, and passes inwards and a little forwards to end at the membrana tympani. It is narrowest at its eentre. Near its orifice it is oval from above downwards, but at its temination it is somewhat hroader from 
side to side. Owing to the obliquity of the membrana tympani, the floor is longer than the roof, and the anterior longer than the posterior wall of the canal.

Its cartilaginous portion, which is a little less than half an inch ( $11 \mathrm{~mm}$.) in length, is formed by the incomplete tube of cartilage already described, with fibrous membrane to complete its upper and front part.

The osseous portion of the tube, a little more than half an inch ( $1+\mathrm{mm}$.) in length, is slightly curved, with its convexity looking upwards and backwards (fig. 496).

The lining membrane is a reflexion from the skin externally. It is thick and strong in the cartilaginous, but becomes thinner in the osseous portion; especially is this the case near the membrana tympani, over which it is reflected to form its cuticular layer. In the cartilaginous portion the demis is supplied with numerous hairs, and sebaceous glands open into their follicles. Tubular ceruminous glands. the orifices of which stud the whole of the cartilaginous portion, appear as dark points to the naked eye.

Fig. 496. -SECTION of THE MIDDLE AxD Extersil EAR.

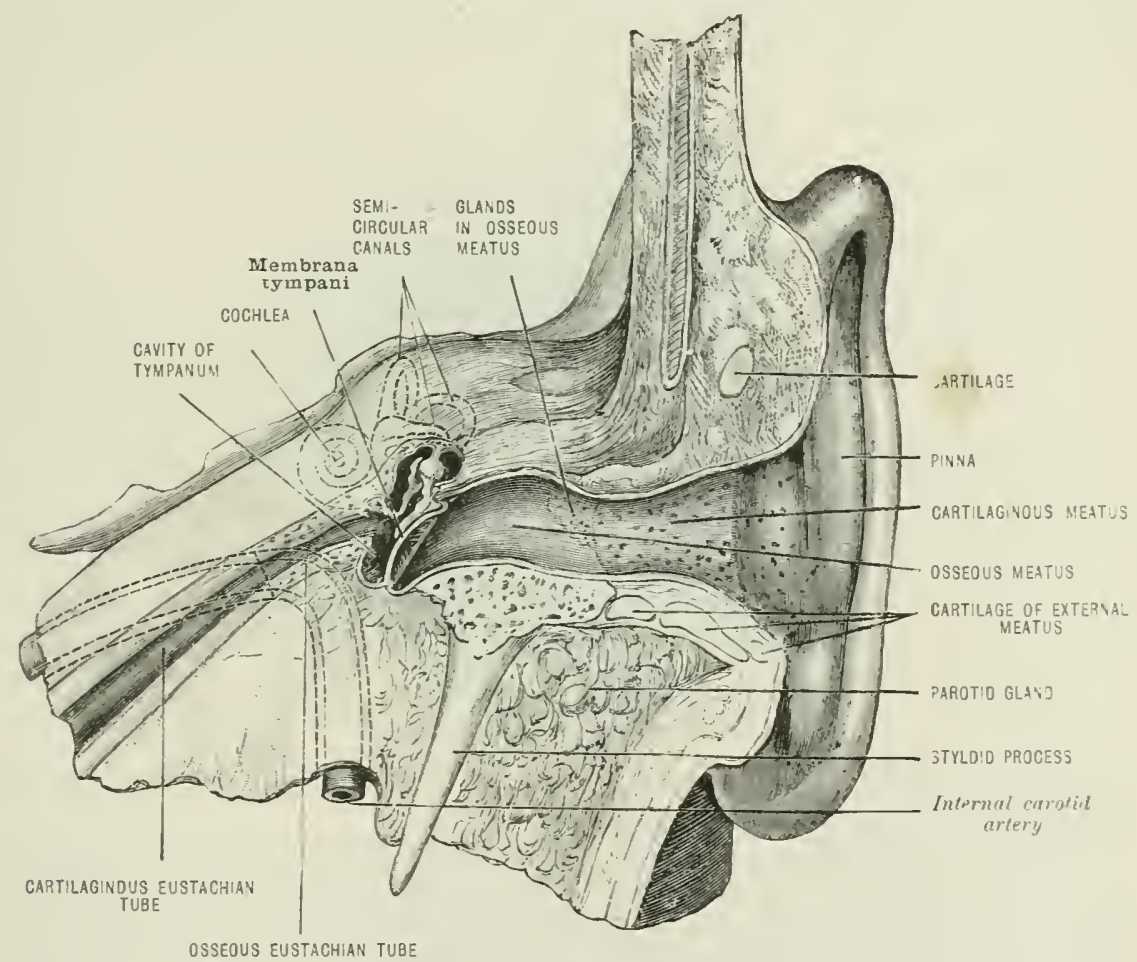

These glands extend a short distance into the upper and back part of the bony meatus, in the form of a triangular patch, but elsewhere they appear to be absent.

The arteries are derived from the posterior auricular. temporal, and internal maxillary; and the nerves from the auriculo-temporal and the auricular branch of the ragus.

\section{THE MIDDLE EAR}

The Membrana Tympani is an irregularly rounderl concare membrane stretched obliquely across the bottom of the osseons meatus in such wise as to form an obtuse angle with its upper wall (accorling to Von Tröltsch, 140 ${ }^{\circ}$ ) and an acute one with its lower.

The circumference of the membrane is lodged in the groove of the tympanic 
ring (fig. 498A). Nbove and in front where the ring is wanting there is a slight recess known as the noteh of Rivinus, and here the membrane is extended outwards, to mite with the grooveless margin of the tympanum to form rhat is known as the Rivinian segment.

The shape of the membrane varies with that of the inner end of the meatus. Its long axis is from above downwards and forwards. The membrane, broadly viered, is concare extemally, and convex towards the cavity of the tympanm. This is mainly due to the traction of the handle of the mallens, which descends (1) liquely downwals and backwards between its two inner layers to a point a little below the centro of the membrane. This curvature is decpest at the umbo, opposite the flattened extremity of the handle. In front of and below the umbo, extending towarls the periphery, the membrame is slightly convex externally.

At the anterior superior pole, the short process of the malleus is plainly visible as a rounded point projecting outwards. A fold of the membrane passes backwards, and another forwards from this spot, and above these folds may, under favorable conditions. he seen two short, tightly stretehed strix, which, taking origin from the romers of the notch of Rivinus ahove, converge as they descend to meet at the short process. The membrane between these strix and the edge of the notch is thin and flaceid, and appears above the short process as a small pit-like depression

Fig. 497.-Exterial View of tine Left Membraxa Tympani. (Enlarged from life.)

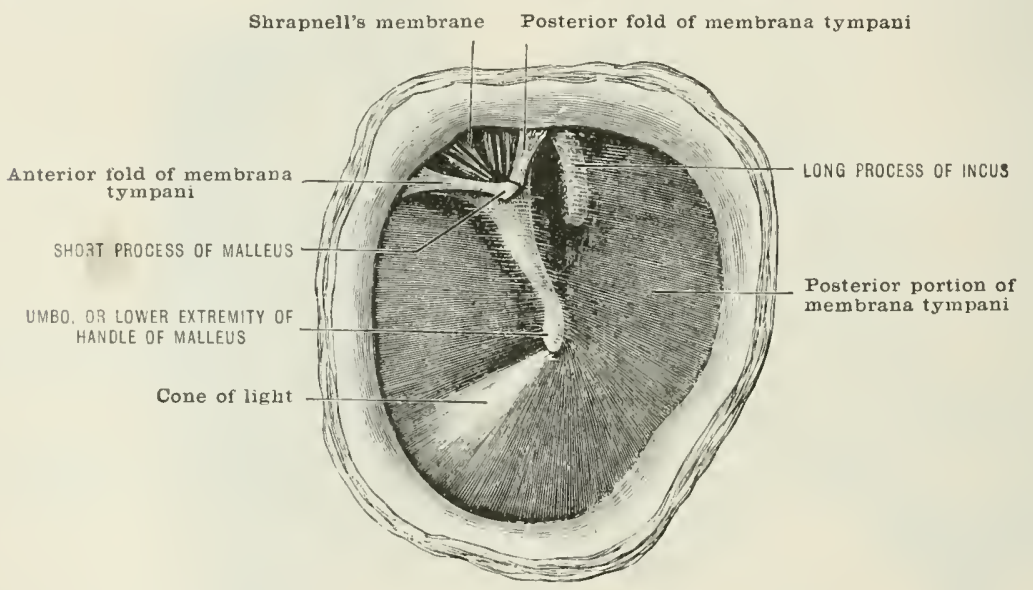

(menbrana Shrapnclli). An anastomosis between the tympanic ressels and those of the external moatus oceurs at this spot.

Viewed from within, the head of the malleus is seen ahove the membrane articulating with the incus, its curved handle passing downwark and slightly backwarks betwern its layers, and strongly projexting from the inner surface. The chorda tympani nerve may be seen crossing the neek of the malleus forwards to the Glaserian fissure. Folkls of the membrane oceur in front of and helind the malleus, bounding what are known as the anterior and posterior pouches of the membana tympani. The frese margin of the posterior pouch is commonly well marked. Passing slightly dewnwards and outwards to the base of the handle of the mallens, is the strongly marked fold containing the tendon of the tensur tympani monsele.

Structure.-The momhrant tympani consists of three layers-a special fibrous layer, with a cuticular covering extemally continuous with that which lines the "xternal auditory meatus; and a mucous lining intemally derived from the tymlanice eavity.

The fibrous layer consists of two lamcllat closely commected-an external, in which the fibres radiate from the handle of the malkens; and an internal, the fibres of which are arranged concentrically, and are especially strong at the circunference. 
The membrane of Shrapnell is extremely thin, and consists only of the outer and inner layers, the fibrous layer being absent.

The handle of the malleus descends between the two inner layers, accompanied by the ressels, which are often clearly visible in the living membrane.

The Tympanic Cavity or nuiddle ear is a narrow space which intervenes between the external auditory meatus and the labyrinth of the internal ear (figs. 496 and $49 \mathrm{~S}_{\mathrm{A}}$ ). It is a narrow irregular cavity, varying in width from a twelfth to a sixtl of an inch (2 to $4 \mathrm{~mm}$.), and having a total height of a little more than half an inch $(15 \mathrm{~mm})$. It consists of two parts, a lower and narrower, bounded externally by the tympanic memlirane, and an upper and wicler part, ealled the attic, or epitympanum, which is continued backwards as the mastoid antrum into the mastoid air cells. It is prolongerl downwards and forwards into the Eustachian tube, through which it communicates with the pharynx. It contains air, and it is crossed from without inwards by a movable chain of bones-the tympanic ossicles-which conduct vibrations from the membrana tympani to the internal ear.

Fig. 498.-Internat View of Right Membrana Trupani. (Enlarged.)

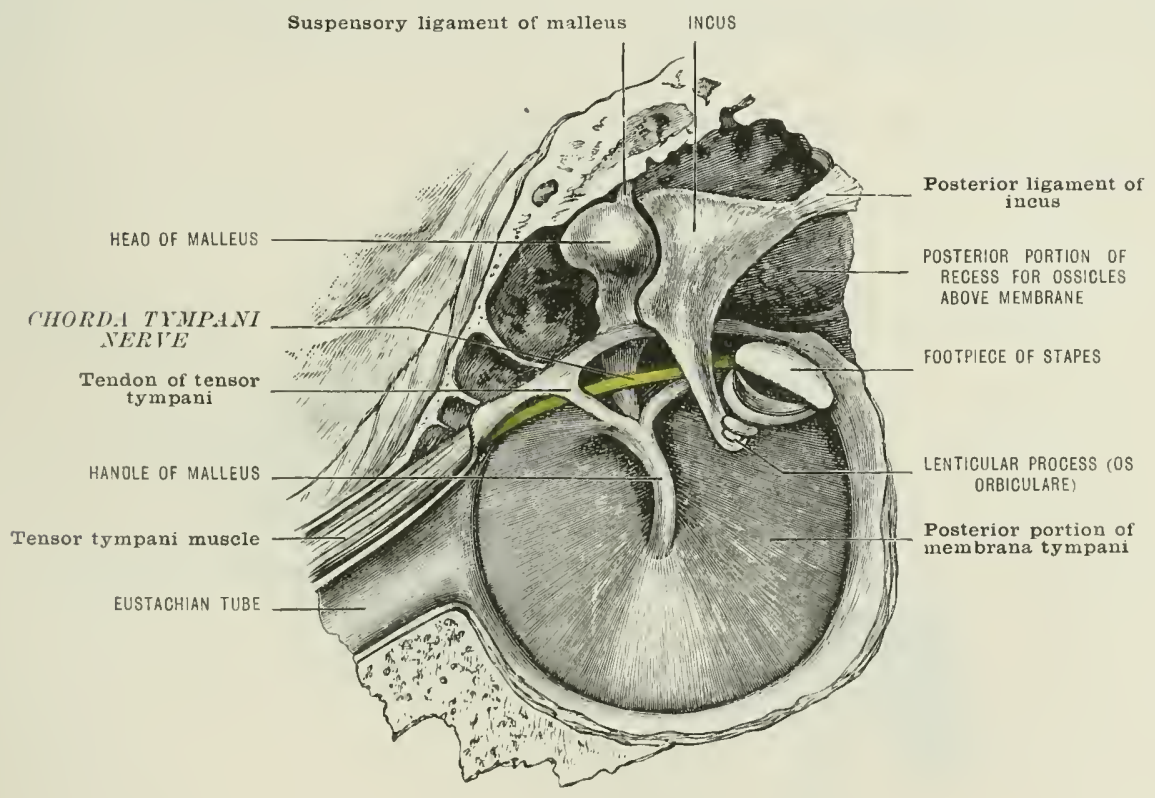

The roof is a thin plate of the petrous part of the temporal bone, which separates the cavity from the midcle fossa of the skull.

The floor is narrower than the roof. It is formed by the tympanic plate, and it separates the cavity from the jugular fossal.

The outer wall is formed below by the tympanic membrane, and above by a part of the squanous portion of the temporal bone.

The chorda tympuni nerce, which traverses the outer wall, enters by a minute orifice, the aperture of the iter chordæ posterius, and leaves the cavity by the iter chordæ anterius, which leads into the canal of Huguier. The (ilaserian fissure lies inmediately below the latter orifice, but these minute openings are hidden by the mucous lining.

The inner wall is rerticil, and looks directly outwards. It presents, anteroinferiorly, a rounded prominence, the promontory, marked by grooves for the tympanic plexus, and caused hy the first turn of the eochlea. In front of the promontory is the commencement of the Eustachian tube (fig. 498. ), ahove is the outer extremity of the canal for the tensor tympani muscle bounded by a prominent rilge of bone called the cochleariform process, and behind it is a recess, the simms tympani, which intervenes between the fenestra ovalis above and the fenestra ro- 
tunda below. The fenestra ovalis leads into the vostibule of the internal ear (fig. 498. ). and in the recent state it lodges the base of the stapes. The fenestra rotunda is closed by the secondary membrane of the tympanum, which separates the scala tympani of the cochlea from the tympanie cavity. Above the fenestra ovalis there is a rounded ridge of bone, indicating the position of the aqueduct of Fallopius, which contains the facial nerve.

The posterior wall presents the hollow pyramid which lodges the stapedius muscle and the openings which lead into the mastoid cells; these vary much in size, and receive a mucous lining from the cavity.

Anteriorly the tympanic cavity is continued into the Eustachian tube, and it is separated from the carotid canal by a thin plate of bone.

The Eustachian tube is about one and a half inches (37 $\mathrm{mm}$.) in length, passes from the tympanum downwards, forwards, and inwards. It is partly bony and partly cartilaginous.

The osseous portion (fig. $49 S_{\mathrm{A}}$ ) is about half an inch (13 $\mathrm{mm}$.) in length. It commences just below the orifice which transmits the tendon of the tensor tympani muscle, and, gradually contracting, ends at the isthmus by a jagged and oblique orifice between the petrous and squamous portions of the temporal bone. To it is attached the cartilaginous portion of the tube, which is about an inch in length

Fig. 498A.-Horizoxtal Section of Left Temiporal Boxe, showixg the Variocs PARTS OF THE EAR.

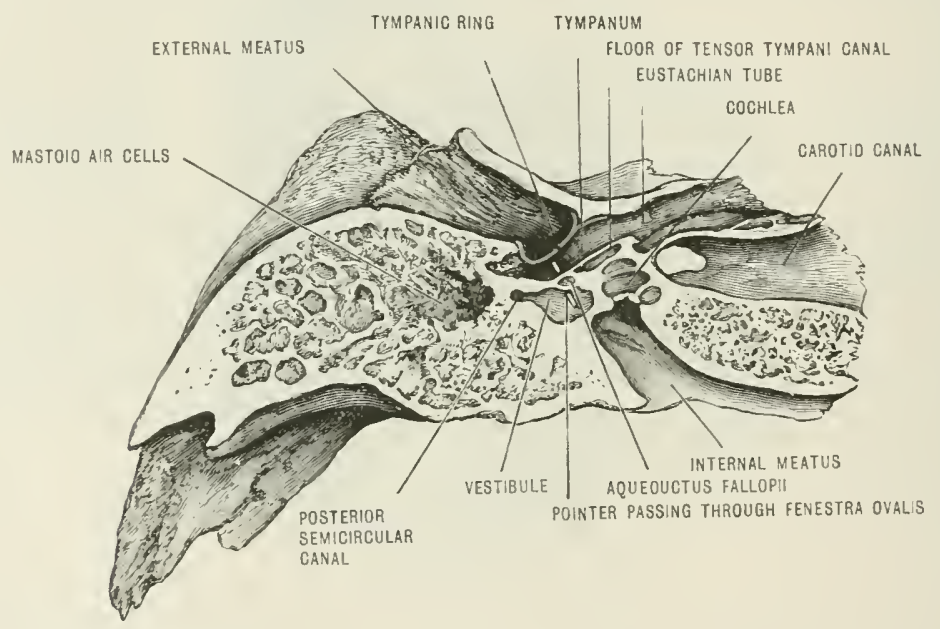

(2t mm.). This is composed of an elongated triangular plate, so folded upon itself as to leave an interval below which is completed by fibrous tissue. At first the canal is narrow, but it becomes much expanded towards its trumpet-shaped termination. Its orifier, which is somewhat oval, opens into the upper part and side of the pharynx, on a level with and just behind the inferior meatus of the nose.

The mucous membrane possesses a ciliated lining. It is thin near the tympanic cavity, but it is much more vascular, thicker, and possesses mucous glands and adenoil tistue near its pharyngeal orifice.

Sections of the cartilaginous portion of the tube show that the cartilaginous plate is curled round like a hook with the bend above and the shank internal. The memlaranous portion is thin where it is attached to the tip of the hook, but that it hecomes much thicker below. A small space near the bony portion of the tuhe, immediately below the hook, remains permanently open, but elsewhere the walls are in contact, exeept when separated by the action of the tensor palati muscle, or when foreibly driven asunder, as in the act of sneczing, ete.

A number of small sesamoil fibro-cartilages, some of which are visible to the naked eye, are buried in the sulmucous tissue. 
The ossicles of the ear are described on pages 66-68.

Articulation of the Ossicles. - The malleus with the incus.

The oblong articular surface which descends as far as the neck, on the posterior surface of the head of the malleus, is divided into two portions by a nearly rertical edge. The incus presents a corresponding surface sinilarly divided into two portions, and both of these surfaces are coated by a delicate layer of hyaline cartilage. $A$ thin capsule, from the inner surface of which a delicate redge-shaped meniscus projects from above into the cavity of the joint, is attached to the grooves, which limit the articular surfaces. The mechanism has been compared br Helmholtz to the ehere movement inside the key of a Genera watch, and permits considerable glicling between the two bones.

The incus with the stapes.-This joint is formed by the convex surface of the lenticular process (orbicular bone) which terminates the long crus of the incus and the corresponding concare surface of the head of the stapes. Both surfaces are covered with a layer of hyaline cartilage.

The elastic capsular ligament permits but very slight separation between the

Fig. 499.-Sectiox of the Trupdxus, etc. (Enlarged.)

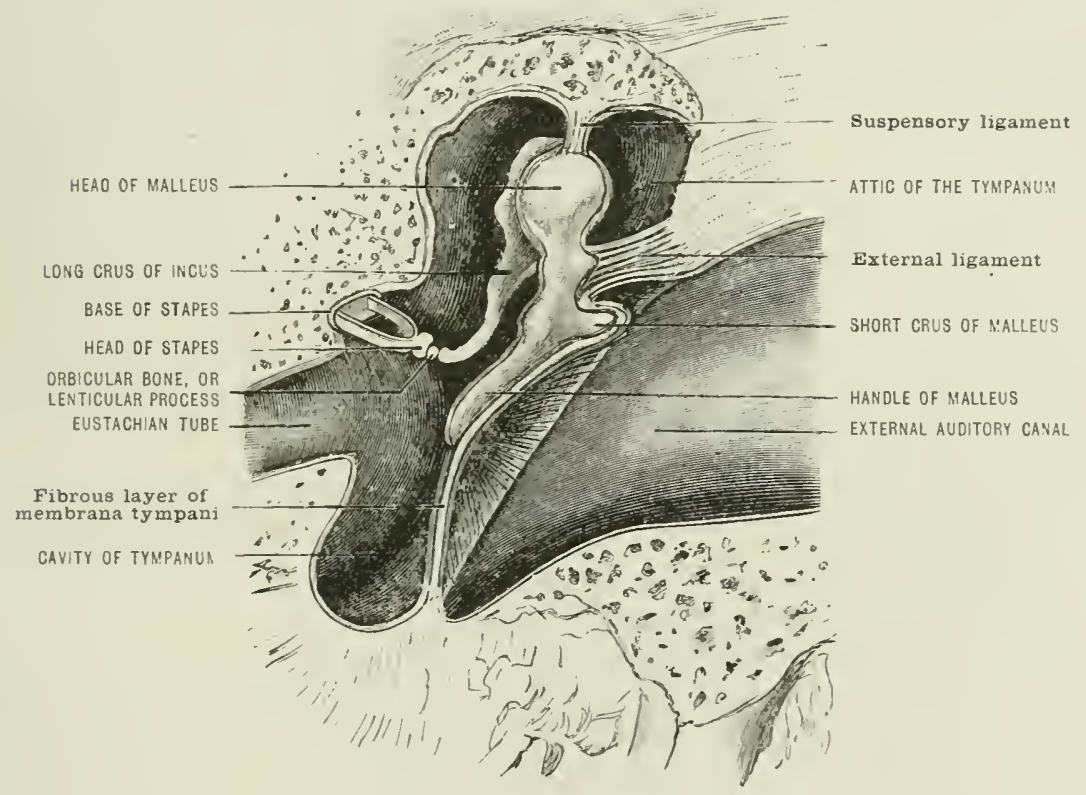

hones. lut allows a somewhat freer lateral morement. This articulation has been regarded by some writers as a sychondrosis, but it is now usually described as a true joint.

The stapes with the margin of the fenestra ovalis.- The so-called annular ligament is not equally broad throughont, and consists of elastic fibres which radiate as they pass outwards from the edge of the footpiece of the stapes to the margin of the fenestra. According to Tornbee, these edges are covered by a thin layer of cartilage.

The Ligaments of the Ossicles. - In addition to the capsular ligaments alreacly described, certain well-marked banils himit the movenents of the osicles.

The superior ligament of the malleus descends as a firm romded hand from the upper and outer wall of the tympanic cavity to the hearl of the malleus. It limits the ontward movement of the handle of the mallers.

The anterior ligament of the malleus is broad and stromg. According to Helmholtz it encircles the long process of the malleus, and is inserted into the fore part of its neck and head. 
Some of the fibres of this ligament have been described as musenlar under the name of the laxator tympani muscle. But although oreasionally museular fibres ean be letected, in the majority of eases they apleare to he absent.

The external ligament of the malleus prevents the handle of the malleus being tumed too much outwarls. It jasses from the matrgins of the noteh of Rivinus to the short proeess of the malleus.

The ligament of the incus. - The short crus of the incus is covered with a larer of fibro-cartilage and rests on a depresiom of the pusterior trmpanic wall, close to the orifice leading into the mastoid cells. The postorior ligament binds the process to this wall.

The Muscles of the Tympanum.-Two muscles-the trusortympani and the stapedius, both of which lie within bony amals-transmit their tendons into the cavity of the tympanum for insertion into the chain of assicles.

The tensor tympani is a pemmiform muscle about half an inch in length; it arises in small part from the cartilaginous Eustachian tube and adjacent surface of the sphenoid hone as well as from the wall of the eanal in which it lies. The tendon, which extends outwards almost at a right angle to the belly of the muscle, ean be traced some distance inwards on its lower aspect. It is inserted on the inner margin of the handle of the malleus, near its root. The tendon glicks within a sheath continuous with the periostemm lining the canal and surrounded by mucous membrane. This musele draws the handle of the malleus, and with it the membrana tympani, inwards.

The stapedius is a prriform muscle; it arises from the interior of the pyramidal eminence which projects from the pusterior wall of the tympanum. The tenclon, which ean be traced inwards for more than half the leingth of the muscle, passes through the aperture at the summit of the eminence, to be inserted into the posterior aspect of the neck of the stapes. Its tenclon, like that of the tensor trmpani, is surromeled by a fibrous sheath enveloper in the trmpanic mucous membrane. This muscle depresses the posterior, whilst at the same time it slightly raises the anterior, end of the footpiece of the stapes.

Nerves.-The stapedius is supplied hy the facial nerve. The tensor tympani receires a filament from the otic ganglion which is probably derived from the mutor portion of the fifth nerve.

The Mucous Membrane of the Tympanum is continuous through the Eustachian tuhe with that which lines the pharvnx. It is thin and transparent, and in places it is easily detached.

Sereral vascular folds extend from the tympanic walls to the ossicles, all of which receire a complete covering of mucous membrane.

The folds clivide parts of the eavity into pouch-like recesses, four of which, lying in relation with the malleus, are of some importanec; they are the superior and inferior external pouches and the anterior and posterior pouches of Trölsch. The superior extrmal pouch lies in the epitympanic region, to the outer side of the hearls of the malleus and ineus, and above the anterior and external ligaments of the malleus, which separate it from the inferior external pouch below. The inferior external pouch lies between the last mentioned ligaments abore and the short process of the malleus below. It is of special clinical importance because it is bounded externally hy the flaceid portion of the membrana tympani, anteriorly it is closel but posteriorly it opens into the general eavity. The pouches of Tröltsch lie in front of and behind the handle of the malleus, and they are separated by a fold of mucous membrane which envelops the chorda tympani nerve.

The mucous membrame of the roof of the trmpanmm and that which lines the memhrana tympani and coyers the oxicles jowsesses a flattened non-ciliated epithelimm. Elsewhere for the most part, inclucling the Eustachian tube, it is colmmmar and ciliaterl.

Vessels and nerves of the tympanum.-Arteries.-The tympanic branch of the intemal maxillary which passes through the Glaserian fisture, and the stylomastoid branch of the posterior aurieular which passes through the Fallopian canal, supply the front and back part of the tympanie cavity, and form a raseular chain around the circumference of the membrana trmpani. In addition to these chief branches the hiatus Fallopii transmits the petrosal branch from the 
midlle meningeal, whilst fine branches leave the carotid artery as it traverses the carntid canal and pass into the tympanic cavity. The ascending pharyngeal sends branches to the Eustachian tube, some of which reach the trmpanum.

Veins. -The veins empty into the superior petrosal sinus and into the temporomaxillary vein.

Nerves. - The tympanic mucous membrane is supplied by the tympanic plexus which oceupies the grooves on the promontory and inmer wall of the carity.

The plexus is formed by the following nerves.

The tympanic branch of the glosso-pharyngeal, which enters the cavity through a foramen in the floor; a communicating branch from the carotid plexus of the sympathetic, which passes through the carotid canal.

A branch from the great superficial petrosal, which enters by the inner wall close in front of the fenestra ovalis; and one from the small superficial petrosal, which enters near the canal for the tensor tympani.

The course of the chorda tympani nerve has already been sufficiently inclicated (page 762 ).

\section{THE INTERNAL EAR, OR LABYRINTH}

The INTERNAL EAR, or LABYRINTH, is the essential part of the organ of hearing, and receives the terminations of the auditory nerve.

The Osseous Labyrinth is divided into three portions: the vestibule, the semicircular canals, and the cochlea-recesses hollowed in the subtance of the petrons portion of the temporal bone.

Fig. 500.-The Osseots LABrrinth of the Right Side.

(Moditied from soemmerring. Enlarged.)

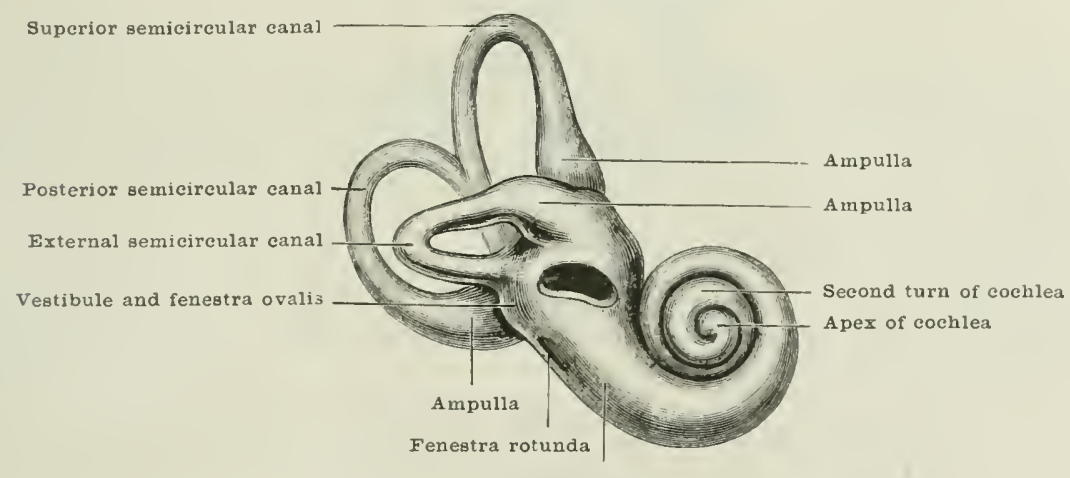

Commencement of first turn of the cochlea

The Vestibule lies betreen the cochlea and semicireular canals, on the inner side of the tympanum (fig. 459. $\mathrm{A}$ ). It is a laterally compressed ovoidal carity, and is about one-fifth of an inch in horizontal and rertical measurement.

The outer wall presents the fenestra ovalis filled with the foot-piece of the stapes and its ammular ligament. On its inner wall there is a small saucer-like depression, the fovea hemispherica, perforated below and in front ly sireral minute orifices (macula cribro:a) for the filaments of the auditory nerve. Immediately behind this is a vertical ridge, the pyramilal cminence or crista restibuli, hehind which is the orifice of the aqueductus vestibuli.

On the roof there is a second depression, oval in shape, the fovea hemielliptica. The two depressions are separated by the pramidal eminence.

Behind, the semicireular canals open hy five orifices; and in front hy means of a large oval opening, apertura scalæ vestibuli, the restibular carity communicates with the scala vestibuli of the cochlea.

The Three Semicircular Canals are placol above and behind the restibuls. They are unequal in length, but each forms the greater part of a circle, is laterally 
compresicel, and measures about one-twentieth of an inch (15 mm.) in diameter. One extremity of each canal is suddenly dilated to nearly double its size to form the ampulla. As two of the anals join to open by a common oritiee, eollectirely they present only live openings:

The superior semicircular canal, the highest of the eanals, is almost vertical, and is directed transiersely. I smooth eminence on the anterior surface of the petrous bone closely corresponds to the summit of its arch. Its anmullary end is at the outer extremity, and presents a separate opening at the upper part of the vestilule: the opposite end, which is not dilated, joins to form a common orifice with the sinilar extremity of the posterior canal.

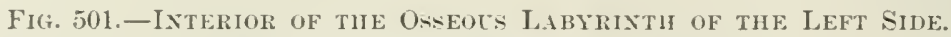
(Modified from Soemmerring. Enlarged.)

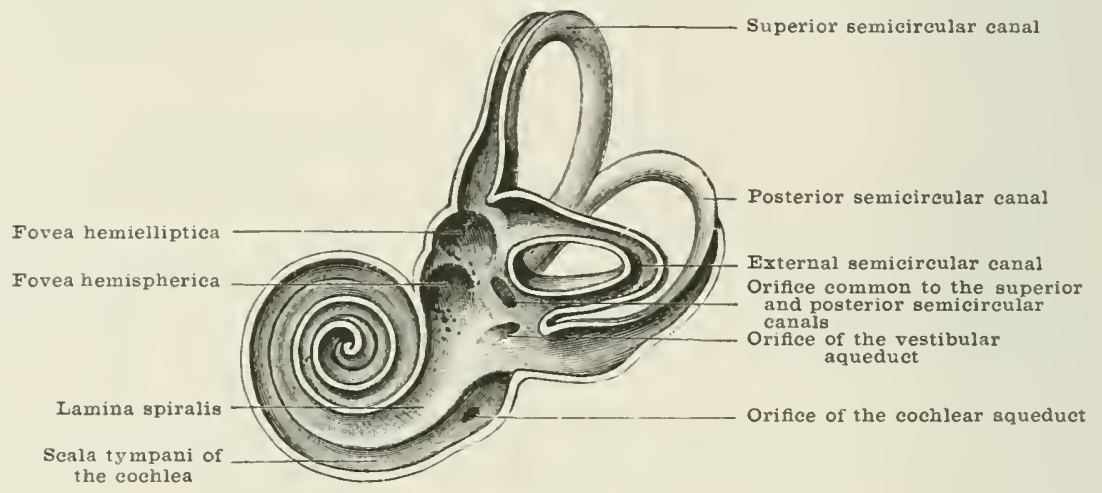

The posterior semicircular canal is the longest. Its dilated end is placed at the lower and back part of the vestibule; its non-dilated extremity joins the -uperior canal. It is placed nearly vertically, and is directed backwards.

The external semicircular canal eurves horizontally outwards, and presents two openings, of which the anterior is ampullated, in the upper and back part of the restibular eavity.

The Cochlea his a rough resemblanee to a snail's shell, and coils itself almost lorizontally immediately in front of the restibule. Its base corresponds to the lower and front part of the fundus of the internal auditory meatus (fig. 495A),

Fig. 50\%.-IxTerior of the Osseots CochleA. (Eulargel.)

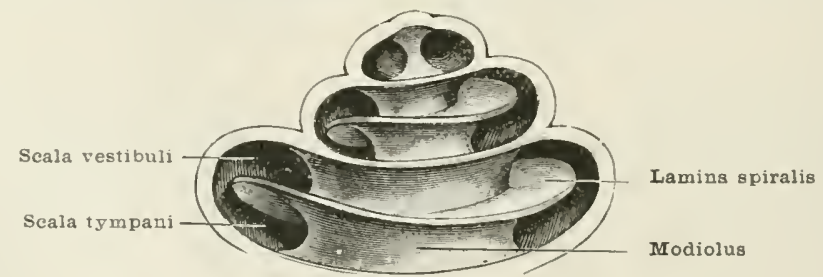

and is there marken hy the series of minute holes which form the tractus spiralis foraminulentus, whilst its apex is directed forwards and ontwards, towarts the "I)

The cochlea is about a quarter of an inch $(6 \mathrm{~mm}$.) in longth, and its basal measurement is nearly the same. It is enmposed of a central pillar. the modiolus, or columella, around which curls for two and a half turns a spiral canal, which contains a delicate spiral shelf or plate. the lamina spiralis. This partially divides its eavity into two portions, as it follows its windings from base to apex. Near the apex it encls in a hook-like process, the hamulus, which bounds a small opening, 
the helicotrema. The osseous spiral canal is nearly an inch and a half (atunt $3.5 \mathrm{~cm}$.) in length. The lamina spiralis is thin and dense in structure at its edge. but it is spongy and chamnelled with canals for nerves and blood-ressels where it starts shelf-like from the modiolus.

The spiral canal of the modiolus coils round the pillar as it tunnels the hase of the spirill lamina.

In the recent state, membranous structures complete the bony partition into two separate chambers, or scalie: the scala vestibuli and the scala tympani, which communicate through the helicotrema at the summit of the cochlea.

The scala vestibuli commences from the cavity of the restibule; in its first turn it is somewhat narrower than the scala tympani.

The scala tympani commences at the fenestra rotunda. which is filled with the secondary membrane of Scarpa, and forms a kind of winlow which shuts it off from the avity of the tympanum. Tear its commencement is the small orifice of the aqueductus cochler, which lodges a minute rein, and forms a communication with the subarachnoid space.

The central axis, or modiolus, extends from the base to the apex of the cochlea. It starts with a broad base where it corresponds with the first turn of the cochlea, and it is pierced ly minute canals to receive the filaments of the cochlear division of the auditory nerve. In the second coil the axis is diminished by more than half, and it teminates in the remaining half coil or cupula in a bony plate. the infundibulum, which expands towards the summit of the cochlea, with which it

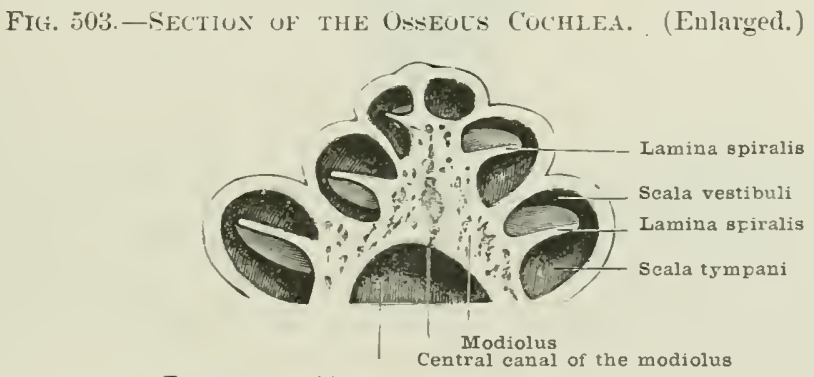

Termination of internal auditory meatus

becomes continuous. The central canal of the modiolus runs through its centre.

The Membranous Labyrinth, which lies within the bony labyrinth just described, receives the terminations of the auditory nerve. It i. for the most part separated by the perilymph from the membrane which lines the bony chambers. and it contains within its own carity the fluid endolymph. In the restibule and semicircular canals it bears a near resemblance (though it is much smaller) to the enclosing structures, but in the cochlea it not only dirides the bony canal into the two scale, but forms between them a third space, the canal of the cochlea.

Within the vestibule the membranous lahrrinth consists of two sacs, which do not directly communicate: the utricle, connected with the semicircular canals: and the saccule, with the cochlea.

The Utricle is the larger. It is ohlong, laterally compressed; it occupies the upper and back part of the cavity, and is in contact with the wall of the forea hemielliptica. Filaments of the aurlitory nerve are distributerl to the wall of the sac opposite the crista restibuli, passing through the bony foramina already described. Its wall is here thicker than elsewhore, and calcarens particles (otoliths) are attached to its imner surface. Behind, the cavity communicates by five orifices with the semicircular canals.

The Saccule, which is slightly Hattened, occupics the front and lower part of the carity at the opening of the seala vestibuli of the eochlea. From the hollow of the forea hemispherica it receives numerous nerve filaments. and presents a thickened area with attached otoliths. 
The membranous canal of the cochlea is comnected with the saceule by a short calnal, canalis reuniens.

The two sacs are indirectly connected by means of a snall tube. dnetus enrlolrmphaticus, which leaves the saccule, joins the commencement of a minnte camal which passes to the utricle, and descends in the aqueductus vestibuli to teminite in an enlargement, the sacens endolymphaticus.

Flg. 504.-Menbraxous Labyrixth (Magxified), With Nerves.

(Modified from Breschet.)

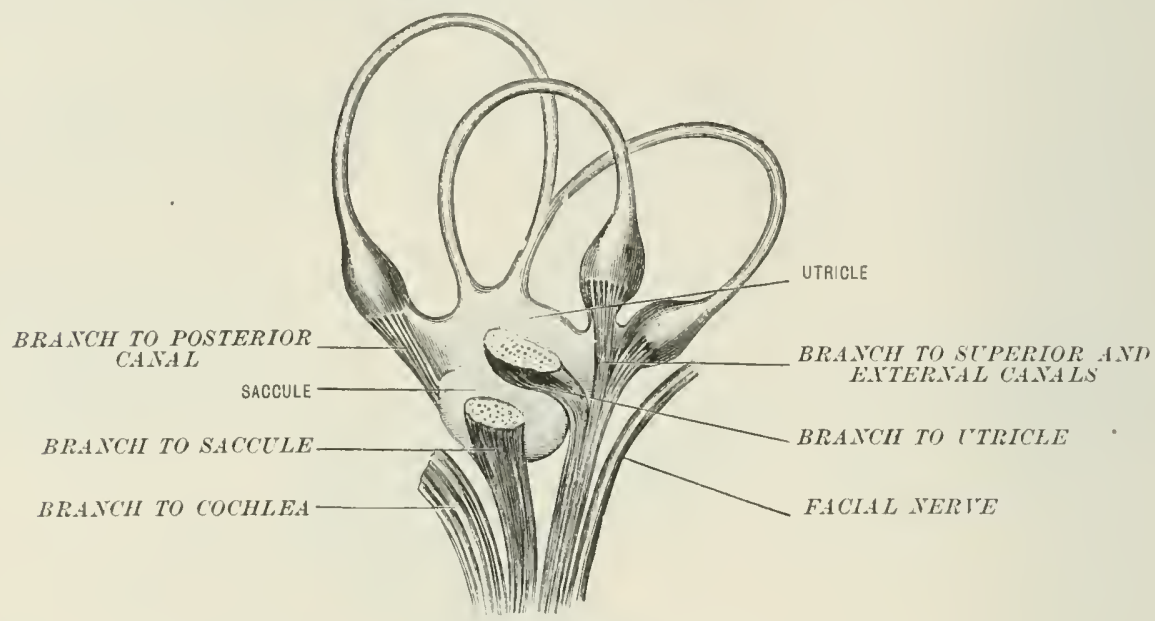

Within each semicircular canal the membranous labyrinth oceupies less than a third of the area of the tube, but follows its curves and repeats its ampullary enlargement; and here the wall of the menbranous canal is thicker and more oparue, and more completely fills the cavity. The membranous ampullex are Hattened on their external walls, where they receive vascular and nervous filaments,

Fig. 505. - ENLARged Diagamitic View af Meniranous Labyrinti.

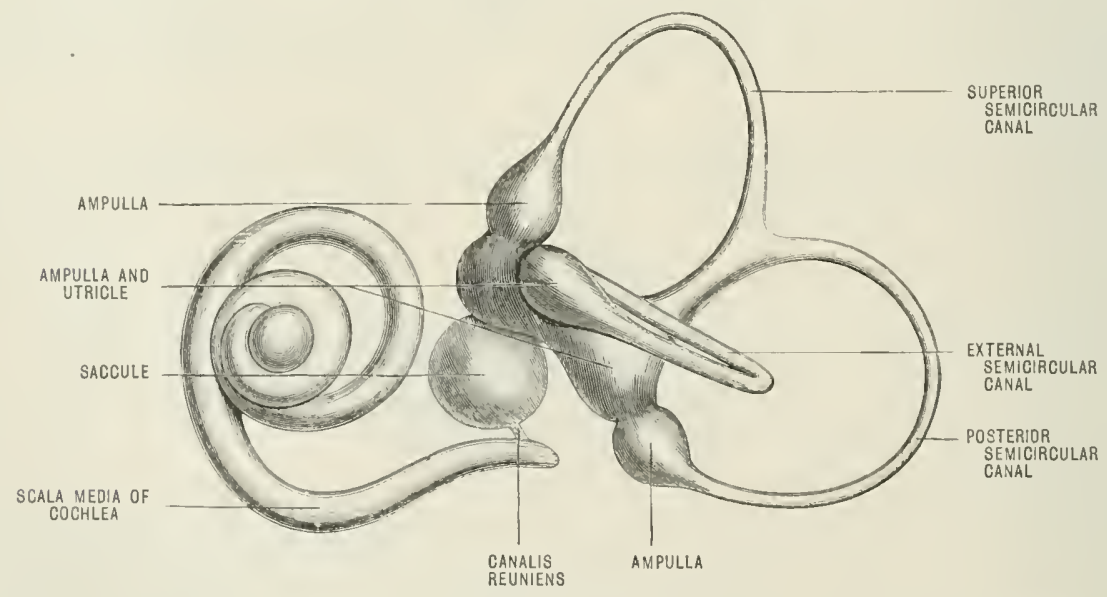

and their cavities are partially divided hy a transverse crest or ridge (crista acustica). The outer convex horder of each membiranous anal is fixed to the osseons wall.

Structure.-The membranous labyrintl consists of three layers: a tunica propria, with a fibrous investment extenally, and an epithelial lining within.

Within the cochlea, the membrumons structures divisle the canal into thee compartments. The lamina spiralis (which in macerated specimens only partially 
divides it) is continued into a projection from the periosteum of the outer wall (spiral ligament) by means of a distinct membrane, membrana basilaris, thus completely roofing in the seala tympani which before communicated with the scala vestibuli. In addition, a delicate membrane, the membrane of Reissner, stretches from the upper surface of the lamina internal to its free edge to the periosteum of the outer wall, shutting off a small triangular space (scala media) from the scala restibuli; the sides of this space are bounded by the two membranes (basilar and Reissner), and its base which lies externally is formed by the osseous wall with its periosteal lining. This canal is lined with epithelium, winds through the whole length of the cochlea, and is commonly known as the ductus cochlearis,

Fig. 506.-Exlarged View of Loxgitudixal Sectiox of the First TlRx of THE CochleA, SHOWING THE Positions AND Bouxdaries of the Three SCAl..

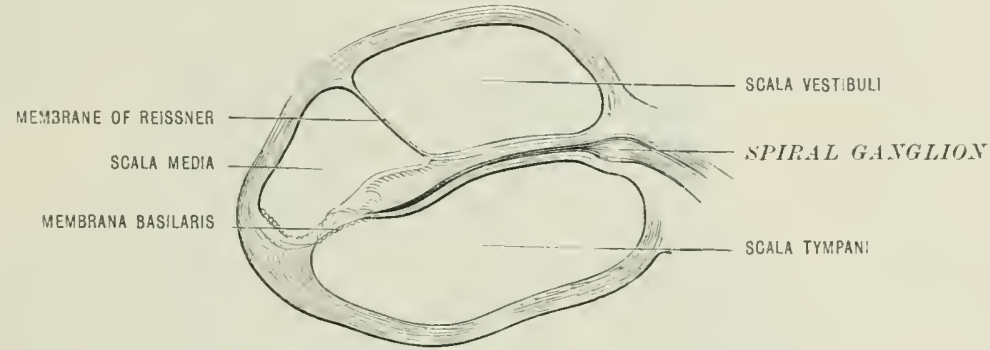

or membranous canal of the cochlea. It ends blindly by pointed extremities, one situated at the apex of the cochlea and the other at its base, the latter lies in relation with the floor of the vestibule and receives the small canal already lescribed, the canalis reuniens, which proceeds from the saccule. The canal of the cochlea and the saccule are thus brought into communication.

The Auditory Nerve divides into two portions before it reaches the fundus of the internal auditory meatus.

The superior division consists of three branches which pass to the crista restibuli, through special openings, to be distributed to the utricle and the ampullary enlargements of the superior and external semicircular canals.

The inferior division supplies the cochlea through the foramina of the tractus. forminulentus; also a branch to the saccule, the filaments of which yass through the openings of the forea hemispherica; and a longer branch to the posterior semicircular canal, which reaches it by a special channel, the foramen singulare, situated behind the foramina which transmit the filaments to the saccule.

Vessels.-The internal auditory branch of the basilar artery, which acrompanies the auditory nerre, supplies both the vestibule and cochlea, with their membranous contents. The veins correspond and open into the inferior petrosil sinus, which also receires the minute veins which traverse the aqueductur vestibuli. 


\title{
THE TUNGILE
}

\author{
BY ARTHUR HENSMAN, F.R.C.S.
}

REVTED FOR SECOND EDITION BY ARTHUR ROBINSON, M.D., M.R.C.S.

LECTLRER ON ANATOMY IS THE MIDDLESEX HOSPITAL MEDICAL, SCHWOL; EXAMINER IX ANATOMY FOR THE CONJOINT BOARD OF EXGLAND

The tongue is a freely movable, highly sensitive, and muscular organ, and is endowed with the special sense of taste. It participates, moreover, in the function of speech, and plays an important part in mastication and deglutition.

Its mper surfice. or dorsum, with its sicles and tip, are free, whilst its hase is attached hy muscles to the hyoid bone and lower jaw. Folds of mucous membrane loosely connect it with the epiglottis and soft palate, as well as with the symphysis of the lower jaw. From heneath its rounded horders the mucons covering becones continuous with the inner surface of the gums. The anterior two-thirds of the tongue occupies the floor of the mouth, lying between the halves of the lower jaw, with its convex dorsum overarched by the vault of the palate, and its sides and tip in contact with the teeth and gums. The posterior third of the dorsum, situated in the anterior wall of the pharynx, forms a rounded surface overhanging the epiglottis.

The mucous membrane, which is really a modified skin, covers the whole of the free surface of the tongue. It forms three folds: the glosso-epiglottidean in comnection with the epiglottis; and on each side of the median fold-franum epiglottidis-is former the glosso-epiglottidean pouch, or vallecula, which is bounded externally by the more rounded latcral fold. On each side of the tongue, near the junction of the posterior and middle third. the membrane ascends to form the anterior pillars of the fauces, and in front beneath the tip it forms the sharp fold of the frænum linguæ (fig. 509), which extends forwards to the back of the symphysis.

A slight longitudinal groove, the median raphe, divides the dorsum of the tongue along its anterior two-thirds. It encls posteriorly near a small foramen, the foramen cæcum, which represents the upper termination of the thyro-glossal duct. The orifice, howerer, is not at all constant in the adult tongue, although ocasionally it is present and may sometimes lead into the still patent duet which tumels the tongue as far as the boly of the hroid bone. The course of the obliterated duet may in many ases be dimonstratril.

The formen exermu is easily seen in the foetus at the angle of meeting of two shallow groores which form the V-shaped line hehind the circumvallate papille. These grooves indiante the line of junction of the anterior and posterior portions of the tongue, and are faintly visihle in the alult organ.

The papillie crowd the interior two-thirds of the dorsum as well as the sides amd tip of the tongue. hut at the back they are suall and hirlden by the cpithelial coating. Of the japille three chief kinds ean be distinguished.

The circumvallate or calyciform papilla are the largest, but they are few in number, varying from seven or eight to twelve, and they form a $\mathrm{V}$-shapred line in front of and parallel with the gronves already mentioned. 
Each papilla presents a narrow attached base and a broad free end, and is seated in a circular cup which is surrounded by a rim or vallum.

Upon the hases of most of these papilla a central depression marks the orifice of one or more glands. Secondary papillæ lie hidden under the thick epithelial covering both of the chief papilla and the cireular rim which surrounds it.

The fungiform papillæ are more thinly covered with epithelium, and are redder in colour than the smaller papillie amongst which they are scattered. They occur irregularly over the dorsum. sides, and tip of the tongue, and are most numerous in the two latter situations; each papilla is attached by a comparatively narrow base and has a broader, rounded. and free extremity, studded with smaller secondary papilla.

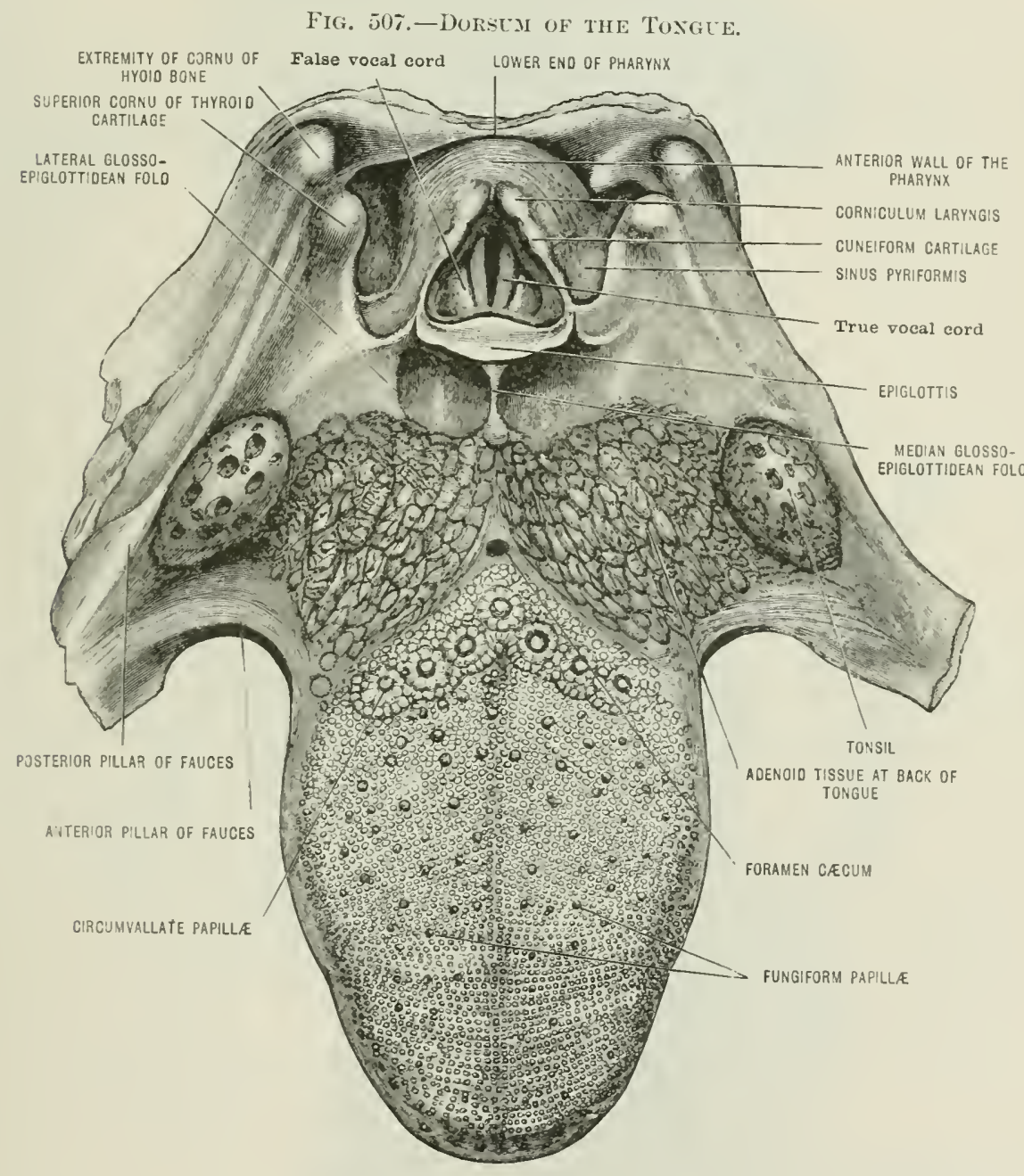

The filiform or conical papillæ, named from their general shape, thickly beset the whole of the dorsum, sides, and tip of the tongue in front of the circumvallate group. They faintly ridge the organ with delicate lines, which posteriorly lie parallel with the circumvallate papillæ, but become more and more transwerse in direction as they approach the tip and silles of the tongue. They present secondary papille upon their surfaces thickly overlaid with epithelium.

The lingual glands are especially abundant near the foramen cæcum and in the neighborhood of the circunvallate papillie, as well as along the borders of the tongue. 
I special group forms an elongated mass. the gland of Nuhn, on either side of the organ, and just beneath its tip. It oceupies the groove between the genio-hyoglosins muscle and the inferior lingualis.

Fri. 508.-The: F(ETAI, TUNite.

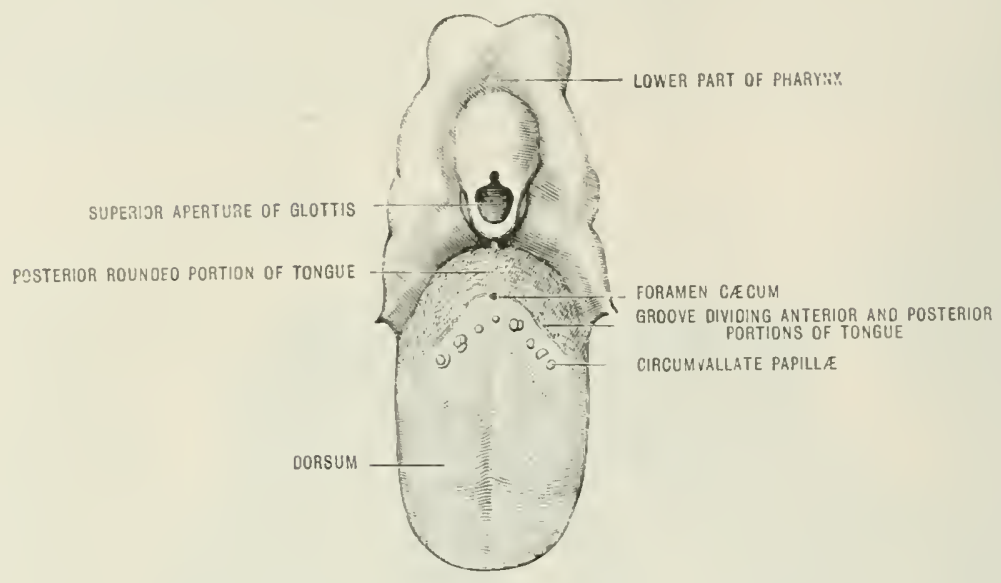

Flg. 509.-UNDER SURFACE OF TIE TUNGEE WITH MI'A.LES.

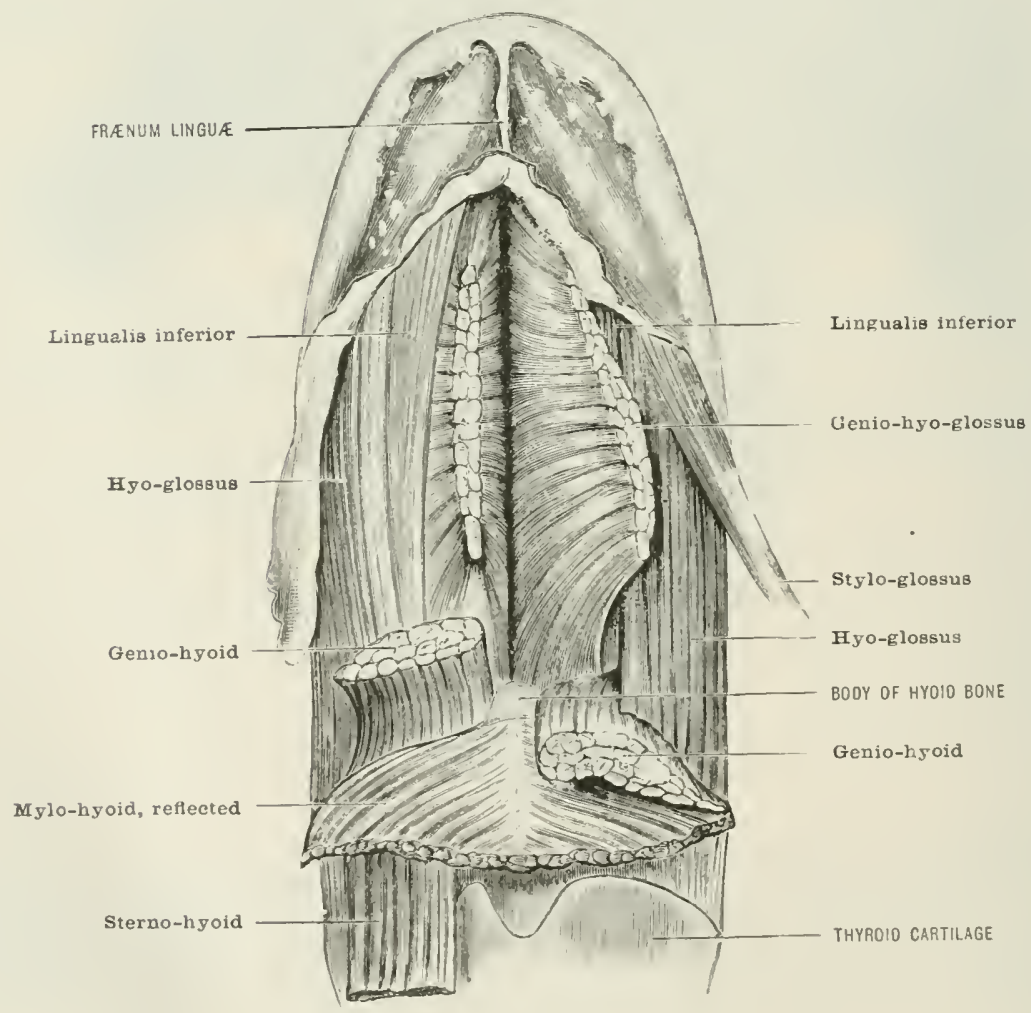

The mucous membrane of the posterior third of the tongue contains abundant lymphoid tissue, collected into rounded masses. This often becomes much diveloped, and gives to this part of the tongue an irregular nodular appearance. 
Fig. 510.-Traxsyerse Section throlgh THE Left Hilf of the Tusgte. (Magnified.)

(From a preparation by Mr. J. Pollard, Middlesex Huspital Museum.)

Transverse muscular flbres

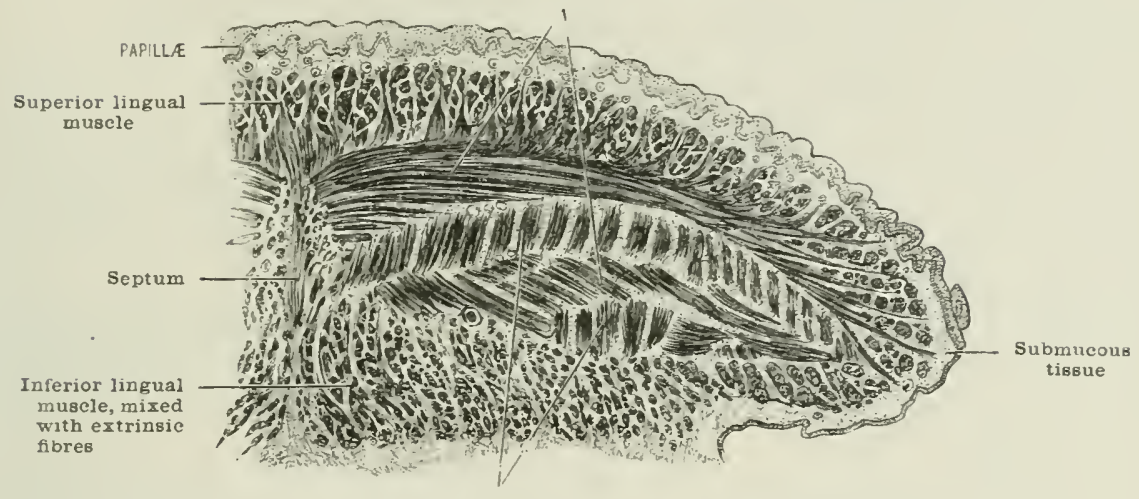

Vertical muscular fibres

Fis. 511. - SIDE VIEW of THE TONGEE, WITH ITS MLSCIES.

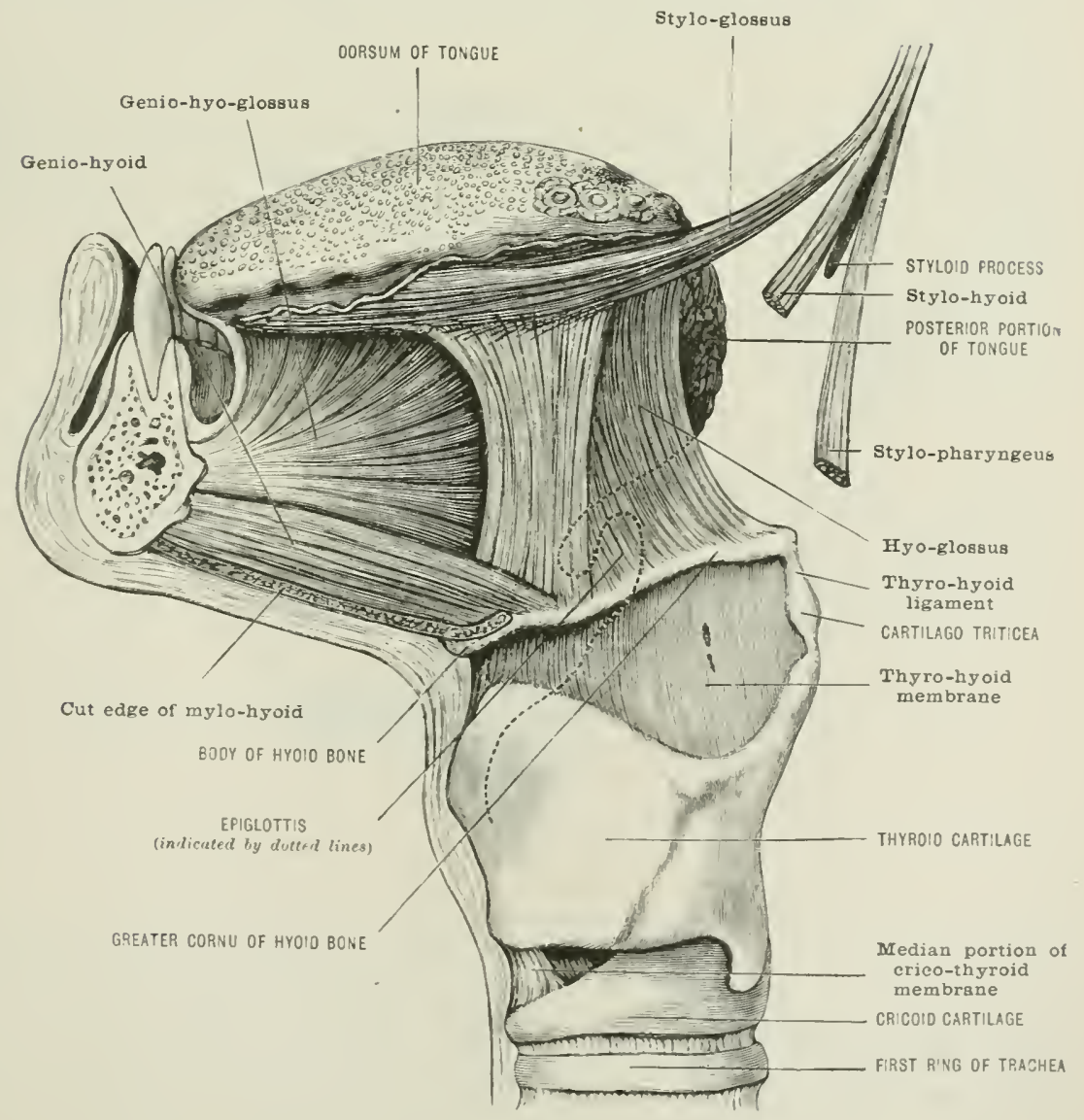


I fibrous septum separates the halves of the tongue and extends in the middle plane from base to apex; and a strong fibrous membrane, the hypoglossal membrane, passes from heneath the hase of the tongue to the body of the hyoid bone.

The Muscles of the Tongue.--The muscles of the tongue are both extrinsic, and special or intrinsic.

The extrinsic musales are the hyo-glossus. genio-hyo-glossus, stylo-glossus, palito-glossus, and a small part of the superior constrictor. (For extrinsic muscles of tongue see page's 451-454.)

The intrinsic muscles.-The lingualis superior constitutes a superficial longiturlinal stratum, which extends from the base to the tip of the organ, immediately beneath the mucous membrane. The fibres form short fascicles attached to the overlying tissues, and are placed between the hyo- and stylo-glossi muscles of the opposite siles of the tongue, both pairs of which, near the base, overlap the fibres of the lingualis.

The inferior lingualis is composed of two bands which reach from the base to the apex on the under surface of the tongue. Posteriorly some of the fibres become attached to the body of the hyoid bone. Each of these bands is placed between the hyo- and genio-hyo-glossus, and near the tip some of its fibres mix with those of the stylo-glossus muscle.

The transverse fibres mixed with fat lie between the two muscies just described, and form a considerable part of the bulk of the tongue. They take origin from the median fibrous septum, and, curring outwards and upwards, are inserted into the sides and dorsum of the organ.

The vertical fibres decussate with the transverse, and pass from the dorsum to thrs under surface of the tongue in curves with their concavities looking outwards. The fibres become shorter as they approach the margin of the tongue.

Arteries.- The arteries are derived from the lingual, facial, and ascending pharrngeal.

Nerves.-The nerves are-the lingual branch of the mandibular division of the fifth, which supplies the papilla of the fore part and sides of the tongue; the lingual branch of the glosso-pharyngeal, which supplies the base and sides, including the circumrallate papillie; the fine branches from the superior laryngeal, which reach the root close to the epiglottis, and a lingual branch from the facial (Testut).

The hypoglossal supplies the muscular substance of the tongue, as well as most of the extrinsio muscles; and the chorda tympani through the facial contributes also some filaments.

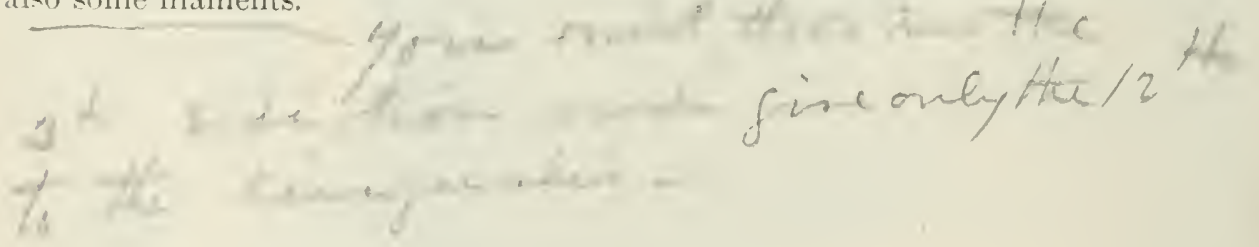




\section{THE NOSE}

\section{BY ARTHUR HENSMAN, F.R.C.S.}

REVISEN FOR SECOXD EDITION BY ARTHUR ROBINSON, M.D., M.R.C.S.

LECTURER ON ANATOMY IX THE MIDDLESEX IFOSPITAL MEDICAL SCHOOL; EXAMISER IY ASATOMY FOR IHI. COXJOINT LOARD OF EXGLAND

The nose includes a visihle external portion. the nose proper; and an internal cavity, the nasal fossa.

The Nose Proper is triangular in shape; its root ahove is at the foreheat, from which the bridge or dorsum slopes downwards and forwards to end in a rounded

Fig, 512.-Side VIEW of THE Nose, Showisg its CARTILAgEs, ETe.

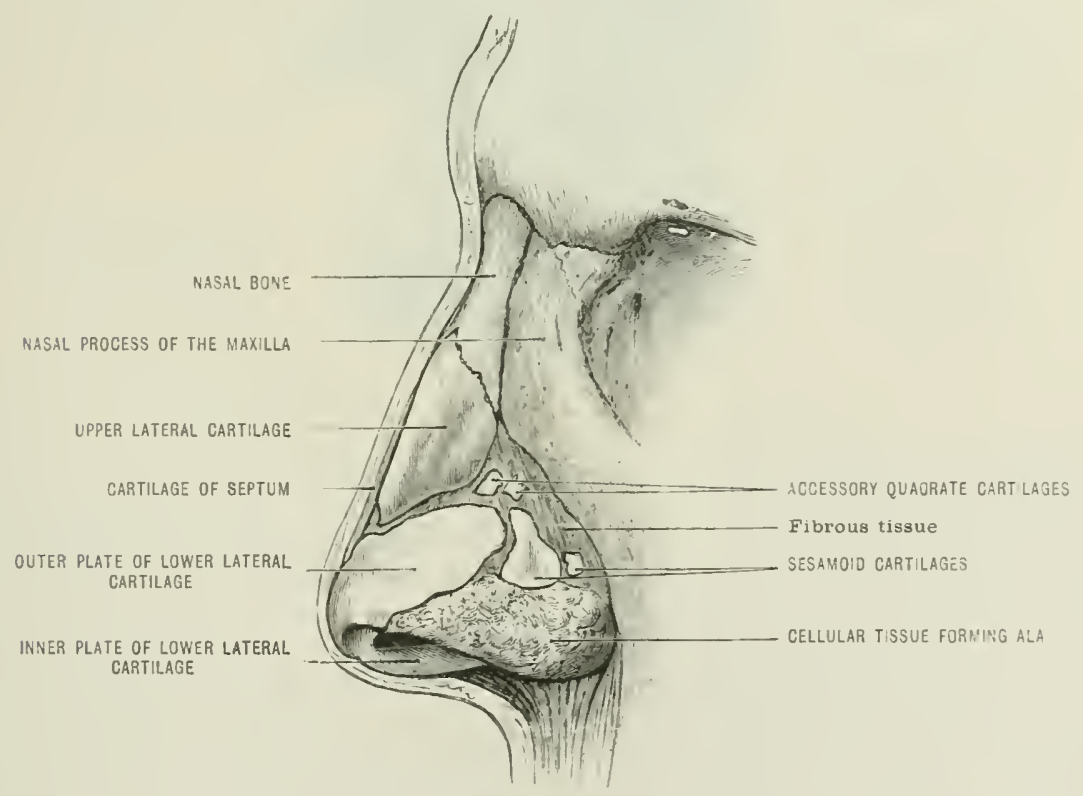

tip or lobe. The base below overhangs the upper lip; it here presents two mificethe nostrils, which are divided by the columna.

The nostrils are protected hy stiff hairs, and each opens into a cavitr. extendine a little above the cartilages, eallerl the vestibule. Its sides slope from the dorsum outwards and hackwards, and terminate below in the alæ or wings, which lomml the nostrils externally. It presents a dense unvieleling bony framework, formed by the two nasal bones, with the nasal processes of the maxillae above. and hy the 
projecting anterior nasal spine below. To this is added a riclding cartilaginous portion, which completes the organ, and forms its chief part.

The nose is enveloped in skin, lined by a mucous membrane, and suplplied with rossels and nerves, and its cartilages are acted upon hy small muscles.

The cartilages.-The principal cartilages are five in number: a pair above, the superior lateral; a pair below, the inferior lateral; and the cartilage of the septum, the persistent unossifierl remnant of the facial segment of the chondrocranium (page 90). With these must be included a group of small irregular cartilages known as sesamoid and accessory quadrate.

The cartilages, ensheathed in perichondrium, are for the most part loosely held together by tough intervening fibrous tissue, and this in tum becomes continuous with the periostem of the surrounding bones.

The upper lateral cartilages are nearly flat and somewhat triangular in shape, each presenting an outer and an inner surface.

Their anterior margins are continuous above with the rounded borders of a shallow groove which furrows the cartilage of the septum; but below for about twothirds of their extent, though their edges are closely applied to the borders of the

Fig. 513.-ANTerior View of the Nose, Sholrixg its CARTIlages, etc.

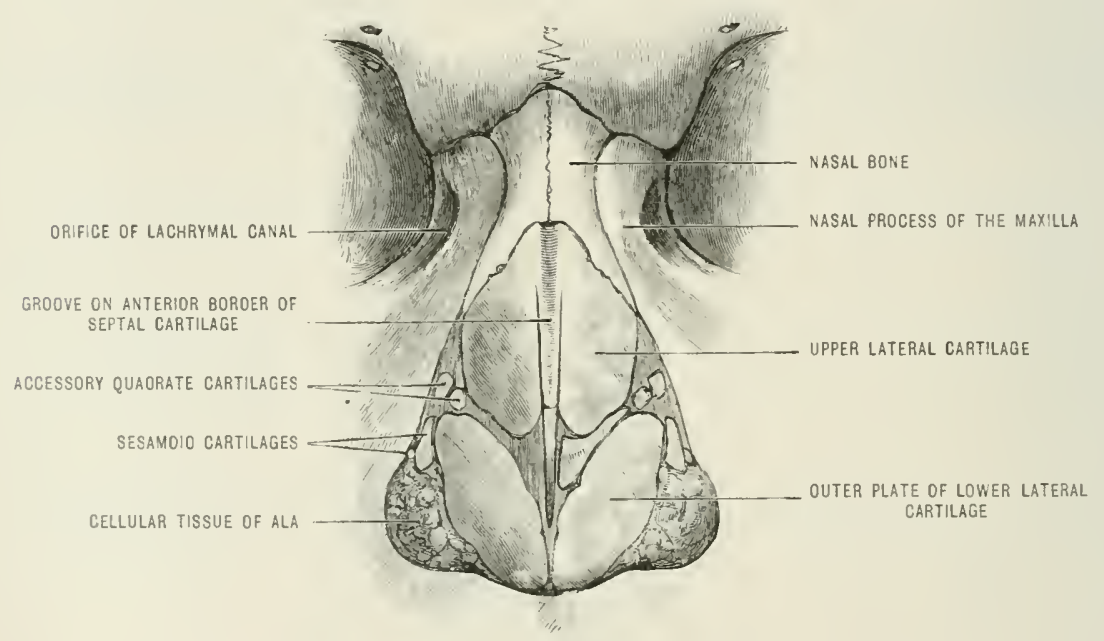

groove, there is on each side a narrow cleft of separation which opens out below into an angular notch.

Their curved posterior margins are firmly attached superficially by somewhat jagged edges to the nasal bones; but deeply, and especially near the septum, they underlie these bones for a considerable distance.

The rest of the border is smooth, free, and loosely connected by interrening fibrous tiscue to the nasal process of the maxilla.

Their inferior borders are comnected with the lower lateral cartilages; one or more narrow jlates of cartilage oceasionally intervene and fill the fibrous interval. On account of their continuity with the sejtal cartilage. the upper lateral cartilages should be rogarded as its wings or lateral expansions. (Henle.)

The lower lateral cartilages are thin, pliant, and curved, and so folded backwards that each forms an inner and an outer plate.

The inner plates are loosely attached to one another, where they meet below the septum to form the tip of the nose and fore part of the columna.

'Th' outer plates are oval, and eurve backwards above the masses of dense (cllular tissue which form the ala. They naintain the contour of the nostrils, and serve to keep these orifices open. Posteriorly they are comnectred by fibrous tis-ue to the nasil margins of the superior maxillary bones. 
In this tissue are embedded several extremely thin and irregular cartilages named sesamoid, and above these commonly a pair still smaller, called accessory quadrate.

The septal cartilage fills in the triangular interval of the bony septum. The anterior border is attached to the nasal bones at their junction below the crest. Beyond it presents a shallow groove, the borters of which are at first continuous with the upper lateral cartilages, as alrearly described. This groove becomes narrowed by the gradual approximation of its horders, which ultimately meet in a faint transverse ridge below. Still lower, it clips for a short distance between the inner plates of the lower lateral cartilages, which meet beyond it to form the tip of the nose.

The posterior border is connected with the perpendieular plate of the ethmoirl, whilst its inferior is attached to the romer, which is often channelled like the ethmoid plate to receive it. The anterior part of the lower border is attached to the anterior nasal spine.

The eartilage does not simply dip into the groove which is more or less marked on the upper surface of the nasal spine. lout hroadens out to obtain the widest possible, though somewhat lax, attachment to it. Viewed from below, it appears to "mbrace the snine. The border of its rounded angle in front is somewhat

Fig. 514.- I'xner View of the Nose, shuWIXg its Cartilages, etc.

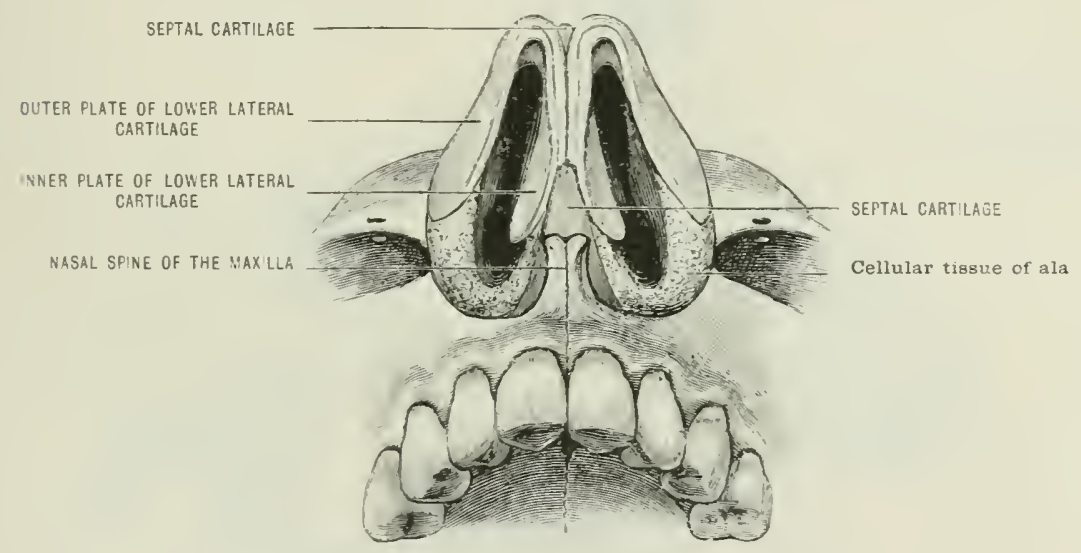

thickened hefore terminating in a thin smooth edge. It is extremely thin near the cenntre.

The shape of the septal cartilage raries in relation to the extent of ossification in the bony septum, and eren in the adult a strip of cartilage may extend for a varying distance backwards and upwards between the vomer and ethmoid, sonetimes eren reaching the boly of the sphenoid bone.

It may he here noted that the septum of the nose is alnost always straight in chililren and in aboriginal skulis (cighty per cent.); but in Europeans it is deflected to one or other side in the proportion of three out of erery four.

Jacobsonian cartilages. - In the septal cartilage above the opening of Stenson"s canil' there is a small pouch which presents a minute opening below. This is the representative of the so-called Jacohsonian organ. A strip of cartilage underneath this, firmly arlherent, but distinet from the septal cartilage, is known as the Jacubsonian cartilace.

Muscles.- The muscles are seven in number, and may he grouped as dilators and constrictors. The latter are comparatively feelsle in their action.

The dilators. - The pyramidalis nasi is a downward prolongation of the wcipito-frontalis. Each nuuscle descends on the side of the nose, to blend, after hecoming tendinous. with the compressor nasi. They diverge from one another as they pass downwards. The levator labii superioris alæque nasi arises from the nasil process of the maxilla. 
It divides in its passage downwards, one slip being inserted into the cartilage of the wing, the other extending to the upper lip to blend with its muscular fibres.

The two foregoing muscles may be regarded as extraordinary or reserve muscles of elilatation.

The dilator naris consists of two small muscular slips, recuniring a lens for their proper demonstration; in some cases they are absent.

The dilator naris anterior is a small and indistinct muscle. It is placed between the skin and cartilage of the ala.

The dilator naris posterior arises from the edge of the nasal notel of the maxilla and the sesamoid eartilages, to be inserted into the margin of the nostril. In paralysis of the facial nerre, a deep inspiration through the nostril produces complete collapse of its cartilaginous wall, thus showing the importanee of the dilator muscles in keeping patent the nasal orifices.

The constrictors, or compressors.-The compressor naris arises from the

Fig. 515.- Section showixg Bory axi Cartllagixols Septur.

The dotted lines indicate the course of the auterior palatine canal.

NASAL BONE

Frontal sinus

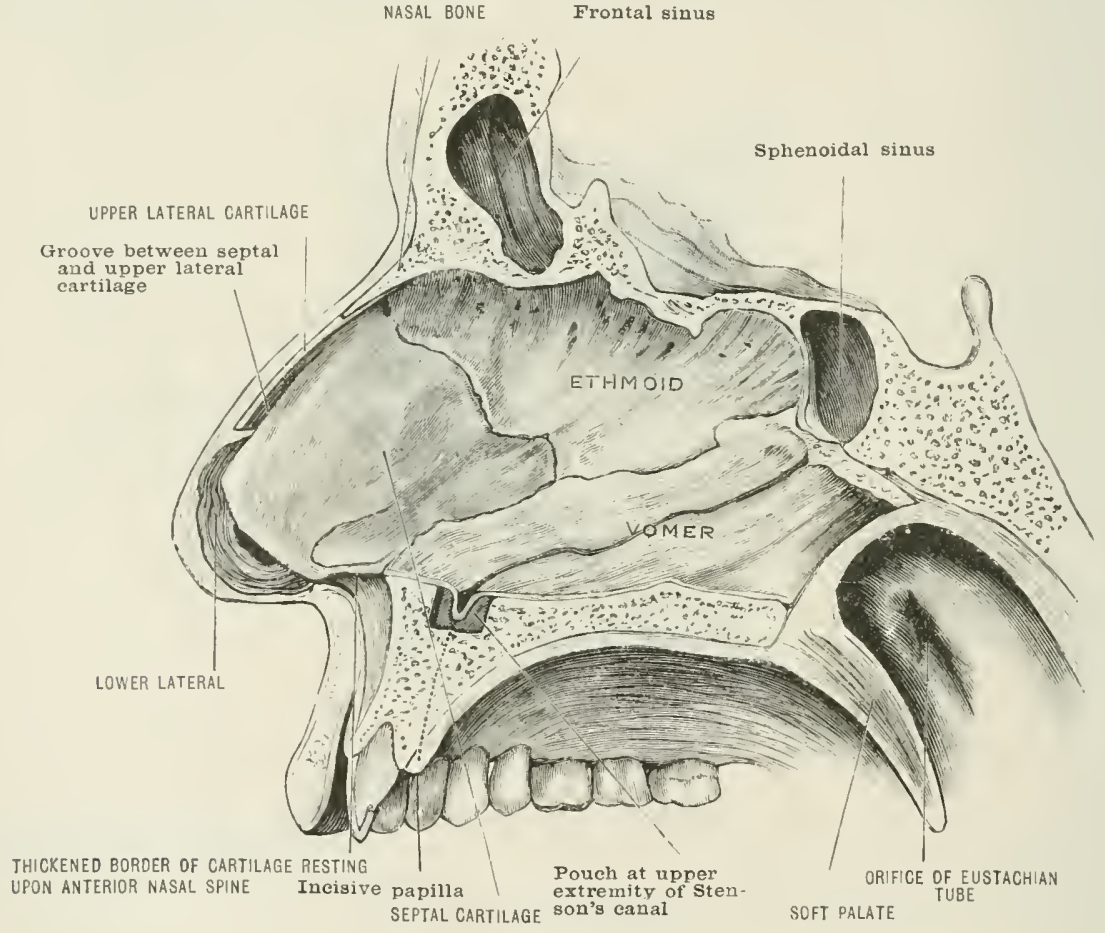

maxilla near the incisive fossa, its fibres mixing with those of the levator anguli oris. It expands as it passes inwards, to end in a thin aponeurosis, which joins with its fellow as well as with the prramidalis, and it also blends with the subcutaneous tissue over the bridge of the nose.

The depressor alæ nasi arises from the incisole fossa; its fibres pass upwards to the septum and posterior part of the wing.

The compressor narium minor consists of a few indistinct fibres, oecasionally found between the alar cartilage and skin over the tip of the nose.

These museles are all suplilied lyy the facial nerve.

The skin covering the nose is for the most part thin and freely movable upon the subjacent parts, hut at the tip and over the eartiliges it is much thicker and more adherent and furnished with numerous sebaceous glands.

The mucous membrane becomesemtinuous with the skin at the nasal orifiees, and posteriorly with the membrane which lines the nasal fosite. 
The vessels.-The arteries of the nose which arise from the facial are the lateralis nasi and the artery to the septum derived from the coronary of the same trunk. This latter also supplies the ala. The nasal branch of the ophthalnic and infriorlyital are distributed to the sides and dorsum.

The veins terminate by joining the facial and ophthahmic.

The nerves.-The nerves are supplied by the facial, which is motory, and by the infratrochlear and nasal branch of the ophthahnic division of the fifth and the infraorbital nerve, which are sensory.

The nasal fossæ.-The nasal fosse have been ahready described (page 79 ).

The mucous membrane (pituitury or sifheiderimin). - In the recent state the area of the fos-ie is much contracted hr its mucous lining. This is loosely folder around the lower edges of the turbinal hones, and extends heyond them in front and beluind. Especially is this marked where it envelops the inferior turbinal lone, and it is here rery thick and spongy. It is, morener, thick where it covers the septum, but thin at the bottom of the meatuses and within the sinuses.

Fig. j16. MILscles of THE Nose. (After Bourgery.)

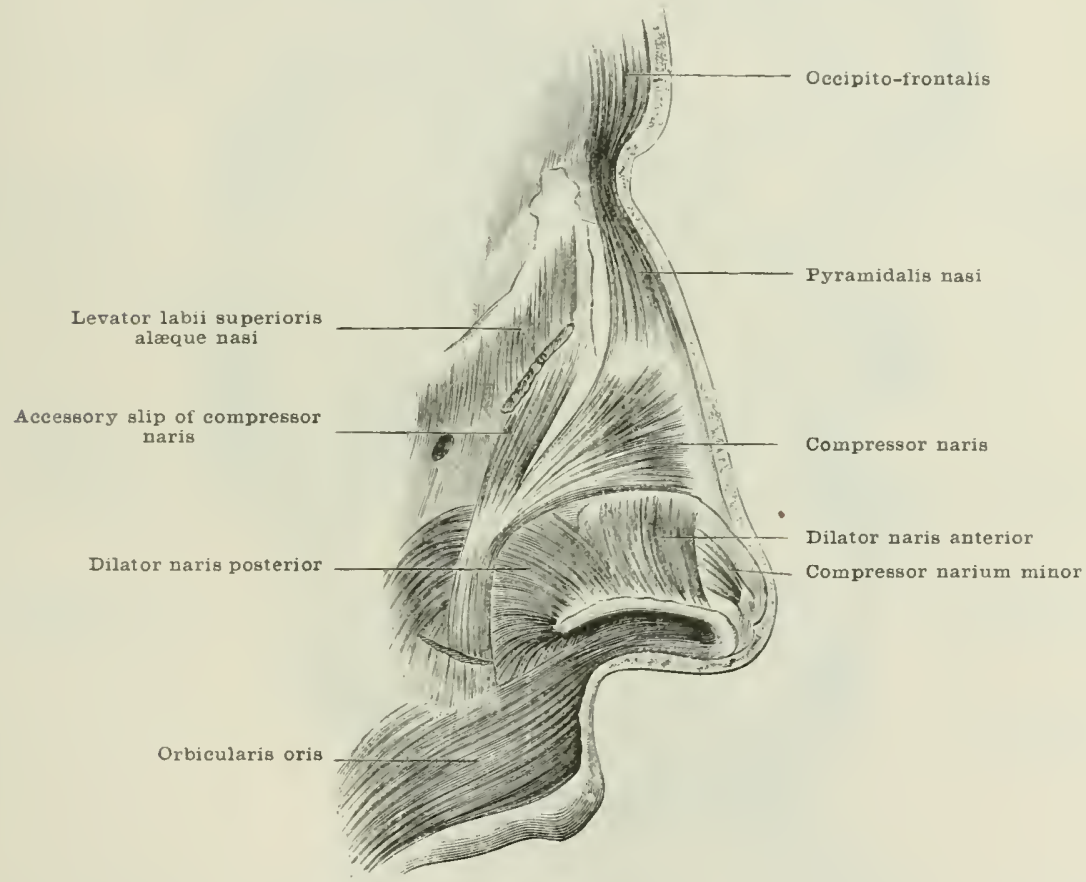

Some of the openings into the nasal cavities which are apparent in the dried skull are quite hidden in the recent state; those, however, which lead into the air-space: together with the lachrymal duct remain patent, though the bony orifices are much, resluced in size. There is a small conieal rlosed sac, close to the seltum at itfore part, which indicates the position of the now obliterated canal of stenson. The termination is marked in the mouth by the incisive papilla. The membrane is continuous in front through the anterior nares with the skin; helind, it extends through the posterior nares to line the naso-pharrnx, the Eustachian tube, the tympanum and the mastoid cells. It is intimately adherent to the periosteum and perichondrium. The acinous glands which aro imbedrled in its structure secrete for the most part a thin watery fluid. They are esperially large over the inforior turbinal bone, and very numerous at the middle and back of the fosse near the orifices of the posterior nares.

The vestibule is lined with a scaly epithelinm; more posteriorly the nasil earity is dirided into an upper olfactory and a lower or respiratory region. The 
olfactory region is linerl with a colummar unciliated epithelium. The mucous membrame is here of a rellowish colour, thicker than dsewhere, and eontains the olfactory cells of Mix sichultze.

The hower or respiratory is a much wicker portion, in which the copthelium is colmmnar and ciliated, and includes the inferior turbinal bome with the lower jart of the fussil.

Inmediately behind the vestibule there are two shallow depressions separated hy a ridge, the agger nasi, or naso-turlinal; the area below the ridge is the atrium of the middle meatus. It is bounded posteriorly by the anterior vertical horker of the middle turbinal, beneath which it is continued into the middle moatus. The upper depresion is the snleus olfactorius; it learls upwards and backwark to the olfactory region of the nasil fossia.

The roof presents but one opening posteriorly, which leads into the sphenoidal sinns. The orifices in the cribriform plate are entirely closed orer.

FIf. 517.-OBLIQLE SECTION PASAIXg THRUCGH THE NASAL FUS-E, JET IN FRONT OF THE Posterior Nares. (Seen from behind.)

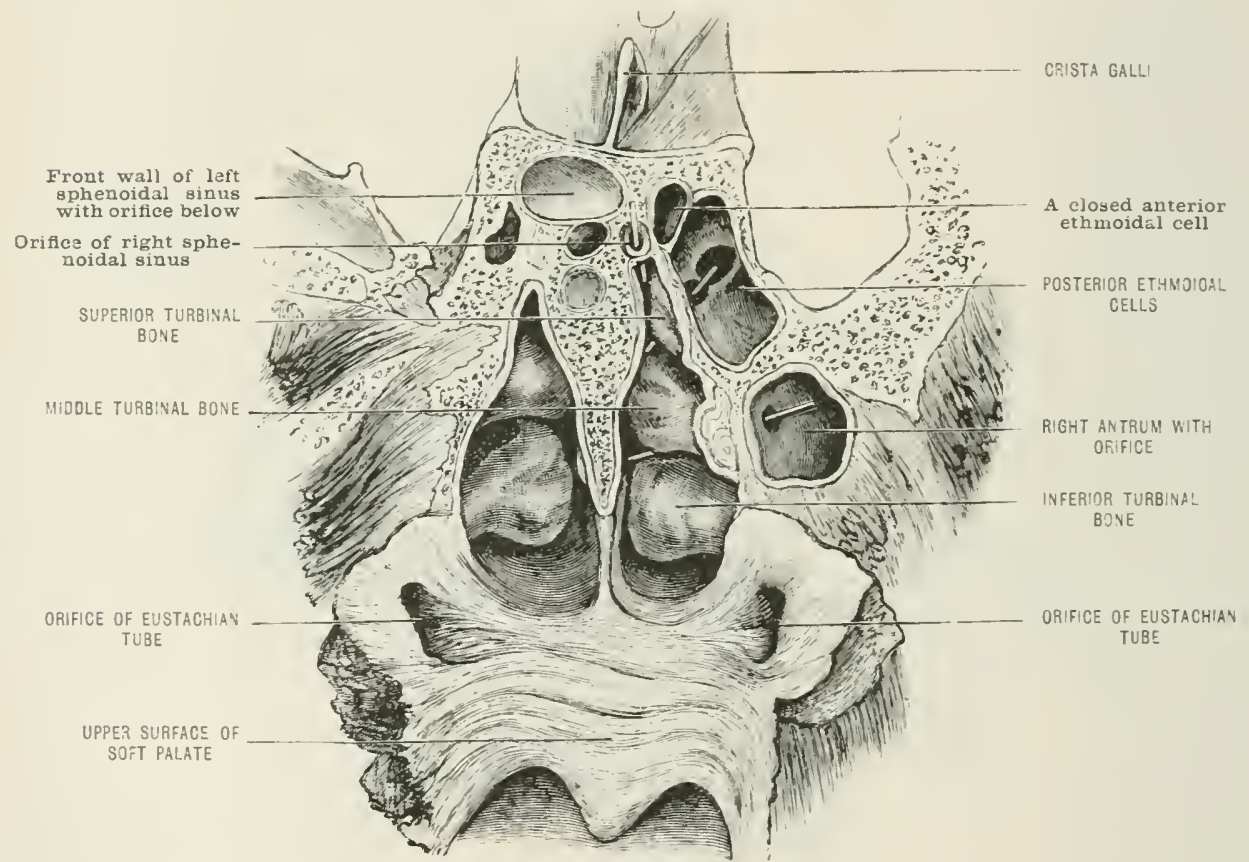

In the floor the openings leading into the anterior palatine canal are closed. The small cul-de-suc already described indicates their position.

The superior meatus is the shortest of the three; it liss in the posterior thirel of the outer wall under cover of the superior turbinal bone, and it has but a single opening, which leads into the posterior ethmoidal cells. The spheno-palatine formen is entirely covered by membrane.

The middle meatus lies in the pesterior two-thirls of the nasal chamber under cover of the mirlde turbinal bone. On its onter wall is a romeled eminence, the bulla ethmoidalis, which is perforated log the aperture of the middle ethmoidal (ells; and in front and bolow this is a curved groove, the sulcus semilumaris, which is continued above, hy the infunlihulum, into the frontal sinus; it receives the openings of the anterior cthmoidal cells and the antrum.

The inferior meatus is the longest of the three; it lies under cover of the inforior turbinal bone, and it receives the natal duct anteriorly. The mucous membrane is arranged around the opening in a circular valve, the valve of IIasner, which is sometimes double (page stis). 


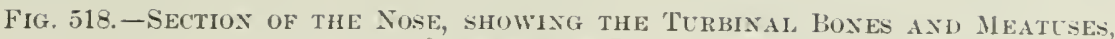
WITH THE OPENINGS IN DUTTED OETLIXE.

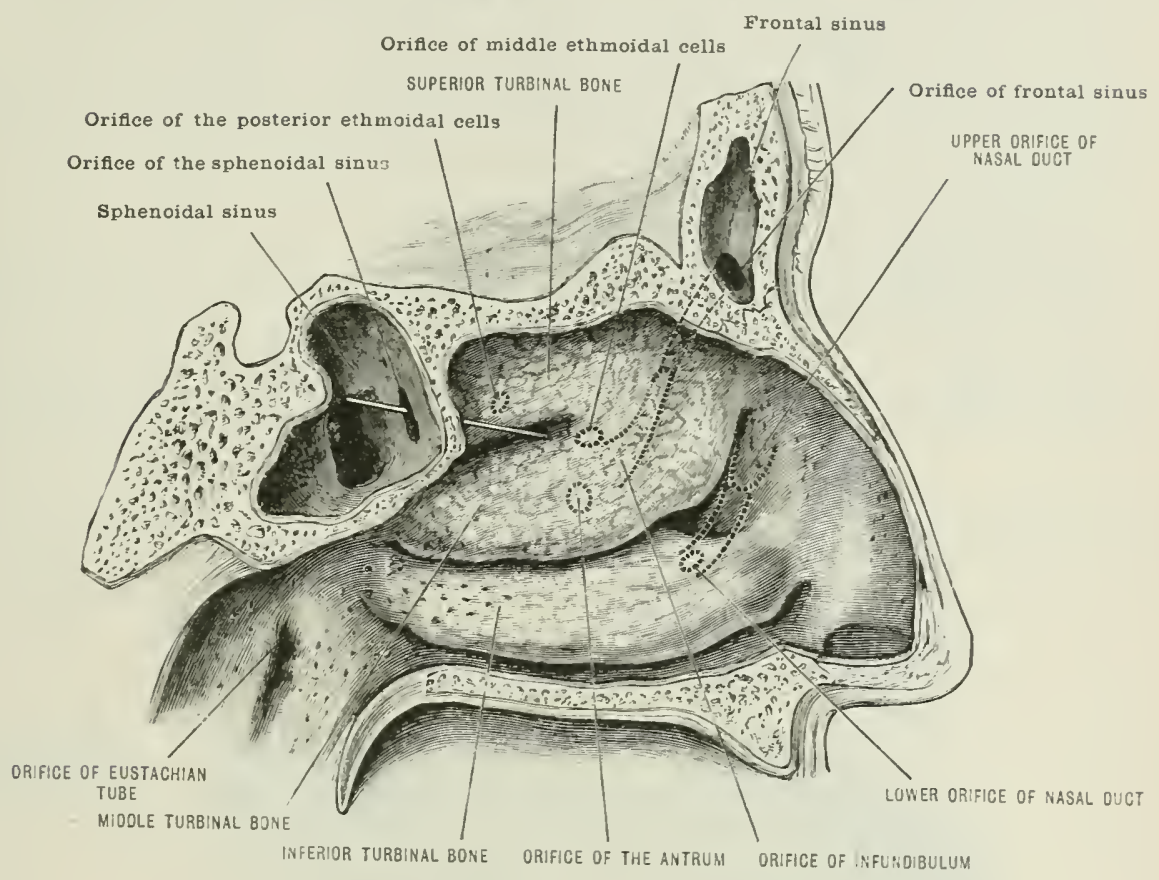

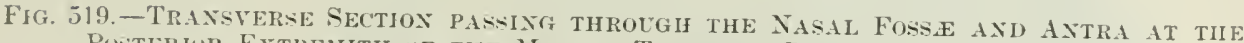
Pusteriur Extreitit of the IIDLle Turbixal Boxe. (Seen from the front.)

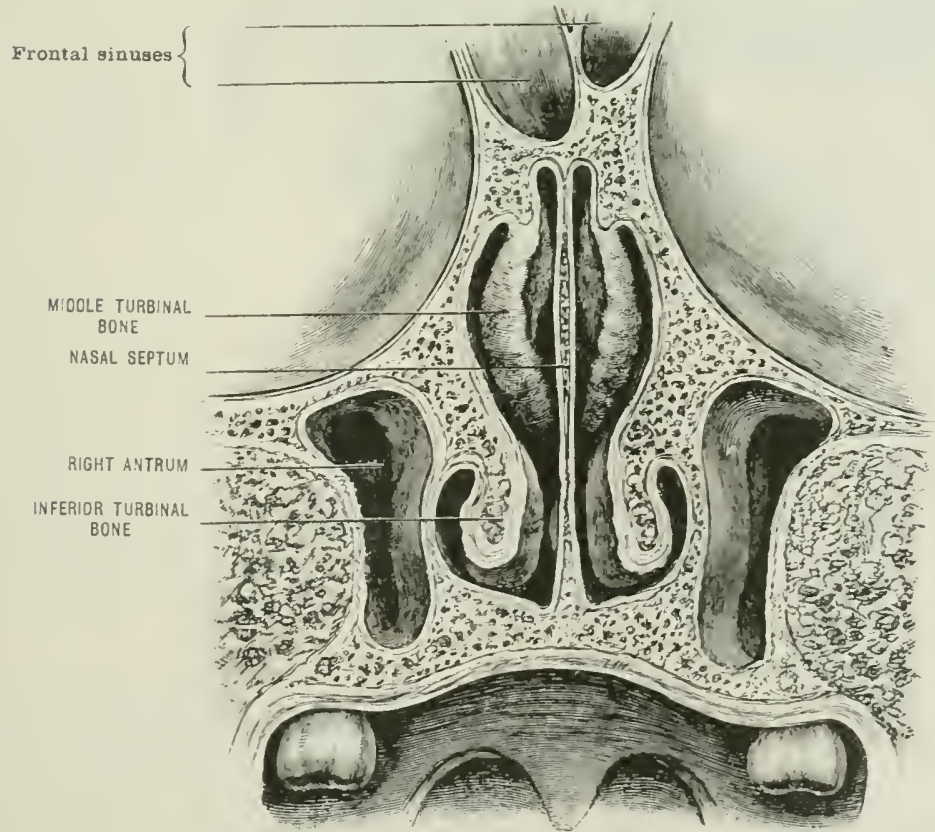


The nerves.-The olfactory or special nerves of smell, the filaments of which pass through the foramina in the cribriform plate of the ethmoid bone, lie for some distance in the grooves of the bony walls before terminating in the schnoiclerian membrane.

Those which supply the septum ramify in its upper fifth, whilst those which rach the onter walls are distributed in two groups-a posterior, to supply the membrane covering the superior turbinal bone, and an anterior, to rmify in the membrane orer the middle turbinal bone and the smooth surface of the othmoid in front of this.

In addition to the special nerves of smell, the eavity is supplied with nerves of common sensation derived from the fifth pair.

The nasal branch of the ophthalmic supplies the front and upper part of the septum, the anterior part of the roof and also the anterior part of outer wall of the nasal fossa.

The Vidian, with the upper nasal branches of Meckel's ganglion, supply

Fig. 5:0.-Nerves of the Nasal Cavity.

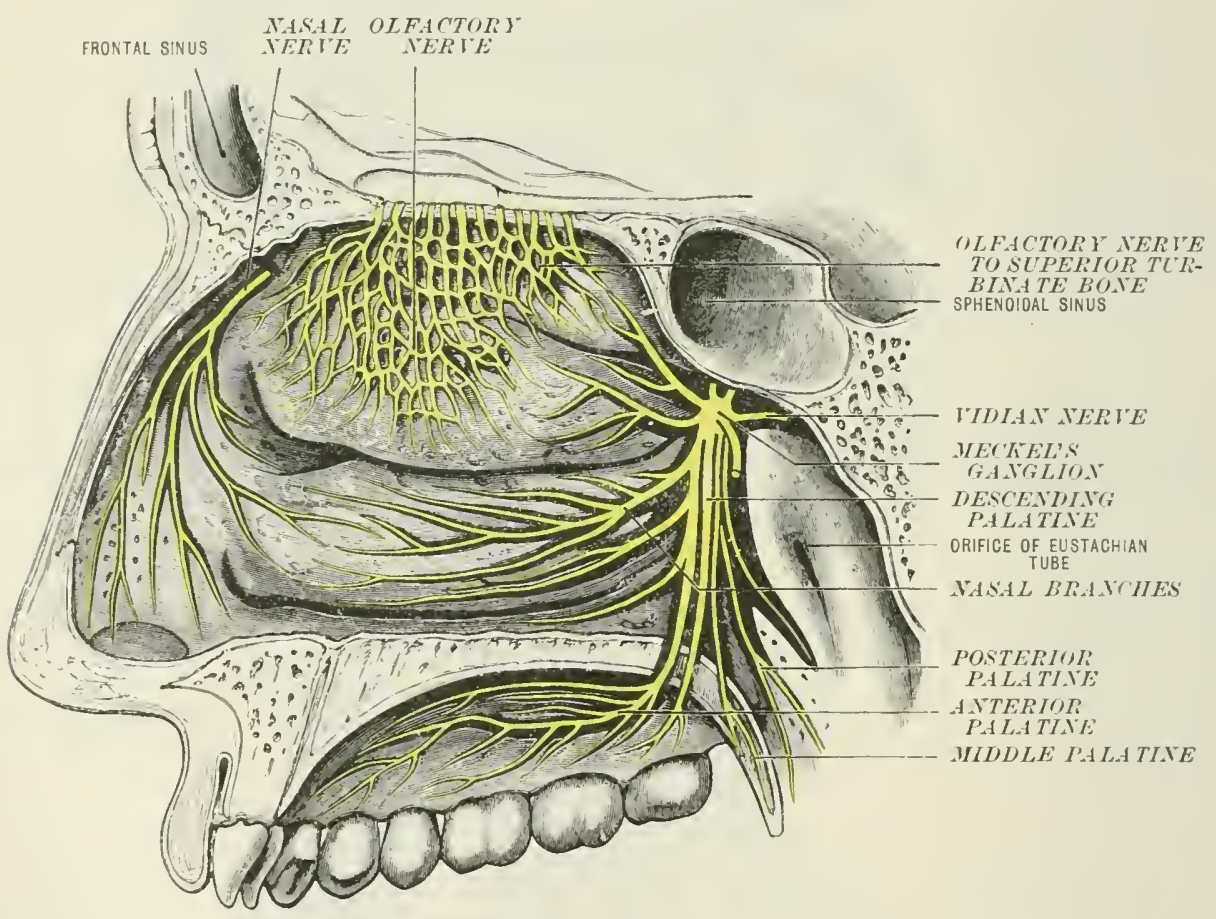

the upper and back portion of the septum, the loof, and the outer wall, including the superior spongy bone.

The naso-palatine supplies the lower and posterior portion of the septum.

The anterior dental branch of the maxillary division of the fifth nerve is distributed to the anterior part of the inferior meatus and inferior turbinal bone.

The anterior or large palatine nerve supplies in its course downwards the posterior part of the mildle and lower turbinal hones.

The arteries are distributed as follows:-

The spheno-palatine, from the internal maxillary by its internal or nasopalatine branch, supplies the septum as it courses downarls and forwards in the groove on the romer to the incisor formen. Its external branches supply the antrum (also supplied by the alveolar branch of the facial) and frontal sinus, the ethmoidal cells, and inner surfaces of the turbinal bones with the meatuses. It enters the cavity through the spheme-patatine foramen. 
The anterior and posterior ethmoidal arteries derivel from the ophthalnic supply the upper portion of the septum, the roof, the outer vall (anteriorly) and the anterior and posterior ethmoidal cells.

The descending palatine of the internal maxillary sends a few small branches to the back of the inferior meatus and lower turbinal bone.

The Vidian and pterygo-palatine supply the back part of the roof.

The branch to the septum derived from the superior coronary of the facial ramifies in the membrane covering its lower and front portion.

The reins form a plexus in the nucous nembrane, especially marked at the lower and hinder portions of the fossa. The emissary trunks accompany the arteries, the spheno-palatine joins the pterygoid plexus, the ethmoidal pass to the ophthalmic vein but also have communications with the meningeal veins, and the anterior part of the plexus is drained by reins which pass forwards to terminate in the tributaries of the facial rein.

Communications are formed with the veins within the cranial carity, through the cribriform foramina and foramen cxecum, and also with the facial vein through small foramina in the nasal bone and nasal process of the maxilla.

The lymphatics form a well-developed plexus, which communicates, through the lymphatics surrounding the elfactory nerves, with the subdural space within the cranial cavity, posteriorly with the pharyngeal lymphatics, and anteriorly with the limphatics of the face. 


\title{
SECIION TII \\ THE THORAX
}

\section{INCLUDING THE ORGANS OF VOTCE, RESPIR.ATION, AND CTRCTLATTON}

\author{
BY ARTIUR HENSIIN, F.R.C.S.
}

REVISED fOR SEroNd EDITION BY ARTHUR ROBINSON, MI.D., MI.R.C.S.

LECTURER ON ANATOMY IN THE MIDDLESEX HOSPITAL MEDICAL SCIOOL; EXAMIXER IN ANATUMY FOR THE COYJOINT BOARD OF EXGLAND

\section{THE THORAX}

T TuE thorax, or trunk of the body-lying between the neek and the aldomen-. is formed partly of bones and partly of soft connecting tissues. In the living body it is constantly varving in relation to the respiratory urocess. The cavity is hounded in front by the strinum and upper six costal cartilages and intermal intercostal muscles; behind by the thoracic vertehre and posterior ends of the ribs; and laterally by the ribs with the internal and external intercostal muscles.

Its form is conival, flattened in the adult from before backwarts. so that its transwerse is its greater diameter. In the human foetus, as in the lower animals, it is flattened laterally, its antero-posterior diancter being the greater.

It is narmw above, where the ribs are short, and broal below. (Mwing to the backward set of the hinder extremities of the rils, the boties of the vertelore project forwarls into the cavity, which thus, on a transrerse section, alppears more or less eordiform.

The superior aperture is bounderl, in front by the upper margin of the sternum; behind by the body of the first thoracie vertebra; on each side hy the first rib. It measures in a well-formed ardult alout two and a quarter inches frim liefore backwards, and four and a quarter inches from side to side. The rils slope downwarls towards the sternum, the upper marem of which corresponds to the intervertebral substance between the seeond and thirel thoracie vertelure. It transmits the following struetures:-(1) The stemo-hvoid and sterno-throid muscres, amel more derply at thin layer of the deep eervical fascia which bleids below with the sheath of the rreat vescels and the pericardium; (2) the thymus aland in the infant,

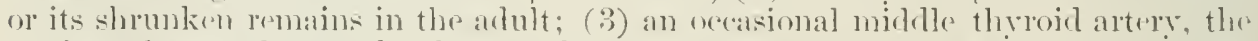

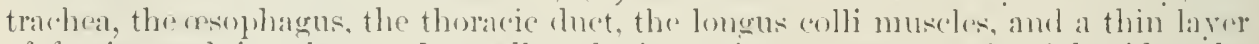
of fascia overlying them. Iaterally: the immonuate artery (on the right side). the common calotirl and suldelavian (on the left), with the intermal mammary and superior intereostal arteries; the imominate and inforior thyroid reins; the phrenie, phemmogastric, and sympathetic nerves. with the lelt recurrent laryngeal, some eardiac branches, and the anterior branches of the first thoracic nerve. On each 
side, in aldition, there is a small portion of the apex of the lumg with its pleural covering.

The lower opening, or base, is limited in flust by the ensiform artilase, behimel be the twelfth thoracie vertelora, and laterally by the twelfth rils.

The diaphragm arches upurarls to form a vaulted floor to the intervening space. It is alout one inch higher on the right side than on the left. and its flattened central portion is lower than either of the lateral arehes. The thoracie carty is mucle deeper behomd than in front.

The following struetures jass through the lower opening of the thorax:-(1) The aorta, vena azyos major, thoracie duet, the trumks of the efferent lymplaties from the lower interenstal spaces, and, occasionally, the left sympathetic nerve jaks

Fig. 521.-Axterior VIEW of the Thorax, With Octises of the DIAPHISAGI AND LUNGS.

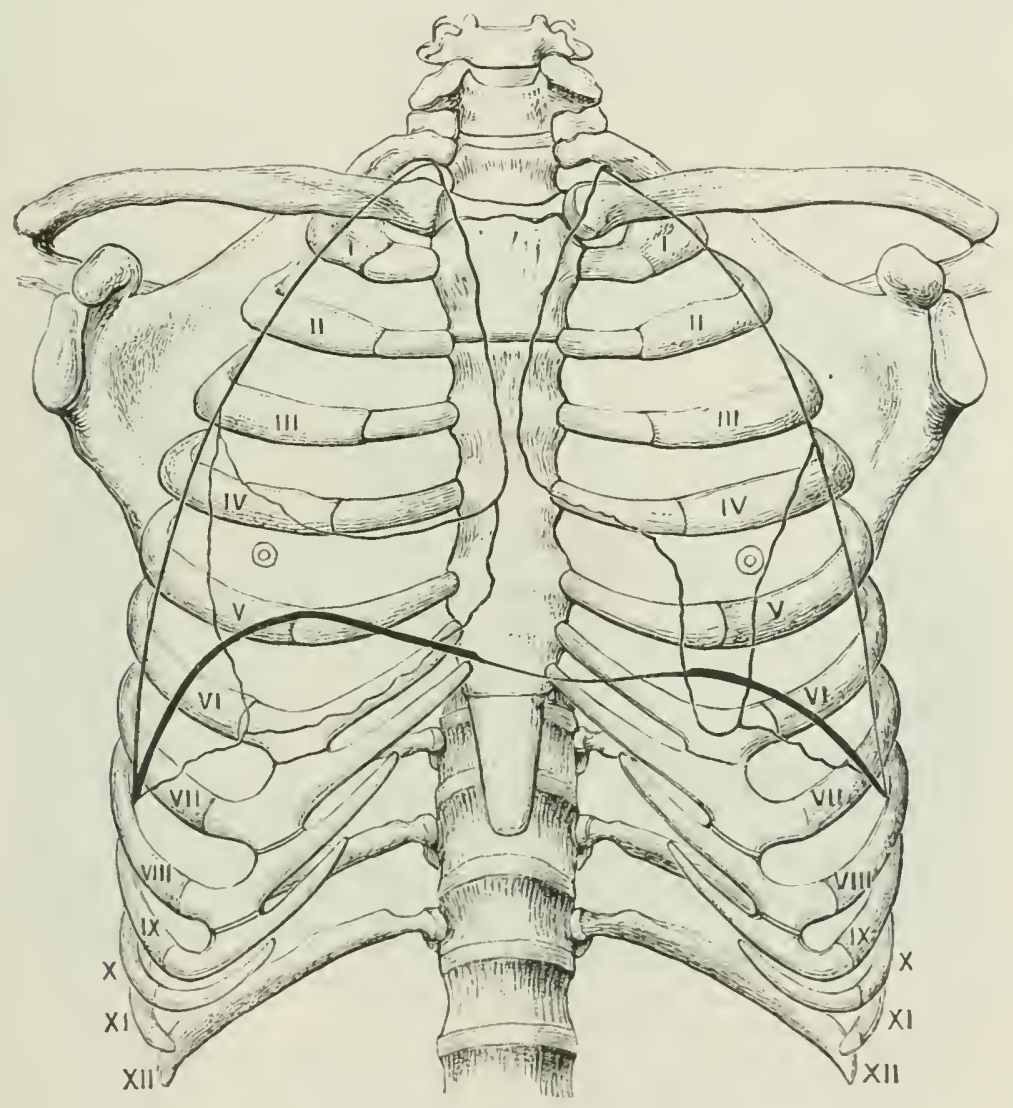

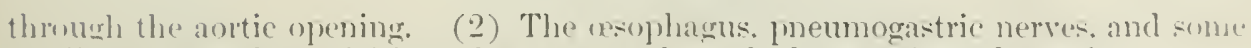

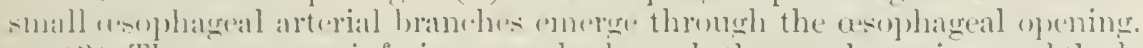

(3) The vena calat inferior asereds through the caval openinge and the branches

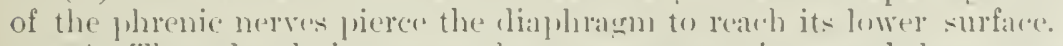

(4) The splanchnir nerves. the rena azgeres minor, and the sympathetie trunk of rach sirle pass through the wrurit.

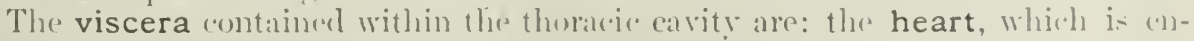
closid in the perieardium; and tlu lungs, with their pleural investments.

The heart lies hetween the lunes in the sir-alleri mediastinal space. This is bounded on each sile by the reflexions of the pleure, which pas from the fromt to

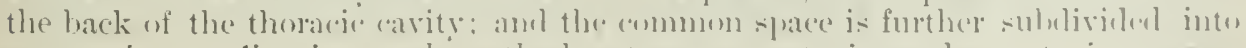
a superior mediastinum abue the heart sale, an anterior and a posterior lespec- 
tively in front of and behind it, and a middle mediastinum which contains the heart itself.

The superior mediastinum has the following boundaries:- the manubrimm with the origins of the stermo-lhyoid and stemo-thyroid muscles in front; the bodies of the four highest thoracie vertehre behind, with the lower portions of the longus colli muscles; and on each side the plemral saes. Above, the boundary corresponds with the superior aperture of the thorax, and below with a nearly horizontal plane passing backwark from the articulation between the manubrim and gladiolus of the sternum, to the lower part of the body of the fourth thoracic vertebra. This

Fig. 522. - Superior View of a Section of the Thorax, PAssixg throtgh the Stersta

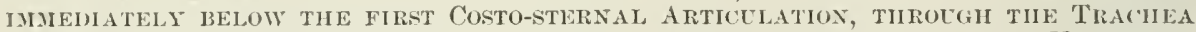

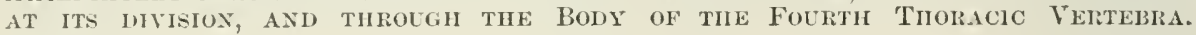
(Brame.)

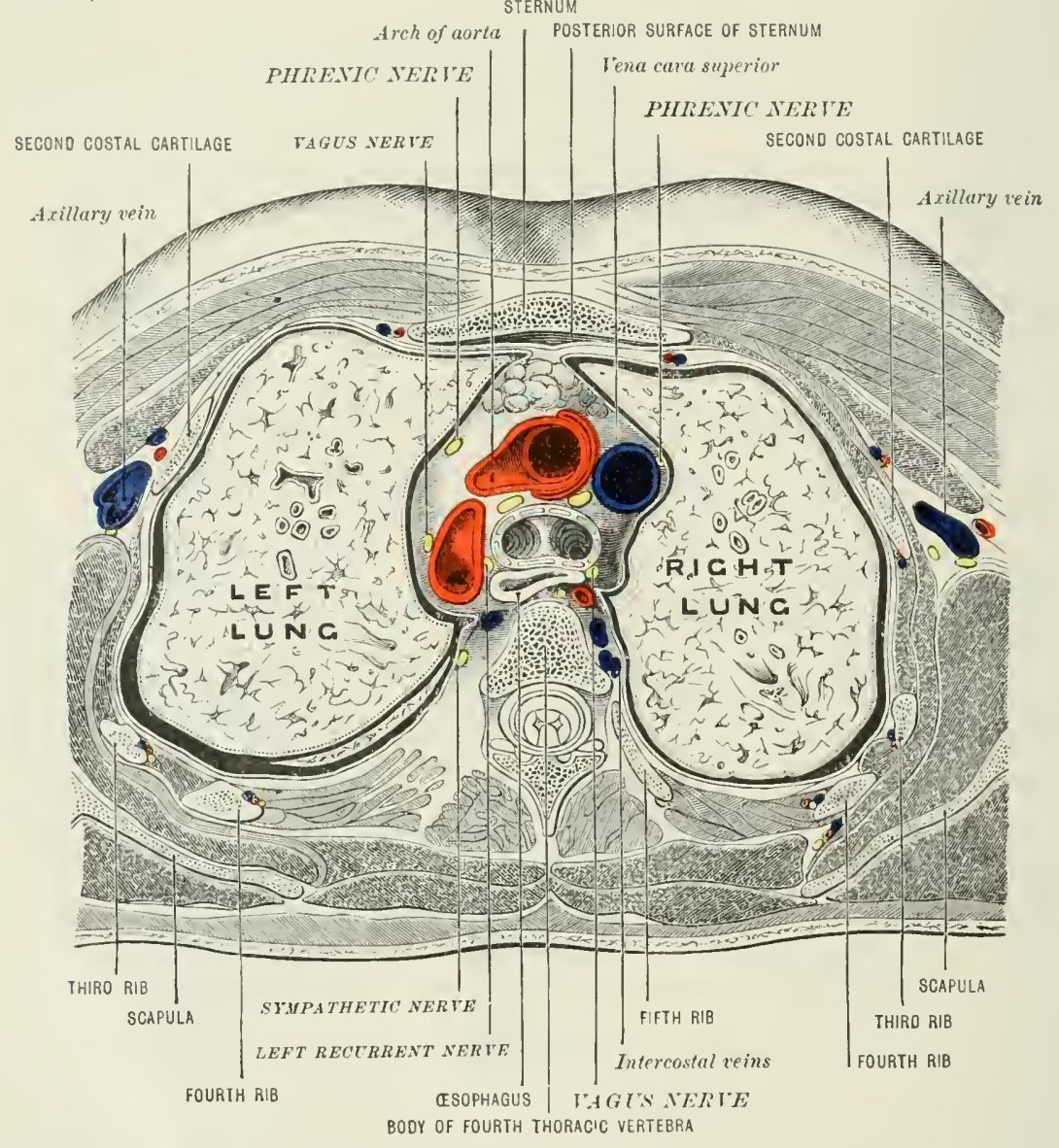

iower plane nearly eorresponds with the upper part of the pericardium and roots of the lungs.

The superior meliastinmm contains the thoracic portion of the trachea, nesophagus, thoracic duet, the arch of the alorti, the innominate artery, thiroidea ima, and thoracie portions of the left earotid and left subelavian; the inmeminate veins and nyper part of the superior vena cava, the teminations of the inferion thyroid and internal mammary veins of both sides, and the superior intercostal rein of the left side; the two pnenmogastrie nerves, with the left reeurent, the phrenic and cardiac nerves; the thymus gland or its remains, and some bronchial lymphatic glands, with the superior stemo-pericarliac ligaments. 
The middle mediastinum contains the heart, the ascending portion of the aorta and the pulmonary artery, the superior vena cava (lower half), all of which are placed within the perieardium; and in addition the phrenic nerves and their companion arteries, the termination of the azygos vein, the roots of the lungs. with some hronchial lrmphatic glands.

'The anterior mediastinum is narrow above, lying behind the sternum opposite the second, third, and fourth cartilages. Below, it opens out into a quadrangular space, having nearly the whole of the lower half of the sternum, the lower edge of the fourtl, the fifth, part of the sixth, and the termination of the seventh cartilages of the left side, with the triangularis stemi musele in front (fig. 521). The pericardium forms its posterior wall. The space merely contains some small lymphatic ghands and areolar tissue, and a few irregular bands, the inferior sterno-pericarcliac ligaments, with the thymus gland or its vestiges. It corresponds to the area of cardiac dullness.

The posterior mediastinum is hounded in front hy the roots of the lungs and posterior surface of the pericardium, and behind by the thoracic vertebral column below the fourth thoracic vertebra. On each side it is hounded liw the pleural saes.

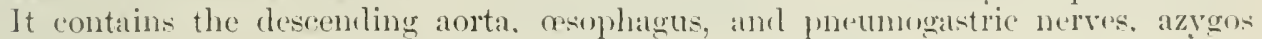
veins, thoracic duet, and lymphatic glands.

\section{THE ORGAXS OF VOICE}

\section{THE LARINI}

The larynx is the organ of the voice, and the protector of the air passages from the intrusion of foreign bolies. Br its closure, moreover, it retains the air within the chest eavity, contributing to the fixity of the thorax, a condition which is escential to the due performance of a variety of muscular actions.

It consists of a framesrork of eartilages held together by ligaments and acter ulum by muscles (extrinsic and intrinsic). It is linerl ly a very sensitive mucous membrane, and supplied with blood-ressels, nerres, and lymphatics.

The cartilages of the larynx are nine in number. Some of these are single. sone are arranged in pairs.
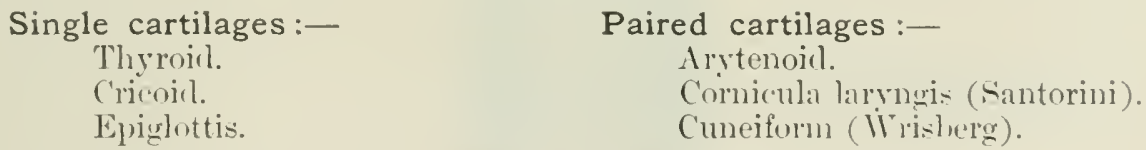

From their general structure they may be arranged as follows:-

$\begin{array}{lc}\text { Hyaline :- } & \text { Yellow elastic:- } \\ \text { Thyroid. } & \text { Epirgotis. } \\ \text { Cricoid. } & \text { Cornicula larygis. } \\ \text { Arytenoid (the tip of the arytenoid } & \text { Cuneiform. } \\ \text { is yellow clastic). } & \end{array}$

In the anteater there extends backwarls from each side of the epiglotti- to the summit of the arytenoids a continuous rim of yollow elastic eartilage. It is the broken remnant of this which in man forms the eornieula and the euneiform cartilages. (Bland Sutton.)

The THYROID CARTILAGE forms thr front and sicles of the upper part of the Jarrnx, heing platerl above the crionicl. It consists of two nearly square srmmetrical plates, or alae, united in front, where they form the pomm Ackmi, but widely 
separated behind. They inchule luetweren them an angle varying from $80^{\circ}$ to $90^{\circ}$, and are somewhat oblignely inclined, their outer surfaces looking slightly downwarls as well as outwards. Eitcll plate hats an outer and an inner surfice and four horders. The upper and lower pusterior angles of each plate project upwards and downwards to form its sllperior and inferior cormua.

The outer surface is smooth, and is erosied by an oblique and often vory faintly detined line, or by an ocensional fihrous band. This is marked at each extremity by a small tuberele. These tubereles are more pronomeed in old subjects. The line and the adjacent cartilage give attachments to the thro-hroid and stemothyroid muscles, and the inferior constrictor which orerlaps the sinaller portion of the ala lying behind the line.

The inner surface is also smooth; it is concave, and in contact with the mucous membrane which lines the sinus pyriformis, with branches of the laryngeal nerves and ressels, and with the extemal thyro-arytenoid and lateral crico-arytenoid museles.

Fig. 523.-Front View of the Carthages of the Lajyxi. (Modified from Bourgery :und Jacob.)

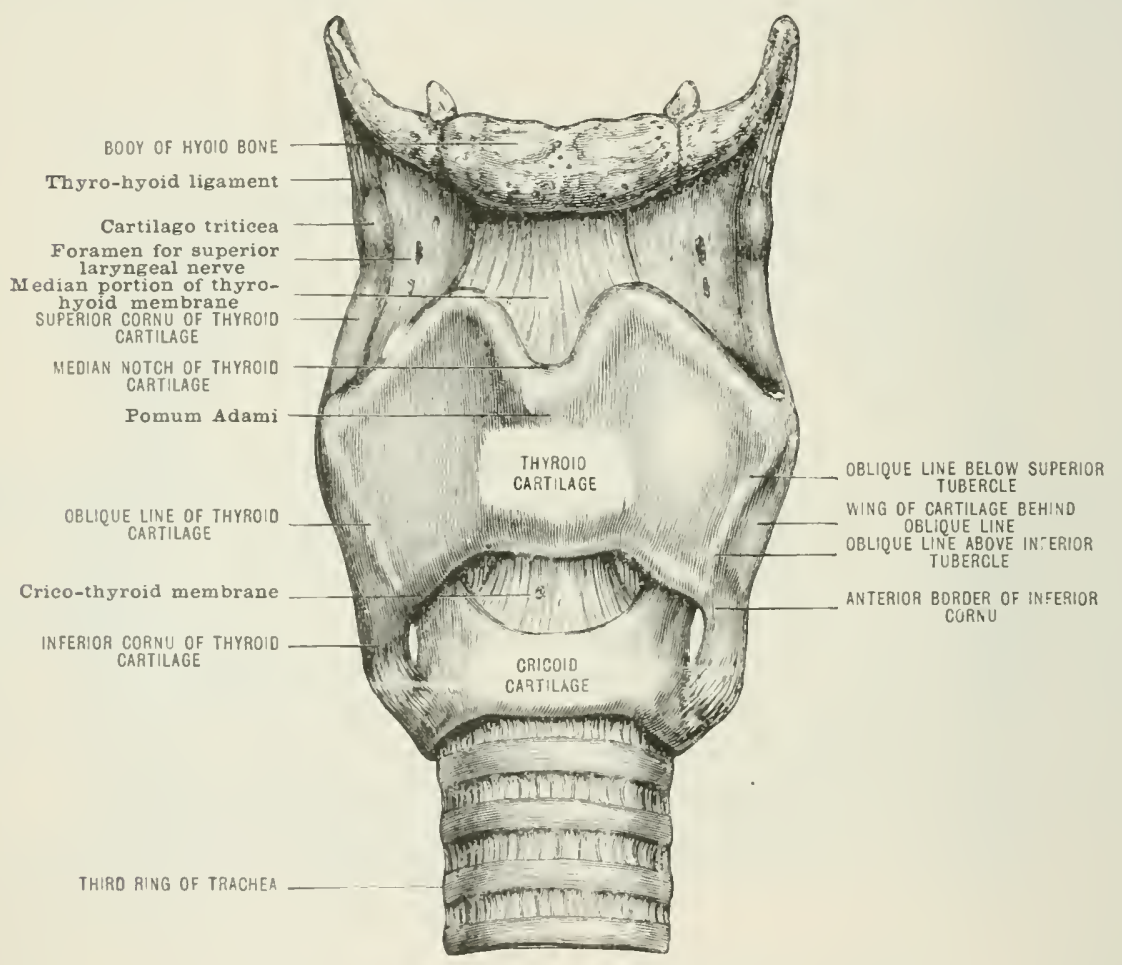

The anterior or isthmic border, which is also the shortest, corresponds to the junction of the two alie in the molian line in front; very prominent above, where it forms the pomum Adami, it heromes depressed before again projecting less markedly below. P'ostreriorly, at the angle of junction it grives attardment to the stalk of the epiglottis, the true and filse rocal cords, the thro-arytenoid and thrroepiglottidei muscles.

The superior border, which gives attachment to the thro-hroid memhrame, is sinuous. Slightly depressed posteriorly, it rises in front, and then beeomes alompty seoped out and "rerted to form the silde of the great median noteh.

The inferior border is somewhat sinnous. It gives attachment in front to the midelle portion of the crien-throid membrane, and behind to the crico-throvid muscle, and presents the smali tubercle already noticed at the termination of the oblique line. 
The posterior border, thick and rounderl. projerts alove and below into the superior and inferior cormua, and gives partial insertion to the stylo- and fralatojharyngei muscles.

The superior cornua project inwards as well as upwards and hackwards. To their tigs are attached the thyro-hyoid lisaments, and near root of each ajpears the tuberele at the upper end of the oblique line.

The inferior cornua are short, hlunt processes. They project inwards as well as downwards and forwards. By means of small oval concave facets (rlirected (ownwarls as well as inwarks) placed on their inner faces, the inferior cornua articulate with the facets on the sides of the cricoid cantilage. They give partial attathment to the inferior constrictors of the pharmx and crico-thyroid muscles in arklition to the ligaments of the joint.

The CRICOID CARTILAGE is thick and strong, and forms a complete ring around the lower part of the larynx. Behind, it presents a quadrate surface, but narrows

Fig. 524.-Side View of The CARTilages of THE LaRYxx. (Modified from Bourgery and Jacob.)

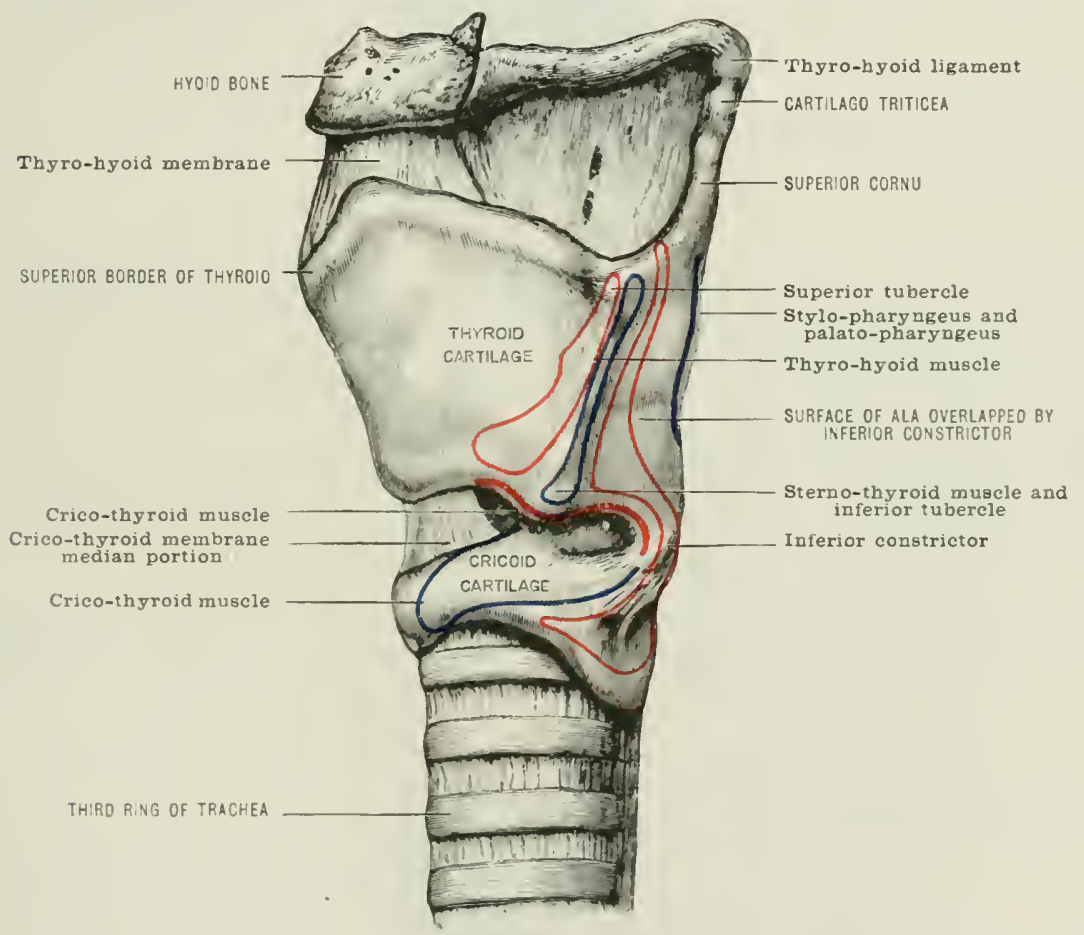

rapilly in its anterior half to only one-fourth or onc-fifth of its posterior depth. Hence its comparion to a signet ring. It thus possesses an anterior and a posterior portion, and a superior and inferior border, and presents four articular surfaces.

The posterior quadrate portion is divided behind hy a median vertical ridgr. which separates two broad and shallow depressions. To this ridge some of the longitudinal fibres of the asophagus are attached, and the depressions grve origin to the posterior erico-arytenoid muscles.

The anterior portion is narrow and rounded. and gives attachment in fiont to the crico-thyruil muscles. and more josteriorly to some filures of the inferior (') mstrictor of the pharmx.

Between these two halves of the ring, hut nearer the lower lorrler. is placed the oval surface (looking upwards and outwards) for articulation with the inferior cornu of the thrroid ('artilage.

The inner surface is smooth and lined by mucous nembrane. 
The superior border homds the quadrate plate above, and then passes obliquely downwards and forwards. An oval, convex, obliquely placed articular surface, mpon which mores the arrtenoid eartilage, separates these two prortions of the upper borline on each side.

The oblique half gives attaehment to the crico-thỵoid membrane, and, laterally and external to this, to the lateral crico-arytenoid muscle.

The inferior border-horizontal, and often deeply notehed at the sides-is attached to the first ring of the trachea by fibrous memirane.

The arytenoid cartilages are irregular, three-sided prramiels, which articulate

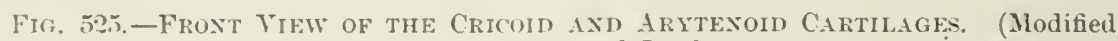
trou Bourgery and Jacoh.)

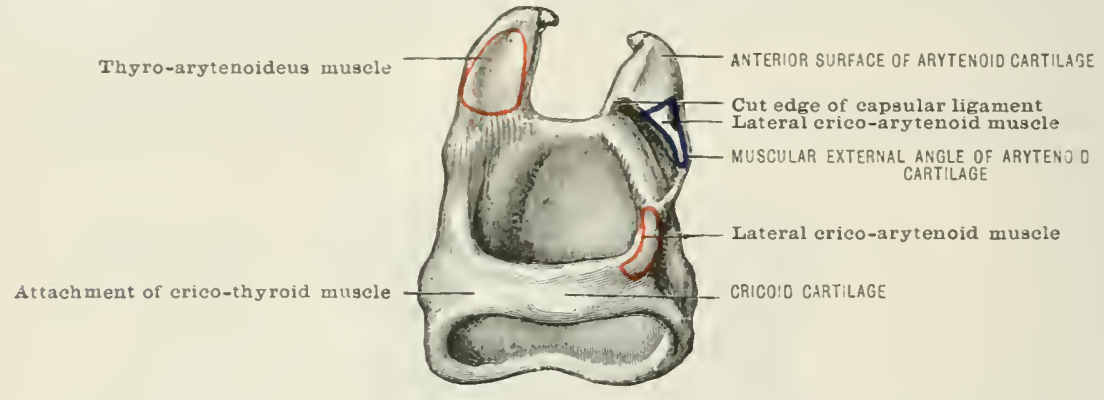

hy their hases with the oblique facets on the superior border of the cricoid cartilage, and support upon their apices the cornicula laryngis.

The space hetween them in certain animals has been likened to the mouth of a jitcher, and hence their name. Each cartilage presents three surfaces, divided by three borders, with a base, apex, and angles.

The surfaces. - The posterior is concare, smooth, and gives attachment to the arytenoid muscle.

The anterior is irregular and convex. It gives attachment by a small tubercle to the fillse vocal cord, and also to the thyro-arytenoid muscle.

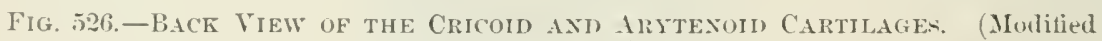
from Bourgery aud Jacob.)

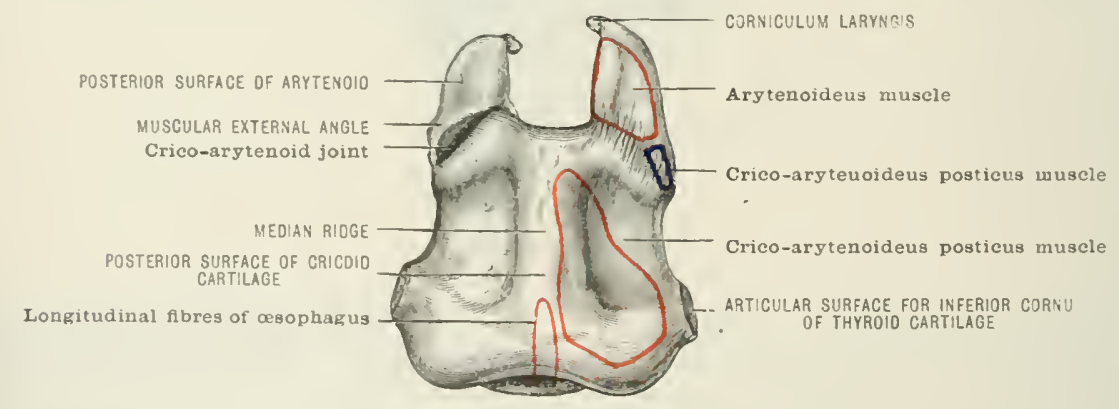

The internal is almost flat, smooth, and narrow, and covered by mucous: membranc.

The base is obliquely holluwerl, and presents internally the facet for articulation with the cricoid "artilage'.

The angles. - The anterior is jurolonger for the attachment of the true rocal

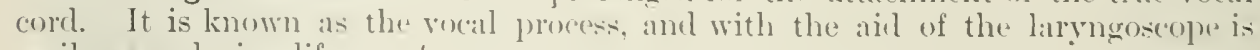
easily som during life.

The external or muscular is thick and hlunt. and gives attachment in front to the lateral erien-arytemoil, and behind to the pesterior erico-arytenoid muscle. 
The internal is unimportant; it is tied to the corresponding cartilage and to the

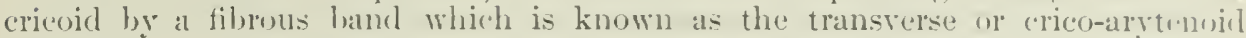
ligament.

The borders.-The two internal, which limit the narmw innor faee, are nearly parallel and alnost rerticul; whilst the external slopes upwards. inwards: and backwarls.

The apex projects inwards and backwarls, and supports the corniculum. The cartilage here becones fibrous in structure.

The EPIGLOTTIS is a median leaf-like plate of yellow elastic cartilage attached hy a stalk inferiorly to the retiring angle of the thrioid cartilage below the median noteh. When denuderl of its murous covering, it is seen to be pitted with numerous depresions for the lorlgment of glands (fig. 530 ).

Placed with its lingual surface above, and its stalk in front, it has boen compared to an elongated sadclle. It varies very considerably both in shape and inclination, its leaf-like portion being sonetimes considerably eurled upon it:elf. It is placerl nearly vertically in the adult, but in children is frequently so much depressed that its posterior free surface is inclined below its anterior. Hence its variable appearance when examined in the living subject with the laryngoscope. It is somewhat repressed and folded upon itself during deglutition.

Its anterior or lingual aspect is free above and corered with mucous memlirane. which lower lown is reflected forward upon the base of the tongue in three foldsone median (which encloses elastic tissuc) and two lateral-the glosso-epiglottidean folds. Beneath the mucous membrane the deeper attached portion of this: surface is tied to the hyoid bone by a median elastic membrane, named hyo-epiglottidean ligament, and by small bands of muscular fibres.

A ruantity of elastic and fatty tissue, closely blended with the hyo-epiglottidean ligament above, connects the epiglottis to the thyro-hyoid membrane in front. This is known as the periglottis (fig. 528). Still lower, the fibro-elastic ti--ue which forms the thyro-epiglottirlean ligament attaches the stalk to the throricl wartilage.

The posterior or laryngeal surface, concaro-convex from above downwards, and concave from side to sille, is free and covered with mucous membrane for it: whul. extent. About its centre it projects backwarls to form the cushion of the epiglottis.

The lateral margins, which are free ahore, grive attachunent below to the ary tenoepiglottidean folds of mucous membrane which form the boundaries of the suluriul aperture of the larynx. and also on each side to a fold of the membrane, containing filuous tissue, which runs upwards to the posterior pillar of the faucesthe pharyngo-epiglottidean fold.

The CORNICULA LARYNGIS, or cartilages of Santorini, are the two little conc-shajurl yellow elastic caltilages which projert backwards and inwards from the summits of the arytonoils, with which they are sonetimes directly continuous. A joint, howerer, is usially present.

The CUNEIFORM CARTILAGES, Ol' cartilages of Wrisberg, are placed within the aryteno-epiglotticlean frolls. These small conical and chongated rellow elastic cartilages prorlue the thickenings of the forks in front of the cornicula.

Calcification.-The hyaline eartilages of the larynx are especially june to calcify after mirlle lifr. but the vellow elastic cartilages take no share in the proces. The little cartilago triticea, howerer. which lies in the thyro-hyode ligitment. is fropuently converted into lone.

In the thyroid cartilage the deposit of hony salts usually commenow near the posterior horier and in the comma, extending forwards into the lower part of the ala, and tinally upwarls, until in adranued cases the whole cartilage is involvel.

In the cricoill cartilage the calcification conmeneses abose on each sille in the neighlourhoor of the crico-arytenoid joints, and extends downwards. and finslly both forwarls and backwarks.

In the arytennicl the calcilication commences in the hase. lut it finally involves the whole cartilage with the "xopption of the summit, where the hraline strueture (as already noted) disilpears.

The ligaments (extrinsic).-The thyro-hyoid membrane is composed 
mainly of elastio fibres. It is attached below to the upper margin of the thyroid cartilige, and above to the upper and hindermargin of the hyoid bone. It presents a thick eentral fortion (stretching betwern the median notch and the body of the hyoid bone), and thimer latroul portions, leoser in texture, which are piereed by the superior laryngeal nerves and arteries. Posteriorly, the membrane is loosely "ommeted with the smperior cormua of the thrrend cartilage, and above these it is hounded on cach side hy thickened bands, the thyro-hyoid ligaments, which pass between their tips and the wrater comma of the hyoid home.

A little grain-like cartilage (cartilago triticen) is usually imbedded in this band just above the superior thyroid cormu.

The eentral portion of the membrane is mainly subcutaneons, a bursa intervening where it is overhung by the body of the hyoid bone.

Its latral portions are covered by the thyro-hyoid muscles. Posteriorly it is separated from the epriglotis by the mucous membrane at the base of the fongue and the areolar fatty tissue already described. It is piereed by the intemal laryngeal ressels and nerves.

The crico-thyroid membrane (intrinsic) is composed chiefly of elastic tissue. It presents a prominent rounded median portion overlapped slightly by the cricothyroid muscles, but between these muscles it is subentaneons. It is erossed by a small anastomotic arch formed by the crico-thrroid twigs of the superior laryngeal artery; one or two small holes, which pass through it, transmit vessels from the areh to the interior of the larynx.

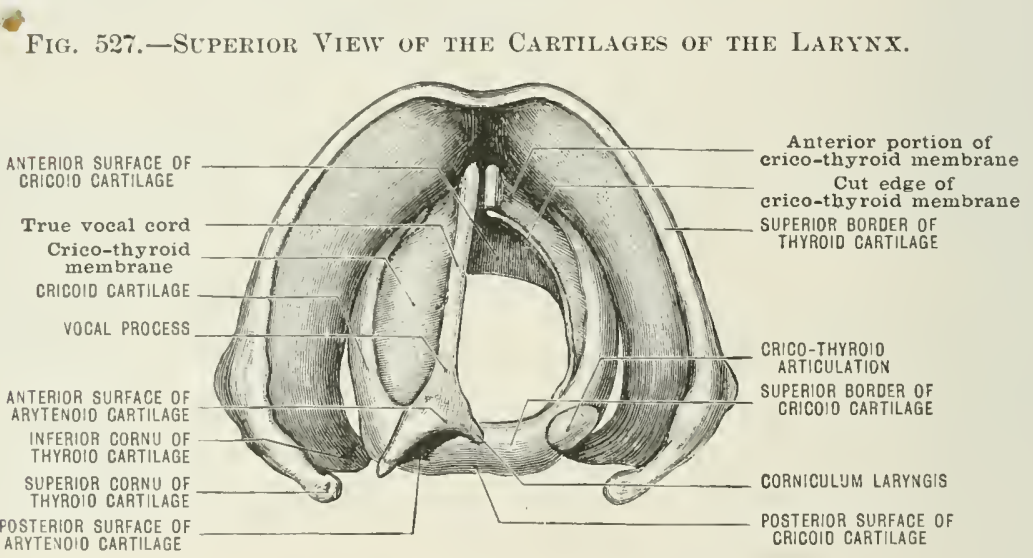

This median portion of the membrane stretches between the borders of the two cartilages. The lateral and thinner portions pass upwarls from the immer borter of the upper margin of the cricoid cartilage in contact with the larvingeal mucous membrane, and within the embrace of the thyroid eartilage, to form the true vocal cords or inferior thyro-arytenoid ligaments. These elastie hands extend from the rocal processes of the arytenoid eartilages to the retiring angle of the thyroid near its centre.

The lateral portions of this membrane are covered superficially by the throarytenoid and lateral crico-arrtenoid muscles.

The superior thyro-arytenoid ligaments are contained within the arched folds of mucous membrane which form the falie vocal cords. They consist of a $\mathrm{f}$ ' $\mathrm{W}$ bundles of fibrous tissue.

The crico-arytenoid or transverse ligament has been already sufficiently notiecrl.

The Joints of the Larynx.-The crico-thyroid joints are limed by a symovial membrame, embracerl hy a thin capsule of radiating fibres, and often strengthened posteriorly by a well-marked fibrous band. They permit of movement between the two eartilages upon an axis passing transversely through both joints, and a limited gliding of the cricoid mpards and backwards. As can be shown on the living body, the cricoid is the cartilage which swings between the inferior thyroid cormua. 
The crico-arytenoid joints posises a synovial membrano enveloped in a thin and moderately loose eapsule, strengthened posterioly hy a band passing betweren the reresid and the immer and back part of the arytenoid-the posterior cricoarytenoid ligament; and intemally hy the interarytenoid band, which is oceafionally ligamentons- the crico-arytenoid ligament.

The rricoid artieular surface is oral, convex, and ollique, with its lone axis passing from belind, forwards, and outwards. The opposed articular surfice on the base of the arytenoid is also oval, lut it is concave with its long axis bassing from before bickwards.

It follows that the two surfaces never completely cover each other at any one time. The arytenoid rotates on a vertical axis near to and parallel with its imner surface, and it also glides forwards and inwards, or in an opposite direction. These movements are associated-the glicling forwards and inwarls with the in ward rotation, and the gliding outwards and backwards with the outward rotation.

Fig. 528.-Side Vieiv of the MITacles and Liganents of the Larixx.

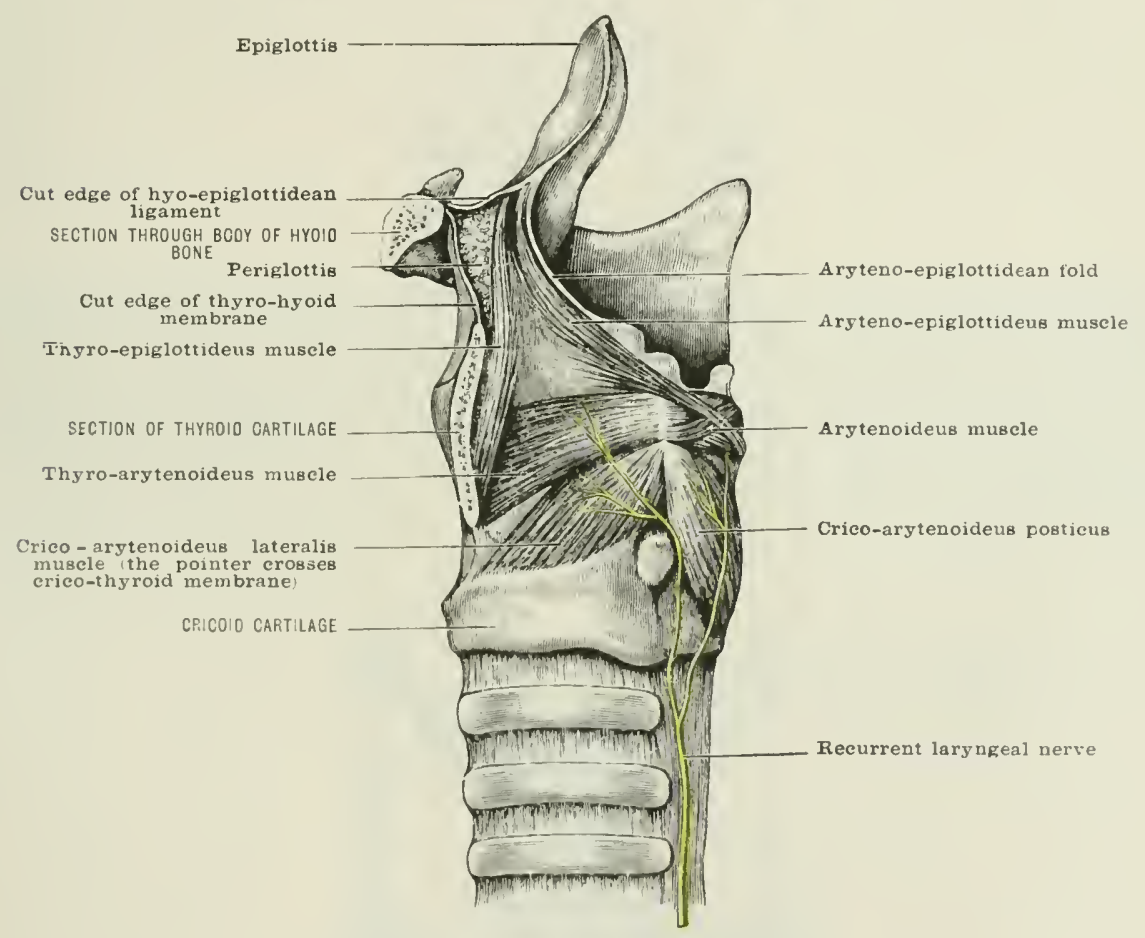

The Muscles. - The musces are divisible into an extrinsic gromp, lassine between the larynx and parts herond; and an intrinsic group, helonging entirely to the organ itsolf.

The extrinsic muscles are the sterno-throid, thrro-hyoid, strlo- and palatopharygei, and the inferior eonstrictors of the pharrox. It should he noted that the museles which fix the hyoid bone, and also these which close the bower jaw, assist the artion of the above mentioned.

The intrinsic muscles.- The crico-thyroid is attaned below to the fromt and side of the ericoid cartilage, and above to the lower border of the thrrobl raltilage. The lower fibres, which are horizontal and often distinct, pass to the fromt horice of its inferior comu, and act hy julling the eriend directly lackwarts, whilst the spreacling fibres which form the rest of the muscle swing the cricoid hetween the crico-thyroid joints, pulling it upwark as well as backwards. Both portions of the moscle make tense the rocal corks, and are supplied by the external larygeal nerve. It is overlapperl laterally by the sterno-thyroid, having beneath it a small 
portion of the crico-thyroid membrane and some of the lower fibres of the lateral crico-arytenoid miuscle. The central portion of the crico-thyroid membrane appears in the angular interval between the two muscles.

'The crico-arytenoideus posticus arises from the quadrate surface situated on aich side of the posterior median ridge of the cricoill cartilage. Its fibres rapidly converge to be inserted into the posterior portion of the outer angle (muscular process) of the arytenoiel cartilage.

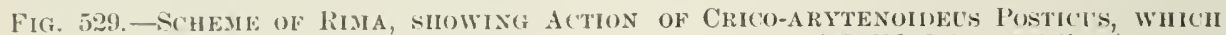
DRAWS TIIE ARYTEXOID CARTILAGE FROM I TO II. (Modified from Stirling.)

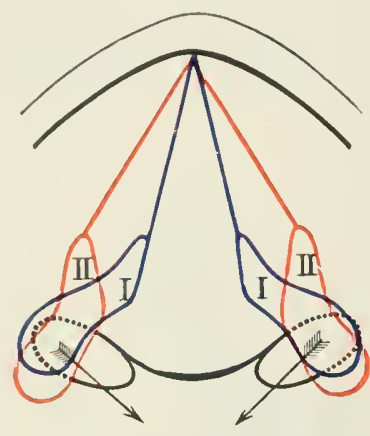

The upper fibres are chiefly concerned in rotation of the arytenoid cartilage, whilst the lower produce its gliding movement. It is a dilator of the rima glottidis.

Sone of the lowest fibres occasionally pass to the inferior cornu of the thyroid cartilage, and are known as the kerato-cricoideus or kerato-thyroideus.

It is covered posteriorly by nucous membrane, and is supplied by the recurrent larvngeal neve. A few of the longitudinal fibres of the cesophagus arise from the ridge which separates the two muscles.

Fig. 530.-Posterior View of Thyroid Cartilage with Epiglottis.

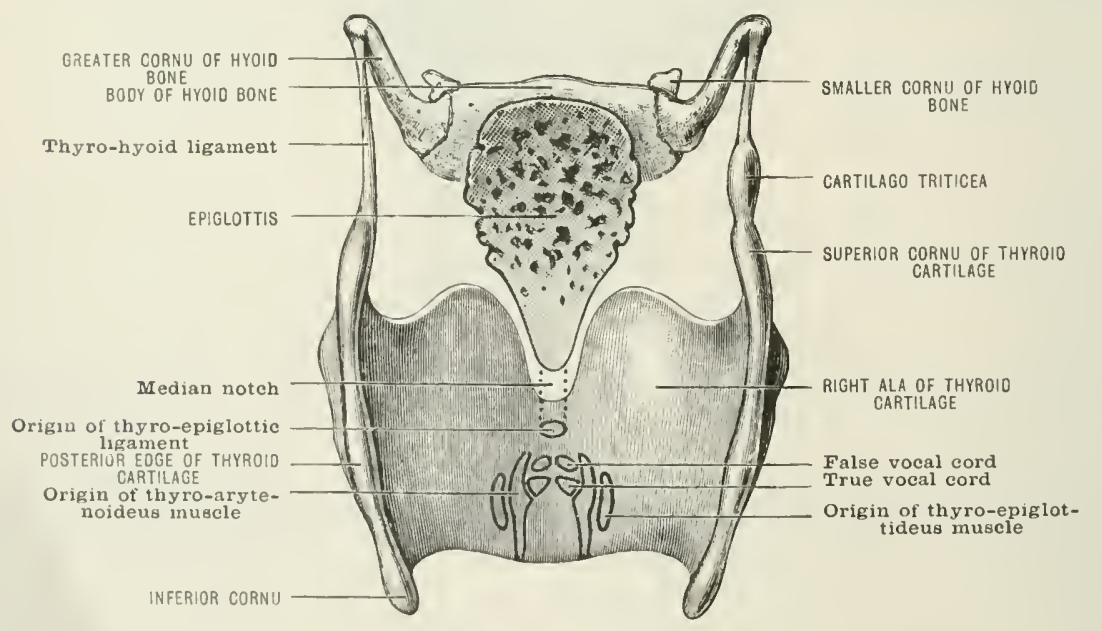

The crico-arytenoideus lateralis arises from the upper borcler of the ericoid cartilage between the origin of the erico-thyrotel and the crien-arytenoid articulation. It narrows to bo inserted into the fore part of the muscular process of the arytenoid cartilage. It draws the cartilage forwark, relaxing and approximating the cords.

It is overlapped by the thyroid cartilance, and anteriorly by the crico-thyroid 
muscle; internally it is covered by mucous membrane. The upper portion is antignous to the thyro-arytenoid, with which it is oceasionally blended. It is supplied by the resurent larvingeal nerve.

The thyro-arytenoid muscle, which is platerl above the foregoing, arisces broadly from the lower two-thirds of the inmer surface of the thyroid cartiline elose to its retiring angle, and slightly from the extrinal surface of the crien-thy-

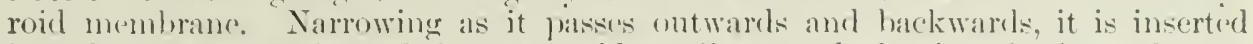
into the anterior surface of the arytenoid cartilage, and also into its base close to

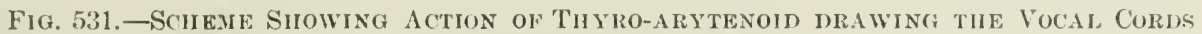
AND VOCAL Processis leros II TO I, (Modified from Stirling.)

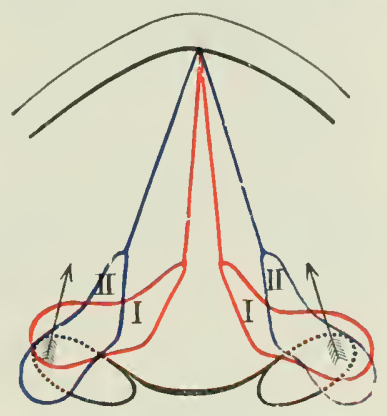

the attachment of the lateral erico-arytenoid muscle. Some few of its fibres palss onwirds and become continuous with the oblique fibres of the arytenoid muscle.

The lower portion of the musele lies parallel to and blends with the outer surface of the rocal cord. The upper and thimer portion is placed immodiately beneath the mucous membrane, and overlies the rentricle and laryngeal pouch.

These museles by rotating the arytenoid cartilages draw the rocal processes downwrds and inwards, and thus approximate the rocal cords. By pulling forward the cartilages, they relax the cort as a whole. According to some authorities, the fibres attached to the outer border of the vocal cord act upon it by

Fig, 53:- - SCHEME SHOWING ACTION OF ARYTExUIDEIS DRAWHAG ARYTENOII CARTLAGE fron Nentral. Position I to II, (Modified from Stirling.)

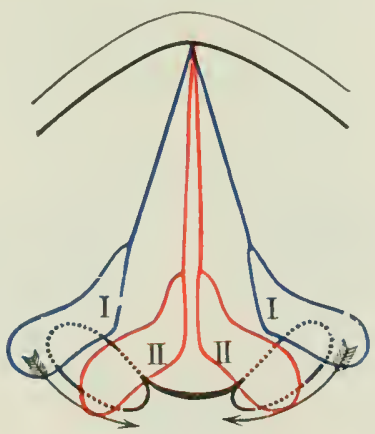

modifying its elasticity, tightening a portion in front and relaxing the remainder, in this somewhat resembling the stop-action of the finger on a violin string.

The fibres lying near the trus vocal cords, in the angle between the midhlle and lower sections of the laryngeal cavity, are fropuently described as a separate poution called the thyro-arytenoideus internus; they form a triangular prismatic lomble, attached anteriorly to the thyroid cartilage and the anterior part of the true rocal cord, and posteriorly to the arytenoid eartilage in the neighbourhoul of the rocal process. The remainder of the muscle, the thyro-arytconoideus externus, is a 


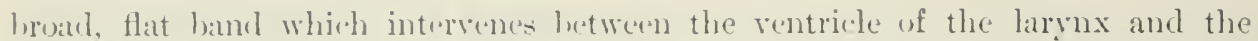
inner surface of the throid cartilige.

The arytenoideus consists of transverse fibes pasing from one arytenoid cartilage to the other, and attached to their posterior concare surfaces. Superfiedally are some olligue filmes. which decussate where they meet. These pats from the outer angle of one cartilage lowaw to the summit of the opposite. A few of these filores pass onwarks to the aryteno-epiglottidean fold and sirle of epriglottis. These, reinforeed hy filmes attached to the smmmit of the arytement artilage. constitute the aryteno-epiglottideus muscle. A few filmes blend with the thryoarvtenoisl musele.

The arytenoidens approximates and depresses the arytenoid cartilages. These actions are assisted by the aryteno-epiglottidei, which depress the epiglottis and contract the sulperior ajerture of the laryn.

The thyro-epiglottideus (sometines described as part of the thro-arytenoid) consists of fibres attacherl below to the throbid cartilage which, spreading alore, reach the aryteno-epightotictean fold, and the outer wall of the laryngeal pouch as well as the ejiglottis. (For the nerve-supply of the laryngeal muscles see page 912.)

The Interior of the Larynx.-The superior aperture, or opening of the glottis, is triangular in shape, wide in front, narrow behind, and placed so oblinuely as to be almost vertical in the living sulject. Above and in front it is boundert hy the epiglottis, behind and below by the interarytenoid notch, whilst on each side stretches the aryteno-epiglottidean fold containing muscular and ligamentous fibres. This fold presents two thickened areas, one at the summit of the arvenoid cartilage, and one just in front and above this, formed by the bulging of the cornicular and euneiform eartilages respectively.

Bomeled internally by this fold, and externally by the wing of the throrod cartilage, is a shallow defression-the sinus pyriformis.

The cavity of the larymx extemels from the aperture above described to the lower border of the erieoid eartilage.

It: lining of mucous membrane varies much in its colour and thickness and its fixity to the structures which it overlies. On the surface of the true voral cords it is extremely thin. pale and adherent, whilst above and below this it is more vascular and nore loosely attached to the underlying jarts. The submucous tissue contains numerous elastic fibres and mucous glanels.

The carity is naturally divicled into two portions-supra- and infra-rimaldivich ly the glottis or interval hetween the two true rocal cords.

The suprarimal portion corresponts to the space between the wings of the thyroid cartilage. It is broad and triangular above, hut narrower below, and its wills are much deeper in front than behind. Immediately abuse each rocal cort is an ollong depresion-the ventricle-hounded above by the crescent-shaped edge of the false voual cort, below by the straight margin of the true vocal corel, and externally hy the thyro-arytenoid muscle. The ventricle extends nearly the whole length if the rocal cords, and is lined by a thin and tightly adherent mucous membranc: It allows the free vibration of the true vocal cords in the probution of somnd. From the anterior part of the rentricle there cxtends upwards, for about half an inch, a sulall hlinel sac, named the laryngeal pouch. This reaches as high as the upper borter of the thyroid cartilage; its mouth below is narrow and guarder hy two little fokls of muens membrane. A delicate fibrous investment is contimed from the true voral cord around the sae. Some fatty tissue is enclosed within this. and its muenus lining contains numerous glanfls. On its outer side are some fibres of the thyro-arytenoid muscle; whilst on its inner sicle is a thing layer of muscular fibes, derivel from the aryteno-epighttileus. and sometines known as Iilton's muscle, or the compressor sacculi laryngis.

The superior or false vocal cords stamel farther alpirt than the true, and camnor

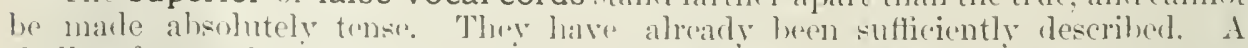
shallow fosil-the fossa innominata-is ohservble, repecilly during phonation.

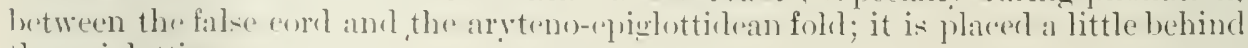
the epiglottis.

The inferior or true vocal cords are the structures encerned in the production of the voice. They stretch from the rocal processes of the arytenoid eartilages to the 
throrid cartilage, their tension and position rarying under museular artion. The cords are pearly white in alpearanee, and present thattened surfares where they fare arch other internally, with a free sharp edge above. It is this eelge which is thrown intorihations during phonation.

They are, arcorling to 'Testut, ahout four-fifths to one inch long (20) to $24 \mathrm{~mm}$.). in the cuale, and threes- to four-fifths of an inch ( 15 to $20 \mathrm{~mm}$.) in length, in the fimale.

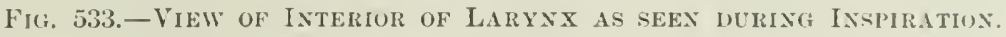

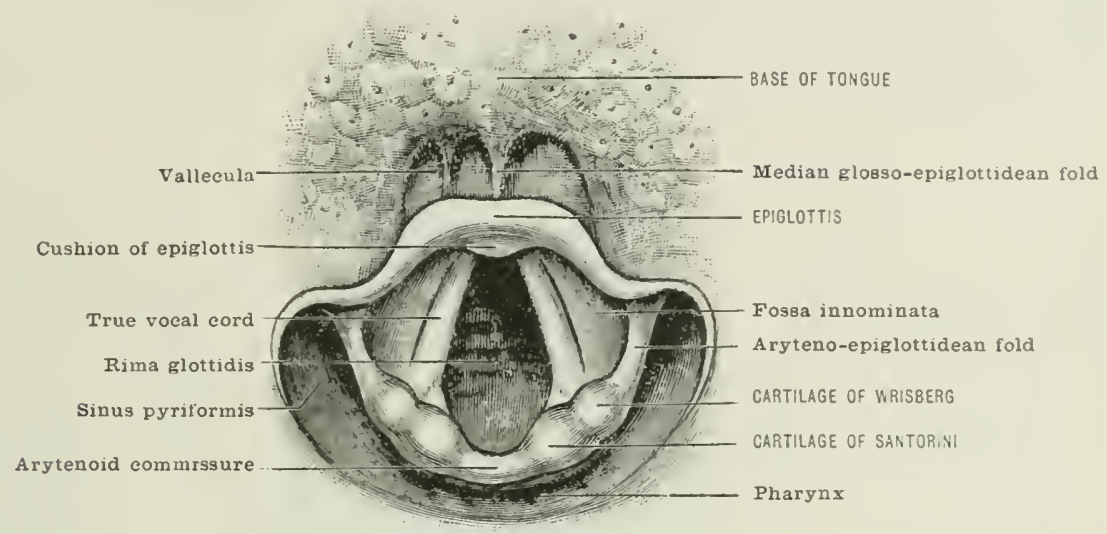

The rima glottidis is the chink bounded on each side by the vocal corrds and the inner surfaces of the arytenoid cartilages with their rocal processes; the intercordal portion is known as the glottis rocalis, and the interarytenoid part as the glottis respiratoria; the length of the former is the same as that of the rocal corls, amel that of the latter is about a quarter of an inch $(6$ to $7 \mathrm{~mm}$.) in the male and .) to $6 \mathrm{~mm}$. in the female. (Testut.)

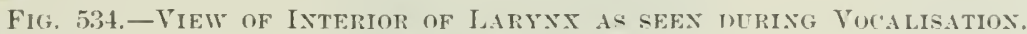

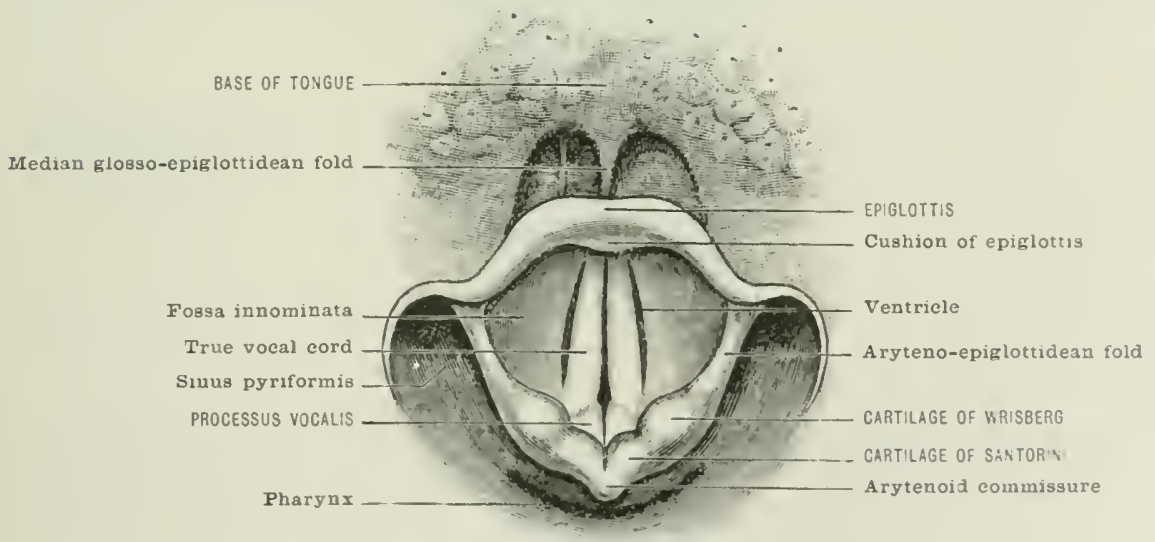

It is linited helind ly the interarytenoid fold, and presents the appuname of an clomgaterl triangle.

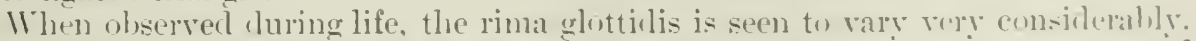
On inspriation the vocal corels. whilst almest touching in front, are sepratated

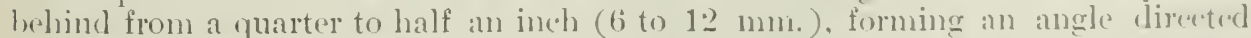
outwarls. where they terminate in the vocal processes. the glottis presuting a lozengre-shaped appearance. 
On phonation the cords beome parallel and closely approximated, and the vocal prencesses apmenching each other cause the anderle to be turned inwards.

The infrarimal portion of the linymx rapidly widens out into a nearly circular cavity at the lomere border" of the cricoid cartilage, from which point it is continumes with the lumen of the tracheat.

Nerves.-The nerves of the larrmx are derived from the superior and inferion (rowrent) laryngeal lowanches of the vilgus.

The superior laryngeal.- The sencory nerve of the laryx gives off near its orimin behind the carotid sheath a long and slender filament, which is principally 1novtor. This (external) branch is distributed to the crico-thyroid muscle, a few mimute filaments reaching the mucous membrane of the laryx.

Its larger and main branch (internal) is sensory, and passes through the

Fig. 535.-Nerves of the Laryax. (Posterior view.)

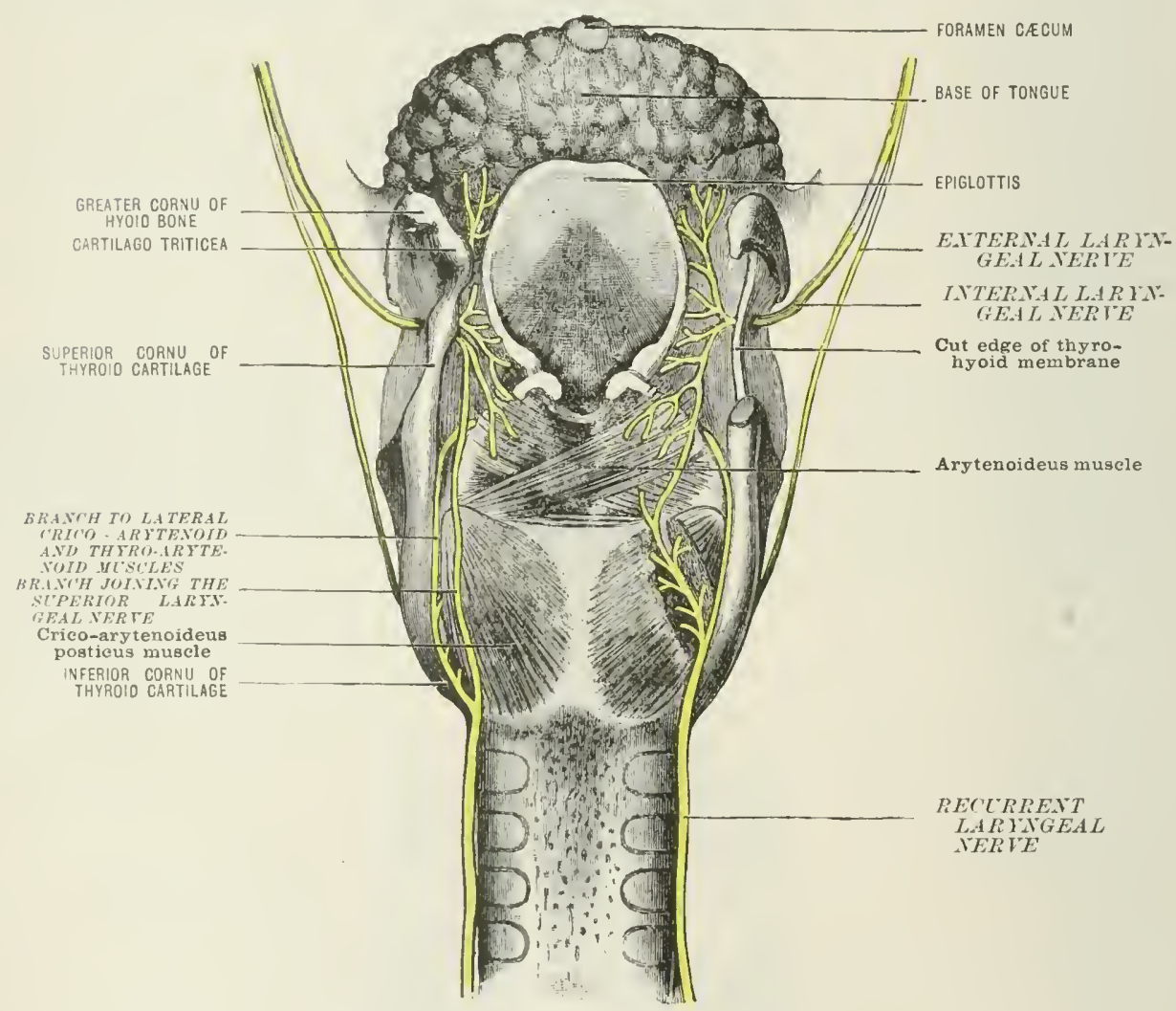

aperture in the thym-hyoid membrane above the superior laryngeal artery. It divides beneath the mucous membrane which lines the sinus pyriformis, ristributing branches upwards to supply both surfaces of the epiglottis and the base of the tongue immediately in front; inwards to the aryteno-epiglotticlean fold and its neighlmuhood; whilst others pass downwards to the mucous membrane of the decper portions of the larynx as far as the true rocal cords.

The inferior (recurrent) laryngeal, the motor ner've of the larrux, ascencls in the groove between the trachea ancl wesophagus, hoth of which structures it supplies. It reaches the laryx below the edge of the inferior constrictor, and immediately hehind the crico-thyroid joint. It this spot it rlivides into two liranches: an anterior to suply the thym-arytenoidens, crico-arytonoideus lateralis, with the muscles of the "lightettis; and a posterior branch to the crico-arrtenoideus posticuss and arytemoidens. 
The superior laryngeal emmmunicates with this branch by a slemeler filanumt, which pasese downwards near to the posterior borter of the thyroid cartilage. This communication sometines takes place bencath the posterior erico-arrtenoid muscle.

The arteries are lerived from the superior and inferior throbid, the epriglottis receiving some twigs from the dorsalis lingue of the lingual.

The veins correfomel with the arteries; and the lymphatics, which are scanty, follow the ressels and end in the deep cervical glands.

\section{THE' TRAC'HE-A}

The trachea, or air-tube, which is cylindrical in shape. hut flattenerl posteriorly, extends from the lower border of the fifth cervical vertelma to the fourth or fifth thoracic vertehra. It is contimuous with the larrux above, and divides into the wo hronchi below. It measures from four and a half to five inches (10 to 12) (cm.) in leneth, and is nearly an inch $(2 \cdot 5$ con. $)$ in width.

Relations.-In its cervical portion it rests upon the cesophagus, which curves somewhat to the left at the root of the neck; wn each siche, but especially on the left, it comes into relatiomship with the lateral lobes of the thrroid gland, the inferior thyoid arteries, and the remurent larrngeal nerves (these latter running upwarls gain the kateral groove between the trachea and oesophagus); and lastly, it is in relation with the sheath containing the common earoticl artery internal jugular vein, and pnemonogatric nerve.

In front it is arosied, opposite the second, third, and fourth rings. by the isthmus of the throvid bodr; above the isthnus it is concealed in part by the fyramidal bohe of the thyroid and ly the levator glandule throirlea musce, and it is crossed he the intrinal torminal branches of the superior throid arteries. Below the isthmus the inferior thyroid veins, the thyoidea ima artery, if it is fresent, and the remains of the thymus glanel lie in close relation with it, and more anteriorly, separater from it by the serep cervical fascia, are the anterior jugular veins and their anastomosis ahove the sternum.

It is overlapped on each side ly the stemo-hroicl, stemo-throid, and stemomastmid muscles, and the interval betwern the muscles of the two sides is crosicel by a strong deep and a thimmer superficial laver of derf cervical fascia, whilst still more superficially lie the superficial fascia and slin.

In its thoracic portion the trachea still rests upon and retains its comnedion with the asophagus, which splarates it from the spine. It lies between the two pleural sacs and premmogastric nerves. In front of it is the sternum with the origins of the stemo-hyorit and stemo-thyoid muscles, the thymus gland, the deep' cardiac plexus, the aortic arch which rosses the tuhe just above its hifureation. the commeneements of the innominate and left common carotid arteries and the left innominate rein which roses the routs of the latter vessels. On its right sicle are the plemral sae, the vagus nerve, and the imnominate artery, and on its loft

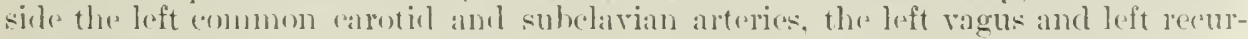
rent nerves, and the left pleural sale.

Structure.-The trachea is marle up of a series of imperfect cartilaginous ringr:

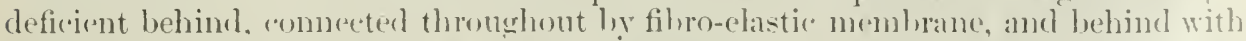
muscular fibres (the trachealis muscle), a sprecial laver of yollow clastic fibres, and a lining of mucous memlinine.

The cartilaginous rings vary in number from sixten to twents. They are ineomplete. heing defieient in the hinder third, and are commected in a eontinuous series by a fibrous membrane, which diviches to enclose them, but remites in the narrow intervals between. It forms a definite layer where the cartilages are wanting, so that it may le regarded as complete throughout the tube. The inside of 
the trachea is ridged transversely hy the rings, which are rounded on their inmer surfaces; hut it is companatively smooth externally, where the outer surfaces of the rings are flattencel.

The first cartilage is broarl, and is oecasionally united with the cricoid above. or second ring of the trachea below.

The last cartilage is likewise broakl and strong, and semds a corred beak downwarls and hackwarks at the point of hifureation of the tracheal. It forms an imperfect ring on each side alove the commenesment of the corresponding bronchus.

Two cartilages not nucommonly unite in part. and thus present a bifureated appearance.

The fibres of the trachealis are unstriped, and form a transierse larer at the

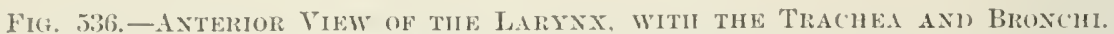

(Modified from Bourgery.)

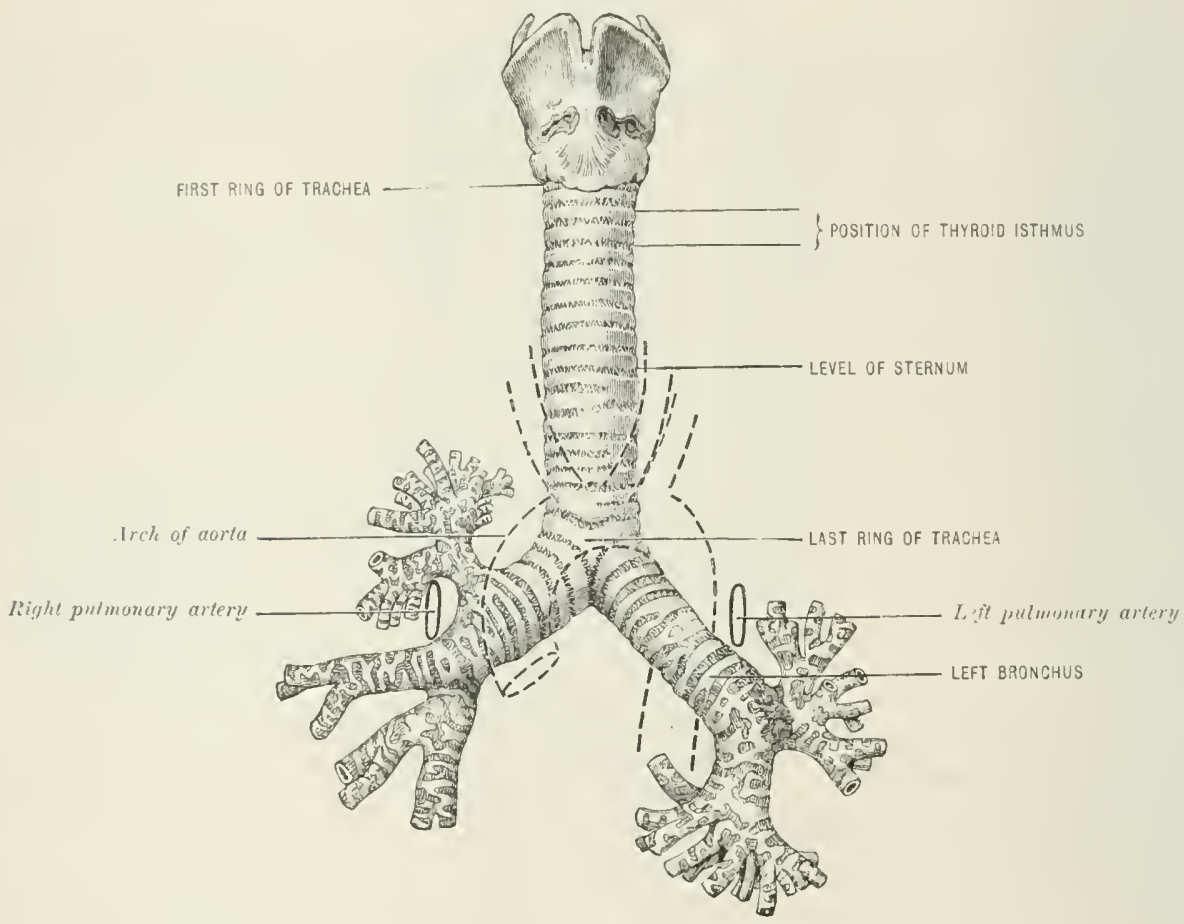

posterior flattened part of the tube, with an indistinet layer of longitudinal fibres superinumsecl.

The yellow elastic fibres, which exist througlout the entire mucoms membrane, form a definite and cleer layer at the posterior flattened portion of the tube. They are gathered into strong longitudinal thattened bands, especially well seen at the lower part of the trachea, and where the fibres ecparate to jass into the brombi.

The mucous membrane is smooth and pinkish in colour; it is provided with mmonems glands, wisecially at its hinder part, and is lined by a colummar ciliated epithelium.

The arteries are derivel from the inferior thyroid.

The veins join the thymid plexuses; and the nerves are supplied hy hranches from the fonemongatric, the recurrent laryngeal, and sympathetic. 


\section{THE BRONCIII}

The right bronchus (iig. 5.36), from its (ommmencement to the origin of its first branch, is about one inch in length (25 mm.). It is shorter and wider than the left, and in direction nore horizontal in its passige to the reot of the lung.

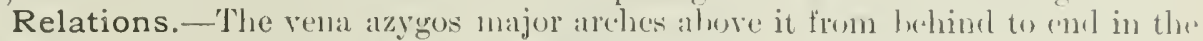
superior venat caval, which latter is placed anteriorly. The right pulnomary artery is at first below, and then in fiont of it.

The left bronchus is about two inches in length (50 1mm.) outeicle of the. lomg. It is more obliegue, longer, and narrower than the right.

Relations. - It lies beneath the areh of the aorta, and rests upon the osophagus and the descending aorta. The left pulmonary artery lic's in front of it. On looking down the tratehe the dividing ridge between the two bonchial orifices is seen to be on the left of the midlle line, more of the right orifiee for this reason being visible. This explains the fact that foreign bexdies entering the trachea most commonly become lodged in the right bronchus.

Above the point where it is arossed by the pulmonary artery the right hondens gives off an eparterial branch to the upuer lobe of the right lung. Below the proints where they are crossed by the pulmonary arteries, in the sulsstance of the lumgs, both bonchi give off two series of hyparterial branches, lateral and donsal, which rise alternately. The clorsal branches pass towards the posterior borders of the lungs, and the lateral branches curve outwards and forwards towards the anterior borilers. The first lateral loranch on the right side supplies the midelle lober and the first lateral branch on the left sicle the mplere lobe, all the remaining livparterial branches are distributed to the lower lobe. In addition to the two main sets of hyparterial branches a number of small arcessory bronchi arise from the anterolateral aspect of each stem hronchus; of these one which rises on the right sirle a short distance below the level of the first clorsal hronchus is called the cartiac bronchus, becanse in some mammals it supplies a sperial lolw of the right lung which lies below and posterior to the heart. "This small bronchus is the fourth branch from the right stem bronchus.

As the pulmomary artery passes fownwards in the lung it lies on the posteropxternal asperet of the stem bromehus between the lateral and clersal branches, and the pulmonary rein is situated on the opposite side of the tube.

\section{THE THYROID BODY UR (IIANI)}

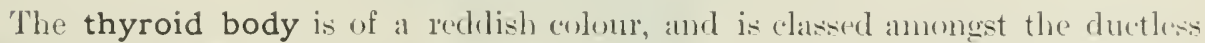
glands. It consists of two lateral lobes, and a comnecting isthmus whirlo unites them lelow.

The gland is convex and roumeded on its outer surfanes, but dexply it is momleded to the parts which it overlies. It commonly woighs from one to twe onnces. but is larger in the fonale, and is often inereased in size during menstruation.

The lateral lobes are prriform in shape, with their broal ends betow, and masures about two inches (.50 mmo.) in length, three-puatersuf an inch (1s mm.) in hreadth, and alout an inch (2.) mm.) in thickness near the nindelle.

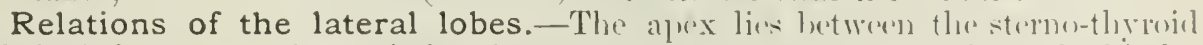
and the inferior constrictor of the pharyex. the lister separating it foum the limele part of the alat of the thyrescl eatilage and its inferior eormu. The hase is rommlext;

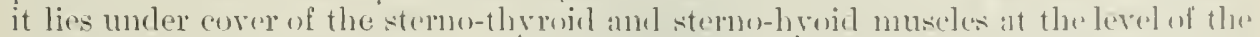
sixtly ring of the trachea and alwit three-fuarters of an inch (1.5 mm. ) abure the

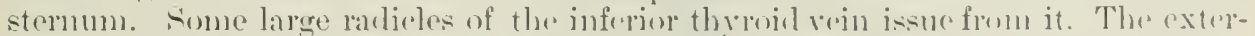

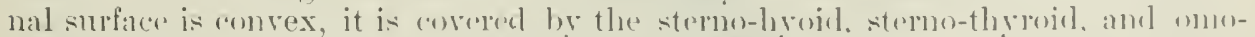

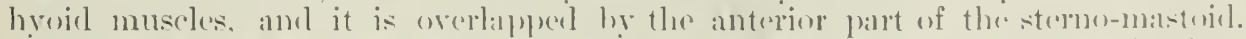

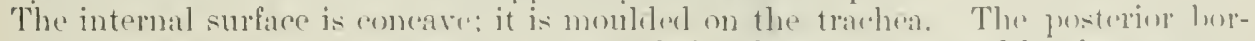

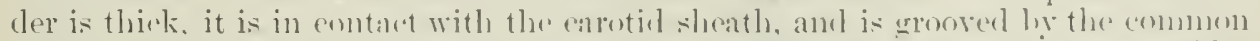

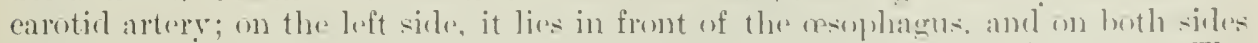
in front of the recorrent laprogeal nerve and the inferion theroid antery. The anterior horler is thin, alowe it is in relation with the intremal terminal hianch of 
the inferior throblartery, and in the lower part of its extent it is united to its fellow of the oplosite side by the isthmus.

Relations of the Isthmus. - The isthmus varies in hreaclth from a quarter to three-quarters of an inch ( 6 to $15 \mathrm{~mm}$.). Its anterior surface is convex and it lies in relation with the dere fiscia, anterior jugular poins, superticial fiscia and skin. Its posterior concare surface rests upon the second, third, and fourth rings of the trachea. Its extremities are commected with the lower parts of the inner borders of the lateral lohes. Its lower border gives exit to some trilutaries of the inferior thyroid reins and its upper border is in relation with the anastomosis between the

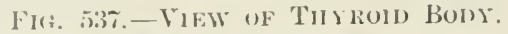

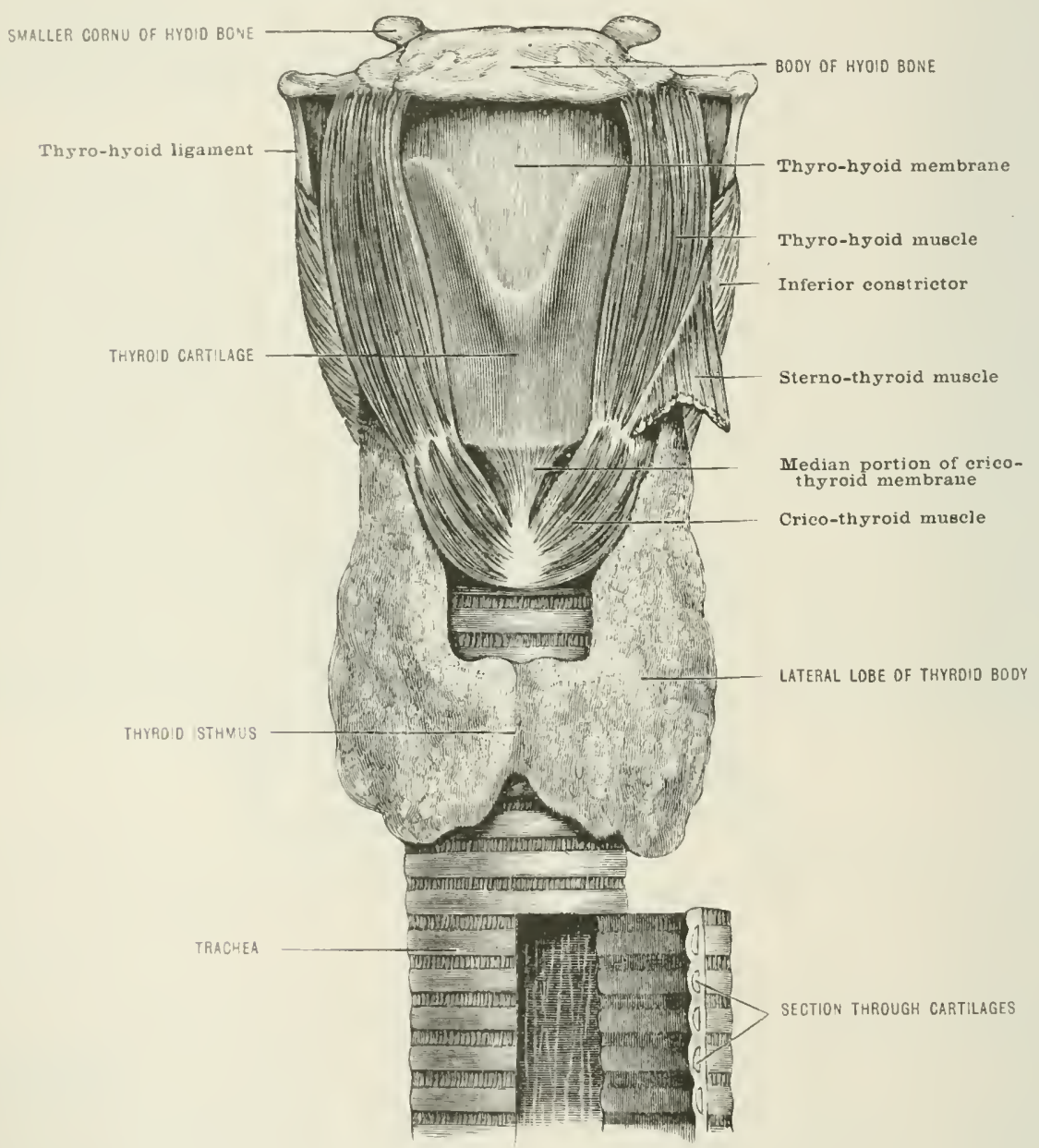

internal teminal bramehes of the superior thyroid arteries, frequently a pramidal process springs from it, and the levator glandulæ throidea, if present, is attached (1) it.

The pyramidal process is viriahle; when present it is attached by its base to the mper loorter of the isthmus or to the aljarent part of the left lateral lobe. It is the remains of a duct. the thyro-glossil duct, which extends in the foetus from the foramen cacem of the tongue, lehind the hyoid bone, to the isthmus of the thrroid body, which is developed from its lower extremity.

The capsule and suspensory ligaments. - A fibrous capsule of deep cervical fitcia completely encloses the thyroid body and sends septa inwards between its 
lobes. The superficial ressels ramify beneath it and from its inner and back part two broad bands, the suspensory ligaments, pass upwarls to the rricoid cartilage.

Structure.-The thyroid liody, enveloperl in a dense but thin corering of

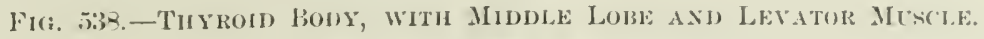

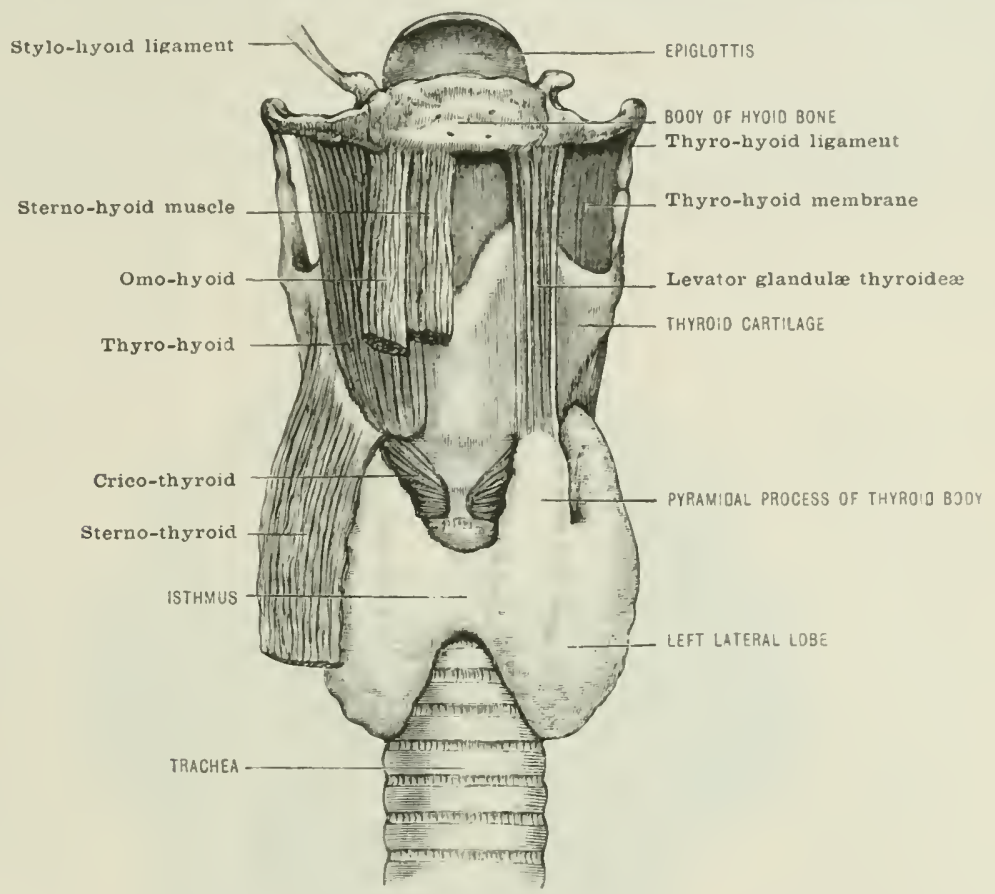

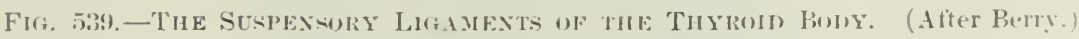

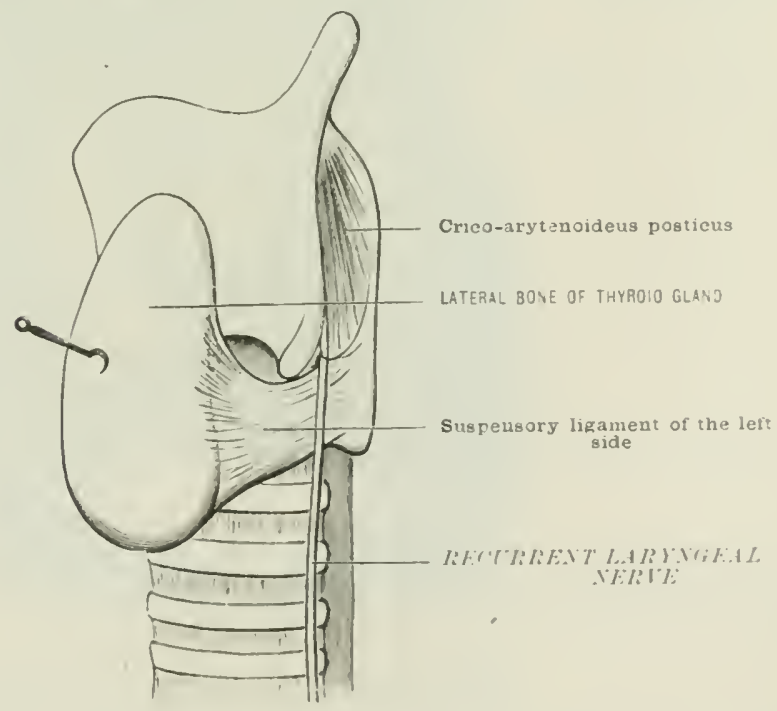

arcolar tissue, is marle up of a number of cheser follicles. These are surrounderl hy an open vascular meshwork supporterl hy the interstitial connective ti-sue. Thes follieles are grouped into irregular lobules, ind these form in turn the lohes of the 
rland. Both the interior of the follicles and the spaces in the comnecting areolar tissue may become filled with colloil material.

Vessels.-The arteries-which are relatively very large and frequently amastomese-are the two superion thrreids. the two inferior thyroids, and an oceasional hranch which ascencts on the front of the trachea, the thyroidea ima. This latter is derived either from the innominate artery or from the arch of the arorta.

The superior thrmid anteries deseend to supply the apices and inner and fore parts of the lateral lobes: whilst the inferion ascend to supply their outer and hinder portions below.

The veins are the superior midelle and the inferior thyroid. The two former join the internal jugular vein, and the latter the inmominate of the corresponding side.

The nerves are derivel from the midlle crrical ganglion of the sympathetic.

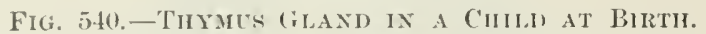

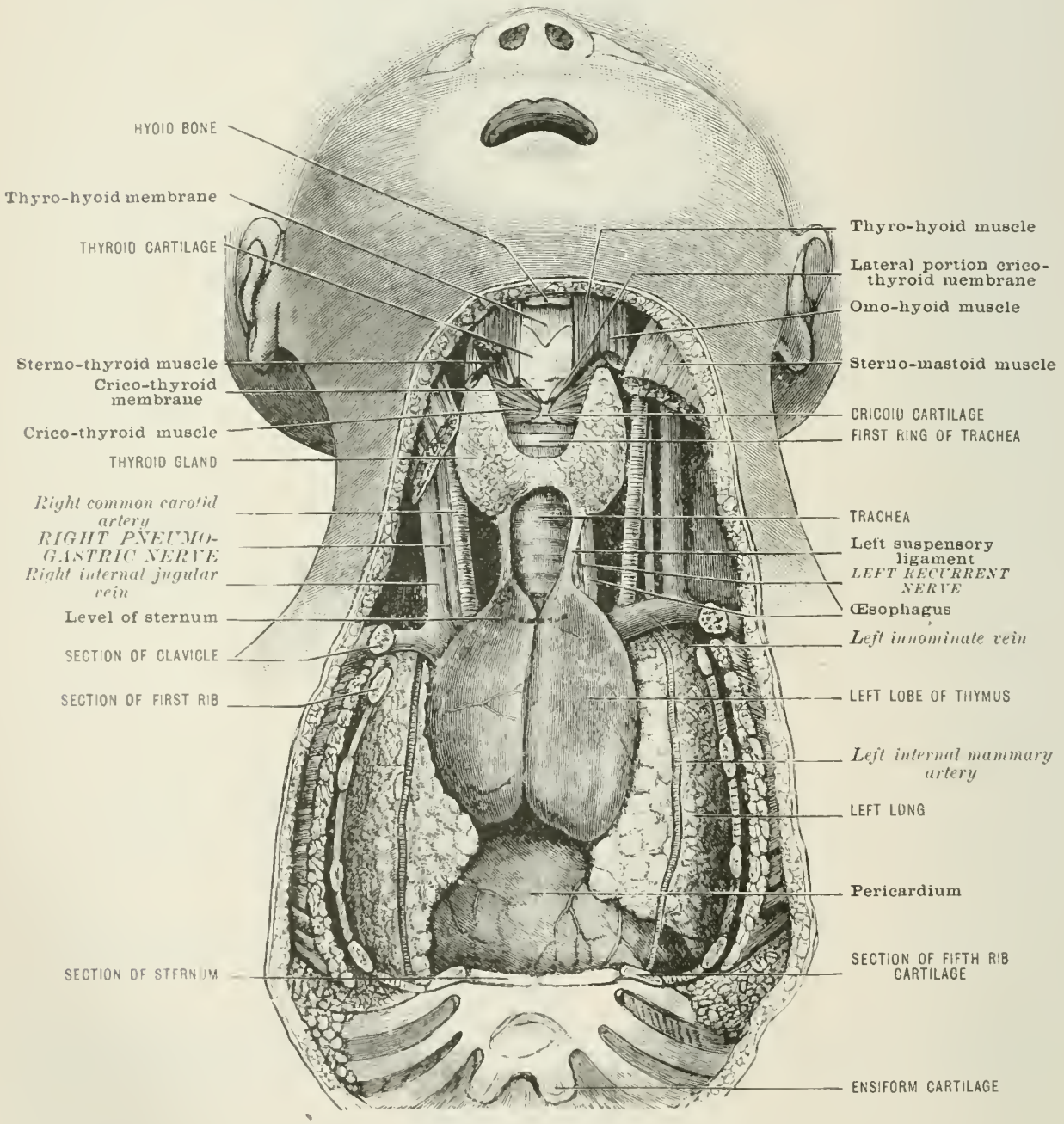

THE TIIVIS BODV OR (ILANI)

The thymus body, lilie the thymil, is ductless. It reaches its highest derelopment ahout the end of the second rear. Althengh it oceasionally retains a considerable size in the adult, it usually disappears or slorivels away to an insignifieant restige. 
It is commonly mark up of two elongated, nearly equal pramidal lobes of a greyish pink colour. which meret each other near the middle line; lut they vary in number and are ineonstant in size. There may le but a single lobe present, or a third may intervene between the other two. Sometimes the right lobe and rometimes the loft lobe is the larger.

The thymus body is about two inches (50 mun.) in length, aloout one inch and a half ( $: 7^{*} \mathrm{~mm}$.) in lieadth at its hase, and a (quarter of an inch (16 1mm.) in thicknoss.

Its weight at birth is about half an ounce.

Relations. - The thymus borly at the period of its fullest derelopment lins

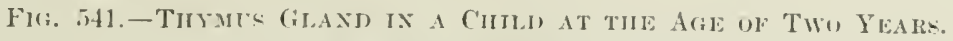

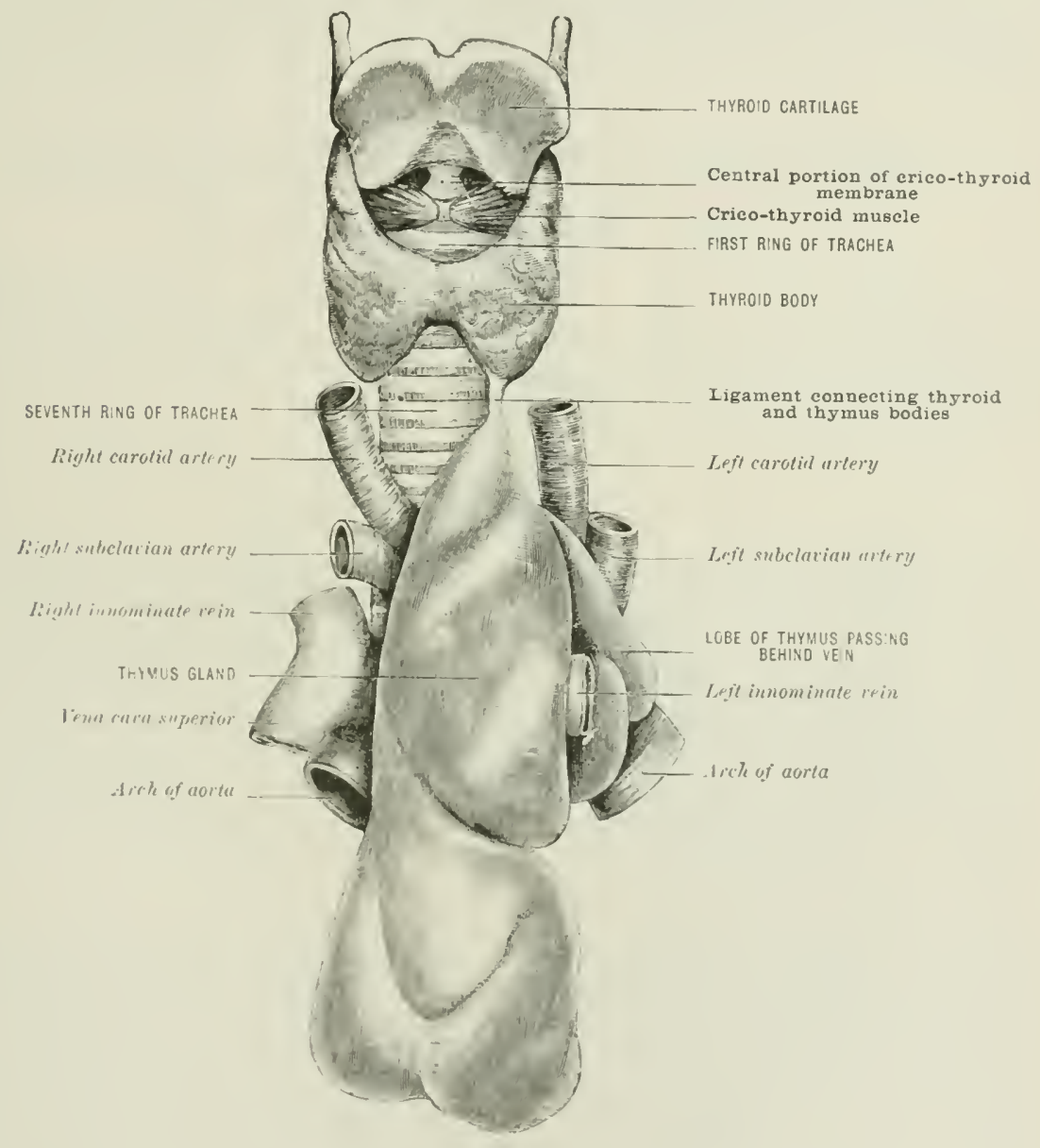

fartly in the thorax and partly in the neck. It extenels upwarls as far as the thyoud body covered hy the stermo-hyoid and thyroid muscles, compuletely hiding the trachea and the carritid sheaths. Below, it decends into the superior mediastimmm between the plemal sace and internal mammary ressels as far as the fourth rib eartilages, and lies hehind the sternum. the sterino-hroid, and stemo-thriend muscles, and in front of the pericardium and larger vescils.

Structure. - A thin areolar eapsule invests the lobes of the thymus gland, and extends mpards in the form of two flattencel filorous bands to be attached to each lobe of the thryoid hody. These bands are well marked at the period of hirth, and

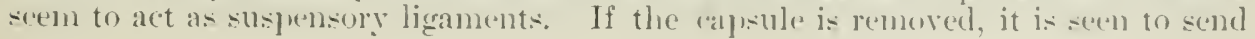


inwards numerous prolongations from its deep surfice, which pass between the lobules to surroumd and (o)mect thems.

The lobules are irregular and many-sided, and consist of numerous lymph follicles. They are gromped around a central tubular cord of comnective tissuc, and when unravellid the lobe can be lengthemel out, the lobules then appearing to be attached to the corel in a spiral fashion.

The vessels.-The arteries are leriverl from the internal mammary and from the superion and inferior thrroids.

The veins join the left immminate and throwel roins.

'The nerves are very minute. and proxed from the sronpathetic and pneumogastric.

\section{THE OR(AAX' OF' REAPTR.TTOA}

\section{THE LUNGS AND PLELRE}

The lungs-which are two in number-are the sperial organs of respiration, and necupy the greater portion of the chest avity. They are separated one from the other by the heart and great ressels, and the other contents of the mediastinal spaces, ant each is encloserl in a pleural sace.

\section{THE PLETRA}

Fich hung is rlosely invested by an invaginated serous sile, the pleural sac. The inner wall of the sac, which is loscly attalehed to the lung substanee and surproumls its root, is the visceral plemra. The outer wall of the sac is the parietal 1)lema. and the two parts are directly continuous at the root of the lung. The parictal plenra covers the inmer surface of the thoracie wall. and it forms the lateral boundary of the mediastinal space of the thorax. Tnder ordinary direumstanes the inner surface of the parietal plemra is in contact with the outer surface of the riscreal pluma, or at the most only a thin larer of serous fluid intervenes, and both surfaces are smooth and glistening; but if the plemal sace is opened the lung shrinks, on alceount of its dasticity, and a spare, the pleural carity, is derelopeet between the two layers.

For convenience of description the parietal pleura may be divided into three parts-the external or contal, the inferior or diapluragmatic, and the internal or merliastinal. The eostal portion of the parietal pleura is in relation with the ribs. the costal wartilanes, the entents of the intereostal spaces, the triangularis stemi, and the subestal musceses to which it is attached by the endethoracie fascia. The diaphramatic portion rests wom the diaphragm, ant the mediastinal part is in relation with the contents of the mediastinal space-that is, on both sides, with the periearlium, the phrenic nerve and its accompanying vescels, on the right sicle in aldition with the ascencling aorta, the superior vena rava, the vena azyons major, the right inmominate roin, the innominate artery and the right vagus nerve; and on the left side the alditional relations are the transverese and lesecurling portions of the aorta, the left common earotid and suldelavian arteries, the

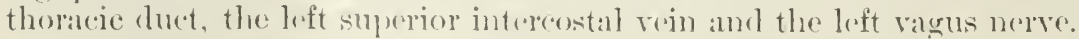

The upper extremity of earh pleural sac extembls into the neck, raching a point

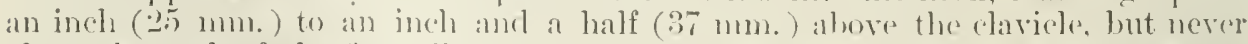
above the neck of the first ril,; it is eovered by a larer of fascia called silson's fascia; it is in relation with the subelavian artery, which lics in a groove on its antero-intermal aspert, and with the soutcmus molins and antiens museles.

The borders of each pleural sace are anterior, inferior and posterior. On the 
right side the anterior border passes obliquely downwards from the apex, behind the sterno-clavieular articulation, to the middlo line, at the junction of the manubrimm with the hody of the stemum (figr. 521), thence it deseends vertically to the lower end of the gradiolus. The lower border extends round the base of the sare, (ommeneing at the lower end of the gladiolus it runs downwarls and outwarls behind the seventh eostal cartilage, still deseending it arosses the serenth, cighth, and ninth ribs reaching the lower border of the latter in the mid-axillary line; passing backwards it comes into relation with the tenth, eleventh, and twolfth ribs, and ascending to the hearl of the latter it joins the posterior horder, and then, turning forwards, it passes along the groove between the perieardium and the diatphragm to its point of commencement. The posterior border extends from the neek of the first rih to the head of the twelfth; it is broad and romuled. The anterior border on the left side descends inwards lechind the sterno-clavicular articulation as on the right side, and reaches the middle line at the same point, then it passes vertically downwards to the level of the fifth chondro-sternal articulation (tig. 521), from this point it rums downwards and outwards behind the cartilages

Fig. 542.-Axteriok View of Fetal Heart, Vessels, and Lungs.

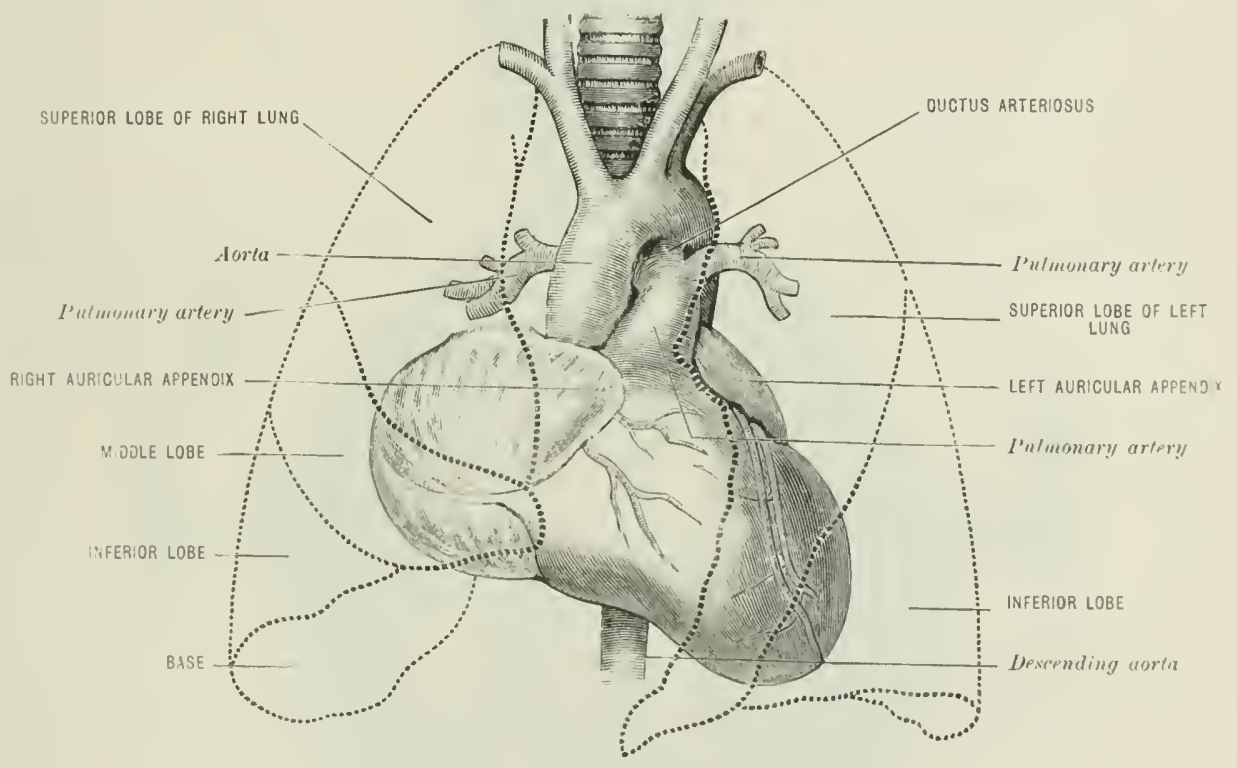

of the fifth and sixth rils to the serenth eosto-chomdral joint, where it joins the inferion bovler. The inferior border deseends across the eighth, nines and tenth

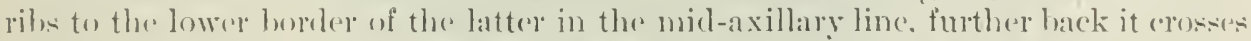

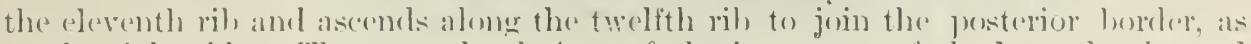

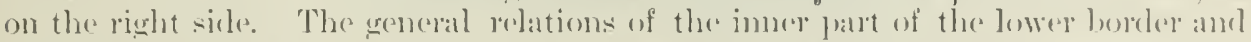
the whole of the posterior borter are the same as on the right side.

The lower extremity of the plemal sare does not extend to the lower extremity of the thorax, laterally: therefore for at shert distance the diaphragm and the lowest intereostal muscles ane in antact.

Below the root of ateh lung a fold of the plemrat deseremels to the diaphragm, the

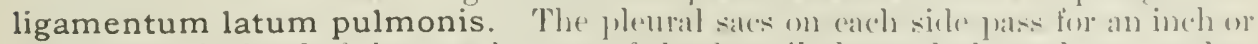
mere above the level of the anterior part of the first rib. beneath the sablene museres. covering the apices of the lungs, and the parictal layer is herestrengthened hy a dome

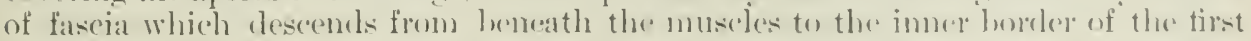
rib. The interval between the two sacs is onsiderahle hoth alove and helow: but

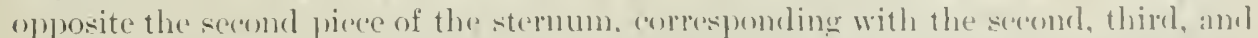

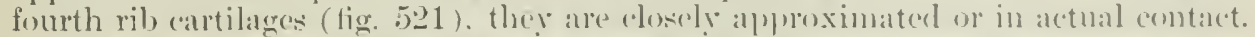

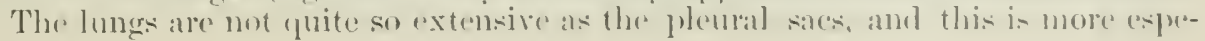


rially the case in the regions of the inferion; and the lower parts of the anterior lorders where two layers of prictal pleura arr in contact with each other, these regions are known as the plemal sinuses, and they vary in extent with the distension of the lungs.

The right pleural sac, though shorter and wider than the left, reaches as a rule somewhat higher in the neck.

The Lungs. - Each lung presents an outer and an inner surface. sabarated by an anterior and a posterior border, with a lase and an apex.

The outer surface is eomrex, and mainly corresponds to the concarity of the inner surface of the lateral wall of the thorax.

The inner surface is concare, and comes into contact with the pericardium and lateral pleural wall of the mediastinal spaces.

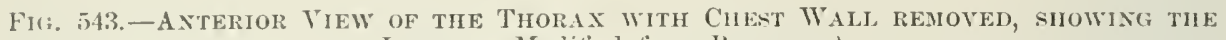
Ltxas. (Motifiel from Mourgery.)

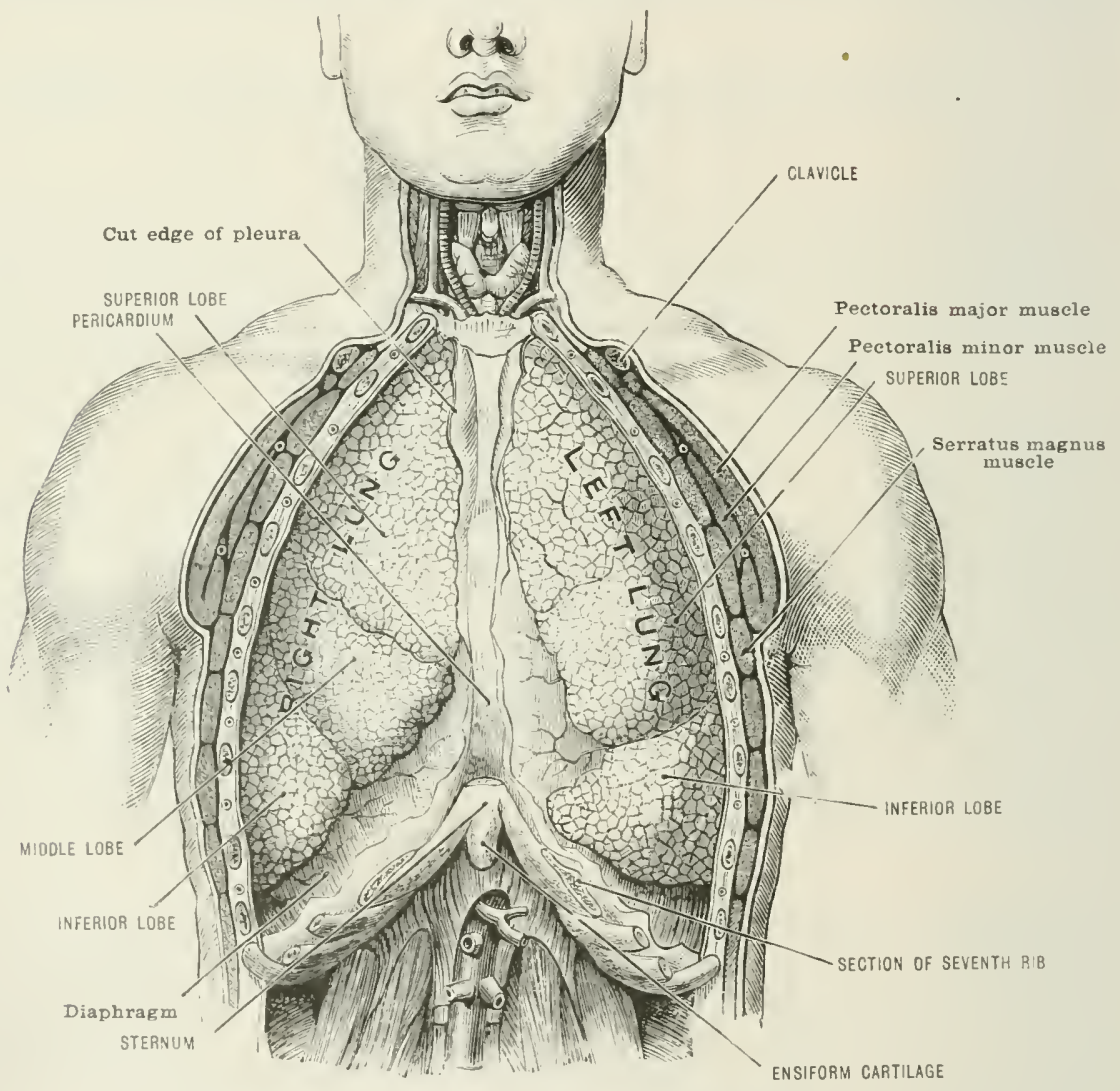

The posterior border is the lomger; it is thick, romeled, and smooth, and ocrupies the groove on the sirle of the vertebral (o)lumm.

The anterior border is thin, irregular, and sharply edged, and is deculy notehed in the left lung leaving the pericardium uncovered.

The base is romeare, and rests on the corresponding areh of the cliaphragm; whilst the apex passes above the anterior part of the first ril to lie beneath the subclavian aptery. Eiah lung is divided into two lobes hy al derp fisime which passes ohliguely upwark and inwarls almost to the root of the oriran. This fiseure commenees at the posterior borker, alvout $7 \div$ an. below the apex, and, sweping round the eonvex surface of the lung, ends near the anterior border below.

In the right lung a second fissure passes from the anterior exlge to reach the main fissmre near its centre, marking off' a third or middle lobe. 
The right lung is somewhat larger than the left; it is also shorter, and, as just mentioned, posicises three lobes.

thove the mirlle of the immer aspect, but nearer to the posterior than the anterior horder, each lung is comnected to the pulnomary vessels and bronchi which form the main jart of its root.

The root of the lung is composed of the pulmonary artery and the pulmonary veins with the corresponding bronchial tube; and, in addition, the bronchial vessels, the branches of the anterior and posterior pulmonary plexuses with some bronchial lymphatic glands and areolar tissue-the whole heing (neased in a pleural covering.

The right root lies hehind the superion eava and upper portion of the right

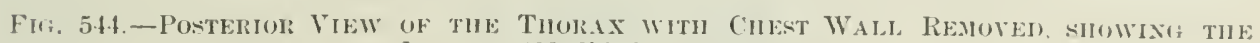
Ifxgs. (Ioditied from Bourerery.)

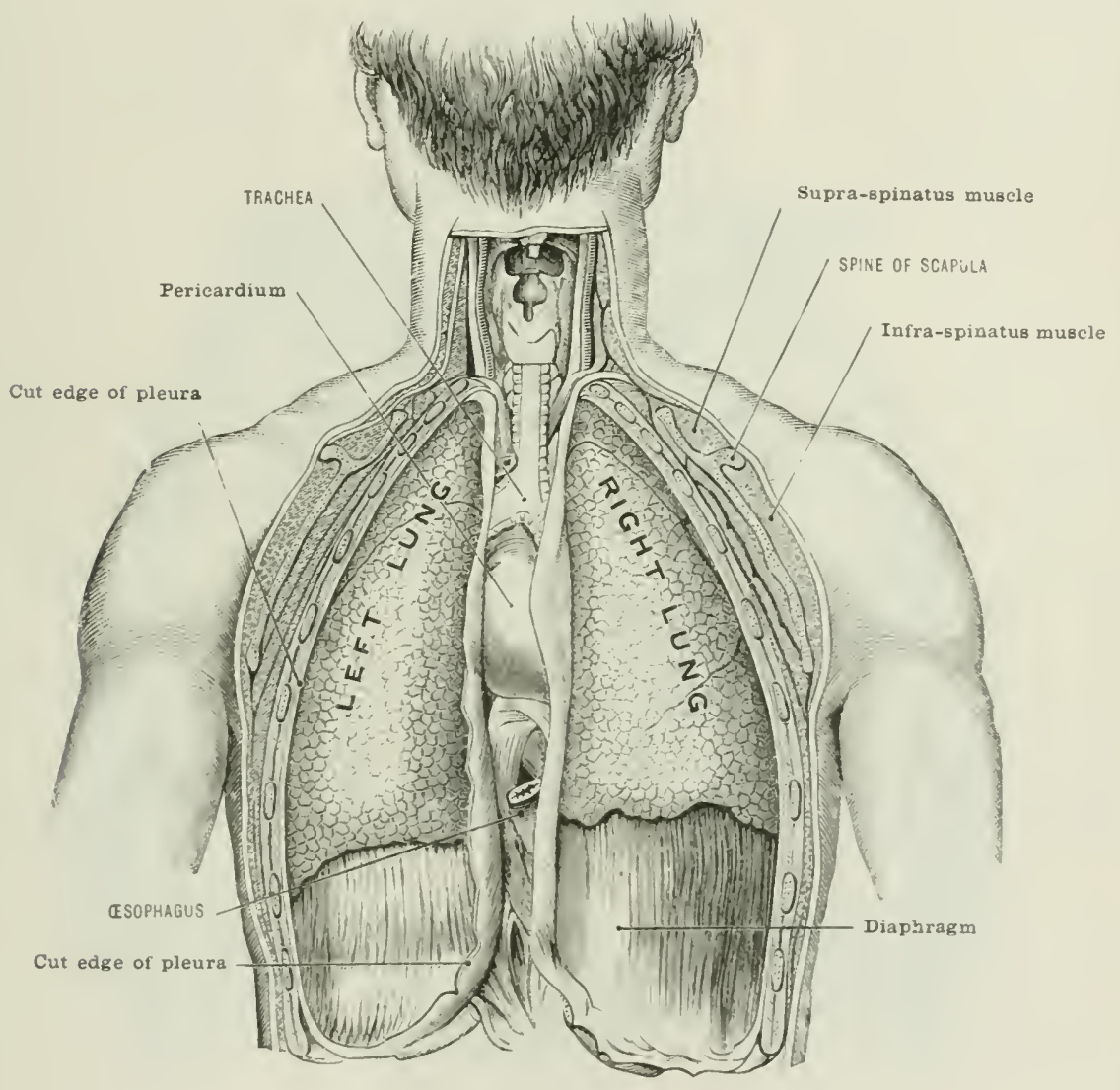

auricle of the heart, the anterior pulmonary plexus and the phrenie nerve; ahove, the vena azygos major arches to join the superior caval behinel is the fosteriof pulmonary plexus, the pmemomogatric nerve, and the venat azrgos major; whilst below is the ligamentum latum pulmonis.

The left root has the pulmumaly plexus and loft phremie in front: above it is

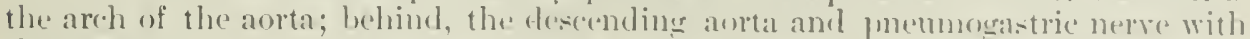

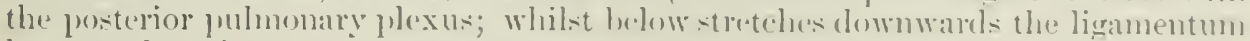
latum puhnonis.

The chief structures contained within the lowt vary in presition on the two sides.

From above downwards on the right side, they lic :1: follow:- bromehus, artery, and uppere vein; whilst on the left side the artery $\mathrm{i}=\mathrm{thc}$ highest, the 
bromelus is placoul next, and the upper vein is again the lowest. From before backwards on both sickes, the arrangement is-upper vein, artery, and bronchus.

The weight of the lungs together is alout forty-two ommers; the right lung is ahont two oune's heavier than the left.

In color the lumgs are of a pinkish white; but they become darker, mottlerl, and even black, as age advaluces.

Structure.-The lungs posiss an external serous coat derived from the plenra, beneath which is a delicate subserous layer.

The parenchyma, or lung substance, is composed of minute lobules con-

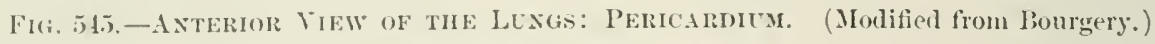

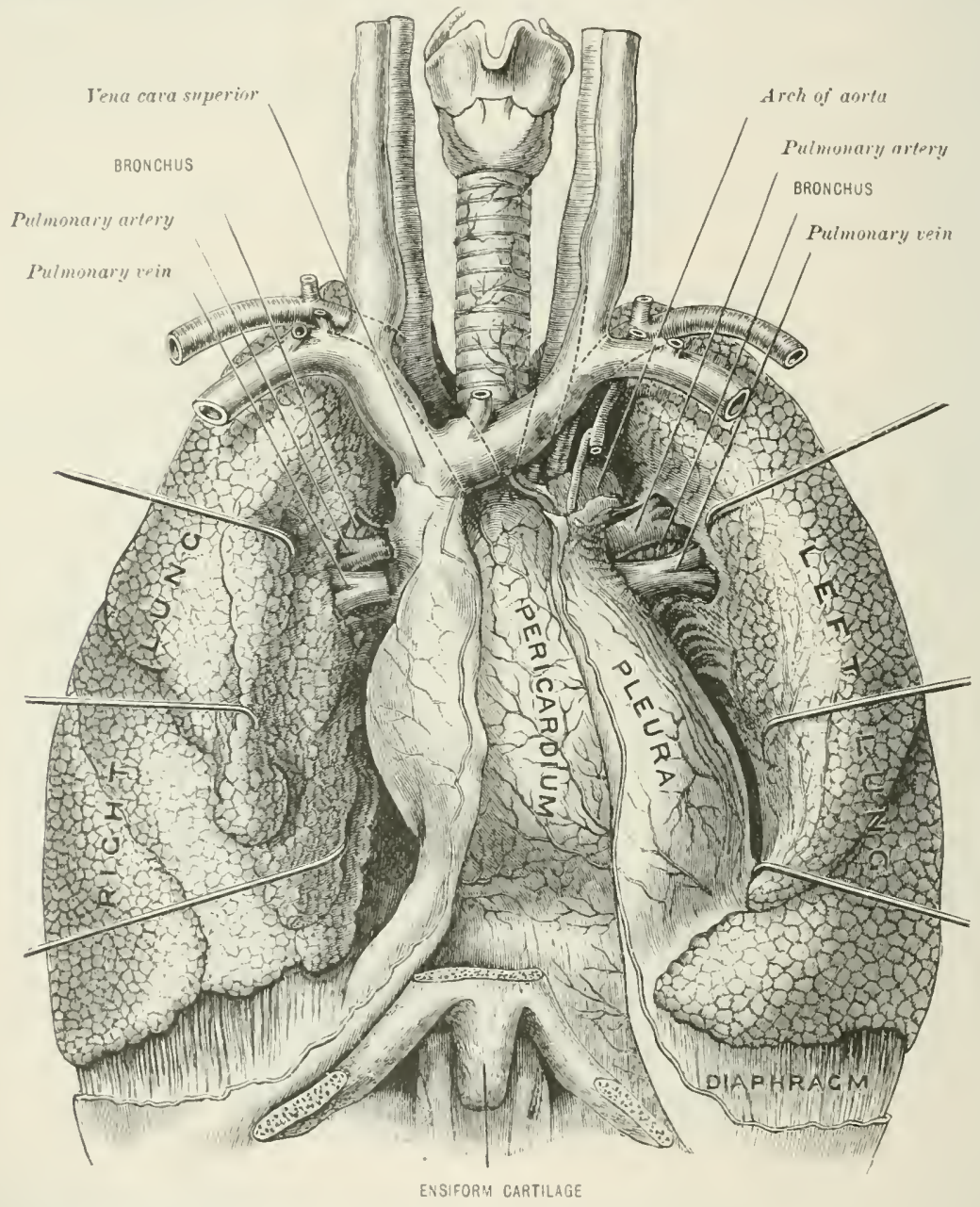

nected by interhbular arenlar tissue. Each lohule is made up of a ramification of a bronchial tube with its chster of terminal air cells, with a minute plexus of pulmonary and bronchial vessels, nerves, and lymphatics.

The vessels. - The pulmonary arteries conver venous blool from the leart to the lungs; they divide into bramches which follow the bronchial tuber, and finally terminate in a flat meshork njon the walls of the interecellular pastages and air cells.

The radicles of the pulmonary veins stalt form this network; they coalesee into barger hamehes which aleenulpany the arteries and ferminate in two large vessels on each sicke, which retmm the arterial blood to the left auricle of the heart. 
The bronchial arteries, one on the right sides and two on the left, are the nutrient vessels of the lumers. The right surings from the first aortice intereostal artery or from the under left bonchial artery. The two left bonchial arterie are branches of the descending thuarcic anota. Fone of their iranches ramify in an open plexus outside the lung beneath the pleura; another sot supply the interlobular areolar tiscue; whilst a thirel set of bronches supply the hronchial tubes with their lining membrane and muscular walls, the walls of the veswess. and the bronclial glands. The ramifiations of this set reateh and mingle with the pulmonary resels, and thus a small quantity of the blond conveyed hy the lonenchial arteries is returned as arterial through the pulnonary veins to the hieart.

The bronchial veins "onsist of a superficial and a deep set, which join, to form a single ressel on each sicle: the right honehial vein opens inte the rena azyos miljor, and the left into the left superior intreostal vein.

The lymphatics form a superficial and a deep set.

The nerves are derival from the anterior and posterior pulmonary plexuses.

\section{THE ORGA IS OF ('TRCLLATION}

\section{THE PERICARDILU}

The pericardium is a cone-shajed, fibro-seroms sac surrounding the heart, with its apex above, and its hase below and adherent to the diaphragn. The fibrous layer is very strong and inelastic, and is compesed of interlateing fihres. Diselow, its connection with the contral tendon of the diaphragn is close and intinate. It is very firmly bound to the wal opening. but loosely attached and easily separable "lswhere. Above, it is lost on the sheaths of the great vessels all of which receive distinct investments, with the single exception of the inferior rena cava, which pierees it from below.

The aorta. sujerior vena cava, buth divisions of the pulnonary artery, with the ductus arteriosus, together with the four puhnomary veins, are all ensheathed in this mamer. The fihrous portion of the pericardium, through the sheaths pro-

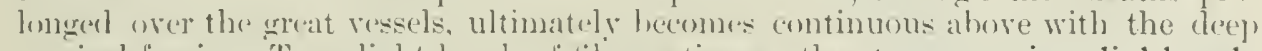

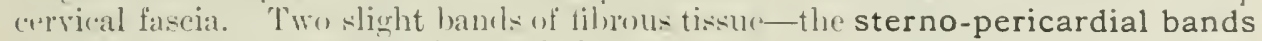
or ligaments-comnect the front of the perieardium, above and below, with the posterior surface of the sternum.

The serous layer is smmoth and glistening. Its parietal portion lines the inner surface of the fibrous bar. The visceral portion is reflected orer the surface of the beart and the roots of the great ressels. the two layers being in close contact. and moistened with a thin secretion to allow the free movement of the heart. A series of pourhes or simuses are thus formerl at the line of reftexion. Between the inferior vena carat and lower left pulmmery vein. the oblique sinus ascents: behind the left auricle, partially investing tlix pulmonary arteries and the pulmonary veins of the right and lift sicles. hetwern which it passes. Small pumehes from the main sae dip between the reins to meet the inflexioms from the sisles of the oblique sinus just noticed, thus completing the serous roverings: to these vesels.

Pouches can be further traced between the inferior vena cava and lower pulnonary vein of the right side, letween the superior vena caval and mejer fulmonary vein of the same sille, and also between the left pulnonary antry anul left upper pulmonary vein.

A tubular prolongation, moreorer, surmounds both the rowt of the pulmonary artery and the aorta in common, and these are the only vessess which can be sail to hive a complete and continuous invostment.

There is, therefore, a communioution belsind them between the right and laft 
sicles of the preriearlial sate: this is the erreat sinus of the pericardimm. The inferrion vena caral receives a very impurfect eovering.

The vestigial fold of the pericardium is a douhling of the serous layer which passes lutween the left pulmonary artery above and loft superior pulnonary vein below. It contains, hesiles some fatty and areolar tisile, the shrunken remains of the left supurior vena cava. It is connerest above with the left superior intercostal rein, and helow with the left auricle am oblique vein of Marshall, - these reins with the (oronary sints having originally formed portions of the left upper cava.

Relations.- In front are fomml the thronus ghand or its remains, areolar tissue, the sterno-prericarliac ligaments. the left triangularis stemi muscle, the internal mammary vesisls, the anterior margins of the pleural sacs and lungs, and the sternmm. Laterally, it is orerlapped by the lungs with their pleural sacs. and it is in rolation with the phrenic nerves and their accompanying ressels. Posteriorly, it is in mation with the (psophagus, and punemogastric nerves, the descending aorta, the theracice chet, and vena azyges major.

On upening the perieardium the following structures mar he observed: the greater part of the right and a portion of the left ventricle with the interventricular sul('ts, the right auricle and right auricular appendix (the latter overlap)ping the ront of the aorta), the auriculo-rentricular sulcus; the first portion of the aorta with the superior vena cava on its right side, and the pulmonary artery at first overlying and then passing to its left side, with the tip of the left auricular appendix. If the heart be rised upwards and to the right, its posterior surfian is se' 1 to consist of the greater part of the left ventricle, and the remaining portim of the right, the interventricular sulens dividing the two. Lying transversely above the ventricle in the auriculo-rentrixular grone is the coronary sinus, receiving some of the cardiac veins, ancl also the oblique vein of Marshall from the hack of the left auricle, the roots of the pulmonary veins, and the very small portion of the inferior cava above the diaphram, may also he noticed.

The two rentricles rest in about equal proportions on the central tendon of the diaphragn. The main branches of the coronary arteries of the heart occupy the grooves

Vessels. - The arteries of the pericardium are doriver from the previcardiac. apeophaceal, and bronchial branches of the thoracic aorta and from the internal nammary and phrenic arteries.

\section{THE HEART}

The heart-enclosed in the pericardium-occupies the greater part of the middle merliatinal space. It is a somewhat Hattened, cone-shaped, hollow, muscular organt.

Position.-In the alult the heart lies olliquely bohind the lower two-thirds of the sternum, projecting considerably to its left side. Its base is rlirected slightly mpwark and backwarls, and to the right; its apex downwals and forwarls, and to the left. The base corresponds to the sixth. seventh, and eighth thoracie vertebre; and the apex to the "hest wall on the left sille, between the fifth and sixth ril) (artilages.

It mal be malperl out on the chest wall in the following manner: a line drawn across the sternum about the level of the lower borders of the second costal cartilages, fassing half an inch to the right and one inch to the left of the sternmm, will inclicate the position of its base, from which the great vesols arise.

The apex, as hofore observed, strikes the chest wall hetween the fifth and sixth rib cartilages on the left sicle, at a spot about a comple of inches (50 1mm. ) below the niplele, and one inch (25 $\mathrm{mm}$. ) to its stemal side, or three and a quarter inches (s1 nmin.) from the minllle line of the stermmo, in the fifth interspace.

The lower border is formed ly the right ventricle and rests on the central tenton of the diaphragn. It is definem by a line curving downwark, commencing at the apex, and crossing chose to the sterno-xiphojel articulation and terninating at the right erlge of the stermm near its junction with the sixth cartilage.

The lateral borders may be completed hy trawing eurved lines upwards from 
the points last named to the ('mels of the balsal line. The right border eomsists entirely of the right auriele, and the left of the loft ventricle.

The position of the auricule-ventricular sulcus is indicated by a line from the thirrl left costal cartilang to the sixth right.

Size and weight.-In the adult the heart measures about five inches (1.2.) mm.) from hase $t(1$ apex. three and a half inches ( $87 \mathrm{~mm}$. ) across where it is hroarlest. and two and a half $(62 \mathrm{~mm}$.) at its thirkest portion. In the male its wight averages about eleren omees, and in the female about nine omures. It increases both in size and weight up to atranced life, the increase being most markel up to the age of twenty-nine years.

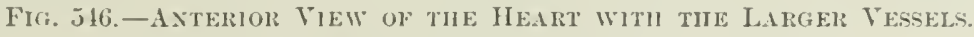

(By permission. Museum of the Royal College of Surgeons.)

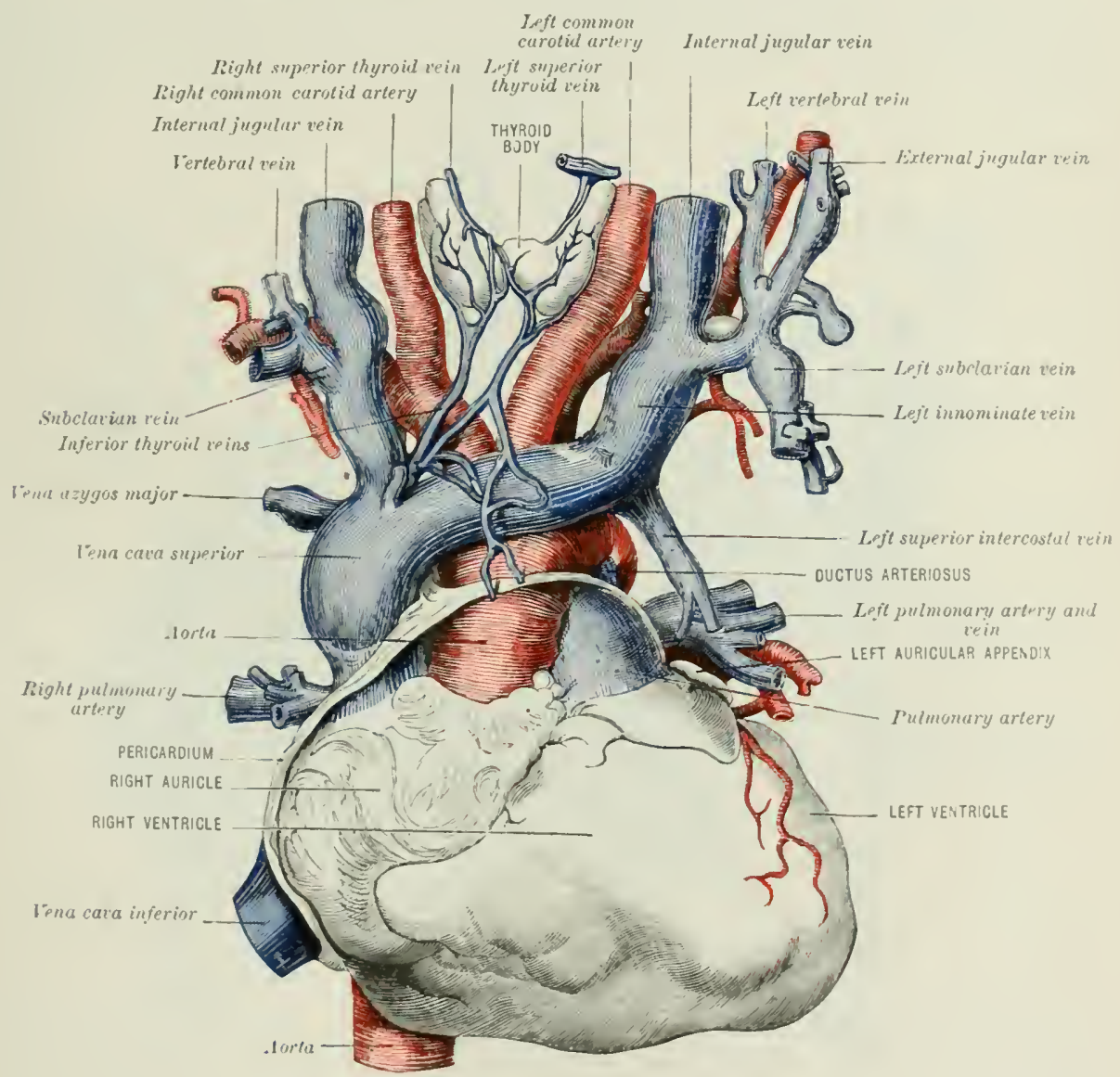

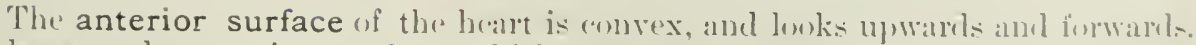
Its lower and posterior surface, which rests jartly on the diaplirigun, is flattenerl. The horders which divide the two surfaces of the heart meret near the alex; the right border is thin and rather longer than the loft, whilst the latter lorder is thich and rounderl.

The aluricles are diviled from the rentricles hy a transwerse enowe. the auriculo-ventricular, which is interrupted in frout liv the oriein of the fulnonary artery. The rentricles are similarly divided from eale of he liy the interventricular groove, which runs ohliquely on the anterior and pusterior surfaces of the heart, meeting below just to the right of the apex where they are continueus. 
The grooves are placed near the borders of the heart, so that the right rentricle is mainly anterior, and the left posterior.

Of the four cavities into which the heart is divided, the right auricle and ventricle constitute its venous side, whilst the left auricle and rentricle belong to its arterial side.

The right auricle receives the renous blood of the body through the two rence carre, and of the henlt through the coronary sinus, and transmits it into the right rentricle. The right ventricle in turn transmits the renous blood to the lungs through the pulmomary artery. From the lungs it is returned arterialised to the left anlicle of the heart by the pulmonary reins. From the auricle it passes into

\section{Fig. 547.- Showng the Position of the Heart and its Valves in Relation to the} Chest WaLLs.

(Reduced from Hensman and Fisher's Anatomical Outlines.)

(The right auricle and ventricle, with the pulmonary semilunar and tricuspid valves, are outlined in blue tints; whilst the left auricle and ventricle, with their corresponding valves, are indicated in red.)

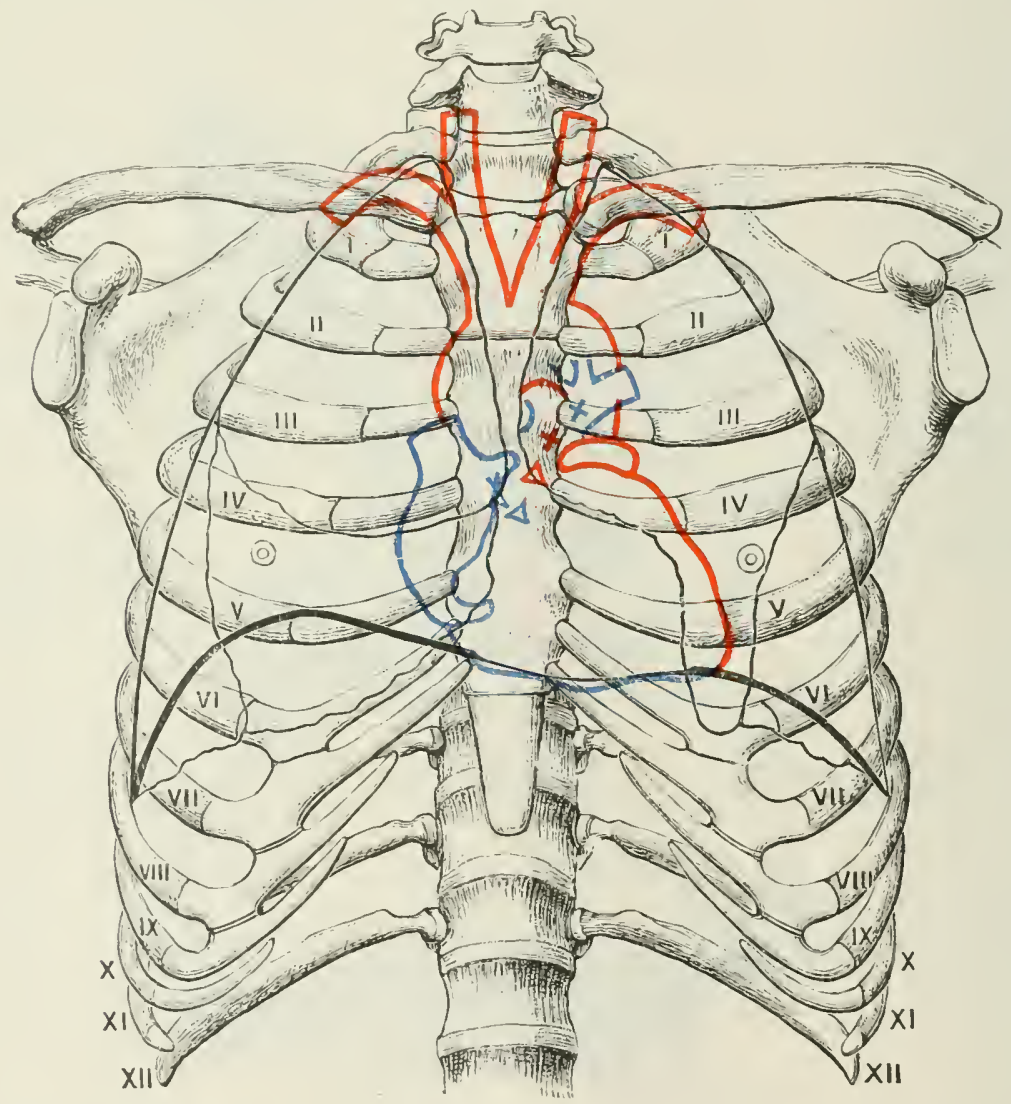

the corresponding ventricle, and thence through the aorta and its branches to all parts of the body, inclucling the heart itself.

The right auricle.- The right auricle forms the upper and right part of the heart; helow it is the right rentricle; to the inner sicle anteriorly it enbraces the root of the pulmonary artery, and prosteriorly it is separated from the left auriche by the interauricular septum, and it is in relation with the right inferior pulmonary vein. It is linel by a smonth and clelicate membrane, the endocardium, which is eontinuens with the inner coats of the hlood-resicels. It presents a large yuarlrangular cavity, the'sinus venosus or atrium, and one much smaller within the auricular appendix. The amiele forms the right and fore part of the hase of the he:art. 
Openings.-Of the three chief openinge, that of the superior cava appentr: at the uplere and hack part of the cavity; whilst at the lower amel hack part is the (1) wing of the inferior cava. The right auriculo-ventricular opening, which leaks into the ventriele, is placed helow and in front: whilst above and in front the avity is prolongerl into the aturienlar appendix.

The orifiee of the coronary sinus lies letween the lowere ravel and aurieuloventricular openinges. liseides these there are allent a sene of small scatteresl orifices, known the the foramina Thebesii.

The superior caval opening is valveles:, and is direterl downwards and fortwalels towards the aturiculu-rentricular opening.

The inferior caval opening is somewhat larger. and is directed upwarls and inwarls. It is usually grarderl by a semnilumar fold, the Eustachian valve, which is much larger in foetal life, and which then serves to direct the current of blosel

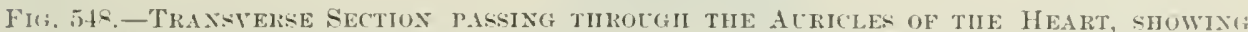

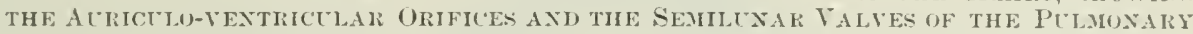
Alitery AND AORT. SEex Fron ABOFE.

(The portions of the auricles removed are seen in Fig. 5is.)

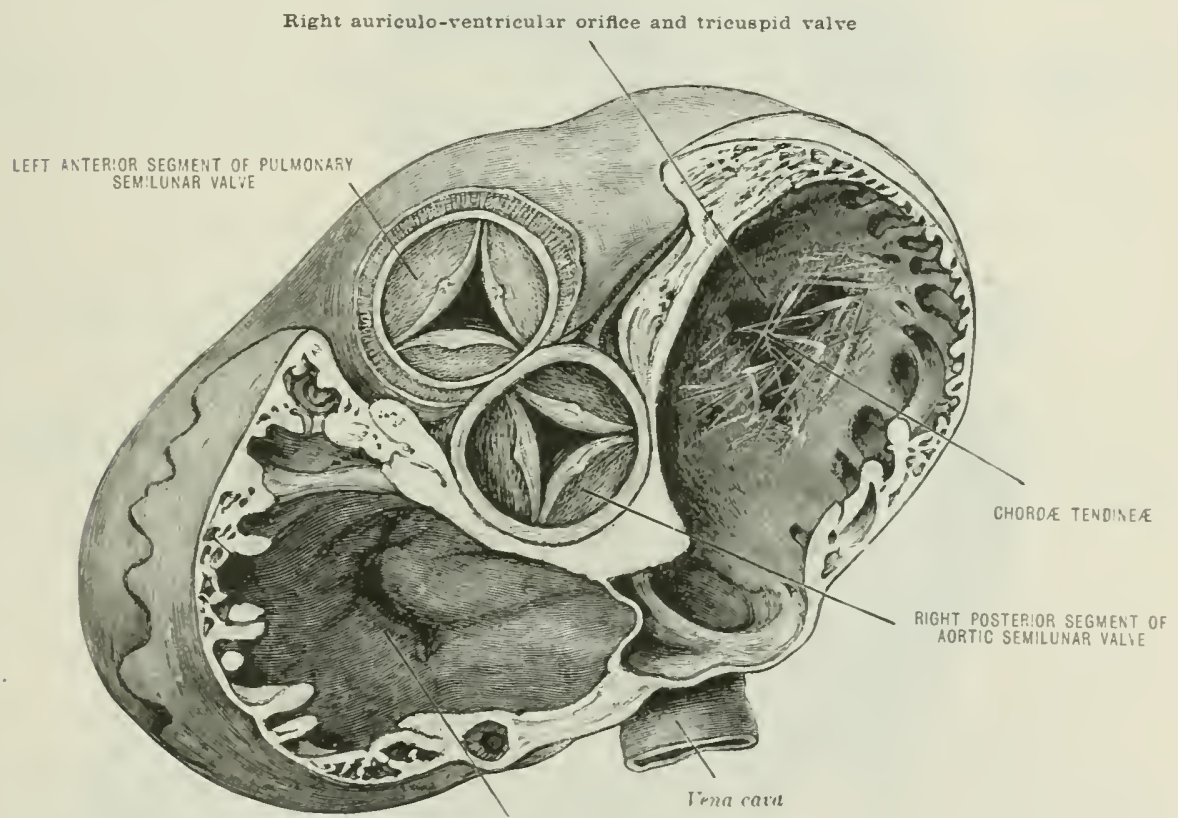

Left auriculo-ventricular orifice and mitral valve

through a formmen in the wall dividing the two auricles. It is attached by it: convex margin to the front and left side of the vein. its free concave edge lonking mpwards and to the right. The left cornu or horn of the cresent is ontinumiwith the anterior edge of the anmulus oralis. Whilst the right horn is lost on the. anricular wall. The Eustachian valve contains interlacing muscular filnes: it is often very incomplete and sunctines perforated.

The coronary sinus retmms the blom from the heart substance, and is guarded by a semilunar or sometimes louble valve, known as the coronary valye. or valve of Thebesius. Like the Eustachian. it is formerl of a fold of the endocarlium. and serves to direct the blowl amrent. lunt does not prevent regrurgitation. It is sometimes perforated, and oreasionally juesents the nost delicate lacework.

The foramina Thebesii.--The greater number of these small orifices end blindly, but the rest are the terminations of minute veins from tha musenlar sulstance (venæ minimæ cordis). (Ine of these, more eonstant than the others, 
the vena Galeni (right marginal), usually opens betow the superior cava, on the septal wall.

The cavity of the right auricle is smooth, "xeept upon its anterior wall. and within the appendix, where it is ridged with nuscular bands (the musculi pectinati), which terminate, abore, along a rilue, the crista terminalis.

The crista teminalis cormegume externaly with a sulcus, the sulcus temi-

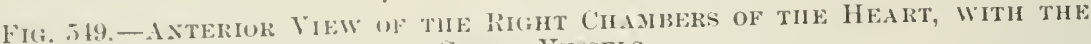
Great Vessels.

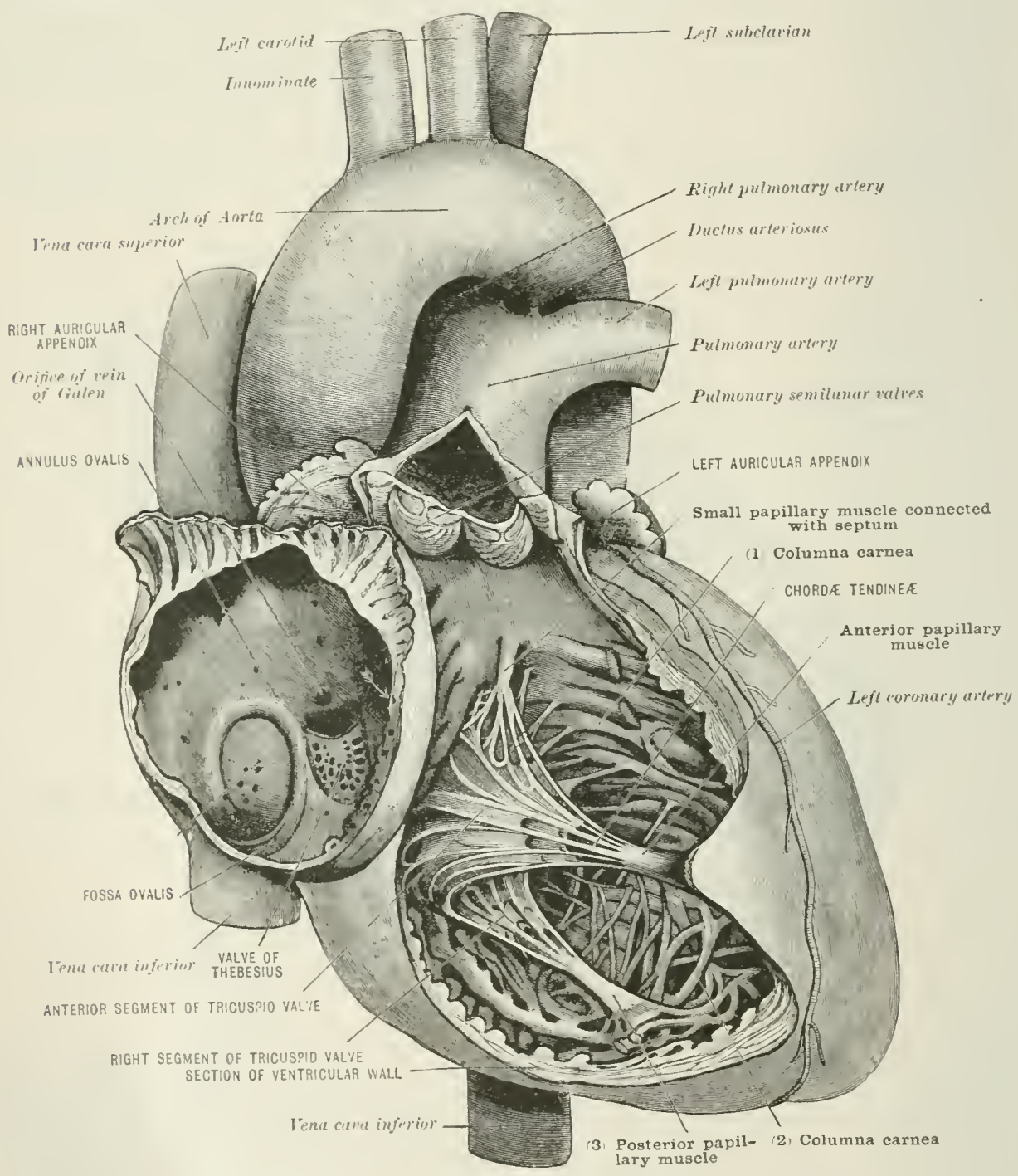

nalis, which runs across the anricte from the front of the superior cava to the left of the inferior caras, and both the groove and the ridge indicate the line of union of the sinus renosus of the frotus with the auricle proper.

At the lower part of the posterior wall or septum which divicles the two auricles, and just above the orifice of the inferior cava, is a smooth oval depression, the fossa ovalis. It mank: the prestion of the opening in the fortal heart. to he described hereafter; amel is bombled by a well-marked romoled edge, the annulus 


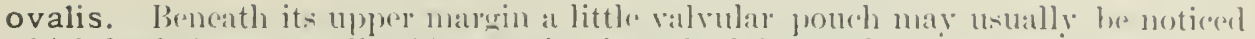
which leads into at sllall orifice passing inte the left aturicle.

The tubercle of Lower-which is plared on the right of the cavity between the orifices of the two calve-is well matked in some of the lower anmals, but it is quite an insignificant eminene in man.

The right ventricle forms the langere part of the heart in front, where it is (onvex; lut helew; where it rests upon the diaphragm, it is tlattenerl. It forms;

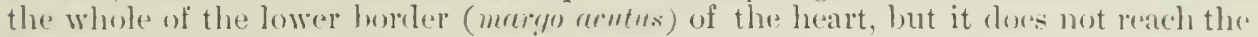
apex, which is formed entirely by the left ventricle.

It lies behind the lower part of the lwoly of the stemum and the antilages of the lifth, sixth, and serenth ribs of the left side.

In form the ventricle is triangular, in section semilumar, and its walls are nuch thinner than those of the left rentricle. Its upper and left angle is continuons with the root of the pulmonary artery; and upon opening the eavity the two arw seen to be continuous through a cone-shaped prolongation-the infundibulum or conus arteriosus.

It the opposite angle there is a second and larger ofuening. leading from the right atricle, the auriculo-ventrieular orifice. It lies below and to the right of the pulumany orifice. The apex of the ventricle points to the left.

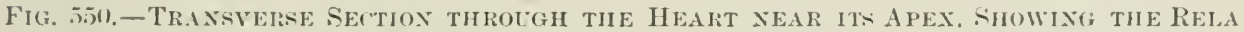
TIVE TIICKNESS OF ITA MTSClLAR WALIS, THE BULAING OF TIE SEPTTY TOWAIBS TIF Rifit Vextricle, and the Shape of the Cavities.

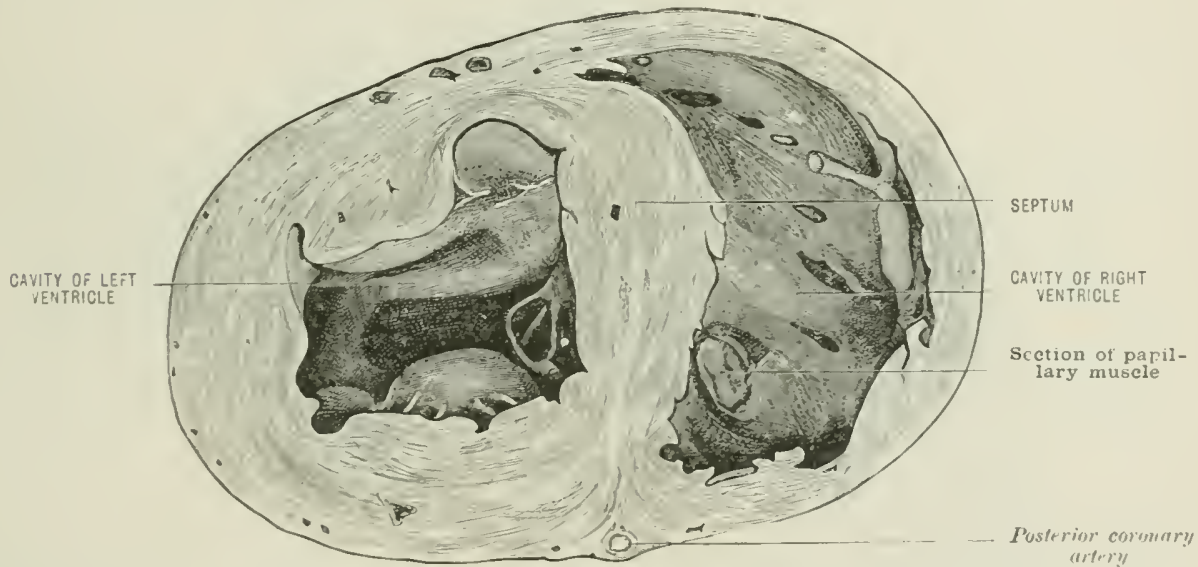

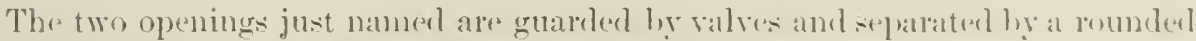
muscular projection of the rentricular wall. The inner surface, "1 body, of the ventricle presents a somewhat eomplieated arrangement of musculal ridges, bands, and columns, which lexeme smaller, more numerous, and more chesely interlaned at the apex amb nur the margin, lont which disilpear in the infundibulum.

These projections, or columnæ carneæ, are usually divilexl into thres sets: (1) mere ridgrs; (2) batuds attached to wither and but elsewhere free; and (B) a third set, the musculi papillares, which need a more detailed description (tig. 5f!?).

A special hand, the sis-ealled moderator band, which is constant in the sherp. is oreasionally a well-marked structure in the human heart, stretelhing hetween it: anterior and septal walls. The musculi papillares are attarehed liy their liroirl end to the rentricular wall, amd ly their watremities to tondinous cords (chordx tendineæ), which restrain and hatrunemise the action of the valves grnarding thes auriculo-rentricular opening. Threse of these are larger and more constant than the rest: an anterior, commeted with the front wall above the morlerator hand; a right, near the matrein, which is also attached to the anterior wall; and a posterior, which arises from the septum. The septal wall of the ventricle so lulges inte the

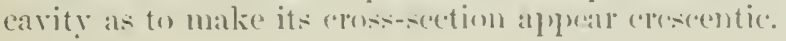




\section{THE OPENINGS ANI THLIR VALVE}

The orifice of the pulmonary artery is eireular and ollipuely placed at the summit of the infunclibulum near the septum. It is guarded hy three valves, the pulmonary semilunar valves. Of these two are placed anteriorly and one posteriorly (fig. jts'). Immerliatcly above and behind each semilunar valve there is a pouch or sinus. There collectively constitute the fuhnonary sinuses, or sinuses of Valsalva.

Earde valve is fommed of a filmous laver within a recluplieation of the lining membrane, which is eontinuous on the mpler surface with the innermost eoats of the artery and on the opposite surface with endocartium of the rentricle.

In the centre of the free straight eelge of each valte there is a little fibro-cartilaginots nolule. the corpus Arantii, and this margin is further strengthened by a drelicate tendinous band. Another fibrons band in like manner strengthens the convex attached portion of the valve, and from this a third set of olyliguely interlacing fibres jaiss throughut the whole valve towards the nodule. Two narrow (resecnt-staped areas, the lunulæ, near the free edge on each side of the nodule, remain almost free from this fibrous invasion, and it is these thinner portions which are in apposition during closure of the valve. A fibrous ring strengthens the julmonary orifice. giving attachment below to the muscular fibres of the heart; whilst ahove, opposite the sinuses of Valsalya, it is deeply hollowed into three semilumar

Fig. 5j1.-INTERIOR VIEW OF THE AORTIC SEMILLXAR VALVE.

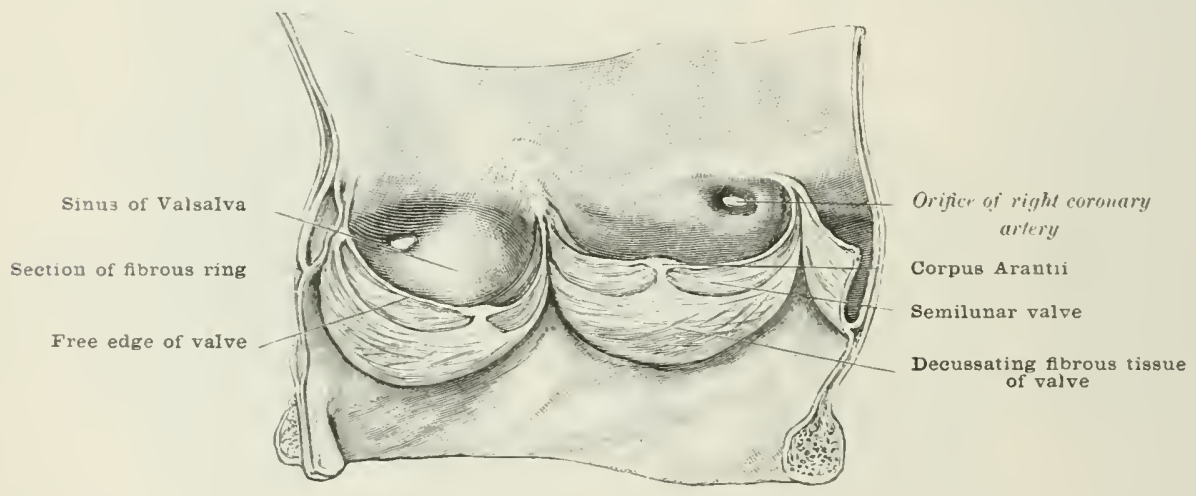

motrhes. The valves are attacherl to the edges of these notches as well as to the hurns which project inwards and separate them from one another. (See fig. 551, of the aortic valyes, in which these charaeters are present and more strongly marked.)

The auriculo-ventricular opening is oval and guarded by the tricuspid valve. The three triangular flaps of this valve are entinuous with one another at their hroad ends, and so form a continuous fold aromel the orifice; but heyond, they projeet with jagged and sharply dentated edges towards the apex of the ventricle.

The chordac tondinese, which ehiofly arise from the papillary muscles aheady described, pass to their free borlers and ventricular surfaces. The largest segment of the valve is placed in front, letween the aurioulo-ventrienlar orifice and the infundibulum, the smallest behind near the septum, and the thirel. which is the most movable, is situated on the right.

smaller segments interveme between the larger flapse. The chorda tendinea, which arise in group from the payilary muscles, divide as they pass to be attached to the edges and ventricular surfaces of the neighbouring seconents. Additional (o)rds are furnished from the rentricular walls, and especially from the septum to the small segment, and some of these are provided with little papillary muscles.

The segments of this valve, exeent at the extremities and margins, contain abundant fibroms and a small amomnt of museular tissue. They are attached by their thickened bases to a fihrous ring which surrounds and strengthens the orifice. The surfaces which look towarls the oprening are smooth, whilst upon the opposite 
surfaces the chorda tendinex form an arched interlacement, which has brem well likened to the fan tracery of Gothic arehiteeture. (Macalister.)

The left auricle is plaeed behind the roots of the aorta and pulmonary arters, with the right auricle orerlapping it, and lying to the right of these structure. Behind, it receives on each side the pulmonary veins, and it is separated ly the pericardium from the wesophagus and the descending thoracic acota. Its narrow and much eurvel appendix arehes round the root of the pulmonary artery, and is the only gart of the auricle to be seen from the front. The cavity of the auricle is smorth, with the exception of the alpendix, in which the musculi pertinati are well marked.

Openings.-Besides the narow opening which leads from the atrium into the appendix, the left auricle presents posteriorly the orifices of the four pulmonary veins, two of which sometimes have a single mouth, whilst a third may he present, "specially on the right vile. The oval auriculo-ventricular opening is plicerl below and in front. Several small orifices, the foramina Thebesii, are also to be found in the cavity. A cresentie indentation on the septal wall, with its concavity upwards and placed above the level of the annulus ovalis, indicates the upper border of the vilve, which has grown upwards to obliterate the foramen ovale, but which now is adherent and forms part of the wall dividing the two

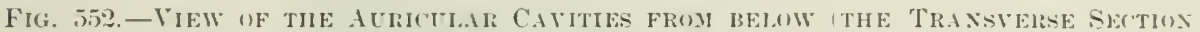
PASSISG ABOIE THEIR MIINDLE).

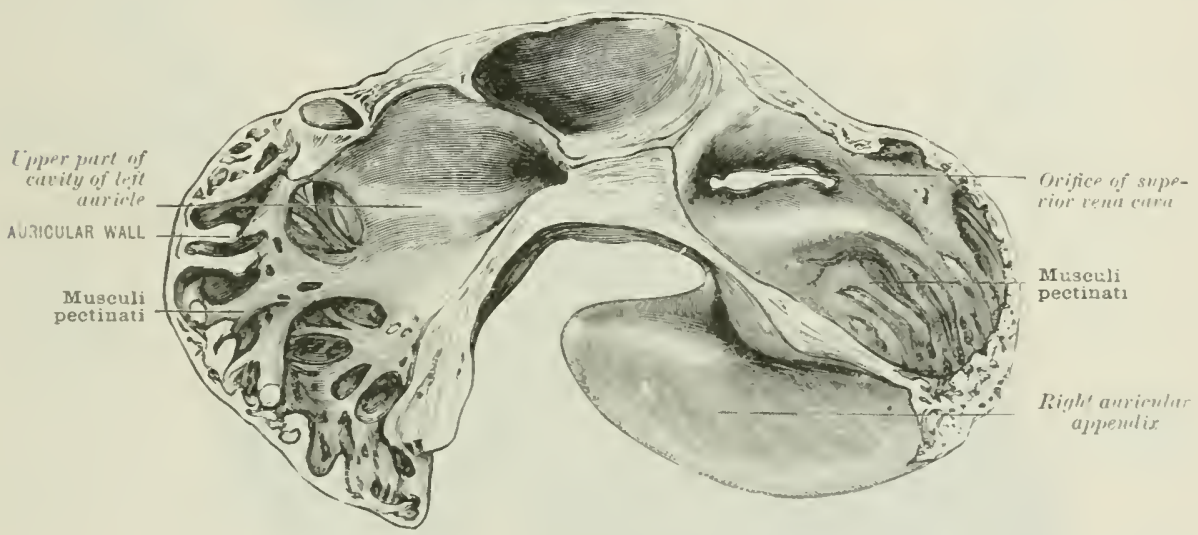

anricles. As already observed, a smoll oblipue orifice sometinses remains unclusel.

The left ventricle forms the chief part of the heart behind, with its alex and left horeler. It is somewhat longer and narrower than the right. It: carity is conical with the apex below and it is somewhat oroiel in transirerse sertion. "It. muscular wall, which is much thicker than that of the right ventriche, is thinnest at the alpex and thichest at the junction of the uper and middle thirds.

The columnæ carneæ are numerous, small, and (owely reticulated, giving to the interior of the ventricle, copecially near the alex, a cavernots aplearance.

The musculi papillares are nsually represented by two larere, sumetimes compoumt. muscular pillans. Which arise from this anterior and the posterion wall respectively; and from these the chordæe tendineæ pass to the relges and surfaces of the two siegments of the hicuspid ralve.

The orifice of the aorta louks smmewhat forwarks, and is guarderl liy throe semilunar valves, which ale similar in structure. lout prosent more strongly

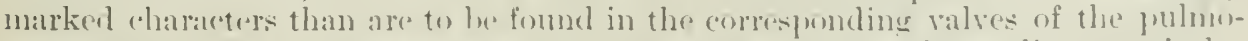
mary antery. One of these sements is placed anteriorly and two lie prosteriorly. It is surrounderl hy a fibrous jing, similar to that which strengthens the pulnonary orifiee, and the wills of that pertion of the cavity which lies immediately below it, the arortic restibule, are entirely fibruus. 
The auriculo-ventricular opening is gualerl hy the bicuspid valve. Its two

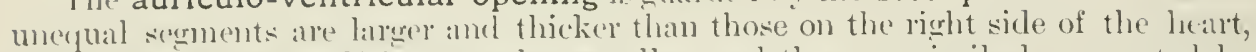
themgh the orifiee itself is somewhat smaller, and they are simblarly sepallated by smaller lobes or (asps. Of the two segments, the one, which is the larger and the more froe and smeotls, is placerl in frent amel to the right between the two openings, whilst the other lies behind and to the left. The filmous ring surrounding the orifice serves to give attaclument to muscular fibres as woll as to the valves. By its right border it is tiod to the abotio ring ly fibroms tissur, which also extemes to the

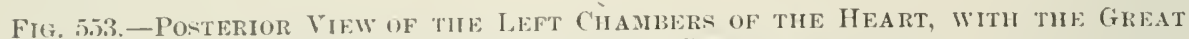
VESSEL ANI TIIE COROXART SINLS LAID OPEN.

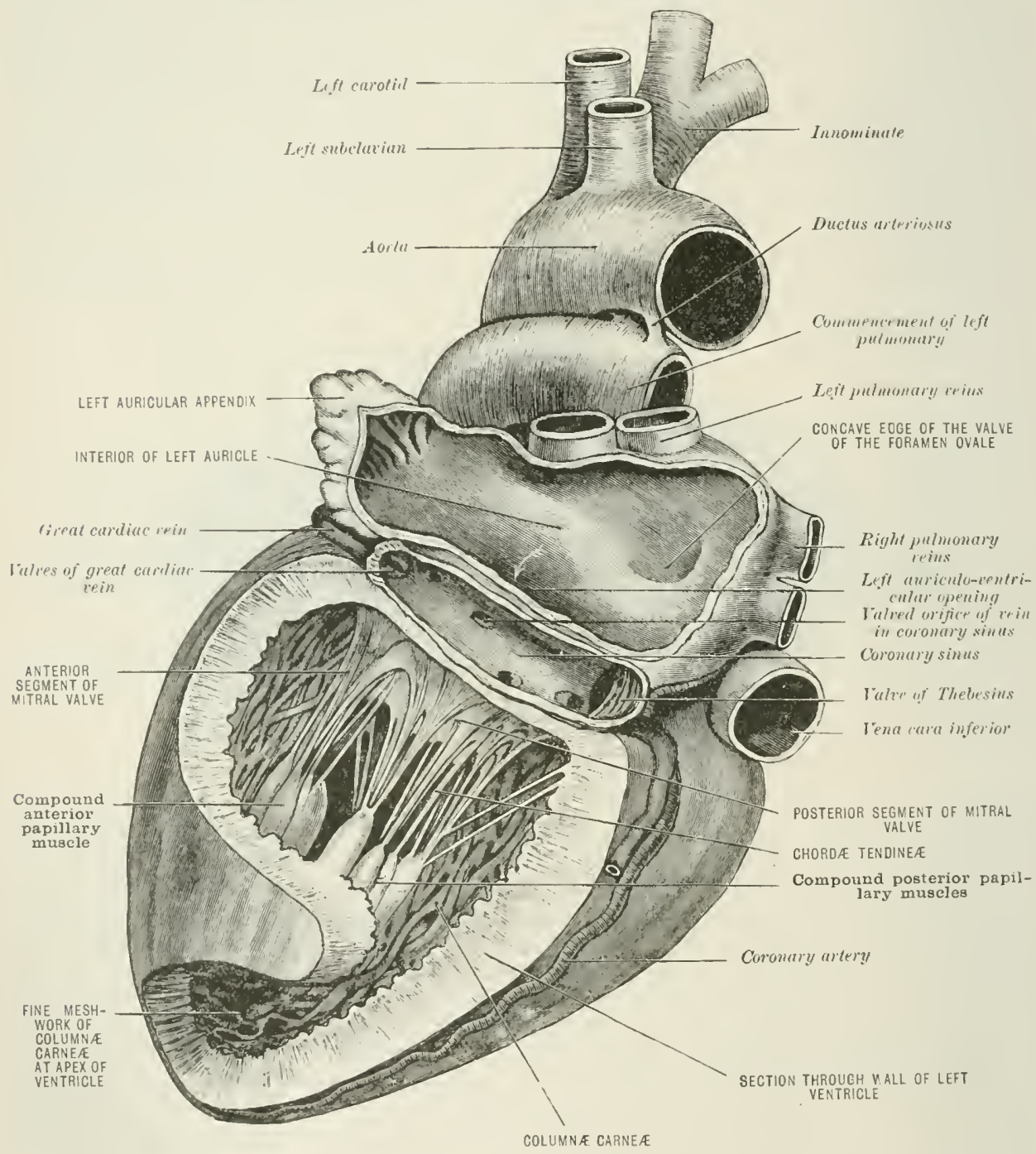

ring sumomoling the tricuspiel valve. In the angular space thus bounded there is imberleded a fiblo-cartilace, which in some mammals is represented by a bome which is known as the os cordis.

The interventrieular septum which separates the cavities of the ventricles is thickest holow. In the greater pald of its extent it comsists of muscular tissue, hut its upper portion, which intervenes met only hetween the two ventricles hut also between the left ventriele and right auriele. is a fibrous septum devord of musclefibres. 
TIIE POSITION OF THE C'HEF ORIFIG ONE TO THE ITHER AND TO THE C'HEST WALL

The pulmonary orifice is placed in front of, and to the left of the right anriculoventricular opening, whilst the aortic orifice is in front of, and to the right of the. loft anriculo-rentrieular opening. The relation of the valvel orifices to the chest wall can only be approximately determined (Fig. joti).

'The pulmonary semilunar valves, which are anterior in fwsition to the aortic. are placed behind the junction of the third rib with the stemum on the left side.

Fig. 5j4.-Showixg the Position of tile Heart axd its Valves ix Relation to the Cirest WaLLs.

(Reduced from Hensman and Fisher's Anatomical Outlines.)

(The right auricle and rentricle, with the pulmonary semilunar and trieuspid valres, aro outlined in blue tint:; whilst the left auriele and rentriele, with their corresponding valves. are indicaterl in red.)

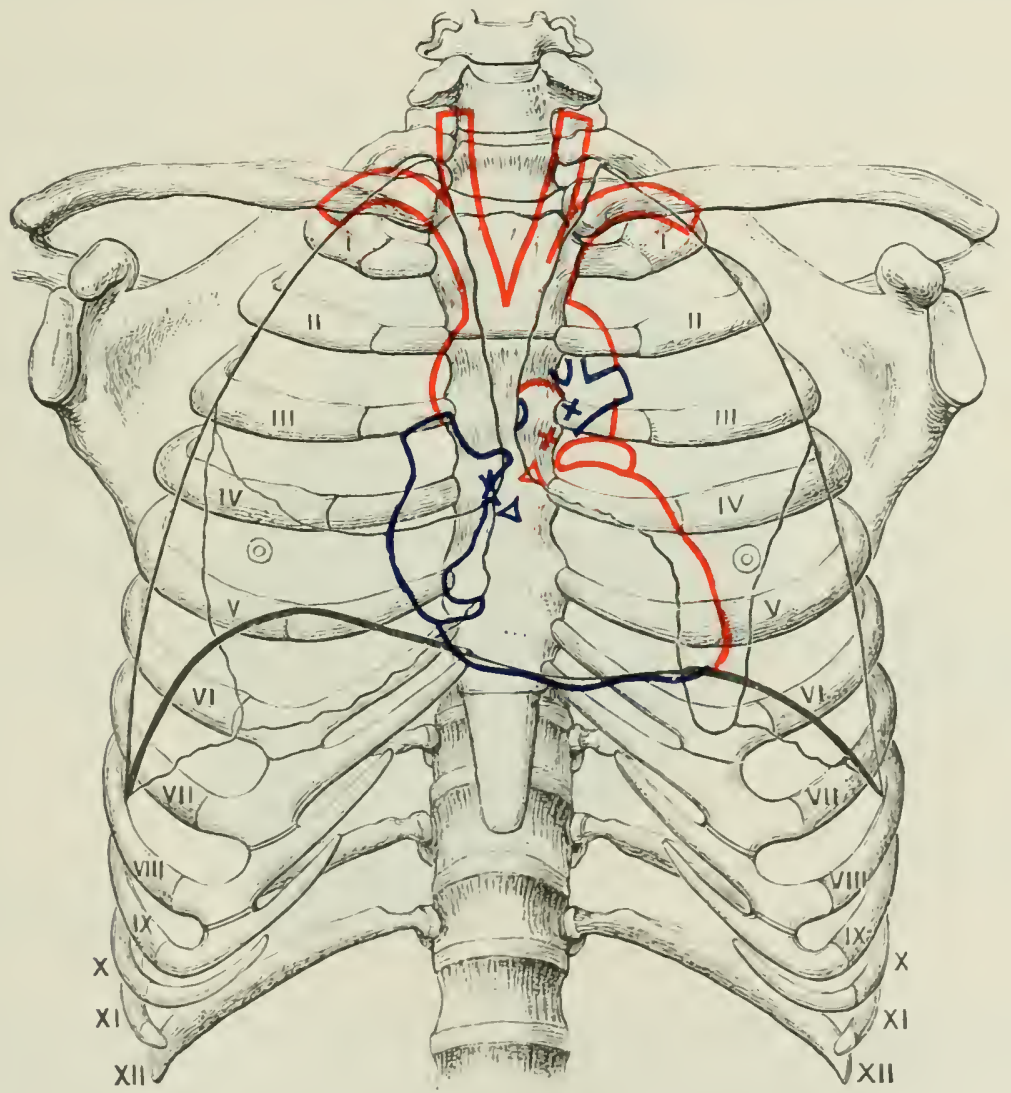

The aortic semilunar valves, more deeply planel. corresponel to the thiril spare, close to the sternum.

'The tricuspid valve is situitel lwhind the strmum mat the midclle line, alwot the level of the fourth spaces.

The mitral valve lies derply behind the strmmm oppesite the fourth cartilage ( Fig. $\bar{j}+7$ ).

The muscular walls of the heart vary very much in thickness. and the fortal liffers from the adult heart in the relative inuscularity of its ehambers.

The right auricle is thinner than the left, the right measuring about one-twolfth of an inch, and the left alwolt one-eighth of an inch in thickness. The right ven- 
tricular wall in the adult is much thinner than the left, being thickest at the base, and thinmest at the apex.

The left ventricular wall is about donble the thickness of the right; and it is thickest where the ventricle is lmadest, heing thinner loth at its base and apex.

\section{THE Vesses ANI NeRYEs}

The arteries.-The two (onenary arteries, right and left, arise, the right from the anterior, and the left from the left posterior sinus of Valsalva just above the froe horders of the right, and of the left posterior semilunar valves.

The right coronary artery passes forwards between the pulnonary artery anil the right auricular appendix, and thend winds to the right borter of the heart, aromm which it turns to gain its pusterior surface. In this course it lise in the auriculo-

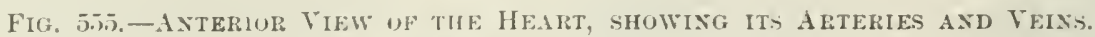

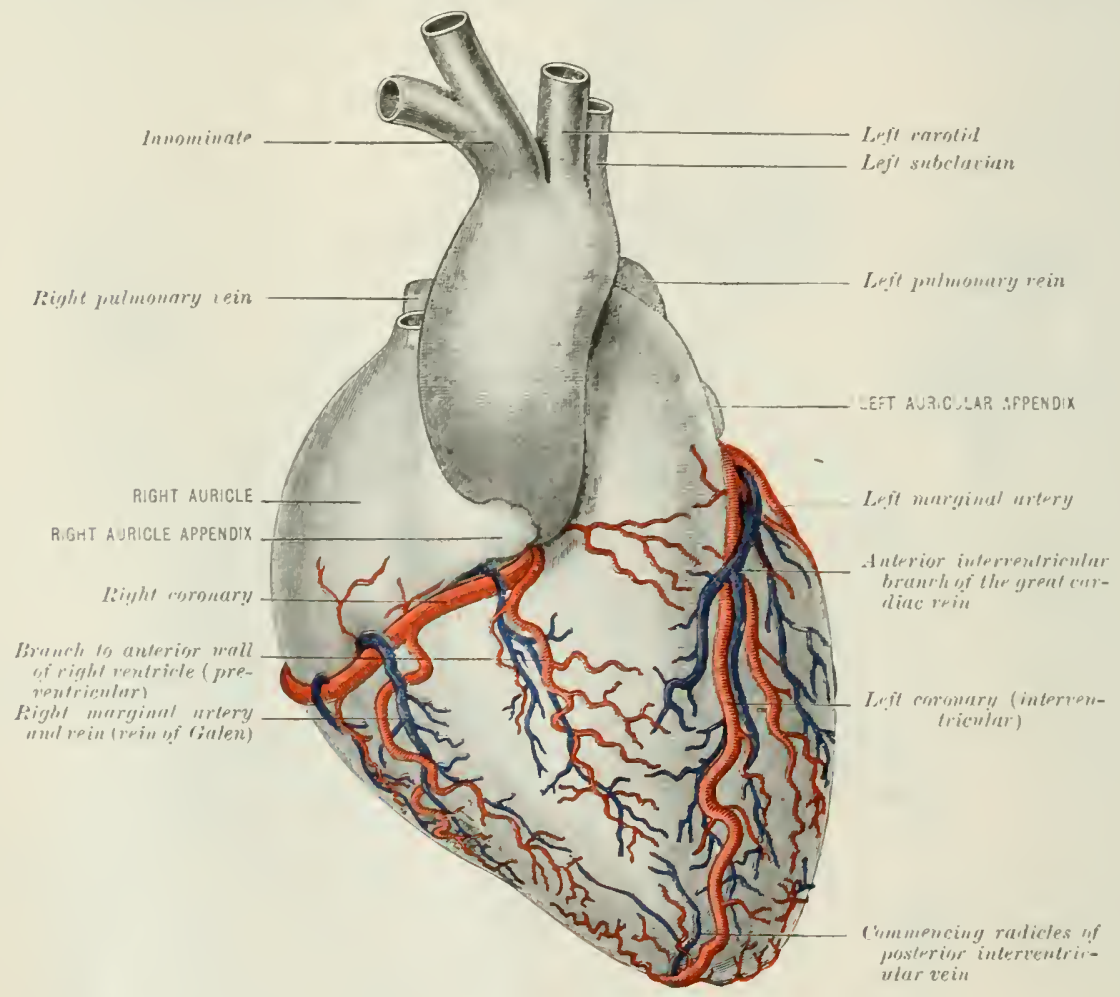

ventricular eroove. At the ammencenent of the posterion interventricular groose it livides into its two main branches, one of which, still farsing onwards in the auriculo-sentricular groner, anastomoses with the loft coromary, whilst the other (interventricular) desends in the furm betweren the ventricles towards the alex, near which it anastomoses with branches derivel from the left coronary artery which have reacherl the postrorior surface of the heart after passing aroumel its apex. In this (o)ture the right cormary artery supplies branches to the right auricle (auricular) ancl rosts of the julmonary artery and aorta, as well as (ome that deserends near the right border of the heart (right marginal), and at second (preventricular) to the anteriol wall of the light ventricle. It supplies both ventricles and the septum.

The left coronary artery pasies for a short distance forwark, between the pulmonary artery and the left auricula: alpendix, and then divides into two prinripal branches, ons of which deseends in the interventricular grouve to the apex of 
the heart (interventricular), around which it semels branches to anastomose with the right coronary; whilst the other winds to the back of the heart in the anrienleventrieular grove, to anastomose after division with the corresponding twigs of the right artery. In this eonrse it gives off a braneh which descends mear the lelt horder of the heart (left marginal), as woll as smaller bramehes to the left auricle, both ventrieles, and the commeneement of the anorta and pulmomary vessels.

The cardiac of coronary veins ateonmany the coronaly alteries and return the bloed from the walls of the heart.

The (so-alled) great cardiac vein aseruds in the anterior intorrentrienlar sulcus, passing round the left side of the heart to its posterior surface in the auriculoventricular groove to temunate in the eommencenent of the colomary sinus. It mouth is usually guarded by two valves, and it receives in its course the left

Fiti. 556. - Posterior VIEW of TIIE HEART, sIIOWING ITS ARTERIES ANI) VEINS.

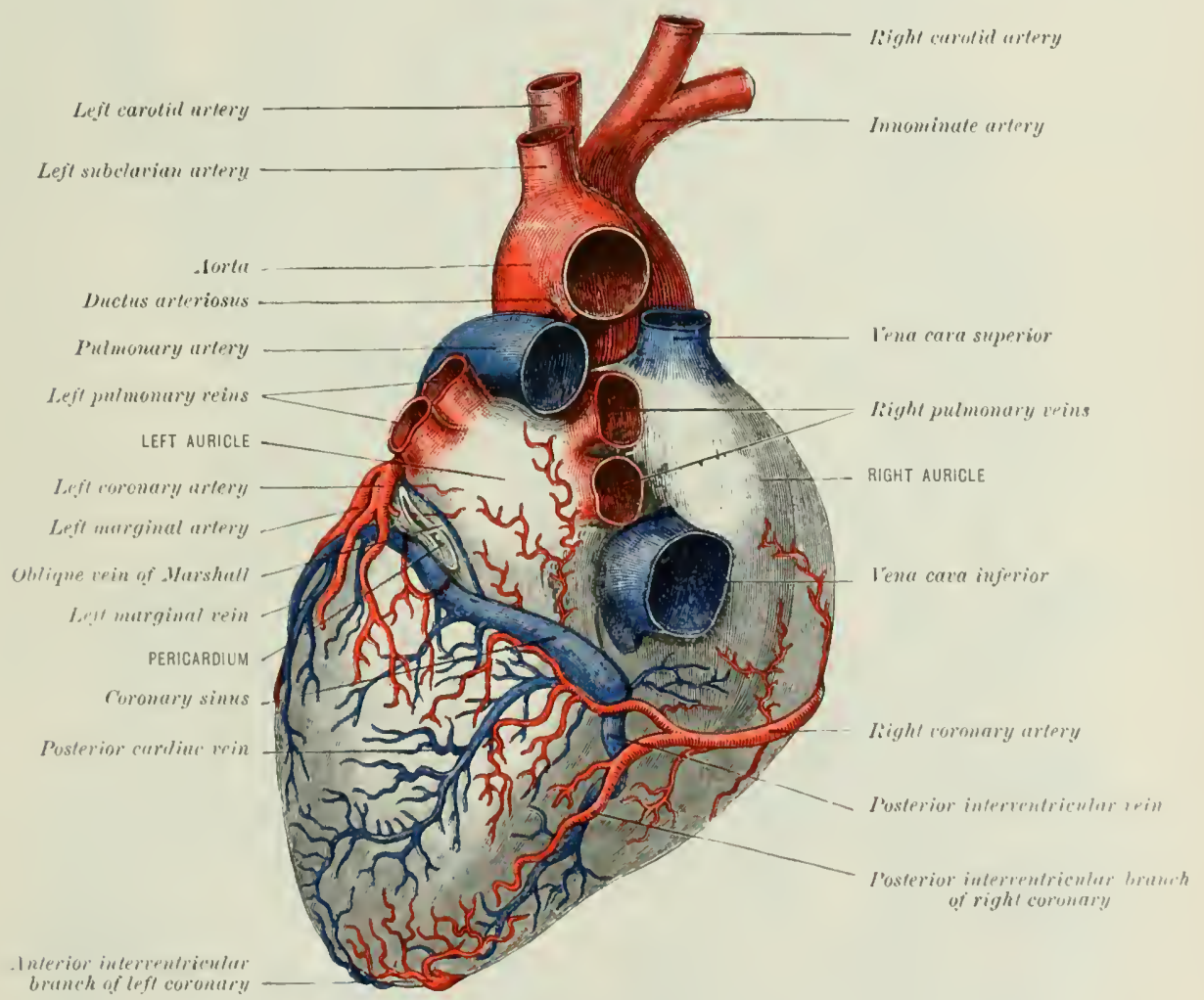

marginal vein, with other smaller veins from the left atriele (the left auricular) amel vesutricle, all of which are guarded ly valyes.

The posterior cardiac vein (posterior interventricular), sometimes the linlecer

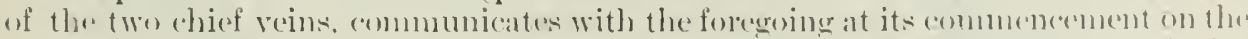
anterior surface above the heart's apex. It ascends in the posterior interventriculat

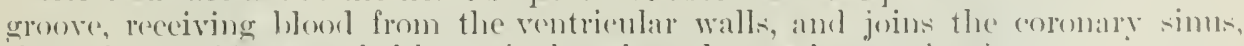
thromerl an orifice guanded by a single valve, close to its termination.

The anterior cardiac veins (preventricular) (onsist of severil small hameles

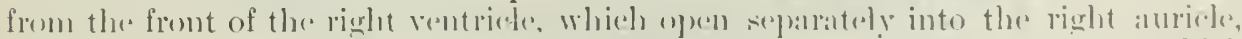
(1) inte) the right anricular vin; and a right marginal vein (vein of Galen), which

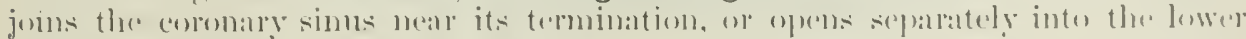
part of the right ambiele (ligs. 549, 5.5.5).

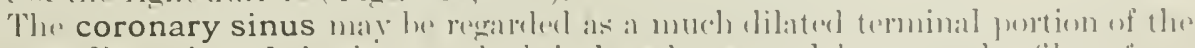

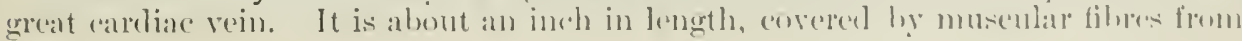




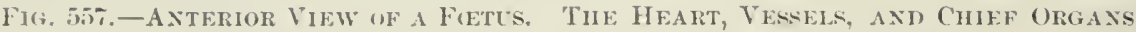
IISPLAYEI, WITH the PLACENTA AND TMBHLICAl, Corn.

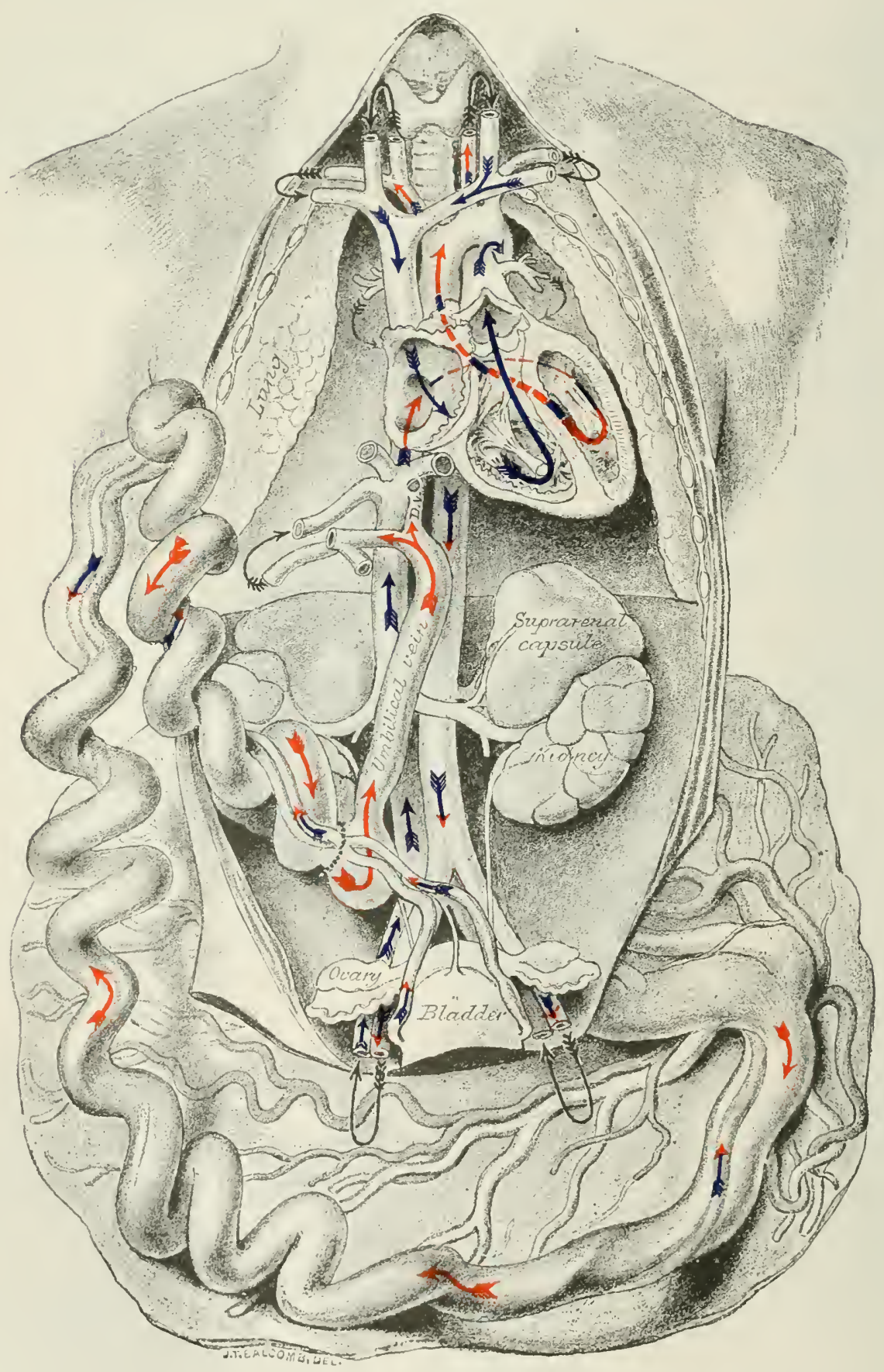


the auricke; and lies in the anrieulo-ventricular groove on the pesterior surfier of

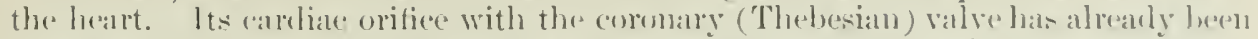
dereribul. Besisles the tributaly reins al really named, a small oblique vein of Marshall may sometimes lese traced from the vestigial fold to the sinus. This little

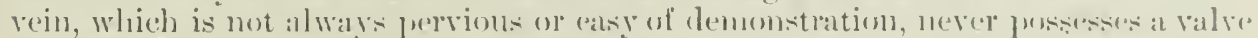
at its orifiee, and like the coronary sinus formed a part of the left sulperior venat (ava of early futal life. The sinus also recerives the fustorior interventrirular vein. one or more riglit aurieular lianches, and sereral post-ventricular veins from the batek of the lift rentricle.

The cardiac nerves desemel into the superior unerliastinum, fassing in fromt of and behind the areh of the anrta, to mite in the formation of the sulperficial and derele cardiale plexuses.

'The deep cardiac plexus, the larger and more inportant, is placed inmuediately alone the pumonary artery at its print of division, lying hetween the trachea and

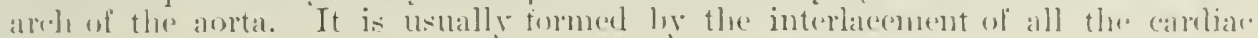
hranches, with the execention of the left siperior cardiac hranch from the sympathetic and the left inferior carliac from the pnemogastric.

A meshwork of branches descencls from the plexus, some pasing to the right and some to the left. 'The' greater number of the right branches follow the reourse of the right coromary artery to form the right coronary plexus; some, homerer. pais forwarls to enter the superticial earliae plexus.

The left hanches. which are both larger and more numeroms, deseremel benoath the corresponding pulnomary artery to join the left coronary plexus; sonue of these fous right and left to join the anterior pulmonary plexuss at the roots of the lungs.

The superficial cardiac plexus, which lies in front of the right pulmonary artery as it passes beneath the arch of the aorta, is formed by the interlarement if the left superficial cardiar branch from the sympathetie, the inferior eardiac from thr pnemugrastric, together with branehes derived from the derel plexus. A small gan grion, the cardiac ganglion of Wrisberg, is sometimes fouml elose to the right sille of the duetus arteriosus. The greater number of the filanents form this julexus ger to the right commary zlexus. fome, howerer. reach the left anterior pulnomary plexus.

The coronary plexuses follow the conrse of the veseces. and their filaments "nter the muscular walls of the leart. Minute ganglia are romecterl with these filiments, and are especially ahumblant near the aurieulo-ventrieular groove.

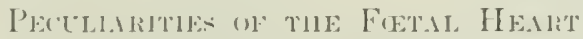

The fortal heart is at lirst alumst rertical in position, lut luring the lattur half

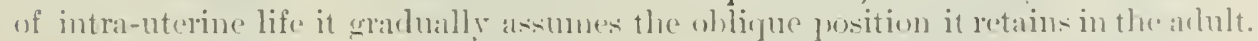

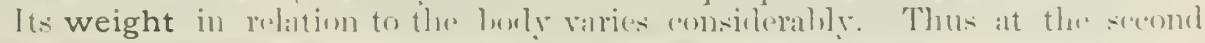

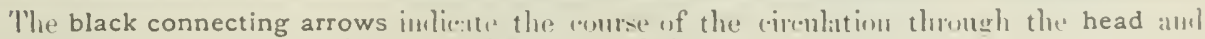
neck, thi upper extremities, the lungs, the liver, aml thi' lower extremities.

'The red arrows shw thr iliretiun of the curent from the placenta, thrush the umbilical vein, ductus venosus ( D. $V^{*}$ ) allil liver, to the uplerer portion uf the inferior vena cava.

The red arrows with the blue tails and the dotted line show the contse of the inmure

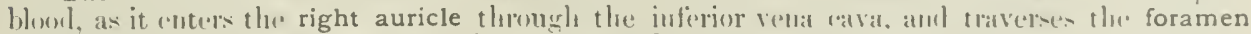

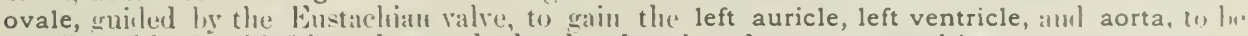

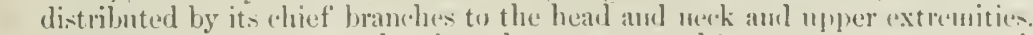

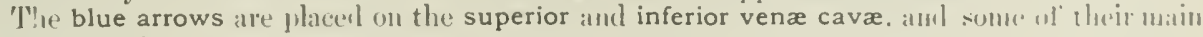
tributary trunks.

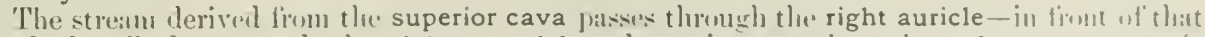
alvearly describerl-to reach the right ventricle; thence it pas-es iutu the pulmonary arery (a

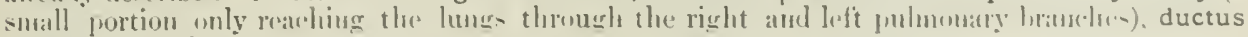
arteriosus, :uld descending aorta.

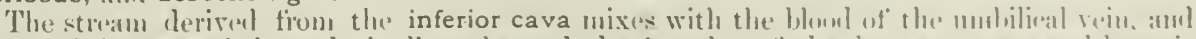

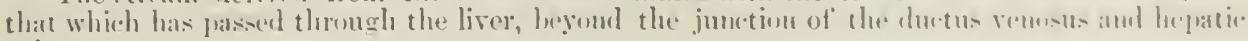
vilis.

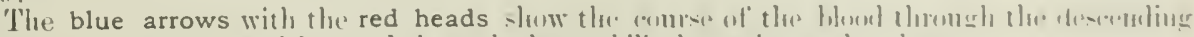

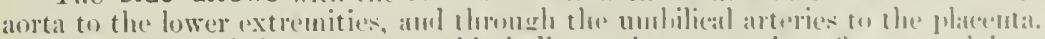

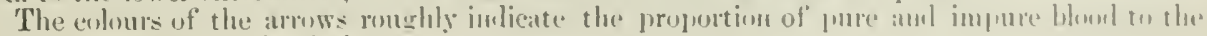
different parts of the circulation. 
month it is about 1 to 50 ; at lirth it is 1 to 120 ; whilst in the adult it is about 1 to 160 .

The auricular portion is at first more capacious than the ventricular, and the right auricle is larger than the left. The ventricular walls are at first about eflual in thickness, but at birth the left wall is the thicker of the two.

The foramen ovale is lingest about the sixth month of intra-uterine life, and there is up to this period a direct communication between the two auricles. The valve of the foramen ovale, however, cradually adrancing upwards beyond the amnulus, on its left side, acts as a perfect valve during the latter half of foetal life, and thus prevents the retum of blood into the right auricle.

The Eustachian valve has already been described; it is of larese size in the foetal

Fig. 558. - Axteriol View of Heart ANd Great Vessels of Fetes, the Anterior CHEST WALL JBET: REMOYEI) AND THE HEART SAC OPENED.

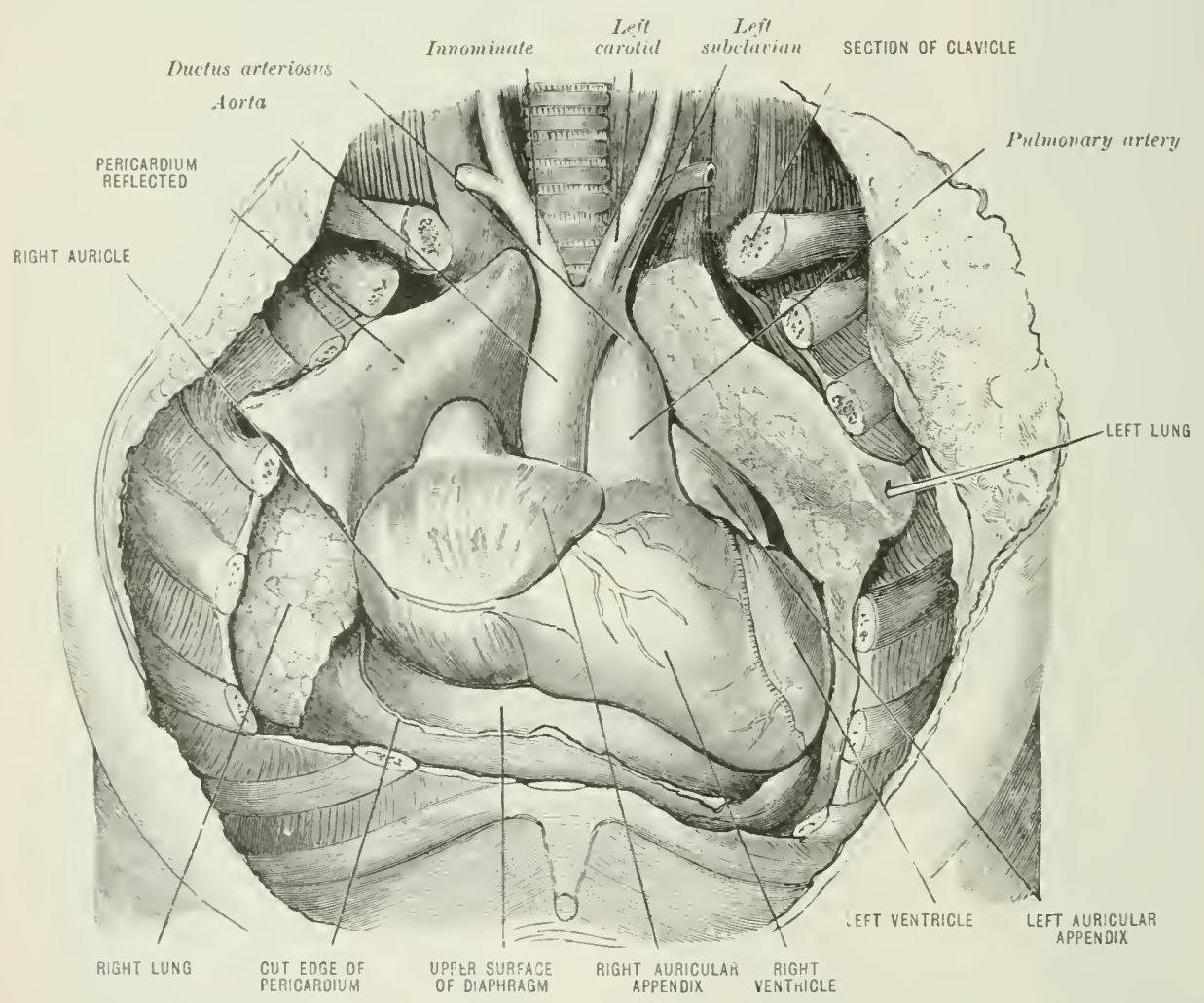

heart, and serves to direct the eurrent of blood from the inferior eava into the left aluricle.

The ductus arteriosus entinues the pulmonary artery onwards to the concarity of the arch of the aorta. to a point just beyomel the origin of the left subclavian artery, and so transmits the hlood from the right ventricle into the descending aorta. The ductus arteriosus during the growth of the pulmonary artery becomes ultimately associated with its left hranch.

The foetal circulation.--The right anricle of the heart reecives its blood from both vene cava, as well as from the coromary sinns. That which is comvered by the superior cara is remous blowel returned frome the head and noek and uper extemities. The inferior cava returns tles blesel from the lower half of the bodr, as well as that which eomese from the placenta throngh the mbilieal rein. This latter stream reaches the inforior eava, in part directly through the ductus renosus, and in part through the liver and hepatire veins. 
The blool of the superior venal cava prasses from the right andride inte the right rentricle, and thenee theough the pulmonary artery (a small fortion only roalding

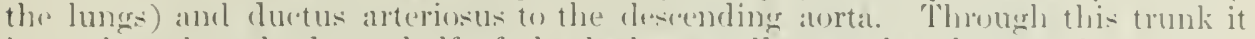
is comslueted to the lower half of the bocly as well as to the placenta through the

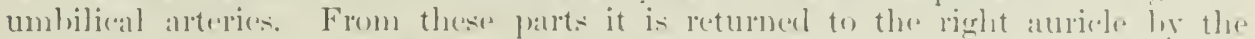

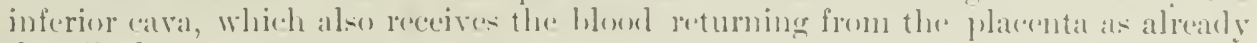
describut.

The e.urgent which jasies through the inferior cava only in a slight deerree mingles with that of the superior cara, as it is guided directly through the foramen ovale by means of the Eustachian valve inte the left auriele. This eavity also reerives a small ynantity of blood (which has traversed the lungs) through the putmonary reins. Fronin the left auriede the blood eurent passes into the left ventrieles and thence through the aorta to the head and neck and the upper extremities. 


\title{
THE ORGANS OF DIGESTION
}

\section{THE ORGANS ABOVE THE DIAPHRAGM}

\author{
BY AR'THIR HENSMAN, F.R.C.S.
}

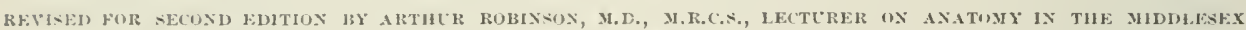
IIUSPITAI. MFDICAL SCHOOL; EXAMIXER IX ANATOMY FOR THE IONJOIXT BOARD OF EXGLAXD

\section{THE MOLTH}

$\mathrm{T}^{\mathrm{II}}$

HE mouth is the carity at the commencement of the alimentary canal which contains the organs of taste and mastication and the greater pairt of those of suecech. It communicates with the exterior through a transverse orifice (the buccal orifice) and with the pharymx through the fauces.

It is bounded anteriorly and laterally br the teeth and alveolar arehes; external to which is a second eavity, often described as the vestibule of the month, which is melosed by the lips and cheeks. Its roof is formed by the hard palate, its floor by the tongue. with the munus membrane reflected from it to the inner surface of the gums over the sublingual glands and the Whartonian ducts; and posteriorly it open: into the fauces. It is lined by mucous membrane, which is continuous with that of the pharyon, and at the outer margin of the lips it is continuous with the skin.

The buccal orifice is a horizontal slit, the extremities or "angles" of which are opprosite the first bicuspid teeth. The orifice is boundet by the upper and lower lips, of which the former is distinguished by a median tubercle, the remains of the free extremity of the fronto-masal process. The lips are covered by a dry mucont. membrane, bright ret in color, and extremely sensitive. containing large numbers of rascular papillie, in many of which are jerre-terminations resembling touch"orpureles. Near to the junction of the skin and mneous membrane are numerous sebacesus follicles. lut these are levoid of hair-bulls.

The substance of the lips consists of the orbicularis oris and a quantity of areolar tissme in which are emheded the comonary ressels, lymphatics, and small lindeles of the inframbital and mental nerves. Around the orifiee of the mouth 'm its inner aspect, and placed heneath the mucous nembrane, are a number of smlall Iobulated glands known as the "labial glands."

The cheeks ronsist of the bureinator muscle. corered externally, first ly a stratum of sulveutaneons fat, then by the dermal muscles, zrgomatici and risorius. and lastly by the skin. Ther are lined with mucous membrane, which contains numerous buccal glands similar to, lout smaller than, the labial glants. Between the integument and the buccinator, in each check, besides vessels and nerves there are several glands, the molar glands. whose ducts yierce the huccinator and open in the restibule opposite the last molar teeth, and a large quantity of fat, which gives retundity to the fertures, and constitutes what is sometimes sjoken of as the sucking cushion of the cheek. ()pposite the serond upper molar tooth is a papilla whith marks the opening of the duct of the parotid gland.

The gums are formed by a layer of tough areolar tissue covering the alveolar processes, and fimly attached to their periostem.

They are coserext on looth aspects hy the mucoms membrane of the mouth, the inner surfares receiving roflexions from the sides and anterior extremity of the tomgue, a mortian fold forming the frammon of that organ; and the outer surfaces recoving reflexions from the cheeks and lijes. In the nedian line above and below the orifiee of the mouth are folets of mueous membrane, forming the frena lahiorum, of which the mpere is the more marked. 


\section{THE PALATE}

The palate consists of two portions, the anterior or hard fulate, and the furt... riur or soft palate.

The hard palate, which is linited in front and laterally hy the alyeolan processes, ends posteriorly in a free border to which the soft palate is attached.

The mueous membrans which covers it is corrugated, thick and somewhat pale, and is firmly bound down to its periostemm. In the median line of the palate is it

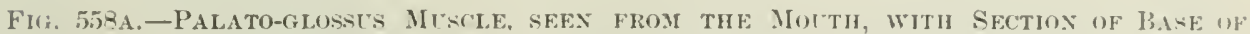
TuNiti:

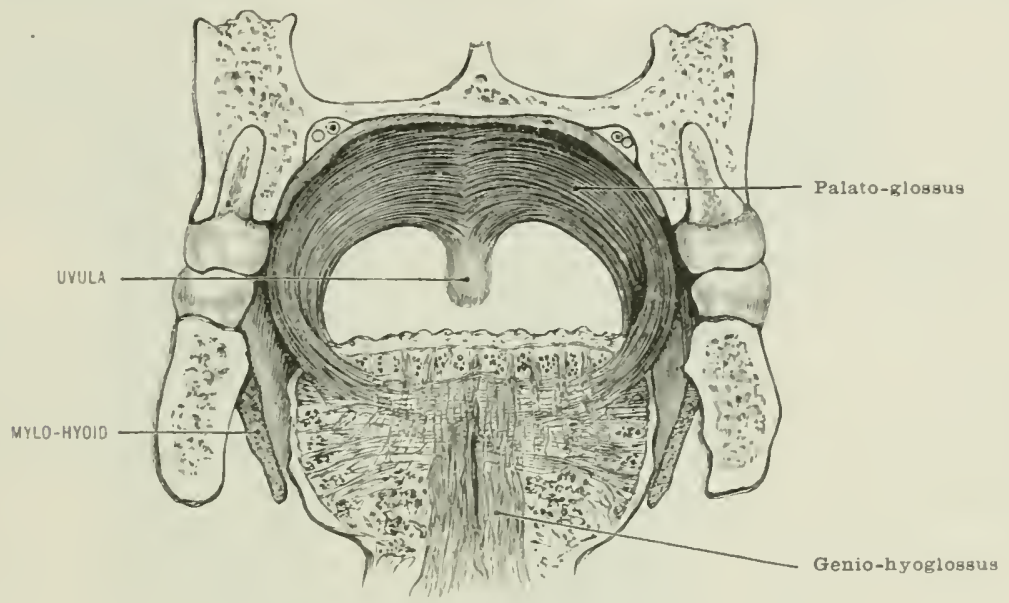

riflese called the raphe; at the anterior extremity of this is a small japillat which mirks the inferior opening of the anterior palatime cands, and extending from its siles, anteriorly, are five or six transverse ridges. The numens membrane roner-

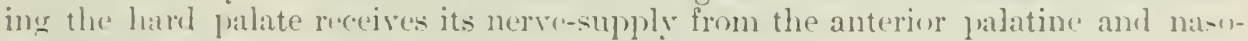
pralatine merres.

The SOFT PALATE (fig. 560) is attacherl to the posterior londer of the harel palate, of which it forms a backward prolongation langing rown at the hack of the muth, amel thus partially separating the latter cavity from the pharyn. It silus are merew in the pharygeal wall, and its lower border is fres.

From the centre of this border a somewhat eonieal process, the uvula, depents. and from the base of this two folds of mucous nembrane on ealch side extend in :In outward and lownarel dinection, reeciving the nane of the pillars of the fauces.

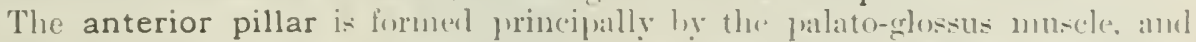
its direction is dewmwarls, outwards, and forwards to the sicle of the base of the tongue.

The posterior pillar is formed principally ly the palato-pharyengets. It

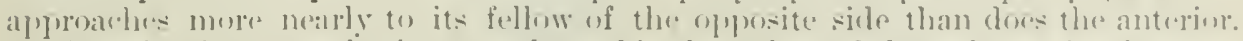

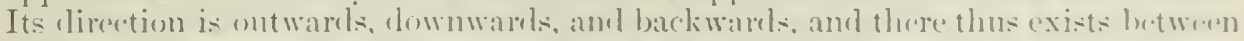
it and the anterior pillatr a trianenlar spare. the tonsillar recess.

The space between the antrion pillars is kmwn as the isthmus of the fauces,

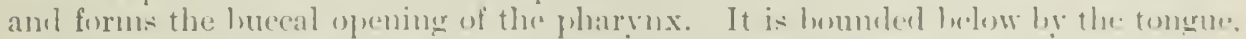
above he the soft palate, and literally ly the pillars of the fances.

The anterior surface of the soft palate is cometre, directerl formarts and downards, and is entinuens with the lower surfater of the hard palate: its 
posterior surface, which is convex, is a continuation of the floor of the nasal cavity, and it forms a part of the anterior wall of the pharyx.

Structure.-The soft palate is a fold of mueous inembrane enchosing an aponemosis, muscles, ressels, and nerves. It is marked in the mildle lineby a raphe indirating the line of junction of the two halves from which it was formed.

The prostrior larer of the mucous fold which is directed towards the eavity of the pharynx is ontinuous with the nasal nucous membrane; the anterior layer lies in the posterios houndary of the mouth and is continuous with the mucous membrane of the hard palate; the lower margin is free. Cilands are numerous in lusth layers, but more especially in the anterior.

The aponeturosis is attached ahove to the posterior margin of the hard palate: laterally it is continuous with the aponenrotic layer of the pharyngeal wall; below, towards the lower margin of the soft palate, it grartually disappears, and it gives attachnent to fibres of the levator palati and the palato-pharyngeus and to the tenchon of the tensor paliti.

The muscles are arranged in layers either behind or in front of the-aponeurosis, and in a horizontal section of the soft palate the following lavers are met with from hehind forwarls: (1) The mucous membrane on the pharyingeal surface; (2) the posterior layer of palato-pharyngeus fibres; (3) the azygos uvula ; (4) the levator lalati; ( .7$)$ the anterior layer of palato-pharyngeus fibres ; $(6)$ the palatal aponeurosis with the tensor palati ; ( 7 ) the palato-glossus; and ( 8 ) the mucous membrane on the buccal aspect.

The Palato-Glossus is described on page 453.

The Palato-Pharyngeus-named from its attachments-is a thin sheet.

Origin.-(1) From the aponeurosis of the soft palate by two heads which are separated by the insertion of the levator palati; (2) one or two narrow bundles from the lower part of the cartilage of the Eustachian tube (salpingo-pharyngeus).

Insertion. - (1) By a narrow fasciculus into the posterior border of the thyroid "artilage neal the base of the superior colnu; (2) by a broad expansion into the fibrous layer of the pharynx at its lower part.

Structure.-The upper head of the musele consists of scattered fibres which blend with the opposite muscle across the middle line; the lower hearl is thicker, and follows the curve of the postrior border of the palate. The two heads with the fasciculus from the Eustachian tube form a compact muscular hand in the posterior pillar of the fauces; the fihres mingle with those of the stylo-pharyngeus, at the lower border of the superior constrictor, and then expand upon the lower jart of the pharyn.

Nerve-supply.-From the pharyngeal plexus.

Action.-(1) Approximates the posterior pillars of the fauces; (2) depresses the soft palate; (3) elevates the pharyx.

The Levator Palati-named from its action on the soft palate-is somewhat rounder in its upper, but flattened in its lower half.

Origin.-(1) The uncler surface of the petrosal anterior to the orifice of the caroticl canal; (2) the lower margin of the cartilage of the Eustachian tube.

Insertion.-The aponenrosis of the soft palate; the trminal fibres of the muscles of each side meet in the middle line in front of the azygos urulas.

Structure.-Its origin is by a short tendon; the muscle then becomes fleshy, and continues so to its insertion.

Nerve-supply.-It is usual to describe this musele as being innervated by the facial through the petrosal branch of the Vidian. The nerve is supposed to reach the muscle through the small palatine nerve from Moekel's ganglion. Stimulation of the facial trunk within the skull of monkeys produces no result on the soft palate, whereas stimulation of the eleventh causes elevation of the soft palate on the same side. The motor branch probably passes to the palate in the upper loranches of the pharyngeal plexus (Horsley and Beeror).

Action.-(1) To raise up the palate and hring it in contact with the posterior wall of the pharymx; (2) when the musele contracts it presses up and eloses the pharyngeal orifice of the Eustachian tube (Cleland). This action is not admitted hy many anatomists. 
The Tensor Palati-naned from its action on the soft palate-is a thin, flat, aurl narrow sheret.

Origin.-(1) The seapherid fossid at the rout of the internal pterygoid flate; (2) the alar spine of the sphenoid; (3) the outer side of the pharyngeal extrenity of the Eustachiam tuhe.

Insertion.-(1) Into the transirese ridge on the muler surfatee of the horizontal plate of the palate bone; (2) the alponeurosis of the soft palate.

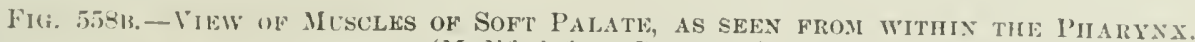

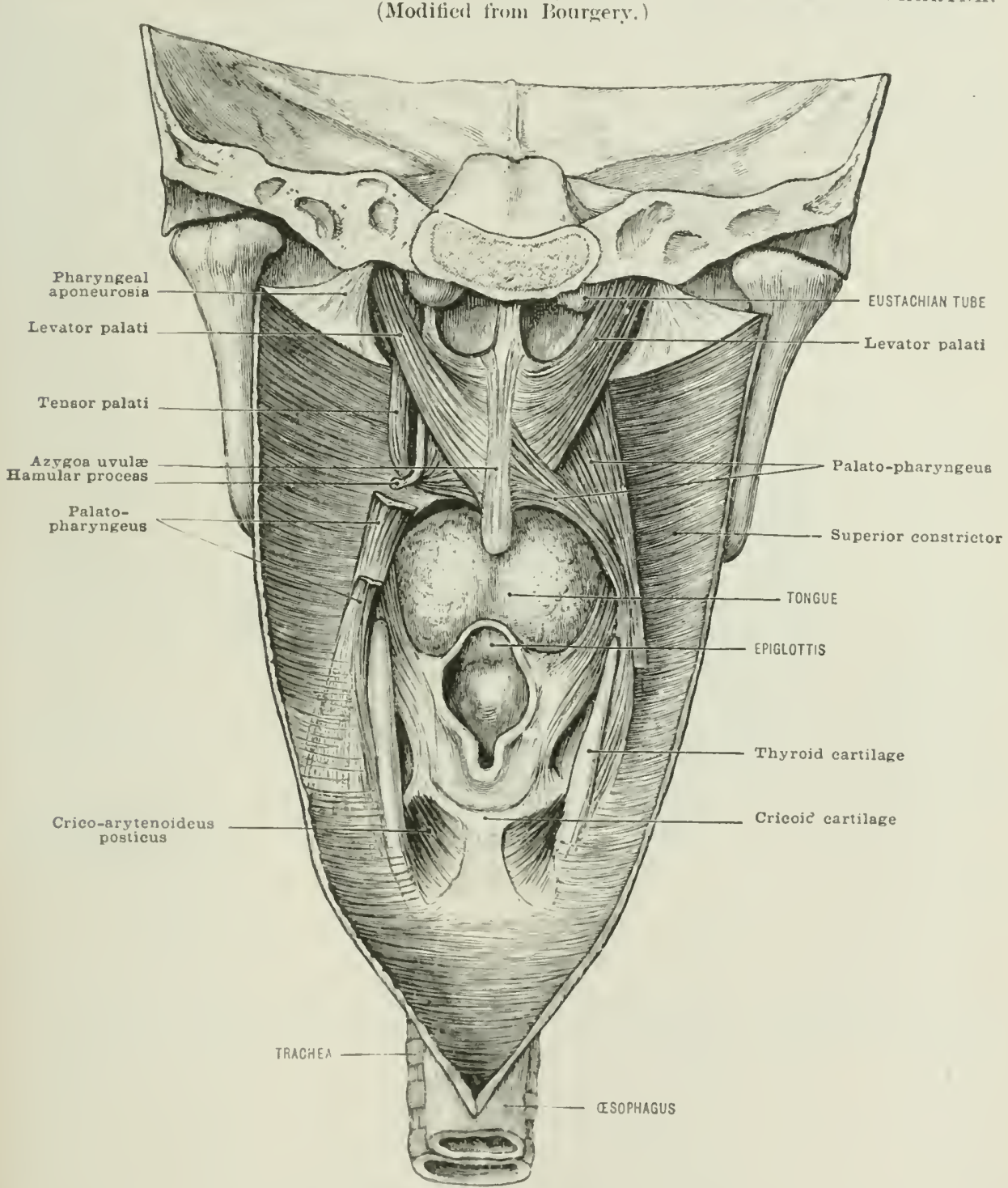

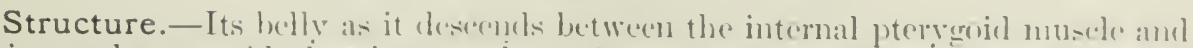

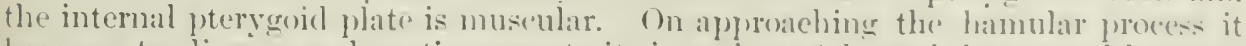
hecomes tendinous, and enntinu(ss so to its insertion. A hursa is interpused betweren the hamular process and the tendem. The belly of the muscle is at nearly al rierht angle with its tendon.

Nerve-supply.-From the otic grangliom on the mandilumlar division of the fifth nerve. 
Actions.-(1) Tightens the soft palite: (2) opens the Eustachian tulue chringr deglutition.

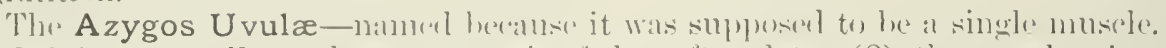

Origin.-(1) Fem the alponemenis of the sult palate; (2) the nasil sjume of the palate home.

Insertion.-Into the w1wli.

Structure. - The mucle comsists of two narrow parallel strips lying on each side of the mirlule line of the palate.

Nerve-supply.- l'robably from the sime source ats the lavator labati.

Action.- To ilraw up, the urulit.

The Mucous Membrane of the soft palate is comtinuous with that of the montl on its anterior asinecet, and with that of the masil chamber on its posterior surface; its epithelimm is colmman and ciliated in the vicinity of the Eustachian

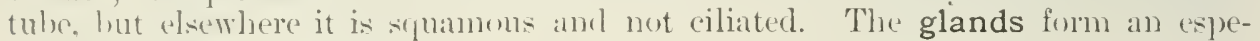
cially thick layer on its superior aspert.

Arterial supply of the soft palate.-(1) Ascending palatine of facial; (2) palatine branch of ascending pharyngeal; (3) twigs from descending palatine of internal mixillary, which enter the smaller palatine canals, and are ristriluted to the soft palate and tonsils, and communicate with the ascending palatine of the facial artery; (4) lingual artery, hy twigs from the dorsal branch.

Nerves to the soft palate.-(1) Branclies from Mrekel's ganglion ('small or posterior palatine' and 'xternal palatine nerve'); (2) tonsillitic branches of glosso-pharygeal nerve; and (3) the nerves supplying the muscles.

The TONSILS (figs. 507 and 560 ) are two borlies situsted one in each of the recesese between the anterior and posterior pillars of the fauces and beneath a small fossal, the supratonsillar reess, which is the remains of the second visceral cleft. Ther an about an inch (20-25 $\mathrm{mm}$.) in length, and half an inclu (12-15 $\mathrm{mm}$.) in width and thickness; but their size is liable to considerable variation.

On their inner surfaces are a number of puncture-like openings (twolve to fifteen on earh tomsil), which form the orifices of small recesses or crepts, into which numerous follicles open. The mucous membrane is continued into, and forms a lining for, these follicles; their walls are surromnled by an aggregation of closed capsules somewhat similar to the solitary glamels of the intestine, and they contain at thick seretion.

The tonsil corresponds in position with the angle of the jaw; it is in relation externally with the superior constrictor muscle, which separates it from the ascending lharygeal artery; about one inch externally and posteriorly to it is the internal carotirl artery, and still more extemally the internal pterygoid muscle.

The arteries of the tonsil are five in number, viz.:-(1) Dorsalis lingue from the lingual; (2) ascenting pharvigeal from the external carotid; (:3) asconding galatine from the facial; (4) tonsillar from the facial; and (5) descending palatine from the internal maxillary.

Thu veins of the tonsil form a plexus which lies upon the onter sicle of the glamel, and opens extemally into the pharyngeal plexus.

The lymphaties of the tonsil ammunicate with those of the dorsum of the tongue, and they pass to a glamb which lies near the angle of the jaw.

The nerves of the tonsil are linduches of the fiftl and glosso-pharyngeal.

\section{TIIE SALITARY (YLANDS}

The three chief sulivary glands are the parotid, the submaxillary (mandihular), and the sublingual. These all pour their secretions into the cavity of the mouth.

The PAROTID GLAND is the laresest of the salivary glands. It lies just helow and in front of the ear, and it varies from a little oree half an omuce to an ounce in weight. 
Its superficial surface is linited above hy the root of the z.ygoma; helhind, l,

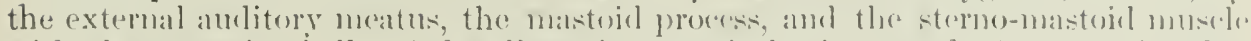
with the posterior inelly of the dignstric; anteriorly, it retents for a varying dis-

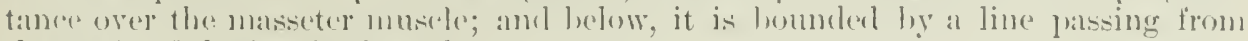
the angle of the jaw backwards.

It is enclosed in an aponeurotic alysule. The apsule is continuous with the

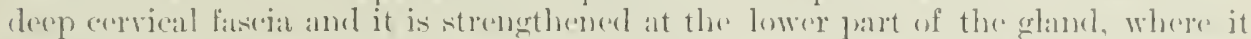
extrme from the styloid proeess to the amgle of the jaw as the style-maxillary

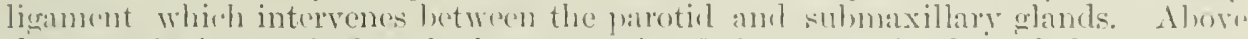
the eapsule is attached to the lower margin of the trumpande plate of the temporal bome and to the posterior lorder of the Glasserian firsure.

The gland is somewhat prismatic in form. peseswing three lorelers and surfares and two extrenities. The onter surface is covered loy fascia and skin and in the lower part of its extent by platysma. Embedded in it areserelal superficial lymphatice glands which receive afferent rassels from the temple, check, evelorows, iper-

Fig. 559.-The Salivaky Glanis.

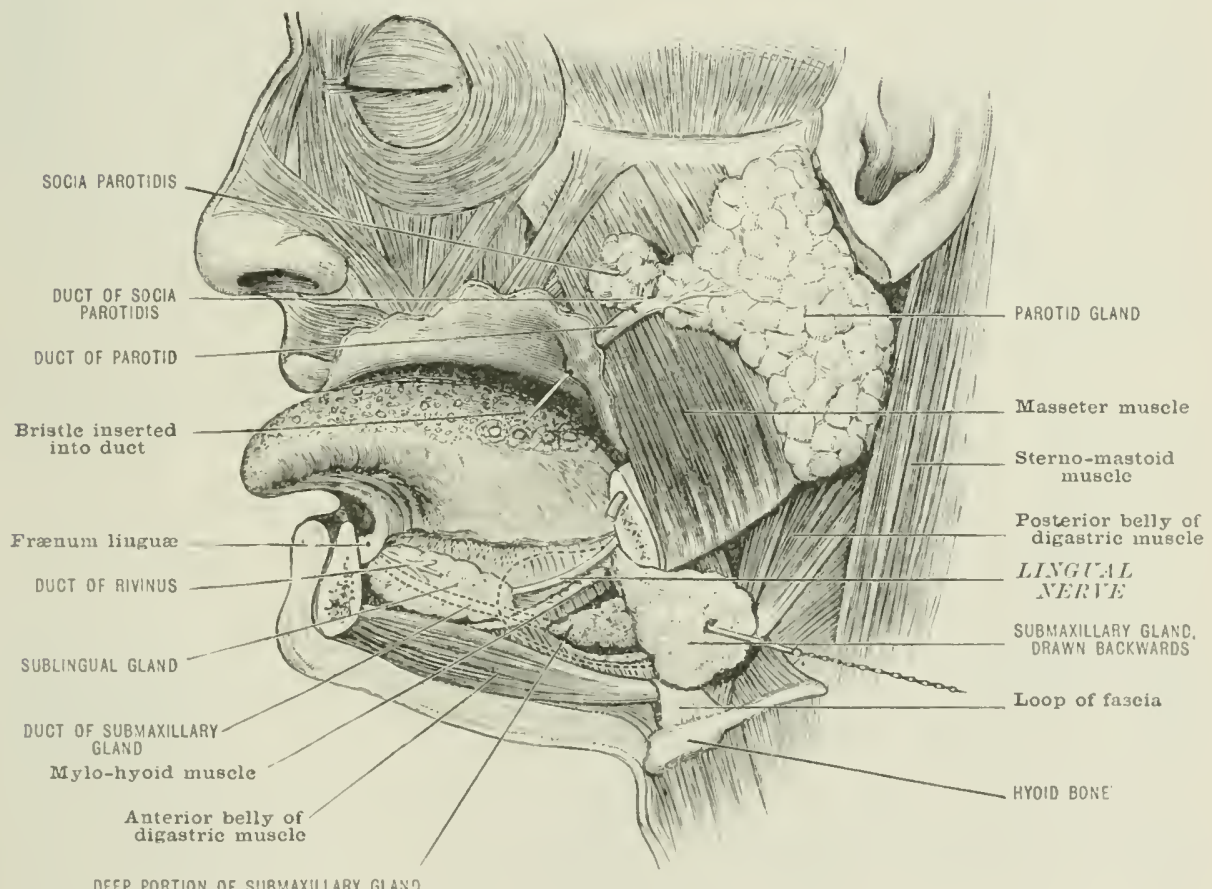

liels, and from the outer aspect of the pima. The posterior surface is in relation with the posterior belly of the digastric, the stoloid process, the stybil group of muscles, the mastoid process, and the pusterior aurieulat artere" A hackward process of this surfare which anhaners the styloil process and insimates itsolf be-

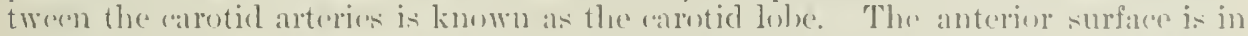

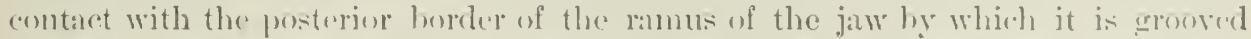

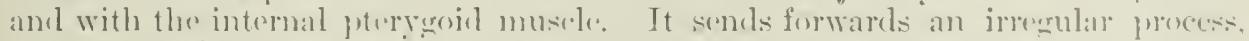

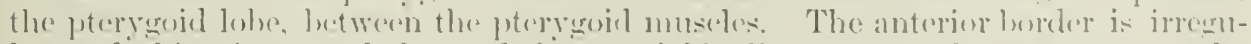

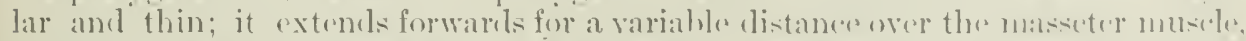

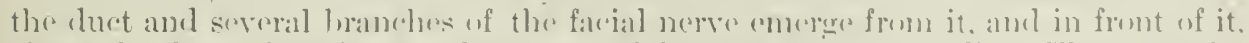

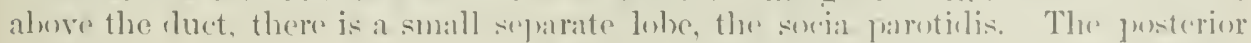

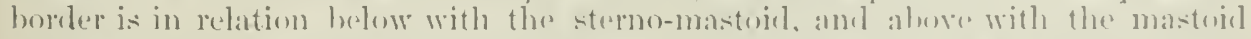
process. The intemal borler is separaterl from the wall of the pharyox hy thes

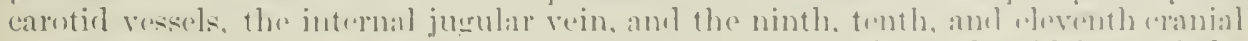

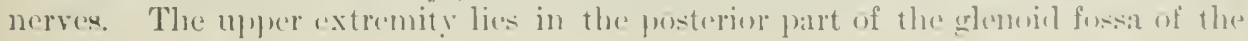


temporal bone. behind the condyle of the jaw, and in contact with the trmpanic plate; the superticial temporal artery and the temporal branch of the facial nerve

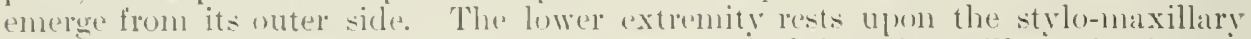
ligament which separates it from the posterion end of the submaxillany grand.

Tithin the sulstance of the gland are the following struetures: The upper part of the external canotid artery with its superficial, temporal, and internal maxilary branches; the commencements of the transterse filcial, orbital, and middle teniporal branches of the superficial temporal artery, and the deep anricular branch of the internal maxillary trunk; the temproro-maxillary rein, its tributaries, and its two torminal branches; the facial nerve, its cervicu-fiacial and temporo-facial clivisions erossing the temporemaxillary rein horizontally, and their terminal branches: the anriculo-temproml nerve. hianches of the great auricular nerve, and a fow deep lrmphatic glands which receive afferent vesseds from the posterior part of the masal fos:al, the soft palate, and the extemal auditory meatus.

The duct of the parotid (Atenson's) issues from the anterior border of the yland and crosses the masseter a finger's brealth below the zygoma. It penetrates the fat of the check and the fibres of the buecinator muscle, between which and the muens menbrane it runs for a short distance before it terminates on the summit of a little papila, by a minute orifice. This opening is placed opposite the crown of the second upper molar tooth. The duct commences ly numerons branches, which convere towards the anterior border of the gland, and receives in its passage arros the masseter the luct of the socia parotirlis. The canal is about the size of a crow-ruill. Its mucoms nembrane is covered by a colummar epithelium. The cont of the duct is thick and tough, and consists of fibrous tissue intermixed with (omtratetile fibres.

The arteries ane derived from those lying in the gland substance and from the posterior auricular artery.

The veins teminate in the temporo-maxillary trunk.

The nerves are derived from the facial, great auricular, the carotid plexus of the sympathetic, and the anriculo-temporal. The latter also conveys a branch derived from the glosio-pharyongl through the lesser petrosal and the otic ganglion. The lymphatics teminate in the sujerticial and rleep cervical glinds.

The parotil gland has been observed to retain its primitive condition, lying over the mandible and masseter muscle. Its lobes are absent in early childhood.

The SUBMAXILLARY GLAND weighs from two to three clrachms and it is encloserl in a capsule of deep cervical fascia, except externally, where it is in contalct with the body of the jaw. It consists of two portions, the superficial and the 4eep). The superficial portion is much larger than the deep portion; it oceupies the fore part of the submaxillary triangle and is prismatic in form. possessing three surfaces and two extremities. The extemal surface lics in the submaxillary fossa on the inner sille of the body of the jaw, and is in relation posteriorly with the internal potergond musche. The lower surface looks downwarls and outwarks: it is coverext ly ileep fiscia, platysma, superficial fascia, and skin; several superficial lymphatie crlands, which receive afterent vessels from the lower part of the face. lie ipon or embeded in it, and it is crossed hy the facial vein am some hranches of the facial nerve. The internal surface rests upon the mylo-hroid, hyo-glossus. amd stylo-glosids muscles and between it and the mylo-hyoid muscle are the mylohyojil nerve and artery and the submental branch of the facial artery. The anterior extremity is in eontact with the anterior helly of the digastric; the posterior "xtremity is grooved by the fareblartery and is in relation with the stylo-maxillary ligament and the gosterior belly of the iligastrie.

The leep portion is a mere tomgur-like projection which rises from the internal surface of the superficial pution at the posterior horder of the mylo-hyojel muscle. It runs forwards and upwards, in comprany with the duct, muler cover of the mylo-

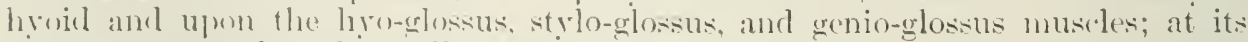
commeneement the sulmaxillary gatngliom lies just alove it, and at its termination it is in close pelation with the sulplingral gland.

The duct of the submaxillary gland (Wharton's) springs from the deep surfare of thesuperficial part of the gland; it passes forwards and inwards accompanying 


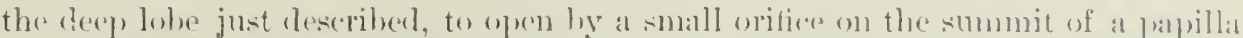

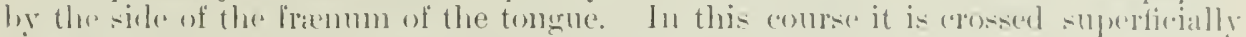

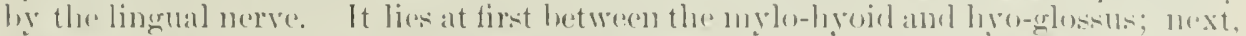

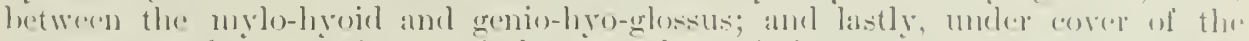

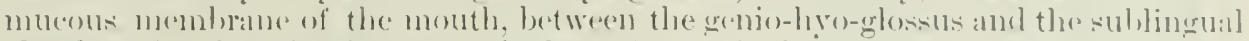

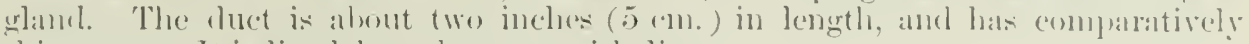
thin coats. It is lined by colummar epithelium.

The arteries to the gitad are derived from the factal and lingual, and they ane arempanied by (o)responling veins.

The nerves procerel from thesubnandihular ganglion, from the molo-hyoid of

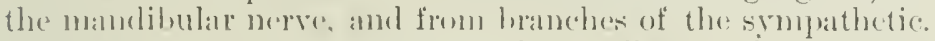

The SUBLINGUAL GLAND-the smallest of the salivaly glands-is alout one

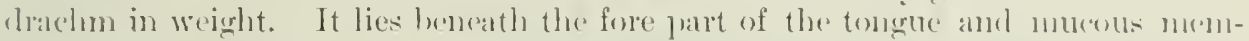
brane of the Hoor of the month, resting decply mpon the mylo-hyoid muscle. Its

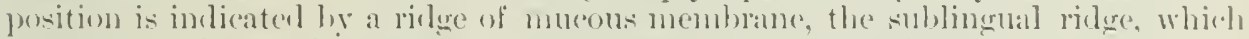
runs outwals and backwards from the framum. It is limited extemally by the sublingual fossa of the mamdible, and internally hy the genio-hyo-glosise, styleglossus, and Wharton's duet; in front it touches its fellow, and behinel it apploaches the drep lobe of the submaxillary gland.

The duet from the main portion of the glanel-the duct of Rivinus or Bartholin -rums alongside the sulmaxillary duct, and opens either into it or on the same. pappilla. The fore part of the gland consists of a chuster of little lobules, wath with its own separate duet-the durets of Walther. They open in a line on the fleor of the mouth, on the sublingual ridge.

The arteries are derised from the sublingual and submental, with their corresponding reins.

The nerves are derived from the gustatory (through the submandibular ganglion) and from the sympathetic.

\section{TIIE PHARYL}

The pharynx is placerl hehind the nose and mouth, and extends from the bate of the situll to the lower part of the ericoid cartilage opposite the sixth cerrical vertebral. The solt palate projects into it from the front, dividing it into a nasal portion above, ancl a buccal portion below.

The ofenings of the two pesterior nares whith are in front, and the orifices of the two Eustachian tules, ome on eareh side, open into the naso-pharrnx; whil-t into the buecal pertion beles the velum are the single epenings of the month in

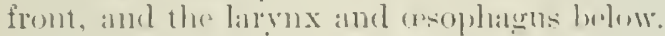

Thus there alre seren openings leadinger into its alvity.

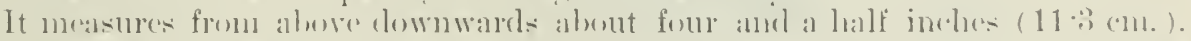

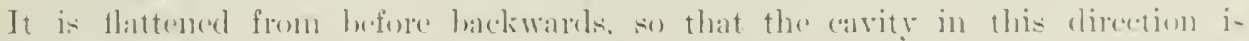

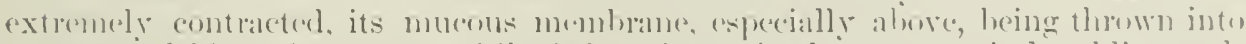

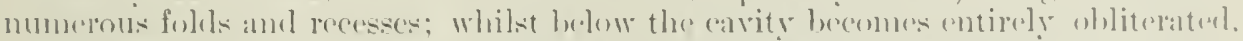
and its anterior and pesterior walls, exeept during the are of swallowing. are in

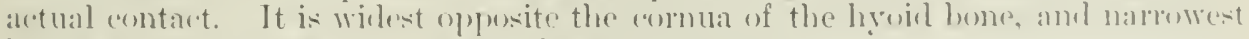
below where it passes inte the (1)ophlagers.

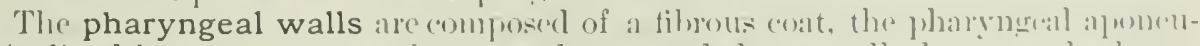

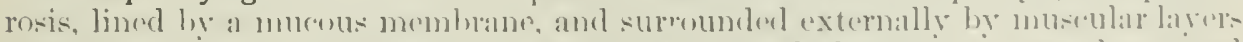

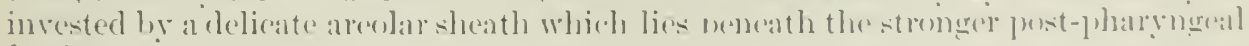
fascia.

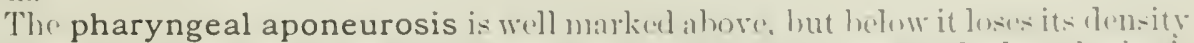

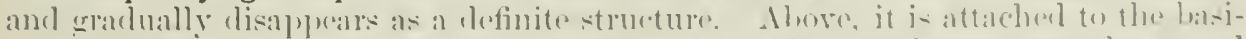
oecipital hone in front of the pharyengeal tuberele. Its attadoment may he trand 
outwarks to the apex of the petrous portion of the temporal home, and thence to

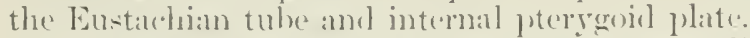

It driscends along the pterygo-maxillary ligament to the posterion of the mylo-hyoid ridge of the lower jaw and passes thence along the side of the tongue to the liyoil lome and laryx.

The mucous membrane of the pharyx is entinuons with the several earities which open into it. It is r losely arlherent to the hase of the skull. thick and spongy and rark in colour. It hecomes thimner where it approaches the openings of the posterior nares and Eustachian tules, and below it is paler and folded longiturli-

Fig. 559A. -Thl Ml'scles of the Pharyxx.

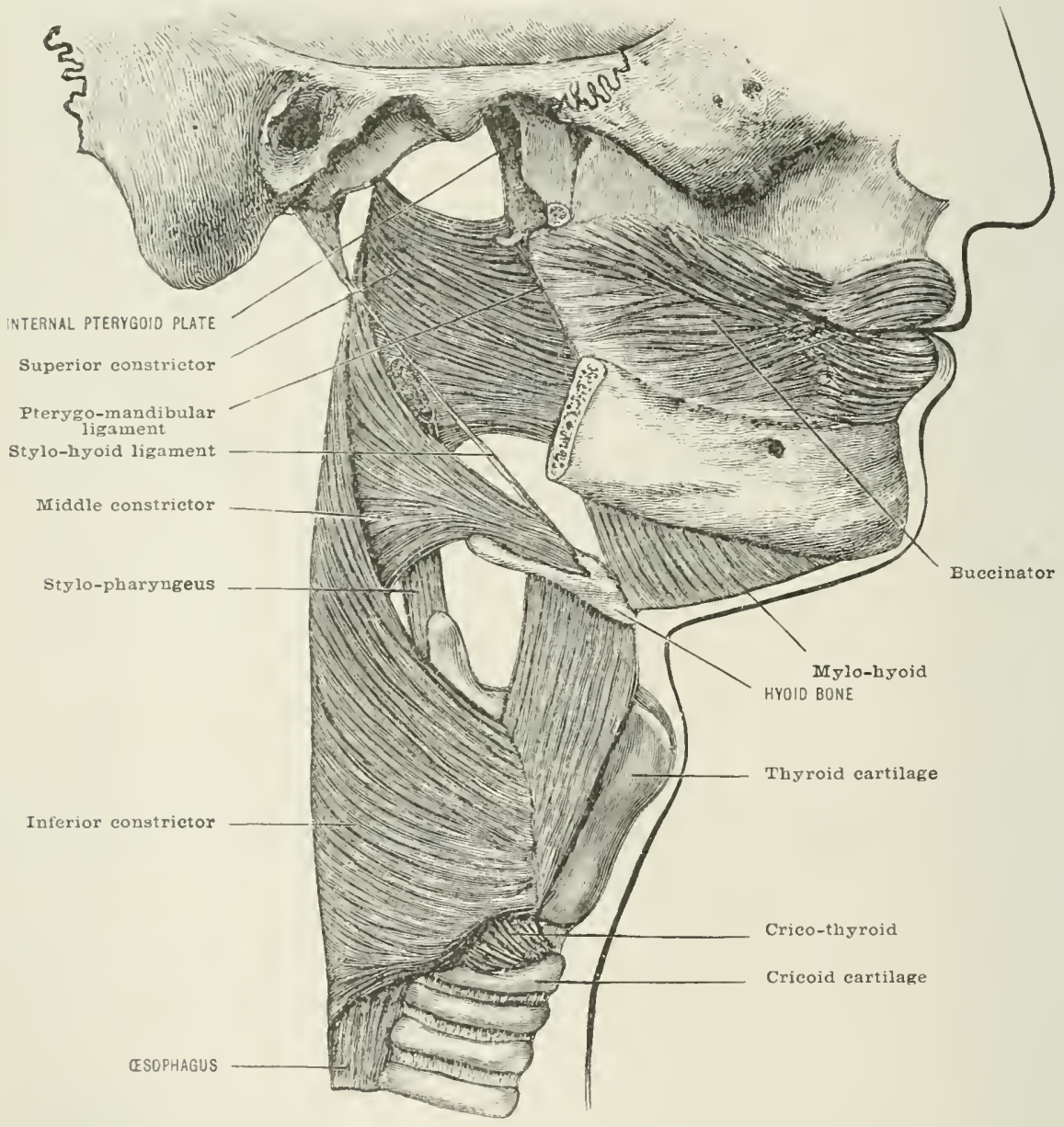

nally. Lymphoid follicles and numerous racemose glands exist throughout the mucous nimubrane.

The apithelium is ciliated and colmmnar in the naso-pharyx, but becomes stratified and scaly in the lower portion.

Muscles.-The muscular coat ronsists of the three constrictor muscles, with additional fibres derivel from the stylo- and palato-pharyngei muscles.

The inferior constrictor is thick and strong. It arises from the throvid cartilage inmerliately behime the ololigue line and superior tuberde, and also from the inferior cormu and the sille of the crienid antilase, hehind the crico-thyroid muscle (fig. 524). The filnes sprearl hadkwards and inwards, the lowest horizontally, whilst those abore ascend more and more ohliquely, and are inserted into the 
fibrous malle of the pharyn. Some of the lowest filores are contimums with the

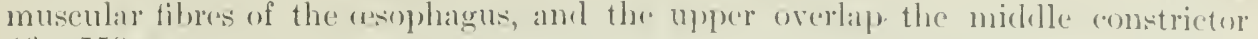
(fig. 5.5). 1 ).

Near the upper border the superior laryngeal nerve and artery pierese the throrelyoid membrame to reach the larynx. The recurrent lingngeal nerve asecends

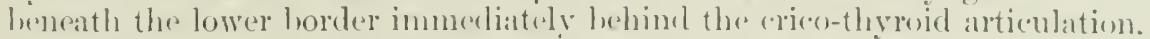

The middle constrictor is a fan-shaperl muscle which arises from the lesser cornu of the hroid bone, the whole lenerth of the greater armu, and from the strle-hyoil ligament. The diverging fildres are inserted into the median raple, and blend ivith these of the opposite side. The lower fibles of the muscle descend beneath the inferior anstrictor to the lower part of the pharynx; the upper overlap the superion (onstrictor, and reach the basilar process of the ocoiplat bone; whilst the midile filureserun tramsiersely (fig. 559. ).

The glosso-pharingeal nerve passes dommards above its upper border, the stylo-

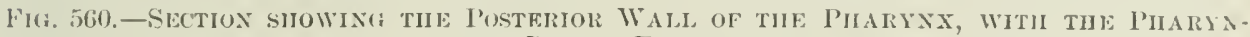
GEAL Bursa, FaCCEs, ETC.

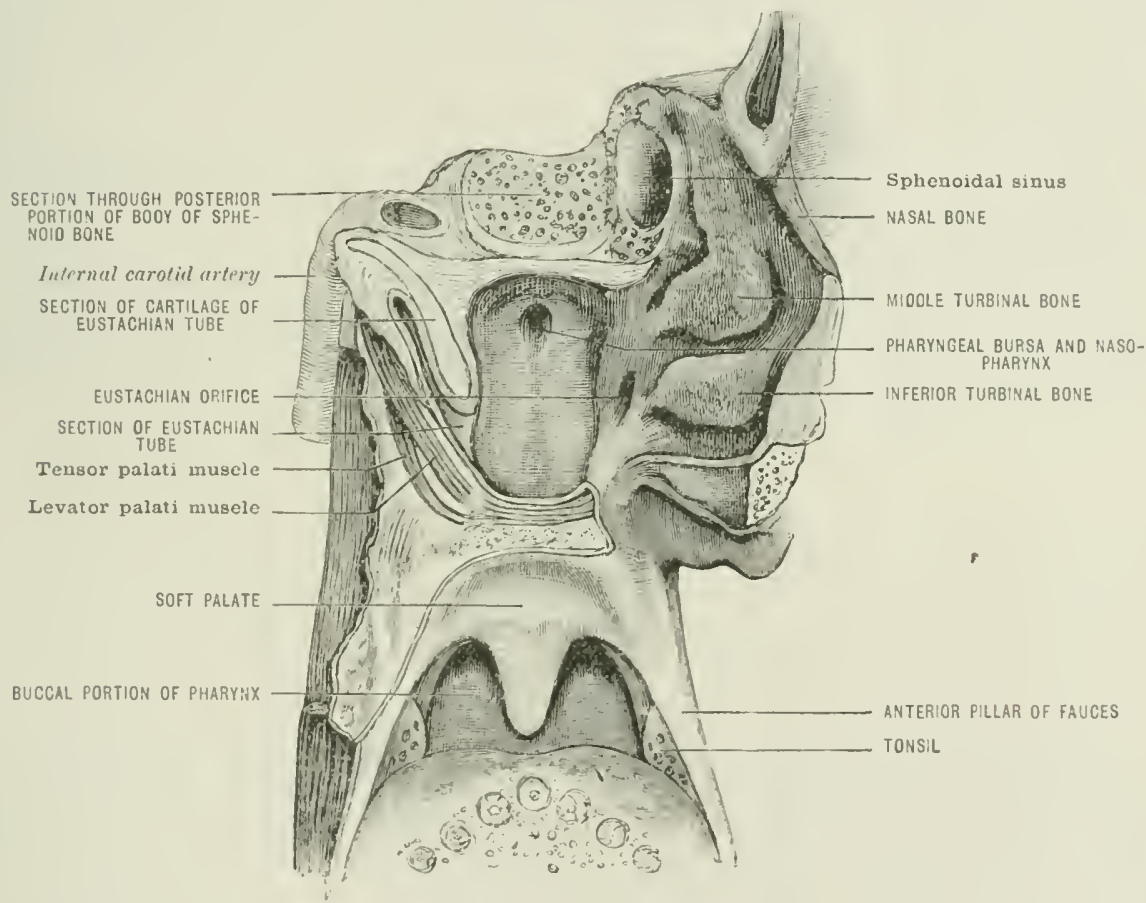

pharyngens is inserted between it and the superior constrictor, and near its origh it 1s orerlapped by the hyo-glossus ame cressed hy the lingual artery.

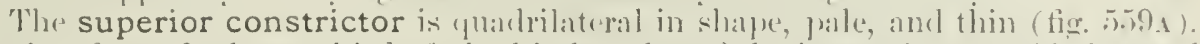

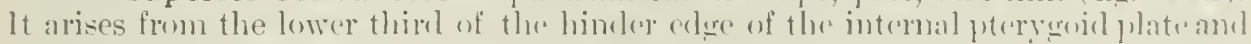
its hamular process. form the perergo-namelibular ligament, from the pesterion fifth of the mylo-hyoid ridge of the mamelible, and form the side of the tonerne. The

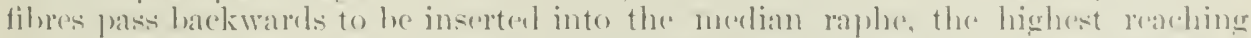
the wharveneal spine. The Enstachian tule and the levator balati muse. le ale

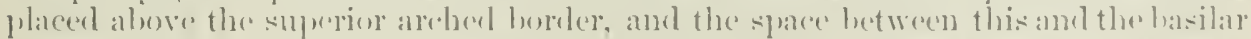

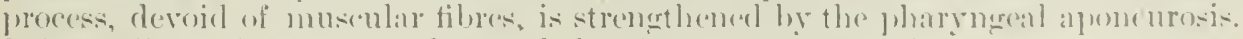
It is semilumar in shaje, aml named the sinus of Morgagni.

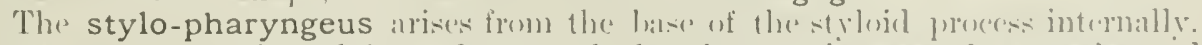

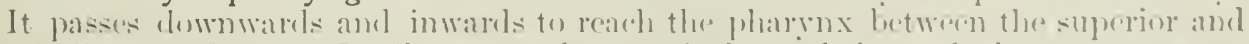

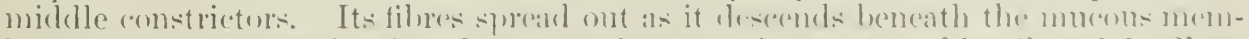

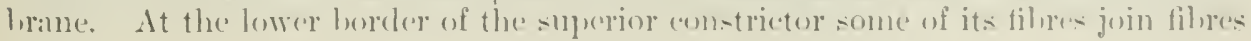


of the palato-pharyngens and are inserted into the posterior border of the thyroid cartilage (fig. 5.5. 4 ); the rest blend with the eonstrictors.

The palato-pharyngeus is described with the muscles of the soft palate.

The muscular ceat of the pharynx is supplied by the pharygeal plexus and the external and rexorrent laryngeal nerves. The stylo-pharygens in supplied by the glosso-pharyuneal nerve.

Relations.-The pharyx is loosely comnected by areolar tissue with the prerertebral fascia, the longus colli, and the rectus capitis anticus major musches, and vertehral columm. Laterally, it is in relation with the styloid process and its muscles, the ninth, tenth, and eleventh cranial nerves, the sujerior laryngeal nerve and its internal and external laryongeal branches, the parotid and throid glands, the sheath of the carotid ressels, the pharyngeal plexus of nerves, the ascending fharyngeal artery, and the ascending palatine hranch of the facial artery; abore, it is separated from the ramus of the mandible and internal pterygoid muscle by a cellular interval; and beneath its investing fascia there is a plexus of reins.

The interior of the pharynx, viewed from behind, presents the seven openings already named. At its upper and back part the mucous membrame forms a rounded projection which corresponds to the anterior recti muscles and on cach siste of this it sinks hackwards, beneath the tip of the petrons portion of the temporal lone, and behind the Eustachian tube, to form a cul-de-sac known as the pharyngeal recess, or fossa of Rosemmüller.

In the roof of the carity just below the body of the occipital bone and in the midlle line, the mucous membrane dips into a little ponch with a contracted orifice. the pharyngeal bursa, which is easily demonstrated in the fotus and young child, but commonly entirely disappears in the ardult.

Embedifed in the roof of the pharynx, in front of the pharyngeal bursa, and between the orifices of the Enstachian tubes, there is a collection of lymphoid follicles which is known as the pharyngeal tonsil, or Luschka's tonsil. This portion of the naso-pharyn is exceetingly liable to become swollen and chronically thickened in naso-pharyngeal catarth.

\section{THE ESOPHAGLS}

The œsophagus is that portion of the alimentary tract which extends between the pharyin and the stomach. It is more constricted than the rest of the canal, being narrowest at its (ommencement opposite the sixth rervical vertebra and fower borrer of the rricosil cartiłage. It is again somewhat contracted in its passage through the diaphragm, which is opposite the upper border of the eleventh thoracic vertebra. It is nine or ten inches (25) (m.) in lengtls, and in its course downwards follows the curves of the rertebral rolumm, until it finally passes forwards in front of, and slightly to the left of the aorta to gain the oesophageal opening in the diaphragm. In addition to these curves it presents two lateral curvatures, one convex towards the loft sicle at the root of the neck and in the upper part of the thorax. ancl the other concave towards the loft in the lower part of the thorax where it leaves the vertelual columm. It lies in the middle line at its commencement oplyosite the sixth cervical vertebra, and anain, at a lower level, opposite the fifth thoracie vertelna.

Relations in the neck.- The axophagus has in front of it the trachea, the posterior portion of the loft lateral lobe of the thyroid gland, and the left recurrent

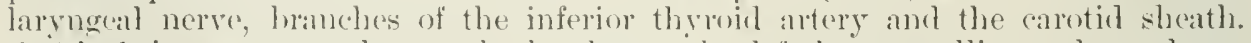
Behind, it rests mpon the vertehral colmm, the left longus eolli muscle, and prevertebral fascia.

On its right side are, flaced the right carotid and right reemrent nerve; and on the left side the left inferior thrmid vescels, loft earotiel altery, left subelavian, and the theracic duct. The recurrent nerves pass upwards on cach side to gain the 
interval between the trachea and respphagus. The loft norve as alrady describerl, lies in front of the tube, and the right at some little distance from it.

In the thorax the ropophagus descents through the supurior and the postagior mediatina. In the superior madiastinmm its anterior relations are the tracluses, with the deep cardiate plexus in front of its hilureation, the loft subchavin and

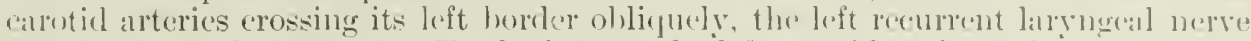
and the areh of the alorta. To the left are the left carotid and subelivian arteries, thre (not of the areh of the aorta, and the left plemral sace. To the right it is in rolition with the right vagus nerve and the right pleural sar. Bobind, it rests

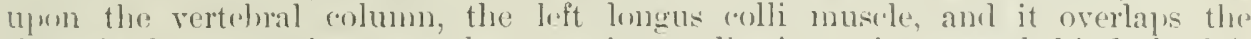
theracie duct. $\quad$ ss it enters the pesterior mediastinum it passes luchind the left hronchus and the right pulnonary artery, resting posteriorly on the rertelural eolumm and thoracic duct. In the posterior moliastinum it has in front of it the pericardiun, which sepalates it from the left auriche of the heart and a portion of diaphragm; it rests mpon the rerteblal columm, the vena azygos minor, superion and inferion, the right antic intereostal arteries, and the thoracose cluet. To the rierht is the right pleural sale, the vena azvgos major, which it partly overlapes, and hesow the thoracic duct. To the left in the upper part is the descending thoracic anrtat, and below the left pleural sac is separated from it hy a little loose areolar tis:sle. It is surrounded hy the asophageal plexus formed hiv the vagi nerves, and at they amerge from the lower part of the plexus the left vagus lies in front of the resolliagus and the right vagus behind.

In the abdomen the resophagus lies in the epigastric region. In front of it is the left lohe of the liver. To the left the left lobe of the liver and the fundus of the stomach. To the right the spigelian lobe of the liver, and behind the decussating filres of the crura of the diaphragm and the left inferior whenie artery.

The arterial supply of the esophagus is derived from the inferior thrord, the (esin)hageal hranches of the arta, the intereostals, the inferior phrenice, and the (o) onary arteries.

The veins acompany the arteries.

The nerves are filaments of the spinal accessory which pass to it lyy the ragus, and the recurrent laryngeal nerves.

After cleath the gullet is sommohat flattened from before larkwards. lut it is morr romeled during life. It is closed except during the passage of food, ete.

Structure.-The wall of the esophagus is composert of three coats-muscular, submucous, and mucous. It is surrounded with elastic allular tisture loosely (onnecting it with the neighbouring structures, and freely fermitting its distension.

The muscular coat is thick, resl, and consists of striped muscular filnes in its upper thind or more. It is male up of two distinet layers.

The longitudinal fibres eommence as three flatteried lands: a strong anterior

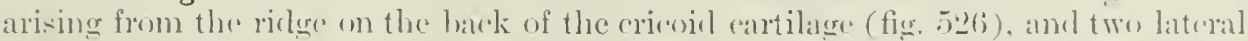
lands wheh blenel with the filues of the pluarnx. These all unite inte a continuous laver which passes below into the muscular coat of the stomach. Sirveral

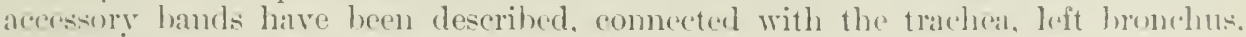
periciurdium, and left pleur:i.

The circular fibres are continuous above with the inferior constrictor, and lulow with the oblique fibres of the stomach; thry form a miform layer which heremes somerhat obliquely disposerl towarts the miclille of the gullet.

The submucous coat loosedy ennmerts the inner munens and onter muscular coats. It is the seat of numeroms raremese erlands whose durtsogren on the surfaces of the mucous membrane.

The mucous coat is thick, reddish above, paler helow, and dreply foldent

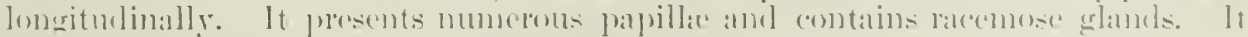

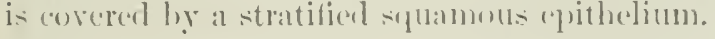




\title{
THE ABI)OMINAT, VISCERA
}

\author{
BY FREDERICK TREVES, F.R.C.S.,ENG.
}

SLRGEUN IX ORDIXARY TU II. R, II, THE DUKK OH XOKK; SLRGEON TO AND LECTURER ON SURGERY AT THE LUSDOX IIOSI'ITAL

\section{THE PERITONEUM}

Its general character.-The peritoneum is a thin and delicate serous membrane which lines the eavity of the abdomen from the diaphragm to the pelvic floor, and invests or corers to a varying extent the riscera which that cavity contains. Viewerl in its very simplest condition, it may be regarded as a elosed sac, the inner surface of which is smonth and perfectly nolished, while the outer surface is rough and is attacher to the tissues which surromed it. Could it be possible for the jeritoneun to be removed entire from the hody by some process of superhuman cliscection, it wonld appear simply as a huge thin-walled bag.

In the male sulject the peritonem forms actually a closed sac; but in the

Fig. 561.-Tlinsyerse Section of the Peritoneal Sac at about the Level OF THE UMBILICUS.

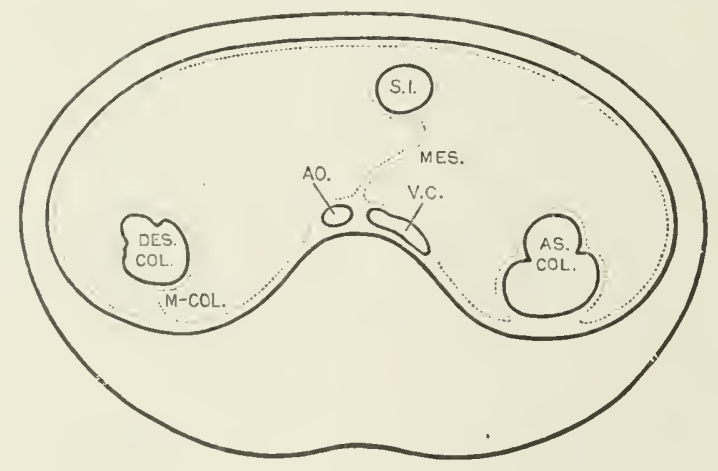

female its wall exhibits two minute punctures, which correspond to the openings of the Fallopian tulves. That part which lines the walls of the abdomen is termod the paricetal peritoneum; that which is reflected on to the viscera is the risceral peritonem. The dispusition of the peritonem may first le stuelied by noting its arrangement as made evielent in transverse seretions of the abelomen at erertain levels.

The first section to be described shows the peritoneum in its simplest conclition. This is a transverse seretion through the body, at alout the level of the upper surface of the fourth humbar vertelira, and therefore alout the site of the mmbilicus (fig. 561). Starting on the inner surface of the anterior abdominal parietes, the peritonemon is soen to atrer the transersalis fascia, and inclirectly the anterior abdominal muscles; then, passing to the left, it lines the side of the abdomen, 
until it reaches the descending colon. This it orecrs, as a rule, in front and on

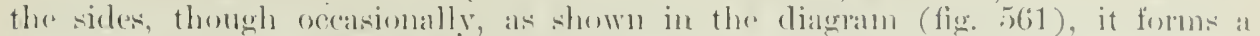

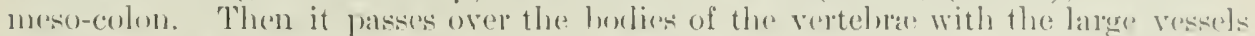

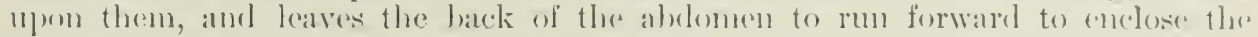
termination of the small intestine, returning again to the spine. The two lavers thus form the mesentery, having betwan them the terminal banches of the superrion mesenteric vesseds. It then jasses orer the right half of the gosterior abrominal wall, covering the aserneling colon in fromt, and at the sides only, nuleses there he a $111(x)-(0)$ lon, and then passes on to the side and front of the abrlonen to the point from which it was first triked.

In tracing the peritonemen in a section of the boxly (fig. 562 ) oplosite the stomach, on a level with the tirst lumbar vertebra, its comre hecomes more complicaterl and aliflicult to follow.

In the sertion aldraty given the peritonem as a simple closed sar cam lx rearlily conerived; but at the level now exposed the seroms membrane lass beense introverted that there appears to be two saes, one lealing from the other. The lisser is inderd but a diverticulum or lublging from the greater, and the manner of its formation is axplained on pag 1002. These two wates are allerl the greater and the lesser sacs of the peritoneum. They (o)mmunicate through a narmw strat or neck, the formmen of Winslow. The lesser sac or "avity is discovered

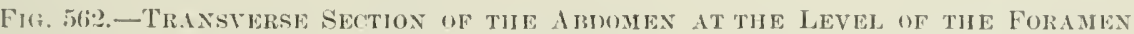
(1) WIXSIOW:

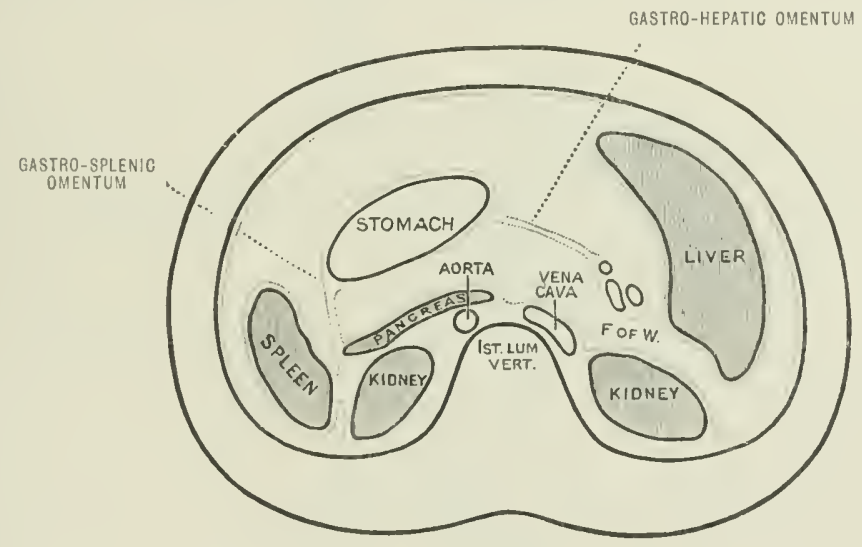

behind the stomach, so that on first opening the abdomen no trace of it is to les

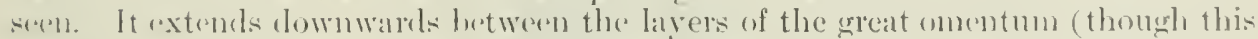
part of the lesser sac is always ohliterated hy adhesion in the adult). It (xtents upwards to the under surfare of the liver, and is limited behind lỵ the penterior alulominal wall; and helow. hehind the gerat omentum, by the transterse mesoalon. Its disposition on vertioal sertion is shown in fig. sibis.

'The foramen of Winslow is situated just helow the liver' it looks forwards and towarls the right, and will readily adnit one or two fingers. It is bommles almwe

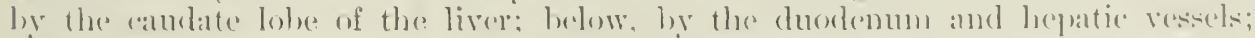

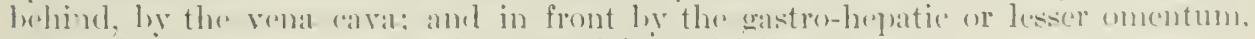
entaining the struetures passing to and from the livere. left.

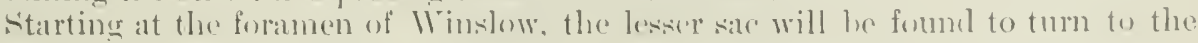

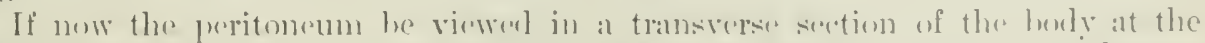

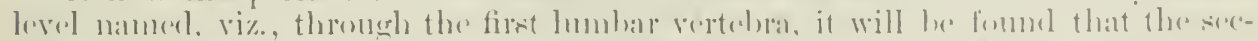

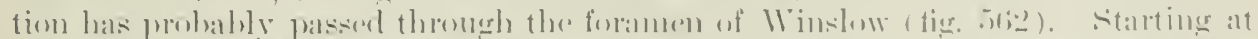

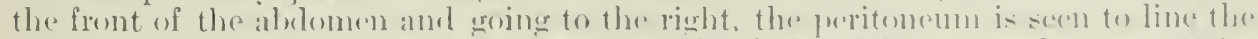

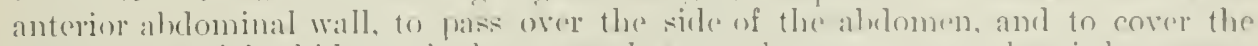

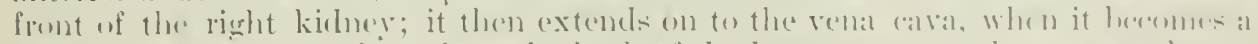

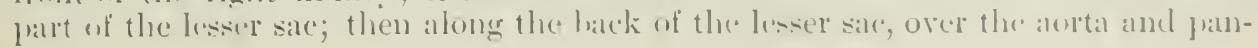


creas, which separate it from the vertelnal column; next it reaches the anterior of the tro internal surfates of the sflueen in front of the hilum. Here it mects with another layer of pritonemm, and helps to form the gratro-splenic omentum. bearing the splecen, it changes its direction, and rums to the riglit to the stomach, forming the posterior layer of the gastro-splenic omentum; it covers the posterior surfare of the stomach, and leaves its upper border to form the posterior layer of the gastro-hepatic omentum, and then passes upwark and to the right to the liver. In this transverse section, it is only seen passing on the right to the hepatic vessels, where it forms the posterior homilary of the formen of Winslow. Here it bends shapply rouml and forms the anterior layer of the gastro-hepatic omentum; and pasing to the left reaches the stomach, which it covers in front. It then forms the

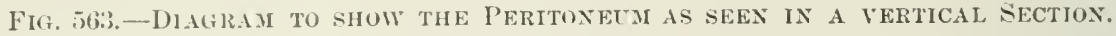
(Allen Thomson.)

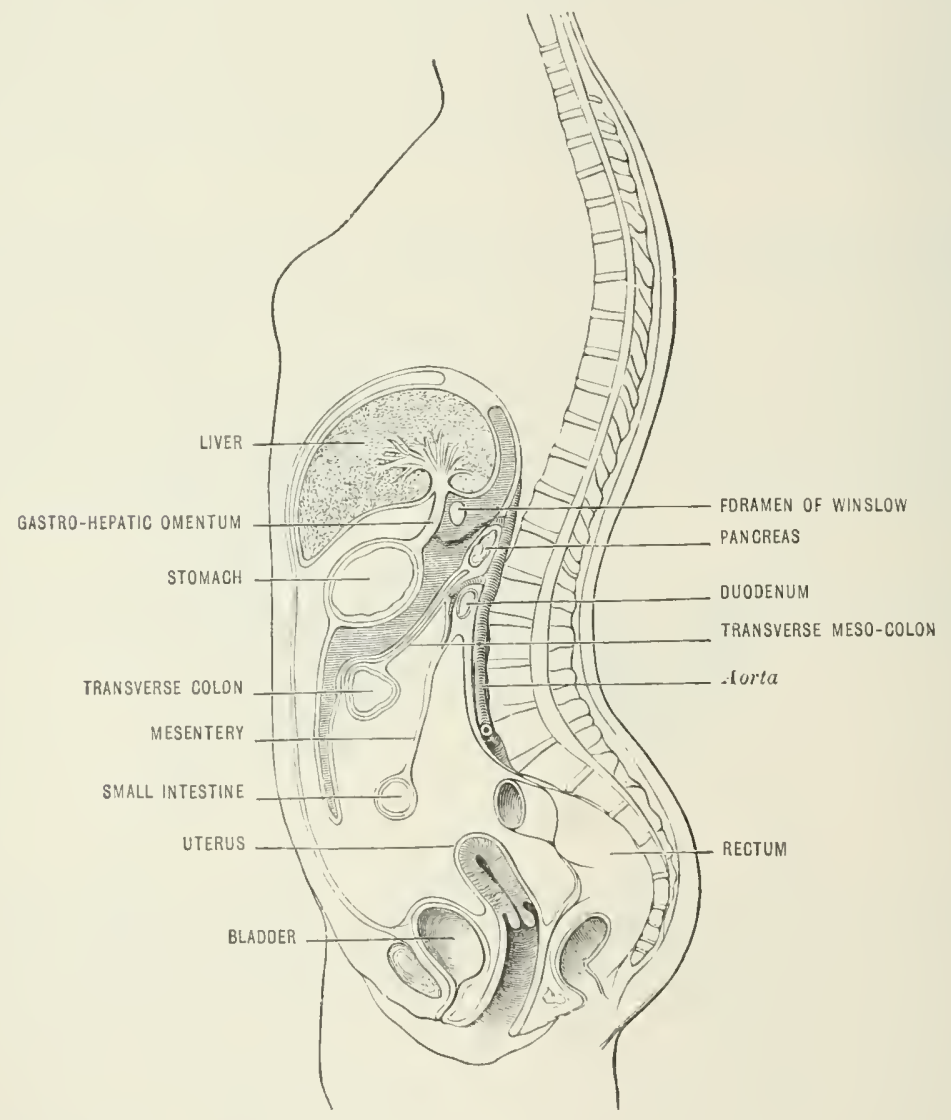

anterior laver of the gastro-splenic omentum. and once more reaches the sulcen. It basses right rouml the spleen to the back of the hilum, where it is reffected on to the loft kinhey (fig. 562). Hener the peritonem passes along the side and front of the ablomen to the point from which it started. In this sation the liver is so diviled as to alpear separated from all connection with the other visecra and the alshominal wall, and to be suremeled ly peritomeum.

The comrer of the pretoneum in a longitudinal section of the body will now

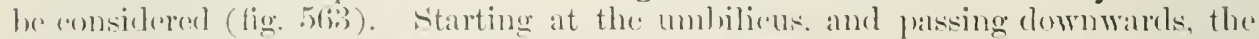
peritonemon is seren to line the anterior aldominal wall. Before reaching the pelvis it covers also the urachus, the derp eprigastric arteris, and obliterated hypogastrie arteries, which ran he seren to form rislges bencath it. For some little way abore the os pubis the peritonemm is loxsely commected with the ablominal wall, a cir- 


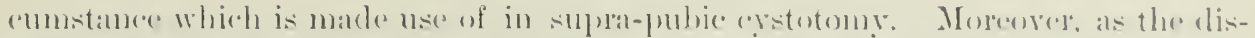

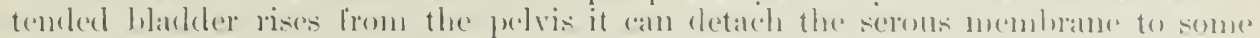
axtent from the anterior parietes. In extreme distrasion of the bualder the peritonemom may be lifted up for some two inches vertically above the symphysis. (1)n

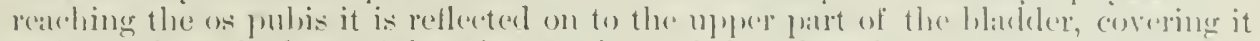
as fill back as the base of the trigene; thenee it is reflereted on to the reetum, which

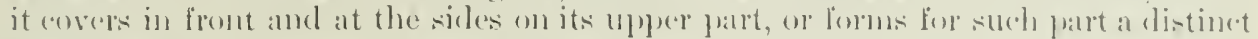
mestr-retum. Between the bladder and rectum it forms the recto-vesical pouch.

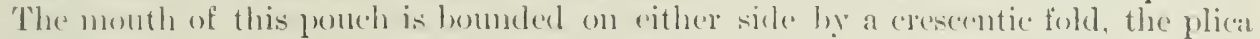
semilumanis. In the female the peritenemen is redlected fom the bladeler on to the

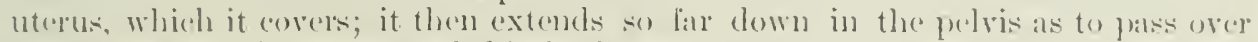

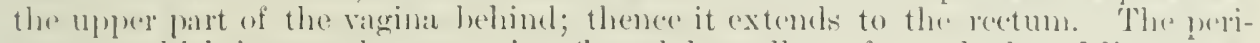
tonemon which invests the uterus is reflecterl laterally to form the loread ligandents. The fold between the vagina and rectum forms the recto-vaginal pouch, or pouch

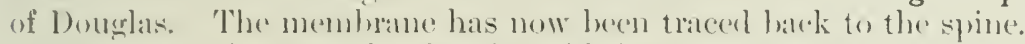

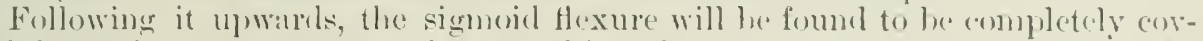
recl by peritoneum, a meso-colon attaching the ent to the aledeminal wall. As

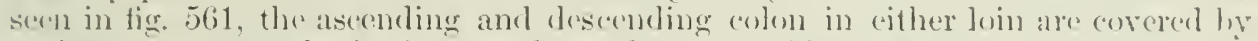
pritonedm, ats a rule, in front and on the outer sides. A little highere 11 in the median line the peritonemen passes forwards, to enclese the small intestine. and,

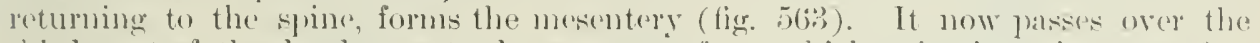

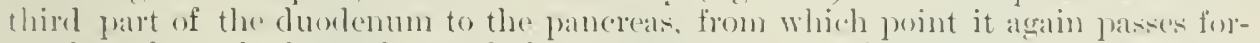
wards to form the lower lityer of the transwerse mese-elon. It invests the transrerse eolon below and partly in front, and then leares it to gasis downwards to talke part in the great omentum. Rumning dowmanels some clistance, it returns and forms the anterior layer of the omentum. On reaching the stomach it goes (1)er the anterior surface, and at the mper borler forms the anteron laye of the lesier or gatstro-hepatic omentum, which extends between the stomach and the liver. It invests the inferior surface of the liver in front of the transwerse fissure, and, turning orer its anterior border. corers the mpler surface. At the posterior linit of the uplere surface it leaves the liver ame goes to the diaphragen, forming the superior layer of the conmary ligament. It cosers the anterior part of the domer of the diaphragm, and, once more reaching the anterion ablominal wall, (an be followerl to the mubiliens, where it was first deseribed. On reforenser to the diagram (tig. 5633), the student might be led to sibjyose that the twe saes as abure clescribed are quite separate. This, of ceruse, is not the ease; lut in al loneritulinal

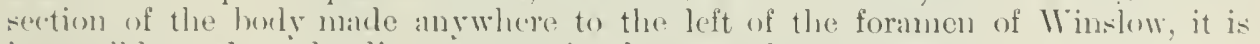
improsilule to show the direct ionnection between the two saes.

The peritonem has only been traced in this longritudinal section so far as it concerns the greater sile. It now remains to follow upen the sanne seretion surh part of the membrame as forms the lesser sac. The peritonem here will be se'm to corer the postorior surface of the stomach; and from thenee it rums upwards to the liver, forming the prosterior layer of the lesser or gastro-hepatie omentum. It reabes the liver behind the transverse tissure. It corers only al part of its poste-

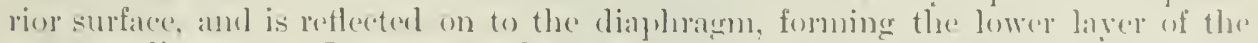

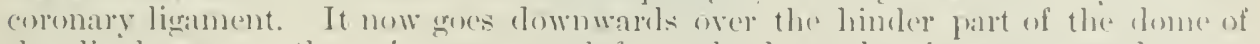

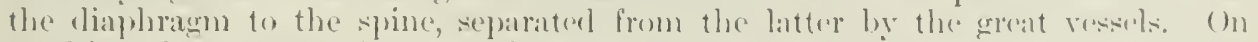

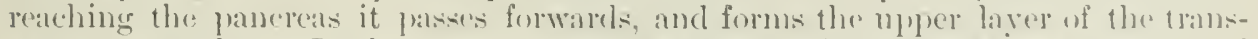

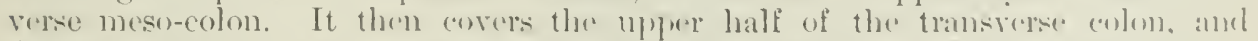

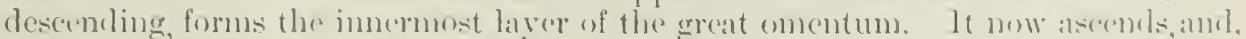

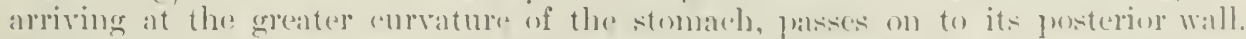

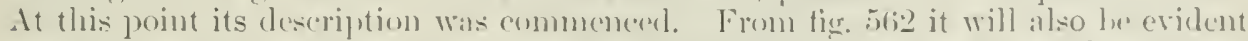

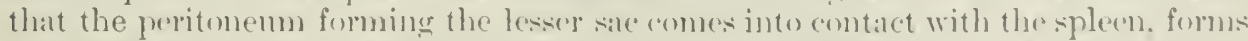

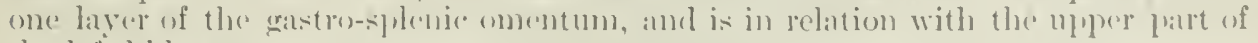
the lett kielney.

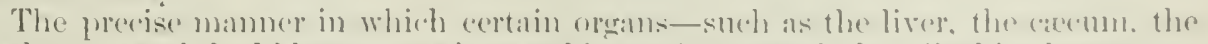

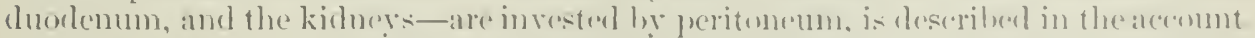

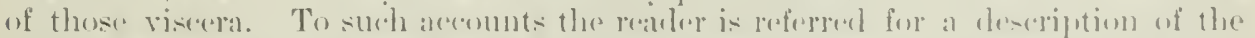
many" "ligrancents" (such as thuse of the bladder and liver) which ase formed hy the pritomemn. 
The great omentum. - It will be seren that the great onentum is formed of four layers of peritomem, thomgh this is quite impossille to demonstrate in an adult, the indiridual layers having become alluerent.

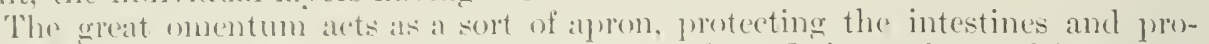
vicling them with a heat-ecomemising covering of fit. It is nearly quadrilateral in shape, and is valrialse in extent.

In tig. sif the great omentum is shown to be commected with the greater emrature of the stomach on the one hame, and the transverse colon on the other. This is the arrangement deserilued in the text. Tnder artain conditions (as shown in fig. $5(i 3)$ the posterior layer of the great omentmo returns to the posterior parietes, and is independent of the transverse meso-colon. This rariation is explained in the arcount of the erolution of the peritonem (page 1002).

Mr. Lookwool has made some investigations on the lengths of the transwerse mesc-colon and great omentum in thirty-three cases. In twenty, under the age of forty-five, only one subject had a great omentum long enough to be drawn beyond thr pubic spine; in five, the omentum reached as far as the pubes. In the cases berond forty-five rears, it was the exeeption rather than the rule to find an omentum which coukl not be pulled beyond the lower limits of the abdomen.

'The lesser or' gastro-hepatic omentum consists of a double layer of peritonemm extencling betwern the lesser curvature of the stomach and the transverse

Fig. 564.-Diagrair to show the Peritoneum As seen in Vertical Section. (Allen Thomson.)

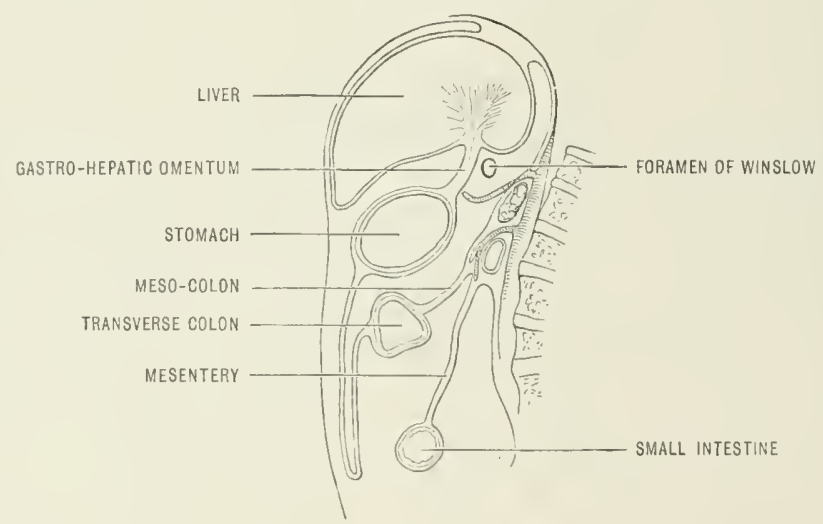

fissure of the liver. If the two anterior layers of the great omentum are traced upurards, they ale seen to encluse the stomach, and then join together again at the lesser curvature to form the lesser or gastro-hejatic omentum (fig. 563). It is ammecterl athore with the transverse fissure of the liver, below with the upper "urvalture of the stomarh; the left "xtemity encloses the osophagus; the right borker contains the hepatic ressels, and is fore, forming the anterior boundary of the formenen of Winslow.

The gastro-splenic omentum commects the left extremity of the stomach with the splecen, continuing the layes of peritomenm which enclose the stomath.

The gastro-phrenic and phreno-colic ligaments.-As the peritonem passes from the diaphragm to the stomach it forms a small fold just to the left of the rropphagus. This is the gustro-phrenic lisament. A stout fold of the membrane also (xtends from the diaphragm (opposite the tenth and eleventh ribs) to the splenie thexure of the colon, anel is known as the phreno-eolic or costo-colic ligament.

Subperitoneal connective tissue.- - In alaburate acount of this tissue has

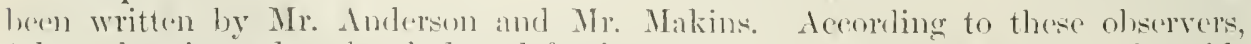
'the subperitoneal and subplemlal fisciac are to be reararded as a portion of a wide system of mesoblastic comnertive tissue which surounds the great ressels of the trunk, acompanying these hranches from origin to termination, and extencling manty in the form of perivascular sheathe to all palts of the becly.' 
The subperitoneal seguent of the tissne they divide into two pertiens: a parietal

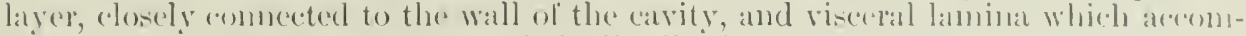
pany the bramehes of the anorta to their alistribution.

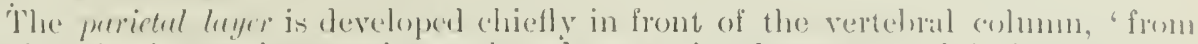
which point it may he traced as a hoak expansion between, and intimately ant-

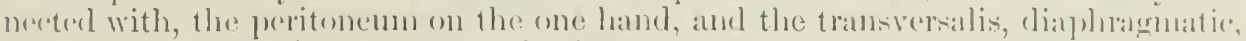

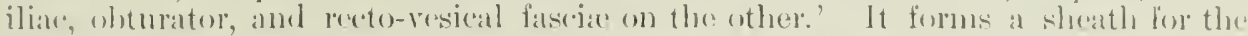

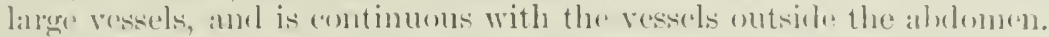

The exiseral portion loblows the course of the hrancles of the atorta, and greatly

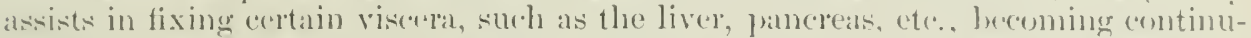

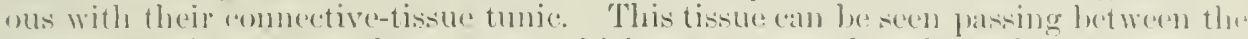
layers of peritonem to those organs which aro comected to the aldominal wall hy diuplicatures of peritonemus.

For an account of the evolntion of the peritonemm, and an explanation of its arrangement in the human body, the student is referred to page !991.

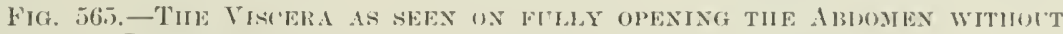

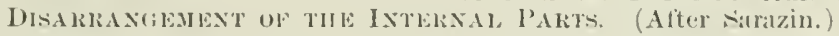

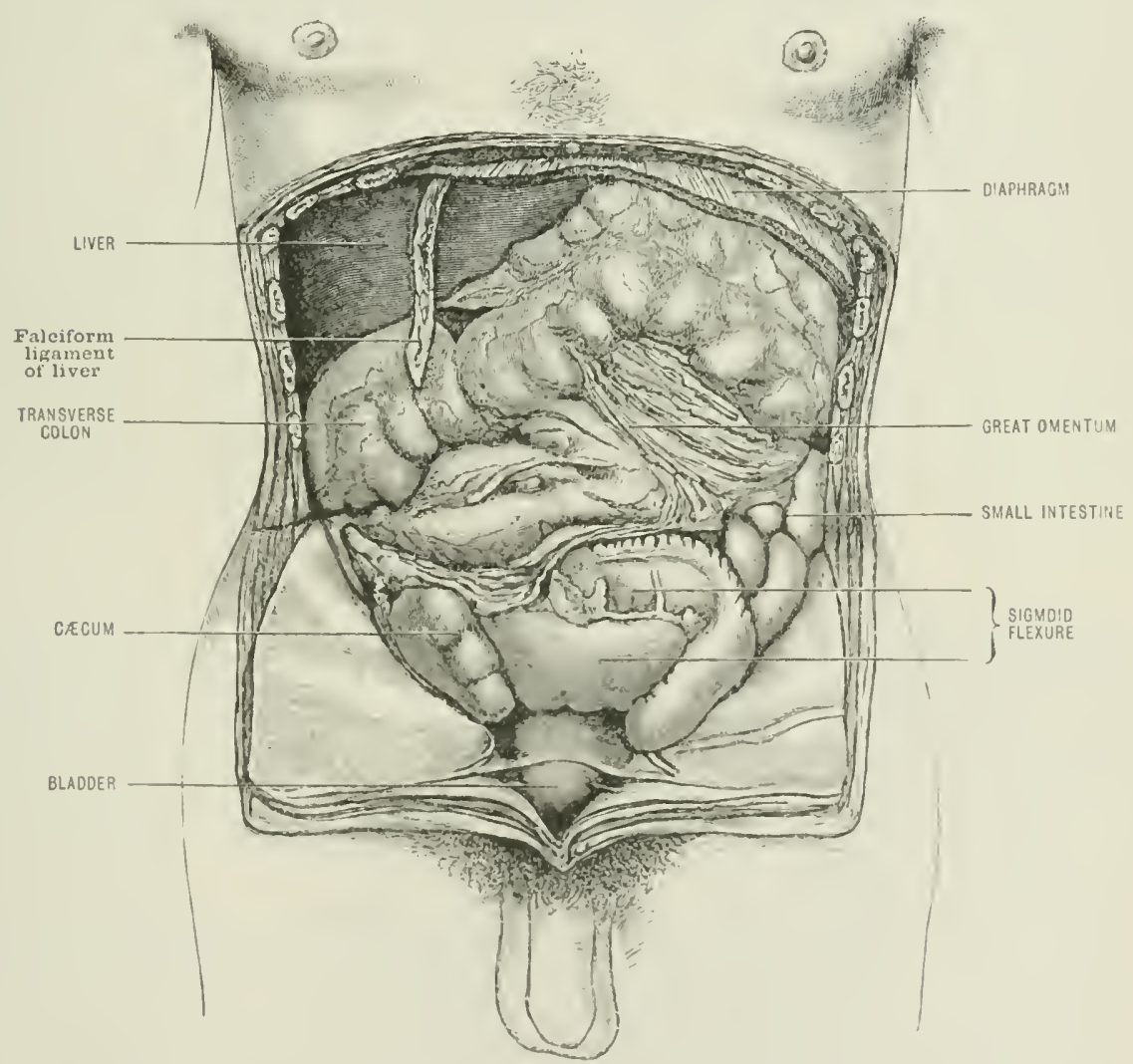

\section{TIIE ABDOMEN}

The abdomen properly comsists of that part of the hody calrity situated betwen

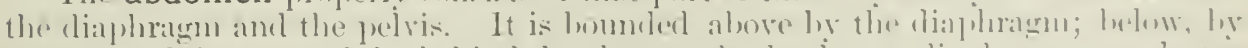

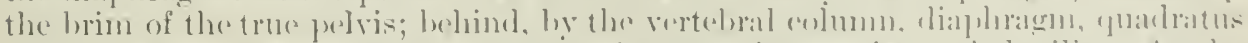

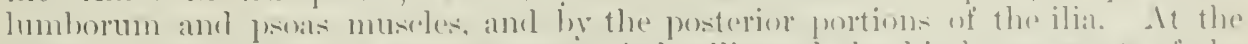
sides it is limited be the anterion parts of the iliat and the hindereserments of the

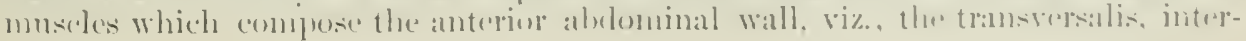


nal oblique, and external obligue. In front. hesiles these muscles, there are the two recti and pramidales musches. External to the peritonem the aldomen is

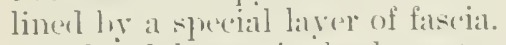

The aldomen is the laterest serous eavity in the hody. Its serous membrame is the jeritonemm, which, through its variots complicated armangements, is always (with one animportant exception) a closed sace so that the viscera are in reality situated outside the (n) losure. The principal viscral found in the abdomen are those comneretel with digestion and the excretion of urine.

On freely laying open an abdomen from the front, the general form of the space is sere to be an irregular hexagon, the sides of which are formed as follows:-The upper two hy the margins of the costal cartikges with the ensiform cartilage hetween; the two lateril sides by the edges of the lateral houndary; and the two lower by the two ligaments of Poupart which neet at the pubes.

In this irrexulat laxagon the following organs can be observed without disarranging their nolmal position (fig. 565). Alove. on the right side under the costal cartilages. can be seen the liver, which extends from the right across the median line to a point helow the left costal cartilages. Below the liver, and lying to the left side, can loe seen the anterior surface of the stomach; from the lower border of the stomach the omentmm extends downwards, and shining through it can be seen the middle part of the trinsverse colon. On each side and below the irregularly folded omentum are cxposed the coils of the small intestine; in the right iliac fossa a part of the csecum appears; and in the left iliac fossa a coil of the sigmoid Hexure is moully evident.

To the left of the stomach and moder cover of the lower ribs of the left side the erdge of the spleen may possibly be observed; and just below the edge of the liver, and abont the level of the tip of the ninth rib, the gall bladder may be seen. The dome of the urinary blakler may be noticed just behind the symphysis pubis and in the median line. The disposition of the viscera in the foetus is shown in fig. 578.

\section{THE STOMACH}

General description.- The stomach is situated in the upper part of the abdominal avity and to the left side. When empty it is found in the left hypochondrimm and left half of the epigastric region. Above it are the liver and diaphragm, while below is the transverse colon. It is somewhat priform in outline, with the small end of the figure twisted unward. Its length is ahout twelve inches, and its wilth four to five inches. The distance between its two orifices varies from three to six inches. Its average capacity is about five pints (two to three litres). It weighs four ounces and a half.

There are two orifices, two borders, and two surfaces to be noticed. The left, splenic, or rarliacend of the viscus is much expanded, and forms the great rul-desar or fumbus. It the right or prorie end there is another slighter expansion. called the antrum pylori or small cill-ele-sur (fig. 5tici).

The cardiac orifice, by whirh the osophagus opens into the stomach, is situated alout three inches from the loft extremity, owing to the bulging to the left of the great rel-rle-sec. The pyloric orifice, or pylorus, is situated to the extreme right, and is more anterion in pesition than the cardiac orifice.

The pylorus is protueed by a thickening of the risceral walls between the duoflenem and stomareh. The direnlar muscular fibres which surromel the stomach are here thickened into a strong ring, thus forming a sphineter which ean be felt from the outside. The longitulinal fibres pass wer the circular fibres, and are not aremerally supposerl to take part in the thickening. 'The nueous nembrane is fushed in hythe museular ring and also thickened. The prorio opening will harlly admit a sixpence, its fullest cliameter being about one-half of an inch 


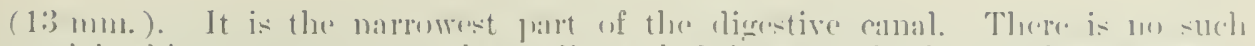

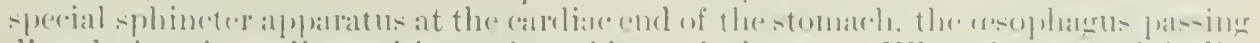

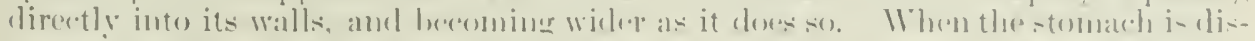

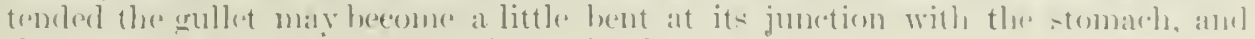

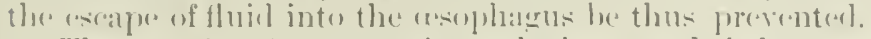

The two borders are situated aldere and lesow, and run between the two

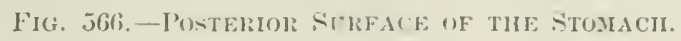

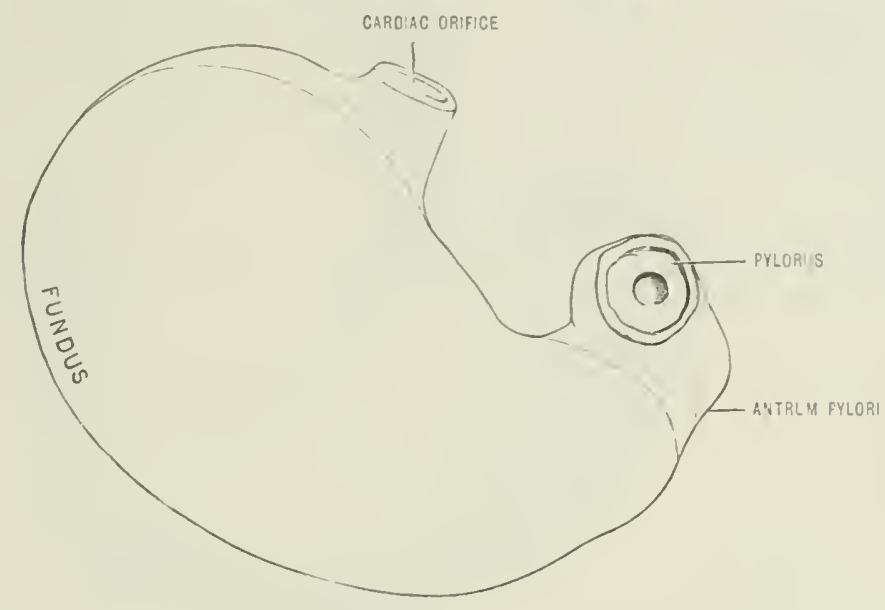

writices. Th. upler is known as the lisecr curvature, and is about thee to five inches longr: it is enurare along its whole length, except near the probus. where it takes part in the antrun pylori (fig. 567). The lower border is called the greater currature, and is convex exeept near the right extremity just before the formation of the antrum lylur. where there is a slight depression. It is about fom times as long as the upper borter.

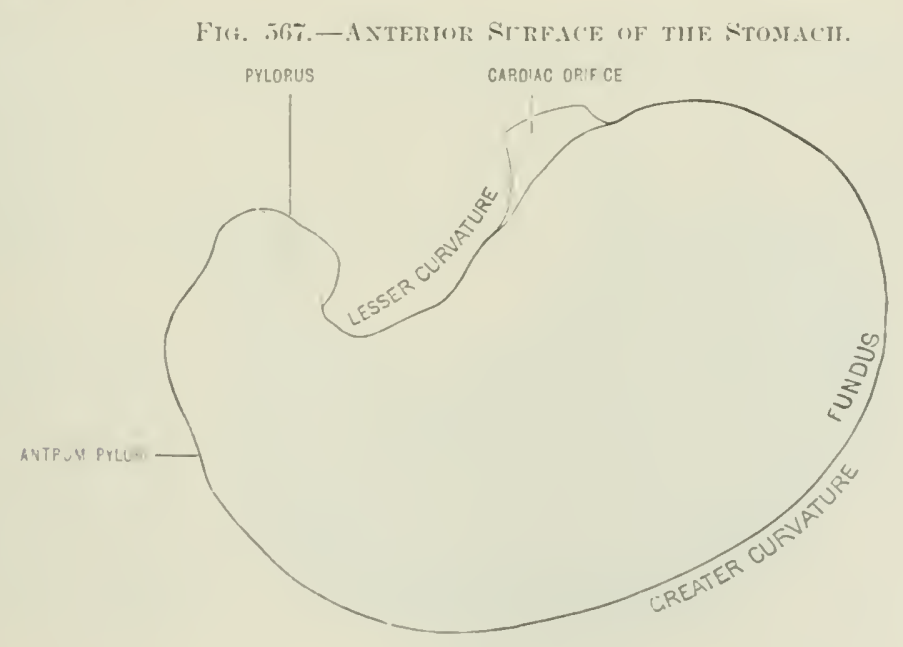

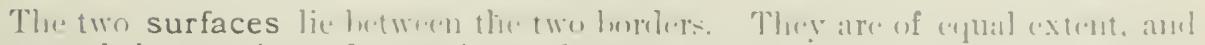

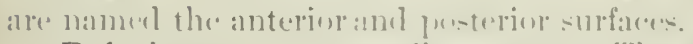

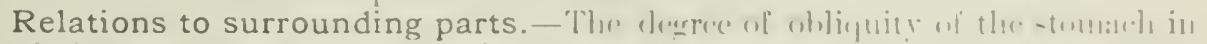

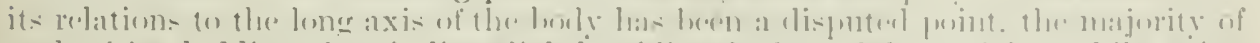
authorities holding that it lies sightly chligully from left to right: while a few

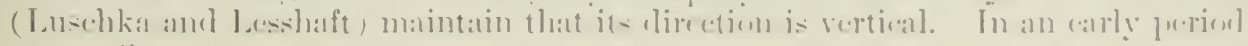


of derelopment the organ is certainly rertical, and in rare instanses this position may be maintained thenghout life. As a rule, howerer, the organ is placed

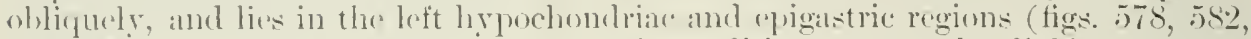
and 5s:i). Its position, moler nommal conchitions, must be liable to much variation.

The cordiuc end. or fundus, reaches as high as the level of the sixth ehoudrersternal articulation, being a little aboye and hehiud the heart apex. The cardince orifice is opposite the serenth left rostal cartilage, and is about one inch from the sternmm. Behind. it is ahout on the level with the hody of the tenth or eleventh dorsal rertebra. The pylores is on a lower level and nearer the surface than the cardiace end, and is opposite a point to the right of the middle line two to three inches below the stermo-xiphoid articulation, on the level of a line drawn between the bony ends of the serenth ribs (fig. is:). Behind, it is on a level with the twelfth thoracic spine (fig. .58). Its position is much influenced by the state of distension of the stonach.

The posterior surface of the stomach looks hackwards and downwards, lying on the trinsterse meso-colon, spleen, splenic artery, pancreas, left kidney and suprarenal capsule, and great abdominal ressels (figs. 586, 590).

A BOVE.

Liver, small omentum, diaphragm.

Ix Front.

(From left to right.)

Diaphragm, abdominal wall, liver.
GEXERAL, REI ATIUNS

UF $\mathrm{THE}$

STOMACH

\section{BEIIND.}

Trausverse meso-colom, pancreas, crur:t, solar plexus, great vessels, spleen, left kilney, and capsule.

BELOW.

Great omentum, transierse colon, gastro-splenic omentum.

The anterior surface looks upwards and forwards. Its relations are of importance in comnection with the operation of gastrostomy. A certain portion of this surfare comes into immediate contact with the abdominal wall; this portion is triangular in shape, is bounded on the right by the edge of the liver, and on the left hy the cartilages of the eighth and ninth rils; and below by a horizontal line passing between the tips of the tenth costal cartilages (fig. 582). Besides the abdominal wall, this surface is covered by the diaphragm and the under surface of the left lobe of the liver (fig. 590).

Relations to the peritoneum. - The stomach is covered by peritonem in its whole extent, exeept immediately along the curvatures and upon a small triangular space at the back of the carliar orifice, where the visens lies in direct contact with the diaphragm and posibly with the upper part of the loft supra-renal capsule. It is enclesed hetwern two lavers. These two layers at its upper border or lesser "urvature come together to form the lesser omentum, and at the lower border or greater enrature extend (lownwark, to form the great omentum (figs. 562, 563). It the left of the esophagns the two layers pass to the diapluagm, forming the gastro-phrenic ligament; and at the fundus they pass on to the spleen, forming the gistro-splenic omentum.

Alteration of position. - Whem the stomach is empty the surfaces are flat and the pyloric end is situatod near the molian plane and under eover of the liver. $\Lambda$ it distends, it acempics the left dome of the diaphragm and tilts up the heart apex. Moreover, it uncergoss sons alteration in position. The greater curvature is elevated and carriod forwards, the anterior surface is clirected upwards, and the posterior downwals, and the pylorus jasses some inches to the right. The pyloric orifiee, which in the empty stomach looks to the right, is so turned as to look hack- 


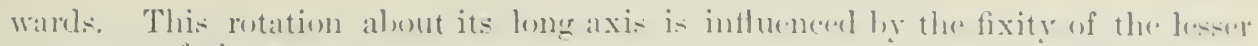
curvature of the orgatl.

Structure.-The walls of the stmmath consist of four coats, -iemus, muscular,

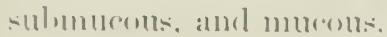

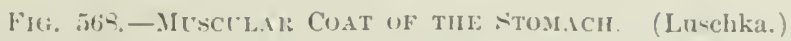

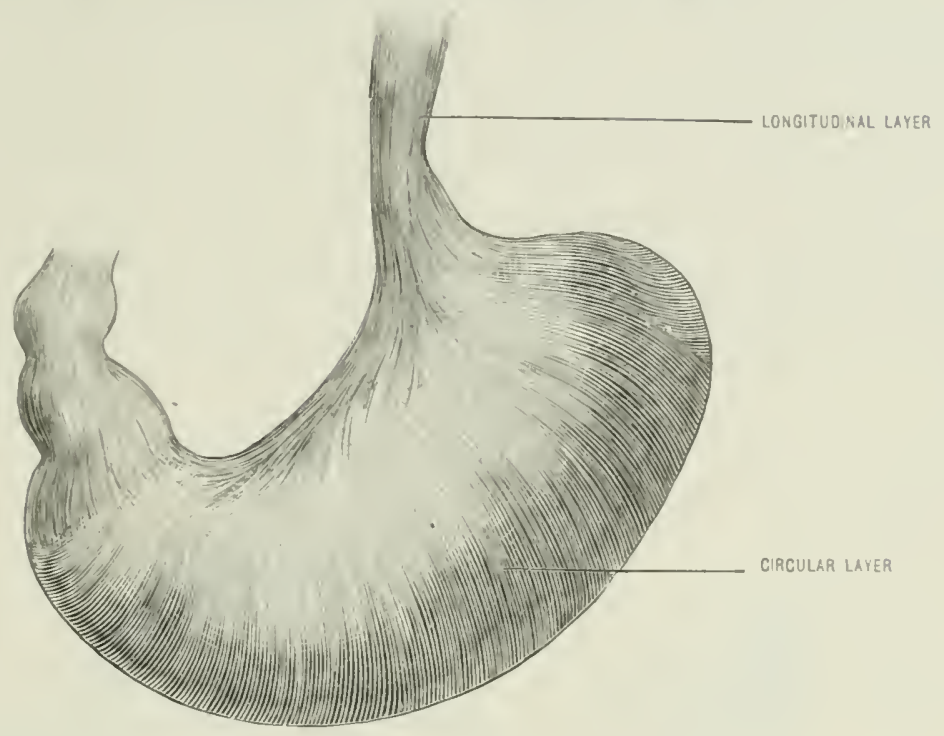

The enterual serous cont is formed by the peritoneum, and hals to the naked rye the usual shiny appearance of that membrane.

The muscular cont consists of three layers:

A longitudinal layer externally, which is continued from similar fibres on the

Fig. 569.-MLscllak CoAt of the STUMach. (Luschka.)

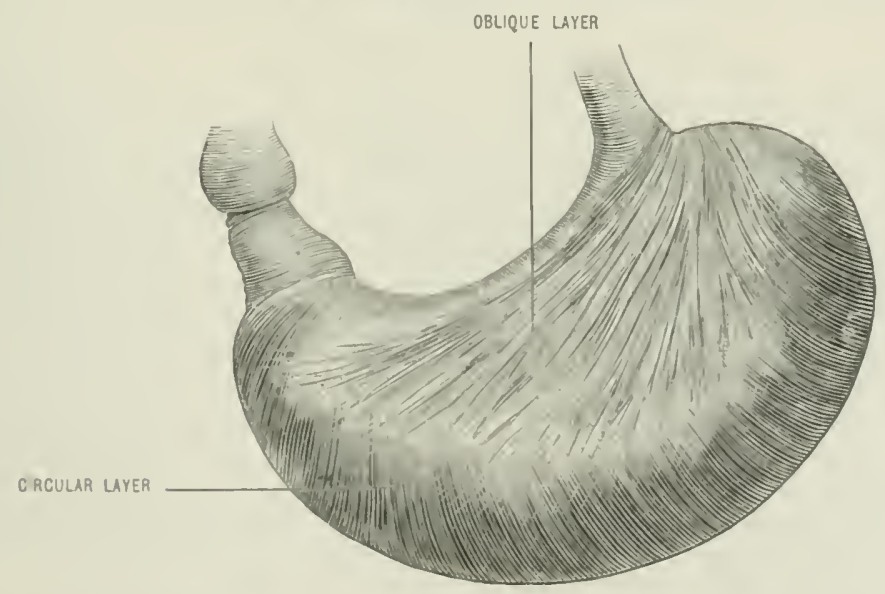

nesiphagus, and is thickest along the curvatures, more particularly the lesirer. At

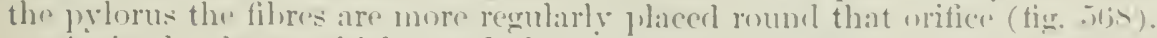

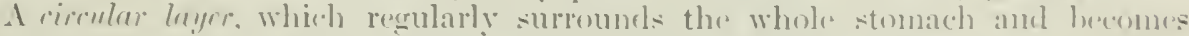
much thicker at the Intorie end. Where it forms the sphineter. These circular

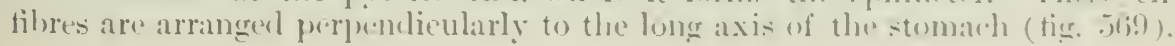


An oblime layer. continuous with the cireular fibres of the resophongus. They

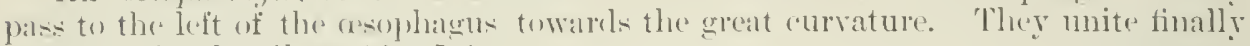
with the (eireular fil)res (tig. siti!) ).

The submucous cont is made up of areolar tissue, in which the blood-ressels lirak up.

The mucous or intermel cout is pink in colour and solft to the tonch, and when the stomach is not distemeled has a rugose appearance. It is corered with colmmer epithelium, and with a lens shows theopenings of numerous glands. A thin layer of musenlar tissue-the musculuris mucoxix-supports the mucous membrane extermally. The mucous membrane is thickest in the pyloricarea and thinnest orer the great rul-de-sece. In the stemachs of poung persons the surface of the stemach mary lestudded by little elevations due to local acemulations of lymphoid tissue.

Nerves.- The nerves of the stomach are the right and left pneumogastric, the right nerve pasing orer the posterior surface, and the left over the anterior. The oryan is also comnceted with the sympathetic system by means of the solar plexus.

Blood-supply. - The stonacli receives its blool-supply from many branches. From the coliace axis there is the gastric artery, which runs along the jesser curve from left to right, anastomosing with the pyloric branch of the hepatic. Along the greater curve rum the right and left gastro-epiploic arteries, anastomosing at the midclle of the horder, the left heing a branch of the splenic, the right a branch of the hepatic throngh the gastro-eluodenal artery. The stomach also receives branches from the splenic (vasa brevia) at the fundus.

The blood of the stomach is returued into the portal vein. The coronary rein and pyloric vein open separately into the portal vein; the right gastro-epiploic rein opens into the superior mesenterie, the left into the splenic.

Lymphatics. - There is a set of glands lying along the greater and the lessers cmintures, and others at the pyloric and cardiac cuds. These are entered by lympluatic ressels begimning in the mucous membrane.

\section{THE INTESTINES}

\section{THE SMILL, INTESTINE}

The small intestine is that part of the intestinal canal which lies between the whorns and the ileo-cacal valve. It is conveniently divided into three portions: the duodenum, jejunum, and ileum. It is of the average length in the arlult male (lwtwen the ages of twenty and filty) of twenty-two feet six inches. In the fomale it is longer, the average length being twenty-three feet four inches. The length is independrent, in the adult at least, of age, height, or weight. The length may vary in the male from thirty-one feet ten inches to fifteen feet six inches. In the fomal a. from twenty-nine feet fom inches to nineteen fect ten inches.

With the excretion of the duodenum, the snall intestine lies for the most part insirle the more fixerl portions of the large intestine (tigs. 565, 578). It is also, with the execption of the duolenum, commected to the posterior alulominal wall hy a presese of preritonemon. the mexentery. This broal membrane is seen to extend from ahove downwark, and from left to right from the duodenum above to the ileocaceal valve below, "melosing the jejuntmo and ilemm along the whole of their extent ( figs. 56 , in (i.), and 599 ).

The duodenum - the first portion of the small intestine-is, unlike the other parts of that bowel. rery dofinite in position and extent. It is that part which is mot containes hy the mesentery. It is formed from the and of the embryonice foresent, and its peroliar position liehind the transverse erolon is due to the rotation from Irft to right of the intestine in the fortus (page 995). It is the most fixed as well as the widest part of the small intestine. It measures one and a half to two ineles 


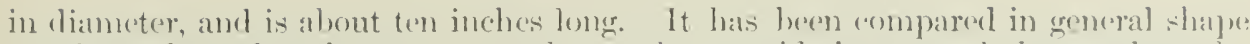
to a horseshere, though mot rery aptly, as the one side is of much lomger than the other. It is arramged in a conved mammer round the patuereas, and readily lends itself to at division into four parts ( figg. 57, ).

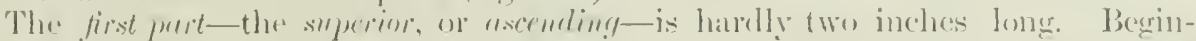
nine at the probus, and batsing upwarks and backwards to the right, it ands at the

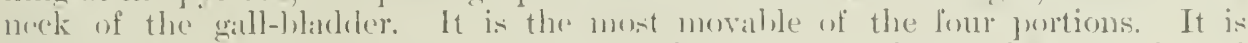

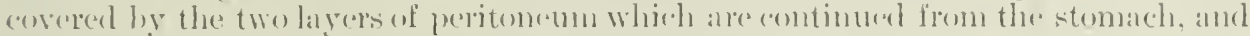

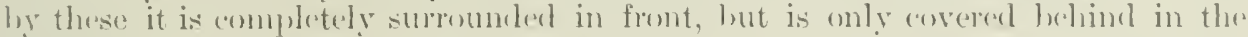
vieinity of the pylorus. Alure it are found the liver (quadrate lobe) and gall

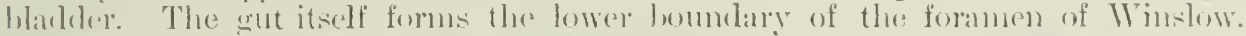
buble it is the panceres; and behind are the common hile-eluct, hepatie vessels and purtal rein.

The seremd prot-the destendiug portion-nen guite three inches long, extends from the nerek of the gall hladiler to the thirel lumbar vertebra, a short hemel marking the separation lutween the first and second parts. This gart is corvereel lip peritoneme in front only, the membrane being derived from a continuation of the superior layer of the transierse meso-colon (fig. 570).

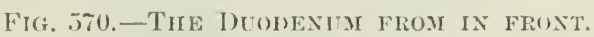

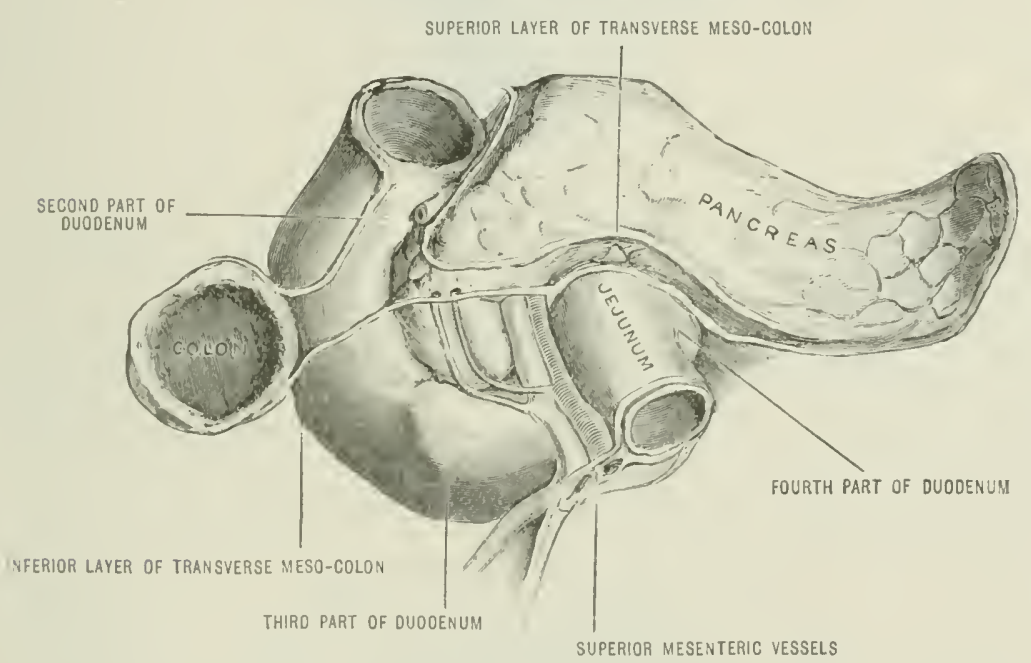

It is more fixel than the first portion. It is in relation in front with the trans-

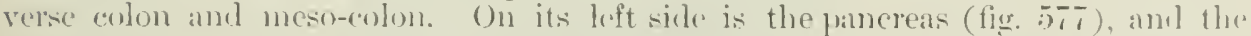
common lible-duct a little more posteriorly. The loop formed by the pancreation-

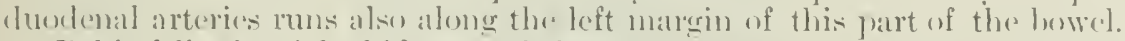

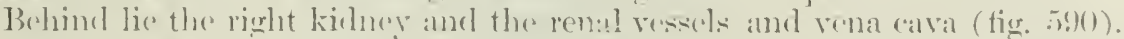

some of the muscular fihres of this part of the duerlenum aresaid to berentinuous with the lobules of the panceres. Inte this segment of the bowel. at it: immer amel back part and some four inches from the probus the common bile-duct and

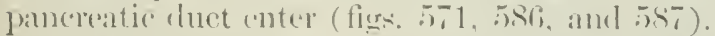

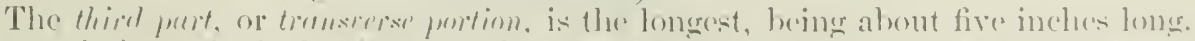

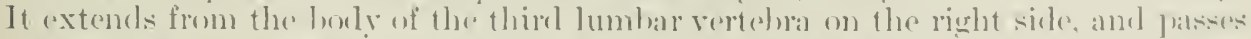
whliguely across the spine to the upper part of the lofi side, ascencling a litte on

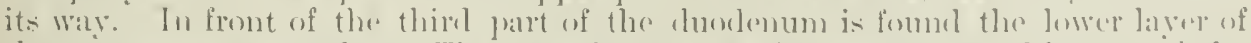
the transwerse meso-colom. The superior mosenteric vessels (roses this part of the

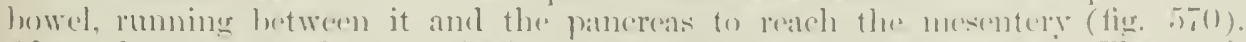

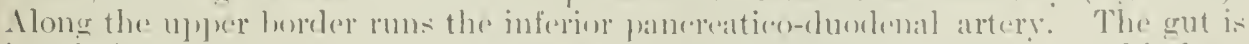

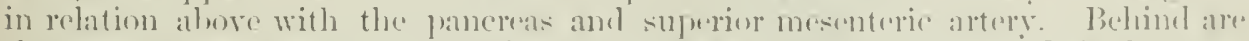

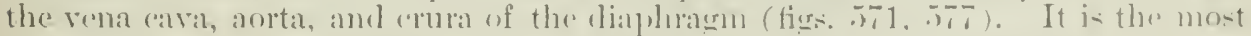

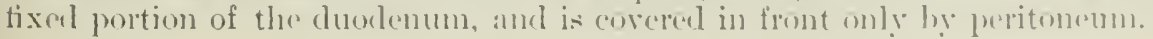




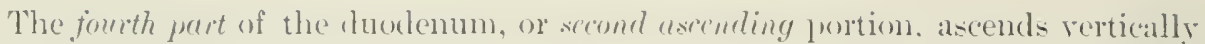
by the left sirle of the sine. This rertical jortion-which is covered entirely in front and partly at the sickes ly prritonemn-is at least an inch in lengtl (figs. 570 , 571 , ancl 572$)$. The end of the duodenum is very firmly tixed in its place by the musulus suspensorius duodeni. This name has been given to a fibrous band that contains, aceorling to Treit\%, some plain muscular fibres, and that descends to the

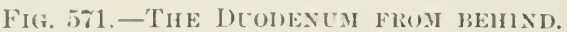

Portal rein

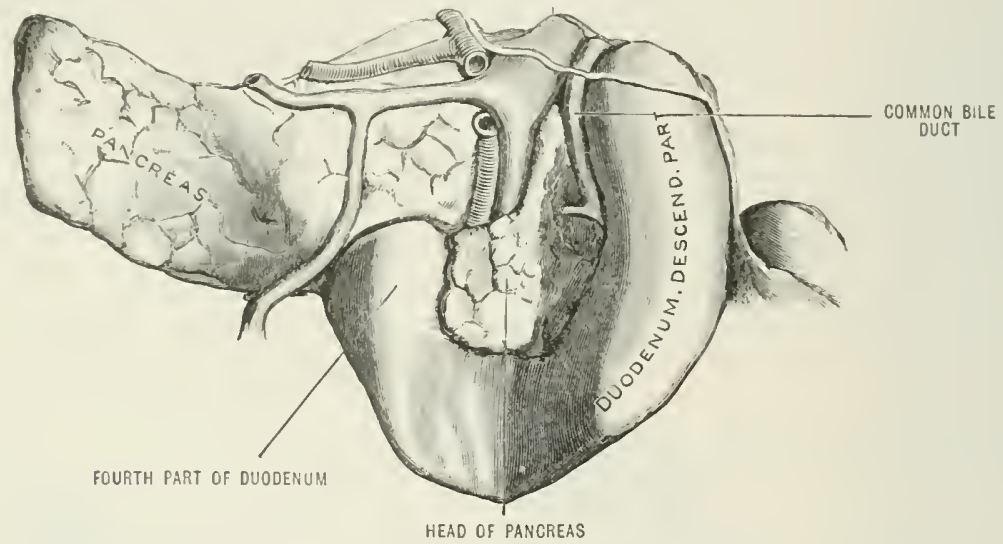

vertical part of the duodenum from the left erus of the diaphragm and the tissues about the coeliac axis.

Mr. Lockwood points out that this band is continued on, after being inserted into the duodenum, between the layers of the mesentery. He suggests the mame of the 'suspensory muscle of the diodenum and mesentery', and sars. 'together with the other constituents of the root of the mesentery, it forms a band of con-

Fig. 5\%:--Tine Fossi Deolnexo-jejuxalis. (Treves.)

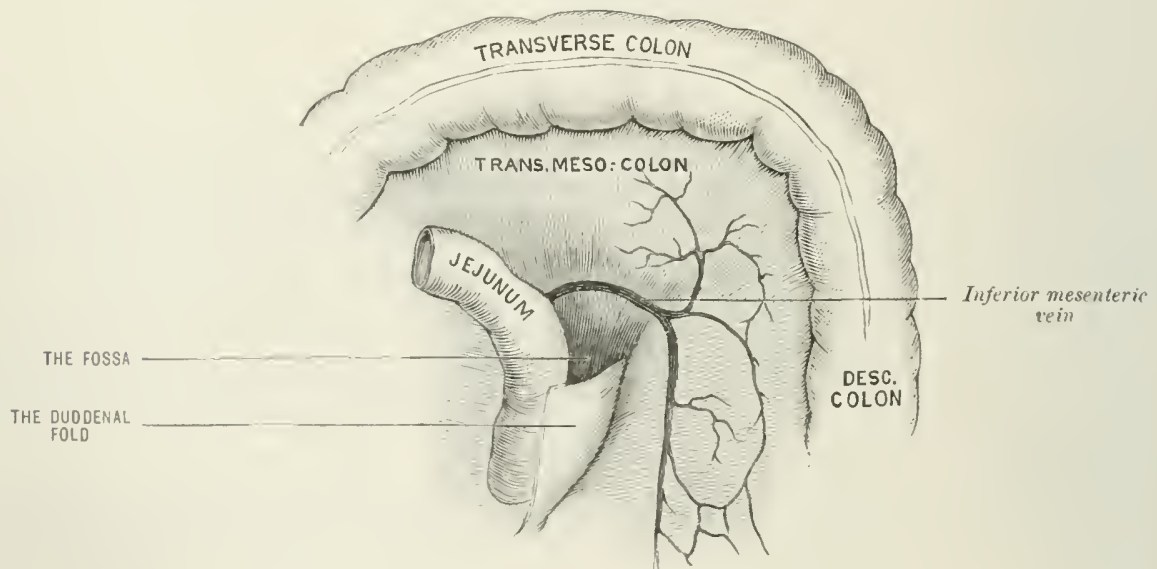

sirlerable strength, sufliciont not only to support the woight of the intestines and nesentery, but alse to resist the presure of the desent of the diaphlagm.'

In commection with the fermination of the duodenum may he mentioned the fossa duodeno-jejunalis. It is formed as a pouch behind a fold of pritonemm. This folel rums from the parietal peritomemu, just to the left of the terminal or fourth part of the cluolenum, and is attacher] in a vertieal line to the anterior 
surface of this portion of the bowel. It is of interest as being the salt of origin uf a retroperitoneal liernias.

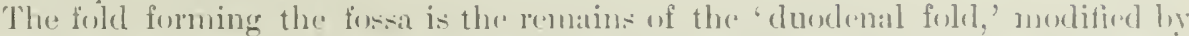
growth and displaced be the poress of unepual developument in the intertinal "anal

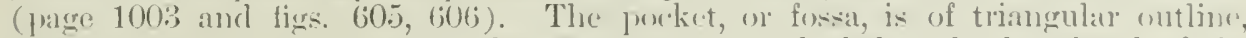
with the lase or orifice upwards. Its ajex extends below the last bend of the duolenum (fig. ji-y). The ("apacity of the fossa raries. In well-marked specimens it will louge the thumb up to the first joint. It is actually oceuped liy the duscleno-jejunal junction or benel. Out of one hundred bodies exanined, I foume this fossa in forty-eight ('xampl's.

Jejunum and ileum. - There is mo mrarying methor in the arrangensent of the inclividual coils of the small intestine.

[n the majority of arlult borlies the small intestine is disposed in an irregrularly (urverl mammer from left to right. The gut, starting from the luoklenun, will first oecupy the contiguous parts of the left sicle of the "pigatric and umbilical regions; the coils then fill some part of the left hypechemdriac and lumbar regioms; they now commonly deseend into the pelvis, reaplearing in the left iliac quarter, and then oceupr, in order, the hypugastric. lower umlilical, right lumbar, and riglit iliare regions. Before reaching the last situation they commonly descend again into the pelvis.

In many instances no kind of methodical arrangement is apporent. The eoils of small intestine most usually found in the pelvis belong to the temmal part of the ileum, and to that part of the intestine that has the fongest mesentery-the part, nanely, that extends between two points, respectively six and elever feet from the cuil of the duodenum. In five out of me hundred eases examined, the coils were arranged in an exactly reverse manner to that just described.

The jejunum (jejunus, empty). - The jejunum is the name given to the upler two-fifths of the suill intestine below the duodenum.

The tern ileum (sis:y, to twist) is applied to the last three-fifths of the lwwel. The ileum ends at the ileo-creal valye. The coils formed by the jejunum and ilem are very movable, aro completely invested by peritomemin, and are suplorted and attached to the posterior parietes by the extensive mombrane known as the mesenterv.

The intrstine alters gradually in rharacter from above downwards. If a secment from the midlle of the jejunum he comprared with a portion of the middle ilem. the following differences would be noted. The diametrer of the jejumum is about an inch and a half, that of the ilemm one and a quarter. The jejunum has thicker walls, is more rascular, and is provided with a more complex mucous memlorane.

Meckel's diverticulum.-From one to three fert from the end of the ilem is sometimes seen a diverticulum, or l, lind tube or cord, coming off from the fres. margin of the bowel. This is Meckel's divertievilum, and represents the remains of the vitello-intestinal duct ( page 994 ).

The mesentery. -The mesentery extemels from the end of the durdenum to the

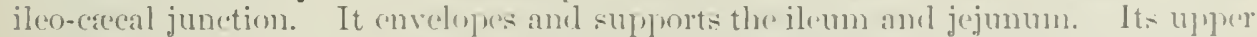

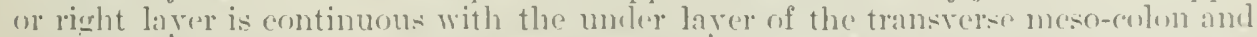
with the peritonem that invests the asomding colon. Its lower or loft laver joins with the sirous membrane that eneloses the deseculing eolon and that forms the sigmoirl mesentery (fir. isi1).

The point at which the mesentery is attarhed ahove is om a lerel with the lower burler of the panereas and just to the left of the vertelual boclies. From thi- point the insertion of the mesentery follows an olligne line that runs downwarts and to

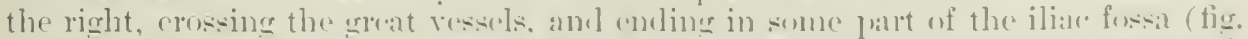

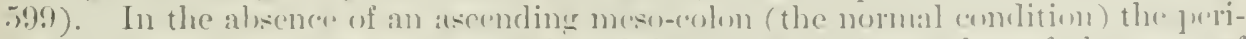

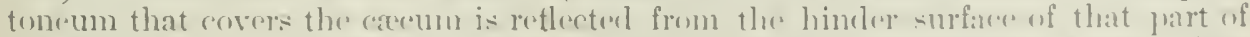
the bowel on to the ponstrior parietes: at this reflexion the mesentery ends. If an

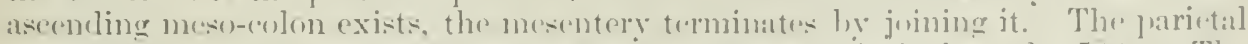

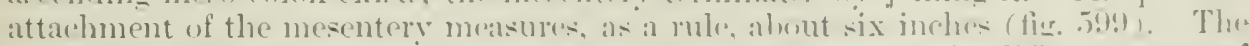
length of the mesentery from the spine to the intestine valies in diffiepent parts of the canal; its average jength may le taken as leetween wight anel nime inches. It 
sorm attains its full length, and within one foot of the end of the duodenum is already six inches in length.

The orlinary type of mesentery conforms to the figure of half a circle, but the membrane is lialile to ensisclerable variation. It is mot uncommon to find the mexintery maintaining a considcrable length up nearly wh the end of the ilemm.

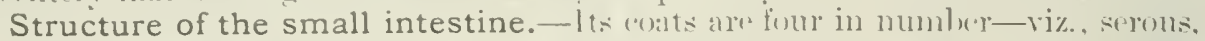
muscular, areolar, and mucous. The intestine receives its serous corering from the pertoneum, and, with the exception of certain parts of the duolentm which have been elescribed. it is eovered entirely by it, save only where the hayers leave it behind to form the mesentery. The line of attachment of the mesentery marks the attacher border of the sulall intestine.

The musculue rout is divided into an extemal longitudinal layer ame an intermal cireular, the cireular being the thicker of the two. Beth layers are uniform aroumel

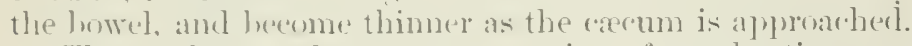

The aredur or submurous cout a)nsists of areolar tissue comnecting the muscular ancl muens tunics. A thin layer of muscular tissure separates the mucous membrane from the areolar coat (muscularis mucosa).

The murous cont. thicker at the upper part than the lower part, is lined throughont with colummar epithelium and is very vascular. The whole surface is onvered

FIG. 573.-PORTION OF TIE SMALL INTESTINE, JAID OPEN TO SHOW THE VALTLLE CONNIVEXTES. (Brinton.)

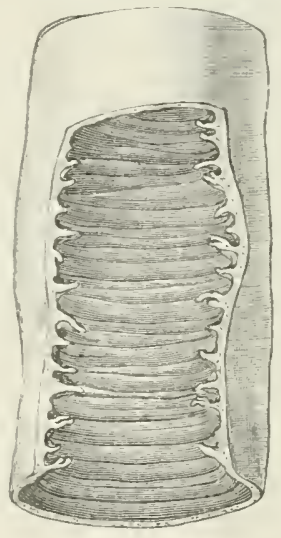

with minute processes called villi: these give the membrane a fincly Hocculent appearance. which has been compared to the pile of velvet. They are largest and most numerous in the duodenum and jejunum, and become gradually shorter, smaller, and fewer on the ileum. Besirles the villi are eertain large folds or valvalatr flaps: these are the ouleula ammirentes. They are permanent crescentic folds of mucous membrane set transversely to the long axis of the intestine. The majority extrul from one-latf to two-thirls of the distance roumel the lumen (fig. 573). The laresest are more than two inches long, and about one-third of an inch wide. Some of the valvulie comniventes lom complete cireles and others spirals. These mucous fold: to mot exint at the logiming of the duolenum. They are rely large just

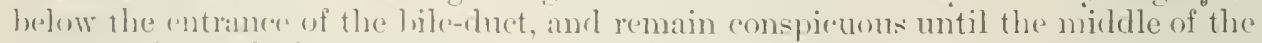

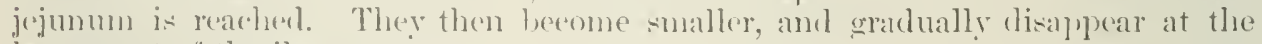
lower part of the ilemm1.

Sartered over the whole of the mueous membrane of the small intestine are numerons minute suft rounded boulies compuserl of retiform tiscure. These are the s(1)-salled solitur!l glames.

Certain patches called l'eyer's putrlese are found in the lower ileun. They are witl, are from one-half tor there inches in lenerth, and about one inch in breadth, and are plated in the long axis of the lowed along a line most remote from the mesentery. They are made nu of an ageregation of solitary glands. 


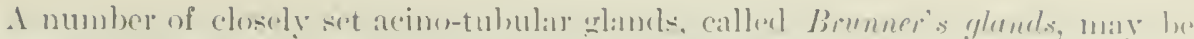
expused hy disiection in the first part of the duslenum.

Blood-supply of the small intestine. - The small intestine receives its bloml

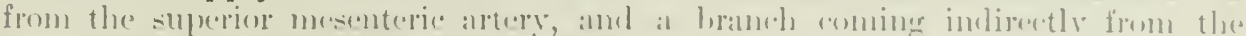

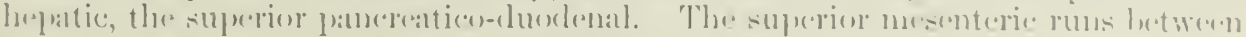

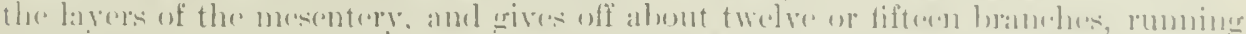

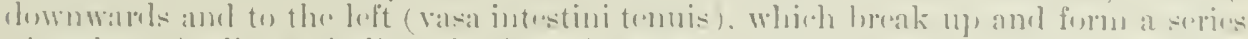
of alrehes, finally enejeding the intestine as small branches. It also gives off it

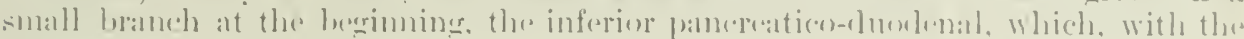

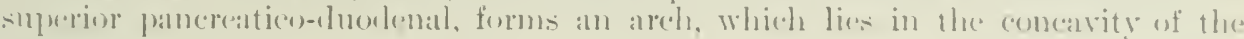

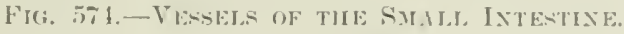

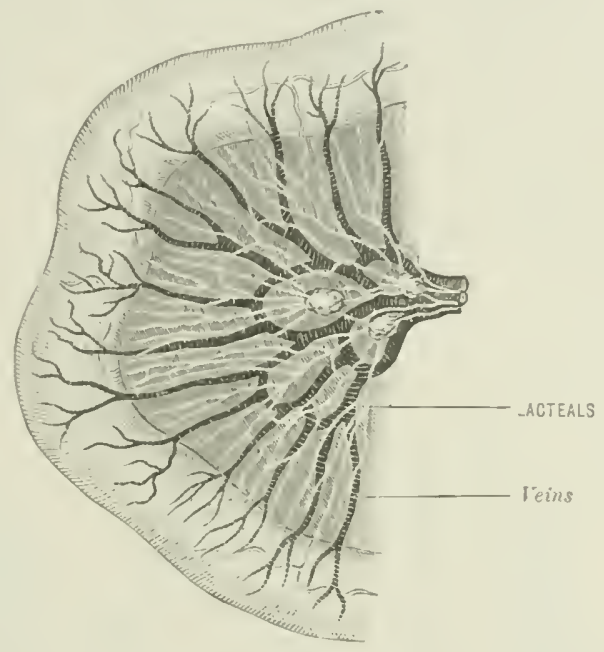

duxlenum and supplies it. The bloor is returned ly means of the superios musenterie vein, which with the sulunic vein forms the prostal (fig, 57t).

The lymphatics form a continumus serios, which is divided into two sets-riz.

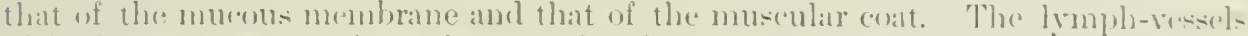

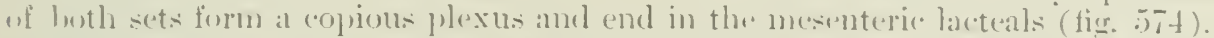

The nerves.-The small intestine is supplierl ly mealls of the superior

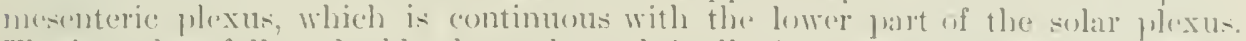

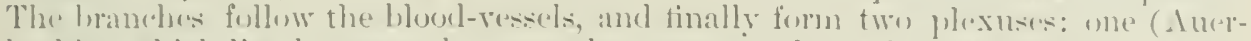

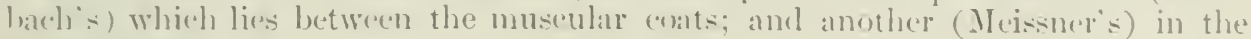
muhmuculs coat.

\section{THE LARQIE INTESTINE}

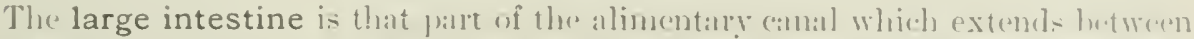

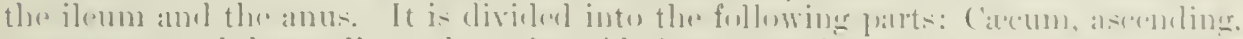

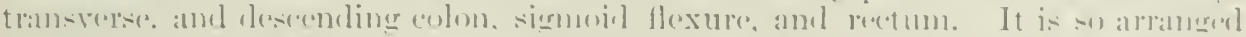

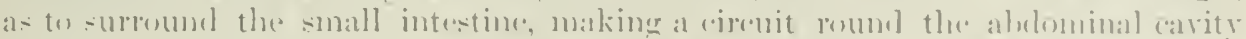

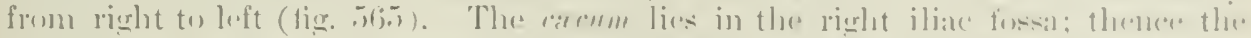

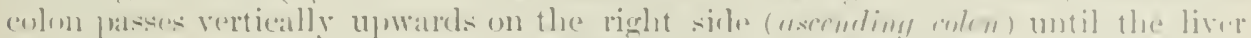

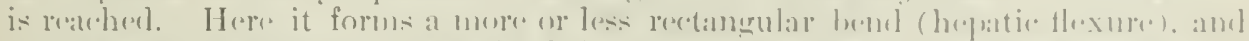

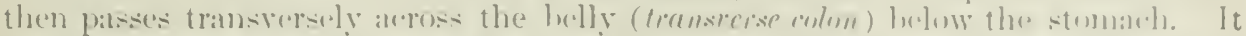

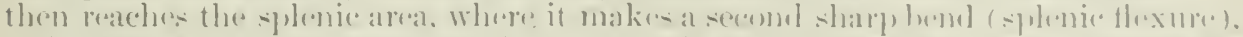

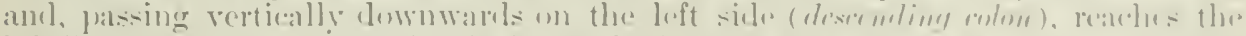

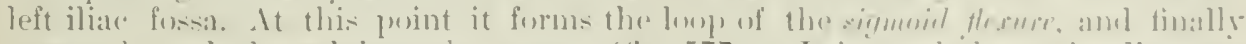

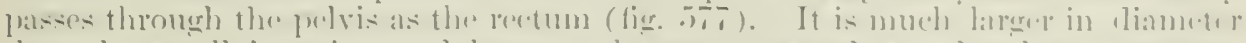

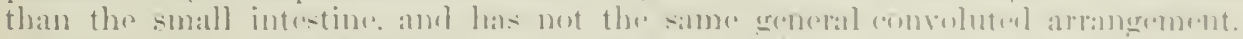

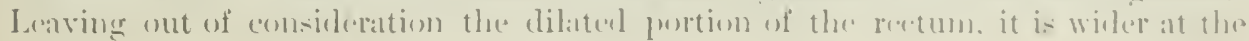


begimning than at the rmel. It varies in wielth at different parts from two and a half to one and a yualtere inedes. 'The lenerth from the root of the alprendix or tip) of the earem to the juint where the meso-rectum enels is, in the male, about four fort cight inches, amel in the female alout four leet six inches.

The extremes found in a mumber of cases, were for both sexes respectively, six feret six inches, and three foret three inches.

The large intestine, in all parts exerpt the rectmon, has a peeuliar arrangement of it: walls, which gives it a very different appearance from the small intestine. It is seremlated, and the salculation is produced by the gut having to adopt its lenetle to three shorter musrular bames which run the course of the intestine. These banch, which are abut 12 $\mathrm{mm}$. wite and $1 \mathrm{~mm}$. thick, are really the lomgiturtinal filores of the muscular wall, which are chiefly collected at three parts (fig. $57.5)$. ()ne hand is situated posteriorly om the attached horder, another rums anteriorly, ancl the third is situated on the imer side of the ascending and descending colon, and on the lower border of the transverse colon. All these bands start at the vermiform appendix, and are lost on the rectum. Along the whole length of the lare intestine, exeept the lower part of the rectum, are certain small appendages (appendires equiploicx), seen mostly along the line of the inner muscular band. Ther are ponches of peritonemu containing fat.

The cæcum, or caput coli.-The ereum is a cul-de-senc forming the first part of the large intestine. It is defined as that part of the colon which is situated

Fig. 575. - The Fotr Typles of Cacum. (Treves.)
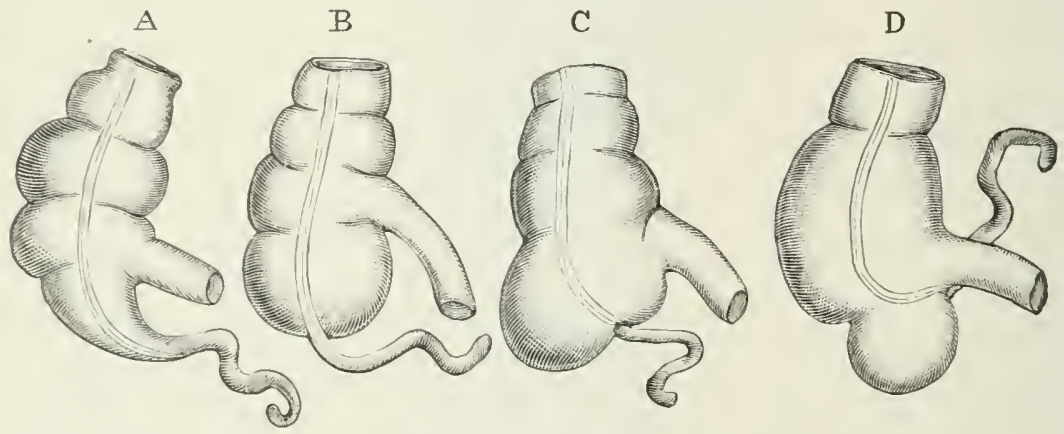

helow the entrance of the ileum. Its breadth is about three inches, and its length about two and a half inches.

It lics in the right iliae fossa, and is nsually situated upon the poos muscle, amel so placel that its apex or lowst puint is just projecting beyond the inner border of that inner muscle (figs. 56.5, 575). It is ertirely enveloped in peritonemm, and is free in the aldominal cavity. The apex of the cecum nsually corresponds with a point a little to the inner side of the middle of Poupart's liganent.

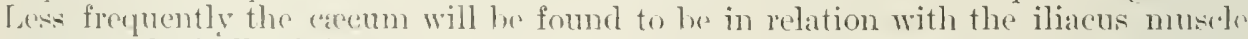
only; or the luilk of the eaput will lie mon that muscle, while the apex rests mon the psoas. In a number of ases the caeum is entirely elear of loth poos and iliacms mmseles, and hanes were the pelvie brim, or is lodged entirely within the

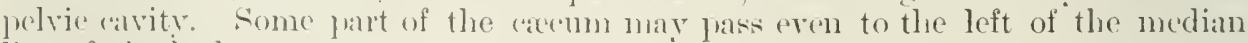
line of the body.

This part of the enton is liable to ensidemale variation.

Its enrintions: maty lu deserihed under foum types:

1. The fortal type is conical in shape the appendix arising from the apex. This prexess is a continuation of the long axis of the colon. The three musenlar lands which meet at the appenclix are nearly at equal distances apart (fig. $575, \mathrm{~A}$.).

2. The secomed form is mere gualdrilateral in shape than the last; the three hands retain their relative positions: the appendix alpeatrs hetween two bulging sacenli, instead of at the summit of a conse (fig. 5.5 , B. ).

$\therefore$ In the thirel type, that part of the caput coli that lies to the right side of the 
anterior hand grows ont of proportion to that part to the left of the hame. Ther anterior wall becomes more derelopere than the posteriors so that the aprex is turnerl so much to the loft and posteriorly that it mearly merets the ileo-eaceal junctions. A false apex is fomed by the highly developed part to the right of the anterior band.

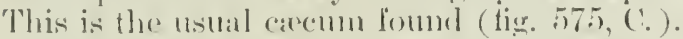

4. In the fourth trpe, the develojment of the part to the right of the anterion band is exersive, while the serement to the loft of the hamd has at rephied. In this form the anterior banel rums to the inferior angle of junction of the ilemm with the receun. The root of the appendix is posterior to that angle. There is no trace of the original apex, and the appendix apjuas to spring almost from the ileo-cecal jumetion (fig. $57 \overline{5}, 1)$.).

()her earietious. - The carenu may vary in its generaldevelopment. It is some-

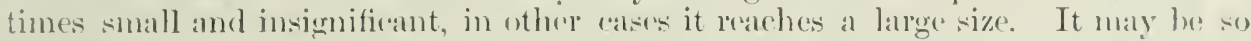
moterl that the ilem passes behind the colom and opens on the right side. The josterior part has been seen much mone developed than the anterior, so that the ilemm has onterexl from the front, and the alpendix has come off form the anterom

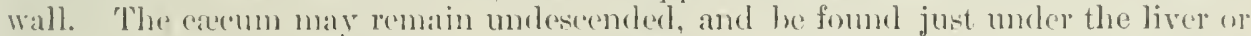

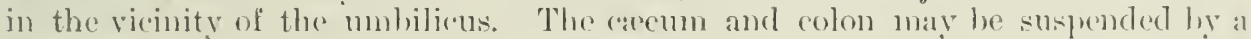
mesentery common to the whole intestinal canal. In such eases the prinutive condition of the peritomeal fold whirh supports the small and large intestine is permanently retained (page 997 ).

The vermiform appendix.-Attached to what is really the original allex of

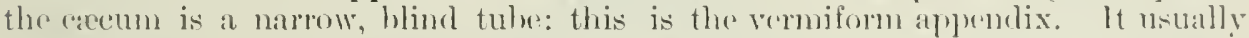
comes off elose to the ileo-careal valve on the inner and posteriol sirle of the lonwel, though orecasionally it forms the true apex of the eacum. In the adult the arerage length is four inclues, the extremes boingone inch and six inches. In the majority of instaneses the appendix is much twisted upon itself. Its usual position is hehind the end of the ileum and its mesentery, and pointing in the direction of the spleen. It way oreasionally aserend rertically behind the eecum.

It has a definite mesentery, which comes off from the left layer of the mesentery of the ilemm. Its origin from this layer is along a straight line which is situated at a short distance from the intestine, and which is not quite parallel with the margin of the howel. In general outline: the mesentery is triangular. In the arlult it whes not extend along the whole length of the tulre. "It is, in fact, too short for the appendix, and it is this that aceoments for the twisterl condition of the little process. Alomg the free margin of the mesentery roms a branch of the ileo-nolic antery.

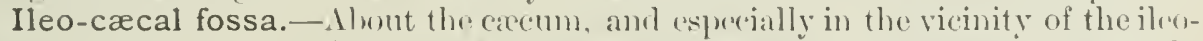
aceal junction, are cortain fossue collectivaly known as the ileos-cacal. Two only appear to be fairly constant. The first, the superion ileoracel, is formed by the

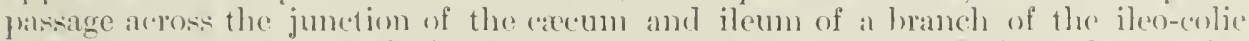
artery, which produces a fold of peritonemon liniting a pouch. It is on the anterior aspeet of the bowel, and the pourb opens downwards.

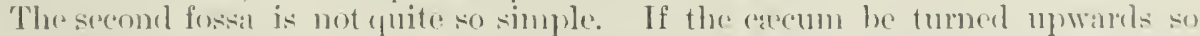

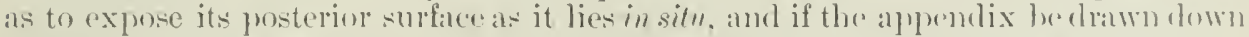
so as to put its mesentery on the stretreh, a peesuliar fold will he foumel to join that mesentery. This fold arises from that borker of the itemn whith is most remote from the insertion of its mesentery. It then passes over the ilen-citarl junction an its inferior asjoret, is allherent ti the caremm, and finally joins the surface of the mesentery of the appendix. This fold is peouliale in the alsomes of any visilite

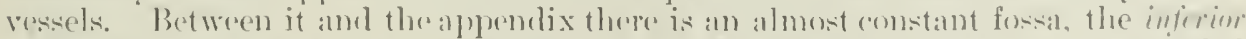

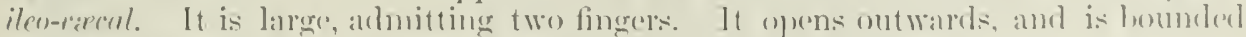
om one siele by the smatl intestine. and on the othere he the raecum.

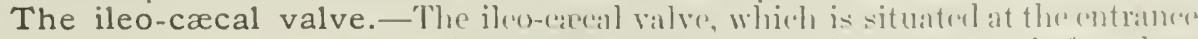

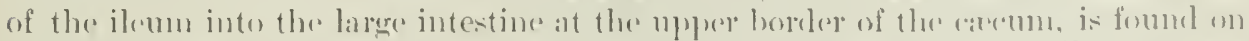

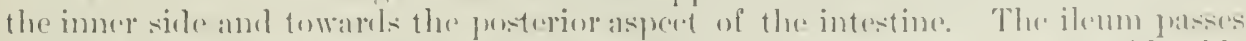

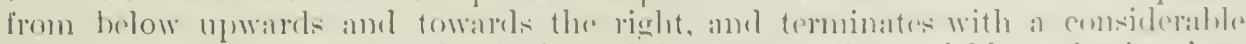

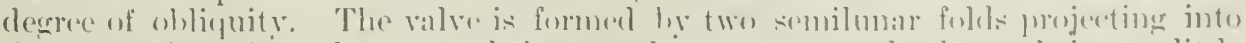

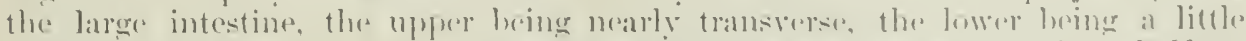
ohligue. The ofening betwern them lakes the formot a narrow slit alume half an inch in length, romeled in front but narrow lechind. At the ands of the slit the 


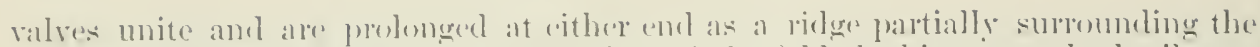

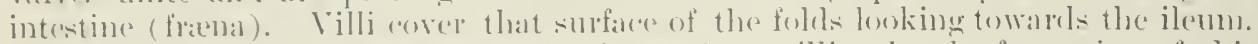
The surtace towalds the larese intestine is free from villi. In the formation of this

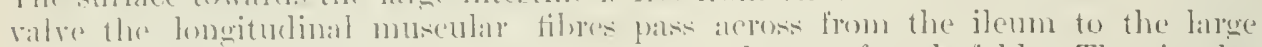
intestine without dipping down between the two layers of eatch fold. The eireular

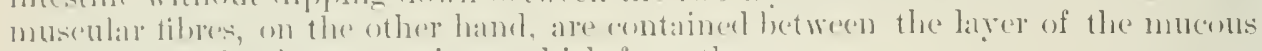

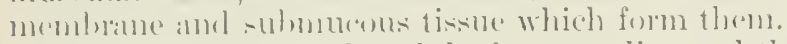

The colon.- In the mult the asconding and the deserending parts of the colom

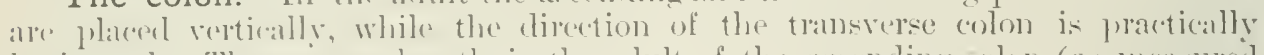

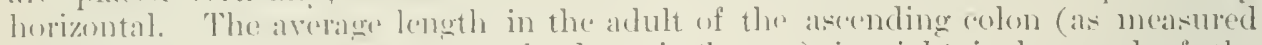
from the tip of the "aremon to the hepatice flexure) is eight inches, and of the

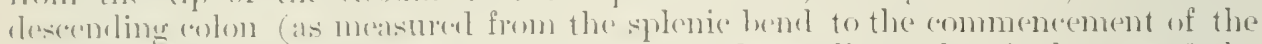

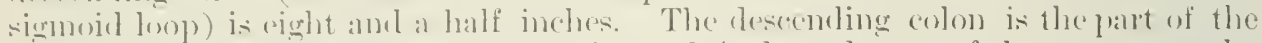
balculowel that is least liahle to variation. It is the only part of the gut except the flumelenm that retains its original position as a portion of the great primary

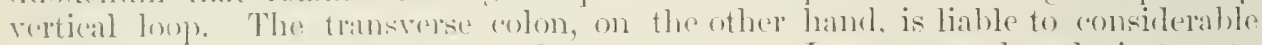
villiation in fougth, position, and arrangenent. Its average length is twenty

\section{Fig. 57t.--section of the Ascending Colox. (Allen Thomson.)}

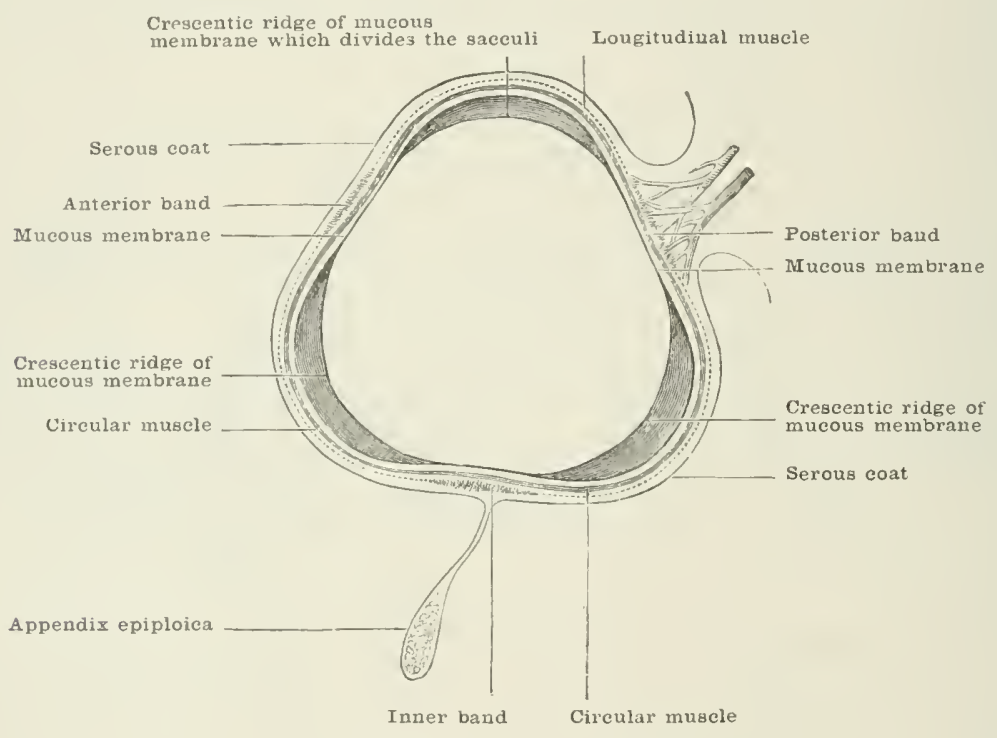

inches in the arlult. It las been found to vary in adults from twelve to thirtythree inches.

The ascending colon.-The asending oolon extruds from the exemm to the inferior surface of the liver extemal to the gall bladder, forming there the hepatice

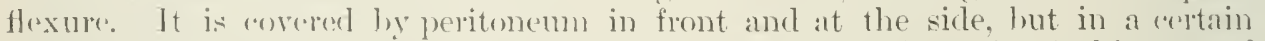
proportion of (ases (twenty-six pere eent. in one huncherl discertions) this part of the large intestine is ammeted with the pesterior wall of the abdomen by a meso-

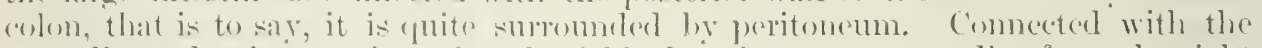
asconcling colon is sometimes fombl a fold of jeritonemm, extending form the right sirle of the gut to the parietes at a little abowe the level of the highest part of the ilise crest. It forms a sluelf upon which rests the extreme right margin of the liver. It might be alllorl the sustentrenlum hepretis.

The ascending colon is in relation behind with the right kirhery. socond portion

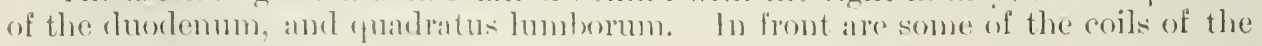
ilo'llum (fig. . T)

The transverse colon:-The transverse colon, smaller in dianeter than the

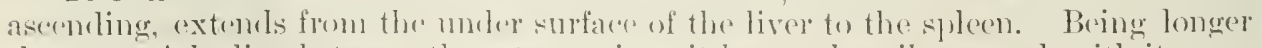
than a straight line betwern these two points. it has to eleserilwan arch with its con- 


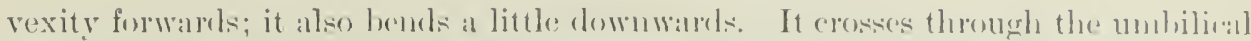

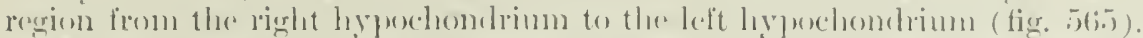

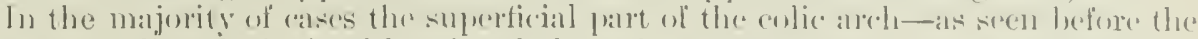

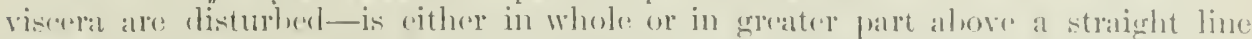

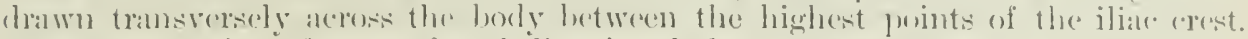
In the proportion of one to four it lies, in whole or in greater part, betow this line (lim. 58,2$)$.

C'ertain remarkable hemels are sometimes formed by this part of the lower. The

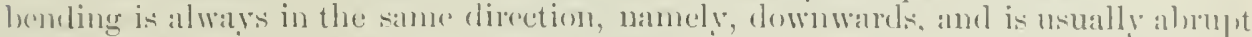

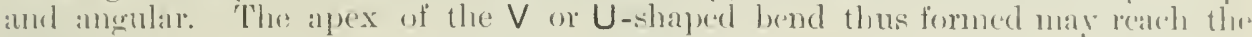
pulus. This hend appuars to lue due to two distinct eatuses: namely, long-continued distension on the one hamel, and to congenital malformation on the othere

'The transerse colon is in pelation above with the liver and anll bladder, the

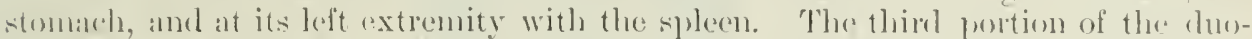
tenum palsists behind it. Bolow are the coils of the small intestine. It is sur-

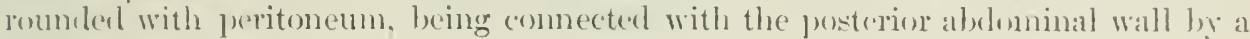
miles(1)-(0)/on.

The descending colon extends from the spleen to the signoid flexure. It is mope mosible than the ascemeliner eolom. It is also narrower. At its heximning it is commerted with the diaphragm, on a level with the tenth and aldenth rils, liy at fold of peritonemm, the costo-rolic ligament (or sustentarulum lienis. from the fact that it supports the spleen). The bend hetwern the transwerse colom and deserenting rolon is called the splenic flexure. The descending colon is situated in the left hypochombliate and humbar regions (fig. 591). Its relations to the preritonemu are thre same as obtain with the aseending colon, that is, it is covered in front and on the sides. A meso-eolon is met with oftener on this side than on the riglat. In one

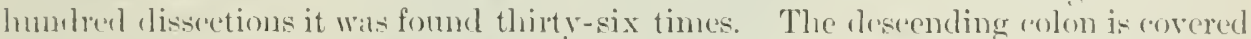
in front hy the small intestine; behind, are part of the diaphragm, the left kidner, and the puadratus lumborum musele (fig. 57.).

The sigmoid flexure and rectum.-The sogment of gnt termed the sigmoid flexure, and theso-called first part of the rectum, form together a single simple

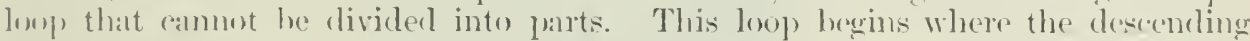

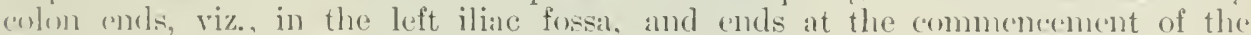

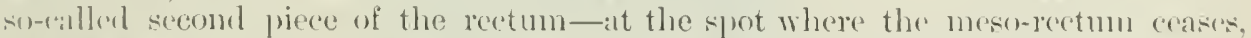
opposite about the thirel piece of the sacrmo in the median line. The lonp when

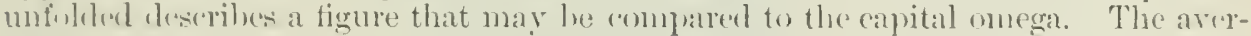
atere length of this sigmoid or omega lowe is serentren inches and a half. The nomal pontion of the loop is not in the left iliac fossa, lout wholly in the prelvis. The most rommon dispmestion of it may now be describerl.

The deserending colon emels just at the outer lurder of the proas. The gut here

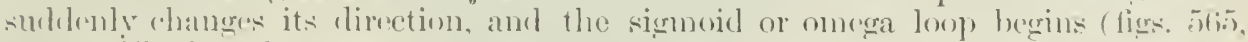

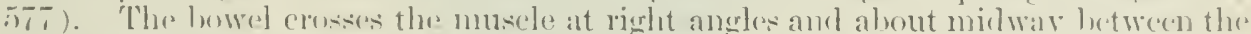

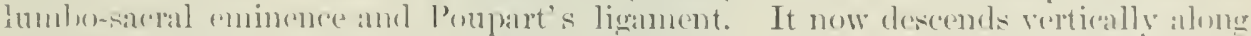

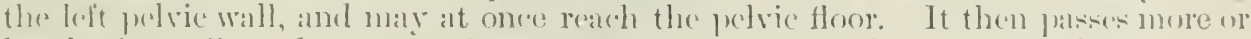

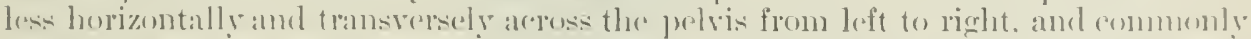

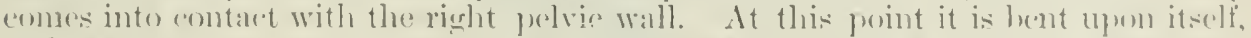

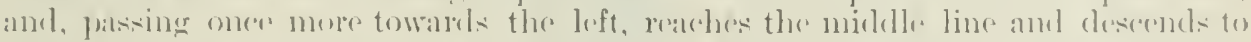

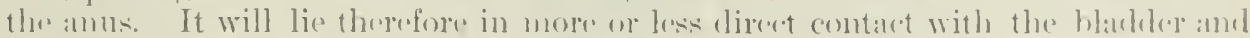

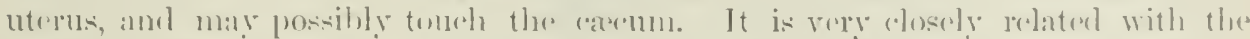

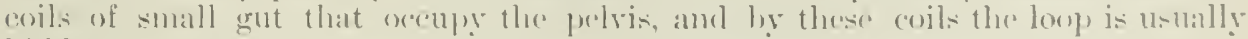
hicklens.

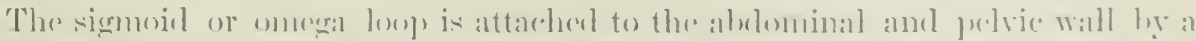

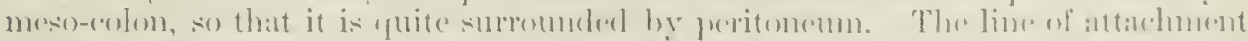

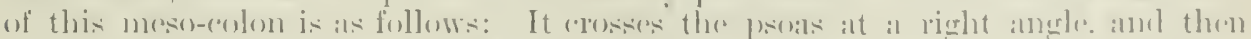

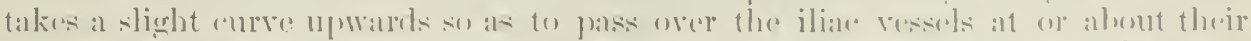

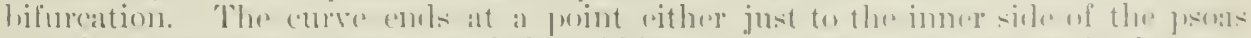

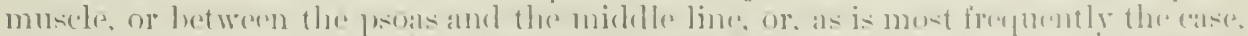

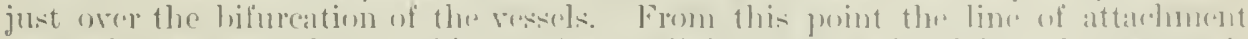

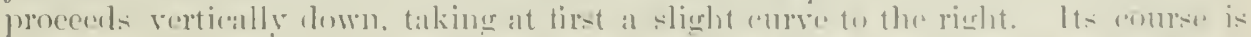

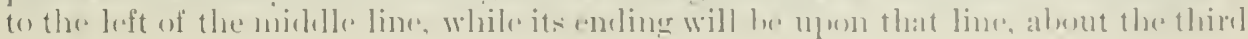


piece of the saleruns. The sigmoid meso-colon measures from one and a quarter to three and a half inches in wilth-i.e., from the parietes to the bowel.

When a desermeling nueso-eolon exists it joins that of the loop, and the line of attallnment is then, as a rule, lirected obliquely access the psoas and the lower end of the kilney, while heyome the pelvic brim the attahment is as above deseribed.

There is often no neso-colon over the josoas, the gut being allherent to that musele.

Flg. 57\%.-Vhew of the Deeper AbDonnal Viscera. (Rüdinger.)

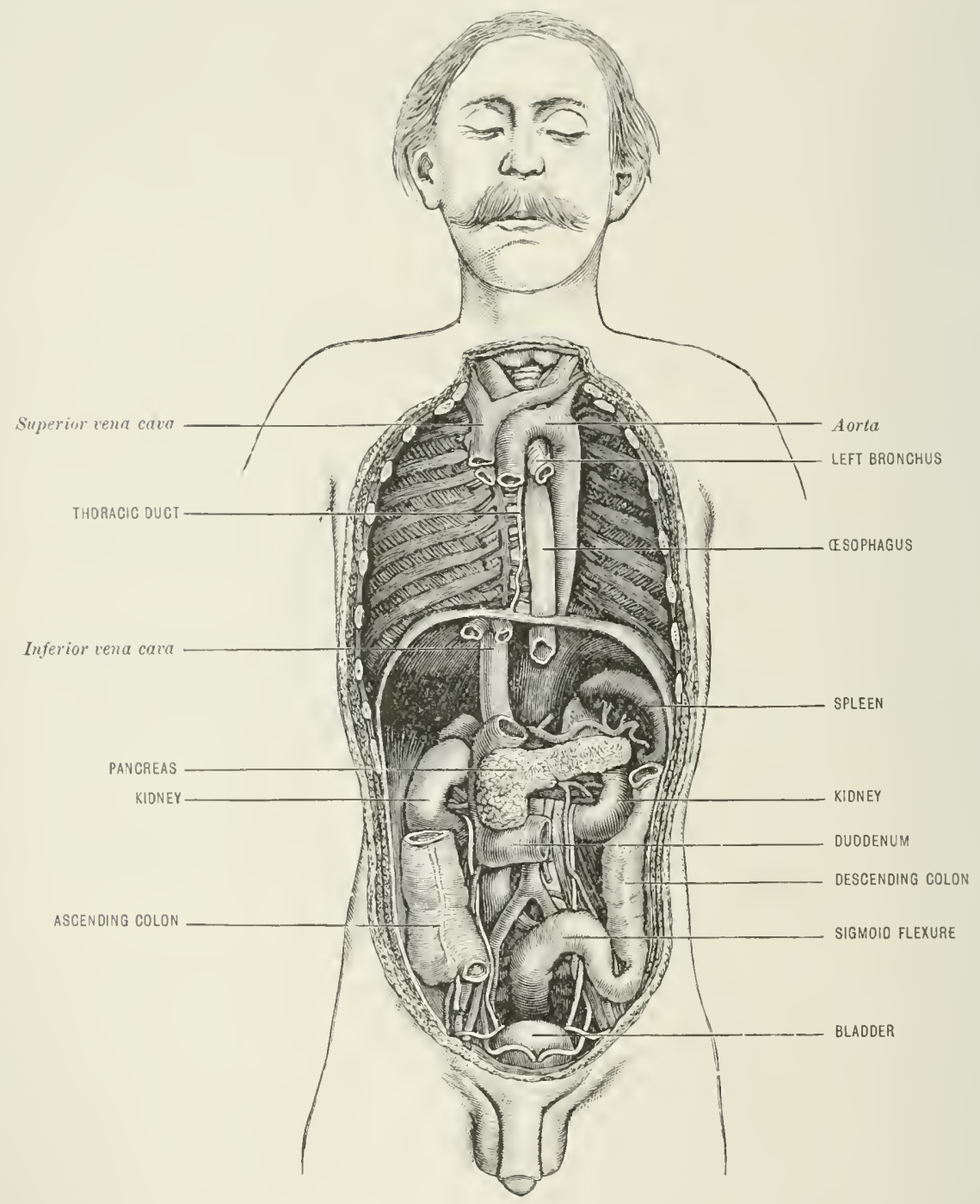

In comnection with the sigmoid nueso-colon is often found a fossa or pouch of peritonemon, known as the intersigmoid fossen. The pouch is formed by the layers of the meso-colon, and is prolueerl by the sigmoirl artery. It is gemially found over the bifurcation of the iliac resseds. The pouch is fumnel-shaped, and the operning looks downwilds and to the left. The fossa varies in depth from one to one and a half inches, and is the seat of the sigmoinl himia.

The rectum.-The reetum has been deseribed as divided into three portions. Such division is guite athltary, and is inconvenient. What is usually described as the first portion has, in the aceount just given, here included with the sigmoid Hexure. 


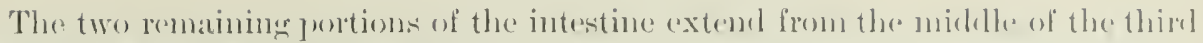
piece of the salerum to the anus.

It would be well if the torm 'rectum' were to les liniterl to that post of the

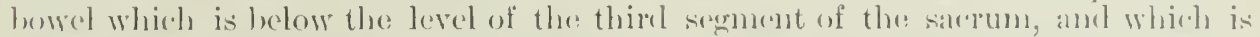

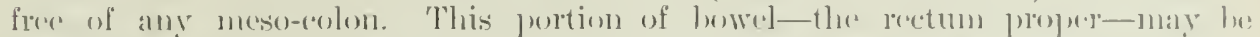
divided into two portions. The lirst portion extends fron the thind piene of the siacrum to the tip of the corecr.

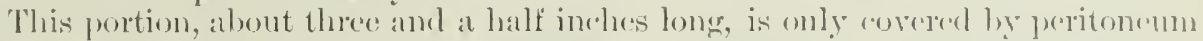
above, and then only over the anterior surlace. Buhned, it is in relation with the

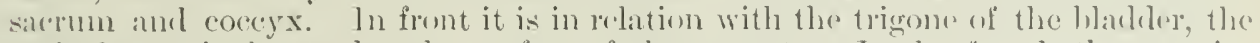
vesieula seminales, and moler surface of the prostate. In the fomale the anteriol sturface is in relation with the vagina and the crevix uteri.

The peritoneum is reflecterl from the rectum to the blackler in the male, and the vagina in the fomale (recto-vesical or recto-vaginal pouch). This petreh rxtends in the male to within alout three inehes of the anus. On the posterior surface of the gut there is no peritonem below a point five inches from the antis.

'The second portion (or what used to be called the third portion) rextends from the tip of the coecry to the anus; it is about an inch and a half lomg. It differs from the first portion in the direction of its curve: while that follows the curve of the sacrum and roceyx, this portion turns lackwarels and rlownwark. It is not comnected with the peritonemm. It is surmounded, after loaving the jorstate, by the internal sphineter, while the levator ani is attached to its side. At its ene the external spluncter is situated; in front is the triangular liganent of the perincuns. Just above the anus the rectum is much dilated.

The anus.- The anus is the aperture ly which the intestine opens extremally. Juring life it is contrated hy the sphimeters, so as to give the skin alround at wrinkled appearanee. Romnd the lower part of the rertum and anus certain muscles that are comnected with its proper function are situated. They are the internal sphineter, the levator ani, and the external sphincter. The levator ani and extemal sphincter will be fomel described in another part.

The intermal sylhineter is a thickening of the circular fibres of the intestine. situated lound the rectum alout an inch above the anus, and extending over half an inch of the intestine. It forms a complete muscular ring. It is two lines thick, ancl is paler than the external splumeter.

The rectum differs from the rest of the colon in presenting perfectly smooth

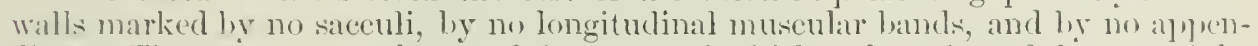
fiers. The micous membrane of the reetum is thicker than that of the rest of the large intestine. Cortain folks, chicetly longitudinal in direction, are secu in the lax state of the tube, which disappear when distended. Houston las described three oblipue samilumar folds, which project into the lmmen of the tube: one in front ly the justatite, and two others higher wl; one from the left sicle, and one on the right, the hirhest.

Structure of the large intestine.-There are four coats: a scrous, muscular. muenus, and submucous.

The semes is derived from the peritoneum, and is mone ol less complete.

The anpendices epiploiese in comnertion with this layer have lecen mentioned (fig. 576 ).

The muscelur roat is divided into circular and longitudinal layers, the longi-

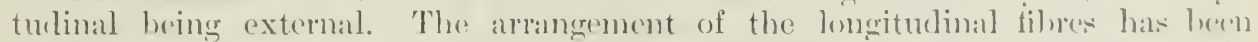

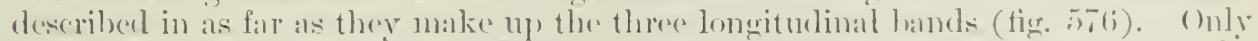

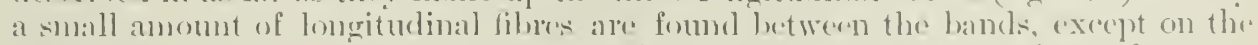
rermiform appendix and lower part of the sigmoil tlexure, where they are alrangexl all rouml.

The circular fibres form a thin laver, and are mostly anllocterl in the interval between the saleruli.

The mucous membrone, separated from the muscular layer hy the sulumuroms leyce, has no villi, and no vallutat emuiventes.

Blood-vessels. - The large intestine is supplied with blomk ly the hranders of

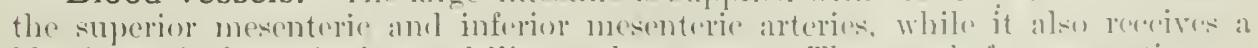

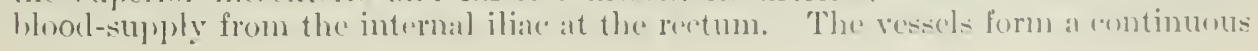


series of arches from the coermun. Where the vasa intestini tenuis anastomose with the ileo-coliea, the first hraneh of the superior mesenteric griven to the large intestine.

The blood-suply of the rectum is from the inferior mesenteric hy the superior hemorrhojdal, from the internal iliae by the middle hamorthoidal, and from the interual pudie by the inferior hamorrheidil. The vessets at the lower end of the rectum as:sume a longitudinal directions, commmicating freely near the anus, and less freely above.

The bitood of the large intestine is turusel into the portal vein by means of the superior mesenterie and inferior mesenterice reins. It the rectum a communication is set up lretween the sristennic and portal system of reins, since some of the blook of that part of the intestins is retumed into the internal iliae veins. In the lower end of the rectun the reins, like the anteries, are arranged longitudinally. This arrangenent is allerl the hamorrhoilal plexus.

The nerves aml lymphatics of the large intestine differ in no important partieular from those of the small intestine.

\section{THE LII'ER}

The liver-the largest gland in the body-is situated in the upper and riglit part of the abdominal cavity (figs. 565,578 ). It is of most irregular shape. It weighs between forty-five and sixty ounces. In females the liver is smaller than in males. It bears a different relation to the body weight at different ages. It forms one-fortieth part of the weight of the body in the adult male, and onethirty-sixth in the alult female. In the foetus, at the fourth month, it is one-tenth the weight of the body, and in the infant at birth one-twentieth (1ig. 57. $)$. It masures from right to left seven to ten inches, from before backwards three to six inches, and six to seven inches from above downards in the thickest part of the right lohe. It is of a chocolate or reddish-hrown color, is solid and firm to the touch, but friable. Its bulk is equal to ninetr-five cubie inches.

In the description which follows it will be noted that there are two bordersanterior and posterior; two extremities - right and left; three surfaces - superior. infurior, and pusterion; five lobes-right, left, qualrate, caudate, and spigelian; five fissures-imubilical, fissure for the ductus venosus, transverse, fissure of the rena cara, fissme for the gall bladder; fire ligaments-coronary. suspensory or falciform, round, right and left lateral.

The liver is soes to be divided by means of a fold of peritonemu-the susjensory ligament-inte two very distinct parts, the right and left lobes (figs. 578, 579).

The anterior border of the liver is well defined, appearing as a sharp thin edge. To the left of the mildle point at the beginning of the longitudinal fissure is the interkbar notch, marking the division between the right and left lobes. Further. to the right is a notrhe for the gall blakkler.

The posterior border is thick, mumed, and fixed, is slightly marked hy the spinil (o)lumm, and notrherl for the rena cara.

The right extremity is thiek, and rounded like the posterior lorder. The left extremity is thin and Hat like the anteriol bomler.

'The surfaces are deceriberl as they areseren in a liver which has been hardened iil sitil.

The superior surface of the liver is convex, and moulded to the surface of the

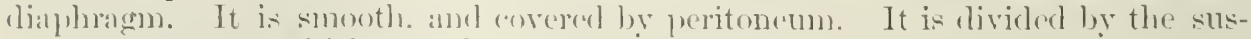
fensory ligament, which runs from lefore lakekwals, into two parts: the right and left lobes, the right division lwing much the large (tig. 579). Ijwo this surface of the loft Inbe is a shallow dippresion for the harart. The surface of the left lobe is much less comvex than that of the right. A consileralde portion of this surface farcs anterionly, and some writer's divicle it into anterior and mpluer surfaces. 
The inferior surface comsists of that palt of the liver in front of and inducliner

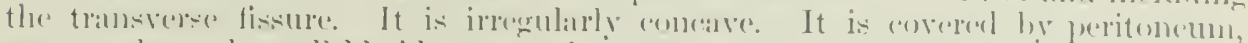

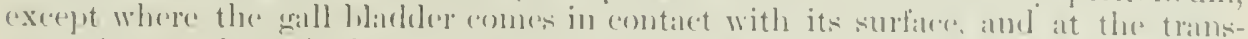

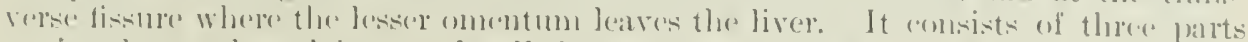

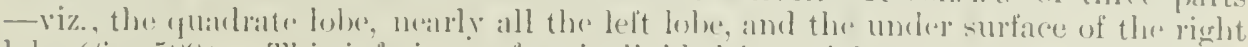

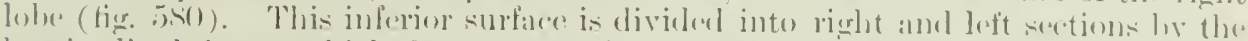
longitulinal fissure which forms the inferior separation lwetwen the right and lalt Iolues. The part of the longitudinal fissure seen on this surface is knewn as the umbilical fissure from its antaining eluring fortal life the mmbilimal vein, the

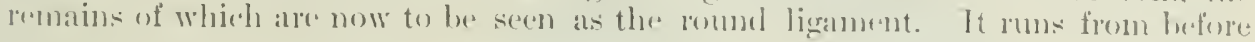

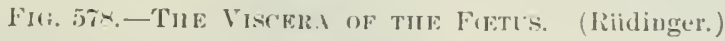

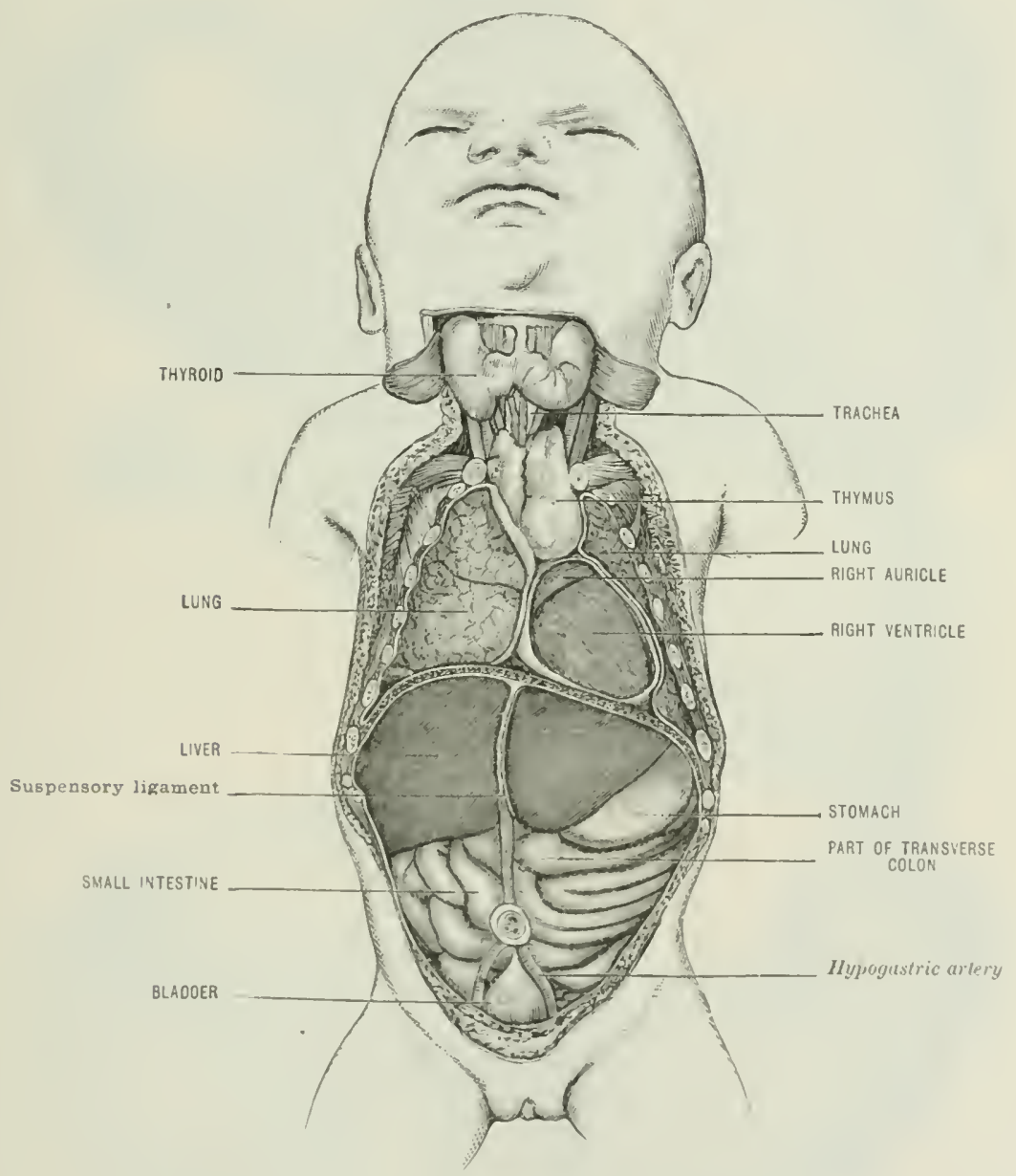

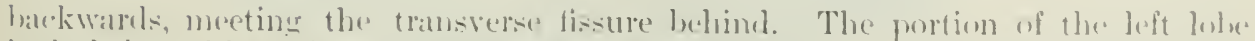
inchuled on this surface is mueh smaller than the similar surfiere of the rient lohe.

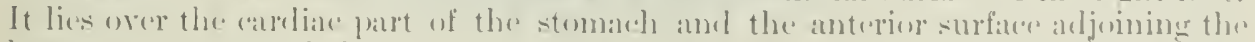

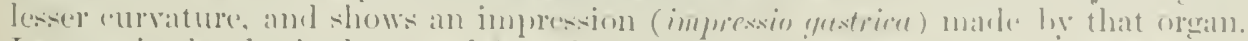
Its anterior berder is shar] and free; lout behind, the separation from the justeriog sllfale is very ill defined.

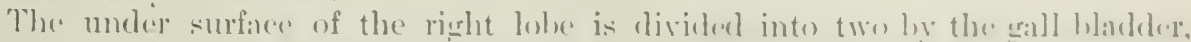

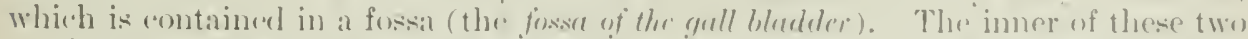

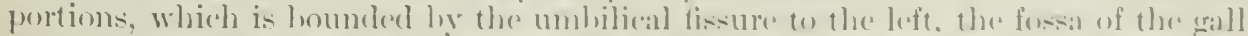

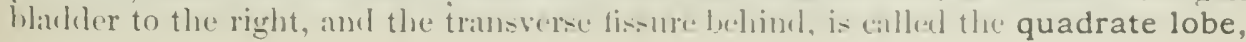


and is connexter with the left lole very often hy a hridge of liver substance (prons hepatis) alcoss the umbilical fissure. "The outer of the two portions is much the larerer. and presents three depresioms upon its surfice: an anterior one for the hepatie llexure of the colnn (impressio colica). a posterior one for the right kithey

FIG. 579.-SUPERIOL SLRFACE OF THE LIVER.

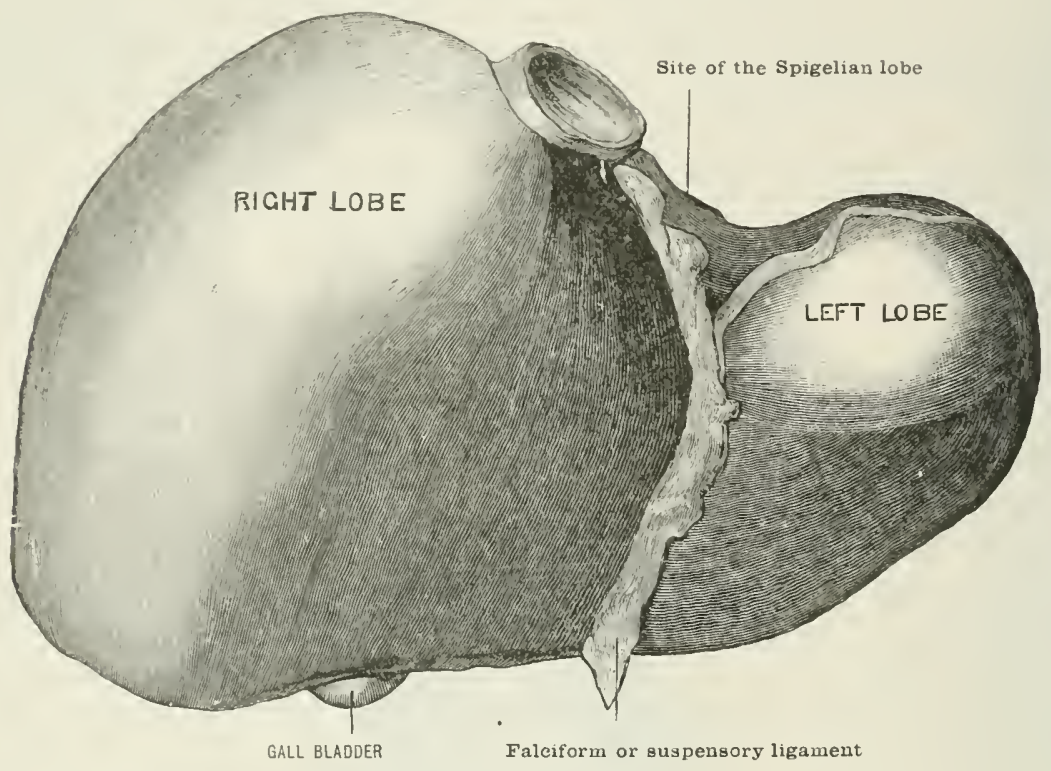

Fig. 580.- - The INFerior Surface of the Liveli.

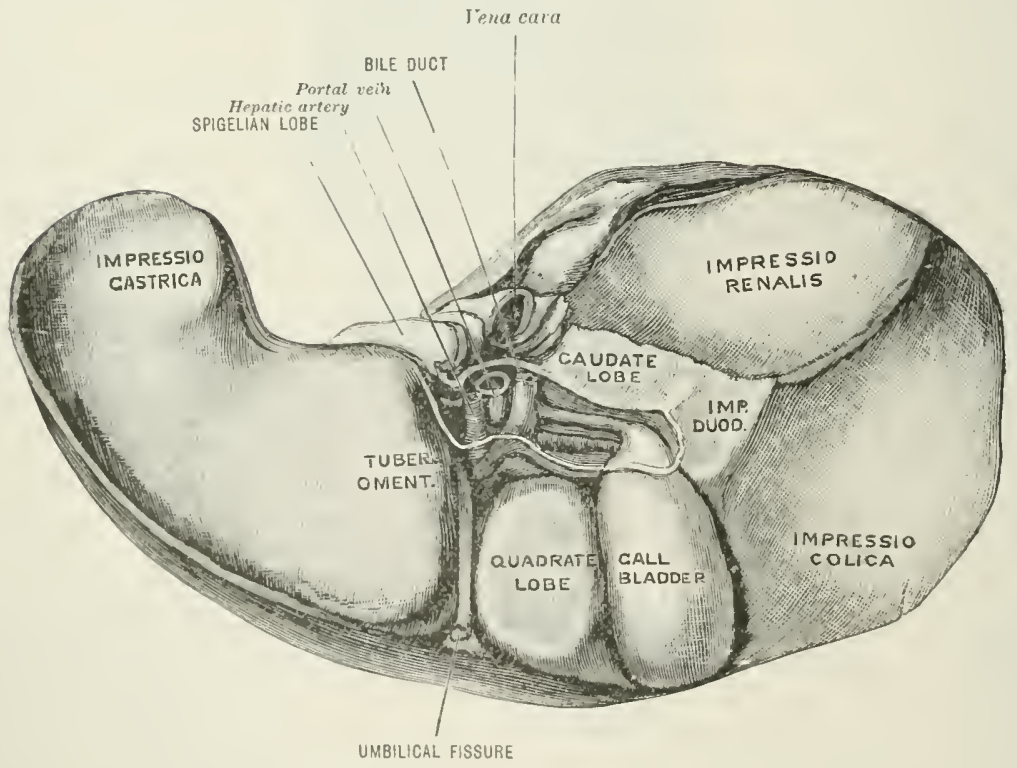

(impressin renalis), and one situated on the inner sirle of the impressio renalis for the descenting part of the duodenum (imprexion duodenalis). In a hardened liver these impressions are well marked, and are sepalrated by well-defined ridges.

The posterior surface is clirected hackwards towaids the vertehrial column, at 
which part it is concave. It includes that part of the liver behind the transwerse fissure, and comsists of the following barts (fig. jol ):-

(1) 'The posterior portion of the lelt lobe, mot very woll defined; it prosents a protuberance (the tuber omentale) in fremt, which projects against the lesiser onsen-

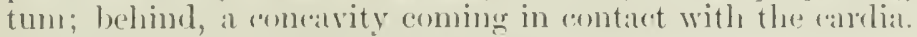

This portion is separated by matns of the fissure of the ductus venosus from (2) the Spigelian lobe, which lies between this fissure and that of the veral cavat. This lobe is directed backwards, is longer from alove downwarts than from side to side, aml is somewhat enncave from side to side. It is opposite to the tenth and cleventh thoracic vertelora, and rests on the crura of the diaphragm. Buhind its

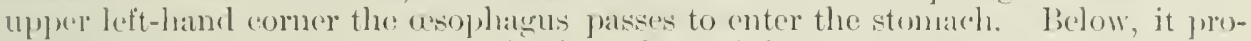
jerts and lomes part of the posterior boundary of the transverse fissure. It is annneeterl with that part of the right lobe which enters into the posterior surface by means of (3) the caudate lobe, which is a small mass of liver substance rumning from left to right behind the transverse fissure. It lies directly orer the foramen of Winslow. It varies a good leal in form; is sometines well defined, at of her tines hardly to be seren. When woll defined, it is about two to three inches long; behind is the termination of the fissure of the vena cava.

Fig. 591.-Posterior Suliface of the Livier.

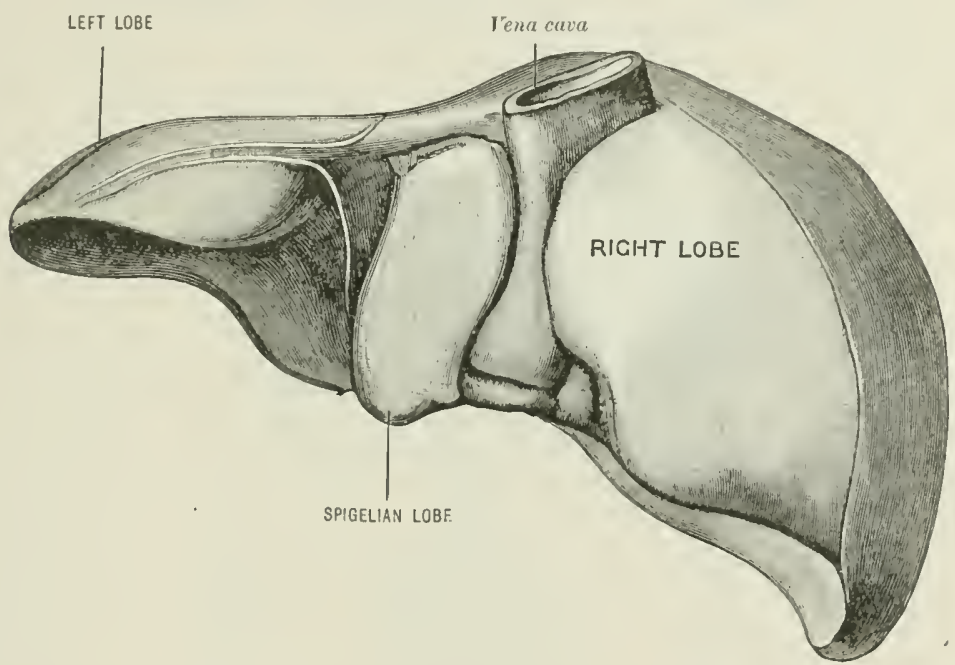

(4) The portion of the right lobe taking part in the posterior surface consists of a strip, two and al half to three inches broal (Quain). "This is unceresed by peritomeme, exeret at the "xtreme right. Jying hetween the two lavers of the coromary ligament dese to thr venal caval and near the caudate lobe is in inneresion for the right suprarenal (alp)sule (impresio semporemelis).

Fissures. The tisstres on the inferior and posterior surfaces of the liver are

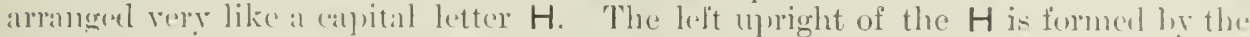
longitudinal fissure; the anteriur jortion containing the umbilical vein is sem on the inferion surface, and is known as the umbilical fissure; the presterien jortion,

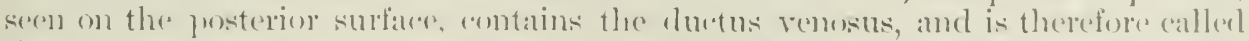
the fissure of the ductus venosus. The trimsirere lon of the $H$ is formed by the transverse 1$)^{\circ}$ portal fissure, which rms across at right angles to the longituilinal fissure, and contains the veriels antoring the liver, vi\%. the portal vein, hepatie artery, and hepatic duet (fig. siso).

The right undiglet of the $\mathrm{H}$ is formed he the fossa of the gall bladder in frout; it is intermpted liy the "audate lobe: and is continued behimel as the fissure of the vena cava, antaining. as its name implics, the inferior vena cava.

General position.-The liver is situaterl in the right hypehomelriar and efi-

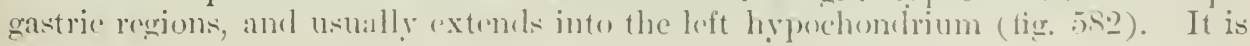




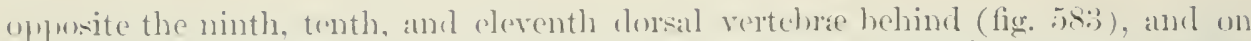
ther right side extends hetween the serenth and eleventh ribs; in front, it lies behind the fifth, sixth, seventh, aighth, and ninth astal cartilages: and its anterior horder corresponels on the right to the line of the maregin of the costal cartilages. and to the luft it is in contact with the anterion abdominal wall below the stemal noteh ( tig. $5+2)$.

The liver is rery movahle, and alters its pusition under various cireumstaness. It is chenessed at each inspiration, the anterion horder heing pushed helow the ribs hy a de(p) beath. When lying down, the liver efge is half an inch above the maroin of the ribs. In chiklen, the sland being larger in proportion to the body

firi. 5-2.-Reldtiun uf the AbDominal Viscera to the Parietes. (Treves.)

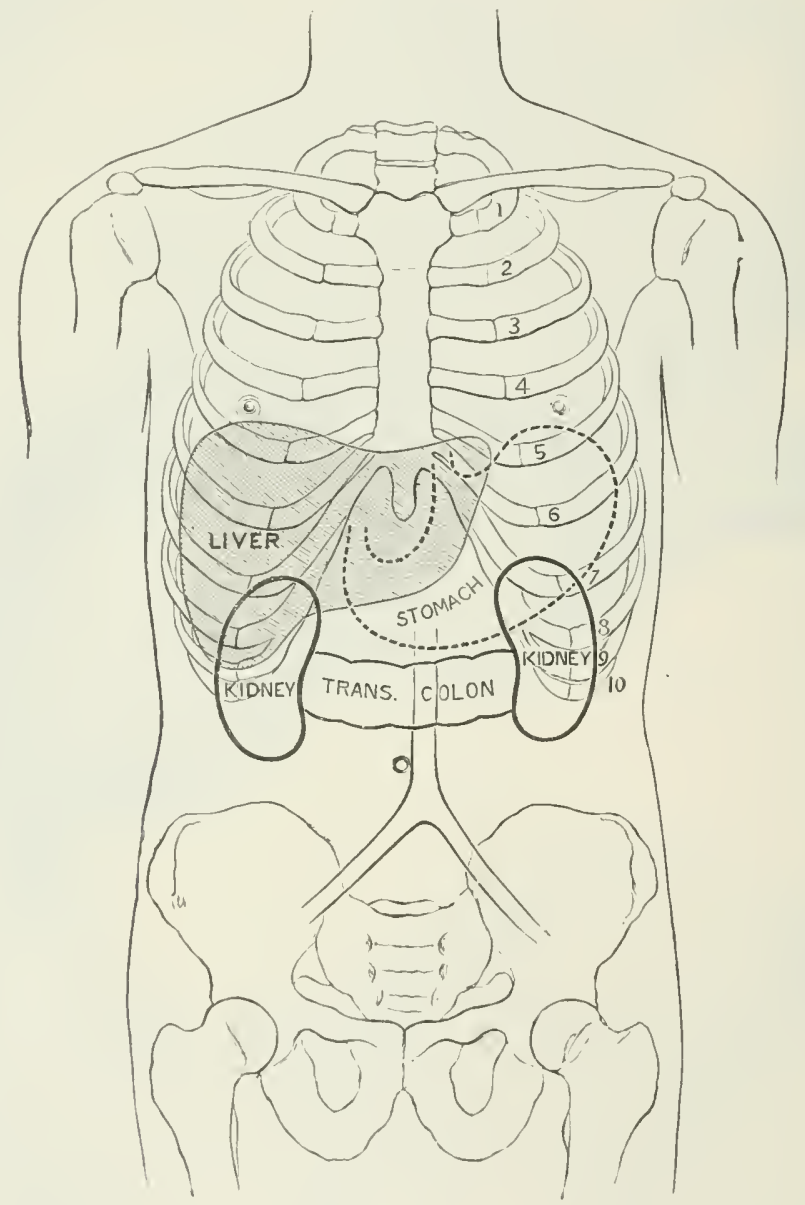

than in the alult state, it extencls below the rils and reaches the left hypochonArium.

The liver's rextreme left point is alwut an incle and a half beyoud the left margin of the sternum; in front, in the misldle line, it reaches to about half way between the xiphoid cartilase and the navel. The lower odge as it crosses the suberstal angle is represonted hy a line drawn from the ninth light to the eighth left costal ("artilage. (Quain.)

lts upper lindit is indicated hy a line erossing the mosostermum elose to its lower end, and rising on the right side in the mammary line to the level of the fifth rib. On the left the line is partically horizontal. Belind, the liver is nearest the surface at the tenth and eleventh thomedice reptehiee. 
Its upper convex surface is in contaret with the whole of the right alleh of the

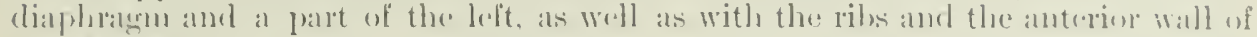
thes ablomint.

The undere surfice - The left lobe lies over the cardiac enel and a portion of the anterion wall of the stomatrob.

The right hole bics oree the hepatic llexure of the colom and right kiluer, and descending gortion of the duskenum.

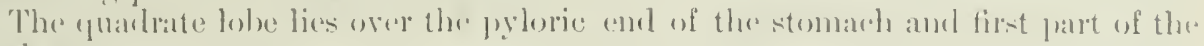
llmilemumis.

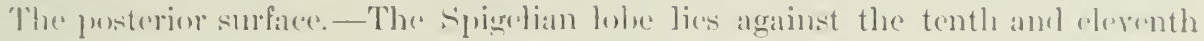

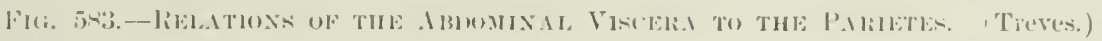

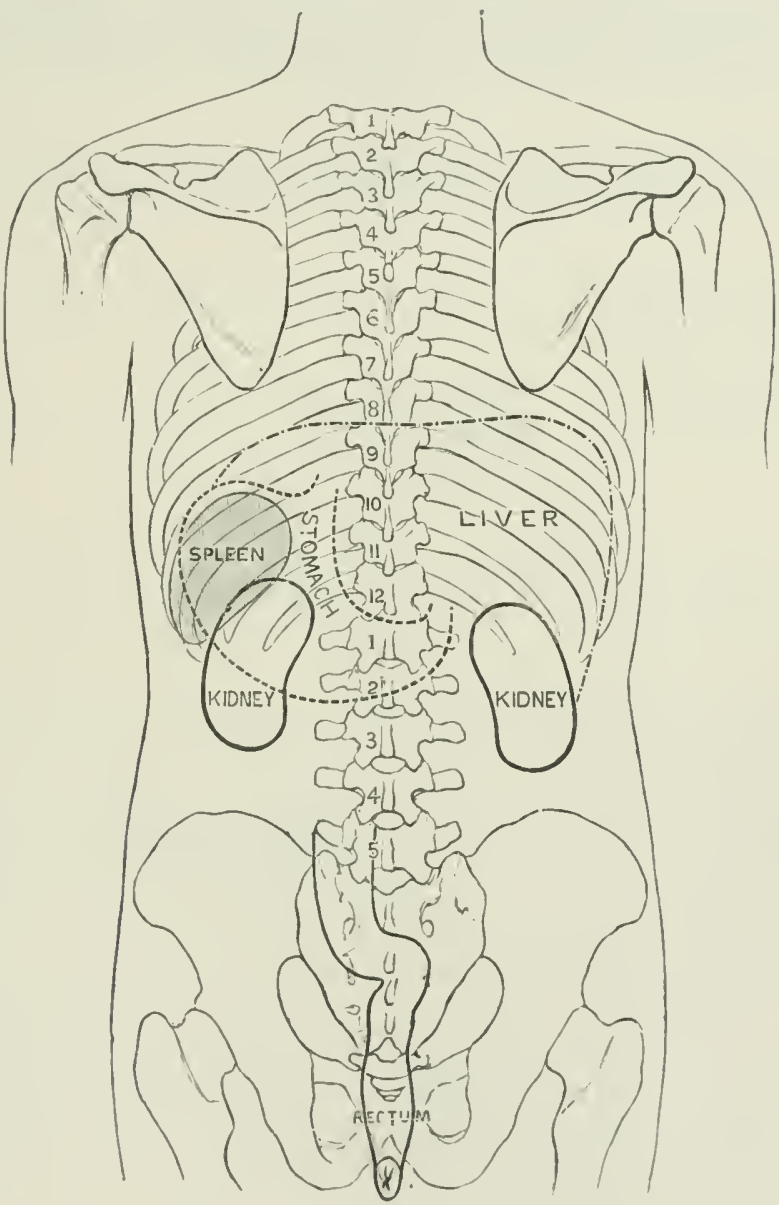

theracie vertehrae, the right arus of the diaphragm, and the lower end of the

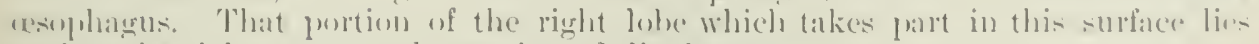
against the right suprallenal (ap)eule and diaphragum.

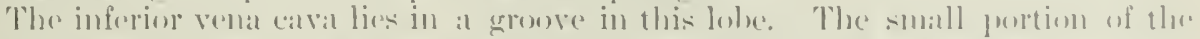

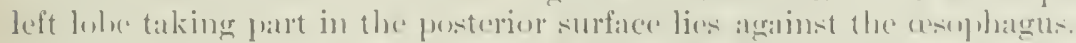

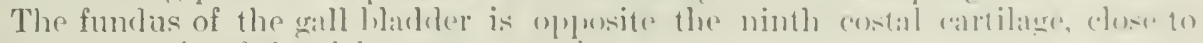
the onter matrin of the right rertus muscle.

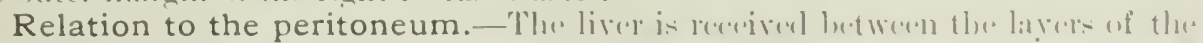

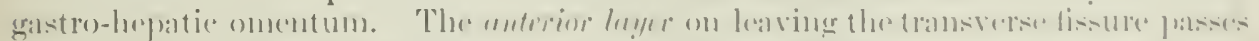

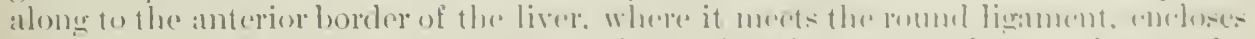

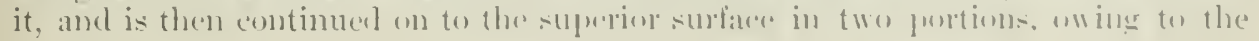


intervention of the romel liganent, the two lavers reflected on to this strueture being known as the suspensory linanent. It the posterior bender of the superion surface it leaves the liver and forms the mper layer of the coronary ligament.

The posterior layer of the galstro-hepatic onentum passes lackwards, corers a portion of the postrerior surface of the liver, and leares menered that part of the right lobe (except the extreme right) which takes part in this surface. It is finally reflected to form the inferior layer of the coronary liganent.

The parts of the liver uncovered by peritoncum are: the transwerse fissure, the fossa of the gall bladder, and that pertion of the posterior surface marle up by the right lobe, and to which allusion has alroady becen made.

Unelerneath the periteneal investment of the liver is a thin fibro-clastic membrane which is intinately adherent to the pritoneum, and is continuous over the liver where the peritonem is defirent. At the transverse fissure this fibrous layer invests the hepatic restels. forming a special sheath which follows the ressels as they 'nter the liver: this structure receives the name of Glisson's capsule.

\section{ABore.}

Diaphragm and anterior wall of abdomen.

\section{ВEHIND.} vertebre; crura of diaphragm; lower end of cesophagus; right suprarenal capsule; great vessels.
Tenth and eleventh thoracic

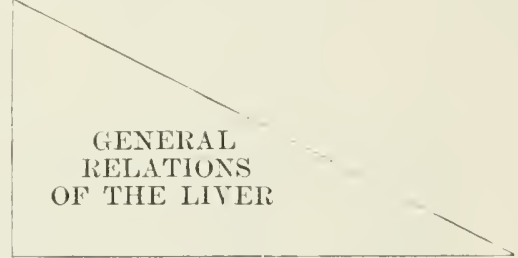

\section{BELOW}

Cardiac ent of stomach ; hepatic flexure of colon ; right kilney ; first aud second portions of duodenum.

Ligaments of the liver.-With the exception of the round ligament, the ligaments are formed by the peritoneum, and (with the same exception) are all attached to the diaphragm. The reflexion of the two lavers of peritonem from the posterior surface of the liver to the diaphragm, as just described, forms the coronary ligaments, the extremities, or lateral continuations, being alled the right and left lateral ligaments. The left lateral ligament is the longer, and is attached to the diaphragn in front of the esophagus. The right is attached to the lack part of the diajhragm.

The broad ligament (falciform or suspensory ligament) is also continuous lehind with the coromary ligament; it is formed liy the adjacent surfaces of the two portions of peritmeun covering the superior surface; it sitends from the umbilicus where is the ajex of the falx. The upper rounded border is comected with the anterior alukmunal wall and diaphragm. The free or anterior horder contains the romel ligament; thr lower or attached border extends from before lackwards on the upurer surface of the liver.

The round ligament is a fibrous cord (the remains of the umbilical rein), extenrting on the free border of the broad ligament from the longitudinal fissure to the mulviliens.

Blood-vessels. The liver recrive its artrial supply of blood from the hepatic artery, a branch of the coliae axis, which pases up between the two layers of the lesser omentun, and, dividing into two hranehes, one for areh lobe, enters the liver at the transrerse fissure. The right branch gives oft a branch to the gall bladeler.

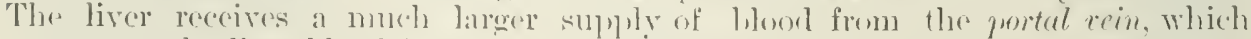

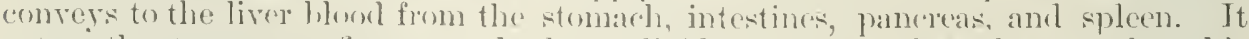

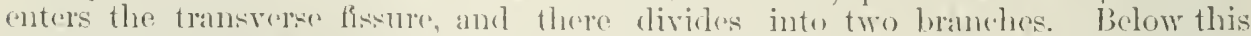
tissure the hepatic artery lies to the left. the bile duet to the right, and the portal vin behind and between the two (fig. 5s.t). These three struetures ascencl to the liver between the layers of the gastro-hepatio onentum in front of the foramen of 
Winslow. At the actual fissure the arder of the threestruetures from luefore hatkwarils is-duct, artery, rein.

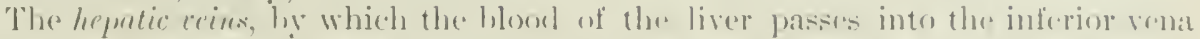

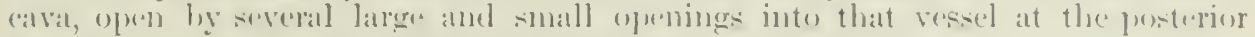
surfiae of the erland at the hottom of the forsat of the remal caval.

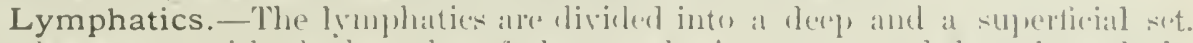
The derpet run with the liranehes of the portal vein, artery, and eluet through the liver, leaving at the transverse fissure, where they join the rescels of the superticial sit.

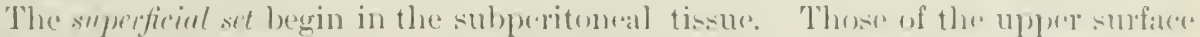

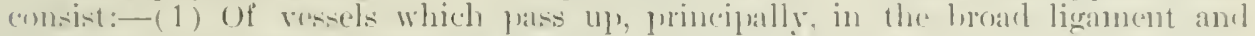
right and loft lateral liganents, thromgh the diaphragm, and so juto the anterior moliastinal glands; oceasionally lymphaties of the right liganent pass straight inte the theracie deet. (2) of a set passing over the anterior border of the liver to the glands in the small omentum ahent the transverse fis-sure.

On the under surface, the lymphatics to the right of the gall bladerer enter the lumbar glands.

These reund the gall bladiler enter the glands of the lesser onsentum.

Those to the left of the gall blarder enter the glands of the opsophagus and lesser rurvature of the stomach.

Fig. 504.-Relatiox of Structures at anil below the Thansleise Fisslie. (Thane.)

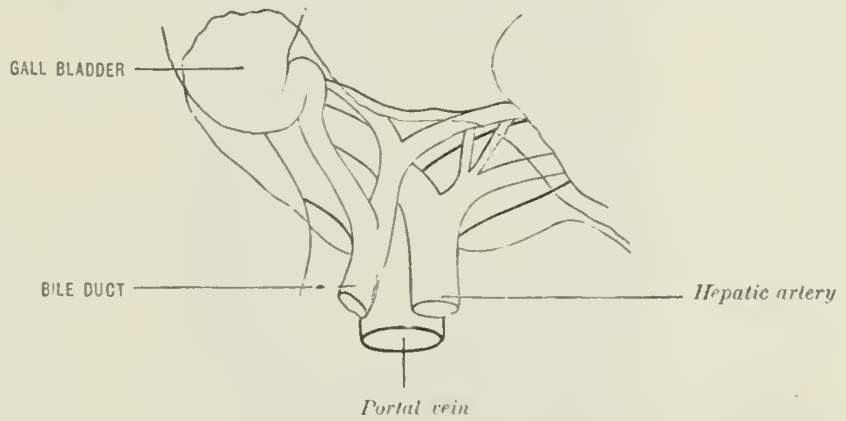

Structure of the liver.-If a section be mate of the liver, the following features in it: gremeral structure nay lo noted:-

Outsirle of all will he seen the investment of prifouenm, which is incomplete in parts, and which has heen alrearly described.

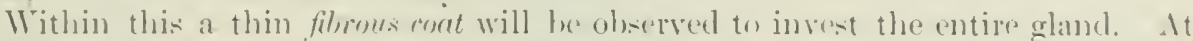
the transverse fisture this enat tums into the substance of the liver with the liranches of the purtal ring.

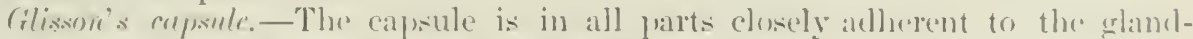
sulstanere and is thickest where the peritonemun is absent.

The liver on sortion is seen to be nuttled, and when a juntion is torn the surfare presents al gramular alpearance. This is produced hy the minute lobules (one twenty-formth to one-twelfth of an inch in rlianeter') of which the liver ti-rine is compered.

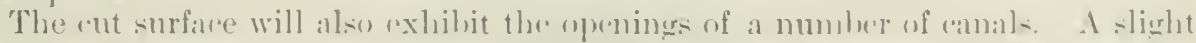
examination will show that these are of two kimb-riz. the anals for the hranedes of the prortal verin and the anals for the hephatio veins.

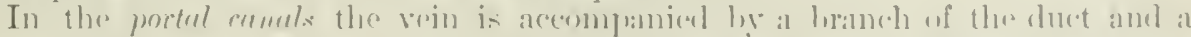
hranch of the hepatic artery. The win hats thick walls which will he secen to be

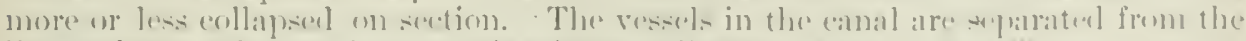

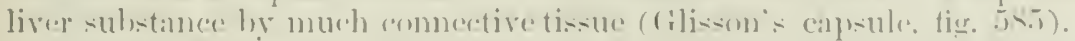

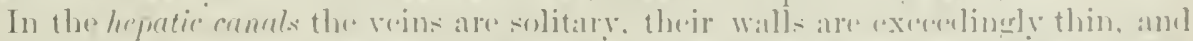

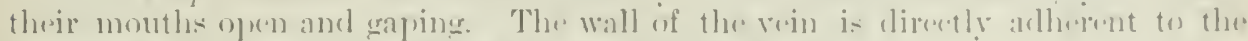

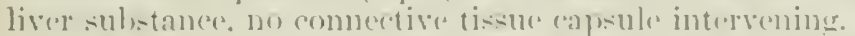

The gall bladder, whith retains the hilr. is situated lwetwen the righte and 
quartrate lobes on the under surface of the liver. It is of prriform nutline. and when full is secul projecting heyol the anterior boreler of the liver, anming in comtact with the abtominal wall oplosite the ninth costal cartilage. It exterels

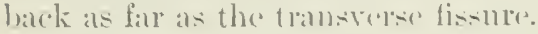

It measures in lometh, from lefore backwarels, from two and a half to fortu inches (75 to $100 \mathrm{~mm}$.), and an inch and a half (3.5 mun.) alcross at the widest part, and will hold about one ounce. The loroal end of the sace is directed formards,

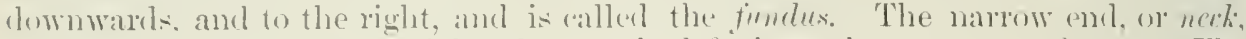
which is rurved first to the right, them to the left, is at the transverse fissure. The intervening part is callud the borly.

It: "ppret surfuce is in eontaret with the liver, lying in the fossa of the gall bladker. It is attaled to the liver hy comnective tissue. The lower surface is (o) vered he peritomemm, which passes irer its sides and inferior surface, though orasionally it entirely suroumls the gall hadder, forming a sort of mesentery to attach it to the liver. The lower surface comes into contart with the first part of the dustenum and hepatic flexure of the colon, and oceasionally with the prowiv encls of the stomach on small intestine, which are often prost mortem found stained with bile.

The nere of the gall blarkler opens into the cyste durt. This is a tube an inch and a half long (3.5 mm.) and one-twolfth of an inch wide (2.3 mm.), which unites with the hepatic duct to form the common duct; it is directed backwards

Fig. 5-5.-Section of a Portal Caxal. (Quain.)

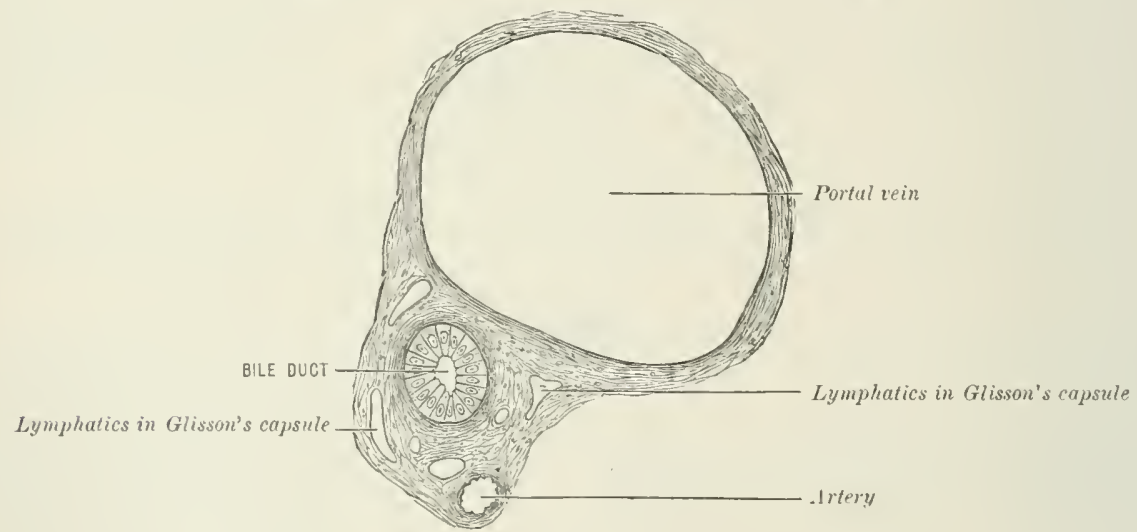

and to the left as it runs in the lesere omentum, the hepatie artery being to the left and the portal vein behind. It joins the hepatic duct at an acute angle.

The heputic durt hegins with a branch from each lobe right and left in the transierse fissure, and is directed downwards and to the right in the folds of the liserer omentum, the hepatic artery being to the left. It is not quite two inches long; its cliameter is one-fifth of an inch ( $4 \mathrm{~mm}$.). Uniting with the cystic duct, it forms the commom bile duet (inctus communis choledochus).

'The common bile duct is about three inches in length. It passes down betwern the layers of the lessor omentum, in front of the portal roin, and to the right of the hepatic artery (fig. 584); it then passes hehind the first part of the duodenum, then betweren the serend part and the head of the pancreas, and conds at the lower part of the serenel segment of the duorlenum by opening into that part of the intestine m its left side and somewhat hehind (figs. 571,586 , and 585 ). It pierces the intestinal wall very oljlicpuely, ruming hetween the muscular layer for

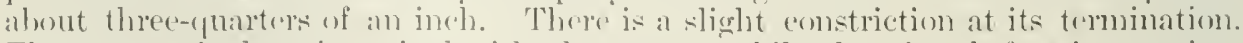
The pancreatic duet is uniterl with the commum hile duet just hefore its terminatiom. There is a slight papilla at their platee of opening on the mucous surface of the duodenum. This piaplis is aluent four inches from the prorus. After the panereatie duet has enterent the lifle duet there is a dilatation of the eommon tube (allecl the ampulla of Vater. 


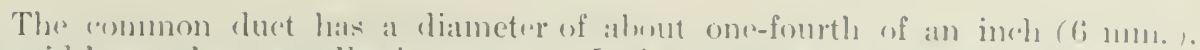
Its wirlth at the anpullat is greater. It is narrowest at its outlet inter the

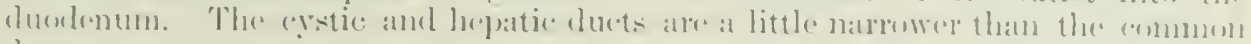
luct.

Structure of the gall bladder.-The wall of the gall hlaklere is mathe up of three coats-serous, musculatr or filnews. and numents.

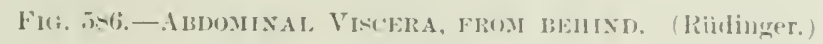

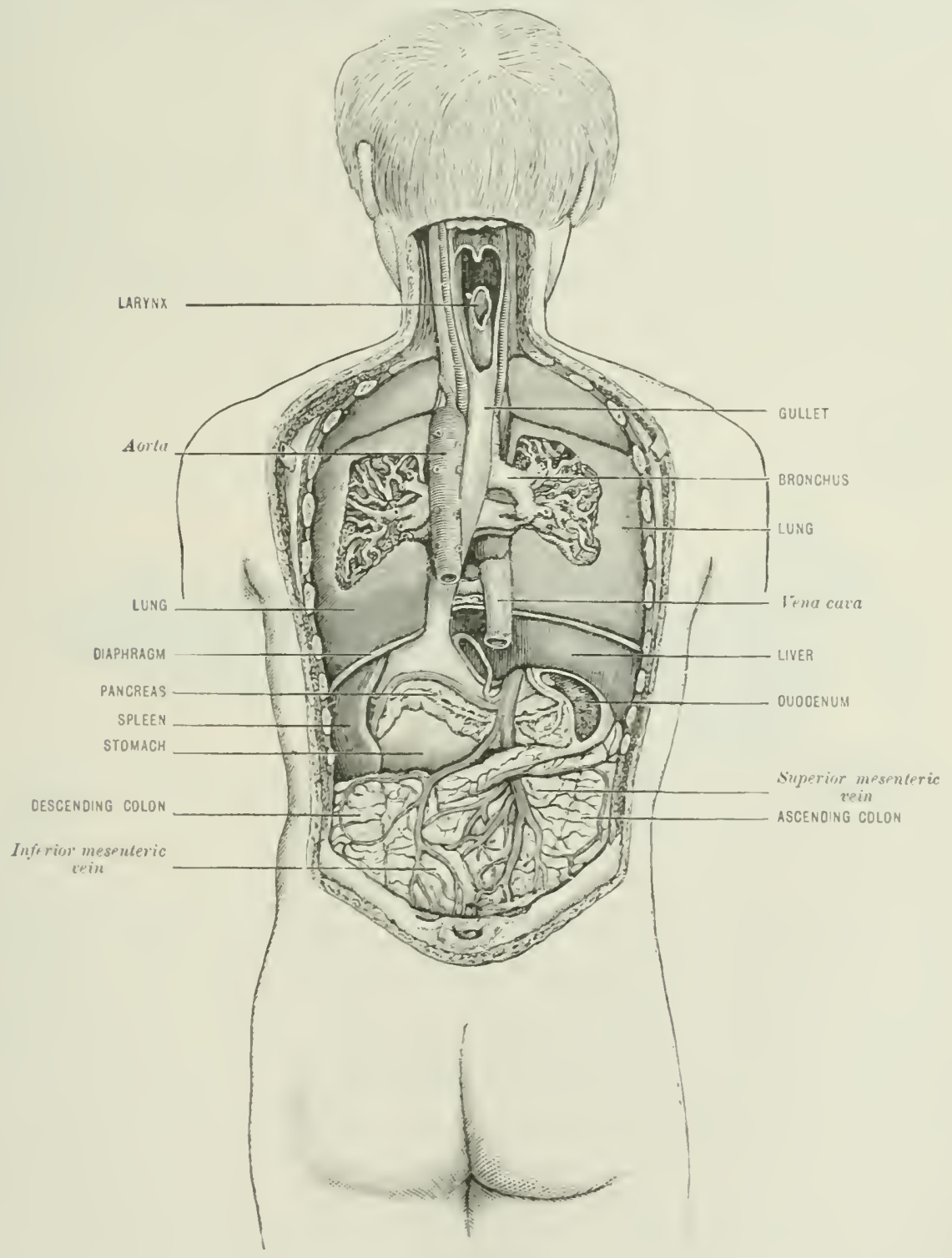

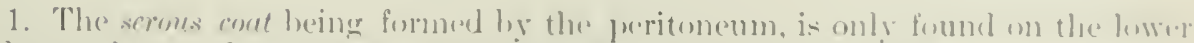

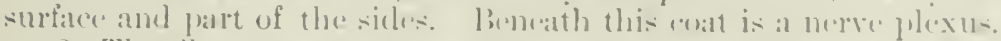

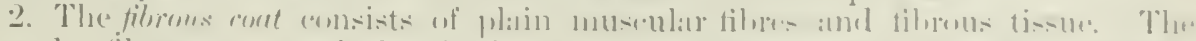

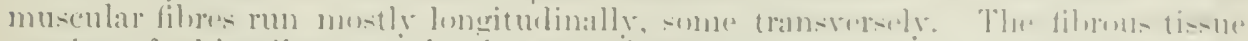
consists of white fibnes ruming in every ilirection. This layer contains the furin-

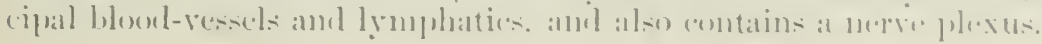




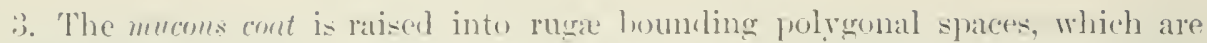
largest ahout the body. It is lined with columnar epithelium, and contains many mucous equnds. At the nexk the mucous membrane forms folds which project into the interior, acting as valves. This layer contains an anastonosis ol blood-ressels, and a fine plexus of lymphatics.

The ducts eonsist of a fibrous and a mueous layer. In the fibrous layer are muscular fihres which are chiefly circular, together with many strong white connective tissue and dastic filures. The mucous layer is lined with columar epithelium, and hat: many mueous orlands. In the eystic duet the mucous membrane is raised into folds, which are cresentic in form, and su directed obliquely as to seem to surround the lumen of the tube in a spiral manner.

\section{VARIETIE OF THE LIVER}

Varieties are more rare in the liver than in alnost any other organ of the body.

The left lobe may be rery small; on the other hand, it may be mueh larger, acesiomally extending in an ittenuated form much more towards the left. The left lolx, ir a portion of it, may be attached only by a pedicle of peritoneum and resscls to the main organ. The gall bladder has been seen through an opening in the upper surface, owing to the depth of the fossa of the gall bladder.

The liver may le subdivided into many lobes, or may show no division at all. It may retain the thick rounded form of the fortus. The gall bladder may be absent, in which case the hepatic duet usually becomes much dilated before it reaches the duodenum.

The gall bladder may he partially divided either transwersely or Iongitudinally. The common duct may enter the bovel independently of the pancreatic duet.

\section{THE PANCREAS}

The pancreas is situated in the epigastric and left hypochondriae regions. It is a compound racemose gland. It lies transversely across the bodr, on a level with the first and second lumbar rertebra, and is deeply placed (fig. 577). It differs in shape as it is exannined in sitn, or removed from the body. "Ihen examined in situ it shows rarious impressions for the different organs with which it is in contact (figs. 570, 571); when removed from the body it appears to be longer, and runs to a point at the left extremity (fig. 587). It is of a pinkish-cream colour and soft in texture. It shows upon its surfare the markings between the lolules of which it is made up. It may le divided into four portions: a head. a neck, a body, and a tail. The pancreas raric considerably in size. Its average length is five to six inches (120 to $1.50 \mathrm{~mm}$.), and its thicknes from half an inch to one inch. It weighs from $2 \frac{1}{2}$ to $3 \frac{1}{2}$ ounces. The head of the pancreas is situated at the right extremity of the gland, and is contained in the loop of the duolenum. It is dise-shaped and flattened from befor hackwarls. The head is bent downards, so that it extends lower than the lower berker of the body. Behind it are found the eommon bile duct, which runs, as a ruke, in a canal in its substance, the vena cava. the left renal rein. and the anta (fig. 5i1). In front are the superior mesenterie vessels, the pancreatico-eluodenal ressels, and the transererse (o)lon and its meso-colon.

The neck springe from the upper part of the hearl in front and turns upwarks and to the left to join the loxly. It lies over the point of junction of the superior mesenterie and portal reins. At its attachment to the head it is grooved by the gastro-durenal and superior pancreatico-duonlenil arteries. In front of it would he the first jart of the rlumblenum.

Acenting to Professor. His, there are three surfaces on the body of the pancreas: anterior, inferior, and posterior. The body extends from the heacl of the 


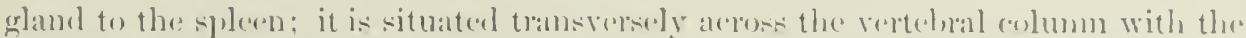
large resionds intervening.

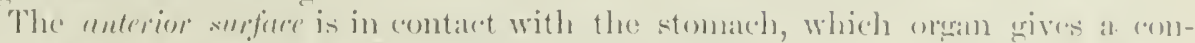

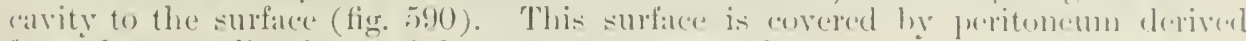
from the asconding layer of the transwerse meso-colom.

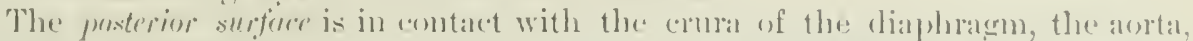
and superior mesenteric vessels, which structures are interposed lectwered it ansel the

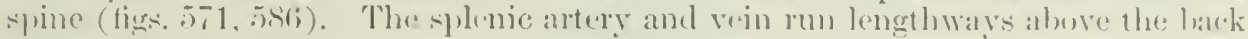
of the upper bortrer of the posterior surface. To the left, the posterior surface is in

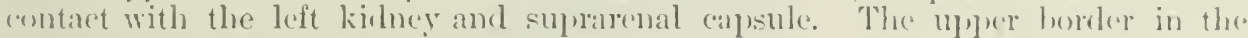
milelle line abuts against the coeliale axis.

The infrior surfare is narew, and lies over the fourth part of the duodemum and

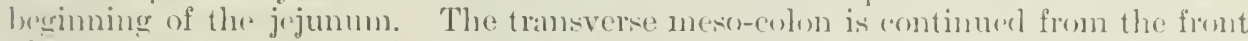
of the head along the borler separating this surface from the anterion surface. The splenic end of the transverse colon lies under the left extremity of this surface. From the moler surface of the transverse meso-eolon a layer of jeritomem passes to the entral part of the inferior surface. The posterior surface is devoid of jeritumemm.

The tail of the pancreas is the name given to the left extremity of the organ; it touches the lower part of the imer surface of the spleen.

Fic. 5-7.-The PaNCREAS AND JTS DICT.

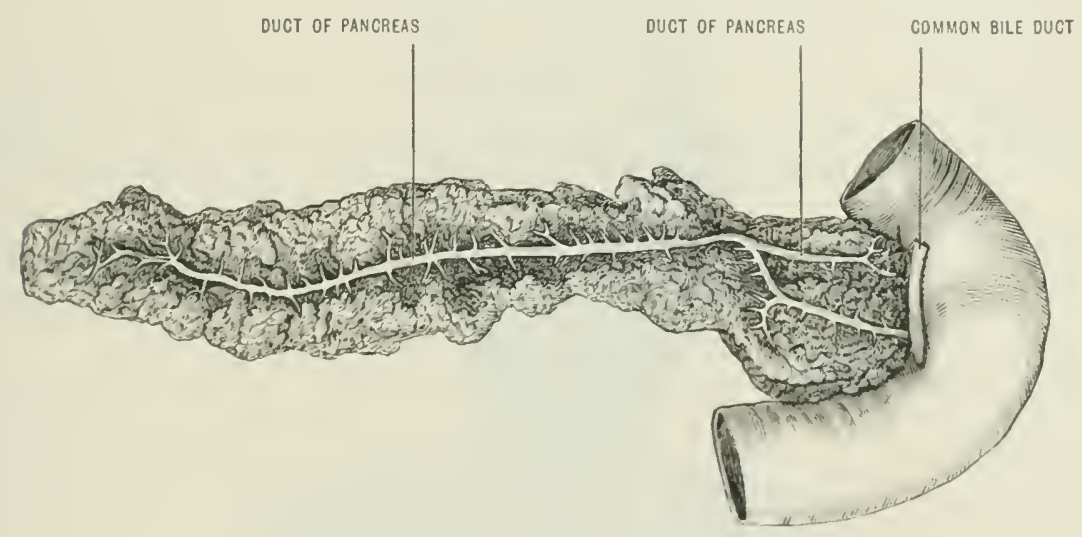

The duct of the pancreas, or the canal of Wirsung, white in appearance, rums from nearly the extrene left of the gland, concealed by the proper sulstance of the

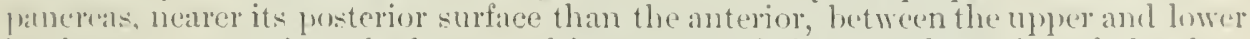
forders, to empty inte the lower and inner part of the second portion of the lundenum with the commm bile duct. It runs sinuously, receiving its branehes as it gnes, which enter nearly at jight angles. These branches are straight. Its dianretre near its formination is ome-tenth of an inch. The pancreatie duet often dowe not join the anmmon bile duct until its termination, ruming sich by sile with it

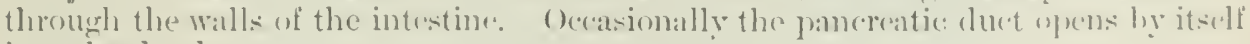
inter the denerinum.

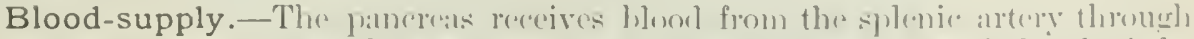

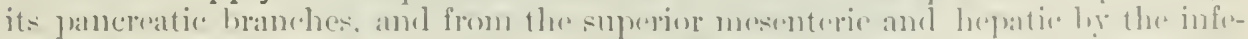

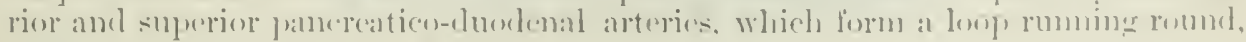
lwow. and to the right of its hatel.

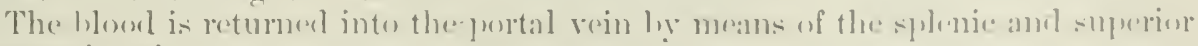
mesenteric reins.

Lymphatics. -The lymphaties terminate in two erlands which lie on the

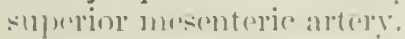

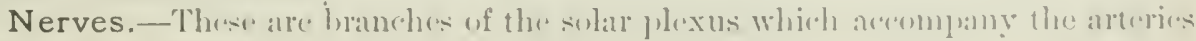
("ntering the grlanel. 


\section{THE SPLEEY}

Position.-The spleen-one of the durtems glands-is situated for the most

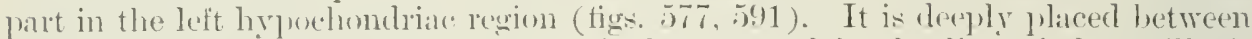
the funclus of the stomath amel the diaploragm, and in the line of the axilla it axtends botween the eighth and aleventh rils. It is covered by the ninth, tenth, and eleventh rits (tig. 5 $50 ;$ ), and is separated from them by the diaphragm, and to a smaller extent by the lumg. Its upper end reaches to the level of the ninth tharacic spine, and its lower and to the level of the first lumbar spine. Its inner extremity is within two inches of the median plane of the hody, and its outer Inundary is posterior to the mill-axillary line. A line draw fom the left stemoclavienlar joint to the tip of the eleventh left rib bounds the anterior margin of the suleen.

It is hluish-red in colour, is soft, and casily lacerated.

Its shape varies, and depents much mpon the condition in which it is examinerl. If soft, and ats usually found after removal from the body, it can only be

Fig. 5\$3.-OLTEI ASPE'T OF TIE SIPLEEN.

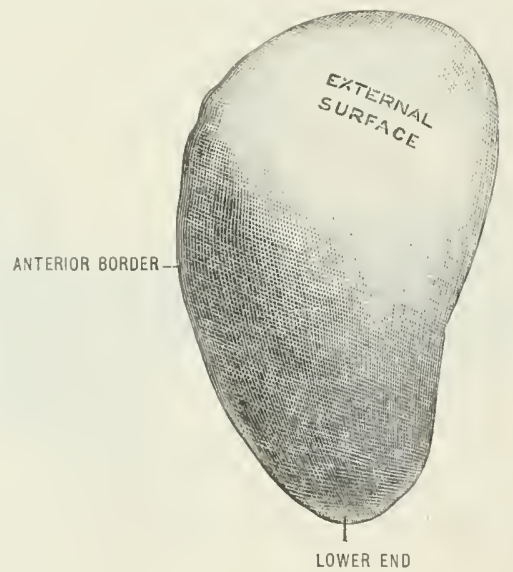

said to have two surfaces, an outer convex and an inner coneave; but if examined after it has heen hardened in situ, after the manner of Professor His, it is seen to be of a much more precise shape, and to present three surfaces (fig. 590).

Viewed from the ontside, it jresents a form which is irregularly oval, wider above than helow, with a hulging of the anterior horder (fig. 588). The three surfaces are the external. anterior, and inner. The external or posterior surface is the largest. It is regularly comvex, and is clirected outwards and backwards and somewhat upwards (figs. 585. $59(1)$ ). It lies against the commeneenent of the areh of the cliaphragm. It is covered ly peritonemon. This surface is named by cunningham the phenic surfice. It is soparated by the peritomem and diaphragm, ancl to some part of its rxtent he the plemra and lung from the eighth, ninth, tenth, amb eleventh ribs. Viewerl from the inside, the two other surfaces an seen to be divided by a distinet vertically dieceted rislese (fig. 500). The anterior of the two looks forwarels, inwards, and a little downwarks. It is concave from above downwards, and from sicle to side. It is a geosl llat the larger of the two, and is semilunar in shatpe (fig. 5s:9). It is in contact with the great cul-ele-sar of the stomach, with the tip of the pancreas, and the axtreme peint of the splenice flexure of the

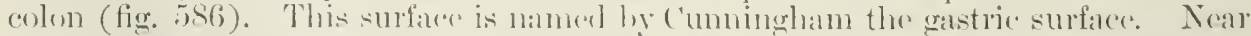
the posterior horder of this surfare and houmed hy the ritge is seen the hilum of

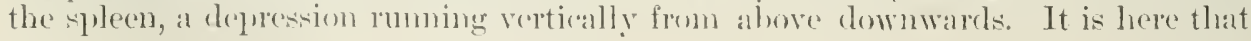




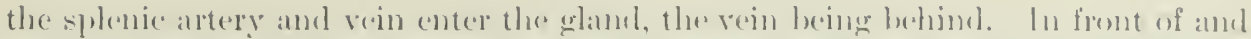

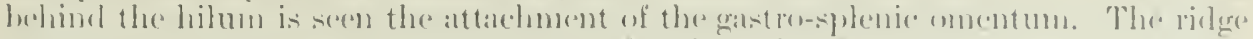

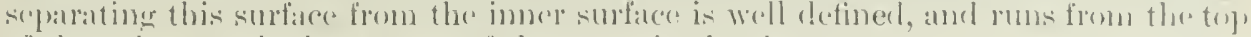
of the splecen to the bower bat of the posterion horker.

Fig. 589.-INXER Asplet of THE SPLkEN.

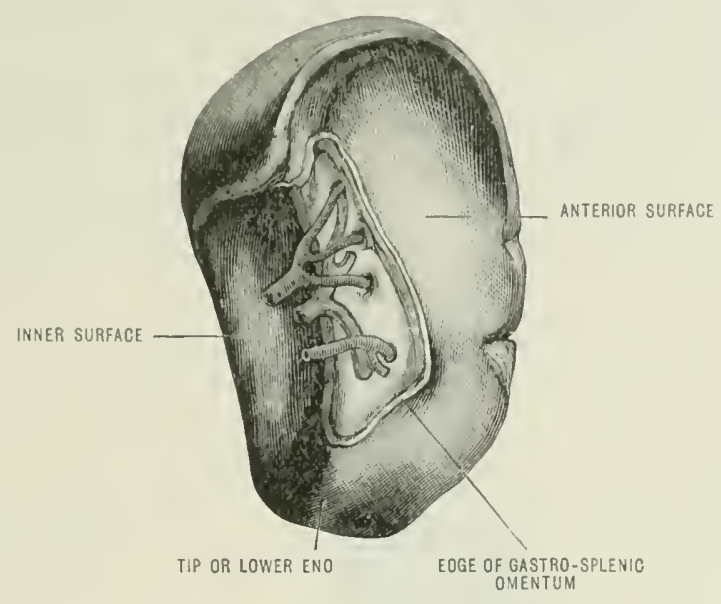

The inner or renal surface is much narrower and slorter than the anterion: It is only slightly concare in both directions. It is directed inwards and downwark, and is in relation with the outer border of the left kidney.

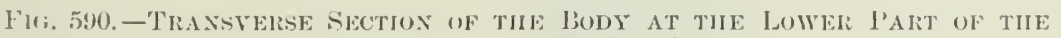
Eirigastric Region. (Rüdinger.)

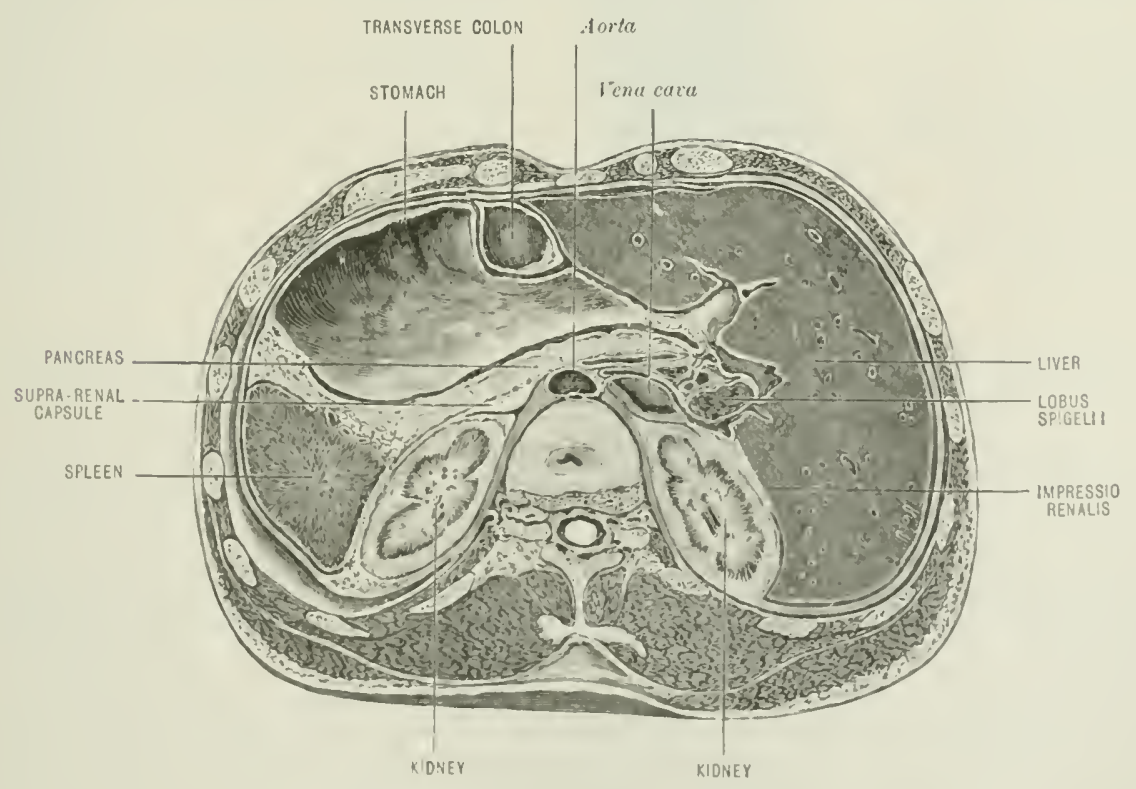

The anterior border of the splecen is more sefined than the pusterion, is

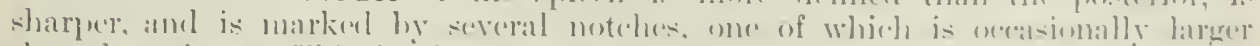
than the others. This berder is amvex. The posterior border is fhimer and 
straighter. It silualrates the renal ant phrenic surfars. The term inner border is applied to the ridge between the gastrie and renal surfaces.

'The lower enel of the spleen is blunt and presents al triangular area which ('unninghan calls the basal surfiare. It lies against the splenic flexure of the eolon

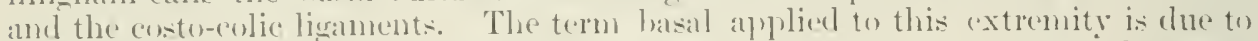
the eiremustance that the shape of the spleen in situ is that of an imegulan tetrahedron with its bas below (Cumningham).

The spleen is set obliquely in the body. Its long axis about corresponts to the line of the tent! ril.

In size it varion, owing to the fart that it increases in limensions after food and under other ciremustances. In the adult it measures generally about five to

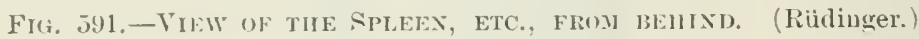

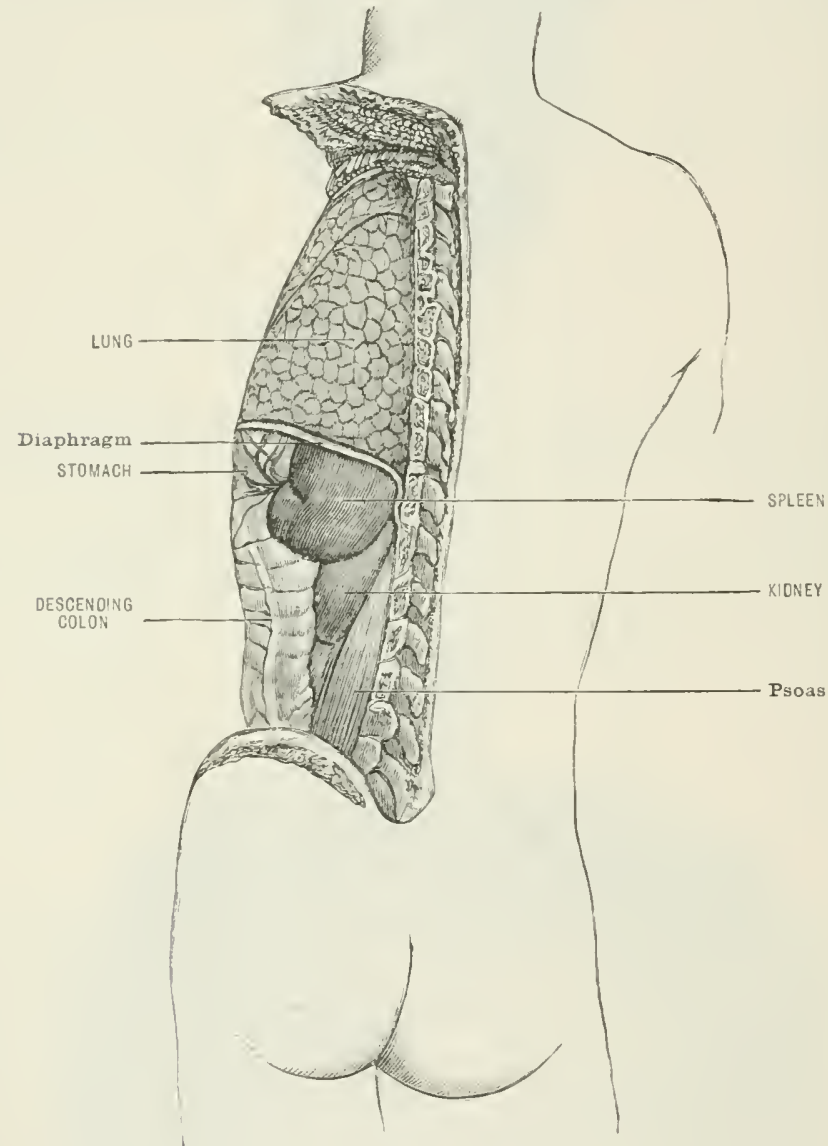

six inches in longth, throe or foul inches in breadth, and one to one and a half inches in thickness; its nsulal volume, according to Kranse, is from nine and threequarters to fifteren ablic inches. Its average weight is one humbed and serenty gramllnes.

It is entirely surroumled hy peritonemm except at the hilmm. On either sirle of the hilum the gastro-splenic liganent is attached. This reflexion of peritoneun, sometimes called the gatsto-s]lenic omentum, passus inwards to the left extremity

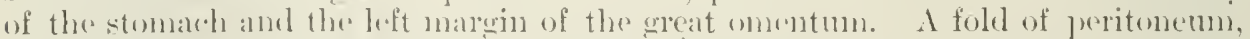
the phreno-splenic ligamant, annects the uppere and of the splenen to the diawhangm. The reflection of peritonenum from the suleen to the left kidney is called the linene-ponal liganument. 


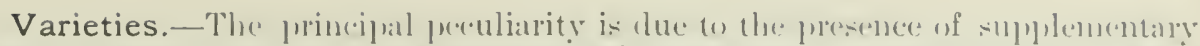

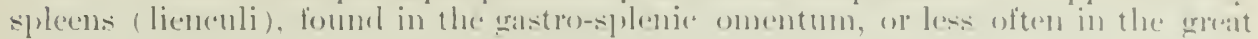
onsentum. From one to twenty of these small horlias mav he mot with. Ther are reel and round, of the same structure as the spleen, and vary in size from a luat to al walnut.

Structure.-Beneath the rovering of jeritonemm is a thin but tough copjente of

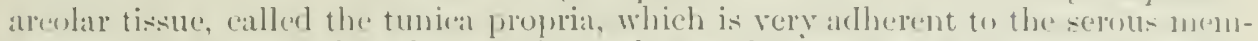
brane. It is remarkably elastie. It sembs a prolongation in at the hilum, which

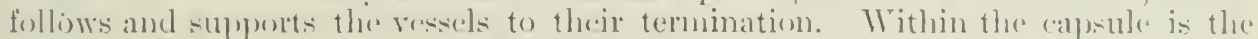

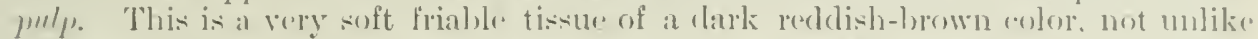

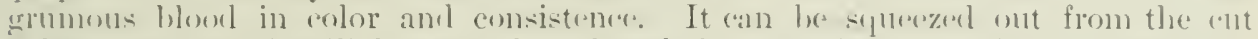
splecen, and then it will he seen that the whole organ is pervaded by a notwork of fine fihres which support the pulp). The larger of these come off directly from the librous calusule, and are called trabecular.

IN Froxt.

Stomach ; splenic flexure of colon.

Outer SidF.

Diaphrigm ; minth to eleventh ribs hetween axillary line.

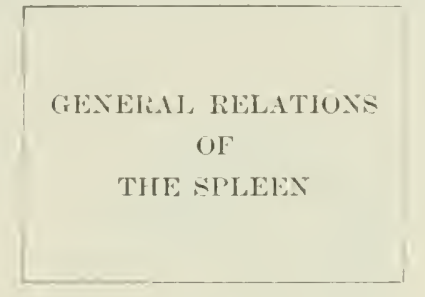

BEIIXI).

Diaphragm.
IXXER SEIDF.

Stonarlı; limereas; let kiduey and capsule.

Blood-supply.-The spleen rexeives its l, lool from the splenic artery, whir.h is: very large in proportion to the body it is going to supply. It divides before "ntering into about six branches. The artery is very tortuous. The vein, on the other latud, is straiglat, and lise below the artery.

- The lymphatics are clivicled inte a superticial and a deep set. The former forms a plexus beneath the peritonemm. The latter are derived from fine peri-

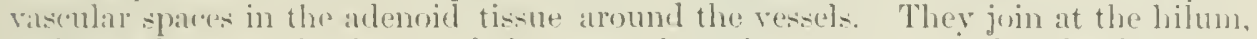
atud pass betwern the layers of the gastro-hepatic onentum to the grands in that neighlourhond.

The nerves are from the solar plexus. They pass in along the splenic artery.

\section{TIE EVOLTTION OF THE PELTTONETM AND AN EXPLAXITIO OF I'T ARRANGEMENT IN THE HEMAN B()I}

The peritoneum is a serous memblane, and is idlentical with other like-uanuer

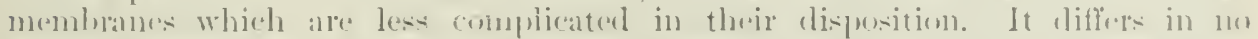

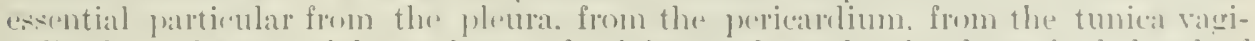
nalis, from the sronovial memblame of a joint. or from the simple valinal sheath of

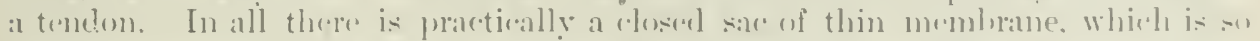
disposed ats to both line a cavity and to invest the structures which enerench upun that ravity.

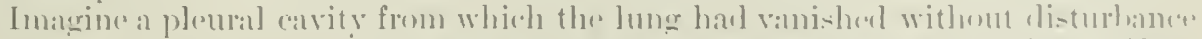

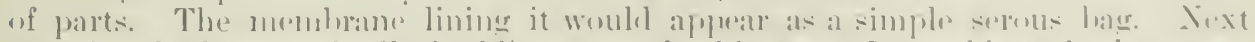

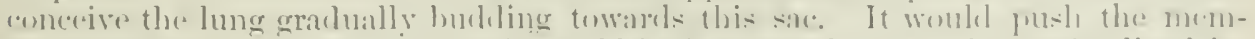
brane luefore it, and as it dirl so it would both eneroach upon the earity lined hy

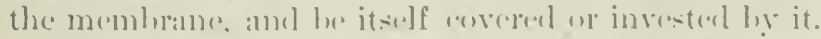

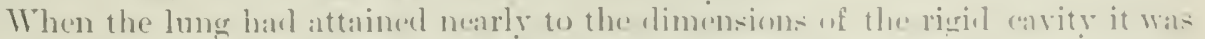

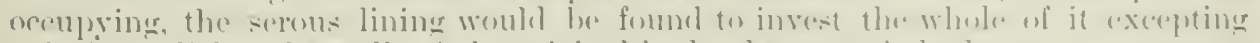
only its perlicle-the stalk of the original bud-the loot of the lang. 
Dthough the therateic space might lw almost ohliterated, the lung would still renain entirely outside the cavity of the serons sace It wonld he convenient then

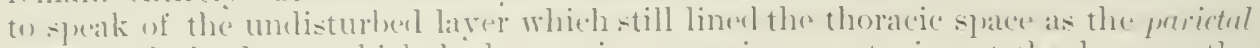
le!!re, and the layer which had come in a pasive way to invest the lung as the risterul leeyer.

In the alulumen a sinilar condition exists. Imagine all the visera to have vanisherl from the aldeminal easity. I great space would exist. bounderl abovely the riaphragm, ledow hy the pelvic floor, and in front and behind by the abrlominail parietes. This space wouk he evenly lined by the pritoneum in the form of a simple alosed sac. As the viscera realpleared they would emerge, as it were, from the posterior wall of the belly. and would project into the earity of the abromen. In su doing they would push lefore them the peritonem lining the posterior wall of the cavity, and would each in turn become invested by the displaced membrane. .11 the abiominal visera are outside the peritoneal eavity although they are whiously within the abdominal space. The peritoneal sar remains entirely cimpty. and its wall. with the exception of the Fallopian orifices, is unbroken.

That part of the simple sac which lines the anterior abdominal parietes is practically the only part which retains its original comnertions undisturber.

()ne main function of a serous membrane is to minimise the effects of friction. Those riscera which ar exposed to most movement, such as the small intestines,

Fig. 5r?.-Diagram of the Printive Aliaritary Caxal.

(A: $a$ indicates the vitello-intestinal dnct; $b$ points to the future position of the cæerum.)

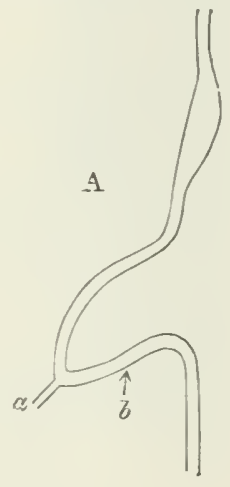

B.

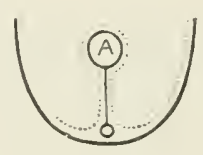

are the most (ompletely invested by the smooth membrane; those which remain fixed. surh as the kidhey, are only casually invested. The morements of the viscera in respiration, the alteration in shape and position which will oxcur in such wrgans as the stomach and bladeler, are provided for by the peritoneum in such al manner that these movenents are practically without friction.

The viserat antained in the abromen are not only numerous, but they are of very complex outline for the most part, and they are disposed in a manner which temils to greatly confuse their redations to one another.

1 bare decoription of the peritenemm, as it is met with in the human subject. must needs be intrieate and (omplicated, and if considered without reference to more primitive and smples ambitions is almost inexplicable. The description may he followerl, but it neets interpretation. and no aceount of this menbrane can be consiclered to be satistactory unlese it be resclered evilent how the enmplex

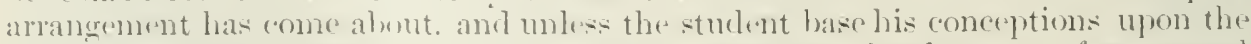
simple anel rudimentary di-josition which an elaborate development of parts anel al remarkable specialisation if structure have renclerel intricate and confusing.

The rambest irlea of the disposition of the peritonesm is to be derived from a sturly of the development amel most rudinentary forms of that membrane. Such a stuily is founded upon an examination of the human embryo at various periods. and of the peritonem in the nammalia and lower animals. 
The simple alimentary tube.-The alimentary wanl first alperats as a simplu.

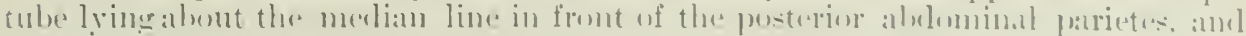

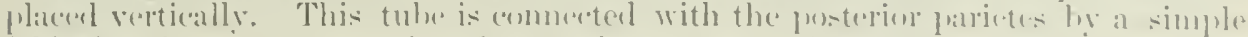

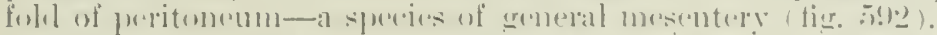

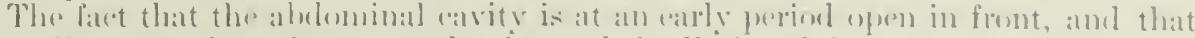

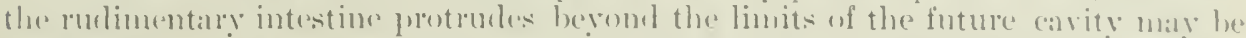

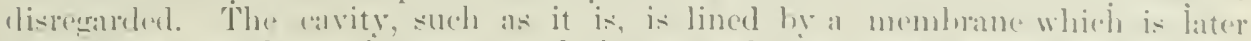

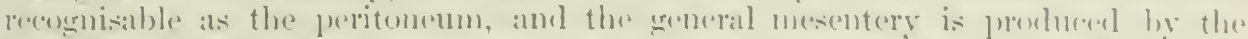

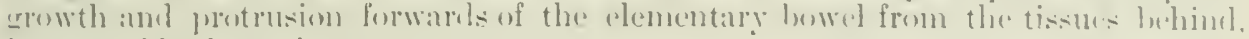
i. '2., outsile the jeritonemom.

The simple straght tube, suspemeled on the pusterion mesial line hy its fold of

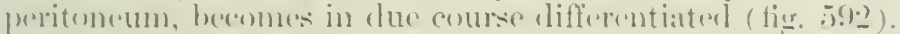

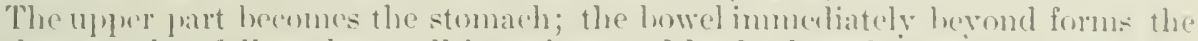
fundenum; then follow the small intestine; and lastly the eolon and rectum.

The pront of separation of the small howel from the eolon is inclieated hy the : 2 y)

It will lu molerstoodalso that the upler part of the mesial peritomeal fold is

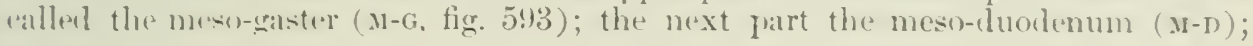

Fig. 593.-Diagray or tile PRIMTtre Almextari CaNal.

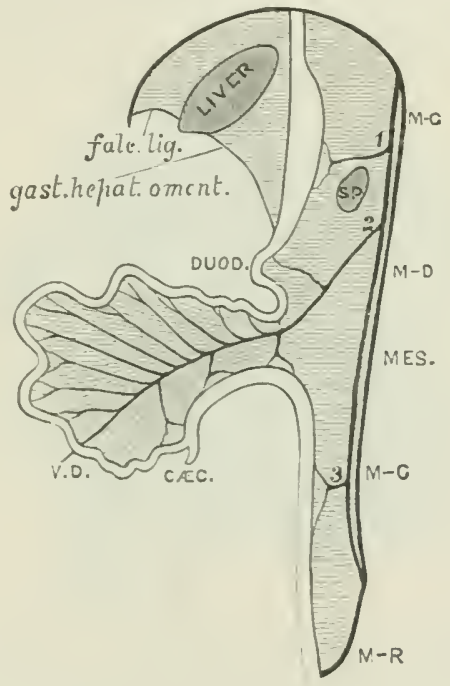

and the succeding portions, in order, the mesentery, the meso-colon, and the mear-

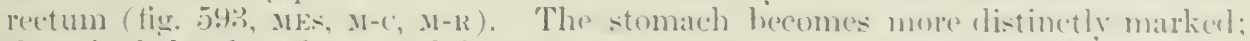
the tuhe below lengthens and forms an intestinal loop, which in the embre projects berond the site of the future umbilieus. taking the mesentery with it.

This elementary condition of the intestinal eanal persists in cortain fully. dreveleped animals. As an example may he taken the alimentary anal of the

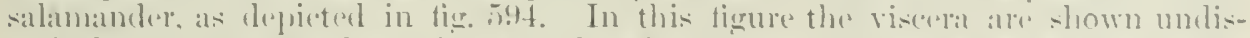

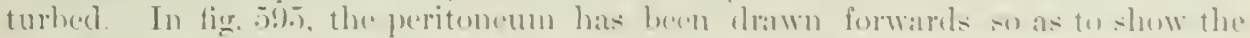
farts in me merlian plame amel well represents the simple arrangement. In many mammals ameng the Erlentates the -imple vertical melian folle of peritonem is

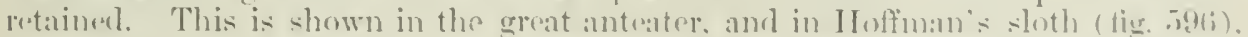

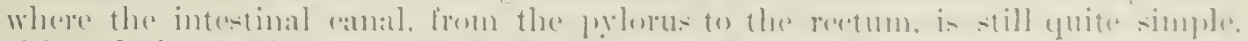

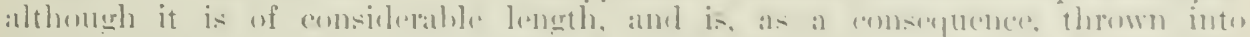
numerous coils. The whole of this long tule is suplenterl ha at single meslian fold

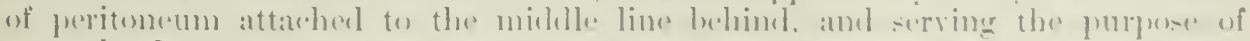

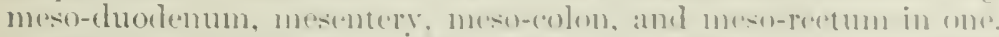

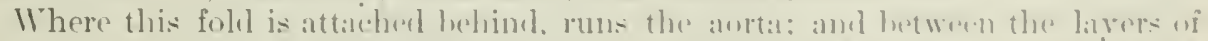

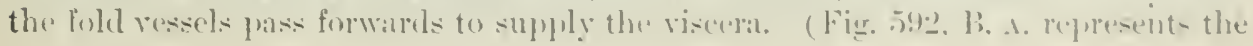
(6i3 
intestinal tuhe to which an artery is masing.) There will be an artery to the stumach (1, fier. 593) and the areat mesenterio artery. The latter ressel will supply the rulimentary eluselenum, the small intestines, the wermm, and sueh part of the colon as is bater on known as the aserencling and transwerse segments. The arrangement of the vesed is shown in figs. 593,2, and 5960 .

The descencling colon and rectum are supplied hy a separate vessel, the inferior

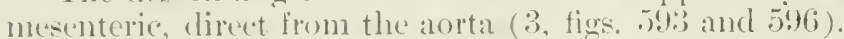

It the summit of the primitive loop which forms the prineipal part of the intestine will he the vitello-intestinal rluct or vitelline stalk (v. D, fig. 5!)3; 1 , fig. 592, A). It is to this woint that the ereat or superior mesenteric artery is directed. The morphological ending of the superior mesenterie artery is at this spot, while branches foss off from either side of it. The student may he reminded that a trace of the vitelline duet may persist in the form of a process known as Meckel's diverticulum, and that this process. when existing, is situated in the lower part of the ileum not fal from the execum (page 967). In the adult the trunk of the artery may lo represented by a line drawn from its place of origin to a point on the ilemin from one to three feet from the casum.

The prinitive intestinal loop increases in length, and forms longer and more complex coils. A large part of these eoils will lie without the abdomen, the anterior ablominal wall being still ineomplete.

$A$ s the loop lengthens, a species of neck forms which tents to become narrower.

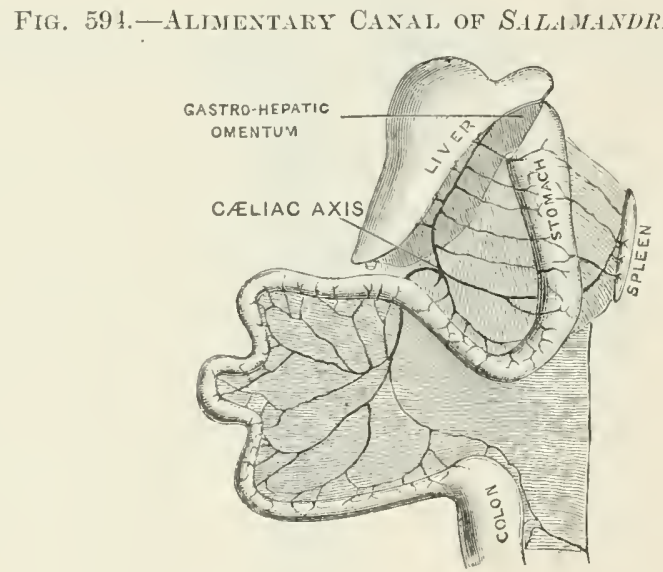

The upper part of this neck or strait is bounded or formed by the duodenum; the lower lart by that portion of the large bowel which is at a later perior known as the transverse colon (fig. 593).

The transverse colon and the duodenum are thus brought near together, and it is notewortly that. no matter how amiplex the relations of the bowel become, these segments of the intestinal tule are never separated. In the narrow neck formed between then runs the trunk of the superior mesenteric artery. The great loop bevond this neck will form the snmall intestine, the creum, and the ascending colon. The descending colon retains its simple connections with the median line (fig. 593).

The mesentery does not increase in the same proportion as the intestines grow, and hence the bowel is thrown into innumerable convolutions. In the buman subject the increase in the brealth of the mesentery is somewhat more noteworthy than its increase in length.

There is a time, then, when the great mass of the intestine is supported ly a simple but extensive mesentery, which is entirely free, and which is attached behind by means of a narrow neek boumled by the iluodenmm and the right end of the transierse colon, and through which the superior mesenterie artery runs.

The great intestinal hop firojects at first anteriorly and mesially. The small intestine is alowe, the large intestine below (figs. 59:, 59.) ). 
As the coils of bowel becone more fully developed, it will be seen that all the

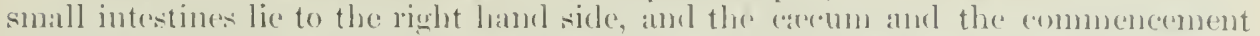
of the colon to the left. The vasal intestini tenuis of the superior mesenterie artery (onserpuently arise from the right siele of the vessel, while the ilen-eolie, right colie", and midelle colie all arise from the left (fig. 5):?:3).

Further development in this direction may not proced, and the combition almeve leseribed is met with in some of the lower mammals as a permanent anrangement (fig. is)(i).

The rotation of the intestinal canal.- Is development proceerls, the plates which ale forming the anterior abdominal parietes apfuroach one another, and the closture of the cavity of the abelomen is imminent. The loops which have up to this time projected beyond the site of the future unbilieus are now withdrawn into the ilveloneme.

Alout this time a remarkalle and guite chaldateristic motion of the general mesentrefie fold takes place. The rotation is from left to right, and is around an axis which may be represented hy a line drawn from the neck or pedicle of the common mescritery to the site of the vitelline duct. This is in fact the line of the superior mesenteric artery (fig. 593). The rotation is therefore at the nerk of the gratat and complex lonp of intetine, which neck, as has been alleady said, is bounded by the duodenum and the right end of the transverse colon.

Fig. 595.-ALMENTARY CANAL OF SALAMANURA HAC'LLOSA.

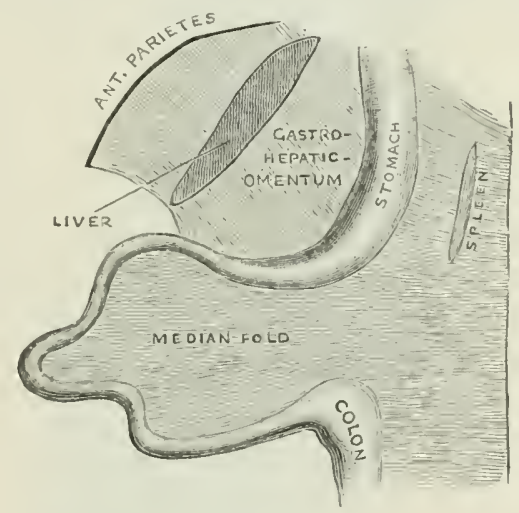

As a result of this rotation, the excum and the ascending colon turn over to the right, while the great mass of the small intestines is brought to the left (fig. 597).

The lower end of the duodenum will consecpuently be carried to the loft; the transverse colon will lie in front of it, instead of below it; and the superior mesentric artery (2, fig. 597), which must still rum between these two segments of the howel, will now be deseribed as passing over the duodenum, or as crossing its anterior surfice. It is needless to saly that in the fully-dereloped budy this artery crosses the left end of the thiml part of the duodenum, and is behind the right enel of the transverse colon. It will be seen that, in spite of this revolution, the duokenmm and the transverse colon still retain their relations to one another, and still mork the neck or perlicle of attachment of the ammome mesenteric fold.

The effect of this rotation of the intestinal tube is shown in the diagram (fig. 597 ).

The eacum and ascending coton are now moved to the right; the transverse colon is more listinetly transwerse; the sulall intestine has passerl over to the left side. The right sick of the mesentery has beeeme the left side, and riot rerret : and the visi intestini tenuis now alperar to arise from the left lumeler of the superior mesenterie artery instead of from the right (tig. 597). The dumlentm is aloust hidelen from view, and has heen lorought into close comtant with the vertebual

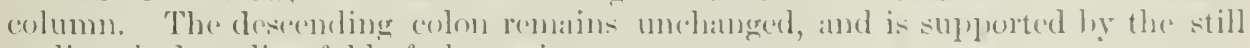
undisturbed median foll of the peritonemon. 
The duodenum still has a meso-duodemum, and is still entirely invested by peritmem.

In man further changes take place. hut in mammals below man the eondition just deseribed is that which represents the nomal arrangement. Fig. 597 may be comsiclered to represent in cliagrammatic fashion the simple intestine of a carnivorous animal.

In the human subjoet ares development may mot proceed beyond this point, and the condition detailed may he met with in the adult as a permanent arrangerment. I have deseriberl somm examples of this ("The Anatomy of the Intestinal ('anal and Peritonemm in Van,' Londom, 1885; and 'Lancet,' Oet. 13, 1885). In these instances the whole of the small intestine, together with the caerum and the ascouling colon, were slung from a common musentery, the attarblinent of which to the posterior parietes was by a narrow neck giving passage to the superior mesenteric artery, and hounded by the duodenum and the transverse colon. In these

Fig. 596.-ALIMENARY CANAL OF CHOLEPUS HOFFMANit.

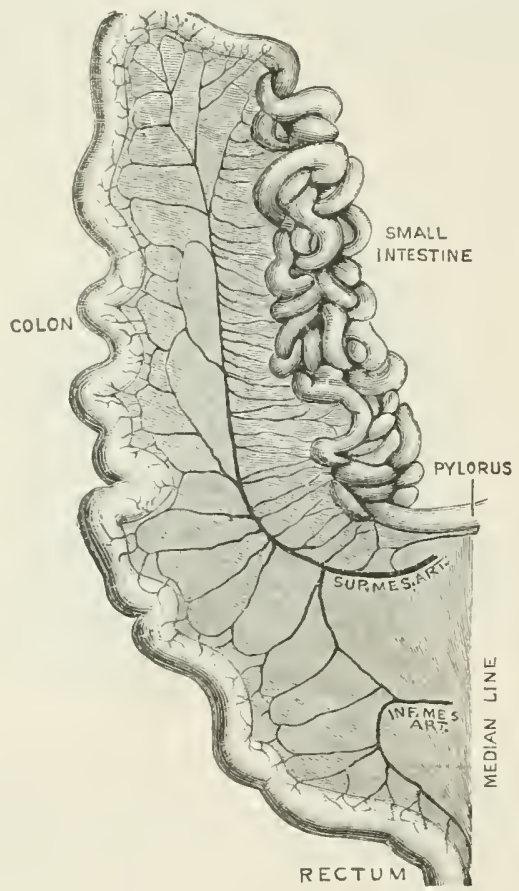

subjects there was no trace of the mesentery proper as it is found in the normal hmman hody. The duodenum had been deprived of its mes-duodenum, and the deseending ineso-colon was (onmaratively scanty; but, with these and some minor exceptions, the resemblance of the arrangement of the bowels to that met with in the lower aninals was rery exact. It is the existence of this inmature condition that predisposes to certain forms of twist or volvulus of the bowel.

The progress of this rudimentary revolution of the intestinal tube may be noted by olserving the progress of the acoum.

That prominent diverticulum liss at first below the loop forming the lesser bowel, and then to its left sille. It is at first without the ablomen, and is gradually withdrawn in the progress of development through the rapidly closing unililical opening.

It then lies about the millle of the botly and just below the liver. Later, it jasses to the right side, and then dere'onds into the right iliae fossa.

It may be pormanently arrested at amy print of its comrse. In the condition known as the congenital mmbilical hernia, the gill, in the anterior abdominal 


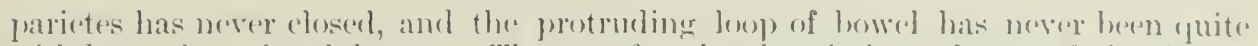
withelawn into the ablomen. The sate of such a herota is male ont of the tirsues

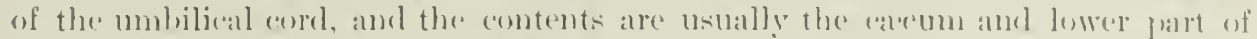
the ileum, and not inlreanently a Meckel's diverticulum. As has heren montioned

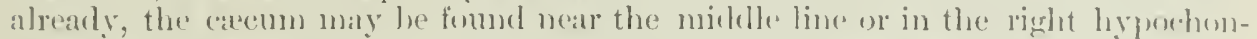

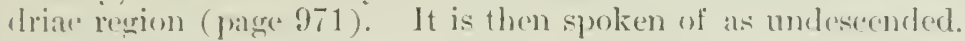

Final changes in the peritoneum.-Further changes in the position of the intestine and in the arrangenent of the peritomeum are finally brought ahout, and these (hamges are almost entirely linited to the humbn subject. The intestine

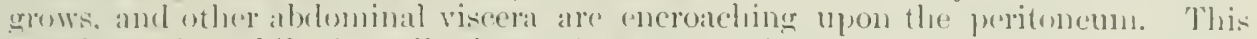
memblane is mobile, is easily draw from one guint to anothere and is ealuable of comsillerable aljustment. It does not, hewever, ("ontinue to grow at the simne rate as the viseral which it serves to eover. "The feritenemon is relatively more extensive in the fortes than in the adult, and in the lower mammals tham in man.

If the viscera grow out of proportion to the peritonewn, it is evirlent that the reflections of that membrane must here and there he shortened; and it is poswible.

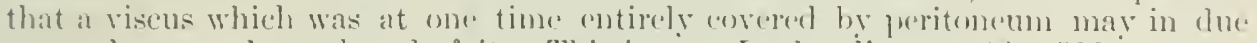
course hecome alumst baned of it. This is sio. In the diagram (fig. 598) a transrerse section of the boly is imagined, the section traversing the spot where the dombenum and transerse colom are in relation at the neck of the oreat common

Fig. 5\%7.-DIAGRAM TU SHOW THE ROTATION OF THE INTESTINAL CANAL.

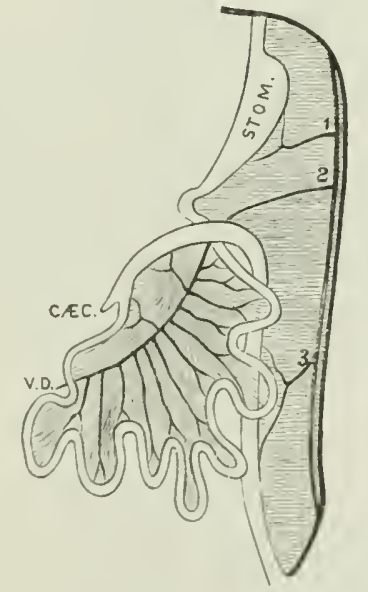

mesentery. Here, by reason of the rotation of the intestine from left to richt, the mesenterie lamina has berome folded upon itself ( $A$, fig. 598). The fold would

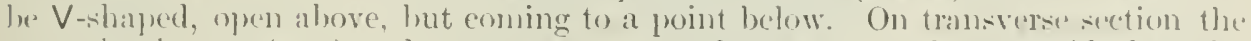

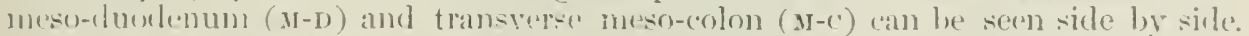

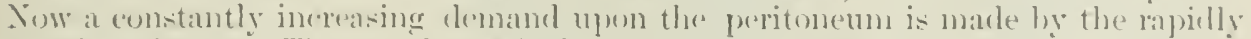
growing viscerat. The menturane is drawn in this direction and in that. There is

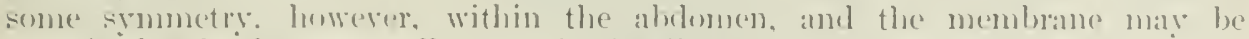

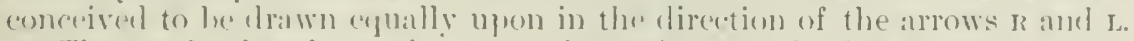

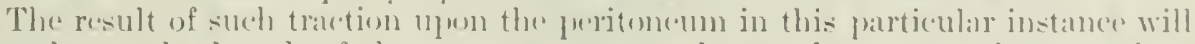

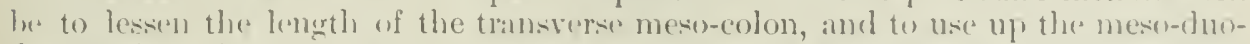

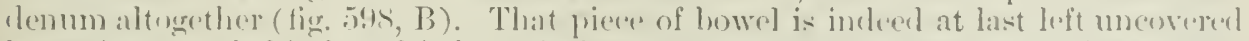

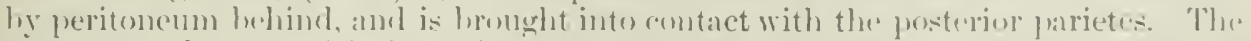

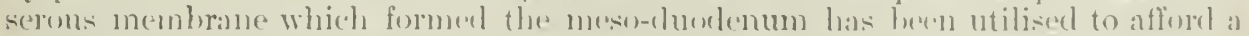
covering for aljacent visora, which are increasing in size, and are pushing the peri-

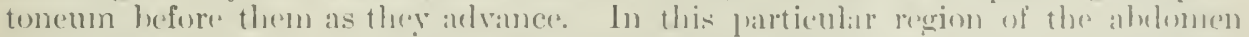
the growth of the liver, stomath, and suleen makr great demamels mun the arljacent

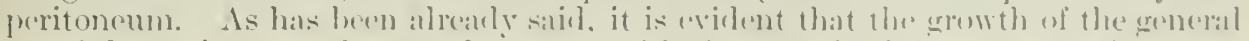

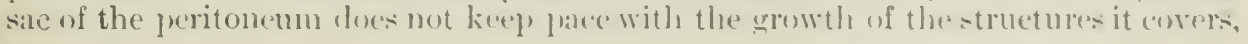


and that it is possible for one orom to be alothed with peritonem at the expense of another.

To complete the aceount of the general relation of the peritoneum to the intestine, the following changes remain to be noticed:-

The meso-colon.-The descending eolon is displaced by the growth of the rest of the lowed to the left side, and comes to ocempy the position which it holds in the fully dereloped boty. The primitive meso-colon is displaeed also to the left, and survives as the descending meso-colon, the sigmoid meso-colon, and the meso-rectum (fig. 599). It may be so curtailed that no listinct fold that can be allerl a desecnding meso-colon is left. and the posterior part of the bowel is in such a case found to be more or less uncosered by the peritoneum. The meso-rectum is a genuine and but little disturbed relic of the simple median vertical fold of the prinitive borly.

Fig. 598.-Diagray to show the Relation of the Peritoneva to the Deodenum.

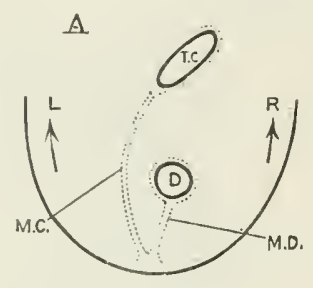

B.

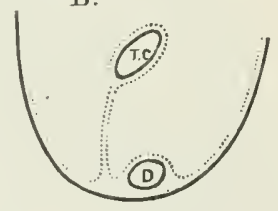

C.

(C)

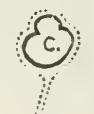

The duodenum is more or less bared of peritoneum, especially so far as its thirel pirt is concerned.

The ascending ablon has. like the descending colon, been deprived of a considerable amount of its peritonemm. This membrane originally belonged to the common mesentery, but so much of it mar have been abstracted from the bowel that this part of the colom may be free from peritonem behind, or may be connected to the posterior parietes by a short mese-colon. The parietal attachments (so-called) of this aseending meso-colon ase entirely acquired, and have no relation whatever to the primary attachment of the median folel-the primitive meso-eolon -to the posterior wall of the aldelomen (fig. 5(19).

The mesentery.-The mesentery proper-the fold belonging to the small intestines-in like mammer and ly a similar proess aequires a new eonnection with the posterior parietes. In using the term 'now connection,' it must he melerstorel that the sie of the peritonemon remains quite unbroken, and that the numbersis duplieatures of the membrane have simply been so readjusted and rlisplaced that it has in more points than one a reflexion from the posterior wall of the abelomen. 
The mesentery is describer as heing attached posteriorly by a very slent lumeler

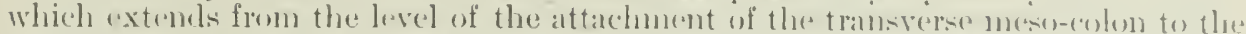
left of the midelle line directly dewn to the rieght iliage fosea where the ilemen falls.

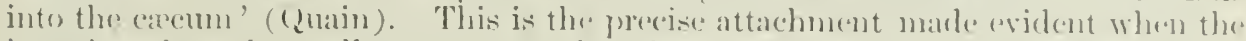
intestines have beroll all ent away and nothing but the stmmp of the mesenter is

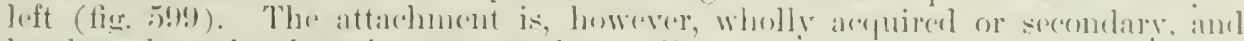
has been hrought about by an extensive realjustuent of the peritoneum. Thire leal

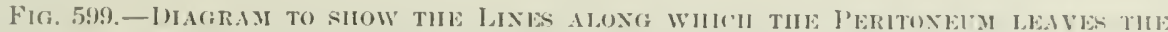

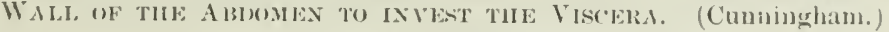

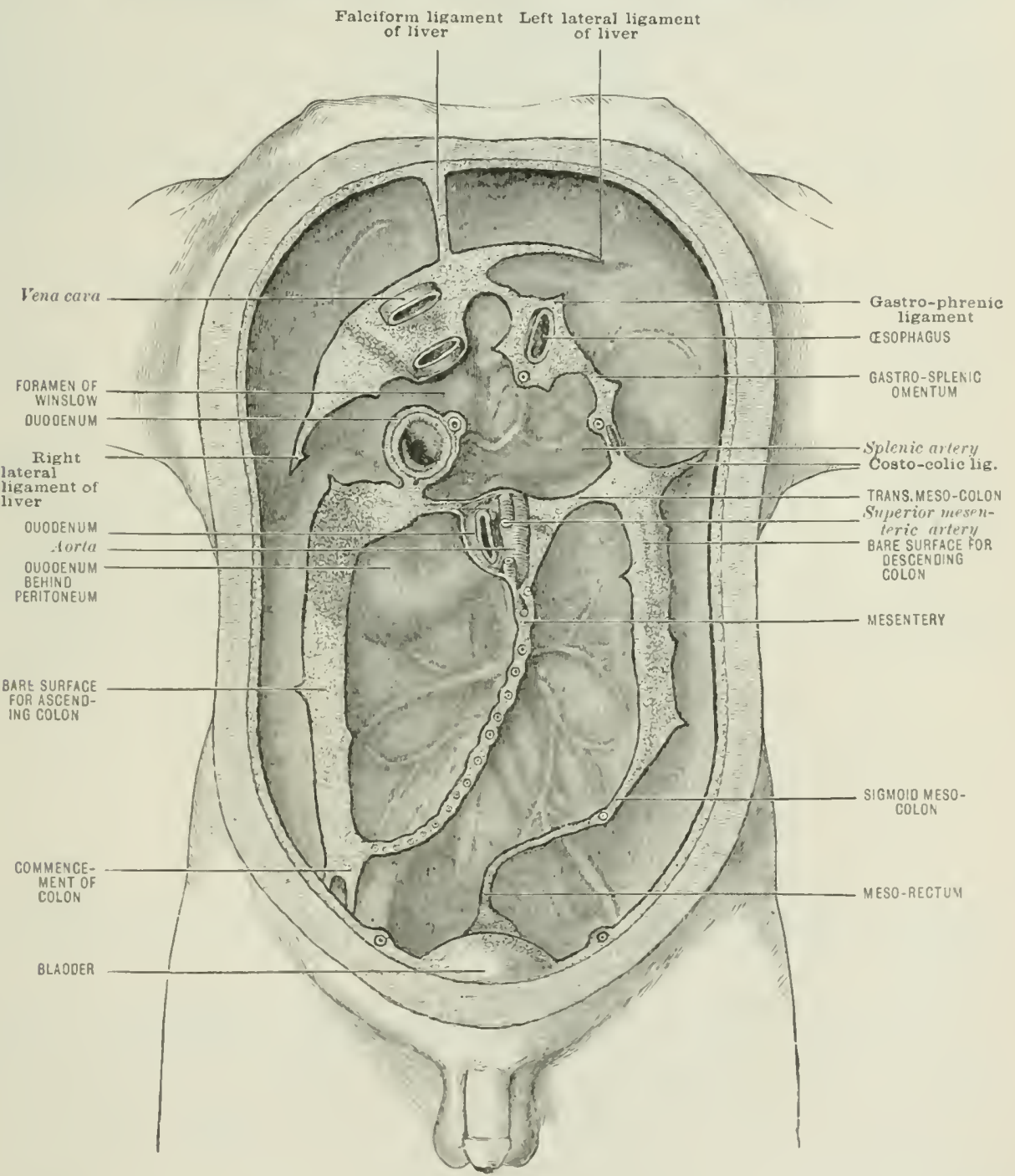

attadument of the mesentery is alout the origrin of the superior mesenteric alrtery,

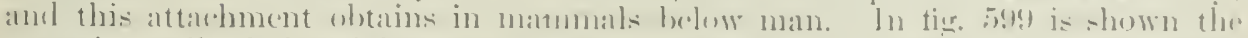

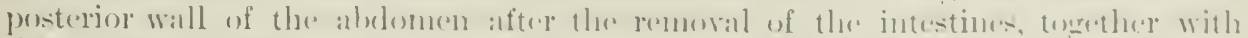

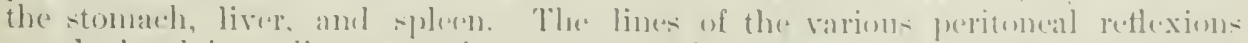

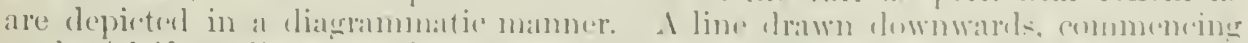

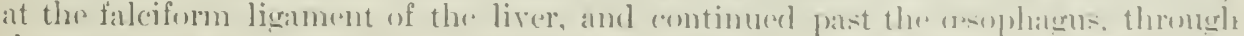

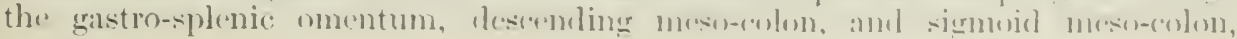


represents the original attadment of the primitive median fold. All other lines of reflexion must be perarded as acquired or secomelary.

The meso-gaster.-It mow remains to consider what heomes of the mper part of the simple primitive fold of freritonem-the meso-gaster (M-G, fig. 598).

The stomach enlarges, assumes more of its characteristic outline, and becomes leserertical.

The liver may be rogarderl as an onterowth from the rundemum. Its conneretions with the great veins of the heart cause it to extend upwards and to the right sicle. As it grows it separates the layers of the highest part of the peritoneal fold, and from this membrane it reoves a covering. The remains of the primitive mesial fold persist in the form of the falcifom ligament (figs. 593, 595, and 599).

The gastro-hepatic omentum. -The connection of the liver to the stomach in intimate, partly through the association of the great gland with the duodenum, and partly through certain blood-vessels which pass to the stomach and liver from thr. aorta. As the stomach enlarges, its dhorlenal cud is drawn towards the right side; the viseus becomes transverse, the left wall beemes anterior, and the right posterior. The layer of peritoneum which stretehes between the two organs is called the gastro-hepatic or lessir omentum. The right or free margin of this omentum was

Fif. 600.-Diagran to sitow tile Foryation of the Great Onextey.

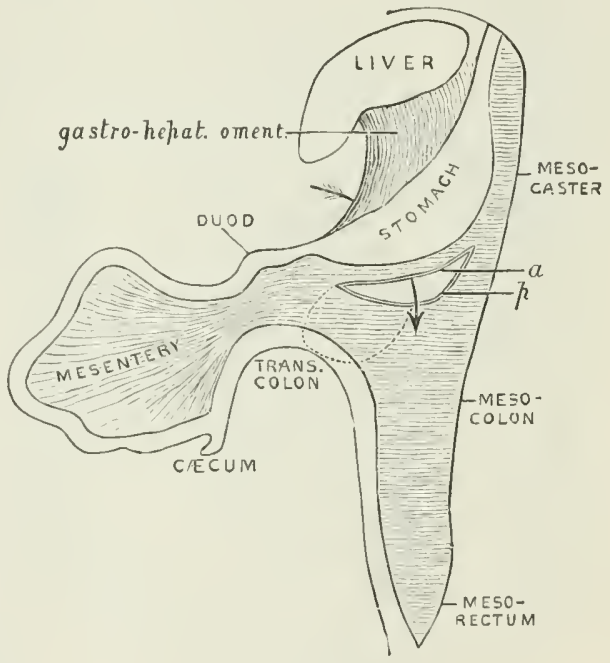

originally anterior, and the whole fold is directly derived, with but little distmbance of the membrane, from the upper part of the primitive meso-gaster (firs. $.793,595)$.

The great omentum. - The formation and disposition of the great onentum are a little diflicult to follow in the alut humam specios, and the student's conception of the right charactere of this fold mal ye a little distorted by a study of certain diagrams which show the omentum from one point of view only. In mammals and in the human foxtus the disposition of the great omentum is rearlily appreciated.

This fold alpreat's als a bulging of the meso-gaster formards and to the left. When the stomach has assumerl its final position, this bulging of the membrane is of eourse entirely in the lirection forwarls.

It first the great omentum forms a slallow and wilk-mouthed hag. Its appearance is such as could be proclumed in imagination if the fingers were to be pressed against the right (fosterior) side of the meso-gaster, and were to force a hag of the yielding membrane before thems. The jendulows laselike projection could he seen frem the left side of the buese-gaster and the wide openinge into the hag from the right (fig. 600). Hore the bag is representerl as cut away. An arrow passing from right to left, i.e., from hehind forvalph, shows the direction of the protrusion. 
The dotted line represents the position of the bagr; "anel prepresent sections of its anterior and posterior walls.

The bag becomes larger and langer, and mone and more penclulous, until it at last hanges down over the transverse colon and the small intestines as a kind of angrom. Its orifice becomes narrowed in time hy the growth of struetures aromul it, and is known as the formuen of 11 instow.

If the finger he introdued into this formen, it will touch the posterior wall of the stomach, and consequently the right (or posterior) layer of the original mest-

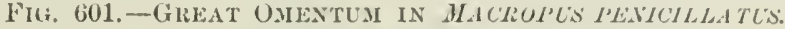

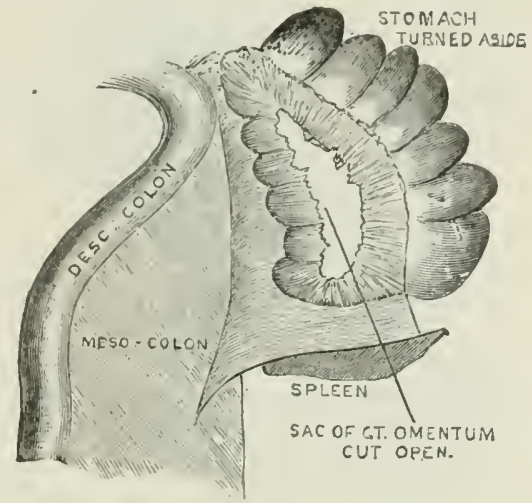

gaster. As both layers of the meso-gaster enter into the formation of this puchell (1) apron, it must of neecssity be formed of four layer's of peritonemm.

The place where the bulging takes place is a natter of importance. Originally such part of the meso-gaster is involred in it as extends from the region of the pylorus to about the middle of the fundus of the stomiach (fig. 600).

In the lower mammals the rudinentary disposition of the great omentum is wall seen. Thus in the two-toed anteater it may be observed in its simplest posilhe

Fig. 602.-Formation of Great OMENTUd AS SEex is Veltical selton.
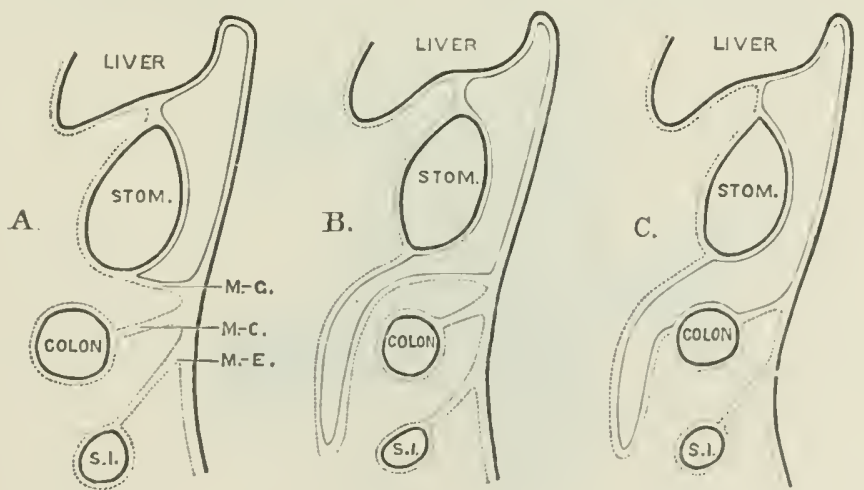

condition. It here takes the form of a slight bater projereting towarels the left. and formed solely by that part of the primitive meso-gaster which is nearest to the

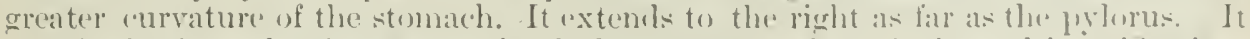

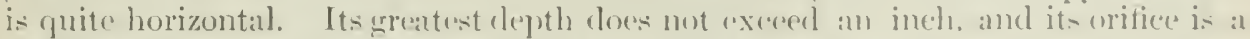
wide, shallow opening upon the right side of the meste-gratere

In higher mammals-ats in some marsupials-the great molentum aplears as al

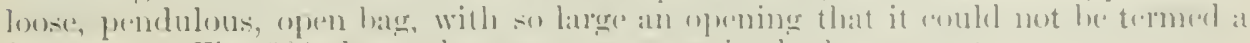
foramen. (Fig. 601 shows the wreat omentmon in the kitnganos.) 
In man and in most of the higher mammals not only is the meso-gaster ( $\mathrm{A}-\mathrm{G}$, fig. $602, \mathrm{~A}$ ) involved in the lulging which forms the great omentum, but

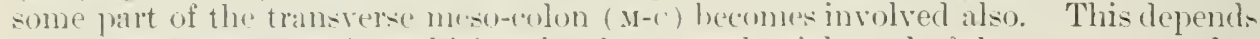
upon the cheseomection which exists between the right end of the transwerse colon and the duodenum. It will be seen from tigs. 6000 and $602 ., \mathrm{A}$, that but a little extension of the bulging of the numbrane is needed for the transrerse meso-colon to become involved. In such cise the anterior layer of the great onentum will

Fig. 603.-Reidtion of Great Omextur to Transverse Colox.

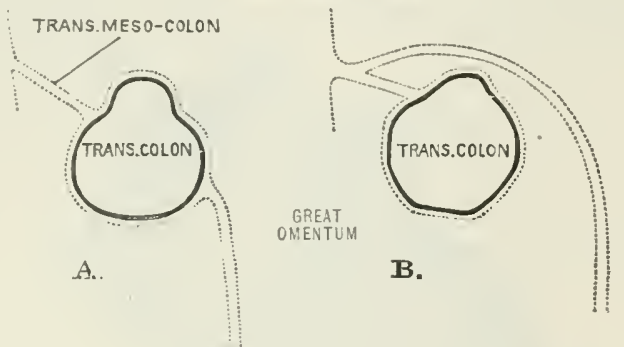

appear to come off from the greater eurrature of the stomach, while the posterior layer will return to the transverse colon and will become continuous with the meso-enlon (figs. 602, $\mathrm{C}$, and $60: 3, \mathrm{~A}$ ). In the adult man this arrangement usually extends throughout the greater part of the width of the great omentum. It is in all instances to be observed in all that part of the great omentum which is about and to the right of the middle line. In the foutus (as in the lower primates) the posterior layer of that part of the great omentum which is quite to the left of the

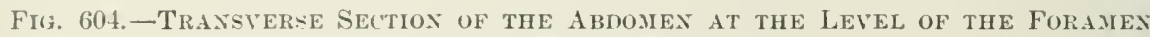
OF TIXSLOW.

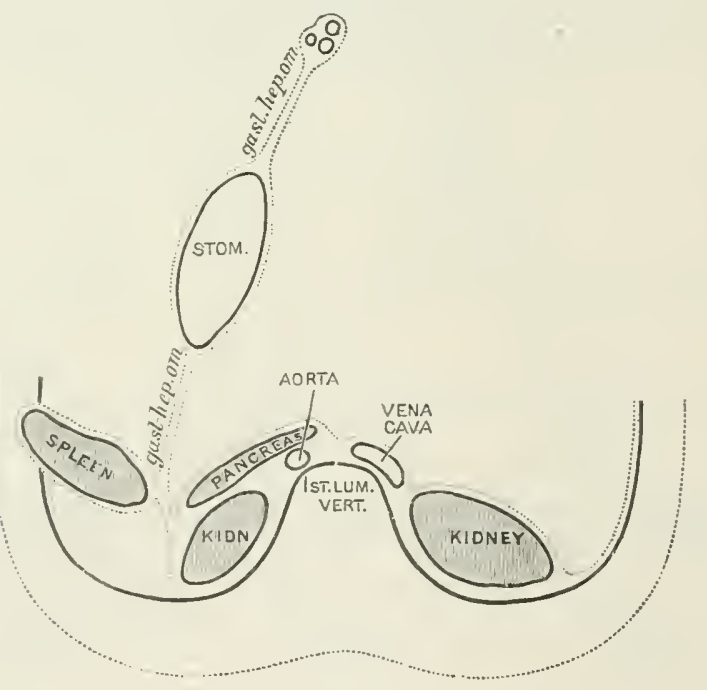

middle line is clear of the transwerse meso-(o)lon. and is obviously derived from the meso-gaster solely (fius. 6(), B, and 608, B).

This difference between the right and the left extremities of the transverse meso-eolon and omentum can sometimes be male ont in the adult man.

The term 'the lesere cavity of the peritonemm' is applied to the cavity formed by this protrusion of the jeritomeun. The term is of use for descriptive furposes, hut it is apt to he mislading if it farors the impression that the gencral sac of the peritoneum is divided into two perfectly distinct parts. 


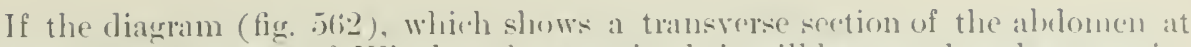

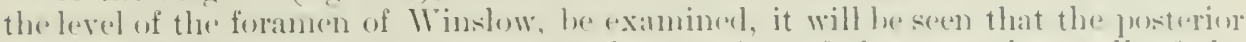
layer of the gatsethereatic omentum. the covering of the posterior wall of the stomach, the right layer of the gastro-sulduic onsentum, and the peritonemo over

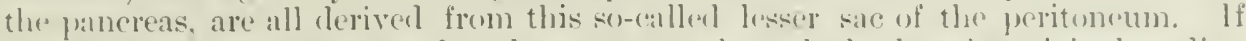
one (o)

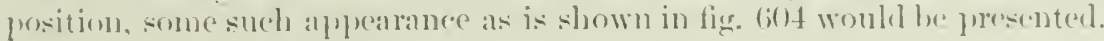

FIG, 605.-INTESTINE OF MACROPLS PENTILLATLS.

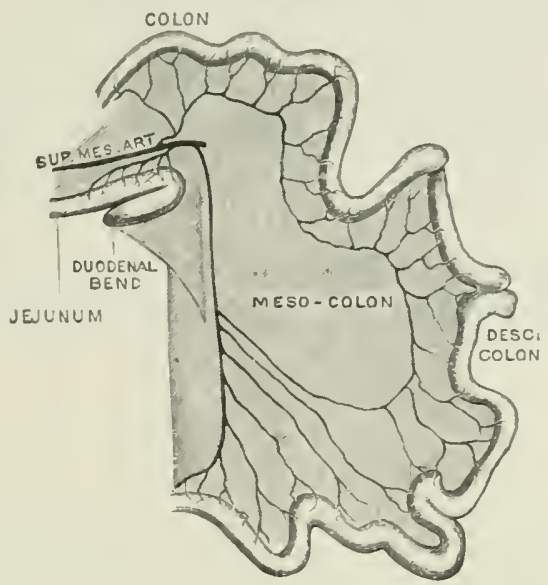

From this it will be sem that the gastro-splonic omentum, the coserings of the stomach, and the gastro-hepatic omentum are all deriverl from the original nuesoEnster, the posterior attachnent of which has becn shifter considerably to the left. The left margin of the formen of Winslow will then be seen to be the free anterior or ventral margin of this simple primitive fold.

The gastro-splenic omentum.-The spleen derelols in the meso-gaster

Fig. 606.-DTUDENAI, FULD OF M.ACROPL'S PESTCILLATLS.

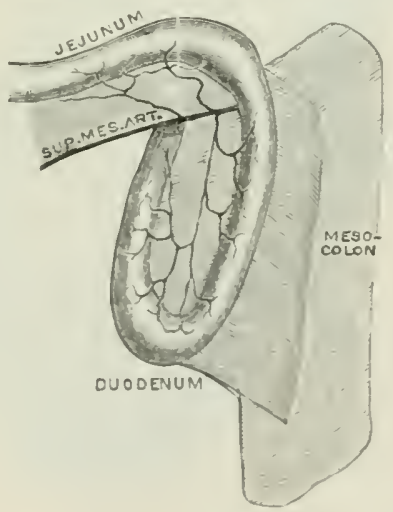

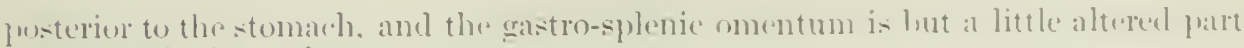
of the original mombrame.

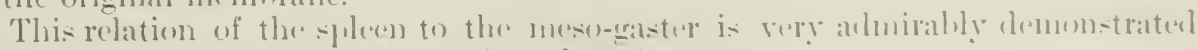

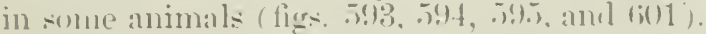

The duodenal fold is to he seen in the herlies of nealrly all mammals luluw man. "xoluding those somewhat lower specoes in which the intestinal tube remains

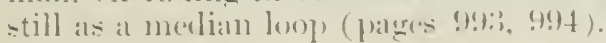


If tigs. 59:3,597, and 59s be examineci, it will be mulerstood that when the rotation of the intestine takes place and the colon rises up and crosses in front of the

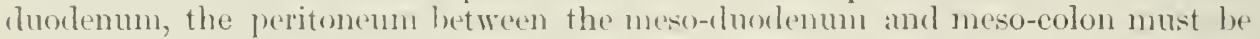
folded upon itself. The folding is $V$-shaped, the alpex of the $V$ heing placed below, and the plieation being in or alout the median line. 'The two membranes on a transverse section would have the relation to one another shown in fig. 598, C.

The thirel part of the duolenum is hrought eloser to the posterior parietes; the peritomem in comnection with it is curtailed; and the selations of the structures around are rearljusterl. As a result of these changes, which ean be followed in many of the lower mammals, a distinct fold is produced which is connered with the third and tominal parts of the duodenum, and is often of eonsiderable size. This fold ean be well sturlied in Mroropms. It appears to come off from that margin of the bowel which is immediately opposite to the attachment of the meso-duodenmm (figs. 605,606 ). It ends below in a free elge, and posteriorty it rither joins the peritonem on the posterior parietes close to the origin of the descending meso-colon, or it joins the meso-colon at some little distance from the spine.

The traction about this somewhat firmly held segment of bowel has been such that it has boren drawn between the layers of its own meso-duodenum. It is hy this fold that is formed the wall of the fossa duodeno-jejunalis (page 966, fig. 572 ). 


\title{
THE URINARY AND RLPRODUCIIVE ORGANS
}

\author{
BY WILIAAM ANDERSON, F.R.C.S.
}

SLRUEOS TU ASD LETTRER ON ANATUMY AT ST. THOMAS'S HESPTAL; PRUFESOR OF ANATOMY IX TIL IROYAL

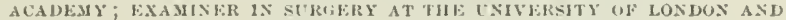

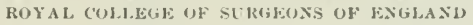

\section{THE KIINEEYS}

T Tle fundamental elements of the urinary apparatus are the kidneys--two I glandular organs situated in the foins behind the peritoncmu, ardh of which is provided with a dnet-the ureter-for the pasiage of the serection to a reservir-the bladder-hy which it is periodically expelled from the borly through a tube of outlet-the urethra.

Fig. 607.-Pustero-INTERxal ASplect OF THE LEFT KidNey.

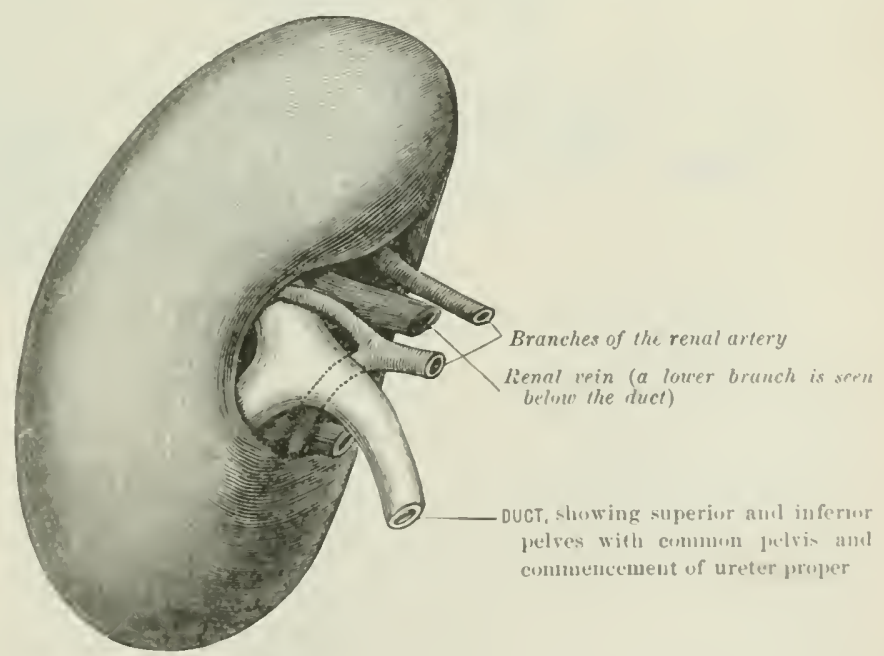

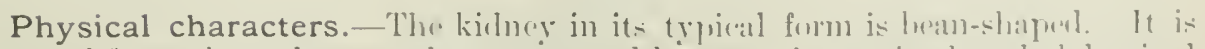

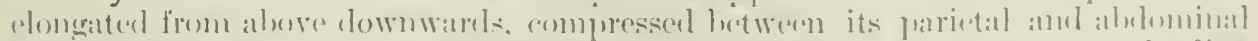
surfares and presents at its anterior and intermal aspect a cleft. the hilum, lealine

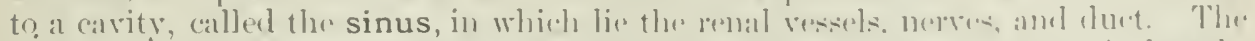

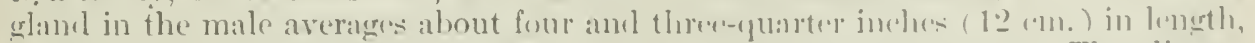

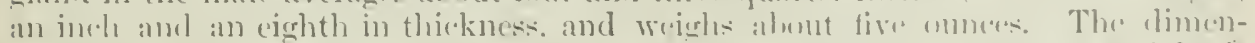
sioms of the female kidhey differ little from those of the male, hent it weight is 100.5 
from one-seventh to one-fifth less. In the ehild the organ is relatively large, but its permanent relation to the body-weight is usual] $y$ attaned at the end of the tenth rear of lifie.

It ufters for description two surfaces, two extremities, and two horders. The anterior or visceral surface is convex, amel looks oliliquely forwards and outwarls; the posterior or parietal surface, les consex than the anterior, looks inwards and hadiwarls; the romeled upper extremity is usually somewhat latrep than the lower, and is placed about half an inch nearer to the median sateital plane of the body. The external border is narrow and convex. The internal border (or sulfice), boking forwark, inwards, and slightly downwards, is relatively hosal, and is fissured vertically in the middle third of its length by thr. lilum.

The hilum is a slit-like aperture bounded in front and behind by two rounded lips of varialsle and morqual thickmes. The posterior lip is nearer to the middle line than the anterior, and between the two pass the renal ressels and nerves, the furt, and a yuantity of fat-learing comnective tissur. The sinus (fig. 609 ), orrupied by the structures just named, is namowest near its entrance, and about

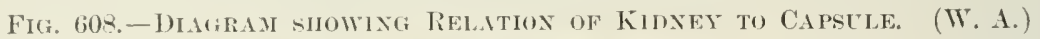

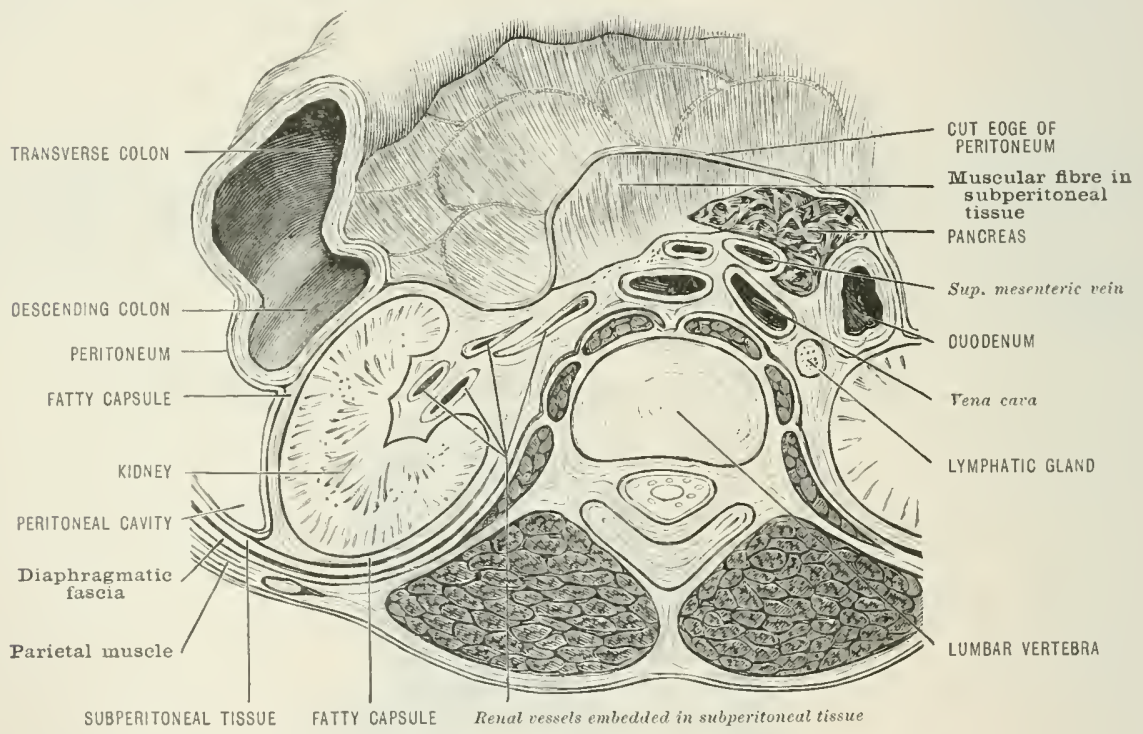

an inch (25 $\mathrm{mm}$.) in depth. Its fundus is piereed by the renal ressels and nerves, and ly the uriniferous tubules; and gives attachment to the primary branches (calices) of the luct.

Investment and fixation.--The entire organ is enveloped and supported by a kind of capsule of fat-bearing comnective tissue derived from the parietal layer of the subperitoneal fascia (fig. 608 ). The arlipose olement is msully small at hirth, but tends to increase about puberty and rluring adult life. When it is scanty, the sulperitoneal imsestment often appears as a tramsparent fascial plane, which in renal operations may lu mistaken for pritonem or faseia transwersalis; or if the fat he excessively diveloped orer the posterior aspect of the orean, it may form a kind of hemial protrusion inte the parietal incision. Should the sustentambre pwer of the fatty capsule beeome inpaired by atrophy from wasting disease, ly the pressure of a loremant utorus or tioht stays, or from any other cause, the phemomenon of movalide of wandering lidhey may be set mp by slight exterial violence, the organ temling to shift its place as far as the attalehnent of its ressels to the main trunk will perunit.

Position and relations. - The kidney is commonly said to lie in the lumbar 
region. It is, however, intersected ly the herizontal anel reationl planess which

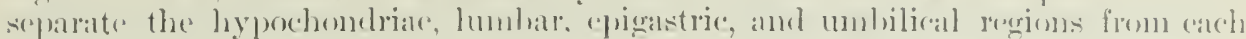
other, and henee belongs to all these sergments of the alorlominal spare. Its

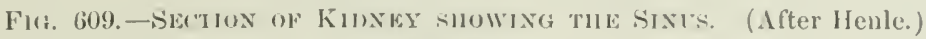

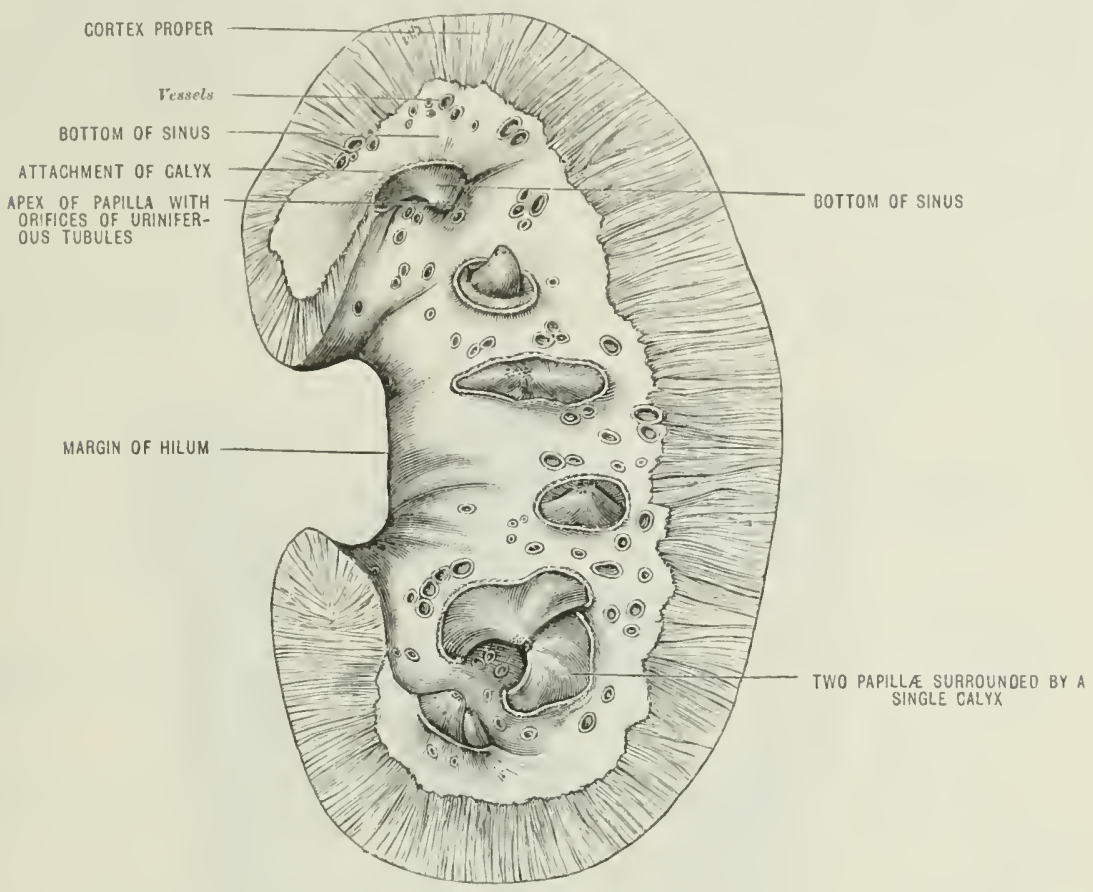

Fig. 610.-Dhagran of Relations of Posterior Serface of Left hilnex.

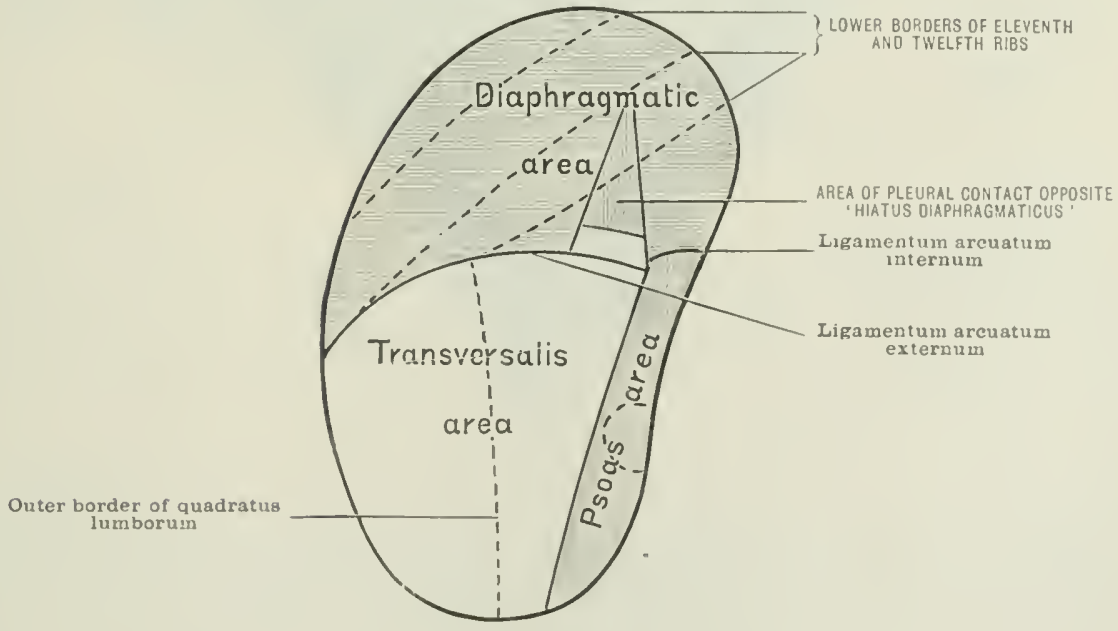

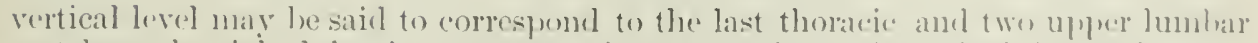
vertebra, the right lying in most (ases from a third to half an inch lower than the left, but exeretions to this rule are not unferpuent.

The posterior surface (figs. (i10, (i11), with the enresponding furtion of the 
fatty eapsule, rests against the posterior alulominal wall, extending upwarts in fronit of the elerenth and twolth ribs and inwards to overlap the tips of the

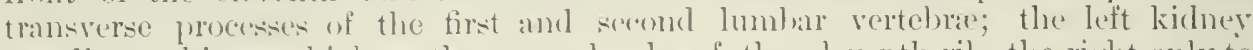

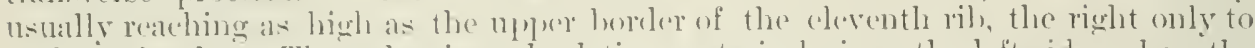
its lower horkler. The only visceral relation posterionly is on the left side, where the splecen slightly orerlaps the kidney oppesite the uplor half of its outer forder. The parletal belations on buth sicles are as follows: (1) the diaphragm, and if a wellmarked hiutus direphergmaticus exist above the ligamentum areuatum extermum, the kidney mar come into rolation with the subplental tissue and pleura; at this point the chest inay become invaded by a circumpenal abseess, or an empyema may

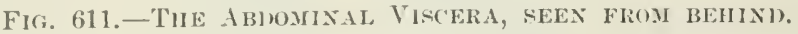

(From the model of His.)

The kirlneys are somewhat lower than usual in their relations to the rilss.

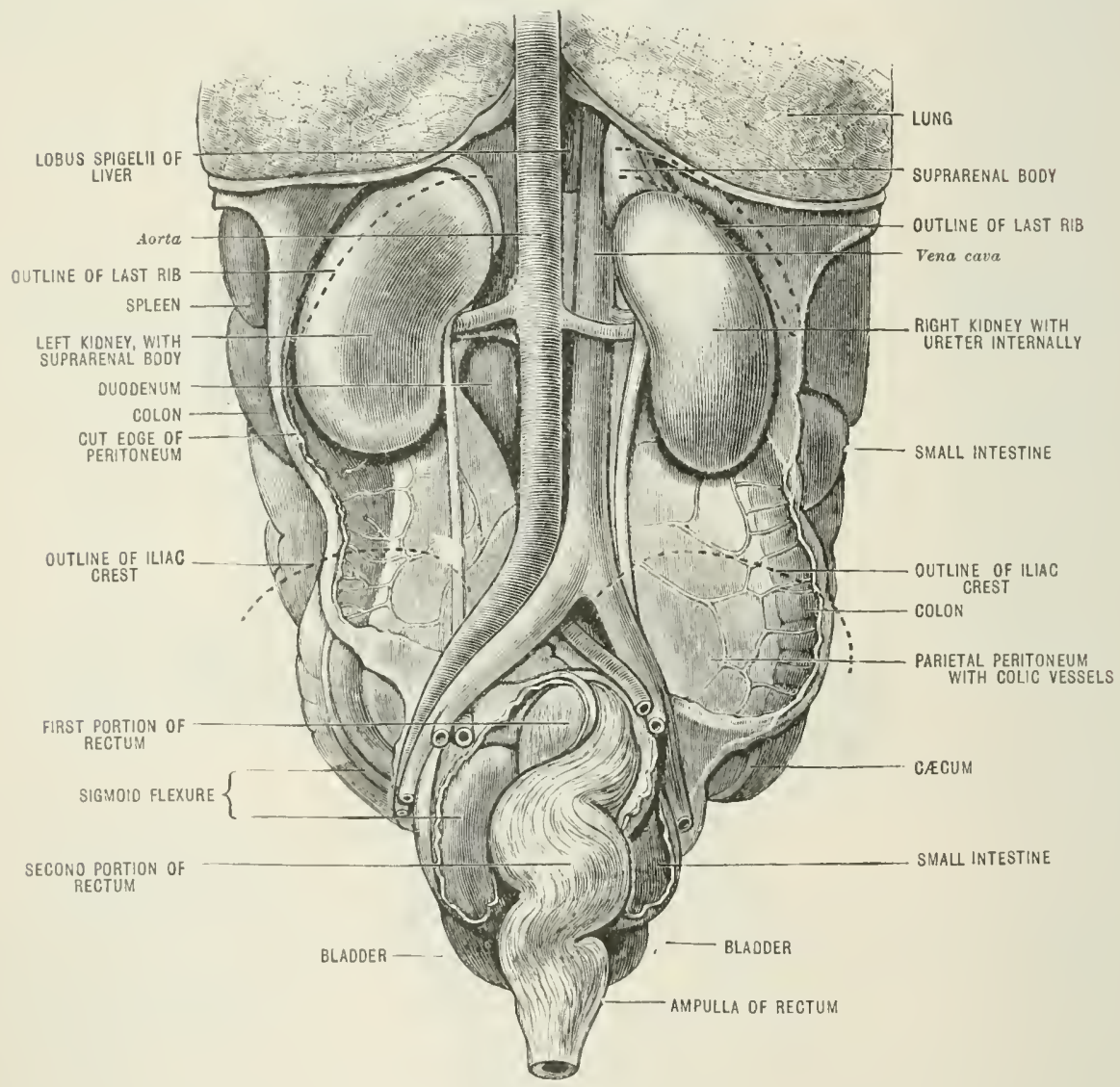

fiml its way form the pleura into the subperitoneal tissue behind the kidney; (2) the anteriof lamella of the posterior aponemrosis of the transwersalis (separating the orean form the yuatratus lumbormo; (3) the posas; (4) the three fasciacdiaphraguatie transtersalis, and iliac-which line thesemuseles respectively; and (j) the last thoracie, the ilio-hypogastrie, and the ilio-ingumal nerves, and the anterior divisions of the first and seromel lumbar vessels, all rumning obliquely downwards and outwates in front of the quadratus lumborum to pieree the transversalis beyomet the outer borter of the puarlatus. Owing to the higher level

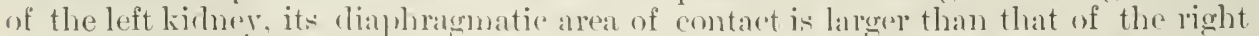
organ. This aria, moreorer, may le inereased on either sicle when the aremate 
ligaments, which give origin to a large portion of the posterior fibres, are attached to the tip of the transperse process of the secomd lumbar vertebra instead of that of the first.

The pleurat has an indirect but important relation to the kidney hesiles the nuere

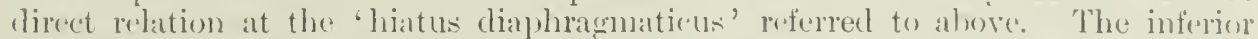
linnt of the pleural sale extends alnowt horizontally outwarks from the lower border of the twelfth theracic vertelora, crosing the last lib near its neck, and the rleventh rilo abont two inches farther outwarels. As a rule, the incision in renal operations may be carried safely to the lower border of the last rib; but, should this bone he absint or very short, the elerenth rib may be mistaken for it, and the ferous mentbrane would then be in dinger. It is probable, too, that the plexura reaches to a lower point in these cases where the areuate lieraments are attarherl to the secend lumbar transeres: process. The presence of a thirtecenth rib would involve a contratetion of the space available for the surgieal exploration of the organ.

The upper extremity of each kichey is crowned hy the supraremal hody (ligs 611, 61.2), which encrouches also wpon its anterior surface and inner border, and is fixed to it hy comnective tissne derived from the subperitoneal fascia.

The anterior or visceral surface (fig. 612) is moulded to the contiguous

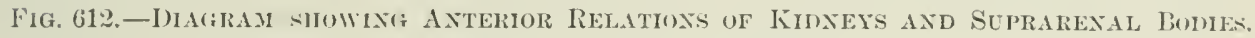

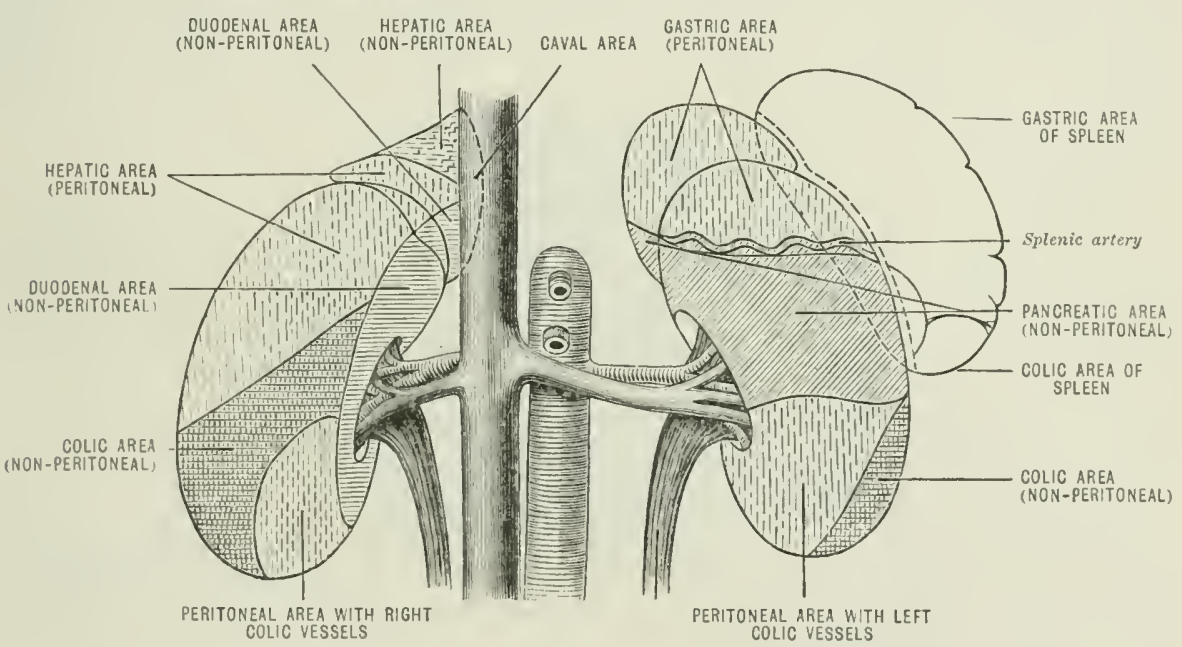

organs. The right kichey is in contact in about its upper half with the renal inpuression on the liver (page 97s), and below with the aserending colon and duorlenum; the hepatic area being covered with peritoneum, while the second stage of the duolenum and more externally the ascending colon are clirectly attached to the surface hy subperitoneal tiscue; but the two nom-peritoneal alreas vary onn-inlerably in their redative proportions, not only in different subjects. but in the same subject under different conditions of distension of the duolenum and the colon. The seend stage of the dunfemmm is also more of less in relation with the riogt remal vessels.

The left kidney lies behind the stomach, the pancreas, the splenie vessils, the descending colon, and the enlie vesecels. Its antrior surface mav lu dividerl into three portions: an upper or gastric area, sepurated from the stomach ly the pritonem of the lesser sac; a middle or pancreatic area, attacherl to the pan-

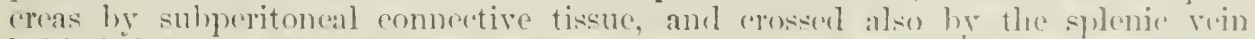
behind the upper horder of the pancreas, and he the splenie artere, which rums in a serpentine course immeliately alwowe the rein: and an inferior ne colic area, the outer portion of which is coveres by the splenie flexure and upler part of the desending colon; the inner hy a layer of peritonem (of the ereater sac) and the colie vessols. 
The outer border of the kidney reaches a point alwout there and a half or four

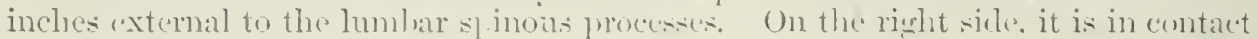
with the liver in its upper half or twe-thirels; on the left, its uple thirel or half rests against the renal grove in the posterior portion of the visceral surface of the spleen.

The inner border of the right lidiny apluaches rery due to the vena cava.

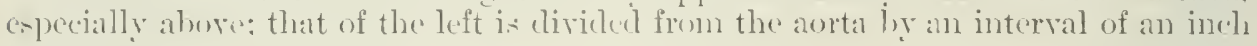
or more.

The position of the kidneys at the Jalek of the aldominal carity involves a certain anoment of pressure upon the organs and their vessels and nerves by the weight of the visera in front when the body is supine, and there is reasom, to believe that their secretory functions are conserinently influenced lyy changes of posture to an extent that may be utilised in therapentics.

The structures lying within the sinus are the renal artery and vein, the renal lymplotice (vesels and glands), a plexus of nerves, the duct, and more or less connective and alipose tissue continuous with the fatty capsule. The remul aitery is a branch of the aorta giren off opposite the first lumbar rertebra and behind the pancreas. On reaching the hilum it usually breaks up into four branches, three of which pass in front of the pelvis to supply the superior, middle, and inferior zones of the organ, while a fourth rums behind the pelvis close to the posterior lip of the hilum and is distributed over the lower half or two-thirds. This may be wounded in an attempt to remore a calculus by incision of the posterior wall of the pelvis. Besides these, irregular vessels may" pierce the gland above or below the hilum (fig. 607 ). The left renul rein receives the spermatic or utero-orarian rein, and is usually somewhat low er than the right. The shortness of the right renal rein should be remembered in the operation of nephrectumy.

Structure. - The kidner when renoved from its fattr investment is seen as a yellowish-red organ eovered by a thin but strong fibrous capsule (tunica propria), which is prolongerl through the hilum into the sinus. where it becomes continuous with the sheaths of the renal vessels. and extencls as far as the attachments of the subdivisions of the duct aroumel the renal papillie. The whole capsule may be easily peeled off from the healthy kicher. except at the bottom of the simus, where it is fixerl hy the ressels and duct; and as the capsular ressels are of small rize. the prowes of stripping is attenderl with little hemorthage when practised in the course of operations upon the living sulject.

()n section through the kidney, its sulutance is found to comprise an external or entiml ant an inner or medullary segment. The medulla consists of a variable number (eight to eighteen) of conical segments ealled pyramids of Mialpighi, the apices of which project into the lottom of the sinus (fig. 609) and are surrounded by the primary segments (calices) of the duct, while their hases are turned towarls the surface, bit ate separated from it and from each other by the cortex. The pyramids arerage in their axial cliameter about three-quarters of an inch, and have a with at the base of ahout two-thires of an inch $(16 \mathrm{~mm}$. ). They are smooth and somewhat glistening in section. and markerl with thelicate stria which converge from lase to apex, and indicate the course of the uriniferous tubules. The blunted apex, or papilla, single or blement with one or eren two of its fellows is embraced liy a calyx, and if eximined with a hand lens will he seen to present a varialle nimbler (twelre to righty) of minuto apertures, the foramina papillaria, through which the secretion escajes into the duret.

The cortex may le dividerl into two portions: a peripheral layer, the cortex proper, which is a little les than half an inch (12 mm.) in thickness, and extenck from the capsule to the hases of the prramids of Malpighi; and processes called columns of Bertin, which tip inwarls letween the Malpighian prymils to reach the hottom of the sinus, where thry are covered ly the fibrous "apsule and more or less adipose tissue (fig. (i13). In section the cortex is somewhat grimular in aspect. and in an injerted kiblusy is seen to be totted with minute points corresponding to vascular grlonseruli lying within thr "aval origin of the uriniforous tubules (eapsules of Bowman). Examined more (dosely it displays a number of small promidal groups of tubules, some belonging to the cortex proper, with the dir bases resting ujon the bases of the Malpighian prymirls, the apices directed towarts, lut not reaching, 
the periphery; others forming a part of the columms of Bertin, and lisposerl almo-t at right angles to the last. These cortical yroups ar (alllent pyramids of Ferrein,

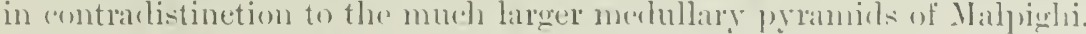

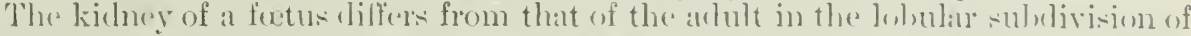

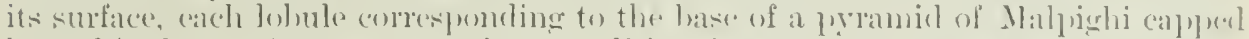

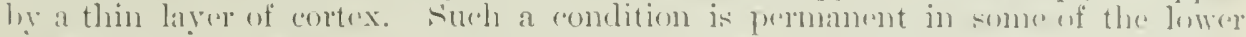

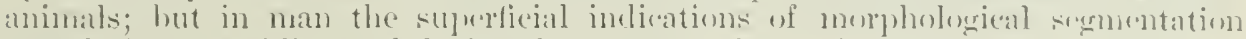

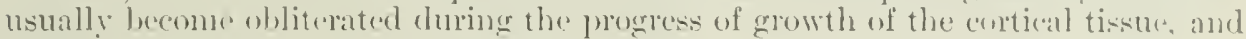
are selikem visible alter the ale of ten.

Uriniferous tubes (tir. (i1-1). - The secreting tubules (ommenee ] a number of spherieal calpsules (capsules of Bowman), which lie in the (o)tex. Firm each

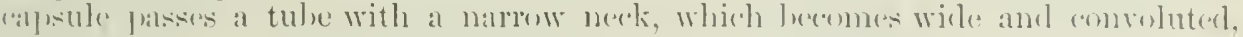
then, nallewing again, runs down into the subjacent Malpighian juramile forms al lenpl (looped tube of Henle), returns into the coltex, where it again becomes dilated and contorted, and, after undergoing a final anstriation, opens into a straisht collecting tube, the axial element of a pyraminl of Ferrein. The collecting tubes run into the Malpighian pyramids, and wnite with each other to form a

Fig. 613.-HORIZINTAL SETION OF KIDAEY, SIUWING TIE SIXTS.

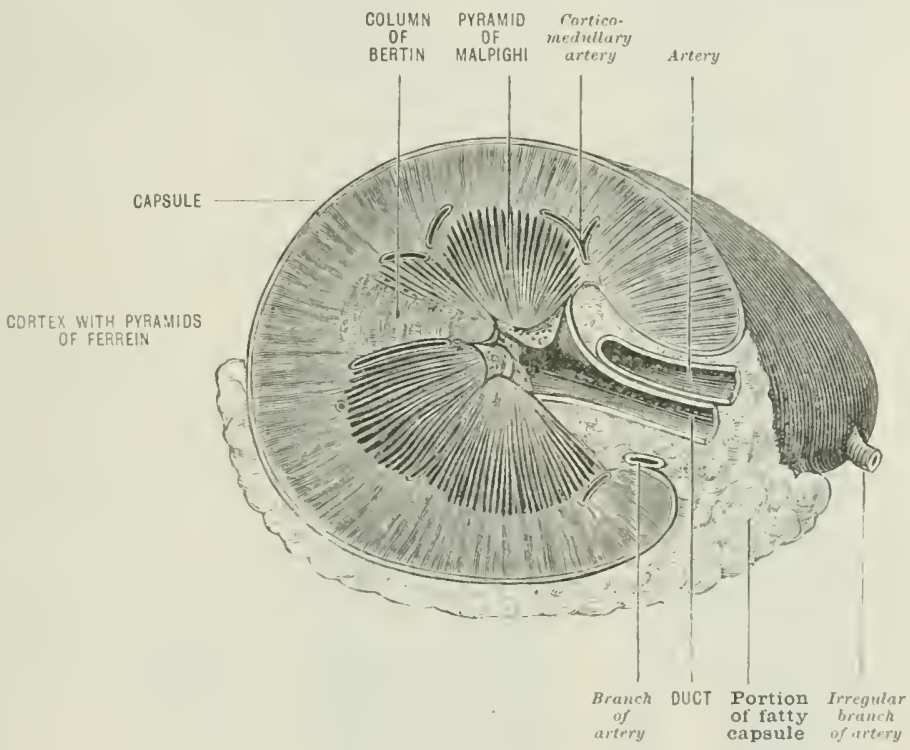

smaller number of larger tubes, which terminate hy opening on to the paprillatry

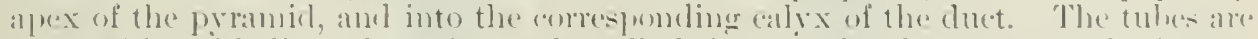

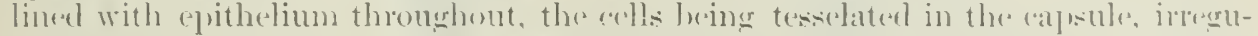

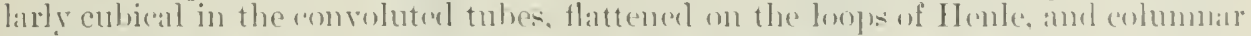
in the eortical ablleveting tules anel in the straight tulues of the meelulla.

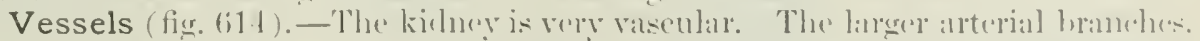

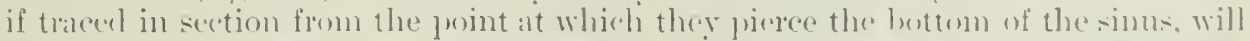

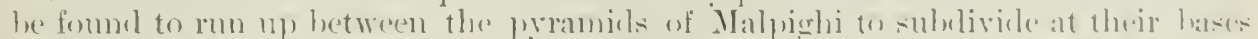
inte cortico-meduilary arches which lie lxetween the (x)rtex and melulla. wiving

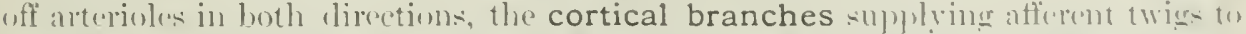

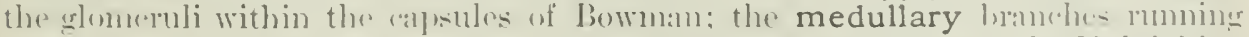

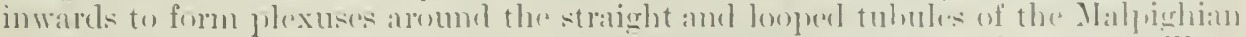

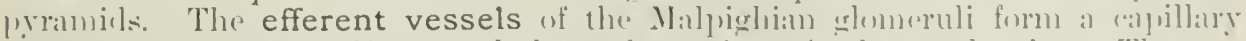

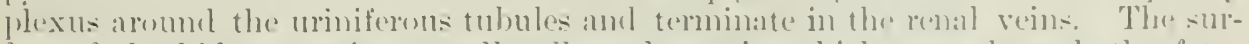

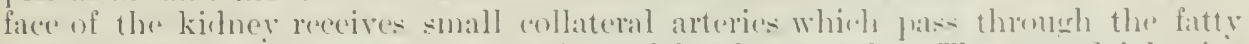

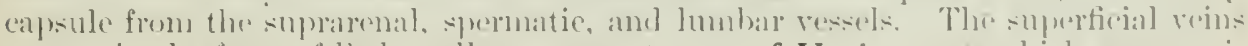
aplear in the form of little stellate grouls (stars of Verheyen which communi- 
cate with the renous plexus in the adipose capsule and hy means of this with the viseeral and parietal reins in the neighbourheml. They are very distinct when the oram is conested. The renal lymphatics may be divided into two set.., capsular and parenchymatous. Ther torminate in a series of glands lying with the renal ruscls in the subperitoneal tissue, and their contents are ultimately comvered into the receptaculum ehrli.

Nerves.-The nerro forn a plexus accompanying the vessels, and are derivel

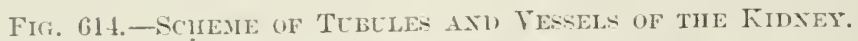

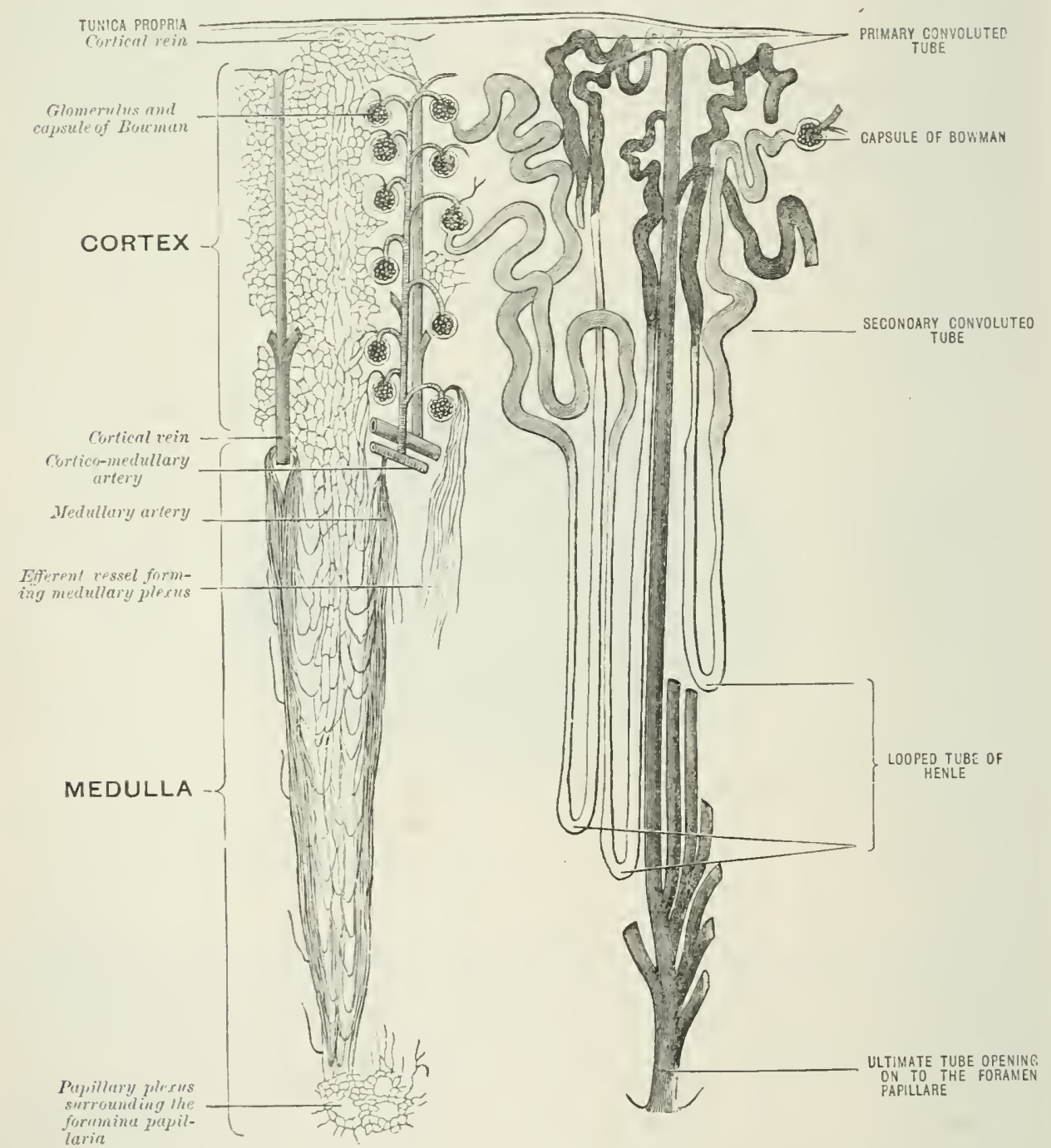

mainly from thespmpathetio through the solar and aortic plexuses, and the splanchnic's. Ther communicate with the spermatic plexus's. Some filaments have also been traced from the pmemnowastrics.

Varieties. - The principal rariations of the kicher are as follows:-

1. In form.- I isproportionate incrases of one or vither climeter, proclueing the long, globular, triangular, and discoid types.

2. In size.-Inepuality; one being sulall, the other compensatingly large.

3. In number. - The organ may he single, then usually oceupying its ordinary 
position in one or other loin; or, still more ranely, it may he triple, in wlich rase the adelitional gland is either lateral or merlian.

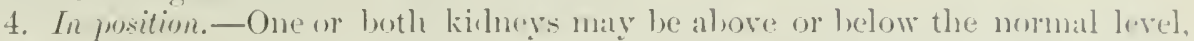

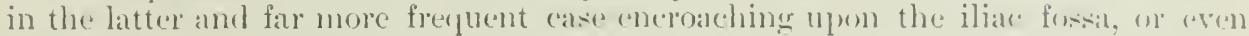
entering the true pelvis in front of or lehind the rectum: or the displarement nua

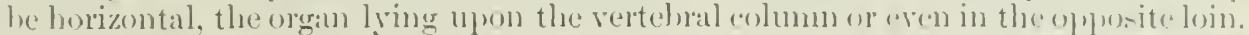

5. By fusion of the two kinhers; the mion involving the lower extremities only ( horseshe kismey '), or the whole length of their inner borker.

6. In mobility. - Endue molility is nsually, if not always. due to a laxity of that portion of the sulperitoneal tissue which comstitutes the fatty alasule: hut at peritoneal meso-nephron is said to have been seen in extremely rare calses of movable kiclney

\section{THE SUPRAREXIL BODIES}

These structures do not fom any part of the genito-urinary apparatus, hut it is comvenient to deseribe them in association with the glands by which they are stiplerted.

'The suprarenal bodies (fig. 615) are two solid viscera resting each upn the

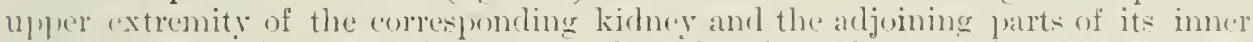
and anterior surfaces, and bound to it hy subperitoneal comnective tiscue. Ther

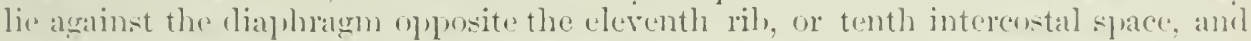
ales salarated from rach other by a space of alout two inches anel a half. The left is usually a little higher than the right, owing to the greater elevation of its kiclner.

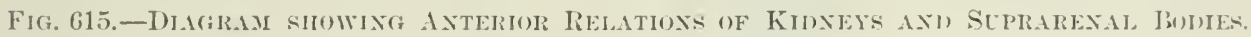

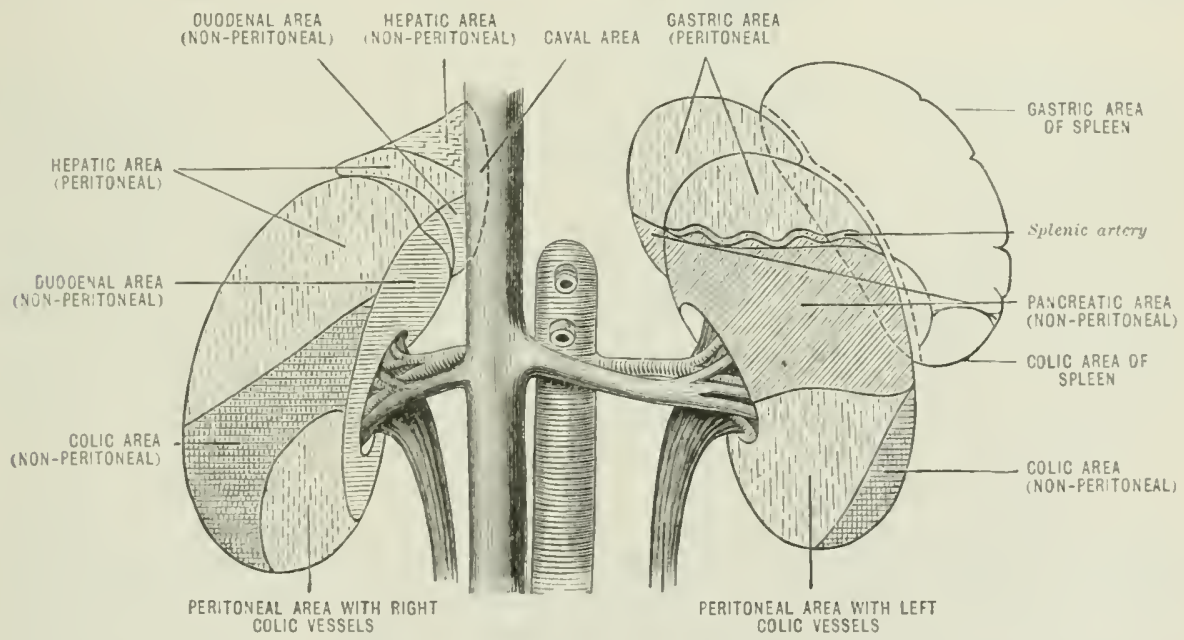

The organ varies widely in dimensions within physiological limits. Its average weirht is alout a drachm, its lueight an inch and a quarter (B) ("mo.), and its greate'st breacth at the base an inch and threso-guartors (4.5 cm.).

The riglitsuprarenal hody is pyramidal in form with the apex directed upwarts. and sonewhat inwarls. Its anterior surface is rolated aluse to a siluedial injuresion upon the uneler and back part of the right lobe of the liver. betwern the lasere of the coronary liganent; intemally to the inferior vena caral which slightly.

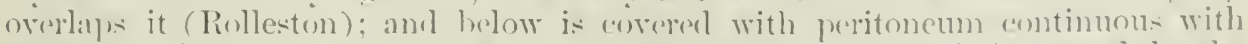
that of the kishey, exeret at its internal inforior angle where it is aroserel hy the hepatic flexure of the duolenum. It is rather firmly adlorent to the livere and the ressels of the two organs anastomose with wach other at this point.

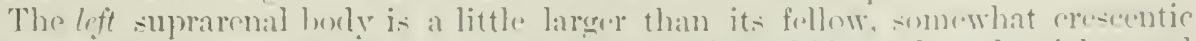
in shape, and encroaches less 11 un the simmit of the kidney than the riefht, and more upon the immer border, reaching even to the hilum. Its anterior surface is 
coverel above hy the peritonenur of the leseresac. which separates it from the stonach: and below, near its internal inferior angle. it is erossed by the upler horder of the pancreas and the splenic artery. Externally it is in contact with the uplex extremity of the slleen. which pasies a little behind it, and its inner borler is separaterl from its antal hy the filues of the diaphragm.

Accessory supraremal botics are often present in the neighbourhood of the principal orwans.

Structure.- On section the organ is found to lue covered by a thin tibrous capsule which sends triberular processes between the cellular elements of its proper sulistance. The parenchyna comsists of a preripheral portion or cortex, of rellowish colnur, except in its deepest layer, which is darkly pigmented, and a central portion or medulla, soft and grevish, and tending to lreak clown under decomposition in such i mamer as to give the appearance of an irregular carity (whence the name suprarenal '(ap)sule').

Vessels and nerves.- It is richly supplied both with resicels and nerves. Its arteries are derived from three sources-the aorta, the plinenic, and the renaland pierce the organ in various places, hut chiefly on the anterior surface along a furrow sonetimes ealled the hilmo. The veins terminate on the right side in the vena cara, and sometimes by means of small branches in the phrenic and renal trunks; on the left, in the left renal vein. The lymphatics pass to the renal ghands. which, like the suprarenal bodies, themselves contain a good deal of pigment. The nerves form a rich and complex interlacement, and are derived chiefly from the solar and renal plexuses, but include filaments from the splanchnics and according to some authors from the phrenic and vagus also. It is disproportionately large in early foetal life, and has nearly ratehed its full growth at the time of birth.

\section{THE RENAL DUCTS}

The excretory duct of the kidney (figs. $607,611,616$ ) is a musculo-mucous canal, expanded and irregularly branched above, narrow and of fairly miform dimensions in the rest of its course. At its origin in the sinus renalis it appears in the form of a number of short tubes, usually eight or nine, called calices, each of which embraces the papillary extremity of a pramiel of Malpighi two or three lines above its apex, or oceasionally two papille may be comnected with a single calrx. The calices arerage about a third to half an inch ( 8 to $12 \mathrm{~mm}$.) in length, and open directly or by means of internediate tubes (infundibula) into two short pasages, the superior and inferior pelves, which in turn combine after a longer or shorter course to form the common pelvis. The inferior and larger pelvis has a diameter of about two-fifths of an inch $(10 \mathrm{~mm}$.); the superior is about one-third less. Occarionally a thirl or middle pelvis is present.

The common pelvis varies greatly in different suljects. It usually appears as a more or less fumnel-shaped portion of the canal, wider above (about three-fifth of an inch-15 $\mathrm{mm}$.), where it lies between the two lips of the hilum: narrow below, where it alrehes fownarls and inwards to lrecome continuous with the relatively uniform portion of the duet known as the ureter proper. In some eases, however, it ean sareely he said to exist as a dilatation. Cunder ordinary cireumstances it is thattened from hefore hackwards, its anterior and posterior walls being in eontact, and its chammel represented hy a fisture. It is in relation behind with the posterior lip of the hilum, from which it is separated hy more or less adipose tissue continuous with the fatty capsule, and occasionally hy an irregular braneh of the renal artery. The renal vin and artery lie in front. imbecled in fat, and antorior to these structures is situated the descending portion of the duolenum on the right sicle, and the pancreas on the loft.

The ureter extends from the termination of the pelvis to the bladder, running in a kind of lymph-space between the lamine of the subperitoneal tiscue. It is a tube of about a fifth of an inch $(5 \mathrm{~mm}$.) in diameter when distented, and is farirly uniform in size, except about two inches bulow the kiclney, where a slight eonstriction is usually fomm (liruee (lark). It length is variously staterl, but the arerage in the male arlult may he taken as about twelve inches (30 cm.), the right leing usually a little the shorter. The excessive estimates sometimes given defend upom 


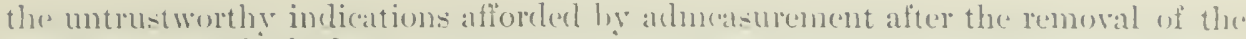
structure from the ludr.

Course and relations. - The tuhes lir abont there inches apart at their (o)m-

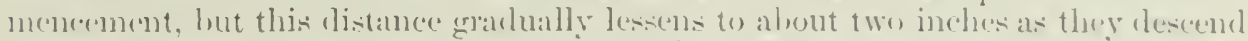

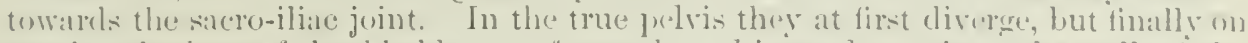

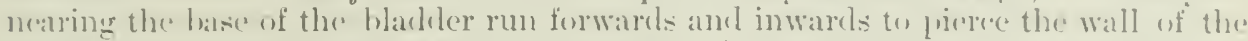
viscus, and at their termination are separated hy a distance of about an inch

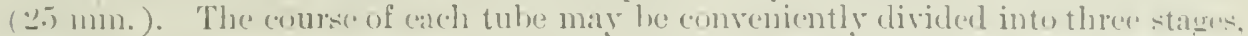

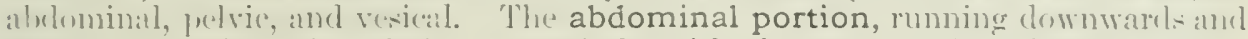
slightly inwarls, is in relation. pusterionly, with the psoas and its farcia, and the genitor-cural noree, and with the common iliae artery near its bifurcation. Antr-

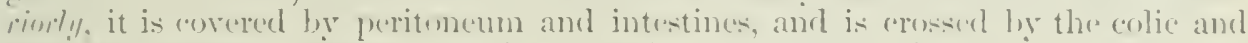

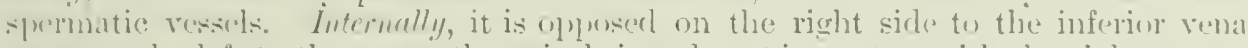

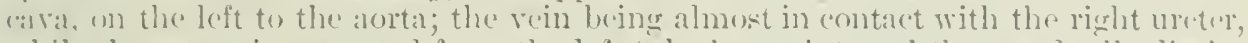
while the artery is separated from the left tuhe by an interval that gralually dininishes from one inch ahove to half an incle opposite the bifureation of the reser. In the female the utero-ovarian reins lie on its inner side.

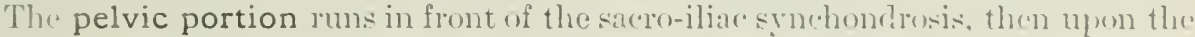

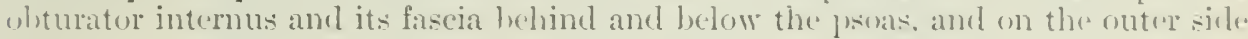

Fig. 616.-Uter Portiox of Dect. (After Henle.)

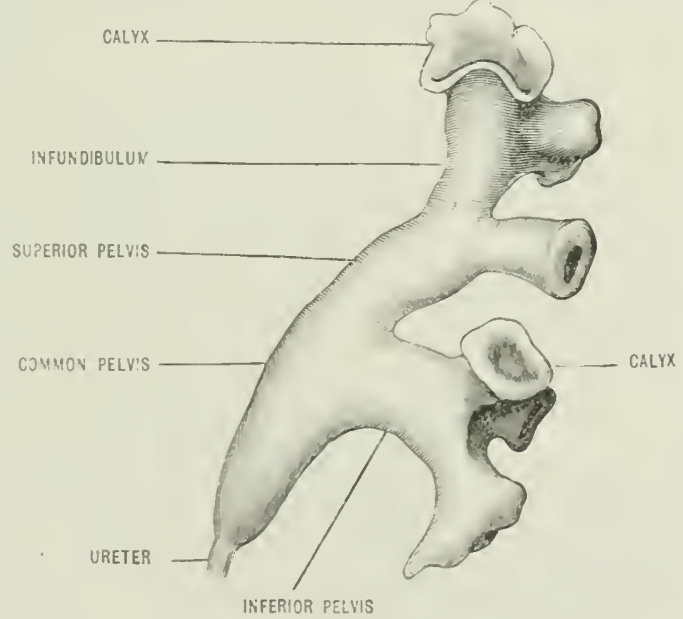

of the pelvic coils of intestine (sigmoirl eolom on left side. small intestine on right). finally leaving the polvir wall to join the bladder. In this position. in the mente it is cressed superiorly and intronally by the ras deferens, and lies under corren of the free extrenity of the vesicula seminalis, separater from its follow he a listance of an inch and a half (37 mm.). In the gemale it runs parallel with, and four te six lines (s) to $12 \mathrm{~mm}$.) from, the corvix uteri, behinel the uterine artery. thender the

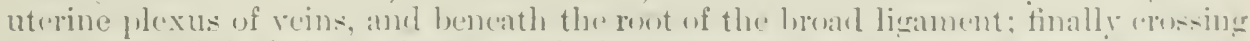

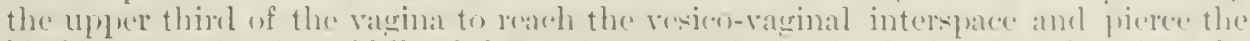

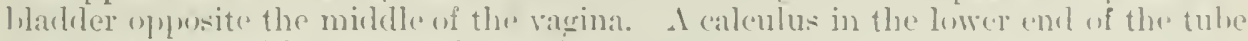
might be eletected hy a vagrimal pxamination.

The vesical portion, alout half an inch (12 mm.) in longth. rums ulliguely

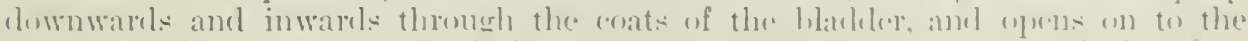

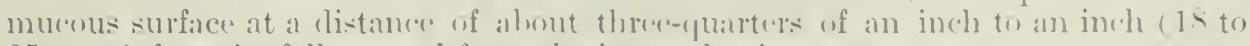
2.5 mom.) from its follow, and from the intemal urinary meatus.

Structure.-The wall of the ureter is about a twenty-tifth of an inch (1 mmm.)

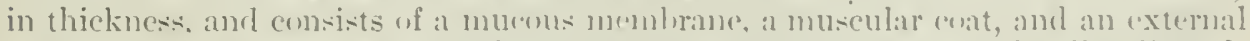
connective tissue investment. The mucous membrane is longitudinally plicated, and is lined with a multiple layer of transitional eprithelium, continums with that 
of the papille above and with that of the hladeler below. Mucous follicles of simple form have been found in the upper part of the eanal. The muscularis is about one-fiftieth of an inch $(.5 \mathrm{~mm}$.) in thickness, and consists of two larers, an external composed of amnular fibres, an internal of fibres longitudinally disposed. After the tube has entered the bladder the circular fibres appear as a kind of splincter around its resical orifice; while the longitudinal fibres spread out to form rith those of the oplusite side a triangular expanse with its apex at the internal urinary meatus and its base corresponding to a line drawn between the two ureteric onifices, the upper (interureteric) and lower (uretero-meatal) fibres forming strong bands which bound the triangle.

Vessels and nerves.-The arteries of the ureter come from the renal, spermatic or utero-ovarian, internal iliac, and resical; the veins terminate in the corresponding trunks; and the lymphatics pass to the renal, lumbar, and pelvic glands and into the receptaculum chyli. The nerves are supplied by the spermatic, renal, and hypogastric plexuses.

Varieties. - The most important rariation consists in the partial or complete duplication of the tube owing to the late union or to the non-union of the superior and inferior infundibula or pelves. In rare cases three pelves may in like manner remain soparate in part or in the whole of their course to the bladder.

\section{THE BLADIER}

The urinary bladder is a receptacle, of which the form, size, and position rary with the amount of its contents. The adult organ in its empty or moderately fillcil condition lies entirely below the lerel of the oblique plane of the pelvic inlet; but when considerably distended it rises into the abdomen and shows itself beneath the parietes as a characteristic mesial projection ahore the symphrsis, a projection which in certain cases ma extend nearly to the level of the cimlilicus. It is invested orer its whole extent by jecto-resical fascia, and is partially corered above and behind hy peritonem (fig. 617).

Form.-When fully distended it assumes in the male an oroid shape with its longest diameter directed downwards and backwark, but in women the transverse diameter is commonly the greatest, owing to the different shape of the pelvic eavity. In the child it is somewhat pear-shaped, the stalk being represented br the urachus.

The form of the empty bladder is still doultful, as the appearances in the dear sulject do not necessarily coincide with the condition existing during life. In . nesial sagittal section it usually appears somewhat cup-shaped, its upper wall presenting a rounded or pyramidal hollow to the intestines, while its carity is represented by a $T$ or $Y$-shaped fissure (as in plate 1 of Symington's 'Anatomy of the Child'). It is probalile that this 'diastolic' form, as it has been termed, is not altogether the normal result of a relaxation preliminary to refilling; but is partly due to the loss of rital clasticity of the muscular wall, and that the healthy living bladder maintains a rounderl or ovoid form even when empty.

The three terms, 'apex' or 'superior fundus,' 'inferior fundus,' and 'neck,' are commonly applied to prarts of the bladker: the first to the point of attachment of the superior ligament or urachus (a relic of the tuhe of communication between the bladder and allantois) which connects it with the umlilicus; the sceond to the lower part of the organ, and the thind to the point at which the resical carity becomes continuous with the urethra; hut the expuressons are all more or less oljectionable, and serve $n 0$ uscful purjose. Inder ordinary distension the so-called 'apex' is as much rounder as the rest of the viseus; the anatomial limits of the 'inferior' fundus' are still undefindel; and the only 'neck' that 'am be assigned to the bladder is represented by the prostate and prostatic urethat

Relations. - The bladder when moderately filled may be said to prosent for 


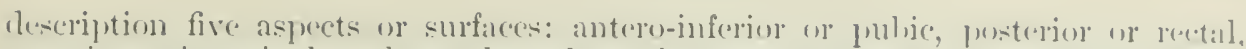

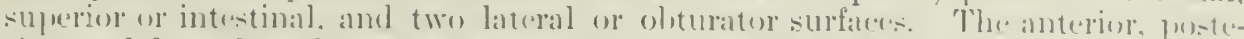

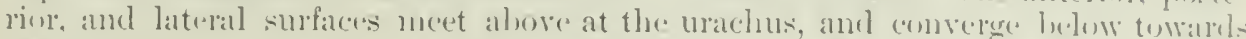

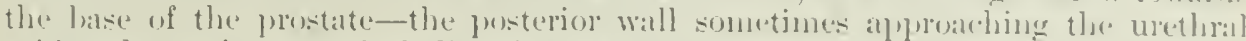

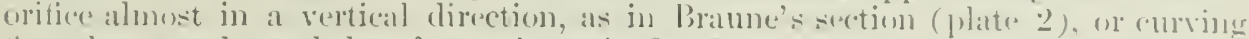
first downwards, and then forwarels, as in fig. 617; and in old suljects this rurve

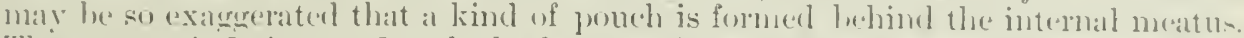

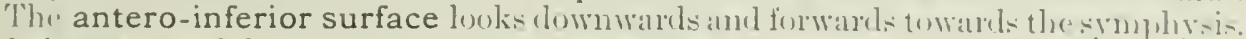

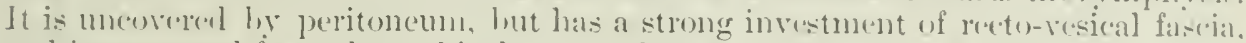
and is separated from the pubic bones and anterior attachments of the oldeturatores interni and levatores ani hy a space known as the cavum Retzii, which contains at

Fig. 617.-Menuax SAgittal, Sectios of tule Male Pelvis.

(From a preparation in the Musemm of St. Thomas's Hospital.

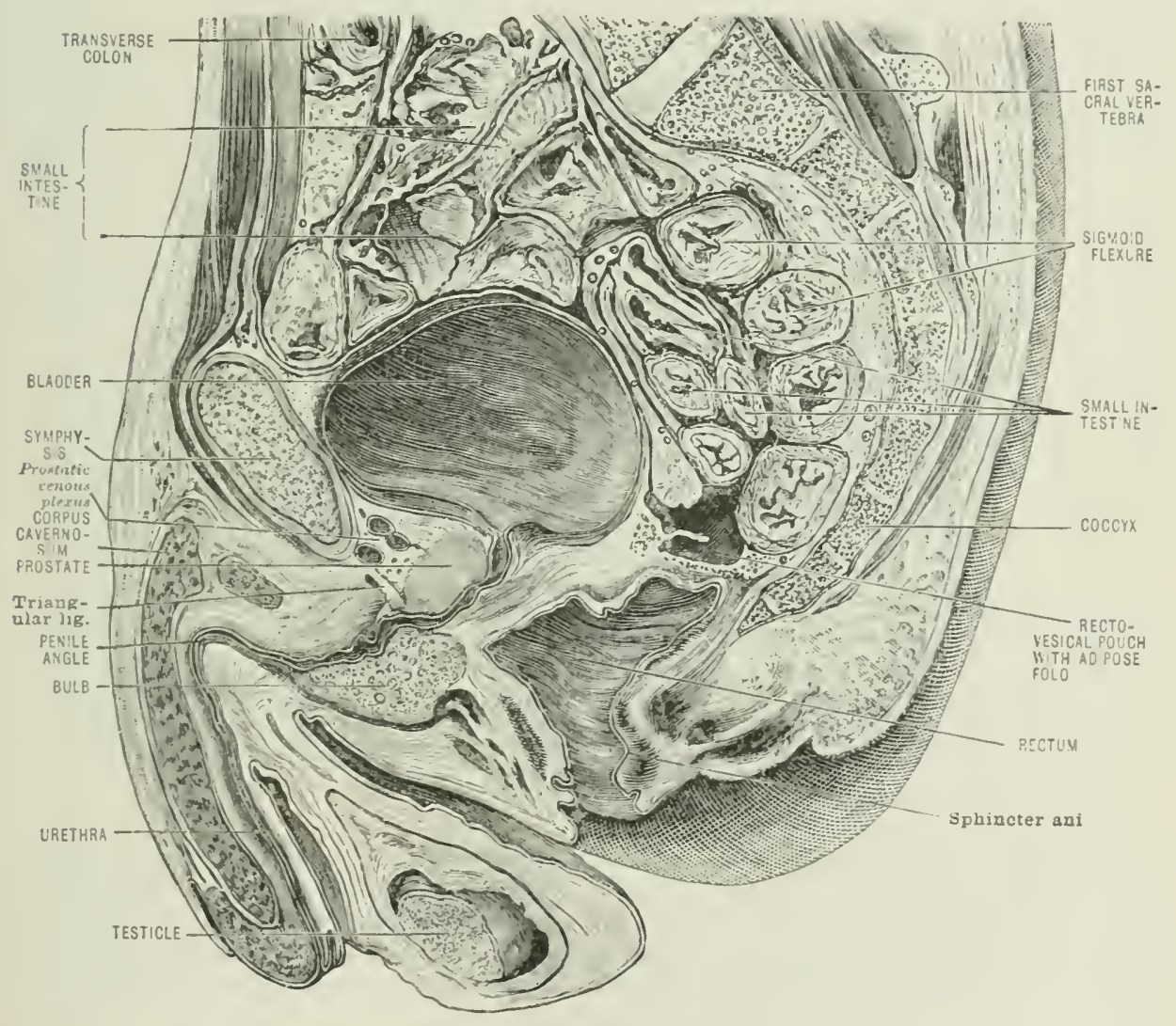

rariable quantity of lonse fat continuous with the pelvic and ahdominal suliperi-

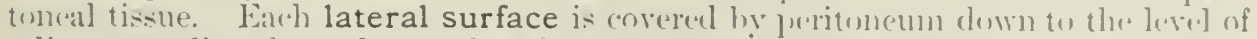

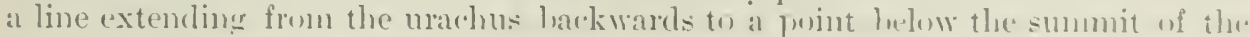

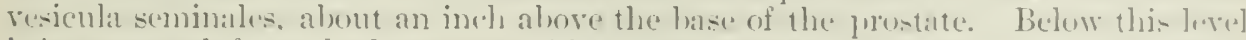

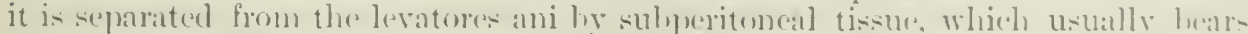

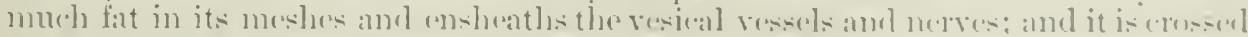

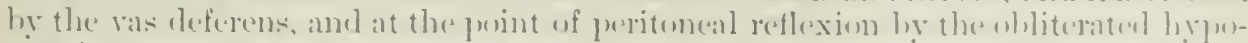

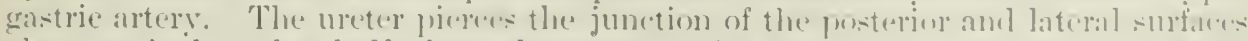

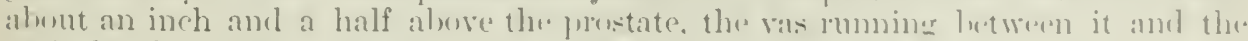

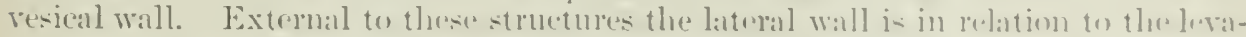
tor ani and the uldurater internus. The posterior surface maly lue divicled intes

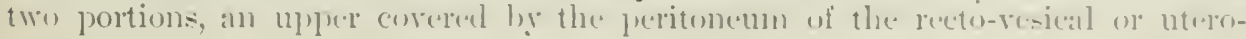


vesiend pouch, a lower in direet contact with the anterior wall of the rectum, and the lower part of the rasa deferentia and resicule seninales. The distance of the

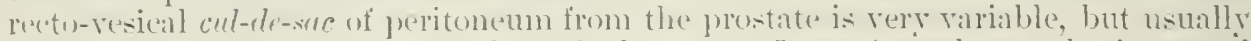

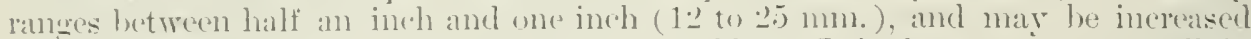
to two inches (.) (.n1.) he distension of the hlachler. It is, howerer, very small in the child. The ureters where they lie at the onter linits of this surface ane near to

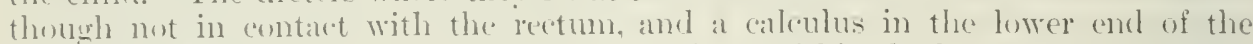
urinary tulu might be folt he an explubation from within the howe. In the lower gertion of the posterion wall in the male is a triangular space, the sides of which alre formed by the diverging rasid deferentia, the base by the line of reflexion of the recto-rosical pouch of peritoneum, and the apex by the meeting of the ejaculatory ducts at the summit of the prostate. It was formerly selected as the position for the intrudiction of a trocar through the rectum into the bladker in cases of retenttion of urine. In the femule the posterior surfaee is atherent below to the exrix uteri and upper part of the anterior wall of the ragina, lout is separated ahore from the bexty of the utrus he a shallow utero-resical pouch of peritonem.

The superior surface is entirely coverel with peritonemm. It looks alunot directly upwards inte the ahdominal carvity, and lies in contact with the small intestines, and sometimes with a portion of the sionoid colon behind there.

Effects of distension. - When the bladker becomes excessively full it rises alose the level of the smphrsis, and in certain chronic conditions of retention maly eren mount as high as the mmbilicus. During the process of distension the anterior wall curries upwarls the peritoneal fold reflected on to its upper surface. This elevation is, howerer. rariable and limitel in extent; at its naximmm it soldme exceeds two inches ( $5 \mathrm{~cm}$.), and in some instances fails even to pass the upper lorker of the srmplysis. hence there is some danger in tapping the blather above the pubes, unless the part is exposed by a careful dissection. In recent rears Garson and Pietersen have demonstrated that the introduction into the rectum of a hag of suitalle dimensions filled with air or water pushes forwart the expanded riscus and may still further increase the arailable space for surgical n)eration, but it clocs not ansure the eleration of the peritoneal fold above the simphrsis.

The relation of the internal urinary meatus to the pelvic wall has become a subjoct of interest since the revival of suprapulic operations upon the bladder. As a rule it lies at some print op mosite the upper half of the symphrsis, but in great distension of the viscus (see Pïdinger, plate 3 ) it may descend to a lower level. On the other hand, in rome chitdren it usually reaches the level of the mper lorrter of the symplysis, and in old persons with prostatic disease it may rise eren above this point. In the male adult it lies from three-quarters of an inch to an inch (2 (m. to 2.5 ('m. ) luhind the symphysis, and about two or two and a half inches ( 5 ('m.) alwe the perinceum.

Structure.-The blatilex mall is composed mainly of unstriped museular filme. invested externally he a layer of recto-vesical fascia and a partial covering of pritoneum, and lined with mucous membrane and submucous tissuc. Its thickness raries greatly in different subjects and in the same subject under different comblitions of clistonsion. It is estimated at about an eighth of an inch when moderately stretrherl, hut may reach half an inch or exen more when completely emitracted. It is somewhat thicker at the trigone.

The arrungement of the peritoneum over the superior. lateral. and posterior walls has been deweribed. and it only remains to mention that its reflexions orer the marhus alowe, and from the sides and back of the bladder below, form the superior, lateral, and josterior false ligaments. The recto-vesical fascia is a well-rlereloped layel of tissue orer the lower part of the viscus. but is greatly attenuated above. It is continuous helow with the eapsule of the prostate, anil pasises on to the pubic bones in front of the lattex organ in the fom of a double foll called the pubo-prostatic or anterior true ligaments, and npon the levator ani at the sirles, where it leflexions are temer the lateral true ligaments, while the urachus alove represents a superior ligament. These tratitional names, howerer, are misteacting and have no practical value. The muscular coat is composed of unstriped fibres, which may be livided roughly into three layers, an 


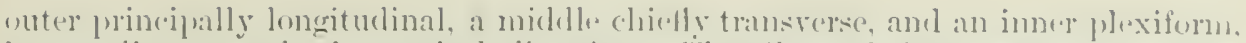

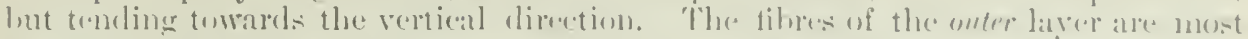

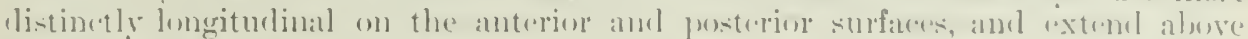

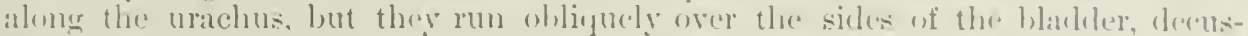

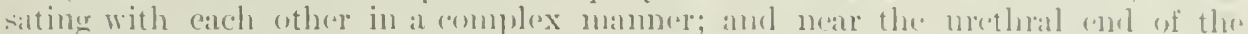

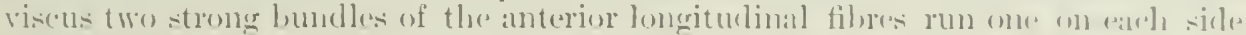
of the milllle line in front of the anterior wall of the prestate and beneath the

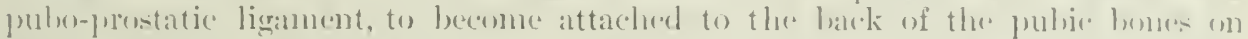
arkh sille of the symphysis (vesico-pubic muscle). 'The lower tiheres of the

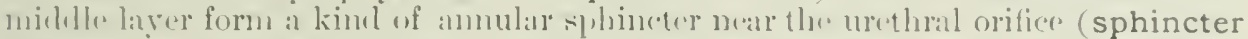

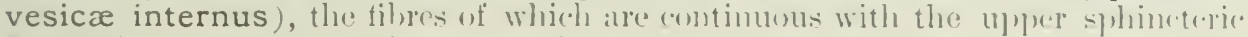

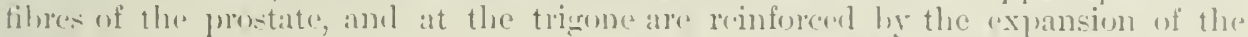

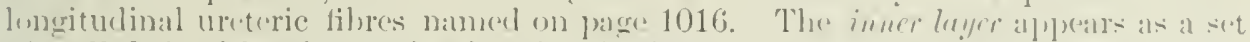
of well-elefined bands rmming in a longiturlinal direction and communieating with

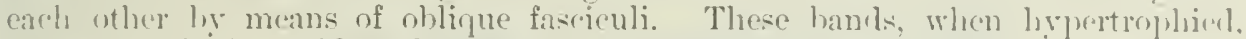

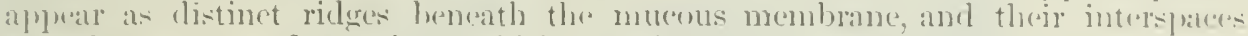
may be secen as depressions which ocalsionally develop inte direrticula. It the trienene, the inner layer is strengthened hy the radiation of the ureterie filores.

The rather course meshwork formed by the decussating musculiu bundles is apte

Fig. 618. - The Posterior Wall of tile Bhainer. (Aiter Henle.)

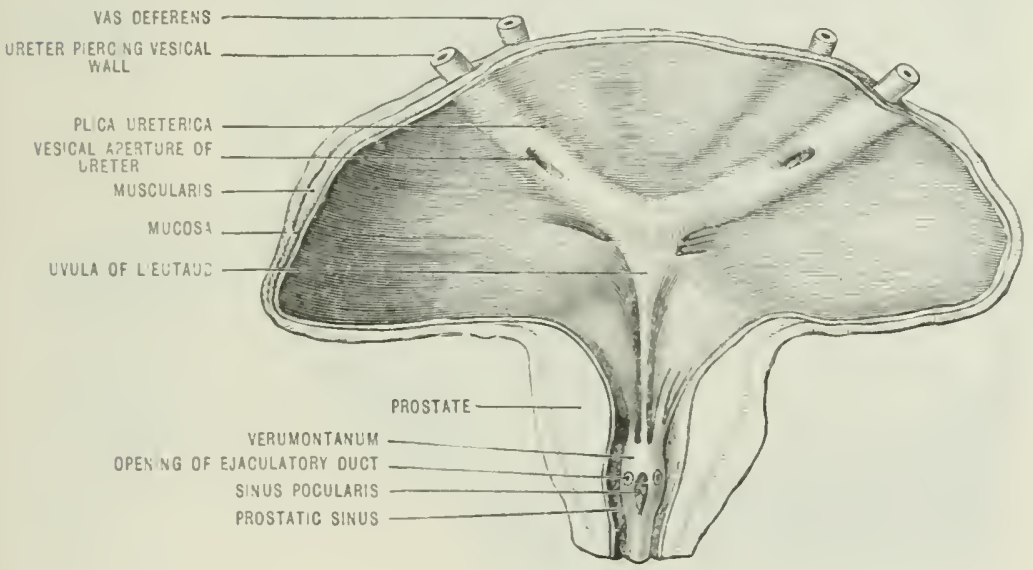

to fresent weak points througly which the mueous membrane may protrude as diverticular sacculations, sumctime of consirlerable size and capalile of loweriner calculen: coneretions. On the other hand, when the muscular tisisue becomes

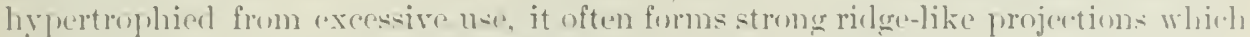
may grive rise to leceptive inpressions during exploration of the cavity with the souml.

The submucous coat consists of a hiorlyly elastic comnective tistue deroid of musular filires.

The mucous membrane is smontl, soft, and reso-coloured during life. In the

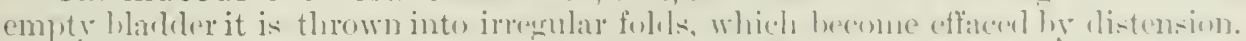
It is molition justeriorly over a triangular area called the Trigone of Lieutaud (fig. 61s), the three angles of which lieat the intrenal meatus and the two ureteric orifiecs, and are at a distance from each other of three-pularters of an inch to an inch (19 to $25 \mathrm{~mm}$.). This region, which lies oppreite to the

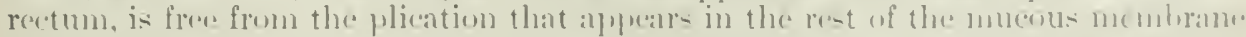

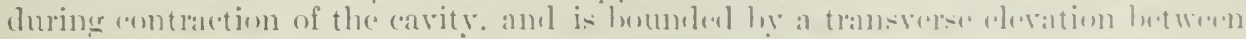

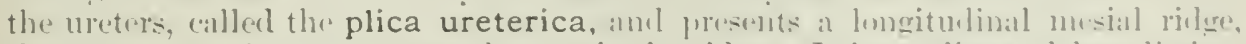

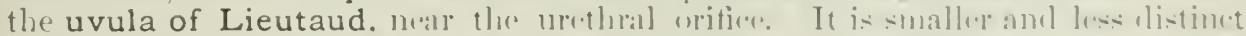

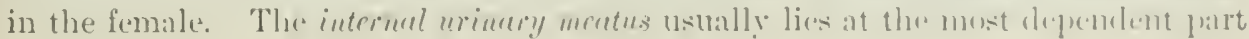


of the badeler, but in morbid conditions of the prostate the borders of the aperture may be considerably elevated above the adjacent resical zone.

The female bladder (fig. (i1!) presents no peeuliarities of importance, excejt that its frontal cliameter is usually increased at the expense of the sagittal dianeter, partly in conseplence of the ereater wilth of the pelvis, and partly owing to the presenee of the ragina and uterus, which encroach upon the space in the middle linc. Lateral asmmetry is very eommon. Furthermore, the symphysis being of lesselepth than in the male, the minary orifice lies nearer its lower border.

In the infant the blaker is said to be an alulominal organ, but this is not strictly accurate. The relatively small prelvic cavity at this period of life is oceupied mainly by the rectum, and there is litte rom for the blatkler, which bence rises

Fig. 619.-Liemox of the Female Pelvis. (After Henle.)

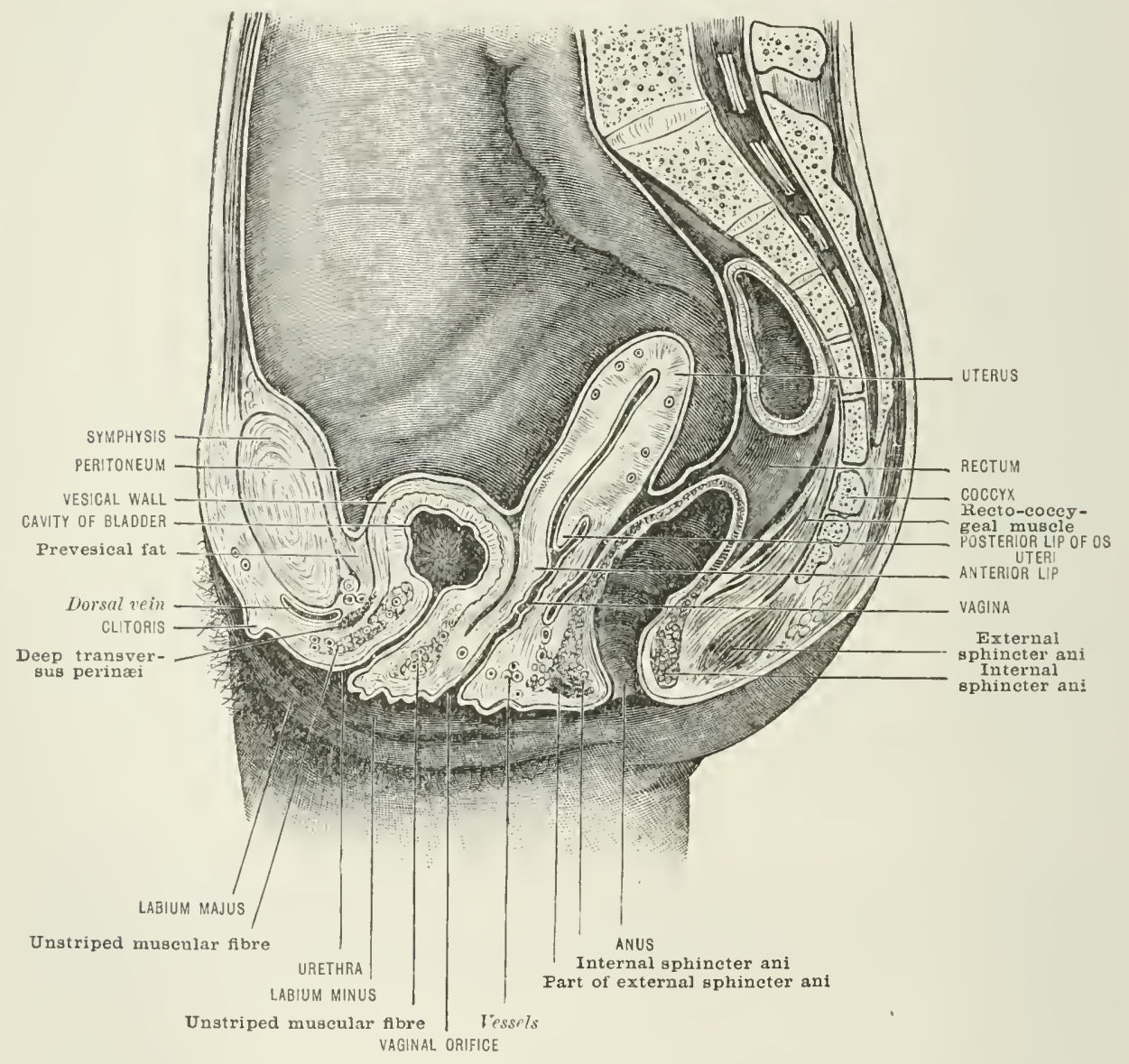

into the abdomen even in molerate degrees of distension; but, as pointed out by symingtom, if a line be drawn from the sacral promontory to the top of the symphysis, fully one-half of the bladder will be found to lie below it, and hence within the pelvis. The intemal meatus, however, is hehind the upper margin of the symphysis, and the whole organ is hener above the horizontal level of the pubic rests. This relation gradually changes from the period at which independent locomotion legins, till, hy the age of six, when the pelvie wall has grown up around the viscus, the position does not differmaterially from that in the adult. It should also be moted that the recto-vesical fold of prritoneum extends in infancy nearly as low as the base of the prostate.

Vessels. - The arteries of the bladder are derived from the internal iliate and 
internal purdic, and in the female somse twiess are also given off by the uterine amel vaginal alteries. The veins terminate in the internal iliar trunk. They form

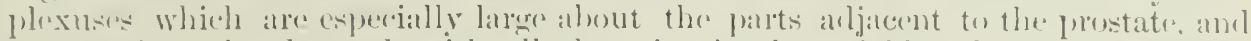

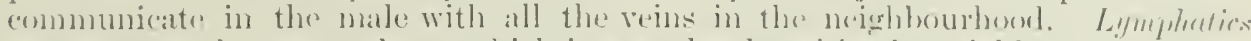

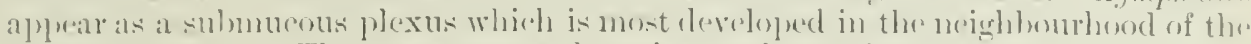
internal meatus. They aceompany the wins and terminate in the intermal ilia. grlands.

Nerves.-The nerves anderiver, party foum the srmpathetie system through

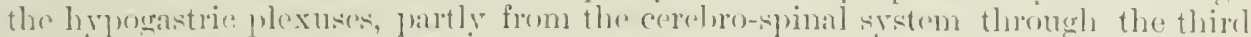
amel fouth sacral nerves. The former supply the mueosil, the latter the muscularis.

\section{THE THLE FEPRODLCTITE ORGATS}

The reproductive organs of the male consist of (1) two testicles or seminal

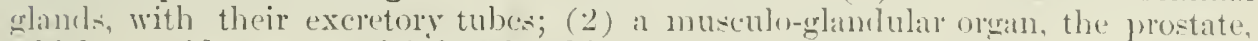
which provides a material for the dilution of the semen, and he its sphincterie contraction aids in the cjaculation of the spermatic fluid, and at the same time interepts its retrograde passage into the hladder; (3) an organ of copulation, the penis; and (1) a canal, the urethra, which pieres the prostate and penis, and serves for the transit of both the generative and urinary sceretions.

\section{THE PROSTATE}

The prostate is a firm dastic and contractile orean, lying between the bladder and the penis, and perforater by the urethra (fics. 620 , $62+$, and 649 ). It is lomphly comprabable to a horse-chestnut in form and dimensions; its broader axtrmity or hase lies uppermost and blends with the vesical splineter, while its apex rests against the superior triangular ligament. Its long axis is rertical (in the erect pusture), or inclines slightly forwards helow (fig. 617), and is nearly an inch and a (quarter (3 cm.) in length. Its transverse diancter, greatest near the liatse, measures about an inch and a half, and its antere-posterior diameter about an inch. Its arerage weight is about six drachus, nearly the same as that of the testicle, and it may be noted that the active evolution of the two organs begins at the same period, at puberty, and that the structural and functional ilevelopment of the one is intimately associated with that of the other during the period of sexual vigor: It offer's for description a base, an apex, and anterior, lateral, and posterior walls. The base is connecter with the musculature of the hiachler. receiving the attachuent of the longitudinal fibres and suromeling the sphineterie portion of the cireular layer at the urethral orifies. It usually lies a little almore thes level of the millle of the symplosis. The apex, resting against the suprior or lecp triangular ligament, is from one-half to three-fourths of an inch (12 to 18 mm.) behind and a little helow the sulppubic angle, and on rectal explorition will lw. found about an inch and a yuater above the margin of the anus. The anterior wall is rounderl, and is eovered by the prostatic plexus of veins and the verionpulic musele and pubo-prostatic ligamento (page 101s). The lateral walls an in contact with the immere borders of the two levatores ani museles and the marcrinal portion of the vemous plexus, and project almo and behind in the form of illdefinerl lateral lobes, which may be lonked upon as the jusistont indication of

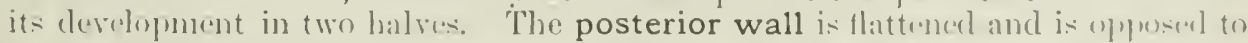
the rectum, from which it is separaterl by some fonnective tiscur and unstriped museular fibres continuous with the subpritoneal tissur and pelve fiscia. Vear its

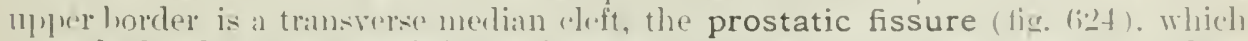

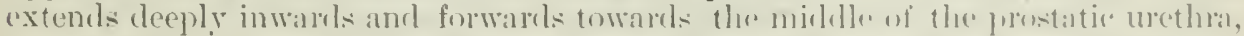
tramsmitting the eommon ejaculatory ducts and the sinus porularis, and in section 
(fig 620 ) appearing as the posterior and inferior houndary of a portion of the substance of the organ, the ser-called 'middle lobe.'

An irexular artery, nsually derived from the internal iliac trunk. is sometimes fomme ruming by the sicle of the prostate to reach the dorsum of the penis, and maly be the somere of langerous hamorrhage in lateral lithotomy. It replaces one or inore of the terminal hamelnes of the internal purlic.

Structure and function. - The prostate is invested hy a fibro-muscular capsule, derivel from the rexto-vesical segment of the pelvie fascia, mstripeel muscle existing in largest proportion orer its rectal aspect, between the opposed borters of the levatores ani. The organ itself is composed of muscular and glandular tissue. The muscular element, comprising both striped and mstriped filnes, represents about one-half of the ontire mass. The unstriped fibres embrace the vesieal spluincter alore, forming with this a ring of great firmmess and strength above the urethral orifices of the cjaculatory sucts, and discharging in all probahility the function of interepting the backward flow of the semen and prostatic fluid into the bladeler during sexual (ongress; betow this point, the muscle is intermingled with gland tisise and striated fihres. The striped fibres lie chiefly in the anterior wall of the

Fig. 620.-SEmi-digramuatic Section of tine Male Pelis.

' MIOOLE LOBE' OF PROSTATE ABOVE THE PROSTATIC FISSURE

SINUS POCULARIS IN PROSTATIC FISSURE VASA OEFERENTIA AND VESICULEE SEMINALES

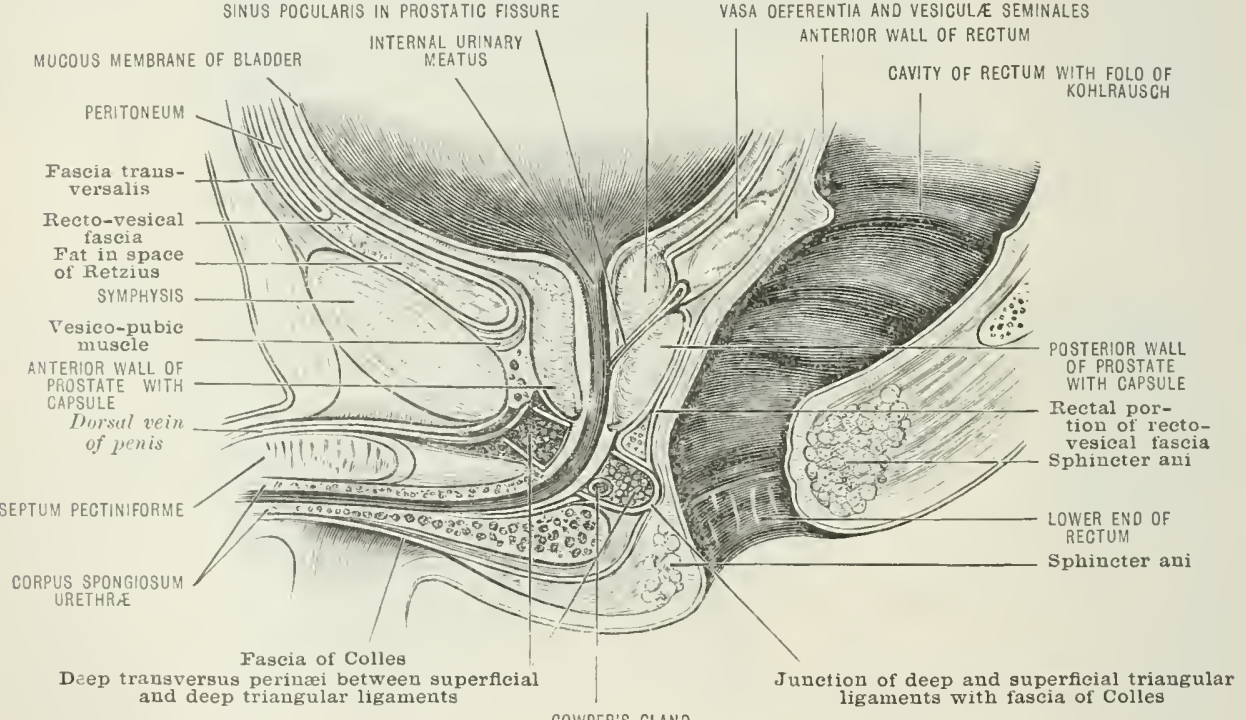

COWPER'S GLAND

ligaments with fascia of Colles

prostatr. but completely meirele the apex of the organ, and are there probably commected with the dexp transversus perinai. The musenlar fibres of both kinds below the ejaculatory clucts undoubtedly initiate the forwarl propulsion of the mingled prostatic and sominal secretions; the ajaculation being further aided by the contration of the deep transversus perintei, and bulbo-cavernosi.

The glands are of the limehed tubular type, and lie ehiefly in the posterior and lateral parts of the orean, their lucts opening into the mrethal recesses (prostatic sinuses ) by the sides of the vermontanum. They serrete a mucus, the prineipal use of which is to dilute and give bulk to the semen, and they are sometimes the seat of pathological coneretions. In addition to the true glands are seen a number of simple follicles in the anterior wall of the prostatic urethra, probally of the sime nature as the rost of the urethal follirles. The prostatic urethra will be described hereafter (jage 1037).

The organ is essentially generative, but serves also to reinforce the vesical sphincter, although its ahsene in the female and its intperfort development in children and runmehs appear to contail no defect in the eontrol of the blarkler. The mmsenlar fibres are, howerer, to some extent represented in the female (page 1042). 
Vessels and Nerves. -The arteries of the prostate ariwe from the aljarent

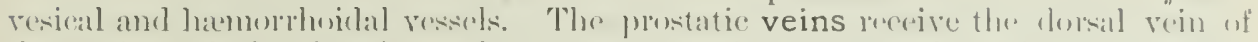
the protis, and after forming a plexus (plexus of Santorini) inveting the anterion and a pertion of the lateral surfaces, terminate in the aljacent resianl verins. The. lymphatics end in the pelvic glands, and a small wland may sometimes lo fonmel on each side nur' the base of the orgall. 'The nerves ate derivel from the hyperastric plexus.

\section{TIE TETTCLE AND TIEIR APPENDAGE AND (ONERINGS}

The two testicles lie in a common pouch of integument called the scrotum, and earle organ is invested in acklition by a series of coverings which join in the mieldle line to form a septum scroti. There are three frincipal larers: an onter (the

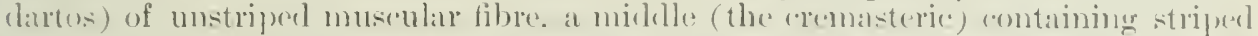

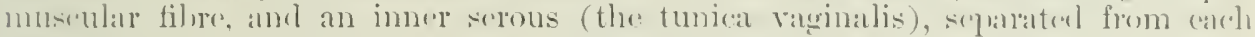
other hy layers of comnective tissue. The coverings (fig. (i21), namerl frome withont

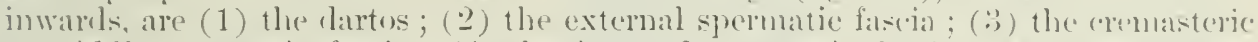

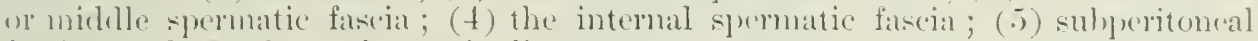
filsia ; and (b) the tunica vaginalis.

Fig. 621. - Holizontal section of the Scrotuy axp Testicle. (Diagrammatic.)

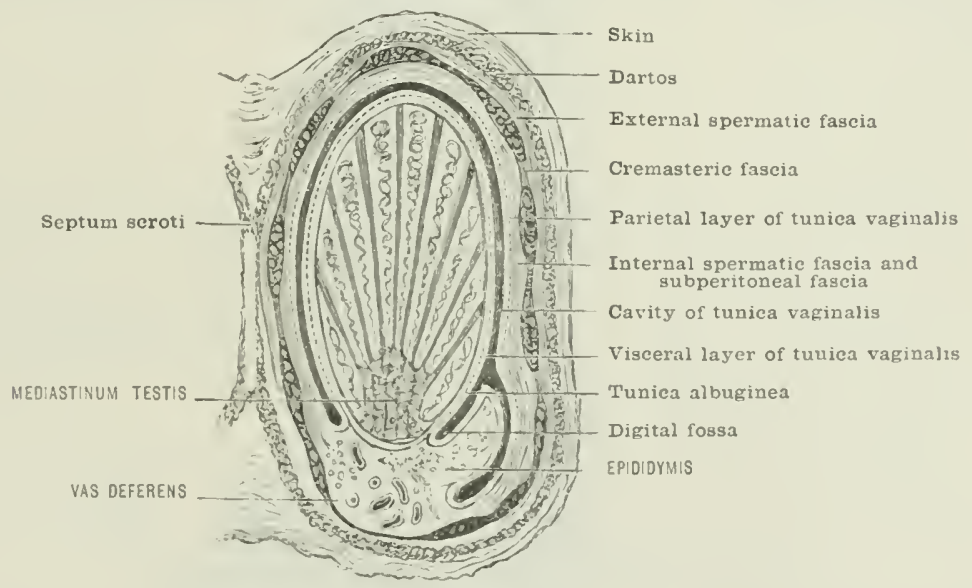

THE SCROTUM.-The scrotal integument is more or ] iss pinmentenl. and anered in the alult with coarse, seattered hairs, and provided with strengly derel-

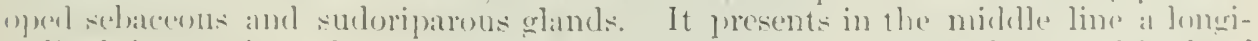
turlinal innpresion, the raphé, from which start on either side a multiturle of

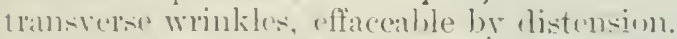

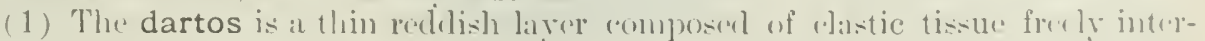

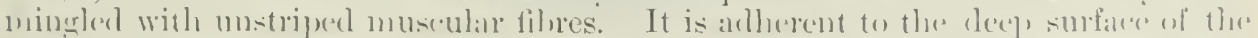

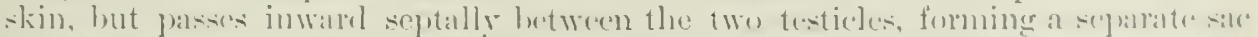

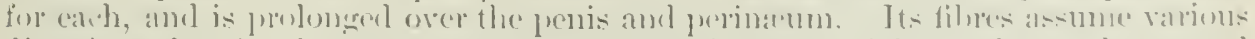

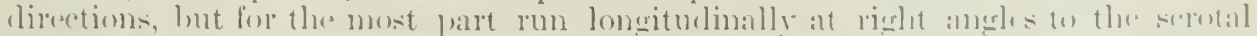

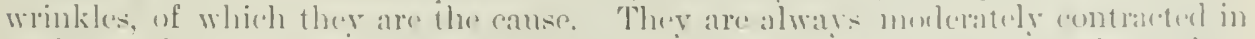

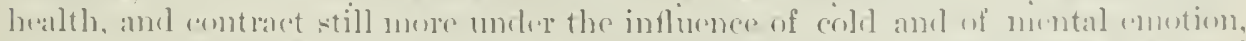

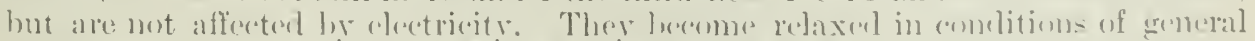

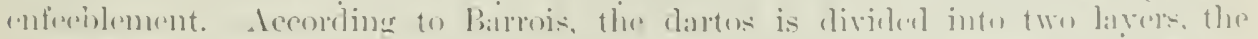

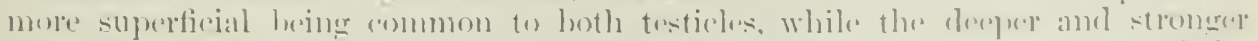
forms a separate investment for cath testiele and assi-ts in the formation of the (s.ptum seroti.

(2) 'The external spermatic or "intercolumnar' fascia comsints of a fatlus.

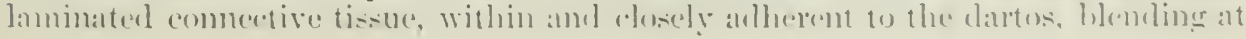


the external inguinal opening with the strong fibous bands crossing the columns of the ring, and prolonged, like the diutos, orer the penis and perineun. It is continums belnind with the deep laver of the superficial perinaal fascial, and above with the superficial fascia orer the symphysis.

(3) 'The cremasteric or middle spermatic fascia is a well-clefined filmo-muscular expansion copering the cord and testicle. It consists of a strong double lamina of areolar and elastic tissue enclosing and comnecting longitudinal bundles of striper muscle, the fibres of which may be traced above to the external inguinal ring, where they are divided into two principal sets: an inner (often absent), attached to the pubic sine and an outer clerived from the lower border of the internal ohlique. and aring from Poupart's ligament opposite the ingunal ring. Below. the tunic hlends with the dartes opposite the lower extremity of the testicle. The cremaster contracts during convulsive expiratory actions of the ablominal muscles and under emotional influences.

(4) 'The internal spermatic or 'infundibuliform' fascia is a delicate connective tissue derived from the fascia transversali:

(5) The subperitomeal fascia beneath the last, and more or less blended with it, is a laminated prolongation of the subperitoneal tissue elosely investing the dements of the cord and testicle. It contains elastic fibres, adipose tissue, and mstriper muscular elements, and is the seat of the fatty tumors of the cord which oceasionally simulate inguinal hernia. The museular fibres form a longitudinally directed hayer on the deep aspert of the enmectire-tissue fibres, and are called 'middle cremaster' by Klem and Barrois to distinguish them from the 'external cremaster' of striped fibres and the 'internal cremaster' described in comnection with the cord.

(6) The tunica vaginalis, a serous investment of the testicle, is described below.

Vessels and Nerves.-The skin and dartos are supplied by branches of the external pudic and superficial perinæal arteries, while the cremaster, the internal spermatic fascia, the subperitoneal fascia, and the visceral layer of the tumica raginalis receive a special branch from the decp epigastric; the corresponding veins communicate with the pudic, the long saphenons, and the dorsal vein of the penis. The lymphatics teminate in the innermost set of the ingminal glands the lymphatics of the testicle itself passing to the lumbar glands). The nerves are derived from the genito-crural and superticial perinas.

THE TESTICLES.-The testicles (tig. 622), two in number, are suspended from the inguinal region by the spermatic eords. The left is supposed to hang somewhat lower than the right in the majority of persons. Each gland consists of two portions, the testicle proper and the epididymis. Its weight as a whole arerages between five and six drachms, rarely attaining the maximum of an ounce; it is about an inch and a half $(4 \mathrm{~cm}$.) in length. an inch and a quarter $(3 \mathrm{~cm}$.) in depth (from the anterior to the posterior border), and somewhat less than an inch (2.2 $\mathrm{mmn}$.) in thickness. It is so suspended in the scrotum that its upper extremity inclines a little more forward than the lower, and its inner surface is turned slightly forwards as well as inwards.

The Testicle proper is shaped somewhat like a kidney bean; it is elongated from above downwark, and thattened from side to side. Its surface is smooth and white, and is covered by the risceral layer of the tunica vaginalis, except where it is in contact with the epididymis.

The Epididymis is adlerent to the posterior and inferior part of the testicle proper and inclines slightly to the outer side. It is enlarged above into a head or globus major, ancl helow into a tail or globus minor, the intermediate portion being called the body.

The Tunica Vaginalis is a scrous sac of peritoneal origin, which bears to the testicle a relation similar to that of the serous pericarclium to the heart. It consists of parietal and visceral layers.

The riseral layer is intimately alherent to the testicle proper, and to the globus niljor and outer part of the body of the eprolidymis, and is prolonged wpwats for about half an inch upon the spermatic cord. (On the outer side and above, it extends into a deep depresion, the digital fossa, between the testicle and epididy- 
mis; but it leaves uncovered nearly the whole of the grobus minor and the internal and posteriof surfices of the borly of the "pididymis, and it is in these situations that an important vascular communication is established between the gland and its coverings.

The parietal layer, eontinumus with the visceral layer at the posterior and inferion parts of the testicle and at the point of reflexion from the spermatic eord, beemes loosely attached to the internal spermatic fascial by neans of a prolongation of th. abdoninal subperitoneal tissuc. It contaius a number of unstriped musenlar fibres rumning hongitudinally and continuous with the intrunal eremaster. [nder normal onditions, the two seroms layers an in contact, the serous fluid being secreted only in sufleient quantity to moisten the opposed surfaces. An undur increase of the amount constitutes the disease known as raginal hydrocele.

Fig. 622.-The Left Testicie with Vessels and Duct. (After Sappey.)

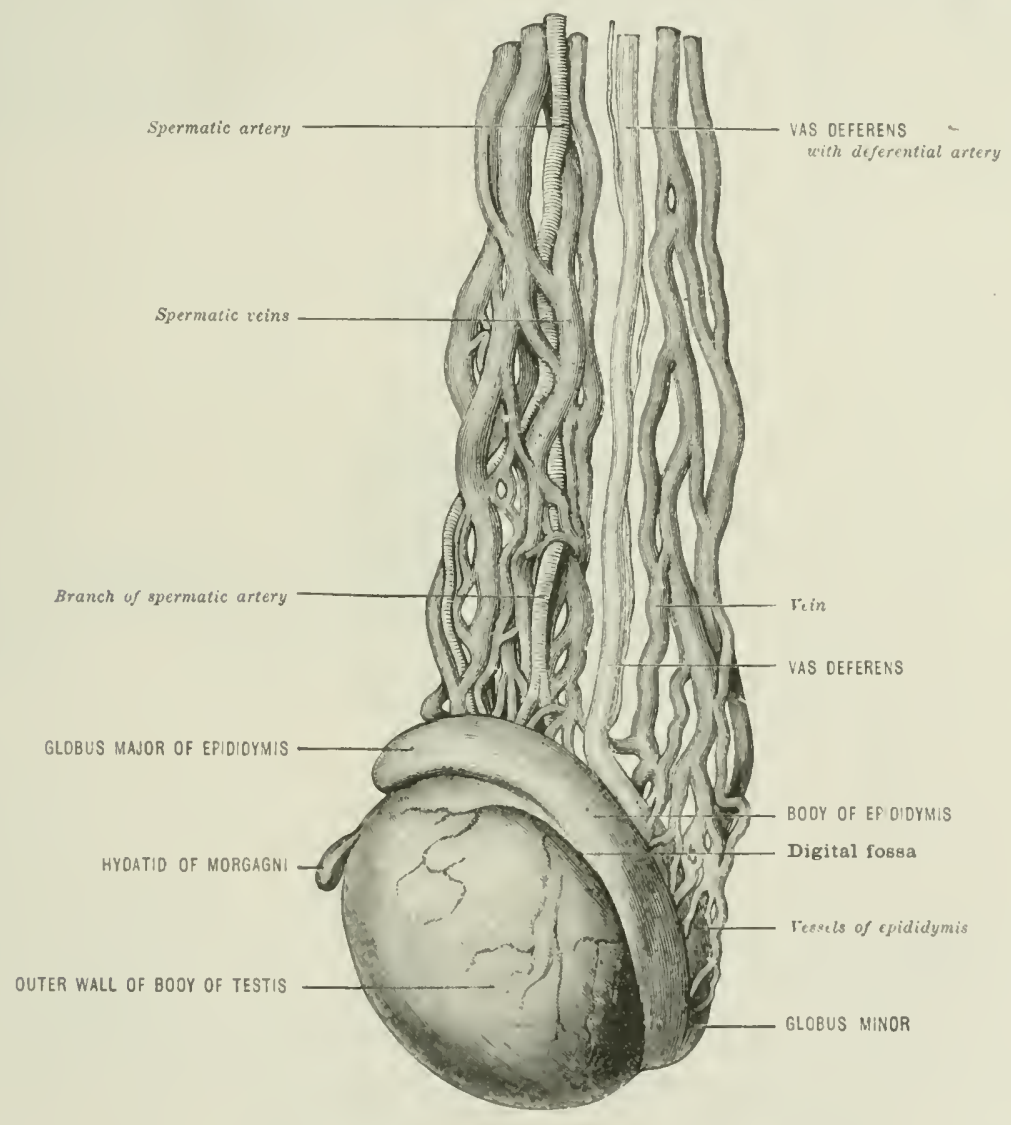

The testicle is occasionally so rotated upon its long axis that the efididymis beeomes turned towards the front of the scrotum. In this case. Wrere a hridrocele to occur, the sac would projert posteriorly. The side to which a detached testicle belongs may be distinguished hy remembering that the avididrmis is attacherl behind, and that the rligital forsia if the tumien vangalis lies on the onter side.

In order to understand the relations of the crean to arljacent struetures it is necessary to learn something of the mechanism of it: lescent. The testicle is at first an abelominal organ lying below the kidney and invested hy a layer of peritonem (mesorchium) which is fimly adherent to its surface in front and at the sides. It is, moreover, connected ly hundles of unstriperl muscular fibres. thr gubernaculum testis, with the pillars of the external inguinal ring and with the dartos at the 
bottom of the scrotum. It bexins to descend in the early part of the third month of foetal life, leaching the internal inguinal ring in the sixth month. It then passes obliquely through the strurtures of the aldeminal wall, preceded hy a pouch of peritunem and pushing hefore it, in suceession, the subpreritoncal tissue, an infunclibuliform prolongation of the fascia tramsersalis, a few fibers of the internal oblique (which form part of the extemal (remaster), and the intercohmmar fascia, which braces together the pillars of the external inguinal ring. At the eighth month it aplears at the external ring, and reaches the bottom of the scrotmm shortly before hirth.

The cause of this migration is still uncertain. The theory usually adopted is that the elescent is effocted partly by the derelopment of the pelvic and lumbar regions which smw upwards, and in a mamner leare the testicle, fixed by the gubernaculum, behind. This accounts for the change of position to the level of the inguinal canal, but the mechanism of the further descent into the scrotum is unknown. It was fomerly attributed to the progressive shortening of the gubernaculum, and in accordance with this view, the mostriped muscular fibres comnecting the bottom of the gland with the serotum are regarded as the remains of the central and principal gubernacular hand, while the lateral bands, ceasing to act after the testicle has reached the external ring, are drawn down into the scrotum and appenr as scattered groups of fibres, the internal cremaster of Henle, lying around the elements of the spermatic cord (fig. 626).

In certain individuals, the descent of one or both testicles into the scrotum is intercepted, and cryptorchism results. This condition is nomal in certain animals (elephants, cetacea, etc.), but in man is always associated with defective evolution of the organ, and consequent suppression of function.

The peritoneal sac carried with the testicle is at first continuous with the abdoninal peritonemm. In most eases the tube of communication gradually narrows, and at length, within a few days after birth, hecomes entirely closed. Sometines, howerer, the process of obliteration is more or less incomplete. should it fail altogether, a portion of the aldominal riscera may pass into the tunica raginalis, and constitute the congenital variety of inguinal hernia; or peritoncal fluid may accumulate in the testicular sac and form a congenital hydrocele. Nore frequently the continuity of the tumica vaginalis with the peritoneum is interrupted; but a slender jouch of peritonem, the processus vaginalis, may rum into the inguinal canal, and even through the extemal ring into the cord, or the tumica raginalis may be prolonged upwards upon the cord for a considerable ristance.

Should any portion of the abdominal contents enter the procesus vaginalis, it may pass through the inguinal canal as a hernia, and descend into the scrotum. If at the same time the upward extension of the tumica vaginalis be present, the hernia with its sac may pass within it or invaginate it, and a surgeon called mpon to operate in such a case would probably open the tunica vaginalis leefore reaching the peritoneal sac, and thus meet with three layers of serous membrane lefore exposing the extruled intestine. A hernia of this kind is called 'infantile.' Crstic tumors may be formed by the distension of small unolliteratert sements of the funicular portion of the tube, and are alled encysted hychoceles of the cord.

Structure (tig. (i2:3).-The testicle proper consists of a tubular parenchyma enclosed within astrong filnous tumic, the tunica albuginea.

The tunica albuginea (figs. 621,623) is a clense, white, inclastic capsule of about one-twenty-fifth of an inch $(1 \mathrm{~mm}$.) in thickness in the greater part of its extent. but reaching two or three times this admeasurement beneath the epididynis where it forms the mediastinum testis, or Corpus Highmorianum. It is perforatced at its uppere and back part hy the efferent seminal tubes which go to form the gholus major of the eprididymis, and from its inner surfiee pass a number of sustentacular proxesese in the form of throul-like filno-museular filaments and delicate septal planes of comnective tissue, the trabeculæ. The mediastinum

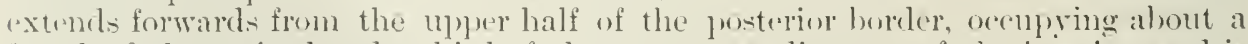
fourth of the sagittal and a thiml of the transverse cliameter of the interior, and is tumnelled by blood-resels and a notwork of seminal tulues (the rete testis). The trabeculæ ratiate from the deep aspert of the mediastinmm to the inner surface 
of the tunica alluginea, and subdivide the interior of the capsule into a number of loculi $(150-200)$.

Within these loculi lie the testicular tubules, supported by a func rotiform connective tissue, which hecomes condensed into a highly vascular lamina rallerl the tunica vasculosa, where it is in contact with the albuginea. The preper secreting sulsstance comsists of fine branching and anastomosing canals. the tubuli seminiferi, about $\frac{1}{12 \pi}$ th of an inch (.2 mm.) in dianeter, and linet with a lisyer of cubical colls in which are develoled the spermatic filments or spermatozoa. The tubules are collected into little bundles, called lobules, about three humdred in mumber, each comprising two or more separate tubes. The number of theses lobules is variously cstimated (300-100), and the total length of the comproment tulules has been calculated roughly at about nine hundred vards. Br the union of the tulueles of the different lobules are formed a number of larger tubes, the tubuli recti, which converge towards the mediastinum, and on entering it loreak up into a plexus, the rete testis; from the rete in turn spring twelve to twenty efferent tuhes, or vasa efferentia, twice or three times as large as the tuluules, and thene, piercing the upper and back part of the albuginea, end in the head of the epididymis (fig. 6203).

The epididymis, representing the second stage in the course of the seminiferous

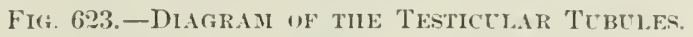

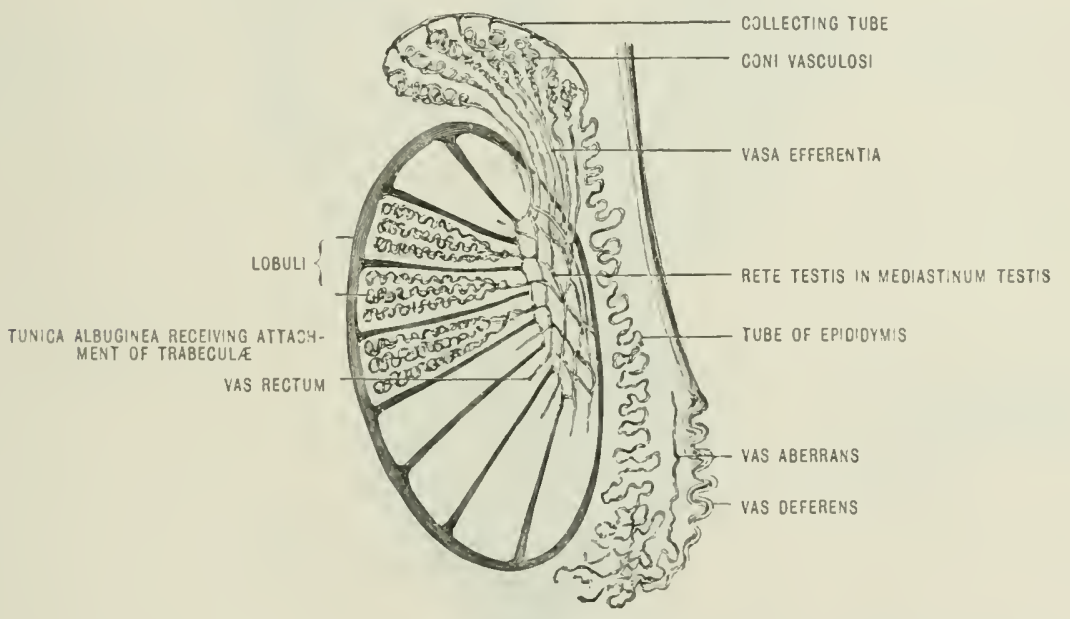

vessels, is invested by a tunica albuginea continuous with that of the testicle proper, but of much greater tenuity. The vasa efferentia, after their escaje from the testicle proper, form each a tulue about six to eight inches in length, lined with ciliated epithelium and coiled in such a mamner as to assume the form of a conical matse, the conus vasculosus, with the apex towards the alhuginea. The coni vasculosi sreuperl togrether constitute the slohus major, and their respectives tubules are collected hy a single anal, the tube of the epididymis, which hy its (omplex coils, fifteen te twenty foet in length, makes up the hody and glohus nuinor of the epielilymis, and finally terminates in the free portion of the iluet, the vas deferens. It presents near its termination one or unere diverticula, the lareret and most constant of which, the vas aberrans of Haller, ranges from an imeh and a half to tifteen inches in length, and rums up hetween the buly of the epielidymis and the emmmencement of the vas deferens. The tuhe of the ejpielielynis, like those of the coni vasculesi, is lined with ciliaterl cpithelium, but its walls are thick, and contain two layers of motrijesl musulat fihres.

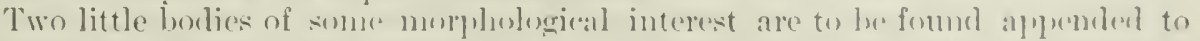

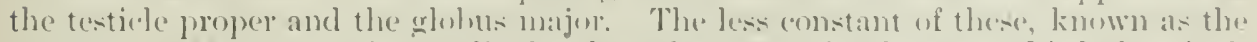
hydatid of Morgagni, is a perdiculaterl sile from (m)e-eighth to olle-thiml of an inch in length, dilated at its free extrenty and containing a clear fluid; the other. 
rarely absent, las about the same dimensions, but is usually sessile and flattened, and inay be sublivided into two or three lobes. It is believed to correspond to the upper end of the Fallopian tube, and to be a relic of the Müllerian duct (page 1057 ), the fortal structure from which are developed the most important parts of the internal genitals of the female.

Another relic, called the paradidymis, or organ of Giraldès, prolnably derived from the Wolftian body (page 1056), is seen over the luwest portion of the spermatic cord immediately above the head of the epididymis. It consists of coiled tubules, blind and dilated at both ends, lying beneath the visceral layer of the funicular portion of the tunica vaginalis. It usually has the appearance of a white or yellowish irregular patch about one-fifth of an inch in dianeter. Any of these embryonic structures may give rise to cystic tumors, and the aberant tubes are probably not an uncommon source of origin of true spermatic cysts containing seminal fluid.

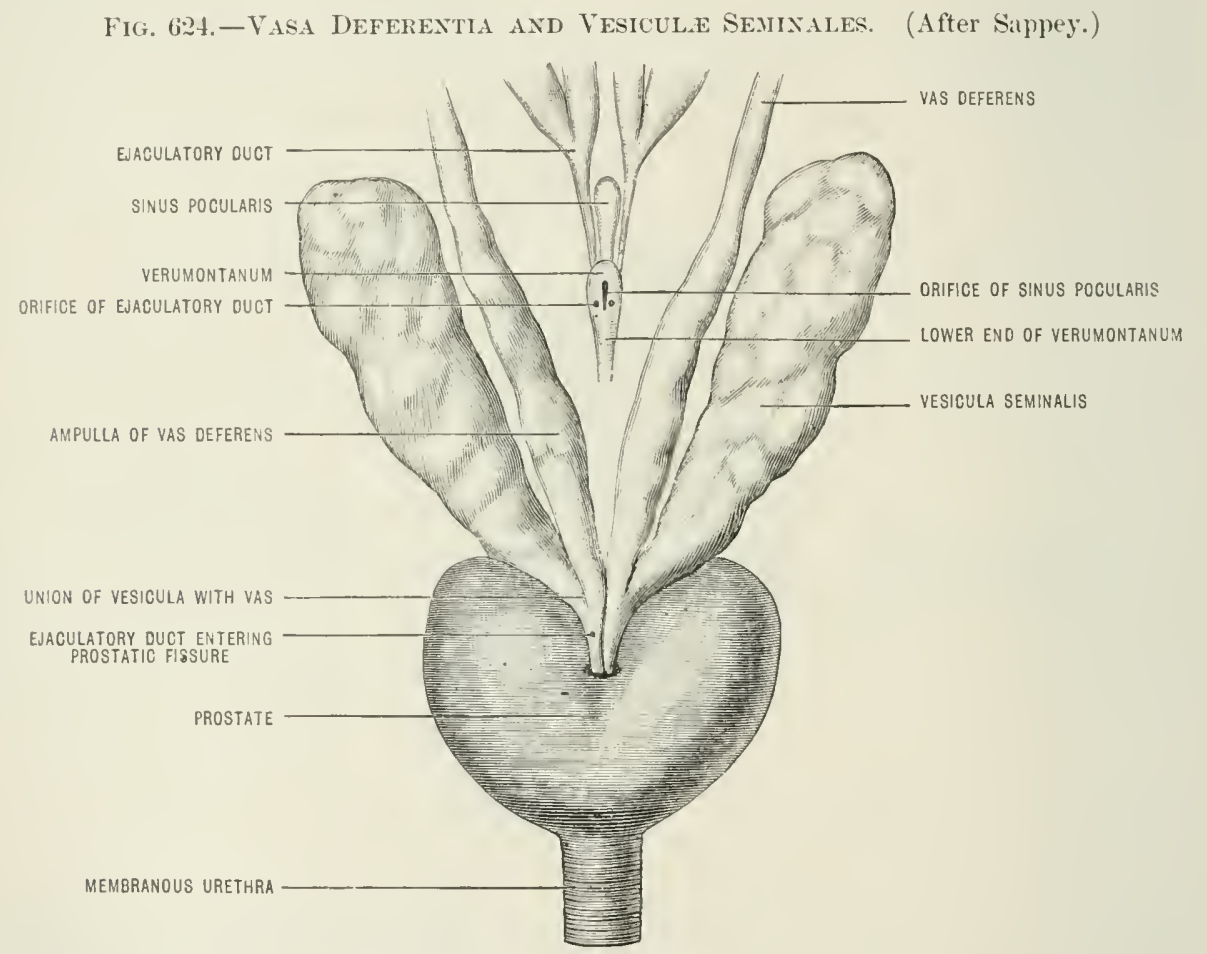

The testicle remains small until the period of puberty, and then, together with the penis and prostate, it begins to undergo rapid development; but in some cases its evolution is arrested before it has attained its full dimensions, and this is particularly liable to occur when its descent into the scrotum has been intercepted, or when a varicose dilatation of its veins appears before adolescence. In old age it usually loses much of its functional activity, but this is not invariably the case.

The VAS DEFERENS is the continuation of the tube of the epidiclymis, and extends from the globus minor to the prostatic portion of the urethra. In the lower part of its course it is slender and tortuous, but it leeomes thicker and straighter as it ascends along the back of the eprididymis (testicular stage), and attains its full size before it reaches the top of the organ. From this point it is the principal element of the spermatic cord, and runs upwards almost rertically as far as the external inguinal ring (fumieular stage); entering the inguinal canal, it runs obliquely outwards, upwards, and slightly backwards to the intemal ring (inguinal stage). It then quits the associated vessels of the cord, and, winding around the origin of the deep epigastric artery to the inner sicle of the external iliac artery and 
in front of the external iliac rein, (nters the pelvis (pelvic stage) close to the iliopubie suture, and runs downwark and backwards over the side of the hladeler, crossing it on the resical sile of the obliterated hypogastric artery and ureter, to rearh the side of the posterior wall of the viseus. Here it lies between the bladeler and the second stage of the rectum, and, becoming enlarged and saceulated, fasses downwarls and inwards towards the base of the prostate, where it narmws and is joined by the lower end of the resicula seminalis. The common tube deserenels ats the ejaculatory duct, to picree the prostatic fissure and ojen into tlie prostatic portion of the urethra. The two vasa deferentia, where they lie in front of the rectum, are separated by a triangular interval, the apex of which is formed by the approxinution of the ejaculatory ducts, and lies imnediately above the prostate. The whole of the pelvic portion of the vas is subperitoneal except near its termination, where it is invested only by reeto-resical fascia and an extension of subperitomeil tissue.

Fig, 625.-Vas Deferexs axd Vesicula simisalis dissected. (After Sippey.)

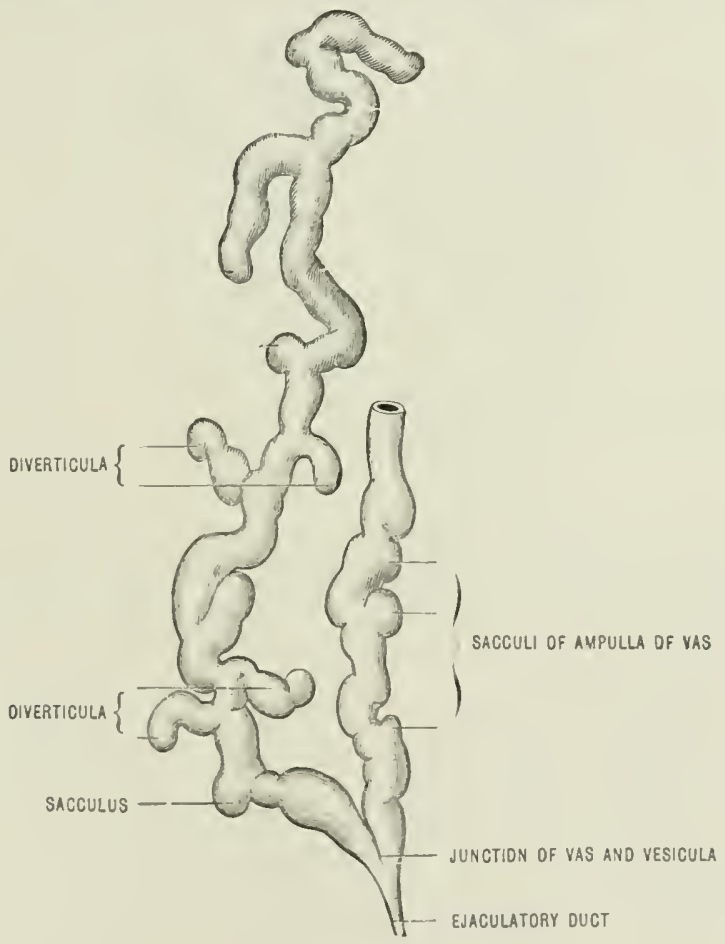

The entire length of the vas deferens arerages about sixteen inches $(40 \mathrm{~cm}$.), of which an inch and a quarter $(3 \mathrm{~cm}$.) may be allotted to the testicular stage, three inches to the funicular stage, an inch and three-guarters to the inguinal stage, and the rest to the pelvic stage. It is cylindrieal and of uniform dianeter (ahout onetenth of an incli) in its funicular, inguinal, and pelvie stages down to the retroresical portion, and its walls are of great thickness, about one-twenty-fifth of an inch $(1 \mathrm{~mm}$. ), while its calibre is extremely small. It is here comprosect of an outer cellular coat containing vesisels and smooth museular fibres, a threefold muscular coat with extcrnal and internal longitudinal and middle cireular lavers, and a mucous membrane lined with eylindrical rpithelium. The ampullated retroresical portion differs from the rest in the thinness of its walls and in its saccollation, and in these resperts approximates to the resiculie sominales (fig. 102.7 ).

The VESICULE SEMINALES are two diverticular reservoirs situated between the bladder and reetum extemal to the ampullat of the vasia deferentia. 
Each vesicula is of somewhat triangular form, its luabd upper extremity lying beneath the peritoneme its apex joining the vas deferens at the hase of the prostate. It averages about two and a quarter inches $(6 \mathrm{~cm}$.) in length and half an inch (12) mm.) in dianeter at its base. It is lobulated on the surface, and on dissection is found to consist of a central tulue from three to five inches $(S-12$ ('m.) ) in length, with two or more short lateral liranches. It is related in fiont to the posterior wall of the blaklder, and hy its upper extrenity orerlaps the ureter; posteriorly it is covered by the recto-vesical punch of peritonemn. for a short distance above; and below this point it lies in direet contact with the front of the rectum, and external to the ampulla of the vas deferens. It beromes comstricted at its junction with the vas. Structurally it consists of a fibrous extermal coat, a michle muscular coat, and an intemal mucous membrane. The muscularis is arranged in three layers, the imeir and outer of which are longitudinal in direction, the intemediate fihres heing transverse.

The mucous memblame is plicated. sacculated. yellowish-brown in colour, and lined with erlindrical epithelium. It is investerl, togrether with the ampulla of the vas, by a kind of sheath of fibrous tissue and hy a layer of smooth muscular filures which is probahly accessory in function to the contractile element of the proper wall of the tubes.

The EJACULATORY DUCT, formed on each side by the union of the ras deferens and resicula seminalis, is an infundibuliform tube about $\frac{3}{4}$ of an inch in length, and about $\frac{1}{s}$ of an inch ( $3 \mathrm{~mm}$.) in wiclth above, narrowing to $\frac{1}{3}$ of that size helow, while the lumen near its opening is not more than $\frac{1}{50}$ of an inch $(0.5 \mathrm{~mm}$.$) in diameter. The two ducts ennerge slightly as they descend, and$ finally, passing behind the so-ealled 'middle lobe' the hinder part of the basal muscular ring of the prostate (page 102.2), pierce the prostatic fissure and open on to the verumontanum on either sile of the orifice of the simms pocularis (fig. 624 ).

Vessels and Nerves of the testicle and its appendages. - The testicle is supplied with blood by the spermatic and deferential arteries, the two ressels anastomosing with each other and with the scrotal arteriss at the lower extremity of the gland. The corresponding veins, spermatic and deferential, form like comimunications and run up in two separate groups. The spermatic reins, large and imperfectly valved, spring from the upper part of the testicle, and, ruming in front of the deferential veins around the spernatic artery, are comnected to each other by means of short transererse hranches; finally, the right ends in the rena cava, the left in the left renal vein. The lymphatics of the vas and testicle acompany the reins. The former temmate in the pelvic iliac glands, the latter in the lumbar glanis.

The free anastomosis between the deferential, spermatic, and scrotal bloodressels explains why the ligature or excision of the spematic veins and artery in varicocele leaves the nutrition of the testicle mimpaired; while the intercommunication of the testicular and scrotal blood and lymph ressels behind the epididymis accounts for the extension of inflammatory affections of the epididymis to the scrotal integument.

The Nerves of the testicle come from the aortic, renal, and hypogastric plexuses.

The resicula seminalis is supplied by the deferential, inferior resical, and middle hamorrhoidal arteries: its veins, large and numerous, form a kind of plexus which receives some of the resical rins, and communicates below and in front with the prostatic plexus: its lymphatics end in the pelvic glands, and the nerves are derived from the hypogastric plexus.

\section{SPERIIATTC CORD}

The spermatic cord is the clongater peelicke of the testicle. It cxtends from the intemal inguinal ring, where its component structures are collected togcther. through the inguinal canal, and into the serotum as far as the summit of the testicle. Its constituent (riments are as follow (fig. 626).

1. The vas deferens, lying with the deferential vessels posterior to the other structures, and recognisible by its cord-like resistance to pressure. 
2. The spermatic artery.

3. The spermatic veins, or jumpiniform plexus, surrounding the artery.

4. Lymphatics running with the reins.

5. Sympathetic nerves accomplanying the artery.

6. The processus vaginalis, oceatsimally seerl ats a thead-like relic of the

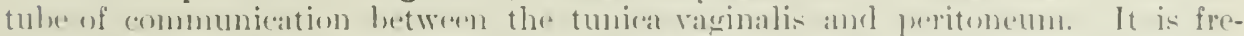
quently patent for a short distance near the internal inguinal ring, and probialily acenusts in great part for the insidions derelopment of hernial protrusions in this rexion.

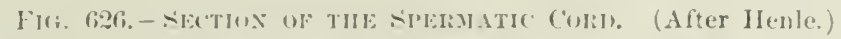

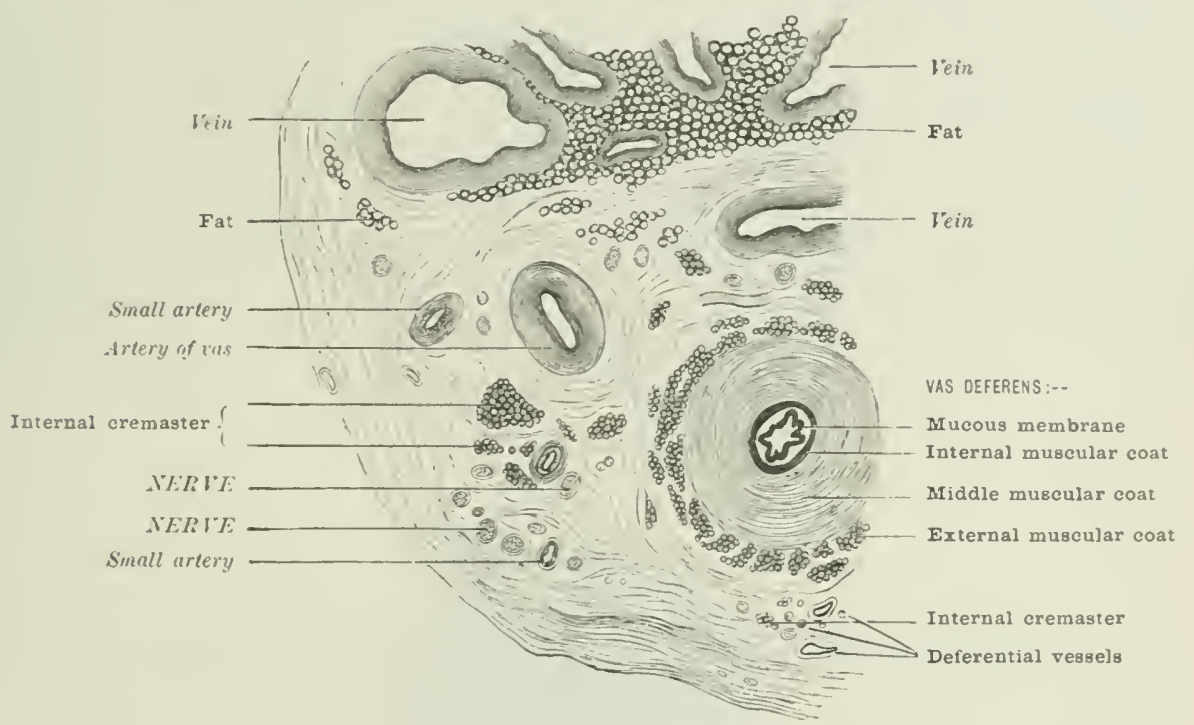

7. The internal cremaster of Henle. Siattered humlles of smooth muscular fibres, sitid to represent the inverted lateral hands of the guhernaculum testis.

$\therefore$ Fat and connective tissue, continuous above with the sulpuritoneal planes of fascia. Inguinal or serotal lipomata or fibromata may take origin from these (') monts and may simulate true hornias.

In the sorotum thes variuls structures are invested by coverings identieal with those of the testicle.

\section{THE PENIS}

The penis is enmposerl of three rod-like segments of erectile tistue, firmly united together and invested hy a sheath comprosel of integmonent, dantos, and fascia (fig. $(i 2)$ ).

Of these three rectile secritents. two, the corpora cavernosa, are placed side by side above or dersally; the thipl, the corpus spongiosum, is perforaterl in the whole length by the unethral canal, and lies on the ventral as jeet of the former, except where it expands distally to form the free end of the orran (fig. fies).

The penis as a whole may he divided into a root. a body, and a terminal enlargement or grans; the root is attached to the sirmphysis and pulice arels: the body, prismatic, with rommloel angles in section. forms the greater part of the free portion of the organ; and the glans is a heart-shapel expansiun. nure (hereleperel in its dorsal than on its rentral aspect, and promenting the urethral wrifice at its distal extremity. The body and grlans are selarated lye a constriction called the neck.

The coverings of the penis are entinumu with those of the testicle. The skin, like that of the scrotum, is pigmented and highly wastice, and unlike the skin 
orer the rest of the body, is deroid of smooth muscular fibres and subcutaneous fat. It contains large sebacenus glands, which in the neighbourhood of the neck of the organ secrete a whitish fatty odourous substance, the smegma præputii. It moves freely upon the subjacent parts except over the glans, where it is firmly adherent. At the neck it becomes peculiarly redundant, and forms a fold, the prepuce, which more or less completely conceals the glans. The deeper layer of the duplicature, which is turned towards and is continuous with the skin of the glans, is sometimes termed 'mucous membrane' which it resembles only in the absence of hairs and sudoriparous glands. A small median plication, the frænum præputii, extends from the prepuce to the lower surface of the glans. This contains ressels of some size, and, if ruptured, may give rise to considerable loss of blood. The preputial orifice is usually large enough to allow the easy retraction of the fold, but sometimes is congenitally constricted, and prevents the exposure of the glans (phimosis). Owing to the composition of the prepuce by two layers of integument, the removal of a complete ring as in the ordinary operation for phimosis impedes the passage of the lymph and blood from the portion left attached to the glans, and hence considerable infiltration of this part may result.

The dartos is continuous with the dartos tissue (page 1023) of the scrotum, and consists of smooth musele, the fibres of which are for the most part disposed longitudinally. It enters into the formation of the prepuce, and according to sappey

Fig. 627.-Traxsierse Section throlgh the Bon of the l'eNis.

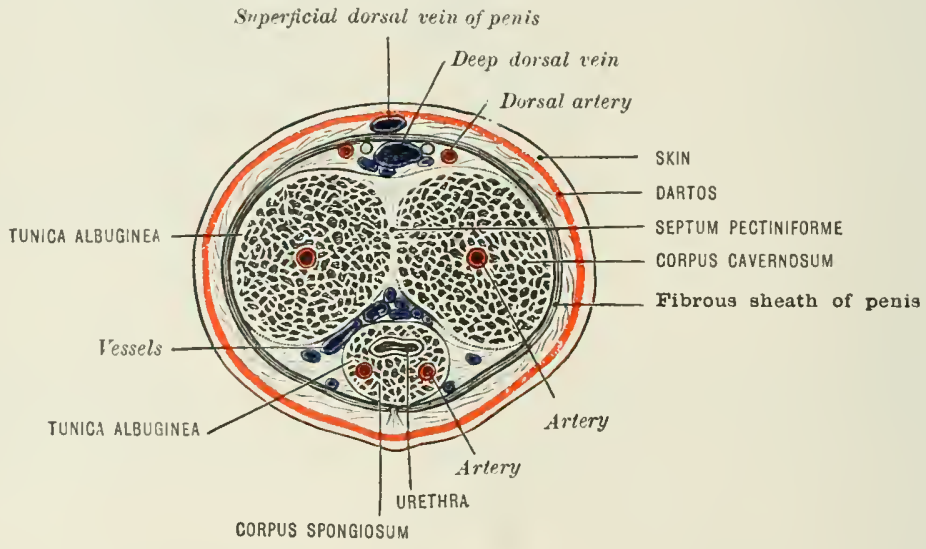

forms a kind of sphincter around the preputial orifice. Beneath the dartos is a loose elastic connective-tissue layer containing the superficial vessels and nerves of the penis, and very liable to infiltration in inflammatory or dropsical conditions and in urinary extravasation. Beneath this lies the fascial sheath of the penis, a complete and highly elastic tunic investing the entire organ as far as the base of the glans, where it fuses with the integument. It is also adherent both to the skin and to the corpus spongiosum along the ventral raphe, and it covers the deep dorsal ressels and nerves and the lateral tributaries which converge to the dorsal vein. This sheath, aided by the dartos and certain processes from the bulbo-caremosi and ischio-caremosi museles, compresses the veins of the penis.

The suspensory ligament of the penis is a strong band of fibrous tissue which passes from the front of the symphysis to the subjacent portion of the organ, blending with the fascial sheath in the middle line and at the sides, and continued into the septum seroti below. The angle of the penis corresponds to the most anterior point of suspension to the symphysis.

The corpora cavernosa constitute the dorsal and larger part of the prenis. They are elosely united in the greater part of their extent, but separate a short distance in front and diverge somewhat widely behind. The posterior extremity of each, called the crus penis, at first enlarges slightly, but tapers as it approaches the subpubic arch; then, becoming tendinous and somewhat flattened, is strongly 
attached to the ischin-pubic rami; and the distal end, pointerl somewhat like the tip of a cigar, is plungerl into the substance of the glans (fig. 62s). The entipe length of the eorpus cavernosmon averages about six inches, and its brealth about half an inch, hut it increases in size by one-third or more when its vaseular spaces are fully distended.

In structure it eonsists of a sponge-like crectile tissue invested by a strong sherath or tunica albuginea. The sheath is about a line in thickness, white, rentarkably tough, and consists of two lamina, an external, of longitudinal filners common to lonth corpora eavernosia; and an interual, of cireular fibres surromeling (ach corpus and forming a mesial septum pectiniforme where the two colpora cavernosil come into contact. The framework of the cavernous structure is formed by a reticular arrangement of fibro-muscular trabecular bands, starting from the immer surface of the albuginea and beeoming more slender as they approach the axis of the body. The branches of the supplying artery run in the trabecula and terminate by opening into the anastomosing intertrahecular spaees which represent the widesy dilated eapillaric's of the organ.

The corpus spongiosum lies in the middle line and below the united corpora eavernosia. Unlike the latter it has no direet attachment to the pelvic bonos, but terminates at each end in a bubous expansion. It may he divided into a glans, a body, and a bulb.

The anterior enlargement, or glans, is somewhat heart-shaperl, its base extending much farther over the dorsal than over the rentral aspeet of the corpora caver-

Fig. 628.-Transterse shetion of the Pexis tirougit the Base of the Glans.

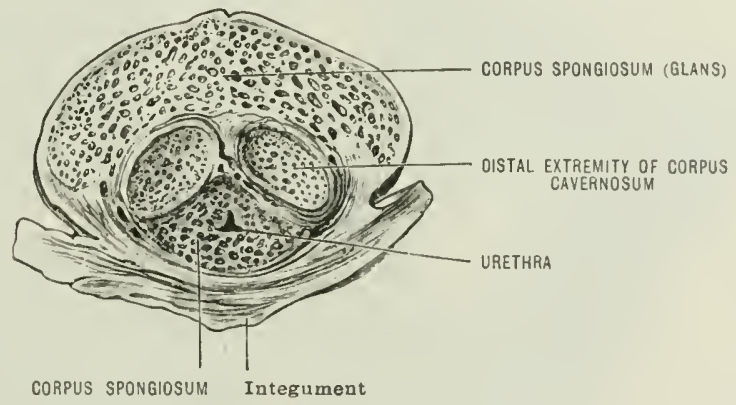

nosa, and showing a distinct indication of division into two lateral lobes in the latter situation. The most prominent part of the base is ealled the corona glandis, and the groove behind this is the neck of the penis or halano-preputial furrow. At its tip it presents a vertical fissure about one-third of an inch in length, the external urinary meatus or nutlet of the urethri.

The glans is composed of erectile tissue with coarse trabecula, and is covered with a firmly adherent layer of skin continuous with the inner larer of the prepuce. Its capacity for vaseular engorgement is much less than that of the corpus caremosum or the rest of the corpus spongiosum, and it does not attain a like clegree of hardness during erection.

The structural continuity of the glans with the corpus spongiosum is prolnaliy not morphologieal. The rexent investigations of Retterer indicate that the greater portion of the glans is developed separately as a part of the cutaneous and fibrous envelope of the penis, and beromes ereetile as a later change.

The body of the erpus spongiosm is eylindrical, uniform in dianeter, ant traversed axially in its whole length by the urethra; it is lorlgerl aluse in al glofere between the two colpora eavernosis, while its ventral aspert is subentaneous execpt where it eorresponds to the attarehment of the scrotum. Strueturally it is provicled with a thin albuginea, hetween which and the uretha lies a narrow latyer of erectile tissue.

The bulb is formed ly an expansion of the erectile structure, ant the prortion of the urethra by which it is traversed mulergoes a well-marked dilatation, and lies 
nearer its upper than its lower surface. It is about an inch and a half in length, and its greatest width is about three-quarters of an inch. It is surrounded by the bulbo-cavernosi muscles, the greater part of the fibres of which bass between it and the corpora cavernosa to blend together in the middle line; and it rests posteriorly against the superficial triangular ligament about half an inch in front of the anus. It is liable to considerable enlargement after middle age.

Muscles.-The muscles of the penis are three on each side-the ischiocaremosus, the bulho-caremosus, and the sujerficial transversus perinei (fig. 629).

The ischio-cavernosus (erector penis) arises from the inner surface of the tuberosity and ramus of the ischium. from the pubie ramus, and from the adjacent root of the crus penis, and is inserted into the surface of the tunica albuginea of

Fig. 629.-The Male Perix.eum. (Moditied from Hirschfeld and Leveillé.)

BULBO-CAVERNOSUS

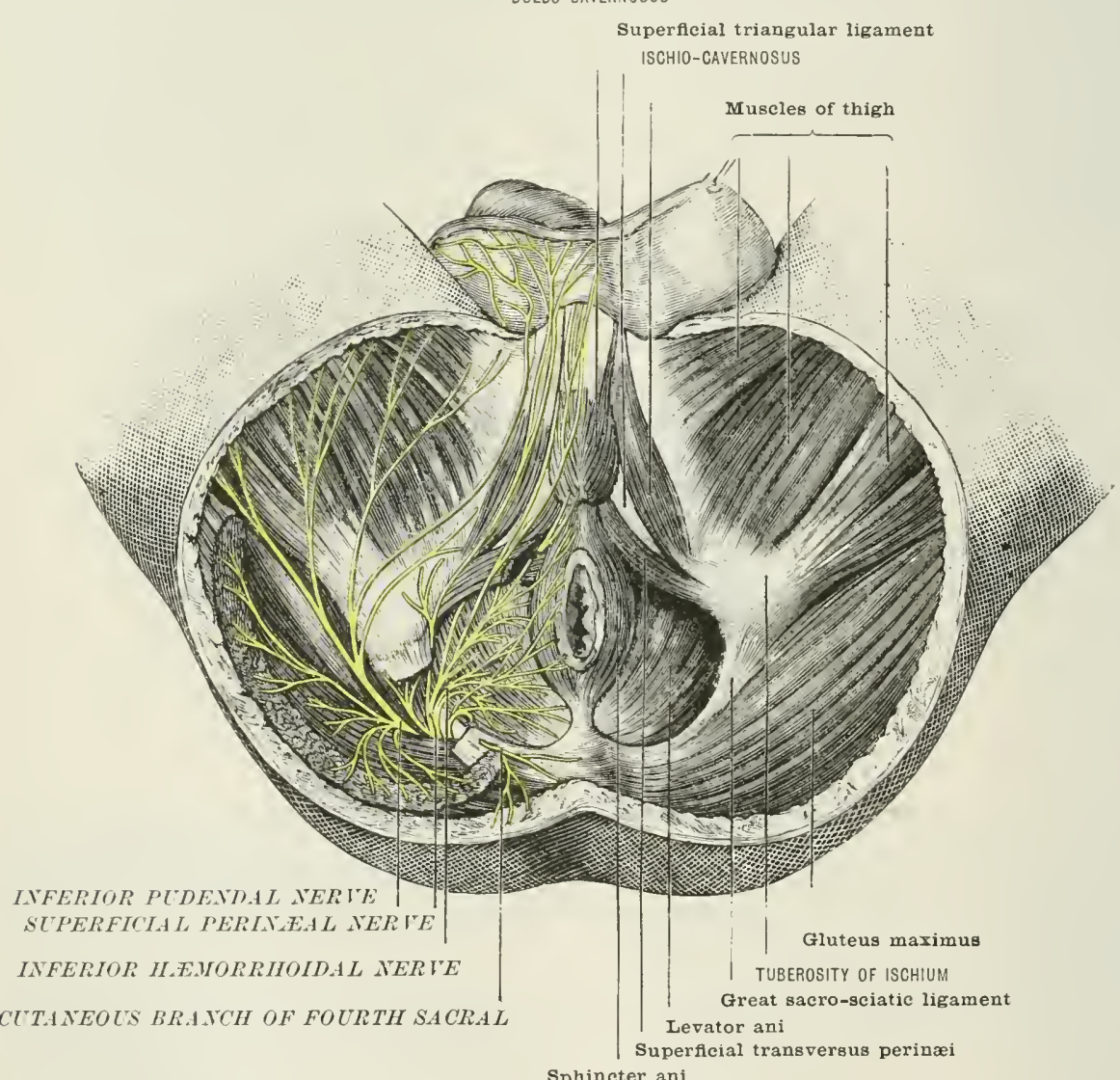

the corpus cavernosum near the point of attachment of the suspensory ligament. A slip, the compressor venæ dorsalis, is occasionally detached from its more distal portion, and becomes inserter into the fascial sheath of the penis over the dorsal ressels, or may blend with its fellow in a narrow tendon in this situation.

The bulbo-cavernosus (accelerator urinæ) arises from a median raphe which extends from the anterior extremity of the sphincter ani along the whole length of the bulb as far as the level of the symphysis. A few of its more posterior fibres pais outwards to become inserted into the superficial triangular liginnent and into the bulh, and a bundle of its most anterior fibres, muscle of Houston, may, like the similar slip from the ischio-cavernosus, form a sling around the corpora eavernosa and herome attached to the fascial sheath of the penis, or it may be inserted into the side of the corpus cavernosum itself. In the former case it acts as 
a compressor of the dorsal vein. The rest of the filures pass around the bull, to beenie lost in the comnertive tissue on the dorsal aspect of the latter, hetween it and the corpora cavernosa; the two muscles thus practieally encirele the bulb, and act as an annular sphincter upon the contained portion of the urethra. It is often joined hy fibres from the sphincter ani and deep transwersis perinate

The superficial transversus perinæi is the most variable of all the prerinat musches. It nsually arises from the inner surface of the tuberosity and ramus of the ischim, blending with the origin of the isehio-cavernosus, and passes inwarks and forwards to its insertion into the tendinous centre of the perinamu, interlacing with the posterior fibres of origin of the bulbo-cavernosus. Some of its fibres may blend with those of the sphincter ani and levator ani.

There three pairs of muscles possess each a thin fascial sheath, and lic in the superficial perinaxal interspace between the fascia of Colles and the superticial triangular ligament. They are supplied by branches of the dere division of the supurficial perineal nerves and ressels.

The action of the penile muscles is not very obvious. The compressores vena dorsalis when present may aid in erection by impeding the retum of venous bloorl from the organ, but there is no reason to helieve that any disadvantage attaches to their absence. The lubbo-cavernosus, with its fellow, is, lowever, of value as a eompressor of the bulbous portion of the urethra, and thus assists in the ejaculation of the semen, continuing the action of the ejaculatory fibres of the prostate and of the decp transversus perinai; and it may also be of service in expelling the last drops of the urine. The compression of the vessels of the bull farours the engurgement of the rest of the corpus spongiosum.

The ischio-caremosus in the absence of its dorsal fasciculus can scarcely justify its older name of erector penis, but it appears to have the power of impresing voluntary movements upon the turgid organ. The superficial transversus perinai is alecessory to the bulbo-cavernosus, fixing the raphe from which its filores arise, and it arlels slightly to the strength of the muscular floor of the pelvis.

\section{Vessels and Nerves of the Penis.}

Artery. - The envelopes of the penis are supplied by the external pudie, the superfedil perinasl, and the dorsal artery; the first from the femoral, the others from the intemal puclic. The corpora caremosa are supplied by the caremons branch of the purlic; the corpus spongiosum hy the special artery of the lublb (internal pudie) and the dorsal artery.

Teins. - The reins of the eoverings of the penis end in one or two superficial dorsal reins which run in the connective tissue layer between the dartos and filscial sheath, and end in the long saphenous and femoral veins. The deep veins of the corpora "avernosa and corpus spongiosum terminate partly in the plexus of sintorini (chiefly through the deep dorsal vein), and partly in the internal pudie. They communicate freely with each other and with the superficial veins.

Lymphotics. - The lymphaties run with the veins, those of the coverings being collected by superficial dorsal trunks which pass to the inguinal glands. The deep lymphatics from the enrpora cavernosa and corpus spongiosmm for the most part join a dorsal cord which runs with the deep dorsal vein to end in the ingumal glands; a few probably reach the pelvic and lumbar glands.

Veres. - The integumentary structures are supplied ly the genital branch of the genito-crural and the superficial perinas hranches of the pudic. The erectile bolies reecive filaments from the dorsal nerve of the penis, the superficial perinteal, and the hypogastric plexus.

\section{THE LRETHRA}

The urethra is the mucons canal extending from the lilackler to the extremity of the glans penis. In its course it pierces the prostate from base to apex, the cleep and superficial triangular liganents with the intervening comprestor mothat and the whole length of the corpus spongiosum. It may hence he divider into three segments:-(1) Prostatic; (2) membranous (the yortion lying in the space betweren the two transverse ligaments); and (3) spongy (fig. 630 ).

The prostatic portion runs almost vertically clownwards from the internal 
urinary meatus, but with a slight forward inclination helow; the membranous portion and the posterior part of the spongy portion as far as the anterior border of the suspensory ligament of the penis describe a curve beneath the symphysis; lastly, the portion of the spongry urethra, beyond the penile angle, follow the direction of the pendent portion of the penis and necessarily follows the morements of that urgan.

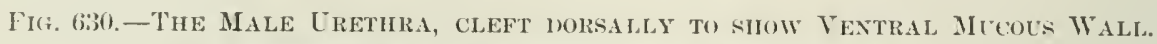

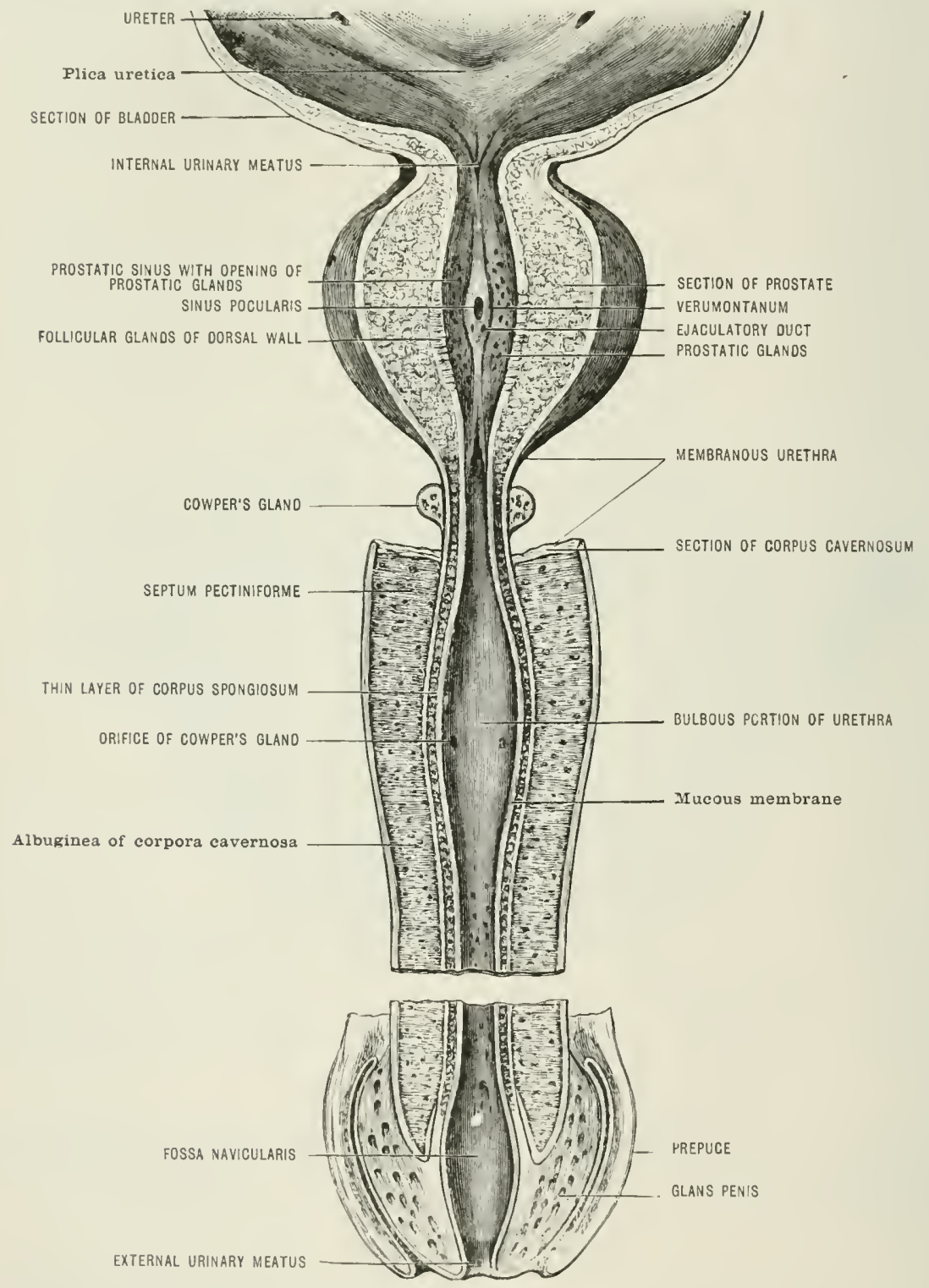

Its average length is still variously stated hy different authorities, but the investigations of Cazenare and Sapprey, confimed as they are hy the frozen sections of Bramme and others, set the matter at rest so far as the physological comblition is concerned. In the ordinary relaxed state of the penis the distance between the internal and external meatis does not usually exceed six inches and a half (16 cm.), and may be less than this when the organ is contrated to its minimum 
degree. But under the test of "atheterism the length of the canal is undoubtedly greater, and may reach seven or eight inches (18-20 cm.) or eren more, owing ti) the traction upon the penis which aceompanies the operation. The canal may be greatly lengthened also hy senile hypertmphy of the prostate, which carrics the internal meatus mowarls towarls the level of the top of the smmphysis.

The diameters of the passiage are searcely caprable of alcurate measurement. In the ordinaly condition it is represented by a tissure, and its linits of siffe dilatilbility ean only be approximately calculated. Otis's investigations show that thesis limits are wider than was formerly believed to be the ease, and he has rmeleavoured to establish als a law that there is a ratio hetween the maximun circumference of the camal and that of the penis, of fom to nine. Thus a penis bavine in its ordinary state a circumference of thirty-six lines should possess a urethrit capable of admitting an instrument of sixteen lines. The sourees of fallacy in such an observation are not inconsiderable, but they do not destroy its value as at practical guide to the surgeon.

The prostatic portion is about an inch and a quarter $(3 \mathrm{~cm}$.) in lengtl, wirler in the middle than at the two extremities, and alnost perpendicular in direction, with a slight inclination downwards and forwards at its lower end. Its anterior wall is concave both in longitudinal and transverse sections, and is studded with the orifies of small mucous follicles; the posterior wall presents a longituclinal ridge called the colliculus seminalis or verumontanum, highest near the midclle and gradually diminishing above and below. A little above the centre of the colliculus may be seen a rather large opening which leads to a cul-de-suc of especial interest for the morphologist, the sinus pocularis or uterus masculinus, and on the lateral margins of the orifice of the sinus are seen two small puncta, one on each sicle, the openings of the ejaculatory ducts. The sinus pocularis and ducts may be traced upwards and hackwards through the prostatic cleft and behind the sphincteric fibres which constitute the prostatic har or middle lobe of the prostate.

In consequence of the presence of the colliculus the urethral fissure appears on horizontal section as a U-shaped eurve with forward convexity. The recesses correspomcling to the extremities of the $U$ are sometimes called the prostatic sinuses, and into these open the orifices of the posterior and lateral prostatic glands.

The imucous membrane of the prostatic urethra is lined with a laminated epithelium. Beneath this is a layer of erectile tissue which constitutes the principal elenent of the colliculus, and is in turn supported by a laver of longitudinal muscle.

The sinus pocularis is believed to be the homologue of the uterus. It is about half an inch in length, and temminates by a blind, slightly dilated extremits. Its walls consist of eonnective tissue intermingled with smooth muscular tibres, and coverel with laminated epithelium. It contains a few simple or conpound plands, in which small concretions are occasionally found.

The membranous portion, hounded above and below by the superior and inferior triangular ligaments, is about half an inch (12 mm.) in length; it is inclinerl downwarls and somewhat forwards, and lies alout an inch (25 mm.) lehind the subpulic ligament, from which it is separated by the muscular fibres of the den transversus perincei and a plexus of veins. It is closely related on either side to ('ow exer's glands.

The mucous membrane resembles that of the prostatic urethra in its epithelium and erectile layer and muscularis, but surrounding these structures is a strong annular bam of unstriped muscle continuous with the filores of the prostate and forming a sphincter of considerable power. This in turn is supported he the striater fibes of the deep transversus perinat. The glands of the mueous menbane, simple and racemose, form suite with these of the anterior wall of the prostatic canal.

The spongy portion extencline to the extremity of the penjis penents two dilatatione with an intermediate portion of narrow but uniform elinensions. The fusterior expansion (pars bulbosa) lies in the hulh, and is ahout an inch (2.) mun. ) in length; the anterior (fossa navicularis) is of nearly the sime rxtent, and is situated within the glams. The penile angle, formed where the flacedel organ falls from the point of susprension at the pubie region. lies about two inehes (5 cm. ) in front of the superticial triangular ligament; and the portion of the canal hedind this is almost horizontal in direction, but with a slight upwarel concarity (fig. 617). 
The muenss membreme of the spongy urethril eontains a large quantity of elastic tisstle and is lined hy a laminated cpithelimm, the superticial cells of which are prismatic in form, while the derper layers ewer in rows of more or less longitulimally ispesesl papillat. It its distal extremity the integumental eorering of the crlans is inflected for ahout a quarter of an incli $(6 \mathrm{~mm}$.), the line of demarcation hetwern the entaneous and mucous structures heing well definerl. The external meatus in representerl hy a rertical slit about a quarter of an inch ( $(i \mathrm{~mm}$.) in length, and is the least elilatable part of the canal; hence in urethral operations it is sometimes necessury to enlarge it by incision.

An axamination of the mueous surfare will show a number of orifices arranged in three longitulinal rows extembing alonger the dorsal wall, and leading to short tubular lepressions which run in a hackwarl clirection (towards the bladder) and are called the lacmax of Morguyni. One of these, termed the lacuma magna or simus of Guim. situated in the mesial line about an inch from the external neatus, is of lirge size, and may arrest the point of an instrument during atheterism. It is bounded hy a little fold of mucous membrane, the ralvule of Guérin, and may attain a elepth of onc-thirl of an inch ( $8 \mathrm{~mm}$.). In addition to these are many simple and compoumel mucous glands, such as appear in the prostatic portion of the eanal; and the duets of Cowper's glands open into the anterior portion of the bulb on the rentral wall.

The muscular cont consists hiefly of longitudinal fibres continuous with those of the blatder, but a cireular layer prolonged from the sphineterie fibres of the mumbranous urethra "xtencls as an onter layer over the bulbous portion of the canal gradually disappearing beyond this point.

As already mentioned, the collapsed urethra is represented by a fissure. This in the glans jenis is rertical in direction. A short horizontal branch is superadded at the mplyel end of the fossa navicularis, giving the fissure the aspect of an inverted T. Ahove this point the horizontal limb progressively elongates, while the vertical limh shortens until the former alone is left, and the rest of the spongy urethr: is represented by a transverse fissure. In the membranous segment the fissure is usually stellate, while in the prostatic region the presence of the colliculus gires it the U-like form alrady described. This progressive change of shape involves a kind of rifling of the tube, and prolably accomts for the spiral form of the normal stream of urine.

The museular tissue of the urethra apjears to be capahle of a peculiar remienlar contraction hy which a catheter left within the urethra is gradually expelled, and an example is known in which an clastic instrmment insecurely tied in situ found its way, in the reverse direction, into the bladder, and formed the nueleus of a calculus.

The female urethra is described on page 1041.

\section{THE FEILAL ORGAIS OF GENERATION}

The female genitals may he divided into (1) an external part, the rulva, representative of structures found in a more highly developed condition in the male; (2) al viginal passinge, the cavity of which appears as a fissure in its ordinary comblition, hut is apalule of rery great dilatation; and (3) an internal apparatus (ompurising the organs of ovulition (oviries) with their ducts, and a musculomucous sace (uterus) in which the orum unclergoes development, and by which the fortus is ultimately expelloul. The valuma and internal organs are intra-pelvic.

The vulva consists of a pair of integmentary folds, the labia majora; two smaller folds, the labia minora; a small perile appendage, the clitoris; and a short passage, the vestibule, leading to the vaginal orifiec. The restibule is 


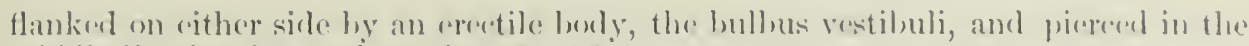

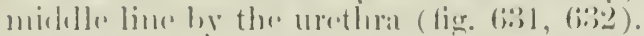

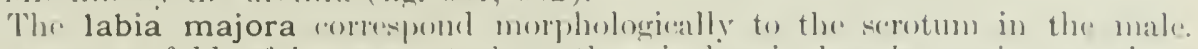

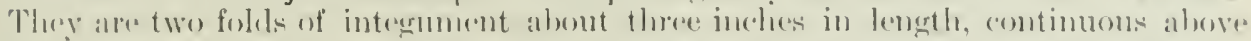
the simphysis, with an aninence callenl the mons Veneris, and merting lwaw in a posterior commissure, or fourchette, abont an inch in front of the ants. Fials

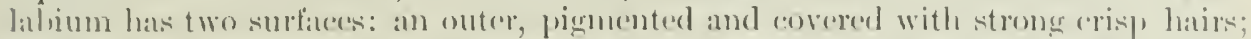
an inmer, in entact with its follow, smooth, prosenting only rudimentary hatis,

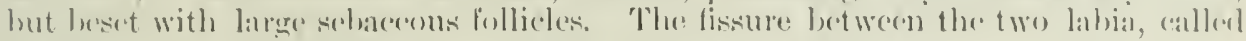
the rima pudendi, is horizontally placerl in the reset posture.

The struetures forming the labia resemble those of the serotmm, lut the dartos

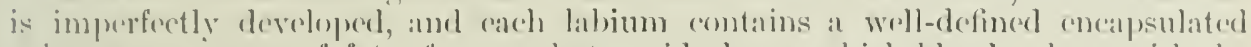
suleutaneous mats of fat, of somewhat ovoid shaje, which hlends above with the

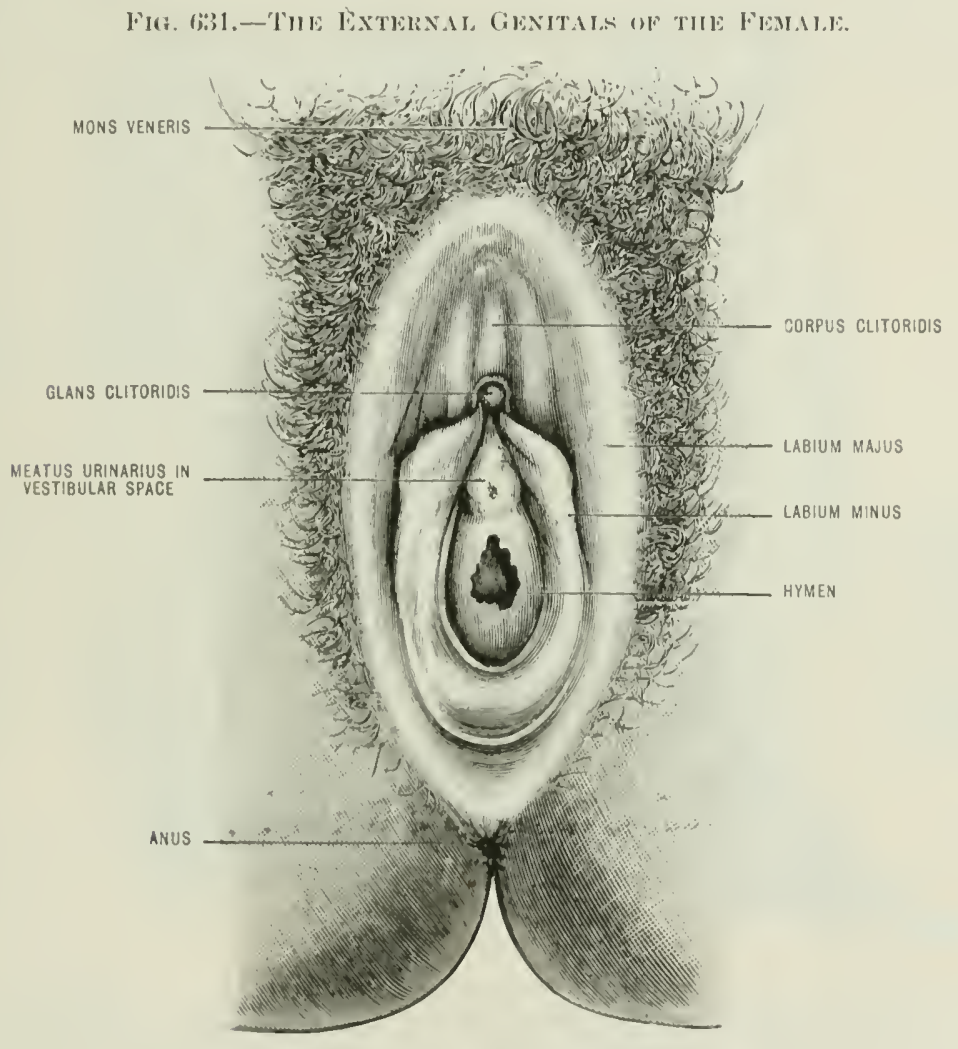

distal extrenty of the romel ligament. I similat mass is oceasionally fomm int the male serotum ats a fatty tumume of the eorel, and una simulate an inguinal hernia.

The labia minora, or nymphæ, are folds dilfering from the latria majora in their relatively small size and in the alsenere of hairs and fat. The two blieations

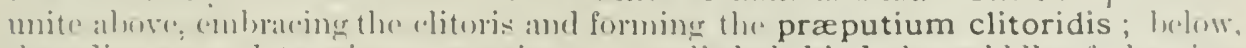
they diverge and terminate oppesite to or a little hehind the mildle of the rinat erenitalis. They are smooth and hairlessem the surface usually of a pale rose colomer,

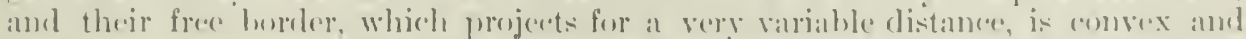

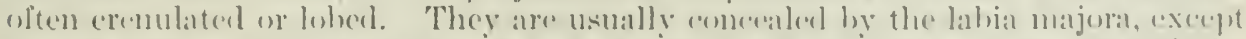

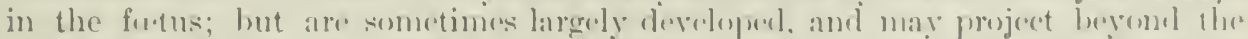

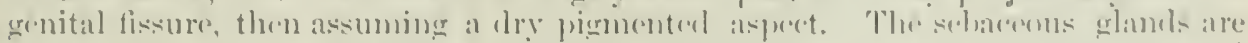

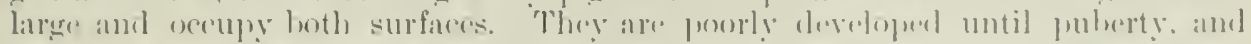
attain their greatest

The vestibule is the space betwen the labia minomat and the vaginal orifice. 
It: boundaries aro ill ilefined posteriorly, and the term is used with different significance loy different anatonists. Opening into it are the urethra, the glands of Bantholin, and a few glands of the sime nature as those of the urethra, surrounding the external meatus.

The glands of Bartholin probably represent Corper's glands in the male, but are moresuperficially placed. They are two little racemose glands, about a third of an inch long, situited one on either side beneath the lateral wall of the restibule and behind the lulhi retibuli. The durt, about three-cuarters of an inch in length. (1)ens immediately in front of the vaginal orifice opposite its meridian.

Vessels. - The vulvar structures are supplied by branches of the external and internal pudic arteries. The veins and in the corresponding trunks, and there is in adclition a free anastomosis with the veins of the round ligament in the subcutanerus fat of the lahimm. The lymphaties terminate for the most part in the inguinal glands, a few jassing to the femoral glands. About the raginal orifice is a nentril territory in which the vulvar and raginal absorbents intercommunieate.

The erectile structures of the rulva correspond morphologically to those of the male organ; the corpora carernosa are represented by the clitoris, and the corpus

Fig. 632.-Diagrayatic Represextation of the Perineal Strecteres ix the Feyale.

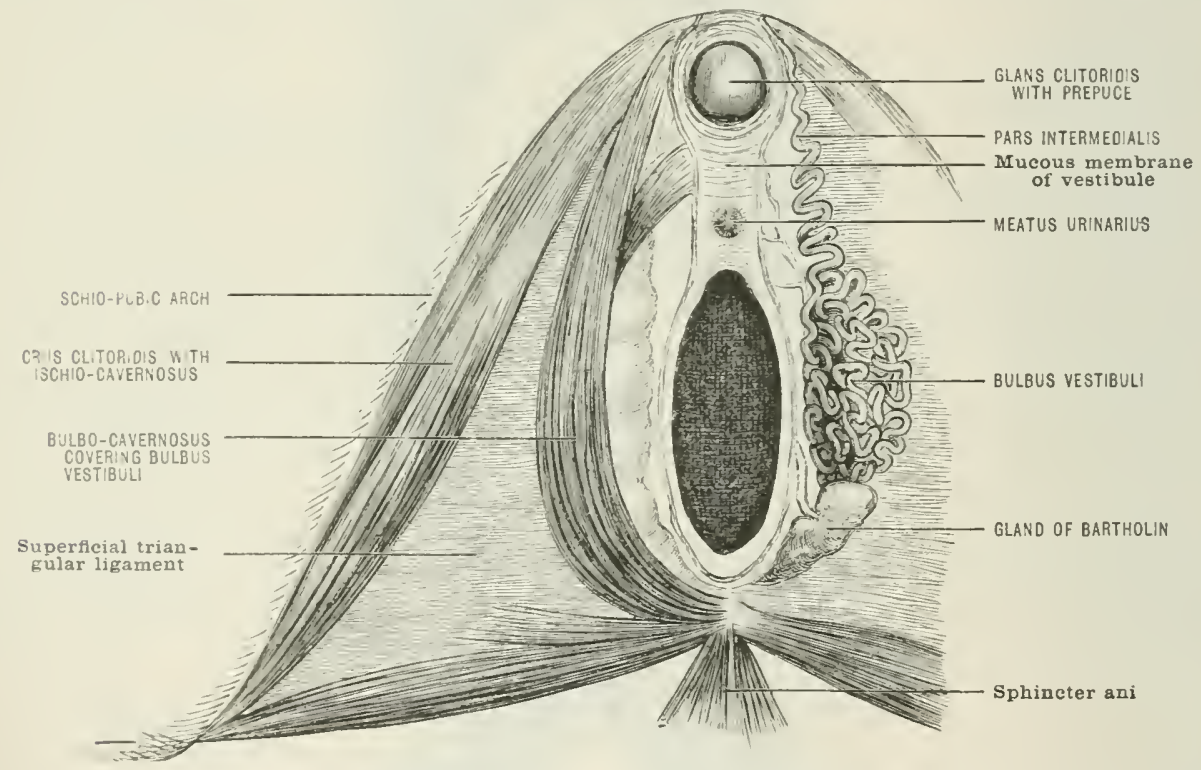

spongiusum, cleft in the female by the vulvar orifice, appears beneath the mueous unembane of the vestibule in the form of two vascular plexuses, one on each side, ahllerl the lublo vestihuli; and an indistinct mesial hand extending from the elitoris to the meatus is believer by Pozzi to represent the anterior part of the corpus spongiosum.

The CLITORIS afpears as a dimimutive penile appendage at the upper part of the rulval, and is cmbracel by a kind of prepuce formed by the union of the two labia minora. It is comprosed of two corpora cavernosa which differ from the corresponding masuline structures only in their size and in their union distally into a romeliel imperforate extremity, the glans clitoridis, covered by a layer of integument. The crura are supported dorsally by a suspensory ligament, and are attachert to the ischial rami in the same manner as in the male.

The rlitoris is relatively smaller in the arlult than in the child, and is almost always eoneealed within the rima pudendi. It is a highly sensitive organ, and is capahle of crection.

The bulbi vestibuli are two erectil. hodics of somewhat pyrifom shape, lying one on either side of the vestibule bencath the mucous nembrane. The larger 
extremity of each is posturior and extencls hackwards nearly to the postcrior (annmissure, touching the gland of bartholin. The narrow anterior cxtrentity, the pars intermedialis of Köhelt, runs forwards to meet its fellow of the ofineste sirlobeneath the clitoris. Superiorly, it is fixed to the superfiedal triangular limanurent of the perinatum, while it is in relation internally to the urethral and vaginal mifiers, and externally is invested by the fibres of the bulbo-arermesus. It consists of arectile tissue, enveloped hy a thin tunial allugrinea. D)uring the rondition of engorgenent it helps to narrow the vestihular portion of the vulva and the entrance of the vagina.

The vessels and nerves of the elitoris and bulli vestihuli are the same als those. of the analogous parts of the male.

Fig. 63:3.-Sectiox of the Fenale Penvis. (Aiter Henle.)

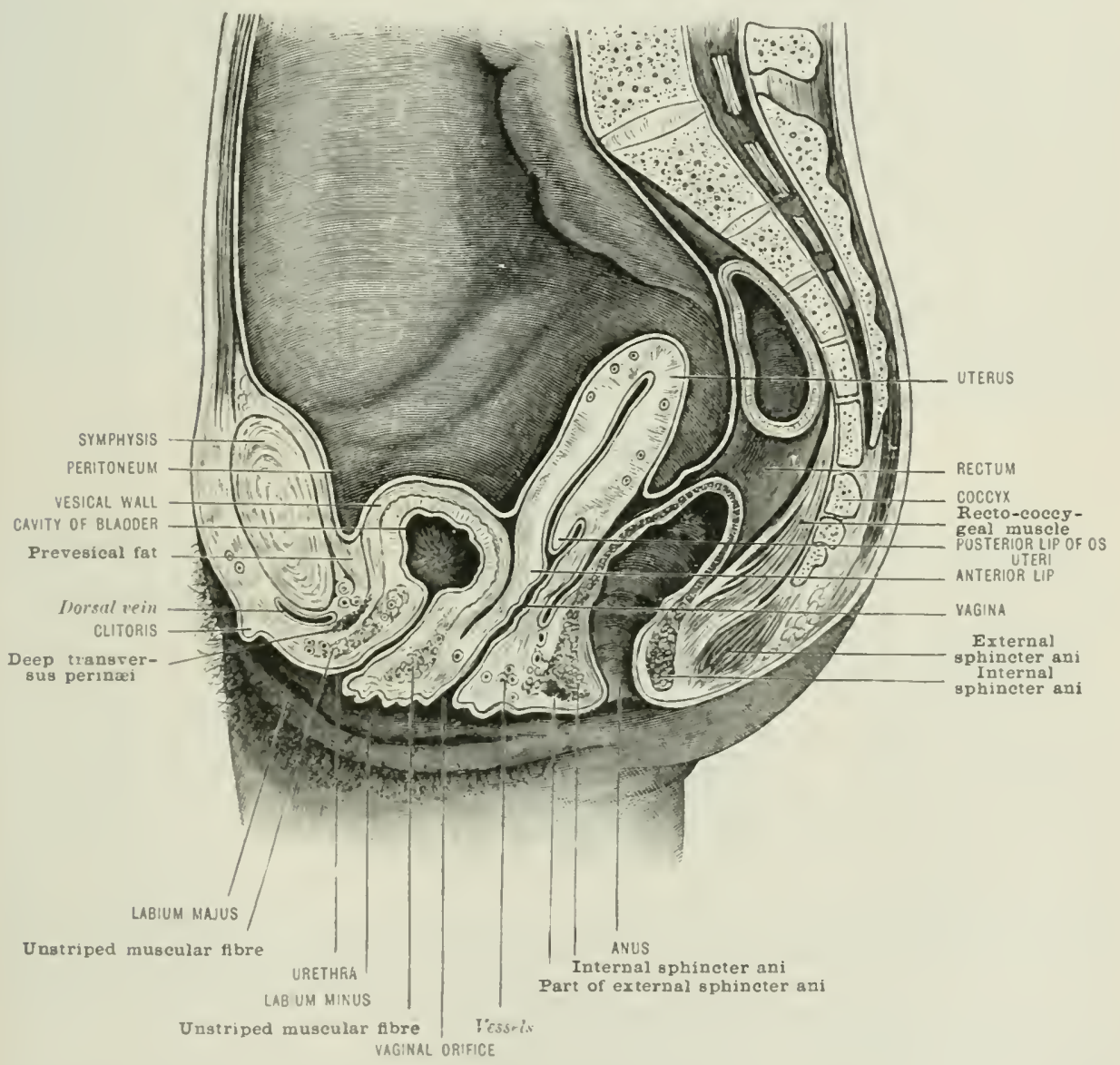

The muscles appernded to the ereetile struetures again are very similar to these described in annertion with the penis. The ischio-cavernosi are identieal in

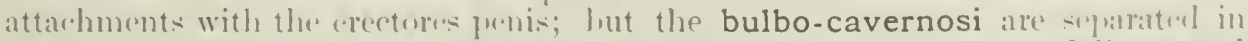

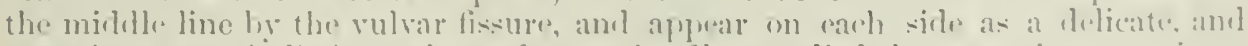
sometimes very indistinct, blume of museular fibres. (alled the constrictor vaginæ,

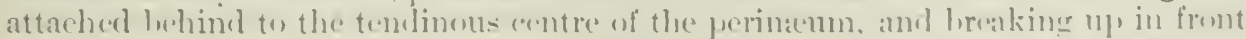
into tendinous slijs which run in elose rexternal relation to the hubli rentilusli,

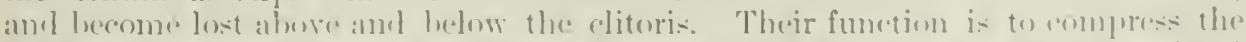

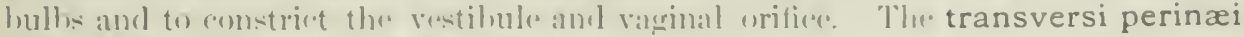
have the same commertions as in the male.

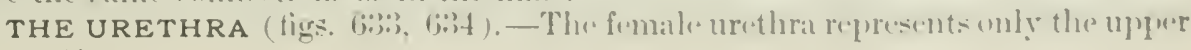


part of the male canal, and is similaty related to the superior and inferior triangular ligaments. It is about an inch and a half (37 mm.) in lengrth, and is directed upwark and slightly hakekwals to open into the blatder about an ineh (25) mm.) behind the midille of the symphysis. Its posterior wall is in contact with the vagina, and it is surromeled in front and at the sides hy a plexus of reins (plexus of Santorini). The posterior margin of the meatus msually presents a tuberenlat prominesnee by which the position of the orifice may be distinguished during catheterism.

As in the male urethra, the narrowest portion of the camal is the external meatus, but the whole tule is suthiciently dilatable in most cases to allow the eareful introduction of the finger while the jatient is under an anasthetic. A case $\mathrm{is}$ recorded hy William Cowpre (169\%) in which, as a result of an imperforate condition of the himen, it beame the chammel of sexual congress.

sitructurally it consists of a highly elastic mucous membrane and a strong muscular coat. The mucosa is lined with three or four layers of epithelial cells, the more smperficial of which are prismatic in form, and presents a few lacume and some rudimentary glandular follicles. The muscular coat is divisible into external rircular and internal longitudinal layers, both interningled with fibres of elastic tissue and with large renous plexuses which may undergo varicose dilatation near the external orifice and form a pile-like tumour. The circular fibres are very strongly developed at the resical end of the canal and constitute a powerful sphincter; these are surrounded by a quantity of striped and unstriped fibres which form an incomplete ring, deficient only in its posterior or raginal segment, and probilily represent the prostatic fibres and the deeptransversus perinæi of the male. It is surrounded by a nuscular sphineter composed of striped and unstriped fibre corresponding to the deep transversus perinei in the male, and partly, perhaps, to the musculature of the prostate.

\section{THE VAGINA}

The vagina is a passage which extends upwards and slightly backwards from its external opening at the vestibule, and teminates above by embracing the neck of the uterus. Its vulvar aperture is guarded in the virgin by a fold of mucous membrane ealled the hymen.

Form and direction (figs. 633, 634).-In its ordinary condition the raginal canal is represented by a fissure which in horizontal section assumes the form of the letter $H$. with a transverse limb about an inch in length and two short vertical limbs (fig. 633). In longitudinal section (fig. 633) the fissure branches above, a short limb (oceasionally ill-marked or absent) passing in front of the anterior lip of the us uteri, a much longer limb extending behind the os to end about threequarters of an inch above the extremity of the posterior lip. The angle of reflexion of the raginal on to the uterine mueous membrane is called the fornix. The lirection of the passage is upwards and hackwards, forming an angle of about $30^{\circ}$ with the long axis of the body, and usually presenting a slight posterior concarity adapted to the eomvexity of the rectal ampulla; the course and clirection, however, vary with the degrese of pelvic inclination peculiar to the individual, and to some extent with the conclition of the biachler and rectum.

The two walls are of very unegual leugth, the anterior measuring about two inches and three-quarters ( $7 \mathrm{~cm}$ ), while the posterior is prolonged upwards nearly an inch $(9.5$ cm. ) further.

Relations.-Anteriorly, it is opposed to the urethra and posterior wall of the blarkler. It is intimately mited with the lower two-thirels of the urethra, but is separated from the uppere thire and from the hladiler by loose comnective tissue continuous with the sulperitoneal faseda. The canal as a whole is narrowest below, and grachally increases as it ascomels, reaching its ereatest admeasurement where it surmumls the os uteri. Its clilatability is momous, as may he inferred from the passage of the fotus in parturition. The ureters piere the vesical wall in front of the vagina :m inch and a guarter helow the lew of the os nteri. Posteriorly, it is in relation with the rectum, but is seprated from it above for about three- 
ynarters of an inch (1S mm.) by the peritoneal rul-de-sue called the pouch of Douglas, in the midelle by suliperitoneal comnective tistur, and below by the tissues of the prinatal borly. In the latter situation the two eamals diverere, and

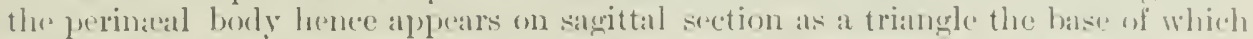
is formed by the integument. Laterally, it is in contare with the vaginal brameh of the uterine artery, and a venous plexus lying in the subperitoneal tissue at the

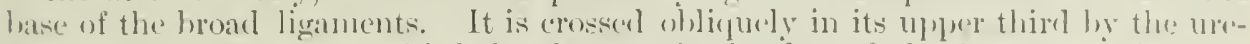
trers, and in its lower two-thirds by the anterior berders of the levatores ani. The. finger passed within the passage and presedel to either sicle may bo made to feel thr. resistance of the prelvie wall, and to ilistinguish the presenes or alssenee of morbiel growths or effusions. The duct of Gärtner, a relic of the Wolffian duct, maly acasionally be found by the side of the upper half of the vagina as a minute tube or filmous ard. 'Two orifices which open into the vagina near the meatus, sometimes called skene's tubes, are regarded by some morphologists as the terminations of criirtner's duets.

The lower end of the vagina pierees the triangular ligament, and it is here that

Fig. 634.-Horizoxtal Section of Vagixa axi anjacext structures. (After Henle.)

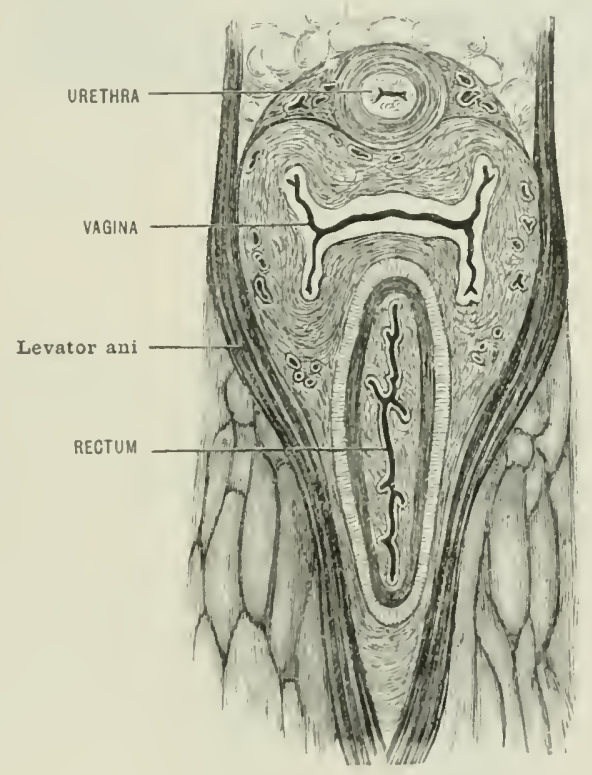

the resistance to dilatation is greatest. The inlet may be temporarily narrowed hy the engorgenent of the bulbi vestibuli, or by the action of the constrictor ragina. and perhays also by that of the levitores ani.

The mucous surface of the lower half or two-thirds of the vaginal presents on the anterior wall a median longitudinal ridge or carina, and on the posterior wall two ridges, the columnæ rugarum, from all of which pass a number of transterge rugæ. These markings diminish in dirtinetness with advanee in age and with sueressive prarturitions. The membrane is of a prale rose colour in periods of yuiesecence, liut becomses turgid during the catamenial prerioxl, and in prexgnaner.

The hymen has been a sulject of much speculation amoingst the learmet and unlearned of all ages. Its very existence was at one time deniod hy many great autherities, and the signitieance to le attached to its presenes or absence is still a question in medieal jurisprutenee. It appears in the virerin as an imperfere septum piereed by an irregular aperture which usually reaches to the anterior vagrinal wall, and leaves a fold of semilunar form behind; hut it may le represented hy al circular enrtain piereed hy one, two, or more apertures. It varise greatly in strength and elasticity, and although it is nearly alwals ruptured by the first alet of sexual con- 
gress, it may remain unbroken until parturition. An imperforate condition of the membrane is oceasionally present, and may necessitate a surgital operation at the commencement of the menstrual period.

Structure.-The vaginal wall is composed of three coats, filsrous, museular, and mueous, and has a thickness of one-eighth to one-sixth of an inch. The outer fibrous coat is clerived from the recto-resical filscial, and holds in its meshes a plexus of veins. The muscular coat comprises two layers of strong unstriped fibres, the outer longitudinal, continuous above with the uterine muscle and with the uterosacral ligaments; and the inner circular and more largely developed near the vulvar aperture.

The mucous membrane is highly elastie, beset with papillæ and covered with a squamous laminated epithelium eontinuous with that of the os uteri and vulva. It has no glands, and hence the fluid which moistens it is rather of the nature of a transudition than of a secretion.

Vessels and Nerves.-The arteries are derived from an inferior branch of the uterine and from the internal iliac, eommunicating below with branches of the external pudic; they run along the lateral aspeet of the passage and give twigs to the anterior and posterior surfaces. The veins, similarly disposed, form a rich network in the muscular and mueous coats, and terminate in the vaginal and uterine trunks. The lymphatics, arranged in two intereommunicating networks, mucous and muscular, from numerous trunks which aceompany the reins and terminate in the pelvie glands, a few from the neighlourhood of the vestibule, however, reaching the inguinal glands. A small gland is occasionally found between the rectum and vagina.

The Nerves come from the hypogastric plexus, the fourth sacral, and the pudie.

\section{THE UTERTS}

The uterus, or womb (figs. 635-638), is a hollow muscular organ lined with mueous membrane. It communicates above with the two Fallopian tubes, and below with the vagina, and lies within the pelvic cavity between the bladder and rectum, fixed in its place by folds of peritoneum and certain bands of unstriped musele. It varies greatly in size and form at different periods of life and under different physiological conditions.

The adult uterus is flattened from before backwards, pyriform in its outlines when seen from the front, and is divided into two main portions, body and cervix, by a transverse constriction, the isthmus. The isthmus may be regarded as the weak point in the organ, and it is here that the various pathologieal flexions take place. Its position in the virgin uterus is about midway hetween the two extremities, but it lies near the junction of the middle and lower thirds in women who have borne children.

The upver portion, or body, presents two surfaces, three borders, and two angles. The anterior surface is almost flat, and is covered by a layer of peritoneum which is rellecter at the level of the isthmus upon the bladder, forming a shallow utero-resical pouch which is octupied by coils of small intestine. The posterior surface is listinctly envex, and covered in its whole extent by a layer of peritoneum which is prolonged downwards orer the neck and for a short distance upon the posterior wall of the vagina before undergoing reflexion upon the rectum to form the recto-vaginal pouch, or pouch of Douglas. The superior border, or base, is thick and rombled, and is covered by the peritonem, which passes from the anterior to the posterior surface. The lateral borders, slightly convex and rumning downwards and inwarks, correspond to the line of attachment of the peritemeal folds called the broad ligaments. The superior angles, at the junetion of the superior with the lateral horkers, give attachment to the oviduets or Fallopian tubes. The term fundus is lonsely applied to the upper part of the body.

The cervix is cylinclrical in section, wider in the midlle than above or below, and may be divided into thres portions, - an uples supravaginal zone, a midlle zone of vaginal attachment, and a lower intravaginal zone, the os uteri. The supravaginal zone, representing alout one-half of the neck behind and two-thirds 
in front, is in relation anteriolly with the blalder; posterionly it is covered with the peritonemon of the anterior wall of the pouch of Jonglas, and at the sides it is commested with the loroul lignment, in which he the utrine ressels and the uroter, the latter at a clistance of a little over half an inch. 'The zone of vaginal attach-

Fig. 635,-The Female Orgaxis or Gexeration. (Modified from Sappey.)

(Varinal divided and laid open behind.)

POSTERIOR SURFACE OF BODY OF UTERUS

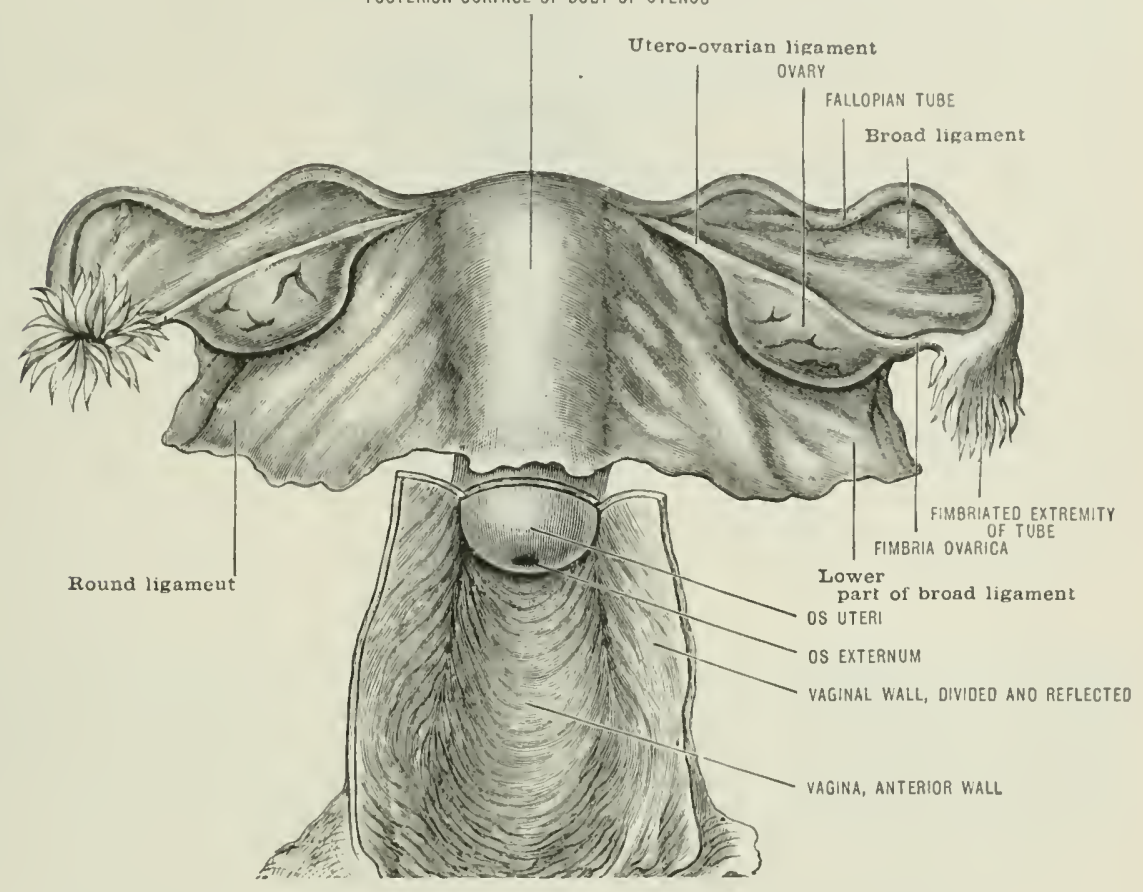

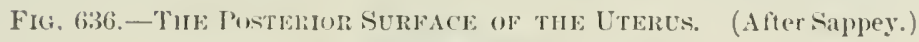

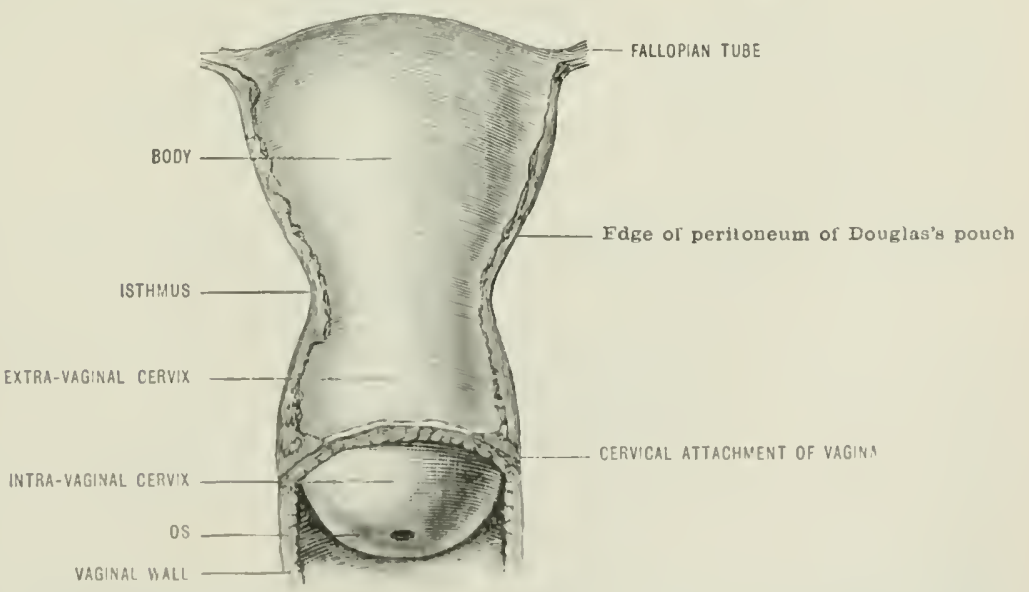

ment is obliquely set, extending higher lehind than in frout, and has a repeth of about omefith of an inch $(5 \mathrm{~mm}$. $)$. The intravaginal zone, or os uteri, is

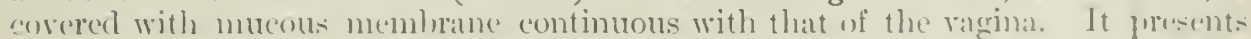
the external alperture of the uterine carity, usually in the form of a tramsrerse tis- 
sure, ahout a quarter of an inch ( 6 mm. ) in length, hounded by two prominent labia, anterior anel yosterior, hoth of which are in contact with the posterior wall of the ragina. The anterior lip is the thicker, the shorter, and the lower; the posterior lip is longer on account of the greater height of the posterior vaginal fornix. After childbirth the labia usually become notched and irregular.

Dimensions. - The size of the uterus varies within wide limits. Its average

Fig. 63\%.-Frodtal Section of the virais Utelits. (After Sappey.)

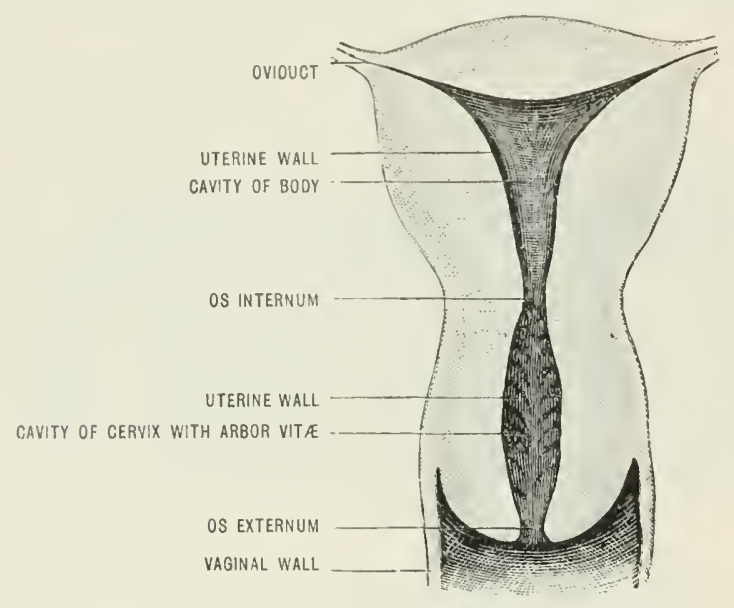

length in the nulliparous adult is about two and a half inches $(6 \mathrm{~cm}$.) and its greatest breadth about an inch and a half $(4 \mathrm{~cm})$, but in women who have bome children these dimensions are about one-fifth greater. Its weight averages seren drachms in nulliparæ, nine to twelve drachms in multiparæ.

Direction.-The direction of the uterine axis is undoubtedly variable, and it is

Fig. 638.-Sagittal Section of the Virgin Uterus. (After Sappey.)

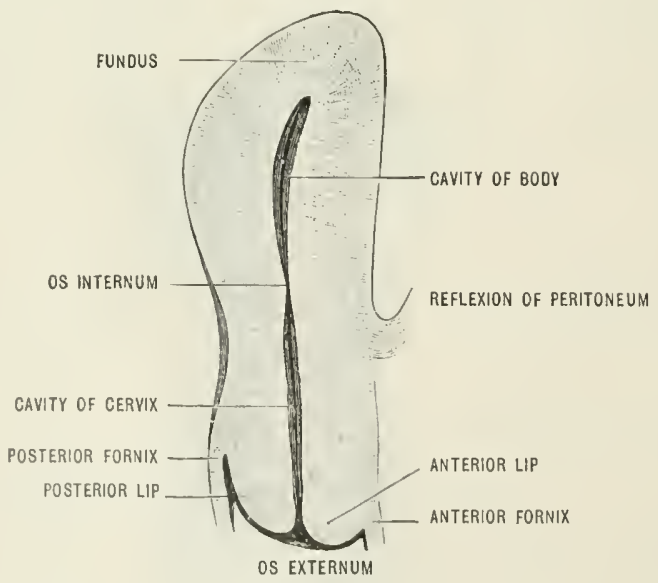

probable that olserrations male after death are open to misinterpretation. It appears to coincide muler ordinary circumstanees with the long axis of the body, hoth in the recumbent and erect postures, but may be inclined forwards to the extent of $15^{\circ}$ or $20^{\circ}$ when the blarlder is empts, or may be deflected to the right when the rectum is full, and is furthermore aftected by the condition of the neighbouring intestinal coils. 
Variations in form according to age.- In young (hildren the body is but slightly developed in proportion to the cervix, and the proninener of the intravaginal serment is relatively great. In the virgin uterus of a voung adult the length is atout equally dividerl between hody and cervix, but after childhirth the borly never returns to its original size, and its length when involution is enmplete

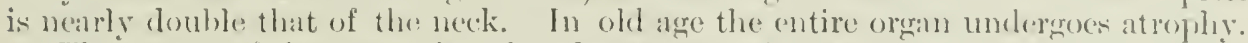

The cavity of the uterus is redued to a fissure by the antero-posterior flattening of the walls. It is divisible into two secgments, that of the hody and that of the nerk. The shape of the cavity of the body is that of a triangle with eonvex sides (in the virgin) and three open angles. It the two superior angles are the orifices of the oriduets, and the lower angle presents the os uteri internum or aperture of inmmunication with the neck. The walls are smooth, and moistened with mucus.

The avorage length of the cavity in the nulliparous adult is about two inches (5 cm.); in multipare, two and a quarter to two and a half inches (5.5 to 6 cm.). The greatest transverse diameter is a little less than half of these measurements.

The cavity of the neck is fusiform, terminating in the os internum above, and in the os externum below. The superior opening is eireular, the inferior usually in the form of a transverse fissure. The mucous lining of the anterior and posterior walls presents ridges which bear some resemblanee to those of the vagina, but are dependent upon the arrangement of the immermost layers of the muscular wall, and not upon a simple plication of the mucous membrane. The whole length of each wall is traversed by a longitudinal nearly median ridge or stem, from which pass a number of branches in an outward and slightly upward direction. The figure formed by these folds is designated by the name of arbor vitx uterina; it is most marked in the young, and tends to effacement after repeated parturitions. The cavity usually contains a plug of alkaline mueus.

Structure.-The uterus is composed of three coats-an outer sero-fibrous, a miclille muscular, and an imner mucous. The serous membrane eovers the upper half or two-thirds of the anterior surface, the whole of the supravaginal portion of the posterior surface, and the summit. The lower portion of the anterior wall is separated from the bladder by cellular tissue continuous with the subpreritoneal fascial, and a thin layer of the same structure may be demonstrated over the lower part of the posterior surface and laterally into the base of the broad ligament on either side between the two peritoneal lamina. Owing to this disposition of the sul,serous tissue, the whole of the eervix uteri may be amputated without encroaching upon the peritoneal cavity.

The muscular coat constitutes the greater part of the thickness of the organ. The arrangement of the fibres is very complex, but a fairly satisfactory division into three layers may be demonstrated:-a thin outer layer, partly longitudinal, partly transwerse in flirection, continuous with the muscular fibres of the oviducts. vagrina, round, ovarian, and utero-sacral ligaments, and with the museular expansion in tho broad ligaments; a middle layer, very thick, its fibres plexiform, rumning in all elirections, and intermingled with large venous plexuses in the horly of the uterus, the innermost strands forming splineteric rings around the os interium and around the orifiees of the oviduets; and a thin internal layer, longitudinal in the body, and producing the ridges of the arbor vita in the corvix.

The mucous membrane of the borly is smooth and pale, lined with cylindrical ciliated eprithelium, and pierced by innumerable tubular grlands. The riliary motion is from within nutwarls. The inucens membrane of the eavity of the reek is thicker and is plieated in the manner already deseribed; its epithelium is ciliated down to the external opening, but there undereges a transition into the squanous laminated epithelium which eovers the intragumal portion of the ws. Many tulumlar and racemose mueous glamels open into the furrows of the arlwe vitax. and these are liahle to patheslogieal changes which cause them to assume a vesculat characeter, when they aresometimes linewn unler the faneiful name of ovula Nabothi.

Ligaments. - The so-called ligaments of the nterus are of two kinds, jeritoneal ami muscular.

The peritoneal ligaments are six in number: two lateral, two anterior, amel two josterior. 
The lateral or broad ligaments (fig. 6.9.9), (allect also alæ vespertilionis from their fancied resemblance to the wings of a bat, are formed by a chuplicature of peritonemen extending from the sides of the uterus and vagina transiersely ontwards to the sides of the pelyis. The two layers of peritonem are continuous above and form the fres borker of the fold, but diverge laterally and below, where they pass on to adjacent structures. Each ligament presents two surfaces and four borters. The superior or free border is rejresented by the summit of the plication, which turns anomel the oviduet and follows a sinuous course towards the side of the pelvis, its outemest extremity lying extomal to the fimbriated extremity of the Fallopian tule and forming a sliarp fold, the ligamentum infundibulo-pelvicum, which convers the orarian vesels. The internal border is attached to the sides of the uteris and ragina, the two lamine separating to transmit the uterovicinal vessels, and musculur hands, which pass from the uterus into the peritoneal fold. The inferior border is attached to the levator ani and recto-vesical fascia; its lamine are separatel by fat-bearing cellnlar tissue (sulperitoneal) which gives passage to ressels and nerves and to the ureter; and the anterior layer is nuch shorter than the posterior, owing to the higher level of its point of reflexion. The external border lies against the obturator fascia, and tmomits the uterine ressels and the round ligament.

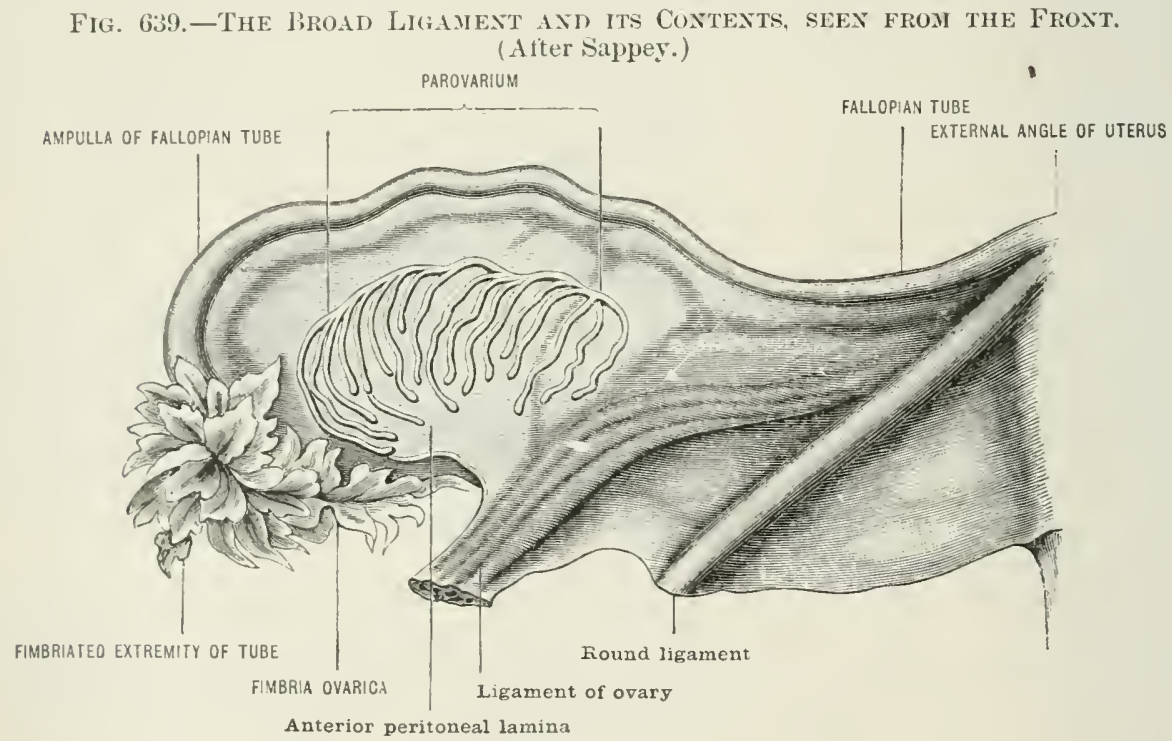

The structures enclosed between the two layers of the broad ligament are:-(1) The ovary and its ligament, the former projecting from the posterior lamina am invested by a molified epithelimm; the latter, composed of unstriped muscular fibre, passing between the side of the uterus and the inner or lower extremity of the orary. (2) The Fallopian tube, lying at the upper margin inmediately beneath the print of continuity of the two lamina; its outer fimbriated extremity turned backwards and inwarls to the ovary, and attacher by one of the fringes to the outer or lower end of the orean. It does not reach quite to the pelvic wall. (S) The round ligament, a muscular hand rumning downwards and outwards, forming a ridge leneath the anterior lamina, and eventually passing to the internal inguinal ring and through the inguinal canal into the labium. (4) Fotal relies: (a) the epovarium, or epoophoron, a gromp of twelve to twenty effete tubules of the IVoltian boxly lying close to the attached border of the ovary, hearing a certain resemblane in plan to the valsal eflerentia of the testicle, and joining a kind of collecting tuhe ahore. (b) The duct of Gärtner, a canal representing the lower part of the llollian luct. is constant in certain amimals (cow, ete.) as at tube running on each side of the uterus and vagina, and opening at the lower end 
of the latter passage. In the human subject it is sometimes foumd in the form of a small muscular cord, or epithelial eanal, near the cervix uteri or uprer part of the vagina. Aecording to some anatomists, its lower end is oreasionally found as a little tube opening into the sile of the vulva near the urinary meatus, lut it is douhtful whether the tube in question is more than a mucous eluct. (c) The par-

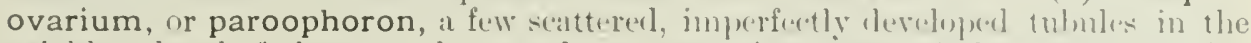
neighbourhood of the epoüphoron, also representing traces of the Winltian loody. They are ustally seen as small whitish or yellowish grains in the infant, lut are rarely demonstrable in the adult. (d) The hydatid of Morgagni, a long ledienlaterl resicle of the size of a millet seed or lea, occasionally dependent from the fimbriae of the tubes. is leelieved to be a relic of the Wolfitian borly. (e) Sinall perluneulated cysts often found on the posterior layer of the broarl ligament and derived from the parovarium. (5) The uterine, ovarian, and funicular ves:-s.s. anastomosing near the angle of the nterus; and the uterine plexus of nerves. (6)

Fig. 640.-Diaganiatic Section of the Beidi Ligamext.

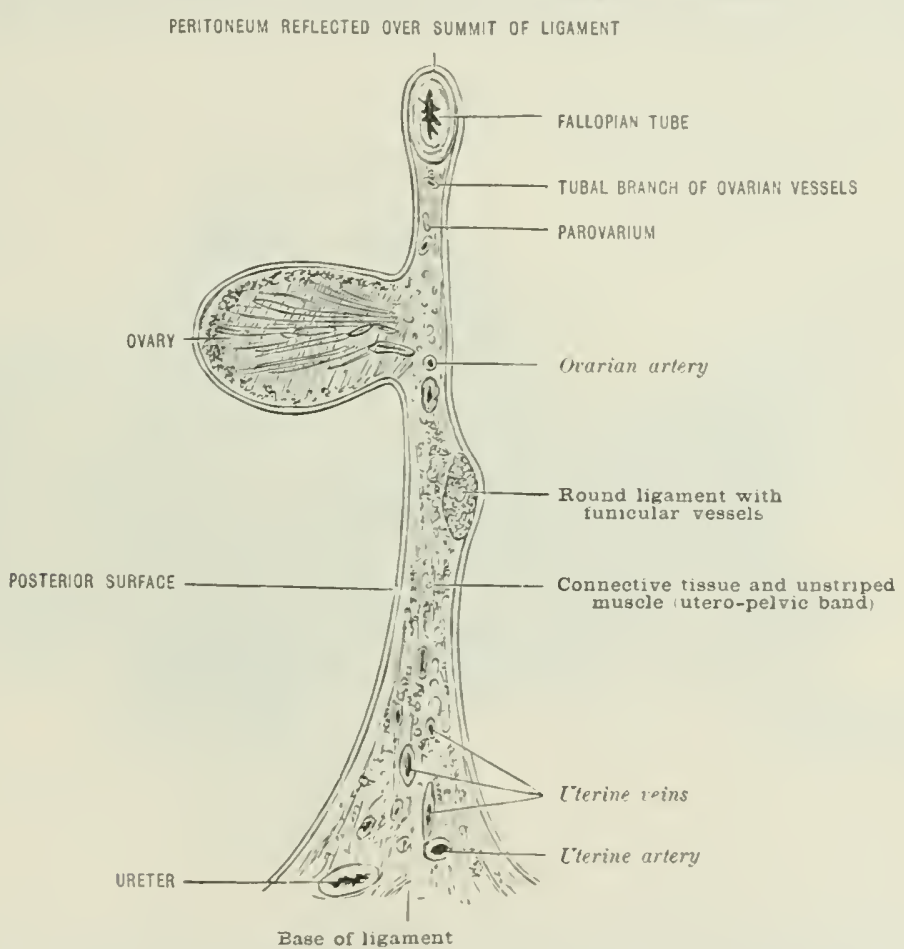

A yuantity of loose adipose collular tissne lying letween the muscular and wtler struetures and the serous membrane, and in continuity with the sulperitumal fiscial of the prolis. ( $T$ ) Involuntary muscular fibres pasing from the oluturitur fascra to heenme attached to the siles of the uterus and ragina, ensheathing the resocels and serving as a support to the uterus. They may be compared with the filmo-mnseular subperitomeal hands supporting the third stage of the duestenum. the transwerse colen and sulall intestimes, and are escontially sustentacular in redirtion to the viscera and to their ves: els : and nerves.

The posterior peritoneal or recto-uterine ligaments are two wholl folls which run harkwards from the intrapuritoneal purtion of the revix mori and ravinal to berome continuous with the peritoneal investment of the soromel stales of the reetum. They form the lateral houndaries of the pouch of benglats. and hetweren

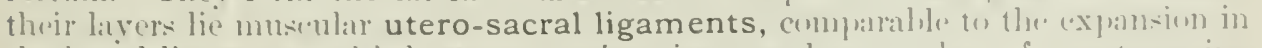

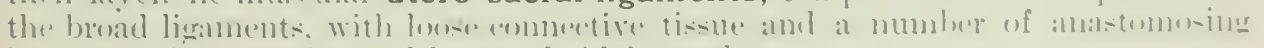

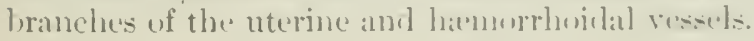


The anterior peritoneal nr utero-vesical ligaments are two ill-defined folds which pass one on each side from the cervix uteri to the bladkler.

The muscular ligaments lying leeween the peritoneal folds are four pairs: three in the broad ligiments, the romel or utero-inguinal, the utero-ovarian, and the utero-pelvic, and one in the posterior liganents, the utero-sacral. They have alrearly been lirietly referred to.

The round or utero-inguinal ligament (fig. 639 ) is a cord, about five inches in length, attacherl to the uterus just below the Fallopian tube, and there continuous with the superficial uterine fibres. From this point it runs obliquely downwards, outwards, and forwarls, immediately beneath the anterior layer of the broad ligament, to reach the pelvic wall; it then loops around the curve of the deep epigastric artery on the inner side of the extemal iliac artery, and enters the inguinal amal at the intemal ring. In its course through the canal it is supplemented by a set of striped fibres, some derived from the muscular walls of the abdomen, others apparently of independent origin; and it may be accompanied by a tube of peritonem, the canal of Nuck, which is constant in the foetus and not infrequently persistent during childhood and even adult life. 'The ligament then gires off a few

Fig. 641.-Section of the Pelvis showing the Liganents of the Uterus.

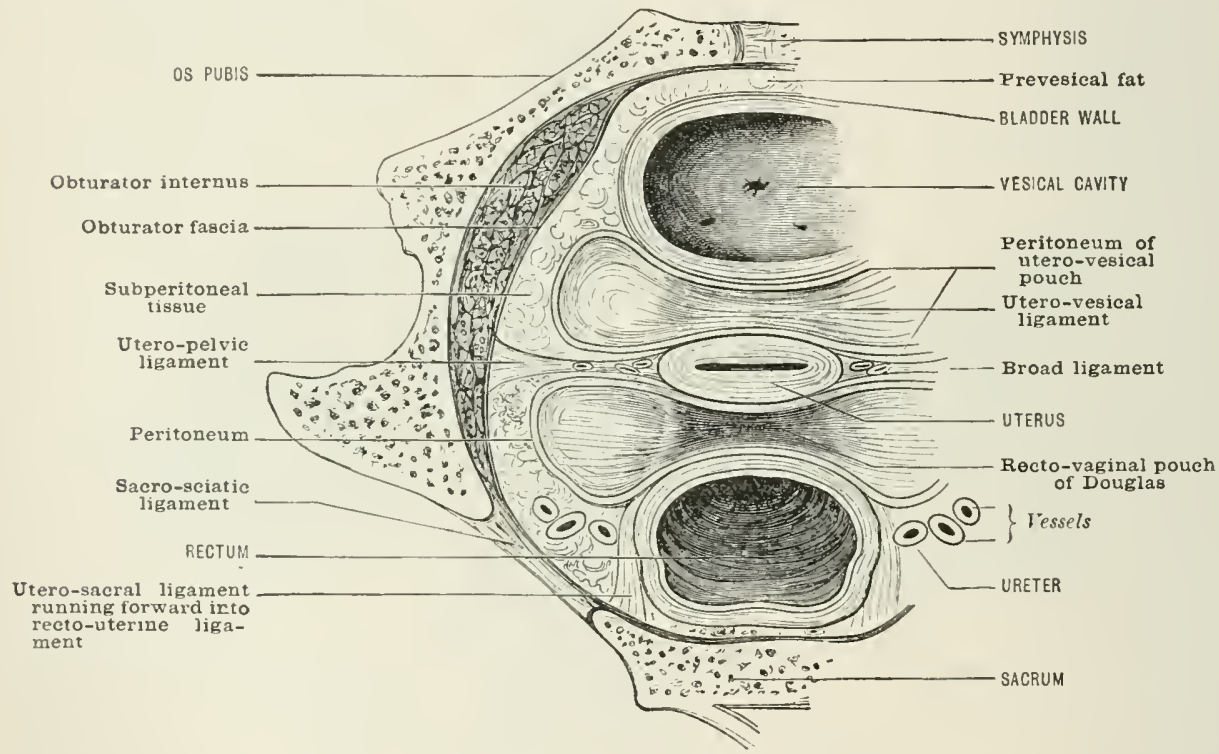

of its newly acquired striped fibres to the pillars of the ring and to the pubic spine, and, emerging from the external ring, finally breaks up into a number of delicate fasciculi which become lost amongst the interlobular connective tissue of the large pad of fat which occupies the labium majus.

In structure it is composed of unstriped muscle with areolar and elastic tissue, reinforced in the inguinal canal by striated muscular fibres and fumicular vessels and nerves. The funicular artery, conveyed by the round ligament, is a branch of the superior vesical. It is accompanied by a plexus of veins, and anastomoses in the labium with hranches of the external pudic, and at the superior angle of the uterus with the uterine and orarian.

The utero-sacral ligaments (fig. (641) are flat muscular bands, extending from the highest part of the "rvix uteri, where they are more or less continuous with the uterine fibres in the recto-uterine proritoneal folds, to the sides of the sacrum onposite the lower borkle of the satere-iliac synchondroses. They run one on each sirle of the rectum near the junction of the first and second stages of this portion of the intestine, closely connecter with its museular coat, and more anteriorly are in lateral relation with the pouch of Douglas. 
The utero-pelvic ligaments (tig. 6t1) are the (xpansions of museular tistur already described in commection with the broul ligament. They radiate from the fasciat over the obturator internus to the sieles of the uteres and valdina, and entheathe the utro-ratinal vessuls and nerres.

The utero-ovarian ligaments (fic. $(3: 39)$, or ligaments of the ovaries, ar. short rounded cords continuous with the uterine filures at the superior ande of the organ behind the Fallopian tule, and joining externally the inner end and attacherd horder of ach ovary. These varius ligamentous structures all serve to maintain the normal position of the uterus. In arldition, the utero-ovarian lisament airls in the fixation of the ovary, and the round and utero-pelvie ligannents form protective sheathis for ressels and nerres.

\section{THE FALLOPIAN TUBES OR OVIDUCTS}

The Fallopian tubes (fig. 639) represent the upper extremities of the Müllerian duets, and may probably be regarded as cornua uteri both in strueture and morphology. They are two trumpet-shaped tubes structurally continuous with the

Fig. 642.-The Broad Ligamext axn its Costexts, Seex fros the Froxt, PAROVARIUY (After Sappey.)

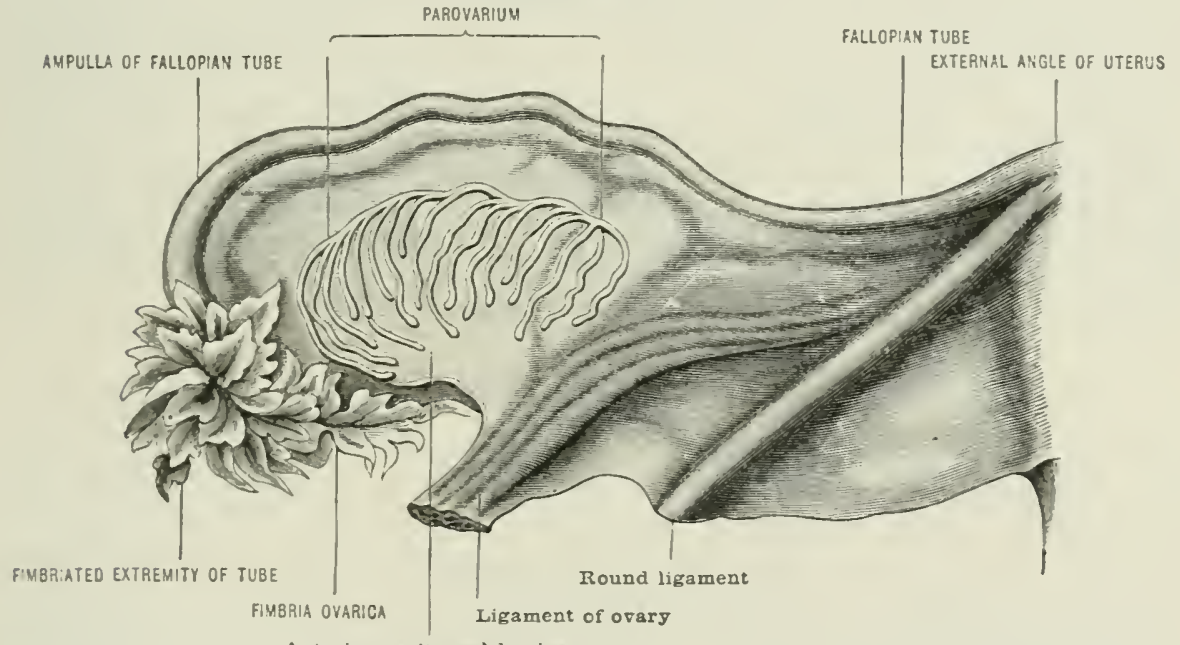

Anterior peritoneal lamina

superior angles of the uterus, and rumning between the two lavers of the broad ligaments to beeome closely comected with the oraries, partly by direct attachment, partly hy a peculiar contiguity. Each duct opens internally into the uterine carits: and its external orifice establishes a continuity between the tubo-ovarian mucous membrane and the peritoneum, but undor normal circumstances is elosely applicd to the surface of the ovary, and reecises the ora which are detacheel from the grland, transmitting them to the uterine carity. It is about four and a lialf inches (11 cm.) in length, straight, narrow, and somewhat eorl-like at its uterine end for a distance of about an inch and a half; Hexuous, and imegularly dilated in the rest of its length as far as its free extremity, where it hecomes expanded into a trumpet-

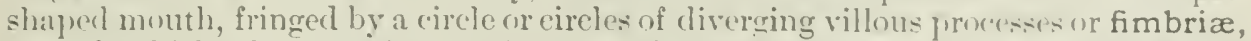
one of which, the fimbria ovarica, or tubo-ovitian ligument, is attathed to the

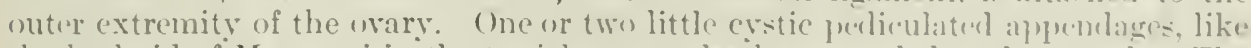
the hyrlatid of Morgagni in the testicle, may also be alpenderl to the meuth. The aperture (ostium abdominale) in the mirlile of this expansion is very small. mot more than half a line or a line in diameter, but its mucous membrane may he prolongerl for some distance along a furrow in the tuln-m)varian ligament.

The narrow extremity, or isthmus, has a diameter of about an eighth of an inch 
(:3 1 mm.), the dilated portion or ampulla measures about a third of an inch (S $\mathrm{mm}$.), and the teminal expansion cxchsive of its fringes has a with of about a ruarter to a third of an inch, the free fimbria langing in length from two-fiftls to three-fifths (10 to $15 \mathrm{~mm}$.) of an inch, while the fimbria orarica attains an inch or eren two inches ( $2 \cdot 5$ to $\tilde{5}$ (an. ). Acecssory fimbriated extremities are occasionally met with.

The direction of the oviduet traced from its uterine attachment is transversely outwards as far as the midlle of the ovary; berourl this point the tube winds in a flrxuous course backwards and inwards around the gland in the mammer elescribed helow.

Structure.-The tube has four coats-scrous, cellular, muscular, and mucous. The serous coat, remerented by the fold at the free border of the broad ligament, is ineomplete, like that of the small intestine, the muscular tunic being uncovered by pritonem for about one-fourth or one-fifth of its cireumference along the line of attachment of the two serous lanince, and henee a rupture of the duct may lead to an escape of its contents either into the peritoneal cavity or into the interserous space. The cellular coat is a kind of adrentitia, rich in vessels, and continuous with the sulpueritoneal tissue of the broal liganent. The muscular coat, about the sixtieth of an inch in thickness, consists of circular and longitudinal fibres; the latter for the most part sparingly distributed outside the former, but near the outer extrenity of the tube appearing also as an innermost layer. The circular larer is most attenuated near the fimhriated extremity. The mucous membrane is chameterised mainly by its plications. The folds are longitudinal in direction, and relatively simple in the isthmus, where the cavity appears as a stellate fissure when cut across; but in the ampulla the multiplication of surface is very complex, and in a transverse section presents a deceptive appearance of branching tubular glands within the depth of a thick mucosa. At the fimbriated extremity of the tube, the plications are continued on to the fringes. The epithelium is cylindrical and ciliated, the motion being towards the uterus. At the trumpet-shaped extremity it passu by transition into the parement epithelium of the serous membrane. The subepithelial tissue contains a longitudinal muscularis mucose.

\section{THE OTARIES}

The ovary (fig. 635) is a paired organ which projects strongly from the posterior surface of the broad ligament. Its longest cliameter averages an inch and a half, its greatest breaclth about three-quarter's of an inch, its thickness ahout half an inch; and its weight is ordinarily about 100 grains. The right is usually a little larger than the left.

Form, position, etc.-The typical shape resembles that of a broad almond. In anatomical preprations it appears as a horizontal appendage to the back of the broad ligament with an anterior attached border, a posterior free border, superior and inferior surfaces, an inner extremity connected with the utero-ovarian ligament, and an outer extremity receiving the fimbria ovarica of the Fallopian tube: it is most probable lowerer that the position is clifferent when the organs are in situ under normal cireunstances. Symington in his examination of frozen sections in children found the ovary lying in a sagittal plane against the side wall of the pelvis with its long axis nearly vertical, so that its surfaces were internal and external, its borders anterior and posterior, and its extremitis upper and lower, while the Fallopian tule ran upwards along the anterior attacher border of the gland, then arching backwarks above its upper extrenity to end in the fimbriat; and where the finbria are fully developed they may embrace the posterior free borker, and thus the tube is wome alnost completely around the gland, learing only the lateral surfaces cxposed. The extemal surface is said to lie against the 
pelvie wall in a loollow between the intrual iliac antery and vein, hut there is rerery reason to believe that it is very variable in the adult. "The laxity of its ennections, the liability to changes of position during prennaney, and the wanging relations of the contiguous visecra make it diflicult to aceept any one of the many views as absilutely correct. The organ when enlarged may be folt theourh the vagina, and, better, through the rectum, and its position with regard to the surface is indicated hy a point alout two inches to the inner side of the anterior superior spine of the ilium. The surfaces and free border are of a dull white, and after pulserty are scarred by hreaches of surfaces due to the dehiscence of ripe ova; the attached lowder is picieed by the orarian vessels and nerves which lie between the lavers of the broad ligament, and their point of entrance is termed the hilum.

Structure.-The ovary consists of a parenchyma and a kind of capsule, or tunica albuginea. The latter, mulike the tunica albuginea of the tertis, is a modification of the stroma of the gland, and does not excecrl the two-hundred-andfifticth of an inch in thickness; it is crowned with an epitheliun (columnar) differing in character from that of the serous membrane witl which it is connected. The true gland-structure is a mass of connective tissue and unstriped muscle with ressels and nerves. It is very vascular in the neighbourhood of the hilum. where the veins are peculiarly large and closely set, and is condensed into a kind of cortex beneath the albuginea. The cortex is about half a line in thickness, and con-ists of interlacing bundles of white fibrous tissue, which pass insensibly into the faintly fibrillated tunica albuginca, ancl cnclose multitudes of small ressels called ovisacs, or Graafian follicles, in whicl the ora are developed.

The majority of the ovisacs are microscopic, but as they ripen and approach the surface they increase in dimensions, and may even attain the size of a large white currant. Their rupture leads to the scarring already mentioned, and the emyty capsule slowly disippears when impregnation has not occurred; but under the influence of the vascularisation of the organs during pregnancy, it may undergo a remarkilile development and form a yellow plicated body known as the corpus luteum.

\section{VESELA AND NERVES OF THE UTERUS AND ITS APPEYDAGE}

The verels are the uterine, ovarian, and funicular, all of which are pairecl. The uterine artery (fig. $64 \%$ ), a branch of the internal iliac, rums from its origin in a downward direction along the pelvic wall as far as the base of the loroad ligament; then, crossing horizontally towards the cervix uteri in front of the nueter, it gives oft :ome small vaginal and vesical branches, and runs upwards in a serpentine eourse close to the side of the body of the uterus, supplying transwerse branclues to the anterior and posterior walls of the organ. These anastomose with their fellows aeross the mildle line, one larger branch opposite the junction of the horly and cervix, forming with the corresponding vesed of the other side, the arterial cirche of Huguier.' Finally they communicate at the upper angle with the terminal twigs of the ovarim and funicular arteries. The uterine veins are of very large size, and on leaving the uterus form a plexus in the muscular tiste of the hroml ligaments, at length joining a trunk whirh runs side hy side with the artery to end in the internal iliace vein.

The ovarian artery, arising from the aorta (like the spuruatice in the male). crosise the common iliac artery, and is conducted into the hroal ligament by the

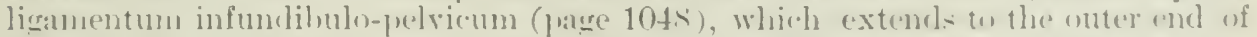
the oriduct. It breaks up into two divisions: (1) The tubel, which runs along the

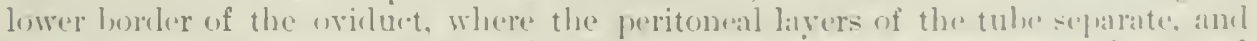

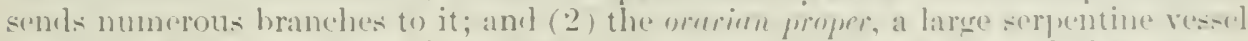
which gives off many large hranches into the hilum of the gland, and then jastes to the angle of the utcrus, where it enels ly anastemosing with the uterine and funicular arteriss.

The ovarian veins, very larelely developeel about the lilum of the wary, appear as a plexus in the broad ligament. and, reaching the margin of the purase, 
assume a pampliniform arrangement around the artery. The right ends in the vena caval, the left in the renal rein.

The funicular artery is an offset of the verical. It joins the round ligament at the internal liner. and clivides inte ascending and deseending branches, the former rumning backwarls in the substance of the liganent as far as the angle of the uterus, where it commmicates with the ovarian and uterine; the latter passing with the ligament throurh the ingruinal canal inte the labium, there anastomosing with the external puclic. It is acompanied by its vin.

The lymphatics (tig. 6t3) of the nterus and Fallopian tubes form plexuses in the mucous memhiane, in the muscular walls, and beneath the peritoncun. Those of the orary oricrinate in the frerifollieular tissue around the Graafian resicles, and escape at the hilum. The efferent ressels from these three organs may be divided

Fig. 643.-Didcilay of the Arteries AxD Lryphatics of the Fedile Gexerative ORGAXS.

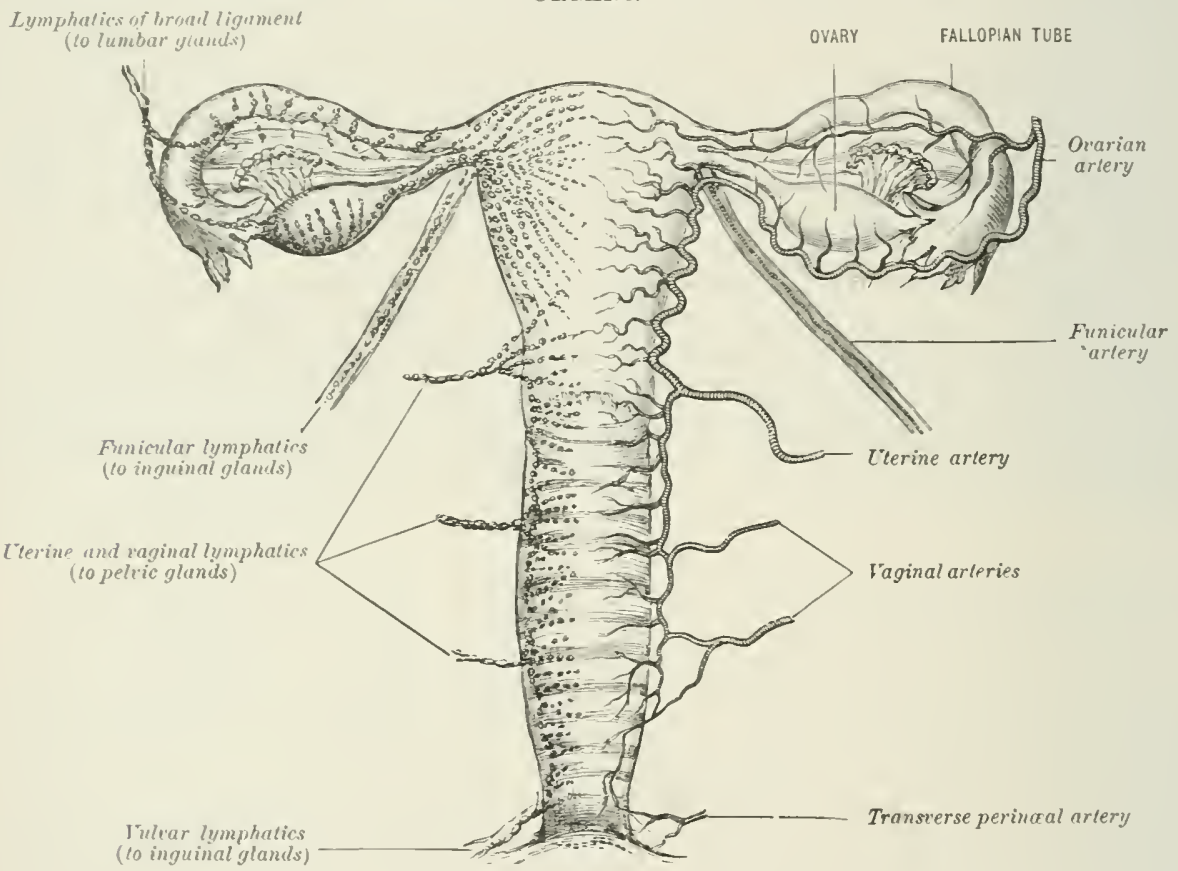

into three groups with intercommunicating territories. (1) The first. including those of the body of the uterus, those of the ovary, and those of the Fallopian tube, unite ly the side of the ovarian ressels and run with the reins to teminate in the presertebral glands in front of the aorta and vena cara; (2) the second, those of the cervix uteri, form two trunks which run along the base of the broad ligament with the uterine vein to end in the pelvic glands which lie beneath the hifurcation of the iliac artery; (3) the third, those of the round ligament. follow this structure and end in the inguinal or lower iliac glands. Here as elsewhere the lymphatics are collateral with the veins.

The nerves of the uterns are lerived from the third and fourth sacral, the hrpogastric plexus of the sympathetic, and from the renal plexus, which also supplies the oraries and oriduct. 


\section{DEVELOPMENT OF THE GENTTO TRINARY ORGASS}

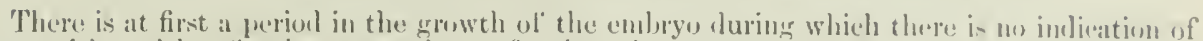
any provision ather lior the generative or for the urinary lunction. A little later the rudinent-

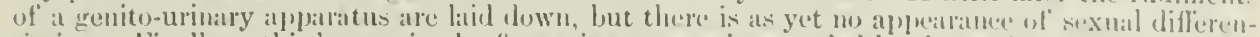
thation. Finally, a thim stage in the formative proessis is oceupied hy the ovelution of the orerans

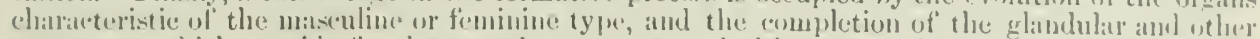
strutures, which provile for the secretion, storage, and ultimate expulsion of the urine firem the buly. It will be seen that in the comlse of these developmental changes certain of the structures eoncerned appear and assume their permanent chancters gralually and without altw'ation of plan; others, nriginally employed for purposes menmeeted with the genito-mrinary system, become adapted to take their place in this section of the econony; sthers helonging to the system from the first ane brouglit into a special emdition of functional activity only to undergo ("onversion (1) a different use later our while uthers anain may, according to the sex assumed fiy the foetus, either dwindle into useless relies without ever taking any shane in the work of the lionly, or mily hecome elaborated into important and efficient parts of the reproductive oreanism.

Fig. 644.-Diarian of thl: Printtive Gexito-urisary Orgaxs befole DifFerextiation of Slix. (After Henle.)

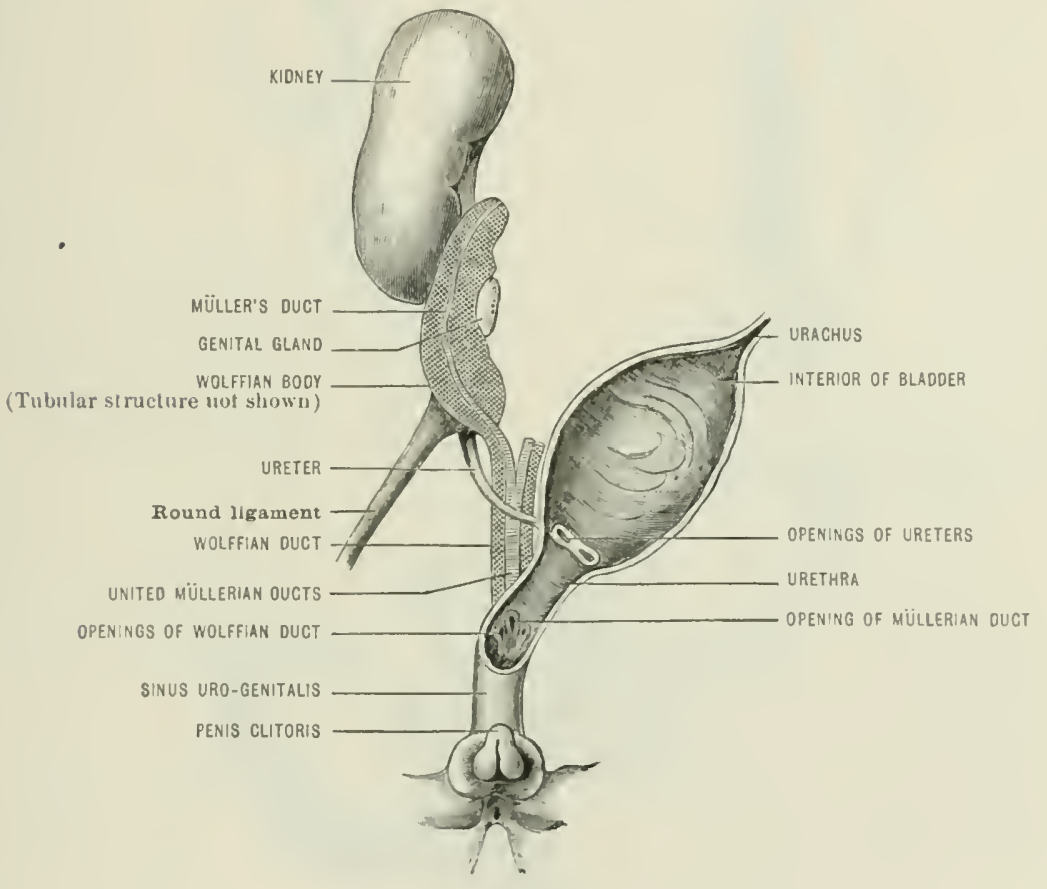

The earliest appearance is that of a tube called the Wolffian duct, which opens hy it - himiler

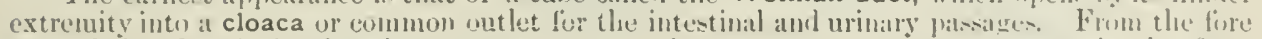
fart of this duct is eleveloped a temporary organ, the pronephros, or head-kidney, in the firm of vasenlar glomeruli. Bohind this soun alperar a number of tuber, which upen at riefit angles into the mid portion of' the luct, and constitute the mesonephros, mid-kidney, or Wolffian body. Still firther bank, fiom the juster ior end of the duct, springs the metanephros, ur hindkidney, a mesoblastic growt arouml a hollow branching protrusion from the duct, with which

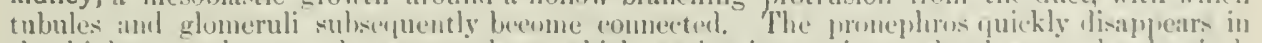
the higher vertebrates; the mesmephros, which reaches its maximm derelupmint hy the sixth

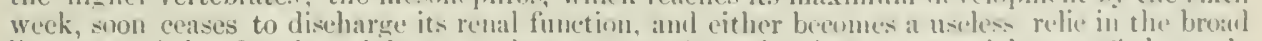

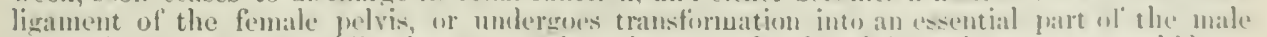

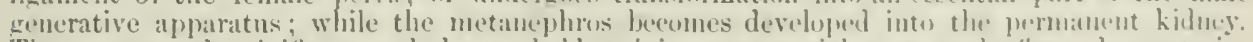
The ureter and uriniferous tubules probably originate as special unterowtis frum the pusteriug part of the Wubfian anct. The morphology of the suprarenal louly is somewhat douldfiul, hut it

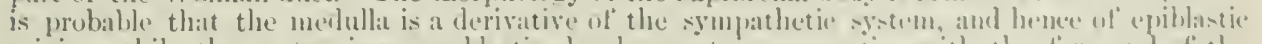

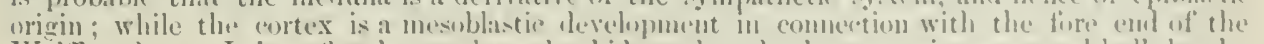
Wolffial duet. It is at first larger than the kilney, hut the litter attains an equal bulk ly the 
tenth weck, and then continues to increase, becoming eonsiderably the greater by the end of foctal life: but eren at birth the suprarenal bodies are proportionally much larger than in the adult.

The urinary bladder appears in the second month as a transformation of the pedicle of the allantois, a stricture which has already done service in conveying the vessels of the embryo to the placentit. The allintuis is a hypoblastic sac invested ly a layer of mesoblast, and communieating with the hiud gut. That portion of it which lies within the body becomes dilated at its central part into the urinary bladder, lut remains narrow at both extremities, forming in front the urachus; and behind, the whole urethra in the female, and the upper part of the prostatie urethra in the male.

The generative apparatus is developed from the Wolffian ducts and from two other paired stmetures chesely related to these, lut of somewhat later formation-the Mïllerian ducts and the genital glands.

From the Wolffian body its tubules and its duct are formed, in the male, the whole of the Fig. 645.-Developiest of time Urixo-gexerative Orgaxs, Female type.
(After Henle.)

(The parts forned from the Midllerian duct in this and the sneceeding diagram are indieated hy horizontal shading; those formed from the Wolffian borly and duct, by diagonal cross-hatching.)

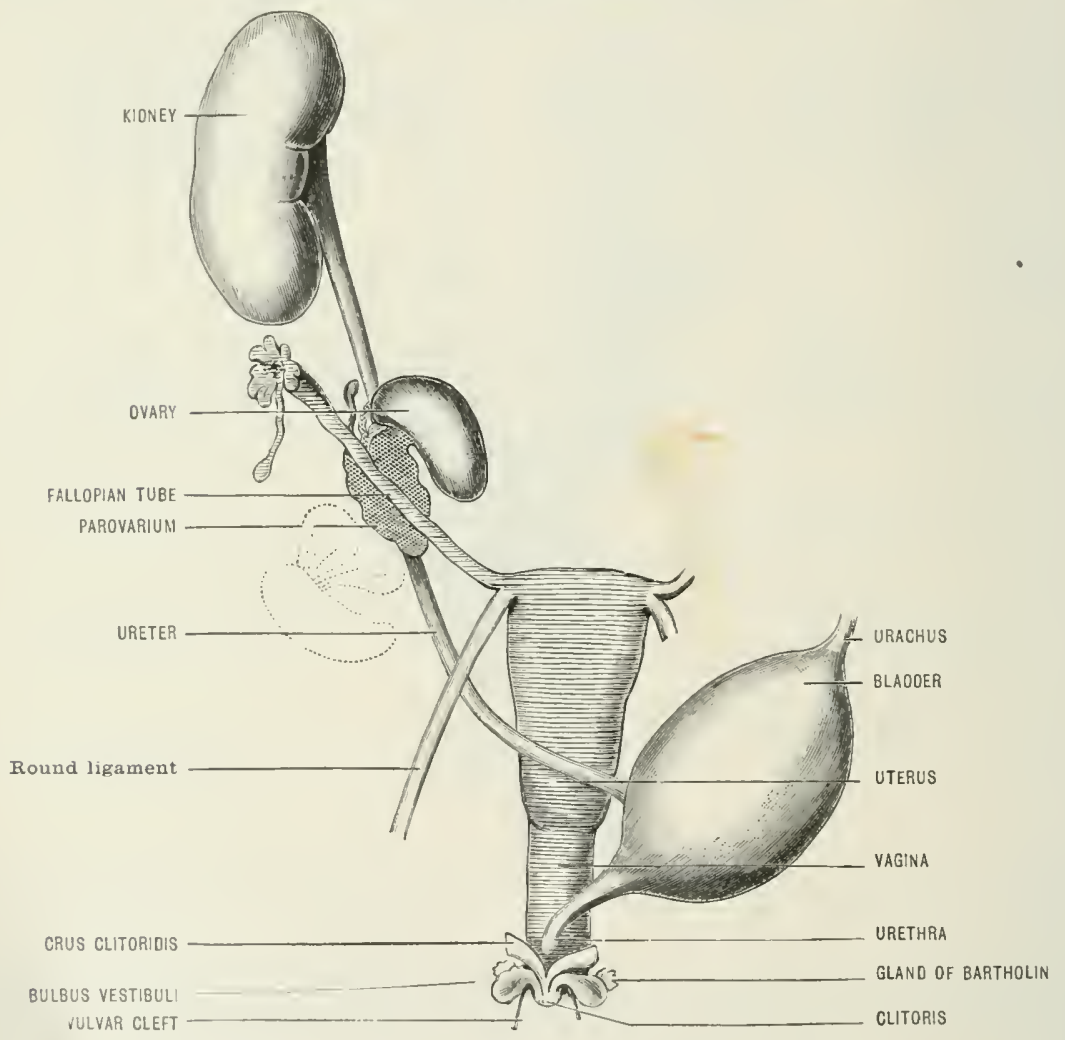

excretory tubes outsirle the borly of the testicle, namely, the vasa efferentia, the enni vasculusi, the tube of the epididymis, the vas deferens, the ejaculatory duct, and the paradidymis (the organ of Giraldes). In the female the structure dwindles amay, leaving its vestiges as the parovarium and the duct of Gäirtuer (the latter being oceasionally demomstrable in the hmman sulyject).

'The genital gland arises ats a rilge, partly mesoblastic and partly due to a thickening of an epithelial layer, the germinal epithelium, on the imer side of the Wrolffian body. The eells, at first indeterminate, soun becone differentiated to form the Graafian follicles and ova in the female, and the epithelium of the seminiforous tubes in the male; the rest of the orary or testicle being developed from the mesoblast of the rilge. The gland is at first attached to the Wolffin hody. The latter is itself' fixed to the pesterior wall of the alulnminal eavity by a duplicature of peritoneum ealled the mesorchium, or mesovarium, from which a little fold containing musenlar filme is prolonged downwarls to becone the gubernaculum testis in the male, or, after connection with the uterus, the round ligsument in the female. 
The Müllerian duct leerius as a slender cord lyiner parallel to, and on the outer siele of: the

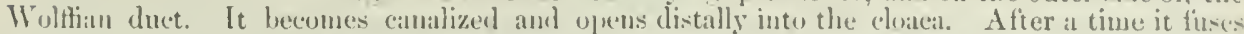
with its fellow mesially a short distance above the terminal aperture, and the conjoint tube is lu,uml together. with the atjacent Wolffian ducts into a kind of stem callerl the genital cord. In the male the If iillerian duet never apprears to discharese any funetion, and its useless relics are to le traced in the sinus pucularis and liventid of Morgand; but in the female it gives rise to nearly

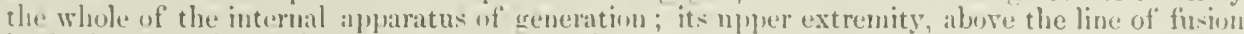
in the human subject, formine the ovidnet am its hyllatid aplemdagre, the eonjoint tube develnpine the uterms and vignas. Tariations in the point of fusion of the two ducts may learl to the ahormality if a two-horned uterus, of even a dubble nterus and vagina. Fxceptionally Miiller' inet may finm a mdiurentary uterus in the male. In such cases the testes are well developeel, int the penis remains very small.

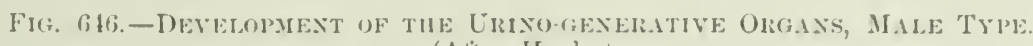

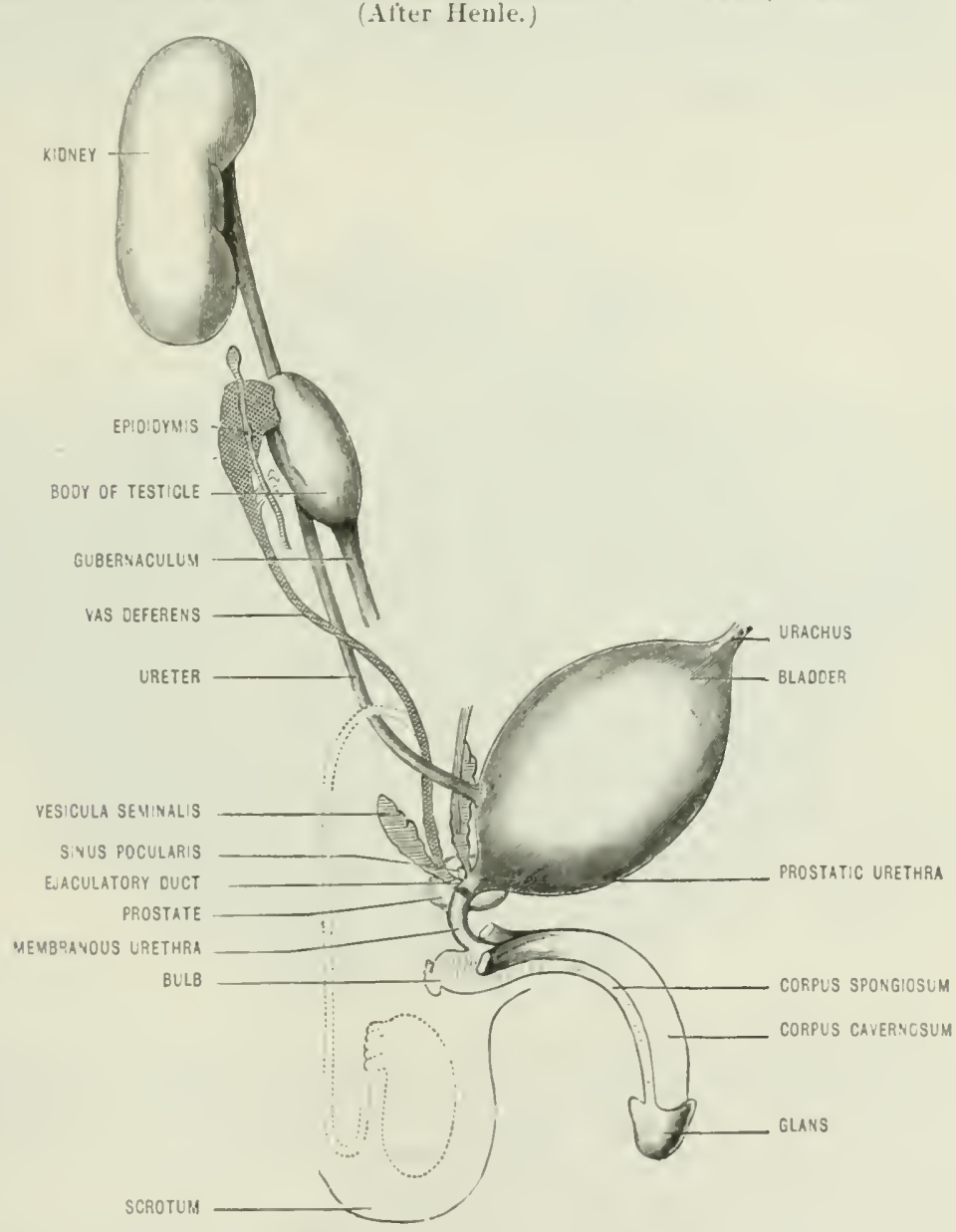

The external genitals are leveloperl about the eloaeal ontlet comumon to the genito-urinary amb jutestinal canals. 'The first change is the appearauce of a genital cminence, the future elitorior fenis, at the ventral extremity of the cloasal fisture about the fifth or sixels week. I fortnight later thr cluaci is livinled ly a transverse septum inte two parts, a dorsal or anal, and a ventral or uru-genital (uro-genital sinus); the sejtum itself persisting as the perineal lunly in the frumale, and the portion of the perineum lying leetween the serutmu and anms in the male. Its absesnee or incomplete levelopnent accumts for certain eongenital malformations well known to teratuloघi-ts. The uro-genital sinus next umlergoes challuges which grive the extornal stamp of sex. At first the urethra upens into the suus lehiud the cenital pouninence. In the female this remain: fermanent, the lips of the sinus expand into the lalija majora; two rilges within the sinus, ex-

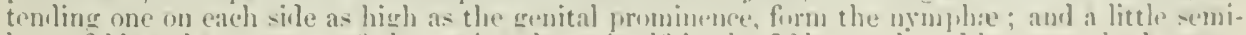
lunar felle at the entranee of the vagina show itselt in the fifth month and beromes the hymen; 
while the genitill endnence censes to enlurge and remains as the clitnris. In the male the erolutionary proeesese go fitther. 'The margins of the uro-genital sinus fuse in the midlde line to close in a prolongation of the urethat on the ventral aspect of the genital eminence and to form the scrotmm. the process being conchuled almut the fitteenth week; finally, a pouch of peritoneum makes its way on each side through the abdomimal wall into the corresponding balf of the scrotum, and into this the testiele ultimately descends, guides by the gubernaculom (page 1025). The glands of Cowper or Bartholin in buth sexes are formed by involutions of epithelium near the ront of the ruilimentary elitoris or penis.

Shunld the process of mesial finsiun fail, the urethra may present a fistuluus opening on its rentral side, or may remicin cleft from the meatus upwarls for a greater or less distance. In the more ag gravated forms the defect of union involves the scrotum also, and leads to a spurious hermaphroclism in which is perpetnated a smperficial resenublance to the female genitals, the simulation being male greater ly the imperfeet descent of the texticles. All these congenital defects alre clearly accounted for by iscertained facts in morjhology ; but there is a malformation which our present knowled ge does not sitisfactorily explain-that known as "extroversion of the bladiler," in which a non-closure of the ventral parietes below the umbilicus comeides with a fissure in the anterior wall of the allantuic bladiler, and leads to an extrusion of the posterior wall of the visens. Mr. Shattock suggests that the condition is perhaps the result of an undue extension furwards of the eloacal fissure; but the problem cannot yet be regarded as solved.

\section{THE PERIN ELM}

The term perinæum ( $\pi$ spi, vaiw) has been variunsly apllied by anatomistsfirstly, in its original and generil meaning, to the soft parts comnected with the pelvic outlet; secondly, to the anterior or genito-urinary segment only of these parts; and thirdly, to the tissues separating the vulvo-vaginal and ano-rectal passiges. It is here employed in the first and broader sense, the expression "perinem proprer' being used for the second application, and that of "perinat horly' for the third.

The outlet of the pelvis is a lozenge-shaped space bounded in front by the symphysis and subpubic ligament, behind by the tip of the cocerx, and on each side by the conjoined rami of os pubis and ischim, the tuber ischii. and the inferior horder of the great sacro-sciatic ligament. The latter structure is orerlapped to a variable extent by the gluteus maximus, which also covers the tuber ischii when the thighs are extended; but the glutei are merely accessory to the true boundaries.

The dimensions of the outlet in the male and female are given on page 146. The further anatomy of the parts differs in the two sexes.

\section{THE MALE PERIN ELM}

The integument of the perinæum is pigmented, beset with scattered hairs, and provided with large sebaceous and sudoriparous glands. Its deeper lisyers contain an abunclance of smooth muscular filbre continuous with the dartos of the scrotum, and thrse are so clisposed around the anal margin as to corrugate the skin into radiating folks during their contraction.

The lamburlks of the region are for the most part well-defined. The symphrsis in front is obseured hy the root of the penis, which may be traced batckiards as a soft median prominence as far as a point an inch anterior to the anus. On each side the pulice and ischial rami may be felt rumning outwards and hackwards to (xpand into the ischisl tuherosity, which is moovered by the gluteus maximus when the thigh is llexecl. Extending backwarls and inwards from the tuberosity may be deterted, in thin suljects, the reistance of the great sacro-sciatic ligament; and still more posteriorly the corerx is felt in the midelle line immediately beneath the skin. The anal aluerture, surroundect lev ratiating furrows, lies a short distance in front of the eocerx. and on carch sile of it is a depression called the ischio-rectal fossi, the superficial aspect of which depends upon the amount of fat which oceupies it. 
The ferinseum is divided arbitrarily into two barts by a line drawn transterecely

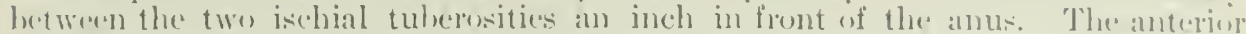

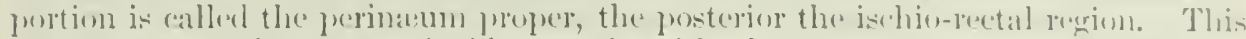

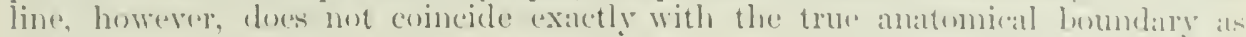
revialed hy discection.

The ischio-rectal region comprises the parts surmomeling the anms ambl the isching-rectal foside.

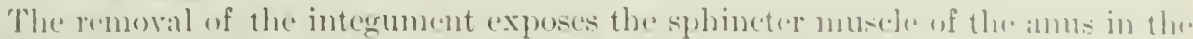

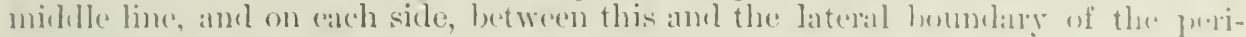
nirem, the external aluerture of the ischion-rectal forsat.

The sphincter ani externus is a volunt:1ry muscles smromeling the antus, and

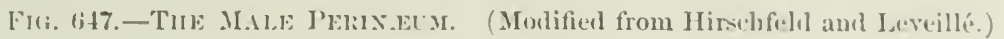

BULBO-CAVERNOSUS

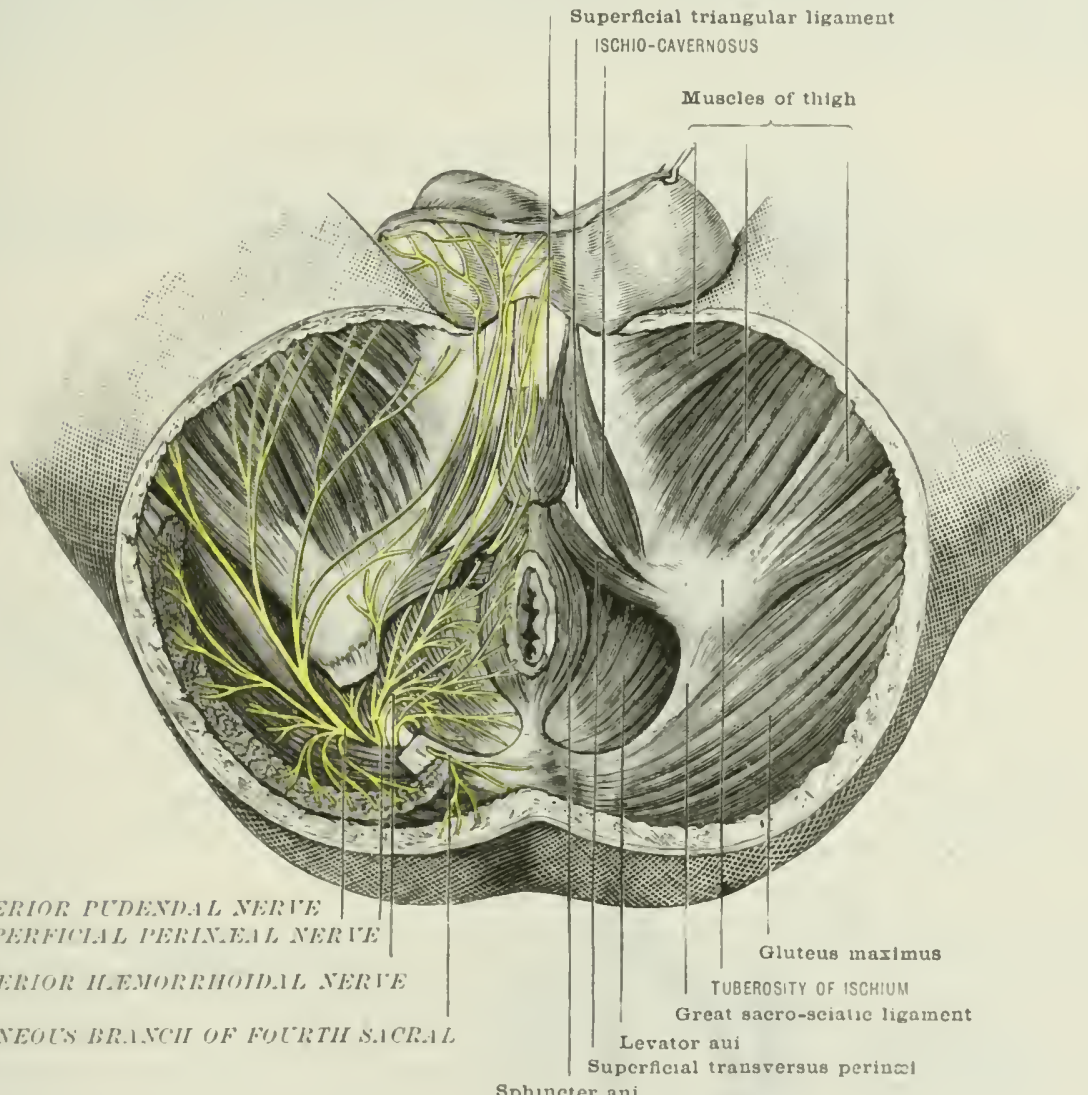

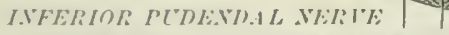

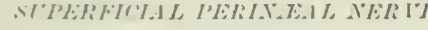

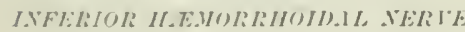

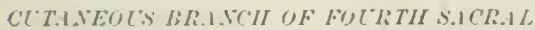

Sphıncter ani

attacherl, in front to the temlinens center of the perinam (where it ment- the

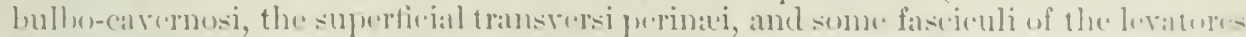

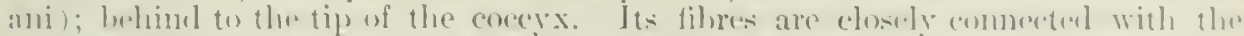
skin, ancl superficial hundles pass forwards he the sirles of the andes a fow deros-

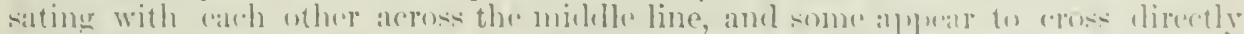

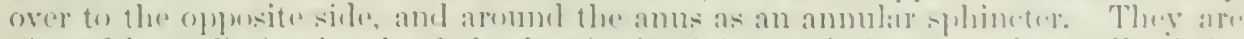

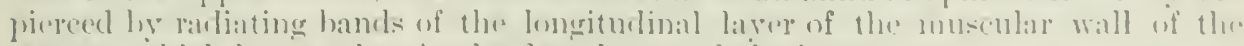
rectum, which luesome lest in the deep lityers of the integument.

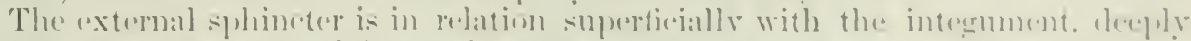
with the levatores and am internal sphineter; on the outer side with the fat of the

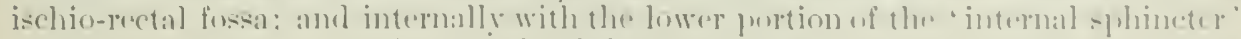

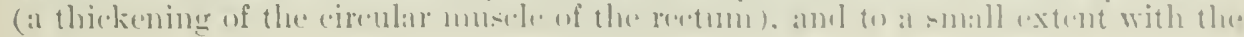


rectal muens membrane. It is supplied by the inferior hamorhoidal branches of the internal purlic arterr; its reins, of large size and very liable to varicose dilatation, terminate in the inferior hemorrhoidal and fuclie veins; its lymphatics ofven into the inguinal glancls; and its nerves are derived from the perineal, the pudic, and the fourth sacral.

Action.-The external sphincter, by virtue of its elasticity, gives some passive aid to the intemal splimeter in maintaining the elosure of the anus and the retention of the contents of the rectal cul-de-sac under ordinary conditions; but it: active aml more important function is to close the anal aperture firmly during the contraction of the levatores ani and other constrictor muscles of the abdominopelvic cavity in porerful muscular efforts not comnected with defecation (as in romiting, urination, parturition, expiration, etc.). This it effects partly through the approximation of the opposite sides of the anus by its longitudinal fibres, and partly by the ring-like contraction of its circular fibres. It also airls in flexing the coccrix. and in fixing the tendinous eentre of the peringum during the contraction of the bulbo-cavemosi.

\section{THE PELVIC FASCIF AND MISCLES}

In order to understand the constitution of the ischio-rectal fosse and their relation to adjacent parts, it is necessary to review the muscular elements of the pelvic wall, and the arrangement of the pelvic fascire.

Fig. 648.-DiakA.I OF THE PELVic FASCIA.

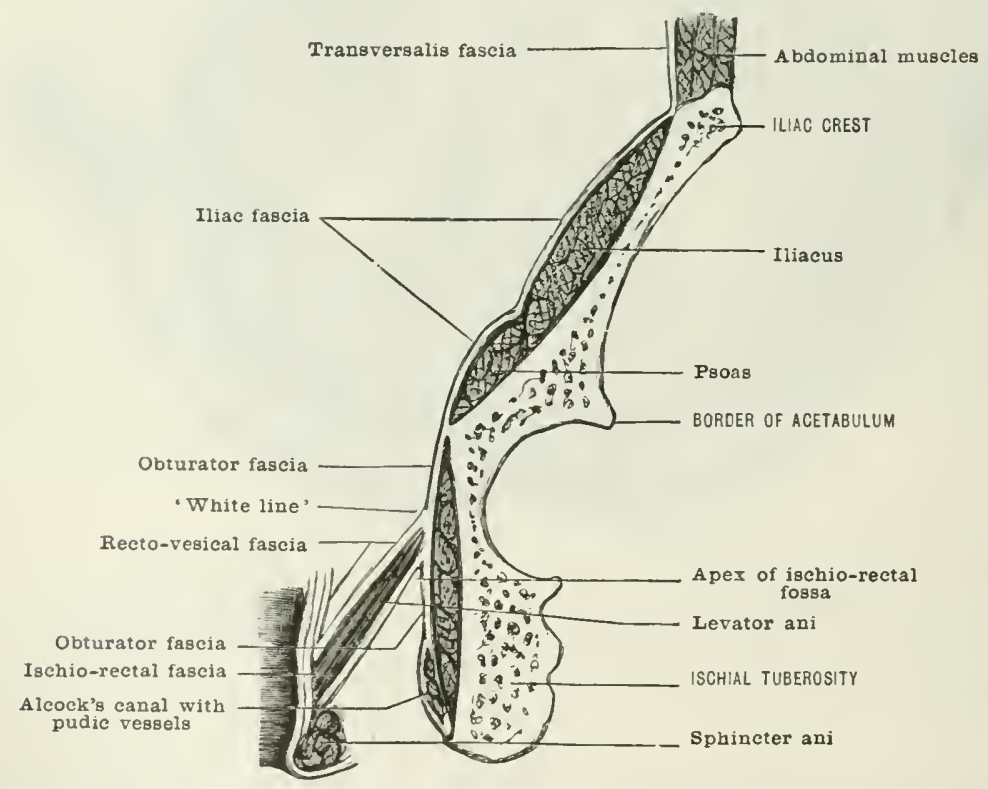

The osseo-ligamentous framework of the walls of the true pelvis is constituted by the two ossa innominata below the ilio-pubic line and posterior border of the pubic erest, by the sacrum and cocerx, and by the sacro-sciatic, sacro-iliac, and interpubic ligaments, and the obturator membrane. Supplementing these structures on each side of the median line, are four muscles: the obturator internus, the pyriformis, the coceygens, and the levator ani, together with their fascial investments.

The obturator internus and pyriformis have already heen described (pages 35.53.55). The fascia covering the inner aspect of the former muscle bears a rery important relation to the intrapelvic structures. 
The obturator fascia (figs. 645,650 ) is attached abore to the ilio-pulice line, as far batek as the sacro-iliate joint and to the posterior lip of the "rest; lectoxe, to the back of the symphysis, the inner lip of the lower borler of the ischio-pulide ramus, and the inner border of the ischial tuberosity; and behind it skirts the osseous borlar of the great sciatic noteh as far as the ischial spine, but at the lescrer sciatic noteh passes out of the pelvis with the muscle, and alyears in the purtfenoral recrion of the thigh. At its horders it is closely related to the fascia iliaca above, the fascia of the pyriformis behind, and the deep triangular ligament below. Its outer surfece is in contact with the muscular fibres of the obturator internus; it: inner surface is clivided into two portions by a curved land of fibres called the: 'white line' or arcus tendineus, extending from the inner aspect of the ischial spine to the back of the os pulis, a little external to the symphysis. The upper or pelvic segment above the white line is separated from the pelvic viscera hy subperitoneal tissue; the lower or ischio-rectal segment, below the line, enter: into the formation of the outer wall of the ischio-rectal fossa. This portion forms a sheath (canal of Alcock) for the pudic ressels and nerves about an inch above the inner margin of the tuber ischii. The fascia gives off from its inner surface at

\section{Figr, 619. - IItscles of the Floor of the Pelvis.}

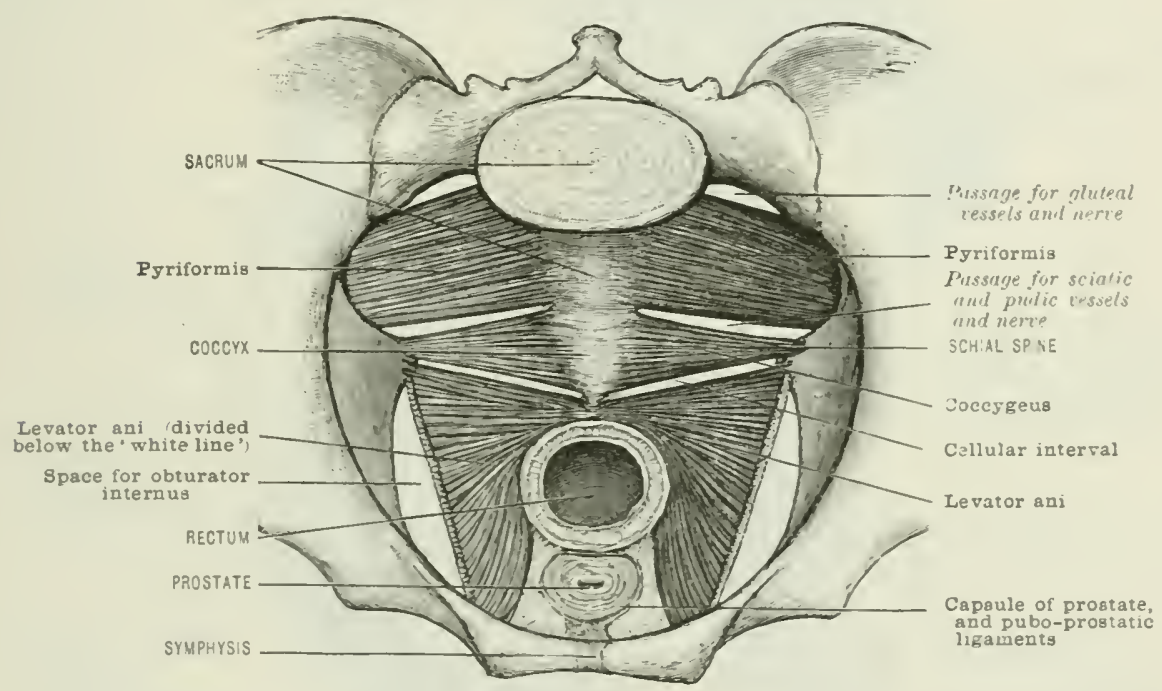

the white line two thin lamina: one, the recto-vesical, to the visceral surface of the levator ani; the other, the ischio-rectal, to the parietal aspect of the same muscli.

The levator ani muscle (figs. 648, 650), with its fellow of the opposite silte. constitutes the greater part of the muscular floor of the pelvis. and acts as a suptum betwen the pelvic eavity and the ischio-rectal fossa. It arises antoriorly from the back of the os pulis. just external to the attachment of the jubo-vesical muscle. posteriorly from the inner side of the ischial spine below the origin of the eocergeus, and hetwen these two points from the whole length of the 'white line.' It fihres form a tlat plane of considerahle strength, and pass downwarls, backwards. and inwarls to their insertion, the most posterior into the tip of the cocerx; thu-w next in orler joining the oppusite muscle in a merlian raplie extending from the cucery to the tendinuse centre of the perineum, and the rest heenming lest upron the side of the reetum, interlacing with the longitudinal layer of the museular wall of the gut, a few fibres perhaps running in front to the preanal raphe. Iis twosurfaces maly he termed viseral and parietal; the former, looking forwarls as well at upwarels, iinvesterl hy a laver of faseia, the recto-vesical. and is further separated from the

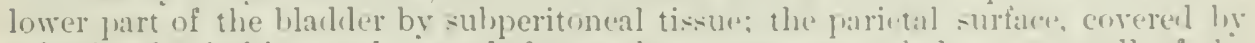
a fiscia, the ischio-rectal or anal, forms the greater frirt of the outer wall of the ischio-rectal fosst. The anterior and posterior horelers of the muscle are free (and 
here the two investing fascice hecome continuous with each other). The anterior lurder crosies the side of the prostate, and is connected with the corresponding

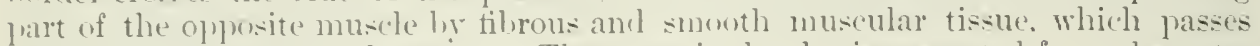
luetween the prostate and rectim. The posterior horler is separated from the anterior marein of the cocergeus hy an indistinct echlular interspace.

In the fentule the anterior fibres of insertion are connected with the side of the ragina. interlacing with the lomgitudinal filures of its muscular tissue without becoming actually inserted into the passige.

The levator ani is supplied hy twigs of the inferior hremorrhoiclal resels and nerves, and receives also liranches from the fourth and fifth sacral nerves.

Action. - The special action from which the muscle derives its name has been questioned l,y Rüdinger, who helieres that its essential function is to compress the rectum. A study of the rlirection of the fibres. however, leaves little doubt that the result of the contraction of the muscle as a whole, and in association with its fellow, is to draw forwarls the encerx and elevate the pelvic floor and riscera, and

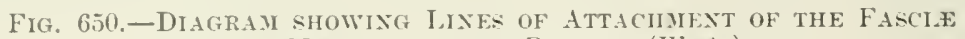
AXI) MLSCLE OF TIFE PELYis. (W. A.)

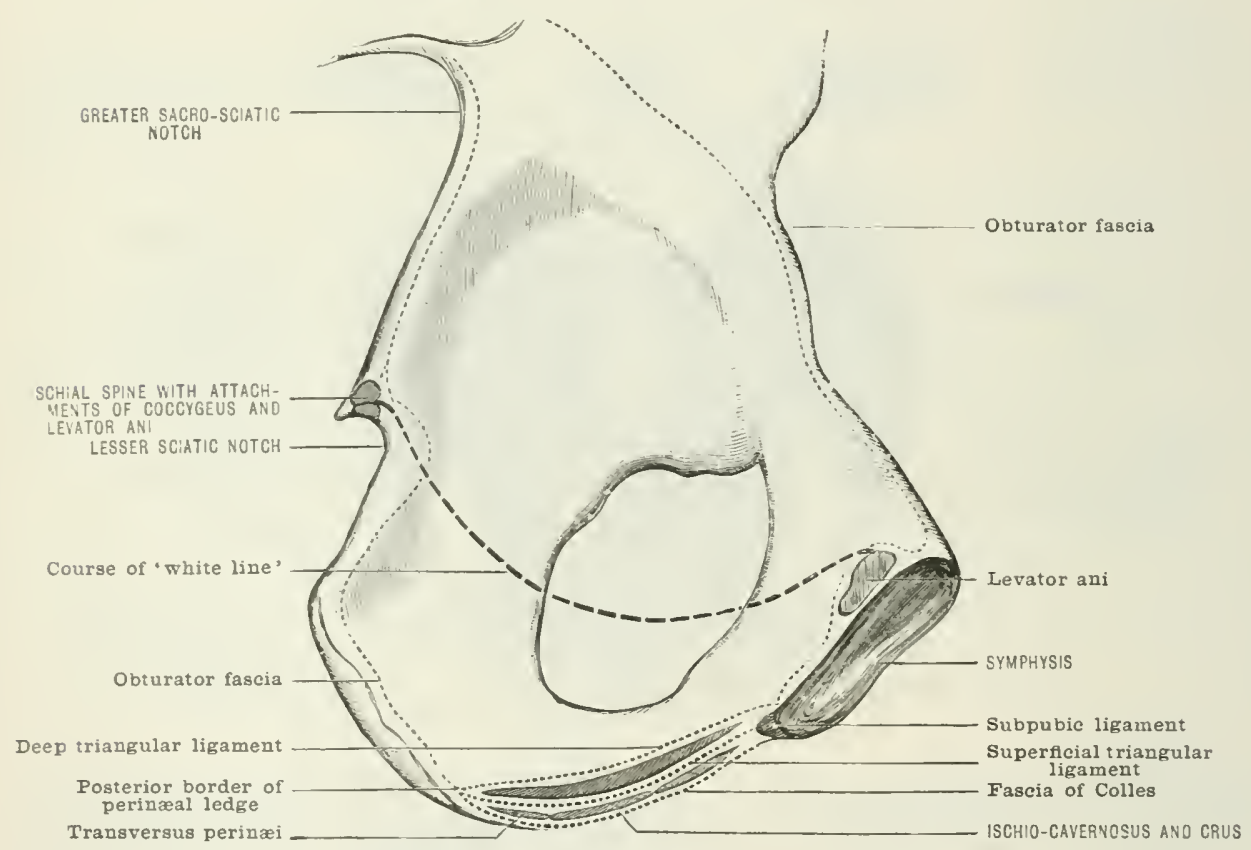

thus lessen the long diameter of the aldomino-pelvic cavity and aid in the compression of the abdoninal and pelvic viscerit. Its action as a compressor of the rectum is probably unimportant, but it is possible that it exercises some influence upon the circulation in the prostatic plexus and in the larese pelvic veins which occupy the recess between the muscle and the viscera, and may also assist in the expulsion of the prostatic secretion by direct lateral compression of the organ. In the female it may constrict the lower end of the ragina, where the passage lies between the free borders of the two muscles.

The coccygeus is a thin and rather unimportant plane of muscular fibres, supported hy and hlending intimately with the lesser sacro-sciatic ligment. It arises from the inner surface of the ischial spine above the levator ani. and passes hackwards and inwarks, expanding to hecome inserterl into the sides of the cocerx, the lateral sacro-coecrgeal ligament, and the last two pieces of the sacrum." Its visceral surface looks ilmost firectly forwarks and is corered by a continuation of the recto-resical fascia. Its parietal surface is in contact with the lesser sacro-sciatic 
ligament. Its superior borrler is separated from the inferior loorder of the pryifornils ly the vessets and nerves which escape from the pelvis helow the latter musele. Its inferior lenrler is redated to the posterior lorder of the levator and. The musele is often piorerel hy filannents of the fourth and fifth sacral and cocergeal nerves, which supply it and form a kind of plexus on its prelvic surface. It aids the levator ani in drawing forwalls the cocerx.

Thr. recto-vesical fascia mily be reganded as a lamina dretaclied from the oliturator fatcia at the level of the upper lescler of the 'white hine.' From this

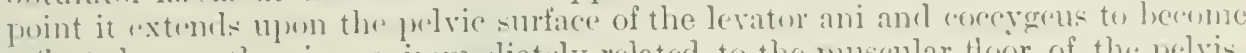
reflectel 1 pon the viscera immediately related to the muscular floor of the pelvis.

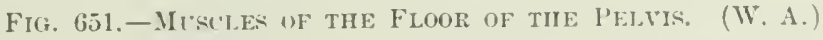

(A prortion of the ischial and pubje homes samn away.)

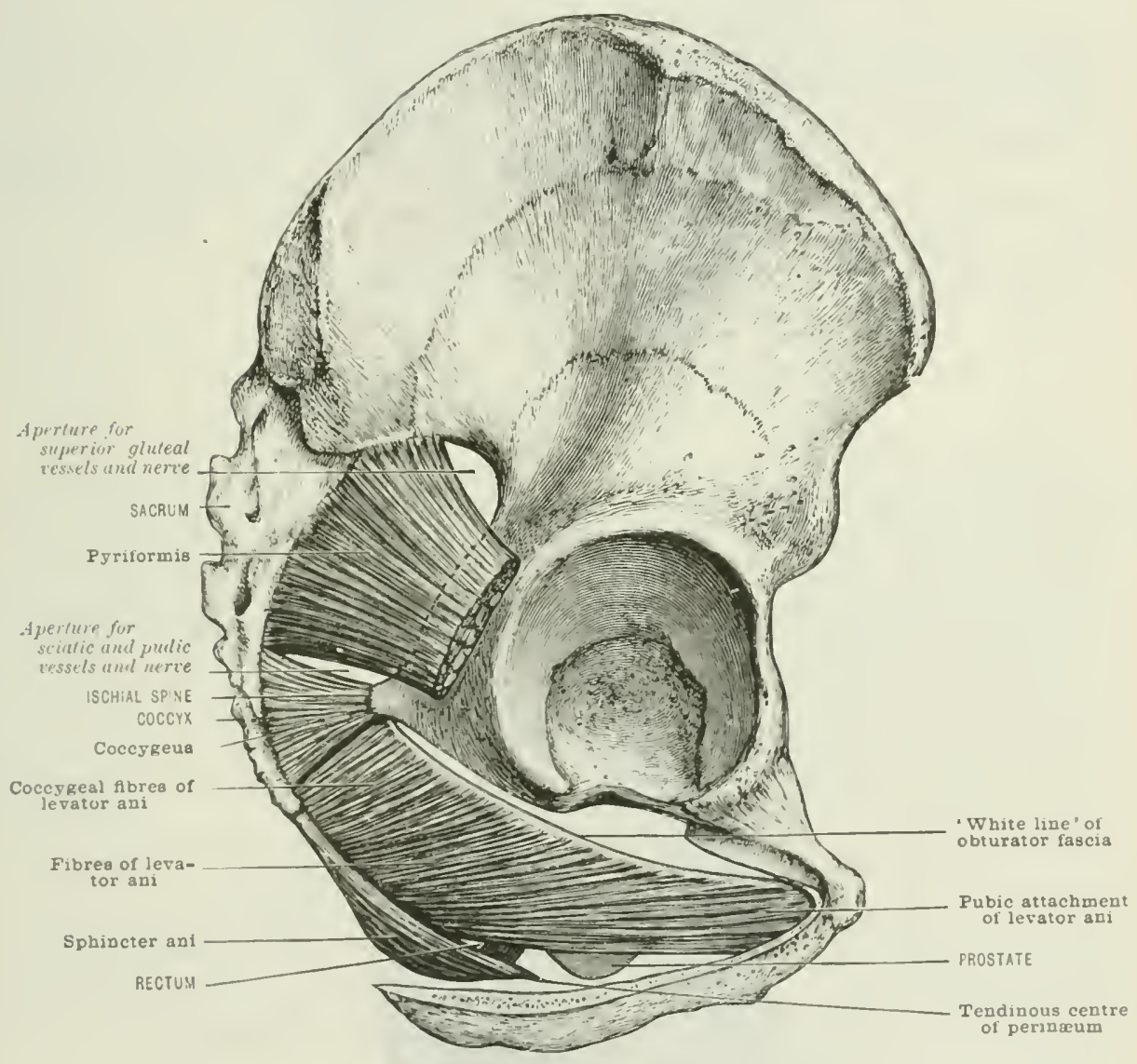

namely, the prostate and hathler (forming the eapsule of the former and the etrue ligaments' of the latter), the vasa deforentia and verienlae seminales, the lenwer part we the rectum, and. in the fentale, the vagina and uterus. Its viseeral portion is (ask to trace in the immerliate neighlourhool of it- reflexion, hut it hecomes lest elistinct as it lecedes from this point, and at length is mulemonstralile.

The ischio-rectal or anal fascia, originating at the white line lxelow the faseial attardment of the levator ani, closely invests the grarietul or ischion-rectal surface of this museles, and that of its neighliome, the coneregens. to lylend in the region of the anus with the dew faseial envering of the external splineter. In front it passes above the perineal struetures, luecoming continums with the superior triangular ligament (a peolongation of theoliturator fasedia), and meeting with the recto-vesical 
fascia, at the anterior border of the levator ani; while behind it extends backwards for a variable distance to join again with the obturator fascia. In this way the two fiscie, obturator and ischio-rectal. close in the ischio-rectal fossa abore, in front, and hehind, but leare it widely open below.

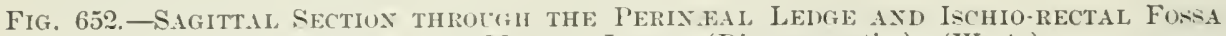
TO THE LEFT OF THE MHDLE LINE. (Diagrammatic.) (W. A.)

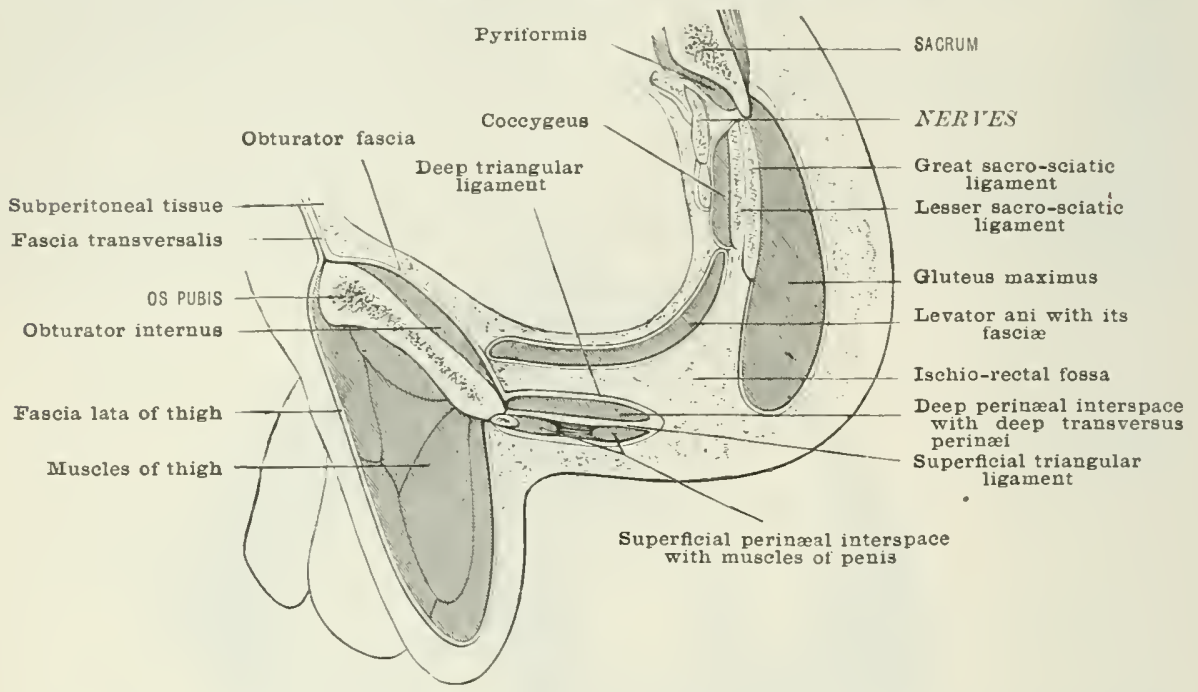

The ischio-rectal fossæ (figs. $64 \bar{i}, 648,652,653$ ) are two deep interspaces, one on each side, left by the divergence of the obliquely directed muscles of the pelvic floor (levator ani and coccygeus) from the rertical pelvic wall. Each fossa

Fig. 653.-SECTION SHOWING THE IsCHIO-RECTAL Fossa iN ITS Relations to the PELTiC Viscera. (W. A.)

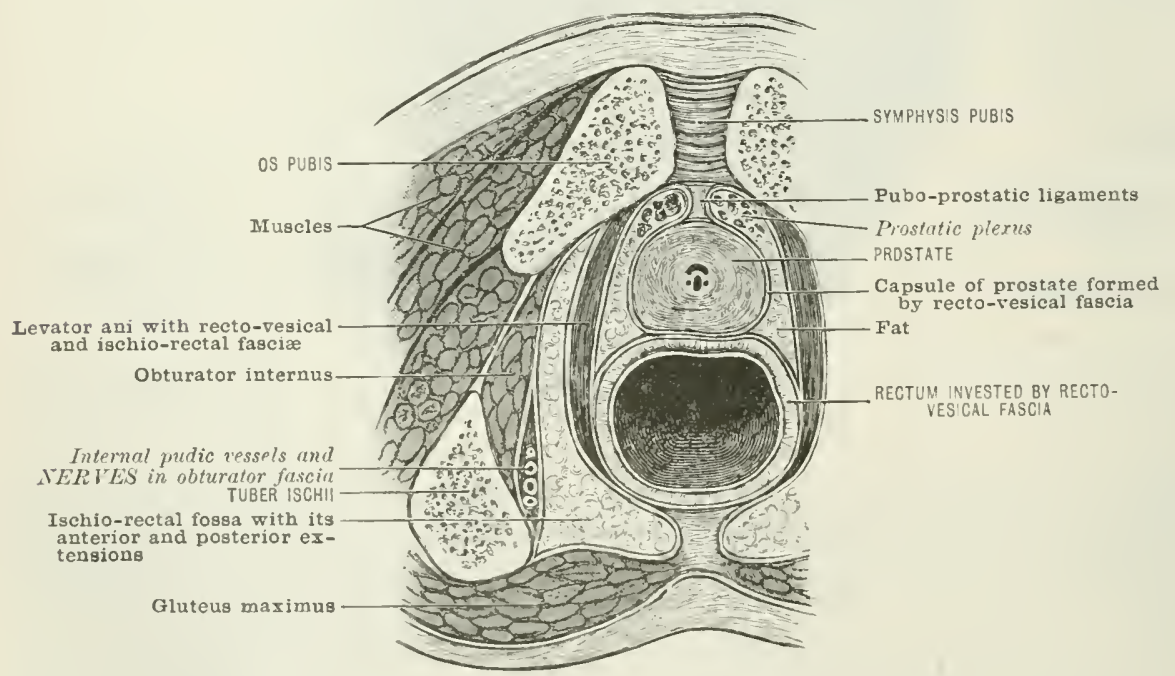

is bounded cxtermally ly the unturator internus below the level of the white line, the corresponding portion of the obturator fascia (with Alcock's canal and the pudic ressels and nerves), and the os innominatum; and internally by the levator ani and coccrgeus and the ischio-rectal fascia. Superiorly, the rertical outer wall 
is joined by the sloping inner wall where the ischio-rectal fascia joins the oluturator fascia, so that the sipace is angular $\wedge$ in outline in frental section. So far all anatomists are agreed, but the remaining bomblaries require further investigation.

If the finger be introduced into the anterior part of the fossa, it will neet the line. of junction of the triangular ligaments with the fascia of Colles; and above this will be found an anterior recess of considerable size cetending forward nearly as fir as the symphysis, between the superior triangular ligament and the under surface of the levator ani, and limited internally by the prostate and pubo-prostatic ligaments, and externally by the pubic and isehial rami. At the back part of the space will be felt the border of the great sitero-sciatic, ligament, and ahove this a posterior recess rumning backwards for a variable distance towards the sacrum. Both of these derpu extensions are lined by the ischio-rectal and obturator fascia, and filled with fat and connective tissue. The isehio-rectal fossa must then be described as an anvil- or T-shaperl ravity with anterior and posterior recesses running the one above the perineal ledge, the other above the sacro-sciatic ligaments.

Contents. -The ischio-rectal fossa is filled with loose adipose tissue continuous with the sulurutaneous fat of the buttock, and traversed from without inwards the inferior hismorrhoidal hranches of the purlic artery, and by the associated vein: and some twigs of the internal pudic nerve passing to the sphineter ani and adjacent skin and mucous membrane.

The veins are usually somewhat dilated near the anal margin, and when morbilly colared constitute the condition known as hemorrhoids or piles. Nen the pesterior borker of the triangular liganents the pudic vessels and nerves give off their superficial perinzal branches, which almost immediately enter the sujerficial perinaal interspace.

A small branch of the fourth sacral neve may be seen turning over the back of the space to reach the anal integument.

\section{THE PERINATM PROPER}

The perinæum proper (figs. 647,652 ), considered apart from the portion of the common interument which corers it in, is a curious triangular ledge of tis-ue stretched almost horizontally across the angular interval between the two ischiopuhic rami. It is piereed liy the urethra (and also by the vagina in the female). and comprises three strong fascice which enclose within two interfascial spaces the ront of the penis with the muscles appended to it, the compressor urethre muscle. Cowper's glankls. and a number of ressels and nerves. Above it lie the prostate and levatores ani with their fatsice, and the anterior recess of each ischio-rectal fis:-il.

The perinaal integument has already been described. On removal of the skin with jts lartos and the superficial layers of superficial fascia, a deeper phane uf fascia will he exposerl, connected firmly with the ischio-pubic rami. This is the fascia of Colles (the deep layer of the superficial perinat fascia), the most superficial of the three trut perinat facicies.

The fascia of Colles is a fibrous lamina of consillerablestrength. It is attareherl on each side to the lower marerin of the ischin-pubic ramus and to the ischial

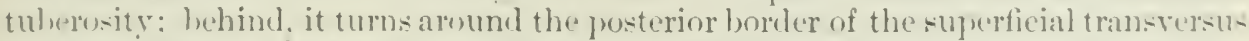
printed nuscele to fuse with the posterior borders of the superficial and eleep triangular liganents and form the free horker of the 'perinasl ledge': anteriorly. it becomes continuons with the external fascial investment of the scrotum and the farcial enrering of the jenis.

It $\mathrm{i}$ : letwern this laver and the inferior triangular ligament that extravasation

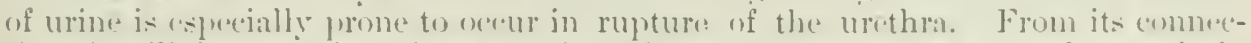
tions: it will leseren that the extension of the fluid would he arrested justeriorly and laterally hy the connection of the fascia of Colles with the triangular ligament:

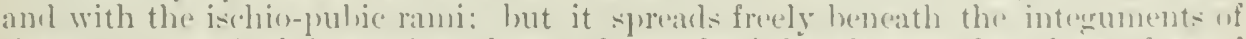
the serotum and of the penis as far as the neck of the glans, and to the surface of the abdomen. On the trunk, it may run in an upward direction everen to the axilla.

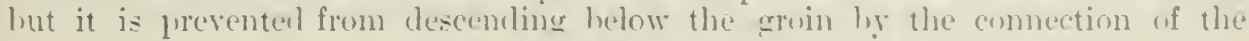


abdominal fascia with Poupart's ligament and to the margin of the saphenous (op)ening.

Superficial perinæal interspace (figs. 64. $6.52,6.54)$. - Detaching the fascia of Colles from its connections, the dissector opens the superficial interfascial space and exposes its contents, namely:-(1) The crura of the corpora caremosil with the ischio-cavernosi; (2) the bulb of the corpus spongiosm with the bulbocavernosi; (3) the capricionsly scattered filures of the superficial transversi perinæi; (4) the arteries of the corpora cavernosa and the dorsal arteries of the penis with their associated veins and lymphatics; (5) the dorsal nerves of the penis; and ( $(j)$ the superficial perinæal vessels and nerves. The roof of the space (the so-ealled floor) is formed by the inferior triangular ligament.

The transersi perinei, the crura penis with the ischio-cavernosi, and the bulh with the bulho-eavernosi, have been already described (pages 1034, 1035). . Each of the muscles named has a fascial sheath of its own, distinct from the fascia of Colles.

The artery of the corpus cavernosum enters the crus immediately after piercing the inferior triangular ligament; the dorsal artery of the penis, reaching the interfascial space more anteriorly with the dorsal nerve. runs forwards to the dorsum of the united corpora cavernosa to take its place between the rein and nerve; the superficial perinæal vessels and nerve given off from the internal

\section{Fig. 654.-Diagray of tile Superfictat AND Deep TridNgllar Liganexts.}

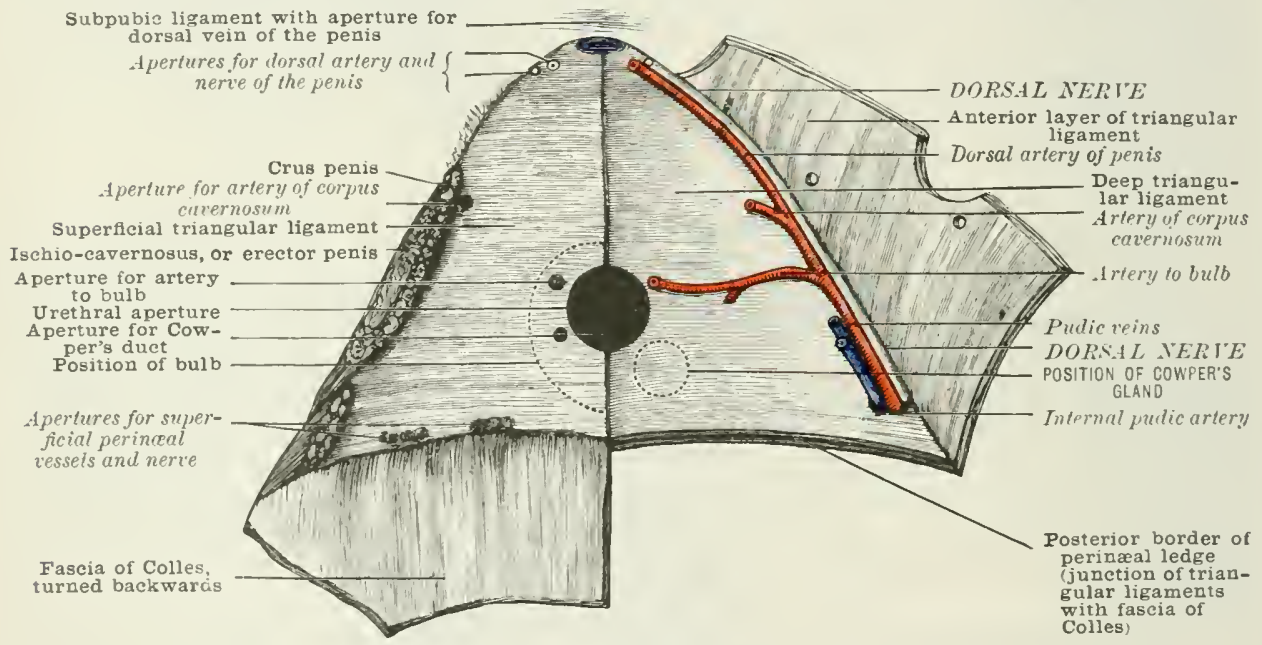

pudic trunks in the ischio-rectal fossa enter the interfascial space near the free border of the perinxal ledge. These divide into two sets of branches, prosterior or deep, to the penile museles, and anterior or superficial to the scrotal and perineal integument; the latter piercing the fascia of Colles and the scrotal investment continuous with it to reach the skin.

The superficial perinceal interspace then may be said to contain the root of the penis, with the muscles, vessels, and nerves connecterl with it.

Superficial or inferior triangular ligament ("the anterior layer of the triangular ligament') (fig. (5.52). - On removing the contents of the superficial interspace the dissector exposus the under surfice of the inferior or superficial triangular ligament. This structure forms almost a horizontal plane in the crect posture of the hody, and consists of strong hands of fibrous tissue, rumning for the most part in a transierse direction across the subpubic arch to be attacherl firmly to the ischio-pulic rami above the line of attachment of the fascia of Colles and of the penile muscles. Anteriorly, it is separated from the subpulic; ligament hy an interval which transnits the dorsal vein of the penis; posteriorly, it blends with the fascia of colles and with the superior triangular ligament to form the hinder border of the perinxal ledge; and superiorly it is intimately related to the deep transversus perinat 
muscle. It is picied by:-(1) The urethra, alout an inch and a çuarter lxehw the symphysis; (2) the duets of (umper"s glands. one on "ateh sille of the purterier part of the urethral oprenings; (:3) the arterics of the luth, somewhat external to the last; (t) the arteries to the corpora cavernosa, more anteriorly and (elose to thes lateral attachment of the liganent; (j) the dorsal arteries and nerves of the penis, at the margins of the liganent near its apex. The dorsal vein with some atecomfanying lymphaties rums through the inter-pace between the triangular and subyulic. ligaments" (fig. 65t).

Deep perinæal interspace (figs. $620,6.5,6.54$ ). - If the superficial triangular ligament be now detached, the deep perincal interspace will be laid open. Thi space is somewhat werge-shaperl in sagittal section, in consequence of the mamne in which the two triangular ligaments aploach ach other before their unim at the posterior border of the perinatal ledge. It is oecupied by the following structures:-

(1) The membranous urethra, surrounded ly its annular sphincter of snooth muscular fibres.

(2) Cowper's glands, seen as two white pea-like bodies, one on each side of the posterior segment of the urethra. Their ducts pieree the superficial ligament.

Fig. 655.- Tertical Froxtal section of the Pelyis, silomilg Fascie. (Morlified from Braune.)

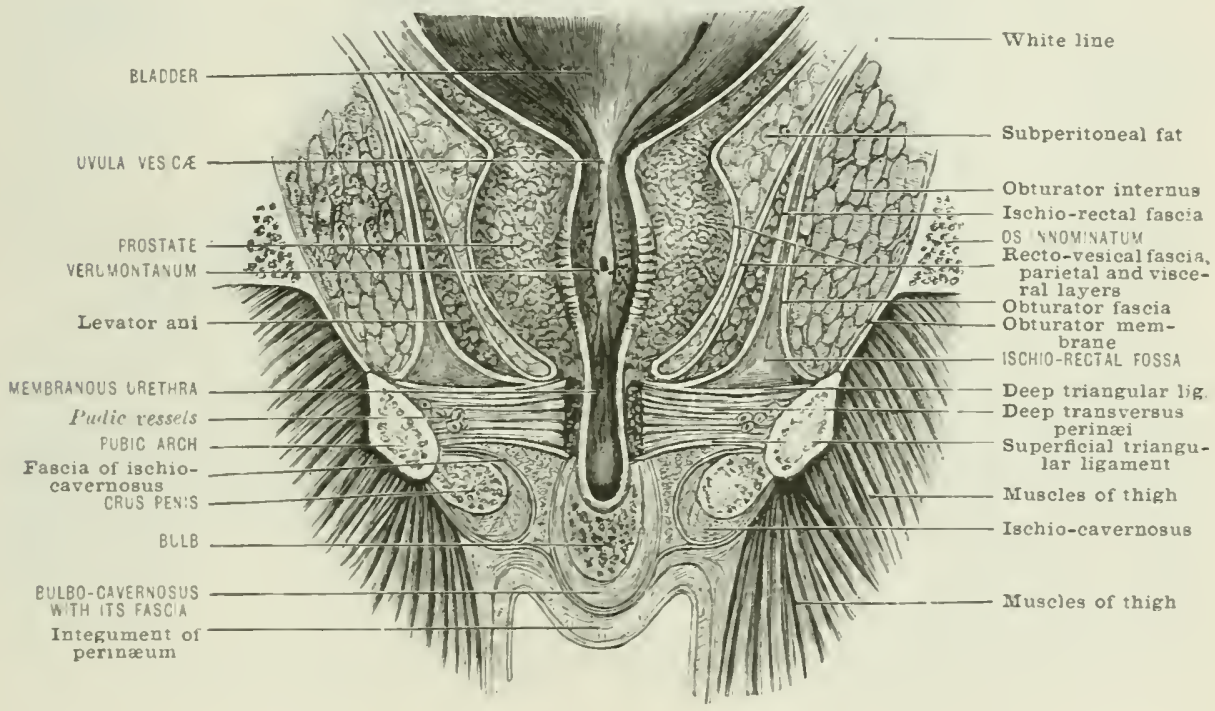

(3) The internal pudic arteries, lving close to the ischin-pubic rami imbeclied in the fibrus of origin of the compresire urethrae muscle, giving off eath an artery to the bulh as well as some trigs to Cowpers gland and to the muserular ti-cur surrounding the urethra, and terminating by division inte the artery of the corpus cavernosum, and the dorsal artery of the penis. These branche with the ar-ondated reins have heen seen to pass through the superficial triangular liganment into the superticial perinseal interspace.

(4) The pudic veins, acempanving the arteries. Their tributaries form a plexus aromed the urethra, and in the sulstanee of the fibres of the deep transversus prinai. This plexus, which is often largely dereloped in ald persons. receives the reins of the corpus sponerosmm and corjura earernosa. and (onmmunicates frech with the dorsal vein of the penis. and through this with the prostatie plexus.

(5) The pudic lymphatics, acempranying the reins and teminating in the pelvie glands.

(6) The dorsal nerves of the penis, the terminal brancher of the intemal 
pudic nerves, accompany the arteries; each nerve gives off filaments to the deep transversus perinzei, and then pierces the fore part of the superficial triangular liganent with the elorsal artery.

(i) The deep transversus perinæi, compressor urethræ, or muscle of Guthrie.-The muscular tissue of the deep perinaal space has been a source of great confusion owing to the multiplicity of the names which have been assigned to various portions of it; lut the description given by Henle may be accepted as at once the simplest and the most accurate. The transversus perinæi profundus of Henle is elosely connected with the suprerior and inferior triangular ligaments. It arises from the inner surface of the ischio-pubic ramus. by tendinous bundles which separate to form a kind of channel for the pudic vessels and dorsal nerve of the penis, close to the bone. From this origin the greater part of the filores run across the subpubic angle in a transverse direction in front of and behind the membranous urethra, enclosing Cowper's glands and the deep reins of the penis, and join a more or less indistinct mectian raphe; while others pass more or less obliquely forwards in front of the urethra and behind the dorsal rein to become attached to the pubic ramus on the side opposite to the bony attachment. A small accessory bundle (the 'sagittal layer' of Henle) may sometimes be found ruming directly forwards to become inserted into the upper surface of the bulb and into the comnective tissue hetween the corpora cavernosa; and the name 'muscle of Wilson' has been given to a few fasciculi, often difficult to demonstrate, rumning from the sulpubic ligament to the membranous urethra.

The arrangement of the fibres differs considerably in different suljects, and much complexity has been introducer into the study of the muscle by the artificial segregation of certain of its parts under special names, such as levator urethra, constrictor urethre, ete.

Its action is partly to compress the membranous urethra and thus assist the expulsion of urine and semen. and party to intercept the flow of blood through the reins of the penis, and so aid in erection. It also exereises compression upon Cowper's glands, and effects the discharge of their secretion during seminal emission. It is supplied by a branch from the dorsal nerve of the penis.

The deep or superior triangular ligament (figs. $650,652,65 t$ ) is in some sort a prolongation of the olturator fascia across the pubic arch, the continuity of the two fiscice, however, being interrupted by the attachment of their deep fibres to the inner edges of the ischio-pubic rami. "Inferiorly it is in intimate relation with the deep transversus perinei; while superiorly it forms on each side the floor of the anterior extension of the ischio-rectal fossa; and in the middle line it is separated from the apex of the prostate by a prolongation of recto-resical fascia, and by a laver of smooth muscular fibre, the prerectalis of Henle, in which end the greater part of the anterior longitudinal filires of the rectum.

It is picred by the purlic artery and rein and the dorsal nerve of the penis. The dorsal rein of the penis passes between it and the subpubic ligament.

\section{THE FEMALE PERINEUM}

The female perinæum (fig. 6.56) differs from that of the male, partly in the perforation of the whole of its fascial and muscular structures in the middle line hy. the vulvo-raginal passige, and partly in the adaptation of the perinatal muscles to the modified conditions of the external genital apparatus. The corporal caremosa penis are represented by the relatively diminutive corpora clitoridis; the ischiocavernosi are proportionately resuced in size, but differ in no other material respect: the corpus spongiosm is divided into two lateral segmonts, which are represented by the bulbi vestibuli and partes intermediales; and the two lulbo-cavernosi are sejurate, and aplear in an attenuated form, sprearl over the erectile tissue as an attenuated plane of fibres, the compressor vaginæ, which is often difficult to recognise on lissection; while the median riphe miting the two muscles in the male gives place to the genital fissure. 'The superficial transversi perinæi difter only in size from those of the male; but the deep transversus perinæi is of course eleft by the ragina, and its fibres are relatively thin and weak and in 
great part unstriped. The glands of Bartholin, although morphologically iulenticall with Cowper's inlands, are less dereply jlaced.

The greater development of the connective-tisine structures betweren the genital canal and the thim stance of the reetum, lealines to the formation of the perinzal

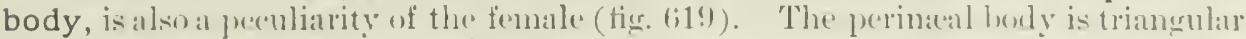

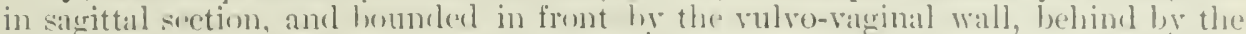
anterios wall of the rectum, and below by the interument between the posterion

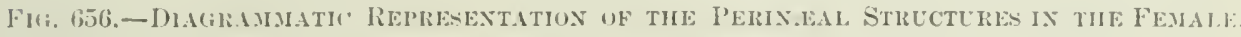

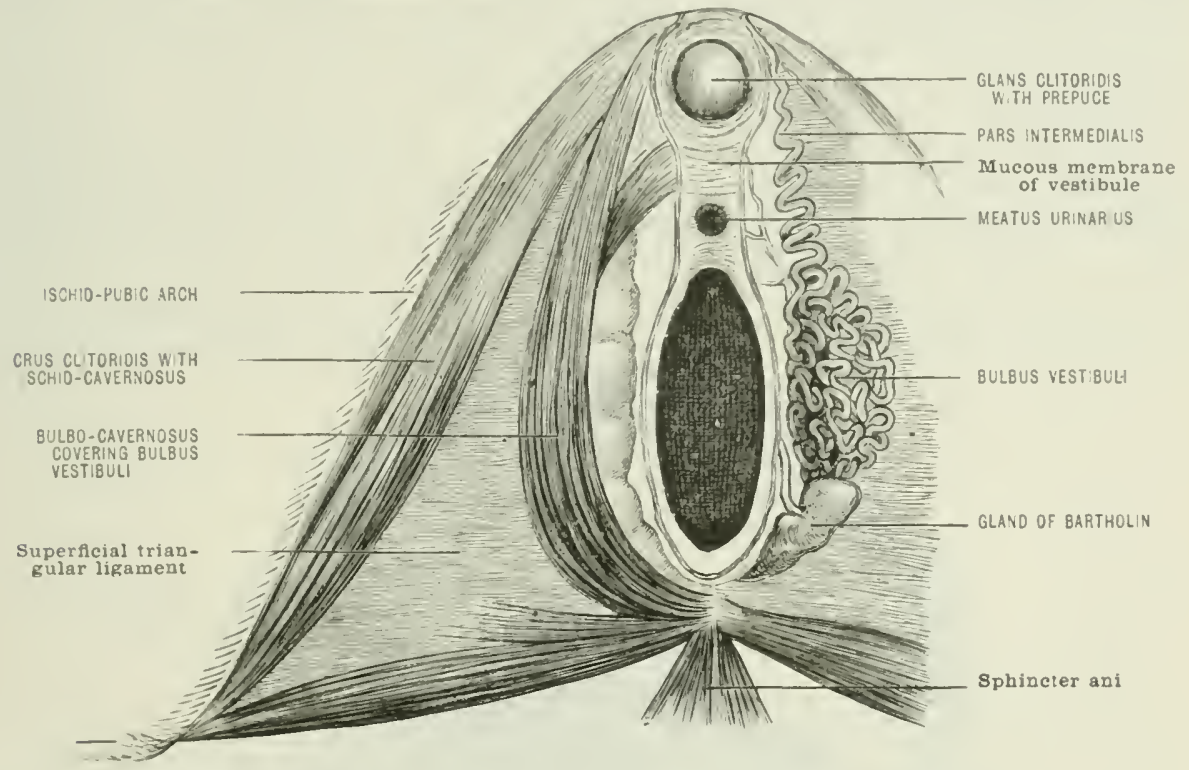

rulvar commissure and the anal aperture. It consists of a strong meshwork of comnective tissue freely intermingled with fibres of elastic tissue and unstrijed nuscle, and is traversed by the various muscles which meet at the tendinous centre of the perineum. It heomes stretched to a remarkable degres rluring the jussage of the child's head in labour, but is saved from rupture by its strength and elasticity.

\section{THE MAMME}

The mammary glands are two pectoral organs whichs srecete the milk in thw female, but remain permanently rudimentary and functionless in the male.

The female mamma (in which term is incluled the gland with its inveting

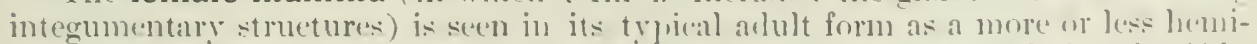
spherieal eminence upon the front wall if the chest over the third, fourth, fifth. and sixth rils, and extending transwersely from the borkler of the sternm to the anterior margin of the axilla. It is surmounter men its midelle lw a small wartlike process. the mammilla or nipple, which lise in the centre of a cireular area of altered skin callerl the areola.

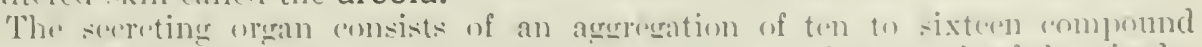

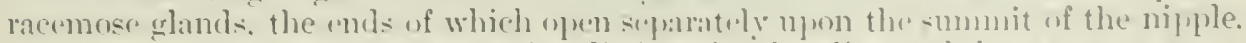
These compenent elements are quite distinet in the dis-refuel hreast as so many 
lobes of somewhat jymmidal form, with their hases at the periphery and the apices convereting towards the manmilla. Ther are helet together and sulportex by a

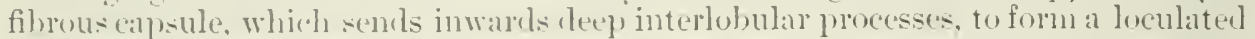
framework for the erlandular chements; and superficial processes ruming to the skin and enclosing stunta-1nammary fat-containing spaces or adipose fossæ. 'The posterior atsuect of the cap sule also ancloses other fat-sparces (retro-mammary) and

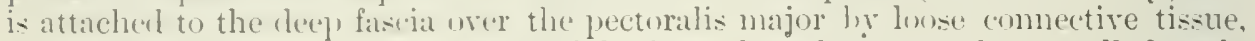

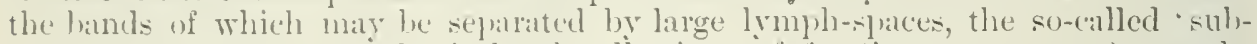
mammary burse.' Finally, isolateel collections of falt (intra-mammany) may be found burierl andidst the lobules of the gland. It is the fat lying in the subcutaneous adipose forse and between the gland lobules that gives smoothness and miformity of surface to the hreast, and when it becomes absorbed during lactation or in conditions of emaciation, the lobular structure of the gland is distinctly mannifest.

structurally each of the component lobes may be regarded as a modified sebaceous gland. and hence an appendage of the skin. Each is provided with a single excretory tube (lactiferous or galactophorous duct). which on approatehing the

Fig. 65\%.-The Fendak Mayua Derixg LActatios. (After Luschka.)

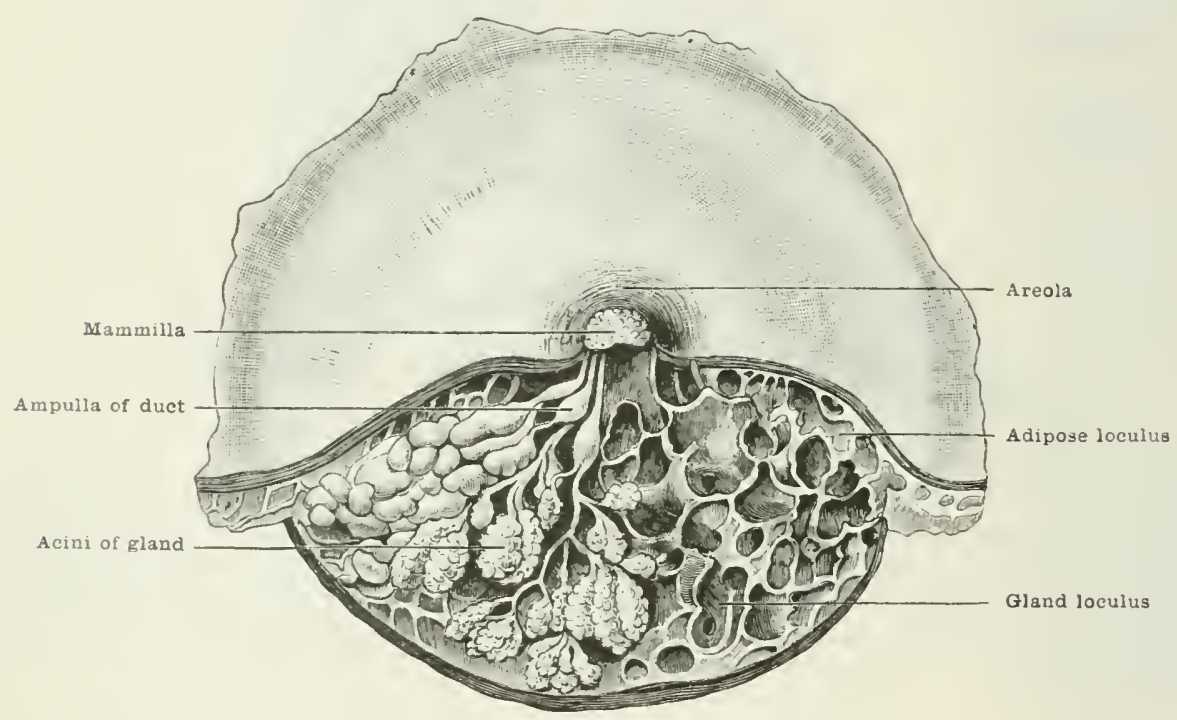

niphle is dilated into a sinus or ampulla, and finally ends by a constricted orifice at the alpex of the nipule. The acini and smaller tulses are lined with cubical epithelium, which becomes replaced by columnar cells in the excretory ducts.

Acecenry glands of small size-half a line to two lines in diameter, and to the number of tive to fifteen-are normally found under the skin of the areola, and olen on to the summit of the nipple.

The gland as a whole is not circular in outline, but usually presents three cusps -ome towards the sternum. sometimes overlippling the bone; the others towards the axilla, one above and the other betow; smaller extensions, moreorer, pass from the base of the gland to the deep fascia, and may pieree it and lis upon or in the fibres of the pectoral muscle (Heidenhain). These proceses are commonly left behind in amputation of the breast, and may form nuclei for recurrent growth in malignant disease.

The mammilla and aresla are specially molified portions of the mammary integument. The mammilla is placed a little internal and inferior to the centre of the glanel, and points forwards and outwarks. It is of somerwat conical form, averaging alwut half an inch in lolgeth. and terminating hy a rounderl extremity which is piereed hy the orifices of the lacetifereus ducts. It is of pinkish colour, 


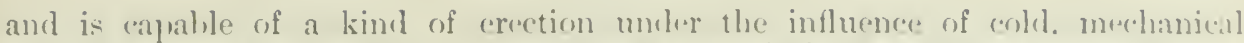
stimulus, or mental ensotion. In somse persons it is nommally retraterel into at dellesion of the interument, and only projects in response to stimulation.

The areola is ahout an inch in lianeter. and is chatracterisel he it: piemontation.

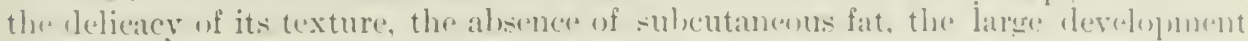

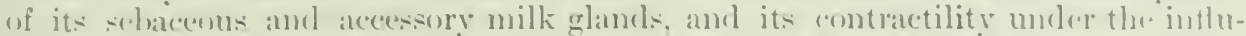

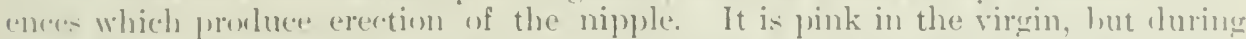

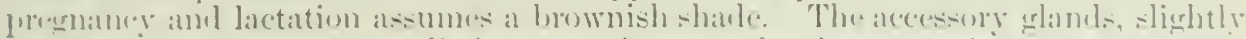
marken in the virein, form distinet prominences after innmegnation (tubercles of Montgomery).

The contractility of the nipple and aresla is clue to the prosenere of rirculare

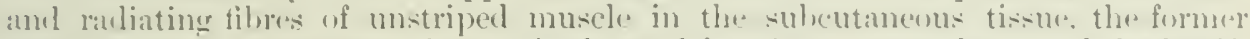
folsing into the sulstance of the nipple. and forming a metwork around the laretif-

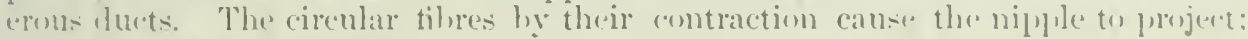
the racliating filues retract it.

Variations according to age and functional activity.-At hirth the grane] i(1) ly about ons-fifth to one-third of an inch in diameter. The niplyle with itdatos is woll formed, and the seereting structure is represented by shightly ramifienl ducts which contain a milky fluic. Growth is slow up to the time of pulwert after this. development progresses rapidly, lut no distinct indication of subdivision into lobes is present motil impregnation takes place. Somm slight engorgement of

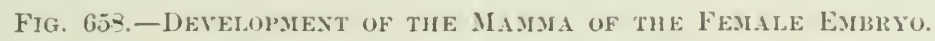

( 7 inches in length $\times$ \%).) (After langer.)

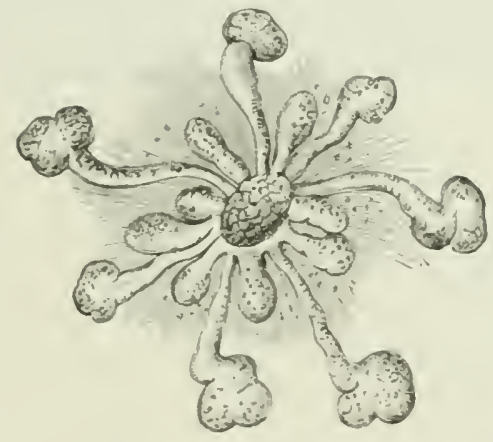

the loreast may, however. oeem at the menstrual perind, when a rellowish glutinum: serpetion may sometimes be rexpelled from the ducts. In pregnaney and during lastation the evolution of the gland-structure is remarkably active. The whole hreast enlareres, the superficial fat underenes alsorption, the vesoce heome lilated and their wills thickened; the areola and nipple increase in size. and the furmer heromes more or less deefly pigmented. After the end of lactation the lireast

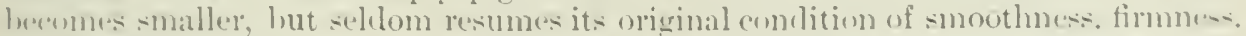
and elasticity, and some traces of the fiermentation of the areola remain furmanent. In olil are the enlandular structure atrolohy.

The male breast differs from that of the female in the early armes of it wolu-

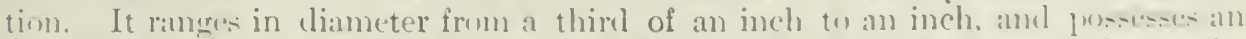

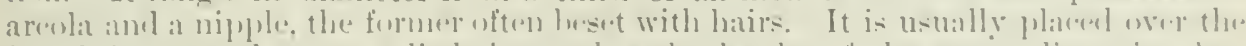

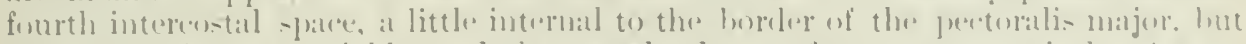
its justion is very variable, and the two glands atre often uns-mmetrinal. A tum-

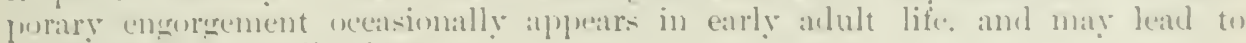
inflammatory (omplelicitions.

Vessels and nerves. - The arteries are lerivenl from the intermal mammary

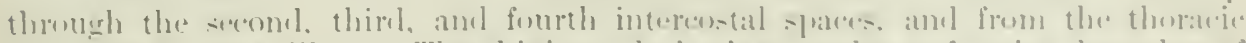

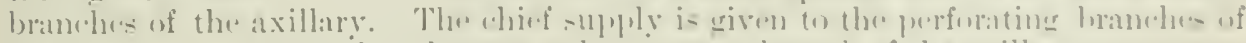
the internal mammary, lint the external mammary batuch of the axillary artery maly be of latre size in the female. 
The veins terminate in the enresponding trunks. The superficial veins become risibly enlarged during freecriancy and lactation.

The lymphatics, originating in the cellular intersaces of the gland. form trumks which accompany the veins; the majority teminating in the costal group) of axillary glands, the others in the retrosternal chain. The integrment of the nipple and areola, as well as the rest of the skin over the mamma, is richly supplied with lymphatics, and as these communicate freely with the ressels of the other side across the middle line, infection may be convered to the glands of the side (1) pposite to the prinury seat of discase (Volkmamu). In eancer of the breast the leep eervical glands about the subelavian vessels may become implieated by extension from the axilla as the liscase alvances.

The nerves are derived from the supraclavicular branches of the cervical plexus, and from the intercostals. The glandular twigs are traced by Eckhard to the fourth, fifth, and sixth intercostals.

Development. - The breast appears about the serenth week of foetal life as a eireular epidermic ridge, enclosing a central depression, the cells of whieh grow inwards and furm branehiug tubular ducts that radiate beneath the nipple (fig. 658 ).

Abnormalities. - Small supplementary lacteal glands, in addition to the normal accessory structures beneatl the areola, are frequently present around the margin of the principal gland, and may be found in front of the sterumm, in the axilla, and below the claviele, and there is reasun to believe that many of the adenomata and cancers take origin in these relundant structures (Roger Tilliams). Besides these, large supernumerary mamme, having all the characters of the typical organs, bave also been met with in various situations-in the axilla, over the back, the abdomen, and even on the thigh. These are in all probability atavistie. Absence of the mamma is extremely rare.

The nipples may be double, or even triple on each breast, or may be wanting altogether.

In a few instances an abnorinal development of the gland tissue has been known to occur in the male, and milk has been secreted in sufficient quantity to nourish an infant. A slight and temporary enlargement of the gland about the period of puberty is not infrequent. 


\title{
THE SKIN
}

\author{
BY WIILIAM ANDERSON, F.R.C.S.
}

SULGEON TO AND LECTURER ON ANATUMY AT ST. THOMAS'S MUSHTAL; RPUFFSUIR OF ANATOMY IS TIU: ROYAL

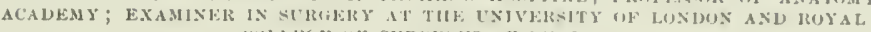

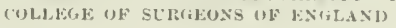

The skin is a membranous investment forming the entire external surfice of the buly and its members, and is continuous at certain points with the internal lining of the alimentary, respiratory, and urinogenital (anals.

Its extent has been estimited at alwut 15,000 syluare em. in an arlult male of medium size (Sappey). In thichness it varies comsiclerably in different purtions of

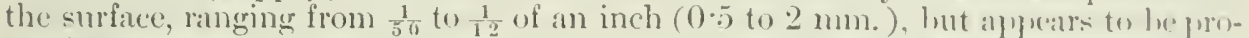
portionate to the amomnt of pressure or friction to which the barts an halitually subjocted. Thus it is thickest mom the naje, barek, and shoulders, and on the palms and soles, while on the front of the trunk and wn the florsal asperet of the hambls and fect it is relatively thin. It jo highly elastice and is calahlo of stretcheing to a consiflerable extent without rupture of its coutinuity, and of regaining its original condition when the extending foree is remoxed. This puality is esper-

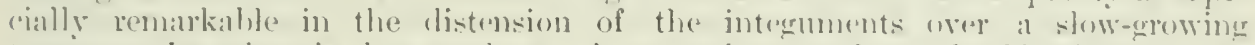
tomeme. Its colour is due partly to pigmentation, partly to the hoorl within it:

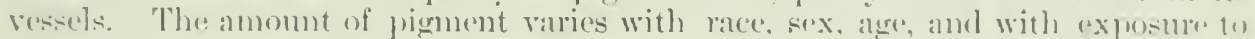
sun and air; and is mormally arreater in certain portions of the skin (axillat. -crotum.

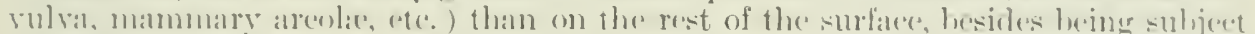

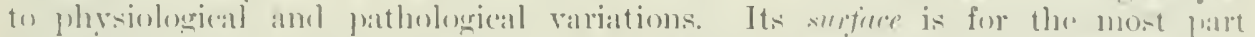

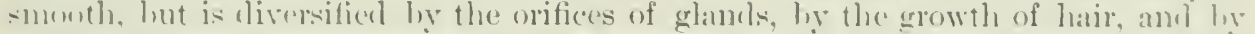
various furrows and elevations. Permament linear ridges are present upom the

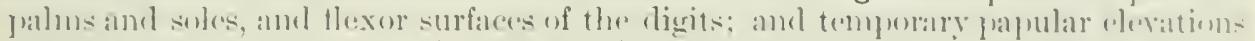

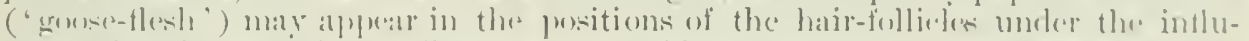

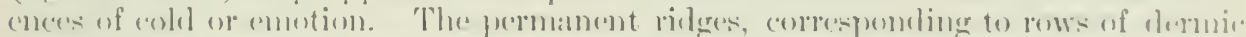

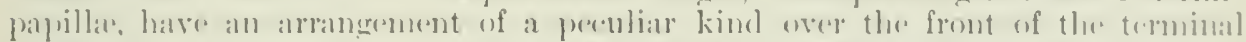

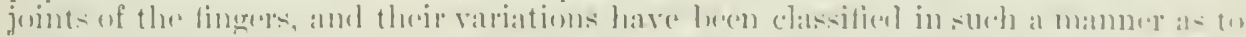

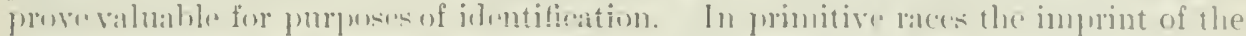
thumb, hats lween usenl as a kind of signature.

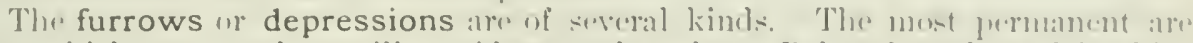

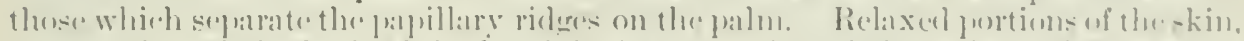
such as that of the hate of the hame huring extension of the wrist and tingers an

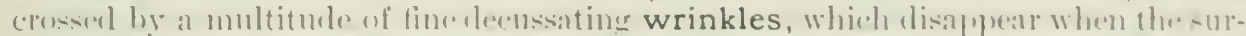

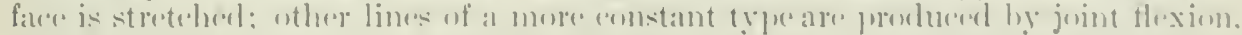

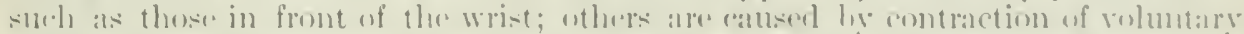

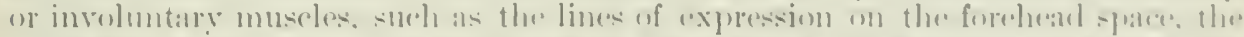

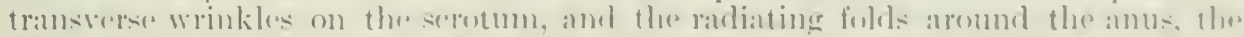

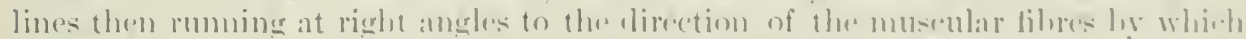

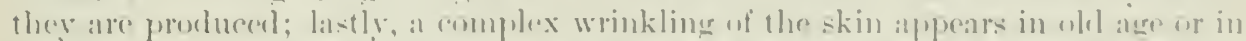

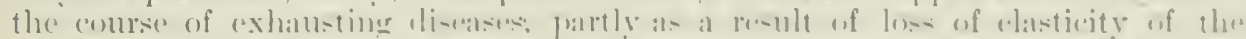

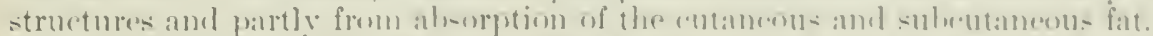

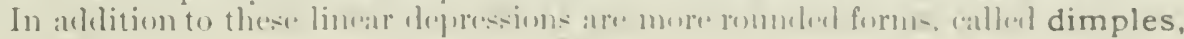
64

$10 T: 3$ 
some of which, as those on the chin and checks and at the uhnar horder of the palne correspond to the points of attachment of mustular fibres into the deep surface of the skin, and are male evident by the contraction of these fibres; while others depend upon the attachment of the skin by fibrous bands to the bony eminences, as of the albow, shoulder, vertehre, and posterior iliac spines, and are seen only when the subentanenus allipose tissue is well developecl.

The skin is separated from the superficial bones and inuscles, etc., by a subeutaneous structure, comprising white fibrous and elastic tisues, fat, and, in certain situations, layers of striped or unstriped muscle. The subcutaneous filmoms tissue over the greater part of the body is arranged in two planes, known as the superficial and deep layers of the superficial fascia, separated by a layer of fat. It is closely blended with the deep aspeet of the skin, but only loosely united to the deep fascia investing the museles, and permits the cutaneous and subcutaneous structures to move more or less freely over the deep parts. In some situations, moreover, where the integument is exposed to repeated friction over suljacent bones or other hard structures, its movements are facilitated by the development of sac-like interspaces in the subeutaneous tissue, called bursæ. Exceptions to this rule of mobility of integument are found in the head and face, where the skin is intimately connected with the subjacent muscular and tendinous tissues, and in the palnis and soles, where it is firmly attached to the deep fascia.

The subcutaneous fat raries considerably in amount and character in different parts of the body. It is entirely absent on the penis and scrotum and is largely developed over the nates, palms, and soles, where it serves as pads or cushions. In the scaly it appears as a single uniform layer of ovoid lobules between the derm and the aponeurosis of the occipito-frontalis muscles; on other parts of the surface it is somewhat unequally distributed, and shows a tendency to accumulate in ap'parent disproportion in certain localities, as on the abdomen, over the symphysis pubis, about the mamme in females, etc. Everrwhere, except perhajs on the scalp. it may undergo rapid and visible increase or decrease under the influence of changes of nutrition.

The subcutaneous planes of striped muscle are comparatively scanty in man when compared with the great panniculus carnosus of the lower mamnalia. They are best represented by the platysma myoides on the neck. Unstriped muscular fibre, present in all parts of the skin as an appendage to the hair-follicles and sebaceous glands, is found also in some parts of the subeutaneous tissue, as in the scrotum and perinsem, around the anus, in the mammilla, and beneath the mammary areola.

Structure of the skin.-The skin is separable into two distinct layers-a deeper, the derm, cutis vera, or corium; and a more superficial, the epiderm, cuticle, or scarf-skin. The latter, morphologically representing the epiblast, is a purely epithelial cell-growth, while the derm, which is developed from the mesoblast, is of highly complex organisation.

The derm is composed of elastic tibrous tissne intemixed with fat resicles, and bundles of unstriped muscular filmes, traversed liv a rich plexus of blood and lymph-ressels and of nerves, and enclosing hair bulbs and selaceous and sudoriparous glands. The superficial layers are of finer structure, free from fat, and form a multitude of eminences, called papillæ, which project upwards into corresponding depressions in the sulustance of the epiderm. The fibrous bands composing the deeper layers are coarser and less compact, intermingled with fat lohulis, and pass without any definite line of demarcation into the subeutaneous tissue. The muscular fibres appear as appendages to the hair and its sebacens follieles, and are known as arrectores pilorum. Two or three bundles are attached to each hair-sheath below the sebacrous gland opening into the follicle, and are so arranged as to be eapalile of "ompressing the acini of the gland, and of rendering the direction of the hair-shaft somewlat nore perpendicular to the surface from which it emerges. This latter artion proluces the 'bristling of the hair' which is believed to beome of the manifestations of extrme terror, but which occurs in many persons in association with mental excitement of various kinds.

The fibrous tiscue rums for the most part in bundles parallel to the surface, intercrossing at rarious angles in a mamer that alpleats to be regulated upon a 


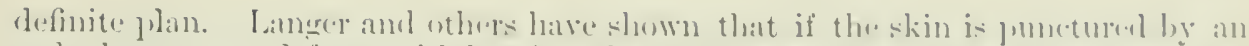
awl, the alperture loft on withllawing the implement is nest lomml, but linear or

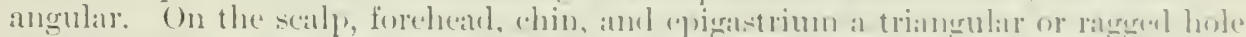

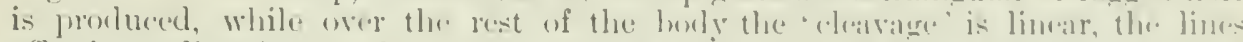
affecting a direction nearly at right anghes to the longe axis of the limbs, and on the

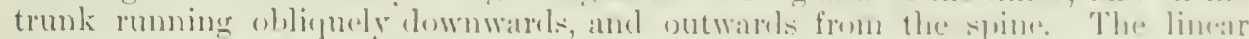
cleavage indieates that the bumlles rum mathly in me direction, while the "incom-

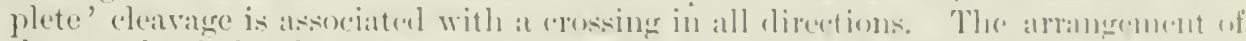

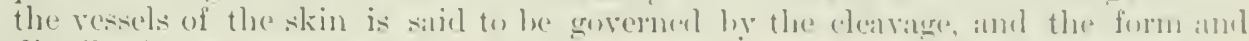

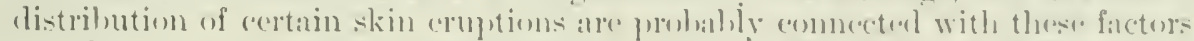

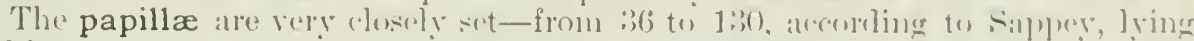

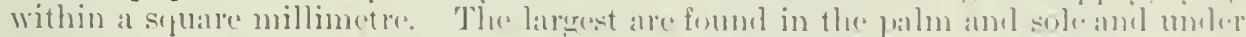
the nail, reaching a height of half a line or a line (1 to 2 mum. ): the smallest. distributer over the face, scotum, and matmmillar, having only a third or a fourth of these dimensions. The forms ustually assumed atre these if simple (a)

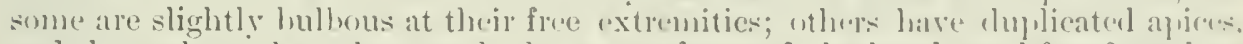
and those about the palmare and plantar surfaces of the hands and feet form lone

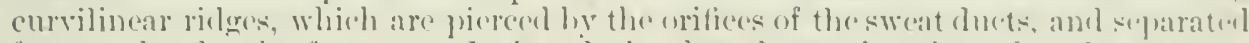
from each other hy furrows. It is anly in these latter sitnations that the arrangement of the papilize is unconeraled ly the epiclemis. Structurally, the papilla consists of a delicate fibrous tissue containing restels and nerves, or, in coptain situations, a special tactile boxly. Its subejislemix surfaes and that of the interpapillary depressions is modified into a delicute, structureless lamina, callut the membrana basilaris.

The epiderm, or cuticle, is a layer of varying deptle, the thichness hemer regulated chiefly he the anoment of pressure or friction to which the part is halistually suljected. Its deep asject is moukled to the pajullary latyer of the derm, while itfree surface gives little or no indication of the paysllary aninenese except on the polms and soles, but it displass mumberless apertures of eglands and hair-follicles, which it lines with tubulatr prolongations. Structurally, it consists contirely of apthelial cells of valous shapes. The component cells may he diviled into five distinet larers, arrangerl from within wutwark in the following orller: (1) The stratum basilare, or generative layer, annsists of a single set of nucleated, prismatic colls. the.

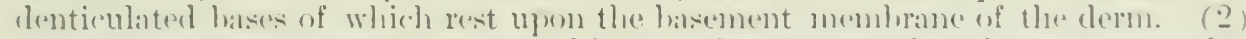

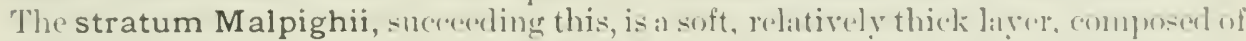

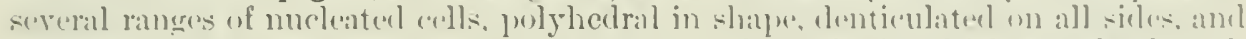

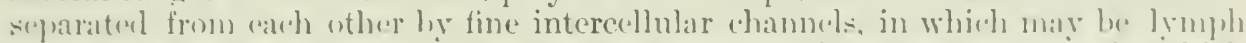

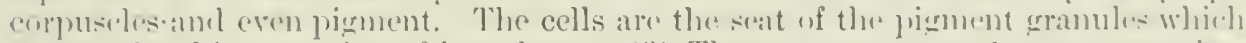

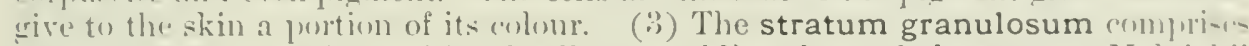
two or three lityers of transitional a cells, resembling those of thestritum Malpighii

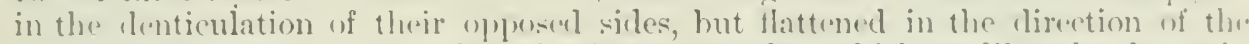
surface and enntaining a mumber of minute gramules. which rearlily take the stain

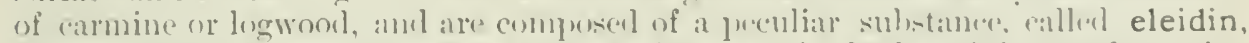
or kerato-hyalin, that is silil to be the active agent in the keratinio trans-formation

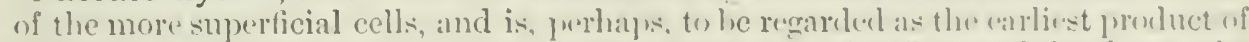
the retrograde ehange which ends in keratinisation. (4) The overlying layere. the stratum lucidum of 0 dil, represents the first stage of the hormy ehange. It i-

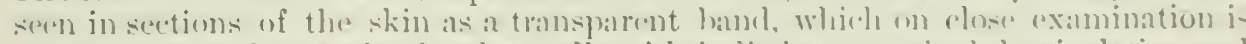

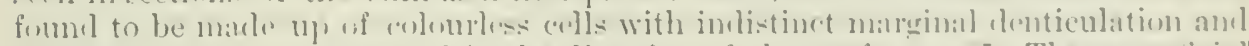

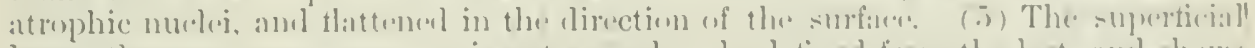

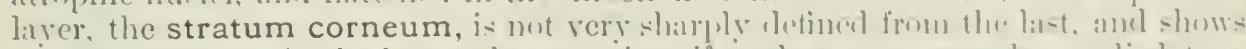

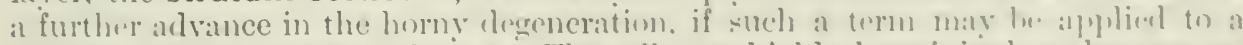

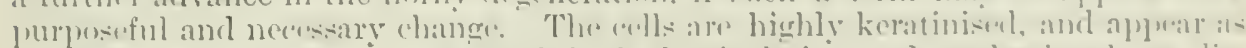

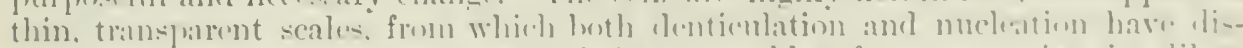

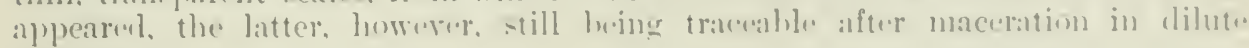
alkalies.

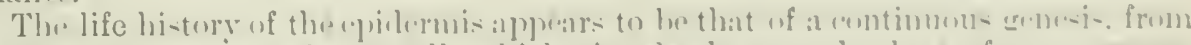

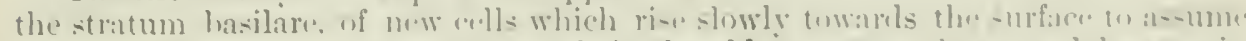

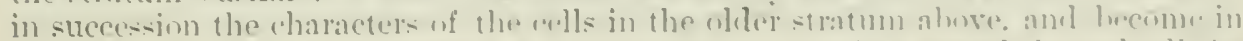

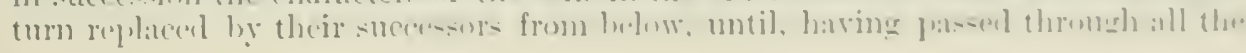


grades leading to complete keratinisation. their career is ended and they are cast off from the stratmm cormeum. No vessels exist in any part of the epidern, lut nerve-tibrils are saicl to penetrate as far as the stratum IIalpighii.

In the more recent methods of skin-grafting the surgeon takes a plane which usually includes all the layers of the epidermis, and even the extreme tips of the papillie of the dem (as shown by the minute bleeding points left on the surface from which the graft has been eut). The absence of the deeper and more highly vitalised epidernic cells in the pellicle separated by a blister is probably responsible for the almost uniform failure of transplantation of this material.

\section{VESELS OF THE SKIN}

The arteries of the skin form a network in the subcutaneous tissue, and from this arise branches which pass outwards into the elem, and, after supplying twigs to the glands and hair-bulls, unite into a second network beneath the papillax, supplying these latter with fine arterioles. which finally break up into a capillary plexus. The veins commencing within the papilla form a subpapillary network which ends in the subcutaneous veins. The lymphaties have a like arrangement.

Nerves.-The skin is richly supplied with nerves. lut in varying degrees in difterent regions. Everywhere the nerves form plexuses in the rlerm. the network becoming finer as it approaches the epiclerm, forming a rich subepithelial network immediately beneath the stratum basilare. From this, delicate fibrils have been traced outwards as far as the stratum Malpighii, where they terminate. The integumentary nerves end in three different way-some in subcutaneous bodies, the corpuscles of Pacini or Vater; others in lermie structures, the corpuscles of Meissner and Krause; and a third, or epidermic set, are believed to terminate in minute bulls.

The corpuscles of Pacini may be found attached, like berries, to the nervestems lying in the subcutaneous tissue in various parts of the surface, hut most abundantly on the digital nerves. They are not confined to the cutaneous nerres, but are seen also upon mixed nerres, stich as the intreostal; upon artieular, periosteal, and other nerves; and even on srmpathetic filaments, such as those of the mesentery. They are of oral form, and range in size from $\frac{1}{25}$ to $\frac{1}{5}$ of an inch (1 to $5 \mathrm{~mm}$.). Structurally, they consist of a connective-tissne envelope elerived from the perineurium and a series of thirty to sixty concentric fibrous tunics each, lined on buth sides by endothelium; within is a contral structureless core. The nerve-fibre pierces one of the poles of the corpmscle and reaches the central enre, where it loses its mrelin and subdivides into delicate ramitications, which end in small bultons enlargements. Each horly is supplied by a set of ressels that form plexuses and loops in the lavers of the eapsule.

The tactile corpuscles of Meissner are of smaller size and more limited distribution than the lacinian bodies. They belong almost entirely to the hands and feet, hut may be found also orer the railial side of the forearn, in the mammilla and the red border of the lips, as well as in the free border of the conjunctiva and in the mueous mentrane of the tip of the tongue. They are particularly numerous over the pulp of the terminal phalanges, where the sense of touch is most acute. They lie within certain of the papillw, which they oceupy to the exchusion of resscels, and appear as solicl, olive-shaped bodies about $\frac{1}{25}$ of an inch in length $\left(\frac{1}{10}\right.$ of a mm.) placed with their long axes at right angles to the surface. Each is joined at its deeper extrenity by one, two, or more nerves. In structure the corpuscle consists of a commective-tissue capsule, like that of the Pacinian body, derived from the perineurium; within this is a solicl eellular structure, in which the nerve cylinder, eleprived of its myehin, breaks up into filaments, to end either in bulhous or discoid enlargements:

The spheroidal end-bulbs of Krause, found in the conjunctiva and mucons membrane, and in a modified form in the prepuce and glans penis and elitoridis, hrar some resemblance to the tactile corpuscese and to the central core of the Parinian bodis. They consist of a connectire-tissue capsule enclosing a cellular structure in which the nerve terminates. 


\section{THE APPENIAMCE OF TIIE SKIN}

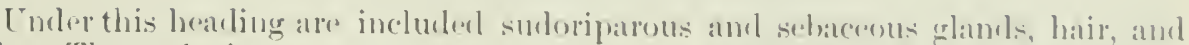
nails. The sudoriparous glands, which secpete the sweat, and probably a certain

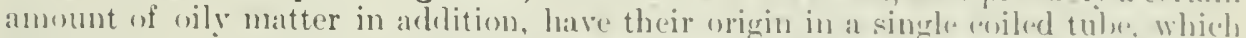

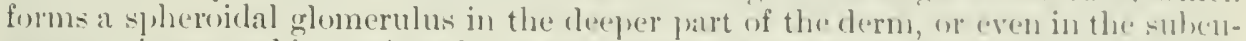

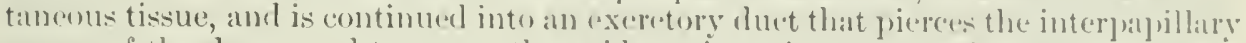

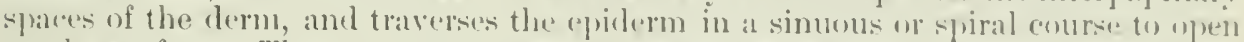
wh the surface. They are most mumereus on the palums and soles, least so on the hatek of the neck and trunk aml on the lower limbs. Salpuer estinutes the total number over the whole besly at $2,000,000$. The glomernli range form one twohumbled and fiftietl of an inch $(0.1 \mathrm{~mm}$.) to a line $(2 \mathrm{~mm}$.) in diameter, and are latgest in the axilla and groin and alwut the mammary areolas. The tube wall

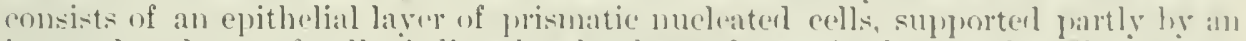
incomplete layer of cells, hedieverl to he those of unstriped nutroular fibre, parily.

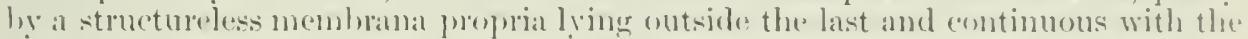
basement membrane of the derm. 'The 'museular' laver is alsent in the excretory duet. Allied to the surloriparous grands are the ceruminous glands of the extemal aulitory meatus, which have the same structure, hut primitively ojen into the hair-follieles; and the ciliary glands of Moll, opening on the free bertere of the lids, which do not form glomeruli.

'The sebaceous glands are found over the whole area of the skin ex('p)t on the palms and soles. They differ fom the sudorijarous glands in their racemose form. in their alumest constant relation to the hairs, in the oily nature of their seretion, and in their complatatively smerficial position. The greater number discharge their enntents into the hair-follicles, one, two, or more heing attacherl to rach hair; others open directly on to the surface, and either present a rudimentary laik emerging form the excretory durt or are altogether unemenected with hair: as in the lahlia minora and manmary areolat. It is these last which attain the

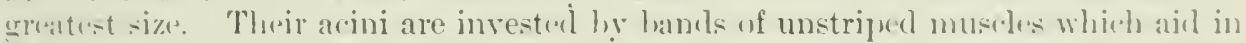
the "xpulsion of their contents, and in the case of the larger hairs act as "arrereteres pilormin.'

The nails are esentially an epielemic specialisation. Rulimentary in man, they are laregely develoged in many of the lower animals, taking the form of claws

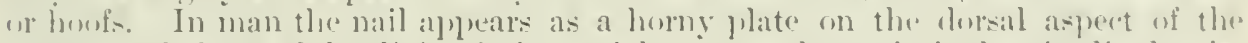
terminal phalanx of the digit; it is straight, or nearly so, in its longitudinal axis.

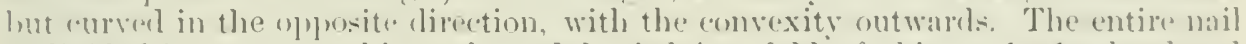
is divilerl inte a root, thin, suft, and luried in a fold of skin; a body, hard and keratinisul, Inngitudinally ridged on its dorsal aspect, and "xtending from the rout to the line at which the alpundage eras's to be comnected with the skin; and a free extremity, which, mules restrimed by artificial means, tonds to grow intu a daw-like form and may cure orep strongly towarts the palmar surface of the digit. The point at which this joins the pulp of the finger is callew the angle.

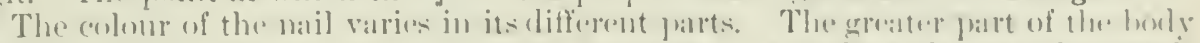

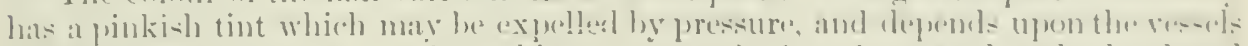

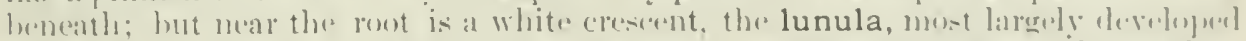

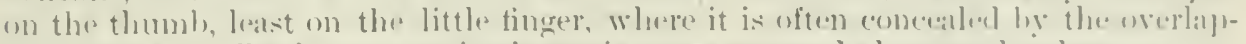

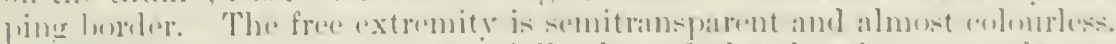

The-urfare of the nail, esperially that of the thumb, maty umer enetain eir-

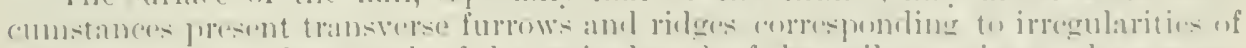
nutrition; and as the growth of the entire length of the nat orempies on the arerage

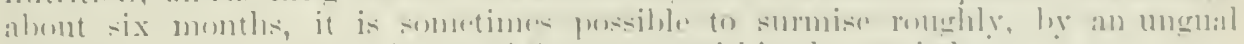

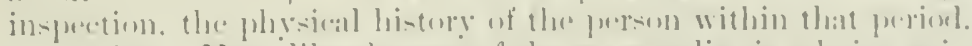

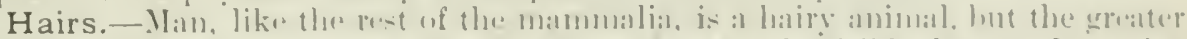

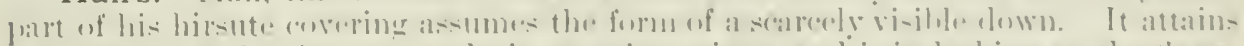

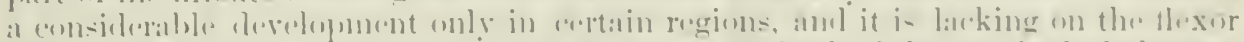

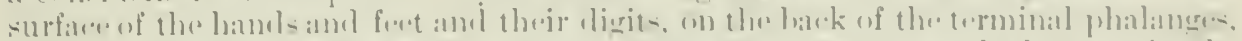

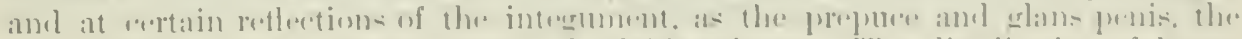

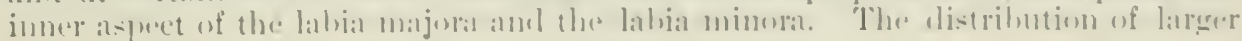


and smaller hairs in the two sexes is too familiar to require description. The direction taken by the hairs in the varjous parts of the body is fairly constant and may be traced in eateh region to or from certain centres or vortices, such as these upon the crown of the head, at the extemal anditory meatus, in the axilla, the fold of the groin, and elsewhere.

The hair not only varies in charaeter and development in different parts of the surface, but presents consirlerable racial and individual variations in each region. Talking the hair of the head as a type, we may find it either straight, wary, curlerl into ineomplete or complete spirals, or minutely tufted like wool, and each of these varieties is associated with peculiarities in the transverse sectional area; thus, in the straightest hair the section is circular or nearly so, while in the wary, curly, and woolly hair it is oval or elliptical, the greatest difference between the largest and smallest diameters being found in the woolly hair in which the radius of the curve is smallest. In length the highest develomment is attained in straight hair, and the growth is nearly always greater in the female than in the male. In some regions the erowth becomes luxuriant from infancr; in others, as upon the pubic regions in both sexes and on the lips and cheeks of the male, its full development is deferred until puberty or later. As age adrances, the hair-bulbs are liable to undergo premature atrophy upon the summit of the head in men, while the growth may continue to progress in other parts of the body, even to extreme senility; and a loss of pigment in the hair, usually beginning on the head and extending later in a somewhat capricious way to the other regions of the body, is another sign of local failure of nutrition which may or may not be associated with senile degeneration of the tissues generally. Pathologieally, the hair is subject to many changes, into which it is not necessary to enter here.

The first growth of hair begins about the fifth month of fotal life, but this crop (lanugo) is entirely shed within a few months of birth. The process of shedding and new formation groes on throughout life.

The typical hair has its root in a dermic papilla sunken at the bottom of a deep follicle which runs more or less obliquely through the whole or greater part of the thickness of the skin. The hair-follicle is cylindrical or oval in section and fairly uniform in diameter in the greater part of its length, but expanding below where it contains the bulb of the hair. Into it open the orifices of the sebaceuns glands appended to the hair; very rarely also the duct of a sweat-gland.

Structurally, the follicle consists of an invagination of the elements of the skin, with the addition of a partial lining derived from the generative papilla of the hair; and its wall comprises three lamince. The external or dermic coat is continuous with the derm, and is composed of two layers of fibrous tissue, the nore extemal being longitudinal in direction, the inner transverse. At the bottom of the follicle it is reflected upwards as the papilla, which constitutes the essential and generative element of the hair-root. The mildle or hyaline coat is an invagination of the structureless basement membrane, upon which rest the deepest cells of the epidermis. This becomes lost upon the papilla. The internal epithelial coat is dirided into two secondary layers called, respectively, the outer and inner root-sheaths. The outer root-sheath, from the opening of the follicle down to the openings of the sebaceous ducts, includes all the layers of the epiclemis, but below this point loses the stratum granulosum and the stratum eornemm, and is reduced to the stratum Malpighii and stratum basilare. The inner root-sheath, unrepresented in the epiderm and probably a derivative of the hair-papilla, consists of three layers: the layer of Henle, formed by a single set of polyhedral cells; the layer of Huxley, sinilarly constituted, but with the component cells more elomgated and less closely compacted; and the cuticular layer, composed of a single set of thin, imbricating cells, clear and transparent, with atrophic nuclei.

The hair proper is a cylindrieal or oval shaft expanded ledow into a liulh, where it caps the paprilla, at the hottom of the follicle. The shaft, fairly uniform in diameter in the sealp-hairs, consists of a molullary axis, surromoled by a cortical eoat and invested by a "utienlar layer. The medulla, (onstituting abont one-fourth of the entire diameter of the hair, is a soliel crlincler, white ly reflected light, dark by transmitted light, and is eommosed of closely compacted nucleated cells, filled with pigmentary and fatty granules and air-hubhles. It is 
formed below by a layer of eells which anclose and cown the papilla. Down

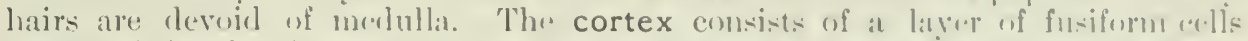
elongated in the direetion of the lair, and these, like the melullary rells, arr. nucleated and contain pigmentary granules. The epidermis of cuticle is a lityor

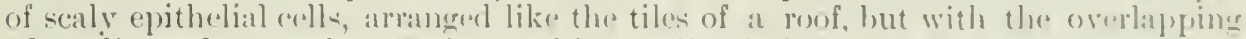

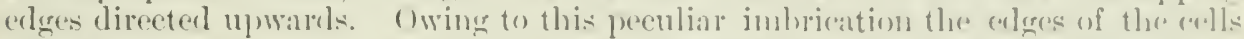

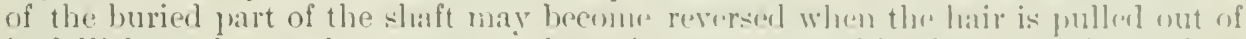

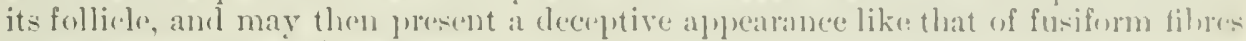
rollexl spirally aroume a $\mathrm{s}$ tem.

As the shaft structures approach the papilla they gratually change their character. The bulh itself ansists of an inner layer of prisunatic aells lying lirectly in contact with the dermic fapilla, and representing the stratum basilare of the epidermis; a middle layer of polyhedral (e)lls like those of the stratum Malpighii, and an outer layer of keratinising (cells corresponding to the stratum grantolown. but devoid of eleirlin.

The papilla is a cone of connective tistere into the entre of which is prolongerel a vaseular loop from the subcutaneous plexus. Nerves are not seen in the parillal, but fine twigs have been traced into the deeper fart of the follicular wall, thre losing their mrelin and forming terminal fibrils, some longituelinally, somr circularly arranged, outside the hyalin layer. 'The special tactile hairs of the lower animals present a more complex nervous and vascular apparatus, but these are not represented in man. 


\title{
ON SURGICAT
}

AND

\section{TOPOGRAPHICAL ANATOMY}

\author{
By W. H. A. JACOBSON, M.Cir.Oxon.
}

ASSISTANT SURGEON, GUY'S HOSPFTL

\section{SUPERFICIAL ANATOMY OF THE HEAD AND NECK}

\section{THE CRANIUM AND SCALP}

Bony landmarks. - These should be studied with the aid of a skull, as well as on the living subject. In the middle line, behind, is the external occipital protuberance, or inion, the thickest part of the rault, and corresponding internally with the meeting-point of six sinuses. From this point the superior currerl lines pass out towards the mastoid processes, and indicate the first part of the course of the lateral sinuses, which, after rumning horizontally outwards, turn downwards in the mastoid bone. The position of these important ressels would be more correctly indicated by a line drawn first from the external occipital protuberance to the ipper borker of the mastoid process, one inch behind the extemal anditory meatus. This line gives the transverse and longer part of the sinus. A shorter line, from the ending of the first to the tip of the mastoid, will indicate by its uplere two-thirds the sigmoid portion of the sinus and the bend by which it communicates with the transverse part (Macewen). (Fig. 660.)

About two inches and three-quarters ( $65 \mathrm{~mm}$.) above the external occipital protuberance is the lambda, or meeting of the sagittal and lambdoidal sutures (posterior fontanelle, small and triradiate in shape). It is uscful to remember, as cuicles on the scalp to the aloose two important points, that the lambla is on a level with the supraciliary ridges, and the external occipital protuberance on one with the zygomatic arches.

The point of junction of the lambdoidal and squamous sutures, the asterion, is placed about three-rfuarters of an inch lehind and half an inch above the upper part of the posterior border of the mastoid (fig. 659). The bregma, or junction of the coronal, sagittal, and, in early life, the frontal suture (anterior fontanelle, large and lozenge-shaped), lies just in front of the centre of a line drawn transversely orer the cranial vault from one preaurienlar point to the other (fig. 659). The pterion, or junction of the frontal, parietal, temporal, and sphenoid bones, lies in the temporal fossa, one and a half to two inches behind the external angular process of the frontal, and about the same distance above the zvgoma (fig. 659). This spot also gives the position of the trunk and the anterior and larger division of the middle meningeal artery. The zygoma can be traced backwards to its roots 
in front of the ear, while from its anterior extremity the funger, carried upwists along the outline of the malar, trates the temporal ridge along the sinde of the skull which marks the uppere limit of the temporal fossa, and the attachments of the temporal muscle and farsia. In the trmporal fossa lie the musele, and the

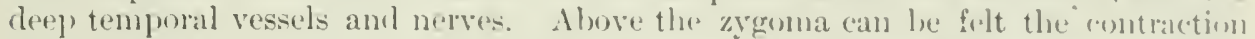
of the temporal; and below, that of the masseter musele; the former less distincty owing to its covering of fascia, attached below by two layers to the upper lumblip of the zygoma. In the zyomatic fossa, lying inside the zygoma, are the lowep part of the temporal, and the two pterygoid muscles, trigether with the internal mixillary vessels, and the mandibular division of the fifth nerve, and tlo.jr liranches.

The anterior inferior angle of the parietal bone, and its great importance as a

FIG. 659. -The SKULL.

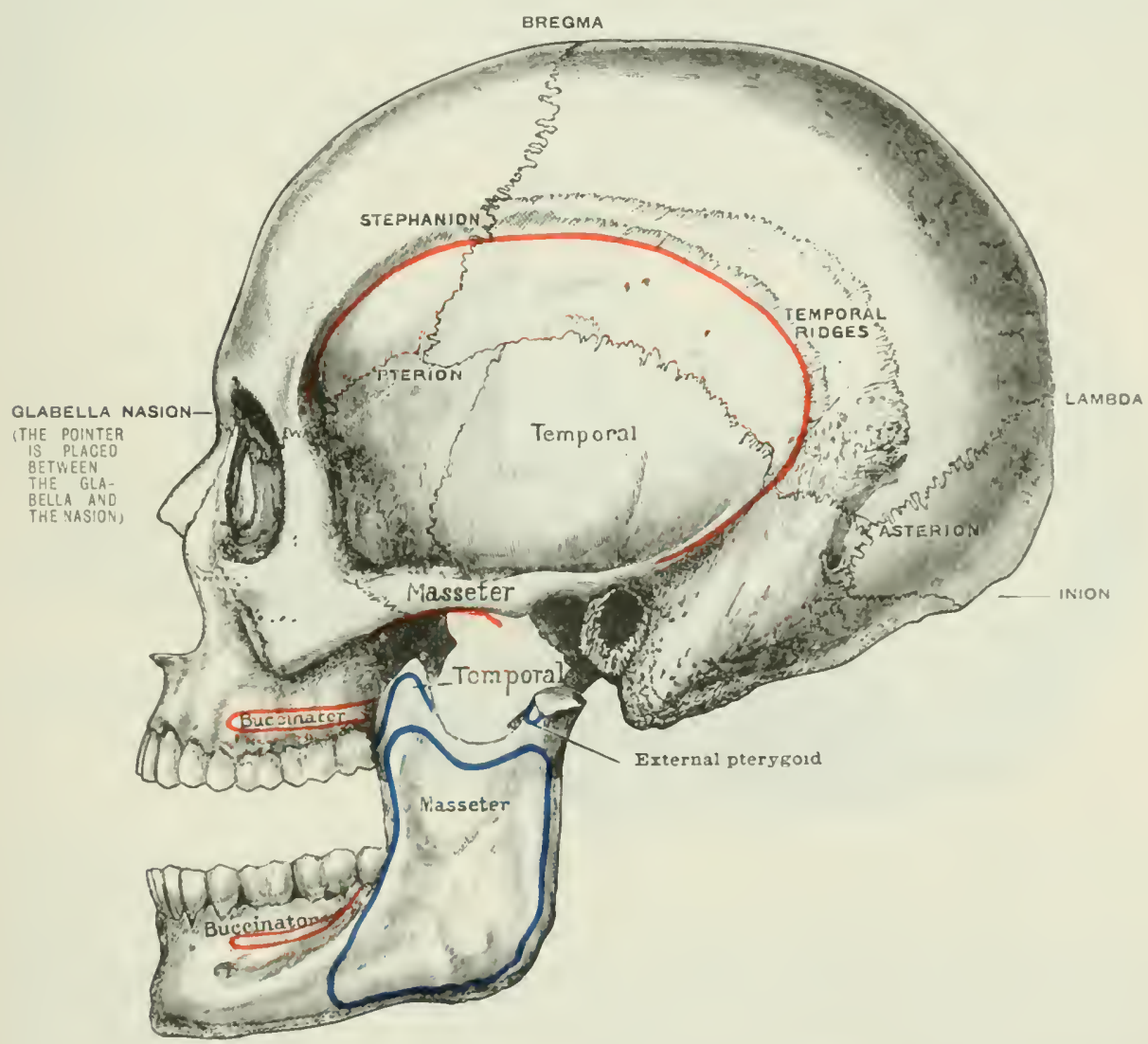

limmluark, has alreaty been given. Tho posterior inforior ander of this lume (ereored ly the lateral sinus) lies a litte aluse and helind the hase of the mastuil. ori a level with the routs of the zygoma (tig. (init) ). Iust below and in front of the tip of the mastoid the transverse precess of the atlats can le made out in a spare suliject.

The average thieknes- of the alult skull-(a)l is ahent one-fifth of an inch (Holilen). The thicket gart is at the extermal oreipital protulurance, where the lwne is often three-puanters of an ind in thickness. The thinnest gart of the skull vault is over the temporal fout of the stuamous. The extreme fragility of the skull here is partly compensaterl for hy the thickness of the soft parts; if these.

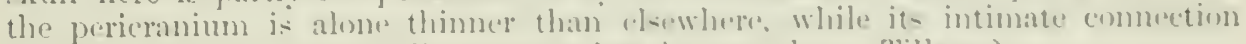
with the bones make exphallamatona les frepuent here (Tillaux). 
In front, the circumference of the bony orbit can be traced in its whole extent. The supraorbital noteh lies at the junction of the inner and middle thirds of the suprarbital arch. When this notch is a complete formen, its detection is much less easy. Hhove the suprambital arch is the supraciliary ridge, and higher still the frontal eminence. From the supraorbital notch, a line drawn downwards and slightly outwarls, so ats to rum between the two bicuspid teeth in each jaw, passes wer the infraorbital and mental foramina (Holden). The infraorbital foramen lies about a cuarter of an inch below the margin of the orbit. The mental foramen in the adult is placed midway between the upper and lower margins of the jaw, and is a little over a yuarter of an inch below the cul-de-sac of mucous membrane between the lower lip and the jaw' (Treves).

THE BONY SINUSES. - The frontal. - The development of these by the twentieth or twenty-fifth rear may render a fracture here much less grave in the adult than would otherwise be the ease, the inner table, if now separated from the outer, protecting the brain. Mr. Hilton showed that the absence of any external prominence here does not necessarily imply the absence of a sinus, as this may be formed

\section{Fig. 660.-Temporal, Bone, showixg Suprameatal, Thaxgle. (Barr.)}

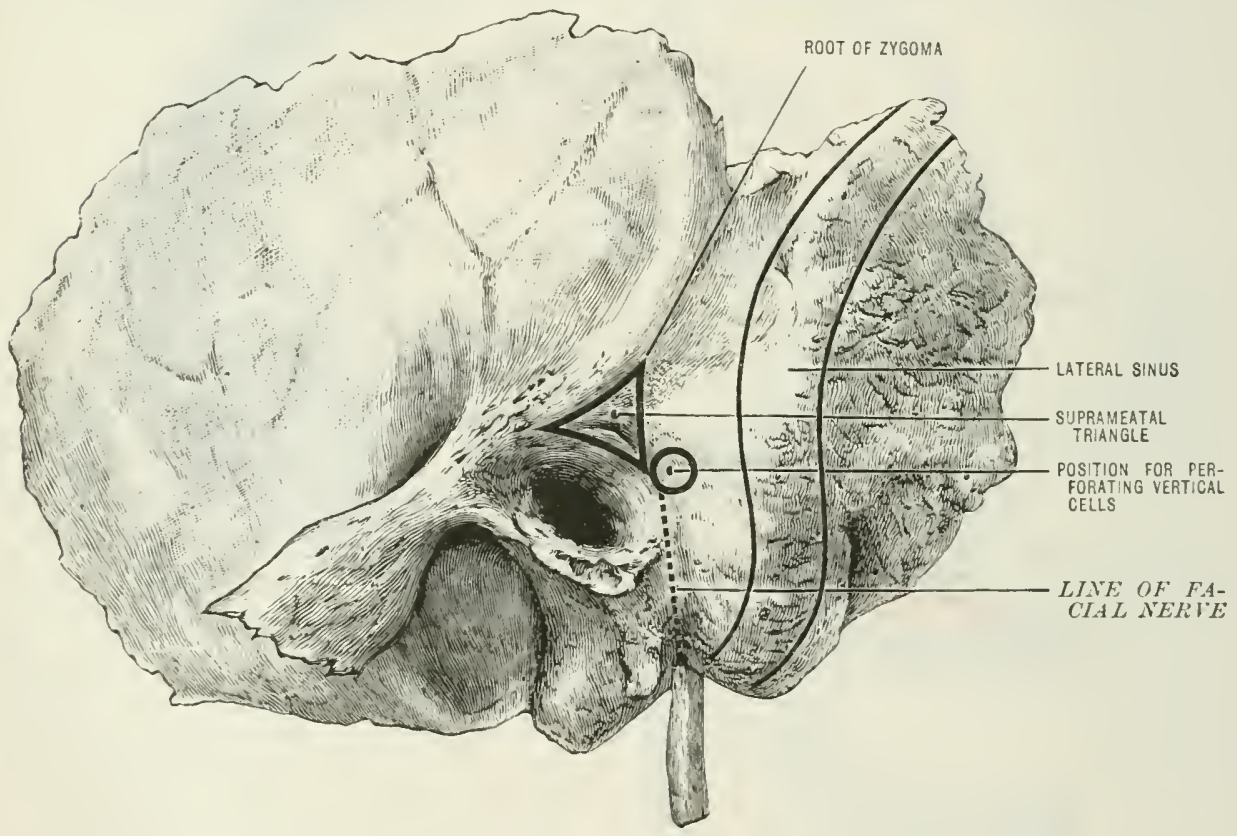

hy retrocession of the internal table. In old people these sinuses may enlarge ly the inner table following the shrinking hrain. Again, a very prominent bump here loes not necessarily point to the existence of a sinus at all, being due merely to a heaping up of bone.

When well dercloped. the frontal sinuses may reach two inches upwards and one and a half inches outwark, occupving the greater part of the vertical portion of the frontal bone. When very small, they scarcely extend above the nasal process. Even when present, they are often asymmetrical. The sinuses are separated by a septum. Each sinus narows downwards into the infundibulum. This 'is deeply placed behind the nasal process of the maxilla and near the inner wall of the orlit. Its termination in the middle meatus is ahout on a level with the palpebral fissure' ('Thane and (iodlee).

The communication of these sinuses with the nose accounts for the frontal hearlache in ozena, and the fact that a patient with a compound fracture opening up) the sinuses can blow out a flame held close by.

The mastoid sinuses are armanger in two groups, of the utmost importance in 


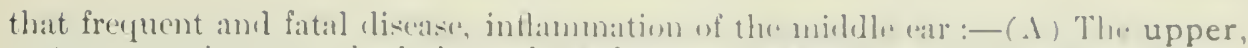

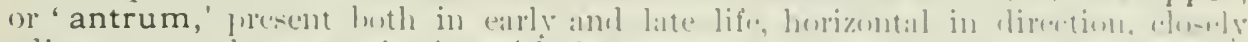
adjacent to and (onmmuncelting with the tympanum. (li) Th., lower, uf vertical. This groul is not develoned in earty lifi.

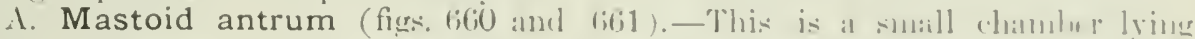

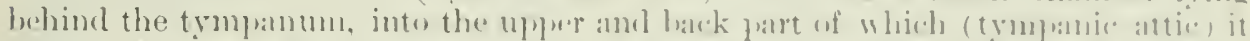

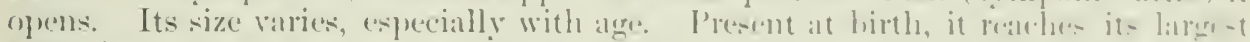

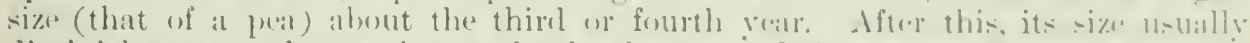

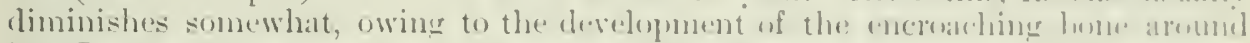

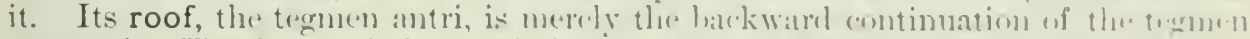

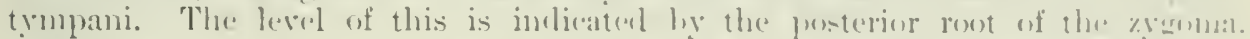

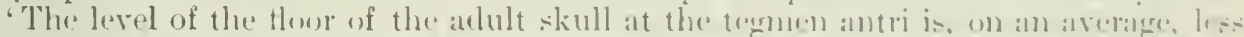

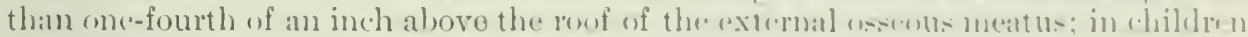

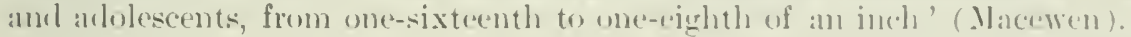

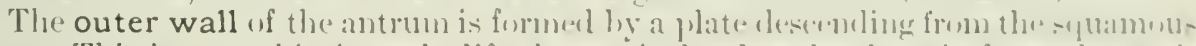
lone. This is very thin in carly life, hut as it terelops hy heme-it from the lurjosteum, the depth of the antrum from the surface incrases. Vaceweng give - the

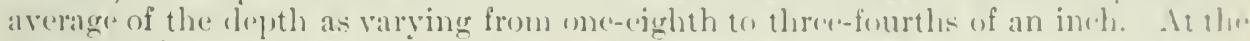

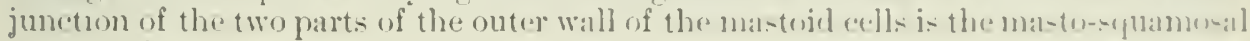
suture, often present at juberty. Through the floor, the antrum inmminniente-

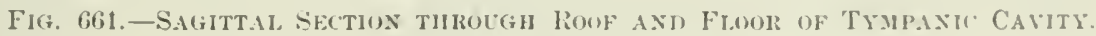

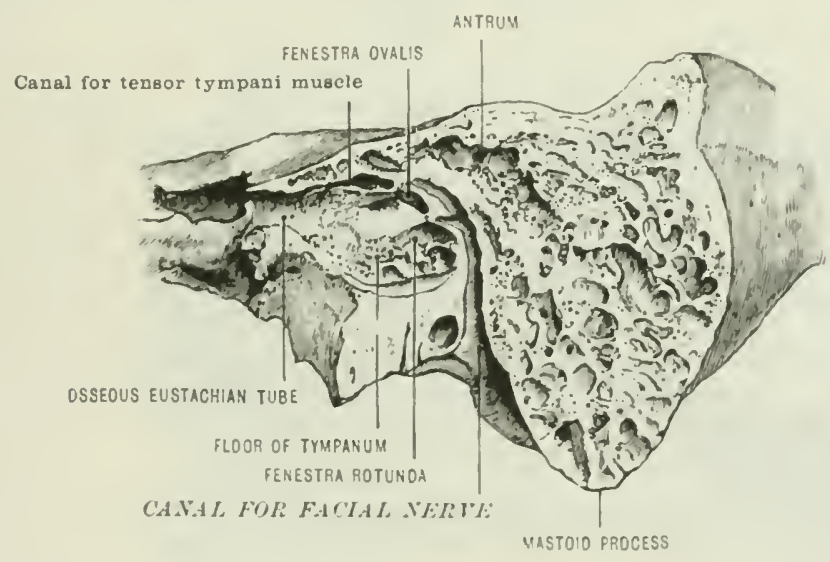

with the lower or vertical cells of the mastoid. This floor is on a luwer level than the opening into the tympanum, and thus drainage of the antrum i- liflicult. thisl fincling its way more realily into the lower alls. Behind the mantoid antrum and cells is the hend of the sigmoid part of the lateral sinus. with it-short de-cesuling portion (tig. 660). Macewen gives the following guides for thi- part of the

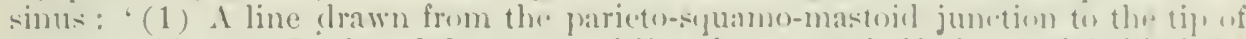
the mastoirl. (2) In the arbut, a vertual line drawn one-half of an inch twhind the posterion lomy wall of the extermal anditory meatus. and lutwern the leve lo of the roof and the floor, will, in the majority of cases, indiente the po-ition of the

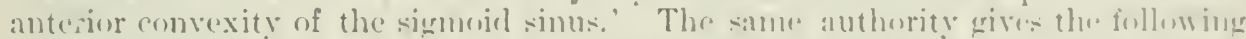
directions for exploring this important vesed: 'An opening in the lume, with it:

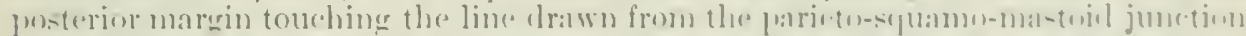
(1) the tip of the mastoicl. and within the parallels of the rouf and thene of the

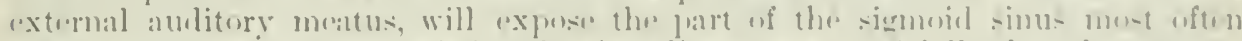

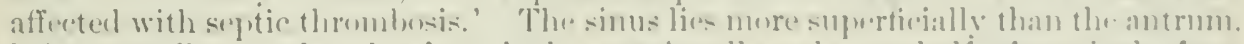

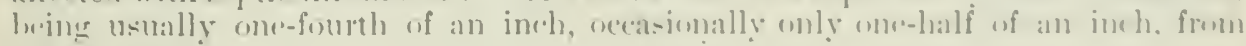
the surfare.

The exact position of the antrum, a little above and helhinl the external anditury meatus, is represented hy Macewerls supromeatal triangle. This in a triangle

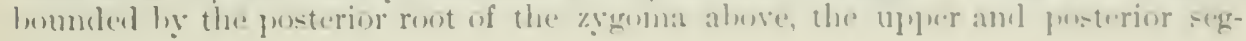


ment of the bony external meatus helow, and an imaginary line joining the above boumlaries (fig. (660). "Roughly speaking, if the orifice of the external osseous meatus be bisected horizontally, the upper half would be on the level of the mastoid antrum. If this segment he again bisereter vertically, its posterior half would again correspond to the junction of the antrum and middle ear, and immediately behind this lies the suprameatal fossa' (Macewen). When opening the antrum througrh this triangle, the operator should work forwards, and inwards, so as to avoirl the sigmoid sinus (fig. 660 ); while, to avoid the facial nerve (fig. 660 ), he should bring the root of the zycoma and the upper part of the bony meatus as close as possille. The level of the base of the brain will be a few lines alore the posterior root of the zrgoma (fig. 6.59) and about one-quarter of an inch above the roof of the bony meatus (Macewen).

B. The lower or vertical cells of the mastoid are developed later than is the antrum, and vary much in their contents. In only about trenty per cent. do ther contain air.

'The veins pussing from the mastoid cells and tympanum fall into three chief groups - (a) those opening into the lateral sinus; $(b)$ those passing through the mastoid formen into the occipital and sealp reins; (c) those running through the petroscuamosal suture to the dura mater. As all these reins carry connective-tissue

Fig. 662.-Horizontal Section of Left Teiporal Bone, showing the Varlot's PARTS OF THE EAR.

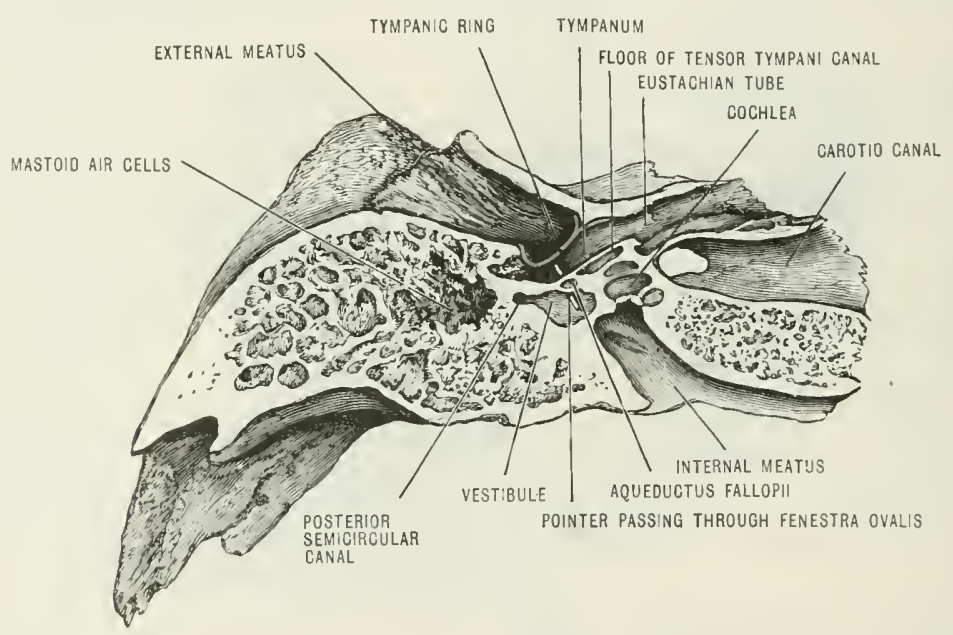

sheaths, inflammation may reach-( 1 ) the lateral sinus, causing septic phlehitis; (b) the soft parts outside, causing cellulitis, periostitis, ete.; (c) the dura mater and brain, leading to meningitis and abscess.

The sphenoidal sinuses are less important surgically, but these points should be remenhered:-(1) Fracture through them may lead to bleeding from the nose. which is thus brought into communication with the middle fossa; (2) the communication of their mucous membrane with that of the nose may explain the inveteracy of certain cases of ozana; (3) here and in the frontal sinuses rery clense exostoses are sometimes formed.

THE SCALP.- The importance of the scalp is hest seen from an examination of its layers (fig. 66.3). These are-(1) skin; (2) subcutaneous fat and fibrous tissue; (3) the occipito-frontalis and aponeurosis; (4) the subaponeurotic layer of connective tissue; $(5)$ the pericranium and subpericranial connective tissue.

The first three layers are connected and move together. (1) The union of the skin, and its density, are to enable: it to meet pressure, and also to prevent it rucking into folks. Furthermore, they account for the extreme pain of inflammation here, and the difliculty of raising a hlister on the scalp. The presence of 
hairs and sebaceous glands is of mueh nure importance than appears an fir-t. Thes the rooting of the formere is se firm that in the (atse of voume wommen the whole sealp may be tom off hy mehinery. 'Tly" sebaceous glands hatr alsu

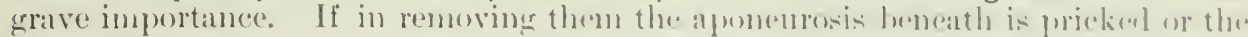

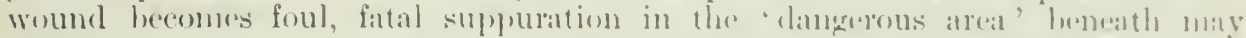

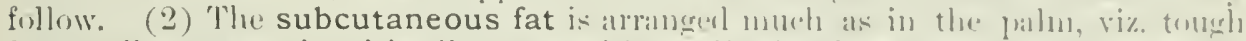
fatty pellets are enclosed in tibous partitions, lippine from the skin to the thim laver, and thus tring the three layers tugether. (3) The occipito-frontalis and

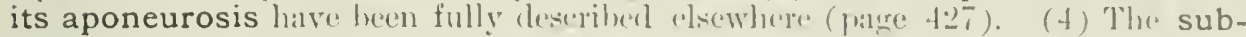

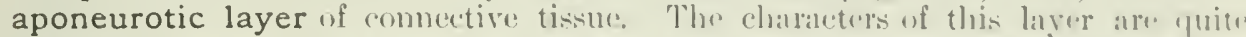

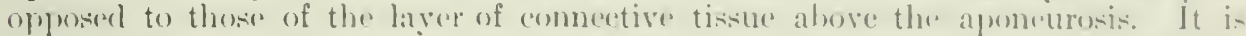
looser, delicate, and fatless. From theseresult the free molislity of the stalle, the fact that it ean lee tom away, and (most important of all) the lacility with which inflammatory products ean sprear in this layer. The perils of pus jent up here are extreme, viz. sloughing of the salp, or heerosis of the bones, blomel-puisonine.

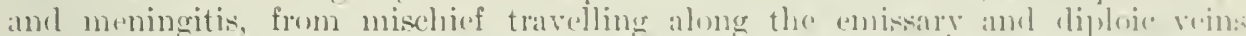

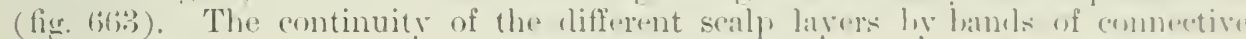
tissue passing from the skin to the oedpito-frontalis, and thence along vessels.

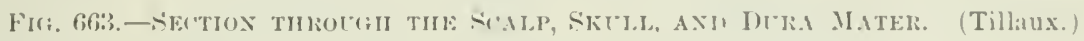

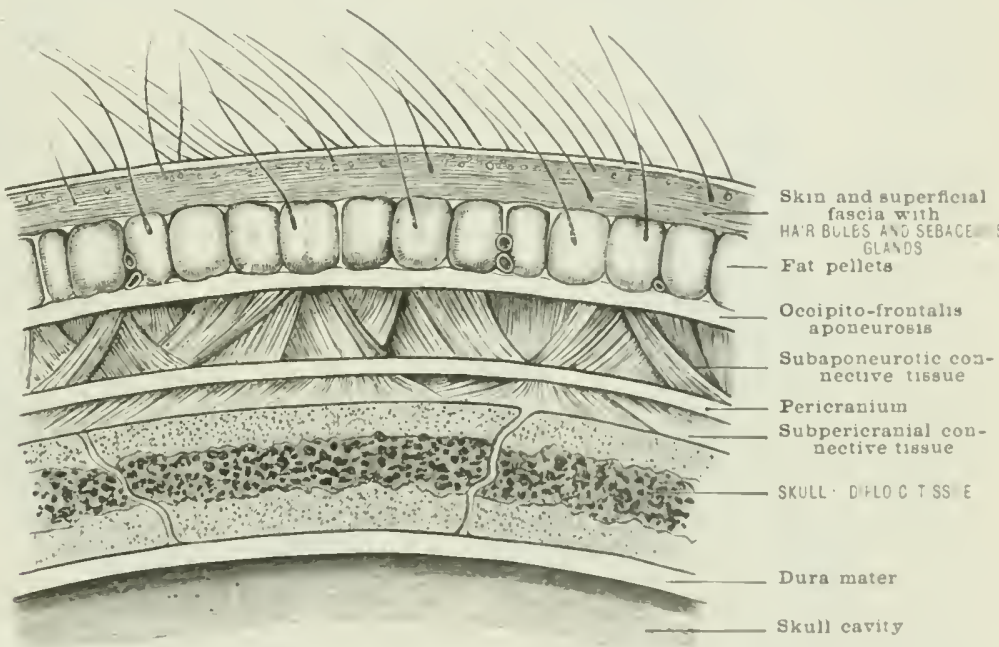

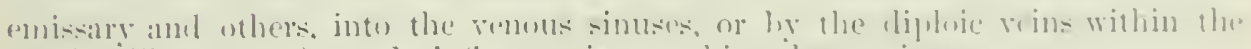
skull, will areoment for sealp inflammation reabhing the meninges.

Of the vessels of the scalp, the arteries are jeculiar in their jucition. 'Thus:

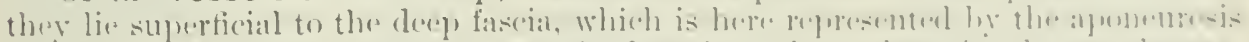

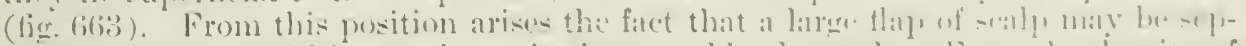

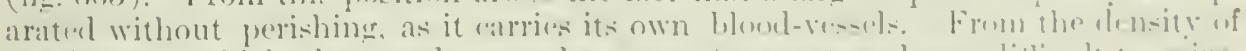

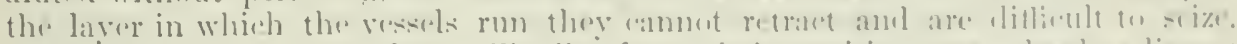

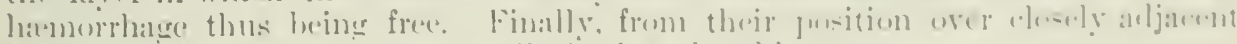

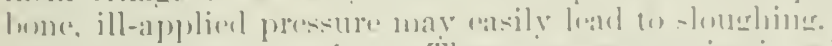

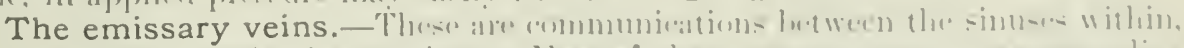

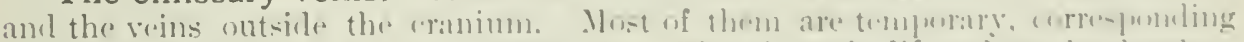

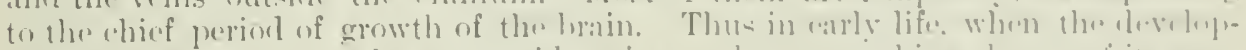

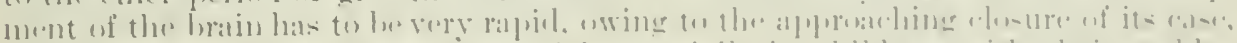

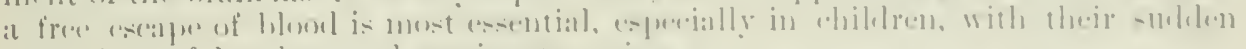

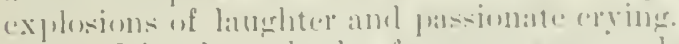

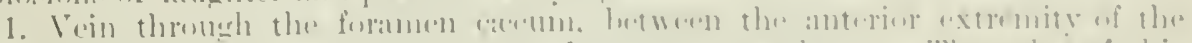

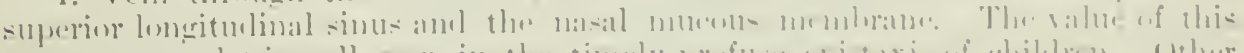

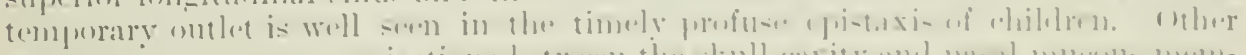

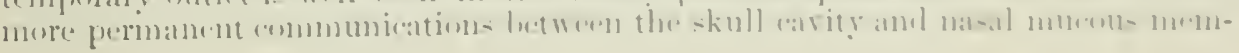


brane pass through the ethmoil and internal orbital foramina. The fact that the nasal mucous membrane is loose and ill-supported on the turbinater lomes allows its ressels to give way readily, and thus forms a salutary safegtaard to the brain, warding off many an attack of alpoplexy.

2. Tein through the mastoid furamen, between the lateral sinus and the posterior aurieular and occipital veins. This is the largest, the most constant, and the most superficial of the enissury reins. Hence the old rule of aply lying blisters or leeches orer it in cerebral congestion.

3. Vein through the posterior superior angle of the parietal between the superior longitulinal sinus and the reins of the saly.

4. Vein through the pusterior condyloid foramen between the lateral sinus and the (lec l) reins of the neck.

5. Tein through the anterior condyloid foramen between the occipital sinus and the derp reins of the neck.

6. Ophthalmic veins communicating with the cavernous sinus and the angular rein. These veins may be the sourer of fatal hinol-poisoning, by convering out of reach septic material, in acute periostitis of the orbit, or in osteitis, of clental origin, of the jars.

7. Minute veins through the foramen ovale between the cavernous sinus and the pharingeal and pterrgoid reins.

S. Communications between the frontal diploic and suprantital reins. between the anterior temporal diploic and deep temporal veins, and between the posterior temporal and occipital diploic reins and the lateral sinus.

The grarity of these emissary veins and their free communications with othors is show by the readiness with which they hecome the seat of septic thromboris, and thus of blood-poisoning, in cranial injuries, erysipelas. suppuration of the scalp, and necrosis of the skull.

Structure of cranium.-Two layers and intervening cancellous tissue. Each layer has special properties. The outer gives thickness, smoothness, and uniformity, and, above all, elasticity. The inner is whiter, thinner, less regulare. g. the depressions for ressels, Pacchionian bodies, dura mater, and brain. Its chief characteristics are its fragility (vitreous) and absolute inelasticity. The diploë, formed by ahsorption after the skull has attained a certain thicknesis. reiluces the weight of the skull without proportionately redueing its strength, and provides a material which will prevent the transmission of ribrations.

Results of the above varying elasticity. -1 blow on the heal may fracture the intemal table only, the extemal one and diploë escaping. This is difficult to diagnose, and thus it is impossible to judere of the severity of a fracture from the stite of the external table. This may he whole, or merely cracked, while the internal shows many fragments, which may set up meningitis. or other mischief.

Anatomical conditions tending to minimise the effects of violence inflicted upon the skull.-(1) The density and mobility of the scalp. (2) The dome-like shape of the skull. This, like an egg-shell, is calculaterl to hear relatively hard blows and also to allow then to glide off. (3) The number of bones tends to break up the force of a blow. (4) The sutures interrupt the transmission of riolence. (j) The internal membrane (remains of fatal peri(steum) arts. in rarly life, ats a linear buffer. (6) The elasticity of the outer table. (7) The overlapping of some bones, a. the parictal hy the squamons; and the alternate hevelling of arljacent bones, e.g. at the coronal sinture. (S) The presence of ribs, or groins, e.g. ( $(1)$ from the crista galli to the internal occipital protulerance; (b) from the ront of the nose to the zygoma; (c) the temporal ridge frem orhit to mastoirl; (d) from mastoil to mastoid; (e) from the external orcipital protuluerance to the foramen marnum. (9) Buttresses, e.g. malar and zygomatic processes. ant the greater wing of the sphemoicl. (10) The mobility of the head upron the spine.

\section{CRANIO-CEREBRAL, TOPOGRAPHY}

To make as clear as posible the prints of practical importance which have, of late yours, been put on a definite basis, and which the surerem nay lave to recall and act upon at very short notice, cranio-('erehral topography will be spoken of 
umler the following hudings: $A$. Relation of the brain as a whole to the skull. B. Relation of the chief sulci and convolutions to the skull. (') Localisation of the chief sulci and convolutions. Buf(ure allulling tu the ahowe, it is neessary to say distinctly that the following surface-matrings and

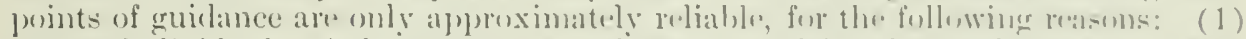

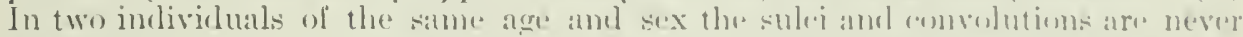
preciscly alike. (2) The relations of the (n) volutions aml sulet to the surfare vary in different indiviluals. (3) That as the surface areat of the seall and wuter aspeet of the skull are erreater than the surfice area of ther hrain, and als the

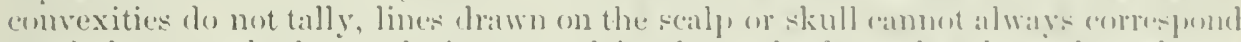
precisely to cerehral comrolutions or sulei. It results from the alowe that when a cletinite area of the surface is sabl to correspond areurately in any individual to :s

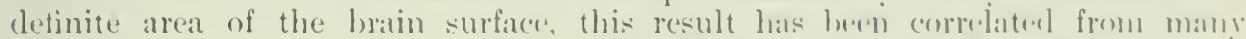
examinations; and that as surface-matrings, shape, and processis of skull andil

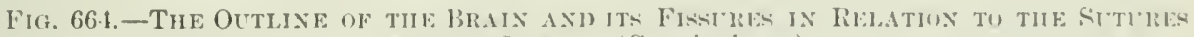
(1) TIE SkFli. (Cummingham.)

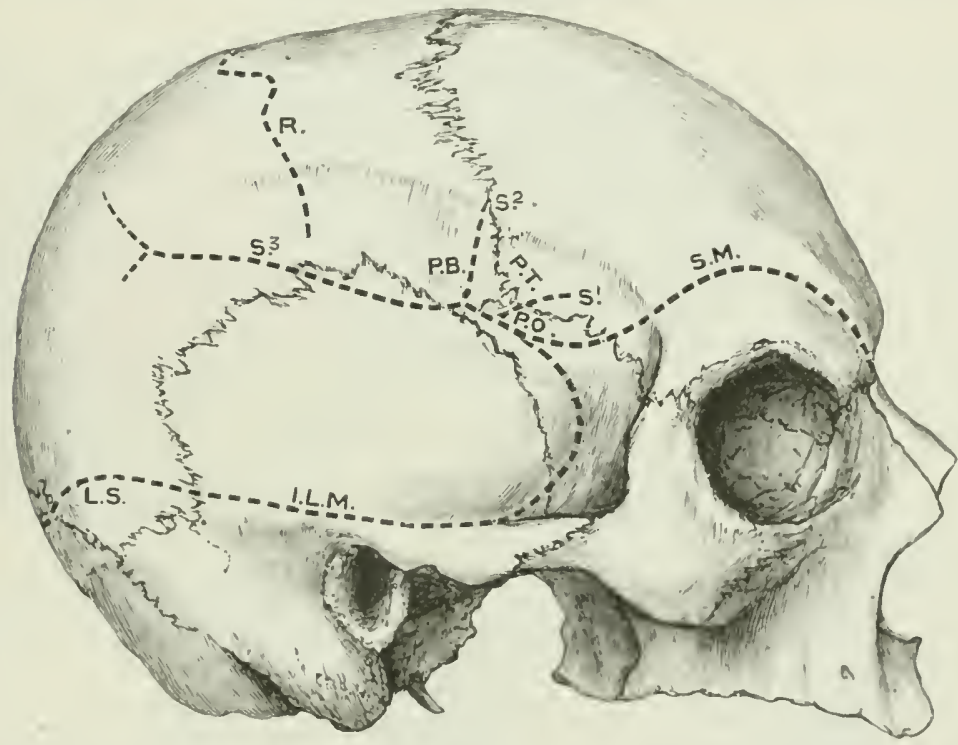

s.y. Suprariliary marein of the erehrum. 1.I...y. Inferu-lateral marein of the cerelorum.

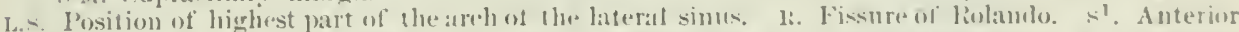
horizontal limb of sylvian tissure. $s^{2}$. Anterior asemeling limb of Sylvian fissure. $\mathrm{s}^{3}$. Insterior

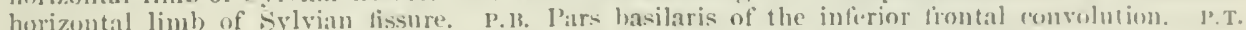
Pars triangularis of the inferior fiontal innolution. P.o. Pars orhitalis of the inferior frontal convolutious.

arrangensent of lirain surface are all lialle to sariations in different indiviuluals, the

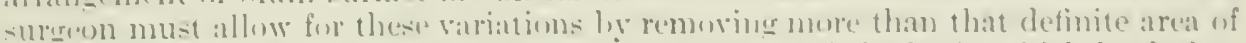

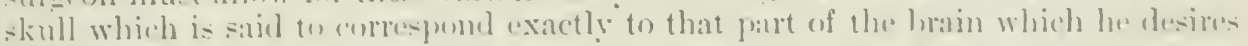
(1) "Xjus?

A. Relation of the brain as a whole to the skull (ligr. lifid almel firif).-

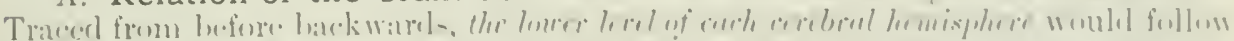

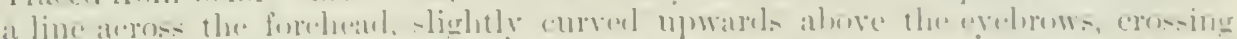

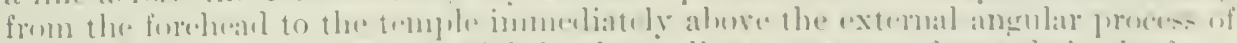
the fromtal. It then le

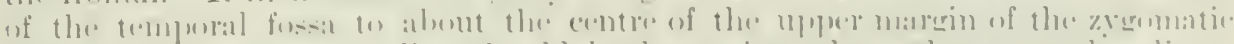
areh. From this puint a lise should he drawn ju-t alowe the external anditury

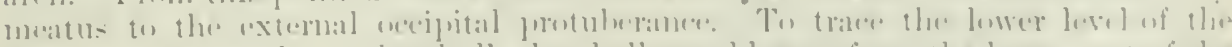

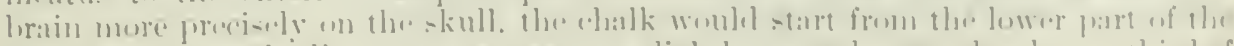

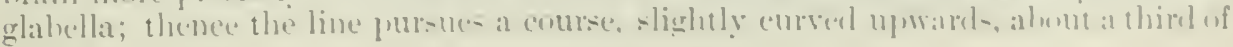


an inch above the supraorbital margin; next, crossing the temporal crest about half an inch above the external angular process, it passes not quite horizontally, but descending slightly to a point in the temporal fossa just below the tip of the great wing of the sphenoid (pterion), an incl behind the external angular process. From this point the line of the level of the brain, now convex forwards and corresponding to the anterior extremity of the temporo-sphenoiclal lobe, would dip down, still within the great wing of the sphenoirl, to about the centre of the zygoma. Thence the line would travel along the upper border of this process about a quarter of an inch above the roof of the external auditory meatus, and thence just above the base of the mastoid and the posterior inferior angle of the parietal, and so along the superior curved line, and corresponding to that of the tentorium and horizontal part of the lateral sinus, to the external oceipital protuberance.

The upper margin of each hemisphere would be represented by a line drawn from just below the glabella, sufficiently to one side of the midclle line to allow for the falx and superior longitudinal sinus, to one immediately above the superior external oceipital protuberance and inion (1. 1091).

B. Relation of the chief fissures and convolutions to the skull. Localization of the chief sulci and convolutions. These headings will be taken together.

It will be well to first indicate the position of the chief sutures which mark off the parictal bone, under which lies that part of the brain which is most important to the surgeon-the motor area. The upper limit of the bone will be indicated ly the line already spoken of as giving the upper margin of the hemisphere-the sagittal line, or suture (p. 1091). The anterior limit of the parietal bone, formed by the coronal suture, may be traced thus: The point where it leaves the sagittal suture (the bregma) will be found by drawing a line from a point just in front of the external auditory meatus (the preauricular point) (p. 1091, figs. 659 and 66.5 ) straight upwards on to the vertex; from this point a line drawn downwards and forwards to the middle of the zygomatic arch would inclicate that of the coronal suture. Tnder this suture lie the posterior extremities of the three lateral frontal convolutions; for the frontal lobe lies not only under the frontal bone, but extends backwards under the anterior part of the parietal, the fissure of Polando, which separates the frontal from the parietal lobe, lying from one and a half to two inches lehind the coronal sutmre.

The squamoso-parietal suture, which marks the lower border of the anterior two-thirds of the parietal bone, is not so easy to define. owing to the irregularity and variations of its curve. Its highest point is usually one and three-quarter inches above the zyoma.

The lambdoid suture, which forms the posterior houndary of the parietal hone, will be marked out by a line which starts from a point (lambda) two and three-quarter inches ahore the extemal occipital protuberance, and runs downwards and forwark to a point on a level with the zygoma, one and three-quarter inches behind the meatus.

The position of the chief sulci will now be given:

Sylvian fissure (figs. 664 and 665 ). - The point of appearance of this, on the outer side of the brain, practically corresponds to the pterion (fig. 6.59) - a point which lies in the temporal fossa, about an inch and a half behind the extemal angrular process and about the same distance above the zygoma. From this point the Sylvian fissure, which here separates the frontal and parietal from the tempor()sphenoidal lobe, runs hackwards and upwards, ascending gently, at first in the line of the squamo-parietal suture, then crossing this suture about its centre, and thence. ascending more rapiclly, it climbs up to the temporal ridge, to end three-quarters of an inch helow the parietal eminence. Its termination is surrounded by the supramarginal convolution, to which the parietal eminence corresponds with sufficient accuracy. Such being the surface-marking of the ehief or posterior horizontal limb of the fissure of sylyius ( $s^{3}$, fig. ( 664$)$, it remains to indicate briefly the two shorter limbs which lound the inferior frontal convolution, which, on the left side, contains the centre for speech (Broca's convolution). Of these, the anterior horizontal ( $\mathrm{s}^{1}$, fig. 66it) runs forwards across the termination of the coronal, just above the line of the spheno-parietal suture. The ascending limb ( $\mathrm{s}^{2}$, fig. 
664) runs upwark for alwnt an inch just lwhind the termination of the conound

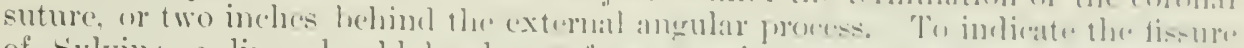

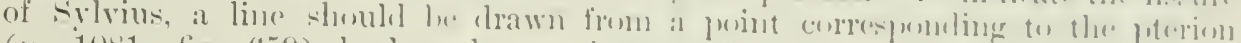

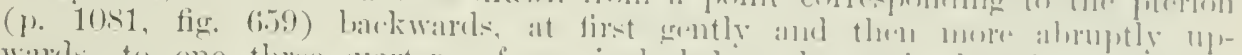

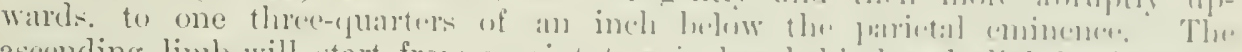
ascending limb will start from a point two inehes lwhimb ame slightly aluew the

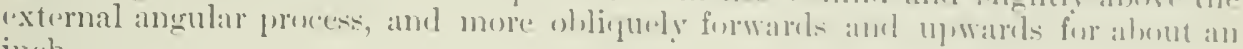
inch.

Fissure of Rolando.-This must impurtant fir-um, armunl which the mutur area is grouped, rums downwarels and forwards, seplatating the fontal and prarietal

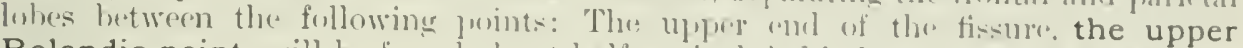
Rolandic point, will be foumd alust half an inch behind the centere of the salgittal

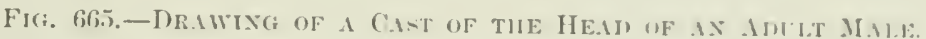

(Prepared hy Professor Cinninghan to illustrate cranjo-cerebral topographyy.)

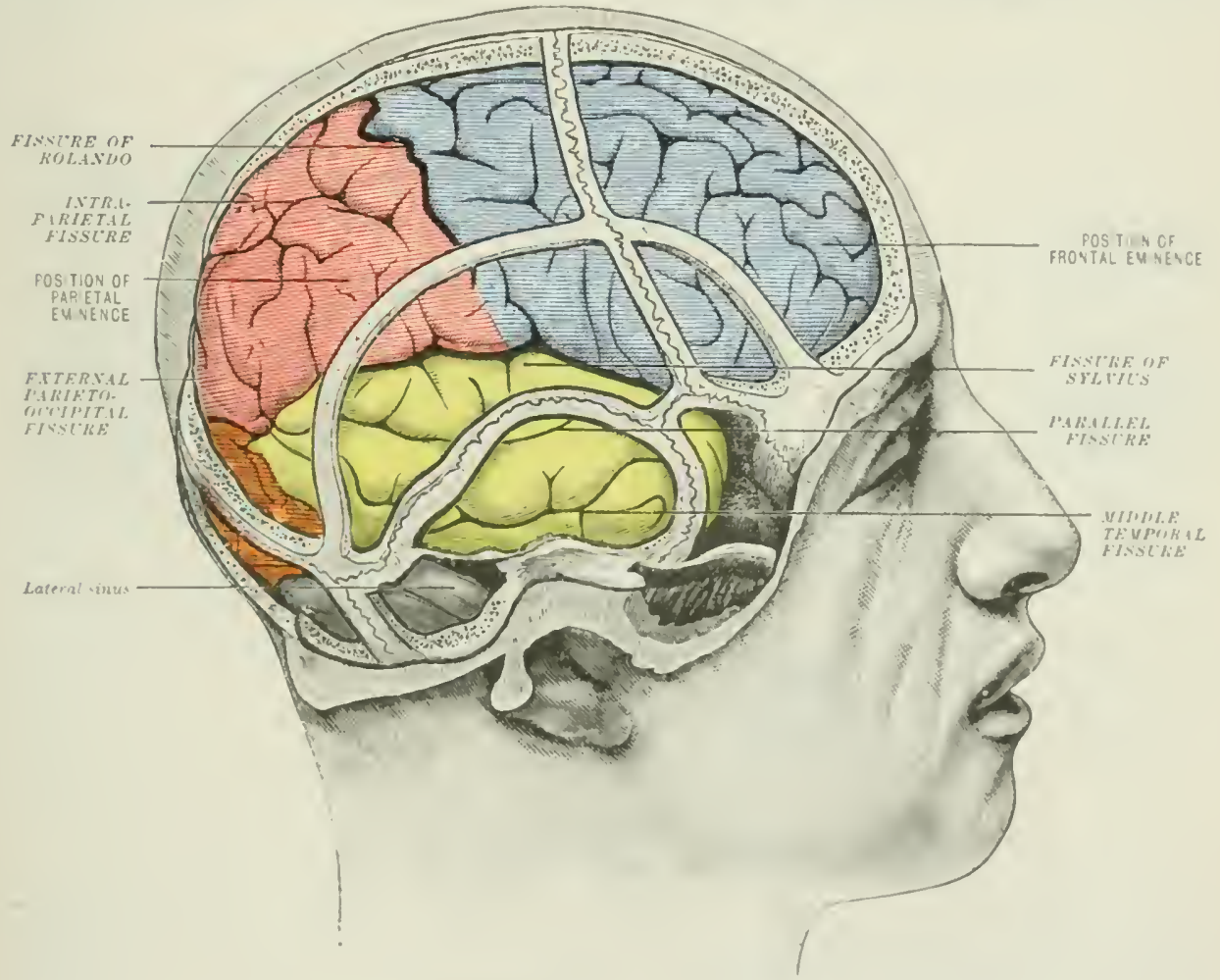

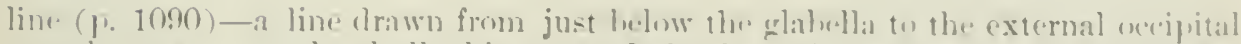

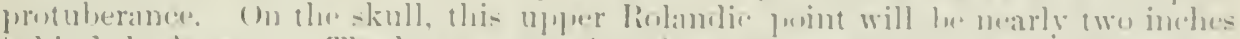
lehind the bremal The lower extrenty of the fi--ure inferior Rolandic point,

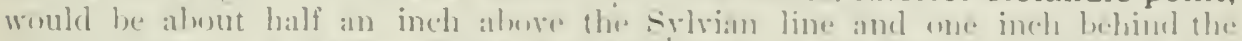

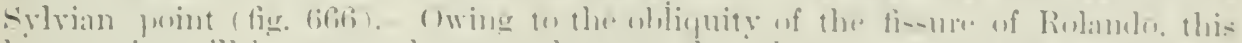

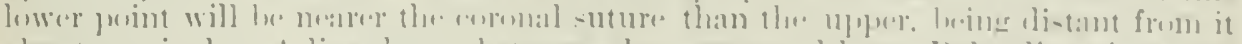

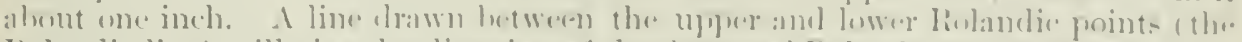

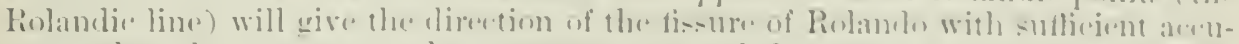

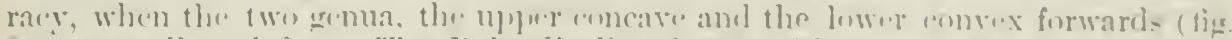

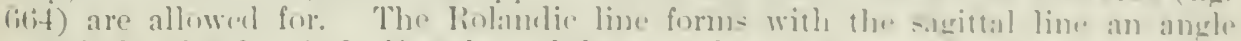

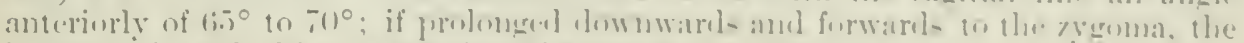
line would reach this process alunt it went re (Le Furt). 
To find the fissure of Rolando the following methods have been employed. In a griven case it is well to cmploy them all, so that any error in one may be checked by another measurement:

I. The upper and lower Rolandic points are found as above directed, and the Rolandic line is dratw between then.

II. The upper Rolandic point is taken two inches behind the bregma, or junction of the coronal and sagittal sutures. The position of the lower and of the fissure is thus determined: From the very end of the external orbital process, where this rises up to join the tempolal crest, draw a horizontal line two and a quarter inches long, and from the extreme end of this draw a vertical line of a little over one inch. Between these upper and lower Rolaudie points, passing rather obliquely forwards, lies the fissure of Rolando (Lucas, Championnière).

III. Here (1) the sagittal line is taken; (2) and (3) at a right angle to this two lines are drawn vertically orer the sicle of the skull, - the one starting from the pre-iuricular point (fig. 666), the other at the level of the posterior borter of the mastoid process, - and meeting the sagittal line about two inches behind the second; (4) from the junetion of the lines 1 and 3 , one is drawn diagonally down-

\section{Fig. 666.-Cranio-cerebral, Topograpiry. (Anderson and Makins.)}

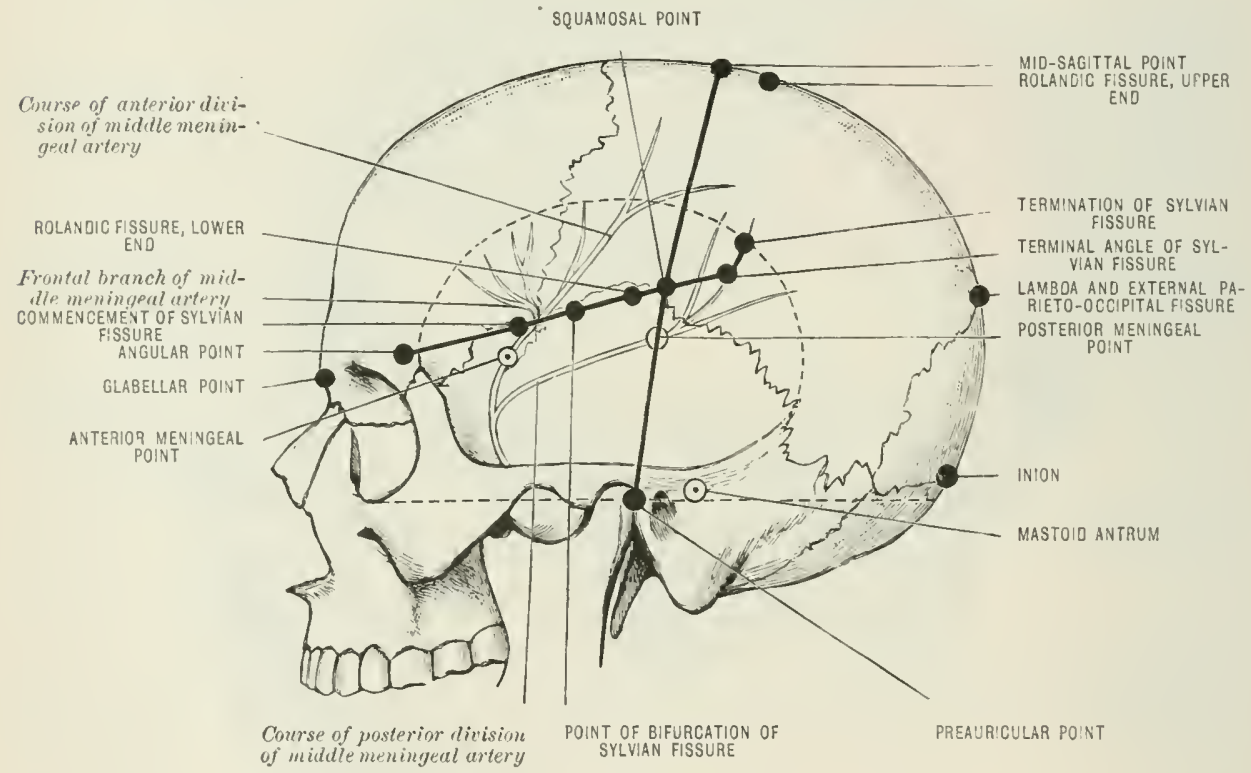

wark, reaching 2 about two inches above and a little in front of the exterual auditur. meatus (Reid and Gollece).

I: "The fissure of Rolando may be found by the measurements given by Makins and anderson (fig. 6666 ).

The external parieto-occipital fissures.-The upyer end of this will appear just in front of the lambla.

Before leaving this subject, the attention of the student and surgeon is drawn to fig. 666 and the method which it illustrates-that of Andersom and Makins. As claimed by these surgeons and anatomists, their method fultils the requirements of any practical seheme of eranio-cerebral topography, viz. : (1) The cranial landmarks cmployerl shall be distinct, and subject as little as possible to rariations in redation to the general proportions of the skull-eap); (2) that the guiding lines, dreaw by the aid of these landmaks. shall adapt themselves to skulk of varying size and confomation; and (:3) that no special apparatus shall be recpuired for the localisation.

The method recommended by Anderson and Makins is the following: The 
cranial landmarks (fice. 666 ) are (1) the glabellar point, in the millinfe of the. nasial eminemee, on a level with the uplue margin of the orhits; (2) the inial point,

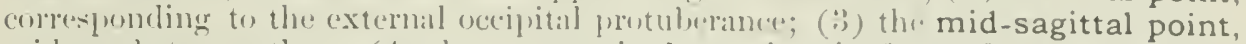

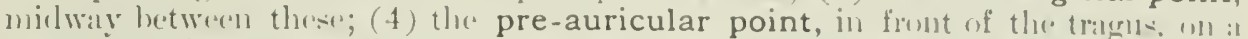

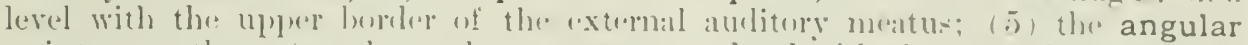

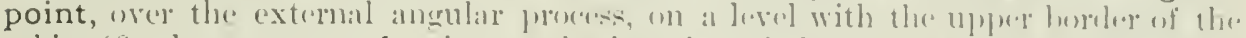

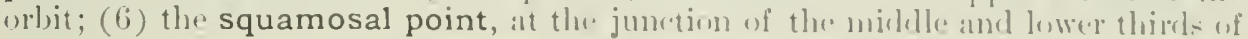

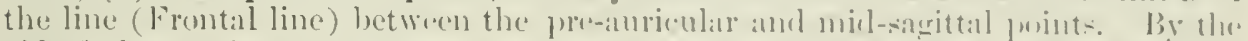

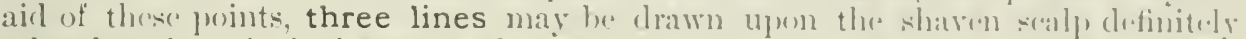
related to the principal tissures of the outer surfare of the brain: (1) The sagittal line, from the glabellat to the indon; with this line colnojules the longiturlinal fi-:ure. (2) The squamosal line, from the angular to the squamosal point, and alnut two inches beromel in this line and its continuation lies the fisture of sryius. (3) The frontal line, from the jne-auricular to the mid-sagital print. The fis-ture of Rolando erosses this line at an acute ande. Its uppere end, carried to the midline, lies three-eighths of an inch behind the mid-sagital proint; its lower end, in the squamosal line, three-eighths of an inch beyond the squamosal point.

\section{TIE FACE}

The outline of the different bones-nasal, upper and lower jaws, malar, and zygoma-can be readily traced.

Arteries.-The supraorbital artery can be felt beating just alowe its motch (junction of imer with outer two-thirch of supraorbital arch); the temporal it-alf can be felt where it crosses the root of the zyoma just in front of the tragus, itanterior branch about an inch and a quarter alose and bohind the external angular process of the frontal; the occipital (1. 1102) pulsates near the mirldle of a line drawn from the occipital protuberance to the masteid preces:s the posterior auricular behind the apex of the mastsid. The external carotid lies behind the ascemling ramus of the jaw. The facial (fig. 667) erosess the jaw just in front of the mas-iter; if divided, both ends nust be secured here. It ain be felt again at little behing the angle of the mouth, just beneath the mucous membrane (it here gives off the coronaries, which can also be folt, lying deeply, if the lip is taken between the finger and thumb); and again by the side of the nose, as it runs up (1) the tomber onli. To trace the course of the farial artery a line should lwe drawn from a print a little abowe and outside the tip of the erreat cornu of the hyoid to the lower gart of the antrior burler of the masseter. and thence to one coutside and alwore the angle of the mouth. and so onwards, extermal to the angle of the mose, up to the inner eanthus. The little frontal artery is of importance, as it mourishes the flat when a new mose is talien from the forehearl.

I line drawn frem the tip of the lohule of the ear to a point midway between the mose and uppere lip gives the level of the parotid duct, which opens inte the mouth opposite the second upper molar tootl. The level of the duct would he

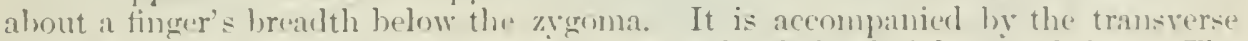
fardal artery alove, and the inframbital branch of the facial nerve ludow. The sheath of the parotid, continuous with those of the masseter and strmo-mastoid, is strong enough to causis most "xyuisitely gatinful temsion when inflammation of the crland is preserent.

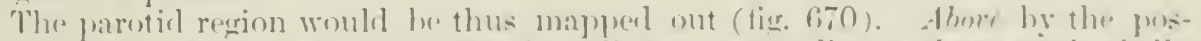

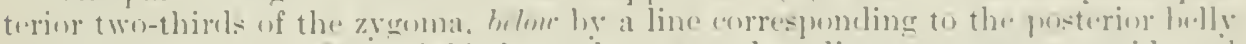

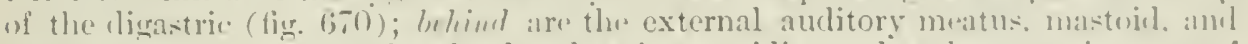
strmomastoid. In front the gramel and socia parotidis orerliap the pusterior part of the milsseter. to a variahle degree (fier. (0ij 0 ).

"The proximity of the parntid to the styhicl procese, to which the pharynx is

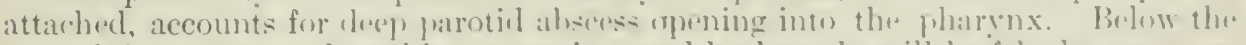

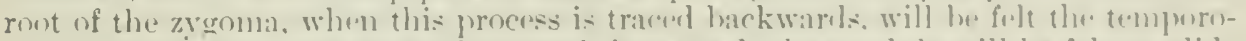
mamelihular joint: amb when the month is opened. the condyle will he folt to gride forwards upon the eninentia articularis. 


\section{THE EYELIDS AND LACHRYYNAL APPARATUS}

The structure of the lids.-The different layers are of much practical importance. (1) The skin is delicate and fatless, and contains yigment, the olject of this being to protect the eye from bright light. It helps to explain the "dark circles" of later life. (2) Areolar tissue. Owing to its looseness and delicacy,

Fif. 66\%.-SCHEME of the FACIAL ARTERY.

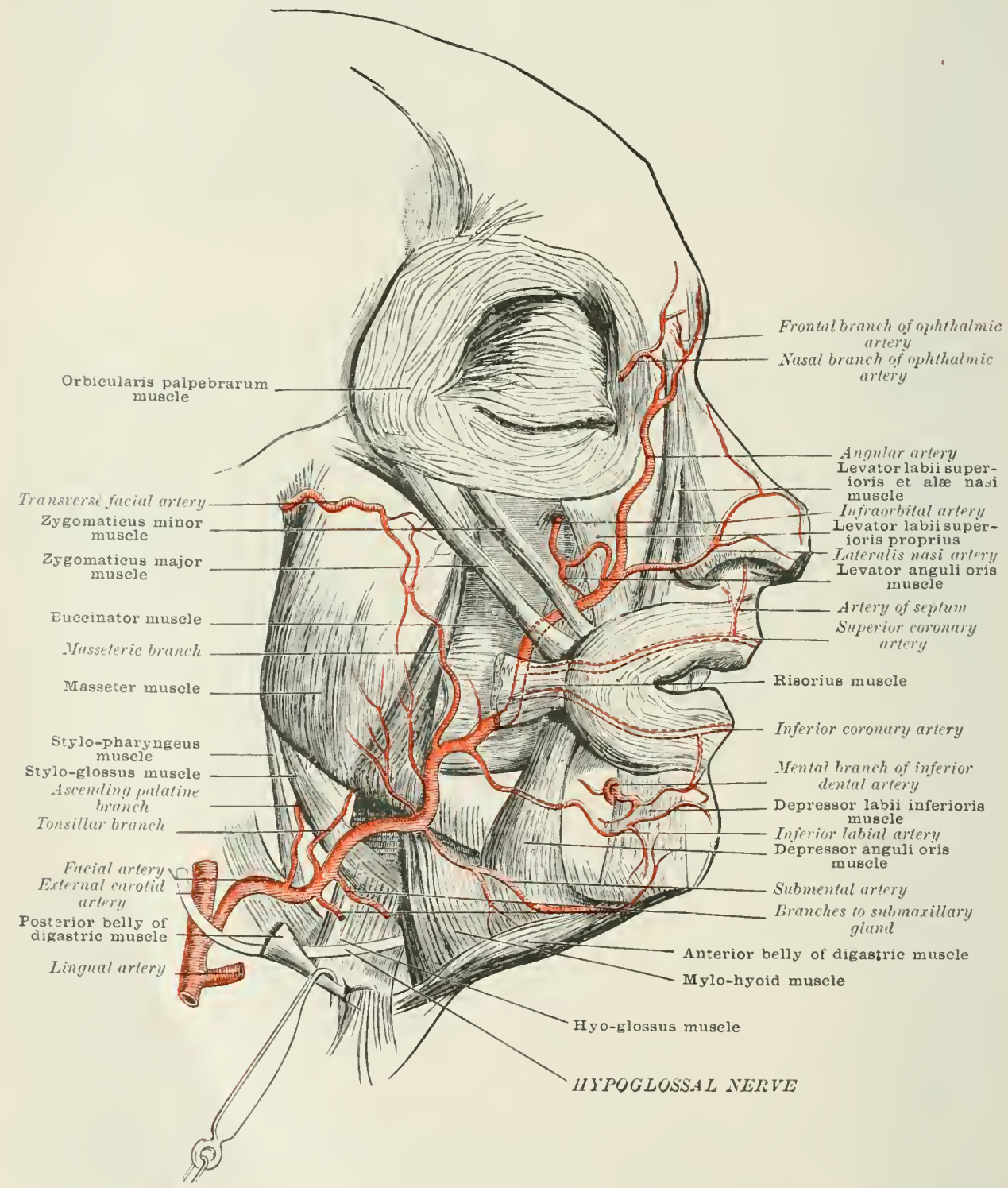

this is very liable to infiltration, as in ascites and erysipelas. (3) Orbicularis. Paralysis of this, the jalluebral portion, leats to epiphora, the puncta being no longer kept applied against the eye. (4) Palpebral ligament, reaching from the orbit to the tarsal cartilage. This is usually strong enough to prevent hamorrhage, due to fractured hase of skull, becoming subeutaneous. (5) Levator palpebræ. (6) Tarsal cartilage; in reality, densely felted fibrous tissue. (T) Meibomian 
glands, lashes, and sebaceous follicles. IAmali-iel inflanmution starting in

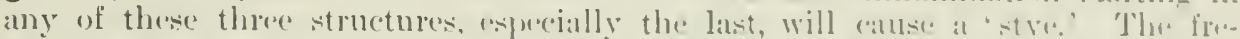

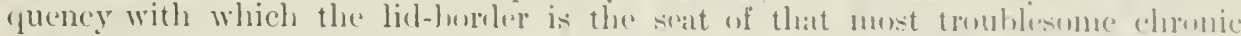

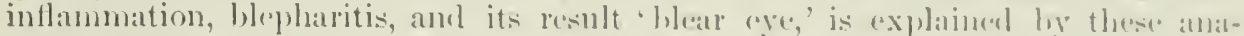
tomical points. Its cireulation is terminal and slow; half skin and half mucums membrane, it is noister and more liahle to lecal irritation than the skin; while it numerous ghands readily participatr in amy inflammation. (S) The conjunctiva. To trace this inportant membrane, the liks shonkl le everterl, when the followiles will be noted. The enojunctivan orer the tarsal part of the lith is clesedy allherent. and throngh it, a series of nearly straight, parallel, light pollow lines and granules, the Meibonian glands, ean be secen. Beyond the tarsi, the conjunctiva, mon las]-

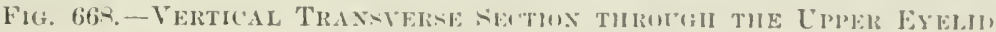
(Atter Waldeger :ud Fuchs.)

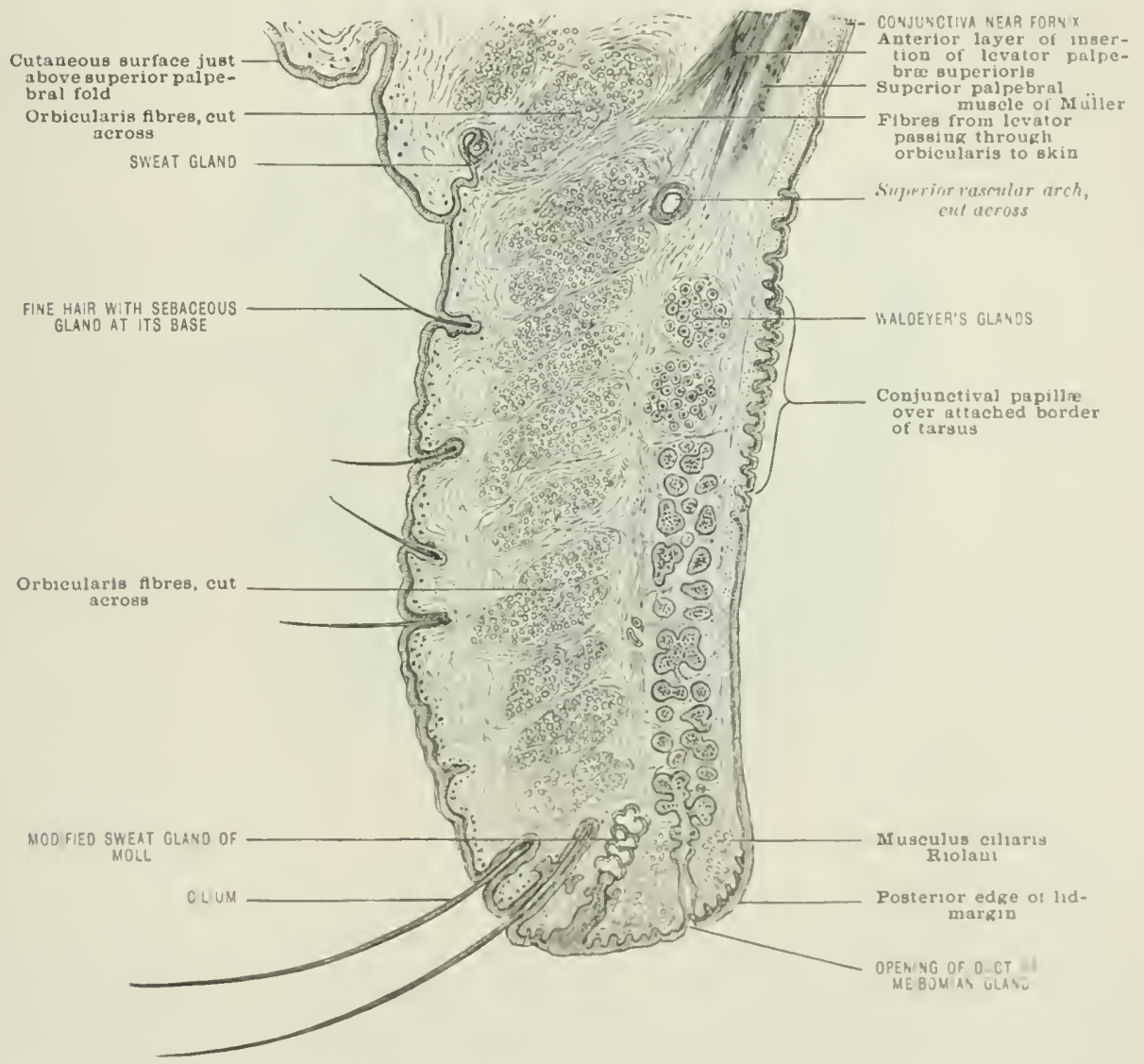

petral, is thicker and freely movalule. owing to the alhundant sulmuecus tis-are.

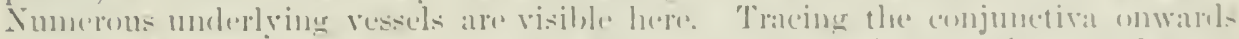

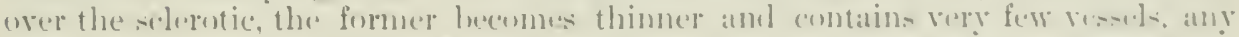

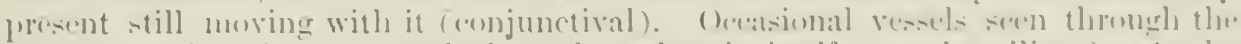

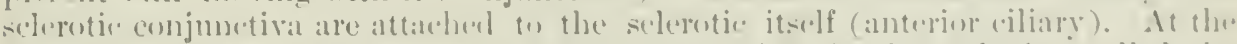

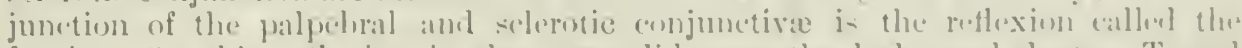

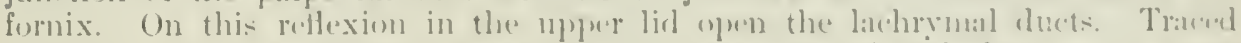

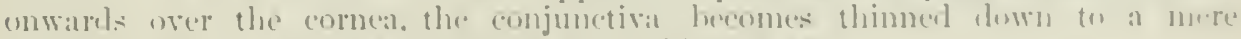

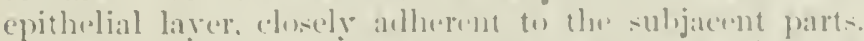

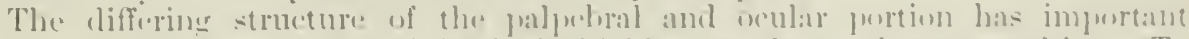

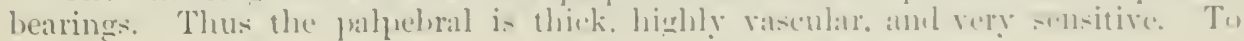


this vascularity we owe the chemosis, or hot, red, tense swelling of purulent ophthalmia. The expuisite suffering of the same disease, or that callecel by a foreign huxly, is explained by the numerous nerve-papillac. To the thiekness and almulance of the connective tis-ste are Ine the contration and permanent thickening which may oceur in granular lids. The so-callud granulations. met with in this disease on the palpebral conjunctiva, ane really little nodules of hyjertrophiced lymplioir follicles, or mucous glands, which abound here.

The position of the lachrymal puncta should be noted; owing to their hackward direction, the lids must be previously everted. The puncta are kept open ly a minute filorons ring.

Each is situated on a minute papilla at the junction of the immer and straight thire of the lis with the outer curverl two-thirls. Close to the inner anthus. in addition to the puncta and papillex, should be noted the caruncula lachrymalis, with

Fig. 669.-The Lachryal apparates axd masal Dicto. (Bellamy.)

(Bristles are introluced into the puncta lachrymalia.)

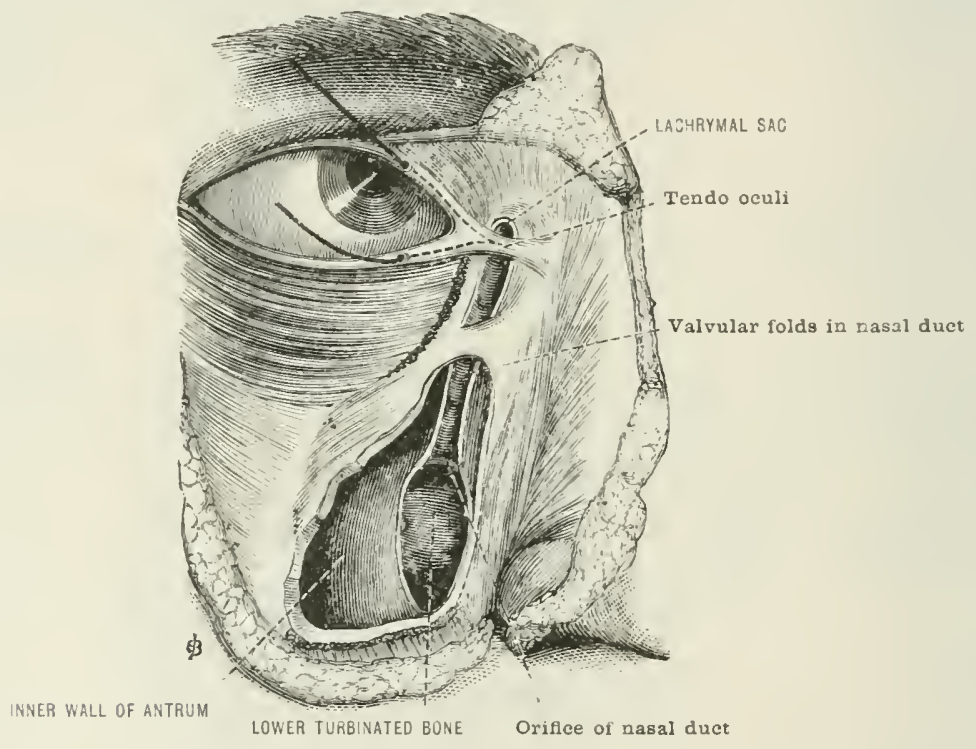

its delicate hairs, and the plica semilumaris, which corresponds to the third eyelicl of certiain bireks.

The lachrymal sac is the most important of the lachrymal apparatus, from its disfiguring cliseases; it lies in a bony groove, between the nasal process of the maxilla and the lachrymal bone. The tendo oculi crosses it a little above its centre (fig. 669). Thus two-thirds of the sac are helow the tendon, and in suppuration the opening is marle below it also. The angular artery ascends on the nasal side of the sac. The manipulation of a probe along the lachrymal passages should thus be practised:- The lower licl leing drawn ontwards and clownwards by the thumb, the probe is passed vertically into the functum, then turned horizontally and passed on till it reaches the inner wall of the sac. It is then raised rertically, and pushed steadily along the duct clownwards, and a little outwards and backwarls, till the floor of the nose is reached.

If the eyes are openeel naturally, the creater part of the cormea, behind it the iris, with the pupil in the centre, on either sicle of the cornea some of the sclerotic, the semilunar fold and carmele ean be seen. 


\section{THE $M()[$ TH}

On the Hoor, in the centre, is the fremum lingrute. In liviling the franum for

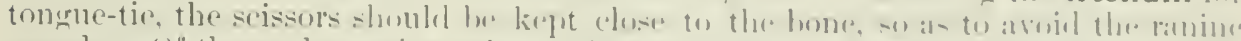

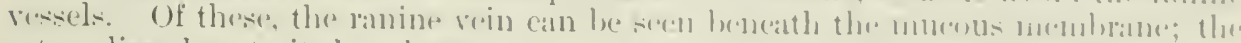
artery liess close to it, hut derper.

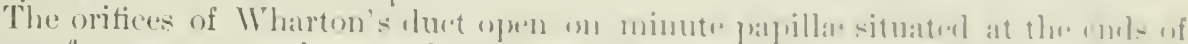

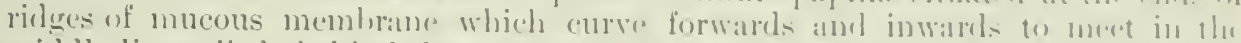

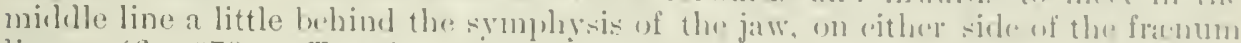

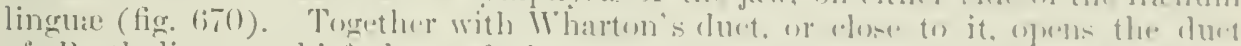
of Bartholin, or chief duct of the sublingual gland. If the aluse folls = li,

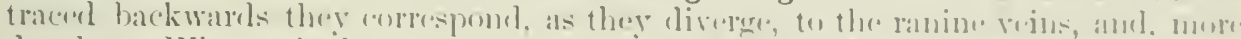

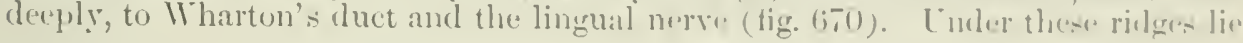

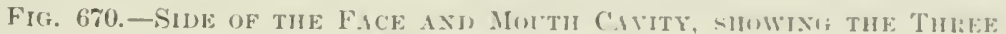
SAIMARY GIANIS.

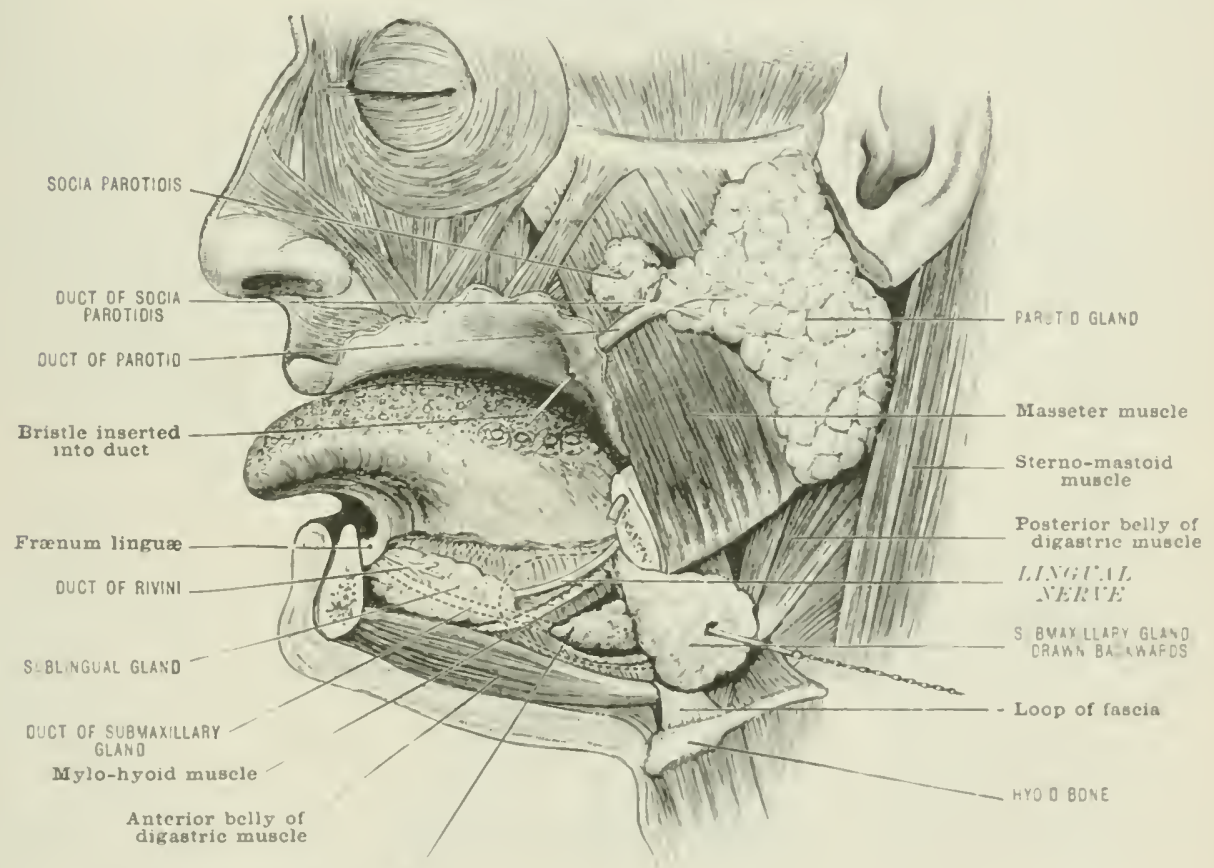

DEEP PORTION OF SUBMAX LLARY GLASD

the sublingual glands, the majority of whose ducts open on the surfare of the

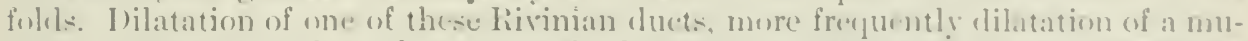

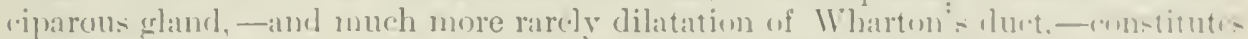
a 'ramula.' 'The submaxillary gland can he felt nearer the angle of the jaw lying

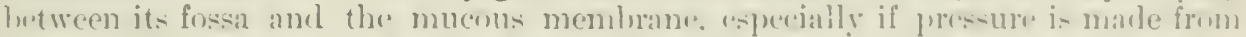
wut-ide. The attachment of the genio-hyo-glossi ("an he folt helhind the -ymphysis: the division of the museles allow: the tongue to come well ant of the

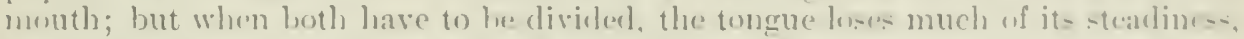
and way easily fall back wer thr larvox durine the alministration of the anate-

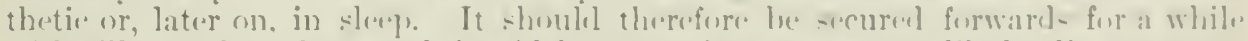

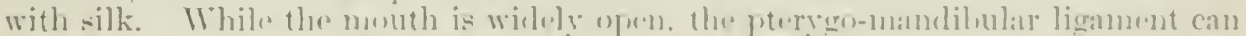

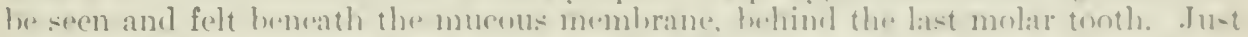
below and in front of the lowrer attarhment of this ligament, the lingual nerve "an

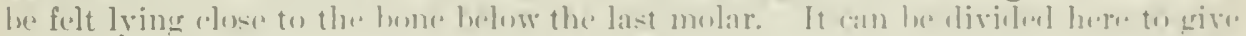

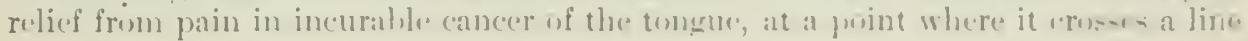


drawn from the last molar tooth to the angle of the jaw, by entering a knife nearly three-quarters of an inch behind and below the tooth, and cutting towarks it on the bone (Moore). Another and fir simpler and surer method is to draw the tongue out of the mouth and expose the nerve where it lies superficially under the mucous membrane thus made prominent between the sicle of the tongue and gums, the centre of the incision being opposite to the last molar tooth (Roser, Létiérant).

Behind the last molar tooth am be felt the coronoid process, and higher up, just behiml and insirle the tooth, the hamular process of the sphenoid. This process is a lantmark to the site of the posterior palatine canal, which lies just in front of it, and which transmits the posterior and descending palatine branch of the internal maxillary, together with the anterior or great palatine nerve. The ressel and nerve run forwards in grooves towards the anterior palatine canal, and their position must be remembered in raising the flaps during the operation for

Fig. 671.-Section of the Skeld añ Bris is the Mfedia Plane. (Braune.)

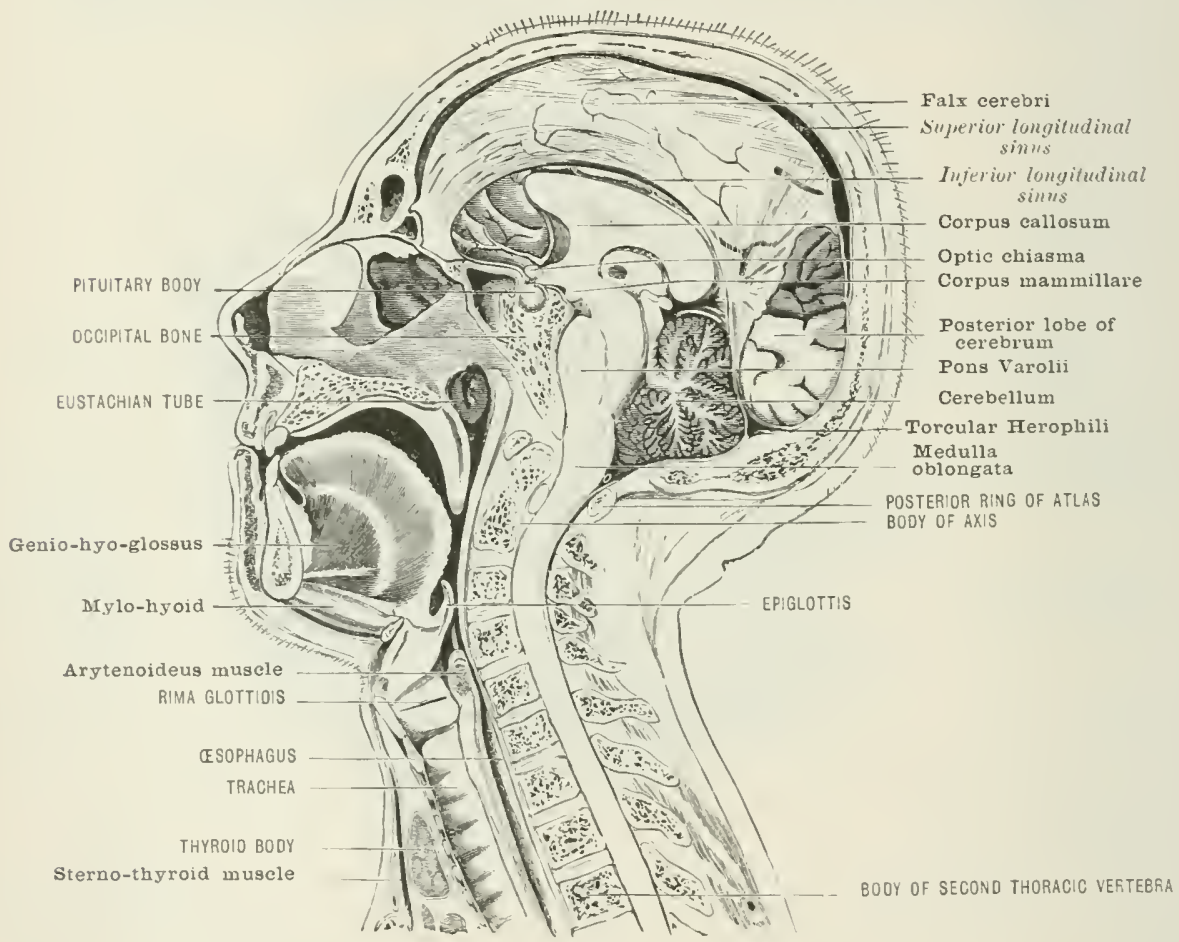

closure of a deft in the hard palate. To ensure the vitality of the flaps the incisions must be made close to and parallel with the upler alreolus.

On the inner side of the comolid. between it and the tuberosity of the upler jaw, is a recess where a temporal abscess will point, having travelled down under the fascia and zygoma. When a patient breathes deeply through the mouth, and the head is thrown back, the soft palate is raised, the pillars are separated, and the urula and fauces, with the anterios and posterior pillars, the tonsils, and the hack of the pharrnx are exposerl. This portion of the pharyngeal nueous membrane would lie orer the lower bart of the second and the upper part of the third eervical rertebre, the anterior arch of the atlas corresponding to the lerel of the posterior nares, and the body of the axis to the lesel of the soft palate (fig. 6ir). If a finger be introduced past the soft pralate to this part of the spine and turned upwards and downwards, it is possible to examine the upper four or five and, in children, six vertebre, as far as the anterior surfaces of their hodies. "The part of the column which is accessible to a strilght instrument introduced through the 


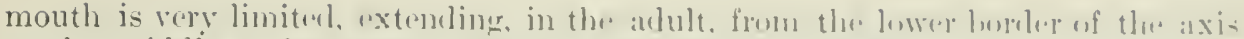

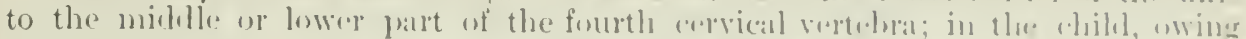

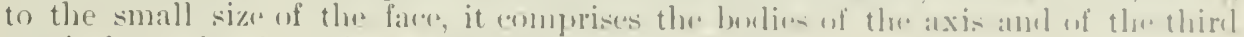
cervical vertehra.' ('Thame and (iedler, from ('hipault.)

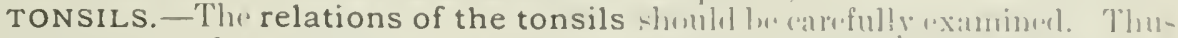

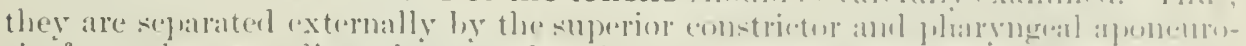

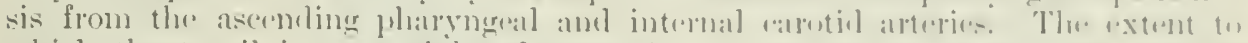

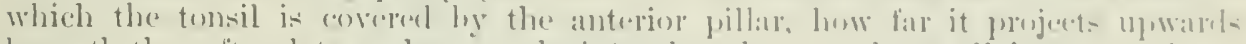

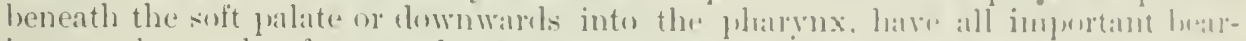

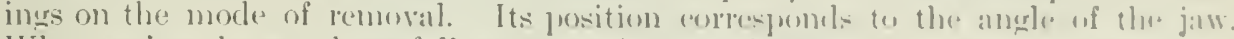
When serious bamorrhage follows operations on the tonsils. it ustally andu- from ome of the numerous fonsillar arteries, which is enlalrexl. and inet from the ascentine phatringeal or internal caroticl.

The finger introduced downwards at the back of the mouth, eprially if

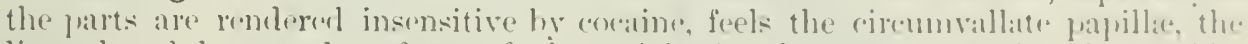

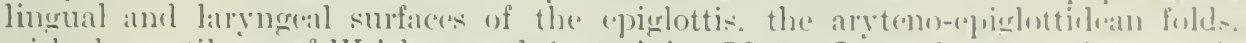
with the artilages of Wrisburg and santorini. If the finger be moved upwards behinel the soft palate and tumed upwares to the hisis of the skull, allul thell forwards. it will inplinge on the posterion nares. soparated ly the romer. and,

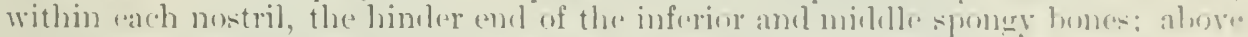
and hehine is felt the hasilar process of the skull, the vatult of pharyer, and upper cervical spine (fig. 6i1).

The size of the nares, one inch hy half an inch, and the presconce of any artemoids, are especially to he moted. The richness of the naso-pharynx in glandular structures, its proneness to inflammation, and of this intlammation to

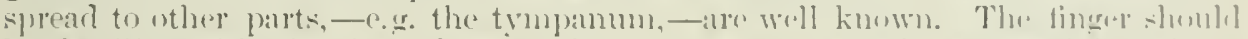

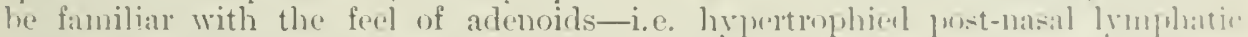

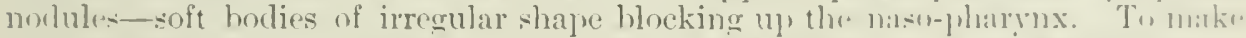

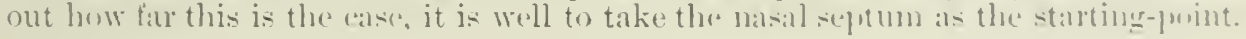

\section{THE: TPSITTE}

Butweres the diverging pillars of the suft palate is the isthmus faucium,

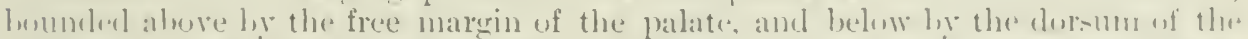

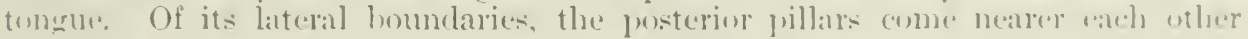
th:m thr anterior. In paring the edges of a cleft soft palate, the following

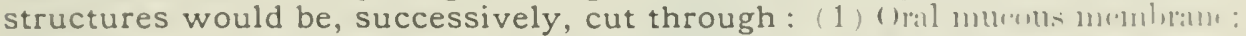

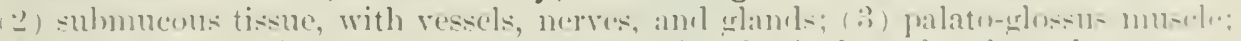

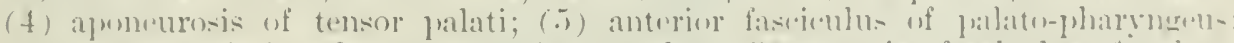

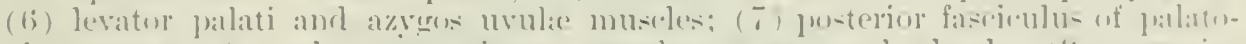

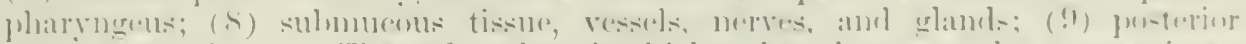

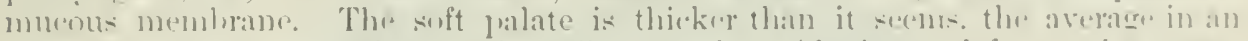

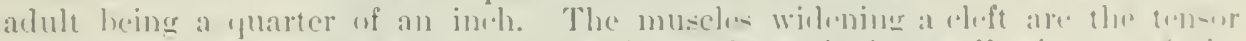

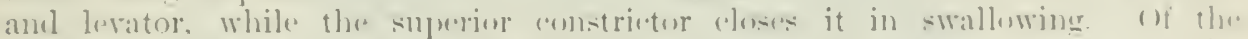

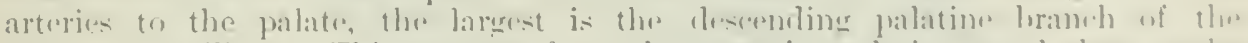

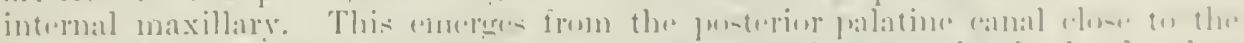

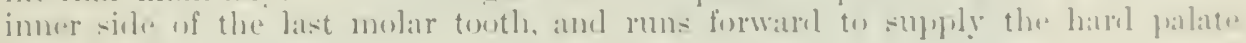
( piage $49(i)$.

\section{THE $\mathrm{N}(1) \mathrm{F}$}

On the face the outline of the nat:al lume

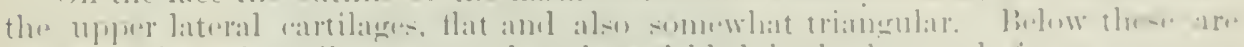

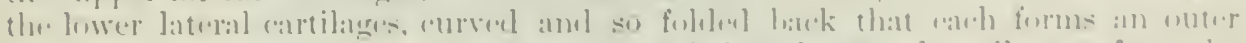

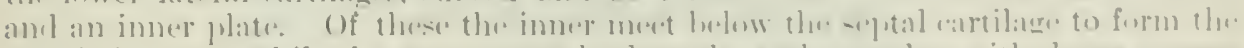

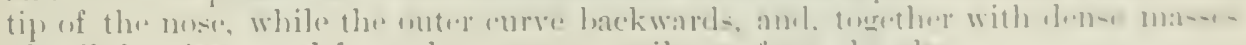

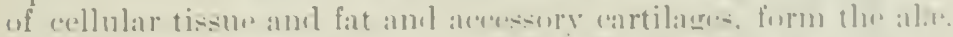

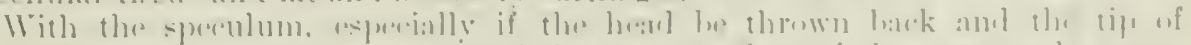

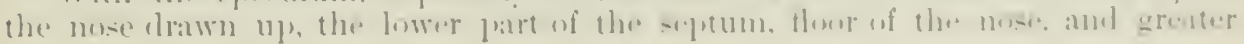




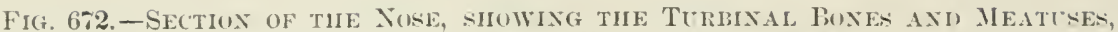
WTH THE OPEXIXGS IN DUTTED OLTLINE.

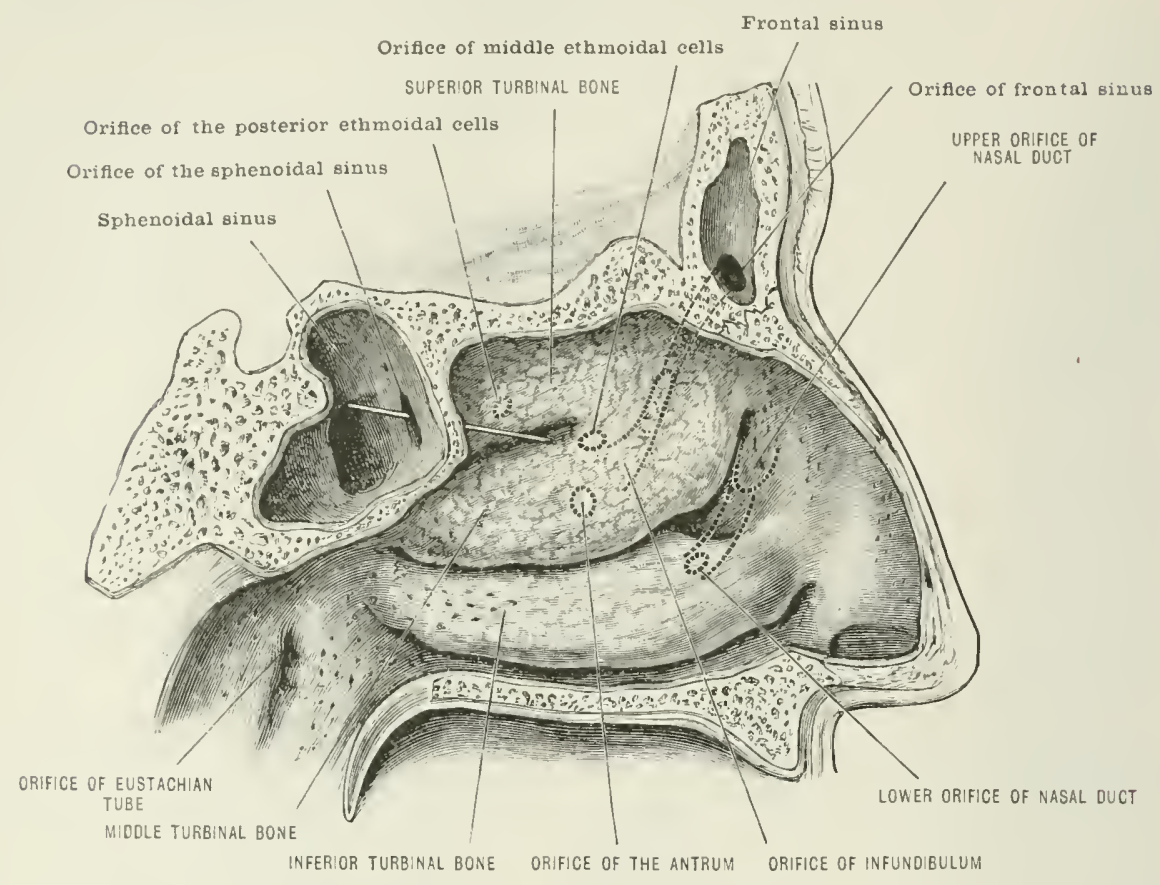

Fif. 673.-Section showing Boxy and Cartilaginots Septem.

The dotted line indicates the course of the anterior palatine canal.

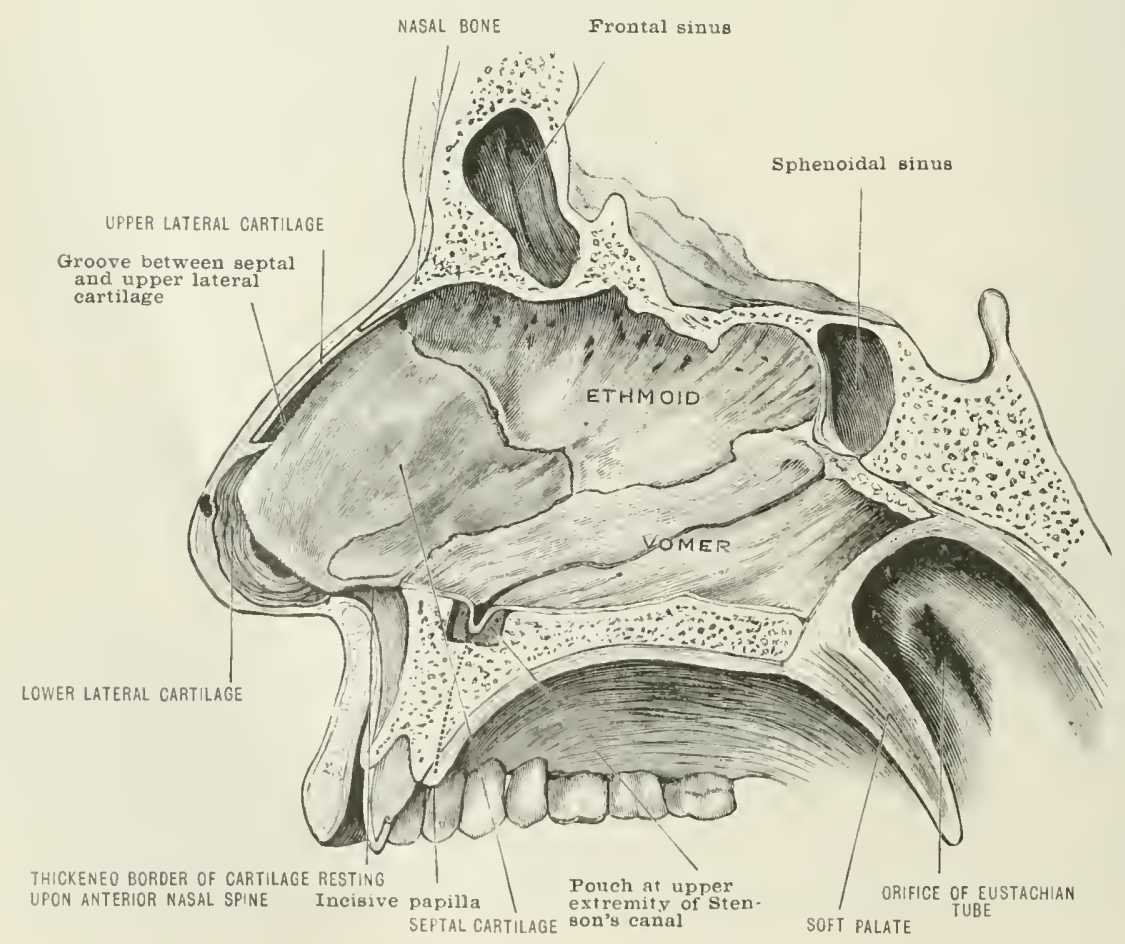


portion of the inferior turhinated bene can be serol. On throwing the laval further

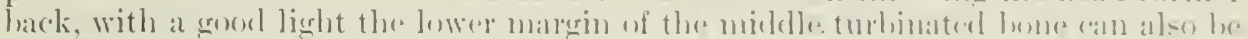
made out. This is much higher up and nearly en at level with the rout of the nasil

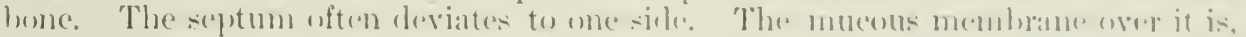

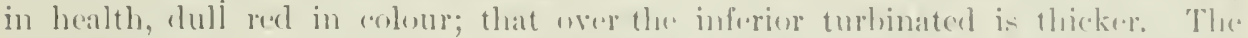

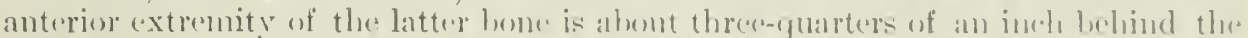

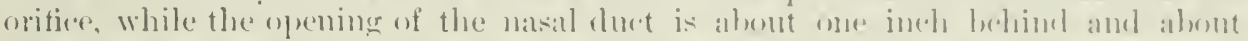
there-puarters of an ineh ahove the floor. The oprening into the antrum is -ituaterl

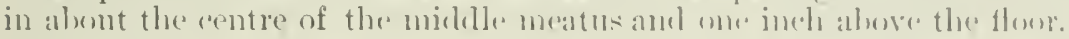

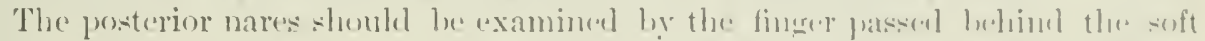
palate. Eateh oval aperture measures, in the ailult skull, alumt lalf an incle trans-

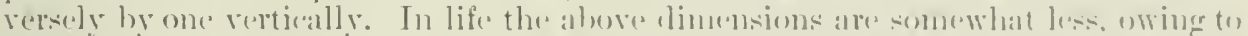

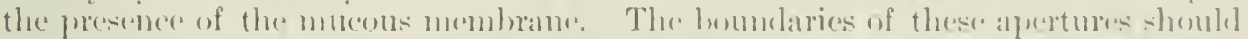

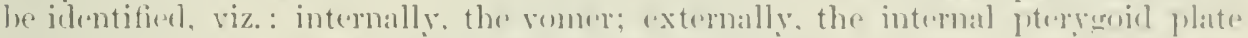

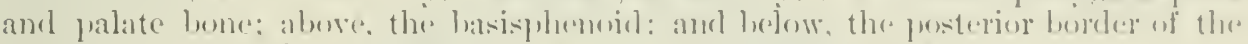
horizuntal plates of the palate bones and pesterior nasal spine.

\section{TIIE NEC'K}

Landmarks in the middle line.-Passing from the symphys to the sulpitclavicular notch is the borly of the hyovil. which is nearly on a lered with the angles of the jaw. On either sicle of the holy are the great cornual. The nly borders of these are the guides to the lingual artiries. Below the hyoid is the thirnhyoid space, which corresponds with the epightos and the mper alperture of the larynx. Thus, if the throat be cut abore the hyoid, the mouth will he opened ancl

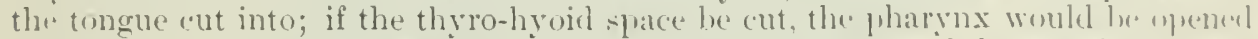
and the epiglottis wounded near its base. Behind the centre of the anterion natrein of the thyroid is the rima glottidis. The projection of the thyroid notels is mon

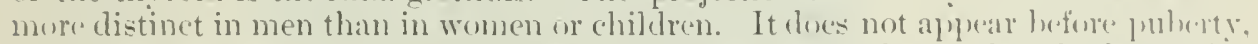

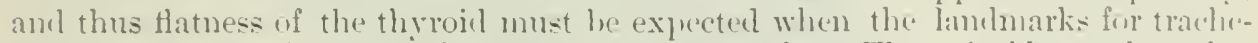
otemy are sought for in children with short fat necks. The cricuid, w the when hamil, is always to be marle out. It corresponts in horizontal plane to the following:- (1) The fifth eervical vertelba. (2) The junetion of pharyx and 11 siphagris: from the narrowing of the tule here. foredgre bodies may lodge at this puint

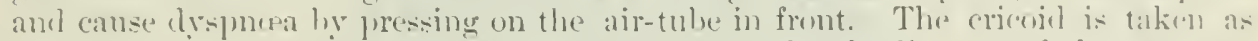

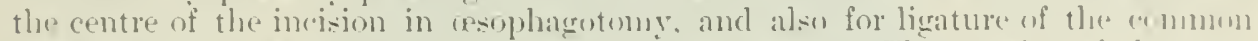

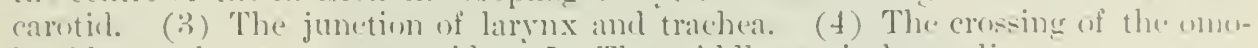

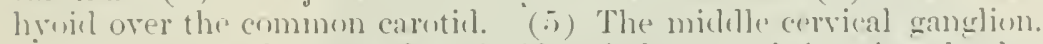

The distance between the cricoil and the manulurium is muly alont an incle and a half. When the neck is stretched. alunt there-quarters of an inch more is silinerl. Thus, as a rule, there are not more than seren or ejoht trandheal rings alwere the

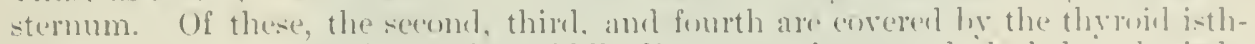
mus. The parts met with in the millle line-(11) above. and (b) bulow the i-th-

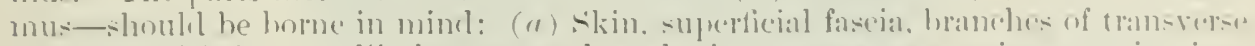

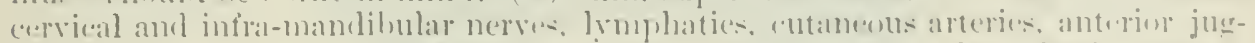

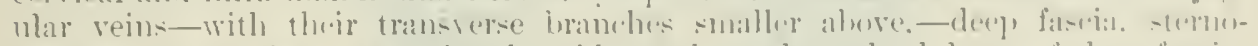

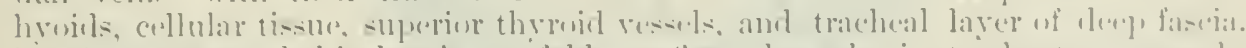
The importane of this last is two-folel. as. first, the tule in trachentemy maly les

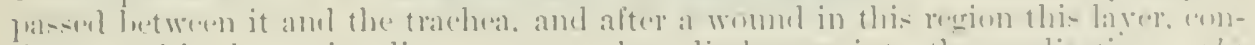

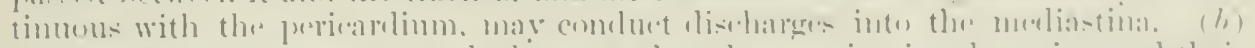

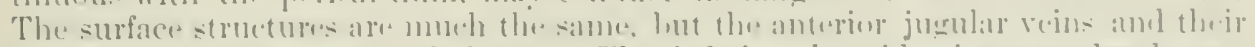

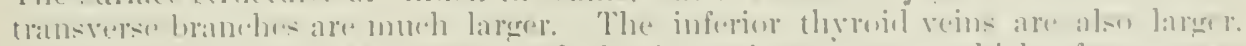

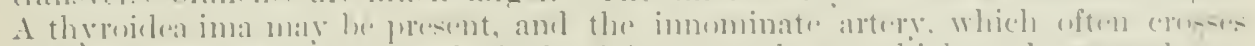

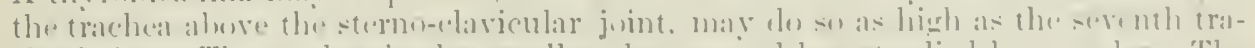

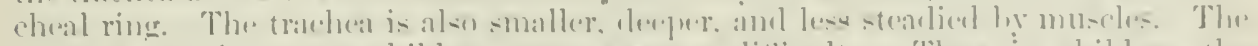

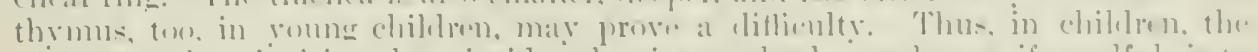

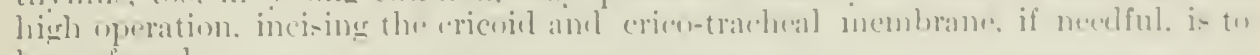
be preferment.

The sterno-mastoid is the landmark for sereral important ofwations. Its 
inner border, the thicker and better marker of the two, overlaps the carotids; the common carotid corresponding, as far as the upper border of the thyroid, with a line drawn from the sterno-clavicular joint to michay between the mastoid process and the angle of the jaw. The artery can be best compressed above the level of the cricoid, as here it is less deeply covered. The transwerse process of the sixth cervical vertehra is called the carotid tubercle, after Chassaignac, who adrised compression of the carotid at this point. This process lies two to three inches abore the elavicle. Compression below it will command the rertebral as well. The student should recall the deep relations of the sterno-mastoid, which he may

Fig. 674.-Thymes Ghaxi ix a Chin at Birth.

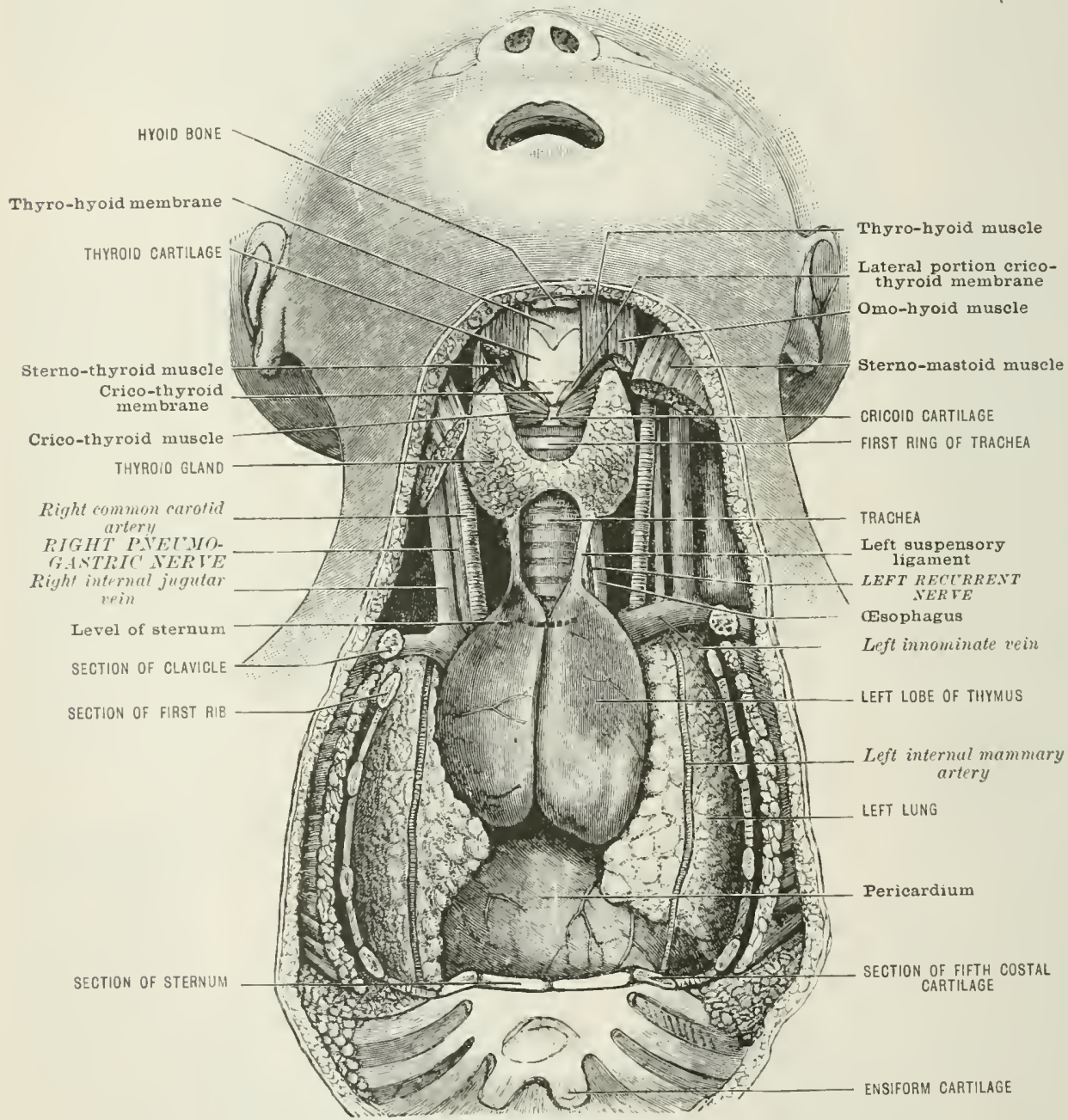

classify as vessels, nerves, muscles, glands, and bones; or, according to their position, (1) those above the level of the angle of the jaw; (2) those between the angle of the jaw and the omo-hyoid; (3) those betow the omo-hyoid.

Of the two hearls of the sterno-mastoid. the sternal is the thieker and more prominent, the clavieular the wirler. A stal, through the space (or interval) which lies between the two hearls would wound the fifulcation of the innominate on the right sirle, and the common carotid on the left.

The position of the anterior jugular, "urring outwarks to pass bencath both origins of the muscle a little above the clavicle, and the extorual jugular, crossing 


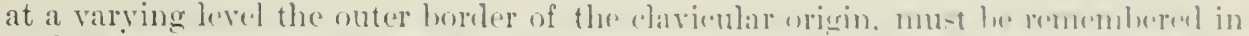

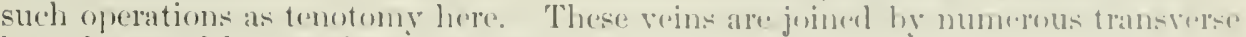
branches, and becone larger lolow.

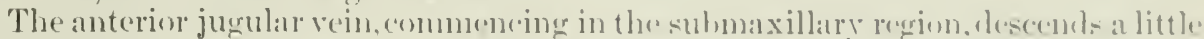

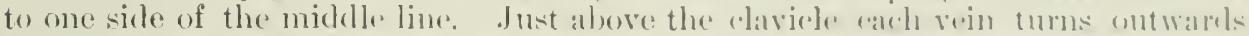

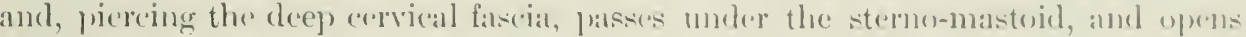
into the external jugular or subelatian vein. It has no ralvers.

Behind the sterno-clavicular joint liws the communement of the immoninate veins, the bifureation of the inmominate artery on the right, and the erommum

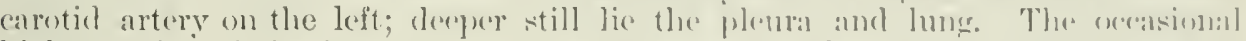
high position of the innominate on the tratehes may be a print of importanee in tracheotomy, both at the time of the operation and bater ons, fom the fatal facility with which a metal tube, if long retained after a low trachentoms, may ulcerate into the ressel.

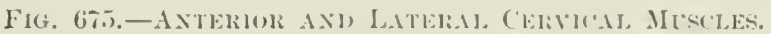

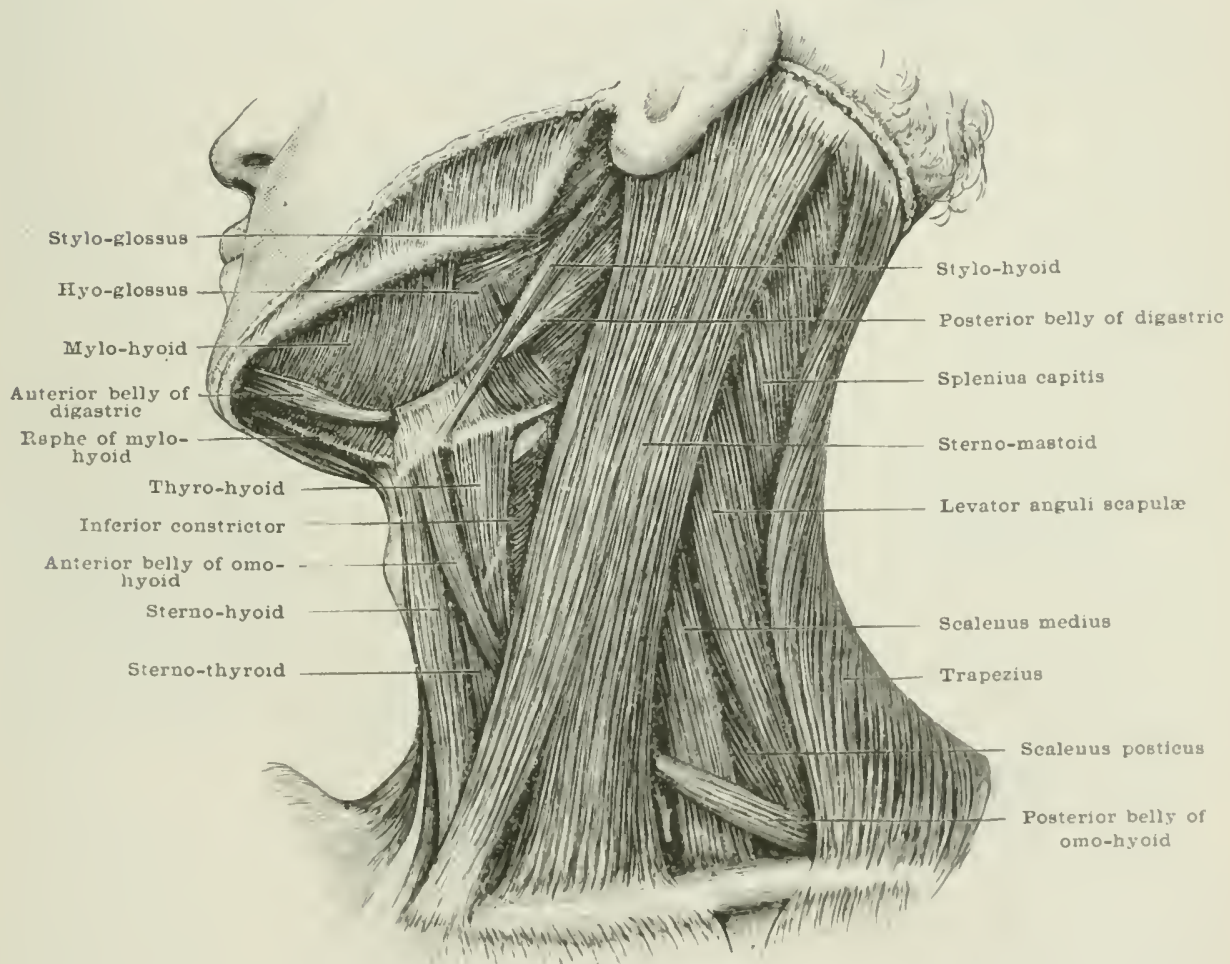

In front of the sterun-mastoid is the anterior triangle, which is subdivided

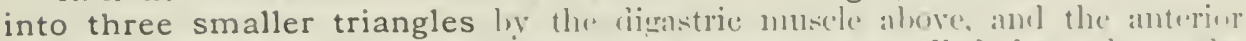

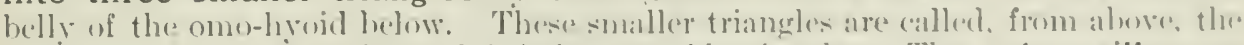
submaxillary, thes superion and inferior antid triangles. The submaxillary or supra-hyoid triangle is lumbled above hy the jaw, amel a line dralwh latek to the

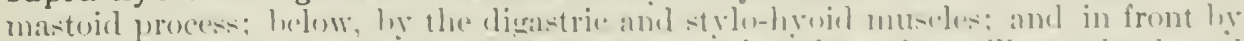
the mirllye line of the neek. This space contains the submaxillary glame, and

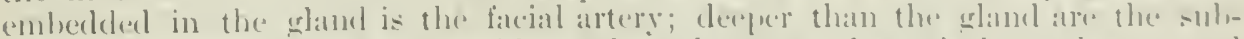

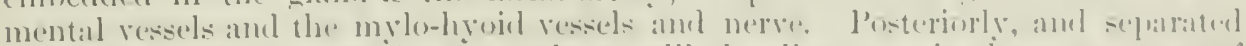

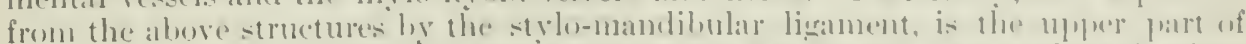

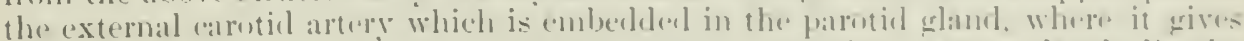

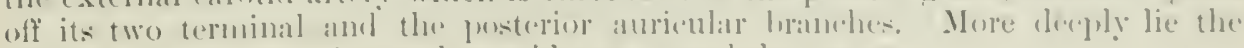
internal jugular vein, internal canotin artery, and the ragus. 
The superior carotid triangle is bounder above by the digastric, below by the omo-hyoid, and behind by the stemo-mastoid. It contains the upper part of the common carotid and its branches, the external being somewhat anterior to the internal. All the bramehes of the external carotid, save the three just given, are found in this space, together with their veins, the internal jugular vein, the vagus and sympathetic nerves, and, for a short distance, the spinal aceessory, together with those nerves which lie in front of and behind the carotids.

The inferior carotid or tracheal triangle is bounded above by the omo-hroid, bohind by the stemo-mastoid, and in front by the middle line of the neck. It contains the lower part of the carotid sheath and its contents, with, behind it, the inferior laryngeal nerve and inferior thyroid ressels, and to the inner side the trachea and thyroid gland.

The position of the branches of the external carotid should be remembered. The superior thyroid, arising just below the level of the great comu of the hyoid bone, passes downwards and forwards to the back part of the thrroid cartilage and upper part of the thyroid body. Many of its branches are important in surgery. The superior laryngeal perforates the thrro-hyoid membrane. The sternomastoid passes ontwards into the middle of the muscle, across the carotid sheath. The crico-thyroid crosses the space of the same name just below the lower border of the thyroid cartilage. The little hyoid branch runs to the lower border of the hyoid bone. The lingual artery arises from the parent trunk, opposite the tip of the great cornu of the hyoid, and passes forwards just above the great cornu, and thence to the sicle of the tongue. In the first part of its course, before it reaches the hyo-glossus, it is curved, at first ascending, and then, having ascended slightly, before it reaches the hyo-glossus, and while it lies under it, its curve is gentle, with the concarity upwards; beyond the hyo-glossus, as it lies on the museles of the tongue beneath the mucous membrane, it is tortuous. The lingual vein, it will be remembered, does not run with its artery, but lies superficial to the hyo-glossus. It receives the two small venæ comites, which run with the lingual itself just before it crosses the common carotid. The line of the facial artery (fig. 667), which often arises with the lingual, has been given on page 1091. The occipital artery (fig. 667 ), starting on the same level as the facial (i.e. a point a little above and outside the tip of the great cornu of the hyoid bone), follows a line drawn upwards and outwards, first to the interval between the transverse process of the atlas and the mastoict process, the former bone being felt just below and in front of the tip of the latter; thence, lying in the occipital groove of the mastoid, the artery ascends gradually, enters the scalp, together with the great oceipital nerve, at a point about midway between the extemal occipital prominence and the mastoid process, to follow, tortuously and superficial to the aponeurosis, the line of the lambdoid suture (1. 10ss).

The surface-marking of the digastric and omo-hyoid, which subdivide the anterior triangle into the three smaller subtriangles above described, should be noted. The line of the posterior belly of the digastric corresponds to one drawn from the apex of the mastoid process to a point just above the junction of the great comu and body of the hyoid bone; and from this spot, which gives the point of meeting of the two tendons, one slightly curving upwards to a point just behind the symplyysis menti, would give that of the anterior belly.

To trace the omo-hyoid, a line should be drawn from the lower margin of the sirle of the hyoid bone ohlinuely downwards, so as to cross the common carotid opposite the cricoid cartilage, and thence curving outwards under the sterno-mastoid at the junetion of its middle and lower thirds, and then onwards and still outwards, parallel with and a little above the clavicle, as far as its centre.

Posterior triangle.-This shows in its-lower part a wite depression, the suprachavicular fossa. Here the brachial plexus may be felt, and, by pressure downwards and backwards, just outside the outer nargin of the sterno-mastoid, the pulsation of the subcharian artery can be stopped against the first ril). This ressel curves upwards and outwards from behind the sterno-elavieular joint to disappear behind the centre of the elaricle, the highest point of the curve being half an inch to an inch above the bone. The artery on the left side lies more dieply than the 
right, and does not rise so high into the merk. 'The sulvelavian vein lies at a lower

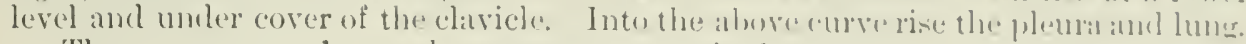

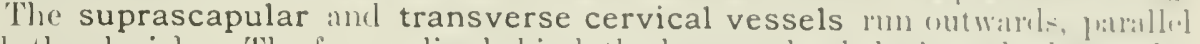

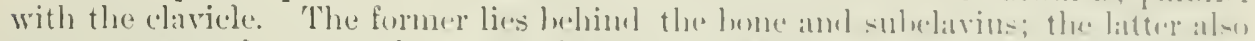
runs transversely ontwards, across the root of the neek, lut on at slightly lightwe plane, and thus a little alore the clavicle.

Crossing the stemo-mastoid a littl. obliguely, in a line drawn from the angle. of the jaw to the centre of the elavicle, runs thi external jugular vein. Alout

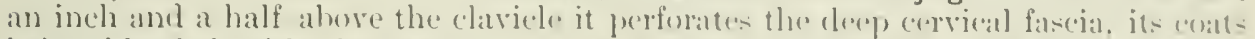
being blenderl with the opening. The dilated part hetween this pront and the

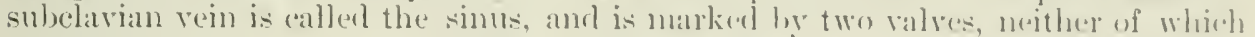

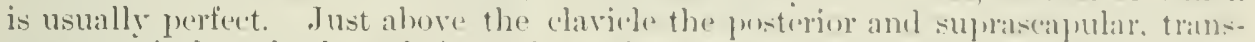
verse cervical, and a branch from the cephalic reins. form a plexus orer the thipl part of the subclavian.

Opening into the external jugular, in the midule or lower third of its cumrse, is

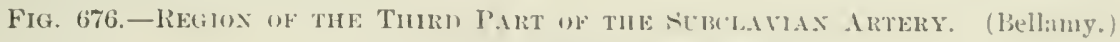

(The shoulder represented inpresiedl.)

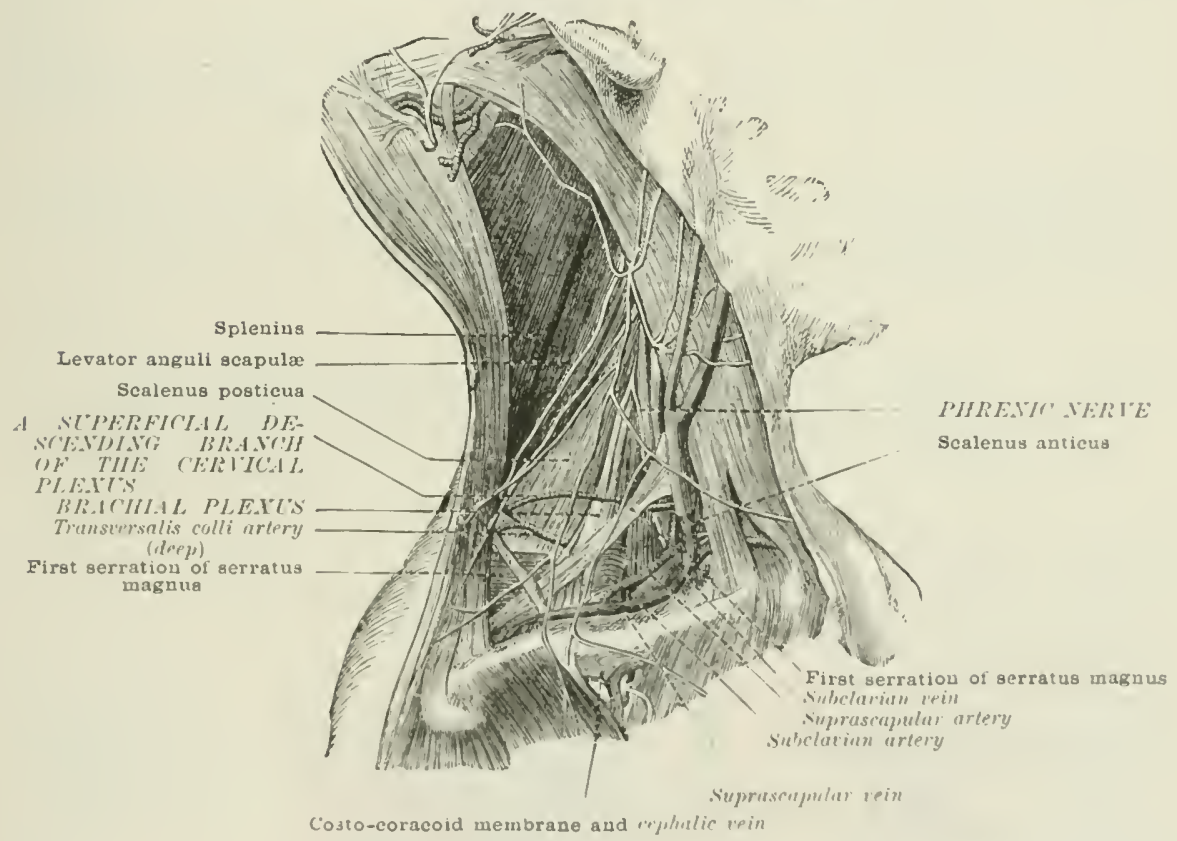

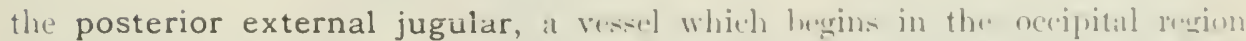

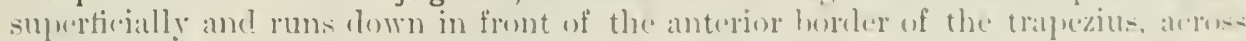
the josterior triangle.

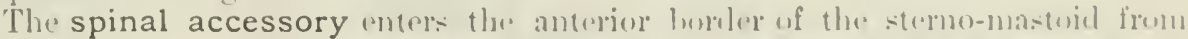
wne to one and a half inches lwow the alprex of the mastoble along a line drawn

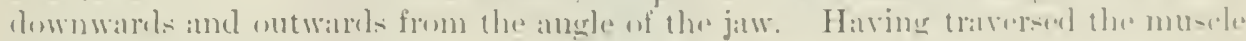

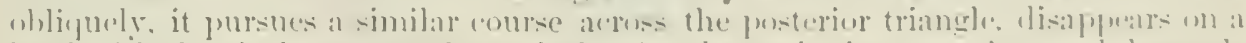

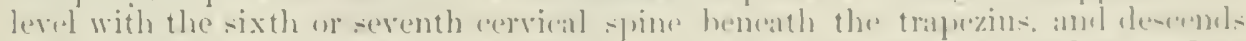

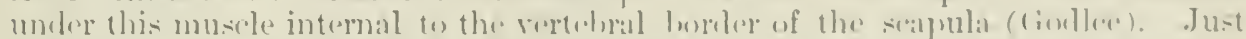
ahore the centro of the stemo-masteil, the small occipital, great auricular, am

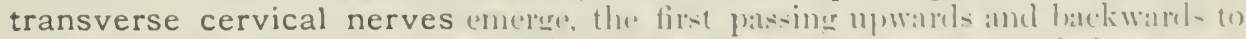

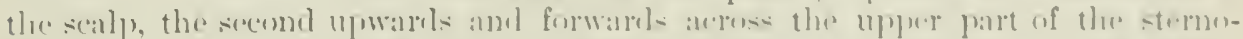

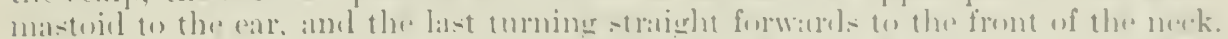

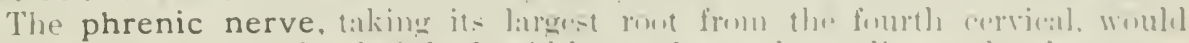

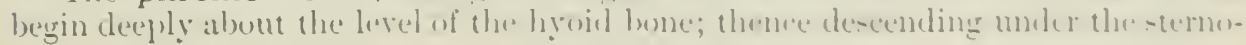


mastoid, and passing obliquely inwards across the scalenus anticus (the posterior lurrlers of the above two musiles roughly correspond to each other in the lower

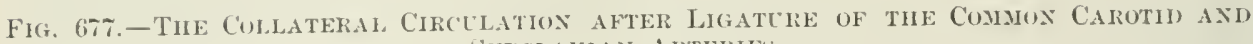
SEBCLAVIAY ARTERIES.

(A ligature is placed on the common carotid and on the third portion of the subclavian artery.)

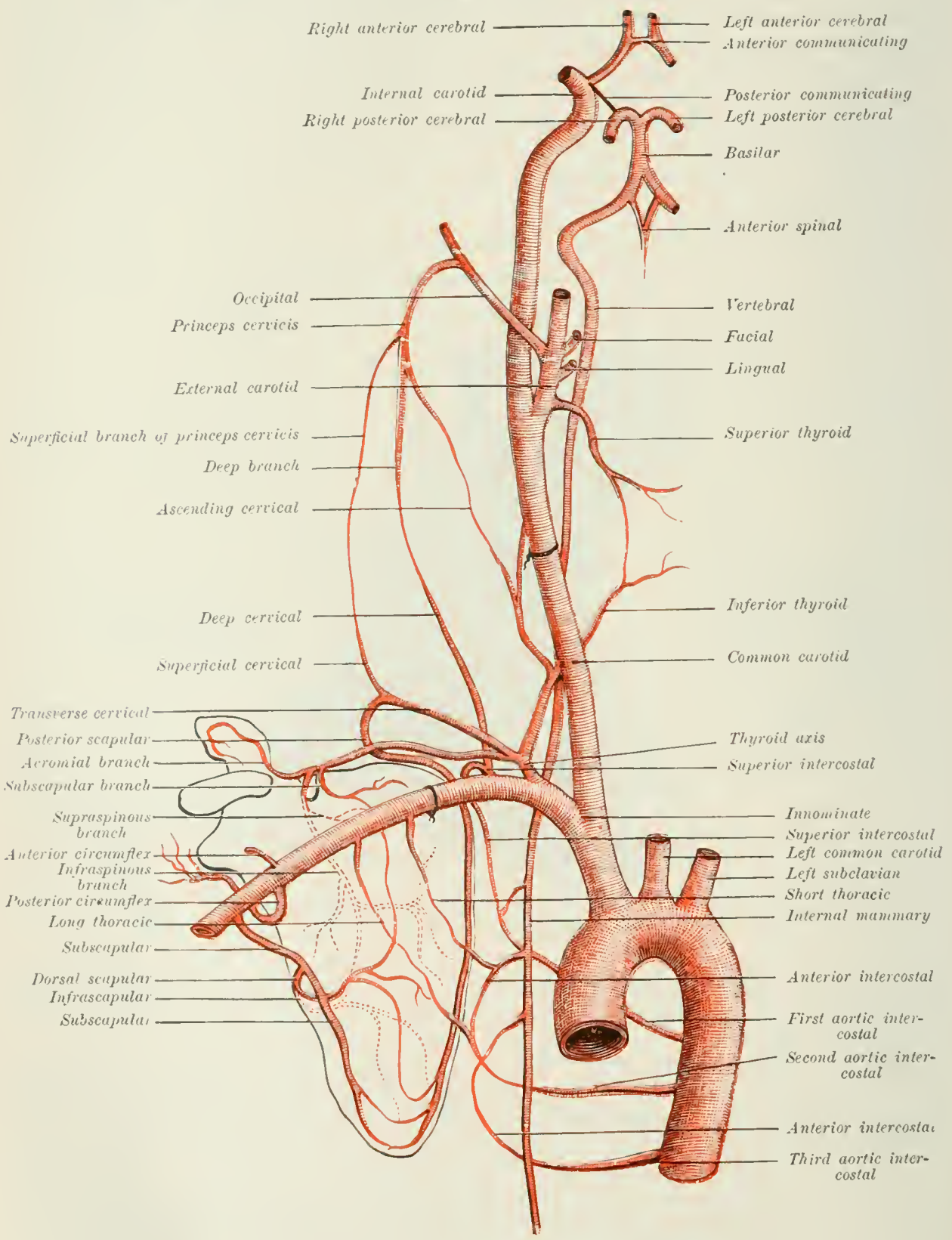

part of the neck), it descends under the subclavian rein and clavicle to enter the thorax.

The level of the brachial plexus (upper border) would be given ly a line 
drawn from the ericuid cartilages to the wentre of the rlavicle. The lowest curd

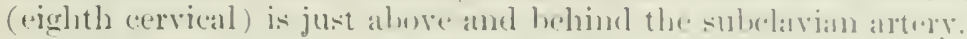

Collateral circulation after ligature of the common carotid (lig. $1 ;-7,-$

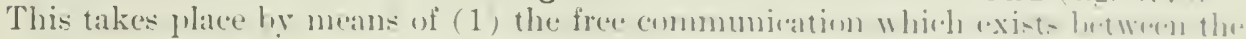

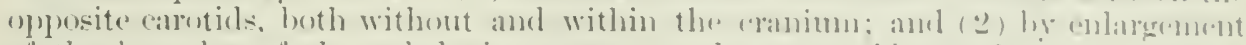
of the branches of the sulxelavian artery on the sande sile as that on which the

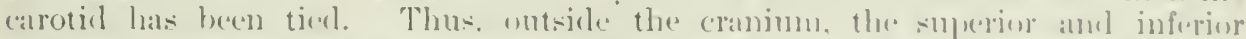

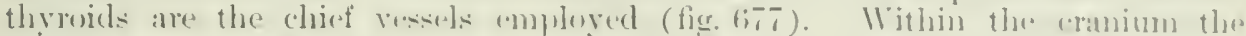
vertehral replaces the internal careitil.

Collateral circulation after ligature of the second and third parts of the

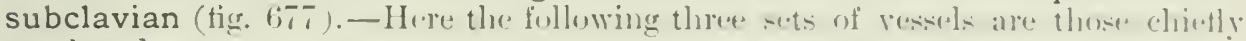
emplesed:

The suprasapular, the posterior? scapulitr,

with

SThes acromio-thoracie, infra- ancl

The superior intereostal, the aortic) intercostals, and the intermal wammary,

Numerous umamed hranches) jasiong through the axilla from liranches of the subclavian,

with Branches of the axillary.

Deep cervical fascia.-The arrangement of this must be remembered-( alwie, and (b) helow, the hyoid hone. The latter is far the mor important.

(1) Arrangement above the hyoid bone.-Here two chief layers, superficial

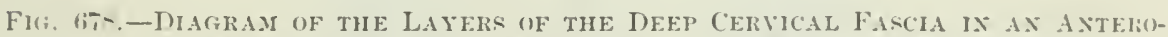
POSTERIOR SECTHX OPPOSITE TO TIE STERXYY. (Tillaux.)

(The prevertebral layer an he seen passing down in front of the longus colli.)

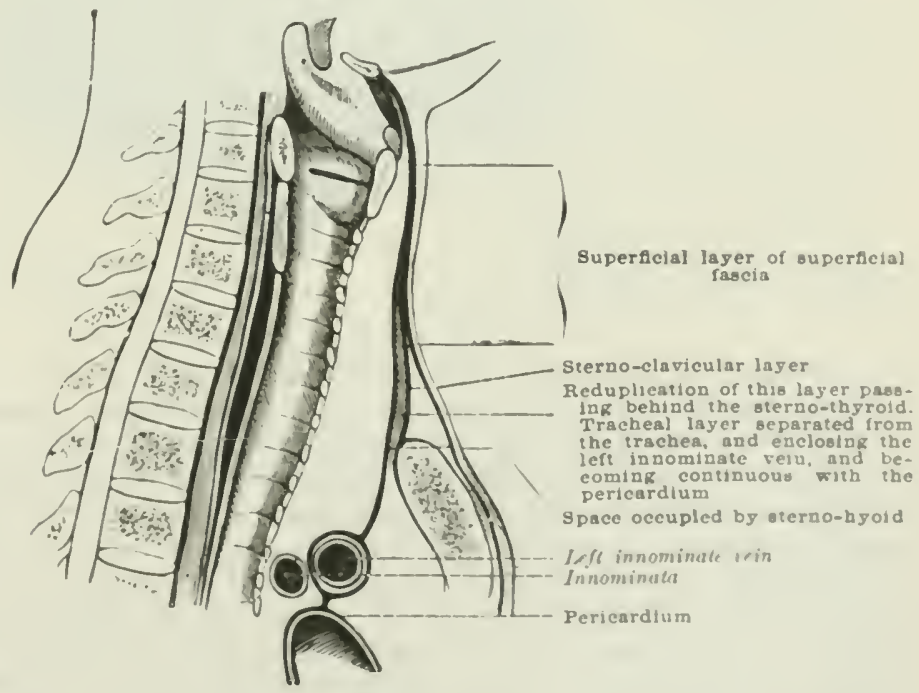

and deep, ean be made out:-(i) The superficial, trand upward-from the hyorid

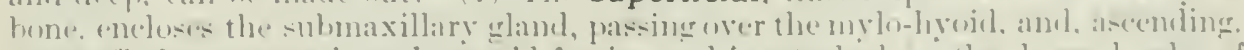

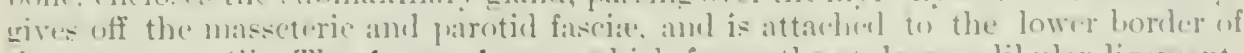
the zyoma. (ii) The deeper layer, which forms the -tylo-namblitular ligament,

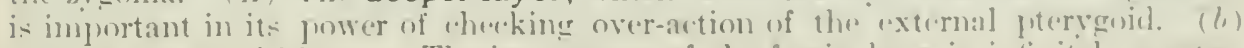
Below the hyoid bone.-Tlu impertanere of the farcia here is infinitely greater. 
Four layers must be remembered: (i) Superficial, or subcutaneous; (ii) sterno-clavicular; (iii) tracheal; (iv) prevertebral. These should first be traced horizontally. (i) Superficial, or subcutaneous. This starts from the liganentum nuche, encises the trapezius, forms the roof of the posterior triangle, where it is perforated by branches of the superficial cervical nerves and the external jugular vein. Passing on, it encloses the stcrno-mastoid; and, passing over the anterior triangle, it meets its fellow in the middle line. Thin behind, it is thickened anteriorly, where it is united to the next laver. Behind this thickened union lie the anterior jugular veins. (ii) Sterno-clavicular. This is best marked below. In the middle line it mects its fellow, and blends with No. i. here also. Passing outwards, it encases the depressors of the hyoid bone, finally blending with No. i. at the posterior border of the sterno-mastoill. (iii) Tracheal. This lies under the depressors of the hyoid, over the trachea, also eneasing the thyroid gland. Farther out, it forms the carotid sheath, and, blending with No. iv. over the anterior scalene, is thus brought into continuity with Nos. i. and ii. also. (iv) Prevertebral. This layer passes orer the longus colli and rectus eapitis anticus major.

The above layers should also be traced vertically, with especial reference to

Fig. 679.-Diaghy of the ARRANgenent of the DeEp Cervical, Fascia, the Section PASSING throtgh the Claticle. (Tillaux.)

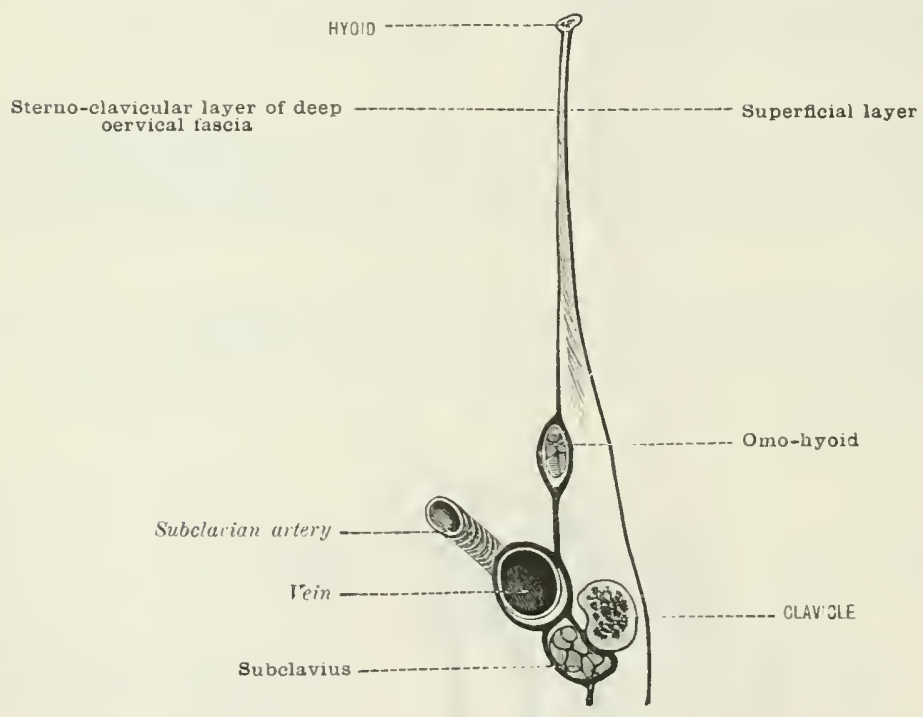

their relations at the level of the top of the stcrnum and the clavicle. ( $\alpha$ ) At the level of the top of the sternum. (i) Superficial, passes over the sternum. (ii) Sterno-clavicular; this, descending in front of the depressor muscles, divides just below the thyroid cartilage into two layers, which are attached to the front and back of the sterium. Between these lie some fat and a small gland. (iii) Tracheal; this passes down over the trachea into the thorax (middle mediastinum). Is it deseends, it encases the left innominate vein, and ends by blending with the fil,rous laver of the pericardium. Mr. Hilton suggested that the attachment of this fascia above. and that of the central tendon of the liaphragm below, to the pericardium served to kerp this sae duly stretched, and so prevented any pressure of the lungs upon the heart. (iv) Prevertebral; this, lescending behind the oesophagus, dips into the prosterior mediastinum. ( $\beta$ ) At the level of the clavicle. Only two of the above layers are met with so far outwards as this-(i) Subcutaneous, which passes over the clavicle; (ii) sterno-clavicular, which, laving eneased the omo-hyoid, passes behind the clavide. blends with the sheath of the subelavius, and gives as sheath to the subclavian vein. That to the artery is derived from No. iii. at the sealenus anticus. 
The following uses and important points with regard to the aniatemy of the deep cervical fiscia should be muted: (.1) It forms certain definitely enclosed spaces in which pus or growths may form, and by the walls of which the-ce

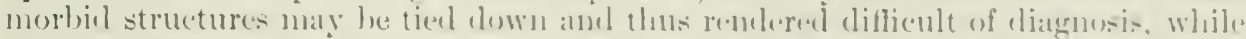

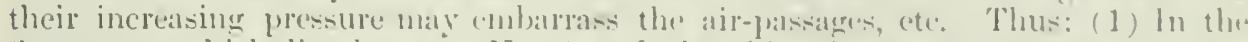
first space, which lies between No, 1 and the skin, the struetures met with, the platysma and superficial hanches of the cervical plexus, an unimpertant. Any

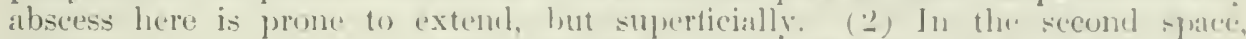

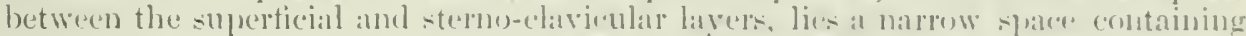

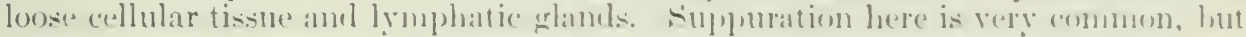
nsually cones forwatrels. (B) This is the largest and most important of all. It is

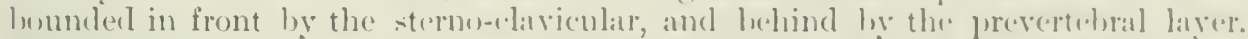
Its contents are-larynx. trachea, osophlaarus, thyoid, caroticl sheath, glands; and below, brachial plexus, subchivian artery; and ahundant loose cellulatr tis-ue for

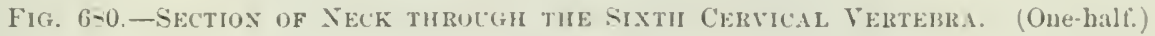

(Briune.)

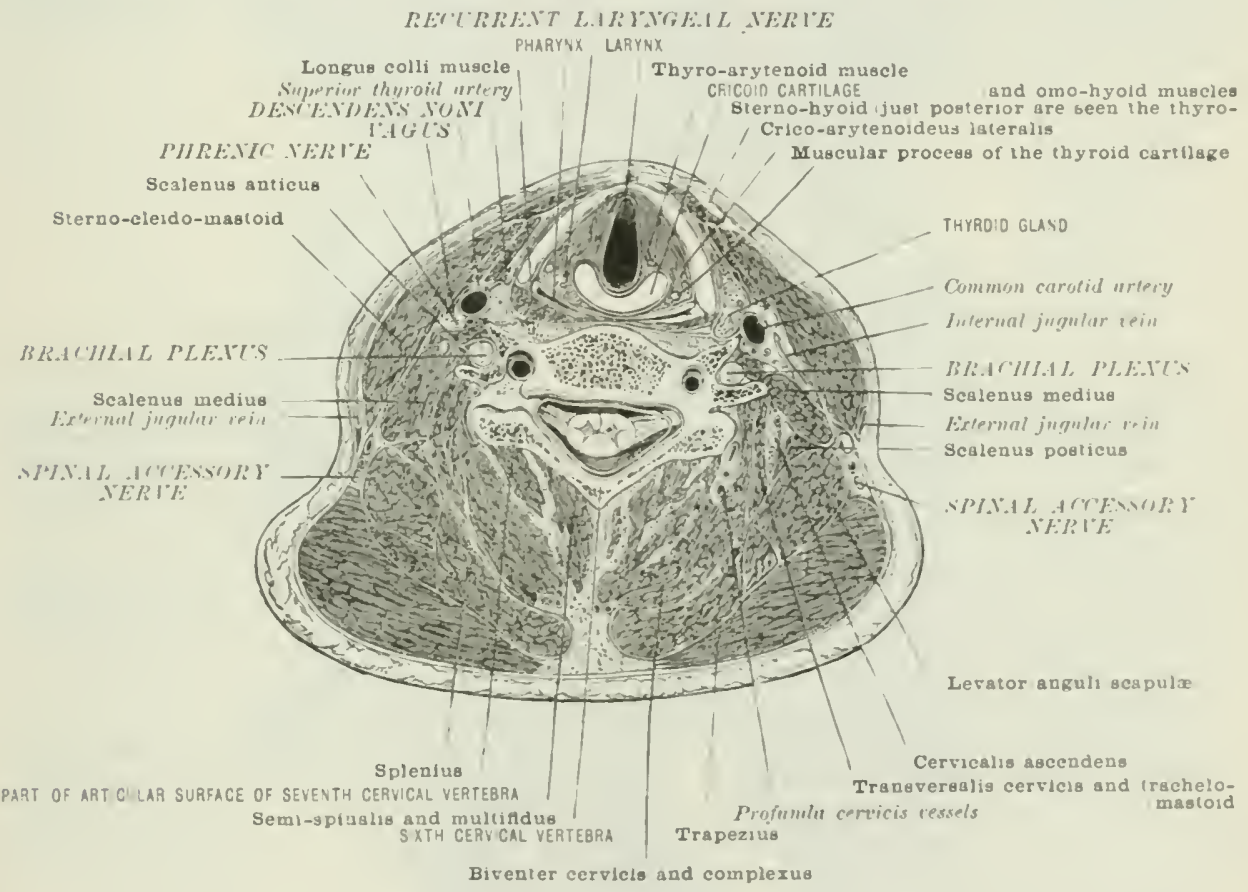

the movenents of the neck. Suppuration is somewhat rarer here: hut cither pus

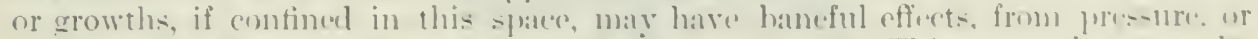
from their tendence te travel behind the sternum. (4) This spare. between the

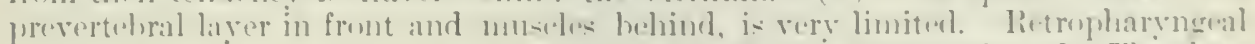

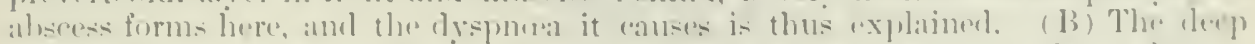

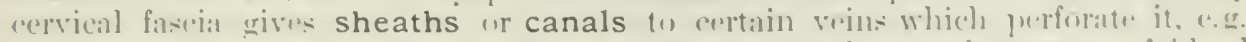

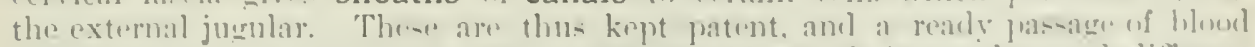

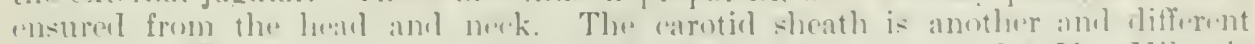
instance. (C') it helps to resist atmospheric pressure. (I) Mr. Mlilunl': sllogetion as to its action on the pericardium has alrealy luen mentinnel.

linfor. learing this lecion, the arrangement of the lymphatic glands of

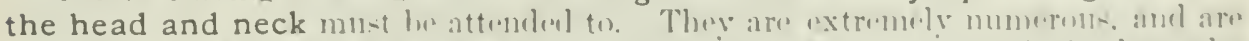
chictly arranger in the following sots: (1) Occipital, or suboccipital, along the attachiment of the neeipitalis. (2) The posterior auricular, ower the insertion of the sterno-mastnicl. (3) The parotid, just in front of the ur. partly on 
and partly in the substance of the parotid gland. (4) The submaxillary, under the ecrvical fascia, in the digastric triangle. This very important group receives lrmph from the lower part of the face, lips. front of tongue, floor of mouth, and all the salivary glands. They drain into the superfieial and deep cervieal glands. (5) Superficial cervical glinds. These lie along the external jugular, hetween the platysma and (leep fascia. They receive lymphaties from the occipital, posterior auricular glands, the ear, and upper neck, and also some of those from the parotid and suhmaxillary regions. They drain party into the deep cervical, partly into the axillary glands. (6) Deep cervical. These consist of two sets, -upper and lower, -lying along the earotid sheath. They receive lymph from the superficial cervical and submaxillary glands, the inside of the cranium, and pterygoid region, deep muscles of neck, palate, tonsils, larynx, pharynx, thyroid body, and upper part of trachea and asophagus. The deep cervical glands empty into each other and below into the mediastinal and axillary lymphatics, the right lymphatic duct, and thoracic duct. Two other groups of glands-the one superficial, the other deep-must be remembered. (7) The suprahyoid group is a term given to a few glands situated in the middle line under the deep fascia below the chin. (S) Retropharyngeal glands. These lie hetween the upper part of the pharyn and the rectus capitis anticus major. They receive lymph from the naso-pharyn and drain into the deep cervical glands.

\section{SLPERFICIAL ANATOMY OF THE THORAY}

Bony points. - The top of the sternum corresponds (in inspiration) to the fibro-cartilane between the second and third thoracic vertebre, and is distant about two and a half inches from the spine. If traced downwards, the subcutaneous sternum presents a rilge opposite to the junction of the manubrimm and body, and the second costal cartilages on either side. At its lower extremity the xiphoid cartilage usually retires from the surface, presenting the depression of the scrobicutus corchis or 'pit of the stomach.' 'This is opposite to the seventh costal cartilages and the expanded upper end of the recti, and corresponds to the ninth thoricic vertebra behind.

Sterno-clavicular joint.-The expanded end of the clavicle and the lack of proportion between this and the stemal facet, on which largely depends the mobility of this, the only joint that ties the upper extremity closely to the trunk, (an be easily made out through the skin. Behind the joint lie, on the right side, the immominate artery, right imnominate rein, and pleura; on the left, the left innominate vein, the left carotid, and the pleura.

Acromio-clavicular joint.-On tracing the clavicle ontwards, it is found to rise somewhat to its articulation with the acromion. This joint has very little mobility, and owes its protection to the strong conoid and trapezoid ligaments hard hy. Owing to the way in which the joint-surfaces are bevelled, that of the elavicle looks obliquely downwards, and it is an upward displacement of the elavicle which usually takes place on to the acromion.

Ribs.-In counting these, the position of the second is denoted by the transverse line at the junction of the manubrim and body of the sternum. "The nipple, in the male, lies botween the fourth and fifth, nearly an inch outsicle their cartilages. The lower border of the great pectoral corresponds to the fifth ril,. The seventh, the longest of the ribs, is the last to articulate with the sternum. When the arm is raised, the first three digitations seen of the serratus magnus correspond to the fifth, sixth, and seventh rihs. The ninth rib is the most oblique. The reventh and twelfth cam he felt outside the erector spina. Owing to the olsiquity of the ribs, their stemal ends are on a much lower livel than their rertebral extremities. "Thus the first rib in front corresponds to the fourth rib hehind, the second to the 
sixth, the thirl to the seventh, the fourth to the eighth, the fifth te the ninth, the sixth to the tenth, and the seventh to the elevernth. If a hurizental lime lue (lrawn round the body from before hackwards, at the level of the inferior angle of $t h_{1}$. scapula, while the arms are at the siles, the line womldent the stermum in font between the fouth and fifth ribs, the fifth rib at the nipple line, and the ninth ril, at the vertehral column' (Treves). 'Those most fropuently lomkin ar the sixih. seventh, and righth. The way in which the ribs are embinlient in the sofe part-

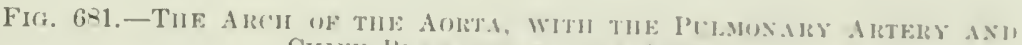

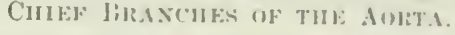

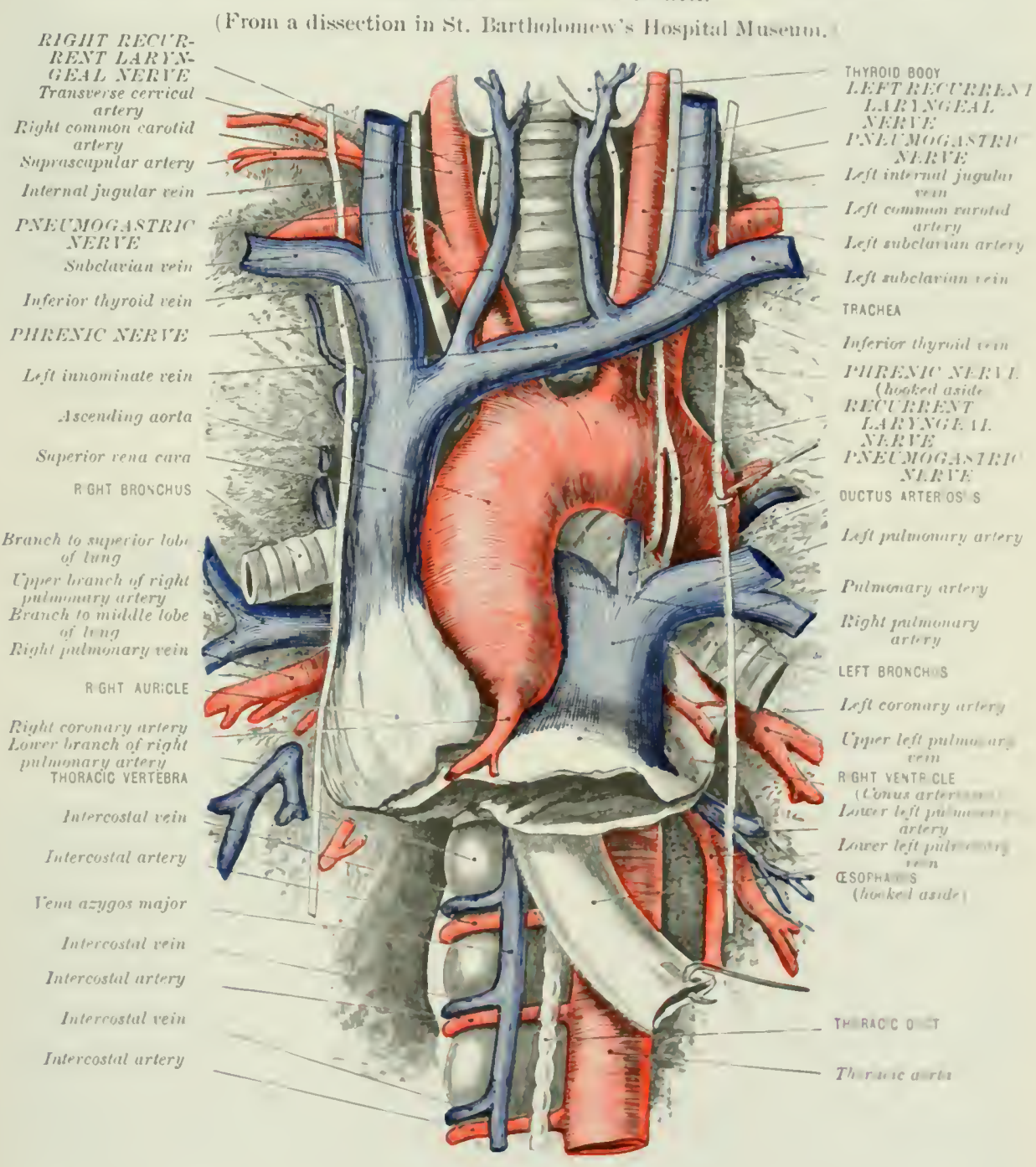

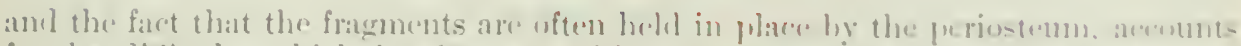

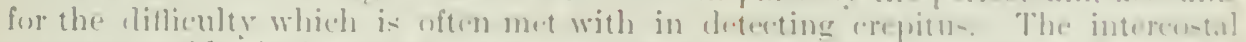

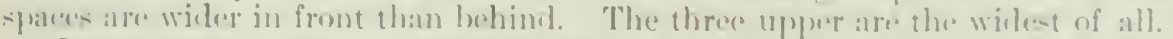

Structures passing through the upper aperture of the thorax.- If a

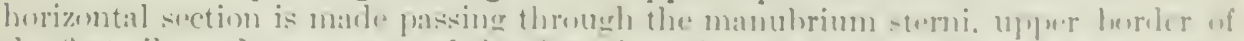

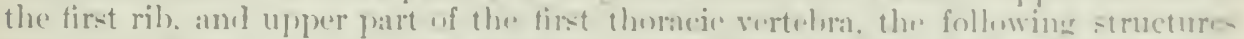

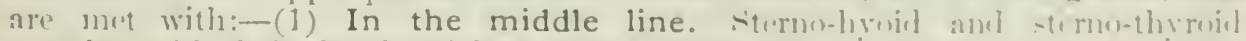

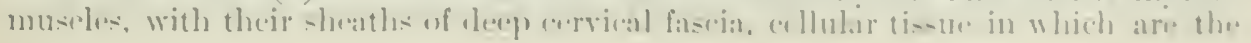


remains of the thrmus sland, the inferior thrond veins. the trachea and tracheal fascia, the esophatgus and longus colli inusels. Between the trachea and asophagns are the recurrent laryngeal nerves. (2) On each side. The apex of the lung, covered by pleura, rises alout an inch and a half above the first rib. Between it and the trachea and asophagus lie the following: the intemal mammary artery, the phrenic nerve; on the right side, the imnominate vein and artery, with the vagus between the two, the cardiac nerves, amb the right lymphatic eluct. On the left side are the common carotid and subelavian arteries, with the left ragus between them, the eardiace nerves, and the thoracic duct. Farthest hack and on each side are the trunk of the sympathetic, the superior interenstal artery, and the tirst thoracic nerve.

Structures found in an intercostal space.-(1) Skin; (2) superficial fascia, with cutaneons ressels and nerves; (3) deep fascia; (4) cxtemal intereostal; (5) cellular interval between intercostals, containing trunks of intereostal ressels and nerves; (6) intemal intercostals; (7) thin layer of fascia; (8) subpleural connective tissue; (9) plenra (fig. 682).

The mamma.-This lies partly over the sheath of the pectoralis major and partly orer the serratus magnus. It is usually described as reaching from the third to the fifth or sixth rib, and from the sternmin to the anterior border of the axilla. It is most important to remember that the breast is often a much more extensive structure than would be included in the above very limited description. Thus (1) the hreast is not encapsuled at its periphery, its tissue branching and breaking up here

Fig. 68\%.- Section of tile Sixth Left Ixtercostal Space, at the Jexctox of THE ANTElior Axn Posteriok TimRds. (Tillanx.)

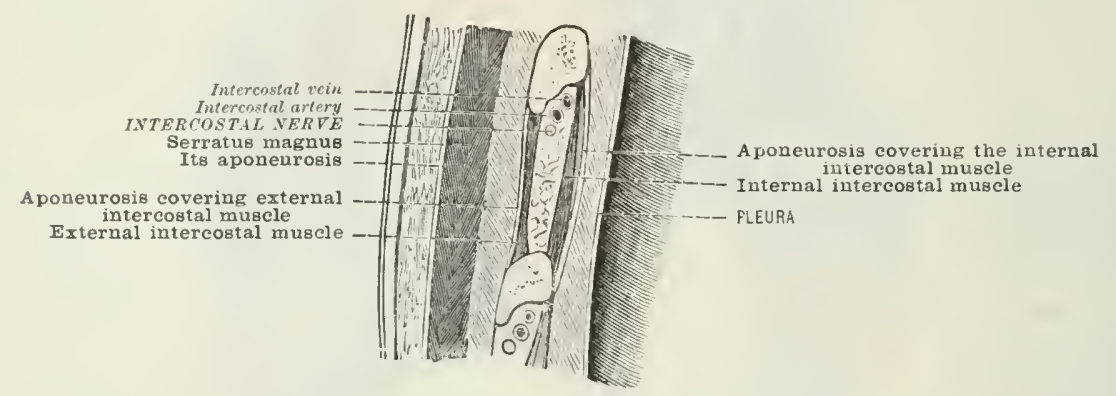

to become continuous with the superficial fascia (stiles). (2) The ligamenta suspensoria contain breast tissue. (3) There is a lympluatic plexus, and, often, minute lobules of breast tissue, in the pectoral fascia (Heidenhain). In the malc the nipple is placed in the fourth space, nearly an inch outside the cartilages of the fourth and fifth ribs. On the nipple itself open the fifteen or twenty ducts which dilate beneath it, and then diverge and loreak up for the supply of the lobules. The skin over the areola is very adherent, pigmented, and fatless. Here also are gromps of little swellings corresponting to some twenty large sebaceous follicles. The skin over the breast is freely movalle, and mited to the fascia which encases the organ, and thus to the interholular connective tissue, by bands of the same structure-the ligamenta suspensoria. Inder the breast, and giving it its mobility, is a cellulo-fatty layer, the seat of submammary abseess. The nerves which supply the breast are the anterior cutaneous branches of the second, third, fourth, and fifth intereostal nerves, and the latrial branches of the last three. The comnection of these trunks serves to explain the diffusion of the pain often observed in painful affections of the breast. Thus pain may be referred to the sirle of the chest and back (along the above intercostal trunks), over the seapula, along the imner side of the arm (along the intereosto-humelinl nerve, a branch of the second intereostal), or up into the neck, probably along the supra-chavicular branch from the cervieal plexus, which eommmicates with the second interestal (Treves). The gland is smpplied ly the following arteries: the aortie intercostals of the second, third, fourth, and fifth spaces, sinilar intercostal branches from the 
internal mammary, which run outwarks, two small branclues to rach spaces, pure-

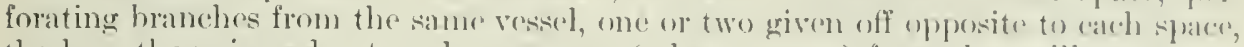
the long thoracie and extermal mammary (when present) from the axillary.

The lymphatics may be divided into two sets-( $\Lambda$ ) The majerity which go along the chief vessels to the glands in the axilla, where the following erouls are to be found: (1) Axillary; (2) subseapular; (⿱口) ) partoral, along the long thoracic; (4) subclavian, or infra-, and supraclavicular. All these anastomose with each other, and also with (B) a much smaller sot of lymphatios, which pass from the inner part of the breast, through the anterior ends of the intercostal space, to the internal mammary or anterion intreostal lymphatic glamels. Thus they reach the mediastinal and ileeper lymphaties.

Parts behind manubrium.-There is little or no lung hehind the first leme of the stemum, the spare beiner oerupied hy the trachea and large vessels, as follows: -The left innominate vein crosses hehinil the sternum just betow its upper horkler. Next come the great printary branches of the arotic areh. Deeper still is the tril-

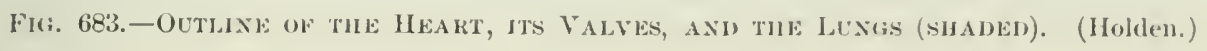

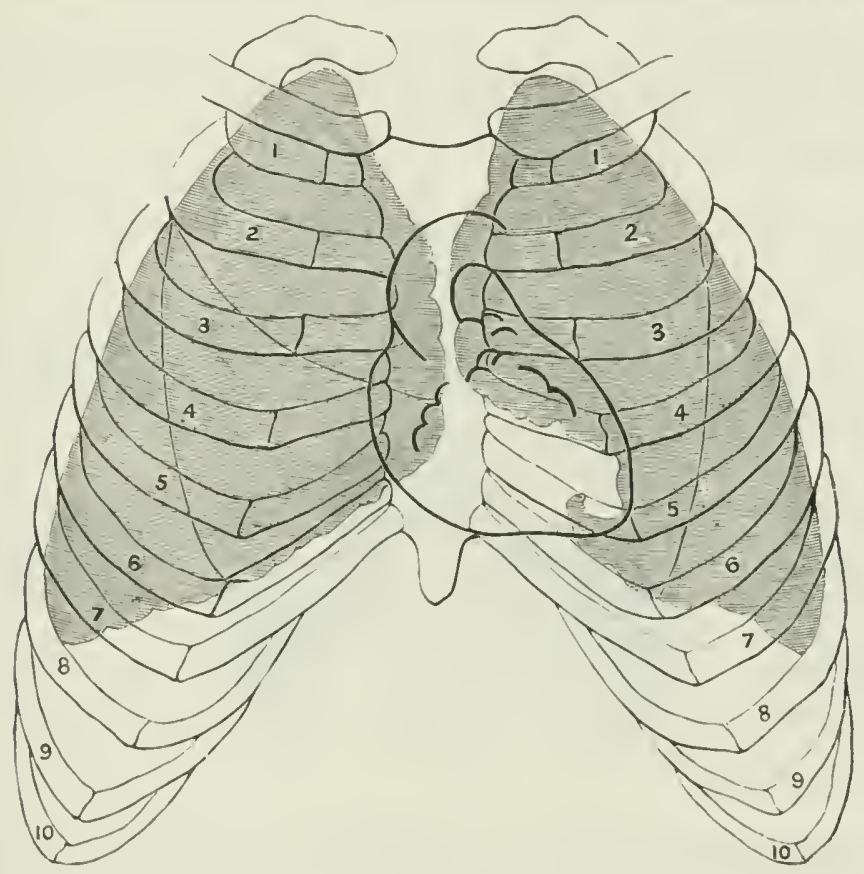

chea, dividing into its two bronchi opposite to the junction of the first and second bones of the sternum. Deppest of all is the asuphagus. Shout one inch from the upper horder of the stemmm is the highest part of the atortie areh, lying on the bifurration of the trachea (Holden).

Outline of the lungs. Their relation to the chest-wall.-The alex of the lung rises about an inch and a half (from half an inch to an inch and threr-yluarters) above the first rib into the lase of the posterior triangle lying lowind the inner

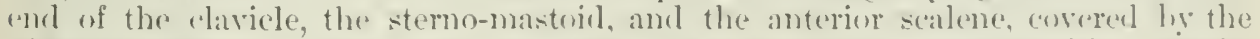

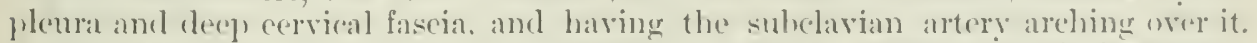
From the apices the thin anterior borders converge inwarks helhind the stemoclavicular joints, and the first piece of the sternum to the junction of this with the secomel, alnost merting at this point. Thenes the two herilers deserend parallel and close to each other (the right sometimes passing just beyond the mildle line), and thus covering over the heart and large vesesels, to al jeint midway between the fourth pair of costal cartilages, where they eliverege, liut wot to an eyual degrees. The right 
elecends in an almost straight line as far as the sixth chondro-stermal joint. The left is deeply notched (incisura cardiaca). The lower horders of the lung pass downwares and outwarels across the sides of the chest from the sixth chondrostemal joint to the tenth thoracic spine. In the nipple-line the lung reaches the sixth rib, in the posterior fold of the axilla, the eighth, and opposite the angle of the scapula (the arms being close to the sides), the tenth rib. Thur. to map out the lung. a line should be drawn from the apex, a point about an inch and a half above the first rib, a little outside the sterno-mastoid musele. obliquely inwards, behind the stermo-clavieular joint, to near the centre of the junction of the first and second bones of the stemum. Thence, on each side, a line should be drawn slightly convex as far as a similar point on the sternum lying opposite the articulation of the fourth chonclo-stemal joint. On the right side the line may be dropped as low as the sixth chondro-sternal joint; on the left (to show the incisura cardiaca) a line should lo thawn sloping outwarts from the fourth chondro-sternal articulation along the lower border of the fourth rib, across the fourth interspace, to a point about an inch and a half below the left nipple (male) and an inch to its inner side. This point, lying in the fifth space, marks the apex of the heart. The lower border of the lung will be marked on the right side by a line drawn from the sixth chondro-

Fig. 694.-Diagray of the Relatioss uF the Thoracic Viscera to the WALLS OF THE CHEST. (Bellamy.)

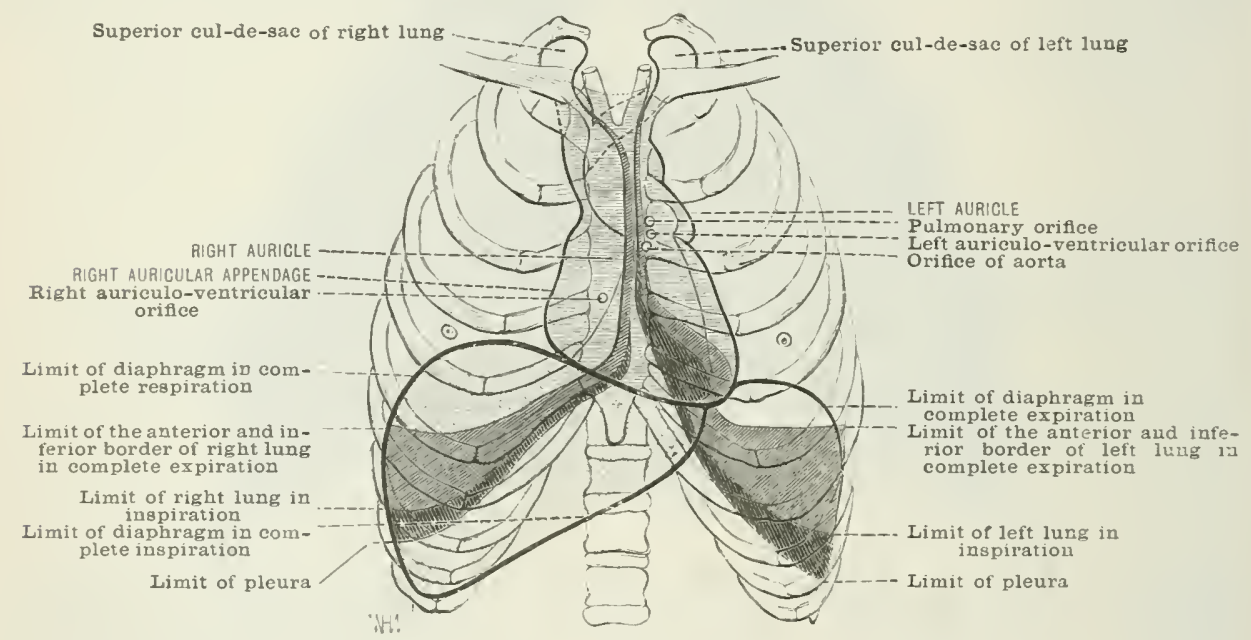

sternal articulation across the side of the chest down to the tenth thoracic spine. The lower border of the left lung will follow a sinilar line, starting on a level with a similar joint (sixth chondro-sternal joint), but much farther out than on the right sicle. i.e. in the fifth space. about three inches to the left of the midllle line, or a point corresponding to the heart's apex. This margin of the lung descends about an inch and a half in deep inspiration, according to Godlee. The position of the great fissure in each lung may be ascertained apmoximately by drawing a line from the second thoncic spine to the sixth rib in the nipple line; and the smaller fissure of the right lung extends from the middle of the foregoing to the junction of the fourth costal caltilage with the stemum. It will be seen from the alove that there is little lung behind the namubrium. The comnective tissue here hetween the lung margins contains up to puberty the thymus, and, later. its remains. The pleura reaches lower down than the lung. Thus its lower margin reaches along the serenth rib cartilage near the sternum; in the axillary line it has reached the lower marein of the ninth rib; farther lark it reaches as low as the twelfth rib, or the eleventh thoracic spinc. Thus it may be neneel in operations in the loin. e.g. on the kidney, or in removing the twelfth rils. Mr. Holken thus draws attention to this lower level of the pleura: "Since the pleura lines the insiele of the last rib, a musket-ball or 
other foreign hody, lowe in the pleural sae and rolling on the diaphragm, might fall to the lowest part of the sace, which would he between the eleventh and twelfth rilss. The ball might lo extracted here. The ehest might also he tapped here, hut

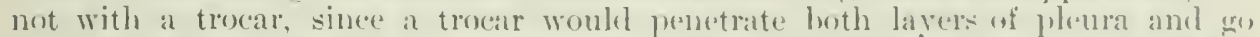

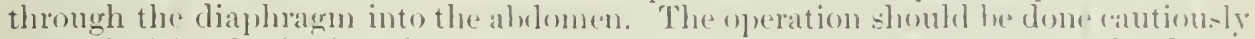
by an incision beginning ahout two inches from the spine, wh the onter hordere of the erector spina, on a level hetween the spines of the eleventh and twellith thorarin. vertebre. The intareostal artrey will not be injured if the opening be made below the mirllle of the space, which is very wide.

Outline of the heart. Its relation to the chest-wall.-The upler limit of the heart (base) will be definerl by a line crossing the sternum a little above the. upper borter of the thiril costal cartilage, reaching about half an inch to the right and about one inch to the left. Its apex correspouds to a point in the fifth space, about two inches below the male loft nipple, and an inch to the imer sidc. Thipoint will be about three inches from the left horeler of the sternum. The right border (right auricle) will be given by a line, slightly convex outwarls. dlatw

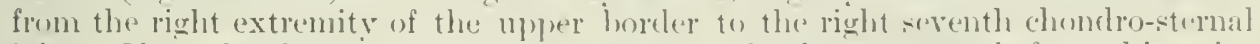
joint. If another line, sindilarly slightly conver, he drawn onwarls foum this point across the last piene of the sterinm, just above the xighoid cartilige, to the apex. it will give the lower horler (right rentride). which rests on the central tenchom of the diaphragm. The left border (left ventricle) will he griven hy a line, convex to

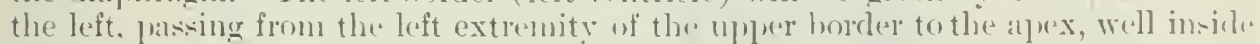
the nipple line. This line should be three inches from the midlle of the strmum at the level of the fourth costal cartilage.

If a cirele two inches in diameter he describer around a point nichay between the left nipple and the lower end of the gladiolus, it will define witl sufficint atedracy for pratetical purposes that part of the heart which lies immerliately hehind the chest wall. and which is uncurered hy lung or plema (Latham).

The valves.-The pulmonary valves (the most superficial) lie, in front of

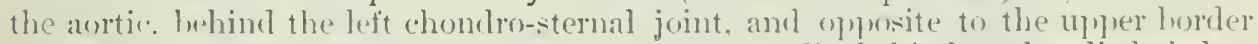
of the thirl costal cartilage. The aortic valves lio behind and a little helew these, opposite to the immere ent of the thirl interestal space, and on a level with the lower borer of the thirl costal artilige. The auriculo-ventricular openings lin at a somewhit lower level than that of the aortio and pulmomary. Thus the tricuspid valves lie behind the sternum at the level of the fourth intereustal space; and the mitral valves, the most deeply placed of all. lie a little to the left of these. brehinel the left erlege of the sternum and the fourth left costal cartilage.

"Thus these valves are so situated that the mouth of an ordinary-sized stethosone will coser a portion of them all, if placed over the juncture of the thire interestal space. m the left side, with the -terum. All are corered hy a thin layer of lung; therefore we hear their action botter when the breathing is for a moment surpembled' ( Holdin).

Relation of vessels to the wall of the thorax.-Aortic arch.- IThe asceneliner part reaches from a sput behind the sternum, al little to the loft of the centre, on al level with the thiml left costal caltilage. to the uppere horeler of the

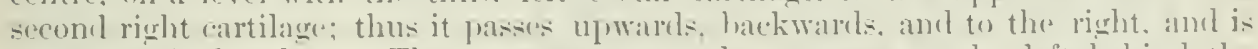

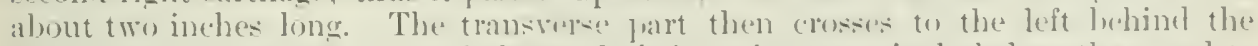
sternum (the highest part of the areh being about an inch ledow the moteh). rearhing from the socond right enstal cartilage to the lower loorder of the fourth

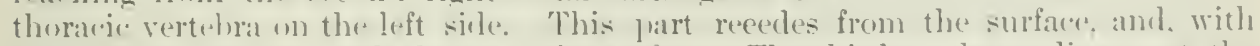
the next. cannot be marked out on the surface. The thirl, or deseending part, the shortast of the threse, reaches from the lower borter of the fourth to that of the fifth therierie verteluris.

Innominate artery.-I line drawn from the top of the areh, about an ineh

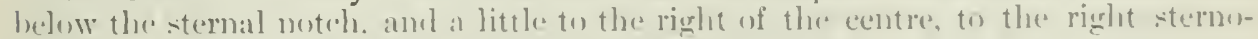
clavicular joint. will give the line of this vescel.

Left common carotid. - This veriel will be drotert by a line somewhat sim-

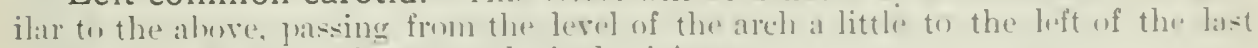
atarting point to the loft stemen-elavienlan joint.

Left subclavian artery. - I line from the end of the transterse arch, luhinel 
the left of the -termum, straight upwards to the claviele, delineates the rertical thoracic (ourse of the long loft suhelavian artery (sheild).

Innominate veins. - The left, three inches long. extends very obliguely from the left sterno-clavieular joint, to a point half an inch to the right of the sternum, in the tirst intercostal space. The right, about an inch long. descends almost vertically to the above froint from the right sterno-clavicular joint.

Venæ cavæ. - The superior deseends from the point ahove given for the merting of the innominate reins in the first intercostal space, close to the stemum, and perforates the right anricle on a level with the third eostal cartilage. The inferior vena cava.- The opening of this vein into the right auriele lies under the milllle of the fifth right interspace and the arljacent part of the sternum.

Internal mammary artery.-This descends lohind the clavicle, the costal cartiliges, and the first six spares. about half an inch from the edge of the stemum. In the sixth intercostal space it divides into musculo-phrenic and superior epigastric arteries.

\section{THE ABDOMEN}

Skin markings; bones and muscular landmarks.-The linea alba, or meting of the aponeuroses of the great aldominal muscles over, under, and hetween the reeti, reaches from the apex of the xiphoid cartilage to the symphysis. It is best marked above the umbilieus. Its little vascularity and comparative thimmess fit this line for the point of election for many of the operations on the ahdominal eavity. In the linea alba, a little below its centre, is the umbilicus. This corresponds to the level of the fibro-eartilage between the third and fourth lumbar vertehre, the tip of the third lumbar spine (Windle), the highest point of the iliae crests, and a point three-quarters of an inch to one inch above the bifur(ation of the aorta.

On mels side of the linea alba, and about two and a half to three inches from it (accorling to the muscular development), a line, curved with a slight convexity outwards, the linea semilunaris, denotes the point of division of the abdominal aloneuroses, reaching from the ninth costal cartilage to the pubic spine. Between the linea alha and the linea semilunaris run the three linese transversa, of which one is plared at the mombilicus, another at the xiphoid eartilage, and a third between the two. on a level with the tenth costal cartilage. There is, rarely, a fourth below the numbilicus.

In very corpulent suljects two deep transverse furrows run across the abdomen. One runs across the narel and completely conceals it; the other is lower down, just above the fat of the pubes. In tapping the hladder above the pubes in such a case, the trocar should be introduced where this line intersects the linea allua (Holicin).

A transverse line drawn from one anterior superior spine to the other crosses at ahout the level of the top of the promontory of the sacrum. Such a line will always show whether the prelvis is horizontal or not (Holden).

Poupart's ligament corresponds to a line drawn with a slight curve downwards between the anterior superior spine and the pubie spine. The first of these bony prominences corresponds to the starting-point of the abore ligament, the attachment of the fascia lata to the ilimm, the meeting of the fleshy and aponeurotic parts of the extemal olylique (demoted be a line drawn upwards from this spine to the ninth costal cartikage, or often a little anteriorly to these points), the point of emeresence of the external cutaneous nerve, and part of the origins of the internal oblique, transrersalis. and tensor vagince femoris. The pubie spine marks the outer pillar of the external abdominal ring, the mouth of which corresponds to the crest, or that part of the pubes lying between the spine and the srmplysis. 
The ring, and especially its outer pillar, can easily be felt by invaginating the scrotal skin with a finger, and mohing upwarls and outwarks. In a fomale batient, if the thigh be alducterl, the tense temlen of the arlduetor honers will lead up to the site of the ring. The internal ring is situated about half an inch alure the centre of Poupart's ligament; oval in shape, and nearly vertical in direction, it has the arehing fibres of the transeresalis allowe it, and to its innor side the deep epigastric artery. The canal rums obliquely downwards and formwards between the two rings. In the adult it is alout an inch and a half long. but in early life, and in adults with a large hemia dragging upon the parts, the two rings are much nearer, and may be one hehind the other. If the external ring be exposed, and the finger thrust carefully up the eanal, the following structures will be noted:-After the finger has carefully dilaterl the eanal, its tip will be prerented from entering the abdomen by the infundihuliform fascia. If it he prosed dommwards, it will feel Poupart's ligament, which, with the meeting of the filscial transversalis, forms the floor; above, it will be anresterl by the arehing fibres of the

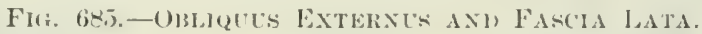

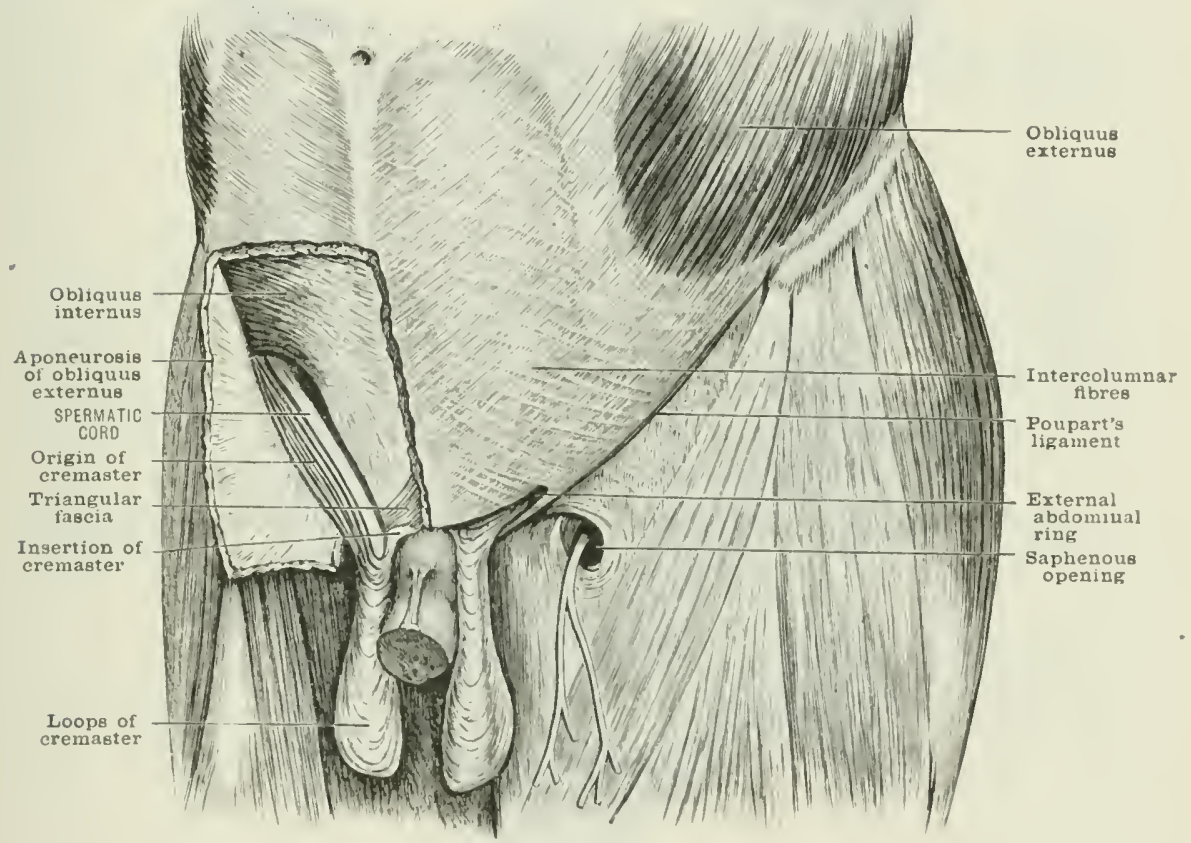

internal obligue and transwersalis, coming down to the pertineal line to form the conjoined tendon. Towards the abdominal wall the finger will feel the ayonemosis of the extemal ohligue strotehing over the whole anterior aspect of the canal: if turned towards the belly cavity, the finger would feed less resistant lavers. viz. extra-peritoneal fat and jeritonemu, and, helinel the external ring, the conjoinest temelon. The finger would, of eourse, also take notices of the spermatio corel in the male and the round ligament in the female, and investigate any alteration in the formere amel isolate the vas deferens.

Vessels in the abdominal wall.-The thres superficial hamelus of the

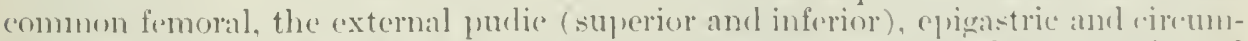
flex iliac, supply the lower part of the alelominal wall and the arljacent armin amel genitals. The only others that have to be remembered ane the deepe epigatstries and

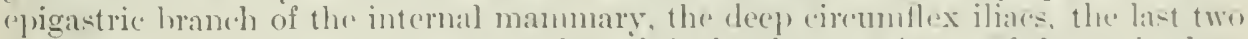

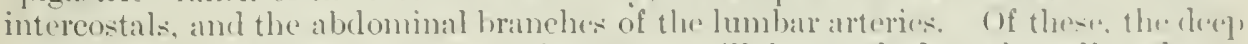
eproastric is the most important: its comres will be marked out by a line drawn from a point just internal to the erente of P'oupart's ligament. upwarels and 
inwards to the inner side of the internal ring, and thenee to a point about midway between the pubes and umbilicus. Hore the ressel, which at first lies between the peritonem and faseia transwersalis. perforates the latter and, passing over the fold of Douglis, enters the sheath of the rectus. It then runs upwards, closely applienl to the batek of that muscle, and, a little above the level of the umbiliens, divides into lranches which anastomose with the epigastric or abdominal branch of the internal mammary.

Lymphatics.-It is suffieiently correct to say here that those above the nmbilieal line go to the axillary, and those below that line to the femoral glands.

Nerves.-The lower seven intercostals and the ilio-hypogastric and ilioinguinal supply the aldominal wall. The sixth and seventh intercostals supply

Fig. 6×6. -THE VISCERA AS SEEN ON FILLY OPEXING THE ABDONEY WITHOTT

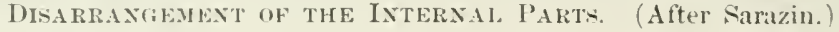

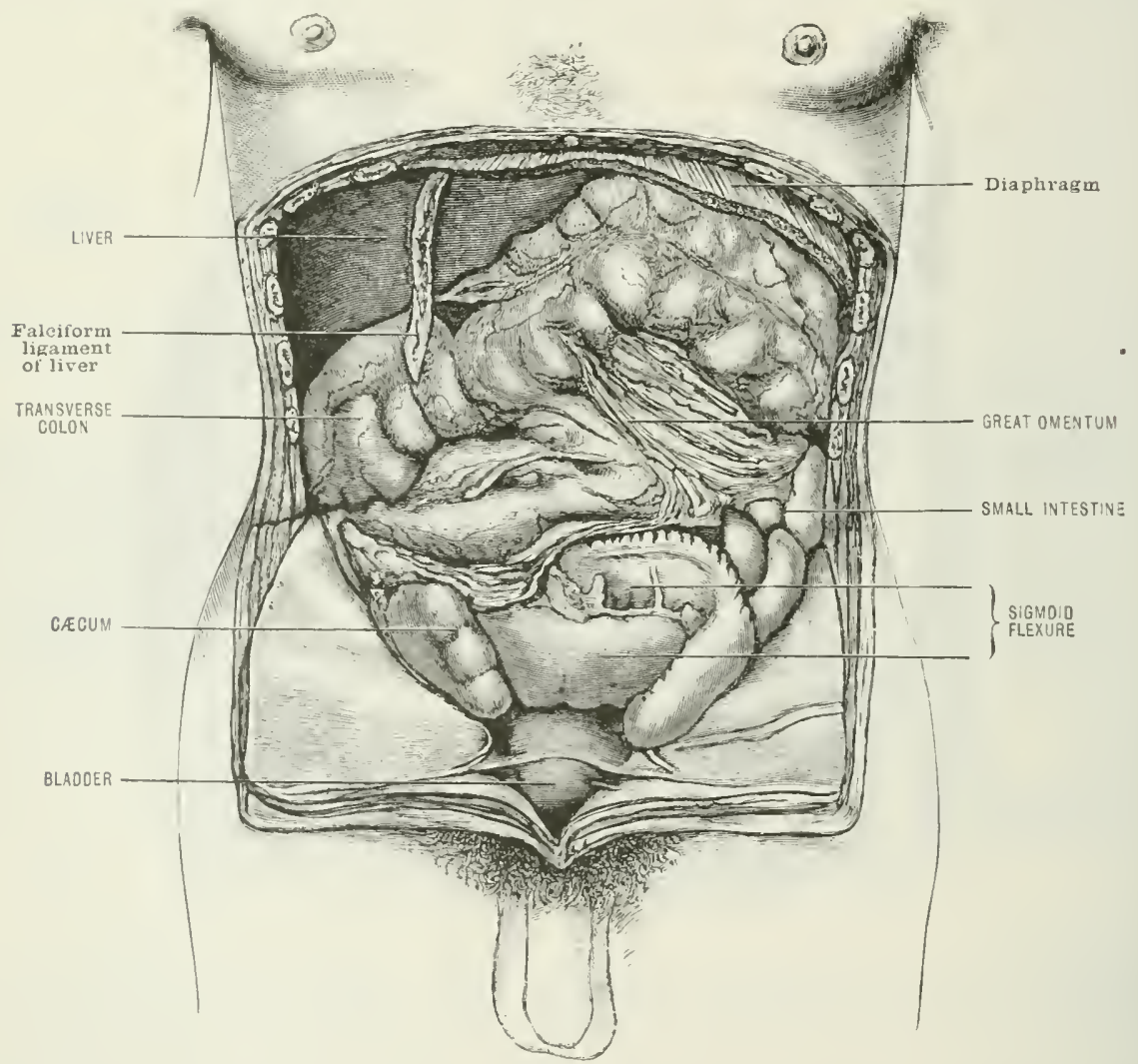

the skin wer' the pit of the stomach'; the cighth the area of the midlle linea transversa: the tenth that of the unbilieus; the last thoracic. ilio-inguinal, and ilio-hypogastric, the reginn ahove Poupart's ligiment, and that of the pubes. The ilio-hypogastric supplies the skin over the isternal ring; the ilio-ingninal that over the cord and serotum. The last thoracic and ilio-hypogastric cross the iliac erest to suply the skin of the buttoek.

Viscera and visceral regions. - The general form of the abdominal spare. and the relations of the sereral organs before they are disturbed from their normal positions, are given on pages 9.59 and 960 . The arbitrary regions into which the abdomen is usually divided are described at the end of this article.

The diaphragm.-The upper linit of the abdomen rises to the following levels: Its epntral tenelon to about the lower enel of the sternum, or the seventh chomelro- 
stremal joint; the right half to about the level of the lifth rib, or albunt one inch below the nipple; the left half not rising ynite so high.

Viscera behind the linea alba. - Fom ithore dewnwarts there are the following (tig. (isti):-(1) Above the umbilicus-the left lobe of the liver, the stomach, the transverse colom, part of the great omentum, the pancereas and solar plexus. (2) Below the umbilicus-the rest of the grat (monetum, corering in the small intestines and their mesentery. In the child, the bladeler oceupies at partly abdominal position; anel in the alult, the same viscus, if distended, mal

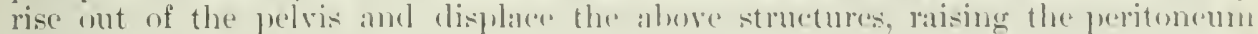
until. if distended half way to the mombilietus, there is an area of nearly two inches safe for operations above the s!mphysis. The gravid uterus also rises along the linea albal.

The liver (figs. 579, 5.5, and ns1). - In the crect position, the anterior thin mige of the liver projects about half an inch below the costal cartilages, but can only be made ont with difliculty in this prosition. It may also be displaced downwards by pleuritic effusion or tight lacing. The liver is also, proportionately, much larger in little chilstern.

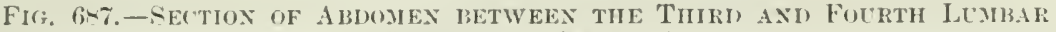
VEKTLBK.玉. (Braune.)

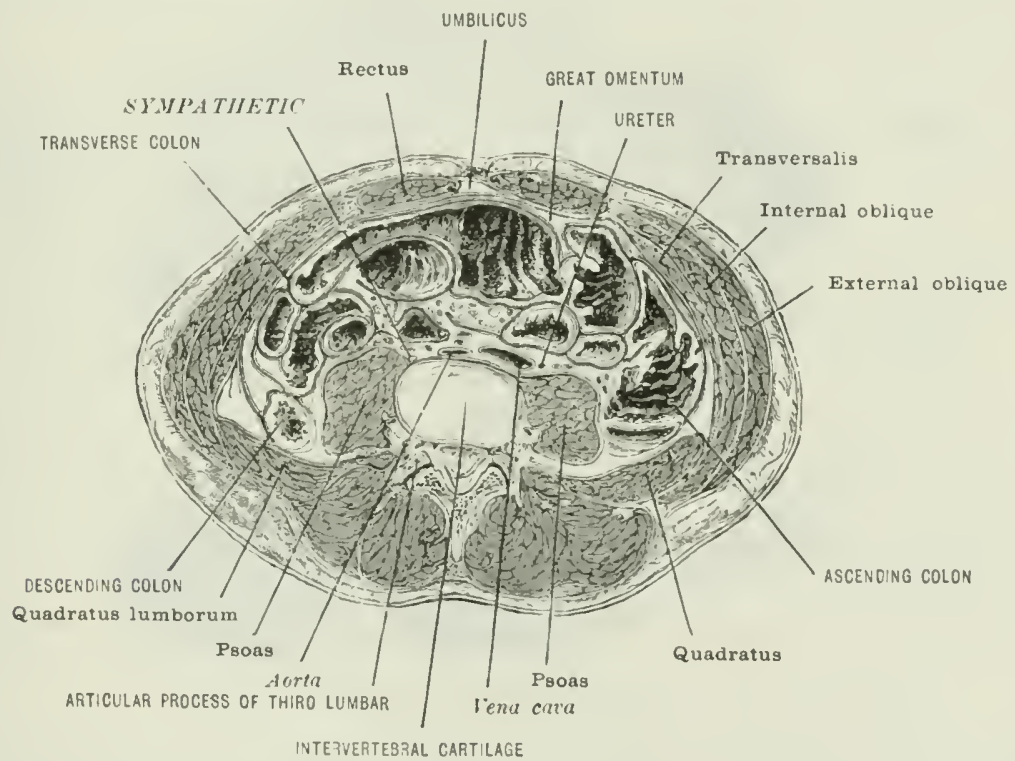

Of the three parts of the liver (aceording to the regions which it oceupies), that in the right hypochondrium corresponds to the lower marcin of the thorax; but in the epigastric region the anterior margin, ruming obliguely across from the ninth right to the eighth left costal cartilage. croses the nuddile line about a hand's brablth below the stemo-xiphoid artienlation (Godlec). The size of the left lobe varies. In infants it will oceupy the left hepochondrium; in adults its extent to the left will vary from a point an inch and a half or two inches levond the sternum to the loft nipjle line. The level of the upper horder varies also with position, respiration, ete. It may be represented, on the right, hy a line drawn aluent one inch helow the nipple, along the seventh ril, towards the middle line, the fifth chombro-stemal joint, and the sterno-xiphoid artieulation (or contral tendon of the diaphragm); on the left side it does mot reach guite so high: thus its level would be marked by the sixth ehondm-sternal joint. Behind, the liver wombl be below the hase of the right lung. on a level with the tenth thoracie spine ( fiers. 708, 709, ancl 710$)$.

Gall-bladder.-The fundus of this. situated in a fossia on the under surfare of 
the right lolve of the liver, and having the quadrate lobe to its left, lies opposite to the right ninth costal cartilage. close to the outer edge of the rectus. It is in contact with the hepatic flexure of the colon and the first piece of the eluodenum.

Stomach (figs. 566-.569, p. 960). - This organ raries in position more than any other, owine to its mobility, save at the cardiac orifice, and to its varying distension. When empty and contracted, it lies far back in the abdomen, under the left lohe of the liver, and in front of the pancreas. When much distended, its prloric end moves to the right, and the organ comes forwards, pushing against the lirer and ahelominal wall; and upwards, against the diaphragm, and thus against the heart and left lung. If moderately distended, the cardia will be found under the seventh left chondro-sternal joint, about one inch beyond the sternum. The pylorus is very mohile, but a spot near the end of the cartilage of the eighth rib will denote it with sutficient acruracy. It is on a deeper plane than the cardia. Byn joining these two points with lines representing the lesser and greater curvatures, the stomach can be marked out (figs. 709, 709). The usual inaccuracies committed in delineating the stomach are as follows: The viseus is marked too horizontallystulents forget its oblique position. The greater curvature and fundus are not

Fitr. 638. - Diltray showryg Reiatiox of Kidsey to Capsule.

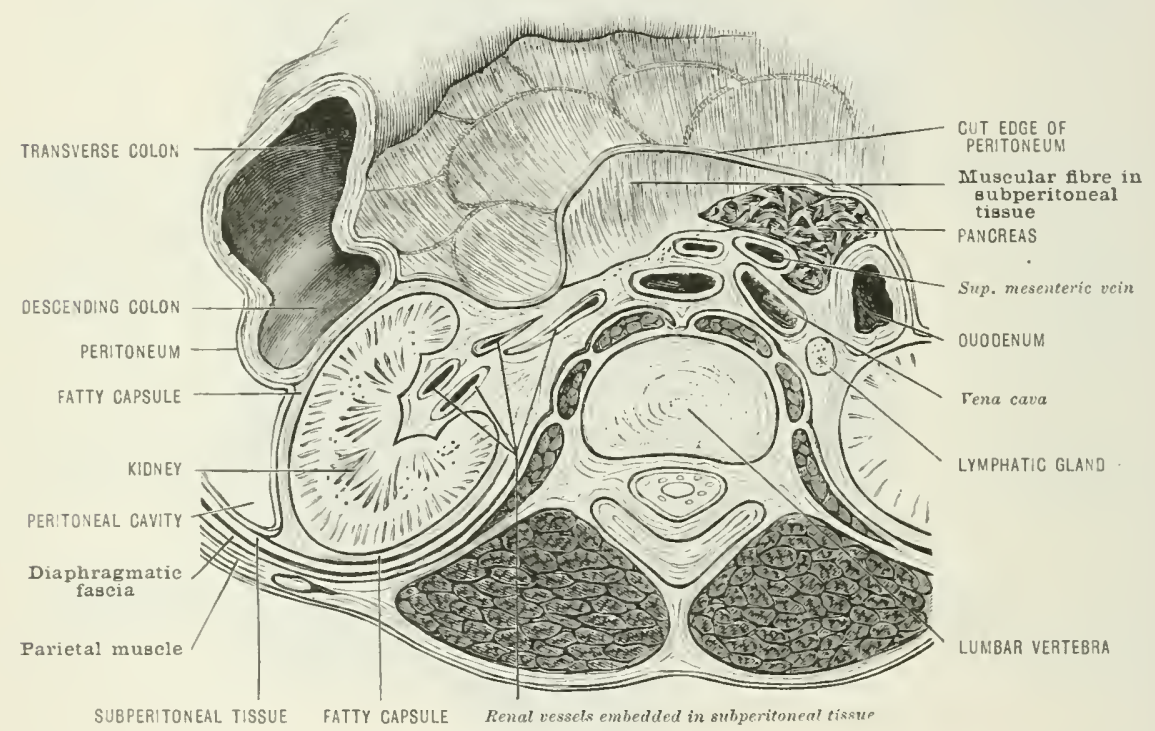

marked high enough on the left side. They are placed high up under the left arch of the diaphragm, well to the left of the middle line, as high as the sixth chondrosternal joint. The lesser curvature is usually made too curved and too horizontal (Sheild).

The pancreas.-This lies a little ohliquely behind the stomach, crossing the aorta, inferior eava, and spine about the junction of the first and second lumbar vertebre, or three inches above the umbilicus (fig. 587, p. 987, and fig. $710.1 \%$. 1147). A little lower is the thircl piece of the duodenum, reaching to within an inch of the umbilicus (Godlee).

Intestines-(A) Small. - The only parts of these that can be localised at all refinitely are the duodenmm and its junction with the jejunum and the ending of the ileum in the e:ecum. The first piece of the duodenum lies in the right hypochondrium, usually near the gall-bladder (vide sumra), reaching from the pylorus upwards, backwards, and to the right. This is the most mobile of the three parts. The second, or deseending, is in relation with the head of the pancreas, and reaches the right lumbar region, descending as low as the second or third lumbar vertebra. The third, or oblique, portion passes from the third lumbar vertebra obliquely from light to left across the second, and, ascending, ends in the jejunum on the left side 
of the spine. This portion of the intestine heing firmly secured in platee by fibres from the left crus of the diaphrimm and the commoncement of the mesentery, accounts for rupture of the intestime usually oecurring near this spot.

()f the jejunum and ileum it may bresid that, if molistencled, the coils of the jejunum (about oight feet) aceupy rather the left side, and that of the ilemun (twelve feet), the right sirle, in addition to the central regions, where the jejumm

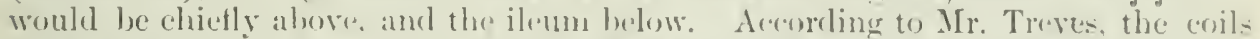
mest usually found in the pelvis belong to the terminal part of the ileme and that part of the intestine which has the longest mesentery, vi\%: that extending betwen two points respectively six and eleven feet from the end of the luodenum. But ats there is no elefinite limit between the jejonum and ileums so is there no regular arrangement of their coils. If present, a Meckel"s liverticulum would arise from one to three feet from the termination of the ileum.

The uper limit of the mesentery would be narked ly a spot about thre. inches above the umbilicus and a little to the left of the centie of the bodr of thes sreond lumbar vertebra. From this point it extends obliquely to the right iliat fossa, where it ends in the ileo-cecal junction, about four inches above the centre of Poupart's ligament. Its arerage length is about eight inches.

(B) Large intestine. - The cæcum measuring about two and a half inches both in its vertical and transverse diancters. lies in front of the ilio-posts. and should be so mapped out behind the anterior abdoninal wall as to lie above the outer half of Poupart's ligament, and with its apex or lowest point projecting just beyond the inmer borler of the poas, and thus erresponding to a point a little to the imner side of the centre of Poupart's ligament. Not unfrequently it lics more external, still in the right iliac region, but entirely on the iliacus. "The ileo-cæcal valve, or junction of the small and large intestines, corresponils to a point about two inches internal to and a little above the anterior superior sine. The hase of the vermiform appendix, which usually comes off close to the valve wn the posterior wall of the cecum, would be represented hy the above point with suflicient accuracy. The appentix itself, averaging four inches in length. of the size of a goose-quill, and usually twisted on itself owing to the shortness of it. mesentery, generally projects hehind the wecum, ileum, and mesentery, in the direction of the spleen (Treves), or downwads to the left, st as to approach the hrim of the pelvis. The ascending colon, covered by small intestine, lies ilecply as it passes up over the kidney through the right lumbar region. The hepatic anil splenic flexures lie deeply also in the hypochmolriar regroms. the splenic beine higher than the hepatic, and behind the stomach, while the former is in contact with the under surface of the liver. Between the wo courses the transverse colon, in ahse contact with the great curvature of the stonach, and varying in position from one, two, or three inches above the mmlilicus, to one nearer or cren frew this point. The descending colon follows a siniline coure to the ascending; and the sigmoid Hexure oceipurs the left iliar fossa, and from this point passes over the brim of the pelvis. Except at its hepatic and slonic flexures. the colon can be examined through the parictes, airlul hy an andesthetic. The cecum is the most superficial of all.

Landmarks for lumbar colotomy.-(1) The lower forcler and tip of the lan rib, which varies in length; (2) a point half an inch hehinel the centre of the iliare 1.rest, this point being fouml hy acrurate measurement along the crest between the anterior and posterior spines (. Allingham): (3) a line drawn rertically upwards from the last-mentioned pont to the last rib. This gives with sullicient correctness the line of the onter relge of the quarlratus, and the prosition of a normal colon.

Iliac or anterior colotomy.-Thw incision here, whether for opening th.

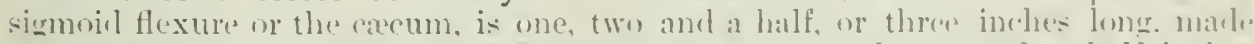
parallel with the outer pant of l'ouparts ligament. and ome and a half indlue aluse it.

The kidneys. - These lie at the back of the alulominal cavity so denply in the

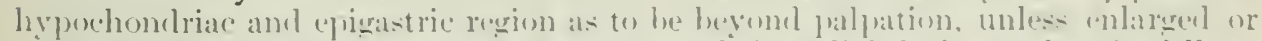
umbly molites. The lower mil of the right being slighty lewer than its fellow. eneroaches in health upon the lumbar and eprostric region. These organs lie much 
higher than is usually supposed to be the case, the upper two-thirds of the right and all the left kidney being behind the ribs. To mark them in from the front the following points should be noted: The upper extremity should reach as high up as the seventh costal cartilage, close to the costo-chondral junction. The lower end, about four and a half inches below this point, should be above a line drawn horizontally through the umbilicus, though it is to be remembered that the rierht often encroaches upon this line. Relatively to the vertebre, the kidners lie along the sides of the last thoracic and the first three lumbar. A vertical line carried up to the costal arch from the centre of Poupart's ligament has one-third of the kidney to its outer side, and two-thirds to its imner side, i.e. between this line and the median line of the body. The distance between the two kidneys and between each viscus and the middle line is thus given by Thane and (iodlee: The position of the superior pole is indicated by a spot about two inches from the middle line, the hilum is placed at the same distance. and the inferior pole about two and a half to three inches from the mirldle line. The shortest distance between the two kidneys, 'at the upper part of their mesial borders,' measures about two and a half inches.

\section{Fig. 689.-Transverse SECTION OF THE ABDOIEN THROUgh THE KIDNEYS AND Pancreas, at the level of the first Lumbar Vertebra. (Braune.)}

\section{Inferior cara}

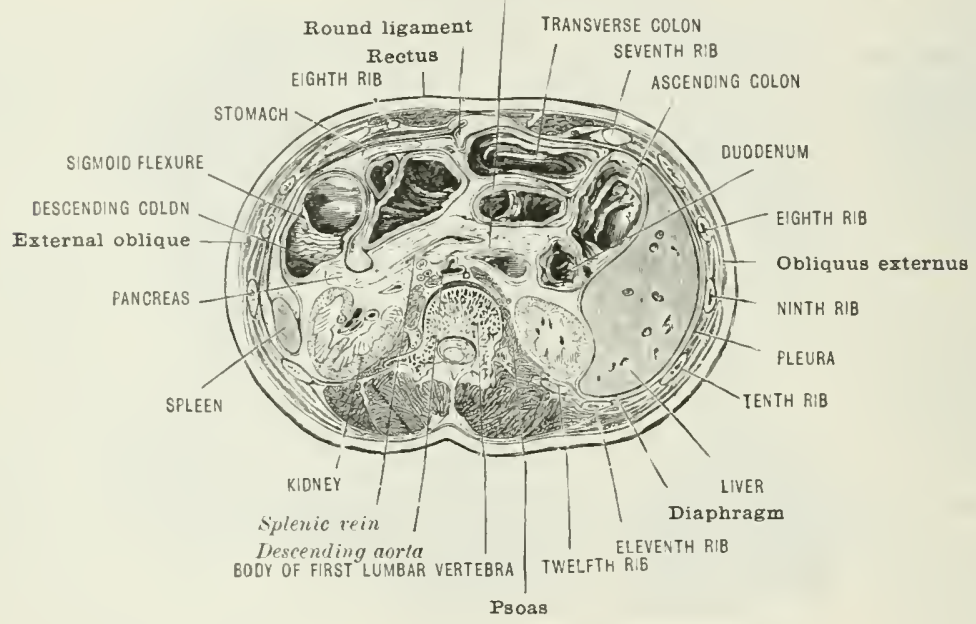

On the posterior surface of the body the kidney's houndaries are indicated by the following:-(1) A line parallel with, and one inch from, the spine, between the lower edge of the tip of the spinous process of the eleventh thoracic and the lower edge of the sinous process of the third lumbar vertebra; (2) and (3) lines lrawn from the top and bottom of this line outwards, at right angles to it, for two inches and three-yuarters: (4) a line parallel to the first, and connecting (2) and (3). Within this parallelogram the kidney lies (Morris).

The spleen (figs. 585 and 589 ). - This lies very obliquely from above downwards, and from within outwards, in the left hypochondrium: thus its long axis corresponds closely with the line of the tenth rib. It is placed opposite the ninth, tenth, and eleventh ribs externally, being separated from these ly the dialihragm; and internally it is connected with the great end of the stomach. Below, it orerlaps slightly the outer border of the left kidney (figs. 690, 709, 710, and 711). Its highest point is on a level with the spine of the ninth thoracie, and its lowest with that of the eleventh thoracic vertebra. Its inmer end is distant about an inch and a half from the median plane of the body, and its outer about reaches the mid-axillary line (Codlee). In the natural condition it camnot be felt; but if enlarged, its notched anterior margin extends downwards towards the umbilicus, and is both characteristic and readily felt. 
Aorta and iliac arteries.-The aorta enters the ahromen opyosite the last thoracic vertebra (a point five to six inches above the unbilicus. or rather alwore the mid-point between the infrasternal depresion and the umbilicus (Thane and (irdlee), and thence, lying to the left of the sline divides into the two common ilines opposite the disc between the third and fourth lumbar vertebre, or olposite the body of the fourth lumbar vertebra. This point is about one ind below and to the left of the umbilicus, and on a level with a line lrawn across the highest part of the iliac crest. I line lrawn from this puint. with a curve slightly outwards, to just within the centre of Poupart s liqument. will give the line of the

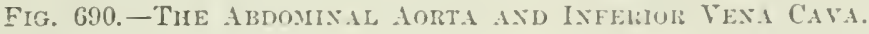

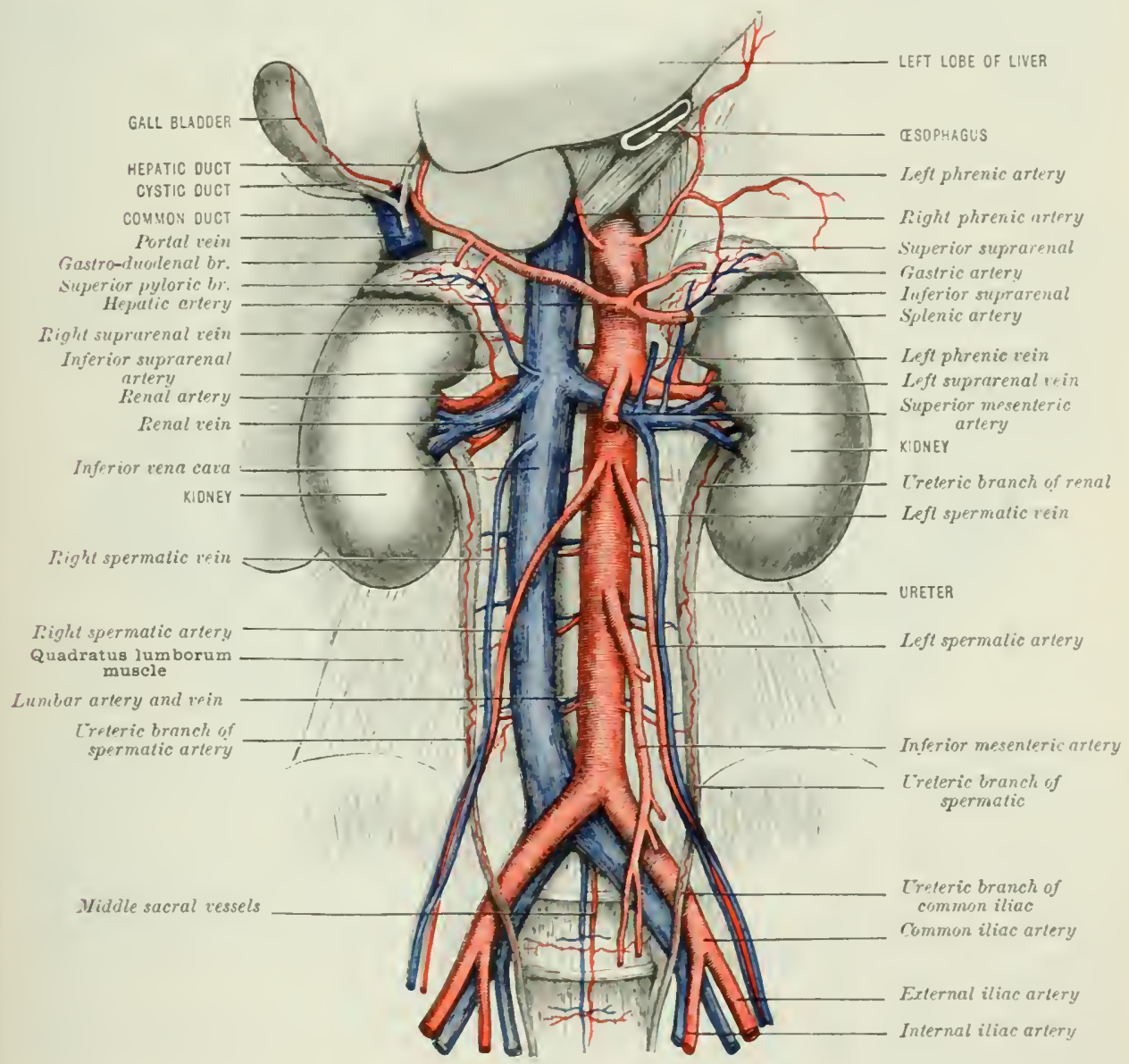

iliac arteries; the first two inches (about) giving the average length of the common iijac.

The site of some of the branches of the aorta inay be thus approximately rememberul.

The coliac axis is given off immediately ifter the aorta has perforated the diaphragm; directly below this is the superior mesenteric artery. About one inch lower flown, or three inches above the umbilicus. the renal arteries are given off. About one inch alove the umbilirus would be the level of the inferior mesenteric artery.

Collateral circulation after ligature of the common iliac.-The chicf vessels here are:- 
ABOVE.

Internal mammary and lower intereostals

Lumbar

Middle sacral

Superior hamorrhoidal
BELOW.

with

with

with

with

\section{Deep epigastric.} Lateral sacral.
Ilio-lumbar and circumflex iliac.

Inferior and middle hamorrhoidal.

\section{Collateral circulation after ligature of the external iliac:-}

\author{
Deep epigastric \\ Deep ciremutlex iliae \\ Giluteal and seiatic \\ Comes nervi ischiadici \\ Ohturator \\ Internal pudic
}

with

with

with

with

with

with
\{ Internal mammary, lower intercostals, and lumbar.

Ilio-lumbar, lumbar, and gluteal. Internal and extemal circumflex. Perforating branches of profunda. Cireumflex and epigastric.

External pudie.

\section{Collateral circulation after ligature of the internal iliac:-}

Siciatic

Hamorrhoiclal arteries

Pubic branch of obturator

Branches of pudic

Circumflex and perforating of $\}$ with profunda

Lateral sacral

Circumflex iliac with

with

with

with

with

with
Branches of profunda.

Inferior mesenteric.

Vessel of opposite side.

Branches of opposite side.

Sciatic and ghteal.

Middle sacral.

Ilio-lumbar and gluteal.

\section{THE PERINAUM AND GENTTALS}

Bony boundaries.-These are the same in either sex. Above and in front is the srmphysis pubis, rounded off by the subpubie ligament; diverging downwarts and outwaids from this point on either side are the rami of the pubes and ischium, cnding at the tuberosities of the latter. In the middle line behind is the apex of the coecrx; and reaching from this to the tuberosities are the great sacro-sciatic ligaments, to he felt hy deep pressure, with the lower border of the gluteus maximus overlapping them. The depth of the perinæum varies greatly, from two to three inches ( 30 to $75 \mathrm{~mm}$.) in the posterior and outer part to one inch or less in front.

In the midkle line, extending longitudinally through the perinemm, is the raphe, the guide to the urethra, and 'the line of safety' (on account of the small size of the vessels here) for operations on it.

An imaginary line drawn transversely across the perinam from one tuber ischii 'to its fellow diviles the lozenge-shaped space into two triangles-(1) An anterior, or urethral; and (2) a posterior, or rectal.

The central point of the perinæum is in the arlult nearly an inch ( $25 \mathrm{~mm}$.) in front of the anus, or midway hetween the centre of the anus and root of the scrotum. Hore the following structures meet, viz., the sphincter ani, the two transverse perinatal museles, the accelerator minas, and the levator ani. It also eorresponds to the centre of the lower margin or hase of the triangular ligament. Its development varies much in different bodies. A little in front of this point is the bulb, with the corpus spongiosum passing forwarls from it. This would also be the level of the artery of the bulb, so that in lithotomy the incision should always begin helow this point. A linife introduced at the central point, and carried backwards and 
very slightly upwarls, should enter the membranous urethra just in foront of the prostate. If pushed more derely, it would enter the neck of the hladiler. In lateral lithotomy the knife is enterexl an inch and a half (37 mm. ) in fornt of the anns and

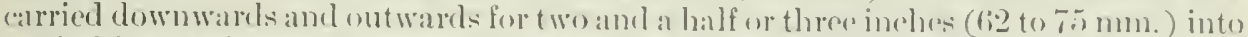

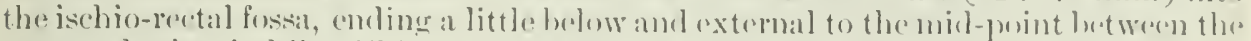
anns and tuber ischii. This incision berins dereply and ends moresuperficially. In the deeper part of the incision the knife is arried along the stafi througl, the membrancus urethra into the blalder. The parts divicled in the operation are-sin,

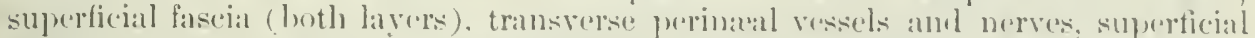
perinat vessels and nerves, inferion hamerrhoidal vessels and nerves, transversus perinar muscle, hase of triangular ligament (anterior layer), membranous urethra

Fig. 691.-Tin Male Perix.ley. (Motified from Hirselıfeld aud Leveillé.)

BULBO-CAVERNOSUS

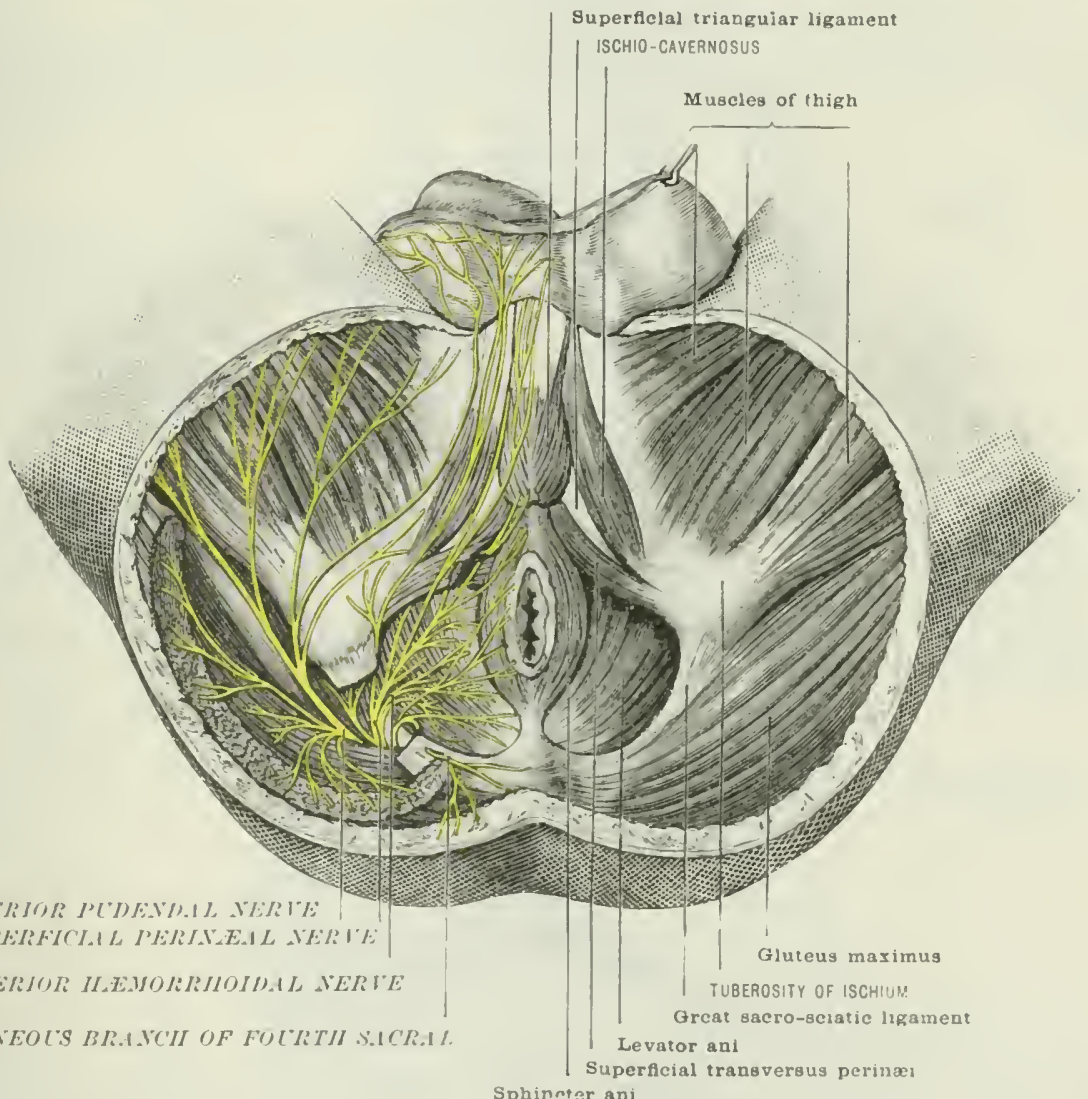

Sphinnter ani

and deep muscles, a venous plexus, posterior layer of triangular ligament, prostatie urethra, and left lohe of prostate and its eapsile in part, with some of the fiheres of the fevator prostatie. In median lithotomy, an incision an inch and a half loner is male through the erental temdinous point and raphes so as to hit the membranous urethra. The following struetures are divided:- - kin and fascie; some of the

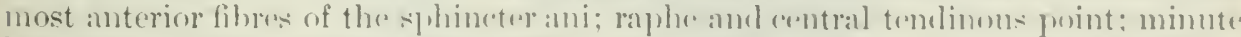

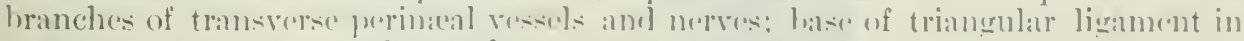

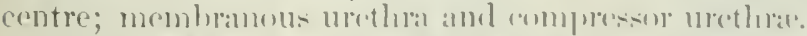

The attachments and arrangements of the superficial fascia (fig. 693) must he traced and remembered. (I) the two layers of which it enmsists, the superficial

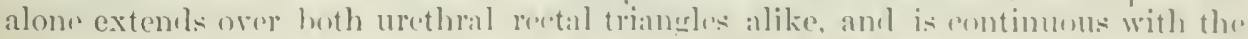
similar struetures in adjacent merions. the only difference being that, if traced for- 
wards into the serotum and penis, it loses its fat, and contains dartos fibres. The deeper layer, found only orer the urethral triangle, is called the fascia of Colles (fig. 693). Attached at the sides to the rani of the pubes, behind to the base of the triangular ligament, and open in front, it forms a somewhat triangular pouch, containing the superficial vessels, nerves, and muscles, the bulb, and adjacent part of the urethra. Owing to this space being closed behind and open in front, and to its containing the above struetures, fluids extravasated within this space will obviously tend to make their way forwards into the serotum, penis, and lower part of the abdominal wall.

The urethra.--This can be examined in part with the finger, but much better with the aid of a sound. The anterior, or penile, part is movable; the posterior, or leeper, more fixed. It is narrowest at the meatus and where the membranous urethra passes through the triangular ligament. It is widest in the prostatic part

\section{Fig. 692.-Deep Dissectiox of Male Perixaur. (Roser.)}

The bulb is slightly raised and the rectum drawn backwards, in order to make clear the membranous urethra and prostate, which are shown incised as in the lateral operation of lithotomy.

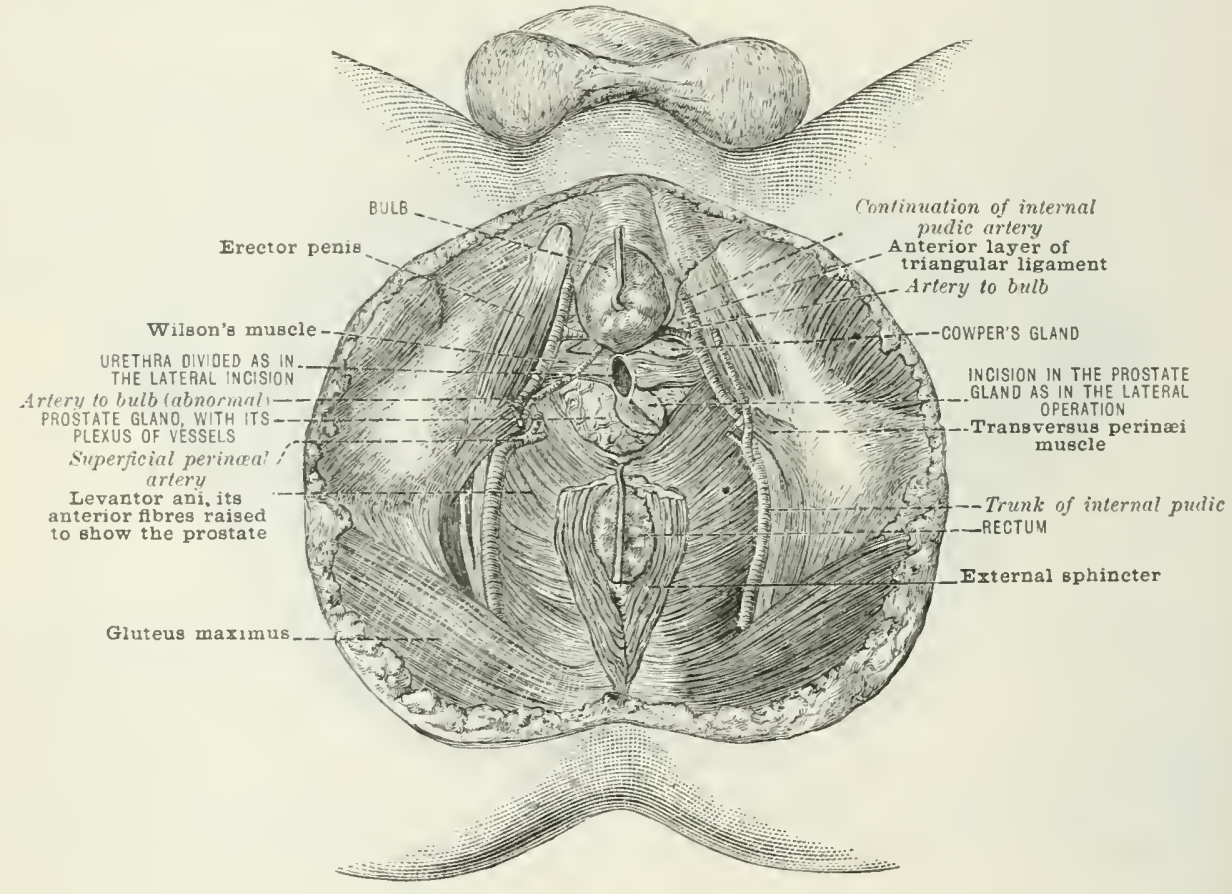

and the fossa navicularis. One of the most important landmarks is the triangular ligament, the hase of which can just be felt in a thin perinæum. The membranous urethra passes through this, about three-quarters of an inch above the central point of the perincum, about the same distance below the subpubie ligament, or an inch below the symphysis. Ahove the urethra run the dorsal vessels and nerves of the penis. The fixation, undilatability, surrounding museular fibres, and clnse neighhourhoor of a large amount of erectile tissue (the bulb), all account for difficulties in introlucing instruments past this point. It is here also that the urethra is most liable to be damaged by a fall or blow. The attachment of the deep layer of superficial fascia to the base of the triangular ligament accounts for the fact that urine extravasated from a ruptured urethra, or through an opening behind a stricture, passes usually not hackwards into the anal triangle, but forwards into the scrotum and abdominal wall. The other structures in relation with the triangular ligament are shown in fig. 693. 
FIG, 693.-TIF ARTERIES OF THE PERIXYI.

On the right side of the perinamm (left sicle of this figure) Colles's fatiat has been turned back to show the superficial ressels. On the left side the superficial vessels have been cut away with the anterior layer of the triangnlar ligament to show the deep vessels.

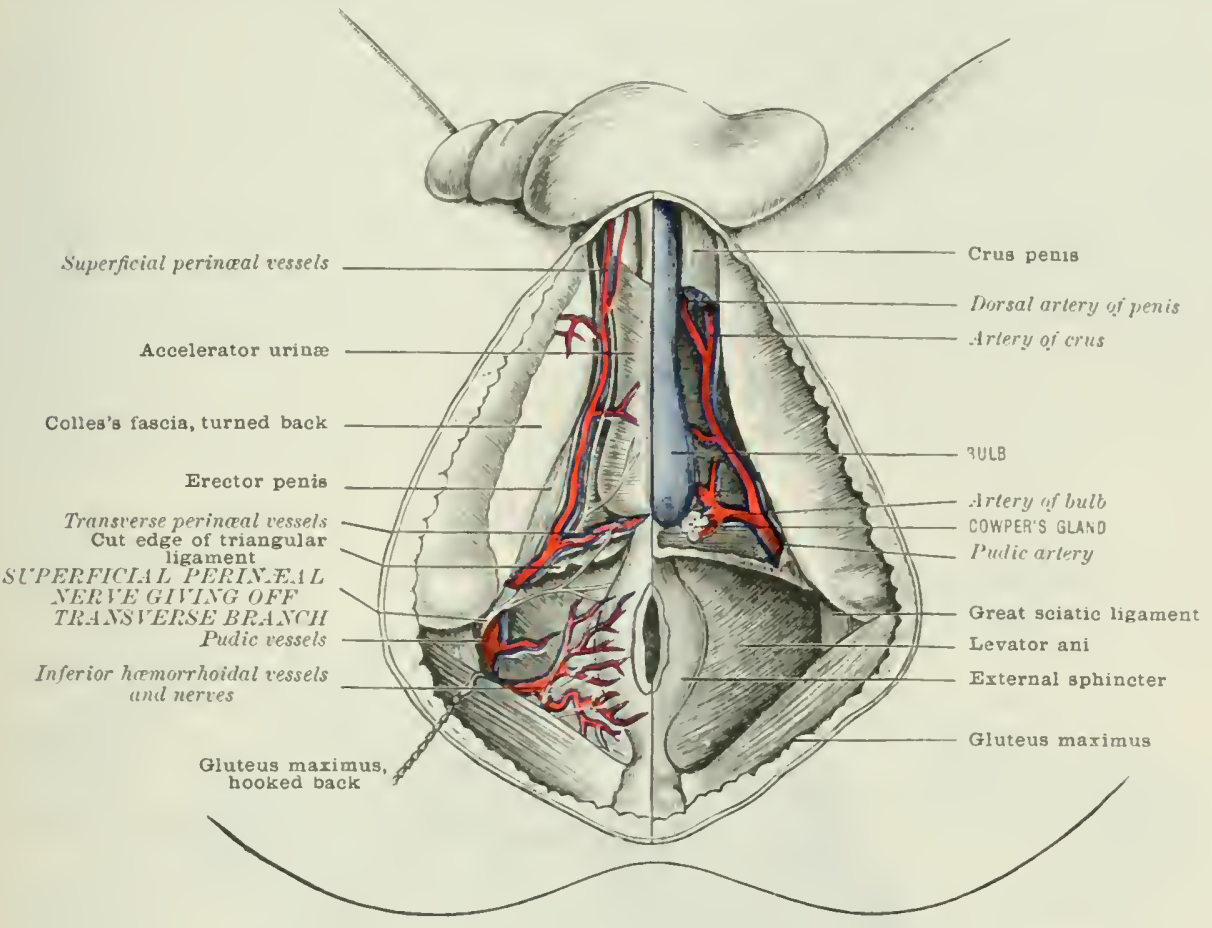

Fici. 6.4. - SagitTal section uf Male Pelvis ix the Mesial Lise. (One-third. (Braune.)

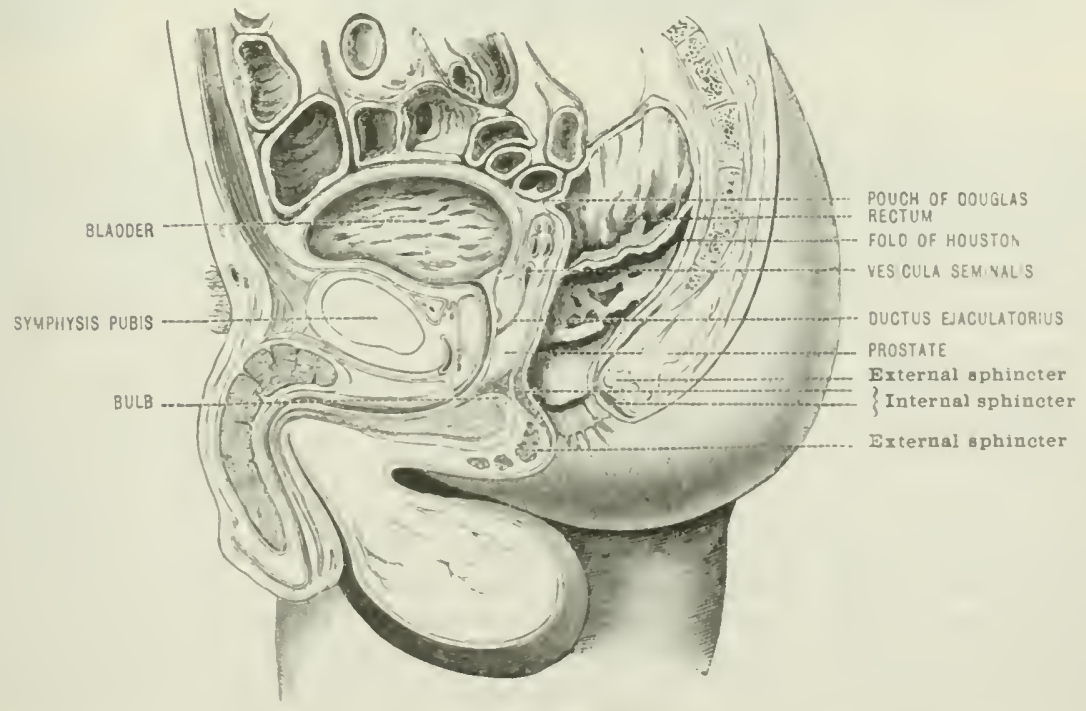


The prostate (figs. 692 and 694). - The relations of this inportant organ should be studied, whenerer possible, with the finger and somm. Loughly complarable to a chestnut in form. size, and dimensions. its baste situaterl below the neek of the bladder, blends by its musenlar tissue with this organ. As the long axis of the prostate is rery ohliegue, the hase will be directed upwards and backwards (fig. (694). The apex, resting atganst the upper or dereper la yor of the triangular ligament, lies about half an ineh behind the sulpulse angle. This part of the orean "an be detected by the finger alwout one and al half inches above the anal orifica, through the anterior wall of the rectum. Continumus with this, ame a little highere up. the posterior surface can also be malde nut through the seconel part of the howel. The anterior surface receives the puln-prostatic ligaments, and on this surface lies the greater part of the prostatic plexus (fig. 6ig(i). The lateral marrins of the gland are embracel by the anterior horders of the leratores ani. The urethra, in its course through the organ from base to apex in the midclle line, lies rather nearer to the anterior than the posterior surface. The ejaculatory cluets, as ther jaks obliquely through the prostate to upen at the margins of the sinus pocularis. mank off a portion of the gland which lies between each duct helow and the neck of the bladder above (fig. (594). It is obvious that, if this portion be enlargerl,

Fur. 695. -

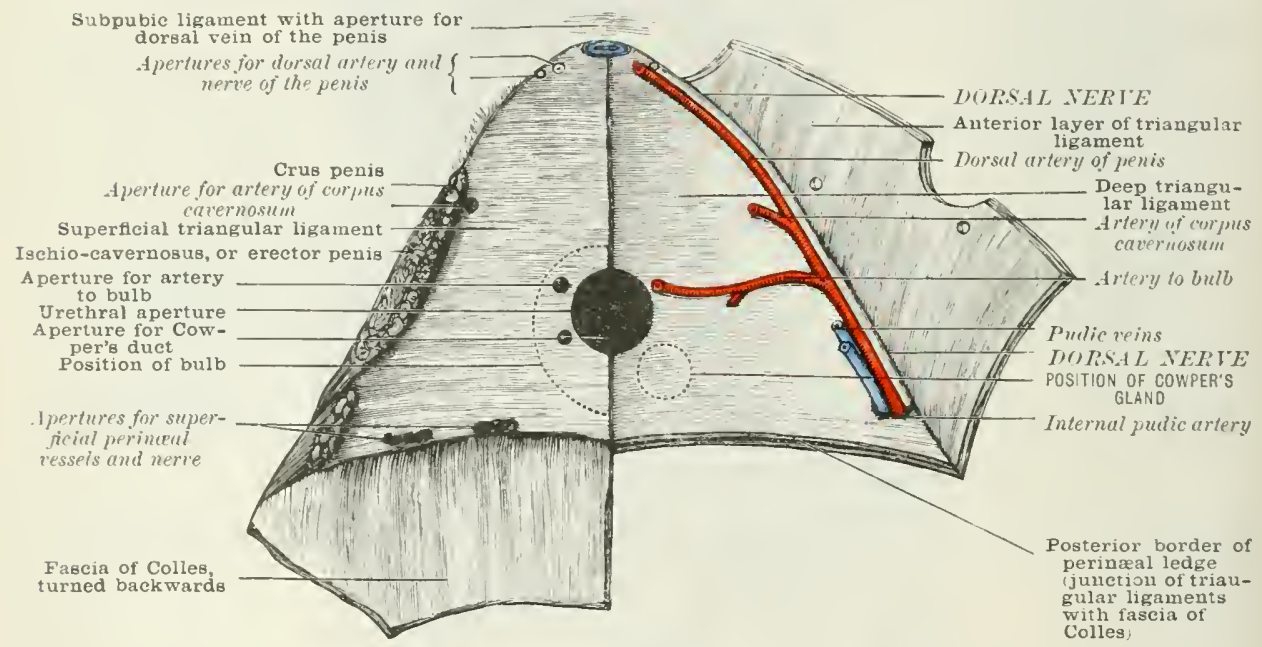

olstruction to the escape of urine from the blalder must follow. C $\mathrm{p}$ to pulserty, the prostate is imperceptible per rectum. In alolescence the orwan. while to be felt, is softer and more rounded, and lacks the dharacter and shape which distinguish the organ in adult life. The capsule (fig. $6966^{\circ}$ of the organ must he remembered. It is formed by a layer from the recto-resical fasedal, and under it, expecially on its anterior and lateral aspucts (fig. 696i), lies the prostatic plexus, formed rlicefly by the breaking up of the dorsal vein of the penis.

The continuity of the above sheath of the postate with the recto-resical fascia on the upper surface of the levator ani and the sides of the hladder forms the roof of the perinsem and fart of the floor of the pelvis. If by mistale an incision, as in lithotomy, is arriol through this prostatic sheath, the cavities of the pelvis will he openerl and extravasation of fluids into the (onnective tissue, which everyhere follows the layers of pelvic fascia, will follow. Before leaving the relations of the prostate, the rearler should consider the layers which will be met with in cutting down to this organ from the surface. The following fasc(iae and muscular layers will be mot with alternately (Cumingham): (1) skin and superficial fascia; (2) fascia of Colle; (:3) superticial primal muscle; (4) superficial layer of triangular ligament; (5) eompressor urethrar; (6) derel layer of triangular liga- 
ment; (7) levator ani; (8) capsule of prostate. Further, these fascie of the urethral triangle (p. 1123) are so armangerl as to form a superficial deep compartment, and within one or other of these all the structures of this most inupertant division of the perinem are found. Thus the superficial compartment is lommled, in front, ly the fascia of Colles; hehind, hy the triangular liganent; laterally, by the attachment of these to the margins of the pulise arch; and, helpind. by the blencline of the fascia of (olles with the base of the triangerular liganuent. The (omtonts of this compartment are given wish wore. 'The deeper compartment is the interval between the two lavers of the triangular ligandent.

Ischio-rectal fossa.- Most of the lumblaries of this space (p. 106i3) can loe made out with the finger in a thin subject. The loose, poorly vitalised fat which ocempies it, the dependent position of the part, its terminal blood-supply, its exposure to colel and damp, and the close vicinity of deeomposing fieces, all account for the frepuency of abscess here. The position of the pudic vescels and nerve in their sheath of ohturator fascia, on the couter wall, ahout an inch and a half above the lower margin of the tuber ischii, must be remembered.

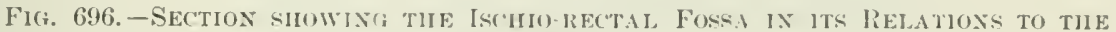
P'EITIC Viscera.

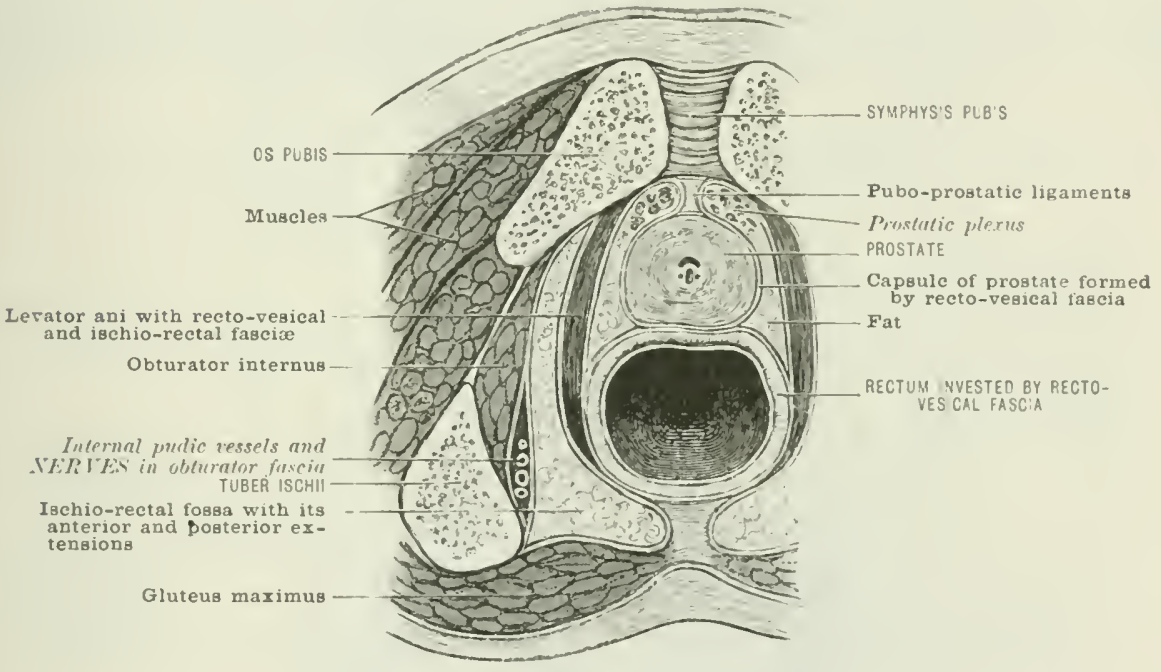

Anus.-The tightly closed andition of this orifice in health and the purkering of the skin around, duc to the sphincter and corrugator cutis ani, are characteristic. Dilated reins, external piles, or tags of skin resulting from the shrinking of these, are also common. A white line, varying in clistinctness in lifferent suljects, marks the junction of the skin anel micous mombrane, and the interval between the external and internal splumeters.(Hilon). Anomers the numerous folds: ahout the anal orifiee, a fissure or uleer may be hidelen, esperially on the cocergeal aspect; the abundant nerve-supply to this region and the large distribution of the fudlie nerve to the genitals, and the junction of this nerve with other branches of the sacral plexus, explain the acuteness of the suffering, and its wide distrilution in these affections (Hilton).

Rectum.-The following points an be male out by the finger introlued here: (1) The thickenerl, roll-like feed of al contracted external spluneter; (2) the narrower. more expanded, internal sphinetor extending upwards for an inch from this: (3) the condition of the is hio-rectal fosse on wither side; $(f)$ the momhranous urethra in front, cepecially if a staff has heen introluced: (5) just heyond the sphineters. or an inch and $a$ half within the anus. lies the prostate: (6) converging towards the base of the prostate, and forming the siles of the triangular suace, are the ves- 
culce seminales and ejaculatory ducts. These can rarely be felt unless diseased and enlarged; $(\bar{T})$ it is within this triangular space that a distended bladker can be fult, and, if the prostate is not enlarged, punctured, the trocar being driven in the direction of the long axis of the distencled viscus, i.e. towards the unbilicus. $A=$ a rule, the recto-resical pouch is reflected at a distance of three and a half or even four inches $(87$ to $100 \mathrm{~mm}$.) from the anus. In the female the distance is only three inches, or eren less. ( $S$ ) sometimes the lowest of the folds of Honston, on about the same lerel as the prostate, semilunar in form and about half an inch in width, can be made out (fig. 694).

The position of this and the other two folds of Houston should be remembered. as their presence, if well dereloped and if the howel be empty, may interfere with the passage of instruments.

In addition to the structures which can be felt, those which can be seen with a speculum, especially if the hody be seen in the semiprone or genupectoril position, must be noted. Starting from immediately within the anus are some six or eight rertical folds of mueous membrane, the columns of Glisson.

Fig. 697.-Diagrall of the Pelyic Fascia.

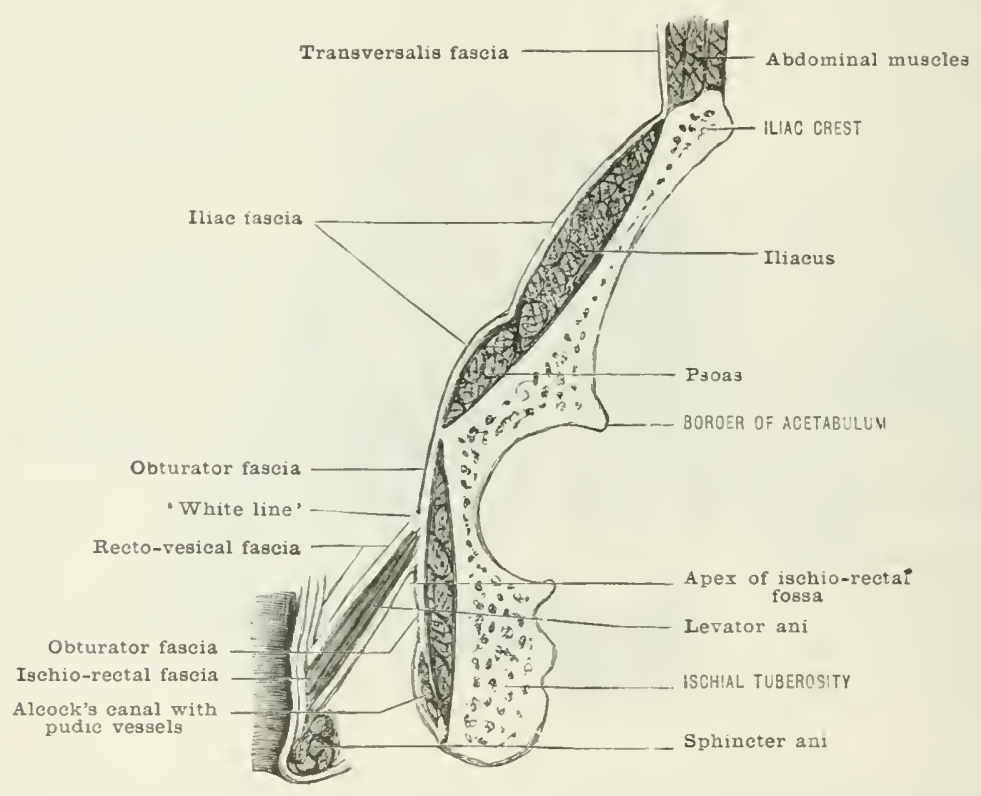

Between these columns lie little pockets or lacunse, the sinuses of Morgagni, just above the external sphincter. In the above-mentioned columns the hremorrhoidal ressels ascend and descend, intercommunicating by numcrous transverse branches.

The above "xamination refers chiefly to the male. It remains to refer to rectal examination in the female. Anteriorly, the soft perinæal body and rectovaginal septum will be met with, and, through the latter, the cervix and os uteri, and, higher up, the lower part of the eervix uteri. More laterally the ovaries may be felt, but the Fallopian tubes. mnkess enlarged and thickened, are not to be made out. The student should be familiar with the fecl of a healthy recto-nterine or recto-resical pouch, accorling to the sex, and the coils of intestine which it may contain, so as to be alble to contrast this with any collection of inflammatory or other fluid or mischief rescencling from the upper pelvis, e. o. from the rermiform appendix. Posteriorly, eertain structures are met with in either sex. After a very short interval (splineter and ano-cocergeal body). the finger reaches the tip of the roceyx and explores the hollow of the sacrum. On each sile is the ischial tuberosity and wall of the true pelvis. The finger, hooked outwark and upwards, cones 
on the border of the falciform proesess of the great sacro-seiatic liganent patsine between the above-mentioned hones.

The pelvic fascia and its ehief lavers are shown in fig. (j9). These are deseribed at page 106(0. The following main points will readily be seen: That the fasciat has one important aspect towards the pelvic, and anchther towards the isehio-reetal fossil and perineun, and thus naly he interferesl with during operations, or affected by infammation arising in either region. That its numerous processes and sheaths, while they serve to isolate different structures, are continuwus and that thus septic mischief may, as in the neck, spreat most widely. With this fact go two other points: one, that with the planes of this faseia run lavers of connection tissue; the other, that in the slaces tightly girt hy this farcia lie litrese renous plexuses, e.e. resical, hamorrhoblal, prostatic, and, if septic mischinef roach these plexuses, it is out of reach of surcical treatment. The closeness of the fascia to the hip-joint will also be seen. In children with a thin acetabulum and hip disease this fascia beconnes mueh thickened, thus shutting off the pelvic carity from suppluration in the joint.

\section{FEMIILE EXTERIII, GENITALS}

Under the above healing are included, for convenience sake, the lathia majora and winora at the sides; and, in the midcle line, from ahove downards:-(1) The glans clitoridis with its prepuce; (2) the vestihule; (3) the urethral orifice; (4) the

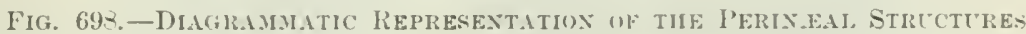
II TIE FEMALE.

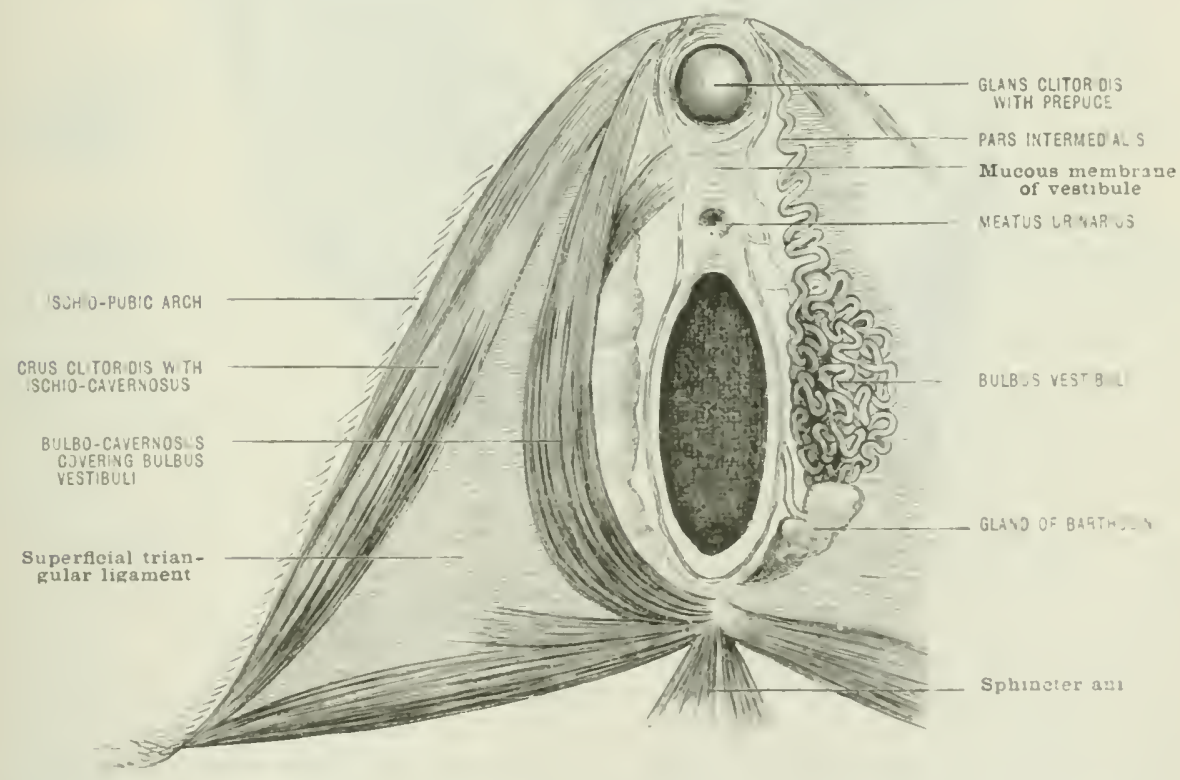

vaginal orifiee with the hymen or its remains: (j) the forsat navicularis: (lit the fourchette; ( 7 ) the skin iver the hase of the perinceal hods.

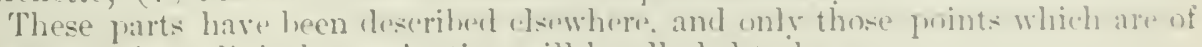

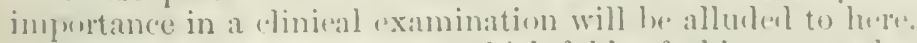

The labia majora are two thick folkl: of skin, (otered with hair on their outer surface, especially above where they unite (unterion anmmisarner) in the mons

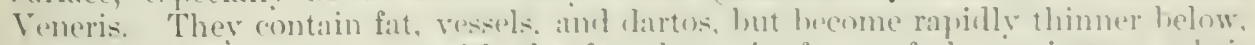
where they are continuous with the fourbette in front of the jerinam (their posterior commisiure).

When the ahow folds are drawn aside, the labia minora, wr nymphæ, alplear, 
not projecting, in a healthy adult, beyond the labia majora. They are small folds of skin, which meet ahove in the prepuce of the clitoris, and below blend with the labiat majora about their centre.

The glans ditoridis. covered by its prepuce, oceupies the middle line above.

Below it comes the vestibule, a triangular smooth surface of mucoms membrane, hounderl above by the clitoris, helow by the upper margin of the vaginal orifice, and laterally ly the labia minora. In the midlle line of the restibule and towards its lower part, about half an inch (12 $\mathrm{mm}$.) below the glans ditoridis, and an inch (25) mm.) abore the fourchette. is the meatus or opening of the urethra (figs. 6is. 699).

The vaginal orifice lies in the middle line between the base of the restibule

Fir. 699.-Section of the Feyale Pervis. (After Henle.)

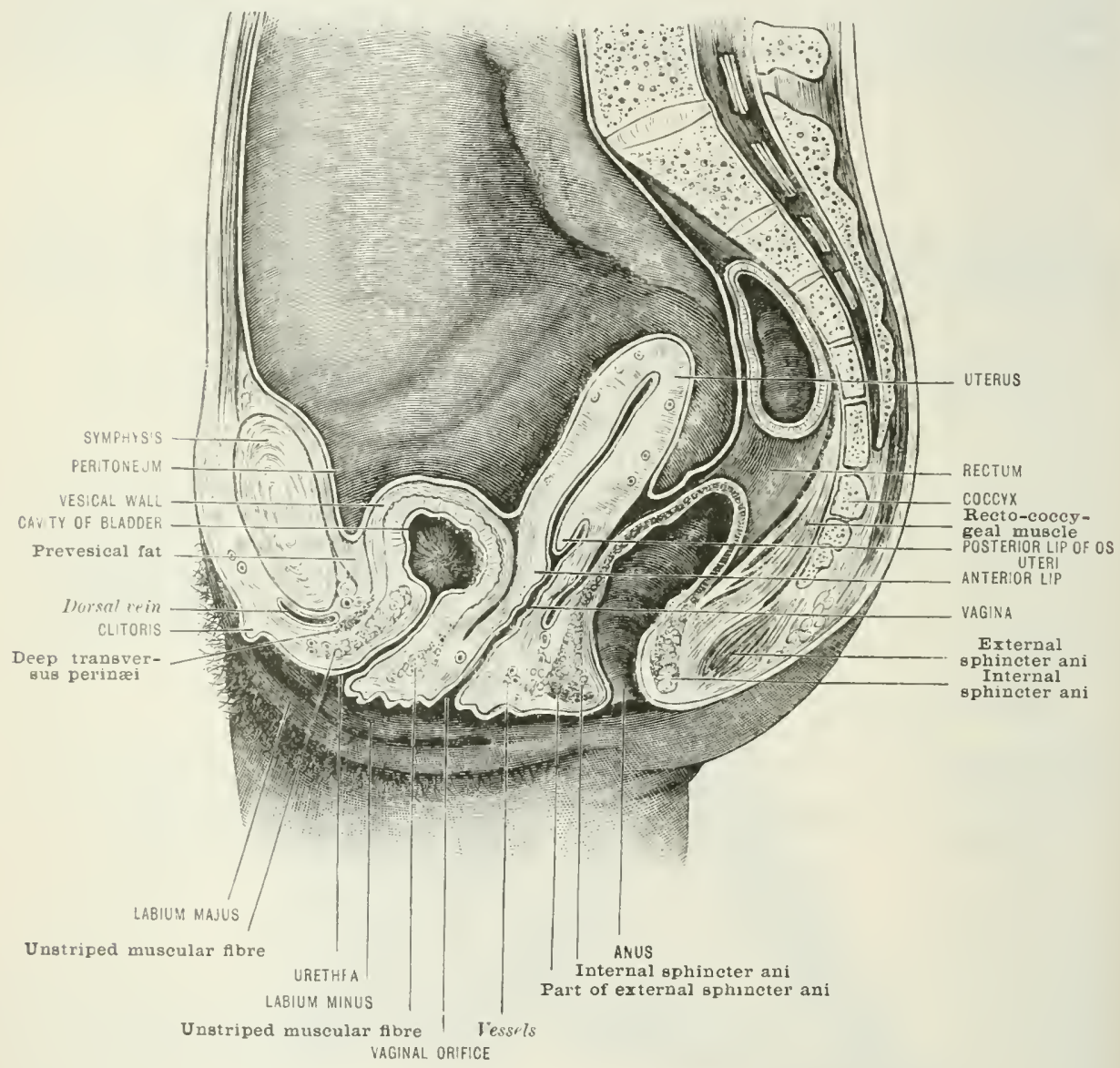

above, and the fossa navicularis below. Its orifice is partially closed in the vircin hy a fold of mucous membrane, the hymen (fig. (i31). This is nsually erescentic in shape, attached below to the posterior margin of the vaginal orifice, and with a fres edge towards the base of the vestibule. In some cases it is diaphragmatic, i.e. attached all around, but perforated in the centre (fig. 698 ).

The shrivelled remains of the hymen probably eonstitute the carunculæ myrtiformes. On either side of the vaginal orifice, at its lower part, lie the racemose, muciparous sland of Bartholin, situated beneath the superficial peringal fascia and sphincter vagine. Their ducts rum slightly upwards and open, external to the attachment of the hymen, within the labia minora.

Fourchette and fossa navicularis.-The fourchette, as stated above, is the lower commissure of the labia majora. Nommally the inner aspect of this is in 
contact with the lower surface of the lymen. When the fourchette is pulled ilown by the finger, a shallow depresion is seen, the fossa navicularis, with the fourchette for its posterior, and the lymen for its anterior boumdar?.

Examination per vaginam.-The finger, introluced paist the gruteal eleft.

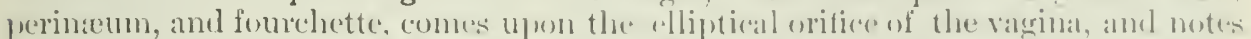
how far it is patulous or narrow; the puresence ol otherwise of any spatsu from the

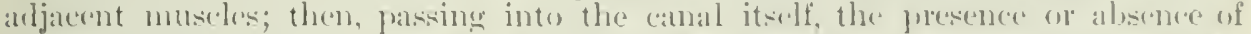
rugae, a naturally moist, or a dir comblition are observerl. In the anterior wall the cord-like track of the urethra cain be detected; and further up than this. if a sount be passed, the posterior wall of the blakler. The anterior wall of the valgina is two to two and a half inches lome. The posterior wall, three inches loner forms the recto-vaginal septum, and through it any fieres poresent in the lwwel are easily felt.

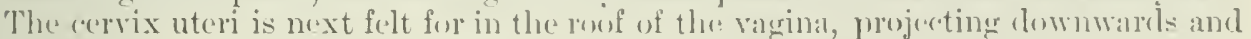
backwards in a line drawn form the umbilious to the corery. Berseles its direction,

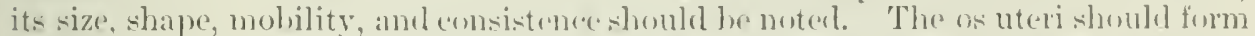
a dimple or fissure in the centre of the cervix. Of its two lips the posterior is the thicker and more Hesly freling of the two. The vaginal anls-de-sor or formiers are next explored. The should les soft and clastic, giving an impression to the finger similar to that when it is introlurerl into the angles of the mouth. Any resistance felt here may be rlue to sears, swollings commerterl with the uterus (displacements, or myomata), effusions of hlood or inflammatory material, and, in the case of the lateral culs-rle-sac, a displaced or enlarged oviry, or dilatations of the Fallepian tulus.

\section{HERTIA}

\section{PARTS CONCERNED IN INGLINAL HERNIA}

In inguinal hernia, as in femoral and mombilical, there is a weak spot in the abdominal wall-one weakened for the needful passage of the texticle from within to outsile the abdomen. The parts immerliately concemed are the two abdominal rings, "xternal and internal, and the canal. Now, it must be remembered at the outset that the rings and canal are only potential - they do not exist as rings or eanal save when opened up ly a hernia, or when so rinale hy the scalpel. "The canal is merely an obligue slit or that-sided passige. The extermal and internal rings areso intimately blended with the structures that pass through them, and so filled hy them, that they are potential rings ouly.

EXTERNAL RING.-This is usually clescribed as a ring: it is really only a separation or gap in the aponeurosis of the external olificue, ly which in the male the testiele and eord, and in the fomale the romel ligament hy whed the uterus is kept tilted a little forwards, pass unt from the abdonsen. The size of this opening. the development and strength of its sides or pillars, the fascia elosing the ring-all vary extremely. Formation: ly clivergener of two fasciculi of the external oblixue aprinemrosis. Boundaries: two pillars-(1) Internal, the smaller, attalderl to the srmplyyis and hleudiner with the suspensory ligament of the penis; (2) external. strongere, attacherl to the pubie spine and blending with Pouprart's ligament, and so with the faseia lata. On this outer, stromger pillan rests the corrl (amel su the weight of the testicle), or romml ligament. Shape: triangular or ellijetial. with the hase downorils and inwarts towarls the pubic crest.

Intercolumnar fascia. External spermatic fascia.-C'This. derivel from the

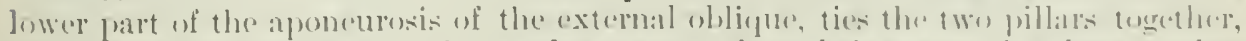

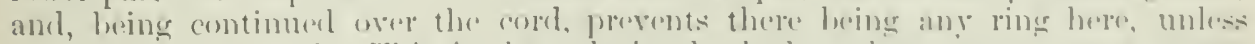

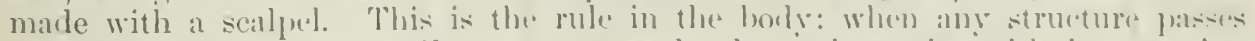

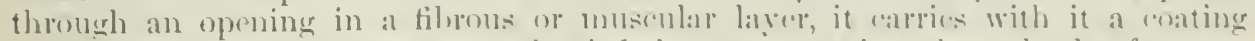
of tissue from that layer; e.g. the inferior caria passing through the foramen 
quadratum in the diaphragm, and the membranous urethra through the triangular ligament.

Effect of position of the thigh on the ring.-As the lower pillar is blended with Poupart's ligament, and as the fascia lata is connected with this, morements of the thigh will affect the ring much, making it tighter or looser. 'Thus extension and abduction of the thigh stretch the pillars and elose the ring. In flexion and adduction of the thigh the pillars are relaxed; and this is the position in which reduction of a hernia is attempted. In flexion and abduction of the thigh, the ring is open; and this is the position in which a patient should sit, to try on a truss, and cough. If the hernia is mow kept up, the truss is satisfactory.

Helping to protect this most important spot, and preventing its being more than a potential ring, are not only the two pillars, and the intercolummar fascia, but also

Fig. 700.-The PARts coxcersed ix Ixglixal Hersia.

(From a dissection in the Hunterian Musenm.)

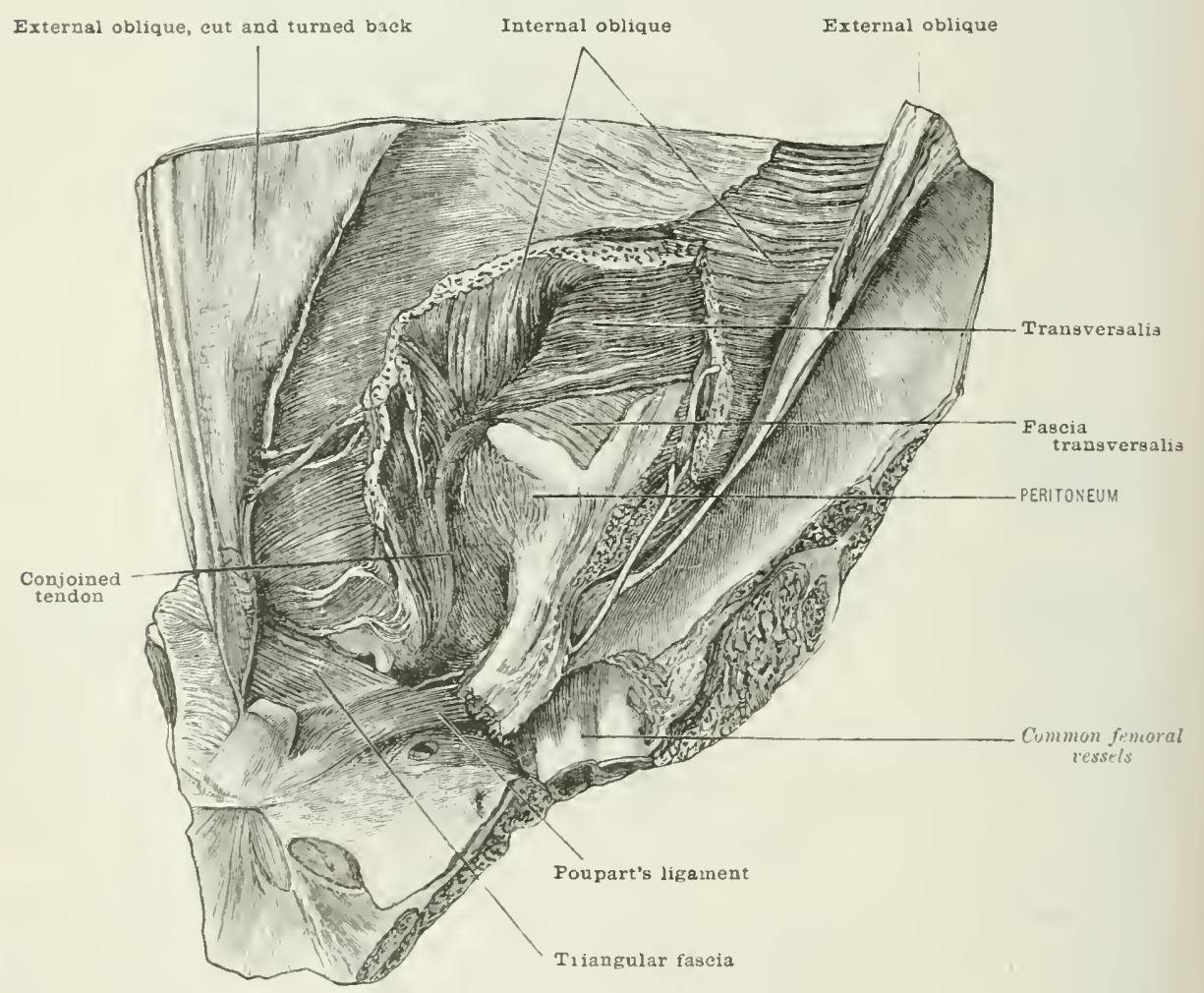

a struture which has been called a thirc or posterior pillar, namely, the triangular fascia. This has its base above at the lower part of the linea alba. where it joins: its fellow and the aponeurosis of the external oblique, and its apex downwards and outwarks, where, having pasierl behind the internal jillar, it blends with Gimbernat's ligament. Again. the ennjoined tendon of the internal oblique and transversalis curving inwarts and downwarls to be attached to the ilin-pectineal line and spine is a most powerful protection, behind, to what is otherwise a weak sjot and a potential ring.

INGUINAL CANAL.-This is not a canal in the nsual sense, lut a chink or flatsirfed passage in the thickness of the ahdominal wall. The descriptions of the canal usually griven apply rather to the diseaserl than to the healthy state. It was a canal oner, and for a time only, i.e. in the later months of fortal life. It remains weak for a long time after, but only a vestige of it remains in the well-made adult. On the inner surface of the abiomen we have a few inconspicuous inguinal 
fossettes; on the outer surface a separation hetween the fasciculi of the "xtrinul oblique, carefully closed and protected; in the interval leetween the two surfaces lies the eorl or round liganent, in the thickness of the alshominal wall.

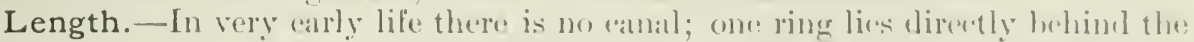
other, so as to facilitate the masy pastige of the testis. In the arlult it meatures

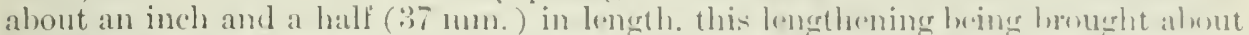
ly the growth and separation of the alate of the pelvis. 'This increased cololiguity gives adelitional safety.

Direction.-From internal to extemal ring, downwards, forwards, and inwards.

Boundaries.-For convenience sake, certain limits (largely artificial) have been namerl-

(1) Floor. -This is best marked near the outlet, where the cord rests on the

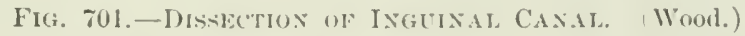

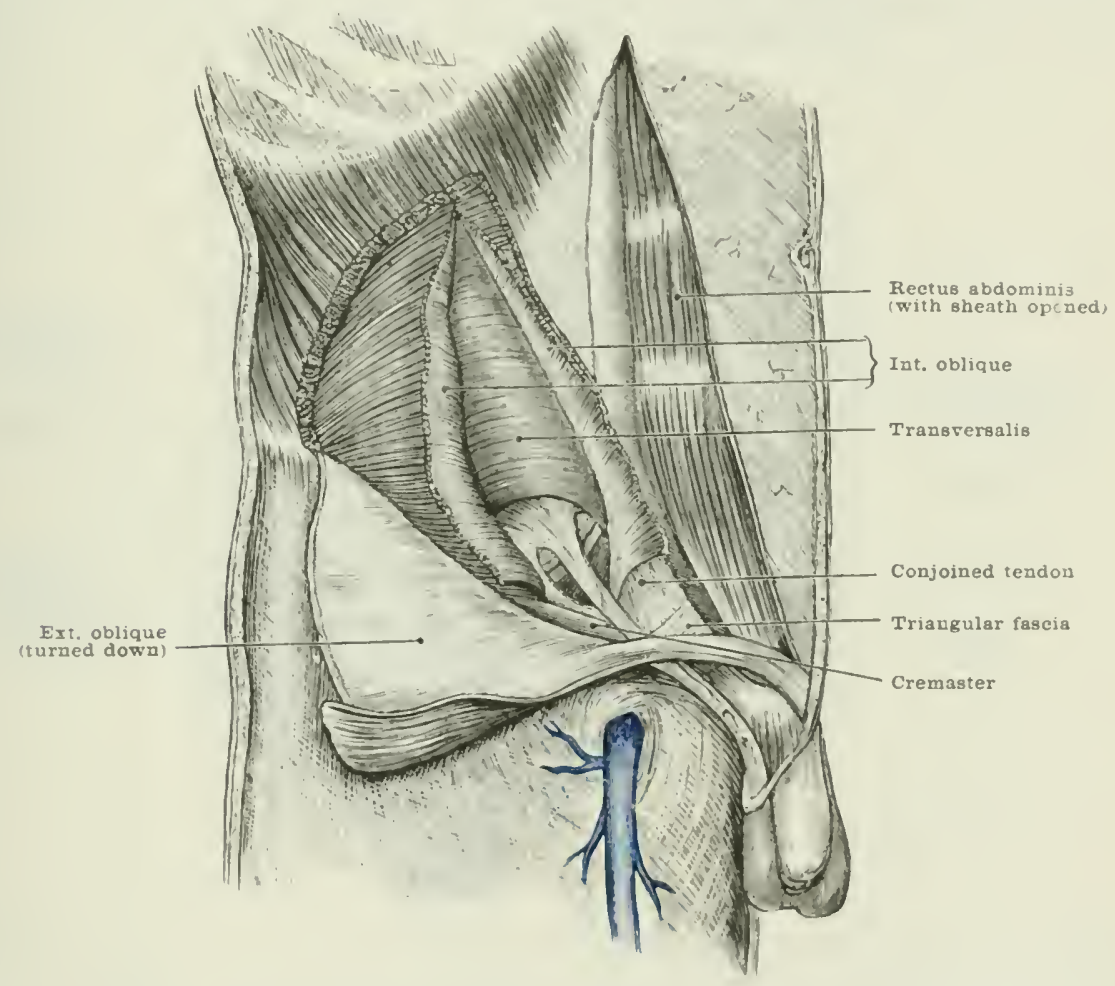

growed upper margin of Poupart's ligament. The meeting of the transversalis fascia with this ligament forms the floor.

(2) Rerof.-The apposition of the museles and the arehed horder of the intermal oblique and transversilis.

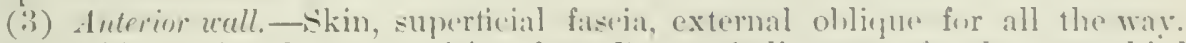
Intemal obligue, i.e. that part arising from l'oupant's ligament, for the onter thirel ()I $\mathrm{s}()$.

(4) Posterior wall. -For the whole extent, transwersalis fascial extratperitoneal tissue, and peritomeum. For the inner two-thirds, conjoined temlon of internal oblique and transwersalis, and the outer edge of the triangular fiscils, when developed. Of the structures forming the posteriol wall, the transtersalis farciat is tho strongest. It is thicker and hetter marked at its attachments below; these are -(a) externally to inner lip of iliar crest: (b) to l'oupart's ligament between the anterior superior spine and the femoral vescels: loce it joins the fascia iliaca: (r) 
opposite the femoral vessels it also joins the fascia iliaca, and forms with it a funnel-shaped sheath; ( $l$ ) internal to the femoral vessels the fascia transversalis is attached to the ilio-pectineal line, behind the conjoined tendon, with which it hlends.

INTERNAL RING.-It has already been said that the term 'ring' is here misapplierl except in an artificial sense, it when an opening is marle by a scalpel; or in a pathological one, as when a hernia is making its way by opening up the parts. The terms 'intermal' and 'external' are also misapplied as far as their usual application to the middle line of the body is concerned. The terms apply to depth only. The 'internal ring' is not a ring in the least, but merely a funnel-shaped expansion of the transversalis fascia, which the cord carries on with it as it escapes from the abdomen. This expansion may be weakened, but it is never an opening save when made so artificially.

Site.-Midway between the anterior superior spine and spine of pubes. Shape:

Fig. 702.-Dissection of the Lower PARt of the AbDominal Wall from withix, the Peritoneud havisg beex removed. (Wood.)

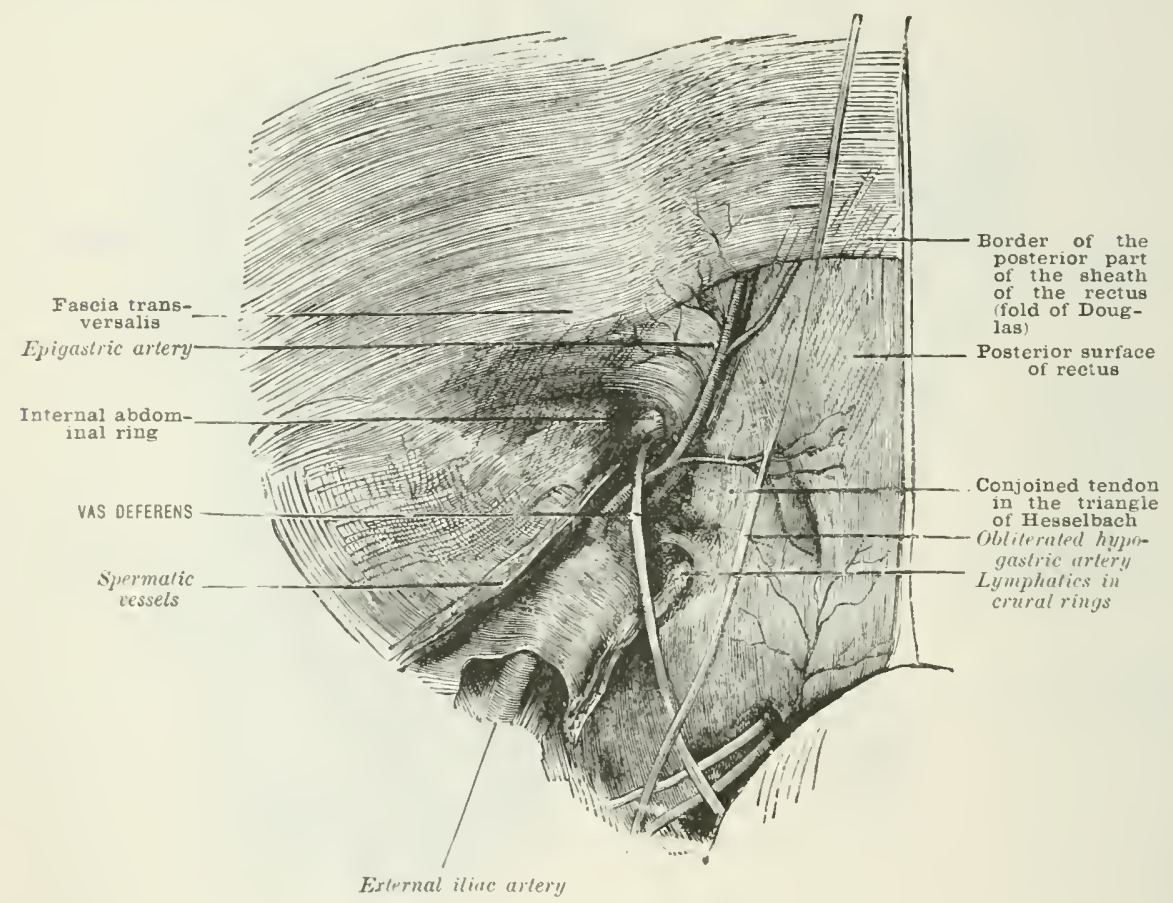

oral, with the long liameter upwards. Dimensions: one inch (25 mu1.) hy half an inch. Both these are artificial. Boundaries: entre of l'oupart's ligiment, about half an inch below. Internally, the deep epigastrie artery (fig. 702 ); and thus the inner side seems to he better defined. But the outer side is really the better defined, as here the transversilis finscia is descending to Poupart's ligament, to form the deep 'crural' arch, and to help to close in the great gap' or noteh between Poufart's ligament and the innominate bone. Owing to the artery lying to the inner side, the incision, in entting to relieve the deep constrietion of an inguinal hernia, should always be made directly upwarls, so ats to aroid the alore vessel.

Coverings.- There are two chief forms of inguinal hernia:-

1. The common form : external, or oblique.-External, breause it appear: (at the internal ring) external to the deep epigastric artry. Oblique, lreatuse it traverses the whole of the inguinal canal, entering it at its inlet and learing it at its outlet.

B. Rarer form: internal, or direct.-Internal, because it appears internal 
to the deep epigastric artery. Direct, lucance, instral of making its way down the whole oblique canal, it eones by a short ent. as it were. only inte the lowrr part of the canal, and then morges by the sime opening as the other.

A. Oblique, external inguinal hernia.-This (ontilins its coverings is follows:-

(1) At the internal ring, or inlet, it olutains three:-(a) I'eritomann; (b) extrat-peritoncal fat; (c) infundibuliform fitscia, or the layer of transwersalis fitsial prolonged at this spot along the cort.

(2) In the canal it obtains one. As it cmerges lwenth the lower lumer of the internal oblique, it gets some tibres from the cremaster.

(3) At the external ring, or outlet, the hemia olutins three. viz.: (1) Intercolumnar fiscia; $(b)$ superficial firseia; ancl $(c)$ skin.

B. Direct or internal inguinal hernia.-This does not come through the internal ring, but, making its way through the yosterior wall of the lower third of the canal-i.e. the conjoined tendon, either jushing this forware or splitting itgets its coverings only from struetures in relation to this part of the canal. They are-(1) Peritoneum; (2) extra-peritoneal fat; (3) transersalis fascia not the

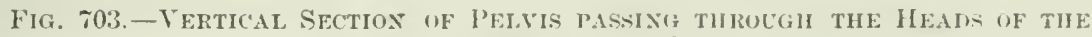
THIGH Boxes. (Blandin.

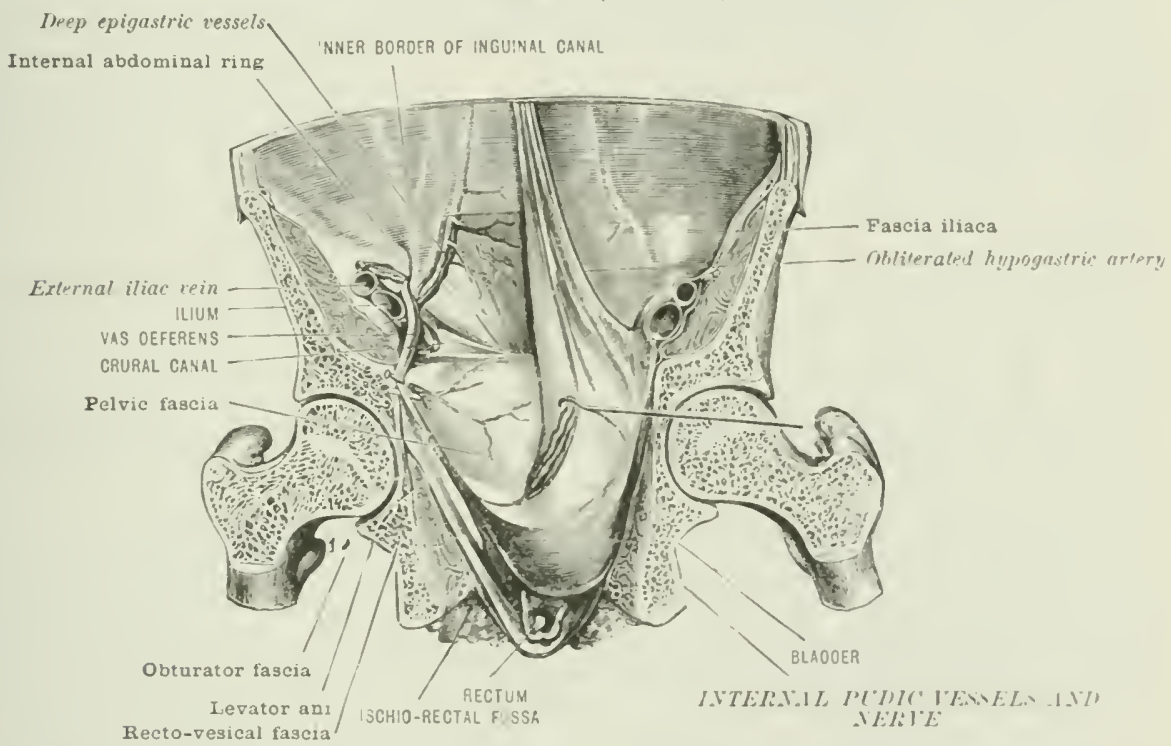

specialised part at the internal ring or infundihuliform fascia); ( 4 ) conjoined tendon of internal olslique and transversalis. At the outlet of the external ring the coverings obtained are the same as in the ollique hernia, viz. (5) intercolumnar fiscial ( (i) superficial fiscia; ( 7 ) skin.

Hitherto the two forms of inguinal hernia have been considered from the superficial aspect, that in which they are met with in lractice. The inguinal remions shumb also bestudied as to the posterior aspect of its so-ralled rings and canal, as these have to bear the early stress of a commeneing hernia. It is agranet this alsect that a piece of omentum or intestine is eonstantly and insidious ly pressing, and rndearouring to malie its way out. Furthermore. when either of the alwore constituents of hernia have made their way a little farther, and got out into the internal ring or into the (anal. the pationt is no lonerer sumel.

On the posterior wall are certain cord: and deperesons, matking off regroms which correspond to these on the surfien.

Thus, there are three luminent cords, and three fossæ.

Three cords-(1) Melian, or urachus; (") laterill, or the obliterated hypogastric arteries. 
(1) Median, or urachus: This interesting fortal relic, the intra-ablominal part of the allantois, passes up between the apex of the bladder and the umbilicus, and hy $\Leftrightarrow$ doing-(a) keeps the bladder up, especially in early life, when the pelvic: cavity is but little develeperl; (b) it keeps the bladder well up so that it shall he ahore the level of the uretha, and so more easily emptiod; (r) it provides, by thus kerping up the bladder: that it shall enlarge in a clirection which will admit of the greates amount of distension, i.e. one between the Inwer or yielding part of the ahdominal wall and the hollow of the rectum, which is compressible.

(2) The obliterated hylogastric arterics. These, the remains of vessels which luring fortal life carry the inmpure blood of the foetus out to the mother through the umbilicus, run uj) and join the urachus at the umbilicus. In relation to these cords are the following fossæ: (a) An internal one, between the urachus and the obliterated hypogastrie artery. This eorresponds, on the anterior surface, to the extermal abdominal ring. 'Through this fossa comes direet inguinal hernia. (b) Between the obliterated hypogastric artery and the deep epigastric artery, running upwards and inwards to form the outer boundary of Hesselbach's triangle, is a middle fossa. This is the smallest of all. (c) The external fossa is outside the (terp epigastric artery. It is the most distinct of the three, from the way in which the cord or round ligament passes down within a glove-like process of the transversitis fascia. This fossi corresponds to the internal ring.

Varieties of inguinal hernia according to the condition of the vaginal process of peritoneum. - Inguinal hernix have above been classified according to their relation to the deep epigastric artery. It remains to allude to the arrangement of these same hemia according to the varying condition of the processus funiculo-vaginalis. This pouch of peritoneum, which pares the way for the pas-age of the testis before this organ makes its start, eventually beconies the tuniea vayinalis below, in this fashion: Very soon after birth the process becomes oblit"rated at two spots-one near the internal ring, and one just above the testicle. The obliterative process, commeneing first above and descending, and then, ascending from below, the shrivelling continues until nothing is left save the tunica raginalis hwow. The following are possible outcomes from an imperfect obliteration of the jrocess-the first, alone, is common:-

(1) If the process does not close at all, a descending hernia is called congenital. This may make its way into the scrotum. The testis is now enreloped and concealed by the hernia.

(2) If the process is closed only above, i.e. near the internal ring. the hernia may make its way behind the unobliterated processus funiculo-vaginalis. To this variety of inguinal hernia the name infantile has been given. Its only importance is that during any operation for such a hernia three layers of peritoneum would have to be divirled before the hernial contents could be reached. If, again, during some exertion, the hemia rupture the obliterating septum which has formed above, the condition of things to be lealt with is practically that of a congenital hemia.

(3) If the processus funieulo-vaginalis be closed below and not abore, a patent tubular process of peritoneum will lead down as far as the top of the testis. Any Inenia into this process is ealled a hernia into the funicular process.

Inguinal hernia in the female.-The inguinal canal in women is smaller and narrower than in men. Inguinal hernia is, therefore, uncommon in the female sex, and only occurs before adolescence, in patients who happen to be the subjects of an unobliterated processus funiculo-vaginalis, which extends for a varving distance along the round ligament, and is called the canal of Nuck. Inguinal hernia in the fomale is, therefore, alwars congenital. It is, practiealiy, always of the olilique variety, and travels along the round ligament towards the labium majus. Its coverings will be the same as those of the oblique variety in the male, save that the cremaster, as a listinct muscle, is absent, and any fibres of the internal oblique which may be present are but little developed.

Causes of hernia.-It will he well, while the anatomy of hernia is being considered, to refer brielly to the eauses, as many of these are intimately bound up with the anatomy of the frarts. Amongst the chief are the following:-

(1) Hereditary, viz. weakness of ahdominal wall; openness of rings.

(2) Weak spots.-(a) The presence of the cort; (b) deficiency of some of the 
layers below; (c) persistence of the original process of peritoneum; (d) a long mesentery or suspensory ligament of the intestines. Mr. Lockwood has shown that the mesentery is relatively larger in infancy, and that there is a rapid decrease after the second year. In adults its length is about eight inches, and any lengthening of the mesentery beyond this point is likely to be combined with a protuberant belly. He shows further, with regard to the range of descent or the excursus of the intestines, that it is extremely rare to find a mesentery so short, or attached so high, as to prevent the intestines escaping or being drawn from the abdomen.

The long mesentery of infancy and childhood is usually associated witl considerable downward drecent of the intestine; and in the adult it is quite common to find that the small intestines will pass an inch and a lalf bevond the right crumal arch, one inch beyond the pubes, and up to the left erural arch.

(3) Stretching of the abdominal walls by pregnancies, etc.

(4) Increase of the volume and weight of the parts within: c.g. omentum by deposit of fat in it.

(5) Sex. Thus, men have larger inguinal rings. Women have a larger femoral arch, and one less well filled in by muscles, and with less strong fascir meeting, e.g. iliac and transversalis.

(6) Cough, asthma, bronchitis, habitual fretfulness or crying.

(7) Straining to expel urine, as with phimosis, stricture, stone in bladder, etc.

(S) Straining in defecation.

(9) Lifting heavy weights.

(10) Results of wounds or abscesses which have weakened the abdominal wall.

(11) Whatever diminishes the abdominal cavity, e.g. tight lacing.

\section{FEMOR.AL HERNIA}

As many of the parts concerner here are also met with in inguinal hernia, one description, given now, will suffice.

With regard to descriptions of the inguinal and femoral regions, it is always well to bear in mind the following:-(1) That the so-called rings and canals are merely weak spots in the inguinal and femoral regions, and that they do not exist distinctly, and do not get beyond the potential stage, unles made by a scalpel or a hernia; (2) that at the fold of the groin most of the layers blend together, and that descriptions of them as separate layers, for convenience sake in learning them, are more or less artificial; (3) that the description of these layers has been most needlessly complicated by the number of terms used, many of which are simply substitutes for others; (4) many of these terms are not only useless but incorrect, e.g. siphenous, crumil, etc.

Parts concerned in femoral hernia. (1) Skin and superficial fascia of groin.-The latier consists of two layers: ( 1 ) Superficial iayer of superficial fascia.-Fatty, met with oxer the whole grom, and continuous with the superficial fascial of the rest of the borly. (b) Deep layer of superficial fascia.-Thin and membranous, only met with over the lower third of the almlominal wall and to the inner side of the gromin. It is continuous through the sorotum with the deep layer of the superficial fascia of the perinem. Just below Poupart's ligament it is joined to the fascia lata. From these two facts it results that in rupture or giving way of the urethat the extravasated urine may come forwards by way of the genitals (page 1124) and from the continuity of the fuscia make its way on to the abdomen, but not lown on to the thigh.

Between the two layers of superficial fascia lic the superficial glands of the groin, the superficial branches of the (ommon fi-moral artery. one or two cutaneous nerves, and some veins desereding to the saphenous opening to join the long saphena vein.

(2) Poupart's ligament.-This is also known as the erural arch, a misnomer. as 'crus' neans legr. A description of its shape and attarhments is given on page. 1114. Owing to the connection of the fascia lata to its lowre londer, the 'saphenous opening,' which is situated in the fascia lata, and has its upluer comn 72 
blending with Poupart's ligament, will be affected by movements of the thigh, much as is the extenal abdominal ring, being tightened and stretched when the limb is extended and abducted, relaxed when it is adducted and flexed.

The parts beneath the ligament which block up the gap between it and the inmominate bone are of the utmost importance in preventing the escape of a femoral hernia.

The different structures are arranged in three compartments, named from without inwards-A. Outer, or iliac; B. Central, or vascular; and C. Inner, or pectineal. Of these. the first is the largest; the secont or central one lies on a plane slightly more superficial, or nearer to Poupart's ligament, than the other two; while the innermost compartment differs from the other two by not communicating with the pervis, being closed above by fascia (vide infira). (A) The outer, or iliac, compartment is bounded in front by Poupart's ligament and the iliąe fascia, which is here blending with it, behind by the ilium, externally by this bone and the sartorius, and internally by the ilio-pectineal septum, which, descending from the blending of the iliac fascia and Poupart's ligament ahore, passes down to the ilio-pectineal eminence, and thence to the inner aspect of the front of the capsule of the hip-joint. This compartment transmits the ilio-psoas and anterior crural and extemal cutaneous nerves. (B) The central, or vascular, compartment is bouncled, in front, by Poupart's ligament and the transversalis fascia, which here blends with it, forming the so-called deep crural arch, and at the same time descencls on to the front of the femoral sheath. The posterior boundary is formed by the meeting of the ilio-pectineal septum externally and the pectineal fascia or sheath from within-internally Gimbernat's ligament, and externally the iliopectineal septum. This central compartment transmits the external iliac vessels and crural branch of the genito-crural nerve. This lies to the outer side of the artery, the vein internally. Between the rein and the base of Gimbernat's ligament is the femoral canal (ride infia). (C) The innermost, or pectineal, compartment is bounded by the peetineal fascia continuous with the pubic part of the fiscia lata, and behind by the pubic ramus. It lodges the upper end of the pectineus musele, and the handle of a scalpel passed upwards along the musele would be prevented from passing into the pelvis by Gimbernat's ligament and the blending of the pectineal fascia with the upper border of the pulic ramus.

(3) Gimbernat's ligament.-.This is merely the triangular intemal attachment of Poupart's ligament. Its apex is attacheil to the pubic spine; of its three borders, the base is free towark the vein and the femoral eanal. Its upper border is continuous with Poupart's ligament, its lower is attached to the ilio-pectineal line.

(4) Fascia lata.-Two portions are deseribed over the upper part of the thigh:- ( $a)$ An iliac, extemal and stronger, attached to Poupart's ligament in it: whole extent and lying over the sartorius, ilio-psoas, and rectus. (b) A pubic, internal, weaker, and much less well defined, is attached abore to the ilio-pectineal line and the spine of the pubes. The upper comu of the 'saphenous opening' is at Gimbernat's liganent, and at the lower cornu the two portions of the fascia blend.

Their relation to the femoral vessels. -The iliac portion, being attached along Poupart's ligament, passes orer these. The pulbie portion, fastened down orer the pectineus, which slopes down on to a deeper plane than the adjacent museles, passes behind the femoral vessels to end on the capsule of the hip-joint.

(.5) Saphenous opening.-This is doubly a misnomer. It is not an opening, hut an oval depresion, situated at the spot where the two parts of the fascia lati diverge on different levels. As without dissection it is not an opening, but an oval depression, fossa ovalis would have been a better term, were it not otherwise employed. Though the fascia lata is wanting here, there is no real opening, as the deficiency is made up by the deep layer of superficial fascia, or cribrifom fascia, which fills up the opening. The tern 'saphenous' is also misipplied: et rmologically, it means 'very evident.' Now, it is notorious that in very many subjects this opening only becomes plain when rendered an artificial one hy disseetion; and that thus, with the limiter opportunities of one or two subjects. it is by no neans easy to verify the details about it which have been described as constant. 
Lies of the 'saphenous opening.' - Though a weak spot, it is so on purpuses to transmit the saphena to the femoral vein, ancl the superfiedal to the deep lymphatios. The depression is present in order to allow the saphena vein to be protected from pressure in flexion of the thigh.

Site. - At the inner and npper part of the thigh, with its centre an inch and a half below and outside the spinie of the pubes.

Dianeters. One inch (25 1 mm.) vertically, hy a half or three-quarters of an inch. Shenpe: oval, with its long axis downwark and outwards. Turs extremities or cormun: upper blending with Cimbernat's liganent; lower, where the two parts of the fascia lata meet. Tuo borders: outer also known as the ligament of Hey, or femoral liganent, or faleiform process of Burns. Semilunar in shape, arehing downwards and outwards from Gimbernat's ligament to the inferior cornu. This lies over the femoral ressels, and is adherent to them; to it is fixed superficially the cribriform fascian (ride infire). The inner horder is much less prominent, owing to the weakmess of the pulic part of the fascia lata which forms it.

(b) Femoral sheath. -This is a funnel-shaped sheath. carriod out by the femoral vessels under Poupart's ligament, and contimuns albose (in front) with the transversalis fascia as it deserends to the liganent, lining the innes surface of the abdominal wall, and (hehind) with the iliae fascia, and below continuous with the proper sheath of the fenoral vessels.

It is not only fummel-shaped, hut large and loose, for two reasons: (1) That there be plenty of room for the femoral vein, and the slowly moving venous current in it to asorid without compression; (b) to allow of all the movements of the thigh taking place-flexion and extension-witheut undue stretehing of the veswes.s. By. two comnertive tissue septa the sheath is divided into three compartments-the outer for the artery, the midrle for the vein, and the internal one for the fomoral canal (vide infru). Thus one septum lies lotween the artery and vein, and another betwern the vein and the femoral canal.

(7) Femoral canal.-Definition: the inmermost division of the femoral sheath. The fiscia transversalis and fascia iliaca meet directly on the outer side of the femoral artery, but not so closely on the inner sille of the femoral vein. Hince a space exists here, perhaps to prevent the thin-walled vein. with its slugrish current. being pressed upon. Thus, a slight gat exists here-not a canal, unless so made by a knife or hy the dilating influence of a hernia. Length: ahout therequarters of an inch (19 mm.). Limits: below, saphenous oplening; above, femoral ring (rille infir ).

Boundariss. Externally, a septum between it and the vein: internally. hase of Gimbernat's ligament and meeting of fascia iliaca and transwersalis: lehind, fascial iliaca; in front. fascia transiersalis.

Contents. - Cellular tisste and fat, continuous with extra-peritoneal fatty layor. A lymphatic gland, which is inconstant. Lymphatics passing from superticial (groin) glands to those deep in the iliac fossa.

(s) Femoral ring.-This is mainly an artificial product. It is the uppere or ahtominal opening of the femoral canal. Shrupe: oval, with its long axis transverse. It is larger in women. Bounduries: internally, Cimbernat s liganent; externally, the femoral vein; in front. Poupart's ligament and the thickening of the transiversalis fascial attached to it. and ealled "the deep crural arch "; behind, the pectineus and the ilio-pectineal line. It is closed by the septum crurale, which is a barrier of fatty comnective tisite. continuous with the extra-peritoneal fatty larer. perforated by linphaties pasing from the superficial to the deep groulp.

Position of vessels around the ring.-Outside. the femoral vein: above. the epigastric ressels; towards the inner side there may be an unimprant hranch between the epigastric antery alwere and the obturator below.

If, instead of the above unimportant branch, the obturator artiry comes off

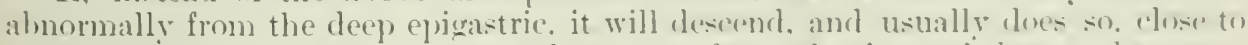
the junction of the external iliac and ammon femoral rein, and thus to the outer. and so the safe, side of the ring (fig. 704. 1). In a very few enses it curves mure inwards, rose to fimbermat's ligament. and thus to the inner sirle of the ring, and is then in great danger (fig. 704 . B). Sir Willian Lawrence calculaterl that thi= trook place once in a hundred eats.

Course of femoral hernia.- It tirst this is lownwards in the femoral canal. 
A pouch of peritoneum having been gradually, after repeated straining, coughing, ete., pushel through the weak spot, the femoral ring, further weakened perhaps, together with all the parts in the femoral arch, by ehild-bearing, some extra effort will force intestine or omentum into this pouch and thus form a hemia. Thus formed, femoral hernia passes at first downwards in the femoral canal as far as the saphenous opening, lut, as a rule, does not go farther downwards on the thigh, but mounts forwards and upwards, and somewhat outwards, even reaching the level of Poupart's ligament. The reasons for this change of position are-(1) The narrowing of the femoral sheath, funnel-like, i.e. wide above but narrowed below; (2) the unrielding nature of the lower margin of the saphenous opening; (B) the fact that this margin and the outer border are united to the femoral sheath; (4) the

Fig. 704.-Irregllarities of tire Obturator Artery. (After Gray.)
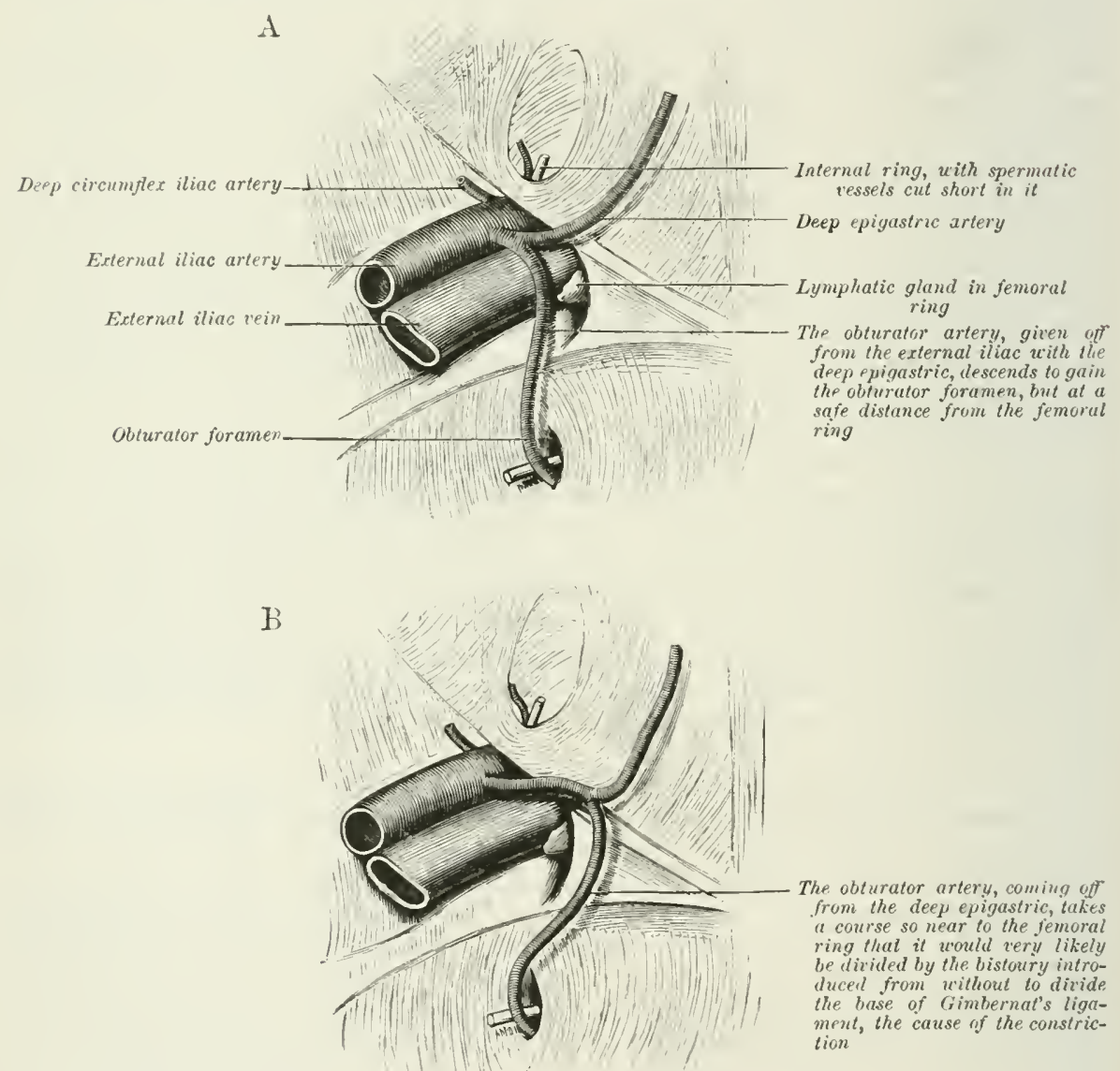

constant flexion of the thigh; (5) the fact that vessels (chiefly reins) and lymphaties deseend to the saphenous opening, the reins to join the saphena rein, and the lymphaties to join the deeper group: these descending vessels serve to looj upwards or suspend a femoral hernia, and thus prevent its further course downwards.

Coverings of a femoral hernia.-(A) At the upper or femoral ring it obtains peritoneum, extra-peritoneal fat, and septum crurale.

(B) In the canal, a coating of the femoral sheath.

(C) At the external or superficial opening, further coverings of cribriform fascia, skin, and superficial fascia are adderl. 
Some of these may be deficient by the hernia bursting through them, or they may be matted together. Sir A. Conper thought this especially likely to occur with the layer of femoral sheath and septum crurale to which he gave the name of fascia propria.

\section{PARTS CONCERNED IN UMBILICAL HERNIA}

A hernial protrusion at the umbilieus, or exomphalos, may oreur at three distinet periods of life, aceording to the anatomy of the part. Any account of umbilical hemia would be incomplete without an attempt to explain how this region, originally a most distinct opening, is gradually closed and changed into a knotty mass of scar, the strongest point in the abdominal wall.

During the first weeks of foetal life, in addition to the urachus, umbilical arteries, and vein, some of the membranes and a portion of the intestine prass through the opening to join that part of the digestive tract which is developed outside the abdomen up to a certain time, and then re-enters that cavity. Occasionally this condition persists, owing to failure of development, and the child is born with a large hernial swelling ontsicle the abdomen, imperfectly covered with skin and peritoneum. To this condition the tem congenital umbilical hernia should be applied.

Later on in fotal life it is the umbilical ressels alone which pass through this opening. At birth there is a clistinct ring, which ean be felt for some time after in the flaceid walls of an infant's belly. If this condition persist, a piece of intestine may find its way through, forming the condition which should be known as infantile umbilical hernia.

This condition is not uncommon. Why it is not more frequently met with is explained by the way in which this ring of infaney is elosed and gradually converted into the dense mass of sear tissue so familiar in adult life. This is brought about (1) by ehanges in the ring itself; (2) hy ehanges in the ressels which pass through it.

(1) Changes in the ring itself.-The umbilical ring is surrounded by a sphineter-like arrangement of elastic fibres, best seen during the first few days of f(etal life, on the posterior wall of the belly. In older infants these fibres lose their elasticity, become more tendinous, and then shrink more and more. As they contract they divicle, as by a ligature, the ressels passing through the ring, thus aceounting for the fact that the eord, wherever divided, drops off at the same sprot and without blecting.

(2) Changes in the vessels themselves. -When blood conses to traverse these, their lumen contains clots, their muscular tissue wastes, while the connective tissue of their outer coat hypertrophies and thickens. Thus, the umbilical ressels and the umbilical ring are, alike, converted into scar-tissue, which blends together. This remains weak for some time, and may be distended by a hernia (infantile).

Finally, we have to consider the state of the uml,ilicus in adult life. The very dense, unyielding, fibrous knot shows two sets of filores:-(1) Those decussating in the middle line; and (2) two sets of circular fibrous bundles which interlace at the lateral boundaries of the ring. The lower prart of the ring is stronger than the upper. In other worls, umbilical hernia of adult life, when it comes through the ring itself and not at the side, always eomes through the upper part. In the lower three-fourths of the umbilieus the umbilieal arteries and urachus are firmly closed by matting in a firm knot of sear-tissue; in the upper there is only thr umbilical vein and weaker sear. To the lower part run up the umbilical arteriws and the urachus. Owing to the rapid growth of the ahdominal wall and pelvis before puberty, and the fact that the urachus and the umbilical arteries, leeing of scar-tissue, elongate with difficulty, the latter parts depress the umbilicus ly reason of their intimate connection with its lower half.

Coverings of an umbilical hernia.-These, more or less matted together, are: -(1) Skin; (2) superficial faseia, which loses its fat over the hernia; (3) prolongation of sear-tissue of the umbilicus gradually stretched out; (4) transversalis fascia; 
(5) extra-peritoneal fatty tissue; (6) peritoneum. If the hernia come through above the umbilieus, or just to one side, the coverings will be much the same; but, instear of the layer from the umbilical scar, there will be one from the linea alba.

\section{THE BACK}

Median furrow.-This is more or less marked according to the muscular development. lying between the trapezii and complexi, in the cervical region, and the erectores spinx lower down. The lower end of the furrow corresponds to the interval between the spines of the last lumbar and the first sacral vertehræ (Holden).

Vertebral spines.-Those of the upper cerrical region are scarcely to be made out even by deep pressure. That of the axis may be detected in a thin subjeet. Over the spines of the middle three cervical vertebræ is normally a hollow, owing to these spines receding from the surface to allow of free extension of the neck. The seventh cervieal is prominent, as its name denotes. Between the skull and atlas, or between the atlas and axis, a sharp-pointed instrument might penetrate, especially in flexion of the neck.

Of the thoracic spines, the first is the most prominent; the third should be noted as on a level with the inner end of the seapular spine, and in some cases with the bifurcation of the trachea; that of the serenth with the lower angle of the seapula; that of the twelfth with the lowest part of the trapezius and the head of the twelfth rib. The obliquity and overlapping of the thoracic spines is to be remembered.

Of the lumbar spines, the most important are the second, which corresponds to the termination of the cord, and that of the fourth, which marks the highest part of the iliac crests and the bifurcation of the abdominal aorta. The lumbar spines project horizontally, and eorrespond with the vertebral bodies. The third is a little above the umbilicus.

Owing to the obliquity of the thoracic spines, most of them do not tally with the heads of the corresponding ribs. Thus, the spine of the second corresponds with the head of the third rib; the spine of the third with the head of the fourth rib; and so on till we come to the eleventh and twelfth vertebre, which do tally with their corresponding ribs (Holden).

- The lower ribs may be felt outside the erector spina, but, in eounting them from below, it must be remembered, as pointed out by Holl, that in quite a considerable percentage the last rib is so abnormally short that it does not reach as far as the outer border of the sacro-lumbalis; or so rudimentary as to more resemble a transverse process. In these eases the lower end of the pleura may pass from the lower part of the twelfth thoracic vertebra, almost horizontally to the lower edge of the eleventh rib.

Muscles.-The student will remember the great number and complexity and the numerous tendons of the muscles which run up on either side of the sime; the firmmess and inextensibility of their sheaths; the large amount of cellular tissue between them; and the fact that towards the nape of the neck these muscles lie exposed insteal of being protected in gutters, as is the case below: all these anatomieal points explain the extreme painfulness and olstinacy of sprains here.

Trapezius. - To map out this musele, the arm should he raised to a right angle with the spine. The external oceipital protuberance should be dotted in, and the superior nuehal line pasing out from this; below, the twelfth thoracic spine should be marked; and externally, the outer third of the clavicle and the commeneement of the seapular spine. Them a line should be drawn from the protuberance rertically downwards to the twelfth thoracic spine; a second from about the midrle of 
the superior nuchal line to the posterior and outer third of the clavicle; and a third from the last thoracic spine upwards and outwards to the spine of the scapula.

Latissimus dorsi.-The arm being raised alove a right angle, the spines of

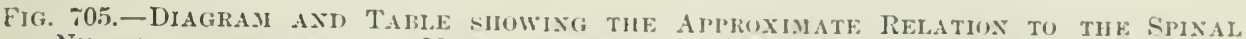

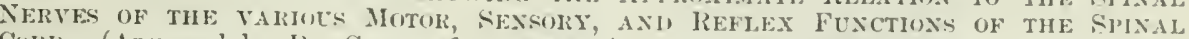
Cokn. (Arranged by Dr. Gowers from anatomical and patlologrical data.)

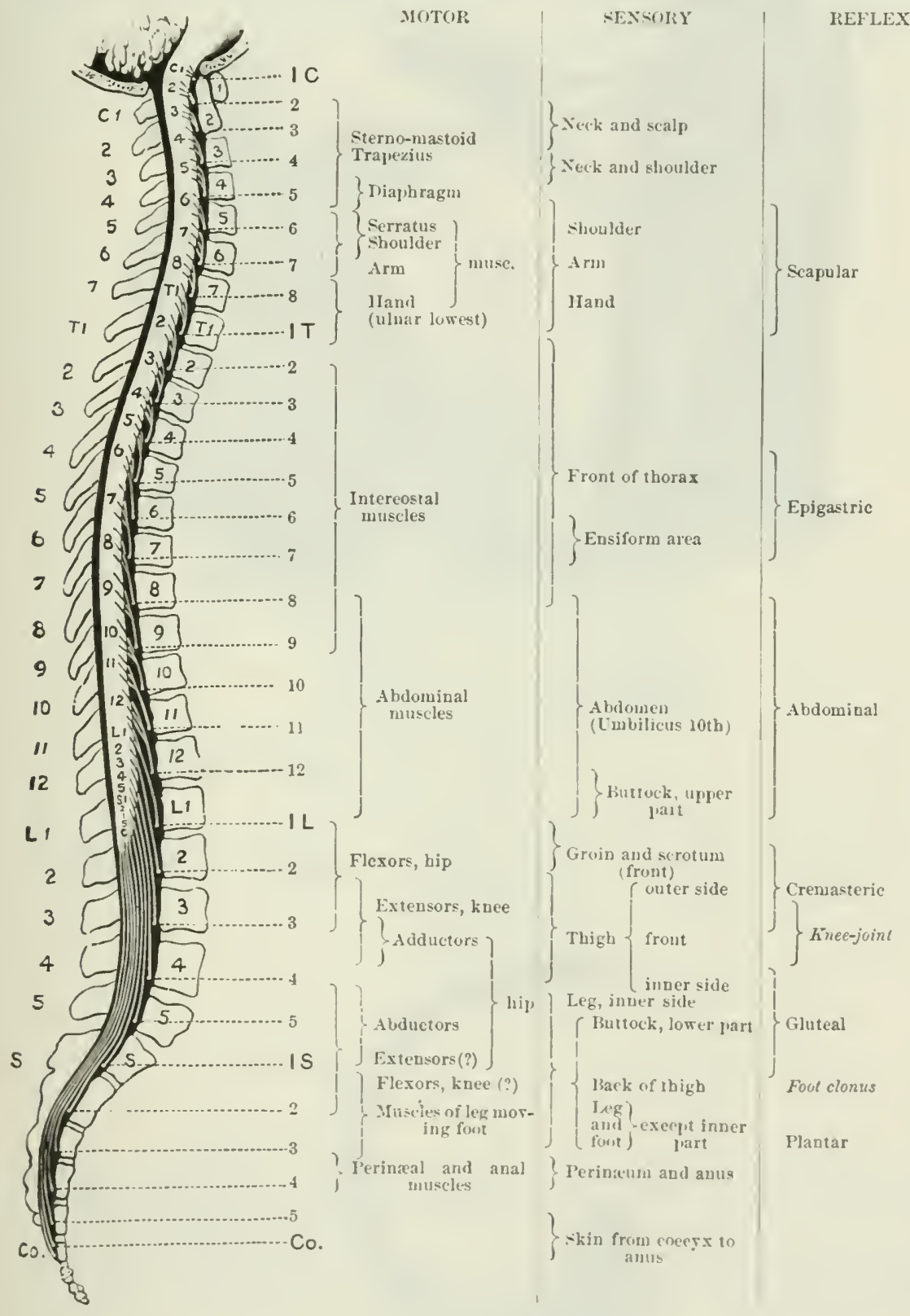

the sixth thoracic and the third sacral vertebrx should be marked: then the outer lip of the crest of the ilium, the lower two or three ribs, the lower angle of the scapula, and the posterior fold of the axilla, and finally the bicipital groore should all be marked. 
Fig. 706.-Chiej Arterial Axastomoses on the Scapula.

(From a dissection in the Hunterian Museum.)
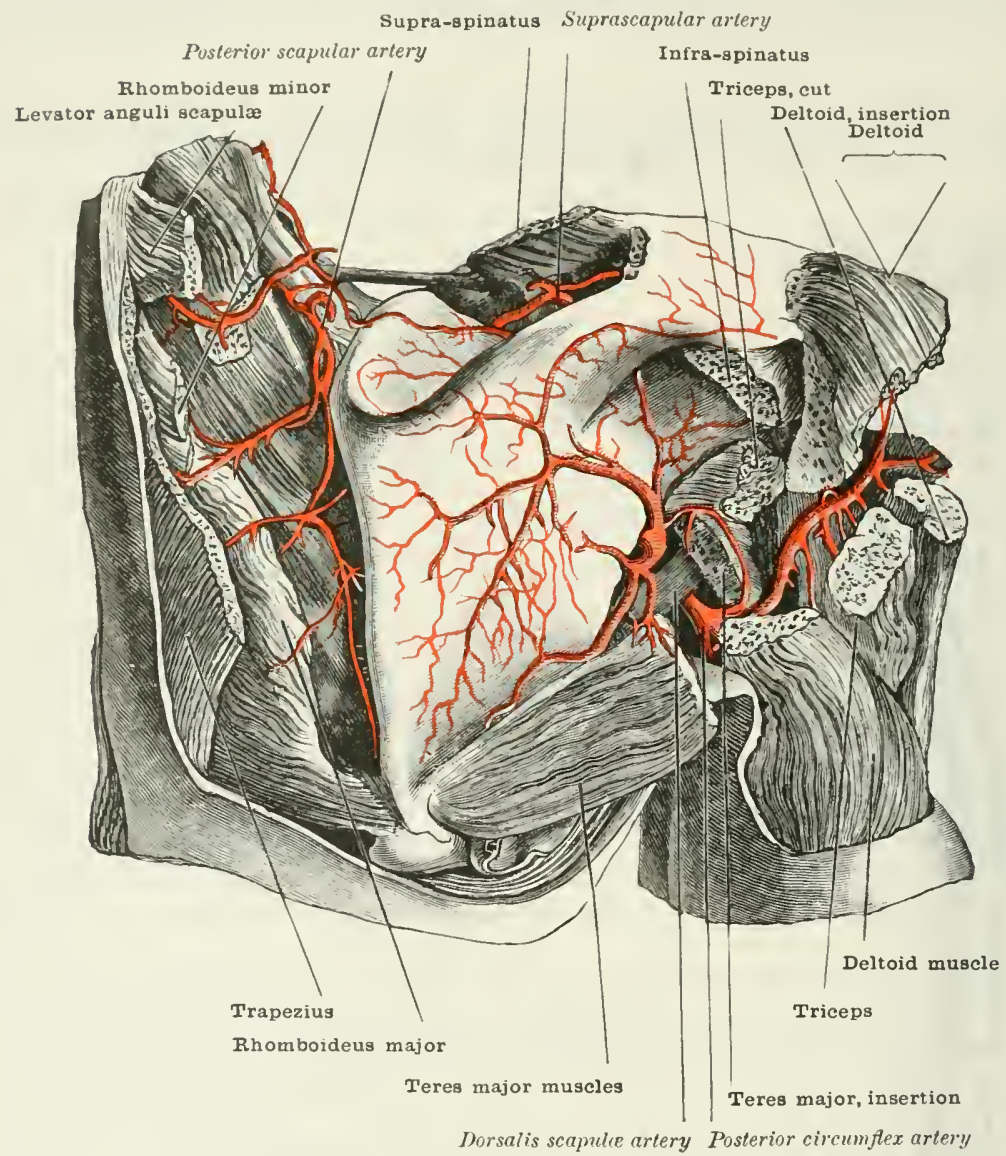

Fig. 707.-Arrangement of Lumbar Aponeurosis at Level of Third LUMbar VERTEBRA.

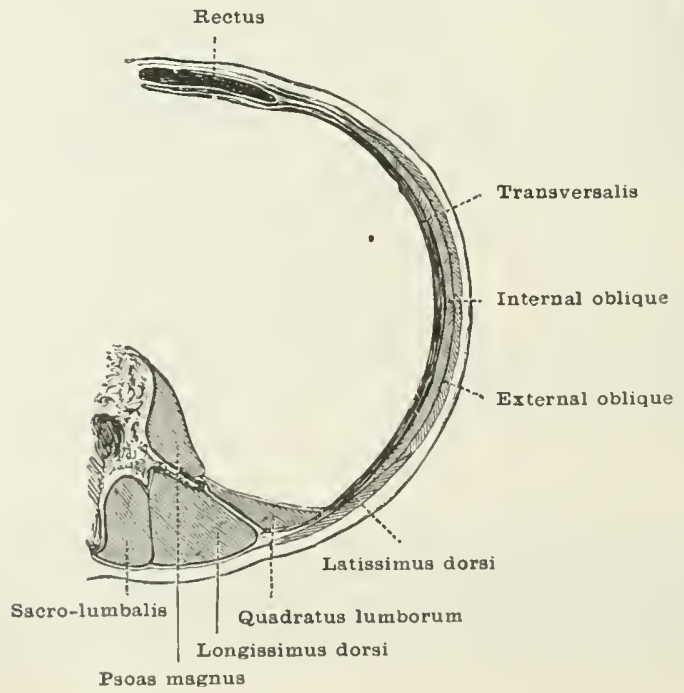


A vertical line from the sixth thoracic to the third sacral spine will give the spinal origin of the muscle. Another from the third sacral spine to a point on the iliac crest, an inch or more outside the alge of the erector spina, will give the origin of the muscle from the sheath of the erector spina and the ilium. I line from the sixth thoracic spine, almost transversely at first, with increasing slight obliquity over the inferior angle of the seapula to the axilla and bieipital gromer. will mark the upper border of the muscle. Another very ohlique line from the point on the iliae crest upwards and outwards to the axilla will give the lower border and the tapering triangular apex of the insertion. The muscle may he attached to the angle of the scapula, or seprarated from it by a bursa.

Fig. 708.-Relations of the Abnominal Viscela to tire Anterior Parietes. (Treves.)

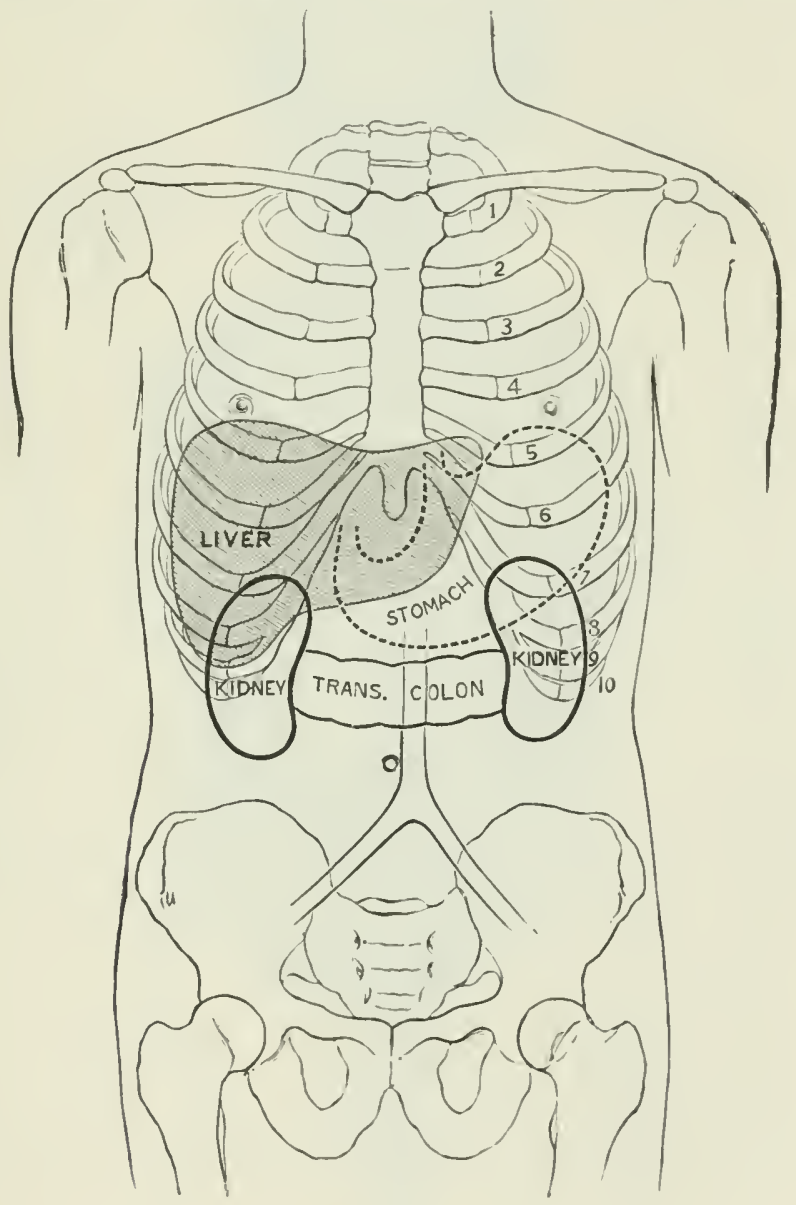

Triangle of Petit.-This small space lies above the crest of the ilium, at about its eentre, bounder by the anterior edge of the latissimus and the posterior borker of the external oblique.

Origin of spinal nerves.-It is very impurtant to remember the relations of these to the vertebral spines. in determining the results of disease or injury of thr. cord and the parts thereby affected. The above relation may be given hiriefly als follows:-

The origins of the eight cervieal nerves arrespond to the cord between the oreiput and the sixth cervieal spine. The upper six thoracic come off hetween the above spine and that of the fourth thoracie vertebra. The origins of the lower six thoracic nerves correspond to the interval between the fourth and the tenth thoracie 
spines. The five lumbar arise opposite the eleventh and twelfth thoracic spines; and the origins of the five sacral correspond to the first lumbar spines. The diagram and table (fig. 705), arranged by Dr. Gowers from anatonical and pathological data, show the relations of the origins of the nerves to their exits from the rertebral canal, and the regions supplied by each.

Scapula, its muscles and arterial anastomoses.-Amongst the landmarks in the back, the student should be careful to trace the angles and borders of the scapula as far as these are accessible. The upper border is the one nost thickly covered. With the hands hanging down, the upper angle corresponds to the upper border of the second rib; the lower angle to the seventh intercostal space; and the

Fig. 709.-Relations of the Abdominal Viscera to the Posterior Parietes.

(Treves.)

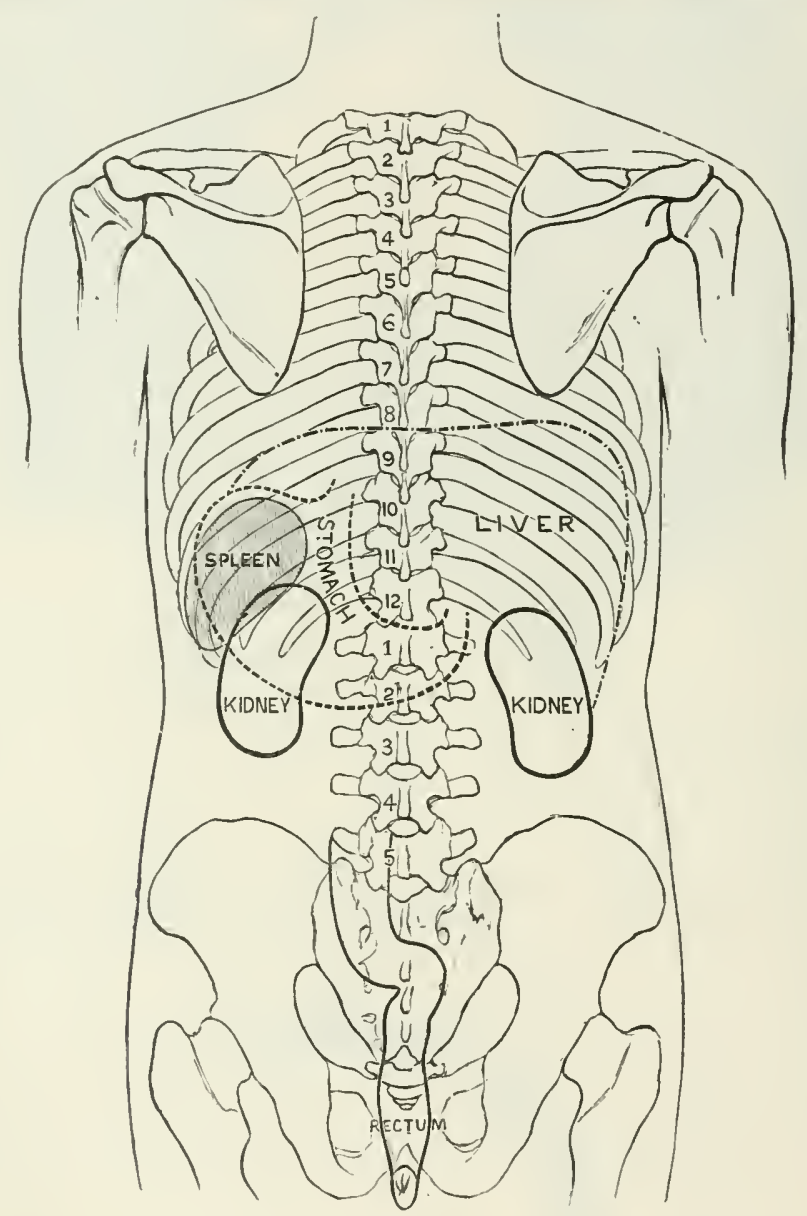

root of the spine of the scapula to the interval between the third and fourth thoracic spines. Fig. 706 shows the chief arteries around the scapula. The anastomoses on the acromial process between the suprascapular, acromio-thoracic, and cireminflex arteries are not shown.

Lumbar fascia.- In the loins, the muscles which fill in the space between the last rib and the crest of the ilium should be carefully noted, owing to the frequency of operations here. When the latissimus dorsi, the oblique, the transversalis, the erector spinæ, and quadratus have been described, the lumbar fascia (the posterior aponemrosis of the transversalis), and the three layers into which it divides posteriorly (fig. 707 ) should be remembered.

Viscera.-Ceveral of these, which can be mapped in behind-viz. the kidneys, 
spleen, etc. -have been already mentioned (pagres 1119, 1120). Sce also page 1119 for the incision for lumbar colotomy.

The commencement of the trachea and œesophagus has been given in front as corresponding to the fifth cervical vertebra. If examined from behind, this point, owing to the obliquity of the spines, would be a little lower down. 'The trachea, shout five inches long, descending in the middle line, bifureates opposite to the

Fig. 710.-Amoninat Vischa, fron bemind, (Riidinger.)

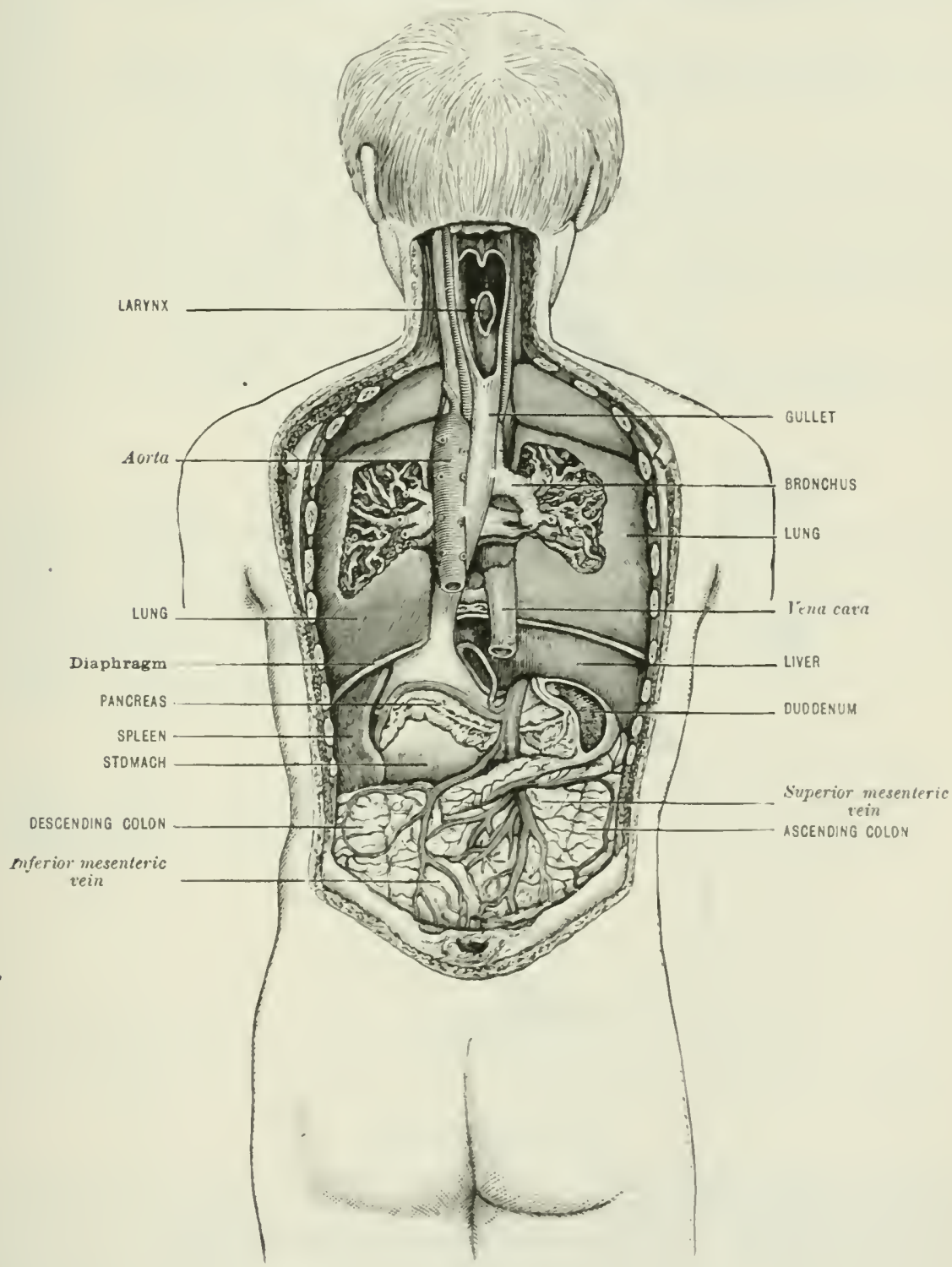

interval between the third and fourth thoracic spines. The bronchi enter the lungs at about the level of the fifth thoracic spine, the right being the shorter, wider, and more horizontal. The œsophagus, about ten inches in length, starting in the middle line, curves, at once gradually to the left, and to the root of the neck; from this point it tends to regain the middle line up to the fifth thoracic vertebra; thence finally turns again, and more markedly to the left, and passes 
through the diaphragm opposite to the tenth or eleventh thoracic vertebra, or the ninth or tenth thoracie spine.

The aorta reaches the left sicke of the vertebral column, with its areh just ahove the fourth thoracic spine, and thence descends on the front of the column, with a slight tendency to the left, to bifureate opposite the fourth lumbar spine.

The following table, from Holden and Windle, with additions, will be found very useful in determining the relation of numerous viscera and other structures to the bodies of the vertebra.

Fig. 711.-View of the SPleex, etc., From Beilisd. (Rüdinger.)

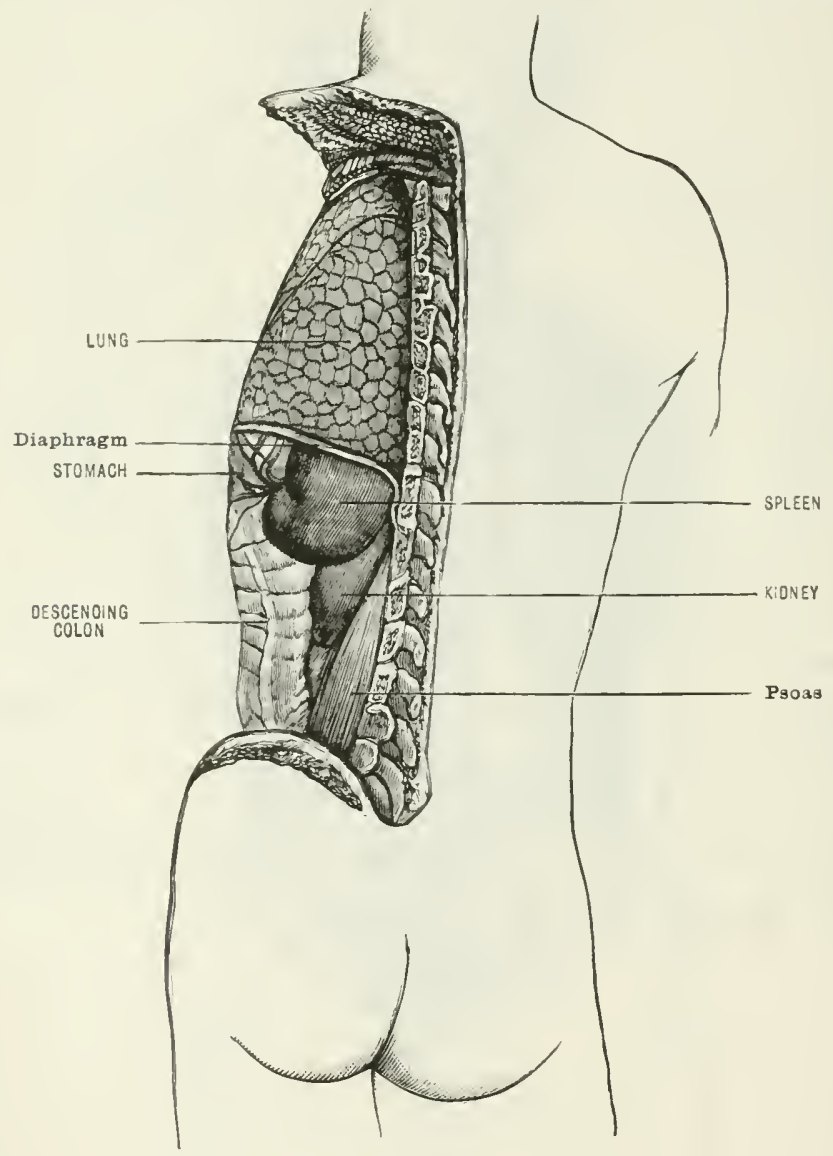

Cerviteal

First. Level of hard palate.

Second. Level of free edge of upper teeth.

Second and third. Superior cervical ganglion of sympathetic.

Fourth. Hyoid bone. Upper aperture of larynx.

Fifth. Middle rervical ganglion, thyroid cartilage, and rima glottidis. Between this and the last would be the bifurcation of the common carotid.

Sixth. Cricoirl cartilage. Ending of pharynx and larynx.

Seventh. Inferior cervical ganglion. Apex of lung, ligher in the female than in the male. Arch of thoracic duct. 


\section{THORACIC}

First. Summit of arch of subelarian (fiodlee).

second. Level of episternal notch. This is usually opposite the fibro-cartilage hetween the second and third. Bifureation of innominate (iodlece).

Third. Level of junction between the manubrium and the gladiolus. This is sometimes opposite the fifth. Lowest limit of superior nediastinum. Bifureation of trachea. Beginning of superior cava. Highest part of aortic areh.

Fourth. Second piece of artic arch reaches spine. Arch of vena azyos major.

Fifth. Termination of third piece of aortic arch.

Fifth to eighth. Base of heart.

Sixth. Puhmonary and aortic valves. Commencement of aorta and pulmonary artery. End of superior cava.

Seventh. Mitral orifice.

Eighth. Trieuspid orifice.

Ninth. Lower level of manubrium. Openings in diaphragm for inferior vena cara and œesophagus. Upper linit of spleen.

Tenth. Level of tip of xiphoid cartilage. Lower limit of lung posteriorly. Cpper limit of liver comes to the surface posteriorly. CEsophagus passes through diaphragn. Cardiac orifice of stomach.

Eleventh. Lower border of spleen. Suprarenal capsule.

Twelfth. Lowest part of pleura. Aorta passes through diaphragm (upper border). Cceliac axis (lower border). Pylorus. Upper border of kidney.

\section{LCMBAR}

First. Pancreas. Pelvis of kidney. Renal arteries (ending).

Second. Spinal cord ends at junction of first and second. Third piece of duodenum. Receptaculum chyli. Lower end of left kidney.

Thircl. Umbilicus, opposite fibro-cartilage, between this and fourth. Lower end of right kidney. Lower limit of liver on right side.

Fourth. Bifureation of antic arch. Highest part of iliac crest.

Fifth. Commencement of superior rena cava.

\section{SACRAL}

Third. End of first piece of rectum. Lower limit of spinal nembranes. Coceyx (tip). End of second piece of rectum.

\section{SUPERFICIAL ANATOMY OF THE LPPER LIMB}

\section{THE SHOLLIDER}

The following surface-marks, of the greatest inportance in determining the nature of shoulder injuries, cam be made out here:-The clavicle in its whole extent, the acromion process, the great tuberosity, and upper part of the shaft of the humerus. Much less distinctly, the position of the coracoid process and the head of the humerus can be made out. The anterior marcin of the clavicle, convex internally and concave externally, can lw madr out in it: whole extent, the bone, if traced ontwards, being found not to he horizontal, hut riwing somewhat to its junction with the acromion. The tip of this process. when the arm hangs by the side, is in the same line as the external condyle and the styloid process of the rarlius. (On the inner sidn. the head and intermal condrle of the humerus and the strloid proces of the ulna are in the same line. Thus the 
great tuberosity looks outrards, the head inwards, and the lesser tuberosity somewhat forwards. Between the two tuberosities runs the bicipital groove, which, with the arm in the above position, looks directly forwards. In thin subjects its lower part can be clefined. Besides the tendon and its synorial sheath, the insertion of the latissimus dorsi, the humeral branch of the acromio-thoracic artery, and the anterior eircumflex artery run in the groove. When the fingers are placed on the acromion, and the thumb in the axilla, the lower edge of the glenoid cavity can be felt; and if the humerus be rotated (the elbow-joint being flexed), the head of the humerus can be felt also.

The characteristic roundness of the shoulder is due to the deltoid, supported by the head of the humerus and the tuberosities (fig. 715). Close to the clavicle, between the contiguous origins of the pectoralis major and deltoid, is the infraclavicular fossa, in which lie the cephalic vein and the humeral branch, of the acromio-thoracic artery. On pressing deeply here, the coracoid process can be marle out if the muscles are relaxed and the axillary artery compressed against the second rib.

On raising the arm and abducting it, the different parts of the deltoid ean often be made out-viz. fibres from the lower border of the spine of the scapula, the outer edge of the acromion, and the outer third or more of the front of the clavicle;

Fig. 712.-Transverse Section throvgh the Right Shoulder-Joint, Showing the Structures in contact With it. (Braune.)

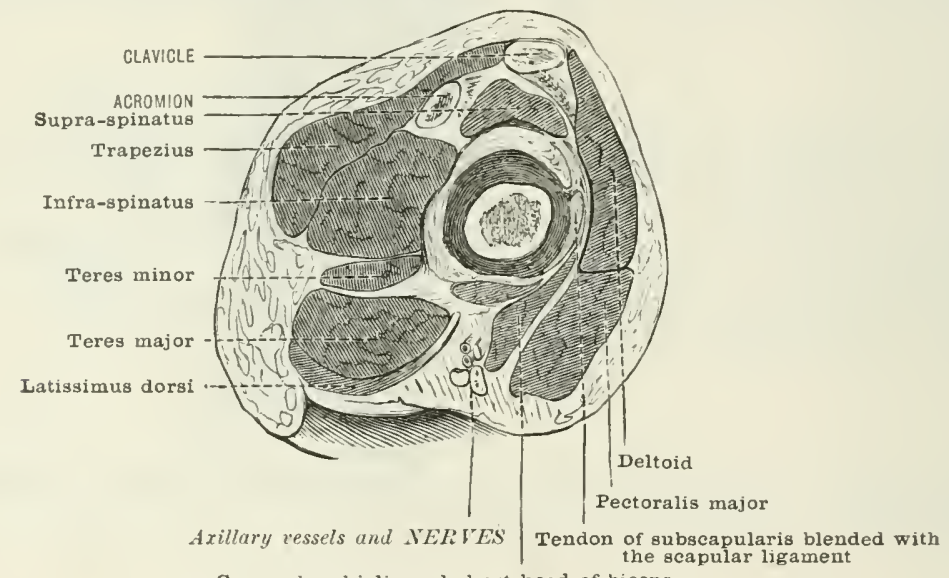

Coraco-brachialis and short head of biceps

the characteristic knitting of the surface owing to the presence of museular hundles, separated by depressions caused by the tendinous septa, will also be seen. The nnuscle will be narked ont by a base-line reaching along the above bony points, and two sicles converging from its extremities to the apex, a point on the outer surface of the humerus, about its centre. To malp out the pectoralis major, a line should be drawn down the lateral aspect of the stemum as far as the sixth costal eartilage, and then two others marking the borders of the muscle-the upper corresponding to the deltoid, the lower starting from the sixth cartilage, and the two converging to the folded tendon. whieh is inserted as a double layer into the outer bieipital ridge. 'The pectoralis minor will be marked out by two lines, from the upper border of the third and the lower border of the fifth rib, just external to their cartilages, and meeting at the coracoid process. 'The lower line gives the level of the long thoracic artery; the upper, where it meets the line of the axillary artery, that of the acromio-thoracie.

When the arm is abducted and the humerus rotated a little outwards, the prominence of a well-developed coraco-brachialis comes into view; a line drawn from the centre of the clavicle along the inner border of this muscle to its insertion into the humerus gives the line of the axillary artery.

The depression of the axilla is best marked when the arm is raised from the 
side to an angle of about $45^{\circ}$, and when the muscles bounding it in front and behind are contracted. In proportion as the arm is raised, the hollow locomes less, the head of the humerus now projecting into it. When the folds are relaxed

Fig. 713.-Tine BrachiA, AKTERY.

(From a dissection in the Musem of the Royal College of Surgeons.)

Suprascapular artery and nerve

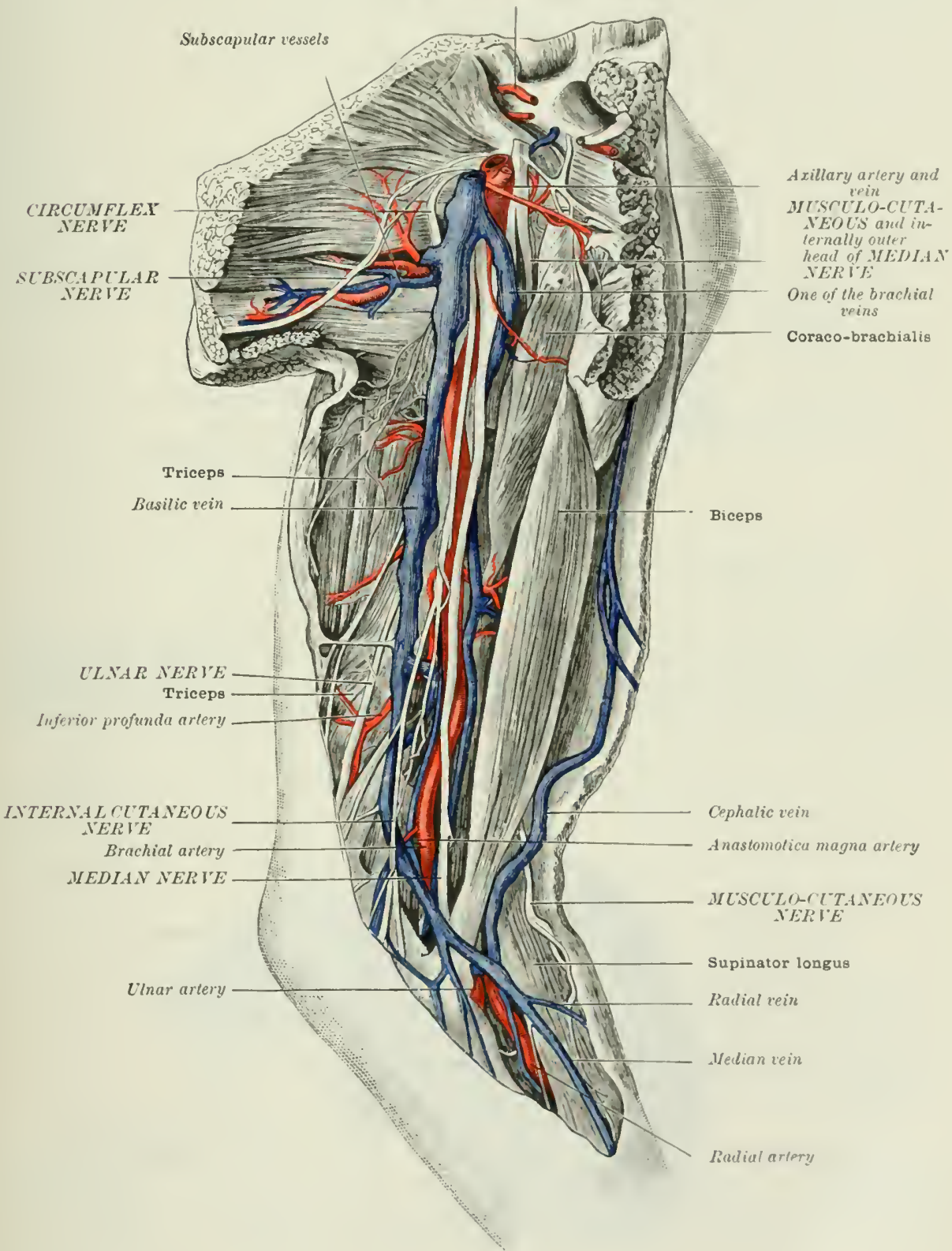

by bringing the arm to the side, the fingers can be pushed into the space so as to examine it.

The direumflex nerve and yosterior circumflex vessels wind round the humerus under the deltoid, a little above the eentre of this muscle. 
To trace the synovial membrane of the shoulder-joint is a comparatively simple matter (fig. 715). Covering both aspects of the free edge of the glenoid ligament, it lines the inner aspect of the capsule whereby it reaches the articular

Fig. 714.-Sectiox timotgh the Minnle of the Right Upper Ary. (Heath.)

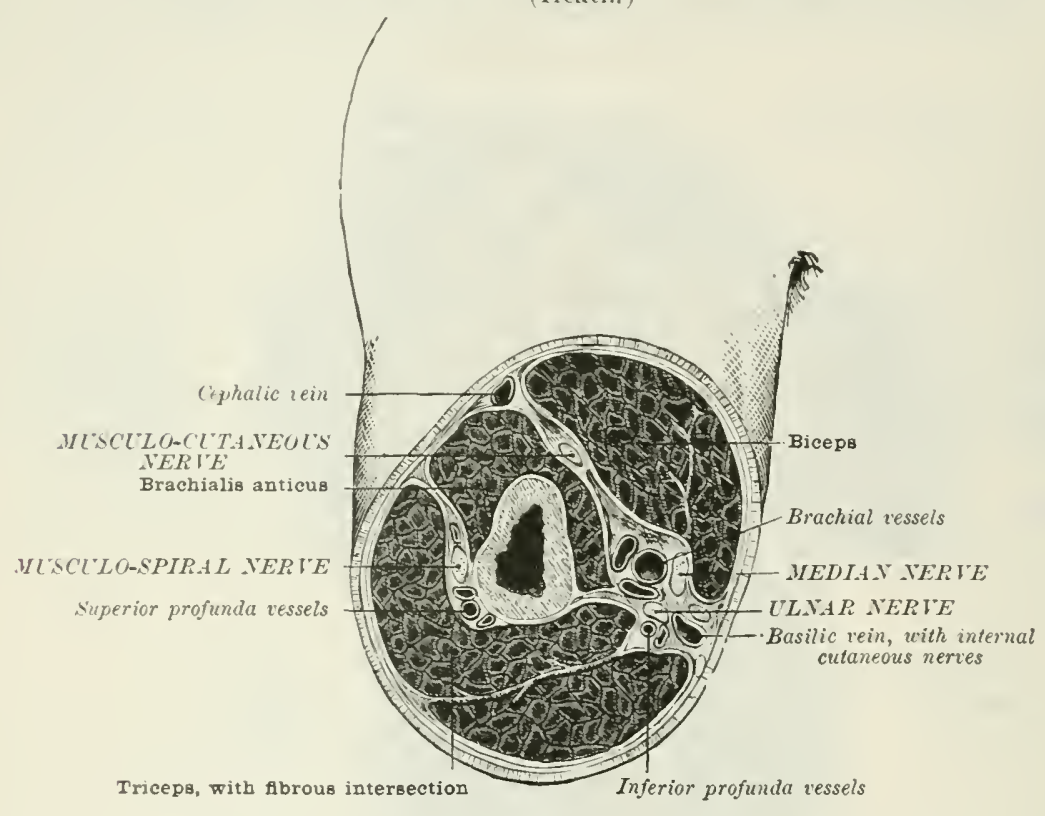

margin of the head of the humerus; there is a distinct reflection, below, from the eapsule on to the humeral neck before the rim of the cartilage is reached. An extensive protrusion of synovial membrane takes place in the form of a synovial bursa, at the inner and anterior part of the capsule, near the root of the coracoid

Fig. 715.-Diagramatic Sectiox of Shotlder throcgh Bicipital Groove. (Anderson.)

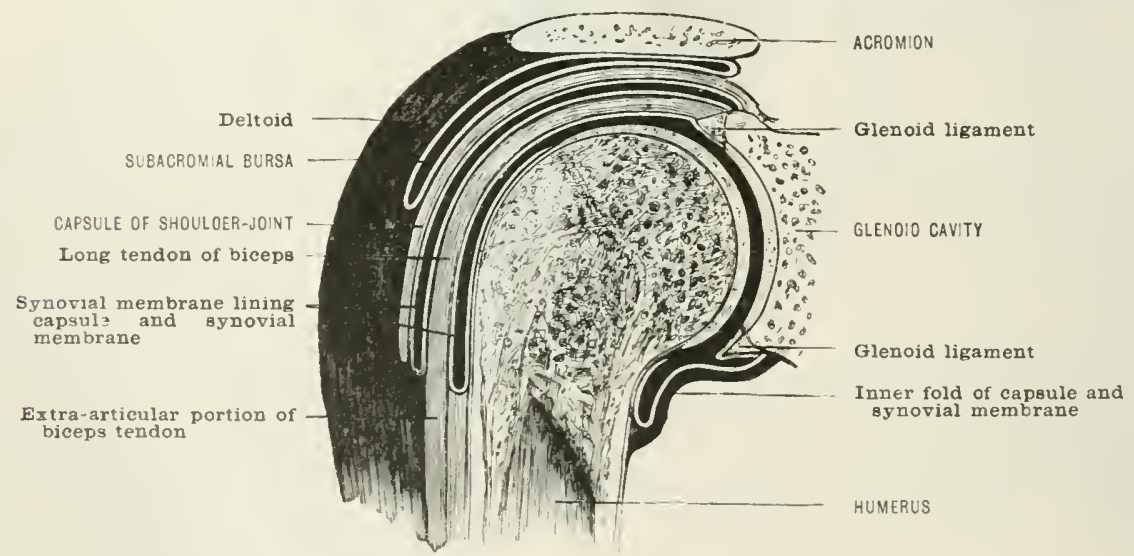

process under the tendon of the subseapularis. Another protrusion takes place hetween the two tuberosities along the hicipital groove, as low as the insertion of the pectoralis major. A third symovial protrusion may be seen, but not frequently, at the outer or posterior aspect, in the form of a bursa, under the infraspinatus 
tendon. Thus the continuity of the eapule is interupterl hy two and sometimes three apertures.

The shaft of the humerus is well covered by museles in the greater part of its extent, especially alwe. Below the inseption of the deltoid, the outer borker of the bone can he tracerl downwals into the external supracondyloid ridge. The

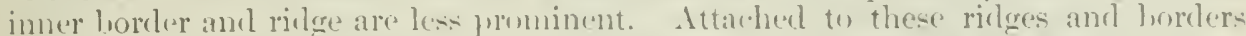

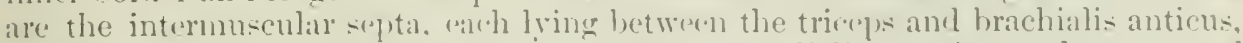
and the outer one griving origin to the hrachiorarlialic (supinator longus) and extensor carpi radialis longior as well. The outer septum is perforated by the

Fig, 716.-BACK VIEW OF THE SCAPLLAR ML'CLES AND TRICF'S.

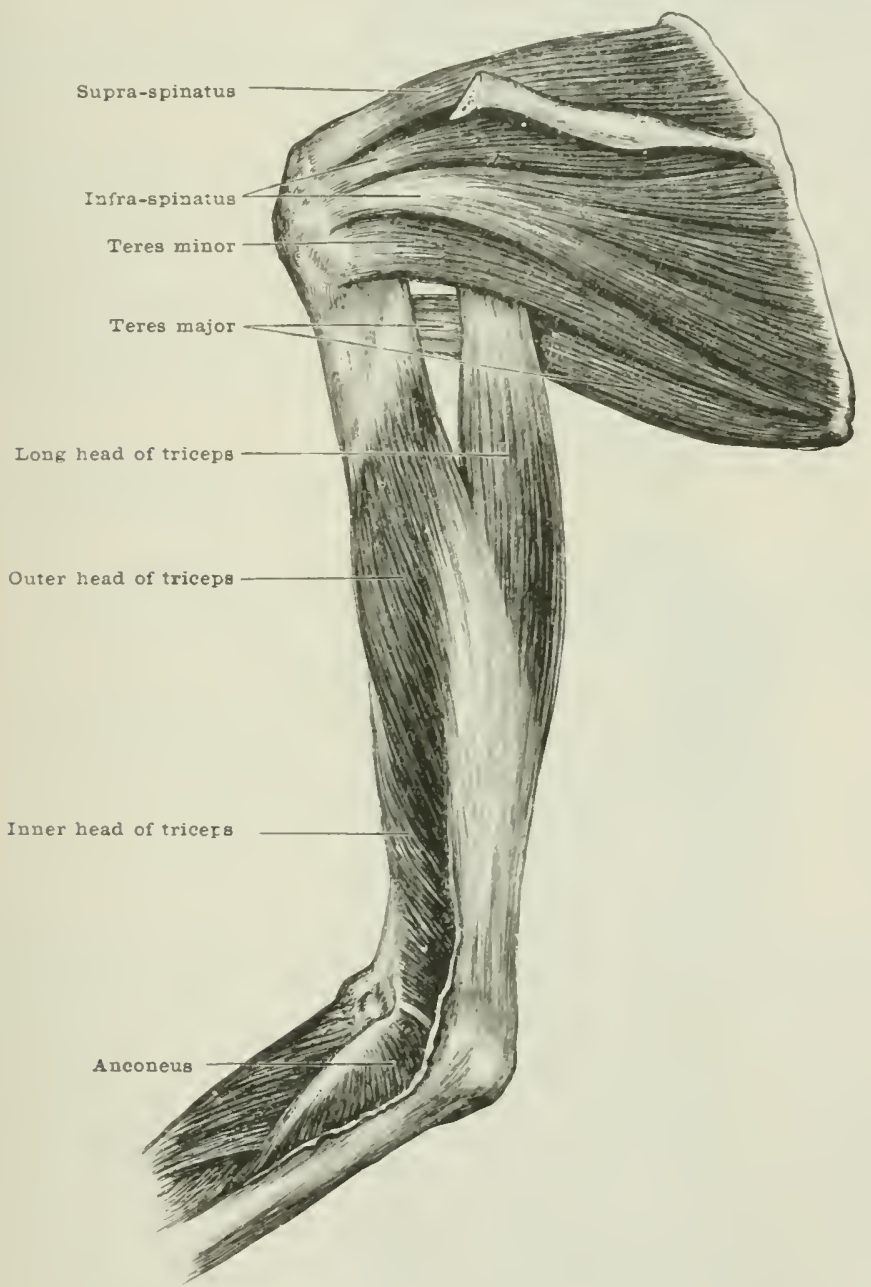

superior profundat veseds and the musentin-s,iral nerve, the inner by the inferior profuncla and ansstomotica magrla arterjes and the uhar nerve. Oin either sille of the well-known prominenere of the biceps is a furrow. Along the outer aseends the eephalic vein. The inner eorreponds to the line of the bisilic rein which lies superfirial to the deep fiscia below the midlle of the amm, and superficial and internal to the hrachial vessels and meelian nerv.

A line drawn along the inner exlye of the licepe frem the insertion of the tere major to the mitrlye of the hend of the ellow corregunds to the brachial

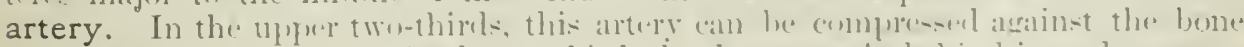

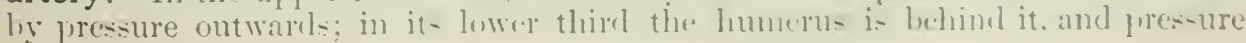


should be marle backwards. The superior mofunda comes off from the highest part of the artery and courses with the musculs-spiral nerve (fig. 714); the nutrient artery arises opposite the midele of the humerns; the inferior profumba below the middle, and courses with the ulnar nerve through the intermuscular septum to the lack of the internal condyle. The anastomotica is given from one to two inches above the hend of the ellow.

The centre of the arm is a landmark for many anatomical structures. On the outer side is the insertion of the deltoid; on the inner that of the coraco-brachialis. The basilic rein and the nerve of Wrisberg here perforate the deep fascia, going in reverse directions. The inferior profunda is here given off from the brachial; the merlian nerve also crosses the artery, and the uhnar nerve leaves the inner side of the ressel to pass to the inner aspect of the limb.

The brachialis anticus can be mapped out by two pointed processes which surromnd the insertion of the deltoid, and which pass downwards into lines corresponding to the two intermuscular septa, and then converge over the front of the elhow to their insertion into the coronoid process.

The median nerve can be traced by a line drawn from the outer side of the third part of the axillary and first part of the brachial artery, across this latter ressel about its centre, and then along its inner border to the forearm, where it passes between the two heads of the pronator radii teres.

The ulnar nerve lies to the inner side of the above arteries as far as the middle of the arm, where it leares the brachial to course more inwark and perforate the internal intermuscular septum and get to the back of the internal condyle.

Fig. 71\%.-Vertical Sectiox of the Elbow. (One-half.) (Braune.)

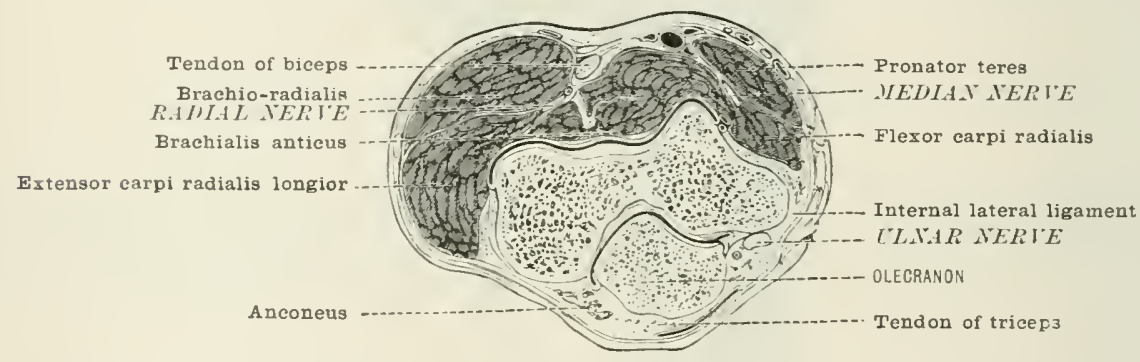

The musculo-spiral nerve can be traced hy a line beginning behind the third part of the axillary artery, then carried vertically down behinl the uppermost part of the brachial, and then, just below the posterior horder of the axilla, eurving backwarls behind the humerus and slightly downwards, just below the insertion of the deltoid. Thus, passing from within ontwards and from before backwards in its groove with the superior profunda vessels, it again comes to the front by perforating the external intermuscular septum at a point about opposite to the junction of the middle and lower thirds of the arm, and passes clown in front of the external supracondyloid ridge, lying here between the brachio-radialis and brachialis anticus. to the level of the extemal condyle, where it divides into radial and posterior interosseous. The former of these accompanies the radial artery to the front of the arm. the latter travels backwards to the back of the forearm.

On the back of the arm is the triceps muscle, with its three heads and tendon of insertion, all brought into relief in a muscular subject when the forearm is strongly extended. Of the three heark, the inmer is the least distinct, arising below the musculo-spiral gronve, reaching to each intermuscular septum, and tapering away above as high as the teres major. The outer head, arising above the groore as ligh as the creat tuberosity, appears in strong relief just below the deltoid; while the middh or long heat, arising from the scapula just below the glenoid cavity, appears betwoen the tures muscles. The tendon of insertion, passing into the upper and hack part of the olecranon orer a deep bursa, is shown by a somewhat depressed area. 


\section{'THE ELBOW'}

The bony points, condyles, olecranon, and lead of radius, and their relation to one another, should be carefully studied. 'The internal condyle is the more pron-

Fig. 718. - Lungitedinal Section of the Elisuw-Jeint. (One-half.) (Braune.)

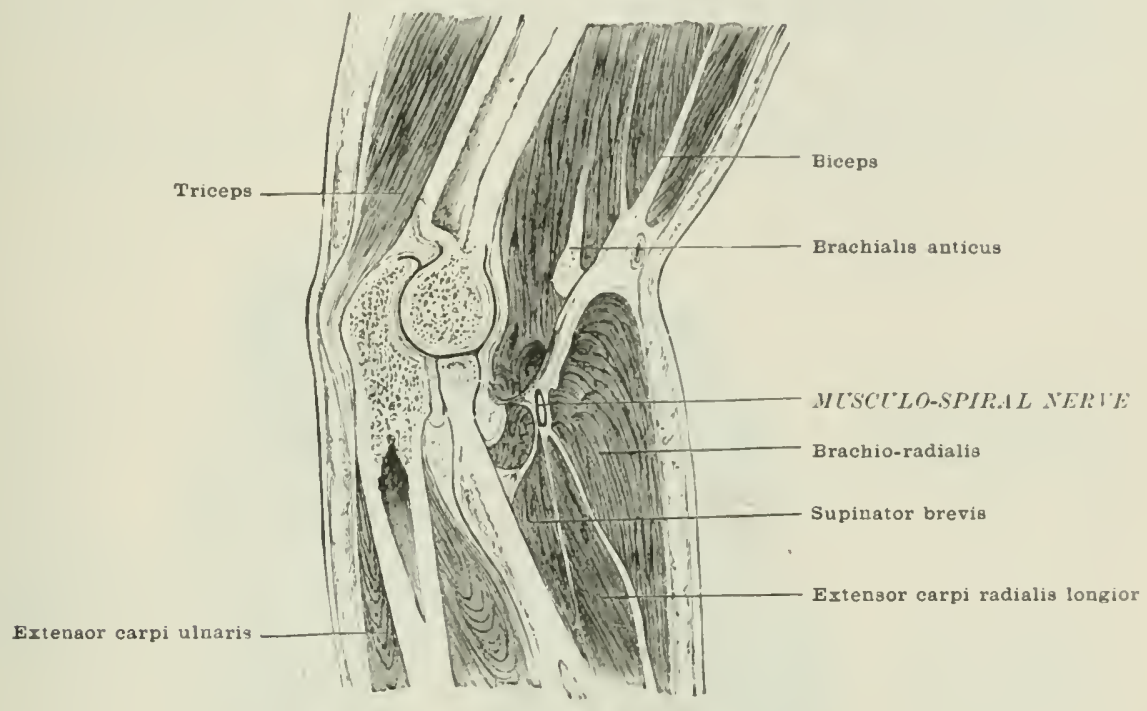

Fig. 7I9.-Bext of the Elbow. (One-hatli.) (Blandin.) IATERYL CITALEOIS NERIE

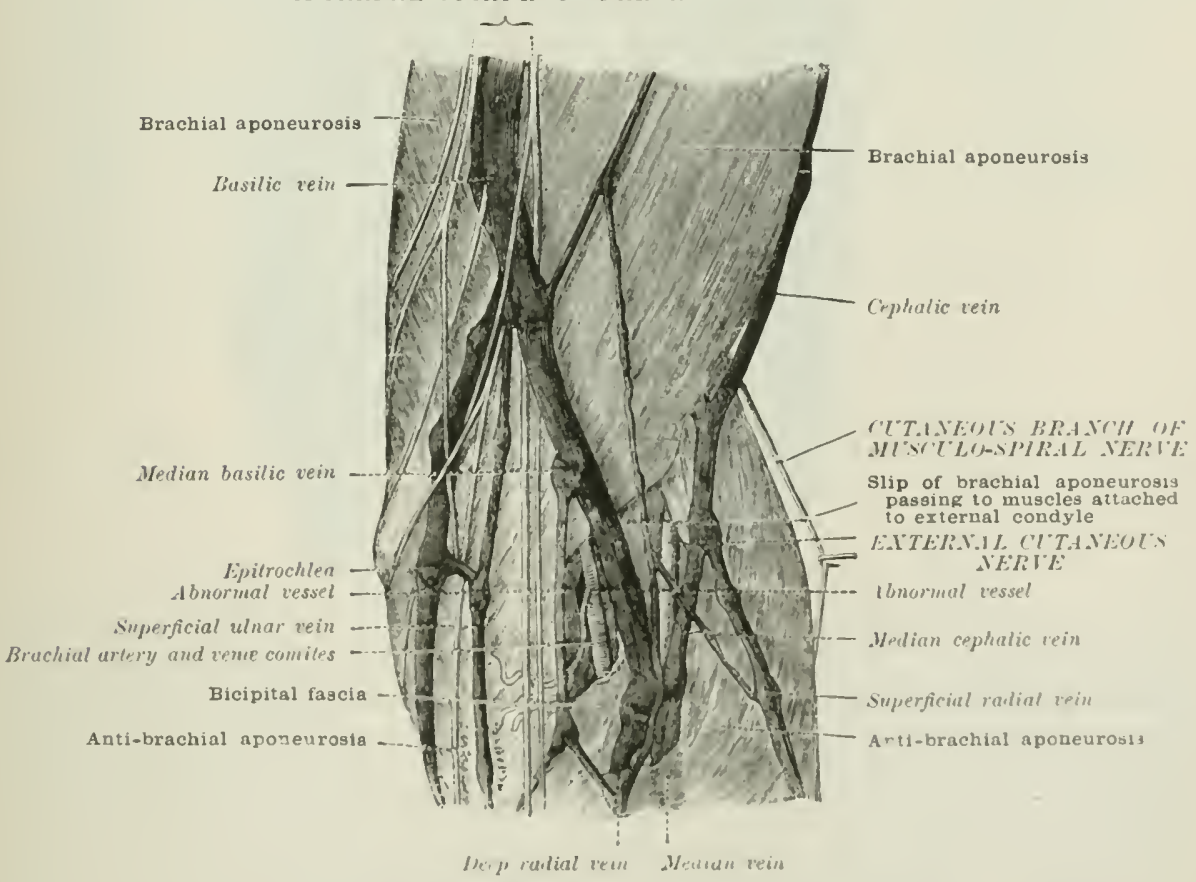

inent of the two, is directed hackwards as well as inwards, and lies a litfle abore its

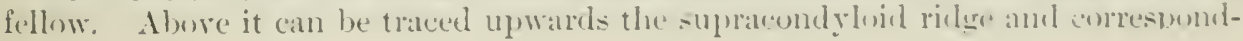


ing septum. The rxtcrual condyle is more rounded, and thus less prominent; below, and a little behind it, the head of the radius can be felt moving under the capitellum when the forearm is supinated and flexed. A depression marks this spot and corresponds to the interval between the anconeus and brachio-radialis and exterior carpi radialis longior; at the back, the upler part of the olecranon is corered by the triceps. The lower is subeutaneons, and separated from the skin hy a bursa. If the thumb and second finger be placed on the condyles and the index on the tip of the olecranom, and the formam emmpletely extended, the tip of the olerramon rises so as to be on the line joining the two conclyles. In

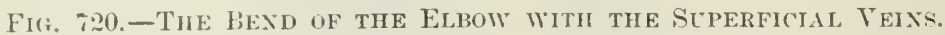

(From a dissection by Dr. Alder Smith in the Musemm of St. Bartholomew's Hospital.)

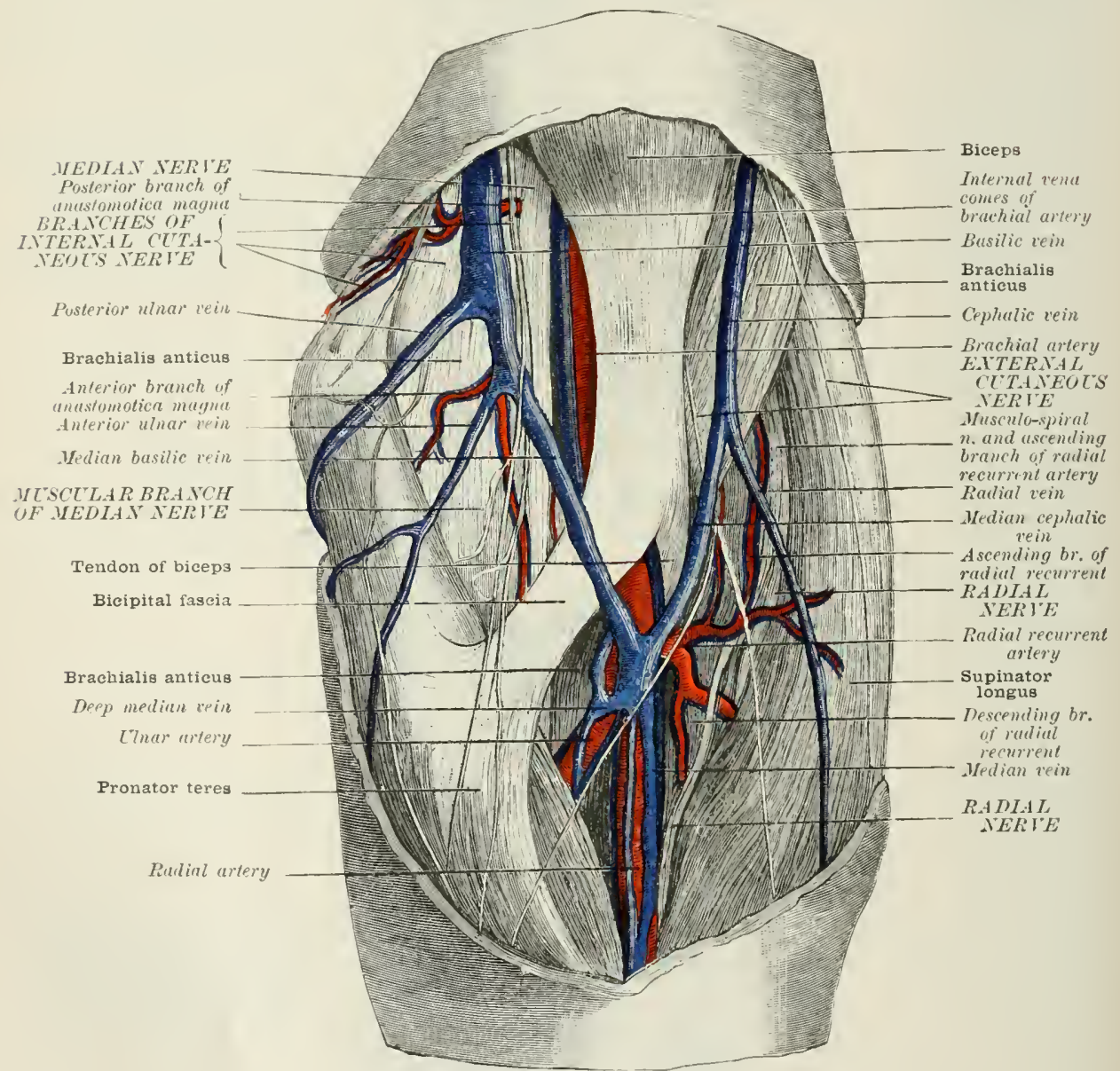

Hexion at a right angle, the olecranon is below the line of the condyles, and in complete flexion yuite in front of them. Betwe'n the inner condyle and olecranon is a pit, in which lie the unar nerve and the anastomosis between the inferior profunda and the proterior uhar recurrent arteries. The coronoid jrocess is so well coverect by muscles, ressels, and nerves, that its position camot be distinctly marle out.

Swelling, rlue to effusion into the joint, appears on either sicle of the triceps tendon, and som obliterates the depression below the extemal condrle. $\lambda$ superficial swelling over the tip of the olecranon is due to effusion into the bursa between the soft parts and that bone. A decper, less casily defined, swelling in the same 


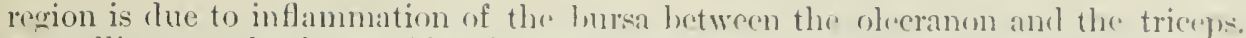

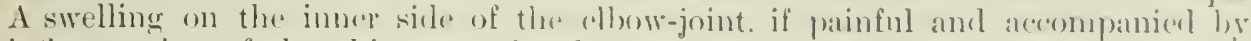
inflammation of the skin, may be due to miselhief in the epitrochlear gland situated just above the intermal condyle, and receiving lymphaties from the innere borker of the forearm and the two inner fingers.

The hollow in front of the elbow.- The deliener of the skin lore mulst always be home in mincl in the alplication of splints. The $\mathrm{M}$-like arrangement of the superficial veins as moully described is by no means comstant (figs. 719 , 720). The merlian hasilic is the vein usually chosen for venesecetion, owing to its larger size and its being fimly smpporterl ly the suljacent bicipital fascia which separates it from the brachial artery; but the median eephalic is the saf ere. 'The. median basilic is erossed by branches of the internal cutaneous nerve, while these

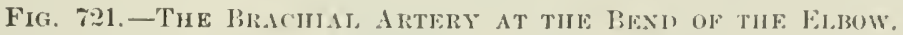

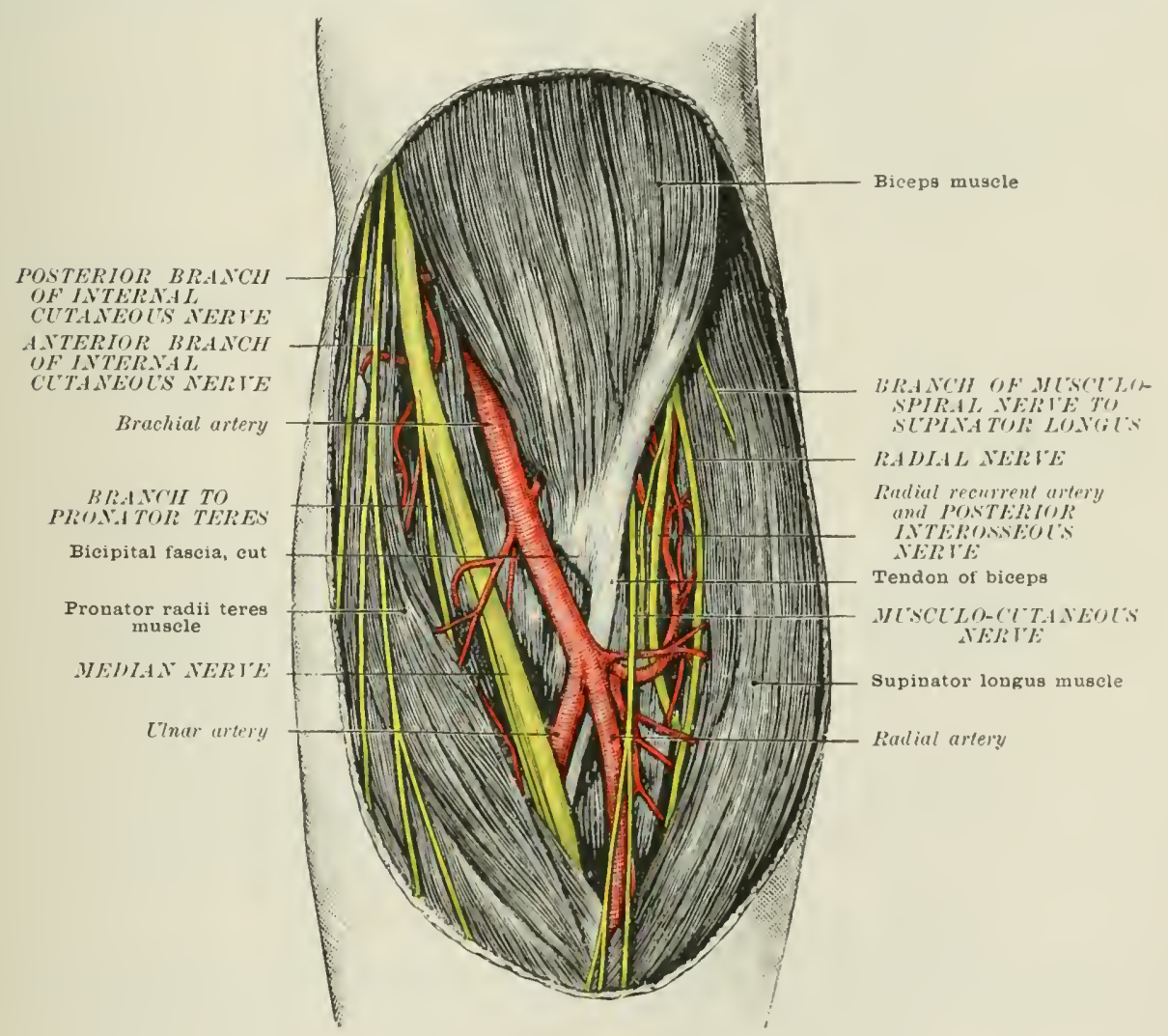

of the musculo-cutaneous lie under the median erphalic. In the semiflexed position, the fold of the elbow is seen, a little above the level of the joint. This forms the base of the triangular fossa below the albow, the outer side corresponding to the brachio-radialis, the imner to the pronator radii teres, and the anex to the meeting of these museles. The tenclon of the hiceps can he easily made out in the centre of the fossa, giving off alove the hicipital fascia from its imner sick to fasten down the flexors of the forearm. Under the tendon on its inner sisle lie the brachial artery and the median nerve for a short distaner. The musculo-spiral lics outside. the fossa, between the brachio-radialis and the hrachialis anticus. The hrachial usually bifurcates opposite to the neck of the radius.

The arterial anastomoses about the elbow-joint are as follow: The radial recurrent runs up uncler corer of the hrachio-ratlialis to anastomose with the 
superior profunda. The anterior uhar recurrent ascends on the brachialis anticus to join the anastomotica magna under the pronator radii teres. The posterior ulnar recurrent makes for the interval between the internal condrle and the olecranon, to join with the inferior profunda and anastomotica magna. The posterior interosseous recurrent ascends, between the supinator lrevis and the anconeus, to anastomose on the back of the external condyle with the superior profunda. It further joins, w a large anastomotic arch across the back of the joint, with the anastomotica magna and posterior ulnar recurrent.

Fig. 722.-DIAGRAM OF THE ANASTONOSE OF THE BRACHAL A RTERY. (MacCormac amd Anderson.)

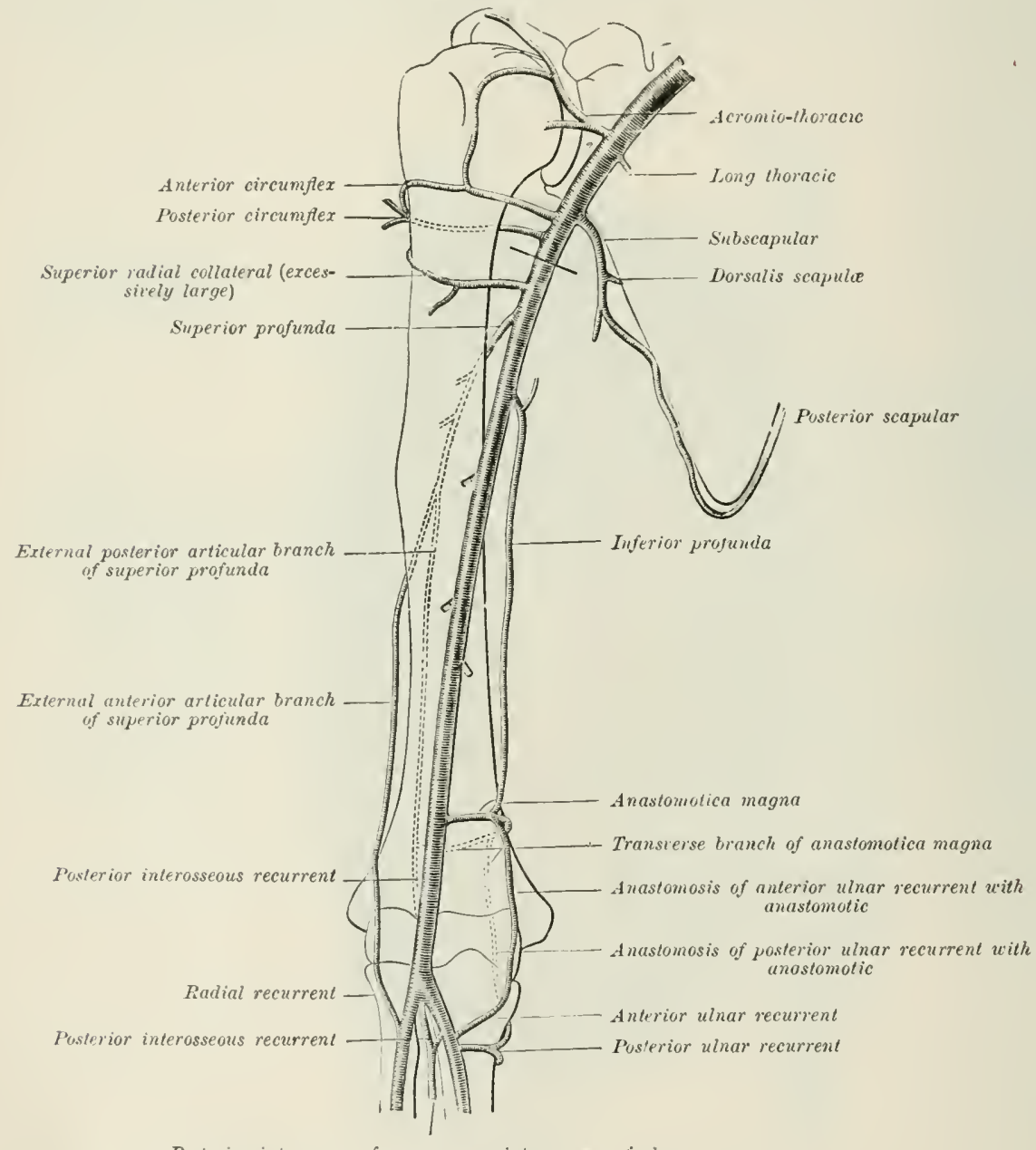

Posterior intcrosseous from common interosseous of ulnur

The following table of the vessels anastomosing on the front and back of the condyles will be useful:-

Internal condyle $\left\{\begin{array}{cc}\text { Front.-Anastomotica magna. } & \text { Anterior ulnar recurrent. } \\ \text { Inferior profunda. } & \text { Pack.-Anastomotica magna. } \\ \text { Inferior profumla. } & \text { Posterior ulnar recurrent. }\end{array}\right.$ External condyle $\left\{\begin{array}{r}\text { Front.-Superior profunda. Radial recurrent. } \\ \text { Back.-Superior profunda. Anastomotica magna. Inter- } \\ \text { osseous recurrent. }\end{array}\right.$ 
It will be seen that the amastomotiea magna is the artery most largely cmployed, distributing branches everywhere, save to the front of the external condyle.

\section{THE FOREARM}

Bony landmarks.- The ulna can be easily traced down from the olceranon to the styloid process; the bone becomes somewliat rounded below, and lies between the flexor and extensor carpi ulnaris. The tip of the styloid process corresponds to the inner end of the line of the wrist-joint. The radius is covered above hy the brachio-radialis and radial extensors of the carpus, and the outline of the bone is less easily followed. Its styloid process is readily made nut below, a finger's breadth above the thenar eminence. It is places on a slightly lower level than that of the styloid process of the ulna. Thus, a line drawn straight between the two processes would fall a little below that of the wrist-joint, this being shown by a line drawn between the two processes forming a slight curve, with its concavity

Fig. 723.-Sectiox throcan the Minnle of the Right Foreary. (Heath.)

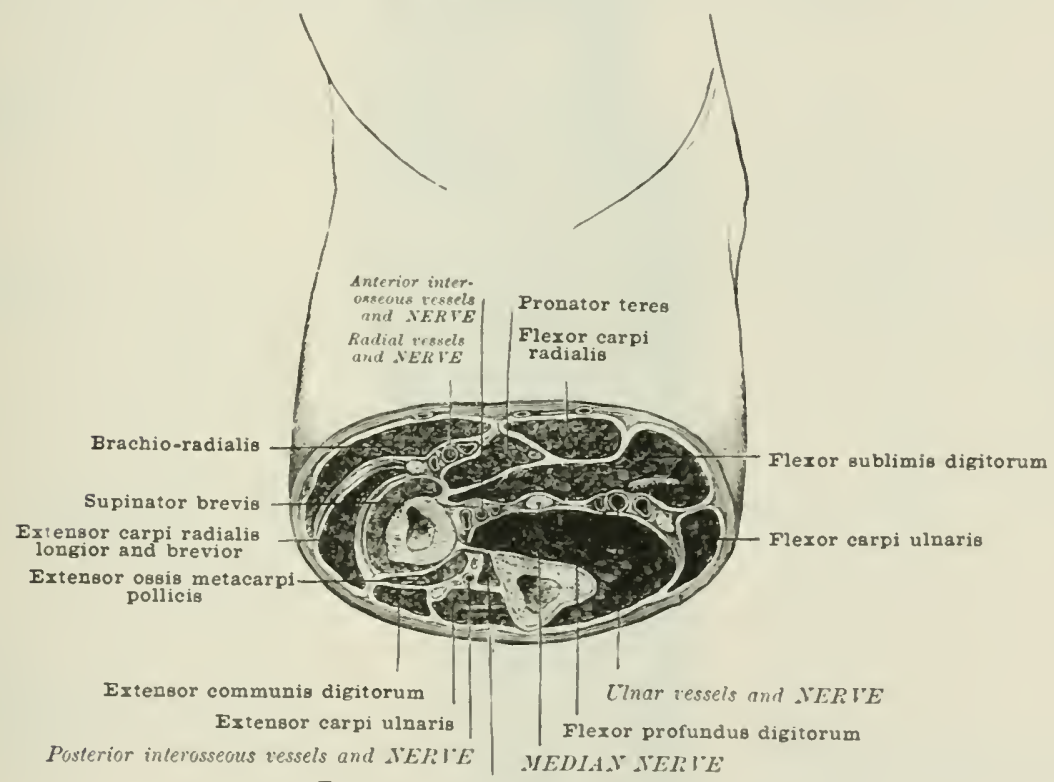

Extensor securdi iuternodii pollicis

downwards (corresponding to the concavity of the lnwer surface of the radius and fibro-eartilage) about half an inch (12 mmi.) above the straight line given alove.

The radial styloid process is covered hy the extensor ossis metacarpi and primi internodii pollicis, while firther out lies that of the extensor secundi. The lones are nearest to each other in enmplete pronation, and farthest apart in complete supination. On section, the bones are found at every point nearer to the back than to the front of the limb. but increasingly so above. "The lower the seetion proceeds down the limb, the less will the lomes be covered at the sides, and the more equally will the soft parts he distributed aluut the anterior and posterior aspects of the limb. It will be noticed that where one bone is the most substantial, the other is the more slender, as near the elbow and wri-t; and that it is alout the centre of the limb that the two are most nearly of equal strength ' (Treves). IV"hen the limb is pronated, the interosseness space is narrowal: in supination and the mislposition it is widened out. In pronation, hoth stylobl proxesos can he di-tinctly made out; in supination, that of the ratius is mist distinct, as now the skin and soft parts are stretched and raised over that wf the ulua. 
Fig. 724.-The ARterifs of the Foreary With the Superficial PAlyar Arch.

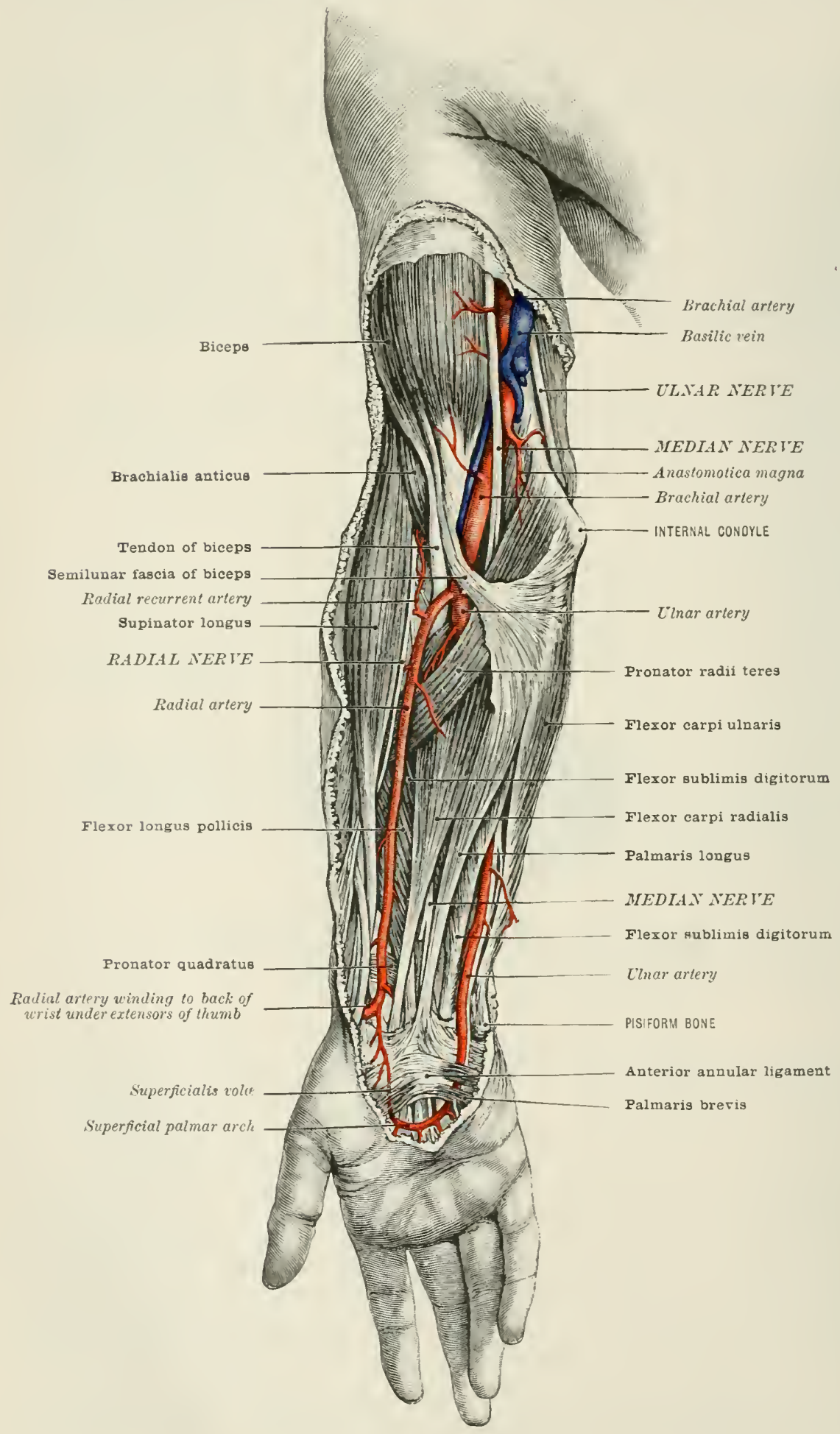


Soft parts.- Along the outer border descend the brachio-radiali; and ranlial extensors of the carpus, fleshy alove, tendinoms lekw. . Hout an inch and a half above the styloid proeess of the radius, a fleshy swelling directed obliquely downwards and forwarls from behind, across this suter lorder of the forearm, demotes the extensors of the thumb crossing those of the carluns.

Along the inner border is the fleshy mass of the pronator teres and flexors, the ulna being covered by the flexor carpi unaris and flexor profundus. The tendon of the pronator is inserter into the radius a little below its centre-a point of importance in the treatment of fractures, and in amputation. The flexor carpi uharis tendon can be folt just alove the wrist making for the pisiform bone; and just external to it lies the ulnar artery, about to jass over the anterior anmular

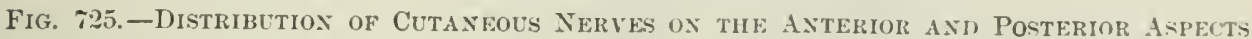
oF TIIE SUPERIOR Extreilty.

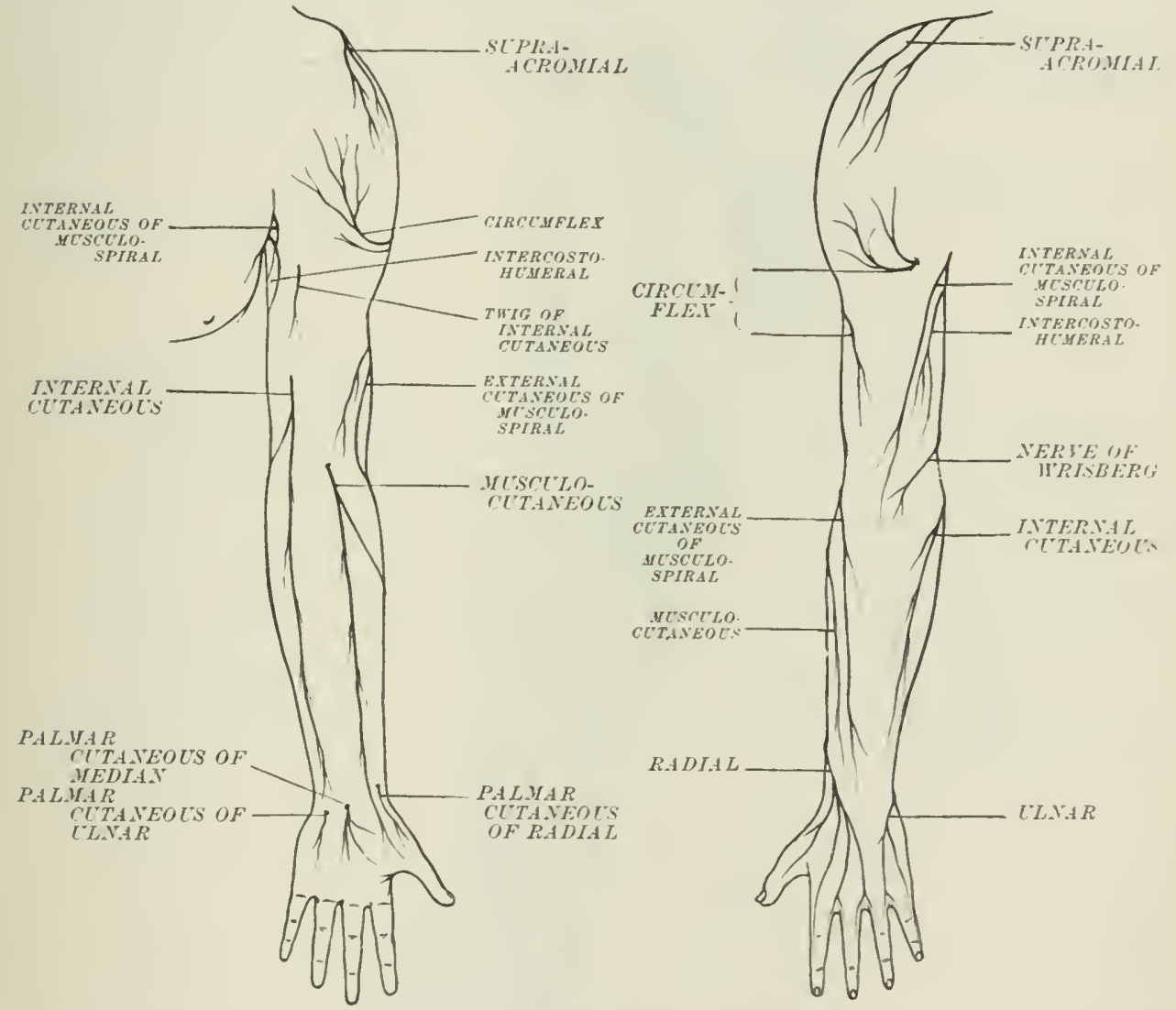

ligament. The course of the artery is denoted ly a line drawn from the frunt of the internal condyle to the outer edge of the pisiform bone. If it le drawn from the bifurcation of the brachial, this line must in its upper third be made strongly convex inwarls, in order to mark the upuer part of the artery, here thickly covered by muscles. The line of the ulnar nerve is one drim from the interval between the internal condyle and the olecranon to the inner side of the ulnar artery just ahove the wrist. The nerve joins the artery at the junction of the upper anil middle thirds of the forearm. The median nerve runs in a line drawn from the inner side of the brachial artery, in the ellow triangle, to al point heneath, or just to the inner side of, the palmaris longus just alowe the wrist. The radial artery will he marked by a line drawn from the centre of the lend of the ellow (where the brachial artery divides oppusite to the neck of the radius) to a point just 
internal to the racial styloid process descending along the inner edge of the brachioradialis. The radial nerve will be marked by the same line (it lies just external

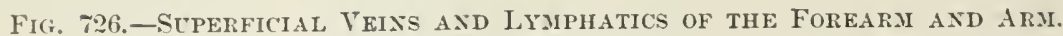

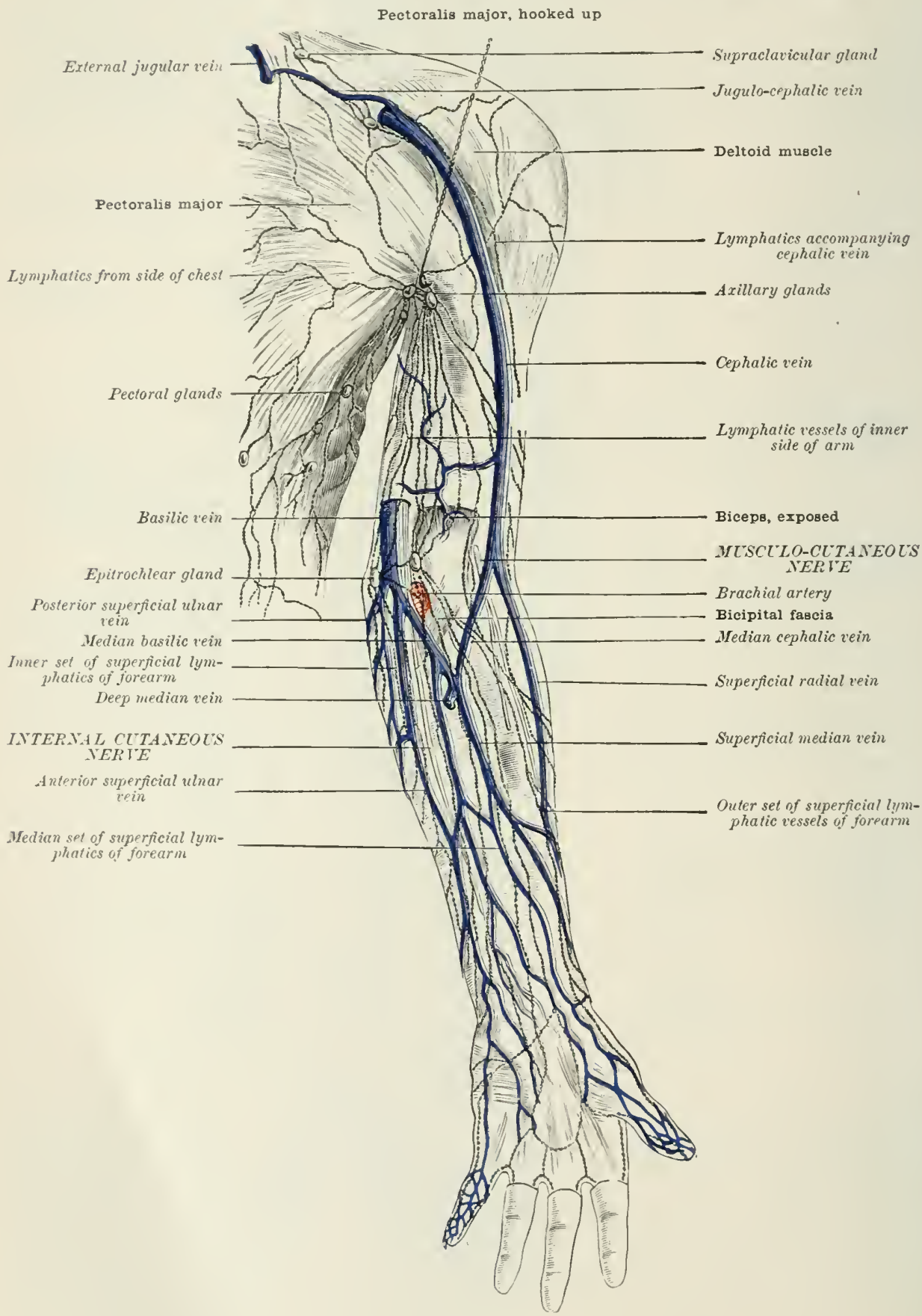

to the artery) for its upper two-thirds; it then leaves the artery about three inches above the wrist-joint, and passes to the back of the forearm under the tendon of 
the brachio-radialis. The anterior interosseous artery runs down on the interosseous membrane and passes to the back of the forearm by perforating it below. The posterior interosseous lies between the superficial and deef extensors. These small arteries reinforce the palmar through the carpal arches, and thus loring down blood after ligature of the trunks above.

The front of the forearm is sulpulied by the musculo-entaneous on the outer, and the internal eutaneous on the inner side; just above the wrist the fralmar cutaneous branches of the median and ulnar perforate the deep fascia (figr. 725 ). The back of the forearm is supplied by the musculo-spiral and posterior branches of the musculo-cutaneous externally, and the posterior branches of the intemal cutancous internally (fig. 725). The arrangement of the superficial lymphatics, shown in fig. 726, may be briefly described as follows:-

The lymphatics of the upper extremity are superficial and deep; the former run with the superfieial veins, the latter with the deep ressels. As a rule, there are no glands below the elbow. The majority of the lymphaties open into the axillary glands, and terminate on the left side, in the thoracic duct, on the right, in the right lymphatic duct. $A$ few, accompanying the cephalic rein, reach the subclavian or infraclavicular glands, and thus communicate with the lymphaties of the neck.

Fig. 727.-Reiatrox of the Palmar arches to the folis of the Palm. (Tillaux.)

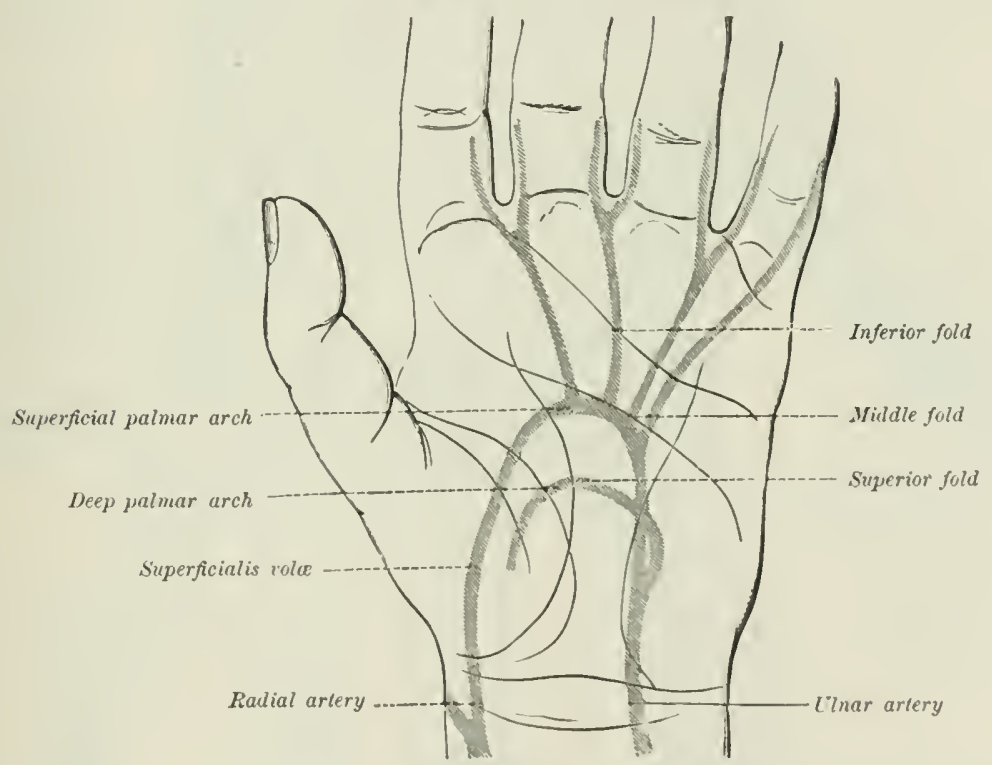

\section{THE WRIST ANII) HAND}

Bony points. - On the inner sille, the strloid process and, farther outwards, the head of the ulna can be mirle out. On the outer sile, the ratial styloid process descends about half an inch (12) $111 \mathrm{~m}$.) lower than that of the rarlius, and is somewhat anterior to it. Abduction of the hand is thus less free than adduction. In Collese fracture, the line of fricture, usually transwerse, cruses the radius about an inch above the apex of the strlobil process. Between the apex of the styloid process and the ball of the thumb a bony ridge can be felt, with some diflienliy, formed liy the tuberele of the scaphnicl and the ridge of the trapezium. It a corresponding point on the inner sicle the pisiform can be more readily distinguisher. On the front of the metacarpo-phalangeal joint of the thumb the sesamoisl bones can be distinguished.

At the back of the wrist and hand the cumeiform bone can be felt below the head of the ulna; and more towarks the midelle line the prominemce of the os 
masnum, which supports the third or longest digit, and is the bone of the carpus most exposed to injury. A line drawn from the base of the fifth metacarpal bone to the radio-carpal joint, slightly curved downwards, will give the line of the carpo-metacarpal joints (Windle).

IThen the fingers are flexed, it will be seen that in each case it is the proximal bone which forms the prominence; thus, the knuckle is formed by the head of the metacirpal the interphalangeal prominence by the head of the first phalanx, and

Fig. 728.-ANastonoses Axin DIstribltion of the ARteries of the HAND.

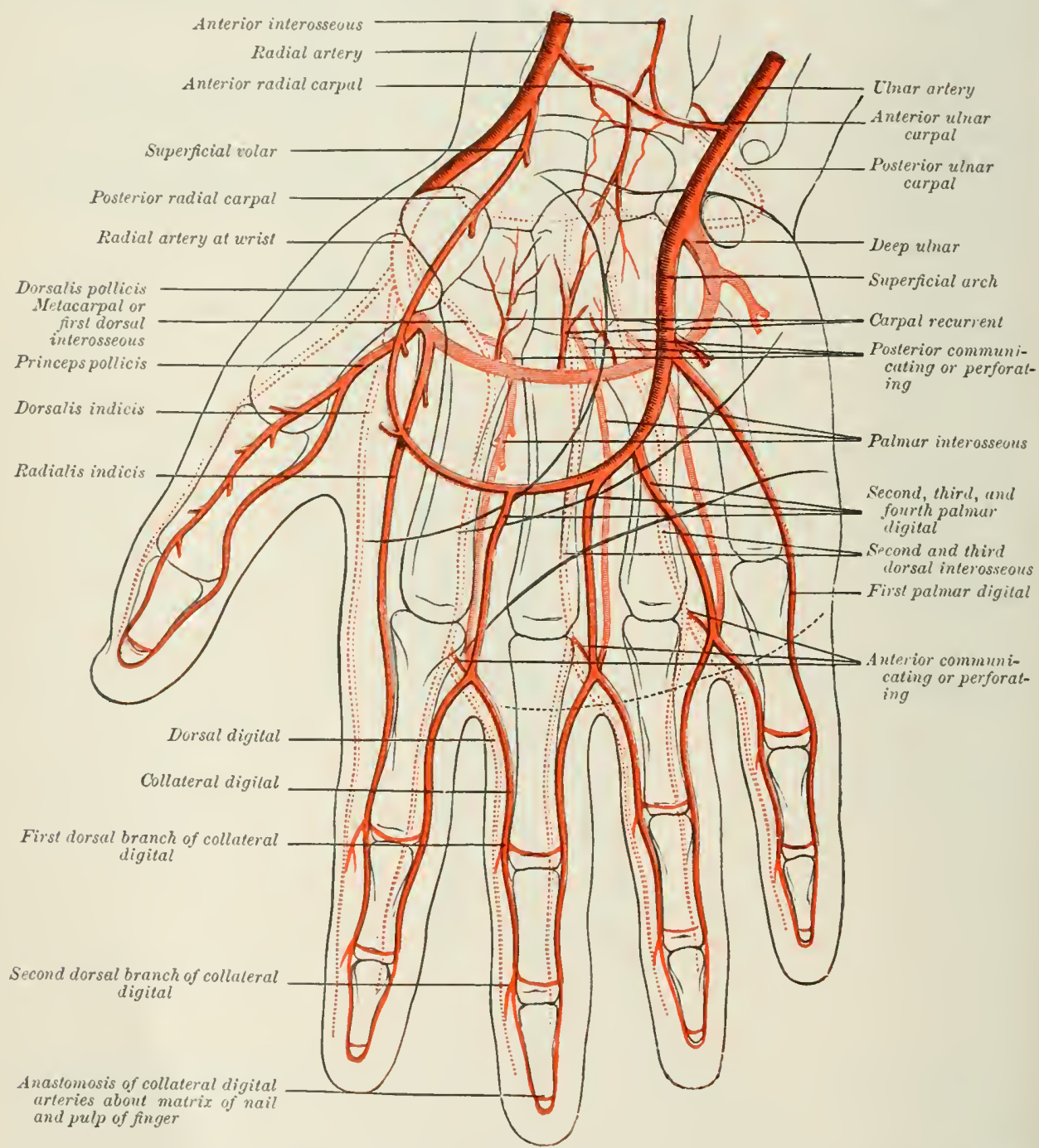

the distal one by the hearl of the sceond. Thus. the joint in each case lies below the prominence, the distal joint being one-twelfth of an inch ( $2 \mathrm{~mm}$.). the interphalangeal one-sixth $(4 \mathrm{~mm}$.), and the metacarpo-phalangeal one-third ( $8 \mathrm{~mm}$. below its prominence.

Skin folds. - Two or three of these are seen on the palmar surface of the wrist; two lower down, and usually close together; and one less well marked a little higher ul, upon the forearm. None of these correspond exactly to the wrist-joint (page 1159). The lowest "precisely crosses the areh of the os magnum in the line of the third metacarpal bone' (Tillaux), and is not quite three-quarters of an inch 


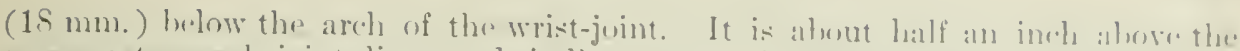
carpo-metacarpal jeint line, and indicates very fairly the uplep burele. of the anterior amular ligament.

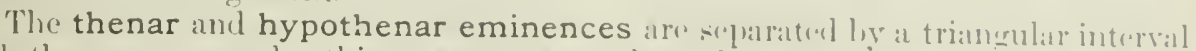

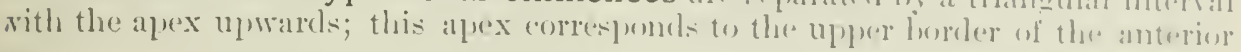

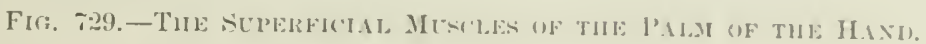

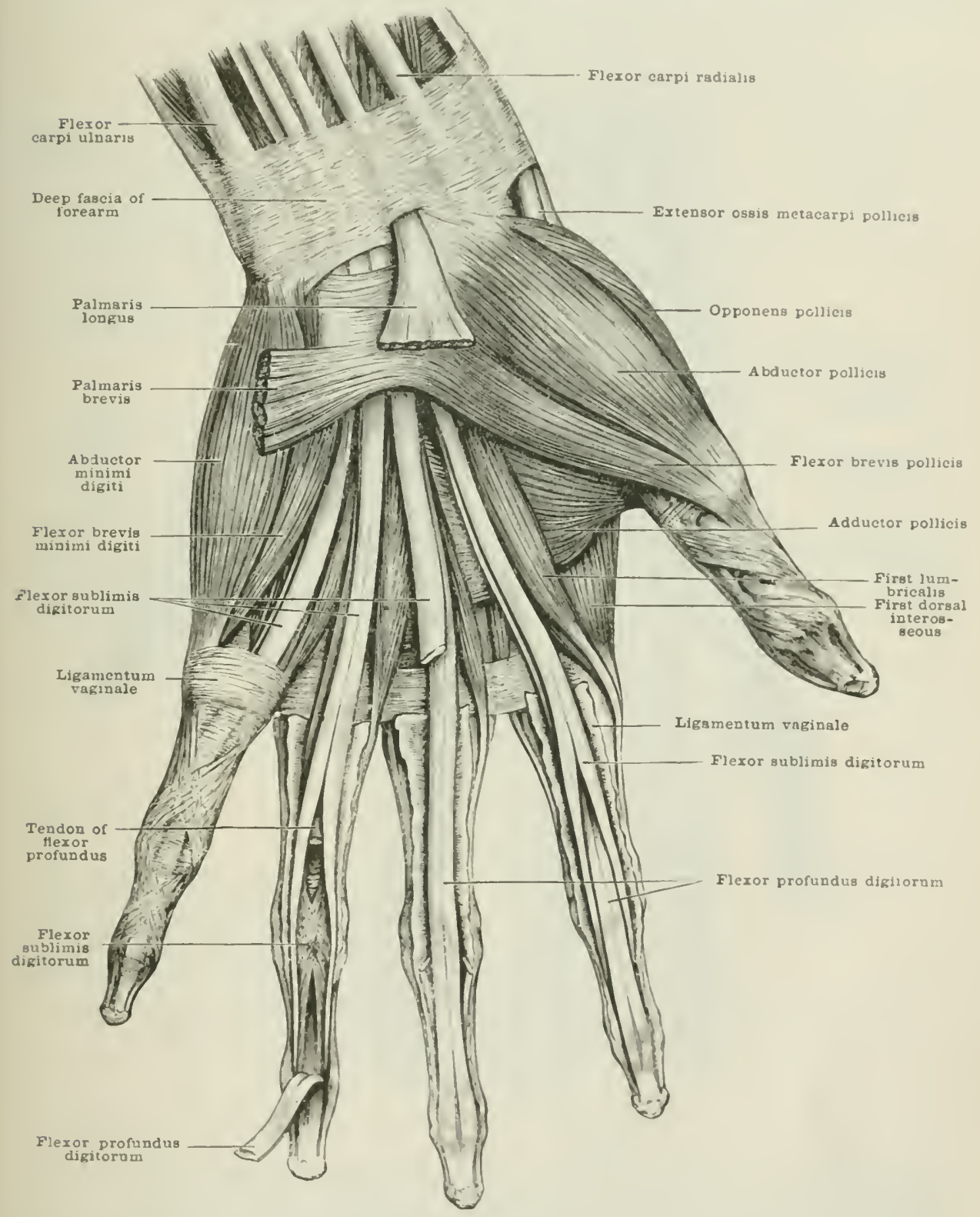

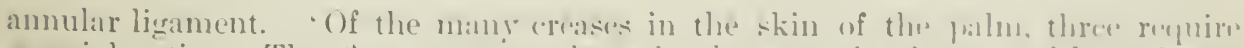

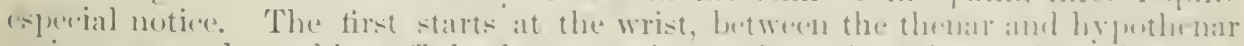

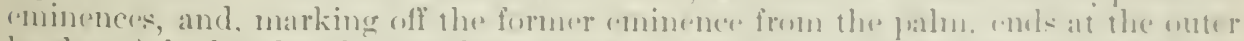

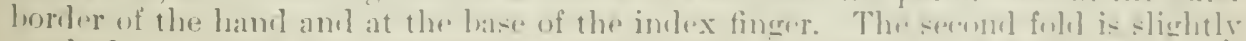

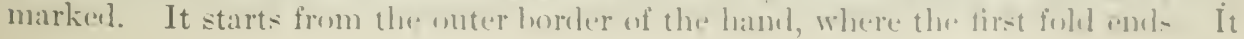


runs obliquely inwards across the palm, with a marked inclination towards the wrist, and ends at the outer limit of the hypothenar eminence. The third, lowest, and best-narked of the folds starts from the little eleration opposite the cleft between the index and middle fingers, and runs nearly transversely to the ulnar horder of the hand, erossing the hypothenar eminence at the upper end of its lower fourth. An unimportant erease, running obliquely from the third to the second fold, gives to these markings the outline of the letter $M$. The first fold is produced by the adduction of the thumb. the second, mainly by the bending simultaneously

Fig. 730. - The Deeper Muscles of the Paly of the Hand.

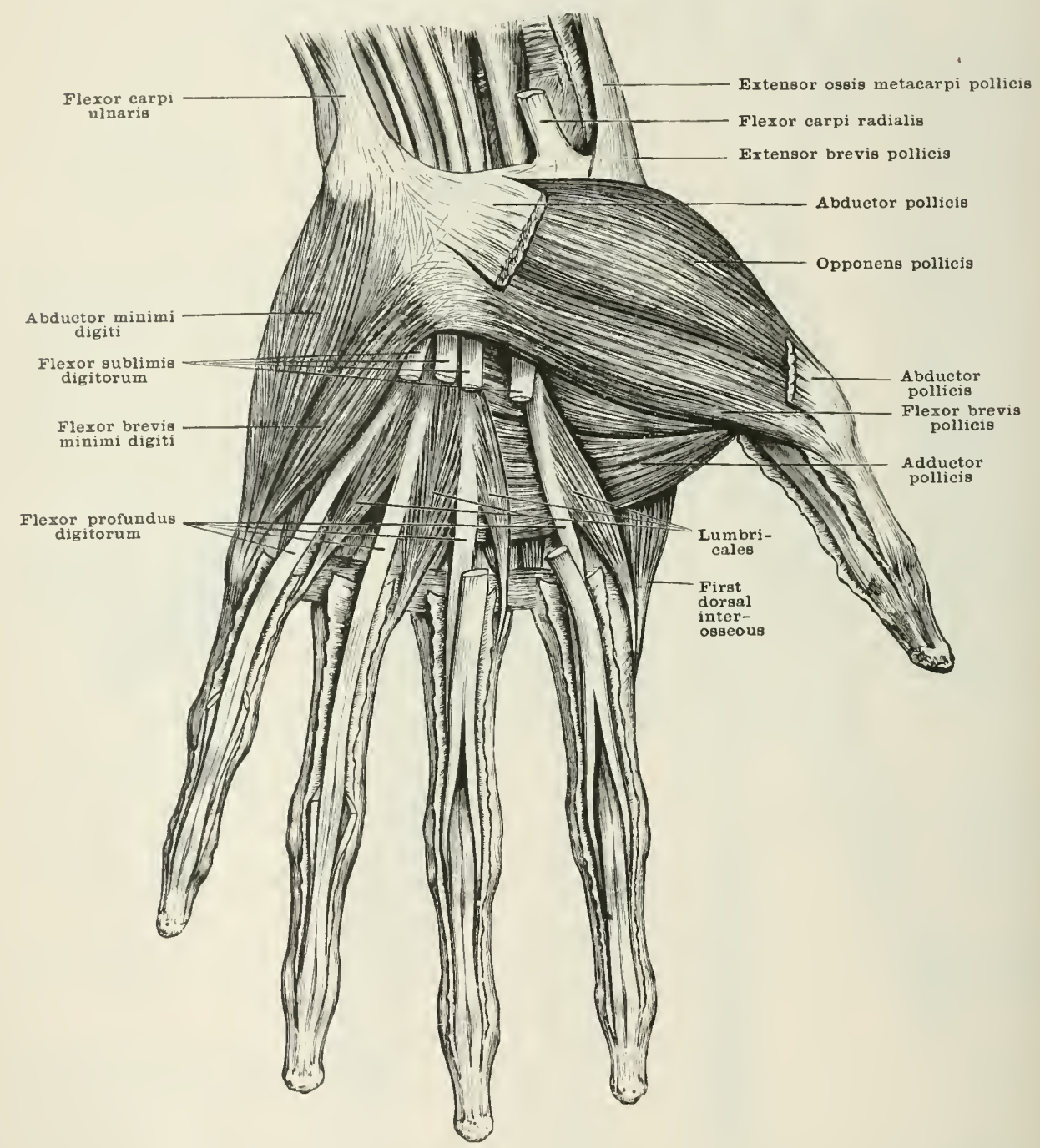

of the metacarpo-phalangeal joints of the first and second fingers; and the third by the flexion of the three inner fingers. The second fold, as it crosses the third metacarpal bone, about corresponds to the lowest part of the superficial palmar arch. The third fold crosses the neeks of the metacarpal bones, and indicates pretty nearly the uprer limits of the syovial sheaths for the flexor tendons of the three outer fingers. A little way below this fold, the palmar fascia breaks up into its four slips, and midway between the fold and the webs of the fingers lie the metacarpo-phalangeal joints. Of the transverse folds across the fronts of the 
fingers, corresponding to the mutacarpo-phalangeal and intorphalangeal joints, the highest is placed nearly three-(puarters of an inch (18 mm.) betow its corresponding joint. The middle folds are multiple for all the fingers, and are exactly opposite to the first interphalangeal joints. The lowest creases ane single, and are

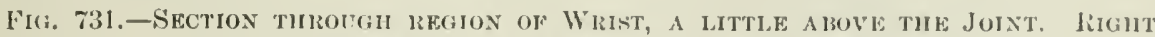
SHLE, UPPER HALF OF THE SECTION. (Tillaux.)

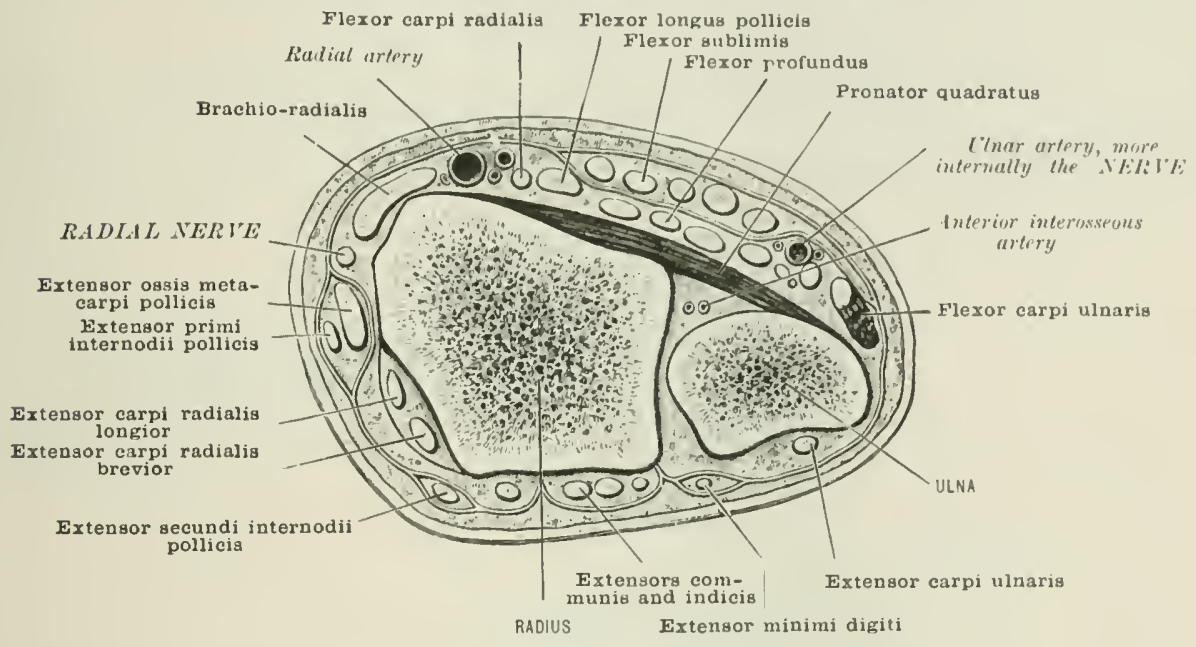

placerl a little above the corresponding joints. There are two single creases on the thumb corresponding to the two joints, the higher crossing the motatarpu-phalingeal joint obliquely. The free elge of the wels of the fingers, as measured from the palmas surface, is alout three-quarters of an inch $(18 \mathrm{~mm}$.) from the mutilcarpo-phalangeal joints (Treves).

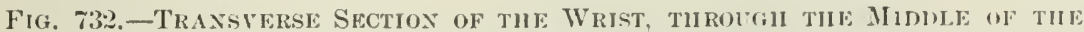
P'ISIFORM BONE.

Sheath of flexores sublimis and profundus digitorum and flexor longus pollicis, enclosed by the annular ligament

Cut tendon of palmaris longus | TLN.IR VERLE

Sheath for flexor carpi radialis Radial origin of annular ligameut Sheath for extensor ossis metacarpi and primi internodii pollicis

IRuliul ressels
Sheath for extensor osis metacarpi and primi internodii pollicis

OS MAGNUM heath of extensor sec
internodii pollicis

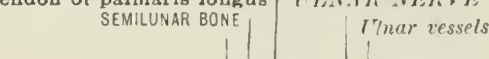

SCAPHOIO

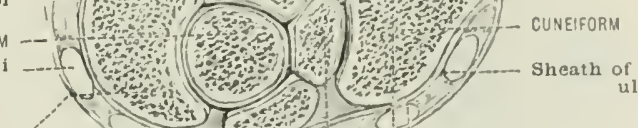
of exten
ulnaria

Sheath of extensores carpi radialis, longior and brevior

Sheath of extensor communis and indicator UNCIFORM

Sheath of extensor m:nimu digiti CUNEIFORM

SEMILUNAR

The superficial palmar arch, formed ly the uhar anatomocine with the

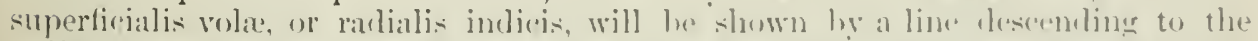

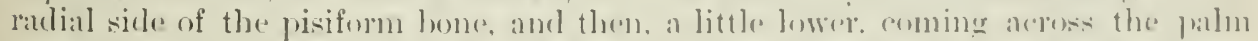
on a line with the thumb when outstreteleet at right angles with the index finger. The digital arteries, the main lontehes of the superficial arch run ilowmarels 
along the interosseous spaces, and bifureate half an inch above the webs of the fingers; the imnemost digital does not lifureate. The digital arteries then descend along the sides of the fingers under the digital nerves, giving off twigs to the sheath of the temolous, which enter by apertures in it, and run in the vineula raseulosa. It is owing to the readiness with which these tiny twigs are strangled by infammation that sloughing of the tendon takes place so readily and imeparably. The deep palmar arch, formed by the radial and communicating branch of the ulnar, lies about half an inch nearer to the wrist than the superficial.

Fasciæ and sheaths.- The two annular ligaments bind down and hold in place the numerous tendons about the wist. The anterior, when healthy, cannot be rletected. It is attached to the pisiform and cumeiform bones on the inner, and to the seaphoid and trapezium on the outer, side. The unar nerve and ressels, the superficinlis volix, and palmar cutaneous branches of the median and ulnar pass over

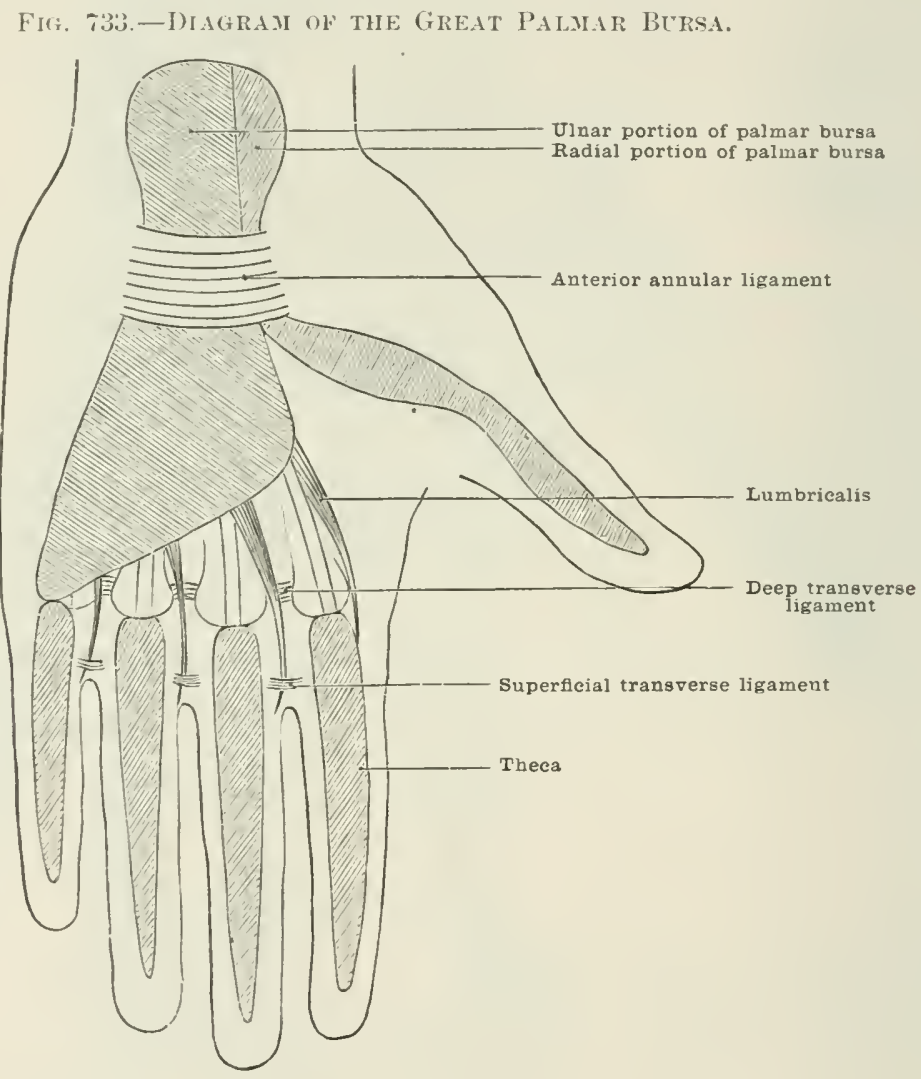

it. The ulnar artery and nerve are especially protected by their pusition hetween the pisform and hook of the unciform, and also hy a process of the Hexor ealri ulnaris, which passes between the two bones, thus forming a kind of tumnel. 'The flexor' carpi rulialis passes through a separate sheath formed by the liganents and the groose in the trapeziun; while beneath the ligament lie the Hexor tendons, the merlian nerve, and accomplanying artery. Attached to its upper borler is the deep fitciat of the foream, and to its lower the jahmar fascia and the palmaris longus fersclon, while from the outer and inner parts arise some of the thenar and hypothenar nuscles. The upper lwrkel of the anterior amnular liganent enresponds to the lower of the two lines which cross the wrist just ahove the thenar and hypothenar enunenees. The large srnovial sheath, for all the flexors of the fingrers, reaches leneath and below the anterior ligament as far as the middle of the palm, and above the wrist for an inch and a half or two inches (37 to $50 \mathrm{~mm}$.). 
The posterior annular ligament is attacherl to the hack of the outer margin of the radius above the styloid process, and internally to the back of the cunciform and pisiform. It entains six tendon-compartments, of which four are on the rarlius. The outermost contains the two first pxtensors of the thumb; the second the two radial extensors of the carpus; the thirl, the extensor serundi internodii;

Fig. 734.-Sectios of Carpes, thinotin the Uxchom Bose, (Two-thirds.)

(Bellituy aiter Henle.)

$$
\text { MEDLAN NERVE }
$$

Flexor longus pollicis Flexorea sublimia and profundua

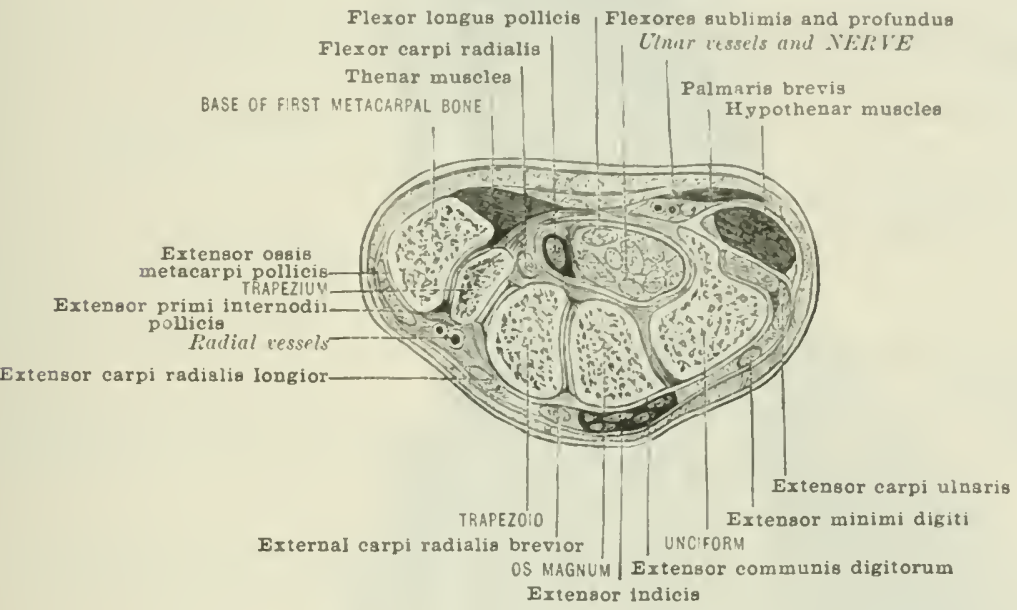

the fourth transmits the extensor communis and extensor indicis; the fifth, lying hetween the radius and ulna, the extensor minimi digiti; and the sixth, lying- just nutsile the styloid process of the uhna, the extensor carpi ulnaris. The sheaths for the last two extensors are the only ones which follow the tendons to their inser-

Fig. 735.-Horizontal Sectiox of the Haxd throlgi the Carpo-yetacarpal Juixts. (Bellamy after Henle.)

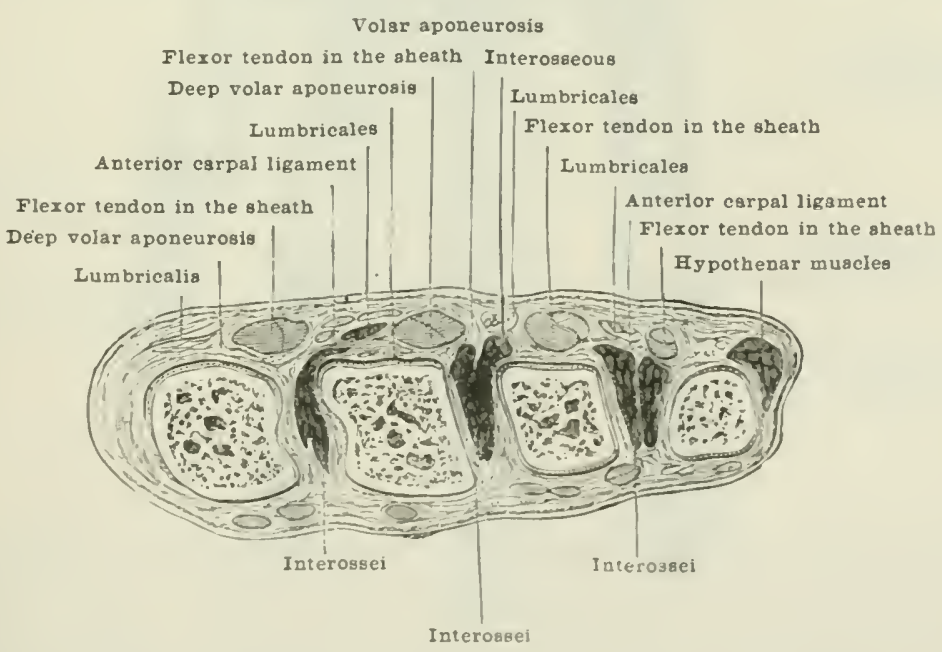

tion, the others ending at a rarying distame beluw the annular ligament. The lower border of the postrerior correspunds to the ulyer margin of the anterior annular ligament.

The palmar fascia, hy its strength. toughnes. numerous attachments. and $\pi \cdot 4$ 
intimate comnection with the superficial fascia and skin, is well adapted to protect the parts beneath from pressure. The thenar and hypothenar muscles are enclosed in two processes, which are thinner so as not to interfere with the contraction of the subjacent muscles. The central part, pointed above at its attachment to the

Fig. 736.-TexinoNs UPON THE DORSum of THE HaND.

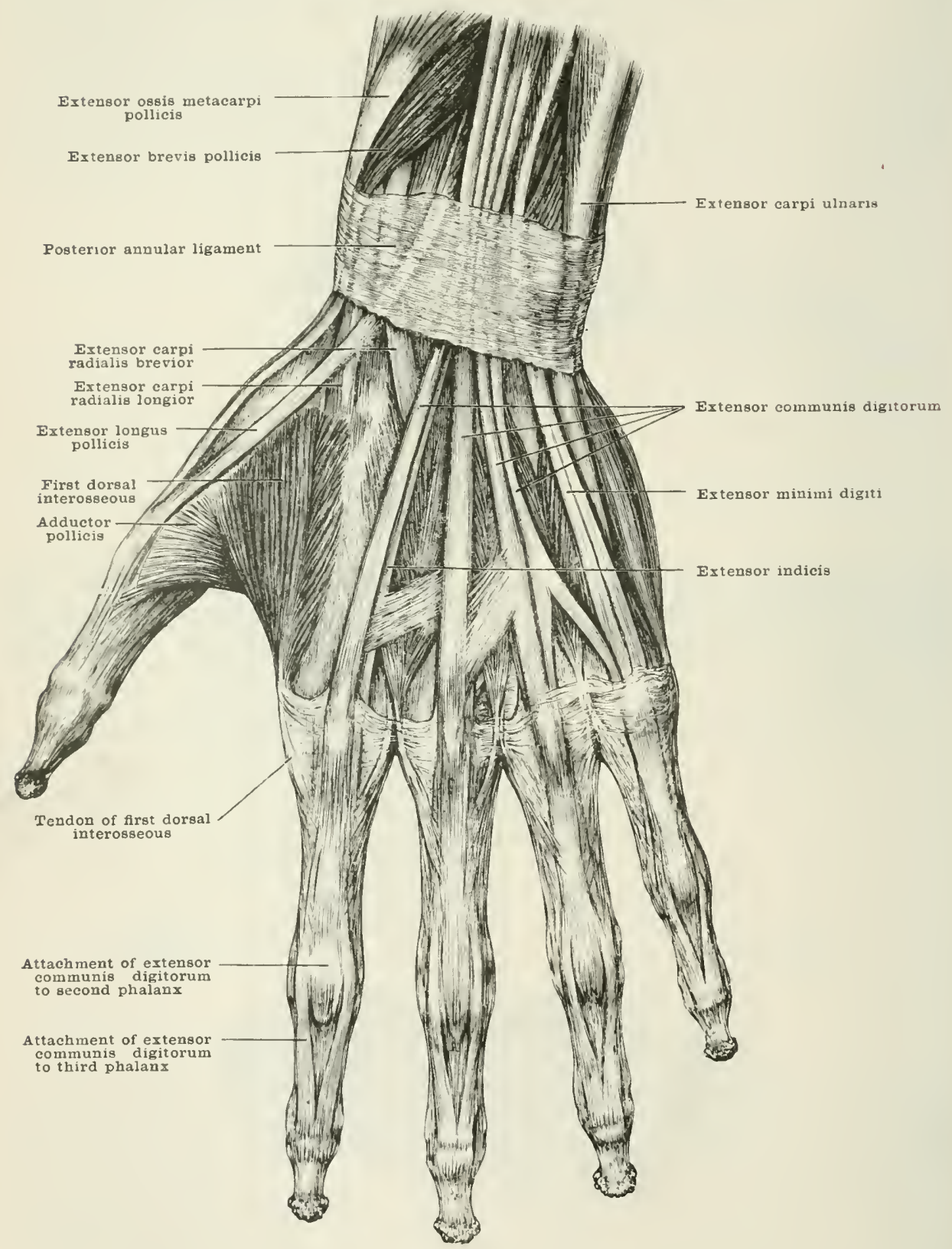

annular ligaments, spreads out fan-like below, and gives off four slips, each of which bifurcates into two processes. which are attacherl to the sides of the first phalanx of each finger and into the transverse ligament which ties the heads of the metacarpal bones together. Transverse fibres pass hetween the processes into which each of the four slips bifurcates, and thus form the beginning of the theea, which is 
continued down to the finger to the hase of the last phalanx. It is the contration of the palmar fascia, especially of the slips to the two inner fingers, which gives rise to Dupuytren's contraction.

Synovial membranes.-Beneath the anterior annular licament lie two synovial sacs, one for the flexor longus pollicis, and one for the superficial and derply flexors of the fingers. They extend ahove the annular ligiment to from one anil il quarter to one inch and a half (31 to:3 imm.) below. That for the long flexor of the thumb reaches to the base of the last phalanx. 'That for the finger-flexors gives

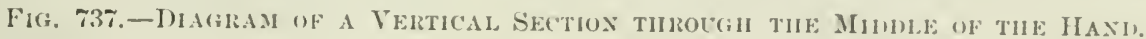

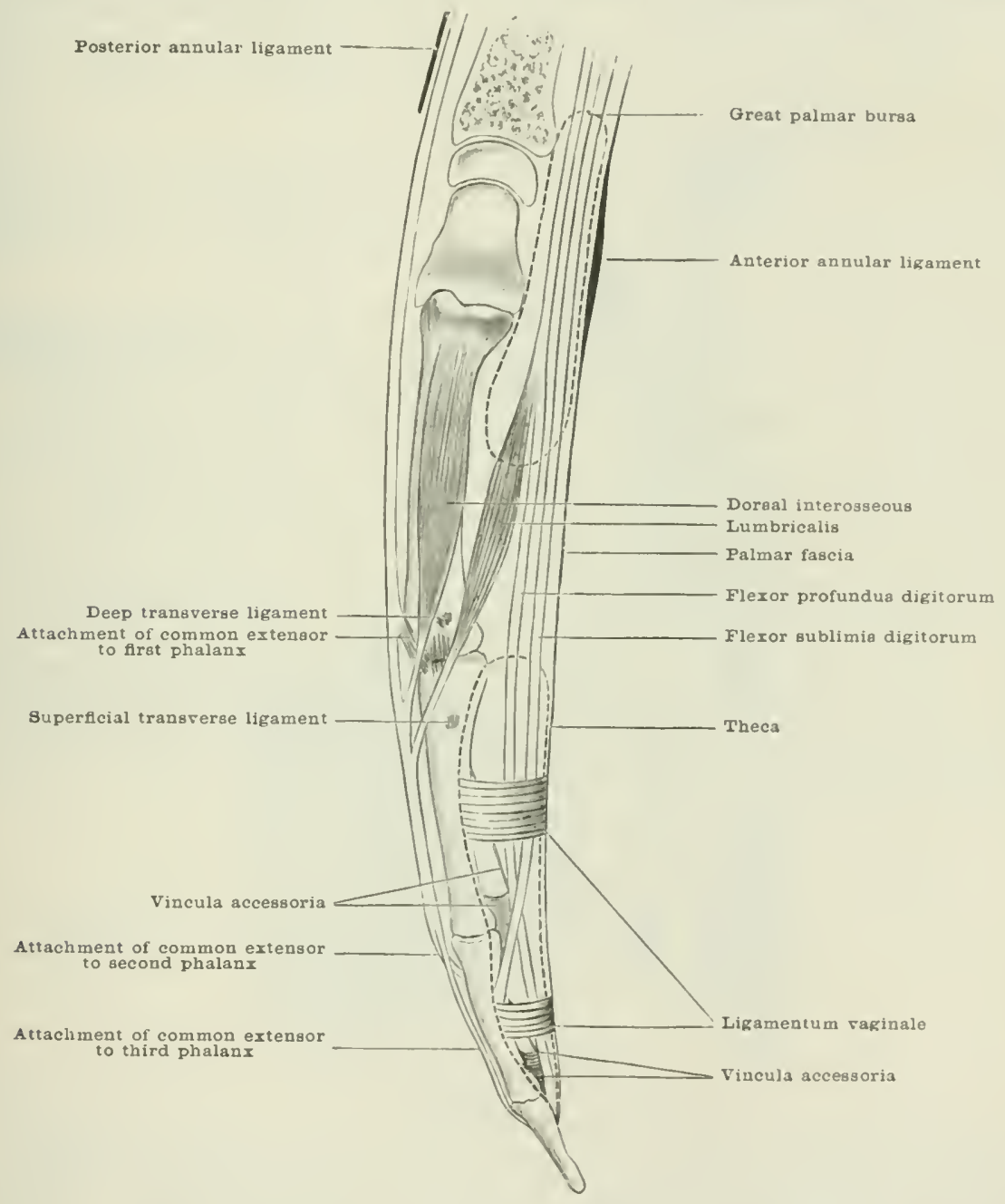

off four processes. The one for the little finger also roaches to the latie of the list phalanx. Those for the index, mirldle, and thirl fingers, end alwut the midlle of the metacarpal bones. Traed from the insertions of the flexor profundus, the digital synovial sheaths extent upwards into the palm as far as the hifureation of the palmar fascia (page 1169), i.e. into a proint about spypesite to the necks of the metacarpal bones, denoter on the surfece by the crease which corresponels to the flexion of the fingers. Thus, about half an incli (12 mm.) separates the sheaths of the outer three fingers from that large srmovial sac beneath the amnular ligament. There is no synovial sheath beneath the pulp of the fingers or thumb, 
this part lying on the periosteum of the last phalanx. The synovial sheaths, as they pass beneath the amnular ligament, are somewhat constricted.

Deeper down are the articular synovial sacs, five in number: (1) Between the interarticular cartilage and the hearl of the ulna; (2) between the radius and the interarticular cartilage above, and the scaphoid, and semilmar and euneiform helow; (3) between the trapezium and first metacarpal bone; (4) between the pisiform and the euneiform bone; (5) between the two rows of carpal bones, sconding two processer upwards between the three bones of the upper row, and three downwards lietween the four of the lower row; these three processes being also continued below into the inner four carpo-metacarpal and three intermetacarpal joints.

Beneath the palmar fascia covering the thenar eminence are the following struetures:- - iuperticialis volat, abduetor pollicis, opponens pollicis, radial head of short flexor, tendon of long flexor, uhar head of short flexor, princeps prollicis, and radialis indicis arteries. metacarpal bone of the thmmb, with the tendon of the flexor carpi radialis and trapezium.

Beneath the central part of the palmar fascia are the superficial arch and its digital branches; the ulnar and median nerves, with their branches; the flexors, superficial and deep, with their synovial sheath; and the lumbrieales; then a layer of connective tissue (the only structure which prevents matter pent in by the palmar fascia from making its way back out through the dorsum), the dieep areh, the interossei, and the metacarpal bones.

In the hypothenar eminence under the fascia are part of the ulnar artery and nerve, the abductor and flexor brevis minimi digiti, the opponens, the deep branch of the ulnar artery and nerve, and the fiftl metacarpal bone.

The back of the wrist and hand.-The posterior ammular ligament has already heen described with the anterior. On the outer side is the so-called 'snuff-box space' (tabatiere anatomique of Cloquet), a triangular hollow, bounded towards the radius by the two first extensors of the thumb, and towarls the ulna by the extensor secundi internodii. The scaphoid and trapezium, with their dorsal ligaments, form the floor. In the roof lie the radial vein and branches of the radial nerve. More deeply is the artery following a line from the apex of the styloid process to the back of the interosseous space. The different tendons have alreadr been given. Between the first two metacarpal bones is the first dorsal interosseous muscle, which forms a fleshy projection against the radial side of the index metaarpal, when the thumb and index are pressed together. On its palmar aspect is the adductor pollicis. Wasting of the former muscle is a ready inclication of injury or disease of the ulnar nerve.

\section{THE LOWER E.TTREMITI}

THE THIGH

Bony landmarks.-Miny of these, such as the anterior superior spine of the ilium and the spine of the pubes. have alrealy been mentioned.

The head and shaft of the femur are well covered in, save in the rmaciated. The hearl lies just below Poupart's ligament, under the ilio-psoas and a little to the outer side of the centre of that ligament. The outline of the condyles an be traced when the knee is Hesed, and. on the outer side, a small portion of the shaft is accessible between the biceps and vastus extermus.

Trochanter major.-This most valuable landmark is most prominent when tho limb is rotated inwards or adducted; it lies at the bottom of a depression when the femur is everted. The only struetures of inportance between it and the skin are the expanded insertion of the gluteus maximus and the hursa beneatl the muscle. This is often multilocular. The top of the great trochanter is about 
three-quarters of an inch (18 mm.) below the level of the fomoral head, and, when the femur is extended, is a little below the centre of the hip-joint. This part of the bone is covered by the gluteus medius. The slightness of the prominener of the great trochanter in the living sulject compured with that in the skalcton is explained hy fig. 738, which shows how the deserelling gluteus medius and minimus fill up the space between the ilium and trochanter.

Nélaton's line.-This most useful gruile is a line drawn from the anterior superior stine to the most prominent part of the tuberosity of the ischimu. In normal limbs, the top of the great trochanter just touches this line. In dislocation, fractures of the neck, and in wasting of the neck, as in osteo-arthritis, the relation of the trochanter to Nélaton's line liceomes altererl.

The top of the great trochanter is a guide in Mr. Adams s operation for division

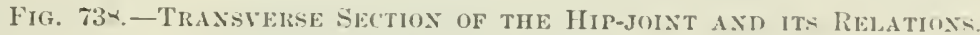
(O)e-thiml.) (Braume.)

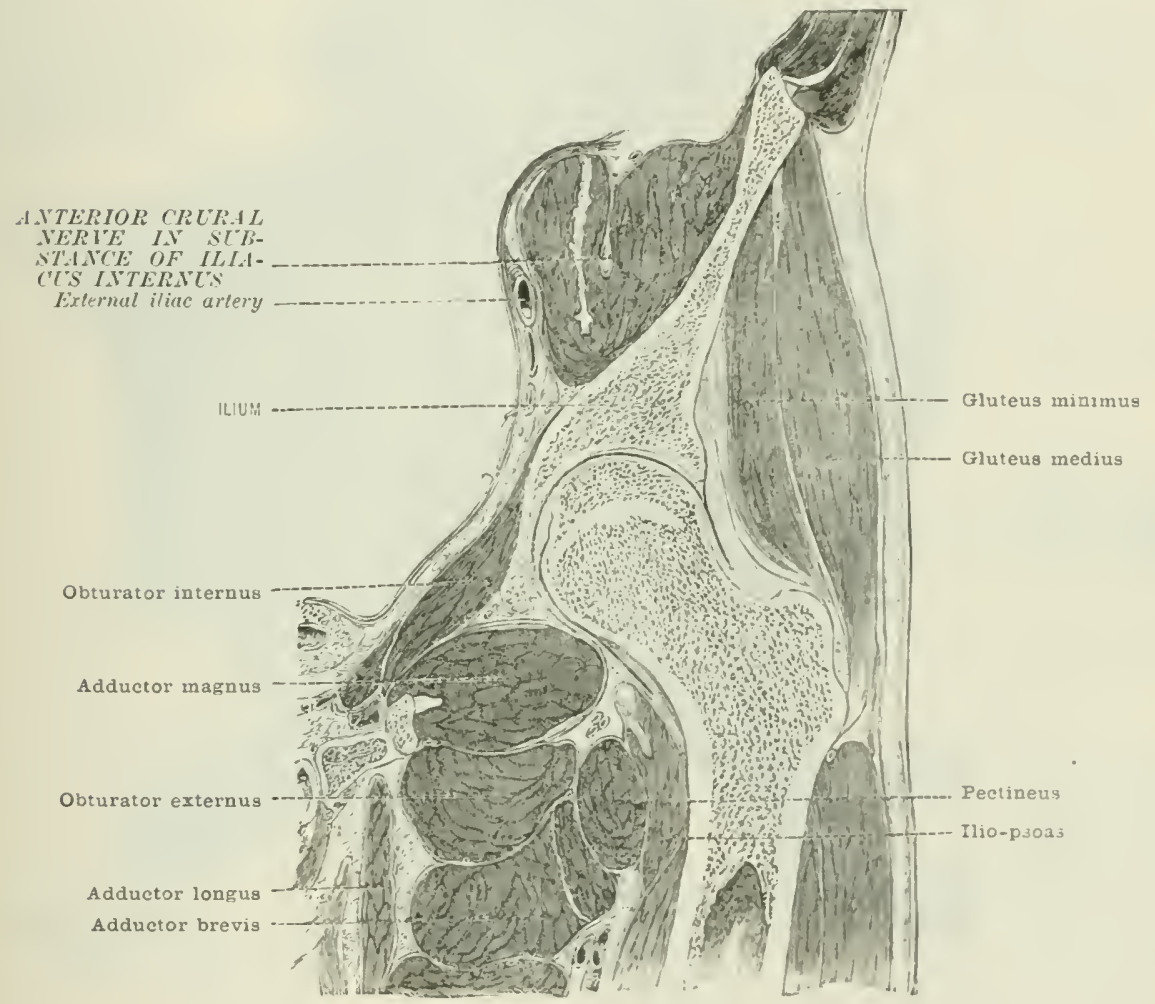

of the neck of the femur, the puncture being made and the saw entered one inch (25) mm.) above and about one inch in front of this point.

Bryant's triangle.-Mr. Bryant makes use of the following in lecicling the position of the great trochanter." The pationt heing flat on his lack, (1) a line is dropped rertically on to the couch from the anterior superior spine; (2) from the top of the great trochanter a straight line in the long axis of the thigh is drawn to meet the first; (3) to eomplete the triangle, a line is chawn from the anterior superior spine to the top of the trochanter. This line is practically Nélaton's. The second line will be found diminished on the dimaged or disiased side.

Muscular prominences.-The t(nsor vagina f'moris (ilin-aponeurotic muscle) forms a prominence beginning just outside the surtorius and reaching downwarls and somewhat backwards to the stromg fiscia lata, three to four inches (75 to 100 mm.) below the great trochantrer. Brow this point, as far as the outer tuberosity of the tibia, the strong ilio-tibial band can le felt. The sillorius, the chicf land- 
mark of the thigh, forming a boundary of Scarpa's triangle, Hunter's canal, and the popliteal space, can be readily brought into view by the patient's raising his limb. In the middle line the rectus muscle stands out in bold relief, with its tendon of insertion and the patella, when the leg is extended. On either side of this muscle is a furrow, and on either side, again, of this furrow the rasti become prominent. Between the vastus internus and adductor muscles is a depression indicating Hunter's canal. At the upper and immer third of the thigh, if the limb be abducted, the upper part of the adductor longus comes into strong relief. On

Fig. 739.-The Mescres attachen to The Proes. (From a dissection in the Hunterian Museum.)

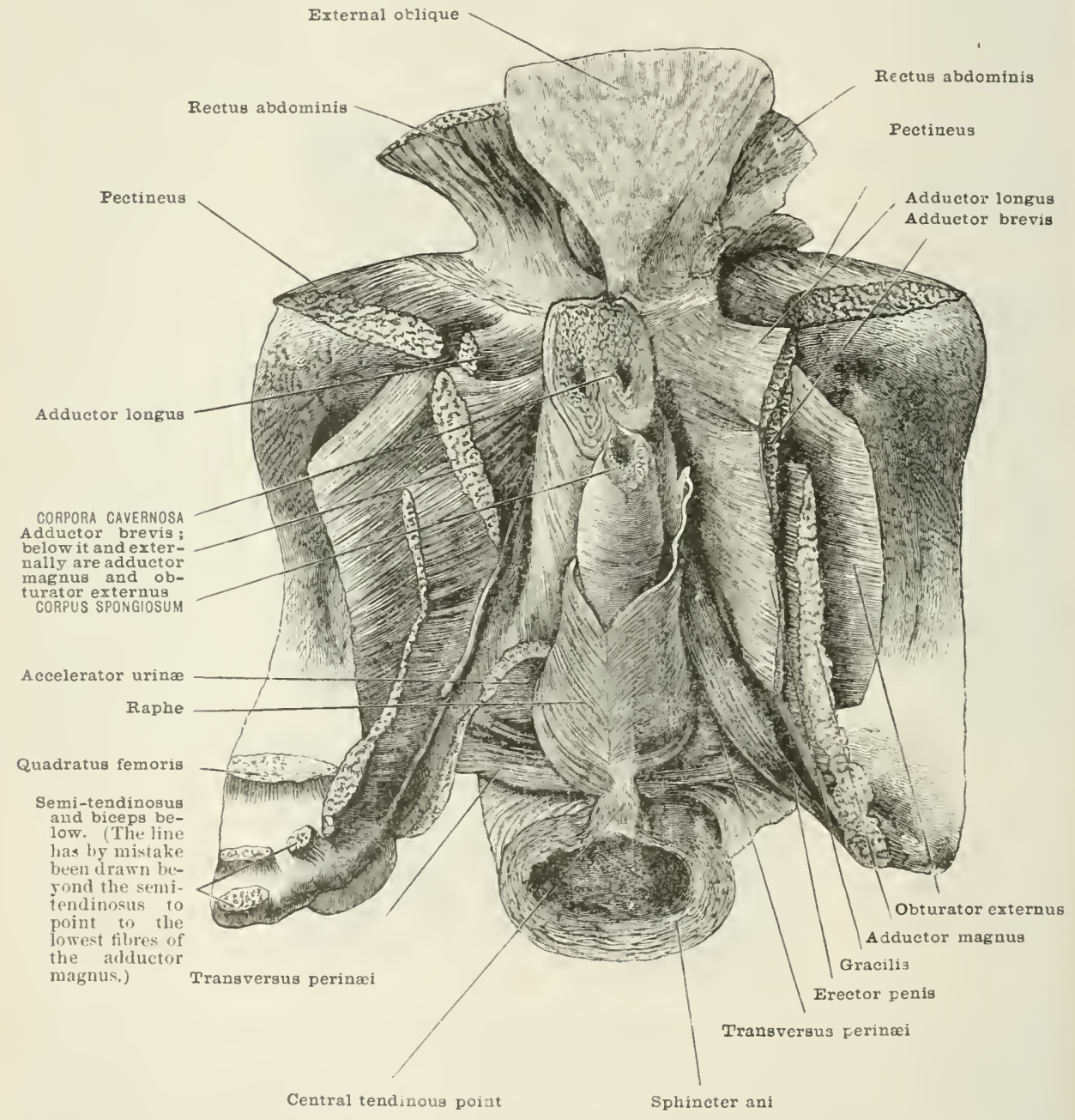

the inner side below, above the knee-joint, the vertioal fibres of the adductor magnus end in a powerful tendon coming down to the adductor tubercle (fig. 752). This replaces here the internal intermuscular sejtum, and the insertion of the tendon markis the level of the lower apiphrsial line of the femur. At the outer and hack part of the thigh the vastus extemus is separated from the biceps by a groove which indicates the external intermuscular septum.

Poupart's ligament.-The ablomen is scoulated from the thigh by a fold, best marked in flexion-the inguinal furrow. In this, pressure detects the meeting of the aponeurosis of the external ohlique and the fascia lata, i.e. I'oupart's liga- 
ment, extending hetween the anterior superior spine of the ilium and the spine of the pubes. The line representing it shonld be lrawn slightly ennvex downwarls, owing to the attachment of the deep fiscia. It forms the base of scarpa's triangle; its inner attachment hends with the trimgular (imbernat's ligament. The rarts passing under Poupart's ligament and their arrangement have been given elsewhere.

Scarpa's triangle (fig. 741). - Tmmediately below Poupart's ligament, a hollow is seen corresponding to this region, the outer and inner boundaries of which are

Fig. 740.-Diagray of Arteriks of TIIGir.

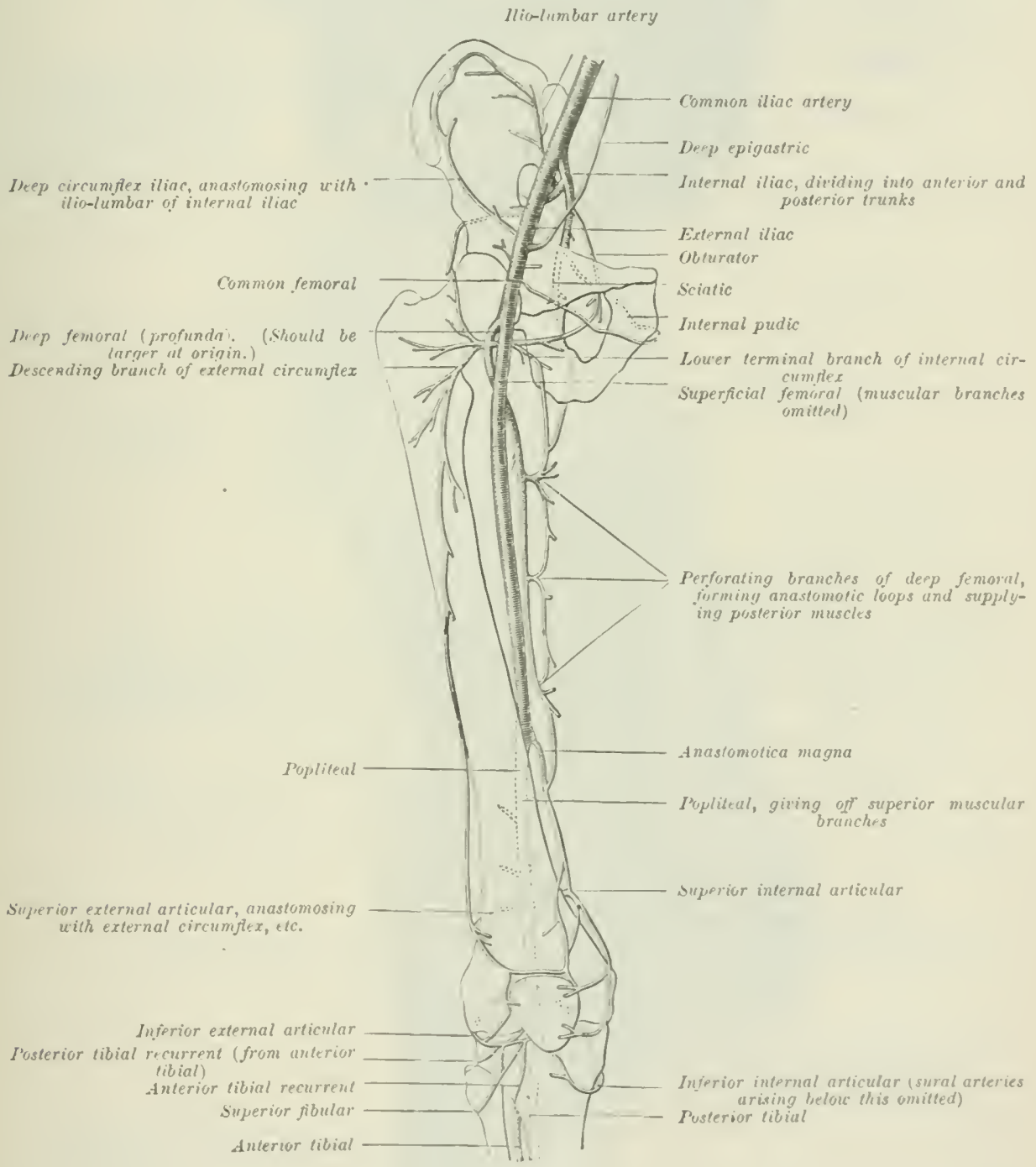

hrought into view when the limb is raised, the adductor longus especially when the limb is abdueted, and the sartorius where the thigh is flexed and adducted and carried towards its fellow. Iying superficially in the hase of the triangle, the lymphatic glands can be detected in a thin person (fig. 769 ). They lie in two groups $-(a)$ One horizontal in a line with Poupart's ligament, and receiving lymph from the genitals, the lower part of the ahdominal wall, and the inner aspect of the buttock; (b) a vertical set lying along the great vessels receiving lymph from the 


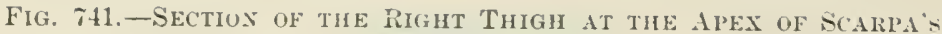
TRIATGL, (Heath.)

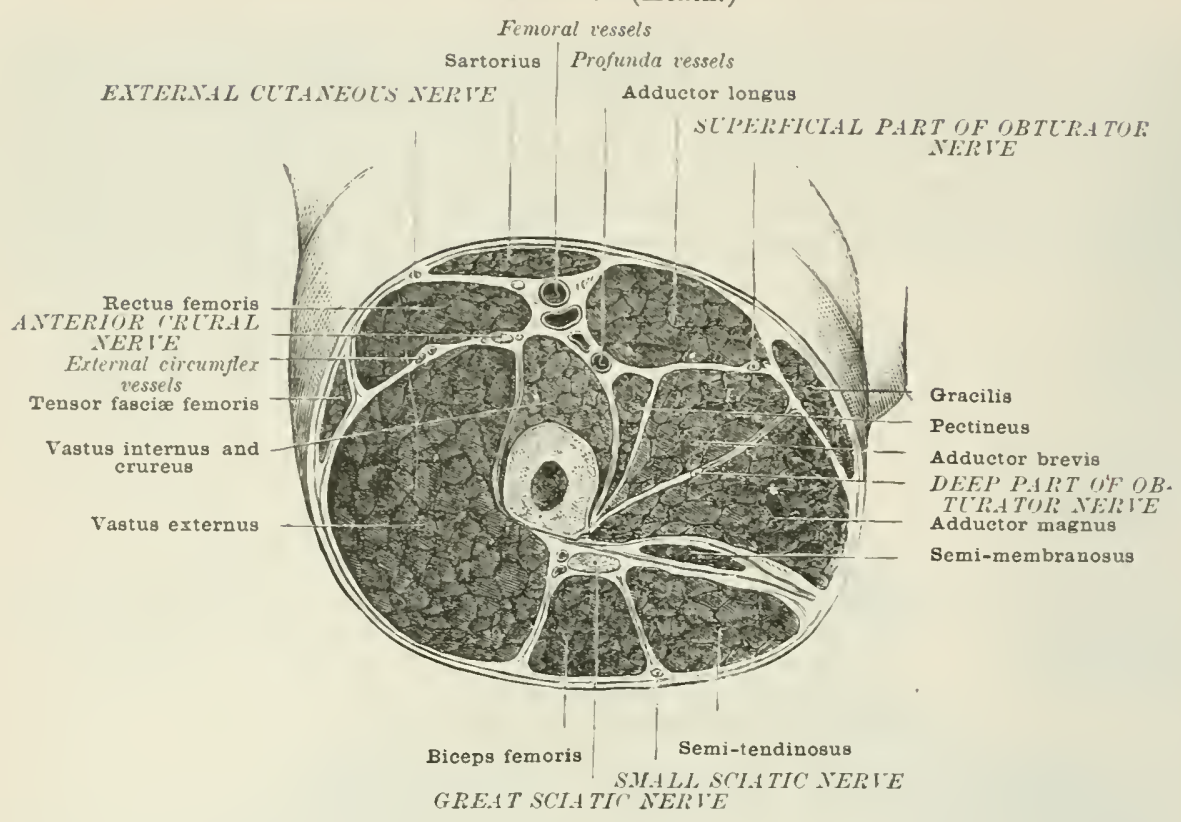

Fig. 742.-Superficial Dissection of the Front of the Thich, (Hirschfeld and Lereillé.)

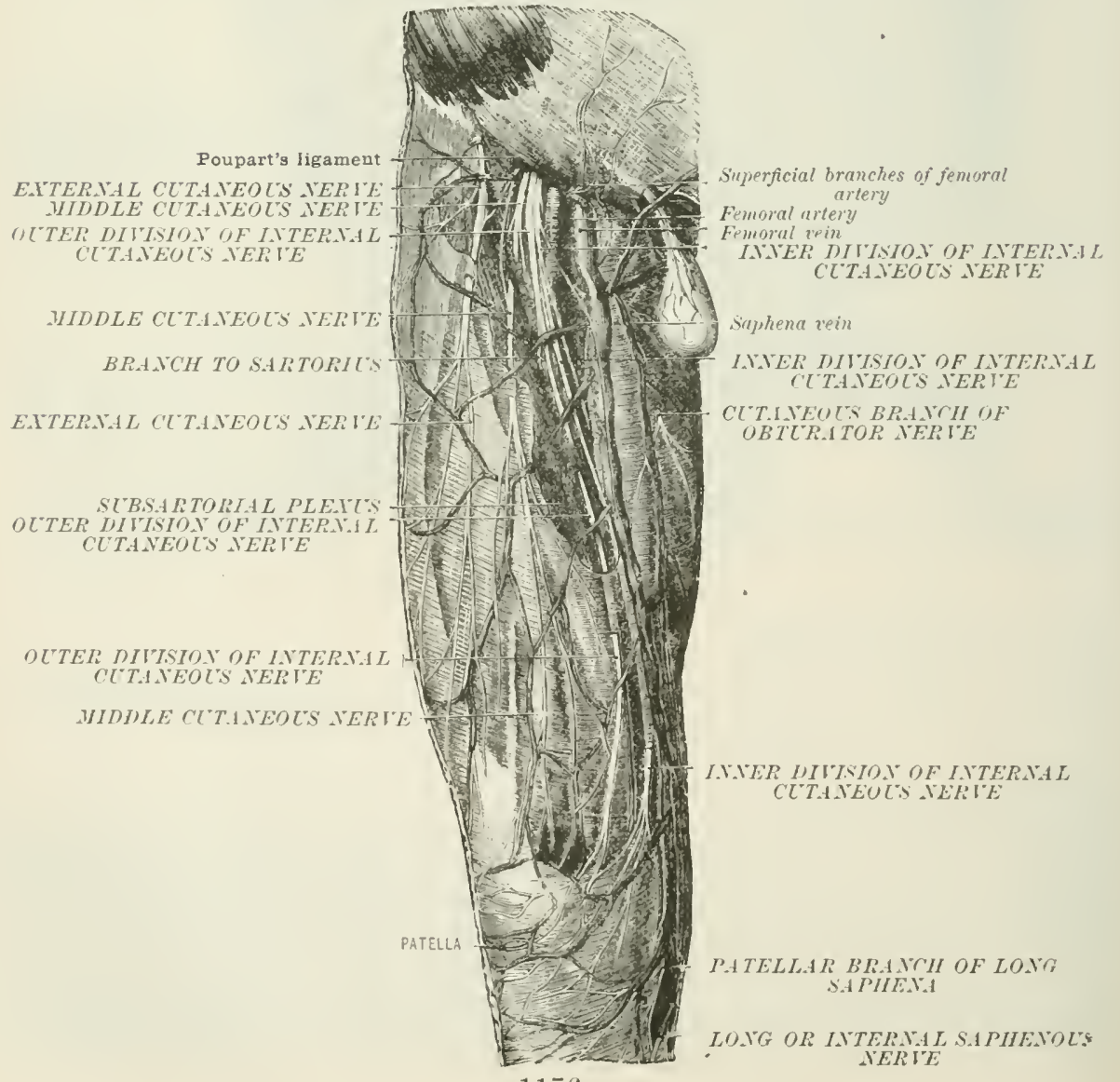

1176 
limb. According to Mr. Treves, a fow of the superficial genital lomphation, amel all those from the perinarum. (ro) into the vertical group.

Saphenous opening. -The depresion arrespouling to this is placerl just

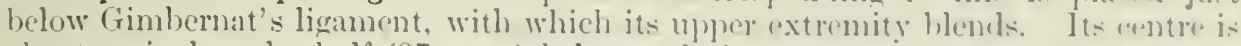

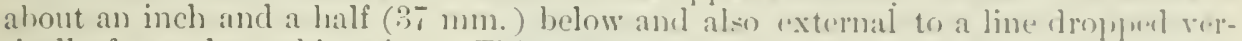
tically from the pubic spine. This and the other structures comerneet in fornoral

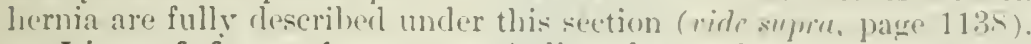

Line of femoral artery.-A line drawn from the midepuint between the

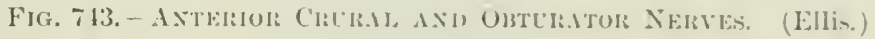

$$
\text { Fenura' rein }
$$

Finoral "rtery

Pectineus

OBTCRATOR (A.VTERIOR IUI, )

OBTUR.ITUR (POSTERJUR

III $15(1) .5)$

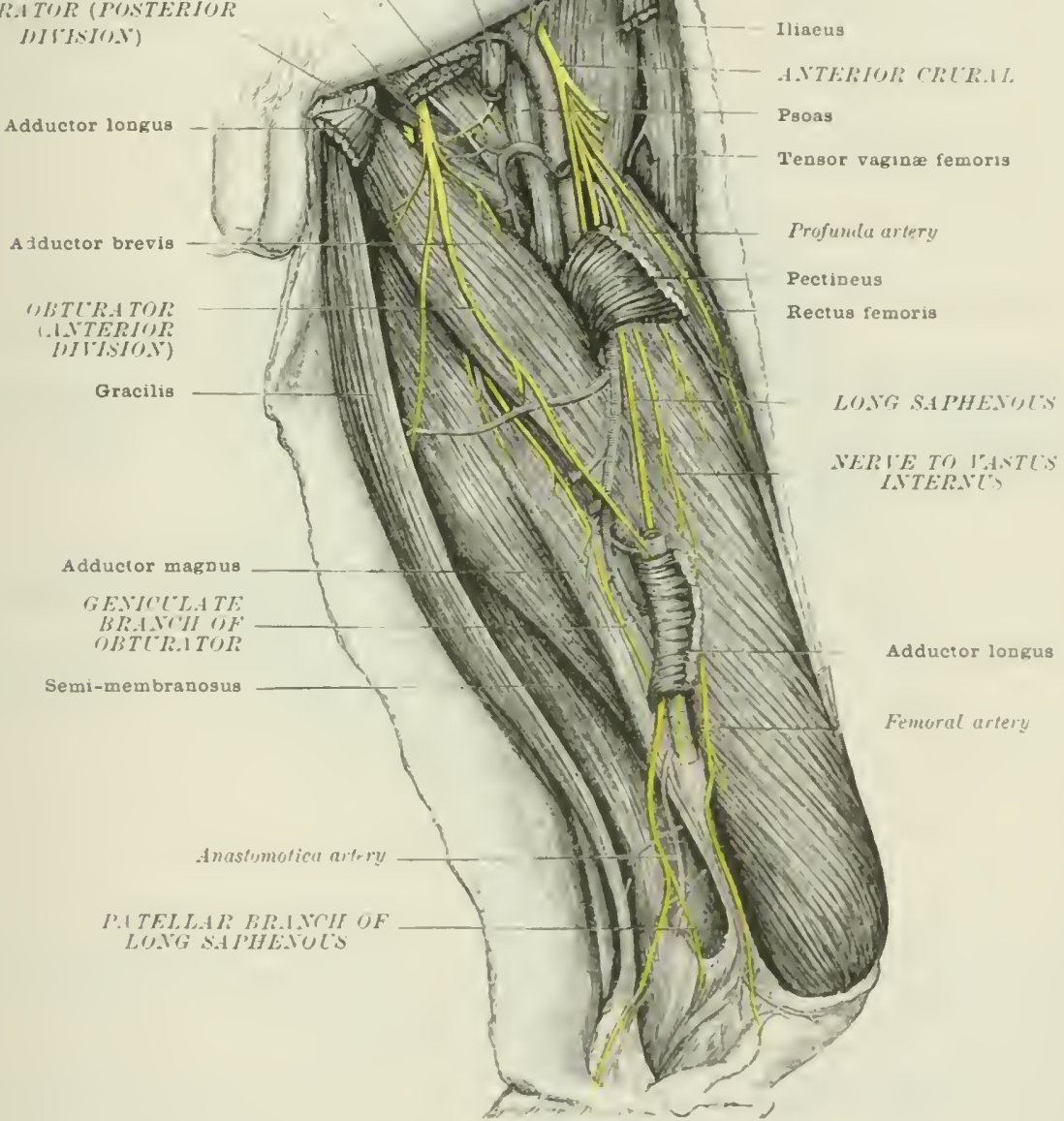

anterior superior spine and the srmpleysis pubis to the adductor tubercle will

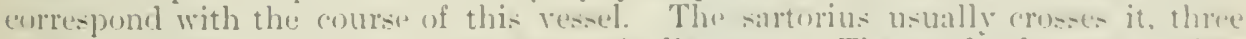

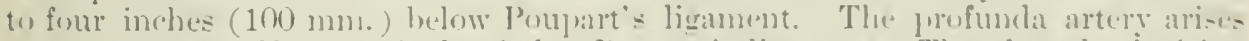
an inch and a half to two inches helow I'nupurt": ligament. Therefore the incison

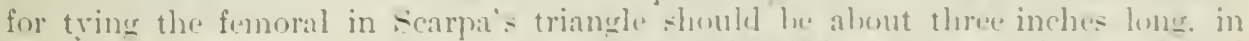
the line of the artery, and hegin about the inches belnw l'ompart - liganume and

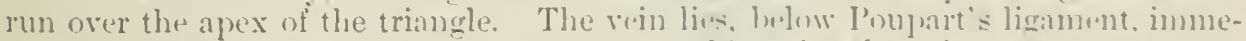
diately to the imner sicle of the artery. From this puint the vin gets on ton an somewhat deeper plane, though still very close to the artery, and gradually inelining lack- 
warls, lies behind its companion at the apex of the triangle, and below lies somewhat to its onter sicke.

From the apex of Scarpa's triangle a depression runs down along the inner aspect of the thigh, corresponding to the groove already mentioned (page 1175) between the rastus internus and the adduetors. Along this groove lies the sartorius, and beneath it Hunter's canal. The rein has here got somewhat to the outer side. The long saphenous nerve lies also in the canal, but not in the sheath. The above-mentioned space terminates at about the junction of the middle and lower thirds of the thigh, in the opening in the adductor magnus by which the artery enters the upper and inner part of the popliteal space. The long saphenous, the larcest branch of the anterior crural nerve, having crossed the femoral vessels from without inwarls, accompanies them as far as the opening in the adductor

Fig. 744-Section of Thigh throlgh LPPEk PART of Hexter's Caxal. (IV. A.)

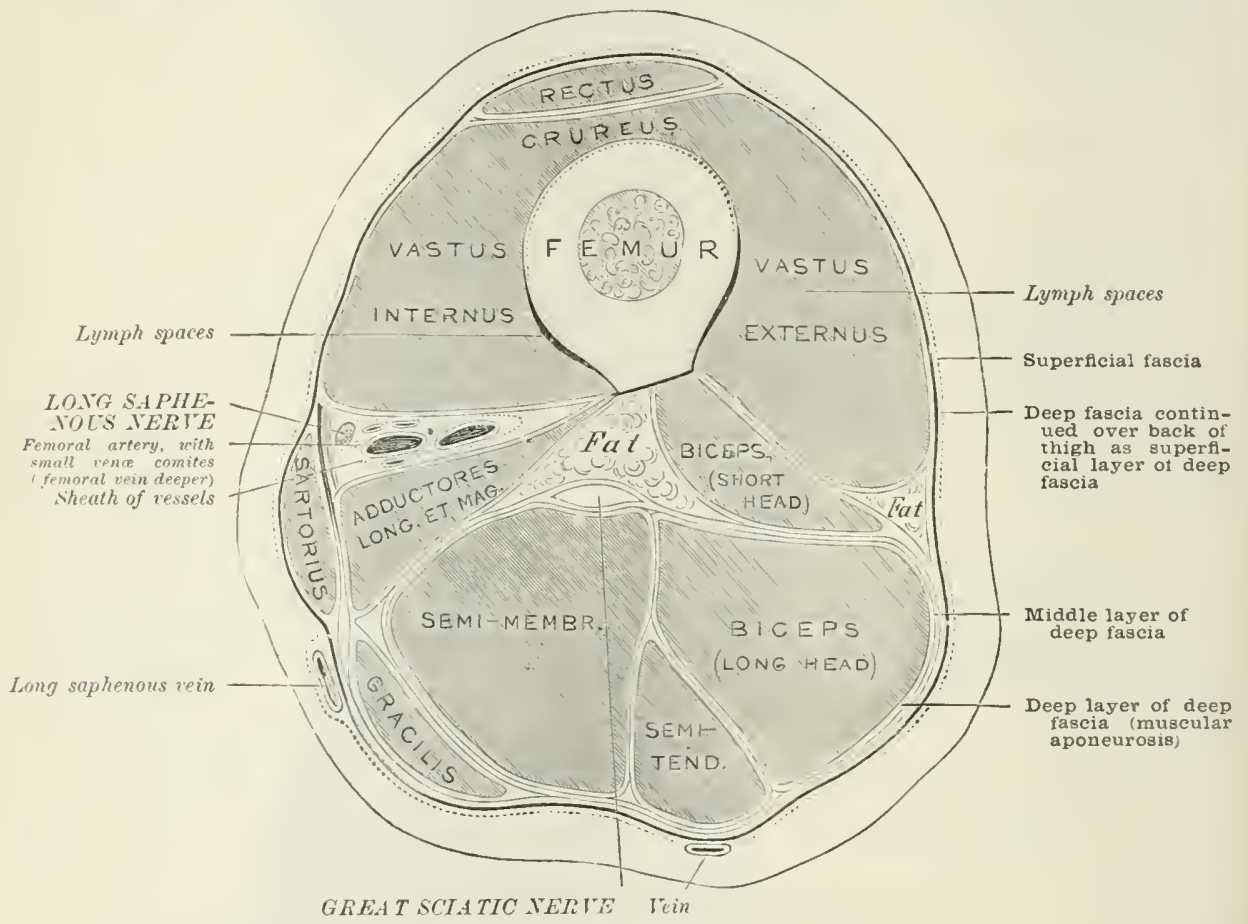

magnus. Here it perforates the aponeurotic roof, and is prolonged under the sartorius, accompanied by the superficial part of the anastomotic artery, to perforate the fascia lata between the sartorius and gracilis, and run with the long saphena vein at the upper and inner part of the leg.

Pressure may be applied to the femoral artery-(1) Immediately below Poupart's ligament: it should here be directed backwarls so as to compress the vessel against the brim of the pelvis and the eapsule of the hip-joint; (2) at the apex of Searpa's triangle, the pressure here being direeted outwards and a little backwards, so as to command the vessel against the bone; (3) in Hunter's canal the pressure should he directed outwards with the same object. Care must be taken, especially above, to avoid the vein, which lies very close to the artery, and also the anterior crural nerve, which enters the thigh about half an inch (12 mm.) outside the artery, and at once breaks up into its hranches, superficial and deep. 


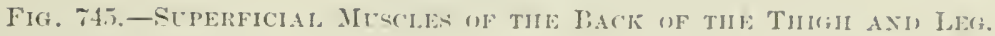

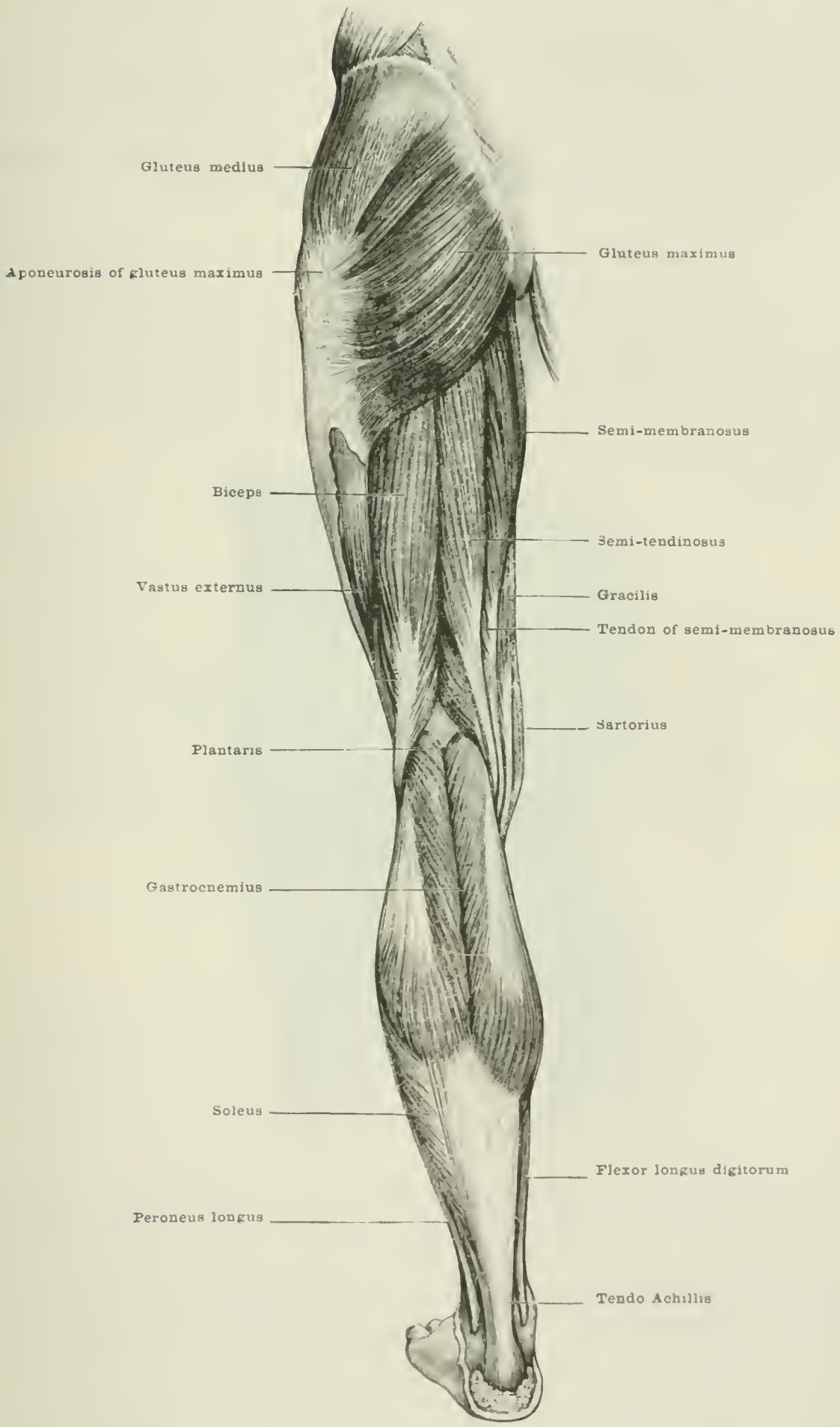




\section{THE BLTTOCKS}

Bony landmarks. - The finger readily traces the whole outline of the iliac crest. Behind, it terminates in the posterior superior spine, which corresponds in level to the second sacral spine and the centre of the sacro-iliac joint (Holden).

The third sacral spine marks the lowest limit of the spinal membranes and the cerebro-spinal tluid; it also corresponds to the upper border of the great sacrosciatic notch.

The first piece of the cocerx corresponds to the spine of the ischium (Windle). Its apex is in the furrow just behind the last piece of the rectum.

\section{Fig. 746.-Position AND Direction of the Superficial Ixeisioxs which vilst BE made ix order to Reach the Gluteal, Sciatic, and Pudic Arteries.}

A.B. Ilio-trochanteric line divided into thirds, and corresponding in direction with the line of the gluteus maximus. The incision to reach the gluteus maximus is indicated by the dark part of the line. Its centre is at the position of the upper and middle thirds of the ilio-trochanteric line, and corresponds with the point of emergence of the artery from the great sciatic noteh.

A.C. Ilio-ischiatic line. The incision to reach the sciatic or pudic artery is indicated by the lower dark line. This is also to be male in the direction of the fibre of the gluteus maximus. Its centre corresponds to the position of the lower and middle thirds of the ilio-ischiatic line.

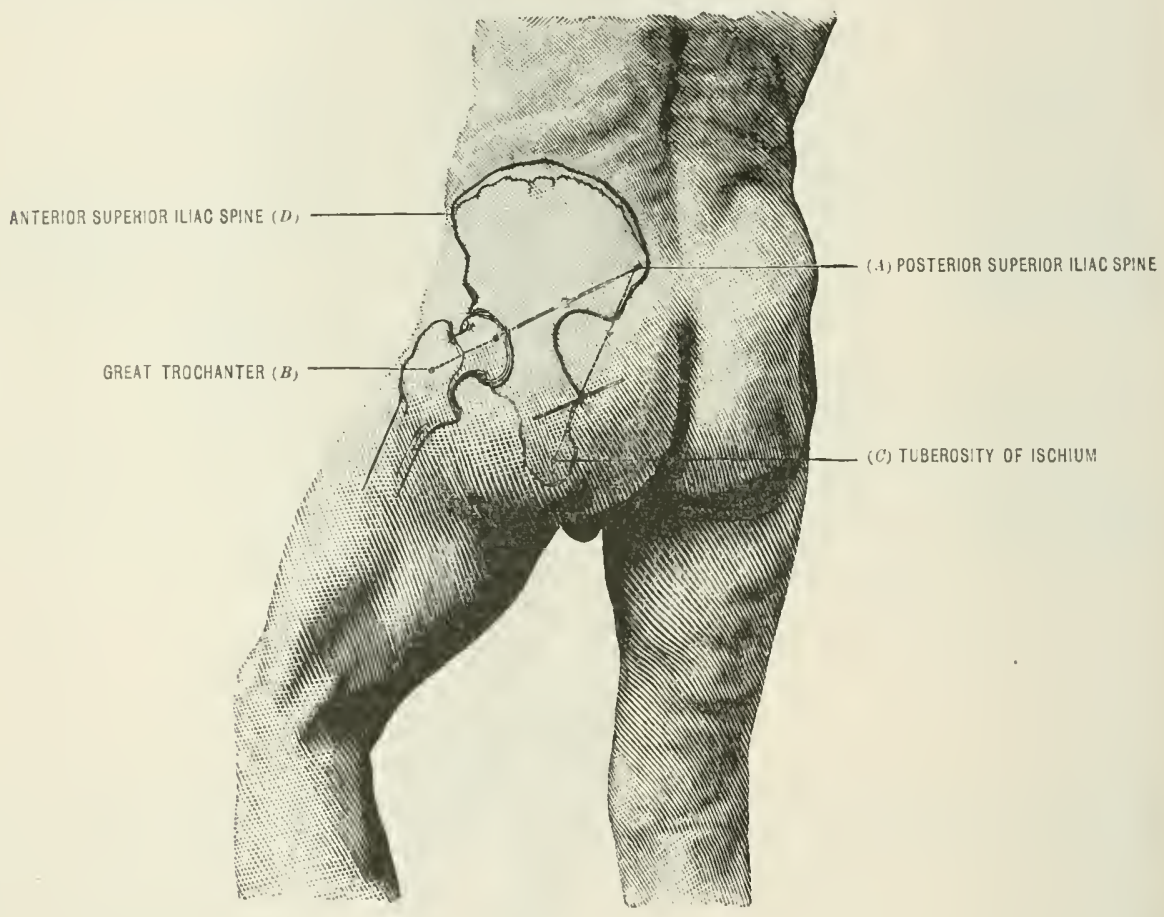

The tuberositics of the ischium are readily felt by deep pressure on either side of the anus. In the erect position they are covered by the lower margin of the gluteus maximus. In sitting they are protected by tough skin, fascix, with coarse fibrous fat, and often by a bursa known, according to the patients in whom it becomes enlarged, as 'weaver's, coachman's, lighterman's, drayman's' bursi.

Gluteus maximus.-The 'fold of the buttock' neither' corresponds accurately. to, nor is caused by, the lower margin of this muscle. It is really duc to creasing of the skin adherent here to the coarsely fibro-fatty tissue over the tuber ischii during extension. But in carly hip disease, in which flexion of the joint is almost unvaryingly present, both the fold and the gluteus maximus disappear with characteristic rapidity. The prominence of the buttock is mainly rlue to the glutens 
maximus, especially behind and helow, and in less degree to the other two frlutei in front. Under the lower edge of the glutels maximus the edere of the erreat salerosciatic ligament ean be felt on deep pressure.

Nerves and vessels. - The following superficial nerves can be markm in over the buttock (fig. 770). Behind the great trochanter, branches of the external cutaneous. Coming down over the crest, the lateral cutaneous branch of the last dorsal (about in a line with the great trochanter), and behind this the lateril branch of the ilio-hypogastric. Two or three offsets of the posterior primary branches of the lumbar nerves aros the hincer bart of the iliac crest at the outcr margin of the erector spince. Two or three twigs from the posterior divisions of the sacral nerves pieree the ghteus maximus close to the coccrx and sacrum, and ramify outwards. Finally, over the lower horder of the ghiteus maximus turn upwards branches of the small sriatic and inferior ludendal and fourth sacral nerves.

Great sciatic nerve (figs. $748,74 !)$. -The point of emergence below the

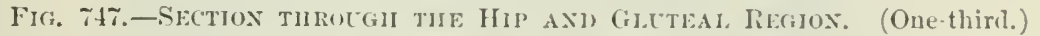

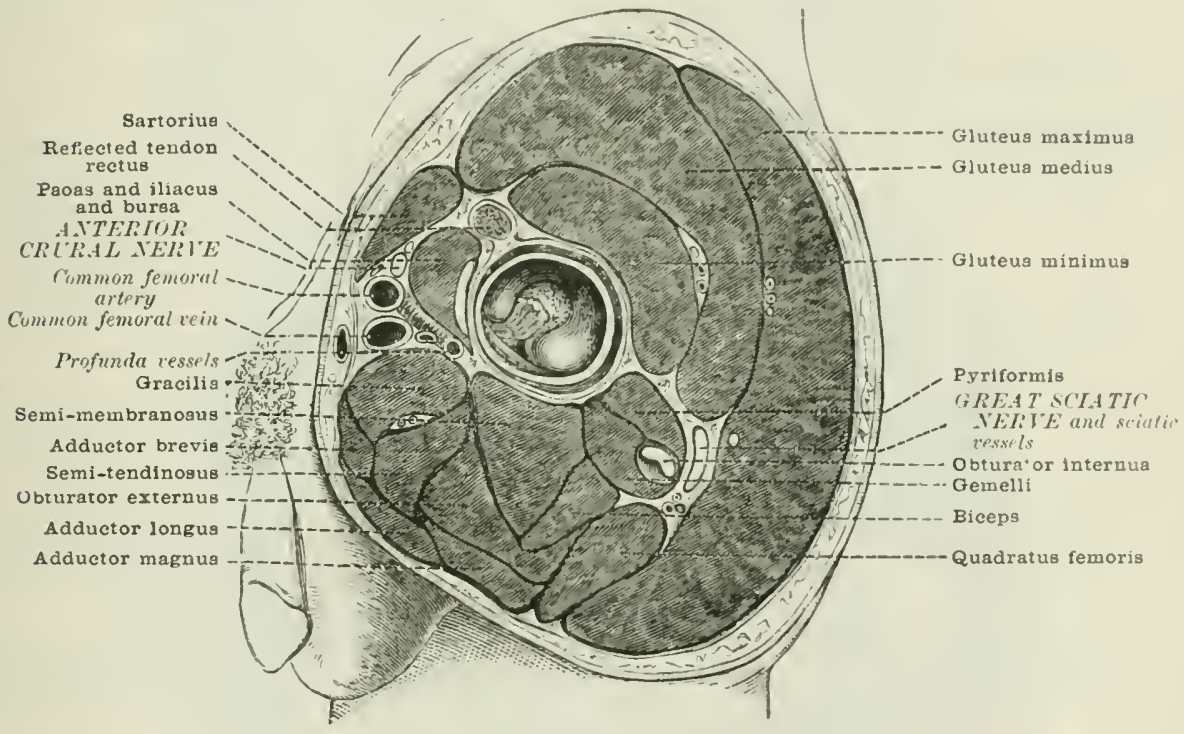

gluteus maximus and the track of this nerve will be given by a line drawn from a spot a little internal to the middle of the space between the great trochanter and the tuber ischii to the lower part of the back of the thigh. The inferior puctendal perforates the deep fascia about an inch (25 $\mathrm{mm}$.) in front of the tuber ischii, and turns forwark to supply the genitals.

Gluteal artery.-If a line be drawn from the posterior superior spine to the anex of the great trochanter, the limb being slightly flexed and rotated inwarks. the point of emergence of the artery from the upler part of the great siere-sciatic notch will correspond with the junction of the upper and miltle third of this line (fig. 746) (MacCormac). The gluteal nerve emerges immerliately betow the artery, and sends branches with the derper jortion.

Sciatic and pudic arteries. - The limb being rotated inwards. a line is drawn from the posterior superior spine to the outer part of the tuher ischii. The juint of exit of the above arteries will correspond to the junction of the midclle and lower thirls of this line (MacCormae). 


\section{THE KNEE}

Bony landmarks. - The patelli, the condyles, the tuberosities of the tilia, the tubercle of the tibia, the head of the tibula.

The patella. - The limb being supported in the straight position, and the extensor muscles relaxed, the numerous longitudinal stria or sulei on the anterior surface of this bone can be detected. In these are embedded tendinous liundles of the reetus, so as to give firmer leverage. The fact that these fibres, thus tied down,

Fig. i43.-The Gleteal Regiox, With the Gluteal, Sciatic, Axd Pldic Arteries.

(From a dissection by W. J. Walsham in St. Bartholomew's Hospital Museum.)

The inferior gluteal branch of the seiatic artery has been drawn inwards over the tuber ischii with the reflected origin of the gluteus maximus musele.

Gluteus medius, turned up

INFERTOR GLLTEAL NERVE Gluteus minimus

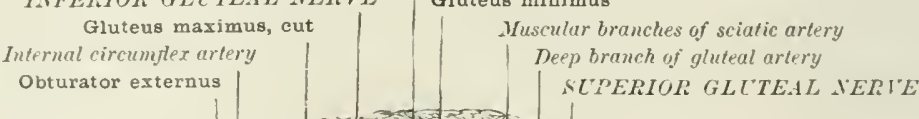

Insertion of gluteus medius
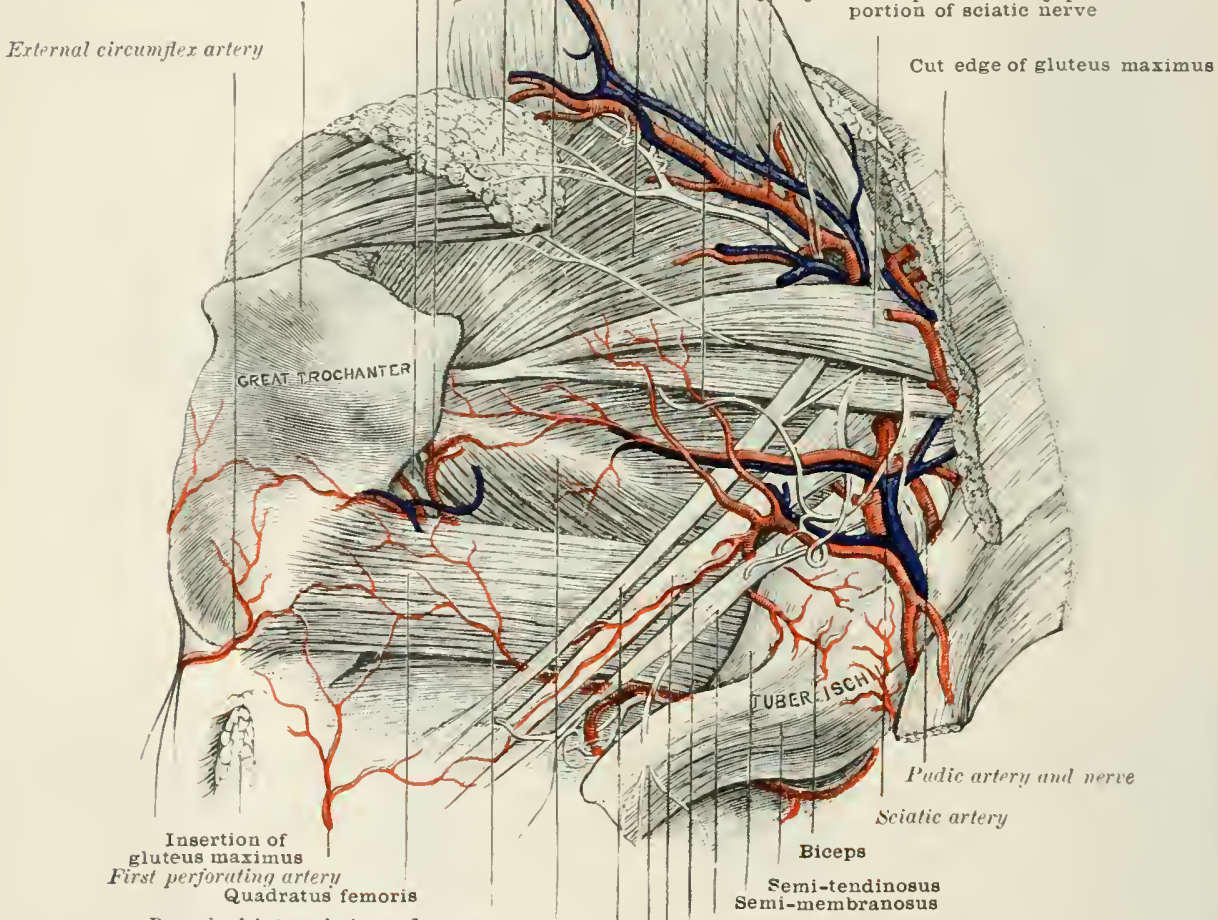

Branch of internal circumfex artery

Obturator internus with the two gemelli

LESSER SCIATIC VERVE

Arteria comes nervi ischiatici

POPLITEAL PORTIONOF GREIT SCIATIC NERIE LONG PIDENDAL NERIE

PERONEAL PORTIOY OF GREAT SCIATIC NERIE

are liable to fold in between the ends of the bone after fracture, is a ready explanation of the difficulty of ensuring bony union here (Macewen). The patella is separated from the tilia by a pad of fat and a deep bursa, save at its insertion. It has the following relation to the femur in different positions:-(1) In extension, the patella rises over the condyles, and in full extension only the lower third of its articular surface rests upon that of the condyles; its upper two-thirds lies upon the hed of fat which covers the lower and front part of the femur. (2) In extreme flexion, as the prominent anterior surface of the condyles affords leverage to the 
quadriceps, the patella needs to project very little; thus, only its upper third is in contact with the femur, its lower two-thirds now resting on the lad of fat between it and the tibia. (3) In semiflexion the middle third of the patella rests upon the most prominent part of the condyles (Humpliry). While the bone now affords the greatest amount of leverage to the quadricejs, it is also sulmitter to the greatest amount of strain from this musele, which is acting almost at a right angle to the long axis of the patella. This position may therefore be called the area of danger,' as, in a sudden and violent contraction, the patella may be snappect

Fig. 749.-Deep Dissectiox of the Gluteal, Reglox. (From a preparation in the Hunterian Museum.)

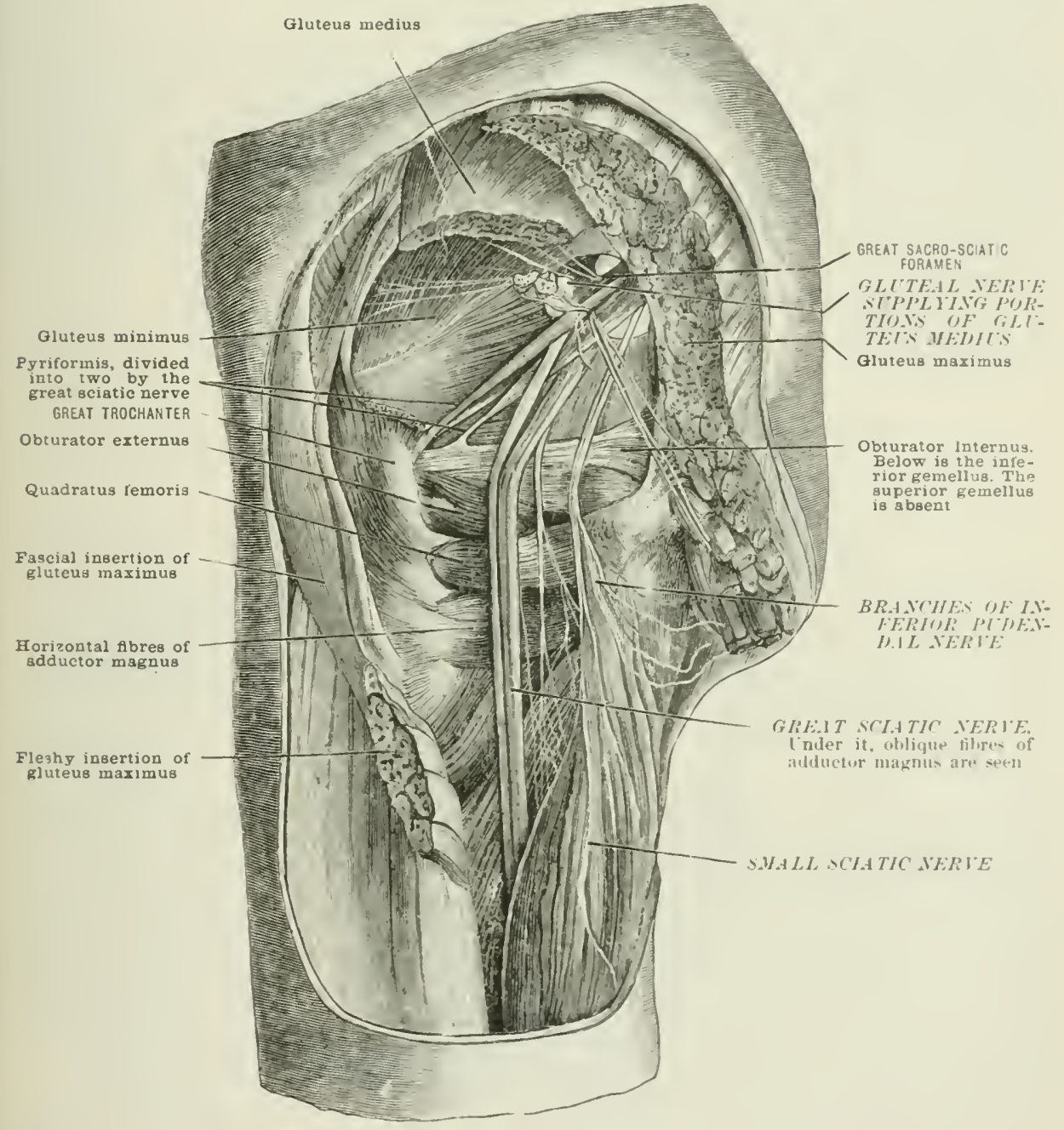

across by muscular action, aided hy the resistance given hy the condyles, in the same way as a stick is snapped across the knee. Below its articular surface for the femur it is separated from the tibia ly a pad of fat and a dee'p loursa, silve at the apex to which the ligamentum patellie is attached. I' hen the knee-joint is bent, the trochlear surface of the former can he macte out. with some lifliculty, underneath the quartriceps expansion. The upper and onter angle of this surface forms a useful landmark (Godlee), as a line drawn from it to the adductur tuhercle marks the level of the lower epiyllysis of the femmr. 
Dislocation of the patella.-The following anatomical facts account for this taking place much more frequently outwards:-(1) The inner edge of the patellia is more prominent, and thus more exposed to injury; it is also well supported, as is seen when, the parts being relaxed, the fingers are insinuated beneath each horler. (2) The pull of the extensor upon the patella, ligamentum patellæ, and tibial is somewhat outwards, as the tibia is directed a little ontwards to the femur, to meet the inward direction of this bone; the femora being directed inwards bere, to bring the knee-joints nearer the centre of gravity, and, so, counterbalance their wide separation above at the pelvis. The outward pull of the quadriceps upon the patella is, in all nomimai action of the muscle, comnteracted by the space taken in the trochlear surface by the external eondyle, this being wider and creeping up higher, and having a more prominent and thus protective lip. In violent contraction, however, these counteracting points may be overcome.

The condyles and tuberosities.- It sliould be noted that on the inner side the prominence of the internal condyle is well marked, and that of the tibial tuherosity is less so, while on the onter side this condition is reversed. Descending to the outer tuberosity, the ilio-tibial band of the fascia lata can be traced. The more distinct outer tuberosity is a good landmark for opening the joint in amputation and excision. It also indicates the lower level of the synovial membrane of the knee-joint. Farther back is the biceps and long external lateral ligament. The

Fig. 750.-Horizoxtal Sectiox of the Kxee-Jorxt. (One-half.)

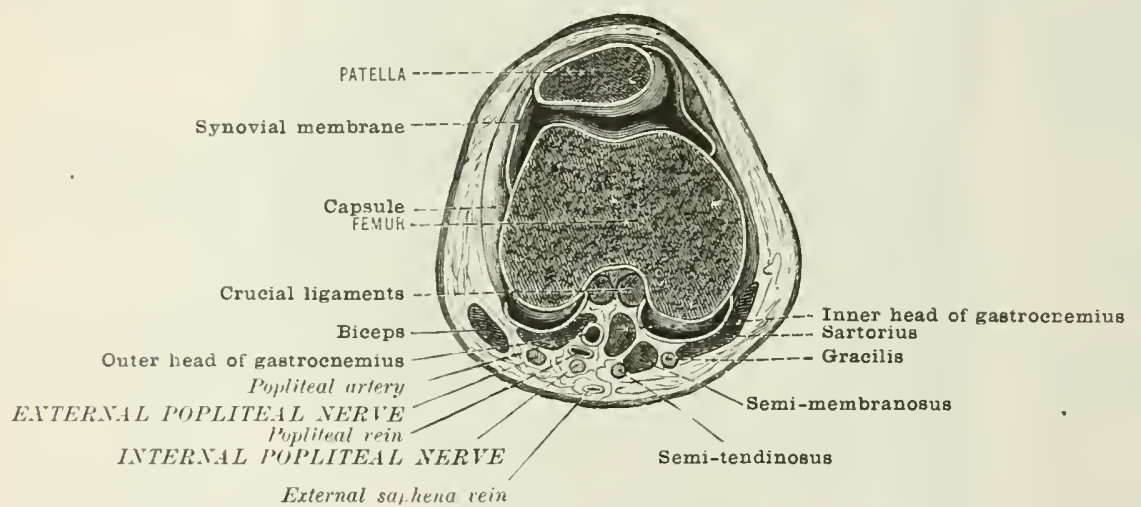

gap on the inner side between condyle and tuberosity is the place for feeling for a displaced intemal filmo-cartilage in 'internal derangement' of the knee. On each condyle, posteriorly, in a thin subject ean be felt its tubercle, which gives attachment to the lateral liganent. Owing to their being placed behind the centre of the bone these ligaments become tight in extension. On the upper part of the internal condyle the adductor tubercle and the rertical tendon of the adductor magnus an be felt during flexion. This bony point is a guide to the lower epiphrsis of the femur, one of the latest to join, miting with the shaft about the twenty-first year. Here the exostoses in adolescents arise. The immer aspect of this condyle faces praetically in the same direction as the head of the femur.

Ligamentum patellæ and tubercle of tibia.-These, in a well-formed leg, shoukl, with the centre of the ankle-joint, he all in the same straight line, a weeful point in the adjustment of fractures (Holden). Behind the upper half of the lignment is the synovial membrane of the knee-joint; below, the lower is separated from the tilia by a deep bursa. In comnertion with all the posterior surface is fat, which serves as a useful packing in the different morements of flexion and extension. The tubercle of the tibia is on a level with the head of the fibula.

Prepatellar bursa.-This usually protects the patella and upper part of the ligamentum patellae. It is liable to be enlargod in those who habitually kneel much. Its chose connection with the gatella and, at the sides, with the joint itself is to be remembered in inflammations of the bursa. Csually, two processes of 
fascia lata, passing off from the siles of the patella upwarks to the thigh and downwarts to the lege, serve to concluet inflammation awaty from the joint.

Synovial membrane (fig. T.j1). - To trace this, the largest of the srmovial membranes, the finger would start from the top of the patella, where it forms it

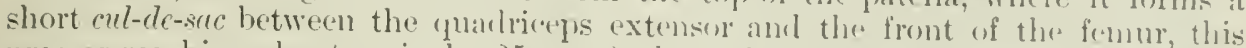

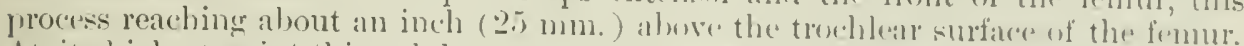
At its highest point this cul-cle-sec communicates with another synovial bursi-like

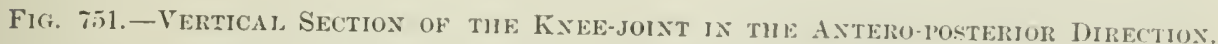
(The symovial bursa usually present above the upper synovial cul-alese is not shown.)

(The houes are somewhat drawn apart.)

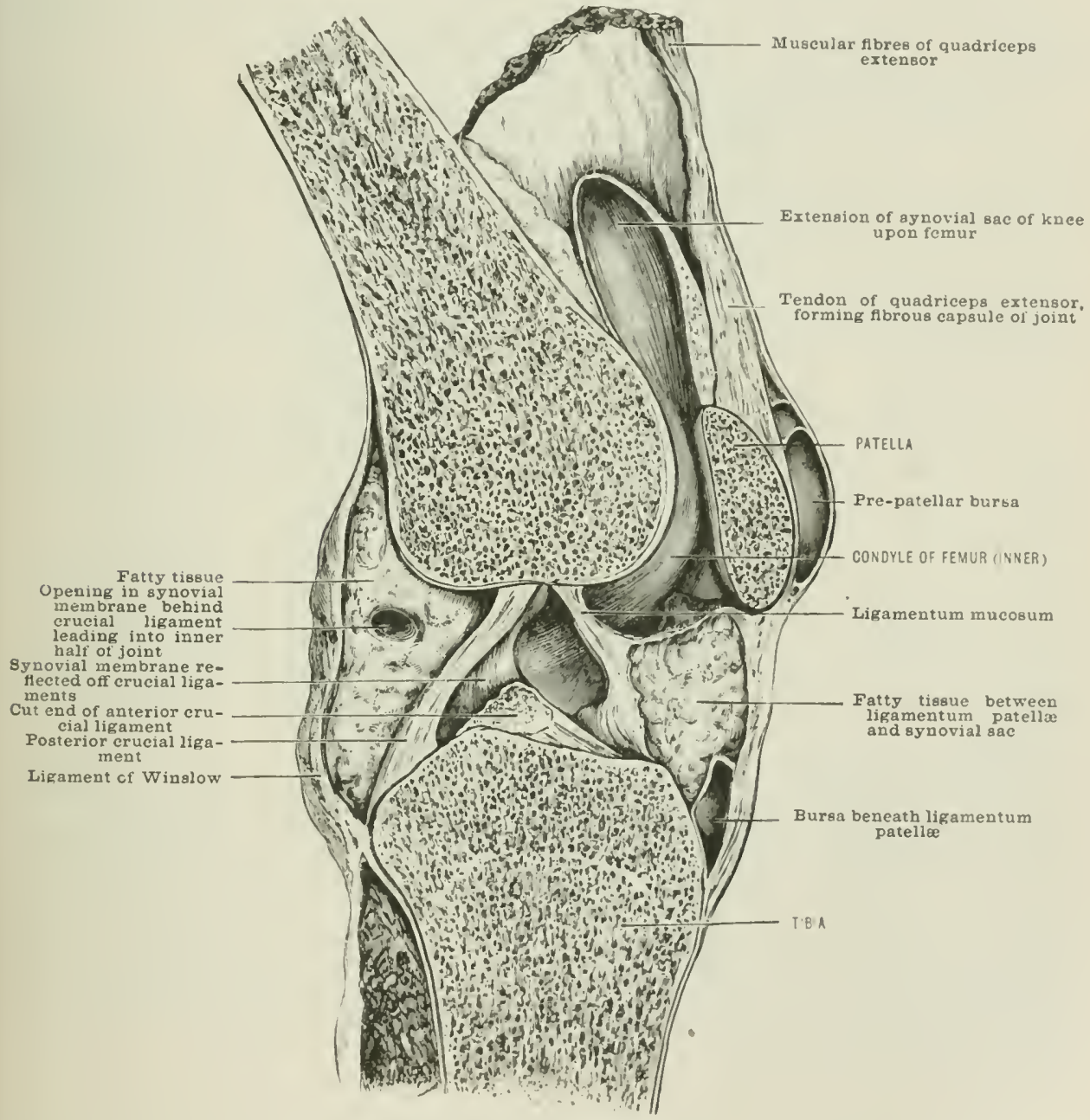

Sac lying between the quadriceps and front of the femur. Thus, synovial membrane will usually be met with two and a half inches $(62 \mathrm{~mm}$.) above the trochlear surface or the upler border of the patella when the limb is extended. Flexing the joint draws the membrane down very slightly. I) uring extension, the aldore pouch is supported by the suberureus. At the silies the spnerial membrane (extends up) under the vasti for about three inche ( $75 \mathrm{~mm}$.) on the inner and rather les on

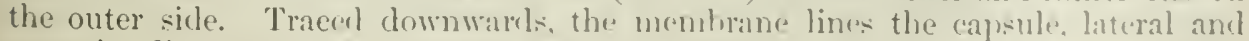
posterior ligaments. -It passes over the greater portion of the crucial ligaments, 
but the posterior surfice of the posterior crucial, which is connected by means of fibro-arenlar tissue to the front of the ligamentmin posticum, and the lower portions of both crucial ligaments, where they are uniterl together, of course eannot receive a complete covering from the membrine' (Alorris). From the ahove ligaments the membrane is conducted, lining the lower part of the capsule and other ligaments, to the semi-lunar cartilages, first over their ulyer surfaces to their free borders, and then along their moler surfaces to the tibia. Between the outer of these and the upper and back part of the tibia is a prolongation of the synovial membrane to facilitate the play of the popliteus tendom. Special folds, with their packing of fat, the ligamenta alaria and mucosa, pass between the femur and patella.

The following bursæ about the knee-joint must be remembered. Some, it will be secn, are much more constant than others:-

A. In front.-(1) One between the patella and skin, the hursa prepatellaris (fig. 751); (2) a deeper one between the ligamentum patella and the upper part of the tibia; (3) between the skin and the lower part of the tubercle of the tibia. This is not constant.

B. On the inner side.-(1) One between the inner head of the gastrocnemius and inner condyle, often extending between the above muscle and the semi-membranosus. This is the largest of the bursa about the knee-joint, and, after arlult life, usually communicates with the knee-joint; (2) one superficial to the internal lateral liganent, between it and the tendon of the sartorius, gracilis, and semitendinosus; (3) one beneath the ligament, between it and the tendon of the semimembranosus; (4) one between the inner tuberosity of the tibia and the semi-membranosus; (5) one between the semi-membranosus and semi-tendinosus. Of the above bursæ, the first two alone are constant. The second and third are often one bursa prolonged.

C. On the outer side.-(1) One between the outer head of the gastrocnemius and the condyle; (2) one superficial to the external lateral ligament between it and the biceps tendon; (3) one under the ligament between it and the popliteus tendon; (4) one between the poplitens tendon and the onter condyle of the femur. This is usually a diverticulum from the synovial membrane.

The following explanations may he given of an inflamed knee-joint usually taking the flexed position: (1) By experimental injections, Brame found that the capacity of the synovial sac reaches its maximmm with a definite degree of flexion, i.e. at an angle of twenty-five degrees. (2) As the same nerves supply the synovial membrane and the muscles which act upon the joint, the flexors being more powerful than the extensors, will help to explain the flexed position (Hilton).

Anastomoses around the front and sides of the knee-joint. - The most important of these take the form of three transverse arches. (1) The highest passes through the quadriceps fibres just above the upper edge of the patella. It is formed by a branch from the deep division of the anastomotica and one from the superior external articular. The middle and lowest arches lie under the ligamentum patelke. (2) The middle arch, formed by bramches from the anastomotica and superior internal articular on the inner side, and the inferior external articular, on the outer, rms in the fatty tissue close to the apex of the patella. (3) The lowest arch lies on the tibia just alove its tubercle, and results from the anastomosis of the reeurrent tilial and the inferior internal articular. Six arteries thus take place in this series of anastomoses.

\section{POPLITEAL SPACE}

In flexion, the hollow of this space appears; in extension it is obliterated ant its boumdaries are ill-rlefined, the only one now to be male out being the semitendinosus and the liceps.

Popliteal tendons. - When the knee is a little bent, and the foot rests on the ground. the following ean lo made out: At the outer side, behind the ilio-tibial band, and rescending to the head of the fibula, is the tendon of the biceps. Parallel and close to its immer border, the external popliteal nerve 


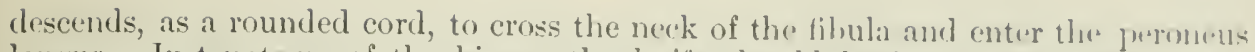
longus. In tenotomy of the biceps, the knife shomld he introduced hetworn the. nerve and the tendon, and made to eut from within ontwark, and thus awaly from the nerve. On the inner side the temdons are thus arranged: Noarest to the inidull. of the popliteal space is the long and more slender tendon of the semi-tendinosta; next, the thicker tendon of the semi-memhranosus; this and the gracilis, which comes next, appear as one tendon, but ly a little manipulation the fingre (and lu. made to sink into the interval between the semi-membranosus, with its thick

Fig. 752.-Sine View of the Poplitsal, Aktedis.

(From a dissection in the IInteriun Musenu.)

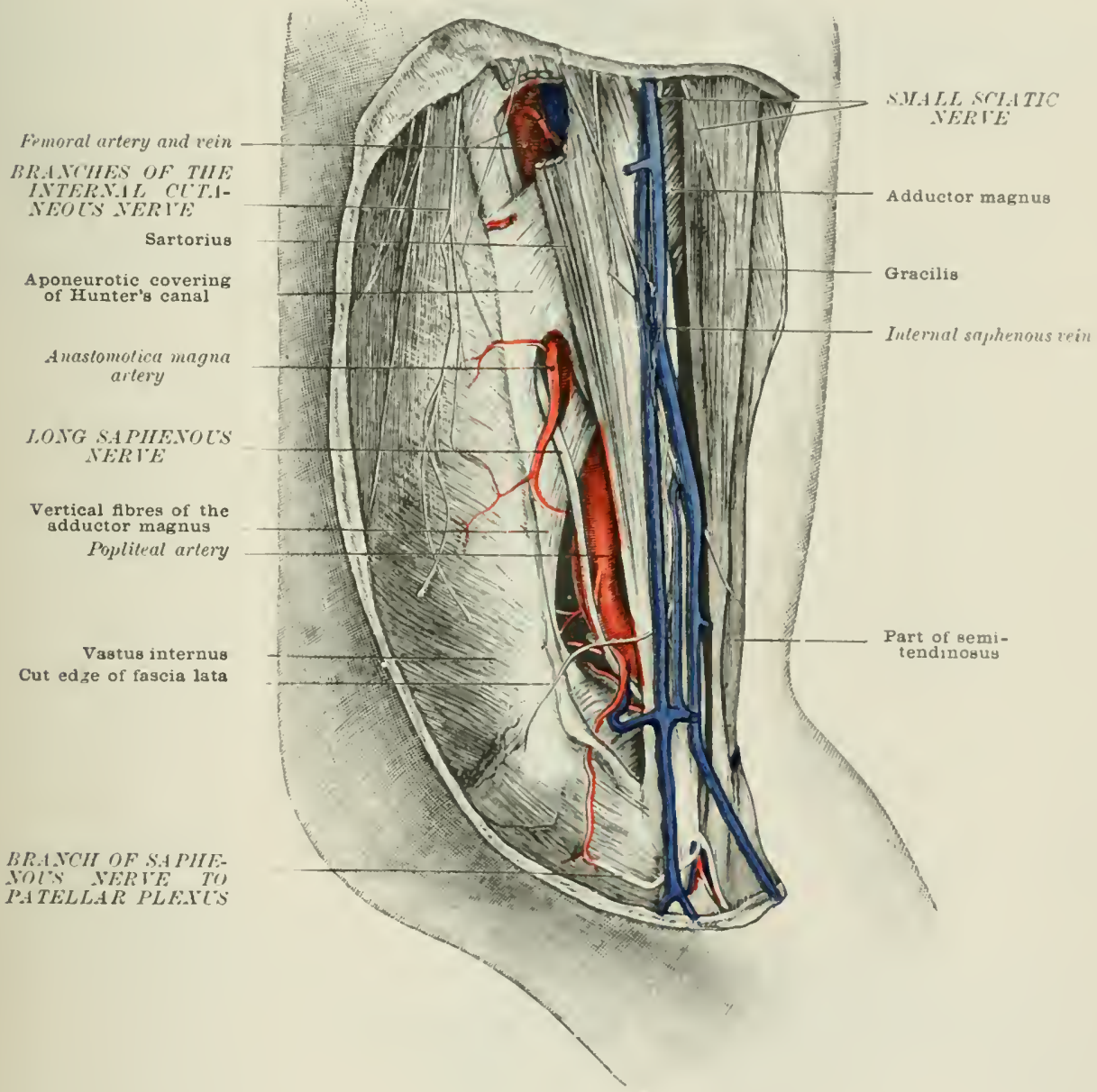

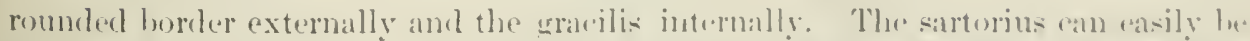
thrown into relief on the inner side of the joint by telling the pationt to aross one $\operatorname{leg}$.

Popliteal vessels.-The artery traverses this space from ahove downwarls. appearing benesth the semi-membranosus, a little to the inmer side of the mildle. line, and then passing down in the centere of the space to the interval hetween the

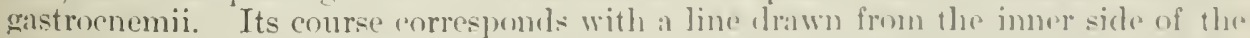
hamstrings to the centre of the lower part of thes sales. The artery lifureates all the

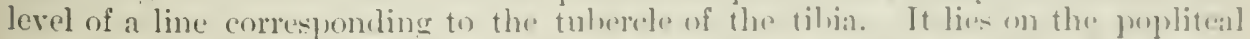
surface of the femur. the posterior liganent, and the gejuliteus. It is the seromel 
of these structures, which usually prevents popliteal aneurism and abscess from making their way into the joint. The popliteal vein, intimately adherent to the artery, lies to the outer side above, but crosses to its imner side below. The walls of this vein are thicker and denser than those of any other vein (Tillaux). The popliteal sheath is also unusually strong. The internal pophiteal nerve crosses the artery in the same direction as the rein by which it is separated from the artery. This nerve is the direct continuation of the great sciatic nerve (fig. 753).

The superior articular arteries course outwards and inwards immediately ahove the condrles; the inferior ones lie just above the head of the fibula and below the internal tuberosity of the tibia (fig. 756). The deep part of the anastomotic artery runs in front of the tendon of the adductor magnus; the superficial with the internal saphenous nerve.

Fig. 753.-Deep View of the Popliteat. Space. (Hirschfeld and Leveillé.)

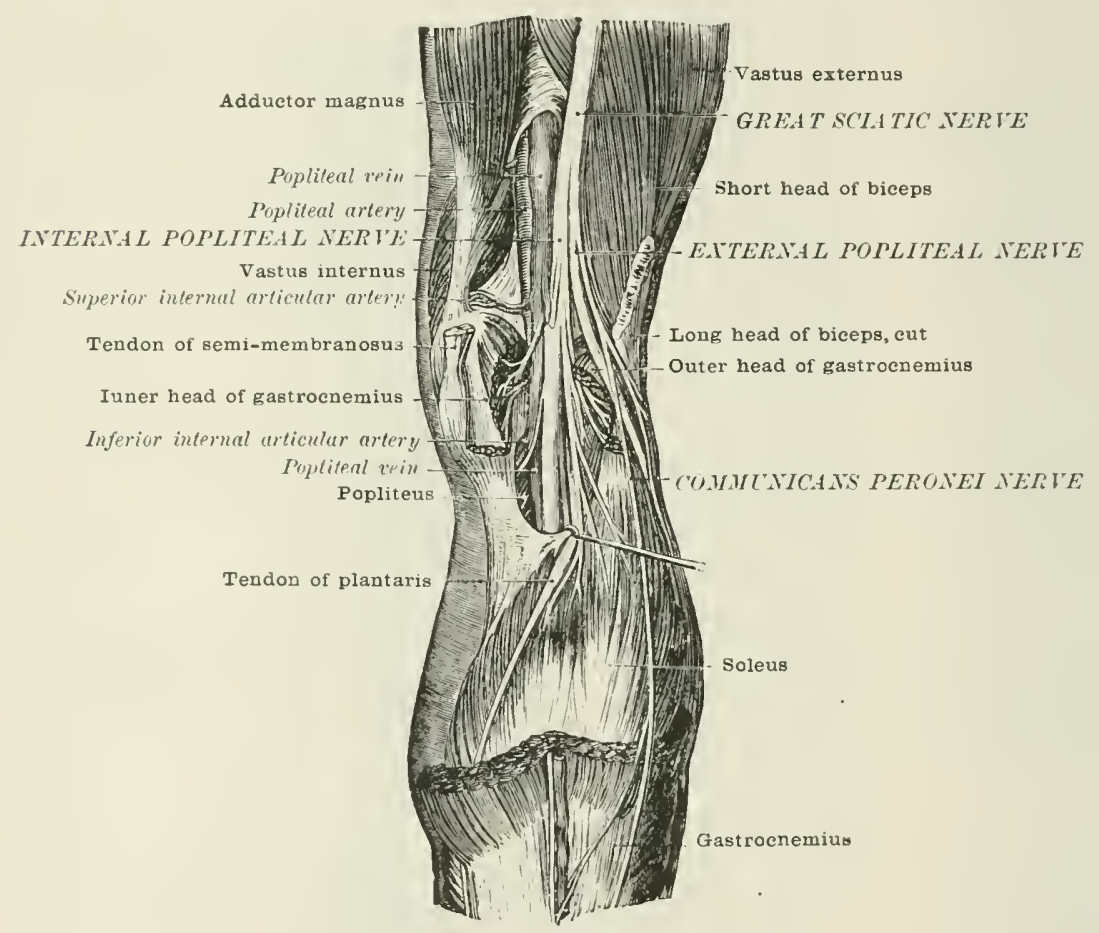

External sapluewons rein and nerre

The external saphenous vein perforates the roof of the popliteal space in its lower part. As a rule, it is not visible unless enlarged.

The popliteal glands are not to be felt imless enlarged.

Bursæ in the popliteal space.-These have been already spoken of (page $11 S 7)$.

\section{THE LEG}

Bony landmarks. - From the tubercle of the tibia descends the anterior border (1) 'shin.' This soon become's sharp, and continues so for its upper two-thirds; in the lower third it disappears, to be orerlail by the extensor tendons. It is curved somewhat ontwards above, and inwards below. The inner border ean also be felt from the inner tuberosity to the internal malleolus. Between these two horders lies the internal surface, subeutaneous, save above, where it is covered by the three tenclons of insertion of the gracilis and semi-tendinosus, and, overlying them, that of the sartorius. The tibia is narrowest and weakest at the junction of 
the middle and lower thirds, the most common site of fracture. Behind the internal malleolus, part of the groove for and the tendon of the tibialis posticus can be felt.

The head of the fibula can be felt distinctly; but the shaft soon becomes burioul amongst muscles till about three inches above the external malleolus, where the bone expands into a large triangular subeutaneous surface. This lies between the peroneus tertius and the other two peronei. The peroneus longus overlaps the brevis, especially in the upper two-thirds of the leg. In the lower third the brevis

Fig. 754.-ANASTOMOSES OF TIBIAL ARTERIFS.

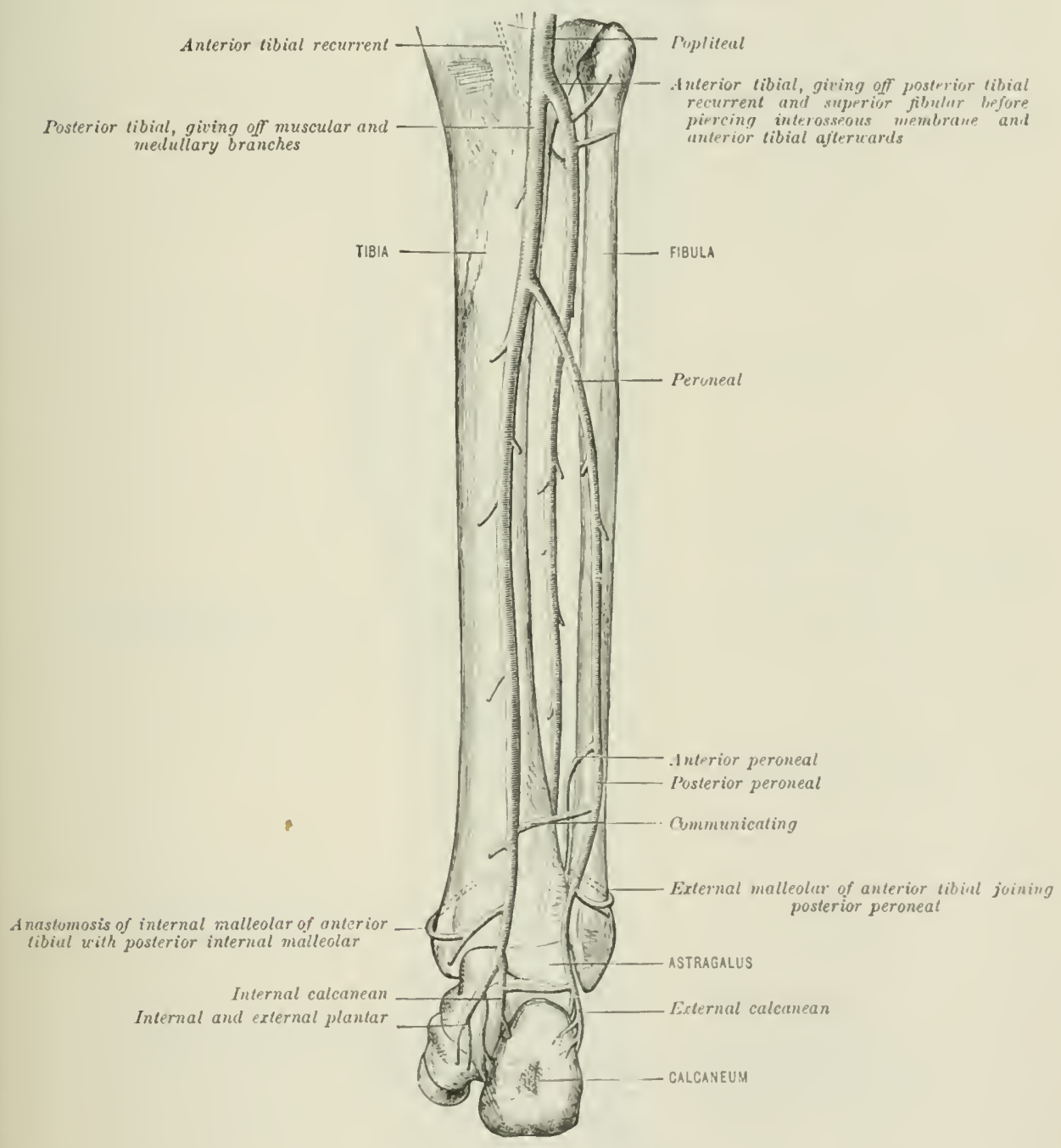

tends to become anterior (fig. 756). Behind the external malleolus these tendons: discend to the foot in rery close relation to the bone. The shaft of the fibula is placed on a plane posterior to that of the tilia, and curves backwards in a direction reverse to that of the tibia.

Muscular prominences.-The space between the tibia and fibula is mainly occupied by the fleshy belly of the tibialis anticus; outside this, and much less prominent, is the narrower extensor longus digitorum; outside this, again, are the peronei longus and brevis. Lower down, in an interval between the tibialis and the 
extensor of the toes, the extensor hallucis, here almost entirely tendiuous, comes to the surface. Behind, the prominence of the calf is mainly formed ly the gas-

Fig. 755.-The Axterior Tibill Artery, Dorsal Artery of the Foot, and Axterior PERONEAL ARTERi, AND THEIR BRANCHES.

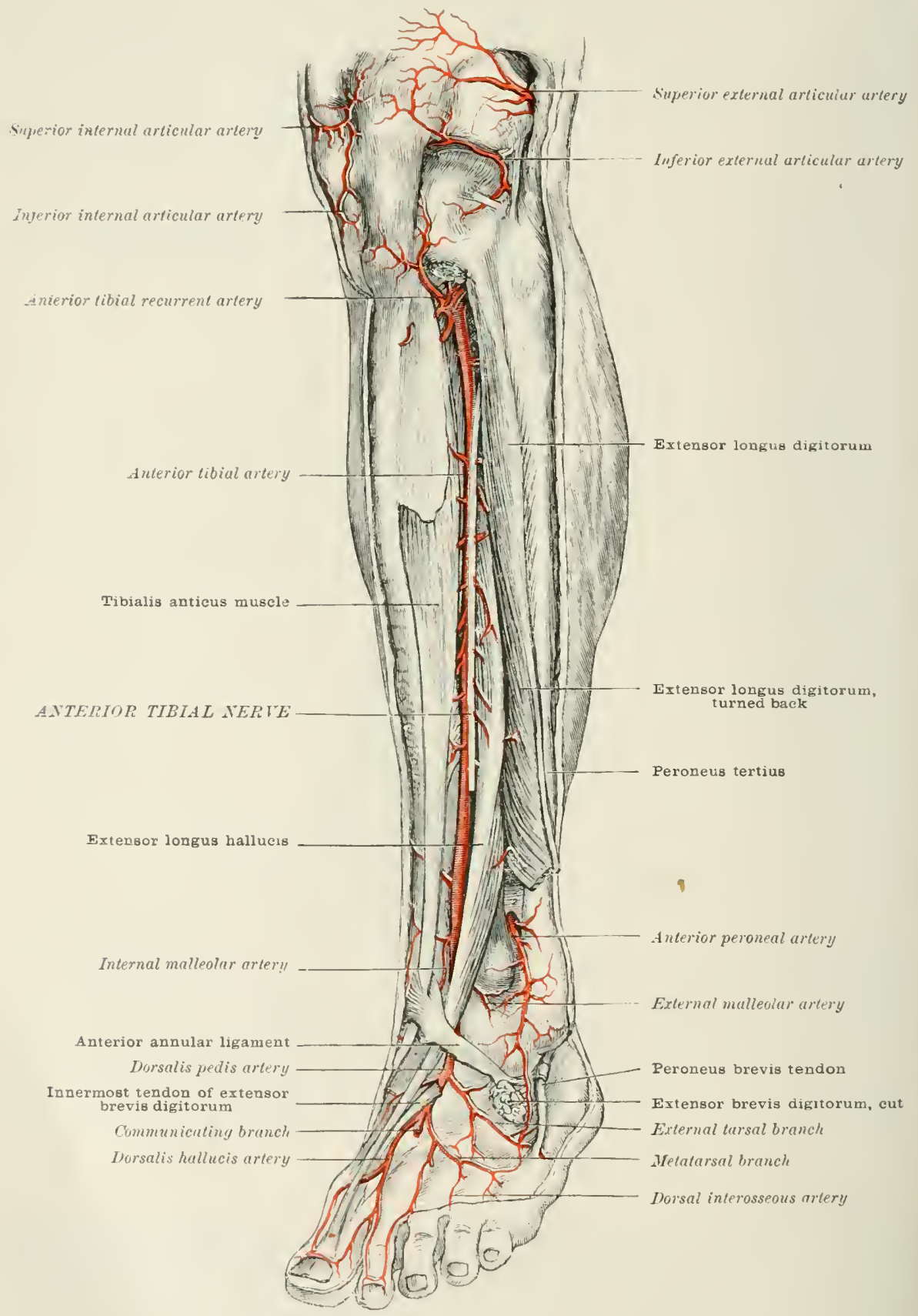

trocnemius. On the patient's rising on tiptoe, the tendo Achillis starts into relief from about the middle of the leg. Of the two heads of the gastrocnemius, the inner is seen to be the larger. On either side of the tendon, but more distinctly on the 
outer side where it is less overlaplyed hy the gatrocnemint, the soleus comen into vie'w.

Vessels.-The saphena veins should be carcfully traced, owing to the tendency of these and their branches to become varicose. The internal, having

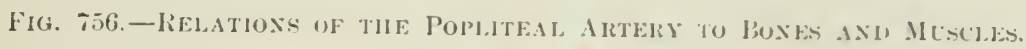

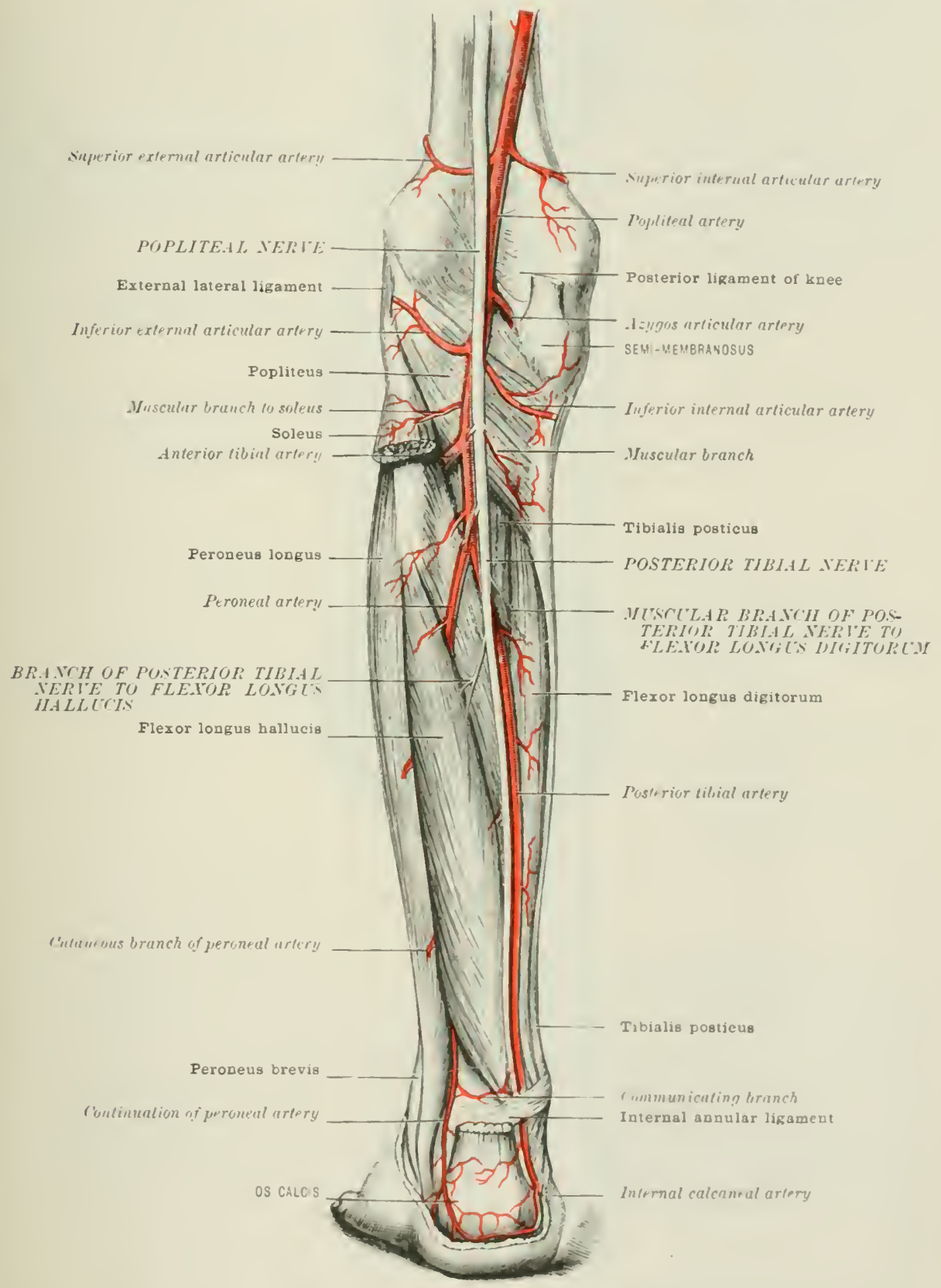

passed from the arch on the dorsmm weer the internal malleolus, runs up the imer sirle of the leg, along the inner horrler of the tibia, to the back of the internal condrle, and then upwards along the thigh, orer the rouf of Hunter"s canal, to the 
saphenous opening (page 1138 and fig. 769 ), where it joins the femoral. The internal saphenous nerve joins it below the knee. having been under the sartorius abore this point (page $117 \mathrm{~s}$ and fig. 752). The external saphenous vein passes behind the external malleolus, runs upwards over the middle of the calf, and joins the popliteal by perforating the deep fascia in the lower part of the popliteal space. This vein is also accompanied by a nerve of the same name throughout its course.

The popliteal artery bifurcates at the lower border of the popliteus, about on a level with the tubercle of the tibia. About two inches lower down the peroneal artery eomes off from the posterior tibial (fig. 756 ).

The course of the posterior tibial corresponds with a line drawn from the centre of the lower part of the popliteal space to a point midway between the tip of the internal malleolus and the inner edge of the calcaneum. In the lower third, the artery becomes somewhat superficial, passing from heneath the ealf muscles, together with the tendons of the tibialis posticus and the flexor longus cligitorum; and in a thin person it can be felt beating in the hollow on the inner side of the tendo Achillis (fig. 756 ).

\section{Fig. 757.-Section of the Rigit Leg in the UpPer Third. (Heath.)}

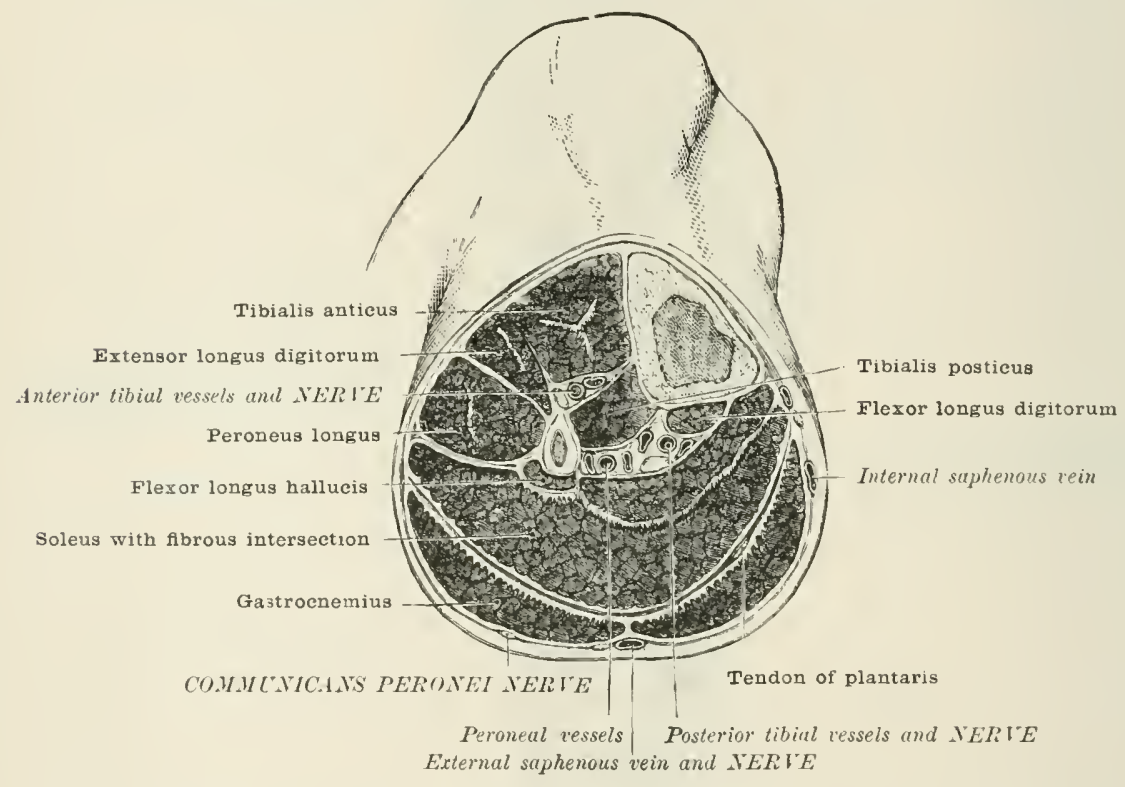

The course of the anterior tibial artery corresponds with a line drawn from a point midway between the onter tuberosity of the head of the tibia and the head of the fibula to one on the centre of the ankle-joint. This line corresponds to the outer border of the tibialis antieus and the interval between it and the extenson. longus digitorm (figs. 755 and 758 ). This is shown when the first of these muscles is thrown into action.

The peroneal artery, given off from the posterior tibial about an inch below the popliteus, or three inches below the head of the filula, runs deeply along the inner border of this hone, covered by the flexor longus hallucis. It gives off the anterior peroneal to the front of the limb about an inch above the level of the anklejoint.

The nutrient artery of the tibia arises from the posterior tibial near its commeneement. It is the largest of all the nutrient arteries to the shafts of long bones.

As a general rule, in amputation one inch below the head of the fibula, only one main artery-the popliteal-is divided. In amputations two inches below the head of the fibula, two main arteries-the anterior and posterior tibials-are 
divided. In amputations three inches below the hear, three main arteries-the two tibials and the freroneal-are dividerl (Holden).

In an amputation through the middle of the leg, the anterior tibial artery

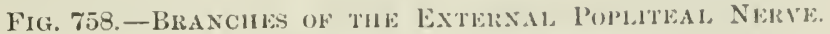

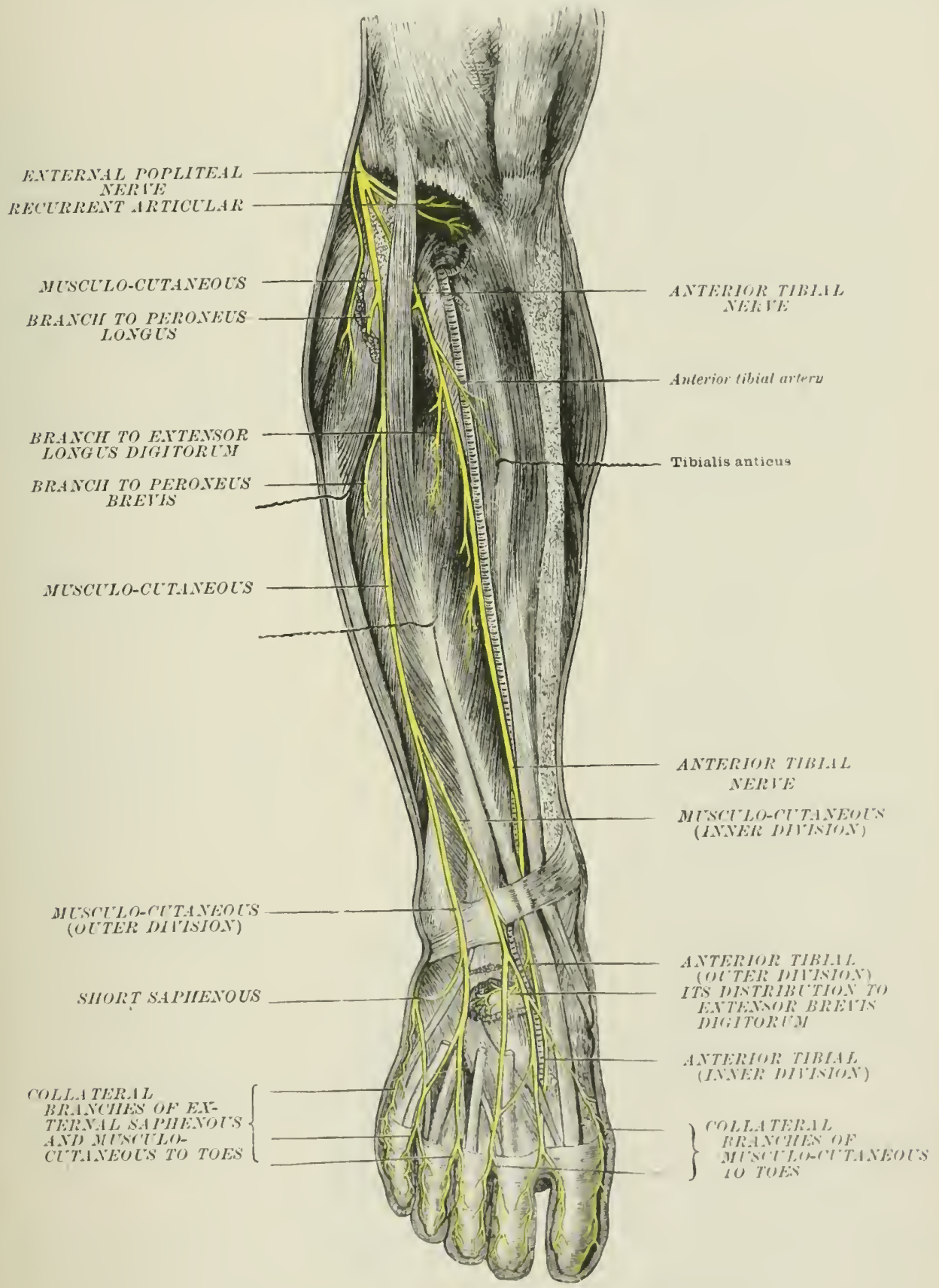

would be found cut on the interossens membrane lectween the tibialis anticus and the extensor longus hallueis, its nerve lying to its inner sich. The prosterior tihial would be between the superticial and herp muscles at the back of the lug lying on 
the tibialis posticus, its nerve being to the outer siele. The peroneal would be close to the fibula in the Hexor longus hallucis.

The musculo-cutaneous nerre, having. passed through the peroneus longus, and then hetween the pronens longus and peronens lorevis, perforates the deep fascia in the lower thirl of the leg in the line of the septum between the peronei and extensors. Directly after, it clivides into its two terminal branches.

\section{THE ANKLE}

Bony landmarks.-Malleoli.-The following are the differences between them: 'The internal is the more prominent, shorter, and is placed more anteriorly than the outer, being a little in front of the centre of the joint. The external descends lower by a half to threc-quarters of an inch, and thus securely locks in the joint on this side; it is opposite to the centre of the ankle-joint, being placed abont half an inch behind its fellow. Owing, howeres, to the greater width of the internal malleolus, its posterior border is on a level with that of its fellow. The anterior margin of the lower end of the tilia can be traced above the ankle-joint, crossed by the tendons given below. Oring to the external malleolus descending lower than the inner, in Syme's and Pirogoff's amputations the incision should run between the tip of the external malleolus and a point half an inch below that of the internal one. When a fracture is set, or a dislocation adjusted, the inner edge of the patella, the internal malleolus, ant the inner side of the great toe are useful landmarks and should be in the same vertical plane, regard being paid at the same time to the corresponding points in the opposite limb (Holden).

Tendons.- ( $A$ ) In front of ankie.-From without inwards are-(1) The tibialis anticus, the largest and most internal. This tendon appears in the lower third of the leg, lying just under the deep fascia, close to the tibia; then, crossing over the loner end of this and the ankle-joint, it passes over the immer side of the tarsus, to be attacherl to the inner and lower part of the intemal cuneiform and the adjacent part of the first metatarsal. (2) The extensor proprius hallucis. This tendon, concealed above, appears low down in a line just external to the last, and then, crossing orer the termination of the anterior tibial ressels and nerres (to which its muscular part lies external), it descends along the inner part of the dorsm to be attached to the lase of the last phalanx of the great toe. (3) and (4) The extensor longus digitorum and peroneus tertius enter a common sheath in the anterior annular ligament. The former then divides into four tendons, which, joined on the first phalanx by slips, three from the extensor brevis, and, a little later, by slips from the lumbricales and interossei, are inserted into the second and last phalanges, $x$ in the fingers. The peroneus tertius is inserted into the upper surface of the base of the fifth metatarsal bone.

(B) Behind.--The tendo Achillis, the thickest of all tendons, begins near the middle of the leg, in the junction of the tendons of the gastrocnemii and soleus. Very broad at its commencement, it gratually narrows and becomes rery thick. Whout an inch and a half from the heel, or about the level of the internal malleolus, is its narrowest point. After this it again expands slightly, to be attacherl to the middle of the back part of the calcaneum. The long tendon of the plantaris runs along its inner side. to hlend with it or to be attached to the calcaneum. On either side of the tendo Achillis are well-narked furrows below. Along the inner, the tenclon of the tilialis posticus and the posterior tilial vessels and nerve come nearer the surface. Along the outer, the external saphenous vein (more superficially) ascends from behind the external malleolus.

(C) On the inner side.-The tendon of the tibialis posticus, which has previously crossed from the interspace between the bones of the leg to the inner side, lim behind the inner edge of the tibia above the internal malleolus, being under the flexor longus digitorum, the two tendons here becoming superficial on the inner sicle of the tendo Achillis. It then passes forwards close below the sustentaculum tali and the head of the astragalus, and then very close to the inferior calcanen-scaphoid ligament (ride infica), and so to its insertion. by numerous slips, into the tarsus and metatarsus, especially the tubercle of the scaphoid. The tendon 
of the flexor longus hallucis cannot be felt. Having passent internally from the fibula, it crosses the lower end of the tibia in a separate furrow, then gromes the

Fig, 759. -THE MICSCLES OF THE FIUNT OF THE Ler.

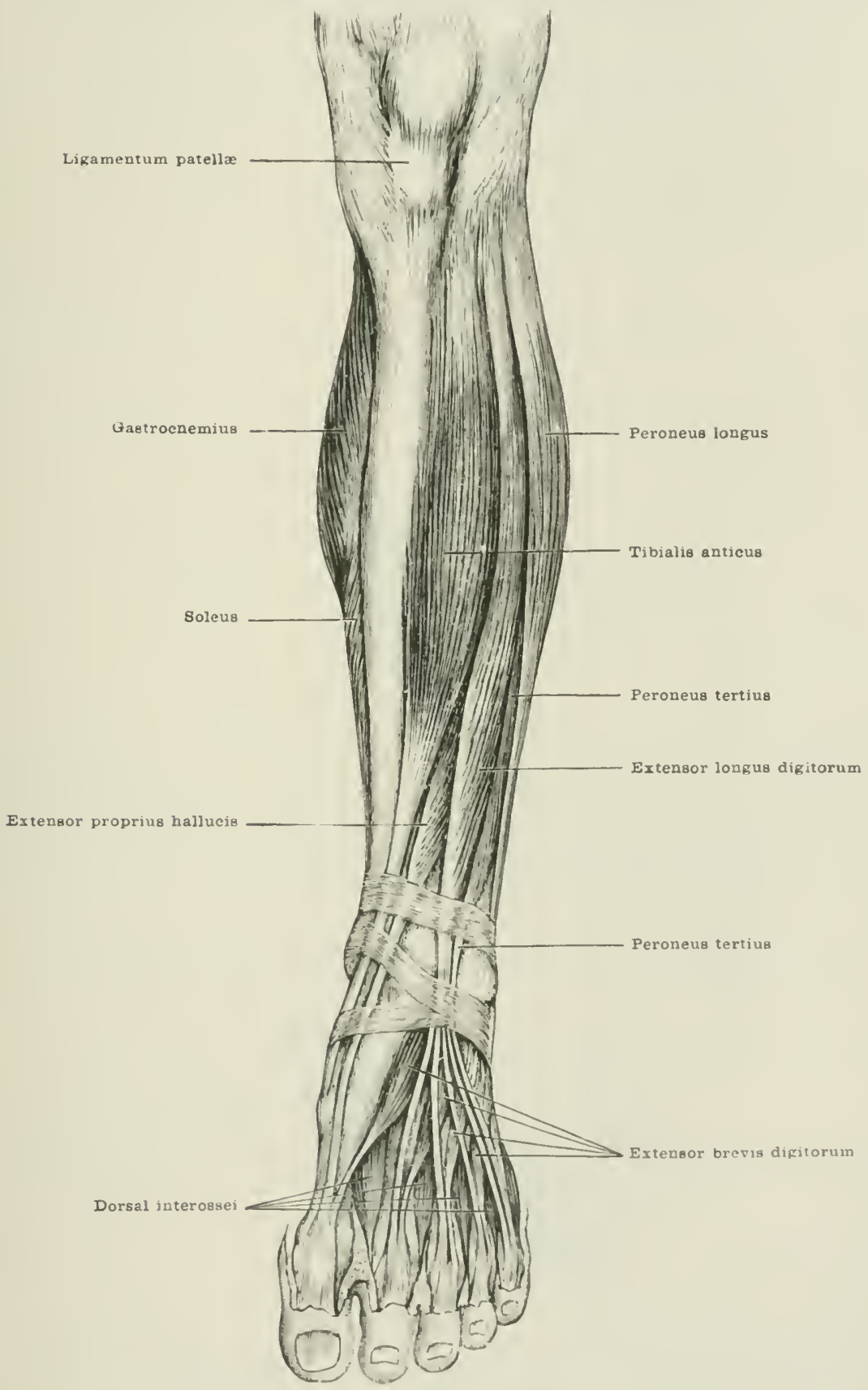

hate of the astragalus, and pases under the sustentaculum tali on its way to its insertion. The arrangement of the structures at the inner ankle from above dewnwards, and from within onwards, is as follows (fig. iti1):-tilialis pusticus, flexor 
longus digitorum, companion rein, posterior tibial artery, companion vein, posterior tibial nerve, Hexor longus hallucis.

(D) Tendons at outer ankle.-The tendons of the two peronei, which arise from the fibula between the extensor longus digitorm and flexor longus hallucis, pass behind the external malleolus. the brevis being nearer to the hone (fig. 755 ). They then pass forwards orer the outer surface of the calcaneum, separated by the

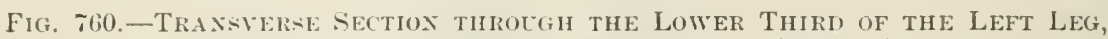
IMIEIATELY ABOTE THF, ANKIF-JOIXT. (Braune.)

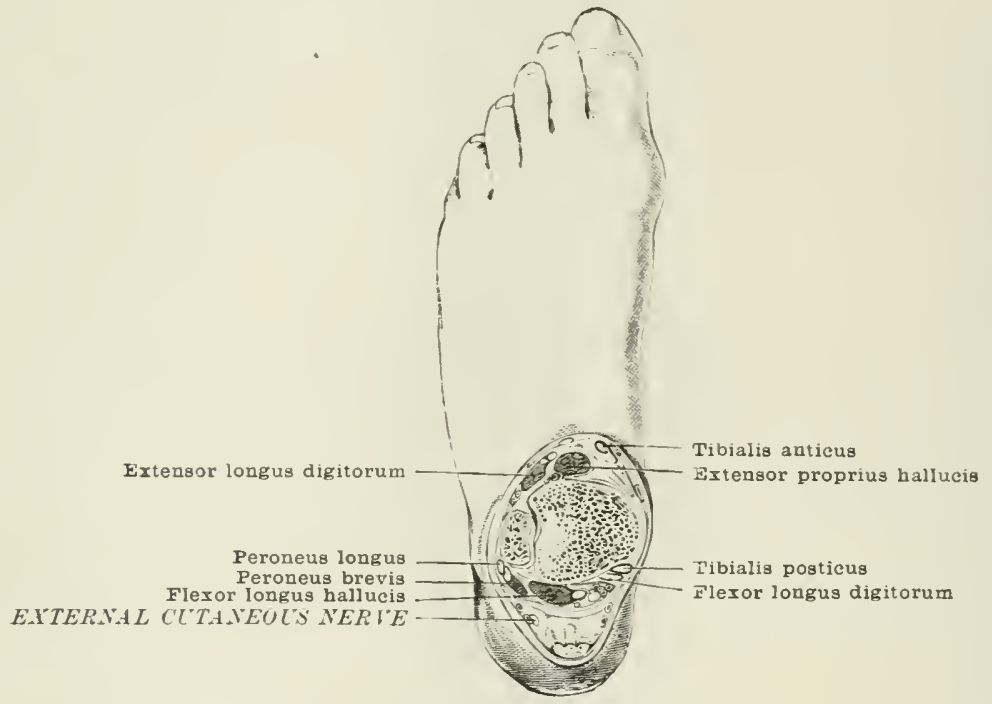

peroneal tubercle when present, and diverge. The brevis-the upper one-passes to the projection at the base of the fifth metatarsal; the longus, lying below the brevis on the alcanemm, winds round the outer border of the foot, grooving the outer border and under surface of the cuboid. Finally, crossing the sole obliquely forwards and inwards, it is attached to the adjacent parts of the internal cuneiform and the back part and under surface of the first metatarsal. While in connection

Fig. 761.-Relations of Parts Behind the Ixyer Maldenic's. (Heath.)

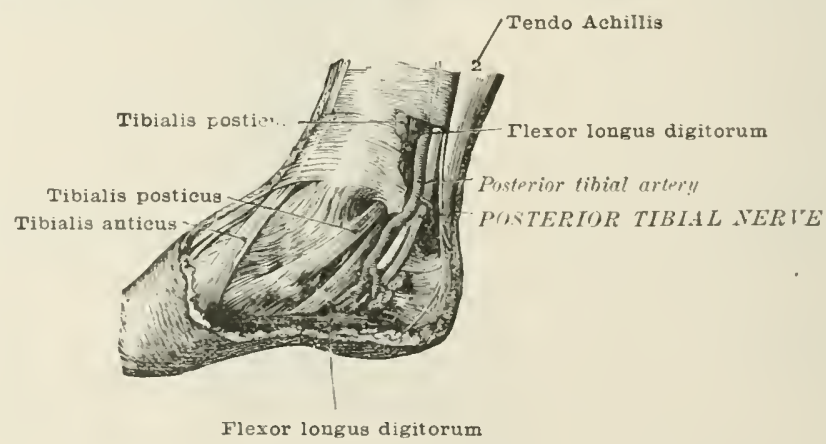

with the under surface of the cubnid, this tenrlon is covered in by a sheath from the long plantar ligament, and often contains a sesamoid hone.

Annular ligaments and synovial membranes of tendons.-These strap-like bands of deep fascia, which serve to keep the above tendons in position, are three in number, viz. :-

(A) External.-This extends from the tip of the external malleolus to the 
outer surface of the ealeaneum. It kens the two peronei in places, and surroumis them behind the fibula in one sheath with a single symovial sate, which extends upwards into the leg for an inch and a half, and sends two processes into the two sheaths in which the temelons lie on the calcancum. Fanther on, while in relation with the cuboid, the peroneus longus has at sceomel symovial shoatl.

(B) Internal. - This crosses from the internal malleolus to the inner surface of the caleaneum. Beneath it are the following canals: (1) Fol the tibialis josticus. This tendon-sheath is lined by a slomorial membrane extemeling from a joint an inch and a half above the malleolis to the seaphoid. (2) For the flexor longus digitorum. The synorial sheath of this temelom is separate from that of the closely contiguous tibialis posticus. It extends upwates into the leg about as high as the sheath just given. It reaches dewn into the sole of the foot; but where the tendon subdivides to enter the thece, catch of these is lined hy a separate srovorial sheath. Next comes (3) a wide space for the postruor tibial vessels and nerve; and, lastly, (4) a canal, like the other two, with a sepulate symorial sheath, for the tendon of the flexor longus hallucis.

(C) Anterior annular ligament.-This is a double structure. (1) Upper, above the level of the ankle-joint, and tying the tandons down to the lower thiri of the leg, it passes transveredy between the anterior crest of the tibia and fibula. Here is one sheath only, with a synorial menbrame for the tibialis anticus. (2) Lower, over the ankle-joint. This band is arranged like the letter $\prec$, placed thus (fig. 759 ). It is attached by its root to the calcaneum, and hy its bifureations to the internal malleolus anil the fascia of the sole. This arrangement of the branches of this ligament is not constant. In this, the lower ammular ligament, there are usually three sheaths with sejarate syorial membranes-the innermost (the strongest in each) for the tibialis anticus, the mext for the extensor froplus hallucis, and the third common to the extensor communis and peroncus: tertills.

Points in tenotomy and guides to the tendons.-The tendo Achillis should be divided about an inch ind a half above its insertion, its narromest point, which is about on a level with the internal mallonlus. The knife should be introluced on the inner side and close to the tendon, so as to avoid the posterior tiljial artery (fig. 7.56 ).

The tibialis anticus is often cut about an inch above its insertion into the internal "meiform, a point which is helow the level of its synovial sheath. The tendon has here the clorsalis predis an its outer side, but surated by the tendon of the extensor proprius hallucis. The knife is introduced on this side.

The tibialis posticus. - The ustull rule for dividing thir tendon is to take a spot tiro inches abore the internal mallewlus. and as acecurately ats posilule midway between the anterior and internal horlers of the leg. This point will grive the immer margin of the tilia. in chose appositim to which the tendon is lying, and is a point at which the temelon is rather firther from the artery than it is below, and is also alove the commencement of its synovial sheath. As sharp-pointed linife is uscul first to open the sheath freely, and then a blunt-pointerl one to livide the tendom. The flexor longus digitorum is usually cut at the same time.

Owing to the great diffeulty in making sure of diviling the tibialis posticus: tendon at this spot, and the risk of eutting the posterior tilial artery (fig. Totj). it has been advised of late years (Parker) to divide this tendon togethe with that of the anticus simultanensly by an incision a litte lwlow and anterior to the tip of the internal malleolus. Other sudes are the position of the astragale-seaphoid joint, and, where the deformity is of some stancling, the crease which denotes the inversion of the foot. The prosition of the two tibial arteris should be moted, and also the lines along which the tendons are emverging-the one aroses the lower

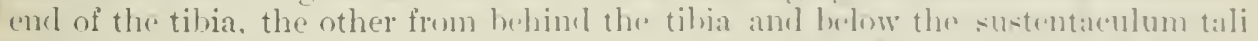

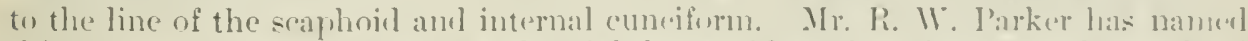
this operation syorlesmotomy, as he righty considers that the astragalo-scaphoid ligaments rerpuire division at the same time.

Peronei. - The peronei, longus and luevis. may he divided wo inches aloove the extrenal malleolus, so as to be above the level of their syorial sheath. The knife should be inserted very close to the lone, so as to lass lietwern the fibula and the 
tendons. Division below the external malleolus is somewhat easier, but as this opens their synorial sheath or sheaths (ride supra, page 1197), it requires scrupulous care as to cleanliness.

\section{THE FOOT}

Bony landmarks. - The following are of the greatest practical importance owing to the operations which are performed upon the foot.

(1) Along the inner aspect of the foot are the following:-

(1) Internal tuberosity of the calcaneum; (2) internal malleolus; (3) one full inch below the malleolus. the sustentaculum tali; (t) about an inch in front of the internal malleolus, and a little lower, is the tubercle of the scaphoid, the gap between it and the sustentaculnm being filled by the calcaneo-scaphoid liganent and the tendon of the tibialis posticus, in which there is often a sesamoid bone; (5) the internal cuneiform; (6) the base of the first metatarsil; and (7) the head of the same bone, with its sesamoid bones helow (Holden).

(B) Along the outer aspect are-(1) The outer tuberosity of the calcanemm;

Fitr. $76^{\circ}$.-Articulatioss of the Foot, Dorsal, Aspect. (Bellamy.)

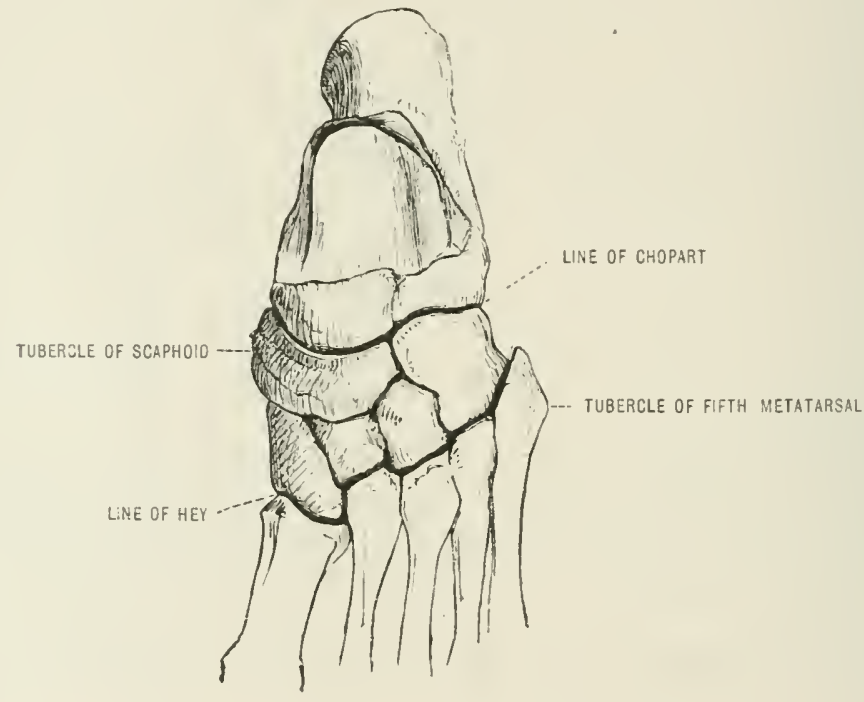

(2) the external malleolus; (3) the peroneal tubercle of the calcanem (when present), one inch below the malleolus, with the long peroneal tendon below it, and the short one above; (4) the projection of the anterior end of the calcaneum, and the calcaneo-cuboid joint, midway between the tip of the external malleolus and the base of the fifth metatarsal bone; (5) the base of the fifth metatarsal bone; (6) the head of this lone.

Levels of joints and lines of operations.-In Syme's amputation through the ankle-joint, the ineision starts (say in the case of the left foot) from the tip of the external malleolus, and is then carried, pointing a little backwarls towards the heel, across the sole to a point half an inch below the internal malleolus.

In Pirogoff's amputation the incision begins and ends at the sime points, but is carried straight across the sole. In each amputation the extremities of the ahore incision are joined by one going straiglit across the ankle-joint, which lies about half an inch above the tip of the internal malleolus.

In Chopart's medio-tarsal amputation (fig. 762), which passes between the astragalus and the seaphoid on the immer side, and the calcaneum and the cuboid on the outer, the line of the joints to be opened would le one drawn across the dorsum from a point just behind the tuherosity of the saphoid to a point corre- 
sponding to the calcanen-culudi joint, just milway hetween the tip of the external malleolus and the base of the fifth motatirsal bone.

In Lisfranc's, or Hey's, or the tarso-metatarsal amputation, the hases of the fifth and first metatarsals must le clefinel. The first of these (an always he detected, even in a stout or swollen foot; on the inser sick the joint lwetwern the internal cuneiform and the first metatarsal lome lies an inch and a half in front of the scaphoid tubercle. In eprening the joint betweren the second metatarsal and the midelle cuneiform, its position (the hase of the former hone projecting upwarls: on to a level one-third or once-fourth of an inch alove the others), and the+ way in which it is locked in between its fellows and the cunciform lones, must lice remombered.

In marking out the flaps for the amputation of the great toe, thr large size of the head of the first metatarsal, and the importance of leaving this so as not to diminish its supporting powrer and the treading width of the foot, and thus of marking out flaps sufheintly long and large, must be borne in mincl. In amputation of the other toes, the line of their metatars(1-phalangeal joints lie's a full inch above the web.

Bursæ and synovial membranes.-The symovial sheath of the extensor

Fig. f63.-Vertical Sectiox through tire Crxeifory axd Cuboin Boxes. (One-half.)

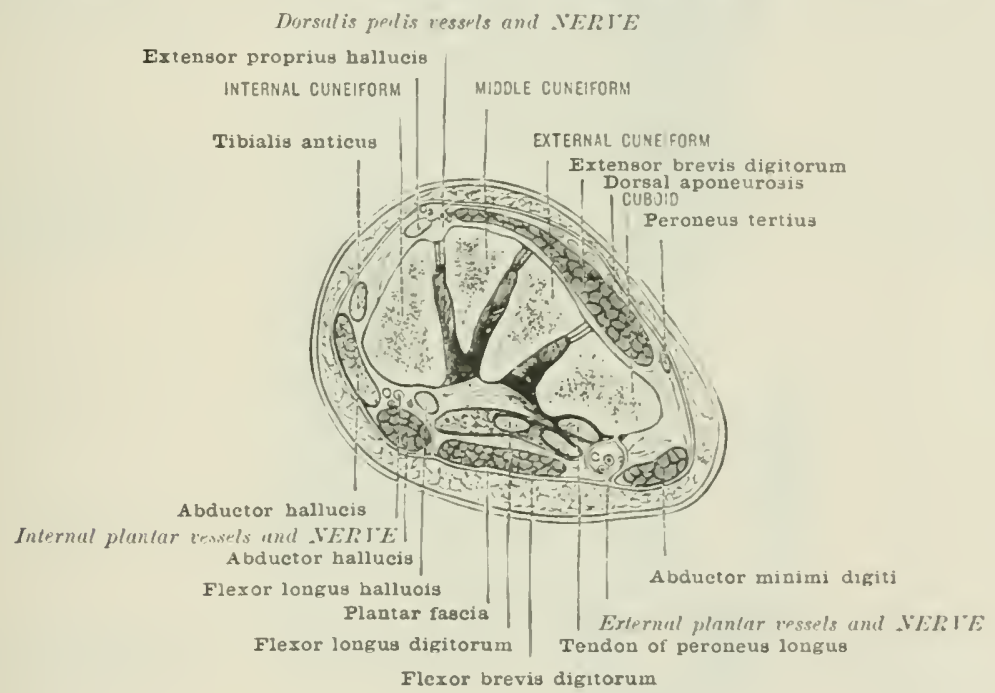

proprius hallucis extends from the front of the ankle, over the justere, as fill as the metatarsal bone of the great toe. There is generally a bursa over the instely, abore, or it may be below; the tendon. There is often an irregular hursa hetween the tendons of the extensor longus digitorum and the projecting end of the astragalus over which the tendons play. There is much friction here. It is well to $h_{x}$ aware that this bursa sometimes communicates with the joint of the hearl of the astragalus (Holden). There is a deep srnovial bursa between the tendo dehilli-

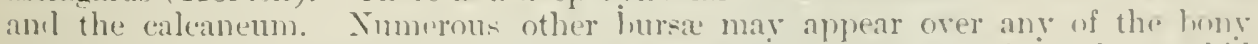
points in the foot, especially when they are rendered over-pominent hy morlicil conlitions.

Synovial membranes.-In addition to that of the ankle-joint, there are six

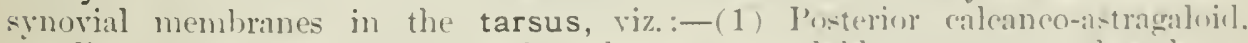
peculiar to these bones; (2) anterior (alcanen-nstragaloid, common to these houns and the seaphoid; (3) between the callaneum and the culojel; (4) hetween the cuboid and the outer two metatarsals; (i) hetween the internal enuneiform and the first metatarsal; (6) a complicated and extensive one. which hranches ont hetwern the seaphoid and cuneiform lones: Ixwern the cumeiforms: betwen the external cuneiform and the cuboid; between the mickle and onter cuncifim and the second 
and third metatarsal hones: and between the second and third, and the third and fourth metatarsal bones (fig. 762).

Dorsal artery.-The line of this is from the centre of the ankle-joint to the upper part of the first interosseons space. On its inner side is the tendon of the extensor proprius hallucis; on its outer, the innermost tendon of the extensor longus digitorum. It is erossed by the innermost tendon of the extensor brevis. The origin of this muscle should be marked on the outer and fore part of the calcaneum.

Fig, 764.-SUperficill Nerves in tile Sole of the Foot. (Ellis.)

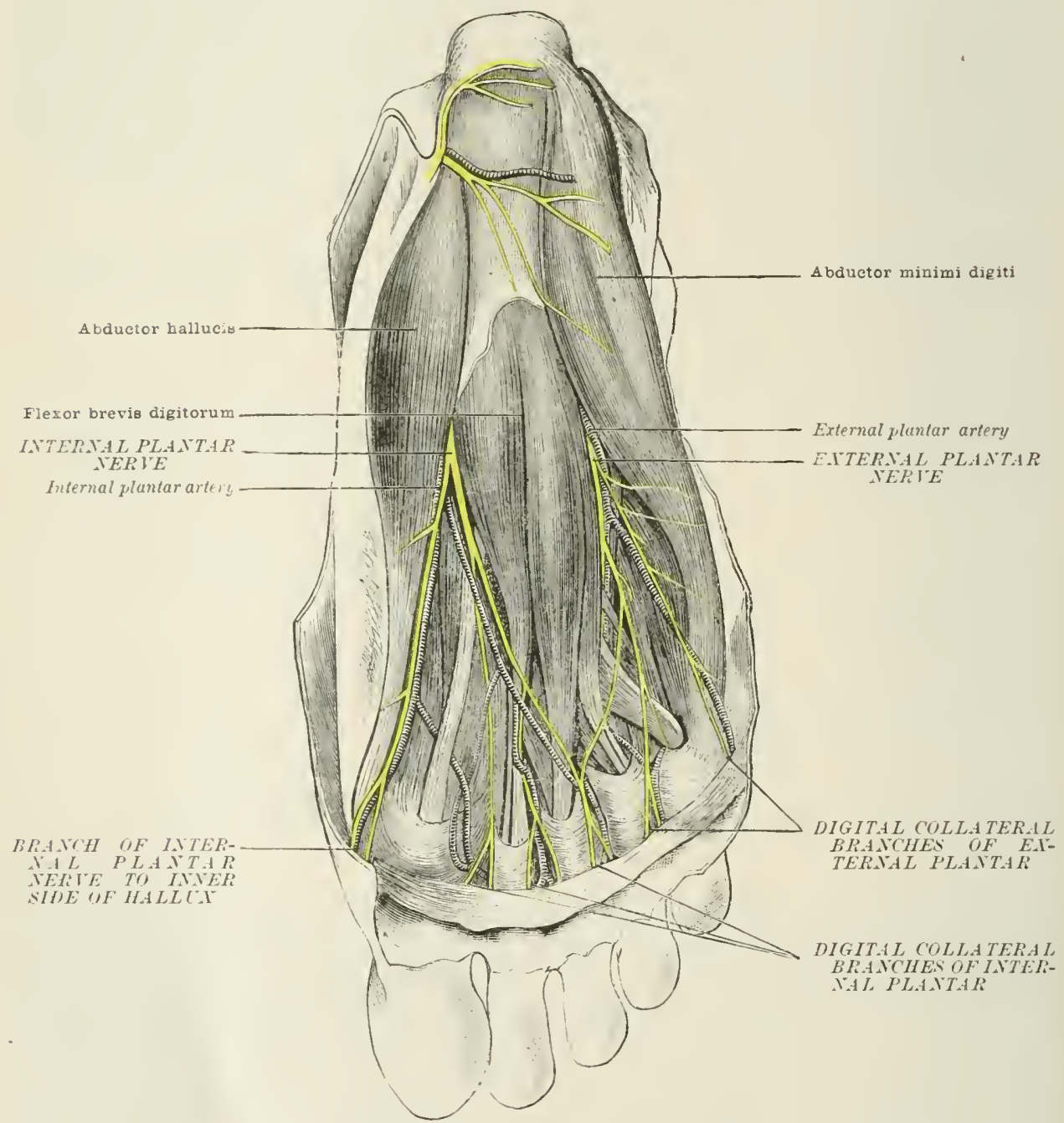

Cutaneous nerves (figs. 764,770 ). - The sites of these, numerous on the dorsum of the foot, are as follows:-The musculo-cutaneous nerve, having ferforated the fascia in the lower third of the leg, divides into two ehief branches, inner and outer, which supply all the toes save the outer part of the little, and the arljacent sides of the first and second. The anterior tibial becomes eutaneous in the first space, and is distributer to the contiguoms sides of the above-mentioned tocs. The external saphenous nerve rum with its rein below the malleolus, and supplies all the outer horder of the foot and the outer side of the little toe. The internal saphenous nerve, coursing with its rein in front of the internal 
Fig. 765.-I'LANTAR AI'TERIES ( DEFI').

(From a dissection in the Hunterian Museum.)

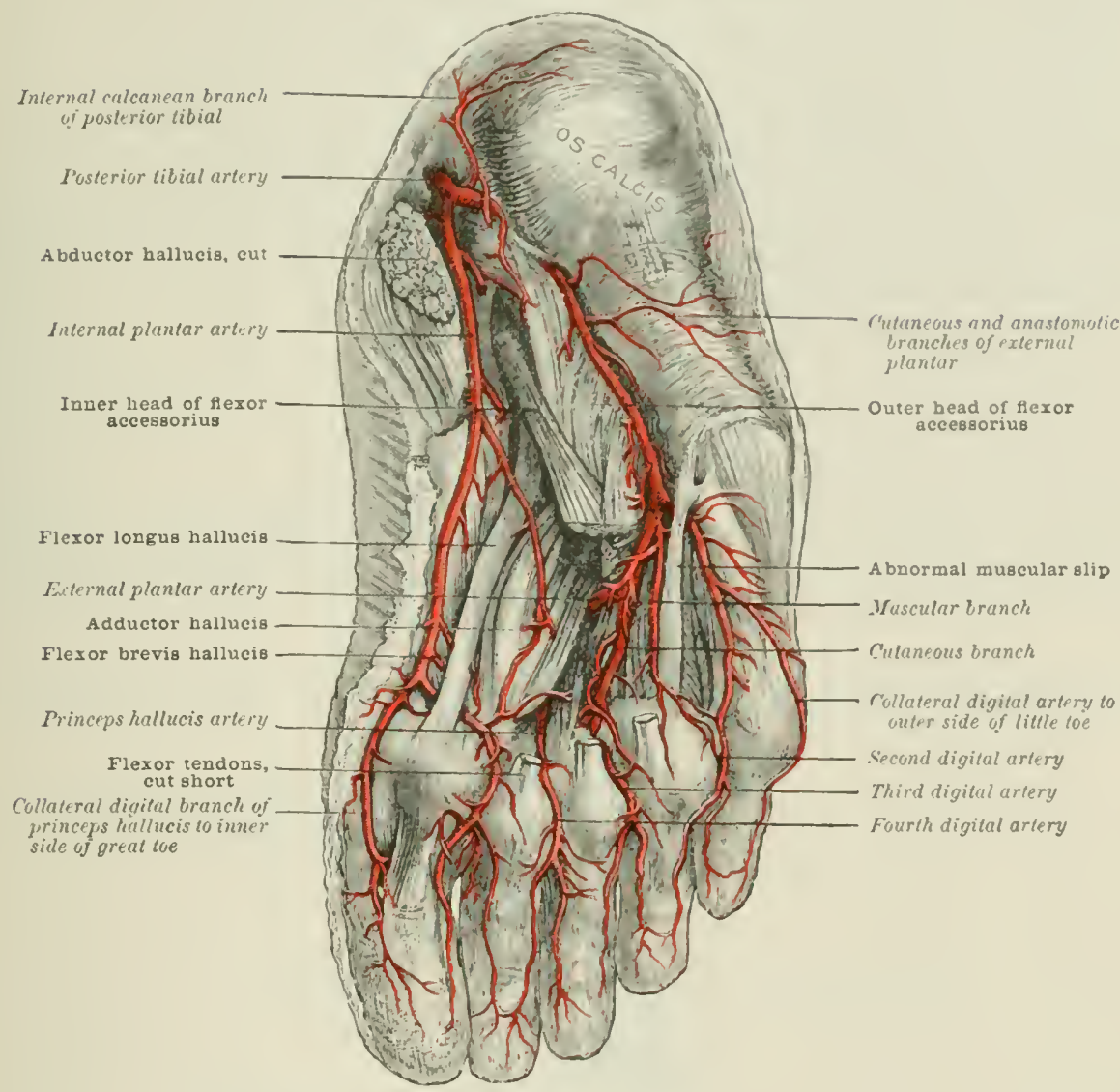

Fig. 766.-Lorgitedisal SEctiox of Foot. (One-third.) (Braune.)

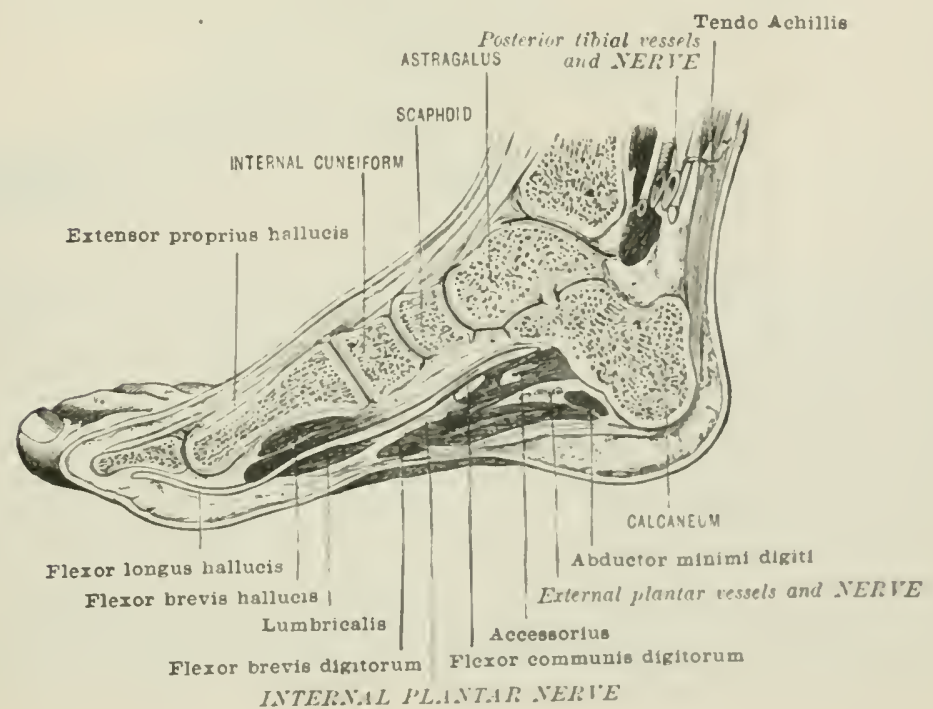


malleolus, supplies the inner border of the foot as far as the middle of the instep.

Plantar arteries.-The line of the internal would be one drawn from the lifurcation of the posterior tibial, or about midway hetween the tip of the internal malleolus and the inner border of the heel, to the middle of the plantar surface of the great toe. The course of the external plantar runs in a line draw from the bifureation, first obliguely across the foot to a point a little internal to the inner side of the base of the fifth metatarsal, and thence obliquely across the foot till it reaches the first space and joins with a communicating branch from the dorsal artery. It thus crosses the foot twice. In the first part, it is more superficial, in the second very deep; it here forms the plantar arch, and is only separated from the bases of the metatiarals by the interossei.

\section{ARCHES OF THE FOOT}

These are two-the longitudinal and the transverse.

(A) Longitudinal arch (figs. 766,767 , and 768 ). - This is by far the most important. Extent: From the heel to the hearls of the metatarsal bones. The tous lo not ard much to the strength and elasticity of the foot (Humphry). Ther enlarge its area and adaj, it to inequalities of the ground, are useful in climbing, and

Fig. 76\%.-The ARCH IN THE ORdixary Position of Staxnixg. (Ellis, of Gloucester.)

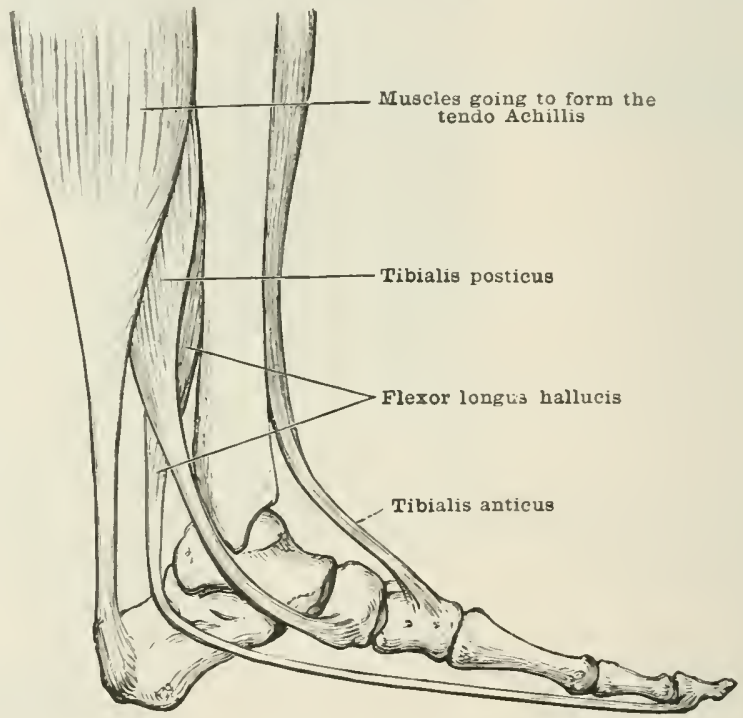

in giving an impulse to the step before the foot is taken from the ground, in the third stage of walking. Two pillars.-Professor Humphry lays stress on the important differenees between these two: (1) Posterior pillar: This consists of the caleaneum and hinder part of the astragalus, viz. only two bones in order to secure solidity, and to (mable the calf-muscles to act rirectly upon the heel, without any of that loss of power which would be brought about hy many moring jointsurfaces. (2) Anterior pillar: Here there are many hones and joints to provide ( 1 ) elastic springiness, and (b) wilth. This anterior pillar may again be clivicled into two: (ii) An inner pillar, very elastic, consisting of the astragalus, scaphoicl, three cuneiforms, and three inner metatarsals. (b) In outer, formed liy the cuboils and two outer motatarsals. This is stronger aud less elastic, and tends to buttress up the immer pillar. Keystone: This is representerl by the smmit of the trochlear surface of the astragalus. It liffers from the keystones in ordinary 
arches in the following imprortant particulars (Humplury): (

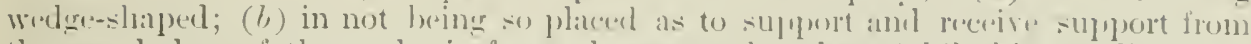

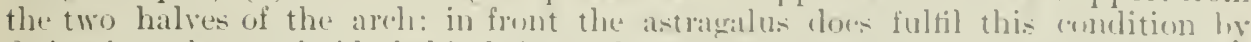

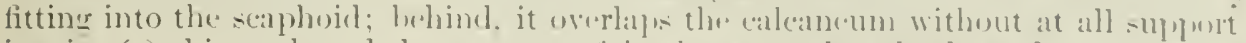

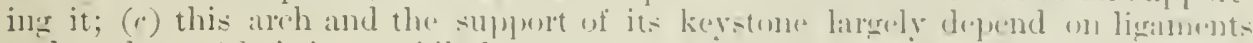

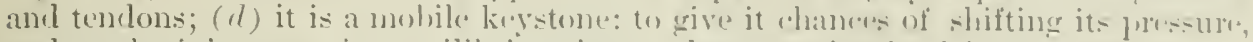

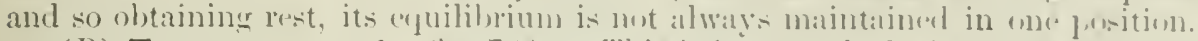

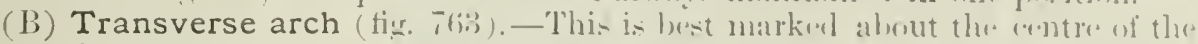
foot, at the instep, aloner the tarso-nutatarsil juints. This, an well as the lomgrtu-

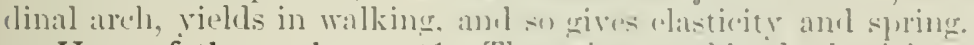

Uses of the arches.-(1) They give comlinid elasticity and strength to the tread. Thus they give fimness, frem qujekness. and dignity, looth in standing and walking, instead of what we see in their alsenes, viz. the linureness of an artificial limb, and the shuflling or hobbling which gros with tight lorets. deformed tow.

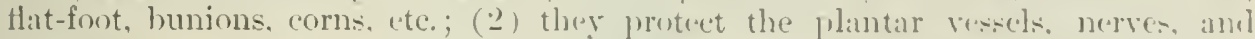
muscle:-; (3) they add to man's height; (4) they make his gait a lerfect combina-

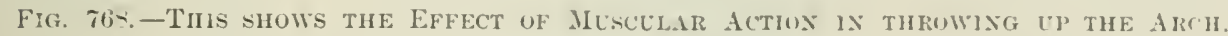

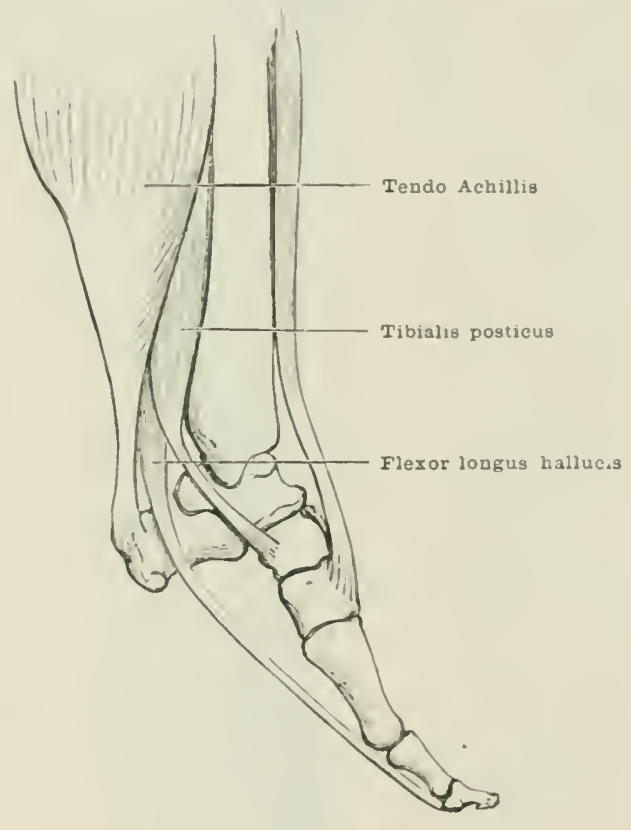

tion of plantigrade and rigitiorarle, as is seren in matn's walking, when he uses first the heel, then all the foot, and then the tow (Humphry).

Maintenance of the arch.-(1) Plantar fascia.-This is ( 1 ) a hinding ti.. letween the pillars of the longitudinal areh; (b) it protects the structures lenenth: (c) it is a self-regulating limanent and protection. Thus, having a yuantity uf muscular tissue attacherl to its upher and back part, it constantly responds hy the contration of this. to the amount of any fresure madr. upin the forot. (20)

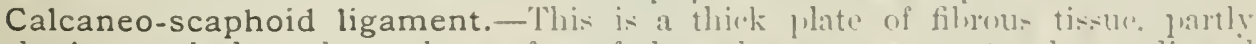
clastic, attacherl to the under surface of the (allanemu, sustentaculum tali, and seaphoiel. It is thickest at its inner sile. where it blemels with the anterior prat of the deltoid liganuent, and where the tibialis pustiens pusses into the sole, griving much support to the heasl of the astragalus. and assioting the fower and s]ring of this ligament (rirle infiru). (B) Calcaneo-cuboid ligaments. (11) Long;(li) short.-These ligaments are the main sulport of the outer. firm, and less elastic part of the longitudinal areh. (4) Tibialis posticus.-The leasne of this musclu.

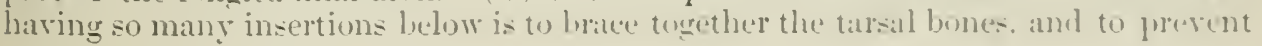


Fig. 769.-The Slperficial Veiss axin Lyyphatics of the Left Lower Limb.

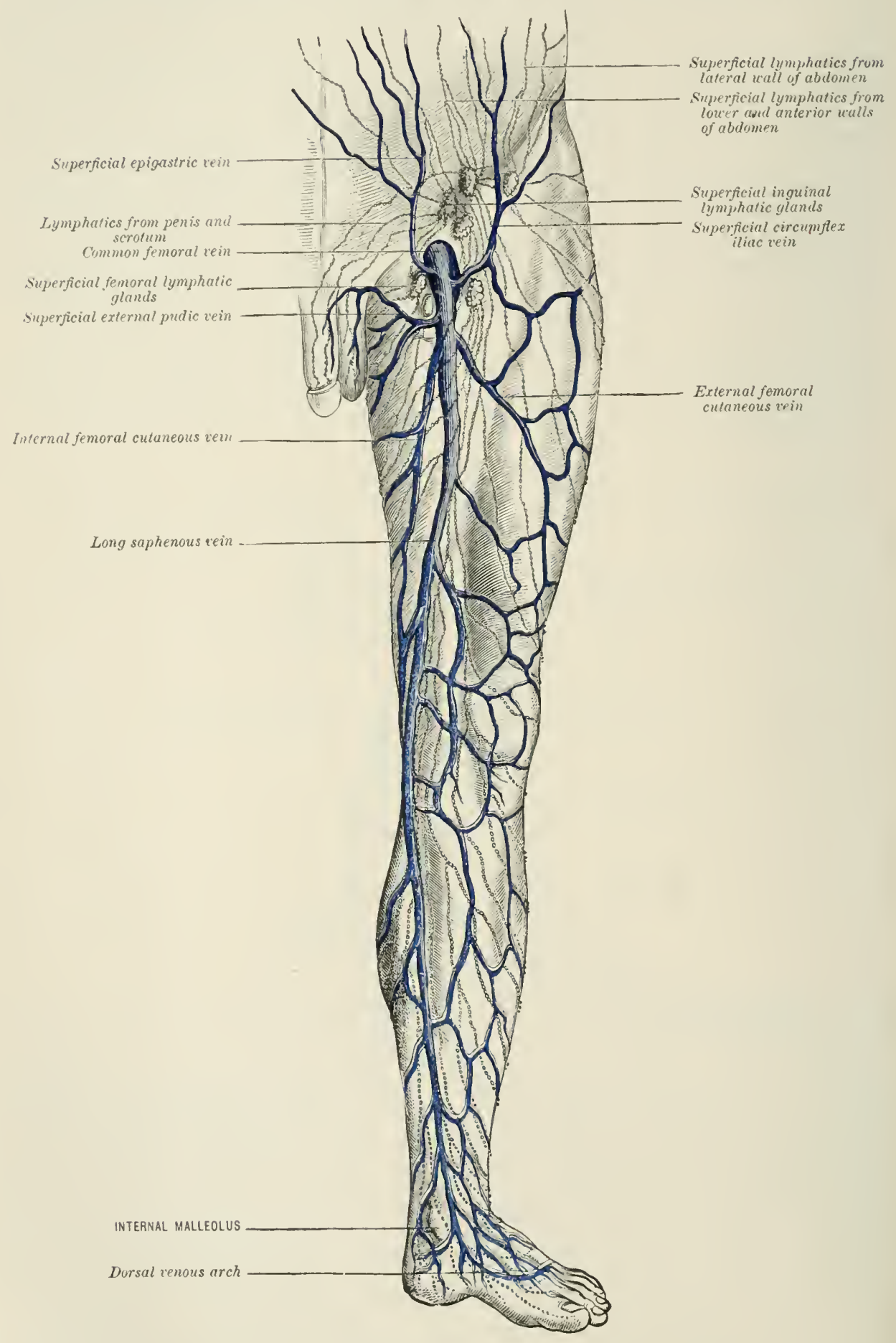


their separation when, in trearling, the rlastic anterior pillar tonds to wirten ont. of these numerous offsets, that to the seaphoiel is the mest important. 'Tlus it strengthens the ealcaneo-seaphoid ligament hy blonding with it, and thus smplorts the arch at a trying time. By coming into action when the heel is raised (fig. Ftis), this tenelon helps the calcanero-scaphoid ligament to support the head of thes astragalus, and to maintain the arch of the foot when the weight of the borly is: thrown forwarl on to the instep. In other words, the tibialis postiens comes intn play just when the heaviest of its duties is devolving upon this ligannent, viz. When the heel is being raised, and the boly-weight is being thrown orer the instep an to the opposite foot. (5) Peroneus longus. - This raises the outer pillar, and stearlies the outer side of the arch. Further, by its strong proces's attached to the first

Fig. 770.-Distribution of Cltaneors Nelives on the Posteriolr axd Axtriof ASPECTS OF THE IXFERIOR EXTREMITY.

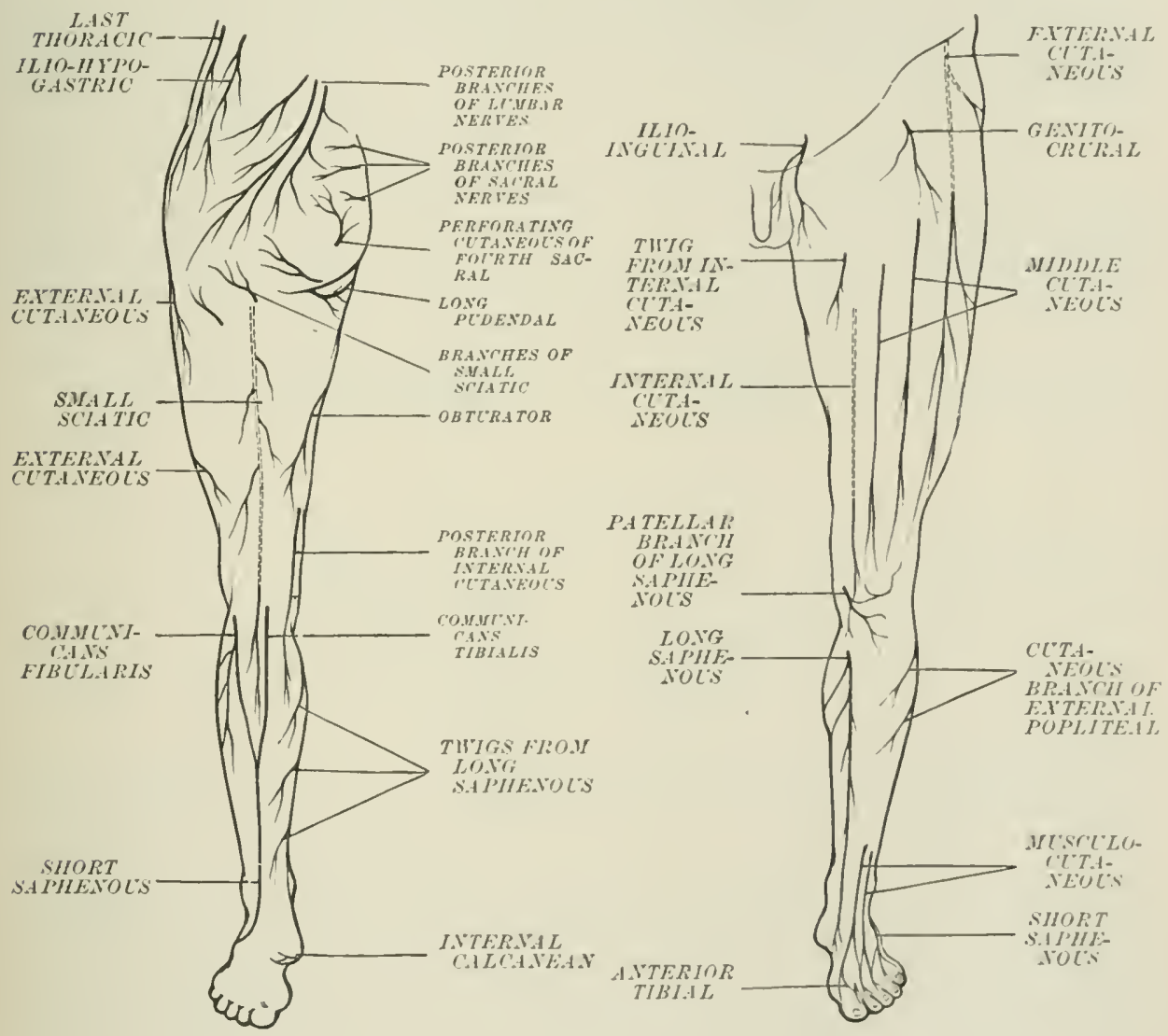

metatarsal bone, it keeps the great toe strapped down firmly against the gromel; thus, keeping down the anterior pillar of the longitudinal arch, it aicls the firmness of the tread (Humphry). (6) Tibialis anticus. -This braces ul the kiystone of the arch. Thus, by kereping up the internal cuneiform, it maintains: the scaphoid, and so indirectly the astracalus, in situ.

(7) Dr. Ellis (of Gloucester) hats llawn especial attention to the action of the long flexors as bow-strings or tic-rods as they tighten in their contraction. and so diminish the distance between their points of attachments to the toes and the spot where the tendons pass round the os calcis, thus brateing up the arch. Of these flexors the flexor longus hallucis has especial influence, as shown hy the stagedancer, who supports herself literally on one toe. The flexor longus digitorum, while of less influence than the Hexor longus hallucis, serves two important 
purposes, one of passing beneath and thus picking up the other one, the flexor longus hillucis. Further, it draws the four smaller toes firmly against the ground, the olject of the smaller toes being, as far as possible, to grip the gromed. (8) The same authority prints out that the possession by the great toe of two phalanges only is to enable it to form a firm solid base, on which not only the flexor longus hallucis and the peroneus longus act, but also the smaller muscles, ly holiling this toe down and keeping it straight in all its length. The two heads of the short Hexor, the abductur and adductor, one pulling one way and one in the opposite direction, and like the two reins of a bridle when both are pulled together, hive a joint or a collective action.' The above three short muscles are to be reganded as one set of flexor muscles whose ohject is to hold down the first phalanx firmly, so that the powerful flexor longus hallucis, acting on the second, exerts all its influence on a straight great toe.

Fig. 769 is introduced here to remind the student of the arrangement of the superficial lymphatics of the lower extremity.

These follow chictly the silphena veins, and enter the inguinal (page 667) and poptiteal glands. The superficial lymphaties of the buttock enter the outer, and thuse over the adchetor muscles the innermost group of the inguinal glands.

The deep lymphatics of the lower limb, comparatively few in number, follow the course of the deeper vesseds. After passing through some four or five glands deeply placed about the popliteal ressels (these glands also receive the lymphatics along the external saphenous vein) the lymph is earried up by lymphaties along the femoral artery to the reep femoral or inguinal glands. These are found around the upper part of the femoral vessels; one very often oceupies the femoral canal.

Fig. 770 shows the distribution of the superficial nerves on both aspects of the limb.

\section{THE REGIONS OF THE ABDOMEN}

\section{BY WILLIAN ANDERSON, F.R.C.S.}

As the plan of segmenting the ventral surface of the abdomen by means of two horizontal and two vertical or nearly vertical lines, has survived the test of time, it might be assumed that it is a resource of some practical value to the physician and surgeon. It is, however, a curious fact that, although the nine historieal regions of the abdomen have been universally accepted in British and continental schools for at least forty years, and may be traced back to a very much more remote period, no attenpt has ever been made to seeure uniformity in the plan of their delimitation. Almost every anatomical writer has, in fact, cleeted to follow a srstem of his own, with the result that there are at the present moment nearly a sicore of different schemes in our recognised text-books. There is little dould that it were better to abandon altogether the pretence of a regional subdivision than to employ terms which have no scientific meaning, lut it may be hoped that some areord will soon be arriverl at.

Whatever system he arlopted, it is necessary that the boundary 'lines' should be converted into planes carried through the whole depth of the abdomen, and defined on the dorsal as well as on the rentral surfice of the trunk, and that the structures cut through liy these planes should be noted, as well as those eomprised within the regions which they separate. It should, of course, be recognised that the relations so definced ean only be approximate, on account of the wide range of fhrsiological variation in the position of the ahdominal contents: but this being understood, a regional trpe would be of material service in medieal edueation.

If we retain the subdivision into nine segments, it remains only to eonsirler the 


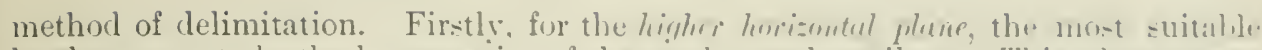
level appears to be the lowest point of the tinth costal cartilage. Thi- plane prases through the second lumbar vertebra posteriorly, and lies about two inches ahore the umbilicus in front. It cuts throush the -tomate the transerese (ofon, the assending and descending colon, the: dumlenun (lower ("mrvature) and small

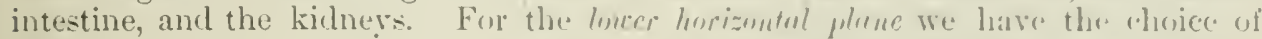
two levels-that of the anterior superior iliate spine, which lies abrut an inch below the level of the sacral promontory, and that of the tulereulum crister, recenty proposed by Professor Cumninghani.

The plane of the tuberculum rriste (intertuberculous plane) lias been adoptid by Quain and Cumningham; hut the lewer of the twe altemative planes, that of the anterior iliac spines, seems the more definite and comrenient for clinical demonstration.

This interspinous plane, carried horizontally hackwards from the symphysis into the true pelvis, cuts the small intestine, the execum or luwer part of the asconding colon, the sigmoid flexure, the upler ent of the rectum, the fundus uteri, the ovaries and Fallopian tubes, and the listended bladeler, and hence forms a valualule gruide to the surgeon.

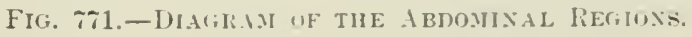

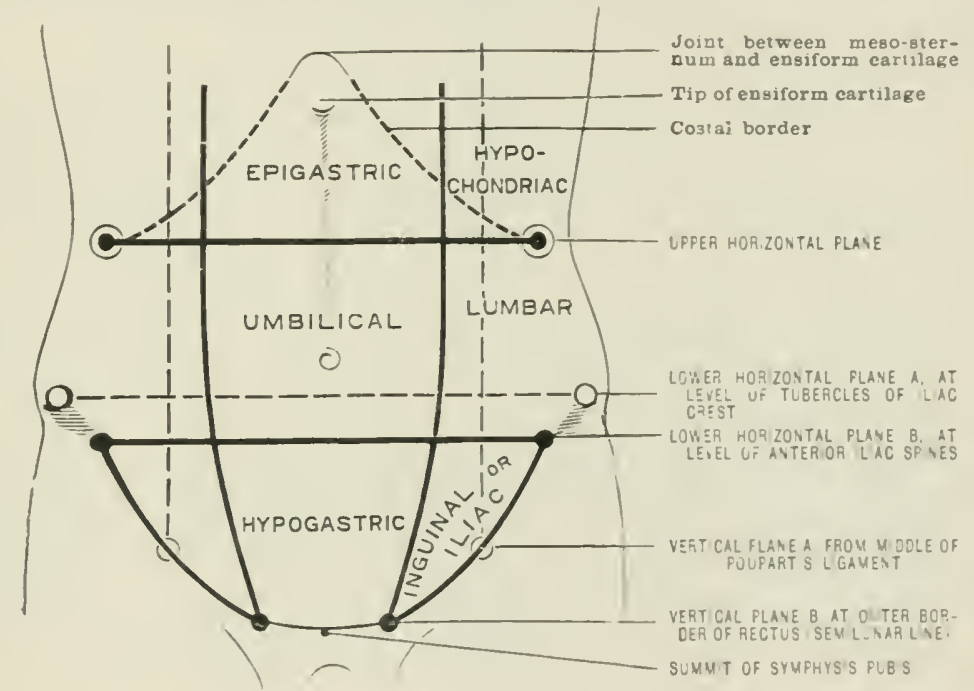

For the longitudinal plane on each side, that corresponding to the "rertical line" of Quain, running upwards parallel to the mesial line from the middle of Poupart": ligament, is already familiar to the greater number of observers; but it has the disadvantage of making the mesial regions rery large in proportion to the lateral regions, the upper lateral regions being till further ruluecel in women owing to the narrowness of the chest when compareer with the width of the pelvis. As an alternative, the outer border of the rectus would be freforable, as it is usually to be localised without difficulty by the lateral infracostal furrow above. and by the pubic spine below; and when these points are indistinct, the lireadth of the paticnt ": hand at the head of the metacarpal bones may he taken as equal to the breadth of the rectus in its upper two-thirds. This jlane. while relucing the width of the mirldle zone without interfering matcrially with "xisting indications of eontents. leaves an inguinal region that inclurles the whole of the inguinal canal. Each pline cuts the kidney, transverse colon, and small intestine, and the vruris lie at or nuar its intersection with the lower horizontal (interspinous) plane: the riglt plane cuts. also the gall bladder, and sometines the cecum; the leit cuts the sigmoid flexure. the stomach (great cul-de-sae), the pancreas, and the sjlecen. The subjoined table will show the contents of the regions adjusted according to this scheme. If the 
rertical plane from the middle of Poupart's ligament be preferred to that here adopted, the name of 'iliac' region must replace that of 'inguinal,' and the two inguinal canals would be transferred to the hypogastric region. The choice of the intertuberculous plane in place of the interspinous plane affects the table chiefly in bringing the lower part of the ascending colon into the right "iliae" region.

The subjoined diagram shows the two principal schemes, and the table offers a summary of the visceral contents:

\section{The Abdominal Viscera regionally arrangcd.}

\section{Right}

Hypochondriac

Liver: portion of right lobe (gall bladder usually cut by longitudinal line).

Kidney: upper and outer

Colon: hepatic flexure and part of ascending colon.

\begin{tabular}{|c|c|c|}
\hline Lnmbar & Umbilical & Lumbar \\
\hline $\begin{array}{l}\text { Kidney: lower and outer } \\
\text { part. } \\
\text { Ascending colon. } \\
\text { Crecum: portion or whole. } \\
\text { Sinall intestine: chiefly } \\
\text { ileum. }\end{array}$ & $\begin{array}{l}\text { Kidneys: lower and inner por- } \\
\text { tion of each, with ureters. } \\
\text { Duodenum: lower flexure } \\
\text { and part of third portion. } \\
\text { Jejunum and ileum. } \\
\text { Transcerse colon: portion. } \\
\text { Sigmoid flexure and com- } \\
\text { mencement of rectum. }\end{array}$ & $\begin{array}{l}\text { Kidney: lower and outer } \\
\text { part. } \\
\text { Small intestine: chiefly jeju- } \\
\text { num. } \\
\text { Descending colon and portion } \\
\text { of sigmoid flexure. }\end{array}$ \\
\hline
\end{tabular}

\section{MIDDLE \\ Epigastric}

Liver: quadrate, caudate, Spigelian, and greater part of left lobes (gall bladder usually cut by longitudinal line).

Puncreas: head and body.

Spleen : upper and inner part.

Kidneys: upper and inner part of each, with pelves.

Suprarenal bodies.

Stomach : middle and pyloric regions, cardiac and pyloric orifices.

Duodenum : first and second portions and termination of third portion.

Small intestine: transverse colon, variable portion.

\author{
LEFT \\ Hypochondriac \\ Licer: portion of left lobe. \\ Spleen: lower and outer \\ part. \\ Pancreas: tail. \\ Kidney: upper and outer \\ part. \\ Stomach: great cul-de-suc. \\ Colon: splenic flexure.
}

'pper horizontal plane at level of louest point of costal border

\section{Inguinal}

Sinall intestine.

Cecum: lower portion, occasionally.

Inguinal canal.

\section{Hypogastric}

Small intestine.

Sigmoid flexure and rectum (portion).

Crecum: lower portion, occasionally.

Ireters.

Bladder : in children, and listended bladder in adults.

Fundus uteri and appendages.

\section{Inguinal}

Small intestine.

Sigmoid flexure: portion. Inguinal canal. 


\title{
SECTION I I
}

\section{VESTIGIAL AND ABNORMAL STRUCTURES}

\author{
BY ARTHLR ROBINSON, M.D., M.R.C..
}

LECTCRER ON ANATOMY IN TIE MIDDLESEX IOSPITAL MEDICAL SCUIML; EXAMINER IN ANATOMY FOR THE CONJOIST BOARD OF ENGLAND

The vestigial structures met with in the human body may be classified in two groups:-

(1) Remnants of organs which played an important part during foetal life.

(2) Structures which appear regulary in the humm borly, hut which prosess little or no function, being merely vestiges of organs which are much hetter dereloped in some of mankind's ancestors.

The abnormal structures which occasionally appear in the human subject are produced by retardation or excess of ordinary developmental processes. by the nomunion of parts which usually fuze together, hy the fusion of parts which usually remain separate, or the formation of organs not usually developed in man. lint which are, however, frequently met with in some of his more or less remote ancestors; organs of the latter class are of atavistic mature, that is, they are due (1) a 'reaplearance of a more primitive organisation, or a reversion to a jimary state.'

\section{THE SKELETON}

\section{THE SKULL}

The epipteric bone.-This term was applied hy Profe-sor Flower to a small bone occasionally found at the bottom of the temporal fossan. separatine the sreat wing of the sphenoil from the anterior inferior angle of the parietal lone. It is of the nature of a Wormian hone, and is due to the appearanere of a centre of as-iticaltion in the region usually occupied by a portion of the parietal hone or the great wing of the sphenoid.

The interparietal bone, or os Incæ, and the præinterparietal bone.-The posterior section of the necipital hone, thi squama oecipitalis, is winally derelopreal from at least three pairs of centres, which alrsuperposed. As a rule, each pair of centress soon fuses into a single mucleus of osification. and the three serments of

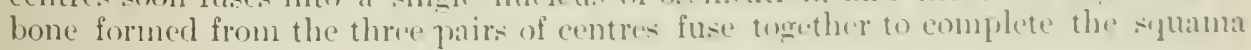
oceipitalis.

Occasionally, howerer, the two upper suments may unite. but remain soparate from the lower segment, and then, in the alult, a bone is fouml lring lutwen the 
parietal bones and above the vecipital. This bone is known as the interparietal lume, or, lreatue it alpears more frequently in ancient Peruvian skulls (five to six precerent.) than in European skulls (one to two per cent.), it is also callect the os Jince.

The interparietal bone may consist of lateral halves, a condition produced by the centres on each side finling to unite across the mithlle line.

In a relatively small number of eases the upper segment alone may remain separate in adult life as a prex-interparictal bone, which corresponds in position with the apex of the oreipital bone; this also may consist of two lateral segments. In a still smaller number of cases both interparietal and pre-interparietal bones may be present in the same skull.

The interparietal hone appears first among mammals, and is best developed in some of the lower forms. The pre-interparietal bones are only constantly present in the horse.

Fontanelle bones.-Accessory centres of ossification occasionally appear in the membranous wall of the skuil in the regions of the anterior and posterior fontanclles, where they give rise to small segments of bone, which remain separate thronghont life. The anterior fontanelle bone lies in the region of the bregma, lretween the parietals and the frontal, and the posterior fontanelle bone is situater at the lambla, between the parietals and the occipital. Both are of the nature of Wormian bones. and the posterior fontanelle bone must not be confounded with the prit-interparietal bone.

Os Japonicum.-This term has been applied to a malar hone, which consists of two separate fragnents, under the idea that a bificl conclition of that bone is more common in the Japanese than in other races; but a double malar bone is not unfrequently met with in other races, and its significance is not at present thoroughly unrlerstood.

\section{THE STERNUM}

Cleft sternum.-Occasionally the sternum, instead of being a single median hone, consists of two lateral parts, each part being connected with the cartilages of the true ribs of its own sicle. This conclition is due to the persistence of one of the embryological phases through which the sternum normally passes, for in the early periock of development each half of the sternum is formed by the fusion of the cartilanous extremities of the upper nine rils, and thereafter the two cartilaginous bars thus produced fuse together to form the single median sternum with which the eighth and ninth ribs subsepuently lose their connection. If the fusion of the two halves of the cartilaginons sternum does not oceur, ossification proceeds in each half, and the conclition of cheft sternum is produced.

Perforated sternum.- Not unfrequently an aperture, of larger or smaller size, is found in the lower part of the body of the sternum. It is filled, in the recent contition, by fibrous tissue or by eartilage, and it is due to the non-mion of the lateral centres of ossification from which the lower part of the sternum is ossified.

Ossa suprasternalia.-The two small bones or romnd nodules of cartilage which are known as the ossa suprasternalia, or Brecht's cartilages, are found, one (m cach side, above the sternum and immediately internal to the sterno-clavicular juint. They are to he lonked upon as rudiments of the epistemal bone, which is net with in so woll-rleveloped a form in the ornithorhynchus.

\section{THE RIBS}

Additional ribs.- There are usually twelve pairs of ribs in the human sulject, but there is embrrological evirenee to show that man has inherited a larger number from his preftecessors. Therefore the ocemrenee of additional ribs is an atavistic phenomenom. In the embryo rudiments of additional ribs are found both at the upper and lower ends of the ordinary series, - at the upper end in connection with the last two cervical rertchre, and at the lower end in connection with all the humbar and sacral vertelure. In the adult, however, additional ribs are only 
met with in connection with the last rervieal and the first lumbir vertebure. The cervieal rib has been found axtending from the serenth cervical vertablat (o) the sternum. As a general rule, howerer, it trominates anteriorly le joining the first

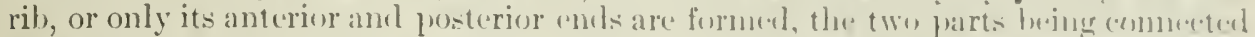
by a band of fibrous tistue. The lumbar rib, when it alpears, alway- temonates liy a free end in the body wall.

\section{UPI'ER ILIMB}

\section{HUMERU'S}

The supracondylar process and foramen.- When it is present. the supracondylar process springs from the immer surface of the humems, a few centinetres above the internal eondyle; it turns clownwards, and is united to the hunerus at a lower level hy a band of fibrous tissur, which is fonnetines rejlaced by bene. In the latter ease, a distinct supracondylar for:anen is formed, through which the merlian nerve passes. 'This formen is very common in the lower mammals, in anphilians, reptiles, and in their fossil ancestors.

The supratrochlear foramen.-This formen is formed when the septum between the coronoid and olecranon fosse is not developurl. It is frepuent in the lower races of mankind, suecially in the south African natives and in the Veddahs. It also occurs in skeletons belonging to the Strone $A$ ge, in the gorilla, the orang, and the lower apes.

The os centrale. - The os centrale is occasionally found as a separate bone in the carpus, lying in an interval hetween the scaphoid. the os magnum. and the trapezoid and trapezium. Its cartilagrinous rudiment is always present at the second month of foetal life, but in the second half of the third month it usually fuss with the scaphoirl, and it is only when the cartilage remains distinct and molergoes separate ossification that an os centrale is present in the adult.

The os centrale is a normal component of the carpus of the orang; it is juesent in most monkeys, and it is a regular carpal element in many of the lower vertebrates.

\section{THE IOWER IIMB}

The third trochanter.-In ahout thirty per cent. of European skelctons the upper part of the gluteal ridge is developed into a prominent third trochanter. This prominence is more rare in nexroes and anthropoid alpes, lut it is very frequently present in lemurs. It is well developed in many of the lower maminals, and it forms a prominent projection on the fenur of the hare.

THE MLSCLLAR SIETEM

(A List of Abnomal Muscles aill be foumd on page 45S.)

\section{THE NERTOUS STITII}

The filum terminale. Extending from the and of the comus mudullaris of the spinal cord to the back of the enerex there is a thin, cord-like strueture, the filum terminale; it forms part of the canda cquina, and is the lower. nen-functional portion of the spinal eorrl. It does not exist luefore the third month of fortal life, for up to that period the spinal cort is coextensive with the spinal canal. Ifter 
the third month, horever, the lower part of the spinal cord ceases to develop in the same matter as the upper part; at birth the functional part of the spinal cord teminates at the third lumbar rertelsa, and in the adult it ends at the level of the second lumbar vertebri, the terminal or eaudal portion of the cord, which is better developed in many rertebrates, being represented in man by the filum terminale. This retrogression of the lower part of the cord is not, however, confined to man, for it is present also in other mammals, and it is particularly well marked in the hedgehog, the filum terminale commencing in this animal in the anterior part of the thoracic region.

In the human adult the filum terminale is about $23 \mathrm{~cm}$. (9 inches) long, and it is divisible into two parts-an upper, about 14 to $15 \mathrm{~cm}$. (6 inches) long, which lies in the subdural space, and a lower part, about $7 \mathrm{~cm}$. ( 3 inches) long, which is closely invested by a covering of dura mater. The first part consists, at its commencement, of an outer layer of nerre-fibres, the fibres of the coccygeal and accessory coccygeal nerres (thirty-first, thirty-second, and thirty-third pairs of nerves), a small amount of grey matter, some substantia gelatinosa centralis, and the lower part of the central canal. The central canal terminates about $4 \mathrm{~cm}$. beneath the conus medullaris, the grey matter about $8 \mathrm{~cm}$. below the same point, and the remainder of the first part of the filum consists, therefore, merely of a few nervefibres and connective tissue. The nerve-fibres of the thirty-second and thirty-third pairs of nerres are quite functionless, and they disappear after a very short course in the second part of the filum, the lower portion of which consists entirely of strands of comnective tissue more or less separated from each other, and attached at intervals to the back of the coceyx.

The pineal body.-This structure, which appears at an early period in the development of the fœtus, is a diverticulum from the roof of the primitive forebrain, or thalamencephalon; it grows backwards, and in the adult lies between the splenium of the corpus callosum and the anterior quadrigeminate bodies, embedded in a fold of pia mater. It never attains a high grade of development in man, nor, in him, does it appear to possess any special functions, but in some of the lower vertebrates it appears to serve the purpose of an unpaired median eye, and, reaching the surface of the body, it is endedded in the parietal foramen in the skull wall. In the higher vertebrates, however, including man, it is displaced from a superficial position by the great derelopment of the cerebral hemispheres.

The pituitary body. - The pituitary body is connected in the adult with the floor of the third rentricle, and it is embedded in the pituitary fossa of the sphenoid bone. It consists of two lobes-an anterior, of somewhat glandular nature, and a posterior, in which remains of nervous structures can sometimes be recognised. The posterior lobe is formed by an outgrowth from the floor of the thalamencephalon, and in man and other mammals the anterior lohe is a divertieulum from the roof of the stomatodieum, or primitive mouth, but in the lower vertebrates the anterior lobe is formed by a diverticulum from the olfactory depression, and consequently its origin in man is a secondary one.

The history of the pituitary body has not yet been fully elucidated, but it is believed that it represents the remains of the ancestral mouth, and that the mouth which is now formed has bean developed by the fusion of a pair of gill clefts.

\section{THE EYE}

The canal of Cloquet or Stilling.-Almost in the axis of the eyeball there is a fine canal passing through the vitreous hody from the optic papilla to the back of the capsule of the lens; this is the canalis hyaloideus, or the canal of Cloquet or Stilling. It is lined by a fine homogeneous membrane, and in the adult it may possibly serve as a lymph passage, but in the fotus it transmitted the capsular branch of the central artery of the retina from the optie papilla to the back of the lens capsule, which at that time was a very rascular structure. 
The plica semilunaris. - It the innere camthus of the pal prebral fiscure there is a small fold of eenjunctival membranc, the plica semilumaris. In many noerpes it contains a small plate of cartilage, and it reperents the third erolid, in nictating membrane, of birds, many reptiles, and some ampleibians. The function of the third eyelid is to cover and clans: the front of the crelall, hut this fonction is performed in man by the uplere eyelid, and conseruently the nictating membrane remains as a rudimentary fold.

\section{I'ASCULAR SYSTEII}

The foramen ovale. - This aperture is found in the interauricular sentum, at the mpler part of the fossa vralis. It is a remmant of a much larerer aperture. which existed before birth for the bastage of hood from the inferior vena caval directly into the left auricle. At hirth, when the lunss become functional, the inferior vena cava blood is diverted into the right ventricle, and in the majority of cases the formmen ovale soon closes, but in one ease in fire the upler part remains olen in adult life.

The sulcus terminalis and crista terminalis.- ${ }^{2}$ pon the anterior surface of the right auricle there is a shallow sulcus, the sulcus tominalis, which extenrls from the front of the lower enel of the superior vena cava to the right of the termination of the inferior vena cara, and unon the inner surface of the auricular wall, in a similar position, there is a rilge, the crista teminalis, in which the upuer ends of the museuli pectinati terministe. Both these structures indicate the line of union of the posterior portion of the primitive heart, the saceus reuniens or sinus renosus, with the second portion or auricle.

The ligamentum arteriosum.-This term is applied to a filrous cord which connects the root of the left pulmonary artery to the unler surface of the arch of the aorta, intervening between the sunerficial carliae plexus on the inner side and the left recurrent larrngeal nerve on the outer side. It is the remnant of the dorsal part of the left fifth aortic arch, one of a suries of ressels arranged in pairs between the ventral and clorsal parts of the aurta of the foetus. When the foetal blood-channels are transformed into the permanent ressels of the adult, the rentral parts of the fifth arches become the roots of the pulmonary arteries, the dorsal part on the left side soon disappears, but the dorsil part on the riglit sirle persists till birth, and through it blood passes from the right rentriele into the aorta. After birth, when the blool of the right ventricle is diverted into the lungs, the dorsal part of the left fifth arch loses its lumen and is converted into a fibrous cord.

The obliterated hypogastric arteries.-The fihrous corls which are known as the obliterated hypogastric arteries are easily seen when the aldomen is openew and the intestines are lifted out of the pelvis. Each corl extends from the anterior part of the upper extremity of the internal iliac artery. under cover of the peritoneum, and beneath the ureter and the vas deferens. or the rumel liganent of the. uterus, according to the sex, to the posterior surfane of the anterior wall of the abdomen, where it ascends with an inward inchation across Hescellach's triande. and behind the lower part of the rectus ablominis muscles to join the urathus is short distance above the apex of the hladkler: hoth the curds then asernil with the urachus to the umbilicus. where they teminate in the cicatrix. "Ther are the remnants of the ventral portions of two lare arteries. the umbilinal arteries. whith convered hlood to the placenta and which formed during the greater part of interuterine life the main continuations of the aorta. The dorsal portions of the umbilical arteries become the common and internal iliac arteries and after hirth. when the placental circulation ceases, the ventral parts are converterl inte fibur cords.

The round ligament of the liver.-This ligament is a round. filirous cord, which extends from the umbilical cicatrix along the lower or free lonter of the 
falciform ligament to the anterior end of the longitudinal fissure, and thence along the anterior part of the longitudinal fissure to the left extremity of the transierse fissure, where it terminates by fusing with the anterior wall of the left branch of the portal vein. It is the remans of the left division of the umbilical rein, a large ressel which returns the blood from the placenta and which divides at its entrance into the body into right and left branches; the right branch clisapluears at an early period of development, but the left persists mint the placental circulation terminates at birth, when it is converted into a solid fibrous cord.

The ligamentum venosum.-The ligamentum venosum is a fibrous cord situated in the posterior part of the longitudinal fissure of the liver. It springs from the posterior wall of the left branch of the portal rein, somewhat to the right of the termination of the round ligament anteriorly, and it terminates ahove in the inferior vena cava. It is the remains of a channel, the ductus renosus, which persists until birth for the transmission of the greater part of the placental bloot directly from the left umbilical vein to the inferior vena cara.

The vestigial fold of the pericardium. - The vestigial fold of the pericurdium, which was first described by Marshall, extends from the left branch of the pulmonary artery to the left superior pulmonary vein. It contains a filorous cord which represents the lower part of the left superior vena cava, a vessel which is very common in mammals generally, but which is generally absent in man.

\section{GEVITO-URINARY SYSTEM}

\section{FEMALE}

The round ligament of the uterus and the ligament of the ovary.-When the ovary is developed, in the lumbar region of the abdomen, it is connected with the labium majus and the lower part of the anterior abdominal wall by a musculofibrous cord, the gubernacular cord of the ovary, which corresponds with the gubernacular cord of the testicle in the male. The male gubernacular cord completely disappears when the testicle is pulled down into the scrotum, but the gubernacular cord in the female contracts to a smaller extent, and the ovary is only pulled down to the back of the broad ligament. As soon as the contraction has proeeded to this extent, the gubernacular corl becomes attached to the side of the uterus below the Fallopian tube, the portion of the cord in front of the attachment becoming the round ligament of the uterus, whilst that behind is converted into the ligament of the ovary.

The hydatid of Morgagni.-The hydatid of Morgagni is a small prriform vesicle attached to the upper bcrder of the broad ligament of the uterus, or to one of the fimbria of the Fallopian tube, by a slender pedicle. It is usnally filled with clear fluid, and it is the modified remnant of one of the Wolffian tubules of the primitive kidney.

The epoophoron, epovarium, or organ of Rosenmüller.-This rudiment of the primitive kidney, or IVolflian lody, lies in the broal ligament of the uterus, between the ovary below and the Fallopian tube above. It eonsists of a series of from twelve to twenty vertical tubules, which commence below in or near the hilum of the ovary, and terminate above in a horizontal tubule which lies parallel with, and a short distance below, the Fallopian tube. The vertical tubules are remains of the upper Wolffian tubules, and they correspond with the vasa recta and the vasa efferentia of the testicle. The horizontal tube is a remnant of the upper part of the Wolffian duct, and it therefore corresponds with the tube of the epididymis in the male.

The paroophoron, or parovarium.-The paroophoron lies in the broad ligament of the uterus to the inner sile of the eponphoron and the ovary. It consists of a number of yellow cords, the remnants of some of the lower Wolfhan 
tubules, and it is homologous with the organ of firbulies in the male. It annot

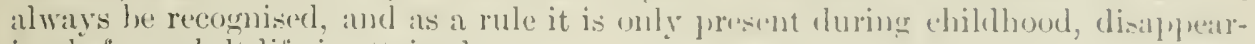
ing leefore aclult life is attainerl.

The duct of Gärtner.-The duret of ciarmer is a small tube, hlint at luth extremitios, which is aceasionally fomme at the side of the neck of the uterus and the upper part of the vagina. It represents at sedion of the lenere part of the Wolftian duct, and corresponds with a portion of the vats deferens of the male.

\section{MAI,E}

The hydatids of Morgagni.- Two luvilutils of Morerami are nut with in the male-the pedumeulated and the sestile. The former is very inconstant; when present it is an oval or profiform resiele, filled with char Huirl, which is attateheel hy a slender pediele to the globus major of the replidymis. It corresponds with the hydatid of Morgagni met with in the fomale, and it is the remmant of (m) of the upper Ifolliam tubules. The sessile hyolatid is more frepuently purent. It is also an ovoid resicle, which is attucherl ly its small enel to cithere the upper extremity of the testicle or to the grosere betwen the testide and the grobus major. It corresponds with the fimbriated end of the Fallopian tube in the female. for it is a remmant of the upper enel of the Miillerian duct from whith the Fallopian tube is developed.

The organ of Giraldès, or parepididymis.-This organ is a remmant of some of the lower Wolfian tubules, and it corresponds with the farovarium of the. female. It lies in front of the lower part of the spermatio corrl, above the epiclidrmis, and either behind the upper part of the tmina vaginalis or just above it. The tubules of which it consists are small, rellowish in colomr. and they alle coilerl together, forming a small body, which is from 5 to $14 \mathrm{~mm}$. in diameter ( $\frac{1}{2}$ of an inch).

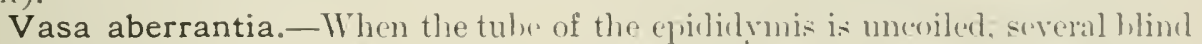
diverticula are found connected with it. They constitute the vasia alurrantia, and the largest of them, which is usually found in the region of the erbobus minor, is: known as the vas aherrans of Haller. It varies in length from 4 to 37 ('m. (1) (1) 1.5 inches), and it is coiled into the form of a small mass 2 to $6 \mathrm{~cm}$. (3 to 3 inches) long. which lies between the body of the epidilymis and the vas deferens. The exart significance of the vasa aberiantia is not certain. but they are probably the remains of some of the Wolflian tubules.

The uterus masculinus, or sinus pocularis. - Th. uterus masculinus lies in the floor of the prostatic portion of the urethra, where it opens, immuliately in front of the highest point of the rerumentmmon, hy an oval opening. It is a

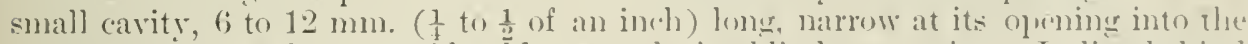
urethra, but it widens considerahly towarks its blinel extrensty. It lies behinet the middle lobe of the prostate gland and lutweren the lateral bohis and the ammom ejaculatory ducts. It is a remnant of the lower parts of the Miillerian duets. from which the uterus, vacrina, and the Fallojian tules are cleveleperl in the fomale, and it corresponds; therefore, with the vaginal, and jusibly with the uterus of the female.

\section{INTEGITIENT}

Hypertrichosis.-The comlition of exersile latirines to which the term

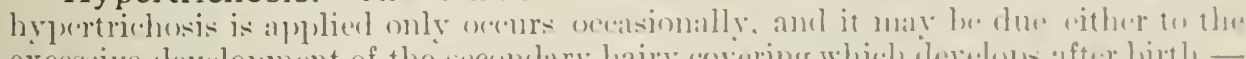

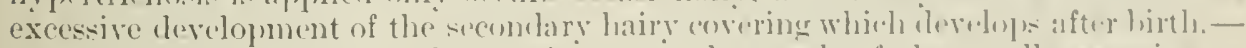

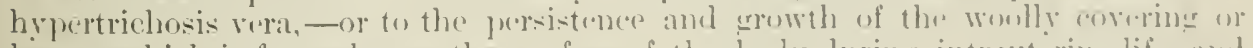
lanugo which is formed wer the surface of the lexly during intraturine lif a and which is usually east off to make way for the secombliry hairs. This latter eomlition is callert psembhypertrichosis lamminosit.

Supernumerary breasts and teats. - The ormerene of ahlitional tait:-

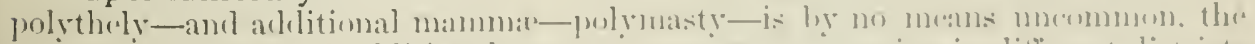
pereentage of cases of additional mammang structures varying in difforent districts from one-half to thirty per cent. 
To understand the position in which the majority of additional mammary organs are found, it must be rememlered that in many mammals the mammary glands are developed as thickened ridges of epithelium, which extend from the axille to the groin. Subsequently the ridges are broken up into separate patches, ealch of which is eapable of development into a distinet gland.

Embryonic mammary ridges have not yet been found in human embryos, but the majority of additional mamme appear along lines extending from the axilla to the groins, - that is, along the lines where we should expect the mammary ridges to be formed during cmbryonic life, - and additional mammary glands or nipples appearing along these lines must be looked upon as of atavistic nature, inasmuch as they are indieations of a reversion to a more primitive organisation. By the careful observation of a large number of eases it has been shown that along a line running from the axilla to the groin, on each side, ten mammary glands may be found in the human sulject, and of these the normal gland is the sixth. "The complete series thes not oceur in any one case, and more than half the number of arcesiory mammary organs which have been observed appear below the normal nipple.

In arldition, however, to ataristie mammary organs appearing along the lines indicated, mammary glands are oceasionally found on the thigh, shoulder, neek, and cheek. Such glands are most probably developed in situ by the abnormal modification of cutaneous glands, and in eonnection with the formation of such abnormal structures it must not be forgotten that all mammars glands are merely modified sebaceous glands. 


\section{N D EX}

[The principul authority for the derimutions of the unatomicul terms giren in this Indre. is IIyrll's 'Onomatologia Anatonicu,' lienna, 1880.]

$\mathrm{ABD}$

ABDOMEx [from abdo, I lide; or, more probably trom adeps, fiat : as if for adipomen, fat belly of swine], the, 9:9)

contents seen on opening the, 960

lymphaties of, parietal, 660 viscer:il, $66:$

lymplı glausls of , parietal, (itil

regions of, 1206 visceral, $66: 2$

surgical anatomy of, 1114

veins of, 630

Abdominal aorta, 550 ; branches, parietal, 5is:3; visceral, 555 ; variations, i5):

muscles, 401-411

nerves of vagus, 773

parietes, structure of, 401 ; topograplyy of ressels and uerves in, $111 \%$

portion of ureter, 1052

ring, exterual, 405, 1114 effect of position on, 11::

intermal, $411,1115,1134$

viscera, 9.5. ; regionally arranged, 1206 lymphaties of. 662

Abducent [ $a b$, fiom ; aluco, I lead], or sixtl cra. nial, nerve, 760

Abduction, 179

A boluctor hallueis [hallux, great toe] numscle, $3 \% 8$; variations, 379

minimi digriti muscle of hand, 343

of foot, 379) ; variations, 381

ossis metatursi quinti muscle, 4is

pollicis [pollex, thmmb] muscle, 339 ; varia tions, 340

Abnormal muscles, $4 ; 8-460$

and vestigial structures, 1209

Accelerator nrince [from its action in hastening the expulsion of the urine] or bublo-cavernosis muscle, 102.4

Accessorius [uccelcre, to be added to] ad iliocostalem (rel sacro-lumbalem), 416

Accessory artery, pudic, $5 \% 0$

band of atlanto-axoirlean capsules, 18.j

cartilakres of nose (quadrate), 891

lachrymal glands, $80 \%$

nerve, obturator. 80 ;

spiual, 773
A I, I

Accessory uncleus of auditory nerve, 760 of trigeminal nerve, 749

sensory, of trigeminal nerve, 7 t9 palatine canals, 59

portion of spinal accessory nerve, \%:? process of lumbar vertelira, 13

suprarenal borlies, 1013

vein, hemiazyo(s), (608

Acervulus [dim. of acertu, a heap] cerebri, or brain sand, $706^{\circ}$

Acetabulum [a ressel for holding vinegar], the 138,143

Acromial attery of acromio-thoracic, 521

of posterior circumflex, 526

of suprascapulatr, 514

end of clavicle, 110

Acromio-clavicular articnlation, 219, 1108

Acromio-thoracic artery, 521 vein, 643

Acromion [ákpov, a snmmit; suos, shonlder] process, 112 ; ossification of, 115

Adduction [ad. to ; duen, I lead], 179

Adductor brevis muscle, 359 ; variations of the, 360

hallncis [hallur, great toe] muscle, 383 ; variations, :3-1

longus muscle, 358 ; variations, $35 \%$

magnus muscle, 361 ; variations, 362

pollicis [ pollex, thumb] muscłe, 342 ; vilrial tious, 343

obliquns muscle, 341

tubercle of femmi, 150

Adipose fussie of lireast, $10 \% 0$

Age, variations of breast aceording to, 1071

variations in form of nterms an'corling to. 1047

Ala [a wing] cinerea [ash-colonred], o1!)

Ala of cerehellum, *14

of nose, 889

of sacrum, 16;

of sphemoid, greater and lesser, 31

of thyroisl cartilage, 901

vespertilionis, 11142

of vomer, 5.4

Alar [ulu, a wing] ligraments of knee, 2.:99 sjine, 32, 7:3 
ALI

Alar [alaris is a eontraction of axillaris] thoracic artery, 524

$$
\text { vein, } 643
$$

Alcock's canal, 813. 1061

Alimentary tube, the simple, 993

Ali-sphenoid bones, 31 ; at birth, 93

Allantois [àias, gen. ài.iàros, a sausage], the, $105 \overline{6}$

Alveolar artery, 495

nerves, $7 . \overline{9}$

point of skull, 81

riclge of maxilla, 5\%

Alveolus [a small hollow ressel] of mandible (inferior maxilla), 63

of maxilla (superior maxilla), 5 r

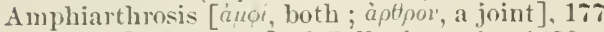

Ampulla [a wine-jur] of Fallopian tahe, 105:

of galactophorous duct, 1070

of semicircular cauals, 41, 917

of Vater, 954

Amputation of great toe, incisions for, 1198

Hey's, incisions for, 1198

of leg, arteries rlivided in, 1192

Listrane's, ineisions for, 1193

Srme's, incisions for, 1190

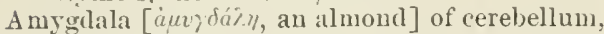
ร1.

Amygdaloid utucleus of eerebrum, 700

tubercle of eerebrum, 700

Anal fiscia, 1063

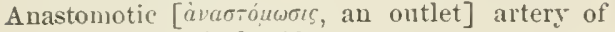
deep cervical, 519

of external plantar, 593

of internal plantar, 596

of middle meniugeal, 494

of seiatie, $5 \% 3$

Anastomotiea magna of brachial artery, 530; variations, 530

of superficial fenoral, 585

Anatomical neck of humerus, 115

Anatomy [àvó, a part; Tépve, I cut], Topographical and Surgical, $10-0$

Anconens $\left[\mathfrak{a}_{\gamma} \kappa \hat{\omega} \nu\right.$, the elbow] musele, $32 \tau$ : nerre to, 795

Anderseh, ganglion of, 768

Augle, cranio-facial, 81

nasal, of maxilla. 57

of neck of femur, 152

of penis, 1037

of pulyes, 143

of rib, 98

anterior, 98

sacro-vertebral, 199

of scapula, 113

subcostal, 109

Angular artery, 425, 428

centre of ossification, of mandible, 6.5

grrus, 685

morement. 179

processes of frontal, 47

vein, 612

Ankle-joint, arrangement of teudons around, 1194

arterial and nerve supply of, 268

ligaments of, 266

movements of, 268

slirgical anatomy of, 1194

Annectant [onnecting] gyri, 687

Anmular [amulus, a ring] limanents of ank]e, 1196; anterior, 368 ; external and iuternal, 369

of wrist, anterior, 311 ; surcical anatowr of. 1168
A PP

Annular ligament of wrist, posterior, 311 ; surgical anatomy of, 1169

Aunulus [a ring] ovalis, 931

Inomalus: musele, 4.58

Ansa [a loop] lyy porlossi, 775, 785

leuticularis, 738

peduneularis, 738

Vienssenii, 830

Anti-clinal rertebra, 12

Antihelix [avii, opposite; $\dot{\imath} \cdot \iota_{5}$, a spiral], the, $8 \pi 1$

Antitragicus muscle, $8 \% 2$

Antitragus [á̀ri, against; $\tau \rho \dot{\gamma} \gamma o s$, a goat], the, $8 \% 1$

Antral arteries of posterior dental, 496 .

Antrum [a caveru or cavity], mastoid, 40, $108: 3$

maxillary (of Highmore), 55, 57

aperture of, 57, e

Anus, the, 975

surgical anatomy of, 1127

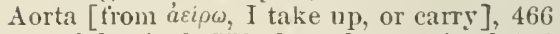
abdominal, 550 ; branches, parietal, 553

topography of, 1121 visceral, 555

variations, 552

arch of: 467 ; brauches of, 471

divisions of, ascending, 468

rescending, $4 \% 0$

transverse, 469 ; branclies, 472

topograply of, 1113

variations of, 47

of branches, $4 \% 2$

foramen tor, in diapluragm, 400

orifice of, 933 ; topography of, 935,1113

thoracie, descending, 545

branches, parietal, 548 ; visceral, 545

relations, 545

Aortie intereostal arteries, 548

isthmus, 470

lymplatic glands, Inmbar, 662

orifice, 9:33: tolograpby of, 935, 1113

plexus of sympathetic, 835

spindle, 470

valves, 933 ; topography of, 934,1113

A pertura scalie vestibuli, -79

Aperture of larrnx, sliperior, 910

palpebral, 839

of thorax, inferior, 899 ; superior, 898

Apex of antrum, 57

of heart, 963

of lung, 960

of orlsit, 76

of petrosal portion of temporal, 35

of prostate, 1021

of sacrum, 17

Iponemrosis [äó, from; reipov, a nerve: so called from a formerly existing confusion between nerves and tendons] of clisphragm, 40 !

epieranial, 4\%

of exterual oblique muscle, 401

of internal oblique musele, 406

lumbar, 408

occipito-frontal or epicranial, 42\%, 1085

pharyngeal, 949

transversalis, 409,411

rertebral, 408,413

Aponeurotic patch in trapezius muscle, explana. tion of, 290

A pophrsis [änó, from; díw, I grow], 15:

A ppendices epiploic: 970 
$\Lambda \mathrm{PP}$

Appendicular elements of skull, 21 of chondral skull, -

Appendix, auricular, $92-$ vermuform, 971

Aquieductus [a conduit] cochle:e, ::7, $;: 3$ Fallopii, :37 vestibuli, $34 ;, 879$

Aqueduct of sylvius, 670,708 grey matter of, 706

Aqueons chamber of eye, -50 humbour of eye, 850

Arachnoid [ápá $\chi^{2} \eta$, a spider's weh) ; eiflor, like], crimial, 676 spinal, 733

Armtius, rentricle of, 719

Arbor vitae uterina, 1047

Arch of anrta, 41;\%. Se Aorta

of atlas, anterior and po-terior, $f$

corpal, anterior, 535 ; posterior, 541

crural, deep, 1139 ; superficial, 11:3-

palmar, deep, 54:3; surgical anatomy of 1168 ; variations, $54:$

superficial, 536 ; suruical an:tomy ot, 1167 ; variations, 535

plantar, $59:$

pubic, $14 t^{\circ}$

of vertebræ, neural, 6

Arches of foot, 1202

function and maintenance of, 120 :

Arciform [arcus, a bow] fibres of medulla, deep, 722 ; external, 722 ; superticial, 722

Areus [a bow] tendineus, 1061

Areola [a small open space] of loreast. 1069

Aru, central point of;, surcical anatomy of, 1154

cutantous nerves of, $8: 2:$

fuscia of, 306

surgical anatomy of, 115:?

veius of, deep, 613 superficial, 639

Arnold, ganglion of (otic), 760 merve of, 772

Arrangement of peritoneum in human hody, explanation of. 991

Arrectores pilorum, 1074

Arteria aberrans of aortic interenstal. 5.50 of superior intercostal, 519

centralis retince, $500,8.51$

comes nervi ischiadici, 5 . $^{3}$

mediani, 533

phrenici, 516

receptaculi, 499

septi narium, tis

thyroillea ima. 47.5

Arterial sicle of heart. 9:2

Irtery, or Arteries $[\dot{a} \rho-\dot{y} \rho$, a strap or suspender: a tenm applied originally to the trachea, which suspends the iuners], tho $46 \%$

accessory pudic, 5\%0

acromial, of acromin-thoracic, 5?

of posterior circumflex, 5:1;

of suprascapular, 511

acromio-thoracic or thoracic axis, 521

alar thoracic, 5:4

alveolar, 496

:Inastomotic of external plautar, 594

of interual plantar, $5: 4$

of middle neniugeal, $\mathbf{4 9 4}$

of sciatic, $5 \% 3$

anastomotica magna, of lurarhial, 530 ; variations, 530

of femoral, 585
$11 \mathrm{~T}$

Artery, or Arteries-

angular, 1-5, it or

auterolateral, ot mildle cereloral, 503

autral, $49 \overline{8}$

articular a\%gos, 59

articular, of extermal plantar, iyl

of intermal cireumblex, is

of internal plant:ar, 5 in

of interosserus riecurrent, $51: 3$

of pepliteal, is $=0$

of posterior circumflex, .j:

of sciatic, is:3

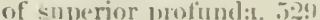

of suprok(aI)

of tentuoral, J!)]

asceuling cervical, 51 1

of exterual circumflex, $5-\frac{1}{2}$

frontal, ju4

palatine, 4-1;

pharyngeal, $|x|$

septal, of spheno-palatine, 490 tricipital, of superior profinula, 5:20

aurlitors, interula, i11, 420

anrieulit, anterior, 491

de(t), .193

left, 173

posterior. 490

right, 47: 936

of occipitil, 490

of styln-1uastoid, 4 (m)

axillary, 520 ; line of, 1150

variations, 521

azy̆gos articular, 590 raginal, 570

basilar, 511

hicipital, of anterior circumflex, 5:5

brichial, 526 : surgical :matomy of, 1153 ; variations, 528

brachio-cephalic (innominate). 474 ; variations, 47.

brouchial, left and right, 545. !f 2

huccill, of tacial, 4 -7 of internal maxillary, 49. of posterior clental, fuf;

to bull, 575

culcunean, external ancl interual, 5y? of extermal plantar, 5!):

ealloso-marurinal of anterior cereloral. 503 (apsular, perirenal, 560)

supurareual, inferior, 560 ; miklle, 561 : superior, $5 . ; \%$

carliac, of gastric, 5isf;

carotid, common, 475: in thorax (leit, 475 : in ruek, fofi: cullateral circulation, 47!): variations, (7) exterual, $1=0$; variatious, $1-11$ intermal, -1!5-

("irpal, radial, 541

rute, iuterior, $5331,53.5$ pesterior, 531 , int

ulnatr, iis.)

catulate. of midldle (eereloral, 503

"ivisl, of rioht plirenic, 55:3

centril, of retini, $500,-\rightarrow-5$

crebellat, inferior, anterior, 5]:2

siperior, 51

posterior, 511

areliral, antorior, 503, 51:

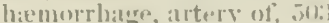

milltle. 51)3. $51: 3$

posterior, .i12. 51:3

cervioal, asimuline. 314

deel, 5]s 
Artery, or Arteries-

cervical, superficial, 516

transverse, 514

of uterine. 570

choroid, anterior, 502

posterior, 512

ciliary, 501, 888

circuntlex, of axillary, anterior, 525; variations, 526

posterior, 526 ; variations, 526

iliac, deep, 578 ; variations, 578 supericial, 583

of thigh, external, 584 ; variations, 584

clavieular, 5:3 internal, 584 ; variations, 584

corcygeal, 572

coliac, 555 ; variations, 555

colic, left, 56: ; midlle, 559 ; right, 559

collateral digital, of fingers, 538

$$
\text { of toes, } 595
$$

intercostals, 549

commissural, of anterior (erebral, 503

communicating, of brain, anterior, 503

posterior, 502

of dorsalis pedis, 601

of occipital, 490

of palm, 545

of peroneal, 592

of posterior tibial, 592

coronary, of heart, left, 473,936 right, 472,936

of lips, inferior, 487 ; superior, 487

of stomach, 556 ; variations, $556^{\circ}$

of corpus cavernosum, 576, 1066

cortical, of anterior cerebral, 503

of middle cerebral, 504

of posterior cerebral, 512

of reual, 1011

costo cervical, 51R

(remasteric, of deep epigastric, 577

of spermatic, 561

erico-thyroid, 483

to crus clitoridis, 576

penis, 573

evstic, 557

(leferential, or artery to the vas, $5 \% 0$

lental, anterior, 496

inferior (mandibular), 494

posterior, 495

descending, of external circnmtlex, 584

palatine, 496

pharyngeal, 496

diaphragmatic, 550

digital, of foot, collateral, 595

dorsal, 600, 601

plantar, 594, 601

superficial, 596

of hand, colliteral, 538

dorsal, 54:

palmar, 538

diploic, 500

(lorsal, of aortic intercostal, 549

digital, of foot, 600,601

of foot, 600

of havd, 542

interosseons, of radial, 541

of lumbar, 554

of penis, 576,1061

scapular, 525

twelfth (subcostal), 550

dorsalis hallucis, 601

indicis, 543

liugrua, 484
Artery, or Arteries-

dorsalis pedis, 600

pollicis, 543

epididymal, of spermatic, 561

epigastric, deep, or inferior, $57 \gamma$; variations, $5 \% 8$

smperticiar, $58: 3$

superior, 518

epiploic, of left gastro-epiploic, 558

of right gastro-epiploic, 557

ethmoidal, anterior and posterior, 501, 897

Eustachian, of pterygo-palatine, 496 of Villiau, 496

ficial, 485 transverse, 491

Fallopian, of ovarian, 56?

femoral, common, 579 ; variations, 581 deep, 583

superficial, 579 ; surgical anatomy of, 1214 ; variations, 581

of firenum lingux, 4>5

funicular, 1088,1099

ganglionic, of anterior cerebral, 503

of interual carotid, 499

of middle cerebral, 503

of posterior cerebral, 512

Gasserian, of internal carotid, 499

of midille meningeal, 494

gastric, or coronary, 5:,6; variations, 556

greater anterior, 556

lesser anterior and posterior, 556

of lett gastro-epiploic, 558

of right gastro epiploic, $55 \%$

gast ro-duodenal, 557

gastro-epiploic, lett, 558

gingival, 496

right, 557

glawdnlar (submaxillary), 487

Glaserian, of internal naxillary, 493

gluteal, 569 ; surgical anatomy of, 1181 inferior, of sciatic, 572

gustatory (lingual), of inferior dental, 495

hæmorrhoidal, inferior, or external, 5\%4

middle, $5 \%$

superior, 562

hemispheral, of inferior cerebellar, 511 of superior cerebellar, 512

hepatic, 556 ; variations, 557

of gastric, 556

of phrenic, 5.53

of superior epigastric, 518

huneral, of acromio thoricic, 523

transverse, 514

ligoid, of lingual, 484

of superior thyrois, 482

hypogastric. 569

ileo-colic, 559

iliac, circumflex, deep, 578 ; variations, 578 snperficial, 583

common, 564; collateral circulation, 565 ; variations, 565

external, 576 ; collateral circulation, 577 ; variations, 577

internal, 566 ; variations, 567

of ilio-lumbar, 567

of obturator, 571

ilio-lnmbar, $56 \%$

incisire, 495

infracostal, lateral, 518

intra-hyoid, 482

infra-orbital, 496

intrascapular, 525

infraspinous, of posterior scapular, 516 
Artery, or Arteries-

iufraspinous, of suprascapular, 515

in 1 ominate, 474: valiations, 475

intercostal, anterior, of int. manmary, 517

aortic, 54

of musc,-phrentic, 518

tirst, 519

superior, 512

interosseous, of arm, common, $5: 3: 3$

anterior, 5:3:3

posterior, 5i31

recurrent, 535

of foot, 600

of laand, dorsal, $5+1$

palmar, 54t

interventricular, iuterior, $472,9.36$

intestinal, isfo

posterior, 473. 937

labial, inferior, 487

lachrymal, 499

of middle meningeal, 494

of uasil. 50 :

recurrent, 499

laryngeal, inferior, of inferior thyroid, 514 of superior thyroid, $4 \div, 3$

superior, of superior thy roid, $4<2$

lenticulo-striate, 503

ligamentous, of ovarian, 562

lingual, 483, $110 \%$

of mumlibular (inferior dental), 495

lumbar, 55:3 ; variations, 554

of ilio-lumbar, 56.

malleolar, extermal, of anterior tihial, 59.8

intermal, of anterior tibial, $5 ! 1-$

of posterior tibial, 593

mammary, external, 5:23

grauclular, $5 \overline{5} 0$

interual, $516^{\circ}$

mandibular (inl'erior dental), 494

marginal, of coronary, left, $4: 3,9: 36$ right. $473, \$ 36$

margino-frontal, 503

masseteric, of facial, 487

of internal maxillary, 495

of temporal, 491

mastoid, micllle, $4<2$

of occipital, 490

of posterior anricular, 491

of stylo-mastoid, 490

maxillary, exterual (tacial), 485 interma], 492

meatil, of sty'o-mastoid, 490

median, 5:3:3

mediastinal, or thymic, 51\% posterior, 545

medullary, of peroneal, 59? of posterior tihial, 59: of remal, 1049

meningeal, anterior, of internal carotid, 499 of ascending pharyngeal, $4-2,713$ of ethmoidals, 501,674

middle or great, 493,674

posternor, of oreipital, $1=9$

small, 495,674

of vertehral, $511,6 \% 1$

mental, of tacial, $4-7$

of mandihular, $19 \pi$

mesenteric, inferior, 562 : variations, $56: 3$ superior, 558 ; variations, 560

metacarpial, $\overline{5} 42$

metitarsal, 600

musculo-phrenic, $51^{8}$

mylo-hyoidean, 495
Artery, or Arteries-

nasal, of infri-orlbital, $4 ! 16$

laterill, 180

of (1)]itluiluic, 50:?

transverse, $50: 2$

of spheno-jalatine, dyi

of nasal tossie, $-!$ t

naso-pratatine, 496,897

of inise, 893

nutrient, of clavicle, 514

of felmur, $5<5$

of fibula, 5y:

of humerus, 5:30; greater tuluerosits.

$5: 6$; up]er end, 530

of ilimm, 5i?

of ralius, 5333

of tibia, $5(1) \cdot 2$

of ulni, 53:3, 53.5

(obturator, 571

oceipital, $48 \infty$

of posterior auriculiır, 491

cesophatgeal, of aortil, 54

of erastric, 556

of inferior thyrois, 514

of left plireuic, 5isis

omental, of hejatic, 557

ophthalmic, $499,-9$ !)

orbital, of anterior cereloral, 503

of infla-orbital, 496

of middle meningeal, 494

of temporal, 491

orbito-frontil, j(1)-1

ovarian, $56 \%, 1053$

palatine, inferior or ascemrling. $1-6$ posterior or lescending. 456 of ascending phiryureill, 4-2

palmar arc], , leep, 543 ; variations, 543 superficial, 536 ; variations. 537

maluelural, 5(1):

of lachrymal. 500

of supra-orlutal, 50u

pancreatic, of hepatic, jisf

of splenic, 5.5 -

pancreatico-duodenal, inferior, 5ij-

sulurvior, 55\%

parietal, of mirllle cerehral. int asceneling. 504

parieto-temporil, 504

parotid, of posterior auricular, $4 ! 10$ of temporal. 19]

pectoral, of acromio-thoracic. 523 of anterior circumtlex, 525

perforatiun, of fout, 5y4

of liamel, 545

of internal mammars. 517

of midrlle meningeal, tid

of profumbit temoris, $\bar{i}-4$

of spluemp-palitine, tis

of sulmental, $4-\tau$

pericarliac, of internal mammary, 517 of uhrenic, interjor, sis:3

of thoraric aurta, it 4 .

perinaeal, superticial, 5\%4, J116it

$$
\text { transverse, 5\%, }
$$

perirenal, itio

peritoneal, of common iliac, isi. of superior epigitstric, 51 -

peroneal, 59l

auterior, $5 ! 12$

posterior, sin:

petrusil, -1!1- 915

phatromeal, arending, $1-1$ of ptervaro-palatine, 496 
$\pm \mathrm{RT}$

Artery, or Arteries-

pharyngeal, of spleno-palatine, 496 of Villan, 496

phrenic, interior, left, 5.;is riwlit, 553

of inferior thyroid, 514 of musculo-plibrenic, 518 superior, 51 (; of superior epigastric, 518

pituitary, 499

plantar arch, 593

digitals, 594, 601

extermal, 593

interual, 596

pleural, 550

pontal, 511

popliteal, 5\&6; surgical auatomy of, 1186; variations, $5=6 ;$

postero-lateral, of posterior cerebral, 512

posterio-median, of posterior cerebral, 512

preventricular, 473,936

prevertebral, 481

princeps cervicis, 490

ballucis, 601

pollicis, $5+3$

protunda, of brachial, inferior and superior, 530 ; variations, 530

of temoral, 583

pterygoid, external and internal, 495

pterrgo-palatine, 496

pterygo-pharyngeal, 496

pubic, of epigastric. 577

of obturator, 57:

pudic, accessory, 570

external, (leep, $5 \times 3$ superficial, 583

internal, 573, 106\% ; surgical auatomy of, 1126

pulmonary, 46?, 923

left, 460

riglit, 466

pyloric interior, $55 \%$ superior, 556

quadrate, 503

radial, 538

in forearm, 535 ; variations, 540

in palm, 543 ; variations, 543

at wrist. 541

carpal, anterior and posterior, 541 recurrent, 540

radialis indicis, 544

ranine, 485

rectal, of lateral sacral, 568

of midlle sacral, 564

recurrent, of deep palmar arch, 545

interosseous posterior, 535

ratlial, 5t1)

tibial, :unterior and posterior, 598

ulnar, anterior and posterior, 533

reual, 560 ; variations, 560

sacral, lateral, 567

midlle, 563 ; variations, 56.4

scapular, dorsal, 5:5

posterior, 516

sciatic, 5\%: ; surgical anatomy of, 1181

sepitum, artery of, 496

sigmoid, 562

spermatie, 561 ; variations, 561

splienoidal, of pterygo-palitine, 496 of spheno-palative, 496

splseno-palatine, 496, 897

spinal, anterior, 511

of inferior thyroid, 514
ART

Artery, or Arteries-

spimal, of intercostals, 5.18

lateral, 510

of lateral sacral, 568 posterior, 511

splenir, 557 ; variations, 558 of lett phrenic, 553

stapedic, 490

sterual, 517

stermo-mastoid, of occipital, 489

of superior thyroid, $4<2$

inferior, of suprasc"upular, 514

stylo-mistoid, 490, 878

sulılaviau, 505; variations, 508 of suprascapular, 514

subcostal, 550

sublingual, 485

submaxillary, $4>7$

submental, 4ti

subscapular, 524; variations, 525 of posterior scapular, 516 of supraseapular, 514

supra-hyoid, 484

supra-orbital, 500, 1091

suprarenal, inferior, 560, 1051

middle, 561, 1051

superior, 553, 1051

suprascipular, 514

supraspinous, of posterior scapular, 516 of suprascapular, 515

suprasterual, 514

suril, 588

tarsal, external and interual, 600

temporal, of posterior cereliral, 512 deep, anterior and posterior, 495 micllle, 491

superficial, 491

temporo-occipital, 512

testicular, 561

thalamic, middle, 502

thoracic, acromial, 521

alar, 524

axis, 521

long. 523

short or superior, 521

twelfth (subcostal), 548

thymic, 517

thyroid axis, 513

inferior, 514

superior, 482

thyroidea ima, 475

tibial, anterior, 596 posterior, 590 ; surgical anatomy of, 1183

tonsillar, of facial. 487 of inferior palatine, 4 -

traclieal, 514

trausversalis colli, 515 liumeri, 514

transverse, of hasilar, 511

cervical, 515

of external circumtlex, $5-4$

facial. 491

humeral, 514

nasal, 502

perinceal, 575

of right coronary, 473

tricipital, of posterior circumflex, 5:36 of superior profunda, 5:29

tubal. $109^{\circ}:$

trupanic, of ascending pharygeal, $4 \mathbf{k}^{*}$ of interual maxillary, 493,915 of midrlle meningeal, $4: 4$ of stylo-mastoid, 491 
$A R^{\prime} \mathrm{T}$

Artery, or Arteries-

tympanic, of Vidian, 496

uluar, 531

in torearm, 531 ; variations, 53:2

in Palu, 536; variations, 533

at wrist, 535

(arpal, anterior and josterior, 5:5

recurrent, anterior aud pusterior, .83:3

mucinate, of posterior cerefral, 51:

of posterior communicating, $5(1) 2$

uracheric, 5\%u

uretal, of ovarian, 562

of renal, i60)

of spentic, jol

meteric, of common iliac, 565

of superior vesical, $5 \% 0$

uterine, $570,105 \%$

of ovariau, 562

varginal, 571

azygos, 571

vas, artery to, 570

rasa brevia, 558

vermitorm, inferior, 511

superior, 51:

vertebral, 509; variations, 510

vesical, inferior, mirldle, and superior, sтo of olsturator, 572

vestihular, 491

Vislian, 496

volar, superficial, 541

xiphoid, 518

zyematico-orbital, 491

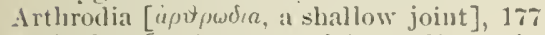

Articular [articulus, a joint; dim. of urtus, limb]-

arteries, of circumflex, posterior, 520

of interosseous recurrent, 535

of plintar, external, 594; internal, 596

of popliteal, 588

azygos, 590

of prolumla, superior, 529

of sciatic, 573

of sipurascapular, 511

of temporal, 491

eminence, 35, 70

merves, of auriculo-temporal, 7.5

of circumtlex, 78 !)

of crural, auterior, 807

of interosseous, posterior, 79.5

of median, 791

of obturator, 805

of popliteal, external, el4; intemal, 817

of tilial, auterior, 815 : josterior, 818 recurrent, of exterual puplitcil, -15 uluar, 7)

process, of atlas, 8 ; of axis, 9 ; of coeces, 17 ; of fifth lumbar vertehril, 13 ; norphology of, 23 : of sacrum, 15 ; of twellth forsal verteluri. 1: ; of typical verteliri, (i; of typical cervical rertebra, 7 ; of typical lumbar vertebra, 12

surface, of acromion, 11: of lucacl of tibia, 153

vein of temporal, 615

Articulations [articulus. a joint], structures entering into the formation of, $]$ it

tabular classiticution of, 179

varieties of, $17 \%, 17-$

acromio clivicular, ?I!)

of ankle, 266

of articular processes of vertebre, 191

astragalo-sraphoil, 273
$\$ \mathrm{HY}$

Articulations-

atlanto-axoilc:au, 1-.;

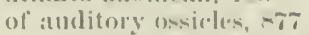

of hodies of the verthrar, 19,

(alcauen ast ragaloul, "y(s)

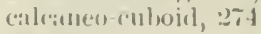

(arpan, :3:35

(a) $u$-1hctacarpu], 24t)

chombrosternal, :21:2

coracu claticular, :2:01)

(c):

costo-l. homl ral, :212

(1) sto-tratistersie, 2010)

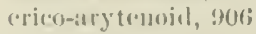

erico-thyouid, 906;

(ullo cumeiform, 272

(cuho metatarsal, 27

("ulur-salphoirl, :7]

of r.lfuw, $22 \%$

of heads of metarirjal bones, 243

of lip, : $41 \mathrm{j}$ of metatursal lemes, $27 y$

of imcus witl stapes, fiT

interchondral, : $: 1$ i

intercocey geal, 20.)

intercuneiform, :2\%:

intermetacin rial, 24?

intermetitiusal, 27!

interphalangeal of fingers, 245

interpubic, 205;

$$
\text { of teres, } 200
$$

intersternal, $21: 2$

of knce, $: 253$

of the laminge of the vertehre, 194

of larymx, $90 t_{j}$

of milleus with incus, 8 ;

uedio-carpal, 2:38

metlo-tarsil, 273

metacarpo-plablangeal, 243

metat:arso-phalamigeal, 27y

oecipito-atlautal, 183

occipito-isuicleau, iss

of the pelvis, 200

of the pelvis with the spine, 192

of pisiform bone with the carpus, 2:3

radio-carpal, 2:3:;

radio-uluar, interjor, 232

midulle and superior, 230

of ralius witlı ulua, 22,

ot ribs witl the vertelste, $20 \mathrm{~s}$

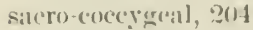

siluro-iliac, :oun

sciplos-cumeiform. 27:

scapular ligaments proper. 221

s'al]

of shruller, 2028

of' skull, 179

of spimous proresses of vertelire, 1!5

of stapes with leuestrat walis. -7?

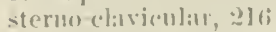

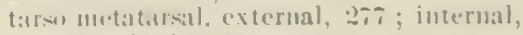

27 ; midhlle. : 27

fomporo-mandibular (maxillary 1-0

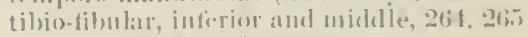
superies, :26:3

of the trawserse proseseses, 195

of the trunk, chasilication of: $1 \leq n$

of the sertubral columm, rlassitication, 150

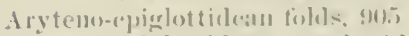

Arveno-epiglottide-u< mu-c.le, 910

Arytenuil [un-n a, a pitcher; eidor, like] carti-

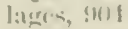

Arytenoidris muscle. 9 l11 
$A C^{\prime}$

Ascendiug branch, of ext. circumflex artery, 584 of' superior cervical gimerliou, 828 of superior profundal artery, 529

branches of cervical plexus, 753

of Neckel's ganglion, 755

cervicul artery, 51.1

fiontal artery, 504 convolution, 6 -2.

palatine artery. 186

pirrietal convolution, 684

pharyngeal artery, 481

root of glosso-pharymeal nerve, 767 of trigemimal nerve, 750

septal artery, 496

Asterion [áripp, a star : from the radiating manner in which the sutures diverge at this spot], the, 71,1080

Astraualo-scaphoid articulation, arterial supply of, 276

ligiments of, 274

movements and nerve-supply of, 276

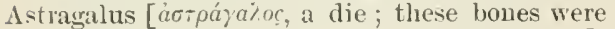
used by the ancients for a game like dice], the, 159

articulations of, 162

ossification of, 163

os trigonum of, 162

Atlanto-axoidean articulations, arterial and nerve-supply of, 185

ligaments of, 185

movements of, 187

Atlas [ Tiaw. I sustain, from its support to the liead], the, 7

museles attarhed to, 11

ossification of:, 20

Atrium [a forecourt] of heart, 928

Attic of tympanum. 40

Attullens [uttollo, I raise] aurem muscle, 431

Attrahens [atraho, I draw forward] aurem muscle, 431

Auditory [umdio, I hear] artery, 511, 883

meatus, exterual, $38,73,87 \%$

interual, $36,86,96$

nerve (eighth cranial), 766 ; branches, 767 , 88.3 ; roots, 766

Auricle [auricula, a little ear] of ear, 871

muscles of, extrinsic. $4: 3]$

of heart, left, 933

intrinsic, 8,2

right, 920

A uricular appendix, $92 \mathrm{~A}$

artery, anterior, 491

of coronary, left, 473 ; right, 472

(leep, 493

of occipital, 490

posteriur, 489 ; topoeraphy of, 1090

of stylo-mastoin, 491

cinalienlus, 37

cartilace, of sacro-iliae articulation, 202

fissure, 37,73

lymplatic glands, posterior, 649

inuscles, extrinsic, 431

intrinsic, 87\%

nerve, anterior, 758

great, 784

of lesser occipital, 784

posterior, 763

of vagus (Arnold's), 7\%?

point of skull, 71

portion of foetal hesut. (939)

process of inferior tubinal boue, 53

septum, 9.3]

surface of ilium, 13!)
B. IS

A uricular veins, of ear. 616,625

of heart, left, 610,937 ; right, 610

Auriculo-temporal nerve. 5os

A uriculo-ventrieular wroove, 927

openings, 928, 932; topograply of, 1113

Axes of skull, 81

Axilla, surgical anatomy of, 1150

Axillary artery, 520 ; variations of, 5:1

border of scipula, 113

fascia, :294

lymphatic glands, 6.55

trunk, 656

nerves, of brachial plexus, 788

vein, 643

Axis (vertebra) [so called from its pirot-like articulation with the atlas], the, 9 muscles attached to, 11 ossification of, 20

basi-bregmatic, of skull, 81

basi-eriuial, of skull, $\alpha 1$

basi-facial, of skull, 81

central, of cochlea, 881

coeliae, 555 ; variations, 555

of pelvis, 146

savittal, of eyeball, 843

thoracie, 521

thyroid, 513

Axous, 740

Azygos [úvyos, single] artery, articular, 590 vaginal, 570

muscle, pharyngis, 45
uvulie, 946

veins, major, 606

minor and tertia, 607

BACK, surgical anatomy of the, 1142

Band, furrowed, 715

ilio-femoral, 247

ilio-tibial, 345

ischio-femoral, 247

moderator, of heart, 931

pectineo-femoral, 248

sterno-pericartial, 9:25

tendino-troclunteric, 248

Bai's, branehial, 90

hyoid, 90

mandibular, 90

thyroid, 90

Bartholin, duct of, $9-19$ vrlands of, 1040,1069

Basal ganglia of cerebral hemispheres, 6!n arey commissure, 70 \% ridge (cingulnm) of tooth, s-

Base of autrum, $5 \%$

of brain, 680

of epididymis, 1021

of heart, $9: 0$

of lung, 9.21

of petrosal portion of temporal bone, 35

of sacrinll, 16

of skull, exterior, 72 ; interior, 8:

of thorax, 898

Basi-brecmatic axis of skull, 81

Basi-cranial axis of skull, 81 region in chondral sknll, 89

Basi-findial axis of skull, Rl

Basi-lyyal bone, or bouly of hyoid, 66 (entre of ossification, (5):

Basilar [busis, the base] artery, 511

bones, 24

sinuk (transverse), 621

suture, 86 
BגS

Basilar vein, 624 ; tributaries, 6:24

Basilic [aceording to Hyrtl, from the Arabic al-basilik, the inner (vein)] rein, 6.11 median, 641

Basi-occipital bone, 24 ; at hirth, 92

biasion [ $\beta a$ ár, hase] the $73,-1$

bisi-sphenoud uncleus, 34

Bertin, bones of, 51 colnmus of', 1010

Bicepls [bis, twice; caput, a lucal] flexor cubiti musele, $30 \%, 1153$; uerve to, 791 ; variations, 308

flexor femoris musele, $36: 3$; variations, $36: 3$

Bicipital artery of anterior circumtlex, $5 \geq 5$ groove of hmmerus, 116,1150 rib, 103

tuberosity of raiius, 12

Bicuspid [bis, twice; cuspis, a point or projection] teeth, 88

valve of heart (unitral), 934; topograpley of, (93.1

Bificl [bis, twice; findo, I cleave] cervical spinous processes, 10

metasternum (xiphoid), $10 \%$

Bile dnet, consmo:ı, 984

Bipeuniform [ pema, a feather] muscles, 283

Biventral [bis, twice; ienter, belly] lolve of rerebellum, 715

Blailder, gall, the, 983 ; duct of, 9s4; structure of, 985 ; topography of, 111 \%

urinary, the, 1016

effects of distension on, 1018

female and infantile, 1020

torm of, 1016

ligaments of, 1018

lymplatics of, 662

relitions of, 1016

structure of, 1018

vessels and nerves of, I $1: 20$

Blood-ressels, scc Arteries and Veins; and for the vascular supply of the various organs, see those orgaus

Bochdalek, ganglion of, 754

boly, cutaneons nerves of, 8:2:?

Bone, or Bones, cancelli [lattices] of, 4 compound, 1

interparietal, 1209

unarrow of, 3

mekullary eavity of, 4

motle of development of, 2

pre interparietal, 1209

jressure and teusion curves, 4

shatits of, 3

structure of: 3

iurlividual-

astraugalus, 159)

atlas, 7

axis, 9

basilar, 24

of liertiu, 51

cilcaueum, or os calcis, 163

carpal, 128

central, of carpus, 132

clavicle, 109

('oce yx 17

cotyloid, 14.3

('uboirl, 16.)

'uucitorm, of earpus, $1: 30$

of tarsus, $16 \%$

epipteric, $4<, 120 !$

rpisternal, 113

('thmoid, 49

fงmแ1, 147
IIR.I

Bone, or bones, mrlivilual-

tibula, 15i

of loot, 159

froutal, 46 ;

of hankl, 1:2s

of head, 21

lij, bone, lis

lumerus, 115

hyoid, liti

ilium, 1:39

inl'us, 67

immominate, $1: 38$

ischimu, 1:39

lacluymal, $5: 3$

lingual (hyoisl), 66

mitgmum, 1:3:

malar, (il

mille'us, 67

mamlible, or inferior maxilla, 62

maxilla, or superior maxilla, 55

metacarpal, I:3:?

metatirsal, 169

nasal, 5.1

oceipital, 24

palate, is

parietal, 44

pittella, 152

pelvis, 145

phalanges, of foot, 17: of land, $13 \tau$

pisiform, 131

pubic, 1.12

rallius, 120

ribs, 98

sacrum, 15

scaphojd, of earpus, 129 of tarsus, 160 ;

sciupula, 111

semilumar, 1:9?

seximnoirl, of foot, 280 of li:mel, : : 45

of skill, 24

splenoid, 29

sphenoinlal turbiual, 51

stapes, 68

sternum, 98

styloisl, of (arpus, 135 process, 67

tarsil, 15:

tempral, 3is

tibia, $15 \%$

traprezimu, 1.41

trapezoirl. 131

turlumal, inferior, 5:

nlna, 1:2:2 sphenoid:ıl, il

nnciform, 1333

vertebra prominums, !

vertolurie. ;

(cervical, i

dorsil, or thorarice 1:?

linmbir, 12

silloril and coccrotal, it

vestigial, 159

vinuer, i3

Worminiul, 12

Boundary zone of linsauer, ifu

Bowman's membrane. - lli

Brachial [ fmetwi, an arm] of nates, 70 of testos, 710

Brachial artery, it? ; - wryical anatomy of: 1153 variation, it:

plexus, i-li ; bramblus almve clavicle, i- 
BR.1

Brachial plexus, branches below clavicle, $7-8$ vene comites, 643

Brachialis anticus muscle, 30 - $115 \cdot 1$ nerves to, 309, 791, 795

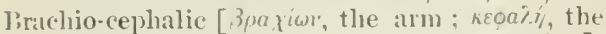
head: so called from its distribution] see Innuninate

artery, 474 vein, 603

Brachio-radialis (supinator longus) musele, 323 ; variations, $3: 21$

Brain, the, 659

basal ganglia of, 699

base of, (ity

epencephalon, 713

lemispheres of. $6 \times 1$

lsmphatics of, 678

meninges of, 672

mesencephalon, 710

metencephalon, 7\%0

sinuses of, 619,711

thalamenceplaton, 704

topography of, $10-\tau$

weight and specific gravity of, 7:27

Brain sind (acervolus cerebri), 706

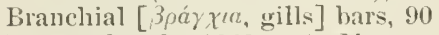

Breast, female, 1069. See Mamma male, 1072

Breasts, supernumerary, 1215

Bregma [ $\beta \rho \varepsilon \chi \omega, I$ moisten], the, $69,-1,1080$

Broad ligament, of liver, the, 922 of uterus, 104 ; ; structures between layers of, $104^{-}$

Broca's ol factory area, 692

Bronchi [3póy,ys, the windpipe], 915

Bronchial [3póy xos, the windpipe] artery, 545, 925

lymphatic glands, 658

nerves, 925

veius, $609,9 \div 5$

Bronchioles [dim. of bronchi], the, 915

Broncho-mediastinal lymph trunk, 657

Bruch, membrane of: 846

Brummer's glands, 969)

Bryant's triangle, 1173

Buccal [bucce, mouth] artery of tacial, 487

of internal maxillary, 495

of posterior dental, $499^{-}$

fat pad, 436

lymphatic glands, 649

nerve of facial, 76.5

long, 757

orifice, 942

portion of pharyux, 949

rein, 614,616

Buccinator [bucciur, a trumpet; from its use in hlowing that instrument] muscle, 436

Bulb, the (metulla oblongata), $7 \cdot 0$

artery of, 575

of cornu of lateral ventriele. $696 ;$

olfactory, 745

ovarian, (j;3:)

uretlural, 10:3:3

Bulbi [bullus, a bulb] restihuli, 1040, 1068

Bulbo cavernosus, or acrelerator uriuse muscle, $10: 34,1079$

Bundle, gromal, of spinal cort, anterior and posterior, 7.11

longitulinal, of crus cerebri, posterior, 709!

of Vieq d'Azyr, 702,

burlach's column, of spinal corel, 74

Burns, talciform process of, 1138
C.AN

Bursa [a sac], great paluar, $31 \tau$ pharyngeal, 95:

prepatellar, 11 4

Bursa of foot, 1199 ; popliteal, 1182

Buttocks, surgical anatomy of the, 11,-

Ceccur [cecus, blind], the, 970 ; variations of, $5 \%$

Calcanean [cal $x$, the heel] artery, external, 59:

of external plantar, 59!) internal, 593

nerve, intermal, -1sic

Calcaneo-astragaloid joint, anterior, 270

posterior, 269

morements of, 270

Calcaneo-cuhoid joint, ligaments, 274

functions of, 1203

nerve-supply and morements of, 276

Calcaneo-plantar cutineous nerve, 819

Calcaneo-scaphoid ligament, external, 270 inferior, 273; functions of, 1:203

Calcanenm [calx, the heel], the, 163

articulations, 164

ossification, 165

Calcar [a spur] aris [of a bird], or hiplocampus minor, the, 696

Calcarine fissure, the, 689

Calcis [cald, the heel] , os, 163. Sce Calcaneum

Calices [atix, a cup] of kidney, 1006, 1010

Callosal tissure, 690

Calloso-marginal artery, 503 fissure, $6=9$

Calyciform (circumrallate) papilla of tougue, 884

Canal, Alcock's, 813, $106 \mathrm{~F}$ carotid, 37

central, of cochlea, 881

clavicular, 110

of Cloguet, 851, 121:

cranio-pharyngeal, 30 ; at birth, 93

dental, anterior, 55,77

inferior, 63,97

ethmoidal, 46, 50, 7R, 82, 97

Fallopian, 37, 41, 91 ?

femoral, 1139

of Huguier, :32, 7.3, 9\%

of Hunter, 1178

hyaloid, 851

infiat-orbital, 55, 97

ingrnimal, 1132

lachrymal, 7\%, 868

malar, 61,97

mandibular, 63,97

membransus, of coehlei, 883

nemo-enteric, 70 \%

of Nuck, 1050

palatine, accessory, 59

anterior, 56,79

external, 59

posterior, 59, 70, 97

of Petit, 850

petro-mastoid, 40

pterygo-palatine, $33,59,70,97$

spiral, 880

Vidian, 32, $0,9 \%$; at birtlı, $9: 3$

of Wirsung, 987

Camaliculi [dim. of conolis, a caual] lachrymales, $-6 \pi$

Camaliculus, auricular, 3 tympinic, $37,7: ;$

Canalis musculo-tubarins, 40, 73 reuniens, 881 
Camals, guhermacular, 72

hepatic, $9 \$ 3$

portal, 983

semicireular, 879

Stenson's, 57

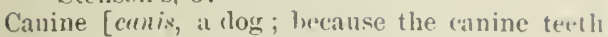
are most prominent in the log eminence, 55

tossa, 55

tceth, 87

Canthus [kartos, the angle of the eye], inner and onter, 840

Capitellnm [dim, of caput, the head], the, 1:20

Capsular [rim. of capsa, a hox] antery, or perirenal, 560

or suprareual, inferior, 560 ; milldle, 561 ; superior, 553

ligament of aeromio-clavicular articulation, $21 !$

of atlanto-odontoid articulation, $1-6$

of earpo-metacarpal joint of thumb, 24:2

of costo-central articulation, $20 \mathrm{x}$

of costo-transverse articulation. 210

of crico-arytemid articulation. 907

of "rico-thyroid articulation, 907

of elbow-joint. 227

of hip-joint, 246

of inco-stapedial articulation, - - is

of interchoudral articulation, 214

of knee-joint, 256

of lateral atlanto axoidean artieulation, $1 \times-5$

of' malleo-ineal articulation, 87

of occipito-atlantal articulation. 1-3

of pisiform-cuneiform articulation, 237

of shoulder-joint, 22\%

of sterno-clavicular articulation, 216

of superior tibio-fibular articulation, 26.1

of temporo-mandilular (maxillary) ar-

ticulation, 180

of vertebral articular processes, 194

vein (supraremal), 632, 1051

Capsule of cerehrum, extermal, 702

Glisson's, !-3

of spleen, $9<9$

of Tenon, s(6)

For eapsule of joints, sce Capsular liga ments

Capsules, Bowman's, 1010, 1011

Caput eoli [the cacim], 970 ; variations, 970

Cardiac [kapdia, heart] artery of gastric, 5.5l;

ganglion of Wrisherg. 939

lymph glauds [superior mediastinal], 6.52

verves of pneumumastric, 77:3

of sympathetic. $\$ 30$

orifice of stomach, !) 60

plexuses, superficial and leep, 8:34. (13!)

veins, anterior and posterior, 610,93 ;

great, (i10. 937

smaller, lilu

anterior, 611

Carina [a keel] of ragina, 10.13

Carotico-climoid ligament, $3 \cdot 1$

Carotid [карów, I induce sleep) : pressure nu them was supposed to ('ause sleep)] -

artery, common, 475 ; collateril circulation. 47! : relation of left artery to chestwall, 1105, 1113 ; variations, (1)!

external, 480: smrgieal anatumy of, $110^{2}:$ : variations, 480

interual, 497

caual, $3 \%, \pi 3$
Ciroticl erland, 1\%

lobe of parestid gl:mel, !)

plexus of sympathetic; , s-3-

triangles, surgionl anatomil of, 110:

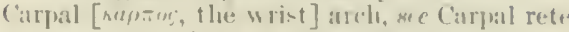
artery, ralial, anteruor and posterior, 5.11 iluar, anterior and juterior, .3:5

boncs, ser Carplls, bulles of

joints of first row, 2:38 of seroml row, 2:35

ligranuluts, 2:3\%, 211

rete [a net], wr carpal arch, anterior and posterior, $5: 3 \cdot 1$

Carpo-metacarpal juints of funers, 210

limaments, 241

of thuml, : : :

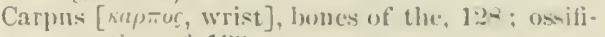
("attion of:, 133

medio-earpal joint, ligaments of, 2:39

moveruents of earpal joints, 240

Cartilaye, articular, of slunller-joint, 225

(o)stal, 102: development of, 103

cri(vill, !w):?

veriotir of chondro-(ranium, e!!

pre-(oratcoirl, 11 i)

splenotic [roin, a werlge; oir, the ear], -9y

titrial, $42 !),-(i t ;$

thyroid, !101

Sice also Fibro-cartiline

Cartilages, ances-ory qualrate, = 91

arytenoid, 504

('iluceiform, (9).

Jacohsonian, 891

of larvmx, [u]

of nose, -90

lateral, -90 ; orierin of, $9 t$;

septal, -91 ; origin of, $41 ;$

sesimuid, $\rightarrow-;$

of Santurini, 945

of Wrisherer, 905

Cartilaginous eraninu, the. -99 ; rimuants of, 95 frimework of ear, -il

portion of Eustachian tube, siti

of extermal anditory meat us, si?

of lioste. $8-$ ! t

rings of trachea, 913

Cartilano tritican [like a wheat grain], 901,

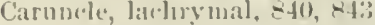

Carmumbe [dim. of caro, lesh] myrtiformes [myrtus, myrtle], 11:30

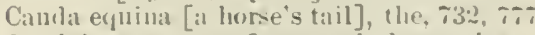

Candal arota. wre Corryeal gromerulu-

Catulate lobe of liver,

Cava [hollow], velu, inferint, (j3) tributaries, 1331 ; variations. (3:;:3 superior. dito:

Caval artery of riglit plirenic, .7.3.3

Carernons wrome, 31

nurves of pernis. lare and -mall, - - ; -

plexus, of sympittlitice, - - -

sinns, 62:2

('ivities of liwart, ().)

Cavity, cotyloil, 1:3-, 14:3

simmuil, of ralims, 1:27

of ulua, [retater, 1:2:3 ; lenser. I:3

of trum julvis, 145

of ulorus, 1117

Carum [a hollow] Tictzij, 1017

(e)ls, ethumoidal, sil, -11: alevelupment ot. in

irouto-ethmosiclal, in

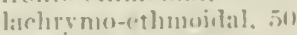

mis-tuill, fll, ]11-;

maxillo-ethmoidal. io 
CEL

Cells, palato-etlumoidal, 50 spheno-ethmoirlal, 50

Central artery of anterior cerebral, $5(13$ of the retina, 500,851

axis of cochlea, $8-1$

canal of cochleis, $8 \times 1$ of spinal cord, 738

conuective tissue of orbit, 86; element (bone) of (arpus, 1:33 wrey matter of thirl reutricle, 70.5 lobe of cerebrum, 6-1)

odontoid ligament, 188

point of arm, topograply of, 1154 of the perinicum, 1122

sulcus (tissure of Roluu(b), 6尺2

tendon of diaplirasm, 400

veiu, cerehral (quuglionic, or deep), 624 of retina, $6: 3$;

Centres of ossification. Sce Ossification, centres of

Centrum [centre] of typical vertehra, 5 ; morphology of, 22

of axis, 9

of fifth lumbar, 13

ovale mijus at miuns, 629

of trpical cervical rertebra, 7 lumbar vertebra, 12

Cephalic [aceordiug to Hyrtl, from the Arabic, al-kifal] rein, $6+1$ median, 641

Cerato-hyals [képas, a hol'n; and v, the letter upsilon], 66

Cerebellar arteries, anterior, or ant. inferior, 512 posterior inferior, 511 superior, 512

commissure, 741

peduncle, superior, 713

root of trigeminal nerve, 750

tract of spinal cord, direct, $7+1$

veins, inferior, $6: 4$; superior, $6: 4$

Cerebellum [dim. of cerebrum]. 670, 713

fibres of: 741

grey matter in interior of, 716

white matter of, 716

Cerebral arteries, anterior, 503, 513 middle, $503,51: 3$ posterior, 512,513 distribution of, 513

hemorrhage, artery of, 503

hemispheres, $(i \overline{0}), 6 \times 1$

convolutions and fissures of, $6<4$

topograply of, 728

lymphatices, deep, 651

veins, $6: 3$

vesicles, 669

Ceruminous glands, 1077

Cerrical [cerix, the neck] artery of uterus, 570 deep, of superior nutercostal, 51s superficial, 516 transverse, 51 is

cardiac nerves of sympathetic, 830 of vagus, 772

enlargement of spinal cord, $7: 31$

firscia, deep, 444, 1105; finctions of, 1134

ganglion, inferior, 830 millle, 8:30

superior. 8:7

lymphatic glamle, deep, 6.5:3 superficial chain, 6io

nerve, superlicial, $7 x$

transverse, topography of, 1103

nerves, anterior primary divisions of, $\mathbf{7} 82$ posterior printary rlivisions of, 775
C'IR

Cervical nerves, relation of. to the muscles of the upper extremity, 798

plexis, 783

branches, deep, 785

superficial, 783

to hypoglossal from, iti

portion of gangliated cord of sympathetic, 827

rih, 103

tubercles of femur, 147

vein, deep, 614,698

transverse, 617

vertebra, typical characters, 7

peculiar vertehre, 7

serentl, $9 ;$ muscles attached to 15

Cervicalis ascendens mmscle, 417

Cervico-basilar ligament, 188

Cerrico-facial division of facial nerve, 765

Cervix [neck] of nterus, 1044; eavity of, 1045

Chambers of eyeball, 850

Characters, general, of futal skull, 90

of typical rib, 99

of vertebra, 5

Check (lateral oceipito-odontoid) ligaments, 188 Cheeks, the, 94:2

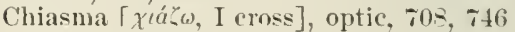
fibres of, 746

Chin, the, 62

Chondro-cranium [xóndoos, cartilage], the, \&?

Chondro-epitrochlermis muscle, t58

Choudro-glossus (hyo-glossus) muscle, 452

Chondro-sterual articulation. 211

movements of, 214

Chondro-xiphoid ligament, 214

Chopart's amputation, incision for, 1198

Chorda [ $\lambda^{\prime}$ oprín, a cord] trunpani, 762

Chorda tendinex, 931,93:3

Chorio-capillaris, 84:, 847

Choroid [xópun, the rhorion : عichos, like : from its vascularity $]$, the, 845,847

artery, anterior, 502 posterior, 512

plexuses. $698,70.1,718$ vein, $6: 24$

Ciliary [cilium, an eyelash], 8.73 arteries, 501, 852

of' lachrymal, 500,853

body, 847

ganglion, 752,864

glauds of Moll, $107 \%$

muscle, 845,846

nerves. long, 752.850

short, $753,850,864$

processes, 845

veins, anterior and posterior, 625 lower josterior, $6: 20$

zolle of iris, 842

Cingulum [a girdle] of gyrus fornicatus, 689 , 694

of teeth, 87

Circle of Willis, 50.1

Circular sinus of cranium, 6:1 inferior (of Winslow), 6:1

Circulation, foxtil, course of, $9: 39$ orgaus of, 925

Cireulus iridis, major et minor, 85?

Ciremuduction [circum, around; duer), I lead], 179

Ciremuference of average skull, 86

Circumflex [eircum, aromb ; Hecto, I bend]artery, auterior. 5\%5; variations, 5:6 external, 5-4: variations, is 4 internal, 584; variatious, 584 
Circumtlex artery, posterior, 5204; ; variations, 5:3; iliac, reep, 5ix; variations, is

nerve, $7 x y$ superficial, $58: 3$

vein, iliac, drep, 617 : smperficial, (i:31, 1i11

Circuntlexus palati muscle, $83,9,911$

Circumvallate [circumrallutus, trenclucel arumul] papillac of tomgrar, 884

Cisteru of I'ecrpuet, or receptaculum clyyli, (i.j!)

Cisterna magna of clanial meninges, pontis, lis

Clarke's colmmm of spinal ('orel, 7::

Claustrum [oleurlo, I shut], the. fou

Clava [a club], the, 72:2 ; nuclens of, 720 ;

Claricle [dim. of elucis, a key : from its shapw], the, 10s)

blood-supply aud ossification of, 1]1

Clavicular artery of acromio-thoracic, 5:21 canal, 110

Clavi-pectoral fascia, 294

Clelt sternum, 108

C'levilo-hyoid muscle, 4.58

Cleillo-occipital [ki.zis, a key ; sifor, like] mus cle, 446

Cleido-occipitulis muscle, $45-5$

Climoid [ri.ivn, a bed ; Eidus, like : trom their re. semblance to the four posts of a heel] processes, anterior, midclle, and posterior, 30,83

Clitoris $[\kappa \% \varepsilon(\omega$, I shut up], the. 10!1

dorsill artery of, 576

nerve of, 814

Clivus [a slope], the, 81;

Cloaca [a sewer], the primitive, 105is

Clorpuet, (anal of, 850

Coats of eyeball, inner or nervous, $\quad 18$ micklle or vascular, 847

onter or fibrous. 846

of Fillopinu tube, 10.51

of intestine. larme, 969 small, 968

of stomath, $96 \% 2$

Coccryeal aorta, sce Middle sacral artery artery, 5\%:

(.ornua, 17

nerve, 810

primary divisions of, anterior, 810

posterior, 781

plexus (nerve), 809

vertehra, 14, 17; ossification of. $2 \mathrm{?}$

Corrergeus muscle, 1062 ; nerve to, - 119

Corryx [kókk's, a cuckoo: from its fincierl likeness to a cuckoo's beak, 17 ossification of. 222

Cochlea [kóxios, a shell fishl $], 41, \&-1)$

Corhlear nerve, 767

Cecliar [nifea, the belly] artery (axis). 55is; topography of. 11:j1; variations, jis

lymph glands, 662

plexus, 835

Colic [ $\kappa \bar{\omega}\rangle .01^{\circ}$, the large intestine] area of anterior surtace of kidney, 10119

arteries, left, $562 ;$ milllle, $559:$ riølit, 5.59

Collateral arteries, digital, of tingers. $53-$ of toes, 595

eminence, 6901

intercostal, 5.4!

tissure, 682,690

Collecting tubes of kidney, 1011

Colles, fascia of 1065

Colliculus [dim. of collis, a hill] seminalis, 11135

Colon [ $\kappa \bar{\omega} \%$ or, the large intestine], $11 \% ?$ ascending, $y \% ?$
Colon, blomel-supuly ot, y.5

dexcendinin, !):3

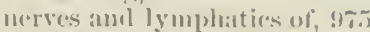

sigmoid He:xure of: 97:3

structure of: 175

transverse, yi:

Colotomu, Immlar, lamuluarks tim, 1119

Colum(ella, the, $\rightarrow$ -

Columust. Liertini, 1010)

carne:e, 9:31, 9:3\%

rogratum of valuina, 10).1:;

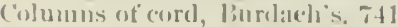

Clatite's, $7: 37$

(ioll's, $7+1$

of unelulla, litteral, $\tau ?$ ?

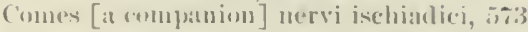
metliani, 5333

phrenici, 516

Comma-shaperl tract, itl

Commissura [(on, together ; millo, I senol] molliโ 05

(ommisistace all flocenles, 7.57

C'omm issmral hranches of anterior cerebral artery, $50: 3$

Commissure [union] of cerehellum, great anterior, ilti

of (erel)rum, anterior (white), 701 ; hasal (grey), fori; mindle (grey), 705; posterior (white), 704, 701; , Tl6;

Gublen's, 7.47

Ievnert's 7.17

optic, 7(12, 7.11; filues of, 7.16

of vagina, justerior, 103 !

Common bile lluct. si-t

carotid arteries, 475; branches and varia. tions, 179 ; collateral circulation after ligature, 479

femoral artery, 579; variations, 5e] veiu, 6.16; variations, 647

iliac artery, 5(il ; collatera] circulation, 5655; variations, $5 t i 5$

veins, 634 ; variations, 634

pelvis of kilney, 1014

('ommmicans peronei nerve, -13

tihilis nerve 817

Communicantes liy joglossi, 7-j

Complexus muscle, $1: 0$

Compressor narium muscle, 432. 891 minur muscle, -9.2

saceouli laryois muscle, 911

wrethra muscle, $106 \mathrm{\alpha}$

vagina muscle, 1 luig

renae dursalis peuis musc]e. 1033

Conarim [conus, a fir mone] or pineal bury, i06 Concha [Ku: $y$, ashell], the, -71

Couductor sonorus, of fiurth ventricle. i1, itt

Coudylar lines, imner and outer, of lemur, 15u rille, extrimal, 11\%

Condyle [kor fivor, knuckle], tertiary meipital, 2-

of bis-ocripital, $20,7: 3$

of femur (internal aml extermal), 1,in ; surgi(al anatonly of, $11-1$

of humerus, iuternal (ulnari, 1:11 external (raclial), 1:31

of mandihle (luwer jaw), (i3) : meck of, 64 miniature, of plialanges (timgrer , 1:3:

Condyloial [nuwision, a kmuckle; Eidur, like] tora-

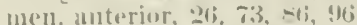

po-terior, $2 \alpha$, is

erutre of usificatinu of mandible, li.

for-il, posterior. 22

tubercle of mumlible, tis 
$\cos$

Conical, or filiform, papillae of tungue, 825

Conjoint tendon, 407

Conjngate dianeter of pelvis, 145 ; measurements of, 146

Conjunctiva [cou. together; jungo, I join], ocular. 841

palpebral, 840, 867

survical anatomy of, 1093

Conjunctival sac, s.t1

Connective tissue, rentral, of orbit, 865 subaponenrotic, of scalp, $10-5$ sulpperitomeal, !58

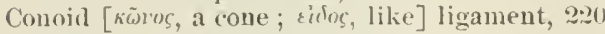
Constrictor muscles of nose, 84: vagina musele, 10.1$]$ of pharyux. 950

Conus arteriosus [kivvos, a cone], 46:, 9:31 medullaris, 734

rasenlosus, $10: 27$

Convolution, post-parietal, 686

Courolutions [con, togetlier; volvo, I roll] of cerebrum, Broci's, 685

dentate, 691, 698

frontal, ascending, 684 ; mferior, 684 ; middle, 684 ; superior, 684

infra-marginal, 688

malgina1, 690

occipital, interior, 695 ; midlde, 687 ; superior, $68 \%$

orbital, anterior, 685 ; internal, 685 ; posterior, $6=5$

parietal, ascending, 686

straight, 685

supramarginal, 686

temporal, inferior, 688 ; middle, 688 ; superior, $6-8$; transverse, 688

Coraco-acromial ligament, 221

Coraco-brachialis nuscle, 305 ; nerve to, 790 ; surgical anatomy of, 1150

Coraco-clavicular ligament, 220 ; origin from subclavius. 281

union, arterial and nerve supply and movements of, 220 ; ligaments of, 220

Coraco-humeral ligament, 2:24

origin from pectoralis minor, 281

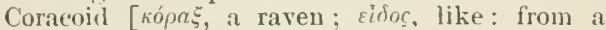
fancied resemblance to a raven's beak ] (or transverse) ligament, 2:21

process, 113

Cord, gangliated, of sympathetic, 826 ; cervical and cranial portion of, 826 ; lumbar and sacral, 833; thoracic (dorsal), 830

genital, 1094

spermatic, 1030 ; constituents of, 1030

spinal, 731 ; deep origin of nerves of, 737 ; extermal characters, 734 ; internal structure, 737 ; meniuges of, 731 ; tracts of, 738

Corvea [comelus, hormy], the, 846

lymphatic spaces of, 8i:

Cornicula [dim. of cormu, a horn] laryngis, or cartilages of Santorini, 905

Cormu [a horn] Ammonis (from its likeness to the horns on the statue of' Jupiter Ammon), or hippocampns major, 697

Cornua, coceygeal, 17

of fiscia lata of tligh, 1160

of hyoid bone, 66 ; centres of ossification for, $9 \dot{3}$

of lateral ventricles, anterior aml posterior, 696 ; inferior or descending. 69)

sacral, 15

of thyojel cartilade, inferiorand superior, $90 \mathrm{t}$ cus

Corona [a crown] ciliaris, 847

gratndis, 10333

of the optic thalamus, $i 84$

radiata, the, 709

Coronal [corond, a crown] section of brain, 671 of skull, 81

suture, 1

Coronary arteries [corona, a crown or circlet : so called becanse tliey encircle the heart ] of heart-

left, course and branches, 473,973

right, course and branches, $4 \% 2.9 \% 2$ variations of, 473

of stomach, 5isfi

branches and variations, 556

of lips, interior, $48 \%$; snperior, 4 \%

ligaments of knee, 259

of liver, $98 ?$

plexus, right and left, 839,939

sinus, $610,929,937$

vein, cardiac, 610,973 ; anterior and posterior, 611,974 ; great, 610,973 ; smallest, 611

gastric, 674

labial, 613

Coronoid centre of ossification for mandible, 64

fossa of humerus, 120)

process of maudible, 64,1096

of ulna, 122

Corpora [plural of corpus, a body] alhicantia [albico, I become white]. Tu2, тUT

clitoridis, 1068

quadrigemina [quadrigeminus, four, placed

in two pairs], 708,710

Corpus [a body] Arantii, 932

callosum [callus, hard], 670, 692

cavernosum [cacerna, a cavern], 1032; artery of. 576

dentatum [dentatus, toothed], 716

fimbriatum [fimbria, a fringe]. 69\%

genienlatum [dim. of genu] externum, 710 intervmm, 10

Highmorianum. 1026

lutenm [yellow], 10.53

spongiosim [spongia, a sponge]. 1031

striatum [stria, a streak]. 699

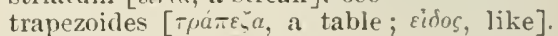
720,766

Corpuscles of Paciui, 1076

tactile, of Meissner, 1076

Corrugator [corngare, to wrinkle] supercili muscle (the muscle that wrinkles the eyelyrows), $4: 30$

Cortex [the rind] of kidney, 1010

of lens, 8.50

of olfactory tract, 744

Cortical arteries of kidner, 1011

hemispheral, of anterior cerebral, 503 of middle cerebral, 504

of posterior cerebral, 512

veins of braiu, superior and inferior, 623

Cortico-medullary arches of kilney, 1011

Costal [costu, a ril)] cartilages, 10:

Costo-central articulation, arterial and nerve supply of, 209

ligamelits of, 208

unovements of, 210

Costo-cervical artery (superior intercostal), 518

Costo-chondral articulation, 210

Costo clavienlar (rhomboid) ligament, 218

Costo-colic ligament, 973

Costo-coracoid ligament, origin of, 115 membrane, 294 
Costo-fascialis nuscle, 4.58

Costo-trinsverse anticulation, arterial and norve supply of, :211

ligameuts of, 210

movements of, $: 11$

Costo-vertebral groove. $10 \mathrm{~s}$

Cotunnius, nerve of, 7.j.)

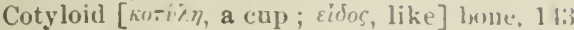
carity (acetahulum), 138, 14:3

foramen, $1+3$ notch, 1.43

Comper's glaurls, 1067 ; development of, $10 . \overline{-}$

Cranial [kpaviov, the skull] tossa, anterior, 8: micille, 8:3; posterior, $=6$

nerves, 7.13 ; general distrilution, 71.i snperticial and deep origins of, itt sinus, ietiuition of: 711

sinuses, venous, 619. Sce also Sinus, for individual sinuses

Cranio-cerehral toposraphy, 10-6

Cranio-facial angle, 81 ; measurement of, 86

Cranio-pharyngeal eanal, 30 ; at hirtl, $9: 3$

Crauium [koviov, the skull], eapacity of averagre, 86

cartilaginous, the, 89 ; remnants of, 9.)

measurements of, arerage, 83,86

membranous, the, 89

results of elasticity of, $10-6$

structure of 1086

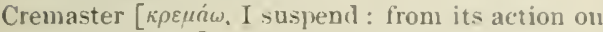
the testis] muscle, 407

Cremasteric artery of leej epigastric. 5T of spermatic, 561

fascia (or middle spermatic), 1021

Crest, falcifornı, 36

of ilium (iliac), 139

malar, of sphenoid, 3 :

obturator, 143

occipital, external, 25 ; internal, 26,86

of pubes, 14:3

of scapular spine, 112

sphenoidal. 30

supramastoill, 35

of tibia, 153

turbinated, inferior and superior, if

Cribriform [cribrnm, a sieve] area, midule and superior, :36

fuscia, 346

plate of ethmoid, 49

tract, spiral, 36

Crico-arytenoil joints, 911

(or transierse) ligament, 911 posterior, 911

Crico-arytenoideus lateralis muscle, 91? posticus muscle, 91:

Crico-thyroid artery, $4 \div 3$

joints, 911

memlirane, 910

musele. 910

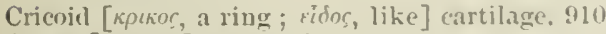

Crista [a crest] vestibuli. 41

galli [gallus, a cock], $49,8 \cdot$ terminalis, $1: 213$

Crown, of teeth, 86 : velation of upper to lower tooth crowus, $>9$

Crucial [crux, a cross] anastomosis of femur, 573,534

ligament of central atlanto-axoirlean joint, 186

of knce-joint, 2\%

ridges of occipital hone, ?-.

Crura [crus, pl. crura, lew] cerebri, ij: of diaphragn, 399
Crura of factal merve, iti]

of stapes, 6 -

Crural arch, 11:3; deep, 111, 11:39

nerve, aluterior, -

of grenito-(")ural, on!

septum, 11:30

Cruretso muscle. :36t

Crus, artery ot the, $5 \pi$

editoridis. 1010

penis, l1i:2

Crust:? [the riml, or crunt]. the, wi erura e*reluri. ill

Crystalline ]1-us, the, Q4y

Cubo-enueiform joint, arterial and nerse supply aud movements of, :2?

lig:turents of. :?:?

('ub)-metatarsal joint, 2 -

Cuboscaphoid joint, arterial amel merve -upuly of, 271

ligamints of, :27!

moxements, 273

Cuboin [no 3ns, a conbe ; enfos, like], the, 16.5

articulations, ligaments, attaclument of mus-

eles, alucl ossitication, lfit;

Culmen [a root'], the of cerebcollum, ilt

Cuneate [emens, a werlgre] lobule of eerebrum, 691

C'uneiform [rmeux, a wedge] bone, carpal. 1:31; uscitication, 13:3

tarsal, external, 168 ; oxsifeation, $16 !$ intermal, 167 ; osvifieation, lemislle, 167 : onsifieation. 16-

cartilages of Wrishere. 943

Cumens [a weslwe], or immeate lobule of cerebrum, 691

Cinpula [a vault] of coclile:a,,-1

rurvator cocrygis muscle, 458

Cushion of the epiglot tis, !)

Cutaueons branches of -en-(1) 'y :ubl mixed nerves. $-19$

Crstic [nic-ts, a blakler or hay] artery, is

duct, $9-4$

plexu< (nerve). (i:37

rein, $6: 36$

I) ARTOs [daptos, flayed] of penis. 111:20 of scrotum, $10 \%$

Date of ossitication of hones of foot. 175 of hamel. 13:3

Declive, the, of cerelellum, ilt

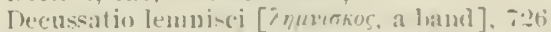

beferential artery lartery to vas deferens. (;014

Deiter's nucledus of atuditory nerve. F(i.)

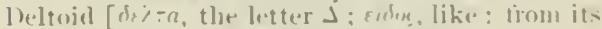
shiupe] liniment of ankle. 263

muscle, 30n: surgical anatomy of, 1151 tubercle, 109

lendrites, ifl

Dental [dens, a tometh] artery, anteriur, fl!ti interior of mantibular 494 posterior. 19.2

canals. anterior, $5.7,7 \%, 47$

formula, adult, - 1 : : (1.)

nerves, interior (mamlibularl. ise superior, 7.51

veins. interior (matslihularl. tilti justerior, blti

Dentary contre of onitication in mandihse, 6.5

I)entate (on) volution, li!l]. figld

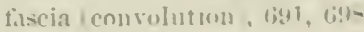

tissure, 6!) 
Depression for Gasscrian grmylion, 83

lateral, of middle fossil bisis cranuii, 8:3

rhomboid, of clavicle, 110

Depressor alse nasi muscle, 4:33, 930

anguli oris muscle, 138

labii inferioris muscle, $4: 39$

thyroider muscle, 4 is

Derm, 10\%4

Descemet's membrane, 816

Descendens hypoglossi nerve, 7\%

Descending branch of external circumflex artery, j-4

loranches of cervicill plexus, f\&4

colon, 1009

of IIeckel's sanglion, 756

cormu (inferior) of lateral rentricle, 697

palatine arteries, 496

pharyugeal arteries, 496

rimus of pubes, $14: 2$

rout of optie nerre, 7t7

of trigeminal nerre, $7 \notin 9$

Development of genito-urinary organs, 1055 For bones, see Ossification, centres of

Diameters of pelvis, 145

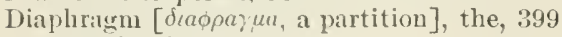
opering in, 401) surgieal auatomy of, 11$] 6$

Diaphragmat sellax, (j73. 675

Diaphragmatic arteries of aortic intereostals, 550 lymphatics, 6.56 plexus (nerve), 835

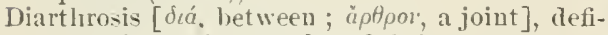
nition and examples of, $17 \%$ subdivisions of, $17 \%$

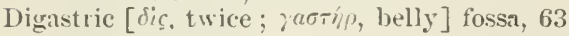
groove, 37,73

muscle, 449

tendon, 450

Digestion, orgass of, 942

Digital arteries of fingers of palmar arch, 538 collateral, 533

dorsal, 542

of toes, collateral, 595

dorsal, of dorsal interosseous, 600

of dorsalis hallucis, 601

plantar (communicating), of dorsalis pedis, 601

of external plantar, 594

fifth (princeps pollicis), (i01

snperficial, of iuternal plantar, 596

fossa of tunica vaginalis, 10:24

nerves of toes, 819

of fingers, 79.

phalanges of foot, $1 \%$ :

of hand, 137

veius of foot, 644

of band, 640

Dilatator naris anterior numsele. 433 posterior nuscle, $4: 3: 3,-5) 1$

Dimensions of kilney, $104: 2$

of oraries, 1090

of uterus, 1084

Dimples, 107:3

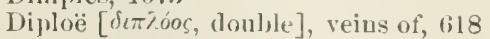

1) ploie artery, 500

Direction of inguinal ('anal, 1161 of uterus, $108 t$

Disc, optic, 84 ?

Distal row of earpus, bones of, 128 surfice (of tootli), sit
Diverticulum [direrto, I turu aside], Mreckel's, $96 \%$

Dorsal artery of elitoris, 5\%6 of penis, 556,1066

branch of aortic intercostal artery, 5.19

of nluar (posterior) nerve, rit

digital arteries of tingers, $54:$ of toes, 600

integument of band, nerve supply of, fy

interosseous arteries of foot, buo

nerve of clitoris, 814 of hand, $54 \mathrm{i}$ of penis, $-06,1067$

(or thoracie) vertelia, peculiar, 12

scapular arterr, 525 typieal, 12,

spinal plexus (renous), 6:-

vein of penis, 638

venous plexus of hand, 640

Dorsalis hallueis artery, 601

indicis artery, 543

lingua artery, $4=4$

pedis artery, 600 ; surgical anatony of, 1242 pollicis artery, 543

Dorso-epitrochlearis musele, 452

Dorsun ephippii [ $\dot{\varepsilon} \phi i \pi \pi \iota 0 \nu$, a saddle, 30,83 ; at birth, 93

ilii, 13!)

of scapula, 111

of tongue, 284

Donglas, fold of, 410

ponch of 1043,1044

Duct, Bartholiu's, 949

common bile, 984

eystic, 984

ejacnlatory, 1030 ; orifice of, 1033

of Gïrtuer, $1043,1: 14$

hepatic, 984

lachrymal, 55, if

Müllerian, 1055

nasal, 80,906

of panereas, $9<7$

of parotid. 948 ; surgical anatomy of, 1091

renal (ureter), 1014

Rivini's, 949

of sublingual gland, 949

Walther's, 949

Wharton's (submaxillary), 942

Tolffian, 1055

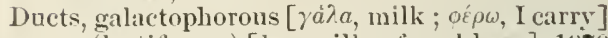
(lactiferous) [lac, milk; fero, 1 bear], 1070

Ductus [duco, I lead] arteriosus (Botalli), 940 cochlearis, 883

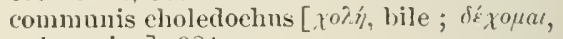
1 receive], 984

endolyuphaticus, 36

perilymphaticus, 37,73

venosus, 635,978 ; fissure of, 979

Duodemal fold, evolution of, 1003

Dnodeno-jejnnalis, fossa, 966

Dnodenum [duodeni, twelve], the, 96.1

Dura [harl] mater [mother], the, of brain, 67:2 of spinal cord, 731 ; differences between it and eranial dura mater, 732

EAr, the external, $8 \% 0$; ligaments and muscles of, 870 ; ressels and verves of, 871

internal, 87!

millle, 873. See Tympanmm

veins of the, 625

Ear-slaped cartilage of sacro-iliae joint, 202

Ehrenritter, ginglion of, 768 
Eightlu cranial (amlitory) nerve, 76.7 ; roots, 766 ; branclies, itiz

C.jaculatory (luct, 10:29; oritice of, $10: 33$

Filastic fibres (yellow) of tracluca, 9) 1 !

lamina (posterior) of cormea, -16;

Elasticity uf crauimu, results of, 111 (i

Elhow, arrangement of superficial veins in front of: 11.5

hollow in tront of, $115 \%$

surerieal anatomy of, 1155

Elbow-joint, anastomoses round, 115\% arterial and nerve supply aud move ments of, ?.2!

Eleidin, 1075

ligaments of: :227

Eleventh cranial (spinal accessory) verve, 819 rib, 1112

Eminence, articular, 35,70

("aluine, 5i)

fromtal, 47,73

nasil, 4 is

olivary, 30.83

parietil, 44

Eminences, liypothenar, muscles of, 343 surgical anatomy of, 1199

thenar, muscles of. 33!)

surgical anatomy of, 1199

Eminentia articularis, 3\%, 0

collateralis, 6900,697

teres, 719

Emissary veins of cranium, $6 \% 2$ of scalp, 1116

Emulgeut [cmulgco, I drain out] or renal arteries, $5(30)$

veins, $6: 31$

Enarthmodia [ $\dot{\varepsilon} v$, in ; $\dot{\rho} \rho$ Apov, a joint], definition and examples of, 177

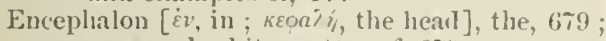
grey and white matter of, 679

Eud-bulbs of Krause. 1176

Enlocarlium [Evoov, within; kapdia, the heart], the, 9:-

Fpencephalm [i்i, upon; reoaii, the heid], the, 670, $71: 3$

Ependymai [ $\dot{\varepsilon} \pi \imath ; \dot{\varepsilon} \imath \delta \mu \alpha$, clothiug], the, 670

Epicerebral spaces, 6 б 8

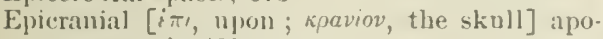
neurosis, 427

Epirlerm, 1075

Epilinlymal artery, $5 f 1$

Epirlirlymis [i-i, upon; diduros, the testicle], the. $10: 4$

tube of, 10:27

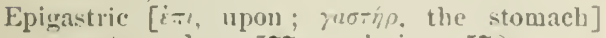
artery, deel, $5 \%$; variations, $5 \%-$

superticial, $58:{ }^{2}$

superior, 518

lymphatice glands, 6.57

recrion, 12112

vein, deel, (it7; superficial, fi31, 611

Epiglottis [в-r, upon; ; $90 \%$; cushion of the, 90.5

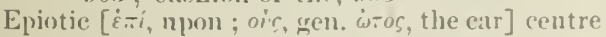
of oscifieation, $4: 3$

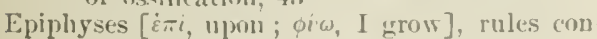
cerning. ?

mossified (costal cartilasres), 10:2

Epiphysial cartilages, 1 lines, 1

Epiphysis rerehri (pineal body), i0.

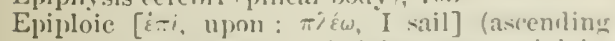
omental, artery of right gastro-ejiploic, $55 \%$
Epiploir (drscending omental) artery of left gitsiro-cepiploice, 5is

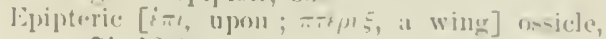
i1, 1:20!1

Episprual spoures, tion

Epristcenal foues, 10.3

Epritlılium [i-л, "1x) ; 11, $[1 . \overline{5} \cdot \overline{-1}$

sulmapisular, - -.00

Epitrorlilear erlaul, 115\%

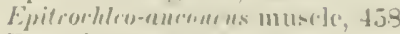

Epriplom, 1211

Epovarim, $111-1211$

Eitlator wi (evebiall, -13

Erentor [eriger, to raise] penis (ischio-cavermosis musele. 103.1

spinil Inuscle, I15

Ethmoirl [ithus, a sieve; eiros, like: from t] pertoratious in its horizontal plate] boure, 4! ; ossilicatium, 50) at birtl, 91

Ethmoidal arteries, anterior and posterior, 532 (atuals, $16,4 ! 9,72,82,97$

(*11s, $50,-, 0$

tissure, 19,82

foramiua, $49,-2$

grooves. 49

notche fli

spine of sphenoid, $30,-3$

veins, anterior and posterior, 626, 934

Ethmo-lachrymal suture, 7

Ethmo-sphenoirlal suture, 8:2

Ethmo-turbiuals, ju

Ethmo-vomerime region of choml ral skmll, -9 plate (at birth), yt;

Eustachian arteries of pterrgo-palatiue, 49\%;

tube, $4 \%$ of Vidian, 496

value, $9: 29)$; in fortus, !ro

Rvolution of peritonem, $5 ! 1$

Ex oceipital bomes, 21: at birth, 9:2

Excretory dukt of killuey, 1051

Extensor [itemlo, 1 stretch out] annuluris muscle, 4.im

brevis rligitormm muscle, 331 m(tnйs musurele, 15\%

polliris muscle, 330

carpi rarlialis brevior masele. 323 arecsonrius musele, fio-

longior muscle, $3: 2: 3$; werve to, 795

mluaris muncle, 320

roreygis musele, tis =

communuis dieritorum muscle, 0321

jullicis muscle, :3:20

longus digitormu unsele, 309

pollicis musele. $3: 31$

undii dimiti mus.le. $1.5 ! 1$

minimi digiti musele. 3:96

os-is mulararpi pollicis muscle, :3:39 molulnrsi hulluris munsile, lis

primi inlermodii halluris lomgnes muscle. 1.je proprous ballocis [proprius, leclongiug to;

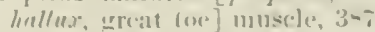

Exteriol uf the skull, (i?)

lixtraspinal veius, $\left(i^{*}: !\right)$

Extrinsic [trtriustens, outward] mu-cles of aluric.le. -1

of laryux. !15

of torigne, $\rightarrow-\infty$

Eve, the. 2.:s!

Evelall. the. examination of, $-4: 3$

eqfuator of: $-4: 3$

queral surfice view of, $-3 ! 1$ 
EYE

Evelids, the, 90 ?

blood-vessets of, 865

grauds of, 865

lympluatiu's of, 865

nerves of, 865

survical anatomy of, 1092

FACE, cutaneous nerres of, 819) stzreicial andtouny of, 1091

Facet [fichlte, a little tace], patellar, of femoral condyle, 151

pyriform, of astragalus, 159

triangular, of astragalus, 159

Facial artery, 455

transverse, 491

bones, :24

lymphatic glauds, deep, 6.53

vessels, superficial, tity

nerre, $\tilde{i} 61$

segusent of chondro-crunium, 90,890

slieleton at birth. 9:2

rein, common, 613

communicating, 614

transverse, 615 ; variations, 614

Falciform [ $f u l x$, a sickle] ligament of fascia lata of thigh, 345

of Burns, 1166

lobe of cerebrum. 6×3, 691

process of temporal bone, 36

Fallopian [from Fallopius, the anatomist] artery, 5t:2

canal, $37,41,-76$

tube, 1051; position of, 1051 ; lymphaties of, $(66: 2,1054$; structure of, 105:2 ; vessels and nerves of, 1054

False ligaments of bladder, 1018

ribs, 98

rocil rords, 911

Falx [a sickle; from its shape] cerebelli, 675 cerebri, 674

Fascia [a bundle], anal, $106:$

axillary, 294

(-lavi-pectoral, 294

of Culles, 106.5

cremasteric (or middle spermatic), 10:24

cribriform, 346

deutate (dentate conrolution of cerelorumu), $691,69 \%$

eudlothoracic, 399

of the forearm, leep, 311

of groin, sunerficial, 1165

of the haud, dorsal, 332

palmar, 33:3 : surgical anatomy of, 1206

hypothenar, 33:?

thenar, 333

of head and neck, reep (cervical), 144

superficial, 4:55

iliac, 318

of fascia lata of thigh, 1138

infundibnliform (propria), 407, 411, 1024

intercolummar, $406,1023,1131$

ischio-rectal, 1102

of the leg, deep, 367

lumbar, 408, 11.16

masseteric, 440

of muscles from scapula to upper limb,

superficial and leep, 300

of muscles passing from trunk to upper extresuity, anterior livision(superticial), 2!):3

posterior division (superficial and deep), $2 \leq 8$
FEX

Fascia, obturator, 1061

orbital, 858

palmar, $333: 3$; surgica] auatomy of, 1169

palpebral, sos

parotid, 440

pectoral, :94

pelvie, 1060

suruical anatomy of', 1129

perinzal, 1116.5

plantar, $3 \%$

prevertebral, 444, 1106

propria (infundibuliform), 407, 411, 10:24

puhice, of fiscia lata of thigh, 1119

recto-vesical, 1018, 1063

spermatic, extermal, 405, 10:23, 1131

temporal, 440

interual and middle, 10:4

of the thigh, deep (fascia lata), 344, 1116

tibial, deep, $37:$ superticial, 344

transversalis, 411

triaugular, of extermal oblique, 404, 1132

of the mpper arm, deep, 306

Fascire of orhit, $85 \%$

pelvic, 1060

Fascial sheatl of penis, 1032

Fasciculus (dim. of fascia) arcuatus, 786

garland-like. of cerebellum, 717

jongitudinalis, inferior, 786

oblique, of pous, 720

perpendicular occipital, ซ

teres of fourth ventricle, 719

uncinatus, 786

Fasciola [dim. of fascia] cinerea [grey], 693

Fances [ foux, the throat], the, 944

isthmus of, 944

pillars of, 944

Female bladiter, the, 1019

genitals, external, 1038 : surgical anatomy of, 11:29

manna, 1069

levelopment and abuormalities, $10 \% 2$

variations according to age, \&e., 1071

ressels, nerves, and lymphatics, $10 \% 1$

pelris, 146

perinaum, 1068

uretlira, 1041

Femoral [ femur, the thigh] arters, 579

branches and variations, 581

line of, $11 \% 5$

surgical anatomy of, 1176

deep (profuncla), 583

camal, 1139

conlyles and tuberosities, surrical anatomy of, 118 :

hernia, parts concerned in, 1137

course of, 1139

covering of, 1140

liganent, 1138

lymphatic glands, deep, 668

ring, 1139

superficial, 667

position of ressels aroumil, 1139

sheath, 11:39

vein, 648

common, 647

variations, 647

deep (protumila), 647

Femur [the thigh], the, $14 \%$

blood-supply, 1:2:

ossification of, 152

Fenestra [a wiudow] ovalis, $39,875,879$

rofunda, 39,875 
Ferrein, pyramids of, 1011

Fibres of medulla, areiform, $7: 3:$,

of cerelsellum, 71 i

of cortex cerebri, intalliemispluerie, long and short, 786

of optic chiasma, 7.46

of pous Varolii, 631, 718

of trachea (yellow (rlastic), 914

Fibro-catilage, cotyloid, of hip, 219

of kuee, external, 25\%

iuternal, 25

interarticular, of acromio-clavicular joint, 219

of sterno-clavicular joint, 叉ls

of temporo-mamlibular articulation, $1-11$ intervertebral, 190

pubic, 207

triangular, of wrist, 23 ?

Fibrous coat of eyeluall, 845

layer of pericardium, y.s

membrane of trachea, 913

Fibula [a clasp], the, 150

development of, 1;i)

Fifth (trigeminal) eranial nerve, i $\$ 9$

divisions of, ophthalmic, ift

mandiluular (inferior maxillary), 7.56

maxillary (sup). maxillary). 153

formen for, 83

Figures, stellate, of lens, -in

Filiform [filum, a threall], or conical papille of tongue, 885

Willet of crus cerebri, $710, \tau-?$

tract of the. $78 \%$

Filum [a thread] terminale of pia mater, $7: 34$, 1211

Fimbria [a fringe], or corpus fimbriatum, $64 \%$, 701

ovarica, 1051

Fimbria [fimbria, a friuge] of Fallojian tubes, 1051

First cervical nerve, anterior primary division of, To:

posterior primary division of, $7>0$

cranial or olfactory nerve, 745

rib, 100

Fissure [findo, I cleave] of auricle. Santorini's, 871

of boue, auricular, $3<, 7:$

ethmoidal, $49, \varepsilon:)$

Glaserian, $35,73,97$

maxillary, 56

pterygo-maxillary, 7 (1, テ๐, 97

spluenoidal, 31, is, -3 , ,

spheno-malar, 78

splieno-maxillary, $; 0,78,9 \%$

of cerehellum, great horizoutal, 714

of cerebrum, calcariue, $6 \times y$

callosal, 690

calloso-mariual, 689

collateral, 6-8, 69t

dentate, or lippocampal, 691

frontul, inferior and superior, fis 1

great longitudiual, 681

trausverse, 681

hippocampal, or dentate, 690

interlohar, $6=1$

intraparietal, $6=6$

occipital, inferior, middle, superior, aml transverse, $6-7$

parallel, 6xo

parieto-oceipital, external and interual.

$6 \times 1,6>9$

perpendicular, intermal, 6-9
Fissure of Iinlaumlo, (i-3, 11,-4)

getII: wi, ti-:;

wrigin of, $1 ;=;$

of :xlvius, 1,-2, 111-!

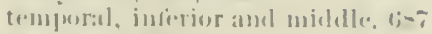

triradiate, $(i-$.

genital, temale, 106,

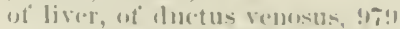

lougitudinal, 9\%7. 979

transicroe, or portal, y-!

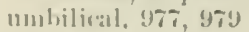

for vena caval, 47

of medulla ublongata, anterior and posterior. $7:: 1$

postatir, 10:21

of spinal corrl, an an-latural, pusteru-latoral, and longitudinal, anterior and posterior, 731

Flexor [flechre, to bond] accessurius digitorum perlis muscle, $3-1$

accessurius loughus muscele. 1.59)

brevis digitorum pedis, or tlexor perforatus misscle, 379

hallucis [hullux, great toce] muscle, $3-2$

minimi (manūs) digiti muscle, $31:$; peelic digriti muscle, :isit

pollicis [pollex; thumb] muscle, 311 perlis, or tlexor brevis liallucis. muscle, 322

earpi raclialis muscle, :31: : nerve to, 793 brevis rel profumlus nuscle, fir!

uluaris musele, 315; nelve 00,791

longus digitorum muscle, 3it

halluc-is muscle, 375

pollicis musele, 32011

ossis metacarpi pollicis musele, 3H1

pertoratus musele, or flexor brevis digitorm perdis, :37!)

profunelus digitorum musle, 31-; nerve to. 794

sulolimis digitorum mu-cle, 315: nerve to, i9]

tendoms of hand, sleeatlss of therae. 333:3

Floating rils. !)

Floccular fosit, 37

Floceulus [dims. of therews, a lowe of woml] of (ereluellum, 7l.

Floor of descerrling pornu of lateral sentrisle. structures in, 6y

of fiuth ventricle, strmetures in, 71 !)

of thirrl ventricle, structures in, i11.;

Fluil, (ereloro-spinal, tise

Futal circulation, $! 3,34$

lieart, peculiarities of, 939 fwostion aml woight, $13: 3$

skinli, enche.ral characters of:, (n)

Fold, aryt(1u)-r.piglottidean, 9015

of i) (onglats, fIII

duerdemal, 966; erulution of:, 11003

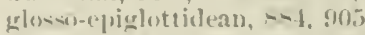

jalpeliral, superior aus interior. 840

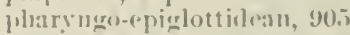

semilumar, wi ronjumetiva, -13

vestigial, of perioardimm, y2t

lolik or creases of palum, surgical analomy uf, 1165

Folit of cerchellum, ;11

Folian or slemler proces of mallen-. ti.

Folium [a leaf] armuinis [aremm, th, smmmit] of errebellum, il:3

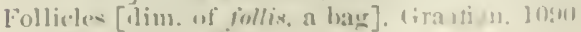
Meilumian. -46 
Fontanelles [dim. of fons, a fountain], anterior and posterior, !et

anterior aud pusterior lateral, !1

Foot, the bones of the, 15 is

arches of, l:0:2 ; levstome of, 120:2 ; pillars of, $1 \div 210$

bursie of, 1199

dorsal artery of, surgical akatomy of, 1200

levels of joints of, 119 -

surgical anatomy of, 1198

srinovial menluranes of, 1199

reins of, 6.4 i $^{\circ}$

Foramen [foro, I pierce] for aosta (in diaphisim), 400

imlitory (miernal auditory meatus), 96

("2x'(11), 46, 49), 8*2

iuterius, 706

posterius (of Vicu d'Azyr), 721

of tongme, 824

centrile cochleare, 37

commune anterins, 6\%0, 697

comlyloid, anterior, $26,73,83,96$

- posterior, 28,73

(osto-trinsverse, of atlis,

of cervical vertebræ, $\tau$

of seventh cervical (vertebra prominens), !

of truical rertebra. 7

dental, interior (mandilular), 63, 97

ethmoidal, 49,82

explanation of term, 5

for tilth cranial nerve, 83

infra-orbital, 55, 97

for intermal carotid artery (occasional), 83

jugular, 73, 86, 96

lacerum medinm, 73, 83

for lesser petrosal nerve, $3 \pi, 83$

magnum, 26, $73,86,96$

of IIajendie, $71 \mathrm{R}$

mandiloular (inferior dental), 63, 97

maxtoid, 73,86

mental, 62

ohturator, 138,143

for osophagus (in diaphragm), 400

optic, $30,76,8: 96$

ovile, $32,70,83,96$

of fietal lieart, 940,1213

vilve of, !) $10,1: 213$

palatine aucessory, anterior and external, $7 \%$ parietal, 4!)

petro-spluenoidal, $36,83,96$

rotumlum, $32,70,-83,96$

sicro-sciatic, great and small, 20 2

sclerace, 845

singulatre, 30

spleno-nalar, 71, 7x, 97

sphemo-palitine. 59, 70, 80, 97

sphenstic; 7:3, 8:3

spiusosum, $3:-71, \infty$

stylo-mastoid, $37,7: 3,97$

supra-(s)rital, 47

suprascapular, 113

supratroclilear, 120

for third ('runial nerve, 83

thyroid [Hpe, an oprening] (obturator), 13\%, 14:

trigeminal, 33\%.94;

for vena cava (iuterior in diaphram), 400

Vesalii, 32,

of Winslow, 45.)

Foramina of skull, primary nerve foramina, 96 secomelary 11 . foramina. 96 transmitting lirs, of facial n1., 97
Foramiua of skull, transmitting loranches of fiftl nerve, $)_{i}$

of Key and lietzius, 70!

papillaria, 1010

sicral, anterior and posterior, 1i

Scarpa's, 5\%, 7:2, $9 \tau$

spinill, 7

Stenson's, i:

Thehesii, (y:3), S:33

Forceps, major, of corpus (allosum, (j-s), (i9)-1 minor, 689, (j9) 4

Forearm, cutineous nerves of, $11(i ;)$ muscular prominences of, 1161 surgical anatomiy of, 1159

Furmatio reticularis, 721, 724, 7:3

Foruix [au arch], the, rol conjunctival, 840 vagine, $104: 2$

Fossa [at ditel or depression]adipose, 1070

of antihelix, 871

of base of skull, anterior, 82

middle, 83

posterior, 86

cauine, 55

condyloid, posterior, 28

coronoid, $1: 0$

digastric, $6: 3$

dierital, of tunica vagiualis, 1024

luodeno-jejunalis, 966

floccular, 37

of yall hladider, 977

glenoid, 35,73

of helix, 8.1

ileo-crecal, 970

iliac, 139

incisive, of mandible, 62 of maxilla 55

infraspinous, 111

imnominata, of larynx, 911

intersigmoid, 974

ischio-rectal, 1074, 1127 coutents of, 1075

jugnlar, 37, 73

lachrymal, 47 , 77

malleolar, of tibula, 158

nasal, 79

navicularis, of uretlura, $103 \%, 1130$

olecranou, 1:0

ovalis, of auricular septum, 9:30

palatine, anteror, $5 \gamma$

pituitary, 30

pterygoid, 3:3, 73

Rosenmiiller's, 952

scaphoid, :33, 7:3 of auricle, 87

sigmoid, greater, 12: lesser, 1::3

splueno-maxillary, 70

subliugual, (iis

sulmaxillary, $(; 3)$

subscapular, 111

supraspinous, 111

supritrochlear, 47

Sylvii, 682, 688

temporal, 70

triangular, of anricle, 871

troclianteric, 1.47

vermiform, 26,$86 ;$

zygomatic, 70

Fossic, adipose, of female breast, 1069

on posterior surfice of ablominal parietes, 1136 
Fos

Fossula [dim. of fossa] cochlearis, 36 vestibularis, :36

Fourchette [a lork] of vagina, 10:39, 11:30)

Fourtl or truchlear cranial nerve, n6:3 sacral nerve, s0-

Fovea [a pit] entralis of retina, 81:3, liemielliptic'a, 41, 875 hemispherica, 41, 875

inferior and superior, of fourtl ventricle, ;1!)

Frenum [a curlo or bridle], artery of, 44.) epiglot ticlis, 881

lingure, 884, 1095 prieputii, $10: 32$

Frenulnm [dim. of fromum] veli, 7 ]0

Frontal [frons, frontis, torehead] artery, 50: of anterior etlumoillal, jol

bone, 46 ; ossification of, is at birth, yt

convolutions of cerebrum, 694

eminence, 47,73

fissures of cerebrum, 684

lohe of cerehrum, $6 s-t$

nerve, $752,-864$

operculnm, 6x:?

process of malar bone, 61

sinuses, 47, 1082; development of, 47 vein, (j4!)

of diplöe, 613

Frontalis mmsele, 4:2

Fronto-ethmoirlal cells, $5 n$ snture, 8:3

Fronto-nasal plate of chondro cranium, 89

Fronto-parietal vein of diploë, 618 opereulum, 682

Fronto-sphenoidal vein of tiploë, 618

Frouto-squimosal suture, 38,71

Fundus [the bottom] of nterus, 1044

l'ungiform [fungus, a mushroom] papilla of tongue, 885

Funicular [dim. of funis, a cord] artery, 1050, 1054

Funiculus [dim. of funis, a corll], anterior, of medulla, , 72:2

('uneatus, $7: 2 \cdot 2$

eracilis, 7:2)

solitarius, 766

Furrow, median, of back, 114: sijuamo-mastoid, 3 -

Furrowed haud, 715

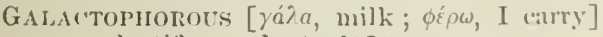
or lactiterons ducts, ] 1071

Galen, vein of, curdiac, 611,937 cerehral, 624

Gall bladier, the, !\&:3

fossa of, 977

structure of, 985

toporraphy of, 1117

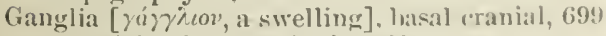
'ranial, of sympathetic,

of glosso-pharyngeal nerve, 762

lumbar, $8: 33$

mesenterica, $836^{\circ}$

ol pnemmogastrie nerve, 770

prostatic: $83 \%$

siseral, 8:3:3

semiluuar, $8: 35$

of spinal nerves, 70

of sympathetic nerves, $8: 20$

thoracic, 830

Gangliated cords of sympathetic, 826 cervical portion, s:26
(iES

(iangliated coml, cranial portion, $=26$

Imubar pution, r:2li

sacral portion, mi:3

thomate pert iem, s.st)

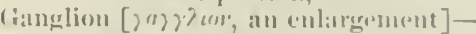

Amlersch's, tife

Armulel's, or otie, f(it)

lioclulalek's, 751

cervical, inferior, R30)

midllle, $8: 30$

superiur, 8:2

ciliary, or lenticoular, 752, 86.5

diaphraguaticum, 78ti, -3.3

Ehrenritter's, flix

Gasserian, 37,750 ; depresson for, $\times 3$

geniculate, $7(6)$

impar [une(1):1] $,-3: 3$

intcrearoticum, dī

jugular, $76 \%$

lenti(ular, $752, k 6 \%$

Meckel's, or nasal, T.j.

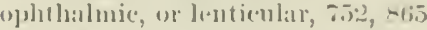

otic, 7 (;0)

petrons, 7fi8

(3) puemogratric root, 770

trunk, iti)

spheno-palatine, or Meckel's, 7.5.5

stellatmm, si:?

sublingual, $7(; 0)$

sulmandihular, or submaxillary, itio

Vilentin's, ijt

of Wrisberg, e:nrliac, 93 ?

Ganglionic artery, of anterinr arelmal, 503

of midclle cereloral. 503

of posterior cerelmal, 51?

veins, 623

Giirtner, duct of, 10.1:3, 1:21!

Gasserian artery, of midnle meningeal, 19:3

hranches of earoticl plexus, \&:31)

ganglion, 37, 750

Gastric [jactip, the stomach] area of anterior sturlace of kidney, 100!)

artery (coronary), 550 ; sariations, 550

of gastro-fepiploie, left, 5is

right, is

lymphatir glands, inferior, litit superior. liti:

lymphatics, inforior and smperior, titis nerve plexus, 8.3.5

sein, $6: 36$

Gastrochemius [zantm, the belly; $41,4 m$, the (alf] muscle, :3ti?); variations, :3il

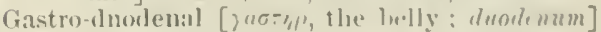
altery, 557

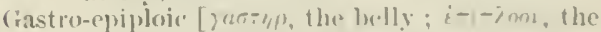
omentum artery, lett. $55 \mathrm{x}$

lymphativ glands. fiti.t riglit, $55 \%$

nerve plexis, loft, - -35 ; right, -35

vein, left, (i:3- ; riglit, $(; 335$

(iastun-hepatice, or lesser omentum, !1.5ivolution of, 1(um)

Gistro-phrenic [opm, di:ıphragm] limame m, 9.58 (iastro-splenic omentmm, !his piolution of, If 10 ;

Gemellus [a twin] inferior musle, sisti: varia tions, :37.

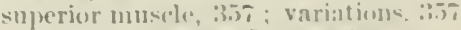

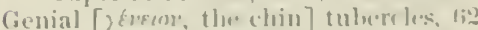

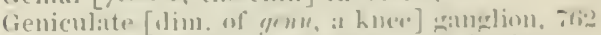

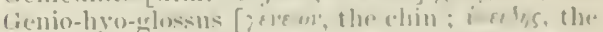

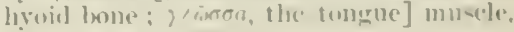
1.5: : mere to, i.is 
(i E.Y

Genio-liyoid muscle, 451 ; nerve to, 75

Genital branch of genito-crural nerve, 8(1)4 corl, 1055

tissure in female, 1068 (r)and, 1055

Genitals, external, development of, 10.5 temale, $10: 38,1129$ male, 1021

Genito-crural nerve, so.

Genito-urinary organs, development of, 1055

Genu of corpus callosmm, 69:? of inner capsule, 701 nervi facialis, 761

Cenua [yени, a knee] of fissmre of Rolaudo, 683

Germinal epithelinm, 105i

(rimberuat's ligament, 404, $113-$

Gingival [gingicx, the gums] arteries of posterior (lental. 496

Giuglymo-arthrodial joints, 178

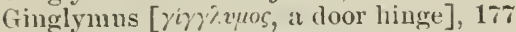

Giraldès, organ of, 1028,1215

Girdle, pectoral, morphology of, 115

Glabella [dim. of glaber, fem. glabru, smooth], $47,81,767$

Gladiolus [dim, of gladius, a sword] sterui, 104

Glaud, carotid, 478

grenital, 1055

lachrymal, $86 \%$

mammary, of temale, 1069

development and abnormalities, 1072

variations accordiug to ace, \&c., 1071

vessels, nerves, aud lymphatics, 1071

of male, 1109

parotid, 946

sublingual, 949, 1095

submaxillary, 948

thymus, 918

throid, 915

Glands of Bartholin, 1040, 1070

of Brumner, 969

cermminons, 1077

ciliary, 1077

of Cowper, 1069

of evelids, 866

lymphatic. see Iymphatic glands

of Xnhn, 886

salivary, the. 946

sebaceous, 1077

of soft palate, 946

solitary, of intestine, 968

sudoriparous, 1077

Glandular (or submaxillary) artery, 487 vein, 614

Glans [an acorn] clitoridis, 1040 penis, $1031,103:$ ?

Glaserian artery, 49:3 fissure, $35,73,97$

Gleno-hnmeral lands, 22

lixament, 224 ; origin from snbclavius, 281

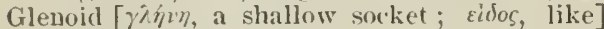
cavity of scapn]a, 113

fussil, 35,73

fossic of finger phalanges, 137

of toe phalimeres, 17:

ligament of interphalangeal joints of foot, 280

of interphalangeal joints of hand, 24i of metacarpo-phalaugeal joints, 243 of shomlder-joint, 2:2.7

lohe of paroticl glamd, 947

Glis=on's capsnle, 98:

Glohus [a ball] major et minor, 1024
GRo

Globus pallidns, 699

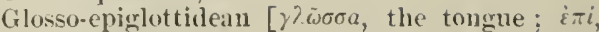

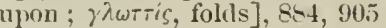
ponch, 884

Glosso-pharyngeal [ $\gamma / \bar{\omega} \sigma \sigma a$, the tomgrue; $\dot{0} \rho v \xi \xi$, plarynx] or ninth cranial nerve, 767

branches, 768 ; loots, 767

communicating brancl from superior cervical ganglion to, 768,828

from vayus to, $\tau 6 \mathcal{Q}, 781$

Glottis [ $\gamma / \omega \pi \tau i s$, the montlipiere of a wind instrnment], the, 909. Sie Larrux

Gluteal [\%ou'os, the bnttock] artery, 569 topograpliy of; 11 s'

inferior, 572

lymphatics, 660,667

nerves, inferior, 810 superior, 810

ridges of temur, 147 of ilinm, 139

reins, 638

Gluteus [Y.7ovtó, the buttock] maximus muscle, 351 ; surgical anatomy of, 1180

medius muscle, 353

minimus muscle, 354

quarius muscle, 459

Goll's columm, 741

Gonion, the, 81

Gower's tract of spinal cord, $\tau 81$

Graafian follicles, 1053

Gracilis [yracilis, sleuder] muscle, 362

Great auricnlar nerve, 784 ; topography of, 1103 cardiac vein, 937

deep petrosal nerve, 75.5, 828

horizontal fissure of cerebellum, 714

longitudinal fissure of cerebrum, 681

occipital nerve, 7 \%9

omentum, 958; evolution of, 1000 ; length of, 958

(anterior) palatine nerve, 756

palmar bursa, 317

prevertebral plexuses, 833

(posterior) sacro-sciatic ligament, 202 origin from biceps femoris, 281

fulciform process of: 202

sciatic nerve, 814 ; topography of, 1180

splanchnic nerve, 832

superficial petrosal nerve, 755

toe, incisions for ampntation of. 1199

transverse fissure of cerel)rum, 682, 702

Greater anterior gastric artery, 556

cornua of hyoid, 66

centres of ossification for, 95

sac of peritonenm, 955

sciatic notch, 140

sigrmoid cavity of ulna, 122

trochanter, 147

tuberosity of humerns, 115

wing of sphenoid, 31

Grey eommissure of cerebrum, 704 matter of cord, 737

of encephaton, 679

in interior of cerebellnm, 716

in medulla, arrangement of, 724

of Sylvian acmeduct, 710

tubercle of liolando, $72: 3$

Groin, superficial fascia of, 111 ?

Groove, antero-lateral, of spinal (ord, 73i

auriculo-ventricular, 927

licipital, 116, 1150

cavernons, 31

eosto-vertehral, 108

digastrie, 3773 
GRO

Groove, etlmmoidal, 49

unfritorbital, 55

interventricular, 927

licluymal, 78

lateval, of erus (evehri, 711

for miklle meningeal artery, 83

musenlo-spiral, 119

mylo-hyoid, $6: 3$

niso-palatiue, 54

obturator, 140)

occipital, 37, 73

oculo motor, of crus cerebri, 711

optic, 30, 8:;

peroneal, of enboid lone, 16i.s

postero-literal, of spinal curl, 735

pterygo-palatime, :3:?

sesimoirl, of first metacarpal, $1: 34$ of first metatarsal, 170

subcostal, 99

for superior longitudinal sinus, 26, s2

umeinate, of mucinate gyrus, 691

Groups of motor cells in spinal cort, $7: 37$

Gubernacular canals, $7:$

Gubermaculum [a rudiler] testis, the, 10:25 development of, 10:7

Gudden's commissure, 746

Guérin, sinns of, 1038

Grims, the, 943

Gustatory [gusto, I taste] artery, 495

Gutbrie, muscle of, $106 \mathrm{j}-$

Gyri [repos, a ring], annectant, 687 operti, 688

Gyrus, angular, 685

fornicatus, or grrus einguli, 690

rectus (straight convolution), 684

uncinate, 683

H.MORRHOIDAL, [ai $\mu a$, blood ; $\dot{\rho} \varepsilon \omega$, I flow]arteries, inferior (external), 574

middle, 570

superior, 562

(rectal) of middle sacral, 564

nerve, inferior, 813

plexus, venous, 63.9

nerve, middle, 837

veins, 639

Ha1r-follicle, 1078

Hairiness, 1215

IIairs, $107 \%$

Half-vertebra (occasioual), 12

Hanular [homus, a hook] process. 33, 72 surgical anatomy of, 1096

Hamulus [dim. of hamus, a hook], 3:3, 72

of cochlea, 42,880

of lachrymal bone, 53

Hand, the, nerve-supply to intermment of dorsum of, 747

skeleton of, 128

surgical anatomy of. 1163

of back of hand, $11 \% 4$

of fuscise aud sheaths of, 1169

skin folds or creases of, 1161

synovial membranes of tentoms of, 1171

of joints of, 1173

thenar and hypothenar eminences of, 1164

Haurlle of mallens, 67

Hard palate, the, 943

Head and face, sinuses of, $109: 3$; surgical anitomy of, 1091
HIP

Heat anel neck, lymphatios of, 6.te veins of, drep, filt

of astragalus, lij sinperticial, 61]

of candiate unclens, 699

of femur, 1.17

of fihula, $15 x$

of himmerns, 115

of mallens, $1 \mathrm{i} 7$

of metacarpal bone, $1: 33$; first, $13 \cdot 1$

of metatarsal lone, 169 ; first, 170

of os magntim. 13:2

of pancreas, $y=-6$

of ratlius, 120

of rilss, is

of stipes, 68

of tilia, $15: 3$

of ulua (lower end), 125

Hean-kidney, or promephros, 1055

Heart, the, $9: 26$

cavities of, $9: 28$

fixtal, peculiarities of, 939

lympliatics of, 658

openings and their valves, 932 topograpliyy of, 935

position of, $9: 26$

relation to chest wall, 1113

size and weight, 927

veins of 610

vessels and nerves, 63:3, 936

Height of average skull, \& $0^{\circ}$

Helicis major et minor muscles, 872

Helicotrenal [ $\dot{\varepsilon} \lambda_{l} \xi$, a spiral; $\tau \rho \dot{j} \mu a$, a hole], the, $8-1$

Helix [ $\dot{\lambda} .\llcorner$, a spiral], the, -70

Hemiazygos vein, 608 accessory, 608

Hemispheral branches of cerebellar arteries, 511, 512

of anterior ('erebral artery, 503 of midlle cerebral, 504 of posterior cerebral, 512

Henle, laver of. $10 \tau$

looperl tule of, 1011

aecessory lichrymal glands of, $\Omega 66^{\circ}$

Hepatic [iratiós, of the liver] artery, 556 variations, 55 \%

of epigastric, superior, 518

of crastrice, 556

of right phrenic, 553

canals, 983

duct, 9-4

lymphatic glauks, 665 ressels, 664

plexus (nerve), 835

reins, $6: 3: 3,982$

Heruia [epros, a luanch]-

parts concerned in femoral, 11:37

inguinal, 1131

mulhilical, 1141

Sce also Femoral, Inguinal, and L'mbilieal

Hey. limament of, 1138

Hey's amputation, incisions for, 1199

Jiatus [a cleft] diaphrammaticus, $100 \mathrm{~m}$

Fallopii, :37, 8:3

sacralis, 15

Irilton, larvingeal musele of, 911

Hilum of corpus dentatum, 710

of kidney. $] 1105$

of ovary, loit;

Hind-kiduey, 10.5)

Hind-liml, $1 \geq 11$

Hipl (innominate) bone, the, 138 
IIP

Hip-lone, development and blood-suplyly of, 144 Hip-joint, arterial aud nerve supply and novements of, 251

ligaments of, 246

muscles in relation to, 251

Hippocampal tissure, 690

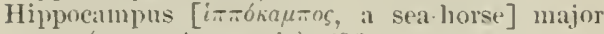
(cornu Ammonis), 696

minor (calcar avis). 6997

Horizontal fissure, great, of cerebellum, 714 r:umus of pubes, 143

section of brain, detinition of, 761 of skull, - -2

Horner's muscle, 867

Huguier, canal of (iter chorda anterins), 32,73 , 97

Humeral artery of acromio-thoracic. 523

Humerus [the shoulder], the, 115 ossification of, 121

topography of, $\mathbf{1 1 5 3}$

Humour, of eye, aqueous, 850 vitreons, 850

Hunter's caual, 1178

Hyaloid [iaios, grlass ; sifos, like] cana], 850

Hsdatid of Morgagni, 1027, 1215

Hymen [i.uin, a membrane], the, 1043

Hyo-epiglotticlean ligament, 905

Hyo-epiglottideus muscle, 459

Hyo-glossus [from attachment to hyoid and tongne, $\gamma \hat{\imath} \sigma \sigma a]$ muscle, 452 ; nerve to, 822

Hroid [ 1 , the Greek letter ; Eidos, like] artery, of lingual [supra-hyoid], 484 bar, 90 of superior thyroid [iutra-hyoid], 482

bone, 66

at birth, 95

origin, 89 ossification. 67

Hypertrichosis, 1215

Hipochoudriac region, 1208

Hypogastric [iró. under; yaoríp, the stomach] artery, 569, 113.5 obliterated, 1213

branch of ilio-hypogastric nerve. 803

plexus (nerve), 8:37

region, 1208

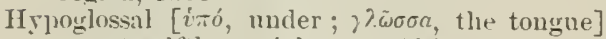
or twelfth erinial nerve, 774

communicating branch to, from vagns, 772 from superior cervical ganglion, 828

membrane. 888

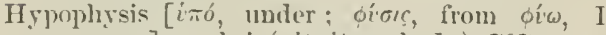
grow] cerehri (pituitury body), 707

IIypothenar [iสó, under; Hźvap, the palm]euninence, 343 : suryical anatomy of, 1165 ; fascia of hand, $33: 3$

ILEO-C.FCA I, fossa, 971

ralve, 971

Ileo-colic artery, 559

Ileum [fỉ ह́w, I twist], tlie. $96 \%$

Iliac [ilia, the flanks] artery of ilio-lumbar, 567

of ohturator, 572

common, 56.4; rollateral direulation, 565,1121 ; topograplyy of, 1121 ; variations, 565

external, 576 ; collateral circulation and variations, 5\% , 1122

lone, 139
IXF

Iliac branch of ilio hypogastric nerve, 803 of last dorsal nerve, 801

crest, 139

tiscia, 348

fossa, 139

lymphatic glands, internal and external, 661 notches, 13:)

portion of fascia lata of thigh, 1138

spines, 139

tuberosity, 139

veins, common, 634 ; tributaries, 634 ; variations, 634

external, 647 ; tribntary, 647

interual, 638 ; tributaries, 638

Iliacus musele, 348 ; nerve to, 807

minor, or ilio-capsularis muscle, 459

Ilio-costalis (sacro-lumbalis) muscle, 415

Ilio femoral hamd, 247

Ilio-hypogastric nerve, 802

Ilio-inguinal nerve, 803

Ilio-lumbar artery, 567

liganent, 199

vein, 634,638

Ilio-pubal ridge. $139,143,146$

Ilio-tibial bank, : $: 45$

Ilio-trochantenc band, 248

Ilium [ilia, the flanks], the, 139

development and blood-supply of, 144

Inpressio colica, 978

duorlenalis, 978

gastric: $: 1,97 \gamma$

petrosa, 691

renalis, 978

suprarenalis, 979

Incisive artery of mandibular, 495

fossa of maxilla (superior maxilla), 5. of mandible (inferior maxilla), 62 nerve of manclibular, 758

Incisor teeth, 87

Incisura [a notch] intertragica, 8\%1 marsupialis, 714 temporalis. 691

Incus [au anvil], 67 ; origin of, 90

Infantile bladder, the, 1021 hernia, 1026

Infraclavicular lymphatic glands, 655

Infracostal artery, lateral, 518

Infracostales (subcostales) [iufia, below ; costa, a rib] muscles, 399

Infra-hyoid artery, 482

Inframandibular (inframaxillary) nerve, 766

Inframarginal (superior temporal) convolutiou of cerebrum, 688

Infra-orbital artery, 496

camal, 55, 97

foramen, 55,97

groove, 5.5

nerve, 764

plexus (nerve), 755,765

Infrarimal [rima, a chink] portion of laynx, 911,913

Infrascapular artery of lorsal scapular, 52.5

Infra-spinatus muscle, 302

Infraspinous artery of posterior scapular, 516 of suprascapular, 515 fossa, 111

Infratrochlear nerve, 752

Infundibula [infunlibulum, a finmel] of kidney, 1014

Infundibuliform or intermal spermatic fascia, $40 \tau, 1024$

Infundibulum [a funnel], or conus arteriosus, $80,9: 31$ 
INF

Infundibulum of brain, $70 \%$

of cochlea, 881

of ethmoid, 50

Iuguinal [inguen, the groin] canal, 1132

heruia, causes of, 1136

coverings of:, 1132

parts concermel in, 1131

lymphatic glauds, deep. $61 ;-x$

supertivial, 66it

region, 1208

Inion [iviov, the occiput], the, $70,10-0$

Inlet of pelvis, 145

thoracic, 108

Innominate artery, 474; topograplyy of, 1114 ; variations, 47.

bone (see Ilip-bone), 138

veins, right and left, 603 ; variations, 601.5; topouraphy of, $111: 3$

Interarticular filsro-eartilace of acromio-claricular joint, 219

of knee-joiut (semilunar), 2.58

of sterno-elavieular joint, 218

of temporo-mandihular (maxillary joint), 180

ligament of chondro-sternal joints, 214 of costr)-central joints, 2112

Intercaveruous sinuses of cranium, $6 * 1$

Iuterehondral artienlations, 214

Interclavicular ligament, 217

muscle, 459

moteh, 104

Interclinoill limament, 33

Interoceyeal articulations, 205

Intercolumnar or exterual spermatic fascia, 406, $10 \cdot 23,1131$

fibres of exterual abdominal ring, 106

Intercondyloid not (h of femur, 150

Intercostal [inter, betweeu; eosta, a rib] arteries-

auterior, of interual mammary, $51 \tau$

aortic, $5+8$ of musculo-phrenic, 5 \} $\alpha$

collateral, of aortic, 54 ?

superior, 518

first, of superior, 519

Iymphatics, 656

lymphatic glands, 657

museles, external. :395

internal, 39.5

action of, 396

nerves, lower, 801 ; upper, 79.5

space, structures $j \mathrm{in}, 1110$

veins, left lower superior, $605,60 \%$

left upper superior, $6 t 1.8$

right superior, lower and upper, $60 x$

Intercunefform joints, $2 \%$

Interior of skull, 81

Interlobar fissures of cerebrum, 68]

Intermetacarpal articulations, : $: 42$

Intermetatarsal articulations. :?!

Intermuseular septa of the sole, :37\% of upper arm, :30ti

Interossei [inter, hetween; os, a hom nuscles of firt, dorsal, 385

$$
\text { plautar, } 385
$$

of hand, dorsal, 338

$$
\text { palmar, } 337
$$

Interossenus artery, anterior and pusterior, 533 common, 533

surgieal anatoms of, $11\left(i^{\circ}\right)$

dorsal, of foot, (ini) of laand, 5.11

palmar, $54+4$
INT

Interossions attery, recurrent, 53.7

cartilatge of sacm ilial syolomolroxis, 202 of sympluysis julis, 207

fibro-cartilages of (arpal joints, 237

liganents of calcane(1)-astragalonil juint, anterior and postorior, 2tis

of ealeaneo-culwisl joint, :274

(1) calou-metararpal joints, 2'-11

of (alpus, $2: 35$

of (1nle)-('uncilorm joints, 272

of culx-metatarsil joint, a.jo

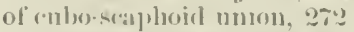

of intremeiform joints, :27:

of interuetarespul joints, $24: 3$

of interuletatarsal juints, 27!

of milklle tarso-metatarsil joint, 2\%

of outer tarso-metatirsal (cubo-meta-

tarwal joint 1, :

of inlerior tibin-fitmlar joint (inferions interossenus ligament !, 26t;

of superior tubio-fibular juint (superior interosseous ligament), :21;1

membrane, radio ulnar, 231

nerve, anterior, $7 ! \cdot)$ tibio-tibular, $2(j 4$

wosterior, $7 ! 5$

ridge of tilmla, 158

Interossens mimus voluris muscle, 459

Interparietal segment of squanu-orcipital bone, $25, \quad 1: 209$

Iuterphalangral joints, 245, 2811

Intersigmoil fossa. 9\%.t

Interspace, perincal, deep, $106 \mathrm{i}$

Interspinales muscles, $42: 3$ superticial, 10 iri

interspinous ligaments, 196

Intertransversiles museles, $4: 3$

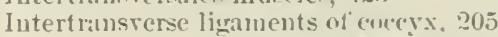
of spiue. 197

Intertrochanteric line. anterior, 14 ; [osterior, 14\%

Intercentricular artery, anterior, 473. 9:3 posterior, 473. y:3\%

groove, 927

vein, anterior, 6111 posterior. (j10, 9:3i

Intervertelial substance of silero-cocregeal juint, 2114

of spine, 1!m ; origin from notorlumerl, $\because-1$

Intestinal arterins of superior mesenteric, ifio

(amal, rotation of, 99. .

lymplatic glancls, $663:$ trunk, tifit

Jymphatics (lacteals), 66i-1

Intestine, larers, !ni!

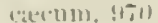

ileo-recal valve, !)

vermitom :1 ym-mlix, !)

(rolun, $4 \%: 3$

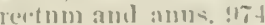

liloml supply atrel structurte of.

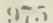

-miall,

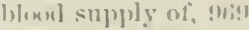

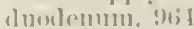

j.jumแm and jl.1um, !1:

i) unpluatios of, !li!

nielevest, !ni?

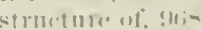

Intestines, topmor:tplyy of. 111 in

Intmalumisplueric nerve filores, -ti

Intrajarictal tio-mene of cerelorum, \i-h 
Intraspinal rejus, (i2!)

Intrinsic nuscles of larynx, 908 of tollywe, s-o

Iris [ $\iota p$ s, the raiubuw], the, 848 [ymplatic spaces in, 853 zones of, $84 \%$

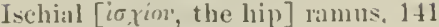
tuberosity, 141

Ischiatic spine, 140

Ischio-cavernosus (erector peuis) muscle, 1034, 1079

Ischio-femoral band. $21 \%$

Ischio-rectal (or anal) liscia, 1063 fossie, 1064; surgical anatomy of, 1127 region, 1053 segment of olsturator fiscia, 1061

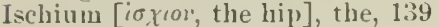
development of, 144

Islant? of Rieil, 688

Isthnie border of thyroid eartilage, 902

Isthmus [a neck] of Fallopian tube, 1051 of fauces, 944,1097

of errorus formicatus, 691

of middle fossa of l)ise of skull, 83

of thyroid, 916

of uterus, 1044

Iter [a route] e tertio ad (quartum ventriculum, \%10

chorda anterius (Hugnier), 97, 875

posterius, $41,9 \%, 8 \% 5$

JAcobsos, nerre of ( $\mathrm{tympanie}$ of glosso-pharyngeal), $76-891$

Jacobsonian eartilages of nose, 891

$J_{i l w}$, lower, sce Mandible upper, sce Maxilla

Jejumun [jejunus, empty], 967

Joints, movements of, 179 structures entering into formation of, 176 varieties of, $17 \%$

See Articulation, for indiviclual joints

Jugular [jugulum, the throat] foramen, 73,86 , 96

fossil, 37,73

ganglion of glosso-pharyngeal, 768

process of ex-oceipital, 26

surface of temporal bone, 37

veins, anterior, 617,1100

external, 616 ; variatious, 617 ; topography of, 1103

internal, 627

posterior, 617

Juculo-rephalie vein, 643

Jugum [a yoke] sphenoidale, 34

KERATO-HYALIX, $10 \% 5$

Kerrto-thyonid muscle, 459

key and lietzius, foramina of, 718

Kidney, the, 1005

exeretory duct of, 1014

heatl-, or pronephros, 105.5

hind-, or metanepliros, 1055

investment and fixation of , 1006

lymphatics of, 665

inill-, or mesomephros, 105.5

nerves of, 1012

blysical characters of, 100 \%

position atul relations of, 1006

structure of, 1010

topourapliy of, 1119

varieties of, 1012
Kidney, ressels of, 1011

Knee-joint, arterial aud uerve supply of, 259

ligaments of, 254

movements of, $2(60$

surgical amatomy of, 1182

symovial membrane of, extent, \&c., 1185

Krause, end-bulbs of, 1076

LABIA [plural of labium, a lip] of cervix uteri, 1046

mạjora, 1038, 1129

minora, 1038,112 ?

Labial artery, inferior, 487

nerves of maxillary, 754

vein, inferior and superior, 613

Labyrinth [7aßíputos, a maze], or internal ear, 879

membranous, 881

osseous, 879

(lateral mass) of etbmoid, 49

Lacerated [lucerum, ragged] forameu, middle, or sphenotic, 83

Lachrymal [lachryma, a tear] artery, 499 of middle meningeal, 494 of nasal, 502

bones, 53

eaual, 868

caualienli, 868

carunele, 840

duct, 55,76

fossa, 47,77

gland, 868

$$
\text { aecessory (Henle), } 867
$$

nerve, 752, 865

papilla, 840

passages, method of probing, 1095

process of inferior turbinal, 53

puncta, 840,868 position of, 109

sac, 868 ; surgical anatomy of, 1094

suleus, 53,78

tuberele, 57

vein, 626

Lachrymo-ethmoidal cells, 50

Lacteals [lac, milk], the (intestinal lymphatics), 664

Lactiferous [lac, milk; fero, I bear] or galactophorous lucts, 1070

Lacuna [lacus, a lake] magna of urethra, 1038

Lacunx of wrethra, 1038

Lambda [ 1 , the Greek letter], the, 69, 1080

Lambdoid [from its resemblance to the Greek letter $\Lambda$; $\varepsilon^{\top} \delta$ dos, like] suture, 44

Lamina [a layer] cinerea, 708

cornea of lateral ventricle, 700

eribrosa of eye, 842,845

elastic, posterior, 846

quadrigemina, 708

spiralis, 880,881

terniualis, 670

Lamina of eervical vertebre, 7, 11

of lumbar vertebre, 12

of sacrum, 15

of typical vertebre, 6

Laminated tubercle (or nodule) of eerebcllum, 715

Lamıgo, 1078

Larue cavernous nerve, 839 intestine, 969

lymphatics of, 664

Laryngeal arteries of inferior thyroid, inferior, 51.1 
I.A IL

Laryngeal arteries of superior thyroid, superior and interior, $4 \times 2,48:$

lymplatics, rleep, 65:

nerves, inferior or recurrent, \%? siperior, 77:

pouch, 911

veins, 627

Larynx [’ápè,, the larynx], the, 901

(artilages of, 901

interior of. 910

joints of, 907

ligaments of, 906

lymphaties of, 652,913

uncous membrane of: 910

nerves and blood-ressels of, 913

supra- and infra rimal portions of, 911

ventricle of, 911

Lateral area of medulla ohlongata, $7: 2: 3$

cartiliges of nose, 890

column of medulla oblongata, 72:2

cutaueous arteries of aortic intercostal, 550 nerves of abdomen, 800 of thorax, 800

depressions of middle fossa of skull, 83

groove of crus cerebri, ill

ground bundle of spinal cord, 738

horn of spinal cord, 737

ligameuts of ankle-joint, 267

of elbow-joint, 227

of interphalangeal joints of fingers, 24;

of kuce-joint, 254

of toes, 280

of liver, $98:$ ?

of metacarpo-phalangeal joiuts, 243

of metatarso-phalangeal joints, 279

occipito-atlantal, 183

oecipito-odontoid. 1 -8

of temporo-mandibular (maxillary) articulation, 180

of uterus, 1048

vertebral (short) 194

of wrist-joint, $: 235$

mass of atlas, 7

of etlumoid, 49

mixed zone of spinal cord, 738

nasal artery, 488

cartilages, 927 ; origin of, 96

pyramidal tract of cord, 737

root of auditory nerre, 766

sacral arteries, superior and inferior, 567

veins, 638

of midlle saeral, 564

sinuses of cranium, 621

spinal arteries of vertebral, 510

ventricles, 694

Latissimus [broadest] dorsi (of the lack) muscle, 292,1142

Leg, eutaueous nerves of, 823 surgical anatomy of, 1188

reins of, 616

vessels of, topography, 1191

Lens [a lentil], erystalliue, the, 845,849

(apsule of. 845

equator of, 849

poles, 849

Lenticular [lms, lenlis, a lentil] ganglion, 75\%, $x 6: 3$

Lesser anterior gastric artery, 556

cornua of hyoid. 66

occipital nerve, 783

omentum, 958

panereas, 986

posterior gastric arters, 5.5 6
I.IS;

Lesser sac of peritonem, 9.5, !.: sizmonl ("ivity of ulna, 1.:;

splanchuic nerve, -31

sulerficial petrosil nerve, if?

truchinter, 1.17

tuberosity of humerts, 11.5

rentre of ossification for, 121

wing of splenoill, :31

Levator [lemir, to lift up] anguli oris musele, $4: 37$

anguli sapulae muscle, :29n

ani musele, 106il ; nerse to, 80s

cluricula muste, 16it

glandula thyrouilear moscle, 460

lahii superioris musele, 438 alectuc uasi muscle, 43x, 691

menti [uentum, the ihiu], or levator labii inforioris muscle, 4.10

palati muscle, 144

palpebric superioris muscle, 856

Levitores costarmu nuscles, 395

Licentaud, uvula of, 101!s

Ligament, or Ligament. [ligure, to binu]alar, of the knee, isy

annular, of : mkle ; anterior, 368 ; extermal, $3(; !)$; intermal, 369

of wrist, anterior, 311: surgical anatomy of, 116 - : posterior, 311 . surcrical anatomy of, $1166 ;$

ast raualo scaphoicl, 274

of astracalus, 162

atlanto-ixoi(lean, anterior, 185; posterior,

$1 \times 5 ;$ transverse, $1 \leqslant 6$

of auricle, anterior and posterior, -71

of bladder, false and true, 1018

broad, of liver, 9x"y

of uterus, 10.13

calcaneo-astragaloid, antero-interual, 270 exterual, 270; interual, :69; interosse. 0us. :269; posterior, 269

calcaneo-cuboid, inferior (loug aud sbort) and internil, 2 it

calcaneo-scaplobil, external, 270 inferior, 273

of ealcaneum, 164

capsular, see Capsular ligament

cartico-clinois], of sphenoid, 34

carpal (lorsil, 237 pilmar, 237, 23-

carpo-metacarpal, dorsil aud palmar, 241, 2.12

cervico-hasilar, Iss

clicek, of eyelall, exterual and intermal, -60 of spine, 188

chomlro-sternal, anterior, 213

posterior, inferior, and supcrior, 213

chonilru-xiphoid, 212

of rlavicle, 111

(ummun, of vertelire, anteriur, 193

pusterior, 19:3

(omuid, :2:11

coraco-aterumial, 221

corac(o-clavicular, 200

(oraco-linumeral, (2).1

cor:moicl, 221

corounry, of knee, 259

of liver, $9-2$

contu-central (or-tellate), anterior, : 20

costo-clanicular, or rbomlnois, 21 -

costo-colic, 173

costo-coracoisl, 294: origin of: $11 . \overline{1}$

costo) transverse, middle, oll; postelior,

211 : superior, 211 
LIG

Ligriment, or Ligaments(otyloit, 249

(rico-thyroid, ?)

crueial, of central atlantu-axuidean joint, 186 of knee-joint, 25\%

cubo-cuneiform, dorsal, interosseous, and plantar, 272

cubo-metatarsal, dorsal, 278; plimtar, 278; iuterosseons, 2Ts

culo-scaphoil, dorsal, interosseons, and plantar, $271,27:$

of cuboid, $166 ;$

deltoil, of ankle, 267

lorsal, of carpus, $2: 3 \tilde{z}$

fitciform, of fisceia lata of thigh, 345,1138

femoral, 1138

of femur, 152

of filula, 159

gastro-phrenic, 958

of Gimberuat, 404, 1138

glenoid, of interphalangeal joints of foot, $2<0$

of liand, 245

of metacarpo-phalangeal joints, 243

of shoulder-joint, 225

gleno-humeral, $2: 24$

of Hey, 1138

of hip-bone, 143

of lummerus, 120

hyo epiglottidean, 905

ilio-femoral, 247

ilio-lumbar, 199

ilio-trochanteric, 248

of incus, 39, 87

infrapubic, 206

interarticular, of costo central articulation, $: 21,8$

of chondro-sternal articnlation, 214

interclavicular, 217

interclinoid, of sphenoid, 3:3

intercuneiform, dorsal, interosseous, and plantar, 272

intermetacarpal, dorsal, and palmar, 242

intermetatarsal, dorsal, interosseous, and plantar, 279

interosseous, of calcaneo-astragaloid joint, anterior, 270

posterior, 269

of calcanco-culsoid joint, $2 \pi .4$

of carpo-metacarpal joint, 241

of carpus, $2: 38$

of costo-transverse artiıulatiou, 211

of cubo-cuueiform joints, $27 \%$

of cubo-metatarsal joints, :7\%

of cubo-scapluoitl nuion, $27 \%$

of intercuneiform joints, 27:

of intermetacarpal joints, 243

of intermetatarsal joints, 279

of sincro-iliac joint, $20 \%$

of t:urso-metatarsal joint, middle, $27 \%$ outer, 278

of tilso fibular joints, inferior, 266 snperior, 264

interphalangeal, of tingrers, 245

of toes, $2 \times 0$

interspinous, 196

intertransverse of cocerx, :(1). of spine, 197

intervertebral, 190

of larynx, extrinsie and intrinsic. 90.)

lateral, of ankle, $2(j i)$

of ellow, 227

of interphalongeal joints of foot, 280
LIC:

Ligament, or Ligaments-

lateral, of interphalangeal joints of hand, 245 of knec-joint, 254

of liver, 982

of metacarpo-phalangeal joints, 243

of uetatarso-phalancreal joints, 299

of temporo-mandibular (maxillary) articulation, 180

of uterus, 10 to

of vertebre (short vertebral), 194

of wrist or ralio-carpal joint, 235

of liver, 98:

medio-carpal, anterior and posterior, 239

metacarpal, $24: 3$

metacarpo-phalaugeal, 24:3

Inetutirsal, 278

metatarso-phalangeal, 279

oblique, of middle radio-ulnar articulation, 230

oliturator, of stapes, 878

occipito-atlantal, asterior, 183 ; oblique, 183 ;

lateral, 183; posterior, 183

occipito-cervical, 188

occipito-odoutoid, see odontoid

odoutoid, central or snspensory, 188 check or lateral, 180

orbicular, of radius, 230

orloito-tarsal, 858

of os calcis, 164

of the ovaries, 1051, 1214

palmar, of carpus, 237,238

palpebral, $86 \%$

petro sphenoidal, 39

phreno-colic, 958

plantar, long and short, 275

posterior, of aukle. $26 \%$

of carpus, 237, 239

of elbow, $2: 27$

of knee, 255

of wrist, 234

of Ponpart, 404, 1114, 1138

surgical anatomy of, 1174

proper, of the scapnla, 2.21

pterygo-spinous, of sphenoid, 34

pubic, anterior, 206; interior, 206 ; pos-

terior, 205; superior, 20.5

pho-prostatic, 1018

radio-carpal, anterior and posterior, 234

radio-nlnar, anterior and posterior, 232

of radius, 128

recto-nterime, 1049

rhomboid, or costo-clavicular, 218

roumd, of liver, 982,1213

of uterus, 1050,1214

sacro roccygeal, anterior, 204 ; posterior, 205

sacro-iliae, 201

sacro-lumbar, 199

sacro-sciatic, great, or posterior, 202 small, $20 \%$

scaplio-cuneiform. 272

of scaphoid (tarsal) bone, 167

of scapula, 114, 221

of sphenoid, 34

spheno-mandihular (maxillary), $1=0$

spino-glenoid, 22:?

stellate, or anterior costo-centual, 208

sterno-clavicular, anterior, 217 ; posterior, 216

sterno-pericardial, 9:25

of sternum, 106;

stylo-hyoid, 3!)

stylo-mandihular (maxillary), 180

supricormual, of coceyx, $20 \%$ 
I.I :

Ligament, or Ligaments-

suprascapular, or transverse, 2:21

supraspinous, of ('oceyx, 30 ).

of vertehise, 195

suspensory, central odontoid, 188 : origin of, 281

of evelsill, 8jo

of lens, $\times 15,850$

of malleus, 67,877

of penis, 1032

of thyroid gland, 917

tarsil, external, 429)

intermal [tenclo oculi], 42y

tarso-metatarsal, 277

thyro-arytenoid, inferior and superior, $9060^{\circ}$

thyro-epiglot tillean, 905

thivo-liyoiri, 906

of tiliai, 1 iso

tibio-fibular, anterior and posterior, 2(i-1 anterior and posterior inferior, 20iti

transverse, of central atlanto axoillean joint, $181 i$

dorsal, of medio-carpal joint, 2:3!)

of hearls of metacirpals, 24 ; of metatarsals, 279

of hip, 249

lumeral, 225

of inferior tibio-fibular articulation, 266

of kilee-joint, 259

of larynx, or (rico-arytenoil, 906

of seapula, 221; inferior, 22:2

superficial, of palmar fascia, 333 of plantar fiscia, 106?

trapezois, 220

triangular, of urethra, inferior (anterior layer of), 1066

superior or deep (posterior

of ulna, 125 layer), 1065

utero-jnguinal, 1050

utero-pelvic, $1(15)$

utero-sicral, 949, 1051

utero-resical, 104!?

of uterus, muscular, 1050 peritoneal, 1047

of Winslow, 255

Ligamellta brevia of hand, 333

longa of tingers, 333

sulflava of spine, 194 ; functions of , 192

vatuinalia of tingers, 3333

Ligamentous artery of ovarian, $5(x)$

Ligamentum arcuatum externum, $399,4(1)$

denticulatum, 7:3:3 internum, 349

cluctus arteriosus, 1213 venos!1s, 121.4

infumlibulo.pelvicum, 104 ช

latum pulmonis, 9:1

mucosum, 2in!)

Nuchir, $196,2-2,1250$

patellie, 367 ; surgieal anatomy or, 11-1

pectinatum iriolis, -40

teres [round], 249 ; origin of, $2-1$

Winslowii, 2in

Lignlat of fontly rentricle, ils

Limbic lobe of cerehrom, (i9) 2

Limbus [a border], corneal, 246

Limen [a threshold] insulac, bis

Line condylar, of temur, imner and onter, 1 in intertrochanteric, of femur, anterior, $14 \%$ : posterior, 1.17

naso-lambioidal, $: \because 7$
I.11B

Iine, Nélaton's, 1173

nuchal, iuferior, 2.5 : micllle, 25; superior, $\because 3$

obliyne, of (clavicle, 1(t)

of mamblible (interior maxilla), (ja)

of ranlius, 120i

spiril, "1' fomule, 117

white, of obturator fiascial, loli]

Linea [a line] allat [white], 401, 1111: vister: behind, 1117

asperat [mole 1,117

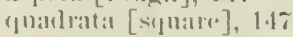

semilnuaris, for ; sm revical anstomy ofi, 111.1

splendens [shining], 7:29

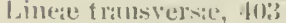

Lingrial [limgun, the tongue] artery, 4-3. 110:of mandilublar (inferior dental), 4his

lone (xer IIyoid), 66

glands of mueoms membrane, sir.

Iymplattic (glamds, 6is?

nerve [gustatory], 759; methods of diviling, 1095

of tilcial, ofi.

of glosso phatymgeal, 7 (i9)

vein, 1037

lingnalis muscle, superior and inlerior, who

Lingula [dim. of lingma, a tongue] of cerehellum, 714

of splewoil, 31 : at hirth, 93

Lips, the upper and lower, !) 1 ?

of hicipital groove, 116

of iliac (rest, 1:3!)

Lisfrane's amputation, incisions for, 1199 tubercle on dilst rib, 1011

Lissaner, bonndary zone of, $7+1$

Lithotomy, lateril, parts ('it durime operation of, $112:$ :

Liver. tha, !5t;

blood-ressels, 982

general position, 979

ligaments, (1)?

lymplatics of, deep, 704

relations, 981

silperticial, 7113

structure, $48 ; 3$

topograplyy of, 111 \%

varieties, !181;

weicht of, 976

Lobes of cerchellum, biventral, 715

hocenlus, 715

posterior, 71 t

quallate, 714

sionsler, 714

tomsillar, 715

of cerehrum, s-

rentril (island of lieil). tive

filleifirm, (i)1

frumtal. (is-1

limblice, 69:2

aceipital, 6i;

olfuctory, ti-4

pariet:al, $6,-i$

temproml (temporo-sphemoidal), di-t

of liver, eamclate, ! 1 ,

y lualuate, 177

Sirgelian, 979

of lung. [s:?

of theruid. !ls

Lobule of cerehellmu, thatrafe:mel posterior. ilt

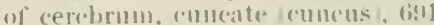

faracentral. 1;901

"ylialrate (pricrumens), 691

silperior parietal. $6-6 j$ 
LOB

I.oluule of ear, -07 of testis, 10:\%

Lobulus centralis of cerebellum, 711 gracilis of cerchellim, 71. lingualis, 691

Locus [a spot] ceruleus [blue] of fourth ventricle, 719

Iong buceal nerve, 757 ciliary nerves, $75: 2$

(or midhle) subseapular nerves, 788

(or terminal) branches of brachial plexus, 788

(or interual) saphenous nerre, sis

pudendal nerve. 81:

root (seusory) of lenticular ganglion, 752

thoracic artery, 5:23

Loncrissimus [longest] dorsi [of the back] musele, 417

Longitudinal bundle of mesencephalonposterior: 713 superior, 715

fissure. great, of cerehrmm, 681 of liver, $97 \%$

sinuses of craninm, inferior (inferior sagittal), $9: 21$

superior (superior sagittal), 619

spinal veins, anterior and posterior, 630

Longus colli muscle, $45 \%$; nerves to, 785,788

Looped tube of Henle, 1011

Lower, tubercle of, 930

Lumbar arteries, 553 ; variations, $55 t$ of ilio-lumbar, 56 \%

colotoms, laudnurks for, 1119

ealargement of cold, 734

fascia, 408,1146

lymphatic glauds, 661 trunk, 66:

nerves, anterior primary divisions of, 802 posterior primary divisions of, 781

plexus, s0:2 ; branches, 802

portion of gangliated cord, 833

regiou, 1208

ribs, 103

veins, 632 asceuding, 633

vertehrie, 12,13 ossification of, 21

Lumbricales [lumbricus, an earthworm] muscles of foot. $3 \times 2$ of haud, 335

Lung, the, 920

Jymphatics of, 658

relations to chest-wall, 1111

ront of, structures forming, 923 relation of structures in, 923

structure of, 924

vessels, nerves, aud lymphatics of, 924 weight, 923

Innulse [dim. of 7ma, the moon], the, 932

Lympluatic [lymplu, water] duct, right, 648 , 65.3

glands of abdomen and pelvis, parietal, 661 , 662

visceral, 66

aortic, or median lumbar, 662

auricular, posterior, 649,1107

axillary, 6isi

bronclial, 650

buccal, (it!)

carliae, 658

('ervic'al, upper ambl lower, 65:3 superficial chain, 65

('oliac, 66:)
LYM

I.ymplatic glands, epigastric, 657

epitrochlear, 65.j

of extremity, lower, deep, 668 superficial, $66 \%$

11pper, deep, 655 superticial, 65.5

facial, deep, 6.53

femoral, deep. 668 superficial, 667

gastric, inferior, 66 it superior, 663

gast ro epiploic, 664

of head and neck. deep, (i.:) superficial, 649

hepatic, 665

iliac, internal and exterual, $6(61$

infraclavieular, 65 :

inguinal, deep, 668 oblique and vertical, 667

intercostal, anterior and posterior, 6.7\%

lingual, (652

lumbar, median aud lateral, (i62

mammary, interual, 657

maxillary, interual, 653

merliastiual, 6.58

mesenterie, 664

meso-colic, 664

occipital. 649,1107

parotid, 649

pectoral, 655

popliteal, 668 ; surrieal anatomy, 1206

post-pharyngeal, 653

psoas, or tramsverse lumbar, 662

pnlmonary, 658

sacral, 661

sapheuous, or superficial femoral, 667 splenic, 665

sterual, or anterior intercostal, 657 or anterior mediastinal, 658

sterno-mastoid, 649

of stomacl, 66:3, 999

subelavian, 655

submaxillary, 650

suboceipital, 649,110 T

sulsseapular, 655

suprahyoid, $650,110 \mathrm{R}$

of thorax, parietal, $65 \%$

tracheal, 658 visceral, 658

system (or spaces) of eyehall, 861

of orbit. 86

Lymplıatics, the, 648

of abdomen and pelris, parietal, deep, 661

visceral, 662

superficial, 660

of bladder, 662

of brain, $651,6 \% R$

boncho-mediastinal trunk, 65\%, $65 \overline{2}$

diaplragmatic, 656

of extremity, lower, deep, 668 superficial, $66 \%$

11]per, deep, $6 \overline{5} 5$ superficial, 6.5.5

of eychall, 861

of eyelids, 867

of face, 649

of Fallopian tubes, 662,1054

uluteal, 660, 667

of head and neck, deep, 6.i1

smperficial, 649

of heart, 658

intercostal, 656

intestinal trunk, 664 
LYM

Lymphatics-

of intestine, large, 661, !) small, $6(64$, (n)

of kidneys, 6(iis, 101:

of laryux, 65: 912

of liver, (leep, 66.i, 704 superfieial, 6it., 70):3

of linmg, 658, 9:4

of mammary gland, 6is;

meningeal, 651

of montl and tongure, (iis)

of neck, 64!)

of nose, 651, 8!1

of asophagus, 6533 , $155^{2}$

of orbit, 651

of ovaries, 66? 1054

of pancreas, 665,987

of pelvis, 661

of penis, $661,10: 35$

of pericarlinm, 658

of perinsum, 661

of pharynx, 6i:2

of prostate, 1023

pudie, 1067

of reetum, 662

of sealp, 649

of serotum, 661, 1012t

of spinal core, 678

of spleen, 665,9911

of stomach, 663,964

of suprarenals, 665,1014

of temporal foss:1, 651

of testicle, 662, 1030

of thorax, parietal, deep, (6.5) superficial, 650

of thymus, 6.58 visceral, 6.5

of thy roid, 652

of tongue, 65:2

of tracliea, 652

of ureters, 665,1016

of uterus, $662,105$.

of vagina, 66 ?

of vas delerens, 1031

of zygomatic fossa, 651

Iymphoid tissme of tongue, 88\%

Iyre, the, of formix. 701

MACULA [a spot] lutea [yellow], 84t

Magnum [ureat], toramell, 27 os, $13: 3$

Majendic, foramen of; $6 \pi \%, \pi 18$

Malar [mala, the cheek]-

bone, 61

ossification of, $6: 2$; at birth, 95

canals, 61, y7

centre of ossifieation of mixilla, $\bar{j}$ -

nerve of temporo-facial, 764

of temporo-malar, 754

process of maxilla, 57

Male breast, 107

pelvis, 146

reproductive organs, 1021

Malleolar arteries of anterior tibial, 592

fossa of tibula, 150

of posterior tibial, 593

Malleolus [rlim. of malleus, a bamuer] of fibula, external, 158; development of; 15 !) ; nur greal anatomy of, 1194

of tibia, intermal, 153,156

Malleus [a hammer], the. 67 ; origin of, 90

Malo-maxillary suture, 77
II A X

Malpighi, pyramirls of, 10111

Ilanmat [the breast], the female, 10 (bi)

development and absuormalitien, 10\%:-

Iymphaties of, (i.ili. 1051

surrical anatumy of, 1110

variations acompling to age, de, 1171

vessels and nerves, 1071

milile, $10 \% \mathrm{ro}$

lymphatics of, 'jixli, 10:1

Mammie, superummerary, 1:215

M:amuary artery, external, 5:::3

interusl, 516, 1114

ndouslular arterios of aurtic interrostals, -in)

lymphatic oflunds, internal, tis

veins, internal, (ios)

Mammilla [nipfle], 106:); abnormalities, 107]

Mammillary processes of vertel)ra, 1:

Hanclible (or mferior maxilla), ti2 ossilication, 64

at birth, (15)

Mandibular [mando, 1 chew] artery, or interior dental, 19]

batr, !l

(a)tal, 6:3

division of fith nerve, Tisti

for:ment, 63

gland (sulmaxillary), !) l!

nerve, or interior dental, $\%$ -

spine, li:3

vein, (ill;

Mamubrimm [a limolle] of malleus, 67 of sternum, 104 ; structures hehind, 1111

Marginal arteries, right and left, $9: 36 ;$

convolution of rerebrum, $69(4)$

sinuses of ('r:ulum, $6: 20)$

reins, right and le1t, 611,937

Margino-frontal artery of anterior cerebral, is)3

Margo [margin] acutus [s]arj!] of leart, !si] obtusus [blunt], !1:22

Marshall, oblicfue vein of, $92(6,939 !)$

Misseter [uaconoua, to (b)w] muscle, 4.11

Masseteric artery of facial, $1-5$

fiscia, 411)

of internal maxillary, 4 !s

of temporal, 491

nerve, 757

vein, 614,616

Mrastoid [unotós, a nipple; eifos, like] antrum, 40, 1083 ; development of, 44

artery, mirlale, $4-2$

of occipital, 4 ())

of posterior aurienlar, 490

of st plo-luastoid, 490

cells, 40 ; entissary veins from, $111-1$

fortumen, 7is, -

nerve of lexis uccipital, $;->3$

process, :37. 7:: ; development of 4.4

sinuses, the, $111-2$

vein (emisciry), $6: 2,2,1 ; 2$

Maxilla [check bune], or sllperior maxilla, in uscification, jo

at hirth, !n

For Inferior maxilla, se Mabdible

Naxillary antrum, is

artery, exterual (liccial), $f-5$ )

interual, $1 ! \%$

centre oi ossitication, i-

tissure, 56

interior (mandibular division with merse, 756

lymphottie glamls, intermal, tiot:

iserves, recurrent, 7.3.3

process of interior turbinal bune, 73 
$\operatorname{Mix}$

Maxillary process of malar hone, fil of palate lone, 59

sinus (antrum), 52

(superion maxillary) division of tith nerve, 7 isi

tuberosity, 5.5, 7.?

vein, anterior, (il)

interual, (il.)

Maxillo-premaxillary suture, 56,72

Meatal [mentus, a passiage] artery, 490 nerves, 750

Meatus, aulitory, external, : $2,73,909$ interual, $36,8(i, 96$

urinary, external, 1033, 1038

internal, 1018, 1037

relation to pelvic wall, $1(11$ -

Mentuses of nose, 57,894 ; orifices in, 80

Meckel's cave, 37

diverticulum [diverto, I turn aside], 967

gauglion [nasil or spheno-palatine], 756 roots iud brauches, 756 space, in dura mater, 673

Median artery [comes nervi mediani], 53:3 furrow of loack, 1142

lymphatic glands (aortic lumbar), 66:2 nerve, 790

in arm, surgical anatomy of, 1154

in forearm, surgical anitomy of, 1161

plexus, renons, anterior, $6+1$

raphe of tongue, 8xt

Median [from Arabic at-maljan, vein of Madjan] vein, deep, 641,643

superficial, $6+1$

basilic, $6+1$

cephalic, $6+1$

Merliastinal, or thymic arteries, 517

lymphatic glinds, $65 \mathrm{~s}$

veins, 434

Mediastinum [molius, the middle; sto, I staud] of thorax, anterior, 901

middle, 901

posterior, 901

testis, 1026

superior, 900

Medin-tarsal joints, 273 ; movements of, 276

Medulla [marrow, trom melius, middle] of kidney, 1010

olylongata, the, $670,7: 0$

fissures of, 721

internal structure of, 721

veins of, 625

Merinlary laminae of lenticular moleus, 699

veins, 630

velum, inferior, 715,718

superior, 718

Meralli-spinal veins, 630

Ieilomian follicles, हैil

If issuer, tactile conpuscles of, 1076

Membrana [the skin of an animal] basilaris, $107 \overline{5}$

of corhlea, 883

Slirapuelli, 874

suprachoroiclea, $8.15,846$

tympani, 87:3 ; structnre of, 874

Membrane, Bowman's, 816

of Bruch, 846

(rico-tlyyroid, 906

Descemet's, 8.16

hypoglossal, $8 \times 2$

of Reissner, हर:?

Sclumeiderian, 8!:3

thyro-hyoid. 905

of trachea, 913
MFT

Membranous canal of cochlea, 883

eranimm, 8!

lahyrintll, the, 881

urethra, 1037, 1106

Meningeal [uim, ascending phatryngeal, 4*\%, 673

of ethmoirlits, 501, 67:

mirlille or great, $49: 3,673$; grooves for, 83

posterior, of occipital, 489 of vertebral, 511,673

small, 495

lympliatic vessels, 651

nerves of glosso pharyngeal, 768

of hypoglossal, 75

of viums, 772

veins, middle, 616

extr:t-medullary, 629

Memmges [ $\mu \bar{j} v\rangle_{5} 5$, a membrane] of hrain, 670 of spinal cord, 731

Meniugro-rachidan [ $\rho a \chi^{\prime} s$, the spine] veins, 6:9

Meniscus [dim. of $\mu$ inv the moon] of malleoincal joint, 876

Ilental [mentum, the chin] artery of facial, 487 of mandibular, 495

foramen, 62

nerve of mandibular, 7.59

protuberance, 62

Irento-hyoideus muscle, 460

Mento-Meckelian centre of ossitication in mandible, 64

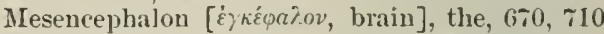

Mesenteric [ $\mu \varepsilon \sigma o \varsigma$, middle; $\varepsilon \dot{\nu} \varepsilon \rho \rho \nu$, an intestine] artery, inferior, $56 \%$; variations, 563 superior, 558 ; variations, 560

topography of, 1121

lymphatic glands, 664

plexuses (nerve), superior and inferior, 835

reins, inferior, 637 superior, 636 ; tributaries, 636

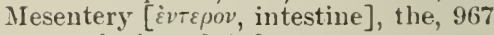
evolution of, 998

Mesethmoid [i, oriugin of: 96

Mesial [ $\mu \varepsilon \sigma o \varsigma$, middle] root of anditory nerve, 765

Meso-colic lymphatic glands, 664

Meso-colon, the, evolution of, 998

Meso-gaster [ $\mu \varepsilon \sigma o s, ~ m i d d l e ; ~ \gamma$ aoríp, stomach], the, 1000

Meso-palatine suture, 57,72

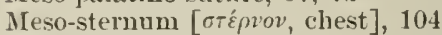

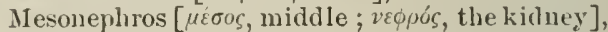
the, $10 \overline{5} 5$

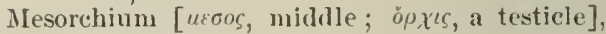
1025,1055

Mesorariun, 1055

Metacarpal artery (first dor:al interosseous), 54:2 bones, 1:33

ossitication of, 137

union of hearls of: $24:$,

Metacarpo-phalangeal joint of thuml, 24.4 joints of four inner fingers, 243

Metacarpus [kr.pmós, wrist], hones of the, 1333

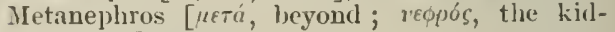
ney ], 1055

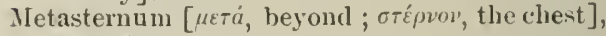
104

II etatarsal artery, 600 bones, 169

o.sification of, $1 \% 2$

union of heads of, 27 !

Metatarso-plialangeal joints, 279 ; movements of, 280 
$M \mathrm{Er}$

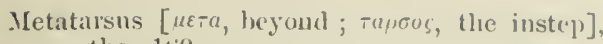
the, 169

Ietencephalon, the, $670,7: 0$

Methods of determining derp origin of spinal nerves, 73o

Metopic [ $\mu \varepsilon \dot{\tau}-\omega \pi$ ov, the forehearl] suture, 47

Meynert's coumissure, 747

Mid-kirluey, the, 1055

Ililk teetli, 89

Iliniature condyles of (finger) phalanges, $1: 3$

Mitral (bicuspid) valve, 933 topormplyy of, 933,1113

Moderator band, 931

Modiolus [the nave of a wheal], 41 , हैiा, 881 central rimal of:, 881

Molar [mole, a mill: from their arinding action] teeth, upper and lower, of thirel (wistom), \&s

Moll, eiliary glands of, $10 ; 7$ moditied sweat grlands of, 866

IIons [a momntiin] Veneris, the, 1039

IIontgomery, tubercles of, 1070

Monticulus [mons, a momntain] cerebelli, 715

Morgigni, liyclatid of, $10: 27,1215$ siuus of. 951

Morphological neck of humerus, 121 relation of patellar ficet to articular portions of femoral condyles, 152

Morplology [ uature of, 1

of pectoral girdle, 115

of seapula, 115

of skill, 89

of spine, 22

of transverse ligaments of lieads of metatarsal bones, 221

Motor [moreo, 1 move] nerves of erelids, -67

nucleus of glosso-pharyngeal, 767 of trigeminat, 750

root of lenticular ganglion, $75 \%$ of otic gangrlion, 760

Ionth, the, 942

lymplatics of, 652

suruieal :matomy of, 1095

vestibule of, 94:

If ucous membrane of blarder, 1019

of Fallopian tube, 105:

of laryux, 910

of nose, 892

of uesophingis, 953

of pharyux, 94!)

Scluneitlerian, 893

of small intestine, 969

of soft palate, 94t;

of stomach, $!(i-1$

of tongue, 8*4

of ureter, 1015

of uteriss, 1047

of vagrima. 104.4

surface of ragina, 1144

Miller, orhital muscle of; 858

superior jalpebral muscle of, 856 , 866

Miillerian duct, 1055

Inultifislus [multus, many ; fimlo, I cleave] spinit muscle, 42:

Mnscle, or Muscles-

actions of:, 234 ; ad vantares of oblicpue at taclı. ment of tendons. 2-5 : arrerture's pilormm, 1074 ; constrictor vacina. 1041 : division of muscles into the threc orders of levers. 285 ; importance of the direction of the
MIS

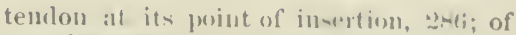
muscles passmg wer morr than one juint, $2 \times 1 ;$

Muscle attachunents, nature of, 2-i; of temulums,

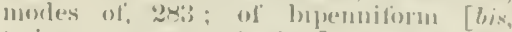
twice ; pennm, at foatleer] muscles, $2 \times 33$; of liventral [bix, and renter, a belly] muscles, ax:; of multipenuiform [mullus,

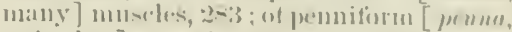
a feither] museles, inos; functions of :

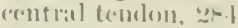

of (iutlirie, loris

metamorphosis of, into liganents, 2-1 intu temlens, $: 2 x)$

migration of, 28Y

nerve-supply of, $2 \times 1$

homenclat ure of, reasons for, 282

shape ot, varicties in, 2-2

structure of $2 \times 3$

abluctor hallucis, 378

lomgus jollicis, or extronsur onis metal earpi pullicis, 3:29

minimi digriti, foot, $3 \%$ ?

hant, :313

ossis motalursi quinti, tix

jollicis, 3:3y

abmormal, 458

accelerator urince (lulbo-(avernosus), 10:3-t

accessorius ad ilio-fostalem, 416

adductor brevis, 369

hallucis, $3-3$

longus, 33.52

maknus, 361

ossis metatarsi quinti, 4 is

pollicis, or arlaluctur pollicis transvers11s, $31 \%$

oblicpus, $3 \cdot 11$

anconens, $32 \%$

anomalus, 158

antitragicus, $8 \% 2$

arytemo-cpiglot tidens. 910

arvtenoideus, 9111

attollens aur'm, 4:31

attrahems anrem, 431

azyeros pharymgix, 450 urulax, y-1

of back, classifieation ol, 414

biceps tlexor culbiti, 307; surgical anatomy ol, 1154

femoris, 363

brachialis anticus, 310

sturgical anatouly of, 11 ixti

brachio-rallialis, or supinator longus, 321

buccinatur, 436;

hulbo-cavernosus (accelerator urinat, 1034

cervicalis ascomatems. 11 \%

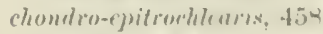

chomdru-glossus, 152

viliary, $2.15,-17$

rirenimflexus palati lansor palatil, $333,9.45$

reido-hynid. bis

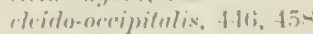

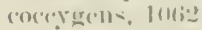

complexus. 1:31)

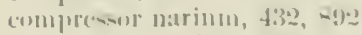

minur, - ! $\left[r^{-2}\right.$

sicruli laryngis, 911

methre, just

vaginas. Iniv

velle dorsalis penis, 1113 !

(onstrictor. of platary, inferior, s.a)

minlille. 951

stiperior, 951 
ML'S

Iuscle, or Muscles-

coraco-brachialis, $30 . \overline{3}$; strorical anatomy of, 1153

corrugator supercilii, 4:30

costu-jusciulis, 453

cremaster, 40 i

internal (lenle), $10: 0$

crico-arytenoiblems lateralis et posticus, 910

(ricu-tlyyruid, 910

crureus, 367

curcutor coccyyis, 458

leltoid, 300 ; surginal anatomy of, 1151

depressor al:e nisi, 433, 892

aueruli oris, $43 \mathrm{k}$

labii inferioris, -139

thyroidea, 1.58

diaphragm, 3m\%. Sice Disphragm

digastric, 449

dilitutor naris, anterior, 433, 892 posterior, 433, 892

dorso-epitrochlefuris, 4is

of ear, extermal, extrinsic, 431 intrinsic, 872

midlle, 878

cpitroclleo-rinconcus, 458

erector peuis (isclio-cavernosus), 1034 spinx, 415

extensor umularis, 458

brevis cligitormu manus, 458

perlis, 391

pollicis, or extensor primi internodii pollicis, 330

carpi radialis accessorius, 4.55

brevior, 323

longrior, 323

ulnaris, $3: 2$

coceyyis, 458

conmmus digritorum, 324

incicis, $: 3: 32$

longus digitorum (pedis), $3 \gtrless 9$

pollicis, or extensor secundi internodii pollicis, 331

modii digiti, 459

minimi ligiti, 326

ossis metacarpi pollicis, 329 metatarsi hullucis, 458

primi internodii pollicis, or extensol brevis pollicis, 330

proprius hallucis, 387

hullucis lougus, 453

secundi internodii pollicis, or extensor

longus pollieis, 331

flexor accessorius digitormm peelis, 381 longus, 459

brevis digitorum pedis, 379

hallucis (pollicis perlis), :382

minimi digiti (hand), 343 perl is, 384

pollicis, 3.11

carpi radialis, 313

nluaris, 315

longus digitornm (perlis , 374

hallucis, $: 374$

pollicis, 320

ossis metacarpi pollicis, 341

perforatus, :379

profundus digitornm, 31s

sublimis digitorum, 315

frontalis, $42 \%$

gatstrocnemius, 369?

gemellus inferior, 357

superior, :357
Muscle, or Muscles-

grenio-hyo-glossus, 45:

genio-hyoicl, 451

gluteus maximus, 351 ; surgical anatony of, 1180

unclius, 353

minimus, 354

quartus, 459

erracilis, 362

helicis mạjor et minor, 8\%:

of Hilton, or compressor sacenli laryngis, 112

hyo-epiglottideus. 459

hyo-glossus, 452

iliacus, $3 \cdot 18$

minor, or ilio-cupsuluris, 459

ilio-rostalis (or saero lumbalis), 415

incisivi (musculi), 43i)

infracostales, 3999

infra-spinatus, 302

intercluricular, 459

intercostal, external, 395

interual, 395

interossei, of foot, dorsal, 385 palmar, 385

of hand, dorsal. 3:3 palmar, 337

interossens primus rolaris, 459

interspinales, 423

intertransversiles, 423

ischio-cavernosus (erector penis), 10:34, 1041

kerato-thyroid, 459

of larynx, extrinsic and intrinsic, 908

latissimus dorsi, 292 ; surgical auatomy of, 1142

levator anguli oris, 437

ani, 1061

scipula, 290

claviculix, 460

glandulx thyroidex, 460

labii inferioris, 440

superioris (proprius), 439 alxque nasi, 432

menti, 440

palati, 944

palpebra superioris, 856

levatores costarum, 397

lingualis, 888

longissimus dorsi, 417

longus colli, $45 \%$

lumbricales, of foot, 382

of haud, $33 \overline{5}$

masseter, 441

mento-lyoideus, 460

of moutl, classification of, 434

of Miiller, orluital, 858

superior palpeloral, 856, 859

multifidus spina, 420

mylo-glossus, 460

mylo-hyoid, 450

olilique, of eye, inferior, 856

superior, 855

ohliguns abłominis extermus, 404

auris, 872

internus, 408

capitis, interior, 424

superior, 12:

oloturatol (externus, 362

internus, 356

oceipitalis, 427

oc(ipito-fromtalis, 127

occipito-heypid, 460

occipito-scripulur, 2!2, 461 
Muscle, or Mnseles-

omo-lyogil, 44 t

opponens minimi digiti, 3.4

pollicis, :31

orbicularis oris, 134

palpelorarmm, 429

orbito-palpectoml (silppey), 850

of palate, solt, ! $4: 3$

palato-crlossus, 45:i, 9.14

palato-pharyugens, $9.1,9.2$

palmaris brevis, $3: 34$

Iongus, 314

pectineus, 350

pectoralis major, 29.1 ; surgical anatomy ud, 1153

minor, 298; surgical anatomy of; 1153 peronco-calcuncus internus, 460)

peroneo-tibialis, 460

peroneus brevis, 393

longus, $39: 3$

quarlus, 4tit)

quinti digiti, 460

tertius, 391

of pharyux, 950

plantaris, 371

platysma myoides, 426

popliteus, 371

minor, 160

prerectalis (Henle), 11168

promator radii quadrat us, 321 teres, $\$ 313$

psoas magmus, 346 ; parius, 348, 460

pterygoil, exterual, 442

interval, 444

pterygoideus proprius, 460

pterygo-spinous, 460)

pyramidalis abdominis, 402

nasi, 432,891

pyriformis, 355

quadratus femoris, :35R

lumborum, 410

meuti, 439

(puill riceps extensor femoris, 36:

recti, of eye, 856

rectus abrominis, 402

capitis anticus major, 456

medius, 461

minor, 457

lateralis, $42^{\bar{i}}$

posticus, major, 424

femoris, 366

minor, 4.3

stermalis, 461

retrahens aurem, 43:

rhombo-alloileus, 461

rhomboideus major, 29.5

minor $\cdot 4(1)$

risorius, 437

rotator humeri, 4(i)

rotatores spinie, 4:33

sacro-lumbalis (ilio-rostalis), 416

salpiugo-pharyngeus, y44

sartorius, 350

scaleuus anticus, 454

merlius, 455

posticus, 455

semi-membramosus, :36.

sem ispinalis colli, 4:2 dorsi, 420

semi-tendinosus, :3(it

serritus macnus, 2918

posticus inferior, 413
IIt:

Mnsile, ar Muscles-

serratus jostions superios, 411

suleus, :37?

sphineter ani, external, l(1):? internal, $4 \% 5,10.5$

resicare interums, l(1)!

spimalis (torsi, fl!)

spleniss capitis, 111 (olli, 414

stapuedius, $-\mathrm{is}$

stermalis, ditil

sterno-rodeido-mastorid, 145

surgical ansitomy of: lo!s!)

stermo-hyoil, 4.17

stcrun-fliytoit], fis

stylo-glosisus, 15;3

stylo-hyoul, 4ist

stylo-plaryngens, 951

sulbanconelss, 310

suldrlavins, :296;

sulicostials, 3019

sulncrurrus, :3it

subseapularis, :30:3

supinator rollii hrevis, 322 lomgns, :3:21

seture-claciculuris, diil

supra-spinatus, 301

temporal, 411

tensor palati, 94.)

tarsi, $1: 30$

tympani, 878

vigine temoris, $85 \%$

teres miljor, 3114 minor, :30:3

thyro-arytanoideus, gog

thyro-epiglot tisleus, 9Ji)

thyro-hyoid, 4ts

tilialis antieus, $3=7$ posticus, 376

tibio-fuseinlis anticus, 401

trachealis, 911

tracliclo-mastoict, 41!)

tragicus, 872

transversalis abdominic, 10 colli (cervicis), 418

transversus anris, 87:

nuehix, 290, 461

jerlis, $3-1$

perinci, decp, I068 superficial, 1034, 1116-

trapezins, 2-8 : surgical anatomy of. $114^{\circ}$ ? triangularis stemi, 3!)

triceps extensor cubiti, 30! ; smrgimal anatomy of, 11:t

sure, :3tit)

triliceo-glossus, $4(j)$

of tympantm, s-5

vasius extromus, :36t

internus, $: 367$

vesico pulic, 101-

7ygomaticus major, $1: 3$ minor, 4:3!)

Mruscular lig:auments of uterus, lof?

Ifusculi jurisivi, 435

p:1pillares, !)31, 933

pectinati, 91311

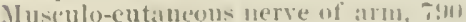

Masinlo-phrenic artery, ils

of lew. $-1,3,1: 3110$

Musculo-spiral grouve, 11 ?

Herve, 795; suruical anatomy of 11.5.

Musculus riliaris liw)lani, A(i.)

precrectalis (Henle), lowi- 
IITS

M[usculus suspensorius aluodeni, !66i

Mylo.glossus muscle, 46i)

IIylo-hyoid [ $\mu i \cdots v$, a mill] artery, 495

groove. 133

inuscle, 4 ino

nerve, $75 \%$

ridse, 63

\section{NAIIS, 1077}

Nares, posterior, size of, 1097

Sarial [nares, the nostrils] orifices, anterior and posterior, s0

Niasal [nusus, the nose] angle of maxilla, 57 artery of ethmoialals, iol

of infra-orbital, $496 ;$

lateral, $48 s$

of ophthalmic' 502

of spheno-palatine, 496

transverse, $50: 2$

hones, 54

at birth, 95

ossification, 55

cirtilages, lateral, origin of, 96

inct, 80, 868

eminence, 47

tosse, 79 ; at birth, 92

ganglion (Meckel's), 755

lymphatics, 651

nerve, 752, 864,896

inferior, 756

superior, 755

of anterior dental, 754

of maxillary, 754

noteh, 47

portion of pharynx, 949

process of maxilla, 57

sinuses, 73, 79

spine, auterior, 47,80 posterior, 59, 80

veins, 612,625

transverse, 613

Nasion [uctus, the nose]. 81, 728

Niso-lambdoidal line, 7.29

Naso-palatine artery, 496 groove, 54

nerve [uerve of Cotunnius], 755

Nates of corpora quarlyigemina, 710

Neck, cutaueous nerves of, 821

lymphatics of, 650

surgical anatomy of, 1099

triangles of, anterior, 1101

carotid, inferior and superior, 1102

posterior, 1102

submaxillary, 1101

supra-hyoj(l, 1101

tricheal, or inferior carotil, 110:

veins of, deep, 627

$$
\text { superficial, fil6 }
$$

Vélaton's line $11 \% 3$

Nerve-fibres, functions and structure of, $6 \% 1$

foramina of skull, primary and secondary, 96

ronts, spinal, 739)

tracts in thalamencephalon and prosencephalon, 717

Nerve, or Nerves-

ablominal, of vacus, 7 .

ablucent, or sixth cranial, 760

"Wveolar, of mandibular, 75 !)

Aruold's, 772

articular, see Articular nerves

anclitory, or eiglıtl (ranial, 765 )
NER

Nerve, or Nerves-

auricular, anterior, ins

great, $7 \& 3$

of lesser occipit:1, 783

posterior, 763

of vagus (Aruold's), 772

amriculo-temporal, 758

axillary, of lorachial plexus, ico

buecal, of farcial, 76.5

long, 757

calcanean, interual, 818

'alcuneo-plantar cutaneous, 818

carrliac, of sympathetic, 83.1

of vagus, (ervical and thoracic, 773 cavernous, 838

cervical, primary divisions, anterior, 702

superficial, 783

posterior, 779

cervico-facial, of facial, 765

chorda tympani, 763

ciliary, lone and short, $753,850,864$

circumflex, 788

coccygeal, divisions of, anterior, 809

posterior, 782

cochlear, of aurlitory, 767

communicantes hypoglossi, 784

of Cotuunius, 755

cranial, 743. See Cranial nerves

crural, anterior, 806

of genito-crural, 804

cutaneous, of abdomen, 801

calcaneo-plantar, 818

external, 806

of hand, 797

internal, of arm, 790

of leg, $80 \tau$

lesser, 789

middle, 807

of musculo-spiral, 790

palmar, of median, 793 of ulnar, 794

perforating, of fourth sacral, 808

of popliteal, external, 814

of pulic, 814 interual, 815

of thorax, 801

dental, inferior (mandibular), 759

superior, 754

descendens hypoglossi, 775

dorsal, of elitoris, 813

of peuis, 813,1067

ficial, or seveuth cranial, 761

of great auricular, 783

frontal, of ophthalmic, 751,8154

genital, of genito-crural, 8()4

genito-crural, 804

glosso-pharyugeal, or ninth cranial, 767

gluteal, superior, 810

inferior, 810

bemorrhoidal, inferior, 813

hypogastric, of ilio-hy pogastric, 803

livpogrossal, or twelfth cramial, 7it

liac, of ilio-hypogastric, 803 of last dlorsal, 801

ilio-hypongastric, 803

ilio-ingminal, 804

incisive, of manrlibular, 758

inframandibular (inframaxillary), 765

infra-orlotal, of facial, 76.1

infratrochlear, of nisal, 752

iutercostal, upper, 79!)

lower, 8010

intercosto-hmmeral, 800 
Nerve, or Nerves-

interossums, anterior, 79 ?

Jacoloson's, 768 posterior, 795

lahial, of maxillary, 754

lachrymat, of ophithalmic, iss

laryngeal, superior and inferior, 762

lingual (or gustatory). 7.j) of facial, 76.4

of gloss(1-) harynges], 769

lumbar, primary divisions of, anterior, -01

malır, of facial, 76 posterior, 701

ot orbital, 7.5.

mandibular (interior denta]), 75-

masseteric, of mandibular, 7.57

mastoid, of great auriculat, i*t of lesser occipital, 78:3

meatal, of amrienlo-temporal, 75. of mandibular, iss

median, 790,115 ]

meningeal, of glosso-pharyugeal, 768 of liypoglossal, 7 ii

recurrent, of mandibular, 756 of maxillary, 75; ot vaturs, $77: 3$

mental, 759

museulo-cutaneons, of arm, 7!) of $\operatorname{leg}, 815$

musculo-sp)iral, 79.5

mylo-hyoid, of madibular, 759

nisil, $752,864.896$

interior, 756

superior, 755

ot anterior dental, 75

of maxillary, 754

naso-palatine, of Meekel's ganglion, 755

obturator, 805

accessory, 805

occipital, great, $\div$ ๆ9

lesser, 783

smallest, 779

oculo-motor, or third cranial, 74

resophageal, of vagus. $77: 3$

olfactory, or tirst cranial, 745

optic, or secoml cranial. 716

orlital, of maxillary, 753

of Meckel's ganglion. 755

orbito-temporal, of maxillary, 753

palatine, anterior (great), 756

exterual, 756

posterior (small), 756

palmar cutancous, of mediau. 792 of vlnar. 794

palpebral, 755

parotid, of auriculo-temporal, t5-

jatellar, of long silphenons, sils-

yectinens, 807

pertorating cutaneous, of fourth steral, sos perinas, of fourth sacial, su-

of purlic, $81:$ :

superficial, 813, 1066

petrosill, deep, grent, Tis, 8:22 suall, \&:20

superficial, external, $76 ?$

wreat, $75 \overline{5}, 76 \%, 4-i$

lesser, $76: 2$

pharyugeal, of erlosso-pharyngeal, 76?

of Nleckel's raurlion, $756^{\circ}$

of sympatletic, sis

of ragus, 77\%

phrenic, $7 \times 5,1103$

conmunitating hranch $t 0$, i:
Norve, or Norres-

plantar, external and internal, $-1 !$ dieritals, sl9

junemumeastrice, or tenth cramial, itig

[opliteal, exterual, $\rightarrow 1$ intermal, klis

poryeroid, external, rof; intermal. 75\%

pulemilal, lontr, $\times 1 \cdot$ ?

jualic, 81:

pulmonary, of vagus, $7: 3$

radial, 79.5

recurrent articular, of popliteal, - - is (inferior) laryngeal, 7\%:?

meningeal, of mambihular, 7.jt; of maxillary, 75:3 of varus, if:

sacral, primary divisions of, anterior, -4k fontll, 808 josterior, i-i

saplienous, extermal or slort, -17

sciatic, great, 81 loner or internal, $=(1-$

smaill, 81:3

septal, of Meckel's ganglion, 7.5.)

(1) nisal, 75:2

of Suemmerringr, 812

of soft palate, 94ti

spheno-palatine, of maxillary, 754

spinal, 7\%6

deep origin of, i:37

veneral distribution of" is

roots of, 7i: 796

tognegraphy of, 114 i

spinal aceessory, or eleventh cranial, is:, 1103

splanchuice. great, 8:31

liserer, - -31

smallest, 831

stipedial, 76:3

stylo pharyugeal, 769

sulse:apular, lower, midlles, and muner, ;so

sipra-acromial, 784

supraclavicular, i-4

supramandihular (supramaxiliary), $76 . \overline{-}$

supra-orbital, of ophthalmic, $7.5 \mathrm{i}$

suprascapular, 787

supustermal, irt

supratruchlear, of ophthishir, 7.il

sympatletic, s:26

gatugriated corels of, -2.)

crallial amel cervical portion, s.2

lumbar portion, $83: 3$

Saleral portion, -8:3;:

thoracic portion, -30

plexuses of, sre Plexuse, nerve

temporal, of ficial, iti-l

of mimiliular, os

of orbital, 753

smperficial, ois

tempmoro-ticrial, of ficeial, itit

temuro-milar, 7.):

thoracere, anterior, external and int., ind posterior, i- i

(or (lursal) spinal, 799

spinal. primary divs., :utcror, -111

tirit, igs

posterior, $>-1$

list, $-(1) 1$

tilial, allutrior, -15

just(r)iur, -1 -

tomsillar, Ttis

trigemimal, or tiftl cramial, i I! 
XFE

Verre, or Nerves-

trigeminal, divisions of, mandilunlar, 756; maxillary, 753 oplithalinic, 750

trocllear, or fourtl erimuia], $7 \neq 8$

tympanic, of glossu-pharyncreal, 76- >79 of sympathetic, $8: 28, \div 9$

uluar, 794,1154

ot uterus, 83-, 105;

vayus, or pueumogastric, 769

to vals leferens, $8: 3$

vestibuliur, of auditory, $7 \mathrm{~s}$

Vidian, 755

of $1 \mathrm{r}$ risberg, 789

Nervous coat of eyelall, s.ts

Vervuli [rlim. of nerms, a nerve] gringirales of luaxillary, 7 ist

of mandibular (inferior lental), 758

Vervus communicans peronei, $\$ 15$ tibialis, 817

recurrens rami primi (Luschka), 751

"Nervus furealis," 810

Teural arch, 5 ; morphologr of, 23

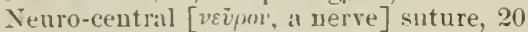

Tenro-enteric canal, 707

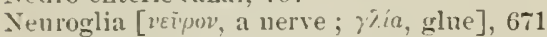

Veuron, 738

Tiuth cranial (glosso-pliarmgeal) nerve, 726 roots, $7: 26$

Nipple, 1069: abnormalities of, 1071

Nipjles, smpermumerary. 1215

Corlule [clim. of nodies, a knot] of cerebellum, 715

Nose, the, $-29,1097$

cartilages of, - 899

floor ot: $\% 9$

meatuses, 894

mucous membrane, 893

muscles of. 892

root: 79,893

septum, 79, 891

vessels aud uerves, -93, a f94

Notch, cotyloid. of" acetaluulum, 143

ethmoidal, $40 ;$

iliac, anterior and posterior, 139

interclavieular, 104

intercondyloid, of femur, 150

nasal, 43

ptervgoid, 33

of Rivini, $40,8 \% t$

scitpular, 111

sciatic, greater and lesser, 140

sigmoid, of mandible, 64

spheno-palatiue, 60

supra-orbital, 47

suprascapular, 113

trigreminal, :36

Totocliorlal [irons, the back; xopoin, a cord] region in the chondral skull, 89

Suelual [Arahic nuqrah, loollow at nape of neck] lines, 25

Nuck, (:aual of, 1050)

Nucleus [a kerncl] -

accessory, of auditory nerve, 766

of trigeminal nerve, 750

sensory, of trigreminal nerve, $\div 0$

ambiguus of medulla, 726

amyorilaloirl, 700

("iuilatus, 6!)!)

of the clavis, $72 \%$

enneatus, т:27

of descendiug ront of fifth nerve, to9

emholiformis of corebellum, il 6
OCC

Nucleus-

of ficial nerve, $i 61$

fastigrii of cereluellnm, 716

luuiculi teretis, i66;

glohosis of cerebellum, 716

large-celled (Deiter's) of anditury nerre, 765

(motor, or nucleus ambiguus), of glossopharyugeal, 767

lateralis of medulla, 726

of lens, 850

lenticularis, 699

motor, of trigeminal nerre, 751

olivary, 727

small-celled (chief) of auditory nerve, 764 ;

(sensory, or accessorio - vago - glosso pharyngeal) of glosso-pliaryngeal, 767

termental (red), 710

of third and fourth nerres, 709

Nuhn, gland of , 886

Nutrient artery of clavicle, 514

of femur, 585, 1192

of humerus, greater tuberosity, 526 shaft, 530

of ilium, 572 upler end, 530

medullary, of fibula, 592 of tilia, 592

of rarlius, 533

of ulua, 535

Nymphx [vi $\mu \phi \eta$, a bride], or labia minora, 1039

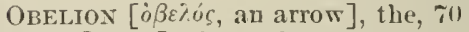

Obex [a har], the, 718

Oblique diameter of pelvis, 146 measurement of. 146

fascieulus of pons Varolii, 720

line of claviele, 109

of fibula, 158

of mandible (inferior maxilla), external and interual, $6:, 63$

ot radius, 126

muscles of orbit, inferior, 857

superior, 856

ridge of seapula, 111

of tibia, 156

of ulna, 125

sinus, 925

vein of lieart (Marshall's), 610, 926, 936

Obliquus auris muscle, 872

capitis inferior muscle, 424

superior muscle, 42\%

externus abdominis muscle, 404

iuterums nusele, 406

Obturator [obturo, I sto] up] artery, 5\%1, 1140

crest, 143

tàscial, 106]

foramell. 138,143

urnove, 140

ligament of stapes, 878

muscle, exteruns, 362

internus, 356 ; nerve to, 812

nerve, 80 ; aecessory, 805

vein, 63:38

Occipital [ob, against : commt, head : the part of the heal opposite the forchead] -

artery, 488; topograplyy of, 1102 of posteriov aurieular, 491

bone, 24; at hirth, 92

development of, 29 
Occipital-

condyles, 28, 73

convolutions of cerelorum, $6 \times 5$

crest, extermal, 25) internal, 26, sti

fissures of (eet)rmm, lis

groove, 37, 73

folse of cerebrum, $6 \approx 6$

lymphatic glands (suboceipital), (649)

nerves, great, 7i!)

small, 78:3 : tupography w1, 110:' smallest, 779

point, $70,-1$

protuberance. externa], 2.) internal, 25

sinus of cranium, $6: 0$

suture, 69

vein, 614

of diplö̈, 619

Occipitalis muscle, 427

U(cipitu-atlantal articulation, 183

O(cipito-cervical ligament, 1 -8

Oceipito-frontalis, aponerurosis, 427,1085 muscle, 427

(recipito-hyoil muscle, $\$ 60$

Occipito-mastoid suture, 86

()cipito-scapular muscle, 461

Occipito-temporal convolutions of cerebrum, superior and inferior, 691

Ocular conjunctiva, 840

muscles, insertions of, 8.44 actions of, 856

Oculo-motor groove of erus cerebri, 710 nerve (third cranial), 747 divisious of, 747

Gdontoirl [udois, a tooth: eisos, like] ligrament (central occipito-odontoid), 18process, 9 ; morphology of, 22

Esophageal [niw, oiow, I (arry; $\phi a)$ fir, to eat]arteries of aorta, 548

of gastric (comonary). 556

of inferior thymid, 514

of left phrenic, 55i3

of right gastru-epiploic, 557

1ymphatics, upper, (55:?

thoracic, 6.58

nerves of vagus, $77 ;$

plexus (nerve), 773

reins, 609

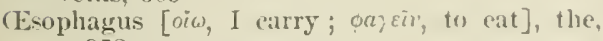
952

relations of, in neck, 952

structure, $95: 3$

$$
\text { in thorax, }\lfloor, 5,3
$$

Olecranon [ $\dot{\omega}\rangle \dot{\varepsilon} \dot{1} \eta$, the elhow : Konvion, the hearl], the, $12: 3$

fossa, $1: 0$

process, 122

Olfactory [olfacere, to smell] bulb, its

lobe of cerelirum, 681

nerve, $7.15, x ! 6$

sulcus [straight], 685

tract, 745

Olivary emiuence of sphenoirl, in, \&3 process, :30, 8:3

Olive, superior, 766

Omental (epiploir arteries of right gastro.epip. loie, 5.it

(descenting epiploic) of laft gastrurpiploic, $55 \mathrm{x}$

Omentum [the (aul enr-losing the howels], gristro-splenic, 959: evolution uf, 10143 great, 95<: evolution at, 1000
Oncentum, ereat, lenutlı of, 9im

lessirer, or wastro-luputic, 9.58 ; crolution of, 10011

()no-liyoir] [ijpoc, a shomlder] muscle, 1.17

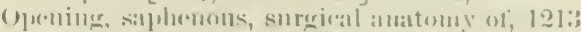

(1)errolum [a lidl], the, liv:-2

(1)hryon [inpie, evelsuw], \&1

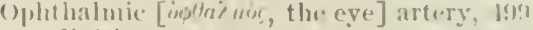

livision (lirst) of fifth cranial nerve. 751

Eampliou (riliary or lenticular), 7.5:

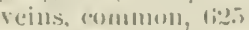

inferior, til6, tioti: tributaries, (i2:5

superior, 6:25; trilmlaries, 6itif

Opistlion [i-iofher, hinder], is

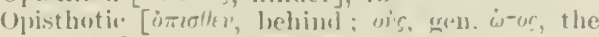
ear] centre of ossification, $4: 3$

Opponens [opposing] minimi ligiti muscle, 311 pollicis muscle,, 31$\}$

Optic [o-touru, I see] chiasma, iox, TH6

commissure, its, ifti

perluncles of: 71

disc, +1.$)$

furamen, $311,76, \times 3,96$

groove, 30. $\times 3$

nerve, 7110

sluesthe of, 7.16

ralliation, 7.16

thalamus, $7(1.7$

eoroua rudliata of $\tau 17$

tract ifti

1) ra [ore, an erlge] serrata, 845

Ophicular bone, eit

liniment, :2:30

tubercle of inrols, bir

Orbicularis oris [mlliculus, a little circle; 0. oris, montli] muscle, 4:34, 11 i.4

jalpebrarmm [pulpubu, evelin] musc]e, 42!

Orbis'ulus riliaris, $\times 46$

Orbit [mbitu, a cirrle. ], the, $:: 3$

arringement of countents of, 8.54

alleries of, $-(j ; 2$

tiscria of 857

lymphatirs of the, 651

museles of, $x-5.5$

muscular attarhuments in, 79

uerres ut, $86: 3$

roins of the 1i:5. 863

Orbital artery of antrior cerehral, 5113

of infra-orbital, 49 ;

of milllle meningeal. 4 ! 4

of t(יm]w)

(o) colutions of cerelorum, $(i-5$

rillve, sfi.1

tascia, $x$ jo

margin of frontil lobe, di-i

musle, -in

merve, or temporo-malar, in.

fiom Meckel's ranglion, 7.,i)

operemlanus, fim:?

periote-11m, s.j-

Hlite, of fromtisl, .11:

process of maliar home, til

vriu, (i)

of palate lome, 6 it

() rlitu-froutal artery of mithlle ferehral, iut

Orbitu-jalpelbral mu-rle, - is!

Orhitu-splenentirle. :31

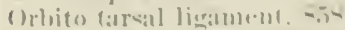

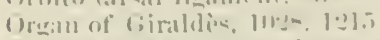

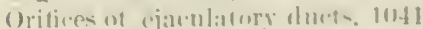

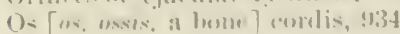

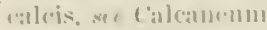

แ11\%แแแ 13: 
os

Os planum of ethnoid, 49 trigonum, $1\left(i^{-2}\right.$; derelopment of, 163

Os $[0$, oris, month $]$ ientrale, $1: 211$ ineac, 120 !

ja|ronicum, 1210

uteri, internum et externum, 1047

Ossa suprasternalis, 1210

Osieous spiral lamina, 41

lahyrintl, 879

portion of Eustachian tube, 8; 6

portion of externil anditory meatus, -73

Ossicles [osiculum, al little bone], epipteric. 4 . il

anditory, 67, 6; origin of, 90

Ossification, centres of, iu-

astragalus, 163

itlas, 20

axis, 20

cilcaneum, or os alcis, 165

('alpal bones, 1:3:;

clavicle, 111

('uboid, 166

cuneiform bones of tarsus, exterual, 169 internal, $16 \mathrm{~s}$ miditle, 168

etlımoid, , 50

femur, 15:

fibula, 159

trontal, 48

lip bowe, 144

lumerns, 121

hroid, 95

lachrrmal, 53

malar, 6 ?

mandihle. or inferior maxilla, 64

maxilla, or superior maxilla, 58

metacarpus, $13 \pi$

metatarsus, $1 \%$ :

masal, 55

occipita\}, 29

palate, 60

parietal, 16

pittella, 153

phalanges, of foot, 175

radius, 128

of hand, 139

rilss. 103

scaphoid, of tarsus, 167

sca1) 1] 114

splseuoid, 34

sternum, 107

strloid process, 90

temporal, $4: 3$

tibia, 157

turbinals, iuferior, $\tilde{i}, 3$ sphenoidal, 52

tympano-hyal, 90

ulua, 125

vertebre, cervical, sixth or seventh, 21 coccygeal, 2 lumbar, 21

sacral, : 2:2

typical, 19

romer, 5

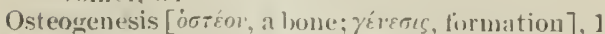

Ostium [an opening] aldominale of Fallopian tube, 1051

Otic: [oris, the ear] gangrion [Arnold's], 760

Outlet of pelvis, $146,1096 \mathrm{i}$; dimensions of, 146

Ovarian [orum, an egre] arteries, 56:2, 1053

bulb, fi:?

Iymphaties, $66 \% 2$

veius, 63:3, 105
P.I.

Ovaries [orum, an egg], the, 1052

Ovicluets (or Fallopian tubes), the, 1051

Ovisilcs, or (il'atian follicles, 105:;

Orula [dim. of ormm] Nabothi, 1047

PACCHIONIA. glands, (iTi ; structure of, 672

Pacini, (orpuscles of, 1076

Pacinian corpuscles, oft

Palate, the, $14: 3$

arterial and nerve supply of, 946

mucous nembrane of, $y \dot{q} 6$

museles of: 944

structures cut in paring elges of cleft, $109 \%$

surcricil anatomy of, 1097

hone, the, is

ossification of, 60

at birtls, 95

Palatine artery. iscending or inferior, $4=0$ of ascending pharyugeal, 48? descending or posterior, 496

canals, acressory, 59 anterior, 56,80

extermal, 59 posterior, 59 , 70

foramina, 72

fossa, auterior, 57

nerves, auterior (great), posterior (small), and extermal. 756

sntures, $\tau 2$

reiu, inferior or descending, 61 t superior, 616

Palato-ethmoidal cells, 50

Palato-glossus muscle, 453,943

Palato-pharvngens muscle, 944, 952

Palato-quadiate bone, representative of, in man, 90

Palmar arch, deep, 543

brauches and rariations. $\overline{5} 43$

surgical anatony of, 1168

superficial, 536

surgical anatomy of, 116 \%

variations, $53 \%$

bursa, great, 317,1170

cutameous nerre of median. 793

of nluar, 795

fascia, 333 ; surgical anatomy of, 1169

superficial trausverse ligaments of, 333

Palmaris l,revis muscle, 334

longus muscle, 314 ; nerve to, 791

Palpebra] [palpebra, eyelid] ajertnre, 768

artery, 502

of lachrymal, 500

of supra-orbital. 500

conjunctira, $840,866^{\circ}$

fascia, 858

folds or grooves, juferior and superior, 840

limament, immer (or tendo oculi), $339,86 \%$ outer, eicit

muscle, inferior, $86 i_{i}$ superior, $85 \%, 859,86 \%$

seius, inferior, 614

superior, 613

Pampiniform [ mumpinus, a tendril] plexus, 63:

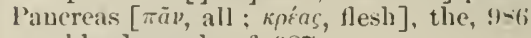

blook-supply of 987

duct of, $987^{\circ}$

lesser, 986

lymphatics and nerves of; 66.5. 9x-

topographe of: 111 .

Pancrentic area of anterior surface of kiluey, 1009 
PAS

Pancreatic artery, greater, of splenic, j.s lesser, of hepatic, int;

Irmplnatics, 665

of splenic, , sis

plexus (nerve), 835

l'ancreatico-aluodenal artery, inferior, 5is

plexus (nerve), 80,5

superior, j.37

vein, 6i36

Papilla [a teat], lachrymal, s.t0 optic, 84:

Palpillie of kidney, 1011

of the skin, 107.j

of tongrue, ori

Paracentral loloule, 690

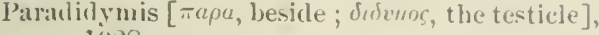
1028

Parallel fissure of cerehrum, 6-3

Parenchyma of lung, $92 \mathrm{t}$

l'arepididymis, 1215

Parictal [paries, at wall] artery, 504

boue, 44

ossification, 46

at birth, 9.1

convolution, ascencling, 686

emillence, 44

lobe of cerebrum, 685

lolule, superior. $6-6$

lymphatic glands of pelvis, 660

of thorax, superficial and deep, 6.56

lymphatics of pelvis. 660

of thorax, 650 ;

vein of diploë, external, 61 .

Parieto-mastoid suture, 71, ef

Parieto-occipital fissure, $68 \%, 690$

vсin of diploë, $(\$ 19$

Parjeto-temporal artery, 50 -

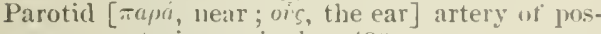
terior auricular, 490

of temporal, 491

fascia 440

gland, the. 946

duct of, 948 ; surgical anatomy of 1091 vascular and nervous supply, y4s

$15 \mathrm{mphatic}$ glands, superficial, (if!)

nerves of auriculo-temporal, s03

vein, 614,615

Paroiiphoron, 1049, 1214

Parovarium, the, 1042,1214

Pars basilaris of inferior frontal convolution, 685 bulbosa of prethra, 1037

ciliaris retinas, 845,845

frontalis, of central lobe, 68 -

intermedia of Wrisherg, 761

intermedialis (Kiibelt) of vagina, 1041

orbitalis of inferior frontal cunvolntion, 6 6<.;

parieto-falciformis, of ceutral lobe. fi-

temporo-parictalis, of central lobe, 689

triangularis of inferior frontal convolution, (i $2 . \overline{5}$

Patella [a small pam], the. 15:2

dislocation of , mechanism, 1121

ossification of, 153

relations to temoral comlyles, 11-1

surcrieal anitomy of, $11 \times 2$

Patellar bramelues of long saphenous nerve, an-

ficet on femoral conclyle, 1.31 ; morplublugical relation to articnlar jortions of the conclyles, 153

rete [a net], $;-i !$

Pecquet, eistern of (rereptaculnu ehylj, fis!)

Pectineo-fenoral liaud, ifs

Pectineus [ preten, the pubic boure] muscle. $: 350$
P'il:

I'ectincus, norve to. $7-.5$

I'ectoral [ fuctus, tles hratst] artery of aclominthoracine, 5iol

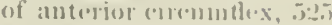

fascial, :?!

girclle, morjiluslogy of, 11 .

Iymphatis erlands, 6is:

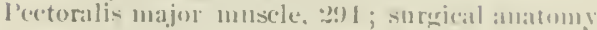
of, 11 is?

minor muscle, 2!r ; surgical amatumy of: 11.53

l'eculiar rils, 100, 10:3

vertubit, $\approx, 12,13$

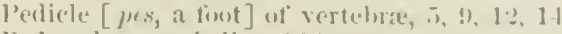

Pedumcles, cerebellar, 71. ifi

of optic thalamms, 717

of pineal loxly, ios), f(1t;

Jelvic fascice, 10k0; surgical anatomy of, $11: y 9$

plexus (nerve), 837

portion of nreter, 1015

serment of olstumator filscia, 1061

viscer: lymplatir's of , 662

Pelvis [a basiu] the, 115

axis of 146

dianeter's of: 115

false, $14:$

faseice of, 1060

inlet of, 14.5

lymphatie wlankls of parietal. 6fil

lymphatices of: (iti)

meisurements ut: 146

outlet of, 146, 10is; dimension - of, 14 ; position of 14 i

sex diflitences, 116

true 14.7

veins of: 63 -

Pelvis of killuev, superior, inferior, and (o) 11101,1014

P'enile [ mnis, a tail] amrle, the, lu: :

l'enis [atail], the, 10:31

coveriness of, 1031

(utameons nerves of, -y:?

dorsal artery of, itifi, lokit; nerves of, 1065

lymplattices of titit

structure of; lo:33

susfen-ory ligament of, $103 \% 2$

Perforated space, anterior, lis!! : posterier. (i-1)

Perforating arturies, anteriur, of plattat digjt:als, ints

lateral, of juf(ermal matmmary, 517

of midlle menimeral, 1!4

of palinar arch, deep, ifis

pusterior, of external plantar, ה!H

of profuncla femoris, je

of :ulumestal, $4=7$

('utameon< merve of fourth sir.ral, - 1 ! ?

lericarcliac artery of intermal mamumar, il:

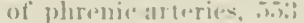
of thorariv aurta, if

veins liotis

Pericarlium [-:0, aromud : nemplis, the he:art]. the, !1:.5

lymplatices of, tine

relations of, !): 2 t;

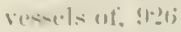

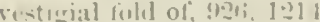

I'erierlottis, the, !mis

Perilyulu, the -1

Perinatal arteries. sujuerticial, 洪 I

tr:1u>re.

lexly in temale. 11m!t

fastia, deels, anterour layer. lum 
PEI:

l'eriucal falscia, decp. posterior (smperior), 1068 superficial, dee's laver of [Colles'], $1060^{\circ}$ interspace, superficial, contents of, 1060 sleep, contents oi, 1067

lymphatics, superficial, litil nerves, the, s13

brausch of fourtle siccral, s09

Pเrinxum [ $\pi \varepsilon \rho$, arouml : raw, I an situated], centril point of, 1122

femille, 1060

male, $10.5 \%$

proper, $106 \mathrm{is}^{2}$

surgical anatomy of, 11:2

triaumles of, 11 :

Periorlita, 85-

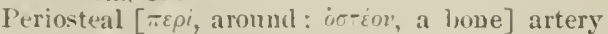
of supra-orlital, 500

P'eriostenm, orluital, 8.5 -

Periotic [ $\pi \varepsilon \rho$, aroumb; ois, the ear] capsule, 89

cartilarges, 89

Perirenal, or capsular arteries, 560

Peritoneal artery of common iliac, 565 of superior epigastric, 518

ligaments of blatder. 1018 of liver, 982 of uterus, 10ts

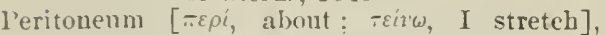
arrangement of, explained, 991

evolution of, 991

final changes in, 997

semeral characters of, 9ist

greater and lesser sacs of, $955,95 \tau$

recto-varimal pouch of, 957

recto-resical pouch of, 9.57

tracel in longitudinal section of the body, 957

in transwerse section, $95 . i$

Peroueal $\left[\pi \varepsilon_{p} w^{\prime} \eta\right.$, the pin of a buckle] artery, 592

anterior, 59:2

posterior, 592

suruical auitomy of, 1192

groove of calcaneum. 163 of cuboid, l6i.

nerre [exterual poplitea]], 215

tubercle of calc:urmm, 163

Permei tendons, where divided. 1197

I'sroneo-cralcrueus intermus muscle, 460

P'eronen-libialis muscle, 460

Peroneus [reporm, the pin of a buckle, or the fibula] brevis musc $\cdot$ le, $: 39: 3$

lougus muscle, $39: 2$; action upon arches of foot, $1: 20.5$

quartus muscle, 460

quinti digiti nuscle, 460

tertius [the thirrl] muscle, 391

P'erpendiculin fissure, intermal, $6=2$ plate of ethunoirl, 49

I'es [a foot] or erusta of crus cerelori, 711

anserimns [moser, a groose], 664

lippocampi, 697

Petit, triangle of, $11 \cdot 15$

P'etro-mastoicl canal, 40

I'etro-ocripital suture, ef

Petro-sphenoiklal foramen, :36, 86,$96 ;$

ligament, :39

noteh, 8i;

provess, :36

suture, 83

Petro-sruamosal suture. 36

l'etro-sipamous simms of cranion, 619, 623

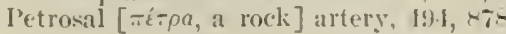

PLA

Petrosal nerve, deep, great, 755, 8:28 small, $8: 8$

superficial, external, $76: 2$

great, $755,76 \%, 8 \div !$

lesser, $76 \div$

foramen lor, 3 i, $8: 3$

portion of tenporal lone, 35 ; at hirth. $9: 3$

sinuses, superior and inferior, 6222

Petrous gancrtion of glosso-pharyngeat, 76s

Peyer's patches, 969

Phalauges $[0 a i a\rangle$, a rank of soldiers: from their regularity] of fingers, 137 ossitication of, 138

of toes. 172

ussification of, 175

Pharyugeal [óp $y^{\xi}$, , the throat] aponeurosis, 949

artery, ascending, 481

of pterygo-palatine, 496

of splieno-palatine, 496

of Vidian, 496

bursa, 952

lymphatics, 652

muscles, 949

nerves of glosso-pharyngeal, 769

of Meckel's gauglion, 756

of superior cervical ganglion, 828 of vagus, 772

recess, 952

tousil, 952

tubercle, 73

veins, 626

walls, 950

Pharyngo-epiglottidean fold. 905

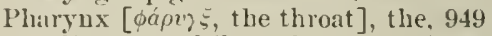

dirisions of (buccal and nasal), 949

interior of, 951

musceles of, 950

Phrenic [ $\phi p^{\prime} l$, the mind: the diaphragm was supposed to be the sent of the mind] -

artery, inferior, 553 ; variations, 553

of inferior thyroid, 514

of musculo-plirenic, 518

of superior epigatric, 518 superior, 516

nerve, the, $785,110: 3$

communicating branch from brachial plexus to, 780

reius, inferior, 633

Phreno-colic ligament, 958

Pia [tencler] mater [mother], cerebral, 67 spinal, $7: 32$

Pillars of the external ablominal ring, 406, 1131

of the finces, 944

of the fornix. anterior and posterior, 701

Pineal [ pinus, a tir-cone] body, 705,1212

Pinna [a feather], the, $8 \% 0$

cutaneous nerves of, $>21$

Pirogoff's allputation, 11 !

Pisiform bone [ pisum, a pea], 131 articulations with (anpus, 233

Pituitary [piluita, the nasal secretion] body (gland), 707,1212

membrane (Achneilerian), $7 * 3$

Plantar [ plantu, the sole] arch, 629

arteries, extermal, 5!9?

intermal, $59 \%$

surgical anatomy of, $120 \%$

eligrital, 594, 60)

fascia, ::77; functions of', 1203

nerres, external aml internal, 819

cligritals, 81!)

Plantaris [ plontu, the sole] muncle, $3 \pi$ 1 
PL.I

Plate of lateral nasil cartilages, jumer and onter, \&uu

fromto-nasil, s9

pteryoid, internal and ('xternal, :3:; ; orimin of: 90

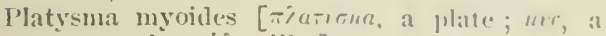
muscle; sidos, like] muscle, 120;

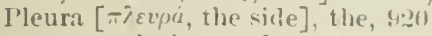

relation to cliest-wall, 1112

('ostalis, y::0

lyuphatics of, 6.58

pulmonalis, !) 20

Pleural arteries,

P'lexus, nerve, cranial or spinallorachial, ホー

cervical, 7-:3

cocescreal, 809

unlae, $7 \% 3$

iutra-orlsital, $755,7(15)$

luulsar; \&02

patellat, \& 17

pulusomary, posterior, э:?;

sicral, 869

subsartorial, $80 \%$

subtrapezial, $7-5$

sy้mpathetic-

nortic, 8:35

carliac, superficial am] 1eep, $\times 34$. !):3!

carnticl, 828

cavernous, \&2o

coliac, 83.;

coronary (gastric), $\$ 35$

(carliac) left and right, $-3,3.9 \%$

eystic, 835

diaphragmatic, $8: 35$

gast ro-epiploir, right and lett, B:3is

hiemorlioidal, middle, 8.37

hepatic, 835

hypogastric, $83 \%$

mesenterie, superior and inferior, $\$ 3$.

pancreatic: 83.5

pancreatico-duolemal, Q:35

pelvic, $83 \%$

prevertebral. great, $83-1$

prostatic, 837

ploric, 835

renal, 835

solar, 835

spermatic, 8.37

spleuic, 83.5

suprarenal. $\times 35$

uterine, $8: 39$

varinal. $8: 39$

vesj(:al, 837

venoms-

anterior median, of forearm, (i)!

choroid, of lateral ventricls., li? = of fourth rentricle. 718

of third ventricle, it):;

dorsal, of hand, $6+0$

hiemorrhoidal, (6.39

pampiniforn , 6.3:

prostati(n-resical. (i3:)

pterysoid, 615

of Santorini (female uretsra !, $101:$ ?

spinal, anterior and postrrior, lis-

vesical. 63:)

Plica [a fold] semilunaris, $4(1),-11,1 \geq 1 \div$

ureterica, 1019

Plica ciliares, $8 \$ 5$

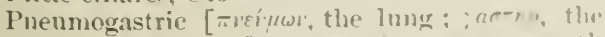
stomach] nerve vagus, wr teintl (ranial), 769 1'l:?

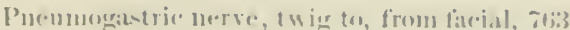
urigin, T(i!)

l'oles, of eveluill, sl:

ut lows, - -19

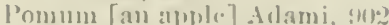

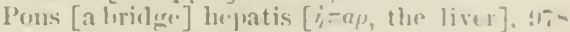
Varulii, lizl, 7 !!!

tilues of, 6 ,

vius oti, $(i+2,5$

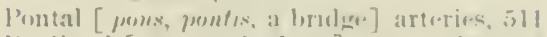

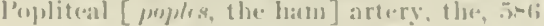
surericisl anatumy ot, $11-\bar{r}, 11 ! r$ !

liurs:t, 1:2u; ariatiolls; , i- ij

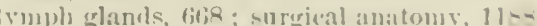
merves, extcruil, $\mathrm{x} 11$ interual, 817

-pure, sureical anatomy of, 11-1;

vein, 616 ; smryical anitumy $01,11-2$ variations, 6i.17

I'opliteus [ joyles, the h:tm] muscle, :: 1 minor muse] $e^{2}, 4(i)$

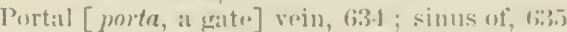
tributaries, $6: 36$

(*auls

tis-ure, or 1 ransiverse. of liver, 4\%?

l'artin [a part] major et minor ol' trigeminal nerve, 74 !)

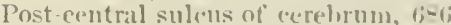

l'osterior ultactory lobule, 6!1:2

l'ostro-lateral arteries of posterior cerebral, 51:2

l'ostero-median arteries of anterior ('-rebral, 513

l'ost-erlemojel tulyerecle, 33.)

l'ost-olivary suleus of medulla oblongata, 721

post-parietil convolution, $(j=6$;

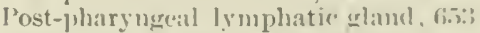

l'ost-splenoicl centres of os-ifieation, 34 at lirth, 9:3

['ost-rentricular veius 43 ! !

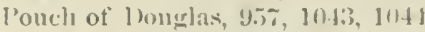

larymucal. ?"I?

recto-vaginal, 9.5. 1044

rectu-resical, 9.5

Pompart's ligament, fu1, 1111, 11:3\%, 11\%।

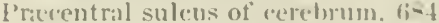

Precounens or yualrate lolmle of eorelirum, 6-;

Procinterparicetal lonse. 1201!

Priejutimu eliturirlis, 1u:is)

Procertalis musele of Mrinle, J16i-

Pre-coracoid estililugr, 115

l're-maxillary ('ontro of' maification, is

l're-molar te.eth (bic'mspid-), -

're-palatime (*ntre of osilieation. is

l're-patellar lursa, surgical anatom! w1. 11-4

prepulee, 1 he, 10:3::

l're.sphenoid lune. :31: at hirtl, :2:;

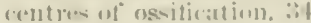

I're-sterumm, 111

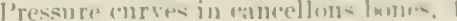

l'reventricular artery, 173, !38; veins, (i] $1,93 \%$

l'revertelural artery wi: anemelin pharyngeal, $1-1$ lisioial, HI, Jllli

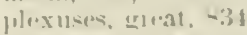

l'rimeres rersicis artery, 4 ! 0 halluris arlory, fiul pullio.io arto.ry, il:

l'roxis, alcromion, 11 :

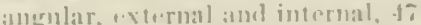

anriculatr

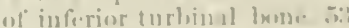

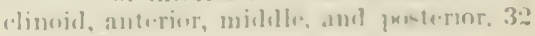
(y) 
PRO

I'rucess, coracoid, 114

(orunoid, of ulna, l:2

of mandible, 64 : toposraply of, 1096 costal of ittlas, $\alpha$

of axis, y

of "ervieal vertebre. ?

of seveluth (eervical, 10

of sitcrimi, 15

ethmoilal, of inferior turluinal home, 53

titleitiorm, of liurns, 11:3-

frontal, of malar bonte, fil

hamular, 3:), 72 ; topogataluy of, 1096

of incus, long and short, 67

lachrymal, of inferior turbinal lone, 53

malar, of maxilla, it

of malleus, Folian, slort and slemler, 67

mimmillary [dim. of mamma, breast], 1:? morphology ot, 24

mastoid, $3 \pi, 73$

maxillary, of inferior turbinal boue, 53

of malur boue, (i)

of palate bome, 54

masal. of maxilla, 58

olontoid, g

olecranon. 12\%

olivary, 31). 83

orbital, of malar bouse, 60

of palate lone, 60

petro splienoidal, 36

sphenoirlal, of padate bone. $\overline{5}$

styloid, $37,67.73$; at birtl, 90

of hase of third metacarpal, 135

of tilsula, 1 is

of radius, 127

of ulua, 124

supracondyloid, 119

of thyroid glamil. middle of pyramidal, 916

turbinal, of lachrrmal hone. 53

tympano-hyal, at birth, 90

uncitorm, of ethusoid, 50

of unciform bone, 133

vacrinal, of teluporal bone, 39,73

verustorm, of cerebellum, superior aud

interior, 714

zyomatic, of malar bone, fil

Processes, articnlar, of vertebrat, $5,6,8,9,12,13$, 15. 17

norphology of, 2:3

ciliary,,$\rightarrow 0$

spinons, of vertebra, $5,(i, 9,10,12,13,15$ hifid, 11

transierse, of vertelıx, 5, 7. R, 12, 13, 16, 17

norphology of, $2: 3$

processus cochleariformis, to

funiculo-viginalis. $11: 36$

gracilis of malleus, br

retirularis of ('ord, 719

valumalis of peritonemu, $10 \% 20,1031$

Profumla [profunlus, (lecle] astery of femoral, $5 \times ; 3$

of brachial, interior and superior, 52y variatiols, 5:30

vein, 617

Promontory of : $:$ ar'lum, 1 is

of tym

P'ronator [ fromus, fiuce downwards] quadratus [square] musele, :3:21

radii teres muscle, $31: 3$; nerve to, 791

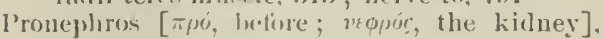
105.5

Pro otic [-pris, hefore; wis, the ear] contre of ossification, $4:$
PYI

1'rosencephalon, 670 ; nerve tracts in, 717

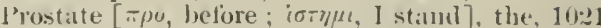
structure and functions, 10:2:2 surgicul anatomy of, $1126^{\circ}$ vessels atud nerves of $10 \% 3$

Prostatic fissure, 10:21

plexus, nerve. 8.37 vellous, 677

simses, 102:), 1037

urethra, 11137

Prostatico-resical renous plexus, 639)

P'rotuberauce, occipital, extermal, intermal, 25

l'soas [vó, the loin] lymph ulands, $66^{\circ}$ (miguus) muscle, $34 t ;$; nerve to, $80^{\circ}:$ parvis muscle, $3+8,460$

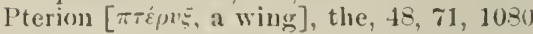

l'terotic centre of os:ification, 13

Pterygoid [ $\pi \tau \dot{\varepsilon} \rho v_{\zeta}$, a wing] artery, .19.

fosia, 33, 5\%. 73

muscle, extermal, 442 ; nerve $10,75 \alpha$ interual, 444 ; nerve to, 757

noteh, 33

plates, 33 ; origin of, 90

plexus (venous), 615

riclue, 32,70

veius, 615

Pterygoileus proprins muscle, 460

Pterygo-maxillary fissnre, 70

Pteryo-palatine artery, 496 (alual, 3:3, 59, 70, 97 grroove, :33

Pterygo-pharyngeal artery, 496

Pterygo spinons liganent, 34

Pterygo-spmons muscle, 460

Pnbes [mubescens, covered with laair], the, $14: 2$

Pulsic arel, 146;

artery, of deep epigastric, 578 of obturator, 57:

ligaments, 205, 206

portion of faseia lata of thigl, 1119

spine, 143

Pubo-prostatic ligaments, 1018

Pudeudal [purco, I am ashamed] nerve, long, 812

Pudic [ pulco, I au ashamed] artery, accessory, 570

extermal, superficial and deep, 5s3. $11: 0$

internal, 573, 1067 ; topograuphy of, 1181

lymphatics, $106 \%$

nerve, 812

vein, $(j ; 3,106,17$

Pulmonary [pulmo, lung] artery, 462, 923 oritice of, 93i

topogratjly at", 935

in tietus, 463

after birth, 463

lymplı glands, 1 is̄

nerves, anterior, 7\%:

plexus, posterior, 773

simuses (of Valsilval), $4(\mathrm{ir}, 93: 2$

valves, 932 ; topography of, 935,1113

veins, the, tiot

Pulvinar [a conshion], 7(15)

P'uncta cruenta (vel vasculosa), $(i-9)$

lachrymalia, \&ij7

Pmuctmm [a point] lachrymale, 875

Pipillary zone of iris, 8.ju

P’utamen [a sliell or husk]. 6!)!

Pyloric artery, inferior, 5is

silperior, 5.56

oritice of stomatol, 960 
PYI.

Pyloric plexus (nerse), 83.5 vein, 636

P'ylorus [ $\pi$ ir wooc, a gatekecper], the, g(i)

l'yramid of cerebellum, 71\% of tympanum, posterior, $40,-2 i$

Pyamidal budy of medulla, 7:2 process of thyroid, 9li; tracts of cord, anterior and lateral, it1

Pyramiclalis ablominis muscle, $10 \%$ nasi muscle, 432, 8!1:?

Pyramids of Ferrein, 1011 of Malpighi, 1016

Pyritormis [pirus, a pear] miscle, 3.5

QCADRATE artery of anterior cerelyal, 50:3 cartilage of nose, acresisory, -9] lobe of cerebellum, 7.54 of liver, 978

lobule of cerebrum (pracumeus), 71.1

Quadratus [square] femoris muscle, $35 k$ lumbormm muscle, 410 ; nerve to, 8133,810 menti [quadralus, square; morum, clinin] (depressor labil inferioris), 439

Quadriceps extensor fimoris muscle, 365 nerve to, s08

RADIAL artery, in forearm, 533 surgical anatomy of, llfil variations, 540

in the palm (eleep palmay arch), 543 variations, 543

at the wrist, 541

carpal, anterior aul posterior, 541 recurrent, 540

eondyle (external) of humerus, 120 nerve, 796 ; surgical anatomy of, $116 \%$ vein, superficial, 611

Ratialis inclicis artery, 544

Ralio carpal joint, ligiments of, $2: 34$ movements of, 235

Raclio-uluar joints, inferior, :23: midrlle. 230

Radius [a spoke], the, 126 superior, :230 ossitication of, 128 morements of, on ulua, 2:33

Rami [plural of remus] communicantes of ran gliated cord, lumbar, $83: 3$ thoracic, 8:?2

of midrle and inferior cervical ganglia, -30) of superior cervical ganglion, 828 of sympathetic system, white aud wrey, - 27

Ramus [a bramch] of ischium, 111 of mandible, 63 occipitalis of cerebrum, lisfi parietalis of ocejpital artery, 67t of pubes, descenting, 142 horizontal. $11: 3$ subentaneons malae, 754

Ranime [rama, a frog] artury, 42.5

Raphe [paoin, a seam] of corpus callusum, (is):? merlian, of tongue. 8st of the scrotum, 1023

Receptaculum [a vesiel] chyli [rivon. juice], 6.5?

Recess of ischio rectal tossa, anterior and pos terior, $106: 3$

pharvngeal, 951

tonsillar, 941

Recessus infiundibuli, $70 \mathrm{~s}$

Rectal (bxmorrhoidal) artery of lateral sacral, 567
Iil IR:

Rectal artery, miallo (milllle licuorrhoidal), 570

of mirklle sacral, $3(; ; 3)$

examination in the fiomale. 11:3

triangle, $112: 2$

Recti [rretus, st laight] muscles of orhit, s.)े;

Rer(n-uterine ligant.nts, $10 \cdot 19$

liexto-vaginal pench of peritnetum, 97.5, 1041

Rectu-sesical fiscrial, 101poncle of peritome+11m, מ7is

lectum [molus, straiglit], the, 97\%

lymphat ie's of, tit:?

surcieal anatomy of, 1127

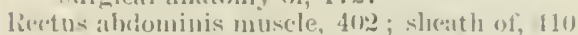
appitis auticus major musele, nerve $(1),->i)$ merlins muscle, ifil minor muscle, 157 nerve (1), 7 -

lateralis muscle, 1:25; nerve to, to

pust ic:us matjor inuscle $e^{2}, 421$ nuinor muscle, 4.34

femoris muscle, $366 i$

sternalis muscle, $16 ;$

Lecurrent arteries of deep palmar arch, 545 interosscous, 53i)

larliat, 511

tibial, anterior and posterior, 59 uluar, anterior and posterior, $5: 3 ;$

nerves, articular, of external popliteal, -15 laryugeal, 772

meninureal, of mandilular. $\overline{t i t}$ tj

of maxillary, 754

of vauts, 7t2

Recussus [reculion. a recoiling] pinealis, 706

lied (tegmenta]) muclens, 71$]$

Regions of the alulomen, 1:20t;

Leissmer, membrame of, s83

Rena] [ren, the kinlney] arteriss, jiil

variations, 560 toprouraphy of, 1121

of lumbar, 554

duct, 1011

lymplatics, 6tis

plexus (nerve), 935

veins, $6: 31$

Reproductive organs in the fomale, 1032

in the male, 1021

liespiration, organs of, !1:!

liestiform [restis, a corrl] bouly of jons, i2:?

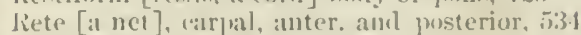
tentis, I I : 2 t;

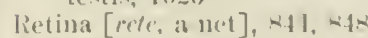

lietinacula [ertinere, to hold bilek ] of ialesnle of hip, 217

lictinal arteries, - -51

pigment layer, -14

lietrahens [retirho, I lraw louck] :utrem muscle, l::2:

Revehent nerve (arry ramus commmnicans, - - t;

lihinencephalon, (i- i

lihombu-rilloirlrus muscle, fii

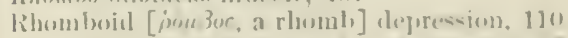

lig:ment, :21 : arierin from sulwlavius. :-1

lihomboisleus major murla, :a!s?

minor musele, :y!:?

lihombirls, nerve to, $7-7$

liils. the, !ls

lin.ipital. 1111

rervival, 16:3; variations in, 104

develupument wi. I0:3

Immliar, 10 I 
lillis

Ribs, jeculiar, 100

variations in mumlece and shape, 103, 1210

Riclge, hasal, of tecth, -7

external condylar, 11

gluteal, of feinur, 147

of hip hone, 139

ilio-pubal, $139,143,146$

interosseous, of tibulit, $1 \mathrm{is}$

oblicpue, of infraspinous tossa, 111

of ulua, 125

of tibia, $156^{\circ}$

simpracondyloid, 119

of trapezium, 133

Rima [a chink] grottidis, 911 pulendi, $10: 39$

Riug. abdominal, external, 1114, 1131 ; effect of position on, 113? internal, 1115, 1134

fentoral, 1139; position of vessels round, $11: 39$

Riurs, (artilaginous, of trachea, 913

Risorius [rideo, I langh] muscle, 437

Rivini, notch of, $4(1,8 \% 4$

Rivinian segment of tympanum, 8\%t

Rivinus, dnct of, 949

Rolantic point, inferior, 1089

Rolando, tissure of, 682,1089 ; development of. 682

tuberele of, 723

Roof bones of skull, 2t

Roots of auditory nerve, 765

of glosso-pharyngeal nerve, 767

of lenticular ganglion, $75:$

of lung, structures forming, 960

of Meckel's ganglion, 755

of olfactory nerve, 7.45

of optic nerve, 746

of otic ganglion, $\tau 60$

of penis, 1031

of spinal nerves, $740, \tau \tau 6$

of tooth, 86

of trigeminal nerve, 749

Rosenmiiller, fossa o1;, 952 organ of, 1214

Rostrum [a beak] of corpus callosum, 693 of splenoid, 30

Rotation of intestinal canal, 995

Rotator humeri nuscle, 461

Rotatores spinæe muscles, 423

Romul ligament of liver, 982, 1213

of uterus, 1050.1213

Rugre [wrinkles] of vagina, 1043

SAC, lachrymal, 868

pleural, 920

of peritomeum, crreater, 955

lesser, 955,957

Sareule [lim, of succus, a bay], the, 881

Sacral [sucer, sacred] aorti, see Sacral arteries, mindle

arteries, lateral, superior and inferior, 567 of middle sacral, 563

cormua, 15 micllle, 564 ; variations, 564

foramina, 15

groove, 16

lymph glands, f61

nerves, fourtli, 809

plexus, 809

prinary divisions of, anterior, 809 posterior, 782

portion of gangliaterl roril, 833
SCA

Sacral promontory, 15

veins, lateral, $6: 30$ middle, 634

rertebric, 24

Sacro-coceyeal articulation, 204

ligaments of, 204; morphology of, 231

Sacro-iliac articulation, or syuchomelrosis [oin, together; xúvopos, curtilage], 200

Sacro-lumbalis (ilio-costalis) muscle, 415

Sacro-lumbar ligament, 199

sacro-vertebral angle, 199

dillerences in miale and female, 200 measurements of; 200

Sacrum [sacer, sacred : the hone was offered as a sacrifice by the ancients], the, 14 .

morphology of:, 24

ossifieation of, 22

sexual differences in, 17

Sagittal [sogitto, an arrow: from its straight direction] axis of eyeball, 843

layer of transversus perinai muscle, 1106

section of brain, definition of, 671 of skull, 81

sinuses (longitudinal) of cranium, inferior, 619 ; superior, 618

suture, 44

Salivary glands, the, 946

Santorini, cartilages of, 905

fissures of, 871

plexus of (female urethra), 1042

Saphenous [from Arabic al-säfin, lirlden; less

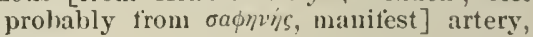
585

lymph glands (superficial femoral), 667

nerve. loug or internal, 808 short or extermal, 817 ; varieties, 817

opening, $345,1138,117 \tau$

veins, long (internal), 644

short (external), 644

topography of, 1191, 1188

Sappey, orbito-palpebral muscle of, 859

Sartorius [sartor, a tailor] muscle, 350 ; nerve to, 808

Seala [a staircase] tympani, 42, 881 vestibuli, 42,881

Scaleni, nerve to, 785,788

Scalenus [ $\sigma \kappa \alpha \lambda \eta v \sigma o$, of unequal sides] anticus muscle, 454

medins muscle, 455

posticus muscle, 455

Scalp, lymphatics of, superficial, 649

surricil anatomy of, 1084

topography of vessels of, 1085

Scalp and face, superficial veins of, 611 ; anterior, 612 ; lateral, 615; posterior, 614

cutaneous nerves of, 819

Scapho-eumeiform articulation, 272

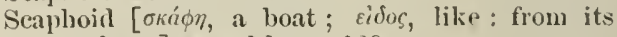
shape] (arpal bone, 1:29

lossia, $: 33,73$

of lielix of auricle, 871

tarsal bone, 166 ; ossification, 167

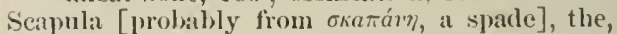
111

arterial anastomoses of, 1146

morplology of', 115

muscles of, surgical anatomy of; 11.1ti

ossitieation of, 11.1

Se'tpular ligaments, 221 notch, 111

Scarpa's foramina, 57, 72, 97

triaugle, surgical anatomy of, 11\%5 
Schneilerian memInane, s!l:3

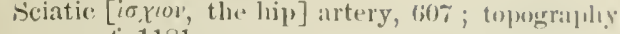
of, 1181

nerve, greatt. 814; topkerrapluy of; 11-1 small, -11

notch, greater, 140

vains, $6 ; 38$ lesser, 110

Seleral suleus, 8+1

Selerotis: [бis mpos, harri], the, 8.15

Scrotum [a skin], ('utaneous merves of, …: integument oft, 10::3

lymphaties of, (i61

septum of, 10:3

vessels anil nerves of, $102 \mathrm{f}$

Solnareous glaturls, 107\%

Second cervical neve, anterior primary division of: 782

posterion primary division of, $7=11$

(ranial (optic) nerve, 74 '

division (maxillary) of liltl nerve, rib, 101

Semicircular canals, extermal, $40,11,8-10$

posterior, 41, 880

superior, :\%, $41,-80$

semilunar lone, 1:y

cartilasr's of kuee, external, 258

foll of conjunctiva, $8 t^{\circ}$

intermil, 25.5

ganglia, $8: 35$

valves, aortic, 93:3; topography of, 9.33

pulmonary, 932: topouraphy of, 931

Semi-memhramosus muscle, 364

Semi-spinalis colli muscle, 422 lorsi muscle, $1: 00$

Semi-teudinosus muscle, :364

Sensory nucleus of glosso-pharyngeal nerve, 767 accessory. ot trigemiual, 750

Septal artery, ascenting, $4 ! 96$

cartılage, - -1$) 1$

nerve of Meckel's ganglion, 7.5 of nasal, 752

Septum [sepio, I herlge in], auricular, a:s1 attery ot, 496

filjrous, of tomgue, 838

lucidum, $\tau 0: 2$

nasi, 79 , 8!1

pectinitorme, $10: ;: 3$

posticum, of spinal arachnoid, Tit

scroti, 10:3

ventriculat, 968

Serratus [serra, a saw] magnus muscle, 2!13 posticus inferior muscle, 413 superior muscle, 111

Sesamoid [orgator, a small sced. sesame ; tifos, like] bones of arreat toe, $2-0$

bones of interphalangeal joint of great toe, $2 \times 0$

of thumb, 245

cartilages of nose. s!ll

grovers on head of first metanarjal, 1:if

plate, plantir, 27!)

of first metitarsal, 17u

Seventh cranial (ficial) nerve, otil

slseath, femoral, 11:3!)

of optic nerve in orbit, 861

of parotid, 10!)1

Shoulder joint, ligraments of, 2.2.2

movements of, 2:?ti

muscles in relation to, 2.25

relation of biceps tenden to, :2:21

cause of roumlness of, 1150)

surface markings of: 1149

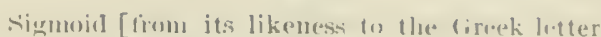
sigmul arlery, istio

ravity uf rulius, 1 :

of uha, greatre. 1:2:

lexirer. 1:3:3

flexure of colom, !1:-:

notele of mandible; ij

sinus, li:2:

Siuns [a hollow] alle parrat, or splu.uo parietal, (is:;

of : iorta, flin

basilatr, 6:21, (i:-)

(:Ivernous, bilil), 1it:?

rircular, 621, $6 \%$ ?

inferior, of Winslow, fi:l

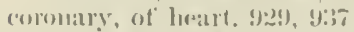

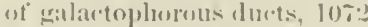

of incérin, lll:io

jugn laris, (62:2

of kiduey, 1(10.; ; stuctures lying in, 1010

lateral, li21, 1;:-

lomgituman, interior, 6:21, 65:2 superior, 61!), (172

of Morgagni, !)il

oblique, of hrart. 9:2

olylignus, or stringht, 1;:0, 1;7:

oreipital, 6:0), (ii:?

pedis, $16 ; 3$

perpendiculuris, or straight. (i:3), ti:-

pethosal, interior and supurior, ti2: 211

pet ro-*ip namous, (i:?:?

fornlaris, 10:3\%, 1:215

of portal vein, 63.34

lyritomis of laryux, !ll)

rectus, or straight, $1: 20,1 ; 5:-2$

rhomburelalis, 737

sarrittal, or lomgitmlinal, inferior, (i1!), tit:

sigmoil, 62:2

silperior, $\left.(j] \%, 6 i^{-}\right)$

splieno-parietal, 6is3, 6i:?

straight, $6: 00,6 \%:$

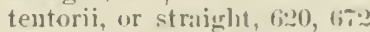

transwerse, $6: 1,6 \%:$

uro-genital. 105;

venosns, or at rimm, (1)2

Sinnses, rthmojalial (cells), .50

limintil $, 47,1(1): 2$

intercarernoms, $6: 21$

maroinal, (6:?)

misstoid (cells), 40, 10 $=2$

11:เsal, $\% 3, \% 9$

prostatie, 1021, 10:3\%

sphemoiclal, $30,80,111-; ;$

of Valsalva, or puluonary, $\|_{i}-, 43: 2$

ventus, of ('ranimm, fil!

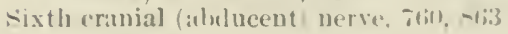

skin, 1073

appeurlages of, 115

nerves and versels of, joriti

structure of, lot i

Skult, anterior aspect of, : :

batse of, exterior. i:

remions ol: $: \because 3$

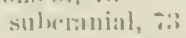

subureipital. :

rygomatic, ;:i

at hirth. !n

lomes of / classitiontiun. . 21

exterior ofi, li!!

lateral :1siect of, -11

pusterion :a-pert of, itl

superior asjuet ui, li?

interior of, -1 
SKr

Skull, interior of, base of (hloor). \$2 tosse of anterior, $-\cdots$ midulle, 83 posterior, $-1 ;$

section oft, coromal, =1

horizontal, -2

satrittal, El

lot:al, general characters of, 90

nerve foramina of; 96

sknll-cilp, average thickness of. 1093 measurements ot (average). -

Slcnder lobe of erebellm, 715 process of malleus, 67

Fmall cavemons nerve, 838

deep petrosal nerve, 828

intestines, lymphatics of, 664, 969

hloor-supply. 969

nerve-supply, 969

structure of: (1)

occipital nerve, 783; topography of, 1103

posteriorl palatime nerve, 756

sille-sciatic: ligameut, 202 ; origin from (ocevgeus, $2 \approx 1$

sciatic nerve, 811

Suallest splanclunic nerve, 831

Sinegma preputii, 1032

sunff-box space of hand, 1172

socia [a companion] parotidis, 947

summering, nerve of, or long pudendal, 812

sofit palate, 943

pirts cut in paring edges of cleft, 1097

Solar [sol, the sun] plexus. 835

Solens [soler, a sole-tish] mmarle, 372

Solitiry irlands of intestine, 968

Space, epicerebral, 6is

epispinal, 678

intervaginal. of optic nerve, 861

Ieckel's, 67:3

perforated, anterior, 706 posterior, 679

subarachnoid, $6 \% 0,678$

of optin nerve, 861

subdural, 675, 6\%

of optic nerve, 861

Tenon's, 860

Spaces, lymphatic, of eveball, 862

of Fontana, 846 of orhit, 864

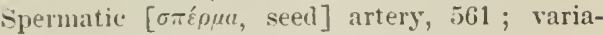
tious, 561

cord. $10: 30$; constitueuts of, 1030

fascia, middle and intermal, 1023, 1024, 1131

plexus (nerve), 8:37

reins, (i3i2

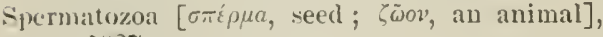
1027

splieno-ethmoidal cells, 50

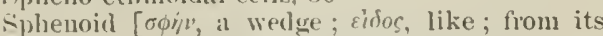
wedering in the other bones of the skull] bone, the, 29

ossitication of: 34

at birth, 9.2

sphenoidal artery of pteryono-palatine, 496

crest, 30 of spleno-pislatime, 196

tissure, $31,77,8: 3,97$

process of palate, 59

sinuses, :30, 80, 10स:;

turlinal bomes, 51 ; at birth, 94

Silueno-malar fissure, to

foranina. 71, 78. 97

suture, 71

Spheno-mandibular (maxillary) ligament, 180
SI'I.

Spheno-maxillary tissure, $\tau 0$, is, $9 \tau$

fissa, 7()

ligament, 180

Spheno-palatine artery, 896

foramen. $59,70,-0,97$

ganglion (Neckel's), 755

nerves, 754

notch, io

vein. 616,$896 ;$

Spleno-parietal sinus of crumium, 623,672 suture, 71,83

Sphenotic [ $\sigma \phi \eta^{\prime} r$ a wedge; oi s, the ear] cartilage, 89

foramell, 73,83

Sphincter $[\sigma \phi / \gamma\rangle \omega$, I bind $]$ ani exterus, ,1059

ani internus, 975,1059

iridis, -48

Sphincter vesicae interuns, 1019

Spigelian lobe of liver. 1078

Spinal accessory nerve, 773 , topography of, 1103

arteries, anterior, lateral, and posterior, 511 of aortic intereostals, 549

of deep cervical, 519

of inferior thyroid, 514

of lateral salcrals, 568

columm, 17 ; curves of, 19 ossification, 19

cord, the, 731

aracbnoid of, 732

dura mater of, 731

external character of, 734

interual structure of, 737

pia mater of, 733

tracts of, 737

nerves. 776

elassification and number, 778

deep origin of, 736

general distribntion, 778

primary divisions, anterior, 782

posterior, 779

roots of, $737,7 \tau 6$

topography of, 777,1145

plexus, venous, anterior and posterior, 629

portion of spinal accessory, 773

veins, 628

longitudinal, anterior and posterior, 630

Spinalis dorsi muscle, 419

Spine, alar, 32, 73

bones of the, 5

ethmoiclal, 30, 83

frontal, auterior, 47,80

posterior, 59, 80

iliac, anterior and posterior inferior aud superior, 139

mandibular, 6.3

nasal, 44

of palate bone, 59,80

pubic, 143

of scapula, 112

of tibia, 153

Spino-rlenoid ligament, 222

Spiral canal of modiolus, 42,880

limina, osseous, 41

line of femur, 147

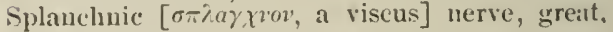
831

lesser, 831

smallest, 831

Spleen [ $\sigma \pi \lambda \cdot \dot{r} \cdot$, the spleen], the, 988

si\%e and varieties of, 990,991

structure, relations, and blood- and nervesupply, 991

topograpliy of, 1120 
SPI

Splenial [splenimm, a parl] centre of ossification in mandible, 64

Splenic artery, i5\%; variations, 5.,8 of left phrenic, isj3

lymphatics, 665

nerve plexus, 833

vein, $6: 37$

Spleninm [a pad] of corpus callosum, 69:

splenius [ $\sigma$ riminoov, a bandage: from its binding down other muscles] capitis muscle, 414 colli muscle, 414

Sipongy prortion of urethra, 10:3

Spot, yellow, of eye, $-4 ; 3$

Syuamo-mastoid furrow; 38

Syuamo-occipital bone, 25

squamo-sphenoidal suture, 71,83

siquamosil portion of temporal bone, 30 at birth, 93

Syuamous [squmma, a sealo] suture, 44, 71, - 3

Stapedic [stupes, a stirru]] artery, 490

stapedius nusele, 878; 11erve to, $7(j 33$

Stapes [a stirrul1], 68 ; origin of, 90

Stars of Verheyen, 1011

Stellate figures of lens, $\sim 49$

(anterior costo-central) ligament, 20s

Stenson's (auils, it

duct, 949

formuina, 72

Stephanion [otionns, a crowu], 71

Sterual abnormalities, 108

artery of internal mammary, 517

end of clavicle, 110 of rilss, 9 -

lymphatic glands, 6.57

Sternalis muscle, 461

Sternebre, 104

Sterno-claricular articulation, 216; structures behind, 1108

layer of deep cervical fascia, 1106

Sterno-cleirlo-mastoid [ki.zis, a key, clavicle] muscle, 445 ; nerve to, 785 surerical anatomy of, 1099

Sterno-hyoid muscle, 447

Sterno-mastoid artery, inferior, of suprascapular, 514

of occipital, 489

of superior thrroid, $4=2$

lymplatic glands, $6 \cdot 19$

Sterno-pericurdial bands or ligaments, 92-;

Stermo-thyroitl muscle. 448

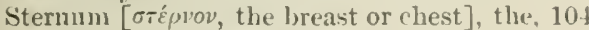

blood-supply and development of, 106

cleft, 108, 1:210

ossification and abnormalities of, 107

in the young subject, 10.4

stomach, the, 960 )

alterations of position, 962

lympliatics of, 662,964

nerves and blood-supply of, 964

structure, 963

topograpliy of, 1118

Straiglit convolution (gyrus rectus), 65.5 sinus of cranium, 620 sulens (olfactory), $6 x_{i}$

Stratum basilare, $10 \pi \bar{i}$

cornetum, 1075

granulosum, 1075

incidum, 1075

Malpighii, 1075

zonale, $7+3$

Stria [a stripe or streak] pinealis, 705,747 terminalis, $r(x)$

Stria acustica, $; 19$
Sil. 13

stricc longitulinales, 73.1

merlullares, 71!

St ylo-glossus muscle [firm attaclument to styloid atud tongue, jimera], 4is:;

Stylo-lovoirl muscle, 150 ; nerve to, itil, iti)

styloid [rivor, a pen; exlus, like] lone of carpus oreatsional), 137

pruecess, $37,67,7: 3$

at birtl, , fl

morphology and drevelopment of, 90 se'glnents of: (it

of hase of thirel metacarpal, l:3is of titula, 158

of radius, $1: y$

of ulua, 1:5

Stylo-maudibular (maxillary) ligrmunt, $1 \approx 0$ )

stylo-mastoid altery, $490,-$ -

foramen, $37,73,97$

stylo-maxillary (mandibular) limament, list

Stylo-pharyngens muscle, 9iil ; nerve to, 7(j)

Subanconeus muscle, 310

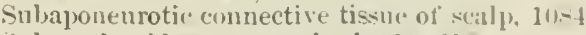

Subarachnoid sprace, cerebral, 6 it $6,6 i$;

tissue, cerebral, 676

$$
\text { spinal, } 734
$$

spinal, $\pi 34$

Sulc:apsular epithelium of lens, -.50

subclavian artery, the, 505, $111 ;$; tirst portion, 50.5

second portion, 506

thirel portion, 5117

variations, ito

of supriscapnlar, $\$ 14$

lymphatic glands. 6.5

veiu, 643 ; variations and tributaries, 6.13

Suhclavius muscle, 296 ; nerve to, :er

Subcostal angle. 10!!

artery (last dursal), 5.50

srowe, 99

rein, (in)-

subcranial region of hasis crauii, 7i:

subcrureus muscle, $36 \pi$

Sublural space, $6 \pi \overline{5}, 67-$

subliugual artery, $t-\overline{5}$

duct (livinis), 9.19

fos:at. 6:3

gitnglion, $\tau 60$

igland, !) $4 !), 10-i)$

Submandibular (submaxillary) ganglion, foll

Submaxillary artery, 4-7

duct (Wharton's), 94

toss:1, $6: 3$

ganclion (submandibular), T(i)

glamd (submandibular), !1. $\alpha$

van'ular and nerve supply of, y) 43

lymph glands, tiint)

triangle of nocti, 1101

vein, 614

Sulmental artery, $4=7$ vin, (i) 1

Subuasal point, -1

Sulucripital lymphatic glancls, filg recrion of basis eranii, $7:$

Suhperitoneal artery of counective tissuc. !is

sulssartorial merve plexus. $=(1)$

Subscapular artery, .34 ; variations. 52.5 of pusterior seapular. itti of suprasc:upular, ilis

Liesa, 111

lrmplatic glands, 65.5

nerves, lower, milllle, and upper, i-2

rein, 61:3 
$S{ }^{*} 13$

Subscupularis muscle, ;00:3

substantia fermginea, 719 gelitinusa centralis, 7:30

liolindi, 737

nigra of (erura cerelori, $67 i$

reticularis alba, 691

spongrosil. Tix

Subtlialamic hody, 710

subtrapezial nerve plexus, $7-5$

Sudoriparoms glamis, 1077

Sulcus [a turrow]-

of cerehellum, cerehelli superior, 715

lateralis dorsilis, $7 \geqslant 1$

ventralis, $7: 21$

loneritudinalis medianus, 719

partmedianus dorsalis, 721

parapyramidalis, 7:21

post-olivary, 7:21

of cerelirum, central, (is:2

centralis insulie, $6 \times 8$

choroideus, 705

cirenlaris Reilii. 682

fronto-marginalis, 684

occipitalis anterior, 728

olfictory (straight), 685

paracentralis, $6=9$

post-central, 686

pra-ceutral, 684

subparietalis, 685,689

lachrymal, 53

seleral, 8.4

of spinal cord, longitudinalis posterior, 734 paramedianus torsalis, 734

ternimalis, $1: 1: 3$

Superciliary [supercilium, eyebrow] ridge, 47, 73

Supinator [supinus, fice upwards] longus muscle,

(see Brachio-rallalis), 321 ; nerve to, 795 radii brevis muscle, 328

Supra-acromial nerves, $7 \times 4$

Supraclavicular nerves, $i \& 4$

Supraclavicularis muscle, 461

Supracoudyloid process, 119, 1211

ridge, 119

Supracormual limament of cocerx, 205

Supra-hyoid lymphatic glanels, 650 triangle, 1101

Supramaudibular (supramaxillary) nerve, 76.5

Supraunarginal couvolution, $6 \times 6$

Supramastoil erest, 35,37

Supra-occipital segment of squamo-oceipit:l loone, 25

Supra-orlbital artery, 500

foramen, 47

werve, 796

noteli, 47

rirleses, 17

veill, 613,616

Suprarenal arteries, inferior, 560, 561, 1014 miclile, 561, 1014 superior, 5.33, 1014

bodies, 1013

accessory, 1013

structure, 1014

ressels and nerres, 1014

lymphatics, 66.5

nerve plexus, $8: 35$

veins, 632,1014

Suprarimal portion of laryux, 911

Sinprascapular artery, 514

foramen, 113

ligament (trausverse), 2:1

nerve, 757

noteh, 113
SL'I

Suprascapular vein, 61 i

sinpra-spinatus muscle, 301

sumaspinous artery of posterior seapular, 516 fossa, 111 of suprascipular, 515

ligaments of coccyx, 205

of verteliac, 195

suprasterual artery of :uprascapular, 514 nerves, 754

Supratrochlear artery, 514

formmen, 120,1211

fossa, 47

nerve, 752

sural [sum, the calt of leg] arteries, $58 \beta$

suruical neek of lumerus, 117

Surgical and topographical amatomy of-

iludomen, the, 1114 ; revions of, 1206

abdomiual sing, external, 404, 1114, 1132 eflect of position on, 113\% interual, 411, 1115

amputations of leg, arteries cut in, 1192

ankle, the, 1198

anuular ligaments of ankle, 1196 ; of wrist,

anterior, 1168 ; posterior, 1169

auterior tibial artery, 119:

anus, 1127

nerve, $1: 00$

aorta aud iliac arteries, 1121

arches of the foot, 1200

arm, the, 115:2

axilla, 1150

back, the, 1142 of wrist and hand, $11 \% 2$

biceps muscle, 1153

bicipital groove, 1150

brachial irtery, 1153

brachialis anticus muscle, 1154

bursae of foot, 1199

buttocks, the, 1180

cœliac artery, 11:1

coraco-brachialis muscle, 1150

crural arch (Poupart's ligament), 113 \%

cutameous uerves of forearm, 1163

deep cervical fuscia, 1103 crural arch, 1138

deltoid muscle, 115

diaphragm, 1116

dorsal artery of foot, 1200

elbow, the, 1155

arterial anastomoses aroumd, 115\%

veins in front of, arrangement of, 1157

eyelids and lachrymal apparatus, 109:2

fice, 7090

fascia lata of thigh, 1116

pulic and iliac portions of, 1119

fascix and sheatlus of hand, 1169

female extermal genitals, 11:9

femoral artery, 1175

cautl, 11339

ring, 1130

position of vessels aronud, 1139

sheath, 1139

foot, the, 1198

forearm, the, 1159

fosse on posterior surface of alodominal parictes, 1117

gall bladier, 111 \%

gluteal artery, 1181

great sciatic nerve, 1181

head and face, 1091

heart, relation to the chest wall, 111:3

hernia, fenoral, course of, 1139 coverings of:, 1140 
$S L^{*} \mathrm{~L}$

Surgical and topographical anatomy of -heruia, parts concerned in, $11:$; inguinal, coverings of, 113.1 (aillses of, 1136i parts concerned in, 1131 umbilical, coverings of, 1141 p:irts concerneal in, 1141

hypocastric arteries (obliterated), 1135

inguimal canal, 1115, 11:22

interosseons arteries of arm, 116;;

intestines, large and small, 111-

ischio-rectal fissa, 11:2

jugular vein, extermal, 1103

kidneys, 1119

knee, the, 11:2

latissimus dursi muscle, 1142

leas, the, 118x

linea alloa, 1114 semilunaris, 1111

Lisfranc's or Hey's amputation, liness of incision for, 119!

liver, 1117

lower extremity, 1172

lumbar faseia, 1146

lungs, outlines and relations to chest walls. 1111

mamma, the, 1110

manul,rium, parts belind, 1111

median nerve, 11.jt, 1161

mesenteric arteries, 1121

montli, the, 1095

musculo-cutaneons nerve on foot, 1:00

musenlo-spiral nerve, 1154

nares. posterior, $109 \%$

neck, the, 1099

triangles of, anterior, 1101

earotid, inferior and superior, 110\% posterior, $110^{\circ} 2$

submaxillary (supla-hroid), 1101

nose, 1097

palate, solt, 1097

palmar arch, deep, 116 a

fascia, 1169

iuperficial, $116 \pi$

pancreas, 1118

parotid gland, 1091

patella, the, 1182

pectoralis major et minor muscles, 1150

pelvie fitscia, 1129

perinæum aud genitals, 112:2

triangles of, 112:2

peromeal artery, 1102

peronei muscles, 119\%, 1205

plantar arteries, 1202

fiscia, functions of, 1211:3

plenra, relitions to chest wall, 1112

popliteal space, $11 \varepsilon 6$

ressels, 1107

Poupart's ligument, 1116, 113 i

prostite, 1126

pullic artery, 1181

radial artery, 1161

nerve, $116 ?$

rectum, 1127

saphena veins, 1181

saphenous nerves, 1:001

scalp, the, 1084

seapula, muscles and arterial an:istumoses,

1146

sciatic arters, 1181

shouliter, the, 1149

skin folds or creases of the palm, 1165

spinal accessory nerve, 1103
$\mathrm{HIT}$

Surgiral and topmeraphical anatomy of-

spinal nerves, origin of; 114:

splecen, $11: 0$

sterno-ravicular joint, stuctures belund, $110 \alpha$

sterno-mastoid muscle, 1us!?

stomaleh, 1110

Syme's amputation, lines of incision, 119x

synovial nemblanes of loot, 1199

of lamel, 1171

of kmer, 118.5

of shouliler, 115:2

trudlo Achillis. where divided, 1197

tomelons atombl ankle, arrangement of, 1194 tenutumy, gniles fior, at ankle, 11!)

thenar am hypotlenar eminesces, 11 tis

thichl, the, 117:-

thoracic ressels, relations focluest wall, 111 t

thorax (superficial), 1109

tibial artery, posterior, 11!?

tibialis antir.us muscle, 12115 tenton, 119 \%

posticus nuscle, $1: 203$ tendor, $11 ! 17$

thes, great, lines for anuputation of, $12(x)$

tonsils, 109 i

trapezius muscle, $114 \%$

triangle of P'etit, 1145

tricels muscle, 115.1

ulnar artery in dorearm. 1161 nerve, 1154,116$]$

umbilical horma, comsenital, 1141 inlautile, $11+1$ ot" adult lile, 1141

ring, chanores in aldult life, 114

vesicls, changes in atult lite, 1141

urachus, 1135

urethira, the, 11:24

valves of heart, topocrajuhy of, $111: 3$

viscera and visceral regions. 1116

behind linta alla, 111\%

relations of, to vertelnat 1146

wrist amb hand, the, 11 (i:3

Suspensury [*ub, unler; pulo, I hang] ligis ment, central ulontuid, $1-8$

origin from sheath of notochern, :-5!

of evelall, -is

of lius, $8.14,-i 0$

of malleus, fiT, $-\tau$

of penis, 11332

of thyroill, !17

Sustentaculumi [xustento, I smpurt] lejotis, y\%: lienis, 973

tali [tulus, the antragalus] ], 1133

sutures [sulum, il seam], varieties of, true, fill-e, aul erocover], $1 \%$;

basilar, eti

('orom:1, 41. 69

ethmo-lachrryul, is

ethums)-sphenoital, -2

frontal, or metopice $17,6 !)$

fromtonethmoilal, $x=$

frunte-parietal, or coronal, 41,69

iroutu-sifuamusel, 3-, il

interparietal, or sagittal, 11,64

lambloid, 41, (it)

malo-maxillary, is

mixillu-premaisillary, 56, 7:

mesu. palatime, 5i, 7-2

metopiri, 4\%, 6?

nenro-cutral, :0

oreipital, 69

ocipito-mastuid, -6 
Surgicul and toporraphical anatomy ofoccipito-parietal, or lambloid, 44, (99 parieto-mastoid, 71,86

petro-oceipital, 86 petro-sphenoidal, 83 petro-synamosial, 35 sagittal, 44, 69

spheno-nuslar, 71

splieno-parietal, 71,83

sytramo-sphenoidal, $71,8: 3$

squamolns, 4i, 71,83

trillsierse, - -0 palatine, 7:

zyomatic, 7l

Sweat-glands, 1077

sirlian point of skull, 708

sylvius, arperluct of, 700

fissure of, 682

fossa of, 682, , 188

ventricle of, 702

Srme's amputation, incisions for, 1198

Sympathetic, gangliated corls of, 826 cervical portion of; 827 crunial portion of, 827 lumbar portion of, 833 sacral portion of, 833 thoracic (dorsal) portion of, 830

nerves, the, 8:6. See also Plexus, sympithetic

of orbit, 864

root of lenticular ganglion, 752

of otic ganglion, $\$ 28$

Symphysis [oív, together; фíw, I grow] pubis, the, 205

Synarthrosis [oiv, together; á $\rho \theta \rho o v$, a joint], classes of, 178

definition of, 177

examples of, 177

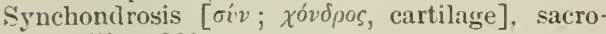
iliac, 200

Synovial membrane of acromio-clavicular articulation, 219

of ankle joint, 268,1196

of astragalo-sciphoirl joint, 274

of atlanto-axoidean joint, central, 187 lateral, 185

of calcaneo-astrayaloid joint, anterior, $2 \% 1$

posterior, 270

of ealcaneo-cuboid joint, 276

of cirpo-netacarpal joints, 241

joint of thumb, 212

of carpus, 240

of costo central articulation, 209

of costo-transverse articulation, 211

of cuho-metatarsal (outer tarso-metitar-

sal) joint, 278

of ellow joint, 2:9

of hip joint, 250

of interclsondral articulation, 214

of intermetatarsal joints, 279

of interplualangeal joints, 245

of knec joint, 259 ; surgical anatomy of, 118.5

of metacarpo-phalangeal joints, 243 of oceipito atlantal articulation, 183 of radio-carjal joint, 235

of radio-ulnar joint, superior, 2:30

of shoulder joint, 225,1152

of steruo clavicular articulation, 218

of tarso-inetatarsal joints, mirldle, 278

outer (cul,o-metatursal), 270
Synovial membrane of temporo-mandibular (max illary) articulation, 180

of tibio-fibular joint, inferior, 266 superior, 26.4

of vertehral articular processes, 1 (?) membranes of foot, surgicul anatomy of, 119 ()

of joints of hand, surrical antonty of, 1172

of tendons of hand, surgical anatomy of, 1171

Systemic arteries, the, 466 ; veins, 602

TABATİ́RE [snuff-box] anatomique, 1172

Tactile corpuscles of Meissner, 1076

Tania [taıvia, a band] hippocampi, 69 \% semicircularis, 701

Trenia tectre [tectus, rooled], 69:;

Tail of mucleus caudiutus, 699 of pancreas, $98 \%$

Tapetun [tapete, a carpet], 694

Tarsal arteries, internal and external, 600 cartilages, 866

ligament (palpelıral), external, 429, 867 interual, 429, 867

Tarso metatursal joints, interual, 277 midclle, $27 \%$

onter (cubo-metatarsal, 278

Tarsus [тарбós, a broad surface], boues of, 159 of eyelids, 840,866

Teats, superuumerary, 1215

Teeth, the, 86

milk, 89

permanent, 86

relations of erowns of upper to lower, 89

'Tegmen [a roof'] tympani, 37, 39, 83

of crura cerebri, 711

Tegmental, or red uncleus, 711 region of pons, 720

Tela [a web] choroidea, inferior, $6 \pi 6,-18$ superior, $70: 2$

Temporal [tempora, the temples] artery (superficial), 491

deep, anterior and posterior, 495 mirdile, 491 of posterior cerebral, 512

bone, 3 ī

ossification of, 42 ; at birth, 93

convolutions of brain, 688

fascia, 440

fissures of brain, 687

tossa, 70

lobe of cerebrum, 687

lymphatic vessels, 653

iu uscle, 441

nerves of facial, 76 is

of manrlibular tlivision, $75 \%$

superficial, of auriculo-temporal, 7.s of temporo-malar, 754

operculum, 682

ridges, 44,70

veins, commun, 615

deep, til 6

midlle, 615

superficial, 615

of diploë, 618

Temporo-facial division of facial nerve, rit

Temporo-malar nerve, 754

Temporo-mandibular (maxillary) articulation, 180

Temporo-maxillary vein, 616

Temporo-occipital artery, 512 
TE.

Tendino-trochanteric baml, ?la

Tendo [tendere, to strotoh] Achillis, $: 3 \%: 3$; where divided, 1197

oculi, $4: 29,839,867$

Teuon's cilpsule, 878 space, 878

Tenotomy, guides for operation at ankle, 11!r

'Tension curves of eancellous lones, 1

Teusor palati muscle, 9.15 tarsi muscle, 130 ty'mpani muscle, 978

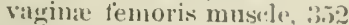

Tenth eramial (memmogastric) nerve, 769 ril, 102

Tentorial groove of uncinate gyrus, (i91 surface of cermbral hemisplieres, (ixy

Tentorium [a tent] (erehelli, 675

'Teres [roumd] major muscle, 30.1 minor muscle, $30: 3$

Testes of corpora quadrigumina, 710

Testicles [dim. of lestis], the, 10:24 Jympliatics of, 662 structure, 1026 vessels and nerves of, 111301

Testicular artery of spermatic, 561

Thalamencephalon, the, 670 , 70.1 nerve tracts in, $; 1$ -

Thalamic [ $\theta \dot{a}$ apus, a herl] arteries, middle, 5t).

Thebesius, foramina ot, 929,933 vilue ol:. 929

Thecie [ 333

Thenar [tivap, the palm of the linul] eminence, muscles of, :3:39

fascial, 3.33 surgical anatomy of, $116 \overline{5}$

Thighs, nuscles and fasciae of, 344 surerical antitomy of, 1172

Third cranial (oculo-motor) nerve, 747 foramel lior, 8:3

trochanter, 1.17

Thoracic artery, acromial, 521

alar, 5:4

axis, 521

long, 52:

slort or superior, 52]

twelith or subcostill, $5.1<$

duct, 648 , (iis) ; viriations, 660

inlet, 108

lymphaties, 656

nerves, anterior, extermal and internal, $7-8$ posterior, $\tau<x$

cardiac, ; $\%: 3$

spinal, primary livisious of, an. terior, igti

posterior, 781

first, 796 ; variation, $796^{3}$

last or twelftl, 8n 1

portion of gangliaterl cord, -30)

veins, $602,6.13$

twelfth, (it)?

ressels, relations to chest-wall, 1111

Thorax [Hispas, a breastplate], the, 892

aperture of: lower, 899

upper, sis

structures passing through, 110!?

mediastina of, 8!)?

movements of, :215

skeleton of, 108

surerical anatomy of, superficial, 1109

viscera contained in, 8!:y

Thymic arteries, 517

reins, 605
TIRA

Thymus [thyme] bor]y or gland, als

lymphatios of , ti.,

st rulcture of , (9)!

ressels and nervets of, (3i), 920)

Thyre-irytemois] liganents, inforior (rue) ant superior (fillare veral corrls), tout; numscle, 9o:!

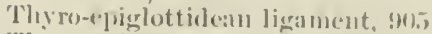

Thyro-epiglottideus muscle, !)u

Thyro-glessal duct, 9)

Tliy ro-hyal rentre of osilieation, 9j

Thigre-hyals, t;i;

Thyro-hyoirl ligamonts, 9ot;

membrane, $)(x)$;

miscle, fis: nerve to, 775

Thyroid [Heper, a shield] atrtery, inferior, 51:?

axis, 513

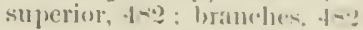

latr, 911

looly, or gland, 915

liganlents of, 917

structure of, 91 \%

vessels and nerves, s:30, 913

cartilage, 901

foramen (olsturator), 13₹, 14 :

lymphatic's, 6i:2

veins, milllle, $6: 27$

interior, right :und left, $(i \cdot)-\alpha$

superior, $6: 27$

Thyroillea ima [ima, lowest] : irtery, 45i5

Tilia [a pipe or tlute], the, 1.53

ossification of, 157

surgical anatomy of, $11 \times 4$

Tihial arteries, anterior, $594 ;$; surgical anatomy oft, 11 s8

pusterior, 590 ; surgical anatomy of; $11 \times 8$

recurrent, anterior and pusterior. (i) 99

nerves, anterior, 81.$)$ : branches, -15

posterior, s16; lirumches, sli;

Tibialis antirus musele, $3-7$

tendou, effect on plantar arch, 1:30.5 where divisled, $11 \%$ t

posticus muscle, :3it;

temlon, eflect on plantar areh, 1:30:3 where elivinted, 11!s

Tibro-fusciolis anticus muscle, Jibl

Tonerie, the $x-1$

arteries and nerves of, an

lymphaties of, tis:?

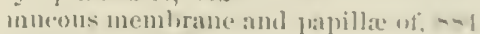

muscles of, son

septum of, s-se

Tonsill:ur arteries of : asending palatine, $1-7$ of fillial, $.1-7$

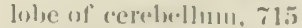

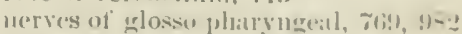
rovess, !1]

Tousils, the, 9lti

surcikal andtomy ol, 11!!

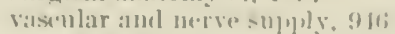

pharyngeal, 9:il

Touth, conlponent parts of, -ri

Topograplucal Inalomy, se sureical and tupo graluhical atlatomy

Topograplyy, (ranio cerehral, lin-1; at spinal nerve., is

Toren]ar [a wine jrem] Heroubili, : 2 ;

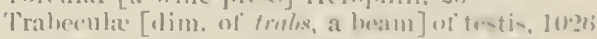

Trabecular recrion in the ehoudral stiull, -!)

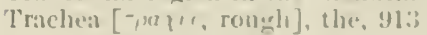

struclure (15, 9)13 
T R.I

Trachea, vascular and mel'vous sujply, 914

Tracheal artery of inferior thyoid, 51 1 layer of decp cervical fiscia, 1106 lympluatic glands, 65o

$$
\text { vessels, } 652
$$

triangle, or inferjor carotill, 110:

Trachealis muscle. 914

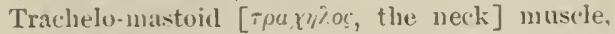
419

Tract, or 'Tracts, direct cerehellar, $;+1$

of the fillet, 782

irontal pontine, 7.1

Gower's, 781

nerve-, in thatamencephalou and prosencephalon, 717

olfactory, 745 ; cortes of, 745

pyramidal, anterior and lateral, 741

of spinal cord, 737

ureal, 846

Tractus intermerlio-lateralis, 737 spiralis foramimulentus, $80 \mathrm{~s}$

Tragicus muscle, 8\%?

Tragus [Tpa;os, at goat], the, 871

Transversalis abclominis muscle, 408

colli artery (sce Transverse cervical), 515 muscle, 41 o

fascia, 411

humeri artery (see Subs(apular), 514

Transversus auris muscle. 87:

nuchie nuscle, 290, 461

perlis muscle. 384

perin:ei muscle, deep, 1069

superficial, 1034, 1068

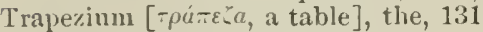
of the pous, 720

Trapezius muscle, 288 ; nerve to, 785 surgical anatomy of, 1142

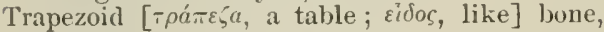
132

ligament, 220

Triaugle, Bryaut's, 1173

of neck, anterior, 1101

carotid, superior and interior, 1102 posterior, 110:

submaxillary, 1101

of perinæum, rectal, 1122

of Petit, 1145

urethral, 1122

Scarpa's, surgical anatomy of, 1175

Triangular fascia, 404, 113:2

fibro-cartilage of wrist, 232

Cossa (fossil of autihelix), 871

ligament, inferior (anterior layer), 1066

superior or deep (posterior layer), 1068

space at base of bladder, 1017

Triangularis sterni muscle, 398

Triceps [tres, three; eapul, head] extensor cubiti

muscle, 309 ; nerve to, 795 surgical anatomy of, $115-$

sura muscle, 36 !

Tricipital artery of posterior circumflex, 526

Tricuspirl [tres, three; cuspis, a point] valve, (1):2 ; toposraphy of 1113

Trigeminal foramen, 36,96 nerve (fifth cranial), 719 noteh, 36

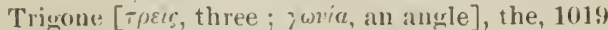

Trienonum habenulic [dim of hubewe, a rein], 705 hyporlossi, 71!

olfartorium, 69 ?

os, 162

varri, 71 )

Trimdiate fissure of cerebrum, 605
TUE

Triticco-glossus muscle, 461

'Trochanteric fossa, 147

'Trochanters [Tpojá I roll] of femur-

greater, 147 ; surgical aluatomy of 1172

lesser, 147

thint, 147

Trochlea [tpo xi ia, a pulley], the, 120

of superior oblique muscle, 857

Trochlear artery of lachrymal, 500 nerve, or fourth eranial, 748

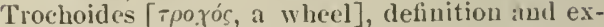
amples of, 178

True ligaments of bladder, 1018 pelvis, 145

ribs, 98

rocal cords, 911

Tulal artery, 10.54

T'ulye, collecting, of kidney, 1011 of epididymis, $102 \%$ looped, of Henle, 1011

Tuber cinereum, 707 omentale of liver, 979 valvulæ, 715

Tubercle, accessory, of lumbar vertebra, 12 adductor, 150 of atlas, anterior and posterior, for transverse ligament, 8

of calcaneum, anterior, inner and onter, 163 cervical, of fenur, superior and inferior, 147 condyloid, of mandible, 64

deltoid, of clavicle, 110

geuial, 62

lachrymal, 57

laminated, of cerebellum, 715

Lisfrane's, 100

of Lower, 931

mammillary, of lumbar vertebrit, 12

ot optic thalamus, anterior and posterior, 705

orbicular, of incus, 68

peroneal, of calcaneum, 163

pharyugeal, of basi-occipital, 27,73

post-glenoid, 35

of rib, 98

of Rolando, 723

of tibia, 153 ; surgical anatomy of, 1184

Tubercles of Montgomery, 1070

Tuberculum [dim. of tuber] acusticum, 719,766

Tuberosity, bicipital, 126

of clavicle, 109

of lifth metatarsal, 17:

of humerus, greater and lesser, 115

of ilium, 139

of ischinm, 139

of maxilla, 5.5, 72

of palate bone, 59

of scaphoid, carpal, 129

of tibia, $15:$

tars:ll, 166

Tubules, uriniferons, 1011

Tubuli recti of testis, 1027 seminiferi, 1027

'Tumica albugiueat of ovary, 1053 of penis, 1032 of testis, $10: 26$

propria of kidney, 1010

vaginalis, 102.1

rasculosa of testicle, 1027

Turbinal process of lachrymal, 53

Turbinals [turloo, a whirl] (ethmo-turhinals), inferior, 52 ; ossification of, 53 at birth, $9 \tilde{i}$

spluenoilal, 51 ; at birtlı, 94 superior, 49 
TUR

Turlonated [turbo, a whirl: from their coiled nature] erests of maxilla, 5fi of palate lume, in

Twelith (last) dorsal artery, 5iso) cranial or hypoglusil nerve, 7.1 rib, $10^{\text {2 }}$

Tympanic artery of ascençing pharyngeal. 182 of intrornal maxillary, $4 ! 13,-7-$ of mislle meningu:il, $4 ! 11$ of stylo-mistoicl, 49]

(ausliculns, 37,73 of Vidian, $49 x$

cavity, 875

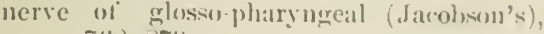
$768,87 !)$

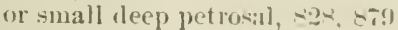

plate, :3\%. $\%: 3$

plexns, 879

portion of tempora] lone, $3 . \overline{3}$; at birth, $4: 3$ vein, 615

Tympano-lyal process, 90 ; (entre of msilication, ())

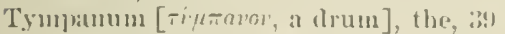

meisllrements of, 12

muscles of - -17

osivieles of, siti

promontory of, 39

proper, 40

roof of 83

ressels and nerves of $87^{2}$

vestibule and semicircular canals of, 11

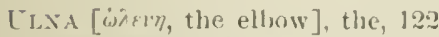
us ification of:, 125

Uluar artery, 531 ; surgical anatomy of. 11 (il, 1154

in forearm, 531 ; variations, 531

in the paim (superficial palmar areh), 5336 ; variations, 533

at the wrist, 535

carpal, anterior aud posterior, 53i

recurrent, anterior and posterior, 533 comblyle of humerus (internal), 120 uerve, 794 ; snrgical anatomy uf, 1163 vein, superficial, anterior and posterion, tit1

Lmbilical tissure of liver, 972,979

hernia, coverings of, 1141

parts roncesned in, 1141

varieties of, 1141

region, $120 x$

ring, changes in, in atult life. 1141

rein, 63:38

resiels, changes in, in arlult life, 1111

Tmbiliens, 402

Lmbo [the hoss of a shiekl] of usembram tympani, 87i

[neiform [uncus, a hook] hone, the, 1:3:3 process of ethmoir], 50 of unciform bone, $1: 33$

Encinate artery of posterior cerobral. 11 ? of posterior communicating. 5it? convolution (ur gyrus), ti!)!

[neus [a lowk] of monduate gyrus, foll

Unerual [mmmix, a nail] platamges of timgers, $1: 3$; ossification 11 , 1:36

of toes, 17. ; usvifucation ut, 17.7

Tracheric artery of superior vesion],

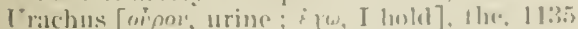

Cretal antery (nreteric) of commun ilaw, ifio of ovitrian, j(i2
I. 15

livetal artery, of renal, ifou

of spermatic, sil

(ureteric) of suluerior wescal, .ion

[riter [niper, I pass water], 1011

Irmiplaties of, lolis

stlueture, 101\%

varieties, 101.5

ves:els and uleres, $\mid 1115$

Trethra [urpen, urine]. the temale, 1011]

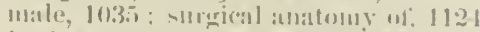

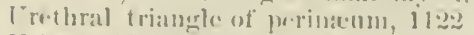

Crinary bladleler, the, lolli neatus, internal, relation to jelvic wall, ju]d

[rxtermal, $10 ;: ;$

Friniferoms tululles, $1+11]$

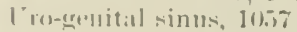

Iterine artery, 605, 10.53 of mistatu, itti?

phexus (nerve), $83 \times, 10.5$

(it)III, 10.$) ;$

I'tero ingurinal (romml) liganuent, 10.50

['toru-ovarian ligaments, I 1.5$]$

[ter(s-p)lvic: liganuents, [11.3]

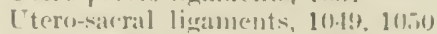

[tero-vesional ligaments, 104!)

[terus [the womblis, the, 1044

ligaments, 1017

lymphatio's wi: tifo?

nerves of $-3-3-105 i 3$

structure of 10.17

rariation accordine to ace, 10.17 masculinus, 10:3\%, 1:15

["triclo [dims. of uterus], the , $8-1$

['veal [um, a grape] tract, stif

[vula [dim. of arm] of cerebellum, 71\% of [, ivitatal], 101!)

ut palate, 9.4

Fifixd [a sheath], thet, 10.42

(i) 11 and direetion, 10.12

lymplatic's, (iti:), 1044

relations, J11.43

structure, 1044

vesscels ami nemes, 1044

Vaginal arteries, it

azygus artery, $5 \pi 1$

('ximmination, topmeraphy, 1131

plexis inerve), -3-

juroess of temporal lune, [1], 73

Vilgus [mgo. I wanler] (jmemugastrie) nerve. i(i?)

Valentin, gaumlion of, 754

Valleenla of cerehellum, itt of tollene, ה-1

Valsalva, simuses uf, flic, !1:2

Valve, Eustachiam, !12!) : in dirtus, ! 10 of foramen owale (in fertus), 19.90

ilew-1"inal, !1\%:"

of Tly.lusins, !r?!

of Venssells, 71 T

Valve's of lieilrt, hicouspis]. or mitral, !ist semilunar, aurtie, $93: 3$ [illmon:uy 932

fricuspiu], !13:2: topmgr:ıpliy of. 111:

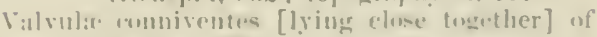
intmatine. !hilinérin, jo:i-

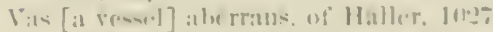

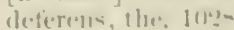

arti.re to, 5)

nervec to, -32 
VAS

Vasa aberrantia. 1215

hrevia of splenic artery, 558 veius, 133 \%

eflerentia, $10: 2 \%$

intestinj tenuis, 560

Vascular cont of eyeball, 847

Vistus exteruns miscle, $36(i ;$

internus and crureus, 365 ; division between the two muscles, 367

Vater, ampulla of", $y<4$

Vein, or Yeins, divisions of the, 602

of abdomen, $6 ; 30$

acromial thoracic, 643

angular, 613

anricular, anterior aud posterior, 616

of beart, left, 610,937 right, 610

axillary, 643

azygos major, 606

hasilar, 6:24

minor et tertia, 607

hasilic, 641

brachial, 643

merlian, 641

brachio-cephalic, 60:2 ; variations, 606

of brain, 6:3

bronchial, 609,925

buc'al, 614,616

(apsular, or suprarenal, 632, 1051

cardiac, anterior, 610,937

great, $610.93 \%$

josterior, 610,938

small, 610

smaller anterior, 611

(entral, of retina, 626

cephalic, 641

cerebellar, inferior, 624

cerebral, 6:3 superior, 624

central or (leep, 624

cortical, 623

cerrical, (leep, 614, 628

transverse, 617

choroid, 624

eiliary, anterior and posterior, 625 lower posterior, 626

circumflex iliac, deep, 647 superficial, 631, (64t

of shoulder, 643

coronary, of heart, 609,937

of lips, inferior and superior, 613

of stomach, 6336

of eranium, see Sinuses

cvstic, 636

(lental, inferior (mandibular), 616 posterior, 616

diaphragmatic, or phrenic, 633

digitul, of foot, 644 of haud, 640

of diplö̈, 618

tor:al, spinal, 629

of penis, 633

of ear, 625

emissary, of cranium, 672 of mastrid, 622,672

emulerent, 6:31

epigastric, 1eep. 6.47 superficial, $6: 31,6.11$

ethmoidal, anterior and posterior, 6:6, 897

extra-spinal, 629

facial, common, (i13

conmunicating, 613.614

trausverse, $61 \%$; variations, 614

\section{VEIX}

Vein, femoral, common, (it7

cntaneous, extermal and intermal, 644 (leep. 647

of foot and leg, 646

fiontill, 612

of diplö̈, 618

fronto-sphenoirlal, of diploë, 618

of Galen, of brain, 624, 702 of lieart. $611,930,937$

gastrie (coronary), 6:36

gastro-epiploje, left, 6337 riglit, 637

glandular (submaxillary), 614

gluteal, 638

haterrorhoiklal, 639

of head and neck, deep, 617 superficial, 611

of heart, 6019

hemiazygos, 607 accessoria, 608

hepatic, 633,982

iliac, common, 634 ; variations, 634 external, 647 internal, $6: 38$

ilio-lumbar, 634, 638

innominate, 603 ; variations, 605

intercostal, superior, 604, 608

interventricular, anterior, 610 posterior, 610, 937

intra-spinal, 629

jugular, anterior, 617, 1100 external, 616 ; variations, 617 internal, 627 posterior exterual, 61 \%

jugulo-cephalic. (i4:3

labial, inferior and superior, 614

lachrymal, 626

laryngeal, 627

lingual, 627

of lower extremity, deep, 646

lumbar, 633 superficial, 644 ascending, 633

mammary, interual, 605

nandibular, 616

marginal, left and right, 610,937

masseteric, 614, 615

mastoil emissary, 622. 672

maxillary, internal, 615 anterior, 614

mediam basilic, 641 ("ephalic, 641 reep, 641,643 superficial, 641

mediastinal, 605

of medulla oblongata, 625

medullary or medulli-spinal. $6: 30$

meningeal cranial, midlle, 616 spinal, extramednllary, 629

mesenterie, inferior, $6: 37$ superior, $6: 36$

nasal, 625

lateral. superior and inferior, 613

transverse, $01: 3$

of neck, deep, 627

superficial, 616

ob)lipue, of Marshall, 610

obturator, $(i 38$

occipital, 614

of diploë, 619

(esophageal, 609)

ophtlualmic, ('ommon, 625

inferior, 616,626 
VEIS

Vein, ophthalmic, superiur,

of orbit, $6 \% 55$, $8\left(i^{\circ}:\right.$

orbital, 615

ovariatu, 633, 10.53

palatine, inferior or descendingr, lil t superior, fili;

palpehral, inferior, 61 .

superior, 613

pancreatic, $13: 37$

pancreatico-duodenal, 637

purietal, external, of diploei. 6is

parieto-occipital, of diploë, 619

jarotid, til.t, 615

of pelvis, 6:3s

pericarcliae, 60.5

peroneal, 686

pharyugeal, 626

phrenic, inferior, 633

plexnses of, see Plexuses, venons

of pons Tarolij, 62:5

popliteal, 646 ; surerical anatomy of, 11 variations, 646

portal, 634

post-veutricular, 939

preventricular, 611,937

profunda, 1547

pterygoid, fil.

purlic, ti35, 1067

pulmonary, 602

pyloric, 636

radial, superficial, 611

renal, 6:31

sacral, middle, 634 ; lateral, 639

saphenous, long or internal, fit4; surgical anitoms of, 1191

short or exterual, 644 ; sulrical anat. olly of, $11 \varepsilon$ ?, 1191

of serly and face, superficial, 611

sciattic, 6:3-

spermatic, $6: 32$

sphemo-jalatine, 616,897

spinal. 628

of spinal cord, 630

splenic, 6:37

subclavian, 643 ; variations. $64: 3$

subcostil, biog

submaxillary, 614

submental, 61 t

subsiapular, 643

supra-orbital, 1i12, 61k

suprarenal, $6: 32,1051$

suprascapular, fi17

systemic, 602

temproral, (common, 615

lee 1). 616

millle and superticial, 61.5

of diploë. (ils

temporo-maxillary, 1 ili

thoraric, long, 1543

of thorax, $\left.60^{\circ}\right)$

thymic, 6015

thir roid, 693

tibial, (i.16

tympanic, (i15

ulnat, superficial, fitl

umbilical, $6: 3-$

of upper extremity, (leep, 61:3

uterine, 1053

superficial, 6:30

vasa brevia, of splenic, 13 i

of vertelura (borlies), 630

vertehral, (i)

Vesaliau, 616
VF:S

Vena azygos major, tio)(; IIIIur, (iv) tertia, $($ io)

('ava inferior, 631 tixure in liver for, 90 variations, (ii3:3

superior, foo:; ; topougraphy of: 111. variations. $(; 0)$

cospuris striati, (i) 1

Galeni l cardiace), 1j11, 935

lemiaygos, tat

ilcessoria, liow

magni lialeni (cerehral), 6i24, it)?

porfice, see l'ortal vein

salvatella, $(j .1)$

Vente bisis vertebrac, 6:30

comites, brachial, fidi3 tilial, (i16

cordis minimte, (it) y, y2y jarvac, 611

vorticusic [rorter, a whirlpool] $,-1.5,-53$

Velum [a veil] interpositum, o(l):

medullary, of cerebellum interior, 7 is, it

Venous sirle of heart, y27

superior, 71\%

Ventricle [dim. ni wuter, the belly] of Arautius. 718

of brain, lateral, fiof,

tifth (Sylviaul), 6, 6 , 701

fourtl, 6iil, 718

third, $670,-114$

of heart, left, $! 3: 3$

right, $\{131$

of laryux, !11

Veutriculir walls of fortal heart, 9at

Ventriculus terminalis of cord, 737

Verheven, stars of, 1011

Vermiform [ermis, a worns] appendix, 971

artery of posterior inferior cerebcllar, 511 of superior (erebellas, 51:

fossa (basis erauii), 26 , di

process of ecrehellum, inferior, 71.5

superior. 711

Vertebra [urtere, to tum: irom its motatury motim], anti-clinal, 1.)

brody of, norphology of. 2:2

cervical, peculiar, 8 ; typical, 8

lialf vertebra, 1:?

lumbar, peculiar, 1:? : truical, 1?

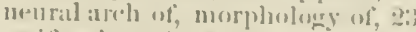

ossification oft, 19

promineus, "1: museles attached to, 11 anitic:ation off, 19

sacral and corecyentil, 14, 17

thoracic or direal, peculiar, 1:2; typucal. 19

trpical, 5

Verteliral aponeurosis, fto

asters, s09: variations, istu

hramelase to, from midelle cerveral watnglions, - :3:!

of rleep corvin:

of limbar sint

columm, arterial and nerve supply and moxement: of, 1!17

rils. ! 10

spine, topospitplyx of, 11 1:

veius, ti:-

Verfebrerelumelral rils, !

Vertelorosternal ribus ! -

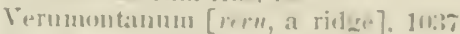

Vesaliau reju, dilit

Vesical [revich, a blather] arteries, 569 
$\checkmark \mathrm{ES}$

Tesical arteries of oluthrator artery, 5i:

lymphatics, $66: 2$

nerves, 8337

plexus, nerve, 2nT velnolls, (ii3)

portion of ureter, 1015

Vesicles [dim. of resicu, a bladtler], cerebral, anterior. middle, and posterior, 669

Vesico-pubic muscle. 101?

Tesicule [dim. of resicu, a bladder] seminales, $10: 29$

Vestibular artery of stylu-mastoid, 491 nerve, $76 \tau$

Vestilule of labyrinth, $41,-79$

of month. 94?

of nostrils, $-\cdots ?,-9 ! ?$

of viluina, 103 !

Festigial and abnormal structures, 1209

boues (e.g. fibula), 1.59

fold of peritardium, $9: 20$

Vieq d'Azyr, bundles of, 702, 707 foranen ("æecum of, $7: 21$

Vidian arters, 490 (anal, 33. 70 ; at birth, 93 nerve, 755

Yieussens, valve of, $71 \%$

Filli [ cillus, slnaggy] of smill intestine, 968

Vincula [small chains] accessoria, 333

Viscera [riseus. p]. riscera, an organ], aldomina] the, 954. 1116

relations of, to rertebræ, 1146

Visceral branches of alıdominal aorta, 55ว of sacral plexus, 810

lymphatics of pelris, $66^{\circ}$ ? of thorax. 658

Vitreous [vitrum, glass] humoul. 850

Vocal cords, true aud false. 912

Volar [rolı, the palm] artery, superficial, $5+1$

Vomer [a ploughshare], 53 ossitication of, 54 at l,irth, 95

Vulva [colvere, to roll], the, 1038

WALDEYER's glinds of eyelids, 866

Walther, ducts of, 949

\section{ZYG}

Wharton's (submaxillary) duct, 848

White line of oluturator fascia, 1061 matter of cerehellum, 716 of encephalou, 679

Trings of sphenoid, greater and lesser, 31

Winslow, foramen of, 95.)

Wirsung, canal of, 957

Trislom teeth, \&w

Wolftian hody, 1055 duet, 1055

Womb, the, 1044. See Lterus

Wormian bones, 48

Wrisberg, cardiac ganglion of, $9: 39$ rartilages of, 905 nerve of, 118 ,

Wrist, surgical anatomy of, $116:$; joint, the, see Radio-carpal articulation skin-folds of, 1164

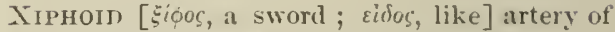
superior epigastric, 518 (artilage, 104

YELLOW elatic fibres ot trachea, 914 spot of eye, 843

ZEIss's glands of evelids, 866

Zone, boundary of Lissatuer, 741 mixed lateral, of spinal cord, $7+1$

of uterus, intravaginal, 1044 supua vaginal, 1044 of vaginal attachment, 1044

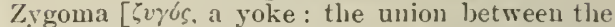
facial bones and those of the side of the head], the. 35

relation of, to cranial contents, $7.2-7$

Zygomatic tossa, 70 ; Irnuphatics of, 651 process of malar bone, 61 region, 71 suture, 70

Zygomatico-orbital artery, 491

Zygomaticus major muscle, 431 minor muscle, 439 


$$
\text { , }
$$








\section{Date Due}

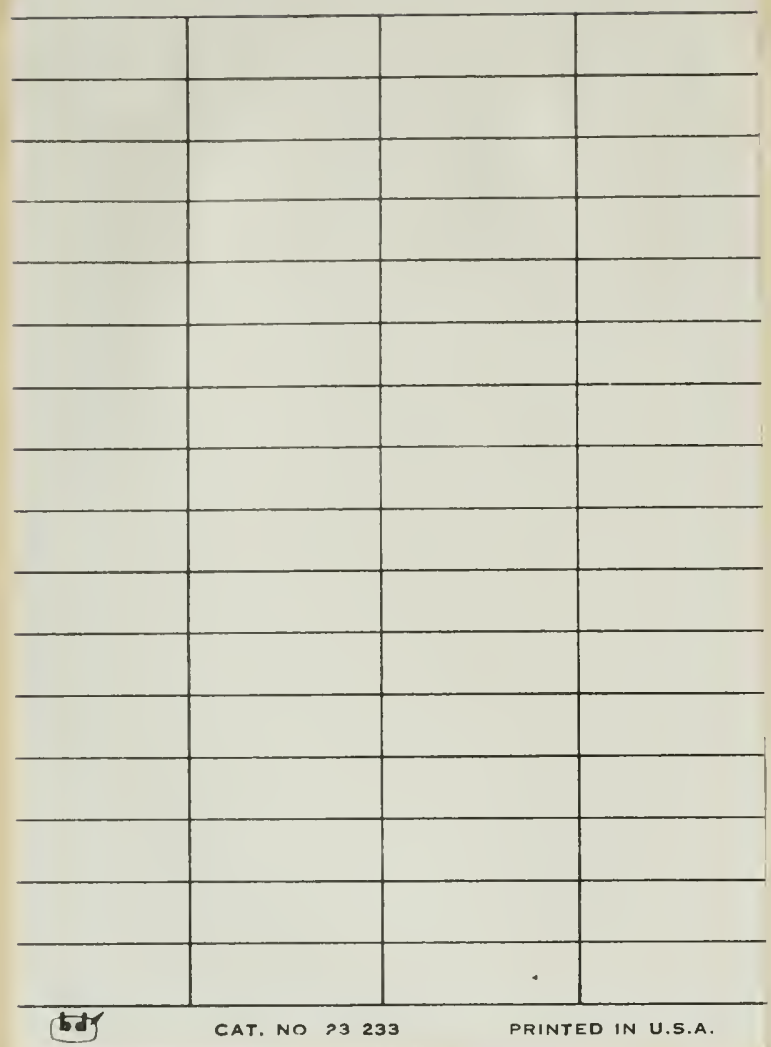



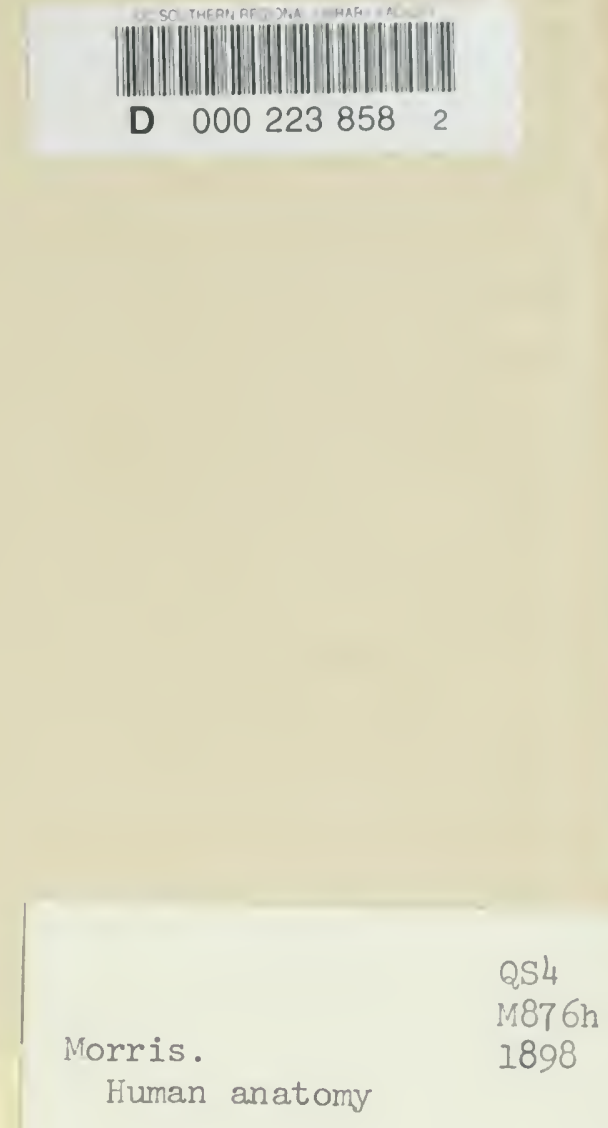

Morris .

Humen anatomy

QS4

M876h

1898

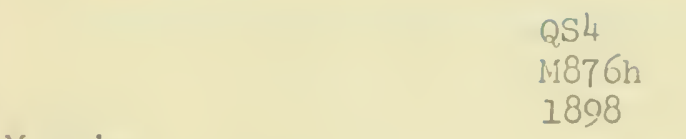

CALIFORNIA COLLEGE OF MEDICINE LIBRARY UNIVERSITY OF CALIFORNIA, IRVINE IRVINE, CALIFORNIA 92664 


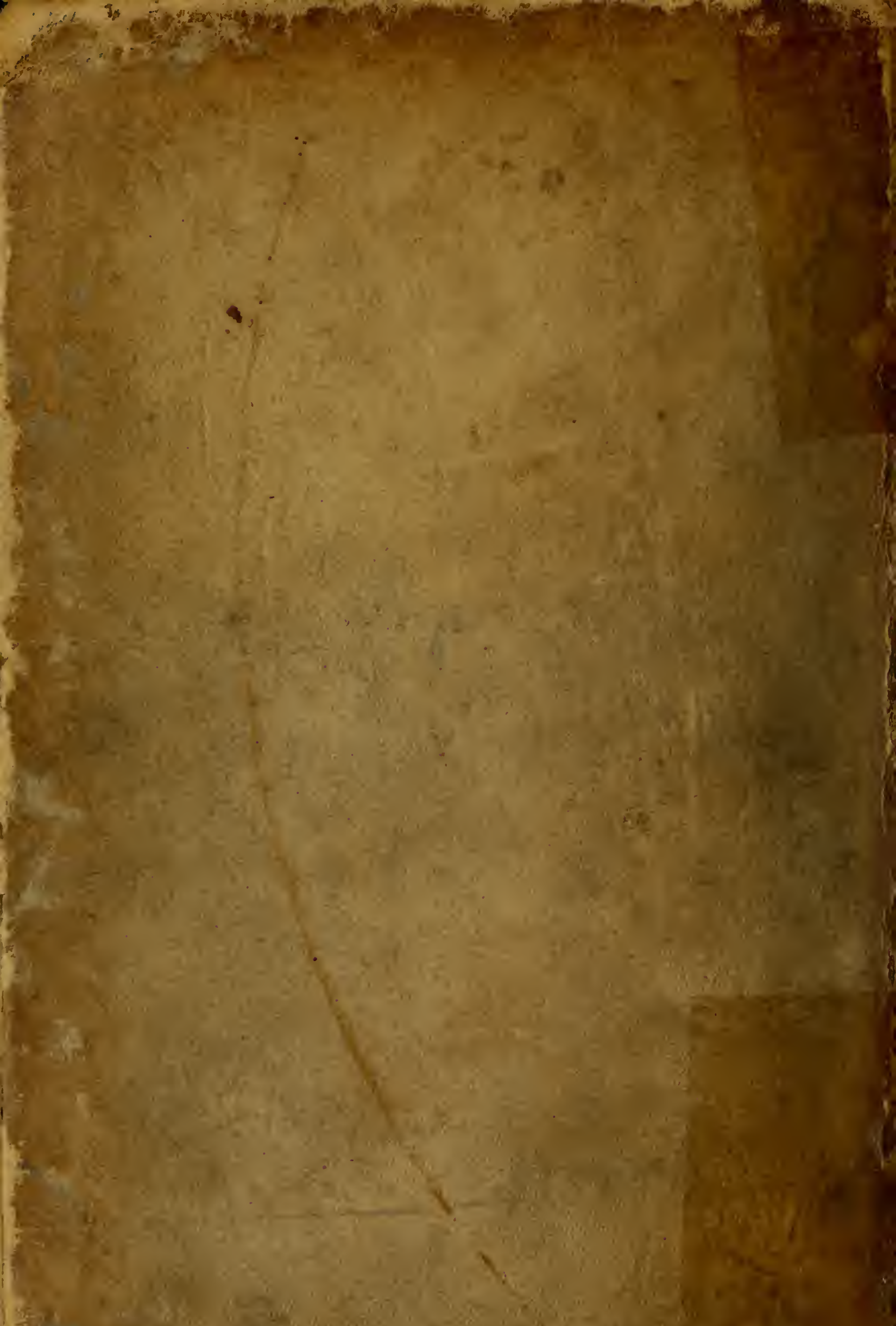

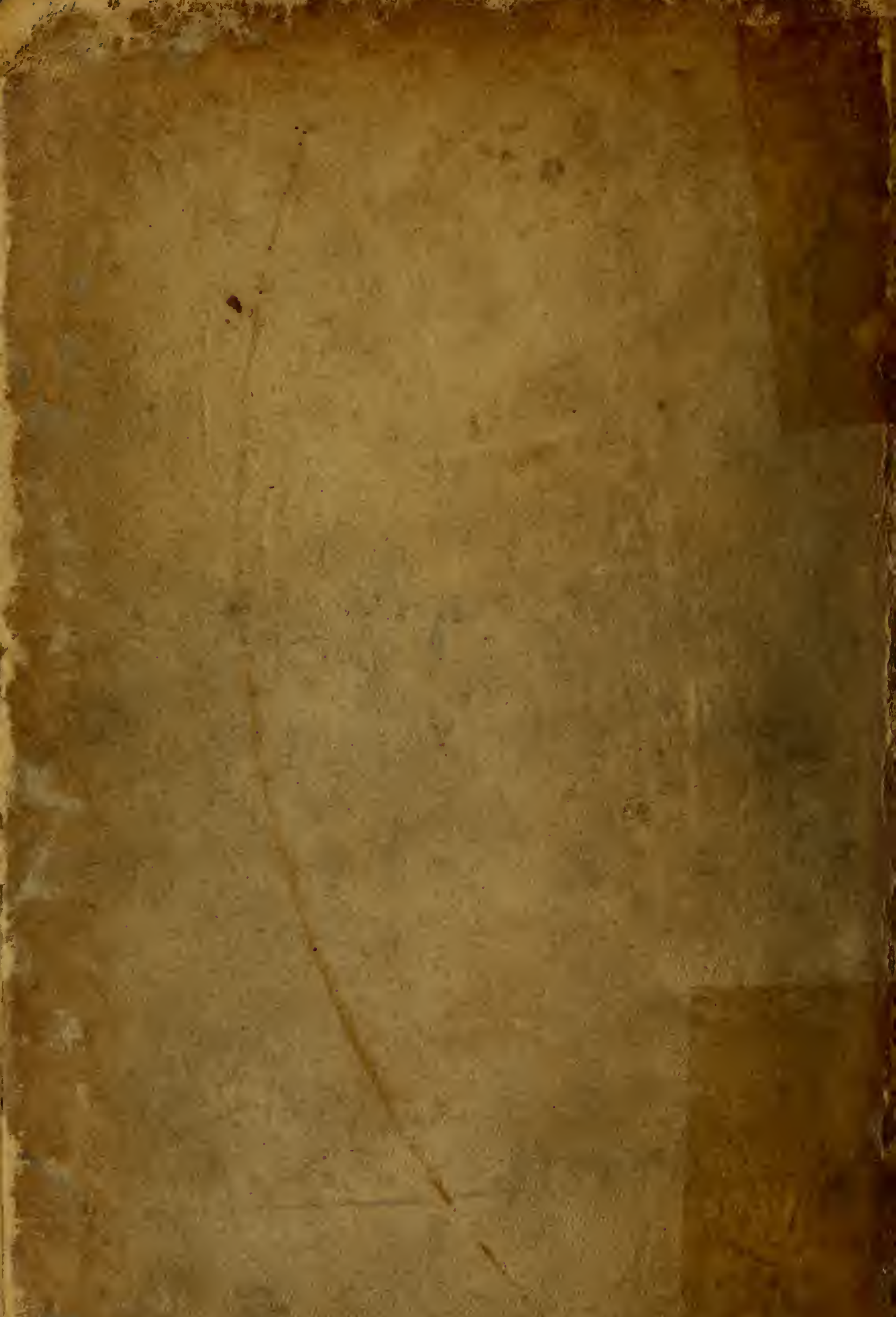

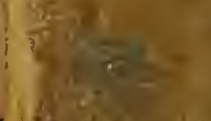

